Contributions to the Geology of Uranium and Thorium by the United States Geological Survey and Atomic Energy Commission for the United Nations International Conference on Peaceful Uses of Atomic Energy, Geneva, Switzerland 1955

GEOLOGICAL SURVEY PROFESIONAL PAPER 300 Prepared as a cooperative effort of the United States Geological Survey and the United States Atomic Energy Commission and published with the permission of the Commission

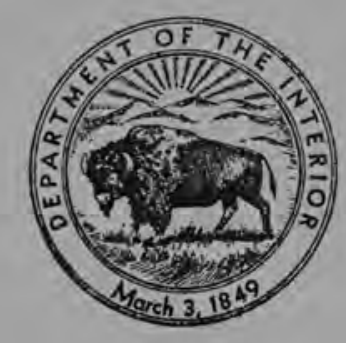




\section{Contributions to the Geology}

of Uranium and Thorium by the

United States Geological Survey

and Atomic Energy Commission for the United Nations International

Conference on Peaceful Uses of

Atomic Energy, Geneva, Switzerland

1955

Compiled by LINCOLN R. PAGE, HOBART E. STOCKING, and HARRIET B. SMITH

GEOLOGICAL SURVEY PROFESIONAL PAPER 300

Prepared as a cooperative effort of the United States Geological Survey and the United States Atomic Energy Commission and published with the permission of the Commission

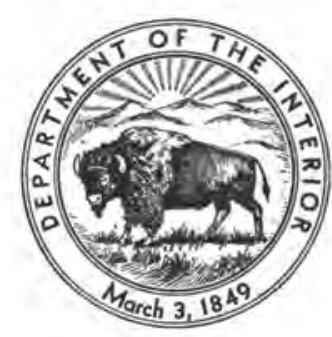

UNITED STATES GOVERNMENT PRINTING OFFICE, WASHINGTON : 1956 


\section{UNITED STATES DEPARTMENT OF THE INTERIOR \\ Secretary of the Interior \\ GEOLOGICAL SURVEY \\ Thomas B. Nolan, Director}

For sale by the Superintendent of Documents, U. S. Government Printing Office

Washington 25, D. C. 


\section{FOREWORD}

The International Conference on the Peaceful Uses of Atomic Energy held in Geneva, Switzerland, in August 1955 provided an opportunity for the first time to present the comprehensive scientific results of the United States Government's intensive investigations of the geology of fissionable materials. These investigations have been carried on since 1944 as a joint program of the Manhattan Engineer District and its successor, the U. S, Atomic Energy Commission, and the U. S. Geological Survey. It is probably safe to say that no other group of materials has been so exhaustively studied in such a short period of time in the whole bistory of the geological sciences.

The results of this program have fully warranted the great effort and expense involved. They have helped in establishing reserves of fissionable materials far beyond original expectations. A large body of valuable data has been added to the sum of geologic knowledge. Solutions to many problems in structural geology, stratigraphy and paleontology, ore genesis, geomorphology, geochemistry, geophysics, mineralogy and petrology, analytical chemistry, and nucleonics have been achieved or have been substantially advanced. Not the least of the results has been the acquisition and training of a large corps of scientific workers who are a priceless asset to the Nation.

It is with a great deal of satisfaction on the part of our two groups that this volume is presented to the public. Most of the papers that appear here, an outgrowth of the participation of the United States in the conference, were a part of that event. Enlarged by data acquired since the conference, increased by contributions which arrived too late for a place in Proceedings of the United Nations, this volume represents the coordinated efforts of the U.S. Geological Survey and the U. S. Atomic Energy Commission to place before the world concise details of the geology of fissionable materials with the hope that this will aid in the promotion of the use of these materials for the benefit of mankind.

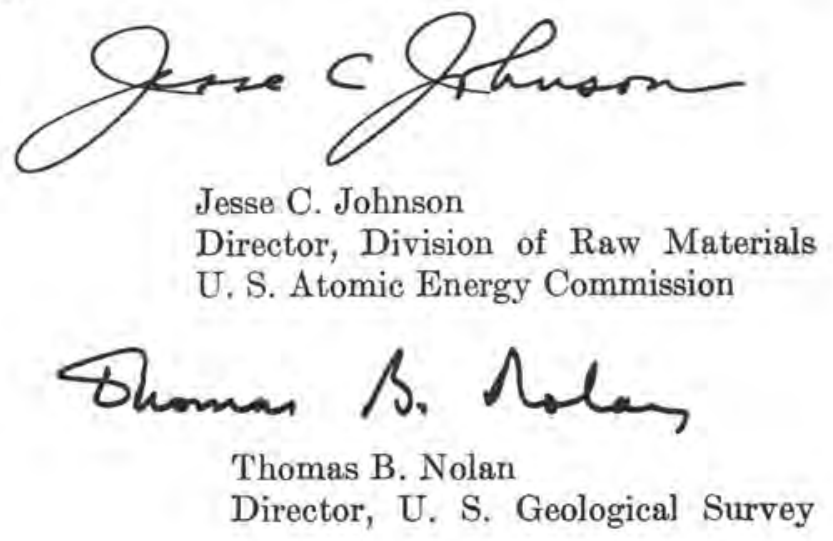




\section{CONTRIBUTING WRITERS AND THEIR AFFILIATIONS}

U. S, GEOLOGICAL SURVEY

\section{John W. Adams}

Zalman S. Altschuler

George E. Becraft

Henry Bell, III

Kenneth G. Bell

Rudolph A. Black

Irving A. Breger

Robert L. Boardman

Howard E. Bowers

Maurice R. Brock

Andrew Brown

Katharine L. Buck

Arthur P. Butler, Jr.

Frank C. Canney

Helen L. Cannon

Louis D. Carswell

James B. Cathcart

Robert R. Coats

Louis C. Conant

Norman P. Cuppels

Frank Cuttitta

Norman M. Denson

Maurice Deul

E. Bartlett Ekren

Warren I. Finch

Tommy L. Finnell

Richard P. Fischer

Philip F. Fix

Val L. Freeman

Clifford Frondel

Robert M. Garrels

James R. Gill

Garland B. Gott
David Gottfried

Frank S. Grimaldi

William J. Hail, Jr.

Lowell S. Hilpert

C. Albert Horr

Harold J. Hyden

Elizabeth B. Jaffe

Daniel A. Jobin

Frank J. Kleinhampl

Montis R. Klepper

- Hubert William Lakin

Esper S. Larsen, Jr.

Thomas S. Lovering

J. Hoover Mackin

William J. Mapel

Harold Masursky

Edward J. McKay

Vincent E. McKelvey

Francis A. McKeown

Alfred T. Myers

James W. Mytton

Jerry C. Olson

Frank W. Osterwald

William C. Overstreet

Lincoln R. Page

George Phair

David A. Phoenix

Arthur P. Pierce

George N. Pipiringos

Forrest G. Poole

Edwin V. Post

Arthur Y. Sakakura
George J. Neuerburg
Robert W. Schnabel

Dwight L. Schmidt

William N. Sharp

Daniel R. Shawe

Eugene M. Shoemaker

Paul K. Sims

Q. D. Singewald

William L. Smith

Mortimer H. Staatz

Frank W. Stead

James G. Stephens

Thomas W. Stern

Lorin R. Stieff

Jerome Stone

Frederick Stugard, Jr.

Vernon E. Swanson

Robert E. Thaden

Paul K. Theobald, Jr.

Edwin W. Tooker

Albert F. Trites, Jr.

William S. Twenhofel

Rollin C. Vickers

James D. Vine

George W. Walker

Stewart R. Wallace

Frederick N. Ward

Alice D. Weeks

Amos M. White

Jesse W. Whitlow

George A. Williams

Irving J. Witkind

Donald G. Wyant

Howard D. Zeller
U. S. ATOMIC ENERGY COMMISSION

Harrison Brown

(California Institute of Technology)

L. W. Carithers

N. J. Clinton

Dudley L. Davis

M. Elner Denson

R. C. Derzay

Philip H. Dodd

Charles G. Evensen

Donald L. Everhart

John W. Gabelman

E. B. Gross

W. D. Grundy

John W. Gruner

(University of Minnesota)

Eugene W. Grutt, Jr.

Donald L. Hetland

Henry R. Hoekstra

(Argonne National Laboratory)

Y. William Isachsen

Jesse C. Johnson

Joseph J. Katz

(Argonne National Laboratory)

Vincent C. Kelley

(University of New Mexico)

Paul F. Kerr

(Columbia University)

W. Scott Keys

John W. King

R. A. Laverty

Robert K. Pitman

Byron J. Sharp

Leon T. Silver

(California Institute of Technology)

Hobart E. Stocking

Ernest E. Thurlow

Charles W. Tom

R. L. White

Hiram B. Wood

Harry B. Young 
Foreword

Contributing writers and their affiliations

Introduction

Natural Occurrence of Uranium

GENERAL SUMMARY

Natural oceurrence of uranium in the United States - a summary, by Hobart E. Stocking and Lineoln R. Page.............

Nuclear fuel for the world power program, by Jesse C. Johnson

Uranium provinces, by Montis R. Klepper and Donald G. Wyant

Distribution and general features of uranium occurrences in the United States, by Arthur P. Butler, Jr, and Robert W. Schnabel

Summary of hypotheses of genesis of uranium deposits, by Vincent E. MoKelvey, Donald L. Everhart, and Robert M. Garrels

URANIUM IN IGNEOUB ROCKS

Uranium in igneous rocks of the United States, by George J. Neuerburg.

Uranium in magmatic differentiation, by Esper S. Larsen, Jr., George Phair, David Gottfried, and William L. Smith...Uranium and certain other trace elements in felsic voleanic rocks of Cenozoic age in Western United States, by Robert R. Coats

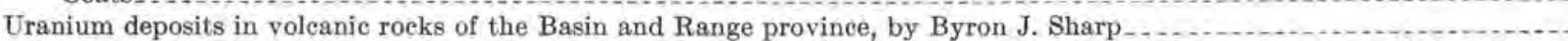

- Uranium deposits at the contact of metamorphosed sedimentary rocks and granitio intrusive rocks in Western United States, by Ernest E. Thurlow.

The possibilities of obtaining long-range supplies of uranium, thorium, and other substances from igneous rocks, by Harrison Brown and Leon T. Silver.

URANIUM IN VEINS

Uranium-bearing vein deposits in the United States, by Donald L. Everhart

Pitchblende deposits in the Central City district and adjoining areas, Gilpin and Clear Creek Counties, Colorado, by Paul K. Sims and Edwin W. Tooker.-.

Summary of wall-rock control of eertain pitchblende deposits in Golden Gate Canyon, Jefferson County, Colorado, by John W. Adams and Frederick Stugard, Jr _...

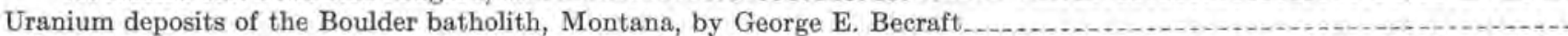

Relation of secondary uranium minerals to pitchblende-bearing veins at Marysvale, Piute County, Utah, by George W. Walker and Frank W. Osterwald ...

Uranium in the fluorspar deposits of the Thomas Range, Utah, by Mortimer H. Staatz and Frank W. Osterwald ......... Geology of the Los Ochos uranium deposit, Saguache County, Colorado, by R. C. Derzay

Uranium-vanadium-copper deposits on the Colorado Plateau, by Richard P. Fischer-

Structural features of the central Colorado Plateau and their relation to uranium deposits, by Eugene M. Shoemaker-Influence of regional strueture and tectonic history upon the origin and distribution of uranium on the Colorado Plateau, by Vincent C. Kelley

Occurrence of uranium in diatremes on the Navajo and Hopi Reservations, Arizona, New Mexico, and Utah, by Eugene M. Shoemaker.

Mineralogy and oxidation

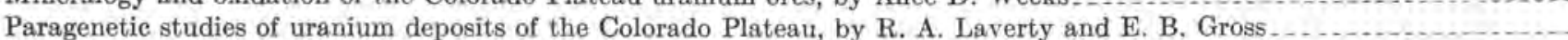

A comparison of black uranium ore deposits in Utah, New Mexico, and Wyoming, by John W. Gruner..................

Regional transmissivity of the exposed sediments of the Colorado Plateau as related to distribution of uranium deposits, by Daniel A. Jobin.

Relation of carnotite deposits to permeable rocks in the Morrison formation, Mesa County, Colorado, by David A. Phoenix -.

Sedimentary features of upper sandstone lenses of the Salt Wash member and their relation to uranium-vanadium deposits in the Uravan district, Montrose County, Colorado, by Robert L. Boardman, E. Bartlett Ekren, and Howard E. Bowers --

Direction of sediment transport in the Triassic and associated formations of the Colorado Plateau, by Forrest G. Poole and George A. Williams.

Channels and related swales at the base of the Shinarump conglomerate, Monument Valley, Arizona, by Irving J, Witkind Significance of roll ore bodies in genesis of uranium-vanadium deposits on the Colorado Plateau, by Daniel R. Shawe ........... Examples of uranium deposits in the Upper Jurassic Morrison formation on the Colorado Plateau, by Philip H. Dodd ........... 
Geology of uranium deposits of the Shinarump and the Chinle formations on the Colorado Plateau, by Y. William Isachsen and Charles G. Evensen ................

Uranium deposits in the White Canyon area, San Juan County, Utah, by Albert F. Trites, Jr., Tommy L. Finnell, and Robert E. Thaden.

Investigation of the Temple Mountain collapse and assoeiated features, San Rafael Swell, Emery County, Utah, by W. Scott Keys and R. L. White.

Guides to uranium deposits in the Morrison formation, Gallup-Laguna area, New Mexico, by Lowell S. Hilpert and Val L. Freeman

Uranium deposits in paludal black shales, Dakota sandstone, San Juan Basin, New Mexico, by John W Gabelman

Uranium in terrestrial sedimentary rocks in the United States exclusive of the Colorado Plateau, by Warren I. Finch..........

Relation of tectonic elements in Precambrian rocks to uranium deposits in the Cordilleran foreland of Western United States, by Frank W. Osterwald.

Geology of uranium in the basins of Tertiary age in Wyoming and the northern Great Plains, by James D. Vine ...............

Lithologic and structural controls of uranium deposition in the southern Black Hills, South Dakota, by Henry Bell, III, Gariand B. Gott, Edwin Vanhorn Post, and Robert W. Schnabel

Uranium in clastic rocks of the Basin and Range province, by Dudley L. Davis and Donald L. Hetland .................

Uranium deposits in Tertiary sedimentary rocks in Wyoming and northern Colorado, by Eugene W. Grutt, Jr...........

Geology and uranium deposits of the Pumpkin Buttes area, Powder River Basin, Wyoming, by William N. Sharp, Francis A. McKeown, Edward J. MeKay, and Amos M. White

Uranium- and thorium-bearing minerals in placer deposits in Idaho, by J. Hoover Mackin and Dwight L. Schmidt ............. Uranium in precipitates and evaporites, by Kenneth G. Bell

Uranium deposits in limestone, by John W. Gabelman

Uranium-bearing coal in the United States, by James D. Vine.

Uranium-bearing lignite and its relation to volcanic tuffs in eastern Montana and North and South Dakota, by Norman M. Denson and James R. Gill.

High-grade uraniferous lignites in Harding County, South Dakota, by John W. King and Harry B. Young Uranium-bearing coal in the central part of the Great Divide Basin, Sweetwater County, Wyoming, by George N. Pipiringos...

Trace elements in coal in the Red Desert, Wyoming, by Harold Masursky

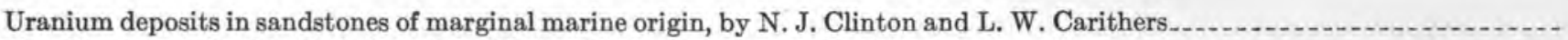
Uranium in marine black shales of the United States, by Vernon E. Swanson.

Uranium in the Chattanooga shale of eastern Tennessee, by Andrew Brown Environment of accumulation of the Chattanooga shale, by Louis C. Conant_. Uraniferous black shale in the northern Rocky Mountain and Great Plains regions, by William J. Mapel . . . . . . . . ....... Uranium in phosphate rock, by Vincent E. McKelvey.

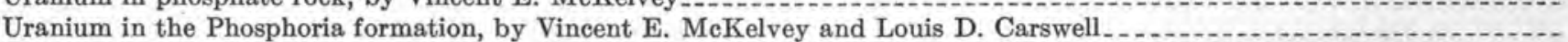
Distribution and occurrence of uranium in the calcium phosphate zone of the land-pebble phosphate district of Florida, by James B. Cathcart

The aluminum phosphate zone of the Bone Valley formation, Florida, and its uranium deposits, by Zalman S. Altschuler, Elizabeth B. Jaffe, and Frank Cuttitta

\section{URANIUM IN PETROLEUM AND ASPHALTITES}

The organic geochemistry of uranium, by Irving A. Breger and Maurice Deul_... Uranium and other trace metals in crude oils of Western United States, by Harold J. Hyden Uranium in asphalt-bearing rocks of Western United States, by William J. Hail, Jr., Alfred T. Myers, and C. Albert Horr.Radioactive elements and their daughter products in the Texas Panhandle and other oil and gas fields in the United States, by Arthur P. Pierce, James W. Mytton, and Garland B. Gott.

\section{AGE OF URANIUM DEPOSITS}

Relations of the origin of host rocks to uranium deposits and ore production in Western United States, by Hiram B. Wood.Isotope geology of some uranium minerals, by Henry R. Hoekstra and Joseph J. Katz. 


\section{Natural Occurrence of Thorium}

Geology of thorium deposits in the United States, by William S. Twenhofel and Katharine L. Buck ............................ 559

Mineralogy of thorium, by Clifford Frondel _....

Thorium deposits in the Wet Mountains, Colorado, by Q. D. Singewald and Maurice R. Brock

Thorium in the Powderhorn district, Gunnison County, Colorado, by Stewart R. Wallace and Jerry C. Olson............ 587

Geology and monazite content of the Goodrich quartzite, Palmer area, Marquette County, Michigan, by Rollin C. Vickers. 593

Monazite in Southeastern United States, by William C. Overstreet, Norman P. Cuppels, and Amos M. White_............. 597

\section{Analytical Chemistry of Uranium and Thorium}

The analytical chemistry of uranium and thorium, by Frank S. Grimaldi.

\section{Methods of Prospecting for Uranium and Thorium}

Techniques for prospecting for uranium and thorium - a summary, by Royal S. Foote and Lincoln R. Page............... Geologic prospecting for uranium and thorium, by Lincoln R. Page

Rock alteration criteria in the search for uranium, by Paul F. Kerr

Subsurface techniques for outlining favorable zones by widely spaced core drilling, by Robert K. Pitman, Philip H. Dodd, and Charles W. Tom.

Heavy-mineral prospecting, by William C. Overstreet, Paul K. Theobald, Jr., Jesse W. Whitlow, and Jerome Stone......... Techniques and guides in exploration for uranium in Shinarump channels on the Colorado Plateau, by Hiram B. Wood and W. D. Grundy

The use of geochemical techniques and methods in prospecting for uranium, by Thomas S. Lovering, Hubert William Lakin, Frederick N. Ward, and Frank C. Canney

Hydrogeochemical exploration for uranium, by Philip F. Fix

Water sampling as a guide in the search for uranium deposits and its use in evaluating widespread volcanie units as potential source beds for uranium, by Norman M. Denson, Howard D. Zeller, and James G. Stephens .

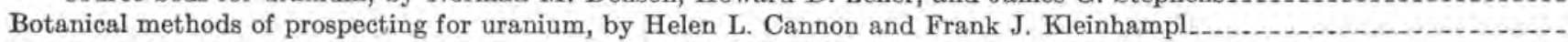
Geophysical-geochemical prospecting for uranium, by M. Elner Denson.

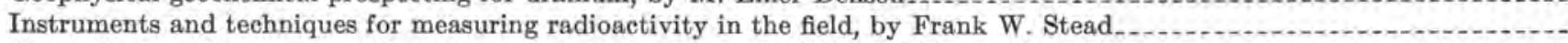

Air seattering of gamma rays from thick uranium sources, by Arthur Y. Sakakura . . . . . . . . . . .

Geophysical exploration for uranium on the Colorado Plateau, by Rudolph A. Black.

\section{SubJect AND Author Indexes}

621

627

633

641

647

651

659

667

673

681

687

705

715

721

Subject index

Author index. 

CONTRIBUTIONS TO THE GEOLOGY OF URANIUM AND THORIUM BY THE UNITED STATES GEOLOGICAL SURVEY AND ATOMIC ENERGY COMMISSION FOR THE UNITED NATIONS INTERNATIONAL CONFERENCE ON PEACEFUL USES OF ATOMIC ENERGY, GENEVA, SWITZERLAND, 1955

\author{
Compiled by Linooln R. Page, Hobart E. Stocking, and Harriet B. Smith
}

\title{
INTRODUCTION
}

The intensive investigations of the uses of radioactive materials made by scientists of many countries during the past decade have focused the attention of geologists on the occurrence of uranium and thorium. During these years geologic studies, prospecting, and exploration have been carried on at an unprecedented rate. The magnitude of this effort greatly exceeded that given to the search for any other mineral commodity during any similar period of history. As a result, knowledge of the geology of uranium and thorium now equals or exceeds that concerning deposits of any other metal, some of which bave been the object of geologic study since the beginning of science. The study of uranium and thorium deposits, as well as other parts of the atomic energy program, was made under conditions that restricted distribution of data and interchange of scientific ideas between all nations.

In December 1953 President Eisenhower in an address before the General Assembly of the United Nations proposed that an International Atomic Energy Agency be established, and that its responsibilities include the devising of "methods whereby fissionable material would be allocated to serve the peaceful pursuit of mankind."

Chairman Strauss of the Atomic Energy Commission elaborated the proposal before the Los Angeles World Affairs Council in April 1954, disclosing there the President's hope that a national scientific organization might convene an international conference of scientists "devoted to exploration of benign and peaceful uses of atomic energy." Through that means the President hoped to "hasten the day when the fear of the atom will disappear from the minds of the people and of governments."

In December 1954 the General Assembly of the United Nations resolved to sponsor a convocation and early the following year issued to all nations an invitation to convene in Geneva on August 8, 1955 in an International Conference on the Peaceful Uses of Atomic Energy. The conference - and its success-is now history.

The United Nations International Conference on the Peaceful Uses of Atomic Energy held in Geneva provided a far broader exchange of information on the beneficial uses of atomic energy than had ever taken place. Because widespread use of atomic energy is $385115-56-2$ possible only if there is an adequate supply of radioactive raw materials, two of the technical sessions (6B and $7 \mathrm{~B}$ ) were devoted to discussions of the occurrence of and prospecting for uranium and thorium. A large number of the papers submitted for these sessions were from the U. S. Geological Survey and the U, S. Atomic Energy Commission (and its contractors) and summarized the results of investigations to date. For the first time it was possible to compare studies made in the United States with similar investigations by geologists of a number of the participating nations, Such interchanges promote an understanding of the processes by which uranium and thorium are coneentrated in the earth and lead to the finding of new deposits.

Since the early days of the development of atomic energy in the United States, the Geological Survey has had an active part in this program, first for the Manhattan Engineer District, and, since its creation in 1946, the U. S. Atomic Energy Commission. The geologic, geochemical, and geophysical work of the Survey on radioactive materials is now, as in the past, being undertaken for the Atomic Energy Commission. The Commission has likewise engaged in extensive geologic exploration and has supported a variety of scientific investigations in this field by other groups.

The more significant results of these efforts, those which have universal applications in the field of uranium and thorium geology, are described in the reports making up this volume. These were prepared for the United Nations International Conference by the Survey and the Commission and most of them are published in the proceedings of the conference. In general the papers prepared by the Geological Survey for session $6 \mathrm{~B}$ of the conferenee-"The natural occurrence of uranium and thorium"- -discuss the broader aspects of the various problems of geology; the papers written by persomel of the Atomic Energy Commission and its contractors describe, for the most part, the various types of significant uranium ore deposits known in the United States. The papers contributed to session $7 \mathrm{~B}$ of the conference- "Prospecting for uranium and thorium"discuss in detail the varied applications of geology, geophysics, geochemistry, and botany to prospecting for uranium, as well as the various techniques used in radiometric surveying in the air, on the ground, and in drill holes, seismic and electrical testing, drill-hole logging, 
physical exploration, water sampling, and many others. One paper, "The analytical chemistry of uranium and thorium," was prepared for session 15B.2-"Analytical methods in raw material production."

These contributions are grouped in four parts and an index to present the full scope of the vast program of the Survey and the Commission and to provide a comprehensive account of available data for the aid of those engaged in exploration of both new and old districts for uranium and thorium. The first part discusses the natural occurrences and distribution of uranium in all major geologic environments: igneous rocks, veins, terrestrial and marine sedimentary rocks, and petroleum and asphaltites, and is summarized in its opening report, "Natural occurrence of uranium in the United States," by Hobart E. Stocking of the Commission and Lincoln R. Page of the Survey. The second report, "Nuclear fuel for the world power program," evaluates source materials and discusses the future of uranium. The papers that follow describe both the general geochemical and structural setting of uranium districts and the specific characteristics of all known types of deposits in the United States.

The second part, "Natural occurrence of thorium," summarizes the geology and mineralogy of thorium and describes various thorium-bearing deposits in the United States.
The third part is a summary of the methods and techniques of analytical chemistry used by chemists working. on uranium and thorium problems.

The fourth part describes in detail the techniques for prospecting for uranium and thorium. Its first paper, "Technique for prospecting for uranium and thorium," is a compilation, by Royal S. Foote, formerly of the Commission, and Lincoln R. Page of the Survey, of the reports that follow on diverse techniques used in geologic, geophysical, geochemical, botanical, and physical exploration, and on the various instruments and devices used in locating and measuring radioactivity in the field.

The fifth part consists of an index of States, areas, and subjects included in all papers in this volume, and an index of authors.

The search for uranium and thorium during the past 10 years has been successful primarily because of the radiation-detection equipment available to the prospectors. This method of prospecting, however, will become less important as the near-surface deposits are found and a more analytical approach will be necessary to find deposits concealed beneath the surface. The presently known geologic, geophysical, and geochemical guides most applicable to the search for buried deposits are presented in this volume. 
NATURAL OCGURRENCES OF URANIUM 


\title{
NATURAL OGGURRENCE OF URANIUM IN THE UNITED STATES-A SUMMARY
}

\author{
By Hobart E. Stocking, U. S. Atomic Energy Commission, and Lincoln R. Page, U. S. Geological Survev
}

\section{CONTENTS}

\begin{abstract}
.

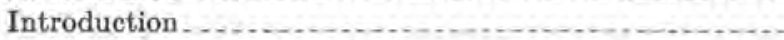

Uranium in igneous rocks.

Uranium in veins.

Uranium in terrestrial sedimentary rocks

Clastic rocks
\end{abstract}

Page

Uranium in terrestrial sedimentary rocks-Continued

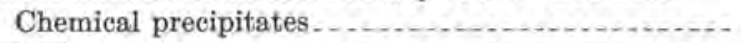
Coals

Uranium in marine sedimentary rocks .............. 11

Uranium in petroleum and asphaltites ............. 11

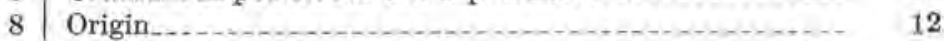

\begin{abstract}
ABSTFACT
Within the boundaries of the United States abnormal amounts of uranium have been found in rocks of nearly all geologic ages and lithologic types. Distribution of ore is more restricted. On the Colorado Plateau, the Morrison formation of Jurassic age yields 61.4 percent of the ore produced in the United States, and the Chinle conglomerate and Shinarump formation of Triassic age contribute 26.0 and 5.8 percent, respectively. Clastic, carbonaceous, and carbonate sedimentary rocks of Tertiary, Mesozoic, and Paleozoic ages and veins of Tertiary age are the source of the remaining 6.8 percent.

In most batholiths the uranium, dominantly in acid-soluble form at intergrain boundaries, systematically inereases in abundance from the mafic to the alkalic end-products of differentiation; in the Boulder Creek batholith, Colorado, the contrary is true. Uraniferous pyroclastic rocks, most of Tertiary age, are widely distributed; associated ore-bearing clastic sedimentary rocks commonly contain appreciable quantities of voleanic debris. Minable syngenetic deposits of uranium are unknown in pegmatites and other igneous rocks.

Pitchblende-bearing veins of Tertiary age are mined at Marysvale, Utah; Ralston Buttes, Gunnison, and Central City, Colo.; and Boulder, Mont. In the Coeur d'Alene district, Idaho, uranium-bearing veins of Precambrian age are known. Numerous other uraniferous veins are found in erystalline rocks of the United States. The pitchblende may be associated with copper, lead, silver, zinc, and gold minerals; with sulfides and fluorite; or with carbonate and silica gangue minerals and only minor amounts of sulfides. In the Thomas Range, Utah, are uraniferous fluorite veins and pipes of ore grade. Secondary uranium minerals occur in the upper parts of many of the veins.

Oxidized and unoxidized uranium and vanadium minerals occur over a wide geographic, stratigraphic, lithologic, and structural range in terrestrial sedimentary rocks. Carnotite, tyuyamunite, autunite, torbernite, and other vanadates, phosphates, earbonates, and arsenides are common in near-surface ores; unoxidized ores at depth contain pitchblende and coffinite, with or without copper and other sulfides. Most ore bodies oceur in fluvial sedimentary rocks of Triassic and Jurassic age
\end{abstract}

in the Colorado Plateau and of Tertiary and Cretaceous age in Wyoming and South Dakota; some ore has been found in eolian, lacustrine, paludal, and marine rocks. The lacustrine Todilto limestone of Jurassic age is the host rock in the Grants district, N. Mex.; lignites of Tertiary age bear uranium in South Dakota and Wyoming. Ore bodies in separate areas have different primary controls; however tectonic and sedimentary structures, earbonaceous material, carbonate and other cements, and variations in permeability appear to affect loealization.

Coarse-grained marine clastic rocks are hosts for minor epigenetic ore deposits in the Colorado Plateau; marine black shales and phosphorites contain low-grade syngenetic uranium.

In the vicinity of uranium ore bodies, water, petroleum, and asphaltic materials contain abnormal amounts of uranium and these together with radon and helium serve as guides to favorable areas.

Absolute age determinations of uranium ores have demonstrated for many of the deposits an age much more recent than their stratigraphic and structural relations suggest. Some ore bodies are of direct magmatic affiliation, others appear to be the result of direct sedimentary deposition, and others may have originated through leaching of their host rock minerals or of overlying volcanic rocks.

\section{INTRODUCTION}

Uranium, discovered by Klaproth in 1789 , has a remarkably wide geographic and geologic distribution. Ten years of intensive study since 1945 by thousands of workers in the United States has shown that uranium occurs in all major geologic environments except those typified by ultramafic and plateau basalt igneous rocks and certain marine sediments. It is impossible to summarize adequately here all categories of uranium occurrence or to give adequate credit to all scientists who have contributed significantly to this knowledge of it. This paper, though it summarizes only those 
papers submitted to this conference, nevertheless gives a brief, but complete, account of all important data available in the United States for use by others in the search for source materials of atomic energy.

Exploitable deposits of uranium result partly from original inhomogeneities in the earth's crust and partly from the interplay of cyclic orogenic and geochemical processes. In the generation, differentiation, emplacement, and crystallization of magma during an orogenic cycle, original inhomogeneities in the crust can be accentuated. Uranium is concentrated in the final fractions of the magma; and from some magmas the last igneous rocks to crystallize or the residual fluids, or both, are uranium-rich. Tectonic events during the final stages of crystallization may determine whether the uranium crystallizes in pegmatites or in other small differentiated granitic or alkalic plutonic rocks, or escapes in hydrothermal solutions and forms veins or other epigenetic deposits.

Uranium may be concentrated further during the subsequent period of weathering, erosion, and sedimentation in and adjacent to a uranium-rich orogenic belt. Complex multiple oxides rich in uranium are relatively insoluble and may accumulate in placer deposits. Uranium from soluble minerals enters the surface and subsurface water and may be deposited in a great variety of environments; that not entrapped reaches the sea and ultimately may be concentrated in black shales and phosphorites. These deposits, through subsequent burial and action of igneous heat and hydrothermal solutions, may be modified to various degrees. Reincorporation of uranium-rich sedimentary rocks in magma and recycling and perhaps reconcentration of the uranium are possibilities. Thus uranium-rich provinces, once established, continue through long periods of geologic time.

In the United States uranium deposits are grouped according to their host rocks or their controlling structure, as deposits in igneous rocks, veins, terrestrial clastic rocks, precipitates and evaporites, lignites, coal, and asphaltic materials, marine black shales, and phosphorites. Most of the ore deposits of uranium occur in the orogenic belt between the 100th and 120th meridians of west longitude; a few occur elsewhere.

\section{URANIUM IN IGNEOUS ROCKS}

Some igneous rocks contain much more uranium than most granites; none is at present a commercial source of this metal. Complete studies of four plutonic, one hyperabyssal, and one volcanic igneous magma series, and incomplete investigations of five alkalic intrusive complexes and one lava series show that the uranium content of the mafic rocks is about 0.3 parts per million (ppm), rising steadily in the intermediate rocks to about
$2.0 \mathrm{ppm}$, and reaching a maximum in granite of about $5.0 \mathrm{ppm}$. Some late potassium-rich, calcium-poor porphyries contain as much as $140 \mathrm{ppm}$. Results of sampling of 116 widely separated rhyolitic and dacitic, glassy to partly glassy, volcanic rocks in the Cordilleran region of Western United States suggest a provincial grouping of uranium content with certain other trace metals. Recent discoveries of ore-grade deposits, probably epigenetic, in Nevada and California, are in those volcanic provinces of high uranium content.

The uranium in igneous rocks occurs as discrete uranium minerals, disposed in the structure of the rock-forming minerals by diadochy and in structural defects, in cation exchange positions, adsorbed on surfaces of grains, and dissolved in fluid inclusions and intergranular fluids. The uraniferous intergranular fluids are leachable in dilute acid and may offer a very low grade, exploitable source of uranium for the future.

\section{URANIUM IN VEINS}

Uraniferous vein deposits in the Western States are mainly Tertiary in age. Most economic deposits are in crystalline rocks of Precambrian, Mesozoic, and Tertiary age. Occurrences in Eastern United States, mostly undated, are mainly in rocks of Precambrian age. Pitchblende, associated with base-metal sulfides or with fluorite, is the principal uranium mineral in vein deposits at depth. Supergene secondary uranium minerals occur in some deposits but are not abundant. Uranium is mined from veins in Colorado, Arizona, Montana, Nevada, and California, but principally from those near Marysvale, Utah.

Felsic extrusive and intrusive rocks are the most common hosts of uraniferous veins; less common are the orthoschists and gneisses, quartzite, metavolcanic rocks, and arenaceous sediments. The vein minerals, for the most part, fill open spaces and were deposited under epithermal conditions; a few, as in Central City, Colo., may have been formed in mesothermal environments. Replacement bodies are rare. Hydrothermal alteration of the wall rocks includes silicification, sericitization, chloritization, argillization, and alunitization. Red hematite zones adjacent to veins are very common. Uraninite, the most common ore mineral, probably is precipitated from hydrothermal sulfate- and carbonate-rich solutions through reduction caused by hydrogen sulfide, sulfur dioxide, or ferrous iron; decrease in temperature and pressure; or through chemical reaction with host rocks.

Similarities in primary mineral assemblages in various veins of ore grade allow the following classification: Type A-uranium, iron, and silica oxides; type 
$\mathrm{B}$ - uranium oxides and iron, lead, and molybdenum sulfides associated with abundant silica and fluorite; type C-uranium oxides, cobalt, nickel, base-metal sulfides, and native silver with abundant carbonate gangue; type $\mathrm{D}$-uranium oxides, iron sulfides, and native gold associated with abundant silica gangue; and type $\mathrm{E}$-uraniferous hydrocarbons.

Veins of type A contain sooty pitchblende with some uraninite and pyrite; quartz and fluorite gangue are sparse. The Moonlight mine, Humboldt, Nev., is an example of this type, though most of the uranium oxides have been altered to autunite, torbernite, and gummite(?), The breceiated rhyolite wall rock of Miocene age has been altered, in part, to clay minerals,

Type B veins may contain uraninite, iron and copper sulfides, galena, sphalerite, and molybdenite associated with abundant quartz and fluorite. The deposits at Marysvale, Utah, are typical examples. An extreme variant of this type are the uraniferous fluorite deposits of the Thomas Range, Utah.

The veins of the Marysvale district, Piute County, Utah, are in Tertiary quartz monzonite and in the unconformably overlying latitic and andesitic volcanic breccia, tuffs, and flows of early Tertiary age, and the rhyolitic flows and tuff-breccias of late Tertiary age. Postrhyolite normal and reverse faults and shear zones of diverse orientation contain ore bodies as much as 800 feet long and 700 feet in vertical extent. Ore shoots occur at intersections of faults and points of change of fault strike. The primary minerals pitchblende, quartz or chalcedony, dark-purple to black fluorite, pyrite, and adularia, occur through a vertical range of 2,000 feet; calcite, jordisite, hematite, magnetite, marcasite, and molybdenite have a more limited vertical range. Hydrothermal alteration is marked by alunite, which preceded the uranium minerals, and by later clay minerals, chlorite, local silicification, and hematite. The hematitic alteration is absent at depth. Alteration of pitchblende to depths of 400 feet has resulted in many secondary phosphates, silicates, sulfates, sulfocarbonates, vanadates, and perhaps oxide (sooty pitchblende).

Uraniferous fluorite pipes, veins, and disseminated deposits in the Thomas Range, Juab County, Utah, though in part of uranium ore grade, are mined for fluorite. The ore contains 65 to 95 percent fluorite and resembles brown, white, or purple clay. It is in soft pulverulent masses or boxworks. The fluorite is associated with montmorillonite, quartz, chalcedony, opal, dolomite, and calcite. Except for a few specimens of carnotite near the surface no uranium mineral is visible; autoradiographs show a uniform distribution of uranium suggesting that it is held in the lattice of the fluorite. As a result of secondary enrichment, the uranium con- tent of the fluorite pipes is highest within 30 feet of the surface; the content is as much as 0.33 percent. These deposits are in dolomitic wall rocks and are closely related in age to topaz-bearing intrusive and extrusive rocks.

Veins of type $\mathrm{C}$ are characterized by the presence of nickel, cobalt, and native silver with pitchblende in a gangue dominately of carbonate, but with minor amounts silica and barite. The Sunshine mine, Shoshone County, Idaho, is a typical example.

Type D veins contain uraninite with gold-bearing pyrite and quartz associated with lead, copper, and silver sulfides. Deposits of this type are represented in the Central City district, Gilpin County, Colo., and probably in the Boulder batholith region, Montana.

In Gilpin and Clear Creek Counties, Colo., pitchblende-bearing veins occur in gneisses and granitic rocks of Precambrian age that are associated with potash-rich dikes of Tertiary age. The veins are fillings in faults of Laramide age that formed at intermediate temperatures and pressures. Hypogene mineral zoning exists in this district. Pitchblende is a local constituent of ores of all zones but is most abundant in galena-sphalerite ores and the composite ores between the galena-sphalerite and pyritic gold ore zones. Pitehblende, characteristically showing colloform texture, was the first mineral to form; it is contemporaneous with quartz and is closely followed by pyrite, chalcopyrite, sphalerite, tennantite, and galena. Carbonate minerals locally form part of the gangue. The pitchblende is in shoots, small pods, or lenses that are systematically arranged in some veins and erratically distributed in others. The shoots are small but contain ore of 1 to 65 percent $\mathrm{U}_{2} \mathrm{O}_{3}$.

In veins of the galena-sphalerite type, where supergene solutions were only slightly acid, torbernite and other secondary minerals occur in the lower part of the zone of oxidation as disseminations in biotite gneiss and amphibolite wall roeks that have been largely altered to montmorillonite.

Similar veins in Jefferson County, Colo,, indicate that pitchblende ore shoots may preferentially form adjacent to wall rocks rich in ferrous minerals.

In the Boulder batholith region uranium minerals occur both in chalcedony veins and in veins mined for silver, lead, zinc, and gold. The silver-lead veins occupy faults cutting quartz monzonite and granodiorite, which have been silicified and sericitized. The vein minerals are galena, sphalerite, tetrahedrite chalcopyrite, pyrite, quartz, chalcedony, and carbonate minerals. Only minor quantities of sooty pitchblende have been found in these veins; however, uranium ore has been produced from the associated chalcedony veins. The chalcedony veins contain pitchblende, and its yellow alteration products, in at least three genera- 
tions of black to gray chalcedony and microcrystalline quartz. Minor amounts of pyrite and chalcopyrite occur in the veins. The granitic wall rocks are silicified, sericitized, and argillized outward from the veins.

Type $\mathrm{E}$ veins contain uranium-bearing hydrocarbons in gangues of calcite and barite, together with a variety of metallic sulfides. Near Placerville, Colo., veins of this type occur in faults cutting sandstones, limestones, and shales of Mesozoic age. The mineralogy is complex and includes at least three stages of mineralization. Calcite, pyrite, and barite are followed by uraniumbearing hydrocarbons, which in turn are followed by chalcopyrite, barite, tetrahedrite-tennantite, galena, sphalerite, fuchsite, and minor amounts of molybdenum and cobalt sulfide. The hydrocarbons are associated with a little autunite and uranophane. X-ray analysis of the hydrocarbons detected coffinite and pitchblende. Analyses of the ash of the hydrocarbons show as much as 9.8 percent uranium.

\section{URANIUM IN TERRESTRIAL SEDIMENTARY ROCKS}

\section{CLASTIC ROCKS}

The principal source of uranium in the United States is in terrestrial sandstones, mudstones, and limestones in which the uranium minerals occur as pore fillings and impregnations. The largest and most numerous of these deposits are in rocks of Mesozoic age on the Colorado Plateau, but similar deposits also occur in Mesozoic and Tertiary rocks on the fringes of the Plateau in Arizona, New Mexico, Utah, and Colorado; and in Texas, North and South Dakota, Wyoming, Montana, Nevada, and California. Uranium occurs in sandstones of Paleozoic age on the Colorado Plateau, and in Texas, New Mexico, Oklahoma, and Pennsylvania. In all, 37 sedimentary units have yielded uranium; 18 have furnished at least 1,000 tons of ore averaging more than 0.1 percent $\mathrm{U}_{3} \mathrm{O}_{8}$.

The Cordilleran foreland in Colorado, Wyoming, Montana, and the Dakotas, east of the main folded and thrusted belts of the Middle Rocky Mountains is becoming an increasingly important source of uranium production from sedimentary rocks. This area is characterized by simple folded mountains alternating with broad, asymmetric basins. Most of these structures appear related to vertical block movements in Precambrian basement rocks. Most uranium deposits in the region show a spatial relationship to the tectonic pattern of both large and small scale.

In the Black Hills of South Dakota and Wyoming the uraniferous districts are on major structural terraces on the Precambrian surface and individual deposits are on similar minor structures in sandstones of Cretaceous age. Likewise in the Colorado Plateau, regional structures, such as uplifts, faults, joints, and igneous masses appear to influence the distribution of ore deposits, although sedimentary structures are the dominant control.

The uranium-vanadium-copper deposits of the Colorado Plateau region form a group of deposits with a wide distribution and many common geologic characteristics. They are in sedimentary rocks of late Paleozoic to early Tertiary age that in places are invaded by moderate-sized stocks and laccoliths of early Tertiary or Late Cretaceous age. Laramide deformation is expressed by several broad folds, flexures, and faults, but in most of the region the beds are nearly horizontal.

Chemical, mineralogic, and geologic evidence indicates that the well-known carnotite ores have been derived by progressive oxidation of primary black vanadium-uranium ores. The primary ores contain uranium in uraninite and coffinite, and vanadium in montroseite and roscoelite. Minor amounts of copper, iron, lead, and zinc sulfides are common; arsenides and selenides are less common. Calcite and gypsum are commonly present; gypsum is rare in primary ore. Most uraninite and coffinite replace or impregnate coalified wood or other carbonaceous material. Primary vanadium minerals occur also in the intergranular space of sandstone.

On oxidation jet-black montroseite alters to paramontroseite and another unknown vanadium oxide, then to blue-black, greenish-black, and purplish corvusite group minerals. The primary uranium minerals oxidize and combine with vanadium to form rauvite. As oxidation continues, carnotite and tyuyamunite develop. These changes are closely controlled by the $\mathrm{pH}$ conditions existing at the time of oxidation; this in part is dependent on ground-water conditions. The nonvanadiferous primary ores contain more abundant copper sulfides with uraninite and on oxidation yield a wide variety of secondary hydrated oxides, carbonates, sulfates, phosphates, arsenates, and silicates. Comparison of the unoxidized Plateau ores in Triassic and Jurassic rocks with those of Eocene age in the Gas Hills of Wyoming show similar mineralogy and paragenesis, but vanadium is absent in ores of Eocene age. In the Texas coastal plain tuffaceous rocks, uranium phosphate, and silicate minerals are associated with arsenic and molybdenum.

Uranium ore bodies in clastic rocks range from small masses only a few feet across to deposits several hundred feet across. The large ore bodies are mainly tabular, forming layers a few feet to as much as 20 feet thick; the long axes of these layers lie almost parallel to bedding, but the layers are undulant and cut across the beds in places. Many ore bodies in sandstone are slightly elongate parallel to the trend of the 
stream that deposited the sandstone. On the Colorado Plateau significant production is mainly from the Shinarump conglomerate and Chinle formation of Triassic age and the Todilto limestone, Entrada sandstone, and Morrison formation of Jurassic age. Major deposits in the Shinarump conglomerate are mined in Monument Valley, Ariz., and White Canyon, Utah. Deposits of equal importance are in the Chinle formation in the Big Indian Wash-Lisbon Valley area and at Temple Mountain, Utah; and near Cameron, Ariz. Both the Shinarump and Chinle formations contain varying amounts of fluvial conglomerates, sandstones, and mudstones in which plant debris is abundant. Copper, copper-uranium, and vanadium and uranium deposits, both oxidized and unoxidized, have been found in both formations; uraninite is the chief ore mineral in most deposits. Exploitable ores, as at Monument Valley and White Canyon, are restricted to the sides and bottoms of channel fillings in ancient swales in the lower part of the Shinarump conglomerate. Ore bodies in the Chinle formation are not restricted to channels or to any particular stratigraphic unit; most, however, are in sandstones or coarse clastics in the lower part of the formation.

The Entrada sandstone in Colorado, New Mexico, and Arizona is a massive, crossbedded, fine-grained sandstone of probable eolian origin. It contains several large vanadium deposits (with minor amounts of uranium) in western Colorado. One of these deposits (at Rifle, Colo.) is also partly in the underlying Wingate sandstone.

A very large part of the United States production of uranium has come from the deposits in the Morrison formation. The Salt Wash member in Colorado and Utah and Brushy Basin member in New Mexico are the most favorable zones; minor deposits occur in the Recapture and Westwater Canyon members in northwestern New Mexico. Vanadium-uranium deposits, having 1 to 20 parts $\mathrm{V}_{2} \mathrm{O}_{5}$ to 1 part $\mathrm{U}_{3} \mathrm{O}_{8}$, predominate in the Morrison formation. These deposits are commonly in belts, such as the Uravan mineral belt, elongated at right angles to the trend of individual deposits. The deposits appear to be localized in the thicker parts of the sandstone lenses by sedimentary structures, such as channels, lenses, and intersections of crossbeds. Many of the deposits are characterized by "roll" ore bodies; that is, layered ore deposits in sharply eurving forms that cut across bedding. These deposits are common in the upper part of the Salt Wash sandstone member, but are less common than tabular bodies. They occur at the base of thick sandstone units where there are many thin, well-defined mudstone layers. The rolls may be several hundred feet long and the long axes parallel eurrent lineation, festoon bedding trends, and scours.

Reasons for the localization of ore deposits within clastic rocks of the Colorado Plateau have been sought as a basis for guides to drilling. Studies of transmissivity on Outlaw Mesa, Mesa County, Colo,, in the upper ore-bearing sandstone of the Salt Wash member show that these carnotite deposits are largest and most frequent where the uppermost layer is most transmissive, greater than 100 meinzer-feet; they are uncommon where the rocks are less transmissive, below 50 meinzerfeet. The smaller deposits are in rocks having transmissivity of 50 to 100 meinzer-feet. The degree of regional transmissivity does not appear to correlate with the position of deposits within a particular fluvial host rock.

Sedimentary structures from which direction of flow of paleostreams can be determined are of considerable aid in predicting favorable areas for uranium deposits. Such structures have apparently guided the flow of ore-forming solutions to local environments favorable to precipitation. As a result elongation of ore deposits can be predicted as parallel to channels and other structures. Thickened parts of sandstones and their trends are significant because in many districts the thicker parts are more prolific. Associated with these structures are variations in grain si e, color, mudstone abundance, and content of carbonaceous material. These features can be correlated with the degree of favorableness of ground for ore deposits, and various types of maps showing their interrelations have been prepared as guides in exploration.

Alteration zones are common in the mudstones below ore-bearing clastic rocks and their thickness can be correlated with the presence of deposits in many places. This is particularly true in the Morrison formation where the red mudstone is altered to green or gray rock for several feet below ore deposits. In the Temple Mountain area, Emery County, Utah, uranium deposits in asphaltic sandstones are associated with collapse structures in strata above the Sinbad limestone member of the Moenkopi formation and above the Kaibab limestone. The breccias and adjacent rocks have been highly bleached and altered. Dolomite and iron oxide impregnated zones formed in the Wingate sandstone during this process. Similar collapse structures are known in the southern part of the Plateau and in the Black Hills of South Dakota.

Although most uranium deposits are in the coarse clastic units of terrestrial beds, ore has been produced from mudstones and siltstones in most of the known uranium districts in the Western United States. These finer clastics are most favorable where they contain large quantities of organic material, as in some of the 
paludal shales of Cretaceous age in northwestern New Mexico.

\section{Chemical PRECIPITATES}

Large ore deposits occur in the lacustrine Todilto limestone of Jurassic age near Grants, N. Mex. Smaller deposits are known in the Kaibab limestone of Permian age in Arizona and Utah and in its equivalent in New Mexico, in the calcareous and arenaceous parts of the Bidahochi formation of Pliocene age in the Hopi Buttes area, Arizona, and in the algal limestones in the Browns Park formation in southern Wyoming. Occurrences of uranium minerals in limestones also are known in western Texas, northern Wyoming, and northern Utah. Calcareous caliche also is uraniferous in places.

The deposits in the Todilto limestone appear to be confined to intraformational, anticlinal folds in the troughs of shallow synclines. These synclines plunge away from the axis of the Zuni uplift and show a rough alinement with faults. The ore bodies are long and narrow; the trends follow the reticulate joint and fold pattern. The primary ore minerals are uraninite, fluorite, pyrite, barite, hematite, and calcite, all of which replace limestone. Oxidation produces tyuyamunite, metatyuyamunite, uranophane, limonite, and manganese oxides that fill joints and vugs and coat bedding surfaces.

The ore in the Kaibab limestone, Temple Mountain, Utah, contains galena, arsenopyrite, and other sulfides associated with realgar. Most of the other uranium occurrences in limestone are of secondary yellow minerals, although uranium minerals are not visible in the freshwater limestone of Tertiary age at Myton, Utah.

The upper part of the Todilto limestone grades eastward into gypsum derived from anhydrite evaporite. This gypsum apparently does not contain concentrations of uranium, although minor occurrences are known in gypsum beds in northwestern Nebraska. Generally, evaporite deposits contain only trace amounts of uranium.

In semiarid regions terrestrial clastic rocks at the surface may contain caliche-type deposits such as the schroeckingerite deposits of the Great Divide Basin, Wyoming. These are rarely of ore grade, but may serve as indicators of buried deposits.

\section{COALS}

Coals interbedded with the clastic terrestrial sediments commonly contain minor concentrations of uranium; more rarely these are of ore grade.

Coals in Eastern United States of Mississippian, Pennsylvanian, and Permian ages, bituminous to anthracite in rank, average about 0.001 percent uranium; more rarely they contain 0.005 percent or more. Ex- ceptionally in central Pennsylvania they contain as much as 0.019 percent. Some shales and underclays associated with average coals contain from 0.002 to 0.005 percent uranium; one in Illinois contains 0.017 percent. Coals of Cretaceous and Tertiary age in Western United States are more uraniferous. In Colorado and in North and South Dakota parts of some coal beds may contain several percent of uranium; some deposits have been mined as ore. Subbituminous coal of the Wasatch formation (Eocene) in Sweetwater County, Wyo., ranges from 0.001 to 0.05 percent uranium; the average is 0.003 percent. Cretaceous coal of the same rank in Sandoval County, N. Mex., contains as much as 0.1 percent uranium.

Widespread lignites in the Ludlow, Tongue River, and Sentinal Butte members of the Fort Union formation (Paleocene) in northwestern South Dakota and adjacent parts of North Dakota and Montana range from 0.001 to more than 10 percent uranium. At Cave Hills, Harding County, S. Dak., 600 tons, assaying 0.4 percent $\mathrm{U}_{3} \mathrm{O}_{8}$, have been mined.

The differences in the uranium content of coals of differing ranks is not entirely a consequence of the availability of uranium. Laboratory experiments demonstrate that peat, lignite, and subbituminous coal extract from aqueous solutions 98 percent of the contained uranium, while bituminous coal and anthracite capture less than a fifth and slightly more than a third, respectively. Investigations have further demonstrated that more than 90 percent of uranium in lignites is in organo-uranium compounds associated with the organic matter of lignites rather than with the extraneous inorganic matter which includes analcite at some localities, jarosite, quartz, gypsum, calcite, and clay minerals.

Uranium itself is one of the several inorganic epigenetic constituents of coals, and although its concentration is in large part dependent on the nature and quantity of various humic constitutents, other factors exercise control. Slightly impure coal is generally richer in uranium than is the pure coal and carbonaceous shale associated with it. Commonly, no uranium minerals can be identified in coals, containing less than 0.1 percent uranium; carnotite, autunite, torbernite, metazeunerite, and coffinite are rare in more highly uraniferous western lignites and subbituminous coals.

One of the most carefully studied subbituminous B-rank coals is in the Great Divide Basin, Sweetwater County, Wyo., where uraniferous coal of Eocene age underlies more than 750 square miles. Deposits of schroeckingerite occur in a graben near the northern edge of the coal field. The thickest coal beds, as much as 40 feet thick, underlie a relatively narrow belt in the trough and the west side of a syncline; those coals con- 
taining the most uranium are on the east side and are thinner. The syncline coincides with a zone of intertonguing, highly permeable, coarse-grained arkosic sandstone beds and less permeable clay, shale, siltstone, fine-grained sandstone, and oil shale. Most of the coal contains less than 0.003 percent uranium; some as much as 0.051 percent. The ash of most of these beds contain 0.003 to 0.023 percent uranjum. The highest concentrations are in coals overlain by gravels of Miocene (?) age. In general the uranium content increases toward areas of greater permeability. Gallium, germanium, iron, molybdenum, lead, vanadium and rare earths appear to have a distribution similar to uranium.

The uranium-bearing lignites in western North and South Dakota and eastern Montana occur throughout 2,000 feet of fluviatile deposits of early Tertiary (Paleocene) or Late Cretaceous age. Above a marked regional unconformity are 250 feet or more of mildly radioactive tuffs and bentonitic elays of Oligocene and Miocene age. Lignites near this unconformity are markedly radioactive; they contain 0.005 to 0.02 percent uranium and average about 0.008 percent. Locally there are significant tonnages of autunite- and metazeunerite-bearing lignite containing as much as 5 percent uranium.

Many geologists believe that the uranium in these coals and lignites was leached from overlying tuffaceous rocks.

\section{URANIUM IN MARINE SEDIMENTARY ROCKS}

Widespread uraniferous marine sedimentary rocks include principally phosphatic rocks of Permian age in Idaho, Montana, Wyoming, and Utah, and of Tertiary age in Florida; and the Chattanooga shale of Devonian and Mississippian age, and some black shales of Pennsylvanian age in the Central States. The uranium content generally is less than 0.02 percent. Marine sandstones, conglomerates, mudstones, and limestones rarely contain concentrations of uranium.

Many of the 200 or more black shale units of Precambrian to Tertiary age in the United States have been sampled. The most uraniferous ores are rich in organic matter (mainly plant debris), pyrite, and phosphatic matter. They are low in calcium carbonate content and yield oil by destructive distillation.

The Chattanooga shale and its equivalents average about 50 feet in thickness throughout much of Eastern and Central United States and contain 0.001 to 0.035 percent uranium. One of the most uniform areas is in eastern Tennessee where the uranium content is from 0.005 to 0.008 percent.

In the northern Rocky Mountains and Great Plains regions black shales of Precambrian to Late Cretaceous age contain 0.005 to 0.01 percent uranium; those of
Mississippian age are consistantly about 0.005 percent throughout wide areas.

Marine phosphorites commonly contain 0.005 to 0.03 percent uranium. The uranium content increases roughly with increasing phosphate content but is generally low in rocks that eontain more than a few percent carbonate. Aluminum phosphate deposits that have been derived from the weathering of marine phosphorites and phosphatic nodules in some marine black shales contain similar amounts of uranium. Most of the uranium in these materials does not occur as a separate mineral phase but substitutes for calcium in carbonate-fluorapatite or crandallite. A few occurrences of tyuyamunite and torbernite have been reported from highly weathered marine phosphorites, however, and these and other secondary uranium minerals, such as carnotite and autunite, are not uncommon in fossil bones and teeth that have been exposed to uranium-bearing solutions after burial. Because the marine phosphorites are of wide extent they contain large tonnages of uranium, some of which can be recovered under favorable conditions as a byproduct of the manufacture of triple superphosphate.

Phosphate deposits in the Phosphoria formation occur in an area of 135,000 square miles in Idaho, Montana, Utah, and Wyoming. Nearly all the phosphatic beds are uraniferous; the content ranges from 0.001 to 0.065 percent. Beds more than 3 feet thick that contain more than 31 percent $\mathrm{P}_{2} \mathrm{O}_{5}$ generally contain 0.01 to 0.02 percent uranium.

The land-pebble phosphate district of Florida covers an area of more than 1,000 square miles. The lower phosphorite part of the Bone Valley formation and the upper residual part of the underlying Hawthorn formation, both of Tertiary age, are mined for phosphate, Samples have shown that the coarser phosphate particles are higher in uranium content and lower in phosphate than the finer grained material. The coarser material contains 0.01 to 0.02 percent uranium; the finer, 0.005 to 0.015 percent uranium. The Bone Valley formation has been leached by acid ground waters and a zone of aluminum phosphate minerals has formed that contains 0.01 to 0.15 percent uranium. Carbonate-fluorapatite, the primary mineral, has been leached, and crandallite, wavellite, and millisite formed.

\section{URANIUM IN PETROLEUM AND ASPHALTITES}

Some Paleozoic and Mesozoic rocks in the Southcentral and Western States contain uranium-bearing petroliferous substances. Concentrations of these substances great enough to form uranium ores are rare.

About 200 asphalt-bearing rocks from Western United States were analyzed for uranium and found 
to contain as much as 0.376 percent uranium in the ash of extracted oil. Other investigations show that uranium is generally enriched in seep oil and in the heavy surface-active fractions of petroleum that adhere to the rocks, as compared to the crude oil fraction of petroleum that is produced at the well head. Some concentrations of metalliferous asphalt pellets found in reservoir rocks in Oklahoma and Texas contain uraninite, coffinite, thorite, and an unidentified uraniumbearing compound that may be a metallo-organic complex. Radium, radon, and helium are found in such reservoirs.
ORIGIN

Comparisons of lead:uranium and lead:lead ratio ages of minerals and determination of ratios of oxygen isotopes in uranium oxides have provided data concerning the absolute age of uranium deposits. As a result many hypotheses accepted in the past have been reexamined. Detailed geochemical studies have supplied data useful in explaining the mechanism of formation of deposits. As a result, most geologists accept an epigenetic origin, with one or another modification for the ores being mined today; low-grade or potential ores are in a large part syngenetic. 


\title{
NUCLEAR FUEL FOR THE WORLD POWER PROGRAM
}

\author{
By Jesse C. Johnson, U. S. Atomic Energy Commission
}

\begin{abstract}
Uranium production already developed is adequate for a major nuclear power program of world-wide extent, Resources of Western Nations total between 1 and 2 million tons of uranium which can be produced at an average cost of $\$ 10$ per pound from high-grade eoncentrates. A considerable reserve in lowgrade shales and phosphates can be exploited at costs as high as $\$ 50$ per pound. Milling eosts, a factor in production, may vary from $\$ 5$ to $\$ 15$ per ton. Ion exchange has had its first commereial application to recovery of metals in uranium mills, and it and solvent extraction by either acid or alkaline solutions constitute the main processes of extraction.
\end{abstract}

Power with which to drive machines has been the most important force in relieving man from physical drudgery and providing leisure for spiritual and mental development, Unfortunately, power expansion already is being limited in many parts of the world by growing shortage of water resources and fossil fuels. But now, there is the prospect of a nuclear power era which may have as far-reaching influence as the Industrial Revolution.

The nuclear power era will have abundant fuel resources. The problem will be the efficient and economic utilization of these nuclear fuels. The location of nuclear power plants will not be determined by the availability of a local fuel supply. Nuclear fuel can be transported by air to any part of the world and transportation costs will have no measurable effect upon the cost of power.

The world's energy resources in the form of nuclear fuels far exceed those of all other types of fuel. There are adequate resources of uranium and thorium for a long-range, expanding world-power program.

Uranium will be the important nuclear fuel for the foreseeable future, according to the present pattern of development and planning. Most reactor programs to be discussed at this conference depend upon uranium as the source of fissionable material, although thorium also may be used.

Since uranium will be a primary source of fuel for nuclear power, it is appropriate for this conference to consider present and potential uranium resources, and the operations related to uranium production. Furthermore, in many countries a survey for radioactive min- erals will be the first major project in their study of a nuclear power program.

Most information about uranium has been gained during the past 7 years, but because of its military importance, much of this information has been a guarded secret. Now the emphasis is on the peaceful uses of atomic energy. The information that may contribute to the development of these uses throughout the world is to be shared. The exchange of information and ideas at this conference should greatly accelerate already fast-moving developments in all phases of atomic energy,

The Western Nations that are cooperating in developing uranium production have achieved notable success. New sources of uranium have been found and brought into production. Former operations have been expanded and ore reserves extended. Information on uranium deposits and the nature of their occurrence has been greatly increased. Special instruments and techniques have been developed for use in exploring for radioactive minerals. New metallurgical processes for extracting uranium from ores have increased recoveries and reduced the cost of production. Byproduct uranium is being recovered commercially from very low-grade materials.

In 1948 the uranium supply of the Western Nations was almost entirely the produet of two mines, one in the Belgian Congo and the other in northern Canada. In the past, there had been little general interest in uranium and throughout most of the world there had been no serious search for it. Even now vast areas, promising geologically, are relatively unexplored.

Today there are major uranium operations in the Belgian Congo, Canada, South Africa, and the United States, Australia, France, and Portugal also are producing uranium with favorable prospects for substantially increased production.

This uranium production program to a large extent has been carried out by private industry operating under the profit incentive system. However, Government exploration and metallurgical research programs have played a major role in supporting private operations and speeding developments.

Expenditures by the United States Government for 
exploration and development of exploration methods have amounted to approximately $\$ 46,000,000$, and for metallurgical research and pilot plant operations more than $\$ 12,000,000$. In 1948 the United States was considered by many to have relatively poor uranium prospects. Ore reserves are now increasing more rapidly than at any time since the program began.

One of the important conclusions to be drawn from the information gathered during the past 7 years is that commercial uranium deposits of considerable size may be found in many areas and under a variety of geologic conditions. It long has been known that in the earth's crust uranium is about as plentiful as lead or zinc, and it is about 100 times more plentiful than silver. However, it was rather generally assumed that concentrations in commercial deposits might be rare. This has not proved to be true.

Because active prospecting and exploration have been undertaken in only a few countries, and these countries are as yet only partly explored, we are unable now to estimate the uranium resources of the world. As the nuclear power program grows and the search for uranium is extended, more and more information will become available about these resources. There is every reason to believe that they will be far larger than we know them to be today. However, the areas now producing or under active development assure an adequate supply of uranium for a long-range power program.

On the basis of present developments and geologic evidence, resources of the producing nations of the West are estimated to be between 1 and 2 million tons of uranium. This is uranium that can be produced at moderate cost, at an average of about $\$ 10$ a pound for $\mathrm{U}_{3} \mathrm{O}_{8}$ in a high-grade concentrate. Although the use of nuclear power is expected to expand rapidly once industrial scale operations prove it to be economical, it may be 1970 , or even 1980 , before there is a substantial uranium requirement for power purposes. In the meantime, the high production rate of the present program cannot be maintained unless there is a military demand or Government stockpiling.

In the more distant future, the fuel requirements for the atomic age may come from the vast low-grade uraniferous phosphate and shale deposits. Reserves of commercial phosphate rock in the United States alone are estimated at 5 billion tons and the uranium content at 600,000 tons. These reserves would be greatly increased by including low-grade phosphatic rock not presently considered commercial. The United States also has an estimated 85 billion tons of marine shale averaging slightly more than one-tenth of a pound uranium per ton. This represents a reserve of 5 to 6 million tons of uranium.
Known deposits of uraniferous phosphate rock and shale in other parts of the world equal or exceed those of the United States in grade and tonnage. For example, the phosphate deposits of Morocco, estimated at 20 billion tons, are uranium-bearing. The Seandinavian Peninsula and other Baltic territories contain very large deposits of uraniferous shale. Uraniumbearing coal and lignite also have been found in several countries.

The cost of extracting uranium as the primary product from phosphate and shales may be between $\$ 30$ and $\$ 50$ per pound. If valuable byproducts can be recovered, the cost may be reduced. Furthermore, uranium can be recovered at moderate cost as a byproduct from some commercial phosphate fertilizer and chemical operations. This already is being done. About 10,000,000 tons of commercial phosphate rock are mined annually in the United States. If all of this rock was processed to phosphoric acid, more than 1,000 tons of byproduct $\mathrm{U}_{3} \mathrm{O}_{8}$ might be recovered annually.

Between the commercial uranium deposits of today and the high-cost uranium resources of the more distant future, there are deposits that could supply uranium at a cost of $\$ 10$ to $\$ 30$ a pound. The resources in this economic class are not well known but they must be large, perhaps several million tons of uranium. These resources will include deposits of types now being mined but which are outside the economic limits prevailing today. We already know of some such large reserves but most of the information on resources in this category must come from future exploration. Experience gained from the present uranium program has demonstrated that higher prices will bring in new sources of production and increase available reserves.

The rapid expansion of uranium production within a very few years has been possible because of major technological advances in exploration and metallurgy.

Geiger and scintillation counters have made it possible for almost anyone to become a prospector, and in areas of excitement about uranium that has been the case. In the hands of geologists, these instruments have greatly speeded systematic exploration and reduced failure to recognize inconspicuous outcrops of radioactive mineral. Highly sensitive scintillation counters weighing as little as 5 pounds are available for ground surveys. Instruments weighing from 50 to 100 pounds are used for airborne surveys. A number of valuable uranium deposits have been found by lowlevel aerial surveys. High-level flying in broad reconnaissance surveys has been directed toward locating favorable areas for more detailed investigations.

With sensitive scintillation logging instruments, used in connection with electric logging, it is possible to determine the position, thickness, and approximate grade 
of a mineralized zone, and to differentiate the various rock types exposed in a bore hole. Instruments have been developed for logging bore holes as small as 2 inches, in diameter.

Although these instruments now are considered indispensable in uranium exploration, the basic work still is detailed field geology and laboratory research. One of the major contributions of the extensive exploration program of the past few years has been the development of scientific information about uranium mineralogy and the nature and occurrence of uranium deposits. This is information of permanent value and will aid the geologist in any area and at any time. Many geological papers have been prepared for presentation at the technical sessions or publication in the proceedings of this conference.

Major advances also have been made in uranium metallurgy, and the processes developed during the last few years have become standard for all new mills. Uranium recovery should be about 90 percent for nearly any type of ore. The costs of processing may vary widely, largely because of the differences in consumption of chemicals required for different ores and in the size of the milling operations. However, for most uranium operations the cost of milling should range from $\$ 5$ to $\$ 15$ per ton of ore. Large plants with favorable metallurgical and operating conditions can have milling costs below $\$ 5$ per ton. These are the costs that should prevail in most established mining and industrial communities. In isolated areas where fuels, chemicals, and labor are expensive, milling cost will be correspondingly higher. It is evident that the cost of milling is an important factor in determining the grade of ore that can be treated profitably.

Probably the most important development in extraction of uranium is the use of ion exchange resins. Ion exchange resins may be used to recover uranium from clarified solutions or directly from pulp. Recovery from pulp eliminates thickening and filtering problems and reduces soluble losses to a minimum. A high- grade uranium precipitate, 60 percent or more $\mathrm{U}_{3} \mathrm{O}_{8}$, is obtained without intermediate upgrading steps. Although ion exchange has been used in water purification for a long time, this is the first commercial application for metal recovery.

Solvent extraction, which has been widely used in the chemical industry, also has been adapted to uranium extraction. Both ion exchange and solvent extraction processes presently are used only for recovery from acid solutions, Recent experiments, however, indicate that ion exchange also may be used for recovery of uranium from alkaline solutions. Either acid or alkaline solutions may be used to dissolve the uranium from the ore. Acid solutions are generally more effective but are not economic for ores high in lime content.

Uranium metallurgy will continue to be improved and new chemical processes will be developed. But no longer is there a wide margin between the costs and recoveries being obtained by efficiently operated modern plants and the results which might be considered theoretically practical. However, a major reduction in the cost of milling certain types of ore could result from a cheap, efficient method of mechanical concentration, such as flotation. This would provide a higher grade product for treatment by the more expensive chemical processes. Research laboratories are working on flotation and other possible methods of mechanical concentration.

This general review of production and resources indicates that uranium no longer can be considered a rare metal. There are extensive deposits throughout the world, and there are processes for extracting the uranium economically. Uranium production already developed is sufficient for a major nuclear power program of world-wide extent. Additional production can be obtained when needed. When the vast low-grade resourees are required, more efficient use of nuclear fuel through improved conversion or "breeding" may offset the higher cost of uranium. 


$$
\text { - }
$$

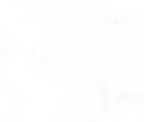

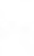

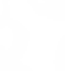

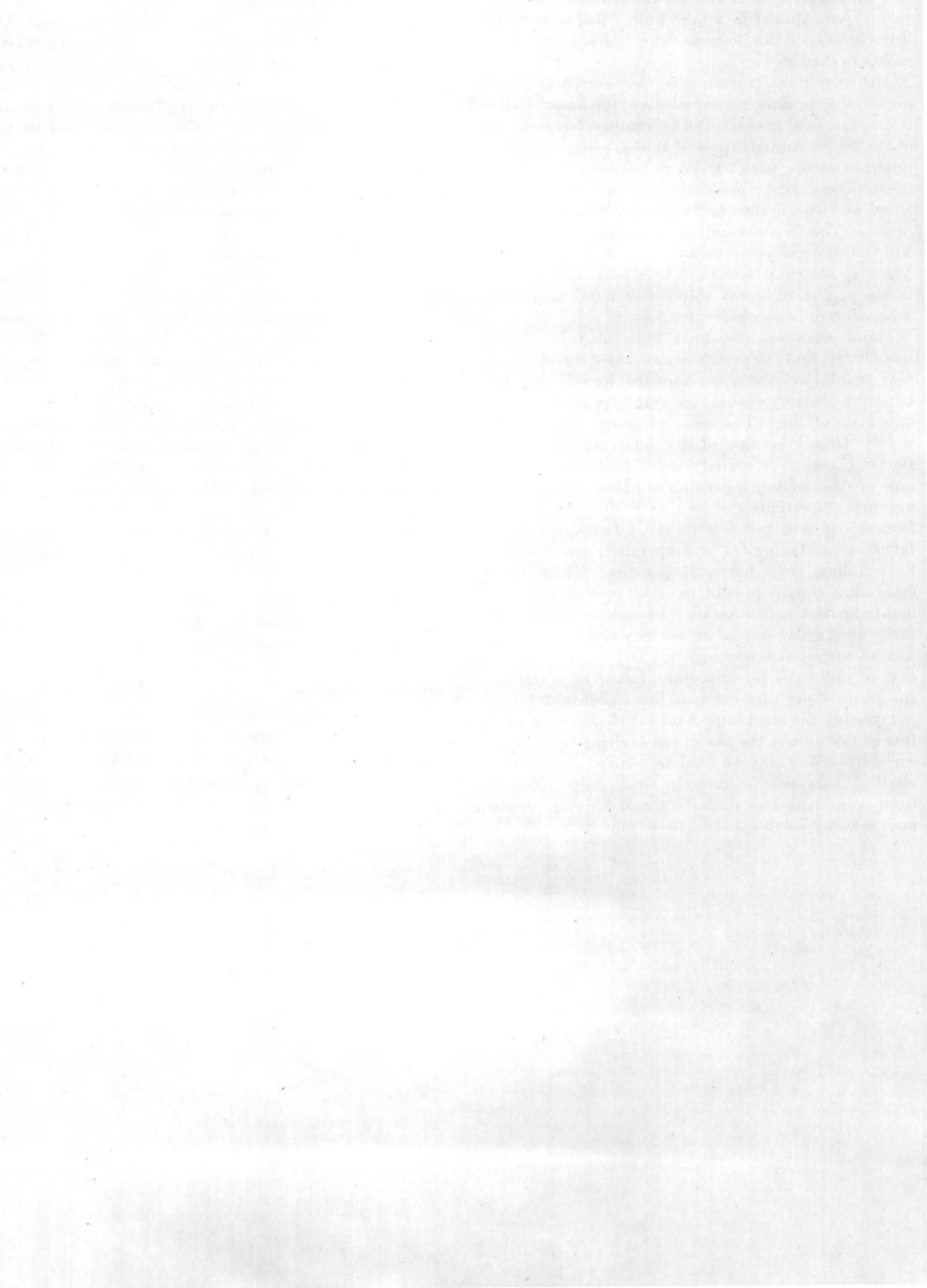




\title{
URANIUM PROVINGES
}

\author{
By Montis R. Klepper and Donald G. Wyant, U. S. Geological Survey
}

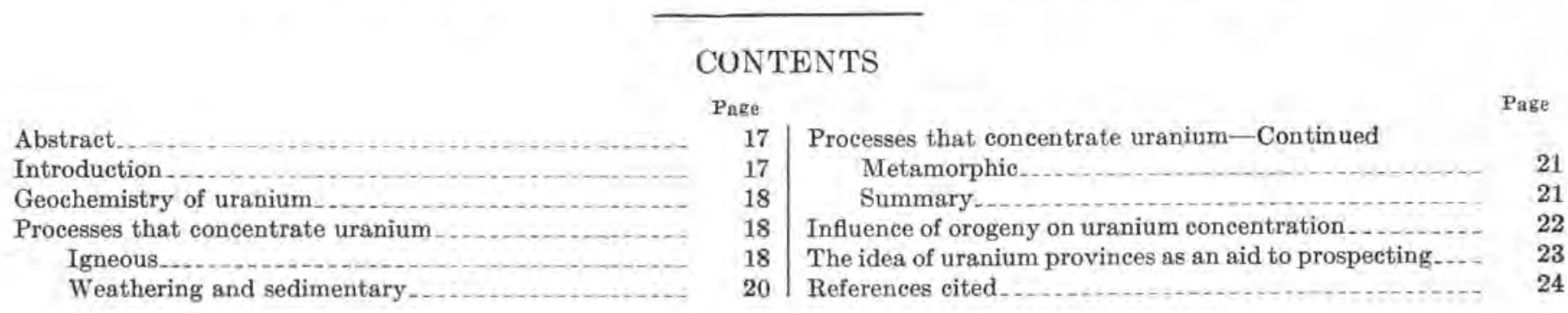

\section{ABSTRACT}

The occurrence of exploitable deposits of uranium probably results, as with most ore elements, partly from the original inhomogeneities in the earth's crust and partly from the interplay of orogenic and geochemical processes which tend to be eyclic. These concepts, if valid, provide a rational basis for predicting areas or geologic settings deserving first consideration in the search for uranium deposits and also for estimating the potential of areas in which uranium deposits are known.

In the generation, differentiation, emplacement, and crystallization of a magma during an orogenic cycle, the original inhomogeneities in the erust can be accentuated. Uranium is concentrated in the final fractions of the magma, and from some magmas the last igneous rocks to crystallize or the residual magmatic fluids, or both, are uranium-rich. Tectonic events during the late stages of ensolidation of a uranium-rich magma probably determine whether most of the uranium crystallizes in pegmatites and other small, highly differentiated granitic or alkalic plutons or whether it escapes in hydrothermal solutions and forms veins and other epigenetic deposits.

Uranium may be further concentrated in and adjacent to a uranium-rich orogenic belt during the subsequent period of weathering, erosion, and sedimentation. Complex multiple oxides containing titanium, niobium, thorium, the rare earths, and uranium are relatively insoluble and may be concentrated in placer deposits. Uranium in soluble minerals enters the ground and surface waters and may be deposited in a great variety of surficial environments if favorable receptors lie across the course of transportation. Uranium that is not thus entrapped reaches the sea where it may be concentrated ultimately in black shale and phosphorite.

Depending on the subsequent orogenic history of an area the surficial deposits so formed may be destroyed by erosion, thus perhaps resulting in the formation of new surficial deposits, or they may be buried and modified to various degrees by igneous heat or hydrothermal solutions or both. In some places, especially in the older Precambrian rocks, uranium-rich sedimentary rocks probably have been reincorporated in magma and the uranium in them recycled and perhaps reconcentrated.

These considerations indicate that original concentrations of uranium tend to result in uranium-rich areas or provinees that persist through long periods of geologic time. Some types of uranium-rich rocks and uranium deposits may be relatively shortlived, but as they are destroyed by erosion or metamorphism, others that are in equilibrium with the prevailing geologic environment are likely to form.

Accordingly, the significant criterion for the recognition of a uranium province is the occurrence of a diversity of types of deposits. Examples of provinces in which a diversity of types of several ages occur are the broad belt extending from Arizona and New Mexico northward to the Dakotas and Montana and the marginal part of the Canadian shield.

In contrast, uranium-poor provinces are likely to be characterized by abundance of mafic igneous rocks and sparsity or lack of granitic rocks, as for example areas of Plateau basalts.

\section{INTRODUCTION}

Most of the world's important uranium deposits are clustered within broad, indefinitely defined areas or provinces, as are deposits of many other metals. The initial concentration of uranium in these broad areas probably occurred during the formation of the earth's crust. Subsequently, owing to the interplay of geochemical and orogenic processes, the uranium in the original areas of concentration has been redistributed and in part concentrated to exploitable deposits.

A uranium province is here defined as a broad and generally indefinitely bounded area in which uranium deposits and uranium-rich rocks are relatively abundant. Commonly, the deposits are of several types and of more than one age. Most of the world's important uranium deposits are clustered in a few such areas; notably the broad belt in and adjacent to the Rocky Mountains, from New Mexico and Arizona to the Dakotas and Montana; the western and southern part of the Canadian shield; the northeastern part of the South African shield; parts of the Australian shield; the 
Erzgebirge and vicinity in central Europe; and probably the Ferghana-Kara Tau region in Russia.

In contrast there are broad areas in which uranium deposits, other than low-grade syngenetic concentrations in phosphorite or black shale, are sparse or lacking. For example, in the eastern third of the United States, in and adjacent to the Appalachian Mountains, no important uranium deposits are known, though there are low-grade syngenetic concentrations in black shale and scattered pegmatites and a few small epigenetic deposits of carnotite in sandstone.

The main geologic features of the uranium-poor Appalachian region are in many respects similar to those of the uranium-rich Erzgebirge and Rocky Mountain regions. Each of these areas is a strongly deformed geosynclinal belt, intruded by granitic plutons of various types; each is flanked and in part covered by erosional debris from orogenic mountains. The Triassic basins and the plateaus underlain by Pennsylvanian nonmarine rocks in the Appalachian region are comparable to the plateaus and intermontane basins within and adjacent to the Rocky Mountains and to the Triassic and younger basins and plains marginal to the Erzgebirge. Nevertheless, in the Appalachian region, uranium concentrations are few, low grade, and mostly of syngenetic origin (black shale and pegmatite), whereas in the Rocky Mountain region, important epigenetic deposits of several types occur in many districts. In the Erzgebirge region, veins have been an important source of uranium for many years (Bain, 1950 , p. 302-305), and strongly uraniferous coal has recently been reported (Davidson and Ponsford, 1954).

Similarly, the geologic histories and features of the Canadian shield, the South African shield, the Fennoscandian shield, and the Brazilian shield are roughly similar, but the first two contain important uranium deposits while the second two contain virtually no known deposits.

\section{GEOCHEMISTRY OF URANIUM}

Data on the uranium content of rocks and fluids are relatively sparse, and estimates of the abundance and distribution of this element in the earth's crust are consequently approximations, though probably of the correct order of magnitude. Estimates of Urey and Brown (in Urey, 1952, p. 233) indicate that uranium is the least common element in the earth, having an atomic abundance of 0.0002 (silicon=10,000). However, the abundance of uranium in the earth's crust is indicated by Fleischer (1953, fig. 2) to be 0.0002 percent, or about the same as that of tungsten and tantalum.

According to Frondel and Fleischer (1955, p. 170), about 103 minerals may contain uranium as a major component (more than 1 percent uranium). In about one-third of these minerals the uranium is tetravalent; in the rest, hexavalent. Fifteen of these uranium minerals are simple oxides or hydrated oxides, 20 are complex titanates, niobates and columbates, 14 are silicates, 17 are phosphates, 10 are carbonates, 6 are sulfates, 8 are vanadates, and 8 are arsenates (Frondel and Fleischer, 1955, p. 171-173). Unidentified uranium compounds occur in some marine carbonaceous shale, lignite and coal, and as intergranular films in igneous rocks. The principal uranium minerals in the large ore deposits are the oxides pitchblende, uraninite, and coffinite; the vanadates carnotite and tyuyamunite; and the complex titanates brannerite and davidite. Uranium does not occur in nature as a native element or as a simple sulfide, arsenide, or telluride. Because uranium can exist in several oxidation states it occurs in a great variety of geologic environments.

\section{PROCESSES THAT CONCENTRATE URANIUM}

The formation of exploitable concentrations of uranium in a uranium province depends on many geologic factors. The processes involved are largely geochemical, though to a large extent they are actuated by orogenic events.

The concept of the geochemical cycle (Goldschmidt, 1922a, b; Rankama and Sahama, 1950, p. 189-190, 243-263, 636-638; Mason, 1952, p. 247-254), though the cycle is idealized and imperfectly known, provides a means of relating the processes that concentrate uranium to the geologic, or orogenic, history of an area, and it thus can be used to predict where concentrations of uranium are likely to occur and what the potential of a particular area may be. It is convenient to think of the geochemical cycle as consisting of three phases that grade into one another: one in which igneous processes prevail, one in which weathering and sedimentary processes prevail, and one in which metamorphic processes prevail. During the igneous and metamorphic phases of the cycle, magma is generated, emplaced, and consolidated, preexisting rocks are metamorphosed, and uranium deposits of igneous and metamorphic origin may be formed. During the weathering and sedimentary phase, preexisting rocks and ore deposits are weathered and eroded, uranium is transported and may be concentrated, and sediments accumulate and are lithified.

\section{IGNEOUS}

The formation of a magma, the upward movement and crystallization, and the subsequent exposure of the resulting igneous rock are a part of the orogenic cycle. The uranium content of rocks formed from a 
magma increases rather constantly from the first- to the last-formed rocks and thus in a general way follows the same path as silica, the alkalis, and rare elements such as thorium, beryllium, columbium, tantalum, and the rare earths (Rankama and Sahama, 1950; Larsen and Gottfried in U. S. Geological Survey, 1953; Billings and Keevil, 1946; Adams and Saunders, 1953).

The earliest differentiates consist chiefly of olivine, pyroxene, and calcic plagioclase, minerals that tolerate only negligible quantities of uranium in their lattices. Consequently, these rocks generally contain less than $1 \mathrm{ppm}$ (part per million) uranium. Later differentiates contain significant amounts of biotite and accessory minerals. Some of these minerals can accommodate in their lattices from $10 \mathrm{ppm}$ to a few percent uranium, and the rocks, such as granodiorites, syenites, and granites, contain from 2 to $6 \mathrm{ppm}$ uranium. The progressive increase in uranium content of rocks of the southern California batholith from gabbro, the oldest, to granite, the youngest, is clearly demonstrated by Larsen and Phair (in Faul, 1954, p. 83). The youngest rocks in some alkalic and silica-alkalic series, for example albite-rich riebeckite granite in Nigeria (MacKay and Beer, 1952), quartz bostonite in Colorado (Larsen and Phair in Faul, 1954, p. 87), and pegmatites from many widely scattered localities (L. R. Page, oral communication), contain from 10 to 100 ppm (0.001 to 0.01 percent) uranium; a pegmatite body in western Canada contains large reserves of rock averaging 0.2 percent uranium (Mawdsley, 1952).

Recent investigations suggest that effusive rocks are generally more uraniferous than their intrusive equivalents, possibly by a factor of $1 \frac{1}{2}$ or 2. Data assembled by Adams (in Faul, 1954) indicate a range from 0.8 to $15.4 \mathrm{ppm}$ and an average of $5.6 \mathrm{ppm}$ of uranium in about 50 voleanic rocks ranging from basalt to rhyolite and taken from many localities over the world. The data show that the uranium content increases as potassium increases and that the uranium content becomes progressively higher in more acidic rocks. Perhaps the best explanation of the higher average uranium content of effusive rocks is that most of the uranium is trapped in dispersed form during the crystallization of effusive magmas, whereas a significant part of the uranium in plutonic magmas is concentrated in residual fluids from which pegmatites and veins may form. This interpretation agrees with the generally held belief that the most favorable settings for hydrothermal deposits of uranium are in the vicinity of plutons of acidic rock.

In some of the relatively more uraniferous igneous rocks, most of the uranium is in the rather common accessory minerals, notably xenotime, zircon, monazite, and allanite (Billings and Keevil, 1946; Jahns, 1953;
Larsen and Gottfried in U. S. Geological Survey, 1953; Larsen in U. S. Geological Survey, 1954). In others, most of it is in relatively uncommon uranium-rich accessory minerals such as uraninite, thorite, thorianite, brannerite, and euxenite.

Most igneous rocks also contain uranium in a form that is readily soluble in weak acids. Hurley (1950) found that as mueh as 90 percent of the total radioactivity of some granites could be removed by leaching the granulated rock with weak acid. He postulated that the acid-soluble radioactive matter was present along fractures and on grain surfaces and may have been due to "supergene enrichment." Larsen and Phair (in Faul, 1954, p. 80) note that "commonly, close to 40 percent of the uranium in most fresh-appearing igneous rocks is readily leachable." They suggest that this leachable radioactive matter may occur " 1 ) in metamict phases of primary silicates [presumably in such accessory uraniferous minerals as zircon, allanite, and thorite], 2) as interstitial material derived from late magmatic, deuteric, or hydrothermal solutions, 3 ) in certain non-metamict partly soluble radioactive accessories, such as apatite, and 4) as adsorbed ions in disseminated weathering products such as iron oxide." Bowie (in Davidson, 1951, p. 330) using autoradiographs found that "**** in an unaltered granite the heavy minerals [accessory minerals] account for nearly all the radioactivity," but, "in rocks slightly altered by pneumatolysis or by ground waters the radioactive elements become distributed along cracks within and as coatings to the feldspars and quartz."

Though the origin and nature of this acid-soluble material are not yet determined, its presence has several important implications. First, it suggests that significant quantities of uranium can be leached from igneous rocks by ground water and perhaps later be concentrated as secondary deposits in coal or other sedimentary rocks. Second, the possibility that some of this acid-soluble material may be a sample of the residual fluids of a magma suggests that a close relationship may exist between the acid-soluble uranium in igneous rocks and uranium in veins and other types of epigenetic deposits.

Veins and other epigenetic uranium deposits of igneous origin are believed to have formed from the late differentiates of a uranium-rich magma where structural conditions were favorable. Thus much of the uranium-rich residual fluid probably drained off to form veins, if through-going fractures tapped the magma chamber at the proper time. If fractures did not tap the chamber at an opportune time, most of the uranium in the residual fluids was probably trapped in the last igneous rocks to crystallize, partly in specific uraniumrich minerals and partly as soluble intergranular films. 
Information on the relation of abnormally uraniferous igneous rocks to hydrothermal deposits of uranium is meager. Bain (1950, p. 282) noted a lack of hydrothermal uranium deposits in areas containing uraniferous pegmatites, but many examples can now be cited of close association of abnormally uraniferous igneous rocks, including pegmatites, with hydrothermal uranium deposits. Some examples are:

1. In the Colorado Front Range, Late Cretacous or early Tertiary pitchblende veins are intimately associated and probably genetically related to uraniferous quartz bostonites (Phair, 1952); some pitchblende veins of this same age also occur in the vicinity of uraniferous Precambrian pegmatites.

2. In the Erzgebirge and Riesengebirge of Saxony, Silesia, and Czechoslovakia uraniferous granite, uraniferous pegmatite, and pitchblende veins are closely associated (Kohl, 1942; Hoehne, 1936; Klockmann, 1882).

3. In the Precambrian shield of Canada, uraninite-. bearing pegmatites and pitchblende veins are in close association, though they may not be of the same age, in the Goldfields region and at Stack Lake on the east arm of Great Slave Lake (Lang, 1952, p. 63, 71); furthermore, the important uraniferous pegmatite at Charlebois Lake (Mawdsley, 1952; Anon., 1954) is only about 100 miles east of the Goldfields pitchblende veins, In the Grenville subprovince, uraniferous pegmatites are abundant and pitchblende veins occur, though none of them are at present commercially important; important uraniferous carbonatites (calcite-fluorite pegmatites) also occur near Bancroft in this subprovince (Lang, 1952, p. 136-151).

Though these examples are too few fully to support a generalization, the writers are inclined to agree with Lang $(1949$, p. 5) that abnormally radioactive igneous rocks may be indicators of hydrothermal uranium deposits nearby. However, they do not necessarily indicate deposits, for tectonic events during the late stage of magmatic consolidation probably determine to a large extent whether most of the uranium in the residual magmatic fluids crystallizes in late-stage igneous rocks, such as pegmatites, or in veins, or in both. If most of the uranium was drained off at a lato stage to form veins, the associated igneous rocks may not be abnormally uraniferous.

\section{WEATHERING AND SEDIMENTARY}

Destruction by weathering and erosion of uraniumrich igneous rocks and veins and of uranium concentrations in sedimentary and metamorphic rocks releases uranium that may be either swept out of the province or reconcentrated in suitable environments.

Whether uranium is retained in or exported from a province appears to depend largely on the climate, topography, and lithology of the area. Climate is probably the most important factor. In a humid climate the water table is high, weathering is intense, and the products of weathering tend to be clay minerals. As the drainage is to the sea, the uranium, whether in solution or adsorbed on particles of clay minerals, will be permanently removed from the uranium province.

At the other extreme, in an arid climate, water tables are far below the surface or are nonexistent. Weathering tends simply to disaggregate existing rocks, and drainage is either intermittent toward the sea or centripetal. In such an environment the uranium brought near the surface by igneous activity cannot be readily exported from the area. Rain that extracts uranium from outcrops of igneous rocks or veins soon sinks deep into the soil or subsoil and may follow subterranean channels for great distances. In so doing it may traverse favorable lithologic types and deposit its uranium in new and perhaps much richer concentrations. Clay minerals do not form in great quantities, and little uranium is lost through adsorbtion by clay particles. Certainly the Western United States and FerghanaKara Tau area owe many of their secondary uranium concentrations to favorable arid climatic conditions that have prevailed for many millions of years.

Soluble uranium in ground and surface waters may be extracted by organisms and incorporated in their tissues (Cannon, 1952); precipitated as secondary minerals such as carnotite and schroeckingerite (Stugard, Wyant, and Gude, 1952); adsorbed or absorbed by certain clays, organic and phosphatic material, and colloidal silica (McKelvey and Nelson, 1950); or extracted to form metallo-organic compounds in petroleum (Gott, Wyant and Beroni, 1952; Erickson, Myers, and Horr, 1954). The deposits so formed include most uraniferous peat, lignite, coal, and petroleum residue, and many deposits of secondary uranium or complex metal-uranyl phosphates, carbonates, vanadates, sulfates, arsenates, and others (Denson and others, 1952; Stugard, Wyant, and Gude, 1952). In many instances, as for example on the Colorado Plateau, it is not clear whether deposits consisting of secondary minerals have been formed by oxidation of primary deposits in place or by precipitation of uranium from migrating solutions in favorable geologic settings.

Whether useful concentrations of uranium are precipitated from migrating solutions is probably largely dependent on the amount of uranium in the carrier, the continuity of flow within a restricted area over a long enough period of time, and the presence of suitable receptors or reagents or of favorable physical conditions, such as alternate wetting and drying, to remove it from solution. 
Many minerals that contain small to moderate amounts of uranium, such as monazite, zircon, xenotime, brannerite, samarskite, and euxenite, are relatively resistant to chemical and mechanical attack. These resistant minerals locally become concentrated in fluvial or marine placer deposits in the vicinity of the source rocks, but most of them become dispersed in terrestrial and nearshore marine sediments without significant concentration. Placers are typically ephemeral, but a few persist and become lithified. Some geologists contend that the uraniferous Witwatersrand and Blind River conglomerates of Africa are fossil placer accumulations that have been subsequently modified and perhaps enriched by hydrothermal solutions (Geol. Soc. of South Africa, 1931); others contend that the deposits cannot be placers (Davidson, 1953), some strongly advocate a hydrothermal origin (Graton, 1930),

Soluble uranium that is not extracted from ground and surface waters is carried to the sea. Apparently most of this uranium does not long remain in solution, for Goldschmidt (1937) and Russell (1945) have shown by different lines of evidence that nearly all the uranium that could have been eroded from the land throughout geologie time is in the sediments rather than in the seawater (McKelvey and Nelson, 1950, p. 44). Uranium may be extracted from sea water by organisms and incorporated in their tissues (Burkser, Shapiro, and Bronstein, 1929; Neuman, 1947) or may be adsorbed or absorbed by certain clays and organic and phosphatic material (McKelvey and Nelson, 1950; Piggott, 1944). Part of the uranium removed by these processes is very sparsely dispersed in large volumes of sediment, but some is concentrated to a rather high degree $(0.005$ to 0.02 percent) in thin units of marine phosphorite and black organic shale that accumulated very slowly,

\section{METAMORPHIC}

Sedimentary rocks when deeply buried, generally during the deformation of geosynclines, are transformed to a rock or liquid that is in equilibrium with its surroundings. At various depths and under the influence of various pressures, either hydrostatic or direeted, the rocks are metamorphosed to gneisses, schists, hornfels, and other forms and under extreme conditions are probably liquefied to magma. As a result of these processes, fractionation and concentration of uranium may take place. In the melting of rocks the first liquid to form should resemble the last liquid fraction of a magma and be rich in silica, potash, alumina, and water, and probably also in uranium and other minor elements that tend to concentrate in residual granitic fluids. If this is so, some magmas produced by ultrametamorphism should be relatively rich in uranium, and, be- cause of their relatively high water content, might be especially likely to yield uranium-rich hydrothermal solutions. Some support for this suggestion is the fact that most of the world's important vein deposits of uranium and many uraniferous pegmatites are in ancient shields or massifs (Bain, 1950, p. 289) where rocks have probably been subjected to at least one episode of ultrametamorphism. The fact that few or no exploitable deposits of uranium have been found in other ancient shields and massifs may be a consequence of an originally inhomogeneous crust, but it is also possible that undiscovered deposits exist in favorable settings within these ancient terranes.

It seems likely that migration and perhaps concentration of uranium also may take place under less severe conditions of metamorphism. Marine black shales commonly contain appreciable quantities of syngenetic uranium, whereas few graphitic slates have been reported to contain abnormal quantities, though several examples of epigenetic concentrations in or near such rock can be cited. In the Rum Jungle area of northern Australia, deposits of uraninite and secondary uranium minerals, along with copper minerals, occur in carbonaceous slates and graphitic sehists; in Middle Asia, U.S.S. R., local concentrations of uraniferous turquoise, kolovratite, volborthite, and other secondary uraniumvanadium minerals occur in graphitic slate of Silurian age (Sosedko, 1933; Adelung, Kushnar, and Chikhachev, 1937; Fersman, 1928) and in chert and earbonaceous shale of Cambrian age (Tyurin, 1944); in the Iron Ranges, of the Great Lakes region, abnormal concentrations of uranium occur locally in graphitic schists and associated iron deposits of Precambrian age (Vickers, R. C., in U. S. Geological Survey, 1953 and 1954). It seems quite probable that deposits of this type could be due to migration and local concentration of syngenetic uranium in black shale under conditions of moderate metamorphism rather than to introduction of uranium from an igneous source.

\section{SUMMARY}

In summing up the processes of concentration, it may be said that under the driving influence of orogenic forces, igneous processes tend to concentrate uranium in late-phase differentiates, notably in pegmatites, small alkalic plutons, and veins or other epigenetic deposits. The concentrations in igneous rocks are syngenetic and though they may be large, they are almost invariably low grade. Vein and other epigenetic deposits associated with igneous rocks are generally small, but some are high grade. Weathering and sedimentary processes may either disperse or concentrate uranium, depending primarily on the climate. Some primary uranium-bearing minerals that are resistant to 
chemical and mechanical attack accumulate in placers. Other uranium-bearing minerals are dissolved, and the uranium is transported by ground and surface waters, from which, if climatic conditions are suitable, it may be precipitated in favorable receptors to form epigenetic deposits of a variety of types. Many clearly epigenetic deposits - for example, uraniferous lignites-are low grade, but some are very large. Some uranium in solution reaches the sea from which it may be extracted to form large low-grade syngenetic accumulation in phosphorites or black shales. Metamorphic processes may yield concentrations of uranium either by converting preexisting rocks to magma, which subsequently may yield uranium-rich differentiates, or by "sweating" uranium out of weakly uraniferous rocks and concentrating it in favorable geologic settings.

\section{INFLUENCE OF OROGENY ON URANIUM CONCENTRATION}

From the preceding discussion it is clear that uranium can be concentrated by various processes and in many geologic environments. The environments that exist and the processes that are active from time to time are largely determined by the orogenic history of a region. The world's important deposits of uranium, excluding low-grade deposits in phosphorite and black shale, are all in or adjacent to orogenic belts as might be expected, because magmas, the primary sources of uranium, are generated and emplaced or extruded in orogenic belts. Though the histories of various orogenic belts differ in detail, all seem to evolve through four general stages (Cady, 1950 , p. $780-785$, Stille, 1940, p. 4-23; Cady, McKelvey, and Wells, 1950): (1) the primary geosynclinal stage, (2) the primary mountain-building stage, (3) the secondary mountain-building stage, and (4) a stage of final differential uplift and local subsidence.

In the primary geosynclinal stage, arcuate belts of subsidence form between major stable elements. Graywacke, argillite, chert, and submarine volcanic rocks, principally spilite, accumulate in the primary geosyncline, and shale and limestone, passing laterally in the direction of the stable block into first-cycle quartz sandstone, accumulate on the mobile shelf adjacent to the primary geosyncline. In stage 2 the primary geosyncline is strongly deformed and intruded by synorogenic batholiths of intermediate composition, and secondary geosynclines are formed. In them accumulates the debris from the primary mountains, consisting mainly of graywacke and shale and locally of arkose and second-cycle quartz sandstone. In stage 3 the geosynclinal belt is again strongly deformed, intermediate to acidic and alkalic plutons and volcanic rocks are emplaced and extruded, and continental sediments accumulate within and adjacent to the mountains.
Highly differentiated small granitic and syenitic intrusive bodies that may be rich in uranium are emplaced at or near the end of this stage, mainly in the secondary geosynclines and adjacent parts of the continental block but locally in the primary geosyncline. Stage 4 is characterized by block faulting and commonly by the extrusion of plateau basalt.

There is little likelihood that important concentrations of uranium form during the primary geosynclinal and primary mountain-building stages. The sediments accumulate too rapidly for syngenetic concentrations to form, and the magmas, mainly of simatic origin and ranging from ultrabasic to intermediate in composition, generally are not sufficiently differentiated to be important carriers of uranium. The lack of uranium deposits in primary geosynclinal belts and basic volcanic chains, such as the Oregon and California Coast Ranges, the Philippine Islands, the Caribbean region, the Aleutian-Kamchatka are, and much of eastern New England and the Piedmont Belt to the south, attests to the general validity of this reasoning.

The optimum time for concentration of uranium occurs during and following the secondary mountainbuilding stage. Uraniferous marine black shales and phosphorites may accumulate in the marginal parts of secondary geosynclines and on adjacent parts of the continental block. The highly differentiated granitic and syenitic intrusive rocks that are emplaced during this stage may be important bearers of uranium which may erystallize in the last-formed igneous rocks or, if structural conditions are favorable, in veins and other types of epigenetic deposits.

During the latter part of the stage of secondary mountain building and the succeeding stage, which is characterized mainly by block faulting and locally by extrusion of plateau basalts, the earlier formed primary concentrations of uranium are attacked by weathering and erosive agencies and, if climatic conditions are favorable, a variety of types of secondary deposits may form. Uraniferous lignites and coals, most of them apparently formed by the leaching of acidic volcanic rocks by ground water, and placer deposits are noteworthy examples.

The enigmatic sandstone-type deposits, typified by those on the Colorado Plateau (Fischer, 1942; Fischer and Hilpert, 1952; Weir, 1952; Finch, 1953), also seem to be closely related to the latter part of stage 3 in both time and space, though their origin is a subject of heated controversy. Most deposits of this type occur in predominantly nonmarine sequences that are the erosional debris of orogenic mountains and consist of interbedded, rather well sorted sandstones and shales. It is not clear whether these deposits were formed by solution of uranium originally dispersed in the sedi- 
mentary prism, with subsequent transportation and redeposition in favorable traps, or by introduction of uranium from an igneous source, but an increasing volume of evidence seems to favor an igneous origin (Stieft, Stern, and Milkey, 1953 ; Rosenzweig, Gruner, and Gardiner, 1954). Uraniferous Precambrian conglomerates (Abraham, 1953; Traill, 1954; Union of South Africa Geol. Survey, 1940; Davidson and Bowie, 1951) are in some respects similar to deposits of sandstone type and may have a similar origin.

In the more ancient parts of the crust, particularly in Precambrain shields and massifs, successive periods of deformation, intrusion, and metamorphism may have accentuated original differences in the uranium content of the crust. Such areas are believed to be particularly favorable sites for uraniferous igneous rocks and uranium deposits of igenous or metamorphic origin.

\section{THE IDEA OF URANIUM PROVINCES AS AN AID TO PROSPECTING}

Understanding the processes that concentrate uranium and being acquainted with the uranium province in Western United States, one infers that the only positive indicator of a province is the presence of a variety of types of abnormal concentrations, regardless of the amount of uranium concentrated in any particular deposit. However, the presence of a single epigenetic deposit in a geologically favorable area is sufficient to suggest that a province may exist, and if several deposits of a single type are known the chance is very good that other deposits will be found. All the concentrations in a province may be of about the same age, but because of the high degree of mobility of uranium, deposits of more than one age are typical. The boundaries of uranium provinces are controlled by the interplay of many geologic and climatic factors and consequently are likely to be rather indefinite. These criteria for the recognition of a province are perhaps obvious and undoubtedly incomplete. Almost certainly they will be sharpened as new discoveries are made and as the points of view of geologists change as a result of increased geologic and geochemical knowledge.

Where there is no information on the presence of uranium minerals or aonormally radioactive rocks, complex geology and the presence of acidic and alkalic igneous rocks, including small bodies of highly differentiated types, and mineralogically complex veins of base and precious metals may point to the favorability of an area for uranium.

The province concept is valuable in roughly appraising the potential of an area in which uranium deposits are known and in pointing out settings within a province in which exploitable concentrations might profitably be sought. If an area is known or thought to be a province every possible setting in which uranium might be localized should be investigated. These include acidic and alkalic igneous rocks and mineralized struetures in the vicinity of such rocks; placers or sites where placers might occur; sequences of continental sandstone and shale, particularly those that contain abundant carbonaceous trash, admixed tuffaceous material, and petroleum residues or that are cut by small acidic or alkalic intrusive bodies; lignite and coal, particularly if it is or was overlain by acidic volcanic rocks or is in a basin through which ground water from a granitic, arkosic, or acidic volcanic terrane drained; metamorphosed black shales; and conglomerate-bearing sequences deposited on a crystalline basement. More specifically, if abnormally radioactive igneous rocks and a few vein deposits have been discovered in a mountainous orogenic belt, one might expect to find more vein deposits in favorable structural settings, particularly in the vicinity of igneous rocks and placers. In the less deformed erosional debris within and marginal to this belt, especially if the climate is arid or semiarid, one should look for deposits of sandstone type, uraniferous lignite or coal, uraniferous petroleum residues, and perhaps placer deposits. If sandstone-type deposits have been found in a basin, one might profitably look for vein deposits in the adjacent mountains, provided that acidic igneous rocks and favorable structures are present.

The same principles apply to ancient shield areas where veins, uraniferous rocks, and placers are most likely to occur in the strongly deformed, metamorphosed and intruded parts; uraniferous conglomerates may occur in peripheral, less strongly deformed metamorphosed and intruded rocks. Though uraniferous coal and petroleum residues are not to be expected, small deposits of uraniferous peat may occur locally.

As a corollary to the idea of a province, the writers would not expect to find more than a sporadic exploitable deposit in relatively recent eugeosynclinal belts or basic volcanic chains such as the California and Oregon Coast Ranges, much of the Caribbean area, Hawaii, the Philippine Islands, the Aleutian chain, and Kamchatka and the Kuril Islands. Similarly, broad areas covered by rather thick sequences of relatively recentundeformed basaltic flows are relatively unfavorable, even though they may be surrounded and underlain by favorable geologic settings. However, where eugeosynclinal rocks and especially basic igneous rocks have been involved in later orogenies and intruded by acidic igneous rocks, they may assume a relatively high degree of favorability, for many vein deposits seem to favor basic igneous host rocks (Lang, 1952, pp. 20-21). 


\section{REFERENCES CITED}

Abraham, E. M., 1953, Preliminary report on the geology of parts of Long and Spragge Townships, Blind River uranium area, District of Algoma: Ontario Dept. of Mines, Progress Rept. 1953-2, $10 \mathrm{p}$.

Adams, J. A. S., and Saunders, D. F., 1953, Uranium content of the lavas of Lassen Volcanic National Park, Calif. [abs.]: Geol. Soc. America Bull., v. 64, p. 1389.

Adelung, A. S., Kushnar, S. A., and Chikhachev, P. K., 1937, Yugo-Zapadnye Kyzyl-Kumy (Southwestern Kyzyl-Kum): Komitet Nauk Uzbekskoi Sovetskoi Sotzialistichechoi Respubliki (Uzbek S. S. R.), Geologiya Uzbekskoi S. S. R., v. 2, p. $99-151$.

Bain, G. W., 1950, Geology of the fissionable materials: Econ. Geology, v, 45, p. 273-323.

Billings, M. P., and Keevil, N. B., 1946, Petrography and radioactivity of four Paleozoic magma series in New Hampshire Geol. Soc. America Bull., v. 57, p. 797-828.

Burkser, E. S., Shapiro, M. Ya., and Bronstein, K. G., 1929, Radioaktivnost kamennykh uglei $\mathrm{i}$ antratzitov Donetskogo Basseina (Radioactivity of coal and anthracite from the Donets Basin): Ukrainskii Khimichnii Zhurnal (Kharkov), v. 4 , no. 2 , p. $95-100$.

Cady, W. M., 1950, Classification of geotectonic elements: Am. Geophys. Union Trans., v. 31, p. 780-785.

Cady, W. M., McKelvey, V. E., and Wells, F. G., 1950, Geotectonic relationships of mineral deposits [abs.]: Geol. Soc. America Bull., v. 61 , p. 1447.

Cannon, H. L., 1952, The effect of uranium-vanadium deposits on the vegetation of the Colorado Plateau: Am. Jour. Sci., v. 250 , p. $735-770$.

Davidson, C. F., 1951, The distribution of radioaetivity: Mining Mag. (London), v. 85, p. 329-340.

- 1953, The gold-uranium ores of the Witwatersrand: Mining Mag. (London), v. 88, p. 73-85.

Davidson, C. F., and Bowie, S. H. U., 1951, On thucholite and related hydrocarbon-uraninite complexes, with a note on the origin of the Witwatersrand gold ores: Great Britain Geol. Survey Bull. 3, p. 1-19.

Davidson, C. F., and Ponsford, D. R. A., 1954, On the occurrence of uranium in coals: Mining Mag. (London), v. 91, p. 265-273; South African Min. and Eng. Jour. (Johannesburg), v. 65 , pt. 2 , p. $721,723,725,727$.

Denson, N. M., and others, 1952, Summary of uranium-bearing coal, lignite, and earbonaceous shale investigations in the Rocky Mountain region during 1951, with description of deposits: U. S. Geol. Survey TEM-341A, 44 p., issued by U. S. Atomic Energy Comm. Tech. Inf. Service, Oak Ridge Tenn.

Erickson, R. L., Myers, A. T., and Horr, C. A., 1954, Association of uranium and other metals with crude oil, asphalt, and petroliferous rock: Am. Assoc. Petroleum Geologists Bull., v. 38, p. 2200-2218.

Faul, Henry, (editor), 1954, Nuclear geology: New York, John Wiley and Sons, Inc., $414 \mathrm{p}$.

Fersman, A. E., 1928, K Morfologii i Geokhimii Tyuya-Muyuna (On the morphology and geochemistry of Tyuya-Muyun): Akad. Nauk S. S. S. R., Trudypo izuch. Radiya i Radioaktivnykh Rud, Leningrad, v. 3, 92 p.

Finch, W. I., 1953, Geologic aspects of the resource appraisal of uranium deposits in pre-Morrison formations of the Colorado Plateau-an interim report: U. S. Geol. Survey TEI-328A, 35 p., issued by U. S. Atomic Energy Comm. Tech. Inf. Service, Oak Ridge, Tenn.
Fischer, R. P., 1942, Vanadium deposits of Colorado and Utah: U. S. Geol. Survey Bull. 936-P, p. 363-394.

Fischer, R. P., and Hilpert, L. S., 1952, Geology of the Uravan Mineral Belt: U. S. Geol. Survey Bull. 988-A, p. 1-13.

Fleischer, Michael, 1953, Recent estimates of the abundances of the elements in the earth's crust: U. S. Geol. Survey Cire. $285,7 \mathrm{p}$.

Frondel, J. W., and Fleiseher, Michael, 1955, A glossary of uranium- and thorium-bearing minerals, 3d ed.: U. S. Geol. Survey Bull. 1009-F, p. 169-209.

Geological Society of South Africa (Honorary Secretary, ed.), 1931, Contributions to a discussion on the origin of the gold in the Witwatersrand system: South African Geol, Soc. Trans., annexure to v. 34,92 p.

Goldschmidt, V. M., 1922a, Stammestypen der Eruptivgesteine: Videnskapsselskapets Skrifter (Oslo), I. Natu-naturv. KI., no. 10,12 p.

- 1922b, Der Stoff wechsel der Erde: Videnskapsselskapets Skrifter (Oslo), I. Nat.-naturv. Kl., no. 11, 25 p.

-1937, The principles of distribution of chemical elements in minerals and rocks: Chem. Soc. Jour., London, pt. 1 , p. $655-673$.

Gott, G. B., Wyant, D. G., and Beroni, E. P., 1952, Uranium in black shales, lignites, and limestones in the United States: U. S. Geol. Survey Circ. 220, p. 31-35.

Graton, L. C., 1930, Hydrothermal origin of the Rand gold deposits-part 1, The testimony of the conglomerates: Econ. Geology, v. 25, supp. to no. 3, 185 p.

Hoehne, Karl, 1936, Uber einige Arsen-, Nickel-, Kobalt-, Silber-, Wismut-, und Uranerz-führende Kalkspatgänge der Grube Bergfreiheit zu Oberschmiedeberg im Riesengebirge: Chemie der Erde, v. 10, p. 432-474.

Hurley, P. M., 1950, Distribution of radioactivity in granites and possible relation to helium age measurement: Geol. Soc. America Bull., v. 61, p. 1-7.

Jahns, R. H., 1953, Distribution of rare elements within granites and granitic pegmatites [abs.]: Geol. Soc. America Bull, v. 64, p. 1440 .

Klockmann, F., 1882, Beitrag zur Kenntnis der granitschen Gesteine des Riesengebirges: Deutsche geol. Gezell, Zeitsch, v. 34, p. 373-426.

Kohl, E., 1942, Grossdeutschlands Vorkommen natürlich radioaktiver Stoffe und deren Bedeutung für die Versorgung mit radioaktiven Substanzen: Zeitsch. Berg-, Hütten-, u. Salinenwesen Deutschen Reich (Berlin), v. 90, no. 8, p. 153-177.

Lang, A. H., 1949, Notes on prospecting for uranium in Canada: Canada Geol. Survey Paper, No. 49-4, 22 p.

- 1952, Canadian deposits of uranium and thorium. (Interium account): Canada Geol. Survey, Econ. Geology Ser. no. 16,173 p.

Mackay, R. A., and Beer, K. E., with contributions by Rockingham, J. E., 1952, The albite-riebeckite-granites of Nigeria: Great Britain Geol. Survey and Museum (London), Atomic Energy Division, Rept. GSM/AED no. 95 (declassified issue), $25 \mathrm{p}$.

Mason, Brian, 1952, Principles of geochemistry: New York, John Wiley and Sons, Inc., 276 p.

Mawdsley, J. B., 1952, Uraninite-bearing deposits, Charlebois Lake area Northeastern Saskatchewan: Canadian Min. and Met. Bull., v. 45 , p. $366-375$.

McKelvey, V. E., and Nelson, J. M., 1950, Characteristics of marine uranium-bearing sedimentarv rocks: Econ. Geology, v. 45, p. $35-53$. 
Neuman, W.F., 1947, The distribution and excretion of uranium, in Pharmacology and toxicology of uranium compounds: Nat. Nuclear Energy Series, Div. VI, v. 1, pt. 1, Chap. 11, New York, MeGraw-Hill Book Co., Inc. [1949]; [Abs.] U. S. Atomic Energy Comm,, Abs. of declassified doc., v. 1, p. 149.

Phair, George, 1952, Radioactive Tertiary porphyries in the Central City district, Colorado, and their bearing upon pitchblende deposition: U. S. Geol. Survey TEI-247, 53 p., issued by U. S, Atomic Energy Comm. Tech. Inf. Service, Oak Ridge, Tenn.

Piggot, C. S., 1944, Radium content of ocean-bottom sediments; Carnegie Inst. Washington Pub. 556, p. 183-193.

Rankama, Kalervo, and Sahama, T. G., 1950, Geochemistry: 912 p., Chicago, Univ, of Chicago Press.

Rosenzweig, Abraham, Gruner, J. W., and Gardiner, Lynn, 1954, Widespread occurrence and character of uraninite in the Triassic and Jurassic sediments of the Colorado Plateau: Econ. Geology, v. 49, p. 351-361.

Russell, W. L., 1945, Relation of radioactivity, organic content, and sedimentation: Am. Assoc. Petroleum Geologists Bull., v. 29 , p. $1470-1493$.

Sosedko, A. F., 1933, Osnovnye resultaty Kyzyl-Kumskoi geokhimichekoi ekspeditzii Akade mii Nauk S. S. S. R. 1931 (Chief results of the Kyzyl-Kum geochemical expedition of the Academy of Sciences, U. S. S. R., in 1931): Akad. Nauk S. S. S. R., Sovet po Izucheniyu Proizvoditel'nykh Sil, Trudy, Ser. Karakalpakskaya, v. 1, Kyzyl-Kumy, p. 5-40.

Stieff, L. R., Stern, T. W., and Milkey, R. G., 1953, A preliminary determination of the age of some uranium ores of the Colorado Plateaus by the lead-uranium method: U. S. Geol. Survey Cire. 271, 19 p.
Stille, Hans, 1940, Einführung in den Bau Amerikas: Berlin, Gebrüder Borntraeger, $717 \mathrm{p}$.

Stugard, Frederick, Jr., Wyant, D. G., and Gude, A. J., 3d, 1952, Secondary uranium deposits in the United States: in U. S. Geol. Survey Circ. 220, p. 19-25.

Traill, R. J., 1954, A preliminary account of the mineralogy of radioactive conglomerates in the Blind River region, Ontario: Canadian Min. Jour., v. 75, no. 4, p. 63-68.

Tyurin, B, A., 1944, Karatauskoye mestorozhdeniye uranovanidievykh rud (The Kara-Tau deposit of urano-vanadium ore): Akad. Nauk S. S. S. R. Izv., Ser. Geol., no. 2, p. 99105, English summary, p. 105-106,

Union of South Africa Geol. Survey, 1940, Gold in the Witwatersrand system, in Mineral resources of South Africa: p. 110-163, Pretoria, Union of South Africa Gov't Printer.

United States Geological Survey, 1953, Search for and geology of radioactive deposits, Semiannual progress report, December 1, 1952 to May 31, 1953: U. S. Geol. Survey TEI330,362 p., issued by U. S. Atomic Energy Comm. Tech. Inf. Service, Oak Ridge, Tenn.

United States Geological Survey, 1954, Geologie investigations of radioactive deposits, Semiannual progress report, June 1 to Nov. 30, 1954: U. S. Geol. Survey TEI-490, 299 p., issued by U. S. Atomic Energy Comm. Tech. Inf. Service, Oak Ridge, Tenn.

Urey, H. C., 1952, The planets, their origin and development: New Haven, Yale Univ. Press, 245 p.

Weir, D. B., 1952, Geologic guides to prospecting for carnotite deposits on the Colorado Plateau: U. S. Geol. Survey Bull. 988-B, p. 15-27.

Anonymous, 1954, La Ronge uranium mines, in Provincial Notes, Saskatchewan: Canadian Min. Jour., v. 75, no. 9, p. 116, 118. 


\title{
DISTRIBUTION AND GENERAL FEATURES OF URANIUM OCGURRENCES IN THE UNITED STATES
}

\author{
By Arthur P. Butler, Jr., and Robert W. Schnabel, U. S. Geological Survey
}

\section{CONTENTS}

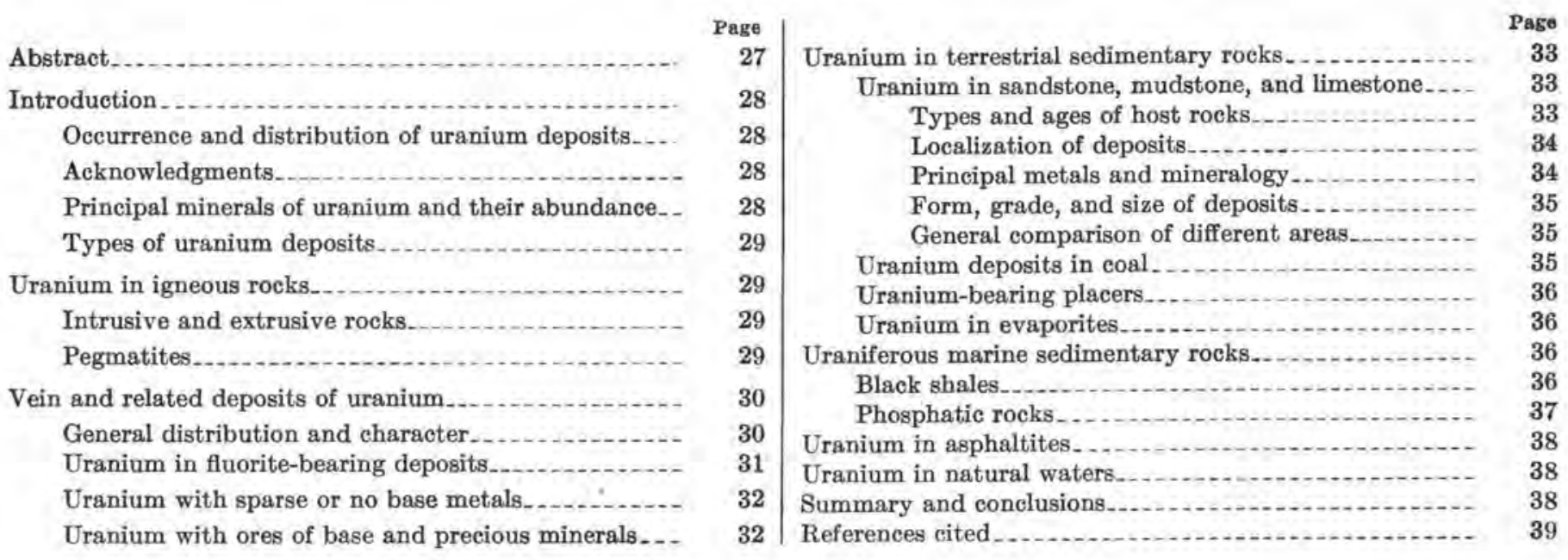

\section{ILLUSTRATION}

FIGURe 1. Index map showing deposits and principal occurrences of uranium in the United States

\begin{abstract}
Concentrations of uranium formed by igneous, hydrothermal, sedimentary, and weathering processes are found in the United States in a large variety of geologic environments. The diversity of environments reflects the great number of natural compounds in which uranium is a major or minor constituent. Most ore deposits are in the western plains and mountain regions between the 100 th and 120 th meridians of west longitude, but a few occur elsewhere. The deposits are grouped according to their host rocks or controlling structure.

Some igneous rocks contain considerably more uranium than is in most granites. None are a present source of uranium and the relation of igneous rocks, enriched or depleted in uranium, to other types of deposits is obscure.

Uraniferous vein deposits in the Western States are mainly of Tertiary age. Most economic deposits are in crystalline rocks of Precambrian, Mesozoic, and Tertiary age. Occurrences in Eastern United States, mostly undated, are mainly in rocks of Precambrian age. Pitchblende, associated with base-metal sulfides or with fluorite, is the principal uranium mineral in vein deposits at depth. Supergene secondary uranium minerals occur in some deposits but are not generally abundant. Uranium is mined from veins in Colorado, Arizona, Montana, Nevada, and California, but principally from those near Marysvale, Utah.
\end{abstract}

Minerals of uranium and other associated metals impregnate terrestrial sandstones, mudstones, and limestones to form ore deposits in rocks ranging in age from Devonian to Tertiary. Such deposits are the principal source of uranium in the United States, and the largest and most numerous of these are in Mesozoic rocks of the Colorado Plateau. Similar deposits also occur in Mesozoic and Tertiary rocks in several western States, and in Paleozoic rocks in Pennsylvania. The deposits are irregular, nearly tabular masses roughly concordant with the enclosing strata. Deposits near the surface contain principally carnotite or tyuyamunite, but uranium silicates, phosphates, carbonates, arsenates, and sulfates are locally abundant. The unoxidized parts of some deposits contain prineipally uraninite, coffinite, and montroseite.

Most uranium minerals are too soft and too soluble to be concentrated in placer deposits. Uraniferous minerals such as monazite and zircon are, however, concentrated in some placers in Idaho and the Southeastern States.

Uraniferous coals of Cretaceous and Tertiary age are widely distributed in many parts of Western United States. Coals containing at least 0.1 percent uranium are found locally in western North and South Dakota and in New Mexico.

Widespread uraniferous marine sedimentary rocks include principally phosphatic rocks of Permian age in Idaho, Montana, Wyoming, and Utah, and of Tertiary age in Florida, and the 
Chattanooga shale of Devonian and Mississippian age and some black shales of Pennsylvanian age in the Central States. Uranium content generally is less than 0.02 percent.

Some Paleozoic and Mesozoic rocks in the South-Central and Western States contain uranium-bearing petroliferous substances. Concentrations of these substances great enough to form uranium ores are rare.

Anomalous amounts of uranium are found in some ground and surface waters but are significant mainly as clues to areas favorable for uranium deposits.

\section{INTRODUCTION}

\section{OCCURRENCE AND DISTRIBUTION OF URANIUM DEPOSITS}

Concentrations of uranium formed by igneous, hydrothermal, sedimentary, and weathering processes are found in a variety of geologic environments of the United States. Nearly all the deposits mined principally for their uranium content are distributed from the western part of the Great Plains physiographic province west of $103^{\circ} \mathrm{W}$. longitude through the Rocky Mountain region to southern California and northeastern Washington. Only one small deposit in Eastern United States has been mined exclusively for uranium. Most deposits are nearly tabular masses in terrestrial sedimentary rocks of Mesozoic and Cenozoic age in the intermontane plateaus and basins. Some are veins in igneous rocks of Tertiary age, and others are veins or related forms of deposits in older crystalline and sedimentary rocks. Uranium is also appreciably concentrated in black shale of Devonian and Mississippian age throughout wide areas in Central United States and in extensive phosphate deposits in several Western States and in Florida. Some uranium is now recovered from the Florida phosphorite as a byproduct in the manufacture of phosphate fertilizer and chemicals (U. S. Atomic Energy Commission, 1954). Many other occurrences of diverse types are known in many parts of the country and further exploration may show that they or other similar occurrences nearby can be mined.

More than half of all deposits and about 75 percent of the deposits containing more than 100,000 tons of ore have been found in the last 12 years. Most of these have been found either near deposits already known or in similar geologic settings elsewhere.

Some deposits, however, such as those in coals of Tertiary age, have been found in geologic settings where uranium was previously unknown; others, such as deposits in marine phosphatic rocks, have been found in geologic settings where the presence of uranium, though noted, was not generally recognized.

The geologic and geographic distribution of uranium deposits in the United States are outlined in this report.

\section{ACKNOWLEDGMENTS}

Much of the merit and timeliness that this account may have is due in large part to colleagues in the Geological Survey and Atomic Energy Commission who have made unpublished information available to us and who have contributed to our work in ways that cannot always be acknowledged by direct citation. In addition, we are particularly grateful to $\mathrm{H}$. N. Jones and C. E. Fix for assistance in compiling references and other data and to our associates who have critically read the manuscript or assisted in the compilation of it in other necessary ways.

\section{PRINCIPAL MINERALS OF URANIUM AND THEIR ABUNDANCE}

Uranium is a lithophile element and is mostly confined to the sialic upper part of the earth's crust (Rankama and Sahama, 1950, p. 632-639; Davidson, 1951). It is less abundant than the base metals and nickel and chromium, but more abundant than the precious metals and some others in common use, such as bismuth, mercury, and tungsten. Its concentration in currently workable deposits is at least 250 times its average abundance of about 0.0004 percent in the earth's crustt as estimated by Schneiderhöhn (1934), Goldschmidt (1937), and later investigators. Its concentration in deposits where it may be extracted as a byproduct is only about one-tenth that in deposits where it is the principal element sought.

Uranium combines as a cation or anion with at least 20 other elements. It is an essential element in nearly 100 minerals and is a minor or extrinsic constituent of nearly 100 other minerals (Frondel and Fleischer, 1955), in many of which it accompanies thorium. Uranium also has an affinity for some biogenic and carbonaceous compounds, with which it is associated in some black shales, coals, and petroleum derivatives.

Uranium is generally an extrinsic element in most minerals formed by igneous processes such as zircon, allanite, monazite, and xenotime, but is an essential element in those minerals that constitute most uranium ores. Uraninite, or its colloform variety pitchblende, and coffinite (uranium silicate) are the most common uranium minerals in unoxidized ores. Davidite and brannerite are less common, but are the principal uranium minerals in some unoxidized ores. The oxidized ores of uranium consist mainly of its highvalent compounds, carnotite, tyuyamunite, torbernite, and autunite. Other minerals of hexavalent uranium predominate in some deposits.

The wide-spread concentrations of uranium in different kinds of host rocks, in different structural settings, and of different origins across the United 
States reflect the lithophilic character of uranium, the number of its valence states, and its chemical activity.

\section{TYPES OF URANIUM DEPOSITS}

Many of the uranium deposits in the United States do not fit readily into any one of the standard classifications of ore deposits, mainly, because the genesis of the economically important deposits in terrestrial sandstones is still subject to considerable controversy. In this account, therefore, the deposits are grouped either by the kind of rock or by the principal structural setting in which they are found. Such a grouping presents some inconsistencies with respect to genesis, but is reasonably consistent with respect to form, size, and tenor of most of the deposits. The grouping used here is as follows: (1) uranium in igneous rocks, (2) uranium in veins, (3) uranium in terrestrial sedimentary rocks, (4) uranium in marine sedimentary rocks, (5) uranium in asphaltites, and (6) uranium in natural waters.

\section{URANIUM IN IGNEOUS ROCKS}

\section{INTRUSIVE AND EXTRUSIVE ROCKS}

Uranium is present in all igneous rocks. It is commonly more abundant in felsic rocks, especially in local masses of soda-rich granite, syenite, and phonolite. The average uranium content of the more common types of intrusive igneous rocks ranges from a fraction of a part per million (less than 0.0001 percent) in gabboric rocks to about $4 \mathrm{ppm}(0.0004$ percent) in granitic rocks (Larsen and Phair, 1954, p. 77). Some alkali-rich rocks contain as much as 300 to $400 \mathrm{ppm}$ ( 0.03 to 0.04 percent) uranium. The general pattern of distribution in extrusive igneous rocks is much the same as in their intrusive counterparts (Adams, 1954).

A considerable part of the uranium in granitic and syenitic rocks is in the major rock-forming minerals, but much of it is concentrated along with thorium in the common accessory minerals. The uranium content of minor accessory minerals is as much as several thousand parts per million.

Some of the uranium in the rocks is locked firmly in nearly insoluble minerals, but much of the radioactivity, and probably much of the uranium also, can be removed by leaching of crushed samples in dilute acids (Hurley, 1950; Brown, Blake, Chodas, and others, 1953; Larsen and Phair, 1954, p. 80-81). The leachable uranium is probably derived from slightly soluble minerals, and from uranium absorbed on surfaces of mineral grains. Easily soluble uranium may be removed from the rock during weathering or some of it can be locally reconcentrated to enrich near-surface parts of the rocks in uranium (Davidson, 1951).

The uranium contents of the different types of rocks in the large composite intrusive masses of calc-alkaline rocks in the United States that have been studied to date, such as the batholith of southern California, the Boulder batholith, Mont., and parts of the Sierra Nevada, Calif., and Idaho batholiths are comparable to the average uranium content of the corresponding average rock types. However, many data from radioactivity measurements suggest that granitic rocks containing more than the average amount of uranium are widespread, if not abundant, in the United States (Butler, 1952) and elsewhere (Davidson, 1951).

The uranium content of some of the more uraniferous igneous rocks found to date in the United States ranges from $5 \mathrm{ppm}$ in granite at the Adams tunnel, Grant and Larimer Counties, Colo. (U. S. Geol Survey, 1954 b, p. 204), and $11 \mathrm{ppm}$ in the Conway granite in New Hampshire (Smith, W. L. and Butler, A. P., Jr., unpublished data), to $22 \mathrm{ppm}$ in bostonite from Sussex County, N. J. (U. S. Geol. Survey, 1954a, p. 258), and $33 \mathrm{ppm}$ in quartz bostonite from Gilpin County, Colo. (Larsen and Phair, 1954, p. 79).

Single samples of some other rocks also contain amounts of uranium comparable to the more uraniferous rocks in this list. No igneous rocks known in the United States, other than a few pegmatites, however, are sufficiently rich in a single uraniferous mineral to permit recovery of the uranium by means of mineral concentration.

Among the more uraniferous rocks studied in some detail, only the quartz bostonite of Gilpin County, Colo., is spatially and perhaps genetically related to uranium deposits. This rock and the pitchblende and other ores of the Central City district, Colorado, may have a common percentage (Lovering and Goddard, 1950, p. 175; Phair, 1952). Phair also infers that some of the pitchblende in the veins was derived by latestage hydrothermal leaching of the bostonites, Little has been reported about the uranium content or distribution of uranium in igneous rocks close to or enclosing other vein deposits of uranium in Portugal, in Cornwall, England, or near Marysvale, Utah. Thus, the relations between especially uraniferous igneous rocks, or between parts of igneous roeks enriched or depleted in uranium, and vein deposits of uranium are obscure, notwithstanding the greater radioactivity (Ingham and Keevil, 1951, Slack and Whitman, 1951) or the greater abundance of uranium-bearing minerals (Davidson, 1951) noted in the peripheral parts of some stocks and batholiths not closely associated with vein deposits of uranium.

\section{PEGMATITES}

In many parts of the United States, zoned pegmatites of granitic composition and rich in potash feldspar 
contain scattered grains of uranium minerals or uranium-bearing minerals (Page, 1950). Uraninite is the commonest uranium mineral. The uranium content of most pegmatites does not differ greatly from that of granitic rocks. A few pegmatites, however, such as that at the Ruggles mine, Grafton, N. H., the mafic pegmatite at the Phillips mine near Peekskill, N. Y. (U. S. Geol. Survey, 1954a, p. 208), and the Bob Ingersoll dike in South Dakota contain notable concentrations of uranium minerals. In addition, several unzoned pegmatites of Precambrian age near Idaho Springs, Colo., have sufficient uraninite associated with biotite dispersed through them to be of nearly marginal grade in uranium (U. S. Geol. Survey, 1954a, p. 137138). However, almost no pegmatites in the United States are rich enough in uranium to support mining for uranium alone (Page, 1950).

\section{VEIN AND RELATED DEPOSITS OF URANIUM}

\section{GENERAL DISTRIBUTION AND CHARACTER}

Most uranium deposits of undoubted hydrothermal origin are found in veins, lodes, or stockworks whose position is controlled by fractures, faults, or the interstices of breccias. The structures generally dip steeply. At some places uranium has been introduced into the wall rocks of the fractures, but this relation is an important feature of only a few deposits in the United States. Pyrometasomatic deposits are few. Replacement deposits of uranium similar to the mantotype of some sulfide ore bodies are not known in the United States.

Most vein and related deposits of uranium in the United States have been distributed from the eastern side of the Rocky Mountains to southern California and eastern Washington (fig. 1). A few small deposits are in the Black Hills. Occurrences of uranium in veins are known in the upper peninsula of Michigan (U. S. Geol. Survey, 1953b, p. 204-206). All the currently productive deposits are in about fifteen areas in Utah, Arizona, Colorado, California, Montana, Nevada, South Dakota, Washington, and Wyoming.

Crystalline metamorphic rocks of Precambrian age, and felsic intrusive igneous rocks of Jurassic, Cretaceous, and Tertiary ages are the host rocks of most of the vein deposits. Tertiary volcanic rocks, unmetamorphosed sedimentary rocks of Mesozoic age, and slightly metamorphosed sedimentary rocks of Precambrian age are each the host rocks of a few deposits.

The majority of vein deposits of uranium in Western United States are not only near intrusive rocks of Tertiary age (Kaiser and Page, 1952), but are probably of Tertiary age too. Occurrences in the Coeur d'Alene district, Idaho, in veins cutting slightly metamorphosed rocks of the Belt series have been dated as Precambrian (Kerr, 1952). Deposits in eastern Washington, and in the Kern River area, California, at present can be dated only as Jurassic or younger. The occurrences east of the Mississippi River are in rocks of Precambrian age and are presumably of that age.

Although the veins are commonly in a particular set of tensional fractures within a district or a small area (Everhart, this volume), few of them are spatially related to obvious persistent structures of large extent. In Colorado, however, most of the vein deposits of uranium are in or near a northeastward-trending belt defined by the principal metal mining districts of the State (King, Leonard, Moore, and Pierson, 1953), and near most of the porphyry stocks of Tertiary age. The trend of this belt is across that of the broad folds and other structures of Laramide age that trend north and northwest.

The assemblage of minerals accompanying uranium in vein and related deposits in the United States is complex in some deposits and relatively simple in others. Because important details of the mineralogy of many deposits are not yet available, a few generalized mineralogic types are taken as rather arbitrary divisions of a wide variety of mineralogic associations. The deposits can be grouped as follows: (1) uranium accompanied by or accompanying fluorite, (2) uranium accompanied by iron as sulfide, and by few, if any, base metals, and (3) uranium accompanying and less abundant than ores of base and precious metals.

Silica in different forms is generally the most abundant gangue mineral in deposits of the first two types, but introduced gangue minerals are relatively sparse in some deposits. Carbonate minerals are relatively abundant in the gangue of deposits of the third type (King, Moore, and Hinrichs, 1952; Everhart and Wright, 1953). Molybdenum occurs in some deposits of all three types.

Veins and related deposits in which uranium is associated with fluorite are the outstandingly important source of uranium mined from veins in the United States, mainly because the fairly large deposits at Marysvale are of this type. The deposits in which uranium predominates over base metals and those in which uranium is subordinate to base and precious metals are less important.

Veins containing the complex assemblage of pitchblende, cobalt- and nickel-minerals, native silver, and base-metal sulfides, all found in many large vein deposits elsewhere, are represented only by nonproductive deposits of the White Signal district, New Mexico (Gillerman, 1952), and in the Coeur d'Alene area, Idaho (Thurlow and Wright, 1950) where the as- 
sociation may be fortuitous rather than genetic (Kerr and Robinson, 1953).

The grade of deposits in veins generally ranges from 0.02 to 0.5 percent $\mathrm{U}_{3} \mathrm{O}_{8}$, but higher grade ore is mined from some veins. Few deposits contain more than 10,000 tons of ore.

\section{URANIUM IN FLUORITE-BEARING DEPOSITS}

Uranium occurs in at least 20 deposits of fluorite ores or fluorite-bearing ores in Illinois (Brown, Emery, and Meyer, 1954), Colorado, Utah, California, and adjacent States (Wilmarth, Bauer, Staatz, and Wyant, 1952). Most of them are inconsequential as sources of uranium or fluorite, and are not shown on the map, but uranium minerals accompanied by fluorite in deposits near Marysvale, central Utah, are presently a source of considerable uranium.

Some fairly large deposits of fluorite contain subordinate amounts of uranium. Fluorite bodies in pipes and veins in the Thomas Range, west-central Utah, contain uranium dispersed through the crystal structure of dark-purple fluorite (Staatz and Osterwald, this volume). The uranium can be recovered only by destroying the fluorite. The fluorite ores of the Jamestown district, north-central Colorado, contain small amounts of base-metal sulfides and sparse

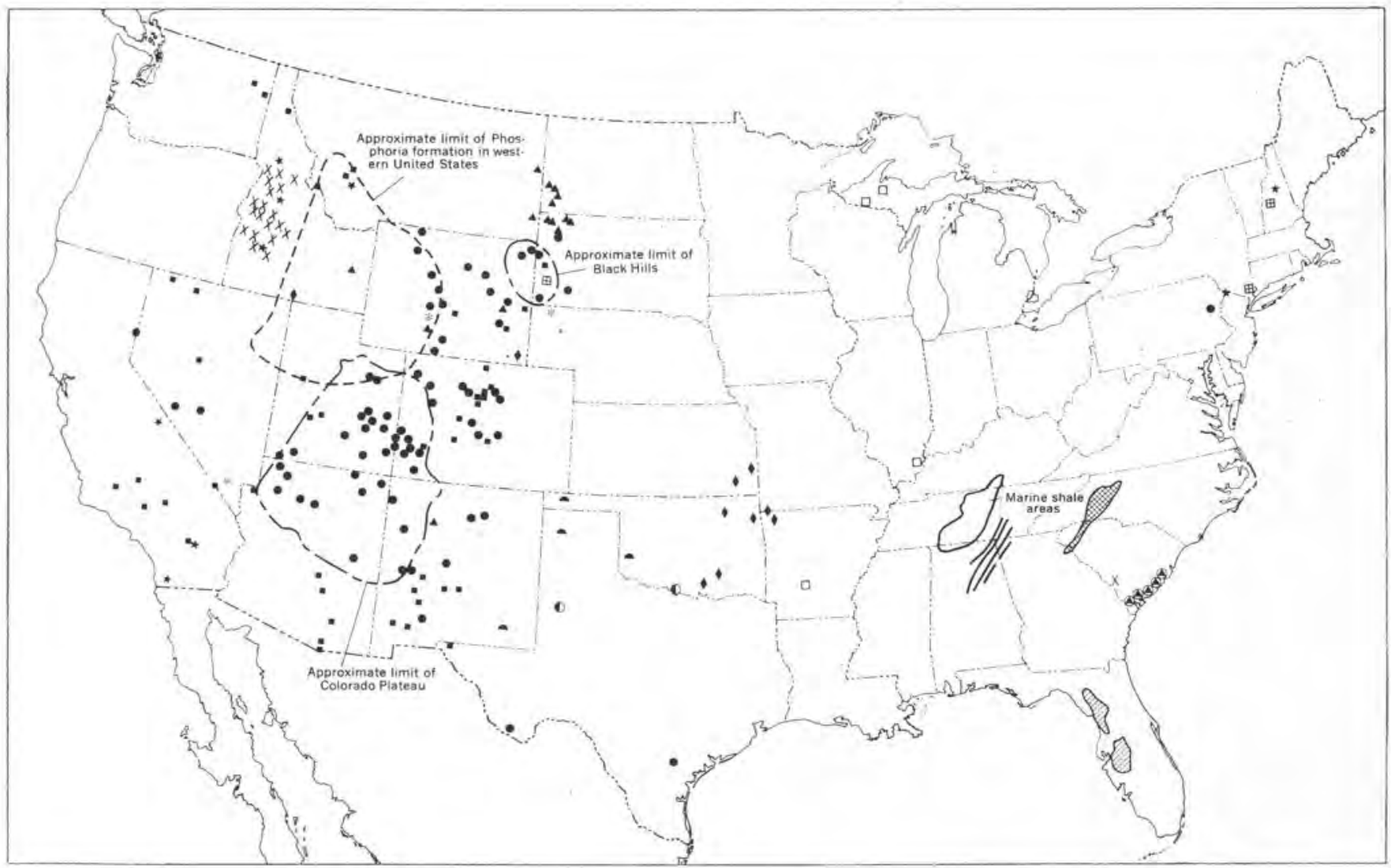

EXPLANATION

\begin{tabular}{|l|c|c|}
\hline \multicolumn{1}{|c|}{ Host material } & $\begin{array}{c}\text { Economic or potentially } \\
\text { economic deposits }\end{array}$ & $\begin{array}{c}\text { Other deposits } \\
\text { mentioned in report }\end{array}$ \\
\hline Igneous rocks & & $\star$ \\
\hline Pegmatites & - & $\square$ \\
\hline Veins & - & \\
\hline $\begin{array}{l}\text { Terrestrial sandstone, } \\
\text { Bimestones, and mudstones }\end{array}$ & $*$ & \\
\hline Coais & $*$ & \\
\hline Evaporites & $\times$ & \\
\hline Placers & & \\
\hline
\end{tabular}

\begin{tabular}{|l|c|}
\hline \multicolumn{1}{|c|}{ Host material } & $\begin{array}{c}\text { Economic or potentially } \\
\text { economic deposits }\end{array}$ \\
\hline Area of abundant plarers & \\
\hline Marine shales & \\
\hline $\begin{array}{l}\text { Outcrop, large area } \\
\text { of marine shales }\end{array}$ & \\
\hline Phosphorites & \\
\hline $\begin{array}{l}\text { Outcrop, large area } \\
\text { of phosphorites }\end{array}$ & \\
\hline Asphaltites & \\
\hline
\end{tabular}

FIOURE 1.-Index map showing deposits and principal occurrences of uranium in the United States. 
uraninite (Wilmarth, Bauer, Staatz, and Wyant, 1952), but are too lean in uranium to be mined for that element alone.

Deposits near Marysvale, Utah, are the outstanding example of fluorite-bearing uranium ores in the United States. Most of the deposits there are in quartz monzonite of Oligocene or younger age in an area of less than a square mile. A few are in volcanic rocks older and younger than the quartz monzonite.

The largest ore deposits are in a set of fractures and faults that strike northeasterly; some ore is in a set that strikes northwesterly; and ore is sparse in a northtrending set (Taylor, Anderson, O'Toole, and others, 1951). Pronounced shoots of ore occur near intersections of fractures or along lines of the change in the strikes of the faults or fractures (Walker and Osterwald, this volume).

The intrusive and younger volcanic rocks in the walls of the veins are altered to clay minerals and chlorite near the surface, but not at depth. They are locally silicified, and red hematite is present in a thin zone around some ore bodies.

The hypogene vein minerals consist mainly of quartz or chalcedony, pitchblende, fluorite, pyrite, and adularia but include calcite, jordesite, hematite, magnetite, and marcasite. They form veins, stockworks, lenticular masses, and breccia cement. Locally, a little pitchblende is disseminated in the wall rocks.

The upper 100 feet of the deposits consists mainly of uranium phosphates, silicates, and sulfocarbonates, accompanied locally by iron and manganese oxides, ilsemannite, carbonates, and gypsum.

The uranium in the veins is found over a vertical range of nearly 2,000 feet. Some veins are mineralized for horizontal distances of 800 feet and vertical distances of 700 feet. The larger deposits at Marysvale are larger than all other known vein deposits in the United States combined and are comparable in size to some of the large deposits in terrestrial sandstones.

Elsewhere, pitchblende and fluorite are accompanied by ilsemannite in veins cutting igneous rock of Jurassic age near Kern River, south-central California; they are accompanied by pyrite, in a fault cutting brecciated, silicified, and sericitized rhyolitic rocks in the Moonlight mine, north-central Nevada; and by base-metal sulfides in another small deposit in southern Arizona. Ore has been mined from the deposits in Arizona and Nevada.

\section{URANIUM WITH SPARSE OR NO BASE METALS}

Deposits of uranium accompanied by some iron as sulfide and by no or sparse base metals are known in seven western States. Ore has been produced from mines in eight areas in these States. Among these, only mines in the Dripping Spring quartzite, central Arizona, have produced more than 1,000 tons of ore, but a few others show promise of having an appreciable quantity of ore.

Although details of the structural settings of deposits differ, nearly all the deposits are localized in fractures or fracture zones cutting the host rock or in the wall rocks of the fractures.

Some of the deposits in central Arizona are within a few feet of the contact between diabase and the Dripping Spring quartzite. They may have been formed at relatively high temperature (U. S. Geol. Survey, 1955, p. 131-132).

Most deposits of this general type consist of secondary minerals near the surface and uraninite or pitchblende below the zone of weathering, generally accompanied by pyrite or marcasite and less commonly by pyrrhotite. Sulfides of copper, lead, and molybdenum are present, but not abundant, in some deposits and absent in others.

Deposits of uranium without base-metal sulfides are present in fractures at or near the contact of granitic rocks and metamorphosed sedimentary rocks near Wellpinit, northeast Washington (U. S. Geol. Survey, 1954a, p. 219) and south of Austin, central Nevada; in crystalline Precambrian rocks in northern Colorado (Sims and Phair, 1953), in southeastern Wyoming and in the Black Hills, S. Dak.; in granitic rocks and in Tertiary volcanic rocks and detrital rocks derived from them at a few places in Kern and San Bernardino Counties, Calif. The deposit near Wellpinit appears to be of several thousand tons in size. The others are smaller.

Deposits in chalcedonic veins and silicified quartz monzonite in the Boulder batholith, west-central Montana (Becraft, 1953), in the Dripping Spring quartzite, central Arizona, and in Precambrian and Mesozoic rocks in west-central Colorado represent deposits that contain subordinate amounts of copper, lead, and molybdenum, and locally silver.

\section{URANIUM WITH ORES OF BASE AND PRECIOUS MINERALS}

Deposits of uranium accompanying a varied assemblage of base-metal sulfides or precious metals, or both, are represented in Arizona, Idaho, Montana, Wyoming, Colorado, New Mexico, South Dakota, and Michigan. Deposits of this general type near Central City, Colo., were the source of the first uranium mined in the United States, but deposits of this type are not a generally important source of uranium today. Only a few of them contain more than 1,000 tons of uranium ore. 
In the Central City district, Colorado, most of the veins fill fractures trending east and northeast, and cut granite gneiss of Precambrian age. Development of sericite and introduction of quartz and pyrite have severely altered the wall rocks of the veins. The uranium ores occur in parts of gold- and silver-bearing pyritic quartz veins where galena and chalcopyrite also are present (Leonard, 1952) and in parts of an adjoining zone of veins containing galena, sphalerite, carbonate minerals, and quartz that constitutes the outer zone of the vein system (Lovering and Goddard, 1950).

Most of the uranium deposits consist of lenses, stringers, and pods less than 100 feet in diameter and form poorly defined shoots within the leaner parts of the main shoots of other ores (King, Leonard, Moore, and Pierson, 1953).

Shear zones of several miles in extent in the Boulder batholith, western Montana, locally contain somewhat similar deposits (Becraft, 1953). Veins of the uraniumpredominant type are also in this area. The veins of this area and the uraniferous pyritic gold ores of the Central City district may represent a type of vein transitional between those in which uranium is predominant to those in which uranium is subordinate to the ores of base and precious metals.

Other deposits and occurrences, mostly similar to some near Central City, are present in Colorado from Caribou, 13 miles north of Central City, southwestward to the San Juan Mountains (King, Leonard, Moore, and Pierson, 1953). A variation of this type is represented by the deposit at the Ralston Creek mine, about 12 miles east of Central City, and by other occurrences in that vicinity. These contain more copper sulfides than are common in most of the other deposits of the Colorado Front Range, and relatively less galena and sphalerite. The deposit of the Ralston Creek mine consists of veins in a quartzose breccia in or adjacent to a carbonate-bearing breccia reef, which trends northwest for many miles (Adams, Gude, and Beroni, 1953).

Other vein deposits of uranium accompanying basemetal sulfides occur in crystalline rocks in northwest Arizona (U. S. Atomic Energy Comm, written communication) and in Precambrian rocks and quartzite of Cambrian age at Lusk, eastern Wyoming (Wilmarth and Johnson, 1954).

In the Sunshine mine, Coeur d'Alene area, northern Idaho, uranium occurs in veins near the veins of silver-base-metal ores, but is not intimately associated with the base metals (Thurlow and Wright, 1950; Kerr and Robinson, 1953). Moreover, it is in different structures from the silver and base-metal ores and may be older than they (Kerr and Robinson, 1953).
The uranium ore may contain no base metals or but small amounts.

Occurrences of uranium in Precambrian rocks in Baraga County, Mich., and in iron formation in the Iron River district, Michigan, are accompanied by copper-, lead-, and zinc-sulfides (U. S. Geol. Survey, 1953b, p. 204-206; Barrett, L. P., and James, H. L., written communication). They are significant mainly because they indicate the presence of uranium vein deposits in that part of the Canadian shield. Countless similar occurrences in the Western States (Kaiser and Page, 1952; Lovering, 1954; McKelvey, 1955) are of little significance as sources of uranium.

\section{URANIUM IN TERRESTRIAL SEDIMENTARY ROCKS}

\section{URANIUM IN SANDSTONE, MUDSTONE, AND IIME- STONE}

Deposits of uranium minerals in terrestrial sandstone, mudstone, and limestone are the largest source of uranium in the United States today. They are most numerous and widespread from Texas and South Dakota westward to Nevada and California (fig. 1.) One small deposit and several occurrences are present in Pennsylvania and New Jersey, Although deposits in sandstone have been known in the Colorado Plateau region since 1899 (Fischer, 1950), most of them have been found since 1947 .

The uranium ore mined in the United States comes mainly from deposits in Mesozoic rocks of the Colorado Plateau, but some ore is mined from deposits in Cretaceous rocks marginal to the Black Hills in Wyoming and South Dakota, from deposits in rocks of the intermontane Tertiary basins of Wyoming and Nevada, and from a small deposit in Pennsylvanian rocks in Pennsylvania. Other occurrences that have not yet produced ore are known in upper Paleozoic rocks marginal to the Permian basin in Texas, Oklahoma, and New Mexico, and in Tertiary rocks of the Texas coastal plain,

\section{TYPES AND AGES OF HOST ROCKS}

Most uranium deposits in terrestrial rocks are in sandstone. Some large deposits in the Grants area, west-central New Mexico, are in limestone. A few deposits are in mudstone.

The sandstone host rocks for uranium deposits are predominantly stream-laid quartzose, arkosic, and tuffaceous sandstone and conglomerate. Many of them contain abundant carbonized fragments of plants. The sandstone units are lenticular. The thicker parts of them represent the channel-fill of the streams that deposited them (Fischer, 1950; Benson, Trites, Beroni, and Feeger, 1952; Witkind, 1954; Miller, 1955). Sparse 
to abundant mudstone as thin lenses, small particles, and pebbles are interbedded with the sandstone in the thicker parts of the lenses. Lateral to the sandstone lenses, beds of mudstone and sandstone alternate and interfinger.

Elongate lenses of impure quartzose sandstone are the host rock of many of the uranium deposits of the Colorado Plateau and those in Mesozoic rocks marginal to the Black Hills. Arkosic sandstone is the host rock of many deposits in central and eastern Wyoming (Troyer, McKay, Soister, and Wallace, 1954; Love, 1954). Tuffaceous sandstone and waterlaid tuff are the host rocks of others in Wyoming, the Dakotas, Texas, Nevada, and California (Finch, this volume). Sandy graywacke is the host rock for a deposit in Pennsylvania (Klemic and Baker, 1954).

Deposits in some areas are near places where the rock is cemented with silica or silica and carbonate (U. S. Geol. Survey, 1954b, p. 64-67). Color of sandstone or differences in color of sandstone are features related to deposits in some areas. The host rock is a light yellowbrown in parts of the Colorado Plateau (Weir, 1952). A purplish-pink iron oxide stain envelops some deposits in the southern Black Hills, South Dakota (U. S. Geol, Survey, 1954b, p. 67). A fairly sharp boundary between pink and buff or gray sandstone is associated with deposits in northeastern Wyoming (U. S. Geol. Survey, 1954a, p. 119.)

The mudstone host rock of deposits is generally interbedded with uranium-bearing sandstone. Specific features of mudstone host rocks are less well known than those of sandstone host rocks because the deposits in mudstone are relatively few and mostly small.

The Todilto limestone in west-central New Mexico is the host rock of most of the uranium deposits in limestone of probable terrestrial origin (McKelvey, 1955), but thin beds of algal limestone in the Browns Park formation of Tertiary age contain some occurrences in south-central Wyoming (Love, 1953). The upper orebearing part of the Todilto limestone is a coarse-grained recrystallized rock characterized by small folds, crenulations, and crinkly distortion of the bedding (Ellsworth and Mirsky, 1952; Rapaport, 1952).

The ages of the host rocks of deposits of this general type range from Devonian to Pliocene (Finch, this volume; Klemic and Baker, 1954; Love, 1953), but deposits are most numerous in rocks of Triassic and Jurassic age in the region of the Colorado Plateau.

\section{LOCAIIZATION OF DEPOSITS}

The widespread distribution of uranium deposits in sandstones of different ages, but of many common characteristics, suggests that deposition was controlled most commonly by composition of the rock and by details of the stratigraphic relations among beds of different composition. Nearly all deposits are in sandstones composed of clay, volcanic debris, or feldspar in addition to quartz sand. Many deposits, but not all, are in parts of the rock that contain considerable carbonaceous plant remains (Weir, 1952; Stokes, 1954). Some ore-bearing sandstones, particularly in the Dakotas and Wyoming, are interbedded with carbonaceous shales; other ore-bearing sandstone, especially in central Utah, is rich in petroleum residues and carbonaceous pellets (Gott and Erickson, 1952).

In much of the Colorado Plateau, and to some extent in the Black Hills, the deposits are in channel-fill sandstones (Fischer, 1950; Stokes, 1954; U. S. Geol. Survey, 1954a, p. 105). In places on the Colorado Plateau and in the Black Hills the favored positions for deposits are the margins of channels where mudstone of the flood plains interfingers with sandstone of the channel (Wright, 1955, p. 145; U. S. Geol. Survey, 1954b, p. 66). The relation of deposits in Tertiary rocks to many local features of the stratigraphy are less clear, possibly because the rocks are less well explored.

Few of the uranium deposits in terrestrial rocks are related to obvious structural features. Most of them are in rocks that are flat lying or dip less than $10^{\circ}$. In west-central New Mexico, however, many of the deposits, without regard to the formation they are in, are alined along major fracture trends (Carlson, W. A., oral communication). In the southern part of the Black Hills deposits tend to be clustered on small structural terraces (U. S. Geol. Survey, 1954b, p. 66-67). Deposits in both terrestrial sedimentary rocks and older crystalline rocks in eastern Wyoming and the Dakotas are clustered near intersections of broad major structures of different directions or near axial parts of major basins (Osterwald, this volume).

Regardless of the precise features that control their localization, the deposits in many areas tend to oceur in clusters.

PRINCIPAL METALS AND MINERALOGY

Vanadium, copper, and iron are the most abundant metals accompanying uranium in most of the deposits in terrestrial rocks. Uranium deposits may be grouped into those in which uranium predominates over copper and vanadium, those in which vanadium predominates, and those in which copper predominates (Finch, this volume; Fischer, this volume). Deposits in which uranium is the predominant element are most numerous in rocks of Triassic age in some parts of the Colorado Plateau and in rocks of Tertiary age elsewhere. Those in wbich vanadium is predominant are most numerous in rocks of Jurassic age on the Colorado Plateau but also occur in rocks of Triassic age there, in Cretaceous rocks in the Black Hills area, S. Dak., and in Pennsylvanian rocks in Eastern United States. 
Most of those in which copper predominates are in rocks of Permian and Triassic age, principally in Arizona and Utah.

All three types of deposits are present in rocks of Triassic and older age; the copper-dominant type is rare in rocks of Jurassic and younger ages; and only uranium-dominant deposits are well represented in rocks of Tertiary age.

The minerals in the unoxidized protore of the copperdominant deposits include pitchblende and uraninite, accompanying iron and copper sulfides, sparse sphalerite, and galena. (Weeks and Thompson,1954). Montroseite also occurs in these ores where vanadium is present. In the vanadium-dominant deposits pitchblende, and locally coffinite, accompany montroseite and unidentified vanadium oxides. In the uraniumdominant deposits, pitchblende is accompanied by sparse sulfides of other metals, principally iron, and by montroseite where vanadium is present. The uranium ores in most areas other than the Colorado Plateau are oxidized. Pitchblende or uranirite has been identified from only two deposits in Wyoming (U. S. Geol. Survey, 1954 a, p. 119,278 ).

The uranium minerals in the oxidized ores are many and varied. In ores with abundant vanadium, the principal uranium minerals are carnotite or tyuyamunite, associated with a variety of other vanadates and high-valent oxides of vanadium. Where vanadium is scarce, the ore minerals include a wide variety of secondary hydrated oxides, silicates, carbonates, sulfates, phosphates, and arsenates of high-valent uranium that differ in amount from place to place. Secondary copper minerals are present in the ores containing copper. Hydroxides or sulfates of iron are present in most deposits.

\section{FORM, GRADE, AND SIZE OF DEPOSITS}

Most of the deposits in sandstone and mudstone are roughly tabular in shape and irregular in outline. Their longer dimensions are parallel to the bedding of the enclosing rocks (Fischer, 1950), and the longest dimension of many deposits is approximately alined with the Iong axes of the lenses in which they occur. In detail, many of the deposits cut across the beds. Some of the deposits are small, elongate, and of concretionary habit (Troyer, McKay, Soister, and Wallace, 1954). The upper and lower limits of most deposits are rather sharply defined. The lateral margins of some are sharp, but those of others are indistinct.

The deposits range from small masses only a few feet across to large masses a few thousand feet in maximum dimension. They are from 1 foot (the common minimum thickness mined) to about 20 feet thick. Deposits in the Todilto limestone tend to be relatively thicker than deposits in sandstone.
The grade of the ore in deposits being mined commonly ranges from 0.1 to 0.5 percent $\mathrm{U}_{3} \mathrm{O}_{8}$ (Butler, 1952), Smaller amounts of higher grade ore are present in some deposits.

The amount of ore in the deposits ranges from a few pounds to several million tons (Johnson, 1955). Between 90 and 95 percent of the deposits are less than 100,000 tons in size, and they contain only about onethird of the uranium in deposits in terrestrial sedimentary rocks. Deposits are largest and most numerous in the Shinarump conglomerate, Chinle formation, Todilto limestone, and Morrison formation, all of the Colorado Plateau region. These formations are of Mesozoic age. Some deposits that individually contain between 10,000 and 100,000 tons of ore are present in Cretaceous rocks in the Black Hills area, South Dakota and Wyoming, in Eocene rocks in central Wyoming and southern Texas, and in Miocene rocks in central Nevada. Deposits elsewhere in the United States are smaller.

\section{GENERAL COMPARISON OF DIFTERENT AREAS}

Uranium deposits in terrestrial sandstones of the United States are largest and most numerous on the Colorado Plateau, where deposits have been known for more than 50 years. Nearly all the deposits in other areas have been found within the last 4 years. Many areas of terrestrial rocks that appear to be favorable for deposits have been much less intensively prospected and explored than the Colorado Plateau region. It is likely, therefore, that other deposits will be discovered outside the Colorado Plateau, and that the deposits are even more widespread than now realized.

\section{URANIUM DEPOSITS IN COAL}

Some concentrations of uranium in impure coals and lignites in Western United States, and in carbonaceous shale adjacent to or interbedded with them, are comparable in size and grade to deposits of uranium in sandstones, Less uraniferous coals are present in the same areas as the uranium-rich coals and also in several other areas. Most of the extensive anthracite and bituminous coals of Paleozoic age in Eastern and Central United States, like coals in general (Rankama and Sahama, 1950; Russell, 1945, p. 1480), contain only traces of uranium (Gott, Wyant, and Beroni, 1952; Patterson, 1954, 1955).

The most uraniferous coals and lignites are beds of Paleocene age in the Fort Union formation in western North and South Dakota and in eastern Montana (U. S. Geol. Survey, 1954a, p. 149-155), beds of Cretaceous age in the Mesaverde formation in north-central New Mexico (Vine, this volume), and beds of Cretaceous age in southeastern Idaho (Vine and Moore, 
1952). Extensive, less uraniferous beds of Eocene age are present in the Wasatch formation in central Wyoming (U. S. Geol. Survey, 1954b, p. 117-118). Several other less extensive uraniferous coals are present elsewhere in the western States (Gott, Wyant, and Beroni, 1952).

The uraniferous western coals are lenticular beds that interfinger with mudstone, sandstone, and tuffaceous sandstone. Some of them are near uranium deposits in sandstone and mudstone. All of them are in areas where products of Tertiary volcanic activity are abundant and widespread. Some coals in North and South Dakota were unconformably overlain in pre-Oligocene time by these volcanic products (Gott, Wyant, and Beroni, 1952; Denson and Gill, this volume). In central Wyoming some uraniferous coals are enclosed by permeable rocks that crop out near such surfaces (U. S. Geol. Survey, 1953a, p. 139-141). In places where the coal beds have been truncated by erosion and are unconformable, the topmost bed of the sequence is generally most uraniferous, and uranium is generally preferentially concentrated in the upper part of the beds (Denson and Gill, this volume). Where the coal beds are enclosed in permeable rocks, uranium increases in the direction in which the enclosing rocks become more permeable and may be concentrated in either the upper or lower part of the bed (U. S. Geol. Survey, 1953a, p. 139-141). The distribution of uranium in the beds and the relation of some beds to superjacent materials rich in volcanic debris suggests that uranium in the coals was derived by leaching from the volcanic material and introduced into the coal by ground water (Denson and Gill, this volume; Miller and Gill, 1954).

However, uranium in silicified coal of Cretaceous age at the Old Leyden mine, east-central Colorado, may be related to Tertiary hydrothermal mineralization in the Front Range nearby (King, Leonard, Moore, and Pierson, 1953).

Meta-autunite is present locally in lignite in South Dakota, but uranium minerals have not been found in many of the uraniferous coals. Much of the uranium in coals appears to be held in several metallo-organic compounds similar in composition to humic acids (Breger, Duel, and Robinson, 1955).

Many of the western coals and lignites are uraniferous throughout areas of tens or hundreds of square miles. Richer parts of the beds, however, are much more local. Some bodies of uraniferous coal contain from 0.1 to 0.5 percent $\mathrm{U}_{3} \mathrm{O}_{8}$, and range in size from those containing tens of thousands of tons to those containing hundreds of thousands of tons of ore. The largest deposits are in South Dakota. Medium-sized deposits are present at La Ventana Mesa, central New Mexico, and small deposits are present in southeastern Idaho, in central Wyoming, and in east-central Colorado.

\section{URANIUM-BEARING PLACERS}

Most of the uranium in placer deposits is in relatively durable minerals, such as monazite and zircon, in which uranium is an extrinsic element. Most uranium minerals are too soft to survive transportation or too easily soluble to survive the weathering and disaggregation of their parent rocks. The principal areas of placers in the United States that contain abundant uraniferous minerals are in central Idaho and in western North and South Carolina (Mertie, 1953). Some placers in Idaho contain appreciable amounts of euxenite, samarskite, and fergusonite, and locally uranothorite, in addition to monazite and zircon (Mackin and Schmidt, 1953; U. S. Geol. Survey, 1954a, p. 205-207). Monazite and zircon are the principal uraniferous minerals in the placers in the Carolinas. The placers may be a source of uranium, but only to the extent that it can be recovered as a byproduct in the extraction of other metals for which the placer minerals are mined.

\section{URANIUM IN EVAPORITES}

Most terrestrial evaporites do not contain appreciable amounts of uranium (Bell, this volume) but scattered patches of tyuyamunite occur in caliche in Quaternary alluvium in southeastern Nevada (Lovering, 1954) and schroeckingerite forms caliche-like blebs and flakes in shale and sandstone in the Green River formation of Eocene age in south-central Wyoming (Wyant, Beroni, and Granger, 1952) Neither of these deposits is commercially significant.

\section{URANIFEROUS MARINE SEDIMENTARY ROCKS}

Uranium is appreciably concentrated in some marine carbonaceous shales and in most marine phosphate rocks. Such rocks contain 0.005 to 0.02 percent $\mathrm{U}_{3} \mathrm{O}_{8}$ (McKelvey and Nelson, 1950). Residual phosphate deposits, such as those in Tennessee which are derived from the weathering of phosphatic limestone, are only weakly uraniferous.

Uranium is distributed relatively uniformly in marine black shales and phosphatic rocks throughout areas of hundreds to thousands of square miles in the United States.

\section{BLACK SHALES}

Most of the appreciably uraniferous carbonaceous black shales in the United States are distributed from the western limit of the Appalachian Mountains in Virginia, Kentucky, Tennessee, and Alabama nearly to to the eastern front of the Rocky Mountains in Wyoming. All are of Paleozoic age (McKelvery and Nelson, 1950). Other weakly uraniferous shales are known farther west (Duncan, 1953). 
In general, the uraniferous black shales contain abundant plant matter, are relatively rich in iron sulphides, are noncalcareous, and some are phosphatic. Uranium minerals are absent.

The Chattanooga shale of late Devonian and early Mississippian age is the most widespread uraniferous black shale in the United States. In Tennessee, where it is most uraniferous, it consists of interbedded black shale and gray claystone. It contains abundant organic matter and some pyrite (Swanson, this volume). The upper 12 to 16 feet of the shale are richest in uranium in east-central Tennessee and contain between 0.006 and 0.007 percent $\mathrm{U}_{3} \mathrm{O}_{8}$, but the shale is uraniferous throughout most of its extent.

Some beds of black shale in the Pennsylvanian sequence of sedimentary rocks in eastern Kansas and adjoining parts of Missouri and Oklahoma that are 2 to 3 feet thick, such as beds in the Hushpuckney member of Moore $(1932$, p. $85,90,97)$ of the Swope limestone of Dunbar and Condra (1932, p. 17, table C) and beds in the Cherokee shale, contain from 0.009 to 0.013 percent $\mathrm{U}_{3} \mathrm{O}_{8}$ (Swanson, this volume). Some of these shales also contain scattered uraniferous phosphatic nodules. Other thin beds of black shale in the Hartville formation of Mississippian(?), Pennsylvanian, and Permian age, known only from samples obtained in oil test wells in eastern Wyoming, contrin 0.005 to 0.02 percent $\mathrm{U}_{3} \mathrm{O}_{8}$ (Duncan, 1953). Most of the correlatives of the Chattanooga shale in Central and Eastern United States are less uraniferous than the Chattanooga shale in Tennessee. In general, many other shales that have been examined either contain less uranium or are thinner and less persistent than those mentioned (Duncan, 1953).

Black shales in the United States are not rich enough in uranium to be a present source of that metal, even though the total amount of uranium in them is tremendous.

\section{PHOSPHATIC ROCKS}

The largest bodies of uraniferous phosphatic rock in the United States are in the Phosphoria formation of Permian age in southeastern Idaho and adjacent parts of Montana, Wyoming, and Utah, and in the Bone Valley formation of Pliocene age in central Florida (fig. 1). Both formations are important sources of high-grade phosphate rocks (McKelvey, Cathcart, Altschuler, and others, 1953). Other smaller deposits, similar to those in the Bone Valley, are present in South Carolina; and phosphatic nodules in some of the black shales of Pennsylvanian age in eastern Kansas and Oklahoma are as uraniferous as the large bodies of phosphatic rock, but make up only a small proportion of the shales (MeKelvey and Nelson, 1950; Runnels, Schleicher, and Van Nortwick, 1953). Uranium in major deposits of phosphatic rock is mainly in the mineral carbonate-fluorapatite (U. S. Geol. Survey, 1954b, p. 157-160).

The Phosphoria formation and its stratigraphic equivalents underlie an area of about 135,000 square miles. It has a thinner platform facies on the east and a thicker geosynclinal facies on the west. The richest phosphate beds are in two phosphatic shale members of the formation in the tightly folded and faulted geosynclinal facies.

In general, the beds richer in phosphate are richer in uranium (McKelvey and Nelson, 1950). Phosphate rock of minable width containing at least 30 percent $\mathrm{P}_{2} \mathrm{O}_{5}$ and 0.007 to 0.03 percent $\mathrm{U}_{3} \mathrm{O}_{8}$, much of it deeply buried, amounts to a few billion $\left(10^{9}\right)$ tons (McKelvey, V. E., written communication).

The largest deposits of phosphatic rock in the Floridian part of the East Gulf Coastal Plain are the landpebble deposits. "Hardrock" deposits of phosphatized limestone in north-central Florida are Iess uraniferous than the land-pebble deposits. Small areas of riverpebble deposits fall within areas of the land-pebble deposits. The land-pebble deposits are mostly in the Bone Valley formation, and underlie an area of about 1,000 square miles in central Florida (Mansfield, 1942).

The Bone Valley formation consists of a lower unit that is composed of phosphatic silt, sand, and gravel, quartz sand, and clay, and an upper unit that is composed mainly of elayey sand (Catheart, Blade, Davidson, and Ketner, 1953). Some of the material in the lower part of the formation is a weathered residuum of the underlying Hawthorn formation, and some of it is the product of marine reworking of the residual mantle. Parts of both units have been exposed to long periods of weathering. Weathering of the lower unit has produced a "leached-zone" in which the rock is characterized by the presence of aluminum phosphate minerals (Altschuler, Jaffe, and Cuttitta, 1955, this volume).

The unweathered part of the lower unit and some of the residuum of the Hawthorn formation are mined for phosphate. This rock contains about 0.008 percent $\mathrm{U}_{3} \mathrm{O}_{8}$ (Catheart, this volume). About one-third of the rock mined is recovered as phosphate products which contain from 0.005 to 0.025 percent $\mathrm{U}_{3} \mathrm{O}_{8}$. The uranium content differs from place to place depending on the composition of the rock mined and the size of the phosphatic particles in it.

The "leached" rock developed from the phosphatic lower unit of the formation is slightly richer in uranium than the unweathered part and contains about 0.012 percent $\mathrm{U}_{3} \mathrm{O}_{8}$ and about 10 percent $\mathrm{P}_{2} \mathrm{O}_{5}$ (Cathcart, this volume). Most of the uranium is concentrated in the aluminum phosphate minerals. 
The volume of recoverable phosphate products in unweathered calcium phosphate rock and the volume of the aluminum phosphate rock derived by weathering are large and amount to about 1 billion $\left(10^{9}\right)$ tons each (Cathcart, J. B., written communication). Some uranium is extracted from the recovered phosphate products of the calcium phosphate zone as a byproduct of the manufacture of phosphate fertilizer (U. S. Atomic Energy Comm., 1954). The utility of the "leached" rock as a source of uranium depends on the feasibility of treating it to recover phosphate and alumina.

\section{URANIUM IN ASPHALTITES}

Uraniferous asphaltlike materials occur in upper Paleozoic and Mesozoic rocks over a wide area from Oklahoma and Texas west to Utah (Erickson, Myers, and Horr, 1954; Pierce, A. P., 1955, oral communication). Only in central Utah are such materials sufficiently concentrated to be a significant component of the uranium deposits in sandstone (Gott and Erickson, 1952).

Uranium-bearing asphaltlike materials form sparsely distributed pellets, stylolite fillings, or fracture fillings, or are disseminated through the pore spaces of some rocks. The uranium is generally distributed evenly through these materials. It is usually accompanied by variable concentrations of other elements of which arsenic, nickel, cobalt, vanadium, copper, and iron are the most common (Gott, G. B., 1955, oral communication). The uranium and other metals appear to be held, in part, in a metallo-organic compound (Gott and Erickson, 1952; Erickson and others, 1954).

The relation between the occurrence of uraniferous asphaltlike materials and petroleum and the manner in which some of them occur suggests that they may represent a residual "surface active" derivative of petroleum (Pierce, A. P., 1955, oral communication). Other asphaltlike substances may represent a liquid, or semiliquid derivative of lignitic materials (U. S. Geol. Survey, 1954a, p. 174).

\section{URANIUM IN NATURAL WATERS}

All ground and surface waters carry some uranium in solution and natural waters in the United States commonly contain about $0.0001 \mathrm{ppm}$ (0.1 part per billion) (Fix, this volume). Some waters close to and draining directly from rocks in which there are uranium deposits, such as effluent mine waters, contain as much as several thousand times this amount. In many areas a content of more than $0.001 \mathrm{ppm}$ in surface waters is sufficiently anomalous to suggest a local concentration of uranium at some place within the drainage basin. In other areas, such as the Colorado Plateau, where uranium deposits are numerous and widespread, however, the minimum con- centration of uranium in surface water that might indicate an anomalous concentration of uranium in the rocks nearby is several times $0.001 \mathrm{ppm}$.

The amount of uranium in ground water coming from some Tertiary sedimentary rocks that contain considerable volcanic debris but no local concentrations of uranium is greater than that in ground water issuing from underlying unmineralized rocks of Eocene and Cretaceous ages in the same areas, but it is less than that in ground water issuing from such underlying rocks in the vicinity of uranium deposits (Denson, Zeller, and Stephens, this volume). These data suggest that it is possible to establish criteria for determining anomalous amounts of uranium in water, that the minimum values of anomalies differ in keeping with differences in geologic environment, and that such anomalies are significant clues to areas favorable for uranium deposits.

\section{SUMMARY AND CONCLUSIONS}

No igneous rocks other than a few pegmatites have a sufficient concentration of uranium in a distinct though disseminated mineral phase to be a submarginal source of uranium.

Nearly all the vein and related deposits worked for uranium are of post-Jurassic age and are probably of Tertiary age. Most of them are closely associated with felsic intrusive or volcanic rocks of Tertiary age. Other than the deposits at Marysvale, few are large. The largest deposits are fluorite bearing. Although some deposits are in the same small areas from which ores of other metals have been mined, most of the better deposits are not closely associated with deposits of other metals.

The largest deposits of uranium in the United States are in impure sandstone and other terrestrial sedimentary rocks. All of the very large deposits are in rocks of Mesozoic age, but many recently discovered deposits, some of medium size, are in rocks of Tertiary age. Most of these are in or closely underlie rocks that have abundant felsic volcanic debris. The areas of Tertiary rocks in Western United States are large and have not been prospected and explored for as long and as intensively as the Colorado Plateau region.

Widespread uraniferous coals and lignites have been known in Western United States for a number of years. The discovery of commercial deposits in them during the last year suggests that they, too, are a promising environment for uranium deposits.

Some marine phosphatic rocks and black shales are very large low-grade deposits of uranium, but only the phosphate deposits are presently a source of uranium. 
Not only are most of the uranium deposits in the western third of the United States, but 90 percent of the minable deposits, regardless of their particular mode of occurrence, are in a vaguely defined belt from 300 to 450 miles wide and 1,100 miles long that trends northeasterly from southern Arizona at least to western North Dakota. Whether this distribution is simply a matter of chance of discovery or the result of still obscure geologic causes is still a conjecture.

\section{REFERENCES CITED}

Adams, J. A. S., 1954, Uranium and thorium contents of voleanic rocks, in Faui, Henry, ed, Nuclear geology: New York, John Wiley and Sons, Inc., p. 89-98.

Adams, J. W., Gude, A. J., 3d, and Beroni, E. P., 1953, Uranium occurrences in the Golden Gate Canyon and Ralston Creek areas, Jefferson County, Colo.: U. S. Geol. Survey Circ. $320,16 \mathrm{p}$.

Becraft, G. E., 1953, Preliminary report on the Comet area, Jefferson County, Mont.: U. S. Geol. Survey Circ. 277, 8 p.

Benson, W. E., Trites, A. F., Jr., Beroni, E. P., and Feeger, J. A., 1952, Preliminary report on the White Canyon area, San Juan County, Utah: U. S. Geol. Survey Circ. 217, 10 p.

Breger, I. A., Deul, Maurice, and Rubinstein, Samuel, 1955, Geochemistry and mineralogy of a uraniferous lignite: Econ. Geology, v. 50, p. 206-226.

Brown, Harrison, Blake, W. J,, and others, 1953, Leaching studies of interstitial materials in igneous rocks [abs.]: Geol. Soc, America Bull., v. 64, p. 1400-1401.

Brown, J. S., Emery, J. A., and Meyer, P. A., Jr., 1954, Explosion pipe in test well on Hicks Dome, Hardin County, Ill.; Econ. Geology, v. 49, p. 891-902.

Butler, A. P., Jr., 1952, The Geological Survey's work on the geology of uranium and thorium deposits: U. S. Geol. Survey TEI-207, 26 p., issued by U. S. Atomic Energy Comm. Tech. Inf. Service, Oak Ridge, Tenn.

Catheart, J. B., Blade, L. V., Davidson, D. F., and Ketner, K. B, 1953, The geology of the Florida land-pebble phosphate deposits: 19th Internat. Geol. Cong., Comptes rendus, v. 11, p. $77-91$

Davidson, C. F. Distribution of radioactivity: Mining Mag. (London) v. 85, p. $329-340$.

Dunbar, C. O., and Condra, G. E., 1932, Brachiopoda of the Pennsylvanian system in Nebraska: Nebr. Geol. Survey 2d ser. Bull. $5,377 \mathrm{p}$.

Duncan, D. C. [Compiler], 1953, Reconnaissance investigations for uranium in black shale deposits of the Western States during 1951 and 1952: U, S. Geol. Survey TEI-381, 87 p., issued by U. S. Atomic Energy Comm. Tech. Inf. Service, Oak Ridge, Tenn.

Ellsworth, P. C., and Mirsky, A., 1952, Preliminary report on relation of structure to uranium mineralization in the Todilto limestone, Grants district, N. Mex.: U. S. Atomic Energy Comm. RME-4020, 15 p., issued by U. S. Atomic Energy Comm. Tech Inf. Service, Oak Ridge, Tenn.

Erickson, R. L., Myers, A. T., and Horr, C. A, 1954, The association of uranium and other metals with crude oil, asphalt, and petroliferous rock: Am. Assoc. Petroleum Geologists Bull., v. 38, p. 2200-2218; [abs.] 1953, Geol. Soc. America Bull., v. 64 , p. 1505.

Everhart, D. L., and Wright, R. J., 1953, The geologic character of typical pitchblende veins: Econ. Geology, v. 48, p. 77-96.
Fischer, R. P., 1950, Uranium-bearing sandstone deposits of the Colorado Plateau: Econ. Geology, v. 45, p. 1-11.

Frondel, J. W., and Fleiseher, Michael, 1955, Glossary of uranium- and thorium-bearing minerals, 3d ed.: U. S. Geol. Survey Bull. 1009-F, p. 169-206.

Gillerman, Elliot, 1952, Uranium deposits of the White Signal district, N. Mex. [abs.]: Geol. Soc. America Bull., v. 63, p. 1329 .

Goldschmidt, V. M., 1937, Geochemisehe Verteilungsgesteze der Elemente, IX, Die Mengenverhältnisse der Elemente und der Atom-Arten: Norske Videnskaps-Akad. (Oslo) Skrifter, I. Mat.-naturv, Kl., no. 4, 148 p. [1938]

Gott, G. B., and Erickson, R. L., 1952, Reconnaissance of uranium and copper deposits in parts of New Mexico, Colorado, Utah, Idaho, and Wyoming: U. S. Geol. Survey Circ. 219, $16 \mathrm{p}$.

Gott, G. B., Wyant, D. G, and Beroni, E. P., 1952, Uranium in black shales, lignites, and limestones in the United States: U. S. Geol. Survey Circ. 220 p. 31-35.

Hurley, P. M. 1950, Distribution of radioactivity in granites and possible relation to helium age measurement: Geol. Soc. America Bull., v. 61, p. 1-7.

Ingham, W. N., and Keevil, N. B., 1951, Radioactivity of the Bourlamaque, Elzevir, and Cheddar batholiths, Canada: Geol. Soc. America Bull., v. 62, p. 131-148.

Johnson, J. C., 1955, Uranium resources for industrial power: Address before a joint meeting of the Atomic Industrial Forum and the Stanford Research Institute, San Francisco, Calif. (Summary, 1955, in Eng. and Min. Jour. v. 156 , no. 5 , p. 75 .)

Kaiser, E. P., and Page, L. R., 1952, Distribution of uranium deposits in the United States: U. S. Geol. Survey Circ. 220 , p. $1-7$.

Kerr, P. F., 1952, Pre-Cambrian uranínite, Sunshine Mine, Idaho: Science, v. 115 , p. $86-88$.

Kerr, P. F., and Robinson, R. F., 1953, Uranium mineralization in the Sunshine Mine, Idaho: Min. Eng., v. 5, p. 495-511.

King, R. U., Leonard, B. F., Moore, F. B., and Pierson, C. T., 1953, Uranium in the metal-mining districts of Colorado: U. S. Geol, Survey Circ. 215, 10 p.

King, R. U., Moore, F. B., and Hinrichs, E. N., 1952, Pitchblende deposits in the United States: U. S. Geol. Survey Circ. 220 , p. 8-12.

Klemic, Harry, and Baker, R. C., 1954, Occurrences of uranium in Carbon County, Pa.: U. S. Geol. Survey Circ. 350, 8 p.

Larsen, E. S., Jr., and Phair, George, 1954, The distribution. of uranium and thorium in igneous rocks, in Faul, Henry, ed., Nuclear geology: New York, John Wiley and Sons, Ine., p. $75-89$.

Leonard, B, F, 1952, Relation of pitchblende deposits to hypogene zoning in the Front Range mineral belt, Colorado [abs.]: Econ. Geology, v. 47, p. 773; Geol. Soc. America Bull; v. 63, p. 1274-1275.

Love, J. D., 1954, Preliminary report on uranium in the Gas Hills area, Fremont and Natrona Counties, Wyo:: U. S. Geol. Survey Circ. 352, 11 p.

Love, J. D., 1953, Preliminary report on uranium deposits of the Miller Hill area, Carbon County, Wyo.: U. S. Geol. Survey Circ. 278, 10 p.

Lovering, T. G., 1954, Radioactive deposits of Nevada: U. S. Geol. Survey Bull, 1009-C, p, 63-104.

Lovering, T. S., and Goddard, E. N., 1950, Geology and ore deposits of the Front Range, Colo.: U. S. Geol. Survey Prof. Paper 223, 319 p. [1951] 
Mackin, J. H., and Schmidt, D. L., 1953, Placer deposits of radioactive minerals in Valley County, Idaho [abs.]: Geol. Soc. America Bull., v. 64, p. 1549.

Mansfield, G. R., 1942, Phosphate resources of Florida: U. S. Geol. Survey Bull. 934, 82 p. [1943]

McKelvey, V. E., 1955, Search for uranium in the United States: U. S. Geol. Survey Bull. 1030-A, p. 1-60.

McKelvey, V. E., Catheart, J. B., Altschuler, Z. S., and others, 1953, Domestic phosphate deposits, in Pierre, W. H., and Norman, A. G., ed., Soil and fertilizer phosphorus in erop nutrition, v. 4, ch. 11, p. 347-376, of Agronomy (a series of monographs prepared under auspices Am. Soc. Agronomy): New York, Academic Press, Inc.

McKelvey, V. E., and Nelson, J. M., 1950, Characteristies of marine uranium-bearing sedimentary rocks: Econ. Geology, v. 45, p. $35-53$.

Mertie, J. B., Jr., 1953, Monazite deposits of the Southeastern Atlantic States: U. S. Geol. Survey Circ. 237, 31 p.

Miller, L. J., 1955, Uranium ore controls of the Happy Jack deposit, White Canyon, San Juan County, Utah: Econ. Geology, v. 50, p. 156-169.

Miller, R. L., and Gill, J. R., 1954, Uranium from coal: Sci, Am., v. 191 , No. 4 , p. $36-39$.

Moore, R. C., 1932, A reclassification of the Pennsylvanian system in the northern Midcontinent region: Kans. Geol, Soe. Guidebook, 6th Ann. Field Conf., p. 79-98.

Page, L. R., 1950, Uranium in pegmatites: Econ. Geology, v. 45, p. $12-34$.

Patterson, E. D., 1954, Radioactivity of part of the bituminous coal region of Pennsylvania: U. S. Geol. Survey TEI-479, 44 p., issued by U. S. Atomic Energy Comm., Tech. Inf. Service, Oak Ridge, Tenn.

1955, Radioactive coal and shale of Pennsylvanian and Permian Age in northern West Virginia: U. S. Geol. Survey TEI-494, to be issued by U. S. Atomic Energy Comm. Tech. Inf. Service, Oak Ridge, Tenn.

Phair, George, 1952, Radioactive Tertiary porphyries in the Central City district, Colorado, and their bearing upon pitchblende deposition: U. S. Geol. Survey TEI-247, 53 p., issued by U. S. Atomic Energy Comm. Teeh. Inf. Service, Oak Ridge, Tenn.

Rankama, K., and Sahama, T. G, 1950, Geochemistry: Chicago, Univ. Chicago Press, 912 p.

Rapaport, Irving, 1952, Interim report on the ore deposits of the Grants district, N. Mex.: U. S. Atomic Energy Comm. RMO-1031, 19 p., issued by U. S. Atomic Energy Comm. Tech. Inf. Service, Oak Ridge, Tenn.

Runnels, R. T., Schleicher, J. A., and Van Nortwick, H. S., 1953, Composition of some uranium-bearing phosphate nodules from Kansas shales: Kans. Geol. Survey Bull, 102, pt. 3, p. 93-104.

Russell, W. L., 1945, Relation of radioactivity, organic content, and sedimentation: Am. Assoc. Petroleum Geologists Bull. v. 29 , p. $1470-1493$.

Schneiderböhn, H., 1934, Die Ausnutzungsmöglichkeiten der deutschen Erzlagerstätten: Metallwirtschaft v. 13, p. 151-157.

Sims, P. K., and Phair, George, 1953, Some features of the pitchblende deposits at the Copper King mine, Larimer County, Colo. [abs.]: Geol. Soc. Ameriea Bull. v. 64, p. 1555-1556.

Slack, H. A., and Whitham, K., 1951, A further investigation of the radioactivity of the Round Lake and Elzevir batholiths: Am. Geophys. Union Trans. v. 32, p. 44-48.
Stokes, W. L., 1954, Relation of sedimentary trends, tectonic features, and ore deposits in the Blanding District, San Juan County, Utah: Technical Report for April 1, 1953 to March 31, 1954, part 1, U. S. Atomic Energy Comm. RME-3093, 33 p., issued by U. S. Atomic Energy Comm. Tech. Inf. Service, Oak Ridge, Tenn.

Taylor, A. O., Anderson, T. P., O'Toole, W. L., and others, 1951, Geology and uranium deposits of Marysvale, Utah, Interim report on the producing area: U. S. Atomic Energy Comm. RMO-896, 30 p., issued by U. S. Atomic Energy Comm. Tech. Inf. Service, Oak Ridge, Tenn.

Thurlow, E. E., and Wright, R. J., 1950, Uraninite in the Coeur d'Alene district, Idaho: Econ. Geology, v. 45, p. 395-404.

Troyer, M. L., McKay, E. J., Soister, P. E., and Wallace, S. R., 1954, Summary of investigations of uranium deposits in the Pumpkin Buttes area, Johnson and Campbell Counties, Wyo.: U. S. Geol. Survey Circ. 338, 17 p.

U. S. Atomic Energy Commission, 1954, Sixteenth Semiannual Report: Washington, U. S. Govt. Printing Office.

U. S. Geological Survey, 1953a, Geologic investigations of radioactive deposits, Semiannual progress report June 1-Nov. 30, 1953: U. S. Geol. Survey TEI-390, 281 p., issued by U. S. Atomic Energy Comm. Tech. Inf. Service, Oak Ridge, Tenn.

- 1953b, Search for and geology of radioactive deposits, Semiannual progress report Dec. 1, 1952-May 31, 1953: U. S. Geol. Survey TEI-330, 302 p. issued by U. S. Atomic Energy Comm. Tech. Inf. Service, Oak Ridge, Tenn.

1954a, Geologic investigations of radioactive deposits, Semiannual progress report, June 1 to Nov. 30, 1954: U. S. Geol. Survey TEI-490, 299 p., issued by U. S. Atomic Energy Comm. Tech. Inf. Service, Oak Ridge, Tenn.

- 1954b, Geologic investigations of radioactive deposits, Semiannual Progress Report, Dec. 1, 1953 to May 31, 1954: U. S. Geol. Survey TEI-440, 247 p., issued by U. S. Atomic Energy Comm. Tech. Inf. Service, Oak Ridge, Tenn.

- 1955, Geologic investigations of radioactive deposits, Semiannual progress report, Dec. 1, 1954 to May 31, 1955: U. S. Geol. Survey TEI-540, 284 p., issued by U. S. Atomic Energy Comm. Tech. Inf, Service, Oak Ridge, Tenn.

Vine, J. D., and Moore, G. W., 1952, Uranium-bearing cosl and carbonaceous rocks in the Fall Creek area, Bonneville County, Idaho: U. S. Geol. Survey Circ. 212, 10 p.

Weeks, A. D., and Thompson, M. E., 1954, Identification and occurrence of uranium and vanadium minerals from the Colorado Plateau: U. S. Geol. Survey Bull, 1009-B, p. 13-62.

Weir, D. B., 1952, Geologic guides to prospecting for earnotite deposits on the Colorado Plateau: U. S. Geol. Survey Bull. 988-B, p. 15-27.

Wilmarth, V. R., Bauer, H. L., Jr., Staatz, M. H., and Wyant, D. G., 1952, Uranium in fluorite deposits: U. S. Geol. Survey Circ. 220, p. 13-18.

Wilmarth, V. R., and Johnson, D. H., 1954, Uranophane at Silver Cliff mine, Lusk, Wyo.: U. S. Geol. Survey Bull. 1009-A, p. 1-12.

Witkind, I. J., 1954, Localization of uranium minerals in channel sediments at the base of the Shinarump conglomerate, Monument Valley, Ariz. [abs.]: Geol. Soc. America Bull, v. 65 , p. 1327.

Wright, R. J., 1955, Ore controls in sandstone uranium deposits of the Colorado Plateau: Econ. Geology, v. 50, p. 135-155.

Wyant, D. G., Beroni, E. P., and Granger, H. C., 1952, Some uranium deposits in sandstone: U. S. Geol. Survey Circ. 220 , p. $26-35$. 


\title{
SUMMARY OF HYPOTHESES OF GENESIS OF URANIUM DEPOSITS
}

\author{
By Vincent E. McKelvey, U. S. Geological Survey, Donald J. Everhart, U.S. Atomic Energy Commission, \\ and Robert M. Garrels, U. S. Geological Survey \\ CONTENTS

\begin{tabular}{|c|c|c|}
\hline & Page & \\
\hline ntroduction. & 41 & Uraniferous black shale _............... \\
\hline rous igneous rocks, pegmatites, and migmatites. & 42 & Uraniferous marine phosphorites... \\
\hline al vein and replacement deposit & 43 & Conclusions_.......................... \\
\hline
\end{tabular}

\section{ABSTRACT}

The distribution of uranium in igneous roeks and veins is explained by Larsen and Phair as a function of the size, valence, and abundance of the uranium ion and of equilibrium between oxidation and reduction. Because of the low concentration of uranium in basic magmas and the large size and tetravalence of the uranium ion, it neither precipitates as a separate mineral nor isomorphously substitutes in plagioclase and other rock-forming minerals. Hence, it concentrates in silicic magmas from which it may be deposited as a minor constituent of accessory minerals in which it ean substitute isomorphously. More uranium is deposited as discrete minerals and less enters the accessory minerals as differentiation proceeds toward the highly hydrous pegmatite stage, probably because increase in the water content of the magma reduces the solubility of tetravalent uranium compounds. During very late magmatic stages the uranium is oxidized to the hexavalent state, which forms relatively soluble compounds in aqueous solutions and is carried off in hydrothermal solutions. Deposition of uranium in veins takes place when eonditions once again become reducing, a conclusion in accord with the facts that the common vein mineral is pitchblende, the one richest in low-valent uranium, and that sulfides are a constant component of pitchblende veins.

The uranium deposits in sandstones resemble those in veins in their mineral assemblage except that many sandstone deposits also contain vanadium, a metal not abundant in most veins. Isotopic studies by Stieff and Stern show that the Colorado Plateau deposits are epigenetic and that the uranium probably came from a deep-seated source. It is possible, however, that the uranium was derived from volcanic ash or other dispersed sources within the sedimentary pile and transported to the site of deposition by circulating waters or petroleum. Whatever the source, the path the ore solutions followed in the sandstones was determined mainly by sedimentary structures, and the precipitation of uranium likely is brought about by reduction, perhaps related to decaying organic matter.

Denson and others have shown that the uranium in many coals and associated carbonaceous shales came from devitrifying volcanic ash, though in others it may have come from the weathering of igneous rocks or from hydrothermal solutions.
Probably the uranium was chemically adsorbed by humates and other organie compounds from solutions migrating through adjacent permeable beds.

Uranium in marine black shales and phosphorites was deriyed from sea water. The precipitation of uranium in the shales probably came about by chemical adsorption by living or dead plankton. Its retention in the shale, however, and possibly its precipitation were related to the reducing conditions of the environment. Precipitation of uranium in the phosphorites took place by chemical adsorption by apatite. Laboratory observations by Neuman and others, together with field relations, show that this process is hindered by abundance of calcium ions, with which uranium competes for structure positions, and by carbonate and hydroxyl ions, which compete with phosphate groups for structure positions and form less stable compounds with uranium.

\section{INTRODUCTION}

Concentrations of uranium more than 10 times the average of the earth's crust, or more than 0.002 percent uranium, are formed by a variety of igneous and sedimentary rock-forming processes, as well as by ore-forming processes as they are ordinarily conceived. The nearly ubiquitous geologic distribution of uranium stems, of course, from its chemical and physical properties, particularly its polyvalence, its large atomic radius, its high chemical reactivity, the relative solubility of many of its hexavalent compounds in aqueous solutions, and its relative abundance compared to some other ore metals. These attributes permit it to form compounds with many other elements, to enter the structure of a wide variety of minerals, to take part in many chemical reactions, and hence to be deposited in many rocks and minerals of diverse origins and compositions. The same properties that lead to the wide geologie distribution of uranium also lead to its dispersion so that concentrations of uranium are not so 
great as those of other, less active metals of comparable abundance, such as lead and molybdenum. The partition of uranium from other elements and then its concentration in valuable deposits seem to be favored by its large radius and high valence, which prevent its concentration in ordinary rock-forming minerals; also, the relative insolubility of its common tetravalent compounds in aqueous solutions leads to the precipitation of uranium in a wide variety of environments where reducing conditions prevail.

In the synopsis that follows, attention is focused on the origin of deposits that are currently and potentially most important economically - specifically, the uraniferous igneous rocks, the hydrothermal veins, the uranium deposits in sandstones, uraniferous coals and associated carbonaceous shales, uraniferous marine black shales, and uraniferous marine phosphorites. Moreover, we give most consideration to those hypotheses which seem most tenable to us.

\section{URANIFEROUS IGNEOUS ROCKS, PEGMATITES, AND MIGMATITES}

The uranium content of igneous rocks is about 0.03 parts per million in ultramafic rocks, $1 \mathrm{ppm}$ in gabbroic rocks, $2 \mathrm{ppm}$ in intermediate rocks, 3 to $4 \mathrm{ppm}$ in granitic rocks, and reaches a maximum of 10 to $200 \mathrm{ppm}$ in a few alkalio granites (Larsen and Phair, 1954, p. 75, $77,87)$. The unmistakable enrichment of uranium in intrusive rocks rich in silica and alkalies is observable also in volcanic rocks (Adams, 1954, p. 94). Some silica-poor rocks, such as lamprophyres, are also relatively rich in uranium, however; Larsen and Phair (p. 86) believe that "the safest generalization that can be made at this time is that the maximum concentration of uranium and thorium is found in the youngest member of a series, regardless of the particular liquid line of descent that the magma may have followed."

The uranium and thorium fractionation in igneous rocks is explained by Larsen and Phair (1954, p. 88-89) as a function of the size, valence, and abundance of the uranium ion and of equilibrium between oxidation and reduction. Because uranium is of a low concentration in basic magmas and because the large size and tetravalence of the uranium ion impose hard-to-meet coordination requirements, uranium neither precipitates as a separate mineral nor isomorphously substitutes in plagioclase and other rock-forming minerals. Hence it concentrates in late-stage magmas from which it may be deposited as a minor constituent of accessory minerals (such as zircon, xenotime, apatite, and sphene) in which it can substitute isomorphously. As differentiation proceeds toward the highly hydrous pegmatite stage, more uranium is deposited as discrete minerals and less enters the accessory minerals, probably be- cause increase in the water content of the magma reduces the solubility of tetravalent uranium. During very late magmatic stages, uranium may be oxidized to the hexavalent state, possibly as a consequence of pressure changes. This shift from reduction to oxidation is shown by the replacement of early formed ferrous magnesium silicates by magnetite. In the hexavalent state uranium forms relatively soluble compounds in aqueous solutions. Some may be deposited as acid-soluble, interstitial material (Hurley, 1950, Picciotto, 1950; Brown, Blake, Chodas, and others, 1953) from residual solutions, but much of the uranium is carried off in hydrothermal solutions. Deposition of uranium in veins takes place when conditions once again become reducing, a conclusion in accord with the facts that the common vein mineral is pitchblende and that sulfides are a constant component of pitchblende veins. Because thorium occurs only in the tetravalent state it is not affected by a change to oxidizing conditions and is probably not transported with uranium in hydrothermal solutions. This hypothesis explains the absence of thorium in pitchblende veins - a previously puzzling phenomenon in view of the rather constant $3: 1$ ratio of thorium and uranium in igneous rocks (Larsen and Phair, 1954, p. 77; Adams, 1954, p. 97).

Pegmatites contain a wide variety of uranium minerals, including uraninite as well as many multiple oxides containing rare earths, niobium, tantalum, and titanium. According to Page (1950, p. 33), uranium minerals appear to be commonest in those bodies that contain an abundance of potash feldspar; in zoned pegmatites they are most common in intermediate zones and cores also rich in potash. The covariation of uranium with potash has also been noted in igneous rocks (Larsen and Phair, 1954, p. 88) and is explained by Adams (1954, p. 94) as a reflection of the exclusion of these two elements (because of their radic and coordination numbers) from common minerals formed during earlier stages of crystallization. Zonation of pegmatites is now believed to result from fractional crystallization of the pegmatite liquid from the walls inward (Page, 1950, p. 22); so, the zonal distribution of uranium in pegmatites also demonstrates its tendency to concentrate in late-stage liquids. Some pegmatites or units within pegmatite, particularly those that contain uraninite, minor amounts of sulfides, and no thorium, are somewhat veinlike in character and may have formed as a result of replacement by or direct deposition from high-temperature hydrothermal solutions.

Certain migmatites in Canada that are composed of thin, parallel bands of granite pegmatite, and biotitebearing schist or gneiss, contain uraninite or uranothorite (Lang, A. H., 1952 , p. 15). The origin of 
migmatites in general is controversial: they may have been formed as a result of partial fusion of sedimentary rocks, by injection of granitic material, or by replacement from high-temperature hydrothermal solutions. The origin of the uranium-bearing migmatites has been little studied, but, as Adams (1954, p. 98) implies, analysis of their uranium: thorium ratios might show whether they have been derived from primary igneous sources or from partial fusion of sedimentary rocks. In any event, the uranium in migmatites was deposited at high temperatures.

\section{URANIUM IN HYDROTHERMAL VEIN AND REPLACE- MENT DEPOSITS}

Three important types of uraniferous veins have been recognized (Everhart and Wright, 1953): nickel-cobaltnative silver veins, silica-iron-lead veins, and irontitanium veins. The nickel-cobalt-native silver veins are characterized by pitchblende, a complex assemblage of sulfides, carbonates, and minor amounts of silica; they occur typically in metasedimentary and metavolcanic rocks and are represented by large deposits such as those at Shinkolobwe and Great Bear Lake. The silica-iron-lead veins are also characterized by pitchblende, but the assemblage of associated minerals is generally a simple one, mainly pyrite, galena, and quartz or jasper. They occur mostly in felsic intrusive rocks; examples are deposits at Urgerica, Portugal, and Marysvale, Utah. The iron-titanium veins are characterized by uranium titanites, such as davidite, and by ilmenite, rutile, and quartz. They occur mainly in igneous intrusive rocks and are typified by the deposits at Radium Hill, South Australia. Disseminated iron oxides are widespread in all these deposits.

As discussed in the foregoing section, uranium in hydrothermal veins is derived mainly from residual solutions arising from late-stage differentiates, generally those rich in silica and the alkalies. The problems of chief concern, then, are the composition and temperature of transporting-solutions, depth and pressure relations at the site of deposition, the chemistry of precipitation, and structural control in the localization of the ore.

Little is known directly about the composition of uranium-bearing hydrothermal solutions, but from the fact that the most uraniferous natural waters are those high in sulfate or carbonate content or both, as well as from experimental data (Gruner, 1952; Miller and Kerr, 1954; Katz and Rabinowitch, 1951, p. 111-120) that indicate the solubility of uranyl sulfates and carbonates in aqueous solutions, it may be assumed that uranium is transported as the uranyl ion (Phair, 1952) in sulfate or carbonate solutions and that they may be either acid or alkaline. Because the physicochemical properties of
$\mathrm{CO}_{2}$ and the system $\mathrm{CO}_{2}-\mathrm{H}_{2} \mathrm{O}$ indicate that under some shallow earth-conditions $\mathrm{CO}_{2}$ can exist as a separate phase with a density approximately that of water, liquid $\mathrm{CO}_{2}$ has also been suggested as the ore-transporting solution (Garrels and Richter, 1955).

From the mineral assemblages and some experimental evidence (Gruner, 1952; Miller and Kerr, 1954; Lang, S. M., 1953) the silica-iron-lead veins that contain sooty pitchblende are classed as epithermal; the other silicairon-lead veins and the cobalt-nickel-silver veins are believed to be mesothermal; and some uraninite (Stevenson, 1951), brannerite (Pabst, 1954), and davidite (Nininger, 1954, p. 55), veins, which somewhat resemble pegmatite deposits, are regarded as hypothermal. The temperature of the transporting fluids and the depth and pressure at the site of deposition of the uranium veins are thus believed to have ranged widely. According to Lindgren (1933, p, 212, 454, 529, 640), epithermal deposits are believed to have formed probably at temperatures of less than $200^{\circ} \mathrm{C}$, at deptins of less than 4,000 feet, and at pressures of less than 140 atmospheres; mesothermal deposits probably formed at temperatures of $175^{\circ}$ to $300^{\circ} \mathrm{C}$, depths of 4,000 to 12,000 feet, and pressures of 140 to 400 atmospheres; and hypothermal deposits likely formed at greater temperatures (possibly several hundred degrees centigrade), depths, and pressures. Field evidence strongly indicates that most of the pitchblende veins were formed at depths shallow enough and at pressures low enough to provide open spaces along regular fissures.

Precipitation of primary uranium minerals in veins may be caused solely by a reduction in the amounts of sulfate or carbonate in solution by whatever cause, by a decrease in temperature or pressure or both, or by chemical interaction with the host rock. Either pressure or chemical interaction with the host rock may result in $\left(\mathrm{U}^{+6} \mathrm{O}_{2}\right)^{+2}$ reduction, which seems to be the factor of major importance in the precipitation of uranium minerals in hydrothermal and many other types of deposits. Experiments by Miller and Kerr (1954) confirming earlier work by Gruner (1952), indicate that pitchblende may be precipitated from uranyl sulfate solutions by the use of hydrogen sulfide gas, according to the equation:

$$
\mathrm{S}^{-2}+\left(\mathrm{U}^{+6} \mathrm{O}_{2}\right)^{+2} \rightarrow \mathrm{U}^{+4} \mathrm{O}_{2}+\mathrm{S}
$$

Ferrous iron also may be a reducing agent for uranyl ion. The reaction:

$$
3 \mathrm{H}_{2} \mathrm{O}+2 \mathrm{Fe}^{+2}+\left(\mathrm{U}^{+6} \mathrm{O}_{2}\right)^{+2} \rightarrow \mathrm{Fe}_{2} \mathrm{O}_{3}+\mathrm{U}^{+4} \mathrm{O}_{2}+6 \mathrm{H}^{+}
$$

goes to completion $\left[\left(\mathrm{U}^{+6} \mathrm{O}_{2}\right)^{+2}<10^{-6}\right]$ at $25^{\circ} \mathrm{C}$ at $\mathrm{pH} 4$ and above throughout a wide range of $\mathrm{Fe}^{+2}$ concentra- 
tion. This may explain the widespread association of iron oxide with pitchblende in vein deposits.

Most of the pitchblende vein deposits show a marked structural control, a tendency to be deposited along straight parts of fractures rather than along crooked parts. In a few deposits pitchblende is found impregnated in wall rock, but most deposits away from through-going structures are along related tensional fractures. Replacement deposits are rare except in carbonate or carbonaceous host rocks and in some hightemperature deposits.

\section{URANIUM DEPOSITS IN SANDSTONE}

The two best known uraniferous sandstone districts are those of the Colorado Plateau and the Witwatersrand. Unweathered deposits in both districts consist of pore-space fillings of uraninite, and pyrite and other sulfides, generally associated with carbon in the form of woody or asphaltic material. Also, coffinite (a hydroxy-substituted uranium orthosilicate) and lowvalent vanadium minerals are common in some of the Plateau deposits, and gold, of course, is an important constituent of the Rand deposits. Individual ore bodies are roughly parallel to bedding, are tabular and generally elongate, and range in size from a few pounds to millions of tons. They are best developed in or along the margins of thicker and more permeable zones within the sandstones, such as ancient stream channels. Deposits are widespread within individual, relatively thin zones but in both the Plateau and Rand districts deposits are found in many beds throughout a wide stratigraphic range. The host rocks are nonmarine, generally fluvial sandstones or conglomerates, though related deposits are occasionally found in other kinds of rocks. The distribution of the deposits is conspicuously related to sedimentary features and is less commonly or only inconspicuously related to fractures and igneous rocks. Alteration of host rocks is not pronounced, although red mudstones are bleached to a gray or greenish color in the vicinity of ore deposits on the Plateau, kaolinite is associated with some deposits on the Plateau, and chlorite is conspicuous in both the Plateau and Rand deposits.

The genesis of uranium deposits in sandstone is controversial, and it is impossible here to review the details of the various theories, much less the evidence on which they are based. Space permits only the following summary of the salient information about the age of the ores and their host rocks, and the source, transportation, and deposition of the ore metals. A full review of the origin of this and other types of uranium deposits is given by McKelvey, Everhart, and Garrels (1955).

Nearly all who have studied the sandstone deposits interpret the paragenetic relations of ore and host-rock minerals to mean that the ores in their present form were deposited after the enclosing rocks. Many believe (McKelvey, Everhart, and Garrels, 1955; Bain, 1952; Coffin, 1921; Fischer, 1937; Gruner, 1954; Hess, 1914, p. 681; Mellor, 1916; Reinecke, 1927; Young, 1917), however, that the chief ore metals were introduced during or shortly after deposition of the host rocks, although most of those who favor a placer hypothesis agree that the sulfides were introduced later. New and convincing evidence on when the Plateau ores were introduced has been presented recently by Stieff, Stern, and Milkey (1953). They show that the mean $\mathrm{Pb}^{206} /$ $\mathrm{U}^{238}$ age, after correction for the common $\mathrm{Pb}$ present, of many samples of Plateau uranium ores is 71 million years, or about half the age of the enclosing rocks. The mean age of samples from ores in the Jurassic Morrison and Entrada formations and the Triassic Shinarump conglomerate are 72,50 , and 73 million years, respectively. These ages are much younger and more uniform than would be expected if the ores were formed at the time of deposition of the host rocks, but they compare favorably to the 60.5 million years determined as the mean age of four pitchblende samples from hydrothermal veins in the Colorado Front Range. Stieff, Stern, and Milkey interpret their results to mean either that syngenetic uranium deposits were redistributed in Late Cretaceous or early Tertiary time or that the uranium was introduced from depth at that time. They regard the first alternative as less probable because in such a redistribution the common lead found in the ores would be transported and redeposited with the uranium and the previously formed radiogenic lead carried away or deposited elsewhere.

Recent age determinations of Rand ores reported by Davidson (1953) and Louw (1954) give ages of 1,682 and 1,850 to 1,950 million years, respectively. Davidson (1954), however, has since revised his figure to 465 to 816 million years. These ages are greater than the Witwatersrand system was previously thought to be, but until Louw's determination is better established the significance of the isotopic data will remain uncertain. L. R. Stieff (oral communication, 1955) believes correction for old radiogenic lead in the ore may signifieantly lower the ages computed by Louw. However, the occurrence of low-density thucholite (a uranium-bearing hydrocarbon) with the gold in the Rand ores - an anomaly hardly explainable if both were placer minerals (Graton, 1930, p. 145)-supports the conclusion that the uranium in the Rand ores is also epigenetic.

It is possible that the maximum age of the Witwatersrand system might be calculated by determining the age of the zircons and other accessory 
minerals by the Larsen method (Larsen, Keevil, and Harrison, 1952).

Several sources have been postulated for the uranium in the sandstone ores: (1) detrital uranium minerals (Bain, 1952; Mellor, 1916; Reinecke, 1927; Young, 1917; Liebenberg, 1948) or chemical or biochemical precipitates of uranium deposited at the same time as the enclosing rocks (Fischer, 1937; MacGregor, 1953); (2) dispersed concentrations in tuffs or ordinary rocks in the sedimentiary column (Gruner, 1954; Hillebrand and Ransome, 1905; Koeberlin, 1938; Proctor, 1953); (3) migrating petroleum or solutions derived from petroleum source beds (Gott and Erickson, 1952); and (4) hypogene solutions (Davidson, 1953; Graton, 1930; Dodd, 1950; Cater, 1954; Rasor, 1952; Waters and Granger, 1953). In our opinion, syngenetic sources may be omitted from further consideration (1) because of the evidence already cited and the facts that uranium on both the Plateau and the Rand occurs at many horizons over a wide stratigraphic range, (2) because uraninite is nearly unknown as a placer mineral (Davidson, 1953), and (3) because uranium, when it is concentrated by sedimentary chemical or biochemical processes, is associated with fine-grained carbonaceous shale or phosphorite, never with coarse clastic rocks (Davidson, 1953).

Dispersed sources within the sedimentary column as a whole seem ample to supply the volume of metals in even more extensive ore deposits than those already known (Hillebrand and Ransome, 1905; Gruner, 1951). Moreover, circulating ground water probably would not be far out of chemical equilibrium with the sediments and hence would not produce the marked alteration effects expected of hydrothermal solutions but not observed in the field. That the process is a workable one is suggested by Denson and others (in Vine and Moore, 1952, p. 1 and 10) who present strong evidence to show that the uranium in lignites in North and South Dakota has been derived from volcanic ash in overlying beds. The hypothesis of a dispersed souree has not been considered in relation to the Rand ores, and no evidence is available on which to appraise its merits. The isotopic data, however, cast some light on the source of the Plateau ores. According to Stieff and Stern (oral communication, 1955; Stieff, Stern, and Milkey, 1953, p. 15), the uranium ores, the galena associated with the deposits, the lead in Tertiary vein deposits in the San Juan Mountains, the Colorado Front Range, and the Tueson Mountains of Arizona, all contain lead that has the same peculiar isotopic composition or that varies systematically from this composition in a manner to be expected when different amounts of $\mathrm{Pb}^{206}$ and $\mathrm{Pb}^{207}$, produced by the decay of uranium, are added. The additional uranogenic lead was formed before its deposition in Tertiary rock. Because the ratio of $\mathrm{Pb}^{207}$ to $\mathrm{Pb}^{206}$ is high, it must contain an increment of lead derived from old radiogenic sources poor in thorium or from sources that have not released much thorium lead. The uniform composition of the lead in these several types of deposits suggests that they have a common source. From the presence of this lead in the Tertiary veins it seems most reasonable to assume that this source lay at depth, possibly in Precambrian thorium-poor, uranium-rich bodies in the basement complex. Syngenetic or penecontemporaneous derivation of the ore from the volcanic ash in the Triassic and Jurassic sediments is improbable because ores in these rocks do not show isotopic differences that would be expected if radiogenic lead that had formed in the ash before the uranium was removed from the tuffs were added. The isotopic data alone do not rule out the possibility that the ores might have been derived from a single source in the rocks above the deposits, but the presence of lead in the Tertiary veins and the fact that many of the deposits lie several thousand feet below the Tertiary make such a source improbable. Because the possibility of lateral secretion on such a grand scale as that required to form the Plateau and Rand deposits has been little explored, the hypothesis of a dispersed source probably deserves further consideration. The isotopic data, however, seem to make it an improbable explanation for the ores of the Colorado Plateau.

The occurrence of uraniferous "asphaltite" in oilstained pore spaces and the similarity of the assemblage of other metals in some asphaltites to that found in smaller concentrations in oil in pools nearby led Gott and Erickson (1952) and Erickson, Myers, and Horr (1954) to conclude that "asphaltite" is residual petroleum and that petroleum fluids may transport uranium to sites of ore deposition, particularly in deposits in sandstone. Goldschmidt (1954, p. 497) postulates a similar source and history for vanadium and other metals in petroleums and asphalts. Crude oils may contain a fraction of a part per billion $\left(10^{-9}\right)$ to a few thousand parts per billion (Erickson, Myers and Horr, 1954; Breger and Deul, in U. S. Geological Survey, 1954, p. 171), most of which seems to be in asphaltenes, but a few analyses of the Plateau oils indicate that the higher concentrations are only in oil that has penetrated a uraniferous sandstone (Breger and Deul, in U. S. Geological Survey, 1954, p. 171). Oil is not common on the Plateau and is unknown in the Witwatersrand system. "Asphaltite" on the Plateau is common in only a few areas (much "asphaltite" is proving to be woody material), and the thucholite in the Rand ores bears a replacement relationship to early uraninite (Davidson 
and Bowie, 1951). For these reasons it seems unlikely that migrating petroleum is the source of much if any of the uranium on the Plateau or the Rand. It is possible, however, that some uranium in both areas may have been transported short distances by fluid hydrocarbons.

Several lines of evidence have been cited to support a hydrothermal source for both Plateau and Rand ores:

1. Both contain ore minerals, like uraninite and sulfides, typical of other hydrothermal deposits (Graton, 1930, p. 73 ; Davidson, 1953, p. 10; Davidson and Bowie, 1951, p. 14).

2. The gangue minerals - quartz (mainly as overgrowths but also in veins in the Rand), chlorite, and clay minerals - are typical of or not incompatible with a hydrothermal association (Graton, 1930).

3. Evidence of movement of mineralizing solutions in the form of altered dikes, vein quartz, and sulfides is found along crosscutting fractures and dikes in the Rand (Graton, 1930, p. 44); and some Plateau ores, particularly those high in copper content, are associated with faults (E. M. Shoemaker, written communication, 1954) or fractures (Bucher, 1953).

4. The uranium content of the ores in sandstone is similar to that of other hydrothermal ores and dissimilar to that in deposits of other origins (Davidson and Bowie, 1951, p. 14).

5. The ores in some parts of the Plateau are zonally arranged around laccoliths (Reinhardt, 1952; Shoemaker, oral communication, 1951).

6. Isotopic data show the Plateau ores, which include vein copper deposits and limestone replacement ores, as well as the more abundant and typical "bedded" deposits in sandstone, to be genetically related to vein deposits of uranium in the same general region.

Some of these features may be explainable in other ways, but one or another of them has been compelling enough to cause syngeneticists in both areas to admit that some of the deposits or some minerals in them are hydrothermal (Fischer, 1937; Liebenberg, 1948, p. 83). The arguments have not been accepted for other deposits or minerals mainly because (1) most of the ores show no relation to structural or igneous features, (2) the host rocks are not so conspicuously altered as are those enclosing most hydrothermal deposits, and (3) vanadium, an important component of some of the Plateau ores, is not an important mineral in other hydrothermal deposits. Those favoring a hypogene source admit the close relation to sedimentary features but believe that in the absence of fractures, solution movement would be controlled by the direction of transmissibility of the rock. They believe the lack of alteration is more apparent than real (Graton, 1930); and because vanadium is a constituent of some vein deposits
(Lang, 1952, p. 16; Goldschmidt, 1954, p. 491; Eckel, Williams, Galbraith, others, 1949 , p. 74), they do not consider its presence in some of the Plateau ores a valid reason for objection to the hydrothermal hypothesis. They thus imagine the deposits to be bedded or "interstitial" quartz-sulfide veins, differing from hydrothermal veins only in that they occupy pore spaces in sandstones instead of fractures.

The specific source of the hydrothermal solutions is undetermined. The Plateau deposits show some spatial relation to laccoliths but intrusive bodies are not widespread on the Rand, though alkalic granites intrude the Witwatersrand system at Vredfort, southwest of the Rand (Reinecke, 1927, p. 108). Nevertheless, Davidson (1953, p. 13-14) points out that the Rand deposits, as well as those of the Plateau, the coppercobalt-uranium ores of the Belgian Congo, and the uranium-copper deposits of Rum Jungle in Australia, are in a group of sediments that overlie a complex of Archean granites, which

*** have undergone domal uplift since the covering blanket of sediments was deposited, due presumably to "younger" granites which are not always exposed ***. May it not be that the ore deposits in each of these regions represents a "front" of mineralization which has emanated, through the older granites from the younger magma below?

The sum of the available evidence indicates to us that the deposits were derived from a deep-seated source and transported along fractures to permeable layers, which they then followed to the site of deposition. The mineral assemblage and fine-grained texture of the ores suggest deposition at relatively low temperature and pressure, possibly in the range normal for watersaturated rocks buried by several thousand feet of sediments. Thus, if a normal geothermal gradient prevailed at the time of deposition of the Plateau ores, the temperature in the host rocks probably was in the range of $70^{\circ}$ to $120^{\circ} \mathrm{C}$. and the pressure in the range of 200 to 800 atmospheres (the range between the hydrostatic and lithostatic load). As to the chemical factors that led to the precipitation of the ore minerals, the low-valence state of the primary minerals suggests that precipitation probably was brought about by reduction, possibly by decaying carbonaceous matter. Sedimentary structures were also important in localizing the ore. The lenticularity of permeable facies served to prevent solutions from dispersing so widely that no appreciable concentration of metals could result on precipitation (Graton, 1930, p. 83). Also, as shown by the common occurrence of ore at bends in ancient stream channels and along the margins of the more permeable zones, certain structures acted as traps for ore. The mechanics of these traps is not understood; it is possible that their lesser permeability 
reduced the velocity of percolating ore solutions sufficiently to allow time for precipitates to form and become fixed, possibly as replacements of organic matter, clay, and other matrix material.

\section{URANIFEROUS COAL AND ASSOCIATED CARBONACEOUS SHALE}

Coal and associated carbonaceous shale beds are generally nonuraniferous, but some rather extensive beds in Western United States (McKelvey, 1955) and elsewhere (Davidson and Ponsford, 1954) contain 0.005 to about 0.1 percent uranium, and a few in South Dakota contain 0.2 percent or more uranium (Gill, in U. S. Geological Survey, 1954, p. 149-155). Most of the uraniferous coals are rather high in ash content and low in rank. Secondary uranium minerals, such as autunite, meta-autunite, meta-tyuyamunite (Gill, idem), and uranocircite (Turner, 1928), are found in some of the higher grade deposits; but the uranium in lower grade deposits is in dispersed form, at least in part in organouranium complexes or ionic organic compounds (Breger, Deul, and Rubinstein, 1955, p. 219). In individual specimens of low-grade coals, the uranium is rather uniformly distributed (Gott, Wyant, and Beroni, 1952), but in larger bodies the uranium content is irregular. In their studies of lignites in South Dakota, Denson, Bachman, and Zeller (in Vine and Moore, 1952) and Miller and Gill (1954) found that in most places only the first lignite immediately below the tuffaceous White River formation of Oligocene age, which unconformably overlies the coal-bearing strata there, is appreciably uraniferous. Moreover, the uranium content of a given layer is highest at the top. Concentrations of uranium may be found in lower beds adjacent to faults or through-going joints or where the beds are in contact with a permeable sandstone Iayer. These relations have been found to characterize several other uraniferous coals in Western United States.

The problems of the origin of uranium in coal and earbonaceous shales are analogous to those of the ores in sandstone but are perhaps not so complex. Because certain land plants concentrate enough uranium to be of value in prospecting for ore deposits (Cannon, 1952), it might be supposed that uranium in coal is concentrated by living plants. It appears, however, that significant concentrations of uranium $-1 \mathrm{ppm}$ or more in the ash-are found only in plants growing on mineralized ground (Cannon, 1952, p. 743). Even there it is exceptional to find a uranium content of $100 \mathrm{ppm}$ in the ash, an amount common in the ash of uraniferous lignites and carbonaceous shales. It thus seems unlikely that the uranium in coaly beds was first concentrated by living plants (Davidson and Ponsford,
1954). Moreover, the irregular distribution of uranium in the individual beds, its regional relation to unconformities, its vertical distribution within individual beds, and its local concentration along fractures and permeable beds indicate that it was introduced after deposition of the enclosing rocks, though its even distribution in individual specimens suggests that it was introduced before coalification (Gott, Wyant, and Beroni, 1952, p. 34).

The source of the uranium itself is even more problematical and may be different from place to place. Because of the relation already described, Denson and his colleagues concluded that the uranium in the Dakota lignites was derived from uraniferous tuffaceous materials in the White River formation. The presence of uraniferous bones in the White River formation as well as the relatively high amounts of uranium in ground water draining from the White River formation tend to support this view. Similar sources have been suggested for uranium in several other uraniferous coals in Western United States. Other sources besides tuff, such as decaying granitic or arkosic rocks or hydrothermal solutions, might be the source of uranium in other deposits. Thus Turner $(1928$, p. 83$)$ postulated that the uranium in peat deposits in Madagascar came from the decomposition of titano-niobates nearby (because these minerals are ordinarily resistant to weathering, it seems more probable that the uranium in these deposits was derived from rhyolitic pumice, which is reported to occur in the alluvium of which the peats are a part) and L. R. Page (oral communication, 1952) suggested that the uranium in a coal bed cut by a sbear zone in the Old Leyden mine at the foot of the Colorado Front Range probably was derived from hydrothermal solutions.

The uraniferous waters now draining certain tuffaceous terranes are conceivably similar to solutions from which the uranium in coals was derived. They contain as much as $0.5 \mathrm{ppm}$ uranium (ordinary waters contain less than $0.001 \mathrm{ppm}$ ), several bundred parts per million of sulfate or bicarbonate or both, are very high in total dissolved solids, and are moderately alkaline (Aberdeen and others, unpublished data, 1952). Because source solutions are thus dilute, the formation of a large uraniferous coal deposit probably takes a long period of time, for the coal must be exposed to a considerable volume of a solution so dilute. Moreover, many coals are not permeable enough to permit passage of large volumes of solution. Thus Breger and Deul (written communication, 1952) were unable to pass water through a column of -50 mesh subbituminous coal, even under a pressure of $15 \mathrm{psi}$ of nitrogen, without mixing diatomaceous earth with the coal to increase its permeability. As Gott and others assumed for other 
reasons, this may mean that introduction of uranium must take place before coalification. It is possible too that differences in permeability account for the concentration of uranium at the top or base of many beds and for its relative enrichment in high-ash beds.

The deposition of the uranium in coal doubtless took place by chemical reaction or absorption. Szalay (1954) has shown that brown coal will absorb uranium from a solution of potassium uranyl carbonate. Moore (1954) found that subbituminous coal, lignite, and peat irreversibly removed more than 98 percent of the uranium from a solution containing $196 \mathrm{ppm}$ uranium (in the form of $\mathrm{UO}_{2} \mathrm{SO}_{4}$ ) to which they were exposed for 12 days. Under the same conditions, wood adsorbed 40 percent of the uranium, a bituminous coal 17 percent, an anthracite 34 percent, graphite 28 percent, charcoal 31 percent, canneloid coal 80 percent, and silica flour none. On the basis of these results, Moore concluded that the uranium is precipitated as a metallo-organic compound. Breger, Deul, and Rubinstein (1955, p. 224), after noting that the $\mathrm{pH}$ of several lignites from the Western States is less than 6.5, observed that $* * *$ certain alkaline uranyl carbonates and alkaline-earth car-
bonates are extremely soluble in water. Typical compounds
are $\mathrm{Na}_{4}\left(\mathrm{UO}_{2}\right)\left(\mathrm{CO}_{3}\right)_{3}, \mathrm{Na}_{6}\left(\mathrm{UO}_{2}\right)_{2}\left(\mathrm{CO}_{3}\right)_{5}$, and $\mathrm{Mg}\left(\mathrm{UO}_{2}\right)\left(\mathrm{CO}_{3}\right)_{3}$.
These compounds are sensitive to acids and break up with the
release of carbon dioxide. If such a uranium-bearing solution
came into contact with a lignite, a zone of low pH, the following
type of reaction would be expected:

$$
\mathrm{Na}_{4}\left(\mathrm{UO}_{2}\right)\left(\mathrm{CO}_{3}\right)_{3}+6 \mathrm{HA} \rightarrow 4 \mathrm{NaA}+\mathrm{UO}_{2} \mathrm{~A}_{2}+3 \mathrm{CO}_{2}+3 \mathrm{H}_{2} \mathrm{O} .
$$

The acids from the lignite, represented by HA, are unknown in structure and, for the sake of balancing the above equation, are assumed to be monobasic. It is conceivable that a compound such as $\mathrm{UO}_{2} \mathrm{~A}_{2}$ might be insoluble above $\mathrm{pH} 2.18$. This is a suggested process to account for the introduction and retention of the uranium in a coal.

\section{URANIFEROUS BLACK SHALE}

Many marine black shales contain 0.005 to 0.02 percent uranium (Gott, Wyant, and Beroni, 1952; Beers, 1945; McKelvey and Nelson, 1950; Russell, 1945, p. 1480). The uranium is in acid-soluble form, but it probably does not occur in a distinct uranium mineral. In the Devonian and Mississippian Chattanooga shale of Tennessee, autoradiograph studies show that the uranium is in organic matter-pyrite complexes (Bates, Strahl, Short, and others, 1954). The largest amounts of uranium (as much as 0.5 percent) in the Cambrian alum shale of Sweden are in lenses of dark bitumen called kolm (Munthe, Westergard, and Lundquist, 1928); the megascopic lenses do not contain an appreciable amount of the total uranium in the shale, but microscopic particles of similar material may be the principal carrier of uranium in the shale matrix. In the Miocene nodular shale in California and the Pennsylvanian Cherokee shale equivalents in Oklahoma, the uranium may occur both in carbonaceous matter and phosphate (Whitehead, 1952). Because the uranium content increases directly with increasing proportions of carbon in many shales (Beers, 1945, p. 11; Burton and Sullivan, 1951), Frederickson (1948) suggests that the $\left(\mathrm{U}^{+6} \mathrm{O}_{2}\right)^{+2}$ ion "is adsorbed between the graphite layers of carbonaceous material, forming a strong structure due to the stable $\mathrm{UO}_{2}{ }^{++}$ion holding the two layers together."

As a group the uraniferous marine black shales are highly carbonaceous and bituminous, high in sulfide content, noncalcareous, somewhat phosphatic (or contain phosphatic nodules in the section), and thin for the period of time they represent. In vertical sequences, the uraniferous black shales are associated with phosphatic rocks, chert, carbonate rock, and sandstone. The black shales are not appreciably uraniferous, however, where thick, high-grade phosphorite beds are present. The richest parts of the Swedish shale are in the middle or upper part of the shale sequence, in or closely adjacent to that part of the sequence which contains maximum amounts of distillable oil, total organic matter, pyrite, and kolm; areally, the richest parts are in tongues, interpreted as embayments in the late Cambrian sea (Josef Eklund, oral communication, 1952). The uranium in the most uraniferous shale known in this country, the Hartville in Wyoming, seems also to have been concentrated near the margin of deposition of that shale.

The problem of the origin of the uranium in the marine black shales is more one of the environment, manner, and causes of precipitation than one of the time of deposition of the uranium compared to that of the host rock or the source of the uranium. Although it is generally assumed that the uranium in these beds is syngenetic, in view of the capacity of carbonaceous materials to adsorb uranium, it is possible that some of the uranium may have been adsorbed after deposition, either from sea water or from water released from other sediments during compaction. Uranium in waters draining overlying beds might be adsorbed also (Glebov, 1941), but because this would not take place until after compaction and perhaps lithification, uranium derived in this way might be concentrated along joints, a phenomenon rarely observed in the marine black shales.

Although most of the uranium in the shales is derived directly or indirectly from sea water, which contains from $1.0 \times 10^{-6}$ to $1.8 \times 10^{-6}$ grams of uranium per liter (G. Koczy, 1950), the question arises whether the uranium has been derived locally or brought to the site of deposition through oceanic circulation. Glebov 
(1941) and Strøm (1948) postulate that uranium is derived from adjacent terranes, presumably during periods when chemical weathering is the dominant process of erosion. This is a reasonable assumption if the basins of deposition are restricted embayments, and it may account for the uranium content of the alum shale, the most uraniferous parts of which apparently were deposited in embayments not far from a granitic terrane (Eklund, oral communication, 1952). It seems unlikely, however, that local sources contributed much of the uranium found in the more widespread black shales, such as the Chattanooga. Moreover, because the uranium content of ocean waters and largeriver waters is about the same -ocean waters range from about $1.1 \times 10^{-6} \mathrm{~g}$ per 1 in surface waters to $1.3 \mathrm{x}$ $10^{-6}$ to $1.4 \times 10^{-6} \mathrm{~g}$ per 1 in deeper waters; river waters range from about $0.3 \times 10^{-6}$ to $20 \times 10^{-6} \mathrm{~g}$ per I (Koczy, 1954 , p. 126) but the waters of no large river contain more than $1 \times 10^{-6}$ to $2 \times 10^{-6} \mathrm{~g}$ per 1 - the identification of source of the uranium in black shales does not seem of critical significance.

Of more importance may be the environment of deposition. The rocks of the phosphorite family of sediments, to which the black shales belong, are generally deposited on a shelving bottom where cold waters rich in phosphate, nitrate, and possibly other elements whose solubility is influenced by $\mathrm{pH}$, upwell from oceanic depths (Kazakov, 1937; McKelvey, Swanson, and Sheldon, 1953). As these waters are warmed, some of the dissolved substances become insoluble and are chemically precipitated or removed from the sea by organisms. The nutrients in these upwelling waters fertilize the upper waters of the sea, producing tremendous blooms of plankton (Brongersma-Sanders, 1948) that lead to the development of anaerobic sapropel on the sea bottom, even in the open ocean (Brongersma-Sanders, 1948). Nutrient-rich fresh waters draining into a restricted embayment may produce the same effect. The close spatial relationship between the maximum amounts of uranium, oil, total organic matter, and sulfides, as well as the concentration of uranium in some shales in embayments or near their margins of deposition, suggests that the formation of a highly reducing environment may be a prerequisite to the concentration of uranium in the shales. According to Goldschmidt (1954, p. 566), precipitation of uranium in black shales "might result from a reduction of sexivalent uranium to the quadrivalent stage by the action of hydrogen sulfide in stagnant bottom waters ***. We may therefore expect accumulation of the solute uranium from sea water by reprecipitation in areas where strongly reducing conditions prevail." It seems probable that appreciable deposition or preservation of uranium takes place only when the $\mathrm{pH}$ and Eh lie within narrow limits-limits that may be approached closely enough in the deposition of ordinary black shales to permit the formation of some sulfides and the preservation of some organic matter, but that are reached only rarely.

Deposition of uranium in the shales might have taken place in one or both of two ways: (1) direct precipitation or (2) chemical adsorption by organic matter (living or dead) or by apatite. The absence of any uranium mineral in the shales tends to preclude direct precipitation. Some marine algae, bowever, concentrate minor amounts of metals (Lexow, Maneschi, and Sa, 1948; Black and Mitchell, 1952), and dead plankton is reported to be an effective adsorbent for uranium (E. W. Steel and E. F. Gloyna, unpublished data, 1953) and other metals (Harvey, 1945; Krauskopf, 1952). Most of the uranium in apatite is thought to be removed from the sea by adsorption, and possibly some of the uranium in the shales may also have been adsorbed by phosphatic materials, Even though biochemical precipitation and adsorption may be the chief mechanisms of deposition of uranium in the shales, these processes are not likely to be effective in the permanent removal of uranium from the sea unless chemical conditions favor or approach those necessary for direct precipitation of uranium. It is possible, however, that living organisms may remove uranium from the upper waters of the sea, where redueing conditions do not prevail, and, after death, carry it to the bottom where the reducing conditions necessary for the retention of uranium do exist (D. E. White, oral communication, 1955).

The uranium in the hydrocarbons in the black shales probably enters these compounds after deposition. Smith (1954), in reporting his discovery of oil in Recent sediments, adopts F. C. Whitmore's earlier hypothesis that "the generation of petroleum is very largely a process of selection and concentration of hydrocarbons originally synthesized by the metabolism of marine (or even terrestrial) plants." Collection and concentration of the hydrocarbons probably begins shortly after burial, and minor amounts of metals probably are dissolved at this stage (Erickson, Myers, and Horr, 1954, Goldschmidt, 1954; p. 497).

\section{URANIFEROUS MARINE PHOSPHORITES}

Marine phosphorites contain from 0.005 to 0.03 percent uranium (McKelvey and Nelson, 1950; Davidson and Atkin, 1953). Traces of secondary uranium minerals are occasionally found in weathered deposits but most of the uranium is in dispersed form. It is acid soluble, tetravalent, and seems to be in the mineral carbonate-fluorapatite, where it probably substitutes for calcium (Altschuler, Clark, and Young, 1954). 
Although there are many exceptions, the uranium content of the phosphorites increases roughly as the phosphate content increases, but, in the Permian Phosphoria formation at least, the uranium content falls off rapidly as the carbon dioxide content rises above 3 or 4 percent, regardless of the phosphate content. Phosphatie limestones are thus only weakly uraniferous, but phosphatic nodules in certain black shales are uraniferous (Runnels, Schleicher, and Van Nortwick, 1953), generally more so than the enclosing shale. Black shales associated with the phosphorite formations are only weakly uraniferous. Fossil bones and teeth contain as much as 0.5 percent uranium without showing a separate mineral phase (Davidson and Atkin, 1953), and the uranium content seems to be greater in older than in younger species (Jaffe and Sherwood, 1951). In the Phosphoria formation, however, beds composed of organic fragments are less uraniferous than other kinds of phosphatic materials.

As with the black shales, much of the uranium in the phosphorites and phosphatic nodules probably was derived from sea water at or shortly after the time the rocks were deposited. Because the phosphorites are more permeable than the shales, more of the uranium in the phosphorites may have been derived from later solutions or redissolved and redeposited by them.

The environment of deposition of the marine phosphorites is much the same as that of the black shales with which they are associated, except that the phosphorites probably accumulate in shallower, more aerated water. The negligible uranium content of modern bones (Jaffe and Sherwood, 1951) and the absence of a separate uranium mineral indicate that precipitation of uranium in the phosphorites must have taken place not by biologic activity or direct precipitation but by one or another of the processes known as chemical adsorption-perhaps simultaneous precipitation or isomorphous substitution of uranium for calcium at some time after the deposition of carbonate-fluorapatite. Moore (1954) showed that phosphate rock adsorbed 63 percent of the uranium present in a solution of $\mathrm{UO}_{2} \mathrm{SO}_{4}$ containing $196 \mathrm{ppm}$ uranium; and Neuman, Neuman, Main, and Mulryan, (1949 a, b, and c) demonstrated that bone (which consists of hydroxyapatite) can adsorb as much as 4.8 percent uranium from a dilute, bicarbonate buffered solution of uranyl acetate, replacing calcium at the surface of the apatite crystal. In other experiments they show (1949c) that the amount of uranium precipitated in bone ash decreases with increase in calcium and increase in bicarbonate ions in solution and with increasing $\mathrm{pH}$, from 6.5 to 8.0. These results indicate

*** that a direct competition exists between calcium and uranium for the combining sites on the bone phase $* * *$ be- tween carbonate ion (which forms a relatively undissociated complex with uranyl ion) and the surface phosphate groups for uranium. The reduced uranium adsorption observed at elevated $\mathrm{pH}$ is somewhat more complicated but, in part, may be viewed as a competition between surface phosphate groups and hydroxyl ions.

Because the uranium in the phosphorites is tetravalent, reduction must help cause precipitation.

Variations in the uranium content of phosphorites of similar $\mathrm{P}_{2} \mathrm{O}_{5}$ content may arise in part from differences in the uranium content of the sea water at the time of deposition, but the most significant variations probably result from differences in the $\mathrm{pH}$, calcium, and carbonate ion concentration of the source water, the length of time phosphate particles are exposed to the sea before burial, and their postdepositional history.

These factors are well demonstrated by the distribution of uranium in the Florida phosphate field. The principal phosphate deposits there are in the Pliocene Bone Valley formation, which formed as a result of the marine reworking of a phosphatic residuum formed on the underlying phsophatic Miocene Hawthorn limestone during an intervening period of weathering. Since its deposition, the Bone Valley itself has been deeply weathered. It now consists of carbonatefluorapatite pellets, montmorillonite, and quartz sand in the lower part, and vesicular, leached rock composed mainly of quartz sand, wavellite, and crandallite in the upper part (Z. S. Altschuler and C. E. Boudreau, unpublished data, 1949; Altschuler, in U. S. Geological Survey, 1953, p. 172). The phosphate pellets of the Hawthorn contain only small amounts of uranium, probably because of the abundance of calcium and carbonate ions in the sea at the time of their deposition. The phosphate pellets of the Bone Valley are much more uraniferous, presumably because they adsorbed more uranium during their second exposure to sea water. As a result of the subtropical weathering to which they have since been exposed, some uranium has been leached out of the Bone Valley pellets, with the result that small pellets are less uraniferous and more phosphatic than the large ones. In the most weathered rock, where carbonate-fluorapatite has been largely destroyed, most of the uranium has been removed. Some has been readsorbed in a zone of secondary enrichment below the zone of most advanced weathering, but some has followed calcium in recombining with aluminum and phosphate to form crandallite (Altschuler, in U. S. Geological Survey, 1953, p. 172).

The reason for the concentration of uranium in the phosphorites rather than the shales where both are present is not clear, but it may be that uranium bears a greater affinity for phosphate than it does for organic 
matter, expressed either at the time of deposition or during later migration of solutions.

\section{CONCLUSIONS}

Origin of the diverse types of uranium deposits reflects the fundamental properties of uranium, chiefly its large ionic radius, its polyvalence, the solubility of many of its uranyl compounds, and the great stability of its uranous compounds under reducing conditions, Thus, its concentration in late-stage igneous magmas reflects the effect of radius and valence in preventing it from entering the structure of common rock-forming minerals. Its migration away from the magma, and its separation from thorium at that stage, arises from its susceptibility to oxidation and the solubility of uranyl compounds. The same effect, including the separation from thorium (Koczy, 1954, p. 120), is illustrated in the behavior of uranium during weathering. Precipitation of uranium may take place in several ways, but its widespread association with carbonaceous matter and sulfides shows that its deposition in a wide variety of deposits is influenced or stabilized by reduction. Precipitation of uranium by chemical adsorption or isomorphous substitution, whether in igneous or sedimentary rocks, is favored where uranium forms a relatively stable compound with the anions present, where it can displace an ion of similar radius and valence, and where the solution carries few ions that can compete successfully with uranium for structural positions.

The chief geologic control in the formation of uranium deposits has to do with the avenues followed by uranium-bearing solutions. These are the usual onesjoints and fractures in crystalline igneous, metamorphic, and sedimentary rocks, and pore spaces in permeable sedimentary rocks-but the occurrence of large uranium deposits in sandstones and lignites emphasizes the importance of lenticular aquifers in channeling ore solutions through sedimentary rocks and in localizing their precipitates.

\section{REFERENCES CITED}

Adams, J, A. S., 1954, Uranium and thorium contents of voleanic rocks, in Faul, Henry, ed., Nuclear geology: New York, John Wiley and Sons, Inc., p. 89-98.

Altschuler, Z. S., Clarke, R. B., Jr., and Young, E. J., 1954, Uranium in apatite [abs.]: Geol. Soc. America Bull., v. 65, p. $1225-1226$.

Bain, G. W., 1952, Uranium in the Dirty Devil Shinarump channel deposit: U. S. Atomic Energy Comm., RMO-66, 40 p., issued by U. S. Atomic Energy Comm. Tech. Inf. Service, Oak Ridge, Tenn.

Bates, T. F, Strahl, E. O., Short, N. M., and others, 1954, Mineralogy and petrography of the Chattanooga shale [abs.]; Geol. Soc. America Bull., v, 65, p, 1230.
Beers, R. F., 1945, Radioactivity and organic content of some Paleozoic shales: Am. Assoc. Petroleum Geologists Bull., v. 29 , p. 1-22.

Breger, I. A. Deul, Maurice, and Rubinstein, Samuel, 1955, Geochemistry and mineralogy of a uraniferous lignite: Econ. Geology, v. 50, p. 206-226.

Black, W. A. P., and Mitchell, R. L., 1952, Trace elements in the common brown algae and in sea water: Marine Biol. Assoc. of the United Kingdom Jour., v. 30, no. 3, p. 575-584.

Brongersma-Sanders, Margaretha, 1948, The importance of upwelling water to vertebrate paleontology and oil geology: K. Nederlandsche Akad. Wetensch., Verh., Afd. Natuurk., Tweede Sectie, Deel 45, no. 4, 112 p.

- 1951, On conditions favouring the preservation of chlorophyll in marine sediments, with an appendix by W. G. Aldershoff. Third World Petroleum Cong. (The Hague) Proc. sec. 1 ; p. 401-413.

Brown, H., Blake, W. J., Chodas, A, A., and others, 1953, Leaching studies of interstitial materials in igneous rocks [abs.]: Geol. Soc. America Bull., v. 64, p. 1400-1401.

Bucher, W. H., 1953, Fracture studies in the Zuni and Lucero uplifts, New Mexico-part 1, Annual report for June 15, 1952 to Apr. 1, 1953: U. S. Atomic Energy Comm. RME3042, 12 p., issued by U. S. Atomic Energy Comm. Tech. Inf. Service, Oak Ridge, Tenn.

Burton, V. L., and Sullivan, G. R., 1951, Carbon content and radioactivity of marine rocks: Am. Geophys, Union Trans, v. 32, p. $881-884$.

Cannon, H. L., 1952, The effect of uranium-vanadium deposits on the vegetation of the Colorado Plateau: Am. Jour. Sci., v. 250, p. $735-770$.

Cater, F. W., Jr., 1954, Geology of the Bull Canyon quadrangle, Colorado: U. S. Geol. Survey Geologie Quadrangle Map GQ 33.

Coffin, R, C., 1921, Radium, uranium, and vanadium deposits of southwestern Colorado: Colo, Geol. Survey Bull. 16, $231 \mathrm{p}$.

Davidson, C. F., 1953, The gold-uranium ores of the Witwatersrand: Mining Mag. (London), v. 88, p. 73-85.

-1954, Discussion [of papers on the Northern Rhodesian Copperbelt]: Inst. Min. Metallurgy (London), Bull., no. 567; Trans., v. 63, pt, 5, p. 241-263. See p, 247. (Discussion of papers by J. H. M. MeNaughton and W. G. Garliek, 1953, same journal, v. 63 , p. 9-20 and 113-124 respectively.)

Davidson, C. F, and Atkin, D., 1953, On the occurrence of uranium in phosphate rocks: 19th Internat. Geol. Cong. Comptes Rendus, v. 11, p. 13-31.

Davidson, C. F., and Bowie, S. H. U., 1951, On thucholite and related hydrocarbon-uraninite complexes, with a note on the origin of the Witwatersrand gold ores: Great Britain Geol. Survey Bull. 3, p. 1-19,

Davidson, C. F., and Ponsford, D. R. A., 1954, On the occurrence of uranium in coals: Mining Mag, (London), v. 91, p. 265273; Bouth African Min. and Eng. Jour. (Johannesburg), v. 65 , pt. 2 , p. $721,723,725,727$.

Dodd, P. H., 1950, Happy Jack mine, White Canyon, Utah: U. S. Atomic Energy Comm, RMO-660, 25 p., issued by U. S. Atomic Energy Comm. Tech. Inf. Service, Oak Ridge, Tenn.

Eckel, E. B., Williams, J. S., Galbraith, F. W., and others, 1949, Geology and ore deposits of the La Plata district, Colorado: U. S. Geol. Survey Prof, Paper 219, 179 p. [1950] 
Erickson, R. L., Myers, A. T., and Horr, C. A., 1954, Association of uranium and other metals with crude oil, asphalt, and petroliferous rock: Am Assoc. Petroleum Geologists Bull, v. 38 , p. $2200-2218$.

Everhart, D. L., and Wright, R. J., 1953, The geologic character of typical pitchblende veins: Econ. Geology, v. 48, p. 77-96.

Fischer, R. P., 1937, Sedimentary deposits of copper, vanadium, uranium, and silver in southwestern United States: Econ. Geology, v. 32, p. 906-951.

Frederickson, A. F., 1948, Some mechanism for the fixation of uranium in certain sediments: Sci., v. 108, p. 184-185.

Garrels, R. M., and Richter, D. H., 1955, Is carbon dioxide an ore-forming fluid under shallow earth conditions?: Econ. Geology, v. 50, p. $447-458$.

Glebov, S. M., 1941, Radioaktivnost Diktionemovykh Slantzev (Radioactivity of the Dictyonema shales): Leningradski Gornyi Institut Zapiski, v. 14, p. 1-12.

Goldschmidt, V. M., (edited by Alex Muir), 1954, Geochemistry: Oxford, Clarendon Press. 730 p.

Gott, G. B., and Erickson, R. L., 1952, Reconnaissance of uranium and copper deposits in parts of New Mexico, Colorado, Utah, Idaho, and Wyoming: U. S. Geol, Survey Circ. 219,16 p.

Gott, G. B., Wyant, D. G., and Beroni, E. P., 1952, Uranium in black shales, lignites, and limestones in the United States: U. S. Geol. Survey Circ. 220, p. 31-35.

Graton, L. C., 1930, Hydrothermal origin of the Rand gold deposits-part I, The testimony of the conglomerates: Econ. Geology, v. 25, supp. to no. 3, 185 p.

Gruner, J. W., 1951, Origin of the uranium deposits in the Shinarump formation, a preliminary study-part II, Annual report for July 1, 1950 to June 30, 1951: U. S. Atomic Energy Comm. RMO-837, 27 p., issued by U. S. Atomic Energy Comm. Tech. Inf. Service, Oak Ridge, Tenn.

— 1952, New data of syntheses of uranium minerals-part I, Annual report for July 1, 1951 to June 30, 1952: U. S. Atomic Energy Comm. RMO-983, 26 p., issued by U. S. Atomic Energy Comm. Tech. Inf. Service, Oak Ridge, Tenn.

- 1954, The origin of the uranium deposits of the Colorado Plateau and adjacent regions: Mines Mag. (Denver), v. 44, no. 3 , p. $53-56$.

Harvey, H. W., 1945, Recent advances in the chemistry and biology of sea water: Cambridge, Eng., Univ. Press, 164 p.

Hess, F. L., 1914, A hypothesis for the origin of the carnotites of Colorado and Utah: Econ. Geology, v. 9, p. 675-688.

Hillebrand, W. F., and Ransome, F. L., 1905, On carnotite and associated vanadiferous minerals in western Colorado: U. S. Geol. Survey Bull. 262, p. 9-31.

Hurley, P. M., 1950, Distribution of radioactivity in granites and possible relation to helium age measurement: Geol. Soc. America Bull., v. 61, p. 1-7.

Jaffe, E. B., and Sherwood, A. M., 1951, Physical and chemical comparison of modern and fossil tooth and bone material: U. S. Geol. Survey TEM-149, 19 p., issued by U. S. Atomic Energy Comm, Tech. Inf. Service, Oak Ridge, Tenn.

Katz, J. J., and Rabinowitch, Eugene, 1951, The chemistry of uranium-part 1: The element, its binary and related compounds: Natl. Nuclear Energy Ser., Div. VIII, v. 5, New York, MeGraw-Hill Book Co., Inc., 609 p.
Kazakov, A. V., 1937, The phosphorite facies and the genesis of phosphorites, in Geological investigations of agricultural ores USSR: Sci. Inst. Fertilizers and Insectofungicides Trans. (U. S. S. R.) no. 142, p. 95-113. (Special issue in English published for 17th Internat. Geol. Cong.)

Koczy, F. F., 1954, Geochemical balance in the hydrosphere, in Faul, Henry, ed., Nuclear geology: New York, John Wiley and Sons, Inc., p. 120-127.

Koczy, Gerta, 1950, Weitere Uranbestimmungevan Meerwasserproben: Akad. Wiss. Wien, Math.-naturwiss. KI., Sitzungsber, Abt. IIa, v. 158, no. 1-5, p. 113-121.

Koeberlin, F. R., 1938, Sedimentary copper, vanadium-uranium, and silver in southwestern United States: Econ. Geology, v. 33, 458-461.p. (Discussion of paper by R. P. Fischer, 1937, in same journal v. 32, p. 906-951.)

Krauskopf, K. B., 1952, Control of trace-element concentrations in sea water [abs.]: Geol. Soc. America Bull., v. 63, p. 1336.

Lang, A. H., 1952, Canadian deposits of uranium and thorium (Interim account): Canada Geol. Survey, Econ. Geology Ser. no. 16,173 p.

Lang, S. M., 1953, Annotated bibliography of selected references on solid state reactions of the uranium oxides: Natl. Bur. Standards (Washington) Cire. 535, 95 p.

Larsen, E. S., Jr., and Phair, George, 1954, The distribution of uranium and thorium in igneous rocks, in Faul, Henry, ed., Nuclear geology: New York, John Wiley and Sons, Inc., p. 75-89.

Larsen, E. S., Jr., Keevil, N. B., and Harrison, H. C., 1952, Method for determining the age of igneous rocks, using the accessory minerals: Geol. Soc. America Bull., v. 63, p. 1045-1052.

Lexow, S. G., Maneschi, E. P. P., and Sa, A. M., 1948, (Preliminary note on the presence of uranium in living things in Argentina): Anales Asociacion Qúimica Argentina 36, p. 203-207 (Spanish text); English abs., 1949, in Nuclear Seience Abs., v. 3, p. 76, and Chem. Abs., v. 43, 3285 h.

Liebenberg, W. R., 1948, Rare minerals in the Banket of the Witwatersrand system: Dissertation, Pretoria Univ., Pretoria, Transvaal.

Lindgren, W., 1933, Mineral deposits, 4th ed.: New York, McGraw-Hill Book Co., Inc., 930 p.

Louw, J. D., 1954, Geological age determinations on Witwatersrand uraninites using the lead isotope method, Appendix on chemical analyses by F. W. E. Strelow: Geol. Soc. South Africa, Trans., v. 57, p. 209-230.

MacGregor, A. M., 1953, The gold-uranium ores of the Witwatersrand: Mining Mag. (London), v. 88, p. 281-282. (Discussion of paper by C. F. Davidson, 1953, same journal, p. $73-85$.)

McKelvey, V. E., 1955, Search for uranium in the United States: U. S. Geol. Survey Bull. 1030-A, p. 1-64.

McKelvey, V. E., and Nelson, J. M., 1950, Characteristics of marine uranium-bearing sedimentary rocks: Econ. Geology, v. 45, p. $35-53$.

McKelvey, V. E., Everhart, D. L., and Garrels, R. M., 1955, Origin of uranium deposits: Soc. Econ. Geologists, 50th Anniversary volume-1905-1955, part I, p. 464-533.

McKelvey, V. E., Swanson, R. W., and Sheldon, R. P., 1953, The Permian phosphorite deposits of Western United States: 19th Internat. Geol. Cong. Comptes rendus, v. 11, p. $45-64$. 
Mellor, E. T., 1916, The conglomerates of the Witwatersrand: Inst. Min. Metallurgy Trans., v. 25, p. 226-291, (diseussion p. 291-333, Mellor's reply, p. 333-348).

Miller, L. J., and Kerr, P. F., 1954, Progress report on the chemical environment of pitchblende, in Annual Report for June 30, 1953 to April 1, 1954, pt. 2: U, S. Atomic Energy Comm. RME-3096, p. 72-92, issued by U. S. Atomic Energy Comm Tech. Inf, Service, Oak Ridge, Tenn.

Miller, R. L., and Gill, J. R., 1954, Uranium from coal: Sei. Am., v. 191 , no. 4, p. 36-39.

Moore, G. W., 1954, Extraction of uranium from aqueous solution by coal and some other materials: Econ. Geology, v. 49 , p. $652-658$.

Munthe, Henr., Westergård, A. H., and Lundquist, G., 1928, Beskrivining till Karbladet Skövde (Description relating to the Skövde map sheet): Sveriges geol. undersokning (Stockholm), Series Aa Kartblad i skalan 1:50,000 med beskrivningar, no. 121, $182 \mathrm{p}$.

Neuman, W. F., Neuman, M. W., Main, E. R., and Mulryan, B. J., 1949a, The deposition of uranium in bone, IVAdsorption studies in vitro: Jour. Biol. Chemistry, v. 179, p. 325-333.

, 1949b, The deposition of uranium in bone, $\mathrm{V}$-Ion exchange studies: Jour. Biol. Chemistry, v. 179, p. 335-340. - 1949c, The deposition of uranium in bone, VI-Ion eompetition studies: Jour. Biol. Chemistry, v. 179, p. 341-348.

Nininger, R. D., 1954, Minerals for Atomic Energy. New York, D. Van Nostrand Co., Ine., 367 p.

Pabst, Adolf, 1954, Brannerite from California: Am. Mineralogist, v. 39, p. 109-117.

Page, L. R., 1950, Uranium in pegmatites: Econ. Geology, v. 45, p. 12-34.

Phair, George, 1952, Radioactive Tertiary porphyries in the Central City district, Colorado, and their bearing upon pitchblende deposition: U. S. Geol. Survey TEI-247, 53 p., issued by U. S. Atomic Energy Comm. Tech. Inf. Service, Oak Ridge, Tenn.

Picciotto, E. E., 1950, Distribution de la radioactivité dans les roches éruptives: Soc. belge géologie Bull., y, 59, p, 170-198.

Proctor, P. D,, 1953, Geology of the Silver Reef (Harrisburg) mining district, Washington County, Utah: Utah Geol. and Mineralog. Survey Bull. 44, 169 p.

Rasor, C. A., 1952, Uraninite from the Grey Dawn mine, San Juan County, Utah: Science, v. 116, p. 89-90.

Reinecke, Leopold, 1927, The location of payable ore-bodies in the gold-bearing reefs of the Witwatersrand: South Africa Geol. Soc. Trans,y v. 30, p. 89-119. [1928]
Reinhardt, E. V., 1952, unpub. info.

Runnels, R. T., Schleicher, J. A., and Van Nortwick, H. S., 1953, Composition of some uranium-bearing phosphate nodules from Kansas shales: Kans. Geol. Survey Bull. 102, pt. 3, p. 93-104.

Russell, W. L., 1945, Relation of radioactivity, organic content, and sedimentation: Am. Assoc. Petroleum Geologists Bull., v. 29 , p. $1470-1493$.

Smith, P. V., Jr., 1954, Studies on origin of petroleum, occurrence of hydrocarbons in Recent sediments: Am. Assoc. Petroleum Geologists Bull., v, 38, p. 377-404.

Stevenson, J. S., 1951, Uranium mineralization in British Columbia: Econ. Geology, v. 46, p. 353-366.

Stieff, L. R., Stern, T. W., and Milkey, R. G., 1953, A preliminary determination of the age of some uranium ores of the Colorado Plateaus by the lead-uranium method: U. S. Geol. Survey Cire. 271, 19 p.

Strøm, K. M., 1948, A concentration of uranium in black muds: Nature (London), v. 162, p. 922.

Szalay, S., 1954, The enrichment of uranium in some brown coals in Hungary: Magyar Tudom. Akad. Acta Geol., v. 2, p. $299-310$.

Turner, H. W., 1928, Review of the radioactive minerals of Madagascar: Econ. Geology, v. 23, p. 62-84.

United States Geological Survey, 1953, Search for and geology of radioactive deposits, Semiannual progress report Dec. 1, 1952 to May 31, 1953: U. S. Geol. Survey TEI-330, 302 p., issued by U. S. Atomic Energy Comm. Tech. Inf. Service, Oak Ridge, Tenn.

1954, Geological investigations of radioactive deposits, Semiannual progress report June 1 to Nov. 30, 1954: U. S. Geol. Survey TEI-490, 299 p., issued by U. S. Atomic Energy Comm. Tech. Inf. Service, Oak Ridge, Tenn.

Vine, J. D., and Moore, G. W., 1952, Uranium-bearing coal and carbonaceous rocks in the Fall Creek area, Bonneville County, Idaho: U, S. Geol, Survey Circ. 212, 10 p.

Waters, A. C., and Granger, H. C., 1953, Volcanic debris in uraniferous sandstones, and its possible bearing on the origin and precipitation of uranium: U, S. Geol. Survey Circ, 224, 26 p.

Whitehead, W. L., director, 1952, Biennial report on Research Project $43 \mathrm{c}$-Studies of the effect of radioactivity in the transformation of marine organie materials into petroleum hydrocarbons, in Am. Petroleum Inst., Rept. of Progress 1950-51, p. 192-201.

Young, R. B., 1917, The Banket: London, Gurney and Jackson, $125 \mathrm{p}$. 



\title{
URANIUM IN IGNEOUS ROGKS OF THE UNITED STATES
}

\author{
By George J. Neuerburg, U. S. Geological Survey
}

\section{CONTENTS}

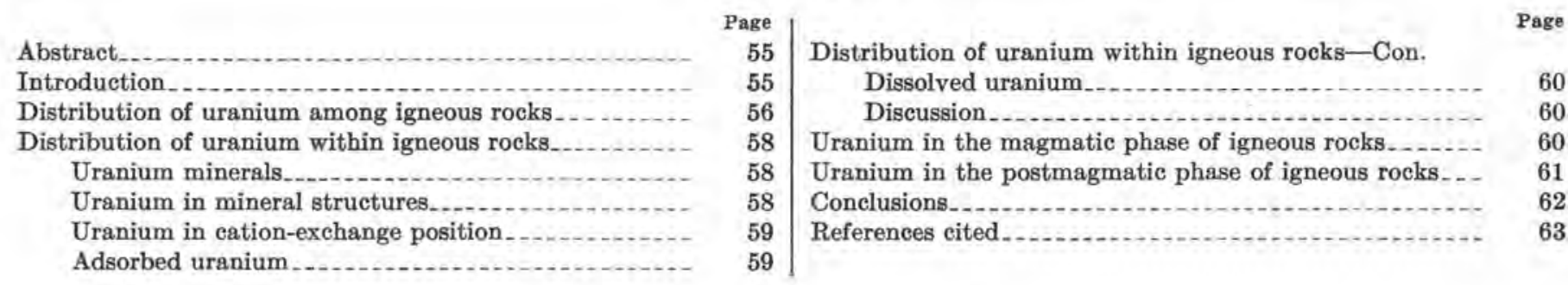

\section{ABSTRRACT}

Uranium is an ubiquitous and very small component of all igneous rocks. The uranium content of igneous rocks largely reflects the chemistry of the rock-felsic igneous rocks generally contain more uranium than do the mafic igneous rocks within any given petrographic association. Equivalent rocks from separate petrographic associations differ in uranium content. The quantity of uranium also varies within seemingly homogeneous rock masses. Uncertain evidence exists for a regional variation in uranium content of igneous rocks beyond that due to petrographic character.

Uranium occurs in six different ways in igneous rocks: uranium minerals as such, uranium disposed in the structure of the rock minerals by diadochy and in structural defects in erystals, uranium held in cation-exchange positions, uranium in unknown form adsorbed on surfaces of crystals, uranium dissolved in fluid inclusions within rock minerals, and uranium dissolved in intergranular fluids.

The amount of uranium in these environments varies from rock to rock, and each is thought to have differing geologic histories, such that the total uranium content of an igneous rock represents the interplay of a complex series of events during and since crystallization of the rock. Thus, the total uranium contents of igneous rocks are dynamic quantities that cannot be referred to any single event. The uranium in the six environments displays differing degrees of reactivity toward and accessibility to solutions passing through the rock.

Current techniques permit crude determinations of the amounts of uranium in the different environments or in groups of the environments. Such information is of potential value to theoretical considerations and to prospecting for uranium ore deposits. Dilute mineral acids dissolve nearly all the uranium in environments other than in the structures of rock minerals. The quantity of uranium held structurally can be referred to the last crystallization or recrystallization of the rock minerals and is the quantity of prime importance to geochemical studies. The readily dissolved, or labile, uranium of a rock is a measure of that part of the uranium content of a rock most likely to have been changed after final consolidation. If uranium aureoles exist around ore deposits, their extent can be measured by the quantity of labile uranium.

The total uranium content of an igneous rock is the sum of the amount of uranium fixed in the rock at the time of final consolidation and the amount of labile uranium, which probably was changed after consolidation of the rock.

Studies of the occurrence and quantity of uranium in igneous rocks are important for two reasons: these rocks are potential low-grade ores, and uranium in currently minable concentrations has originated both directly and indirectly from igneous activity.

\section{INTRODUCTION}

Uranium ore deposits are presumed to have had an igneous origin initially, either directly by magmatic processes or indirectly by way of other geologic processes. Studies of the occurrence and history of uranium in igneous rocks thus supply fundamental data pertinent to appraisals of uranium resources and to the devising of efficient and economic prospecting methods. Additional interest in this subject is impelled by the possibility that igneous rocks themselves are potentially important low-grade uranium deposits.

The data upon which this review is based include that in the published literature and that contained in unpublished reports and analyses made by the U. S. Geological Survey and by the Division of Raw Materials of the U. S. Atomic Energy Commission. Grateful acknowledgment is made to my colleagues in the U.S. Geological Survey for access to unpublished data concerning their current work. 


\section{DISTRIBUTION OF URANIUM AMONG IGNEOUS ROCKS}

The uranium contents of igneous rocks have been estimated in three ways, none of which is wholly satisfactory: by direct chemical measurement, by measurements of the daughter products of uranium, and by radioactivity measurements.

Considerable uncertainty is attached to chemical analyses of uranium, especially to the older analyses, because of difficulties in sample preparation and in analytical procedure involving the determination of very small quantities of uranium. Nevertheless, these data are the best at hand and may be sufficiently accurate for geologic studies.

Estimates of uranium content based on the determination of daughter products are open to serious uncertainty because the daughter products are not always in equilibrium with uranium and, accordingly, may not provide a meaningful measure of the uranium content. This uncertainty is especially critical in rocks containing sulfides, because radium may be enriched many times due to leaching of uranium by acid waters formed during oxidation of the sulfides (Phair and Levine, 1953).

Radioactivity estimates of uranium content may be the most misleading because not only are they subject to the uncertainties arising from possible radioaciive disequilibrium, but they fail to account for variations in the ratio between the amounts of uranium, thorium, and potassium, which varies widely within and among igneous bodies.

Because most of the current information on the uranium content of igneous rocks is based on measurements of radium and of radioactivity, a modicum of suspicion must be accorded to many present concepts concerning the amount of uranium in and its distribution among igneous rocks.

Most igneous rocks contain less than 10 grams per ton of uranium. Contents much in excess of this figure, except for certain rock types (Phair, 1952; Larsen, Jr., 1954a), are chiefly the result of secondary addition of uranium to a rock.

Uranium contents of igneous rocks show considerable variation. In part, the variations are nonsystematic in that they appear unrelated to serial changes of other components in the rocks concerned. In larger part, the variations are systematically related to chemical, petrographic, or structural features of rocks or all three. All variations that have been noted (other than those due to analytical error) are an expression of the geologic processes that affected the igneous rocks of discrete volumes of the earth's crust. The variation in one group of related rocks is not necessarily like that in another, even similar, group of rocks. The following pages summarize systematic variations found to date, as well as the apparently nonsystematic variations. These data, while presenting a seemingly confusing collection of concepts, are not internally inconsistent or anomalous; they are the result of an interplay of geologic events and processes that differ from rock type to rock type and from place to place in the crust.

Perhaps more commonly than not the same rock types from different places and from single bodies have essentially the same uranium content. For example, a large number of basalts from several localities in the Western United States have a common content of about 1 gram per ton uranium (R. S. Cannon and E. S. Larsen, Jr., written communications; Adams, 1954). Most granites contain about 4 grams per ton of uranium. Some, but not all, samples of anorthosite from Wyoming and southern California have a common uranium content of 3 grams per ton.

Many reports imply that the uranium content of any one variety of igneous rock may vary appreciably, not only among specimens from different localities but also among specimens from within seemingly homogeneous masses and outcrops. Thus, granites of superficially similar character from different localities range in uranium content from less than 1 to more than 100 grams per ton (Phair, 1952; Larsen, Jr., 1954a). A fairly uniform pluton of granodiorite in the southern California batholith ranges from 1 to 3 grams per ton uranium (Larsen, Jr., 1954b). Two parts of a single apparently uniform specimen of anorthosite from southern California showed uranium contents of 4 and 11 grams per ton.

A number of explanations have been offered for variations in the uranium content of superfically similar rocks. Most commonly, the differences in the uranium content of rocks have been correlated with the abundance of uraniferous minor accessory minerals, especially zircon (Phair, 1952; Amstutz, 1951; Ingham and Keevil, 1951; Keevil, Keevil, Ingham, and Crombie, 1943). Other petrographic features, such as grain size (Asayama, 1953; Daniels, 1954) and secondary mineralization, have also been offered in explanation. These explanations imply petrographic and chemical dissimilarity among the rocks being compared and give reason to conclude that the rocks being compared, while superficially similar, are not identical.

Differences in the uranium content of apparently similar rocks have been correlated with the geologic positions of the rocks. Radioactivity in some Canadian batholiths (Ingham and Keevil, 1951) and in the alkaline Nigerian granites (Davidson, 1951) is concentrated in the peripheries of the intrusions. Concentrations of radioactivity in Canadian intrusive bodies that are related to structures in the wall rocks have been noted by Gross (1952). Here again, there is reason to think that 
therocks being compared are not identical in every way.

The possibility of otherwise identical rocks containing different amounts of uranium, an intriguing and important problem, is fairly well documented for two occurrences of radium. Petrographically identical dacites from the same flow on Mount Lassen, Calif., have different radium contents (Evans and Williams, 1935), Radium is most abundant in the upper parts of a granodiorite laccolith in Caucasia (Soloviev, 1936), and its distribution appears to be independent of rock type.

Uranium contents of igneous rocks may also vary according to their position in the earth's crust. The possibility is pointed out by Larsen, Jr., and Phair (1954) that volcanic rocks and hypabyssal rocks may contain more uranium than plutonic rocks of similar composition, However, the radium contents of many igneous rocks (Evans and Goodman, 1941) show no appreciable difference between plutonic and volcanic rocks belonging to the same elans, and the uranium contents of granites and rhyolites show no significant differences (Ingerson, 1954). The possibility of systematic differences in the uranium content of correlative plutonic and volcanic rocks requires further exploration.

In many igneous-rock provinees, the uranium of the several differentiates commonly shows serial variations analogous to those shown by other components of the rocks. Serial variations in uranium content differ considerably from province to province and locally within provinces. Perhaps most commonly, the uranium content of the rocks varies directly with the silica content (Ingham and Keevil, 1951; Asayama, 1953; Daniels, 1954; Larsen, Jr., and Phair, 1954; Evans and Goodman, 1941; Davis and Hess, 1949; Larsen, Jr., and Keevil, 1947; Westerveld, 1954), especially among the calc-alkalic plutonic rocks. A similar variation with potassium has been noted (Adams, 1954; Asayama, 1953; Evans and Williams, 1935) and recognized as a parallel enrichment of the two elements during differentiation (Larsen, Jr., and Keevil, 1947); this variation may be most pronounced in calc-alkalic volcanic rocks. Uranium is commonly enriched in hydrothermal and pegmatitic stages of crystallization (Rankama and Sahama, 1950). For example, uranium contents of post-Cretaceous volcanic rocks in the Western United States vary directly with niobium, beryllium, lead, and tin, but not with boron and zirconium (Coats, 1954). The uranium of igneous rocks has been found to vary directly with the order of extrusion or intrusion in volcanic and hypabyssal rocks in California (Adams and Saunders, 1953) in Colorado (Phair, 1952), and in plutonic rocks in California (Larsen, Jr., and Phair, 1954).

In places, uranium contents vary inversely with these same factors. The more mafic border rocks of the $385115-56-5$
Boulder Creek batholith, Colorado, contain 14 grams per ton of uranium in contrast to a content of 1 gram per ton of uranium in the felsic interior, 12 miles away (Larsen, 1954a). Specimens of diabase pegmatite from Arizona contain only 3 grams per ton uranium in contrast to 12 grams per ton in the enclosing diabase. The high uranium contents of some lamprophyres also imply this inverse relationship to silica content.

In a few places, the uranium content shows no change among a group of related igneous rocks of different chemical compositions. This feature is best shown by Piggot's radium analyses (1931) of basalts in Hawaii, which do not differ significantly, either with respect to sequence of extrusion or to composition, which ranges from picrite to trachyte. A few of the granites of the southern California batholith (Larsen and Phair, 1954) have a low uranium content-less than contained by 1 or 2 of the gabbros - which may mean that more than 1 type of uranium variation may take place in a single petrographic province. Finally, the uranium content of related groups of igneous rocks may show no readily discernible relation to other compositional variations among the enclosing rocks, a possibility exemplified by the lavas of the San Juan Mountains (Larsen, Jr., and Phair, 1954).

Different petrographic associations have different uranium contents (Ingerson, 1954), and, in general, the more uraniferous petrographic associations tend to be of rocks with uncommon compositions (Larsen, Jr., and Phair, 1954) and to occur in small bodies. The alkalic associations are generally richer in uranium than the calc-alkalic associations. The White Mountain plutonic-volcanic series of alkalic affinities is twice as uraniferous as the calc-alkalic rocks of the southern California batholith, The uranium contents of associations of similar rocks, such as the southern California, Sierra Nevada, and Idaho batholiths, are similar (Larsen, Jr., 1953).

Attempts to define uranium-rich and uranium-poor igneous provinces have been made by Adams (1954), Keevil, Keevil, Ingham, and Crombie (1943), Asayama (1953), Davidson (1951), Davis and Hess (1949), Aswathanarayana (1954), Coats (1953), and Senftle and Keevil (1947); also, Davis and Hess (1949) suggested uranium epochs. Only Asayama and Coats considered the possibility that the contrasting geographic provinces are instead contrasting petrographic provinces. Although the possible existence of uranium provinces and epochs is suggested by variable contents of uranium in similar rocks from different localities, the arguments offered for this concept are based on comparisons of unlike rocks or mixtures of unlike rocks and are therefore not conclusive.

Explanations for the variations in uranium content 
described in the preceding paragraphs are to be sought in information on the detailed distribution of uranium in the rock fabric, on the history of changes that affect rocks, and in theoretical considerations of the history of rock crystallization.

\section{DISTRIBUTION OF URANIUM WITHIN IGNEOUS ROCKS}

Studies of the distribution of uranium in the fabric of igneous rocks are based upon radioactivity measurements, upon chemical determinations of daughter elements of uranium and thorium, and, only recently, upon chemical determinations of uranium. Both chemicaland radioactivity-measurement techniques must be used in these studies, for they supplement one another in many important ways. Thus the uranium in minerals is best determined chemically, and the point distribution of uranium is determinable only by means of autoradiographic techniques.

Considerable information is available on the distribution of the radioelements as a group and of certain daughter elements of uranium and thorium in the rock fabric; little information is available on the distribution of uranium itself. It is assumed here that information concerning groups of radioelements in the rock fabric can be extended, at least qualitatively, to uranium.

Uranium is thought by this writer to have six modes of occurrence in the fabric of igneous rocks: uranium minerals; uranium substituting in minor amounts for cations in the structures of rock minerals, and uranium located in minor amounts in structural defects of rock minerals; uranium held in cation-exchange position; uranium adsorbed on crystal surfaces, on surfaces of crystallographic discontinuities, and on surfaces of irregular cracks within crystals; uranium dissolved in fluid inclusions contained within rock minerals; and uranium dissolved in intergranular fluids.

\section{URANIUM MINERALS}

Primary or quadrivalent uranium minerals seem to be uncommon in igneous rocks; they occur as minor accessories, usually disseminated throughout the fabric. The so-called secondary or sexivalent uranium minerals are apparently more common and are generally localized along cracks and in aggregates of altered rock minerals. Minerals such as uraninite and betafite are perhaps most commonly primary products of magmatic crystallization, but they may be of deuteric or hydrothermal origin in some rocks. The sexivalent uranium minerals probably most commonly originate in secondary hydrothermal or ground-water processes, but some may be deuteric (Page, 1950).

\section{URANIUM IN MINERAL STRUCTURES}

Small amounts of uranium are contained in many, if not in all, common rock-forming minerals and their alteration products. Most authors imply that such uranium proxies for one or more cations (perhaps also for anions) in the structure of the host mineral. This implication is not wholly justified because the analytically determined uranium may occur in the crystals in several ways that are not related to the structure of crystals. The substitution of uranium for a cation or anion in a mineral structure can be documented only rarely and with difficulty. The concept seems valid for minerals in which the concentrations of uranium are zonally arranged, such as zircon (Larsen, Jr., Waring, and Berman, 1953), and in those minerals thought or known to have an analogous uranium compound, such as thorite. In other minerals, such as plagioclase and quartz, most, if not all, of the uranium is in inclusions of uraniferous minor accessories and along cracks and crystallographic discontinuities (Picciotto, 1950).

Uranium may be disposed in structural defects in rock minerals, defects such as mosaic boundaries, twin boundaries, zonal boundaries (DeVore, 1955), and lineage structure (Amstutz, 1951). Most of the uranium contained within common rock minerals may have this mode of occurrence, judging from the work of DeVore, even though he makes no specific mention of uranium.

The uranium content of any one mineral species within a given rock may vary enormously within and among crystals of that mineral. Zonal variations in uranium and rare-earths content have been noted by Larsen, Jr., Waring, and Berman (1953) and by Brotzen (1952). According to R. H. Jahns (personal communication), the trace-element content of some pegmatite minerals changes along the direction of growth of the crystals, a type of variation that uranium may also show in some crystals. Nonsystematic variations with respect to uranium and thorium were described by von Buttlar and Houtermans (1951). Variations of uranium content among different zircon crystals from single rocks are indicated by Larsen and Phair (1954). Uranium in a minor accessory mineral may differ according to whether the minor accessory is included in hornblende, biotite, plagioclase, other rock minerals, or occurs between the crystals of these minerals. Ample theoretical justification for appreciable variation in the uranium content of rock minerals from erystal to crystal and within erystals is found in several papers on the distribution of minor elements during crystallization (DeVore, 1955; Holland and Kulp, 1949; Neumann, 1948; Neumann, Mead, and Vitaliano, 1954; Shaw, 1953).

Considerable research has been done on the quantitative distribution of uranium and other radioelements among the different minerals of several rocks (Larsen, Jr., 1954b; Keevil, Keevil, Ingham, and Crombie, 1943; Evans and Williams, 1935; Davis and Hess, 
1949; Picciotto, 1950; Davis, 1947; Hee, Derville, and Jarovoy, 1954; Keevil, Larsen, Jr., and Wank, 1944; Larsen, Jr., and Keevil, 1942; Piggot, 1929). Analyses of separate fractions of the major minerals are probably quantitatively misleading owing to the virtually certain inclusion of the uraniferous minor accessories and to the occurrence of radioelements along cracks and crystallographie discontinuities (Larsen, 1954b; Picciotto, 1950; Larsen, Jr., and Keevil, 1942). Analyses of the minor accessories may refer only to the particular grain-size fraction used for analysis. Although the results of studies of this sort probably have no strictly quantitative significance, they define the semiquantitative distribution of uranium among the minerals of any given rock. The highest uranium contents, excluding uranium minerals, are found in the minor accessory minerals and to a considerably lesser degree in the iron oxides, Zircon is generally the most uraniferous of the minor accessories, but in places it is less uraniferous than associated minor accessories such as monazite (Hutton, 1947) or allanite. The amount of uranium in the mafie silicate minerals is small but exceeds that in the feldspars and in quartz.

The relative distribution of uranium among the rock minerals differs from rock to rock. The uranium content of any one mineral commonly increases with the silica of the rock (Ingerson, 1954; Larsen, Jr., 1953). Uranium contents of minerals are apparently usually least contrasted among the minerals of mafic rocks (Picciotto, 1950; R. S. Cannon, personal communication). With few exceptions, the minor accessories and some deuteric minerals (Davis and Hess, 1949) commonly contain most of the total amount of uranium located in the structures of the minerals of a rock.

\section{URANIUM IN CATION-EXCHANGE POSITION}

The occurrence of uranium in cation-exchange position has not been proved, although it is a probable mode of occurrence. Montmorillonite in bentonites from the central United States may contain uranium in this position (Osmond, 1954). Zeolites from southern California contain as much as 28 grams per ton of uranium. Because it is predicted by Goldschmidt (1937) that uranium should not be accommodated in the zeolite structure, these uranium analyses may mean that zeolites contain uranium in cation-exchange positions.

\section{ADSORBED URANIUM}

Adsorption of uranium on crystal surfaces and on a variety of surfaces of discontinuity within crystals has been predicted from theory by DeVore (1955), Neumann, Mead, and Vitaliano (1954), and Jahns (1953); inferred from chemical studies by Piggott (1929),
Brown, Blake, Chodos, and others (1953a, 1953b), and Hurley (1950); and indicated by autoradiographic studies of Gross (1952) and Píciotto (1950). Experimental demonstration of the occurrence of adsorbed uranium will be exceptionally difficult. Current autoradiographic studies have not distinguished between uranium, thorium, and their daughter elements, although the distinction is theoretically possible. Thus, these studies have not fully documented the occurrence of adsorbed uranium. Hurley's work (1950) may be interpreted to mean that much of the radioactivity on grain surfaces and along cracks may well be due almost entirely to daughter elements. Furthermore, Picciotto (1950) believes that some interstitial radioactivity found in autoradiographs is contained in thin films of such secondary minerals as epidote.

The lowering of radioactivity and uranium content in rocks by leaching with mineral acids has been cited as evidence for the occurrence of adsorbed uranium. Where leaching has been done in conjunction with determinations of the distribution of radioactive particles in rock powders (Hurley, 1950), the thesis is convincing. Some studies of leaching of mineral fractions (Tilton, Patterson, Brown, and others, 1955 ; E. S. Larsen, Jr., personal communication) present evidence that uranium is strongly concentrated in the outer parts of erystals and crystal fragments. Most studies of leaching, however, have been inconclusive with respect to the occurrence of adsorbed uranium, simply because much if not all of the leached uranium or radioactive material is derived from the solution of uranium- and thorium-bearing minerals (Brown, Blake, Chodos, and others, 1953b).

Current usage implies that adsorbed uranium, leachable (or acid-soluble) uranium, and interstitial uranium are identical. Leachable uranium includes all uranium that is readily soluble under the experimental conditions, whatever its mode of occurrence in the rock. Interstitial uranium, most carefully defined by Picciotto (1950), includes uranium contained in films and stringers of secondary minerals along cracks and grain boundaries, as well as adsorbed uranium.

The opinion is commonly expressed that interstitial or leachable uranium, in the sense of adsorbed uranium as used here, is a product of the last stages of crystallization of the rock (Gross, 1952; Larsen, Jr., and Phair, 1954). This conclusion seems untenable because the amount of adsorbed material probably changes after crystallization (Hurley, 1950), the material adsorbed on the faces of some crystals is the same material that was adsorbed on the crystal nucleus and remained bound to the surface as the crystal grew (DeVore, 1955), and uranium from dissolved minerals contributes to the quantities of leachable or interstitial 
uranium, or both, that are measured (Brown, Blake, Chodos, and others, 1953b).

\section{DISSOLVED URANIUM}

Uranium may be dissolved in the fluid inclusions of rock minerals (Picciotto, 1950); the suggestion remains to be documented. Uranium in this situation may be only partly related to the crystallization of the rock, for fluid inclusions commonly belong to a number of generations, including many that postdate crystallization. Some fluid inclusions may have formed even during weathering (Folk, 1955).

No direct experimental evidence yet demonstrates that the intergranular fluids of igneous rocks contain dissolved uranium. However, any soluble uranium contained in the rock will be partly dissolved in these fluids. The presence of uranium in streams and ground waters draining terranes of igneous rock and contributing to and interchanging with intergranular fluids is sufficient evidence that intergranular fluids contain some uranium in solution.

\section{DISCUSSION}

There is reason to believe that the amount of uranium in each of its modes of occurrence differs appreciably from rock to rock, and, in places, within small outcrops. Uranium dissolved in fluid inclusions and in intergranular fluids may not constitute any appreciable fraction of the total uranium content of the rock because these fluids are limited in volume. The quantity of uranium in intergranular fluids probably varies by small amounts with crustal position, with rock structure, with climate, and with season. Uranium minerals may constitute a small to large portion of the total uranium in an igneous rock. Because most igneous rocks contain very small amounts of uranium, concentration into discrete uranium minerals is theoretically unlikely. The relative amounts of uranium in structural defects and in diadochic substitution might prove to vary systematically with silica content of the rock. Mafic rocks may contain proportionately more uranium in structural defects than felsic rocks, because the mafic rocks contain fewer minerals with structures receptive to accommodation of uranium. Some evidence for this lies in Picciotto's observation (1950) that alpha activity in mafic rocks is distributed fairly evenly among the rock minerals rather than being strongly concentrated in a few uranium-receptive mineral species as in felsic rocks. The relative proportion of adsorbed uranium probably differs from rock to rock. In part such a variation may be systematic; Picciotto suggests that interstitial radioactivity constitutes a smaller fraction of the total radioactivity of mafic igneous rocks than of felsic igneous rocks. The writer's experiments on anorthosites, which show a 1- to 93-percent variation in leachable uranium, may mean that Picciotto's suggestion is premature. Also, adsorbed uranium probably varies in amount and strength of bonding from mineral to mineral.

The uranium in each of the rock-fabric situations outlined above undoubtedly differs in its accessibility to and reactivity with the various geologic agents affecting the chemistry of a rock. Easily soluble uranium minerals generally occur along passageways for the various solutions that may have passed through the rock. Regardless of the manner in which uranium may be contained within the structure of any one mineral, it is tightly held and protected from reaction with fluids that do not react with the host mineral. Uranium in cation-exchange position should be readily extracted or enriched by various natural solutions. Adsorbed uranium would be especially liable to reaction and to change in amount with solutions passing through a rock. To the extent that fluid inclusions are accessible to and formed by exotic solutions, the amount of uranium they contain may have been appreciably changed during the rock's history. The amount of uranium dissolved in intergranular fluids is exceptionally subject to change in amount from time to time.

In view of the varying accessibility and reactivity of uranium to natural solutions in each of its occurrences in the fabric, the conclusion is unavoidable that the uranium in each occurrence may have and probably has changed in amount and physical state to a different degree and in a different way from that in the other occurrences during the history of a rock.

\section{URANIUM IN THE MAGMATIC PHASE OF IGNEOUS ROCKS}

Theories concerning the distribution of trace elements during crystallization of magmas permit some qualitative generalities concerning the role of uranium. Presumably a magma begins with a certain quantity of uranium. This amount may be increased or decreased by addition of foreign substances to the magma and may be decreased by the loss of uranium-bearing fluids before or during crystallization. During crystallization, uranium is distributed among its several occurrences in proportions and amounts dependent on the prevailing - and changing - geologic and physical-chemical conditions.

The geologic controls on the fixation of uranium during crystallization may be illustrated by means of a few hypothetical examples. If a magma crystallizes entirely as a closed system, the final rock probably contains all of the magmatic uranium. For example, a miarolitic granite should contain more uranium than a massive granite containing swarms of pegmatites and 
aplites, providing the two granites crystallized from magmas of the same uranium content.

If the geologic conditions during crystallization are such that fluids are lost only sporadically, most of the magmatic uranium may or may not be lost to the final rock. If, before fluids are lost, much of the uranium is fixed in minerals that can structurally accommodate uranium, that is, a prime receptor such as zircon, much of the uranium would be retained in the rock. On the other hand, should uranium-bearing fluids leave the magma before crystallization of prime uranium receptors, the resulting rock would contain only a small fraction of the magmatic uranium.

Physiochemical factors also determine in what amounts and what manner uranium will be fixed in the final rocks. If the uranium concentration is high, uranium minerals may form. If the concentration is sufficiently low, most of the uranium may remain dissolved in fluids that leave the rock after crystallization. Should uranium be fixed in some early erystallized mineral and thereby removed from the fluid phase during most of the remaining period of crystallization, and then be released to the remaining fluids when that mineral recrystallizes, it may again be lost to the rock.

A stock of the Boulder Creek batholith, where the more mafic border rocks contain the greatest concentration of uranium (Larsen, Jr., 1953, 1954a), will serve as a hypothetical illustration of these considerations, The initial concentration of uranium in the magma was perhaps sufficiently high to force its fixation in the minerals first crystallizing in the outer parts of the stock. As a result, only a small fraction of the magmatic uranium may have been left to be fixed in the more felsic center. Alternatively, much of the uranium may have migrated out of the stock after crystallization of the border and before crystallization of the interior.

Another possible way in which the crystallization history affects the fraction of magmatic uranium fixed in the final rock is illustrated by Mawdsley's explanation (1953) of the high uranium content of some pegmatites in Saskatchewan, Canada. The pegmatites rich in uranium are fine grained and show evidence of assimilation of limy sediments, whereas associated pegmatites unrelated to limy sediments are coarse grained and relatively poor in uranium. These observations are interpreted by Mawdsley to mean that assimilation of lime from the sediments promoted rapid cooling and forced crystallization of uraninite, whereas those pegmatites not assimilating lime crystallized more slowly and uranium escaped with the late-stage fluids.

The uranium content of different magmas is assumed to have differed widely, but the uranium content of the final product of each magma may provide little if any quantitative clue to the original uranium content of the magma. The relatively low uranium content of basalts and the uniformly higher content of granites implies a similar contrast in the uranium content of their respective magmas. However, this contrast is conceivably, perhaps certainly, aggravated or lessened by differences in the fixative power of the contrasting magma compositions toward uranium, by differences in the geologic environment of crystallization, or, for that matter, even by assimilation of wall rocks. Sullivan (1954) suggests that the uranium of granites was obtained from sedimentary country rocks and implies that the resulting content of uranium in the igneous rock is a function of the composition of the magma. His suggestion serves well to underline the uncertain status of the understanding and interpretations of observations in this realm of uranium geology.

\section{URANIUM IN THE POSTMAGMATIC PHASE OF IGNEOUS ROCKS}

The uranium content of an igneous rock may be changed in many ways after crystallization. Internal readjustments consequent on the cooling of the solidified rock may bring about changes in the distribution of uranium within the rock. Recrystallizations, such as the subsolidus unmixing of perthite, or deuteric reactions, such as chloritization of biotite, may change the uranium contents of these minerals. Recrystallization probably generally results in expulsion of uranium from the mineral being altered; uranium is then deposited elsewhere in the rock fabric or lost from the rock.

Data on the effects of metamorphism, hydrothermal alteration, ground-water processes, and weathering on the uranium contents of igneous rocks are surprisingly few. The few analyses of altered igneous rocks, principally weathered rocks, are compelling evidence that the uranium contents of igneous rocks are generally appreciably changed as a result of alteration. Commonly, the uranium content is decreased, although increases in uranium content are common in the vicinity of uranium ore deposits.

Although the changes of uranium content during alteration of igneous rocks are not well understood, some of the controlling factors may be inferred. The proportional distribution of uranium in the rock fabric will determine the quantity of uranium that may be changed during alteration. The physical chemistry of the altering system, the degree to which the rock is an open system, and the composition of any invading solutions will determine the changes that take place. Permeability and the struetural position of the rocks, which control the passage of solutions, are of major importance because they may induce varying compositional changes from place to place in a single uniform 
rock mass. Both climate and the stage of geomorphic development of a region may dictate what changes will take place as the result of weathering.

\section{CONCLUSIONS}

The principal conclusion of this review is that the uranium content of each igneous rock reflects a complicated history. Ample opportunity existed and exists for repeated change, but not only of the total uranium content, but also of the distribution of uranium among each of its occurrences in the rock fabric. The total uranium content of an igneous rock thus represents the interaction of a complex series of events taking place during and since its crystallization. The total uranium contents of igneous rocks are dynamic quantities that cannot be referred to any single event and that are probably changing from day to day by some infinitesimal amount. Corollary to this proposition is the conclusion that the total uranium content of an igneous rock is a highly uncertain or indecipherable measure of the uranium content of its magma.

Little basis is available for estimating the quantitative effects of an involved history on the uranium content of a rock. It may be that the uranium contents of very fresh, unaltered impermeable rocks are but little changed from the uranium contents existing at the end of crystallization. This possibility seems indicated by the fairly consistent uniformity of uranium content among similar rock types and by a fairly systematic internal variation with gross composition among differentiated rocks such as the southern Califormia batholith.

The natural history of uranium in igneous rocks will not be elucidated solely from quantitative correlations of uranium content with the composition of the containing rock. Much better understanding will be gained from studies of uranium content in terms of the geologic history of each rock. Appraisals of compositional changes in groups of igneous rocks are frequently cast into terms of their crystallization history in a qualitative manner, and such appraisals are among the most meaningful of petrologic interpretations. Two examples of this sort of approach consist of Mawdsley's work (1953) and of Wager's and Mitchell's study (1951) of trace-element variation in the Skaergaard intrusive body. Wager and Mitchell plotted minor-element content against percent of magma solidified. The result provides an excellent example of chemical variation as it has been guided and controlled by pertinent geologic processes.

Extensions of such appraisals to take into account posterystallization history add much to an understanding of the quantitative data yielded by analyses. Again, the Boulder Creek stock (Larsen, Jr., 1954a) may serve as a hypothetical example. It is conceivable to the writer that much of the uranium in this stock may be of supergene origin, its fabric distribution being controlled by structural and mineralogic features of the contrasting rocks in the stock. If the added uranium is in the form of adsorbed uranium, it is possible that platy minerals, like biotite, and platy rock structures, perhaps characteristic of the mafic rocks of this stock, would adsorb uranium from supergene solutions more readily and in larger quantities than the more massive felsic rocks of the interior of the stock.

By this analysis of the uranium geology of igneous rocks, I hope to emphasize the mandatory need for geologic interpretation of uranium analyses and to indicate the misdirection fostered by divorcing analytical data from geology.

Because uranium in each occurrence in the rock fabric shows variable accessibility and reactivity to solutions which may affect the rock, it may be possible to isolate or determine separately the amount of uranium in each occurrence. Some of this quantitative information may be referred to specific events in a rock's history. The information will not only be of theoretical interest but may well prove to be economically important to prospecting and to extractive metallurgy. Current techniques will permit only crude and semiquantitative determinations of the amounts of uranium in each or in groups of its occurrences in the rock fabric.

Autoradiographic studies, although exceptionally tedious and time consuming, offer the greatest promise for quantitative determinations of the amounts of uranium in its several occurrences in igneous-rock fabrics. It is doubtful if the quantitative results would warrant the time and expense involved in this method, but the method has been and will continue to be the prime tool for documenting the distribution of uranium in the rock fabric and indicating its semiquantitative distribution, providing uranium is sorted from thorium and the daughter elements of uranium and thorium.

The quantities of uranium adsorbed on crystal boundaries and internal discontinuities and held in cation-exchange positions might be determined by means of techniques used to study base exchange in clays, soils, and zeolites. This information will be of special interest in studies of the amounts of uranium held in the structure of rock minerals compared with that contained in the structural defects and adsorbed onto the crystal. Furthermore, this sort of study may be useful in prospecting. Large amounts of uranium in cation-exchange position, in zeolites for instance, may serve to indicate passage of uraniferous solutions and to locate the rock through which such solutions passed.

Except in such relatively soluble minerals as apatite, 
metamict minor accessories, and some secondary rock minerals, the uranium contained in the structures of rock minerals and in structural defects of their crystals is probably not appreciably dissolved by weak acids in the laboratory or by the mild solutions near the surface of the earth's crust. The material that is readily soluble in dilute acids includes most oxidized $\left(\mathrm{U}^{+6}\right)$ uranium minerals, uranium adsorbed on crystal surfaces, uranium held in cation-exchange positions, and uranium already dissolved in fluid inclusions and in intergranular fluids. Uranium in these situations-or environments - is also expected to have changed most during the history of any igneous rock. The quantity of uranium that is dissolved from these environments and left undisturbed in the relatively insoluble invironment of structural capture depends, both in the laboratory and in nature, on a number of factors, principally the state of disaggregation-or permeability - of the rock, the mineral species making up the rock and the distribution of uranium among them, the relative bonding strength of adsorbed uranium, and the physical chemistry of the solvent system. The numerous variables involved in studies of the proportions of readily soluble (labile) uranium make absolutely comparable figures between unlike rocks difficult to obtain, but by the judicious use of petrographic and geologic controls, meaningful information should be obtained.

Studies of labile uranium may aid in deciphering the significance of variations in uranium content among rocks. Uranium that is not dissolved may represent substantially the uranium that was fixed in the structures and structural defects of rock-mineral crystals at the time of their completed crystallization, or at the time of their last recrystallization. For example, Phair (1952) found that Iabile uranium, represented largely by sexivalent uranium minerals, in two bostonites contributed a substantial part of their anomalously high uranium contents.

The quantity and proportion of labile uranium may be taken as a parameter of the extent to which the uranium content of a rock changed during ore deposition. For this reason, the aureoles of added uranium surrounding ore deposits in igneous rocks may be measured by the quantity and proportion of labile uranium rather than by the total quantity of uranium in the rock. As a corollary to this suggestion, it may be supposed that exceptionally small quantities and low proportions of labile uranium may identify some rocks that were a source of uranium, possibly deposited elsewhere in economic amounts. These suggestions gain a measure of practical interest in view of the ease with which labile uranium may be measured in the field by chemical techniques being developed by the
U. S. Geological Survey (H. W. Lakin, personal communication).

The labile-uranium content of an igneous rock is also of commereial importance because this is the quantity which may be most easily and economically extracted from an igneous rock by hydrometallurgical techniques. Most of the labile uranium can be removed from crushed igneous rocks with very dilute acids.

\section{REFERENCES CITED}

Adams, J. A. S., 1954, Uranium and thorium contents of volcanic rocks, in Faul, Henry (editor), Nuclear geology; New York, John Wiley and Sons, Inc., p. 89-98.

Adams, J. A. S., and Saunders, D. F., 1953, Uranium content of the lavas of Lassen Voleanic National Park, Calif. [abs.]: Geol. Soc. America Bull., v. 64, p. 1389.

Amstutz, G, C., 1951, Radioaktivitätsmessungen an den Glarner Laven: Schweizer. naturf. Gesell. Verh., Jahresvers. 131, p. 138-139.

Asayama, T., 1953, On the radioactivity of rocks in Japan and vicinity-Part I, Radium contents of voleanic rocks: Kyoto Tech. Univ., Faculty Indus. Arts, Mem. 2B, p, 53-68.

Aswathanarayana, U., 1954, Distribution of radioactivity in the rocks of South India-Part I, Charnockites and associated rocks: Jour. Sci. Indus. Research (Delhỉ, India), v. 13B, no. 2 , p. $87-92$.

Brotzen, O., 1952, Die zonaren Zirkone des Ramberggranites: Geol. fören. Stockholm Förh., v. 74, p. 173-184.

Brown, Harrison, Blake, W. J., Chodos, A. A., and others, 1953a, Geochemical aspects of interstitial material in igneous rocks [abs.]: Geol. Soc. America Bull,, v. 64, p. 1400.

- 1953b, Leaching studies of interstitial material in igneous rocks [abs.]: Geol. Soc. America Bull., v. 64, p. 1400-1401.

Buttlar, H. von., and Houtermans, F. G., 1951, Photographische Messung des U- und Th-Gehaltes nach der Auflagemethode: Geochim. Cosmochim. Acta, v. 2, p. 43-61.

Coats, R. R, 1954, Relationship of uranium and other trace elements to post-Cretaceous vocanism, in Geological investigations of radioactive deposits - Semiannual progress report, Dec. 1, 1953 to May 31, 1954: U. S. Geol. Survey TEI-440, p. 99, issued by U, S. Atomic Energy Comm. Tech. Inf. Service, Oak Ridge, Tenn.

1953, Relation of uranium to post-Cretaceous vulcanism, in Geological investigations of radioactive deposits - Semiannual progress report, Dec. 1, 1952 to May 31, 1953: U.S. Geol. Survey TEI-330, p. 87-98, issued by U. S. Atomic Energy Comm. Tech. Inf. Service. Oak Ridge, Tenn.

Daniels, Farrington, 1954, New methods for uranium exploration and recovery from low-grade ores-Progress report, Jan. 1, 1952 to Jan. 1, 1953: U. S. Atomic Energy Comm. AECU-2663, 24 p. [Microcard copy on file in U, S. Atomic Energy Comm. depository libraries.]

Davidson, C. F., 1951, The distribution of radioactivity: Mining Mag. (London), v. 85, p. 329-340.

Davis, G. L,, 1947, Radium content of ultramafic igneous rocks-Part I, Laboratory investigations: Am. Jour. Sci,, v. 245, p. $677-693$.

Davis, G. L., and Hess, H. H., 1949, Radium content of ultramafie igneous rocks-Part II, Geological and chemical implications: Am. Jour. Sei., v. 247, p. 856-882. 
DeVore, G. W., 1955, The role of adsorption in the fractionation and distribution of elements: Jour. Geology, v. 63, p. 159-190.

Evans, R. D., and Goodman, Clark, 1941, Radioactivity of rocks: Geol. Soc. America Bull., v. 52, p. 459-490.

Evans, R. D., and Williams, Howell, 1935, The radium content of lavas from Lassen Volcanic National Park, Calif.: Am. Jour. Sei., 5th ser., v. 29 , p. $441-452$.

Folk, R. L., 1955, Note on the significance of "turbid" feldspars: Am. Mineralogist, v. 40 , p. $356-357$.

Goldschmidt, V. M., 1937, The principles of distribution of chemical elements in minerals and rocks: Chem. Soc. London Jour., pt. 1, p. 655-673.

Gross, W. H., 1952, Radioactivity as a guide to ore: Econ. Geology, v. 47 , p. $722-742$.

Hee, Mme. A., Derville, R. P., and Jarovoy, J., 1954, Determination of the radioactivity of the Quincy granite by the photographic method: Am. Jour. Sei., v. 252, p. 736-744.

Holland, H. D., and Kulp, J. L., 1949, The distribution of accessory elements in pegmatites-Part I, Theory: Am. Mineralogist, v. 34, p. 35-60.

Hurley, P. M., 1950, Distribution of radioactivity in granites and possible relation to helium-age measurement: Geol. Soc. America Bull., v. 61, p. 1-7.

Hutton, C. O., 1947, The nuclei of pleochroic haloes: Am. Jour Sei., v. 245 , p. 154-157.

Ingerson, Earl, 1954, Geochemical work of the Geochemistry and Petrology Branch, U. S. Geological Survey: Geochim. Cosmochim. Acta, v. 5, p. 20-39.

Ingham, W. N., and Keevil, N. B., 1951, Radioaetivity of the Bourlamaque, Elzevir, and Cheddar batholiths, Canada: Geol. Soc. America Bull, v. 62, p. 131-148.

Jahns, R. H., 1953, Distribution of rare elements within granites and granitic pegmatites [abs.]: Geol. Soc. America Bull., v. 64 , p. 1440 .

Keevil, N. B., Keevil, A. R., Ingham, W. N., and Crombie, G. P., 1943, Causes of variation in radioactivity data: Am. Jour. Sci., v. 241, p. 345-365.

Keevil, N. B., Larsen, E. S., Jr., and Wank, F. J., 1944, The distribution of helium and radioactivity in rocks-Part VI, The Ayer granite-migmatite at Chelmsford, Mass.: Am. Jour. Sci, v. 242 , p. $345-353$.

Larsen, E. S., Jr., 1953, Distribution of uranium in igneous complexes, in Geological investigations of radioactive deposits-Semiannual progress report, June 1 to Nov. 30, 1953: U. S. Geol. Survey TEI-390, p. 240-244, issued by U. S. Atomic Energy Comm. Tech. Inf. Service, Oak Ridge, Tenn.

- 1954a, Distribution of uranium in igneous complexes, in Geological investigations of radioactive deposits-Semiannual progress report, June 1 to Nov. 30, 1954: U. S. Geol. Survey TEI-490, p. 255-261, issued by U. S. Atomic Energy Comm. Tech. Inf. Service, Oak Ridge, Tenn.

$1954 \mathrm{~b}$, Distribution of uranium in igneous complexes, in Geological investigations of radioactive deposits-Semiannual progress report, Dec. 1, 1953 to May 31, 1954: U. S. Geol. Survey TEI-440, p. 202-205, issued by U. S. Atomic Energy Comm. Tech. Inf. Service, Oak Ridge, Tenn.

Larsen, E. S., Jr., and Keevil, N. B., 1942, The distribution of helium and radioactivity in rocks-Part III, Radioactivity and petrology of some California intrusives: Am. Jour. Sci., v. 240, p. 204-215.

1947 , Radioactivity of the rocks of the batholith of southern California: Geol. Soc. America Bull., v. 58, p. 483-493.
Larsen, E. S., Jr., and Phair, George, 1954, The distribution of uranium and thorium in igneous rocks, in Faul, Henry (editor), Nuclear geology: New York, John Wiley and Sons, Ine., p. 75-89.

Larsen, E. S., Jr., Waring, C. L., and Berman, Joseph, 1953, Zoned zircon from Oklahoma: Am. Mineralogist, v. 38, p. $1118-1125$.

Mawdsley, J. B., 1953, Uraninite-bearing fine-grained pegmatite of the Charlebois Lake area, northeastern Saskatchewan [abs.]: Geol. Soc. America Bull., v. 64, p. 1550.

Neumann, Henrich, 1948, On hydrothermal differentiation: Econ. Geology, v. 43, p. 77-83.

Neumann, Henrich, Mead, Judson, and Vitaliano, C. J., 1954, Trace-element variation during fractional crystallization as calculated from the distribution law: Geochim. Cosmochim. Acta, v. 6, p. 90-99.

Osmond, J. K., 1954, Radioactivity of bentonites: Wisconsin Univ., doctoral thesis; U. S. Atomic Energy Comm. AECU2828 [abs.], p. 10. [Microcard copy on file in U. S. Atomic Energy Comm. depository libraries.]

Page, L. R., 1950, Uranium in pegmatites: Eeon. Geology, v. 45 , p. $12-34$.

Phair, George, 1952, Radioactive Tertiary porphyries in the Central City district, Colorado, and their besring upon pitchblende deposition; U. S. Geol. Survey TEI-247, 53 p., issued by U. S. Atomic Energy Comm. Tech. Inf. Service, Oak Ridge, Tenn.

Phair, George, and Levine, Harry, 1953, Notes on the differential leaching of uranium, radium, and lead from pitchblende in $\mathrm{H}_{2} \mathrm{SO}_{4}$ solutions: Econ. Geology, v. 48 , p. 358-369.

Pieciotto, E. E., 1950, Distribution de la radiactivité dans les roches éruptives: Soc. Belge Geologie Bull., v. 59, p. 170198.

Piggot, C. S., 1929, Radium in rocks-Part I, The radium content of some representative granites of the eastern seaboard of the United States: Am. Jour. Sci., 5th ser., v. 17, p. 13-34.

1931, Radium in rocks-Part III, The radium content of Hawaiian lavas: Am. Jour. Sci., 5th ser., v. 22, p. 1-8.

Rankama, Kalervo, and Sahama, T. G., 1950, Geochemistry: Chicago, Chicago Univ. Press, 912 p.

Senftle, F. E., and Keevil, N. B., 1947, Thorium-uranium ratios in the theory of genesis of lead ores: Am. Geophys. Union Trans., v. 28, p. 732-738.

Shaw, D. M., 1953, The camouflage prineiple and trace-element distribution in magmatic minerals: Jour. Geology, v. 61, p. 142-151.

Soloviev, S. P., 1936, The granodiorite laccolith of the Malka River (North Caueasus) and its content of radium: Am. Jour. Sci., 5th ser., v. 32 , p. 380-391.

Sullivan, C. J., 1954, Metallic melting point and ore disposition: Econ. Geology, v. 49, p. 555-574.

Tilton, G. R., Patterson, Claire, Brown, Harrison, and others, 1955 , Isotopic composition and distribution of lead, uranium, and thorium in a Precambrian granite: Geol. Soc. America Bull., v. 66, p. 1131-1148.

Wager, L. R., and Mitchell, R. L., 1951, The distribution of trace elements during strong fractionation of basic mag$\mathrm{ma}-\mathrm{a}$ further study of the Skaergaard intrusion, east Greenland: Geochim. Cosmochim. Acta, v. 1, p. 129-208.

Westerveld, J., 1954, Radioactivity and chemistry of some Indonesian eruptive rocks: K. Nederlandse Akad. Wetensch. Verh., Afd, Natuurk., Eerste Reeks, Deel 20, no. 4. $52 \mathrm{p}$. 


\title{
URANIUM IN MAGMATIG DIFFERENTIATION
}

\author{
By_Esper S. Larsen, Jr., George Phair, David Gottrried, and William L. Smith, U. S. Geological Survey
}

\section{CONTENTS}

\begin{abstract}
.
Introduction .

Mesozoic batholiths of Western United States

Uranium analyses.

Leachable uranium

Uranium in minerals of the southern California!batholith
\end{abstract}

\section{ILLUSTRATIONS}

FigURE 2. Uranium in rocks of the southern California batholith
Page

67
Volcanic rocks

Precambrian Boulder Creek batholith of Colorado_._._._. 73

Summary

References cited

Page
69
70
72
73
73
74

Page

Figure 3. Differentiation and uranium fractionation in Laramide intrusive rocks of the middle and northern parts of the Front Range porphyry belt, Colorado, and granite from Rubidoux

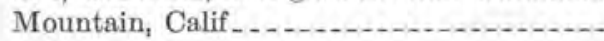

\section{TABLES}

Page

66

TABLE 1. The average uranium content of the rocks of the southern California batholith...............

2. Comparison of uranium content of three batholiths of Western United States.

3. Leachable uranium in a sample of granite from Rubidoux Mountain ......................

4. Leachable-uranium content of rock-forming minerals separated from coarse granite of Rubidoux Mountain ......................

5. Uranium content of separate mineral fractions from the southern California batholith.......

6. Distribution and alpha activity of zircon from rocks of the southern California batholith....

7. Uranium content of lavas in the San Juan Mountains.
TABLE 8. Uranium content of the Modoc lava flows of Powers (1932)

9. Uranium in the intrusive rocks of the White

Mountain plutonic-volcanic series............

10. Uranium content of the minerals in the Conway granite (so-called Redstone types) of New Hampshire.

11. Uranium in the igneous rocks of the Highwood Mountains

12. Uranium analyses of igneous rocks of the Bearpaw Mountains

13. Distribution of uranium in the Boulder Creek batholith, Colorado.

\section{ABSTRACT}

By means of fluorimetric uranium analyses of successive rock types, the path of uranium in differentiation has been traced throughout a wide variety of North American magma series. These include 4 plutonic calc-alkalic series - the southern California batholith, the Idaho batholith, the Sierra Nevada batholith, and the Boulder Creek batholith of Colorado; 1 predominantly hypabyssal calc-alkalic series having alkalic end products-the porphyry series of the Colorado Front Range; and 1 predominantly volcanic ealc-alkalic series-the voleanic rocks and related small stocks of the San Juan Mountains. In addition, less complete information has been obtained on rocks belonging to the so-called Modoc lavas of California and the alkalic rocks of the Highwood and Bearpaw eomplexes of Montana, of Cripple Creek, Colo., of Beemerville, N. J., and of the White Mountains of New Hampshire. With the exception of the Boulder Creek batholith all rocks studied are younger than Precambrian. Each such series has the structures and textures thought to be typical of magmatic rocks. In each of these comagmatic series the average uranium content is low (about $0.3 \mathrm{ppm}$ ) in the mafic rocks, increases steadily (about $2.0 \mathrm{ppm}$ ) in the rocks of intermediate composition, and reaches a maximum (about $5.0 \mathrm{ppm}$ ) in the 
granite. In some highly differentiated series the uranium content became enriched at least twofold and not uncommonly as much as twentyfold (100 ppm) over the average for ealc-alkalic granite; an example is the porphyry sequence of the Front Range in which the differentiation did not cease at the granite stage but proceeded toward an end product extremely $\mathrm{CaO}$ poor (as little as $0.0 \mathrm{ppm} \mathrm{CaO}$ ) and rich in alkalies.

Moderately radioactive accessory minerals such as zircon, sphene, and apatite together probably contribute less than 25 percent of the total uranium to any one rock. Sparse thoriumrich and uranium-rich accessory minerals-thorite, xenotime, monazite, and uraninite - have been found to be more widespread than formerly supposed and account for an appreciable part of the total uranium content in certain granites. According to the present data, however, the rock-forming minerals themselves contain most of the uranium found in the rock. The uranium content of the quartz and feldspar is about half as much as the rock, and the dark minerals-hornblende, biotite, and magnetite - are enriched many times; much, but not all, of this uranium can be leached from the rock-forming minerals by weak acid.

The fact that the maximum uranium enrichment in any one rock series is found in the youngest member, coupled with the ready leachability of much of the uranium, indicate that a substantial part of the uranium is "late." The same data show that not only the total uranium content but the amount of leachable uranium change in a roughly systematic way with rock composition and point to a predominantly petrogenetic control.

In contrast to the rocks already described, the one Precambrian complex studied, the Boulder Creek batholith, shows maximum enrichment in uranium in the early quartz diorites, less in the rocks of intermediate composition, and a minimum in the granites. The uranium-rich quartz diorites are largely concentrated along the outer margins of the batholith, and there is considerable evidence of reaction with and assimilation of metasedimentary wall rocks.

\section{INTRODUCTION}

Research, which has been in progress for the past 4 years, by the U. S. Geological Survey on the distribution of uranium in magmatic complexes has as an ultimate aim the detailed delineation of the role of uranium in petrogenesis. The ease and accuracy with which uranium can be determined analytically make it almost unique among trace elements. However, before maximum use can be made of this knowledge, problems in field and laboratory sampling must first be overcome; work along such lines is now underway.

This report is largely factual. It presents new data, some of them preliminary in nature.

Uranium becomes increasingly concentrated in the residual liquid throughout differentiation during crystallization, partly because of ionic radius and charge. As a result a substantial part of the uranium in any one rock, regardless of bulk composition, appears to be "late"; in nearly all plutonic series so far investigated the youngest members contain the most uranium.

For a brief discussion of the present status of the general problem of the distribution of uranium in igneous rocks, the reader is referred to a recent paper by Larsen and Phair (1954).

\section{MESOZOIC BATHOLITHS OF WESTERN UNITED STATES}

In the calc-alkalic rocks typical of the large Mesozoic batholiths of Western United States, the rocks richest in uranium are granites with high contents of $\mathrm{SiO}_{2}$ and $\mathrm{K}_{2} \mathrm{O}$. The intermediate rocks are more variable in uranium contents than the granites but have on the average about half as much uranium; the gabbros contain on the average less than 10 percent as much uranium as the granites.

\section{URANIUM ANALYSES}

In any group of genetically related rocks the amount of uranium does not follow as simple a relation as do the major constituents. Broad belts rather than narrow bands are the rule when the uranium content of related rocks is plotted on a variation diagram. Table 1 and the variation diagram (fig. 2) show how uranium content varies with differentiation in the rocks of the southern California batholith (Larsen, 1948).

TABLE 1.-The average uranium content of the rocks of the southern California batholith

[R. A. Powell and G. B. Magin, analysts]

\begin{tabular}{|c|c|c|c|c|}
\hline \multirow{2}{*}{ Rock type } & \multirow{2}{*}{$\begin{array}{c}\text { Number } \\
\text { of } \\
\text { samples }\end{array}$} & \multicolumn{2}{|c|}{$\begin{array}{l}\text { Uranium content } \\
(\mathrm{ppm})\end{array}$} & \multirow{2}{*}{ Part of batholith } \\
\hline & & Range & $\begin{array}{l}\text { Aver- } \\
\text { age }\end{array}$ & \\
\hline $\begin{array}{l}\text { Gabbro } \\
\text { Tonalite } \\
\text { Granodiorite... } \\
\text { Quartz monzonite and } \\
\text { granite. }\end{array}$ & $\begin{array}{r}10 \\
18 \\
37 \\
9\end{array}$ & $\begin{array}{r}0.2-0.3 \\
.3-3.0 \\
7-4.8 \\
\text { 2. } 7-6.0\end{array}$ & $\begin{array}{l}0.3 \\
\text { 1. } 4 \\
2.0 \\
4.2\end{array}$ & $\begin{array}{l}\text { Main mass. } \\
\text { Do. } \\
\text { Do. } \\
\text { Do. }\end{array}$ \\
\hline $\begin{array}{l}\text { Tonalite } \\
\text { Granodiorites. } \\
\text { Quartz monzonites and } \\
\text { granites. }\end{array}$ & $\begin{array}{r}3 \\
10 \\
12\end{array}$ & $\begin{array}{l}.8-1.9 \\
.2-1.7 \\
.4-2.6\end{array}$ & $\begin{array}{r}1.5 \\
\text { 1. } 4\end{array}$ & $\begin{array}{c}\text { Desert area. } \\
\text { Do } \\
\text { Do. }\end{array}$ \\
\hline
\end{tabular}

The intrusive rocks of the Mohave Desert area have been excluded from the variation diagram (fig. 2). These include, in order of decreasing abundance, quartz monzonites, granites, and granodiorites, all of which are low in mafic minerals and relatively very low in uranium. These rocks make up only a small part of the batholith and occur as small bodies separated by large masses of rocks older than the batholith.

The average uranium content of the southern California batholith is estimated to be 1.7 parts per million. The batholith underlies about 6,000 square miles within the United States. Its extension into northern Lower California underlies an area about twice as large as its area in the United States and its extension into southern Lower California is of unknown dimensions. 


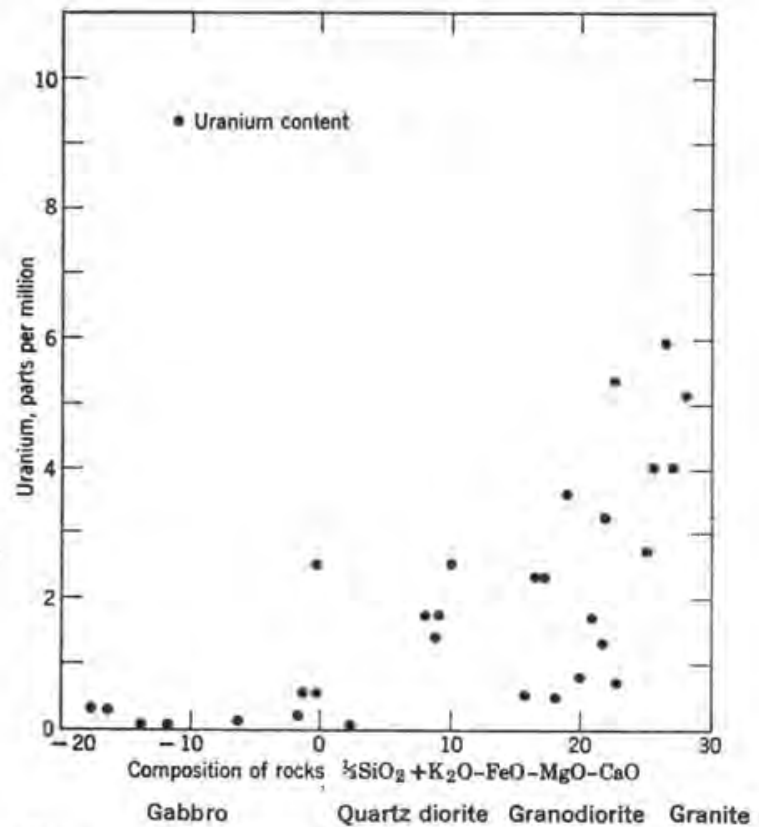

FigURE 2.-Uranium in rocks of the southern Californis batholith.

The batholiths of the Sierra Nevada occupy an area of about 17,000 square miles if the intrusives of the Klamath Mountains are included. The rocks are similar to those of the southern California batholith but have more granodiorite and less quartz diorite. The average uranium content is higher than that of the southern California batholith and is about $2.3 \mathrm{ppm}$. The data were obtained on a suite of samples submitted by Paul Bateman of the U. S. Geological Survey.

The Idaho batholith occupies an area of about 13,000 square miles. It is made up chiefly of quartz monzonite and granodiorite of somewhat variable uranium content. Its average uranium content is about $2.1 \mathrm{ppm}$.

Data on the uranium content of these three batholiths are given in table 2 . The average uranium content for all 3 batholiths is estimated at $2.1 \mathrm{ppm}$. Abundance estimates for the separate rocks are based on relative areas.

TABLE 2.-Comparison of uranium content of three batholiths of Western United States

[Marian Schnepfe and Marjorie Molloy, analysts]

\begin{tabular}{|c|c|c|c|c|c|c|}
\hline \multirow[b]{2}{*}{ Rock type } & \multicolumn{2}{|c|}{$\begin{array}{l}\text { Southern } \\
\text { Cslifornia }\end{array}$} & \multicolumn{2}{|c|}{ Slerra Nevada } & \multicolumn{2}{|c|}{ Idabo } \\
\hline & $\begin{array}{l}\text { Abun- } \\
\text { dance } \\
\text { (per- } \\
\text { cent) }\end{array}$ & $\begin{array}{c}\text { Ura- } \\
\text { nlum } \\
\text { content } \\
\text { (ppm) }\end{array}$ & $\underset{\text { (percent) }}{\text { Abundance }}$ & $\begin{array}{c}\text { Ura- } \\
\text { nium } \\
\text { content } \\
\text { (ppm) }\end{array}$ & $\begin{array}{l}\text { Abun- } \\
\text { dance } \\
\text { (per- } \\
\text { cent) }\end{array}$ & $\begin{array}{l}\text { Urra- } \\
\text { nium } \\
\text { content } \\
\text { (ppm) }\end{array}$ \\
\hline Gabbro...................... & 7 & 0.31 & Some...... & 0.60 & Rare & \\
\hline Quartz diorite.............. & 62 & 1.42 & Rare....... & 1. 2 & 12 & 1.8 \\
\hline Granodiorite.................. & 27 & 2. 03 & Chief rock ... & 2,4 & 31 & 2.3 \\
\hline Quartz monzonite......... & 2 & 4.2 & Abundant... & 3.4 & 25 & 3.1 \\
\hline Muscovite, granite,...... & 2 & 2.3 & & 3.0 & 9 & 1. 6 \\
\hline Fine granodiorite........... & -n.... & n........ & & $\ldots$ & 21 & 1.0 \\
\hline A verage. & & 1.6 & & 2.3 & & 2.1 \\
\hline
\end{tabular}

\section{LEACHABLE URANIUM}

Hurley (1950) showed that the alpha activity of certain granites could be drastically reduced by leaching the granulated rock in dilute hydrochloric acid. Several workers, including members of the U. S. Geological Survey, subsequently found that uranium is the chief radioactive constituent leached. A group at the California Institute of Technology found that in addition to uranium much of the rare-earths content of certain rocks is readily leachable (Brown, Blake, Chodas, and others, 1953a, b).

The exact locus of this leachable uranium is in many respects an enigma, and several hypotheses, none of which is wholly acceptable, have been proposed to account for it. The problem is explored in detail in recent papers by Brown, Blake, Chodas, and others $(1953 \mathrm{a}, \mathrm{b})$.

The fact that leaching sufficient to reduce the uranium content by more than 25 percent commonly dissolves only a small percentage of the rock suggests that the leachable uranium is coated on the surfaces of mineral grains - hence late. At the same time the fact that not only the amounts of total uranium but also the amounts of leachable uranium increase in a roughly systematic way with the amounts of silica and of alkalies in the rocks suggests that the distribution of uranium is not haphazard but is intimately tied to processes of magmatic differentiation. As yet it is not known whether leachable uranium is present in deeply buried rocks. The uranium (IV) of a primary rock mineral is readily oxidized to uranium (VI), in which state it forms soluble compounds, so it seems reasonable to expect some internal redistribution to have taken place in surface rocks. The question of how much, remains,

The percentage of uranium removed from separate splits of a sample of coarse granite from Rubidoux Mountain (Larsen, 1948) from the southern California batholith by leaching in different acids of different concentrations is shown in table 3 . The samples were crushed to pass 20-mesh screens; 5-gram splits were simmered in 50 milliliters of acid for 2 hours. The individual minerals separated from the same rock were leached in 25 milliliters of $1 \mathrm{~N}$ hydrochloric acid by boiling 1-gram samples for 30 minutes in a reflux condenser. The weight of residue and the uranium content of the residue and of the solution were then determined; the pertinent results are shown in table 4 .

These data are approximate in that they neglect the effect of minute impurities, but they show that most of the uranium associated with the common rock-forming minerals is leachable and is released by removal of relatively small amounts of the mineral. Thus the 
patterns shown in leaching the bulk rock are accentuated in leaching the major minerals.

TABLE 3.-Leachable uranium in a sample of granite from Rubidoux Mountain, Calif.

[Frank Cuttitta, analyst]

\begin{tabular}{|c|c|}
\hline A cid & $\begin{array}{l}\text { Uranium } \\
\text { leached } \\
\text { (percent) }\end{array}$ \\
\hline \multicolumn{2}{|c|}{$0.1 \mathrm{~N}$} \\
\hline $\mathrm{HNO}_{3} \mathrm{HCl}$ & $\begin{array}{l}25 \\
59\end{array}$ \\
\hline \multicolumn{2}{|c|}{$1.0 \mathrm{~N}$} \\
\hline $\mathrm{HNO}_{3} \mathrm{HCl}$ & $\begin{array}{l}50 \\
59\end{array}$ \\
\hline \multicolumn{2}{|c|}{$2.5 \mathrm{~N}$} \\
\hline $\begin{array}{l}\mathrm{HCl} \\
\mathrm{HNO} \\
\text { Acetic }\end{array}$ & $\begin{array}{l}59 \\
59 \\
50\end{array}$ \\
\hline \multicolumn{2}{|c|}{$5.0 \mathrm{~N}$} \\
\hline $\mathrm{HNO}_{3} \mathrm{HCl}$ & $\begin{array}{l}59 \\
59\end{array}$ \\
\hline
\end{tabular}

TABLE 4.-Leachable-uranium content of rock-forming minerals from coarse granite of Rubidoux Mountain, Calif.

[A. M. Sherwood, analyst]

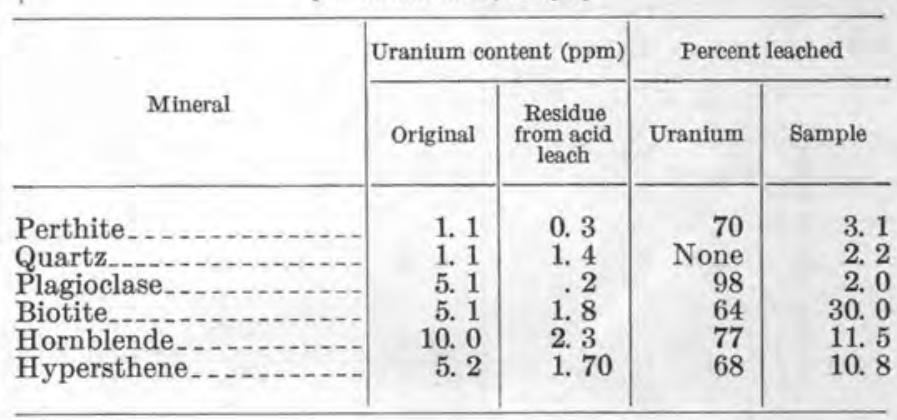

\section{URANIUM IN MINERALS OF THE SOUTHERN CALI- FORNIA BATHOLITH}

It is unfortunate that even the most carefully separated mineral fraction contains numerous microscopic inclusions. These minute impurities limit the significance that can be attached to uranium determinations upon the mineral separates. However the relative volume of such inclusions is very small, and generally the amount of uranium they contribute to the total for the rock is probably negligible. Only unusually should the measured uranium values fail to indicate the proper order of magnitude (see table 5).

TABLE 5.-Uranium content of separale mineral fractions from the Southern California batholith

[A. M. Sherwood, analyst]

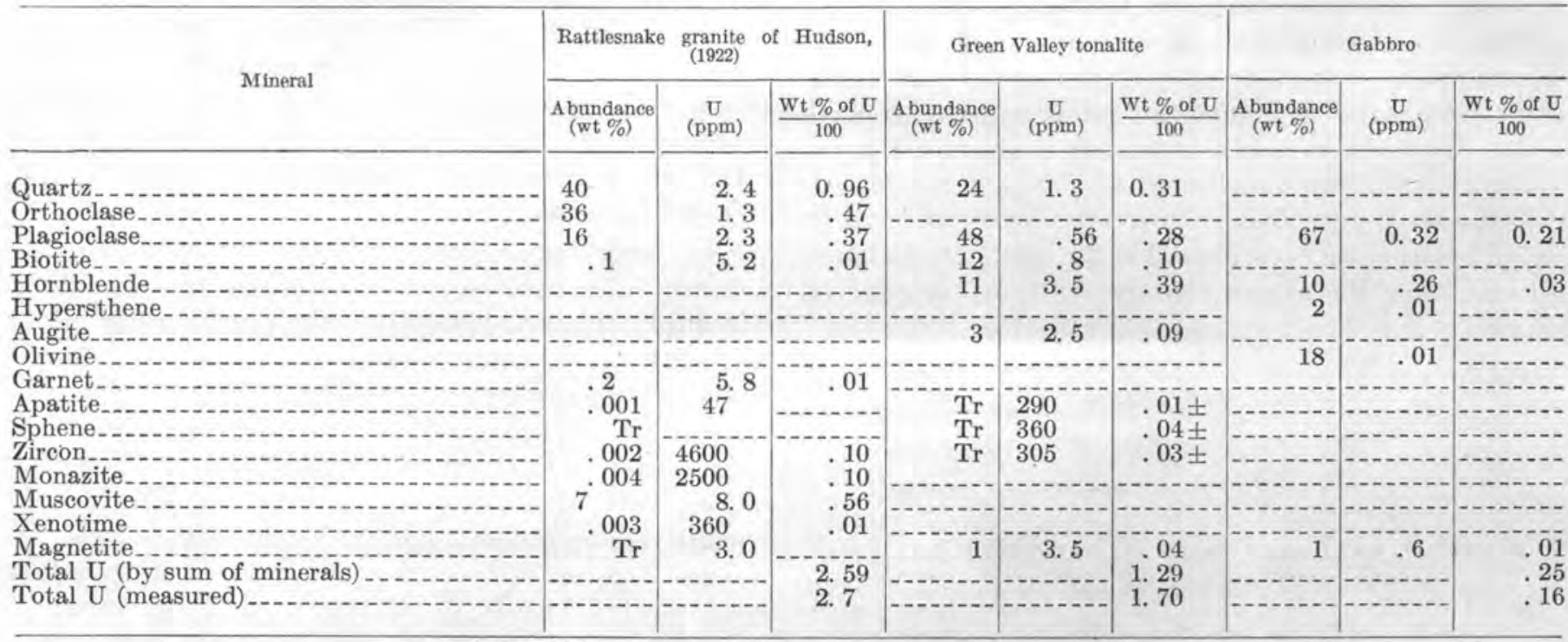

It seems clear from these data that most of the uranium in the rocks is associated with the major rockforming minerals. The common accessory minerals zircon, sphene, and apatite have a relatively high uranium content, but collectively these accessory minerals are not sufficiently abundant to account for more than an estimated 20 percent of the total uranium in the rocks. In general the major minerals do not depart widely in uranium content from the bulk rock: quartz and feldspar contain about half as much uranium as the bulk rock, and biotite, hornblende, and pyroxene contain about the same percentage as the bulk 
rock. The uranium content of the common rockforming minerals tends to increase with the total uranium in the bulk rock as silica increases in the rocks.

Accessory minerals are generally not uniformly distributed. The radioactivity of at least some accessory minerals, such as zircon, increases with the total radioactivity of the bulk rock, from gabbro to granite. Alpha-activity data on zircon separated from the different rocks of the southern California batholith are given in table 6 .

TABLE 6.-Distribution and alpha activity of zircon from rocks of the southern California batholith

\begin{tabular}{|c|c|c|c|c|}
\hline \multirow{2}{*}{ Rock type } & \multicolumn{2}{|c|}{$\begin{array}{l}\text { Zireon content } \\
\text { (ppm) }\end{array}$} & \multicolumn{2}{|c|}{$\begin{array}{c}\text { A]pha activity of zircon } \\
(\alpha \mathrm{rays} / \mathrm{mg} / \mathrm{hr})\end{array}$} \\
\hline & Range & Average & Range & Average \\
\hline Gabbro & $0-50$ & 10 & $30-100$ & \\
\hline Tonalite_. & $20-300$ & 60 & $143-646$ & 307 \\
\hline Granodiorite.............. & $10-200$ & 80 & $433-1235$ & 830 \\
\hline $\begin{array}{l}\text { Quartz monzonite and } \\
\text { granite }\end{array}$ & $5-100$ & 50 & $190-4660$ & 1545 \\
\hline
\end{tabular}

Monazite and xenotime are common in quartz monzonite and granite, especially in muscovitebearing varieties. Monazite appears to crystallize first, followed by xenotime. Colorless isotropic metamict thorite is found in about 1 in 10 granitic rocks. Sphene and apatite have moderate uranium contents.

\section{VOLCANIC ROCKS}

Data have been obtained on lavas in the San Juan tuff of western Colorado (Larsen and Cross, 1956) and the Modoc lava series of Powers (1932) in northern California. The rocks of the San Juan tuff resemble in chemical composition the plutonic rocks of the southern California batholith, but run consistently higher in potash. The lavas may be divided into three major groups separated by large erosional unconformities: pre-Potosi rocks (the most altered) of early Miocene(?) age, lavas of the Potosi volcanic series and their equivalents of Miocene age, and postPotosi rocks of the Hinsdale formation, probably Pliocene in age.

Rocks of the Hinsdale are mildly alkalic; rhyolites of this group contain more uranium (9 ppm) than does any other rock of the San Juan tuff. Within most groups and subgroups the average uranium content tends to increase with silica, but individual analyses for different rock types scatter widely and in general ovierlap (see table 7).

TABLE 7.-Uranium content of lavas in the San Juan Mountains, Colo.

[Marjorie Molloy, Paul Scott, and G. B. Magin, analysts]

\begin{tabular}{|c|c|c|c|c|}
\hline \multirow{2}{*}{ Rock type } & \multirow{2}{*}{$\begin{array}{l}\text { Number of } \\
\text { samples }\end{array}$} & \multirow{2}{*}{$\begin{array}{l}\text { Number of } \\
\text { determina- } \\
\text { tions }\end{array}$} & \multicolumn{2}{|c|}{ Uranium (ppm) } \\
\hline & & & Range & Average \\
\hline \multicolumn{5}{|l|}{ Pliocene(?) } \\
\hline $\begin{array}{l}\text { Hinsdale formation: } \\
\text { Basalt } \\
\text { Trachydolerite } \\
\text { Andesite-basalt } \\
\text { Intrusive andesite. } \\
\text { Latite } \\
\text { Rhyolite }\end{array}$ & $\begin{array}{l}1 \\
2 \\
2 \\
1 \\
1 \\
2\end{array}$ & $\begin{array}{l}1 \\
6 \\
6 \\
2 \\
4 \\
4 \\
2\end{array}$ & $\begin{array}{l}1.1-1.6 \\
1.5-3.4 \\
\text { 2. } 5-3.1 \\
\text { 8. } 6-9.8\end{array}$ & $\begin{array}{l}\text { 1. } 0 \\
\text { 1. } 4 \\
\text { 1. } 9 \\
\text { 3. } 2 \\
\text { 2. } 9 \\
\text { 9. } 2\end{array}$ \\
\hline Miocene & & & & \\
\hline \multicolumn{5}{|l|}{ Fisher quartz latite: } \\
\hline $\begin{array}{l}\text { Quartz latite } \\
\text { Glass }\end{array}$ & 4 & 8 & 2. $8-4.7$ & 3. 7 \\
\hline \multicolumn{5}{|l|}{$\begin{array}{l}\text { Potosi voleanic series: } \\
\text { Piedra rhyolite: }\end{array}$} \\
\hline Quartz latite. & 5 & 7 & 2. $8-5.4$ & 3. 7 \\
\hline Rhyolite.... & 10 & 13 & 2. $5-5.6$ & 4. 5 \\
\hline Rhyolite tuff. & 2 & 3 & 1. $5-3.4$ & 2. 5 \\
\hline \multicolumn{5}{|l|}{ Huerto quartz latite: } \\
\hline $\begin{array}{l}\text { Dark quartz latite } \\
\text { Light quartz latite }\end{array}$ & 1 & & 1. $5-2.4$ & 1. 9 \\
\hline \multicolumn{5}{|l|}{ Alboroto rhyolite: } \\
\hline Quartz latite & 8 & 8 & 2. $6-4.6$ & 3. 6 \\
\hline Rhyolite....... & 7 & 13 & 3. $0-9.0$ & 5. 1 \\
\hline Rhyolite tuff & 2 & 3 & $5.2-7.7$ & 6. 6 \\
\hline \multicolumn{5}{|l|}{ Sheep Mountain quartz latite: } \\
\hline Dark quartz latite & 3 & $\underline{9}$ & 1. $2-3.3$ & 2. 5 \\
\hline Quartz latite & 2 & 5 & 1. $9-4.7$ & \\
\hline
\end{tabular}


TABLE 7.-Uranium content of lavas in the San Juan Mountains, Colo.-Continued

[Marjorie Molloy, Paul Scott, and G. B. Magin, analysts]

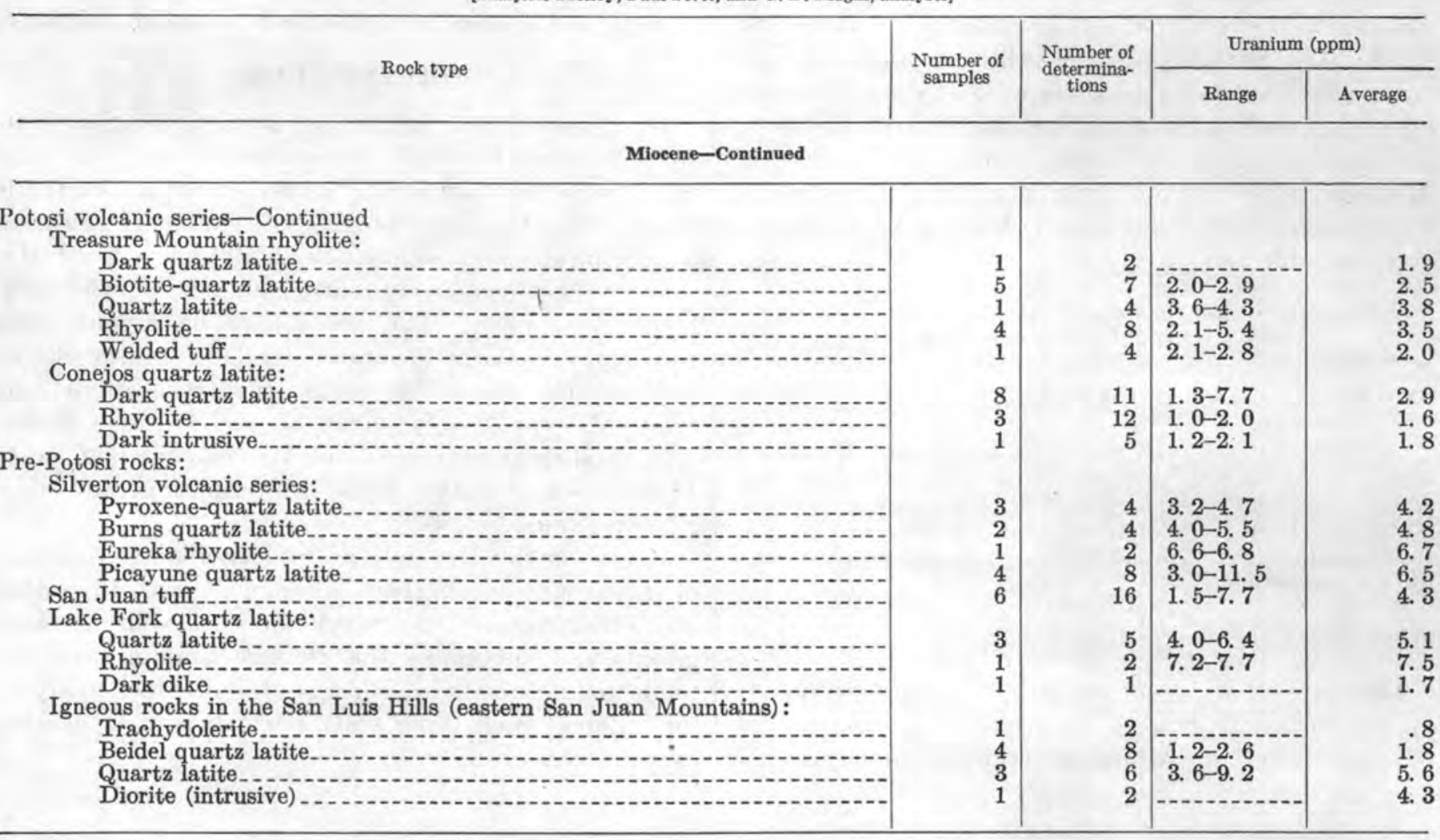

TABLE 8.-Uranium content of the Modoc lava flows of Powers (1932) in California ${ }^{1}$

[J. J. Warr, analyst]

\begin{tabular}{l|l|c|c|c}
\hline Rock type & $\begin{array}{c}\text { Number of } \\
\text { samples }\end{array}$ & $\begin{array}{c}\text { Number of } \\
\text { determina } \\
\text { tions }\end{array}$ & \multicolumn{2}{|c|}{ Uranium content (ppm) } \\
\cline { 2 - 4 }
\end{tabular}

\begin{tabular}{|c|c|c|c|c|}
\hline \multicolumn{5}{|c|}{ Recent } \\
\hline $\begin{array}{l}\text { Obsidian } \\
\text { Rhyolite. } \\
\text { Dacite } \\
\text { Basalt_.......... }\end{array}$ & $\begin{array}{l}4 \\
3 \\
2 \\
2\end{array}$ & $\begin{array}{l}8 \\
6 \\
5 \\
5\end{array}$ & $\begin{array}{r}\text { 5. } 2-7.4 \\
\text { 1. } 2-5.0 \\
\text { 3. } 6-4.2 \\
.25-.8\end{array}$ & $\begin{array}{r}\text { 6. } 0 \\
\text { 3. } 6 \\
\text { 4. } 1 \\
.5\end{array}$ \\
\hline
\end{tabular}

\begin{tabular}{l|r|r|r|r}
\hline \multicolumn{5}{|c|}{ Late Pleistocene } \\
\hline Dacite_............ & 1 & 2 & $3.8-4.0$ & 3.9 \\
\hline
\end{tabular}

\begin{tabular}{|c|c|c|c|c|}
\hline \multicolumn{5}{|c|}{ Pliocene and early Pleistocene } \\
\hline Vesicular basalt_... .. & 1 & 2 & 3. $4-3.7$ & 3. 6 \\
\hline \multicolumn{5}{|c|}{ Pliocene } \\
\hline $\begin{array}{l}\text { Obsidian } \\
\text { Rhyolite... } \\
\text { Andesite } \\
\text { Basalt }\end{array}$ & $\begin{array}{l}2 \\
1 \\
3 \\
4\end{array}$ & $\begin{array}{l}6 \\
2 \\
6 \\
8\end{array}$ & $\begin{array}{l}\text { 4. } 5-5.6 \\
3.7-3.8 \\
1.3-6.0 \\
.18-.85\end{array}$ & $\begin{array}{l}\text { 5. } 1 \\
\text { 3. } 8 \\
\text { 3. } 0 \\
.44\end{array}$ \\
\hline
\end{tabular}

1 Samples from the U. S. National Museum.
Uranium analyses were obtained on a suite of samples representing most of the major units in the Modoc lava series of Powers (1932). According to Powers, who collected and described the samples (1932), the oldest rocks in the series are Miocene in age and the youngest rhyolite is probably less than 300 years old. Uranium in these rocks is more uniformly distributed than in rocks in the San Juan Mountains. The uranium contents of the various rock types are about the same as for their plutonic equivalents. (See table 8.)

\section{ALKALIC LATE-STAGE DIFFERENTIATES}

Not uncommonly, particularly in nonorogenic regions, quartz separates late in the history of differentiation; the normal calc-alkalic lines of descent are shifted toward monzonite and syenite and yield, as an end product, alkalic granite having an exceptionally low $\mathrm{CaO}$ content. The albite-riebeckite granites of Nigeria (Greenwood, 1951), the Conway granite of New Hampshire (Chapman and Williams, 1935), and the late rhyolites and trachytes of the Front Range intrusive sequence of Tertiary age (Phair, 1952) are all extreme differentiates of this type. All are enriched in uranium over normal calc-alkalic granite-biotite granite in the Conway granite to about twice as much, and the other two to many times. 
Some 400 samples of the Laramide "porphyries" of the Colorado Front Range have been analyzed for uranium by one method or another as part of a detailed sampling program investigating the relationship between uraniferous intrusive rocks and pitchblende deposits (Phair, 1952). Forty-five of the same samples were analyzed for uranium by precise methods; the same sample splits were analyzed for major chemical constituents by standard rapid methods. The data, plotted on a triangular $\mathrm{CaO}-\mathrm{Na}_{2} \mathrm{O}-\mathrm{K}_{2} \mathrm{O}$ diagram (fig. 3), show a sensitive inverse relationship between uranium and $\mathrm{CaO}$.

For the purposes of this paper all rocks having a $\frac{\mathrm{CaO}}{\mathrm{Na}_{2} \mathrm{O}+\mathrm{K}_{2} \mathrm{O}+\mathrm{CaO}}$ ratio of less than 0.10 are considered to be $\mathrm{CaO}$ poor. A ratio of 0.10 represents the approximate limit of differentiation in the southern California batholith (fig. 3). Twenty-three of the 45 rocks plotted fall in the CaO-poor field. These include most "bostonites" and many "monzonites" and "quartz monzonites" of previous investigators.

Almost all of the rocks analyzed are enriched in uranium by more than 50 percent over the comparable rock type in the normal calc-alkalic series. The maximum uranium contents (69-138 ppm) are found in the rocks having the least $\mathrm{CaO}$. Those rocks highest in uranium also have $\mathrm{K}_{2} \mathrm{O}$ in excess of $\mathrm{Na}_{2} \mathrm{O}$, but the present data show no consistent differences between CaO-poor types containing a moderate excess of $\mathrm{K}_{2} \mathrm{O}$ and those having a very large excess of $\mathrm{K}_{2} \mathrm{O}$. The $\mathrm{CaO}$ poor rocks containing an excess of $\mathrm{Na}_{2} \mathrm{O}$ over $\mathrm{K}_{2} \mathrm{O}$ have slightly higher $\mathrm{CaO}$ contents than the potassic rocks; most of them show signs of albitization. These rocks have uranium contents that are generally intermediate between the potassic $\mathrm{CaO}$-poor rocks and the earlier more calcic members of the same sequence.

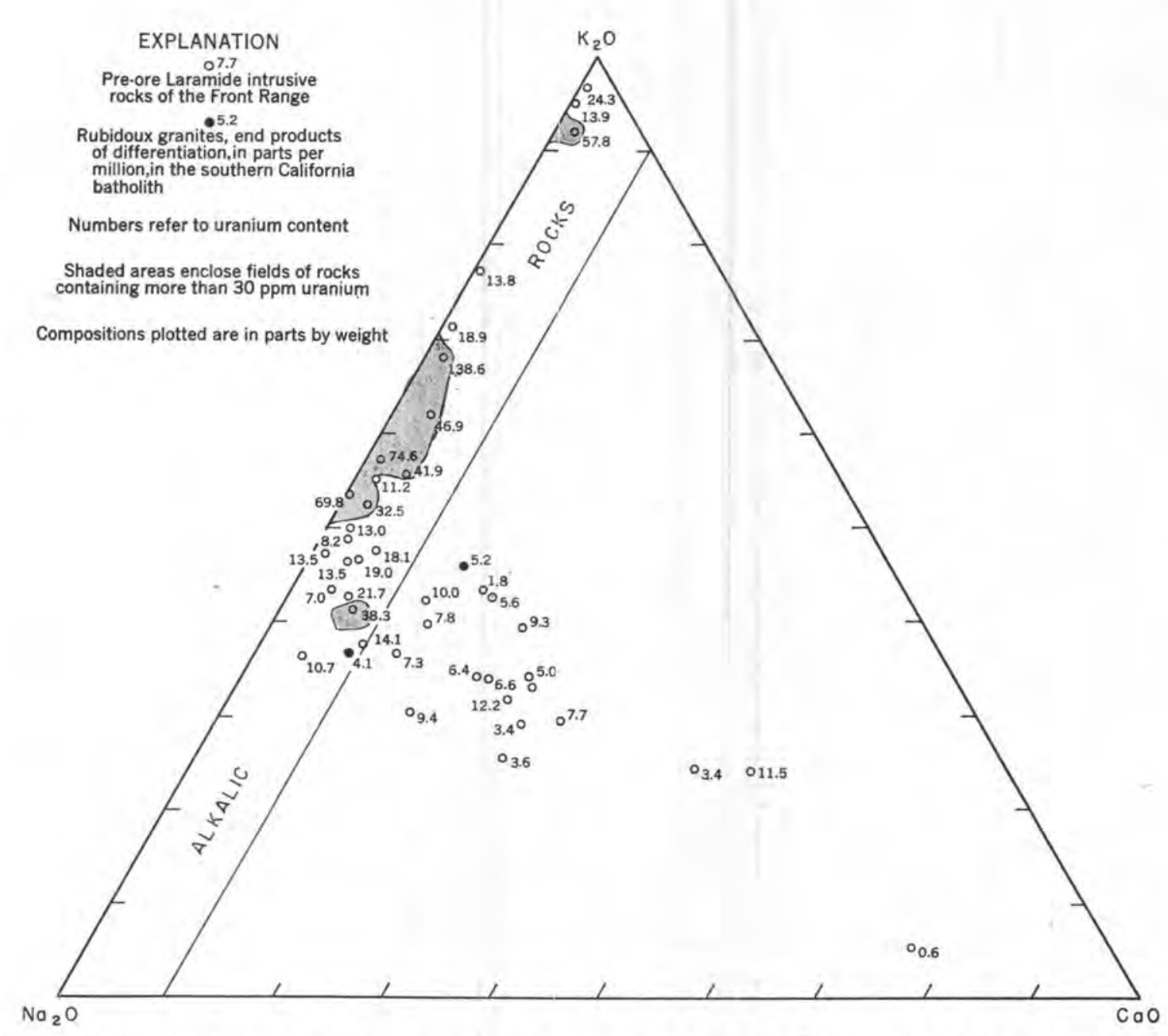

FIQURE 3.-Differentiation and uranium fractionation in Laramide intrusive rocks of the middle and northern parts of the Front Range porphyry belt, Colorsdo, and granite from Rubidoux Mountain, Calif. 
The buildup of uranium in the magmatic residuum apparently culminated in the local deposition of pitchblende at an early stage of metallization in the veins adjacent to the major uraniferous centers of intrusion.

Part of the uranium in the CaO-poor rhyolite and trachyte is in zircon, and some is in allanite, xenotime, and thorite. A maximum of about half of the uranium can be leached in $(1+4) \mathrm{HCl}$ (Phair, 1952).

The uranium content of the granitic rocks in the White Mountain plutonic-voleanic series (Chapman and Williams, 1935) is listed in table 9. A fairly

TABLE 9.-Uranium in the intrusive rocks of the White Mountain plutonic-volcanic series, New Hampshire

[Marian Schnepie and Marjorie Molloy, analysts]

\begin{tabular}{|c|c|c|c|c|c|c|}
\hline \multirow{2}{*}{ Rock type 1} & \multirow{2}{*}{$\begin{array}{c}\text { Areal } \\
\text { extent } \\
\text { (sq. } \\
\text { miles) }\end{array}$} & \multirow{2}{*}{$\begin{array}{l}\text { Percent } \\
\text { of } \\
\text { magma } \\
\text { series }\end{array}$} & \multirow{2}{*}{$\begin{array}{l}\text { Number } \\
\text { of } \\
\text { samples }\end{array}$} & \multirow{2}{*}{$\begin{array}{l}\text { Number } \\
\text { of deter- } \\
\text { mina- } \\
\text { tions }\end{array}$} & \multicolumn{2}{|c|}{$\begin{array}{c}\text { Uranium conten } \\
(\mathrm{ppm})\end{array}$} \\
\hline & & & & & Range & Average \\
\hline 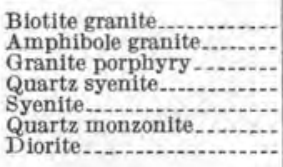 & $\begin{array}{r}315.5 \\
43.3 \\
47.4 \\
43.1 \\
6 \\
1.7\end{array}$ & $\begin{array}{c}68.9 \\
9.41 \\
10.25 \\
9.41 \\
1 \\
.4\end{array}$ & $\begin{array}{r}17 \\
23 \\
2 \\
3 \\
8 \\
2 \\
2\end{array}$ & $\begin{array}{r}42 \\
46 \\
5 \\
7 \\
15 \\
4\end{array}$ & $\begin{array}{l}4.3-19.5 \\
2.3-2.0 \\
6.4-9.4 \\
4.5-7.2 \\
1.2-20.0 \\
1.8-7.6\end{array}$ & $\begin{array}{r}11.7 \\
8.8 \\
8.1 \\
5.9 \\
5.7 \\
4.7\end{array}$ \\
\hline
\end{tabular}

1 Listed chronologically, youngest at top.

regular increase in uranium content with silica content is indicated for the limited range of differentiation thus far studied. The uranium contents of the minerals in two phases of the youngest member of the series, the Conway granite, are given in table 10.

TABLE 10.- Cranium content of the minerals in the Conway granite (so-called Redstone types) of New Hampshire

[A. M. Sherwood, analyst]

\begin{tabular}{|c|c|c|c|c|}
\hline \multirow{2}{*}{ Mineral } & \multicolumn{2}{|c|}{$\begin{array}{l}\text { Biotite granite } \\
(\mathrm{ppm})\end{array}$} & \multicolumn{2}{|c|}{$\begin{array}{l}\text { Amphibole granite } \\
\text { (ppm) }\end{array}$} \\
\hline & Range & Average & Range & Average \\
\hline $\begin{array}{l}\text { Feldspar. } \\
\text { Quartz }\end{array}$ & $2.0-5.3$ & 3.1 & 1.3-2.2 & 1.8 \\
\hline Magnetite.. & $.8-32.0$ & $\begin{array}{r}2.3 \\
15.8\end{array}$ & $1.0-25.7$ & \\
\hline $\begin{array}{l}\text { Amphibole... } \\
\text { Finorite. }\end{array}$ & $16-43$ & 29 & 1. $0-48.8$ & 20.4 \\
\hline $\begin{array}{l}\text { Fluori } \\
\text { Biotite }\end{array}$ & & $\begin{array}{l}14.0 \\
38\end{array}$ & & $\begin{array}{l}63.0 \\
19.7\end{array}$ \\
\hline Ilmen & $47-50$ & 48.5 & & 9.8 \\
\hline Zireor & $252-1750$ & 1202 & $755-2350$ & 1249 \\
\hline Allani & $540-656$ & 617 & & \\
\hline $\begin{array}{l}\text { Astrophyllite } \\
\text { Bulk rock }\end{array}$ & $9.0-18.2$ & iii. 8 & 7. 2 -ii. 6 & $\begin{array}{l}15 \\
8.7\end{array}$ \\
\hline
\end{tabular}

The flows and small stocks of the Cripple Creek volcanic-rock area, Colorado, are an exception to the rule that a high uranium content is associated with a high silica content in any one magma series. Preliminary data indicate that the more silica-rich flows, the latite and phonolite, are poorer in uranium than the younger phonolites, which are richer in nepheline. Here again the maximum uranium content is found in the youngest rocks.

\section{POTASSIC MAGMA SERIES}

In contrast to the rocks already described, $\mathrm{K}_{2} \mathrm{O}$ separated at an early stage in the differentiation of the Highwood Mountain and Bearpaw Mountain series (Larsen, 1940), giving rise to unusual intrusive and extrusive rock types. Each magma series includes several subseries, but the predominant rock types are rich in mafic minerals and are characterized by high $\mathrm{K}_{2} \mathrm{O}$, high $\mathrm{CaO}$, low $\mathrm{Na}_{2} \mathrm{O}$, and very low $\mathrm{SiO}_{2}$. In general these $\mathrm{K}_{2} \mathrm{O}$-rich rocks average 50-100 percent higher in uranium than do their mafic counterparts among normal calc-alkalic rocks.

In the igneous rocks of the Highwood Mountains, shonkinite is the predominant intrusive rock and mafic phonolite the predominant extrusive rock. The rocks analyzed belong to two subseries: the older quartz latite flows, and the younger mafic phonolite-shonkinites and their syenitic derivatives. The latter group are found in layered laccoliths, stocks and dikes (table 11).

TABLE 11.-Uranium in the igneous rocks of the Highwood Mountains, Mont.

[J. J. Warr, analyst]

\begin{tabular}{l|l|l|l|l}
\hline Rock type & $\begin{array}{c}\text { Number } \\
\text { of } \\
\text { samples }\end{array}$ & $\begin{array}{l}\text { Number } \\
\text { of deter- } \\
\text { minations }\end{array}$ & \multicolumn{2}{|c}{$\begin{array}{c}\text { Uranium content } \\
\text { (ppm) }\end{array}$} \\
\cline { 3 - 5 } & Range & Average \\
\hline
\end{tabular}

\begin{tabular}{|c|c|c|c|c|}
\hline \multicolumn{5}{|c|}{ Extrusive rocks 1} \\
\hline $\begin{array}{l}\text { Mafie phonolite.......... } \\
\text { Quartz latite......... }\end{array}$ & $\begin{array}{l}8 \\
2\end{array}$ & $\begin{array}{r}18 \\
5\end{array}$ & $\begin{array}{l}1.6-3.2 \\
2.8-4.9\end{array}$ & $\begin{array}{l}2.7 \\
3.8\end{array}$ \\
\hline
\end{tabular}

\begin{tabular}{|c|c|c|c|c|}
\hline \multicolumn{5}{|c|}{ Stocks ${ }^{2}$} \\
\hline Shonkinite & 3 & 7 & $1.5-4.6$ & \\
\hline $\begin{array}{l}\text { Leucite jolite- } \\
\text { Leucite malignite-_en }\end{array}$ & $\begin{array}{l}1 \\
1\end{array}$ & $\begin{array}{l}2 \\
2\end{array}$ & $.3-3$ & .3 \\
\hline Fergusite............. & 1 & 2 & $2.0-1.8$ & \\
\hline $\begin{array}{l}\text { Missourite............ } \\
\text { Syenite }\end{array}$ & ${ }_{1}^{2}$ & $\begin{array}{l}5 \\
2\end{array}$ & $\begin{array}{l}1.4-2.4 \\
2,1-2.3\end{array}$ & $\begin{array}{l}2.4 \\
2.2\end{array}$ \\
\hline
\end{tabular}

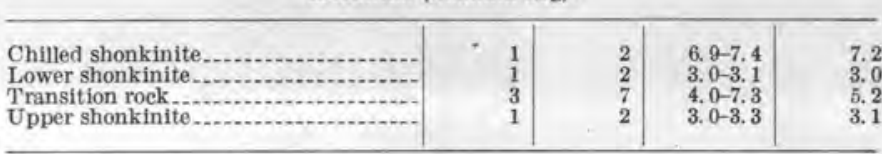

Upper shonkinit

Laccoliths (Square Butte)

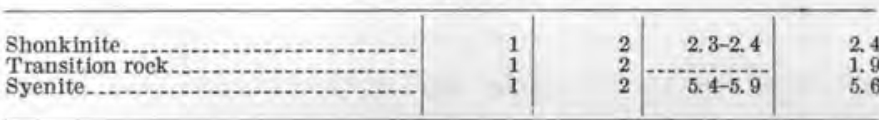

\begin{tabular}{|c|c|c|c|c|}
\hline \multicolumn{5}{|c|}{ Dikes 4} \\
\hline Mafic phonolite & 6 & 12 & 1. $5-2.8$ & 2.3 \\
\hline $\begin{array}{l}\text { 1 Larsen, 1941. } \\
2 \text { Burgess, } 1941 .\end{array}$ & Buie & 939. & & \\
\hline
\end{tabular}

The igneous rocks of the Bearpaw Mountains include some rocks richer in $\mathrm{K}_{2} \mathrm{O}$ than any from the igneous rocks in the Highwood Mountains. Uranium analyses have been obtained on a suite of samples collected by W. T. Pecora, of the U. S. Geological Survey (table 12). 
TABLE 12.- Uranium analyses of igneous rocks of the Bearpaw Mountains, Mont.

[J. J. Warr, analyst]

\begin{tabular}{|c|c|c|c|c|}
\hline \multirow{2}{*}{ Rock type } & \multirow{2}{*}{$\begin{array}{l}\text { Number } \\
\text { of sam. } \\
\text { ples }\end{array}$} & \multirow{2}{*}{$\begin{array}{l}\text { Number } \\
\text { of deter- } \\
\text { minations }\end{array}$} & \multicolumn{2}{|c|}{$\begin{array}{l}\text { Üranium content } \\
(\mathrm{ppm})\end{array}$} \\
\hline & & & Range & A verage \\
\hline 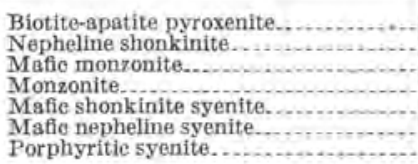 & $\begin{array}{l}1 \\
1 \\
2 \\
1 \\
1 \\
1 \\
1\end{array}$ & \begin{tabular}{l|}
3 \\
2 \\
4 \\
3 \\
3 \\
2 \\
3
\end{tabular} & $\begin{array}{l}1.1-1.2 \\
5.1-5.5 \\
1.4-2.3 \\
4.2-4.8 \\
4.3-4.8 \\
1.7-2.1\end{array}$ & $\begin{array}{l}1.13 \\
5,3 \\
1.8 \\
4.4 \\
4.6 \\
5,0 \\
2.0\end{array}$ \\
\hline
\end{tabular}

\section{PRECAMBRIAN BOULDER CREEK BATHOLITH OF COLORADO}

Preliminary data, based on the uranium analyses of 13 samples (table 13), suggest that the one Precambrian batholith under study, the Boulder Creek batholith of Colorado shows an apparent reversal in the order of uranium enrichment. Along the one section sampled the uranium content is high ( $8-14 \mathrm{ppm})$ in the border quartz diòrite gneisses, intermediate in the less mafic rocks of the middle zone, and lowest in the quartz monzonites and granites, which underlie most of the interior of the batholith. Compared to the younger intrusives already deseribed, this batholith has had a complex history, having been crushed, foliated, and partly recrystallized along its western margin. The mafic border rocks grade into more massive siliceous rocks in the interior, in which primary flow structure, both planar and linear, is commonly preserved. Minor repetitions of more mafic rocks are common throughout the exposed section; in the interior of the batholith these are not enriched in uranium.

The differences in composition of the wall rock in different areas along the original contacts are believed to be reflected, in a broad way, in the composition of the adjacent batholithic rocks and may be reflected in their uranium content as well. Quartz diorites were developed adjacent to areas of mafic schist; granodiorite adjacent to areas of mixed siliceous schist, gneiss, and mafic schist; and quartz monzonite and granite adjacent to areas of older granite gneiss and quartzite. Deepseated processes of assimilation or metasomatism or both were probably involved in the differentiation along with the fractional crystallization. It is hoped that further work will permit an evaluation of the separate effects.

At present it is considered probable that the high uranium content of the border quartz diorite gneisses so far sampled resulted from the local assimilation of, or reaction with, older uraniferous rocks, but the possibility that uranium was introduced during the metamorphism of the outer parts of the complex cannot be discounted.

\begin{tabular}{|c|c|c|}
\hline \multicolumn{3}{|c|}{ [Marian Schnepfe and Marjorie Molloy, analysts] } \\
\hline \multirow{2}{*}{ Rock type } & \multicolumn{2}{|c|}{ Uranium content (ppm) } \\
\hline & Range & A verage \\
\hline \multicolumn{3}{|l|}{ Border zone } \\
\hline 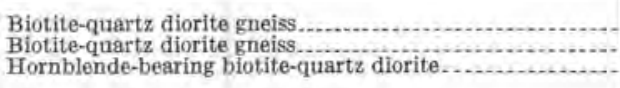 & $\begin{array}{r}14.5-14.5 \\
8.1-7.3 \\
5.5-5.9\end{array}$ & $\begin{array}{r}14.5 \\
7.7 \\
5.7\end{array}$ \\
\hline \multicolumn{3}{|l|}{ Intermediate zone } \\
\hline 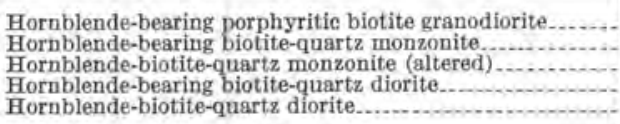 & $\begin{array}{l}5.5-5.1 \\
3.8-3.4 \\
7.3-6.4 \\
5.5-5.5 \\
5.9-6.4\end{array}$ & $\begin{array}{l}5.3 \\
3.6 \\
7.8 \\
5.5 \\
6.1\end{array}$ \\
\hline \multicolumn{3}{|l|}{ Interior zone } \\
\hline $\begin{array}{l}\text { Hornblende-biotite granodiorite. } \\
\text { Hornblende-biotite-quartz monzonite......... } \\
\text { Hornblende-biotite-quartz diorite gneiss,.... } \\
\text { Biotite-quartz monzonite gneiss.............. } \\
\text { Porphyritic quartz monzonite.................. }\end{array}$ & $\begin{array}{l}3.0-3.4 \\
4.0 \\
1.4 \\
1.7 \\
1.7\end{array}$ & $\begin{array}{l}3.2 \\
4.0 \\
1.4 \\
1.7 \\
1.7\end{array}$ \\
\hline
\end{tabular}

1 Samples are listed in order from west to east along a 12-mile section across the western half of the batholith.

\section{SUMMARY}

The results reported here indicate that the change in uranium content of the successive members of any one magma series is less systematic than is the change in major oxides. How much of this variability is real because of the diverse paths open to trace elements during magmatic differentiation and how much is apparent (inherent in the traditional methods of sampling igneous rocks) remains to be determined. The most variable rocks are those of intermediate composition; there is little or no overlap in the uranium content of the gabbroic and granitic extremes in any one magma series. Even in the least favorable instances it is generally possible to define a trend by assembling uranium data on a relatively large number of samples. In all those series studied in which fractional erystallization may be assumed to have been the major factor in differentiation, the trends are similar: uranium is enriched in the youngest rocks, these being generally high in $\mathrm{SiO}_{2}$ and $\mathrm{K}_{2} \mathrm{O}$ and low in $\mathrm{CaO}$ and $\mathrm{MgO}$. The maximum enrichment $(>20 \mathrm{ppm})$ is found in extreme differentiates very poor in $\mathrm{CaO}$. More data are needed on those series in which processes other than fractional crystallization are believed to have played important roles. In such rocks the uranium content developed may depend upon local geological conditions. 


\section{REFERENCES CITED}

Brown, Harrison, Blake, W. J., Chodas, A. A., and others, 1953a, Geochemical aspects of interstitial material in igneous rocks [abs.]: Geol. Soc. America Bull., v. 64, p. 1400.

$1953 \mathrm{~b}$, Leaching studies of interstitial material in igneous rocks [abs.]: Geol. Soc. America Bull., v. 64, p. 1400-1401,

Buie, B. F., 1941, Igneous rocks of the Highwood Mountains. Mont.-Part 3, Dikes and related intrusives: Geol. Soc. America Bull., v. 52, p. 1753-1808.

Burgess, C. H., 1941, Igneous rocks of the Highwood Mountains, Mont.-Part 4, The stocks: Geol. Soc. America Bull., v. 52, p. $1809-1828$.

Chapman, R. W., and Williams, C. R., 1935, Evolution of the White Mountain magma series: Am. Mineralogist, v. 20, p. 502-530.

Greenwood, Robert, 1951, Younger intrusive rocks of the Plateau Province, Nigeria, compared with the alkalic rocks of New England: Geol. Soc. America Bull., v. 62, p. 1151-1178.

Hudson, F. S., 1922, Geology of the Cuyamaca region of California, with special reference to the origin of the nickeliferous pyrrhotite: Calif. Univ., Dept. Geol. Sci., Bull., v. 13, no. 6 , p. $175-252$.

Hurlbut, C. S., Jr., 1939, Igneous rocks of the Highwood Mountains, Mont.-Part 1, The laccoliths: Geol. Soc. America Bull., v. 50, p. 1043-1112.
Hurley, P. M., 1950, Distribution of radioactivity in granites and possible relation to helium age measurement: Geol. Soc. America Bull., v. 61, p. 1-7.

Larsen, E. S., Jr., 1940, Petrographic province of central Montana: Geol. Soc. America Bull., v. 51, p. 857-948.

1941, Igneous rocks of the Highwood Mountains, Mont.Part 2, The extrusive rocks: Geol. Soc. America Bull., v. 52, p. 1733-1752.

- 1948, Batholith and associated rocks of Corona, Elsinore, and San Luis Rey quadrangles, southern California: Geol. Soc. America Mem. 29, 182 p.

Larsen, E. S., Jr., and Cross, Whitman, 1956, Geology and petrology of the San Juan Mountains, southwestern Colorado: U. S. Geol. Survey Prof. Paper 258.

Larsen, E. S., Jr., and Phair, George, 1954, The distribution of uranium and thorium in igneous rocks, in Faul, Henry (editor), Nuclear geology: New York, John Wiley and Sons, p. 75-89.

Phair, George, 1952, Radioactive Tertiary porphyries in the Central City district, Colorado, and their bearing upon pitchblende deposition: U. S. Geol. Survey TEI-247, 53 p., issued by U. S. Atomic Energy Comm. Tech. Inf. Service, Oak Ridge, Tenn.

Powers, H. A., 1932, The lavas of the Modoc Lava-Bed quadrangle, California: Am. Mineralogist, v. 17, p. 253-294. 


\title{
URANIUM AND CERTAIN OTHER TRACE ELEMENTS IN FELSIC VOLCANIC ROCKS OF GENOZOIC AGE IN WESTERN UNITED STATES
}

\author{
By Robert R. Coats, U. S. Geologieal Survey
}

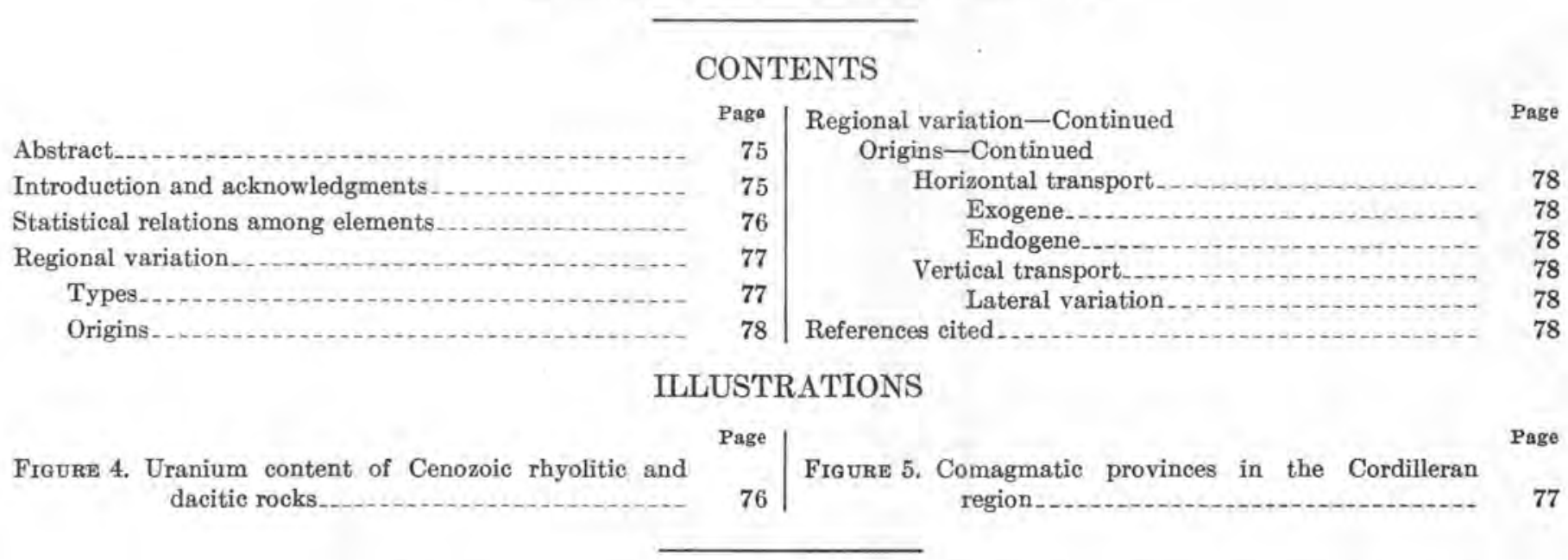

\section{ABSTRACT}

In the Cordilleran region of Western United States very few uranium deposits are remote from surficial manifestations of Cenozoic voleanic activity. On the other hand, broad areas of volcanic rocks are completely lacking in known uranium deposits. To determine whether this lack of known uranium deposits is due to insufficiency of exposures, of prospecting, or of both, or to a real searcity of uranium, rhyolitic and dacitic voleanic rocks, nearly all of which were glassy or partly glassy, were sampled at 116 widely separated localities in Washington, Oregon, Idaho, Montana, Wyoming, Colorado, Utah, Nevada, California, and Arizona. All these samples were analyzed fluorimetrically for uranium, chemically for fluorine, and spectographically for boron, beryllium, lanthanum, lithium, niobium, tin, lead, and zirconium. In about 50 samples manganese was sought and found; tantalum, thorium, and tungsten were sought but not found; and zinc and germanium were sought in some but not found.

The geographic distribution of uranium and some of the other elements studied, as indicated from these 116 samples, is not random; rather high and low values tend to fall into provincial groups, which have been tentatively delineated. The content of uranium has a significantly high positive correlation with that of fluorine, lithium, niobium, tin, and beryllium; a negative correlation with that of lanthanum; and the correlation with lead, boron, zirconium or manganese is not significant.

The provincial distribution may have resulted from the generation of magmas in parts of the crust that differed significantly in their content of the elements studied because of regional differences in the effectiveness of upward transport of these elements. A study of the correlations suggests that these elements were concentrated in rhyolitic rest magmas following removal of other elements by crystallization of early-forming minerals.

\section{INTRODUCTION AND ACKNOWLEDGMENTS}

This investigation was begun as a result of the observed close geographic relationship between known structurally controlled uranium deposits in the Cordilleran region, and the distribution of post-Cretaceous volcanic rocks (Kaiser and Page, 1952). It is also apparent that, although few uranium deposits are remote from areas of volcanic and shallow intrusive rocks, broad areas of volcanic rocks-for example, the Columbia Plateaus, the Sierra Nevada, and the Cascade Mountains - are completely lacking in known uranium deposits. The problem posed by this observation was whether this distribution reflects a real scarcity of uranium deposits in these areas or merely insufficient prospecting, lack of exposures, or both. If, as is believed by many, there is a genetic relation, direct or indirect, between the uranium deposits and postCretaceous vulcanism, then an investigation of the content of uranium in igneous rocks appeared to offer an indirect means of getting an answer to the problem. The investigation is predicated on the existence of uraniferous metallogenetic provinces and on the concept that there is a relationship between the metal content of the igneous rocks of a given comagmatic province and the type of ore deposits found in the province.

In order to obtain results that would permit comparison of rocks from one district, or differentiation 
series, with those of another, sampling was restricted to the felsic end members, chiefly rhyolites and dacites, which were known to have the highest uranium content (Adams, 1952). Glassy and partly glassy rocks were favored to obtain samples as representative as possible of unaltered and undepleted magma. Such rocks might be expected to show obvious traces of any hydrothermal alteration or weathering to which they had been subjected. Obviously, weathered and altered rocks were avoided. One hundred sixteen samples were collected in Washington, Oregon, Idaho, Montana, Wyoming, Colorado, Utah, Nevada, California, and Arizona. All these samples were analyzed fluorimetrically for U, chemically for $\mathrm{F}$, and spectrographically for $\mathrm{B}, \mathrm{Be}, \mathrm{La}, \mathrm{Li}, \mathrm{Nb}, \mathrm{Sn}, \mathrm{Pb}$, and $\mathrm{Zr}$. In about 50 samples $\mathrm{Mn}$ was sought and found; $\mathrm{Ta}, \mathrm{Th}$, and $\mathrm{W}$ were sought but not found; and $\mathrm{Zn}$ and Ge were sought in some but not found. The results are summarized in the table below.

Minor-element content of some rhyolitic and dacitic volcanic rocks of post-Cretaceous age from Western United States

\begin{tabular}{|c|c|c|}
\hline Element & $\begin{array}{c}\text { Arithmetic } \\
\text { average } \\
\text { (ppm) }\end{array}$ & $\begin{array}{l}\text { Range } \\
\text { (ppm) }\end{array}$ \\
\hline 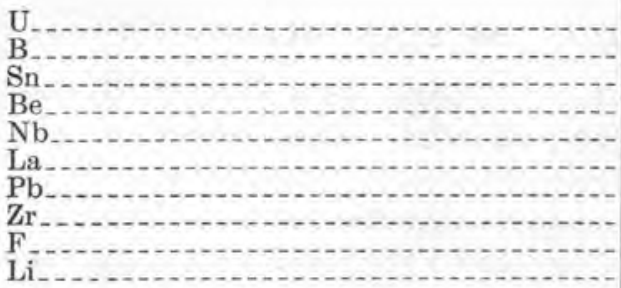 & $\begin{array}{r}5 \\
32 \\
5 \\
5 \\
22 \\
40 \\
24 \\
139 \\
655 \\
46\end{array}$ & $\begin{array}{l}0-30 \\
0-100 \\
0-40 \\
2-20 \\
0-200 \\
0-200 \\
0-90 \\
30-700 \\
0-4300 \\
0-300\end{array}$ \\
\hline
\end{tabular}

The geographic distribution of values showing high and low content of the several elements is not a random one; locally well-defined boundaries can be drawn between provinces with a high content of some elements and those with an average or less than average content. Figure 4 shows the distribution of values for uranium thus obtained. For $\mathrm{Sn}, \mathrm{Be}, \mathrm{Nb}, \mathrm{Pb}$, and $\mathrm{F}$, the pattern of distribution resembles that for $\mathrm{U}$. For $\mathrm{Zr}$ and $\mathrm{Li}$ the resemblance is less marked. The distribution of La is apparently nearly a random one and that of B shows well-marked patterns which differ from those of any other element and in which the highest values are distributed in the California Coast Ranges and along the east front of the Sierra Nevada. The provincial boundaries shown in figure 5 were tentatively drawn to obtain the best fit to the distributions of that group of elements showing the closest coherence, namely, $\mathrm{U}, \mathrm{Be}, \mathrm{Sn}, \mathrm{Nb}$, $\mathrm{Pb}$, and $\mathrm{F}$.

The analytical data used in this paper are the result of the work of P. R. Barnett, N. M. Conklin, W.

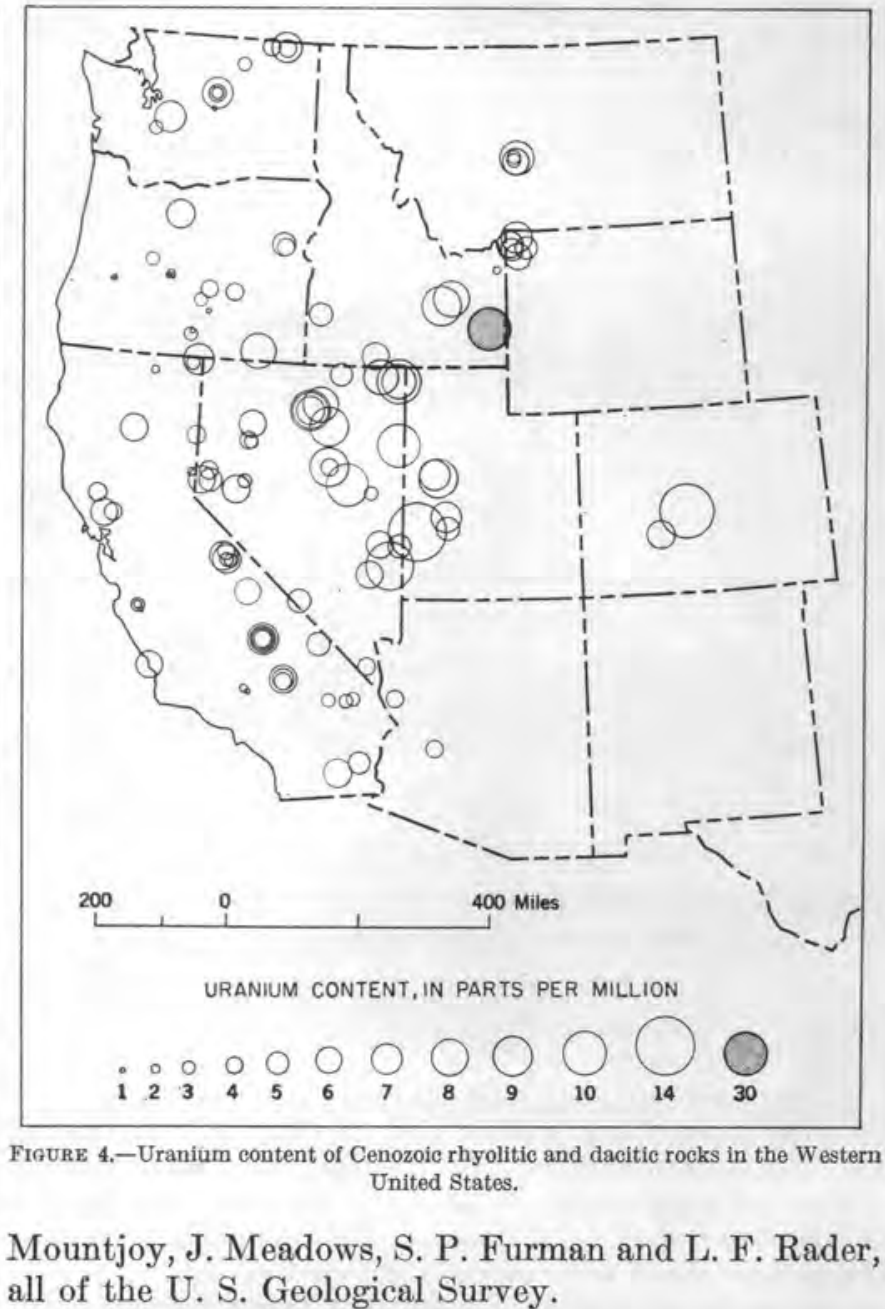

all of the U. S. Geological Survey.

\section{STATISTICAL RELATIONS AMONG ELEMENTS}

Correlation coefficients to determine the degree to which the distribution of the indicated elements resembled that of uranium were calculated by the usual methods and are shown below.

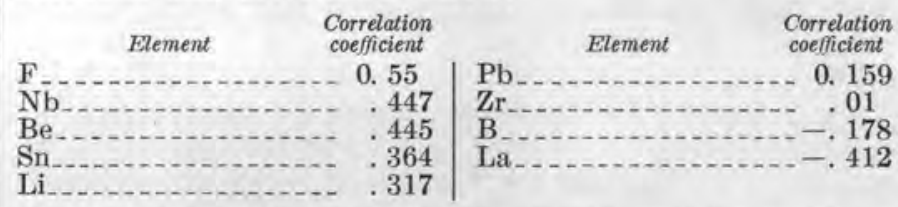

The coefficients for $\mathrm{Nb}, \mathrm{Sn}, \mathrm{Be}, \mathrm{Li}, \mathrm{F}$, and $\mathrm{La}$ reach or exceed the 0.1-percent level of significance; that is, there is less than 1 chance in 1,000 that a correlation this high could be the result of random distribution. The coefficient for $\mathrm{B}$ is about that of the 5-percent level of significance. Coefficients for $\mathrm{Pb}$ and $\mathrm{Zr}$ are not significant. The probable significance of these relationships is that those elements that correlate well with uranium are those typically concentrated in residual magmas, such as in pegmatites. The associa- 


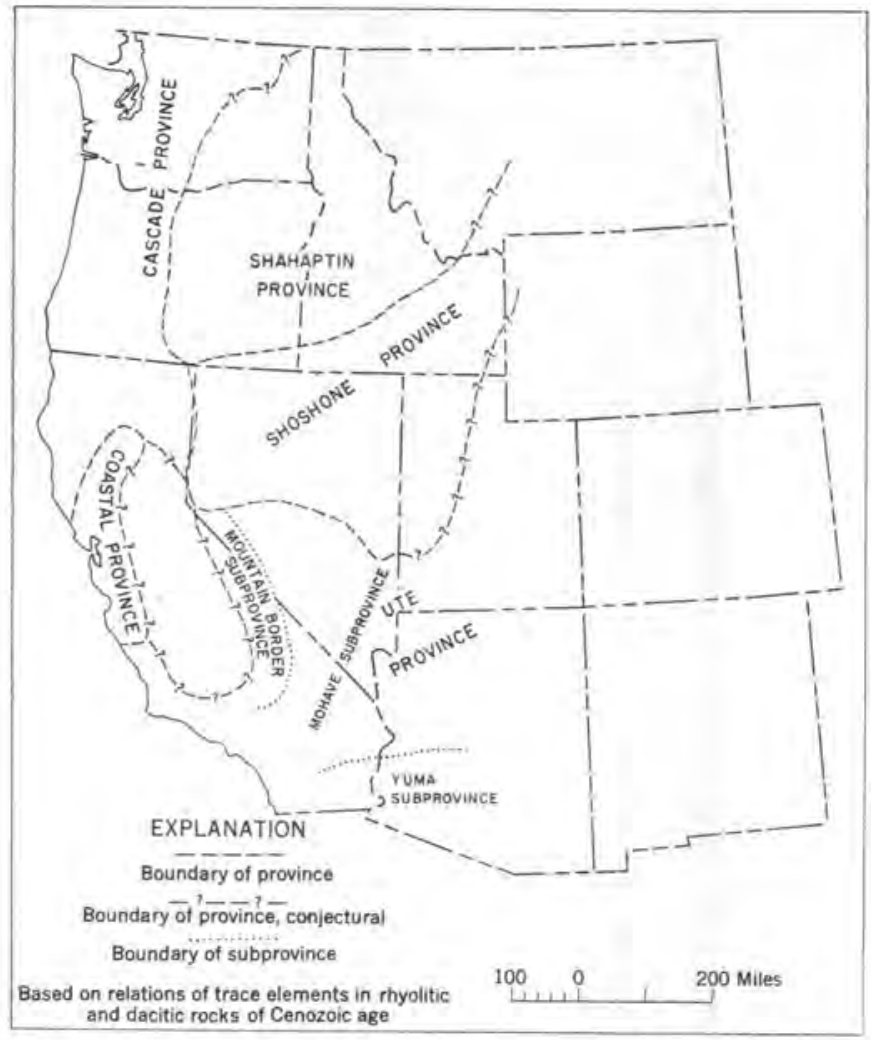

FIGURE 5.-Comagmatie provinces in the Cordilleran region of the Western United States

tion with $\mathrm{F}$ is of a different sort and is possibly attributable to the formation of uranium fluoride compound or complex ion in the magma.

The highest mean-uranium content is found in the rocks of the Shoshone province, with lower values in rocks from the Ute and Coastal provinces (see table below). The values calculated show that the positive deviation shown by the values for the Shoshone province is highly significant, and the negative deviation shown by the values for the Cascade province is possibly significant. The statistical study of the distribution suggests strongly that the Shoshone province is a uraniferous province, or part of a larger uraniferous province, at the levels of concentration indicated in the table, for the type of rocks analyzed. The boundaries as indicated on figure 5 are of course tentative, and, when other aspects of the distribution of uranium are taken into account, the Shoshone province may prove to be part of the larger uraniferous province that includes the Colorado Plateau. A rational explanation for the relative scarcity of uranium deposits in some of the other provinces may be the relative poverty in uranium of the magmas from which some types of uranium deposits are derived.

\section{REGIONAL VARIATION TYPES}

The evidence presented indicates that the regional variations in uranium content in rhyolitic and dacitic rocks are nonrandom in nature. Similar types of variation may be shown for $\mathrm{Sn}, \mathrm{Be}, \mathrm{Nb}, \mathrm{Pb}$, and $\mathrm{F}$. Two types of nonrandom variation of regional extent may be discerned in the distribution mapped. One of these may be described as consisting of apparently random fluctuations in minor-element content about a given level of concentration, with broad areas that are relatively sharply delimited from neighboring areas, which are in turn characterized by rocks showing apparently random fluctuations about a different level of concentration. The other type of nonrandom variation consists of progressive gradational changes in minorelement content within a broad area. This latter is apparently what Pirsson called a "regional progression

Distribution of uranium, with respect to province and content, in 112 rhyolitic and dacitic rocks

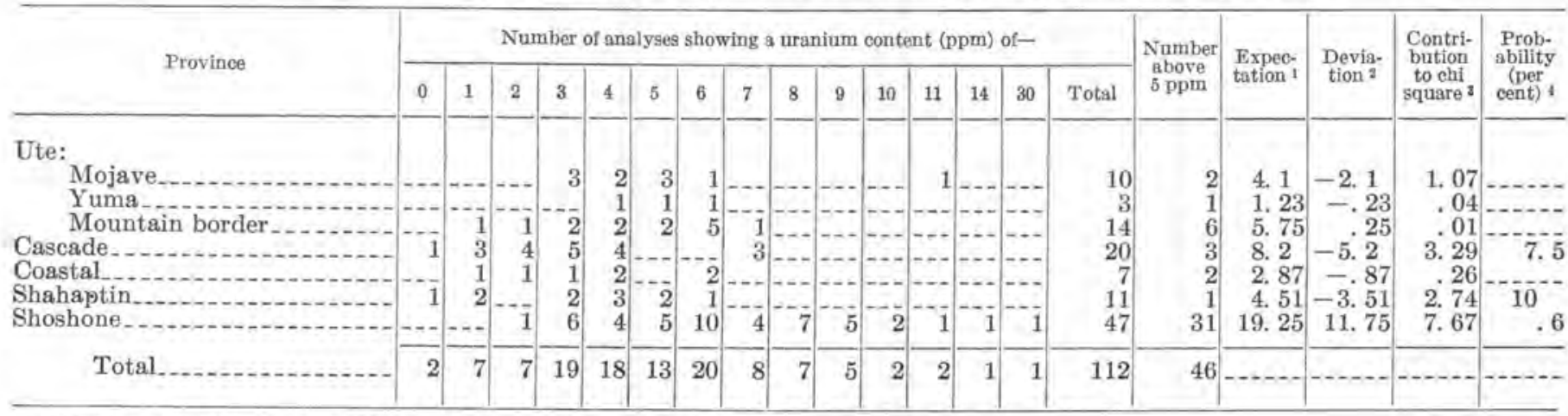

1 Number expected, assuming that the distributions, by value, are the same for all provinces.

2 Deviation of actual values found, compared with numbers expected (which are generally not whole numbers.)

$1 \mathrm{X}^{1}=\frac{\text { (deviation) }}{\text { dectation }^{2}}$ a measure of departure from representativeness weighted for size of sample.

The number of analyses giving values above the mean that might be obtained by a chance drawing of the total number of analyses in the province from the total number of analyses (112). A high probability means that the observed distribution might be readily obtained by chance; a probabilit $\mathrm{y}$ of 5 percent means there is 1 chance in 20 that the observed distribution could be a matter of chance alone. 
of types" (Iddings, 1913). Both types of variation may be present in the Cordilleran region. It should be noted that both types of variation may imply compositional gradients, the differences lying merely in the steepness of the gradient.

\section{ORIGINS}

If we neglect the possibility of initial nonuniformity in the granitic crust, subsequent lateral variation in the concentration of minor elements at accessible levels of the crust may arise in two ways: by lateral variation in the effectiveness of vertical transport, or by horizontal transport. Horizontal transport may be either endogene, operating within the crust, or exogene, operating surficially.

\section{HORIZONTAL TRANSPORT}

EXOGENE

Processes involved in exogene horizontal transport are relatively familiar to us, because they are those of weathering, erosion, and sedimentation. Recently, Cady, McKelvey, and Wells (1950) have pointed out the close relationship between mineral deposits, particularly syngenetic deposits in sedimentary rocks, and the sedimentary facies and geotectonic environment in which the rock was deposited. Any particular example of regional variation can reasonably be attributed to exogene segregation and redistribution where the element in question is known to be concentrated in the minor cycle or in sedimentary rocks characteristic of a particular facies, and where the area in which a particular element is concentrated coincides fairly closely with the distribution of the favorable sedimentary facies. In this study, however, the set of elements that seems most closely associated is characteristically a pegmatitic one, that is, a set of elements characteristic of granitic rest magmas, rather than one characteristic of any particular sedimentary facies. Furthermore, the provincial boundaries that seem to express best the minor-element relationships are quite discordant with those of the major geosynclinal troughs of the Cordilleran region through most of known geologic history. To some extent, of course, this discordance may be a reflection of the somewhat restricted distribution of Cenozoic rhyolitic and dacitic rocks, but the province with the most distinetive chemical characteristics and the best-defined boundary, the Shoshone province, is the one that shows the most pronounced discordance with past geosynclinal trends.

\section{BNDOGENE}

Endogene horizontal transport of material within the crust, if we exempt the short-distance effects of overthrusts, must be by ionic diffusion, gas transport, or liquid transport. Owing to the directions of the prevailing thermal and pressure gradients, such transport is more difficult than transport in a vertical sense. (Again, we may except the migration of petroleum and of ground water.) Stress conditions in the crust apparently make any extensive lateral displacement of magma impossible. Recently, however, Gilluly (1952) has suggested subcrustal transport of sialic material. If such transport takes place, it is probable that it may be, to some extent, differential, because the remelting is also likely to be differential. This mechanism seems to the writer to offer promise as an explanation of progressive gradational changes in the composition of igneous rocks.

\section{VERTICAL TRANSPORT}

\section{LATERAL VARIATION}

Rankama (1946) has shown that certain elements, namely, $\mathrm{Li}, \mathrm{Be}, \mathrm{Rb}, \mathrm{Cs}, \mathrm{Ba}$, rare earths, $\mathrm{Ta}$, and $\mathrm{Pb}$, tend to be more highly concentrated in younger granites, within the area he studied. Rankama attributes the change to the repeated sweating out and upward migration of palingenetic magmas, successively more and more enriched in the elements that enter least readily into the earlier formed minerals. These are largely the elements for which regional differences in concentration are found in this study.

It is here suggested that, in those areas where because of favorable tectonic conditions Rankama's process has been most effective over a long period of time, the concentration of the residual pegmatitic elements will be highest at a given level in the crust; and that rhyolitic magmas, generated at such levels in such areas, will have more of the residual elements than rhyolitic magmas generated elsewhere at corresponding levels. By this hypothesis, tectonic trends and magmatogenic episodes of the Precambrian are responsible for some provincial differences found in younger igneous rocks.

\section{REFERENCES CITED}

Adams, J. A. S., 1952, Some aspects of the geochemistry of uranium [abs.]: Geol. Soc. America Bull., v. 63, p. 1229.

Cady, W. M., MeKelvey, V. E., and Wells, F. G., 1950, Geotectonic relations of mineral deposits: Geol. Soc. America Bull., v. 61, p. 1447.

Gilluly, James, 1952, Connection between orogeny and epeirogeny as deduced from the history of the Colorado Plateau and Great Basin [abs.]: Geol. Soc. America Bull., v. 63, p. $1529-1530$.

Iddings, J. P., 1913, Igneous rocks: New York, John Wiley \& Sons.

Kaiser, E. P., and Page, L. R., 1952, Distribution of uranium deposits in the United States: U. S. Geol. Survey Circ. 220, p. 1-7.

Rankama, Kalervo, 1946, On the geochemical differentiation in the earth's crust: Comm. géol. Finlande Bull. 137, p. 16. 


\title{
URANIUM DEPOSITS IN VOLGANIC ROGKS OF THE BASIN AND RANGE PROVINCE
}

\author{
By Brron J. Sharp, U. S. Atomic Energy Commission
}

\section{CONTENTS}

Abstract....
Gentroduction
Deposits.
Marysvale area, Utah

Page

Deposits-Continued Kings River area, Nevada Other deposits

Conclusions.

\section{ILLUSTRATIONS} Figure 6. Index map showing districts with uranium de-
posits in volcanic rocks of the Basin and
Range province.

Page

FigURE 7. Underground workings in the rhyolite agglomerate in the Marysvale area, Utah ...........

80
Page

80

81

83

83

\section{ABSTRACT}

Voleanic rocks have been generally considered unfavorable hosts for uranium ore deposits. The discovery of uranium minerals in rhyolite at Marysvale, Utah, was the first of several in the Basin and Range province. In addition to the Marysvale occurrence, uranium has been found in veins in rhyolite breccia in the Kings River area, Humboldt County, Nev. Other localities in this region that are known to contain uranium minerals in volcanic rocks include areas in Lassen and Kern Counties, Calif., and in Esmeralda, Lincoln, and Washoe Counties, Nev.

Vein-type uraninite deposits in granitic rocks in the Marysvale district are closely associated with volcanic rocks. Uranium minerals occur in red rhyolite agglomerate and in felsitic to glassy dikes. Uraninite has been identified in the rhyolite agglomerate in close association with fluorite. Other uranium minerals identified are autunite, meta-autunite, torbernite, and uranophane.

In the Kings River area, uranium occurs along a northwardtrending fault which displaces Miocene volcanic rocks. The volcanic sequence was extruded upon an old erosion surface of granodiorite of Jurassic(?) age which crops out north of the ore deposit and is also exposed in mine workings. Uranium minerals include autunite, torbernite, and possibly gummite and uraninite. Gangue minerals are pyrite, quartz, fluorite, and clays. The structure is mineralized throughout its exposed depth of 270 feet.

Elsewhere in Nevada and California uraninite and secondary uranium minerals have been found in volcanic rocks varying from rhyolitic tuff and agglomerate to andesite.

\section{INTRODUCTION}

Several occurrences of uranium have been found in volcanic rocks of the Basin and Range physiographic province (fig. 6). This province includes the Great Basin, an area of interior drainage in Utah, Nevada, and California. Elevations range from about 4,000 to 14,000 feet above sea level. Isolated, nearly parallel mountain ranges which characteristically trend northward are separated by broad alluvium-filled valleys. Evidence of alpine glaciation is apparent in the higher mountain ranges, and remnants of Pleistocene lake shorelines form local terraces in the foothills. The climate is semiarid to arid, and natural vegetation consists mainly of sage, juniper, and several types of conifers.

\section{GENERAL GEOLOGY}

The Basin and Range province was the site of several deep basins of deposition throughout most of the Paleozoic and Mesozoic eras. In Late Jurassic time, the west edge of the province was disturbed by the Nevadan orogeny, with the formation of the Sierra Nevada Mountains. During Late Cretaceous and early Tertiary time, folding and thrusting of the Laramide orogeny occurred along a northward-trending belt which included most of the Basin and Range province and extended into Canada and Mexico.

The major intrusive rocks in the area range in age from Jurassic(?) to Miocene(?). The younger intrusive rocks are in the eastern part of the province, and the older ones are in the western part, apparently related to the Sierra Nevada batholith. Most of the volcanic 


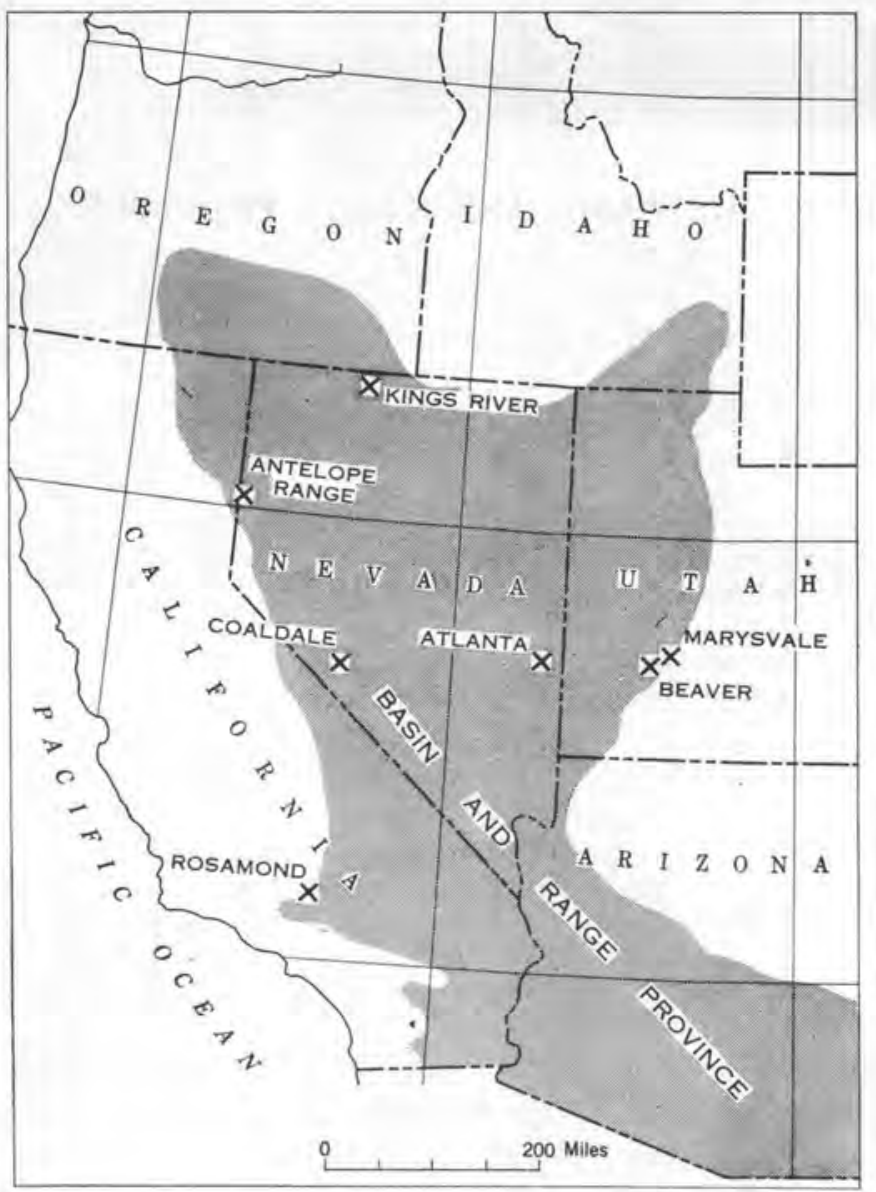

Figure 6,-Index map showing distriets with uranium deposits in voleanie rocks of the Basin and Range Province.

rocks in the province are Tertiary in age. They are present throughout the area, but are particularly abundant in southwestern Utah, northwestern and south-central Nevada, and eastern California.

After the Nevadan and Laramide orogenies, an episode of high-angle faulting, superimposed on older structures, created the Basin and Range physiographic province of sharply defined mountain ranges and alluvial valleys. Most of the high-angle faults are late Tertiary in age and some are still active.

\section{DEPOSITS}

\section{MARYSVALE AREA, UTAH}

Geography.-The Marysvale mining district (fig. 6) is in south-central Utah, about 200 miles south of Salt Lake City. The Antelope Range to the east rises to an elevation of 7,600 feet, which is 2,000 feet above the Sevier River, near the west edge of the area.

General geology.-Several major units of igneous rocks constitute the petrologic environment of the Marysvale area. The Bullion Canyon voleanies, which consists of a great thickness of latite flows, volcanic breccias, and tuffs, represents the earliest igneous activity in the area (Kerr, Brophy, Dahl, and others, 1952). These volcanic rocks were intruded by quartz monzonite and granite. Extrusion of the Mount Belknap rhyolite followed the erosion interval.

Faulting took place both before the erosion interval and at the time of the extrusion of the Mount Belknap rhyolite. Vein deposits in the Marysvale district are best developed in the quartz monzonite. A red rhyolite agglomerate at the base of the Mount Belknap contains uranium minerals along weak fractures which appear to offset the quartz monzonite-rhyolite agglomerate contact. Uranium is also present along small fractures in glassy rhyolite dikes which are presumably feeder dikes of the Mount Belknap rhyolite.

Ore deposits.-Uraninite has been identified both in rhyolitic glassy dikes and rhyolite agglomerate. Finely divided uraninite is closely associated with fluorite, but fluorite also occurs without uraninite. Part of the fluorite may have formed contemporaneously with uraninite, but some is later (Kerr, Brophy, Dahl, and others, 1952). Secondary uranium minerals in the rhyolites are autunite, meta-autunite, torbernite, and uranophane.

Fluorite and uranium minerals occur in lenticular pods and bands along flow planes of the rhyolite agglomerate (Gilbert, 1955). The mineralized zones follow the flow planes in some places, but elsewhere they cut sharply across them (fig. 7 , section $A-A^{\prime}$ ). The ore is commonly associated with lenses of clay, and fluorite has apparently replaced part of this clay in both ore and barren zones.

Glassy dikes, flow planes, clay lenses, and local structures in the rhyolite agglomerate are all closely related to uranium mineralization. The close association of fluorite and uranium may be a key to the mode of emplacement of the uranium. There are indications that they may have been introduced as a late phase of the volcanic activity.

\section{KINGS RIVER AREA, NEVADA}

Geography.-Uranium is found in the foothills east of Kings River valley (fig. 6) in Humboldt County, Nev., about 74 miles north of Winnemucca. The mountains immediately east of the occurrence rise about 2,000 feet above the broad floor of the Kings River valley.

General geology.-The rock units in the Kings River area consist of granodiorite, diabase, agglomerate, rhyolite, vitrophyre, and lake sediments (fig. 8). Granodiorite of Jurassic(?) age (Yates, 1952) crops out north of the mine shaft and is also exposed in the lower workings. Diabase dikes intrude the granodiorite, and larger outcrops of similar material may be extrusive equivalents of the diabase dikes. A volcanic sequence 


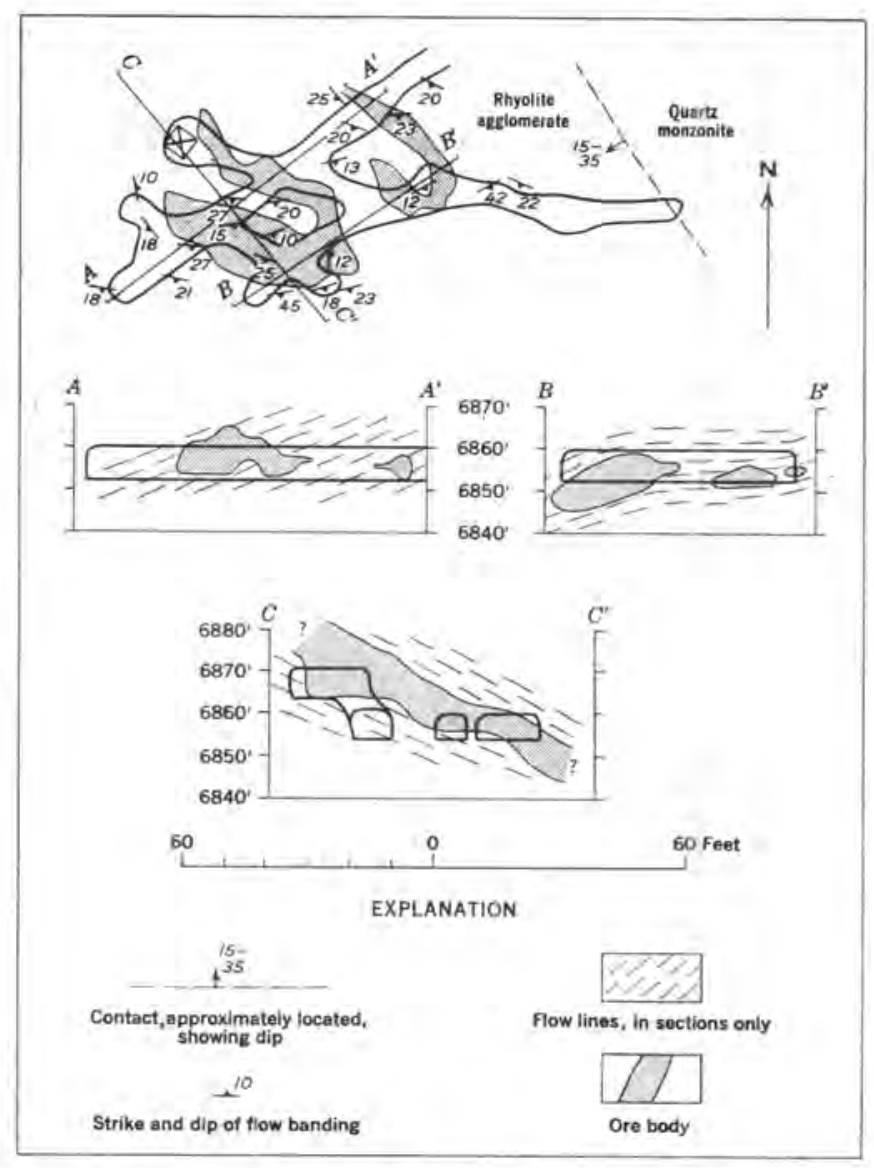

Fiavre 7,-Underground workings in the rhyolite agglomerate in the Marysvale area, Utab.

of agglomerate, rhyolites, and vitrophyre of Miocene age appears to have been extruded over an erosion surface on the granodiorite and diabase. Later lake sediments of Miocene(?) age were deposited in the lower areas near the thick sequence of volcanic rocks.

A series of northward-trending faults displaces the rocks of the area. These faults parallel the mountain front and are both normal and reverse. Uranium minerals have been exposed in mine workings on one of the faults, and anomalous radioactivity has been detected along the surface extension of this structure to the north.

Ore deposits.-The fluorescence of autunite was originally detected along the surface exposure of the northward-trending fault structure. Torbernite, gummite(?), and uraninite(?) occur at depth. Gangue minerals include iron oxides, pyrite, smoky quartz, fluorite, and clays. The structure is mineralized throughout its exposed depth of 270 feet and is one of several parallel faults, but no appreciably radioactive material has been found along the other faults.

Uranium occurs in irregular zones along a northwardtrending fault in volcanic rocks of the Kings River area.
The mineralizing solutions are probably genetically related to the volcanic activity.

\section{OTHER DEPOSITS}

Other occurrences of uranium in volcanic rocks of the Basin and Range province include those in the Antelope Range, Nev. and Calif.; the Atlanta and Coaldale areas, Nevada; Beaver, Utah; and Rosamond, Calif.

Antelope Range area, Nevada and California.-A uranium deposit is situated on the western slopes of the Antelope Range about 30 miles north of Reno, Nev., at an elevation about 6,000 feet above sea level, on the California-Nevada State boundary (fig. 6). Rocks exposed consist primarily of granite of Jurassic age overlain by voleanic rocks of Tertiary age. Gummite and uranophane occur along narrow silicified northeastward-trending fractures in rhyolite and rhyolitic tuff. Other occurrences of uranium nearby in the volcanic rocks suggest that the rhyolite and rhyolitic tuff are favorable units for uranium deposition.

Atlanta district, Nevada.-Uranium in extrusive rocks occurs in the Atlanta mining district, about 50 miles north of Pioche, Nev. Uranium minerals are scattered throughout coarse silicified rhyolite agglomerate, which is exposed for about 500 feet along a low ridge. The agglomerate at the outcrop strikes N. $75^{\circ}$ E. and dips $15^{\circ}-25^{\circ} \mathrm{N}$. The principal ore minerals have been tentatively identified as uraninite, uranophane, and autunite. Numerous steep fractures which trend N. $35^{\circ} \mathrm{W}$. may have localized the mineralization.

Coaldale area, Nevada.-Uranium-bearing rhyolitic tuff is exposed at the southern end of the Silver Peak Mountains, about 4 miles south of Coaldale. The deposit consists of weakly mineralized tuff containing veinlets and small irregular pods of higher grade uranium-bearing rock (Duncan, 1953). Autunite and phosphuranylite coat fractures and partly fill feldsparcrystal cavities in the tuff. Uranium in an unidentified form is also present in small veinlets of siliceous material and in limonite-stained fracture coatings.

Beaver area, Utah.-Several small uranium deposits are situated on the western slopes of the Tushar Mountains near Beaver, Utah. The Mount Belknap rhyolite and Bullion Canyon volcanics previously described for the Marysvale area form the host rock of the deposits near Beaver. Uranium occurs in the Bullion Canyon along dikes which are probably feeder dikes to the Mount Belknap. Autunite, torbernits, and uranophane are also found in small fractures, faults, and shear zones in both volcanic sequences. Gangue minerals include fluorite, pyrite, quartz, chlorite, sericite, and iron oxides.

Rosamond area, California.-Near Rosamond, Calif., uranium is associated with the volcanic rocks of the 


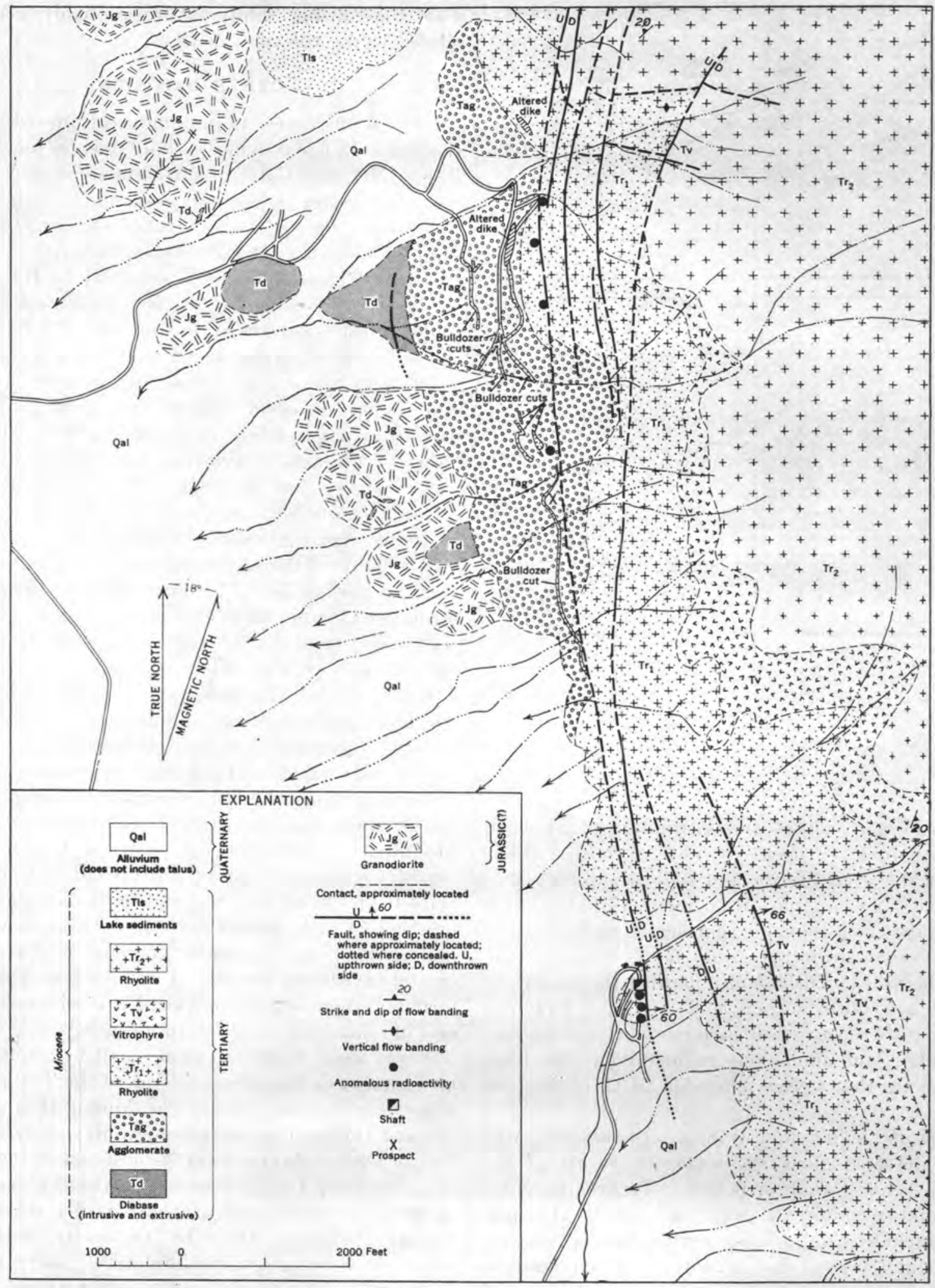

FIGURE 8.-Geologie map of the Kings River area, Humboldt County, Nev. 
Rosamond series of Hershey (1902) of Miocene age. Autunite and gummite(?) have been found in dacite dikes, flows, and tuffs. Small faults and fractures probably controlled the uranium-bearing solutions and localized the deposits.

\section{CONCLUSIONS}

Uranium minerals have been found in volcanic rocks in several localities in the Basin and Range province. Dikes, faults, fractures, and shear zones in silicic volcanic rocks are considered favorable sites for uranium deposition. Fault zones, related to major tectonic features of the Basin and Range province, constitute favorable loci for uranium deposits. Cryptocrystalline silica veinlets, fluorite, pyrite, and clays are commonly associated with uranium minerals in these deposits.
Geologic evidence indicates that uranium and closely associated elements may have been introduced as a late phase of the volcanic activity.

\section{REFERENCES CITED}

Duncan, D. C., 1953, A uranium-bearing rhyolitic tuff deposit near Coaldale, Esmeralda County, Nev.: U. S. Geol. Survey Cire. 291, 7 p.

Gilbert, R. E., 1955, U. S. Atomic Energy Comm. unpub. inf. Hershey, O. H., 1902, The Quaternary of southern California: Calif. Univ. Dept. Geol. Bull. 3, p. 1-29.

Kerr, P. F., Brophy, G. P., Dahl, H. M., and others, 1952, Annual report for July 1, 1951 to June 30, 1952-Part I, A geologic guide to the Marysvale area: U. S. Atomic Energy Comm. RMO-924, 57 p., issued by U. S. Atomic Energy Comm. Tech. Inf. Service, Oak Ridge, Tenn,

Yates, R. G., 1952, Quicksilver deposits of the Opalite district, Malheur County, Oreg., and Humboldt County, Nev.: U. S. Geol. Survey Bull. 931-N, p. 319-348. 



\title{
URANIUM DEPOSITS AT THE CONTACT OF METAMORPHOSED SEDIMENTARY ROCKS AND GRANITIC INTRUSIVE ROCKS IN WESTERN UNITED STATES
}

\author{
By Ernest E. Thurlow, U. S. Atomic Energy Commission
}

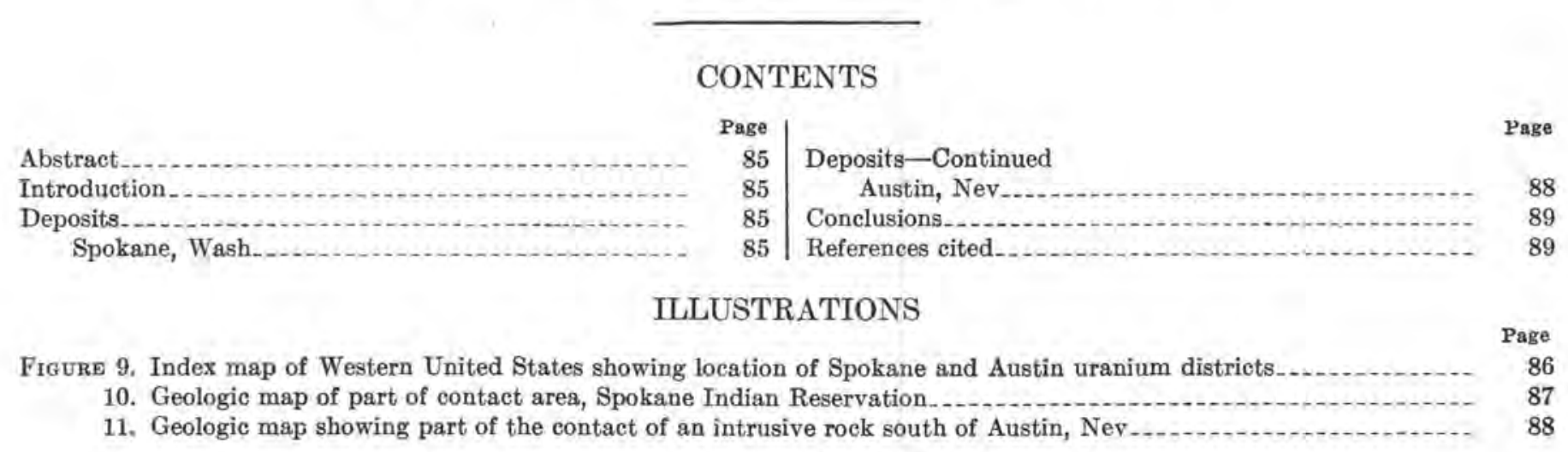

\section{ABSTRACT}

Both primary and secondary uranium minerals occur in the contact zone of granitic intrusive rocks and metamorphosed sedimentary rocks of Paleozoic age in at least two areas in the Western United States.

On the Spokane Indian Reservation in northeastern Washington, autunite and uranophane occur at the contact of the so-called Loon Lake granite of Cretaceous (?) age which intrudes the so-called Deer Trail argillite of late Paleozoic (?) age. Uraninite and pyrite have been found in diamond-drill holes which penetrated the contact zone at depth. Weaver's Loon Lake granite is a coarse-grained, holocrystalline, somewhat porphyritic intrusive rock with aplitic and pegmatitic facies. No primary uranium mineral has been identified in the granite, but secondary minerals are found as much as 20 feet from the contact. Although it is termed argillite, Weaver's Deer Trail is composed of schists and phyllites with quart,zite lenses in the vicinity of the deposit. Mineralization extended at least 40 feet into the metamorphosed sedimentary rocks along shear zones parallel with the contact with no apparent replacement of the host rock.

A similar deposit oceurs near Austin in Lander County, Nev., where uranium minerals are found in fractures in Jurassic (?) quartz monzonite and metamorphosed sedimentary rocks. Uranium is associated with mineralized fractures resembling dikes which are composed of finely divided sericite with varying amounts of vein quartz. Concentrations of autunite and metatorbernite occur in both the intrusive and the metamorphosed sediments but are confined to fractures near the contact zone and small roof pendants of metamorphosed sediments. The metamorphic rocks include hornfelses, quartzites, and phyllites.

\section{INTRODUCTION}

Uranium deposits close to the contact of Paleozoic metamorphosed sedimentary rocks and granitic in- trusive rocks occur in at least two areas in the Western United States; near Spokane, Wash., and Austin, Nev, Autunite is the principal secondary uranium mineral and uraninite has been tentatively identified in drill cores. Concentrations of uranium minerals occur at the contact, in shear zones in the metamorphosed sediments parallel with the contact, and also disseminated in small roof pendants of metamorphosed sediments.

Nearby contact zones have all yielded tungsten ores, and each uranium deposit was discovered as a direct result of the fluorescence of autunite observed when searching for scheelite with an ultraviolet lamp. A zonal arrangement of metals is indicated in the Austin area and silicification is intense, whereas faulting and shearing were more pronounced at the Washington locality with little evidence of replacement of the country rock or introduction of quartz. Since exploration in these areas is not far advanced, observations recorded below are preliminary.

\section{DEPOSITS SPOKANE, WASH.}

Geography.-A potentially important deposit of uranium is situated on the Spokane Indian Reservation in Stevens County, about 50 miles northwest of Spokane (fig. 9), It is in an area of low, rounded hills, with local steep slopes, not far from the confluence of the Columbia and Spokane Rivers. Elevations in the 
general vicinity range from 2,000 to 4,000 feet above sea level. The small town of Springdale, known principally for its tungsten deposits, lies to the east. The climate is mild; total annual rainfall ranges from 16 to 20 inches, with about two thirds of this falling during the winter season.

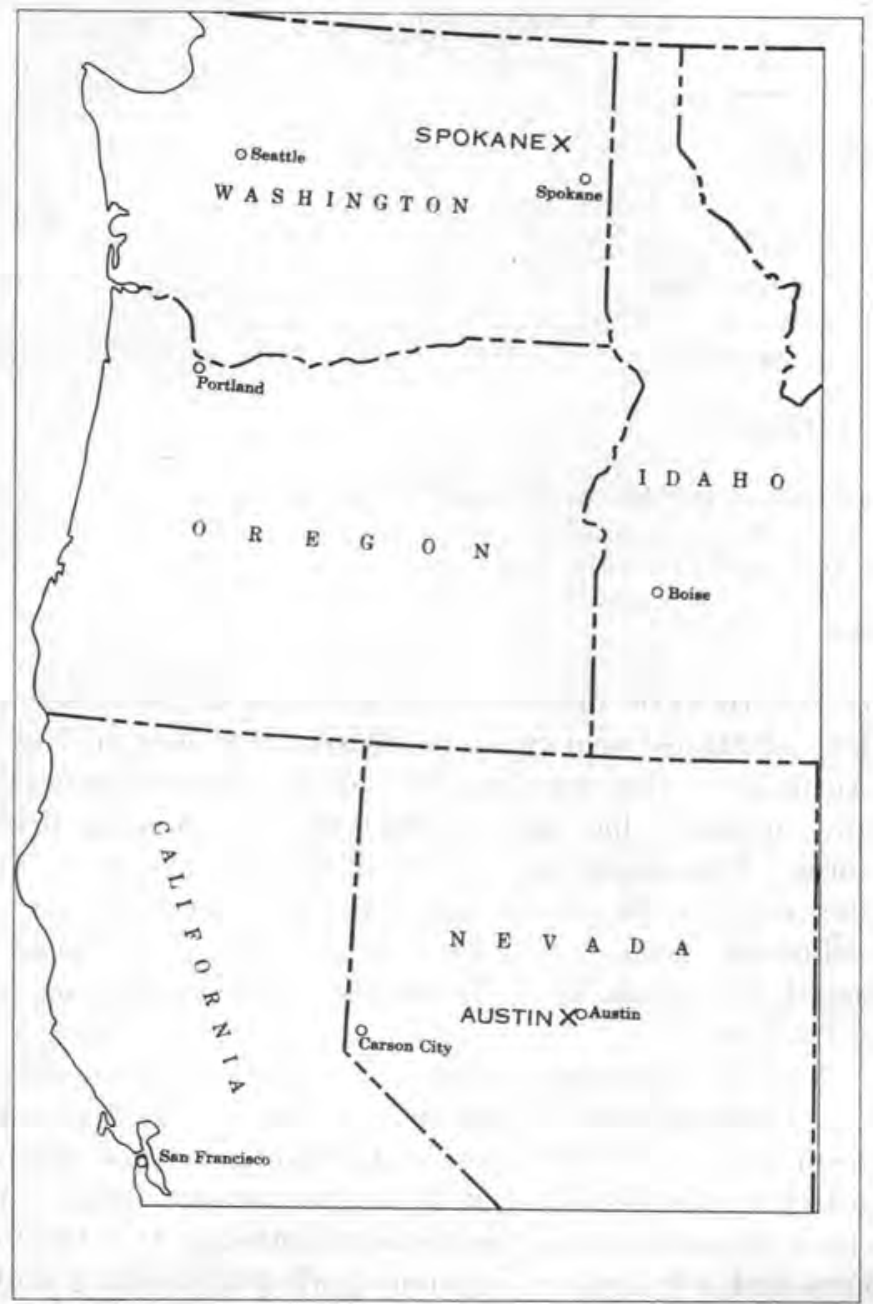

FIGURE 9.-Index map of Western United States showing location of Spokane and Austin uranium deposits.

General geology.-The region is characterized by a diversity of rock types ranging from Precambrian to Recent in age. Nearly two thirds of the area of Stevens County is underlain by a thick series of metamorphosed sedimentary rocks of Paleozoic age which have been termed the Stevens series (Weaver, 1920). These have been intruded and, in places, greatly disturbed by batholithic masses of granite, syenite, and granodiorite. The predominant intrusive rock is the Loon Lake granite of Weaver (1920). Large areas are heavily covered with deposits of glacial drift and with soil. The Columbia Plateaus of basaltic lava so exten- sively developed south of the Spokane River extend northward into this area as long, irregularly shaped tongues.

A total of 40,000-50,000 feet of unfossiliferous sedimentary rocks of probable late Paleozoic age make up the Stevens series of Weaver (1920). Seventeen formational units have been described from this series although some duplication may exist because of difficulties in correlation. The rocks are principally limestones, argillites, and quartzites. The Deer Trail argillite of Weaver (1920) is in the lower part of the series and is the host for the uranium deposit. It is approximately 3,000 feet thick and at this locality is chiefly mica schist and phyllite with a few lenses of quartzite. Mica schist is predominant in the contact zone.

Weaver's Loon Lake granite is a coarse-grained, holocrystalline, somewhat porphyritic intrusive body with aplitic and pegmatitic facies. In the vicinity of the ore deposit an aplitic dike euts both the argillite and the granite and appears to be an unfavorable host rock for uranium concentration.

The metamorphosed sedimentary rocks generally lie in a series of northeastward-trending overturned folds which have been deeply truncated by erosion (Weaver, 1920). While no major tectonic structures cross the region, local faulting is common. The uranium deposit lies on the southeast flank of one of the major folds where Weaver's Deer Trail argillite is in contact with his Loon Lake granite.

Ore deposits.-Uranium occurs in shear zones at the contact of Weaver's Deer Trail argillite and Loon Lake granite and also in a series of similar zones within the metamorphosed sedimentary rocks generally parallel with, and not far from, the contact (fig. 10). The secondary-uranium mineral autunite is also found in the granite as much as 20 feet from the contact, where it may have been deposited by meteoric waters. No direct evidence of primary uranium mineralization is known within the granite.

Autunite and uranophane are the principal uranium minerals in the oxidized zone, and uraninite associated with pyrite has been tentatively identified from drill cores recovered from a depth of 150 feet. Gangue minerals other than pyrite are almost completely lacking, and very little replacement of the host rock is apparent. The process of ore emplacement apparently involved only the filling of shear zones by deposition from ascending solutions. However, the original distribution of the primary ore is obscured by widespread oxidation and probable redistribution of the uranium in secondary minerals. The close association of the uranium with the Loon Lake granite of Weaver (1920) suggests its derivation from the original magma. 
URANIUM AT THE CONTACT OF SEDIMENTARY AND INTRUSIVE ROCKS .

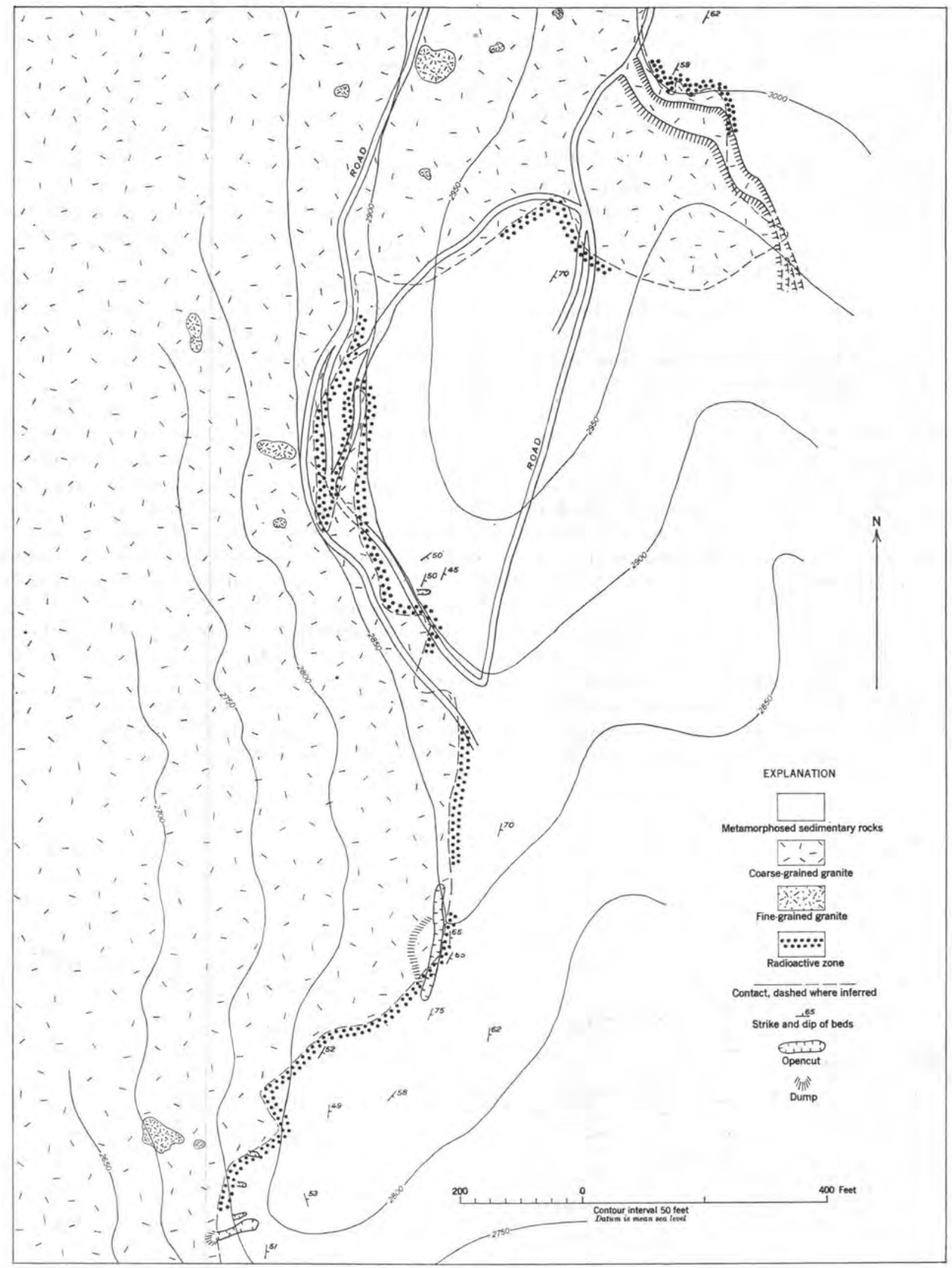

Figure 10.-Geologic map of part of the contact area, Spokane Indian Reservation. 
The average dip of the contact at the outcrop is about $55^{\circ} \mathrm{E}$. Outcrops of the mineralized zone average about 8 feet in width. There has not been sufficient exploration to determine the exact extent of the mineralized zone, although the outcrop is mineralized for at least 2,000 feet.

The general geologic environment at this deposit is repeated over a large area in northern Washington, and a few other occurrences of uranium are known in the region.

\section{AUSTIN, NEV.}

Geography.-Austin, Nev., is in the Reese River silver-mining district in Lander County near the center of the State. Uranium occurs apart from the silver ores near the south edge of the district, about 3 miles south of Austin (Sharp and Hetland, 1954). Elevations range from 6,000 to 7,500 feet above sea level. Streamcut canyons form rounded and moderate slopes, and the foothills are covered by alluvium which is part of the eastern edge of a typical intermontane basin in the Basin and Range province. The climate is semiarid to arid with most of the precipitation in the winter months. Vegetation consists of sage, piñon, and juniper.

General geology.-The Reese River mining district is in the northern part of the Toyabe Range and centers about a mass of quartz monzonite of probable Jurassic age. In the vicinity of the uranium occurrences, a series of metamorphosed sedimentary rocks is in contact with this intrusive body (fig. 11). The meta- morphic rocks are dominantly quartzites and phyllites with minor outcroppings of silicified limestones and hornfelses. Fossils are lacking and the age of the rocks has been variously estimated as Cambrian or Silurian (Ross, 1953; Ferguson, 1929).

The contact of the sedimentary rocks with the quartz monzonite dips about $45^{\circ} \mathrm{S}$. in Veetch Canyon. Roof pendants of metamorphosed sedimentary rocks and other irregularities in the contact appear to have been exposed by differential erosion of a flatter contact at higher elevations.

The quartz monzonite is host to narrow siliceous and intermediate dikes as well as to numerous mineralized fracture zones. A small area of extrusive dacitic rock near the head of Veetch Canyon is presumably Tertiary in age.

Ore deposits.-The secondary uranium minerals autunite and metatorbernite occur in faults and fractures in both the intrusive and metamorphosed sedimentary rocks and are also disseminated in small roof pendants of metamorphosed sedimentary rocks near the contact of these units. The fracture zones apparently served as conduits for ascending uraniferous solutions, which also contained silver, gold, and copper as well as silica and iron. They trend generally eastward and measure 5-100 feet in width and 50 to several thousand feet in length. Dip of the mineralized zones varies from $50^{\circ} \mathrm{N}$. to nearly vertical. In general appearance they resemble dikes and are composed principally of finely divided sericite with varying amounts of vein quartz. These veins form reeflike

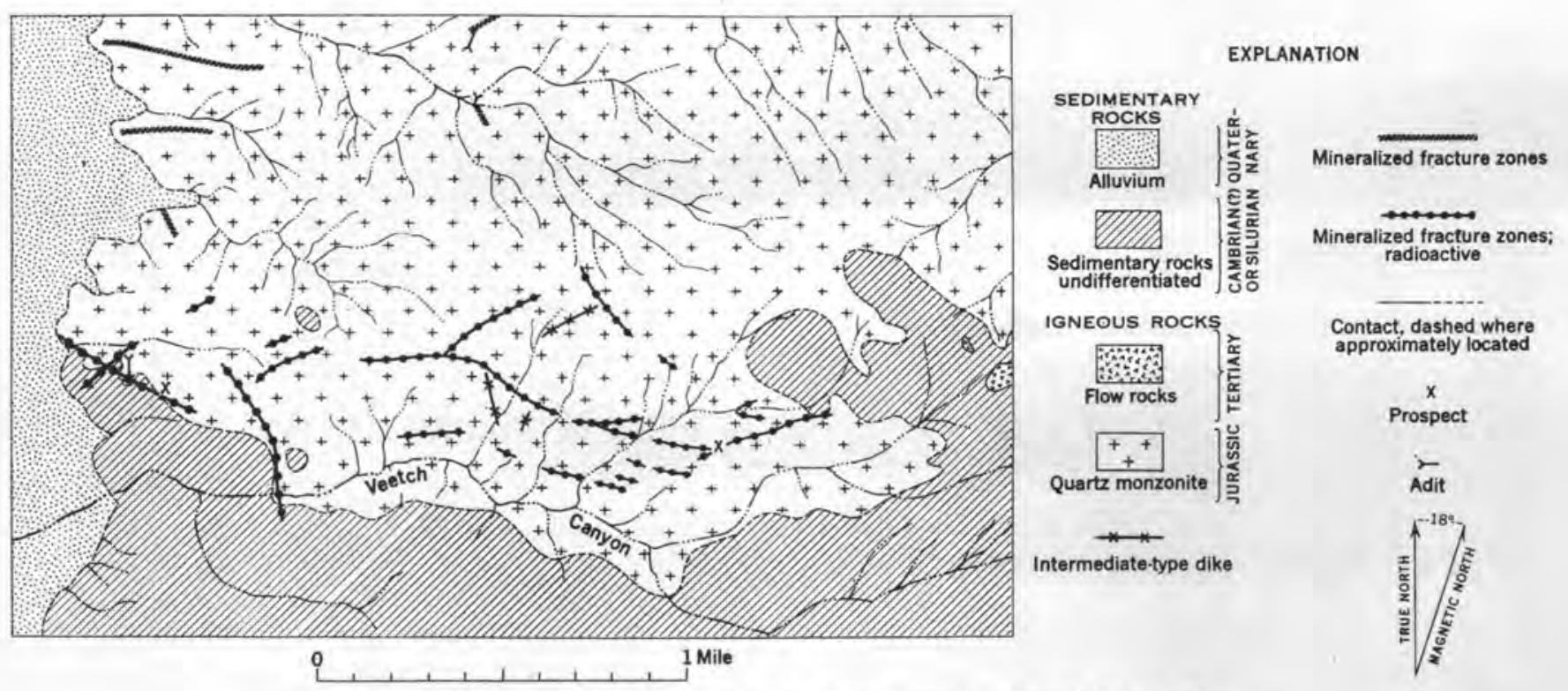

FrGURE 11.-Geologie map showing part of the contact of an intrusive rock south of Austin, Nev. 
ridges in the intrusive rocks, whereas they are inconspicuous in the metamorphosed sedimentary rocks. The distribution of uranium along the fractures indicates that metamorphosed sedimentary rocks were the more favorable host rocks for mineral deposition. The richest concentration of uranium minerals is in a fracture zone in metamorphosed sediments near the intrusive contact.

Silver mines in the central and northern part of the district were developed along similar zones, but no abnormal radioactivity was detected in those areas. Quartz veins containing stibnite lie south of the uranium occurrences, and scheelite has been mined from tactite zones to the east. A zonal arrangement of minerals outward from the central Austin area appears probable, but more detailed study would be required to establish this concept.

\section{CONCLUSIONS}

Uranium deposits closely associated with the contact of granitic intrusive rocks and metamorphosed Paleo- zoic sedimentary rocks show a decided preference for the metamorphosed sediments. The proximity of tungsten deposits may have some genetic significance and would bear further investigation. A lack of gangue minerals makes the mineralized outcrops less easily detected than might otherwise be expected and may partly explain why these reasonably accessible uranium deposits were not found earlier.

\section{REFERENCES CITED}

Ferguson, H. G., 1929, The mining districts of Nevada: Econ. Geology, v. 24, p. 115-148.

Ross, C. P., 1953, The geology and ore deposits of the Reese River district, Lander County, Nev.: U. S. Geol. Survey Bull. 997, 132 p.

Sharp, B. J., and Hetland, D. L., 1954, Preliminary report on uranium occurrences in the Austin area, Lander County, Nev.: U. S. Atomic Energy Comm. RME-2010, 16 p., issued by the U. S. Atomic Energy Comm. Tech. Inf. Service, Oak Ridge, Tenn.

Weaver, C. E., 1920, The mineral resources of Stevens County [Wash.]: Wash. Geol. Survey Bull. 20, 350 p. 


\title{
THE POSSIBILITIES OF OBTAINING LONG-RANGE SUPPLIES OF URANIUM, THORIUM, AND OTHER SUBSTANCES FROM IGNEOUS ROGKS
}

\author{
By Harrison Brown and Leon T. Silver, California Institute of Technology
}

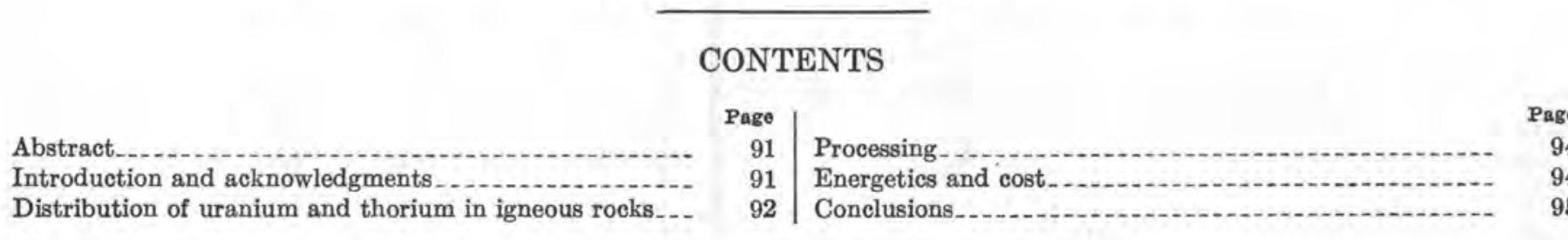

ILLUSTRATION

Page

93

\section{TABLES}

TABLE 1. Distribution of uranium and thorium in granite from Essonville, Ontario .

2. Gross chemical composition of leaches from several types of rocks

(1)

\begin{tabular}{c|} 
Page \\
92 \\
93
\end{tabular} \mid

TABLE 3. Composition of leaches from several pulverized

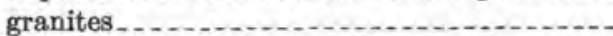

4. Distribution of alpha tracks in thin-section autoradiographs of several granitic rocks.....-
Page

94

95

\begin{abstract}
Most uranium and thorium which have been produced in the world thus far have been obtained from ores of relatively high grade. Such deposits are not very extensive and are found infrequently. When the high-grade deposits of these substances approach exhaustion, it may be that material containing these elements in low concentrations will be the ultimate source.

An average granite contains about $4 \mathrm{ppm}$ uranium and 12 $\mathrm{ppm}$ thorium. If all the uranium and thorium in 1 ton of average granite could be extracted and utilized by means of nuclear breeding, the energy output would be equivalent to that obtained by burning 50 tons of coal. Means are now available for relatively easy extraction of about one quarter of the uranium and thorium from average granite, with an energy profit per ton of rock processed equivalent to that obtained by burning 10 tons of coal.

Results also indicate that a variety of both major and minor substances of industrial importance can be obtained as byproducts of uranium and thorium production from igneous rocks.

The techniques required for extracting uranium and thorium from igneous rocks are well within the realm of present mineraldressing and industrial-chemical experience.
\end{abstract}

\section{INTRODUCTION AND ACKNOWLEDGMENTS}

As the world demand for uranium and thorium increases, the materials which contain these elements in low concentration will have to be used. If atomic energy were to supply a substantial fraction of the world's power requirements, the drain on high-grade deposits would be particularly rapid, primarily as the result of the huge inventories required for reactor construction. For example, power-breeder reactors may necessitate uranium inventories which are more than 500 times the yearly consumption of uranium by neutron capture and fission.

Looking into the future, it is important to know whether a nation devoid of high-grade deposits can obtain uranium from substances which exist in abundance on the earth's surface.

In an attempt to answer this question, this investigation of the possibilities of isolating uranium and thorium from igneous rocks was undertaken. Igneous rocks were chosen for study because they exist in abundance on the earth's surface, and preliminary information indicated that uranium and thorium are localized in crystalline rocks in such a way as to facilitate extraction by chemical and physical means.

The authors of this report wish to acknowledge the work on this investigation by their colleagues W. J. Blake, A. A. Chodos, Richard Kowalkowski, C. R. McKinney, and Aiji Uchiyama of the California Institute of Technology, and G. J. Neuerburg of the U. S. Geological Survey. 


\section{DISTRIBUTION OF URANIUM AND THORIUM IN IGNEOUS ROCKS}

Igneous rocks consist of assemblages of minerals which possess diverse compositions and structures. During the process of rock formation, those elements which exist in such low abundance that they are unable to form separate minerals distribute themselves among the major minerals in proportions determined by the structures of the minerals and by the chemical properties of the elements. Both uranium and thorium possess ionic radii and charges which prevent them from fitting comfortably into the lattices of any of the common major minerals of granite, but they fit into certain of the accessory minerals, such as zircon, allanite, sphene, and apatite. In zircon, for example, uranium and thorium in the $(+4)$ states can substitute for $(+4)$ zirconium.

As a result of these effects, uranium and thorium in igneous rocks appear to be generally localized in those minerals that make up only a small fraction of the weight of the entire rock. In a granite from Essonville, Ontario, for example, that contains $2.74 \mathrm{ppm}$ of uranium, more than 90 percent of the element is concentrated in parts of the rock which make up less than 1 percent of the total weight of the rock, with zircon and sphene retaining the major proportions. The table below shows the concentrations of uranium and thorium in the minerals of the granite at Essonville. ${ }^{1}$ The distribution of uranium and thorium in the granite at Essonville is probably typical of many granitic bodies throughout the world.

TABLE 1.-Distribution of uranium and thorium in granite from Essonville, Ontario

\begin{tabular}{|c|c|c|c|}
\hline Material & $\begin{array}{l}\text { A bundance } \\
\text { (wt percent) }\end{array}$ & $\begin{array}{l}\text { Uranium con- } \\
\text { tent (ppm) }\end{array}$ & $\begin{array}{l}\text { Thorium con- } \\
\text { tent (ppm) }\end{array}$ \\
\hline $\begin{array}{l}\text { Quartz } \\
\text { Plagioclase } \\
\text { Perthite } \\
\text { Magnetite } \\
\text { Apatite } \\
\text { Sphene... } \\
\text { Zircon }\end{array}$ & $\begin{array}{l}24 \\
20 \\
52 \\
.4 \\
.02 \\
.4 \\
.04\end{array}$ & $\begin{array}{l}0.130 \\
.204 \\
.218 \\
2.57 \\
90.5 \\
303 \\
2650\end{array}$ & \begin{tabular}{r}
0.410 \\
\hdashline 5375 \\
2170
\end{tabular} \\
\hline $\begin{array}{l}\text { Composite rock } \\
\text { Acid-soluble material: } \\
\text { Micrograms of element } \\
\text { per gram of rock } \\
\text { Percentage of total.... }\end{array}$ & & $29^{, 90}$ & $\begin{array}{l}17.55 \\
42\end{array}$ \\
\hline
\end{tabular}

Substantial amounts of uranium and thorium in the granite at Essonville are chemically so bound that significant extractions can be obtained by leaching the pulverized rock with dilute acid. Experiments with the granite showed, for example, that 29 percent of the

\footnotetext{
1 Tilton, G. R.; Patterson, Claire; Brown, Harrison; and others, 1954, The isotopic composition and distribution of lesd, uranium, and thorium in a Precambrian granite: U. 8. A tomic Energy Comm. AECU -2840, 52 p., issued by U. S. A tomic Energy
Oomm. Tech. Inf. Service, Osk Ridge, Tenn.
}

uranium, 42 percent of the thorium, and approximately 40 percent of the nonradiogenic lead could be readily removed by leaching the pulverized rock for a short time with cold $6 \mathrm{M} \mathrm{HCl}$.

This strongly indicates that other minor elements might be similarly localized. If this is true, it might be possible to isolate a variety of products from igneous rock without digesting the rock as a whole.

Igneous rocks ranging from tonalites to true granites and of diverse ages and geographic origins respond rather uniformly to simple acid leaching. The soluble fractions from aliquots of these rocks crushed to pass 30 -mesh screens and leached with $1 \mathrm{M} \mathrm{HNO}$ at room temperature for 50 minutes are usually only $0.1-0.6$ percent of the original weights. $\mathrm{Ca}, \mathrm{Fe}, \mathrm{Al}, \mathrm{Si}, \mathrm{P}$ and $\mathrm{K}$ are the major constituents, with $\mathrm{Na}, \mathrm{Mg}, \mathrm{Ti}, \mathrm{Mn}$, and other elements in the minority. The gross compositions of leaches from several granites, granodiorites, and aplites are listed in table 2. They are conspicuously different from the compositions of the rocks themselves.

Uranium, thorium, and rare-earth metals in the dissolved fractions are concentrated 20-100 times more than in the original rocks. These fractions may contain as much as 40 percent of the total weight of these elements in the rocks. Weights of extracted trace elements, determined specirographically, are given for several diverse granites in table 3.

The rate at which the radioactive material is leached with cold acid from the granites is initially quite high and then drops off sharply. Curves showing rate of solution of radioactive materials from several granites are shown in figure 12. Increased rates are induced by higher temperature, but acid consumption from the solution of nonradioactive materials also increases markedly.

The distribution of the acid-soluble radioactive materials in granites has been examined by means of alphatrack autoradiographs of rock thin sections and through extensive separations, analyses, and studies of rates of solubility on individual minerals or selected mineral assemblages.

The alpha-track studies show that the major portion of the alpha-particle activity in most granites originates in microscopic accessory minerals. A smaller fraction of the activity occurs in the major minerals; much of this appears from the spatial relation to originate in microscopic to submicroscopic inclusions and imperfections in the coarser granitic minerals. A third type of site for the alpha tracks is along grain boundaries and fractures where from less than 10 percent to rarely more than 25 percent of the tracks may be found. This interstitial alpha activity emanates from both microscopic discrete minerals - identified with difficulty, 
TABLE 2.-Gross chemical composition of leaches from several types of rocks (treated with $1 \mathrm{M} \mathrm{HNO}$ at room temperature)

\begin{tabular}{|c|c|c|c|c|c|c|c|c|c|c|}
\hline \multirow{2}{*}{ Source of sample } & \multirow{2}{*}{$\begin{array}{c}\text { Total } \\
\text { solids } \\
\text { (mg/100g) }\end{array}$} & \multicolumn{9}{|c|}{ Constituents (wt percent) I } \\
\hline & & $\mathrm{SiO}_{2}$ & $\mathrm{Al}_{2} \mathrm{O}_{3} \mathrm{I}$ & $\mathrm{Fe}_{2} \mathrm{O}_{3}$ & $\mathrm{MgO}$ & $\mathrm{CaO}$ & $\mathrm{Na}_{2} \mathrm{O}$ & $\mathrm{K}_{2} \mathrm{O}$ & $\mathrm{P}_{2} \mathrm{O}_{5}$ & $\mathrm{TiO}_{2}$ \\
\hline $\begin{array}{l}\text { Southern California } \\
\text { Georgia I } \\
\text { Georgia II } \\
\text { Montana. } \\
\text { Ontario }\end{array}$ & $\begin{array}{l}470 \\
540 \\
310 \\
110 \\
150\end{array}$ & $\begin{array}{r}10 \\
4 \\
6.8 \\
\text { 7. } 4 \\
\text { 3. } 4\end{array}$ & $\begin{array}{l}15 \\
16 \\
17 \\
19 \\
20\end{array}$ & $\begin{array}{l}27 \\
15 \\
15 \\
45 \\
47\end{array}$ & $\begin{array}{r}0.5 \\
1.9 \\
1.2\end{array}$ & $\begin{array}{l}22 \\
41 \\
35 \\
14 \\
12\end{array}$ & $\begin{array}{r}\text { 1. } 3 \\
.9 \\
\text { 1. } 7 \\
\text { 3. } 2 \\
\text { 3. } 1\end{array}$ & $\begin{array}{r}14 . \\
5.6 \\
\text { 4. } 9 \\
6.9 \\
8.4\end{array}$ & $\begin{array}{l}8.3 \\
17 \\
19 \\
2.6 \\
\text { 5. } 3\end{array}$ & \begin{tabular}{r}
1.1 \\
.2 \\
\hdashline .5 \\
\hdashline.-4 \\
\end{tabular} \\
\hline
\end{tabular}

${ }^{1}$ Includes rare earths.

TABLE 3.-Composition of leaches from several pulverized granites (treated with $1 \mathrm{M} \mathrm{HNO}_{3}$ at room temperature)

\begin{tabular}{|c|c|c|c|c|c|c|c|c|}
\hline \multirow{2}{*}{ Source of sample } & \multirow{2}{*}{$\begin{array}{l}\text { Total solids } \\
(\mathrm{mg} / 100 \mathrm{~g})\end{array}$} & \multirow{2}{*}{$\begin{array}{l}\text { Radioactive } \\
\text { material dis- } \\
\text { solved (per- } \\
\text { cent) }\end{array}$} & \multicolumn{6}{|c|}{ Trace elements extracted (mg) } \\
\hline & & & U & $\mathrm{Th}$ & $\mathrm{Ce}$ & $\mathrm{La}$ & $\mathrm{Nd}$ & $\mathrm{Y}$ \\
\hline $\begin{array}{l}\text { New Hampshire } \\
\text { Colorado } \\
\text { Georgia I } \\
\text { Georgia II. }\end{array}$ & $\begin{array}{l}420 \\
270 \\
540 \\
310\end{array}$ & $\begin{array}{l}25 \\
15 \\
38 \\
21\end{array}$ & $\begin{array}{r}0.76 \\
.38 \\
.73 \\
.50\end{array}$ & $\begin{array}{l}\text { 4. } 8 \\
\text { 1. } 1 \\
\text { 3. } 0 \\
\text {. } 72\end{array}$ & $\begin{array}{l}\text { 4. } 4 \\
\text { 1. } 6 \\
9.2 \\
\text { 3. } 4\end{array}$ & $\begin{array}{l}\text { 2. } 9 \\
\text { 1. } 1 \\
\text { 5. } 4 \\
\text { 2. } 3\end{array}$ & $\begin{array}{l}\text { 2. } 0 \\
\text { 4. } 73 \\
\text { 1. } 3 \\
\text { 1. } 7\end{array}$ & $\begin{array}{l}0.12 \\
\text { 1. } 0 \\
.49 \\
.37\end{array}$ \\
\hline
\end{tabular}

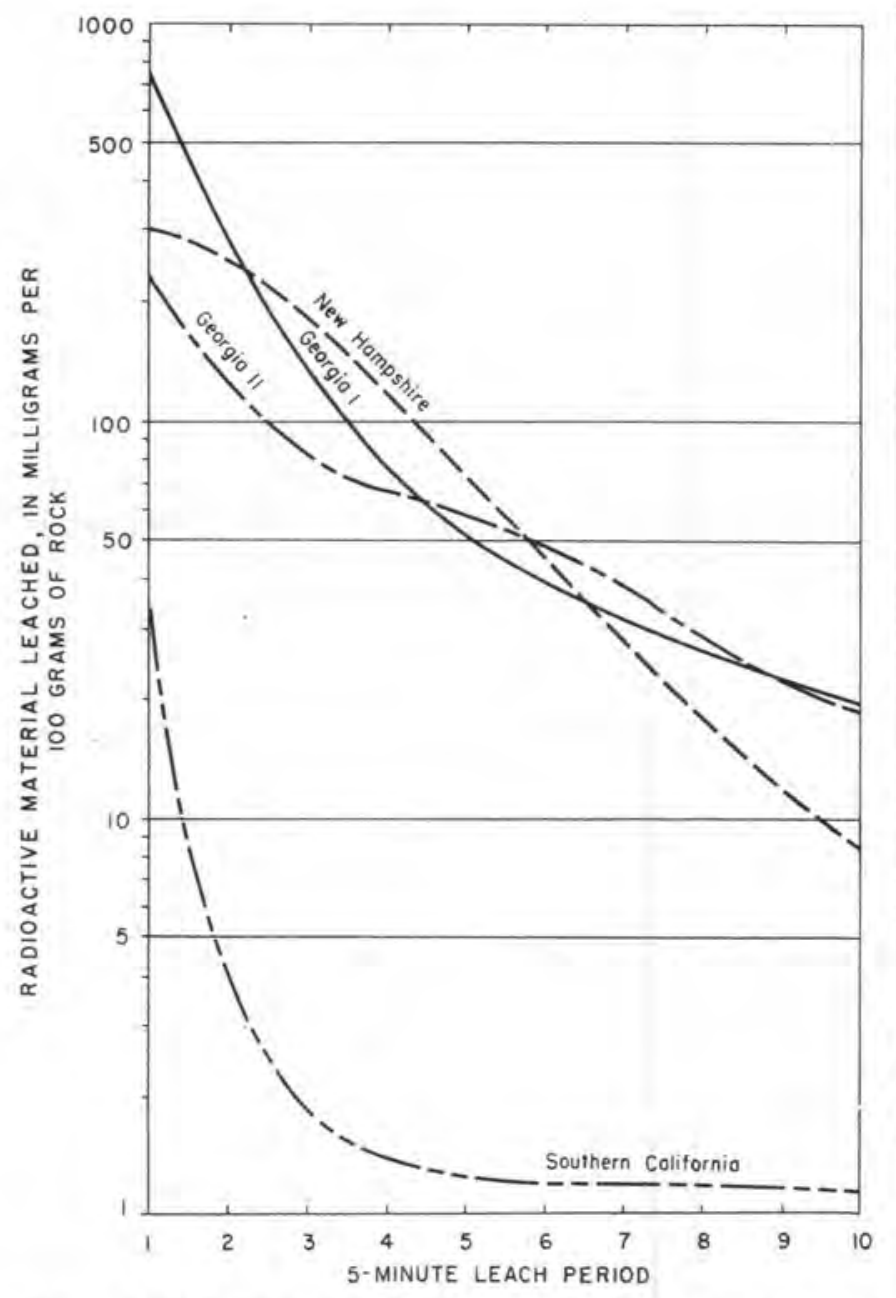

FiaURE 12,-Rate of solution of radioactive materials from several granites leached with $1 \mathrm{M}$ HNOa at room temperature. if at all-and submicroscopic particles. These particles indicate the former existence of a period of mobility for the uranium and thorium in a granite. Such periods may develop in the very late stages of rock crystallization, during a subsequent hydrothermal or metamorphic episode, or during the weathering of the rock. The distribution of alpha tracks in thin section autoradiographs of three granites is given in table 4 .

TABLE 4,-Distribution of alpha tracks in thin-section autoradiographs of several granitic rocks

\begin{tabular}{|c|c|c|c|c|}
\hline \multirow[b]{2}{*}{ Source of sample } & \multirow{2}{*}{$\begin{array}{c}\text { Total num- } \\
\text { ber of } \\
\text { tracks }\end{array}$} & \multicolumn{3}{|c|}{ Distribution (percent) } \\
\hline & & $\begin{array}{c}\text { Major } \\
\text { minerals }\end{array}$ & $\begin{array}{l}\text { Accessory } \\
\text { minerals }\end{array}$ & $\begin{array}{l}\text { Fractures } \\
\text { and grain } \\
\text { boundaries }\end{array}$ \\
\hline $\begin{array}{l}\text { Georgia I } \\
\text { Georgia Iİ } \\
\text { Montana }\end{array}$ & $\begin{array}{l}3,255 \\
2,706 \\
1,034\end{array}$ & $\begin{array}{r}8 \\
14 \\
26\end{array}$ & $\begin{array}{l}83 \\
69 \\
35\end{array}$ & $\begin{array}{r}9 \\
17 \\
39\end{array}$ \\
\hline
\end{tabular}

The solubility-rate studies of various accessory minerals indicate that a few contribute significantly to the cold dilute-acid leaches. Apatite, allanite (particularly if metamict and altered), thorite, bastnaesite, and a few other species are the principal sources of radioactivity. High degrees of metamictization favor increased solubility. The apatite is responsible for much of the $\mathrm{CaO}$ and all of the $\mathrm{P}_{2} \mathrm{O}_{5}$ in solution, and in rocks where other soluble accessories are absent it is the principal source of radioactivity and rare earths in leaches. Allanite and highly metamict and altered aggregates which were probably originally allanite, appear to be the most important sources of radioactivity 
in many of the granites examined. The composition of allanite includes most of the major constituents recognized in the leach extractions, even from rocks where the mineral itself has not been identified microscopically. This compositional factor plus allanite's common association with epidote as a deuteric and hydrothermal mineral, and the limited optical data obtained from some of the coarsest interstitial material, suggests that allanite may be an important constituent in the interstitial material in many granites.

\section{PROCESSING}

The properties of leachable material, as they have thus far been determined, suggest a number of possibilities for the isolation of uranium and thorium, with byproducts, from igneous rocks. The basic steps would be as follows:

1. Quarry the rock, crush and pulverize to grain size.

2. Leach with dilute acid and wash.

3. Neutralize solution and precipitate trace elements. This precipitate will be composed primarily of $\mathrm{Al}_{2} \mathrm{O}_{2}, \mathrm{Fe}_{2} \mathrm{O}_{3}$, and $\mathrm{R}_{2} \mathrm{O}_{3}$ and will carry down with it the uranium, thorium, rare earths, and the majority of potentially useful trace elements.

4. Allow precipitate to settle, remove supernatant solution, and dissolve precipitate in dilute acid. This solution is now sufficiently concentrated to permit direct extraction of uranium, thorium, and other useful trace elements by a sequence of straightforward chemical steps.

If it is assumed that material is being processed which possesses approximately 0.4 percent leachable matter, corresponding to 4 kilograms per metric ton of rock, acid consumption would amount to 40 moles of hydrogen ions per ton of rock processed. Retention of liquid in a pulverized rock amounts to approximately 0.3 milliliter per gram of rock or 300 liters per metric ton. Because rates of solution of leachable material drop to low levels below acid concentrations of about $0.1 \mathrm{M}$, the concentration of the acid should be adjusted so that the hydrogen-ion concentration is $0.1 \mathrm{M}$ after leaching. If 1 ton of pulverized rock were to be barely covered with 300 liters of $0.23 \mathrm{M}$ acid, the hydrogen-ion concentration would drop to $0.1 \mathrm{M}$ following dissolution of all leachable matter.

Utilizing a cycling system involving an initial leach and five washings and using the washings to leach and wash subsequent batches, an overall yield of leachable material of about 85 percent could be obtained under steady-state operating conditions. The product-bearing solution would contain about 3.4 kilograms of dissolved solids (calculated as oxides) per 300 liters, or 11 grams per liter. The solution under steady-state operating conditions would have an acid concentration of about $0.063 \mathrm{M}$. Somewhat over 60 moles of hydrogen ions and 600 liters of water would be consumed per ton of rock processed.

\section{ENERGETICS AND COSTS}

Average granite contains approximately $4 \mathrm{ppm}$ uranium and $12 \mathrm{ppm}$ thorium. If all the uranium and thorium could be extracted from 1 ton of rock, then converted to fissionable material and fissioned in a nuclear reactor, the energy release would be equal to that obtained from burning about 50 tons of coal. It has been seen that on the average about 25 percent of the uranium and thorium in a granite is leachable, and that an actual process yields about 85 percent of the leachable material. Thus, if nuclear breeding and the isolation only of the leachable material are assumed, 1 ton of granite is equivalent in releasable energy content to about 10 tons of coal.

The energy requirements for processing 1 ton of granite must now be determined. Clearly, if this were less than the equivalent of 10 tons of coal, average rock could be processed with a net energy profit.

The energy requirements for quarrying rock, reducing from haulage size to 10 -inch pieces, crushing to 0.25 inch size, and pulverizing to less than 50 mesh has been surveyed by the authors. It appears that these steps would require between 7 and $9 \mathrm{kwhr}$ per ton of rock. Acids and other chemicals would cost between 10 and $25 \mathrm{kwhr}$ per ton, depending upon the acid used (the higher value is computed for nitric acid). Additional direct-energy costs involving disposal of wastes, water pumping, movement of other materials through the process, and maintenance and shop facilities would be about $1 \mathrm{kwhr}$ per ton. To these figures must be added such hidden energy costs as original capital investment, replacement of equipment, and transportation to and from the plant. These are difficult to estimate, particularly if all hidden energy costs are taken into consideration. However, calculations by the author indicate that all hidden costs combined might be expected to be between 0.7 and $2.3 \mathrm{kwhr}$ per ton.

These values added together suggest that total energy requirements, both direct and hidden, would probably lie in the range of 19 to $37 \mathrm{kwhr}$ per ton of rock processed. If it is assumed that $1 \mathrm{kwhr}$ is equivalent to 1.3 pounds of coal burned at 20 percent efficiency, the energy costs would lie in the range of 25 to 48 pounds of coal per ton of rock processed. This is clearly very much smaller than the energy equivalent of 20,000 pounds of coal which could be extracted from a ton of average rock.

Thus, when the problem is viewed solely from the point of view of energetics it is clear that most of the granitic rocks of the earth's crust are at mankind's disposal and can be processed for a net energy profit. This means that the reserves of uranium and thorium available to man can be considered for all practical purposes as infinite. 
Costs per ton of rock processed probably lie in the range of $\$ 1.00$ to $\$ 2.25$ per ton, depending upon the way in which the uranium and thorium are held in the rock and the type of acid used in the processing. This means that if only average granites were processed and no part of the operating cost could be assigned to byproducts, uranium could be produced at a cost of $\$ 550$ $\$ 1,200$ per pound. If thorium is considered to possess one third the value of uranium, the corresponding approximate cost ranges would be $\$ 270-\$ 600$ per pound for uranium and $\$ 90-\$ 200$ per pound for thorium. Values of byproducts would reduce these prices by amounts which are yet to be determined. If byproducts valued at about $\$ 1.00$ per ton of rock could be obtained, as seems possible, the maximum cost of uranium from average granite would be about $\$ 340$ per pound.

It is clear that average granite cannot be processed economically at the present time, but there are large bodies of igneous rocks which possess higher-thanaverage leachable uranium and thorium contents.

\section{CONCLUSIONS}

A substantial fraction of the uranium, thorium, and certain other elements present in igneous rocks can be readily removed by leaching with dilute acid.

More energy can be obtained from average granite in the form of uranium and thorium than is required for processing the rock.

Although the cost of processing average granite is prohibitively high at the present time, a number of igneous bodies possess higher-than-average concentrations of leachable uranium and thorium. Some of these bodies might well be processed competitively in the near future.

Uranium and thorium in the igneous rocks of the earth's crust is sufficient to power a highly industrialized world economy for a very long period of time.

When the situation is examined solely from the point view of availability, no nation which needs uranium and thorium in quantity need by deprived of supplies of these elements. 


\title{
URANIUM-BEARING VEIN DEPOSITS IN THE UNITED STATES
}

\author{
By Donald L. Everhart, U. S. Atomic Energy Commission
}

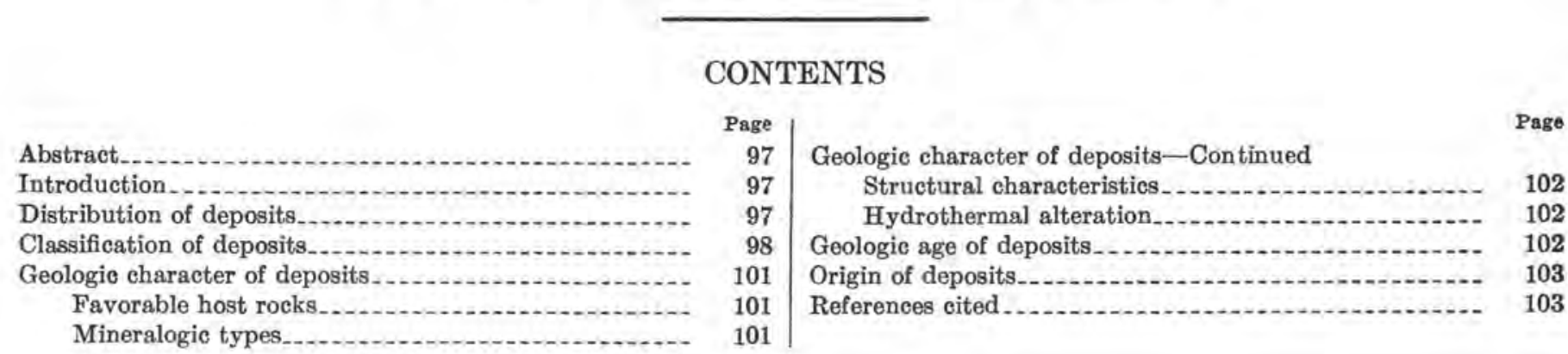

\section{ILLUSTRATION}

FrGURE 13. Distribution of significant uranium-bearing vein deposits

TABLES

TABLE 1. Typieal uranium vein deposits

99 TABLe 2. Geologio character of vein deposits

\section{ABSTRACT}

More than 100 vein deposits in the United States are known to contain significant amounts of uranium minerals, although deposits of this type have not been as important commercially as disseminated deposits in sedimentary rocks.

In the Western United States, the uranium-bearing vein deposits are distributed in an arcuate pattern surrounding the Colorado Plateau and Wyoming Basin. They occur from the Black Hills of South Dakota southward through the Rocky Mountains to southern New Mexico, westward throughout the Basin and Range province of Arizona, Nevada, and southern California, and northward through the Rocky Mountains of Idaho and Montana.

The uranium-bearing vein deposits of the United States may be divided into at least 5 mineralogic types with varying complexity and geochemical character, which may occur in any 1 of 6 favorable host-rock types. In general, the veins occupy zones of structural tension, and except in the Michigan part of the Canadian Shield, the uranium minerals were emplaced in Tertiary time.

The emplacement of uranium in vein deposits of the Western United States appears to be an important part of a complex series of related metallogenic processes which together have produced a uranium province containing many deposits of varying geologic eharacter.

\section{INTRODUCTION]}

Uranium-bearing vein-type deposits are among the foremost sources of uranium ore in the world. Such types of deposits appear to be relatively common in the United States, as they are elsewhere on North America and on other continents, although to date they have not proved to be as important commercially in the United States as have disseminated uranium deposits in sedimentary rocks. In the United States at least 100 vein deposits containing significant amounts of uranium minerals are known.

The vein deposits discussed herein are essentially mineral-filled fractures in which uranium minerals are an important constituent. The metallic ions in the vein minerals are believed to have come originally from sources at depth in the earth's crust, although secondary redistribution is characteristic in many of these deposits. Replacement of host rock by metallic minerals along fractures or shears occurs in some instances, but this mechanism is considered subordinate to open-space filling.

\section{DISTRIBUTION OF DEPOSITS}

In the Western United States, vein deposits containing significant amounts of uranium minerals are distributed, generally, throughout the Rocky Mountain system and the Basin and Range province. In Michigan a few uraniferous veins are located along the southern edge of the Canadian Shield. (See fig. 13.) 


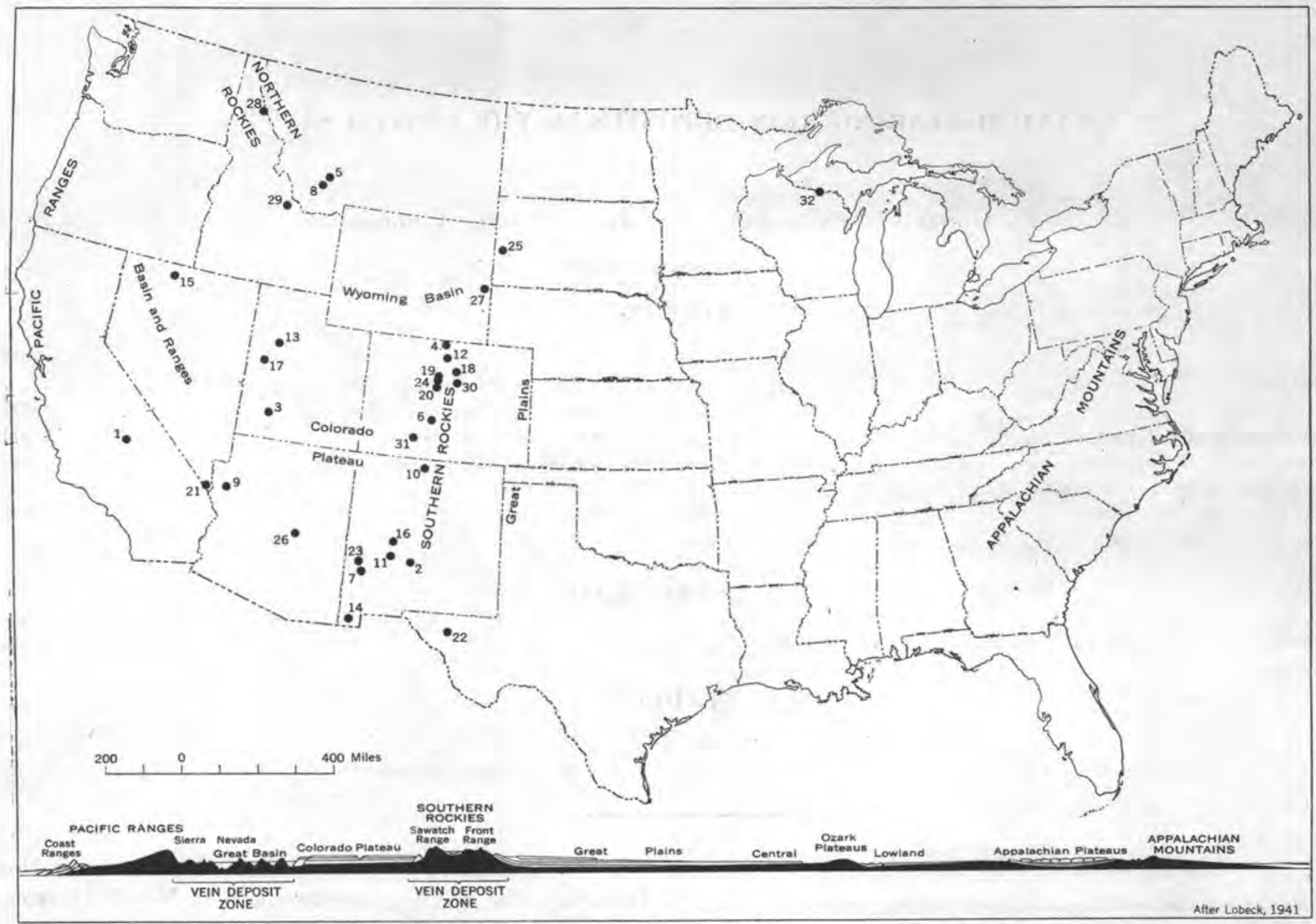

Fiavre 13,-Distribution of significant uranium-bearing vein deposits. (See table 2 for deseription of numbered deposits.)

An interesting spatial relationship is apparent in the Western United States between uraniferous veins and the Colorado Plateaus and Wyoming Basin province (fig. 13). In the northeastern part of this area, minor veins are known in the core of the Black Hills of South Dakota (25 on fig. 13). To the southwest a "belt" of vein deposits includes the Lusk district, Wyoming; the deposits of the Colorado Front Range, extending from the area west of Fort Collins southward through the Front Range mineral belt to the New Mexico border; and into the Southern Rocky Mountains and the Basin and Range province of eastern New Mexico. Uraniferous vein deposits are distributed throughout the Basin and Range province of western New Mexico, Arizona, and Nevada, bordering the Colorado Plateaus on the south, southwest, and west. Northwest and west of the Colorado Plateaus and the Wyoming Basin province, uranium-bearing vein deposits are distributed throughout the Northern Rocky Mountains and in the Middle Rocky Mountains to the south. In the United States the major district of uranium-bearing veins, near Marysvale, Utah, lies in the High Plateaus of Utah that constitute the western border zone of the Colorado Plateaus. West of the Basin and Range province, a few significant vein deposits are known in the Sierra Nevada of California, particularly in the southern part.

\section{CLASSIFICATION OF DEPOSITS}

The uranium-bearing vein deposits of the United States may be classified into several major types, based on significant geologic features. Such classification serves as a basis for understanding the environments under which they may form and the geochemistry of the ore-bearing solutions. It is assumed herein that the two most pertinent characteristics to be used as a basis for classification are favorable host rock and typical mineral assemblages. (See table 1.) The six types of host rocks found to be most favorable for vein deposits in the United States are felsic intrusive rocks, rhyolitic extrusive rocks, schist, and gneiss of sedimentary origin, quartzite, metavolcanic rocks, and arenaceous sedimentary rocks. There are five major mineral assemblage types characterized by (1) uranium and 
iron oxides, silica, and fluorite, (2) uranium oxides, copper, lead and molybdenum sulfides, silica, and fluorite, (3) uranium oxides, copper, cobalt, nickel, lead, zinc, and silver sulfides, and carbonates, (4) uranium oxides, silica, and gold-bearing pyrite, and (5) uraniferous hydrocarbon.

In table 1 the mineral-assemblage types are recorded along with the favorable host-rock types, indicating the nature and incidence of selected type examples of vein deposits in the United States. In table 2, the principal and (or) geologically significant vein deposits of the country are tabulated, summarizing their major geologic characteristics, following the classification scheme shown in table 1.

TABLE 1.-Typical uranium vein deposits

Type A.-Uranium and iron oxide minerals, with some silica and fluorite but generally no apprecisble gangue or other metallic assoeiates. Secondary uranium minerals mostly hydroxides.

Type B.-Silica-rich veins, containing uraninite, iron and copper sulfles, galens, sphalerite, and molybdenite, commonly characterized by abundant fluorite gangue.
Type C.-Uraninite associated with cobalt, nickel, copper, and other base-meta sulfides and silver; characterized by carbonste gangue, as well as lesser silica and

barite.
Type D.-Uraninite associsted with gold-bearing pyrite in silliceous veins. Type E.-Uraniferous hydrocarbons,

\begin{tabular}{|c|c|c|c|c|c|}
\hline \multirow{2}{*}{ Host rock } & \multicolumn{5}{|c|}{ Minersl character } \\
\hline & Type A & Туре В & Type C & Type D & Type E \\
\hline Felsie intrusive rocks.......... & Kern Canyon, Calif......... & \multirow{2}{*}{ Marysvale, Utah 1,......... } & \multirow{4}{*}{$\begin{array}{l}\text { Caribou mine, Colorado, } \\
\text { San Acaeia mine, New } \\
\text { Mexico. } \\
\text { Black Hawk mine, New } \\
\text { Mexico. } \\
\text { Sunshine mine, Idaho...... }\end{array}$} & & \multirow{6}{*}{ Placerville dist., Colorado. } \\
\hline Rhyolitic extrusive rocks.... & Moonlight mine, Nevads.. & & & & \\
\hline $\begin{array}{l}\text { Metasediments (schist and } \\
\text { gneiss). }\end{array}$ & \multirow{2}{*}{$\begin{array}{l}\text { Thomas Range dist., Utah. } \\
\text { Red Bluft mine, Arizona '. }\end{array}$} & \multirow{2}{*}{$\begin{array}{l}\text { Schwartzwalder mine, } \\
\text { Colorado } 1\end{array}$} & & \multirow[t]{2}{*}{ Central City dist., Colorado. } & \\
\hline $\begin{array}{l}\text { Quartzite.... } \\
\text { Metavoleanie rocks. }\end{array}$ & & & & & \\
\hline Arenaceous sedimentary & Iron ore dist., Michlgan... & \multirow[t]{2}{*}{$\begin{array}{l}\text { Golden Gate Canyon } \\
\text { dist., Colorado. } \\
\text { Los Ochos mine, Colondo' }\end{array}$} & $\ldots$ & & \\
\hline rocks. & & & & & \\
\hline
\end{tabular}

1 Consistent ore producer.

TABLE 2.-Geologic character of vein deposits

\begin{tabular}{|c|c|c|c|c|c|c|c|}
\hline $\begin{array}{l}\text { Map no. (fig. 13) } \\
\text { deposit name, and } \\
\text { loc. by state and } \\
\text { county }\end{array}$ & $\begin{array}{l}\text { Host rock: Forma } \\
\text { tion name, litho- } \\
\text { logic type, age }\end{array}$ & Uranium minersls & $\begin{array}{c}\text { Associated metallic } \\
\text { minerals }\end{array}$ & Gangue & Structural features & $\begin{array}{l}\text { Hydrothermal } \\
\text { alteration }\end{array}$ & Geologic age \\
\hline $\begin{array}{l}\text { 1. Kern Canyon } \\
\text { dist, K } \mathrm{K} \text { i } \\
\text { County, Calif. }\end{array}$ & $\begin{array}{l}\text { Sierra Nevada bath- } \\
\text { olith, granodio- } \\
\text { rite, Late Creta- } \\
\text { ceous. }\end{array}$ & $\begin{array}{l}\text { Carnotite, autun- } \\
\text { ite, "sooty } \\
\text { pitchblende." }\end{array}$ & $\begin{array}{l}\text { Pyrite, limonite, } \\
\text { roscoelite, ilsem- } \\
\text { annite. }\end{array}$ & $\begin{array}{l}\text { No appreciable } \\
\text { gangue, minor } \\
\text { fluorite. }\end{array}$ & $\begin{array}{l}\text { North-trending } \\
\text { near-verticalshear } \\
\text { zones. }\end{array}$ & Argillization...... & Post-Cretsceous. \\
\hline $\begin{array}{l}\text { 2. Pitchblende Strike } \\
\text { prospect, Sierrs } \\
\text { County, N. Mex. }\end{array}$ & $\begin{array}{l}\text { Andesite with in- } \\
\text { cluded body of } \\
\text { brecciated chert, } \\
\text { ElPasolimestone, } \\
\text { Ordoviclan. }\end{array}$ & $\begin{array}{l}\text { Uraninite, second- } \\
\text { ary uranophsne. }\end{array}$ & $\begin{array}{l}\text { No appreciable me- } \\
\text { tallic associates. }\end{array}$ & $\begin{array}{l}\text { Secondary ehert } \\
\text { and fluorite. }\end{array}$ & $\begin{array}{l}\text { Northwest-trending } \\
\text { chert inclusion in } \\
\text { Tertiary andesite. }\end{array}$ & Not appreciable... & Tertiary. \\
\hline $\begin{array}{l}\text { 3. Marysvale dist., } \\
\text { Piute County, } \\
\text { Utah. }\end{array}$ & $\begin{array}{l}\text { Quartz monzonite, } \\
\text { granite, and Mt. } \\
\text { Belknap rhyolite, } \\
\text { Tertiary. }\end{array}$ & $\begin{array}{l}\text { Pitchblende, au- } \\
\text { tunite, torbern- } \\
\text { ite, uranophane, } \\
\text { other secondary } \\
\text { minerals. }\end{array}$ & $\begin{array}{l}\text { Pyrite, magnetite, } \\
\text { hematite, jordi- } \\
\text { site, ilsemannite, } \\
\text { umohoite manga- } \\
\text { nese oxides. }\end{array}$ & $\begin{array}{l}\text { Silica minerals, } \\
\text { adularis, fluo- } \\
\text { rite, minor eal- } \\
\text { cite. }\end{array}$ & $\begin{array}{l}\text { Steep fractures } \\
\text { trending N. } 65^{\circ} \\
\text { E. and NW. }\end{array}$ & $\begin{array}{l}\text { Argillization, sil- } \\
\text { ieification }\end{array}$ & Lato"Tertiary. \\
\hline $\begin{array}{l}\text { 4. Copper King mine, } \\
\text { Larimer County, } \\
\text { Colo. }\end{array}$ & $\begin{array}{l}\text { Precambrian gran- } \\
\text { ite with schist in- } \\
\text { clusions. }\end{array}$ & Pitchblende........ & $\begin{array}{l}\text { Pyrite, galena, } \\
\text { sphalerite, copper } \\
\text { sulfides, iron ox- } \\
\text { ides, molybdenite. }\end{array}$ & $\begin{array}{l}\text { Quartz, minor sid- } \\
\text { erite. }\end{array}$ & $\begin{array}{l}\text { Normal fault N. } 75^{\circ} \\
\text { W., dip steeply } \\
\text { southwest. }\end{array}$ & $\begin{array}{l}\text { Serieitization, } \\
\text { chloritization. }\end{array}$ & Tertiary, \\
\hline $\begin{array}{l}\text { 5. W. Wilson claims, } \\
\text { Jefferson County; } \\
\text { Mont. }\end{array}$ & $\begin{array}{l}\text { Boulder batholith, } \\
\text { granitic rock, Ore- } \\
\text { taceous. }\end{array}$ & $\begin{array}{l}\text { Uraninite, minor } \\
\text { secondary min. } \\
\text { erals. }\end{array}$ & $\begin{array}{l}\text { Pyrite, sphalerite, } \\
\text { galena, chalcopy- } \\
\text { rite, traces of silver } \\
\text { minerals. }\end{array}$ & $\begin{array}{l}\text { Silica minerals ex- } \\
\text { clusively. }\end{array}$ & $\begin{array}{l}\text { "Siliceous reefs" } \\
\text { trending N. } 60^{\circ} \\
\text { E., dipping steeply } \\
\text { southeast. }\end{array}$ & $\begin{array}{l}\text { Silicification, ar- } \\
\text { gillization, and } \\
\text { gericitization. }\end{array}$ & Do. \\
\hline $\begin{array}{l}\text { 6. Los Ochos mine, } \\
\text { Baguache County, } \\
\text { Colo. }\end{array}$ & $\begin{array}{l}\text { Precambrian gran- } \\
\text { ite and included } \\
\text { schist and gneiss, } \\
\text { overlain by sand- } \\
\text { stone of the Mor- } \\
\text { rison formation, } \\
\text { Jurassic. }\end{array}$ & $\begin{array}{l}\text { Pitchblende, au- } \\
\text { tunite, urano- } \\
\text { phane. }\end{array}$ & $\begin{array}{l}\text { Marcasite, chalco- } \\
\text { pyrite, bornite, } \\
\text { ilsemannite. }\end{array}$ & $\begin{array}{l}\text { White and black } \\
\text { erystalline } \\
\text { quartz. }\end{array}$ & $\begin{array}{l}\text { Major east-trending } \\
\text { fault zone with } \\
\text { northeast-trend. } \\
\text { ing cross faults. }\end{array}$ & $\begin{array}{l}\text { Silicification and } \\
\text { argillization. }\end{array}$ & Post-Jurassic. \\
\hline $\begin{array}{l}\text { 7. Merry Widow } \\
\text { mine, Grant } \\
\text { County, N. Mex. }\end{array}$ & $\begin{array}{l}\text { Granite and "dia- } \\
\text { base" dikes, Pre- } \\
\text { cambrian, and in- } \\
\text { termediate to } \\
\text { felsic dikes, Ter- } \\
\text { tisry, binsry } \\
\text { granite. }\end{array}$ & $\begin{array}{l}\text { Meta-autunite, } \\
\text { metatorbernite. }\end{array}$ & $\begin{array}{l}\text { Pyrite, ehaleopy- } \\
\text { rite, specularite. }\end{array}$ & Quartz & $\begin{array}{l}\text { Complex faulting } \\
\text { and fracturing. }\end{array}$ & $\begin{array}{l}\text { Sericitization, } \\
\text { silicification. }\end{array}$ & Tertiary. \\
\hline
\end{tabular}


TABLe 2.-Geologic character of vein deposits-Continued

\begin{tabular}{|c|c|c|c|c|c|c|c|}
\hline $\begin{array}{l}\text { Map no. (flg. 13) } \\
\text { deposit name, and } \\
\text { loc. by state and } \\
\text { county }\end{array}$ & $\begin{array}{l}\text { Host rock: Forma- } \\
\text { tion name, litho- } \\
\text { logic type, age }\end{array}$ & Uranium minerals & $\begin{array}{l}\text { Associated metallic } \\
\text { minerals }\end{array}$ & Gangue & Structural features & $\begin{array}{l}\text { Hydrothermal } \\
\text { alteration }\end{array}$ & Geologic age \\
\hline $\begin{array}{l}\text { 8. C o m e t-G r a y } \\
\text { Eagle dist., Jeffer- } \\
\text { son County, Mont. }\end{array}$ & $\begin{array}{l}\text { Boulder batholith, } \\
\text { granitic rocks, } \\
\text { Cretaceous. }\end{array}$ & Uraninite........... & $\begin{array}{l}\text { Pyrite, sphalerite, } \\
\text { galena, chalcopy- } \\
\text { rite, argentite. }\end{array}$ & Crystalline quartz. & $\begin{array}{l}\text { Generally north- } \\
\text { east- to east- } \\
\text { trending "base- } \\
\text { metal" veins. }\end{array}$ & $\begin{array}{l}\text { Argillization and } \\
\text { sericitization. }\end{array}$ & Tertiary. \\
\hline $\begin{array}{l}\text { 9. Wallapai mining } \\
\text { dist., Mohave } \\
\text { County, Ariz. }\end{array}$ & $\begin{array}{l}\text { Precambrian gran- } \\
\text { ite, gneiss, and } \\
\text { schist and Ithaca } \\
\text { peak granite, } \\
\text { Mesozoic? }\end{array}$ & $\begin{array}{l}\text { Uraninite, traces } \\
\text { of autunite. }\end{array}$ & $\begin{array}{l}\text { Iron, zinc, lead, cop- } \\
\text { per, and silver sul- } \\
\text { fides, and sulfar- } \\
\text { senides; manga- } \\
\text { nese oxides. }\end{array}$ & $\begin{array}{l}\text { Quartz, calcite, } \\
\text { siderite, rhodo- } \\
\text { crosite. }\end{array}$ & $\begin{array}{l}\text { Swarm of veins } \mathrm{N} \text {. } \\
30^{\circ}-60^{\circ} \mathrm{W} \text {., with } \\
\text { steep dips. }\end{array}$ & Very slight......... & Post-Mesozoic. \\
\hline $\begin{array}{l}\text { 10. Tusas Mountain } \\
\text { prospect, Rio Ar- } \\
\text { riba County, N. } \\
\text { Mex. }\end{array}$ & $\begin{array}{l}\text { Tusas granite of Just } \\
\text { (1937) and Hope- } \\
\text { well series of Just } \\
\text { (1937) biotite } \\
\text { g a nite and } \\
\text { quartz-mica- } \\
\text { schist, Protero- } \\
\text { zoic. }\end{array}$ & $\begin{array}{l}\text { Uraninite, second- } \\
\text { ary sabugalite, } \\
\text { metatorbernite. }\end{array}$ & Pyrite..... & Quartz-fluorite..... & $\begin{array}{r}\text { North-trending } \\
\text { bodies of included } \\
\text { schist in granite. }\end{array}$ & Chloritization...... & Tertiary. \\
\hline $\begin{array}{l}\text { 11. Plainview pros- } \\
\text { pect, Si e r a } \\
\text { County, N. Mex. }\end{array}$ & $\begin{array}{l}\text { Granite biotite } \\
\text { granite, Protero- } \\
\text { zoic. }\end{array}$ & $\begin{array}{l}\text { Uraninite, second- } \\
\text { ary, uranophane. }\end{array}$ & Galena, specularite- & Chlorite, fluorite.. & $\begin{array}{l}\text { Northeast-trending } \\
\text { fracture zone. }\end{array}$ & Chloritization..... & Do. \\
\hline $\begin{array}{l}\text { 12. Caribou mine, } \\
\text { Boulder County, } \\
\text { Colo. }\end{array}$ & $\begin{array}{l}\text { Caribou quartz } \\
\text { monzonite stock, } \\
\text { Late Cretaceous. }\end{array}$ & $\begin{array}{l}\text { Uraninite, mostly } \\
\text { pitchblende. }\end{array}$ & $\begin{array}{l}\text { Pyrite, chalcopy- } \\
\text { rite, sphalerite, } \\
\text { galens gersdorf- } \\
\text { fite, argentite, } \\
\text { proustite, native } \\
\text { silver. }\end{array}$ & $\begin{array}{l}\text { Quartz chalced- } \\
\text { ony, calcite, sid- } \\
\text { erite. }\end{array}$ & $\begin{array}{l}\text { Two sets of frac- } \\
\text { tures, trending } \\
\text { east and north- } \\
\text { east; dips } 70^{\circ}-90^{\circ} \\
\text { N. }\end{array}$ & $\begin{array}{l}\text { Silieification, } \\
\text { serieitization, } \\
\text { argillization, } \\
\text { chloritization. }\end{array}$ & Do. \\
\hline $\begin{array}{l}\text { 13. Erickson dist. } \\
\text { (Sheeprock Moun- } \\
\text { tains), Juab County, } \\
\text { Utah. }\end{array}$ & $\begin{array}{l}\text { Granite of Tertiary } \\
\text { age. }\end{array}$ & Pitchblende........ & $\begin{array}{l}\text { Pyrite, oxidized co- } \\
\text { balt, copper, and } \\
\text { manganese min- } \\
\text { erals. }\end{array}$ & Fluorite................ & Narrow fissure veins. & Not appreciable... & Do. \\
\hline $\begin{array}{l}\text { 14. Antelope Wells } \\
\text { prospect, Hidalgo } \\
\text { County, N. Mex. }\end{array}$ & Rhyolite, Tertiary... & Uraniferous opal.. & - 10. & Quartz_....... & Highly fractured zone. & Silicification........ & Do. \\
\hline $\begin{array}{l}\text { 15. Moonlight elaims, } \\
\text { Humboldt County, } \\
\text { Nev. }\end{array}$ & .......................... & $\begin{array}{l}\text { Autunite, minor } \\
\text { uraninite. }\end{array}$ & Iron oxides............. & Fluorite................ & $\begin{array}{l}\text { North-trending brec- } \\
\text { cis zone, dipping } \\
60^{\circ} \mathrm{E} \text {. }\end{array}$ & Argillization. & Do. \\
\hline $\begin{array}{l}\text { 16. San Acacia mine, } \\
\text { Socorro County, N. } \\
\text { Mex. }\end{array}$ & $\begin{array}{l}\text { Flows, amygdaloidal } \\
\text { intermediate vol- } \\
\text { canic rocks, Ter- } \\
\text { tiary. }\end{array}$ & $\begin{array}{l}\text { Secondary autunite } \\
\text { torbernite, tyuy- } \\
\text { amunite. }\end{array}$ & $\begin{array}{l}\text { Copper sulphides, } \\
\text { native copper. }\end{array}$ & Copper carbonates. & $\begin{array}{l}\text { North-trending fault } \\
\text { zone. }\end{array}$ & $\ldots$ & Do. \\
\hline $\begin{array}{l}\text { 17. Thomas Range } \\
\text { district,Juab County, } \\
\text { Utab. }\end{array}$ & $\begin{array}{l}\text { Laketown dolomite, } \\
\text { Silurian, and Fish } \\
\text { Haven dolomite, } \\
\text { Ordovician. }\end{array}$ & $\begin{array}{c}\text { Finely powdered } \\
\text { uraninitedissemi- } \\
\text { nated in fluorite. }\end{array}$ & Minor pyrite & $\begin{array}{l}\text { Fluorite (major } \\
\text { mineral). }\end{array}$ & & None................. & \\
\hline $\begin{array}{l}\text { 18. Schwartzwalder } \\
\text { mine, Jefferson } \\
\text { County, Colo. }\end{array}$ & $\begin{array}{l}\text { Hornblende gneiss } \\
\text { and mica schist of } \\
\text { the Idaho Springs } \\
\text { formation, Pre- } \\
\text { cambrian. }\end{array}$ & $\begin{array}{l}\text { Pitchblende, tor- } \\
\text { bernite, autunite. }\end{array}$ & $\begin{array}{l}\text { Pyrite, galena, sphal- } \\
\text { erite, copper sul- } \\
\text { fides, and minor } \\
\text { molybdenum and } \\
\text { manganese min- } \\
\text { erals. }\end{array}$ & $\begin{array}{l}\text { Quartz, ankerite, } \\
\text { adularia. }\end{array}$ & $\begin{array}{l}\text { Northeast-trending } \\
\text { "silica reel" cut } \\
\text { b y northwest } \\
\text { trending fractures. }\end{array}$ & $\begin{array}{l}\text { Silicification, seri- } \\
\text { citization, minor } \\
\text { chloritization. }\end{array}$ & Do. \\
\hline $\begin{array}{l}\text { 19. Carroll mine, Gil- } \\
\text { pin County, Colo. }\end{array}$ & $\begin{array}{l}\text { Idaho Springs for- } \\
\text { mation, Precam- } \\
\text { brian. }\end{array}$ & $\begin{array}{l}\text { Pitchblende, tor- } \\
\text { bernite. }\end{array}$ & $\begin{array}{l}\text { Pyrite, galena, cop- } \\
\text { per and silver sul- } \\
\text { fides. }\end{array}$ & Quartz............ & $\begin{array}{l}\text { East-trending frac- } \\
\text { tures. }\end{array}$ & $\begin{array}{l}\text { Silicification, ar- } \\
\text { gillization. }\end{array}$ & Do. \\
\hline $\begin{array}{l}\text { 20. Cherokee mine, } \\
\text { Gillpin County, Colo. }\end{array}$ & $\begin{array}{l}\text { Quartz-biotite schist, } \\
\text { Idaho Springs for- } \\
\text { mation, Precam- } \\
\text { brian. }\end{array}$ & $\begin{array}{l}\text { Pitchblende, minor } \\
\text { gilpinite. }\end{array}$ & $\begin{array}{l}\text { Galena, pyrite, sphal- } \\
\text { erite, copper sul- } \\
\text { fides, minor silver } \\
\text { minerals. }\end{array}$ & $\begin{array}{l}\text { Quartz, calcite, mi- } \\
\text { nor fluorite, si- } \\
\text { derite, rhodo- } \\
\text { chrosite. }\end{array}$ & $\begin{array}{l}\text { Vein system strikes } \\
\text { east dips very } \\
\text { steeply north; ver- } \\
\text { tical in places. }\end{array}$ & $\begin{array}{l}\text { Silicification and } \\
\text { minor sericitiza- } \\
\text { tion. }\end{array}$ & Do. \\
\hline $\begin{array}{l}\text { 21. Green Mountain } \\
\text { mine, Clark County, } \\
\text { Nev. }\end{array}$ & $\begin{array}{l}\text { Dolomite, Mississip- } \\
\text { pian. }\end{array}$ & $\begin{array}{l}\text { Kasolite, dumon- } \\
\text { tite. }\end{array}$ & $\begin{array}{l}\text { Malachite, cuprite, } \\
\text { cerrusite, limonite. }\end{array}$ & Calamine............ & $\begin{array}{l}\text { Steeply dipping brec- } \\
\text { cia zone. }\end{array}$ & None.......... & (?). \\
\hline $\begin{array}{l}\text { 22. Van Horn dist., } \\
\text { Culberson County, } \\
\text { Tex. }\end{array}$ & $\begin{array}{l}\text { Schist and dolomite, } \\
\text { Precambrian. }\end{array}$ & Carnotite .......... & $\begin{array}{l}\text { Copper sulfides, py- } \\
\text { rite. }\end{array}$ & Silica minerals.... & $\begin{array}{l}\text { North-trending } \\
\text { shears, dipping } \\
\text { easterly. }\end{array}$ & Not appreciable... & Early Tertiary. \\
\hline $\begin{array}{l}\text { 23. Black Hawk mine, } \\
\text { Grant County, N. } \\
\text { Mex. }\end{array}$ & $\begin{array}{l}\text { Porphyritic biotite } \\
\text { gneiss, Precam- } \\
\text { brian. }\end{array}$ & Pitchblende......... & $\begin{array}{l}\text { Pyrite, galena, chal- } \\
\text { copyrite, niccolite, } \\
\text { rammelsbergite, } \\
\text { smaltite, native } \\
\text { silver. }\end{array}$ & Carbonstes, quartz. & Fissure veins.......... & Silicification........ & $\begin{array}{l}\text { Late Cretaceous ot } \\
\text { early Tertiary(?). }\end{array}$ \\
\hline $\begin{array}{l}\text { 24. Wood-Calhoun } \\
\text { mine, Gilpin County, } \\
\text { Colo. }\end{array}$ & $\begin{array}{l}\text { Granite gneiss, Pre- } \\
\text { cambrian. }\end{array}$ & .......do. & $\begin{array}{l}\text { Gold-bearing pyrite, } \\
\text { minor copper and } \\
\text { zinc sulfides. }\end{array}$ & Quartz_... & $\begin{array}{l}\text { East-trending fissure } \\
\text { veins. }\end{array}$ & $\begin{array}{l}\text { Silicification and } \\
\text { minor sericitiza- } \\
\text { tion. }\end{array}$ & Tertiary. \\
\hline
\end{tabular}


TABLE 2.-Geologic character of vein deposits-Continued

\begin{tabular}{|c|c|c|c|c|c|c|c|}
\hline $\begin{array}{l}\text { Map no. (fig. 13) } \\
\text { deposit name, and } \\
\text { loc. by state and } \\
\text { county }\end{array}$ & $\begin{array}{l}\text { Host rock: Forma- } \\
\text { tion name, litho- } \\
\text { logic type, age }\end{array}$ & Uranium minerals & $\begin{array}{l}\text { Associated metallic } \\
\text { minerals }\end{array}$ & Gangue & Structursl festures & $\begin{array}{l}\text { Hydrothermal } \\
\text { alteration }\end{array}$ & Geologic age \\
\hline $\begin{array}{l}\text { 25. Bald Mountain } \\
\text { mining dist., Law- } \\
\text { rence County, s. } \\
\text { Dak. }\end{array}$ & $\begin{array}{l}\text { Schist and gneiss } \\
\text { (metosediments), } \\
\text { Precambrian. }\end{array}$ & $\begin{array}{l}\text { Pitehblende, au. } \\
\text { tunite. }\end{array}$ & $\begin{array}{l}\text { Gold-bearing pyrite } \\
\text { and chalcopyrite. }\end{array}$ & Quartz............... & $\begin{array}{l}\text { Northeast-trending } \\
\text { fissure zone. }\end{array}$ & Silieifieation........ & Tertiary. \\
\hline $\begin{array}{l}\text { 26. Red Blufi mine, } \\
\text { Gila County, Ariz. }\end{array}$ & $\begin{array}{l}\text { Dripping springs } \\
\text { quartzite, Pre. } \\
\text { cambrian. }\end{array}$ & $\begin{array}{l}\text { Finely dissemi- } \\
\text { nated pitch- } \\
\text { blende, second- } \\
\text { ary metatorber- } \\
\text { nite and others. }\end{array}$ & $\begin{array}{l}\text { Pyrite, minor cop- } \\
\text { per and minor } \\
\text { lead sulfides. }\end{array}$ & $\begin{array}{l}\text { Minor fine. } \\
\text { grained quartz. }\end{array}$ & $\begin{array}{l}\text { Dominant vertical } \\
\text { fractures trending } \\
\mathrm{N} .75^{\circ} \mathrm{W} \text {. and } \\
\text { minor set trend- } \\
\text { ing N. } 20^{\circ} \mathrm{E} \text {. }\end{array}$ & $\begin{array}{l}\text { Hematitization } \\
\text { and minor siliei- } \\
\text { cation. }\end{array}$ & Tertiary(?). \\
\hline $\begin{array}{l}\text { 27. Silver Oliff mine, } \\
\text { Niobrara County, } \\
\text { Wyo. }\end{array}$ & $\begin{array}{l}\text { Quartzite, Cam- } \\
\text { brian. }\end{array}$ & $\begin{array}{l}\text { Uranophane, } \\
\text { minor urani- } \\
\text { nite. }\end{array}$ & $\begin{array}{l}\text { Pyrite, silver, copper } \\
\text { sulfides. }\end{array}$ & Caloite............... & $\begin{array}{l}\text { High angle reverse } \\
\text { fault, trending } \mathrm{N} \text {. } \\
20^{\circ} \mathrm{E} \text {. }\end{array}$ & None. ............. & (7). \\
\hline $\begin{array}{l}\text { 28. Sunshine mine, } \\
\text { Shoshone County, } \\
\text { Idaho. }\end{array}$ & $\begin{array}{c}\text { St. Regis formation } \\
\text { of the Belt series, } \\
\text { Precambrtan. }\end{array}$ & Pitchblende........ & $\begin{array}{l}\text { Pyrite, arsenopy- } \\
\text { rite, chalcopyrite, } \\
\text { stibnite, tetrahed- } \\
\text { rite, galens, eryth- } \\
\text { rite. }\end{array}$ & Quartz, siderite... & $\begin{array}{l}\text { Tensional fracture, } \\
\text { frending east and } \\
\text { dipping } 60^{\circ}-80^{\circ} \\
\text { south. }\end{array}$ & Hematitization.... & $\begin{array}{l}\text { Generally consid- } \\
\text { ered Tertiary; } \\
\text { Precambrian se- } \\
\text { cording to Kerr } \\
\text { and Kulp (1952). }\end{array}$ \\
\hline $\begin{array}{l}\text { 29. Surprise claims } \\
\text { near Gibbonsville, } \\
\text { Lemhi County, } \\
\text { Idaho. }\end{array}$ & $\begin{array}{l}\text { Quartilte of the } \\
\text { Belt series, Pre- } \\
\text { cambrian. }\end{array}$ & $\begin{array}{l}\text { Autunite, meta- } \\
\text { torbernite. }\end{array}$ & Limonite_.......... & 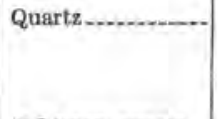 & $\begin{array}{l}\text { Fissure striking N. } \\
60^{\circ} \text { W., dipping } \\
\text { steeply northeast. }\end{array}$ & Hematitization.... & (?). \\
\hline $\begin{array}{l}\text { 30. Golden Gate Can- } \\
\text { yon dist., Jefferson } \\
\text { County, Colo. }\end{array}$ & Amphibolite......... & $\begin{array}{l}\text { Pitchblende, } \\
\text { uranospinite, } \\
\text { torbernite. }\end{array}$ & $\begin{array}{l}\text { Chalcopyrite, pyr- } \\
\text { rhotite, chalcocite, } \\
\text { and bornite. }\end{array}$ & Feldspar, quartz... & $\begin{array}{l}\text { North-to northwest- } \\
\text { trending tensional } \\
\text { faults. }\end{array}$ & Not appreciable... & Tertiary. \\
\hline $\begin{array}{l}\text { 31. Placerville dist., } \\
\text { S a n M i } u \in 1 \\
\text { County, Colo. }\end{array}$ & $\begin{array}{l}\text { Dolores formation, } \\
\text { sandstone, conglo- } \\
\text { merate, and mud- } \\
\text { stone. }\end{array}$ & Thucholite......... & $\begin{array}{l}\text { Pyrite and sulfides } \\
\text { of copper, lead, } \\
\text { zine, molybde- } \\
\text { num, and anti- } \\
\text { mony; erythrite. }\end{array}$ & $\begin{array}{l}\text { Calcite and bor- } \\
\text { nite. }\end{array}$ & $\begin{array}{l}\text { Fault striking N. } \\
45^{\circ}-50^{\circ} \mathrm{W}_{4} \text { dip- } \\
\text { ping } 60^{\circ} \text { north- } \\
\text { east. }\end{array}$ & Argillization ....... & (?). \\
\hline $\begin{array}{l}\text { 32. Iron district oc- } \\
\text { currences, Michl- } \\
\text { gan. }\end{array}$ & $\begin{array}{l}\text { Iron-bearing forma- } \\
\text { tion, slates and } \\
\text { quartzite; Upper } \\
\text { Huronian. }\end{array}$ & Uraninite.......... & $\begin{array}{l}\text { Numerous iron } \\
\text { minerals. }\end{array}$ & Not appreeiable.... & Tensional fractures.. & Not appreciable... & $\begin{array}{l}\text { Later Preoam. } \\
\text { brian. }\end{array}$ \\
\hline
\end{tabular}

\section{GEOLOGIC CHARACTER OF DEPOSITS}

\section{FAVORABLE HOST ROCKS}

It has been noted (Everhart and Wright, 1953) that major uranium-bearing vein deposits of the world generally occupy fracture zones, either in granitic intrusive rocks or in metasediments. In the United States several significant vein deposits have also been noted in rhyolitic extrusive rocks (chemically related to granitic rocks), in metavolcanic rocks associated with metasediments, and in unmetamorphosed arenaceous rocks.

A large proportion of the significant vein deposits are in granitic host rocks, ranging in age from Precambrian to late Tertiary (nos. 1-13, table 2). These rocks range from true granite to rocks as mafic as diorite, but most are in the granite-granodiorite-quartz diorite range. For the most part, the rocks are medium to coarse grained and characterized by extensive fracturing. In Precambrian terrane they are commonly metamorphosed to granite gneiss.

In parts of New Mexico and Nevada, uraniferous vein deposits are in rhyolite. In Socorro County, N. Mex., the volcanic rocks are intermediate in composition (nos. 3, and 14-16, table 2). These volcanic rocks are Tertiary in age and are generally fresh, although sub- jected to argillization and silicification adjacent to the veins.

Most of the remaining significant vein deposits are in metasediments (nos. 17-29, table 2). Quartzite (nos. 26-29) and micaceous schist appear to be the most favorable hosts among the metasediments, although in places dolomite is predominant. Ages of these rocks range from Proterozoic to Mississippian, but most are Precambrian. Amphibolite and hornblende gneiss, interbedded with metasedimentary rocks, are the favorable host rocks in Jefferson County, Colo. (Adams, Gude, and Beroni, 1954).

Unmetamorphosed arenaceous sedimentary rocks are the host for a uraniferous hydrocarbon-bearing vein in San Miguel County, Colo., on the eastern margin of the Colorado Plateau (no. 31, table 2), and for the upper part of a uraninite vein in nearby Saguache County, Colo. (no, 6).

\section{MINERALOGIC TYPES}

Any attempt to group ore deposits by mineralogic types is complicated by unique, local features and variations and by exceptions to apparent natural groupings. Nonetheless, it is proposed herein that at least five dis- 
tinct mineral assemblages occur in the uraniferous vein deposits of the United States (table 1).

In a few deposits, where only the oxidized zone of the deposits has been explored, the major uranium minerals are secondary; and no important metallic associates are present except iron, usually in the form of hydrated oxides (type A, table 1). Silica minerals and fluorite may be present as gangue but generally only in minor amounts. Typical examples of this mineralogic assemblage are the carnotite- and autunite-bearing veins cutting the Sierra Nevada batholith, in Kern Canyon, east of Bakersfield, Calif. (no. 1, table 2). Notable variations in this type are the uraniferous fluorite deposits of the Thomas Range, Juab County, Utah (no. 17 , table 2).

One of the major mineral assemblages in uraniferous vein deposits of the world is the "siliceous-pyrite-galena" type (Everhart and Wright, 1953). This type is widely represented in the United States (see table 2) and has constituted the source of most vein-deposit ore produced in the country. These veins characteristically are highly siliceous and contain primary uraninite (most commonly in the variety pitchblende), iron and copper sulfides, galena, and less commonly, sphalerite (type B, table 1). Many of them have an appreciable content of molybdenum minerals as well and are characterized by abundant fluorite gangue (along with the quartz) and by heavy hematite staining. In the oxidized zones the secondary uranium minerals most common are "sooty pitchblende," autunite, torbernite, and uranophane; and the other metallic oxides and hydrous oxides are typical oxidation products of basemetal deposits. Perhaps the best known examples of this type are the deposits of the Marysvale district, Piute County, Utah, although the common copper minerals present in other deposits in this mineralogic type are rare.

A third mineralogic type (type $\mathbf{C}$, table 1), also important among world uranium producers, has been described as the "nickel-cobalt-native silver ore type" (Bastin, 1939). This type is represented in the United States but contributes only a minor part of total production. The veins are characterized by uraninite (usually in the variety pitchblende) associated with cobalt, nickel, copper, and other base-metal sulfides, and silver. Carbonate minerals are the predominant gangue, along with lesser silica minerals and occasional barite. Secondary alteration of primary uranium minerals in this ore type largely forms "sooty pitchblende," but torbernite, autunite, and other secondary uranium minerals may be present. As in type B, heavy hematite staining is characteristic. The Black Hawk mine, Grant County, N. Mex., is perhaps the most typical example of this assemblage in the United States.
A fourth mineralogic type consists of pitchblende associated with gold-bearing pyrite in highly siliceous veins. Several small deposits in the Quartz Hill district, Gilpin County, Colo., typify this category.

A distinctive mineralogic vein type, in which the uranium mineral is the hydrocarbon thucholite, occurs in the Placerville district, San Miguel County, Colo. This deposit, similar to the Nicholson mine, Lake Athabaska district, Saskatchewan, also contains a complex assemblage of iron, copper, lead, zinc, molybdenum and antimony sulfides, and erythrite.

\section{STRUCTURAL CHARACTERISTICS}

As in the majority of the uraniferous vein deposits of the world, those in the United States are characterized by "open" structural features. Almost without exception, the vein deposits lie in districts where rocks have been subjected to tensional forces simultaneous or before mineral deposition. In detail, the ores show typical evidence of open-space filling in nearly all cases. The intensity and distance from fractures at which replacement by uranium minerals of host rock has taken place depend on the nature of the host rock itself. In quartzite (as in the Red Bluff mine of Arizona) or in dolomite (as in the Thomas Range of Utah) replacement by uraninite and associated minerals extends several feet outward from the controlling fractures.

\section{HYDROTHERMAL ALTERATION}

Hydrothermal alteration effects, of different degrees, are evident adjacent to nearly every uraniferous vein deposit in the United States (table 2). The chemical and mineralogic nature of these effects differs markedly from one environment to another and is determined largely by the complex physiochemical interrelationship of the host rock and the invading solutions. Silicification is prominent, where the invading solutions were rich in silica, and particularly in granitic host rocks. Argillization is common in igneous host rocks of nearly all types. The nature of such clay alteration has been thoroughly studied (Kerr and others, 1956) at Marysvale, Utah. Sericitization is prevalent where abundant potassium was available, as is chloritization, where iron and silica were both abundant. Hematitization is one of the most prominent features of uranium-bearing hydrothermal veins and adjacent rocks throughout the world. In the United States this effect is particularly evident in metasedimentary host rocks.

\section{GEOLOGIC AGE OF DEPOSITS}

As shown in table 2, evidence is remarkably consistent that all the uraniferous vein deposits of the Western United States were formed during the Tertiary and 
were closely related in time to the igneous activity of that period. One instance of conflicting evidence is an age determination (Kerr and Kulp, 1952) indicating that the ores of the Sunshine mine, Idaho, are Precambrian. In Michigan the deposits appear to be later Precambrian, as are all others that have been determined in the Canadian Shield farther to the north.

\section{ORIGIN OF DEPOSITS}

In the United States, as in other parts of the world, the following postulations for the emplacement of uranium minerals in vein deposits appear valid:

1. Because the more felsic magmas, and intrusive and extrusive rocks derived from them, are the most uraniferous known, the residual fluids forming hydrothermal solutions at the end of a granitic or syenitic magmatic cycle constitute a rich source for uranium.

2. These uraniferous solutions, under high pressure and temperature, follow well-developed tensional, openspace fractures in the crust, as an access upward.

3 . Uranium, in the uranyl ion, begins to find conditions favorable for precipitation in the higher temperature mesothermal to hypothermal zones. The host is most commonly the parent granitic rock. If the solutions contain a complex assemblage of base-metal ions, the gold-uranium or cobalt-nickel-silver type of ore may be deposited in the mesothermal zone. Metasedimentary and metavolcanic rocks appear to be the most favorable hosts for the precipitation of this type of assemblage. Fine-grained dissemination of hematite in and around the veins also typifies these deposits.

4. The simpler ore types (types A and B, table 1) appear to be deposited throughout a larger range of temperatures and pressures, approaching the epithermal zone at the lower end, and occur most frequently in felsic intrusions. These types appear to be particularly susceptible to subsequent, near-surface oxidation effects, giving rise to the "sooty pitchblende" variety of uran- ium oxide and variable combinations of secondary phosphates, sulfates, arsenates, vanadates, hydrous silicates, and hydrous oxides. Such host rocks are also commonly affected by alteration effects of the hydrothermal solutions, as expressed by zoning of clay, silica, chlorite, and other "alteration" minerals. Hence, caps of secondary minerals and alteration commonly characterize the deposits down to as much as 200 feet from the surface, and extensive physical exploration is necessary to ascertain the true primary nature of the deposit.

In the Western United States the emplacement of uraniferous vein deposits has occurred in a broad horseshoe-shaped zone surrounding the Colorado Plateau, Wyoming basins, and Black Hills districts of disseminated ores in sedimentary rocks. These deposits occur in rocks in which the migration of ore solutions and precipitation of minerals from them must have been accomplished more easily through open-spaced fractures rather than through pore spaces. There is a strong suggestion that the "uranium province" of the entire Western United States is the result of a complex series of interrelated metallogenic processes, of which the emplacement of the vein deposits was an integral part.

\section{REFERENCES CITED}

Adams, J. W., Gude, A. J., 3d, and Beroni, E. P., 1954, Uranium occurrences in the Golden Gate Canyon and Ralston Creek areas, Jefferson County, Colo.; U. S. Geol. Survey Circ. 320.

Bastin, Edson S., 1939, The nickel-cobalt-native silver ore type: Econ. Geol. v. 34, p. 1-40.

Everhart, D. L., and Wright, R. J., 1953, The geologic character of typical pitchblende veins: Econ. Geol., v. 48, p. 77-95.

Just, Evan, 1937, Geology and economic features at the pegmatites of Taos and Rio Arriba Counties, N. Mex.: N. Mex. School of Mines Bull. 13, p. 7-70.

Kerr, P. F., and Kulp, J. L., 1952, Pre-Cambrian uraninite, Sunshine mine, Idaho: Science, v. 115 , p. 86-88.

Kerr, P. F., and others, 1956, Alteration and uranium mineralization at Marysvale, Utah: Geol. Soc. America Mem. (in press). 



\title{
PITCHBLENDE DEPOSITS IN THE CENTRAL GITY DISTRICT AND ADJOINING AREAS, GILPIN AND GLEAR CREEK GOUNTIES, COLORADO
}

\author{
By Paul K. Sims and Edwin W. Tooker, U. S. Geological Survey
}

\begin{tabular}{|c|c|c|c|}
\hline & \\
\hline & Page & & Page \\
\hline Abstract. & 105 & Uranium deposits-Continuerl & \\
\hline Introduction... & 105 & Localization of ore......... & 108 \\
\hline Geologic setting ...... & 106 & Supergene alteration.......... & 109 \\
\hline Uranium deposits_..... & 107 & Grade of primary and secondary deposits .............. & 110 \\
\hline 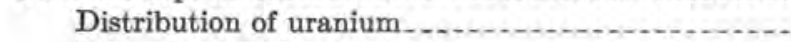 & 107 & 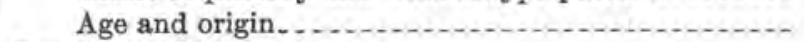 & 110 \\
\hline Mineralogy and paragenesis...... & 107 & Future of district.......... & 110 \\
\hline Structure............ & 108 & References cited.... & 110 \\
\hline Relation of deposits to wall rocks.- & 108 & & \\
\hline
\end{tabular}

\section{ABSTRACT}

The Central City district and adjoining areas, in Gilpin and Clear Creek Counties, Colo., are in the mineral belt of the Colorado Front Range, an area of coextensive Laramide intrusions and mineral-producing districts. The Central City district is characterized by gold-, silver-, and sulfide-bearing quartz veins. Small quantities of high-grade pitchblende ore have been shipped intermittently from the district since 1872, largely as a byproduct of gold mining. The total production exceeds 100,000 pounds of $\mathrm{U}_{3} \mathrm{O}_{8}$.

The country rock consists of a wide variety of folded and highly metamorphosed gneisses and granitic rocks of Precambrian age, which are intruded by many small dikes and stocks of porphyritic igneous rocks, principally monzonite and bostonite of early Tertiary age.

The vein deposits occur in faults of Laramide age that trend eastward, northeastward, and northwestward. They are largely fissure fillings that formed at intermediate temperatures and pressures. In the Central City district, a pattern of hypogene mineral zoning is well developed. A core area containing pyritic veins is surrounded by an area containing galena-sphalerite veins; an intermediate zone contains veins of composite type composed of minerals characteristic of veins in both the core and fringe areas. Pitchblende, a local constituent of the ores, is associated with veins of all types, but it is most abundant in composite and galena-sphalerite veins. Pitchblende, characteristically showing colloform texture, was the first ore mineral to form; it was deposited contemporaneously with quartz and was followed closely by pyrite, chalcopyrite, sphalerite, tennantite, and galena. Carbonate minerals locally form a part of the gangue.

The pitchblende occurs in shoots, small pods, or lenses that are systematically arranged in some veins and erratically distributed in others. The shoots are small, the largest being about 40 feet high, 20 feet long, and a maximum of a foot thick. Most of the ore is selectively mined and hand sorted, and the material shipped ranges from less than 1 percent to as much as 65 percent $\mathrm{U}_{3} \mathrm{O}_{9}$.

The pitchblende was leached and altered by acid meteoric waters in the oxide portions of the veins. In veins of the galenasphalerite type, however, where the supergene solutions were only slightly acid, some of the uranium was reprecipitated as torbernite and other secondary minerals in the lower part of the zone of oxidation. The torbernite was preferentially deposited in biotite-quartz-plagioclase gneiss and amphibolite wall rocks that had been altered largely to montmorillonite. Locally the torbernite replaced these rocks.

\section{INTRODUCTION}

The first discovery of pitchblende in the United States was in 1871 on the dump of the Wood mine on Quartz Hill, a mile southwest of Central City. Since that time the Central City district has been the source of a small amount of high-grade uranium ore and more than 100,000 pounds of $\mathrm{U}_{8} \mathrm{O}_{8}$ has been shipped from the region. Most of the ore was mined before 1917 and was used as a source of radium. The Central City region was this country's principal source of pitchblende ore until 1951 when the Marysvale district became the chief producer. The uranium is in sulfidebearing quartz veins of early Tertiary age.

The Central City district (lat $39^{\circ} 48^{\prime}$ N., long $105^{\circ} 30^{\prime}$ W.) is in south Gilpin County, Colo., about 30 miles west of Denver, on the east slope of the Front Range. The adjoining districts of Idaho Springs, LawsonDumont-Fall River, Freeland-Lamartine, and Chicago Creek are south and southwest of Central City. The area is mountainous and ranges in altitude from 7,500 
feet to about 11,000 feet. The region is in the mineral belt of the Front Range, an area of extensive Laramide intrusions and mineral-producing districts.

The geology of the Central City region has been described by Bastin and Hill (1917), and the geology of the area to the south and southwest, in North Clear Creek County, has been described by Spurr, Garrey, and Ball (1908). Recently Lovering and Goddard (1950) presented an excellent summary of the geology of all the mining districts in the Front Range. The uranium deposits have been studied by several geologists and mining engineers; the most important publications resulting from these investigations are by Pearce (1895), Moore and Kithil (1913), Rickard (1913), Aladorf (1916), and Bastin $(1914,1916)$. This report, prepared by the authors, includes work done by A. A. Drake, J. E. Harrison, C. C. Hawley, F. B. Moore, J. D. Wells, A. E. Dearth, and R. H. Moench, of the U. S. Geological Survey.

\section{GEOLOGIC SETTING}

The Central City district and adjoining areas are in the core of the Front Range, a region consisting dominantly of complex metasedimentary, metasomatic, and intrusive igneous rocks of Precambrian age. These rocks are cut by faults of Laramide age and by many small dikes and plugs of intrusive porphyries of early Tertiary age.

In the Central City region about one half of the Precambrian rocks are metasedimentary and half granitic. Interlayered biotite gneisses-biotite-quartz-plagioclase gneiss and sillimanitic biotite-quartz gneissare the most abundant metasedimentary rocks, but lime-silicate rocks and amphibolites are locally present. The granitic rocks are principally quartz monzonite gneiss, granite gneiss and pegmatite, granodiorite, biotite-muscovite granite, and a variety of pegmatites. These rocks are folded along northeast-trending axes. The folds are mostly open and have moderate-dipping limbs, but locally they are closed. The Tertiary intrusive rocks range in composition from granodiorite to granite; monzonites and bostonites are the most abundant and widespread types. The fault pattern is similar throughout the Central City region, but it differs somewhat in detail from area to area. In the Central City district and the nearby Fall River area, the earliest faults persistently trend northwest and dip steeply north. Later faults are generally less persistent and strike from east to north-northeast; they generally dip steeply to moderately and have small displacements. The faults in order of age sequence trend northwest, east, east-northeast, northeast, and north-northeast.

The veins in the Central City district, and adjoining areas, contain gold-, silver-, copper-, lead-, zinc-, and uranium-bearing ores and formed as hydrothermal fissure-fillings in the faults. Most of the ore is valued principally for its gold and silver content.

The structure and mineralogy of the veins are similar to those described by Waldemar Lindgren (1953, p. 530-532) as typical for mesothermal deposits. The veins range from single well-defined fissure-fillings to complex branching lodes. Although some veins or vein systems are a mile or more long, most are not more than a few hundred feet long. The veins have been mined to depths as great as 2,200 feet. Vein widths range from a fraction of a foot to several feet, but they average a foot or less. The fissures are moderately persistent in strike and dip, and changes in trend and dip commonly are the loci of ore shoots. The walls commonly are smooth and regular.

The wall rocks adjacent to the veins are altered to different degrees, characteristically with an envelope of silicified and sericitized wall rock not more than a foot thick, surrounded by a wider zone of argillized rock.

The principal ore minerals are sulfides and sulfosalts of iron, copper, lead, and zinc; pitchblende, silverbearing sulfosalts, and free gold are locally important. Quartz is the dominant gangue mineral, but calcite, ankerite, rhodochrosite, and siderite are present in some veins.

The veins in the region can be classified according to mineralogy into two main types; one characterized by dominant pyrite and the other by galena and sphalerite. Composite-type veins are present at places and consist of minerals characteristic of both the pyritictype and galena-sphalerite-type veins. Veins of the pyritic type consist predominantly of pyrite and quartz with subordinate chalcopyrite, tennantite, and at places other metallic minerals. Most of the dollar value of these ores is in gold. Veins of the galenasphalerite type contain dominant sphalerite and galena; pyrite is present in minor amounts, and tennantite and chalcopyrite are local components. At places veins of this type, particularly in the Lawson-DumontFall River district, contain rich silver-bearing ores. The composite-type ores are the result of two periods of mineralization. Most commonly, veins of the pyritic type have been reopened and minerals characteristic of the galena-sphalerite-type veins have been introduced. The veins of the composite type have been the principal sources of gold-bearing ore in the Central City district.

A zonal arrangement of the ores is shown by the distribution of veins of different mineralogic types. At Central City a core area about 2 miles in diameter containing veins of the pyritic type is surrounded by a peripheral area containing veins of the galena- 
sphalerite type; an intermediate zone contains veins of the composite type. Veins show similar but less welldeveloped hypogene zonal arrangement in the adjoining Lawson-Dumont-Fall River district. In the Freeland-Lamartine district, the individual veins show zoning, with central segments of pyritic-type ore passing laterally into galena-sphalerite-type ore (Harrison, 1953).

\section{URANIUM DEPOSITS}

Uranium is a local constituent of the veins in the Central City region, where it is associated with veins of all mineralogic types but is most abundant in composite- and galena-sphalerite-type veins. The pitchblende was deposited early in the sequence of vein formation, essentially contemporaneous with quartz and before most of the other ore minerals were formed. At Central City and the adjacent Fall River area, southwest of Central City, the significant pitchblende deposits occur only along veins that trend northwest, west-northwest, east, and east-northeast. The pitchblende is in shoots, small pods, or lenses along the veins; the shoots are small, seldom exceeding a few tens of feet in maximum dimension along the vein and a few inches in width. Most of the pitchblende ore shipped from the region has been selectively mined and hand sorted and has ranged in grade from less than 1 percent to as much as 65 percent $\mathrm{U}_{3} \mathrm{O}_{8}$. The secondary uranium ores that have been shipped are quantitatively unimportant.

\section{DISTRIBUTION OF URANIUM}

During this investigation, more than 100 abnormally radioactive localities have been discovered in an area of approximately 50 square miles, in the Central City region. Of the more than 100 localities, 40 percent have material containing more than 0.10 percent equivalent uranium, and about half of these 40 localities are considered on the basis of geology to be potential sources of uranium ore. Most of the deposits that have been mined and most of the significant prospects are in the Central City district; a few promising occurrences are in the Lawson-Dumont-Fall River, Idaho Springs, and Chicago Creek districts.

The mines containing significant deposits of uranium occur in clusters or small groups that are closely spaced geographically, and most of the other localities having high abnormal radioactivity occur nearby.

Recent work has disclosed that the distribution of uranium deposits shows no distinct relation to the pattern of hypogene mineral zoning, contrary to the previous views of B. F. Leonard (1952).

\section{MINERALOGY AND PARAGENESIS}

Pitchblende is the primary uranium mineral in the vein deposits; in the oxidized parts of the veins this mineral has been altered to green and yellow secondary uranium-bearing minerals; principally torbernite, metatorbernite, and autunite. Uranium-bearing carbonaceous material, possibly thucholite, occurs sparsely at one mine in the Idaho Springs district.

The pitchblende ranges in all gradations from a hard black dense substance with a pitchy luster and a colloform to massive texture to a soft porous fine-grained sooty material with a dull luster. Pitchblende occurs in veinlets, irregular aggregates of spheroidal grains, pellets, and irregular forms. The veinlets and spheroidal forms typically have shrinkage cracks, particularly radial cracks, that at places are filled with later vein minerals. All types of forms are locally fractured and brecciated.

The hard, dense pitchblende occurs in the unaltered veins, and in certain mines it gives way to soft porous pitchblende in the upper parts of the veins. X-ray diffraction powder photograph patterns are sharp for the hard, dense pitchblende; but there is a loss of definition in the pattern of the soft sooty material. E. J. Brooker and E. W. Nuffield (1952) concluded from a study of pitchblende in the Lake Athabaska region, Canada, that the loss of definition in the patterns was related to an increase in the $\mathrm{UO}_{3} / \mathrm{UO}_{2}$ ratio of the pitchblende.

The pitchblende in the Quartz Hill area of the Central City district contains unusual quantities of zircon; locally the pitchblende from this and other areas is relatively high in molybdenum. A pitchblende sample from the Fall River area contains several percent of nickel.

In addition to the principal secondary minerals torbernite, metatorbernite, and autunite, small amounts of kasolite, dumontite, and zippeite have been identified.

Aside from a local occurrence of pitchblende in the western part of the Idaho Springs district, pitchblende in the Central City region was the first metallic mineral to be deposited in the veins. It formed essentially contemporaneously with quartz; pyrite began to crystallize before all of the pitchblende was deposited. The other principal vein-forming minerals - sphalerite, chalcopyrite, tennantite, and galena - clearly are later than the pitchblende. The carbonate minerals, which at places form the gangue, all appear later in the paragenetic sequence than the pitchblende. 


\section{STRUCTURE}

Pitchblende is present in only a small percent of the veins in the Central City region. Where present it occurs in ore shoots or smaller lenses and pods that are separated by vein material essentially barren of uranium. Within the shoots the pitchblende may be either in the principal sulfide ore-bearing veins or in subsidiary veinlets in the adjacent walls.

The uranium-bearing ore shoots in the Central City district are small, and although some have a systematic pattern of occurrence, others are erratically distributed along a vein. Little is known of the uranium-bearing ore shoots in the other districts. At some of the mines in the Central City district, these shoots occur within zones of favorable ground (or zones of ore shoots) that rake westward. The individual shoots differ somewhat in size but nevertheless have comparable dimensions. The largest shoot in one mine-the Carroll mine-has a horizontal (or stope) length of about 15 feet, a height of more than 40 feet, and an average thickness of about 6 inches. The other shoots in this mine are slightly smaller. The ore shoots in the mine are arranged in echelon within the zone of favorable ground, and their axes plunge directly down the dip of the vein.

Within the shoots the pitchblende-bearing ore occurs in a variety of structures. Locally it forms tabular bodies as much as several tens of feet long and high in the plane of the vein, and with maximum widths of about 15 inches; but generally these bodies are smaller. At other places the pitchblende ore occurs as individual seams a few feet in maximum length and generally not more than an inch or two in width, or as local concentrations at the junction of fractures.

\section{RELATION OF DEPOSITS TO WALL ROCKS}

The wall rocks of the pitchblende deposits in the Central City district and adjoining areas include a wide variety of Precambrian rocks and at one place a bostonite porphyry of Tertiary age. The most common wall rocks are felsic rocks-quartz monzonite gneiss, granite pegmatite, and biotite-quartz-plagioclase gneiss-but locally the wall rock is amphibolite or other mafic rocks. In the Fall River area, southwest of Central City, however, pitchblende deposits occur in three veins where they intersect a single type of limesilicate gneiss wall rock that consists predominantly of garnet and quartz; uranium occurrences have not been found where the veins intersect other types of wall rock.

The altered wall rocks associated with the primary veins are characterized by pyritiferous, silicified, and sericitized rock adjacent to the veins surrounded by a broader outer zone of argillized rock. The width and mineralogic features of the altered halo vary, but the differences cannot be correlated wholly with either the type of mineralization or the type of wall rock. Accordingly, altered rocks cannot be used effectively as a guide to primary uranium deposits.

\section{LOCAITZATION OF ORE}

The factors largely responsible for localizing the uranium-bearing ore were the character of the conduits followed by the ore-bearing fluids, structure and lithology of the wall rocks, and the composition and location of the source magma.

The significant uranium deposits occur along certain fracture sets and are absent in others. The important deposits in the Central City district, and also the adjacent Fall River area, occur in veins that trend northwest, west-northwest, east, or east-northeast. These veins occupy the oldest Laramide fractures in this part of the region. The younger northeast-trending fractures either were not in existence at the time of uranium mineralization or were not open to provide access to solutions.

The pitchblende filled openings in the fault fissures; there is little if any evidence of replacement. The openings were produced largely by shear but locally resulted from tension. Shear stresses produced open spaces at the irregularities along both the principal fault fissures and the subsidiary branching fractures that extended for short distances into the walls. Tension fractures were formed principally in wall-rock horses between splits in veins.

Another factor that affected the localization of all types of ore was the structure and lithology of the wall rocks. In many places a vein is tight in one rock but open and ore-bearing in another rock. This control of the ore is related principally to the relative competency of the different rocks and is dependent upon the physical behavior of the rocks to stresses that produced the fractures. The differences in the width of the fracture zones is most marked where the wall rocks differ greatly in lithology and where the foliation and layering in these rocks are intersected by the fractures at a large angle. At many mines in Central City the veins are wide and ore bearing in quartz monzonite gneiss or pegmatite wall rock but weak and nearly barren in biotie-quartz-plagioclase gneiss wall rock.

Calcium- or iron-rich wall rocks may have been chemically favorable for the deposition of some of the uranium-bearing ores in the Front Range (Adams and Stugard, 1956; see also Adams and Stugard, this volume). The marked association of uranium with garnet and quartz-rich lime-silicate rocks in the Fall River area is thought to have resulted from the chemical con- 
trol of uranium deposition but may be due in part to the relative competency of the rock to fracturing. It has been inferred in other areas throughout the world that wall rocks of similar composition to those in the Fall River area have been largely responsible for the precipitation of uranium from the ore-forming fluids.

The uranium-bearing veins in the Central City district are closely related in space to one type of Tertiary intrusive rock, quartz bostonite. Because of this association P. R. Alsdorf (1916), T. S. Lovering and E. N. Goddard (1950, p. 175), and George Phair (1952) have concluded that bostonite magma was the probable source for the uranium-bearing ore fluids. Phair has demonstrated a magmatic enrichment in both uranium and thorium in the quartz bostonite, and he has proposed a possible mechanism that would account for the concentration of uranium with respect to thorium in the derived residual aqueous fluids. The clustering of significant uranium deposits in relatively small areas and the apparent lack of correlation between the uranium deposits and the pattern of hypogene mineral zoning, together with the data presented by George Phair, suggest to the writer that the uranium deposits very likely had a source different from that of the preciousand base-metal ores.

\section{SUPERGENE ALTERATION}

In the oxidized parts of the veins, pitchblende was leached and altered where the meteoric waters were acid, and green secondary uranium minerals were deposited where the solutions were nearly neutral. For the most part, the oxidized portions of the veins were impoverished; but locally, particularly in the lower part of the oxidized zone, the veins were enriched in uranium.

The meteoric waters were relatively acid along veins of the pyritic and composite types; the pitchblende was leached and dissociated, and uranium was not reprecipitated as secondary minerals. The solutions were only slightly acid along veins of the galena-sphalerite type, because these sulfides provide less acid than pyrite on weathering. By reaction with the wall rocks the solutions were locally neutralized, and uranium was reprecipitated at places as secondary minerals.

One vein on Nigger Hill belonging to the galenasphalerite type, which has been opened from the surface to a depth of about 250 feet, shows that pitchblende was completely leached from the surface to a depth of about 100 feet. At a depth of about 100 feet, and possibly above this depth, the uranium was reprecipitated from the supergene solutions as torbernite, an unidentified yellow uranium-bearing mineral, and an unknown form. In the upper part of the vein the uranium was dispersed by the supergene solutions, and except locally, the tenor of the vein was decreased below that of the primary deposits. Below a vertical depth of about 100 feet, pitchblende was not dissociated, but it was locally leached to different degrees; the uranium content of the leached material is far below the equivalent uranium content, indicating relative enrichment in radium and other disintegration products. In the transition zone between leached and unaltered pitchblende, the pitchblende is partly to completely converted to a soft sooty porous substance.

Along two other uranium-bearing veins on Nigger Hill, metatorbernite occurs throughout the lower part of the oxidized zone, but nothing is known concerning the unaltered vein material. One of the veins is barren to a depth of about 25 feet; from depths of 25 feet to the bottom of the deepest workings at 43 feet, metatorbernite occurs sporadically along the vein zone, primarily replacing montmorillonite in the altered amphibolite wall rocks. Metatorbernite is sparse within the sulfide-bearing vein, and all of the pitchblende has been dissociated in this environment. Dump samples from the oxidized part of another vein show that kasolite is present locally where the vein has been almost entirely altered to limonite. Several samples of altered biotite-quartz-plagioclase gneiss wall rock found on the same dump contain abundant metatorbernite. The metatorbernite replaced the altered gneiss adjacent to the vein and was concentrated in the transition zone between moderately and intensively altered gneiss-in the zone where biotite is bleached and partly altered to illite-montmorillinite-type clay minerals.

The work of George Phair and Harry Levine (1953) on the differential leaching of uranium, radium, and lead from pitchblende in $\mathrm{H}_{2} \mathrm{SO}_{4}$ solutions clearly demonstrates the processes that take place in the oxidized zone. In an oxidizing acid environment uranium is leached, and both radium and lead tend to be fixed approximately proportionately. During the alteration, pitchblende, which consists of variable proportions of $\mathrm{UO}_{2}$ and $\mathrm{UO}_{3}$, is oxidized; $\mathrm{UO}_{3}$ forms at the expense of $\mathrm{UO}_{2}$; and $\mathrm{UO}_{3}$, being more soluble than $\mathrm{UO}_{2}$ in dilute acid solutions, is preferentially leached with respect to $\mathrm{UO}_{2}$, radium, and lead. After dissociation of the pitchblende the uranium presumably can be precipitated only by neutralizing the solutions. Neutralization of the slightly acid solutions in the supergene zone of veins of the galena-sphalerite type was accomplished largely by reaction with the wall rocks, and the uranium was reprecipitated as metatorbernite and other secondary minerals. The supergene solutions in veins of the pyritic and composite types, however, originally highly acid because of the abundance of iron-sulfide, were not neutralized, and the dissolved uranium was carried out and probably dispersed in surface waters. 


\section{GRADE OF PRIMARY AND SECONDARY DEPOSITS}

The pitchblende in the primary deposits generally is in small, high-grade seams that are much narrower than mining widths, and the grade of the shipping ore differs, depending to a large extent upon the care taken in mining and sorting. Where the pitchblende bodies are on the vein walls adjacent to the country rock, they generally can be mined separately, commonly by stripping. Probably this type of ore accounted for most of the product shipped from the mines on Quartz Hill. Pitchblende seams that are intimately mixed with other ore minerals in the vein, however, cannot be mined separately, and sorting is tedious. The pitchblende seams that are present in the walls of the sulfidebearing veins can be mined profitably only where the seams are moderately continuous and closely spaced. The uranium ore that was shipped before 1952 was produced largely as a byproduct of gold mining and was concentrated by hand sorting. Some of it contained as much as 65 percent $\mathrm{U}_{3} \mathrm{O}_{8}$. The primary ore shipped in 1954-55 is much lower in grade and seldom exceeds 2 percent $\mathrm{U}_{3} \mathrm{O}_{8}$; some of it is recovered by gravity separation on Wilfley concentrating tables, and some is crudely hand sorted and shipped direct from the mines.

The grade of the secondary uranium deposits commonly is lower than that of the primary deposits. All of these occurrences generally have not been prospected or mined, however, and little is known concerning the grade of individual deposits. At least one secondary deposit, at the Two Sisters mine, has substantial oregrade material. The secondary minerals for the most part coat fracture surfaces in and adjacent to the veins. At the Martha $\mathrm{E}$ mine in the Chicago Creek area, torbernite and autunite occur as pods or flakes along joints or foliation planes in the footwall of a moderately dipping shear zone containing sooty pitchblende and hydrous iron oxide. The average grade of 21 samples is 0.031 percent uranium. A shipment of 2,920 pounds which was selected by hand sorting assayed 0.14 percent uranium. Secondary uranium minerals at the McKay shaft workings, R. H. D. mine, on Nigger Hill, replace altered amphibolite; the average grade of the ore is approximately 0.10 percent uranium, but several tons containing approximately 0.20 percent uranium could be handpicked. Samples of metatorbernite-bearing altered biotite-quartz-plagioclase gneiss from the dump of the Two Sisters mine, Nigger Hill, contain as much as 6.11 percent uranium. The metatorbernite replaces the gneiss and locally coats fractures. A shipment of 510 pounds taken from the dump assayed 1.53 percent uranium.

\section{AGE AND ORIGIN}

Age determinations by the $\mathrm{Pb}^{206} / \mathrm{U}^{238}$ and $\mathrm{Pb}^{207} / \mathrm{U}^{235}$ methods of pitchblende samples from the Wood and Iron mines, in the Central City district, indicate a range in age for the deposits of from 55 to 70 million years (Phair, 1953 written communication). Arthur Holmes (1946) based the beginning of the Tertiary period on similar ages from $\mathrm{Pb}: \mathrm{U}$ ratio determinations.

George Phair (1952) concluded that the uranium is genetically related to quartz bostonite magma, and the writer is in general agreement with this hypothesis. Phair proposed that uranium-rich solutions given off by a cooling quartz bostonite magma at depth rose along planes of weakness provided by porphyry dikes and deposited the uranium in the veins.

\section{FUTURE OF DISTRICT}

The uranium-bearing ore bodies that have been found in the Central City district and adjoining areas are small but generally high in grade. They have been mined largely in conjunction with precious- and basemetal ores, mostly as a byproduct of gold mining. There is little reason to expect the discovery of bodies that are larger than those previously mined, and accordingly, future production of uranium from this region can be expected to come from scattered small pods and ore shoots distributed through the uranium-bearing veins. These bodies can be recovered most economically during the mining of precious- and base-metal ores.

\section{REFERENCES CITED}

Adams, J. W., and Stugard, Frederick, Jr., 1956, Wall rock control of certain pitchblende deposits in Golden Gate Canyon, Jefferson County, Colo.: U. S. Geol. Survey Bull. 1030 (in press.)

Alsdorf, P. R., 1916, Occurrence, geology, and economic value of the pitchblende deposits of Gilpin County, Colo.: Econ. Geology, v. 11, p. 266-275.

Bastin, E. S., 1914, Geology of the pitchblende ores of Colorado: U. S. Geol. Survey Prof. Paper 90, p. 1-5.

-1916, Occurrence, geology, and economic value of the pitchblende deposits of Gilpin County, Colo. (diseussion): Econ. Geology, v. 11, p. 681-685.

Bastin, E. S., and Hill, J. M., 1917, Economic geology of Gilpin County and adjacent parts of Clear Creek and Boulder Counties, Colo.: U. S. Geol. Survey Prof. Paper 94.

Brooker, E. J., and Nuffield, E. W., 1952, Studies of radioactive compounds, IV-Pitchblende from Lake Athabaska, Canads: Am. Mineralogist, v. 37, p. 362-385.

Harrison, J. E., 1953, Relation between fracture pattern and hypogene zoning in the Freeland-Lamartine district, Clear Creek County, Colo.: Geol. Soc. America Bull., v. 64, p. 1431.

Holmes, Arthur, 1946, The Construction of the geological time scale: Geol. Soc. Glasgow Trans. 21, pt. 1, p. 17-152. 
Leonard, B. F., 1952, Relation of pitchblende deposits to hypogene zoning in the Front Range mineral belt, Colorado (abs.): Geol. Soc. America Bull., v. 63, p. 1274-1275.

Lindgren, Waldemar, 1953, Mineral Deposits: New York, McGraw-Hill Co., Inc. 4th ed., p. 530-532.

Lovering, T. S., and Goddard, E. N., 1950, Geology and ore deposits of the Front Range, Colo.: U. S. Geol. Survey Prof. Paper 223.

Moore, R. B., and Kithil, K. L., 1913, A preliminary report on uranium, radium, and vanadium: U. S. Bur. Mines Bull. 70, Min. Technology 2, p. 43-67.

Pearce, Richard, 1895, Some notes on the occurrence of uraninite in Colorado: Colo. Sci. Soc. Proc., v. 5, p. 156-158.
Phair, George, 1952, Radioactive Tertiary porphyries in the Central City district, Colorado, and their bearing upon pitchblende deposition: U. S. Geol. Survey TEI-247, issued by U. S. Atomic Energy Comm. Tech. Inf. Service, Oak Ridge, Tenn.

Phair, George, and Levine, Harry, 1953, Notes on the differential leaching of uranium, radium, and lead from pitchblende in $\mathrm{H}_{2} \mathrm{SO}_{4}$ solution: Econ. Geology, v. 48, p. 358-369.

Rickard, Forbes, 1913, Pitchblende from Quartz Hill, Gilpin County, Colo.: Min. Sci. Press, v. 106, p. 851-856.

Spurr, J. E., and Garrey, G. H., 1908, Economic geology of the Georgetown quadrangle (together with the Empire district), Colorado, with general geology by Sydney H. Ball: U. S. Geol. Survey Prof. Paper 63, 422 p. 



\title{
SUMMARY OF WALL-ROCK CONTROL OF GERTAIN PITCHBLENDE DEPOSITS IN GOLDEN GATE CANYON, JEFFERSON COUNTY, COLORADO
}

\author{
By John W. Adams and Frederick Stugard, Jr., U. S. Geological Survey
}

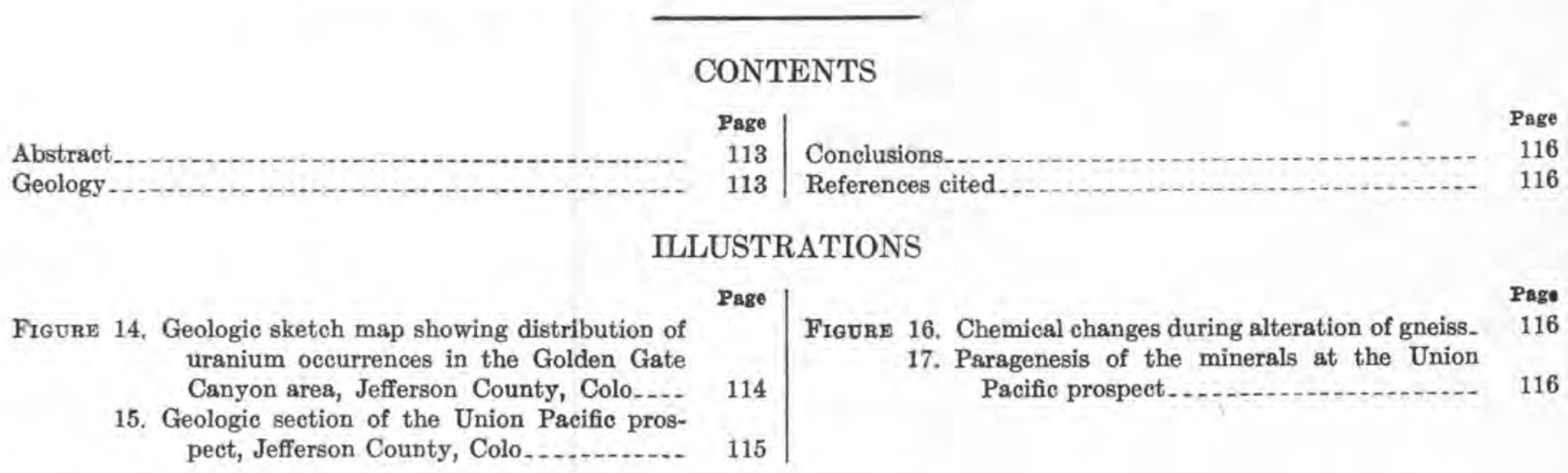

\begin{abstract}
Carbonate veins cutting metamorphic rocks of Precambrian age in Golden Gate Canyon, Colo., contain pitchblende and basemetal sulfides. The veins occupy extensive faults considered to be of Laramide (earliest Tertiary) age and normally contain pitchblende only where they cut hornblende gneiss. At the Union Pacific prospect, which was studied in detail, pitchblende, hematite, and some ankerite formed in advance of sulfides, except possibly for minor earlier pyrite. Base-metal sulfides and most of the ankerite vein-filling were deposited after the pitchblende. Chemical analyses show a high ferrous-iron content in the hornblende gneiss in contrast to low ferrous iron in the adjacent biotite gneiss. It is thought that ferrous iron released by alteration of hornblende was partly oxidized to hematite by the ore-bearing solutions and, contemporaneously, uranium was reduced and deposited as pitchblende.

In other veins, which are not in hornblende gneiss, biotite or iron sulfides may have been similarly effective in precipitating pitchblende. Apparently both the ferrous ion and the sulfide ion can serve as reducing agents and control pitchblende deposition. Rocks rich in ferrous iron or preexisting sulfides are particularly favored sites for uranium deposition.
\end{abstract}

\section{GEOLOGY}

Pitchblende and secondary uranium minerals are found in Golden Gate Canyon, Colo. The deposits, which were discovered in 1951, occur in or near Laramide (earliest Tertiary) fault zones that cut gneisses, schists, and pegmatites of Precambrian age.

During a preliminary study of these deposits (Adams and others, 1953), most of the occurrences of uranium minerals and of high radioactivity anomalies in the area were found where the fault zones cross hornblende gneiss, and conversely, no significant radioactivity has been found along the same fault zones where they pass through other rocks. The distribution of the known uranium occurrences in relation to the hornblende gneiss and the faults is shown on figure 14. In the vicinity of the deposits, quartz-biotite gneiss is adjacent to hornblende gneiss.

The fault zones, or "breccia reefs," are extensive structures as much as 20 feet wide and possibly many miles long. In the area studied they consist of carbonates and potash feldspar as a fine-grained groundmass enclosing rock fragments that have been replaced in different degrees by these minerals. Ankerite is the most abundant carbonate mineral in the reefs and, with potash feldspar, appears to be the product of widespread introduction of hydrothermal solutions into the faults.

At the Union Pacific prospect (fig. 15) pitchblende and base-metal sulfides occur along the hanging wall of a carbonate potash feldspar reef cutting hornblende gneiss. The pitchblende occurs as thin films or more commonly as colloform masses less than 0.1 millimeter in diameter that coat crystals of ankerite of comparable size. The pitchblende-ankerite veinlets are irregularly distributed through intensely altered wall rock and are replaced in different degrees by later sulfides. Both 


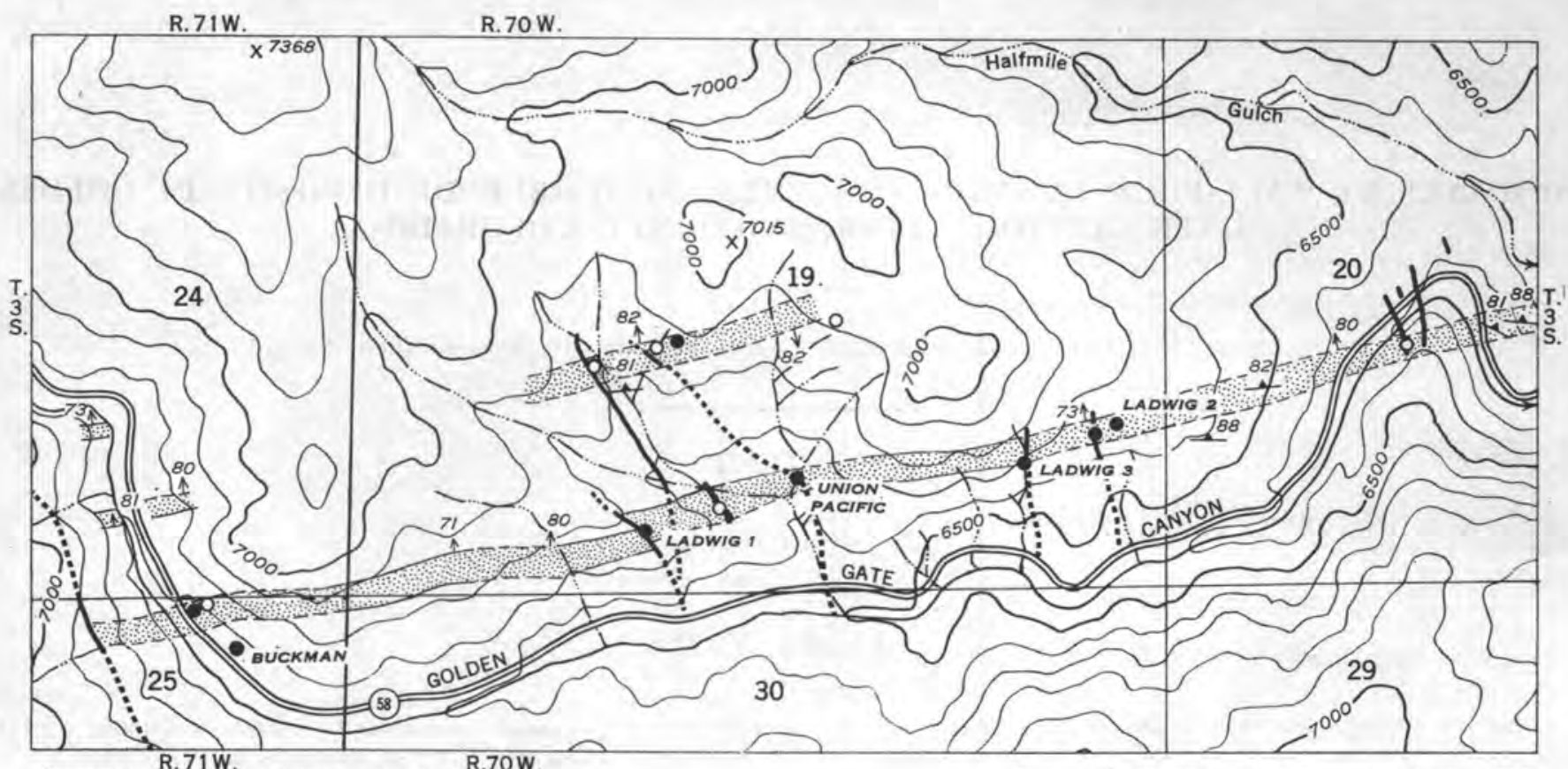

R. $71 \mathrm{~W}$.
Topography from Ralston Buttes quadrangle, 1948

Geology by J. W. Adams and F. Stugard, September 1953
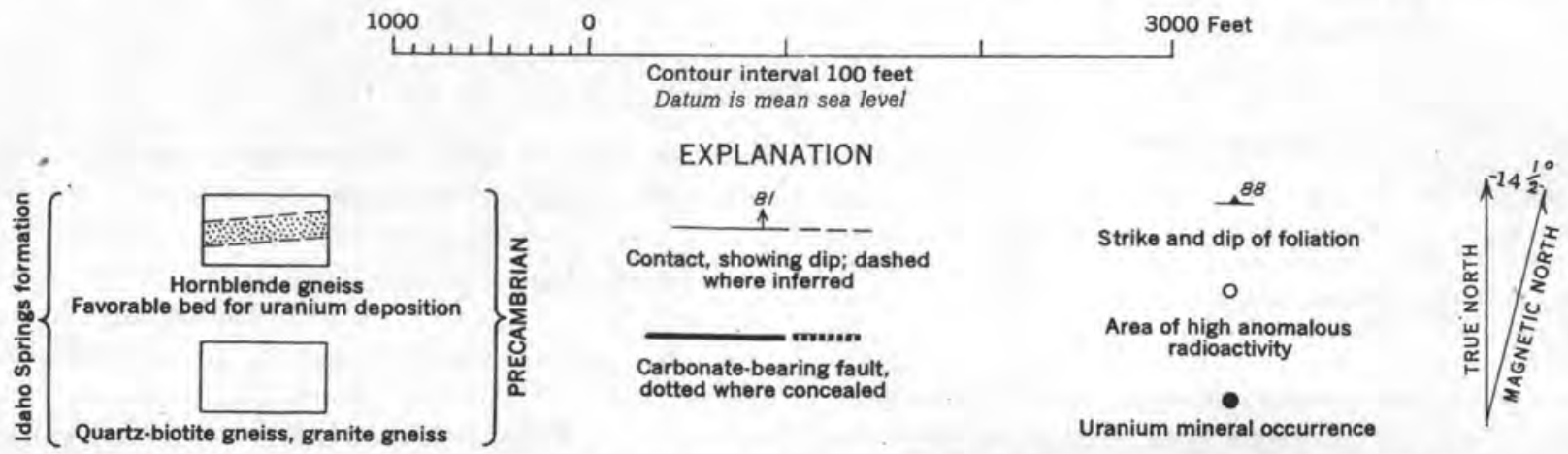

Fiaure 14.-Geologic sketch map showing distribution of uranium occurrences in the Golden Gate Canyon area, Jefferson County, Colo.

pitchblende and hematite have been noted coating crystals of potash feldspar that have grown from the walls of fractures. The deposition of potash feldspar, pitchblende, hematite, and ankerite was followed by the introduction of sulfides which in turn gave way to a final carbonate stage.

The first process in the formation of the ore is thought to have been propylitization of the hornblende gneiss. This resulted in the partial conversion of hornblende to chlorite and some sericitization of plagioclase. The sulfide ion concentration of the solutions was probably low as very little pyrite was formed from the breakdown of the iron-bearing minerals, thus permitting any excess iron to deposit as hematite.

Following or perhaps during propylitization, solutions were introduced that raised the potash content of the gneiss from less than 1 to slightly more than 3 percent (fig. 16). The added potash is in part contained in small clear crystals of orthoclase that line fractures in the rock, but as much or more potash may have replaced the soda of the original plagioclase. This feldspathization of the plagioclase is supported by the distribution of potassium as shown by staining and also by the decreased soda content of the gneiss after alteration (fig. 16).

The precipitation of uranium followed potassic alteration and coincided with the beginning of a carbonate phase. This is shown by the deposition of pitchblende on orthoclase crystals and its intergrowth with ankerite. The precipitation of uranium is thought to have been caused by the reduction of $\mathrm{U}^{+6}$ ions to $\mathrm{U}^{+4}$ by the $\mathrm{Fe}^{+2}$ ions released by the breakdown of hornblende and chlorite. J. W. Gruner (1952) has experimentally produced pitchblende and hematite by reduction of $\mathrm{U}^{+6}$ by $\mathrm{Fe}^{+2}$; hematite formed only when the pitchblende was synthesized in an $\mathrm{H}_{2} \mathrm{~S}$-free environment. In the ore deposit pitchblende and hematite (later ankerite) were deposited at essentially the same time, before the 
formation of all sulfides, with the exception of the very minor pyrite formed during propylitization.

After depletion of the available uranium, several simple copper sulfides, sphalerite, galena, and emplectite (?) were deposited in an intricate network of fractures that only partly follow the original pitchblendebearing veinlets. Deposition of these sulfides was followed by tennantite replacement. It is questionable whether this replacement was part of a continuous period of sulfide deposition or whether a "rest interval" took place. Relations seen in polished sections favor discontinuity with a new wave of solution, containing arsenic and antimony in addition to copper and iron, migrating along the margins of preexisting veinlets. On the depletion of the arsenic and antimony, sufficient copper remained, so that chalcopyrite formed locally throughout the tennantite and along grain boundaries of tennantite and other minerals. With the deposition of chalcopyrite the sulfide mineralization waned, and a vigorous carbonate phase began which was to continue until the close of hypogene activity. The bulk of the carbonate deposited was extremely fine-grained ankerite, succeeded at the last by somewhat coarser grained calcite. The calcite, which is sparse, forms veinlets and fills cavities in the ankerite. Minute pyrite crystals that developed along the edges of the calcite-filled openings indicate that a very weak sulfide phase marked the transition point between the two carbonates. Figure 17 graphically presents the paragenesis of the deposit.

The ore deposit at the Union Pacific prospect is, so far as is known, confined to hornblende gneiss wall rocks. This loealization, repeated at several other uranium occurrences in the area, appears to be largely the result of the composition and texture of the wall rock.

As previously discussed, the deposition of uranium probably was effected by the oxidation of ferrous to ferric iron. Analyses of the two rock types involved showed that the hornblende gneiss contains almost four times as much ferrous iron as the biotite gneiss. Field observations and thin-section studies indicate that the hornblende gneiss was readily altered by the solutions introduced along the fault and that hornblende, the dominant iron-bearing mineral of the rock, was especially subject to attack. It is believed that the release of iron from hornblende and its subsequent reprecipitation provided an effective mechanism for uranium deposition.

The nature of the iron-bearing mineral probably was of little consequence, providing it was reactive and present in sufficient quantity. Thus, a rock rich in

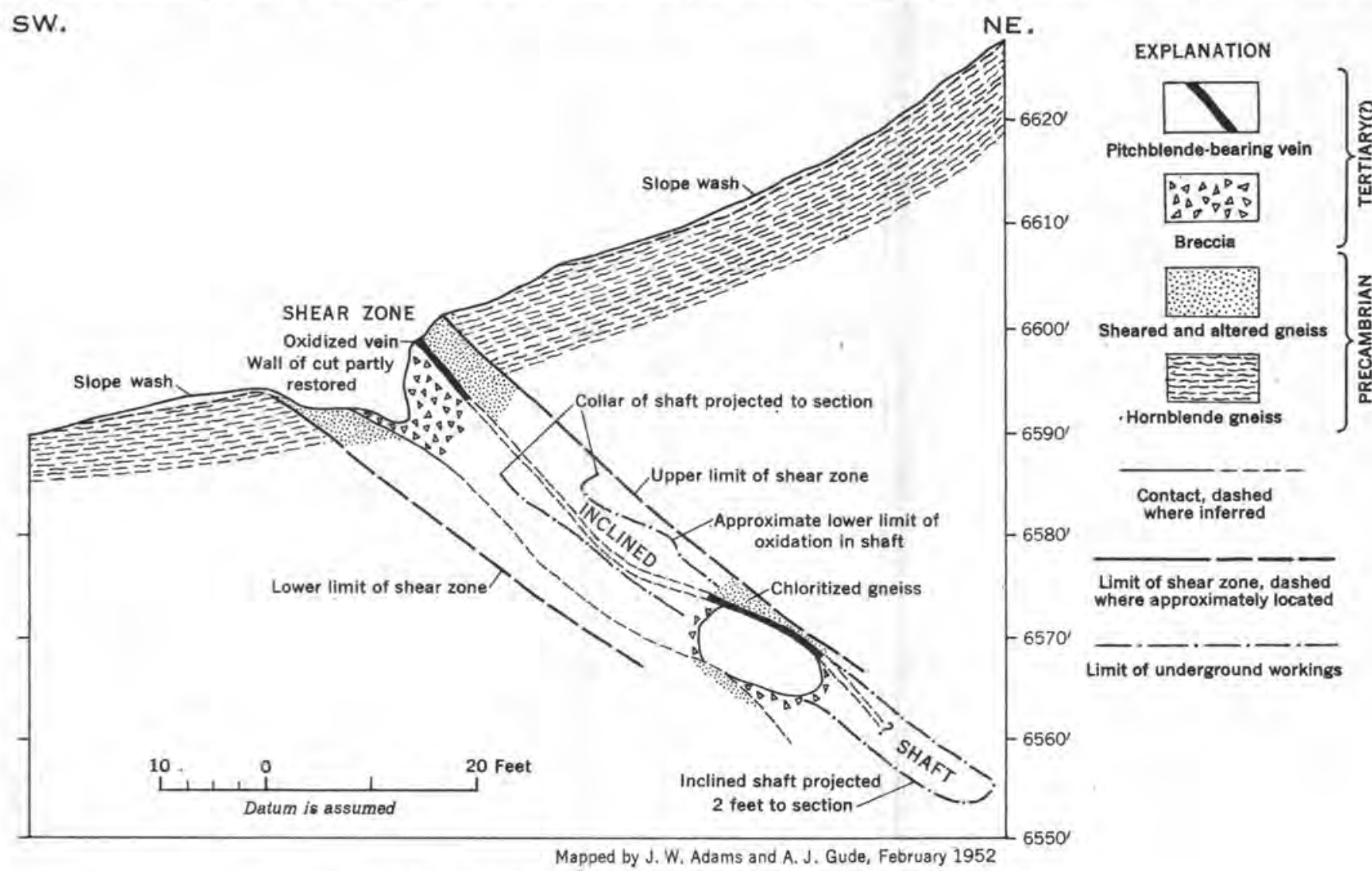




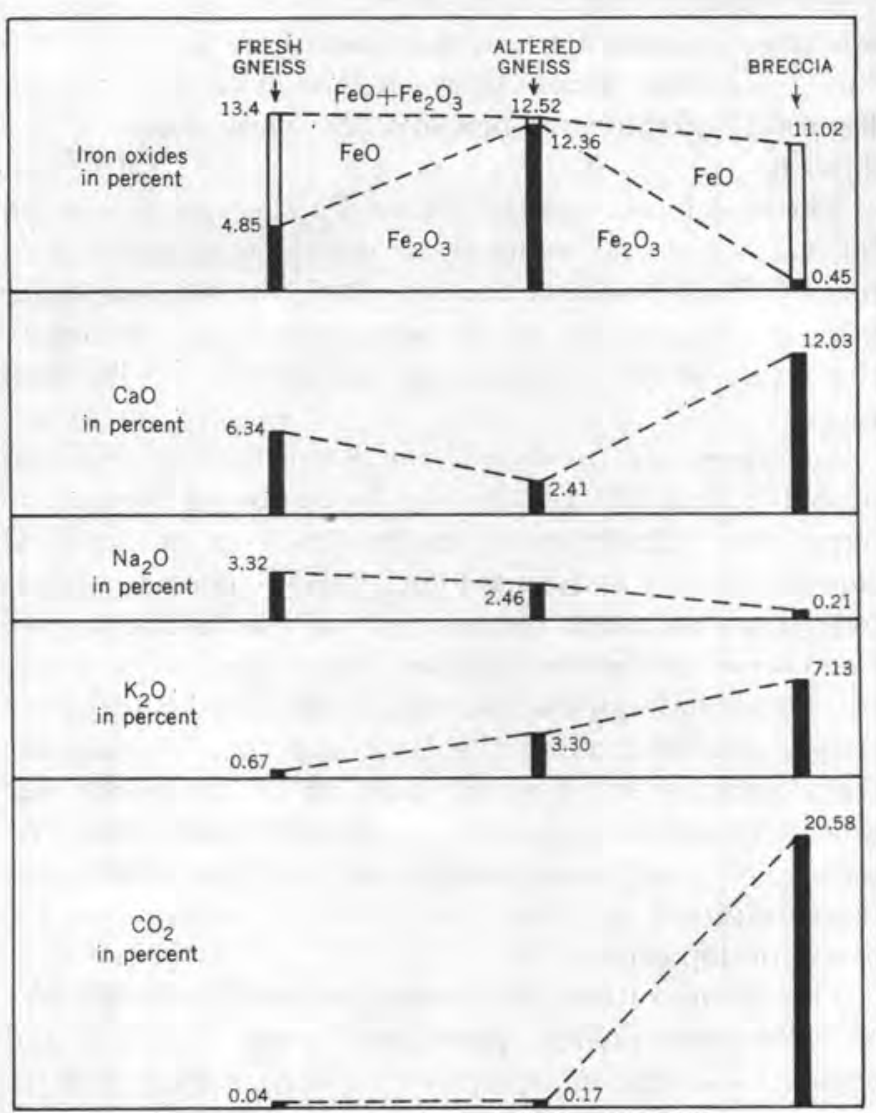

FIGURE 16,-Chemical changes during alteration of gneiss.

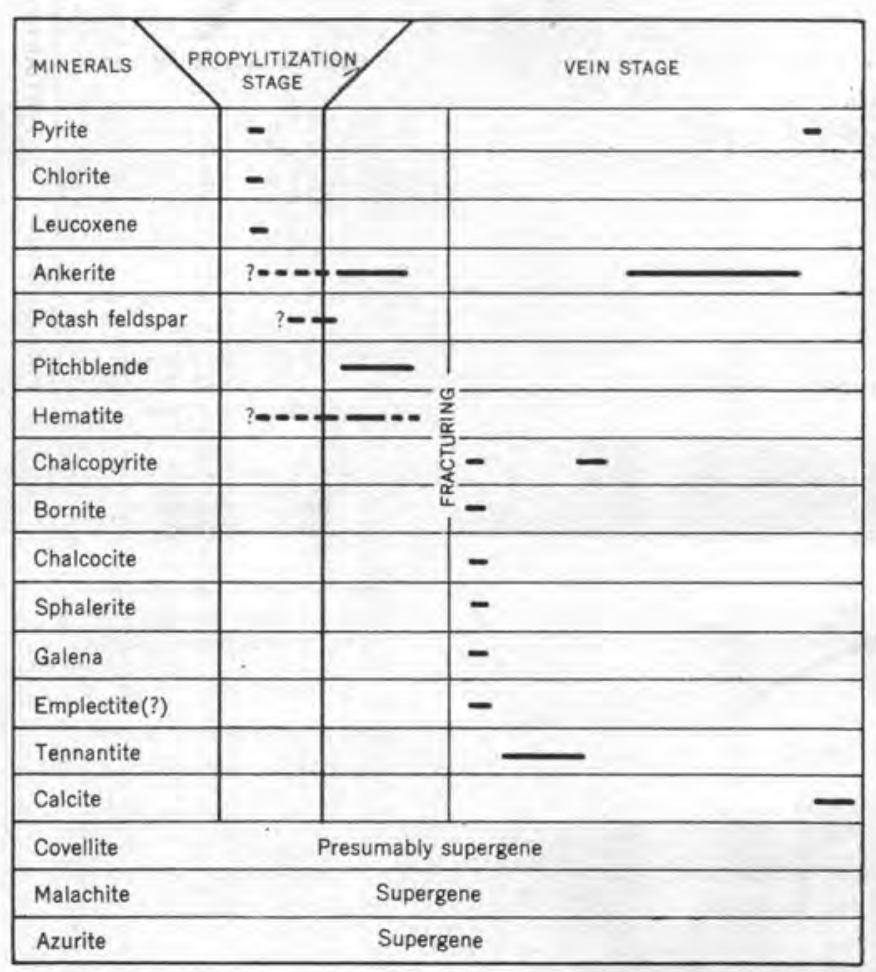

Fraure 17.-Paragenesis of the minerals at the Union Pacific prospect. biotite might be just as effective a precipitant as one containing its iron equivalent as hornblende. In the Joachimsthal district, Czechoslovakia, pitchblende has been observed to be more abundant where the wall rocks of the veins were rich in biotite (Everhart and Wright, 1953).

A direct comparison of the iron content of rocks as a measure of their effectiveness in uranium deposition should be qualified by a consideration of the availability of the iron-bearing mineral to contact with the vein fluids.

Although the rocks classed as biotite gneiss in this report contain layers that are markedly gneissic, they are mostly granoblastic. In contrast, the hornblende gneiss is quite uniformly foliated, with closely spaced layers of light and dark minerals. It would seem reasonable that where vulnerable minerals are alined in planes, as in the hornblende gneiss, they would be far more accessible to the invading solutions than when randomly distributed throughout the rock.

\section{CONCLUSIONS}

The studies made during this investigation lead to the conclusion that pitchblende-bearing veins of the carbonate type are expectable where ample ferrous iron is available in the wall rocks. The difference in the available ferrous iron of the hornblende gneiss and biotite gneiss is thought to have resulted in the localization pattern exhibited by the pitchblende occurrences in the Golden Gate Canyon area.

This conclusion may be of some value in prospecting for uranium in areas of comparable geologic environments; the nature of the ferrous iron-bearing mineral is probably unimportant, so that no special significance should be placed on the presence of hornblende. Biotite, magnetite, tourmaline, and iron sulfides may be equally effective where present in sufficient quantity. In a sulfide environment conditions resulting in the oxidation of either iron or sulfur may precipitate pitchblende. This implies that conditions are particularly favorable for uranium deposition where uranium-bearing solutions have access to rocks rich in ferrous iron or preexisting sulfides.

\section{REFERENCES CITED}

Adams, J. W., Gude, A. J., 3d, and Beroni, E. P., 1953, Uranium occurrences in the Golden Gate Canyon and Ralston Creek areas, Jefferson County, Colo.: U. S. Geol. Survey Circ. $320,16 \mathrm{p}$.

Everhart, D. L., and Wright, R. J., 1953, The geologic character of typical pitchblende veins: Econ. Geology, v. 48, p. 77-96.

Gruner, J. W., 1952, New data of syntheses of uranium minerals, Part I, Annual Report for July 1, 1951, to June 30, 1952: U. S. Atomic Energy Comm. RMO-983, 26 p., issued by U. S. Atomic Energy Comm. Tech. Inf. Service, Oak Ridge, Tenn. 


\title{
URANIUM DEPOSITS OF THE BOULDER BATHOLITH, MONTANA
}

\author{
By George E. Becraft, U. S. Geological Survey
}

\begin{tabular}{|c|c|c|c|}
\hline \multicolumn{4}{|c|}{ CONTENTS } \\
\hline & Page & & Page \\
\hline Abstract... & 117 & Mineral deposits-Continued & \\
\hline Introduction ........ & 117 & Uranium associated with silver-lead veins...... & 120 \\
\hline Structure & 119 & Uranium associated with veins of mixed types_.. & 121 \\
\hline Mineral deposits_......... & 119 & Age of uranium deposits & 121 \\
\hline Uranium deposits............... & 119 & References cited & 121 \\
\hline
\end{tabular}

Figure 18. Generalized geologic map of the northern part of the Boulder batholith, Montana, showing uranium! deposits and radioactivity anomalies.

\section{ABSTRACT}

Uranium minerals and radioactivity anomalies occur in silver-lead veins and chalcedony veins and vein zones in the Boulder batholith of southwestern Montana. Many silver-lead veins in the batholith contain radioactive material, and pitchblende has been identified in a few. These silver-lead veins occupy faults cutting quartz monzonite and granodiorite. Although the displacement along the faults is slight, the wall rock adjacent to most faults is intensely silicified and sericitized. The veins have yielded substantial quantities of lead, silver, zinc, and gold. The silver-lead veins consist principally of galena, sphalerite, tethrahedrite, chalcopyrite, and pyrite in a gangue of light-to dark-gray quartz, altered rock, gouge, and subordinate chaleedony and earbonate minerals. No anomalous radioactivity or uranium minerals have been found in similar veins in prebatholithic rocks of the area.

Chalcedony veins, some of which are uraniferous, are distinctly different from the silver-lead veins and with a single exception are known only in the batholith. The veins consist of one or more discontinuous stringers or veins of chalcedony and slightly coarser grained quartz in silicified and sericitized quartz monzonite and granodiorite and in less strongly altered alaskite. Only small amounts of silver ore have been produced from these chalcedony veins.

All of the veins are early Tertiary in age, but the silver-lead veins are probably older than the chalcedony veins. Uranium is closely associated with chalcedony in both types of veins. This association suggests that all of the uranium in the area is of the same age. If so, some of the silver-lead veins must have been reopened during the period of chalcedony vein formation.

\section{INTRODUCTION}

The Boulder batholith, in western Montana, extends from a few miles south of Helena to about 20 miles south of Butte and is 1,500 square miles in area. Although the area is mountainous, the topography is not rugged but characterized by smoothly rounded ridges commonly about 1,000 feet above the major valleys. Most of the higher valleys were occupied by glaciers in the Pleistocene epoch, but typical alpine cirques are rare.

Early in the spring of 1949, uranium minerals were discovered in veins in the batholith near Boulder, Mont. (fig. 18), and subsequently, more than 100 radioactivity anomalies have been detected. Detailed geologic mapping of the batholith and a study of the uranium deposits began in 1950. Previous geologic work done in the vicinity of the uranium deposits had been of a reconnaissance nature in connection with studies of the mineral deposits in and near the batholith. The most complete studies are by Knopf (1913), Billingsley and Grimes (1918), and Pardee and Schrader (1933). The author is indebted to the geologists of the U. S. Geological Survey who have mapped in the area and have made their information available for this report, and particularly to D. M. Pinckney, S. Rosenblum, and D. Y. Meschter for their aid in the study of the uranium deposits.

\section{GEOLOGY}

The principal rocks of the area are quartz monzonite and granodiorite of the Boulder batholith. These rocks, with a few notable exceptions, do not have a 


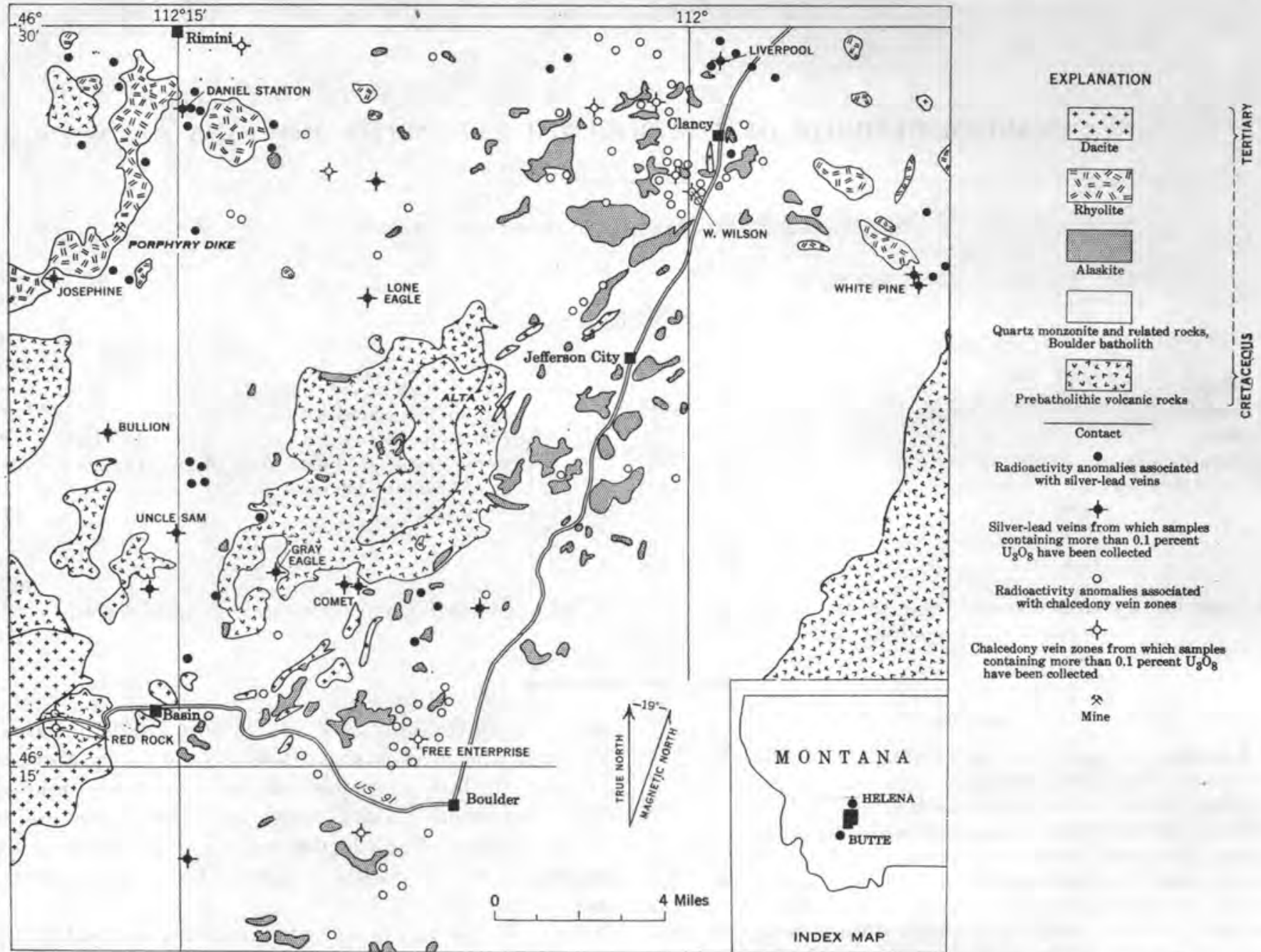

FIGURE 18.-Generalized geologie map of the northern part of the Boulder batholith, Montana, showing uranium deposits and radioactivity anomalies.

great range in mineralogical or chemical composition, but they have a considerable range in texture and fabric. In the detailed mapping the batholith was divided into 23 units based principally on the textural differences apparent in hand specimens.

The rocks of the batholith cut sedimentary rocks ranging from Precambrian to Mesozoic in age near the northern margin of the batholith, and elsewhere the batholith cuts Cretaceous volcanic rocks. The volcanic rocks consist of coarse- and fine-grained fragmental rocks, mainly of andesitic composition, tuff flows (Fenner, 1948) of quartz latitic composition, and subordinate lava flows. Associated with the volcanic rocks are numerous diorite porphyry intrusive bodies. The distribution of the prebatholithic volcanic rocks suggests that only the upper part of the batholith has been uncovered in the area of the uranium deposits.

The batholithic rocks and locally the older volcanic rocks near the margin of the batholith have been in- truded by silicic rocks-including aplite, alaskite, alaskite-porphyry, and pegmatite - all designated as alaskite on figure 18 . The silicic rocks occur principally as dikes, but gently dipping sheets are common, and a few large bodies of irregular shape have been recognized. Most of the alaskite is confined to a moderately well-defined northeastward-trending zone that approximately parallels the eastern boundary of the batholith.

The youngest igneous rocks in the area are rhyolite and dacite. The rhyolite in the western part of the area occurs almost exclusively as flows, remnants of which now cap mountains and ridge crests, whereas most of the small rhyolite bodies shown in the northeastern part of figure 18 are plugs or dikes. The dacite occurs as tuff beds and dikes. Almost all the dikes are in a northeastward-trending zone somewhat more sharply defined than the zone of alaskite intrusions (fig. 18). The large area of dacite near the center of the map consists 
mainly of tuff and other fragmental rocks and is cut by many small dacite dikes. Most of the dacite tuff in the area occurs as valley fill or as remnants on valley walls. The surfaces on which the dacite tuff's and rhyolite flows rest indicate that extensive erosion took place between the intrusion of the batholith and the extrusion of the volcanic rocks.

There is no direct evidence of the relative ages of the dacite and rhyolite because the two rocks have not been observed in contact, but geomorphic evidence suggests that the rhyolite may be older than the dacite. The rhyolite, which appears to be more resistant to erosion than the rather poorly consolidated dacite tuff, caps ridge crests and appears to have been deposited on a surface of relatively low relief. The dacite tuff appears to have accumulated in valleys at a somewhat later stage of erosion.

\section{STRUCTURE}

Detailed maps of the batholith show many strong northeast- and east-trending structures. Several gross features of the area, such as the long dimension of the batholith, the zone of alaskite intrusions, the belt of dacite dikes, and many of the larger steam valleys, are oriented N. $20^{\circ}$ E. to N. $30^{\circ}$ E. Numerous veins, shear zones, and faults fall into two dominant sets-a generally east-trending set, and a N. $60^{\circ} \mathrm{E}$. trending set, both of which dip steeply. Almost all the shear zones, which locally contain silver-lead veins, trend east. These zones are as much as 200 feet wide, but no evidence indicates large-scale lateral displacement. Chalcedony veins occupy many faults in the vicinity of Clancy and Boulder. These faults near Boulder and west of Clancy trend premoninantly N. $60^{\circ} \mathrm{E}$., those east of Clancy trend predominantly east.

\section{MINERAL DEPOSITS}

The mineral deposits in the northern part of the batholith are probably of at least three different ages. The oldest deposits, which include all of those that have yielded substantial amounts of metals, occur in the east-trending shear zones and are common in the batholith and in the prebatholithic volcanic rocks. These are principally silver-lead deposits, but some contain important amounts of gold and zinc and minor amounts of copper. Examples of this type of deposit are the Alta mine in the prebatholithic volcanic rocks and the Comet mine in the quartz monzonite of the batholith.

Dacite dikes cut several of the silver-lead veins, and dacite tuffs and rhyolite flows rest on erosional surfaces developed after the formation of the veins.

The cbalcedony veins and vein zones that locally contain a little silver but no important concentrations of base metals represent a distinctly different and probably younger type of deposit. The vein zones consist of one or more discontinuous stringers and veins of chalcedony and microcrystalline quartz in altered quartz monzonite and granodiorite and in alaskite that has not been strongly altered. The zones have been repeatedly brecciated and silicified along predominantly northeast-trending steeply dipping faults. Crosscutting of several chalcedony and microcrystalline quartz veinlets in a few vein zones indicates as many as four distinet periods of brecciation and silicification.

All of the chalcedony vein zones are younger than the alaskite, and most of them are older than the dacite. Dacite dikes cutting the vein zones are relatively common, but in a few locations chalcedony vein zones cut dacite dikes. Crosscutting at one location suggests that a dacite dike was intruded during the formation of a chalcedony vein zone. The dike appears to cut the early microcrystalline quartz and the later darkgray to black chalcedony; in turn the dike is cut by a small light-gray chalcedony veinlet that may represent the final phase of silicification in the formation of the chalcedony vein zone. These relations suggest that the formation of the chalcedony veins and vein zones took place over a considerable period of time.

The chalcedony vein zones are localized in two distinct areas of several square miles each, one near Clancy and one near Boulder, and are relatively rare throughout the remainder of the northern part of the batholith.

The youngest mineral deposits in the northern part of the batholith are small deposits of gold in Tertiary rhyolite near Rimini. The rhyolite is intensely altered and cut by many small quartz veinlets. The gold is disseminated throughout the rhyolite and concentrated in limonite-filled fractures.

\section{URANIUM DEPOSITS}

Radioactivity anomalies have been detected at many places in the northern half of the batholith, but very few have been found elsewhere in or around the batholith. One exception is a small uranium deposit associated with a chalcedony vein zone a few miles west of Butte. In the Butte district only very slight radioactivity and traces of pitchblende have been detected scattered at random throughout the extensive mine workings, although the production of other metals from the Butte district far exceeds the total production from all the other mining districts in the batholith.

All but two of the known radioactivity anomalies are in the rocks of the batholith. Uranium minerals and anomalous radioactivity have been found in and adjacent to the silver-lead deposits and in the chalcedony veins and vein zones. No apparent structural differences were noted between the silver-lead deposits in 
the batholith and those in the prebatholithic volcanic rocks. However, uranium minerals have been found only in the silver-lead deposits in the batholith.

\section{URANTUM ASSOCIATED WTTH SILVER-LEAD VEINS}

Moderate to high radioactivity anomalies have been detected at several places on the dump of the Comet mine, and samples containing as much as 0.52 percent uranium have been collected. The Comet mine is in a shear zone in quartz monzonite near the roof of the batholith. The shear zone, which dips steeply and trends about N. $80^{\circ}$ W., has been traced for a distance of about 6 miles. It cuts intensely altered prebatholithic volcanic rocks and quartz monzonite and slightly altered alaskitic rocks; displacement along it has been slight. Several dacite dikes cut the zone and are not sheared or altered. Several silver-lead mines, of which the Comet is the largest, are along the zone. Radioactivity anomalies have been detected on the dumps of five of these mines, but Geiger-counter and scintillationcounter traverses along the entire length of the zone failed to disclose any radioactivity anomalies along the trace of the outcrop. The absence of radioactivity anomalies may be the result of thick cover and thorough leaching of the uranium from the zone near the surface.

In the Comet mine three principal veins that follow the trend of the shear zone and dip steeply to the south and several splits of these veins were explored. Ore minerals included galena, sphalerite, tetrahedrite, and chalcopyrite. The gangue consists chiefly of quartz and altered wall rock. A part of the quartz is a clear crystalline variety, and a part is a dark-bluish-gray fine-grained variety. The wall rock is dominantly quartz monzonite and subordinately alaskite. Adjacent to the vein the quartz monzonite has been strongly silicified and sericitized.

At the Gray Eagle mine about $1 \frac{1}{2}$ miles west of the Comet mine, a sooty black mineral identified as pitchblende occurs intimately intermixed with pyrite in gray crystalline quartz. H. D. Wright and B. H. Bieler (1953) state that uraninite has extensively replaced pyrite.

Selected samples that contain more than 0.1 percent $\mathrm{U}_{3} \mathrm{O}_{8}$ have been collected from the dumps of many other silver-lead mines in the batholith rocks. Among these mines are the Josephine, Daniel Stanton, Liverpool, Bullion, Uncle Sam, White Pine, and several unnamed properties (fig. 18). Radioactivity anomalies have been detected on many other mine dumps.

\section{URANIUM ASSOCIATED WTTH CHALCEDONY VEIN ZONES}

Many radioactivity anomalies have been detected in and adjacent to chalcedony vein zones in the batholitb. Two mines in these zones produced uranium: the Free
Enterprise mine has produced a few tons of high-grade ore and about 150 tons of low-grade ore (Roberts and Gude, 1953a), and the W. Wilson mine has produced several hundred tons of moderately high-grade ore.

The W. Wilson mine is about $1 \frac{1}{2}$ miles southwest of Clancy. The geology of a few square miles in the vicinity of the mine was mapped in 1950 by W. A. Roberts and A. J. Gude 3d (1953b), and subsequently detailed studies of the mine were made by D. Y. Meschter and by H. D. Wright and others (1954).

The dominant rock type in the vicinity of the W. Wilson mine is quartz monzonite with an approximate composition of 45 percent plagioclase $\left(\mathrm{An}_{30-35}\right), 25$ percent potash feldspar, 20 percent quartz, 7 percent biotite, and 3 percent hornblende. Adjacent to each chalcedony vein, the quartz monzonite is altered typically, in poorly defined gradational zones of decreasing intensity outward from the vein. The innermost zone, adjacent to the vein, is characterized by silicification; sericitization characterizes the intermediate zone, and beyond that lies a zone of kaolinization. This alteration is similar to that accompanying the silver-lead veins and nonuraniferous chalcedony veins; no particular feature of the alteration was recognized as specifically diagnostic of or peculiar to the uranium mineralization.

The W. Wilson vein zone consists of 1-5 veins of chalcedony and microcrystalline quartz, locally as much as 3 feet thick but averaging only a few inches in thickness. The interlacing of individual veinlets of quartz and chalcedony along the strike and dip of the vein has resulted in a pattern that resembles crude netting. Uranium minerals were first discovered at the W. Wilson mine in two ore bodies that contained sparse nodules and veinlets of pitchblende and relatively abundant yellow and orange secondary uranium minerals: uranophane, phosphuranylite, uranocircite, metaautunite, and a mixture of oxides referred to as gummite. A few secondary minerals, mainly metatorbernite, meta-autunite, and uranophane, are sparsely distributed along and adjacent to fractures outside of the ore bodies, indicating the transportation and redeposition of some of the uranium by meteoric water. Mr. Meschter (1953, written communication) stated that at least three periods of silicification in the W. Wilson mine can be recognized. The first period is represented by clear microcrystalline quartz; the second, by black to dark-gray chalcedony; and the third, by clear microcrystalline quartz. He concluded that deposition of pyrite, chalcopyrite, and pitchblende was essentially contemporaneous with that of the dark-gray to black chalcedony.

One of the occurrences of uranium minerals in the prebatholithic volcanic rocks is at the Red Rock mine 
about $1 \frac{1}{2}$ miles west of Basin, Mont. The batholith is exposed about 3,000 feet northeast of the mine but may underlie the volcanic rocks at the mine at a relatively shallow depth. The vein consists of light-gray chalcedony in intensely silicified, sericitized, and brecciated volcanic rocks. The entire altered zone is about 300 feet wide and forms a conspicuous northeast-trending ridge. The Red Rock vein differs from the typical chalcedony vein zone of the batholith in that it is a single vein of chalcedony with gradational margins instead of a series of anastomosing veinlets with sharp boundaries.

URANTUM ASSOCIATED WTTH VEINS OF MIXED TYPES

Uranium minerals and radioactivity anomalies have been found in and adjacent to a few veins that have some characteristics of both the silver-lead veins and the chalcedony veins and vein zones. They contain abundant amounts of lead and silver minerals and small amounts of sphalerite in a gangue that is predominantly microcystalline quartz and chalcedony. The mineral assemblage of these veins suggests that they were formed either during an intermediate period of mineralization or during both of the periods described above. A quartz vein in the Lone Eagle mine is an example of a vein of mixed type. The vein is in intensely altered quartz monzonite in which biotite is altered to chlorite and the feldspars are altered to a light- to greenishgray mixture of clay and sericite. Silicified zones of quartz monzonite adjacent to the quartz vein range from less than an inch to several feet in thickness. Faulting and shearing are common throughout the mine. Uranium is present in two forms: as small irregular grains or masses of pitchblende in the vein, and as a sooty black material coating irregular fractures in the vein and in the altered wall rock adjacent to the vein. Wright and others (1954) state that pitchblende has extensively replaced pyrite and in some places has replaced chalcedony and sphalerite that filled fractures in pyrite. They also observed a second generation of sphalerite and pyrite as veinlets cutting the pitchblende.

\section{AGE OF URANIUM DEPOSITS}

All the known uranium deposits are postalaskite and predacite. Data obtained by measuring the lead alpha activity ratio in zircon suggest an age of about 60 million years for the alaskite - very Late Cretaceous or Paleocene (R. W. Chapman, 1953 written communication). W. H. Weed (1912) reports that dacite tuffs in the Deer Lodge Valley, about 30 miles west of Boulder, are contemporaneous with Miocene lakebeds, but in the Townsend Valley, about 30 miles east of Boulder, quartz-bearing tuffs in a similar setting are early Oligocene in age. These two observations indicate that the dacite may be either Miocene or Oligocene in age.

In the chalcedony vein zones the uranium was deposited with the dark-gray to black chalcedony, which was deposited late in the formation of the vein zones but before the intrusion of the dacite. In the silver-lead veins, also, the uranium appears to be intimately associated with dark-gray to black chalcedony or microcrystalline quartz. In several of the silver-lead veins, the chalcedony cuts quartz veins containing galena and sphalerite and therefore is interpreted to be later than the sulfide mineralization. The intimate association of uranium with dark-gray to black chalcedony or microcrystalline quartz in the chalcedony vein zones and in the silver-lead deposits suggests that most of the uranium mineralization may be of the same age and that many of the silver-lead veins were reopened during the period of uranium mineralization.

\section{REFERENCES CITED}

Billingsley, Paul, and Grimes, J. A., 1918, Ore deposits of the Boulder batholith of Montana: Am. Inst. Min. Engineers Trans., v. 58, p. 284-368.

Fenner, C. N., 1948, Incandescent tuff flows in southern Peru: Geol. Soc. America Bull., v. 59, p. 879-893.

Knopf, Adolph, 1913, Ore deposits of the Helena mining region, Montana: U. S. Geol. Survey Bull. 527, 143 p.

Pardee, J. F., and Schrader, F. C., 1933, Metalliferous deposits of the greater Helena mining region, Montana: U. S. Geol. Survey Bull. 842,318 p.

Roberts, W. A., and Gude, A. J., 3d, 1953a, Geology of the area adjacent to the Free Enterprise mine, Jefferson County, Mont.: U. S. Geol. Survey Bull. 988-G, p. 143-155.

Roberts, W. A., and Gude, A. J., 3d, 1953b, Uranium-bearing deposits west of Clancey, Jefferson County, Mont.: U. S. Geol. Survey Bull. 988-F, p. 123-141.

Weed, W. H., 1912, Geology and ore deposits of the Butte district, Montana: U.S. Geol. Survey Prof. Paper 74, 262 p.

Wright, H. D., and Bieler, B. H., 1953, An investigation of the mineralogy of the uranium-bearing deposits in the Boulder batholith, Montana, Annual report [for] July I, 1952 to Mar. 31, 1953: U. S. Atomic Energy Comm. RME-3041, 31 p., issued by U. S. Atomic Energy Comm. Tech Inf. Service, Oak Ridge, Tenn.

Wright, H, D., Bieler, B. H., Shulhof, W. P., and Emerson, D. O., 1954, Mineralogy of uranium-bearing deposits in the Boulder batholith, Montana, Annual report [for] April 1, 1953-Mar. 31, 1954: U. S. Atomic Energy Comm. RME3095, 78 p., issued by U. S. Atomic Energy Comm. Tech Inf. Service, Oak Ridge, Tenn. 



\title{
RELATION OF SECONDARY URANIUM MINERALS TO PITCHBLENDE-BEARING VEINS AT MARYSVALE, PIUTE GOUNTY, UTAH
}

\author{
By George W. Walker and Frank W. Osterwald, U. S. Geological Survey
}

\section{CONTENTS}

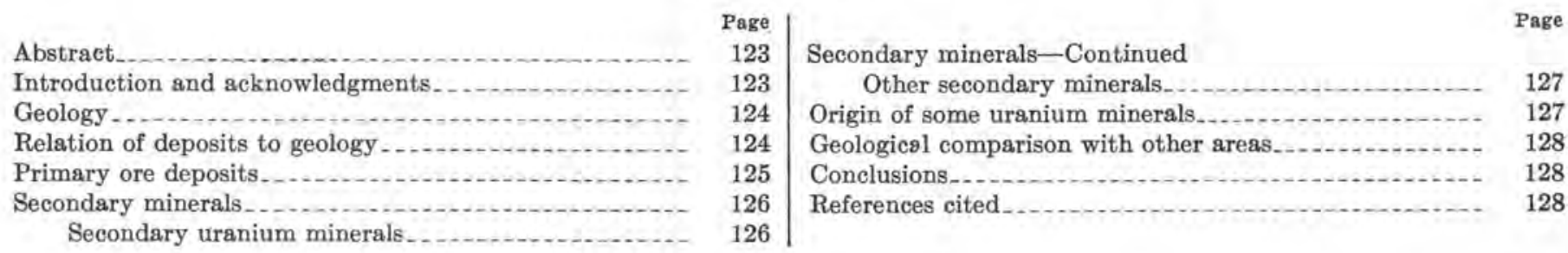

\section{ABSTRACT}

Secondary uranium minerals in vein-type deposits are more abundant at Marysvale than elsewhere in the United States and are the near-surface expression of pitchblende- and fluoritebearing veins at depth. The primary veins and their secondary counterparts yield ore of about the same grade. The gradational boundary between the zone of primary and secondary uranium minerals is extremely irregular, ranging from a few tens of feet to as much as 400 feet in depth beneath the ground surface.

Primary vein minerals include vein quartz, chalcedony, adularis, pyrite, mareasite, calcite, siderite, jordisite, fluorite, hematite, magnetite, and pitchblende. Most commereial deposits of uranium are restricted to quartz-pyrite-adularia-fluorite-pitchblende veins. Some of the pitchblende-bearing veins contain molybdenum minerals. The assemblage of secondary minerals reported at Marysvale contains iron and manganese oxides, ilsemannite, autunite, torbernite, metatorbernite, schroeckingerite, uranophane, phosphuranylite, $\beta$-uranotil, tyuyamunite, rauvite, umohoite, zippeite, johannite, uranopilite, and sooty pitchblende,

Host rocks for the veins include extrusive and pyroclastic rocks of post-Oligocene age, quartz monzonite and other rocks that intrude the extrusive and pyroclastic rocks, and flows and tuffs of late Tertiary age that unconformably overlap the older rocks. Most of the ore mined has been from veins in quartz monzonite.

The host rocks are cut by three sets of vertical to moderately steep faults that trend northeast, northwest, and north. Pitchblende and secondary uranium minerals are most common in northeast-trending faults, less common in northwest-trending faults, and rare or absent in north-trending faults. The uraniumbearing veins pinch and swell, and the ore is commonly localized in shoots in both the primary and secondary zones.

The assemblage of secondary uranium minerals varies, in part, with respect to the type and degree of alteration of wall rock, to the primary mineralogy of the veins, and to the depth beneath the ground surface. The secondary uranium minerals occur as disseminations in altered wall rock and as fracture coatings and are most abundant within 10 feet of the originating vein.

As pitchblende- and fluorite-bearing veins show no marked tendency to be richer in uranium than their overlying secondary counterparts, it is probable that the solution of primary uranium minerals and redeposition as secondary ones occurred essentially in place. Some of the secondary uranium minerals may have been deposited by warm solutions, either juvenile water or heated phreatic water.

The assemblage of secondary minerals is somewhat similar to that of deposits at Wolsendorf, Germany, and in the Boulder batholith, Montana. These deposits, however, contain at least small amounts of base-metal sulfide minerals which are absent at Marysvale. Primary mineralogy of the veins, therefore, seems to have little influence on the assemblage of secondary uranium minerals developed in the oxidized zone.

\section{INTRODUCTION AND ACKNOWLEDGMENTS}

Pitchblende- and fluorite-bearing hydrothermal veins at Marysvale, Utah, grade upward into a complex assemblage of secondary uranium phosphate, silicate, earbonate, oxide, sulfate, molybdate, and vanadate minerals. Rocks in which the deposits occur are of Oligocene age or younger. Since discovery of the Marysvale deposits in 1948, large tonnages of ore have been mined from the zones of primary and secondary uranium minerals.

The principal uranium deposits are confined to an area of less than a square mile centered about 4 miles northeast of Marysvale, in Piute County. The Marysvale area, at an altitude of about 7,000 feet, is in a series of hills in the Sevier River valley; the Tushar Mountains to the west reach an altitude of over 12,000 
feet, and the Sevier Plateau to the east reaches an altitude of 11,000 feet. The climate of the Sevier River valley is semiarid.

This paper is a compilation of published and unpublished information largely accumulated during the past 6 years by personnel connected directly or indirectly with the U.S. Atomic Energy Commission and the U. S. Geological Survey. Special acknowledgment is made to A. O. Taylor; J. W. Gruner, of the University of Minnesota; and P. F. Kerr, of Columbia University, all of whom worked at Marysvale under the auspices of the U. S. Atomic Energy Commission; Eugene Callaghan, who worked in the Marysvale area, mostly before 1938, as a member of the U. S. Geological Survey. Acknowledgment for counsel and assistance also is made to H. C. Granger, H. L. Bauer, Jr., D. G. Wyant, and E. P. Kaiser, of the U. S. Geological Survey.

\section{GEOLOGY}

The Marysvale area is in and near the western edge of the High Plateaus of Utah section of the Colorado Plateaus physiographic province, and is contiguous with the Basin and Range physiographic province on the west. The Sevier River valley, in which the Marysvale area is located, represents a downdropped fault block, or graben, between the upthrown Tushar Mountains to the west and the Sevier Plateau to the east. The area is within an extensive region of Tertiary volcanic rocks; lesser amounts of Tertiary intrusive rocks and Paleozoic and Mesozoic sedimentary rocks are exposed in a few places.

The rocks of the principal mining area are exclusively of igneous origin. Callaghan (1939) separated the rocks into the Bullion Canyon voleanics of early Tertiary age, intrusive quartz monzonite and associated rocks of post-Oligocene(?) age, and the Mount Belknap rhyolite of late Tertiary age. Additional information concerning these rocks and their relations was obtained from descriptions by A. O. Taylor and others (1951) and P. F. Kerr and others (1952). The Bullion Canyon volcanics consist chiefly of breccias, tuffs, and latitic to andesitic flows. According to P. F. Kerr and others (1952, p. 14-15) correlative volcanic rocks overlie sedimentary strata containing Oligocene fossils in southcentral Utah. Small stocks of both porphyritic and nonporphyritic quartz monzonite and granite, presumably of post-Oligocene age, intrude the Bullion Canyon volcanies. Extensive erosion stripped most of the Bullion Canyon volcanics from the principal mining area at Marysvale and exposed the intrusive rocks before extrusion of the Mount Belknap rhyolite of late Tertiary age; the pre-Mount Belknap erosion sur- face had a relief of at least 500 feet. In the mine area the Mount Belknap rocks are mostly rhyolitic and from the base of the section upward consist of thin, yellow, red, or black pitchstone layers, pyroclastic tuff-breccias 2-40 feet thick, and partly glassy red flows showing prominent flow banding and elongate flow vesicles. Partly glassy to devitrified and altered rhyolite dikes, thought by A. O. Taylor and others $(1951$, p. 8 ) to represent feeders for part of the Mount Belknap rhyolite extrusions, crop out and are also exposed in underground workings in the north-central part of the area. Erosion subsequent to the extrusion of the Mount Belknap rhyolite removed voleanic cover over much of the principal mining area leaving granitic rocks exposed at the surface.

Although no major faults have been recogni ed in the principal mining area, many small faults, shear zones, and fractures are exposed in opencuts and underground workings. The faults and shear zones show normal, reverse, and transverse displacements. Dominant trends of the faults and shear zones are northeast, northwest, and north; the north-trending set is less well developed than the other two sets. The northwest set dips about $40^{\circ}-60^{\circ} \mathrm{SE}$., whereas the other sets dip almost vertically. Several periods of movement are indicated by brecciation of wall rocks and early vein minerals and by minor displacement of vein struetures following deposition of late vein minerals. The most active period of faulting and fracturing apparently followed the extrusion of the Mount Belknap rhyolite and preceded the uranium minerali ation; the faults and fractures probably are genetically related to the large high-angle faults that bound the Sevier River valley fault-block. By analogy, these high-angle faults are correlative with other high-angle faults in central Utah which are of Pliocene age (Eardley, 1949, p. 22-23).

\section{RELATION OF DEPOSITS TO GEOLOGY}

Faults and fractures in the quartz monzonite, the dominant host rock, and in the volcanic rocks provided passageways for the ore-bearing solutions and controlled the deposition of the primary vein minerals. The wall rocks are commonly altered near the uraniumbearing structures particularly within a few hundred feet of the ground surface.

Pitchblende and secondary uranium minerals are most common in the northeast-trending faults, less common in the northwest-trending faults, and rare or absent in the north-trending faults. A few faults are continuously minerali-ed over horizontal distances of as much as 800 feet and vertical distances of more than 700 feet, although the uranium content differs from place to place. Within the faults and fractures, 
the uranium-bearing vein material commonly pinches and swells, so that some ore is in pronounced shoots; locally, some of the richest ore occurs in steeply plunging shoots at intersections of different fault sets or at places where faults change strike. Mineralized zones in faults commonly occur as several narrow locally siliceous discontinuous veins separated by clay gouge or hydrothermally altered rock or as breccia cemented by vein minerals.

Contacts between different rock types have influenced the localization of some of the uranium deposits. The contact between quartz monzonite and Mount Belknap rhyolite is highly altered in places, but significant uranium mineralization has taken place only where the contact is slickensided in addition to the alteration. In a few places ore bodies are enlarged beneath glassy agglomerate at the base of the Mount Belknap rhyolite, and elsewhere uranium minerals are concentrated at the contact of quartz monzonite and rhyolite.

At least two main periods of hydrothermal alteration have affected the rocks of the Marysvale area. An early period of alteration, which is in no way related to the later primary uranium mineralization, is most pronounced in the Bullion Canyon voleanics and is characterized by the development of alunite. However, some hydrated hexavalent uranium minerals are associated with alunitic and clay-alteration zones in a few properties (Wyant, 1951, written communication; Stugard and others, 1952). The quartz monzonite, granite, and Mount Belknap rhyolite have been affected by a later period of hydrothermal alteration in which clay minerals were formed, chlorite was either introduced or formed at the expense of biotite, and the rocks were locally silicified. Although many uranium-bearing structures accompany or are enclosed by rocks showing this type of alteration, evidence for a genetic relation is either poor or lacking. Commonly the envelope of altered wall rock thins perceptibly with depth and in deeper workings is absent adjacent to most veins. The clay alteration may be a result of near-surface oxidation of pyrite. A thin alteration zone marked by red hematite around some ore bodies occurs principally in the primary zone; but at places, it persists into the zone of supergene alteration.

Uranium mineralization is later than the Mount Belknap rhyolite as indicated by the presence of fluorite, pyrite, and pitchblende in rocks of this sequence; the rocks also have been altered, probably by the solutions that introduced the vein minerals. The deposits are thought to be of Pliocene age, as the pitchblende and its associated minerals are localized in structures probably related to the large high-angle Pliocene faults.

\section{PRIMARY ORE DEPOSITS}

Pitchblende, associated principally with quartz or chalcedony, fluorite, pyrite, and adularia, occurs in several vein types and is known to have a vertical range of at least 2,000 feet in the Marysvale area. Other minerals in or near the pitchblende-bearing veins are calcite, jordisite, hematite, magnetite, and marcasite. These minerals may have a more restricted distribution than the common gangue minerals.

Pitchblende has several modes of occurrence in the Marysvale area. Most of the pitchblende is associated intimately with fluorite, pyrite, and locally with molybdenum minerals in dark-purple to black veins, vein stockworks, lenticular and irregular masses, and breccia cement. In the dark vein filling, some of the pitchblende occurs as fine-grained discontinuous thin veinlets alternating with thin layers of coarse purple fluorite and layers composed of fine-grained fluorite, pyrite, quartz, and adularia; and some occurs disseminated in a fine-grained black friable matrix composed of fluorite, pyrite, probably quartz and adularia, and clay or fault gouge. Pitchblende, associated with pyrite and adularia, is disseminated in a few brecciated chalcedonic veins. Some of the richest pitchblende concentrations replace the matrix and fill interstices of brecciated finegrained quartz. Pitchblende also occurs separately às isolated small pods, lenses, or disseminations in altered wall rocks, as fillings in elongate flow vesicles near the walls of late Tertiary rhyolite dikes, as thin coatings on joint and fracture surfaces, and in small amounts as replacements in hydrothermally altered wall rocks. The pitchblende occurs in a soft powdery form and in hard lustrous masses; some of the powdery pitchblende, particularly that on joint and fracture surfaces, is thought to be secondary, although none of its associated minerals show evidence of oxidation except near the boundary between the zones of secondary uranium minerals and primary pitchblende.

The dominant gangue minerals are quartz or chalcedony, fluorite, pyrite, and adularia. Most of the vein quartz in the principal mine area is clear to milky white, but near concentrations of pitchblende it is smoky to almost black. Purple to amost black fluorite, either in coarse crystals or in fine-grained powdery masses, is present in virtually all pitchblende-bearing veins; the fluorite content in most veins increases with depth. Colorless or pale-green fluorite is present in alteration halos around uranium-bearing veins and also occurs in separate veins. Pyrite is much more widespread than the pitchblende, and in places unaltered masses remain scattered through the zone of supergene alteration almost to the ground surface. In general, pyrite 
pyritohedra occur in rocks near the veins; and cubes, near barren structures. Adularia occurs both as a gangue mineral in the veins and as a devitrification product of the semiglassy groundmass of the Mount Belknap rhyolite. At places adularia is associated closely with pitchblende and abundant fluorite in the dark veins and at other places occurs as disseminated crystals in pitchblende-bearing chalcedonic veins in which fluorite is a minor constituent; locally, it is also found as euhedral crystals lining vugs in dark-purple fluorite.

Other gangue minerals associated with the pitchblende are magnetite, hematite, marcasite, and jordisite. Fine granular magnetite and zones of red hematitic alteration in which hematite flakes have been deposited selectively on either feldspar grains or their alteration minerals are commonest near pitchblendebearing ore shoots and veins. The hematite alteration zones are near concentrations of fluorite and pitchblende and are commonest within 5 feet of uranium ore. Marcasite, showing cockscomb structure, was identified only in one vein in which it was intimately banded with pitchblende and fluorite. The distribution and relations of tentatively identified siderite are but poorly recorded. Jordisite, black amorphous molybdenum disulfide, occurs close to several veins, particularly near vein pinchouts, and locally in the primary veins themselves.

\section{SECONDARY MINERALS}

The assemblage of secondary uranium minerals reported at Marysvale includes autunite, torbernite, metatorbernite, phosphuranylite, uranophane, $\beta$-uranotil, schroeckingerite, zippeite, johannite, uranopilite, tyuyamunite, and rauvite; other minerals that may be of secondary origin are sooty pitchblende and umohoite. Nonuranium secondary minerals, including iron and manganese oxides, ilsemannite, carbonates, and gypsum are locally present in the Marysvale deposits.

\section{SECONDARY URANIUM MINERALS}

Ore-grade concentrations of secondary uranium minerals in the Marysvale area commonly represent the near-surface altered extensions of pitchblende- and fluorite-bearing ore shoots or veins at depth. Alteration and solution of primary uranium minerals and redeposition of secondary ones occurred essentially in place. Most of the secondary uranium minerals occur within the vein structures although locally some concentrations are as far as 10 feet from the veins. The assemblage of secondary uranium minerals varies, in part, with respect to the type and degree of alteration of wall rocks, to the primary mineralogy of the veins, and to the depth beneath the ground surface. Some data on the distribution of the secondary uranium minerals have been obtained from reports by Kaiser (1952), Kerr and others $(1952,1953)$, Taylor and others (1951), and Granger and Bauer and Wyant (written communications, $1950-51$ ).

In some parts of the principal mining area, secondary uranium minerals extend as much as 400 feet beneath the ground surface, whereas in other parts of the area they extend only a few tens of feet. Throughout the area, the interface between the zone of hard pitchblende and the zone of secondary minerals is extremely irregular and is probably related to fracture permeability associated with faults rather than to any static water table.

Phosphates and silicates.-In general, the uranyl phosphate and silicate minerals are more abundant at Marysvale than are other secondary uranium minerals. Mostly they fill fractures or coat fracture surfaces, but some of the uranyl phosphates are disseminated in veins and wall rocks. These minerals, with the possible exception of phosphuranylite, are concentrated within a few feet of the originating pitchblende-bearing veins or their altered counterparts. Phosphuranylite was identified from only one locality where it is in a zone of alunitic alteration in Bullion Canyon voleanic rocks; no primary uranium minerals were found at this locality. Autunite, torbernite, and metatorbernite are rare or lacking in surface outcrops and are found principally as disseminations and fracture coatings in argillized quartz monzonite 10 feet or more beneath the ground surface. Autunite, one of the most abundant of the secondary minerals, was identified in partly oxidized veins at a depth of 400 feet and hence has a relatively large vertical range. Although torbernite and metatorbernite commonly are intimately associated with the autunite, they have not been found over as great a vertical range nor are they as common in the oxidized veins.

Uranophane and $\beta$-uranotil occur only as fracture coatings and veinlets in quartz monzonite, granite, and rhyolite; they were not found disseminated in any of these rock types. Concentrations of these minerals occur from the surface to depths of 200 feet but are most common within 10 feet of the originating vein. - They are most abundant in surface or near-surface exposures, indicating that they are the most stable of the secondary minerals at Marysvale under near-surface weathering conditions. They are also abundant at the contact between quartz monzonite and the overlying rhyolites and in fractured quartz veins and areas of wall-rock silicification. These two minerals are probably the most abundant of all secondary uranium minerals at Marysvale.

Sulfates and a sulfocarbonate mineral.-The uranyl sulfates zippeite, uranopilite, and jobannite mostly 
form encrustations on mine walls; they are rare or absent in freshly broken ground. Schroeckingerite, a hydrated fluosulfocarbonate of sodium, calcium, and uranium, is commonest as fracture coatings, but in places it is disseminated in altered quartz monzonite. In a few places it has been found in altered rhyolite. Some schroeckingerite forms encrustations and crystals on the walls of underground workings. Virtually none was found in surface outcrops, but it is a common constituent of oxidized veins from about 10 feet below leached outcrops to depths of about 100 feet.

Vanadates.-The uranyl vanadates tyuyamunite and rauvite have not been found in the principal mine area but have been reported from a prospect a few miles from the nearest known occurrence of pitchblende. At this prospect minor amounts of the minerals are associated with uranyl phosphate minerals, principally as fracture coatings.

Oxides.-Some of the pitchblende is powdery black and occurs as fracture coatings and thin seams on primary vein minerals; pitchblende of this character is thought to be secondary. The sooty pitchblende occurs in quartz monzonite, granite, and rhyolite that show different degrees of argillic alteration or silicification. Although it has been found within 60 feet of the ground surface, most of the sooty pitchblende is concentrated near the interface between the oxidized and the unoxidized parts of the veins. Minerals associated with the powdery black pitchblende show little evidence of oxidation except near this interface.

Hydrous uranium molybdate, $-\mathrm{A}$ new mineral was discovered in the principal mine area at Marysvale in 1952 and was subsequently described and named umohoite by P. F. Kerr and others $(1953$, p. 45-51). The mineral is hexagonal, black to bluish black with a bright submetallic luster, and foliated or platy. The chemical composition indicates that it is essentially a hydrous uranium molybdate. It occurs as thin veinlets or disseminated specks in uranium-bearing veins associated either with fluorite, pyrite, quartz, and pitchblende or with jordisite and ilsemannite or alone. Although very little is known concerning the distribution of umohoite, the principal occurrence is just below the oxidized zone in argillized quartz monzonite associated with pitchblende- and fluorite-bearing veins that also contain jordisite and ilsemannite. Most of the umohoite does not occur with the other vein minerals but has been preferentially deposited in thin veinlets and disseminated crystals in the altered quartz monzonite adjacent to the vein. Although P. F. Kerr and others (1953) considered umohoite to be a primary uranium mineral, umohoite may be secondary because it is hexavalent, has a relatively high water content, and is concentrated just below the zone of supergene alteration.

\section{OTHER SECONDARY MINERALS}

Supergene alteration of the pitchblende- and fluoritebearing veins and their enclosing rocks has produced, in addition to secondary uranium minerals, hydrated iron oxides, ilsemannite (a complex molybdenum sulfate), oxides of manganese, a pinkish carbonate, calcite, and gypsum. The hydrated iron oxides are distributed widely in the area but commonly are lacking in the moderately altered quartz monzonite of the high-grade ore shoots; locally, hydrated iron oxides and secondary uranium minerals occur on the same joint. J. W. Gruner and others (1951, p. 248) have pointed out that some, if not all, of the hydrated iron oxides are goethite and that most of the secondary uranium minerals are later than goethite. The ilsemannite occurs closely associated with jordisite, from which it has been derived, in some of the pitchblende-bearing veins.

\section{ORIGIN OF SOME URANIUM MINERALS}

The near-surface ore-grade deposits of hydrated hexavalent uranium minerals have been previously attributed solely to the oxidation of pitchblende-bearing veins, although available evidence suggests that some of these uranyl minerals and part, if not all, of the sooty pitchblende may have been deposited directly by warm solutions, either juvenile water or heated phreatic water.

The deposits of hexavalent uranium minerals are the near-surface expression of quartz-fluorite-pyriteadularia-pitchblende veins; the uranium content in both oxidized and unoxidized deposits is essentially the same. Some of the near-surface deposits of hexavalent uranium minerals do not appear to contain as much fluorite and pyrite as do the pitchblende-bearing veins. In addition, hexavalent uranium minerals at Marysvale are not widely dispersed, as might be expected if oxygenated eirculating ground water had altered primary pitchblende and deposited the uranyl minerals,

The mineralogy and character of the pitchblendebearing veins, particularly in their upper parts, indicate they probably were emplaced under a shallow cover and under conditions of low temperature and pressure (Gruner and others, 1951, p. 251; Taylor and others, 1951, p. 15). A. O. Taylor and others (1951) suggest that the near-surface deposits may be related to solfataric or fumarolic processes. Under these conditions a change in the redox potential of rising uranium-bearing thermal solutions could cause reaction of uranium with available phosphate, sulfate, carbonate, or silicate anions derived through alteration of the wall rocks or from other sources. From such reaction direct precipitation of uranyl phosphate, silicate, carbonate, or sulfate minerals might be expected. 
Although some of the hexavalent uranium minerals were undoubtedly derived essentially in place from oxidation of primary pitchblende ores, some are thought to have been deposited, where suitable conditions were met, by direct precipitation from the same solutions, or ones similar to those, that deposited pitchblende at depth under reducing conditions. A similar hydrothermal process of deposition for some uranyl minerals has been postulated by E. Kohl and H. Haller (1934) for deposits at Wölsendorf.

\section{GEOLOGICAL COMPARISON WITH OTHER AREAS}

The uranium deposits at Marysvale have some characteristics in common with deposits in the Boulder batholith, Montana, and at Wölsendorf, Germany. Primary uranium ores at Marysvale and in the Boulder batholith are concentrated in siliceous veins and shoots within the veins. The mineralogy of the primary veins differs principally in (1) the relatively abundant fluorite and adularia at Marysvale, neither of which have been found in deposits in the Boulder batholith, (2) the greater abundance of pitchblende at Marysvale, and (3) the reported presence of minor amounts of galena, ruby silver, argentite, native silver, chalcopyrite, and arsenopyrite in the Boulder batholith deposits (Roberts and Gude, 1953, p. 132; Thurlow and Reyner, 1950, p. 9 ; Becraft, 1953, p. 7). At both Marysvale and in the Boulder batholith hexavalent uranium minerals, principally uranyl silicates, phosphates, and carbonates, appear to have been formed essentially in place by oxidation of primary ore. The most abundant and widely distributed secondary uranium mineral in the Boulder batholith deposits is uranophane; other secondary minerals include metatorbernite, metazeunerite, autunite, uranocircite (barium analogue of autunite), phosphuranylite, voglite, gummite, and rutherfordine. These minerals occur close to pitchblende-bearing veins or their altered counterparts as does a somewhat similar assemblage of secondary uranium minerals at Marysvale. Phosphuranylite near primary pitchblende in the Boulder batholith deposits is the one notable exception; it is far removed from any known occurrences of pitchblende at Marysvale.

The siliceous veins at Wölsendorf, Germany, contain a relatively large amount of fluorite (Kohl and Haller, 1934) and are reported to contain very minor amounts of chalcopyrite, bornite, sphalerite, pyrite, linnaeite (?), and stolzite. The fluorite contains pitchblende from which a series of secondary minerals has formed. E. Kohl and H. Haller (1934) separated the secondary minerals into two groups, those formed by ground-water alteration, including gummite, uranophane, fourmarierite, uranocircite, torbernite, and autunite, and those formed by hydrothermal alteration, including sooty pitchblende, ianthinite, uranophane, torbernite, autunite, and fourmarierite. The distinction between the two groups was made on the basis of paragenesis, distribution of minerals with respect to the water table and zone of oxidation, and the distribution of minerals with respect to cracks, fractures, holes, and druses. The ubiquitous uranophane, the sooty pitchblende, and the torbernite and autunite suggest a similarity to Marysvale, and it may be that the sooty pitchblende, umohoite, and part of the uranophane, autunite, and torbernite at Marysvale were also formed by hydrothermal alteration of primary pitchblende ores.

\section{CONCLUSIONS}

Concentrations of hexavalent uranium minerals at Marysvale are the near-surface extensions of pitchblende- and fluorite-bearing veins at depth. The veins, emplaced in faults and shear zones in Tertiary volcanic and intrusive rocks, are probably of early to middle Pliocene age. Some of the richest ore, which is about the same grade in the oxidized and unoxidized parts of veins, occurs in steeply plunging shoots at intersections of different fault sets or at places where faults change strike; some ore is concentrated at the contact of the quartz monzonite and the overlying rhyolite. Hydrothermally altered wall rock accompanies some of the uranium-bearing structures, but in general, the zones of alteration thin with depth and are absent adjacent to veins exposed in lower mine workings. Although most hexavalent uranium minerals are thought to have been derived essentially in place from oxidation of primary pitchblende, some of the uranyl minerals, notably umohoite, and part of the uranophane, autunite, and torbernite, and some of the sooty pitchblende are thought to have resulted from the action of thermal solutions either by direct precipitation or by hydrothermal alteration of primary pitchblende.

\section{REFERENCES CITED}

Becraft, G. E., 1953, Preliminary report on the Comet area, Jefferson County, Mont.: U. S. Geol. Survey Circ. 277, 8 p.

Callaghan, Eugene, 1939, Volcanic sequence in the Marysvale region in south-central Utah: Am. Geophys. Union Trans. 20th Annual Meeting, pt. 3, p. 438-452.

Eardley, A. J., 1949, Structural evolution of Utah, in Hansen. G. H., and Bell, M. M., The oil and gas possibilities of Utah: Utah Geol. and Mineralogy Survey, p. 11-23.

Gruner, J. W., Fetzer, W. G., and Rapaport, Irving, 1951, The uranium deposits near Marysvale, Piute County, Utah: Econ. Geology, v. 46, p. 243-251. 
Kaiser, E. P., 1952, The Papsy's Hope autunite prospect, Marysvale district, Piute County, Utah: U. S. Geol. Survey TEM-145A, 10 p., issued by U. S. Atomic Energy Comm. Tech. Inf. Service, Oak Ridge, Tenn.

Kerr, P. F., Brophy, G. P., and others, 1952, Annual report for July 1, 1951 to June 30,1952 , Part I, A geologic guide to the Marysvale area: U. S. Atomic Energy Comm. RMO-924, 56 p., issued by U. S. Atomic Energy Comm. Tech. Inf. Service, Oak Ridge, Tenn.

Kerr, P. F., Hamilton, Peggy-Kay, Brophy, G. P., and others, 1953, Annual report for June 30, 1952 to April 1, 1953: U.S. Atomic Energy Comm. RME-3046, 99 p., issued by U. S. Atomic Energy Comm. Tech. Inf. Service, Oak Ridge, Tenn.

Kohl, E., and Haller, H., 1934, Die Mineralführung der Wölsendorfer Flusspatgänge: Zeitschr. für prakt., Geologie, v. 42 , p. $69-79$.
Roberts, W. A. and Gude, A. J., 3d, 1953, Uranium-bearing deposits west of Clancey, Jefferson County, Mont.: U. S. Geol. Survey Bull. 988-F, p. 123-141.

Stugard, Frederick, Jr., Wyant, D. G., and Gude, A. J., 3d, 1952, Secondary uranium deposits in the United States, in Selected papers on uranium deposits in the United States: U. S. Geol. Survey Circ. 220, p. 19-25.

Taylor, A. O., Anderson, T. P., O'Toole, W. L., and others, 1951, Geology and uranium deposits of Marysvale, Utah: U. S. Atomic Energy Comm. RMO-896, 29 p., issued by U. S. Atomic Energy Comm. Teeh. Inf. Service, Oak Ridge, Tenn.

Thurlow, E. E., and Reyner, M. L., 1950, Free Enterprise uranium prospect, Jefferson County, Mont,: U. S. Atomic Energy Comm. RMO-678, 13 p., issued by U. S. Atomic Energy Comm. Tech. Inf. Service, Oak Ridge, Tenn. 



\title{
URANIUM IN THE FLUORSPAR DEPOSITS OF THE THOMAS RANGE, UTAH
}

\author{
By Mortimer H. Staatz and Frank W. Osterwald, U. S. Geological Survey
}

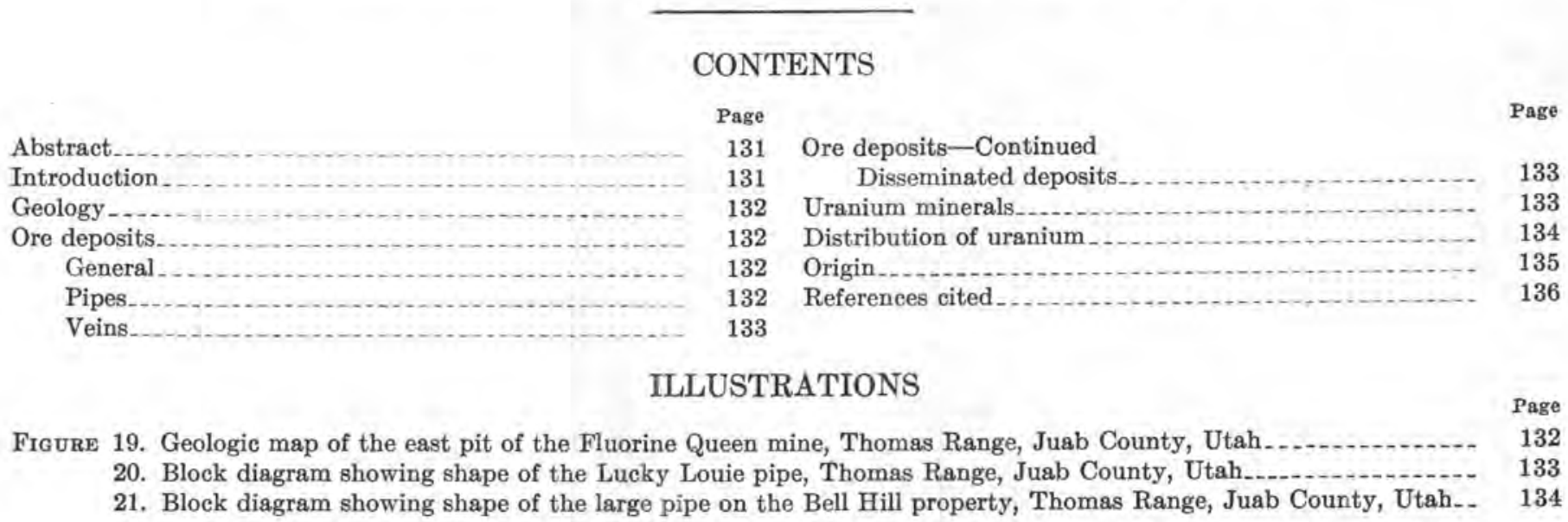

\section{ABSTRACT}

Uranium-bearing fluorspar deposits on Spors Mountain in the western part of the Thomas Range, Juab County, Utah, constitute the largest known reserve of uraniferous fluorspar in the United States.

Spors Mountain is made up largely of a thick sequence of conformable Ordovician to Devonian sedimentary rocks, most of which are limestone and dolomite; the fluorspar deposits are in dolomite of Middle Silurian age. Many small voleanic plugs and dikes intrude the sedimentary rocks. The roeks of the district are cut by close-spaced and complex faults.

The uraniferous fluorspar deposits have three structural habits: (1) oval to irregular pipes, (2) veins, and (3) disseminated deposits. The fluorspar occurs chiefly in the pipes. These differ considerably in size and are for the most part adjacent to faults or adjacent to intrusive breccia bodies. The ore, containing 65-94 percent fluorite, closely resembles brown, white, or purple clay, and forms either soft pulverulent masses or boxworks. The pipelike ore bodies commonly become smaller and lower in grade with depth.

Uranium contents of 155 fluorite samples range from 0.003 to 0.33 percent. The uranium eontent of some individual deposits varies systematically vertically and nonsystematically horizontally. Other deposits show no systematic vertical variation. At most deposits uranium is enriched near the surface, presumably as a result of leaching of uranium from the upper part of the deposit and redeposition by adsorption in the dry underlying fluorite a few inches to as much as 30 feet below the position from which it was removed.

The fluorspar is believed to have been formed from fluorinerich fluids carrying minor amounts of uranium, which rose along faults and shattered zones in the dolomite. These fluids prob-
\end{abstract}

ably were derived from the same source that formed abundant topaz in rhyolites that make up most of the eastern half of the Thomas Range. The uranium was originally dispersed throughout the fluorite, probably within the crystal structures.

\section{INTRODUCTION}

The largest known uraniferous fluorspar deposits of the United States are in the western part of the Thomas Range (lat $39^{\circ} 45^{\prime}$ N., long $113^{\circ} 10^{\prime}$ W.), Juab County, Utah, but like the other known uraniferous fluorspar areas in the United States, this district has not been important as a source of uranium. The term "fluorspar" applies to the deposit as a whole or the mined product as differentiated from the mineral fluorite $\left(\mathrm{CaF}_{2}\right)$, the chief constituent of these deposits.

The Thomas Range is a northwest-trending group of mountains in the eastern part of the Basin and Range physiographic province. It consists of an eastern block 12 miles long by 3-6 miles wide composed of Tertiary(?) rhyolites and tuffs and a western rugged mountain mass called Spors Mountain (Fitch, Quigley, and Barker, 1949 , p. $63-66$ ) which is about 6 miles long and $1 \frac{1}{2}-2$ miles wide and composed mainly of extensively faulted early tormiddle Paleozoic sedimentary rocks. The uraniferous fluorspar deposits are restricted to the western part of the range.

In 1943 the first fluorspar produced in the area came from the Floride mine near the southern end of Spors 
Mountain. No other deposits were known until 1948 when the Blowout, Dell Nos. 1, 2, and 5, Eagle Rock, Fluorine Queen, Hillton, Lost Sheep, Nonella, and Oversight deposits were discovered in the northern mountains. The Lucky Louie was found in the southern end of Spors Mountain in 1948, and the Bell Hill and Harrisite bodies were discovered in 1949.

Total production from the district to January 1, 1953 , was 75,000 short tons of ore containing from 65 to 94 percent fluorite. The ore was used for metallurgical purposes and was not milled before shipment. Mining was by both opencut and underground methods.

\section{GEOLOGY}

The rocks of Spors Mountain are chiefly marine limestone, shale, quartzite, and dolomite ranging in age from Early Ordovician to Middle Devonian (Thurston, Staatz, Cox, and others, 1954 , p. 26-28). The complete sequence consists of limestone of Early Ordovician age overlain conformably by shale and quartzite of Middle Ordovician age, dolomite of Late Ordovician age, five dolomite formations of Silurian age in an apparently conformable sequence, dolomite of Early Devonian age, and dolomite of Middle Devonian age. These rocks are cut by Tertiary (?) plugs and dikes of latite, rhyolite, and dellenite; voleanic explosion pipes filled with breccia are common along the east side of Spors Mountain. Volcanic flows and tuffs of probable Tertiary age surround the Paleozoic sedimentary rocks.

All Paleozoic and Tertiary rocks strike northeast and dip gently northwest. The district is cut by at least five sets of closely spaced faults, but no folds have been recognized. Three sets of faults are older, and two sets are younger than the volcanic rocks.

\section{ORE DEPOSITS}

\section{GENERAL}

More than 40 fluorspar deposits, excluding small veins, are known on Spors Mountain. These deposits are divided into three types: pipelike bodies (figs. 19-21), veins, and disseminated deposits. The fluorite in the ore bodies closely resembles, brown, white, or purplish clay that occurs either as soft pulverulent masses or as boxworks. The most abundant ore is soft, wbite to dark purple, and pulverulent. Two small deposits in the northern part of the range are made up entirely of brown boxwork-type ore. Some deposits contain both boxwork and pulverulent ore; in these the boxworks are commonly pale purple.

Individual fluorite grains approach clay particles in size. White waxy montmorillonite, well intermixed with fluorite, is the chief impurity; quartz, chalcedony, dolomite, calcite, and opal are the other gangue min-

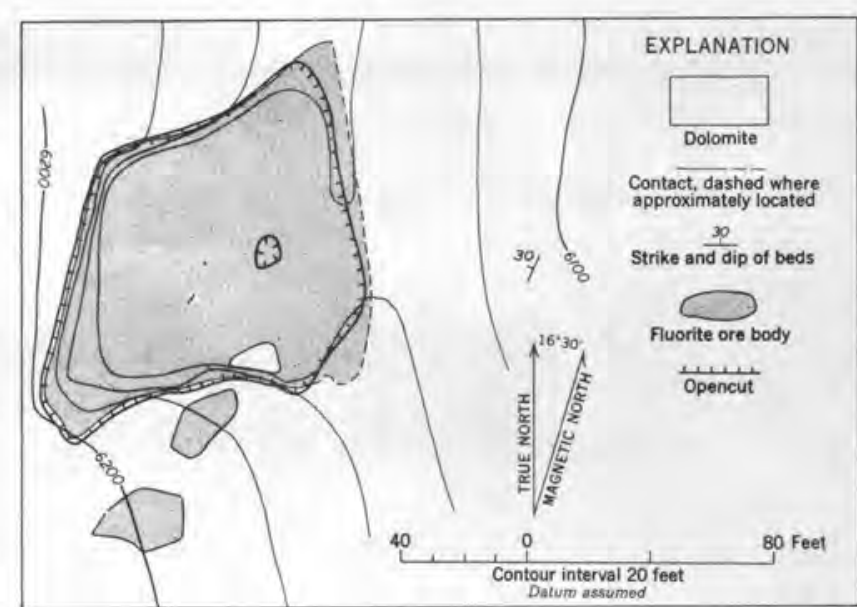

Frevre 19.-Geologic map of the east pit of the Fluorine Queen mine, Thomas Range, Juab County, Utah.

erals. The assemblage of gangue minerals changes from deposit to deposit, and no deposit contains them all. Sulfide minerals are completely absent. Uranium occurs in carnotite, in an unknown uranium silicate, and in fluorite.

The fluorspar bodies have sharp contacts with adjacent dolomite; no alteration of country rock is recognizable even at the largest deposits.

\section{PIPES}

The pipelike bodies are by far the most important deposits in the district; 19 of the 21 deposits from which ore has been produced were of this type, and they yielded 99.95 percent of the total production. The pipes are oval (figs. 19 and 20) to highly irregular (fig. 20) in plan. All pipes have steep walls, and in many the walls are highly irregular. A few pipes are vertical, but most plunge steeply to the northeast or southeast. The Bell Hill ore body changes plunge at about 100 feet below the surface from $52^{\circ} \mathrm{N} .62^{\circ} \mathrm{E}$. to $70^{\circ} \mathrm{S} .81^{\circ} \mathrm{E}$.

At the surface the pipes range from less than a foot in diameter to 155 feet long and 106 feet wide (figs. 19-21). Although a few of the ore bodies are remarkably uniform in size and shape, most become smaller with increasing depth, and a few pinch out abruptly. The Lucky Louie pipe (fig. 20) was 35 feet by 14 feet at the surface, but only 10 feet by 7.5 feet at a depth of 120 feet. The main ore body of the Bell Hill mine (fig. 21) is $\mathrm{H}$-shaped in plan at the surface but lenticular at the 60 -foot level. The shape of some deposits is changed by large horses of dolomite.

The pipes cut all dolomite formations older than Devonian and younger than the quartzite of Middle Ordovician age. Most pipes are either in or adjacent to faults or adjacent to intrusive breccia bodies. Pipes associated with faults are chiefly in the southern part 


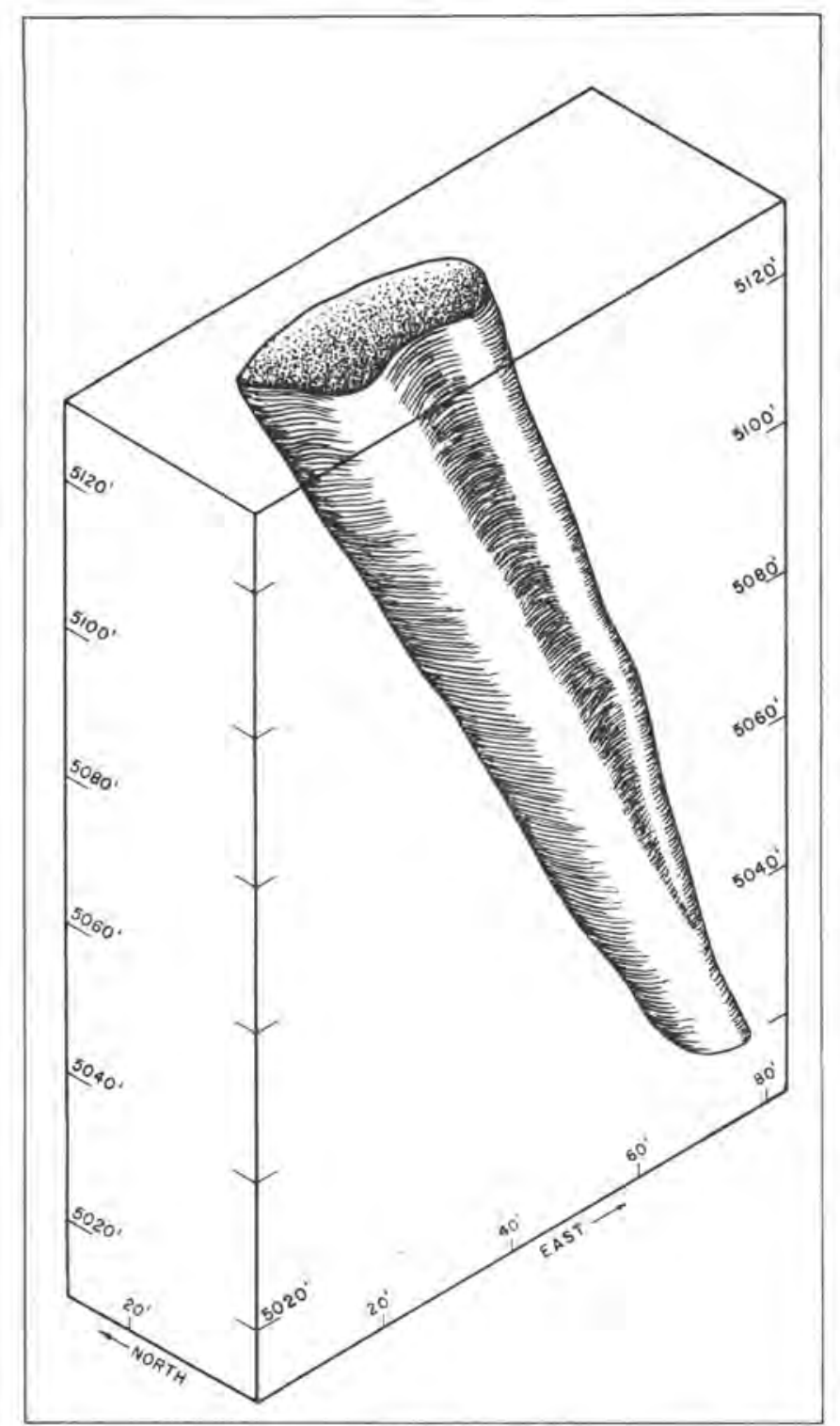

Fraurn 20.-Block diagram showing shape of the Lucky Loule pipe, Thomas Range, Juab County, Utah.

of the district and tend to be irregular in shape; pipes associated with intrusive breccia bodies are in the northern part of the district and tend to be oval in shape. A few ore bodies, however, are not associated with either faults or intrusive breccia bodies. Pipes that go as deep as the contact of the quartzite of Middle Ordovician age do not end abruptly but join with anastomosing veins as much as 6 inches wide that penetrate the quartzite for several feet.

The character of the ore in some deposits changes with increasing depth. The fluorspar of the Blowout pipe contained few impurities near the surface, but at 240 feet the fluorspar contained such large masses of montmorillonite associated with lesser amounts of quartz, calcite, and dolomite that mining ceased to be profitable. The Lucky Louie deposit was composed almost entirely of fluorite at the surface, but it contained angular pieces of chalcedony at a depth of 90 feet and consisted almost entirely of chalcedony at a depth of 120 feet. The main pipe at the Bell Hill mine was uniform in composition to about 130 feet in depth, but below this level a hard vuggy material consisting of quartz and light-colored dolomite appeared at either end of the ore body. Not all deposits, however, show these changes; the Dell ore body, for example, was mined to a depth of 200 feet with no reported change in composition.

\section{VEINS}

Veins, extremely variable in shape, are common throughout Spors Mountain. They range from a few inches to 220 feet long and from less than an inch to 14 feet thick. Most veins cut the same Paleozoic rocks as the pipes, but a few cut tuff. Fluorspar was mined only from the Thursday and Eagle Rock veins, and at neither did the production exceed 55 short tons.

\section{DISSEMINATED DEPOSITS}

Disseminated deposits occur in volcanic rocks along the south and west sides of Spors Mountain. The fluorite content of these rocks rarely exceeds 30 percent, and no attempt has been made to market ore from these deposits. The fluorite occurs in clay-rich layers in the tuff and in cavities and along fracture planes in rhyolite and latite. The deposits are poorly exposed, and little is known of their size and shape.

\section{URANIUM MINERALS}

Most of the fluorspar deposits are abnormally radioactive, but visible uranium minerals are scarce. Yellow powdery uranium minerals were observed at five deposits but were abundant only in the small Eagle Rock vein. These are secondary minerals consisting of at least two distinct species: carnotite, which was found at the Eagle Rock and Bell Hill properties, and an unknown uranium silicate obtained at the Harrisite property. Ordinarily these minerals coat fractures in dolomite or latite adjacent to the ore bodies; at only two properties did the fluorspar ore itself contain visible uranium minerals.

Vanadium and uranium have been found by analysis in fluorspar ore that contains no recognizable vanadium or uranium minerals. Ore from 3 pipes contained $2.5-$ 6.5 times more vanadium than required to form carnotite with the available uranium, and hence, some other vanadium mineral in addition to carnotite must be present. Ore from the main ore body of the Bell Hill mine, on the other hand, contained an excess of ura- 


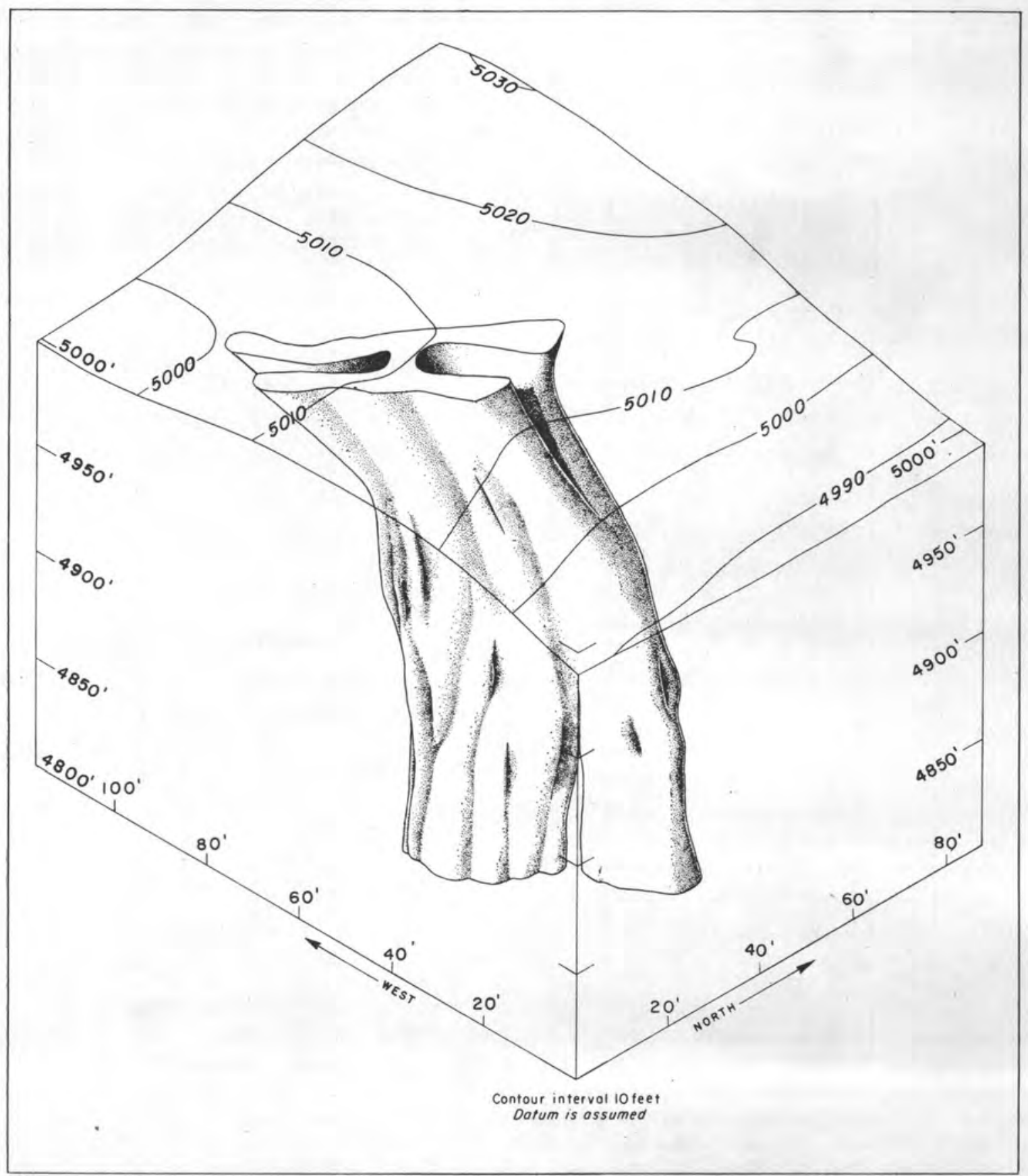

Figure 21.-Block diagram showing shape of the large pipe on the Bell Hill property, Thomas Range, Juab County, Utah.

nium with respect to vanadium, but the analyzed material from this mine was collected near the surface, where it may have been enriched in uranium by secondary processes. Autoradiographs of several ore specimens containing more than 0.10 percent uranium showed no concentration of uranium, but a rather uniform haze was formed across the whole picture. Heavy-mineral separates, some of which were centrifuged, contained no recognizable uranium minerals. Therefore, most of the uranium is probably in a ura- nium mineral of clay-size dimensions scattered through the fluorspar, or it is contained within the fluorite lattice.

\section{DISTRIBUTION OF URANIUM}

The uranium content of veins and pipes differs considerably. Fluorspar samples from throughout the district range from less than 0.003 to 0.33 percent uranium, but samples from only 4 deposits contained more than 0.10 percent uranium. Of these 4 deposits 
3 are small. The fourth deposit is the Bell Hill, which consists of at least 8 closely related pipelike ore bodies. Only 1 of these pipes yielded samples with more than 0.10 percent uranium, but this pipe is the only deposit in the entire district that has yielded a sample containing more than 0.20 percent uranium.

Although the uranium content of an individual deposit differs from place to place even on the same level, the gross uranium content does not change significantly from one place to another except near the surface where it increases sharply. At the large Fluorine Queen deposit near the middle of Spors Mountain (fig. 19), 3 samples from the surface contained 0.019-0.023 percent uranium, and 3 samples from an adit 64 feet below the surface contained 0.006-0.10 percent uranium. A similar decrease in uranium content was recognized in many deposits where workings cut the ore body 30 feet or more below the surface. This increase in uranium content near the surface appears not to be primary zoning but to be a supergene effect related to the present topographic surface.

In both the main ore body of the Bell Hill mine and the east ore body of the Fluorine Queen mine, this change in uranium content takes place near the surface, despite the fact that one of these deposits crops out 1,000 feet above the other. A similar change in uranium content has also been noted in the south ore body of the Lost Sheep mine and at the Oversight ore body, which erop out at intermediate altitude. Of these mines the Bell Hill was the only one developed on more than one level underground and was the only place where the relatively constant uranium content of the lower part of the ore body could be established. A series of samples was taken at the Bell Hill from the opencut, the six underground levels, and a drill hole. The samples from the drill hole and the six underground levels showed no greater deviation in uranium content than was found between individual samples from the same level. The samples from the uppermost level, 66 feet below the surface, and those from the openeut, 4-22 feet below the surface, showed a sharp and significant increase in uranium content above the 66-foot level.

Uranium is commonly dissolved in ground water, and many of its salts are highly soluble. D. M. Sheridan (1953, oral communication) has observed that in the Red Desert of Wyoming, a uranium deposit containing schroeckingerite moves annually with the rise and fall of the water table. The upper surface of a cement slab at the Red Bluff mine, Arizona, used for sorting and loading uranium ore, became impregnated with yellow uranium minerals after an ore pile was left on it through one winter. Similarly, the near-surface increase in uranium content of the Thomas Range deposits is probably caused by slow leaching of uranium from the upper part of the ore body, in part from material being actively eroded. The uranium is carried downward and redeposited in the dry underlying ore at some level between a few inches and about 30 feet below the surface. Yellow secondary uranium minerals occur only in the upper part of the ore bodies and are believed to have been formed during this secondary enrichment. As these minerals are scarce, however, part of the redeposited uranium is probably in other forms, possibly being adsorbed by the fluorite. Leaching would be slow because annual precipitation in the Thomas Range is small. R. L. Ives (1951, p. 783 ) reports about 5 inches of precipitation annually at Dugway, 32 miles to the northeast, the nearest place for which records are available.

Changes in uranium content cannot be connected with changes in grade of the fluorite ore. In fact, the uranium content of any two samples from any location within a pipe may vary in either direction with an increase in fluorite grade.

\section{ORIGIN}

The fluorspar deposits are believed to have been formed during the closing stages of the volcanism that formed the plugs and dikes on Spors Mountain. Fluorspar veins cut intrusive breccia bodies and agglomerate in many places; one small fluorspar pipe partly replaces a small intrusive breceia mass; and a fluorspar vein follows the contact between latite and dolomite. On the other hand, in the Bell Hill mine an intrusive rhyolite breccia cuts the fluorspar body.

Available chemical analyses (see table below) suggest

Chemical composition, in weight percent, of rhyolites from the Thomas Range, Utah

\begin{tabular}{|c|c|c|c|}
\hline & \multicolumn{3}{|c|}{ Samples t } \\
\hline & a & b & c \\
\hline $\begin{array}{l}\mathrm{SiO} \mathrm{O}_{2} \\
\mathrm{Al}_{2} \mathrm{O}_{3} \\
\mathrm{Fe}_{2} \mathrm{O}_{3} \\
\mathrm{FeO} \\
\mathrm{MgO} \mathrm{O}_{2} \\
\mathrm{CaO} \\
\mathrm{Na}_{2} \mathrm{O}_{2} \\
\mathrm{~K}_{2} \mathrm{O} \\
\mathrm{H}_{2} \mathrm{O}+\mathrm{P} \\
\mathrm{H}_{2} \mathrm{O} \\
\mathrm{TiO}_{2} \\
\mathrm{CO}_{2} \\
\mathrm{P}_{2} \mathrm{O}_{5} \\
\mathrm{MnO}\end{array}$ & $\begin{array}{r}\text { 73. } 30 \\
\text { 14. } 27 \\
.34 \\
\text { 1. } 89 \\
.13 \\
.34 \\
\text { 3. } 86 \\
\text { 4. } 76 \\
.39 \\
.11 \\
.03 \\
.06 \\
.03 \\
.07\end{array}$ & $\begin{array}{r}76.54 \\
12.16 \\
.92 \\
.37 \\
.14 \\
.78 \\
3.50 \\
4.97 \\
.11 \\
.05 \\
.09 \\
.16 \\
.02 \\
05\end{array}$ & $\begin{array}{r}74.49 \\
14.51 \\
.57 \\
.32 \\
\text { Trace } \\
1.03 \\
3.79 \\
4.64 \\
.64 \\
\\
\end{array}$ \\
\hline Total ............ & 99.58 & 99. 86 & 99. 99 \\
\hline
\end{tabular}

1 a. Rhyolite plug, Spors Mountain, Utah; L. M. Kehl, U. S. Geological Survey, analyst. b. Rhyolite flow, eastern part of the Thomas Range, Utah; L. M. Kebl, U. S. Geological Survey, analyst. c. Rhyolite flow, eastern part of the Thoms Range, Utah; L. G. Eskins, analyst (Washington, 19i7, p. 183). 
that the intrusive rocks of Spors Mountain and the volcanic rocks of the eastern part of the Thomas Range were derived from the same magma. This magma was rich in fluorine, as shown by the presence of topaz in both the intrusive and volcanic rocks. Topaz in vugs in rhyolite indicates that fluorine continued to be available after consolidation of the main rhyolite mass. Furthermore, secondary uranium minerals in the volcanic rocks in the eastern part of the Thomas Range suggest that the parent magma may also have been the source of the uranium.

The fluorspar deposits are formed by the replacement of the dolomite wall rocks by fluorine-rich fluids derived from the magma that formed the volcanic rocks. Relict structures indicate that replacement was the dominant form of emplacement. This is seen most clearly in the disseminated deposits, where the volcanic rocks are only partly replaced by fluorite. Chert layers in dolomite were traced without interruption into some ore bodies, and Silurian corals replaced by fluorite were found in three pipes.
The fluids that formed the fluorspar bodies could have been rather simple. Except for fluorine, uranium, aluminum, and hydrogen all the elements found in the uraniferous fluorite, montmorillonite, dolomite, quartz, chalcedony, and calcite, which constitute the ore bodies, are abundant in the cherty dolomite wall rocks. Both $\mathrm{Al}$ and $\mathrm{H}$ are abundant in the underlying shale of Middle Ordovician age, however; so only $\mathrm{F}$ and $\mathrm{U}$ need be added from a magmatic source.

\section{REFERENCES CITED}

Fitch, C. A., Jr., Quigley, J. E., and Barker, C. S., 1949, Utah's new mining district: Eng. and Min. Jour., v. 150, no. 3, p. 63-66.

Ives, R. L., 1951, Pleistocene valley sediments of the Dugway area, Utah: Geol. Soc. America Bull., v. 62, p. 781-797.

Thurston, W. R., Staatz, M. H., Cox, D. C., and others, 1954, Fluorspar deposits of Utah: U. S. Geol. Survey Bull. 1005, $53 \mathrm{p}$.

Washington, H. S., 1917, Chemical analyses of igneous rocks, published from 1884 to 1913 , inclusive, with a critical discussion of the character and use of analyses: U. S. Geol. Survey Prof. Paper 99, 1201 p. 


\title{
GEOLOGY OF THE LOS OCHOS URANIUM DEPOSIT, SAGUACHE COUNTY, COLORADO
}

\author{
By R. C. Derzay, U. S. Atomic Energy Commission
}

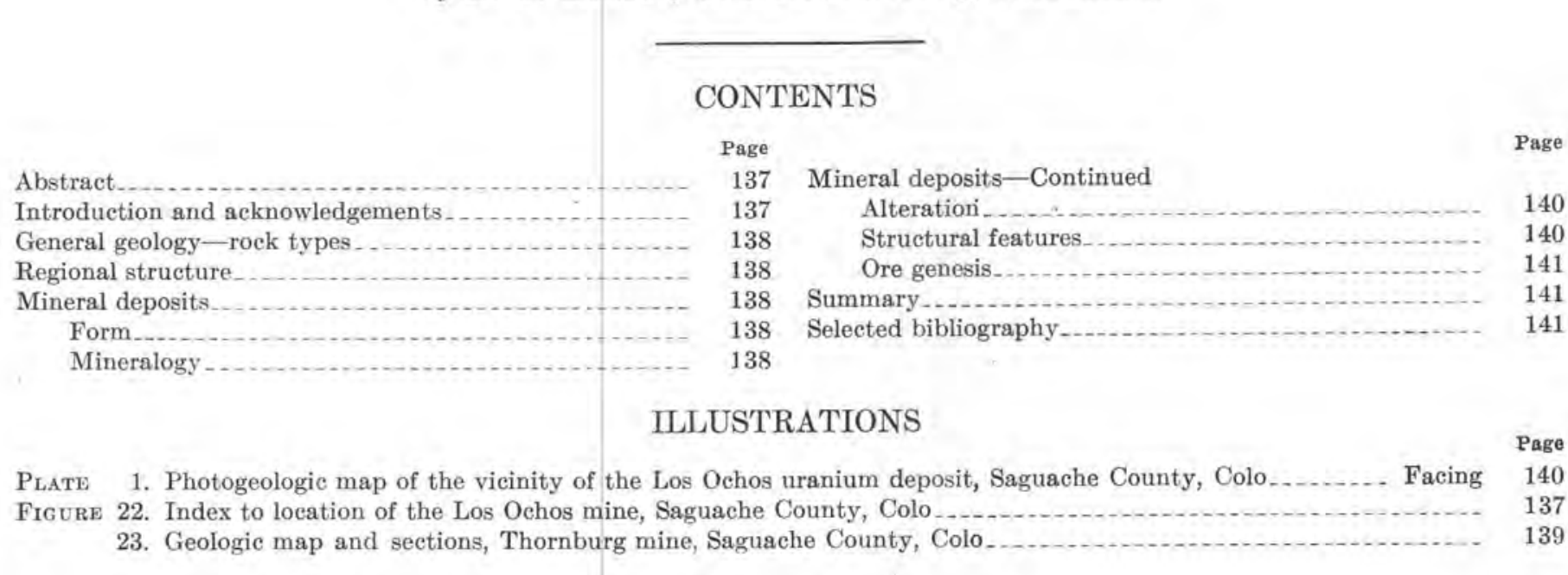

\section{ABSTRACT}

The Los Ochos mine is in the Cochetopa mining district, sec. 4, T. 48 N., R. 2 E., in the northwest corner of Saguache County, Colo.

The surrounding area is underlain by Precambrian schist, granite and gneiss, on which rest the Morrison (Jurassic), Dakota (Cretaceous), and Mancos (Cretaceous) formations. Faults in the Precambrian rocks, the Morrison and the Dakota formations, are favorable sites for the occurrence of uranium in the Cochetopa district.

In the mine area a major high-angle reverse fault (the Los Ochos fault), trending easterly is traceable for several miles. A steeply dipping northeast-trending pitchblende-bearing zone, intensely sheared at the contact of the granite and the Morrison formation, intersects the Los Ochos fault. The two faults form sides of an ore deposit that is triangular in horizontal cross section and essentially a steeply plunging "pipe." The ore body measures 82 feet along the northeast-trending shear, 85 feet in width, and 120 feet along the Los Ochos fault. It extends at least 60 feet above the drift and downward for an undetermined distance.

Mining of this deposit and exploration of nearby prospects indicate that intersections of northeast-trending shear zones and east-trending faults are important ore controls. Fractures in other directions may also have been controlling factors in ore deposition.

\section{INTRODUCTION AND ACKNOWLEDGMENTS}

The Los Ochos mine, of the Cochetopa district, is in sec. 4, T. 47 N., R. 2 E., New Mexico principal meridian, Saguache County, Colo. (fig. 22). It may be reached by driving 12 miles southward from the junction of U. S. Highway 50 and State Highway 114 and then 2 miles eastward on a haulage road. Gunnison, 8 miles west of the junction of Highways 50 and 114, is the nearest city with hotel, airport, and machinery facilities.

This district is at the northeastern edge of the San Juan voleanic province and on the western slope of the Sawatch Range, where Mesozoic sedimentary rocks lap onto Precambrian rocks.

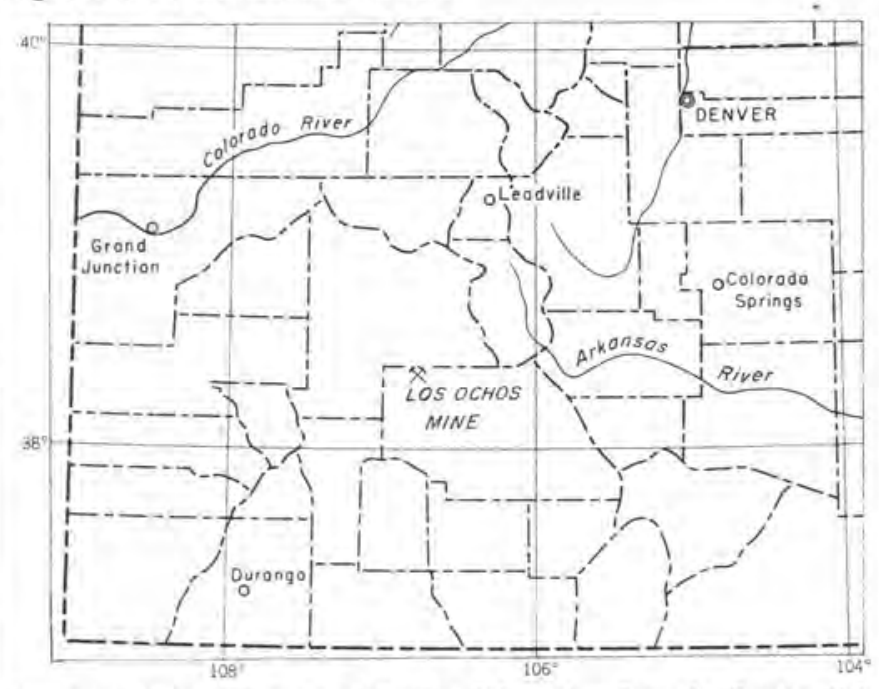

Fraure 22,-Index to location of the Los Ochos mine, Saguache County, Colo. 
The relief of the area is moderate, and the terrain consists of rolling hills covered with grass and sagebrush. Elevations range from 8,500 to 10,000 feet.

To the mine operators, Messrs. Garth and Vance Thornburg, the author is indebted for assistance and cooperation; Roger Malan, Atomic Energy Commission, assisted in mapping; Allan King, John W. Adams, and William Outerbridge, U. S. Geological Survey, performed numerous laboratory analyses. Donald L. Everhart made many constructive suggestions.

\section{GENERAL GEOLOGY-ROCK TYPES}

In the Los Ochos mine area mica schist, granite gneiss, and amphibolite schist of Precambrian age are intruded by granite, granite porphyry, syenite, aplite, and pegmatite and unconformably overlain by arenaceous sediment of Jurassic and Cretaceous age.

The intruded rocks, commonly grading from schist, through gneissic granite, to massive granite, have been thoroughly metamorphosed. The quartz-biotite schists are fine grained and characterized by salt-and-pepper appearance and minor hornblende. In places lit-par-lit injection by the granite may be seen.

The coarse-grained porphyritic pink- to light-red granite is composed essentially of quartz, biotite, microcline, and soda-rich plagioclase. Gray granite of similar texture occurs near the mineralized fault zones. All the gray granite seen has been altered; its feldspars have been destroyed, and decomposition of the biotite has begun, staining the rock with limonite.

The Morrison formation of Jurassic age, about 200 feet thick, lies on a relatively flat erosional surface cut in Precambrian rocks. The lower 60 feet, tentatively assigned to the Salt Wash member, is a white finegrained poorly cemented sandstone. The upper 140 feet, the Brushy Basin member, consists of a series of alternating thin variegated mudstones and sandstones. The mudstone is composed of quartz and clay minerals with some microcline and trace amounts of tourmaline.

The Dakota formation of Cretaceous age disconformably overlies the Morrison. The Dakota is here represented by about a 100-foot thickness of gray- to light-brown slightly silicified crossbedded sandstone with a thin conglomerate of cherty pebbles at the base.

The youngest sedimentary unit in the district is the Mancos shale, of Cretaceous age conformably overlying the Dakota. It is a dark-gray, drab, sandy shale, with a 10-foot-thick white lenticular sandstone at the base.

Quartz latite, andesite, and rhyolite dikes and flows of Tertiary age transgress or cover areas of older rocks.

\section{REGIONAL STRUCTURE}

Four sets of well-defined high-angle faults traverse the region. The best defined set trends east; the others trend northeasterly, north, and northwesterly (pl. 1). Some of the northeasterly faults transect the easttrending set, whereas others have been displaced by it. The north-trending set apparently postdates easttrending faulting. All of the faults are post-Mancos in age, probably Late Cretaceous or Tertiary.

Near the Los Ochos mine a major east-trending highangle reverse fracture, the Los Ochos fault, is traceable for several miles. The fault zone is $1-8$ feet in width, and the displacement ranges from 30 to 180 feet. Grooves on the fault plane observed underground pitch about $6^{\circ} \mathrm{W}$.

Two nearly parallel east-trending faults, 140 feet apart, have been exposed by physical exploration about 2,500 feet west of the mine. The southernmost of these has been mapped as the Los Ochos fault. The block between the two has been moved down and to the east; the two faults converge eastward. Hence, continuation of the mineralized fault may be expected about 100 feet north of the Los Ochos fault at the mine, where the faulted segment is displaced to the east and downward. The north side of the northernmost easterly-trending fault has moved to the west an undetermined distance.

\section{MINERAL DEPOSITS}

\section{FORM}

The ore deposit in the Los Ochos mine is a steeply plunging pipe with a triangular horizontal section. The ore body measures 82 feet along the northeast-trending shear, 85 feet in width, and 120 feet along the Los Ochos fault (fig. 23). Sporadic occurrence of secondary uranium minerals at the surface, on the projection of the pipe, suggests upward continuation of the ore, but extension of the pipe in depth is as yet undetermined.

Other northeast-trending shears, both east and west of the developed vein, and a few northwest-trending shears have been mapped (pl. 1). Preliminary exploration has indicated the presence of uranium along several of the northeast-trending shears. Fractures having a different trend have not yet been explored.

Faults in Precambrian rocks and the Morrison and Dakota formations are favorable sites for uranium oceurrences in the Cochetopa district. Volcanic rocks locally exhibit only low anomalous radioactivity, and no economic concentrations of uranium have been discovered in them. 


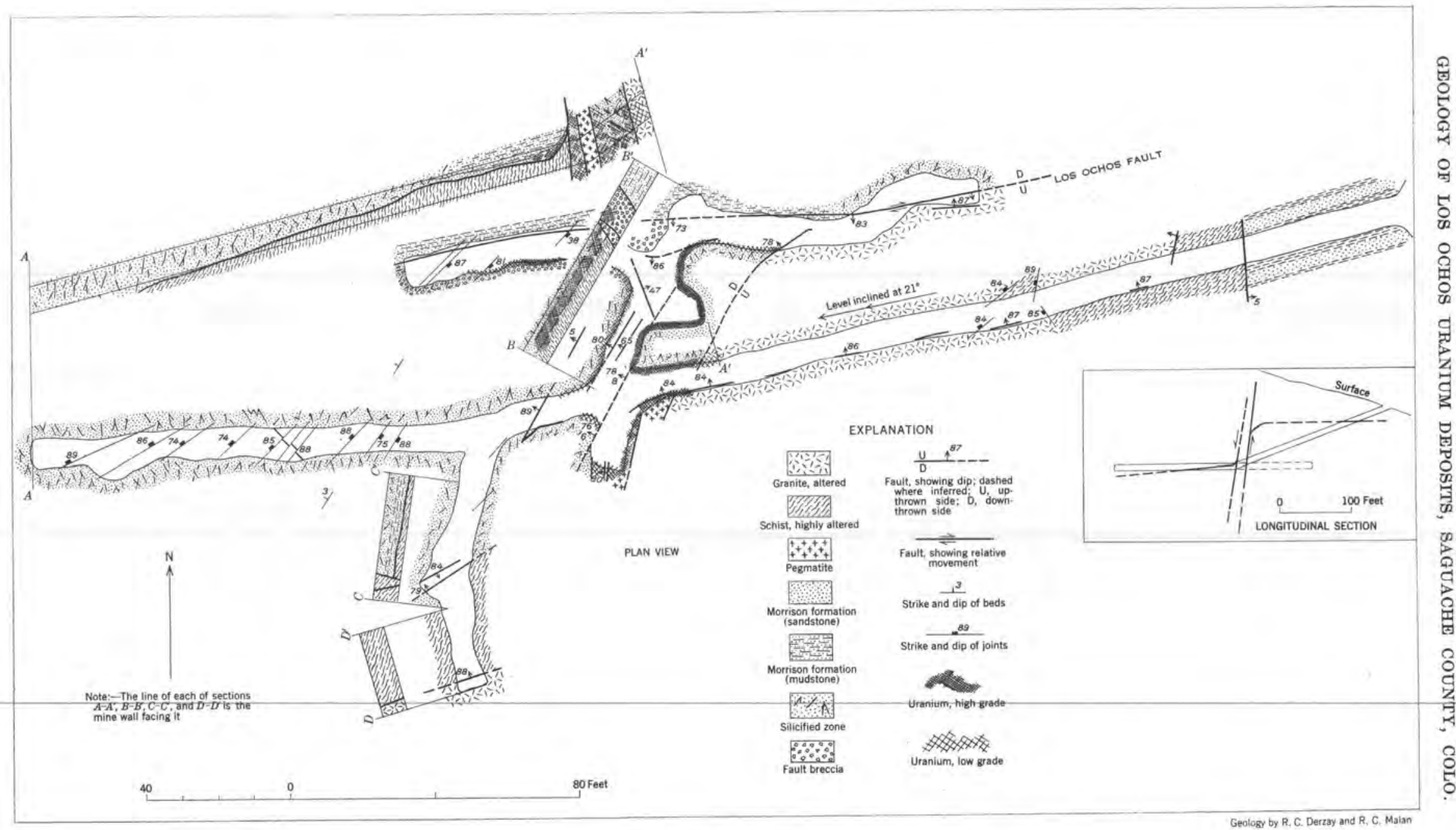

FIGURE 23.-Geologic map and sections, Thornburg mine, Saguache County, Colo. 


\section{MINERALOGY}

The deposit consists predominately of pitchblende that fills the interstices of brecciated sandstone of the Morrison formation and Precambrian granite and schist within the pipe. Studies of the ore show that a black sooty to massive type of pitchblende occurs in veinlets adjacent to clay masses and as finely disseminated grains in fractures. Small $(0.01 \mathrm{~mm})$ grains are also scattered through the quartz gangue.

Sparse yellow to orange-yellow secondary uranium minerals are associated with the pitchblende, notably in pegmatite-bearing zones. A deep-yellow velvety secondary uranium mineral appears on the mine walls after the vein has been exposed for several weeks. These minerals have been studied by X-ray diffraction methods but are not yet identified. Uranophane, autunite, and very sparse torbernite have been noted at the vein outcrop in the Morrison formation. They occur in the interstices of brecciated and recemented mudstone.

The primary mineral assemblage, believed to be epithermal, includes marcasite, chalcedony, and minor ilsemannite. The mareasite is finely disseminated, concretionary, and occasionally reniform. No copper minerals were identified megascopically; however, chalcocite, probably of secondary origin, was tentatively identified by microscopic examination; it appears as a core in small rounded grains of a yellow weakly anisotropic mineral. Spectrographic analyses have indicated traces of titanium, arsenic, barium, cadmium, cobalt, chromium, gallium, lanthium, nickel, lead, strontium, zinc, and zirconium.

Clear to very dark quartz masses, pods, and veinlets; chalcedony; and yellowish barite constitute the gangue minerals.

Based in part on laboratory studies of numerous specimens and in part on observed field relationships, the following sequence of events is indicated: Silicification, fracturing, introduction of marcasite A, fracturing, introduction of marcasite B, introduction of pitchblende, and introduction of kaolinite as fracture fillings. Marcasite A occurs as fracture fillings; marcasite B, which is more yellow, coats marcasite $\mathrm{A}$ in radial aggregates, cuts it in narrow veinlets, and is also found as discrete spherical aggregates within the clay areas of the veins. The sulfide mineralization was accompanied by the introduction of alunite.

\section{ALTERATION}

In the mine area intense hydrothermal alteration obscures much of the original nature of the rocks.
Silicification and kaolinization of the vein zone and wall rocks, where exposed by mining operations, are predominant. Chlorite, montmorillonite, illite, sericite, and iron oxides are also present.

Alteration has not proved an infallible indicator of ore bodies. The exploration heading driven westward from the bottom of the incline (fig. 23) disclosed varying degrees of alteration of the wall rock, but longhole drilling in the areas of intense alteration failed to intersect mineral concentrations of economic grade.

\section{STRUCTURAL FEATURES}

The Los Ochos fault is the most extensive fracture in the mine and is exposed throughout the length of a drift located about 50 feet north of the bottom of the incline (fig. 23). The strike differs locally but averages N. $84^{\circ} \mathrm{E}$., and the dip is $88^{\circ} \mathrm{S}$. This fault is exposed also in an open cut, about 2,500 feet west of the portal of the incline and may be traced for at least $3 \frac{11}{2}$ miles on the surface. It consists of $1-8$ feet of crushed and sheared material, with a persistent seam of gouge 4-12 inches wide. Displacement along this fault ranges from 30 to 180 feet. The north side moved downward, and mullion structure on the fault plane plunges about $6^{\circ} \mathrm{W}$. Movement along the fault occurred both before and after mineralization, for lenses of crushed pitchblendebearing rock are scattered within the fault material.

A second important fault may be traced for considerable distance from the mine. It strikes approximately N. $30^{\circ} \mathrm{E}$. and dips $83^{\circ}$ NW., its northern end terminating against the Los Ochos fault, which displaces it to the east. The fault is normal, the northwest side having moved downward about 65 feet. This fault contains a vein, which is 16 feet wide near the foot of the incline; the width increases rapidly to about 90 feet at the Los Ochos fault, where it forms the pipe or chimneylike ore body. The southern limits of the fault have not been completely explored. The uranium content is greatest at the contact of the granite with the Morrison formation, diminishing markedly in the joint and fracture planes of the granite and gradually in the more permeable Morrison formation.

A third fault, which appears to be upturned into the hanging wall of the northeast-trending shear zone and to then flatten to a dip of $3^{\circ}-5^{\circ} \mathrm{W}$., separates a zone of intensely silicified sandstone of the Salt Wash member above from a highly kaolinized schist below, $\left(A-A^{\prime}\right.$, fig. 23). The fault zone is marked by a dense lightgreen mudstone, which ranges from 6 inches to 2 feet in thickness, and may correlate with a similar zone 


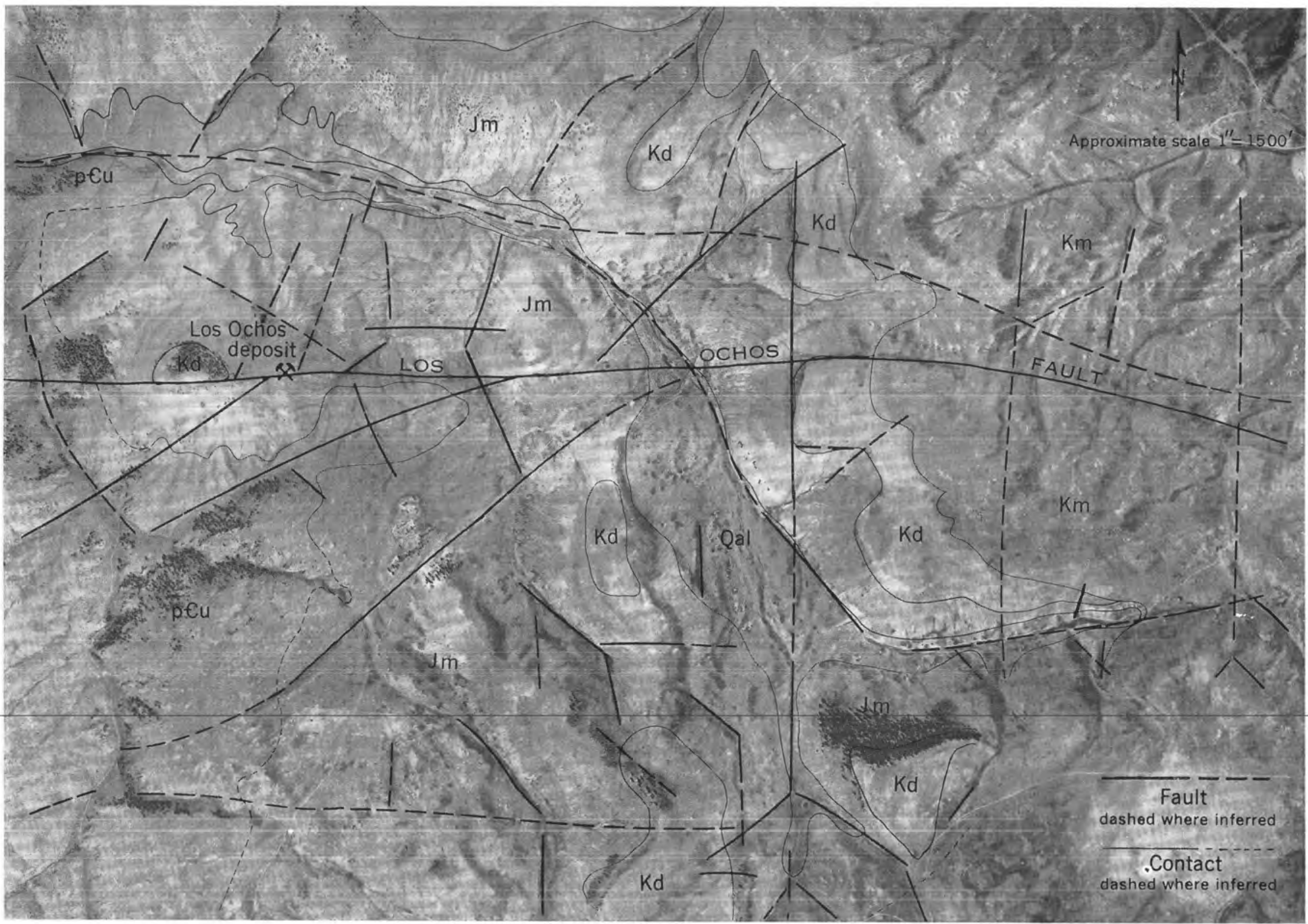

PHOTOGEOLOGIC MAP OF THE VICINITY OF THE LOS OCHOS URANIUM DEPOSIT, SAGUACHE COUNTY, COLO.

Explanation: Qal, Recent alluvium; Km, Cretaceous Mancos shale; Kd, Cretaceous Dakota formation; Jm, Jurassic Morrison formation undifferentiated; p€u, Precambrian granites, gneisses, and schists; crossed hammers, uranium deposit. Geology by R. C. Derzay and R. C. Malan, June 1955. 
noted in the upper part of the incline. If this correlation is correct, the west side of the fault dropped about 65 feet. The Salt Wash member was displaced westward a short distance, a movement which helped to provide open spaces for later mineralization in the northeast-trending shear zone. This fault zone adjacent to the vein and westward has been moderately mineralized, locally as much as 7 feet.

\section{ORE GENESIS}

The sequence of events in the formation of the ore at the Los Ochos mine, in summary, is believed to be as follows:

1. The Morrison and Dakota formations were deposited on Precambrian granite, gneiss, and schist during Jurassic and Cretaceous time.

2. In Tertiary time intense faulting occurred in the area. The northeast-trending fault dropped the Morrison formation about 65 feet on its northwest side. The Los Ochos fault probably had several periods of movement. The first moved the north side to the east, possibly damming subsequent mineralizing solutions with 4-12 inches of gouge. This movement also brecciated the Morrison formation and granite adjacent to it, providing open spaces for hydrothermal ore solutions. Moderate to intense hydrothermal alteration was followed by the deposition of quartz, marcasite, and pitchblende, in that order.

3. Postmineralization movement occurred on the Los Ochos fault. A portion of the ore body may have been displaced by the fault, or premineralization fault gouge may have dammed the ore solutions confining them to the southern portion. Adequate space for channelways and deposition of the ore solutions appears to have been available on both sides of the fault.

\section{SUMMARY}

The Los Ochos uranium deposit occurs in a northeasterly trending zone of shearing and fracturing at the contact of granite and schist of Precambrian age with the Morrison formation of Jurassic age near the intersection with a large east-trending fault. The ore deposit extends at least 130 feet in depth, and considering the magnitude of faulting associated with the mineralization, it probably continues to greater depth. Pitchblende, associated with marcasite, chalcedony, quartz, ilsemannite, barite, and abundant clays, was deposited under epithermal conditions during Tertiary time.

Although exploitation of this single deposit and exploration work at nearby prospects indicate that the intersections of northeast-trending shear zones with easttrending faults are the most obvious controls of the uranium ore bodies, fractures trending in other directions may also have been channelways for mineralizing ore solutions.

\section{SELECTED BIBLIOGRAPHY}

Cross, Whitman, and Larsen, E. S., 1935, A brief review of the geology of the San Juan region of southwestern Colorado: U. S. Geol. Survey Bull. 843, 138 p.

Hunter, J. F., 1925, Pre-Cambrian rocks of Gunnison River, Colo.: U. S. Geol. Survey Bull. 777, 94 p. 


\title{
URANIUM-VANADIUM-GOPPER DEPOSITS ON THE COLORADO PLATEAU
}

\author{
By Richard P. Fischer, U.S. Geological Survey
}

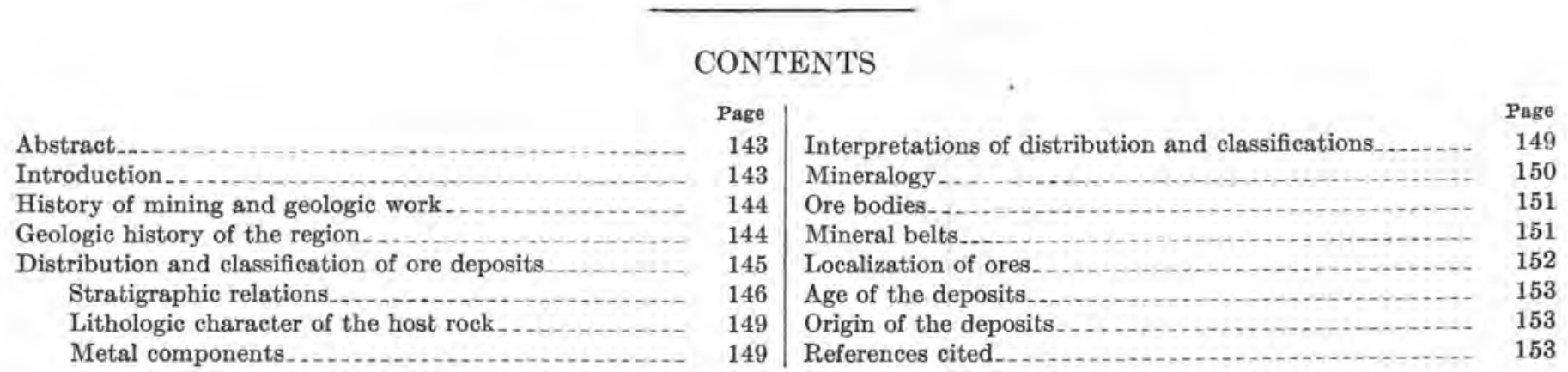

\section{ILLUSTRATIONS}

Figure 24. Index map of the Colorado Plateau region, showing the more productive deposits, the stratigraphic positions Page

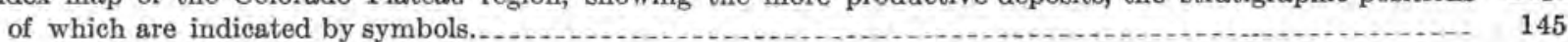

25. Map showing classification of deposits by lithologic character of the host rock $\ldots \ldots \ldots \ldots$

26. Map showing classification of deposits by metal components $\ldots \ldots \ldots$

\section{ABSTRACT}

The uranium-vanadium-copper deposits of the Colorado Plateau region form a group of wide distribution and many common geologic characteristics. They have been the principal source of uranium and vanadium in the United States.

Structurally, the region has been relatively stable since Precambrian time. Exposed rocks consist mainly of late Paleozoic to Tertiary sedimentary strata that have been invaded by moderate-sized stocks and laccoliths of early Tertiary or perhaps Late Cretaceous age. Laramide deformation is expressed by several broad folds and sharp flexures, but in most places the sedimentary beds lie nearly horizontal.

The early ore minerals consist of copper sulfides and lowvalent oxides and silicates of uranium and vanadium. These minerals alter to higher valent oxides of vanadium and to vanadates and other secondary uranium and copper minerals. Sandstone is the principal host rock, and the ore minerals mainly fill pore spaces, though partly replacing sand grains and associated argillaceous and carbonaceous material.

Ore bodies range from small masses only a few feet across to deposits several hundred feet across. The large ore bodies are mainly tabular, forming layers a few feet to as much as 20 feet thick that lie essentially parallel to bedding, but the layers are undulant and cut across the beds in places. Many ore bodies in sandstone are slightly elongate parallel to the trend of the stream that deposited the sandstone; some of the ore bodies in limestone are markedly elongate and follow lines of deformation.

Although these deposits have been found in many formations, ranging from late Paleozoic to middle Tertiary in age, deposits that have yielded significant production are mostly restricted to the Shinarump conglomerate and Chinle formation of Triassic age and the Todlito limestone, Entrada sandstone, and Morrison formation of Jurassic age.

The deposits present peculiar problems of localization and genesis. In most places, the ore minerals were presumably introduced into their present positions by solutions moving laterally through the beds. Sedimentary structures, such as lenses, and associated argillaceous and carbonaceous material apparently influenced localization of many ore bodies. The regional distribution of deposits suggests to some geologists that regional deformation also influenced localization by providing pathways for vertical movement of solutions, and a few deposits show elose association with such vertical pathways. Igneous activity and mineralization of definite hydrothermal origin are not closely associated with the deposits except in a few places.

Radioactive age determinations indicate that the deposits were formed in Late Cretaceous or early Tertiary time. If the ore metals were introduced into the host rock at this time, it seems likely that the metals were derived either from ascending hydrothermal solutions or by lateral or vertical secretion from the associated sediments.

\section{INTRODUCTION}

The Colorado Plateau region comprises the adjoining parts of Colorado, Utah, Arizona, and New Mexico and encompasses an area of more than 100,000 square miles. The uranium-vanadium-copper deposits in the 
region are widely distributed and have many geologic characteristics in common. They have been the principal source of uranium and vanadium in the United States.

Rocks exposed in the region consist mainly of nearly flat-lying sedimentary strata. Most of the ore deposits are in sandstone strata of continental origin. The ore minerals impregnate and partly replace the host rock in dominantly tabular bodies roughly parallel to the sandstone bedding. Because the common geological characteristics of this group of deposits differ considerably from the habits of many other types of metalliferous deposits, they present peculiar problems of localization, genesis, and prospeeting.

\section{HISTORY OF MINING AND GEOLOGIC WORK}

In the past the uranium deposits of the Colorado Plateau have been commonly referred to as "carnotite deposits." Carnotite was discovered in 1898 in southwestern Colorado, but only a small amount of ore was mined in the next decade. From 1910 to 1923, however, these deposits were intensively mined for their radium content, and some vanadium was produced as a byproduct. Mining operations centered in Colorado, but Utah produced a small amount of ore. Only a small amount of carnotite ore was mined from 1923 until 1936. In Colorado intensive mining was resumed in 1936 and continued through the war years spreading to Utah and finally to northern Arizona. Vanadium was the desired metal in this period, but some byproduct uranium was produced during World War II. From 1945 to 1948 mining activity again reached a low level, as demands for vanadium were small and there was no market for uranium ore.

In 1948 when the U. S. Atomic Energy Commission announced its uranium ore-buying program, only 15 small mines were operating; by the end of 1954, however, several hundred mines were producing (U. S. Congress, 1955). Centers of - production have spread westward into central Utah and southward into Arizona and the northwest part of New Mexico (fig. 24). Uranium, of course, is the metal of principal value, and vanadium and perhaps a little copper are now being produced as byproducts.

The vanadiferous sandstone deposits in the Entrada sandstone have yielded a large amount of vanadium and, in recent years, a little byproduct uranium. During recent years the silver-bearing sandstone deposits in the Chinle formation at Silver Reef, Utah (Fischer, 1937), have also yielded a little uranium ore.

The uranium-vanadium-copper deposits of the Colorado Plateau region have been studied by many geologists. R. C. Coffin (1921) prepared the first detailed report on the deposits of southwestern Colorado, and general descriptions of the deposits in the Plateau region were published by F. L. Hess (1933) and R. P. Fischer (1937). The U. S, Geological Survey began a comprehensive study of these deposits in 1939 and continued this work through World War II. Also during the war, Union Mines Development Corporation made intensive geologic studies under government contract. Since 1947 the U. S. Geological Survey has conducted physical exploration and geologic studies on behalf of the U. S. Atomic Energy Commission, which has also done exploration and geologic study with its own staff and through contracts with universities since 1948. Industry has also employed many geologists in recent years. All told, probably more than 1,000 man-years of geologic work has been done in these deposits.

\section{GEOLOGIC HISTORY OF THE REGION}

Structurally, the Colorado Plateau region has been relatively stable since Precambrian time. Paleozoic sedimentary rocks of both marine and continental origin are widely but thinly distributed. The only major deformation in the region in the Paleozoic was that which formed the Uncompahgre element of the late Paleozoic ancestral Rocky Mountains. It resulted in a broad uplift of considerable elevation that projected northwestward into the east-central part of the region. The uplift was bordered on the southwest by the Paradox basin, in which accumulated several thousand feet of evaporites and detrital sediments. Several elongate salt domes or anticlines, trending northwest parallel to and bordering the southwest flank of the Uncompahgre uplift, formed during late Paleozoic time. Salt and gypsum continued to invade and warp the sedimentary rocks until the middle of the Mesozoic era, and movement recurred in Tertiary time.

Continental sedimentation dominated the Mesozoic era until Late Cretaceous time. Rocks deposited consist mostly of sandstone and shale, and they also form widely spread individual units that are fairly thin, totaling only a few thousand feet in thickness. During the Late Cretaceous the region slowly sank largely as a unit and received a layer of shale and sandstone of marine and continental origin several thousand feet thick. Deformation, presumably of Laramide age at the close of the Cretaceous and during early Tertiary time, is expressed in the region by several broad folds and sharp flexures, but these features and the subsequent events of Tertiary deformation, intermontane sedimentation, and erosion are not exactly dated.

Both intrusive and extrusive igneous activity in the Plateau region was of moderate intensity. The intrusions consisted mostly of the injection of mediumsized stocks and laccoliths into the sedimentary cover in the central and eastern parts of the region; these 


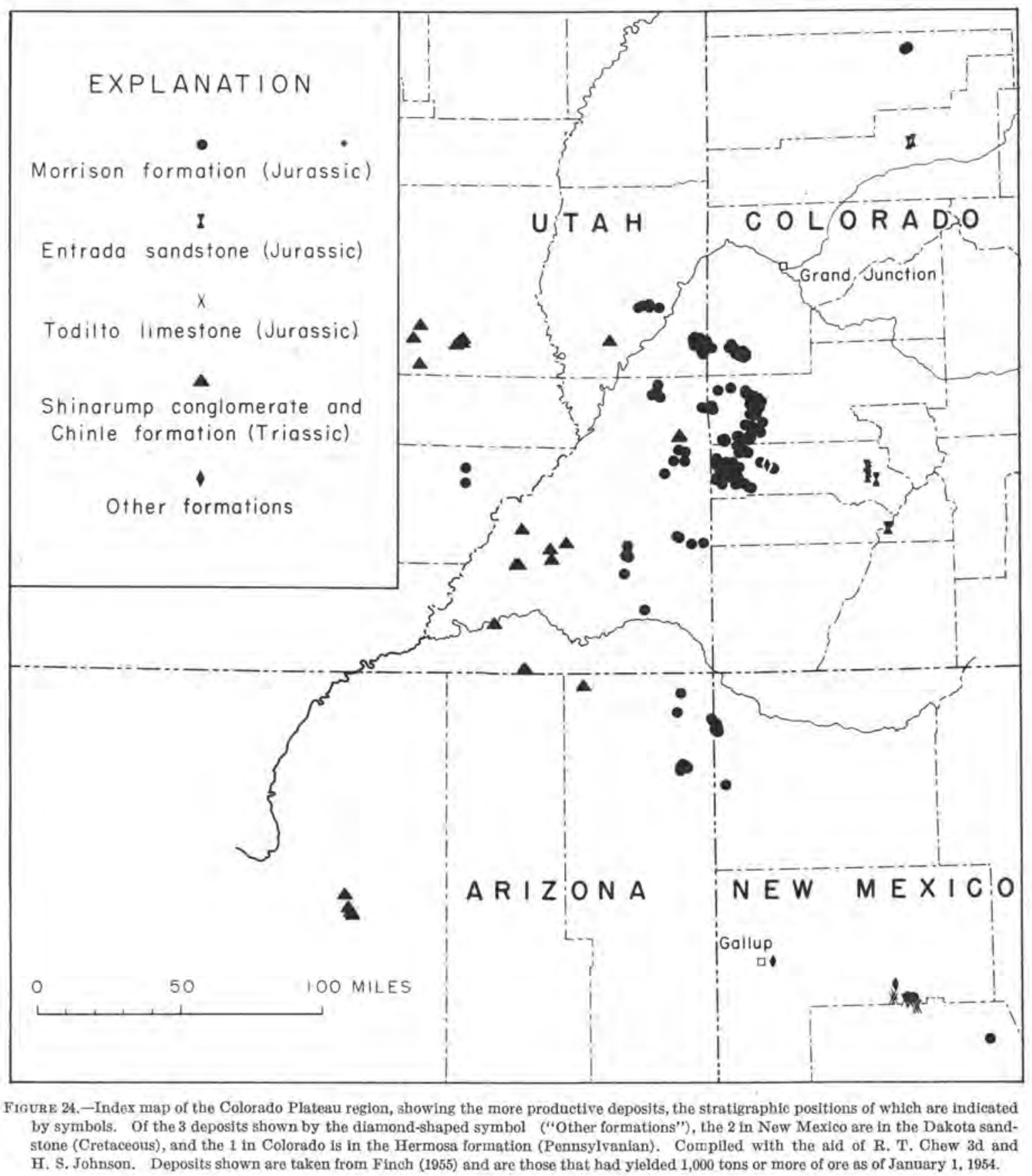

are dated on rather vague evidence as early Tertiary or perhaps Late Cretaceous. Volcanic extrusive rocks are abundant along and beyond the western, southern, and eastern margins of the region; most are of middle to late Tertiary age, but some activity continued even into Recent time.

\section{DISTRIBUTION AND CLASSIFICATION OF ORE DEPOSITS}

Hundreds of uranium-bearing deposits are known in the Colorado Plateau (Finch, 1955), but most of them are small. The maps (figs, 24-26) show only the more productive deposits, those which are reported to have yielded 1,000 tons or more of ore as of January 1, 1954 (Finch, 1955). All these maps are compiled on the same base, and all show the same deposits. The symbols on figure 24 indicate the stratigraphic position of the deposits; those on figure 25, the classification of the deposits by the lithologic character of the host rock; and those on figure 26, the classification by metal components. Note that in the explanation on figure 24 the Entrada sandstone is listed above the Todilto limestone rather than below it, where it should be from the 


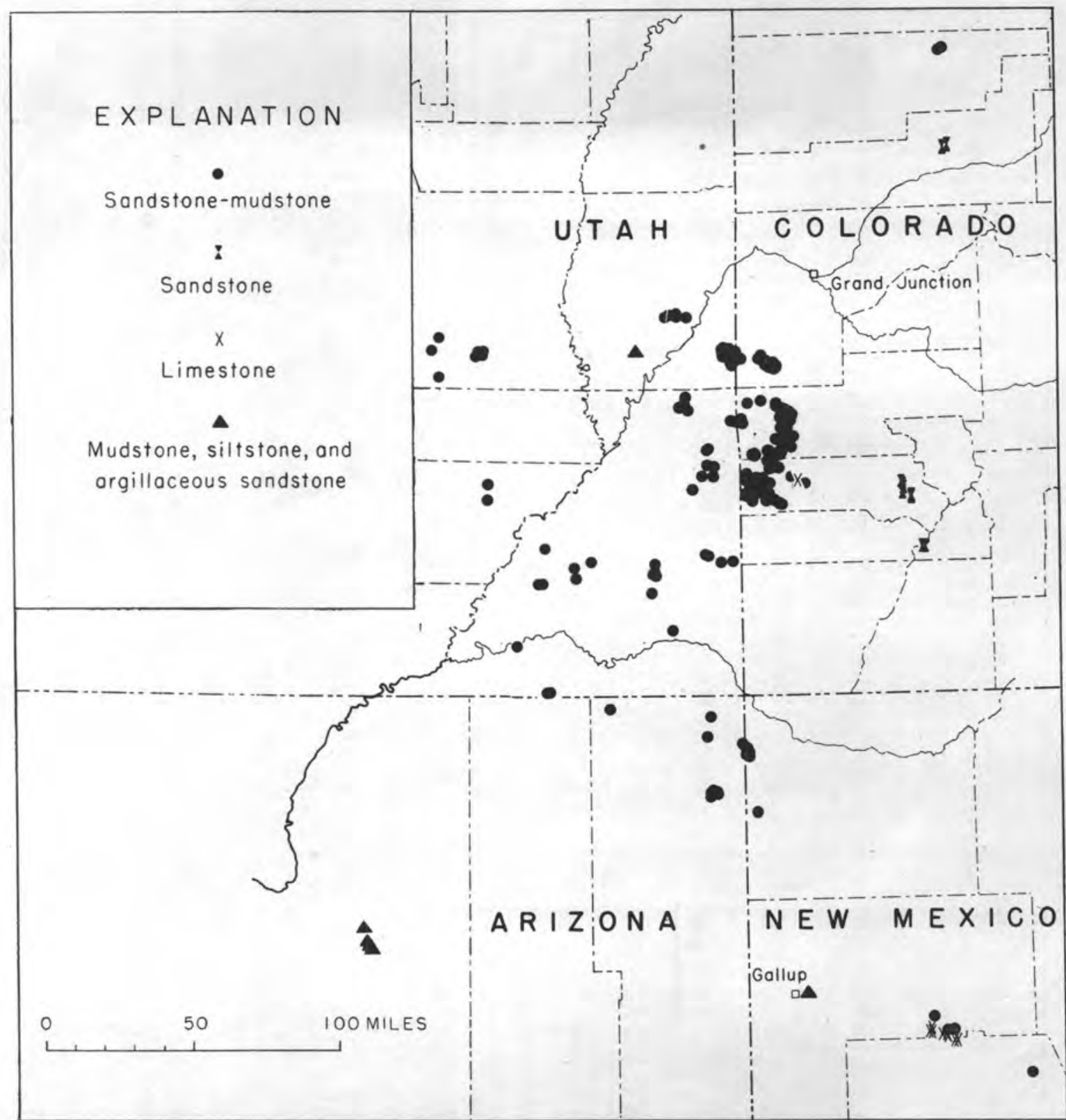

FIGURE 25.-Map showing classification of deposits by lithoiogic character of the host rock. Complled with the ald of R. T. Chew 3d and H. S. Johnson. Deposits shown are taken from Finch (1955) and are those that had yielded 1,000 tons or more of ore as of January 1, 1954.

standpoint of stratigraphic position. This arrangement was used, however, because it is more compatible with the arrangment of classes on figures 25 and 26 .

\section{STRATIGRAPHIC RELATIONS}

Deposits or occurrences of uranium with vanadium or copper are known in nearly all sedimentary formations exposed in the Colorado Plateau region; these formations range from late Paleozoic to middle Tertiary in age. Nearly all of the more productive deposits, however, are restricted to five formations-the Shinarump conglomerate and Chinle formation of Triassic age and the Entrada sandstone, Todilto limestone, and Morrison formation of Jurassic age (fig. 24).

Shinarump conglomerate.-The Shinarump conglomerate is composed of light-colored conglomeratic sandstone interbedded with gray and red siltstone and mudstone; all beds are lenticular. The sandstone beds are poorly sorted and contain argillaceous material in the form of thin lenses, pebbles, and fragments of mudstone; fossil wood is also abundant. Sandstone lenses commonly fill channels cut in underlying rocks. Most of the ore deposits are in the thicker parts of these channel-fills. 
The Shinarump averages $50-75$ feet in thickness in northern Arizona and in southern and central Utah, though it is absent in a few places. It is absent or poorly developed in east-central Utah, Colorado, and New Mexico. The Shinarump accumulated as a stream and flood plain deposit on a broad alluvial plain.

Chinle formation.- The Chinle formation is composed mainly of red and gray shale and siltstone; light-colored sandstone beds, in part conglomeratic, are also present, as are thin layers of limestone and limestone conglomerate. Fossil wood is fairly common. The Chinle formation extends nearly everywhere in the Plateau re- gion and averages several hundred feet in thickness. The formation probably accumulated mostly under flood plain conditions. Most of the Chinle uranium deposits are in conglomeratic sandstone beds, but a few are in highly argillaceous beds.

The uranium deposits in the Shinarump and Chinle formations show an interesting relationship in stratigraphic position with respect to the unconformity between these formations and the underlying Moenkopi formation, as described by Williams and others (1955, written communication). Where present (northern Arizona and southern Utah), the Shinarump is the host

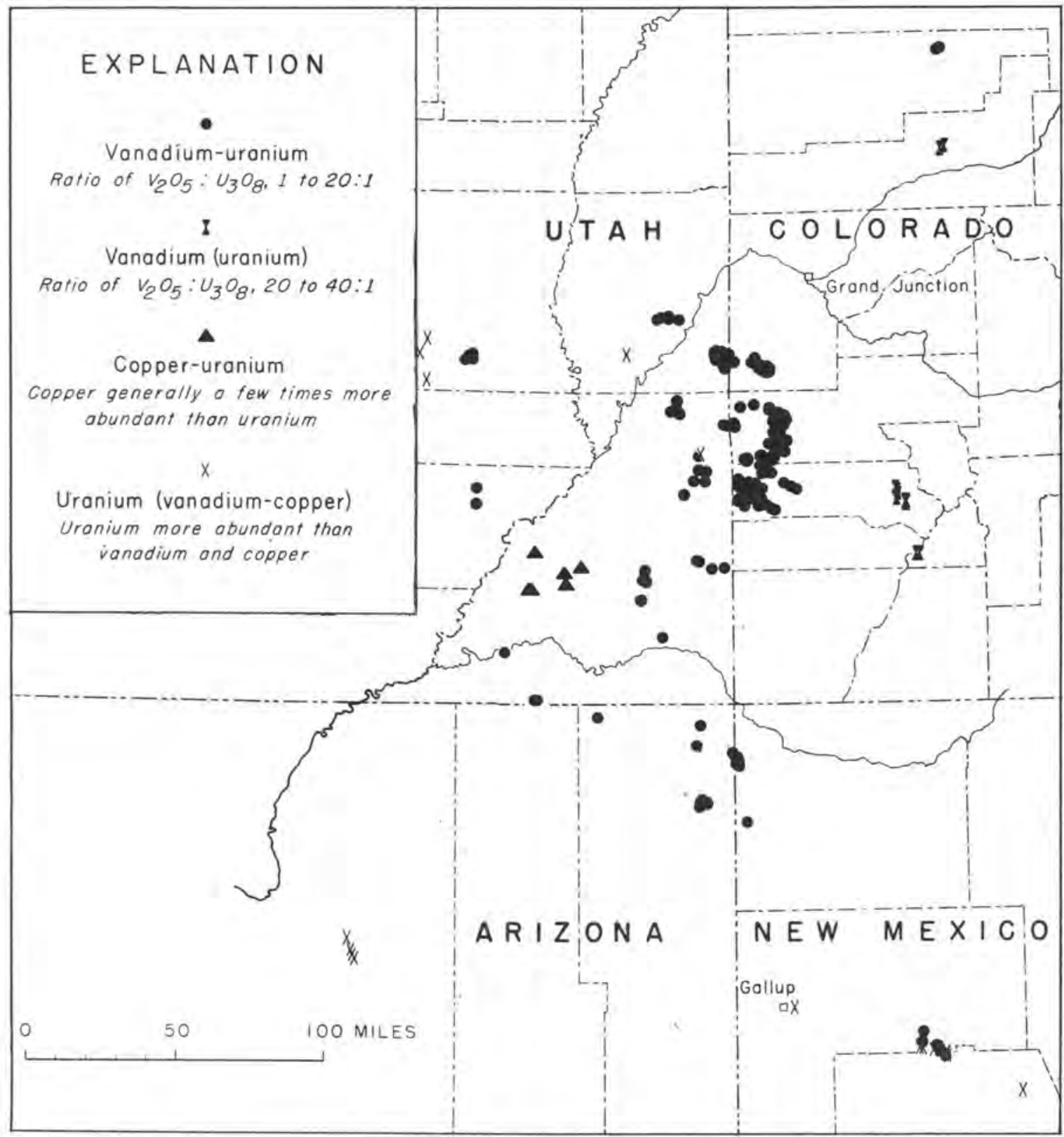

FIGURE 26.-Map showing classification of deposits by metal components. Complled with the ald of R. T. Chew $3 d$ and H. S. Johnson. Deposits shown are taken from Finch (1955) and are those that had yielded 1,000 tons or more of ore as of January 1, 1954. 
rock; northward, where the Shinarump is absent, progressively younger beds of Chinle onlap the Moenkopi and are ore bearing. Of these Chinle beds, the Moss Back member, a conglomeratic sandstone similar in lithologic character to the Shinarump, contains most of the larger deposits known. Williams and his coworkers (1955, written communication) conclude that most of the uranium deposits in Triassic rocks lie within 50 feet of the unconformity on top of the Moenkopi.

Entrada sandstone.-The Entrada sandstone extends almost throughout the Plateau region. In Colorado, New Mexico, and Arizona, it is a massive crossbedded fine-grained clean light-colored sandstone and averages 50-100 feet in thickness. Westward from Colorado the formation gradually thickens to about 1,000 feet in central Utah and is composed of a red fine-grained earthy sandstone. Much of the Entrada sandstone was probably deposited by wind action. No fossil wood or other organic material has been recognized in the Entrada where it is exposed in typical form. Several large vanadium deposits have been mined from the Entrada sandstone in western Colorado; one of these deposits, at Rifle, is also partly in an underlying sandstone that might be the Wingate sandstone.

Todilto limestone.-Where the Todilto limestone is ore bearing in northwestern New Mexico, it averages about 20 feet in thickness and is a dark thinly and irregularly bedded dense to recrystallized limestone. It has the same lithologic character and about the same thickness in northeastern Arizona and in the western part of the San Juan Mountains of southwestern Colorado, but eastward in New Mexico and Colorado it thickens somewhat and contains gypsum. The Todilto is absent in Utah and the northern and extreme western parts of Colorado. The limestone facies of the Todilto contains some carbonaceous material but no recognizable fossil wood. The formation probably was deposited in brackish water.

Morrison formation. - The Morrison formation formerly covered most of the Plateau and pinched out near the southern and western edges; it extends east and north beyond the region. The Morrison averages about $600-900$ feet in thickness. Four members are recognized, which will be described in ascending order. For a more detailed discussion of Morrison stratigraphy the reader is referred to the report by $\mathrm{L}$. C. Craig and others (1955).

The Salt Wash member occupies the southeastern quarter of Utah, the southwestern part of Colorado, and the extreme northern part of Arizona. It averages about 250 feet in thickness and consists of light- colored medium-grained sandstone interbedded with mudstone. The sandstone strata are lenticular, irregularly bedded, and contain some mudstone in the form of thin lenses, pebbles, and fragments; fossil wood is fairly abundant. Most of the ore deposits are in the uppermost sandstone strata and in or near the central, thicker parts of the lenses. Sandstone near ore bodies is stained light yellow brown with iron oxide near the surface and is pale gray and contains finely disseminated pyrite below the zone of oxidation; away from ore bodies the sandstone is dominantly pale red. The mudstone in the Salt Wash is dominantly red, which is seemingly the original color, but near ore deposits * the mudstone immediately below and above the sandstone and the mudstone within the sandstone is altered to gray (Weir, 1952).

The Salt Wash was deposited from streams meandering over a broad flood plain. It was derived mainly from preexisting sedimentary beds exposed in highlands southwest of the area of Salt Wash deposition. Because the southwestern part of the region was closer to the source of sediments, the Salt Wash there contains much sandstone. In the eastern and northern parts of the region, the Salt Wash has more mudstone than sandstone. In the central part of the region, where ore deposits are most abundant in the Salt Wash, the unit contains about equal amounts of sandstone and mudstone.

The Recapture and Westwater Canyon members of the Morrison formation are similar in character, consisting of light-colored sandstone and varicolored shale or mudstone. Each unit averages a few hundred feet in thickness. Both are present in northwestern New Mexico, where they contain a few small ore deposits, but they extend only a short distance into Arizona, Utah, and Colorado. These members also accumulated under stream and flood plain conditions.

The Brushy Basin member extends over all the Plateau region, except perhaps the southwestern part, and it averages $300-400$ feet in thickness. It is composed mainly of variegated mudstones and siltstones, which contain some thin beds of limestone; thick lenses of sandstone, in part conglomeratic, are present in places, expecially in New Mexico, where they contain large deposits of uranium (Hilpert and Freeman, this volume). Fossil wood is common. The Brushy Basin was also deposited in a stream and flood plain environment in which sandstone accumulated in lesser amounts than during the deposition of the other Morrison beds. Brushy Basin type sediments extend far east and north of the Colorado Plateau region and constitute the entire Morrison formation. 


\section{ITHOLOGIC CHARACTER OF THE HOST ROCK}

As described above, the lithologic character of the host rock differs among the ore deposits in the Colorado Plateau region. Differences within a single formation are generally small, but major differences occur between some formations. Deposits can be classified into four categories according to the lithologic character of their host rock, as described below and indicated by symbols on figure 25.

1. Sandstone-mudstone, which includes deposits in sandstone that is interbedded with mudstone and that also contains mudstone lenses and pebbles, but not enough finely divided argillaceous material to occupy all the pore spaces between sand grains; plant fossils are common. Of the deposits shown on figure 25 this class includes all those in the Morrison formation, most of those in the Shinarump conglomerate and Chinle formation, and 1 of the 2 Dakota deposits in New Mexico.

2. Sandstone, which includes deposits in "clean" sandstone. Only Entrada deposits belong to this class.

3. Limestone, which includes all deposits in the Todilto limestone and the deposit in the Hermosa formation in southwestern Colorado.

4. Mudstone, siltstone, and argillaceous sandstone, which includes deposits in rock that is more argillaceous than the first class, sandstone-mudstone; in the argillaceous sandstone probably all or nearly all of the pore space between sand grains is occupied with argillaceous matrix; plant fossils are common. Some of the deposits in the Chinle formation belong to this class, as does one of the Dakota deposits in New Mexico.

\section{METAL COMPONENTS}

The ore deposits may also be classified by the relative amounts of uranium, vanadium, and copper that they contain. A elassification of the deposits by their metal components is given below and shown on figure 26 .

1. Vanadium-uranium deposits, having 1-20 parts $\mathrm{V}_{2} \mathrm{O}_{5}$ to 1 part $\mathrm{U}_{3} \mathrm{O}_{8}$. Nearly all deposits in the central part of the Plateau region belong to this class (fig. 26). Included are all deposits in the Morrison shown, except two in New Mexico, and about a third on the deposits in the Shinarump and Chinle (fig. 24). Further, this elass includes nearly all deposits in the sandstonemudstone category (fig. 25).

2. Vanadium (uranium) deposits, having from 20-40 parts $\mathrm{V}_{2} \mathrm{O}_{5}$ to 1 part $\mathrm{U}_{3} \mathrm{O}_{8}$. The deposits along the eastern margin of the Plateau region in Colorado belong to this group (fig. 26). All of these deposits are in the Entrada sandstone (fig. 24), which contains all deposits in the sandstone category (fig. 25).
3. Copper-uranium deposits, in which the copper content generally exceeds uranium by a few times. This group is restricted to the White Canyon area, in southeastern Utah (fig. 26). All deposits are in the Shinarump conglomerate (fig. 24), and all are classed as sandstone-mudstone deposits (fig. 25). The habits of these deposits, incidently, closely resemble the habits of the so-called Red Beds copper deposits (Fischer, 1937).

4. Uranium (vanadium-copper) deposits, in which the uranium (specifically $\mathrm{U}_{3} \mathrm{O}_{\mathrm{s}}$ ) is more abundant than vanadium $\left(\mathrm{V}_{2} \mathrm{O}_{5}\right)$ and copper. Except for two deposits in east-central Utah, all deposits in this category are along the southern and western margins of the Plateau region.

\section{INTERPRETATIONS OF DISTRIBUTION AND CLASSIFICATION}

The distribution of these deposits geographically and stratigraphically and their differences in metal components suggest a combination of regional and stratigraphic-lithologic influences on the concentration of the ore metals. Although some broad patterns may be discerned, not all relations can yet be completely explained.

The productive deposits in Triassic rocks are all in Arizona and Utah (fig. 24) and most are in lenses of conglomeratic sandstone either in the Shinarump conglomerate or in the lower part of the Chinle formation. These seemingly favorable sandstone beds are either absent or poorly formed in northwestern New Mexico and western Colorado.

Nearly all of the more productive deposits in the Salt Wash member of the Morrison formation are in eastern Utah, western Colorado, and northeastern Arizona. They are approximately in the central part of the area of Salt Wash deposition, where the unit has about equal amounts of sandstone and mudstone. The Salt Wash becomes sandier westward and more shaly eastward. The Brushy Basin ore deposits in New Mexico contain about equal amounts of sandstone and mudstone; elsewhere the Brushy Basin contains more mudstone than sandstone.

The more productive deposits in the Entrada sandstone are restricted to the eastern edge of the Plateau region in Colorado, and productive deposits in the Todil to limestone are known only in New Mexico. No satisfactory explanation is yet available to suggest why these deposits are so restricted in distribution.

Most of the deposits of the uranium (vanadiumcopper) class shown on figure 26 are along the southern and western margins of the region and, geographically, are the most remote from the Entrada deposits, which contain a high ratio of vanadium to uranium-essen- 
tially an opposite metal ratio. This relationship suggests a zonal arrangement of relatively high vanadium in the eastern part of the region and low vanadium in the southern and western parts. On the other hand, a comparison of the lithologic character of the Entrada deposits high-vanadium and low-uranium content with the Utah and Arizona deposits of high-uranium and low-vanadium content also suggests a possible lithologic influence on localization of the amounts of metals in these deposits. As will be described under the section Mineralogy, vanadium minerals mainly occupy open pores in sandstone, whereas uranium minerals commonly replace fossil wood. The clean sandstone of the Entrada offers the open pores for the growth of vanadium minerals but contains no fossil wood, which might be needed to concentrate uranium. In contrast, 5 of the 9 deposits of high-uranium and low-vanadium content in Utah and Arizona (fig. 26) are in highly argillaceous rock (fig. 25), which might not have the open pores for vanadium minerals; but the rock does have fossil wood, with which much of the uranium is associated. Detailed studies should be made to determine whether these metal differences are the result of zonal or lithologic influences, or perhaps even to other factors.

Regardless of whether the low-vanadium deposits in Utah and Arizona are influenced by zonal or lithologic relations, the southeastern part of the Plateau region appears to be a low-vanadium area, for all of the productive deposits in New Mexico are relatively low in vanadium no matter what the type of host rock or the stratigraphic position. Although some of the deposits in this area are shown in figure 26 to be in the vanadiumuranium class, these actually contain only a little more $\mathrm{V}_{2} \mathrm{O}_{5}$ than $\mathrm{U}_{3} \mathrm{O}_{8}$, in contrast to most of the other vanadium-uranium deposits, which contain several times more $\mathrm{V}_{2} \mathrm{O}_{5}$.

The restricted distribution of the copper-uranium deposits (fig. 26) is certainly the most striking geographic relationship evident among the deposits in the Plateau region. There seems to be no likely stratigraphic or lithologic influence to assist in explaining the localization of this class of deposit.

\section{MINERALOGY}

In addition to uranium, vanadium, and copper, the deposits contain small amounts of iron and manganese and trace amounts of lead, cobalt, nickel, molybdenum, chromium, arsenic, and selenium; some fine-grained disseminated fluorspar is associated with ore bodies in the Todilto limestone. Only uranium, vanadium, and copper, however, form constituent parts of oreforming minerals.
The early ore minerals consist of low-valent oxides and silicates of uranium and vanadium; copper sulfides are present in places. In the oxidized zone near the surface, these minerals are altered to higher valent oxides of vanadium and to vanadates and other secondary uranium and copper minerals. For a more detailed description of the mineralogy of these deposits, the reader is referred to the report by Weeks and Thompson (1954).

Characteristically, the ore minerals are fine grained and intimately mixed, so that complete identification and detailed relations are difficult to establish. Nevertheless, the principal ore minerals can be recognized, and the gross relations are established. The mineralogy and mineral habits differ somewhat according to the lithologic character of the host rock and the metal components of the deposit.

In sandstone the early ore minerals mainly occupy pore spaces between sand grains. They also form rich replacements of carbonized fossil wood, commonly pseudomorphosing cell structure and perhaps partly replacing the sandstone enclosing the wood. The minerals also impregnate or replace shaly seams and mudstone fragments in the ore-bearing sandstone. Later secondary minerals occupy the pore spaces, pseudomorphose fossil wood, and coat walls of open fractures. In limestone the early minerals are finely disseminated; later minerals replace these and coat open fractures and bedding planes. In highly argillaceous rock the early minerals replace fossil wood and form small disseminated grains; later minerals replace the earlier ones and coat fractures and bedding planes.

The uranium and vanadium oxides commonly replace fossil wood and to a lesser extent the sand grains and perhaps argillaceous material; fine disseminations in pore spaces also occur. The vanadium silicates dominantly fill the pores in the sandstone and partly impregnate or replace argillaceous material. The copper sulfides replace fossil wood, occupy pore spaces, and partly replace sand grains.

On oxidation of deposits contrining an appreciable amount of vanadium, practically all the uranium combines with vanadium to form vanadates (carnotite and tyuyamunite); likely the available vanadium is derived from the vanadium oxides, for the vanadium silicates appear to be very stable. In deposits with little or no vanadium, the uranium, and copper if it is present, alters to secondary silicates, carbonates, sulfates, phosphates, and arsenates.

The metals show little tendency to migrate during oxidation of deposits containing appreciable vanadium, and under common conditions there is no evidence of secondary concentration or depletion of the metals at or near the surface. More movement of uranium, 
as well as copper, occurs near the surface in deposits low in vanadium, but even so, the migration of metals is generally not conspicuous.

\section{ORE BODIES}

With few exceptions, ore bodies have much the same habits regardless of their metal components, lithologic and structural environments, and stratigraphic positions.

Ore bodies range from small masses only a few feet across to those several hundred feet across. The larger ore bodies are mainly tabular, forming layers ranging from a few feet to as much as 20 feet or more in thickness. The long axes of these layers lie essentially parallel to bedding; hence, they are commonly referred to as the "bedded type," but in detail the layers are undulant and cut across bedding. Some ore bodies, especially those in the Todilto limestone, are distinctly elongate, parallel to bedding, and about equidimensional in width and height. Only a few deposits are known that have their longest dimension erossing bedding.

Although the tabular bodies in sandstone are quite irregular in outline, the trend of elongation usually parallels the course of the stream that deposited the sandstone lens or channel fill containing the ore body, as shown by sedimentary structures such as crossbedding and current lineation and by the orientation of fossil logs. In addition, the peculiar elongate concretionary masses in the ore bodies, which are commonly called ore rolls, have a dominant orientation in the seme direction (Fischer, 1942). These rolls usually form the thickest parts of ore bodies and in some places the richest parts. Some of the more elongate ore bodies in sandstone consist of single rolls.

Typically, these elongate bodies follow along lines of deformation in the limestone, some of which correspond in direction to the trends of structure resulting from regional deformation (Gilkey, 1953).

Throughout the Plateau region ore bodies tend to be clustered in groups, a relationship that is clearly evident on the map prepared by Finch (1955). Clusters range from only a few thousand feet across to a few miles across, and distances between clusters may range from a few thousand feet to many miles. The ground between clusters may contain a few deposits, but most of them are small. In the entire region only a few deposits of economic importance do not appear to be one of a cluster.

Within clusters individual ore bodies may have welldefined edges and may be separated from neighboring bodies by barren rock. Other bodies may be less well defined, and layers of mineralized rock too thin or too low grade to be mined profitably may extend some distance beyond minable ore and may even connect with nearby ore bodies. A cluster and its individual ore bodies generally are elongate in a common direction.

\section{MINERAL BELTS}

Four rather narrow, elongate areas in which the uranium deposits have a closer spacing, larger size, and higher grade than adjoining areas have been recognized and described; the term "mineral belt" has been applied to each.

The Uravan mineral belt (Fischer and Hilpert, 1952), in southwestern Colorado, contains deposits in the Morrison formation. It is about 50 miles long and 1 to 5 miles wide and trends northward but curves west at the north end and southwest at the south end. Individual deposits and clusters of deposits within the belt are elongate normal to the local trend of the belt. A few miles east and north of the belt, the ore-bearing beds change slightly in lithologic character-the sandstone is more thinly and evenly bedded and finer grained. This change probably expresses differences in the geologic environment at the time when these beds accumulated. The belt crosses, at different angles, 3 northwest-trending synclines and anticlines; at least 2 are salt anticlines that originated in late Paleozoic time.

W. I. Finch (1955, written communieation) describes 3 belts of deposits in Triassic formations in Arizona and Utah. The one called the Monument Valley belt is about 8 miles wide and 40 miles long and trends northwestward from the northern edge of Arizona into south-central Utah. The deposits are in the Shinarump conglomerate in conglomeratic sandstone lenses that fill channels; all deposits belong to the vanadiumuranium class. The Shinarump is less lenticular southwest of the belt and locally absent northeast of the belt, The East White Canyon belt, in southeastern Utah, trends westward and ranges from 2 to 8 miles in width and is 30 miles or more long. All of the productive deposits are in channel-filling lenses in the Shinarump and are of the copper-uranium class. The southern edge of the belt borders the area where the Shinarump is locally absent; north of the belt the channel-filling lenses are small and less continuous than those in the belt. The Moab belt extends from central Utah eastward into east-central Utah, where it swings southeastward and perhaps continues into Colorado. It is $10-20$ miles wide and at least 130 miles long. All of the more productive deposits are in the Chinle formation, and they include both vanadium-uranium and uraniumvanadium-copper types. The boundaries are recognized partly on pinch-outs of the Moss Back sandstone of the Chinle, partly in changes in the character of the channel-filled lenses, and partly on other lithologic differences. 
These belts in places parallel and in other places trend at angles to the major structural features resulting from regional deformation.

\section{LOCALIZATION OF ORES}

Relations to sedimentary structural features.-In formations composed of sands and muds laid down in stream and flood plain environments, such as the Shinarump, Chinle, and Morrison formations, the uranium (vanadium-copper) deposits show a close association with certain conditions and structural features of sedimentary origin. Stratigraphic units consisting of fairly thick sandstone strata interbedded with about equal amounts of mudstone are generally favorable over broad areas for the occurrence of deposits. Most deposits are in or near the thicker, central parts of sandstone lenses (Weir, (1952); some lenses fill distinct channels (Witkind, 1956). Individual deposits and clusters tend to be elongate parallel to the flow of the stream that deposited the lens, as shown by crossbedding, eurrent lineation, and the orientation of fossil logs. Carbonized plant fossils are generally more abundant in and near deposits than in the surrounding barren rock (Weir, 1952). Deposits commonly occur in sandstone where the bedding is mixed and mudstone pebbles and carbonaceous material are fairly abundant, as might form in stream channels at places of local turbulence, such as scours and bends (Stokes, 1954); such bodies of sandstone are commonly called trash pockets. To explain those observed relations, most geologists assume that the orebearing solutions migrated along the beds that now contain the deposits, following the more permeable channels and dropping their metals where conditions favored the precipitation of ore minerals.

The influence, if any, of sedimentary conditions and structures in the Todilto limestone and the Entrada sandstone on the localization of ore deposits is not clearly evident at our present state of knowledge.

Relation to regional deformation. - A few uranium ore deposits in the Plateau region are along fractured zones, in which the vertical distribution of ore minerals clearly demonstrates the vertical movement of metals. At Temple Mountain (Keys, this volume), in central Utah, uranium and vanadium minerals are distributed along a strong fracture zone for several hundred feet above and below the Moss Back sandstone of the Chinle, which contains highly productive deposits of the socalled bedded type. The broken rocks in the fractured zone are intensively altered, presumably by thermal solutions. Similar relations, though with less alteration and perhaps with a less conspicuous vertical distribution of minerals, occur at Richardson Basin in east-central Utah and along Roc Creek in southwestern Colorado. These fractured zones have not yielded much ore, though some ore mined at Roc Creek was very rich.

In a few other places in the Plateau region, uranium minerals have been deposited along faults but not in amounts sufficient to constitute ore (Shoemaker and Newman, 1955, written communication).

Near Laguna, in northwestern New Mexico, uranium ore has been mined from a brecciated pluglike body that has been called a breccia pipe. The body is roughly circular, about 25 feet in diameter, and the core has collapsed about 20 feet. The host rock is a thick sandstone bed, in the Morrison formation. The ore, some of which is high grade, is mainly coffinite with abundant pyrite; the ore minerals replace sandstone near fractures and partly fill the fractures.

Numerous "bedded" uranium ore bodies in sandstone in the Plateau region are cut and displaced by faults; a breccia of mineralized rock and a small amount of secondary minerals are common along these faults. Most geologists who have mapped these bodies believe the faulting occurred after formation of the ore, though some have expressed opinions to the contrary. Many of the ore bodies in the Todilto limestone follow lines of wavy or crumbled bedding; it is not yet entirely clear whether these structures resulted from penesyngenetic crumpling or regional deformation, though some of them correspond in direction to the regional fracture pattern (Gilkey, 1953).

Many uranium deposits in the region are within a few miles of the major structural features; most are folds, some of which are faulted. B. S. Butler (and others, 1920 , p. 154-158) originally suggested that the anticlinal folds influenced the migration of the orebearing solutions and thus played a part in localizing these deposits, and many geologists today adhere to this idea. Other geologists interpret this apparent relation to be mainly the result of better exposure along these folds, and they place significance on many deposits that are more remote from the folds. Much more study and exploration will be required before these differences of opinion are resolved.

Relation to igneous activity. - Igneous activity, consisting of intrusive and extrusive bodies, has been intensive in places along the eastern, southern, and western margins of the Plateau region, and several moderatesized stocks and laccoliths, with associated dikes and sills, have intruded the sedimentary rocks in the central and eastern parts of the Plateau region. Some typical uranium deposits are close to these intrusive masses, and a few deposits are actually cut by igneous bodies, but as none of these deposits near igneous rock differ significantly in character from the many deposits that are remote from exposed igneous rocks, geologists in general are not inclined to relate the deposits directly 
to known igneous masses. On the other hand, some uranium is concentrated in or near volcanie vents (diatremes) in the southern part of the Plateau region (Shoemaker, this volume), but these deposits do not appear to be closely related to the more common type of uranium deposit.

Relation to hydrothermal activity.-Vein deposits of precious and base metals of hydrothermal origin are common in some of the centers of igneous activity along the margins of the Colorado Plateau region, especially in the San Juan Mountains area of southwestern Colorado. A few similar veins also occur within or near the intrusive masses in the Plateau region,

Some of the veins in the San Juan Mountains area contain small amounts of pitchblende, and some have roscoelite, the vanadium-bearing mica, intergrown with quartz gangue, Pitchblende-bearing veins are being mined at Marysvale, Utah, just west of the Plateau region.

\section{AGE OF THE DEPOSITS}

Radioactive age determinations of uranium ores from Triassic and Jurassic rocks in the Plateau region show an average age of about 60-70 million years (Stieff, Stern, and Milkey, 1953), which is considerably younger than the estimated ages of the host rocks and which corresponds closely to the estimated time of Laramide deformation of the Late Cretaceous or early Tertiary and to the age of the pitchblende-bearing veins of the Front Range in central Colorado. Unfortunately, the geologie events that occurred in the region at this time are not well recorded, largely because sedimentary beds of that age and younger are absent over most of the region. It seems reasonable to assume, however, that this deformation took place shortly after the deposition of the thick marine sediments of Late Cretaceous age, that the ore-bearing rocks were still deeply buried but likely were being deformed by folding and perhaps faulting, and that igneous activity was probably beginning in places bordering the region and perhaps even within the region.

\section{ORIGIN OF THE DEPOSITS}

Expressed opinions regarding the origin of these deposits have practically run the gamut of possibilities of ore formation, but they ean be generalized into three concepts.

1. The penesyngenetic or early epigenetic concept suggests the metals presumably were derived by secretion from associated rocks during periods of active ground-water circulation shortly after the accumulation of the beds enclosing the deposits. This idea was conceived to avoid the possible difficulties of obtaining active eirculation during deep burial in Late Cretac-

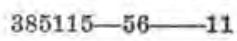

eous time and the seeming lack of influence of later structural features on localization.

2. Later epigenetic formation by vertical and lateral secretion, accompanying the resumption of active ground-water circulation during and following Laramide deformation is another concept; part of the required energy may have been from heat derived from contemporaneous igneous and hydrothermal activity. It was conceived to explain the wide distribution, an assemblage of metals common in sediments, and the lack of habits common to many types of metalliferous deposits.

3. Another concept is that of hydrothermal solutions derived from widely active deep-seated sources rising along vertical pathways and spreading laterally along favorable beds, or perhaps even by a process of "crustal sweating" of thermal solutions. It was conceived to explain the wide distribution of similar deposits, the low intensity and probable low temperature of mineralization, and the lack of habits typical of many hydrothermal deposits.

Each of the three ideas has some inherent points that assist in explaining certain of the observed habits of these deposits; none offers an explanation that appears to be the simple and complete answer. The metals presumably are available from the associated strata, either early or late, provided there are opportunities for solutions, transportation, and concentration. The penesyngenetic idea, however, must be eliminated if the relations on which the age determinations are made require the introduction of the metals, $60-70$ million years ago, rather than a rearrangement and the migration of daughter products at that time. With our present knowledge of the geologic history of the Plateau region, the determined age of the deposits is not in compatible with either the later epigenetic or hydrothermal ideas. Some geologists find it difficult to accept either of these ideas, however, in view of the lack of a more obvious influence by regional structures on the localization of the deposits.

\section{REFERENCES CITED}

Butler, B. S., Laughlin, G. F, Heikes, V. C., and others, 1920, The ore deposits of Utah: U.S. Geol. Survey Prof. Paper 111, $672 \mathrm{p}$.

Coffin, R. C., 1921, Radium, uranium, and vanadium deposits of southwestern Colorado: Colo. Geol. Survey Bull. 16, $231 \mathrm{p}$.

Craig, L. C., Holmes, C. N., Cadigann, R. A., Freeman, V. L., and others, 1955, Stratigraphy of the Morrison and related formations Colorado Plateau region, a preliminary report: U. 8. Geol. Survey Bull. 1009-E, p. 125-168.

Finch, W. I., 1955, Preliminary geologic map showing the distribution of uranium deposits and principal ore-bearing formations of the Colorado Plateau region: U. S. Geol. Survey Min. Inv. Field Studies Map MF 16. 
Fischer, R. P., 1937, Sedimentary deposits of copper, vanadium, uranium, and silver in Southwestern United States: Econ. Geology, v. 32, p. 906-951.

1942, Vanadium deposits of Colorado and Utah, a preliminary report: U. S. Geol. Survey Bull. 936-P, p. 363-394 [1943].

Fischer, R. P., and Hilpert, L. S., 1952, Geology of the Uravan Mineral Belt: U. S. Geol. Survey Bull. 988-A, p. 1-13.

Gilkey, A. K., 1953, Fracture pattern of the Zuni uplift, final report: U. S. Atomic Energy Comm. RME-3050, 40 p., issued by U. S. Atomic Energy Comm. Tech. Inf. Service, Oak Ridge, Tenn.

Hess, F. L., 1933, Uranium, vanadium, radium, gold, silver, and molybdenum sedimentary deposits, in Ore deposits of the Western States (Lindgren volume): New York, Am. Inst. Min. Metall. Eng., p. 450-481.

Stieff, L. R., Stern, T. W., and Milkey, R. G., 1953, A preliminary determination of the age of some uranium ores of the Colorado Plateaus by the lead-uranium method: U. S. Geol. Survey Circ. 271, 19p.
Stokes, W. L., 1954, Some stratigraphic sedimentary, and structural relations of uranium deposits in the Salt Wash sandstone, final report-April 1, 1952 to June 30, 1954: U. S. Atomic Energy Comm. RME-3102, 50 p., issued by U. S. Atomic Energy Comm. Tech. Inf. Service, Oak Ridge, Tenn.

Weeks, A. D., and Thompson, M. E., 1954, Identification and occurrence of uranium and vanadium minerals from the Colorado Plateaus: U. S. Geol. Survey Bull. 1009-B, p. 13-62.

Weir, D. B., 1952, Geologic guides to prospecting for carnotite deposits on the Colorado Plateau: U. S. Geol. Survey Bull. 988-B, p. $15-27$.

Witkind, I. J., 1956, Localization of uranium minerals in channel sediments at the base of the Shinarump conglomerate, Monument Valley, Ariz.: U. S. Geol. Survey Bull. 1030-C (in press).

United States Congress, 1955, 84th Cong., 1st sess., Hearings before the Joint Committee on Atomic Energy on development, growth, and state of the atomic energy industry, Part 1. 


\title{
STRUGTURAL FEATURES OF THE GENTRAL GOLORADO PLATEAU AND THEIR RELATION TO URANIUM DEPOSITS
}

\author{
By Eugene M. Shoemaker, U. S. Geological Survey \\ CONTENTS
}

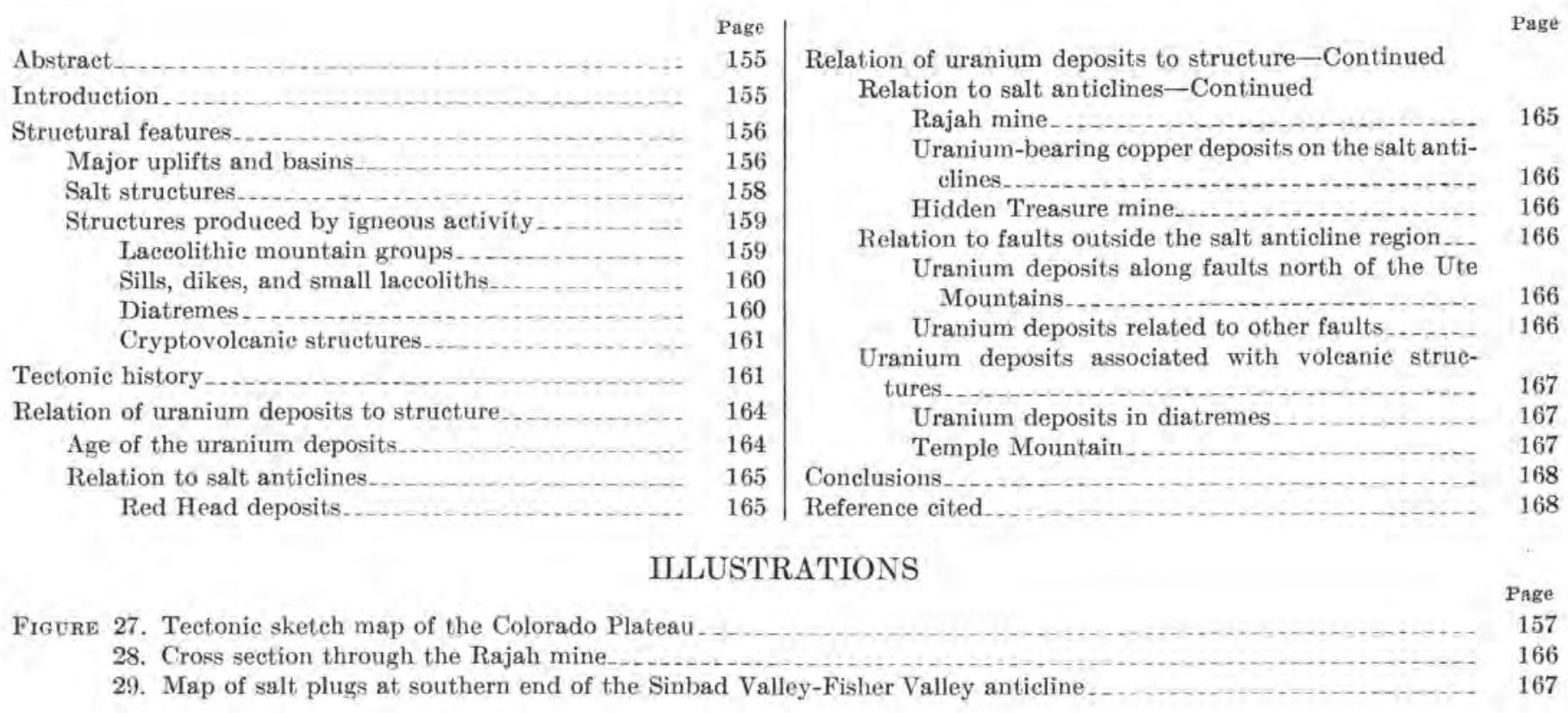

\begin{abstract}
The structural features of the central Colorado Plateau include broad uplifts and basins bounded on one or more sides by monoclinal folds and faults, complexly faulted salt anticlines, intruded igneous bodies of laceolithic and stocklike form, diatremes, and local areas of intense deformation of possible eryptovoleanic origin. Joints and small faults are associated with all major types of structures.

The post-Cambrian tectonic history of the central Colorado Plãteau ineludes major periods of deformation in early Pennsylvanian through Permian time, and in latest Cretaceous through Tertiary time. The major uplifts and basins have diverse histories. All of them underwent renewed deformation or were formed in latest Cretaceous or Tertiary time, but the period of maximum deformation varies from one uplift to another, and for some uplifts it is not known. The salt structures were active from late Pennsylvanian or early Permian through Jurassic tíme and were subsequently modified during at least two periods of deformation, one in latest Cretaceous or early Tertiary and another in late Tertiary to Recent time. The main periods of igneous activity were probably latest Cretaceous and Pliocene.

Lead and uranium age determinations based on lead isotope
\end{abstract}

analyses indicate a Late Cretaceous or early Tertiary age for many uranium deposits of the Colorado Plateau, but the occurrence of uranium deposits in sedimentary and voleanie rocks of Eocene, mid-Tertiary, and Pliocene age show that uranium oreforming solutions also circulated, at least locally, since early Tertiary time. The great majority of uranium deposits show no readily apparent direct relation to regional structures such as faults and joints, though the struetural relations at a number of deposits have been subject to diverse field interpretations. About a half dozen localities in the central part of the Colorado Plateau are known where the field evidence has been interpreted by nearly all observers as indicating a genetic relation between uranium deposits and faults.

\section{INTRODUCTION}

Uranium deposits of the Colorado Plateau occur in a wide variety of structural settings. The large bulk of uranium production is from sandstone beds of a few formations, but deposits are widely scattered over the Colorado Plateau and are found in close spatial association with nearly every major type of regional struc- 
ture known on the Plateau. In the past, the relation of the deposits to the regional structure has assumed a prominent position in the discussion of genesis of the sandstone-type uranium ores.

The purpose of this paper is to review the structural features in the central part of the Colorado Plateau with special reference to the occurrence of uranium deposits. The types of structure are briefly described, and the evidence bearing on the tectonic history of this part of the Plateau is summarized. Relationship of the uranium deposits to the structure in general, and of a few deposits to particular structures, is discussed in the light of the present knowledge of the tectonic history.

Some of the structural features of the Plateau have become classic examples in American geological literature, largely as a result of the brilliant expositions of the pioneers Powell $(1875,1876)$, Gilbert (1877), and Dutton $(1880,1882,1885)$. An unusually large part of the literature on the Colorado Plateau, up to the last few years, is embodied in the reports of the U. S, Geological Survey, perhaps largely because of the impetus of Powell's early interest. The writer has drawn freely on these reports and supplemented the discussion with personal observations made in the course of geologic investigations conducted by the Geological Survey on behalf of the U. S. Atomic Energy Commission.

\section{STRUCTURAL FEATURES}

Structural features of the Colorado Plateau may be classified into three main categories on the basis of origin of the stress under which the structures were formed. These three are: (1) structures related to regional warping or strain, or major uplifts and basins; (2) structures formed in response to plastic deformation of evaporites (surface structure is not necessarily reflected in the basement complex), or salt plugs and salt anticlines; and (3) structures formed in response to magmatic intrusion or volcanic explosion, or mountain domes, laccoliths, dikes, diatremes, and cryptovolcanoes. None of these structural types is completely separate from the others, but the classification is useful for purposes of comparison.

\section{MAJOR UPLIFTS AND BASINS}

As a structural unit, the Colorado Plateau is divided into a number of large uplifts and basins. Uplifts and basins in the central part of the Colorado Plateau (fig. 27) include the San Rafael Swell, Circle Cliffs, Monument, Defiance, and Uncompahgre uplifts, and the Henry Mountains and Kaiparowits basins. Structural relief as measured on formations of Mesozoic age in the central part of the Colorado Plateau is similar from one uplift to another, ranging from 7,500 to 9,000 feet. The deepest basins reflected in rocks of Mesozoic and younger age on the Colorado Plateau are the Uinta, Piceance, and San Juan basins, which are on the northern and southeastern sides of the Plateau and are adjacent to pronounced uplifts of the Middle and Southern Rocky Mountains. More than 12,000 feet of Tertiary sediments fill the Uinta Basin, the deepest of the three basins (Bradley, 1931; Williams, 1950).

Each of the uplifts and the basins is an asymetric fold, bounded on one side by a major monocline. Smaller monoclines are generally found on the crest and gently dipping flank of each of the major folds. Except along the monoclines, dips of the beds rarely exceed a few degrees. Along the monoclines the beds dip steeply and are locally nearly vertical, as along the monocline bounding the eastern margin of the San Rafael Swell, Utah (Baker, 1946), and even locally overturned, as along the Defiance monocline bounding the southeast side of the Defiance uplift, Arizona (Kelley, Wood, Silver, and Smith, 1951). It is perhaps worthy of note that all the major monoclines on the west side of the Colorado Plateau dip eastward and all of the major monoclines on the east side of the Plateau dip westward.

Where the monoclines can be traced in Precambrian rocks they pass into steeply dipping faults, as along the Kaibab monocline in Arizona (Walcott, 1890; Babenroth and Strahler, 1945) and along small monoclines on the north flank of the Uncompahgre uplift in Utah and Colorado. Displacement of younger sedimentary rocks along the monoclines also takes place partly by faulting along the Defiance monocline, Arizona (Darton, 1925), along the monocline bounding the southwest side of the Gunnison uplift, Colorado (Hunter, 1925), and especially along the monocline bounding the southwest side of the Uncompahgre uplift where the flexure is broken by a complex series of normal faults and grabens (Coffin, 1921). Dominant joint systems are commonly parallel to the trends of the monoclines, as along the Waterpocket fold, Utah (Hunt, 1953), and the monoclines bounding the Zuni uplift, New Mexico (Gilkey, 1953).

Viewed as a group, the major uplifts of the central Colorado Plateau resemble a cluster of ice floes riding up one on another as in an ice jam. Thus, it seems reasonable to regard the mechanics of origin of the uplifts as analogous to "ice jam mechanics." In this view the individual uplifts of the Plateau represent somewhat rigid tilted blocks of the earth's crust overriding one another along reverse faults. The basins are formed on the depressed sides of the overridden blocks. Major monoclines are formed by flexure of the layered sedimentary rocks over the faulted edges 


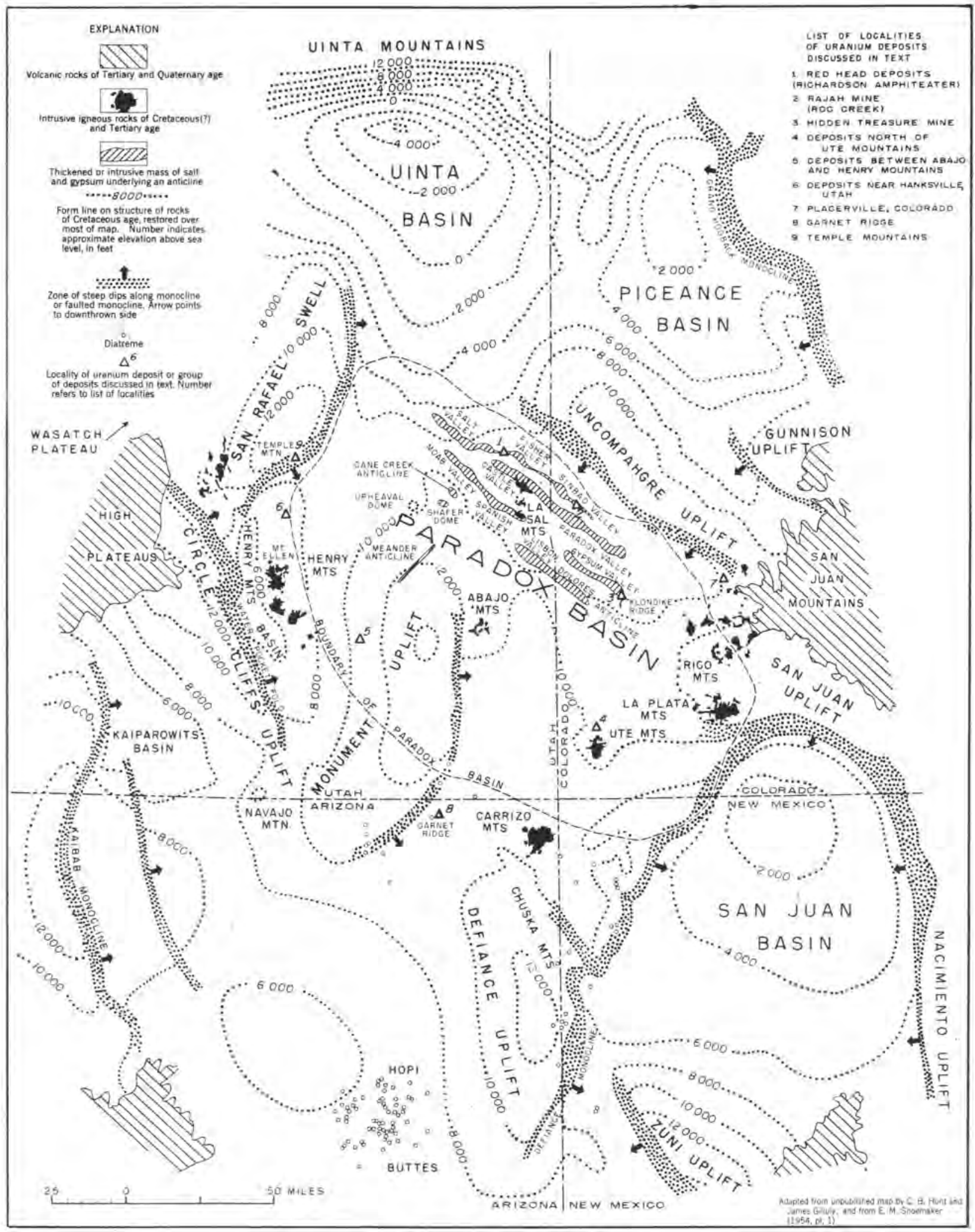

FIGURE 27.-Tectonic sketeh map of the Colorado Plateau. 
of the more rigid Precambrian basement rocks. Minor monoclines are formed over subsidiary breaks in the major units. This hypothesis implies that the major monoclines pass into reverse faults at depth as suggested by Baker (1935), but it is also in harmony with the conclusions of Dutton (1885) and of Gilkey (1953) that the stresses were transmitted to the sedimentary rocks at the surface in almost a vertical direction. The hypothesis does not imply that all of the uplifts were formed at the same time or in response to the same system of forces, for the histories of the individual uplifts are diverse despite the similarity of many of their gross features (see p. 161-163).

\section{SALT STRUCTURES}

Salt structures of Colorado and Utah occur mainly in a northwest-trending belt between the eastwarddipping monoclines on the west side of the Colorado Plateau and the westward-dipping monoclines on the east side of the Plateau. The principal structures are a series of five collapsed anticlines which contain cores of salt and intermixed gypsum and clastic sediments. All the salt structures are localized in a basin of evaporites of Pennsylvanian age known as the Paradox basin (Baker, Dane, and Reeside, 1933) (fig. 27). Wells drilled in the salt cores of some of the anticlines have penetrated as much as 10,000 and 11,000 feet of salt without reaching the base of the evaporite section. The original undisturbed thickness of the evaporite sequence in the deeper parts of the Paradox basin is not known, but the proportion of the estimated minimum volume occupied by some of the intrusive salt to the volume of its potential source suggests that the original thickness was locally more than 5,000 feet. As younger Peunsylvanian and Permian rocks are the principal beds intruded by the salt, the total thickness of rocks of late Paleozoic age may be more than 11,000 feet in the deepest part of the Paradox basin.

The general structure and history of the salt anticlines was correctly inferred by Prommel and Crum (1927) in an early study of the salt structures of Utah. Subsequently, detailed maps of the Utah salt structures were published by Baker (1933, 1946), Dane (1935), and McKnight (1940). Because of unfavorable exposures of the flanks of the salt bodies in the Utah salt anticlines, the conclusions of Prommel and Crum were not confirmed until a detailed map of the Gypsum Valley salt anticline in Colorado was completed by Stokes and Phoenix (1948). The Gypsum Valley anticline is a conspicuous anticline that contains beds as young as the Mesaverde group of Late Cretaceous age and is localized over an intruded salt body. Stokes and Phoenix showed that the intrusive core of the Gypsum Valley anticline was formed by the end of Permian time, and the intrusive rocks were exposed at the surface. The intrusive mass continued to rise as successive beds of Mesozoic age were deposited around it, and remained partly exposed at the surface until it was covered in late Jurassic and Cretaceous time. Some time after the deposition of the Mesaverde formation a fold was formed over the salt, probably during regional compression. Finally, the crest of the anticline collapsed.

Completion of detailed mapping of the Colorado salt structures and reexamination of the previously mapped anticlines of Utah (Cater, 1954; Shoemaker, unpublished) shows that the same general sequence of events that took place in the Gypsum Valley district also took place in most of the salt anticlines, though the individual anticlines vary in struetural detail.

The two best exposed intrusive masses in the core of the salt anticlines are in Sinbad Valley, Colo., and Fisher Valley, Utah (Shoemaker, 1954, pls. 2 and 3). On the Sinbad Valley-Fisher Valley anticline, concentric patterns of folds in the residual caps of the intrusive salt and gypsum masses and the trends of arcuate collapse faults in the rocks of Mesozoic age overlying the intrusive masses show that the plastic evaporites intruded as roughly circular and elliptical plugs. Individual plugs range from $1 / 2$ to about 1 mile in diameter. A large intrusive mass underlying Sinbad Valley is a composite of at least five distinct structural units and is 8 miles long by 3 miles wide.

Along the Sinbad Valley-Fisher Valley anticline, individual plugs and composite masses of salt and gypsum are strung out, from $1 / 2$ to 8 miles apart, like loose beads on a string. These masses are probably conneeted at depth to an elongate ridge of salt and gypsum along the length of the anticline. The separate intrusive masses may be thought of as cupolas extending up from the underlying salt and gypsum ridge.

Joint systems along the Salt Valley anticline, Utah, which is a northwestward extension of the Sinbad Valley-Fisher Valley anticline, form a series of areuate joint patterns similar to the arcuate fault systems around the Sinbad Valley intrusive mass. Thus, by analogy with Sinbad Valley, the salt core of the Salt Valley anticline is inferred to be composed of four discrete intrusive masses, one lying at the center of each system of arcuate joints.

A distinct change in the structure of the salt cores is found in successive anticlines southwest of the Sinbad Valley-Fisher Valley-Salt Valley anticlinal system. This change may possibly be related to progressive thinning of the original deposits of evaporites and possibly to distance from the Uncompahgre uplift, which was the source of late Pennsylvanian and Permian clastic sediments through which the salt masses rose. 
The plugs along the Sinbad Valley-Fisher Valley-Salt Valley lineament tend to be the most isolated and to conform most nearly to a circular outline. A plug at Roc Creek, Colo., closely approached in size and outline some of the representative salt stocks of the gulf coast region. Along the Castle Valley-Paradox Valley lineament, next to the southwest, structural units in the salt and gypsum core of the anticline seem to be somewhat larger than the Sinbad Valley plugs, Bulbous masses of salt and gypsum at either end of Paradox Valley, Colo., are connected by a narrower ridgelike body. The structure of the core in the northwest half of the Castle Valley-Paradox Valley lineament is locally complicated by the intrusion of laccoliths at the top of the salt and gypsum mass.

Two distinct intrusive units are inferred to lie along the Moab Valley-Spanish Valley anticline. Whether the two units inferred along the Moab Valley-Spanish Valley anticline are connected by an intrusive salt and gypsum ridge along the length of the anticline cannot be definitely determined, but Hunt (in preparation) believes that the laccoliths of the southern La Sal Mountains, which lie along the southeast extension of the anticline, may be injected at the top of an intrusive salt and gypsum mass as are the laccoliths in the northern La Sal Mountains.

Gypsum Valley appears to be underlain by a continuous long intrusive ridge of salt and gypsum. No tendency for the ridge to be divided into discrete plugs is known although different parts of the ridge were more active than others in Jurassic time.

The Lisbon Valley-Dolores anticline is known from drilling to be partly underlain by a thickened mass of salt and gypsum, though none of the Pennsylvanian evaporite sequence is exposed at the surface. No evidence suggests that the evaporites have anywhere intruded beyond their normal stratigraphic position.

The transition in structure of the salt cores from the Lisbon Valley-Dolores anticline on the southwest to the Sinbad Valley-Fisher Valley-Salt Valley lineament on the northeast appears to be a progressive change from thickened masses not intrusive beyond the original stratigraphic position of the salt to long ridgelike intrusive masses and then to discreet circular to oval intrusive units. Probably these differences are due to deeper burial of the northeasternmost salt structures and consequent greater height of the intrusive column of salt, which would permit the plastic evaporite masses to be drawn out into discreet stocklike units.

Meander anticline, a narrow complexly faulted northeast-trending fold that follows the canyon of the Colorado River, has been interpreted by Harrison (1927), Baker (1933, 1946), and McKnight (1940) as a salt structure of recent origin. Removal of the load along the canyon apparently has caused upward flowage of the plastic beds coincident with the canyon. Though Prommel and Crum (1927) and Stokes (1948) have suggested that Meander anticline is localized over an older salt structure, as are the larger northwest-trending anticlines, no conclusive evidence has been brought forward to support this interpretation.

Upheaval dome is one of the most spectacular and controversial structures in southeastern Utah. It conforms closely in configuration with Nettleton's ideal theoretical salt dome (Nettleton, 1934) and is in close proximity to proven salt structures. These facts led McKnight (1940) to favor interfretation of Upheaval dome as a salt plug, and the reported thinning of the Wingate sandstone of Triassic age across the dome has led many geologists, among them Stokes (1948), to support the salt plug hypothesis with considerable conviction. Conversely, the structure of the central part of the dome and the results of recent geophysical studies (Joesting and Byerly, 1954) lend support to the hypothesis of Bucher (1936) that Upheaval dome is of cryptovolcanic origin (see "Cryptovoleanic struetures"). It is possible, though it seems unlikely, that the dome owes its present form to both salt intrusion and cryptovolcanic forces.

\section{STRUCTURES PRODUCED BY IGNEOUS ACTIVITY}

\section{IACCOLITHIC MOUNTAIN GROUPS}

The laccolithic mountains of the central Colorado Plateau include the Henry, La Sal, and Abajo Mountains of Utah, the Ute Mountains of Colorado, and the Carrizo Mountains of Arizona. The Henry Mountains are the area in which laccoliths were first described and named by Gilbert (1877). Navajo Mountain, on the Utah and Arizona border, has also been considered a member of this group though no igneous rock is exposed. The Rico and La Plata Mountains of southwestern Colorado have also generally been considered members of the central Colorado Plateau laccolithic mountains family as they are practically identical to the central Plateau laccolithic mountains in general structure and petrography of the principal igneous rocks.

Present-day concepts of the structure of the mountains in the central Plateau are due largely to Hunt (1953), who remapped the Henry Mountains in detail. Hunt has shown that each of the Henry Mountains is underlain by a broad structural dome from 6 to 15 miles in diameter. At the center of each dome lies a stock. Four of five of the Henry Mountains domes and the dome of Navajo Mountain are each about 6 miles in diameter but vary in height; the height of each dome Hunt found to be nearly proportional to the diameter of the central stock. He further found that the sur- 
face area of each of the domes was nearly equal to the original surface area of the undeformed rocks plus the area of the exposed stock. These relations have been interpreted to indicate that the domes were produced by the vertical thrust of the magma which formed the stocks.

The laccoliths of the Henry Mountains are tongueshaped masses that radiate from the stocks. They are 1 to 4 miles in length and $1 / 2$ to 3 miles in width. Both linear bulges and dikes on the roofs of the laccoliths radiate from the stocks. The laccoliths are generally concordant but gradually cut upward in the section toward their distal ends. On the distal end of some laccoliths the roofs are faulted upward to form bysmaliths. A dozen laccoliths, three bysmaliths, and several irregular crosscutting intrusive bodies surround the stock on Mount Ellen, largest and most complex of the Henry Mountains.

The structure of the La Sal Mountains has been found to be closely comparable to that of the Henry Mountains (Hunt, in preparation). Each of three main mountain masses of the La Sals has been found to be underlain by a broad dome with a stock at the center surrounded by a cluster of laccoliths. The northern and southern domes are superposed on salt structures and the laccoliths are intruded mainly near the top of the salt and gypsum masses. A significant feature of the stock in the northern mountain is the occurrence of breccia pipes, which strongly suggests that the stock was connected to the surface sometime during the igneous activity (Hunt, in preparation).

A reconnaissance study of the Ute Mountains has shown them to be made up of about 30 major laccoliths and bysmaliths surrounding 2 stocks (Shoemaker and Newman, 1953). The plan of intrusion is closely comparable to the Henry Mountains type, though the stocks are so close together that laccoliths from each stock overlap. A low dome, which has not yet been accurately defined, underlies the mountains.

The Carrizo Mountains are composed mainly of sills (J. D. Strobell, oral communication), and in this character they are closer in structure to the La Plata Mountains (Eckel, 1949) than to the Henry Mountains. The La Plata and Rico Mountains are each underlain by pronounced domes, with stocks at the centers, and include many sills and laccoliths (Eckel, 1949; Cross and Ransome, 1905). The Abajo Mountains have not yet been studied in detail adequate to verify their structure, but they probably conform to the Henry Mountains type.

The laccolithic mountains are scattered without apparent relation to the other major structural features of the Colorado Plateau. They are in the centers of the basins, on the flanks and noses of the uplifts, and, among the salt structures, on both anticlines and a syncline. There is however, a certain apparent regularity in the distribution of the laccolithic centers, as though the processes involved in the magmatic activity had specific broad requirements of space. The mountain groups are rather evenly spread over the central part of the Plateau. If the Henry Mountains are considered as a group and the Rico and La Plata Mountains grouped together, the distance from one main group of laccolithic mountains to the next nearest group ranges from about 30 miles to about 60 miles, the spacing becoming closer to the east. Rather than planes of weakness in the basement complex, the fundamental control of the location of the laccolithic mountains may be "cells" of magma related to much broader structures in the subcrust.

\section{SHLS, DIKES, AND SMALL LACCOLTTHS}

Two groups of small laccoliths, sills, and associated dikes that appear to be unrelated to the laccolithic mountain groups occur in the central part of the Colorado Plateau. Thin but extensive sills accompanied by a large group of dikes occur in the San Rafael Swell, Utab. Most of the sills are composite, consisting mainly of alkaline diabase injected by syenite (Gilluly, 1927). A group of small laccoliths and sills occurs on the southeast end of the Gypsum Valley salt anticline; no dikes or stocks that may have fed them are known to be exposed.

\section{DIATREMES}

About 250 diatremes are scattered over parts of northeastern Arizona, northwestern New Mexico, and southeastern Utah. The diatremes are associated with flows and tuffs of Pliocene age that rest on remnants of a surface of low relief. This surface is preserved in parts of Arizona and New Mexico but has been entirely removed in southeastern Utah. The diatremes are funnel-shaped volcanic vents, and they flare to a width of a mile or more at the level of the Pliocene surface onto which they erupted. Where the Pliocene surface has been stripped away, the uppermost part of the diatremes is also absent and the exposed vent is smaller. Generally the vents range from a few hundred feet to half a mile in diameter where they are exposed at depths of 1,000 to 2,000 feet below this Pliocene surface.

Though some of the diatremes have been recognized for a long time as volcanic necks (Gregory, 1917; Williams, 1936), it remained for Hack (1942) to demonstrate the general structure of the diatremes. A wide variety of material fills the diatremes; the material found at any one exposure depends largely on the stage of development of the diatreme and the level of ex- 
posure. In its upper part a fully developed diatreme is filled with tuff and limestone, and locally even laminated clay, evaporites, and bedded chert. Lower in the vent these sediments give way to tuff, breccia, huge blocks of country rock, and finally agglomerate and solid igneous rock. Much of the tuff filling, which in some vents is at least 2,000 feet thick, is well bedded and shows many features of fluvial deposition, such as cross-lamination, channels, and unconformities. The dips of the beds steepen with depth and are commonly vertical and intensely deformed in the deeply eroded vents. In some vents the bedding is obscured by shearing along small closely spaced thrust faults. Igneous rocks associated with the diatremes are nearly all alkaline basalts ranging from monchiquite to minette. In a few vents micaceous serpentine tuff and serpentine tuff similar to kimberlite have been found (Malde, 1954; Allen and Balk, 1954). Diatremes in southeastern Utah and adjacent parts of Arizona can be arranged in a series to show progressive development, which appears to involve subsidence in the vent and collapse of the walls of the vent.

\section{CRYPTOVOLCANIC STRUCTURES}

Structures of uncertain origin that resemble in many ways some of the diatremes of the Navajo-Hopi Reservations but are unaccompanied by exposed igneous rocks are widely scattered over the Colorado Plateau. The best known of these structures is Upheaval dome, which consists of a pronounced dome chaotically broken in the center and surrounded by a ring syncline. The entire structure is about 3 miles across. MeKnight (1940) described the central part as containing broken blocks of White Rim sandstone of Permian age, but personal observations have convinced the writer that the sandstone masses are in reality sandstone dikes that cut the highly deformed Moenkopi formation of Triassic age. The sandstone masses are narrow and dikelike in form. These masses cut across the beds of the enclosing Moenkopi formation, and some of them branch, forming a rudimentary anastomosing system. The source of the sand may well have been the White Rim sandstone. Aeromagnetic surveying has revealed a pronounced magnetic anomaly over Upheaval dome, which strongly suggests the presence of igneous rock at depth (Joesting and Byerly, 1954). The main feature that is difficult to explain by Bucher's (1936) eryptovolcanic hypothesis is the thinning of the Wingate sandstone of Triassic age over the dome. It should be noted that the Wingate is not only thinned but also in places puckered along what appear to be small roughly radial folds. McKnight's suggestion that the Wingate has been thinned by shearing along planes roughly parallel to the bedding seems possible. $385115-56-12$
It is also possible that the sandstone has flowed locally as a loose sand aggregate.

Another enigmatic structure in southeastern Utah that may be of cryptovolcanic origin occurs at Temple Mountain, in the San Rafael Swell, about 20 miles from the intrusive alkaline diabase bodies in the southern part of the swell. A series of small chimneylike collapse structures are localized in the center of a gentle structural dimple about half a mile across. Several other similar but smaller structural dimples have been reported from the vicinity. At Temple Mountain beds are dropped into two of the chimneys, like trap doors hinged on one side to undisplaced rocks. The downward displacement is as much as a few hundred feet. Small breccia pipes 10 to 20 feet across are adjacent to one of the chimneys. Fractures in the down-dropped beds appear to be "healed"; small planes of displacement within the chimneys are exceedingly difficult to detect. Other geologists who have studied this structure have suggested that it is caused by solution and collapse in underlying limestones of Permian age, A ground magnetic survey revealed no local anomaly underlying the chimneys (Warrick, R. E., written communication).

\section{TECTONIC HISTORY}

The Colorado Plateau emerged as a tectonic unit sometime before the beginning of the Cambrian. During the early and middle Paleozoic it was a stable mass, alternately a partly inundated shelf and then a lowland marginal to seas on the west (McKee, 1945; 1951). The first major deformation of the central part of the Plateau began sometime in the late Mississippian or early Pennsylvanian and continued intermittently into Triassic time (Baker, 1935). During this period of deformation the Paradox basin became outlined and filled. First filling of the basin was mainly with evaporites, then with limestone, and finally with clastic sediments shed from the ancestral Uncompahgre uplift which rose simultaneously on the northeast side of Paradox basin. The evaporite section exposed nearest to the Uneompahyre, in Sinbad Valley, contains abundant interbedded arkose shed from the ancient highland. A second pulse of uplift along the ancestral Uncompahgre in late Pennsylvanian or near the beginning of the Permian resulted in the spread of a sheet of arkose (the Cutler formation) far out into the Paradox basin. Folding in the basin, accompanying this pulse, probably started salt intrusion. That the salt began to rise near the beginning of Cutler deposition can be demonstrated by pinch-out and overlap of Cutler strata on the flanks of the Fisher Valley and northwest Paradox Valley salt structures.

Slight renewed uplift in Late Permian or Early Triassic time and also in mid-Triassic on the ancestral 
Uncompahgre uplift is recorded by two angular unconformities, one beveling beds of the Cutler, and the other, beds of the Moenkopi formation of Triassic age, on the flank of the uplift. Similar unconformities on the flanks of the salt structures may indicate that this uplift was accompanied by some compressive folding over the structures. A third angular unconformity occurs locally within the Moenkopi formation around the intruded salt. Parts of the ancestral Uncompahgre crystalline basement remained exposed until late in the Jurassic on the eastern edge of the Colorado Plateau, but these may have been merely residual highlands and not the result of renewed uplift. Similarly, the salt masses maintained themselves at the surface until late in the Jurassic as sediments were deposited around them; however, angular unconformities between formations of Jurassic age on the flanks of the salt masses are not known. The close balance between the rise of the salt and sedimentation suggests that the main motivating force for the movement of the salt masses was the actual loading of sediments on their periphery.

During most of the Cretaceous the central part of the Colorado Plateau was relatively stable, but sank epeirogenically in the Late Cretaceous, receiving an average thickness of about 5,000 feet of sediments. Strong folding just west of the Colorado Plateau, which began near the middle of the Cretaceous, does not appear to have been reflected in the central part of the Plateau until near the end of Cretaceous time (Spieker, 1946).

The exact placing of the periods of deformation in the central part of the Colorado Plateau is subject to some uncertainties, partly beeause beds younger than Montana in age (middle to late Late Cretaceous) are missing from the central Plateau and partly because deformation has taken place at several different times around the periphery of the Plateau. Subsidiary folds of the Circle Cliffs uplift are bevelled by a smooth erosion surface that is overlain by beds tentatively correlated with the Flagstaff limestone (Spieker, 1946) of Paleocene(?) age. Speiker suggests that the date of the folding may coincide with post-North Horn formation and pre-Flagstaff folding to the northwest on the western margin of the Wasatch Plateau, a disturbance which now may be placed with some confidence in the mid-Paleocene. On the other hand, as the youngest beds involved in the folding of the Circle Cliffs uplift are in the Mesaverde formation in the Henry Mountains basin where the formation is of mid-Montana (midLate Cretaceous) age (Hunt, 1953; Cobban and Reeside, 1952), it is possible that the folding may date to late Montana. Evidence from the San Juan Basin, on the east side of the Plateau, suggests that some of the uplifts were formed by latest Cretaceous time. Pebbles of crystalline rocks, probably from Precambrian formations, are found in the Ojo Alamo sandstone of latest Cretaceous age in the middle of the San Juan Basin (Reeside, 1924; Cobban and Reeside, 1952). The source of these pebbles is not certain; they may have come from the vicinity of the San Juan uplift to the north, or from uplifts on the east side of the San Juan Basin or possibly even from the south. In any event, they suggest that the Precambrian basement was exposed along uplifts possibly marginal to the basin. The San Juan Basin was already formed as a basin of local deposition in latest Cretaceous time, and it seems likely that initial deformation on some of the uplifts surrounding the basin-the San Juan, Nacimiento, Zuni, and Defiance uplifts-took place at this time.

The only known stratigraphic evidence that may yield a precise assignment of the age of the laccolithic mountain groups of the central Colorado Plateau is also found in the San Juan Basin. The McDermott member of the Animas formation, which underlies the Ojo Alamo sandstone of latest Cretaceous age, is largely a tuff composed mainly of "andesitic" debris (Reeside, 1924). As the MeDermott member is traced northward in the San Juan Basin the amount of igneous material in it increases, and the fragments of detritus reach a maximum size directly opposite the La Plata Mountains, which lie 12 miles distant from the nearest McDermott strata. Boulders of porphyry from the $\mathrm{McDermott}$, some as much as 3 and 4 feet across, are lithologically similar to the diorite porphyry of the La Plata Mountains. Preliminary study of the traceelement composition indicates that the composition of boulders in the McDermott is like that of the laccolithic rocks of the central Colorado Plateau (including the La Plata Mountains) and is significantly different from the igneous rocks of the San Juan Mountains. The conclusion seems justified that at least some of the coarse debris in the McDermott member of the Animas formation was probably derived from the La Plata Mountains igneous center, and that some of the intruded masses of the La Plata Mountains are probably of latest Cretaceous age.

A latest Cretaceous age is not precluded for any of the central Colorado Plateau laccoliths, and with the lack of definite evidence to the contrary, it seems reasonable to assume that most of the laccolithic clusters of the central Plateau were intruded almost contemporaneously. Even though most of the mountains have formed actual topographic highs since latest Cretaceous time, a Cretaceous age seems to the writer to be compatible with geomorphic relations of the mountains, though the geomorphic evidence has also been interpreted by Hunt (1953) as supporting a mid-Tertiary age. 
No direct stratigraphic evidence is available for dating the anticlines that were formed over the old salt structures sometime after the deposition of the Mesaverde. Initial folding of the Cretaceous may have been contemporaneous with the deformation of eastward-facing monoclines on the west and south sides of the Colorado Plateau, probably in the period of latest Cretaceous to mid-Paleocene. However, northwest-trending faults, some contiguous with the salt anticlines and probably roughly contemporaneous with one or more periods of renewed folding on the anticlines, trend across the monocline bounding the southeast side of the San Rafael Swell and appear to be independent of the structure of the swell. Folding on the anticlines may also have occurred during deformation of the westward-facing monoclines on the east side of the Plateau where the strongest movements seem to have occurred in the latter part of the Eocene or later. One point of evidence on the relative ages of the laccolithic intrusions and post-Mesaverde folding on the salt anticlines is the fact that the laccoliths of the northern La Sals occupy the collapsed southwestern limb of the Castle Valley-Paradox Valley fold, suggesting that igneous intrusion was later than or contemporaneous with the folding and first stages of collapse. In summary, the post-Mesaverde folding was later than the deposition of the Mesaverde (middle to late but not latest Late Cretaceous); northwest-trending faults contiguous with the salt anticlines trend across a monocline of possible latest Cretaceous or midPaleocene age, which suggests different ages for the monocline and the 1 ost-Mesaverde folding and collapse on the salt structures; a series of laccoliths of possible latest Cretaceous age are localized in the collapsed limb of a salt anticline, a position which suggests that initial post-Mesaverde folding and collapse of the salt struetures may not be later than latest Cretaceous. The best hypothesis that appears to fit these tenuous and somewhat conflicting lines of evidence is: initial deformation along the monoclines on the south and west sides of the Plateau, initial folding of Cretaceous strata over the salt masses, and intrusion of the laccoliths all took place about the same time, somewhere near the end of the Cretaceous.

That deformation occurred repeatedly during the Tertiary on the peripheral parts of the Colorado Plateau can be demonstrated, but it is not known to what extent all of these movements were reflected in the central part of the Plateau. The Uinta Mountains on the north edge of the Plateau rose repeatedly, perhaps almost continuously during the Eocene, while the Uinta Basin subsided, receiving a thick accumulation of sediments shed, in large part, from the adjacent mountains (Bradley, 1931; Kay, 1934). Successive formations of Eocene age overlap each other on the flanks of the mountains. Some deformation followed the deposition of the youngest Eocene strata, perhaps close to the end of the Eocene or early in the Oligocene. Renewed movement which affected formations of Eocene age occurred probably about this time on the north end of the San Rafael Swell, and the entire fold of the swell may have been rejuvenated. The Circle Cliffs uplift was apparently not affected however, for the early Tertiary strata deposited across the northern end of the uplift are not folded. The Grand Hogback monocline, which marks the northeast boundary of the Plateau, was formed mainly after deposition of Eocene strata which are flexed sharply along the fold (Gale, 1910). Similarly the main Tertiary deformation of the Uneompahgre uplift is of late Eocene or post-Eocene date, as mid-Eocene strata are involved in the folding along the north side. In the San Juan Basin folding occurred at the end of the Paleocene and also after deposition of Eocene strata.

No stratigraphic record of the main part of the Oligocene is preserved on the Colorado Plateau, perhaps because of relative tetonic quiescence during this epoch or perhaps because the drainage of the Plateau must have become integrated at this time and sediments were transported entirely out of the province.

Toward the close of the Miocene or beginning of the Pliocene the Plateau began to be uplifted epeirogenically (Longwell, 1946). At almost the same time, the east end of the Uinta Mountains arch began to collapse (Bradley, 1936). Block faulting in the High Plateaus of Utah also probably began. How many of the minor structures in the central part of the Colorado Plateau may have been formed or rejuvenated during the general uplift it is impossible to say, but their number may be considerable.

Renewed deformation has occurred on some of the major uplifts of the Colorado Plateau in late Pliocene and Pliestocene time. Fine-grained Pliocene deposits are tilted on the flanks of the Defiance and Zuni uplifts (Hack, 1942; McCann, 1938). The San Juan uplift may have been rejuvenated late in the Pliocene (Atwood and Mather, 1932). The Uncompahgre uplift may have been raised an additional 1,500 feet since the cutting of Unaweep Canyon, a windgap across the crest of the uplift. Terrace gravels composed of rocks derived from regions to the east of the Uncompahgre and transported through the windgap now lie about 1,500 feet below the windgap on the west side of the uplift.

Eventually, as a result of the uplift, the drainage pattern of the Colorado Plateau was incised, and collapse of the salt anticlines was renewed. The earliest stages of collapse on the anticlines probably followed 
shortly after the initial folding, as a result of readjustments in the plastic cores on release of the compressive stresses. Some collapse may also have accompanied later periods of deformation on the Plateau. When the drainage channels were incised, the level of active ground-water circulation was lowered, and further collapse began as a result of the solution and abstraction of salt. The crests of the anticlines became breached, and with the removal of load from above the centers of the intrusive masses, the plastic evaporites were pressed from beneath the sides and ends of the newly formed valleys and up in the centers where the confining seal of rocks had been removed. Late Tertiary and Quaternary movement in the evaporites is recorded by a thick series of folded Pliocene(?) deposits in Castle Valley and in Pliocene(?) and Pliestocene deposits in Fisher Valley within which there are three angular unconformities.

\section{RELATION OF URANIUM DEPOSITS TO STRUCTURE}

Uranium deposits have been found on the Colorado Plateau in nearly all the major kinds of sedimentary rocks and in more than half of the sedimentary formations ranging in age from late Paleozoic through late Tertiary. A number of deposits are also localized in the igneous intrusive rocks of possible Late Cretaceous and Tertiary age and in voleanic rocks of Tertiary age. More than 85 percent of the known deposits, however, are in sandstone and conglomeratic sandstone strata of the Shinarump conglomerate and Chinle formation, both of Late Triassic age, and of the Morrison formation of Late Jurassic age. Most of the deposits consist of sandstone and minor amounts of mudstone impregnated with and partly replaced by minerals of uranium, vanadium, and in places copper or other metals. At least two generations of ore minerals are present in some of the deposits, an early generation consisting mainly of low-valent oxides, sulfides, and silicates; and a later generation consisting mainly of intermediateto high-valent vanadates, carbonates, and silicates. Most deposits in which the ore minerals are in part or wholly high valent can be interpreted as having been derived by oxidation of deposits consisting largely of low-valent minerals. Generally the deposits are tabular and tend to follow the bedding of the sandstones, though the distribution of ore minerals does not follow the lamination of the sedimentary host in detail.

Most uranium deposits in sandstone are intersected by joints and many by faults. In most of these deposits that have been studied in detail, joints do not appear to have influenced the distribution of ore minerals in any immediately recognizable way, except for the occurrence of soluble vanadates, sulfates, and other highvalent minerals of evident secondary origin that coat fracture surfaces. Similarly, most faults appear merely to have offset the deposits which they intersect. The relations of a number of deposits to joints and faults, however, have been subject to different field interpretations by different geologists, and nearly all observers have agreed that a few uranium deposits in sandstones on the Colorado Plateau have been localized by faults.

\section{AGE OF THE URANIUM DEPOSITS}

The principal data on the age of the uranium deposits of the Colorado Plateau are the lead-isotope determinations of uranium ores and minerals obtained by Stieff and Stern (1952) and Stieff, Stern, and Milkey (1953). Stieff and Stern showed that the ages calculated from the $\mathrm{Pb}^{206} / \mathrm{U}^{238}$ and $\mathrm{Pb}^{207} / \mathrm{U}^{236}$ ratios in specimens of massive uraninite from beds of Triassic age of southeastern Utah are about the same, within the limits of error of the method, as the ages calculated by the same methods for specimens of uraninite in vein deposits in the Front Range of Colorado. The calculated ages of the Front Range deposits are about 60 million years, and these calculated ages have been used by Holmes (1946) to assign a value to the beginning of the Tertiary. The precise geologic age of the Front Range deposits is not accurately known but they lie in the range of latest Cretaceous to early Tertiary (Lovering and Goddard, 1950). The calculated ages of the uraninite samples from southeastern Utah range from 65 to 75 million years. This indicates a Late Cretaceous or early Tertiary age for these minerals, as contrasted with the Late Triassic age of the host rock (about 160 million years according to Holmes). Stieff and Stern further showed that a large number of Colorado Plateau ores, mainly from the Morrison formation of Jurassic age, have about the same calculated lead: uranium age as the massive uraninites from Triassie strata. The calculated ages of ores from the Morrison formation average 75 million years. This work strungly suggests that the main period of uranium mineralization on the Colorado Plateau was in Late Cretaceous or early Tertiary time.

Uranium deposits of younger age, however, are known from a number of localities on and immediately adjacent to the Colorado Plateau. In the Uinta Basin uranium deposits in the Wasatch and Uinta formations of Eocene age cannot be older than Eocene. Other uranium deposits have recently been discovered in the Browns Park formation of late Miocene or early Pliocene age on the northern edge of the Colorado Plateau. Low-grade uranium-bearing rock has been reported from volcanic formations of probable Miocene age in the San Juan Mountains (Burbank and Pierson, 1953). Uranium deposits are localized in diatremes of Pliocene age on the Navajo and Hopi Reservations 
(see p. 179-185). At Marysvale, in the High Plateaus of Utah, uranium deposits are found in volcanic rocks of middle or late Tertiary age. It may be concluded, then, that although the great bulk of the uranium deposits on the Colorado Plateau may be of Late Cretaceous or early Tertiary age, uranium-bearing solutions were circulating at least locally on or adjacent to the Colorado Plateau later than early Tertiary time.

\section{RELATION TO SAIT ANTICLINES}

The principal region of vanadium and uranium production from the Morrison formation corresponds closely to the region of the salt anticlines (Fischer, 1944). If the conclusions that the bulk of the uranium deposits in southeastern Utah are of Late Cretaceous or early Tertiary age is valid, the regional structures of primary interest that may be related to uranium mineralization are those that were in existence in Late Cretaceous and early Tertiary time. The salt intrusive structures are known with certainty to have been in existence at the time of mineralization, regardless of the age of the ores. It seems unlikely that the coincidence of the principal region of production of vanadium and uranium from the Morrison formation with the region of the salt structures is purely accidental.

The detailed relations of uranium deposits to specific faults and fractures on the salt anticlines are subject to considerable differences in interpretation. That divergent opinions should exist is not surprising in view of the demonstrably complex history of the structures. Collapse faulting occurred repeatedly during the Tertiary, and the assignment of a specific age to any except the latest faults is generally not possible. Displacement on many of the older faults has probably been repeated many times. A further complicating factor is that most of the deposits investigated up to now consist mainly of oxidized ore. Some migration of the ore metals has taken place, as is shown by the occurrence of secondary uranium and vanadium minerals along faults, joints, and even the walls of mine workings. In view of these complexities, inclusive generalizations on the relation of the ores to faults and fractures are exceedingly hazardous.

Many of the earlier students of uranium deposits on the Colorado Plateau came to the conclusion that with a few notable exceptions the deposits are older than the faults and fractures that intersect the ore (Hess, 1914, and 1933; Coffin, 1921; Fischer, 1937 and 1942). Most of the work on which these conclusions were based was done in the region of salt anticlines. Because so much of the collapse structure can be shown to be of comparatively recent origin, it seems likely from the present knowledge of the structural history that the belief that most of the ore is older than most of the faults, or, more precisely, that most of the ore is older then the latest displacements on most of the faults, is correct. A few deposits that are outstanding exceptions to this generalization have been explained as secondary concentrations of ore minerals derived from previously formed deposits. From an alternative point of view, it is also conceivable that the exceptional deposits that are related to faults, even though composed largely of oxidized minerals, mark the sites of primary (Late Cretaceous to early Tertiary) mineralization, and are controlled by faults that were in existence in latest Cretaceous or early Tertiary time.

Nearly all observers have agreed that the following few deposits have been localized by faults:

Red Head deposits.-The uranium deposits on what are now called the Red Head claims in Richardson Amphitheater, Utah, were among the first from the Colorado Plateau to be described in the geological literature (Boutwell, 1905). They are localized along a fault system connecting the Salt Valley salt anticlines with the Fisher Valley salt anticlines (fig. 27). The exposed ore is mainly restricted stratigraphically to the base of the Kayenta formation. Ore minerals, mainly tyuyamunite, calciovolborthite, and conichalcite (Hillebrand and Merwin, 1913; Weeks and Thompson, 1954), are distributed along joint surfaces in highly fractured sandstone, along fault planes and in the fault gouge, and in small concretionary nodules scattered through the sandstone. The ore is concentrated in a westtrending zone of strong fracturing and also along fractures trending obliquely to this zone.

Rajah mine.-At the Rajah mine, ore has been produced from rich veinlike pods along one of the major faults that displaces the formations of Mesozoic age over the Roe Creek salt plug. In the fault zone, which is several feet wide, the ore occurs as lenses and pods in the fault gouge and breccia and as stringers along the planes of slippage. Most of the ore left in the walls of the stopes is near the footwall of the fault zone. Some of the ore from the pods in the fault was very high in grade, and it was evidently from one of these pods that the material was taken in which uranium was first discovered on the Colorado Plateau (Kimball, 1904) and from which the mineral carnotite was first described (Friedel and Cumenge, 1899), Ore has also been produced from two layers that extend away from the fault in to the hanging wall formed by the Salt Wash sandstones member of the Morrison formation (fig. 28). Carnotite, micaceous vanadium minerals, and copper carbonates are disseminated in relatively thin layers that follow the bedding of the sandstone. Little mineralized ground has been found in the Wingate sandstone of 


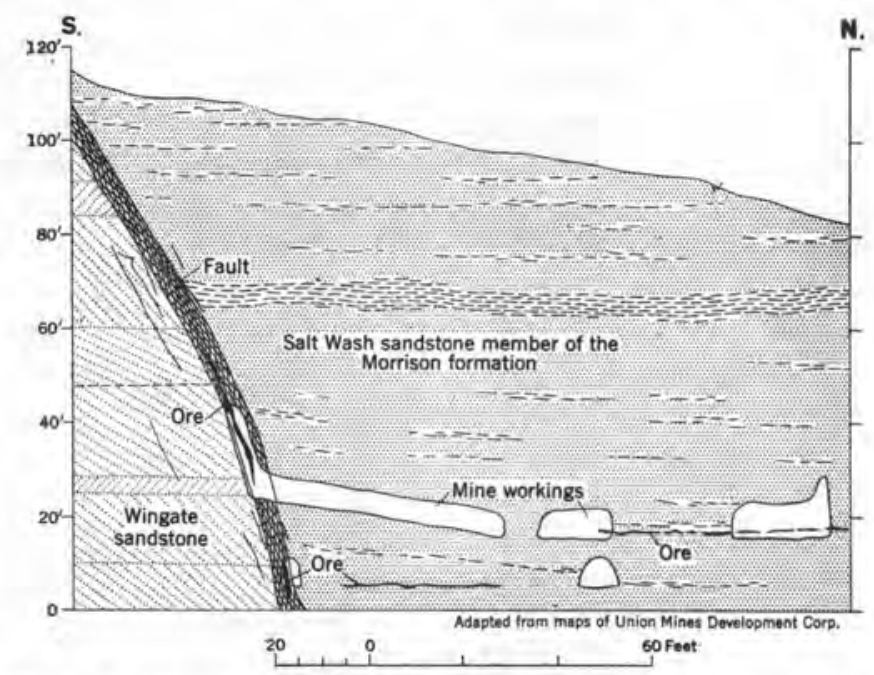

FinURE 28.-Cross section through the Rajah mine. Patterns suggesting sedimentary features are diagrammatic only. Joints and small faults are not shown.

Triassic age which forms the foot wall of the fault. The ore in the fault occurs both above and below the known levels of mineralization in the walls. Other deposits along faults over the Roc Creek plug are found in the Chinle formation and the Wingate sandstone, both of Triassic age, and the Kayenta formation of Jurassic(?) age. A sample of carnotite ore from the Kayenta formation adjacent to one of these faults gave a calculated $\mathrm{Pb}^{206} / \mathrm{U}^{238}$ age of 60 million years (isotopic data given in Stieff, Stern, and Milkey, 1953).

Uranium-bearing copper deposits on the salt anticlines.-Besides uranium deposits a number of copper deposits, some known to contain uranium, occur on the salt anticlines. Most of the copf er deposits are along faults but some are disseminated in bedded sedimentary rocks and show no obvious relation to faults. The best developed vein deposits of copper occur along faults trending perpendicular to the lengths of the anticlines (Fischer, 1936). Several copper deposits occur in formations of Paleozoic age adjacent to the salt masses and in rocks of Mesozoic age overlying the salt masses on the Sinbad Valley-Fisher Valley anticline (fig. 29). The relation between the copper deposits and the uranium deposits is not certain, but the two types of deposits are closely associated and may have the same relation to the structure on the Sinbad Valley-Fisher Valley anticline. Some, but not all, of the copper deposits in Sinbad Valley contain a small amount of uranium. Fischer (1936) believes the vein copper deposits are different in origin from the uranium deposits.

Hidden Treasure mine.-The Hidden Treasure mine is on a vein deposit along a fault on the southeast end of the Gypsum Valley salt anticline. The vein contains sparse copper minerals in a celestite gangue. Small amounts of uranium and vanadium are also contained in the vein, but the mineralogy has not been studied in detail. Manganese minerals are also distributed along the faults in the same vicinity and a deposit of manganese occurs nearby in the Summerville formation of Jurassic age. Small loccaliths of diorite lie about a mile south of the Hidden Treasure mine.

\section{RELATION TO FAULTS OUTSIDE THE SALT ANTI- CLINE REGION}

About the same relation between uranium deposits and faults and joints as has been noted on the salt anticlines is found outside of the region of the salt structures. The great majority of deposits show no readily apparent relation to regional structures (Hess, 1933; Fischer, 1936). More recently discovered ores in formations of Triassic and Permian ages do not appear to be an exception to this general observation (Finch, 1953). Structural relations at a number of deposits, however, have been subject to diverse field interpretations. Because the Colorado Plateau, including the central part, has probably undergone several periods of deformation during the Tertiary, it is not unlikely that most of the uranium deposits are older than many, if not most, of the regional structures. Again, a few deposits are obvious exceptions to this general rule, and it is possible to interpret these deposits either as of later origin than most of the uranium deposits or as localized on early structures that were present at the time that most of the uranium deposits appear to have been formed (Late Cretaceous to early Tertiary).

Uranium deposits along faults north of the Ute Mountains.-Deposits of low-grade uranium-bearing rock are scattered along an arcuate zone of faults north of the Ute Mountains. Two sets of faults are present, one arcuate around and the other radiating from the northern part of the Ute Mountains, and it is possible that faults are related to the emplacement of the northern stock in the mountains. Traces of copper minerals are present in some of the igneous rocks, and along the radial and arcuate faults. Uranium occurs along both the arcuate and radial faults and is disseminated in Jurassic strata adjacent to the faults.

Uranium deposits related to other faults.-Uranium deposits related to regional structures have been reported from a number of other localities scattered across the central Colorado Plateau. A vertical fracture filled with a silica vein containing uraniferous chalcocite, was reported in the Moenkopi formation of Triassic age in the area between the Henry and Abajo Mountains, Utah, by Benson, Trites, Beroni, and 


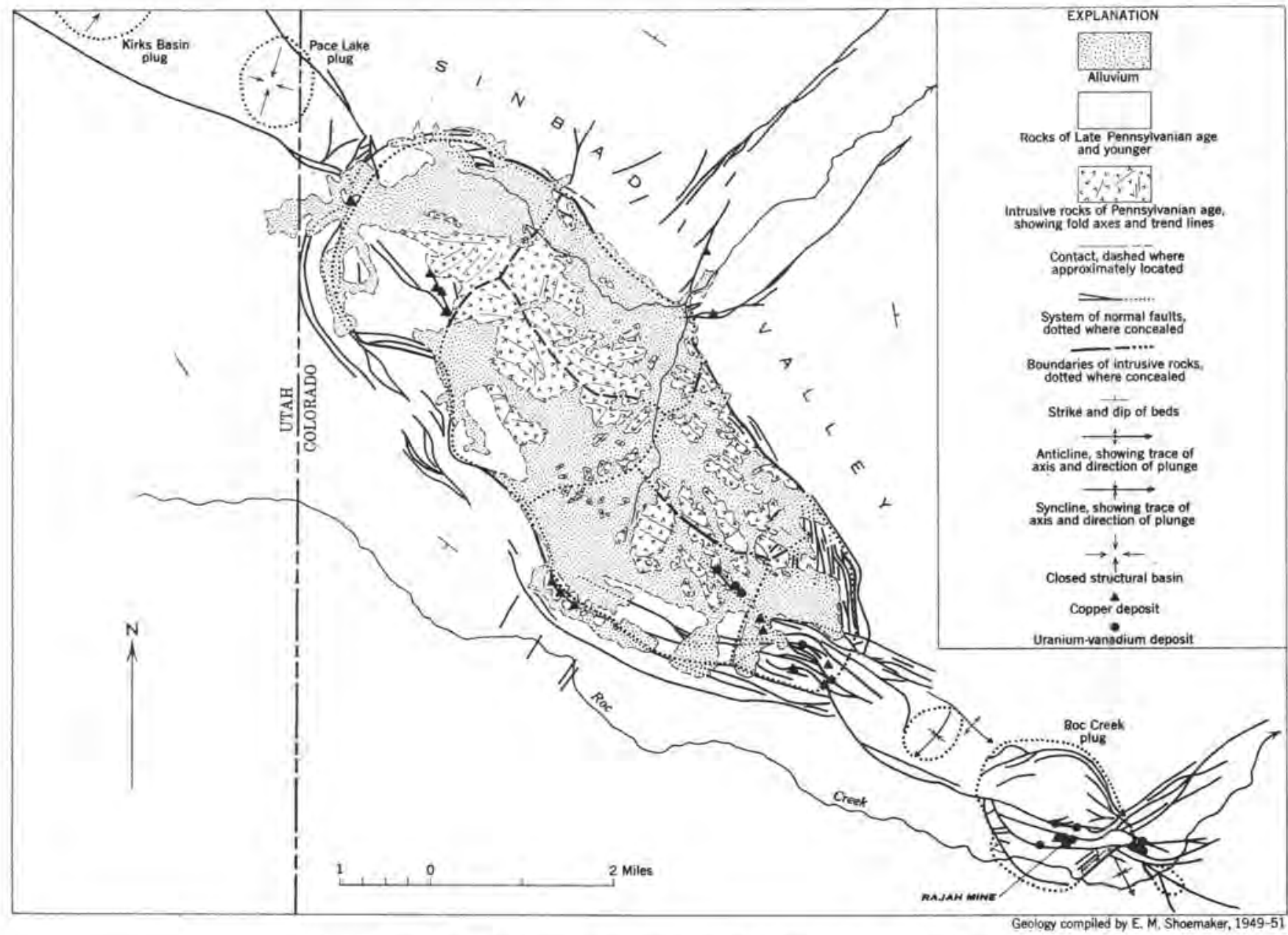

Fiaure 29.-Map of salt plugs at southern end of Sinbad Valley-Fisher Valley anticline.

Feeger (1952). Uranium-bearing copper dep osits along faults near Hanksville, Utah, have been reported by geologists of the U. S. Atomic Energy Commission, but no description has been published of these occurrences. Veins carrying pitchblende, copper sulfides, and asphaltite have been described from Placerville, Colo. (V. R. Wilmarth and R. O. Vickers, written communication).

\section{URANIUM DEPOSITS ASSOCIATED WITH VOLCANIC STRUCTURES}

Uranium deposits in diatremes.-Uranium deposits are localized in diatremes in widely separated parts of the Navajo and Hopi Reservations in Arizona, but the bulk of the known deposits are in the Hopi Buttes area. One deposit at Garnet Ridge, in the northern part of the Navajo Reservation, comprises small coneretionlike concentrations of uranyl and cupric vanadates and copper carbonates in sandstone adjacent to a micaserpentine tuff dike radiating from a diatreme. In the Hopi Buttes area, uranium is widespread in limestones and in some fine-grained clastic beds in the diatremes, but most of the known deposits are sub-ore grade. Some of the highest known concentrations of uranium in the Hopi Buttes diatremes occur in thinly laminated siltstone and shale overlying sedimentary unconformities within the vents. Much of the uranium may be contained in a phosphate mineral, perhaps apatite. The writer has suggested (p. 184) that the uranium is syngenetic in both the limestone and fine-grained clastic beds within the diatremes and that the uranium, phosphate, and perhaps much of the carbonate have been derived from the alkaline basalt magma associated with the diatremes, which is unusually rich in water and phosphate and is moderately uraniferous.

Temple Mountain.-The collapse structure at Temple Mountain, Utah, has been a locus of migration of uranium-bearing solutions, as was first recognized by Hess $(1922 ; 1933)$. Uranium, vanadium, chromium, and arsenic minerals, as well as asphaltite, are disseminated in the rocks of the collapse structure. A great deal of ferruginous stain colors the chimney filled with broken Wingate sandstone of Triassic age, and a zone impregnated with asphaltite spreads out in either direction from this chimney along the base of the 
unfaulted Wingate sandstone which forms the prominance of Temple Mountain. Traces of chromium minerals and small roll-like deposits of uranium and vanadium ore are distributed in the lower part of the Wingate in this impregnated zone. Some small veinlets of earnotite have also been reported from the Wingate on the prominence. Hess interpreted the minerals of these occurrences as derived by leaching through the action of hydrothermal solutions rising along the faults of previously emplaced uranium-vanadium deposits in the Chinle formation surrounding the collapse structure. Alternatively, the collapse structure may be responsible for the localization of intense mineralization in the Chinle formation at Temple Mountain.

\section{CONCLUSIONS}

The post-Cambrian tectonic history of the central Colorado Plateau includes two principal periods of deformation, the first extending from Pennsylvanian into Permian time and the second beginning in latest Cretaceous and extending through the Tertiary into Quaternary time. Joints and faults cutting rocks of post-Paleozoic age and associated with major folds, salt structures, and structures produced by igneous activity probably range in age from latest Cretaceous to Quaternary. Some fractures were probably formed during early movements near the end of the Cretaceous, but many are probably of later origin and early faults may have undergone repeated displacement.

If the age of the majority of uranium deposits is accepted as latest Cretaceous or earliest Tertiary, as suggested by lead:uranium age determinations, the observed structural relations of the deposits can be considered compatible with the inferred structural history. The large majority of deposits that have been studied in detail have been interpreted as older than specific joints and faults that intersect the ore; the structural relations of a number of deposits have been diversely interpreted; and a few deposits are clearly localized by fractures and faults. It is possible to interpret some of the deposits localized by faults either as Late Cretaceous or early Tertiary in age, or as secondary concentrations of ore minerals derived from previously formed deposits, or as primary deposits formed later than the principal period of mineralization postulated for the majority of deposits. Regional structures in existence at the end of the Cretaceous may have influenced in a broad way the distribution of uranium deposits, as suggested by the coincidence of the principal region of productive deposits in the Morrison formation with the region of salt anticlines.

\section{REFERENCES CITED}

Allen, J. E., and Balk, Robert, 1954, Mineral resources of Fort Defiance and Tohatchi quadrangles, Arizona and New Mexico: N. Mex. Bur. Mines Mineral Res. Bull. 36, 192 p.

Atwood, W. W., and Mather, K. F., 1932, Physiography and Quaternary geology of the San Juan Mountains, Colo.: U. S. Geol. Survey Prof. Paper 166, 176 p.

Babenroth, D. L., and Strahler, A. N., 1945, Geomorphology and structure of the East Kaibab monocline, Arizona and Utah: Geol. Soc. America Bull., v. 56, p. 107-150.

Baker, A. A., 1933, Geology and oil possibilities of the Moab district, Grand and San Juan Counties, Utah: U. S. Geol. Survey Bull. 841, 95 p.

1935, Geologic structure of southeastern Utah: Am. Assoc. Petroleum Geologists Bull., v. 19, p. 1472-1507.

1946, Geology of the Green River Desert-Cataract Canyon region, Emery, Wayne, and Garfield Counties, Utah: U. S. Geol. Survey Bull. 951, 122 p.

Baker, A. A., Dane, C. H., and Reeside, J. B., Jr., 1933, Paradox formation of eastern Utah and western Colorado: Am. Assoc. Petroleum Geologists Bull., v. 17, p. 963-980.

Benson, W. E., Trites, A. F., Jr., Beroni, E. P., and Feeger, J. A., 1952, Preliminary report on the White Canyon area, San Juan County, Utah: U. S. Geol. Survey Circ. 217, 10 p.

Boutwell, J. M., 1905, Vanadium and uranium in southeastern Utah: U. S. Geol. Survey Bull. 260, p. 200-210.

Bradley, W. H., 1931, Origin and microfossils of the oil shale of the Green River formation of Colorado and Utah: U. S. Geol. Survey Prof. Paper 168, 58 p.

1936, Geomorphology of the north flank of the Uinta Mountains: U. S. Geol. Survey Prof. Paper 185-I, p. 163-204.

Bucher, W. H., 1936, Cryptovoleanic structures in the United States: 16th Internat. Geol. Cong. 1933, Rept. v. 2, p. 1055-1084.

Burbank, W. S., and Pierson, C. T., 1953, Preliminary results of radiometric reconnaissance of parts of the northwestern San Juan Mountains, Colo.: U. S. Geol. Survey Circ. 236, $11 \mathrm{p}$.

Cater, F. W., Jr., 1954, Geology of the Bull Canyon quadrangle, Colorado: U. S. Geol. Survey. Quadrangle Map GQ 33 (with text).

Cobban, W. A., and Reeside, J. B., Jr., 1952, Correlation of the Cretaceous formations of the western interior of the United States: Geol. Soc. America Bull,, v. 63, p. 1011-1043.

Coffin, R. C., 1921, Radium, uranium, and vanadium deposits of southwestern Colorado: Colo. Geol. Survey Bull. 16, $231 \mathrm{p}$.

Cross, C. W., and Ransome, F. L., 1905, Deseription of the Rioc quadrangle, Colorado: U. S. Geol. Survey Geol. Atlas, folio 130 .

Dane, C. H., 1935, Geology of the Salt Valley antieline and adjacent areas, Grand County, Utah: U. S. Geol, Survey Bull. $863,184 \mathrm{p}$.

Darton, N. H., 1925, A résumé of Arizona geology: Ariz. Bur. Mines Bull. 119, p. 11-298.

Dutton, C. E., 1880, Report on the geology of the High Plateaus of Utah: U. S. Geog. and Geol. Survey Rocky Mountains Region, v. 32, 307 p.

1882, Tertiary history of the Grand Canyon district: U. S. Geol. Survey, Mon. 2, 264 p.

1885, Mount Taylor and the Zuni Plateau [N. Mex.]: U. S. Geol. Survey, 6th Ann. Rept,, p. 105-198. 
Eckel, E. B., 1949, Geology and ore deposits of the La Plata district, Colorado: U. S. Geol. Survey Prof. Paper 219, $179 \mathrm{p}$.

Finch, W. I., 1953, Geologie aspects of the resource appraisal of uranium deposits in pre-Morrison formations on the Colorado PJatean-an interim report: U. B. Geol. Survey TEI-328A, 35 p. issued by U. S. Atomic Energy Comm. Tech. Inf. Service, Oak Ridge, Tenn.

Fischer, R. P., 1936, Peculiar hydrothermal copper-bearing veins of the northeastern Colorado Plateau; Econ. Geol., v. 31, p. $571-598$.

-1937, Sedimentary deposits of copper, vanadium, uranium and silver in Southwestern United States: Econ. Geology, v. 32 , p. $906-951$,

-1942, Vanadium deposits of Colorado and Utah, a preliminary report: U. S. Geol. Survey Bull. 936-P, p. 363-394.

- 1944, Simplified geologic map of the vanadium region of southwestern Colorado and southeastern Utah: U. S. Geol. Survey Strategic Minerals Inv, Prelim. Map 3-226 (with text).

Friedel, Charles, and Cumenge, E., 1899, Sur une nouvelle espéce minérale, la carnotite: Soc. chim. Paris Bull., 3d ser., v. 21 , p. $328-331$.

Gale, H. S., 1910, Coal fields of northwestern Colorado and northeastern Utah: U. S. Geol. Survey Bull. 415, 265 p.

Gilbert, G. K., 1877, Report on the geology of the Henry Mountains: U. S. Geog, and Geol. Survey Rocky Mountains Region, (Powell), 160 p.

Gilkey, A. K, 1953, Fracture pattern of the Zuni uplift: U. S. Atomic Energy Comm. RME-3050, 40 p., issued by U. S. Atomic Energy Comm. Tech. Inf. Service, Oak Ridge, Tenn.

Gilluly, James, 1927, Analcite diabase and related alkaline syenite from Utah: Am. Jour. Sci., v. 14, p. 199-211.

Gregory, H. E., 1917, Geology of the Navajo country, a reconnaissance of parts of Arizona, New Mexico, and Utah: U. S. Geol. Survey Prof. Paper 93, 161 p.

Hack, J. T., 1942, Sedimentation and voleanism in the Hopi Buttes, Ariz.: Geol. Soc. Ameriea Bull., v. 53, p. 335-372.

Harrison, T. S, 1927, Colorado-Utah salt domes: Am. Assoe. Petroleum Geologists Bull, v. 11, p. 111-133.

Hess, F. L., 1914, A hypothesis for the origin of the carnotites of Colorado and Utah: Econ. Geology, v. 9, p. 675-688.

1922, Uranium-bearing asphaltite sediments of Utah: Eng, and Min. Jour,-Press, v, 114, p. 272-276.

1933, Uranium, vanadium, radium, gold, silver, and molybdenum sedimentary deposits, in Ore deposits of the western states (Lindgren volume): New York, Am. Inst. Min. Metall. Eng., p. 450-481.

Hillebrand, W. F., and Merwin, H. E., 1913, Two varieties of calciovolborthite(?) from eastern Utah: Am. Jour. Sci., v. $35, \mathrm{p}, 44 \mathrm{I}-445$.

Holmes, Arthur, 1946, The construction of the geological timescale: Geol. Soe. Glasgow Trans., v. 21, pt. 1, p. 117-152.

Hunt, C. B., 1953, Geology and geography of the Henry Mountains region, Utah: U, S. Geol. Survey Prof. Paper 228, $234 \mathrm{p}$.

(in preparation) Structural and igneous geology of the La Sal Mountains, Utah: U. S. Geol. Survey Prof. Paper; abs., Science, v. 119, p. 477-478.

Hunter, J. F., 1925, Pre-Cambrian rocks of the Gunnison River, Colo.; U. S. Geol. Survey Bull. 777, 94 p.
Joesting, H. R., and Byerly, P. E., 1954, Regional geophysical studies, in Geologic investigations of radioaetive deposits, semiannual progress report, Dec. 1, 1953 to May 31, 1954: U. S. Geol, Survey TEI-440, p. $47-54$, issued by U.S. Atomic Energy Comm. Tech. Inf. Service, Oak Ridge, Tenn.

Kay, J. L, 1934 , The Tertiary formations of the Uinta Basin, Utah: Carnegie Mus. Annals, v. 23, p. 357-372.

Kelley, V. C., Wood, Gordon, Silver, Caswel, and Smith, C. T., 1951, Roadlog for first day-Friday, October 12, 1951: N. Mex. Geol. Soe. Guidebook 2d Field Conf.

Kimball, Gordon, 1904, Discovery of carnotite: Eng. and Min. Jour., v. 77, p. 956.

Longwell, C. R., 1946, How old is the Colorado River?: Am. Jour. Sci., v. 244 , p. $817-835$.

Lovering, T. S., and Goddard, E. N., 1950, Geology and ore deposits of the Front Range, Colo.: U. S. Geol. Survey Prof. Paper 223, 319 p.

Malde, H. E., 1954, Serpentine pipes at Garnet Ridge, Ariz.: Science, v. 119 , p. 618.

MeCann, F. T., 1938, Ancient erosion surface in the Gallup-Zuni area, New Mexico: Am. Jour. Sei., v. 36, p. 260-278.

MoKee, E. D., 1945, Stratigraphy and ecology of the Grand Canyon Cambrian, in Cambrian history of the Grand Canyon region: Carnegie Inst. Washington Pub. 563, p. 5-168.

1951, Sedimentary basins of Arizona and adjoining areas: Geol. Soc. America Bull., v. 62, p. 481-505.

McKnight, E. T., 1940, Geology of area between Green and Colorado Rivers, Grand and San Juan Counties, Utah: U. S. Geol. Survey Bull. 908, 147. p,

Nettleton, L. L., 1934, Fluid mechanics of salt domes: Am. Assoc. Petroleum Geologists Bull., v. 18, p. 1175-1204.

Powell, J. W., 1875, Exploration of the Colorado River of the West and its tributaries: Washington, Smithsonian Inst., $291 \mathrm{p}$.

1876, Report on the geology of the eastern portion of the Uinta Mountains and a region of country adjacent thereto: U. S. Geol. and Geog. Survey Terr. (Powell), $218 \mathrm{p}$.

Prommel, H. W. C., and Crum, H. E., 1927, Salt domes of Permian and Pennsylvanian age in southeastern Utah and their influence on oil accumulation: Am. Assoc. Petroleum Geologists Bull., v. 11, p. 373-393.

Reeside, J. B., Jr., 1924, Upper Cretaceous and Tertiary formations of the western part of the Sau Juan Basin, Colo, and N. Mex.: U. S. Geol, Survey Prof, Paper 134, 117 p.

Shoemaker, E. M., 1954, Structural features of Southeastern Utah and adjacent parts of Colorado, New Mexico, and Arizona: Utah Geol. Soc., Guidebook to the geology of Utah, no. 9, p. 48-69.

Shoemaker, E. M., and Newman, W. L., 1953, Ute Mountains, a laccolithic feature in southwestern Colorado [abs.]: Geol. Soc. America Bull., v, 64, p. 1555 ,

Spieker, E. M., 1946, Late Mesozoic and early Cenozoic history of central Utah: U. S. Geol. Survey Prof. Paper 205-D, p. $117-161$.

Stieff, L. R, and Stern, T. W., 1952, Identification and leaduranium ages of massive uraninites from the Shinarump conglomerate, Utah: Science, v. 115, p. 706-708.

Stieff, L. R., Stern, T. W., and Milkey, R. G., 1953, A preliminary determination of the age of some uranium ores of the Colorado Plateau by the lead-uranium method; U. S, Geol. Survey Circ. 271, 19 p. 
Stokes, W. L., 1948, Geology of the Utah-Colorado salt dome region with emphasis on Gypsum Valley, Colo.: Utah Geol. Soc., Guidebook to the geology of Utah, no. 3, $50 \mathrm{p}$.

Stokes, W. L., and Phoenix, D. A., 1948, Geology of the EgnarGypsum Valley area, San Miguel and Montrose Counties, Colo.: U. S. Geol. Survey Oil and Gas Inv. Map 93.

Walcott, C. D., 1890, Study of a line of displacement in the Grand Canyon of the Colorado, in northern Arizona: Geol. Soc. America Bull., v. 1, p. 49-64.
Weeks, A. D., and Thompson, M. E., 1954, Identification and occurrence of uranium and vanadium minerals from the Colorado Plateau: U. S. Geol. Survey Bull. 1009-B, p. 13-62.

Williams, Howel, 1936, Pliocene volcanoes of the Navajo-Hopi Country: Geol. Soc. America Bull., v. 47, p. 111-172.

Williams, M. D., 1950, Tertiary stratigraphy of the Uinta Basin: Utah Geol. Soc., Guidebook to the geology of Utah, no. 5 . p. 101-114. 


\title{
INFLUENGE OF REGIONAL STRUCTURE AND TEGTONIC HISTORY UPON THE ORIGIN AND DISTRIBUTION OF URANIUM ON THE COLORADO PLATEAU
}

\author{
By Vincent C. Kelley, University of New Mexico
}

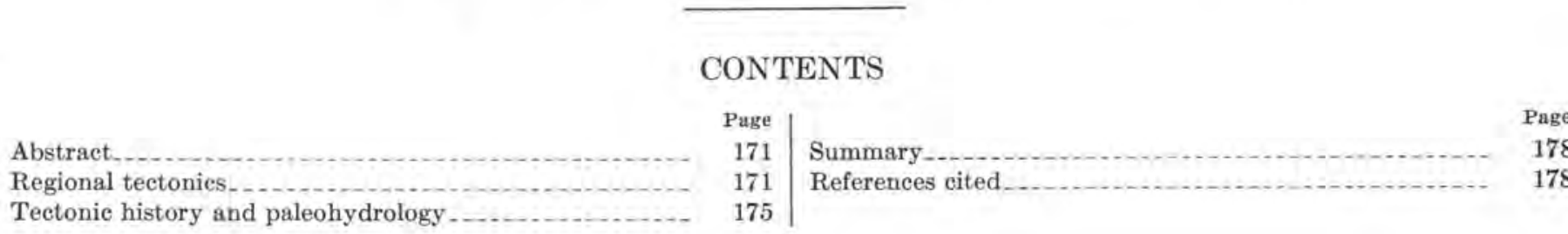

\section{ILLUSTRATIONS}

Page

171

Fiaure 30. Index map of the Colorado Plateau

31. Contours of the main structural units of the

four-corners region
172
Figure 32. Lineaments of the Colorado Plateau and ad-

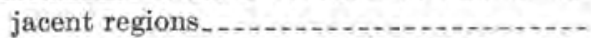

33. Geography of struetural units of the Colorado Plateau and adjacent regions........... 174

\section{ABSTRACT}

Regional structures indirectly influence the distribution and perhaps the origin of uranium deposits on the Colorado Plateau.

A description and analysis of the regional tectonies and a geologic and tectonic history, together with a discussion of the tectonic influence on origin and distribution of uranium, are presented.

Tectonic events, probably as remote as Permian, have affected indirectly the provenances of sediments and the environments in which they were deposited, the paleohydrology, the igneous activity, and the erosional history of the Plateau. These factors are discussed in relation to their probable effect on the origin of uranium deposits.

It is assumed that most of the ore was precipitated from ground water and, because of paleohydraulic conditions, concentrated in the central part of the Plateau.

\section{REGIONAL TECTONICS}

The Colorado Plateau structural province, a part of the Grand Cordillera of North America (fig. 30), embraces an area of 140,000 square miles. Geologically it is a region of broad structural stability within the great mountain system of the Rockies. It is bounded on the east by the Southern (Colorado) Rockies, on the north by the Uinta uplift, on the west by the High Plateaus, and on the south by the Basin and Range fault-block belt of Arizona and New Mexico.

The primary rock masses involved in the deformation of the Plateau consist principally of a dominantly crystalline Precambrian complex and a mass of variably

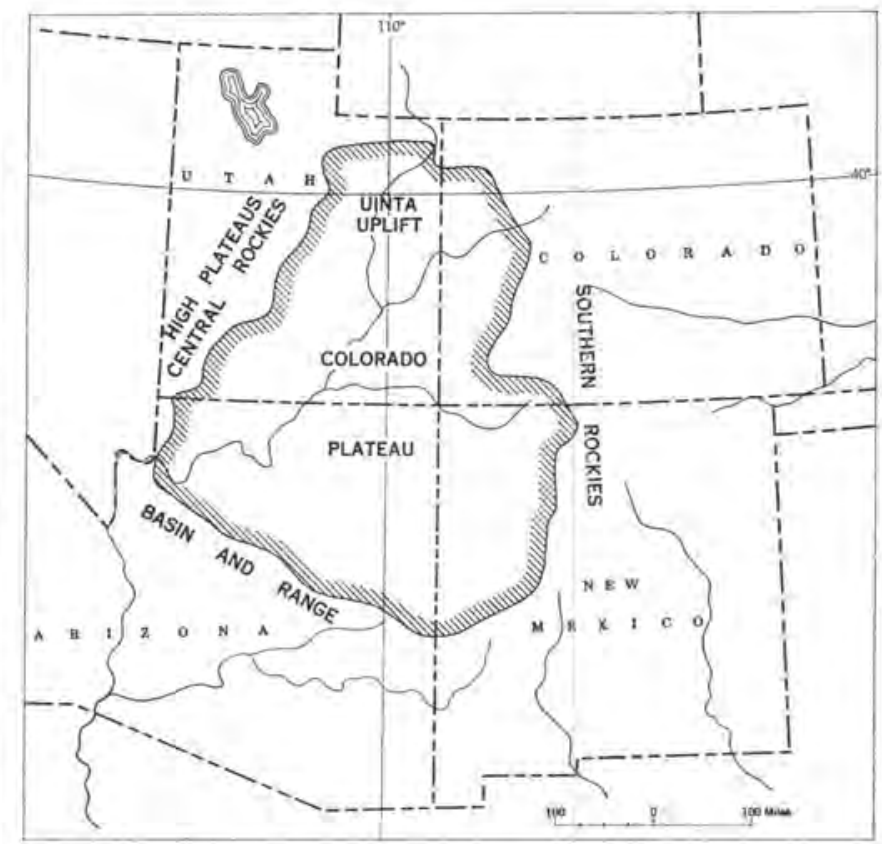

Ficure 30.-Index map of the Colorado Plateau.

bedded sedimentary rocks of the Paleozoic and Mesozoic eras. There is little in the gross form of the sedimentary rocks or in the dominant northeasterly trend of the Precambrian foliation that appears to have guided structural trends. Locally, however, certain northwesterly trending uplifts and accompanying downfolds 


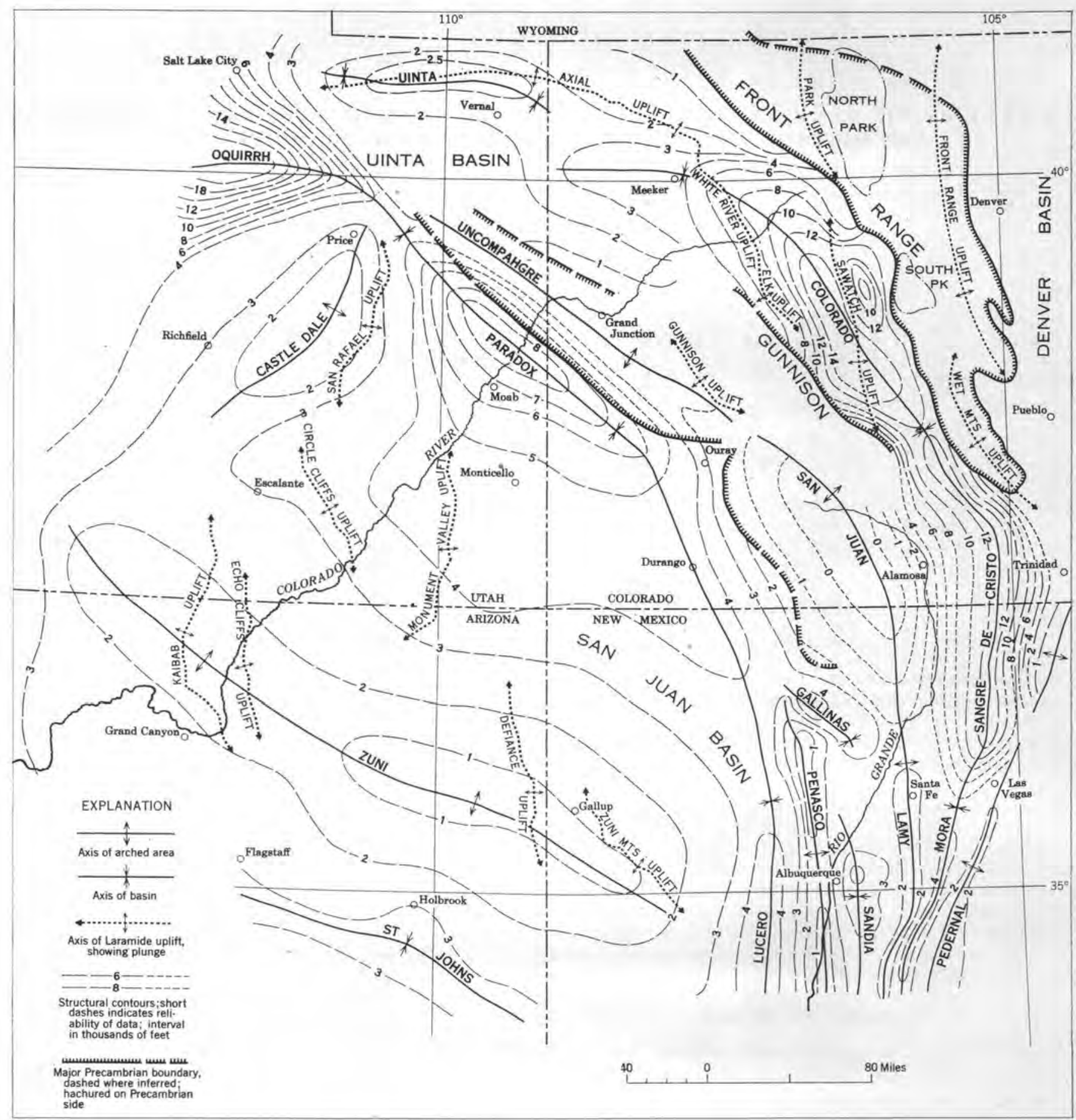

Figure 31.-Contours of the main structural units of the four-eorners region.

that developed across the Plateau during Pennsylvanian and Permian times appear to have controlled some of the later Laramide tectonic trends (fig. 31). Furthermore, this early deformation may have effected a northwesterly trending "grain" of lesser fractures and folds which, together with the dominant elevations of the late Paleozoic Ancestral Rockies, form what may be termed "lineaments" (fig. 32). Within the central
(San Juan) segment formed by these lineaments, there is also a northwesterly alinement of the principle Laramide laccolithic centers into what are termed, in this paper, "porphyry lines" (fig. 32).

The principal Laramide structural features of the Plateau consist of a number of extramontane uplifts and basins whose locations, trends, and forms appear to be closely related to the mechanics of the same orogeny in 


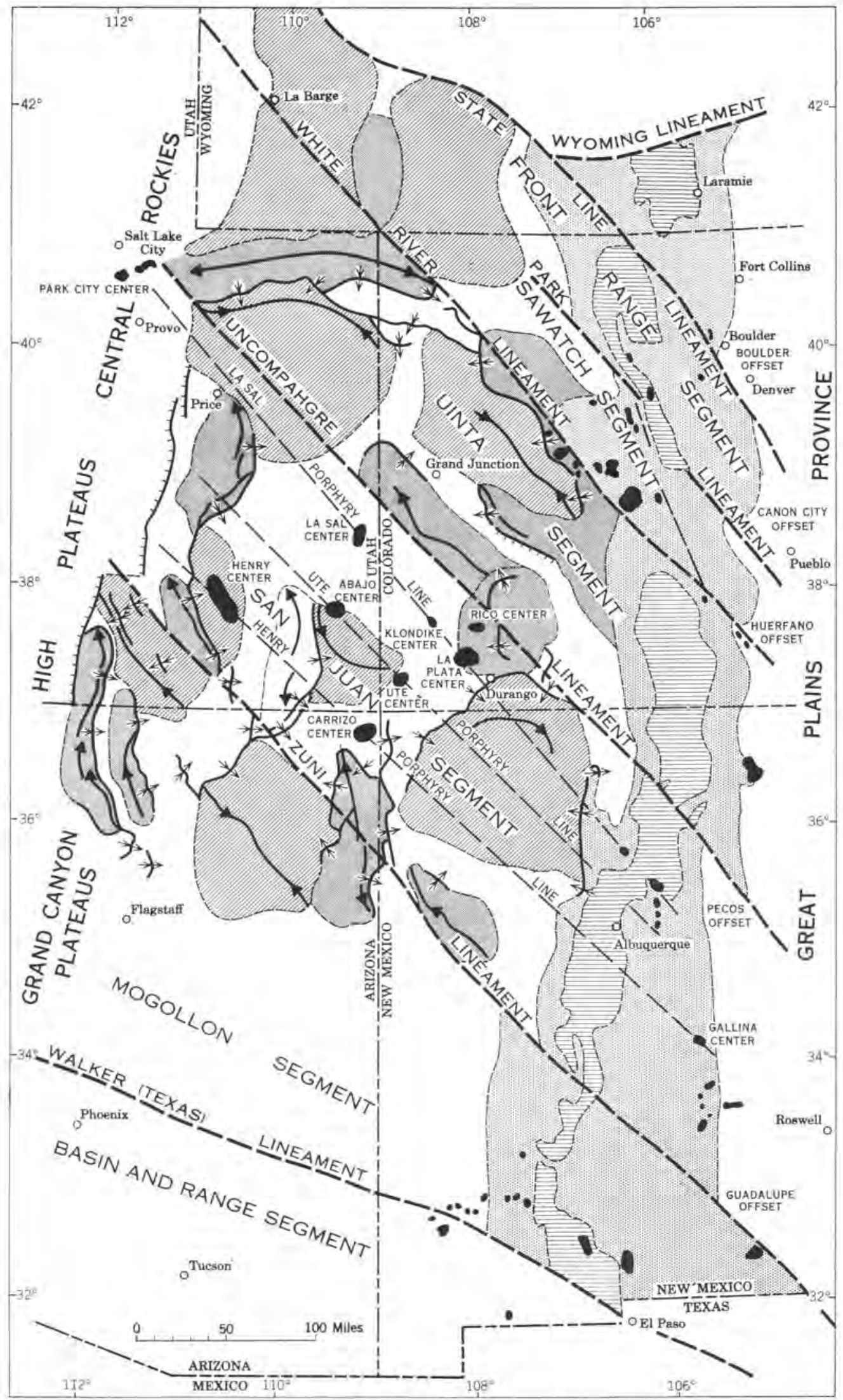

EXPLANATION

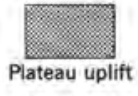

Tilims

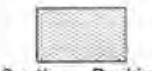

Southern Rockies

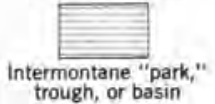

Boundary of tectonic

Highrangle fault, hachures on downthrown side

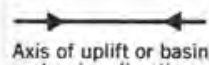

Axis of uplift or basin. of plunge

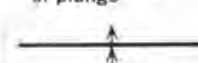

Monocline showing trace of axis and direction of dip

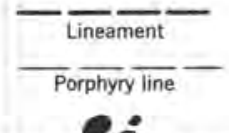

Intrusive centers or domes 


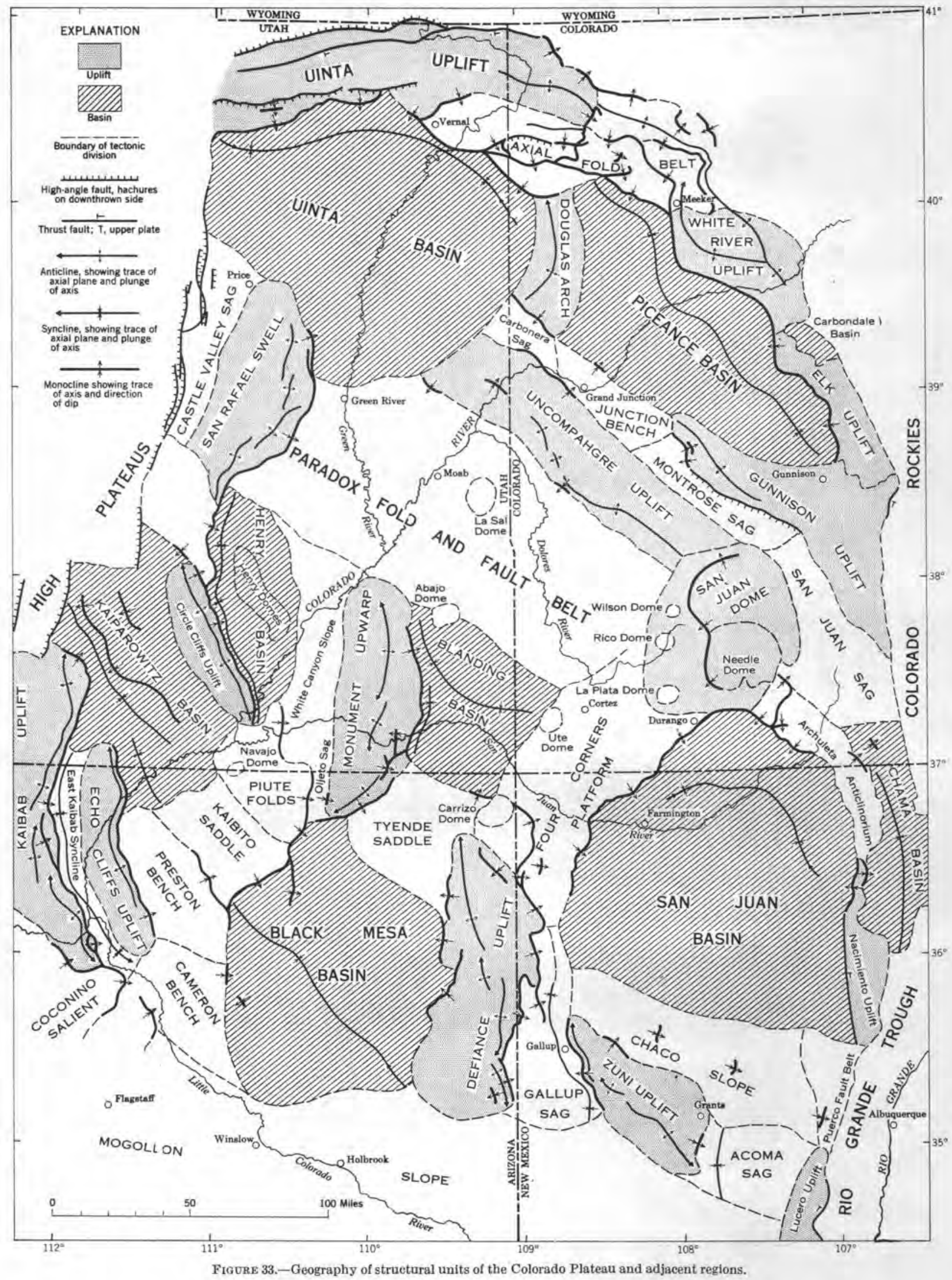


the Central Rockies to the west and the Southern (Colorado) Rockies to the east.

Basins constitute one-third of the total area of the Colorado Plateau, and there are seven large structural basins of considerable range in size, shape, and structural relief. Three major basins (Uinta, Piceance, and San Juan) lie in the north and eastern parts of the Plateau, and four minor basins (Kaiparowits, Henry, Blanding, and Black Mesa) lie in the southwestern part (fig. 33).

Uplifts within the Colorado Plateau are either the result of tangential compression or igneous intrusions. Exclusive of the bounding orogenic uplifts, such as those of the Southern Rockies or the Uinta Mountains, there are nine principal uplifts (fig. 33) whose total area is about 20 percent of the Plateau. Two distinetively oriented groups of uplifts ean be recognized: those of northerly trend and those of northwesterly trend. All are asymmetrical: the southwestern group have their steeper flanks on the east, and the eastern group have steeper flanks on the west.

Intruded large plugs, stocks, and laceoliths have caused doming, and the results of this upthrust extend some distance from the intrusive centers. The La Sal, Henry, and Abajo Mountains are examples of doming by igneous upthrust.

Among the basins and uplifts of the Plateau are a number of other structural elements of lesser tectonic magnitude. These include such features as platforms, slopes, benches, saddles, arches, and depressions (fig. 33 ), which together constitute nearly 50 percent of the Plateau.

Most of the deformation of the Plateau has occurred along monoclines which generally lie between the larger uplifts and adjoining basins (fig. 33). Structural relief along the steep part of a typical monocline is commonly five and as much as ten times that in the adjoining uplift or basin.

Among the hundreds of smaller anticlines and synclines in and marginal to the Plateau, the salt anticlines and piercements of the Paradox fold and fault belt are the most unusual. Fundamentally, they consist of long, nearly parallel anticlines and synelines. Broad valleys have been eroded along collapsed crests of the anticlines, exposing the Paradox member of the Hermosa formation of Pennsylvanian age. Most of the largest uranium and vanadium deposits occur within the Paradox fold and fault belt.

Although the general structure of the Plateau is fairly simple, the piercement and graben structures on the crests of the faulted anticlines are very complex. Collapse is abundantly evident in most of the mapped surface struetures; Jurassic and Cretaceous rocks are commonly displaced downward against rocks in normal position as old as the Pennsylvanian Paradox member of the Hermosa formation.

Salt piercement, which began in Permian time, continued intermittently until Laramide time. Laramide compression probably accentuated the structural relief. The cause of collapse may be partly related to isostatic balance and load-support relations (Kelley, 1955). The salt column may have been in part pressed downward and back into the flanking synclines, but escape of salt longitudinally and upward by additional piercement also seems likely,

Diverse igneous intruded bodies-namely, blocks, dikes, stocks, sills, and laceoliths - are present in and around the Colorado Plateau. So far as is known all are Laramide or younger. The most numerous and most distinctive of these are plugs, small stocks, and associated laceoliths and sills. The most signifieant are the laccoliths of porphyrytic rock such as those of the La Sal and Abajo centers. The porphyry laccoliths are mostly in the central part of the Plateau, within the San Juan segment (fig. 32), and they lie along three northwesterly trending lines. None of the porphyry centers is on a tectonic uplift; instead they are either in or near sedimentary or structural basins or in platform areas.

The regional tectonic pattern has only little direct relation to the distribution of uranium on the Plateau. Indirectly, however, tectonic events, probably as remote as Permian time, have had an important bearing on other geologic features that may have contributed more directly to the distribution of ore. These factors are: provenances of sediments and environments of sedimentation, paleohydrology, igneous activity, and erosion.

\section{TECTONIC HISTORY AND PALEOHYDROLOGY}

Although uranium occurs in almost every formation exposed on the Plateau, almost all commercial reserves are in relatively thin stratigraphic units within the Morrison, Chinle, and Shinarump formations.

In general, deposits of uranium minerals fall into nearly every standard genetic type that has been proposed for deposits of other minerals. However, the great majority of the deposits on the Plateau may be one of another of the following genetic types: syngenetic in sandstone, claystone, coal, or tuff; or epigenetic, having been deposited by ground water and by hydrothermal fluids.

In this report ground water means meteoric water, and hydrothermal refers to fluids considered to be of magmatic origin or, if of meteoric origin, they have been affected by igneous activity. 
Most of the deposits have been oxidized or modified to some extent by ground water. In some places this may have involved only chemical rearrangement in situ or migration and concentration a few feet or a few tens of feet away. Leaching from updip or nearsurface outcrops or from overlying beds may have provided the uranium ions concentrated elsewhere. It is also possible that ground water may have brought the ore from considerable distance.

There are few deposits on the Plateau that are unquestionably hydrothermal by reason of being in fissures or connected directly to mineralized fissures but, in spite of this, the possibility remains that every deposit on the Plateau is indirectly of hydrothermal origin. This possibility is unlikely to be obviated so long as conclusive evidence of a syngenetic origin is lacking.

Paleohydrologic influence on the origin and distribution of uranium ore on the Plateau, through structure, physiography, and climate, is speculative and probably of great importance.

Determinations of geochronology, through use of isotopes, indicate a Laramide age of Plateau uranium ores. However, because these determinations may not eliminate the possibility that ground water might have concentrated ore earlier, only for it to be reworked and redeposited during Laramide time, pre-Laramide hydrology should be considered.

During Shinarump time hydrodynamic conditions were very favorable for concentration of ore in the channel bottoms because the water was unconfined. With the widespread and commonly deep burial of the Shinarump by the Chinle formation and later sandstones, recharge would have diminished because of deep burial and the aridity of later climates. Furthermore, in the middle part of the Plateau the Shinarump may have been unwatered and some unconfined "puddling" in paleostream channels and other low areas may have occurred.

During Morrison time, marked fluvial and lacustrine conditions, probably indicating at least moderate surface-water supplies, returned to the Plateau. The highland areas were principally along the southern rim and to the west of the present Plateau although some lesser highlands probably existed in parts of the present Southern Rockies of Colorado. Surface and subsurface water may have discharged as great playas and lakes at various places in the east-central part of the Plateau.

The gentle warping, suggested by lithologic variations, during Morrison time, may have been accentuated in Late Jurassic and Early Cretaceous time. Along the southern rim of the Plateau, erosion truncated successively older beds. Surface recharge of all of the exposed permeable units must have been widespread. Uranium derived from the eroding outcrops could have been introduced into the Shinarump and Morrison formations at this time, aided by permeability and precipitated by favorable circumstances. Furthermore, since much voleanic activity took place to the south, as is shown by the composition of the thick Early Cretaceous rocks of southern New Mexico, hydrothermal additions to the Early Cretaceous ground-water system of the Plateau region could have been made.

Throughout most of Triassic and Jurassic times ground-water flow in the central part of the Plateau was generally northwesterly toward a discharge area along the Cordilleran geosyncline.

During Early Cretaceous time the entire Plateau, as a part of the Rocky Mountain geosyncline, subsided greatly. The Cordilleran geanticline west and southwest of the Plateau rose continuously and furnished sediment, together with abundant supplies of water. By Middle Cretaceous time the magnitude of the uplifts in the Central Rockies may have been sufficiently great to reverse the direction of subsurface flow in formations of the western part of the Plateau. Toward the end of Late Cretaceous deposition, the Shinarump and Morrison formations of the San Rafael Swell and Henry Mountains areas were buried and were probably below sea level by 10,000 and 7,000 feet, respectively. Similar deep burial of the principal ore-bearing units existed over most of the rest of the Plateau. Temperature in the ground water at these depths may have been about $150^{\circ} \mathrm{F}$. In order for ground water to flow eastward in the ore-bearing formations, there would have to have been an upward escape of ground water through the overlying units by slow mass permeation and movement along fissures to the surface, especially in the low areas near sea level. Theoretically at least, ground water would flow no further east than the coastline of the Cretaceous sea. Beneath this sea it is likely that all ground water would be stagnant and saline. The dense saline water would form a steep barrier across the formations (Hubbert, 1940), blocking eastward flow of fresh water from the source areas. As the Late Cretaceous shoreline fluctuated slowly east and west across a low gradient surface, so would the subsurface interface of fresh and saline water, It is significant perhaps that the zone in which this interface fluctuated includes most of the area within which are found the large ore bodies on the Plateau. In this zone ground water in the Morrison and Shinarump may have been $120^{\circ}-170^{\circ} \mathrm{F}$. It was very slowly moving east and west as the shoreline above it moved, and the water in the zone changed repeatedly from fresh to saline. Within the band in which the interfacing fluctuated the $\mathrm{pH}$ and other chemical features of the ground water probably would have changed repeatedly.

The comparatively simple tectonic and hydrologic 
conditions that prevailed on the Plateau during most of Late Cretaceous time were changed greatly with the onset of the Laramide deformation of the Plateau and adjoining areas in late Montana, Lance, and Paleocene times. Deformation, uplift, and erosion in the Central Rockies continued to provide recharge of the aquifers and a hydraulic gradient eastward in the western part of the Plateau. New sources of water and greater hydrostatic pressures developed in the Uinta uplift, Southern Rockies, and probably also along the soutbern rim of the Plateau as it was given a broad general tilt northward. In early Laramide time, while Cretaceous rocks still blanketed the uplifts, changes in ground-water conditions of the Morrison and Shina-, rump formations would have been slight. Gradually however, and even before complete removal of the thick Cretaceous sediments from these newly uplifted areas, some recharge probably would have occurred. This would have reversed the eastward flow of ground water along the eastern and southern side. The Uinta uplift diverted the flow southward. The earliest effect of the orogenies would have been to concentrate the flow inward toward the central part of the Plateau, probably in a north-northwesterly trending groundwater basin centering around the Blanding basin. Some of the relatively dense connate water would have been pushed into deep basins such as the Uinta, Piceance, and San Juan where it may have remained a longer time than in most basins or even be at present. Much salt-water flushing may have been accomplished by Paleocene time.

As erosion and truncation proceeded in the uplifts around and within the Plateau, successively older formations would have been exposed to recbarge, thereby rejuvenating the ground-water flow in each.

It may be observed from the foregoing descriptions that the paleohydrology of the Plateau is complicated and that fluids in the principal ore-bearing units may have moved in several different directions and have had different flow potentials in the various uplifts, basins, and other structural divisions of the Plateau. Temperature in the formations rose with deep burial to those of epithermal conditions during the time when the primary ores were formed and then declined slowly as erosion unloaded and eventually exposed the orebearing units in outcrop. Salinity and probably the $\mathrm{pH}$ of the fluid may have changed many times in the central Plateau as salt water and fresh water alternately replaced one another as the Late Cretaceous sea expanded and contracted.

Tectonic controls on the distribution of hydrothermal activity, and hence deposition of uranium, are implied by the foregoing discussion. Certain special features of geographic distribution of ore, related in particular to hydrodynamics, will be discussed further. A great deal of hydrothermal action very likely occurred in the source area of the Chinle and Morrison formations. Furthermore, the great amount of fine volcanic material in several of the formations of Late Cretaceous age suggest the possibility of hydrothermal activity during that time to the west and along the southwestern side of the Plateau. Hydrothermal fluids entering the epithermal zone became considerably diluted by ground water, and the metals they introduced may have moved far and remained in the ground-water system for long periods. Thus, uranium introduced by hydrothermal fluids during Chinle or Morrison times may have stayed in solution until the period of falling temperature which began with Laramide erosion.

It is clear from field relations that a great deal of hydrothermal activity occurred on the Plateau during Laramide and succeeding times. Alteration in and around the porphyry stocks and laccoliths suggests that a considerable volume of hydrothermal fluid was introduced by igneous activity into the ground water of the surrounding area. It is believed that as a consequence of uplift by igneous intrusion an outward radial flow of the ground water was established, and crystallization of the magma built up a vapor pressure, which was superimposed upon the preexisting ground-water pressure head. During and after subsidence of this pressure, a radial flow of ground water is maintained by reason of the structural and topographic elevation. The modifications of ground-water flow by the rise of the Uncompahgre, San Juan, and Monument uplifts probably caused an increase in volume and velocity of ground-water movement along the Utah-Colorado line. The La SaI, La Plata, Abajo, and Ute intrusive centers would further accentuate the flow to this area. Favored by a concentration of ground-water flow, the presence of many uplifts, and many sources of hydrothermal solutions, it is in this area that most of the uranium and vanadium of the Plateau occurs. Greater concentration of ore is found nearer to the La Sal center than to others, perhaps because ground-water flow, lithology, and local structural channels (salt piercements) were more favorable, and there may have been greater release of uranium from the La Sal center.

Hydrothermal solutions may have flowed into the ore-bearing units as surface flow, as lineal flow from fissures, through pipelike conduits of diatremes and fissure intersections, and by wide-area pervasions. In general, "pin-point," or pipelike, feeding of ore beds by hydrothermal fluids was probably the most common mode of entry. Such a path of the ore solutions would be the most difficult to detect on the surface because conduits may not crop out. Underground mining 
likewise does not ordinarily reveal conduits, especially if they enter a bed from below and do not transact it.

If ore-bearing hydrothermal solutions enter groundwater flow without more than mildly deflecting the flow, the solutions will likely assume the direction of flow of the ground water and there will be a narrow band or streak of ground water carrying the introduced material. If the hydrothermal solutions mingle with ground water along the line transverse to the direction of flow, a wide band of ground water is contaminated. Streaks of ore-bearing hydrothermal fluid moving in an otherwise barren ground-water system might not encounter many channels favorable for deposition of heavy minerals, effective structural traps, or much organic debris; and thus the uranium might be carried long distances.

If the hydrothermal solutions mingle with ground water along the line transverse to the direction of the flow, there would be a wide band of ground water contaminated by the introduced hydrothermal fluid.

Another variable that may operate during contamination of ground water by hydrothermal fluids arises from the possibility that the hydrothermal solution is sufficiently denser than the ground water to maintain a gravity separation between the two within a permeable layer. If a dense hydrothermal fluid enters a bed at its base and remains unmixed with the ground water in the bed, it may underflow the lighter fluid either updip or downdip. Under these conditions the heavy orebearing fluid might accumulate in stagnant pockets near the bottoms of channels, synclines, or the downthrown side of faults. Thus with east-to-west flow the lower west sides of certain north-trending channels or troughs and the bases of small faults downthrown on the east would "puddle" the heavy solution under favorable relations of dip and flow potentials and result in concentrations of ore.

\section{SUMMARY}

Syngenetic deposits, as well as those epigenetic deposits which are a result of the encounter of ore-bearing solutions with favorable conditions for precipitation, are reflections in part of the tectonics of the time. This implies that an indirect tectonic control may be a factor in the origin of all those uranium deposits found in sediments. The history of the circulation of ground water is a sequence of events influenced by past climates, ancient topography, and paleotectonic movements. Repeated changes in direction of ground-water flow have resulted from orogenic movements and the disturbance of old structures by intrusion of magma.

It is certain that there have been several additions of hydrothermal emanations to the ground-water system of the Plateau since the Triassic. Whether or not such solutions carried dissolved uranium, those introduced into the ground water during Laramide time probably considerably modified the ground-water flow potentials. Tectonic uplifts and those resulting from igneous intrusion may have augmented in volume and velocity the flow of ground water in the area along the ColoradoUtah border, and this, together with the many loci of hydrothermal contamination, may have been responsible for the unusual concentration of uranium deposits in that area.

\section{REFERENCES CITED}

Kelley, V. C., 1955, Regional tectonics of the Colorado Plateau and relationship to origin and distribution of uranium: N. Mex. Univ. Pub. in Geol. no. 5, 120 p.

Hubbert, M. K., 1940, The theory of ground-water motion: Jour. Geology v. 48, p. 785-944. 


\title{
OCGURRENCE OF URANIUM IN DIATREMES ON THE NAVAJO AND HOPI RESERVATIONS, ARIZONA, NEW MEXICO, AND UTAH
}

\author{
By Eugene M. Shommaker, U. S. Geological Survey
}

CONTENTS

\begin{tabular}{|c|c|c|}
\hline \multicolumn{3}{|c|}{ Page } \\
\hline Abstract & 179 & Composition of the voleanic rocks \\
\hline Introduction $\ldots \ldots \ldots$ & 180 & 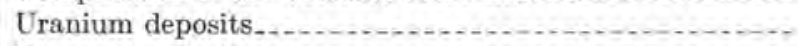 \\
\hline Structure of diatremes...... & 180 & References cited. \\
\hline
\end{tabular}

\section{ILLUSTRATIONS}

Flgtre 34. Map of the Navajo and Hopi Indian Reservations and vicinity, showing the distribution of diatremes, sedimentary and voleanic rocks of Pliocene(?) age, and contours on the Pliocene surface.
Page

Figure 35. Diagrammatie plan views and sections of four diatremes from the Navajo Reservation illustrating successive stages of subsidence

\section{ABSTRACT}

About 250 diatremes are scattered over the Navajo and Hopi Reservations, in Arizona, New Mexico, and Utah. The diatremes are associated with flows and tuffs of Pliocene age that rest on a surface of low relief. The diatremes flare to a width of a mile or more at the level of the Pliocene surface onto which they erupted, and they range from a few hundred feet to half a mile in diameter where exposed at depth of 1,000 to 2,000 feet below the Pliocene surface.

Many kinds of material fill the diatremes. In its upper part a mature diatreme is filled with bedded tuff and limestone and locally with thinly laminated clay and silt, evaporites, and some bedded chert. Lower in the vent these sediments give way to more massive tuff, breccia, huge blocks of country rock, and finally agglomerate and solid igneous rock. Much of the tuff of the filling, which in some vents is at least 2,000 feet thick, is well bedded and shows many features of fluviatile deposition, such as cross lamination, channels, and erosion surfaces. Limestone interbedded with the tuff ranges from massive to thinly laminated, and much of it is argillaceous though a few beds are composed of relatively pure carbonate. The structure and composition of the limestone suggest deposition in shallow ephemeral ponds within the diatremes. The source of the carbonate may have been thermal solutions rising in the diatremes.

The volcanic rocks associated with the diatremes are nearly all alkalic basalts which, in their intrusive phase, would fall under the elassification of the lamprophyres, monehiquite, and minette. A few diatremes contain phologopite-bearing serpentine tuff or a tuff similar to kimberlite. The monchiquites, found ehiefly in the Hopi Buttes area, are distinguished from normal olivine basalts by high concentrations of titanium, phos- phorous, zirconium, barium, niobium, the cerium group rare earths, and water. The minettes are noteworthy for high concentrations of potassium, berium, strontium, beryllium, boron, cerium group rare earths, lead, and water. Both the monchiquites and the minettes are anomalously radioactive, though the radioactivity is much higher in the minettes. Much of the radiouctivity is probably due to thorium.

Uranium deposits are localized in diatremes in widely separated parts of the Navajo and Hopi Reservations, but the bulk of the known deposits are in the Hopi Buttes area. One deposit in the northern part of the reservations' area comprises small podlike concentrations of uranyl-vanadates and copper earbonates in sandstone adjacent to a mica-serpentine tuff dike radiating from a diatreme. In another vent in the northeastern part of the reservations' area, uranium minerals are associated with minette tuff and in-fallen blocks of the Morrison formation of Jurassic age.

In the Hopi Buttes area, uranium is widespread in the limestones and in some fine-grained clastic beds in the diatremes, but most of the known deposits are below ore grade. Some of the highest concentrations of uranium known occur in laminated siltstone and shale overlying sedimentary unconformities within the diatremes. These relations suggest that the uranium is syngenetic in the fine-grained clastic and earbonate sediments and that one of the factors governing the concentration of uranium may have been the rate of sedimentation. If uraniumbearing solutions were being supplied more or less continuously from depth, the uranium may have been concentrated in the beds that were deposited at the slowest rate. A few qualitative chemical tests suggest that uranium is present in the sediments in part as a phosphate, which suggests the possibility that in the Hopi Buttes area the uranium was introduced by solutions derived from the hydrous phosphate-rich monehiquite magma. 


\section{INTRODUCTION}

Dikes and volcanic necks containing alkalic basaltic rocks have been known for many years to be widely distributed on the Navajo and Hopi Indian Reservations, in Arizona, New Mexico, and Utah, an area equal to about one quarter of the State of Arizona (Gregory, 1917 , p. 83-107; Williams, 1936). Most of the exposed volcanic necks are funnel-shaped vents filled chiefly with tuff; for this kind of volcanic vent, Daubree' (1891) coined the name diatreme; his concer tion was a vent drilled by volcanic explosion. The primary evidence for explosive volcanism is the pyroclastic debris that fills the vent. Though the general features of many of the diatremes were long recognized, some of the details of structure, particularly in the diatremes of the Hopi Buttes, were not fully appreciated until the studies of Hack (1942). In the last few years, uranium deposits have been found in or associated with diatremes in widely separated parts of the Navajo and Hopi Indian Reservations. This paper is based on a reconnaissance study which is an outgrowth of a regional investigation of the distribution of elements in the igneous rocks of the Colorado Plateau. A detailed investigation of the diatremes is in progress:

\section{STRUCTURE OF DIATREMES}

About 250 diatremes are located on the Navajo and Hopi Indian Reservations. In many respects they are closely similar to the typical diatremes of eastern Fife, Scotland, (Giekie, 1902) and the Schwabian Alb (Branco, 1894). A few of the Navajo-Hopi diatremes have several features in common with the diamond pipes of South Africa (Wagner, 1914), and in fact, in some of them the pyroclastic material is close to kimberlite in composition. The diatremes are associated with dikes and simple basalt-filled volcanic necks and locally with flows and tuffs interstratified with nonvolcanic sediments of middle Pliocene age (Williams, 1936; Stirton, 1936). These sediments rest upon a surface of low relief which is preserved, though deerly dissected, in parts of the Hopi Buttes area and in the Chuska Mountains and has been completely eroded away over most of the Navajo and Hopi Indian Reservations (fig. 34). Many of the diatremes flare to a width of a mile or more at the level of the Pliocene surface onto which they erupted. Where the Pliocene surface has been stripped away, the uppermost $F$ art of the diatreme is also partly removed, and the exposed diameter of the vent is smaller. Generally the vents range from a few hundred feet to half a mile in diameter where they are exposed at depths of 1,000 to 2,000 feet below this Pliocene surface.

Many kinds of material fill the diatremes; the material found at any one exposure appears to depend largely on the stage of formation of the diatreme and the level at which it is exposed. A generalized description of the vertical distribution of material in a typical or ideal diatreme can be made by the study of certain diatremes which form prominent spires on the landscape, up to nearly 2,000 feet in height, and on the basis of the composite features of many diatremes exposed at different levels of erosion. In its upper part a mature diatreme is filled with bedded tuff and limestone and locally with thinly laminated clay and siltstone, evaporites, and even some bedded chert. Lower in the vent these sediments give way to more massive tuff, breccia, huge blocks of country rock, agglomerate, and ultimately to solid igneous rock.

Much of the tuff-filling, which in some vents is at least 2,000 feet thick, is well bedded and shows many features of fluviatile deposition, such as cross lamination, channels, and erosion surfaces. Limestone interbedded with the tuff ranges from massive to thinly laminated, and much of it is argillaceous although a few beds are composed of relatively pure calcium carbonate. The interstratification of thinly laminated limestone with bedded tuff and the content of finegrained clastic material in the limestone suggest that the limestone was deposited in shallow ephemeral ponds within the diatremes. Hack $(1942$, p. 355, 364, and 366) has suggested that much of the limestone in the Hopi Buttes diatremes is of hydrothermal origin, and some of the limestone is similar to travertines formed by hot springs in nearby parts of Arizona (Harrell and Eckel, 1939, p. 49-50). Some of the limestone in the Hopi Buttes diatremes contains unusual concentrations of phosphate. Because fresh surface and ground water generally contains extremely low amounts of phosphate, the high phosphate content of the limestone may also suggest that the carbonate was in part supplied by rising thermal solutions. The general conditions of sedimentation may be represented by a diatreme of recent origin at Zuni Salt Lake, N. Mex. (fig. 34) (Darton, 1905).

In the upper parts of the diatremes, the beds generally dip gently toward the center of the vent. The dips of the beds increase with depth, and the beds are commonly vertical or intensely deformed in the deeply eroded vents. In some deeply eroded vents the bedding is displaced and partly obscured by many small closespaced thrust faults. Fragments of rocks from all parts of the sedimentary column and, in places, from the crystalline Precambrian basement are generally incorporated throughout the tuffs. The fragments range from minute grains to blocks over 100 feet long. Small fragments are derived from formations that both underlie and overlie the position at which the fragments 


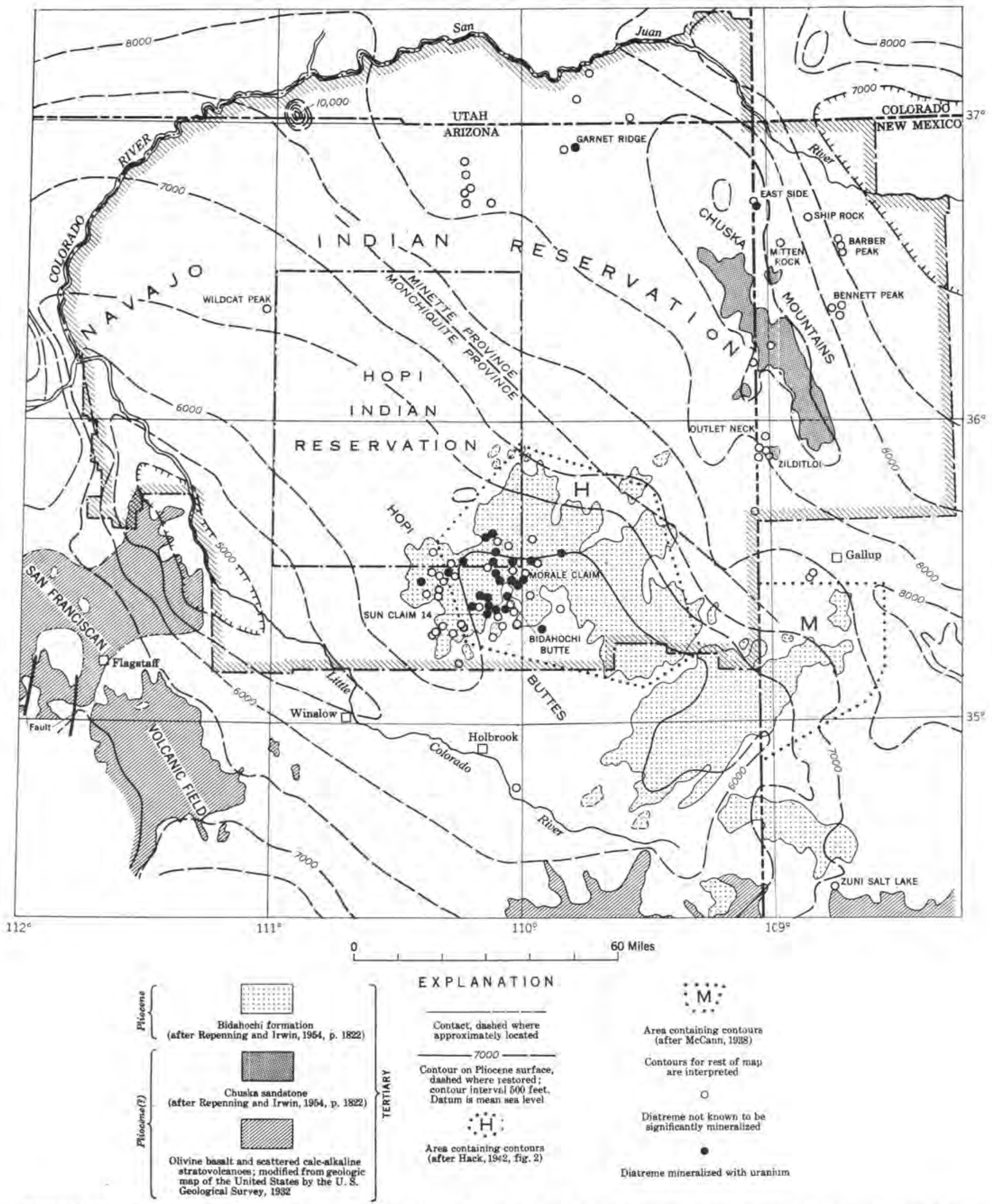

FIGURE 34,-Map of the Navajo and Hopi Indian Reservations and vicinity, showing the distribution of diatremes, sedimentary anci voleanie rocks of Pliocene(?) age, and contours on thi Pliocene surface. 
are found, but fragments in excess of about 10 feet across are, in nearly every case, derived from above. The demonstrable downward displacement of some fragments is more than 2,000 feet. The great thickness and downward increase in degree of deformation of the beds in the diatremes as well as the demonstrable downward displacement of huge blocks incorporated in well-stratified tuff are believed by the writer to indicate large-scale subsidence or collapse of the filling of most of the vents.

Successive stages of collapse are believed to be exemplified by the diatremes at Garnet Ridge, East Side mines, Barber Peak, and Ship Rock (fig. 35). These

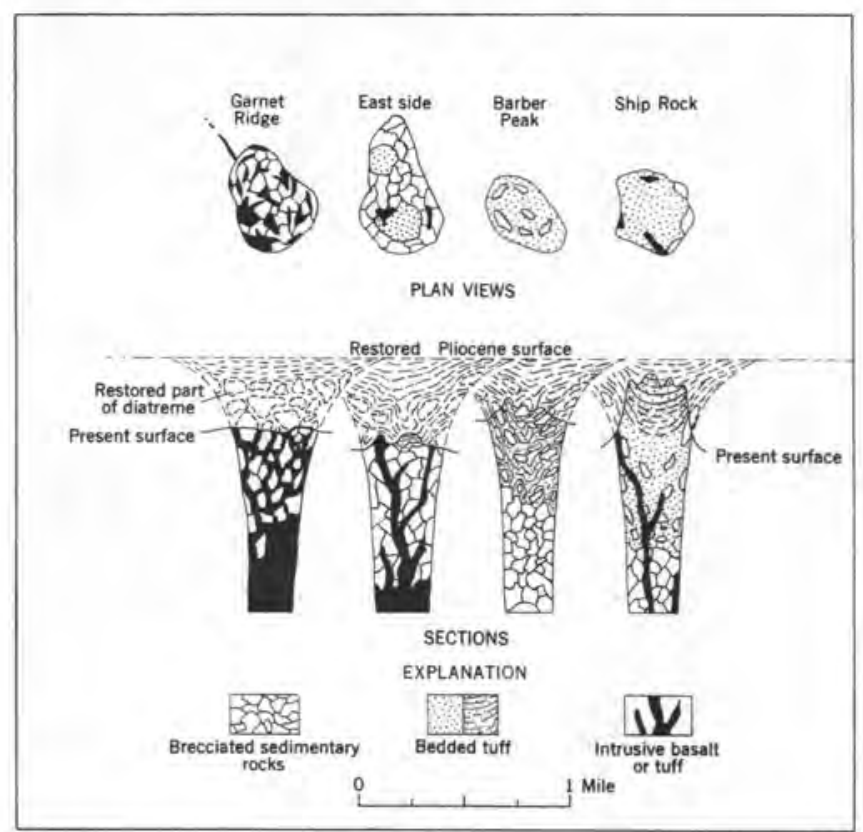

FIGURE 35.-Diagrammatie plan views and sections of four diatremes from the Navajo Reservation illustrating successive stages of subsidence.

diatremes are all eroded to a comparably deep level. Incipient collapse, of a few hundred feet, is found in the diatreme of Garnet Ridge, which is filled mainly with huge blocks of down-dropped sandstone of Jurassic age enclosed in an injected pyroclastic matrix of phlogopitebearing serpentine tuff. In a similar diatreme, at the East Side mines, patches of stratified tuff deposited on the jumbled blocks are preserved at the level at which the diatreme has been eroded. The Barber Peak diatreme is filled with well-bedded tuff through which are scattered large blocks of sandstone of Cretaceous age forming a partial conical screen of sandstone slabs within the tuff. The beds all dip steeply toward the center of the vent. In completely formed diatremes, such as Ship Rock, the bulk of the vent exposed to view is filled with tuff. Only a few large blocks of country rock are found, and these are chiefly in the lower part near the walls of the vent. Near the crest of Ship Rock, a tapering monolith rising about 1,700 feet above the desert floor, the tuff probably extends to considerable depth, passing by degrees into a tuff filled with hugh blocks of country rock, such as at Barber Peak, and finally into a macrobreccia of country rock such as at Garnet Ridge and the East Side diatremes. The differences between these diatremes are probably due mainly to the relative amount of subsidence that has occurred in each vent and somewhat to the differences in the depth at which each vent is exposed.

The source of the tuff filling the diatremes must have been either a cinder cone formed before collapse or material ejected from nearby vents or perhaps both. Some diatremes show unmistakable evidence of multiple explosions, such as large angular blocks of stratified or massive tuff incorporated in a later tuff or breccia. Many diatremes are intruded by dikes, but the dikes cannot have been the source of the tuff which they cut. Many of the diatremes probably became the locus of extrusion of lava after collapse had ceased.

In an attempt to integrate the observed relations into a coherent picture, the following generalized hypothesis of diatreme evolution is proposed. The initial phase of nearly all voleanic activity in the Navajo-Hopi region was probably the explosive drilling of a vent. Such vents commonly were of limited width and may have merged laterally or downward with dikes or may have been entirely unassociated with dikes. In general, they were filled by a quiet upwelling of lava, which in some vents reached the surface and poured out in considerable volume. If the volcanic process ended at this stage, the resulting features would be dikes, basalt-filled necks commonly jacketed with a thin layer of tuff or breccia formed in the initial vent, and flows, some of which would be traceable to the neeks. These features are well represented in the Hopi Buttes and in the vicinity of the Chuska Mountains.

In general, the volcanic process progressed beyond this initial stage. At the site of a neck or a group of dikes, a gradual and progressive subsidence took place. That subsidence took place more or less continuously and over a considerable period of time can be demonstrated at a number of localities by the complex sedimentary record, which includes angular unconformities between beds of tuff interstratified with thinly laminated silts and limestones. The depression created at the surface was filled with sediments chiefly of volcanic origin. The funnel-shaped orifice of the diatreme was enlarged by the inward collapse of the walls of the vent. Perhaps the funnel shape of the vent near the surface of eruption was governed to some degree by the extent of disruption of the country rock during the initial explosion. As the sediments which were deposited at 
the surface were sucked downward and compressed in the narrowing orifice, large blocks derived from the collapsing walls were incorporated in the diatreme filling.

\section{COMPOSITION OF THE VOLCANIC ROCKS}

The voleanic rocks associated with the diatremes are nearly all alkalic basalts which in their intrusive phase would fall mainly under the classification of the two lamprophyres monchiquite and minette (Williams, 1936). Minettes are found in the northeast half at the Navajo-Hopi region, and monchiquites, mainly in the southwest half. A very few monchiquites are found in the same area as the minettes, but the region may be broadly divided into a monchiquite province and a minette province (fig. 34). Serpentine tuff, some phlogopite bearing and some similar to kimberlite, is found in the minette province at Garnet Ridge and in the Zilditloi volcanic area (Malde, 1954; Allen and Balk, 1954, p. 99-118).

The monchiquitic basalts are ultramafic moderately alkalic volcanic rocks. Compared with olivine basalts from the Colorado Plateau, they are distinctly characterized by relatively high concentrations of water, titania, and phosphate. The monchiquites are significantly richer than Colorado Plateau olivine basalts in zirconium, barium, niobium, and the cerium group rare earths.
The minettes, highly potassic basaltic rocks, contain more water and phosphate than the olivine basalts and also relatively high concentrations of barium, strontium, beryllium, boron, cerium group rare earths, and lead.

Both the monchiquites, with an average radioactivity of 0.0012 percent $\mathrm{eU}$ and the minettes with an average radioactivity of 0.0046 percent $\mathrm{eU}$ are unusually radioactive compared with Colorado Plateau olivine basalts, which have an average radioactivity of 0.0005 percent $\mathrm{eU}$. The high radioactivity is due to higher concentrations of both uranium and thorium. (See following table.) The uranium and thorium content of the minettes is notably higher than the average uranium and thorium content in most basaltic rocks (Larsen and Phair, 1954). Another unusual feature of the concentration of uranium and thorium in the monchiquites and minettes is the low proportion of uranium and thorium in the acid soluble or leachable fractions of the rocks. In most igneous rocks with high content of uranium, a high proportion of the uranium is acid soluble (Hurley, 1950; Larsen and Phair, 1954, p. 80-81). Among other factors, the low proportion of leachable uranium and thorium in the Navajo-Hopi alkaline basalts might be due to loss of leachable uranium and thorium during weathering or during the last stages of crystallization.

Uranium and thorium conlent in parts per million of samples of monchiquile and minetle from the Navajo Reservation

[Powdered rock leached in 0.05 molar $\mathrm{HNO}_{3}$ in steam bath for one-half hour. Analyst: J. S. Antweiler, U. S. Geological Survey; calculation: G. J. Neuerburg, U, $\mathrm{S}$, Geological Survey]

\begin{tabular}{|c|c|c|c|c|c|c|c|c|c|c|}
\hline & \multicolumn{2}{|c|}{$\begin{array}{l}\text { Olivine monchiquite, } \\
\text { Bidahoehi Butte } \\
\text { (12.51 percent of rock } \\
\text { leached) }\end{array}$} & \multicolumn{2}{|c|}{$\begin{array}{l}\text { Nepheline monchi- } \\
\text { quite, WIldeat Peak } \\
\text { (12.33 percent of rock } \\
\text { leached) }\end{array}$} & \multicolumn{2}{|c|}{$\begin{array}{l}\text { Basic minette, Outlet } \\
\text { Neck (6.34 percent of } \\
\text { rock leached) }\end{array}$} & \multicolumn{2}{|c|}{$\begin{array}{l}\text { Minette, Bennett Peak } \\
\text { (6.31 percent of rock } \\
\text { leached) }\end{array}$} & \multicolumn{2}{|c|}{$\begin{array}{l}\text { Feldspathic minette, } \\
\text { Mitten Rock }(4,45 \\
\text { percent of rock } \\
\text { leached) }\end{array}$} \\
\hline $\begin{array}{l}\text { Total rock } \\
\text { Leached residue. } \\
\text { Leach }\end{array}$ & $\begin{array}{l}\text { 2. } 2 \\
\text { 2. } 2 \\
2.4\end{array}$ & $\begin{array}{l}6.4 \\
6.3 \\
7.3\end{array}$ & $\begin{array}{l}\text { 4. } 6 \\
5.0 \\
1.6\end{array}$ & $\begin{array}{l}\text { 17. } 5 \\
\text { 17. } 7 \\
\text { 16. } 4\end{array}$ & $\begin{array}{l}\text { 11. } 9 \\
\text { 10. } 7 \\
29.8\end{array}$ & $\begin{array}{l}28.4 \\
29.3 \\
15.7\end{array}$ & $\begin{array}{r}\text { 12. } 3 \\
13.0 \\
1.7\end{array}$ & $\begin{array}{r}31.5 \\
33.3 \\
3.9\end{array}$ & $\begin{array}{r}\text { 10. } 6 \\
\text { 10. } 9 \\
3.1\end{array}$ & $\begin{aligned} 50.1 \\
52.0 \\
9.0\end{aligned}$ \\
\hline
\end{tabular}

\section{URANIUM DEPOSITS}

Uranium deposits are localized in or adjacent to diatremes in widely separated parts of the Navajo and Hopi Indian Reservations, but most of the known deposits are in the Hopi Buttes area (fig. 34). No thorium content greater than the content of the unmineralized igneous rocks is known to be present in the uranium deposits.

In the northern part of the region, uranium-bearing rock is found at the Garnet Ridge diatreme, adjacent to the East Side diatreme, and at Ship Rock. Small coneretionlike deposits of uranyl and eupric vanadates and eopper carbonates are localized in the Navajo sandstone of Jurassie and Jurassic(?) age. The deposits are adjacent to a discontinuous dike of micaserpentine tuff that extends northwest of the Garnet Ridge diatreme. This occurrence has been known as a copper prospect for a long time (Gregory, 1917, pl. 2), and uranium minerals were noted in the prospect a few years ago. Malachite, chrysocolla, volborthite, and metatyuyamunite have been identified in the mineralized sandstone for the writer by M. E. Thompson, U. S. Geological Survey. The uranium-bearing sandstone also contains trace amounts of introduced silver, cobalt, nickel, lead, and thallium. Selected samples contain as much as 2.06 percent uranium, but the 
amount of exposed mineralized material is too small to be of economic importance. Spectrographic analysis of a core drilled through the tuff dike shows that calcium, strontium, nickel, vanadium, copper, and lead are dispersed in the sandstone walls of the dike.

J. W. Blagbrough (oral communication), of the U.S. Atomic Energy Commission, has reported the occurrence of uranium and vanadium minerals in a dike of brecciated sedimentary rocks in the Salt Wash member of the Morrison formation of Jurassie age adjacent to the East Side diatreme. Possibly the uranium and vanadium were simply derived from nearby carnotite deposits in the sandstones of the Salt Wash member. At Ship Rock the writer found slight concentrations of uranium, up to 0.002 percent, associated with amethyst in minette agglomerate within the diatreme.

Uranium deposits were first discovered in the Hopi Buttes area in 1952 by the writer. Since then, private prospecting and radiometric reconnaissance by the U. S. Atomic Energy Commission have shown that the uranium deposits are widespread in the Hopi Buttes diatremes, and shipment of ore was begun from one deposit in 1954. Much of the limestone in the Hopi Buttes diatremes contains from 0.001 to as much as 0.02 percent uranium, and nearly every diatreme that contains exposed limestone is conspicuously more radioactive than the surrounding rocks. Concentrations of uranium higher than 0.02 percent are found in some limestones but more commonly in siltstones and claystones. About 20 of the more highly mineralized diatremes are shown in figure 34. Continued prospecting and geologic investigation may greatly increase this number.

The mineral forms in which the uranium is present in the diatreme rocks is not fully known. J. W. Gruner (oral communication) has identified carnotite (calcium uranyl vanadate) from one of the diatremes, and E. B. Gross (oral comminication), U. S. Atomic Energy Commission, has found liebigite (calcium uranyl carbonate) in claystone from another diatreme. Most of the more intensely mineralized rock contains no visible uranium minerals, and the material is so fine grained that microsçopicidentification of the minerals is difficult. Chemical analysis of a few samples reveals a strong positive correlation between the uranium and the phosphate content of the rocks: (See following table.) The vanadium content of the ore-grade material is less than 0.05 percent. The amount of phosphate is considerably in excess of that required to form the known uranyl phosphates, and the fluorescent uranium phosphates, such as autunite, bassettite, or phosphuranylite, have not been detected. The bulk of the uranium may be contained in very fine-grained apatite.
Uranium and phosphate analyses of selected samples from the
Hopi Buttes

[Analysts: H. Lipp and J. Such, U. S. Geological Survey]

\begin{tabular}{l|r|r}
\hline \multicolumn{1}{c|}{ Sample and location } & $\begin{array}{c}\mathrm{U} \\
\text { (percent) }\end{array}$ & $\begin{array}{c}\mathrm{P}_{2} \mathrm{O}_{5} \\
\text { (percent) }\end{array}$ \\
\cline { 1 - 1 } Claystone, Bidahochi formation & 0.001 & 0.18 \\
Limestone, Sun claim 14_... & .002 & .30 \\
Siltstone, Sun claim 14 & .012 & .38 \\
Siltstone, Morale claim & .041 & .46 \\
Ore, 13 tons, Morale claim & .90 \\
\hline
\end{tabular}

The highest known concentrations of uranium in the Hopi Buttes diatreme are in laminated siltstones that unconformably overlie deformed beds of coarse tuff, tuff-breccia, and agglomerate. At the Morale claim (fig. 34) ore-grade concentrations of uranium are also found in the coarse-grained deformed rocks beneath the unconformity. Smooth erosion surfaces bevel the deformed beds on which the fine-grained laminated rocks lie. An abrupt cessation of sedimentation followed by a renewal of sedimentation at a very slow rate appears to be indicated by the unconformities. Concentrations of uranium approaching ore grade are also found in thick massive claystone in a diatreme south of Bidahochi Butte.

Preliminary evaluation of the data on the uranium deposits has led to a tentative hypothesis on the origin of the deposits. - The widespread distribution of uranium in the limestones in the diatremes suggests the uranium may be syngenetic in the limestones. The uranium may also be syngenetic in the fine-grained clastic sediments. One of the factors governing the concentration of uranium in the different rocks in the diatremes may simply be the rate of sedimentation. If uranium-bearing solutions were supplied more or less continuously from depth, the uranium would be concentrated in beds, such as limestone and siltstone, that were deposited at the slowest rate and would tend to be more dispersed in the coarser beds of tuff, which were deposited rapidly.

Possibly the uranium was derived from the hydrous, phosphate-rich, moderately uraniferous monchiquite magma, as the magma crystallized in the depths of the diatremes or beneath the diatremes. Abnormally high concentrations of phosphate in the limestones suggest the phosphate may have been supplied from depth by juvenile solutions, perhaps together with an appreciable amount of the carbonate. Spectrographic analysis of a mineralized limestone shows that it also contains small, but unusual, amounts of strontium, vanadium, cobalt, and copper, elements that are present in moderately high concentration in the monchiquites. The strong correlation of uranium with phosphate in 
the mineralized rocks suggests the uranium may have been carried in with the phosphate. The uranyl ion is highly soluble in carbonate solutions. The low proportion of uranium in the leachable fractions of the monchiquites may indicate that a considerable proportion of the uranium was lost in the final stages of crystallization of these rocks. However, thorium is also low in the leachable fractions of the monchiquites but is not known to be concentrated in the uranium deposits.

\section{REFERENCES CITED}

Allen, J. E., and Balk, Robert, 1954, Mineral resources of Fort Defiance and Tohatchi quadrangles, Arizona and New Mexico: N. Mex. Bur. Mines and Min. Res. Bull. 36, 192 p.

Branco, Wilhelm, 1894, Sehwabens 125 Vulcan-Embryonen und deren tufferfüllte Ausbruchrohren, das grösste Gebiet ehemaliger Maare auf der Erde: Stuttgart, E. Schweizerbart'sche Verlagshandlung (E. Koch), 816 p.

Darton, N. H., 1905, The Zuni salt lake: Jour. Geology v. 13, p. 185-193.

Daubreé, Auguste, 1891, Recherches Expérimentales sur le Rôle des Gaz à Hautes Températures, doués de trés fortes pressions et animés d'un mouvement forte rapide dans divers phénoménes geologiques: Soe. géol. France Bull., $3^{\circ}$ ser., v. 19, p. 313-354.

Gieke, Archibald, 1902, The geology of eastern Fife: Scotland Geol. Survey Mem., p. 1-361.
Gregory, H. E., 1917, Geology of the Navajo country-a reconnaissance of parts of Arizona, New Mexico, and Utah: U.S. Geol. Survey Prof. Paper 93, 161 p.

Hack, J. T., 1942, Sedimentation and voleanism in the Hopi Buttes, Ariz.: Geol. Soc. America Bull., v, 53, p. 335-372.

Harrell, M. A., and Eckel, E. B., 1939, Ground-water resources of the Holbrook region, Arizona: U. S. Geol. Survey WaterSupply Paper 836-B, p. 19-105.

Hurley, P. M., 1950, Distribution of radioactivity in granites and possible relation to helium age measurement: Geol. Soc. America Bull., v. 61, p. 1-7.

Larsen, E. S., Jr, and Phair, George, 1954, The distribution of uranium and thorium in igneous rocks, in Faul, Henry, ed., Nuclear Geology: New York, John Wiley and Sons, Inc., p. 75-89.

MeCann, F. T., 1938, Ancient erosion surface in the Gallup-Zuni area, New Mexico: Am. Jour. Sei., 5th ser., v. 36, p. 260-278.

Malde, H. E., 1954, Serpentine pipes at Garnet Ridge, Ariz.: Science, v. 119 , p. 618.

Repenning, C. A., and Irwin, J. H., 1954, Bidahoehi formation of Arizona and New Mexico: Am. Assoc. Petroleum Geologist Bull., v. 38, p. 1821-1826.

Stirton, R. A., 1936, A new beaver from the Pliocene of Arizona, with notes on the speeies of Dipoides: Jour. Mammalogy, v. 17, no. 3 , p. $279-281$.

Wagner, P. A., 1914, The diamond fields of southern Africa: Johannesburg, Union of South Africa, The Transvaal Leader, 347 p.

Williams, Howel, 1936, Pliocene voleanoes of the Navajo-Hopi country: Geol. Soc. America Bull., v. 47, p. 111-171. 



\title{
MINERALOGY AND OXIDATION OF THE COLORADO PLATEAU URANIUM ORES
}

\author{
By Alice D. Weers, U. S. Geological Survey
}

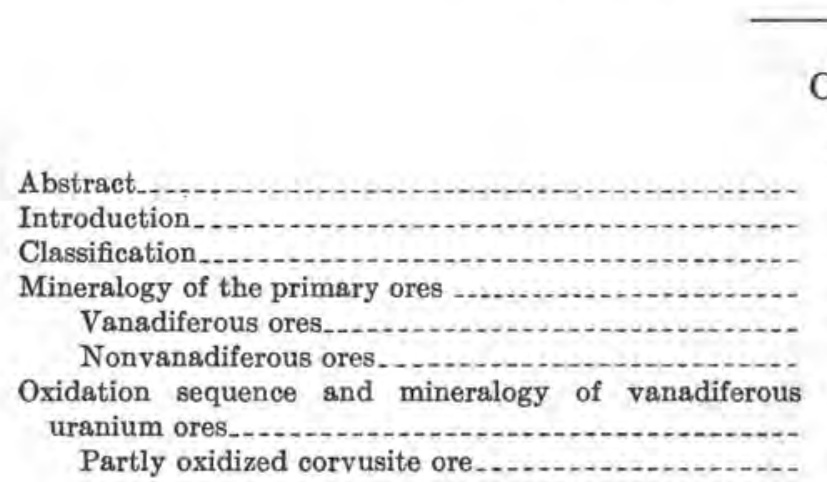

CONTENTS

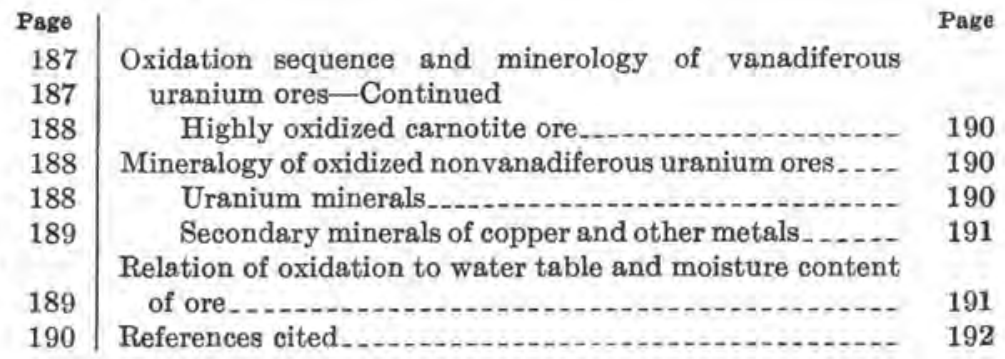

\section{ABSTRACT}

Vanadiferous uranium ores were discovered in western Colorado in 1898, and Colorado Plateau ores have been mined intermittently for radium, vanadium, and uranium. The chief production has been from shallow mines in earnotite (oxidized) ores until recent deeper mining penetrated black unoxidized ore. The ores range from highly vanadiferous through moderate and low to nonvanadiferous urapium ores containing not more than trace amounts of vanadium. Some vanadiferous ore contains small amounts of copper, but in general, it has less copper than the nonvanadiferous ores, which contain as much as 1 percent in a few mines.

Chemical, mineralogic, and geologic evidence indicates that the carnotite ores have been derived by progressive oxidation of primary black vanadium-uranium ores. The primary ores contain uranium in uraninite and coffinite and vanadium in montroseite and roscoelite. Minor amounts of copper, iron, lead, and zine sulfides are common; arsenides and selenides are less common. Calcite and barite are commonly present, and gypsum is rarely present in primary ore. Most uraninite and coffinite replace or impregnate coalified wood structures or other carbonaceous material. The primary vanadium minerals commonly occur in the intergranular areas of the sandstone as well as in coalified wood.

As oxidation begins, montroseite alters to paramontroseite and to another vanadium oxide (undescribed). These in turn are replaced chiefly by the corvusite group of minerals, which are blue black, greenish black, or purplish. The primary uranium minerals oxidize and combine with vanadium to form rauvite. Low $\mathrm{pH}$ conditions produced by alteration of sulfides and vanadium oxides eause the solution of calcite gangue and cement in the sandstone which may become partly recemented with gypsum and iron oxides.

As oxidation progresses, carnotite and tyuyamunite form chiefly from rauvite. The closely related minerals containing vanadium (IV and V) of the corvusite stage of oxidation are replaced by vanadium (V) minerals. The specific ones formed depend closely on $\mathrm{pH}$ of the solutions, presence of certain cations to combine with vanadium, and several other factors. Vanadium fixes all available uranium in uranyl vanadates, and the excess vanadium may form hydrated pentoxide, or more commonly, it combines with calcium, sodium, potassium, magnesium, aluminum, iron, or copper to form many vanadate minerals. The carnotite is remarkably stable, thus fixing the uranium very effectively.

The nonvanadiferous uranium ores differ notably from the vanadiferous, because oxidation of uraninite produces more kinds of secondary yellow and greenish-yellow uranyl minerals, such as hydrated oxides, carbonates, sulfates, phosphates, arsenates, and silicates. These secondary minerals are not as stable and therefore do not form as large oxidized deposits as carnotite.

\section{INTRODUCTION}

Vanadiferous uranium ores were discovered in western Colorado in 1898, and carnotite, a yellow secondary uranyl vanadate mineral, was named the following year (Friedel and Cumenge, 1899, p. 532; Hillebrand and Ransome, 1905, p. 9-31). Except during short intervals, the Colorado Plateau ores have been mined for more than 50 years - at first chiefly for radium (Coffin, 1921), later for vanadium (Fischer, 1942, p. 363-394), and recently for uranium (Fischer, 1950). For many years the production was from oxidized ore in shallow mines, and the Plateau ores became characterized as carnotite ores. Recent extensive exploration and deeper mining, in many places in the Plateau, have penetrated black unoxidized vanadiferous ore below or close to the water table and both oxidized and unoxidized nonvanadiferous ores. Much of the present 
production is from unoxidized ore. The deposits are now generally referred to as sandstone-type uranium deposits rather than carnotite deposits,

Thanks are due many members of the Geological Survey who have advised or participated in this study, both in the field and the laboratory. R. P. Fischer's detailed study of the carnotite and roscoelite ores has contributed much to the knowledge of the oxidized deposits (Fischer, 1942, p. 363-394). R. G. Coleman has contributed to the mineralogy of the primary ores through study of thin and polished sections and minor element content of sulfides. M. E. Thompson has worked on mineral identification by optical properties and X-ray diffraction powder patterns and contributed to the description of new minerals. L. R. Stieff and $\mathrm{T}$. W. Stern, in connection with their age-determination studies (Stieff, Stern, and Milkey, 1953), have identified three new minerals (Stieff, Stern, and Sherwood, 1955 , p. 608-609; Stern, Stieff, Girhard, and Meyrowitz, 1956). R. M. Garrels (Garrels, 1953, p. 12511265; Garrels, 1955, p. 1004-1021) and H. T. Evans (Evans, Jr., and Block, 1953, p. 1242-1250) have studied the chemistry of the ores and the crystal structure of the minerals. Chemists, spectrographers, and $\mathrm{X}$-ray crystallographers have done much analytical work, and many field geologists have aided in the collection of samples.

\section{CLASSIFICATION}

The Plateau uranium ores are classified on the basis of whether or not vanadium is associated with the uranium (Weeks and Thompson, 1954). The presence of vanadium has an important chemical and mineralogic control on the uranium during the oxidation of the ore. Some vanadiferous ore contains small amounts of copper, and in a few places nonvanadiferous ore contains as much as 1 percent of copper. Most of the ores contain traces of other metals such as lead, zinc, molybdenum, cobalt, nickel, and silver. The two main types-vanadiferous and nonvanadiferous-may be subdivided into oxidized and unoxidized ore. Mineralogically the types differ greatly because the affinity of vanadium for uranium tends to make the uranyl vanadates carnotite and tyuyamunite the chief uranium minerals in oxidized vanadiferous ore, whereas the oxidation of uraninite in nonvanadiferous ore produces more kinds of secondary yellow and greenishyellow uranyl minerals such as hydrated oxides, carbonates, sulfates, phosphates, arsenates, and silicates.

\section{MINERALOGY OF THE PRIMARY ORES}

\section{VANADIFEROUS ORES}

The primary vanadium-uranium ores are characterized in general by their black color and the presence of low-valent uranium and vanadium oxides and copper, iron, lead, and zine sulfides, arsenides, and selenides. These ores should not be confused with the blue-black or corvusite ores, which represent an intermediate stage of oxidation. The ores have a great range of vanadium content, and for convenience in description they have been divided into groups on the basis of their vanadium-uranium rations.

Vanadiferous ores with vanadium-uranium ratio greater than $15: 1$ are characterized by the dominance of vanadium silicates over vanadium oxides and the general lack of fossil wood. The unoxidized ores in the Entrada sandstone (Jurassic) of the Rifle and Placerville districts in western Colorado are representative of this group and appear to have a uniform and simple mineralogy. Roscoelite is the dominant vanadium mineral, occupying the intergranular areas as finegrained micaceous aggregates (R. G. Coleman and J. Hathaway, personal communication). In narrow bands of sandstone richly mineralized by roscoelite, the quartz grains are strongly corroded; and in weakly mineralized sandstone, replacement of detrital quartz is less apparent. Montroseite (Weeks, Cisney, and Sherwood, 1953 , p. 1235-1241) is interleaved with the roscoelite aggregates as small, discrete, crystalline rosettes. Paramontroseite may locally supersede montroseite where oxidation has commenced. Calcite or dolomite commonly accompanies the montroseite and roscoelite and appears to be contemporaneous with the vanadium mineralization. The sulfides galena and chalcopyrite accompanied by scarce pyrite and marcasite are minor but persistent.

Ores with vanadium-uranium ratios ranging between $15: 1$ and $1: 1$ occur extensively in the Salt Wash sandstone member of the Morrison formation (Late Jurassic) and to a lesser extent in the Shinarump conglomerate and the Chinle formation (both Triassic) and in other formations. The uranium is fixed in uraninite and coffinite and almost without exception is associated with coalified wood or other carbonaceous material. "Other carbonaceous material" includes the much misused term "asphaltite" which has not, as yet, been established as an abundant constituent of the Colorado Plateau ores. Uraninite replaces the cell wolls of the wood structure in preference to the lumens. If the lumens are vacant, the uraninite also fills them, but commonly the lumens are filled by sulfides. Where the original wood structure was collapsed or vitrainized, or both, during diagenesis, the uraninite intimately impregnates or replaces the wood and faithfully retains the coaly structures. Uraninite deposited in the sandstone bordering fossil wood may show replacement of earlier sulfides and detrital quartz or may be intimately intergrown with calcite or dolomite. Coffinite is al- 
ways found within coalified wood, where it fills the cell cavities. The vanadium occurs as an oxide in only one primary mineral, montroseite, which is easily oxidized to the more commonly observed paramontroseite (Weeks, Cisney, and Sherwood, 1953, p. 12351241; Evans and Mrose, 1955, p. 861-875). In places, montroseite impregnates the fossil wood by filling cell cavities, but the growth of its elongate erystals obscures the wood structure. Its strong crystallinity typically causes the formation of rosettes and intricate and sinuous bands, either in contraction fractures in fossil wood or in interstitial areas of the sandstone. Pyrite and marcasite are the commonest sulfides associated with the primary ores, and two distinct generations of iron sulfides have been recognized. Sulfides formed during diagenesis impregnate or form pseudomorphs after wood or occur as nodules and are considered to have formed before the ore. Euhedral and massive pyrite associated with uraninite and galena are considered penecontemporaneous with the mineralization. Detailed study of the iron sulfides shows that those associated with mineralization have been enriched in cobalt and nickel relative to the diagenetic sulfides (R. G. Coleman, personal communication). Galena is commonly present within the uraninite and as later vein material cutting uraninite, indicating two generations. Calcite-dolomite mixtures with a small amount of barite make up a large part of the gangue. Mines in the Jo Dandy area on the faulted margin of the Paradox salt anticline, Montrose County, Colo., commonly contain an intergranular gypsum cement formed before the ore. Minor amounts of selenides, including clausthalite and eucairite, are found in some mines, and as yet it is not entirely certain that the selenium is derived from and restricted to certain seleniferous stratigraphic horizons.

\section{NONVANADIFEROUS ORES}

Depositsin which vanadium is negligible and uranium is the only ore of importance (except where copper may be locally of commercial importance) occur ehiefly in the Shinarump conglomerate and basal sandstones in the Chinle formation (both Triassic). The ore is found mainly in channels that contain carbonaceous material and mudstone beds; these channels are along the thin edge (pinch-out) of the conglomerate and sandstone beds that fill cuts in the underlying formation (Finch, 1955). The Happy Jack mine (Trites and Chew, 1955), San Juan County, and the Delta mine, Emery County, Utah, are good examples of this group. These ores do not have the intense black of the vanadiferous ores because the black vanadium oxide montroseite is lacking. In the primary ores uranium is contained chiefly in uraninite (Rosenzweig, Gruner, and Gardner, 1954, p. 351-361), and coffinite is scarce or lacking. Fossil wood is again the main control of the uraninite deposition, and the wood is replaced in the same manner as described above. More sulfides are associated with uraninite in some of these ores, and a more complicated mineralization sequence is evidenced by ambiguous relations between the uraninite and sulfides. Two generations of pyrite have also been established in these primary ores, with the pyrite in the uraninite showing rims of unidentified nickel and cobalt minerals - further evidence of nickel-cobalt enrichment accompanying the uranium mineralization (R. G. Coleman, personal communication). Copper sulfides, including chalcopyrite, bornite, chalcocite, and covellite, are dominant in some mines; and lead, zinc, and iron sulfides are dominant in others. Galena is commonly associated with uraninite either as early euhedral cubes or as late vein material. Molybdenum sulfide (?) in trace amounts commonly occurs in mineralized wood. Silver has been noted in spectrographic analyses of sulfide concentrates, but no silver minerals have been identified. Some uraninite ores have very little accompanying sulfide; these ores are difficult to recognize in the field and must be prospected by careful search with Geiger or scintillation counters.

\section{OXIDATION SEQUENCE AND MINERALOGY OF VANADI- FEROUS URANIUM ORES}

The primary ores are stable in reducing environments after emplacement and generally retain their original minerals and texture if they are not exposed to oxidizing conditions. Those ores which have remained below the zone of oxidation; that is, water table; and those that have held their original pore water in tightly enclosed lenses above the regional water table retain their primary character. In the Colorado Plateau, stages of oxidation may be found superimposed on the primary ores because the deposits occur in many different. situations with respect to the water table and also because of different water retention capacities of the pore space of the ore sandstone.

The many vanadium minerals are very sensitive to changes in oxidation and $\mathrm{pH}$ (Garrels, 1953, p. 12511265; Garrels, 1955, p. 1004-1021; Marvin, 1955, p. 326 , and 1954 , p. 1282), and therefore, they serve as convenient indicators to the degree of oxidation and the $\mathrm{pH}$ of the environment during oxidation. Montroseite, $\mathrm{VO}(\mathrm{OH})$, oxidizes readily (Evans and Mrose, 1955 , p. 861-875) to paramontroseite, $\mathrm{VO}_{2}$, when exposed to air, as shown by the alteration of most montroseite specimens after a few months in the laboratory. Four new vanadium (IV) minerals are currently being studied by members of the U. S. Geological Survey. Uraninite is altered as uranium (IV) oxidizes to uranium 
(VI), although this change may not be recognized visually. The early oxidation of the primary uranium minerals probably disperses the uranium into an unknown phase that gives no X-ray powder pattern and that may be coloidal. The sulfides are still fresh and unaltered after oxidation of uraninite and montroseite has commenced.

\section{PARTLY OXIDIZED CORVUSITE ORE}

Further oxidation of the ores in the corvusite stage causes a change from black to blue black; some greenish black and brown also appear at this stage. The vanadium (IV) minerals alter to a group of vanadium compounds containing different proportions of vanadium (IV) and (V) with some calcium and iron.

Vanadium (V) combines with all available uranium (VI) to form the ill-defined and sometimes inconspicuous mineral rauvite (Hess, 1925, p. 63-78), which may be dispersed in microscopic aggregates in massive corvusite or may form glassy gellike coatings on quartz grains, pebbles, or contraction fractures in mineralized wood. Rauvite ranges from purplish black and brownish red in the gellike kinds to orange red in the powdered aggregates.

The best erystallized of the vanadium minerals is melanovanadite, for many years known only from the type locality in Peru and now recognized in several mines in the Plateau. Most of the vanadium (IV) and (V) material shows a very complex and intimate mixture of minerals quite similar in nature and generally referred to as corvusite. The molecular ratio of vanadium (V) to (IV) ranges from 6 in the corvusite originally described by Henderson and Hess (1933, p. 195205) to somewhat lower values in other analyzed corvusitelike minerals (A. M. Sherwood and R. Meyrowitz, written communication).

It is not now known to what extent, if any, the interstitial aggregates of vanadium silicates in the sandstone may be affected by oxidation during the corvusite stage. Water-soluble vanadium derived from corvusite may be adsorbed by sedimentary clays at this stage.

By the time the corvusite stage is reached, some of the associated minerals begin also to show a response to the oxidizing conditions. The sulfides alter to oxides and sulfates, and selenides may alter to native selenium (Thompson, Roach, and Braddock, 1956, p. 156-157). Depending on the relative abundance of calcite with respect to pyrite in the primary ore, part or all of the calcite gangue and cement in the sandstone may be dissolved, and the sandstone may be partly recemented by gypsum and iron oxides.

\section{HIGHLY OXIDIZED CARNOTITE ORE}

As oxidation progresses, carnotite and tyuyamunite form chiefly from rauvite; some may form from other mineraIs. Once crystallized, the carnotite is remarkably stable and fixes the uranium very effectively. The minerals containing vanadium (IV and V) of the corvusite stage oxidize to form vanadium (V) minerals. The specific ones formed depend closely on $\mathrm{pH}$ conditions (Marvin, 1955, p. 326, and 1954, p. 1282), the presence of certain cations to combine with vanadium, and several other factors. Vanadium fixes all available uranium in uranyl vanadates, and the excess vanadium may form the rare hydrated pentoxide navajoite (Weeks, Thompson, and Sherwood, 1955, p. 207-212), or more commonly it combines with calcium, sodium, potassium, magnesium, aluminum, iron, or copper to form one or more of the vanadates - hewettite, pascoite (Hillebrand, Merwin, and Wright, 1914, p. 31-54), rossite (Foshag and Hess, 1927, p. 1-12), sodium vanadate (Weeks and Thompson, 1954), hummerite (Weeks and Thompson, 1954), steigerite (Henderson, 1935, p. 769-772), fervanite (Hess and Henderson, 1931, p. 273-277), volborthite, and calciovolborthite. These vanadates range from brown through red, orange, yellow, and green to nearly colorless.

Considerable vanadium is also present in one or more fine-grained vanadium silicate minerals occurring interstitially in the sandstone or in clay pellets and lenses.

In the Colorado Plateau, carnotite is probably more abundant than tyuyamunite in the oxidized ores of the Uravan mineral belt of western Colorado and eastern Utah (Fischer and Hilpert, 1952, p. 1-13). High calcium content of the sediments in the Grants district and the Ship Rock district of New Mexico causes local predominance of tyuyamunite. In areas where the vanadium-uranium ratio is low, small amounts of other uranium minerals may occur, as uranophane, near Grants, N. Mex., and autunite, andersonite, schroeckingerite, and zippeite in the Thompson district, Grand County, Utah.

\section{MINERALOGY OF OXIDIZED NONVANADIFEROUS URANIUM ORES}

\section{URANIUM MINERALS}

The nonvanadiferous uranium ores differ notably from the vanadiferous because oxidation of uraninite in the absence of vanadium produces more kinds of secondary uranium minerals. These include hydrated oxides, carbonates, sulfates, phosphates, arsenates, and silicates. They are microcrystalline or massive and range from orange through yellow and greenish yellow to 
green. They fill pore spaces or minute fractures in sandstone, conglomerate, or fossil wood and coat joint surfaces and mine walls. Among these minerals, none is as predominant as is earnotite in the oxidized vanadiferous ore (Weeks and Thompson, 1954). In general, these secondary minerals are close to unoxidized remnants of the primary minerals from which they formed. They do not form large deposits of oxidized ore as does carnotite, because their solubilities are much greater than that of earnotite.

The hydrated uranium oxides are rare in occurrence and small in quantity because sulfate, carbonate, or some other anion is usually present to combine with uranium. Small amounts of becquerelite, schoepite, and fourmarierite are closely associated with oxidizing uraninite.

In the oxidation of sulfide-rich uraninite ore, the most abundant secondary uranium minerals are the uranyl sulfates - johannite, uranopilite, zippeite, and other unidentified zippeitelike minerals. These green, yellowishgreen, and deep-yellow minerals are beautifully formed on the walls of Happy Jack mine in White Canyon, San Juan County, Utah (Trites and Chew, 1955).

The uranyl carbonates are commonly formed wherever the sulfide content of the ore is low and the host, or gangue, contains sufficient carbonate, as at Shinarump No. 1 mine, Grand County, Utah (Finch, 1954). Six uranyl carbonates have been found on the Colorado Plateau, including liebgite, rutherfordine, schroeckingerite, and the three new carbonates, andersonite (Axelrod, Grimaldi, Milton, and Murata, 1951, p. 1-22), baylayite (Stern and Weeks, 1952, p. 1058-1060), and rabbittite (Thompson, Weeks, and Sherwood, 1955, p. 201-206). Most of these are readily soluble in water and would be washed away almost as rapidly as they formed were it not for the semiarid climate of the Plateau.

The uranyl phosphates are rare in the Plateau because the sandstone host rock is low in phosphate except where fossil bones are preserved. Small amounts of autunite, phosphuranylite (possibly an alteration product of autunite), torbernite, and bassetite have been found. Small amounts of uranyl arsenates are present: metazeunerite at several localities in Utah and novacekite (Stern and Annell, 1954, p. 675-676) and abernathyite (Thompson, Ingram, and Gross, 1956, p. 82-90) at one locality each. The uranyl silicates, uranophane sklodowskite, and cuprosklodowskite are rare in the Plateau. The unknown sulfates, phosphates, and silicates that are being studied probably include several new minerals.

\section{SECONDARY MINERALS OF COPPER AND OTHER METALS}

Copper, the chief associated metal in some of the nonvanadiferous ore, occurs in many secondary minerals, commonly as malachite, azurite, chalcanthite, antlerite, brochantite, and chrysocolla and rarely as conichalcite, chalcoalumite, and volborthite. Several other metals are present and differ in abundance from one mine to another: iron and manganese in limonite and wad; cobalt in bieberite (commonly dehydrated); cobaltocalcite, erythrite, or cobaltoan pickeringite; molybdenum in ilsemannite or ferrimolybdite; and traces of lead, zinc, nickel, and silver (Weeks and Thompson, 1954).

The presence of brightly colored copper, cobalt, and molybdenum secondary minerals on the rock outcrop or on joint surfaces within a few feet of the cliff face is helpful to the prospector, but many small copper deposits on the Plateau do not contain uranium.

Clay lenses in the ore and mudstone or shale underlying ore are commonly bleached and altered by formation of one or more of the following: Kaolinite, jarosite, alunite, or gibbsite. Fluorescent uraniferous opal and allophane coat some joint surfaces.

\section{RELATION OFTOXIDATION TO WATER TABLE AND MOISTURE CONTENT OF ORE}

Second in importance only to the range of primary composition of the Colorado Plateau uranium ores is their range in degree and depth of oxidation. Oxidation depends on access of air to the ore as in exposed rocks with no soil cover and where evaporation is high, in relatively continuous permeable sandstone beds high above the water table, and in strata truncated downdip by a canyon. Oxidation has been prevented or retarded where water is held in the pore space of the ore sandstone, as in strata protected by thick soil cover, in lenticular sandstone beds surrounded by clay, in strata above a perched water table, and in strata that dip away from the valley wall.

A good example of unoxidized ore below or close to the water table is at the Peanut mine, Montrose County, Colo. The mine is wet because it is situated in a small basin along the axis of the syncline between Paradox and Gypsum salt anticlines (Cater, 1954), and the ore is in tight lenses of crossbedded sandstone (C. Roach and M. E. Thompson, personal communication). The water is being tapped gradually by headward erosion of Bull Canyon. The wet, unoxidized ore consists of montroseite, uraninite, sulfides, and traces of selenides in lenticular sandstones and mudstones cemented by 
calcite. Close above the water table where oxidation has begun, the ore contains an unusual formation of vanadium (IV) minerals.

The Corvusite mine on Beaver Mesa, Grand County, Utah, is a good example of partly oxidized ore with small remnants of unoxidized ore. The deposit was mined intermittently for more than 40 years and was the type locality for the mineral corvusite (Henderson and Hess, 1933, p. 195-205). The mine is on the updip side of the mesa toward the La Sal Mountains, and the ore is in richly mineralized fossil trees and small sandstone lenses interbedded with thick clay that retains moisture in the ore. The mesa is more than 7,500 feet above sea level and has considerable soil cover and vegetation, cool temperature, low evaporation, and possibly more rainfall than the lower parts of the Plateau. All these factors contribute to the continued dampness of the ore and have permitted only partial oxidation although the mine is high above the main regional water table.

The dry mines with highly oxidized ore may be classified in three groups. Some carnotite deposits have been oxidized in place with practically no movement of material. Some have been modified during the corvusite stage of oxidation by migration of watersoluble vanadium downdip and by accentuation of the boundary of ore rolls to form "breakaway surfaces." Ore sandstone directly at the surface of the ground probably has been leached of some uranium and vanadium by alkaline surface and ground water.

The Rattlesnake mine in the north end of Lisbon Valley, San Juan County, Utah, contains highly oxidized ore in dry friable sandstone. The yellow and brown ore has a spotted and banded texture giving the appearance of oxidation in place. Many carnotite-rich logs found in mines appear to be the oxidized product of fossil wood impregnated with montroseite and replaced by uraninite. The wood-cell structure so commonly observed in polished sections of uraninite is destroyed by volume changes during oxidation, and carnotite "logs" show only the gross feature of the wood.

The Club Group of mines (Fischer, 1942, p. 386) on the sandstone bench of the Salt Wash member of the Morrison formation above the San Miguel Canyon at Uravan, Montrose County, Colo., are dry with chiefly oxidized ore and abundant ore rolls with "breakaway surfaces," The strata dip toward the canyon allowing water to drain through the more permeable sandstone beds. Higher on Club Mesa a mine at a depth of 260 feet is also dry and has chiefly oxidized ore with wellformed ore rolls and a small amount of corvusite ore. Water seeping through the sandstone and evaporating on the mine walls forms pascoite. The small pockets of corvusite have barite that is coated with radioactive daughter products. Still higher on Club Mesa a mine at a depth of 500 feet is moderately dry although shale overlying the ore sandstone is wet. The ore is partly oxidized with a few remnants of coffinite and montroseite. This series of mines illustrates the gradation in oxidation and the leaching of water-soluble vanadium compounds where water moves through partly oxidized ore. Another series of mines, called the Lower Group, near Slickrock in San Miguel County, Colo., illustrates the same processes.

Where small dry mesas are capped by the ore-bearing sandstone as at the Eastside Carrizo mines, west of Ship Rock, N. Mex., the chief vanadium mineral on the outerop is vanadium hydromica or another vanadium clay mineral. This uniform light-gray ore is low in uranium, which is present in thinly disseminated yellow grains of tyuyamunite in the sandstone. A coating of tyuyamunite occurs on joint surfaces below a white caliche crust several feet below the surface of the ground. Some uranium seems to have been leached from the surface of the ore sandstone, probably by recent alkaline ground water. Hewettite, a common vanadium mineral in deeper mines, has probably been leached by alkaline ground water also.

Although many details of the oxidation history have not been investigated as yet, the oxidation studies are helping to clarify the problem of origin of the ore by eliminating from consideration those features formed during oxidation and the modifications made by recent ground water.

\section{REFERENCES CITED}

Axelrod, J. M., Grimaldi, F. S., Milton, Charles, and Murata K. J., 1951, The uranium minerals from the Hillside Mine, Yavapai County, Ariz: Am. Mineralogist, v. 36, p. 1-22. Cater, F. W., Jr., 1954, Geology of the Bull Canyon quadrangle, Colo. [with text]: U. S. Geol. Survey Geol. Quadrangle Map GQ 33.

Coffin, R. C., 1921, Radium, uranium, and vanadium deposits of southwestern Colorado: Colo. Geol. Survey Bull. 16, 231 p.

Evans, H. T., Jr., and Block, S., 1953, The crystal structure of montroseite, a vanadium member of the diaspore group: Am. Mineralogist, v. 38, p. 1242-1250.

Evans, H. T., Jr., and Mrose, M. E., 1955, A crystal chemical study of montroseite and paramontroseite: Am. Mineralogist, v. 40, p. 861-875.

Finch, W. I., 1954, Geology of the Shinarump No. 1 uranium mine, Seven Mile Canyon area, Grand County, Utah: U. S. Geol. Survey Cire. 336, 14 p.

- 1955, Preliminary geologie map showing the distribution of uranium deposits and principal ore-bearing formations of the Colorado Plateau region: U. S. Geol. Survey Min. Inv. Field Studies Map, MF 16.

Fischer, R. P., 1942, Vanadium deposits of Colorado and Utah: U. S. Geol. Survey Bull. 936-P, p. 363-394.

- 1950, Uranium-bearing sandstone deposits of the Colorado Plateau: Econ. Geology, v. 45, p. 1-11.

Fischer, R. P., and Hilpert, L. S., 1952, Geology of the Uravan Mineral Belt: U. S. Geol. Survey Bull. 988-A, p. 1-13. 
Foshag, W. F., and Hess, F. L., 1927, Rossite and metarossite, two new vanadates from Colorado: U. S. Nat. Museum Proc., v. 72, p. 1-12.

Friedel, C., and Cumenge, E., 1899, Sur une nouveau minerai d'urane, earnotite: Acad. Sci. Paris, Comptes rendus, v. 128, p. 532-534.

Garrels, R. M., 1953, Some thermodynamic relations among the vanadium oxides and their relation to the oxidation state of the uranium ores of the Colorado Plateaus: Am. Mineralogist, v. 38, p. 1251-1265.

1955 , Some thermodynamic relations among the uranium oxides and their relation to the oxidation states of the uranium ores of the Colorado Plateaus: Am. Mineralogist, v. 40, p. 1004-1021.

Henderson, E. P., 1935, Steigerite, a new vanadium mineral: Am. Mineralogist, v. 20, p. 769-772.

Henderson, E. P., and Hess, F. L., 1933, Corvusite and rilandite, new minerals from the Utah-Colorado carnotite region: Am. Mineralogist, v. 18, p. 195-205.

Hess, F. L., 1925, New and known minerals from the UtahColorado earnotite region: U. S. Geol. Survey Bull. 750-D, p. 63-78.

Hess, F. L., and Henderson, E. P., 1931, Fervanite, a hydrous ferric vanadate: Am. Mineralogist, v. 16, p. 273-277.

Hillebrand, W. F., Merwin, H. E., and Wright, F. E., 1914, Hewettite, metahewettite, and pascoite, hydrous calcium vanadates: Am. Philosophical Soe. Proc., v. 53, p. 31-54.

Hillebrand, W. F., and Ransome, F. L., 1905, On carnotite and associated vanadiferous minerals in western Colorado: U. S. Geol. Survey Bull, 262, p. 9-31.

Marvin, R., 1955, CaO- $\mathrm{V}_{2} \mathrm{O}_{5}-\mathrm{H}_{2} \mathrm{O}$ system [abs.]: Am. Mineralogist, v. 40 , p. 326,1954 , Geol. Soe. America Bull., v. 65, p. 1282.

Rosenzweig, Abraham, Gruner, J. W, and Gardiner, Lynn, 1954, Widespread occurrence and character of uraninite in the Triassic and Jurassic sediments of the Colorado Plateau: Econ. Geology, v. 49, p. 351-361.
Stern, T. W., and Annell, C. S., 1954, A second locality of novacekite: Am. Mineralogist, v. 39, p. 675-676.

Stern, T. W., Stieff, L. R., Girhard, M. N., and Meyrowitz, Robert, 1956, The occurrence and properties of metatyuyamunite, $\mathrm{Ca}\left(\mathrm{UO}_{2}\right)_{2}\left(\mathrm{VO}_{4}\right)_{2}-3-5 \mathrm{H}_{2} \mathrm{O}: \mathrm{Am}$. Mineralogist (in press).

Stern, T. W., and Weeks, A. D., 1952, Second occurrence of bayleyite in the United States: Am. Mineralogist, v, 37, p. 1058-1060.

Stieff, L. R., Stern, T. W., and Milkey, R. G., 1953, A preliminary determination of the ages of some uranium ores of the Colorado Plateau by the lead-uranium method: U. S. Geol. Survey Circ. 271, 19 p.

Stieff, L. R., Stern, T. W., and Sherwood, A. M., 1955, Preliminary description of coffinite-a new uranium mineral: Seience, v. 121, p. 608-609.

Thompson, M. E., Ingram, Blanche, and Gross, E. B., 1956, Abernathyite, a new uranium mineral of the metatorbernite group: Am. Mineralogist, v. 41 , p. 82-90.

Thompson, M. E., Roach, Carl, and Braddock, William, 1956, New oceurrences of native selenium: Am. Mineralogist, v. 41, p. $156-157$

Thompson, M. E., Weeks, A. D., and Sherwood, A. M., 1955, Rabbittite, a new uranyl carbonate from Utah: Am. Mineralogist, v. 40, p. 201-206.

Trites, A. F., Jr., and Chew, R. T., 3d, 1955, Geology of the Happy Jack mine, White Canyon area, San Juan County, Utah: U. S. Geol, Survey Bull. 1009-H, p. 235-248.

Weeks, A. D., Cisney, E. A., and Sherwood, A. M., 1953, Montroseite, a new vanadium oxide from the Colorado Plateaus: Am. Mineralogist, v. 38, p. 1235-1241,

Weeks, A. D., and Thompson, M. E., 1954, Identification and occurrence of uranium and vanadium minerals from the Colorado Plateaus: U. S. Geol. Survey Bull. 1009-B, p. 12-62.

Weeks, A. D., Thompson, M. E., and Sherwood, A. M., 1955, Navajoite, a new vanadium oxide from Arizona: Am. Mineralogist, v. 40, p. 207-212. 


\title{
PARAGENETIC STUDIES OF URANIUM DEPOSITS OF THE GOLORADO PLATEAU
}

\author{
By R. A. Laverty and E. B. Gross, U. S. Atomic Energy Commission
}

\section{CONTENTS}

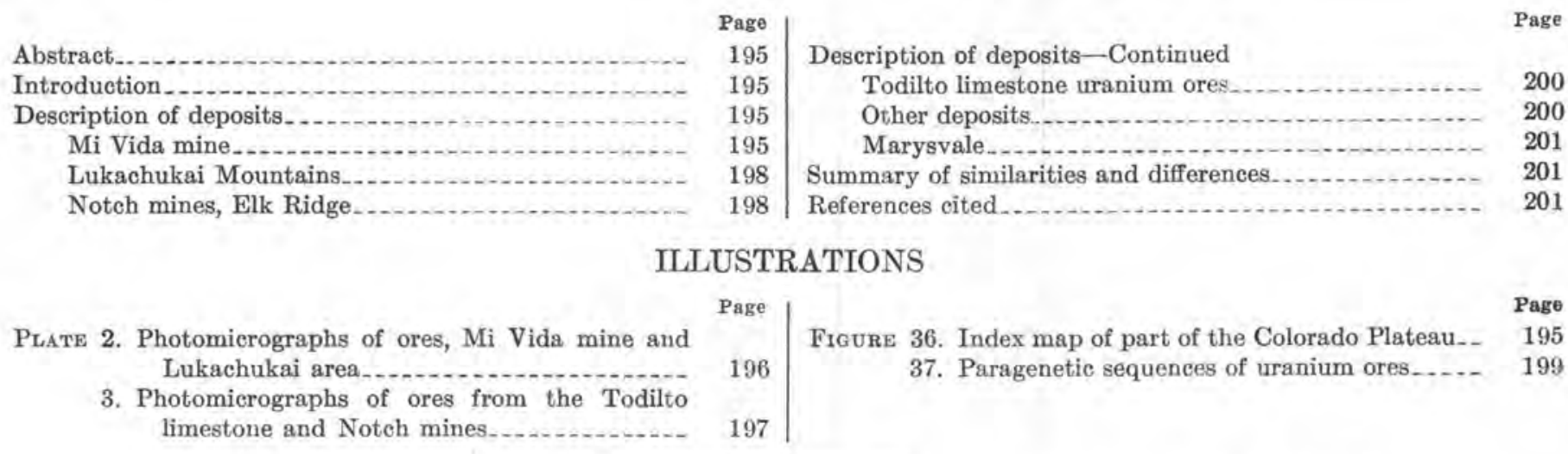

\section{ABSTRACT}

A eompilation of the paragenetic sequences of several uranium ore deposits of the Colorado Plateau presents evidence for the deposition of the ore under reducing conditions by migrating solutions at a time considerably later than the deposition of the host rock.

Host rocks for the uranium all contain organic material, and most contain calcite or limestone, and seams or lenses of mudstone, siltstone, or clay. The organic material and the calcite were the two main precipitants of the black uranium ore minerals, and the lenses and seams of clay-rich rocks are guides in some regions. In places, base-metal sulfides have been preeipitants.

The uranium minerals occur as cements or replacements during the intermediate stage of the cementing sequence. This rules out syngenetic deposition in place and probably places the time of deposition in the Late Cretaceous or early Tertiary.

The fluvial elastic rocks deposited in Mesozoic time in an oxidizing environment are the major uranium-producing formations. Reducing conditions prevailed, owing to decomposition of organic material and limited water circulation; marine submergence in parts of the Cretaceous prolonged this condition.

The major uranium deposits lie in a zone 10-40 miles from laccoliths intruded into rocks of the Plateau in early to middle Tertiary time.

\section{INTRODUCTION}

Detailed studies have been made of the paragenesis of several uranium deposits of the Colorado Plateau (fig. 36): the Mi Vida mine, Big Indian Wash, Utah; the mines near Cove School, Lukachukai Mountains, Ariz.; the Notch mines, Elk Ridge, Utah; and some of the mines in Todilto limestone near Grants, N. Mex. Less detailed studies have been made of the Delta mine and the Temple Mountain deposits in the San Rafael Swell, Utah, the Cal-Uranium and U \& I mines, Big Indian Wash, Utah, the copper-uranium mines in White Canyon, Utah, the Sanostee deposits, Chuska Mountains, Ariz., and the Meeker deposits in northwestern Colorado.

\section{DESCRIPTION OF DEPOSITS MI VIDA MINE}

The unoxidized uranium-vanadium ore of the Mi Vida mine, San Juan County, Utah, occurs in poorly sorted fine-grained subangular calcareous dark-gray sandstones and conglomerates of the Chinle formation of Triassic age. Detrital constitutents are mainly

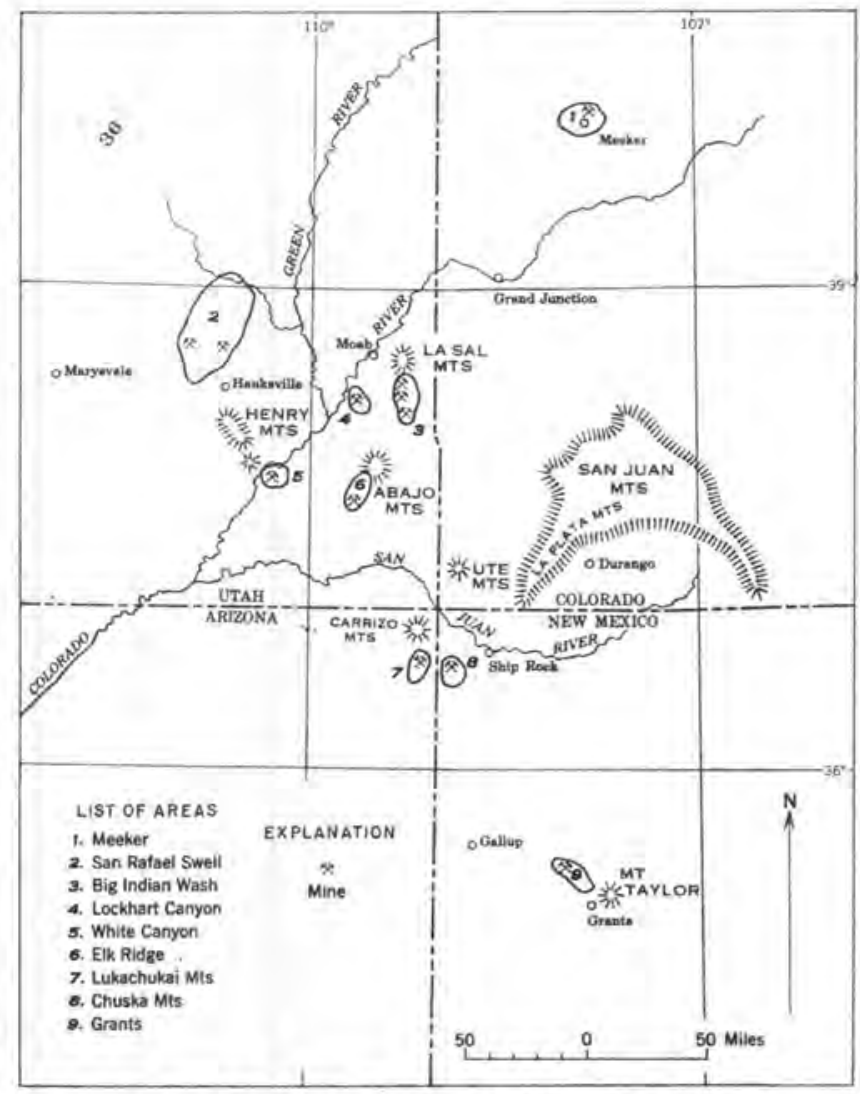

FIGURE 36.-Index map of part of the Colorado Plateau. 


\section{PLATE 2}

A. Mi Vida mine, thin section: Uraninite $(u)$ replacing quartz $(q)$ and feldspar $(f s)$ grains. Vanadium hydromica $(v h)$ has completely replaced former calcite cement.

$B$. Mi Vida mine, thin section: Acicular montroseite $(m o)$ replacing calcite $(c a)$ cement in sandstone containing quartz $(g)$ and mudstone $(m s)$ grains.

C. Mi Vida mine, polished section: Uraninite $(u)$ veining and cementing quartz $(g)$.

$D$. Mi Vida mine, polished section: Colloform uraninite $(u)$ with calcite $(c a)$.

$E$. Mi Vida mine, polished section: Uraninite $(u)$ replacing calcite $(c a)$ in deformed cellular wood structure.

$F$. Mi Vida mine, polished section: Uraninite $(u)$ and calcite $(c a)$ replacing cellular structure in wood. Uraninite is also replacing calcite.

$G$. Lukachukai area, thin section: Calcite $(c a)$ cementing quartz $(q)$ grains coated with hematite $(h)$. All the calcite shown is part of a single crystal.

$\boldsymbol{H}$. Lukachukai area, thin section: Limonite-stained clay and carbonate matrix $(m a)$ in sandstone, with calcite cement $(c a)$ between quartz grains $(q)$.

I. Lukachukai area, thin section: Opaque grains of tyuyamunite $(t y)$ in calcite-cemented sandstone (ca) 
GEOLOGICAL SURVEY
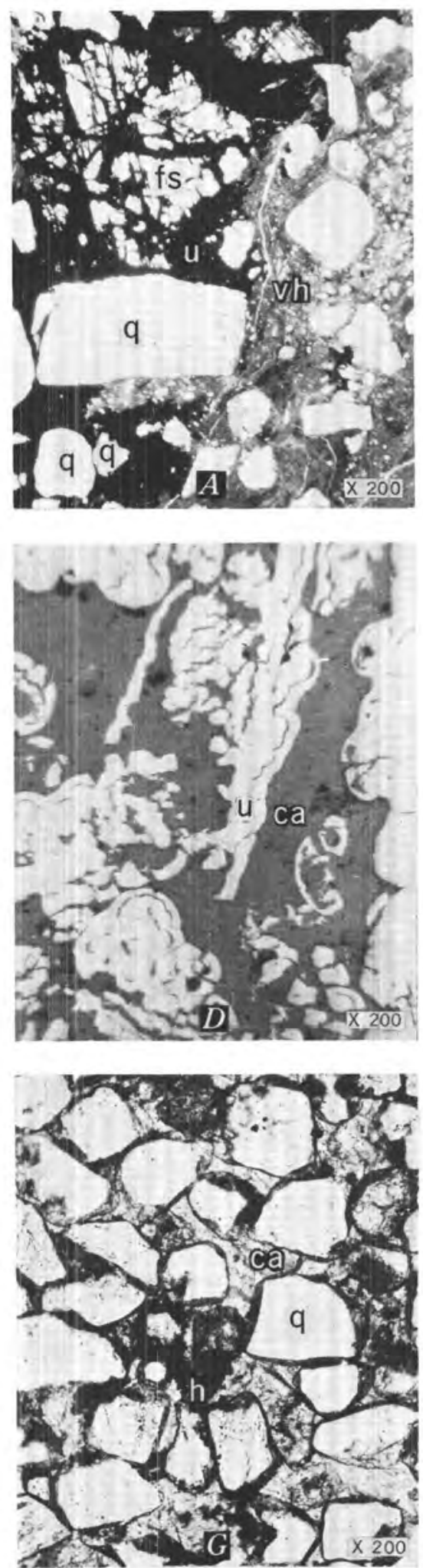
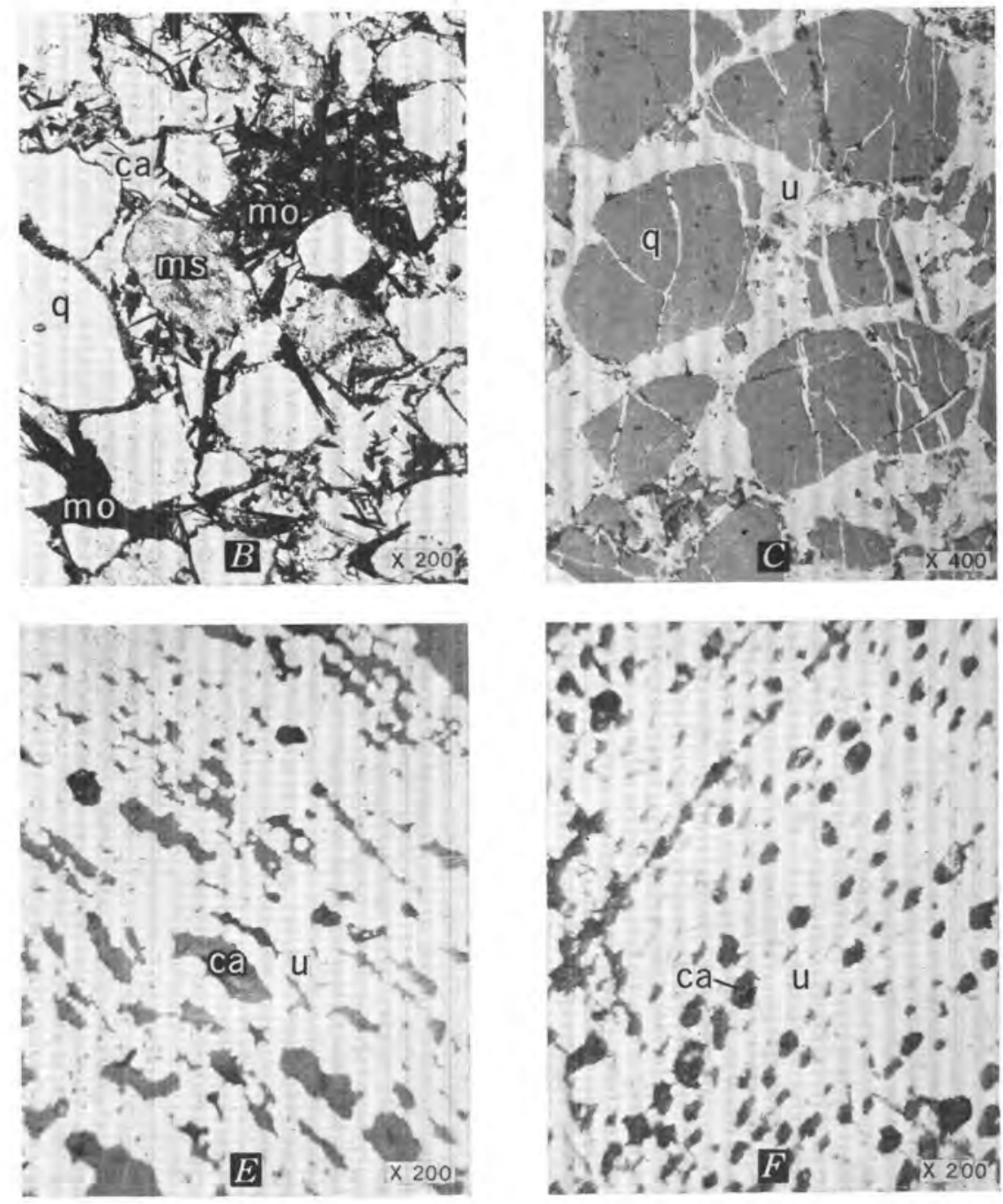

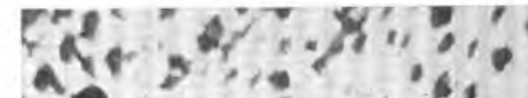
ex

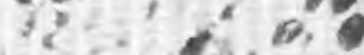
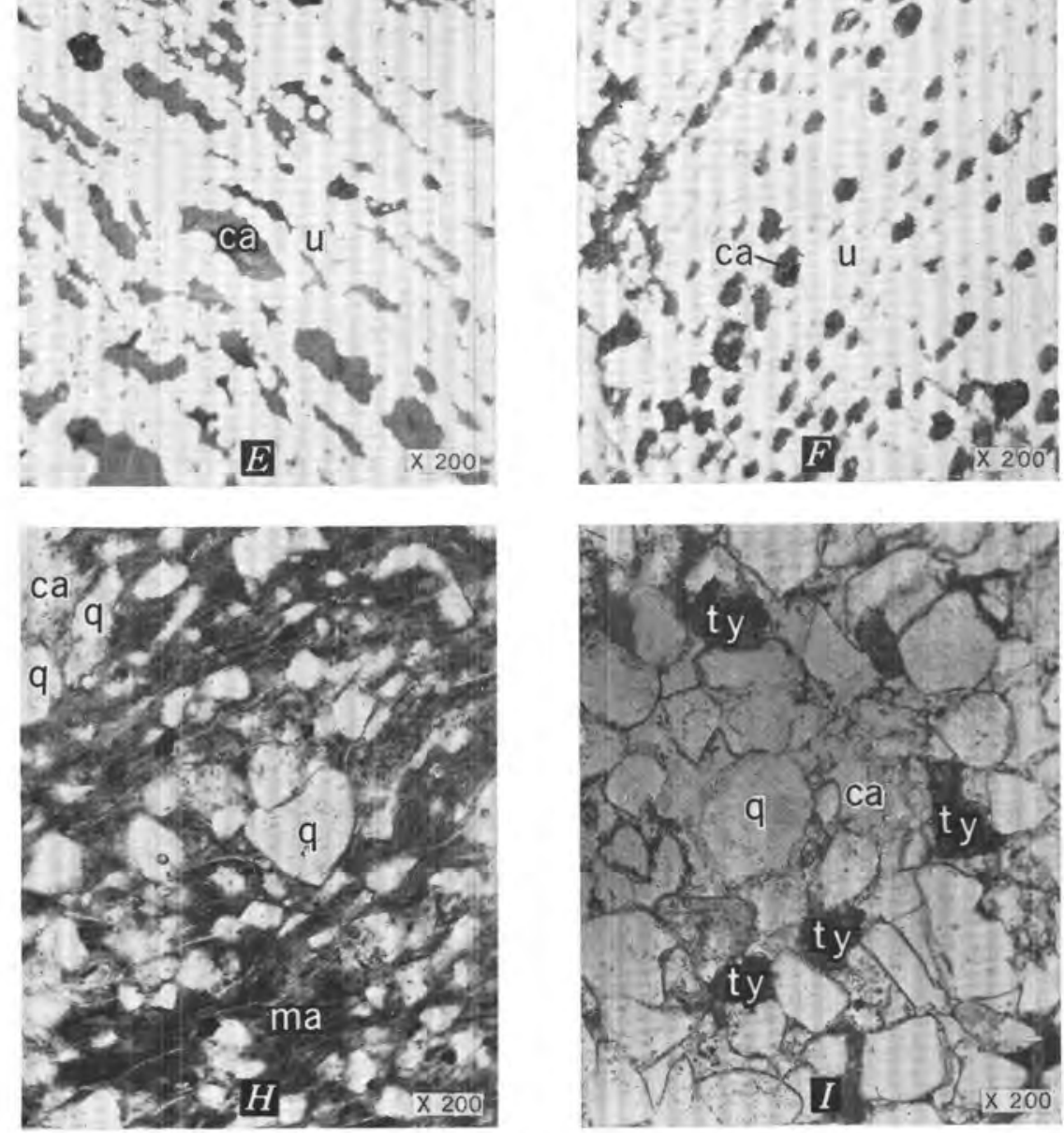

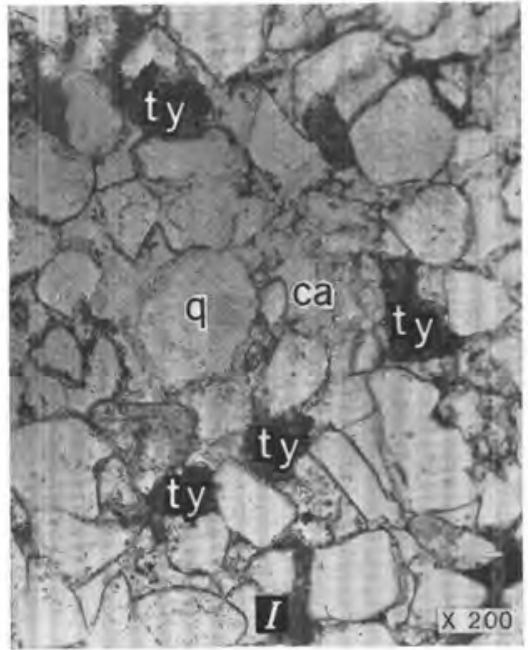

PHOTOMICROGRAPHS OF ORES, MI VIDA MINE AND LUKACHUKAI AREA 
GEOLOGICAL SURVEY
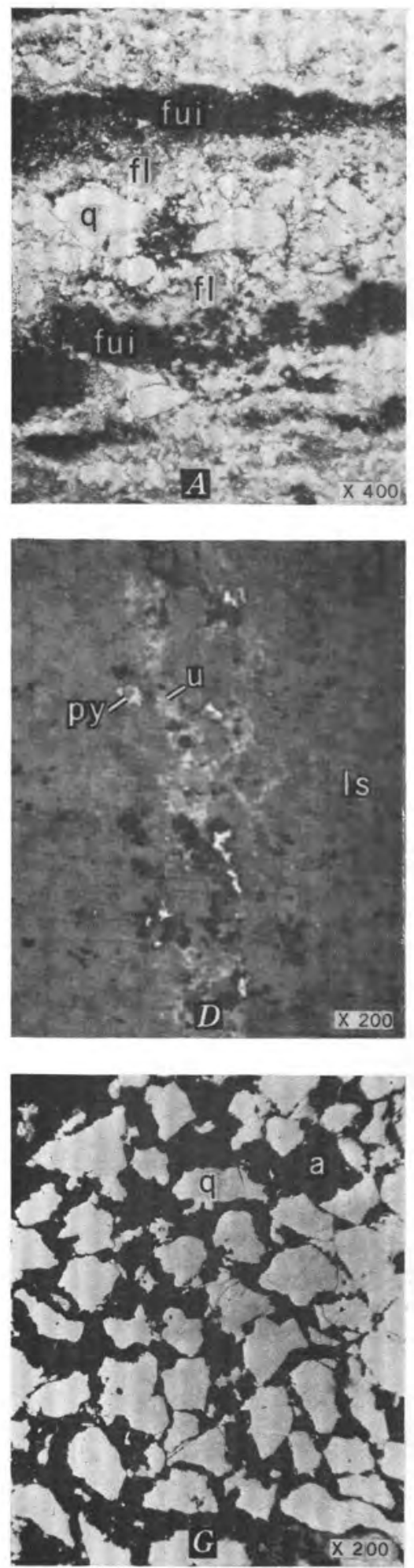
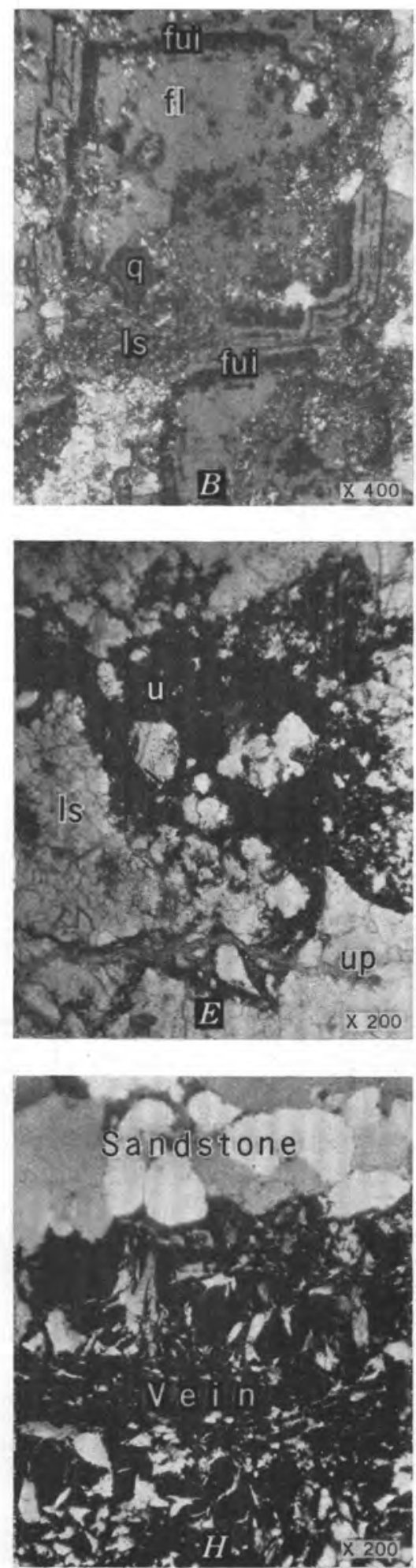

PROFESSIONAL PAPER 300 PLATE 3
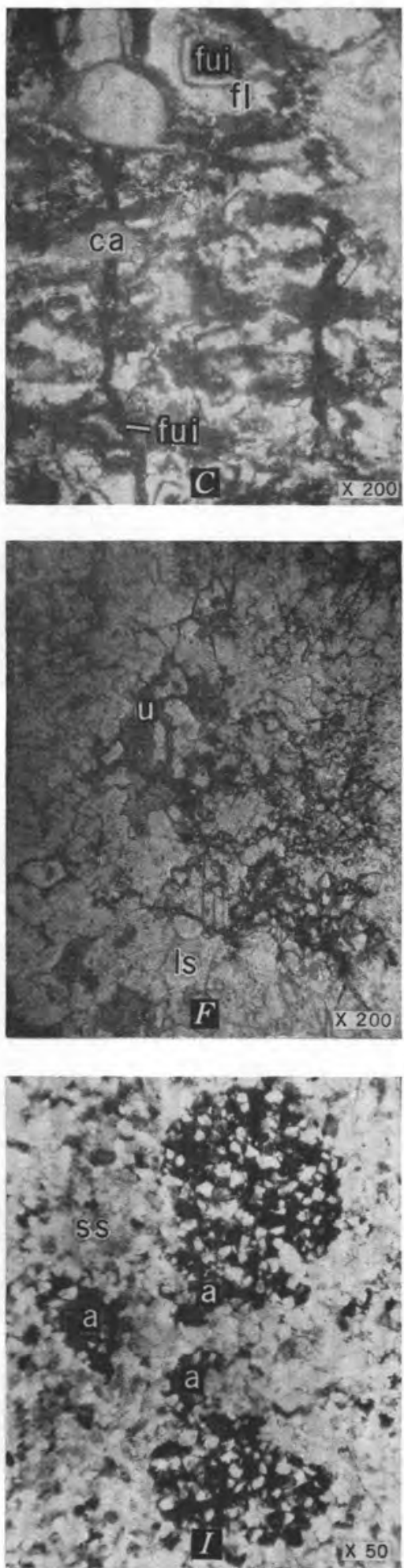

PHOTOMICROGRAPHS OF ORES FROM THE TODILTO LIMESTONE AND THE NOTCH MINES 


\section{PLATE 3}

A. Todilto limestone, thin section: Fluorite $(f l)$ and opaque fluorite-uraninite intergrowth (fui) formed in limestone along seams of very fine grains of quartz $(q)$.

$B$. Todilto limestone, thin section: Fluorite $(f l)$ crystals in limestone $(l s)$. The opaque zones following the crystal structure are fluorite-uraninite intergrowths (fui). The crystal encloses some of the original limestone and detrital quartz $(g)$.

C. Todilto limestone, thin section: Zoned fluorite $(f l)$ crystals cut by veinlets of fluorite-uraninite intergrowth (fui), both cut by late calcite (ca).

$D$. Todilto limestone, polished section: Uraninite $(u)$ and pyrite $(p y)$ formed along a seam in limestone $(l s)$.

$E$. Todilto limestone, thin section: Uraninite $(u)$ replacing limestone $(l s)$. Both are veined by uranophane (up).

$F$. Todilto limestone, thin section: Uraninite $(u)$ formed along grain boundaries in limestone $(l s)$.

$G$. Notch mines, thin section: Asphaltite $(a)$ corroding quartz $(g)$ grains in sandstone.

$H$. Notch mines, thin section: Asphaltite-pyrite-uraninite vein in silicified sandstone. Calcite in the vein has obscure age relations.

I. Notch mines, thin section: Asphaltite (a) nodules in sandstone (ss). 
quartz, accessory feldspar, mica, siltstone fragments, limestone pellets, and plant remains. Illite occurs in mudstone lenses within the ore horizons.

Early cements are barite, illite, minor amounts of quartz in secondary overgrowths, and calcite, which is the principal cement throughout the sequence.

Preceding the intermediate stage of cementation, structural deformation fractured the quartz and feldspar grains and caused recrystallization of the calcite cement (pl. $2 A, C$ ). With the introduction of the mineralizing solutions of the intermediate stage, calcite, uraninite, and coffinite were precipitated by carbonaceous material, usually preserving the cellular structure (pl. $2 E, F^{\prime}$ ). In many places uraninite replaced calcite, but in some places a colloform texture can be seen where calcite followed uraninite (pl. $2 D$ ). Vanadium hydromica and the lower valence oxides montroseite and doloresite replaced calcite cement (pl. $2 A, B$ ). Sulfides were deposited chiefly in carbonaceous material, and also as interstitial cement. Greenockite and much of the galena formed later than the pyrite and chalcopyrite. Calcite was recrystallized, and a small amount of it replaced the ore minerals at the end of the intermediate stage.

A late generation of bematite, calcite, and the oxidized uranium and vanadium minerals formed only in minor amounts.

In summary, replacement textures (fig. 37) show that the precipitating agents were primarily carbonaceous material and calcite cement. Structural deformation followed the early cements and preceded the influx of ore solutions, which were quite active, corroding fractured quartz and feldspar grains (pl. $2 A$ ). The uranium and vanadium ore minerals of lower valence were precipitated with some base-metal sulfides. Lastly, the oxidized minerals corvusite, pascoite, and metatyuyamunite formed from weathering of the intermediate stage cements.

\section{LUKACHUKAI MOUNTAINS}

The oxidized ore near Cove School occurs as cementing material in a fine-grained subangular fairly wellsorted sandstone (pl. 2G). Quartz is the major detrital mineral with accessory feldspar, mudstone fragments, chert, and carbonized plant remains. Many small lenses of mudstone, clay, and argillaceous limestone (pl. $2 \mathrm{H}$ ) are included in the sandstone. Most of the clay in these lenses is illite, but some is kaolinite.

Early cements in the sandstones of the ore bodies in the Lukachukai mines are quartz, chalcedony, bematite, goethite, and clay-probably of the illite group.

Intermediate-stage cements of the sandstone are uraninite, hematite, goethite, illite, and coarsely granular calcite. The calcite occurs in large grains up to 2 centimeters in diameter which may include as many as 10,000 detrital grains (pl. $2 G$ ). Uraninite has been found as a replacement of carbonized wood and as interstitial cement which is almost entirely altered to tyuyamunite. Other minerals are the calcium vanadates: pascoite, hewettite, and rossite.

Among intermediate-stage cements, coarsely granular calcite predominates, but tyuyamunite is the principal ore mineral. The iron and vanadium oxides persist from intermediate stage to the end of the sequence.

Although the periods of deposition of tyuyamunite and the coarsely crystalline calcite overlap, no replacement of calcite by tyuyamunite could be seen. Tyuyamunite derived in place from uraninite is opaque owing to dusty-black inclusions (pl, $2 I$ ). In contrast, tyuyamunite which is not directly connected to any preceding uranium mineral occurs in clear prismatic crystals.

In summary, the cement sequence (fig. 37 ) at the uranium mines in the Lukachukai Mountains shows early silicification, then deposition of uraninite and coarsely crystalline calcite, followed by tyuyamunite. Iron oxide occurs throughout the sequence. In view of the large limestone content occurring as lenses in the sandstone, it is likely that the coarsely crystalline calcite of the intermediate and late stages of the sequence represents recrystallization of limestone rather than introduction of new material.

\section{NOTCH MINES, ELK RIDGE}

Uranium deposits of the Notch claims on Elk Ridge, southeastern Utah, occur mainly in a fine-grained sandstone (pl, $3 G$ ) of the Moss Back sandstone member of Triassic age; but some separate mineralized areas occur in the underlying Moenkopi. A few mudstone and clay seams are found in the ore bodies. Quartz is the major detrital constituent with accessory feldspar, mica, magnetite, and carbonized organic remains.

Earliest cements in the sandstones are calcite, hematite, goethite, and a clay which is probably a member of the kaolin group.

Intermediate-stage cements (pl. $3 G, H, I$ ) include uraninite, asphaltite, pyrite, chalcopyrite, galena, and a black vanadium mineral, probably corvusite. Formation of calcite, hematite, and goethite was continuous from the early cements.

In the late cements calcite, hematite, and goethite continue to end of the sequence. Schroeckingerite and metazeunerite are derived from the uraninite and uraniferous asphaltite. Malachite and volborthite are derived from the copper and vanadium minerals.

Carbonized organic remains appear to be the primary 


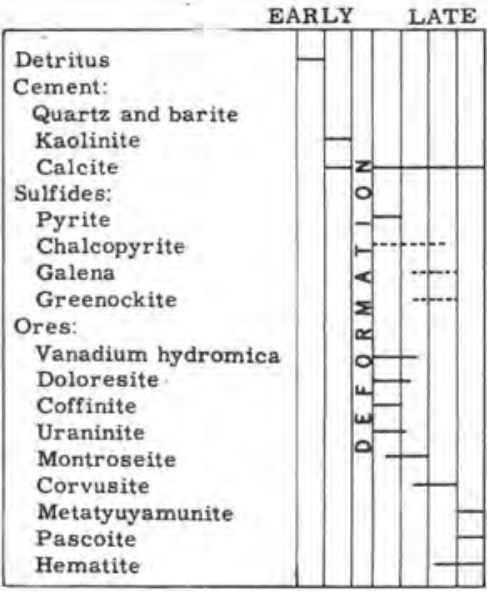

A:-Mi Vida mine, San Juan County, Utah

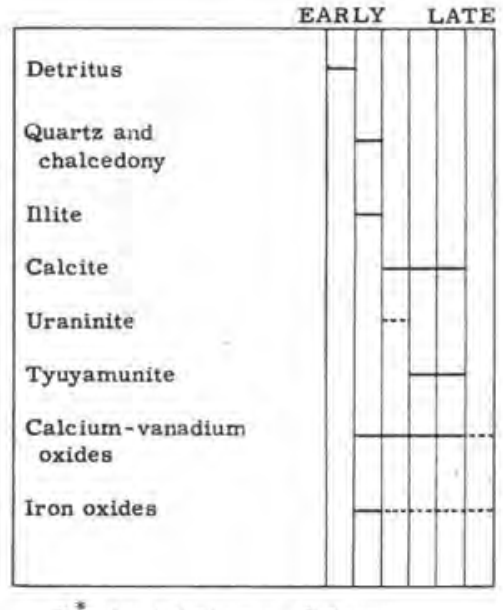

B.-Lukachukai area, Arizona

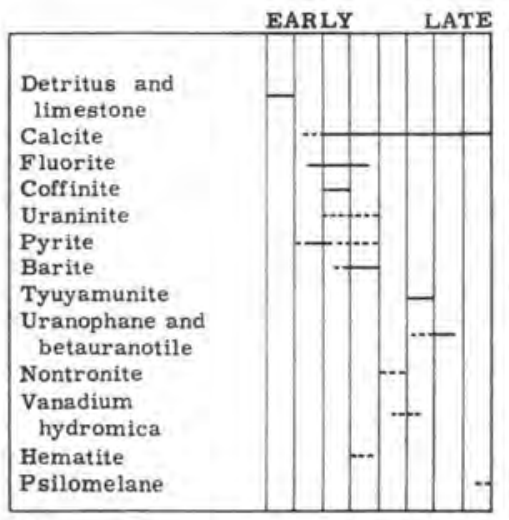

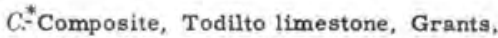
New Mexico

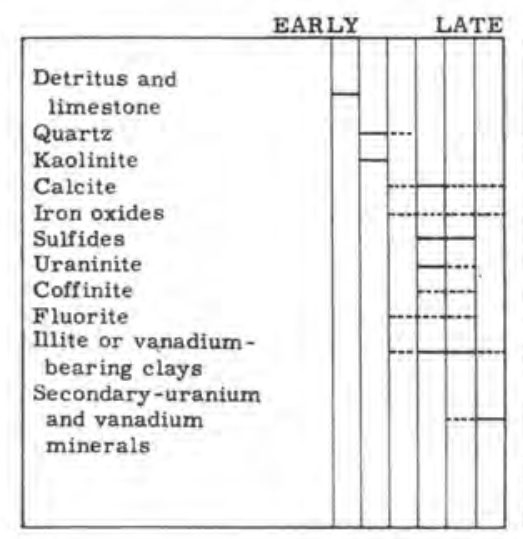

E:-'Composite paragenesis of $A, B, C, D, a n d G$

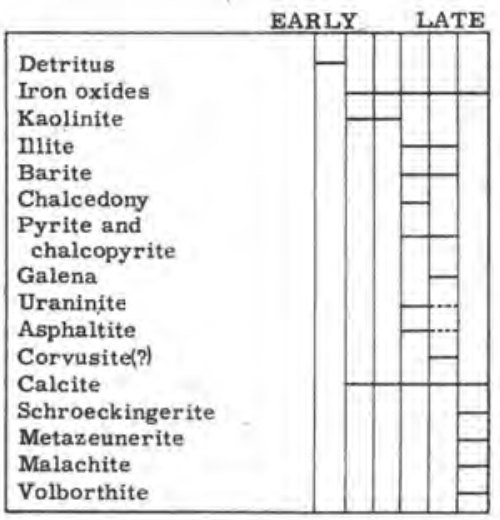

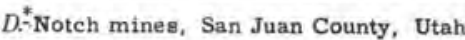

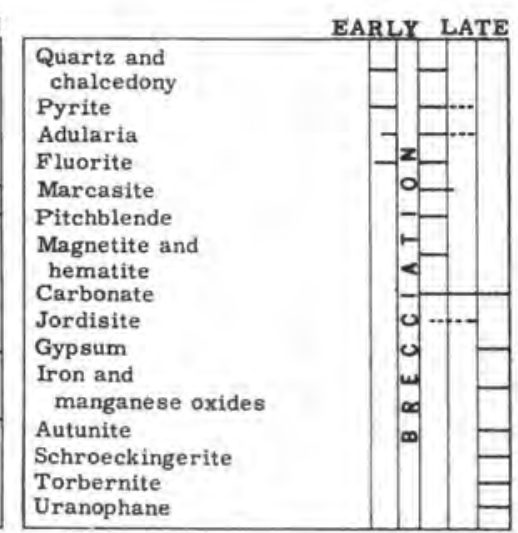

F*Composite, Marysvale, Utah

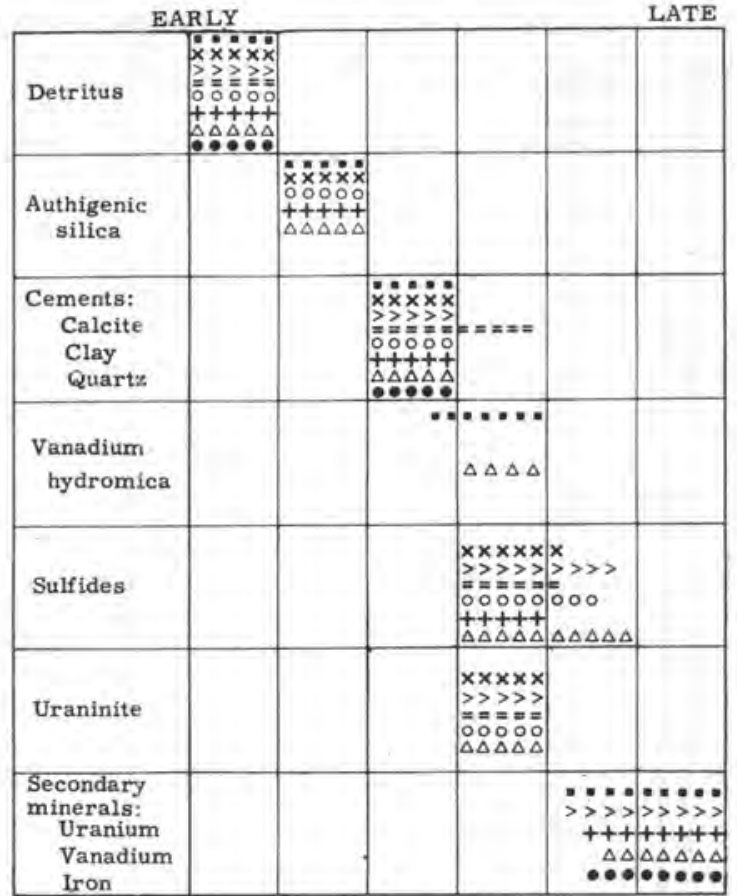

G.:-Composite of eight Colorado Plateau uranium deposits

EXPLANATION

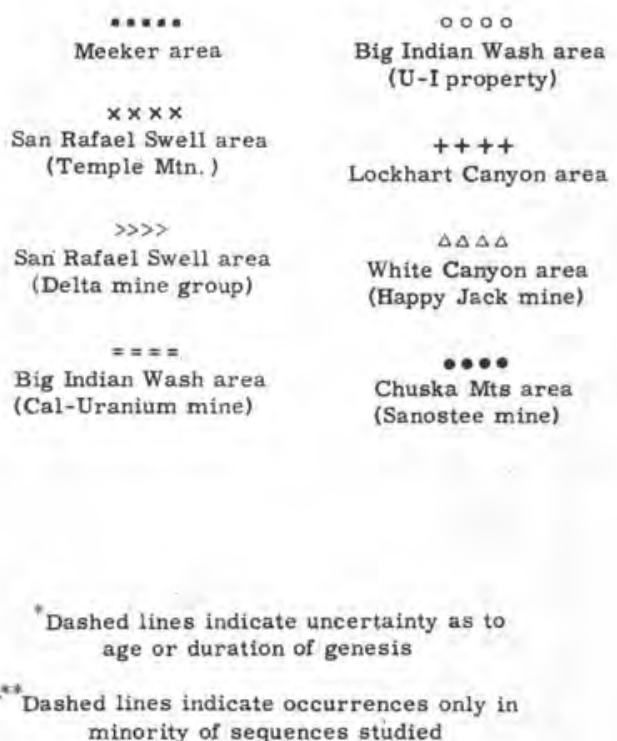

ig Indian Wash area (U-I property)

$+++$

$\Delta \Delta \Delta \Delta$

White Canyon area ppy Jack mine)

$$
\text { Big Indian Wash area }
$$

(Sanostee mine)

FIGURE 37.-Paragenetic sequences of uranium ores.

precipitant for the uranium minerals of the intermediate stage, although a minor amount of uraninite crystallized around earlier grains of chalcopyrite. Some calcite is replaced by the uranium minerals. Uraniferous asphaltite is the principal uranium ore in the Notch area.

In summary, the cement sequence (fig. 37) at Elk
Ridge shows early kaolinization and slightly later silicification. The silicification is overlapped and followed by the uranium ore and the base-metal sulfides. Oxidation of the intermediate-stage cements resulted in formation of uranium carbonates and arsenates, copper carbonates, and hydrated vanadium oxides. Calcite and the iron oxides occur throughout the sequence. 


\section{TODILTO LIMESTONE URANIUM ORES}

The Todilto limestone of Jurassic age is thin bedded and has a maximum thickness of about 25 feet. It is the principal ore zone in the area northwest of Grants, N. Mex., where it is overlain and underlain by barren sandstones.

Thin silty streaks (pl, $3 A$ ) occur in the limestone near the contact with the overlying silty sandstone, but the silt grains constitute less than 1 percent of the total rock. Black uranium ore commonly is concentrated in the upper part of the Todilto, perhaps as a result of increased initial permeability along the silty layers. The effect of the silty layers is most obvious in zones of low-grade ore. Where mineralization has been intense, the limestone has been completely recrystallized; and megascopic bedding, obliterated. The intensity of mineralization increases in the vicinity of such tectonic features as small folds, faults, and joint swarms.

The calcite of the limestone itself appears to be the principal precipitant of the ore minerals. Although the limestone contains considerable organic matter and much of it has a fetid odor, there is very little microscopic evidence that the organic matter affected localization of ore.

The Todilto limestone contains two types of black uranium ore, which are not intermixed in a single deposit. One type consists of extremely minute intergrowths of fluorite and uraninite. The earliest fluorite crystals appear pure except for calcite inclusions. Slightly later fluorite crystals contain zones of clear fluorite alternating with opaque zones which optical and X-ray study indicate are intergrowths of fluorite and uraninite on a submicroscopic scale. The centers of such zoned crystals may be either clear or opaque (pl. $3 B, C$ ). This sequence of clear and zoned fluorite suggests reaction of limestone with solutions which initially carried only fluorine but later carried both uranium and fluorine in varying proportions as deposition proceeded.

The other type of ore is nonfluoritic finely granular uraninite occurring as veinlets (pl. $3 D, E$ ) or replacements in limestone (pl. $3 D, E, F$ ), in places associated with pyrite (pl. $3 D$ ). The deposition of limestone was followed by the introduction of pyrite as an accessory mineral, and this was followed by contemporaneous deposition of uraninite and pyrite. Recrystallized calcite also formed during this intermediate stage.

In all uraniferous deposits in the Todilto limestone, tyuyamunite, carnotite, and uranophane are the principal oxidized uranium minerals. They occur as thin posturaninite veinlets (pl. $3 E$ ) and as rims around the black uranium minerals. Hematite occurs both as pseudomorphs after pyrite and disseminated in recrystallized limestone in and near the ore bodies.
In summary, the paragenetic sequence (fig. 37) shows early fluorite in some places and early pyrite in others. The fluorite was followed by uraninitefluorite intergrowths, and the pyrite was overlapped by uraninite. As the fluorine, uranium, and iron content of the solutions decreased, the recrystallization of the limestone to pure calcite began and continued to the end of the sequence. After the calcite recrystallization was well started and the uranium deposition was completed, the deposition of barite and clay minerals began. Oxidation of uranium and iron minerals completed the sequence.

\section{OTHER DEPOSITS}

Less detailed studies of eight other Plateau uranium deposits also show similarities in paragenetic sequence. These deposits are located at Meeker, the San Rafael Swell, Big Indian Wash, Lockhart Canyon, White Canyon, and Sanostee. All are in sandstones and conglomerates of Permian to Late Jurassic age with the major ore bodies occurring in the Shinarump and Morrison formations.

The detritus is composed primarily of quartz, with minor feldspar; micas; limestone and siltstone pellets; and carbonized organic remains; and a few clay seams or mudstone pellets. Carbonized organic remains occur in all the deposits except the Lockhart Canyon ore body in the Cutler formation of Permian age.

Secondary silica overgrowths are common in sandstones of most of the deposits. Silica was followed by the deposition of calcite, the most abundant cementing agent. Clay occurs less commonly and is usually illite except in deposits of the Morrison formation, where it is kaolinite. Where the sandstone contains much silica cement, mineralization is weak.

Intermediate-stage cements consisting of ores, sulfides, uraniferous asphaltite, and recrystallized calcite occur in different amounts in most of the deposits. The uraninite replaces carbonaceous material only, whereas the vanadium hydromica observed in two deposits has replaced calcite cement of the matrix. Clay cements usually are replaced less than calcite cements. At Temple Mountain, uraniferous asphaltite is the principal ore material. Sulfides, chiefly pyrite, occur in all but the Meeker and Sanostee areas. Copper sulfides are associated with the uraninite at the Happy Jack mine but are rarely observed elsewhere.

Late cements composed of oxidized uranium and vanadium minerals and limonite are more common than the unoxidized intermediate-stage cements, except in the Big Indian Wash deposits. The late uranium and vanadium cements have replaced calcite cement and, in part, the clay.

In summary, the paragenetic sequences (fig. 37), of these eight uranium deposits are very similar. Detrital 
constituents are cemented by calcite, silica, or clay minerals. The ore-bearing solutions corroded some grains and replaced cement. Caleite and carbonaceous material precipitated the uranium and sulfides. Subsequent oxidation of the intermediate-stage cements formed secondary uranium and vanadium minerals.

\section{MARYSVALE}

The uranium deposits at Marysvale, Utah, have been studied, and previous work has been summarized by Kerr and others (1952), who concluded that hydrothermal solutions deposited the ore. For comparative purposes, the paragenesis by P. F. Kerr has been illustrated in figure 37 .

Similarities to the composite paragenetic sequence (fig. 37) are silicification and fluoritization before formation of the ore; contemporaneous fluorite, base-metal sulfides, and black oxides of uranium and vanadium; late oxidation products of metallic minerals.

\section{SUMMARY OF SIMILARITIES AND DIFFERENCES}

Host rocks. - The most striking similarity in host rocks for uranium on the Colorado Plateau is the content of organic material. The organic material may be in the form of petroleum, carbonized wood, or asphaltite; or it may be submicroscopic, as demonstrated by J. W. Gruner (1954).

Most of the host rocks contain calcite or limestone, and seams or lenses of mudstone, siltstone or clay. Most are poorly sorted although uranium deposits occur both in well-sorted sandstones and in conglomerates.

Precipitants.-Organic remains and calcite were the two main precipitants for the black uranium ore minerals. Although lenses of clay and mudstone are used as a guide to ore in several regions, it is not clear whether these lenses are an active precipitant or whether they serve merely to define the conduits along which the ore solutions moved. In some places, notably in Elk Ridge, base-metal sulfides acted as a precipitant for the black uranium minerals.

Cements.-Another striking feature of ore deposits on the Colorado Plateau is the fact that uranium minerals do not occur as detrital grains but as cements or replacements. Further, the uranium mineralization does not begin until the intermediate stage of the cement sequence when the uranium minerals were joined by base-metal sulfides and vanadium oxides of low valence. The oxidized minerals of uranium, vanadium, and copper always occur in the latest part of the cementation sequence, while the iron oxides and calcite usually occur throughout the sequence.
Geologic environment.-The major uranium producing formations on the Colorado Plateau are fluvial clastic rocks deposited during part of Mesozoic time in an oxidizing environment. After burial, reducing conditions prevailed owing to the decomposition of interred organic material and limited water circulation and were prolonged by marine submergence in parts of the Cretaceous.

A number of laccoliths and stocks intruded into rocks of the Plateau in early to middle Tertiary time. Reinhardt (1952) states that the major uranium deposits lie in a zone 10-40 miles from the laccolithic centers.

Regarding the present locations of uranium deposits, several factors must be considered: (1) the host rocks were laid down in an oxidizing environment, and later buried in a reducing environment; (2) the ferruginous cements, containing ferric iron as the dominant cation, occur throughout the paragenetic sequence; (3) the earliest uranium cements, containing the uranous ion as the dominant cation, occur in the intermediate stage of the paragenetic sequence; (4) the uranium minerals do not occur as detrital grains.

Had the uranium been deposited in its present location as waterborne grains, volcanic debris, or material chemically precipitated from runoff or ground water, then at the time of deposition it would have been subjected to oxidizing conditions, and the state of oxidation of the early uranium minerals would be the same as that of the early iron minerals. Because the early uranium minerals are both later in the cementation sequence and also contain reduced uranium ions, they must have been deposited at a time when reducing conditions prevailed owing to burial and organic decomposition. This rules out syngenetic deposition in place, and probably places the time of deposition in the Late Cretaceous or early Tertiary, in agreement with L. R. Stieff and T. W. Stern (this volume).

\section{REFERENCES CITED}

Gruner, J. W., 1954, The problem of the primary ores of the Colorado Plateau in Annual Report for April 1, 1954, to March 31, 1954: U. S. Atomic Energy Comm, R.ME-3094, p. 31-32, issued by the U. S. Atomic Energy Comm., Tech. Inf. Service, Oak Ridge, Tenn.

Kerr, P. F., Brophy, G. P., Dahl, H. M., Green, Jack, and Woolard, L. E,, 1952, Annual Report for July 1, 1951, to June 30, 1952, Part I, A geologic guide to the Marysvale area: U. S. Atomic Energy Comm. RMO-924, 56 p., issued by Atomic Energy Comm., Tech. Inf. Service, Oak Ridge, Tenn.

Reinhardt, E. V., 1952, U. S. Atomic Energy Comm., unpub. inf.

Stieff, L. R., and Stern, T. W., 1955, Interpretation of the $\mathrm{Pb}^{200} / \mathrm{U}^{225} \mathrm{~Pb}^{202} / \mathrm{Pb}^{206}$ age sequence of uranium ores [abs.]: Geol. Soc. America Bull., v. 66, no. 12, pt. 2, p. 1621-22. 



\title{
A COMPARISON OF BLACK URANIUM ORE DEPOSITS IN UTAH, NEW MEXICO AND WYOMING
}

\author{
By JoHn W. Gruner, University of Minnesota
}

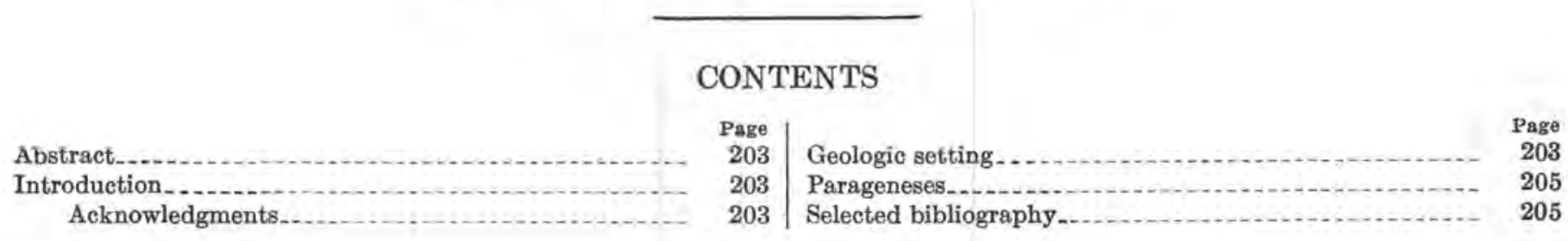

\begin{abstract}
Four areas of important unoxidized uranium deposits are compared. They are great distances apart and range in age from Triassic to Eocene. All of the ores are in poorly sorted arkosic sandstones which contain much organic carbon. Vanadium is absent in ores from the Eocene. Uraninite and coffinite are the identified dark-colored uranium bearers. Parageneses are very similar, and nearly the same geologic processes were operative in producing these concentrations of uranium. Highly reducing conditions were instrumental in the deposition of these "black ores." They are primary in the sense that the oxidized yellow ores are derived from them.
\end{abstract}

\section{INTRODUCTION}

Most if not all of the uranium deposits in sedimentary rocks in the Western United States were originally deposited in the form of reduced uranium minerals; that is, in the uranous state $\left(\mathrm{U}^{4+}\right)$. Because these minerals are almost black, the ores are called black ores. On account of the easy oxidation of the two uranous minerals uraninite and coffinite to the uranyl state $\left(\mathrm{UO}_{2++}\right)$, nearly all deposits display yellow, orange, and green minerals on their outcrops and often to a considerable depth.

In November 1954, black ore was found in the middle of the Wind River Basin of central Wyoming. Comparisons of this material with some of the black ores of the Colorado Plateau show some similarities in mineralogy and texture as well as in processes which led to these concentrations of uranium.

For comparison, deposits in four widely separated localities were chosen: in the Wind River formation of Tertiary age at the Gas Hills anticline in Fremont County, Wyo.; in the Chinle formation of Triassic age at Lisbon Valley, San Juan County, Utah; in the Mossback sandstone at Temple Mountain, Emery
County, Utah; and in the Brushy Basin shale member of the Morrison formation of Jurassic age at Poison Canyon near Grants, Valencia County, N. Mex.

\section{ACENOWLEDGMENTS}

Discussions with many geologists of the U.S. Atomic Energy Commission and the U. S. Geological Survey have been of aid in gaining a comprehension of the local and regional geology.

\section{GEOLOGICAL SETTING}

Except for age differences, the rocks are on the whole similar fresh-water sediments in which volcanic tuffs are dominant constituents, particularly above the sandstones containing the deposits. The angularity of the grains and the arkosic character of the sandstones point to a similarity of source rock of Precambrian granites which crop out within 10 to 20 miles of 3 of the localities. Only the Temple Mountain area is farther from presently recognized granitic outcrops.

The uranium content of these deposits could have been easily leached from weathered granite by ground water. It is, however, less speculative to think of the coarse arkosic sandstones as easy channels for groundwater circulation. "Paleostream ${ }^{1}$ channels," a term used frequently in discussing the Colorado Plateau, have not been identified in any of the four areas as far as the writer is aware, but large structural features such as the Lisbon anticline and San Rafael Swell are present. These could have guided ground waters. The third area, Poison Canyon, lies on the north flank of the Zuni uplift, but the dip on this flank toward the

itThis term designates a channel cut by a stream and almost immediately filled by sedimentary debris. 


\begin{tabular}{|c|c|}
\hline $\begin{array}{l}\text { Lisbon anticline, Utah (Chinle formation, Tri- } \\
\text { assic; st and near Mi Vida mine) }\end{array}$ & $\begin{array}{l}\text { Temple Mountain (San Rafael Swell, Utah, } \\
\text { Moss Back sandstone, Triassic; includes all } \\
\text { black ore of Temple Mountain) }\end{array}$ \\
\hline
\end{tabular}

1. Much shale and siltstone interstratified with sandstone and conglomerate.

2. Red rocks prominent above and below but not in deposits.

3. Little sorting in sandstones.

4. Largely arkosic. Angular to subangular grains.

5. Fine-grained sandstone to mud-pebble colvglomerates.

6. The more irregular and disturbed the beds are, the richer the ore.

7. Clay fragments in matrix very common.

8. Much carbonaceous plant material.

9. Much calcite as cement. Detrital calcit Most calcite recrystallized.

10. Caleite replacing feldspars and probably other

minerals.

11. Considerable muscovite as large scales in some beds.

12. Some secondary authigenic quartz.

13. Pyrite and marcasite replacing all primary minerals.

14. Uranlum as uraninite and microscopic coffinite.

15. Vanadium in reduced state as montroseite, doloresite.

16. Sphalerite, galena, greenockite.

17. Barite.

18. Paragenesis, tentative-Deposition of arkosic sandstone with clay minerals, detrital calcite, and plant reming rims of quartz. Recrystallation of celcito. rims of quartz. Rerstallzation of calcito. Part of word is replecd by calcte. Woo sharted to docay and conthy through this wholo geolo in adsorbed any passed in solutlons thror nith the decer of the wood which fur-

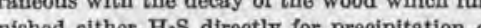
isted elther Has directly for precipitation of ing or wher the contemporaneous precipitation of uroninm and fron $\mathrm{V}$ ans premitalion of urasits minerals (montroselto and dolotest other the that it recrystallized late.
Poison Canyon mine (near Grants, N. Mex., Brushy Basin member of Morrison formation,
Jurassie; includes Mess Top mine) . Shale and siltstone int

, Red rocks prominent above and below but not in deposits.

some sorting in sanditones.

Romewhat arkosic, Rounded to angular.

5. Fine-grained sands

The - inch pebbles. the richer the ore. Clay fragments in matrix very common.

8. Asphaltite and carbonaceous and sillieifled trees. "Dead" oil in many places.

Little calcite except in underlying Moenkopj.

10. No replacement by calcite observed.

11. Little mica.

12. Some secondary authigenic quartz. Quart is replaced by asphaltite.

13. Pyrite replacing other minerals (syngenetic with asphaltite).

14. Uranium 98 microscopie unaninite (and metalloorganic compounds?).

15. Vanadium largely in asphaltite where unostdized.

16. Galens, sphalerite, realgar, sulfur, arsenic in pyrite nodules.

17. Alunite, variscite, mansfeldite. These ane probably secondary.

18. Paragenesis, tentative-Deposition of sandtone with clay minerals and plant remsins Wo wood gradily carbondzed. Asphaltite of unWew grains and possibly replaced a part of the wood, certer ining rere alsolit by the aspheitte as it form whe adsorbod by the asplaitle as it formed. the It eond bea diage the product. It che bection Inthe monoclinal atructure or the San Rafael Swell be it the Tertiary roslon cycle set in. Whether thad any part in the concentration or uranium contain these metals now except in traces.
1. Much shale and silt above and below main ore horizon of sandstone and grit.

. Minor quantities of red rocks near deposits.

Largely arkosic sandstone and grit.

5. Subangular to angular grains.

6. Relatively little disturbance of bedding.

7. Kaolinite as small white aggregates in black ore.

8. Organic black material around sand grains also woody material. Some asphaltite.

9. Oaleite as cement abundant in mine layars of lowestore, All recrystallized. A little gypsum,

10. Calcite replacing feldspers.

11. Very little mica.

12. A little authigenic quartz.

3. Much pyrite in black ore as minute crystals.

14. Uranium as coffinite. Extremely fine grained.

15. Vansdium not yet identiffed in black ores,

16. Galena.

17. No sulfates except gypsum"observed.

8. Paragenesis, tentative-Deposition of arkosic sandstone and grit with plant remains. It is likely that kaolinite or the mineral from which it developed was deposited at the same time be cange It is firly orenly distributed throush the rea and porous now whlle the underlying sits aro well certed with ale cite cement has ben loched ont of ore Pyite is asoonted with be material which costs the sme with a thin sin werial sugests "driedtup" oring Rich osphaltito, as at Tomplo Mountom,

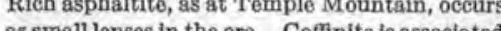
with the black

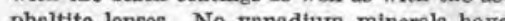
phaitte lenses. No vanatum minerals have becn lantice. It is din thenar orogenle ovent responsible for the olreuthe of the ground whe whlch concentrated slight dip toward the Sen Just a reln. Thi basin may be of early Tertlary age.
. Some sorting in sandstones. Gas Hills anticline area (Fremont Co., Wyo., Wind
River formation, Eocene; largely Lucky Mao No. 20
mine and vicinity)

1. Little shale and silt in the ores but probably below them.

bodies.

3. Very little sorting in sandstones.

4. Coarse arkosic sandstone and grits, conglomerates loeally.

5. Angular grains, large percentage of feldspars.

6. Too few exposures to be sure of lack of disturbance

7. Some elay aggregates but more often somewhat altered feldspars.

Analyses show $0.5-0.7$ percent organic earbon. Carbonaceous material probably too fine grained to be visible. Little calcite but much "primary" gypsum (not dne to weathering).

10. Oalcite probably replaced feldspars being in turn replaced by gypsum.

. Very little mics but some chlorite.

12. No secondary quartz observed.

13. Pyrite replacing all other minerals. Responsible for dark gray of ore.

14. Uranium aranite. Mieroscopically fine grained.

15. No vanadium present.

16. Much gypsum. Apatite as coatings on sand grains.

7. Liebigite, a uranyl carbonate, veins the black ore and Is secondary. Scorodite as veinlets and nests in grit.

. Paragenesis, tentative-Deposition of arkosic sandstone and grit with organle carbon and relatively rare wood. Dark-gray color caused by very fine-grained pyrite which invades all other minerals and looks like the last mineral that formed. The uraninite is so flnely divided that it cannot be visually related to the other minerals. Gypsum forms a part of the matrix and either replaces feldspar directly or calcite which may have replaced feldspar at an earlier stage. At any rate, a case can be made for both replacements. Gypsum fills most cracks and fissures and forms thin layers of satin spar largely parallel to the bedding. Because pyrite is found all through the gypsum, the latter must be earlier. In oxidized portions of the ore, it is now impossible to tel late from early gypsum, except that the pyrite has disappeared and has made room for jarosite.

In some areas in the same type of rock (Stan claims), the mineralization is associated with thin layers of carbonate or hydroxyapatite, which cost the sand grains. Because the uranium is in the structure of the apatite it must be in the uranous state (Ut+) in order to replace the caleium ions of similar radius. This means that the apstite precipitated in a reducing environment in spite of the fact that this rock is light colored. There is little indication that much pyrite ever was present in the strata which contain the apatite. 
San Juan Basin is gentle, and this uplift alone cannot explain the location of the deposits. The same may be said for the Gas Hills anticline area, where no single distinctive structural feature can be made entirely responsible for the position of the deposits. One certain explanation is that vast volumes of ground water containing uranium passed through carbonaceous material which was at a favorable stage of decay to absorb the metal. In its first phase this process could be compared to ion exchangers. There is no mineralogical indication ${ }^{2}$ that the waters were hotter than ordinary ground water under correspondingly thick sedimentary cover.

\section{PARAGENESES}

Similarities and differences in the four deposits are compared below. There are few differences which suggest that the deposits are dissimilar in origin. The absence of vanadium in as large an area as the Wind River Basin is conspicuous. It could be connected with the relative scarcity of plant remains though analyses show considerable organic carbon. Or, perhaps, the Wind River formation as a whole is low in vanadium. The abundance of hydrocarbons as "dead" oil in the Temple Mountain area has not been thought genetically important by most observers. Arsenic

2 Kerr believes that his finding of mieroscopic crystals of arsenopyrite in a drill core in the "Flop-Over" at Temple Mountain is almost proof that hydrothermal conditions existed (symposium at Grand Junction, Colo., March 1955). compounds have been found here; they are also rather common in the Wind River Basin.

The more detailed genetic relations are obscure in all of the deposits because crosscutting of minerals does not mean much where we are dealing with extremely fine-grained aggregates. Besides, such minerals as calcite, gypsum, montroseite, and other vanadium minerals recrystallize easily, which may lead to erroneous interpretations of parageneses. In spite of these drawbacks, the relations definitely show the same pattern for all four deposits.

\section{SELECTED BIBLIOGRAPHY}

Dix, G. P., Jr., 1953, The uranium deposits of Big Indian Wash, San Juan County, Utah: U, S. Atomic Energy Comm. RME-4022, 15 p., issued by U. S. Atomic Energy Comm. Tech. Inf. Service, Oak Ridge, Tenn.

Gruner, J. W., Rosenzweig, Abraham, and Smith, D. K., Jr., 1954, The mineralogy of the "Mi Vida" uranium ore deposit of the Utex Exploration Company in the Indian Wash area, Utah, in Annual report for April 1, 1953, to March 31, 1954: U. S. Atomic Energy Comm. RME-3094, p. 15-26, issued by U. S. Atomic Energy Comm. Tech. Inf, Service, Oak Ridge, Tenn.

Hess, F. L., 1922, Uranium-bearing asphaltite sediments of Utah: Eng. and Min. Jour., v. 114, p. 272-276.

Rapaport, Irving, Hadfield, J. P., and Olson, Richard H., 1952, Jurassic rocks of the Zuni uplift, New Mexico: U. S. Atomic Energy Comm. RMO-642, 60 p., issued by U. S. Atomic Energy Comm. Tech. Inf. Service, Oak Ridge, Tenn.

Stokes, W. L., 1948, Geology of the Utah Colorado salt dome region with emphasis on Gypsum Valley, Colo.: Utah Geol. Soc. Guidebook to the geology of Utah, no. 3, 50 p. 



\title{
REGIONAL TRANSMISSIVITY OF THE EXPOSED SEDIMENTS OF THE COLORADO PLATEAU AS RELATED TO DISTRIBUTION OF URANIUM DEPOSITS
}

\author{
By Daniel A. Jobin, U. S. Geological Survey
}

\section{CONTENTS}

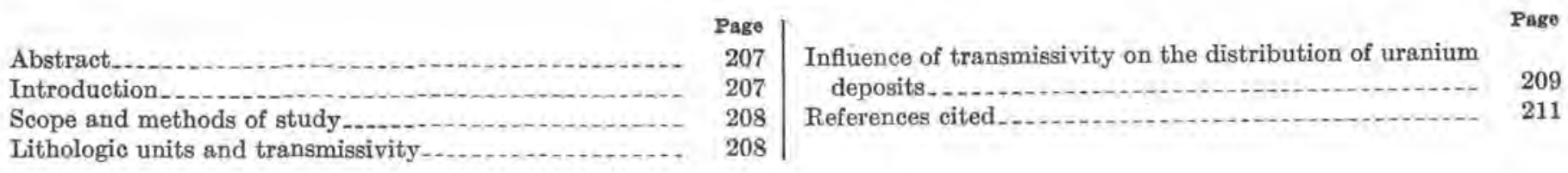

\section{ILLUSTRATIONS}

Froure 38. Transmissivity map of the Navajo sandstone.

39. Transmissivity map of the Shinarump conglomerate and the lower sandstones of the Chinle formation showing distribution of uranium deposits.

40. Transmissivity map of the sandstones of the Morrison formation showing distribution of uranium deposits .........-

\begin{abstract}
A study of regional transmissivity of the sedimentary rocks of the Colorado Plateau has been made to relate differences in transmissivity to the position of ore deposits. Transmissivity is defined as the capacity of a sedimentary rock as a whole to transmit fluids. The coefficient of transmissivity for a sediment at a given locality is equal to the product of its thickness and mean permeability. Permeability is the capacity of a substance to transmit fluids under a hydraulie gradient and by definition is dimensionless.

The sedimentary rocks on the Colorado Plateau may be divided into two groups on the basis of their transmissivity. Shales, mudstones, evaporites, and limestones are essentially nontransmissive by virtue of their extremely low permeability. Conglomerates, sandstones, and siltstones are permeable and, therefore, constitute the transmissive groups, which ean be divided into two groups. One group consists of eolian sandstones which are characterized by uniform permeability and thickness. Changes in permeability and thickness are usually gradational andsmallin range, resulting in similarly small and gradual changes in transmissivity over large areas. The other group consists of fluvial sandstone, siltstone, and conglomerate and is characterized by great changes in permeability and thickness. This group contains most of the known uranium deposits in the Colorado Plateau. Owing to the frequency and range of permeability and thickness, the transmissive capacity of these sediments changes abruptly within short distances. The regional transmissive capacity of fluvial sediments as a whole is low relative to eolian sediments.

Most of the known uranium deposits on the Colorado Plateau occur in fluvial sediments. There is, however, no obvious correlation between position of ore deposits within a particular host rock and its regional permeability or transmissivity.
\end{abstract}

\section{INTRODUCTION}

The Colorado Plateau covers an area of about 130,000 square miles. Outcrops, predominantly Permian and Mesozoic sedimentary rocks, consist largely of fine clastic rocks, eolian sandstones, and interbedded fluvial sandstones, conglomerates, and mudstones. Limestones, evaporites, and marine sandstones are also exposed.

Uranium deposits, which also contain vanadium and copper, are widely distributed in sedimentary strata of the Colorado Plateau. Although the deposits occur in many formations, most of them are found in only a few strata. The deposits are typically pod- or blanketshaped, generally conformable to bedding and other sedimentary structural features, and generally located in or adjacent to the thick parts of a fluvial sandstone or conglomerate stratum. In individual pods the transition from ore to barren rock is generally abrupt, but some ore bodies have fingerlike extensions along individual laminae or an alternation of lean and rich bands, similar to diffusion bands, peripheral to the ore pod. With few exceptions, the ore deposits are not obviously localized by fractures or faults.

The habits of the average Colorado Plateau uranium deposits suggest that the ore minerals were carried by fluid to their present position. This writer believes that the host rocks were saturated or partially saturated and that precipitation took place at a fluid interface, 
which was controlled in different degrees by the contrasting chemical character of the mineralizing fluid and the pore fluid, as well as the transmissive ability of the host rock.

This paper summarizes part of a more inclusive study of the history of fluid movement in the sediments of the Colorado Plateau and attempts to relate the distribution of known uranium deposits in Permian and Mesozoic rocks to the transmissive character of these rocks.

\section{SCOPE AND METHODS OF STUDY}

Beds composed largely of shale, mudstone, limestone, and evaporites were assumed, on the basis of a preliminary set of samples and theoretical considerations, to have no appreciable intrinsic transmissive capacity. Sampling was therefore restricted to regional sedimentary rocks with measurable permeability, such as sandy siltstones, sandstones, and conglomerates.

The ability of sedimentary rocks to transmit fluids, when unfractured and with identical recharge potential and structural attitudes, is a function of their permeability and geometrical configuration and continuity. In this study the intrinsic transmissive capacity or the coefficient of transmissivity of a sedimentary unit at any point over its extent is equal to the product of arithmetic-mean permeability in darcys and thickness in feet. Theis (1938) defined an analogous term, "transmissibility," for use in treating the discharge of a well mathematically. This term has not been used, as the assumptions Theis made for its use are not fulfilled in this study.

The permeability of each lithologic assemblage treated as a unit was outlined by computing the mean permeability of a suite of samples from each of many widely spaced exposures and contouring the resulting values. Permeability determinations were made by two methods; a direct measurement using standard techniques as outlined by Muskat (1946) and an indirect measurement utilizing standard parameters of grainsize analysis. ${ }^{1}$

The data on thickness, continuity, and regional extent were obtained largely from published (Craig and others, 1955) and unpublished work (T. E. Mullins and V. L. Freeman; G. A. Williams and others) of members of the U. S. Geological Survey.

\section{LITHOLOGIC UNITS AND TRANSMISSIVITY}

The rocks of the Colorado Plateau with appreciable intrinsic transmissive capacity may be grouped into two main categories: eolian and marine sandstones and siltstones that have a relatively uniform thickness

\footnotetext{
${ }^{1}$ R. A. Csdigan, of the U. S. Geological Survey, furnished over a thousand grainsize analyses made for sedimentologic studies and worked jointly with the author on a formula for computing permeability from these measurements.
}

and permeability over wide areas and fluvial sandstones and conglomerates that locally are lenticular and exhibit a relatively great range in thickness and permeability. The intrinsic transmissivity of eolian and marine sediments is relatively high; and fluid movement through them relatively uniform. Generally, higher mean permeability, greater thickness and more uniform gradient in both permeability and thickness give the eolian and marine sandstones a higher transmissive capacity than the fluvial sediments. (Compare figs. 38 and 39.) The regional intrinsic transmissivity of fluvial sediments is not only less, but its groundwater circulation is much more complex than that of eolian and marine sandstones. In contrast to the simple geometry and uniform permeability of eolian and marine strata, these fluvial sediments consist of one stratum or more of sandstone or conglomerate which have a large range in permeability and which are separated by relatively impermeable mudstones. Considered individually, each stratum, composed of from one to several lenticular beds, thickens and thins in a highly erratic manner. The permeability gradient within a fluvial stratum changes erratically both vertically and horizontally, but, in general, high mean permeabilities correspond with its thick parts and low mean permeabilities correspond with its thin parts. Transmissivity maps of representative fluvial sandstones and conglomerates are shown in figures 39 and 40.

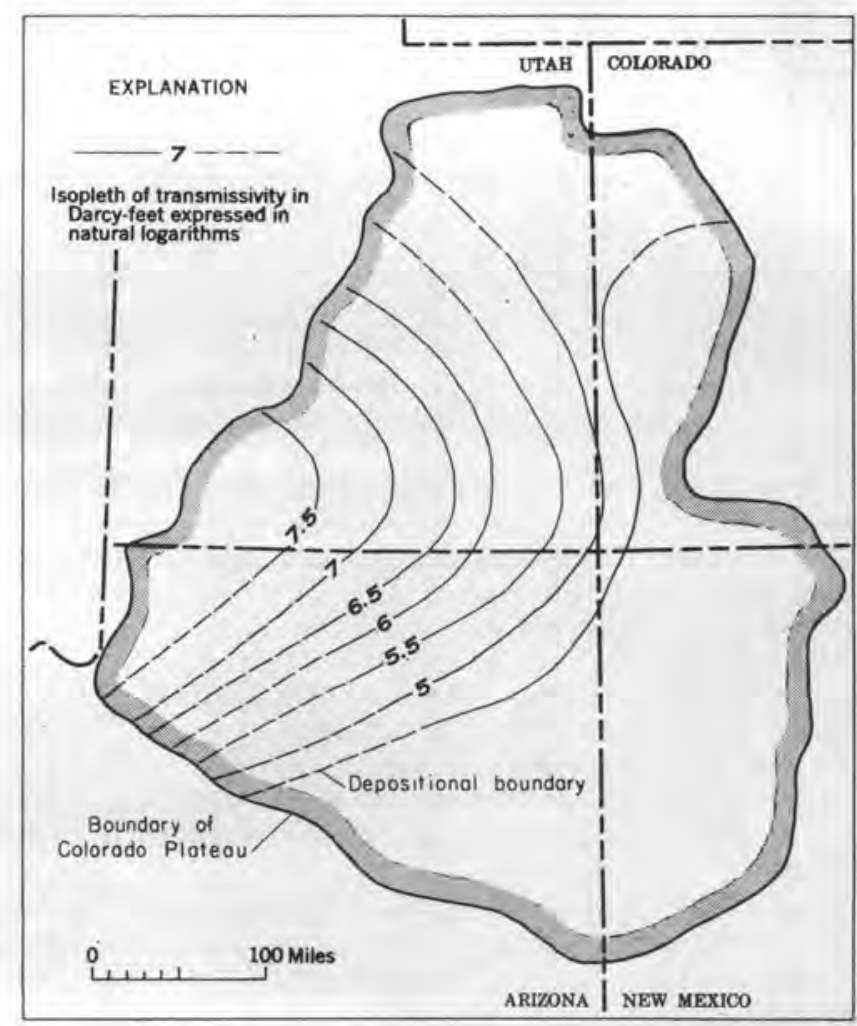

Figure 38.-Transmissivity map of the Navajo sandstone. 


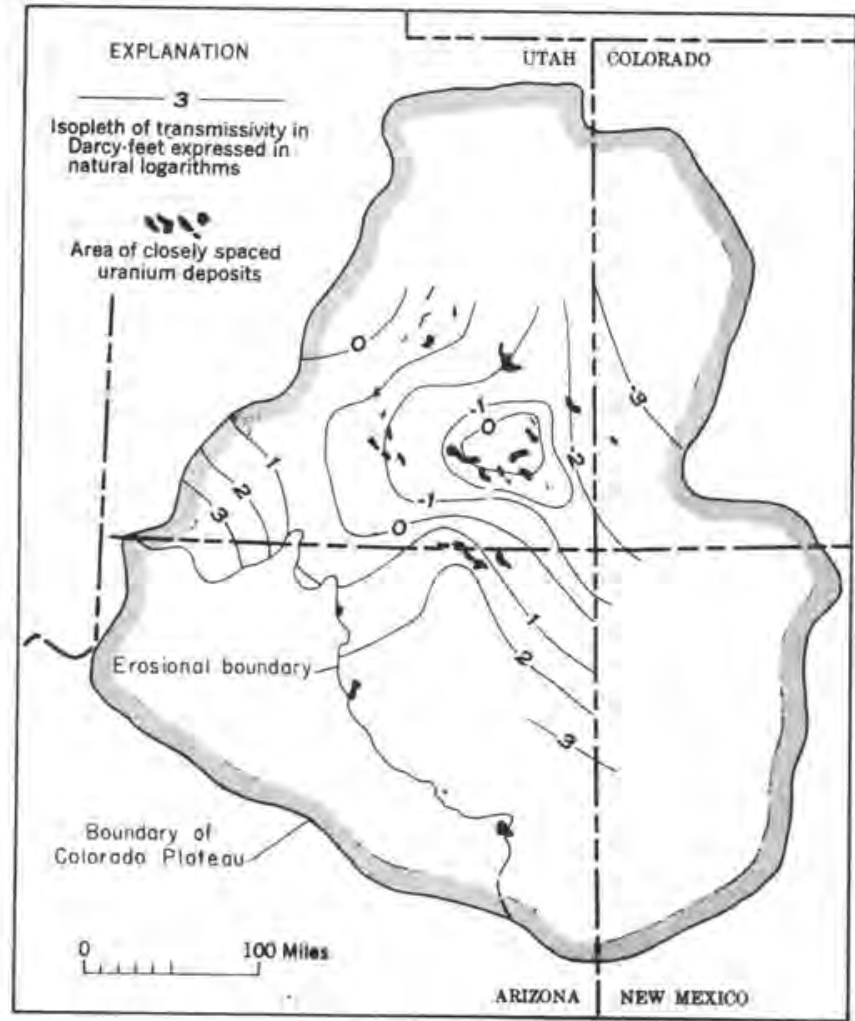

FlgURE:39.-Transmissivity map of the Shinarump conglomerate and the lower sandstones of the Chinle formation showing distribution of uranium deposits.

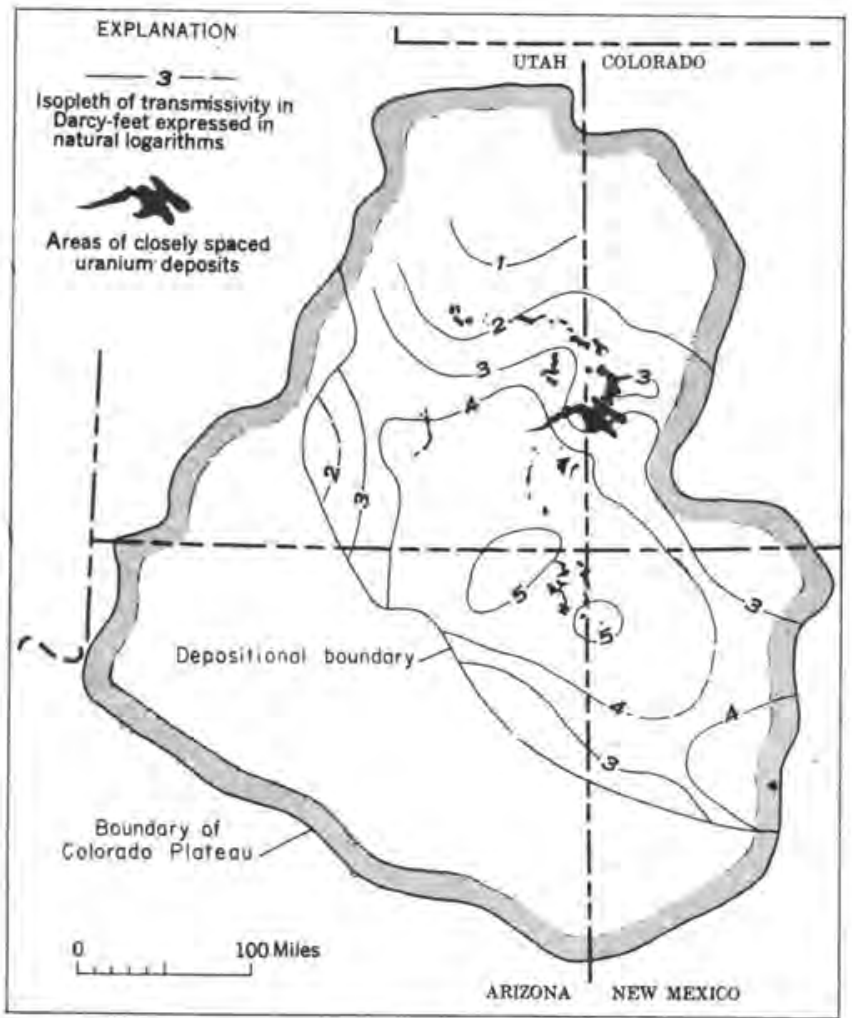

FtGURE 40.-Transmissivity map of the sandstones of the Morrison formation show Ing distribution of uranium deposits.
Fluids moving through fluvial sandstones and conglomerates will have greatly varying rates of movement depending in part on the route taken. The bulk of the movement will be along the thickest and most permeable segments. Many slow moving and even semistagnant fluids will be present in circuitous routes of low permeability and constricted cross section. Though the overall transmissivity of fluvial sediments of the Colorado Plateau is generally low, many examples of their ability to transmit ground water today leave no doubt of past efficacy to transmit fluids many miles.

\section{INFLUENCE OF TRANSMISSIVITY ON THE DISTRIBU- TION OF URANIUM DEPOSITS}

The gross lithologic sequence, transmissivity, and distribution of uranium in the exposed Permian and Mesozoic sedimentary rocks of the Colorado Plateau are shown in the following table. Although few strata are entirely devoid of uranium deposits, a large number of the deposits are confined to essentially tiwo strata, (1) the Shinarump conglomerate (Triassic) and the lower sandstones and conglomerate of the Chinle formation (Triassic) and (2) the sandstones of the Morrison formation (Jurassic). These two groups have many characteristics in common. The habit of deposits within both groups is essentially similar. Pods of ore are mainly conformable to the bedding and are most commonly found in or adjacent to the thick, more permeable, and, therefore, more transmissive parts of the stratum. The regional distribution of deposits in both groups appears unrelated to any particular intrinsic transmissivity range (figs. 39 and 40). Both groups are chiefly composed of fluvial sandstones and conglomerates; are overlain by thick, relatively nontransmissive units; differ greatly in local transmissivity; and have a low to moderate regional transmissive capacity.

The differences in transmissive characteristics between strata of the Morrison and strata of the Shinarump and Chinle seem to correlate with the greater frequency of occurrence and smaller range in size of uranium deposits in the Morrison strata. The bulk of the mined ore and known reserves in the Morrison strata are found in many widely scattered moderatesized deposits. Most of the mined ore and known reserves of the Shinarump and Chinle strata are found in a few widely scattered large deposits.

Other lithologic assemblages that contain significant amounts of uranium are the Mesaverde, Dakota, Burro Canyon, Buckhorn (of Stokes, 1944), Cutler, Entrada, Todilto, and Pony Express units. The first three units are fluvial sandstones and conglomerates; they have transmissive characteristics essentially similar to the Morrison and Shinarump strata, and are 
Summary of lithologic sequence, transmissivity, and uranium distribution in the Colorado Plateau

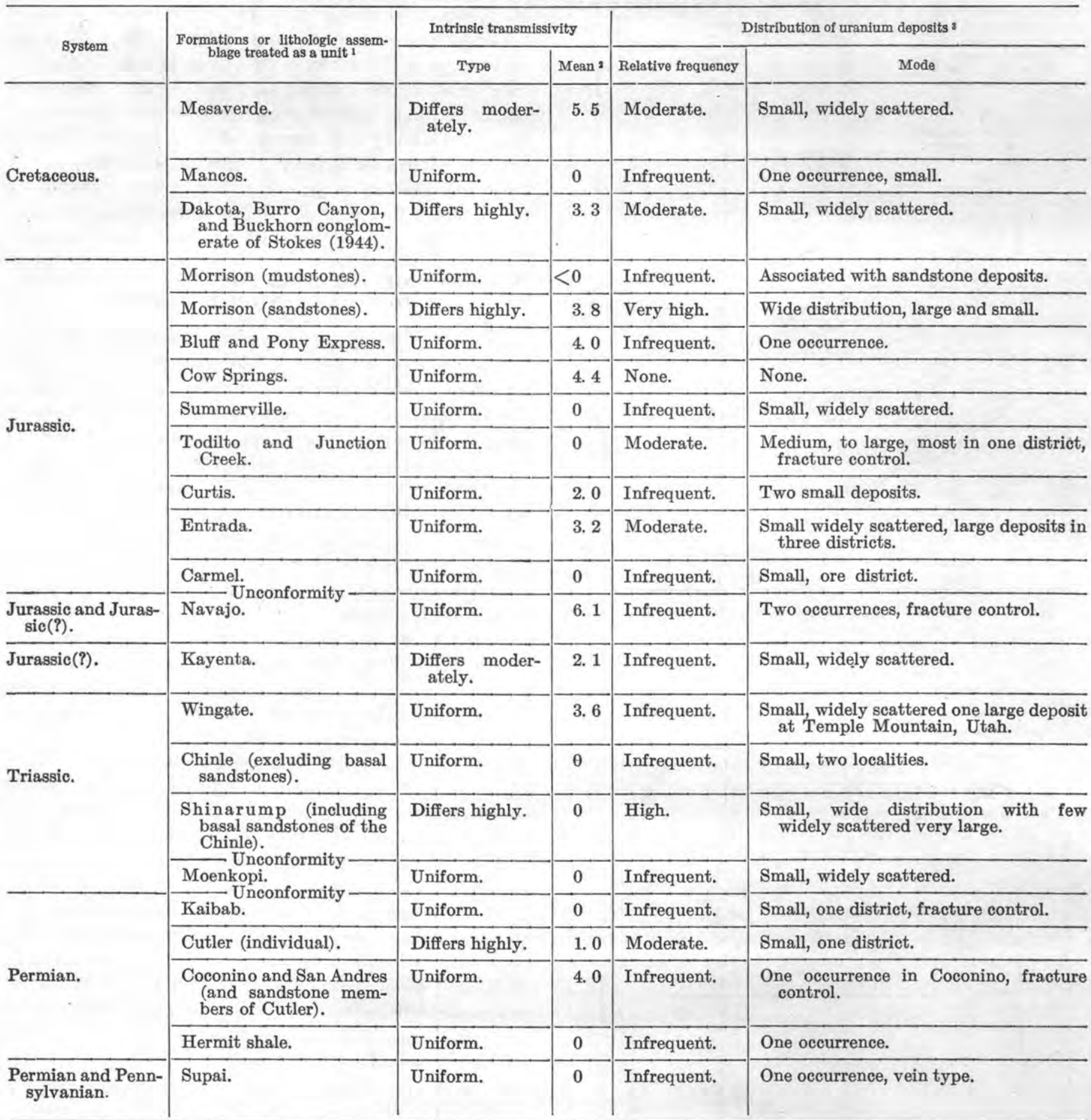

1 Lithologio sequence is in chronological order except where equivalents are treated as individual units.

Natural logarithm of product of arithmetic-mean thickness in feet and arithmetic mean permeability in darcys.

a Warren I. Finch, 1955, written communications; Y. W. Isachen, T. W. Mitcham, H. B. Wood (1955, p. 127-134). 
also overlain by relatively nontransmissive units. The uranium deposits are widely spaced in these strata and are neither as numerous nor as large as the deposits in the Morrison or Shinarump strata.

The Entrada sandstone and Todilto limestones constitute opposite extremes in intrinsic transmissive capacity, and the habit and distribution of uranium deposits seem to be controlled to some degree by these differences. The Entrada deposits are the only known sizable uranium deposits found in eolian or marine sandstones of the Colorado Plateau. Most of these deposits are located in three districts, and in each district the ore bodies represent locally thickened parts of an essentially continuous layer (Fischer and others, 1947). Individual ore bodies are large, relative to the Morrison and Shinarump strata, and exhibit most of the same habits, but on a larger scale and with less distinct boundaries. The Todilto and Pony Express strata, with no intrinsic transmissive capacity, are also unique because they contain nearly all the sizable deposits of uranium found in limestone on the Colorado Plateau, and these are localized by fractures.

In summary, the contrasts in total quantity of uranium and in frequency and mode of distribution of uranium deposits between major intrinsic transmissivity types are striking. Those strata which have a wide range of local transmissivity, that have a moderate to low regional intrinsic transmissive capacity, and that are overlain by a thick nontransmissive unit contain most of the mined ore and known reserves. Strata in this category have a moderate to high frequency of uranium occurrence with the distribution of deposits showing no preferred transmissivity range. With the exception of the Entrada sandstone, units with a uniform intrinsic transmissive eapacity, either high or low, contain only a few small uranium deposits.

The mode of uranium distribution correlates well with intrinsic transmissive capacity in all uraniumbearing units. Generally, as the transmissive capacity increases and the range in local transmissivity decreases, the range in size of deposits decreases.

\section{REFERENCES CITED}

Craig, L. C., and others, 1955, Stratigraphy of the Morrison and related formations of the Colorado Plateau region, a preliminary report: U. S. Geol. Survey Bull. 1009-E, p. 125-168.

Fischer, R. P., Haff, J. C., and Rominger, J. F., 1947, Vanadium deposits near Placerville, San Miguel County, Colo.: Colo. Sci. Soc. Proc., v. 15, no. 3, p. 117-134.

Isachen, Y. W., Mitcham, T. W., and Wood, H. B., 1955, Age and sedimentary environments of uranium host rocks, Colorado Plateau: Econ, Geology, v. 50, no. 2, p. 127-134.

Muskat, Morris, 1946, The flow of homogeneous fluids through porous media: Ann Arbor, Mich., J. W. Edwards, Inc.

Stokes, W. L., 1944, Morrison formation and related deposits in and adjacent to the Colorado Plateau: Geol. Soc. America Bull., v. 55, no. 8, p. 951-992.

Theis, C. V., 1938, The significance and nature of the cone of depression in ground-water bodies: Econ. Geology, v. 33, p. 889-902. 


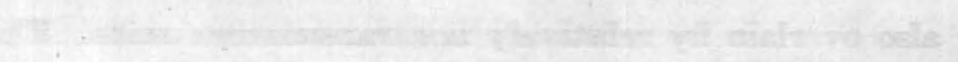

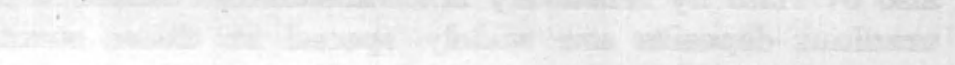




\title{
RELATION OF GARNOTITE DEPOSITS TO PERMEABLE ROCKS IN THE MORRISON FORMATION, MESA COUNTY, COLORADO
}

\author{
By David A. Phoenix, U. S. Geological Survey
}

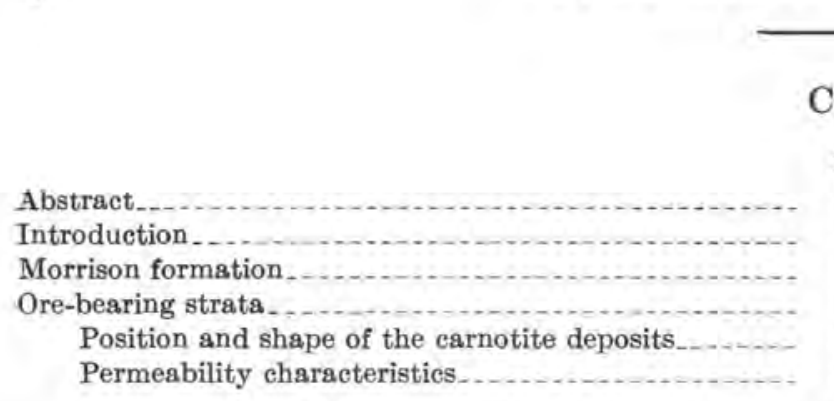

\section{CONTENTS}

\begin{tabular}{|c|c|c|}
\hline Page & & $\mathrm{Pa}$ \\
\hline 213 & Ore-bearing strata-Continued & \\
\hline 213 & Alteration & 21 \\
\hline 213 & Transmissivity ......... & 21 \\
\hline 214 & Conclusions_............ & 21 \\
\hline 214 & References cited..... & 21 \\
\hline 214 & & \\
\hline
\end{tabular}

\section{ILLUSTRATIONS}

Figure 41. Isometric diagram of the area of detailed studies.

42. Geologic logs of three drill cores showing the relations among rock character, porosity, permeability, and gamma-ray activity ....
Page $\mid$ Figdre 43. Transmissivity of the uppermost sandstone layer in two adjoining areas.

44. Graphic summary of the relations between transmíssivity and the carnotite deposits, area of detailed studies.
Page

218

219

\section{ABSTRACT}

The uppermost, almost continuous, layer of sandstone in the Salt Wash member of the Morrison formation of Jurassic age contains most of the carnotite deposits in southwestern Colorado and southeastern Utah. This layer is composed of broadly lenticular strata of sandstone separated by fine-grained laminated sediments collectively called mudstone. The prevailing trend of sedimentary structures is unique to each stratum. This suggests that each stratum was deposited within the channel margins of a shallow aggrading stream while that stream was essentially fixed in position. Carnotite deposits are localized in a mudstone and lenticular sandstone facies.

The permeability of sediments in the uppermost layer is influenced by both lithologic character at the time of deposition and the effects of diagenesis, but in general the sediments expected to be most permeable originally are still the most permeable. Laminated mudstone and siltstone are the least permeable and bedded sandstone is the most permeable, except locally where the original porosity has been reduced by interstitial clay, quartz overgrowths, and calcite and iron oxide cement. The sedimentary rocks are less permeable normal to bedding than parallel to bedding. In the plane of bedding, they sre slightly more permeable parallel to the trend of linear aggregates of sand grains than normal to these aggregates. Lightcolored unoxidized sandstone is also somewhat more permeable than dark unoxidized sandstone and is also somewhat more permeable than dark-colored oxidized sandstone of similar appearance.

Coefficients of transmissivity (the product of the total thickness and average coefficient of permeability per unit thickness) determined on samples from drill holes in an area of $4 \frac{1}{2}$ square miles, which includes the area of the Calamity claim group and the Outlaw Mesa area in Mesa County, Colo., show that carnotite deposits are localized where the rocks in the uppermost layer are most transmissive; they are uncommon where rocks in the uppermost layer are least transmissive.

\section{INTRODUCTION}

The habits of the carnotite deposits in the Salt Wash member of the Morrison formation of Late Jurassic age suggest that the deposits were formed from solutions that moved laterally through the sediments.

This report reviews the physical character of the Salt Wash member, particularly of the sandstone strata near the top of the member that contain most of the carnotite deposits in the Morrison formation. The capacity of these sediments to transmit solutions, and the possible relation of this capacity to the control of deposition of carnotite deposits, is discussed.

\section{MORRISON FORMATION}

In most of the Colorado Plateau the Morrison formation is divided into an upper member, the Brushy Basin, and a lower member, the Salt Wash.

The Salt Wash member is of fluvial origin and is divided into three prominent facies: a conglomeratic 
sandstone facies, a mudstone and lenticular sandstone facies, and a claystone and discontinouus sandstone facies (Craig, Holmes, Cadigan, and others, 1955). Carnotite deposits are almost restricted to the mudstone and lenticular sandstone facies. Lenticular sandstone strata near the top of the Salt Wash member are the most productive.

\section{ORE-BEARING STRATA}

In areas that are favorable locations for ore deposits, the thick parts of individual light-colored sandstone strata near the top of the Salt Wash member are superimposed and form a layer that commonly crops out continuously for several miles. In areas unfavorable for ore deposits the rock in this same stratigraphic interval is mostly mudstone with only thin, sometimes disconnected strata of dark sandstone.

Single sandstone strata are not more than 30 feet thick, but where the thick portions of several are superimposed the strata commonly aggregate 100 feet in thickness. Individual sandstone strata may be narrow, elongate, and somewhat sinuous in plan, but commonly they are tabular and cover broad areas. In most places a single stratum contains tabular units of sand several feet thick, and within each tabular unit the bedding is either horizontal, troughlike or inclined, or a single type of sedimentary structure may prevail in a stratum even though it is composed of several distinct tabular units of sand. Commonly the tabular units of sandstone are separated by a local disconformity.

Linear aggregates of sand grains on bedding surfaces, called current lineation, are abundant in the sandstone strata, particularly where the beds are horizontal or nearly so. Trough cross-stratification (McKee and Weir, 1953), is common in the thick central parts of the strata. These beds commonly contain clay galls, mudstone seams, and fossil wood. Asymmetric ripple marks are present in mudstone and other fine-grained sediments that separate the sandstone strata. These structures indicate the direction of sediment transport and suggest deposition from streams.

Sedimentary structures in a single stratum trend in a common direction. In west-central Colorado this direction is usually northeast or east. Locally, however, strata are found with sedimentary structures that show departures from the prevailing orientation. Detailed mapping in small areas has shown that sandstone strata are elongate lenses that may extend about 3 miles paralIel to the trend of their sedimentary structures; at right angles to this trend the lenses are usually $500-3,000$ feet wide. In the area of detailed study, these relations are well exposed; they are illustrated on figure 41 .

\section{POSITION AND SHAPE OF THE CARNOTITE DEPOSITS}

Carnotite deposits are commonly found in the thick portions of a sandstone stratum. The ore is associated with trough-shaped bedding, accumulations of organic debris, and seams and pellets of mudstone. Some deposits occur where a single stratum changes thickness. Many deposits have also been found above or below places where the thick parts of individual sandstone strata are in contact (fig. 41). The descriptive field term "puncture point" has been applied to these places. In at least one area, lenticular sandstone strata near the top of the Salt Wash member connect with other strata lower in the member. Here the lower sandstone strata also contain ore deposits.

The ore deposits are tabular masses generally parallel to bedding, but in detail they crosscut bedding. Ore rolls, peculiar, concretionlike structures in the ore, are conspicuously elongate in 1 direction, ranging from 10 to 100 feet or more in length. Locally the long axes of the rolls have a common trend, which is parallel to the dominant orientation of fossil logs. Ore bodies are also elongate in the same direction (Fischer and Hilpert, 1952, p. 5).

Although the controls for localization of the deposition are somewhat variable from area to area, precipitation of the metals in most places appears to have responded to the size as well as the chemical composition and transmissivity of the ore-bearing strata.

\section{PERMEABIIITY CHARACTERISTICS}

The permeability of a rock is its capacity to transmit a gas or liquid under pressure. The permeability of sediments is measured with nitrogen and calculated in millidarcy units. Nitrogen instead of water is used because the laboratory procedure for determining the gas permeability of a consolidated sediment is quick and easy. The results are therefore not an accurate measure of the water-bearing properties of the rocks, because nitrogen has a much lower coefficient of viscosity than water and because gas does not react with the sediments. The water permeability of the sediments, particularly those containing clay, is probably less than is indicated by the data presented here.

The permeability of about 900 specimens was determined in the laboratory. Each specimen was cylindrical, 0.75 inch long, and 0.05 inch in diameter. About 50 specimens were taken from the outcrop and the rest from diamond-drill cores. All specimens were collected from one area where details of the geology are well known (fig. 41).

The permeability of some specimens was measured across the bedding, whereas the permeability of other 


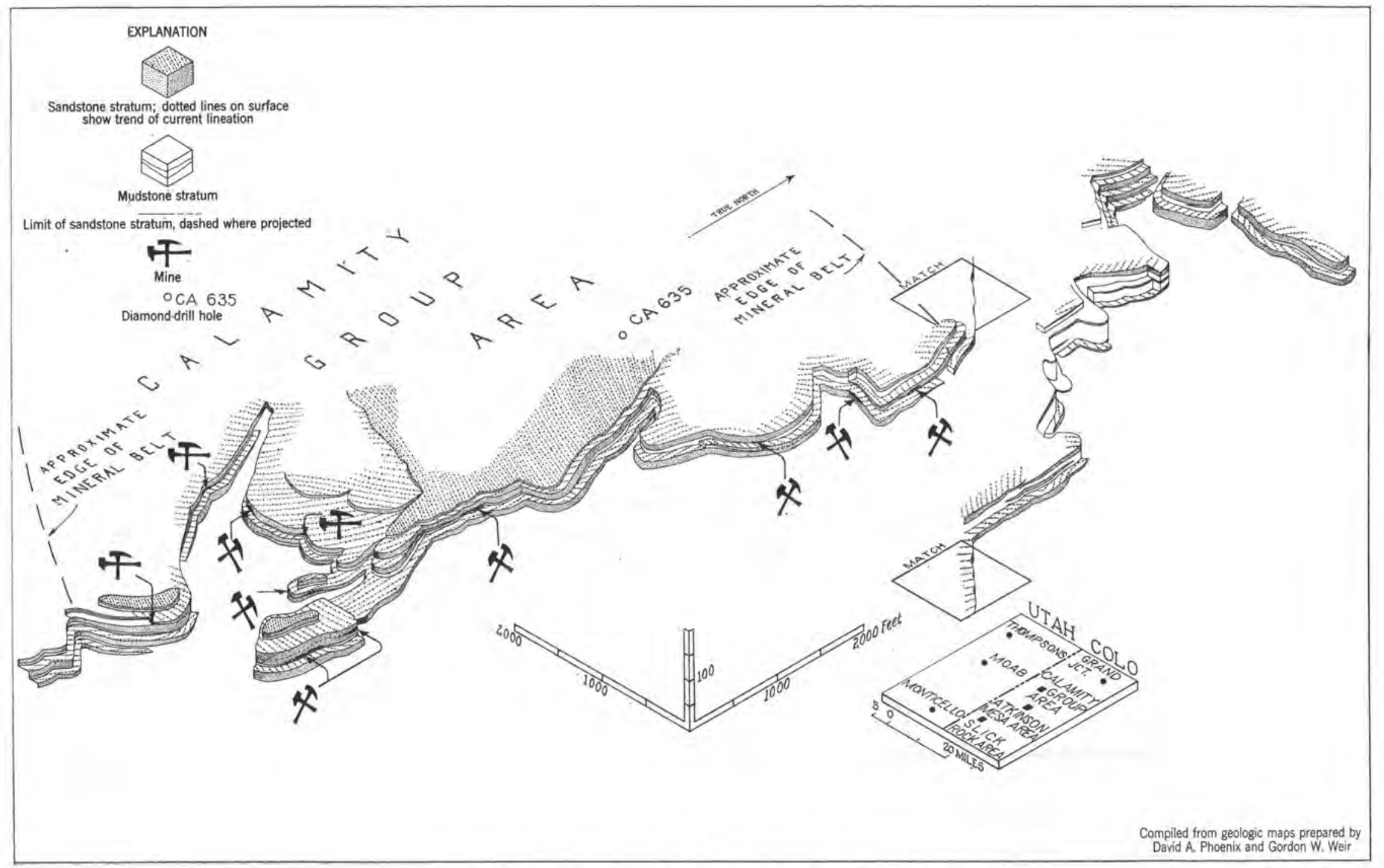

FIaURE 41,-Isometric diagram of the area of detalled studies, Mesa County, Colo. 


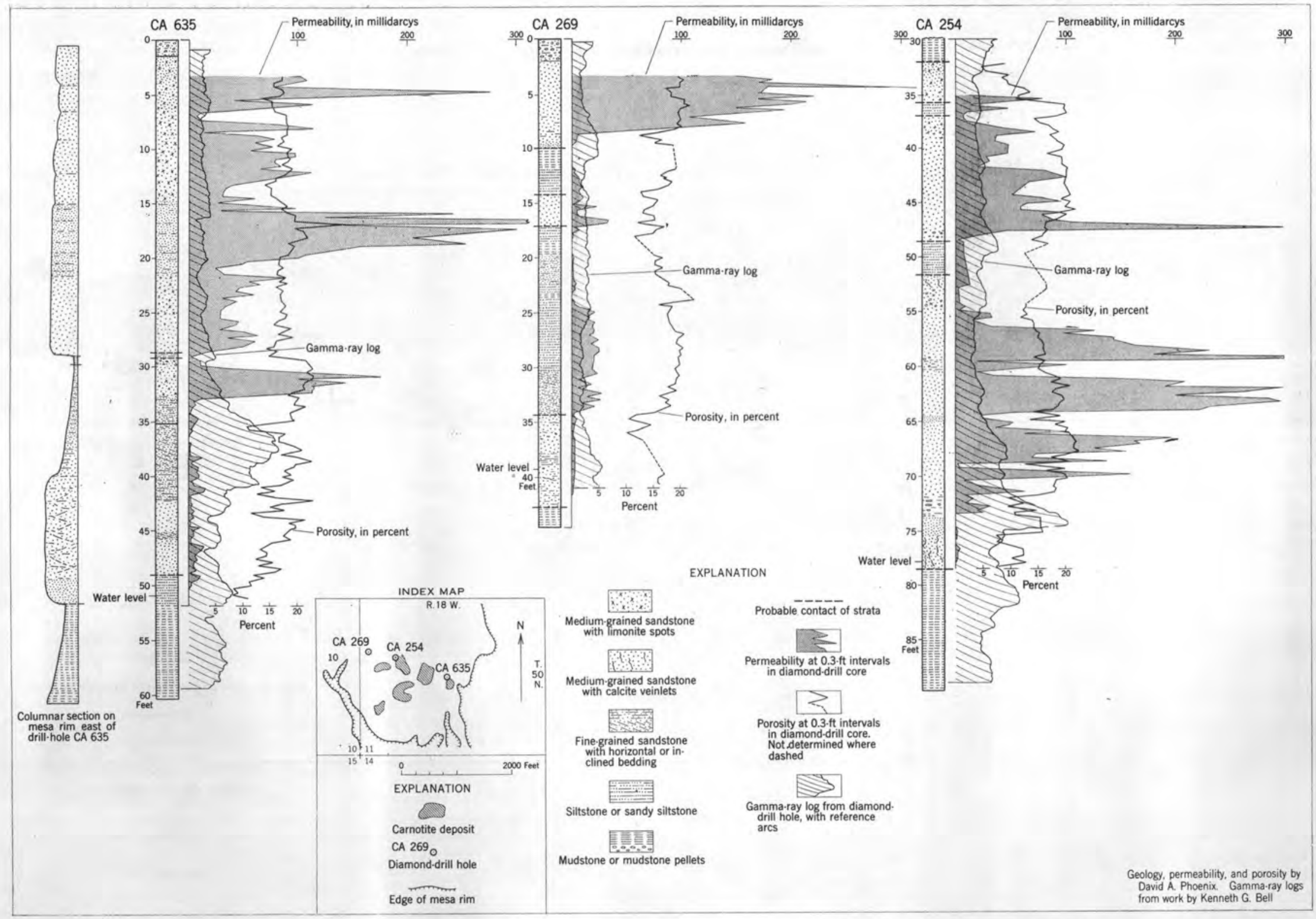


specimens was measured within the bedding, parallel to the trend of sedimentary structures. The permeability of rock specimens from drill cores was determined parallel to the bedding. Specimens selected for permeability measurements were free of any joints or fractures detectable with the naked eye or with the aid of a hand lens. Sediments with differing permeability were studied in thin section to determine the effects of diagenesis on the porosity of the rocks.

The permeability characteristics of drill cores from the upper part of the Salt Wash member are shown on figure 42. Although the permeability logs are complex in detail, they indicate a systematic rise and fall in permeability. Each complete fluctuation corresponds to a unit of sediment that has nearly constant lithologic characteristics throughout; these lithologic units are 3-6 feet thick. The permeability of each unit, particularly the most permeable ones, is lowest near the bottom and top and usually at a maximum near the middle of the unit. For some units the maximum permeability is $100-300$ millidarcys; in others it is much less. The units with the highest permeability are light-colored fine- to medium-grained sandstone; the least permeable are the laminated fine-grained dark sandstone or siltstone units.

Drill core CA-269 (fig. 42) represents ground unfavorable to deposition of ore. The permeability log of this core illustrates permeable units of sandstone, but they are thin. Most of the core is composed of nearly impermeable units of dark fine-grained laminated sediments. The average permeability of this core is about 30 millidarcys. The permeability logs of cores $\mathrm{CA}-254$ and $\mathrm{CA}-635$ are of ground favorable for ore deposits. Both these logs illustrate at least five permeable units of light-colored sandstone, and the nearly impermeable units are thin. The average permeability of each of these cores is about 60 millidarcys.

Core CA-635 was obtained from near the outcrop, and the permeable units within it were related to details of the outcrop. On the nearby outcrop, the upper part of the Salt Wash member is composed of three strata of sandstone. Tabular units in the strata crop out as ledges several feet thick that in profile have a rounded appearance similar to roll structures in the ore deposits. These units of sandstone within the strata correspond to the units in the geologic log that have permeability characteristics usually greater than 100 millidarcys, Fine-grained laminated sediments or mudstone between sandstone strata correspond to units in the geologic log with permeabilities of less than 30 millidarcys.

The zigzag detail in the permeability logs of the larger units may be due to local differences in the cementing minerals, to original depositional features, or to fractures induced while collecting the specimens,

The permeability of specimens taken parallel to the plane of bedding and current lineation is 5-15 millidarcys greater than that in specimens oriented at right angles to the trend of current lineation. Where slight changes in color show the bedding, the drop in permeability across bedding is usually less than 15 millidarcys. Where bedding is emphasized by films of mudstone, the drop in permeability is sometimes as great as 100 millidarcys. In laminated sediments the permeability is always less across laminae than in the plane of lamination. In the plane of lamination the permeability is usually 10-30 millidarcys, but normal to laminae the permeability is never greater than 5 millidarcys. The influence of postdiagenetic openings on the determination of permeability could not be measured in the laboratory, but judging from the thin sections of these sediments, it is believed to be small.

\section{ALTERATION}

The degree of alteration in the sediments is related to the permeability of the sediments. Thin sections of nearly impermeable fine-grained dark sediments where sandstone strata are thin and discontinuous contain somewhat corroded quartz grains usually embedded in a matrix of red-brown clay. Overgrowths on the quartz grains are generally lacking in these rocks, and interstitial clay appears as ragged closely packed flakes. Rounded grains of magnetite and ilmenite are also present. In thin strata of dark permeable sandstone, a clay, similar to that in less permeable associated sediments, is partly altered to illite(?), ilmenite is sometimes altered to leucoxene, and magnetite is partly oxidized.

The light-colored sandstone-permeable rock that is contained in the layered sandstone strata - is usually an interlocking mosaic of sand grains with porosity reduced by the interpenetration of quartz grains with quartz overgrowths. The amount of quartz removed by solution and the amount deposited as overgrowths is approximately equal. Illite(?) occupies many of the interstices, leucoxene is a common minor constituent, and magnetite is absent.

At the base of the lowest layered sandstone stratum in the upper part of the Salt Wash member ond at the base and top of permeable units within the sandstone stratum, silica overgrowths and calcite are abundant and fill most of the pore spaces. A minutely crystallized mineral, possibly tyuyamunite $\left[\mathrm{Ca}\left(\mathrm{UO}_{2}\right)_{2}\left(\mathrm{VO}_{4}\right)_{2} \cdot 7-10\right.$ $1 / 2 \mathrm{H}_{2} \mathrm{O}$ ], was observed in some thin sections of rock collected from the base of permeable units in the sandstone strata. 


\section{TRANSMISSIVITY}

In the area of detailed study, geologic logs of almost 2,000 cores describe the upper part of the Salt Wash member in as many places. Where sandstone strata are thin, at least 40 feet of dark fine-grained sedimentary rocks was penetrated in the stratigraphic interval elsewhere occupied by sandstone strata. In places where sandstone strata are thick, a maximum of 90 feet of sediments was drilled before all the sandstone strata were fully penetrated. The transmissivity was determined at points spaced $300-400$ feet apart over an area of about $4 \frac{1}{2}$ square miles.

The coefficient of transmissivity is the average coefficient of permeability per unit thickness times the total thickness in the same units. Because measurements in the field are in feet, the millidarcy coefficient of perme-

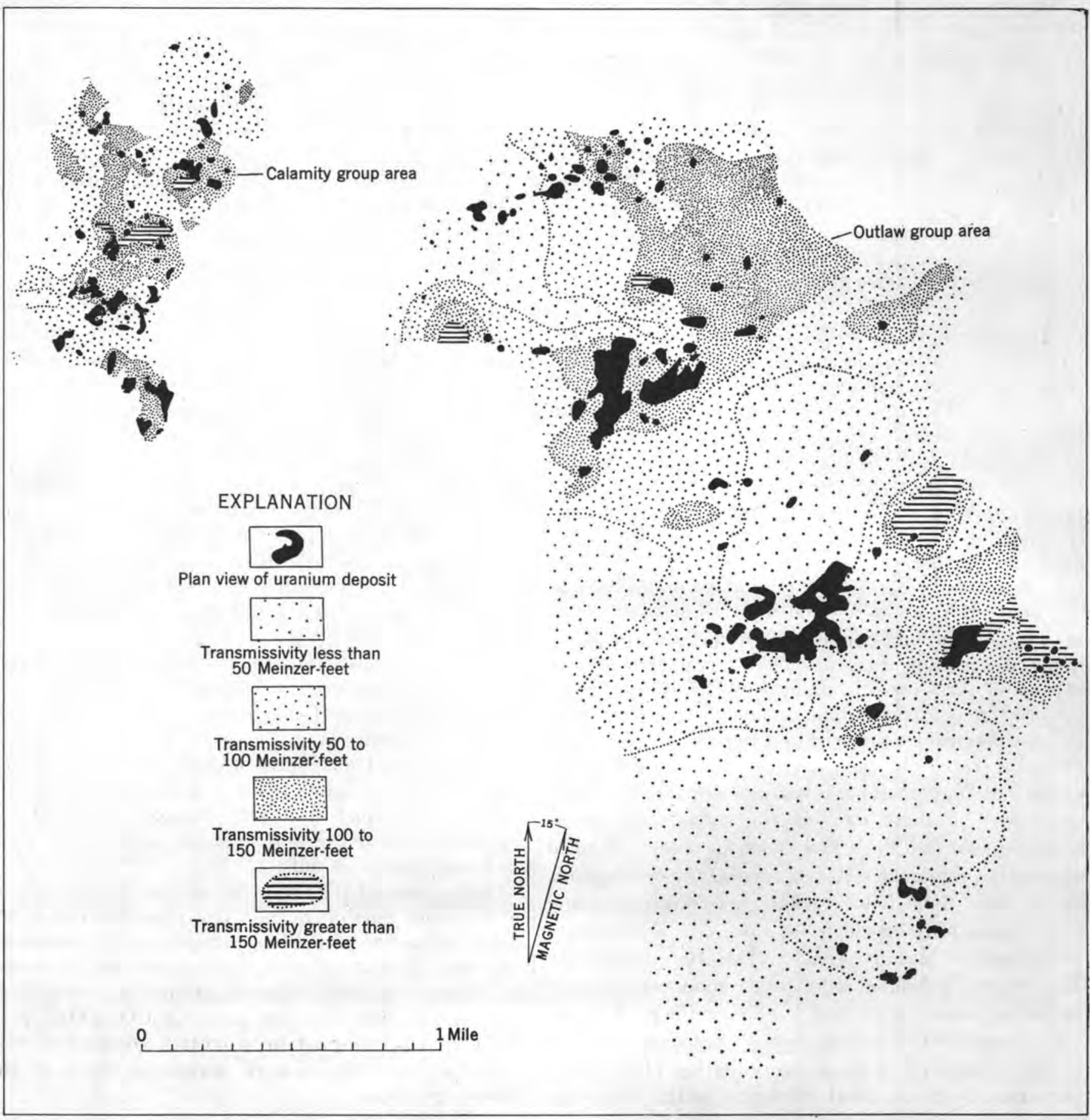

FIOURE 43.-Transmissivity of the uppermost sandstone layer in two adjoining areas, Mesa County, Colo. 
ability is multiplied by a factor of 0.021 to convert it to the Meinzer coefficient of permeability. Thus, transmissivity is shown in Meinzer-feet.

Average permeability values were determined for each rock type described in the written logs. The thickness in feet of each rock type in the log is multiplied by its representative average permeability, and the sum of these values for the various lithologic units in each geologic log is the transmissivity of the upper part of the Salt Wash member at the point drilled. In the region studied the transmissivity of the uppermost Salt Wash member ranges from a low of about 5 to a high of about 275 Meinzer-feet (fig. 43).

In the area studied, most of the productive deposits are found where the upper part of the Salt Wash member has a transmissivity greater than 100 Meinzerfeet. Where the layer has a transmissivity between 50 and 100 Meinzer-feet it contains isolated, or sometimes clusters of, small deposits, but these are apparently randomly distributed. Where the upper part of the Salt Wash member has a transmissivity less than 50 Meinzer-feet, it is essentially barren.

Figure 44 compares the area underlain by each transmissivity range with the total area of ore deposits and the tonnage of ore in each range. This summary shows that, although the most highly transmissive parts (greater than 150 Meinzer-feet) of the uppermost Salt Wash member constitute only 2 percent of the area studied, they are most likely to contain ore deposits. However, a larger target for the drill, as well as the greatest amount of ore-grade rock, is where the transmissivity is between 100 and 150 Meinzer-feet. About

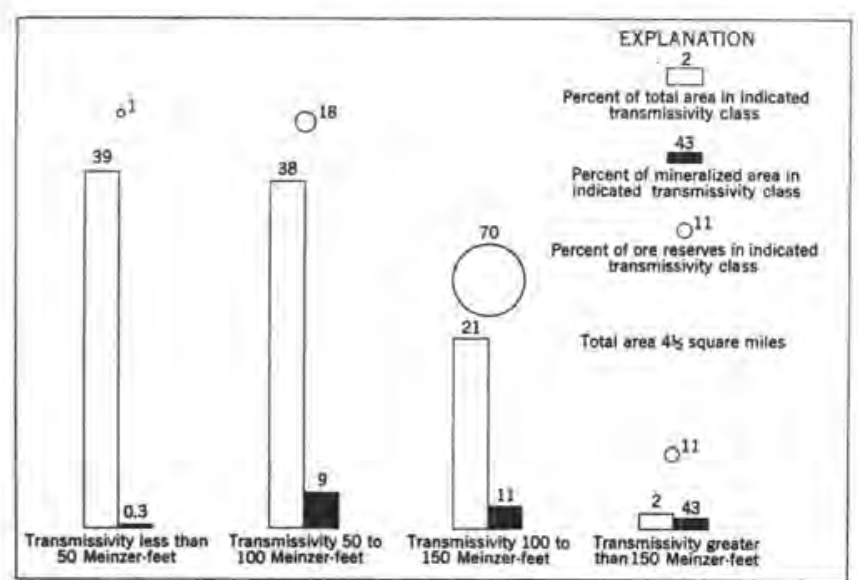

FigURE 44.-Graphic summary of the relations between transmissivity and the carnotite deposits, area of detailed studies, Mesa County, Colo.
21 percent of the area is underlain by sediments with these characteristics. Only 18 percent of the reserves are found where the transmissivity of the sediments is between 50 and 100 Meinzer-feet, and a sharp drop in total reserves is indicated where the sediments are least transmissive. Therefore, 77 percent of the area is underlain by rocks with negligible reserves of ore.

\section{CONCLUSIONS}

Sandstone strata of the Salt Wash member of the Morrison formation that are favorable to the deposition of ore form a complex, nearly horizontal interconnected system of sedimentary structures that have a prevailing eastward or northeastward orientation. Ore deposits are localized at connections between strata, where the strata change in size, and where the strata are thickest. Internally, the strata contain many obstacles in the form of local disconformities, bedding, laminae, mudstone lenses, and sedimentary structures. These affect the rate and direction of solution movement, and ore deposits are localized where the obstacles are numerous.

The transmissivity of the upper part of the Salt Wash member is a measure of the capacity of these strata to transmit solutions laterally. In the area of study this capacity varies from a high of about 275 Meinzer-feet to a low of 5 Meinzer-feet or less; the ore deposits are localized in the most transmissive parts.

If the mineralizing solutions have been in a static environment since shortly after Salt Wash time, then the areas of high transmissivity can be regarded as places where the metals could accumulate but not readily escape. On the other hand, if the mineralizing solutions continued to move laterally through the permeable sediments after Salt Wash time, then mineral deposition probably responded to changes in the velocity of the solutions and to changes in the hydrostatic pressure; other factors such as changes in temperature of the solutions may have influenced mineral deposition but to a degree not yet known.

\section{REFERENCES CITED}

Craig, L. C., Holmes, C. N., Cadigan, R. A., and others, 1955, Preliminary report on the stratigrapby of the Morrison and related formations of the Colorado Plateau region: U. S. Geol. Survey Bull. 1009-E, p. 125-168.

Fischer, R. P., and Hilpert, L. S., 1952, Geology of the Uravan mineral belt: U. S. Geol. Survey Bull. 988-A, p. 1-13.

MeKee, E. D., and Weir, G. W., 1953, Terminology for stratification and cross-stratification in sedimentary rocks; Geol. Soc. America Bull., v. 64 , p. $381-390$. 


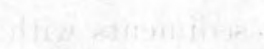

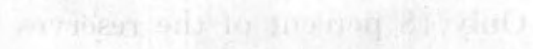

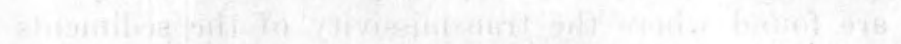

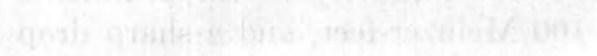

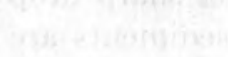




\title{
SEDIMENTARY FEATURES OF UPPER SANDSTONE LENSES OF THE SALT WASH MEMBER AND THEIR RELATION TO URANIUM-VANADIUM DEPOSITS IN THE URAVAN DISTRICT, MONT- ROSE GOUNTY, GOLORADO
}

\author{
By Robert L. Boardman, E. Bartlett Ekren, and Howard E. Bowers, U. S. Geological Survey
}

\section{CONTENTS}

\begin{tabular}{|c|c|c|}
\hline \multicolumn{3}{|c|}{ Page } \\
\hline Abstract... & 221 & \multirow{2}{*}{$\begin{array}{l}\text { Upper sandstone lenses of the Salt Wash member-Con. } \\
\text { Trends of sedimentary structures. }\end{array}$} \\
\hline Introduction & 221 & \\
\hline Upper sandstone lenses of the Salt Wash member........ & 222 & Relation of sedimentary structures to deposits........... \\
\hline Character and extent & 222 & 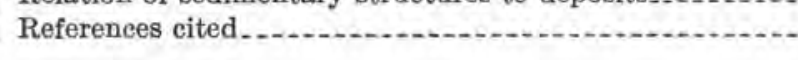 \\
\hline \multicolumn{3}{|c|}{ ILLUSTRATIONS } \\
\hline & Page & \\
\hline $\begin{array}{l}\text { FIGURE 45. Generalized geologie map of the western part } \\
\text { of the Uravan district..... } \\
\text { 46. Map showing relation of resultant direction } \\
\text { of the trends of sedimentary struetures and } \\
\text { ground favorable for ore in the western } \\
\text { part of the Uravan district }\end{array}$ & 223 & $\begin{array}{r}\text { FigURE 47. Club Mesa area showing the relations of the } \\
\text { deposits and ground favorable for ore to } \\
\text { the trend of sedimentary structures and } \\
\text { thickness of the ore-bearing upper sand- } \\
\text { stone of the Salt Wash member } \\
\text { 48. Diagrams showing strike of joints, primary } \\
\text { sedimentary structures, mineralized logs, } \\
\text { and ore rolls in the Blackfoot mine, Uravan } \\
\text { district........ }\end{array}$ \\
\hline
\end{tabular}

\section{ABSTRACT}

A detailed study of the rimrock formed by the upper sandstone lenses of the Salt Wash member of the Morrison formation of Jurassic age in the Uravan district was completed late in 1954. These lenses contain all the principal uranium-vanadium deposits in the district. The data acquired during this study have been integrated with information derived from detailed mine mapping, from cursory mine examinations, and from partial compilation of the logs of more than 3,000 drill holes of the U. S. Geologieal Survey in the district.

The trend of sedimentary structures in the Uravan district are, in general, eastward, normal to the northward trend of the Uravan mineral belt. The long axes of the ore bodies and the trends of areas geologically favorable for ore are nearly parallel to the strike of the sedimentary features. An in-echelon arrangement of ore deposits on Club Mesa and Long Park is believed to be a reflection of an in-echelon arrangement of the sedimentary structures in those areas.

The individual sandstone lenses of the upper part of the Salt Wash may not be extensive regional aquifers. It is improbable that the ore-bearing sandstone lenses of the productive Long Park area were continuous or connected with the principal orebearing sandstone lens in the Club Mesa area.

Data concerning the sedimentary structures, together with known fracture relations, make it unlikely that the genesis, localization, and concentration of ore in the Uravan district were controlled by faults or fractures. The relations observed in this study are perhaps more easily explained by the leaching, solution, and concentration of ore penecontemporaneously with deposition of the sandstone.

\section{INTRODUCTION}

The Uravan district is in the northwestern part of Montrose County in southwestern Colorado. The principal uranium-vanadium deposits occur in the western part of the district (fig. 45). Natural boundaries of the district are Paradox Valley, on the southwest; the Dolores River, on the west; the Mesa Creek drainage, on the north; and the Uncompahgre Plateau, on the northeast. Altitudes in the western part of the district range from about 4,900 to 7,000 feet above sea level; locally in the Uncompahgre Plateau, altitudes reach 8,000 feet. The climate is semiarid.

The oldest rocks exposed are Precambrian granitic and metamorphic rocks which crop out along the southwestern flank of the Uncompahgre Plateau. Overlying these basement rocks are gently dipping formations of marine and terrestrial sedimentary rocks ranging in age from late Paleozoic to late Mesozoic. Quaternary alluvium, gravel, and landslide material obscure older 


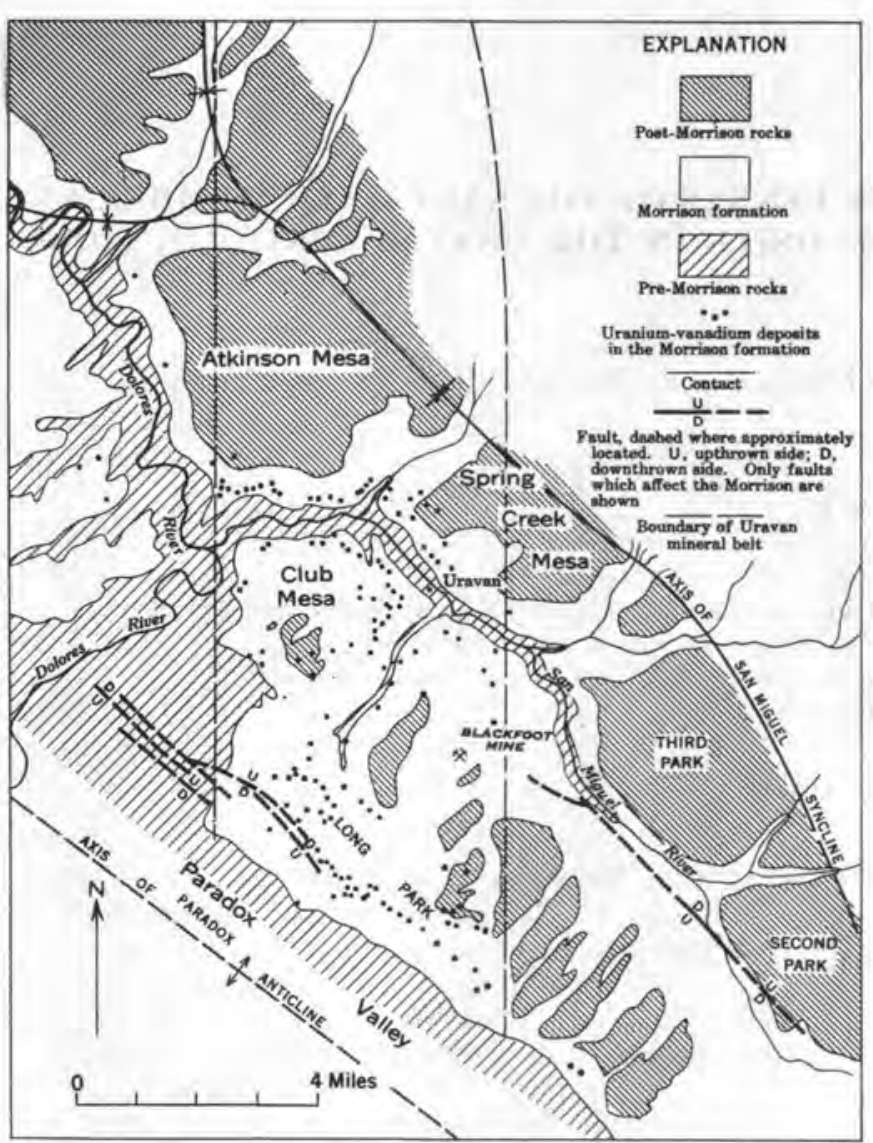

FtaURE 45.-Generalized geologic map of the western part of the Uravan district, Montrose County, Colo.

rocks in many places. A general description of the sedimentary beds exposed in the Uravan district has been given by Fischer (1942).

The Uravan district lies between two major northwest-trending structures; the Uncompahgre Plateau uplift, on the northeast, and the salt anticline that underlies Paradox Valley, on the southwest. Along the flanks of these structures high-angle strike faults and zones of intensely jointed sandstone strata are common. Between these structures is the San Miguel syncline, which strikes northwestward through the central part of the district (fig. 45). The sedimentary beds dip about $5^{\circ}$ or less toward this synclinal axis in most of the district; however, high on the flanks of the major folds the dip steepens sharply to $15^{\circ}$ or more.

Except for one very small prospect in the Burro Canyon formation of Early Cretaceous age, all the known uranium-vanadium deposits in the Uravan district are in the underlying Morrison formation of Late Jurassic age. The Morrison formation in the district is divided into 2 members: the Brushy Basin shale member, which a verages about 400 feet in thickness, and the underlying Salt Wash sandstone member which averages about 300 feet in thickness. Only 2 uranium-vanadium deposits of 1,000 tons or more have been found in the Brushy Basin member in the district; all other deposits of 1,000 tons or more, as well as most of the minable ore bodies, are in sandstone lenses in the upper part of the Salt Wash member. As much or more uranium-vanadium ore has been produced from the Uravan district as has been produced from any other mining district on the Colorado Plateau.

A detailed study of the rimrock formed by the upper sandstone lenses of the Salt Wash member in the western part of the Uravan district was completed in 1954. The horizontal extent and geologic character of the sandstone lenses were recorded, and the trends of sedimentary structures were determined from festoon cross-laminations, ripple- and current-lineation marks, and crossbedding (McKee, 1948; Stokes, 1947). The data compiled during this study have been used to determine the approxumate limits of ground that is believed to be geologically favorable for the occurrence of ore. These data have also been used to aid in planning drilling in unexplored ground at a distance of several hundred feet or more behind the rim. This has been integrated with information derived from detailed mine mapping, from cursory mine examinations, and from partial compilation of the logs of more than 3,000 U. S. Geological Survey drill holes in the district. Together, these data give a general picture of the mode of deposition, extent, and structure of the upper sandstone lenses of the Salt Wash member and provide a basis for relating sedimentary features to ore features throughout the area studied.

\section{UPPER SANDSTONE LENSES OF THE SALT WASH MEMBER}

\section{CHARACTER AND EXTENT}

The Salt Wash member in the Uravan district is composed of a series of terrestrial sandstone, siltstone, and mudstone lenses. A sandstone lens is defined here as a mappable unit that is generally a single layer of sandstone but in places may be two or more layers of sandstone separated by thin beds of mudstone and siltstone. The lenses range from a few hundred feet to several miles in length and are as much as several thousand feet in width. The sandstone lenses constitute about 50 percent of the Salt Wash member throughout the district, although the ratio of sandstone to mudstone and siltstone varies considerably in short distances. In many places the sandstone is quartzitic and grades to quartzite. Commonly, 3 to 5 sandstone lenses, each 20 feet or more thick, are prominent along the outcrop of the Salt Wash member. The sandstone lenses generally exhibit scour-and-fill bedding in the vicinity of ore deposits. The prominent sandstone lens 
or lenses in approximately the upper 100 feet of the Salt Wash member contain the largest uraniumvanadium deposits in that member. The detailed study was made of only this part of the Salt Wash section in the productive western part of the district. Similarly, the U. S. Geological Survey's drilling projects in the district have been planned almost exclusively to test the upper sandstone lens or lenses of the Salt Wash member.

Preliminary analysis of the data suggests that the upper sandstone lenses of the Salt Wash may not be extensive regional aquifers. In some places they appear to be enclosed by relatively impermeable mudstone beds. The fact that the principal ore-bearing sandstone lenses pinch out between the richly mineralized Club Mesa and Long Park areas (fig. 46) make it improbable that these lenses were continuous or connected at this locality. The principal ore-bearing sandstone lens along the southwestern part of the bench around Atkinson Mesa (fig. 46) pinches out northward on the rim. In general, information based on drill cores shows the upper sandstone lenses of the Salt Wash member to be thin and discontinuous northward and eastward under the Atkinson Mesa, Spring Creek Mesa, and Long Park areas. The upper sandstone

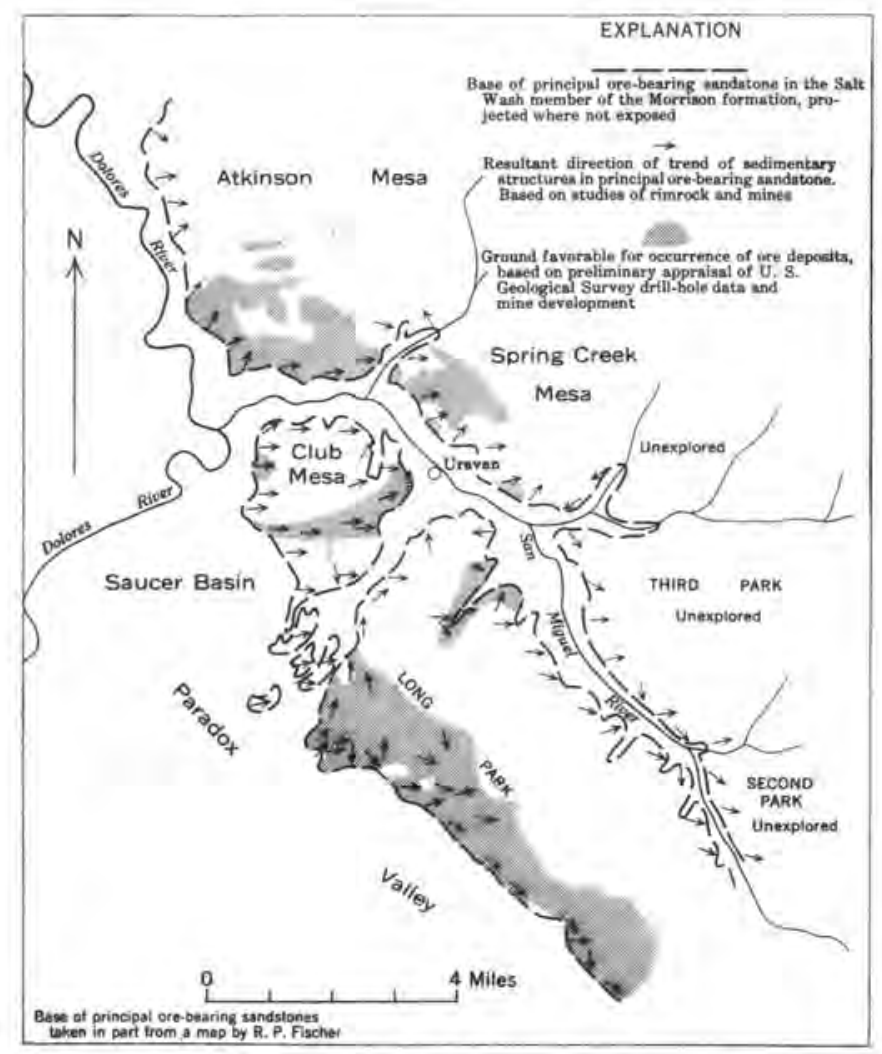

FInURE 46.-Map showing relation of resultant direction of the trends of sedimentary structures and ground favorable for ore in the western part of the Uravan district, Montrose County, Colo. lenses along the east flank of Paradox Valley, northwest of Long Park, become thin and split into several beds at the east margin of Saucer Basin (fig. 46). It is possible that the lack of thick continuous sandstone lenses in the upper part of the Salt Wash member in the Saucer Basin area facilitated removal of sediments by erosion and resulted in the topograhpic basin present today.

\section{TRENDS OF SEDIMENTARY STRUCTURES}

In the western part of the Uravan district, the trends of sedimentary structures in upper sandstone lenses of the Salt Wash member are, in general, eastward. An average northeastward trend was observed in the northern part of the area studied, and an average southeastward trend in the southern part. Figure 46 shows the resultant direction of several hundred primary sedimentary structures that were observed in the outcrops and in mines. Although the consistency ratio is not indicated for the directions plotted, it is generally high (fig. 47).

The strike of the sedimentary features is nearly parallel to the long axes of ground that is believed to be geologically favorable for ore (fig. 47) on the basis of preliminary appraisal of U. S. Geological Survey drill-hole data (Weir, 1952) and of mine development,

Fischer and Hilpert (1952) noted the parallelism of the orientation of fossil logs and long axes of ore rolls and ore bodies. They also noted an in-echelon arrangement of the ore bodies within deposits in the Club Mesa and Long Park areas. The long axes of the ore bodies are, in addition, nearly parallel to the strike of the sedimentary features and favorable ground, as shown in the Club Mesa area (fig. 47). It is believed that a strict relation between the parallelism of ore-body axes and trends of sedimentary structures exists, and that an in-echelon arrangement of the ore bodies is a reflection of an in-echelon arrangement of sedimentary structures. This arrangement of sedimentary structures is likely the result of shifting channels of late Salt Wash streams.

The parallelism of ore bodies (mineralized logs and ore rolls) and primary sedimentary structures is clearly shown in the Blackfoot mine (fig. 48), located about $2 \frac{1}{2}$ miles northeast of Long Park (fig. 45). Figure 48 also shows a point diagram of the joints mapped in the Blackfoot mine. A conjugate joint system related to the regional structure is apparent, but there is no evidence of any correlation between the trends of fractures and of ore bodies. The writers concur with Fischer's observation (1942) that “****all joints related to regional structures are believed to have been formed later than the early ore minerals," on the basis of the mapping of the rimrock and the mines that has been completed to date. All known faults in the 


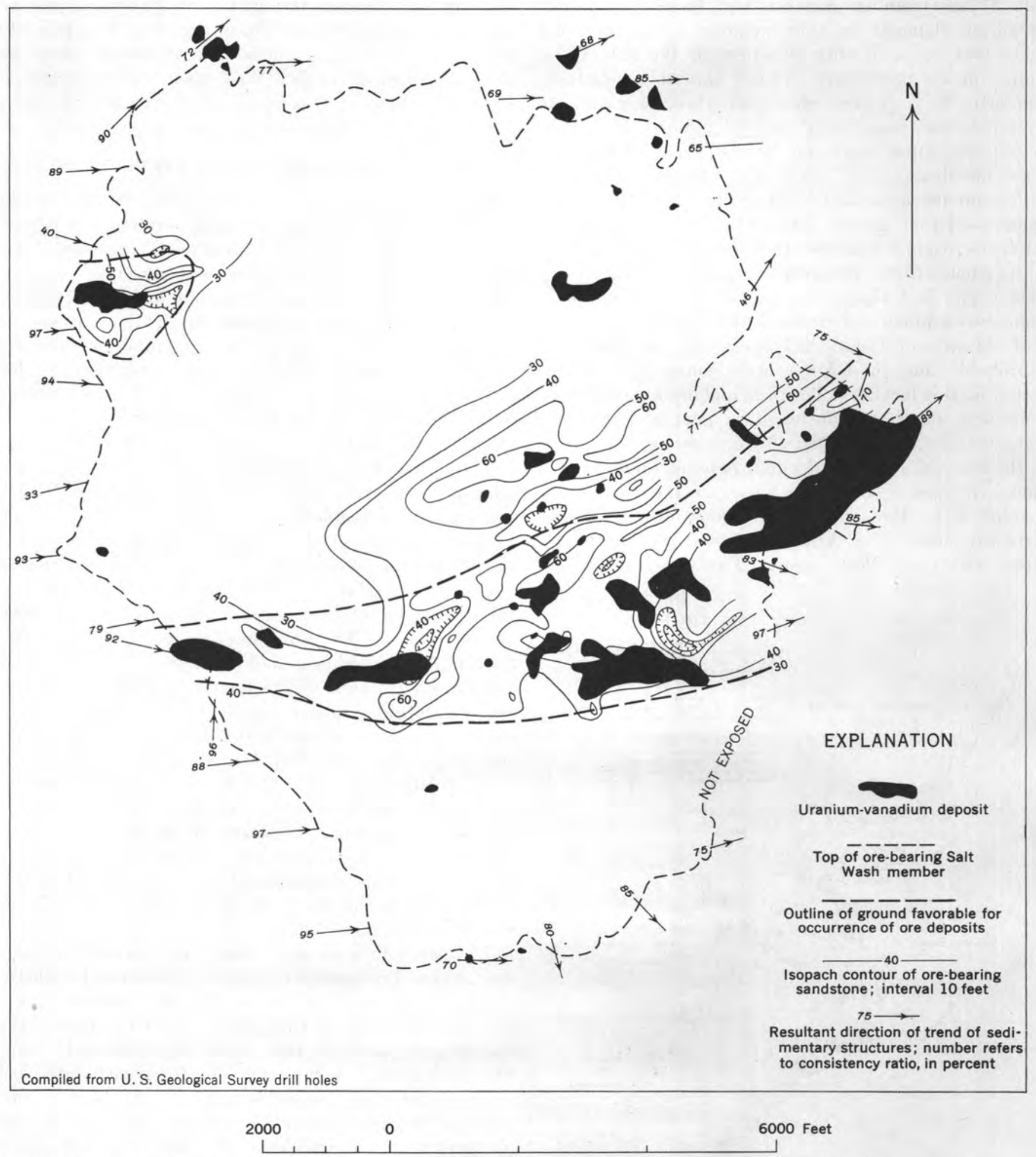

FiaURE 47.-Club Mesa area showing the relations of the deposits and ground favorable for ore to the trend of sedimentary structures and thickness of the ore-bearing upper sandstone of the Salt Wash member. 


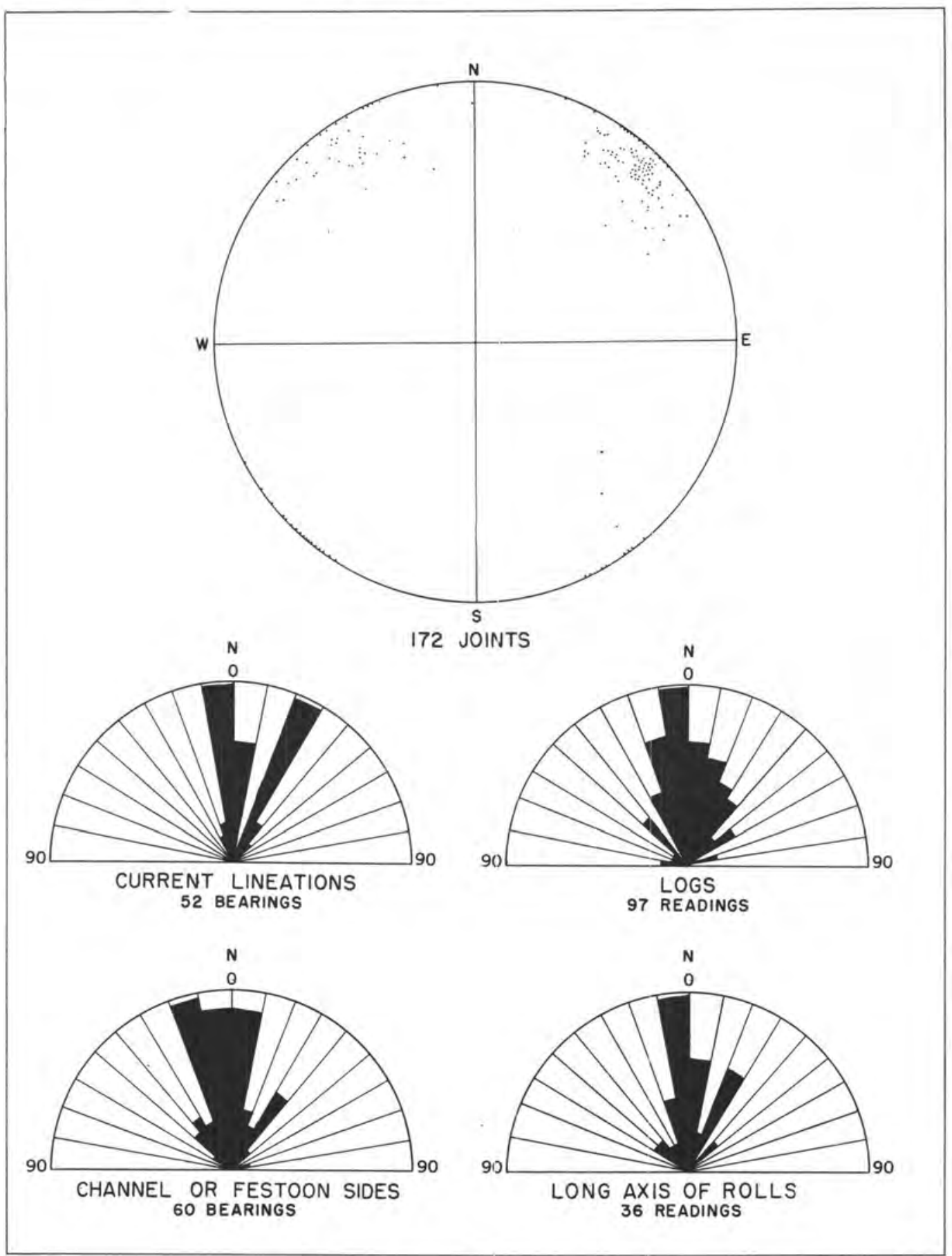

FIQURE 48.-Diagrams showing strike of joints, primary sedimentary structures, mineralized logs, and ore rolls in the Blackfoot mine, Uravan district, Montrose County, Colo. 
district that cross ore bodies displace the ore. Many of these faults contain ore gouge and breccia derived from the displaced ore.

\section{RELATION OF SEDIMENTARY STRUCTURES TO DEPOSITS}

It is appropriate to apply in a preliminary manner some of the foregoing observations to the concept of the Uravan mineral belt and to hypotheses of the origin and localization of the ore. The Uravan mineral belt, as described by Fischer and Hilpert (1952), is about $4 \frac{1}{2}$ miles wide and strikes about north through the west-central part of the district (fig. 45). The concept of such a belt in the district cannot be seriously questioned on the basis of present knowledge. Except for three large deposits east of the belt and southeast of Long Park, there are no known deposits of significant size outside of the belt in this district. The belt tends to become wider in the vicinity of Paradox Valley than it is to the north. The common orientation of ore rolls and fossil logs normal to the trend of the belt is believed to be directly related to the average eastward orientation of sedimentary features. Where the sedimentary structures parallel the mineral belt, the orientation of ore rolls and fossil logs is likewise parallel, as in the Blackfoot mine (fig. 48). The present application of the mineral-belt concept in the Uravan district might best be summarized as follows: where upper sandstone lenses of the Salt Wash member are appraised as geologically favorable for ore, it is expected that a much greater concentration of large ore bodies will be present within the Uravan mineral belt than outside of the belt in the Uravan area. This concept is being further tested by drilling by the U. S. Geological Survey in ground that is appraised as geologically favorable for ore east of this area.
The source of the uranium and vanadium and the factors that controlled the emplacement of the ore bodies remain imperfectly understood. Although such features as primary sedimentary structures, carbonaceous material, and "altered" mudstone apparently have a direct relation to the localization of most of the ore bodies in the Uravan district, these sedimentary and lithologic features are abundant in adjacent barren sandstone. It is improbable that the origin and localization of uranium-vanadium deposits in the district were in any manner controlled by known faults or fractures. If the observations concerning the trend of sedimentary structures and the fracture relationships described above are valid, as we believe, one must appeal to unproven conduitive fractures for a hypogene source of the ore-bearing solutions. Many such conduits may be needed to explain deposits in relatively isolated sandstone lenses. The deposits are more easily explained, perhaps, if it is assumed that the ore elements were originally contained in some part of the sediments at the time of deposition and were subsequently concentrated by solution and precipitation in approximately the present positions of the ore bodies.

\section{REFERENCES CITED}

Fischer, R. P., 1942, Vanadium deposits of Colorado and Utah: U. S. Geol. Survey Bull. 936-P, p. 363-394.

1944, Vanadium region of southwestern Colorado and southeastern Utah: U. S. Geol. Survey Strategic Minerals Inv. Prelim. Map 3-226.

Fischer, R. P., and Hilpert, L. S., 1952, Geology of the Uravan mineral belt: U. S. Geol. Survey Bull. 988-A, p. 1-13.

McKee, E. D., 1948, Classification and interpretation of crosslamination [abs.]: Geol. Soc. America Bull, 59, p. 1378.

Stokes, W. L., 1947, Primary lineation in fluvial sandstones, a eriterion of current directions: Jour. Geology, v. 55, p. 52-54.

Weir, D. B., 1952, Geologic guides to prospecting for carnotite deposits on Colorado Plateau: U. S. Geol. Survey Bull. 988-B, p. 15-27. 


\title{
DIREGTION OF SEDIMENT TRANSPORT IN THE TRIASSIC AND ASSOCIATED FORMATIONS OF THE COLORADO PLATEAU
}

\author{
By Forrest G. Poole and George A. Williams, U. S. Geological Survey
}

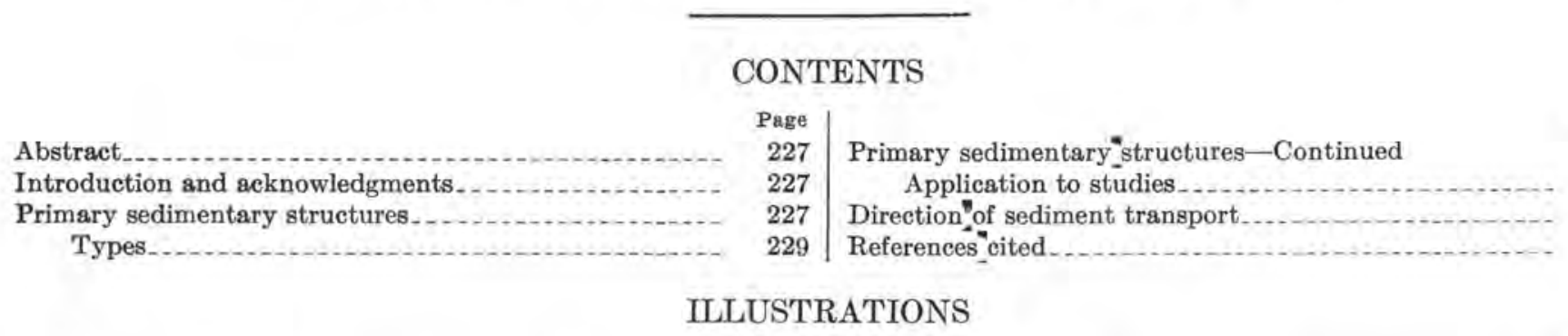

FIGURE 49. Primary sedimentary structures that show direction of sediment transport
50. Maps of the Colorado Plateau area showing directions of sediment transport in the Shinarump conglomerate and the Moss Back sandstone of the Chinle formation.

\section{ABSTRACT}

Clastic sediments in certain depositional environments develop characteristic features, called sedimentary, primary, or original structures, that reflect the direction in which the transporting medium was moving. These structures include channels, crossstrata, current lineation, and ripple marks; cross-strata are the most useful.

From primary structures the direction of transport can be determined, and, as many ore bodies are localized in channelfilling sandstones and tend to be elongate parallel to the channels, these structures are useful guides in the exploration for uranium and vanadium ore deposits. In addition to original structures, fossil-log orientations can be used to supplement the data.

Sedimentary-structure studies on the Colorado Plateau have been made on rocks that range in age from Permian through Jurassic. Studies made in the Moenkopi formation, Shinarump conglomerate, and Chinle formation, all of Triassic age, indicate a northwestward direction of sediment transport. The Wingate sandstone of Triassic age and Navajo sandstone of Jurassic and Jurassic (?) age show a southeastward direction. The Kayenta formation of Jurassic (?) age and the Entrada sandstone of Jurassic age have a southwestward direction and the Salt Wash, Recapture, Westwater Canyon, and Brushy Basin members of the Morrison formation of Jurassic age, in general, show a northeastward direction of sediment transport.

\section{INTRODUCTION AND ACKNOWLEDGMENTS}

Studies of primary sedimentary structures are being made as part of a detailed stratigraphic study of Permian through Jurassic formations of the Colorado
Plateau area in order to interpret better the geologic history of the Colorado Plateau as related to the localization and distribution of uranium and vanadium orè deposits.

Many geologists helped accumulate the vast amount. of field data pertinent to this paper; however, special thanks are extended to G. W. Weir and O. B. Raup, who collected and assembled much of the information.

The method used by the authors in making sedimentary-structure studies is after Reiche (1938) as modified by O. B. Raup (written communication).

\section{PRIMARY SEDIMENTARY STRUCTURES}

Continental and marginal-marine sediments commonly possess primary sedimentary structures that reflect the direction in which the transporting medium was moving. The most useful sedimentary structures for this purpose are channels, current lineation, ripple marks, and cross-strata (fig. 49). From these sedimentary structures the direction of the transport can be determined and the location of the source area can be inferred. Sedimentary structures are divided into two groups: those that can be used to determine a specific direction of transport, and those that indicate alternative but opposite directions of transport. (See fig. 49.) 
Generalized section of upper Paleozoic and Mesozoic strata in southeastern Utah and adjoining parts of Colorado, Arizona, and New Mexico

[Waved line indicates unconformity]

\begin{tabular}{|c|c|c|c|c|c|c|c|}
\hline System or series & Group & \multicolumn{2}{|c|}{ Formation } & Member or tongue & $\begin{array}{l}\text { Thickness } \\
\text { (feet) }\end{array}$ & Description & $\begin{array}{l}\text { Direction of } \\
\text { sediment } \\
\text { transport }\end{array}$ \\
\hline $\begin{array}{l}\text { Upper and Lower(?) } \\
\text { Cretaceous }\end{array}$ & & \multicolumn{2}{|c|}{ Dakota } & & $0-200$ & Sandstone and shale, gray and brown; cliff-forming, widespread & \\
\hline Lower Cretaceous & & \multicolumn{2}{|c|}{ Burro Canyon } & & $0-250$ & $\begin{array}{l}\text { Sandstone, light-colored, conglomeratic, and green and maroon } \\
\text { mudstone; mesa capping; absent in western part of area. }\end{array}$ & \\
\hline & \multirow{4}{*}{\multicolumn{2}{|c|}{ Morrison }} & Brushy Basin & $300-500$ & $\begin{array}{l}\text { Shale (or mudstone), varicolored, some sandstone lenses; forms } \\
\text { slopes; widespread. }\end{array}$ & Northeast \\
\hline & & & & Westwater Canyon & $0-350$ & $\begin{array}{l}\text { Sandstone, light-colored; forms cliffs and benches; absent in } \\
\text { northern part of area. }\end{array}$ & Northeast \\
\hline & & & & Recapture & $0-680$ & $\begin{array}{l}\text { Shales, red, and sandstones; forms cliffs and benches; absent in } \\
\text { northern part of area. }\end{array}$ & Northeast \\
\hline & & & & Salt Wash & $\overline{0-400}$ & $\begin{array}{l}\text { Sandstone, light-colored, and red mudstone; forms cliffs and } \\
\text { benches; widespread. }\end{array}$ & Northeast \\
\hline Upper Jurassic & \multirow{5}{*}{ 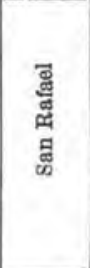 } & \multicolumn{2}{|c|}{ Bluff } & & $0-55$ & Sandstone, red, massive; forms cliff; absent in northern part of area & \\
\hline & & \multicolumn{2}{|c|}{ Summerville } & & $0-400$ & $\begin{array}{l}\text { Shale, red and gray, and thin sandstone; forms slopes; thickens } \\
\text { wsetward; widespread. }\end{array}$ & \\
\hline \multirow{2}{*}{. } & & \multicolumn{2}{|c|}{ Curtis } & & $0-100$ & Sandstone, light-colored; absent in southern Utah. & \\
\hline & & \multicolumn{2}{|c|}{ Entrada } & & $50-1,000$ & $\begin{array}{l}\text { Sandstone, light-colored; forms cliff; thickens westward to red } \\
\text { earthy sandstone. }\end{array}$ & \\
\hline $\begin{array}{l}\text { Upper and Middle Ju- } \\
\text { rassic }\end{array}$ & & \multicolumn{2}{|c|}{ Carmel } & & $0-600$ & $\begin{array}{l}\text { Sandstone, red, earthy; thickens westward to gray and red shale, } \\
\text { limestone, and gypsum; widespread. }\end{array}$ & \\
\hline Jurassic and Jurassic(?) & \multirow{3}{*}{ 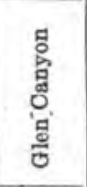 } & \multicolumn{2}{|c|}{ Navajo } & & $0-2,000$ & $\begin{array}{l}\text { Sandstone, red; irregularly bedded; forms bench; absent in eastern } \\
\text { part of area. }\end{array}$ & Southeast \\
\hline Jurassic(?) & & \multicolumn{2}{|c|}{ Kayenta } & & $0-300$ & $\begin{array}{l}\text { Sandstone, light-colored, massive; cliff-forming; absent in western } \\
\text { Colorado. }\end{array}$ & \\
\hline \multirow{7}{*}{ Upper Triassic } & & \multicolumn{2}{|c|}{ Wingate } & & $0-400$ & $\begin{array}{l}\text { Sandstone, red, massive; cliff-forming; absent in eastern part of } \\
\text { area. }\end{array}$ & Southeast \\
\hline & & \multirow{5}{*}{\multicolumn{2}{|c|}{ Chinle }} & "A" unit of Gregory & $0-350$ & Siltstone, red, and sandstone; forms ledges and slopes; widespread & \\
\hline & & & & Owl Rock & $0-450$ & $\begin{array}{l}\text { Limestone, gray, and red siltstone; forms ledges and slopes; wide- } \\
\text { spread. }\end{array}$ & \\
\hline & & & & Petrified Forest & $\overline{0-700}$ & $\begin{array}{l}\text { Claystone, variegated; forms slopes; widespread; absent in north- } \\
\text { ern Utah. }\end{array}$ & \\
\hline & & & & $\begin{array}{l}\text { Moss Back sand- } \\
\text { stone }\end{array}$ & $0-150$ & $\begin{array}{l}\text { Sandstone, light-colored, conglomeratic; cliff-forming; fills chan- } \\
\text { nels; widespread. }\end{array}$ & Northwest \\
\hline & & & & Monitor Butte & $0-250$ & Claystone, gray, and sandstone; forms slopes; widespread & \\
\hline & & \multicolumn{2}{|c|}{ Shinarump } & & $0-250$ & $\begin{array}{l}\text { Sandstone, light-colored, conglomeratic; cliff-forming; fllls channels, } \\
\text { widespread. }\end{array}$ & Northwest \\
\hline \multirow{3}{*}{$\begin{array}{l}\text { Middle(?) and } \mathbf{L} \text { Lower } \\
\text { Triassic }\end{array}$} & & \multirow{3}{*}{\multicolumn{2}{|c|}{ Moenkopi }} & & $0-700$ & $\begin{array}{l}\text { Siltstone, red, and sandstone; contains ripple marks; forms slopes } \\
\text { and ledges; widespread. }\end{array}$ & \\
\hline & & & & Sinbad & $0-200$ & Limestone; absent in eastern part of area & Northwest \\
\hline & & & & & $0-200$ & $\begin{array}{l}\text { Siltstone, red; contains ripple marks; forms slopes and ledges; } \\
\text { thins eastward. }\end{array}$ & \\
\hline \multirow{6}{*}{ Permian } & & \multirow{2}{*}{ 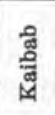 } & \multirow{6}{*}{ Cutler } & Hoskinnini & $0-120$ & $\begin{array}{l}\text { Siltstone, red; absent in northwestern part of area; forms steep } \\
\text { slopes and cliffs. }\end{array}$ & \\
\hline & & & & White Rim & $0-230$ & Sandstone, white; cliff-forming; absent in eastern part of area & \\
\hline & & \multirow{4}{*}{ 영 } & & De Chelly & $0-850$ & $\begin{array}{l}\text { Sandstone, light-colored; cliff-forming; absent in northern part of } \\
\text { area. }\end{array}$ & Southwest \\
\hline & & & & Organ Rock & $250-800$ & Siltstone, red; forms steep slopes; absent in northern part of area & \\
\hline & & & & Cedar Mesa & $0-1,250$ & $\begin{array}{l}\text { Sandstone, light-colored; thickens northward; forms cliffs and } \\
\text { benches. }\end{array}$ & Southeast \\
\hline & & & & Halgaito & $0-500$ & Siltstone, red, and sandstone; absent in northern part of area & \\
\hline $\begin{array}{l}\text { Permian(?) and Penn- } \\
\text { sylvanian. }\end{array}$ & & Rico & & & $300-500$ & $\begin{array}{l}\text { Sandstone, red, siltstone, and light-gray limestone; forms cliffs and } \\
\text { ledges; widespread. }\end{array}$ & \\
\hline
\end{tabular}



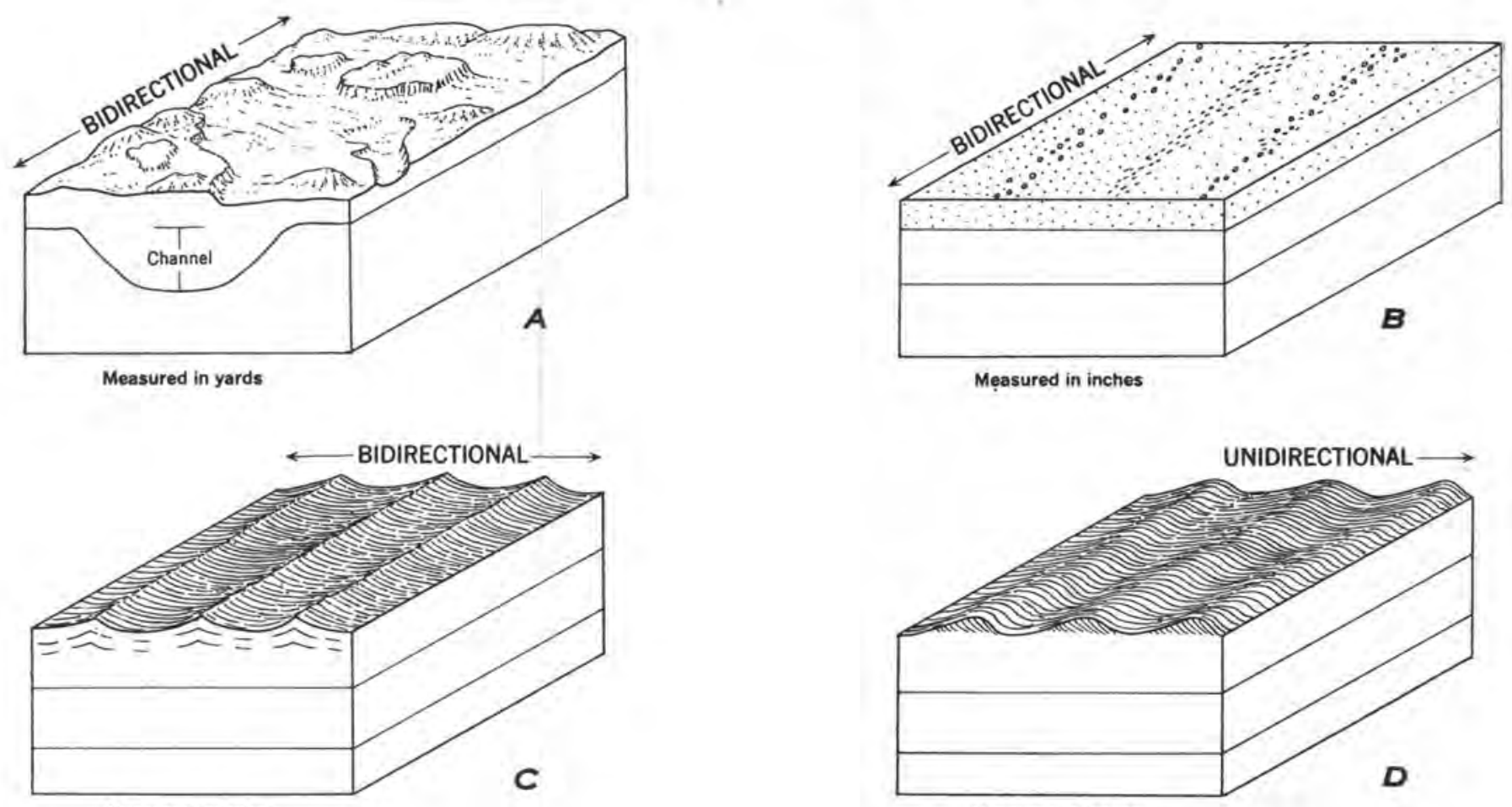

Measured in inches

Measured in inches

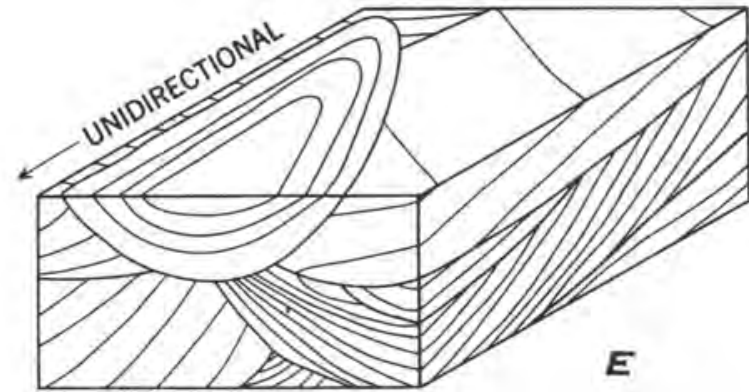

Measured in feet

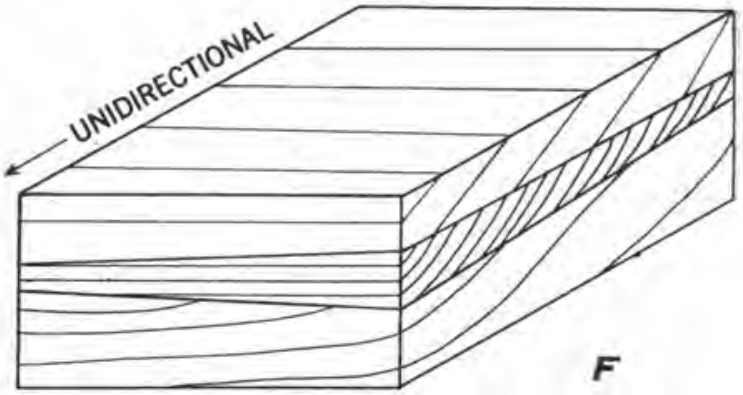

Measured in feet

FIGURE 49.-Primary sedimentary struetures that show direction of sediment transport. $A$, Channel; $B$, eurrent lineation; $C$, oscillation ripple marks; $D$, eurrent ripple marks; $E$, trough cross-stratifieation; $F$, planar cross-stratification.

\section{TYPES}

Channels are elongate troughs, symmetrical or asymmetrical in cross section, that were cut by a stream into one bed or into underlying beds (fig. $49 \mathrm{~A}$ ) and subsequently filled by sediment. Good exposures of channels, which are parallel to the direction of streamflow, may be used to determine the trend of the ancient stream; however, the orientation of the sedimentary structures of the channel fill may not coincide with the orientation of the channel because of sediment received from tributary streams.

In some stratigraphic units, current lineation is a common sedimentary structure on bedding planes (Stokes, 1947). Lineation consists of linear aggrega- tions of sand grains arranged parallel to the direction of current movement (fig. $49 \mathrm{~B}$ ).

Ripple marks are both symmetrical and asymmetrical. Symmetrical or oscillation ripple marks indicate only the trend of the streamflow (fig. $49 \mathrm{C}$ ) and must be supplemented by other sedimentary-structure data. The direction of transport is normal to the ridges. Asymmetrical or current ripple marks have a short steep slope on the down-current side (fig. $49 \mathrm{D}$ ). Obviously, the asymmetrical type is the most useful ripple mark in determining direction of current movement.

Cross-strata are the most useful of the primary structures in determining direction of transport because they are the most common structure. Cross-stratifica- 
tion terminology used in this paper is that of McKee and Weir (1953). Trough cross-stratification is probably the most common type in the sandstones studied on the Colorado Plateau (fig. $49 E$ ). The trough pattern is the result of two steps: erosion that produces plunging troughs, and filling of the troughs by thin concave layers conforming, in general, to the shape of the trough floors. The closed end is interpreted to be in the up-current direction and the open end in the downcurrent direction. The trough cross-stratification in this area is essentially the same as the festoon crosslamination in the Casper formation of Wyoming described in detail by Knight (1929). Knight attributes a marine origin to the festoon cross-stratification in the Casper formation; however, the term "festoon" is widely used by geologists to describe trough crossstratification in fluvial sediments on the Colorado Plateau.

Planar cross-stratification is the result of erosion that produces a planar surface on which stream sediments are subsequently deposited (fig. $49 F^{\prime}$ ).

\section{APPICATION TO STUDIES}

Sedimentary structures are useful in the exploration for uranium and vanadium ore deposits of the Colorado Plateau. Many ore bodies are localized in channel-fill sandstones of the Shinarump conglomerate, Chinle formation, and the Morrison formation and have a tendency to be elongate in the direction of streamflow (Lowell, 1955). If a direction of sediment transport in the channel can be determined, the amount of drilling required to outline the channel or the ore body may be reduced, as shown by Stokes (1953) and Lowell (1955).

Cross-strata are particularly useful sedimentary structures in determining the direction of sediment transport and in reconstructing depositional environments because they may develop in all environments in which sand is deposited; whether or not cross-strata are present depends upon the velocities of currents and supplies of sand. Cross-strata are made by water and wind, and in many instances it is impossible to distinguish the two types of bedding; however, in general, the angle of inclination in a stream deposit is less than that in a wind deposit.

In making a study of cross-strata, a basic assumption is made that one component of the dip direction is in the down-current direction. Studies of the direction of dip of cross-strata involves taking a number of measurements on the surfaces of the cross-strata with a compass and then determining the resultant-dip bearing of all
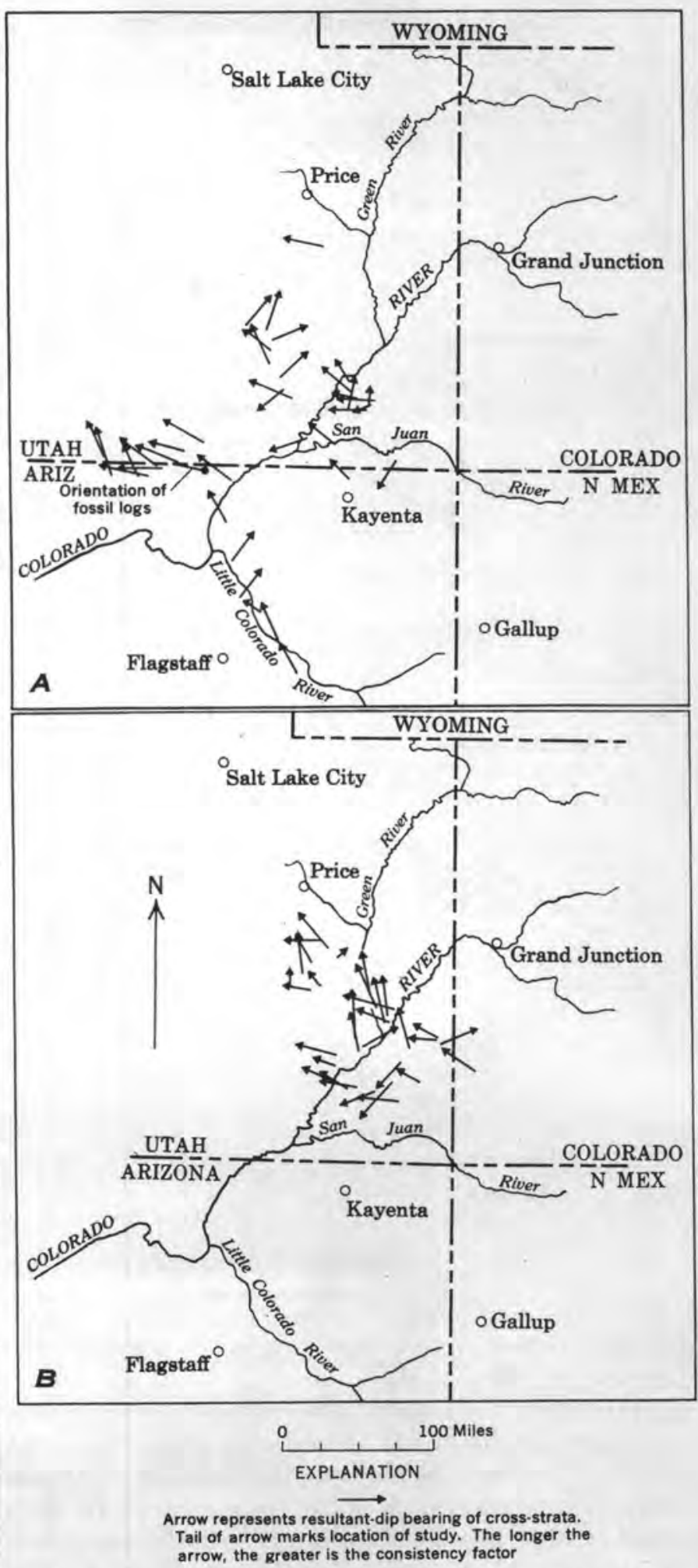

Finure 50.-Maps of the Colorado Plateau area showing directions of sediment transport in the Shinarump conglomerate $(A)$ and the Moss Back sandstone $(B)$ of the Chinle formation. 
the measurements. Care is taken to make only one measurement in each set of cross-strata. In studying trough cross-stratification, the direction of maximum dip is recorded where possible, but in many places most of the trough is covered and a reading is taken on a small part of a trough. If enough measurements are taken on parts of troughs an average of these readings should indicate the general trend of the current. The number of measurements required at any one locality depends on the amount of variation in the dip direction ${ }^{1}$ of cross-strata.

Ripple marks are important in paleogeographic interpretations (Bucher, 1919; Pettijohn, 1949). Ripples formed by wind generally have a higher ripple index - the number obtained in dividing the wave length by the amplitude - than those formed in shallow water.

Sedimentary structures can also be used in stratigraphic correlation. Similar types of sedimentary structures indicating like directions of transport are evidences of a similar environment of deposition and can be used, in conjunction with lithologic characteristics and stratigraphic position, to support the correlation of a unit across wide gaps in outcrop (Reiche, 1938). Although cross-strata are the most abundant and therefore the most useful sedimentary structures, a combination of cross-strata, channels, current lineation, and ripple marks should be used where possible to determine the direction of transport, and sufficient measurements must be made to assure adequate sampling.

\section{DIRECTION OF SEDIMENT TRANSPORT}

Sedimentary-structure studies of continental sediments of the Colorado Plateau (see table) indicate that in rocks of Permian age the Coconino sandstone had a southward direction of transport (Reiche, 1938), the Cedar Mesa sandstone member of the Cutler formation

1 The amount of variation in dip direction is represented by a consistency ratio or factor, expressed numerically from 0 to 1.00 (Reiche, 1938). If all measurements are in the same direction, the consistency factor would be 1.00, whereas if the readings are evenly distributed through $360^{\circ}$ the consistency factor would be 0 . In an ares where the regional dip is in excess of $4^{\circ}$, each measurement is corrected to its original attitude by means of a Wulff stereographic polar net. The measurements are then plotted graphically or calculsted mathematically to determine the resultant-dip direction. had a southeastward direction of transport, and the De Chelly sandstone member of the Cutler formation was transported toward the southwest (Reiche, 1938). Sediments of the Moenkopi formation, Shinarump conglomerate (fig. $50 \mathrm{~A}$ ), and Moss Back member of the Chinle formation (fig. $50 \mathrm{~B}$ ), all of Triassic age, were transported in a northwestward direction. Sediment transport in the Chinle formation, in general, shows a northwestward direction in Utah and a northward direction in northern Arizona. Sediments of the Wingate sandstone of Triassic age and Navajo sandstone of Jurassic and Jurassic (?) age were transported southeastward. The Kayenta formation of Jurassic(?) age and the Entrada sandstone of Jurassic age have a southwestward direction. In the Salt Wash, Recapture, Westwater Canyon, and Brushy Basin members of the Morrison formation of Jurassic age, sediments, in general, were transported northeastward (Craig, Holmes, Cadigan, and others, 1955).

\section{REFERENCES CITED}

Bucher, W. H., 1919, On ripples and related sedimentary surface forms and their paleogeographic interpretation: Am. Jour. Sci., v. 47 , p. $149-210,241-269$.

Craig, L. C., Holmes, C. N., Cadigan, R. A., and others, 1955, Stratigraphy of the Morrison and related formations of the Colorado Plateau region, a preliminary report: U. S. Geol. Survey Bull. 1009-E, p. 125-168.

Knight, S, H., 1929, The Fountain and the Casper formations of the Laramie Basin: Wyoming Univ. Pub. in Science, Geology, v. 1, no. 1, p. 1-82.

Lowell, J. D., 1955, Applications of eross-stratification studies to problems of uranium exploration, Chuska Mountains, Ariz.: Eeon. Geology, v. 50, p, 177-185.

McKee, E. D., and Weir, G. W., 1953, Terminology for stratification and cross-stratification in sedimentary rocks: Geol. Soc. America Bull., v. 64, p. 381-390.

Pettijohn, F. J., 1949, Sedimentary rocks: New York, Harper and Brothers, $526 \mathrm{p}$.

Reiche, Parry, 1938, An analysis of eross-lamination; the Coconino sandstone: Jour. Geology, v. 46, p. 905-932.

Stokes, W. L., 1947, Primary lineation in fluvial sandstones, a criterion of current direction: Jour. Geology, v. 55, p. 52-54. - 1953, Primary sedimentary trend indicators as applied to ore finding in the Carrizo Mountains, Ariz. and N, Mex.Part I: U. S. Atomic Energy Comm. RME-3043, 48 p., issued by U. S. Atomic Energy Comm. Tech. Inf. Service, Oak Ridge, Tenn. 


\title{
GHANNELS AND RELATED SWALES AT THE BASE OF THE SHINARUMP CONGLOMERATE, MONUMENT VALLEY, ARIZONA
}

\author{
By Irving J. Witkind, U. S. Geological Survey
}

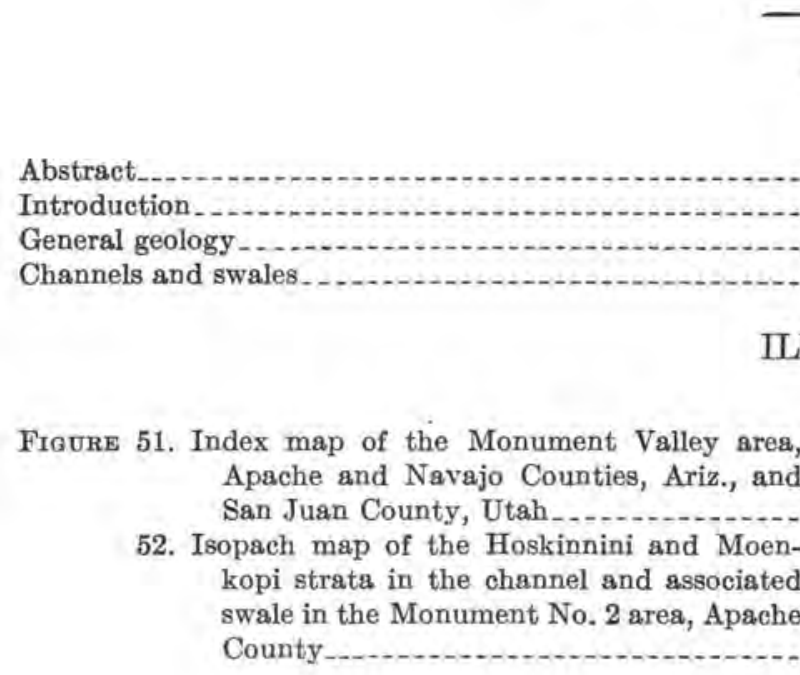

CONTENTS

Pazo

233

233

234

235
Swales associated with channels

Present methods of locating concealed channels

Proposed method of locating channels and swales.......

References cited
Page

235

237

237

237

Page

FigURE 53, Isopach maps of two widely separated areas, showing channel-and-swale relations, $\mathrm{Nav}$ -

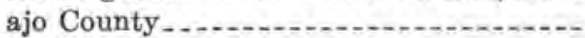

54. Isopach maps of two areas where swales are exposed but channels are not, Navajo County ........................................

\section{ABSTRACT}

In Monument Valley, Ariz., uranium-vanadium ore deposits are found in channel sediments at the base of the Shinarump conglomerate (Upper Triassic). This relation between channels and uraniferous ore deposits has been demonstrated so repeatedly that prospecting in the area has evolved into a search for, and exploration in, these channels. The channels range in width from 15 to 2,300 feet, are scoured as much as 150 feet into underlying strata, and may be classified as short (less than 2 miles in length) and long (greater than 2 miles in length). Channels are traced below the surface either by geophysical techniques or by drilling. However, it is estimated that many more channels are concealed than are exposed.

Channel-and-swale relations may be of help in finding concealed channels. In a few localities, the axis of a channel follows the axis of a broad elongate swale; whether this is true of all channels has not been established. The swales are too large for visual observation; however, they are apparent on isopach maps. In general, the swales range in width from 1 to 3 miles and have about 40 feet of relief. Locally the channels end but the swales continue; this extension of the swales beyond the channels may assist in the discovery of concealed channels. On isopach maps of selected areas, prepared by photogeologic methods, swales are apparent but no channels are exposed. Subsequent exploration, either by geophysical methods or drilling, may permit the tracing of these swales below younger strata. It may be possible to locate and outline channels in the ground so delineated.

\section{INTRODUCTION}

Since 1948 the Colorado Plateau, in the southwestern part of the United States, has been the scene of intensive prospecting and exploration for uranium-vanadium deposits. This search has centered in Utah, Colorado, Arizona, and New Mexico. The principal host rocks are the Morrison formation and the Entrada sandstone of Jurassic age and the Shinarump conglomerate and the Chinle formation of Triassic age.

In Monument Valley, Apache and Navajo Counties, Ariz. (fig. 51), uraniferous ore deposits are scattered irregularly throughout channel sediments at the base of the Shinarump conglomerate. Detailed drilling by the U. S. Atomic Energy Commission as well as by private industry has demonstrated this relationship so repeatedly that most of the prospecting in that area has evolved into a search for, and exploration in, channels.

In time, all the channels exposed at the surface will be found. Of prime importance, then, is a method for the discovery of those channels concealed beneath younger strata. In this paper it is suggested that channels in the Shinarump are associated with swales in the Moenkopi and that this relation offers possibilities for the discovery of concealed channels. 


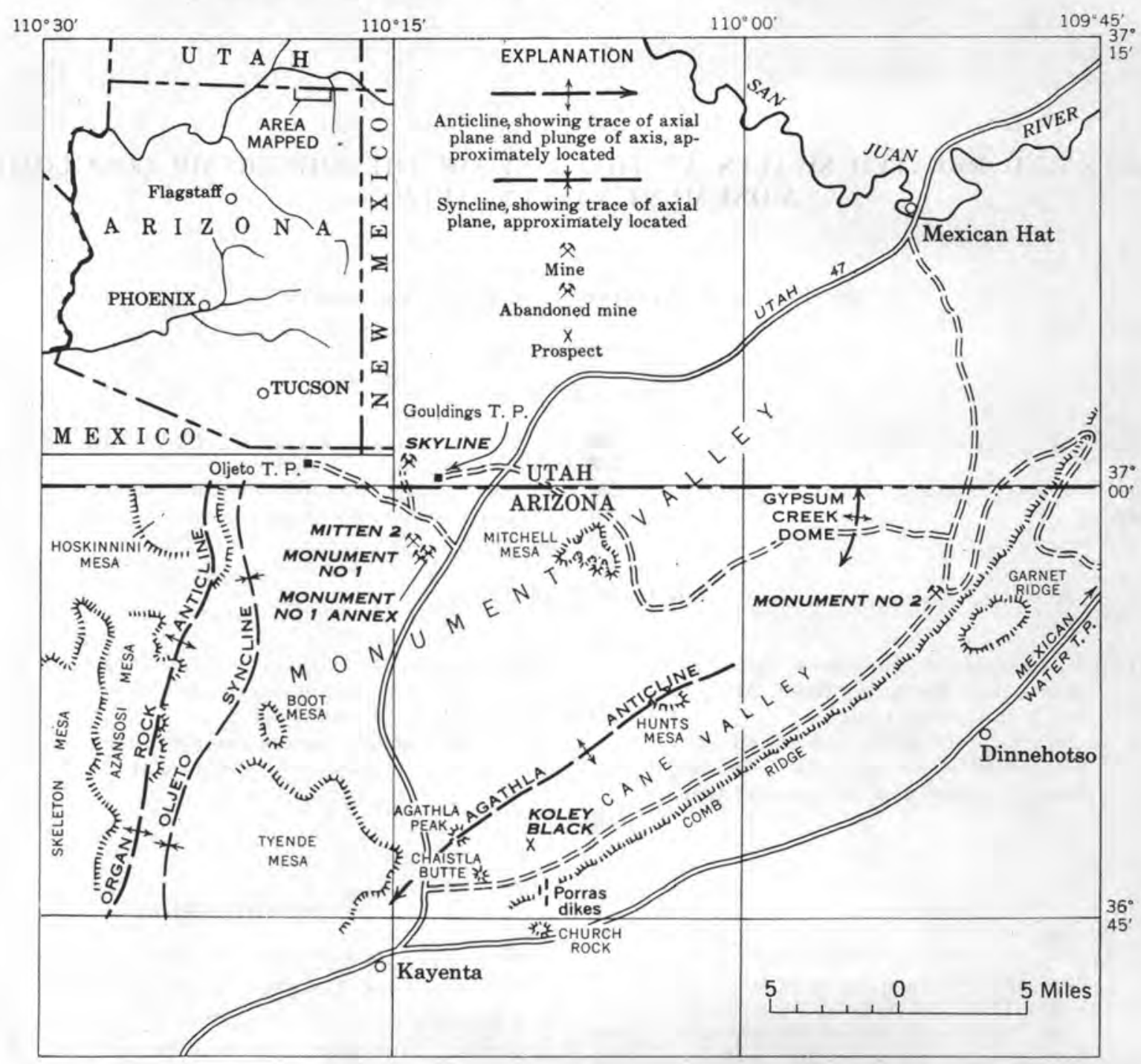

FiGURE 51.-Index map of the Monument Valley ares, Apsehe and Navajo Counties, Ariz., and San Juan County, Utah.

\section{GENERAL GEOLOGY}

In Monument Valley about 5,000 feet of sedimentary strata is exposed. These range in age from the Cutler formation (Permian) to the Salt Wash sandstone member of the Morrison formation (Jurassic). Of these units the Shinarump conglomerate of Late Triassic age has received the most attention, primarily because it is the host rock for deposits of uranium-vanadium ore.

The Shinarump is a light-gray to buff massive crossbedded conglomeratic sandstone strongly cemented by calcite, iron oxide, and clay. Wherever completely exposed it forms cliffs about 50 feet high. In most localities overlying strata have been removed, and the eroded surface of the Shinarump is hummocky and irregular. Most of the mesas and buttes are capped by this unit. Where dissection has not been as extensive, the Shinarump commonly forms a narrow bench above which rise the slopes and cliffs of younger formations. The conglomeratic facies of the unit consists predominantly of pebbles of quartzite, quartz, and chert in a matrix of medium- to coarse-grained quartz sandstone. Commonly the coarser grained facies are near the base of the unit and the finer grained sediments near the top. Locally the formation contains fossil wood and clay boulders of all sizes and shapes. Throughout most of Monument Valley the unit is about 50 feet thick, although in places it thickens and pinches erratically. The Shinarump rests uncomformably upon the red shaly siltstones of the Moenkopi formation (Early and Middle(?) Triassic). Locally, relief on the unconformity is slight and in most places does not exceed 5 feet. Swales and scour channels in the top of the 
Moenkopi are prominent exceptions, and these accentuate the unconformity. Several channels are cut as much as 150 feet into the underlying strata.

These underlying strata, the Moenkopi formation at the top and the Hoskinnini tongue of the Cutler formation at the base, consist of dark reddish-brown siltstone and sandstone beds which are as much as 350 feet thick in the western part of the area and which thin to about 80 feet in the eastern part.

The basal contact of the Hoskinnini is an unconformity, remarkably free of relief, which separates the slope forming reddish-brown even-bedded siltstones and sandstones of the Moenkopi and Hoskinnini from the cliff-forming light-tan massive crossbedded De Chelly sandstone member of the Cutler formation. The Hoskinnini, however, makes up only 15-40 feet of thesestrata. The remainder consists of the Moenkopi formation, which in this area elosely resembles the Hoskinnini in lithologic character and color.

\section{CHANNELS AND SWALES}

In general, channels are symmetric and asymmetric scours cut in the top of the Moenkopi formation and filled with Shinarump conglomerate (Bain, 1952; Witkind, 1953, 1954). Commonly, the channels are exposed along mesa edges as $U$-sbaped scours filled with conglomeratic sandstone and overlain by younger beds of the same material. However, in some places the overlying beds of the Shinarump have been removed, and here the channel sediments appear as ridges of gray conglomeratic sandstone bounded by the red shaly siltstones of the Moenkopi formation. The channels range in width from 15 to 2,300 feet and in the Utah part of Monument Valley are scoured as much as 150 feet into the underlying strata. The great majority of the channels are about 350 feet wide and have been scoured about 75 feet into the underlying strata. Some channels do not exceed 2 miles in length; in gross aspect they resemble the bowl of a spoon. Other channels can be traced for many miles. Commonly, the channels are relatively straight; a few, however, are sinuous. Most of the channels trend northwestward but seem to be distributed at random. The channel floors are irregular and are marked with shallow elongate depressions, many of which contain ore deposits. Channel sediments cannot be differentiated from the remainder of the Shinarump conglomerate, although more fossil wood seems to be in channel sediments than elsewhere.

Over a large area, the top of the Moenkopi is marked by elongate swales of such low relief and great width that they are not readily perceptible from the ground. In general the swales range from 1 to 3 miles in width and have a relief of about 40 feet.

The Shinarump underlies about 400 square miles of the 700-square-mile area of Monument Valley; it is not present in the remainder as a result either of erosion or nondeposition. Only about 40 square miles of Shinarump is exposed; the remaining 360 square miles is either concealed beneath surficial deposits or buried beneath younger consolidated strata. An examination of these 40 square miles has disclosed about 60 channels. If the channels are distributed at random (an assumption that is yet to be proved), and if this ratio persists, about 540 channels might be concealed in the remaining 360 square miles. In this relatively small area the number of completely concealed channels is estimated to be in the hundreds. Therefore, parts of the Shinarump, especially those that are concealed beneath relatively thin surficial deposits, seem worthy of investigation.

\section{SWALES ASSOCIATED WITH CHANNELS}

In a few localities in Monument Valley, isopach maps of the Moenkopi and adjacent strata illustrate the association of elongate, broad, shallow swales with some channels (fig. 52).

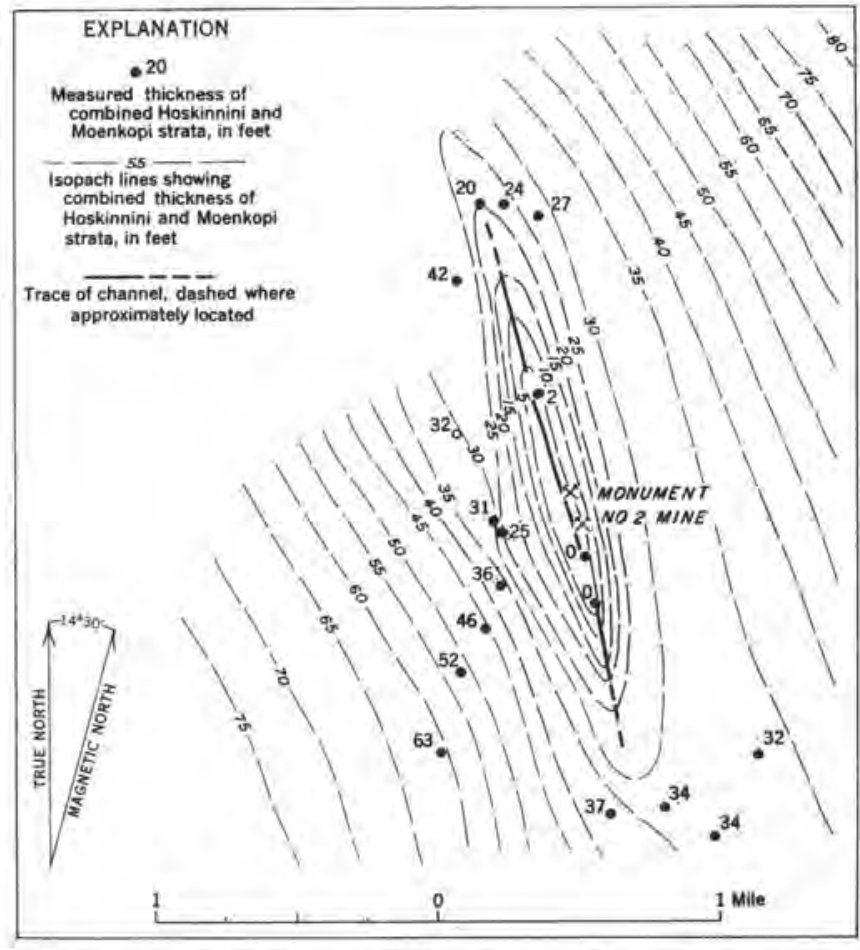

FinURE 52,-Isopach map of the Hoskinnini and Moenkopi strats in the channel and associated swale in the Monument No. 2 area, A pache County, Ariz.

The Monument No. 2 channel, with rich deposits of uranium and vanadium ore, and its accompanying swale, are a good example of such an association. In this area the Shinarump crops out in a series of jagged, serrate hogbacks, in one of which the channel is exposed. The channel is about $1 \frac{2 \pi}{4}$ miles long and 

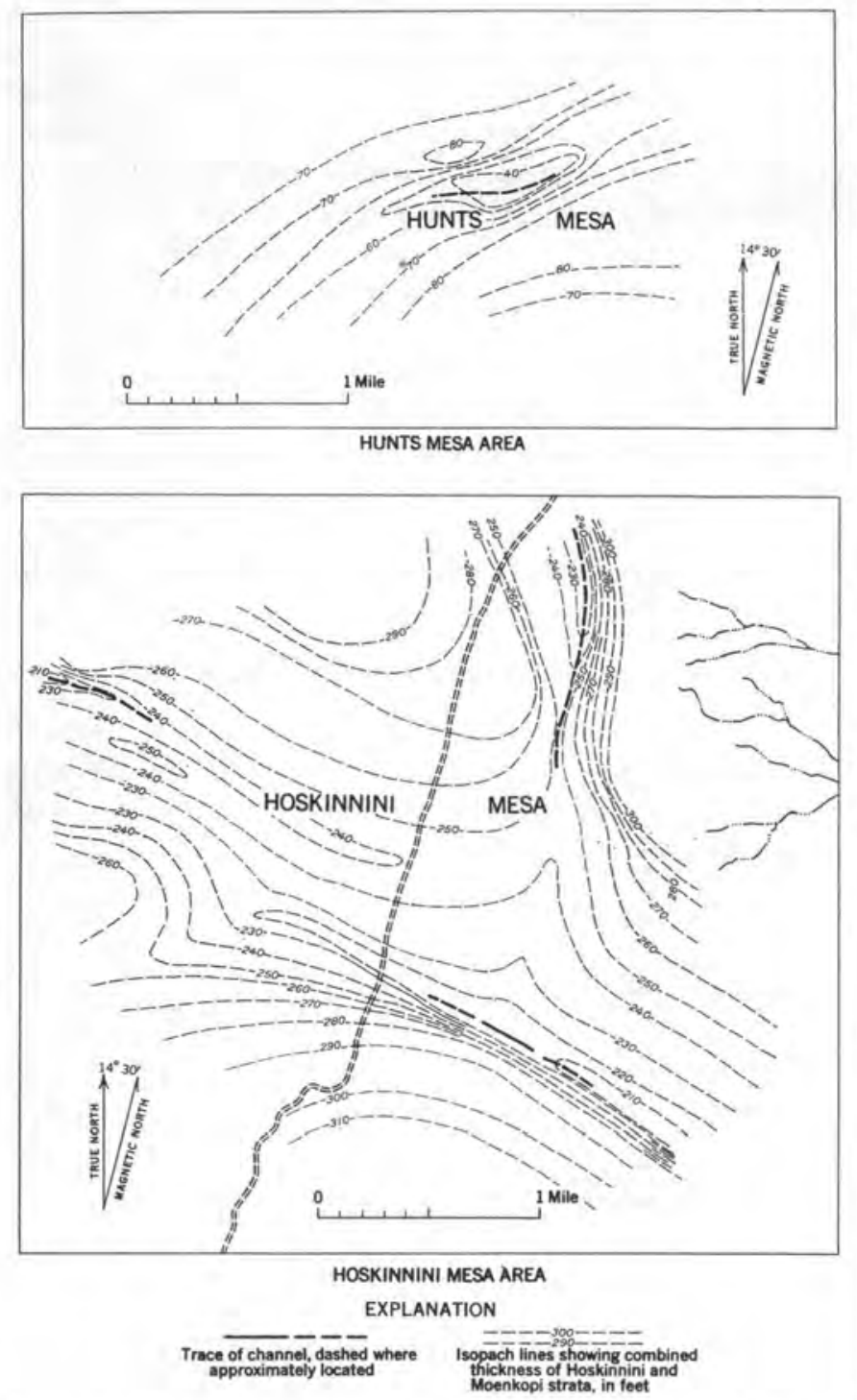

FioURE 53,-Isopach maps of two widely separated areas showing channel-and-swale relations, Navajo County, Ariz.

as much as 700 feet wide in its central part, is cut about 50 feet into the underlying strata, and trends about N. $18^{\circ} \mathrm{W}$. An isopach map of Moenkopi and Hoskinnini strata in the general area suggests that the channel lies along the axis of a swale that trends parallel to the channel, is about 3 miles wide, and can be traced 3-4 miles. Relief in the swale is about 50 feet. In this general area the combined thickness of the Moenkopi and the Hoskinnini tongue of the Cutler formation is about 80 feet. The west edge of the swale is about $1 \frac{1}{2}$ miles west of the channel. From that point eastward across the swale, the combined thickness of the units decreases gradually to about 30 feet at the edge of the channel. Here, the channel has been scoured about 50 feet into the underlying strata; thus about
30 feet of Moenkopi and Hoskinnini and 20 feet of underlying sediments has been removed. East of the channel these strata show an even increase in thickness until the regional figure of 80 feet is once again attained about $1 \frac{11}{2}$ miles to the east.

The swale accompanying the Monument No. 2 channel cannot be traced northwestward, owing to lack of exposures; however, it can be traced southeastward. Similar conditions exist elsewhere (fig. 53). Swales have been delineated in two other areas (fig. 54) where channels are not exposed.

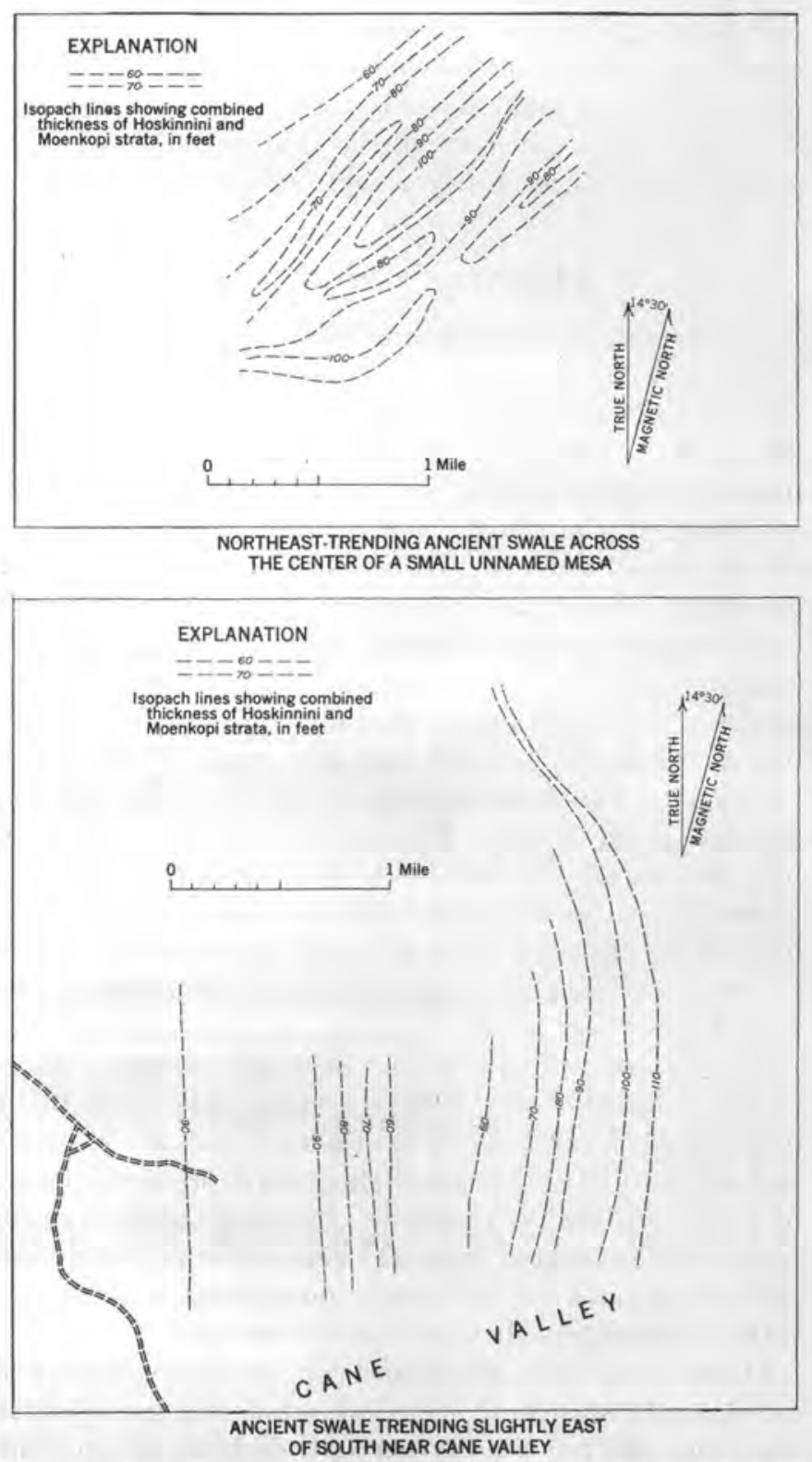

FIGURE 54.-Isopach maps of two areas where swales are exposed but channels are not, Navajo County, Ariz. 
In some parts of Monument Valley several channels are close together. The accompanying swales in these areas do not present as clear cut a relation as that shown by 1 channel and 1 swale.

\section{PRESENT METHODS OF LOCATING CONCEALED CHANNELS}

Two methods have been used to trace the channels beneath younger strata: the more common is drilling; the other relies on geophysical techniques, especially electrical resistivity and seismic refraction. Gravity and self-potential methods have not been successful. Some of the details on the geophysical methods used and results obtained are discussed in a paper by Wantlund and Casey (1952). Other work on geophysical methods has been done by R. A. Black, W. H. Jackson, and R. M. Hazelwood (written communication).

Both techniques have generally been used where part of a channel was exposed. Thus, it was possible to begin at a known exposure and continue to trace it with a minimum of difficulty and expense. However, as the number of known unexplored channels becomes less, a rapid and economical method of locating concealed channels will be necessary.

\section{PROPOSED METHOD 'OF LOCATING CHANNELS AND SWALES}

Experience in Monument Valley has indicated that the best method of contouring the base of the Shinarump over large areas is to prepare isopach maps of the underlying strata by photogeologic methods. The basal contact of the Hoskinnini tongue is used as a datum, rather than the Moenkopi-Hoskinnini contact, because it is more easily recognized in the field and on aerial photographs. As the unconformity between the De Chelly and the Hoskinnini is featureless, except for the regional eastward thinning of the beds, local variations appearing on the isopach maps are the result of irregularities in the top of the Moenkopi. These variations are the result of postdepositional erosion rather than vagaries in the deposition of the Moenkopi.

The extent and position of swales can best be noted on isopach maps, which are compiled most easily by photogeologic methods. Field measurements, although more accurate, are difficult and time consuming. Isopach maps of different parts of Monument Valley have been prepared by both methods. The coincidence of channels and swale axes, as indicated by these studies, suggests that swales outlined on isopach maps are favorable areas for exploration for concealed channels.

\section{REFERENCES CITED}

Bain, G. W., 1952, Uranium deposits in southwestern Colorado Plateau: U. S. Atomic Energy Comm. RMO-982, 59 p., issued by U. S. Atomic Energy Comm. Tech. Inf. Service, Oak Ridge, Tenn,

Wantlund, Dart, and Casey, R. D., 1952, Field tests for the United States Atomic Energy Commission on the use of the seismic geophysieal method for tracing "buried channels" in the Monument Valley area, Arizona: U. S. Bur. Reclamation, Eng. Geology Br., Geol. Rept. G-123, 68 p.

Witkind, I. J., 1953, Monument Valley, Arizona, Project, in Search for and geology of radioactive deposits - Semiannual progress report, Dec. 1, 1952 to May 31, 1953: U. S. Geol. Survey TEI-330, p. 34-36, issued by U. S. Atomic Energy Comm. Tech. Inf. Service, Oak Ridge, Tenn.

- 1954, Localization of uranium minerals in channel sediments at the base of the Shinarump conglomerate, Monument Valley, Arjz. [abs.]: Econ. Geology, v. 49, p. 804-805; Geol. Soc. America Bull., v. 65, p, 1327. 


\title{
SIGNIFICANCE OF ROLL ORE BODIES IN GENESIS OF URANIUM-VANADIUM DEPOSITS ON THE GOLORADO PLATEAU
}

\author{
By Daniel R, Shawe, U. S. Geological Survey
}

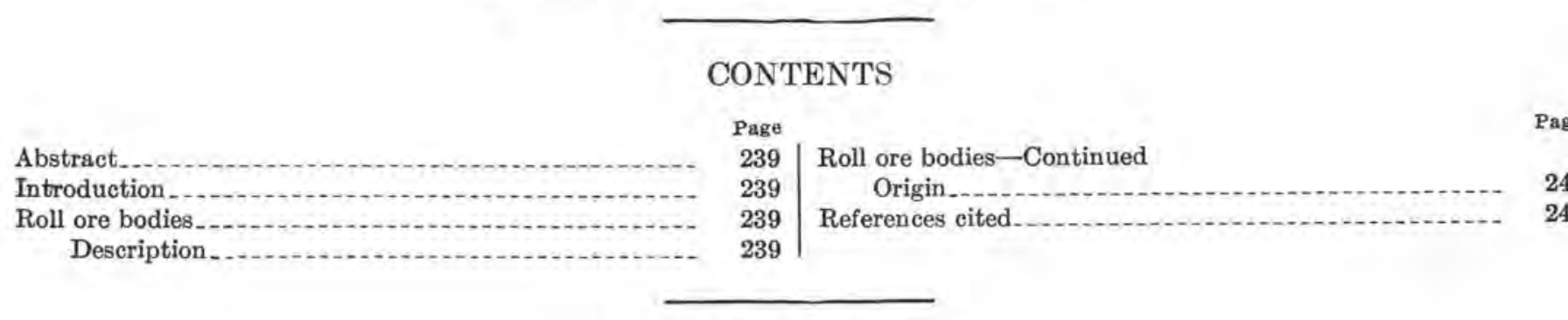

ILLUSTRATIONS

age

Figure 55. Cross-sectional forms of roll ore bodies

\begin{abstract}
Roll ore bodies are generally layered deposits that erosseut sandstone bedding in sharply curving forms. They are found principally in sandstone lenses and layers, usually in the upper part of the Salt Wash sandstone member of the Morrison formation of Jurassic age; they are less common than tabular deposits both in this member and in other ore-bearing units of the Colorado Plateau.

Roll ore deposits are found principally near the base of thick sandstone units where numerous thin well-defined mudstone layers are interbedded with thin sandstone layers. In places, rolls, which commonly terminate against an upper and lower mudstone layer, are split into two distinet rolls by the development along their axes of a third thin mudstone layer. The long axes of rolls may be continuous for many hundreds of feet in the plane of thin sandstone layers. In many places rolls have continuity with tabular ore bodies which are essentially parallel to bedding planes.

It is possible that roll ore bodies were formed by precipitation of minerals at an interface between solutions of different composition and density, and that flow of the ore-bearing or active solution as it passed through connate waters in the sediments was influenced strongly by local sedimentary features.

Many similarities between roll ore bodies and the more common tabular ore bodies in sedimentary rocks on the Colorado Plateau suggest a common origin for the two types. Thus, analysis and interpretation of details of roll ore bodies may clarify genesis of the uranium-vanadium ore deposits on the Colorado Plateau.
\end{abstract}

\section{INTRODUCTION}

Similarities between roll ore bodies and the more prevalent tabular ore bodies in sedimentary rocks of the Colorado Plateau suggest a common origin for the two types. Similarities include internal structure, mineralogy, and associated altered zones. Moreover, the types in many places intergrade. Thus, close study and interpretation of details of roll ore bodies may help clarify the genesis of the uranium-vanadium ore deposits of the Colorado Plateau.

\section{ROLL ORE BODIES \\ DESCRIPTION}

Roll ore bodies are generally layered deposits that cut across sandstone bedding in sharply curving forms (Fischer, 1942). In cross section, rolls commonly show $\mathrm{C}, \mathrm{S}$, and "socket" shapes (fig. $55 A, B$, and $C$ ), but in plan are linear; many elongate rolls curve abruptly at their extremities into "noses." Roll surfaces are fractures that separate mineralized rock from barren rock. The fractures are best developed in roscoelite- and carnotite-bearing oxidized rolls but are also present in uraninite- and montroseite-bearing unoxidized rolls of similar form and distribution.

Most rolls are found in sandstone lenses and layers in the upper part of the Salt Wash sandstone member of the Morrison formation of Jurassic age; however, they are less common than tabular deposits, both in this and in other ore-bearing units of the Colorado Plateau. 
Most roll ore deposits are near the base of thick sandstone units where numerous thin well-defined mudstone layers are interbedded with thin sandstone layers. Where mudstone splits or partings are less well defined, tabular ore bodies predominate. Although rolls commonly terminate against an upper and lower mudstone layer, in places they are split into two distinct rolls by a third thin mudstone layer along their axes (fig. $55 D$ ). Rolls may bulge above places where thick parts of sandstone strata are in contacttermed "puncture points" - and noses of rolls may be situated under these places: (D. A. Phoenix, oral communication.)

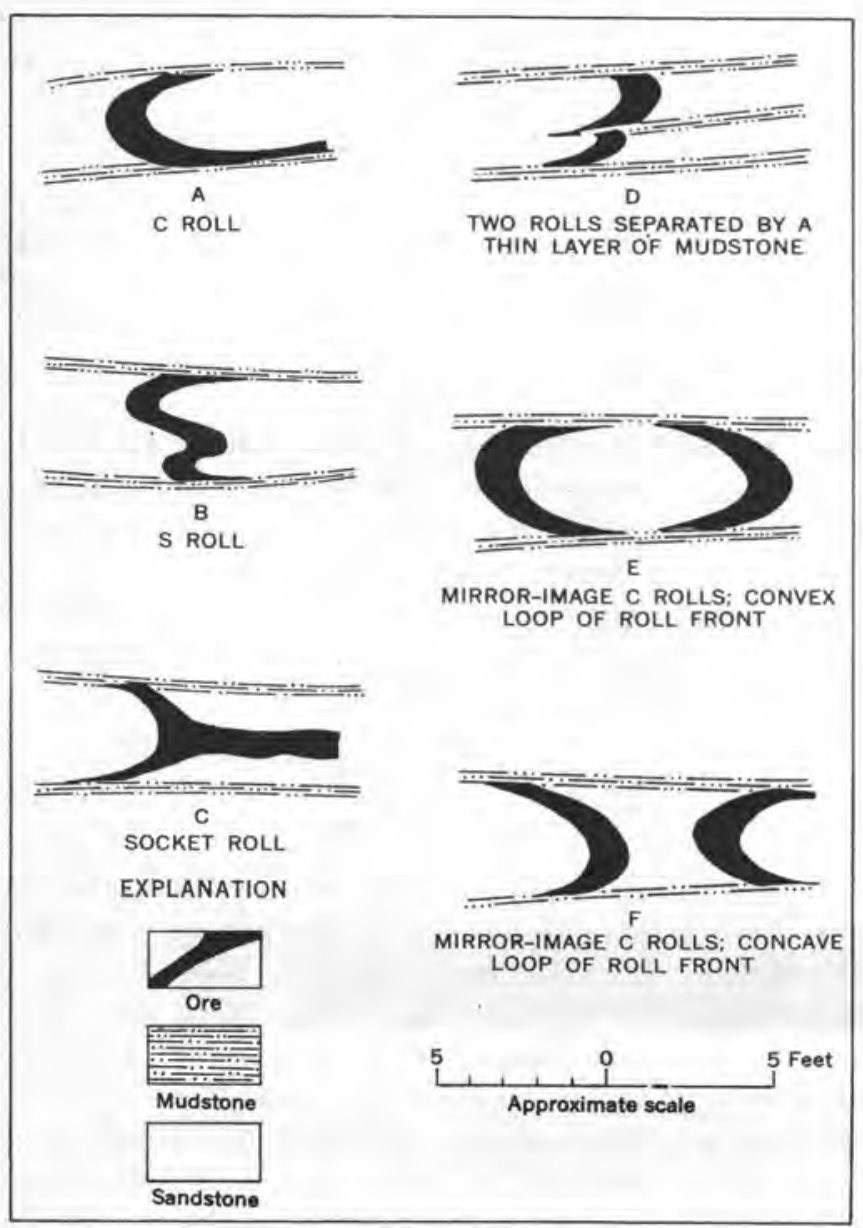

FICURE 55.-Cross-sectional forms of roll ore bodies.

Rolls may be continuous for several hundreds of feet along thin sandstone layers. Essentially, roll ore bodies in any particular sandstone layer are all segments of a continuous roll front, and in places appear to be lacking as a result of flattening of rolls into tabular form. The axes are characteristically sinuous in plan and commonly double back on themselves so that cross sections through loops in the roll fronts show mirror images of the roll shapes on either side of the loops (fig. 55E, $F$ ). Individual roll fronts in different sandstone layers show little similarity in local distribution. In many places rolls grade into tabular ore bodies which are essentially parallel to bedding planes (fig. $55 A, C)$.

Detailed mapping of sedimentary structures underground has shown the general coincidence of the long axes of rolls with the trend of such structures as current lineation, trough cross-stratification, and local channels in the thin sandstone layers in which ore is found. The relation between position of ore and sand-filled local channels or thicker parts of sandstone layers remains to be demonstrated. However, the consistent relation between trends of the long axes of ore bodies and sedimentary structures probably reflects the orientation of the most permeable units in the sandstone layers (Lowell, 1955; A. E. Flint and R. L. Boardman, oral communication).

Rolls commonly lie against mineralized carbonized logs or are indented where such logs lie across the general trend of the roll. Logs typically lie in or just under thin mudstone layers which contain abundant carbonized plant debris, and thus the upper edges of roll ore bodies are most commonly adjacent to logs.

Many rolls of uranium-vanadium ore show concentric layering parallel to ore surfaces (fig. $56 \mathrm{~A}$ ). Commonly, the concave surfaces of rolls show sharp transitions into barren rock, whereas the convex sides of rolls commonly show more gradual transitions into barren rock, or may even be continuous laterally into tabular ore bodies.

The distribution of minor elements across roll ore bodies is asymmetric. For example, in a deposit in Navajo(?) sandstone near Rifle, Colo., layers rich in galena and chromium minerals are parallel and adjacent to ore layers in both roll and tabular bodies (fig. $56 \mathrm{~B}$; R. P. Fischer, oral communication). In ore deposits in the Salt Wash member, layers rich in hematite or limonite, calcite, and selenide commonly lie concentrically on the concave side of roll ore bodies (fig. $56 \mathrm{C}$ ).

Hematite and magnetite comprise more than half the heavy detrital minerals in the unaltered Salt Wash sandstone member, but they are sparse in altered rock on the convex side and absent in altered rock on the concave side of some rolls where normal amounts of other heavy detrital minerals occur. These rolls contain an abundant, unidentified black opaque mineral probably altered from detrital magnetite or hematite, or both.

In summary, rolls are layered ore bodies that cut sharply across sandstone bedding. In plan the long axes of rolls may be several hundred feet in length, in many places sinuous, and locally oriented parallel to sedimentary structures. In cross section, minor ele- 
ments in ore bodies are distributed asymmetrically, and alteration seems more extensive on the concave side of the deposits.

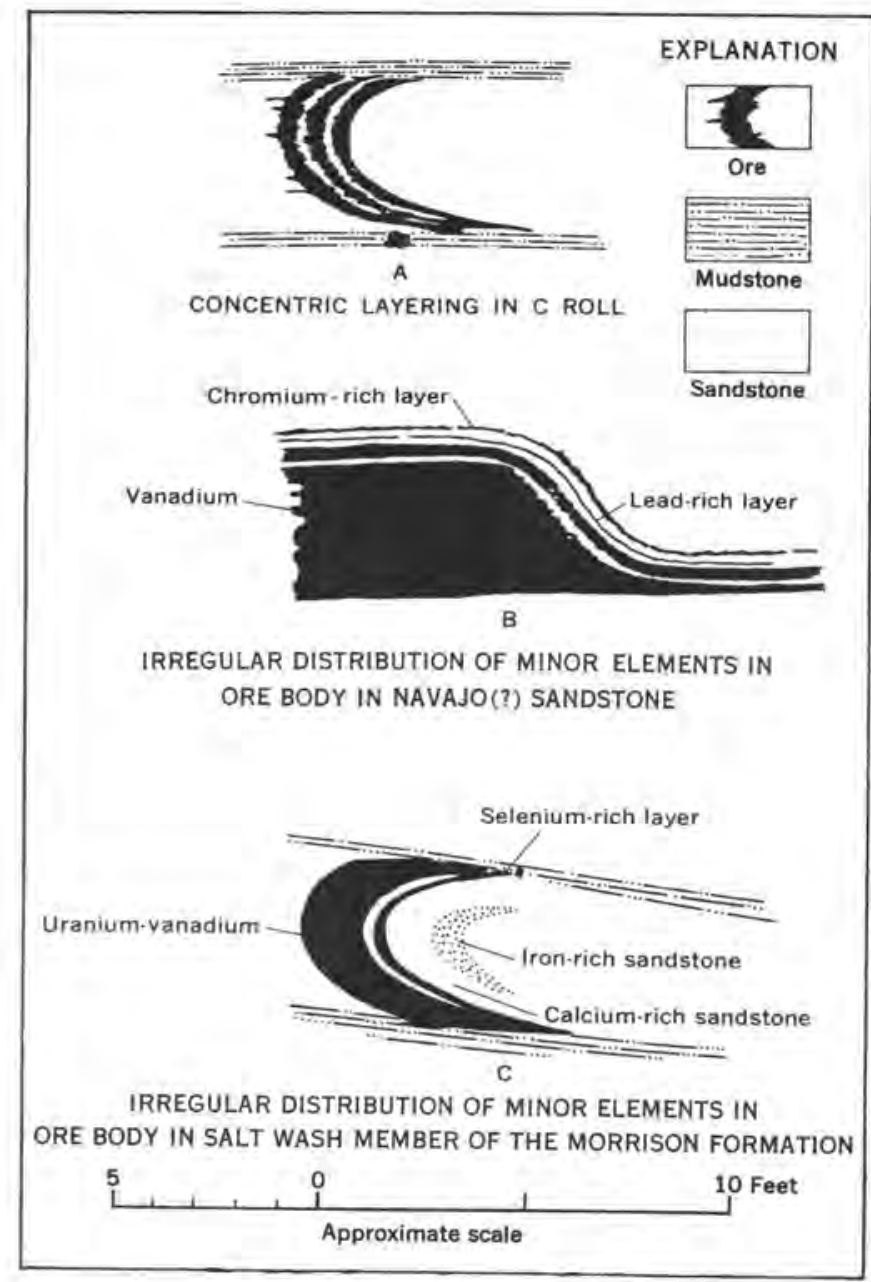

Frgure 56.-Detalls of roll ore bodies.

\section{ORIGIN}

A possible explanation of these features is that roll ore bodies were formed by precipitation of minerals at an interface between solutions of different composition and density, and that flow of the active or ore-bearing solution as it passed through connate waters in the sediments was influenced strongly by local sedimentary structures.

It is postulated that at the time of ore deposition warm-water solutions moved freely through many of the formations of the Colorado Plateau. The solutions moved through more permeable channels, altering and strongly leaching the sediments. Possibly uranium and vanadium as well as other elements were leached from the sedimentary rocks by solutions passing through them. As warm water moved through cooler connate water, well-defined solution pathways became established and interfaces between warm and cool water became fixed. It is further postulated that along these interfaces elements or ions in solution in the moving warm water were precipitated in the cooler surrounding water. According to this hypothesis, slight oscillation of the essentially static interfaces would account for the concentric layering in the deposits, and different response of various elements or ions to temperature and concentration differences across the interfaces would account for the asymmetric layering of minor elements in ore bodies. Active leaching continued within the areas of warm-water movement while ore deposition took place.

Roll ore bodies are thought to be localized where numerous thin mudstone layers divided a moving sheet of warm water and funneled it into many small channels with resultant sinuous roll fronts and the development of mirror-image rolls on the sides of the fingers of moving warm water. Permeable blocks such as carbonized logs have modified the configuration of roll fronts. Puncture points in thin mudstones permitted the orebearing solutions to move into overlying sandstone, thereby accounting for the absence of roll ore beyond, and for roll bulges above, these points. It is further postulated that tabular ore bodies were deposited at an interface between connate water and an overlying sheet of warm water essentially parallel to the bedding.

\section{REFERENCES CITED}

Fischer, R. P., 1942, Vanadium deposits of Colorado and Utah: U. S. Geol. Survey Bull. 936-P, p. 363-394.

Lowell, J. D., 1955, Applieation of eross-stratifieation studies to problems of uranium exploration, Chuska Mountains, Ariz.: Econ. Geology, v. 50, p. 177-185. 


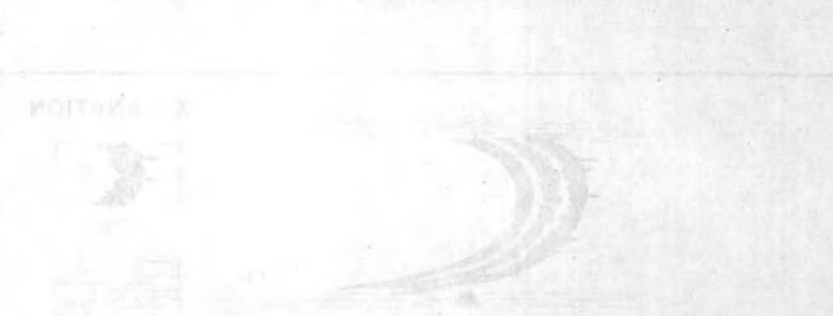

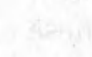

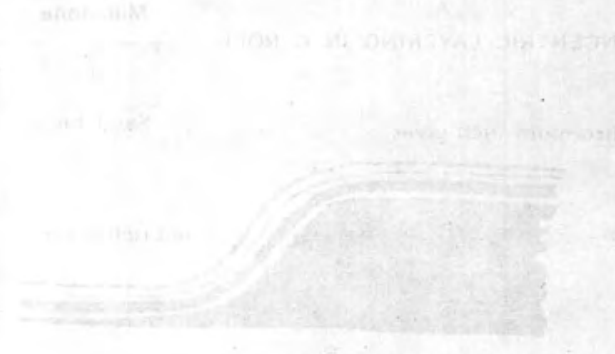

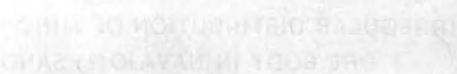
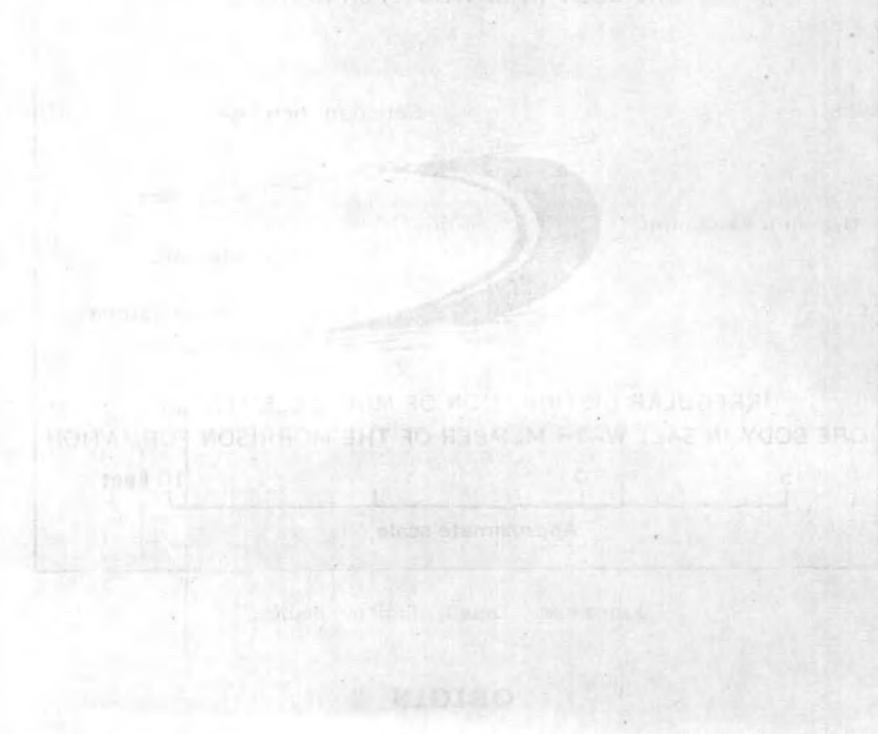

\section{.}

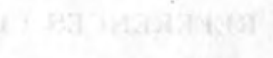
$621-77$ 


\title{
EXAMPLES OF URANIUM DEPOSITS IN THE UPPER JURASSIC MORRISON FORMATION OF THE COLORADO PLATEAU
}

\author{
By Philip H. Dodd, U. S, Atomic Energy Commission
}

\section{CONTENTS}

\begin{tabular}{|c|c|c|c|}
\hline & Page & & Page \\
\hline Introduction ............ & 244 & Hypothesis of ore controls & 261 \\
\hline 4B mine and vicinity & 245 & Summary & 261 \\
\hline 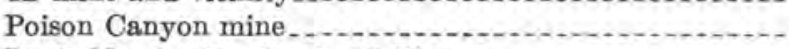 & 250 & References cited & 261 \\
\hline
\end{tabular}

\section{ILLUSTRATIONS}

Frgure 57. Location of mines studied, Morrison formation, Colorado Plateau...................

58. Isopach and facies map of Salt Wash sandstone member of the Morrison and facies map of Recapture shale member of the Morrison, Utah, Colorado, Arizona, and New Mexico .......................................

59. Geologic map showing ore deposits, ore trends, and sedimentary facies, Lukachukai Mountains, Apache County, Ariz

60. Lines of equal percent of sandstone of favorable color, AD sandstone unit, Mesa 41/2, Lukachukai Mountains, Apache County, Ariz.

61. Geologic map of $4 \mathrm{~B}$ mine and vicinity, Mesa 4312, Lukachukai Mountains, Apache County, Ariz

62. Sections showing distribution of uranium and associated carbonate, 4B mine, Mesa 41/2, Lukachukai Mountains, Apache County, Ariz

63. Ratios of vanadium oxide to uranium oxide, 4B mine locality, Mesa 41/2, Lukachukai Mountains, Apache County, Ariz.

64. Geologic map showing relation of ore bodies to the thickness of the so-called Poison Canyon sandstone and to faults, Poison Canyon and Mesa Top mines, MeKinley County, N. Mex
Page
244
245
246
247
248
249
251

Figure 65. Fence diagram of the upper part of the Morrison formation in the Poison Canyon area, McKinley County, N. Mex, and variations in grain size of sandstone unit of Brushy Basin member.

66. Ore distribution related to faults and fractures, Poison Canyon east pit, McKinley County, N. Mex

67. Structure-contour map on base of ore-bearing unit, Basin No. 1 mine, San Juan County, Utah

68. Isopach map of ore-bearing unit, Basin No. 1 mine, San Juan County, Utah..........

69. Map and sections of Basin No. 1 mine, Cottonwood Wash, San Juan County, Utah

Page

70. Isopach map showing thickness of altered mudstone below ore-bearing sandstone, Basin No, 1 mine, San Juan County, Utah.

71. Ratios of vanadium oxide to uranium oxide, Basin No. 1 mine, San Juan County, Utah.

72. Geologic map showing uranium deposits, Wedding Bell group of mines, Bull Canyon, Montrose and San Miguel Counties,

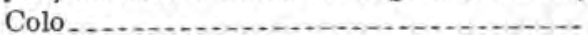

\section{ABSTRACT}

The 4B mine and vicinity, Poison Canyon mine, Basin No. 1 mine, and the area of the Wedding Bell group were chosen to illustrate common but controversial geologic features of deposits in the Morrison formation (Upper Jurassic) of the Colorado Plateau.

These are on the flanks of major regional structures, and the host beds dip from $1^{\circ}$ to $2 \frac{1}{\circ} 2^{\circ}$. Fractures are prominent in the $4 \mathrm{~B}$ and Poison Canyon mines but only slightly developed in the
Basin No. 1 mine and Wedding Bell group. Secondary minerals occur on fractures in the Poison Canyon deposit, and curved fractures bound ore rolls in the Wedding Bell group. Vertical fractures do not control ore in the $4 \mathrm{~B}$ or Basin No, 1 mines. Minor faults with associated fractures in the Poison Canyon mine displace the ore body, and increased grade and thickness is found adjacent to the faults; however, the Poison Canyon ore body is elongated along the trend of sedimentary struetures which is normal to the faults and fracturing. 
All deposits are in the channel facies of lenticular interbedded sandstone andmudstone. The host sandstone has been altered from light red to light gray or tan. The associated mudstone lenses also have been altered from red and brown to gray to bluegreen near ore bodies. Carbonate concentrations are associated with ore pods in the $4 \mathrm{~B}$ and Basin No. 1 mines.

The ore bodies are, with the exception of rolls, nearly concordant tabular disseminations of ore minerals filling interstices of sandstone. They have an irregular outline but are generally elongated parallel to the trend of sedimentary structures; a number of ore bodies, although irregularly spaced, may form rough groups along this trend.

The $4 \mathrm{~B}$ mine and Wedding Bell group are oxidized deposits containing high-valent uranium and vanadium minerals, and the Poison Canyon and Basin No. 1 mines contain low-valent ore minerals that are believed to be primary. The ratio of vanadium to uranium ranges from $0.5: 1$ in Poison Canyon to $40: 1$ in zones of the Basin No, 1 mine. Zoning of metal ratios is suggested in the $4 \mathrm{~B}$ area and Basin No. 1 mine.

Carbonaceous material is associated to some extent with all the ore bodies; some is replaced by ore minerals and some, although within the ore body, is not replaced.

The deposits are probably epigenetic. It is believed that pressure and temperature changes were unimportant in precipitation of the ore minerals. The facies change between fast- and slackwater fluvial sediment is believed to represent significant $\mathrm{pH}$ and Eh changes in environment which localized deposition. The deposits consequently display a preferred orientation and localization along the trends of channel lithofacies.

\section{INTRODUCTION}

The uranium deposits discussed below were chosen to illustrate geologic features which are common but whose importance is controversial. The selected de-

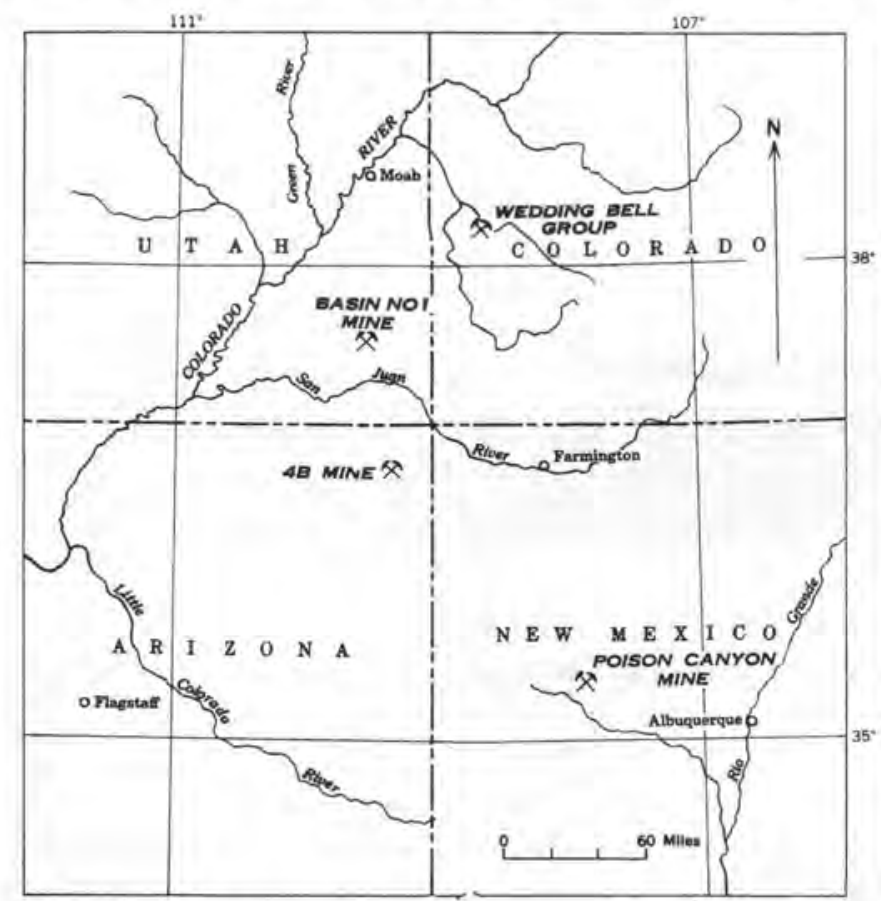

Figure 57.-Location of mines studied, Morrison formation, Colorado Plateau. posits are the $4 \mathrm{~B}$ mine and vicinity, Poison Canyon mine, Basin No. 1 mine (described by R. K. Pitman), and the area of the Wedding Bell group, all of which are in the Morrison formation of Jurassic age (fig. 57).

A test pit sunk by Thomas Talbert in 1881 is tne first recorded mining of Colorado Plateau uranium-vanadium deposits. By 1910, deposits had been discovered in many of the districts which are productive today. From 1910 to 1923 the deposits in the Morrison were mined for radium and vanadium. With lower cost vanadium in South America and high-grade pitchblende in the Belgian Congo, most of the properties were closed. A renewed demand in 1936 for vanadium opened the mines; production continued through 1945, recessed, then renewed in 1948 in response to the urgency for domestic production of uranium. Major discoveries of uranium deposits in other formations of the Colorado Plateau have not displaced the Morrison in importance, for it currently accounts for the largest production and reserves of uranium ore on the plateau.

Craig, Holmes, Cadigan, and others (1955) have defined the extent and lithofacies of the Upper Jurassic Morrison formation (fig. 58) and its four component members, all of which bear ore at various stratigraphic horizons. Controls localizing the ore deposits are imperfectly understood. No genetic connection between laccolithic intrusive bodies and the ore deposits has yet been established. Major tectonic structures such as faults, shear zones, and flexures have not been satisfactorily demonstrated as controls. Sedimentary structures, although they have limited regional control, do appear to influence the shape and local distribution of individual ore bodies. Sedimentary facies may make one locality more favorable than adjacent areas; interfaces between fast- and slack-water deposits and presence of abundant carbonaceous material are accepted factors related to ore localization. Empirical criteria of limited reliability for the recognition of zones favorable for exploration for ore bodies are light-tan and light-gray sandstone, green to gray alteration of adjacent mudstone, finely disseminated pyrite or limonitic alteration, and concentrations of coalified plant debris.

Epigenetic origin of the deposits is suggested by a number of factors: (1) Late Cretaceous or early Tertiary age, determined by studies of uranium and lead isotopes (Steiff and Stern, 1953); (2) occurrence in formations ranging in age from Pennsylvanian through Tertiary (Isachsen, Mitcham, and Wood, 1955); (3) deposits containing low-valent uranium and vanadium minerals not in equilibrium with the zone of oxidation; (4) replacement textures of ore in fossil wood and bone; and (5) corroded quartz sand grains. 

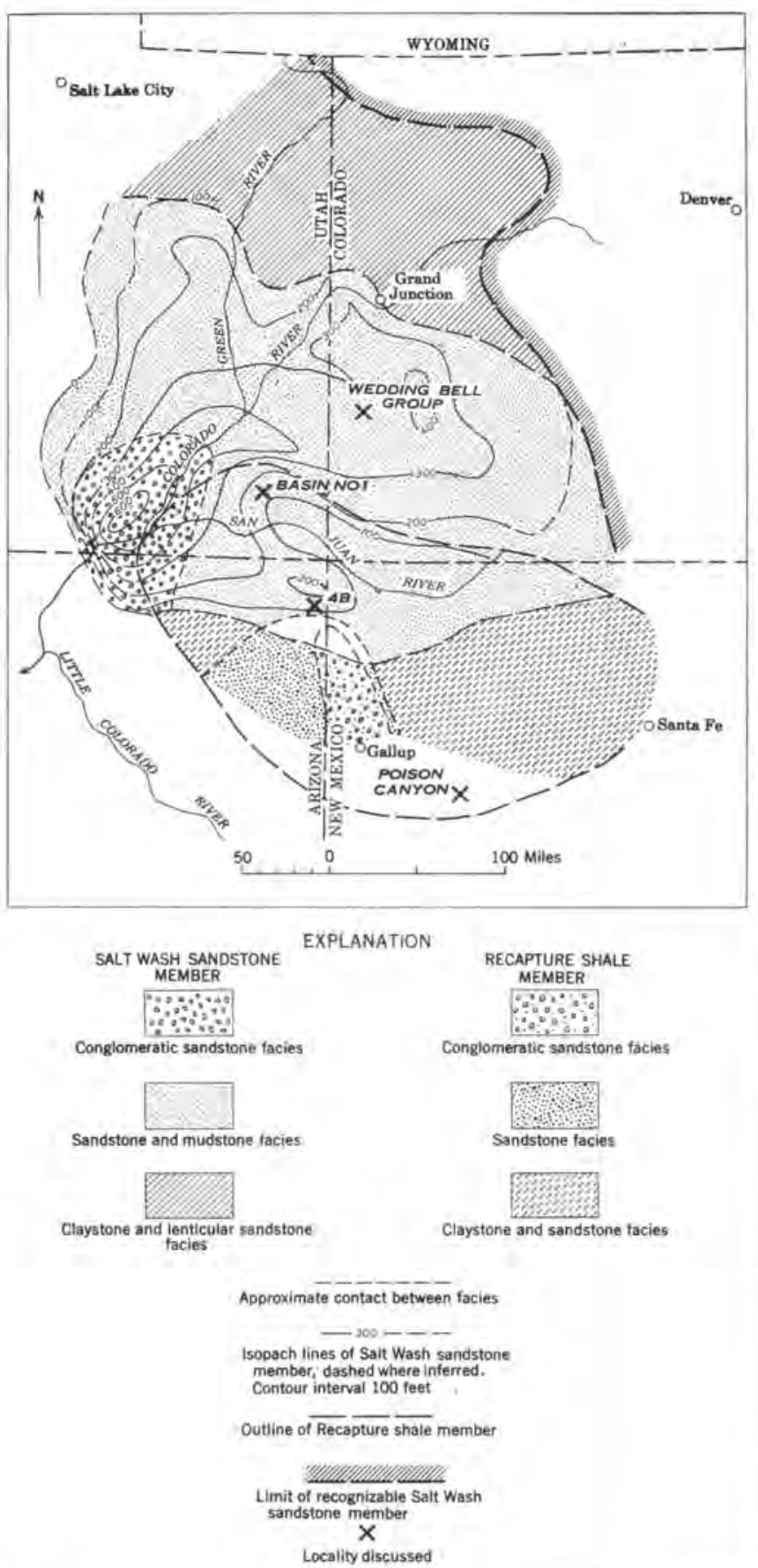

FIGURE 58.-Isopach and facies map of Salt Wash sandstone member of the Morrison and facies map of Recapture shale member of the Morrison, Utah, Colorado, Arizona, and New Mexico. (After Craig, Holmes, Oadigan, and others, 1955.)

\section{B MINE AND VICINITY}

The 4B mine (figs. 57, 59) is on Mesa 41/2 (Beam, in preparation; Masters, 1953) on the northeast flank of the Lukachukai Mountains, Apache County, northeastern Arizona. The mine was opened after exploratory drilling in 1951 and 1952.
Stratigraphy.-In the vicinity of the Lukachukai Mountains, 3,000 feet of fluviatile, lacustrine, and eolian sediments was deposited during the Triassic and Jurassic periods. These include the ore-bearing fluviatile deposits of the Salt Wash member of the Morrison formation of late Jurassic age. An additional 6,000 feet of marine and continental sediments was deposited before the Laramide deformation and subsequent erosion which stripped Cretaceous and early Tertiary rocks from the Lukachukai Mountains. The Pliocene(?) Chuska formation rests on the Laramide unconformity and is intruded by basalt.

Three facies of Salt Wash (fig. 59), representing different depositional environments, were mapped by Masters (1953). The Salt Wash member on the west end of the Lukachukai Mountains is composed of thick massive sandstone beds with relatively few mudstone lenses. This facies grades into an intermediate zone of interbeded lenticular sandstone and mudstone which in turn grades southeastward into a flood-plain facies of mudstone, siltstone, and occasional thin and discontinuous sandstone lenses.

Structure.-The northwestward plunging Lukachukai anticline dips $10^{\circ}-30^{\circ} \mathrm{SW}$., a reversal of the gentle $1 \frac{112^{\circ}}{}$ NE. dip of the Defiance uplift (fig. 59), This anticline, and the syncline which lies immediately to the south, are assumed to be of Laramide age.

Mesa $4 \frac{1}{2}$ is on the south flank of the syncline where the dip averages $11^{1}{ }^{\circ} \mathrm{NE}$. Structure mapping in several areas on the north side of the Lukachukai Mountains disclosed minor terraces, but none of these correlate with concentration of ore bodies.

Ore controls.-The ore bodies are confined to the zone of interbedded sandstone and mudstone which trends north to northeast across the mountains (fig. 59). Masters (1953) believes the calcium carbonate content of the member increases from west to east as does the abundance of observed carbonaceous plant fossils.

The ore deposits on Mesa 41/2 are restricted to lenticular light-gray or very-light-tan sandstone. In many places the ore bodies are adjacent to zones of barren light-red sandstone within the same lens (fig. 60, 61). Isopach maps and structure-contour maps drawn on the base of the ore-bearing unit demonstrate that the lightgray color coincides with areas of thick sandstone. The light gray may represent an alteration from red sandstone, a color change restricted to permeable zones and possibly related to ore introduction. On Mesa 41/2, as in other mining areas, the ore bodies occur as irregularly spaced, roughly alined groups (fig. 60). The individual bodies of ore are irregularly tabular and in many places are elongate parallel to the trend of sedimentary structures and to adjacent ore bodies (fig. 61). 


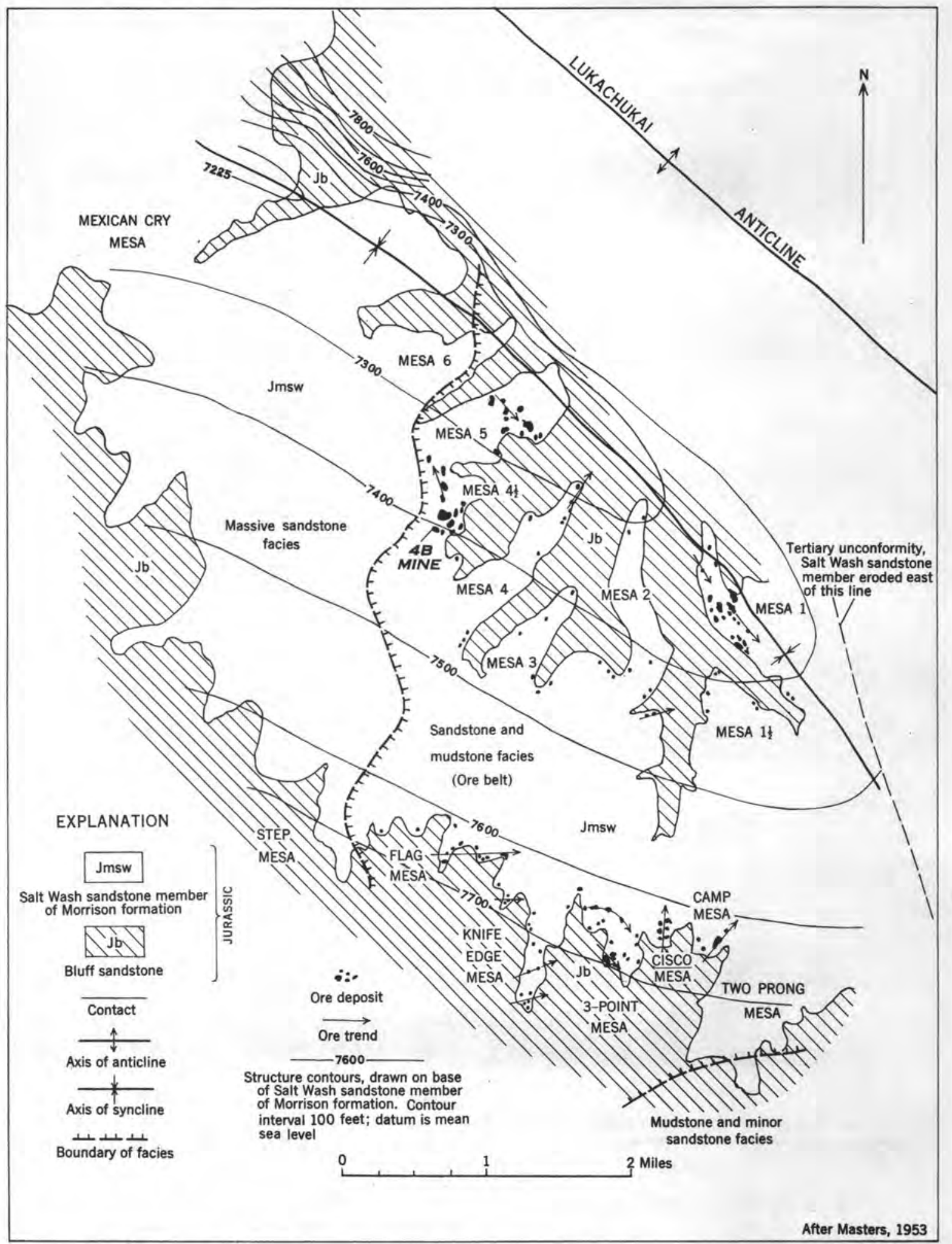

FigURE 59.-Geologio map showing ore deposits, ore trends, and sedimentary facies, Lukachukai Mountains, Apache County, Ariz.

Beam (in preparation) mapped fracture concentrations associated with ore bodies in the $4 \mathrm{~B}$ mine and 709 mine (fig. 61). He states that "fractures in ore are closelyspaced, well defined planes with nearly vertical dips.
Fractures in barren ground are wider spaced, poorly defined planes and have, generally, lower dips." Only a poor correlation between concentration of fractures and the distribution of ore bodies exists; all ore pods are not 
fractured and conversely all intensely fractured zones are not mineralized. Cross sections of the generally flat and tabular ore bodies (fig. 62) fail to indicate a vertical distribution of ore that might be expected if it were intimately controlled by concentrations of vertical fractures.

Beam believes zones of carbonate-impregnated sandstone are associated with the ore. The carbonate

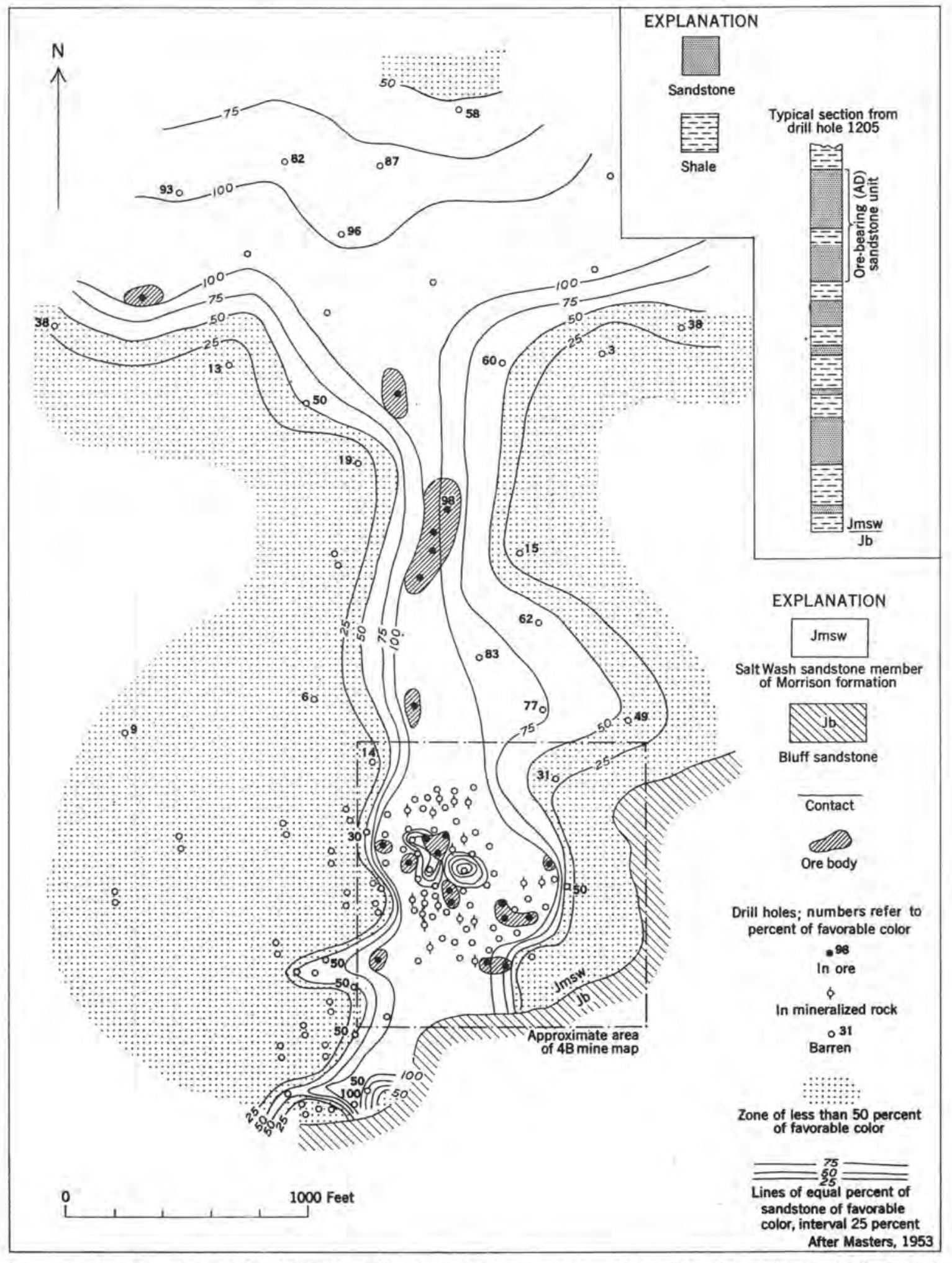

Ftoure 60.-Lines of equal percent of sandstone of favorable color, AD sandstone unit, Mesa 41/2, Lukachukat Mountains, Apache County, Arix. 


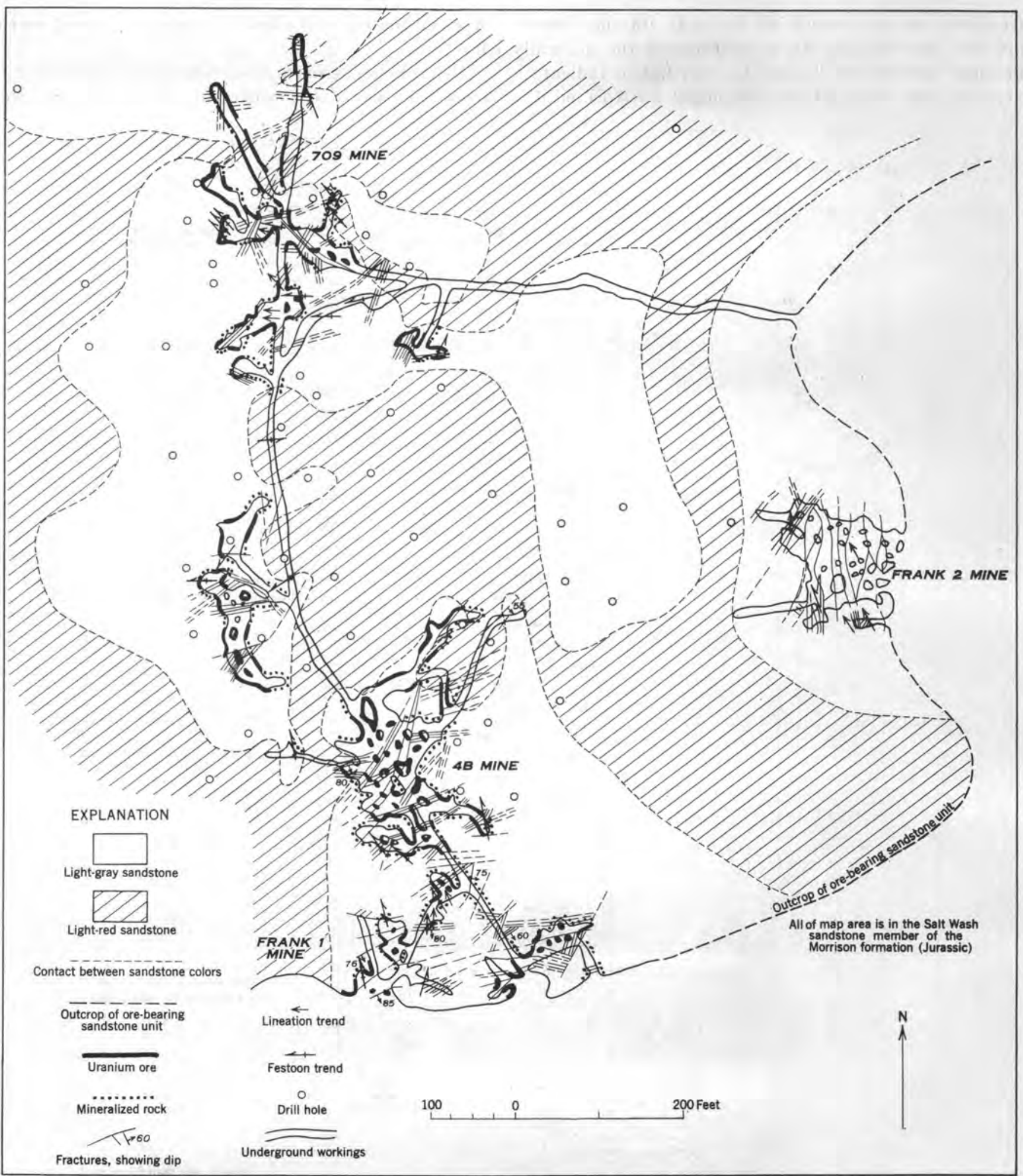

F1GURE 61.-Geologic map of 4B mine and vicinity, Mesa 413/2, Lukachukai Mountains, Apache County, Ariz.

bodies are flat tabular masses a few inches to 6 feet in $/$ colorless to red and black calcite, probably due to a thickness and as much as 160 feet long. They generally parallel the bedding but in detail may be discordant. The carbonate ranges from relatively pure, nearly mixture of iron, manganese, and vanadium oxides; some of the carbonate may be ankerite and siderite. The carbonate is interstitial to sand grains which are 


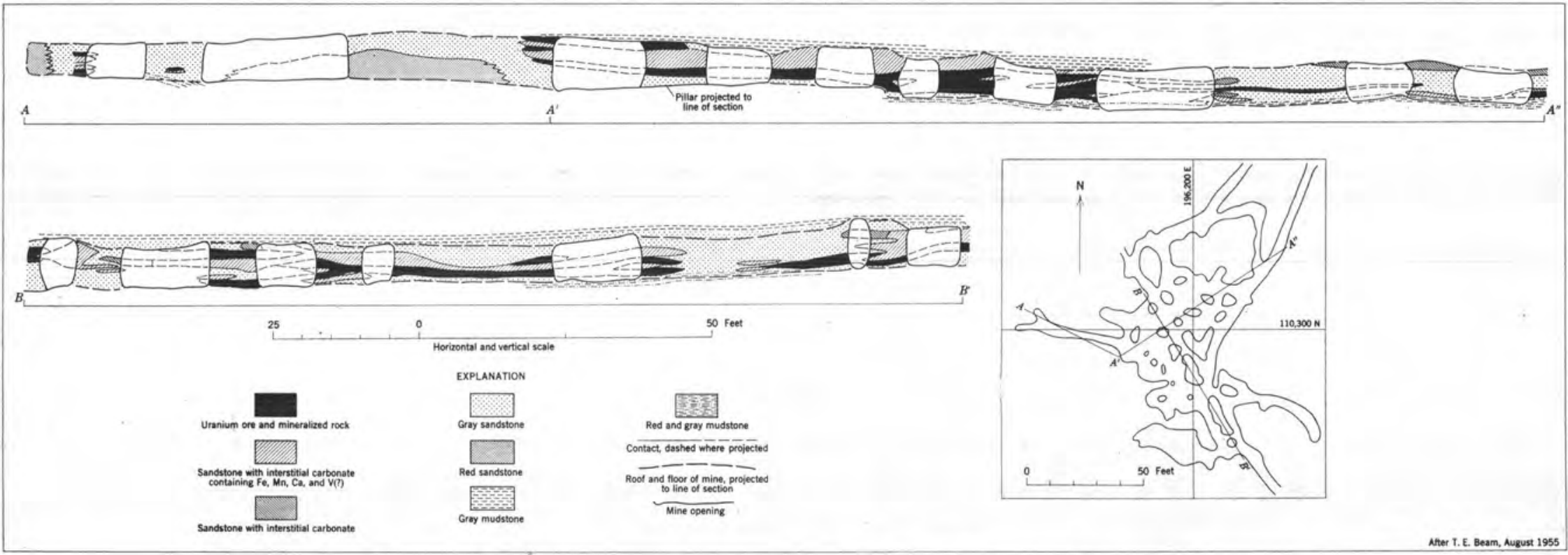

FIGURE 62.-Sections showing distribution of uranium and associated carbonate, 4B mine, Mesa 4B, Lukachukai Mountains, Apache County, Ariz. 
slightly corroded. Masses of carbonate 1-10 inches across form a poikiloblastic texture. Ore appears to be nearly always in contact with carbonate-rich zones that either overlie or underlie it.

Mineralogy.-Mineralogical study of the $4 \mathrm{~B}$ mine is still in progress, and available data allow only generalizations. The ore is mostly oxidized, and the following oxidized ore minerals have been identified: metatyuyamunite, pascoite, melanovanadite, hummerite, rossite, and metarossite (Gruner, Gardiner, and Smith, 1954). Traces of uraninite have been tentatively identified as partial replacement of fragments of carbonaceous material. Probably the ores before oxidation were of the uraninite-montroseite type. Fine-grained hematite and goethite are abundant, in many places as pseudomorphs after pyrite, and as earthy coatings of mudstone galls.

The average ratio of vanadium to uranium on Mesa One is $2: 1$, and the average on Mesa Five is $7: 1$. The average vanadium:uranium ratio of samples taken from drill cores on Mesa $4 \frac{1}{2}$ in the vicinity of the $4 \mathrm{~B}$ mine is $5.2: 1$. The ratios of the metals indicate that there is a tendency toward vertical zoning on Mesa 41\%2. Cross sections by Crew and Lowell (written communication) illustrate a slight stratigraphic spread of ore deposits

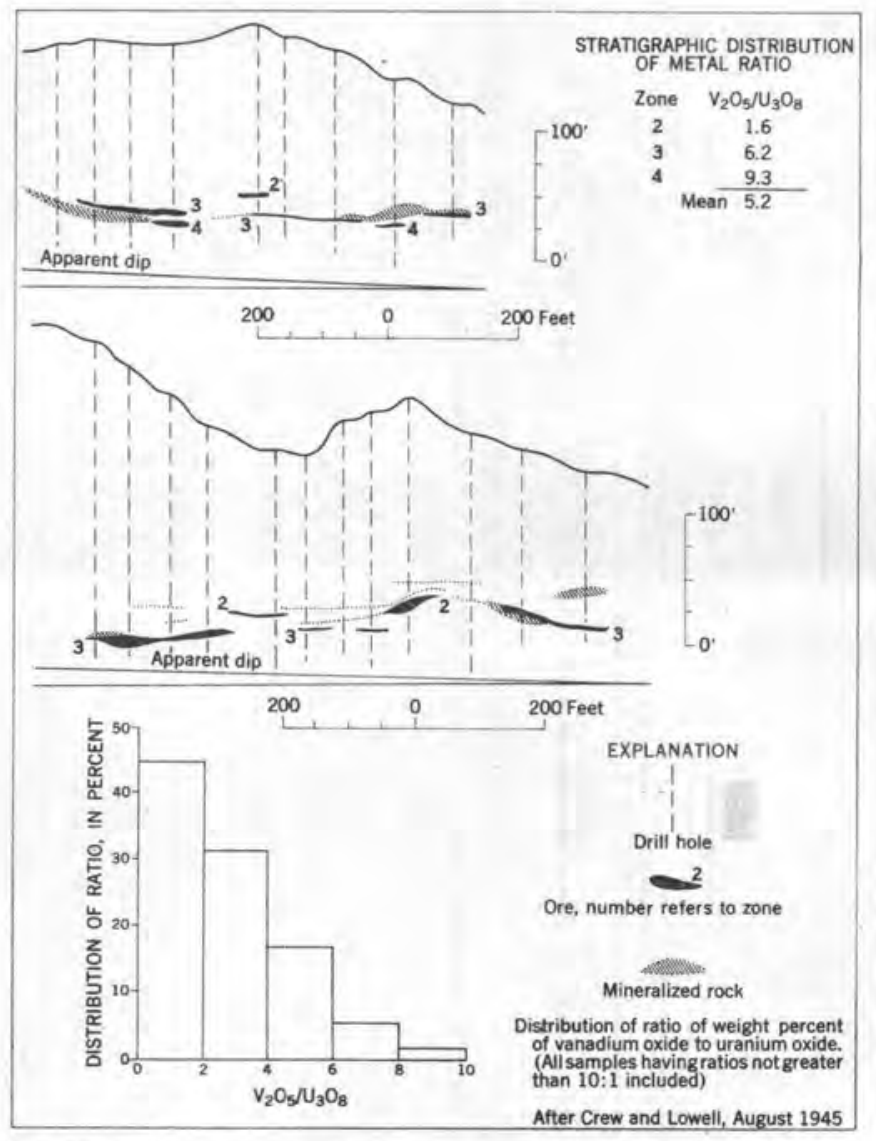

FioURe 63.-Ratios of vanadium oxide to uranium oxide, 4B mine locality, Mesa 4132, Lukachukai Mountains, Apache County, Ariz. within the same general ore-bearing unit (fig. 63). Using the zones delineated by them it is found that the upper (no. 2) zone has a vanadium:uranium ratio of $1.6: 1$, the middle (no. 3) zone has a ratio of $6.2: 1$ and the lower (no. 4) zone has a ratio of $9.3: 1$. It is not known whether this zoning is a primary or a secondary feature. The histogram in figure 63 demonstrates that although the arithmetic mean of the metals ratios for Mesa $4 \frac{1}{2}$ is $5.2: 1,45$ percent of the samples had ratios of less than $2: 1$. This may more nearly represent ratios of the metals in the primary unoxidized ore.

\section{POISON CANYON MINE}

The Poison Canyon mine is in southern McKinley County, N. Mex., about 10 miles north of the town of Grants.

Regional stratigraphy.-Commercial uranium deposits are located in the Todilto limestone, Morrison formation, and Dakota sandstone on the northeast flank of the Zuni uplift, which extends 55 miles between Grants and Gallup, N. Mex. The flanks of the Precambrian core of the Zuni uplift are successively overlain by the Abo, Yeso, and San Andres formations of Permian age; the Chinle formation and Wingate sandstone of Triassic age; the Carmel formation, Entrada sandstone, Todilto limestone, Summerville formation, Bluff sandstone, and Morrison formation of Jurassic age; and the Dakota sandstone, Mancos shale, and Mesaverde group of Cretaceous age (T. A. Konigsmark, written communication). Three members of the Morrison formation are recognized: the basal Recapture member, Westwater Canyon member (ore bearing), and the Brushy Basin member (ore bearing).

Regional structure.-The Zuni uplift is a broad northwestward-trending anticline on the south edge of the San Juan Basin. The sedimentary rocks of the northeast flank generally dip $1^{\circ}-10^{\circ}$ north and northeast. Subsidiary folds are related to faults either as drag folds or as monoclines reflecting faults in the crystalline basement (Baker, 1935). The Bluewater fault west of Poison Canyon strikes west of north, is vertical, and has a displacement of 570 feet; lesser faults have a similar trend. Sets of joints are vertical and the major sets parallel fault directions. Gilkey (1953) concluded that the fracture pattern of the Zuni uplift would develop from uplift rather than by lateral compression. The major tectonic activity is post-Dakota and preMiocene.

Local stratigraphy and petrology.-The Poison Canyon deposit is in a thick sandstone unit near the base of the Brushy Basin member. It is separated from the underlying Westwater Canyon member by about 20 feet of pale-blue-green mudstone. The sandstone unit appears to represent continued deposition by a stream, 
which built up multiple lenses of coarse clastic rocks interbedded with minor seams of mudstone and conglomerate, and zones of mudstone galls. This sandstone unit is 45 feet thick near the mine, but thins southeastward and grades northwestward into a thinner silty unit (figs. 64,65). Near the mine the sandstone is medium to coarse grained; it becomes increasingly finer grained to the southeast and northwest. The sand grains at the mine range from 4 to $1 / 16$ millimeter in diameter and are mostly subround. Average composition of the sandstone is 48 percent quartz, 39 percent microcline, 7 percent plagioclase,
6 percent limonite cement and ore and other minerals. Cross bedding and lineations indicate deposition in east-northeastward-flowing streams. Coalified fossil plant and fossil bone fragments are common in the ore-bearing sandstone. The Mesa Top mine (fig. 64) is also located in the thicker portion of the eastward extension along the sedimentary-structure trend of the sandstone unit containing the Poison Canyon mine.

Local structure.-The dip adjacent to the Poison Canyon mine is $2^{\circ} \mathrm{N}$. No major fault intersects the mine, but a series of minor faults with displacements of 2-12 feet strike west of north and dip $65^{\circ}-75^{\circ}$ both

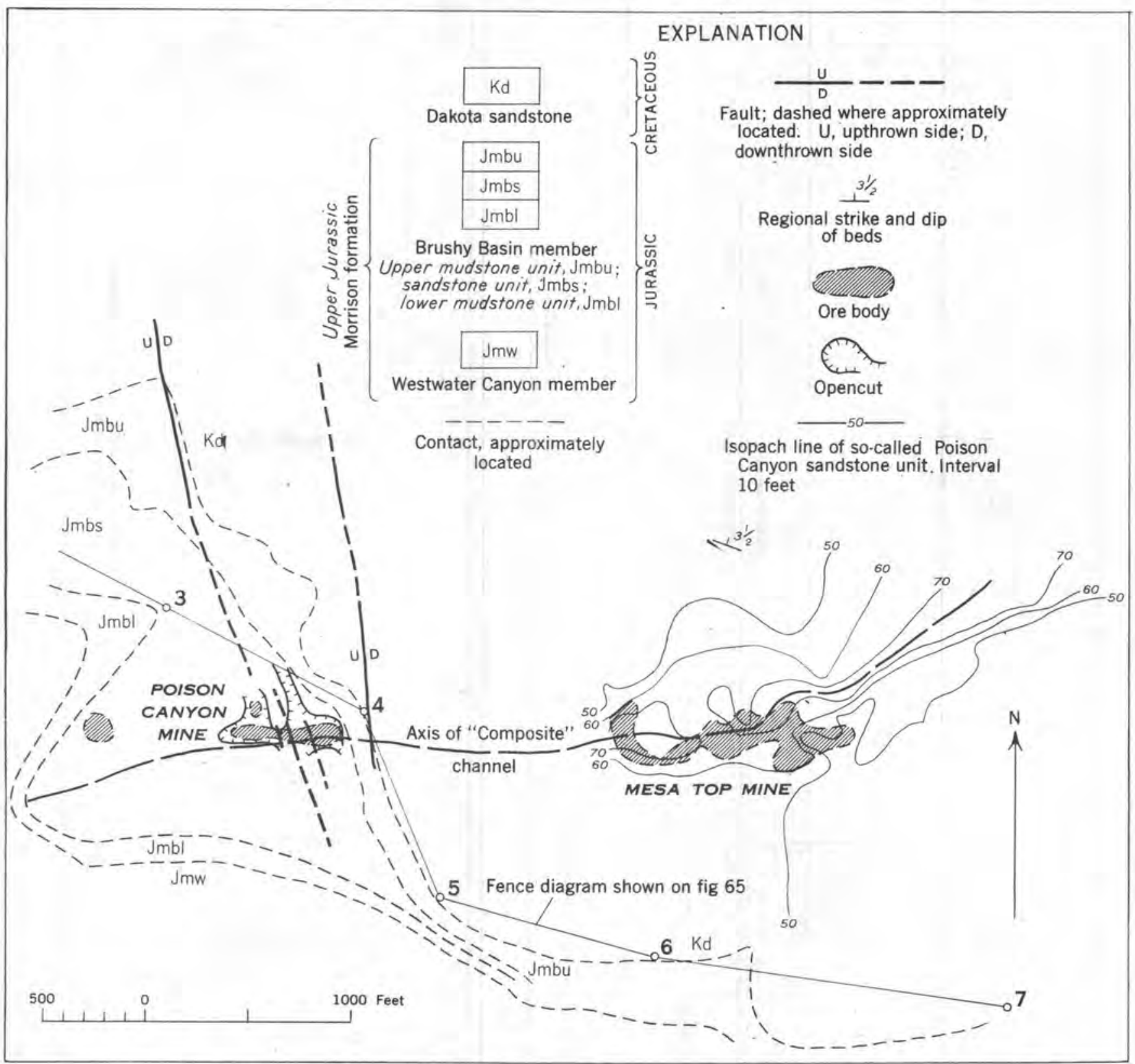

Froure 64.-Geologic map showing relation of ore bodies to the thickness of the so-called Poison Canyon sandstone and to faults, Poison Canyon and Mesa Top mines, MeKinley County, N. Mex. 


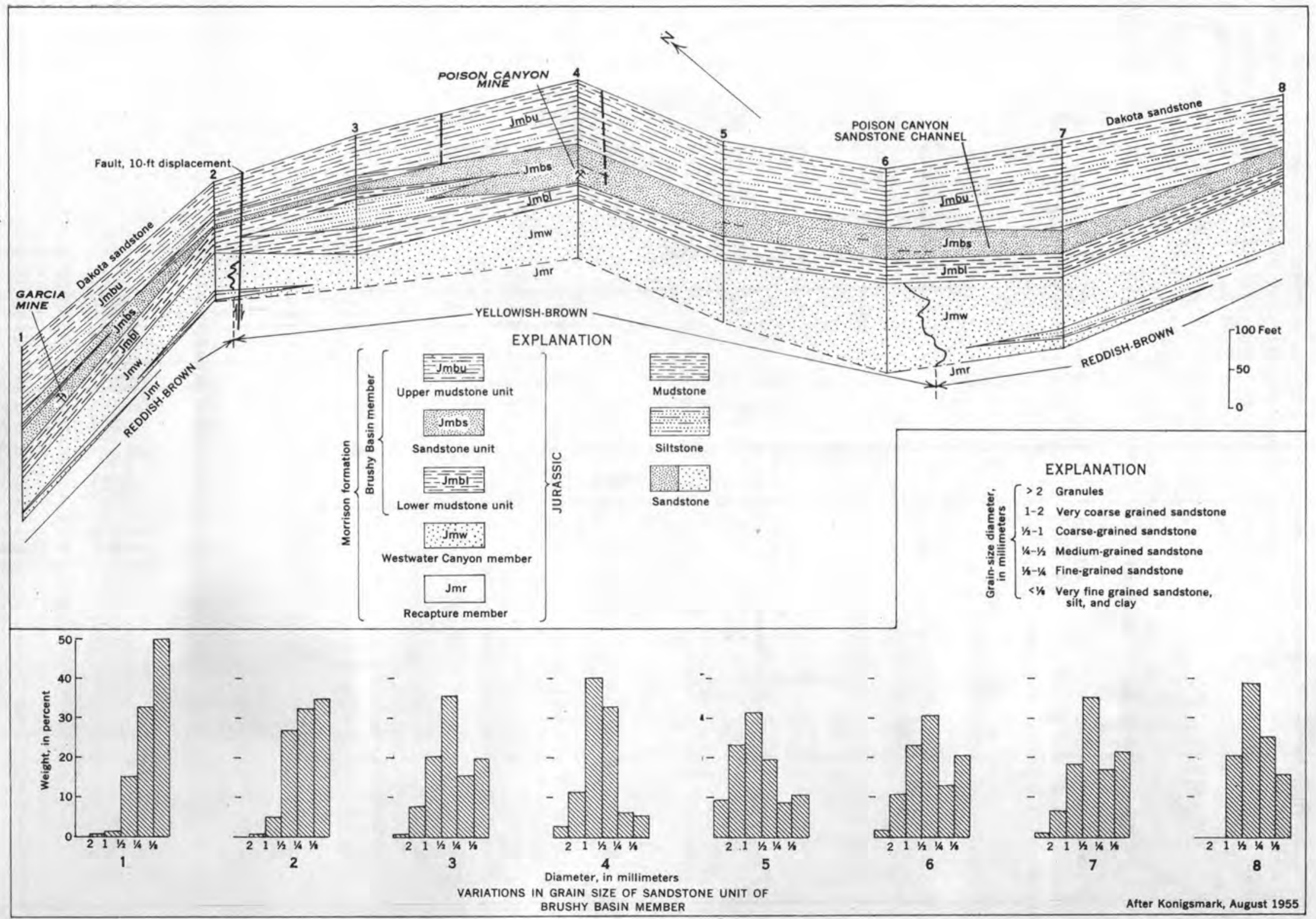


east and west. Fracture zones appear to be related to the faults and have a smilar strike and dip.

Ore controls.-The body is elongate along the trend of sedimentary structures and is localized in the central thick coarse-grained portion of the sandstone unit. The ore body is cut by faults and fractures intersecting it nearly normal to the long axis and is slightly offset vertically across the faults (fig. 66). This might suggest that the faults were postmineralization and had no influence on localization. However, Konigsmark (written communication) has stated that grade and thickness of ore increases adjacent to the faults, indicating an influence on localization. Only secondary minerals are found on fault and fracture surfaces.

Some coalified plant fragments and some fossil bones in otherwise barren sandstone above the ore are uranium bearing. Most ore-impregnated sandstone is within a few feet above the mudstone which underlies the so-called Poison Canyon sandstone.

Minerology.-Ore in the Poison Canyon mine is classed as uranium-low vanadium; the ratio of vanadium to uranium averages $0.5: 1$. The primary vanadium mineral has not been identified. Except for secondary minerals on fracture surfaces the ore is generally unoxidized.

The primary uranium mineral, coffinite (Gruner, Gardiner, and Smith, 1954), is intimately associated with a black carbonaceous material, tentatively called asphaltite, which impregnates the sandstone of the ore body.

Metatyuyamunite, believed to be secondary, is observed as yellow halos in the sandstone around coffinite and along fractures cutting or adjacent to the ore body. Meta-autunite occurs as fine plates on fracture surfaces.

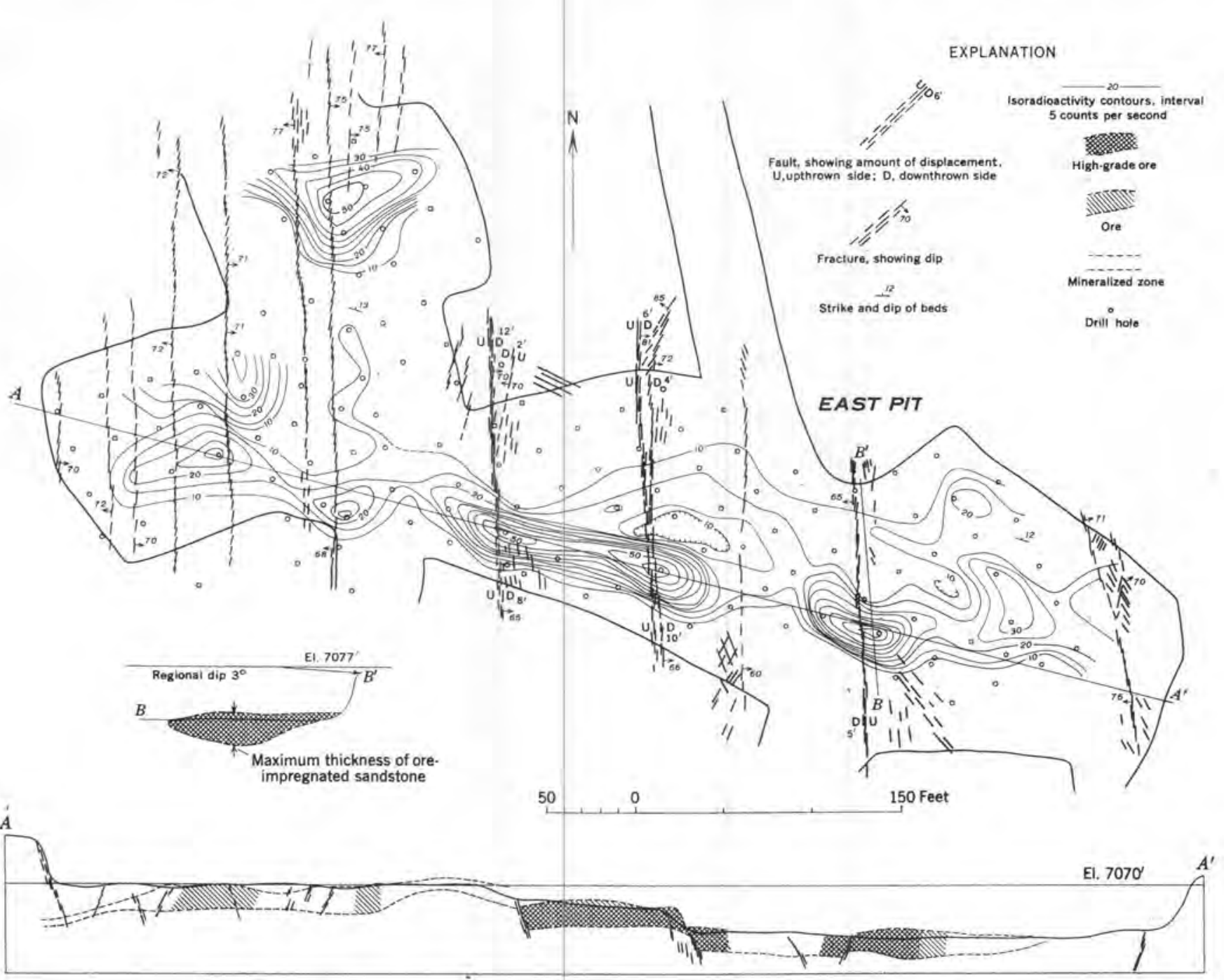

Figure 66.-Ore distribution related to faults and fractures, Poison Canyon east pit, MeKinley County, N. Mex. 
Pyrite is fine grained but abundant in the black ore. Traces of galena have been noted.

\section{BASIN NO. 1 MINE}

By R. K. Pitman

The Basin No. 1 mine is in the Cottonwood Wash mining district approximately 13 miles west of Blanding, San Juan County, Utah. Vanadium-uranium deposits were discovered in the area in 1930, and the Basin No. 1 mine was developed as a result of an exploration drilling program in 1951.

Stratigraphy.-Formations exposed in the district range from the Jurassic and Jurassic(?) Navajo sandstone to the Upper Cretaceous Mancos shale. The Jurassic Morrison formation, which contans the uranium deposits, is subdivided into the Salt Wash member (210 feet thick), the Westwater Canyon member (150 feet thick), and the Brushy Basin member (400 feet thick). All major ore deposits are contained in the upper portion of the Salt Wash member.

Only upper beds of the Salt Wash member are exposed in the mining area. Here the Salt Wash consists of fluviatile channel sandstone facies interbedded with marginal mudstone facies typical of flood plains. These have a general eastward trend which agrees with the regional depositional pattern for Salt Wash streams (Craig, Holmes, Cadigan, and others, 1955).

The Salt Wash sandstone member is normally fine to medium grained and is mostly well sorted. The color is commonly light gray to buff, but may be a very light red. Subangular quartz grains are the major constituent, with minor amounts of salmon-colored chert, feldspar, and traces of heavy minerals. Calcite is a common cementing material in the sandstone. The mudstone and siltstone colors range from dark red and brown to greenish gray, and in many places the light-colored mudstones appear to have been altered from originally darker colored rocks.

Coalified plant remains are commonly found in the Salt Wash member along the marginal zones of channel sediments. Remains of large trees are common in some of the mines of the area, but in the Basin No. 1 mine these have been so flattened that they appear as carbonaceous layers.

Structure.-The Cottonwood area is on the east flank of the Comb monocline where the eastward dip of the sedimentary rocks changes from $6^{\circ}, 2$ miles west of the Basin No. 1 mine, to approximately $1^{\circ}$ near the mine.

Economic geology.-Subsurface mapping from drill cores adjacent to the Basin No. 1 mine shows that the ore body is in an area of rapid change from a channel to a flood-plain lithofacies (Pitman, Dodd, and Tom, this volume). Structure contours on the base of the ore-bearing sandstone indicate that a very shallow scour is in close alinement with the thickest part of the ore body (fig. 67). This evidence is supported by an isopach map which shows that the thickest part of the ore-bearing unit alines very well with the scour (fig. 68).

Underground mapping of the ore body also indicates that greatest thickness coincides with the stream channel fill. The directions indicated by the few lineation features and intrachannel scours noted underground in the ore sandstone substantiate the trend of the channel as determined by drilling (fig. 69). All the ore bodies do not occur at the base of the sandstone but are irregular tabular bodies at slightly different horizons in the same sandstone unit and are generally adjacent to thin mudstone beds or layers of clay galls.

Many ore lenses were found to terminate in the vicinity of mudstone seams and clay galls. Individual lenses terminate abruptly, and although the ore is mostly concordant with bedding, it may become sharply discordant over limited areas (fig. 69). Interstitial calcite occurs as cement in the sandstone in many places di. rectly below the ore and in a few places above it.

Alteration of the red or brown mudstones and siltstones to gray-green in the vicinity of uranium deposits is a common phenomenon on the Colorado Plateau (Weir, 1952). However, in this deposit the distribution of alteration does not consistently correspond with the thickest part of the ore body. Figure 70 was constructed by contouring the thickness of altered mudstone below the ore-bearing sandstone; on this was superimposed the outline of the mine workings. An area with no alteration was found direetly below the central part of the deposit. Thus, there is a general correlation between altered mudstone and the proximity of ore, but no direct correlation between amount of alteration and ore grade or thickness.

Mineralogy.-The Basin No. 1 deposit is below the water table and contains uranium and vanadium minerals of low oxidation state which are considered to be primary (Garrels, 1955). This is in contrast to the other mines in the Cottonwood district which, with one exception, are above the water table and contain only secondary uranium and vanadium minerals.

Uraninite replacing the cell walls in coalified plant remains has been identified. A polished section showed such a specimen to consist of alternating irregular bands of shiny and dull black material. The shiny bands, probably asphaltite, contain no uranium. In contrast, the dull black bands with a deformed wood structure still apparent contain uraninite as minute streaks within the former cell walls. Metatyuyamunite has been identified as wall coatings in the mines. Vanadium occurs as a very fine granular black mineral tentatively identified as montroseite. In adjacent 
EXAMPLES OF URANIUM DEPOSITS, MORRISON FORMATION, COLORADO PLATEAU

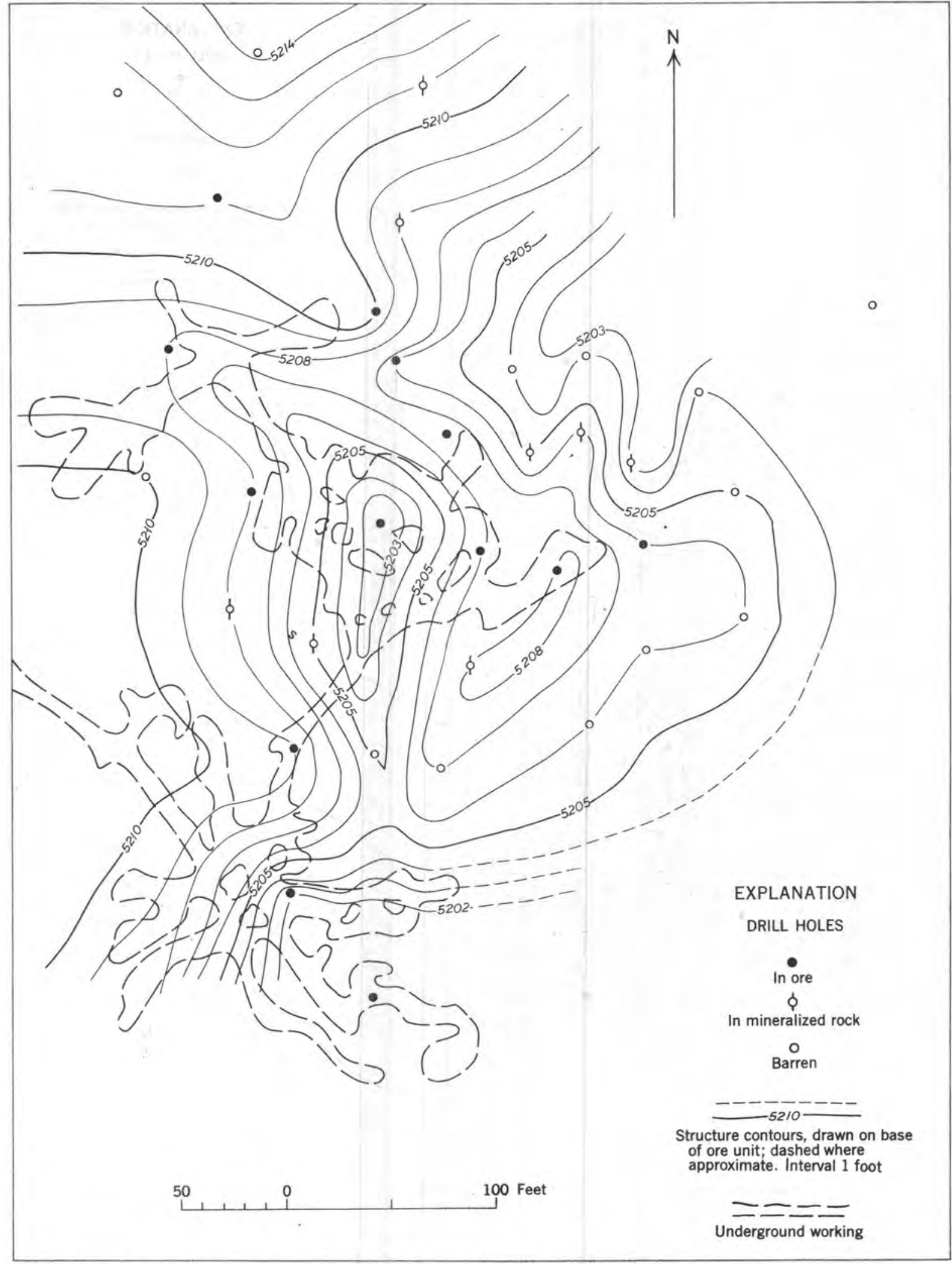

Figure 67.-Structure-contour map on base of ore-bearing unit, Basin No. 1 mine, San Juan County, Utah. 


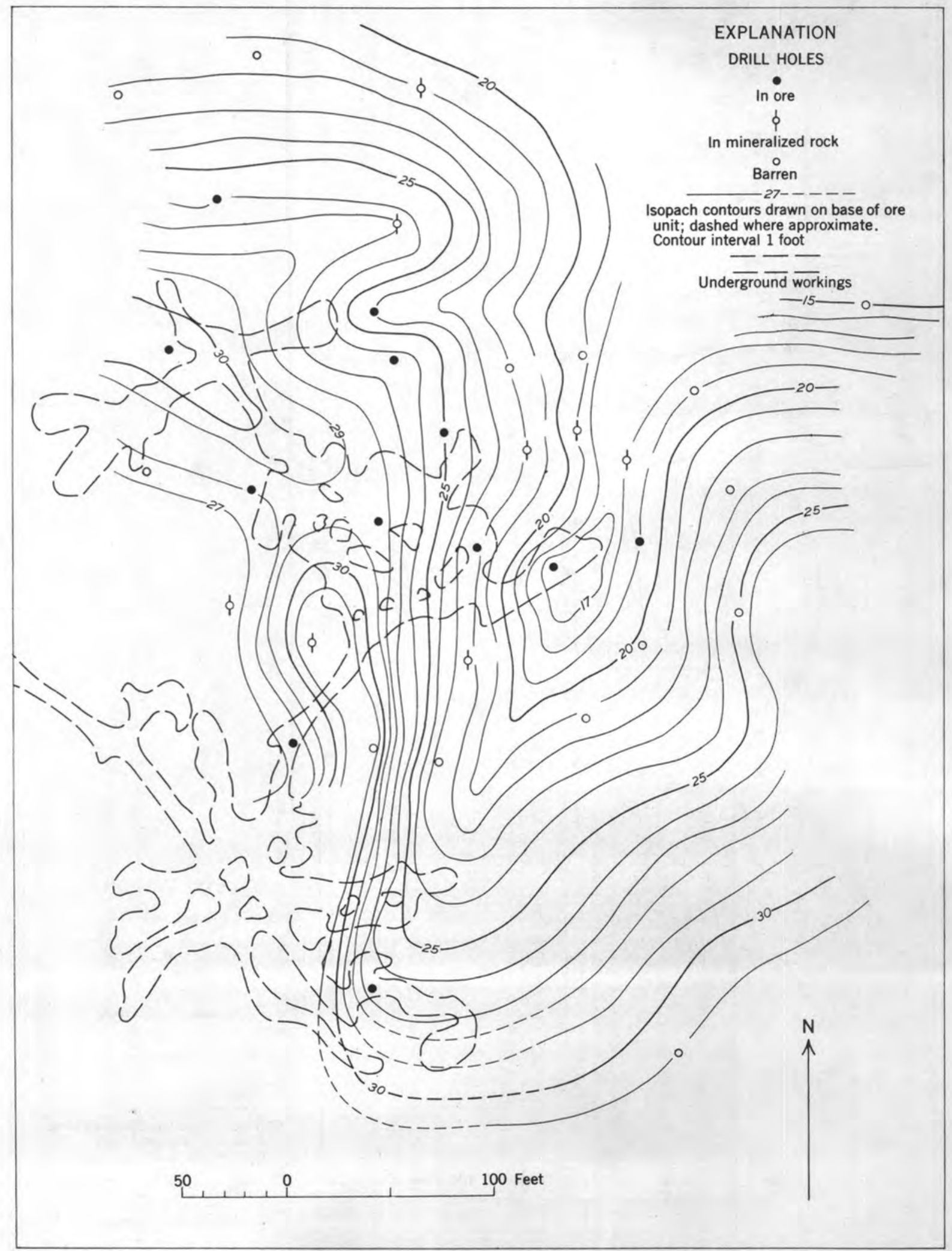

Figure 68.-Isopach map of ore-bearing unit, Basin No. 1 mine, San Juan County, Utah. 


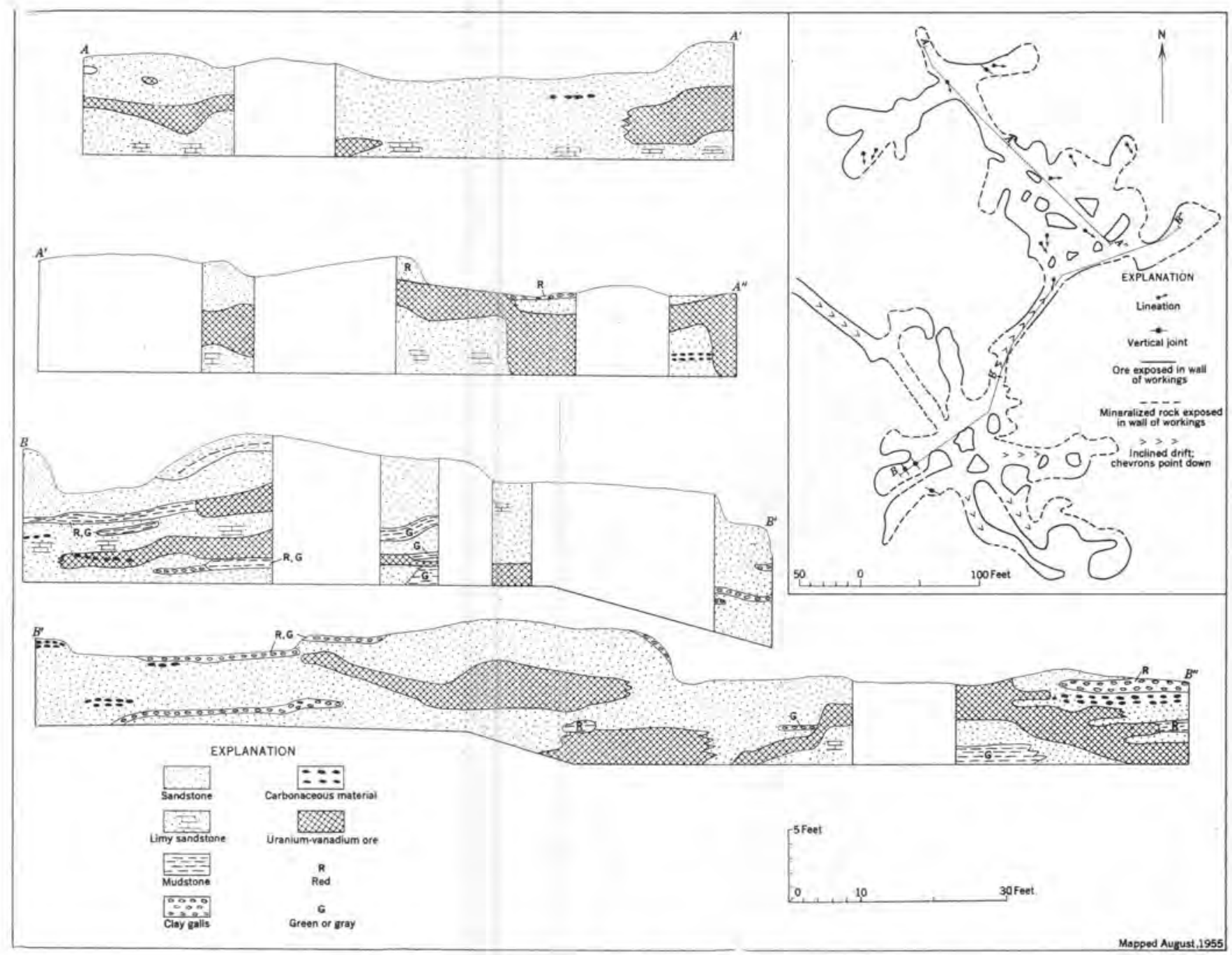

Figure 69.-Map and sections of Basin No. 1 mine, Cottonwood Wash, San Juan County, Utah.

mines corvusite, pascoite, and metarossite are recognized. The ore deposits of the district, classed as high vanadium, have a vanadium : uranium ratio of 10:1. The ratio in the Basin No. 1 mine ranges from $5: 1$ to $40: 1$ and has a zonal arrangement. In the northern ore lens the vanadium: uranium ratio is approximately 5:1 near the center and increases outward to more than 20:1 near the perimeter (fig. 71). In contrast, the ratio is low on the perimeter of the southern and central ore lenses but increases near the center of the deposits. Traces of galena have been identified in the ore.

\section{WEDDING BELL GROUP OF MINES}

The Wedding Bell group of mines is in Bull Canyon, Montrose and San Miguel Counties, Colo. Production of vanadium from the Bull Canyon area began during World War I. The present phase of uranium mining began in 1948. Details of geology of the $385115-56-18$
Wedding Bell group of mines are taken largely from Dickson, Blair, Hart, and others (1955).

Structures.-The Wedding Bell group of mines is on the northern flank of the northwestward-trending Gypsum Valley anticline (a salt structure). Twentyfive miles to the northwest are the laccolithic La Sal Mountains.

Sedimentary rocks in the Wedding Bell group strike N. $55^{\circ} \mathrm{W}$. and $\operatorname{dip} 2 \frac{1}{2}{ }^{\circ} \mathrm{NE}$. Fracturing is restricted to vertical longitudinal and transverse tension joints (fig. 72) related to the northwestward-trending salt anticline and to less common eastward-trending curved joints.

Stratigraphy and sedimentation.--Sedimentary rocks ranging in age from the Triassic Chinle formation to the Cretaceous Dakota sandstone are exposed in the area. Uranium-vanadium mineralization in the Wedding Bell group is restricted to the Salt Wash member of the Morrison formation, which is 405 feet thick and 


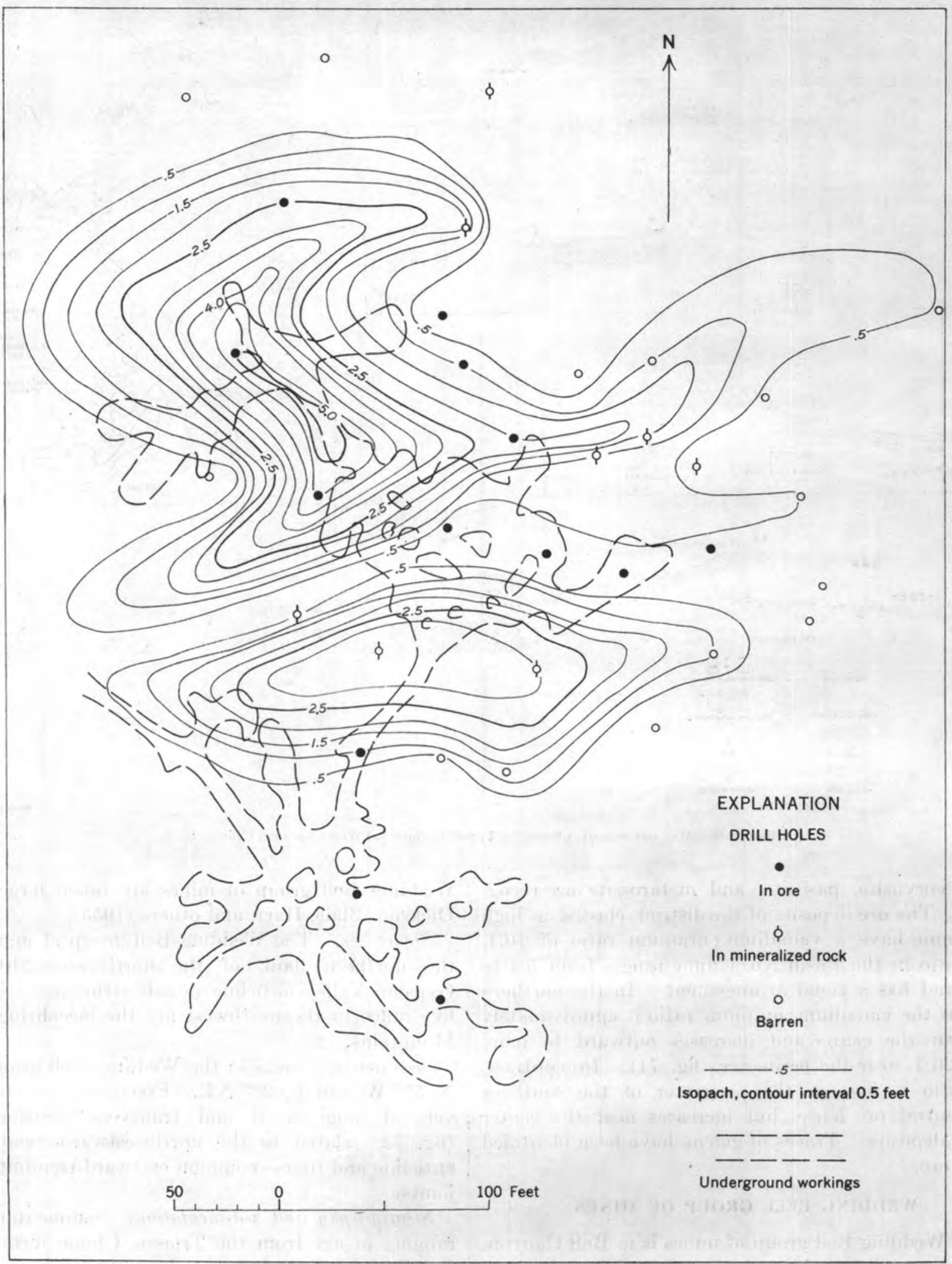

FIGURE 70.-Isopach map showing thickness of altered mudstone below ore-bearing sandstone, Basin No. 1 mine, San Juan County, Utah. 


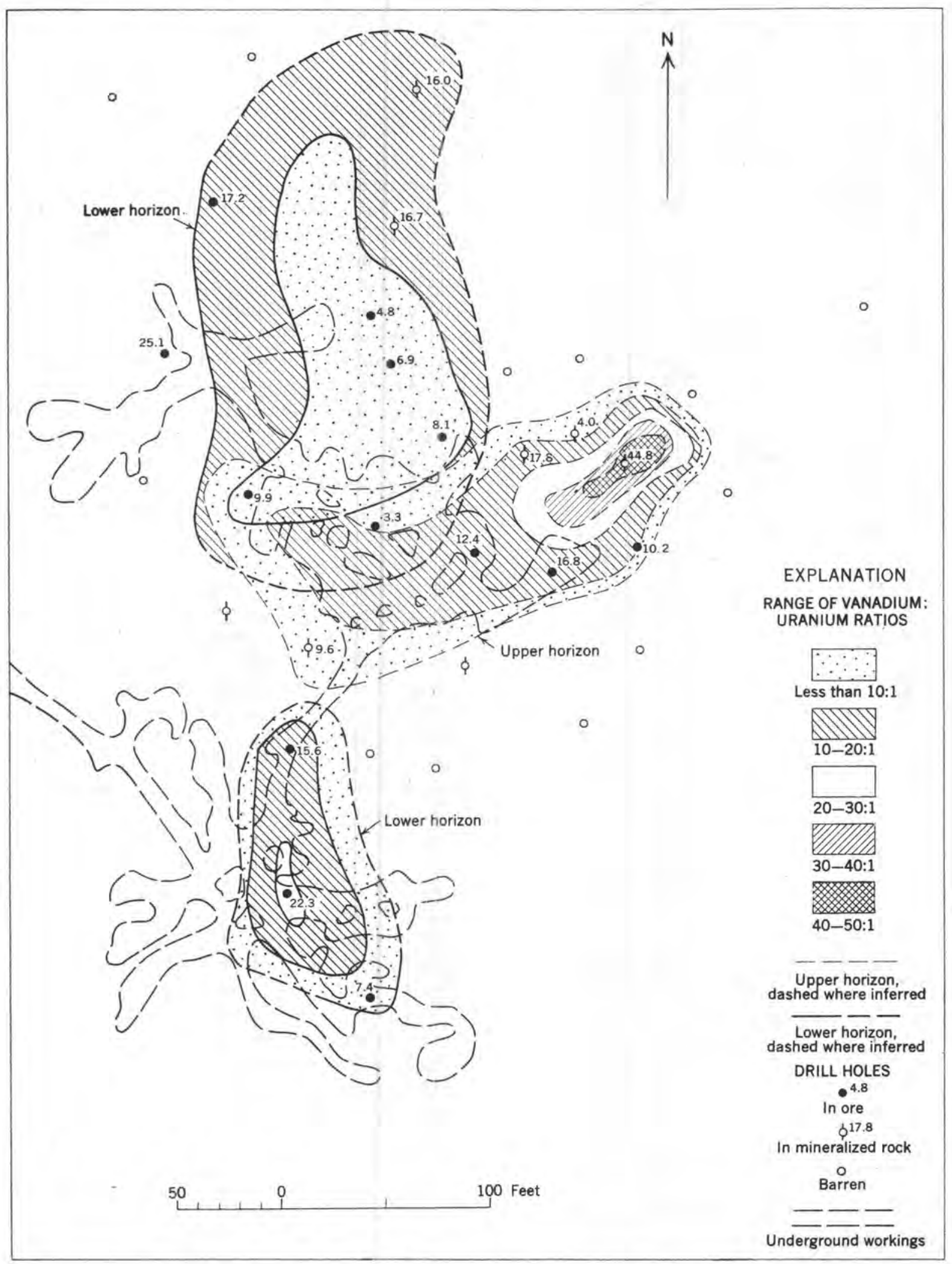

Figure 71,-Ratios of vanadium oxide to uranium oxide, Basin No. 1 mine, San Juan County, Utah. 
consists of lenticular pink or gray to tan very fine- to fine-grained sandstone with intercalated red and grayish-green mudstone and siltstone. Humic hydrocarbons derived from vegetal material are abundant. Rapid lateral and vertical facies changes characteristic of fluvial sediments are commonplace. Streamflow (fig. 72) is shown by orientation of crossbedding to to have been eastward.

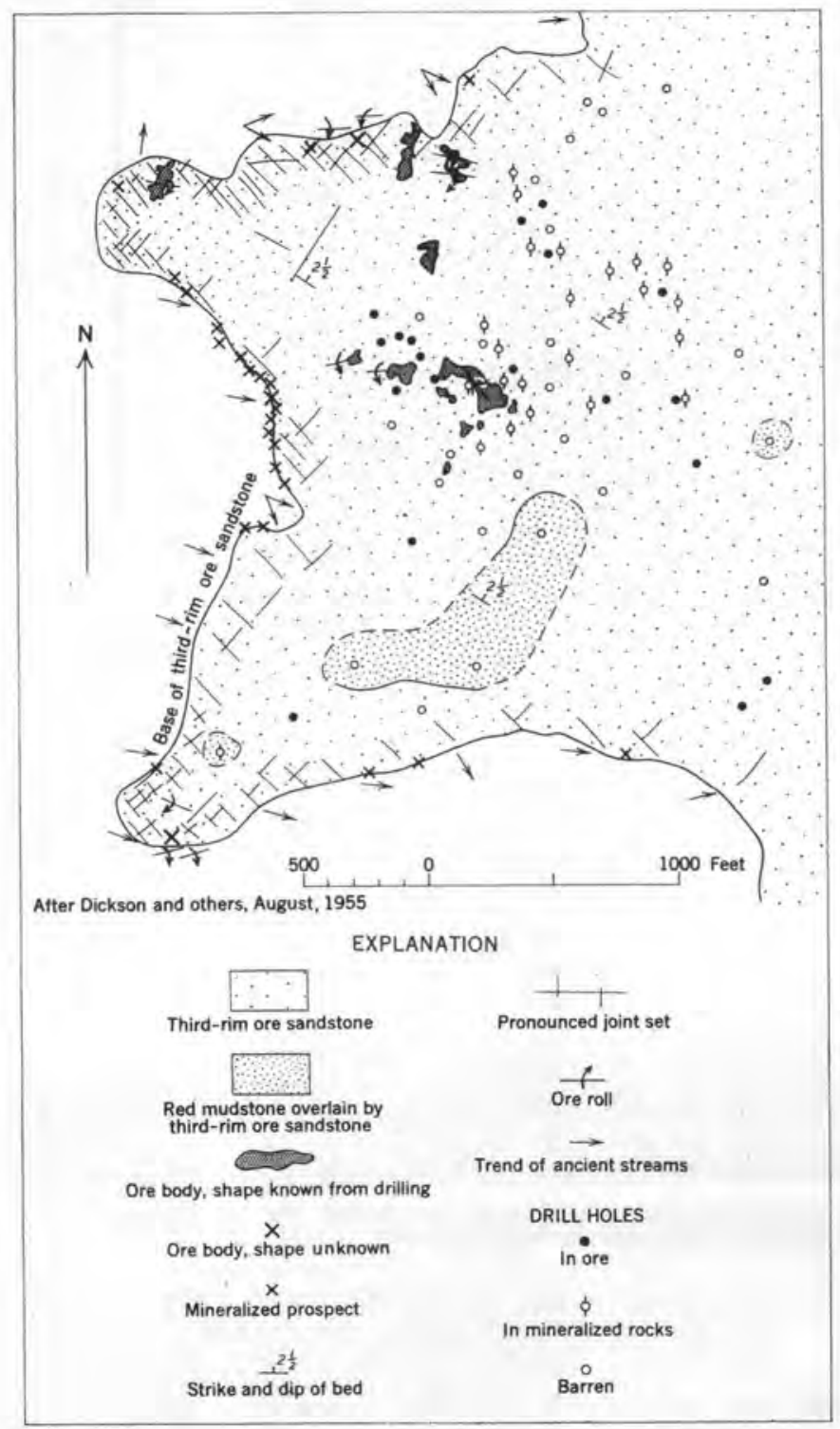

Ficure 72.-Geologic map showing uranium deposits, Wedding Bell group of mines, Bull Canyon, Montrose and San Miguel Counties, Colo.

Economic geology.-Most uranium-vanadium ore in the Wedding Bell group of mines is in the third prominent sandstone unit, 300 feet above the base of the Salt Wash member. This host unit ranges from 25 to 43 feet in thickness and generally exceeds 30 feet in the vicinity of ore, where it is gray to tan. Twenty feet higher in the section is a pink to gray sandstone, ranging in thickness from a few to 25 feet, in which the Jacknife mine is located near the southwestern tip of the area (fig. 72). No other ore deposits have been found in this unit, possibly owing to low transmissivity,

All ore deposits in the Wedding Bell group are above the water table and contain high-valent uranium and vanadium minerals. Ore minerals identified include tyuyamunite and vanadium hydromica. Ore bodies have two basic habits: the nearly flat bedded deposit, which is tabular but irregular in plan and essentially concordant with bedding; and the roll deposit, which is discordant, prominently elongate in one dimension, and bounded by a variety of curved surfaces. The bedded deposits may have sharply defined limits, sometimes with a slight increase in grade near the margins; other bedded deposits may decrease in grade both laterally and vertically, with poorly defined limits. The roll deposits have one distinct discordant curved limiting surface between ore and barren host rock, and the opposite boundary is irregular and gradational; many roll deposits have thin sheets of ore extending along bedding planes beyond the commercial ore body. The curved roll surface may be either convex or concave outward from the ore body. Less common forms may be sigmoidal. Along the well-defined surface, where mineralization was strong, some quartz has been dissolved, and the resulting concentration of ore minerals makes a plane of weakness along which the rock breaks in mining (Fischer, 1942). These features suggest a diffusion-front phenomena. The presence of curved joints in barren sandstone, however, supports the interpretation by Isachsen (oral communication) that the curved fractures are pre-ore and controlled deposition. The long axes of adjacent rolls, which generally lie nearly horizontal, are oriented eastward in the Wedding Bell area.

Alteration.- It has long been recognized that in the Salt Wash member red or pink sandstone is unfavorable for the localization of ore and that host rock becomes favorable only where altered to gray or tan (Weir, 1952). In the Wedding Bell area, much of the Jacknife unit is unfavorably colored.

Green mudstone beds underlie the Wedding Bell group except in areas known to be barren, where the mudstones are red (fig. 72). A very faint limonite staining in the form of small specks appears to coincide with broad belts of favorable ground, and individual ore bodies are bounded by a crude halo of somewhat more intense limonitic coloration.

Ore guides. - In general, ore deposits in the Wedding Bell group of mines are restricted to gray and tan sandstones having a thickness between 30 and 40 feet, to areas of high humic-hydrocarbon content, to areas 
having green rather than red mudstones at the base of the ore-bearing sandstone, and to areas of thickest and most intense limonite coloration. Within such favorable sandstones, ore may occur as either tabular bodies or rolls.

\section{HYPOTHESIS OF ORE CONTROLS}

Ore genesis of deposits in the Morrison formation has no completely satisfactory explanation, but data are accumulating that suggest an epigenetic formation. The evidence is derived from (1) age determinations by uranium and lead isotopes (Stieff and Stern, 1953), (2) increased stratigraphic range of host rocks (Isachsen, Mitcham, and Wood, 1955), (3) primary ore minerals not in equilibrium with zones of oxidation (Garrels, 1954), and (4) minor replacement textures. The origin and composition of the mineralizing fluids are fields for continued research. Any exploration program, however, must be founded on some hypothesis of ore localization.

The following hypothesis, not dependent on the origin, is proposed to fulfill this need. The mineralizing fluids followed zones of greatest transmissivity which, in the Morrison formation, are the channel facies of the fluviatile sediments. Because there is not evidence for ore-mineral precipitation caused by changes in temperature, which may never have been higher than those resulting from a normal geothermal gradient, or caused by changes in pressure, which must have been essentially constant in the nearly horizontal zone of movement, other physical or chemical phenomena, or both, must be considered. One is the possibility that $\mathrm{Eh}$ and $\mathrm{pH}$ changes are responsible for ore-mineral precipitation.

Coalified plant material has been postulated as a precipitating agent. Isolated fragments may be replaced by ore minerals, but unreplaced fossil plant material within the ore is also known (Fischer, 1942). The "trash pocket" accumulations of fossil plant remains contain ore bodies, but usually not of major size.

It is postulated, therefore, that the ore deposits are localized in channel sandstones adjacent to lenses of mudstone or on the channel margins. Points of rapid facies change represent rapid change in physical and chemical environment and consequently are the most probable loci of effective but unknown reactions which result in uranium-vanadium deposition.

\section{SUMMARY}

All of these selected deposits are in the proximity of a major regional structure such as the Lukachukai anticline on the flank of the Defiance uplift, the Zuni uplift, the flank of Comb Ridge monocline, and the area between the Paradox Valley and Gypsum Valley salt anticlines. The beds in the vicinity of all mines dip $1^{\circ}-2 y 2^{\circ}$. Although concentrations of fractures generally coincide with ore bodies in the $4 \mathrm{~B}$ mine, there is no evidence for vertical control; a correlation of ore grade and thickness with small faults and fractures which displace the Poison Canyon ore is overshadowed by elongation of the deposit at nearly right angles to the faults and parallel to the trend of sedimentary structures; ore rolls of the Wedding Bell are bounded by curved fractures variously interpreted as pre-ore and post-ore; and in the Basin No. 1 mine the few joints mapped had no relation to the ore.

Ore minerals of all described mines impregnated fluviatile sandstones that probably were deposited in the channel environment. All host rocks are interbedded with mudstone and contain coalified plant fragments which, when within the ore body, may be selectively replaced by ore minerals.

Individual ore bodies are elongate, and groups of deposits trend parallel to sedimentary structures of the host rock, but in detail they may be discordant and overlap within a limited zone.

The ratio of vanadium to uranium in these deposits ranges from $40: 1$ to $0.5: 1$ and, at the $4 \mathrm{~B}$ and Basin No. 1 mines, a zonal arrangement of the ratios of the metals was found.

No alteration of the type commonly associated with hydrothermal activity was noted. However, all host sandstones are light gray or tan and appear to have been altered from light red. Mudstone also may have been altered from red to gray green adjacent to ore,

The deposits are probably epigenetic, although genesis has not been demonstrated. It is believed, however, that $\mathrm{Eh}$ and $\mathrm{pH}$ changes were major factors causing precipitation of the ore minerals and that pressure or temperature changes were unimportant. The facies change between fast- and slack-water sediments is believed to represent a significant environment change of $\mathrm{pH}$ and $\mathrm{Eh}$ which localized ore deposition. The deposits consequently display a preferred orientation and localization along the trends of sedimentary structures.

\section{REFERENCES CITED}

Baker, A. A $A_{2}$ 1935, Geologic structure of southeastern Utah: Am. Assoc. Petroleum Geologists Bull, v. 19, p. 1472-1507.

Beam, T, E, Ore occurrence study, Mesa $4 \frac{1}{2}$ mines, Lukachukai Mountains, Apache County, Ariz.: U. S. Atomic Energy Comm. RME. [In preparation]

Craig, L. C., Holmes, C. N., Cadigan, R. A., and others, 1955, Preliminary report on the stratigraphy of the Morrison and related formations of the Colorado Plateau region; U. S. Geol, Survey Bull. 1009-E, p, 125-168. 
Dickson, R. E., Blair, R. G., Hart, H. R., and others, 1955, Results of drilling in Bull Canyon, Montrose and San Miguel Counties, Colo., with a review of favorability criteria used-part I: U. S. Atomic Energy Comm. RME-42, p. 1-67, issued by U. S. Atomic Energy Comm. Tech. Inf. Service, Oak Ridge, Tenn.

Fischer, R. P., 1942, Vanadium deposits of Colorado and Utah: U. S. Geol. Survey Bull. 936-P, p. 363-394.

Garrels, R. M., 1955, Some thermodynamic relations among the uranium oxides, and their relation to oxidation states of the Colorado Plateaus: Am. Mineralogist, v. 40, p. 10041021.

Gilkey, A. K., 1953, Fracture pattern of the Zuni uplift: U. S. Atomic Energy Comm. RME-3050, 40 p., issued by U. S. Atomic Energy Comm. Tech. Inf. Service, Oak Ridge, Tenn.

Gruner, J. W., Gardiner, Lynn, and Smith, D. K., Jr., 1954, Mineral associations in the uranium deposits of the Colorado Plateau and adjacent regions: U. S. Atomic Energy Comm. RME-3092, 48 p., issued by U. S. Atomic Energy Comm. Tech. Inf. Service, Oak Ridge, Tenn.
Isachsen, Y. W., Mitcham, T. W., and Wood, H. B., 1955, Age and sedimentary environments of uranium host rocks, Colorado Plateau: Econ. Geology, v. 50, p. 127-134.

Masters, J. A., 1953, Geology of the uranium deposits of the Lukachukai Mountains area, northeastern Arizona: U. S. Atomic Energy Comm. RME-27, 23 p., issued by U. S. Atomic Energy Comm., Tech. Inf. Service, Oak Ridge, Tenn.

McKee, E. D., 1951, Sedimentary basins of Arizona and adjoining areas: Geol. Soc. America Bull., v. 62, p. 481-505.

Stieff, L. R., and Stern, T. W., 1953, The lead-uranium ages of some uraninite specimens from Triassic and Jurassic sedimentary rocks of the Colorado Plateau: U. S. Geol. Survey TEI-322, 15 p. [microcard copy in U. S. Atomic Energy Comm. depository libraries]; 1952, Geol. Soc. America Bull. [abs.], v. 63, p. 1299-1300.

Weir, D. B., 1952, Geologic guides to prospecting for carnotite deposits on Colorado Plateau: U. S. Geol. Survey Bull. 988-B, p. 15-27. 


\title{
GEOLOGY OF URANIUM DEPOSITS OF THE SHINARUMP AND CHINLE FORMATIONS ON THE GOLORADO PLATEAU
}

\author{
By Y. William Isachsen and Charles G. Evensen, U. S. Atomic Energy Commission
}

\section{CONTENTS}

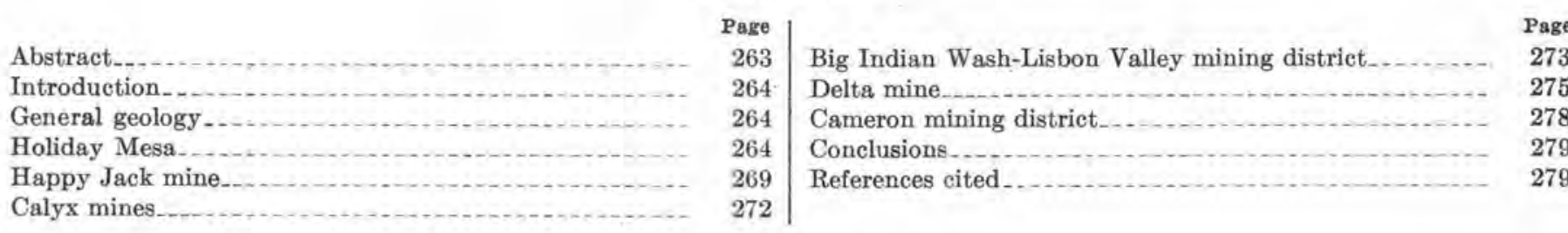

\section{ILLUSTRATIONS}

Figure 73, Outcrop of Chinle and Shinarump formations and laccoliths on the Colorado Plateau.

74. Relation of ore to the pre-Shinarump surface of the Moenkopi formation before and after regional folding.

75. Relation of ore to percentage of clay in lowermost 10 feet of Shinarump conglomerate.

Page

Figure 79. Maps showing distribution of ore, Happy
Jack mine and vicinity, White Canyon,

(1)

76. Relation of ore to color of altered rock ....

77. Comparison of assays of samples collected along contact of Moenkopi and Shinarump formations, west end of Holiday Mesa ancient channel

78. Vanadium to copper ratios of assays from uranium-bearing cores.
265 San Juan County, Utah.............

80. Zone of oxidation and equilibrium ratios, Happy Jack mine, White Canyon, San Juan County, Utah...................................

81. Generalized geologic map of Lisbon Valley, San Juan County, Utah.............

82. Maps showing structure of the Delta mine area and outcrop pattern of the Moss Back sandstone in the San Rafael Swell, Emery County, Utah.

83. Structure contours on the base of the orebearing sandstone, Delta mine, San Rafael Swell, Emery County, Utah.

84. Block diagram of area near Cameron, Ariz showing location of Huskon elaims ......
Page

271

274

\section{ABSTRACT}

Significant uranium deposits are known in two formations of Late Triassic age on the Colorado Plateau: the Shinarump conglomerate and the Chinle formation. Major ore deposits in the Shinarump are mined in the Monument Valley area of Arizona and the White Canyon area of Utah. Important deposits of uranium in the Chinle formation are known in the Big Indian Wash-Lisbon Valley area and the Temple Mountain area, both in Utah, as well as the Cameron area in Arizona.

The Shinarump conglomerate is a continental deposit consisting dominantly of light-gray sandstone with lenses of grit and conglomerate, and lesser interbedded mudstone. Basal Shinarump fills former stream channels eut in underlying beds. Carbonaceous plant material is a common constituent of this filling. Commercial ore is restricted to channel fill. Ore preferentially lies low on the flanks of these channels or at their base.
Ore bodies in the Shinarump conglomerate tend to be elongated parallel to channel trends and commonly are localized along a sandstone-mudstone interface.

The Chinle formation is predominantly a fluvial sequence of red to brown siltstones and mudstones interbedded with sandstones and conglomerate. Carbonaceous plant remains are widely distributed in the formation, and asphaltite occurs locally. Ore bodies in the Chinle are not restricted to channels nor to any one stratigraphic unit in the formation; however, most major deposits occur in sandstones or coarser clasties within the lower half of the formation. In some of the larger ore deposits in the Chinle formation at Big Indian Wash major ore controls appear to be struetural rather than sedimentary.

Copper, copper-uranium, and vanadium-uranium deposits have been found in both these formations. Oxidized and unoxidized ore minerals commonly occur together, resulting in rather exten- 
sive mineralogic suites. The dominant economic mineral in most deposits is uraninite. Ore minerals occur mainly as disseminations in sandstones, siltstones, and conglomerates and as grains replacing carbonaceous plant material and calcite cement.

Localization of ore in channel-fill and other permeable clastic units suggests that transmissivity is a dominent physical ore control. Geochemically, the place of ore deposition appears to be largely determined by the distribution of such substances as earbonaceous matter, calcite, certain clays, and possibly pyrite capable of causing precipitation of the uranyl ion through changes in Eh and $\mathrm{pH}$, as well as by adsorption and base-exchange phenomena. Where uranium occurs in an asphaltite-uraninite complex, as at Temple Mountain, the hydrocarbons are regarded as having migrated into the ore zone later than the uraninite.

Bleaching of or other discoloration of red beds, both below and above certain uranium deposits in the Shinarump and Chinle formations, suggests alteration associated with ore deposition. Isotopic age determinations indicate that uranium is epigenetic; the source of the uranium is not known.

\section{INTRODUCTION}

The diverse geology of uranium in the Shinarump conglomerate and the Chinle formation of Late Triassic age on the Colorado Plateau is illustrated by individual descriptions of six mining districts or mines of major economic and geologic importance: Holiday Mesa district, Happy Jack mine, Calyx mines, Big Indian WashLisbon Valley district, Delta mine, and Cameron mining district.

\section{GENERAL GEOLOGY}

The Shinarump conglomerate is exposed over large areas in the southern part of the Colorado Plateau (fig. 73). It is a fluvial deposit composed mainly of light-gray fine- to medium-grained sandstone, with lenses of very coarse sandstone and conglomerate, and lesser intercalated mudstone. Major ore-producing areas in the Shinarump are the Monument Valley and White Canyon areas (fig. 73), where ore occurs in basal sandstones and conglomerates filling former stream channels.

The more widespread Chinle formation gradationally overlies the Shinarump and disconformably overlies the Moenkopi where the Shinarump is absent. The Chinle consists of fluvial red, purple, gray, and variegated mudstone and siltstone, with some interbedded sandstone and conglomerate. The Chinle is the source of most of the uranium in the Big Indian Wash-Lisbon Valley area, Utah, and lesser amounts in the southern part of the San Rafael Swell, Utah, and the Cameron area in Arizona. Ore occurs in several stratigraphic units of the Chinle formation, but the Moss Back sandstone member is currently the most productive.

Uranium ore deposits may be classified, according to associated metals, into these types: uranium, copperuranium, copper-uranium-vanadium, and uraniumvanadium types. All are represented in the deposits selected for illustration, although the uranium-vanadium type accounts for the greatest production.

The age of uranium mineralization on the Colorado Plateau, based on the ratio of lead to uranium age determinations, is Late Cretaceous or early Tertiary (Stieff and Stern, 1953). Furthermore, field studies of many deposits indicate that the ore is epigenetic (Isachsen, Mitcham, and Wood, 1955). The source of the uranium is unknown.

The rapid growth in economic importance of these formations is shown by their yielding an increase in uranium from 15 percent to more than 40 percent of the total production of the Plateau during 1952-55.

\section{HOLIDAY MESA}

Holiday Mesa district is on the west side of the Monument Valley uranium area (fig. 73) and 1 mile northwest of Oljeto Trading Post, San Juan County, Utah. D. E. Trimble (1952) first found uranium ore on Holiday Mesa. The ore bodies in the Monument Valley area range in content from a few tons to several hundreds of thousands of tons.

Structure.-Holiday Mesa is on the steeply dipping eastern limb of the Organ Rock anticline, one of several asymmetrical folds superimposed on the Monument upwarp. The mesa is on the lower inflection of the structure, where the easterly dip decreases from $8^{\circ}$ to $2^{\circ}$. Joint sets trend north and northeast and are more common on the west end of the mesa. Frequency of joints in the Shinarump decreases where the unit thickens in former stream channels.

Stratigraphy and sedimentation.-In the Monument Valley area former stream channels as much as 275 feet deep and 3,000 feet wide were eut into the Moenkopi formation and filled with Shinarump clastic rocks. All ore deposits in the area occur in the Shinarump sediments in these channels and in downward extensions of ore into the underlying Moenkopi formation and De Chelly sandstone member of the Cutler formation. Channel filling generally contains greater amounts of mud-pellet and quartz-pebble conglomerates than the more widespread medium- to coarse-grained interchannel sandstones.

Occurrence of ore.- Ore bodies on Holiday Mesa and elsewhere in Monument Valley are generally elongated parallel to channel trends (fig. 74) and lie near the base of the channels. As a result of regional folding, the apparent bottom of the channel on Holiday Mesa was tilted downdip and corresponds with areas of highly anomalous radioactivity as measured in drill holes by gamma-ray logging. The occurrence of ore, however, appears to correspond more closely with the original erosional scour (fig. 74). 


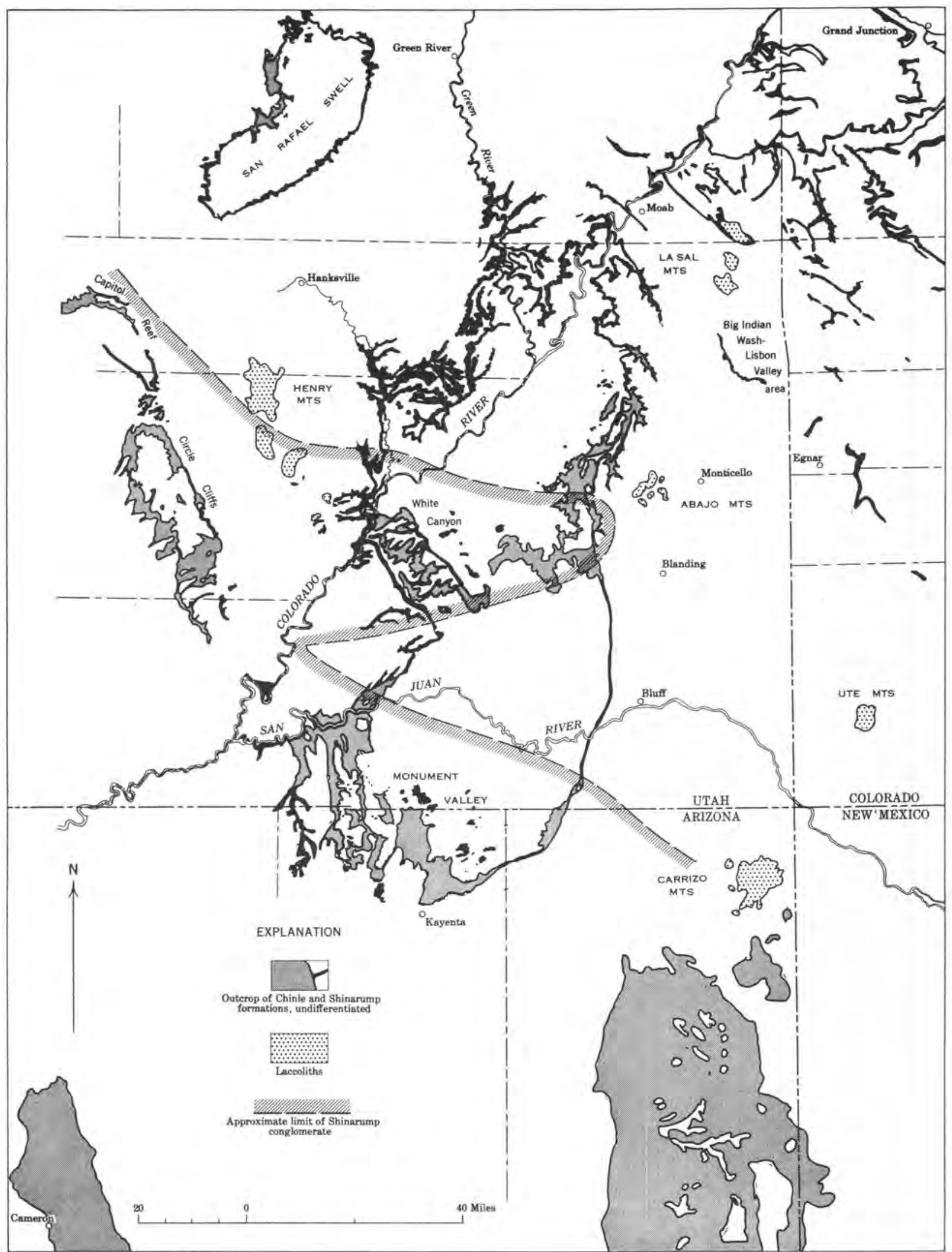

Figure 73.-Outerop of Chinle and Shinarump formations and laccoliths on the Colorado Platean. 


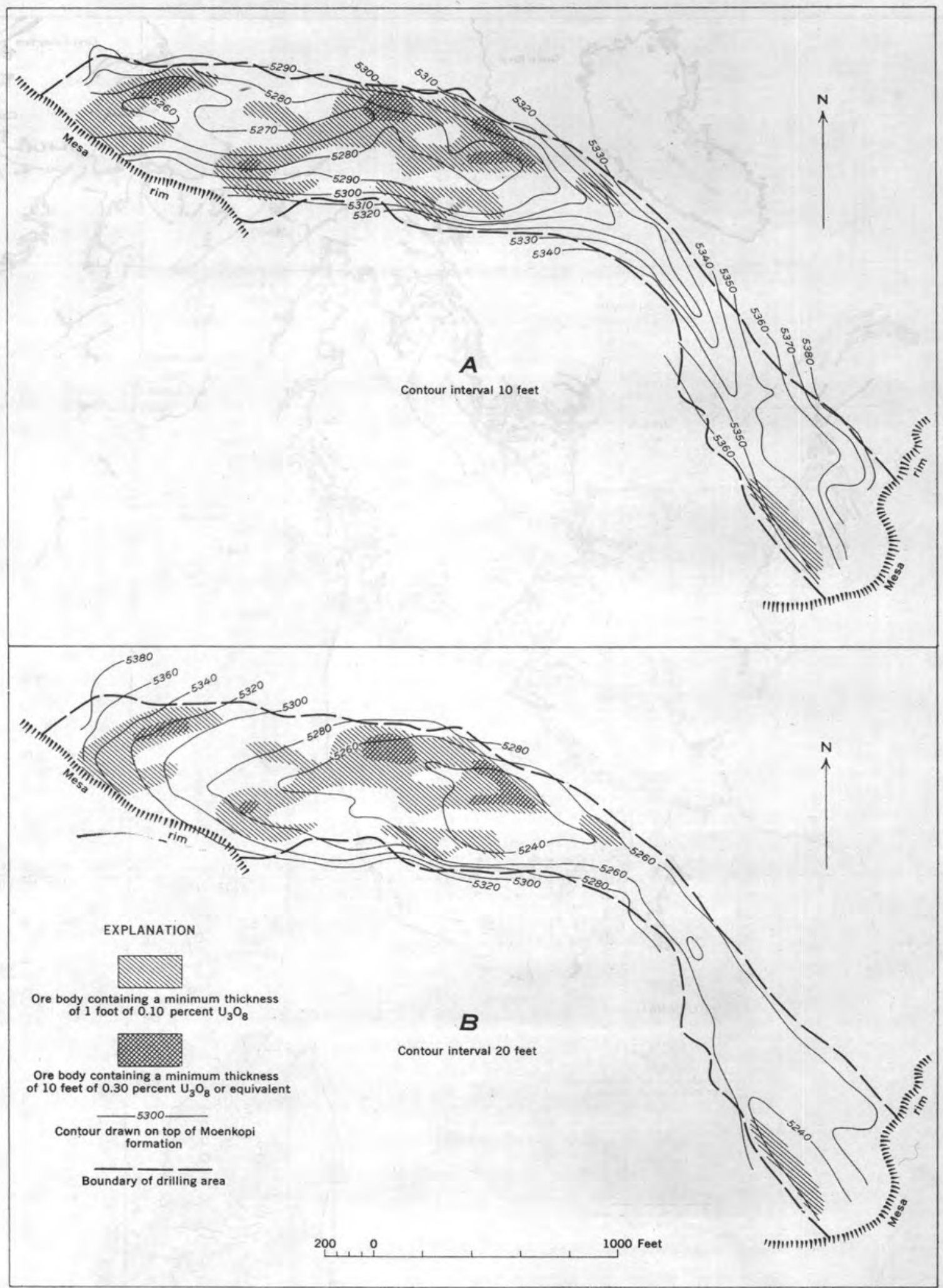

Figure 74.-Relation of ore to the pre-Shinarump surface of the Moenkopi formation: $A$, before regional folding: $B$, after regional folding (that is. at present). 
On Holiday Mesa the grade of the uranium ore bodies decreases gradually toward their edges, both laterally and vertically; thus, weakly mineralized sandstone may extend considerably beyond the limits of commercial ore (fig. 74). Elsewhere in Monument Valley material of ore grade generally ends abruptly. Empirically, the optimum quantity of mudstone associated with ore deposition appears to be 10 to 20 percent, but several ore bodies (fig. 75) are found in zones of greater mudstone content. Areas containing greater than 25 percent mudstone appear to have been relatively impermeable barriers. Large pellets and blocks of Moenkopi material, occurring generally near the contact, contain only trace amounts of uranium. Carbonized plant remains are abundant in the Holiday Mesa channel and probably helped concentrate the uranium.

Immediately beneath the Shinarump conglomerate the Moenkopi formation has been altered to different depths from yellowish-brown to chalky-white clays by reduction and almost complete removal of ferric iron. In oxidized areas of Monument Valley a study of the colors of altered mudstone in ore-bearing, in slightly mineralized, and in barren ground indicates a general correlation between intensity of mineralization and intensity of alteration; favorability of the ground increases as the alteration colors range from yellowish brown through gray and green to chalky white (terms are those of the National Research Council color chart). In unoxidized areas the range of alteration colors is more restricted. Holiday Mesa was the first unoxidized area to be studied in this manner, and there an order of color favorability for unoxidized areas was assumed from the uranium contents of drill holes. The colors correlate well with ore (fig. 76) except at the east end of the mesa. Here, the broad flat part of the channel was apparently unfavorable for uranium deposition although large quantities of mineralizing solutions may have passed through the zone. The eight colors most indicative of ore on Holiday Mesa did not occur in the altered mudstones examined on Flatiron Mesa, an area of almost no ore.

The general correlation between ore and thickness of altered Moenkopi appears to be due to passage of greater quantities of mineralizing solutions over a given part of the Moenkopi-Shinarump contact. In some

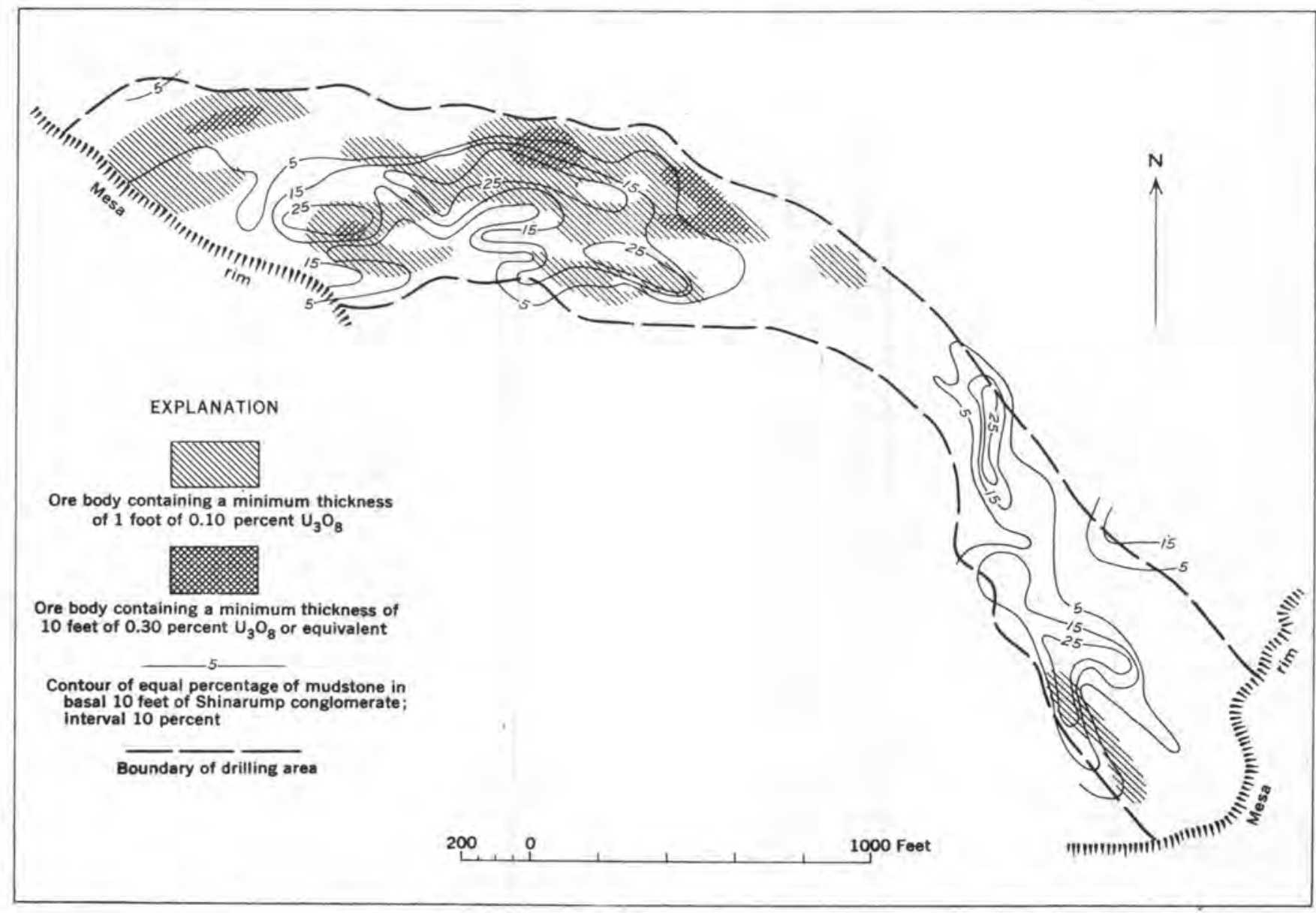

Figure 75,-Relation of ore to percentage of clay in lowermost 10 feet of Shinarump conglomerate. 


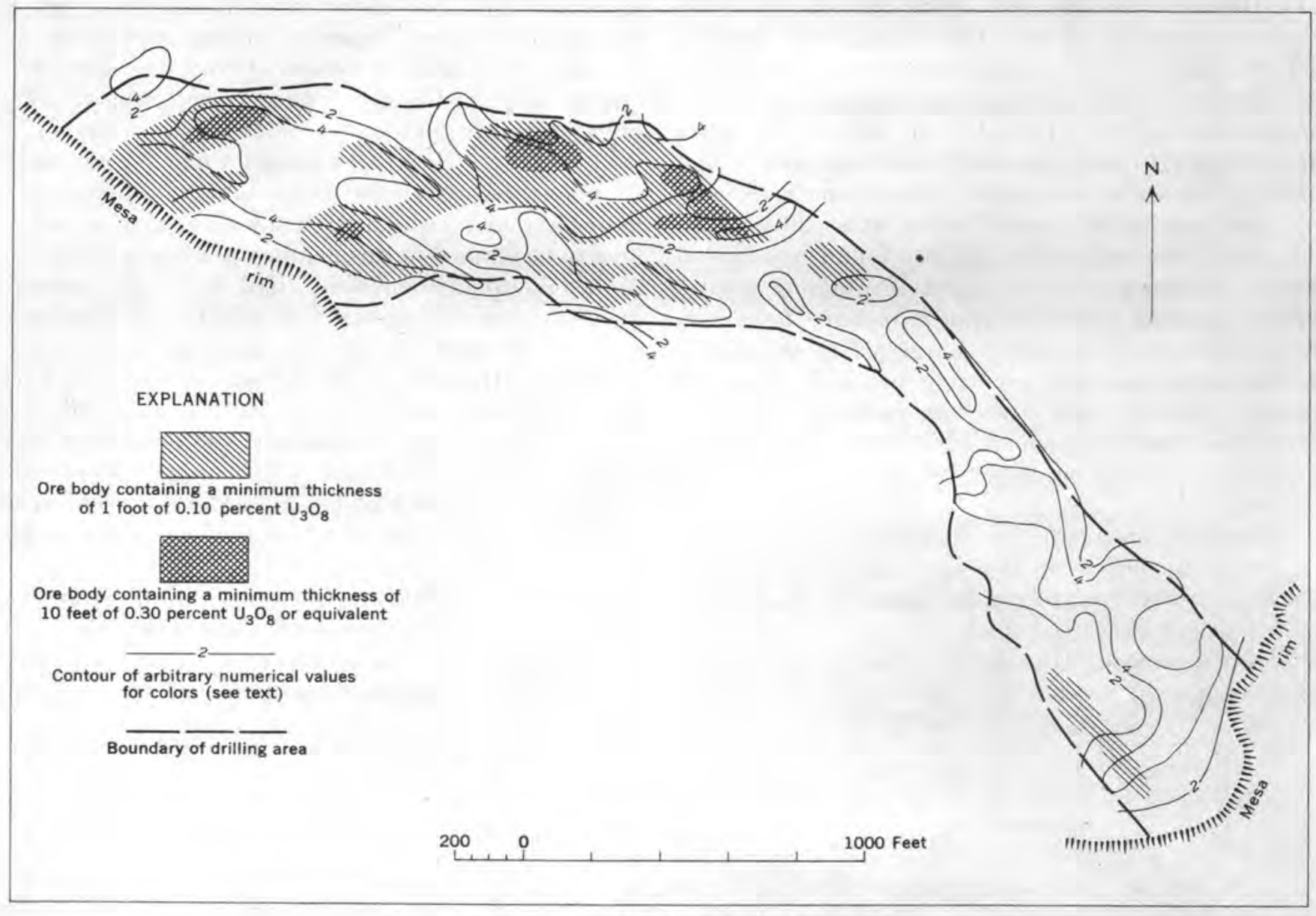

FiguRE 76.- Relation of ore to color of altered roek.

places, the thickness of the altered zone varies inversely with the mudstone content of the overlying Shinarump because the mudstone in the Shinarump also has been altered, possibly lowering the reducing ability of the solutions, and because increased mudstone content lessens permeability near the contact and thus decreases the volume of solution reaching the Moenkopi.

Mineralogy.-Unoxidized ore minerals on Holiday Mesa are uraninite and montroseite(?). The secondary minerals corvusite, tyuyamunite, hewettite, torbernite, and volborthite occur in the more oxidized areas within a few hundred feet of the mesa rims (E. B. Gross, personal communication). The ratio of vanadium to uranium averages about $2.5: 1$ on Holiday Mesa and increases eastward across Monument Valley. Chalcopyrite and bornite are widespread in the unoxidized ore zone; assays of copper average about 0.5 percent at Holiday Mesa, with copper content decreasing eastward. The host rock is composed of detrital quartz, kaolinite, and chert; cementing materials are silica, calcite, and iron oxide.

Supergene alteration-Migration of copper-bearing acidic solutions away from the uranium-vanadium ore body during oxidation, and precipitation of copper carbonates as a halo surrounding ore, are indicated by a graph of assays along a mineralized rim on Holiday Mesa (fig. 77). High vanadium:copper ratios in the oxidized west and east ends of the mesa (fig. 78) correspond very closely with more intense mineralized zones. In unoxidized parts of the deposit within the mesa, however, the copper content is relatively uniform and vanadium:copper ratios largely reflect vanadium eoncentrations. Comparison of figures $74 \mathrm{~A}$ and 78 indicates a general relationship between primary uranium and vanadium concentrations in the unoxidized parts of the mesa. A close relationship between localization of uranium and vanadium is shown in the oxidized zone. This may be the result of uranium being precipitated in direct proportion to the quantity of vanadate ions available.

Ore controls and guides.-Ore controls and guides for the Monument Valley area, in general, and Holiday Mesa, in particular, are as follows: (1) ore occurs in and below Shinarump scour and fill sediments in stream channels cut into the Moenkopi formation, (2) areas of marked change from clean sandstone to 


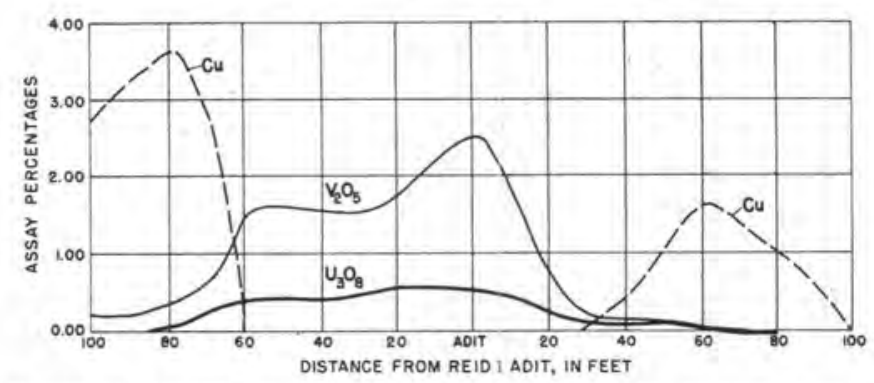

FIGURE 77,-Comparison of assays of samples taken at 1-foot intervals along the contact of the Moenkopi and Shinarump formations, west end of Holiday Mesa ancient channel.

about 25 percent mudstone are favorable for uranium deposition, (3) both thickness and intensity of alteration in mudstones of the Moenkopi increase adjacent to ore, (4) occurrence of secondary copper minerals may suggest ore bodies nearby, and (5) radioactivity increases gradually toward ore bodies in relatively broad, flat-bottomed channel fillings.

Sediments that fill ancient stream channels in the Shinarump have two characteristics that may be useful in tracing their courses in mesas capped by that formation: the tendency for joints to be more widely spaced on the thicker channel sediments, and the tendency for channel fills to have higher topographic relief because greater compaction of the flanking sediments of the Moenkopi formation has arched them upward.

\section{HAPPY JACK MINE}

The Happy Jack mine in White Canyon, San Juan County, Utah (fig. 73), was first located as a copper prospect in 1900 and was mined in 1906 and in 1914. Butler, Loughlin, Heikes, and others (1920) included the property, then called the Blue Dike, in their compilation of Utah ore deposits, and were the first to note uranium sulfate in the mine. The Happy Jack was the first copper-uranium deposit in the Shinarump conglomerate to produce primary uraninite and copper sulfide ore, and uranium has been mined there since late 1949.

Regional structure.-The White Canyon mining district is on the gently dipping west flank of the Monument upwarp. Beds have a nearly uniform N. $15^{\circ} \mathrm{W}$. strike, and dip $1 \frac{1}{\circ}{ }^{\circ}$ to $2 \frac{1}{2}{ }^{\circ} \mathrm{SW}$. A few minor northwest-trending vertical faults occur in the district,

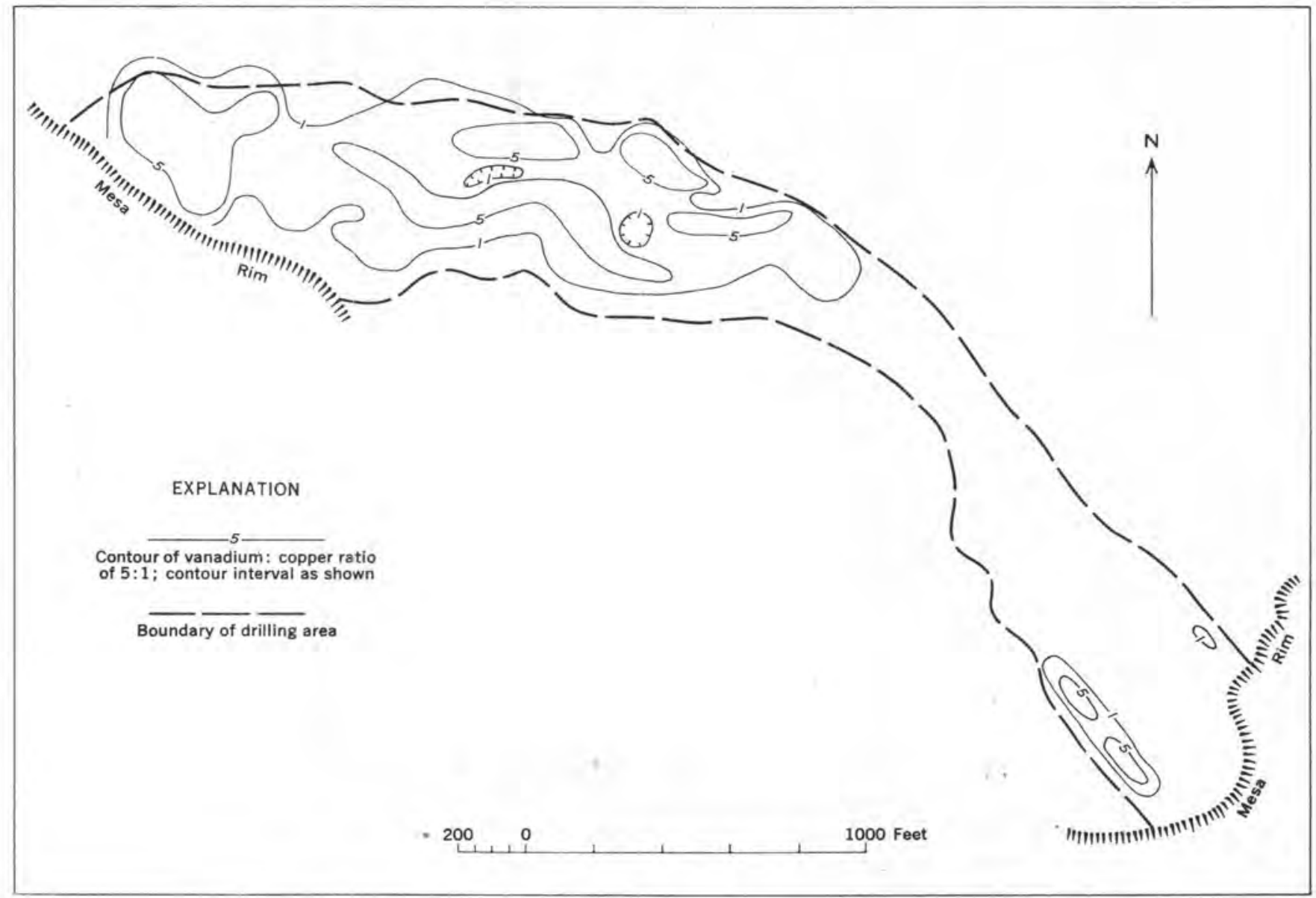

FigURE 78.-Vanadium to copper ratios of assays from uranium-bearing cores. 
but none are near the mine. A vertical joint system is developed in some beds; the dominant set strikes N. $50^{\circ} \mathrm{E}$., and the minor set strikes N. $55^{\circ} \mathrm{W}$. The diorite and monzonite intrusive masses of the Henry Mountains (Hunt, 1953), 18 to 20 miles west of the mine, are the closest known outcrops of igneous rocks.

Stratigraphy. Sedimentary rocks exposed in the White Canyon district range from the Hermosa formation of Pennsylvanian age to the Navajo sandstone of Jurassic age. The Happy Jack mine and other deposits of the district are in the Shinarump conglomerate, which had a northeast source. The Shinarump locally has an upper and a lower unit. Ore is restricted to the lower unit which contains poorly sorted, coarse- to fine-grained quartz sandstone and siltstone and fills former stream channels in the underlying Moenkopi formation. The cement is composed of unidentified clay minerals containing shards suggesting a pyroclastic derivation. The upper unit, which extends into interchannel areas, is a light-gray fineto coarse-grained conglomeratic sandstone. Coalified plant fragments, while present in both units, are more abundant in the lower and more lenticular unit.

Occurrence of ore.-Sedimentary structures, rather than tectonic structures, appear to influence ore localization. Miller (1953) states that three types of fractures occur in the Happy Jack mine: joints, small faults (displacement 1-foot) caused by regional tension, and minor faults resulting from differential compaction. He says that no primary uranium mineralization is associated with any of these.

In the Happy Jack mine, as elsewhere in the White Canyon district, ore deposits are confined to fluvial sediments in ancient stream channels (Dodd, 1950; Miller, 1953; Lowell, in preparation). Broad shallow depressions in the Moenkopi surface may have controlled the erosion and deposition by Shinarump streams. In the vicinity of the Happy Jack the first sediments to fill the former stream channels are extremely lenticular. The Happy Jack deposit is in a broad shallow basin on the Moenkopi surface, with a restricted channel outlet to the southwest (fig. 79A). Maximum relief from the lowest point in the depression to the divide separating it from the Sunrise-Gonaway channel to the east is about 28 feet. The basin containing the Happy Jack deposit is 600 to 700 feet across and has a relief of only 10 feet. The Sunrise-Gonaway channel averages 500 feet in width and has been scoured 10 to 12 feet into the top of the Moenkopi formation. Most ore is in the deeply scoured parts of the channels, and only a minor amount extends onto the flanks.

A positive correlation exists between ore and parts of the channel containing abnormal amounts of mud-

stone interbedded with the sandstone in the lower 10 feet of the Shinarump (fig. $79 B$ ). A plot of the distribution of carbonaceous fossil plant material within the ore-bearing basal 10 feet of the Shinarump indicates a coincidence of carbonaceous concentrations with areas of high mudstone.

Mineralogy.-Gruner (1952, p. 14) has identified the following suite of minerals from the Happy Jack ore body:

Primary (unoxidized)

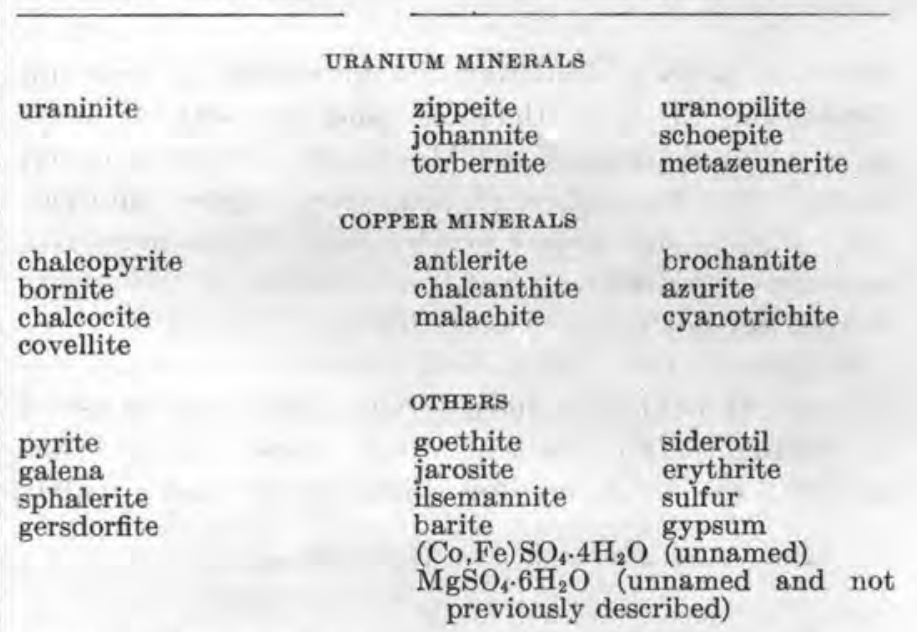

The major uranium ore mineral in the Happy Jack mine is uraninite, which occurs in very fine granular masses and sometimes as colloform blebs less than three microns in size. It replaces fossil wood fragments and, where associated with chalcopyrite, shows preferential replacement of cell walls, whereas chalcopyrite fills the cells. The contact of uraninite with chalcopyrite, chalcocite, and covellite is always irregular. Miller (1953) and Gruner and Gardiner (1950) have commented on quartz boundaries being indented by replacing sulfides, but we have seen etched quartz only where it is in contact with uranium minerals. Secondary overgrowths on quartz grains, common in the Shinarump, have been replaced locally by uraninite. More of the clay cement is replaced by uraninite than are the quartz sand grains. Uraninite veinlets as wide as $1 / 2$ inch cut across 2 -inch beds of mudstone.

Alteration.-Beneath many of the Shinarump channel fillings the normal hematitic red of siltstones and sandstones of the Moenkopi formation has been altered to light gray or tan. It is postulated that this alteration, though present in some barren areas, may be an effect of the mineralizing fluids. Ore-bearing rocks of the Shinarump are either gray or light orange-brown, and barren sandstone is generally pale red.

The Happy Jack deposit well illustrates changes effected by an oxidizing environment on the primary 


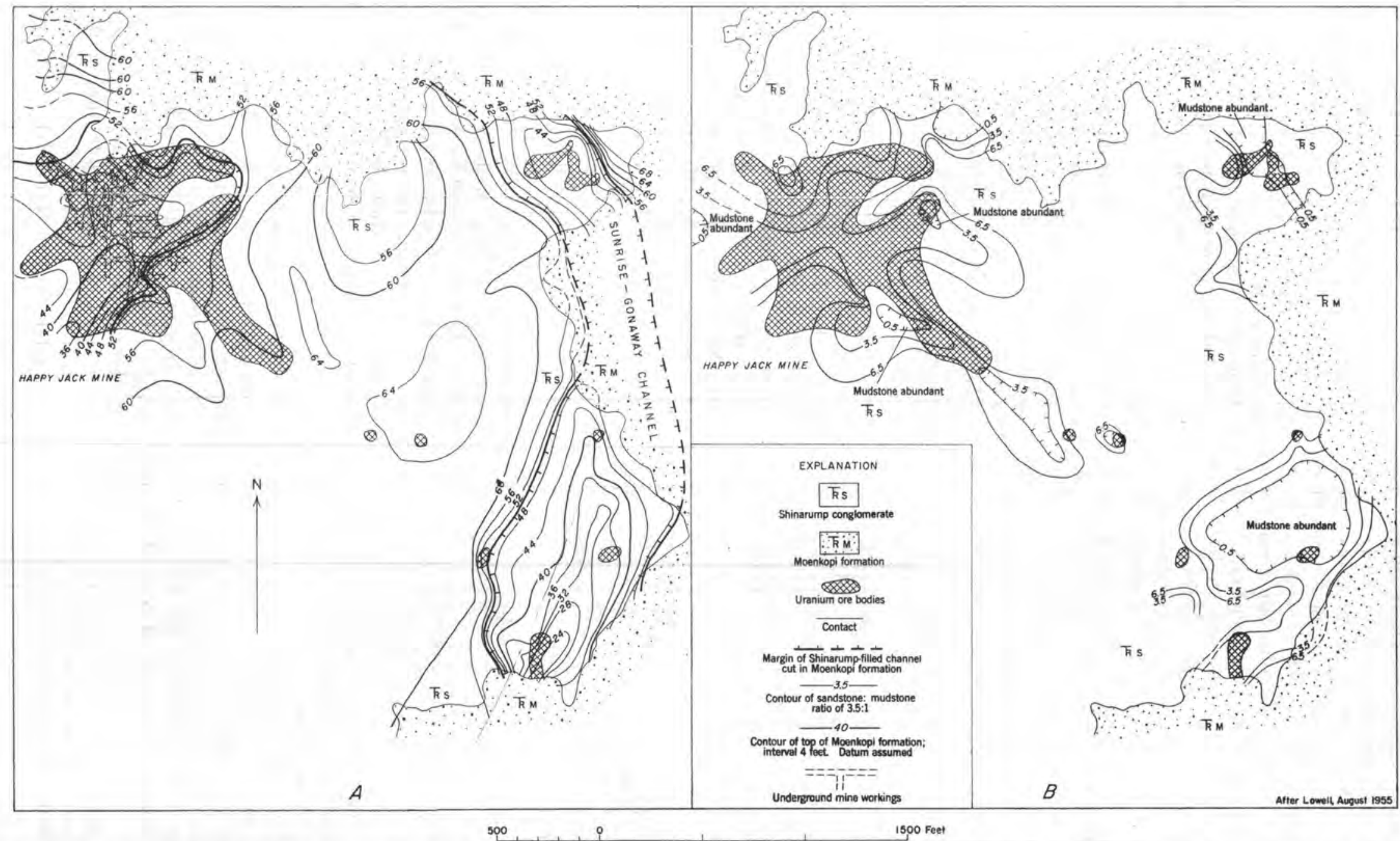

要

FIGURE 79.-Maps showing distribution of ore, Happy Jack mine and vicinity, White Canyon, San Juan County, Utah: A, structure contour map of the top of the Moenkopi formation showing distribution of ore in the scours; $B$, distribution of ore relative to mudstone abundance in Shinarump rocks filling scours. 
uranium oxide-copper sulfide ore (Dodd, 1950). Because of relatively impermeable overlying rocks, oxidation of the Happy Jack deposit has progressed horizontally inward from the exposed rim of the mesa rather than vertically down from the mesa cap. Oxidation has progressed more rapidly than erosion and has developed a secondary ore zone, generally paralleling the outcrop, in which copper sulfides have been altered almost completely to copper sulfates or carbonates (fig. 80). Uraninite has been altered locally to schoepite, the hydrated oxide, or more commonly to the sulfates zippeite and johannite, and rarely to the sulfate uranopilite and the phosphate torbernite.

Sulfate waters resulting from oxidation have preferentially removed uranium from its radioactive decay products during recent time (Dodd, 1950) and have left the uranium unevenly distributed (fig. 80).

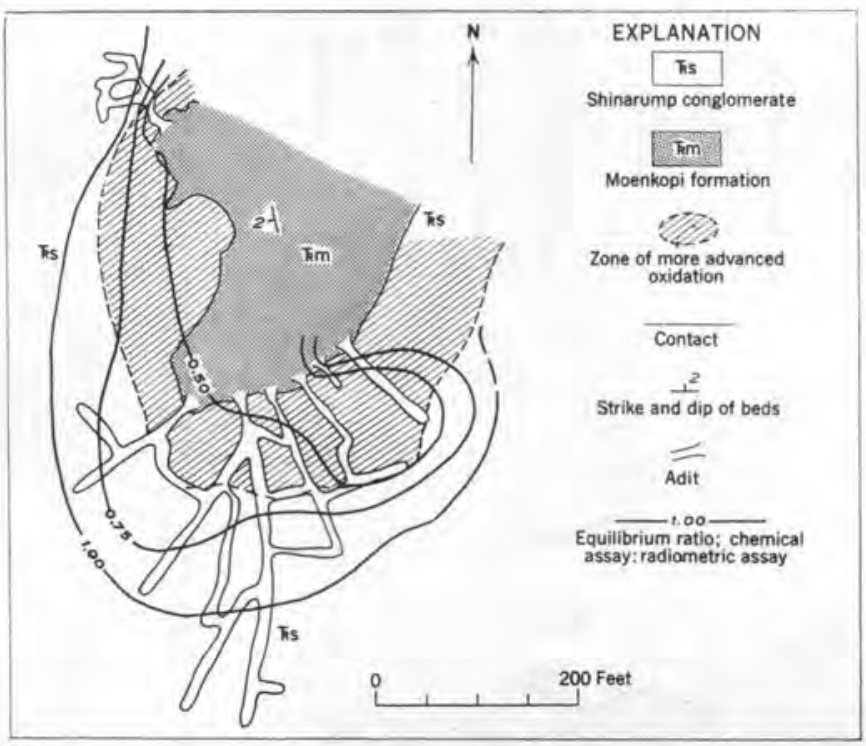

FIGURE 80.-Zone of oxidation and equilibrium ratios, Happy Jack mine, White Canyon, San Juan County, Utah.

Genesis.-An epigenetic origin of the deposits has been proposed (Dodd, 1950; Miller, 1953). This is corroborated by the isotopic determinations of an age of 55 million years (Stieff and Stern, 1953) for two specimens from the Happy Jack mine. Because the ore is localized in channels, it is believed the ore-bearing fluids migrated laterally, controlled by permeability. Precipitation appears to have been caused by changes in $\mathrm{pH}$ or Eh accompanying changes of content of such substances as carbonaceous material, pyrite, and clay minerals in the host rock. There is no evidence that changes of temperature or pressure precipitated the uranium whose source is unknown.

\section{CALYX MINES}

The Calyx group of mines are on Temple Mountain near the southern part of the San Rafael Swell, Emery County, Utah (fig. 73 and insert, fig. 82). The larger ore bodies contain reserves measured in the tens of thousands of tons.

Structure.-The San Rafael Swell is a broad, relatively flat, asymmetrical upwarp. Temple Mountain, an erosional remnant within the swell, contains a complex, altered collapse zone that is described by Keys and White (this volume). The Calyx mines lie south of the collapse area in beds dipping $8^{\circ}$ to $11^{\circ} \mathrm{SE}$.

Stratigraphy and sedimentation.-Sedimentary rocks exposed in the San Rafael Swell range from the Coconino sandstone of Permian age to the Morrison formation of Jurassic age.

Major uranium-vanadium ore in the Calyx area occurs in the Moss Back sandstone member of the Chinle formation. The host rock is a gray mediumto coarse-grained sandstone containing discontinuous lenses of conglomerate and mudstone and abundant coalified wood fragments. Calcite cement is common in the Moss Back elsewhere in the San Rafael Swell, but in the Calyx area the dominant cement is asphaltite. Coalified wood fragments are common in the Moss Back. The ore-bearing sandstone in the Calyx No. 3 mine rests upon a green mudstone along a gently undulating contact marked by scours as deep as 3 feet and is overlain by a quartz-pebble conglomerate in mudstone matrix, ranging from 6 inches to 3 feet in thickness.

Economic geology.-Uranium occurs in several formations of the Temple Mountain collapse zone (Keys and White, this volume), but major production has come from the Moss Back in the Calyx mines area (named from the prevailing method of opening the mines through large calyx drill holes). Ore deposits in the Moss Back are elongate tabular bodies with marginal fingerlike extensions projecting outwards as much as 50 feet (Witkind, Robeck, Barton, and Izett, 1954). Deposits are about 300 feet long, 20 feet wide, and 4 feet thick, and tend to be elongated downdip (Keys and White, this volume).

Within the host rock, ore occurs as disseminations in sandstone around carbonized logs, against mudstone contacts, as stringers along cross-laminae, and as irregular pods and blebs. Three types of hydrocarbons are associated with the ore-bearing sandstone throughout the area (Baumgardner and Noble, 1955); namely: liquid hydrocarbon which is a nonuraniferous, darkbrown to black, combustible fluid of the viscosity of heavy oil; dull resinous asphaltite, a plastic, nonuraniferous solid which melts and burns readily when ignited, 
emitting a petroliferous odor; and uraniferous asphaltite, a brittle subvitreous solid which emits a sulfur dioxide odor when heated but which does not sustain a flame. The distribution of these types of hydrocarbons in the only Calyx mine mapped in detail, the Calyx No. 3 , is as follows: liquid hydrocarbon occurs predominantly above the ore-bearing sandstone, rarely within it; the dull resinous variety is restricted mostly to barren zones within the ore, although occasionally pellets of this material are found within ore; brittle asphaltite is found only in the uranium ore and is everywhere uraniferous (Baumgardner and Noble, 1955).

Mineralogy.-The practically unoxidized Temple Mountain uranium-vanadium ore has been commonly referred to as uraniferous asphaltite. However, Weeks and Thompson (1954) advocate classification of the ore on the basis of mineral assemblage as "pitchblende associated with a hard carbonaceous substance variously described as high-rank coal or polymerized petroleum residu (thucholite?)." On the basis of preliminary study, Stieff and Stern (in Witkind, Robeck, Barton, Izett, 1954) have suggested that the chief uranium mineral may be coffinite.

Montroseite is found in unoxidized ore. Corvusite and vanadium hydromica are common; other oxidized uranium and vanadium minerals reported from Temple Mountain (Witkind, Robeck, Barton, and Izett, 1954) are: carnotite, tyuyamunite, metazeunerite, schroeckingerite, zippeite, rauvite, metatorbernite, uvanite, pintadoite, hewettite, and pascoite. The vanadium: uranium ratio of the ores is about $3: 1$.

Ore guides and genesis. - Guides to ore in the Calyx area include carbonaceous plant remains and abnormal thickness of the ore-bearing sandstone (Witkind, Robeck, Barton, and Izett, 1954). In the Calyx No. 3 mine, Baumgardner and Noble (1955) consider impermeable mudstone at the base of the ore zone as a criterion of the presence of ore.

Distribution of the three classes of hydrocarbons shows that their volatile content decreases in direct proportion to proximity to uranium. It is argued that the Temple Mountain occurrences originated as primary uranium deposits of the uraninite-montroseite type, similar to the ores of Big Indian Wash. Fluid hydrocarbons were later introduced and subsequently polymerized to varying degrees by radiations from uranium, the degree of polymerization depending upon nearness to uranium. This interpretation disagrees with the hypothesis of Gott and Erickson (1952) that the uranium was introduced simultaneously with the fluid hydrocarbons. During polymerization, uraninite was replaced in part to form the present asphaltite-uraninite (pitchblende) association; such a mechanism for the formation of naturally occurring hydrocarbon-uraninite complexes has been advanced by Davidson and Bowie (1951). This interpretation would also explain the anomalous "corrosion" and "replacement" of quartz sand grains by asphaltite, for replacement of quartz by uraninite from hydrous mineralizing solutions (a phenomenon commonly observed in nonasphaltic ore bodies), was followed by replacement of uraninite by introduced hydrocarbons.

The age of a sample of asphaltic uraninite ore for this area has been calculated by isotope ratios (Stieff and Stern, 1954) to be 60 million years.

\section{BIG INDIAN WASH-LISBON VALLEY MINING DISTRICT}

The Big Indian Wash-Lisbon Valley uranium district is in San Juan County, Utah (fig, 73). The first uranium mined in the area came from the Big Buck mines in the Cutler formation where small-scale production began in 1948 and continued sporadically until 1953. Uranium was first discovered in the Chinle formation in 1952.

Structure.-Large uranium deposits occur on the southern flank of the northwest-trending Lisbon Valley anticline. Large laccoliths occur 6 miles to the north and 25 miles to the southwest (fig. 73). Shoemaker (1954a) presents evidence for a Late Cretaceous age of these intrusive bodies.

The Lisbon Valley anticline is a salt structure formed primarily by plastic flowage and local thickening of salt and gypsum (Baker, 1933; Dane, 1935; Stokes, 1948). The Lisbon Valley fault, a major displacement, and minor associated faults cut the anticline longitudinally and place the Jurassic Morrison formation in contact with the Pennsylvania Hermosa formation (fig. 81). This fault dips steeply northeast and has a stratigraphic throw of at least 3,800 feet. Movement along this fault is thought to have resulted from differential uplift of the footwall block during intrusion of salt and gypsum rather than collapse of the hanging-wall block afterward; this interpretation is based on the fact that the upthrown southwest side is considerably more domed, more steeply dipping, and more fractured than the downthrown side (Isachsen, 1954).

The major joints along the anticline are longitudinal, a feature shown to be characteristic of flexures resulting from vertical forces (Gillkey, 1953). Transverse joints are less evenly distributed and less pronounced than longitudinal joints. Besides the longitudinal and transverse tension joints there are many oblique shear joints (Dahl, Fisk, Volgamore, and others, 1955) and a number of unevenly distributed fracture zones which lack noticeable displacement but are reflected in the development of small, straight, valleys trending between $\mathrm{N}$. and $\mathrm{N} .10^{\circ} \mathrm{E}$. These fracture zones were first described by W. H. Bucher (oral communication), 

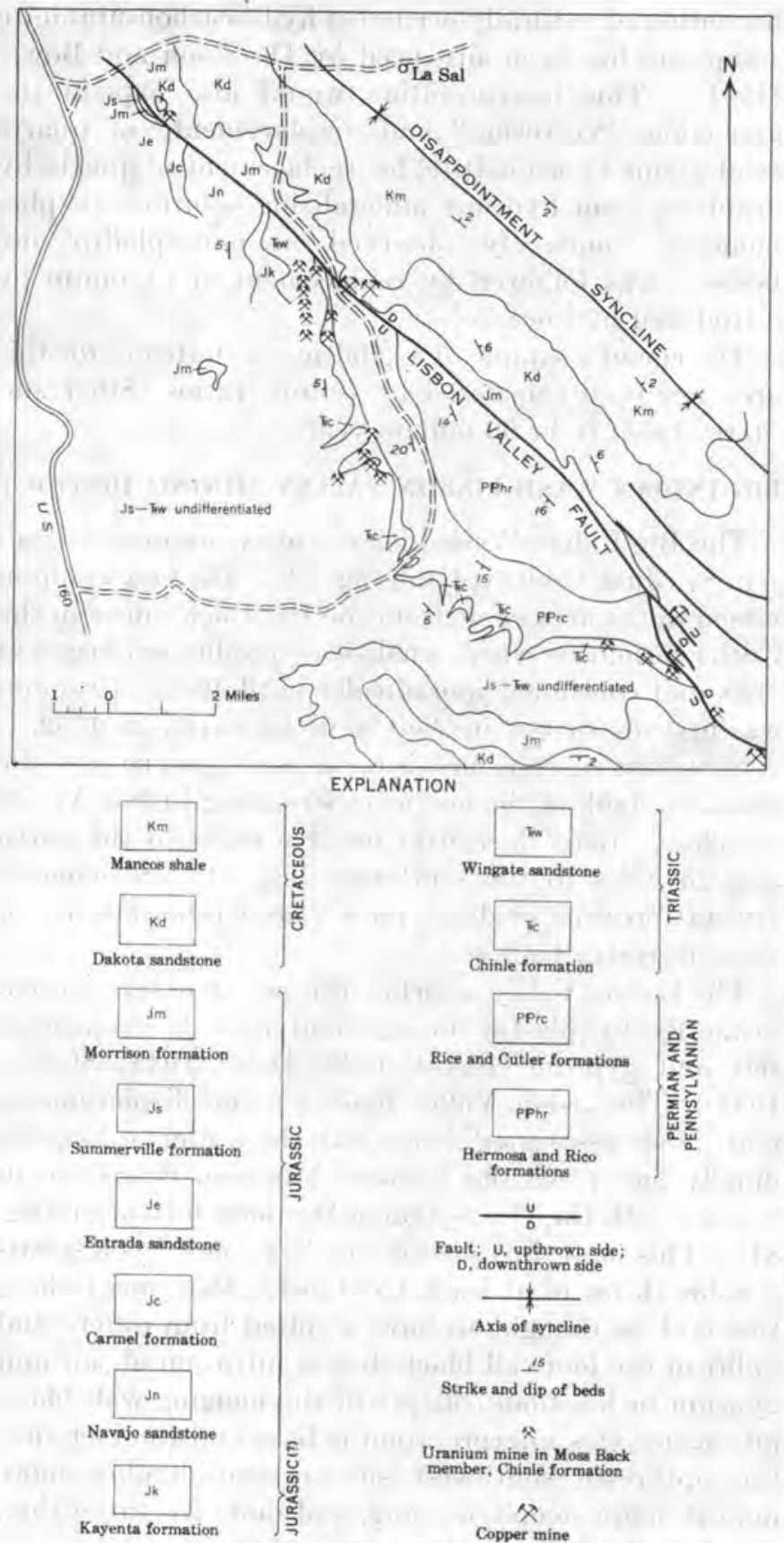

Figure 81.-Generalized geologic map of Lisbon Valley, San Juan County, Utah.

who noted that some of them have a close spatial relation to ore bodies. He interpreted such zones as reflected deep-seated faults.

Stratigraphy and sedimentation.-Sedimentary rocks exposed in the district range from the Hermosa formation of Pennsylvanian age to the Mancos shale of Late Cretaceous age. Ore in the Chinle is restricted to the basal Moss Back sandstone. At some places the ore horizon lies directly on bevelled beds of the more steeply dipping Cutler formation; at others it is separated from the Cutler by a few feet of barren gray mud- stone of the Chinle formation. The Moenkopi formation which underlies the Chinle to the west and east does not crop out here; perhaps it was pinched out lower on the flanks of the anticline.

Rapid horizontal and vertical changes of facies, characteristic of a fluvial deposit, are common in the Moss Back. Scour and fill, crossbedding, and ripple marks, all characterizing turbulent flow, are widespread. Laminar flow is represented in some beds by stream lineation. Intraformational unconformities are commonly exposed in mine walls but can seldom be traced more than a few hundred feet. The trend of sedimentary structures in the ore zone at Big Indian Wash indicate that the clastic rocks of the Moss Back came from the southeast.

Occurrence of uranium and vanadium.-In the Big Indian Wash-Lisbon Valley area, uranium deposits lie within a half-mile-wide strip which borders the Chinle escarpment and parallels the strike of beds for a distance of 15 miles. Most known ore bodies are in the northern part of the anticline, adjacent to Big Indian Wash. All are elongated approximately parallel to the strike of the beds and all except one are 6,200 to 6,700 feet above sea level. The single exception, which is about 5,840 feet above sea level, lies along the Lisbon Valley fault in the southern part of the mining district. Maximum thickness of ore in the Moss Back is 30 feet and the average is 8 feet. Host rocks include mediumand fine-grained sandstone, siltstones, and conglomerates containing pebbles of mudstone and limestone. The host rock enclosing the best ore is fine- to mediumgrained quartz sandstone with calcareous cement. Coalified plant matter is widespread in the ore bodies but the average content, even in rich ore, may not exceed 0.5 percent (Steen, Dix, Hazen, and MeLellan, 1953). Ore does not impregnate the host rock uniformly, nor does it follow in detail primary sedimentary structures such as bedding; instead it characteristically occurs in small irregular pods, blebs, and stringers which only roughly parallel bedding.

Mineralogy.-The mineralogy and petrography of the deposits have been described by Steen and others (1953); Gruner, Rosenzweig, and Smith (1954); and Gross (1955). The dominant ore mineral is uraninite, which contains minute intergrowths of coffinite; the most abundant vanadium minerals are vanadium hydromica, and montroseite with very fine intergrowths of doloresite. The oxidized minerals tyuyamunite, corvusite, and pascoite are developed along and adjacent to joint surfaces.

Both uraninite and montroseite replace calcite cement, and uraninite replaces coalified logs and carbonaceous debris. Calcite fills cells in carbonized wood; uraninite replaces cell walls and locally extends into 
cells by replacement of calcite. It is suggested that calcite is diagenetic and thus prevented the flattening of logs by compaction. Pyrite is fairly abundant and commonly replaces fossil plant material. Small quantities of barite, fluorite, greenockite, sphalerite, and galena have also been reported. Chalcopyrite and malachite are very rare. Dominant detrital minerals in the sandstones and siltstones are angular to subangular quartz, plagioclase, and microcline; muscovite is abundant locally. Calcite fills interstices, corrodes quartz along grain surfaces, and in ore replaces feldspar to a minor extent; other cements are quartz, barite, clay aggregates, and chlorite. Microscopic examination indicates that primary uranium minerals were introduced contemporaneously with pyrite and chalcopyrite, and later than the cement (Gross, 1955).

Alteration.-Near ore bodies there is a tendency for the gray-green color which characterizes the ore horizon to extend into overlying mudstones of the Chinle formation which are generally red. This change is attributed to differences in color of the clay fraction, which are not yet understood, and to abstraction of hematite. According to W.K. Keller (oral communication), no difference exists in gross mineralogy between the red and green clays.

Ore controls and genesis.-Controls of ore deposition, both known and postulated, may be classified into three categories: local, areal, and regional.

Permeability, as reflected in lithologic types, is an important local control. In addition, the distribution of such substances as carbonaceous matter, pyrite, calcite, and possibly certain clays, has influenced the localization of ore, probably by causing precipitation of the uranyl ion through changes in $\mathrm{Eh}$ and $\mathrm{pH}$, as well as by adsorption and base-exchange phenomena.

Localization of ore in ancient-channel fill, as advanced by Dix (1954), has not been adequately tested by subsurface data compiled to date. The close spatial relation between ore and fracture zones trending N. $10^{\circ}$ E., strongly suggests a fracture control of ore solutions as advanced by W. H. Bucher (oral communication).

The Lisbon Valley anticline appears to have exerted the most important areal control of ore deposition as exemplified in the apparent restriction of ore to a narrow vertical interval. A general anticlinal control of ore was initially postulated in 1953 by Steen and others.

Two peculiarities of stratigraphy associated with the Lisbon Valley anticline that may have influenced ore localization are: (1) the absence beneath ore of the relatively impermeable mudstones of the Moenkopi and its probable occurrence downdip as a cap for hypothetical rising ore solutions (Dahl, Fisk, Volgamore, and others, 1955), and (2) the bevelled surface of the
Cutler formation beneath the Moss Back which provides permeable arkose lenses as possible conduits for hypothetical ore solutions rising along the Lisbon Valley fault (R. R. MeLellan, oral communication). The occurrence of copper deposits along the fault (Isachsen, 1954) suggests the plausibility of copperuranium zoning in the district, with ore solutions gaining entry along the Lisbon Valley fault.

Proximity of the Big Indian Wash-Lisbon Valley mining district to the La Sal and Abajo laccolithic mountains to the north and southwest (fig. 73) is considered significant by many geologists. The laccoliths, consisting mainly of diorite porphyry and monzonite porphyry, with minor syenite intrusive bodies (Hunt, 1954), may have both a chemical and a structural relation to neighboring uranium deposits. Shoemaker (1954b) notes that the syenite of the La Sal Mountains is anomalously enriched in copper and suggests that a rough zonal relation may be indicated between copper and uranium deposits around the La Sal Mountains.

A nonhydrothermal source for the uranium has been proposed by Gruner, Rosenzweig, and Smith (1954) who suggest that uranium was leached by ground water from volcanic tuffs and reprecipitated in its present sites.

\section{DELTA MINE}

The Delta mine is in the southern part of the San Rafael Swell, Emery County, Utah (fig. 73 and insert, fig. 82). The anomalous surface radioactivity of the Delta mine outcrop was discovered first by members of a U. S. Atomic Energy Commission airborne scintillometer crew in June 1952 (G. E. Klosterman, written communication).

Structure.-The Delta deposit is localized along the southern edge of a structural terrace on a monocline which forms the southern margin of the San Rafael Swell, one of several major upwarps on the Colorado Plateau (fig. 82). Neighboring faults and dikes of analcite diabase are also shown on figure 82 . A vertically dipping conjugate joint system is developed in competent beds of the area; joint sets strike northeast and northwest.

Stratigraphy.-Sedimentary rocks exposed in the San Rafael Swell range from the Coconino sandstone of Permian age to the Jurassic Morrison formation. Copper-uranium-vanadium ore occurs in the Chinle and is restricted to the lower third of a sandstone lens, 33 feet above the base of the formation (Keys, 1955). The lens is 31 feet thick at the mine and pinches out several hundred feet to the north and south. The Moss Back is unmineralized at the Delta mine and lies above the ore horizon, separated from it by 23 feet of mudstone.

The host is a massive fine- to medium-grained sand- 


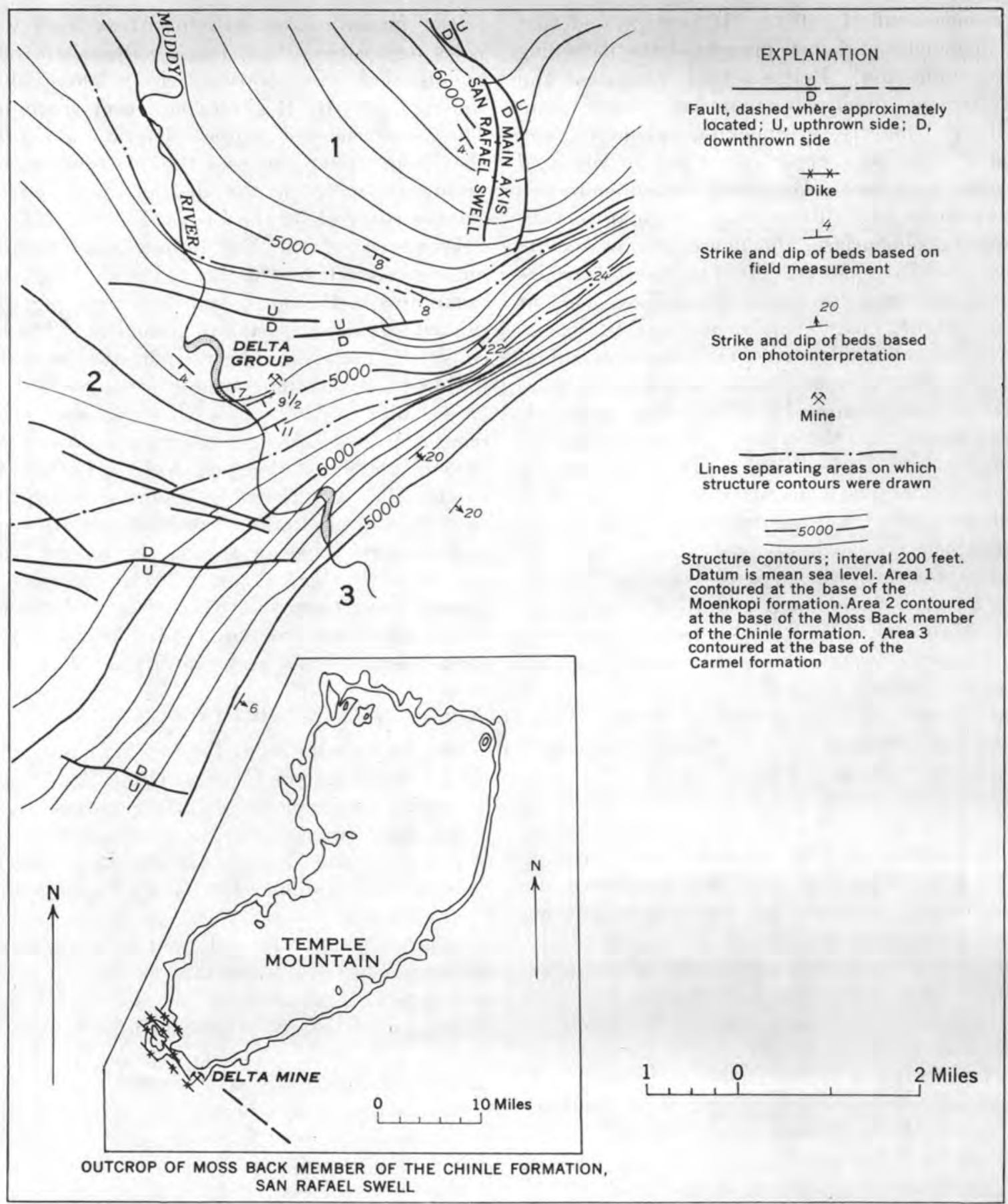

FIGURE 82.-Maps showing structure of the Delta mine area and outcrop pattern of the Moss Back sandstone in the San Rafael Swell, Emery County, Utah.

stone containing widespread coalified plant remains. Within this unit the most favorable rock is thin-bedded, fine-grained, micaceous sandstone with interbedded mudstone. In strongly mineralized areas in the mine, all rocks including mudstone, are ore bearing. Ore lies on a relatively impermeable basal green mudstone containing illite and kaolinite. Occurrence of ore.-The Delta ore body is crudely in figure 83. Most ore occurs where the base of the oblong with the longer dimension trending northeast. Thickness of ore is highly variable; the maximum is 20 feet (Keys, 1955).

Plotting the distribution and intensity of joints did not reveal any relation to localization of primary minerals.

Irregularities at the base of the ore zone are shốwn 


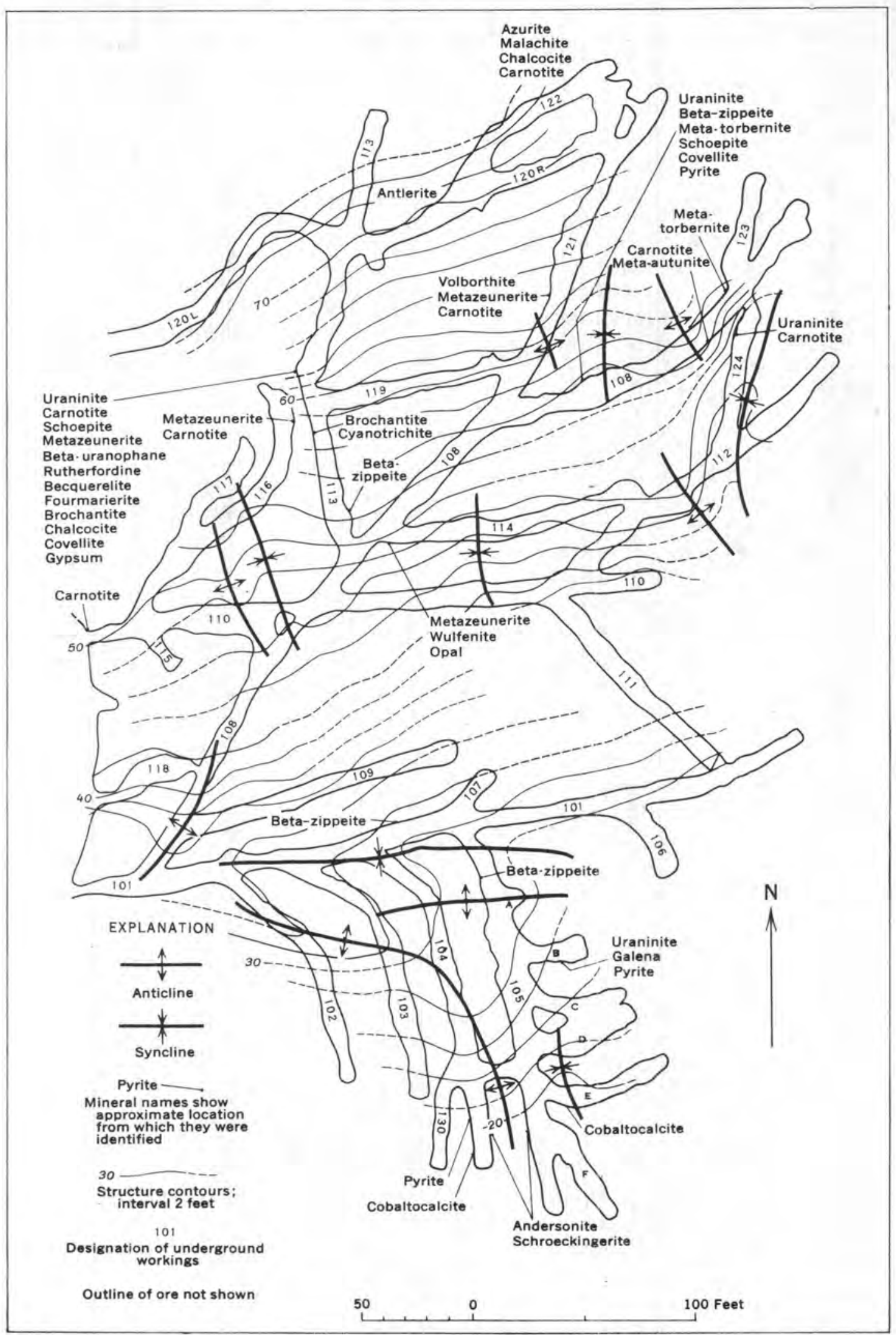

FIQURE 83.-Structure contours on the base of the ore-bearing sandstone, Delta mine, San Rafael Swell, Emery County, Utah. 
ore is undulatory. Whether these undulations are due to scouring, differential compaction, or flexuring is a matter of conjecture. Because the Chinle is a fluvial deposit, the first two alternatives are logical. Mineralogy. - Carnotite and zippeite disseminated in sandstone account for most of the ore; uraninite locally replaces fossil logs (Keys, 1955). Disseminated secondary uranium minerals surround these logs as halos with radii as much as 25 feet. Other secondary uranium minerals are listed according to locality of collection (fig. 83). Associated nonuranium minerals, excluding the detrital grains, are pyrite, galena, chalcocite, covellite, wulfenite, volborthite, cobaltocalcite, malachite, azurite, brochantite, chalcanthite, and antlerite. The uranium to vanadium ratio is highly variable, ranging between $10: 1$ and 1:5.

Alteration.-A distinct mineral zoning occurs in the Delta mine; in the northern workings copper minerals are abundant, particularly malachite and azurite which occur in several 2 -foot thick beds containing as much as 11 percent copper (Keys, 1955). Areas which have escaped oxidation contain uraninite in association with chalcocite and covellite. In the central part of the mine, the dominant oxidized uranium mineral is carnotite, with torbernite and metazeunerite increasing northward. In the southern workings, beta-zippeite is the principal secondary ore mineral. Galena and cobaltocalcite occur in the southern workings, but are lacking elsewhere in the deposit (Keys, 1955).

The copper and uranium were introduced contemporaneously or nearly so as in the Happy Jack ore body. Zoning of uranium minerals in the Delta mine is considered by the writers to have resulted from downdip supergene redistribution of elements within an original primary copper-uranium-vanadium ore body. Vanadium may have been introduced as montroseite or as a vanadium-bearing clay or both. The absence of montroseite and its oxidation product, corvusite, and the affinity of carnotite for clay-rich sandstone with interbedded mudstone, however, suggest vanadiumbearing clay. The mechanism of redistribution was probably oxidation of copper sulfides to provide the sulfate ion which in turn mobilized the uranyl ion. This ion was then transported downdip and reprecipitated as relatively insoluble carnotite, torbernite, and metazeunerite by vanadate, phosphate, and arsenate ions respectively. In the absence of these anions the uranyl ion could be transported still further until precipitated as a sulfate (beta-zippeite) or one of a number of minor secondary minerals (fig. 83).

Alteration of red mudstones to green can be seen in the mine, but assay values are independent of these color variations (Keys, 1955).

\section{CAMERON MINING DISTRICT}

In 1952 Charles Huskon, a Navajo Indian, made the first discovery of important uranium mineralization in the Chinle formation near Cameron, Ariz. (figs. 73 and 84). This area, containing about 20 mines, is on the west flank of the Black Mesa basin, a few miles east of the East Kaibab monocline in an area having a uniform dip of $1^{\circ}$ to $2^{\circ} \mathrm{NE}$. (Hinckley, 1955). Fracturing is common; a major joint set strikes northwesterly and a less apparent set strikes northeasterly. However, no relation between structure and mineralization has been observed.

The Permian Kaibab limestone and the Triassic Moenkopi, Shinarump, Chinle, and Wingate formations, as well as scattered basic lava flows and cinder cones of late Tertiary age, crop out in the area. All the important ore deposits (fig. 84) are in the lower 60 feet of Gregory's C member of the Chinle formation (Gregory, 1917), which is normally a purple to gray mudstone. Uranium is concentrated in the somewhat sandy and silty mudstone lenses which occupy ancient scours. Scours have a general northeasterly elongation and are as great as 40 feet in depth and 750 feet in width. Ore is concentrated in the lower parts of scours, particularly in areas containing accumulations of carbonaceous debris. Besides these lenticular deposits, some commercially unimportant scattered pods of ore-grade material occur throughout the C member of Gregory (1917) in the vicinity of fossil wood.

Ore occurrence.-Ore bodies are roughly elliptical in plan view and saucer-shaped in cross section. The largest ore body in the Cameron area is 450 feet long and 300 feet wide. The thickest section of ore-grade material measures 11 feet.

Ore bodies may occupy a number of different positions within scours. Huskon No. 1 and No. 3 (fig. 84) are uniformly mineralized ore bodies which fill the lower parts of scours and bave a horizontal upper surface. Highest grade ore occurs at the base of scours and in concentrations of carbonaceous material. Huskon No. 2 (fig. 84) and No. 10 are examples of irregular podlike ore bodies within a scour and which were apparently controlled by concentrations of carbonaceous plant material and by variations in permeability of the scour and fill sediments. These pods range in size from less than 1 ton to 1,000 tons and from low-grade ore to high-grade uraninite-impregnated carbonaceous fragments. Huskon No. 7 (fig. 84) is a transition between the lens and pod forms.

Mineralogy.-Principal ore minerals are metatorbernite, meta-autunite, and uraninite, with minor amounts of uranophane, sabugalite, metazeunerite, and 


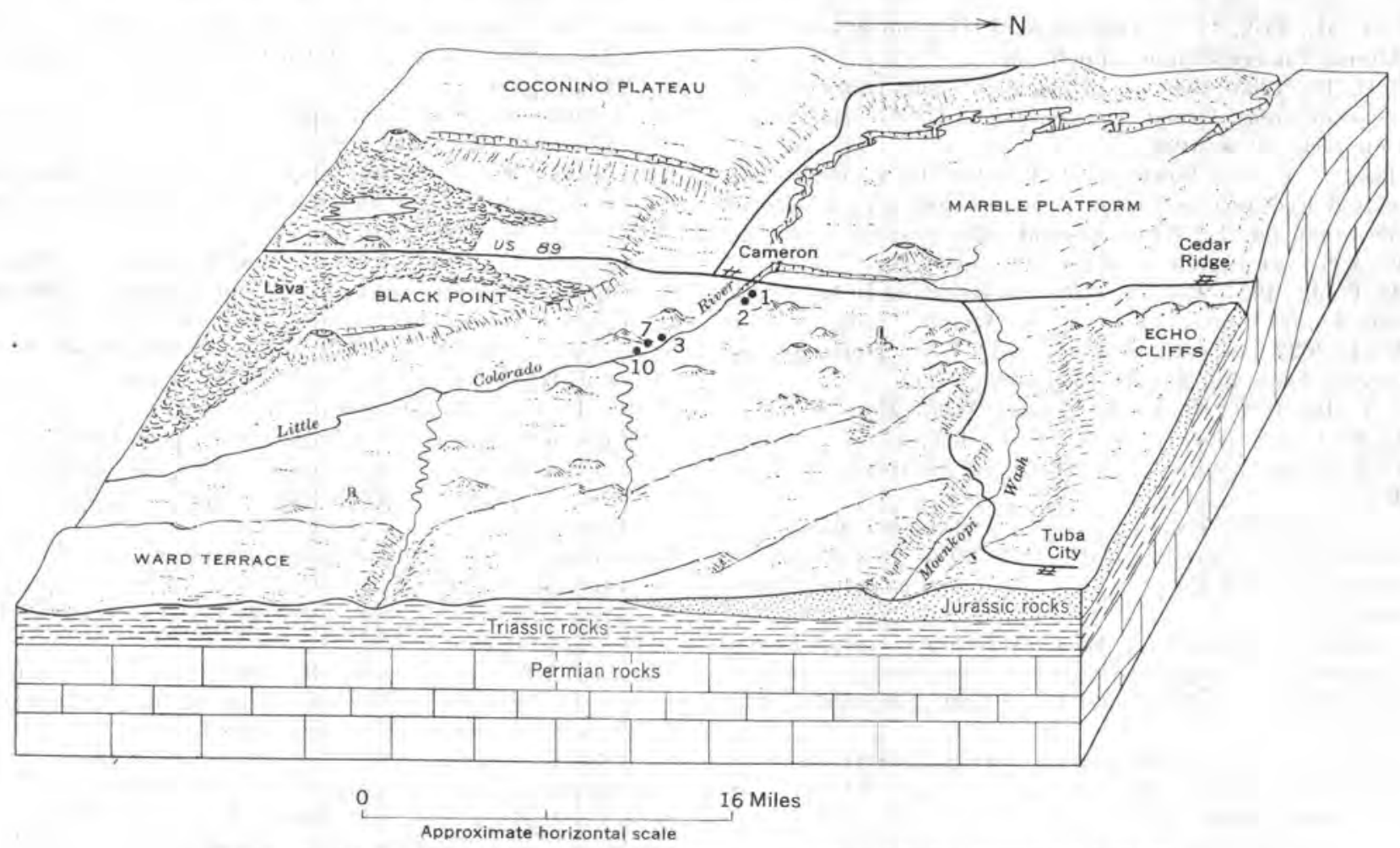

Figure 84,-Block diagram of area near Cameron Ariz., showing location of Huskon claims 1, 2, 3, 7, and 10.

zippeite (Gruner, Gardiner, and Smith, 1954). Gangue minerals are montmorillonite, quartz, kaolin and sericite (from feldspar), gypsum, limonite, jarosite, pyrite, calcite, barite, smaltite, and sphaerocobaltite. Vanadium content in the ores is low, attaining a maximum ratio to uranium of $1: 7$. Ore bodies in the area lie at shallow depths and are almost completely oxidized.

Alteration.-All ore bodies in the area are surrounded by light-brown to yellowish-brown alteration halos which cut across the normal purple and gray beds of the Chinle C of Gregory (1917). These halos are characterized by a high content of jarosite and hydrous iron oxides, seriticization of feldspar, and an increase in trace amounts of molybdenum near the ore (Hinckley, 1955).

Ore controls and ore guides.-Ore is restricted to the lower 60 feet of the Chinle C of Gregory (1917), occurs in ancient scours containing mudstone of relatively high sand and silt content, and is closely associated with carbonaceous material, some of which it impregnates. An increase of cobalt bloom (sphaerocobaltite) and trace amounts of molybdenum near the ore has been noted.

\section{CONCLUSIONS}

This study of uranium ore bodies and ore districts in the Shinarump and Chinle formations on the Colorado Plateau did not reveal clearly any specific type of genesis.
Known or hypothetical areal controls of primary ore localization are diverse, including Triassic erosional and depositional features, and subsequent tectonic structures as old as Laramide age. Also some ore bodies after oxidization have been partially redeposited in Recent time by ground-water circulation.

Localization of ore in channel fill and other permeable clastic units suggests that transmissivity is a dominant physical ore control. Geochemically, the loci of ore deposition appear to be largely determined by the distribution of such substances as carbonaceous matter, pyrite, calcite, and certain clays capable of precipitating the uranyl ion through changes in $\mathrm{Eh}$ and $\mathrm{pH}$, as well as by adsorption and base exchange. Where uranium occurs in an asphaltite-uraninite complex, as at Temple Mountain, the hydrocarbons are regarded as having been introduced, as fluids, later than the uraninite.

Although the source of the uranium is unknown, isotopic age determinations indicate that the uranium is epigenetic.

\section{REFERENCES CITED}

Baker, A. A., 1933, Geology and oil possibilities of the Moab district, Grand and San Juan Counties, Utah: U. S. Geol. Survey Bull. 841,95 p.

Baumgardner, Luther, and Noble, E. A., U. S. Atomic Energy Comm. unpub. inf.

Butler, B. S., Loughlin, G. F., Heikes, V. C., and others, 1920, The ore deposits of Utah: U. S. Geol. Survey Prof. Paper 111, $672 \mathrm{p}$. 
Dahl, H. M., Fisk, I. T., Volgamore, J. H., and others, U. S. Atomic Energy Comm. unpub, inf.

Dane, C. H., 1935, Geology of the Salt Valley anticline and adjacent areas, Grand County, Utah: U. S. Geol. Survey Bull. 863, 184 p. [1936].

Davidson, C. F., and Bowie, S. H. U., 1951, On thucholite and related hydro-carbon-uraninite complexes, with a note on the origin on the Witwatersrand gold ores: Great Britain Geol. Survey Bull. 3, p. 1-19.

Dix, G. P., Jr., 1954, The uranium deposits of Big Indian Wash, San Juan County, Utah: U. S. Atomic Energy Comm. RME-4022 (revised), 15 p., issued by U. S. Atomic Energy Comm. Tech. Inf. Service, Oak Ridge, Tenn.

Dodd, P. H., 1950, Happy Jack mine, White Canyon, Utah: U. S. Atomic Energy Comm. RMO-660, 25 p., issued by U. S. Atomic Energy Comm. Tech. Inf. Service, Oak Ridge, Tenn.

Gilkey, A. K., 1953, Fracture pattern of the Zuni uplift: O. S. Atomic Energy Comm. RME-3050, 40 p., issued by U. S. Atomic Energy Comm. Tech. Inf. Service, Oak Ridge, Tenn.

Gott, G. B., and Erickson, R. L., 1952, Reconnaissance of uranium and copper deposits in parts of New Mexico, Colorado, Utah, Idaho, and Wyoming: U. S. Geol. Survey Circ. 219, $16 \mathrm{p}$.

Gregory, H. E., 1917, Geology of the Navajo country-a reconnaissance of parts of Arizona, New Mexico, and Utah: U.S. Geol. Survey Prof. Paper 93, 161 p.

Gross, E. B., 1955, U. S. Atomic Energy Comm. unpub. inf.

Gruner, J. W., and Gardiner, Lynn, 1950, Annual report for period June 8, 1949 to July 1, 1950: U. S. Atomie Energy Comm. RMO-612, 35 p. (Microcard copy on file in U. S. Atomic Energy Comm. depository libraries.)

-1952, Mineral associations in the uranium deposits of the Colorado Plateau and adjacent regions with special emphasis on those in the Shinarump formation, pt. 2 and 3: U. S. Atomic Energy Comm. RMO-566, 40 p., issued by U. S. Atomic Energy Comm. Tech. Inf. Service, Oak Ridge, Tenn.

Gruner, J. W., Gardiner, Lynn, and Smith, D. K., Jr., 1954, Mineral associations in the uranium deposits of the Colorado Plateau and adjacent regions (interim report): U. S. Atomic Energy Comm. RME-3092, 48 p., issued by U. S. Atomic Energy Comm. Tech. Inf. Service, Oak Ridge, Tenn.

Gruner, J. W., Rosenzweig, Abraham, and Smith, D. K., Jr., 1954, Annual report for April 1, 1953 to March 31, 1954: U. S. Atomic Energy Comm. RME-3094, 37 p., issued by U. S. Atomic Energy Comm. Tech. Inf. Service, Oak Ridge, Tenn.

Hinckley, D. N., 1955, U. S. Atomic Energy Comm. unpub. inf.
Hunt, C. B., 1953, Geology and geography of the Henry Mountains region, Utah: U. S: Geol. Survey Prof. Paper 228, 234 p. [1954].

1954, Structure and igneous geology of the La Sal Mountains, Utah [abs.]: Science, v. 119, p. 477-478.

Isachsen, Y. W., 1954, Ore deposits of the Big Indian WushLisbon Valley area: Utah Geol. Soc. Guidebook to the geology of Utah, no. 9, p. 95-105.

Isachsen, Y. W., Mitcham, T. W., and Wood, H. B., 1955, Age and sedimentary environments of uranium host rocks, Colorado Plateau: Econ. Geology, v. 50, p. 127-134.

Keys, W. S., 1955, U. S. Atomic Energy Comm. unpub. inf.

Lowell, J. D., in preparation, U. S. Atomic Energy Comm. rept.

Miller, L. J,, 1953, Uranium ore controls of the Happy Jack deposits, White Canyon, San Juan County, Utah: U. S. Atomic Energy Comm. RME-33, 34 p., issued by U. S. Atomic Energy Comm. Tech. Inf. Service, Oak Ridge, Tenn.

Shoemaker, E. M., 1954a, Structural features of southeastern Utah and adjacent parts of Colorado, New Mexico, and Arizona: Utah Geol. Soc. Guidebook to the geology of Utah, no. 9 , p. $48-69$.

1954b, Distribution of elements in sandstone-type uranium deposits, in Geologic investigations of radioactive deposits; semiannual progress report, June 1 to Nov. 30, 1954: U. S. Geol. Survey TEI-490, p. 58-78, issued by U. S. Atomic Energy Comm. Tech. Inf. Service, Oak Ridge, Tenn.

Steen, C. A., Dix, G. P., Jr., Hazen, S. W., Jr., and McLellan, R. R., 1953, Uranium-mining operations of the Utex Exploration Company in the Big Indian district, San Juan County, Utah: U. S. Bur. Mines Inf. Circ. 7669, 13 p.

Stieff, L. R., 1954, Geochronology, in Geologic investigations of radioactive deposits; Semiannual progress report, June 1 to Nov. 30, 1954: U. S. Geol. Survey TEI-490, p. 266-267, issued by U. S. Atomic Energy Comm. Tech. Inf. Service, Oak Ridge, Tenn.

Stieff, L. R., and Stern, T. W., 1953, The lead-uranium ages of some uraninite specimens from Triassic and Jurassic sedimentary rocks of the Colorado Plateau: U. S. Geol. Survey TEI-322, 15 p. (Microcard copy in U. S. Atomic Energy Comm. depository libraries); abs, 1952, Geol. Soc. America Bull., v. 63, p. 1299-1300.

Stokes, W. L., 1948, Geology of the Utah-Colorado Salt Dome region with emphasis on Gypsum Valley, Colorado: Utah Geol. Soc. Guidebook to the geology of Utah, no. 3, 50 p.

Trimble, D. E., 1952, U. S. Geol. Survey unpub. inf.

Weeks, A. D., and Thompson, M. E., 1954, Identification and occurrence of uranium and vanadium minerals from the Colorado Plateau: U. S. Geol. Survey Bull. 1009-B, p. 13-62.

Witkind, I. J., Robeck, R. C., Barton, W. R., and Izett, G. A., 1954 , U. S. Geol. Survey unpub. inf. 


\title{
URANIUM DEPOSITS IN THE WHITE CANYON AREA, SAN JUAN COUNTY, UTAH
}

\author{
By Albert F. Trites, Jr., Tommy L. Finnell, and Robert E. Thaden, U, S, Geological Survey
}

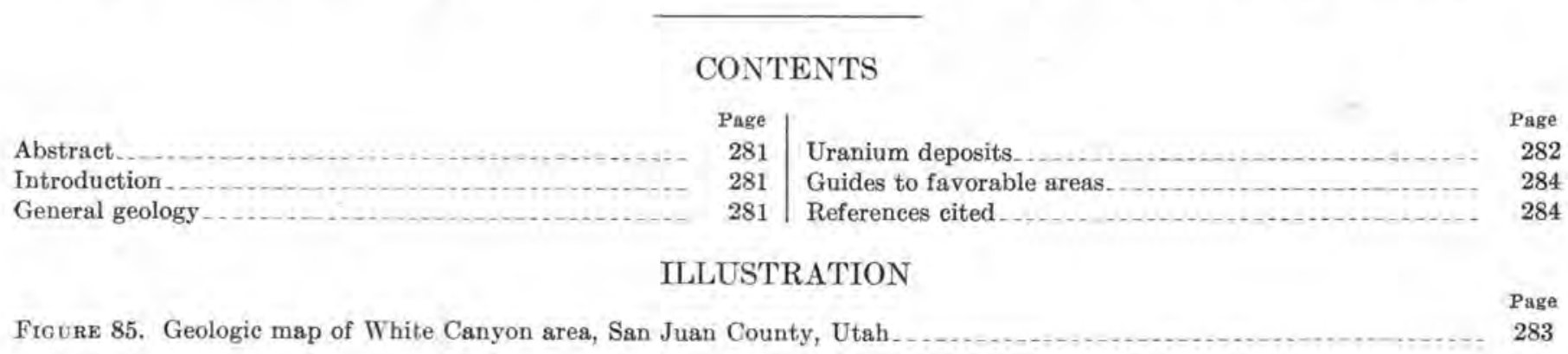

\begin{abstract}
The geology of approximately 560 square miles has been mapped in the White Canyon area, San Juan County, Utah. The area consists of sedimentary rocks, more than 4,000 feet thick, which range in age from Pennsylvanian to Jurassic and have a regional dip of $2^{\circ}-3^{\circ} \mathrm{SW}$. Normal faults are present in the northwestern and southwestern parts of the area.

The uranium deposits occur where the Shinarump conglomerate fills channels cut into beds of the Moenkopi formation. Most of these channels are within a broad band of Shinarump conglomerate ranging from 8 to 15 miles wide. All of the known highgrade deposits are in channels that are within 3,000 to 15,000 feet of the edge of the band of Shinarump conglomerate.

The major control of the uranium deposition appears to have been lithologic; the most favorable bed is a clayey sandstone immediately overlying a bed of siltstone or mudstone and containing carbonized vegetal material. Branches and bends in channels, and scours in the floor of channels, may have provided the conditions for the deposition of favorable rocks.

In addition to uraninite, the uranium minerals include hydrous oxides, silicates, phosphates, and arsenates.
\end{abstract}

\section{INTRODUCTION}

The White Canyon area, near the center of the Colorado Plateau, is between the Colorado and San Juan Rivers in southeastern Utah (lat $37^{\circ} 40^{\prime} \mathrm{N}$., long $110^{\circ} 15^{\prime}$ W.). The area is in the west-central part of San Juan County, about 60 miles by road west of Blanding, Utah. The White Canyon project is a part of a regional mapping program on the Colorado Plateau. Approximately 560 square miles have been mapped in the White Canyon area at a scale of $1: 48,000$.

\section{GENERAL GEOLOGY}

Rocks in the White Canyon area range in age from Pennsylvanian to Jurassic and comprise a sedimentary section more than 4,000 feet thick. The nearest exposed igneous rocks are in the Henry Mountains about 12 miles west and in the Abajo Mountains about 25 miles northeast of the boundaries of the area. A generalized stratigraphic section of the rock formations is presented in the table below.

The area is on the west flank of the Monument upwarp, and beds have a regional dip of $2^{\circ}-3^{\circ}$ southwest and strike northwestward. Small local flexures occur in parts of the area.

Many normal faults cut the Moenkopi and Cutler formations in the northwestern part of the White Canyon area and cut rocks of the Glen Canyon group in the southwestern part. Most of the faults in the northwestern part strike N. $65^{\circ}-75^{\circ} \mathrm{W}$, and their maximum vertical stratigraphic displacement is about 100 feet. Many of the surfaces of the faults in the northwestern part of the area have been coated by limonite or calcite. The red sandstones and siltstones have been bleached as much as 3 feet on either side of the faults. The faults in the southwestern part of the area strike N. $30^{\circ} \mathrm{E}$. to $\mathrm{N} .30^{\circ} \mathrm{W}$., and the displacement along these faults is as much as 250 feet. Joints are abundant throughout the White Canyon area, and the major trends are N. $65^{\circ}-80^{\circ}$ W., N. $70^{\circ}$ E. to due E., N. $30^{\circ}-40^{\circ} \mathrm{E}$, and N, $10^{\circ} \mathrm{W}$. to N. $10^{\circ} \mathrm{E}$.

$385115-56-19$ 
Generalized stratigraphic section, White Canyon area, San Juan County, Utah ${ }^{1}$

\begin{tabular}{|c|c|c|c|c|c|}
\hline System or series & Group & Formation & Member or tongue & Thickness (feet) & Description \\
\hline $\begin{array}{l}\text { Middle and Upper } \\
\text { Jurassic. } \\
\text { Unconformity }\end{array}$ & \multicolumn{3}{|c|}{ San Rafael group undifferentiated. } & $200+$ & Shale and sandstone, red, calcareous. \\
\hline $\begin{array}{l}\text { Jurassic and Jurassic } \\
\text { (?). }\end{array}$ & \multirow{3}{*}{ 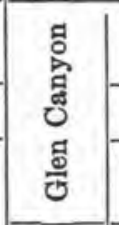 } & Navajo sandstone. & & $600+$ & $\begin{array}{l}\text { Sandstone, cream-yellow, massive, cross- } \\
\text { bedded. }\end{array}$ \\
\hline Jurassic(?). & & Kayenta. & & $200 \pm$ & Sandstone, dark-red, thin-bedded. \\
\hline \multirow{6}{*}{ Upper Triassic. } & & Wingate sandstone. & & $300 \pm$ & $\begin{array}{l}\text { Sandstone, reddish-brown, massive, cross- } \\
\text { bedded. }\end{array}$ \\
\hline & \multirow{5}{*}{$-\cdots-1$} & \multirow{4}{*}{ Chinle. } & Upper member. & $100 \pm$ & $\begin{array}{l}\text { Sandstone, siltstone, and mudstone, reddish- } \\
\text { brown, thin-bedded, calcareous. }\end{array}$ \\
\hline & & & Middle member. & $250-425$ & $\begin{array}{l}\text { Mudstone and siltstone, calcareous and ben- } \\
\text { tonitic, variegated. }\end{array}$ \\
\hline & & & Sandstone member. & $0-100$ & Sandstone, gray and brown conglomerate. \\
\hline & & & Lower member. & $150-245$ & $\begin{array}{l}\text { Clays, gray to variegated, and gray to brown } \\
\text { lenticular sandstone and conglomerate. }\end{array}$ \\
\hline & & $\begin{array}{l}\text { Shinarump con- } \\
\text { glomerate. }\end{array}$ & & $0-75$ & $\begin{array}{l}\text { Sandstone, yellow to gray, and siltstone, } \\
\text { claystone, and conglomerate. }\end{array}$ \\
\hline $\begin{array}{l}\text { Lower and Middle (?) } \\
\text { Triassic. }\end{array}$ & & Moenkopi. & & $175-350$ & $\begin{array}{l}\text { Siltstone, dark-brown to grayish-red, thin- } \\
\text { bedded, fissile, and very fine-grained } \\
\text { ripple-marked sandstone, brown to yellow } \\
\text { shale, and white to pink fine-grained sand- } \\
\text { stones containing clay balls locally; mica } \\
\text { abundant. }\end{array}$ \\
\hline \multirow{4}{*}{ Permian. } & \multirow{4}{*}{ 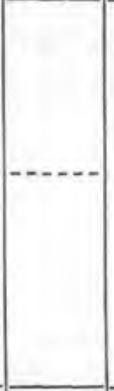 } & \multirow{4}{*}{ Cutler. } & $\begin{array}{l}\text { White Rim sand- } \\
\text { stone member. }\end{array}$ & $0-20$ & Sandstone, cream-yellow, fine-grained. \\
\hline & & & Hoskinnini tongue. & $80-100$ & $\begin{array}{l}\text { Siltstone, reddish-brown, massive-bedded, to } \\
\text { fine-grained sandstone. Contains inter- } \\
\text { bedded cream-yellow limestone-pebble } \\
\text { conglomerate in western part of area. }\end{array}$ \\
\hline & & & $\begin{array}{l}\text { Orga n } \\
\text { tongue. }\end{array}$ & $100-300$ & $\begin{array}{l}\text { Siltstone, reddish-brown, micaceous, and } \\
\text { very fine-grained sandstone. }\end{array}$ \\
\hline & & & $\begin{array}{l}\text { Cedar Mesa sand- } \\
\text { stone member. }\end{array}$ & $1,000 \pm$ & $\begin{array}{l}\text { Sandstone, cream-yellow, crossbedded, with } \\
\text { red shale locally near the top. }\end{array}$ \\
\hline $\begin{array}{c}\text { Pennsylvanian and } \\
\text { Permian(?). }\end{array}$ & 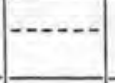 & Rico. & & $575 \pm$ & $\begin{array}{l}\text { Sandstone, siltstone. shale, and limestone, } \\
\text { interbedded, gray, red, and purple. }\end{array}$ \\
\hline Pennsylvanian. & ----- & Hermosa. & & $400-1,000$ & $\begin{array}{l}\text { Limestone, gray, cherty, with gray, buff, and } \\
\text { red calcareous sandstone and shale. }\end{array}$ \\
\hline
\end{tabular}

1 In part from Gregory (1938) and Benson and others (1952).

\section{URANIUM DEPOSITS}

The uranium deposits in the White Canyon area occur in channels that have been cut into beds of the Moenkopi formation and filled by sandstone, siltstone, claystone, and conglomerate of the Shinarump conglomerate. Most of these channels are within a broad outcrop belt of Shinarump conglomerate ranging from 8 to 15 miles in width. This belt extends across the area, from beyond Deer Flat on the east to beyond the Colorado River on the west, a distance of more than 20 miles. The northern edge, or pinchout, of the belt of Shinarump is, in general, irregular with many lenses of Shinarump extending outward from the main mass.
A few isolated patches of Shinarump conglomerate occur in the area north of the main belt. The southeast edge of the belt of Shinarump conglomerate (near head of Red Canyon, fig. 85) is more regular and has a general trend of N. $80^{\circ} \mathrm{E}$. The extent of the Shinarump conglomerate is not known southwest of Red Canyon, because it is deeply buried beneath younger rocks. Most of the Shinarump conglomerate within the belt ranges from 8 to 80 feet in thickness, although locally it is absent.

Of the 64 channels that have been mapped in the White Canyon area (fig. 85), 16 are known to contain at least 1 uranium deposit with a minimum grade of 


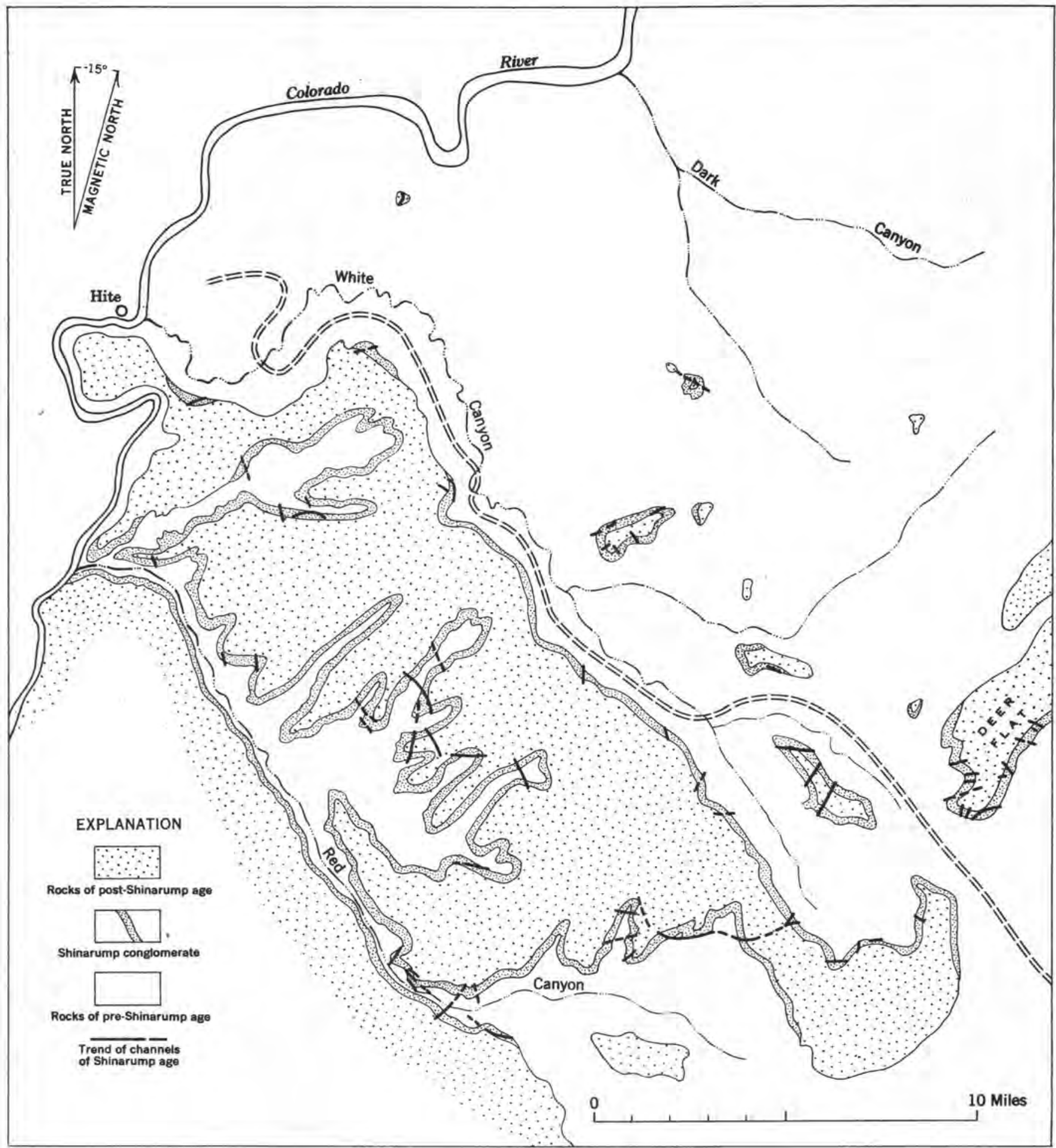

Frgure 85.-Geologic map of White Canyon area, San Juan County, Utah.

0.10 percent $\mathrm{U}_{3} \mathrm{O}_{8}$. In addition, 8 channels-possibly more - contain low-grade uraniferous material. The trend of channels in the area is shown in figure 85 . Channels range from 30 to 650 feet in width and from 4 to 50 feet in depth. Uranium deposits do not show a preference for channels of a particular size or shape, but seem to have selected a lithologic setting. All the known high-grade deposits occur where Shinarump conglomerate fills channels that are within 3,000 to 15,000 feet of the pinchouts of the Shinarump. 
The emplacement of the uranium deposits is believed to have been controlled principally by the lithology of the sediments filling the channels. Channel segments filled with a high percentage of sandstone and containing few, if any, mudstone or siltstone beds appear to be unfavorable for deposits; channel segments with too high a percentage of mudstone or siltstone beds are equally unfavorable. Within favorable channels a sandstone lens immediately overlying a bed of mudstone or siltstone, and containing a high percentage of clay cement and pebbles, appears to be the most highly mineralized bed in many of the mines in the area. Trashy carbonaceous material is present in most of the ore-bearing beds and may have been important in depositing the uranium minerals. Trash and finer grained material appear to be concentrated at branches and bends along the channels.

Uraninite occurs in most of the deposits that have been mined behind the oxidized rim outcrops. Secondary uranium minerals are abundant in many of the deposits and are listed in the following table.

Secondary uranium minerals from deposits in the White Canyon area, San Juan County, Utah

\begin{tabular}{|c|c|c|c|}
\hline Type & Mineral & Composition & Major occurrences (mines) \\
\hline $\begin{array}{l}\text { Hydrous oxide } \\
\text { Silicates } \\
\text { Sulfates } \\
\text { Arsenate } \\
\text { Carbonates }\end{array}$ & $\begin{array}{l}\text { Becquerelite } \\
\left\{\begin{array}{l}\text { Cuprosklodowskite } \\
\text { Uranophane }\end{array}\right. \\
\left\{\begin{array}{l}\text { Zippeite } \\
\text { Johannite. } \\
\text { Uranopilite }\end{array}\right. \\
\left\{\begin{array}{l}\text { Phosphuranylite } \\
\text { Torbernite. } \\
\text { Metazeunerite }\end{array}\right. \\
\text { Bayleyite } \\
\text { Schroeckingerite }\end{array}$ & 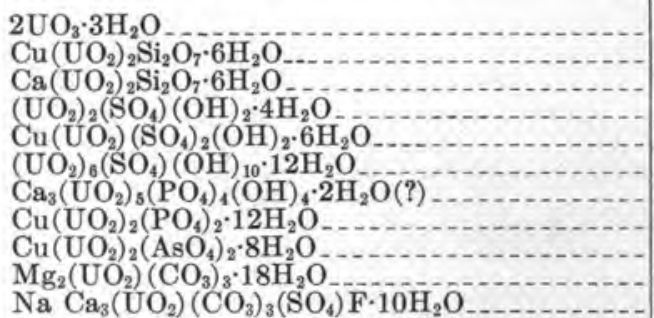 & $\begin{array}{l}\text { Posey. } \\
\text { Posey. } \\
\text { North Point. } \\
\text { Happy Jack. } \\
\text { North Point, Posey. } \\
\text { North Point. } \\
\text { Markey, Jomac. } \\
\text { Hideout. }\end{array}$ \\
\hline
\end{tabular}

Sulfide minerals, including chalcopyrite, pyrite, bornite, and sphalerite, are disseminated with the uranium minerals in many of the deposits, and galena and marcasite occur in the Happy Jack mine. In deposits exposed at the surface, crude supergene and oxide zones have been formed. Supergene sulfide minerals are chalcocite and covellite. Many of the secondary uranium minerals, copper carbonates and sulfates, and abundant iron oxides have been formed in the zones of oxidation.

\section{GUIDES TO FAVORABLE AREAS}

The guides to favorable areas in the White Canyon area are divided into three groups: primary guides, secondary guides, and tertiary guides. Primary guides are closely associated with the ore deposits and extend only a few feet from the deposits. They are covellite pods, secondary uranium minerals, abnormal radioactivity, and carbonized wood (coal). The presence of jarosite in some of the deposits suggests its usefulness as a primary guide.

Secondary guides may extend from tens of feet to hundreds of feet beyond the limits of the deposits. These secondary guides may prove useful in indicating sites for core drilling. The secondary guides are branches, bends, and basins in channels; clayey sandstone overlying siltstone or mudstone in the channel; disseminated sulfide minerals, especially chalcopyrite, covellite, and bornite; secondary uranium minerals; secondary copper minerals; carbonized wood and trash; and abnormal radioactivity.

Tertiary ore guides are large-scale features that may be useful in determining large areas favorable for deposits. Pinchouts of the Shinarump conglomerate may have restricted and concentrated uranium deposits in some parts of the area. Channels may also be considered as tertiary ore guides.

The large number of channels filled with Shinarump that have been mapped in the White Canyon area, and the frequency of uranium deposits within these channels, suggests that the area is favorable for the discovery of additional deposits. Any channel with a scour deeper than 5 feet may contain significant quantities of uraniferous rock somewhere along its length. The best guides for favorable areas for uranium deposits along the channels seem to be the secondary guides.

\section{REFERENCES CITED}

Benson, W. E., Trites, A. F., Jr., Beroni, E. P., and Feeger, J. A., 1952, Preliminary report on the White Canyon area, San Juan County, Utah: U. S. Geol, Survey Circ. 217, 10 p.

Gregory H. E., 1938, The San Juan country, a geographic and geologic reconnaissance of southeastern Utah: U. S. Geol. Survey Prof. Paper 188, 123 p. 


\title{
INVESTIGATION OF THE TEMPLE MOUNTAIN COLLAPSE AND ASSOCIATED FEATURES, SAN RAFAEL SWELL, EMERY GOUNTY, UTAH
}

\author{
By W. Scotт Keys and R. L. White, U. S. Atomic Energy Commission
}

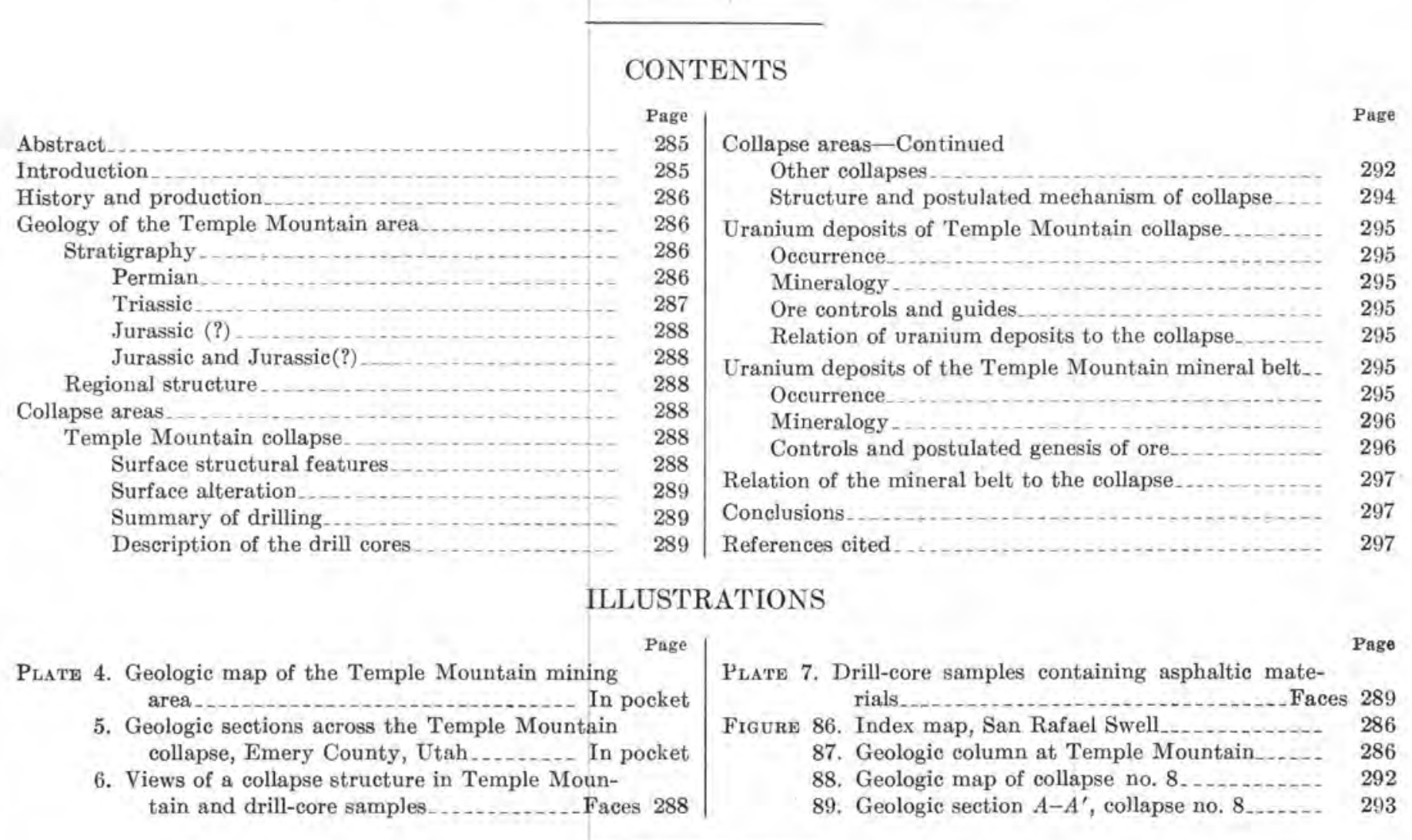

\section{ABSTRACT}

The Temple Mountain collapse was drilled to investigate the genesis of its structure and its relation to the uranium ores and to test for ore at zones deeper than those locally productive. Two other smaller collapses were also drilled.

The Temple Mountain collapse is about 500 feet wide by 2,000 feet long; the maximum subsidence is 300 feet. The collapse is characterized by a synclinal depression, with a brecciated and bleached center. Drilling shows that the rock has undergone flowage, brecciation, and alteration at depth. Minerals identified include pyrite, galena, arsenopyrite (?), realgar, uraninite, and abundant asphalt.

Limestones normally present in the stratigraphic section are missing in most of the holes, thus supporting the hypothesis that solution of carbonate rocks was at least partly responsible for the collapse of overlying sediments. A new ore horizon, consisting of chert remnants of the Kaibab limestone cemented by asphaltic sandstone, was found immediately above the Coconino sandstone.
More than 95 percent of the uranium production of the Temple Mountain region has come from an area about 2,000 feet south of the collapse.

\section{INTRODUCTION}

The Temple Mountain collapse is a small structural basin with a breceiated and bleached cylindrical eore. The uranium deposits associated with it extend through a greater thickness of rocks than at any other locality on the Colorado Plateau. This fact, together with the intense bleaching in the collapse and the occurrence nearby of large ore deposits in the Moss Back member of the Chinle formation, has created much interest in the structure of the collapse.

The purpose of the drilling (Keys, 1954) was to investigate the genesis of the collapse and its relation to the uranium ores and to test for ore at horizons 
deeper than those locally productive. The program was started on November 8, 1954, and was finished June 28, 1955. A detailed geologic map of the Temple Mountain district was prepared during the drilling, and all available data on drilling and mines were compiled.

Temple Mountain is on the southeastern flank of the San Rafael Swell and about 44 miles southwest of Green River, Utah (fig. 86). It can be reached by traveling 4 miles west from Green River on paved U. S. Highway 50, then 33 miles south on Utah Highway 24 , a graded road, and thence 7 miles northwest on a graded road.

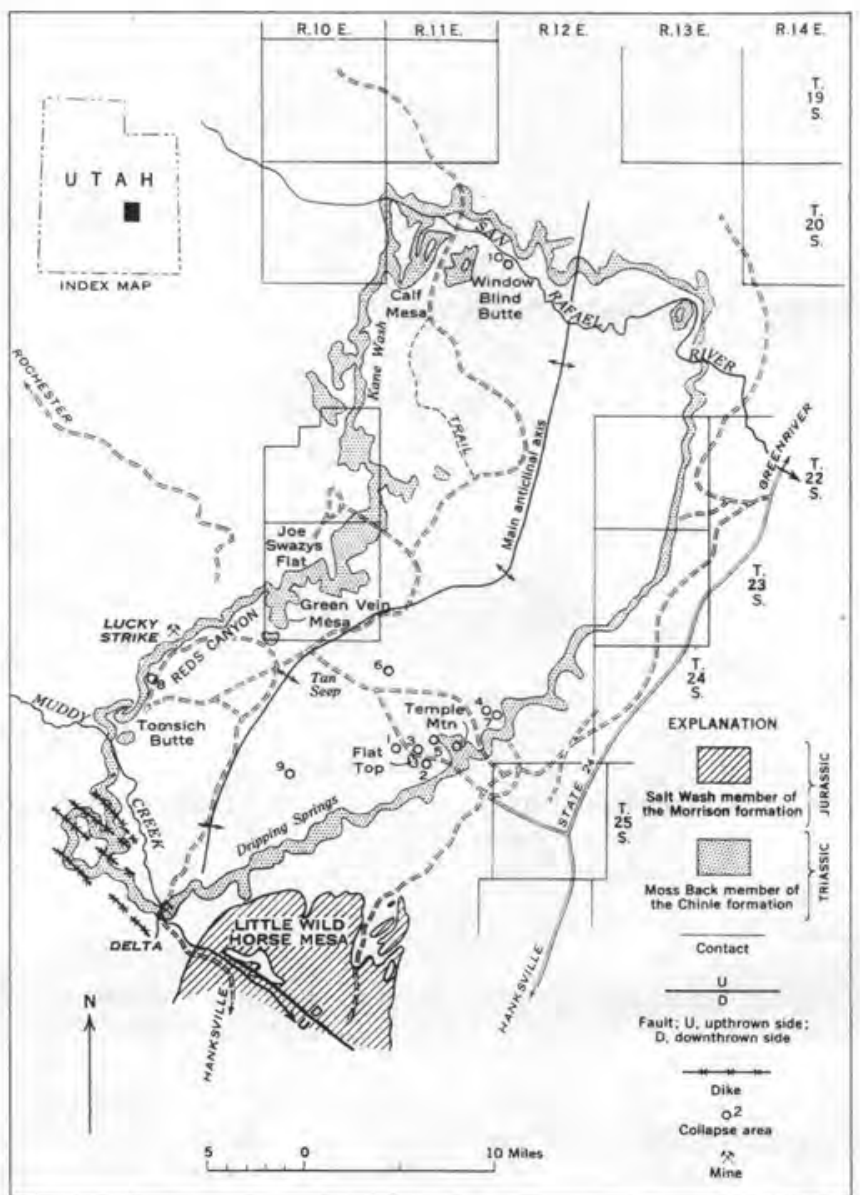

Figure 86.-Index map, San Rafael Swell, Emery County, Utah.

Many reports have been written on the geology of the Temple Mountain mining area. Dana Kelley, of Columbia University, did detailed mineralogic work on some samples of core from hole V-1. R. A. Laverty and E. B. Gross, of the Atomic Energy Commission, identified some of the minerals from the collapse. P. H. Dobbs, W. J. Blosil, and W. R. Kastelic, Atomic Energy Commission geologists, assisted in the field mapping.

\section{HISTORY AND PRODUCTION}

The uranium-vanadium ores at Temple Mountain were discovered before 1904, but the production was very small until 1948 when the present period of mining activity began. Production from 1948 through June 1952 exceeded 50,000 tons, averaging 0.19 percent $\mathrm{U}_{3} \mathrm{O}_{8}$ and 0.54 percent $\mathrm{V}_{2} \mathrm{O}_{5}$. Since that time production has steadily increased, averaging 6,000 tons per month from 1952 to 1955 inclusive. Most of the ore bodies being mined at the time of this investigation were discovered by drilling between December 1951 and May 1952, by the Atomic Energy Commission.

\section{GEOLOGY OF THE TEMPLE MOUNTAIN AREA}

\section{STRATIGRAPHY}

The stratigraphic sequence of bedrock formations in the Temple Mountain area is shown graphically in figure 87 .

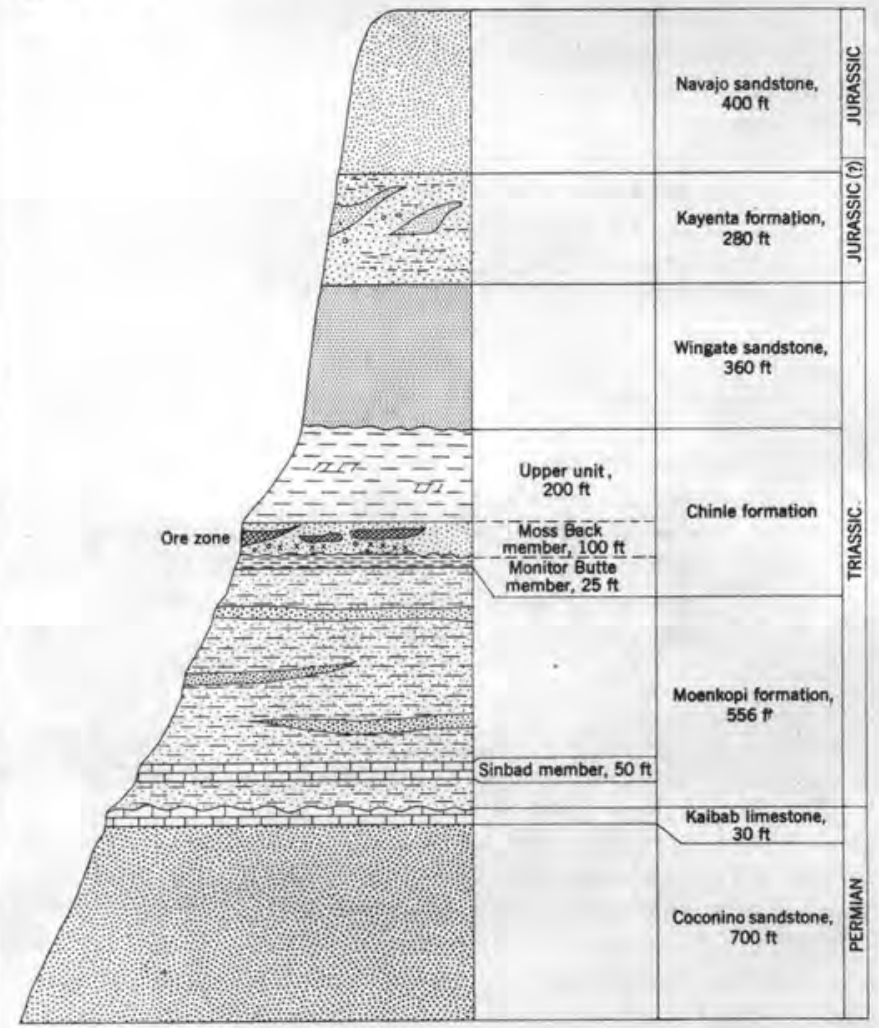

Figure 87.-Geologic column at Temple Mountain, Emery County, Utah.

PERMTAN

Coconino sandstone.-The Coconino sandstone of San Rafael Swell has been correlated with the Coconino of the Grand Canyon region because of lithologic similarities and because of their common position beneath Permian marine limestone. The Coconino sandstone is more than 700 feet thick in the canyon of the San Rafael River (Gilluly and Reeside, 1928). 
The uppermost 50 feet is exposed 1 mile north of Temple Mountain. Typical Coconino sandstone is tangentially crossbedded, gray to brown, fine to medium grained, and cemented with calcium carbonate. Of the theories on its origin, an eolian origin is favored by most.

An unusual feature of the Coconino in the Temple Mountain area is the high asphaltic content in the uppermost part. As much as 45 feet of petroliferous Coconino has been cored in the collapse area. Uranium mineralization was seen at the top of the Coconino in several drill cores. Most significant, however, is the fact that the Coconino does not appear to be brecciated in the collapse area.

Kaibab limestone,-Approximately 30 feet of marine Kaibab limestone is exposed less than 1 mile north of Temple Mountain. There is great range in thickness throughout the San Rafael Swell, however; and a maximum thickness of 90 feet of Kaibab has been measured 13 miles southwest of Temple Mountain. Erosional "windows" occur where the Kaibab was removed before Moenkopi deposition (Gilluly and Reeside, 1928).

The contact between the Kaibab limestone and underlying Coconino sandstone is gradational, and the base of the Kaibab consists of limy siltstones and sandstones which probably represent reworked Coconino. Most of the Kaibab is dark-gray to black limestone, which is sandy in many places. Chert geodes with fillings of calcite and asphalt are abundant in the upper part. The Kaibab north of Temple Mountain appears to contain more asphalt than at other places, both in vugs and interstitially.

The Kaibab limestone is not present in any of the holes drilled in the Temple Mountain collapse. A sandy bed containing chert concretions and nodules occurs at the Kaibab horizon. Although similar material may form the basal conglomerate of the Moenkopi formation, this bed is here referred to as the conglomerate zone of the Kaibab limestone. Most of the uranium of ore grade found in drilling the collapse is in this unit.

\section{TRTASIIC}

Moenkopi formation,-A marked erosional unconformity separates the Kaibab limestone from the overlying Moenkopi formation of Early Triassic age throughout the San Rafael Swell. A basal conglomerate, averaging 5 feet in thickness, contains many chert and limestone fragments derived from the Kaibab limestone.

The Moenkopi formation is composed chiefly of red to brown mudstone, shaly siltstone, and fine-grained sandstone which is micaceous in some strata. The lenticular beds range in thickness from less than 1 inch to 10 feet. Some of the sandstone is crossbedded and contains abundant ripple marks. On the north side of Temple Mountain, the Moenkopi formation is 556 feet thick, which is about 100 feet less than the average thickness in the San Rafael Swell.

The Sinbad limestone member, which is about 30 feet thick and consists of buff to gray thin-bedded sandy limestone, occurs approximately 90 feet above the base of the Moenkopi. This limestone member is of marine origin, although most of the Moenkopi was probably deposited in shallow lagoonal waters under arid conditions. The Sinbad is petroliferous at isolated localities near the north part of Temple Mountain.

The Sinbad limestone is usually missing within the collapse, and most of the Moenkopi is structurally disturbed and bleached and contains asphalt. Some uranium is in brecciated material that is thought to be Moenkopi,

Monitor Butte member of the Chinle formation.-The Monitor Butte member of the Chinle formation consists of 25-40 feet of gray, purple, maroon, and yellow variegated siltstone and sandstone. This unit, locally called the "pinto zone," grades into the Moenkopi formation in places, but the contact also appears to be locally disconformable. The "pinto zone," which heretofore had been assigned to the Moenkopi, is now considered to be Chinle because it is more like the Chinle overlying the Moss Back member in color and sorting than the remainder of the Moenkopi.

Moss Back member of the Chinle formation.-The orebearing sandstone in the Temple Mountain area has previously been called the Shinarump conglomerate, but recent stratigraphic work by the U. S. Geological Survey suggests it is correlative with the Moss Back member of the Chinle formation at White Canyon (Williams, 1953). In the vicinity of Temple Mountain the Moss Back member ranges from 50 to 125 feet in thickness with an average thickness of 100 feet in the mining area. The lithology of the Moss Back member is extremely variable but normally consists of limy poorly sorted gray to brown sandstones and some conglomerates. The pebbles are composed of limestone, gray to black chert, quartz, and quartzite. Carbonaceous and silicified plant remains are common in both sandstones and conglomerates. Abundant gray-green mudstone lenses are intercalated throughout the Moss Back, and festoon or trough cross-stratification is common.

Upper unit of the Chinle formation.-The upper unit of the Chinle, above the Moss Back, ranges from 185 to 265 feet in thickness and has an average thickness of 200 feet. The lithologic units of the upper unit of the Chinle are typically lenticular with only a few major units traceable for more than a few hundred feet. Rock 
types in the upper unit of the Chinle, in order of decreasing abundance, are siltstone, sandstone, mudstone, and conglomerate. These rocks are red, purple, and gray throughout the rest of the San Rafael Swell, but at Temple Mountain they are chiefly gray and brown because of the asphalt and siderite. Most of the Chinle formation is thought to be of fluviatile origin.

Some uranium-vanadium ore is found in the upper unit of the Chinle around the main collapse. Within the collapse zone the Chinle formulation has undergone considerable structural disturbance and bleaching, and it is only through recognition of the coarse clastic fragments that it may be identified.

Wingate sandstone.-The Wingate sandstone is separated from the underlying Chinle formation by an erosional disconformity, but the upper contact with the Kayenta formation is gradational. The average thickness of the Wingate is 360 feet on Temple Mountain. It is a light-brown to buff fine-grained thickly crossstratified to massive sandstone of eolian origin. The grains are well-sorted frosted quartz, cemented by calcium carbonate. Blocks of the Wingate formation within the brecciated collapse area are usually recognizable because of the character and uniformity of the sand grains.

On both the north and the south parts of Temple Mountain, the Wingate formation contains large amounts of petroleum, filling the interstices, and it shows intense surface bleaching. The weathered sucfaces appear white, but fresh surfaces are light to very dark gray. In this area of color alteration there is considerable dolomitization at the base of the Wingate, and some uranium-vanadium ore occurs in the lower two-thirds of the sandstone.

\section{JURASSIC(?)}

Kayenta formation.-A small amount of altered Kayenta formation probably remains on the top of the north part of Temple Mountain, but it is inaccessible, and nothing is known of the character of the Kayenta in the collapse area. Typical Kayenta elsewhere in the San Rafael Swell consists of about 280 feet of buff to brown fine-grained shaly sandstone in lenses from 5 to 10 feet thick. A few thin lenses of mudstone and conglomerate are scattered through the formation and indicate a partially fluviatile origin.

\section{JURASSIC AND JURASSIC(?)}

Navajo sandstone.- The Navajo sandstone bas been eroded from Temple Mountain and remains only along the hogback southeast of the mining area. It consists of more than 400 feet of a light-tan well-sorted eolian sandstone, devoid of asphalt. It is characterized by long sweeping cross-strata between horizontal bedding planes, which may be as much as 50 feet apart.

\section{REGIONAL STRUCTURE}

Temple Mountain lies 7 miles south and east of the principal anticlinal axis of the San Rafael Swell. The average strike of the axis is N. $20^{\circ} \mathrm{E}$., but in the central part, north of Temple Mountain, the trend changes for a short distance to N. $70^{\circ} \mathrm{E}$. (fig. 86). The curvature of the axis may denote an area of structural stresses which may account for the concentration of collapses in the vicinity of Temple Mountain.

The northeast flank of the swell dips steeply to the east, with the beds dipping a maximum of $85^{\circ}$. To the north and the southwest, these beds flatten very rapidly, and the strike also changes markedly. In the vicinity of Temple Mountain, the dip ranges from $4^{\circ}$ SE. at the north end of the mountain to $9^{\circ} \mathrm{SE}$. on the south edge of the mining area (pl. 4). Temple Mountain and the adjacent mining area lie in a minor synclinal warp on the flank of the anticline. The collapse occurs in the northern part of this minor flexure.

The faults in the Temple Mountain region generally strike east and are nearly vertical. The throw on these faults ranges from several feet to several tens of feet, and the amount of displacement differs within short distances; many of the faults merge into joints along the strike. Commonly there is a well-developed set of joints on each side of a fault. Several faults strike toward the collapse area but lose all vertical displacement before reaching the collapse. A graben that lies between two of these faults, west of the collapse, may be related to the subsidence within the collapse area.

In addition to the joints which are parallel to the main faults, there are two sets of vertical joints. The stronger set strikes N. $50^{\circ} \mathrm{W}$.; and the weaker set, from N. $10^{\circ} \mathrm{E}$. to N. $60^{\circ} \mathrm{E}$. Both sets are apparently related to the anticlinal uplift of the San Rafael Swell. The direction of jointing changes south of the fault which crosses the Lopez incline; the stronger set trends east, and the minor set trends north to N. $10^{\circ} \mathrm{E}$. (pl. 4). The random joints and faults within the collapse area were apparently caused by adjustment between subsiding blocks and are believed to have no relation to the collapse.

\section{COLLAPSE AREAS}

\section{TEMPLE MOUNTAIN COLLAPSE}

\section{SURFACE STRUCTURAL FEATURES}

The collapse on Temple Mountain is within an elliptical area about 2,000 feet long and 500 feet wide (pl. 4). Within this area, beds of the Moenkopi, Chinle and Wingate formations, characterized by brecciation, plastic flow, and alteration, have settled into the collapse. Around the edge of the collapse, both normal 

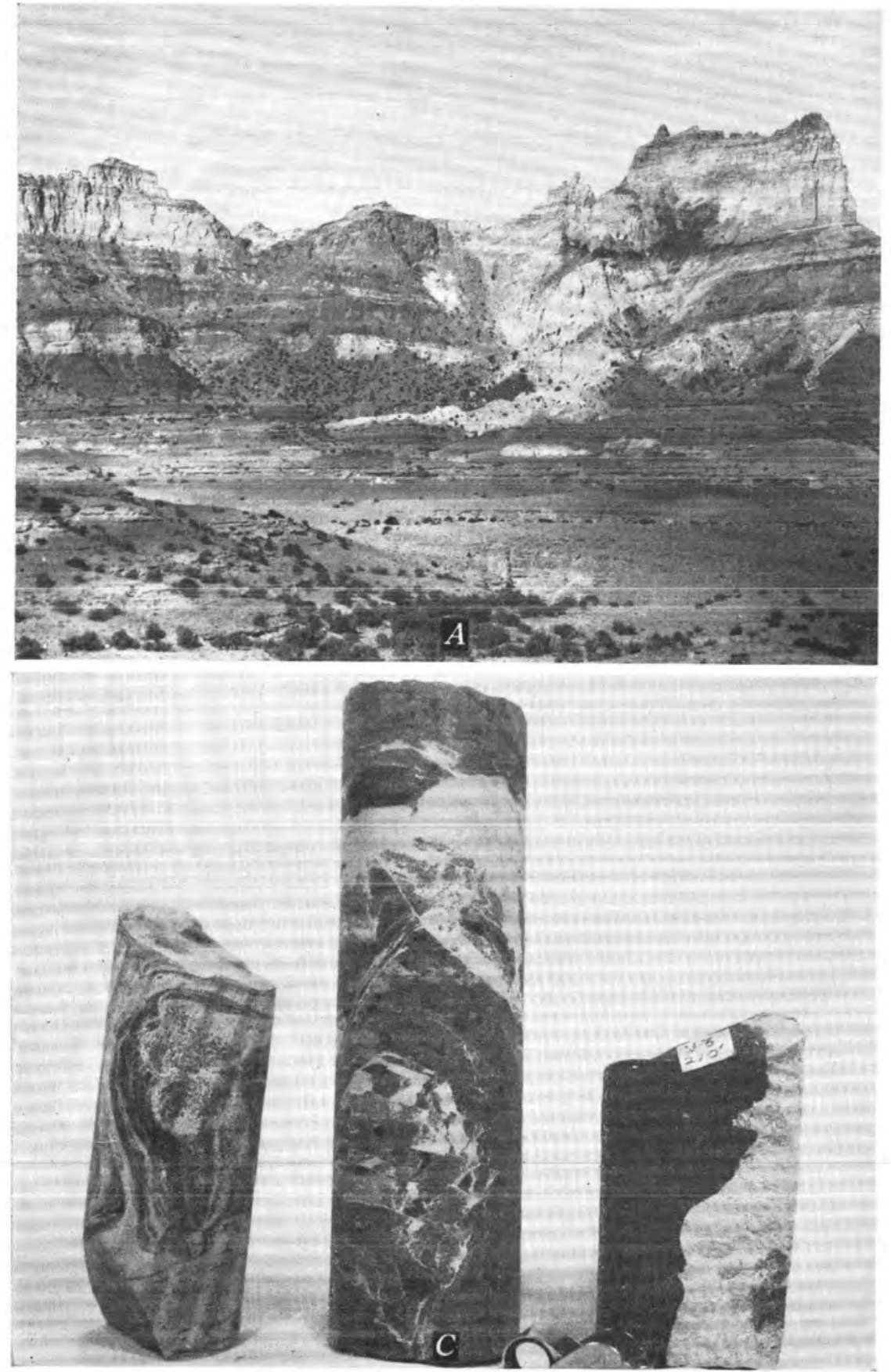

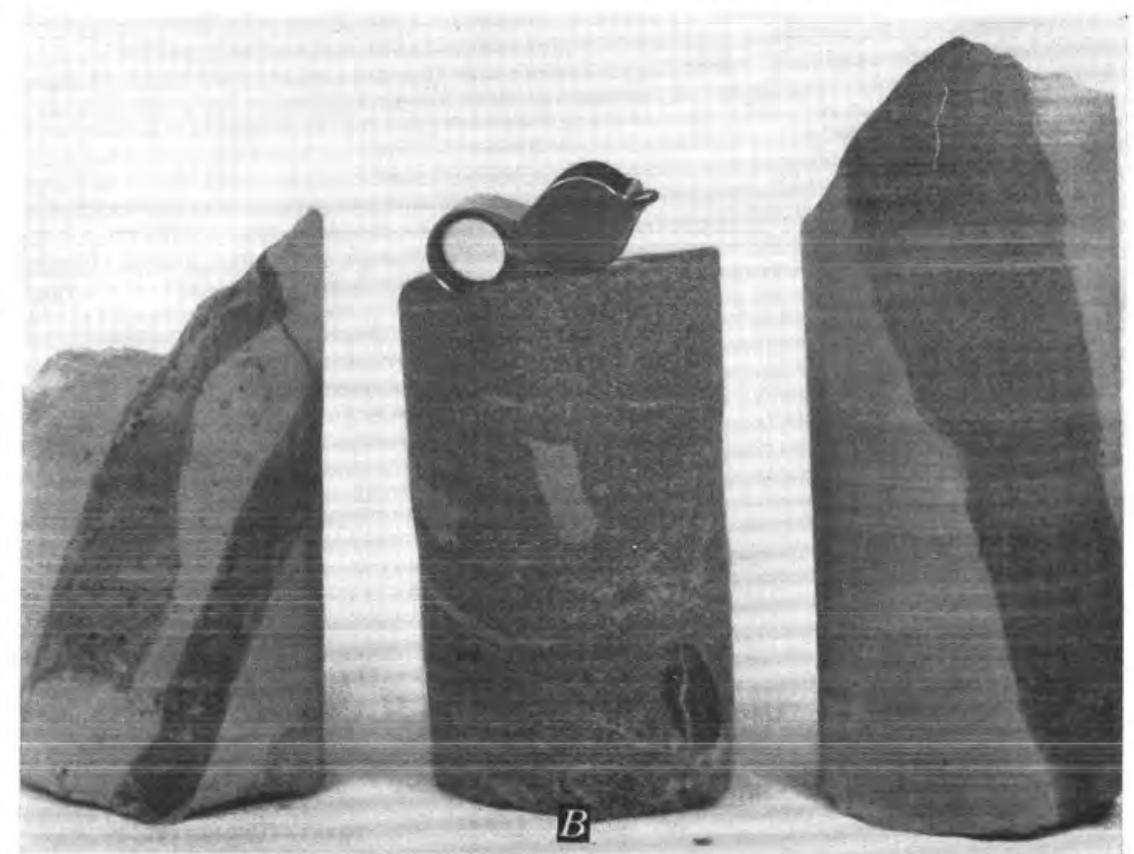

VIEWS OF A COLLAPSE STRUCTURE IN TEMPLE MOUN. TAIN AND DRILL-CORE SAMPLES

A. On the west side of Temple Mountain beds dip toward collapse zone where ferrugination and bleaching are extensive.

$B$. Sandstone "dikes" in siltstone. Center core shows fragments of mudstone in sandstone, with black chert pebble of the Chinle formation.

C. Asphalt-impregnated sandstone and siltstone. Partial asphalt saturation has emphasized fractures in center core and possible flow structures in core at left. 

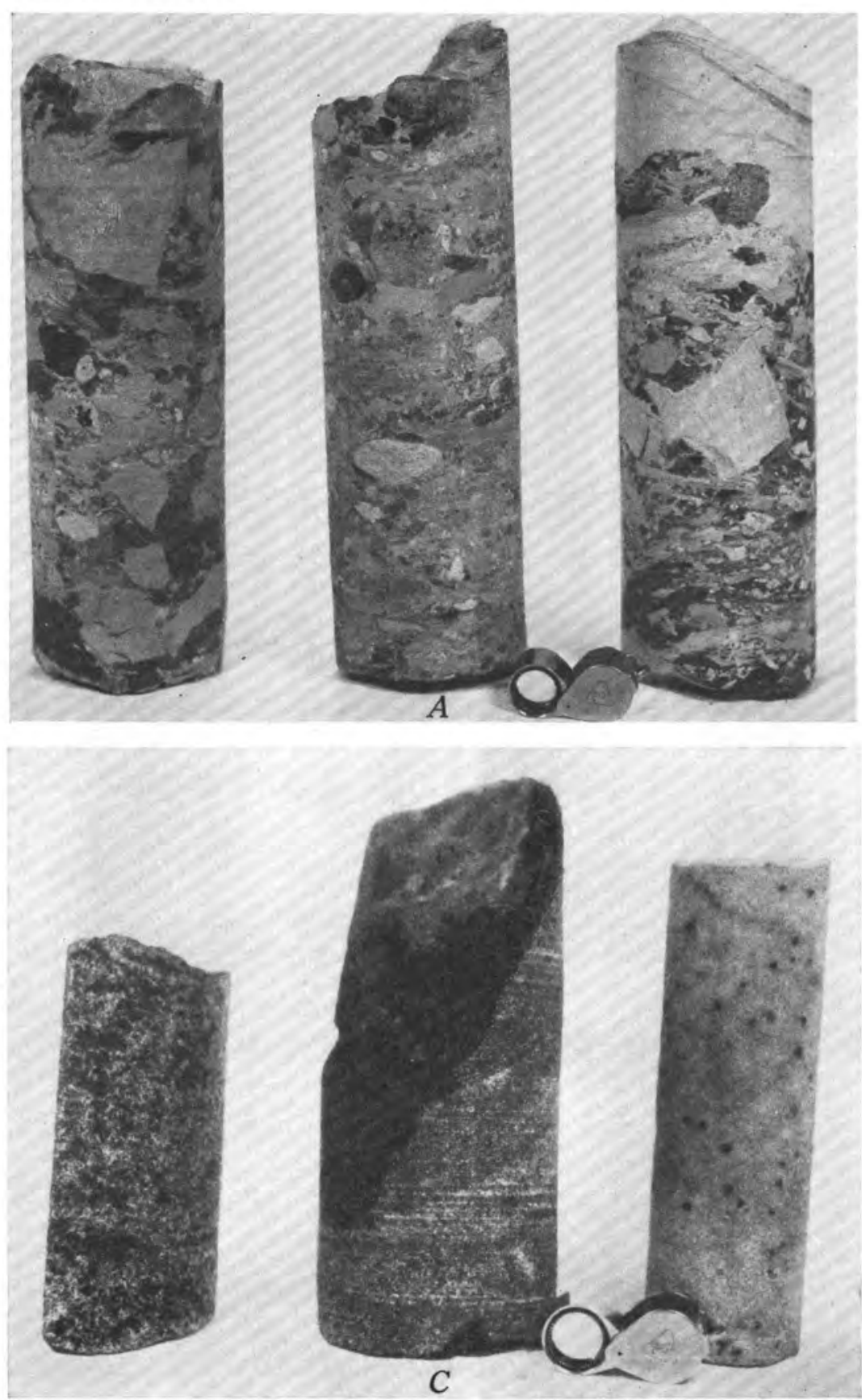

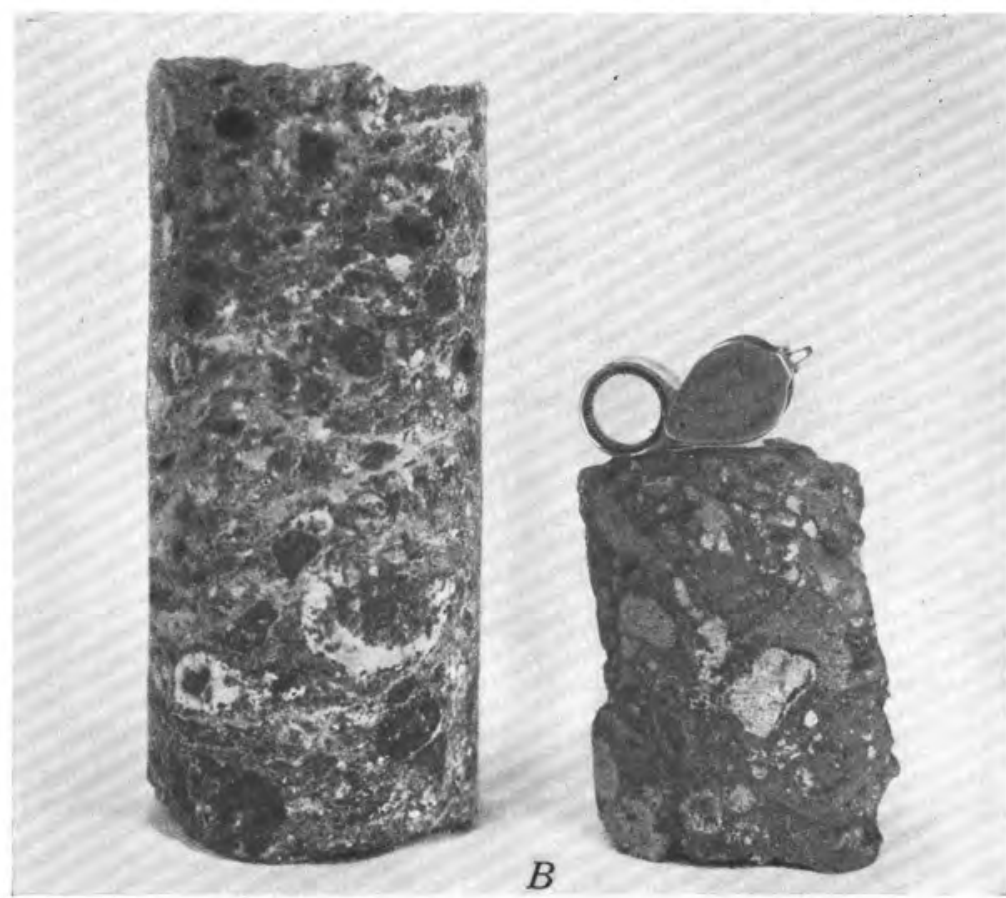

DRILL-CORE SAMPLES CONTAINING ASPHALTIC MATERIALS

A. The cores have typical breccia fabric. Fragments are cemented by sandstone containing asphaltic material. Pebbles in center core are derived from the Chinle formation.

$B$. Chert geodes and nodules in core samples of the conglomerate of the Kaibab limestone. The larger specimen contains unmineralized asphalt. The smaller specimen is cemented by hard asphalt-bearing pitchblende, pyrite, galena, and arsenopyrite(?).

$C$. Core samples of Coconino sandstone showing variation from partial to complete asphalt saturation. Core at right contains concentrations of galena which have partly replaced quartz grains. 
and altered beds dip as steeply as $31^{\circ}$ toward the core (pls. 4-6).

Along the ridge between the north and south parts of Temple Mountain are large blocks (pl. 4), mostly of Wingate sandstone, which have slumped into the collapse with little accompanying brecciation. On the west side of Temple Mountain there is an irregular elongate extension of bleached rock called the "tongue" (pl. 4). Blocks or sections of Chinle rocks have subsided extensively in this part of the collapse, but brecciation and alteration make identification difficult.

Flow structures are not abundant at the surface, but contorted bedding planes and sandstone dikes are found near the "tongue" (pl, 4). Tightly contorted mudstone and sandstone beds, probably Chinle, can be seen below a large slump block of the Wingate formation southeast of drill hole V-3. Sandstone dikes up to an inch wide and 20 feet long crop out just north of the same hole. These dikes fill fractures in the Monitor Butte member of the Chinle formation and are parallel to a vertical fault bounding part of the collapse.

\section{SURFACE ALTERATION}

Bleaching of the redbeds is one of the most obvious chemical alteration effects on the surface. This bleaching is probably due to the reduction or removal of iron oxides, and may have been caused by the introduction of asphalt. J. W. Gruner (1954, p. 5) has concluded that removal of hematite can not be doubted where a gray or white rock must have been red originally. The bleaching is more intense in the collapse core and decreases in intensity toward the margin of the synclinal depression. The farthest lateral extent of the bleaching occurs in the Chinle and Wingate formations. This is partly due to the greater permeability of these beds in comparison with the underlying Moenkopi formation. The bleached margin in the Moenkopi around the collapse generally does not exceed 20 feet. All of the gray Wingate observed on the north and south parts of Temple Mountain contains a large amount of residual oil as grain coatings, and the white appearance of the weathered surface is caused by the removal of the asphalt, which has reduced the ferric iron oxides. The highly permeable Moss Back member of the Chinle formation also contains some petroleum. Bleaching of the Moss Back is widespread and extends outside the Temple Mountain area.

The base of the Wingate sandstone is extensively dolomitized in and near the collapse zone. Dolomite lenses on both the north and the south parts of Temple Mountain undoubtedly represent erosional remnants of more extensive dolomitization. The formation of this dolomite appears to be genetically related to the collapse. Dolomitization appears to have originated at $385115-56-20$ numerous centers throughout the sandstone and developed into spherical concretions in which the dolomite has partly replaced quartz sand grains. Where these spherules coalesce, vugs lined with rhombohedral dolomite crystals are common, and the original texture of the sandstone is obliterated.

Within the collapse, ferrugination is common at the top of the Chinle formation and in the Wingate sandstone. Siderite, with minor hematite and botryoidal goethite, forms lenticular masses which have partly or wholly replaced sandstone of the Chinle formation. These large masses of siderite have been called gossans, presumably because of their similarity to sulfide ore bodies that have been oxidized. It appears more likely that the iron was deposited as siderite, along with the dolomite, since no casts or remnants of sulfides have been found. This interpretation is further supported by the occurrence of siderite at a depth of 220 feet in drill hole $\mathrm{V}-5$.

The source of the iron in the siderite is not known. Pyrite is generally more abundant in the rocks of the collapse than in bleached rocks of the Moenkopi formation within the San Rafael Swell, suggesting that most of the iron in the collapse came from below the Coconino sandstone because that unit contains very little iron.

The source of the magnesium in the dolomite is uncertain. It may have come from below the Coconino sandstone along with the siderite, since dolomite was found at a depth of 450 feet in drill hole V-7, but magnesium also has been found in the Moenkopi formation by chemical analysis (P. F. Kerr, personal communication).

\section{SUMMARY OF DRILLING}

Thirteen holes were drilled, totaling 7,500 feet, with an average core recovery of 93.3 percent. Exceptionally poor recovery in unconsolidated sandstones in holes $\mathrm{V}-12$ and $\mathrm{V}-13$, in collapse no. 8, lowered the average core recovery.

\section{DESCRIPTION OF THE DRILL CORES}

A summarized description of the drill cores is given in the following tables.

Structures.-The drill core is characterized by breccia, flow structures, fractures, alteration, and pyritization. At least 50 percent of the drill core lacks notmal sedimentary features, such as bedding planes and graded bedding. Bedding planes are commonly highly inclined, up to $80^{\circ}$ from horizontal, in those parts that show normal sedimentary features. Sandstone dikes, some several feet long and an inch wide, are widespread in the core (pl. 6). These dikes, which normally cut bedding planes at a steep angle, usually consist of medium-grained sandstone with interstitial asphalt; 
this rock type contains some of the uranium. The dikes extend into areas where rocks appear to be undisturbed. Some bifurcate or swell and contain angular inclusions of the surrounding matrix. Parallel alinement of clay chips within a few dikes indicates flowage. The common contortion of bedding planes is best shown where asphalt selectively impregnates sandstone beds (pl. 6).

Fracturing is common in the more competent beds, with displacements usually less than 1 inch. Successive stages of fracturing demonstrate the varied and repeated stresses involved in subsidence. Many of these small faults have been invaded by sandstone dikes and by gypsum and pyrite veins.

A breccia fabric, common in the collapsed area, consists of poorly sorted subangular to angular fragments of asphaltic sandstone in a mudstone matrix or contor ted mudstone fragments in a sandstone matrix (p ]. 7). Stream-worn chert and quartz pebbles, derived from the Chinle, are also observed in this breccia zone nearly 300 feet below the base of the Chinle outside the collapse. Most of the breccia is well cemented by dolomite, clay, or asphalt, and core recovery was good in spite of this brecciation.

Summary of drilling data, Temple Mountain collapse, collapse no. 5 and collapse no. 9, Emery County, Utah

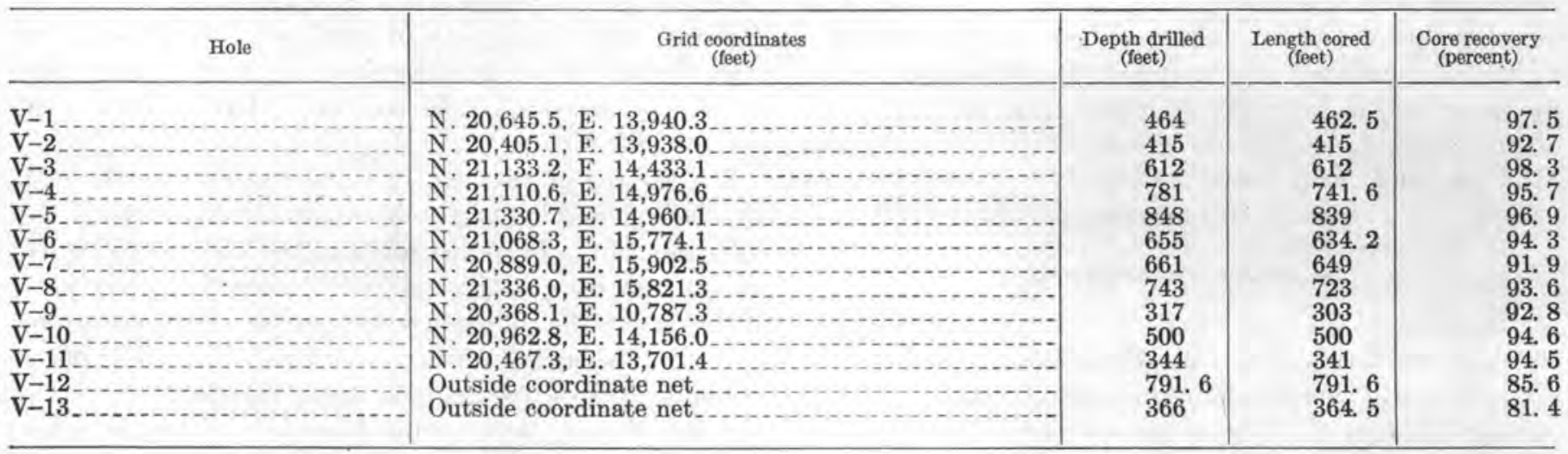

Summary description of drill cores

\begin{tabular}{|c|c|c|}
\hline Hole & Structures & Accessory minerals \\
\hline V-1. & $\begin{array}{l}\text { Sandstone dikes abundant to } \\
\text { top of Coconino sandstone; } \\
\text { some fractures and faults } \\
\text { throughout hole; some flow } \\
\text { structure at } 135 \mathrm{ft} \text { and } 320 \\
\text { ft. }\end{array}$ & $\begin{array}{l}\text { Asphalt: some to } 300 \mathrm{ft} \text {, abundant to } 350 \mathrm{ft} \text {, some } \\
\text { in the conglomerate zone of the Kaibab(?) lime- } \\
\text { stone and sparse in Coconino. Gypsum: some } \\
\text { in upper two-thirds of hole. Calcium carbonate: } \\
\text { some at } 185 \mathrm{ft} \text {. Pyrite: some to } 100 \mathrm{ft} \text { and at top } \\
\text { of conglomerate zone. Galena, realgar, and orpi- } \\
\text { ment: in Kaibab conglomerate zone. }\end{array}$ \\
\hline V-2. & $\begin{array}{l}\text { Sandstone dikes, fractures, } \\
\text { faults, and flow structures } \\
\text { throughout hole; some brec- } \\
\text { ciation. }\end{array}$ & $\begin{array}{l}\text { Asphalt: } 0-409 \mathrm{ft} \text {, includes } 40 \mathrm{ft} \text { of Coconino sand- } \\
\text { stone. Pyrite: sparse throughout hole. Limo- } \\
\text { nite: some in Coconino sandstone. Calcium car- } \\
\text { bonate: sparse in conglomerate zone. }\end{array}$ \\
\hline V- & $\begin{array}{l}\text { Some brecciation and flow } \\
\text { structure to top of Coconino } \\
\text { sandstone; some fracturing. }\end{array}$ & $\begin{array}{l}\text { Asphalt: some throughout hole. Pyrite: sparse } \\
\text { throughout hole. Calcium carbonate: sparse at } \\
\text { various horizons. Some realgar and orpiment (?) } \\
\text { at } 440-462 \mathrm{ft} \text {. }\end{array}$ \\
\hline V- & $\begin{array}{l}\text { Some brecciation to } 385 \mathrm{ft}, \\
\text { and abundant to top of } \\
\text { Coconino sandstone; faults, } \\
\text { fractures, and dikes to top of } \\
\text { Coconino; some flow struc- } \\
\text { ture. }\end{array}$ & $\begin{array}{l}\text { Asphalt: abundant to } 400 \mathrm{ft} \text {, sparse to conglomerate } \\
\text { zone, abundant in Kaibab and Coconino. Pyrite: } \\
\text { sparse throughout hole. Galena: found with } \\
\text { pyrite. Gypsum: throughout hole. Limonite: } \\
\text { some in Wingate(?). Calcium carbonate: abun- } \\
\text { dant in Sinbad limestone member and lower Moen- } \\
\text { kopi. Realgar: sparse at } 690 \text { and } 720 \mathrm{ft} \text {. }\end{array}$ \\
\hline$V-5$ & $\begin{array}{l}\text { Formations near normal to } \\
700 \mathrm{ft} ; \text { abundant breecia } \\
\text { from } 720 \mathrm{ft} \text { to top of Co- } \\
\text { conino sandstone; a few } \\
\text { sandstone dikes from } 420 \mathrm{ft} \\
\text { to top of Kaibab. }\end{array}$ & $\begin{array}{l}\text { Asphalt: abundant in intervals from } 0-150 \mathrm{ft}, 310- \\
380 \mathrm{ft}, 725-825 \mathrm{ft} \text { sparse in finer sediments, abun- } \\
\text { dant in disturbed zone. Pyrite: sparse in lower } \\
\text { part of hole. Gypsum: sparse in upper two-thirds } \\
\text { of hole. Calcium carbonate: sparse to } 300 \mathrm{ft} \text {. } \\
\text { Marcasite, limonite, hematite, galens, orpiment, } \\
\text { and siderite: present. Realgar: some above ore. }\end{array}$ \\
\hline
\end{tabular}
Anomalous radioactivity 1

370-374 ft: ore, 0.29 percent $\mathrm{U}_{3} \mathrm{O}_{8}$ average chemical assay. 143-144 ft, 398-399ft, and 402$403 \mathrm{ft}$ : strong radioactivity. $126.5-127 \mathrm{ft}, 406-406.5 \mathrm{ft}$, and 414-416 ft: weak radioactiv-

362.5-363.5 ft: weak radioactivity.

Maximum counts per second: 99.

Maximum counts per second: 147.

$822.5-823.5 \mathrm{ft}$ and $828.4-829.4$ ft: ore, 0.37 percent $\mathrm{U}_{3} \mathrm{O}_{8}$ average chemical assay. 
Summary description of drill cores-Continued

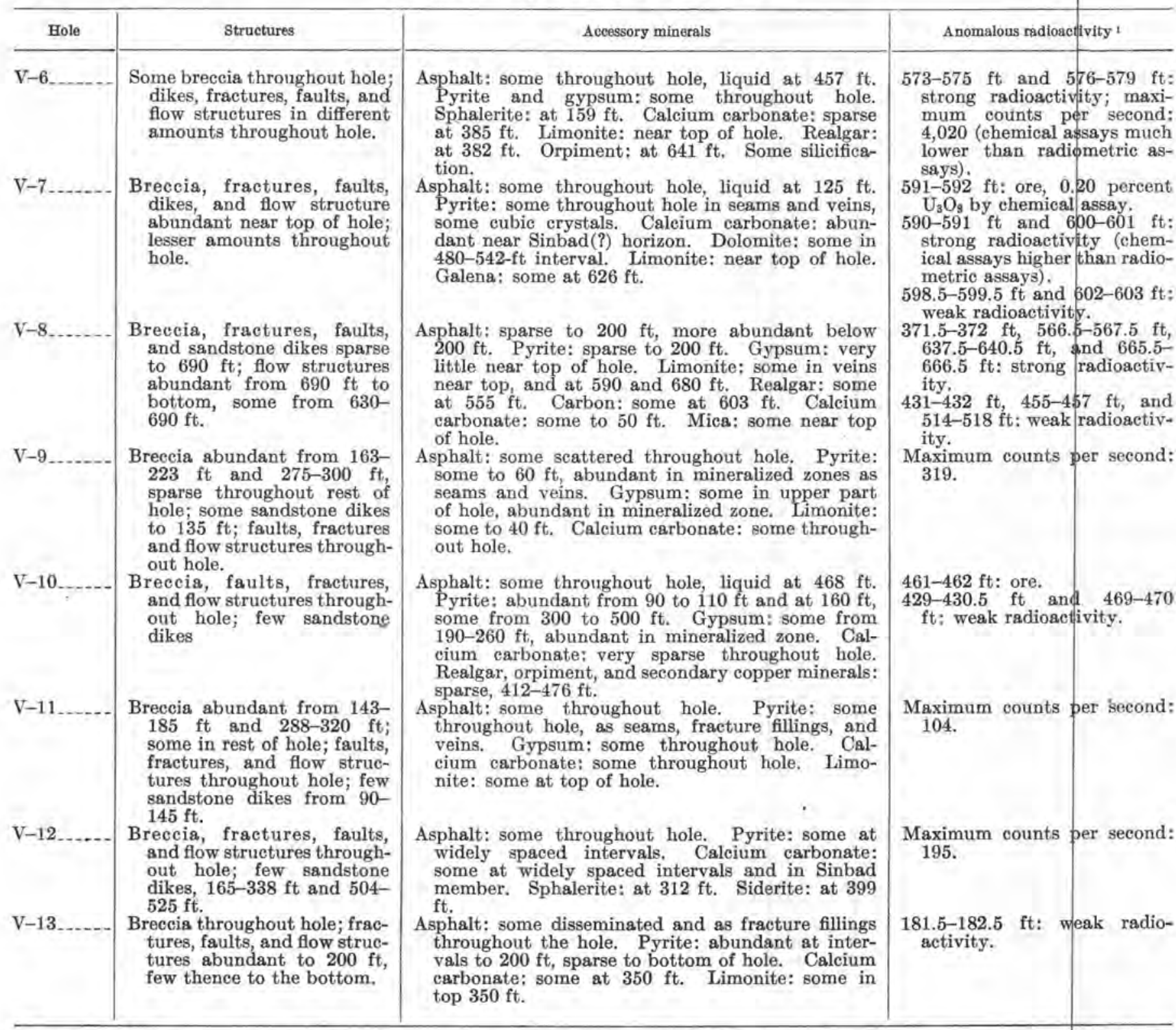
units).

1 A verage gamma background count in holes $=10-30$ counts per second; average gamma-ray reading for 0.05 percent $\mathrm{U}_{2} \mathrm{O}_{8}=1,400$ counts per second (average for three logging

Alteration.-The color of most of the nonasphaltic part of the core is altered from the typical red of Moenkopi and Chinle formations to gray-green or white. This indicates chemical reduction or removal of iron oxide, and in places formation of kaolinite and illite, Along asphalt-filled fractures in the Moenkopi, a bleached border occurs in the wall rock.

Early stages in the alteration are represented by the formation of clay. Kaolinite and illite (or sericite) occur as veinlets, commonly concentrated along contacts between breccia fragments. Veinlets of secondary kaolinite replace some of the original interstitial kaolinite, and secondary kaolinite rims some of the ore-bearing nodules in the conglomerate zone of the Kaibab limestone (Kelley, 1955).

Silicification has formed brown chalcedonic quartz veinlets up to 6 inches wide, and also overgrowths on quartz sand grains.

Dolomite, siderite, and limonite were introduced after silicification. Although a large part of the original cement of the coarser grained sedimentary rocks was calcite, little is now present in the core, and dolomite is prevalent. Thin sections show that dolomite embays some of the quartz grains. Nodular development of dolomite, common in the Wingate at the surface, is also observed in a core from the Coconino. 
Mineralogy.-Pyrite, galena, arsenopyritē, a little sphalerite, and a uranium-bearing hydrocarbon were introduced last and constitute the mineralizing sequence in the rocks of the collapse area (Kelley, 1955). Realgar is common, but its relation to the other minerals is unknown.

Pyrite, the most common mineral in this group, comprises as much as 25 percent of the core in places. It occurs most commonly as disseminated euhedral crystals and fine-grained masses. Pyrite replaces mudstone, quartz grains, and the carbonate and clay cement in sandstone, and occurs as veinlets along fractures. Pyrite is scattered through all of the disturbed zone, including the ore zones, and shows no preferred spatial relation to the uranium.

Galena occurs as fine disseminations in the matrix of the breccia, as subhedral crystals in the ore zones and as small masses partly replacing quartz grains and dolomite in the upper part of the Coconino. In hole V-1 abundant galena occurs below the asphalt zone in otherwise normal Coconino (pl. 7). It is also present, along with pyrite, in uranium-bearing hydrocarbon nodules.

Uranium-vanadium minerals are sporadically distributed in the cores, especially in those recovered from holes drilled on the "tongue," but there are concentrations in and near the conglomerate zone of the Kaibab limestone (pl. 7). Uranium ore 4 feet thick was cored in the conglomerate zone of the Kaibab in hole V-1 (pl. 5). In contrast, uranium in minor amounts was found more than 220 feet above the Kaibab limestone.

The $\mathrm{V}_{2} \mathrm{O}_{5}-\mathrm{U}_{3} \mathrm{O}_{5}$ ratio in the cored material ranges from $1: 1$ to a high of $5: 1$. Vanadium content is usually greater in the diverse rocks involved in the collapse than the average for the Calyx mining area southeast of Temple Mountain where ore occurs in the Moss Back member of the Chinle formation.

The highest grade ore consists of uranium in hard asphaltic nodules and pellets interspersed in asphaltic sandstone. By X-ray diffraction, pitchblende was identified in the asphaltite from hole $\mathrm{V}-1$, and arsenopyrite tentatively identified (Kelley, 1955). The term "asphaltite," as used here, refers to any solid hydrocarbon of apparent petroliferous derivation. Microscopic work indicates that both pyrite and galena were deposited before the asphalt, but relative ages of the pitchblende, arsenopyrite, and asphalt are not known (Kelley, 1955).

\section{OTHER COLLAPSES}

Nine collapse structures are known in the southern part of the San Rafael Swell in addition to the large collapse at Temple Mountain, and one collapse occurs in the north end of the swell (fig. 86). These collapses crop out at different stratigraphic positions within the Moenkopi formation.

As on Temple Mountain, all of the collapses have a bleached area centering on a synclinal depression or structural basin containing brecciated material. Blocks of formations younger than Moenkopi have subsided into the depression in the Moenkopi. Petroliferous material and pyrite are common in these collapses, but no ore-grade uranium is known in any collapse other than the one at Temple Mountain.

Hole V-9 in collapse no. 5 and holes V-12 and V-13 in collapse no. 8 were cored without finding ore. Only traces of uranium were reported from a hole churn drilled in collapse no. 4.

Collapse no. 5.-One hole (V-9) was drilled in a small collapse about 2,000 feet west of the Temple Mountain tongue. This collapse, no. 5, lies along the projection of the long axis of the Temple Mountain collapse and is within an east-trending graben which may be a continuation of the Temple Mountain collapse. The graben is 3,400 feet across and less than a mile long and

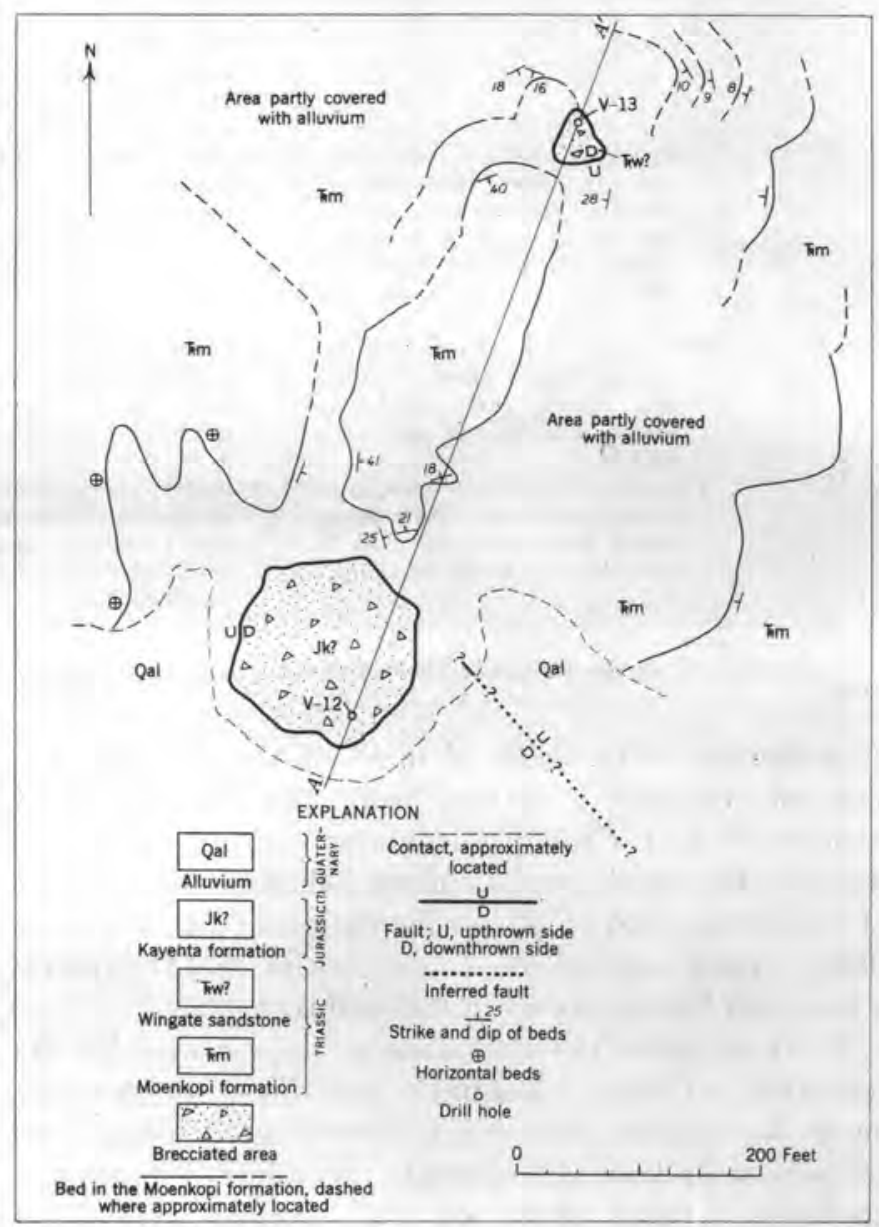

Figure 88.-Geologic map of collapse no. 8, Red's Canyon, Emery County, Utah. 
has a stratigraphic displacement of 35 feet on the north side and 70 feet on the south side. The collapse is an elliptical altered area, about 150 feet in diameter, within the garben. Strata bordering the collapse have a maximum dip of $18^{\circ}$ toward the center. The drill core is very similar to those from the Temple Mountain collapse: brecciation, flow structures, and fractures are prevalent. Asphalt and pyrite are abundant throughout the core, and galena is found in the conglomerate zone of the Kaibab limestone. No uranium minerals were found. Cuttings recovered from five air-rotary holes drilled between collapse no, 5 and the "tongue" on Temple Mountain, and within the graben, indicate that only undisturbed strata, including the Kaibab limestone, were penetrated.
Collapse no. 8.-Two holes were drilled in collapse no. 8 in Red's Canyon on the west flank of the swell (fig. 86). This collapse is over 600 feet long and 300 feet wide (fig. 88). Copper minerals and some asphalt are exposed at the surface in two blocks of Wingate and (or) Kayenta which lie at opposite ends of a synclinal depression (fig. 89). A hole was drilled in each of these blocks in order to determine the amount of collapse and the degree of similarity to the Temple Mountain collapse. Breceiation, flow structures, and fractures, as well as pyrite and asphalt, are common in both cores. Neither hole intersected rocks containing more than a radiometric equivalent of 0.01 percent $\mathrm{U}_{3} \mathrm{O}_{8}$.

Hole V-12 was drilled a short distance inside the

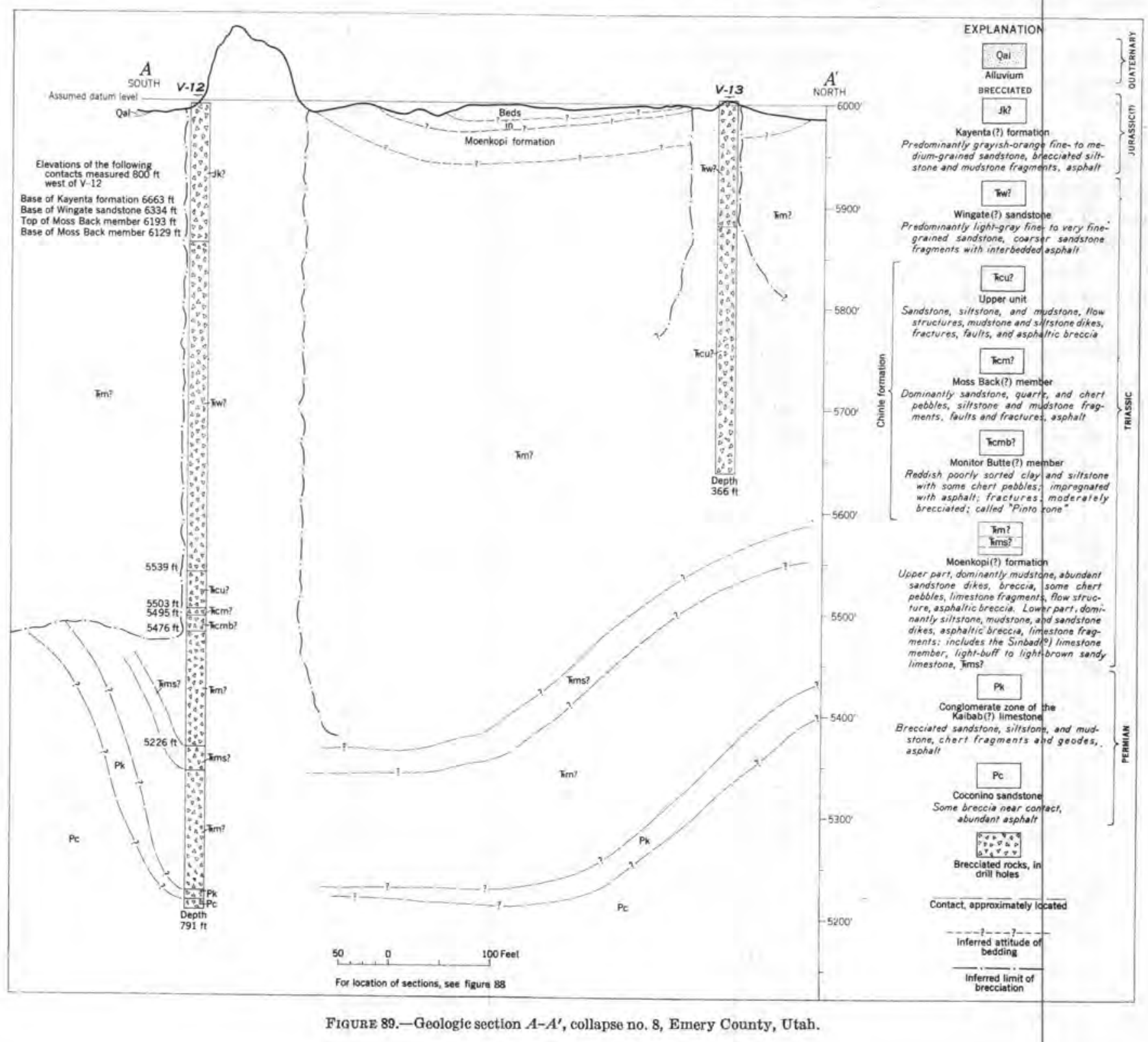


edge of the largest block and 120 feet below the contact of the Moenkopi and Chinle exposed on a nearby cliff. Formations logged from the surface downward are (fig. 89): Kayenta formation and Wingate sandstone 0-459 feet, upper unit of the Chinle formation 459-495 feet, Moss Back member of Chinle formation 495-503 feet, Monitor Butte member of Chinle formation 503519 feet, Moenkopi formation 519-772 feet, conglomerate zone of the Kaibab limestone 772-782 feet, and Coconino sandstone from 782 feet to the total depth at 792 feet. The base of the Wingate sandstone on the surface is 335 feet above the collar of the hole; so it can be seen that this contact has subsided 794 feet. Similar evidence indicates that the base of the Moss Back member has dropped 623 feet. The difference in subsidence between the base of the Wingate and the base of the Moss Back is $\mathbf{1 7 1}$ feet, possibly owing to a thinning of the Chinle formation below the subsiding block of Wingate.

Measured thicknesses of Moenkopi on the western side of the San Rafael Swell range from 620 feet near collapse no. 8 to a maximum of 750 feet in the southwest part of the swell, whereas the vertical difference from the top of the Moenkopi on the surface to the base of the Moenkopi in the drill hole is 892 feet. This difference is obtained by projecting the top of the formation 800 feet horizontally to the drill hole and calculating the difference in elevation between the top of the formation and the base in the drill hole. These figures indicate that the Moenkopi has thickened or subsided at least 142 feet and probably as much as 272 feet and suggest that removal of material from below the Coconino is partly responsible for the collapse (fig. 89).

Hole V-13 was started a short distance inside the edge of the smaller collapse block, which is about 40 feet in diameter (fig. 88), and the drilling penetrated 120 feet of probable Wingate sandstone before reaching brecciated Moenkopi strata. This hole was completed in the Moenkopi.

\section{STRUCTURE AND POSTULATED MECHANISM OF COLLAPSE}

Drilling results leave little doubt that the structure on Temple Mountain is a single large collapse at depth, but with a different surface expression, although directions of dip of surface blocks might suggest 2 or 3 separate collapses. Large blocks, such as the one drilled in hole V-5, appear to show a normal stratigraphic sequence, but subsidence has caused irregular sagging of the Moenkopi and Chinle formations between large blocks.

The drilling results also indicate that the zone of brecciation and flowage extends no more than a few feet downward into the Coconino sandstone in the Temple
Mountain collapse. This downward limit of brecciation, together with the absence of the Kaibab limestone and Sinbad limestone member of the Moenkopi within the collapsed areas, suggests that collapse was caused, at least in part, by the solution of carbonate rocks. Nevertheless, removal of these two limestone beds fails to account for all of approximately 300 feet of subsidence at the Temple Mountain collapse or approximately 800 feet of subsidence at collapse no. 8 in Red's Canyon. The combined thickness of the 2 limestone units, based on measurements throughout the San Rafael Swell, is probably not less than 70 feet nor more than 150 feet. Although there are places in the swell where the Kaibab was removed by pre-Triassic erosion, it is assumed that under the collapse areas both these limestones were removed by solution. This assumption is supported by the presence of the Sinbad throughout the swell and of the Kaibab in holes drilled 1,900 feet west of the "tongue."

The amount of subsidence may have been increased by lateral outward flowage at depth. Cores obtained from below subsided blocks showing normal stratigraphic sequence suggest that material has been forced laterally outward into space created through solution of limestone, possibly by the weight of the subsiding mass of rock. Flow structures and the poorly cemented sandstone observed in the cores indicate that much of the clastic material was unconsolidated and flowed under pressure to other parts of the collapse. Removal of cement by solutions would facilitate flow. In hole V-5, where 700 feet of normal strata were cored before distorted rocks were seen, at least 90 feet of lower siltstones and mudstones of the Moenkopi is missing; the limestones are also missing (pl. 5). A similar incomplete Moenkopi section is found in collapse no. 8 (fig. 89). If the limestones were dissolved for a considerable distance outward from the collapse center. the unconsolidated sediments might have flowed into the space thus provided. This may explain the removal of the Moenkopi within parts of the collapse, and hence part of the indicated amount of subsidence.

Additional space for collapse was probably furnished by subsidence of the Coconino sandstone, as at Temple Mountain and collapse no. 8. The magnitude of this deep subsidence has been indicated by projecting the tops of the Kaibab limestone and Sinbad limestone member of the Moenkopi formation into the collapse area, using regional dip, from the nearest outcrops less than a mile away. The resulting indicated vertical relief of the synclinal flexure in which the Temple Mountain collapse occurred is shown in plate 5. The syncline found in the Coconino in collapse no. 8 (fig. 89) indicates that such struetural relations are characteristic of the larger collapses. The subsidence of the Co- 
conino may have been due to removal of carbonate rocks of greater depth. The collapses in the southern part of the swell occur in a zone roughly parallel to a strong east-trending fault pattern (fig. 86), but solution activity may have been localized by joints or faults which may have no surface expression, if calcareous rocks were removed from several intervals in the section.

\section{URANIUM DEPOSITS OF TEMPLE MOUNTAIN COLLAPSE}

\section{OCCURRENCE}

Uranium-vanadium ores are found in the Temple Mountain collapse from the top of the Coconino sandstone upward to the top one-third of the Wingate sandstone, through nearly 1,200 feet of sedimentary rocks. Ore bodies in the Wingate range from a few inches to 4 feet in thickness, usually parallel to bedding. Lenticular bodies of ore up to 100 feet long occur near the base of the Wingate, just above the dolomitized part. Smaller ore bodies also occur in the upper part of the Wingate.

On the east side of the collapse, uranium-bearing asphaltite pellets occur along a vertical fracture in an unnamed mine near drill hole $V-\gamma$ (pl. 4), and orebearing asphaltite cements a breccia under a large subsidence block of Wingate in the same area. In the Fumarole mine, on the "tongue" (pl. 4), high-grade pods of asphaltic ore up to several feet long are found along fractures. In this mine, ore is also disseminated through brecciated sandstones of the Moss Back member.

Asphaltite pellets and carnotite have been observed for a distance of 40 feet along an inclined fracture in the upper Chinle, south of Sugarloaf (pl. 5). Small ore-grade asphaltite lenses are also found in the area of ferrugination on the west side of the north part of Temple Mountain.

Mineralized asphaltite discovered by drilling in the collapse is also distributed along fractures and bedding planes. Most ore is found in the conglomerate zone of the Kaibab limestone, while some ore is along the bedding and fractures in the Moenkopi. A minor amount of mineralized asphaltite is disseminated in the top of the Coconino sandstone.

\section{MINERALOGY}

All primary uranium in the Temple Mountain collapse occurs in a hard, brittle asphaltite, as pellets, veinlets, or sheets of hydrocarbon ranging from a fraction of an inch to more than 5 feet long. These hydrocarbons have partly replaced quartz grains (Gruner and others, 1953, p. 16). In the Wingate, much smaller spherules of the same kind of uraniferous hydrocarbon are localized between the quartz grains with little apparent replacement of quartz. The ore in the Wingate is unusual because of the high vanadium content, the $\mathrm{V}_{2} \mathrm{O}_{5}-\mathrm{U}_{3} \mathrm{O}_{8}$ ratio being as high as 14:1.

Realgar and native arsenic are associated with the asphaltic ore in the Fumarole mine on the "tongue." Pitticite and orpiment in this mine are probably oxidation products of realgar and native arsenic.

The largest quantities of secondary vanadium minerals occur in the Wingate sandstone, as oxidation products of the asphaltic ore. Hewettite and carnotite occur commonly in the workings in the Wingate as grain coatings in sandstone and along fractures. No secondary uranium-vanadium minerals were found in the drilling.

\section{ORE CONTROLS AND GUIDES}

Both fracture and bedding plane control of ore are eyident in the Temple Mountain collapse. Ore is found along fractures throughout the collapse. These fractures probably served as channelways through which the ore-bearing solutions passed to permeable zones in breccias and along bedding planes.

Arsenic minerals appear to be related genetically to uranium and are the best guide to ore in the collapse.

\section{RELATION OF URANIUM DEPOSITS TO THE COLLAPSE}

The uranium-vanadium ore and the Temple Mountain collapse bear a close spatial relation. All ore, except that in the Moss Back member, is strictly confined to the vicinity of the collapse. The filling of fractures and the cementation of breccia by asphaltic ore show that the ore was either deposited during late stages of subsidence or after collapse was complete.

It is likely that brecciation and fracturing which accompanied subsidence provided a channel for mineralizing solutions. It remains to be determined, however, whether asphaltic ores in the collapse resulted from redistribution of the mineralization in the Moss Back or whether the collapse provided a channelway for ascending mineralizing solutions. Either process took place below the zone of oxidation. The fact that uranium is found both above and below the Moss Back in the Temple Mountain collapse tends to support deposition by ascending solutions. No uranium ore has been found in any of the other collapses, either by drilling or by surface inspection.

\section{URANIUM DEPOSITS OF THE TEMPLE MOUNTAIN MINERAL BELT \\ OCCURRENCE}

Most of the uranium production at Temple Mountain has come from the Calyx or North Mesa area, which is a bench of sandstone of the Moss Back member 
between the south part of Temple Mountain and the eastern hogback. The ore in this area is largely confined to what is here named the Temple Mountain "mineral belt." The belt trends approximately $\mathrm{N}$. $30^{\circ} \mathrm{E}$., has a maximum width of 2,000 feet and a minimum width of 500 feet near the ends and is at least 8,000 feet long (pl. 4). All of the large mines of the district are found within this belt. Individual ore bodies are elongate nearly at right angles to the trend of the belt and range in size from small pods to bodies 600 feet in length, 100 feet in width, and 20 feet in thickness. Four faults, which cut across the north side of the old south workings, have dropped the Moss Back member more than 100 feet. Reconstruction of the prefaulting structure also places those old workings within the mineral belt.

Bedded ore is commonly 20-50 feet above the base of the Moss Back member. In some places two ore lenses, separated vertically by several feet of barren rock, have been mined. Uranium-vanadium-bearing asphaltite pellets within the ore bodies are usually localized along bedding planes, particularly crossbedding, although some pods transgress sedimentary features. Several ore rolls have been recognized in the Calyx area mines, but the significance of these features is not known.

In the Calyx no. 3 mine a green mudstone, usually less than 3 feet thick, underlies the ore-bearing sandstone throughout the workings (Baumgardner and Noble, 1955), and a bed of conglomerate cemented by mudstone generally overlies the ore.

\section{MINERALOGY}

The uranium-vanadium ore within the mineral belt is similar mineralogically to most of the ore in the collapse. Almost all of the ore is in asphaltite in sandstone, and some of this asphaltite has obviously replaced carbonaceous wood. Identifiable carbonaceous wood is sparse in the ore-bearing unit but is abundant in conglomerate just above the ore, where many logs have been silicified. All of this carbonaceous material is nonuraniferous, though it may contain abundant pyrite and nonuraniferous vitreous asphaltite. Several occurrences of high-grade asphaltic ore have been noted in sandstone directly below logs imbedded in the overlying barren conglomerate. In the ore sandstone the wood appears to have been replaced by pyrite and (or) asphaltite and may form the nucleus of high-grade pods.

High-grade uranium ore seems to have an affinity for areas containing a concentration of mica, probably muscovite.

All stages of apparent replacement of both quartz grains and cement by uranium-bearing asphaltite
(Gruner and others, 1953, p. 16) have been observed in thin section (Baumgardner and Noble, 1955). Uranium is present in this hydrocarbon as uraninite and coffinite (Witkind and others, 1954) and possibly as an organic complex (Gruner and others, 1953, p. 17). The uraninite is very finely disseminated, and no megascopic particles have been found.

Ore from the Moss Back member in the Temple Mountain mineral belt has an average $\mathrm{V}_{2} \mathrm{O}_{5}-\mathrm{U}_{3} \mathrm{O}_{8}$ ratio of $3: 1$. Calcium carbonate, usually the major cement in the Moss Back, is a very minor constituent of the ore sandstone, constituting probably less than 1 percent. Selenium is particularly abundant in the asphaltic ores; an average uranium-selenium ratio of about $950: 1$ is reported from the Campbird no. 7 (Cannon and Stillman, 1952 , p. 3).

The following secondary minerals have been reported from the uranium ores of the Temple Mountain-Calyx area by different authors, and are listed in probable order of decreasing abundance:

$\begin{array}{ll}\text { Carnotite } & \text { Schroeckingerite } \\ \text { Rauvite } & \text { Zippeite } \\ \text { Corvusite } & \text { Sulfur } \\ \text { Metatorbernite } & \text { Realgar } \\ \text { Metazeunerite } & \text { Brochantite } \\ \text { Hewettite } & \text { Malachite } \\ \text { Pascoite } & \text { Azurite }\end{array}$

Carnotite is the only abundant secondary uraniumvanadium mineral at Temple Mountain. It occurs as irregular bands adjacent and subparallel to margins of asphaltic ore bodies and as coatings on asphaltite pellets and along fractures. Some of these coatings have formed since the earlier mines were opened. Where oxidation has proceeded farthest, asphaltite is pitted or almost completely removed, leaving soft and friable sandstone. The other secondary uraniumvanadium minerals listed occur in minor quantities along with carnotite.

In the Moss Back member the degree of oxidation appears to be inversely related to thickness of rock cover. The largest quantity of carnotite occurs in the south workings where several washes cut through the Moss Back and much of the upper part of the member has been removed by erosion.

\section{CONTROLS AND POSTULATED GENESIS OF ORES}

Fault control of ore is clearly shown only in the Lopez mine (pl. 4), although localization of ore along faults has been reported from other mines. In the Lopez incline small bodies of ore have been mined from within a vertical fault zone trending east and having a downthrow of 70 feet on the south side. Elongation of other ore bodies parallel to the stronger set of a regional joint system might also be taken as evidence 
of fracture control, although this is also the average direction of sedimentary trends in the area. Detailed mapping will be necessary to establish a definite relation with either feature.

Confinement of ore-bearing solutions to a sandstone bed by two relatively impermeable mudstones is probably the most obvious local ore control in the Calyx no. 3 mine. Ore distribution is locally controlled by bedding planes within these sandstone beds. Permeability and precipitants in the form of carbonaceous material and (or) asphaltite are probably the two most important factors controlling the deposition of ore in the Moss Back membei.

One important guide to exploration for ore in the Moss Back member of the Calyx area is a zone of favorable ground, the Temple Mountain mineral belt, trending $\mathrm{N} .30^{\circ} \mathrm{E}$, which has been delineated by compiling data from drill holes and underground workings (pl. 4). This trend may be a guide to exploration outside of the Temple Mountain area.

Change in color from red to buff in the Monitor Butte member of the Chinle formation near the Vanadium King workings (pl. 6), has been suggested as a guide to ore. However, this is the only locality at which discoloration in the Monitor Butte is shown near ore; no such alteration is seen accompanying other deposits in the Temple Mountain area. Therefore, it seems more likely that this bleached area is the result of percolation of ground-water solutions along a fault zone which is subparallel to the rim.

Drilling has disclosed abundant liquid asphalt, which is definitely unmineralized downdip from the Temple Mountain mineral belt, but no uranium ore has been found associated with an abundance of liquid asphalt in the Temple Mountain area. Scattered ore has been found updip from the belt along with a minor amount of liquid asphalt, but no large production has come from this area.

If uranium deposition in the Temple Mountain mineral belt is considered to bave taken place near an oilwater interface before breaching of the San Rafael Swell, a mineral zoning similar to the Temple Mountain mineral belt could result. This would produce a mineral belt parallel to the strike of the beds and limited to a certain elevation. Distillation of the more volatile constituents after breaching of the anticline may have produced the different end products (residual oil, asphalt, and asphaltite) now present on Temple Mountain. Uranium and vanadium are found concentrated in the hard asphaltite end products.

\section{RELATION OF THE MINERAL BELT TO THE COLLAPSE}

The mineralogy of the uranium-vanadium ores in the collapse area and those in the Temple Mountain mineral belt are similar in that all of the uranium occurs in a hard asphaltite. The chief difference is in associated minerals; galena and realgar are abundant in the collapse area, but only a small amount of galena and realgar are known in mineral-belt ore deposits. In addition the average vanadium content of the ores in the collapse is higher than the average for the mineral belt.

Fracture control is important in the collapse area, whereas only one occurrence of fault control is known in the mineral belt. Elongation of ore bodies in the mineral belt is parallel to the stronger set of regional joints, the direction of dip, and the sedimentary trends.

Bedding control of ore is obvious in both areas; selective emplacement in certain horizons is probably due to differences in permeability.

The ore in the collapse has a wide stratigraphic distribution without apparent preferred orientation in plan, whereas ore on the Calyx bench is confined to the Moss Back member and is localized within a welldefined mineral belt which parallels the strike of beds. Proximity of this mineral belt to the collapse and the extension of a slightly uraniferous sandstone from the collapse to the mineral belt may be significant of genetic relationships.

\section{CONCLUSIONS}

The Temple Mountain collapse is characterized by brecciation and flowage, extending downward to the top of the Coconino sandstone. The collapse was at least in part caused by the solution of limestone beds and the flow of temporarily unconsolidated sediments. The other collapses in the San Rafael Swell appear to have the same origin. The concept of a Temple Mountain mineral belt evolved from the distribution of ore as shown by mine maps and drill hole data. It trends N. $30^{\circ} \mathrm{E}$. and is parallel to the strike of the beds. No apparent structural relation exists between tbe Temple Mountain mineral belt and the collapse; however, the similarities in mineralogy and the proximity of the two suggest some genetic relation.

A new ore horizon was discovered in the conglomerate zone of the Kaibab limestone within the Temple Mountain collapse. Uranium ore in the collapse and in the mineral belt is confined to the asphaltite.

\section{REFERENCES CITED}

Anderson, A. H., and Miller, R. D., 1952, U. S. Atomic Energy Comm. unpub. inf.

Baumgardner, Luther, and Noble, E. A., 1955, U. S. Atomic Energy Comm, unpub, inf.

Brooke, G. L., 1952, U. S. Atomic Energy Comm. unpub. inf.

Cannon, H. L., and Stillman, R. M., 1952, U. S. Geol. Survey unpub. inf.

Gerhard, R. C., 1953, U. S. Atomic Energy Comm, unpub. inf, 
Gilluly, James, and Reeside, J. B., Jr., 1928, Sedimentary rocks of the San Rafael Swell and some adjacent areas in eastern Utah. U. S. Geo. Survey Prof. Paper 150-D, p. 61-110.

Gruner, J. W., 1954, Experimental studies of color changes from red to gray in silts and shales as applicable to uranium ore districts, in Ann. Rept. for April 1, 1953, to March 31, 1954: U. S. Atomic Energy Comm. RME-3094, p. 5-14, issued by U. S. Atomic Energy Comm. Tech Inf. Service, Oak Ridge, Tenn.

Gruner, J. W., Gardiner, Lynn, and Smith, D. K., Jr., 1953, Uranium-bearing carbonaceous and asphaltic materials of the Colorado Plateau, in Ann. Rept. for July 1, 1952, to March 31, 1953: U. S. Atomic Energy Comm. RME-3044, p. 14-19, issed by U. S. Atomic Energy Comm. Tech Inf. Service, Oak Ridge, Tenn.
Hinckley, D. N., 1952, Investigation of subsurface isorad methods, Temple Mountain, San Rafael district, Utah: U. S. Atomic Energy Comm. RME-4019, 26 p., issued by U. S. Atomic Energy Comm. Tech. Inf. Service, Oak Ridge, Tenn.

Kelley, D. R., 1955, U. S. Atomic Energy Comm. unpub. inf. Keys, W. S., 1954, U. S. Atomic Energy Comm. unpub. inf.

Murphy, F. M., 1944, U. S. Atomic Energy Comm. unpub. inf. Sheridan, M. J., 1951, U. S. Atomic Energy Comm. unpub. inf. Williams, G. A., 1953, U. S. Geol. Survey unpub.inf.

Witkind, I. J., Robeck, R. C., Barton, W. R., and Izett, G. A., 1954, U. S. Geol. Survey unpub. inf.

Wyant, D. G., 1953, U. S. Geol. Survey unpub. inf. 


\title{
GUIDES TO URANIUM DEPOSITS IN THE MORRISON FORMATION, GALLUP-LAGUNA AREA NEW MEXICO
}

\author{
By Lowell S. Hilpert and Val L. Freeman, U. S. Geological Survey \\ CONTENTS
}

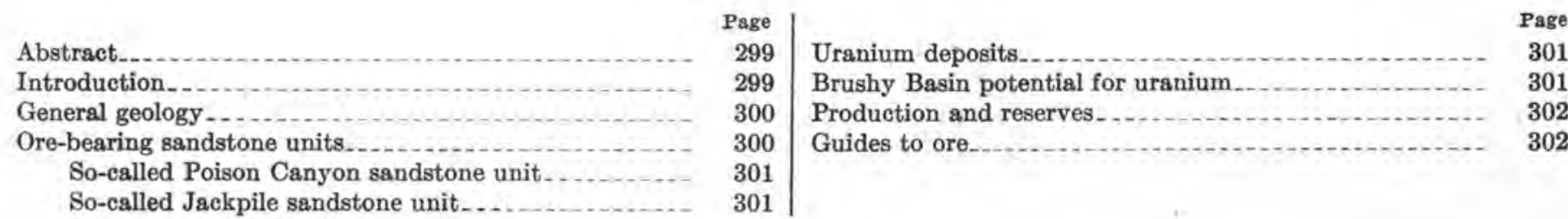

\section{ILLUSTRATIONS}

Figure 90. Index map of northwest New Mexico showing Gallup-Laguna area and locations of figures 91 and 92

91. Generalized geologic sections showing the stratigraphic relations of the uranium deposits in the Morrison formation, northwest of Grants, N. Mex

92. Generalized geologic sections showing the stratigraphic relations of the uranium deposits in the Morrison formation, north of Laguna, N. Mex.

\section{ABSTRACT}

Uranium ore production from New Mexico constitutes a significant part of the total production from the Colorado Plateau. About 90 percent of the ore from New Mexico has come from the area that extends from Gallup to Laguna, in MoKinley and Valencia Counties; and over 95 percent of the area's production has come from the Todilto limestone and Morrison formation of Jurassic age. Although the area's first production came from the Todilto limestone, the production from the Morrison rose rapidly from 1951 to 1954 , and by September 1954 it exceeded that from the Todilto. In September 1954 the reserves in the Morrison in the Gallup-Laguna area constituted most of the reserves in New Mexico and an important part of the reserves of the Colorado Plateau.

Until recently the deposits in the Morrison formation were believed to be distributed almost equally through the three members of the formation in the area. From base to top, these are the Recapture, Westwater Canyon, and Brushy Basin members. Recent work shows, however, that most of the deposits in the Morrison-in fact, all the larger deposits - are in the Brushy Basin member. The Brushy Basin generally consists of claystone with subordinate amounts of sandstone, conglomerate, and some relatively thin limestone lenses; it ranges from a knife edge to about 375 feet in thickness. Preliminary work by the writers shows that the larger deposits in the Brushy Basin member generally occur in coarse-grained sandstone units where the units are thicker. Preliminary ore guides and methods of prospecting have been developed for two of these sandstones, the so-called Poison Canyon and so-called Jackpile sandstone units. Because of their relatively great uranium potential, these units and others of the same type in the Brushy Basin member perhaps should be primary exploration targets in the search for uranium in the Gallup-Laguna area.

\section{INTRODUCTION}

In the Gallup-Laguna area (fig. 90) of New Mexico, productive uranium deposits are in the Todilto limes stone, Summerville formation, Morrison formation, and Dakota sandstone. Between 1953 and 1955, the Morrison formation in this area increased greatly in significance because of new discoveries.

Fieldwork by the writers in 1954 indicates that the larger known uranium deposits in the Morrison formation in the Gallup-Laguna area are confined to specific sandstone units in the Brushy Basin member. This paper presents a preliminary description of the general characteristics of two of these sandstone units and points out how these characteristics can be used as guides to ore.

Many of the data presented are based on information provided by mining men in New Mexico and personnel of the U. S. Atomic Energy Commission. Special acknowledgments and thanks for assistance are due personnel of the Lea Exploration Co., Anaconda Copper Mining Co., Haystack Mountain Development Co., and the St. Anthony Uranium Co. 


\section{GENERAL GEOLOGY}

Productive uranium deposits in the Gallup-Laguna area (fig. 90) are in sedimentary rocks of Jurassic and Cretaceous ages. These rocks generally dip northward at a low angle and form an almost continuous outcrop for about 80 miles, extending from Gallup to the west side of the Rio Grande valley. Locally the rocks are folded broadly and broken by faults; and north of U. S. Highway 66 , between the towns of Grants and Laguna, they are intruded and largely buried by the Mount Taylor volcanic field.

The sequence of sedimentary rocks containing the productive deposits are, in ascending order, the Todilto limestone, Summerville formation, Bluff sandstone, and Morrison formation, all of Jurassic age; the sequence is unconformably overlain by the Dakota sandstone of Cretaceous age. All these rocks except the Bluff sandstone, contain uranium deposits. In September 1954, the Todilto, Morrison, and Dakota were the only formations in the Gallup-Laguna area that were known to contain significant deposits.

The Morrison formation in this area is divided, from base to top, into the Recapture shale member, Westwater Canyon sandstone member, and Brushy Basin shale member. The Recapture is a fine- to mediumgrained friable sandstone that contains some beds of silty claystone. It ranges from about 20 to 185 feet in thickness and has distinctive alternating light-gray and reddish-brown units.

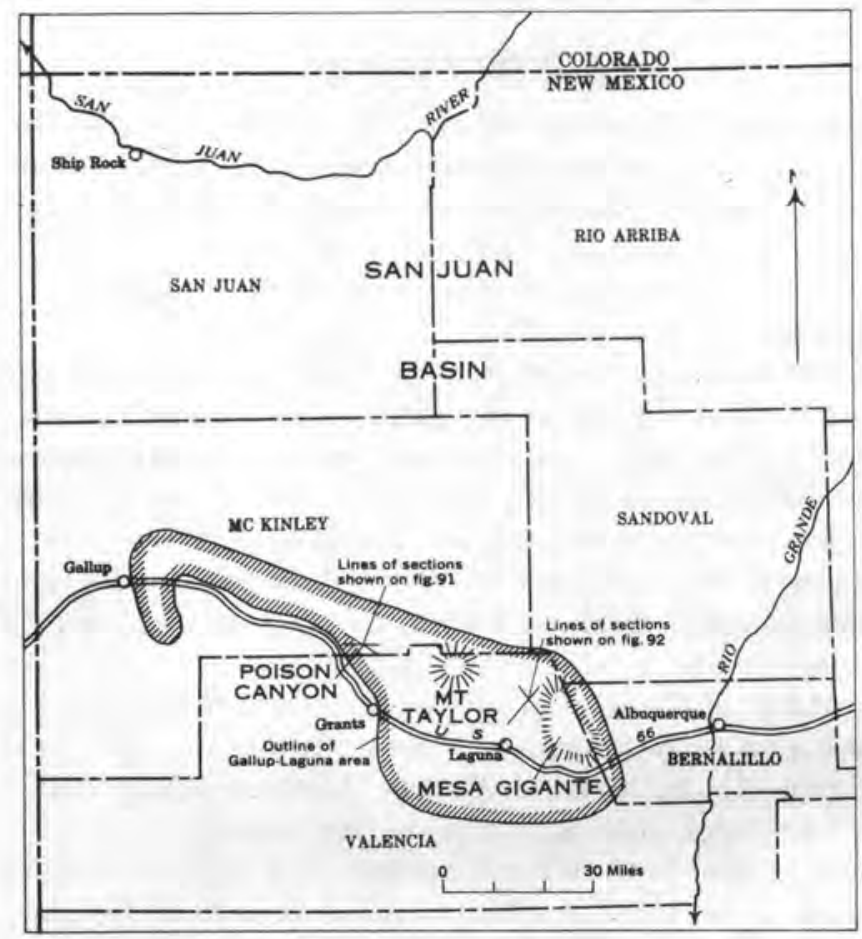

Figure 90.-Index map of northwest New Mexico showing Gallup-Laguna area and locations of figures 91 and 92 .
The Westwater Canyon is predominantly a mediumto coarse-grained pebbly sandstone that contains some thin units of claystone. The Westwater Canyon ranges from a knife edge to about 200 feet in thickness and from yellowish gray to reddish brown. It locally interfingers with the underlying Recapture and overlying Brushy Basin members. In the eastern part of the area, it is locally absent, and there the Brushy Basin rests directly on the Recapture member.

The Brushy Basin member is predominantly a grayish-green claystone with subordinate lenses of hard medium-grained locally calcareous green sandstone. These lenses, generally ranging from a few inches to a few feet in thickness, are chiefly quartz grains and abundant interstitial clay. Locally, however, the Brushy Basin contains relatively thick lenses or units of coarser grained sandstone that generally range from several feet to 175 feet in thickness. The Brushy Basin ranges from a knife edge near Gallup to a thickness of about 375 feet north of Laguna. The differences in thickness are mainly the result of pre-Dakota erosion after broad folding.

\section{ORE-BEARING SANDSTONE UNITS}

In the Gallup-Laguna area nearly all the known uranium deposits in the Morrison formation are in the relatively thick, coarse-grained sandstone units of the Brushy Basin member which can be distinguished from the thinner lenses of hard medium-grained green sandstone.

The ore-bearing units range from white to moderate brown but are generally yellowish orange. Near deposits, they are yellowish gray. The units are composed mostly of quartz, some pink feldspar, and a few other minor accessory minerals; white specks, probably kaolin, are common. These sandstone units are locally conglomeratic, crossbedded, show scour-and-fill features, and are quite friable. Carbonaceous debrissuch as small logs, tree limbs, and reeds - and claystone lenses and galls are present at certain places and are most abundant near deposits. The general features of these sandstone units indicate a fluvial origin, as do the many channels filled with the sandstones in the underlying claystone.

Two of these sandstone units in the Brushy Basin contain all the larger deposits. ${ }^{1}$ The unit in the vicin-

1 In 1955, after this paper was written, significant uranium deposits were dis covered in T, 14 N,, R. 10 W., about 8 miles northwest of Poison Canyon. These deposits are in the Westwater Canyon member of the Morrison formation. Although the Brushy Basin member is present at this locality, it is predominantly claystone and the so-called Poison Canyon sandstone is absent.

Discovery of these deposits greatly enhances the uranium potential of the Westwater Canyon member in the Gallup-Laguns area. Preliminary and somewhat meager information indicates these deposits are where the Westwater Canyon member is thicker and where it has the same other characteristics as those given in this paper for the so-called Poison Canyon and so-ealled Jackpile sandstone units in the vicinity of deposits. 
ity of Poison Canyon (fig. 90), northwest of Grants, is referred to as the so-called Poison Canyon sandstone. The second unit, which contains the Jackpile mine, is referred to as the so-called Jackpile sandstone.

\section{SO-CALLED POISON CANYON SANDSTONE UNIT}

The so-called Poison Canyon sandstone crops out at the head of Poison Canyon and is exposed for about 2 miles to the eastward and also to the westward from Poison Canyon. From drill-hole information the socalled Poison Canyon sandstone is known to extend northward from the outcrop for at least half a mile. This unit merges with the Westwater Canyon about 2 miles northwest of Poison Canyon. Eastward from the point where it merges with the Westwater Canyon, it rests upon a 15- to 25-foot-thick unit of the Brushy Basin shale member, and is assigned by the writers to the Brushy Basin. The thickness of the so-called Poison Canyon sandstone ranges from 35 to 90 feet, but most of the deposits occur where this sandstone is more than 50 feet thick. The relatively thick parts of the sandstone generally range from about 500 to 1,000 feet wide and from 1,000 to 2,500 feet long, they have a dominant eastward trend. Two generalized cross sections (fig. 91), compiled from drill-hole information and outcrops, show the relationship of the deposits to the sandstone thickness.
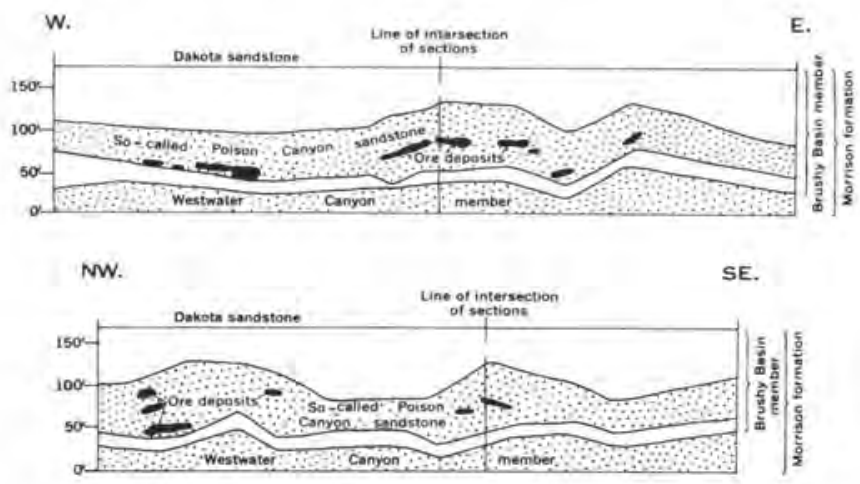

ㄴ, 5 Mines

Frauks 91--Generalized geologic sections showing the stratigraphie relations of the uranium deposits in the Morrison formation, northwest of Grunts, N. Mex.

\section{SO-CALLED JACKPILE SANDSTONE UNIT}

The so-called Jackpile sandstone constitutes the upper part of the Brushy Basin and is unconformably overlain by the Dakota sandstone. The so-called Jackpile sandstone is present throughout an area of at least 200 square miles, but its limits are not known. It is best exposed north of Laguna (fig. 90) between Mesa Gigante and the eastern edge of the Mount Taylor volcanic field, where it generally ranges from about 60 to 175 feet in thickness. About 7 miles northeastward from Laguna, it thickens to a maximum of about 175 feet. It appears significant that all the known deposits in the area north of Laguna and between Mesa Gigante and the eastern edge of the Mount Taylor volcanic field are in the vicinity of this maximum thickness where the sandstone generally exceeds 150 feet in thickness. Two generalized cross sections (fig. 92), drawn from outcrops and drill-hole data, show this relationship. Moreover, beneath the thicker part of the so-called Jackpile sandstone, the rest of the Brushy Basin member is largely sandstone which is lithologically similar to the so-called Jackpile sandstone.

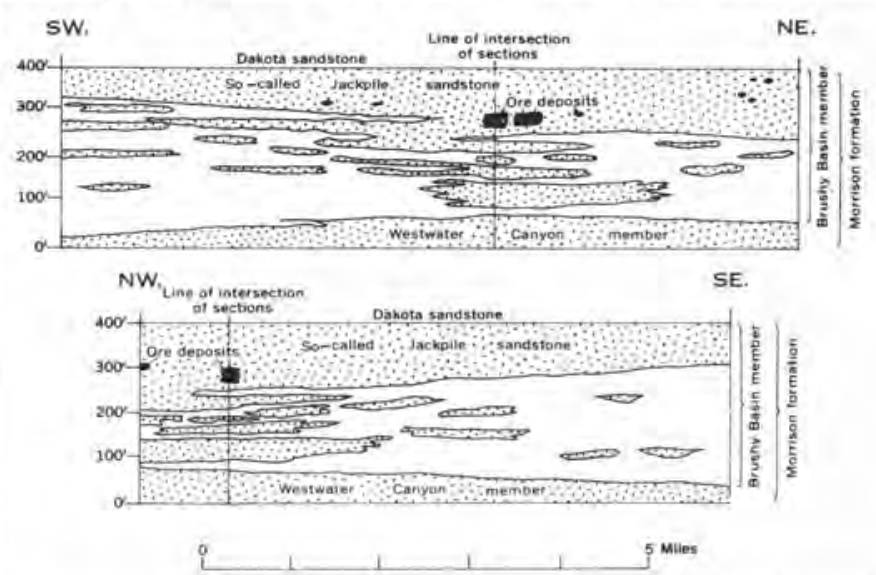

F1GUre 92,-Genernlized geologio sections showing the stratigraphic relations of the uranium deposits in the Morrison formation, north of Laguna, N. Mex.

\section{URANIUM DEPOSITS}

The Morrison uranium deposits in the area consist of concentrations of black and yellow uranium minerals in tabular bodies. These bodies generally follow the bedding and range from about a foot to several tens of feet in thickness and from several feet to hundreds of feet in width and length. The amount of ore in these bodies ranges from a few tons to many hundreds of thousands of tons.

\section{BRUSHY BASIN POTENTIAL FOR URANIUM}

The so-called Poison Canyon and Jackpile sandstone units of the Brushy Basin shale member contain all the larger uranium deposits, and these two units and others of similar type in the Brushy Basin contain nearly all of the Morrison deposits in the Gallup-Laguna area. Some measure of the relatively great uranium potential of the Brushy Basin can be determined by comparing mine production and reserves of the Brushy Basin with production and reserves of other formational units in the Gallup-Laguna area, with the production and reserves of New Mexico, and with the production and reserves of the Colorado Plateau. The comparisons are based on figures that are applicable at the end of September 1954. 


\section{PRODUCTION AND RESERVES}

About 98 percent of the ore produced from the Morrison formation in the Gallup-Laguna area has come from the Brushy Basin shale member, mostly from the so-called Poison Canyon and Jackpile sandstone units. This production represents 50 percent of the total ore produced from the area and about 45 percent of the total uranium ore produced in New Mexico.

The commercial significance of uranium in the Gallup-Laguna area was not realized until after the discoveries made in 1950. Between 1950 and 1952 little ore was produced, as this time was spent in prospecting and exploitation of ore bodies. The production from the Brushy Basin member (and other units in the Gallup-Laguna area), therefore, represents only about 2 years of mining effort. Even so, the Brushy Basin production from this area constitutes a significant part of the total from the Colorado Plateau.

Almost the entire reserves for the Morrison formation in the Gallup-Laguna area are in the Brushy Basin. These reserves represent about 90 percent of the total reserves in the Gallup-Laguna area and about 85 percent of the reserves for New Mexico. These Brushy Basin reserves, moreover, constitute an important part of the reserves in the Colorado Plateau. Almost all Brushy Basin reserves are in the so-called Poison Canyon and so-called Jackpile sandstone units.

Because only a small percentage of the Brushy Basin shale member in the Gallup-Laguna area has been explored, the potential reserves of this member are probably many times as great as the known reserves.

\section{GUIDES TO ORE}

The general characteristics of the so-called Poison Canyon and so-called Jackpile sandstones make it possible to recognize these units at the outcrop and to extend and define their limits by drilling. Also, these characteristics may have application in searching for and defining other similar units in the Brushy Basin of the Gallup-Laguna area.

In the so-called Poison Canyon and Jackpile sandstones, ore guides are summarized as follows:

1. Deposits are generally localized in the thicker parts of the units. In the so-called Poison Canyon sandstone they are found mostly in areas where the thickness exceeds 50 feet. Deposits are found in the so-called Jackpile sandstone where the thickness exceeds 150 feet.

2. Yellow-gray sandstone.

3. Abundant carbonaceous debris.

4. Abundant claystone lenses and galls.

The sandstone color and the abundance of carbonaceous debris and claystone are of limited use, because it has not been determined how far away from the deposits these features are found. However, when observed collectively with optimum thickness, they should indicate ground most favorable for ore deposits; and once a target area has been defined, drilling can give specific location of the deposit. 


\title{
URANIUM DEPOSITS IN PALUDAL BLACK SHALES, DAKOTA SANDSTONE, SAN JUAN BASIN, NEW MEXICO
}

\author{
By John W. Gabelman, U. S. Atomic Energy Commission
}

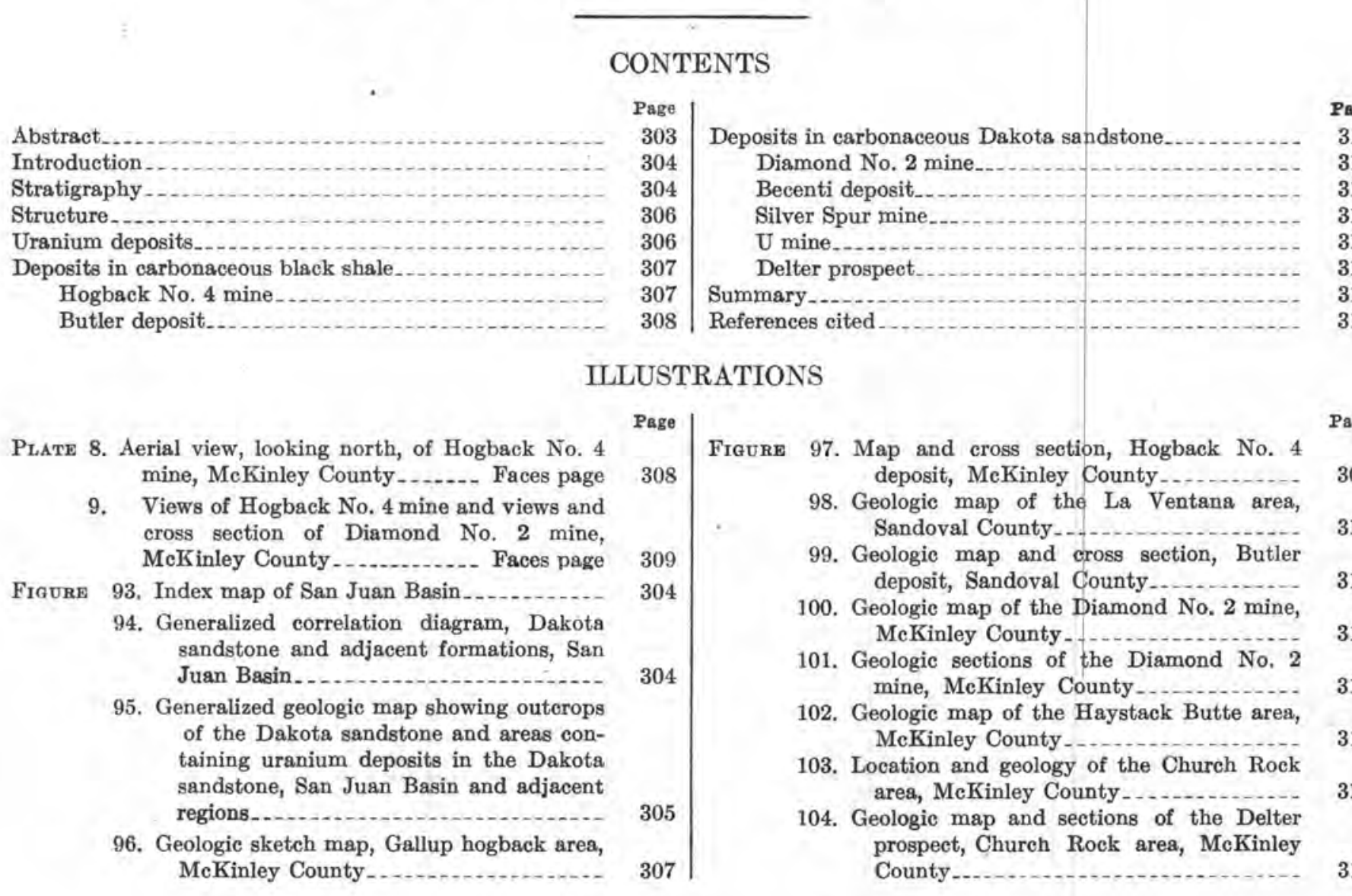

\begin{abstract}
Uranium deposits of commercial grade are present in the basal black shales of the Dakota sandstone of Cretaceous age around the south and east upturned edges of the San Juan Basin, northwestern New Mexico. These shales are paludal and littoral and constitute portions of minor cyclothems formed before deposition of Dakota beach sands and final inundation by the Mancos sea. These discontinuous shale beds interfinger with, and are enclosed by, equally diseontinuous stream-channel and floodplain sandstone lenses. The shales are richly earbonaceous and locally grade into peat and low-rank coal. They contain miniature lenses and channels filled with fine- to medium-grained sandstone. The interbedded sandstone layers and lenses are gray, medium to coarse grained, and highly contaminated with carbonaceous mascerated plant material.
\end{abstract}

Epigenetic secondary uranium minerals whose deposition was locally joint controlled occur most commonly in the carbonaceous sandstone lenses of greatest lithologic variability. The lenses are as much as several feet thick and are enclosed by carbonaceous shale or mudstone beds. Yellow uranium minerals impregnate the most carbonaceous portions of the sandstone. Less commonly, beds of black carbonaceous shale or peat overlying stream-channel sandstones have been mineralized, rather than the neighboring sandstones. No uranium minerals are apparent in the shales, and the uranium is presumed to be adsorbed by the carbonaceous matter.

Deposits in the sandstone lenses have been exploited, but those in shale or peat, although of high grade, are not amenable to present processing methods.

The Diamond No. 2 and Becenti deposits in carbonaceous sandstone beds and the Hogback No. 4 deposit in black carbona- 
ceous shale are in the Gallup area of the Zuni uplift, southwestern San Juan Basin.

The U-mine and Delter prospects are in earnotite impregnations of Dakota sandstone in the Church Rock area on the northeast flank of the Zuni uplift near Gallup. The Delter deposit is in an ancient stream channel cut into the underlying Morrison formation.

The Silver Spur and Small Stake deposits, in the Grants area of the Zuni uplift, southern San Juan Basin, are in a basal carbonaceous sandstone of the Dakota capped by shale. The Butler deposit is in the Nacimiento uplift, on the east side of the San Juan Basin, in a thin peat lens in the basal zone of interbedded black shale and sandstone of the Dakota sandstone.

\section{INTRODUCTION}

Carbonaceous shale containing uranium ore occurs at the base of the Dakota formation, which crops out around the edges of the San Juan Basin of northwestern New Mexico (fig. 93). Uranium deposits in paludal black carbonaceous shale and in related interbedded sandstone and coal are locally of ore grade. These deposits are so closely related to Dakota sandstone ore bodies and to the structure of the San Juan Basin that all are discussed together. Less important deposits of similar lithologic relations occur at the base of several sandstones of the Mesaverde in the San Juan Basin.

\section{STRATIGRAPHY}

The San Juan Basin contains sedimentary rocks of Paleozoic, Mesozoic (fig. 94), and Cenozoic ages which

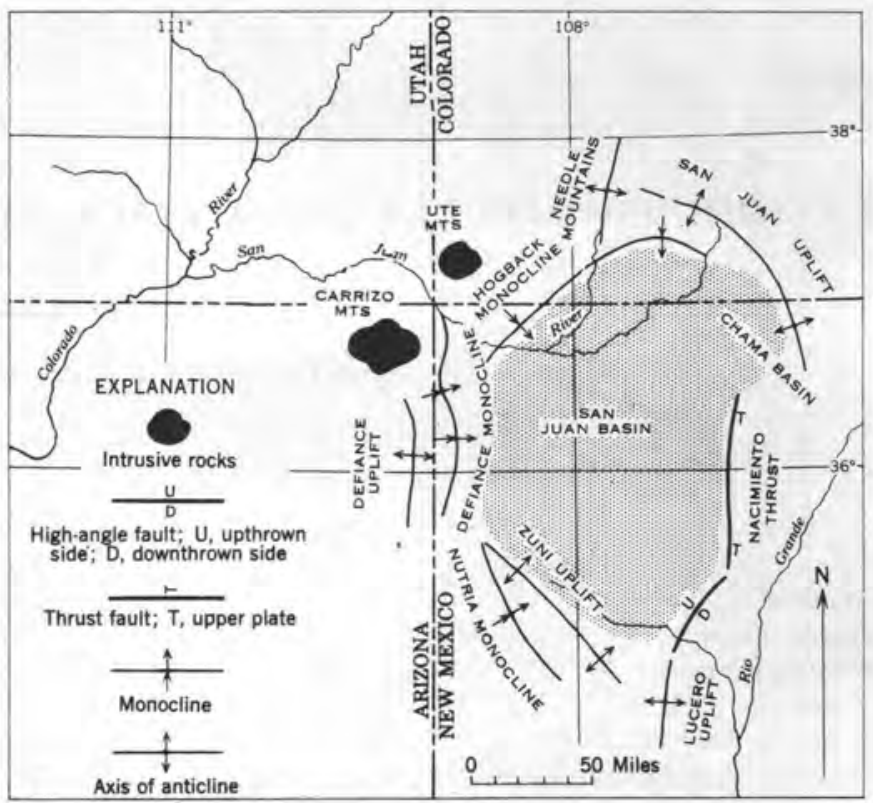

Figure 93,-Index map of San Juan Basin, N. Mex.

are partially exposed in concentric bands around its edges (fig. 95). The Dakota sandstone is the lowest Upper Cretaceous formation in the San Juan Basin and in most areas crops out as the resistant caprock of hogbacks. The Dakota consists of a lower unit of interbedded and interfingering sandstone, carbonaceous

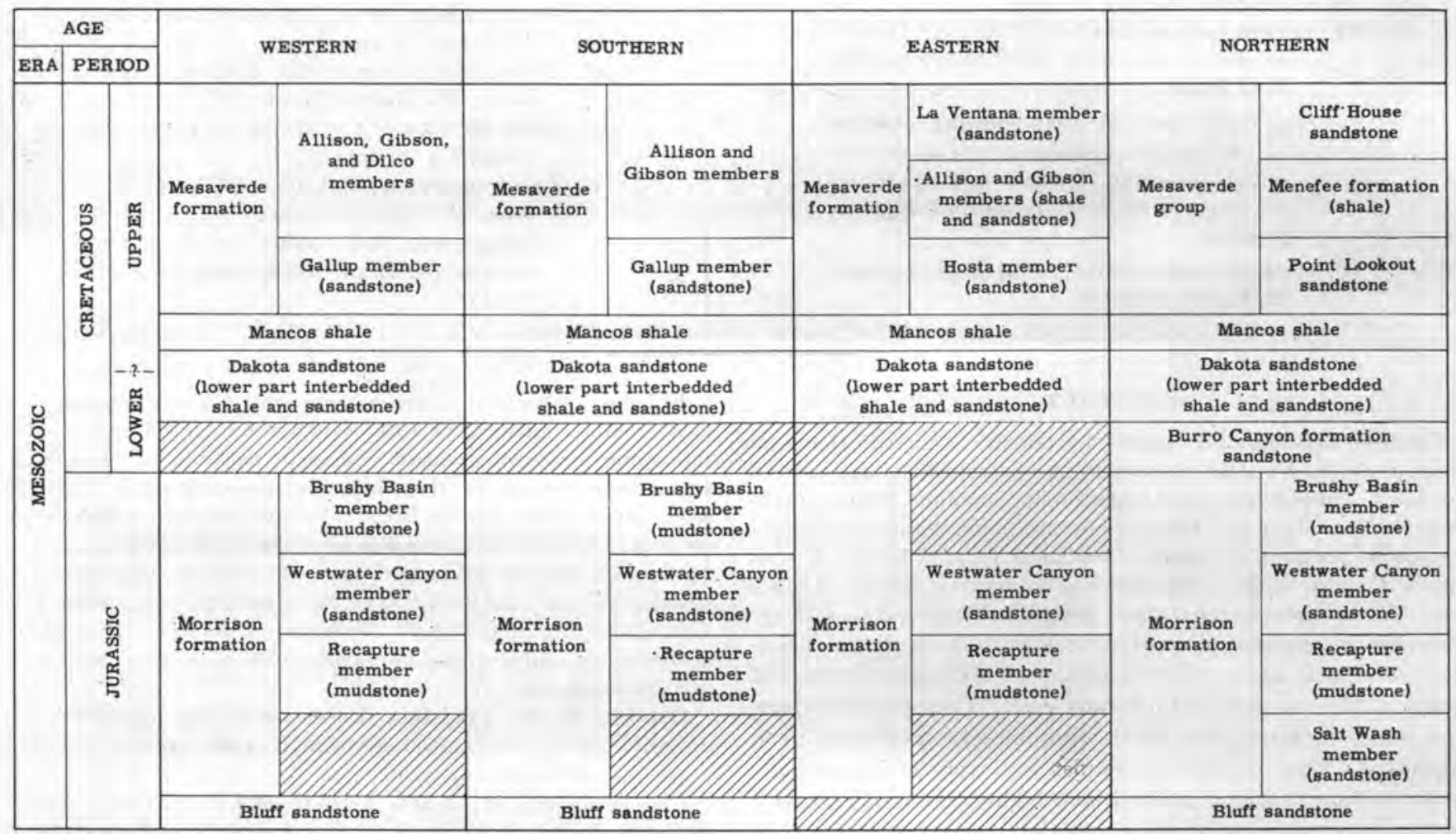

FroURE 94.-Generalized correlation diagram, Dakota sandstone and adjacent formations, San Juan Basin, N. Mex. 

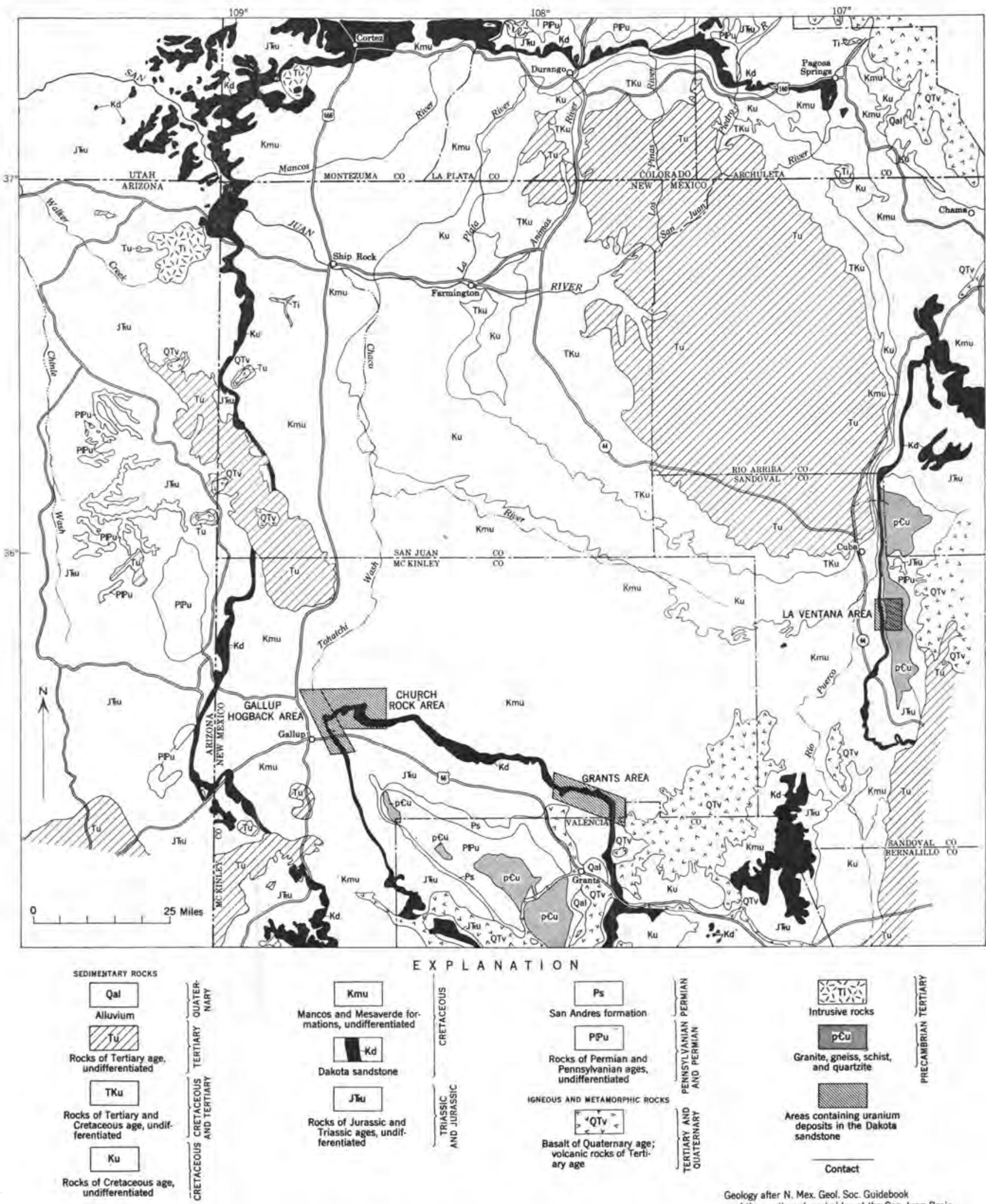

EXPLANATION

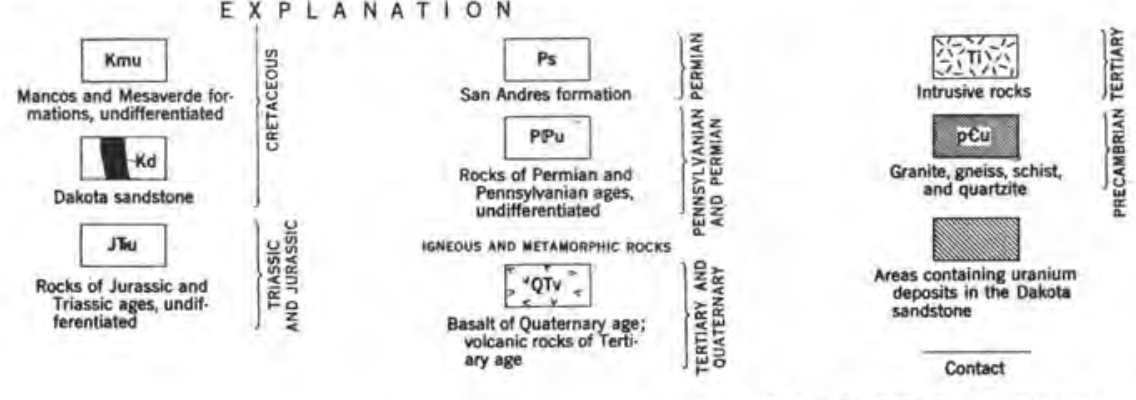

Geology atter N. Mex. Geol. Soc. Guidebook

F1nURE 95.-Generalized geologic map showing outcrops of the Dakota sandstone and areas containing uranium deposits in the Dakota sandstone, San Juan Basin"and adjacent regions, New Mexico, 
shale, and low-rank coal, and an upper unit of thick sandstone.

The Dakota sandstone overlies the variegated Brushy Basin member, or, where that is absent, the gray coarse poorly sorted Westwater Canyon member of the Morrison formation. The lower Dakota unit contains lenses and interfingering beds of fine- to medium-grained poorly sorted crossbedded sandstone. The sandstones contain local concentrations of coalified plant material. Interfingering carbonaceous shale is silty and contains numerous lenses of siltstone and gray sandstone. Local increases in sapropelic content result in gradations to peat and lignite.

The lower unit is best characterized by its rapid lateral lithologic variation. Beds of each rock type enclose small irregular bodies of other types. Long, narrow lenses of siltstone or sandstone, commonly several inches wide, are miniature channel fills in the black shale.

Throughout the Colorado Plateau the Dakota sandstone marks the transition from continental deposition of the Upper Jurassic to marine deposition of the Upper Cretaceous. It was deposited along a migrating strandline which probably moved southward across the San Juan Basin and finally buried the Jurassic landmass, the source of Morrison clastic rocks. The sandstone of the Dakota therefore extends diagonally upward and southward across time lines.

The lower Dakota units represent a combined paludal and lagoonal environment retreating ahead of the encroaching beaches and offshore bars of the upper unit. Moderately active streams are suggested by poor sorting and torrential crossbedding. Sandstone lenses are broad channel fills suggesting braided stream courses.

\section{STRUCTURE}

Diagenetic structures in the lower unit of the Dakota are common; most are the result of slump, where partly consolidated sandstone beds slid into channels along surfaces which are continuous with bedding planes that die out in the shales. Also, thinly layered shale and silt beds crumpled from lateral pressure and sliding.

Structures in hogbacks along the margins of the San Juan Basin resulted from uplift of bordering tectonic units in Laramide (Eocene) time, as shown by the overlap of hogbacks by the Wasatch formation along the east margin. The more severely deformed hogbacks and monoclines are more closely related to bordering uplifts than to basin subsidence. Locally hogbacks are crossed by faults originating in the uplifts, such as in the Nacimiento thrust block and the Zuni Mountains. However, such faults are uncom- mon; the most prevalent structures are small cross and diagonal folds, joints, and faults which have resulted from the uptilting of the beds. Folds and joint patterns are closely related geometrically, and folds indicating stress relief in incompetent or thin-bedded sediments are analogous to relief along joints in competent beds. These small structures are remarkably similar in the several widely separated hogbacks and are directly involved in the localization of uranium and other related minerals. The hogbacks also contain similar but very large plunging cross folds. The mechanics of deformation of small structural features were the same as those of the large features.

A joint pattern diagonal to the bedding strike and a reticulate pattern of fold axes have been noted in several deposits.

\section{URANIUM DEPOSITS}

Within the basal interbedded sandstone and shale zone of the Dakota, uranium occurs both in black carbonaceous shale and in coarse- or medium-grained carbonaceous sandstone, although seldom in commercial amounts in both rock types at the same deposit. The lower Dakota rocks contain intricately arranged lenses of sandstone, siltstone, black mudstone, and vegetal accumulation. Barren sandstone lenses occur within bodies of uraniferous shale. Uranium is restricted to 1 or 2 units despite the occurrence of favorable carbonaceous trash in adjacent barren beds. The greatest concentrations of uranium are in richly carbonaceous sandstone or in carbonaceous shale, or peat, in which the host rock is mostly mascerated vegetal trash. No uranium minerals are visible in the shale or peat, and it is presumed that uranium was adsorbed by the carbon (Vine, Bachman, Read, and Moore, 1953). Yellow secondary uranium minerals (principally carnotite) impregnate the carbonaceous sandstone.

Gruner (1954) has suggested that all Colorado Plateau carnotite-type ores which have a high vanadium content represent the oxidation in place of black uraninite or coffinite ores, and it is possible that the lower sandstone ores in the Dakota are so oxidized. The principal evidence for this conclusion is the low solubility of uranium vanadates (carnotite, tyuyamunite, and others) under oxidizing conditions. Because a strong reducing environment precipitates uranium as uraninite or coffinite, the uranium and vanadium may have been brought to their present position under mild acidic and oxidizing conditions, probably as a uranyl sulfate. As would be expected according to these conditions, two ore bodies recently discovered below the oxidized zone at the Diamond No. 2 mine are composed entirely of primary pitchblende ore.

The ratio of uranium to vanadium in ores in Dakota 
sandstone ranges from $1: 1$ to $1.68: 1$. In ore-bearing black shale with no uranium minerals, it ranges from $6.3: 1$ to $10: 1$. This difference indicates that, although uranium and vanadium were nearly equal in amount or that uranium greatly exceeded vanadium as introduced in solution, uranium was adsorbed on carbon, whereas vanadium was not. Thus the relative amount of vanadium is greatly increased in the sandstone ores. However, the reducing environment presumed to exist during initial introduction, by virtue of deep burial,would probably prevent precipitation of carnotite, regardless of the vanadium excess required to form the mineral.

\section{DEPOSITS IN CARBONACEOUS BLACK SHALE}

\section{HOGBACK NO. 4 MINE}

The Hogback No. 4 mine is in McKinley County, N. Mex. (fig. 96). The ore bed is a black shale 1-3 feet thick that is extremely fissile and can be split into paper-thin sheets, with abundant partially carbonized
R. 18 W.

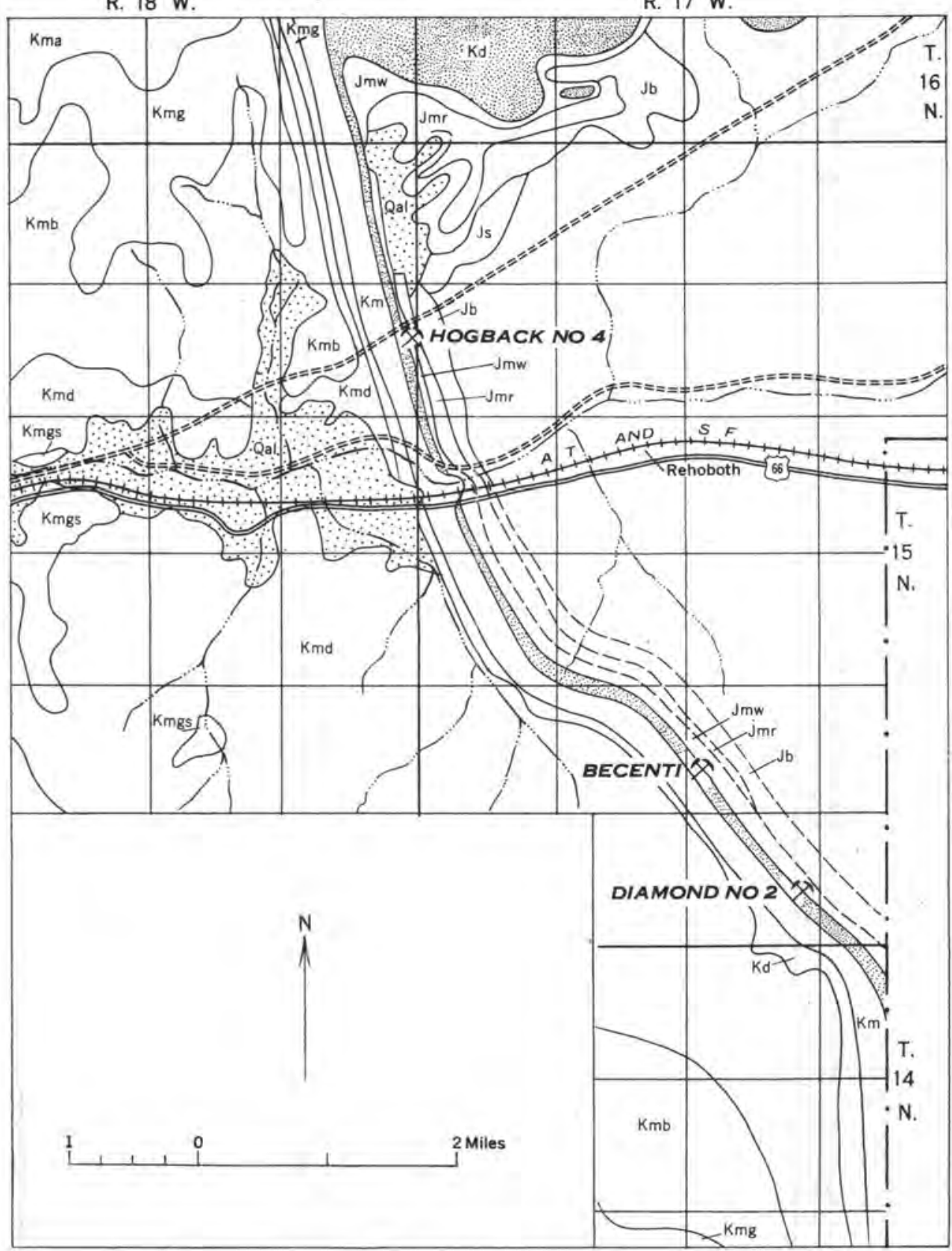

\section{EXPLANATION}

$\therefore$ Qa

Alluvium

Kma

\begin{tabular}{|l|}
\hline$K m g$ \\
\hline$K m b$ \\
\hline$K m d$ \\
\hline$K m g s$ \\
\hline
\end{tabular}

\begin{tabular}{|l|l}
\hline Kmigs \\
\hline
\end{tabular}

Mesaverde formation

Allison non-ore-bearing member, Kma; Gibson coal member, Kmg; Bartlett barren member, Kmb; Dilco coal member, Kmd; Gallup sandstone member, Kmgs

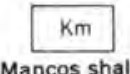

Mancos shale

Kd

Dakota sandstone

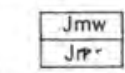

Morrison formation Westwater Canyon member, Jmw; Recapture member, Jmr

$$
\begin{aligned}
& \text { Jb } \\
& \text { Bluff sandstone } \\
& \text { Summerville formation }
\end{aligned}
$$

Older formations not shown

Contact, dashed where approximately located

父- 
plant fragments. Locally it is very nearly a peat. It contains numerous thin gray carbonaceous fluvial crossbedded sandstone lenses averaging $3 / 4$ inch in thickness and 18 inches in length. A map of the mine is shown in figure 97 and a general view in plate 8 .

Stratigraphy.-The lower part of the Dakota sandstone, in which the uranium deposits occur at the Hogback No. 4 mine, is described below.

Section of lower Dakota sandstone at Hogback No. 4 mine Dakota sandstone:

Sandstone, light-buff, medium-grained.

Shale, light-gray, very thin-bedded, yellow-stained--

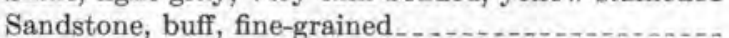

Clay, brown and gray shale, limonite-stained.......

Sandstone, gray, thin-bedded, fine-grained, with thin shale lenses; indistinet erossbedding.-

Sandstone, green, thin-bedded, elay-rich.............

Shale, gray, interbedded with black carbonaceous shale and thin sandstone beds.

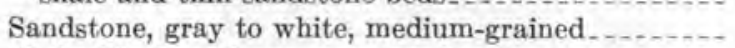

Shale, black, earbonaceous, ore-bearing ............

Sandstone, brown to orange, fine-grained.........

Shale, gray, lenses out locally ......................

Sandstone, grit, yellow-brown, coarse- to very coarsegrained, moderately arkosic, poorly sorted, massive; contains small mud balls and carbonaceous vegetal trash; fine grained and uniform at top....

Mudstone, gray to black, and earbonaceous shale...

Sandstone, brown, fine-grained; carnotite in vacated carbonaceous-trash holes

Mudstone, light-gray

Sandstone, gray to brown, clay-spotted, fine-grained, quartzose

Westwater Canyon member (sandstone) of the Morrison formation.

Structure.-In this area the Gallup hogback forms the steep west and southwest flanks of the Zuni uplift, the northwest nose of which is about 2 miles north of the Hogback No. 4 mine. The Dakota sandstone and the Gallup sandstone member at the base of the Mesaverde formation which dip $35^{\circ} \mathrm{W}$. and $75^{\circ} \mathrm{W}$. respectively, form caprocks of 2 hogbacks which trend northward and are separated by a narrow valley in the Mancos shale. A cross fault is suggested by a water gap several thousand feet north of the mine, and a small cross fault striking east-northeast apparently bounds the north side of the deposit (fig. 97). Other faults near the deposit show less than 3 feet of movement. One set of joint strikes N. $70^{\circ} \mathrm{W}$. and dips $60^{\circ}-70^{\circ} \mathrm{SW}$.; a second set strikes N. $15^{\circ} \mathrm{E}$. and dips $60^{\circ}-70^{\circ} \mathrm{SE}$. One to three feet of movement on joint surfaces (pl. $9 A, B$ ) probably resulted from tilting of the hogback. On joints nearly parallel to the strike of the beds, the updip side usually has been raised (fig. 97), although many joint blocks have moved indiscriminately.
Tectonic folds of large or moderate size are absent; however, small diagenetic slump (?) folds occur in the shale beds of the hanging wall, and the ore-bearing shale bed is strongly wrinkled. Some of the crumpling in the shale may have resulted from stresses during Laramide (Eocene) time.

Uranium deposits.-Mineralized shale has been exposed by an open pit that extends about 700 feet along the strike, is 80 feet in maximum width, and is 60 feet in depth on the crest of the Dakota hogback (fig. 97). Except for the small cross fault there is no obvious external structural control for localization of the ore body or its variation in grade. The shale contains no recognizable uranium minerals. The introduced gangue minerals are limonite, gypsum, and jarosite. The jarosite and gypsum occur in lenses and in thin veinlets between beds.

The top of the sandstone of the footwall has been exposed by stripping, which extends nearly 100 feet dowrdip from the outcrop. The top surface of the normally brown sandstone of the footwall is strongly stained with limonite. The surface is not planar but undulates irregularly. The irregularities may be depositional. However, scarps with as much as 2 feet of relief are geometrically disposed and result from movement along joints parallel to the strike (pl. $9 A, B$ ). Locally the surface is knobby with spherical limonite concretions. Hard limonite joint fillings, which originally extended into the shale, stand out as small ribs.

Uranium solutions have deposited yellow secondary minerals in a sandstone bed $13-15$ feet below the orebearing shale in holes formerly occupied by carbonaceous trash, but the amount of uranium in the lower bed is minor.

Ore controls.-No broad ore controls are apparent because the same lithologic character and apparent lack of small structures exist in adjacent unmineralized areas. The occurrence of the ore body at this particular locality is not readily explained. Within the orebearing bed, however, veinlets of jarosite and gypsum suggest the movement of solutions along joints, although whether such movement is primary or secondary is unknown because both origins are possible for these minerals. In most uranium deposits, however, these minerals suggest oxidation from pyrite.

Several hundred tons of ore-bearing black shale have been shipped from the mine, but the uranium is not readily extractable from the shale by leaching processes. The ratio of uranium to vanadium is $6.3: 1$.

\section{BUTLER DEPOSIT}

The Butler uranium deposit is in the Nacimiento Mountains, about 6 miles northeast of La Ventana, Sandoval County, N. Mex. (fig. 98). 


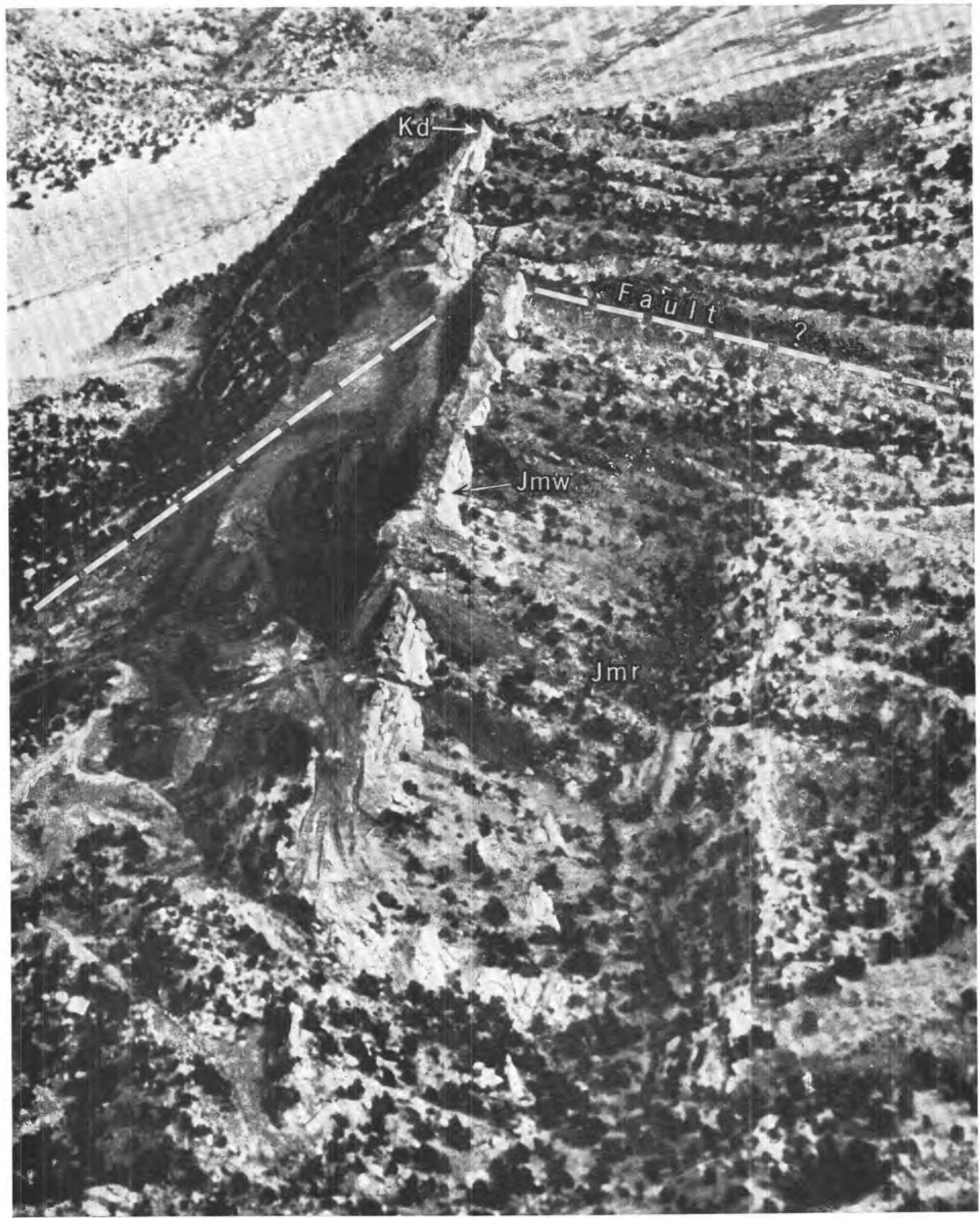

AERIAL VIEW, LOOKING NORTH, OF HOGBACK NO. 4 MINE, McKINLEY COUNTY, N. MEX.

Dakota sandstone (Kd) and Westwater Canyon (Jmw) and Recapture members (Jmr) of the Morrison formation. 

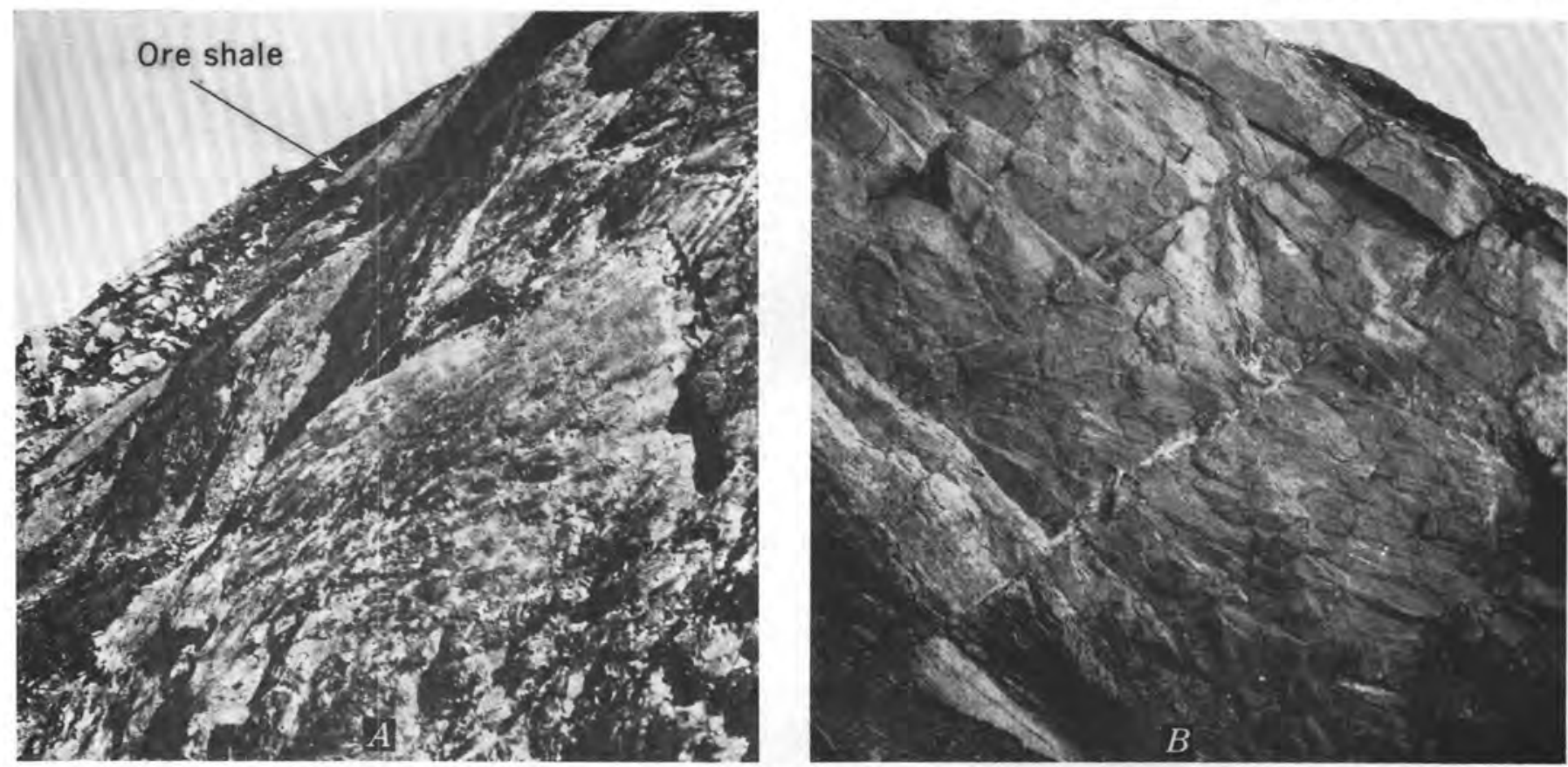

Views of Hogback No. 4 mine, MeKinley County, N. Mex. A. Detail of footwall surface, looking north from mine; note ripple marks and linear features. $B$. Cross-sectional view of joints in sandstone of the footwall, looking south from mine.
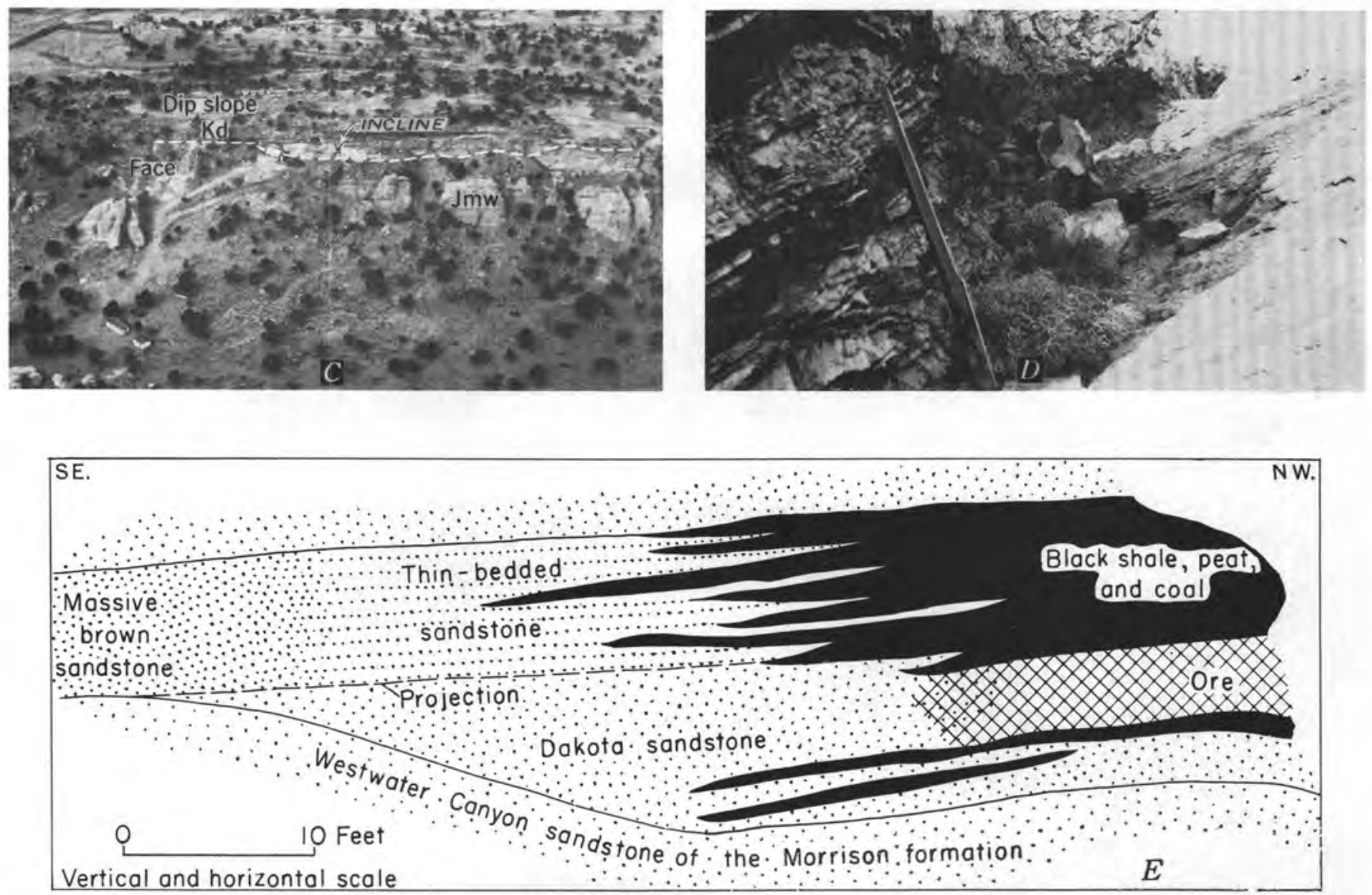

Diamond No. 2 mine, Nutria monocline, McKinley County, N. Mex. C. Aerial view of mine, looking southwest. Dakota sandstone (Kd), and Westwater Canyon member (Jmw) of Morrison formation. D. Outcrop of Diamond No. 2 ore zone and shale of the hanging wall; note lithologic variability. $E$. Interfingering shale and sandstone of the hanging wall. 


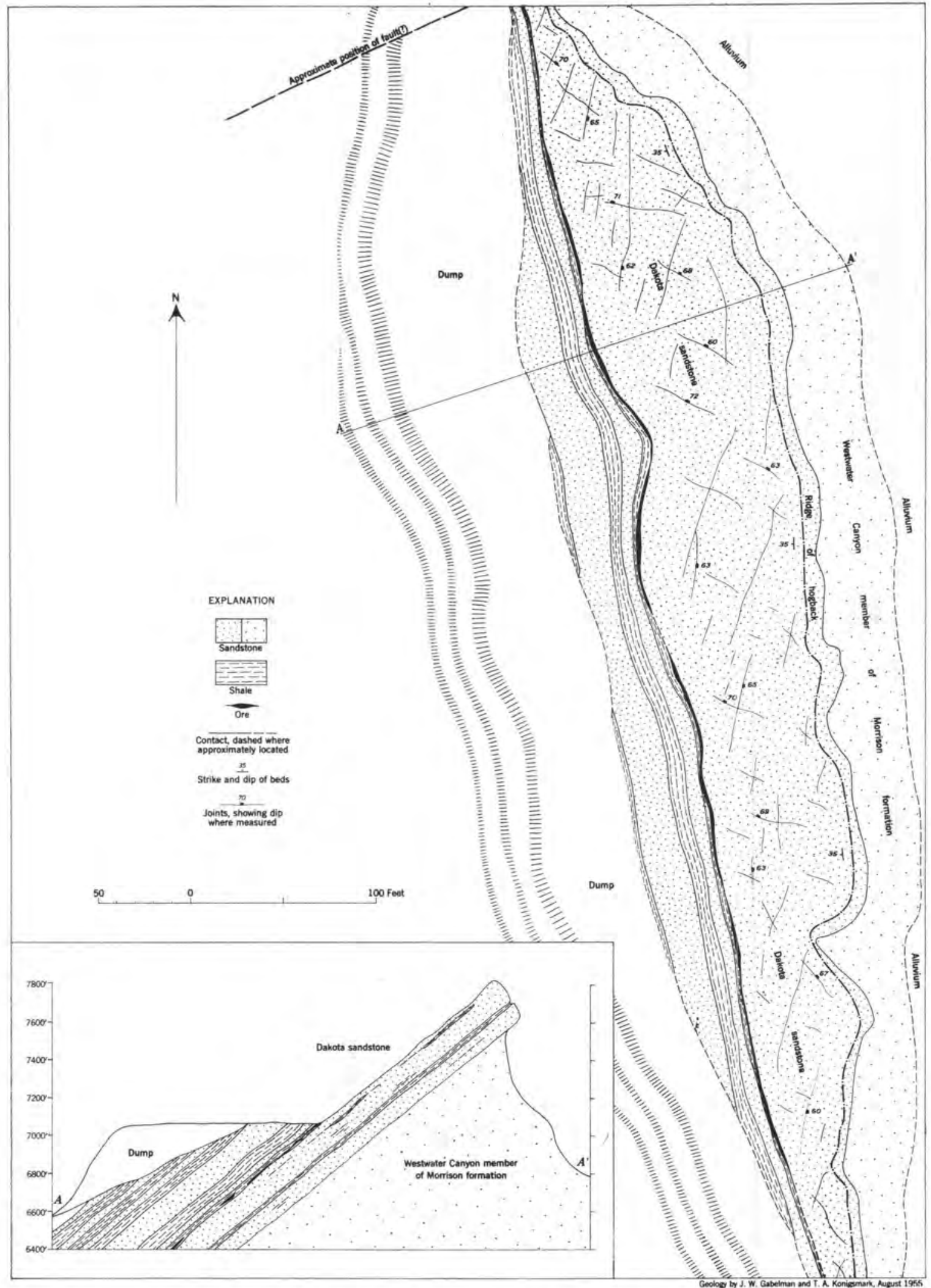

FıUURE 97.-Map and cross section, Hogback No. 4 deposit, McKinley County, N. Mex. 

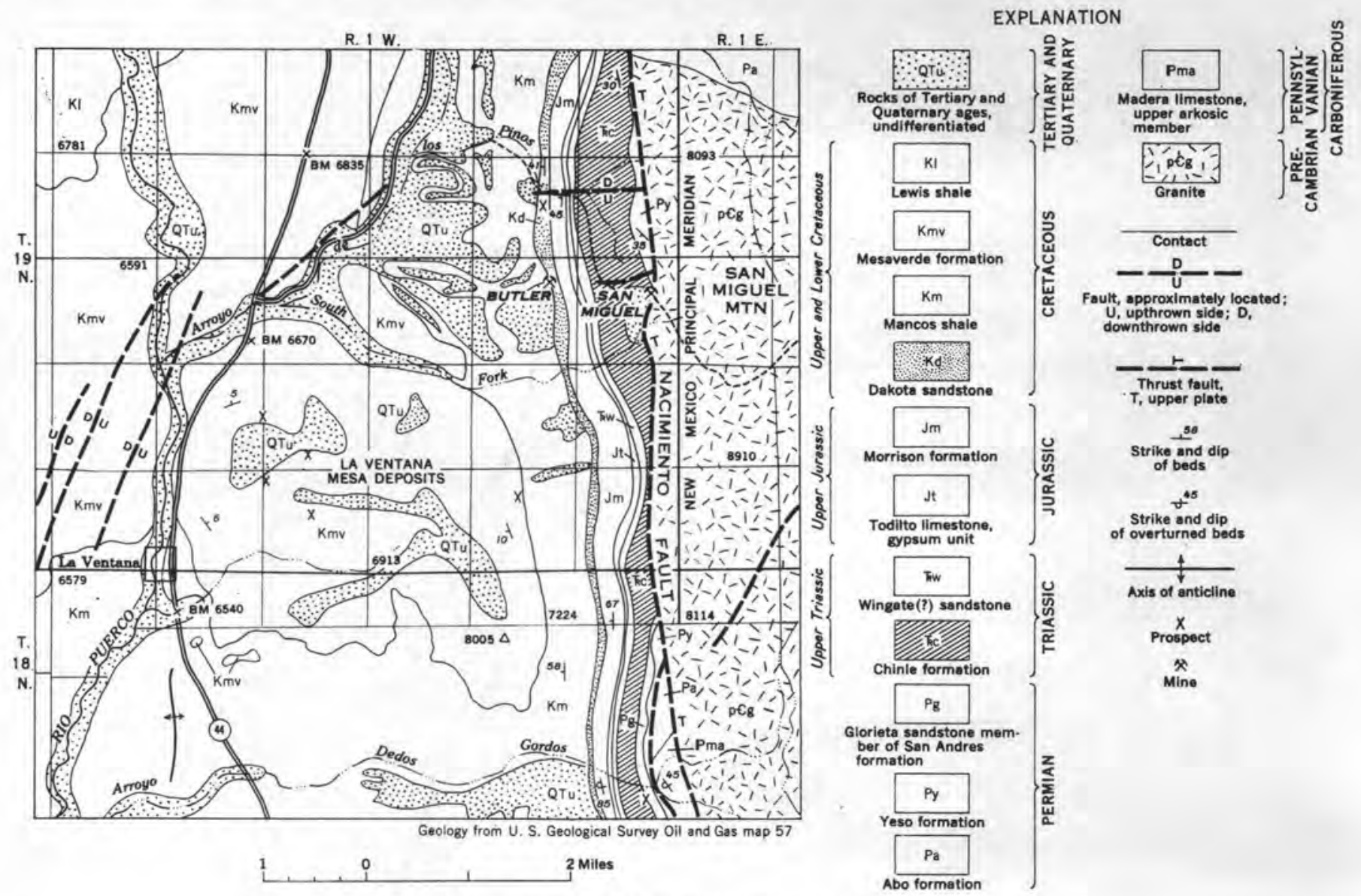

Figure 98.-Geologic map of the La Ventana area, Sandoval County, N. Mex.

Stratigraphy.-Formations present in the area of the Butler deposit are shown in figure 94, and the beds immediately associated with the uranium deposit are listed below.

\section{Section of the Dakota sandstone at the Butler deposit}

Dakota sandstone:

Sandstone, silty, thin-bedded

Sandstone, tan, fine-grained, quartzose

Shale, silty, gray, thin-bedded, rich in clay and carbonaceous debris

Sandstone, gray, fine-grained, silty, elay-rich........

Peat, black, ore-bearing

Morrison formation, Westwater Canyon member: Sandstone, gray, massive, fine-grained, quartzose, rich in clay and carbonaceous trash

The mineralized peat unit is a poorly bedded porous friable aggregate of mascerated partly carbonized plant fragments. It has a poorly developed nearly cubic joint pattern in which joints are oriented diagonally to the strike of the bedding.

Structure.-The beds have been tilted by drag resulting from the overthrusting of a granite block along the Nacimiento fault; the granite crops out about 1 mile east of the deposit. The Dakota hogback in the sole of the thrust strikes north and dips $45^{\circ} \mathrm{W}$. In San Miguel Canyon, less than 1 mile north of the deposit, a tear fault offsets the hogback several hundred feet; smaller tear faults cut the hogback near the mine. The deposit is about 300 feet south of a tear fault along which beds have been dragged through an arc of $70^{\circ}$ (fig. 99); the uranium is confined to the are of drag. Displacement on the fault is less than 50 feet. A diagonal fault of 5-10 feet displacement, which possibly branches from the tear fault, bounds the downdip side of the deposit.

Small crenulations, common in the shale beds, do not extend into the sandstones. It is noteworthy that these folds closely resemble those on the Gallup hogback, where there is no thrusting.

Uranium deposits.-The carbonaceous material contains a maximum of 1.4 percent $\mathrm{U}_{3} \mathrm{O}_{8}$ within the outcrop and along the dip for more than 100 feet. The ratio of uranium to vanadium is $10: 1$. The exact size and shape of the irregular body are unknown. The north side of the ore body is exposed from the hogback crest down the dipslope of the hogback to its abrupt termination by a diagonal fault. No uranium minerals occur 


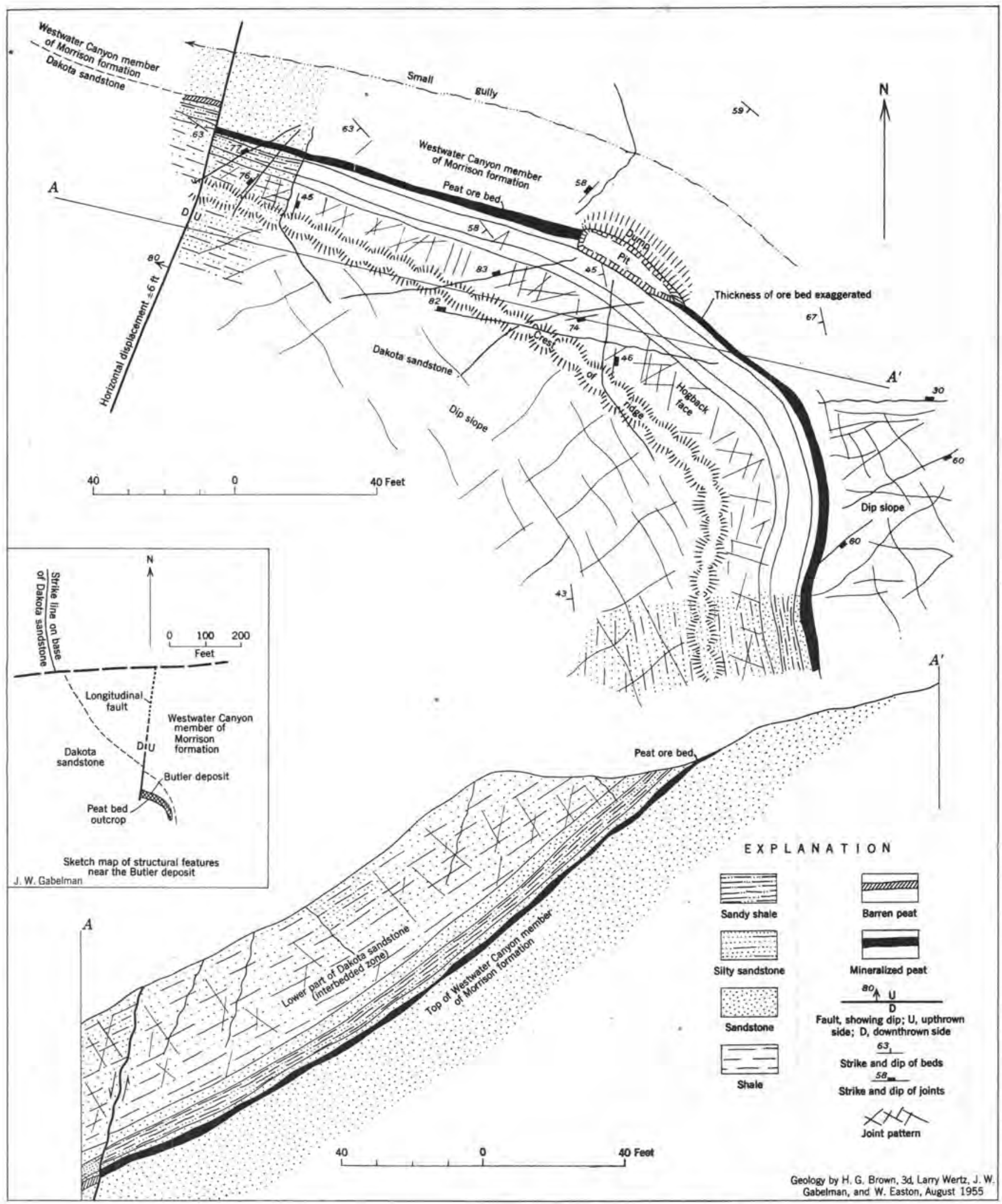

Figure 99.-Geologic map and cross section, Butler deposit, Sandoval County, N. Mex. 
in the fault, in any related joints in sandstone or shale, or in sandstone.

No uranium minerals are visible, but bedding and joint surfaces are coated with jarosite, gypsum, and limonite, and the enclosing sandstones are impregnated with limonite and calcite. The uranium is contained entirely in the peat. Downdip termination of the uranium against the diagonal fault suggests damming in a structural trap after tilting of the sediments. This would further suggest that the solutions were descending, probably as ground water.

Related deposits.-Low-grade mineralization has occurred in the same black-shale bed in Los Pinos Canyon (Read, 1952) about 2,000 feet north of the Butler deposit, and other deposits probably occur between the 2 deposits. Mineralization effects are identical in both occurrences. Another deposit, presumably in the same shale horizon, occurs in Arroyo de Dos Gordos, about 5 $5 \frac{1}{2}$ miles south of the Butler deposit. Approximately 3 miles southwest of the Butler deposit, black shale and coal at the base of the La Ventana and Hosta members of the Mesaverde formation contain similar low-grade uranium for several thousand feet around La Ventana Mesa (Vine, Bachman, Read, and Moore, 1953).

\section{DEPOSITS IN CARBONACEOUS DAKOTA SAND- STONE}

\section{DIAMOND NO. 2 MINE}

The Diamond No. 2 mine is in McKinley County, N. Mex., about 3 miles south of the town of Rehoboth (fig. 96). A plan of the mine is shown in figure 100, sections in figure 101 , and views in plate $9 C, D$.

Stratigraphy.-The formations present are similar to those at the Hogback No. 4 mine.

Section of basal Dakota rocks at the Diamond No. 2 mine

Dakota sandstone:

Sandstone, tan, limonite-stained, fine-grained, with Feet

fluvial erossbedding ........................ 8

Shale, black, wrinkled, with lenses of peat, mud, sand, and silt; hanging-wall bed.

Sandstone, gray, thin-bedded, poorly sorted, orebearing; abundant lenses of mud, shale, and carbonaceous material.

Shale, black, carbonaceous ...

Sandstone, gray, poorly sorted, crossbedded, arkosic

The wrinkled shale (pl. $9 D$ ) above the ore is similar to the ore bed at the Hogback No. 4 mine, about 5 miles to the northwest. The bed is extremely variable in lithologic character, with lenses and minute channels filled with sandstone, siltstone, and mudstone. On the outcrop about 30 feet southeast of the incline this bed abruptly interfingers into sandstone (pl. $9 E$ ). The bed also thins and pinches out downdip (figs. 100, 101). This shale lens and the other beds of the Dakota be- neath it fill a channel scoured into the underlying Westwater Canyon sandstone member of the Morrison formation, a cross section of which is exposed in the hogback face (pl. $9 C$ ). The shale lens has about the same shape as the entire channel fill but appears to be slightly larger. However, other shale beds originate not far beyond where this bed dies out, so that, in general, several large rarely overlapping shale lenses exist at various elevations in a fluvial sandstone zone. Each shale lens may be in a channel. The aerial view (pl. $9 C$ ) shows the channel and the lensing of the hangingwall shale. Ore bodies seem to occur along the abrupt southern margin of the lens.

The ore bed is a medium-grained poorly sorted quartz sandstone with little or no feldspar. It is strongly crossbedded locally and contains small thin lenses and channels of mudstone, shale, carbonaceous debris, and cannel coal. Some small channels contain minute local scours. Limonite and small amounts of calcite constitute the principal cement, but the sandstone is quite friable, and a weak pressure bond between the silica particles may be the only cement at many localities. White clay is a common cement in and near mineralized sandstone and may be an introduced gangue. Small detrital mudstone and claystone pellets are present.

Structure.-The deposit is in the Gallup hogback, a part of the southwest flank of the Zuni Mountains (figs. $94,96)$. The structure of the hogback closely resembles that at the Hogback No. 4 mine several miles to the northwest. Here the hogback strikes N. $35^{\circ}$ W. and dips $30^{\circ}$ SW., although broad structural and stratigraphic irregularities cause variations of as much as $10^{\circ}$ (fig. 100). Principal joints strike east and N. $10^{\circ} \mathrm{W}$. and form a nearly cubic pattern almost symmetrical about the strike of the hogback. The eastward-trending joints dip $45^{\circ} \mathrm{N}$., and those trending west of north dip at high angles. In this area the axis of the Zuni uplift has a northwest plunge of probably less than $3^{\circ}$. The strike of one minor joint set is normal to the bedding strike, and dips are at a high angle; another minor set is horizontal. Shear movement is generally less than a foot on the eastward-trending set, and locally there has been movement of several inches on the horizontal set.

Large folds are absent, but a reticulate network of small folds is prominent. Numerous short echelon cross folds, from several inches to 80 feet wide, plunge parallel to the dip of the hogback. In general smaller and shorter folds, parallel to the strike, are less common. The small longitudinal folds tend to occur between, rather than across, the plunging folds. The folds are probably tectonic, as indicated by the regular geometry of the pattern. Small irregular crenulations, as in the Hogback No. 4 and Butler deposits, are common in the 


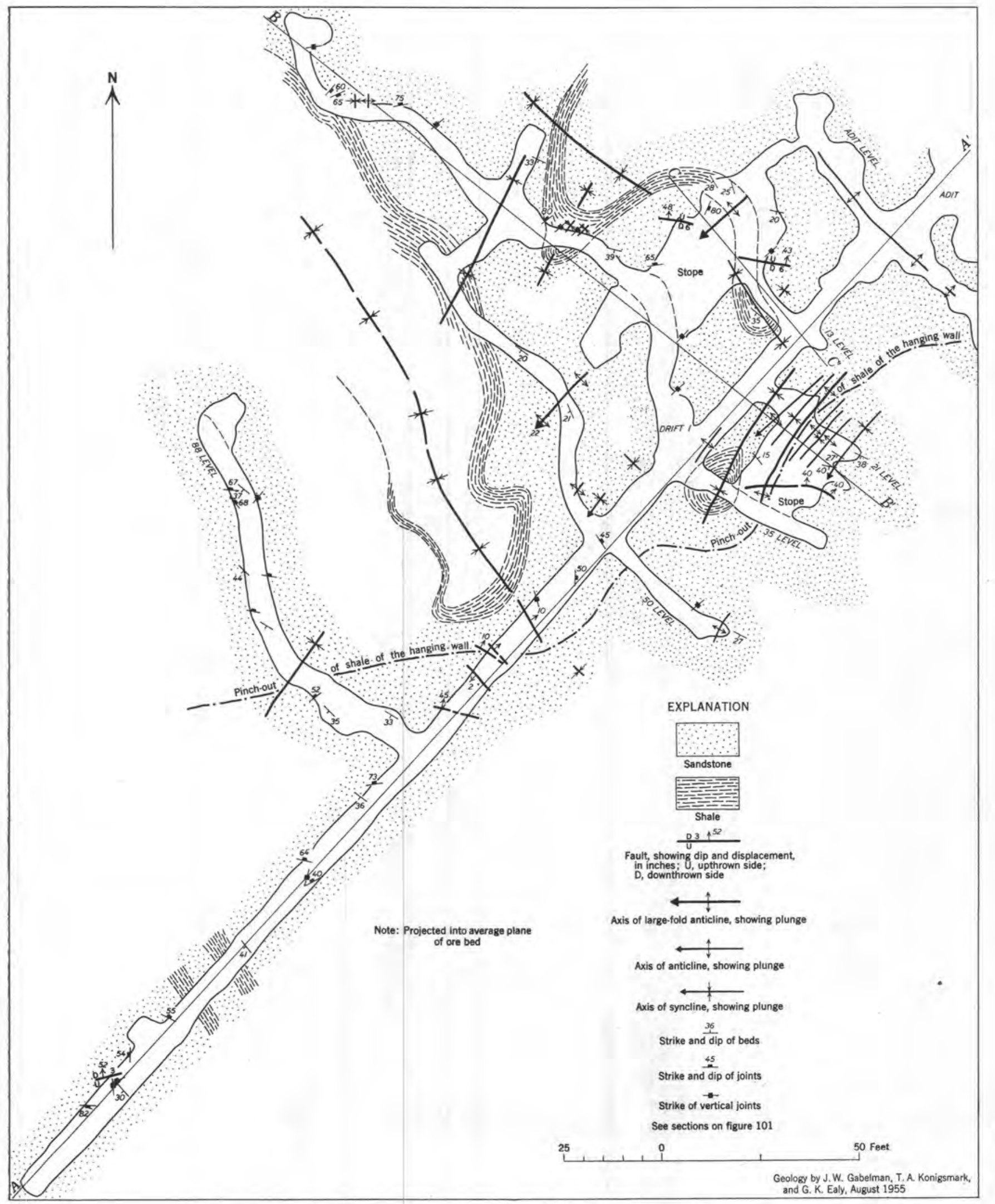

FinURE 100.-Geologic map of the Dlamond No. 2 mfne, MeKinley County, N. Mex.

$385115-56-21$ 


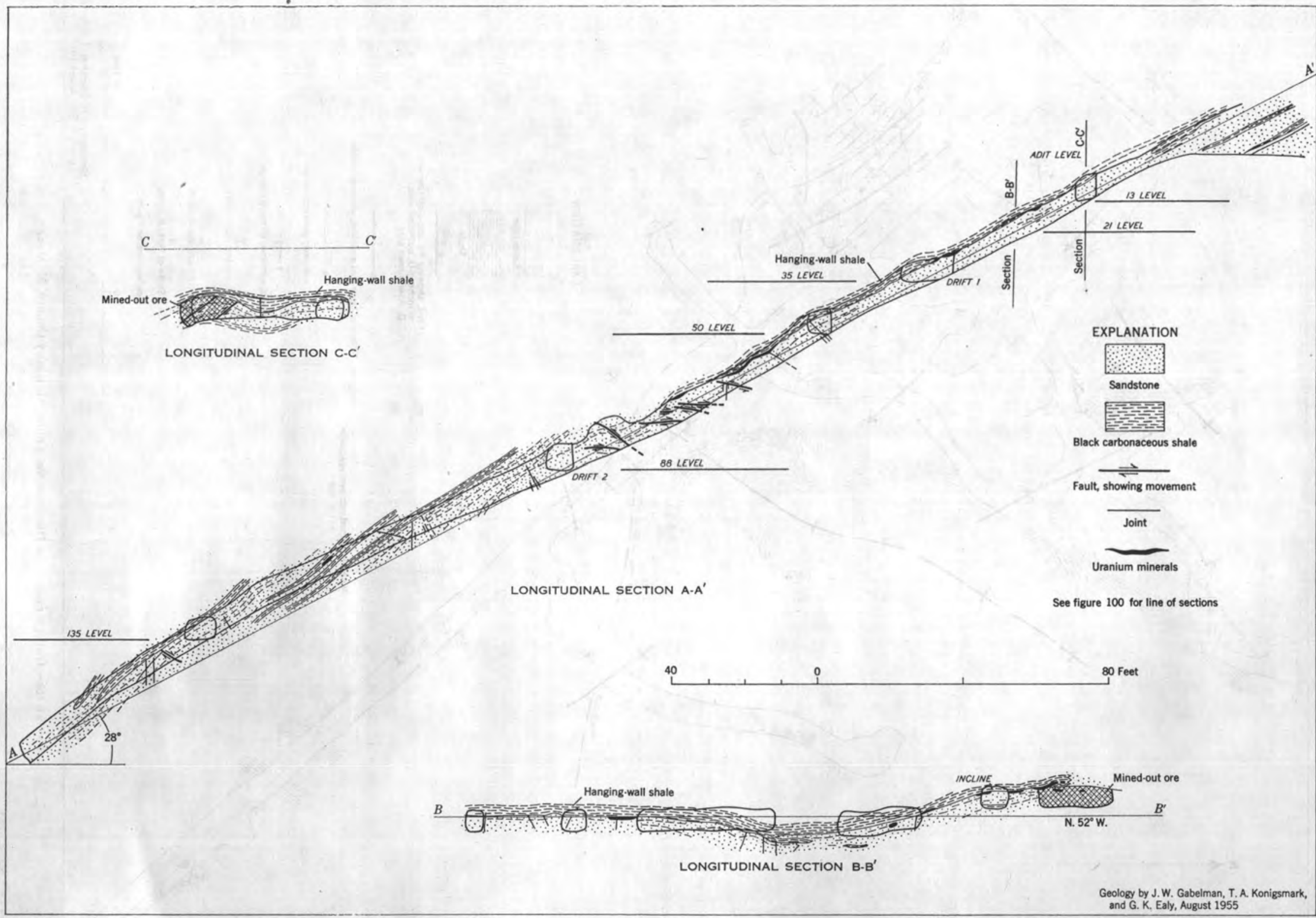


shale and to a lesser extent in the small sandstone lenses within the shale. These folds are consistently less than 1 foot wide. Their irregularity indicates they may be diagenetic.

Uranium deposits.-Uranium minerals in the sandstone occur in pods and elongate lenses which plunge downdip. Two large pods (stopes of figs. 100, 101) averaging about 60 feet in length, 20 feet in width, and 4 feet in thickness, have been mined out. They occurred in echelon, about 50 feet apart, on either side of the mine incline (fig. 100). The pods were confined to a lenslike area about 150 feet in strike length and 250 feet in dip length, and have the thickness of the sandstone. Two additional undeveloped ore bodies have been discovered several hundred feet downdip.

With few exceptions, uranium deposits are confined beneath the black-shale caprock but they commonly protrude as much as several feet from beneath the shale edges. Mineralization is not uniform beneath the shale. Pods are further confined beneath the axes of the plunging cross folds and, to a lesser extent, the longitudinal folds.

Many small pods and lenses of carnotite-impregnated sandstone several inches to several feet wide underlie similarly sized radioactive-shale and cannel-coal lenses and protrude several inches beyond the edges of the shale, as do the ore bodies. The small pods are also localized beneath small folds and crenulations and faithfully follow the distribution of folds and shale lenses within the mine area. Carnotite impregnates the sandstone, fills holes formerly occupied by carbonaceous trash, and fills bedding and joint fractures. The sandstone adjacent to carbonaceous debris is unusually rich. Mineralization locally extends into the shale of the hanging wall, but the shale contains no recognizable uranium minerals. The ratio of uranium to vanadium is $1.68: 1$. Gangue eonsists of jarosite, limonite, and calcite; limonite is not abundant but calcite impregnation is common.

Mineralization in the Diamond No, 2 mine was strongly controlled lithologically and structurally. Lithologic controls are the carbonaceous-shale caprock, carbonaceous trash, and clay-rich impregnations. Structural controls are the stream channels, cross and longitudinal folds, and the prominent joints. It is uncertain whether joints served as local channels, but it is obvious that they commonly served as barriers. Ore guides include the presence of paludal black shale, zones of highly variable lithologic character, debrisfilled sandstones, and folds.

The ore-bearing sandstone has been bleached from a normal brown to white within 3 feet stratigraphically and 100 feet laterally of mineral deposits. The several sandstone beds beneath the ore bed become pro- gressively darker brown downward. In addition to the removal of iron oxide cement, bleaching may result from the introduction of, or replacement of, cement by white clay, which is a common close associate of carnotite. Calcite is also closely associated with mineralization, but in moderate amounts as the ore is distinguished by its relatively low lime content in comparison with many other sandstone ores. Much of this calcite may have been an original cement because most of the lower part of the Dakota is somewhat limy. The underlying Westwater Canyon sandstone member is locally stained pinkish red 250 feet northwest of the mine and beyond, resembling burned-coal or clinker-bed outcrops, although no coal is known in the sandstone.

The epigenetic impregnation of sandstone with uranium and the downdip orientation of ore pods suggest deposition from solutions moving parallel to the dip in thin aquifers after tilting of the beds.

Descending ground-water solutions would be expected to travel on top of impervious layers and down the troughs of synclines rather than along anticlinal axes beneath shale beds. Also, impounding of solutions at depth is required unless uranium ions were supplied by passing solutions owing to the reducing environment. No downdip impounding structure is known, although sandstone that pinches out into shale could serve the purpose. However, had the solutions been descending, mineralization would be expected in the synclines. The restriction of ore to anticlines, where synclines are nearby, implies some sort of hydrostatic or intratelluric pressure to drive the solutions as high as possible. Rising solutions fit these conditions. The reducing environment occasioned by carbonaceous material was a prime factor in precipitation, but why sandstone rather than adjacent peat and strongly carbonaceous shale became the host rock cannot be explained.

\section{BECENTI DEPOSIT}

The Becenti mine is in McKinley County, N. Mex., about 1 mile northwest of the Diamond No. 2 mine (fig. 96).

Section of rocks in the lower interbedded zone of the Dakota at the Becenti deposit

Dakota sandstone:

Sandstone, reddish-brown, fine-grained, erossbedded; Fet local pebble conglomerate at base.............. - 15

Shale, gray, and black earbonaceous shale, irregularly interbedded; small sandstone and siltstone lenses and small channels ................................

Sandstone, brown, poorly bedded, quartzose, finegrained, ore-bearing; shale partings and disseminated earbonaceous trash are common; local ripple

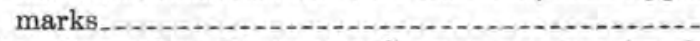

Morrison formation, Westwater Canyon member (sandstone). 
Because the Becenti deposit occupies a position on the Gallup hogback similar to that of the Diamond No. 2 deposit, its structural features are similar, even to the presence of small cross folds in the plane of the bedding. However, the folds are small; they average about 6 feet in width, and their axes vary about $35^{\circ}$ from the direction of dip of the bedding. Near the mine the hogback strikes N. $27^{\circ} \mathrm{W}$. and dips $30^{\circ} \mathrm{SW}$. The components of a square joint pattern strike N. $50^{\circ}$ E. and N. $15^{\circ} \mathrm{W}$. The joints are vertical.

As at the Diamond No. 2, carnotite impregnates the sandstone directly beneath the impervious shale cap and locally fills bedding and joint surfaces. The lithologic and structural controls are the same as those at the Diamond No. 2 mine. The ratio of uranium to vanadium is $1.51: 1$.

\section{SILVER SPUR MINE}

The Silver Spur mine (Mirsky, 1953) is in the Haystack Butte area, McKinley County, N. Mex., about 12 miles northwest of Grants (fig. 102). The Haystack Butte area is on the Thoreau homocline, which forms the gently dipping northeast flank of the Zuni Mountains. Sedimentary rocks, cropping out in cuestas, dip $2^{\circ}-5^{\circ} \mathrm{NE}$. Zones of cross faults and shallow cross folds occur at intervals of several miles along the homocline. The Haystack Butte area is in a zone of such faults and folds, but the nearest fault is nearly a mile from the Silver Spur mine.

As at the Diamond No. 2 and Becenti mines, the ore bed is a coarse-grained carbonaceous sandstone overlain by black carbonaceous shale. The footwall bed is a thin blue mudstone which overlies the Brushy Basin member of the Morrison formation. Maximum development of the ore bed is in a broad channel which is traceable for about 2,000 feet.

Mineralization has occurred in pods, six of which are known, elongated parallel to the secondary joint direction and perpendicular to the crossbedding. Yellow secondary uranium minerals, of which tyuyamunite is the most common, impregnate the sandstone in areas of abundant carbonaceous trash and are associated with jarosite, gypsum, calcite, and limonite. The ratio of uranium to vanadium is $1: 1$.

\section{U MINE}

The U mine (Mirsky, 1953) is in the Church Rock area (Sharp, 1955), McKinley County, N. Mex., about 10 miles east of Gallup (fig. 103). The Church Rock area is on the Thoreau homocline or northeast flank of the Zuni uplift just east of the northwest nose of the uplift. The sedimentary rocks dip $4^{\circ} \mathrm{N}$. No local structures are known.

The lower part of the Dakota sandstone contains the same zone of interbedded fluvial sandstones and paludal shales as at the Silver Spur deposit. The mineralized bed is a light-gray fine-grained sandstone, 3 feet thick, enclosed by black carbonaceous shale, 15 feet above the contact with the Westwater Canyon member of the Morrison. The sandstones in this zone are locally ripple marked.

The components of a cubic joint pattern in the upper part of the Dakota sandstone strike N. $20^{\circ} \mathrm{E}$. and $\mathrm{N} .70^{\circ} \mathrm{W}$., with the bedding as the third component. However, joints are irregular and poorly developed in the lower interbedded zone.

Mineralized sandstone is exposed in 3 adits in the ore bed; 2 are 100 feet long, and the third is 300 feet long. Each follows a separate mineralized zone. The zone in the longest adit is $1 \frac{1}{2}$ feet thick and 3 feet wide directly beneath black carbonaceous shale. Mineralization has affected only the top half of the ore bed. The mineralized body is long and sinuous, trends generally northward (downdip), and locally swells into larger pockets. Carnotite impregnates the sandstone and lines the contact with the overlying shale. The shale is locally radioactive but contains no recognizable uranium minerals.

\section{DELTER PROSPECT}

The Delter prospect (fig. 104) is in the Church Rock area, McKinley County, N. Mex., about $3 \frac{1}{2}$ miles northwest of the U mine (fig. 103). Here the Thoreau homociine is closer to the nose of the Zuni axis, and the sedimentary rocks strike generally N. $70^{\circ}$ E. and dip $4^{\circ} \mathrm{NW}$., forming large dissected cuestas.

At the Delter prospect the lower paludal and fluvial sediments of the Dakota fill a channel cut into the underlying Westwater Canyon sandstone member (fig. 104). At the mine the channel is 200 feet wide, 30 feet deep, and trends about $\mathrm{N} .30^{\circ} \mathrm{E}$. The lower interbedded zone of the Dakota consists of alternating conglomeratic to fine-grained sandstone and black carbonaceous shale.

The mineralized body is an elongate lens 50 feet wide and 2 feet thick which occupies the bottom of the channel and, although undeveloped, is presumed to follow the channel for some distance. Carnotite impregnates the lowest sandstone bed of the Dakota directly over the Westwater Canyon contact. The host sandstone is capped with black carbonaceous shale and is strongly contaminated with angular carbonaceous trash fragments. 


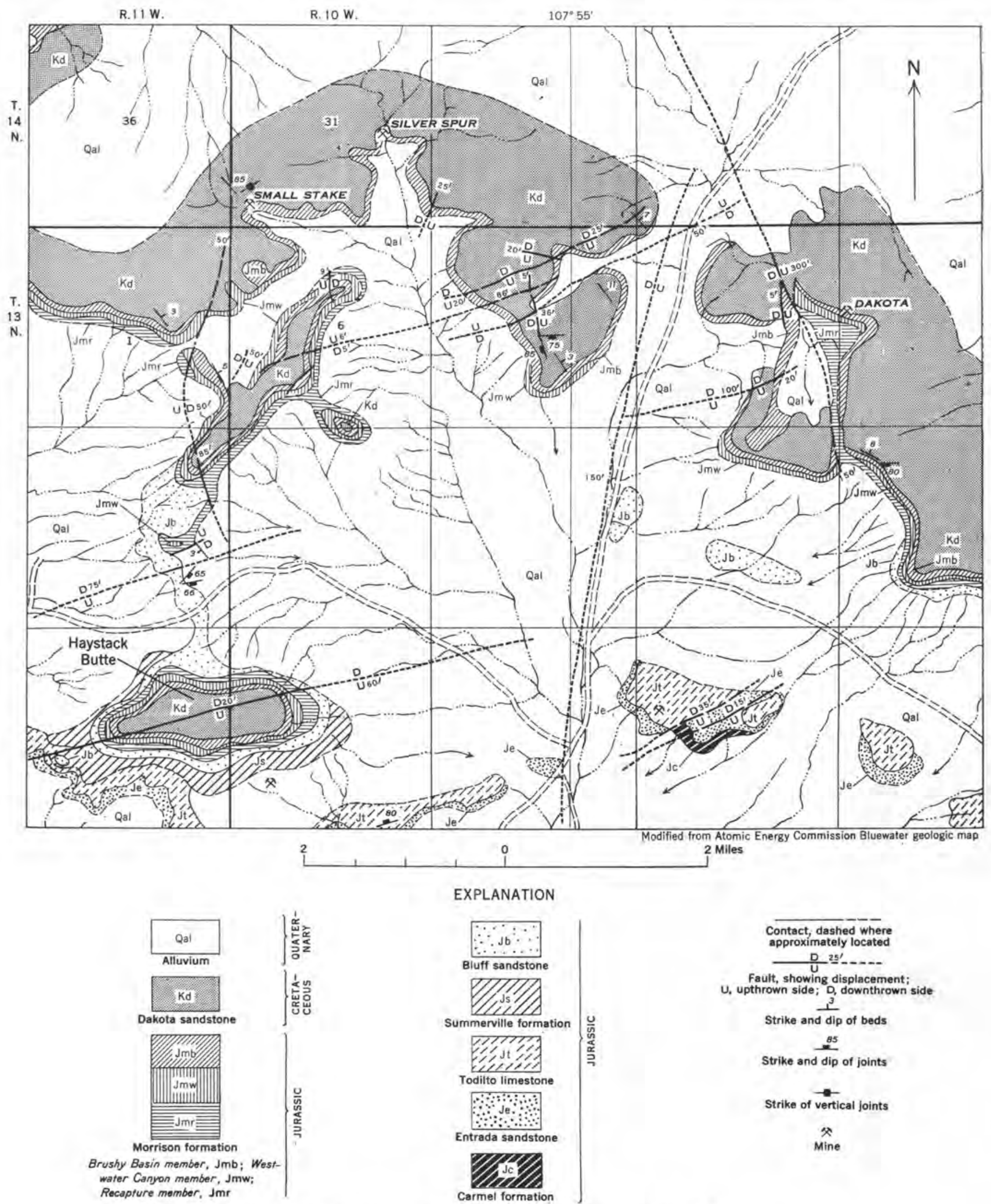




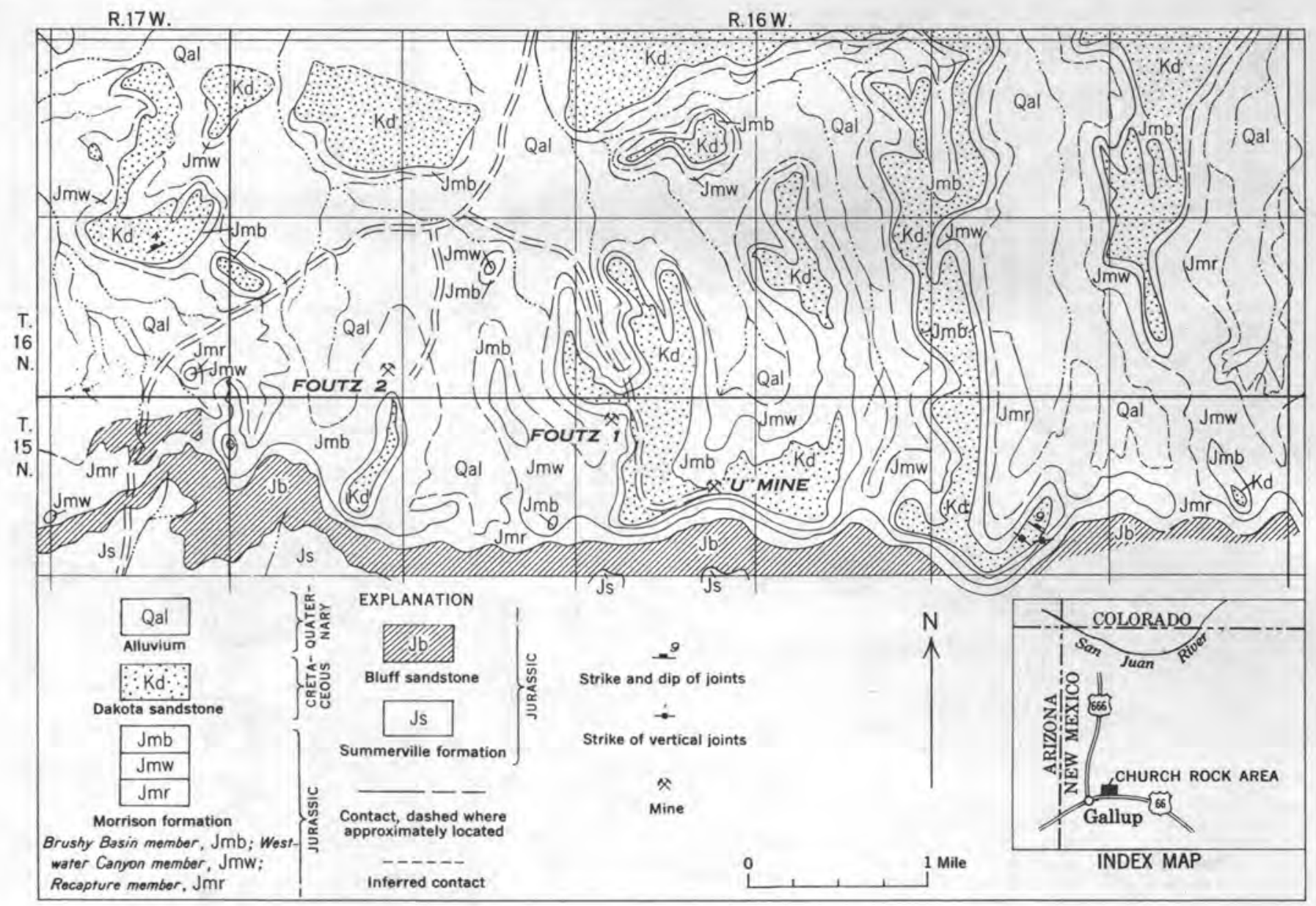

FinUre 103.-Location and geology of the Church Rock area, MeKinley County, N. Mex.

\section{SUMMARY}

Even though uranium deposits in the Dakota sandstone in the southern and eastern San Juan Basin differ widely in geographic location, structural setting, locaIizing features, and in minor textural and environmental detail, they have many features in common.

Mineralization has been confined to the lower zone of interbedded carbonaceous sandstone, richly carbonaceous shale, peat, and low-rank coals of the Dakota. Because uranium occurs in other nearby formations, uraniferous solutions probably migrated through many associated sedimentary units. Yet, because none of the immediately enclosing formations are so equally rich in carbonaceous matter or uranium, the reducing environment offered by the carbon probably trapped vagrant uranium in this zone. Migration of solutions and subsequent deposition of uranium within the zone were governed by local lithologic and structural features. The even greater quantity of carbonized matter (principally coal) and the apparent lack of uranium in the higher part of the Mesaverde in the same region is not readily explained unless by the greater lithologic variability or the lower rank of carbonization in the lower zone of the Dakota.

Within the zone, mineralization occurred either in black shale or in the sandstone immediately beneath the shale cap, even though these units may differ in elevation throughout the zone. No mineralization occurred in sandstone overlying the shale. Except at the Butler deposit where impounding of solutions by a small fault is suggested, these features indicate the rise of solutions against or along overlying semi-impervious barriers under intratelluric or hydrostatic pressure. Only at the Hogback No. 4 deposit is there a nearby solution channel in the form of a possible bounding cross fault. In others, the absence of noticeable crosscutting channels suggests lateral migration.

The mineralogy is invariably 1 of 2 related types: either carnotite impregnating sandstone or uranium contained in carbonaceous matter in such a way that 


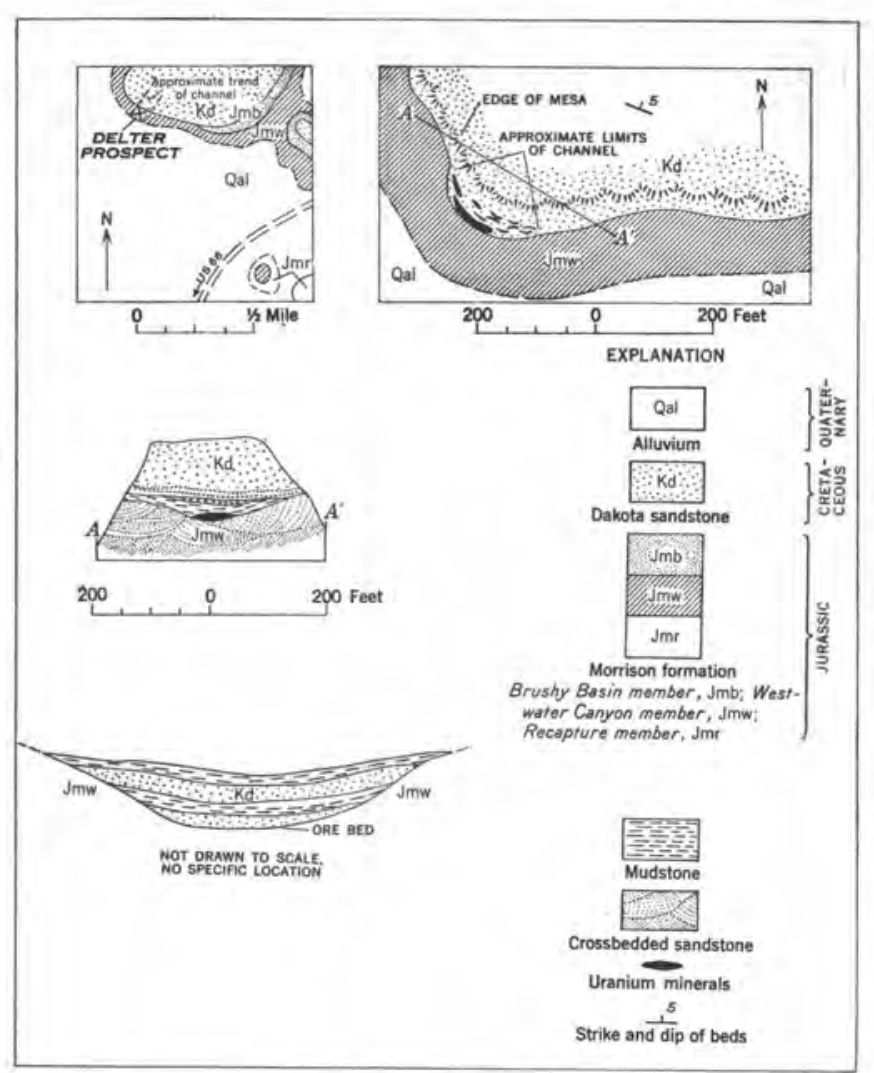

Fiaure 104.-Geologic map and sections of the Delter prospect, Church Rock ares, McKinley County, N. Mex.

no uranium minerals exist. The ratio of uranium to vanadium is generally about $1: 1$ in the sandstones and $8: 1$ in the black shales. The gangue is always jarosite, gypsum, and limonite.

Close investigation reveals that deformational structures usually govern the distribution of mineralization. These structures are generally small folds or joint faults whose geometric pattern indicates a tectonic rather than a depositional origin. With the exception of the Delter channel and the Butler and Hogback No. 4 deposits, mineralization commonly took place under the crests of anticlines. Because the controlling structures are Laramide or later, Tertiary migration of uranium is implied.

A local lithologic control, the presence of carbon, invariably governs the position of mineralization. Where the capping shale pinches out, the sandstone ore also terminates, even though it commonly protrudes slightly beyond the limits of shale. At the Diamond No. 2 mine ore is localized principally along the abrupt pinching out of a shale bed along one side of a stream-channel fill.

Usually a combination of lithologic, structural, and stratigraphic features governs the occurrence of ore. Thus, only the crests of anticlines were mineralized beneath extensive shale caps, and only those anticlines which are capped by shale contain ore. At the Diamond No. 2, only those shale-capped anticlines near the largescale pinching out of the shale contain ore. Along miles of carbonaceous shale or peat outcrop, some localities involving a possible cross-fault feeder are mineralized, but not all faults cutting black shale were mineralized.

There is no evidence that uranium was originally present in the Dakota sandstone. The known lithologic and structural controls suggest that the formation was simply a favorable host rock for vagrant uraniferous solutions.

\section{REFERENCES CITED}

Gruner, J. W., 1954, The problem of the primary ores of the Colorado Plateau, in Annual report for Apr. 1, 1953 to March 31, 1954-Part IV: U. S. Atomic Energy Comm. RME-3094, 37 p., issued by U. S. Atomic Energy Comm. Tech. Inf. Service, Oak Ridge, Tenn.

Mirsky, Arthur, 1953, Preliminary report on uranium mineralization in the Dakota sandstone, Zuni uplift, New Mexico: U. S. Atomic Energy Comm. RME-47, 21 p., issued by U. S. Atomic Energy Comm. Tech. Inf. Service, Oak Ridge, Tenn.

Read, C. B., 1952, U. S. Geol. Survey, unpub. inf.

Sharp, J. V. A., 1955, Uranium deposits in the Morrison formation, Church Rock area, McKinley County, N. Mex.: U. S. Atomic Energy Comm. RME-79, 19 p., issued by U. S. Atomic Energy Comm. Tech. Inf. Service, Oak Ridge, Tenn. Vine, J. D., Bachman, G. O., Read, C. B., and Moore, G. W., 1953, U. S. Geol. Survey, unpub. inf. 



\title{
URANIUM IN TERRESTRIAL SEDIMENTARY ROGKS IN THE UNITED STATES EXCLUSIVE OF THE GOLORADO PLATEAU
}

\author{
By Warren I. Finch, U. S. Geological Survey
}

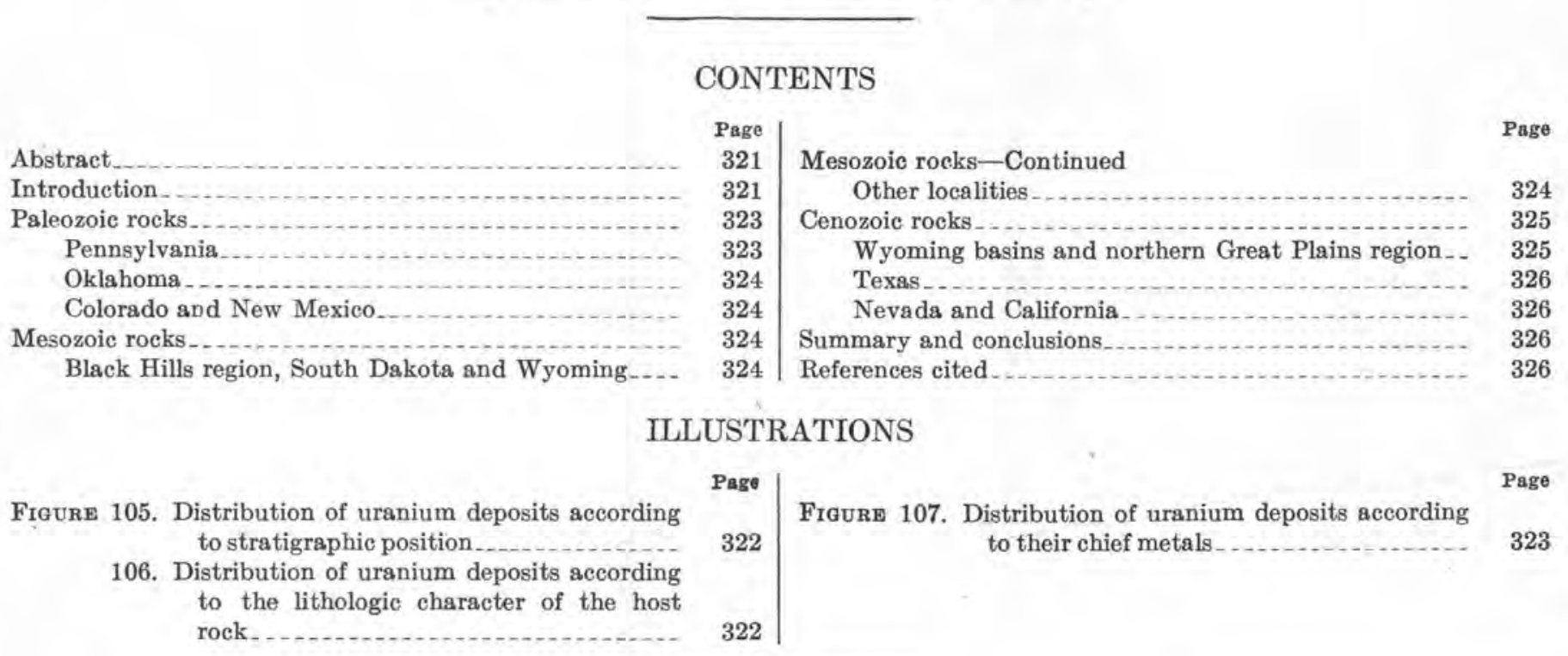

\begin{abstract}
Large uranium deposits occur in sandstones of Cretaceous age in the Black Hills region of South Dakota and Wyoming and in tuffaceous sandstone of Tertiary age in Wyoming, Texas, and Nevads. Small deposits occur in terrestrial sedimentary rocks in Pennsylvania, Oklahoma, New Mexico, and other places exclusive of the Colorado Plateau.

Carnotite deposits in sandstone of Cretaceous age in the Black Hills are clustered in poorly defined areas in the northern and southern parts of the region. The deposits contain more vanadium than uranium and consist of irregular tabular or lenticular layers that, in general, follow the bedding and have distinct boundaries. The main ore minerals are carnotite and corvusite. The most favorable areas for large deposits are where sandstone lenses that contain abundant mudstone and thin-bedded sandstone coincide with structural terraces.

Economic uranium deposits were discovered in tuffaceous sandstones of Tertiary age in the Wyoming basins in 1951 and in the Texas coastal plain and Nevada basins in 1954. Large areas of similar rock types in the United States remain untested. In general, these uranium deposits have different habits, mineralogy, and apparent geologic controls than those in Mesozoic sandstones of the Colorado Plateau and Black Hills regions.

The Tertiary deposits occur most commonly as poorly defined bodies of disseminated uranium arsenate, silicate, and phosphate minerals in poorly bedded tuffaceous sandstone or sandy tuffaceous rocks. Relation of the deposits to sedimentary structures is obscure. Vanadium and copper minerals are generally absent,
\end{abstract}

except in Nevada where abundant carnotite has been reported. Uraninite occurs in several deposits in Wyoming. Carbonaceous material is either absent or apparently unrelated to the uranium minerals. The known deposits are nearly or completely oxidized and some appear to be related to the Recent topography and ground-water systems.

Small deposits in upper Paleozoic rocks of Pennsylvania, Oklahoma, New Mexico, and other places are similar to those on the Colorado Plateau. The host rocks are most commonly lenses of light-colored sandstone, and the ore deposits are closely related to the sedimentary structures. Uranium minerals replace carbonaceous material and are commonly associated with vanadium and copper minerals and altered mudstone.

Other small deposits of uranium are found in terrestrial rocks of many ages in many places throughout the United States.

\section{INTRODUCTION}

Uranium deposits are widespread in terrestrial sedimentary rocks in Northeastern and Western United States outside of the Colorado Plateau. Large uranium deposits occur in sandstone of Cretaceous age in the Black Hills region of South Dakota and Wyoming and in Tertiary sandstone, arkose, and tuffaceous formations in Wyoming, Texas, and Nevada (fig. 105). Small deposits occur in terrestrial formations in many ages in Western and Northeastern United States. 


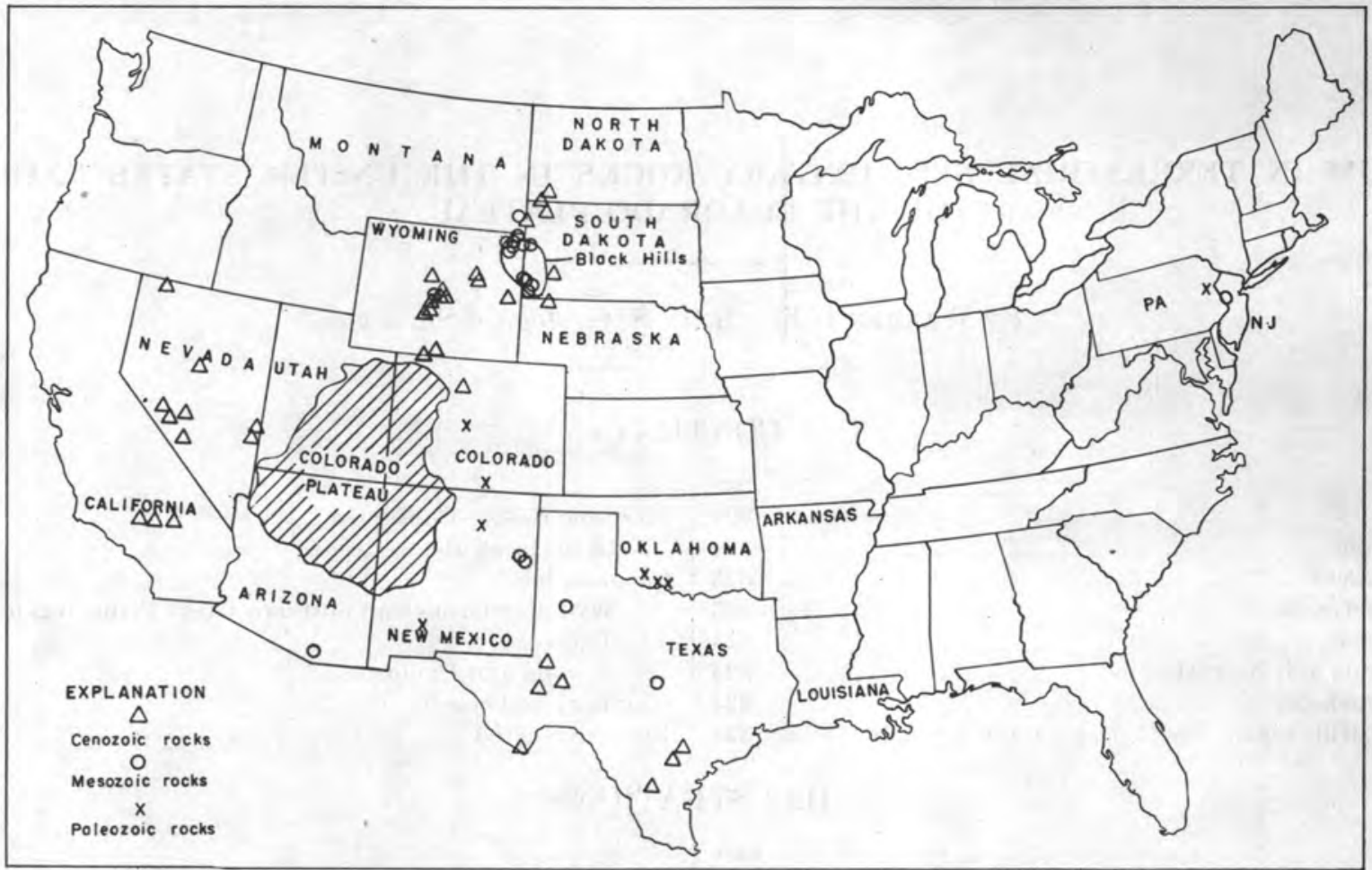

FrGURE 105.-Distribution of uranium deposits according to stratigraphle position in terrestrial sedimentary rocks in the United States exclusive of the Colorado Plateau.

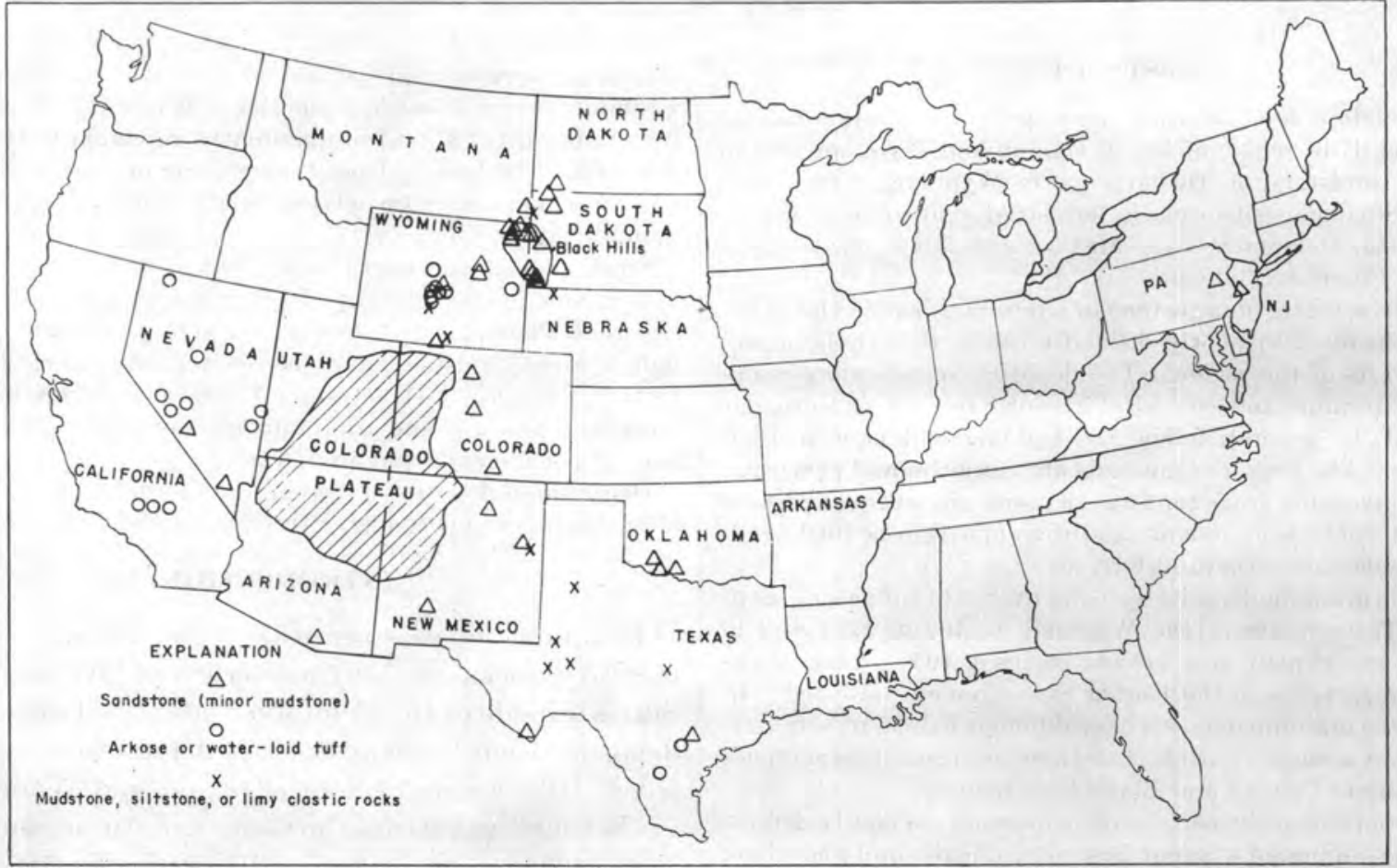

Fioure 106.-Distribution of uranium deposits according to the lithologic character of the host rock in terrestrial sedimentary rocks in the United States exclusive of the Colorado Plateau. 
Each deposit or group of deposits here described is plotted according to the age of the host rock (fig. 105), lithologic character of the host rock (fig. 106), and the chief ore metals (fig. 107). The types according to lithologic character are sandstone (includes sandstone and conglomerate that may contain some interbedded mudstone and arkosic or tuffaceous material); arkose or water-laid tuff; and mudstone, siltstone, or limy clastic sediments. Chemical precipitates (mainly limestone) and vein deposits in terrestrial rocks are not discussed in this paper. The relative abundance of uranium, vanadium, and copper is used to classify the deposits in figure 107. The metals are listed in order of abundance for each type of deposit. However, vanadium minerals are the main ore minerals in some small uranium, vanadium, and copper deposits because vanadates contain about five times as much uranium as vanadium. Generally, the major ore minerals in the small uranium, vanadium, and copper deposits are uranium silicates, phosphates, and arsenates. The uranium content in all the deposits described in this report is generally greater than 0.10 percent $\mathrm{U}_{3} \mathrm{O}_{8}$.

\section{PALEOZOIC ROCKS}

Uranium deposits occur in Devonian and Pennsylvanian formations in eastern Pennsylvania, in the Permian formations in southwestern Oklahoma, and in
Pennsylvanian and Permian formations in central Colorado and New Mexico (fig. 105). These deposits occur in widely distributed localities in different stratigraphic zones, and most occur in fluviatile sandstone. In general, the deposits in the west contain more copper than uranium, and those in the east contain more uranium than copper (figs. 106, 107). Copper deposits have been known in many of these localities for a long time, but most of the uranium-deposits have been discovered only in the past decade.

\section{PENNS YLVANIA}

In Pennsylvania, the uranium deposits with vanadium and copper occur in coarse graywacke conglomerate near the base of the Pottsville formation of Pennsylvanian age on the north limb of the Panther Valley syncline and in graywacke sandstone near the top of the Catskill formation of Devonian age on the south limb of the Panther Valley syncline (Klemic and Baker, 1954). Although only four deposits are known in a small area of poor exposures, deposits of larger size may be present. The ore minerals are disseminated in deposits that are lenticular masses a few feet to several hundred feet across. The uranium minerals in the deposits in the Pottsville formation are carnotite, tyuyamunite, and uranophane, whereas the uranium minerals in the deposits in the Catskill formation are autunite,

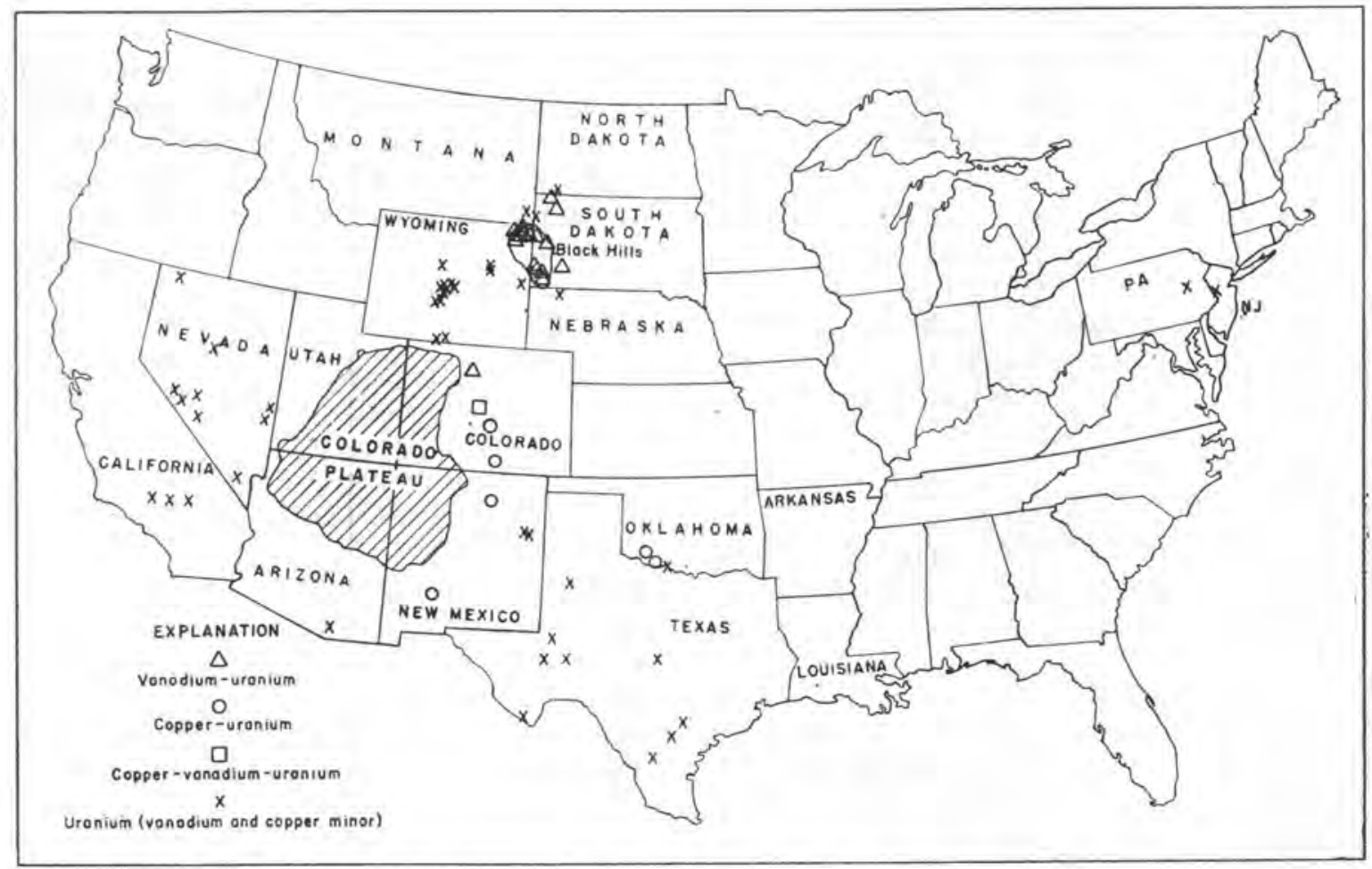

FiodRE 107.-Distribution of uranium deposits according to their chlef metals in terrestrial sedimentary rocks in the United States exelusive of the Oolorado Plateau. 
kasolite, and uranophane. Carbonaceous material is rare in both formations.

\section{OKLAHOMA}

In Oklahoma, uranium occurs in the Garber sandstone of Permian age on the gently dipping south flank of the Wichita uplift in Tillman, Cotton, and Jefferson Counties, Okla. (Beroni, 1954, p. 213). Although the Garber sandstone is generally referred to as part of the Permian red beds, the copper- and uranium-bearing beds are nearly always light-colored lenses. The uranium deposits consist either of copper and uranium minerals in fine-grained sandstone and siltstone or of uranium associated with asphaltic arkosic sandstone. The main minerals in the copper-uranium deposits are torbernite, autunite, uranophane, malachite, and azurite in heavily iron- and manganese-stained sandstone. Replacement of wood fragments is common. These deposits are small; similar deposits of uranium probably occur with the copper in Permian red beds in the adjacent part of northern Texas.

\section{COLORADO AND NEW MEXICO}

Colorado and New Mexico copper-uranium deposits occur in upper Paleozoic sandstone in four widely separated areas that form an arc about the east border of the Colorado Plateau (fig. 105). In Mora County, N. Mex., copper and uranium minerals occur in lightcolored medium-grained arkosic sandstone lenses in the normally red sequence of the steeply dipping Sangre de Cristo formation of Pennsylvanian and Permian(?) age (Tschanz, 1953 , p. $81 ; 1954$, p. 72). Copper deposits with little or no uranium occur in carbonaceous shale, limestone, and siltstone beds that are interbedded with the sandstone. The copper-uranium deposits are associated with carbonized plant remains, gray and black clay galls, and small thin lenses of hematitic altered sandstone. The uranium minerals are metatyuyamunite and uraninite. Chalcocite, chalcopyrite, other sulfides, and uraninite replace carbonaceous material. A similar deposit of copper and uranium in the Sangre de Cristo formation has been reported in the Cucharas district, Huerfano County, Colo. (Baltz, 1954, p. 222). Another deposit of copper and uranium has been reported in sandstone of the Abo formation of Permian (?) age in Sierra County, N. Mex.

In Park County, Colo., a copper-vanadium-uranium deposit occurs in the Maroon formation of Pennsylvanian and Permian age on the northeast flank of the Garo anticline. Tyuyamunite and carnotite are disseminated or fill fractures in three beds of medium- to coarse-grained sandstone. Malachite, volborthite, red and black vanadium minerals, and limonite are associated with the uranium minerals. The deposits are a few tens of feet in width and range from a few feet to several hundred feet in length.

\section{MESOZOIC ROCKS}

Large uranium deposits occur in sandstone of Cretaceous age in the Black Hills region of South Dakota and Wyoming (fig. 105). Isolated small deposits occur in Triassic rocks in Pennsylvania, New Jersey, and Texas; in Jurassic rocks in Wyoming and New Mexico; and in Cretaceous rocks in Arizona. In general, the deposits in the Black Hills region occur in sandstone and contain more vanadium than uranium. The other deposits occur in sandstone, siltstone, or limy siltstone and contain less vanadium and copper than uranium. The deposits in these Mesozoic rocks were discovered in 1951 or later and as a rule are not yet well developed.

\section{BLACK HILLS REGION, SOUTH DAKOTA AND WYOMING}

In the Black Hills region, vanadium-uranium deposits occur in the Inyan Kara group of Cretaceous age, which encircles the Black Hills uplift. The Inyan Kara group, comprising the Fall River, Fuson, and Lakota formations, has been folded into gentle anticlines and monoclines subsidiary to the major uplift. The Fall River sandstone in the upper part of the Inyan Kara group contains most of the large deposits. The ore-bearing rocks are generally lenticular light-colored fine-grained sandstone, either interbedded with thin dark-colored shales or irregularly bedded with mudstone.

Although these deposits contain more vanadium than uranium (ratio of $\mathrm{V}_{2} \mathrm{O}_{5}$ to $\mathrm{U}_{3} \mathrm{O}_{8}$ commonly $3: 1$ ), some of them consist mainly of carnotite, whereas other contain large amounts of corvusite. The deposits are generally tabular layers of disseminated minerals, but some concretions and rolls occur locally. Limonite, hematite, calcite, and manganese oxide are associated with much of the ore. The deposits range from bodies a few feet across that contain a few tons of ore to bodies several hundred feet across that contain many thousands of tons of ore.

The most favorable areas for large deposits in the southern part of the Black Hills are where sandstone lenses that contain abundant mudstone or shale coincide with structural terraces (Gott, Bell, Cuppels, and others, 1954, p. 101). Similar favorable conditions probably exist in the northern part of the region. The deposits in the Black Hills region are similar to the vanadium-uranium deposits in the Morrison formation of Jurassic age on the Colorado Plateau.

\section{OTHER LOCALITIES}

Uranium is also found in several other places. Deposits, which are below ore grade, occur in the Newark 
group of Triassic age in Bucks County, Pa., and Hunterdon County, N. J., as lenticular masses in sandstone and contain more uranium than vanadium or copper; the uranium minerals torbernite and uranophane are disseminated and are associated with limonite and clay. Uranium occurs in carbonaceous siltstone of the Dockum group of Triassic age in San Saba and Lubbock Counties, Tex. A small uranium deposit occurs in the Morrison formation of Jurassic age in central Wyoming near the large deposits in the Tertiary rocks (fig. 105). Several deposits in sandstone or limy sandstone beds of Late Jurrassic age in Quay County, N. Mex., contain carnotite or tyuyamunite as the main ore mineral. A uranium deposit has been reported recently in arkosic sandstone beds near the base of the Cretaceous in Santa Cruz County, Ariz; ; kasolite is disseminated in the rock.

\section{CENOZOIC ROCKS}

Uranium occurs in Cenozoic rocks in the Wyoming basins and the northern Great Plains region, in the Texas coastal plains, in the Nevada basins, and in California lakebeds. In the Wyoming basins and northern Great Plains region, uranium and vanadiumuranium deposits occur mainly in sandstone (commonly tuffaceous and muddy) and arkose formations that range from Paleocene to Pliocene in age. In the Texas coastal-plains region, uranium deposits with minor amounts of vanadium and copper occur in tuff and sandstone formations of Eocene and perhaps Oligocene age. In Nevada and California, uranium deposits occur in tuffaceous sandstone of the Miocene and Pliocene lakebeds.

Economically important deposits were discovered in Tertiary rocks in the Wyoming basins in 1951, and in the northern Great Plains, Texas coastal plains, and Nevada basins in 1954. Large areas of simila rocks in the United States remain untested. The mineralogy, habits, and apparent geologic controls of these deposits differ somewhat from those in the Mesozoic sandstone formations of the Black Hills and of the Colorado Plateau.

\section{WYOMING BASINS AND NORTHERN GREAT PLAINS REGION}

Uranium deposits occur in Tertiary rocks in an elongate area 160-200 miles wide and more than 500 miles long which extends northeastward from Colorado across Wyoming into Nebraska and South and North Dakota.

In general, the deposits occur in progressively older Tertiary rocks southwestward across this area. The deposits are in the Fort Union formation of Paleocene age in southwestern North Dakota and northwestern South Dakota; in the Wasatch and Wind River forma- tions of Eocene age in central Wyoming; in the White River formation of Oligocene age in southwestern South Dakota, northwestern Nebraska, and easternmost Wyoming; and in the Browns Park formation of Miocene (?) age and North Park formation of Pliocene (?) age in southern Wyoming and northern Colorado. Within the Tertiary rocks the largest deposits are in rocks of Paleocene and Eocene age. In general, the deposits may be divided into three types: type 1, deposits in carbonaceous sandstone associated with uranium-bearing lignite beds; type 2, small concretionary deposits in sandstone; and type 3, poorly defined tabular disseminated deposits in sandstone, arkose, or mudstone.

Type 1 deposits occur in the Fort Union formation of Paleocene age in southwestern North Dakota and northwestern South Dakota. In the same area, and in southeastern Montana, type 1 deposits also occur in the Arikaree formation of Miocene age and in the Hell Creek formation of Late Cretaceous age. Most of these deposits occur in sandstone interbedded with uranium-bearing carbonaceous shales and lignite beds (Gill, 1954, p. 149). The uranium minerals are commonly yellow (meta-autunite I and metatyuyamunite) and are disseminated in the rock. The deposit in the Arikaree is in thin lenses of fresh-water limestone and siltstone. Denson, Bachman, and Zeller (Miller and Gill, 1954) have suggested that the deposits in the lignite region are genetically related to the disseminated uranium present in the superjacent beds of volcanic ash.

Type 2 deposits occur in a red lenticular sandstone facies of the Wasatch formation of Eocene age in the Pumpkin Buttes area of central Wyoming. These deposits consist of uranium that is mainly in nodules of uranophane and carnotite a few inches across and commonly several feet long. Nodules of iron and manganese oxides are commonly uranium bearing. Many of the uranium-bearing nodules are replacements of fossil wood, and some contain uraninite. These deposits are thought to have oxidized in place, and their deposition is though to have been caused mainly by carbonaceous material.

Type 3 deposits include the remaining deposits in Tertiary rocks in this area. The uranium minerals, mainly uranium silicates, and phosphates are disseminated in poorly bedded arkose, sandstone, and siltstone.

The ore bodies are poorly defined tabular bodies. Uraninite, carnotite, and liebigite have been found in some of these deposits. Carbonaceous material is sparse. These deposits range from bodies a few feet across that contain a few tons of ore to bodies several hundred feet across that contain many thousands of tons of ore. The known deposits, which are mainly those that crop out, appear to be analogous in origin to caliche, and the configuration of some may be related. 
to Recent topographic and ground-water conditions. Others are probably related to obscure sedimentary and structural features and may be primary deposits that have oxidized more or less in place.

\section{TEXAS}

Uranium deposits in Tertiary rocks occur in tuff and tuffaceous sandstone formations of late Eocene or early Oligocene age in southeastern Texas and in a limy sandstone unit of Pliocene age in western Texas. The small deposits in western Texas, which contain less vanadium than uranium, consist of metatyuyamunite in vugs in limy sandstone.

The large uranium, with minor vanadium and copper, deposits in southern Texas occur in the flat-lying Jackson formation of Eocene age and perhaps in the overlying beds of Oiigocene age. The ore-bearing beds consist of poorly bedded and mostly unconsolidated marine, brackish-water, nearshore, and continental beds of light-colored tuff, sand, and sandy clay. These deposits were discovered only recently, and their mineralogy is not well known. Yellow and green uranium minerals, probably uranium phosphate and silicate minerals, occur along fractures, bedding planes, and disseminated in the rock. Large amounts of arsenic and molybdenum occur with the uranium, according to $\mathrm{L}$. B. Riley of the U. S. Geological Survey (personal communication). The best mineralized rock appears to be associated with hydrated iron oxides, bentonite, and rocks that are characterized by mixed and irregular bedding. Carbonaceous material is rare and commonly shows no spatial association with the ore. The deposits range from bodies a few feet across that contain a few tons of ore to bodies several hundred feet across that contain many thousands of tons of ore. The deposits appear to have been concentrated by ground water from a disseminated voleanic source.

\section{NEVADA AND CATIFORNIA}

Uranium deposits occurring mainly in tuff in the Miocene lakebeds of Nevada and southern California have been known for many years, but economic deposits were not discovered until 1954.

In Nevada, uranium, with minor vanadium and copper, is disseminated in water-laid sandy, clayey, or arkosic tuff of Miocene lakebeds. Uranium minerals are rare, as the uranium appears to be contained in an indistinguishable phosphate mineral, possibly fluorapatite. Yellow uranium minerals have been reported in a few localities. The high-grade ore is most common along weak to strong shear zones and fractures and is associated with limonite. Carbonaceous material, gypsum, calcite, and other minerals commonly associated with uranium deposits in terrestrial sedimentary rocks are generally absent. The deposits range from bodies a few feet across that contain a few tons of ore to bodies several tens of feet across that contain a few hundred tons of ore. The uranium is thought to have been concentrated by ground water.

Small quantities of autunite and gummite occur in tuffaceous sedimentary rocks in the Rosamond formation (local usage) of Miocene age in the Rosamond prospect near Mojave, Kern County, Calif. (Walker, 1953). Uranium minerals occur mainly on fracture and joint surfaces and to a lesser extent are disseminated in tuffaceous rocks adjacent to faults. Several similar deposits occur west of the Rosamond prospect in Kern and Mojave Counties, Calif.

\section{SUMMARY AND CONCLUSIONS}

Large uranium deposits occur in sandstone formations of Cretaceous age in the Black Hills region of South Dakota and Wyoming and in formations of Tertiary age in the Wyoming basins and northern Great Plains, Texas coastal plains, and Nevada basins. Small deposits occur in terrestrial sedimentary rocks in California, Arizona, New Mexico, Colorado, Oklahoma, Pennsylvania, and New Jersey.

Although most of the deposits are scattered throughout much of the western part of the United States, several regional relationships are indicated. Deposits in upper Paleozoic rocks occur circumferentially about the east border of the Colorado Plateau. The Black Hills region contains large deposits clustered in the southern and northern parts of the Black Hills uplift. Deposits in Tertiary rocks of the Wyoming basins and northern Great Plains region lie in a northeastwardtrending belt about $160-200$ miles wide and 500 miles long. The ore-bearing formations in this belt become progressively younger from north to south. Within the Tertiary rocks, the largest deposits occur in rocks of Paleocene and Eocene age.

In general, the deposits in Paleozoic and Mesozoic formations occur in sandstone (minor mudstone) that was deposited by streams and contain greater amounts of vanadium or copper than uranium. On the other hand, the deposits in Cenozoic formations occur in arkose, tuff, and tuffaceous sandstone that were deposited in closed basins or lakes, by streams, or under nearshore conditions. These Cenozoic deposits commonly contain less vanadium or copper than uranium.

\section{REFERENCES CITED}

Baltz, E. H., Jr., 1954, New Mexico and southeastern Colorado, in Geologic investigations of radioactive deposits-Semiannual progress report, June 1, 1954, to Nov. 30, 1954: U. S. Geol. Survey TEI-490, p. 219-222, issued by U. S. Atomic Energy Comm. Tech. Inf. Service, Oak Ridge, Tenn. 
Beroni, E. P., 1954, South-central district, in Geologic investigations of radioactive deposits - Semiannual progress report, June 1, 1954 to Nov. 30, 1954: U. S. Geol. Survey TEI-490, p. 213-218, issued by U. S. Atomic Energy Comm. Tech. Inf. Service, Oak Ridge, Tenn.

Gill, J. R., 1954, Northwestern South Dakota, southwestern North Dakota, and eastern Montana, in Geologic investigations of radioactive deposits-Semiannual progress report, June 1, 1954 to Nov. 30, 1954: U. S. Geol. Survey TEI-490, p. 149-155, issued by U. S. Atomic Energy Comm. Tech. Inf. Service, Oak Ridge, Tenn.

Gott, G. B., Bell, Henry, III, Cuppels, N. P., and others, 1954, Black Hills, S. Dak., in Geologic investigations of radioactive deposits-Semiannual progress report, June 1, 1954 to Nov. 30, 1954: U. S. Geol. Survey TEI-490, p. 99-106, issued by U. S. Atomic Energy Comm. Tech. Inf. Service, Oak Ridge, Tenn.
Klemic, Harry, and Baker, R. C., 1954, Preliminary summary of uranium occurrences in Carbon County, Pa.: U. S. Geol. Survey Circ. 350,8 p.

Miller, R. L., and Gill, J. R., 1954, Uranium from coal: Sci. Am., v. 191, no. 4 , p. $36-39$.

Tschanz, C. M., 1953, Guadalupita, N. Mex., in Geologic investigations of radioactive deposits - Semiannual progress report, June 1, 1953 to Nov. 30, 1953: U. S. Geol. Survey TEI-390, p. 81-90, issued by U. S. Atomic Energy Comm. Tech. Inf. Service, Oak Ridge, Tenn.

1954, Guadalupita, N. Mex., in Geologic investigations of radioactive deposits-Semiannual progress report, Dec. 1, 1953, to May 31, 1954: U. S. Geol. Survey TEI-440, p. 72-73, issued by U. S. Atomic Energy Comm. Tech. Inf. Service, Oak Ridge, Tenn.

Walker, G. W., 1953, Rosemond uranium prospect, Kern County, Calif.: Calif. Div. Mines Special Rept. 37, 8 p. 



\title{
RELATION OF TEGTONIC ELEMENTS IN PRECAMBRIAN ROCKS TO URANIUM DEPOSITS IN THE CORDILLERAN FORELAND OF THE WESTERN UNITED STATES
}

\author{
By Frank W. Osterwald, U. S. Geological Survey
}

\section{CONTENTS}

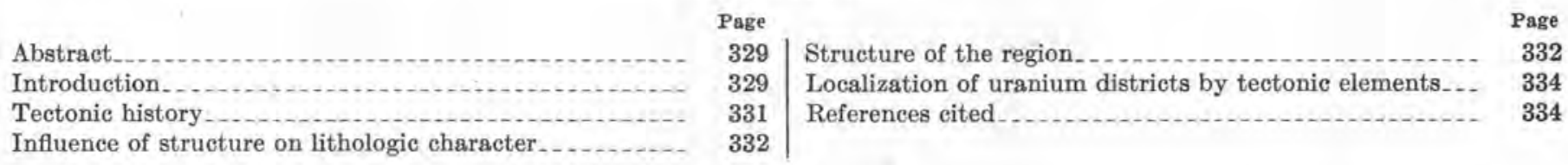

\section{ILLUSTRATIONS}

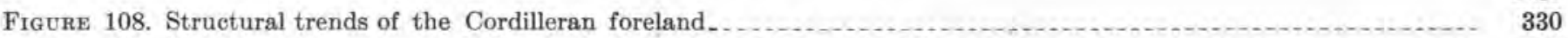

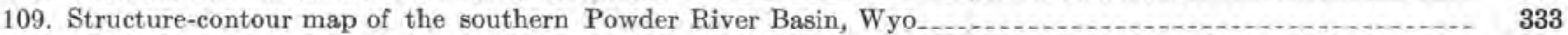

\begin{abstract}
The Cordilleran foreland is a large area immediately east of the main folded and thrusted belts of the Middle Rocky Mountains. Within the foreland a series of simple folded mountains alternates with broad asymmetrie basins. Most of the structures are caused by vertical movements of blocks in the Precambrian basement rocks that are expressed at the surface by flexures and high-angle normal and reverse faults.

Many of the tectonic elements of the region were active at various times during geologic history. The tectonic pattern of the region is related to structures in the Precambrian rocks which have influenced the later movements, and it is likely that the pattern is the result of a set of large structures which were established during the Precambrian.

Most uranium deposits in the Cordilleran foreland, irrespective of the type of deposit, are related to the tectonic pattern on both a small and a large seale. They are clustered where large northwestward-trending structures, such as major basins and mountain ranges, are intersected by later more subdued northeastward-trending structures; where large northwestwardtrending structures are intersected at acute angles by in-echelon faults or folds; or near the axial parts of major basins. Structurecontour maps, showing the configuration of the Precambrian basement rocks, may be used to point out areas of structures favorable to the deposition of uranium, even though only flatlying Tertiary sedimentary rocks erop out at the surface.

The observed relation is thought to be caused by one or more of the following: (1) Repeated deformation along old structures has influenced sedimentation, resulting in rock types favorable for concentration of uranium in restricted positions with respect to the various tectonic features; (2) intersections of major tectonic elements may be places in which the energy levels are changed, allowing small amounts of uranium to be released from rock minerals and to be concentrated in places of favorable lithologic character and structure; (3) margins of major tectonic
\end{abstract}

elements may be places in which the energy levels are changed, allowing uranium to be released and concentrated in smaller, oblique folds and faults; (4) repeated deformation of old structures causes even relatively young Tertiary rocks to be slightly deformed and jointed, thereby providing a favorable structural environment for uranium deposition. The areas of high energy change also provided foci for volcanic activity during Tertiary time.

\section{INTRODUCTION}

The Cordilleran foreland is a broad region of distinctive structural elements that trends northward parallel to and east of the Cordilleran geanticline (fig. 108). The predominant geologic structure within the foreland is a series of anticlinal mountains and broad asymmetric basins that contrast sharply with the folds and overthrusts related to the Cordilleran geanticline to the west. The mountains of the foreland are bordered by flexures and high-angle normal and reverse faults. Many structures are covered by nearly flatlying sedimentary rocks of Tertiary age. The eastern margin of the foreland is beneath the Tertiary rocks of the Great Plains and has not been defined.

The discovery of uranium deposits within the foreland led to a study of where and why uranium is concentrated in this tectonic environment. Deposits of metallic minerals other than uranium minerals are few and widely scattered, and most are in outcrop areas of Precambrian rocks. Uranium deposits, however, are widely distributed throughout the region as disseminated uranium and uraniferous lignites in the sedimen- 


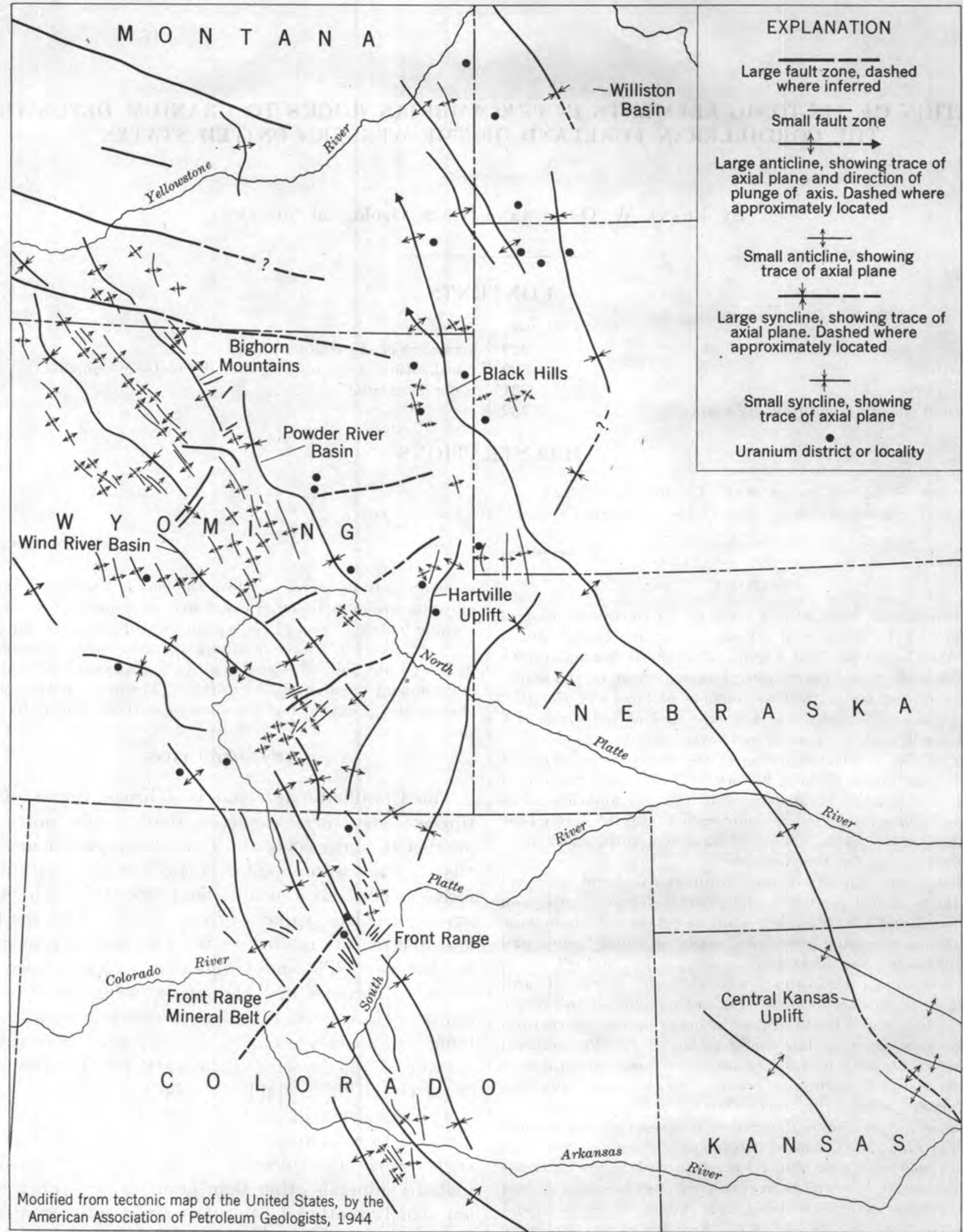

FioURE 108.-Structural trends of the Cordilleran foreland. 
tary rocks of the basins and as veins in the crystalline cores of mountain ranges.

Through the studies that are still in progress it is hoped that criteria for areas tectonically and structurally favorable for accumulation of uranium will be developed to aid in the search for new uranium districts. Structure-contour maps showing the configuration of the top of the Precambrian rocks are being compiled for a large part of the Cordilleran foreland. Such maps, based on available geophysical or well-log data, make it possible to project structures for considerable distances, even though concealed by a thick cover of nearly flatlying Tertiary rocks. It is believed that use of the Precambrian as a datum plane eliminates most of the effects of unconformities. In addition, structures of Precambrian age undoubtedly have influenced the location and direction of later structures that are fundamental controls for localizing uranium. Therefore, the configuration of the basement beneath known uranium districts might serve as a guide to uranium deposits in other areas.

\section{TECTONIC HISTORY}

Many large-scale and small-scale structures of the foreland record earth movements. In many places preexisting structures controlled the pattern of later structures (Thom, 1947, p, 176). These major controlling structures include the ancestral Rocky Mountains, which formed during the Pennsylvanian period on the site of the present Front Range (fig. 108) and adjacent ranges (Eardley, 1951, p, 230-233); the central Kansas uplift (fig. 108), which was elevated in pre-Mississippian time, in Pennsylvanian time, and in Late Cretaceous or early Tertiary time (King, 1951, p. 49); the Williston basin of western North Dakota and eastern Montana (fig. 108), which occupies about the same position as an early Paleozoic depositional basin (King, 1951, p. 61); the large eastward-trending trough in central Montana, which is filled with a thick series of sedimentary rocks of late Precambrian and Mississippian age (Eardley, 1951, p. 287) and has a belt of in-echelon faults on the north side and sharp flexures on the south side of the trough owing to movements during the Late Cretaceous, apparently along steep fractures bordering the old trough (Eardley, 1951, p. 341-342); the prominent Laramide anticlines in Wyoming which began to form early in geologic time (Curry and Curry, 1954, p. 2155); and the Tertiary uplifts in the Beartooth and Bighorn Mountains and in the Black Hills that coincide with Precambrian structures (Cloos and Cloos, 1934).

Precambrian structure also influenced later deformation on a small scale; only a few examples are given here.
Pre-Oligocene faults and folds in the Bighorn Mountains (fig. 108) follow the trend of primary foliation planes and joints in Precambrian granitic rocks (Osterwald, 1949). Precambrian fractures in granitic rocks of the Front Range in Colorado (fig. 108) were reopened during Pennsylvanian time and filled with sand (Vitanage, 1954; Crosby, 1897); repeated movement during Tertiary time, as shown by correlation of Tertiary erosion surfaces, has sheared the sandstone dikes. Isopach contours of Pennsylvanian rocks in southeastern Wyoming show that some structural trends during the Pennsylvanian period bad about the same trends as the present tectonic units and occupied about the same position.

Widely scattered observations indicate that the predominating structural trends in the Precambrian rocks are northeastward and northwestward. Near the Front Range mineral belt (fig. 108), early lineation and foliation in Precambrian rocks trend northeastward and later lineation trends northwestward (P. K. Sims and others, written communication). Precambrian structures in rocks of the Medicine Bow Mountains of southern Wyoming trend northeastward (Blackwelder, 1926); similar trends are found in the Laramie Range, Wyo., and in the Hartville uplift, Wyoming (fig. 108). Metamorphic rocks in the Bigborn Mountains, Wyo., have pronounced lineation and probable zones of overthrusting that trend northeastward, but somewhat younger Precambrian granitic rocks have northwesiward-trending structure (Osterwald, in press). The tectonic pattern of present structures parallels these Precambrian trends (fig. 108).

The distribution of mountain ranges in the foreland is related in part to the distribution of Precambrian granite massifs (Thom, 1947, p. 176). Precambrian cores of many ranges in the foreland, and also in Kansas and Oklahoma (Hiestand, 1935, p. 950), are granitic in the center and metamorphic around the margins.

The thrust or reverse faults marginal to many ranges have led some authors (for example, Beckwith, 1941, p. 1481-1482) to postulate that horizontal compressive stresses caused much of the deformation within the region. The marginal thrusts, however, may have been produced by the vertical or near-vertical uplift of rigid blocks of Precambrian rocks, together with a slight amount of rotation of individual blocks during the uplift. These thrusts may be in part similar to the thrust that is marginal to a salt dome at Boling Dome, Tex. (Halbouty and Hardin, 1954), to the marginal upthrusts around plutonic intrusions (Cloos, 1933), and to the fractures produced in pressure-box model experiments by Link (1930, p. 498). 


\section{INFLUENCE OF STRUCTURE ON LITHOLOGIC CHARACTER}

The lithologic eharacter of some Mesozoic rocks of the foreland exhibits a close relation to both regional and local structure. The clastic material composing the rocks was derived, in large part, from the rising Cordilleran geanticline to the west; the result is an eastward gradation from coarse-grained to finer grained rocks. Local uplifts (Eardley, 1951, pl. 16) probably influenced the sedimentation in their immediate areas by locally providing coarser grained clastic material. Because some of the resulting rocks provide favorable hosts for uranium deposition, the influence of structure on lithologic character is important in the localization of uranium deposits. An example of the influence of regional structure is the Morrison formation of Jurassic age, which in the foreland consists of siltstone and other argillaceous material with lenses of sandstone and freshwater limestone, but which grades westward into sandstone. Although uranium minerals and radioactivity highs are widely scattered throughout the Morrison rocks in Wyoming, important uranium deposits are known only in the Colorado Plateau region, where sandstone is most abundant. Clastic rocks of Cretaceous and Tertiary age resulting from local uplifts provide favorable hosts for uranium deposits in the Black Hills.

The influence of local structures on lithologic character is illustrated best by some of the Lower Cretaceous sandstones in the southern part of the Powder River Basin, Wyo. (fig. 108), which thicken near the axial parts of anticlines (Curry and Curry, 1954); the thickest part is slightly down the structure from the crest of the anticline. The thickening is repeated in several stratigraphic units of different ages on the same structure, and deposition of the sandstones was influenced by repeated uplift of the growing structure. Similar thickening is probably on many anticlinal structures in the region. In the Black Hills the heavy-mineral suite of some sandstones of Early Cretaceous age contains minerals similar to those found in Precambrian rocks, suggesting that the sandstone formed during uplift of the Black Hills and that the Precambrian rocks were being eroded at that time (Crowley, 1951). Similar Cretaceous rocks contain commercial uranium deposits in this area. Because the lithologic character of the beds and the mineral suites in these areas were influenced by structures, it is believed that regional tectonics also were important in controlling the location of uranium by determining the location of favorable host rocks.

Paleocene sediments in some basins of the foreland are thickest in structural troughs, near and parallel to uplifts (Mackin, 1947, p. 103; Van Houten, 1948). Lower Tertiary conglomerates at the edges of some basins in south-central Wyoming grade rapidly into shale and coal beds (Knight, 1951) as a result of abrupt changes in the tectonic conditions, rapidly rising mountains at the basin margins, and more slowly subsiding basin centers. Stable areas bordering downwarped unstable troughs, where rocks of dominantly mediumgrained sediments are abundant, seem to be favorable localities for uranium deposition, as in the Williston basin region (fig. 108) and the Great Divide Basin, Wyoming.

Relatively young tuffaceous rocks crop out in some basin interiors, partly because the interiors are eroded less than the margins of the basins and partly because a greater thickness of sediments is deposited in the basin troughs. As tuffs are possible source rocks of uranium, their presence in basins is a favorable indicator for the occurrence of ore deposits. Examples are small patches of tuffaceous sedimentary rocks of Oligocene age in the Powder River Basin (fig. 108) which may have been source rocks for the uranium deposits in underlying rocks of Eocene age (Love, 1952). Deposition of favorable beds in the underlying rocks, equally necessary for the localization of deposits, was probably controlled by tectonic conditions during Eocene time. Regional unconformities beneath tuffaceous sediments probably controlled movement of uranium; disseminated deposits and uraniferous lignites commonly are parallel to and beneath such unconformities (E. J. McKay, oral communication).

\section{STRUCTURE OF THE REGION}

The various structures of the foreland can be divided into three large classes to show the relation of uranium deposits to the struetural pattern. Large-scale structures include large mountain ranges, major basins, and fault zones, with structural relief as much as a few tens of thousands of feet; some are several hundred miles long. Intermediate-scale structures are large folds and faults superimposed on large-seale structures. These have a structural relief of a few hundred feet; few exceed several tens of miles in length. Small-scale structures are folds, faults, and joints of a size which, although not important in the large-scale localization of uranium, nevertheless may be very important in controlling individual deposits.

Large- and intermediate-scale structures within the Cordilleran foreland are outlined on figure 108. The three sets of large-scale structures which trend northwestward, northeastward to north-northeastward, and west-northwestward, are of Preeambrian age. The northwestward-trending set is the most pronounced but is disrupted in part by the northeastward-trending set, which is probably younger. The west-northwestward-trending set appears only in central and southern 
Montana and consists of long, almost-parallel faults or fault zones in Precambrian rocks (Chamberlain, 1919) that apparently offset the northwestward- and northeastward-trending large-scale structures of Precambrian age.

Most of the known uranium districts within the foreland are in four structural environments: areas near major-basin axes along northwestward-trending large-scale structures, areas in which northwestwardand northeastward-trending large-scale structures intersect, areas in which groups of in-echelon northwestward-trending intermediate-scale structures are superimposed on northwestward-trending large-scale structures, and areas over or near large faults or fault zones in Precambrian rocks which are associated with northeastward-trending large-scale structures.

Uranium districts near major-basin axes are best illustrated by the Powder River Basin (fig. 109), the Williston basin (fig. 108), and the Great Divide Basin of
Wyoming. Most of the deposits in the Powder River Basin are located east of the basin axis (as drawn on the Precambrian surface). Many are located along a zone in which the slope of the surface increases. Most of the known deposits are at the north end of the group of deposits shown on figure 109, where the basin floor is interrupted by a northeastward-trending large-scale structure that has little or no surface expression. Little information is available concerning this structure, but it is probably a belt of fault blocks in Precambrian rocks. Figure 109 shows also the outline of an area which was prospected with airborne scintillation counters; anomalies and deposits were found only at the west end of the area near the basin axis, the east end is barren.

Uranium districts in areas of intersecting northwestward- and northeastward-trending large-scale structures include vein deposits in the Hartville uplift (fig. 108) which have been described by Ball (1907) and Larsen, Hess, and Schaller (1926), and in the northern Laramie

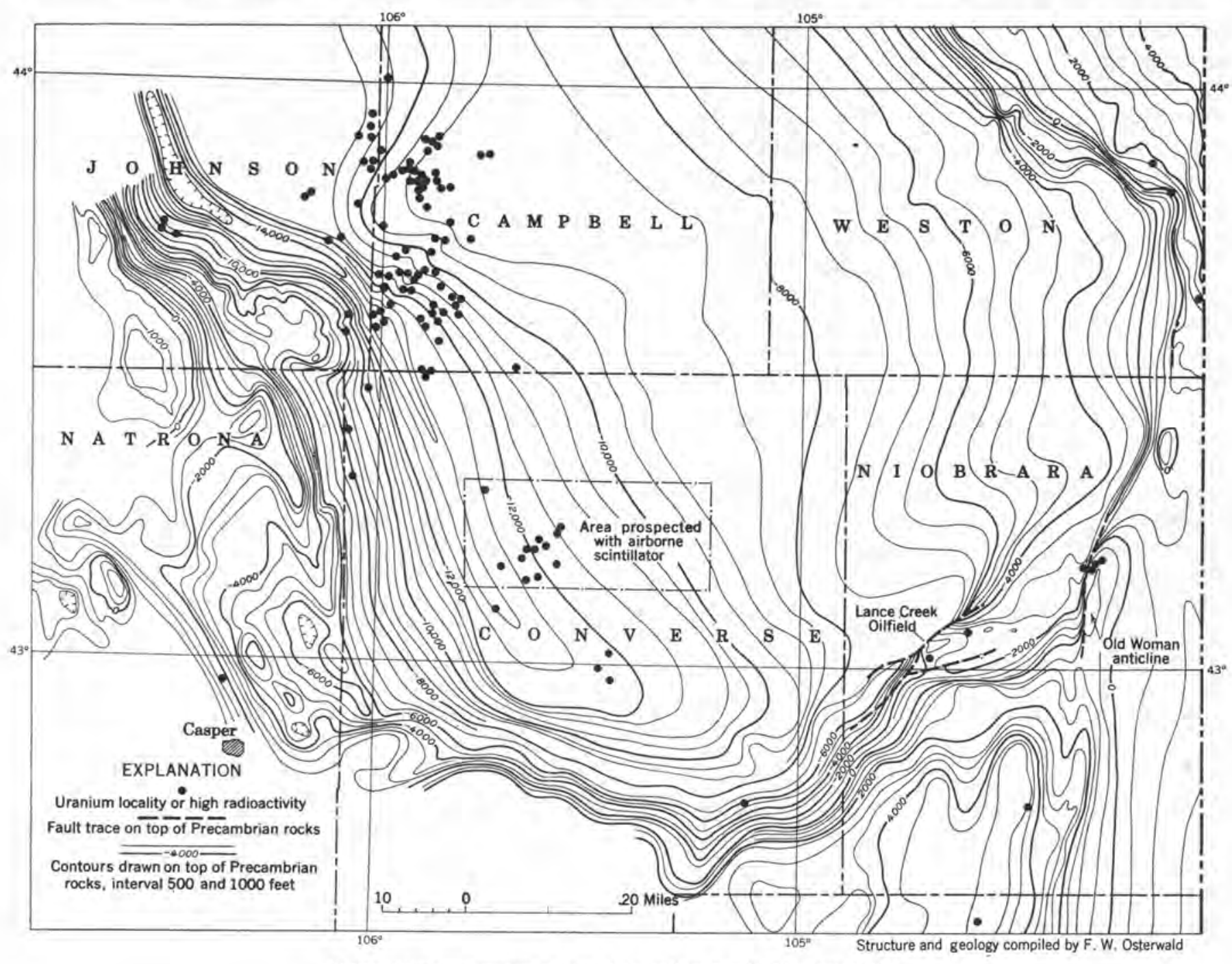

Figdre 109.-Structure-contour map of the southern Powder River basin, Wyo. 
Range, Wyo., and in disseminated deposits in southcentral Wyoming (Love, 1953).

Uranium deposits in or near zones of in-echelon intermediate-scale structures superimposed on northwestward-trending large-scale structures include the vein deposits in the Colorado Front Range, the disseminated deposits in the Black Hills, and the disseminated deposits along the southwest margin of the Wind River Basin (see fig. 108).

Uranium deposits over or near zones of large steep fractures associated with northeastward-trending largescale structures are illustrated by the deposits on the flank of the Old Woman anticline, Wyoming (fig. 109).

\section{LOCALIZATION OF URANIUM DISTRICTS BY TECTONIC ELEMENTS}

The intersections of two major tectonic elements trending northwestward and northeastward which seem to be favorable for localization of uranium may be areas in which the energy levels were increased slightly by an increase in the geothermal gradient, by faulting and folding, or by a combination of the two factors. The slight increase caused uranium, probably dispersed throughout the rocks as adsorbed or absorbed ions, to be expelled, moved, and later concentrated.

Margins of major tectonic units may be places in which the energy levels are changed by the same factors mentioned for intersections of tectonic elements, allowing uranium to be released and concentrated in smaller structures. However, the uranium probably would be merely raoved upward and laterally and be redispersed if favorable environments providing local points of low-energy level were not present. Such environments are provided by the in-echelon faults along the east margin of the Colorado Front Range (fig. 108) and the anticlinal noses that localize deposits on the flanks of the Black. Hills (fig. 108). However, the ore is not localized in the intermediate-scale structures but in small-scale structures probably related to them. The uranium in the Front Range pitchblende vein deposits may have been dispersed originally in Precambrian igneous and rnetamorphic rocks, and the uranium in the Black Hills disseminated deposits may have been dispersed in sedimentary rocks of younger age. The forces that mobilized, expelled, and concentrated the uranium in both areas were probably similar and were probably active during Cretaceous or Tertiary time.

The repeated deformation along Precambrian structural trends and the gradual, long-continued growth of structures may have caused nearly flat-lying Tertiary rocks to be slightly warped and jointed. Gentle folds and associated joints in Pliocene rocks in southern
Wyoming indicate that at least some deformation took place late in Tertiary time. These minor structures in Tertiary rocks may have provided places of low energy which localized uranium mobilized by larger structures below. A possible example is the deposits in Tertiary rocks overlying the flanks of the Lance Creek oilfield (fig. 109).

Clusters of small plugs, dikes, necks, sills, and flows crop out in the Black Hills of South Dakota and Wyoming, in the Sweetwater arch of central Wyoming, and in the Leucite Hills of south-central Wyoming. Others that do not crop out are known from geophysical exploration. Most of the volcanic rocks are Tertiary in age, and some may have been the source for much of the pyroclastic material found in widespread sediments of Tertiary age (Carey, 1954, p. 34). These alkaline volcanic rocks seem to be related to tectonic features in a manner very similar to that of the uranium. deposits. The areas in which the energy levels were relatively high may have been raised even bigher locally to permit small bodies of magma to form. W. Burbank (written communication) pointed out that in the formation of magma the energy level necessary for transfer of energy is so high that a silicate liquid results, and that previously mobilized elements may become mixed with material of the silicate melt. For these reasons, some of the bodies of igneous and pyroclastic rock may have provided uranium, which was later concentrated into deposits.

\section{REFERENCES CITED}

Ball, S. H., 1907, Copper deposits of the Hartville uplift, Wyoming: U. S. Geol. Survey Bull. 315-B, p. 93-107.

Beckwith, R. H., 1941, Structure of the Elk Mountain district, Carbon County Wyo.: Geol. Soc. America Bull., v. 52, p. $1445-1486$.

Blackwelder, Eliot, 1926, Pre-Cambrian geology of the Medicine Bow Mountains: Geol. Soc. America Bull., v. 37, p. 615658.

Carey, B. D., Jr., 1954, A brief sketch of the geology of the Rattlesnake Hills: Wyoming Geol. Assoc. Guidebook, 9th Ann. Field Conf. p. 32-34.

Chamberlin, R. T., 1919, A peculiar belt of oblique faulting: Jour. Geology, v. 27, p. 602-613.

Cloos, Ernst, and Cloos, Hans, 1934, Precambrian structure of the Beartooth, the Big Horn, and Black Hills uplifts and its coincidence with Tertiary uplifting [abs.]: Geol. Soc. America Proc. for 1933, p. 56.

Cloos, Hans, 1933, Plutone and ihre Stellung im Rahmen der Krustenbewegungen: 16th Internat. Geol. Cong. Rept., v. 1, p. 235-253. [1936]

Crosby, W. O., 1897, Sandstone dikes accompanying the great fault of Ute Pass, Colo.: Essex Inst. Bull., v. 27 for 1895, p. 113-147.

Crowley, A. J., 1951, Possible Lower Cretaceous uplifting of Black Hills, Wyo., and South Dakota: Am. Assoc. Petroleum Geologists Bull., v. 35, p. 83-90. 
Curry, W. H., Jr., and Curry, W. H., III, 1954, South Glenrock, a Wyoming stratigraphic oil field: Am. Assoc. Petroleum Geologists Bull., v. 38, p. 2119-2156.

Eardley, A. J., 1951, Structural geology of North America: New York, Harper and Brothers, 624 p.

Halbouty, M. T., and Hardin, G. C., Jr., 1954, New explorstion possibilities on piercement-type salt domes established by thrust fault at Boling salt dome, Wharton County, Tex.: Am. Assoc. Petroleum Geologists Bull., v. 38, p. 1725-1740.

Hiestand, T. C., 1935, Regional investigations, Oklahoma and Kansas: Am. Assoc. Petroleum Geologists Bull., v. 19, p. 948-970.

King, P. B., 1951, The tectonics of middle North AmericaMiddle North America east of the Cordilleran system: Princeton, N. J., Princeton Univ. Press, 203 p.

Knight, S. H., 1951, The Late Cretaceous-Tertiary history of the northern portion of the Haann Basin, Carbon County, Wyo.: Wyoming Geol. Assoc. Guidebook, 6th Ann. Field Conf., p. 45-53.

Larsen, E. S., Hess, F. L., and Schaller, W. T., 1926, Uranium minerals from Lusk, Wyo.: Am. Mineralogist, v. 11, p. 155-164.

Link, T. A., 1930, Experiments relating to salt-dome structures: Am. Assoc. Petroleum Geologists, v. 14, p. 483-503; discussion, p. 503-508.
Love, J. D., 1952, Preliminary report on uranium deposits in the Pumpkin Buttes area, Powder River Basin, Wyo.: U. S. Geol. Survey Circ. 176, 37 p.

1953, Preliminary report on the uranium deposits in the Miller Hill area, Carbon County, Wyo.: U. S. Geol. Survey Circ. 278, 10 p.

Mackin, J. H., 1947, Altitude and local relief of the Bighorn area during the Cenozoic: Wyoming Geol. Assoc., Univ. of Wyoming, and Yellowstone-Bighorn Res. Assoc., Guidebook, Field Conf. in the Bighorn Basin, p. 103-120.

Osterwald, F. W., 1949, Structure of the Tongue River area, Bighorn Mountains, Wyo.: Wyoming Geol. Assoc., Guidebook, 4th Ann. Field Conf., p. 37-38.

- Structure and petrology in the northern Bighorn Mountains, Wyo.: Geol. Survey of Wyoming Bull. [In press]

Thom, W. T., Jr., 1947, Structural features of the Bighorn Basin rim: Wyoming Geol. Assoc., Univ. of Wyoming, and Yellowstone-Bighorn Res. Assoc., Guidebook, Field Conf. in the Bighorn Basin, p. 173-177.

Van Houten, F. B., 1948, Origin of red-banded Early Cenozoic deposits in Rocky Mountain region: Am. Assoc. Petroleum Geologists Bull., v. 32, p. 2083-2126.

Vitanage, P. W., 1954, Sandstone dikes in the South Platte area, Colorado: Jour. Geology, v. 62, p. 493-500. 
3954 


\title{
GEOLOGY OF URANIUM IN THE BASINS OF TERTIARY AGE IN WYOMING AND THE NORTHERN GREAT PLAINS
}

\author{
By James D. Vine, U. S. Geological Survey
}

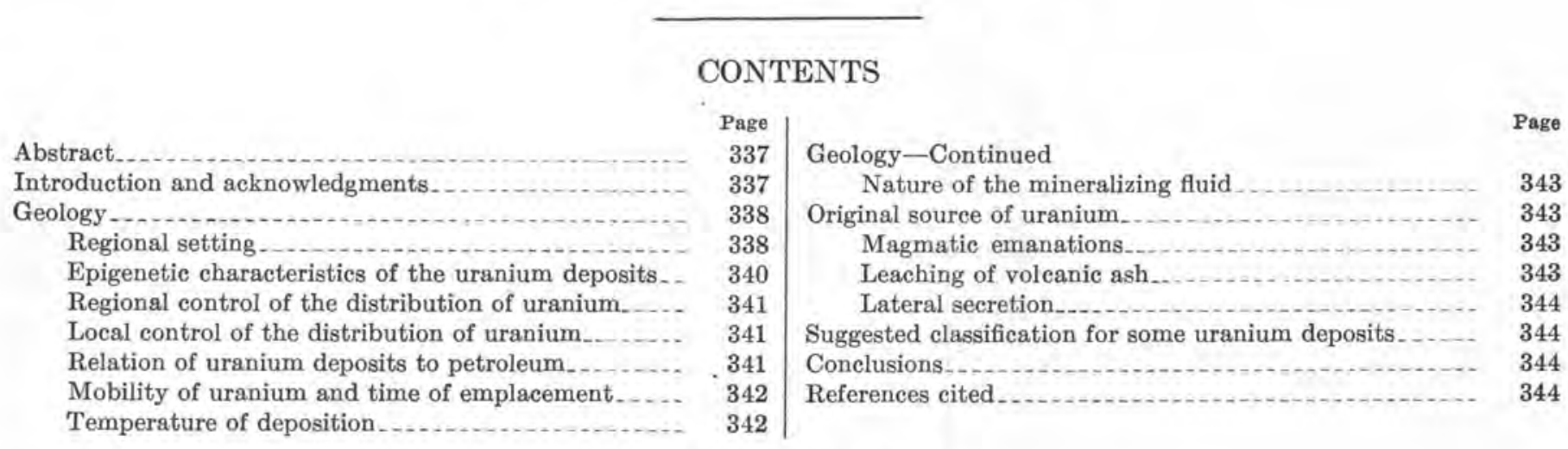

\section{IILUSTRATION}

Figure 110. Uranium deposits in the basins of Tertiary age in Wyoming and the northern Great Plains.

\section{ABSTRACT}

Uranium deposits of commercial size and grade are being explored and mined in the Wyoming Basin and the northern Great Plains physiographic provinces of Wyoming and adjacent parts of Colorado and North and South Dakota. These deposits occur in sedimentary rocks in or adjacent to basins of thick Tertiary deposits, in many places remote from metallic vein deposits. The concentration of uranium in sandstone, limestone, and coal is thought to be secondary in origin, and the deposition of uranium is thought to be from mineralizing solutions that travel through the strata, as evidenced by the crosscutting relation between uranium minerals and the primary sedimentary structures. Tectonic structures, primary sedimentary struetures, and the gross variations in the permeability of the strata probably control the distribution of uranium by determining the direction and volume of flow of mineralizing ground water. Local variations in lithologic character provide physical and chemical conditions favorable for the deposition of uranium. Any apparent spatial relation between the distribution of uranium and petroleum is probably fortuitous. The lack of equilibrium of uranium and its radioactive-decay products in many localities and the occurrence of uranium in caliche, travertine, and pediment gravel suggest recent transportation and deposition of some of the uranium. Deposition of uranium probably took place in a moderate- to low-temperature environment even though low-valence uranium minerals occur in some districts.

Three hypotheses for the origin of the uranium are considered: from thermal solutions genetically related to magmatic intrusions, from the leaching and concentration of disseminated uranium in superjacent voleanic ash of Tertiary age, and from the reconcentration of disseminated uranium in rocks laterally equivalent or adjacent to the host formation. Available evidence indicates that all three hypotheses are permissible except for explaining the origin of the uraniferous Dakota lignite, in which the evidence for the leaching of the voleanic ash is preeminent. The following classification for the deposits, based on the immediate source of the uranium-bearing solutions and the environment of deposition, is suggested: Surficial, vadose, and hydrodynamic.

\section{INTRODUCTION AND ACKNOWLEDGMENTS}

Knowledge of the occurrence of uranium in the basins of Tertiary age in Wyoming and the northern Great Plains has been greatly expanded during the past few years. Since 1951 large tonnages of uranium ore have been developed in the Edgemont district of South Dakota in the southern Black Hills. Smaller deposits of ore have been mined in the Powder River and Wind River Basins, at Crooks Gap, and in the northern Black Hills in Wyoming; and in the Cave Hills area of South Dakota.

The purpose of this report is to compare the geological features of some of the different types of deposits and to discuss ideas concerning the origin and depositional control of the deposits. A classification of sedimentary uranium deposits is proposed.

Although some of the areas mentioned were studied or briefly examined by the author, he is indebted to various colleagues for many of the observations and ideas. Liberal use has been made of many preliminary 
government reports, but because these reports are not available to the public, no specific reference has been made to them.

\section{GEOLOGY}

\section{REGIONAL SETTING}

The sediments of Tertiary age that contain uranium deposits in central and eastern Wyoming and adjacent parts of Colorado, South Dakota, and northwestern
Nebraska (table below) occur chiefly in the Wyoming Basin and the northern part of the Great Plains physiographic provinces (Fenneman, 1940).

The Wyoming Basin includes a group of structural and topographic basins in central and southern Wyoming including the Wind River, Great Divide, Washakie, and Powder River Basins. The northern Great Plains extends eastward from the Wyoming Basin into Nebraska and the Dakotas. (See fig. 110.)

Uranium districts in the basins of Tertiary age in Wyoming and northern Great Plains

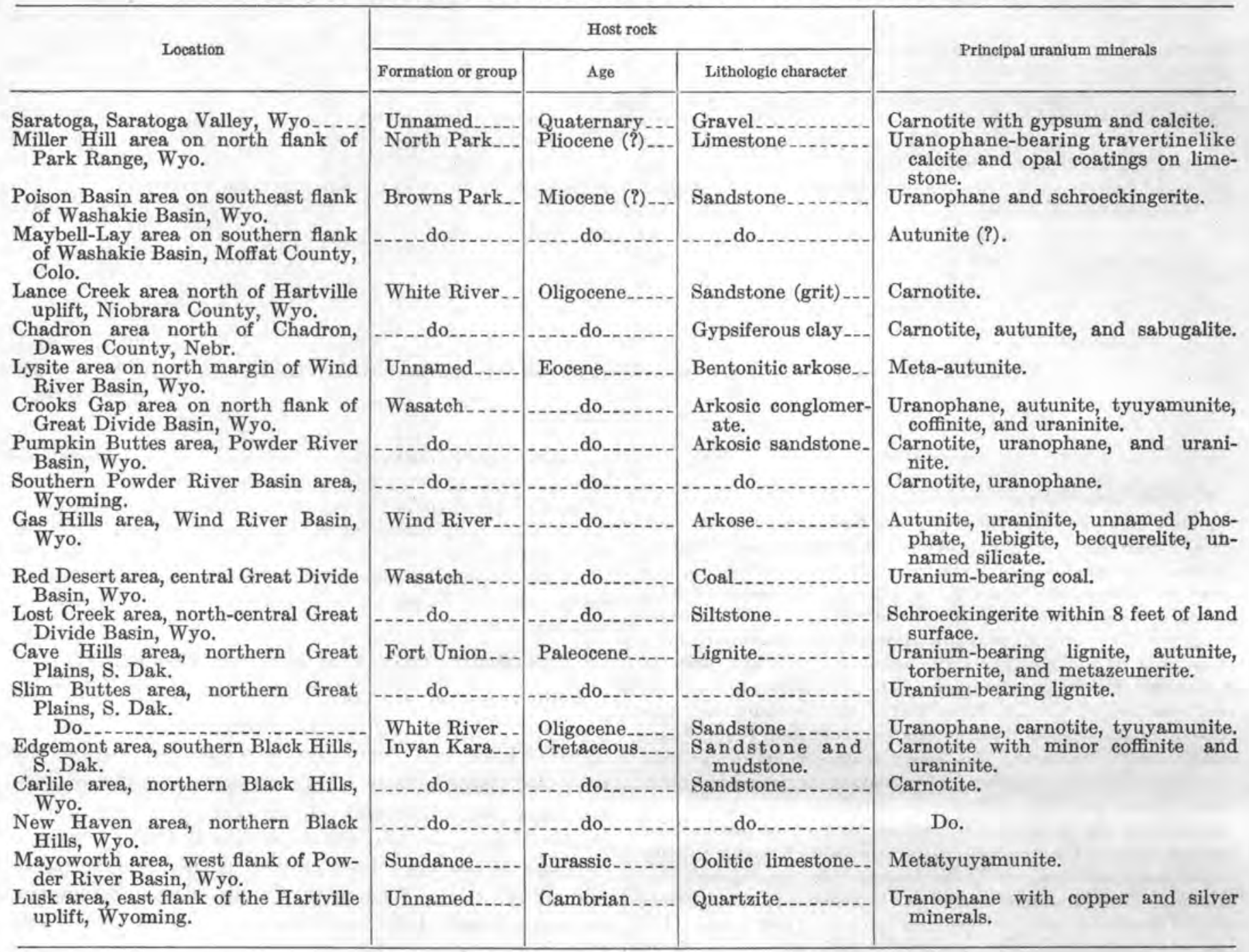

Superimposed on the major tectonic features of the mountain ranges and intermontane basins are a number of smaller features including folds, faults, and centers of igneous activity. Many folds occur along the peripheries of the basins in the outcrop belts of Paleozoic and Mesozoic age. High-angle thrust faults occur locally along the flanks of major uplifts and are probably genetically related to the Laramide orogeny. Normal faults are common throughout the region and locally cut rocks as young as Pliocene. Locally, as along the south flank of the Granite Mountains, north of the Crooks Gap uranium deposit, normal faults nearly parallel preexisting thrust faults. Centers of volcanic activity in the region include laccoliths or stocks, volcanic plugs, and flows. Three centers of volcanic activity in central and eastern Wyoming are the northern Black Hills, the Rattlesnake Hills, and the Leucite Hills. A fourth center is in the Elkhead Mountains northeast of Craig, Colo. The volcanic rocks of the Leucite Hills and the Rattlesnake Hills are character- 
EXPLANATION

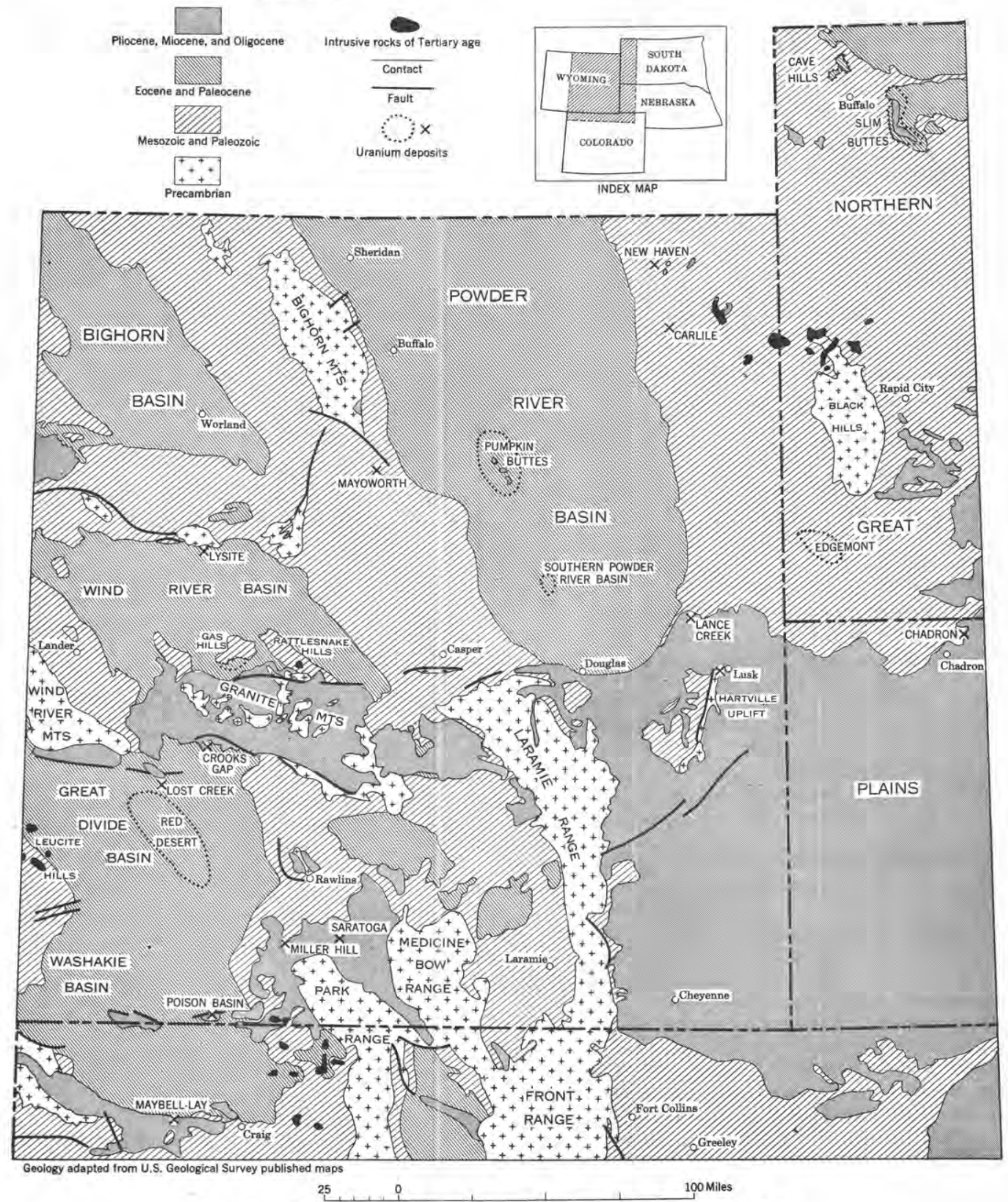

FICURE 110.-Urantum deposits in basins of Tertiary age in Wyoming and the northern Great Plalns. 
ized by high potassium and sodium contents, respectively. The pyroclastic debris in Oligocene and younger Tertiary sediments did not necessarily originate from these known volcanic centers, as they are generally regarded as pre-Oligocene in age. The Yellowstone River-Absaroka Range region in northwestern Wyoming is a more likely source of the younger Tertiary pyroclastic rocks.

\section{EPIGENETIC CHARACTERISTICS OF THE URANIUM DEPOSITS}

Epigenetic characteristics of uranium deposits in sedimentary rocks include interstitial mineral matter superimposed upon and transecting the primary bedding structure. For example, small concretionary structures with a characteristic nueleus or symmetry are a common type, but broad, irregular regional variations of interstitial mineral matter are also included. These are grouped under the general heading of epigenetic characteristics because they are thought to be the result of transportation and deposition of mineral matter in solution after deposition of the enclosing sediments. Epigenetic features are common to all the uranium deposits discussed in this paper.

Uranium is only one of a number of metallic and nonmetallic ions commonly transported by ground water. Much of the mineral matter contained in ground water is transported and redeposited as interstitial cementing material or authigenic overgrowths. Such phenomena are so common that they attract little attention. When this interstitial cementing material forms concentrically laminated layers about a nucleus, the structure so formed is a concretion. In many districts uranium minerals form one or more layers of such concretionary structures.

Concretionary structures several inches to several feet in diameter contain uranium minerals in sandstone beds in the Pumpkin Buttes district (Love, 1952). Some have a core of carnotite and uranophane surrounded by black manganese and iren oxides, whereas others have a core of pyrite surrounded by uraninite. These concretions may contain more than 10 percent uranium. Locally the secondary mineral matter partly replaces the original sand grains, indicating that these structures were formed in place. These concretionary structures, found over many square miles in the Pumpkin Buttes district, are contained within a large mass of sandstone of the Wasatch formation of Eocene age that is pink due to interstitial iron oxide cement. The borders of this large mass of pink rock are characterized by pink and yellow concentric color banding that transects the primary-bedding structure of the sandstone. The color bands are probably due to hydrous iron oxide stains but are locally accompanied by yellow uranium minerals. Unlike the previously mentioned concretions, these structures have no nucleus and no symmetry but have the appearance of wave fronts of slowly migrating mineral matter. Whether or not the concentric bands of interstitial mineral matter actually do migrate through the sandstone is not known.

In the Edgemont district, spherical calcite concretions as much as several inches in diameter are common in some sandstone beds of the Inyan Kara group. Similar concretions containing carnotite are also found. Large ellipsoidal or roll-shaped calcareous concretions as much as several feet in diameter in the New Haven area of the northern Black Hills district contain carnotite, which forms a rich outside band or "roll" on the carbonate-cemented concretion. In many districts, irregular envelopes or thin sinuous bands of iron oxide stains surround the ore bodies. Silica, either in the form of authigenic overgrowths of quartz on sand grains in sandstone as a replacement of limestone by chalcedony or opal is commonly associated with uranium deposits. In the Chadron area of northwestern Nebraska, uranium minerals occur locally at the base of a thick gypsum facies of the White River group of Oligocene age, and the uranium minerals are believed to be secondary.

Evidence of epigenetic mineralization in limestone and coal differs slightly from that in sandstone, although the interpretation of the origin is similar. Uranophane occurs along fractures and in vugs in the Miller Hill area limestone, and metatyuyamunite replaces oolites in limestone in the Mayoworth area (Love, 1954). In the Miller Hill area aggregates of uranophane with calcite and opal produce thin travertine-like deposits on the undersides of limestone boulders as well as in vugs in brecciated limestone. Because uranium minerals are rarely visible in coal, with the notable exception of that in the Cave Hills area of northwestern South Dakota, the distribution of uranium must be determined by radiometric methods in the field or by laboratory analyses. Both field and laboratory studies of the lignite in western North and South Dakota (Miller and Gill, 1954) indicate an unsymmetrical distribution of uranium in the tops of most beds and a close areal and vertical increase in uranium content of lignite near the base of the Oligocene strata that unconformably overlie the lignite-bearing Cretaceous and Paleocene rocks. Uranium in coal in the Red Desert area seems to be related to zones of high permeability in the enclosing strata. Thus, the erratic or crosscutting distribution of uranium in limestone and coal is in part comparable to the epigenetic emplacement of uranium in sandstone deposits. 


\section{REGIONAL CONTROL OF THE DISTRIBUTION OF URANIUM}

Because uranium in the basins of Tertiary age in Wyoming and the northern Great Plains is thought to be concentrated in certain sedimentary strata by solutions that move through the pore and fracture spaces of the rock, those features of the regional geologic setting that determine the direction and volume of flow of ground water also bear directly on the distribution of uranium deposits. The gross hydrologic characteristics of the basins of Tertiary age of Wyoming and the northern Great Plains are influenced by the tectonic and sedimentary structure, lateral and vertical variations in permeability, topography, and climate. The normal hydrologic system may be locally upset by orogeny, igneous intrusion, deep erosion, or faulting. Meteoric water that enters the ground-water system chiefly along the flanks of the mountains is thought to proceed toward the surface near the center of the topographic basin. Thus, the concentration of groundwater flow near the basin trough may in part account for the Pumpkin Buttes, Lost Creek, and Red Desert deposits occurring near the centers of these basins. On a smaller scale, the location of the Poison Basin and Maybell-Lay deposits near the axes of basins may be explained in a similar manner.

A second factor of the regional geologic setting that may bear on the distribution of uranium is the size and relative position of the body of rock that constitutes the source of the mineral in solution. Proximity to, and the amount of uranium available from, the source probably control to a large extent the number, size, and grade of deposits in the region. Possible source types are discussed under origin of the uranium.

\section{LOCAL CONTROL OF THE DISTRIBUTION OF URANIUM}

Within a given district favorable for the deposition of uranium, local variations in the physical and chemical characteristics of the sedimentary rocks probably determine whether the deposits occur individually or as groups. Such local control is readily apparent, for example, in the uraniferous coal deposits of the northern Great Plains and in the Red Desert area of central Wyoming. Moore (1954) demonstrated in the laboratory that peat, lignite, and sub-bituminous coal can extract as much as 98 percent of the uranium from aqueous solution. Thus, the amount of uranium present in a low-rank coal may be proportional to the amount of uranium-bearing water that has passed through the coal. A study of the uranium-bearing limestone in the Miller Hill and Mayoworth areas suggests that the deposition of uranium was due to chemical reaction of the solutions with limestone.
The control for the distribution of uranium in sandstone-type deposits is less apparent but probably consists of a combination of physical and chemical characteristics. The variation in the lithologic character of the host rock in sandstone-type deposits is such that there seems to be no single dominant characteristic of the environment that serves as the principal control for all deposits. Coarse-grained arkosic fluviatile sandstone is the principal rock type common to the Crooks Gap, Gas Hills, and southern Powder River Basin deposits. The Lance Creek deposit oecurs in coarse-grained sandstone or grit, whereas quartzose sandstone of possible eolian origin is characteristic of the host rock in the Poison Basin and Maybell-Lay deposits. Calcareous cement is common in many districts and may control the distribution of uranium in some of the Pumpkin Buttes deposits. Carbonaceous material in the form of coal, carbonaceous clay, coalified wood fragments, or petroleum residue is common in many districts and may provide part of the local control for the Gas Hills, Pumpkin Buttes, Crooks Gap, Poison Basin, and Maybell-Lay deposits, For example, a concretion containing uranium minerals surrounding a nucleus of fossil wood was found in the Pumpkin Buttes district. No carbonaceous material is evident, however, in the Lysite and Lance Creek deposits.

The host sandstone in most of the districts appears to be highly permeable, but at Lysite the uranium occurs in a bentonitic sandstone, apparently of low permeability. The role of permeability is difficult to evaluate because the present permeability is not necessarily the same as the permeability at the time of mineralization, and because uranium may be deposited either within or marginal to the zone of greatest original permeability, depending on other local features. For example, the highest grade uranium-bearing coal in the Red Desert area is in those coal beds adjacent to coarsegrained (presumably more permeable) sandstone beds, whereas uranium in the Gas Hills area occurs within the coarse-grained facies of the Wind River formation. In the Pumpkin Buttes district uranium occurs both within and near the margins of sandstone channel deposits. Because of the delicate balance that evidently exists between the tendency for uranium minerals to form and tho tendency for solutions to dissolve and remove them, onily slight variations in lithologic character and structure may be effective in changing the environment from one of solution to one of deposition.

\section{RELATION OF URANIUM DEPOSITS TO PETROLEUM}

Erickson, Myers, and Horr (1954, p. 2217) have suggested a genetic relation between some uranium deposits in Utah and breached anticlinal structures 
that have served as traps for the accumulation of petroleum. Because oifields are plentiful in Wyoming and are located in the same sedimentary basins as the uranium deposits, there has been speculation regarding a possible genetic relation between the two. There are 3 producing oifields near the Crooks Gap uranium deposits, 1 near the Lance Creek deposit, several breached anticlines as well as producing fields near the Gas Hills district, and many fields in the Powder River Basin close to the Pumpkin Buttes and Black Hills districts. In most of these areas, with the exception of the Black Hills, the oil-producing formations are older than the uranium-bearing strata. The Poison Basin, Maybell-Lay, and Miller Hill deposits have been actively prospected for oil and are in areas considered favorable for the accumulation of oil.

Many hydrocarbons contain small amounts of uranium, and asphaltic residues in particular commonly contain fairly large quantities of uranium. Asphaltlike carbonaceous materials have been found closely associated with some of the uranium deposits. However, the quantity of uranium in some of the larger deposits is far greater than could be deposited from, or transported by, petroleum. Therefore, the excess of uranium contained in asphalt as compared with that contained in crude oil suggests that whatever uranium is present in oil becomes concentrated in the heavy asphaltic fraction rather than being extracted by other rocks. Any apparent relation between the distribution of oil deposits and uranium deposits is probably a fortuitous one due to the ubiquitous character of both oil and uranium and the similarity of good oil-reservoir rocks to good uranium host rocks.

\section{MOBILITY OF URANIUM AND TIME OF EMPLACEMENT}

Uranium deposits in the Tertiary basins of Wyoming and the northern Great Plains are thought to form subsequent to the deposition of the enclosing strata. Conceivably uranium could be emplaced at any time after the sediments are laid down, but because the enclosing strata include rocks as young as Pleistocene, the mineralization would have had to be quite recent if all the deposits were formed simultaneously. No reason is known, however, why the mineralization could not have been a continuous process for each deposit ever since the enclosing sediments were laid down or since the emplacement of the body of rock that constitutes the source for the uranium.

Abundant evidence suggests that uranium is still being deposited. The marked disequilibrium in many districts between uranium and its natural radioactive decay products suggests either recent deposition, weathering, or migration of the uranium. Such occurrences as the calichelike accumulation of schroeckingerite at Lost Creek, the uranium in pediment gravel at Saratoga, and uranophane-bearing calcite and opal travertinelike coatings on the undersides of limestone boulders in the Miller Hill area suggest recent deposition.

These phenomena suggesting the mobility of uranium in a sedimentary environment may represent something similar to the yellow bloom sometimes observed near uranium deposits, particularly evident during the dry season but frequently lacking during the rainy season. However, bloom is generally thought to represent an outward migration and dissemination of mineral from a concentrated source, whereas there is no known concentrated source near Lost Creek, Miller Hill, or Saratoga. Perhaps these deposits represent recent surficial concentration of uranium from a disseminated source. If so, a similar concentration of uranium from a disseminated source may account for some of the larger subsurface deposits. A concentration near the surface may be due to evaporation, but the ready mobility of uranium suggests that a concentration at depth may be due to some other physical or chemical process.

\section{TEMPERATURE OF DEPOSITION}

A distinction is commonly made between the black or low valence (quadrivalent) uranium minerals, uraninite, pitchblende, and coffinite, and the carnotitetype high valence (hexavalent) uranium minerals such as carnotite, autunite, uranophane, and schroeckingerite, because the black ores are normally thought of as primary and in some areas the high-valence minerals are derived from the primary ores by oxidation in place. Both types occur in the Tertiary basins of Wyoming and the northern Great Plains. (See table, p. 338). Because the black ores are thought to be hypogene, a genetic relation to thermal solutions is commonly implied. However, Gruner (1954) demonstrated that pitchblende could also form at normal room temperature. As a result of a study of the fields of stability for certain uranium ions under variable conditions of acidity and oxidation-reduction states, R. M. Garrels (written communication, 1954) suggested specific mineral assemblages that he believed might be characteristic of certain environments of deposition. Although he favors primary deposition of the Colorado Plateau type deposits, with the elements in their lower valence states, he does not deny the possibility of primary deposition of the carnotite-type ore. Thus, the significance of primary and secondary uranium minerals may be that they are clues to the environment of deposition and not to genesis.

There seems to be no reason, therefore, why both the black and the carnotite-type uranium minerals could 
not have been deposited simultaneously in different parts of the same deposit, the difference being due to the acidity or oxidation-reduction potential of the local environment such as may occur between the zone of vadose water and the zone of saturation. Thus, the position of the ground-water table may account for carnotite-type ore near the surface and black ore at depth in the Gas Hills deposit. Because no evidence of hydrothermal alteration is associated with any of these deposits, and no compelling mineralogical reason exists for assuming the necessity of a high temperature for deposition, most of the uranium deposits in the Tertiary basins of Wyoming and the northern Great Plains are thought to have been deposited at moderate to low temperatures.

\section{NATURE OF THE MINERAIIZING FLUID}

The wide stratigraphic and geographic distribution of uranium, the wide range in lithologic character of the host rocks, and the wide variety of depositional environments indicate the ubiquitous character of uranium. The mineralizing fluid required to transport and deposit so widespread an element must be so common as to have occurred frequently during the past. Ground water in areas where active deposition of uranium is thought to be continuing today provides a ready means of studying this mineralizing fluid. Samples of spring and well waters in these areas have been analyzed for uranium and found to contain 0.010.15 grams of uranium per ton of water, many times the average of less than 0.001 grams in the average terrain. Nevertheless, these quantities represent very dilute solutions, which are commonly used for domestic purposes.

\section{ORIGINAL SOURCE OF URANIUM}

The available evidence suggests that uranium deposits in the basins of Tertiary age in Wyoming and the northern Great Plains are epigenetic, and that uranium is slowly deposited from dilute moderate- to low-temperature aqueous solutions that pass through the pore and fracture spaces in the strata and deposit uranium in or near paths of greatest ground-water flow. Deposition probably results from chemical reaction or delicate changes in the physical and chemical environment. The source of the uranium contained in this mineralizing solution is unknown; this knowledge would help to guide the search for uranium. Of the several hypotheses and many variations of each that have been proposed for the origin of uranium, magmatic emanations, voleanic leaching, and lateral secretion seem to warrant most serious consideration.

\section{MAGMATIC EMANATIONS}

Uranium deposits may be genetically related to intrusive igneous rocks. Uranium deposits in the northern Black Hills are spatially closely related to exposed igneous rocks. In the southern Black Hills and at Lusk, buried laccoliths and stocks are inferred. Uranium and such elements as vanadium, copper, arsenic, selenium, phosphorous, and fluorine are thought to originate from hydrothermal fluids expelled from a cooling igneous intrusive body. According to Emmons $(1940$, p. $183-202)$ the elements present in a liquid magma but not required in the crystal structure of the common igneous rock-forming minerals tend to concentrate in the residual magmatic fluids as cooling and crystallization of the magma progress. Mineral deposits result where these fluids are expelled and react with the surrounding cooler rock. Criteria such as close spatial relations between the deposits and igneous intrusion, coincidence of the time of intrusion and formation of the deposits, or hypogene zoning of the deposits away from an igneous center can be used as evidence that a genetic relation exists between the two features. Because such criteria are not recognized for some uranium deposits, particularly those in younger sediments near the centers of Tertiary basins, they are classed as telethermal deposits.

This hypothesis is favored by many because magmatic emanations are thought to be quite rich in metal content. Furthermore, variations in the metal assemblage of the several districts could be caused by variable metallic contributions from different igneous centers or by variation in the composition of fluids emanating from the same igneous center over a period of time.

\section{IEACHING OF VOLCANIC ASE}

A second hypothesis is that many of these uranium deposits are genetically related to the disseminated uranium present in superjacent beds of volcanic ash, In 1950, Denson, Bachman, and Zeller proposed a volcanic origin for the uranium in the Dakota lignite region (Miller and Gill, 1954); Waters and Granger (1953) considered but rejected a similar origin for the Colorado Plateau deposits. According to this hypothesis the uranium and such elements as vanadium, copper, arsenic, selenium, phosphorous, and fluorine, normally concentrated in magmatic fluids under deepseated conditions, are extruded during volcanic eruption and are presumably contained in the glassy portion of the volcanic ash (Koeberlin, 1938). Because the uranium and the associated elements are not bound in the crystal structure of discrete minerals, a large proportion is presumably available to leaching by ground water. If the water-soluble uranium in volcanic ash consisted of only $10^{-6}$ tons of uranium per ton of rock (about $1 / 4-1 / 10$ the total uranium content) there would be approximately 10,000 tons of available uranium per cubic mile of voleanic ash. At least 
10,000 cubic miles of volcanic ash has been deposited in the Wyoming Basin and northern Great Plains area since Eocene time alone. This would make about 100 million tons of uranium available to ground water. These suppositions are supported by analyses that show unusually high concentrations of uranium, phosphorous, arsenic, selenium, molybdenum, lead, copper, nickel, cobalt, zine, and vanadium in water issuing from these volcanic-ash beds.

\section{LATERAL SECRETION}

A third possible explanation of the origin of uranium is the leaching and concentration of uranium from rocks laterally equivalent to the host formation or from adjacent formations. This hypothesis is referred to in this paper as lateral secretion. From a comparison of the average composition of igneous rocks, sandstone, shale, and limestone (Rankama and Sahama, 1950), it may be seen that all rocks contain at least minute quantities of uranium and associated elements. Quantitatively there may be enough of these elements in any large volume of rock so that through a process of leaching and concentration any rock may constitute a possible source. Little is known, however, about the availability to ground water of uranium and its associated elements from various types of sandstone, mudstone, arkose, and conglomerate, which constitute the bulk of the early Tertiary sediments. Otherwise the arguments favoring this hypothesis are very similar to those for the leaching of volcanic rocks.

\section{SUGGESTED CLASSIFICATION FOR SOME URANIUM DEPOSITS}

A classification of sedimentary uranium deposits could be based on any one or a combination of characteristic features such as size, grade, mineralogy, type of host rock, age of the mineralization, or origin. The following classification is based on the immediate source of the uranium-bearing solutions and the environment of deposition. Every possible situation may not be covered, and some deposits may include characteristies of two or more classes.

Surficial deposits are near-surface deposits of uranium formed by the evaporation of uraniferous ground water. These deposits may be concentrations of uranium that was formerly disseminated throughout a large volume of rock, or they may represent a reconcentration of uranium around a large ore body that is being weathered. Examples of these deposits are found in the Lost Creek and Saratoga areas.

Vadose deposits are within or below a large disseminated source, probably at or above the water table. Examples of these deposits are found in uranium-bear- ing lignite of the northern Great Plains and the limestone in the Miller Hill area. Similar deposits may also occur in sandstone.

Hydrodynamic deposits are within or adjacent to permeable rock units that form part of a hydrodynamic system through which deep ground-water circulation proceeds below the water table. Where deposition occurs in the absence of excess oxygen it is possible for the black low-valence minerals to form. The ultimate origin of the uranium in these solutions could be magmatic emanations, leaching of volcanic ash, or lateral secretion. These deposits are exemplified by the Black Hills districts and possibly others such as the Gas Hills district where black ore has been found.

\section{CONCLUSIONS}

The occurrence of uranium in the basins of Tertiary age in Wyoming and the northern Great Plains is in accordance with a pattern similar to other natural phenomena. Rapid progress is being made by the uranium geologists in revealing this pattern. The hypotheses for the origin and accumulation of uranium may be compared to the hypotheses for the origin and accumulation of petroleum. They serve in a like manner to focus attention on those areas where the search for uranium or petroleum may be most successful.

\section{REFERENCES CITED}

Emmons, W. H., 1940, Principles of economic geology: New York, McGraw-Hill Book Co., Inc., 528 p.

Erickson, R. L., Myers, A. T., and Horr, C. A., 1954, Association of uranium and other metals with crude oil, asphalt, and petroliferous rock: Am. Assoc. Petroleum Geologists Bull., v. 38, p. 2200-2218.

Fenneman, N. M., 1940, Physiography of Western United States: New York, MeGraw-Hill Book Co., Inc., 528 p.

Gruner, J. W., 1954, The origin of the uranium deposits of the Colorado Plateau and adjacent regions: Mines Mag., v. 44, no. 3 , p. $53-56$.

Koeberlin, F. R., 1938, Sedimentary copper, vanadium-uranium, and silver in Southwestern United States: Econ. Geology, v. 33 , p. $458-461$.

Love, J. D., 1952, Preliminary report on uranium deposits in the Pumpkin Buttes area, Powder River Basin, Wyo.: U. S. Geol. Survey Cire. 176, 37 p.

Love, J. D., 1954, Uranium in the Mayoworth area, Johnson County, Wyo.-a preliminary report: U. S. Geological Survey Circ. 358,7 p.

Miller, R. L., and Gill, J. R., 1954, Uranium from coal: Sei. Am., v. 191, no. 4, p. 36-39.

Moore, G. W., 1954, Extraction of uranium from aqueous solution by coal and some other materials: Econ. Geology, v. 49 , no. 6 , p. $652-658$.

Rankama, Kalervo, and Sahama, T. G., 1950, Geochemistry: Chicago, Univ. Chicago Press, 912 p.

Waters, A. C., and Granger, H. C., 1953, Volcanic debris in uraniferous sandstones, and its possible bearing on the origin and precipitation of uranium: U. S. Geol. Survey Circ. 224, 26 p. 


\title{
LITHOLOGIC AND STRUGTURAL CONTROLS OF URANIUM DEPOSITION IN THE SOUTHERN BLACK HILLS, SOUTH DAKOTA
}

\author{
By Henry Bell III, Garland B. Gott, Edwin Vanhorn Post, and Robert W. Schnabel, U. S. Geological
} Survey

\section{CONTENTS}

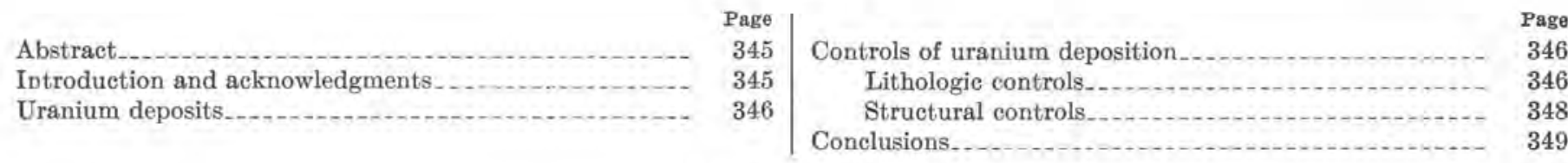

\section{ILLUSTRATIONS}

FIGURE 111. Strueture contours and uranium deposits, Edgemont mining district, Fall River County, S. Dak 112. Diagrammatic cross section showing the relation between the types of sandstone in the Inyan Kara group.... 348

\section{ABSTRACT}

Uranium deposits in the southern Black Hills of South Dakota oecur in nonmarine sandstone of the Inyan Kara group of Early Cretaceous age. These rocks form hogbacks and cuestas around a central mountainous area that was uplifted and folded during Laramide time. The principal ore minerals are earnotite and tyuyamunite, with lesser amounts of corvusite and rauvite. The distribution of the deposits indicates that lithologic charaeter, structure, and geochemical environment are important factors influencing the localization of the uranium minerals.

Uranium deposits have been found in three types of sandstone: (1) both yellow oxidized and dark partly oxidized uranium and vanadium minerals have been found in fine-grained sandstone, generally less than 5 feet thick, interbedded with laminated carbonaceous siltstone; (2) a few large carnotite deposits have been found in thick crossbedded noncarbonaceous sandstone, generally fine to medium grained, with many scour-and-fill structures; and (3) numerous small occurrences of carnotite of little economic importance have been found in lenses of finegrained homogeneous sandstone separated by thin beds of mudstone.

The greatest density of uranium deposits is in areas of abrupt changes in dip or in areas where abnormally low dips coincide with favorable lithologic character. Structural terraces are favorable locations, particularly along their margins. The size of the deposits appears related to the magnitude of the structures. Locally, joints and fractures that cut uranium deposits are mineralized.

The association of carbonaceous material and partly oxidized uranium and vanadium minerals in thin sandstones and laminated siltstones suggests that a reducing environment was favorable for the localization and preservation of uranium deposits. Most of the deposits have a halo of purplish-pink iron
}

oxide stain that is used as a guide in prospecting. A spatial relation exists between carbonate-cemented sandstone and uranium minerals in a few deposits.

\section{INTRODUCTION AND ACKNOWLEDGMENTS}

Uranium deposits were discovered in 1951 along the southwest flank of the Black Hills, a small isolated mountain range about 160 miles long and 60 miles wide in western South Dakota and eastern Wyoming. By 1954 uranium ore was being mined from several dozen deposits in a 30 -square-mile area in the southern Black Hills near the town of Edgemont (lat $43^{\circ} 22^{\prime} \mathrm{N}$., long $103^{\circ} 45^{\prime}$ W.).

The deposits are in the nonmarine formations of the Inyan Kara group of Early Cretaceous age. This group of rocks is 500-600 feet thick and in ascending order consists of the Lakota sandstone, the Fuson formation, and the Fall River sandstone. These formations are composed predominantly of sandstone. Locally, however, mudstone or interbedded sandstone and siltstone predominate. The formations are lithologically very similar and therefore difficult to distinguish. The Inyan Kara group is underlain by compact clays and marls of the Morrison formation of Jurassic age and is overlain by the marine Skull Creek shale of Early Cretaceous age.

With the exception of one small occurrence of uraninite, no deposits of unoxidized uranium and 
vanadium minerals are known in the Edgemont mining district. However, the uraninite suggests that it and some low-valence vanadium mineral-deposited, perhaps in Cretaceous or early Tertiary time and subsequently oxidized-were the primary source of the uranium and vanadium in this district.

The Inyan Kara rocks form prominent hogbacks and cuestas around a central elliptical mountainous area of Precambrian igneous and metamorphic rocks and Paleozoic and Mesozoic sandstones, limestones, and shales.

The sedimentary rocks surrounding the Precambrian core have been folded into anticlines and domes and, in places within the uranium-producing areas, are strongly jointed. Few faults have been observed-none with greater than 100 feet of displacement.

Compilation of this report is based on work of the authors and L. R. Page, W. A. Braddock, V. R. Wilmarth, J. D. Ryan, N. P. Cuppels, W. E. Bales, and R. D. Smith, all of the U. S. Geological Survey.

\section{URANIUM DEPOSITS}

Carnotite and its calcium analogue, tyuyamunite, are the most conspicuous and most important ore minerals mined from the deposits in the Inyan Kara group, but corvusite and rauvite are important constituents in some mines. Uraninite, becquerelite, hummerite, autunite, and metahewettite are also present in some deposits but have not been found in ore-grade concentrations. The uranium minerals occur as interstitial and fracture fillings and as coatings on sand grains and joint surfaces. In some deposits they comprise thin irregular concentric bands and halos. The ore forms both conformable tabular masses and irregular pod-shaped bodies that transgress textural boundaries and structures in the host rocks.

The yellow uranium vanadates, carnotite and tyuyamunite, predominate in thick noncarbonaceous sandstone deposits and are locally known as yellow ores. Deposits that contain a high proportion of rauvite and corvusite as compared to carnotite and tyuyamunite are largely restricted to thin sandstones interbedded with highly carbonaceous siltstones and are locally known as black ores. Deposits with a large proportion of black ore are less oxidized than deposits with only yellow ore. In general, the ratio of vanadium to uranium in the black ores is greater than 1.5 and in the yellow ores is less than 1.5.

Iron oxide, iron- and manganese-rich calcium carbonate, and carbon are variously or collectively associated with the uranium deposits. A pink iron oxidestained sandstone forms a halo around many of the deposits. This stain is so persistently associated with the deposits that it serves as a useful guide in prospect- ing. Iron- and manganese-rich calcium carbonate occurs in many sandstones of the Inyan Kara group as nodules, interstitial cement, and fracture fillings. Carnotite and tyuyamunite impregnate the porous sandstone that surrounds the carbonate nodules and occur marginal to carbonate-filled fractures in a few deposits. Carbonaceous material is closely associated with the deposits in the Fall River standstone (area 3, fig. 111). These deposits contain black ore and are less oxidized than the deposits in areas 1 and 2. Carbonaceous material is sparse in the deposits of area 2, in which the yellow uranium vanadates predominate over corvusite and rauvite. The deposits in area 1 are noncarbonaceous, and their ores are completely oxidized.

Evidence exists that both uranium and vanadium have been moved in Recent time by ground water. In some deposits, carnotite and tyuyamunite have moved as much as 20 feet downdip from corvusite and rauvite. In other deposits the yellow uranium vanadates are deficient in radium, indicating that migration of uranium may still be in progress. This probability has been substantiated by the discovery in one of the ore deposits of a musk-ox bone partly impregnated with carnotite. A carbon-14 age determination showed the bone to be 9,700 years old. In another deposit a small amount of radioactive barite coating a joint surface assayed about 7 parts per million radium. Thus, some of the radium has also migrated from the uranium during Recent time. There is less evidence to show recent movement of vanadium, but hewettite has been found at several localities in fractures below deposits containing corvusite, and traces of hummerite occur on the walls of recently opened mines from which high-vanadium black ore was mined.

\section{CONTROLS OF URANIUM DEPOSITION}

Lithologic character and structure have influenced the localization of the uranium deposits. Also, the structural attitude of the host rock and lithologic characteristics such as porosity, permeability, heterogeneous texture, continuity and thickness of the sandstone lenses, scour-and-fill structures, carbonaceous debris, and cementing material are important. Variations in lithologic character and structure probably have significantly influenced the migrant uraniumbearing solutions and played a part in the deposition of uranium minerals. Little is known about these geochemical relations in the Edgemont mining district.

\section{ITTHOLOGIC CONTROLS}

The sandstones in the Inyan Kara group are predominantly quartzose and are cemented by variable quantities of clay, carbonate, iron oxide, and silica. 


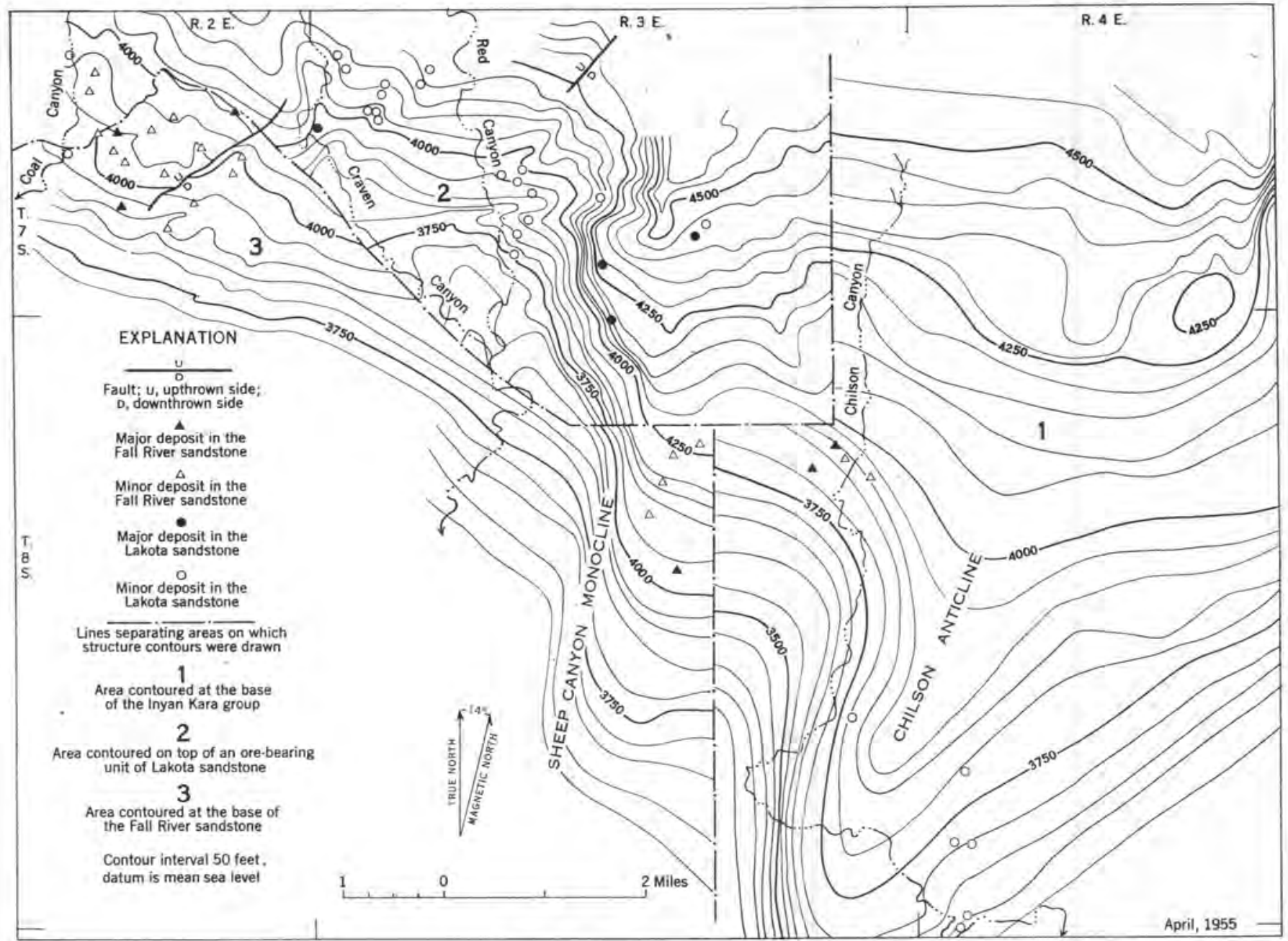

FIGURE 111,-Structure contours and uranfurn deposits, Edgemont mining distriot, Fall River County, 8. Dak,

They are extremely variable in texture, structure, and thickness. White detrital clay fragments, chert, and carbonaceous materials are irregularly distributed but are abundant in certain places. Thin, discontinuous beds of coal occur sporadically. Pyrite is generally rare but is abundant where associated with carbonaceous material. Both iron and carbonate concretions abound locally.

The uranium deposits are restricted to three distinct types of sandstone, each having different physical characteristics. For the purpose of this discussion these sandstones are designated as types A, B, and C, which are respectively the dominant host rocks in parts of areas 1,2, and 3 in figure 111. The relation between these types of sandstone is illustrated in the diagrammatic cross section (fig. 112).

Type A sandstone is characterized by its heterogeneity: it is fine to coarse grained, conglomeratic, noncarbonaceous, poorly sorted, extremely variable in texture, and intricately cross stratified. At certain places it contains a sedimentary breccia in which the matrix is a medium- to coarse-grained sandstone, and the fragments are white siltstone ranging in size from pellets to blocks as large as 2 feet across. The breceia fills small scours within the sandstone. This type of sandstone forms elongate bodies as much as 100 feet thick, 1 mile wide, and at least 3 miles long. In some places the sandstone truncates older rocks of different lithologic characters, but at other places this disconformable relation is not evident. The uranium ore is concentrated mostly in medium-grained sandstone containing clay fragments. The deposits are tabular masses of irregular outline generally parallel to the bedding but may locally cut across bedding and textural changes. The predominant ore minerals are carnotite and tyuyamunite, but corvusite and hewettite occur sparingly. The largest single uranium deposit in the southern Black Hills occurs in this type of sandstone.

Type B sandstone forms units as much as 250 feet thick and several miles wide, but of unknown length. The units are a series of lithologically similar sandstone 


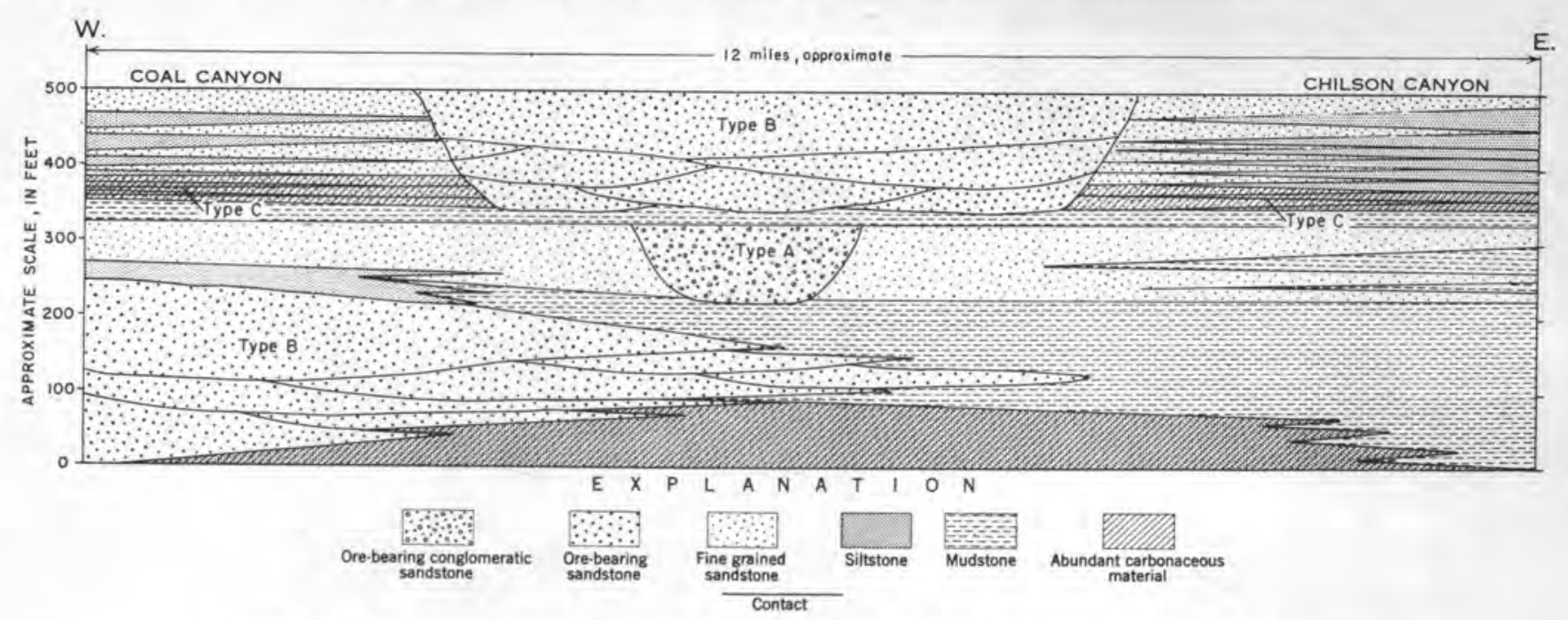

Fioure 112.-Dlagrammatic eross section showing the relation between the types of sandstone in the Inyan Kara group.

lenses that truncate and overlap the underlying lenses. The sandstone appears to grade laterally into a facies of relatively thin sandstones interbedded with mudstones. Type B sandstone is fine to medium grained, homogeneous in texture and structure, and contains scattered pockets and streaks of carbonaceous debris parallel to the bedding. Type B sandstone is best developed in the lower part of the Lakota sandstone in area 2 and in the Fall River sandstone throughout the southeastern part of area 3. Many of the uranium deposits in this type of rock are associated with carbonaceous material, although some have been localized adjacent to fractures. The principal ore minerals are carnotite and tyuyamunite, but minor amounts of the high-vanadium black ores occur in some deposits. The deposits are numerous but with few exceptions small, and their total production has been of minor importance.

Type $\mathrm{C}$ sandstone is part of a 25 -foot-thick sequence of thin well-sorted fine-grained sandstones that alternate with thin-bedded and laminated carbonaceous siltstones. Macerated carbonized plant remains and disseminated crystals and nodules of pyrite are abundant, particularly in the siltstone beds. The uranium deposits are restricted to sandstones generally less than 5 feet thick. Thicker sandstones tend to be barren or to contain only small deposits.

The deposits in type $\mathbf{C}$ sandstone are of a magnitude of 5,000 tons or less. All these deposits contain black ore having a high percentage of corvusite and rauvite and are less oxidized than any of the deposits in the southern Black Hills. A large part of the ore produced in the Edgemont mining district has come from a group of deposits in this type of sandstone. These are the Fall River sandstone deposits in the western part of area 3 (fig. 111).
The ore deposits in sandstone types A, B, and C are restricted to the Fall River and Lakota sandstones. Sandstones in the Fuson formation are mineralized in only a few places, and production from them has been negligible. Barren sandstones in the three formations are of several types. One is a conspicuously white noncarbonaceous fine-grained even-textured structureless sandstone that is generally cemented with clay to such an extent that its permeability appears to have been effectively reduced. Another type of barren sandstone is similar to type $\mathrm{C}$ described above but is interbedded with calcareous or highly argillaceous mudstones rather than with carbonaceous siltstones. Other types include those sandstones in which the permeability has been effectively destroyed by silicification or by carbonate cement.

\section{STRUCTURAL CONTROLS}

The localization and relative size of uranium deposits in the Black Hills appear to be controlled by structures of various sizes.

The Black Hills uplift is an elongate northwestwardtrending dome, the east and west sides of which dip more steeply than the northwest and southeast ends. The known uranium deposits are in the areas of gently dipping rocks at the northwest and southeast ends of the uplift.

Superimposed upon the regional Black Hills uplift are several anticlines, which, as they plunge northward and southward off the dome, interrupt the homoclinal dip of the beds. Figure 111 shows the relation of one of these anticlines and smaller structural features with the ore deposits in the Edgemont mining district. This illustration shows that the west limb of the Chilson anticline is interrupted by a southward plunging structural terrace on which the dip is less 
than $3^{\circ}$. This limb of the Chilson anticline continues west of the terrace as the Sheep Canyon monocline, which dips as much as $20^{\circ} \mathrm{W}$. The largest known deposits and greatest reserves in this district are located on the structural terrace between the monocline and the anticline. In addition to the ore deposits shown on this terrace (fig. 111), there are large lowgrade deposits on the terrace that under present economic conditions cannot be mined without beneficiation. These deposits are several times larger than any ore-grade deposit in the area.

The second most important uranium-producing area within the Edgemont mining district is a group of deposits in the Fall River sandstone between Coal and Craven Canyons in the northwestern part of area 3. These deposits are on another, smaller, structural

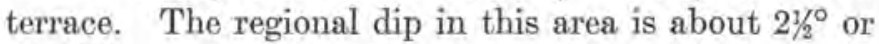
$3^{\circ} \mathrm{SW}$., whereas the dip across the terrace averages about $1 y_{4}^{\circ}$. Detailed strueture-contour maps show that all these deposits occur in the area of abnormally low dip or near the margins of the terrace where the dip steepens appreciably. This group of deposits is restricted to that part of the terrace underlain by the favorable sandstones of type $\mathrm{C}$. The deposits in this area are smaller than those on the terrace between the Chilson anticline and the Sheep Canyon monocline.

The deposits in the Lakota sandstone in area 2 west of the Sheep Canyon monocline are mostly restricted to small terraces and anticlinal noses, although a few do not appear to be related to either type of structural feature. The production from these deposits has been small.

Faults with displacements greater than 100 feet are not known in this area. With the possible exception of the fault between Coal and Craven Canyons in area 3 (fig. 111), faults do not appear to be related in any way to the deposits. In area 3 it is improbable, but not impossible, that the fault rather than the terrace influenced the localization of the deposits.

Some of the deposits have been controlled by fractures. Fractures that cut uranium deposits are commonly filled with uranium minerals. In one of the large deposits on the terrace between the Chilson anticline and the Sheep Canyon monocline, uranium minerals have been traced discontinuously for more than
4,000 feet along a set of closely spaced northwestwardtrending vertical fractures. In another mine in this same area, rich concentrations of yellow uranium minerals and considerable limonite have been found at the intersections of several variously oriented fractures. In still another mine, carnotite is concentrated in bands as much as 2 inches wide along vertical joints in a homogeneous sandstone, and radioactivity anomalies enclosing and parallel to apparently unmineralized joints have been outlined. In a few places, carnotite and tyuyamunite are associated with iron- and manganese-rich carbonate fracture fillings.

\section{CONCLUSIONS}

The uranium deposits in the southern Black Hills are composed of partly oxidized black ores in a highly carbonaceous environment and oxidized yellow ores in a slightly carbonaceous or noncarbonaceous environment. The restriction of the least oxidized ores to carbonaceous rocks probably has resulted from the greater stability of the original minerals in the reducing environment of carbonaceous materials. The yellow ores may have resulted from more complete oxidation because of the absence of organic material in a porous aquifer.

Carnotite and tyuyamunite occur in carbonatecemented sandstone in a few deposits, but generally the uranium is restricted to noncalcareous rocks. It is possible that an environment of carbonate-bearing sandstone inhibits the deposition of uranium except in the transitional zones between carbonate- and noncarbonate-bearing rocks.

The greatest concentration of uranium deposits and the largest deposits in the Edgemont mining district are found where favorable lithologic character and favorable structure are superimposed. The most favorable structures are the large structural terraces. Steeply dipping structures are unfavorable. The size of favorable structures appear to have influenced the size of the deposits; the largest deposit in both homogeneous and heterogeneous sandstone is on a large structural terrace. On the most favorable structures, however, deposits containing black ores tend to be smaller than deposits with only carnotite and tyuyamunite. 



\title{
URANIUM IN GLASTIC ROCKS OF THE BASIN AND RANGE PROVINGE
}

\author{
By Dudley L. Davis and Donald L. Hetrand, U. S. Atomic Energy Commission
}

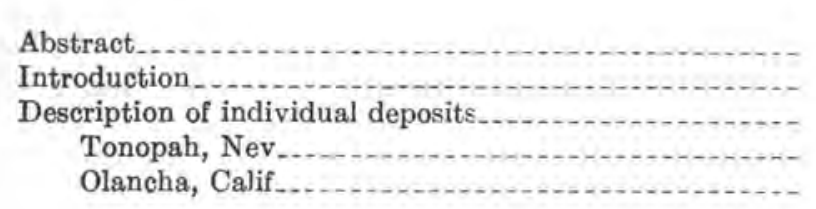

\section{CONTENTS}

\begin{tabular}{|c|c|c|}
\hline Page & & Page \\
\hline 351 & Description of individual deposits-Continued & \\
\hline 351 & Other deposits & 358 \\
\hline 352 & Conclusions....... & 359 \\
\hline 352 & References cited & 359 \\
\hline
\end{tabular}

\section{ILLUSTRATIONS}
FIGURE 113. Index map showing uranium deposits in clastic rocks of the Basin and Range province. 114. Geologic map and section of Olancha area_ 115. Geologic map of Silver Queen group, Ton- opah mining district.

Frgure 116. Isoradioactivity lines of Silver Queen group, Tonopah mining district..........
logic map of uranium deposits in

117. Geologic map of uranium deposits in

\section{ABSTRACT}

Uranium occurs in Tertiary lake sediments and water-laid tuffs at widely separated areas in the Basin and Range province of Nevada and California.

Miocene lake sediments near Tonopah, Nev., are composed chiefly of uniform finely stratified pyroclastic rocks and diatomaceous earth interbedded with discontinuous lenses of collophanite and uraniferous opal. Uranium minerals have not been identified, but anomalous radioactivity can be detected over an area about 1 mile wide and 8 miles long. Trenching and drilling have exposed marginal-grade material to a depth of 40 feet in 1 locality.

Near Olancha, Calif,, gently dipping lakebeds of the Coso formation of Schultz (1937) of Pliocene age contain autunite on fracture surfaces in iron-stained zones. The locality is characterized by extensive faulting and volcanism. Only select samples from this area contained ore-grade material.

Stratified rocks in the Virgin Valley of northwestern Nevada consist of early Pliocene water-laid vitreous tuff and diatomaceous earth which contain discontinuous layers of opal. Small amounts of earnotite occur as fracture coatings or fine layers in the opal lenses, and a yellow fluorescent mineral, possibly schroeckingerite, is disseminated in the volcanic tuff.

A uraniferous deposit in water-laid tuff in Lander County, Nev., occurs in a topographic basin near the head of Dacie Creek that is surrounded by hills of rhyolite, andesite, and basalt. Appreciable radioactivity appears to be confined to minor fractures in the tuffs, although no uranium minerals have been observed.

Near Hawthorne, Nev., carnotite occupies a series of closely spaced vertical fractures in tuffaceous sandstone of the Esmeralda formation. The area is capped by basaltic flows, and a small rhyolite plug is in fault contact with the uranium-bearing sandstone.

Carnotite-type minerals have been found in a thin bed of soft water-laid tuff in the Panaca formation of Pliocene(?) age in Lincoln County, Nev. Minor amounts of carbonaceous material are present, and there is no apparent alteration or silicification of the mineralized stratum.

The uranium minerals in all the deposits generally are not in rudioactive equilibrium, and the uranium content as determined by radiometric analyses is usually lower than by chemical analyses. This would suggest recent formation of the uranium minerals. Structural control is not readily apparent in any of the deposits, but small fractures and faults may have localized mineral concentrations.

\section{INTRODUCTION}

The Basin and Range physiographic province of the United States includes Nevada and parts of Arizona, Utah, and California. It consists of rugged, nearly parallel, northward-trending mountain ranges and broad arid troughs with interior drainage. Elevations range from 4,000 to 14,000 feet above sea level. The valleys are filled with thick accumulations of waterlaid pyroclastic rocks, silts, fanglomerates, and evaporites. Ephemeral saline lakes and playas are found in many of the valleys as a result of interior drainage and arid climate. Gently sloping alluvial fans extend from 
the mouths of canyons toward the low central portions of most of the valleys.

Evidence of alpine glaciation is apparent in the higher mountains, and shorelines of Pleistocene lakes can be observed locally along the foothills. The highly alkaline soil of many of the valleys supports little vegetation other than salt grass and sage, but several types of conifers abound in the mountainous areas. The climate is semiarid to arid; therefore the region is sparsely settled because habitable areas are dependent upon surface-water supplies.

The region was a geosyncline during much of the Paleozoic and Mesozoic eras and great thicknesses of sedimentary rocks accumulated. In Late Jurassic time, the Nevadan orogeny accompanied the uplift of the Sierra Nevada Mountains, which bounds the province on the west. Erosion has exposed the granitic core of this range. During Late Cretaceous and early Tertiary, folding and thrusting of the Laramide orogeny deformed the sediments in a southward-trending zone that extends from Canada to Mexico.

The principal intrusive rocks range from Jurassic(?) to Miocene(?) in age. Younger plutonic rocks are found in the eastern part of the province, whereas those in the west appear to be related to the Sierra Nevada batholith. Extrusive volcanic rocks, varying in composition from rhyolite to basalt, are Tertiary to Recent in age.

High-angle faulting subsequent to the Laramide orogeny determined the present topography of long graben valleys partially filled with alluvial debris from the intervening mountains. Some of the faults are still active, as evidenced by local displacement of alluvial fans along the flanks of some mountain ranges.

Miocene and Pliocene lakebeds and water-laid tuffs containing low-grade uraniferous zones with local concentrations are large areas worthy of investigation which were not previously recognized as potential sources of uranium. The location of several such deposits is shown on figure 113. Figure 114 shows a typical example of the geologic environment for the uranium deposits described.

\section{DESCRIPTION OF INDIVIDUAL DEPOSITS TONOPAH, NEV.}

Geography.-Tonopah, in the southwestern part of the State, is in a region of typically arid desert climate and physiography. Vegetation consists of sparse sage and greasewood, and mean annual precipitation is less than 10 inches. Relief is moderate, with elevations ranging from 5,600 feet in the intermontane valleys to 7,160 feet at the crest of Butler Mountain.

Geology.-The geology of the Tonopah area has been described by Spurr (1905) and Ferguson and

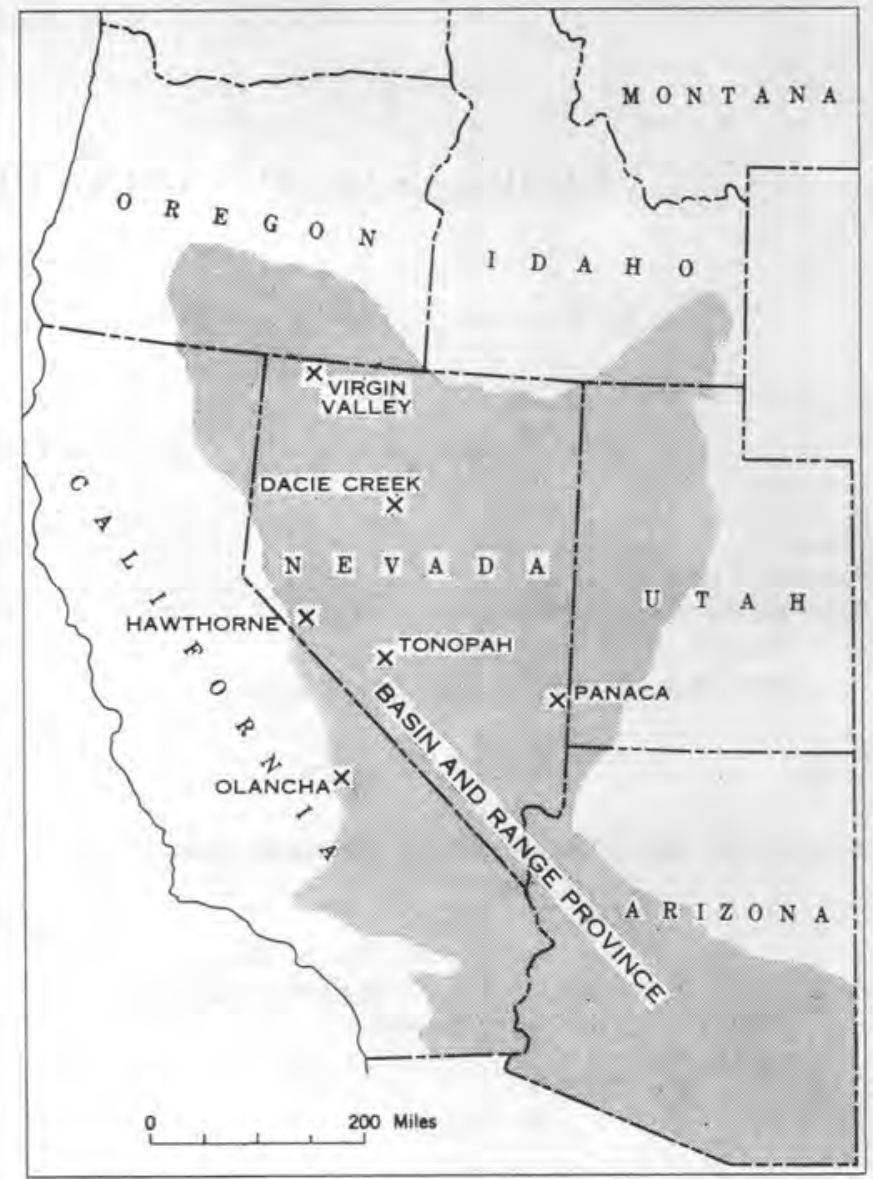

FrgURE 113.-Index map showing uranium deposits in clastic rocks of the Basin and Range area.

Muller (1949). Recently discovered uranium occurrences lie about 3 miles west of the central part of the Tonopah district in the lacustrine Siebert tuff (Miocene) of Spurr (1905). Weak shearing associated with this better uranium area may be the surface expression of northward-trending normal faulting which largely preceded deposition of the Siebert of Spurr (1905). The lacustrine tuffaceous beds, host rock of the uranium, are flat lying and are covered in part by a thin mantle of soil and Recent alluvium. (See fig. 115.)

The Siebert tuff of Spurr (1905) consists of more than 600 feet of uniform finely stratified rhyolitic pyroclastic rocks and diatomaceous-earth lakebeds and are late Miocene in age. They rest unconformably upon older Tertiary lavas and are conformably overlain by andesitic and rhyolitic flows and welded tuffs. To the northwest, Pleistocene basaltic flows overlie these rocks with angular unconformity. The waterlaid tuffaceous host rock for the uranium deposit is interbedded with discontinuous lenses of uraniferous opal and collophanite which are usually less than 1 foot thick. Ferruginous sandstone is exposed near the north end of the radioactive area. The relation 

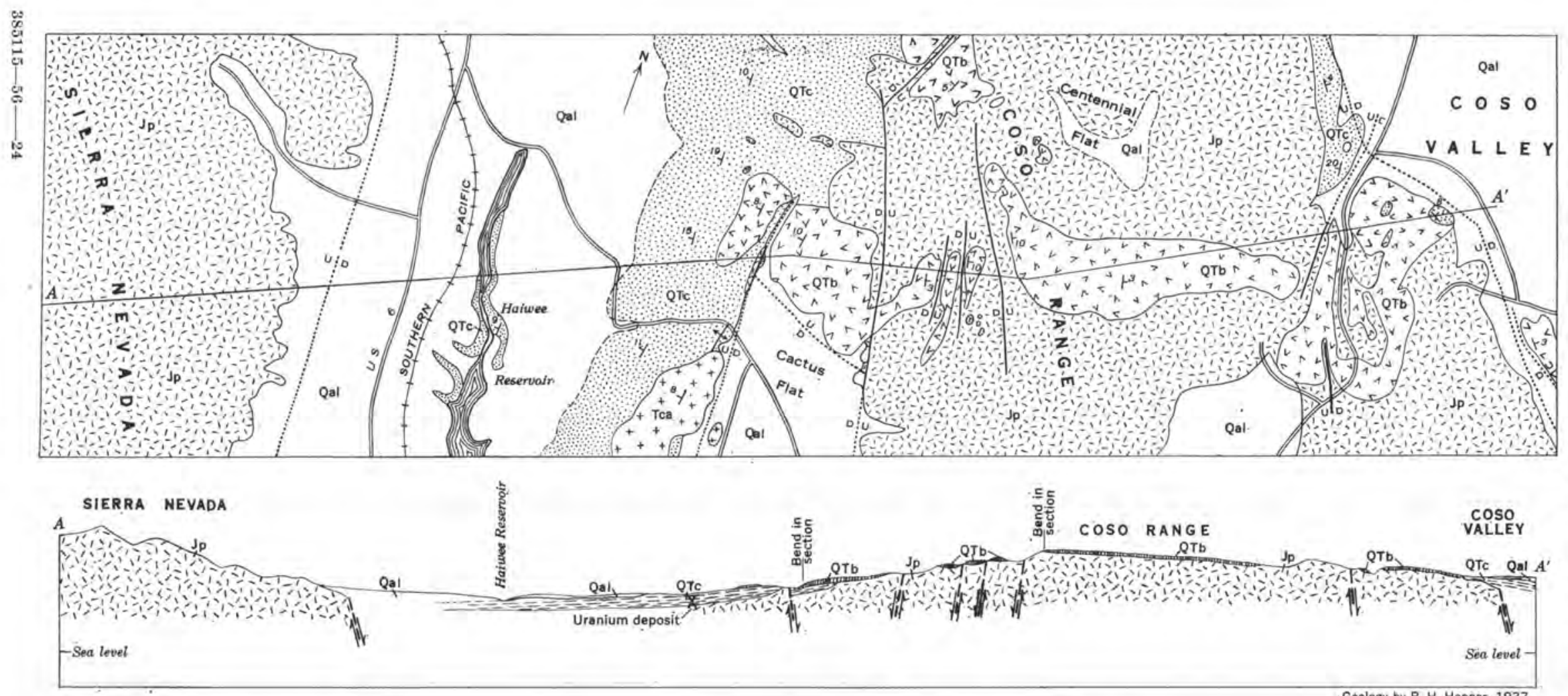

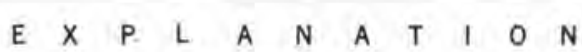

SEDIMENTARY AND METAMORPHIC ROCKS
Map Section
$\begin{gathered}\text { Qal } \\ \text { Younger alluvium and lake deposits }\end{gathered}$
$\begin{gathered}\text { Cormation (fanglomerate } \\ \text { and lake beds) }\end{gathered}$

$$
\begin{gathered}
\text { Map Section } \\
\text { Fault, dotted where concealed; } U \text {, upthrown } \\
\text { side; } 0 \text {, downthrown side } \\
\text { Strike and dip of beds }
\end{gathered}
$$

FiGURE 114.-Geologic map and section of Olancha area, California. (Geology by R. H. Hopper 1937,) 
354

GEOLOGY OF URANIUM AND THORIUM, INTERNATIONAL CONFERENCE, 1955

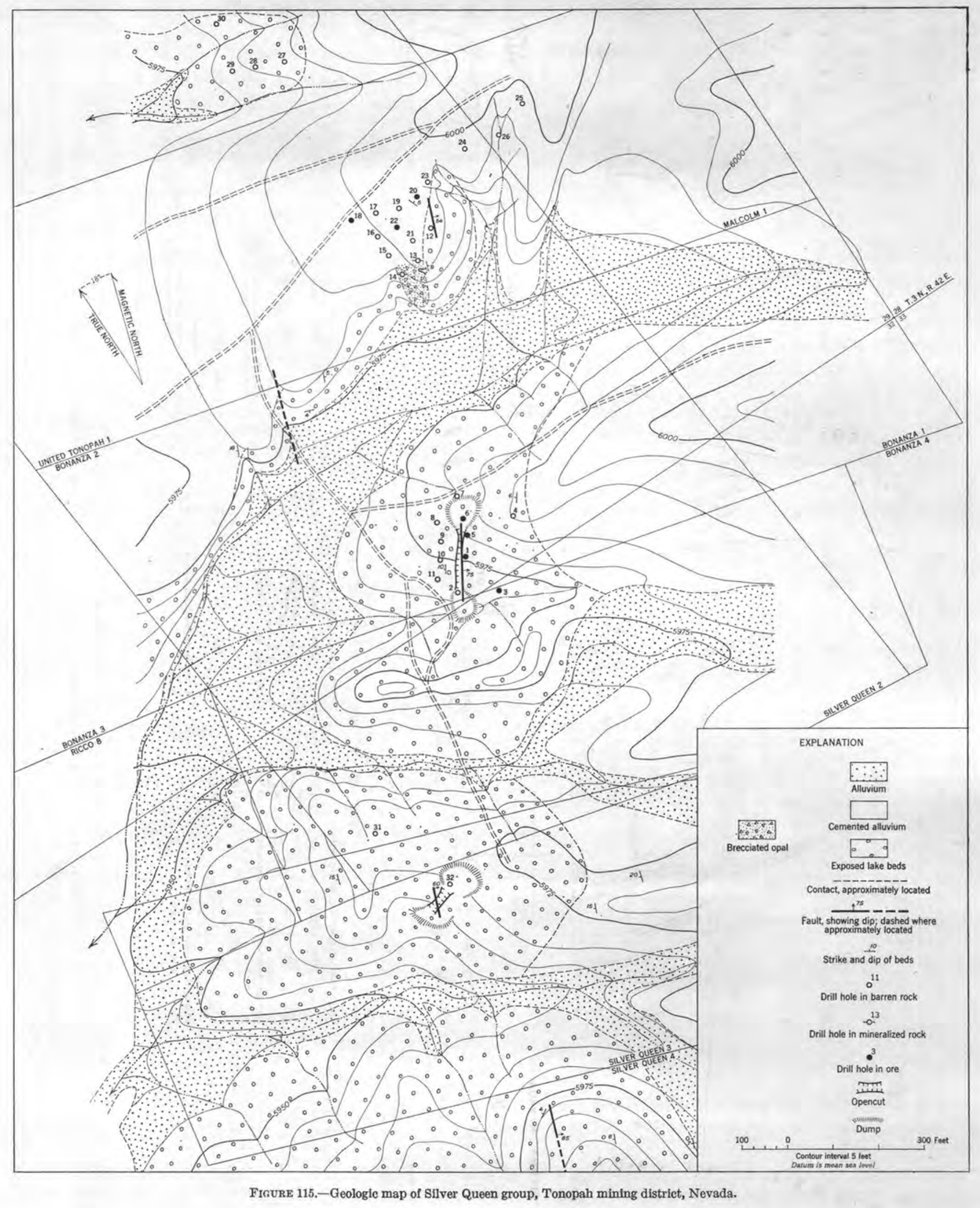


between this rock and the tuff is unknown, but the sandstone may represent shore or delta deposition.

Ore deposit.-Anomalous radioactivity extends over an area about 1 mile wide and 8 miles long and within this area are local concentrations of higher radioactivity. Gamma-ray logging of a few boreboles indicates radioactivity to a depth of 40 feet along northward-trending weak vertical shearing and iron staining. No distinctive uranium minerals have been identified at this locality, although yellow radioactive coatings are found on collophanite and opal. Samples contain as much as 50 percent collophanite intimately mixed with bentonitic clay, and preliminary tests indicate that most of the uranium is contained in the collophanite. No vanadium has been reported.

Evidence exists that the uranium is of hydrothermal origin. It may have been concentrated along the northward-trending shear zone, which shows conspicuous iron staining in contrast to the normally white beds. The geologic map of the Tonopah quadrangle shows that a strong northward-trending fault typical of the Basin and Range province disappears under the Siebert tuff of Spurr (1905) near the north end of the anomalous area (Ferguson and Muller, 1949). Weak northward-trending shearing present in areas of better mineralization may be the surface expression of this fault. Recurrent movement along the fault, subsequent to deposition of the Siebert of Spurr (1905), may have accompanied late Pliocene (or younger) volcanism, and the uranium minerals may have been introduced along the fault zone at that time. If the isoradioactivity map (fig. 116) is superimposed upon the geologic map (fig. 115) the relation of radioactivity to structure is readily apparent.

Another suggestion is that the entire tuffaceous horizon contains small amounts of uranium, which has been leached during normal erosion and reconcentrated in the present mineralized beds. This concept is supported by evidence of widespread anomalous radioactivity and by the possibility of base-exchange adsorption of uranium from ground water by naturally activated bentonitic clays. Recent field study and careful sampling indicate that the uranium is probably of hypogene origin (see figs. 115, 116).

\section{OLANCHA, CALIF.}

Geography.-Olancha is near the south end of Owens Valley, immediately east of the Sierra Nevada. Owens Lake, now partly filled with a thick accumulation of evaporites, sand, and volcanic debris, occupies the central portion of the valley just north of Olancha.

The region is characterized by extremely rugged topography along the east front of the Sierra Nevada, deep valleys partly filled by alluvial fans and voleanic debris, and deeply dissected sedimentary rocks of Paleozoic age which form the Panamint and Argus Ranges to the east. The climate is as varied as the topography. The high Sierras receive heavy snowfall during winter, but annual precipitation in the Panamint Valley, 50 miles to the east, averages less than 5 inches.

General geology.-The older rocks of the Argus and Panamint Ranges were folded, faulted, and intruded in pre-Tertiary time. In the area mapped (fig. 114), structures of Cenozoic age involve Jurassic (?) and Tertiary (Quaternary?) rocks. Block faulting of relatively recent movement uplifted the Coso Range and depressed Owens Valley. Movement after volcanism has displaced the lava sheets as much as 600 feet along the west flank of the range.

The Coso formation of Schultz (1937) is essentially flat lying; minor variations in dip from $10^{\circ}$ to $20^{\circ}$ are due to tilting by the relatively recent faults, Movement along some of these faults has continued to the present time.

Lake sediments and tuffs of the Coso formation of Schultz (1937) in which the uranium minerals occur have been described by Knopf and Kirk (1918). The formation is either late Pliocene or early Pleistocene in age and consists of alluvial gravels, fanglomerates, tuffs, pumice, and lacustrine sediments. It has an exposed thickness of approximately 500 feet in the area mapped, where it rests upon an erosion surface cut in the granitic rocks of the Coso Range and is conformably overlain by basaltic lava flows. The basal 300 feet consists of reddish arkose, sandstone, and gravel derived from granite in the Coso Range. Above these, about 200 feet of well-stratified thin-bedded white and light-buff lakebeds are interbedded with white rhyolitic tuff, pumice, and green clay beds. The volcanic material is well sorted and was probably laid down in a lake. Fish bones have been found in the lake sediments. East of the uranium deposits in beds of the Coso formation of Schultz (1937), basalt flows rest directly upon Late Jurassic(?) granite of the Coso Range. These ore-bearing beds may abut the Quaternary fault zone which bounds the east front of the Sierra Nevada, but Recent alluvium covers this contact.

Ore deposits.-Uranium minerals occur in green bentonitic clay beds in the tuffaceous horizon of the Coso formation of Schultz (1937). Three zones of caliche, separated by a sequence of lake sediments and tuffaceous beds, lie above the ore-bearing beds (fig. 117). These zones range in thickness from 2 to 6 feet and consist of well-indurated coarse angular grains of arkose cemented by caliche. The uranium-bearing strata usually occur 30-40 feet below the lowest caliche zone. 


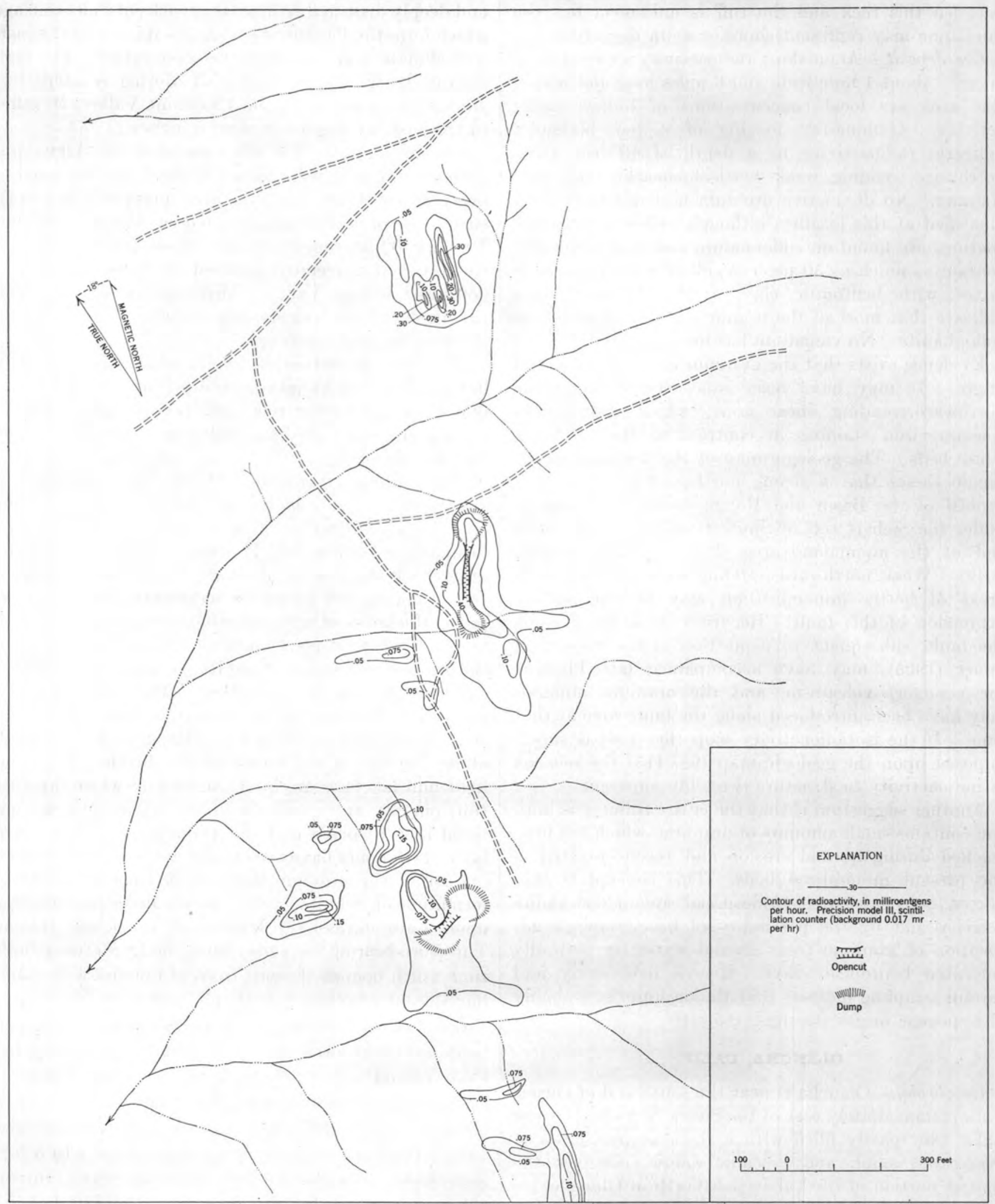

FIOURE 116.-Isoradioactivity lines of Silver Queen group, Tonopah mining district, Nevada. 


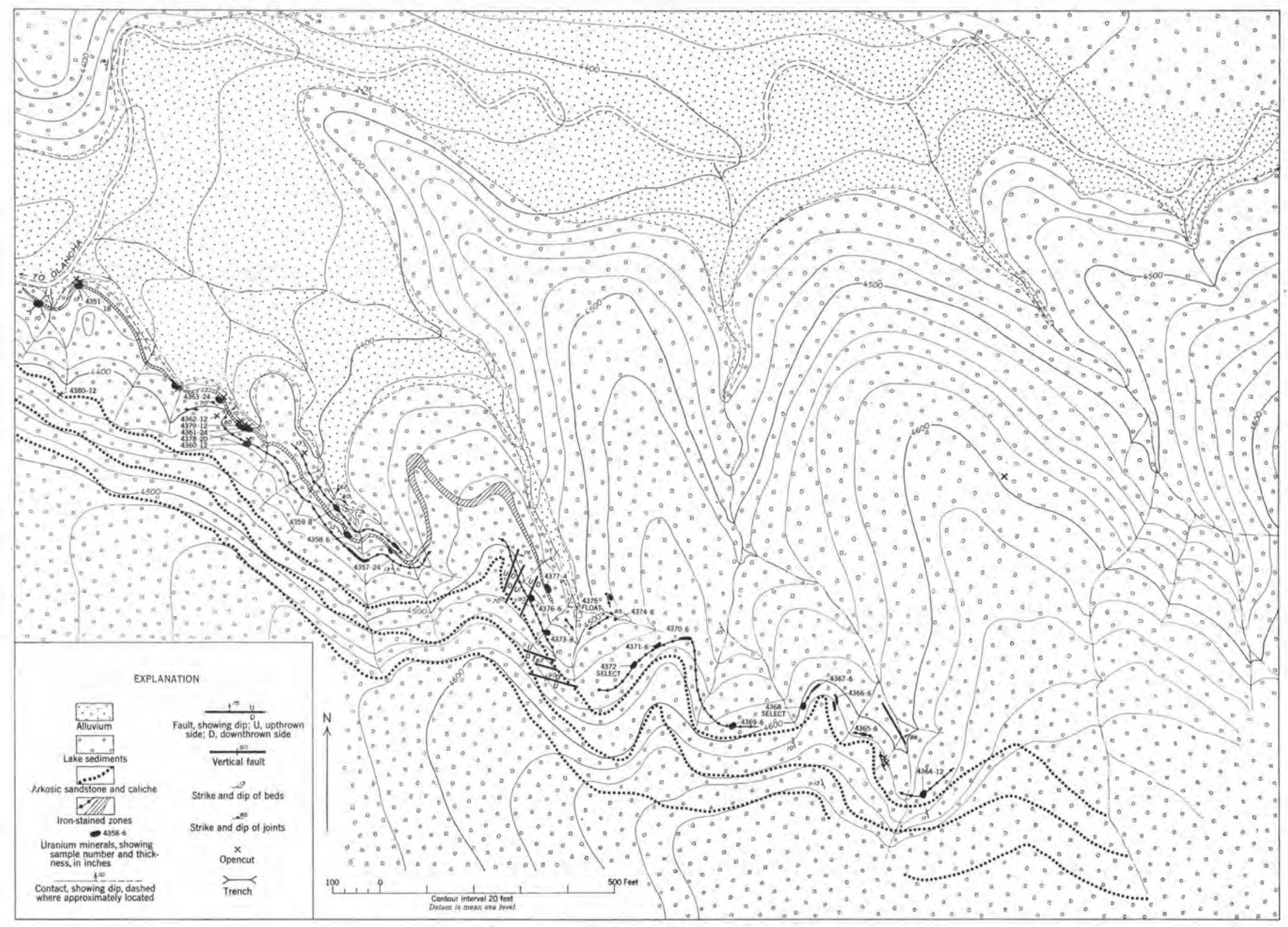


Three persistent radioactive horizons 8-24 inches thick are found in a 20 -foot zone which crops out for 2,000 feet along the south side of an eastward-trending canyon which has been eut in the soft tuffs. All 3 of the radioactive layers are within, or contiguous to, prominent bands of iron oxide staining which range from 1 to 4 feet in width.

Radioactive minerals are autunite and uraniferous opal which fill tiny fracture planes in bentonitic clay beds and fine sandstone. Some layers of strongly radioactive sandstone show no discrete uranium minerals. No channeling or carbonaceous trash was observed. About 1 mile north of the uranium deposit anomalous radioactivity indicates the presence of uranium in the bentonitic beds that have been mined for clay. A pumice deposit about 1 mile south of the uranium locality exhibits weak radioactivity. Jurassic(?) granite which crops out $2 \frac{1}{2}$ miles to the east is not abnormally radioactive nor are the basal arkosic sandstones of the Coso formation of Schultz (1937).

The uranium may have been deposited syngenetically with the tuffaceous material and later leached by ground water and reprecipitated in the bentonitic clay beds. Evidence supporting this concept is the lateral extent of the radioactive outcrop and the uniform mineralization of thin clayey beds. The presence of the caliche-cemented arkosic beds above the ore zone, however, would hinder downward migration of vadose water. Absence of carbonaceous plant debris suggests that the bentonite has an adsorptive effect.

It is also possible that the deposit is of hypogene origin. Hydrothermal solutions rising along fault zones exposed east of the deposit may have been trapped by the clayey horizon, with resultant deposition of uranium minerals. Pyrite, presumed to have been deposited with the uranium, may have oxidized to form the iron-stained bands which now accompany the more intense radioactivity. This theory of origin is supported by the recent discovery of uraninite veins cutting granite at a deposit approximately 2 miles south of the area described.

\section{OTHER DEPOSITS}

Virgin Valley, Nev.-A uranium occurrence in the Virgin Valley of northwestern Nevada (E. E. Thurlow, written communication) is similar to those discussed above.

Rocks of the area consist of early Pliocene water-laid vitreous tuff and diatomaceous-eartb beds, capped locally by basalt flows and lake-terrace gravels. Silicified rbyolite dikes have intruded the tuff series. The tuff and diatomaceous earth beds contain numerous discontinuous lenses of opal.

Uranium minerals are carnotite and a fluorescent yellow mineral believed to be schroeckingerite. Carnotite occurs principally as fracture coatings in the opal, and schroeckingerite(?) is disseminated in the diatomite and tuff.

Dacie Creek, Nev.-The Dacie Creek area is situated in northwestern Lander County, Nev. The deposit occurs in a topographic basin near the source of Dacie Creek which is surrounded by mountains of rhyolite and andesite capped by basalt flows. The host rock is thinbedded water-laid tuff overlain by rhyolite. Thin lenses of opal conform with the bedding of the tuff.

Uranium minerals have not been identified. Both rhyolite and tuff show anomalous radioactivity, with the highest anomalies confined to minor fractures in the tuffs. The bedding is nearly horizontal with many small fractures throughout, but no major faults have been mapped in the immediate area.

Hawthorne, Nev.-This deposit is in the Garfield Hills about 10 miles southeast of Hawthorne. The host is a medium- to fine-grained tuffaceous sandstone, a member of the Esmeralda formation of Tertiary age. The area is capped by andesite and basaltic flows. What appears to be a small rhyolite plug is in fault contact with the uranium-bearing sandstone northwest of the deposit.

Carnotite is concentrated along closely spaced vertical fractures exposed by a cut approximately 200 feet long. Many pebbles and boulders in Recent alluvium are coated with yellow secondary uranium minerals.

Panaca, Nev.-Carnotite(?) occurs in a thin bed of soft water-laid tuff in the Panaca formation of Pliocene(?) age in Lincoln County, Nev. This formation consists of stratified water-laid tuffs that range in grain size from silt to medium-grained sand. Occasional thin layers of coarser material are found near the contact with underlying sedimentary rocks of Cambrian age or earlier volcanic rocks of Tertiary age. The beds are essentially flat lying, but near the contacts with older rocks they may dip as much as $4^{\circ}$ toward the center of the valley. No post-Panaca deformation was observed.

The formation has been assigned to the Pliocene on the basis of mammalian fossils, but it may actually belong in late Pliocene or early Pleistocene, as deposition followed a period of mid-Pliocene orogeny $(\mathrm{H} . \mathrm{E}$. Wheeler, oral communication).

The bed in which the uranium occurs is a thinly laminated very fine-grained tuff containing minor amounts of carbonaceous material. The horizon has been exposed for 200 feet and ranges from 6 inches to 2 feet in thickness. Although there is no apparent alteration or silicification of this bed, occasional lenses of opal occur stratigraphically above it. 


\section{CONCLUSIONS}

Lake sediments and associated water-laid tuffs of Miocene and Pliocene age which contain uranium are large areas worthy of further investigation.

Carnotite, tyuyamunite, and schroeckingerite(?) as well as uraniferous opal and collophanite are locally concentrated in these deposits; in some, no uranium minerals have been identified. The uranium minerals in all the deposits described generally are not in radioactive equilibrium, and the uranium content as determined by radiometric assays is usually lower than by chemical analyses. This would suggest recent formation of the uranium minerals.

Structural control is not readily apparent in any of the deposits, but small fractures and faults may have localized mineral concentrations.

\section{REFERENCES CITED}

Ferguson, H. G., and Muller, S. W., 1949, Structural geology of the Hawthorne and Tonopah quadrangles, Nev.: U. S. Geol. Survey Prof. Paper 216, 55 p. [1950].

Hopper, R. H., 1947, Geologic section from the Sierra Nevada to Death Valley, Calif.: Geol. Soc. Amer. Bull. 58, p. 393-432.

Knopf, Adolph, and Kirk, Edwin, 1918, A geologic reconnaissance of the Inyo Range and the eastern slope of the southern Sierra Nevada, Calif.: U. S. Geol. Survey Prof. Paper 110, $130 \mathrm{p}$.

Schultz, J. R., 1937, A late Cenozoic vertebrate fauna from the Coso Mountains, Inyo Canyon, Calif.: Carnegie Inst. of Wash. Pub. 487 , pt. 3, p. 75-109.

Spurr, J. E. 1905, Geology of the Tonopah mining district, Nevada: U. S. Geol. Survey Prof. Paper 42, 295 p. 


\title{
URANIUM DEPOSITS IN TERTIARY SEDIMENTARY ROCKS IN WYOMING AND NORTHERN COLORADO
}

\author{
By Eugene W. Grutr, Jr., U. S. Atomic Energy Commission
}

\section{CONTENTS}

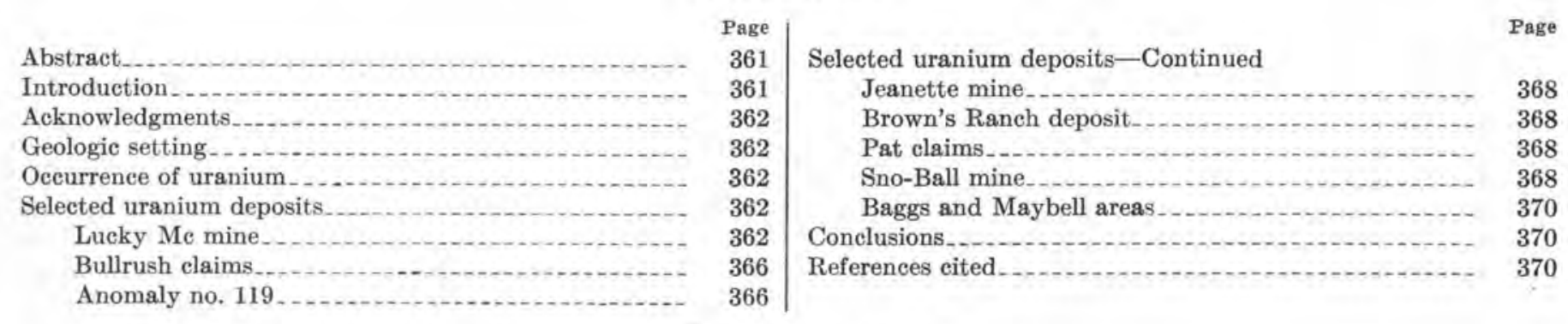

\section{ILLUSTRATIONS}

FIGURE 118. A generalized stratigraphic chart of Wyoming

119. Map showing ore-bearing areas of Wyoming-

120. Index map to localities.

121. Vertical section through an ore bench, Lucky Mc mine, sec. 23, T. 33 N., R. 90 W., Fremont County, Wyo., showing distribution of uraninite and liebigite...

122. Cross section through Bullrush prospect, sec. 29, T. 33 N., R. 90 W., Fremont County, Wyo
Page

363

364

365

366

367

Figure 123. Vertical section through pit, Anomaly 119, sec. 11, T. 45 N., R. 75 W., Campbell County, Wyo ....................

124. Vertical seetion through uranium ore bodies, Pat claim, sec. 3, T. 37 N., R. 73 W., Converse County, Wyo ............

125. Vertical section, generalized, through outcrops on Sno-Ball claim, sec. 28 , T. 28 N., R. 92 W., Fremont County, Wyo_..

Page

\section{ABSTRACT}

The discovery of carnotite ores in sandstone strata of the Wasatch formation (Eocene) in the Powder River Basin of Wyoming in 1951 was the forerunner of other uranium discoveries in widely separated parts of Wyoming and in adjacent Moffat County, Colo.

The deposits all have similar geologic environments in sedimentary bost rocks of Eocene, Oligocene, or Miocene age. Most deposits occur in medium- to coarse-grained or conglomeratic sandstones of fluviatile origin. Torrential crossbedding is a common feature of these sandstones, and they characteristically contain carbonaceous material and calcareous, ferruginous, or phosphatic cement.

The character of ore mineralogy in different areas suggests the probability of mineral provinces. Uranium vanadates are abundant in the Powder River Basin; phosphates and arsenates are the common minerals in the Wind River Basin; and silicates and sulfates are plentiful in the Green Mountains, Great Divide Basin and Washakie basin. The presence of uraninite has been established in the Wind River Basin, Powder River Basin, Green Mountains, and the Washakie basin.
Stratigraphic and lithologic ore controls are important in all districts, and evidence indicates that structural features play an important though often obscure role. Fractures have been mapped as an ore control at several deposits. The size and shape of individual deposits differs greatly within the same area. The deposits containing uranium minerals disseminated in sandstone strata as grain coatings and interstitial fillings seem to be the best.

\section{INTRODUCTION}

Discoveries of uranium in clastic sediments of Tertiary age in Wyoming were made.in the Red Desert of the Great Divide Basin in 1936 by the recognition of schroeckingerite in shales of the Wasatch formation (Eocene) and in 1951 by identification of carnotite in sandstone beds of the Wasatch formation in the Pumpkin Buttes area, Powder River Basin (fig. 118). Ores containing carnotite were discovered in clastic sediments of the Inyan Kara group (Cretaceous) in the Black Hills of South Dakota and Wyoming in 1951. 
These deposits occur in outwardly dipping strata that flank the southern and western parts of the Black Hills uplift. In September 1953, uranium phosphates were discovered in the Wind River formation (Eocene), in south-central Wind River Basin. Subsequent prospecting uncovered deposits in widely separated parts of Wyoming, northern Colorado, and southeastern Montana.

\section{ACKNOWLEDGMENTS}

The author is indebted to his colleagues for much of the field data presented herein, and to the many friendly mine owners. Dr. John Gruner supplied much of the mineralogical data.

\section{GEOLOGIC SETTING}

The area is characterized by rugged mountains with Precambrian granite cores, flanked by strata of Paleozoic and Mesozoic age, which dip beneath Tertiary formations in intermontane basins. Much of the present relief is due to Tertiary faulting, commonly localized near the margins of basins.

Sedimentary rocks in the uranium-bearing areas range in age from Cambrian to Pliocene, with only the Silurian period not represented (fig. 118). Thickness and character of individual formations differs laterally, and in general the sedimentary units are thickest in the western part of Wyoming. All rocks of the Paleozoic and Mesozoic eras, through the Sundance formation of Late Jurassic age, were deposited in epicontinental seas. The Morrison formation of Late Jurassic age is of fluviatile origin, and in general the Cretaceous strata are of brackish-water or marine origin. Sedimentary rocks of Tertiary age are fluvial, derived from erosion of local highlands and deposited as valley fill. Formations of Eocene, Oligocene, and Miocene age, the most frequent hosts for uranium, are composed of shales, siltstones and fine- to very coarsegrained arkosic sandstones and conglomerates. The widespread occurrence of permeable arkosic sandstones in these formations contributed to deposition of uranium. Widespread lignite beds are present in sedimentary rocks of Paleocene and Eocene age. Rocks of Oligocene, Miocene, and Pliocene age, in addition, commonly contain large quantities of tuffaceous material and other volcanic debris.

Stratigraphic correlation is difficult within Tertiary formations, as few strata are continuous over large areas. As a rule, strata are nearly horizontal or gently dipping, except in areas of faulting or folding, where steep dips have been measured.

\section{OCCURRENCE OF URANIUM}

Uranium occurs in clastic sedimentary rocks of Tertiary age in widely scattered localities in eastern and middle Wyoming, in southeastern Montana, and in a small part of northern Colorado. Ore in more than 5 -ton test lots has been produced from over 50 individual properties, and a number have produced more than 1,000 tons.

Most of the uranium produced has been from deposits detected by abnormally high surface radioactivity in sandstones of the Wind River, Wasatch, and Browns Park formations. Although sandstone is the usual host rock, uranium has been found in granite, schist, shale, mudstone, lignite, and limestone. Stratigraphic and lithologic features have been major controls of mineralization, but both regional and local structural features are also important.

Definable mineral provinces in Wyoming are shown on figure 119 where mineral types are arranged in approximate order of importance under each listed area. Recent discoveries of uraninite in the Wind River Basin, Powder River Basin, Washakie basin, and the Green Mountains indicate that much of the nearsurface secondary ore came from oxidation of uraninite or coffinite.

\section{SELECTED URANIUM DEPOSITS}

\section{LUCKY MC MINE}

The Lucky Me mine is near the southwest limb of the dissected Gas Hills anticline, Fremont County, Wyo., 50 miles east of Riverton, Wyo. (fig. 120). In this area the Wind River formation was deposited unconformably on an irregular surface eroded on sedimentary rocks of Mesozoic age. Formations exposed on the flanks of the Gas Hills anticline range from the Chugwater formation (Triassic) to the Frontier formation (Cretaceous age). Sedimentary rocks ranging from Eocene to Miocene in age are exposed on the Beaver Rim escarpment several miles to the south. This southward receding escarpment, the southern margin of the Wind River Basin, has a relief of 500-1,000 feet.

The Lucky Mc mine is in the upper part of the Wind River formation, host for most deposits in the area. This formation, which dips gently to the south in this area, ranges from a knife edge to slightly more than 500 feet. Claystones, siltstones, and thin redbeds predominate in the lower part of the Wind River formation, but crossbedded very coarse-grained arkosic sandstones, conglomerates, and thin mudstones make up the thicker upper part.

The host rocks are friable coarse-grained gray and brown arkosic sandstones and conglomerates interbedded with thin gray and brown lenses of carbonaceous shale and mudstone. The lenticular nature of beds and torrential crossbedding are consistent features, indicating deposition in turbulent streams. Some car- 
URANIUM DEPOSITS IN TERTIARY SEDIMENTARY ROCKS IN WYOMING AND NORTHERN COLORAD

\begin{tabular}{|c|c|c|c|}
\hline \multicolumn{2}{|r|}{ SYSTEM } & FORMATION & CHARACTER \\
\hline \multirow{6}{*}{ 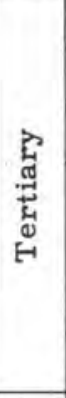 } & Pliocene(?) & North Park formation & Tuff, sandstone, and bentonitic claystone \\
\hline & Miocene(?) & Browns Park formation & Sandstone, tuffaceous, conglomerate, and marl \\
\hline & Oligocene & White River formation & Claystone, tuffaceous, and arkosic conglomerate \\
\hline & \multirow{2}{*}{ Eocene } & Green River formation & Shale, marlstone, and sandstone \\
\hline & & $\begin{array}{l}\text { Wasatch and Wind River } \\
\text { formations }\end{array}$ & Sandstone, shale, claystone, and conglomerate \\
\hline & Paleocene & Fort Union formation & Sandstone, shale, and coals \\
\hline \multirow{8}{*}{ 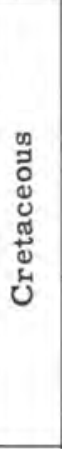 } & \multirow{5}{*}{ Upper } & Lance formation & Sandstone, shale, and coals \\
\hline & & Lewis shale & Shale, gray, and lenticular sandstone \\
\hline & & Mesaverde formation & Sandstone, shale, and coals \\
\hline & & Cody shale & Shale, gray, and lenticular sandstone \\
\hline & & Frontier formation & Shale and sandstone \\
\hline & & Mowry shale & Shale and some bentonite beds \\
\hline & Lower & Thermopolis shale & Shale, black, and some sandstone \\
\hline & & Cloverly formation & Sandstone, conglomerate, and bentonitic claystone \\
\hline & Unper & Morrison formation & Claystone, siliceous, and silty sandstone \\
\hline 离 & & Sundance formation & Sandstone, glauconitic, and shale \\
\hline 3 & Middle & Gypsum Springs formation & Siltstone, gypsum, and anhydrite \\
\hline & Lower & Nugget sandstone & Sandstone, massive, bedded \\
\hline & Triassic & Chugwater formation & Shale, red, siltstone, and gypsum beds \\
\hline & & Dinwoody formation & Siltstone, dolomitic, shale, and sandstone \\
\hline & Permian & Phosphoria formation & Dolomite, phosphatic, and mudstones \\
\hline 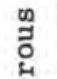 & Pennsylvanian & Tensleep sandstone & Sandstone, limestone, and chert \\
\hline 芩 & \begin{tabular}{|l|} 
Pennsylvanian, \\
Mississippian \\
\end{tabular} & Amsden formation & Shale, limestone, and some sandstone \\
\hline Uึ & Mississippian & Madison limestone & Limestone, massive, bedded \\
\hline & Devonian & Darby formation & Dolomite and shales \\
\hline & Silurian & (Missing) & \\
\hline & Ordovician & Bighorn dolomite & Dolomite, massive \\
\hline & & Gallatin limestone & Limestone, shaly, and limestone \\
\hline & Cambrian & Gros Ventre formation & Shale, fissile, and some limestone \\
\hline & & Flathead quartzite & Sandstone, conglomeratic \\
\hline & Precambrian & Unnamed & Granite and schist \\
\hline
\end{tabular}

FInURE 118.-A generalized stratigraphic chart of Wyoming. 


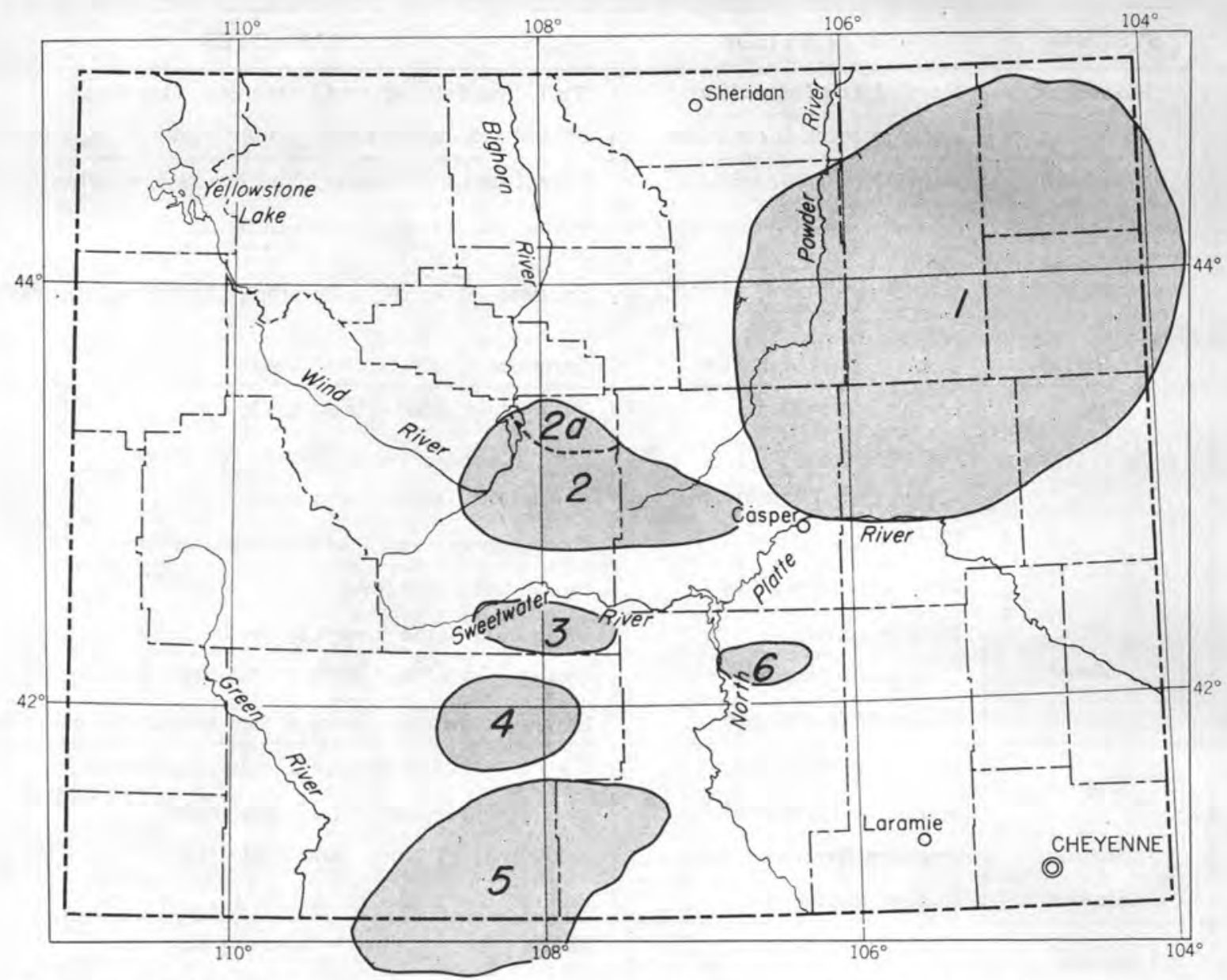

FIGURE 119.-Map showing ore-bearing areas of Wyoming. Mineral groups characteristic of each are listed in order of decreasing abundance in the ore.

1. Powder River Basin and Black Hills: vanadates, silicates, oxides.

2. Wind River Basin: phosphate, oxide, arsenate, fluor-phosphate, earbonate, $2 a$, Owl Creek Mountains: silicate, phosphate, sulfate.

3. Green Mountains: silicate, phosphate, oxide.

4. Great Divide Basin: sulfate.

5. Washakie basin and surrounding area: silicate, phosphate, sulfate, oxide.

6. Shirley Mountains: vanadates.

bonaceous fossil plant remains are disseminated in the sandstone, which is cemented with ferruginous, argillaceous, calcareous, or phosphatic materials.

Open pit mining has exposed shallow irregular southward-dipping ore bodies which differ greatly in size and shape. The closely spaced bodies, which together form the deposit, typically follow bedding and sedimentary structural features but locally transect such features in later fractures or faults.

The dark primary ores usually occur as ellipsoidal deposits within the main body of mineral concentration. These ore lenses, which are up to several feet thick and as much as 15 feet wide, characteristically pinch and swell. Uranium seems to be most concentrated in places of greatest fracture density and in the lenses of coarse-grained sandstone that were the most permeable. A set of vertical fractures which strike N. $70^{\circ} \mathrm{W}$. to N. $35^{\circ} \mathrm{E}$. are prominent and appear to have been important in localizing ore (J. P. Hadfield, Jr., 1955, oral communication).

The primary ore minerals uraninite and coffinite are disseminated in microscopic particles in dark very coarse-grained angular arkosic sandstone cemented by gypsum and calcium carbonate. Waxy gray-green uraniferous carbonate-fluorapatite, found as cement and in fracture fillings, may also be primary. The ore contains large amounts of finely divided pyrite which imparts the dark coloration. Liebigite, a light-green secondary uranium carbonate, commonly occurs on fracture faces and fills seams in the richest primary ore. Many secondary minerals found in this deposit, in addition to liebigite, are meta-autunite, yellow uranium phosphate (unidentified), phosphuranylite, sabugalite, rutherfordene, metazeunerite, metatorbernite, and uran- 


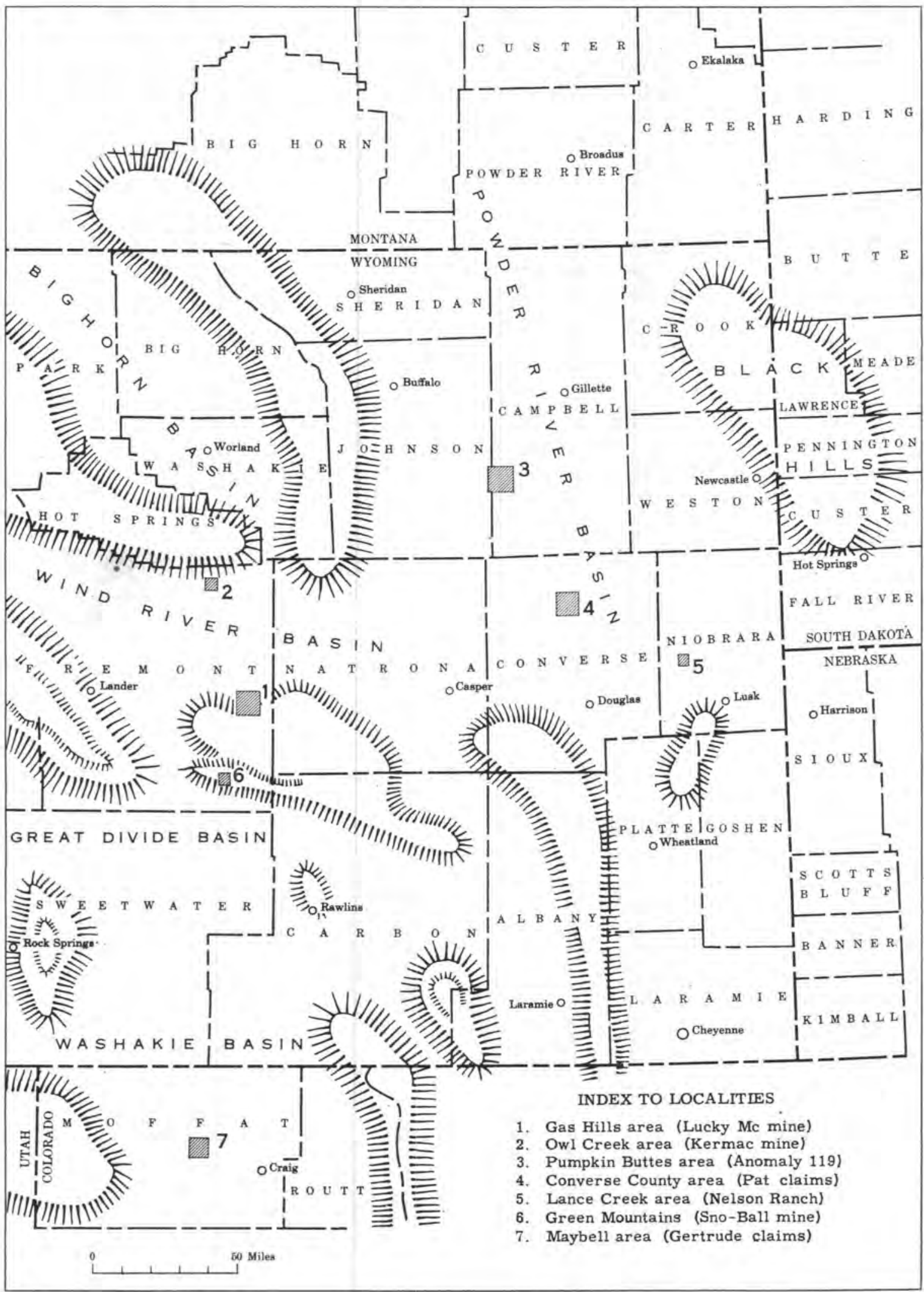

Figure 120.--Index map to localities. 
ophane (John Gruner, 1954, written communication; Coleman, 1954).

Secondary uranium minerals surround the primary ores as halos or are irregularly disseminated throughout the oxidized sandstone strata in pockets, bands, or "rolls." The deposit as exposed is a partially oxidized ore body containing unoxidized remnants of original ore (fig. 121).

Limonite, jarosite, pyrite, and gypsum are common associated minerals. Native selenium has been identified in minute particles, and an unknown selenite or selenate mineral occurs in reddish streaks (John Gruner and Robert Coleman, 1954, written communication). The presence of molybdenum is revealed by conspicious bluish coatings of illsemanite on mine walls as a result of oxidation. A large halo of bleached and ferruginous yellow- to orange-stained sandstone laterally surrounds the entire deposit. This alteration is probably a secondary effect of oxidation of pyrite. Oxidized ores commonly show equivalent uranium to be higher than uranium determined chemically, whereas primary or partly unoxidized ores tend to have higher chemical assays than radiometric assays (Grutt and others, 1954).

The small amount of carbonaceous material present is not enough to constitute a control on uranium deposition. Many recognizable fragments of carbonaceous material contain no uranium. Higher than normal content of calcium carbonate in the sandstone cement may be an important factor in the precipitation of uranium, and proximity to an underlying unconformity and impervious shales capable of regulating solution flow may also have been important.

\section{BULLRUSH CLAIMS}

The Bullrush claims, situated in the Gas Hills area in sec. 29 , T. 33 N., R. 90 W., contain uranium in a geologic environment similar to that of the Lucky Mc mine (fig. 120). Uranium occurs in several gently dipping blanketlike zones, conformable with bedding, in coarse-grained arkosic sandstones of the upper Wind River formation. The near-surface mineral concentration, as shown by preliminary exploitation, consists of autunite, meta-autunite, and uranophane. The lowest ore deposit (fig. 122) is unoxidized, as determined by drilling. This dark-gray ore contains pyrite but the primary uranium minerals have not been determined.

\section{ANOMALY NO. 119}

Anomaly no. 119 mine is northeast of the Pumpkia Buttes in sec. 11, T. 45 N., R. 75 W., Campbell County, Wyo. (fig. 120). The immediate region, near the synclinal axis of the Powder River Basin, is rolling,

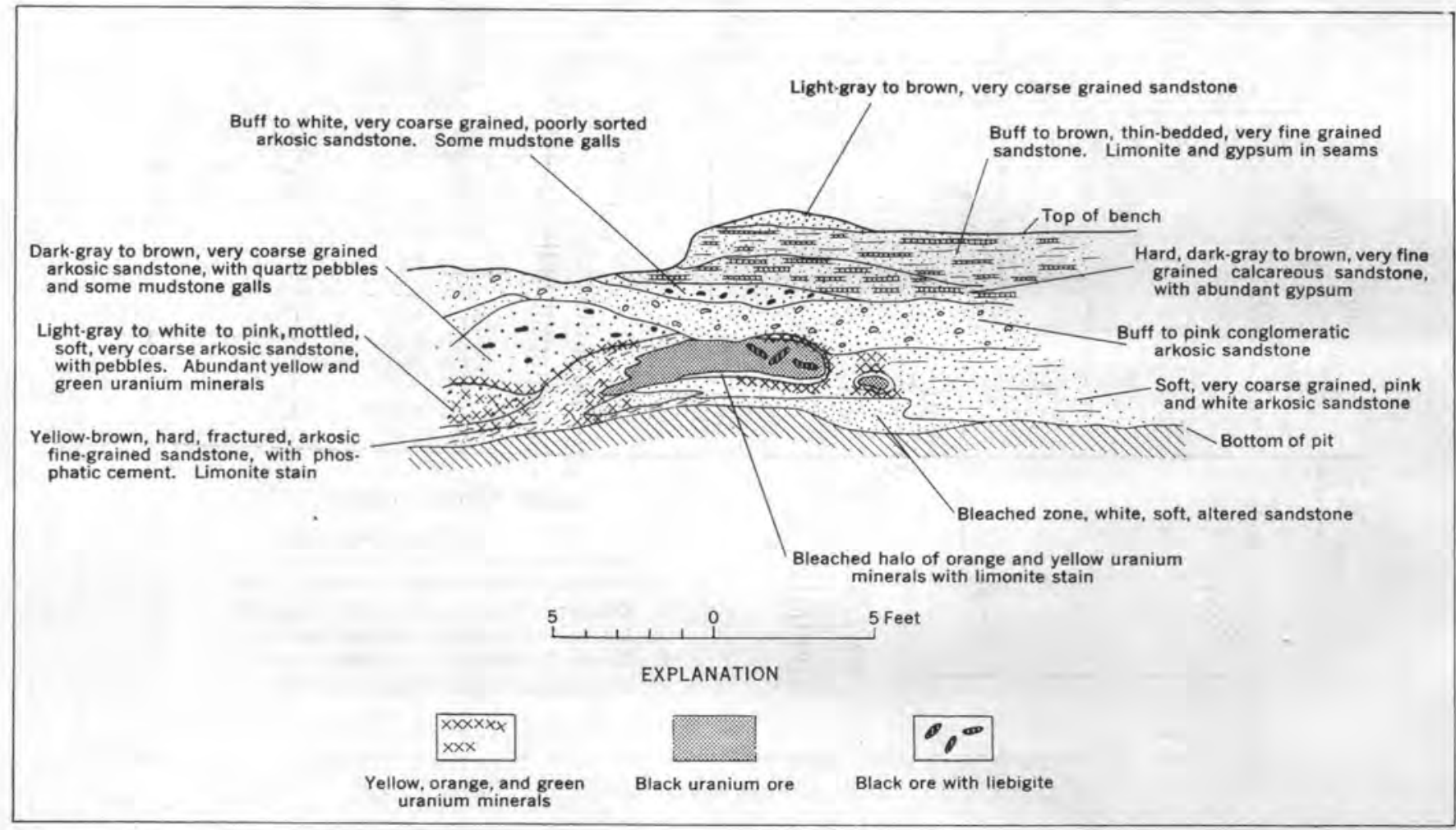

FiauRz 121.-Vertical seetion through an ore bench, Lucky Mc mine, sec. 23, T. 33 N., R. 90 W., Fremont County, Wyo., showing distribution of uraninite and liebigite. 


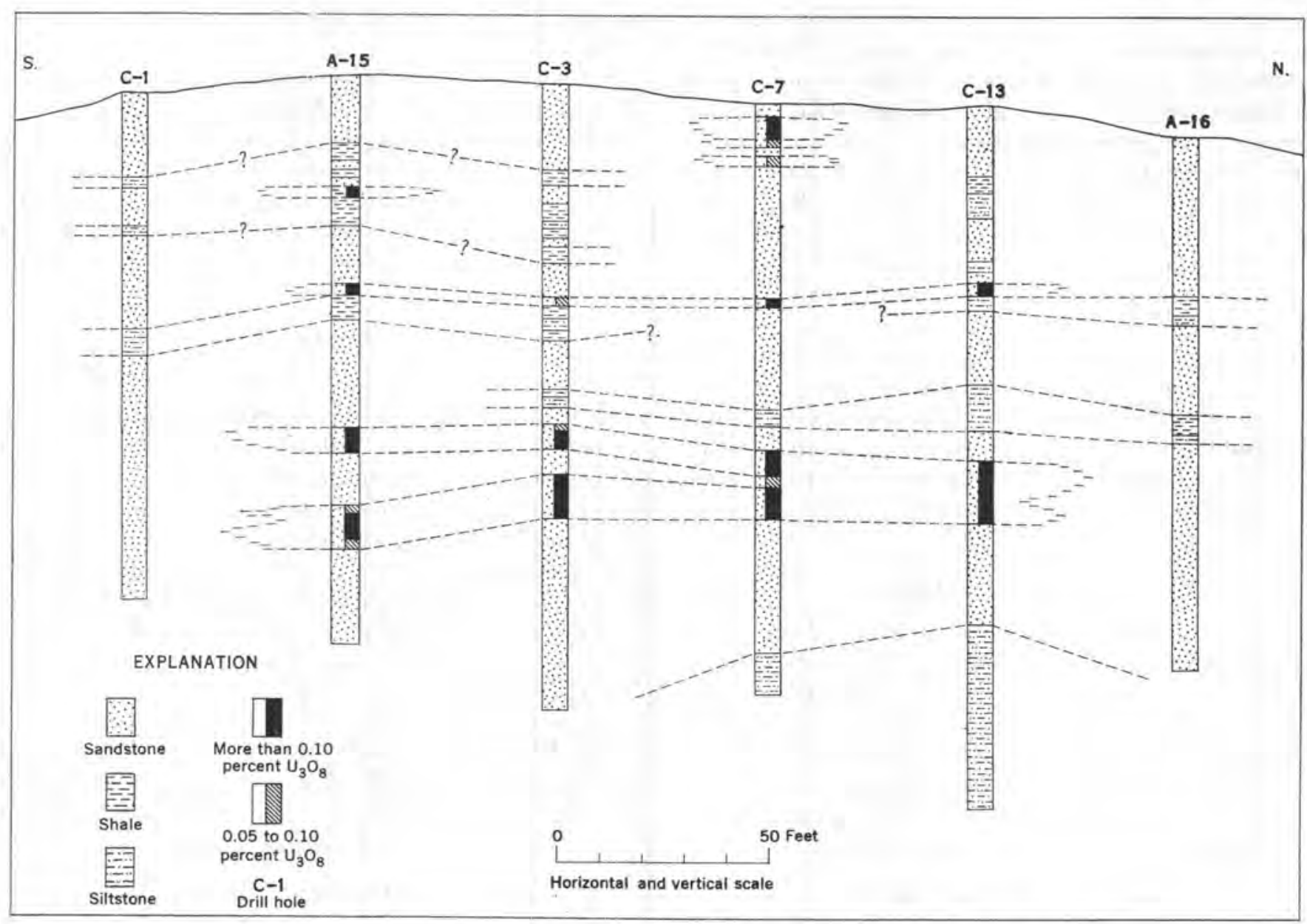

Figure 122.-Cross section through Bullrush prospect, sec. 29, T. 33 N., R. 90 W., Fremont County, Wyo.

well-dissected terrain. Pumpkin Buttes rise almost 1,000 feet above the surrounding area.

All rocks of the area are assigned to either the Wasatch formation of Eocene age or to the White River formation of Oligocene age. The Wasatch formation is up to 1,500 feet thick and is composed of shales, mudstones, interbedded lenticular beds of fine- to coarsegrained crossbedded sandstones, and several persistent coal beds. The White River formation capping the buttes is a coarse-grained to conglomeratic sandstone with siliceous cement.

The Wasatch formation is host for all large occurrences of uranium in the area, and most of the 121 uranium deposits, of which Anomaly 119 is one, are found in a red sandstone which is up to 500 feet thick and stratigraphically near the middle of the formation (Troyer and others, 1954). The sandstone of this zone is arkosic and contains much calcareous and ferruginous cement and, in places, considerable fossil carbonaceous material.

Uranium concentrations have been disclosed by two elongate open pits. The host is thin- to massive-bedded coarse-grained arkosic sandstone with abundant crossbedding. Uranium occurs in extremely irregular zones and impregnations following bedding in a few places but elsewhere transecting all sedimentary structural features. No obvious feature seems to control emplacement of the ore deposit. Hard layers and caleareous sandstone concretions occur sporadically throughout areas where uranium ore is commonly mined; most of the friable mineral-bearing sandstone contains uranium as grain coatings or interstitial matter between sand grains. Carbonaceous plant material is disseminated in the sandstone and in places is associated with highgrade pockets of ore.

The uranium mineralogy here in the Powder River Basin is simple as compared with that of the Wind River Basin. Although the primary mineral uraninite has been discovered intimately associated with disseminated pyrite in an unoxidized part of the deposit (Sharp, 1955), the dominant uranium minerals are carnotite and tyuyamunite. Minor uranophane has also been identified. The secondary minerals are in tortuous bands ranging from bodies a fraction of an inch 
to several feet in thickness. The most striking single feature of the entire deposit is the concentration of carnotitebearing ores along the zones of contact between pink sandstone and gray or buff sandstone that appears bleached. Ore is more plentiful on the gray and brown side of the contact zone (fig. 123). In all probability the mineralizing solutions were responsible for the alteration of the pink sandstone to brown and gray. This color change is the best single guide to ore.

Coarse-grained sandstone of high permeability and lenticular mudstone lenses may have exercised control over deposition by influencing flow of mineralizing solutions. Some ore is concentrated in areas of higher than average fracture density, with abnormal amounts of calcareous cement, and a persistent underlying shale bed determines the lower limit of mineral concentration in several parts of the pit. Much of the mined ore assayed about 0.4 percent $\mathrm{U}_{3} \mathrm{O}_{8}$.

\section{JEANETTE MINE}

The Jeanette mine in sec. 22, T. 45 N., R. 75 W., in the Pumpkin Buttes area (fig. 120), is similar in many respects to Anomaly 119. Pink sandstones of the Wasatch formation are altered to gray in carnotitebearing zones, and uranium shows marked tendency to concentrate in and around fossil carbonaceous material. Uraninite in intimate association with pyrite also has been reported from this mine (Sharp, 1955).

\section{BROWN'S RANCH DEPOSIT}

The Brown's Ranch deposit in sec. 22, T. 43 N., R. 76 W., in the Pumpkin Buttes area (fig. 120), lies within coarse-grained sandstone lenses of the Wasatch forma- tion but shows marked differences to those described above.

A cluster of uranium-bearing concretions, which range individually from a fraction of a cubic foot to several cubic feet, has yielded over 200 cubic feet of ore assaying about 5 percent $\mathrm{U}_{3} \mathrm{O}_{8}$. Uranophane and small amounts of carnotite occur in these concretions, intergrown with manganese and iron oxides and calcium carbonate. Color changes and carbonaceous materials do not appear to be ore guides.

\section{PAT CLAIMS}

On the Pat claims in sec. 3 , T. 37 N., R. 73 W., Converse County, Wyo. (fig. 120), carnotite and uraninite occur disseminated in bedded deposits in gray and brown sandstone strata of the Wasatch formation. This deposit has been investigated only by drilling, and many details of its character are not known. Deposition has favored coarse-grained arkosic sandstones containing carbonaceous materials and some calcareous cement. A distinct change in lithology, which seems to influence the local ground-water level, occurs at the discomformable contact with the underlying Fort Union formation and may have been a factor in localization of ore (fig. 124). Native selenium has been identified in the primary ore as tiny particles in association with pyrite, uraninite, and carbonaceous material (J. Gruner, 1954, written communication).

\section{SNO-BALL MINE}

The Sno-Ball mine, on an anomaly discovered by airborne radiometric surveying, is in the Crooks Gap section of the Green Mountains in sec. 28 , T. 28 N.,

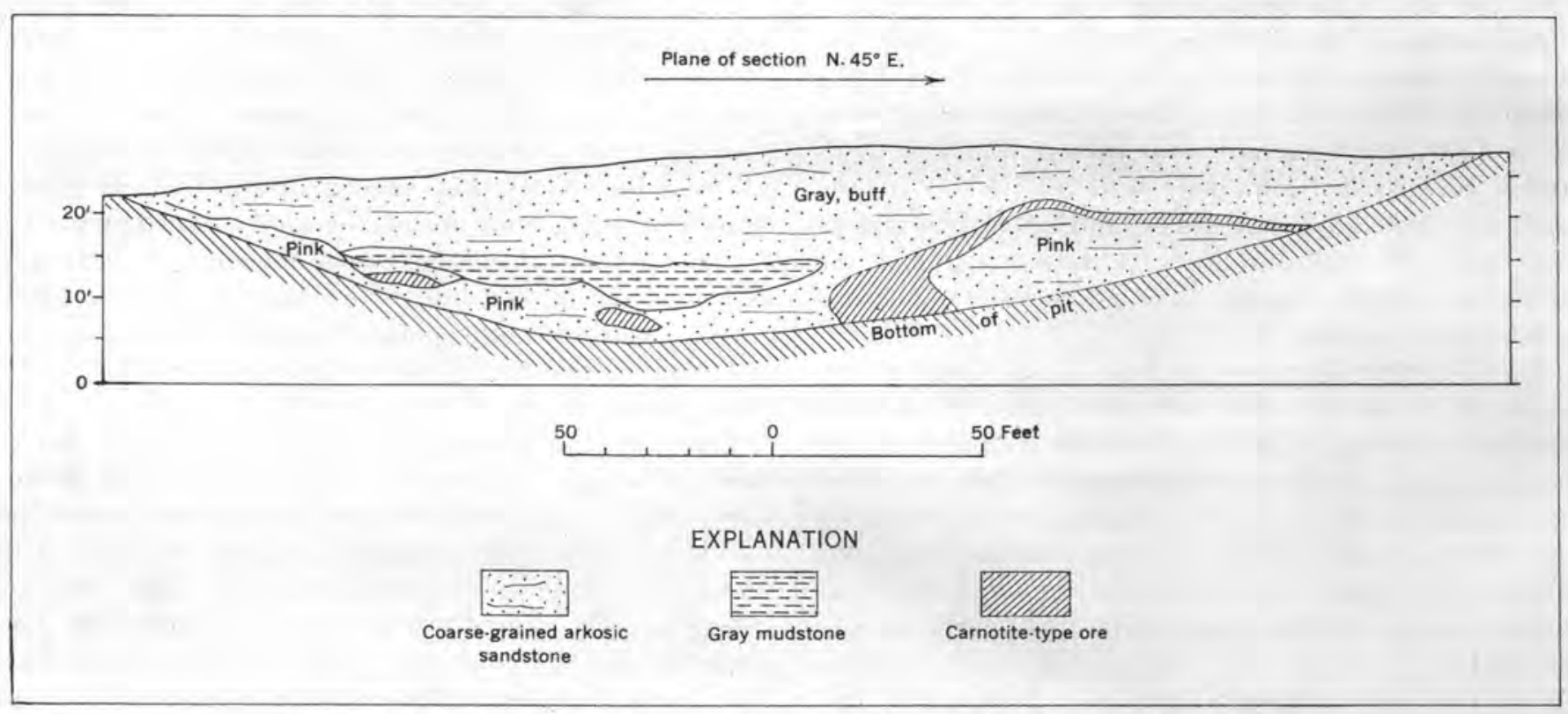

FigURE 123.-Vertical section through pit, Anomaly 119, sec. 11, T. 45 N., R. 75 W., Campbell County, Wyo. 


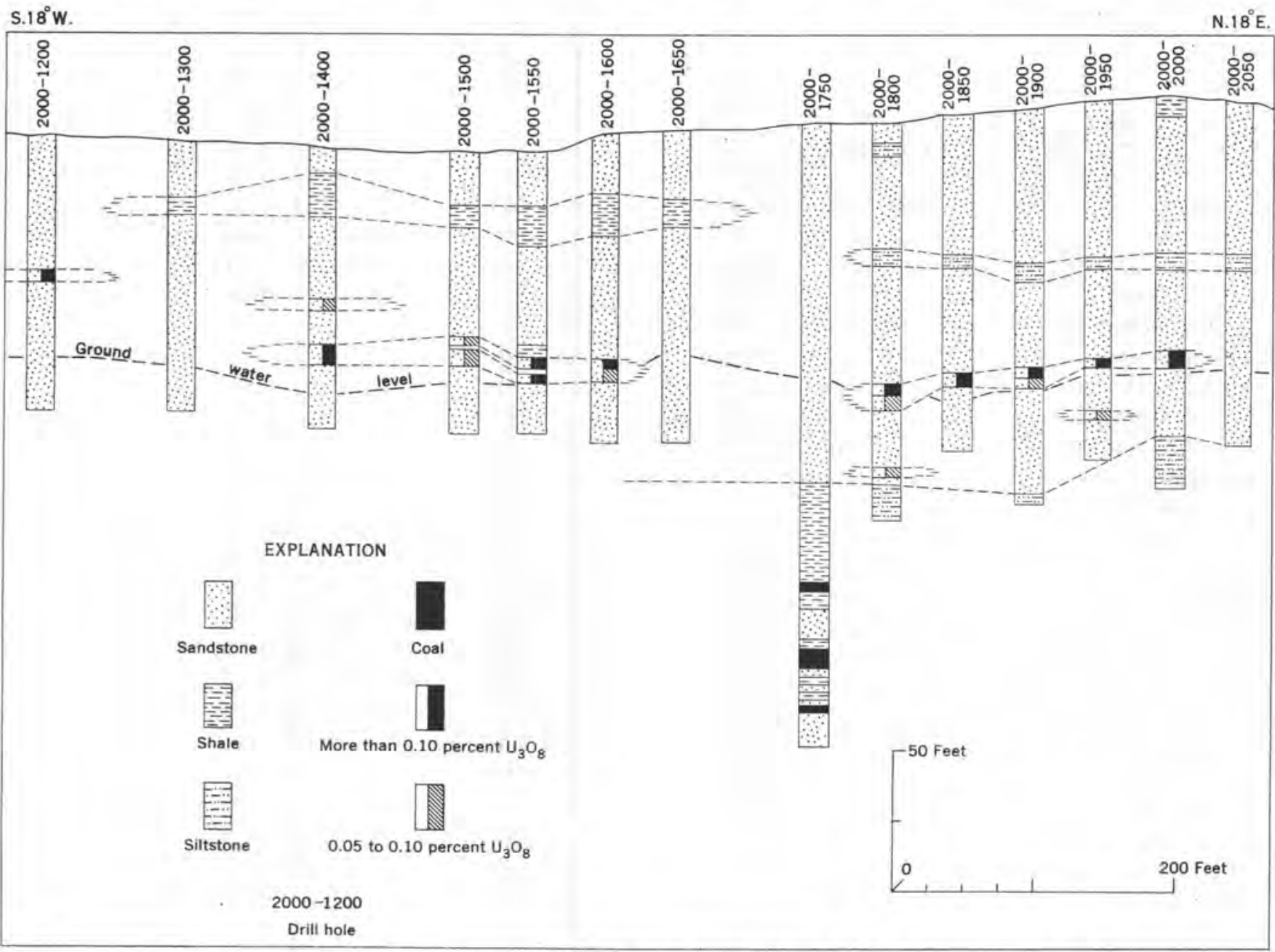

Figure 124.-Vertical section through uranium ore bodies, Pat elaim, sec. 3, T. 37 N., R. 73 W., Converse County, Wyo.

R. 92 W., Fremont County, Wyo., about 65 miles north of Rawlins (fig. 120).

The region exhibits complex structural features unu has an equally complex geologic history. The northwestward-trending Green Mountains are locally more than 8,000 feet in altitude and are underlain mostly by strata of Eocene age. A prominent northward-dipping thrust fault bounds the range on the north, and the Great Divide Basin is the topographic boundary to the south. The thrust fault, which was active during much of the Tertiary period, probably influenced sedimentation during the Eocene period by continually rejuvenating source highlands (Gooldy, 1947; Whalen and Norton, 1955). The Fort Union formation (Paleocene) and older rocks were strongly folded before deposition of the Wasatch formation (Eocene), but continued movement also caused folding in the strata of Wasatch age, which overlies the older rocks with an angular discordance. Sedimentary rocks present range in age from Cambrian to Miocene.

Most of the uranium deposits are in the Wasatch formation, which averages over 800 feet in thickness and is composed of an alternating series of lenticular boulder beds, arkosic conglomerates, fine- to coarsegrained arkosic sandstones, siltstones, and carbonaceous shales.

At the Sno-Ball mine mineral concentration is confined to the lower beds of the Wasatch, in lenses of very coarse-grained angular arkosic sandstone and conglomerates of granite cobbles. Extreme irregularity of bedding is accompanied by torrential crossbedding. Thin dark carbonaceous mudstone layers are intercalated in the section. The mineralized zones are irregular and often sporadic in distribution.

Most ore mined in the open pit has come from the top of a persistent carbonaceous mudstone layer, which dips approximately $15^{\circ}$ east. This ore zone attains a thickness of several feet, swells and pinches in direction of dip, and is irregular in shape along the strike. Uranium is disseminated as grain coatings and as interstitial or cementing material in lenticular beds of coarse-grained poorly sorted arkosic sandstone and in 
upper parts of the carbonaceous mudstone immediately underlying or imbedded with the sandstone ore.

Abundant carbonaceous fossil plant fragments are present throughout the ore zones and in many places are associated with the highest grade ore. A few small steeply dipping faults and fractures have been mineralized, but in general bedding planes seem to contain more uranium than fractures do.

A white, seemingly bleached sandstone zone of different thicknesses in the basal part of the Wasatch formation is apparent for over 1,000 feet along the strike and is especially conspicuous in the mine area. This band is localized in the more permeable layers and may be the result of alteration accompanying mineral deposition.

The dominant ore mineral is uranophane in earthy yellow grains and as paintlike smears along fractures in granite cobbles and boulders. Minor amounts of phosphuranylite occur with the uranophane. Uraninite from dark carbonaceous mudstone has been identified in minor amounts. Limonite, the dominant associate mineral, is present as earthy interstitial fillings and as stain in and around mineralized zones. Lenses of permeable sandstone and layers of carbonaceous mudstone or sooty fossil carbonaceous material facilitated ore deposition (fig. 125).

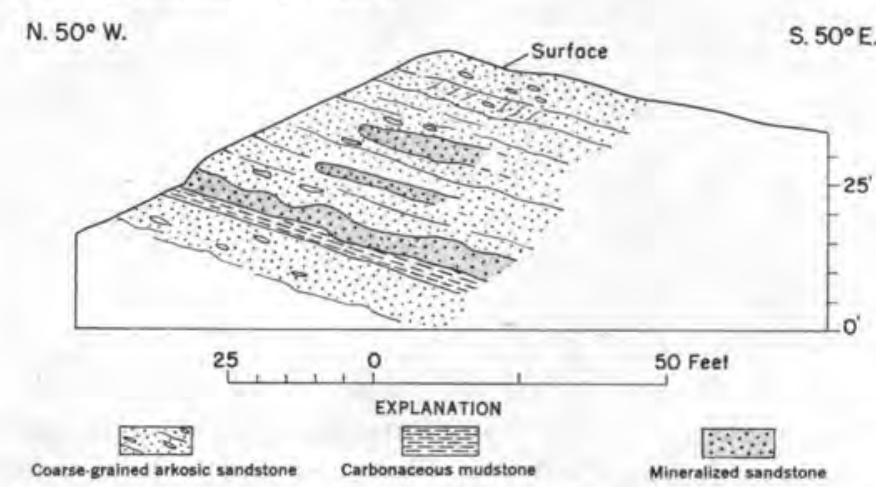

Figure 125.-Vertical section, generalized, through outcrops on Sno-Ball claim, sec. 28, T. 28 N., R. 92 W., Fremont County, Wyo.

BAGGS AND MAYBELL AREAS

The Washakie basin of southern Wyoming and northern Colorado also contains economically significant deposits, principally of uranophane, in the Browns Park formation of Miocene(?) age. The basin is an area of about 1,500 square miles. The Browns Park formation comprises sandstones, sbales, and tuffaceous beds unconformably overlying older strata. Two uranium deposits, similar in many respects, are the Poison Basin claims in sec. 4, T. 12 N., R. 92 W., 6 miles west of Baggs, Wyo., and the Gertrude claims in sec. 17 , T. 7 N., R. 94 W., northeast of Maybell, Moffat County, Colo. (fig. 120).

Uranophane with meta-autunite and schroeckingerite are the common secondary minerals and are disseminated in lenticular bedded deposits in fine- to mediumgrained sandstones, which are often highly crossbedded. Small quantities of uraninite associated with gypsum, calcium carbonate, and limonite have been identified in the Poison Basin claims.

Driliing has disclosed gray unoxidized ore in both areas, but the identify of the uranium mineral has not been determined. Finely divided pyrite is a common gangue mineral in this ore. Assays in which the chemical conten' exceeds radiometrically equivalent uranium are common.

Fracturing and faulting are known to be important controls in localization of these deposits. Visible quantities of carbonaceous materials are conspicuously lacking.

\section{CONCLUSIONS}

The study of uranium occurrences in clastic rocks of Tertiary age is new, and extensive geologic information is not yet available. A marked resemblance exists between the many Wyoming deposits, however, and those of the more thoroughly studied Colorado Plateau. Wyoming uranium deposits are distinct in the abundance of such compounds as phosphates and arsenates and are characterized by radiometric disequilibrium in most ores.

Widespread unconformities which separate strata of Tertiary age from older sedimentary rocks are common. Uranium deposits occur near such surfaces in several Wyoming areas. These surfaces are boundaries of marked lithologic and structural change which must bave influenced the lateral flow of migrating solutions.

Wyoming represents a new uranium province that is defined almost entirely by occurrences in clastic sediments. As prospecting and exploration progress, it is likely that the areas of known ore deposits will be increased and that significant deposits will be found in sedimentary rocks older than Tertiary.

\section{REFERENCES CITED}

Coleman, R. G., 1954, U. S. Atomic Energy Comm. unpub. inf. Gooldy, P. L., 1947, Geology of the Beaver Creek-South Sheep Mountain area, Fremont County, Wyo.: Unpub. thesis, Wyo. Univ.

Grutt, Eugene W., Hadfield, J. P. and Smith, E. W., 1954, Preliminary report on uranium deposits in the Wind River Basin, Wyo.: U. S. Atomic Energy Comm. RME-1056, to be issued by U. S. Atomic Energy Comm. Tech. Inf. Service, Oak Ridge, Tenn.

Sharp, W. N., McKay, E. J., MeKeown, F. A., U. S. Geol. Survey unpub. inf.

Troyer, Max L., McKay, Edward J., and others, 1954, Summary of investigations of uranium deposits in the Pumpkin Buttes area, Johnson and Campbell Counties, Wyo.: U. S. Geol. Survey Circ. 338, 17 p.

Whalen, J. F., and Norton, D. L., 1955, U. S. Atomic Energy Comm. unpub. inf. 


\title{
GEOLOGY AND URANIUM DEPOSITS OF THE PUMPKIN BUTTES AREA, POWDER RIVER BASIN, WYOMING
}

\author{
By William N. Sharp, Francis A. McKeown, Edward J. McKay, and Amos M. White, \\ U. S, Geological Survey
}

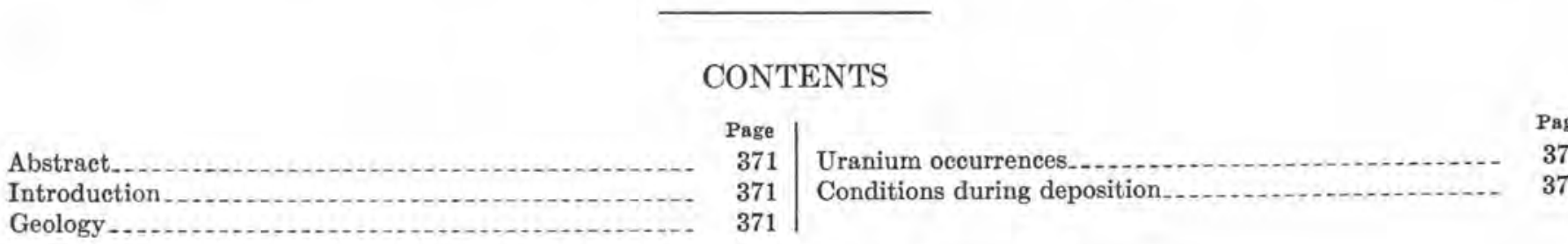

\section{ILLUSTRATION}

Page

Figure 126. Generalized geologic map of Powder River Basin, Wyo

\begin{abstract}
The Powder River Basin is an asymmetrical syneline whose axis trends north-northwest. The west limb folds sharply against the Bighorn Mountains and the Powder River lineament; the east limb rises gently eastward to the Black Hills. In the vicinity of Pumpkin Buttes there is a broad, low-amplitude anticline that plunges slightly to the northwest. The basin is underlain by the Wasatcb formation of Eocene age. Older rocks, including the Fort Union formation of Paleocene age, crop out around the periphery of the basin. Remnants of the White River formation of Oligocene age cap the Pumpkin Buttes.

The regional dip is 30-100 feet per mile to the northwest; the ratio of fine- to course-grained clastic rocks increases to the northwest; and the distribution of the uranium-mineral deposits is related to a zone of predominantly red sandstone in the Wasatch formation.

The Wasatch formation is made up of buff to gray mediumto course-grained arkosic fluviatile sandstone lenses dispersed through drab claystone, siltstone, carbonaceous shale, and thin coal seams. Calcite and iron-manganese oxide concretions are common. The lenses are 500 feet to several miles wide, 1-8 miles long, and 10-100 feet thick. Parts of many lenses in the Pumpkin Buttes area are red. The contacts between red and buff or gray parts transect all sedimentary structual features and lithology within a sandstone unit.

All known uranium deposits are in sandstone and within a zone 500-1,000 feet above the base of the Wasatch formation. Tyuyamunite, carnotite, uranophane, and trace amounts of hewettite and pascoite are disseminated in buff or gray sandstone near and at the contact with red sandstone. Calcite is abundant at the contact. Where the contact is very irregular and podlike extensions of red into buff sandstone are present; concentrations of secondary uranium minerals may occur. Uraninite and paramontroseite associated with pyrite pods occurs as cement in red sandstone near irregular contacts with buff sandstone. Uranophane occurs chiefly in the cores of, and periph-
\end{abstract}

eral to, manganese-iron oxide coneretions. Such concretions may be as much as 22 percent uranium, but deposits are small. Pyrite, low-valence vanadium and uranium minerals, paramontroseite, and uraninite suggest the deposits of oxidized uranium minerals were derived from initial deposits formed under reducing and mildy alkaline conditions. Because all deposits are in sandstone units enclosed by almost impermeable nonuraniferous rocks, the uranium source may be constituents of the sandstone,

\section{GEOLOGY}

The Powder River Basin is underlain by fluvial clastic rocks assigned to the Wasatch formation of Eocene age. Unconformably overlying the Wasatch and capping Pumpkin Buttes are remnants, less than 100 feet thick, of coarse-grained siliceous clastic rocks of the White River formation of Oligocene age. Older

\section{INTRODUCTION}

The Powder River Basin-about 12,000 square miles in area-is a region of prairies and rounded hills in northeastern Wyoming. It is bounded on the east by the Black Hills, on the south by the Laramie Range, and on the west by the Bighorn Mountains. Much of the basin ranges in elevation from 4,000 to 5,000 feet. In the south-central part of the basin several prominent buttes, collectively known as Pumpkin Buttes, rise to an elevation of 6,000 feet (fig. 126).

Deposits of uranium-bearing minerals were first discovered in the vicinity of Pumpkin Buttes in October 1951. This paper briefly describes the mineralogy of the uranium deposits and some of the relationships of the deposits to the regional and local geologic features. 


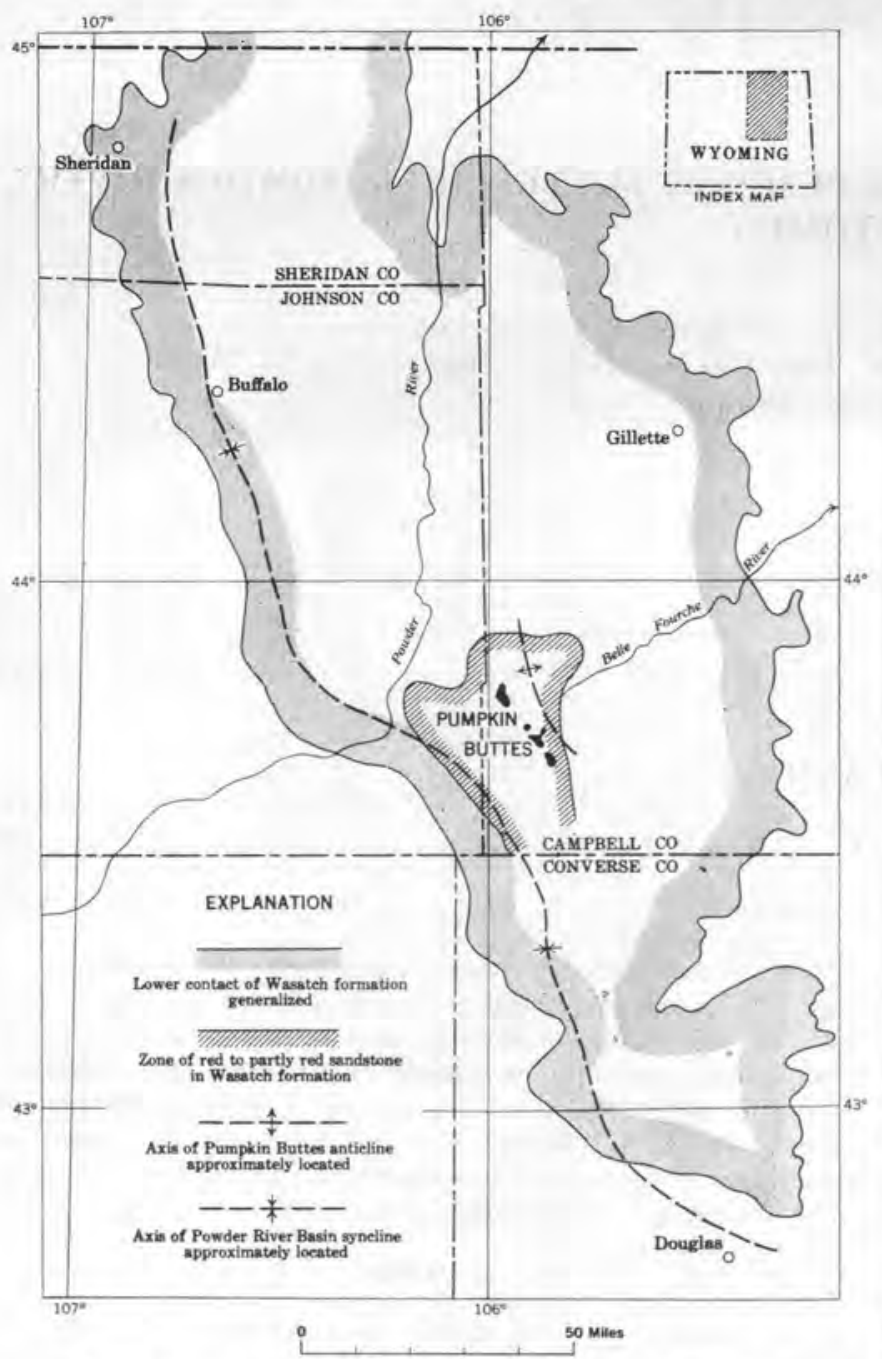

Figure 126.-Generalized geologie map of Powder River Basin, Wyo.

rock units are exposed around the periphery of the basin. These include the nonmarine Fort Union formation of Paleocene age, which is about 3,000 feet thick; and an underlying sequence of marine and nonmarine sedimentary rocks that range in age from Cambrian to Late Cretaceous and have an aggregate thickness of at least 16,000 feet.

The basin is essentially a broad north-northwesttrending asymmetrical syncline with its axis close to the Bighorn Mountains on the west. Faulting is prominent at a few places around the rim of the basin, and a few small faults with 2-10 feet of displacement have been observed in the clastic rocks of Tertiary age near the center of the basin. The regional dip of the Wasatch formation east of the axis is 50-100 feet per mile toward the northwest.

The results of regional mapping indicate that the axis of a broad north-trending low-amplitude anticline lies just east of the Pumpkin Buttes. Dips of this anticline generally range from 30 to 100 feet per mile.

Regionally the Wasatch formation is made up predominantly of interbedded siltstones, claystones, carbonaceous shales, and lignite with sandstone lenses dispersed throughout; the ratio of fine- to coarse-grained rocks is greater in the north, east, and west, than in the south near the principal source area. The orientation of festoon crossbedding, the long dimensions of sandstone lenses, and the axes of scour channels in a siltstone underlying sandstone lenses indicate that the sediments came from an area lying to the southeast. This interpretation is further supported by lateral facies changes; fine-grained clastic rocks and lignite predominate in an arcuate belt west, north, and east of the center of the basin, whereas coarser grained rocks are dominant to the south.

In the Pumpkin Buttes area the Wasateh formation is about 1,500 feet thick and composed of claystone, siltstone, lignite in thin discontinuous beds, carbonaceous shale, a few limestone lenses as much as 3 feet thick, thin-bedded sandstone, and lenticular crossbedded fine- to coarse-grained arkosic sandstone. About a third of the formation is made up of sandstone lenses that are from 500 feet to several miles wide, $1-8$ miles long, and 10-100 feet thick. Such lenses are scattered throughout a sequence of siltstone, claystone, and lignite.

Many of the sandstone lenses in the vicinity of the buttes are partly or entirely reddish, ranging from dark red brown to pink. These colors contrast sharply with the normal buff or gray of most of the sandstone in the Wasatch formation in other parts of the Powder River Basin. The contact between red and buff is generally very sharp and transects all differences in lithology and sedimentary structural features within the sandstone lenses.

The sandstone is generally poorly sorted and friable; and ranges from very fine to coarse grained. Festoon crossbedding is the most conspicuous sedimentary structural feature. At many places, however, the bedding is extremely contorted, and the beds contain abundant carbonized twigs, clay galls, and leaf impressions. Such contorted zones were probably the result of deposition in turbulent water. Some of the contorted beds occur in zones 5-10 feet thick, contain no organic debris, and may be the result of slumping shortly after deposition. Calcite concretions (sand grains cemented with calcite) are another characteristic feature of Wasatch sandstone in the Pumpkin Buttes area. Some concretions are spherical and less than an inch in diameter, and others are cigar-shaped masses 20-30 feet long. Cementation transects bed- 
ding planes as well as changes in composition and grain size. In general the elongated concretions are oriented to the northwest. They do not, however, always parallel the direction of streamflow, which also was generally to the northwest.

The claystone and siltstone are predominantly drab brown or gray, though in places purple, green, and pink tints are common. The siltstone is friable, generally thick bedded, and massive. Lateral changes in the composition and grain size may be abrupt. Claystone, siltstone, fine-grained sandstone, and carbonaceous shale commonly grade laterally into one another.

\section{URANIUM OCCURRENCES}

More than 250 occurrences of uranium-bearing material have been examined in the Pumpkin Buttes area. Uranium minerals are visible in most of the occurrences, though in some the only indication of mineralized material are anomalous radioactivity readings. The large deposits, containing as much as 2,000 tons of ore each, are commonly about 0.3 percent uranium. The deposits all occur within an elliptical area of approximately 350 square miles with Pumpkin Buttes in the center. Within this area about 1,000 feet of Wasatch formation is exposed. The sandstone lenses that contain concretions of uranium are in the lower half of this exposed part of the Wasatch formation.

The chief uranium minerals are uranophane, metatyuyamunite, carnotite, and uraninite. The major vanadium mineral is paramontroseite, which is associated with secondary uranium minerals at several deposits.

Sandstone from the Pumpkin Buttes area containing uranium-bearing material is composed of $40-70$ percent quartz, quartzite fragments, and chert, about 15 percent feldspar, and minor amounts of chlorite, muscovite, biotite, clay, pyrite, marcasite, garnet, tourmaline, epidote, hornblende, aegirine, elbaite (?), hypersthene, and zircon. Calcite, as cement, is a major component at places. The grains of sandstone are generally subangular to subrounded; alteration of feldspar to sericite and allophane is rare. Manganite, pyrolusite, and psilomelane are common in black nodular concretions.

Oceurrences of uranium are classified by their habits and mineralogic associations. Three main types of occurrences are recognized: disseminated uranium minerals in porous sandstone or concentrated around ealcite-enriched sandstone; manganese oxide concretions elosely associated with oxidized uranium minerals; and uraninite concretions with pyrite.

In general, disseminated uranium minerals are found in buft sandstone lenses, especially at and near the contact of buff sandstone and red sandstone. The largest concentrations occur where this color contact is irregular. These irregularities seem favorable places for elongate concretionary masses of calcite to form in the buff sandstone. Uranium minerals commonly saturate the sandstone between closely spaced concretions. At some places yellow uranium minerals occur in a narrow zone, several inches to several feet wide, parallel to the contact of the red and buff sandstones.

Study of thin sections of rocks from disseminated types of occurrences shows that the uranium-bearing minerals metatyuyamunite, carnotite, and uranophane, calcite, and rarely the vanadium-bearing mineral hewettite occur chiefly as interstitial filling. Metatyuyamunite and carnotite oceur as irregular microcrystalline masses and rarely have a platy habit; uranophane is generally acicular. Hewettite, also acicular, is rare; and the crystals range from 1 to 10 microns in width and from 5 to 40 microns in length. The uranium minerals commonly replace calcite and in places fill eracks in calcite, At many places, however, the uranium minerals hewettite and calcite seem to be contemporaneous. Rarely, uranium minerals and hematite replace both potash and plagioclase feldspars.

In most of the uranium deposits in the Pumpkin Buttes area, secondary uranium minerals are associated with concretionary nodules of black, iron-rich manganese oxides which cement and replace sandstone. Some nodules are spherical or tubular and have a core of gray sand speckled with manganese oxide and abundant secondary uranium minerals; other nodules are flat or irregular in shape, and uranium minerals are mixed with specks of manganese oxide in zones peripheral to the black mass. Secondary uranium minerals are associated with manganese oxides not only in isolated discrete concretions but also disseminated in sandstone in zones from 2 inches to 10 feet across. Ferruginous to coaly fossil plant material is associated with many of the manganese nodules. Manganese nodules are found within red sandstone and seem to have no consistent areal or stratigraphic pattern of distribution within individual sandstone lenses.

Thin sections of rocks from eoncretionary types of occurrences show manganite, pyrolusite, and psilomelane rimming detrital grains of quartz and feldspar, filling interstices, and replacing a little feldspar and quartz. Uranophane, metatyuyamunite, and carnotite fill interstices. In places the manganese minerals and uranophane are intergrown.

Uraninite that cements sand in rounded to elongate concretionary nodules, found at two of the larger mines, is commonly associated with pyrite. The pyrite occurs either as the core of a rounded mass of uraninite or as small rounded masses at the edge of or within the mass of uraninite. In places fossil plant material is 
found in contact with or nearly surrounded by uraninite, and no pyrite is visible. All uraninite concretions are surrounded by a thick layer of oxidized uranium minerals.

In thin and polished sections of uraninite-rich sandstone, uraninite rims sand grains and fills interstices. Calcite also fills interstices and is later than uraninite. Radial clusters of uranophane needles occur rarely on patches of interstitial uraninite. Pyrite in some nodules forms the core and presumably was deposited before uraninite.

Occurrences of paramontroseite, an unoxidized vanadium mineral, are much like that of uraninite. It is found in dull-black irregular masses as much as a foot across in red sandstone. The mineral coats and fills interstices between sand grains and commonly replaces feldspar and quartz. Pyrite masses are found at the outer surface of these masses, and green vanadium minerals coat much of the outer surfaces. Coaly fragments occur at places in the pyrite or in contact with the paramontroseite mass.

\section{CONDITIONS DURING DEPOSITION}

Oxidized uranium and vanadium minerals and manganese oxides probably formed in an alkaline oxidizing environment. Studies of thin sections indicate these minerals formed both later than and contemporaneously with calcite. Mineralization is therefore inferred to be related to the same processes that caused a redistribution and crystallization of calcium carbonate.

Polished and thin section studies show that paramontroseite, uraninite, and pyrite formed before and probably contemporaneous with the calcite. This further supports the suggestion that the solution and subsequent precipitation of uranium, vanadium, and iron minerals was closely related to the solution of limy material and deposition of calcite.

Concentrations of uranium, vanadium, iron, and manganese minerals and calcite may best be explained by the redistribution and concretion of these original components of the sandstone lenses. This is suggested by the probable redistribution of limy material within sandstone lenses, the epigenetic change from buff to red associated with uranium deposits in sandstone lenses, the general unaltered condition of clay, the low uranium content of coal and carbonaceous shale between sandstone lenses, and the lack of faults and widespread sandstone units that would serve as channels for interformational distribution of mineralized water. 


\title{
URANIUM- AND THORIUM-BEARING MINERALS IN PLACER DEPOSITS IN IDAHO
}

\author{
By J. Hoover Mackin and Dwight L. Schmidt, U. S. Geological Survey
}

\section{CONTENTS}

\begin{abstract}
Introduetion . .

General geology

Radioactive minerals in bedrock .......................

Effect of glaciation of the supply of placer minerals.....

Effect of aggradation on the tenor of the placer deposits..

Page

Downvalley changes in composition of the heavy-mineral Average heavy-mineral composition of the placer de-

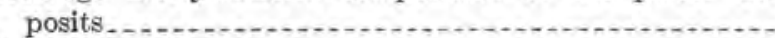

References cited.

\section{ILLUSTRATION}

FiguRe 127. Index map of Idaho

\section{ABSTRACT}

Uranium- and thorium-bearing placer deposits sufficiently large to be worked by dredges have been studied in the northern Rocky Mountains. In the Bear Valley area, Valley County, Idaho, the higher grade parts of the placer deposits commonly contain the following quantities of heavy minerals in pounds per cubic yard: euxenite 1.0 ; monazite 0.5 ; columbite 0.2 ; zireon 0.05 ; garnet 10 ; ilmenite 20 ; magnetite 5.0 . In the Hailey area, Elaine County, Idaho, the higher grade parts of the placer deposits commonly contain the following minerals in pounds per cubic yard: uranothorite 0.5 ; zircon 0.5 ; sphene 1.0 ; garnet 0.1 ; magnetite 10 . The principal uranium-bearing minerals, euxenite and uranothorite, seem to be mutually exclusive in these two areas. In the Cascade-Long Valley area, Valley County, Idaho, no more than traces of euxenite and uranothorite are found in the placer deposits being worked for monazite.

The radioactive placer minerals were derived from quartz monzonite phases of the Idaho batholith. The euxenite of the Bear Valley area, the uranothorite of the Hailey area, and the monazite of the Cascade area, occur as accessory minerals in the quartz monzonite. Segregations of these accessory minerals a few inches to a few tens of feet in diameter, containing as much as 0.05 pound of euxenite per ton in the Bear Valley area, 0.8 pound uranothorite per ton in the Hailey area, and 0.25 pound monazite per ton in the Cascade area, occur in parts of the quartz monzonite which are megascopieally indistinguishable from surrounding rock having much lower content of radioactive minerals. The distribution of these segregations is erratic; there is no tendency for similar high concentrations of the minerals to be in or near pegmatite dikes.

The grade of the placer deposits depends largely on the number and size of these segregations of the radioactive minerals in the quartz monzonite and on the physiographic history of the drainage basin.

\section{INTRODUCTION}

Placer deposits containing radioactive minerals were investigated in several parts of the Rocky Mountains of central Idaho by the United States Geological Survey during the summers of 1952-54 (Mackin and Schmidt, 1953; Reed, 1937). The principal radioactive placer minerals are monazite, euxenite, and thorite; valuable associated minerals are columbite and xenotime. This study was undertaken primarily to determine the origin of deposits drilled concurrently by the United States Bureau of Mines. Earlier reports on gold placers in central Idaho are cited by Reed (1937) and Capps (1940).

\section{GENERAL GEOLOGY}

The placer deposits lie within and around the borders of the Idaho batholith, a complex of granitic rock units ranging from diorite to granite and mostly Cretaceous in age (Ross, 1936; Anderson, 1952). The batholith and its wall rocks are overlain unconformably by several groups of volcanic rocks: early Tertiary Challis volcanic rocks in the eastern part (Ross, 1938), midTertiary Columbia River basalt on the west and southwest (Kirkham and Johnson, 1929) and Snake River basalt of Pliocene to Recent age on the south (Stearns, Crandall and Stewart, 1938).

Three major topographic elements form the physiographic setting of the deposits. The first is a rolling upland surface, with a local relief of 2,000 feet $(600 \mathrm{~m})$, 
preserved in divide areas between broad open valleys that stand 5,000 to 6,000 feet $(1,500$ to $1,800 \mathrm{~m})$ above sea level. This late mature surface is sharply trenched by young canyons of the major streams; the formation of canyons was begun by regional uplift in late Tertiary time (Fenneman, 1931, p. 185-196). The third element is the north-trending range, with crest lines from 8,000 to 10,000 feet $(2,400$ to $3,000 \mathrm{~m})$, commonly asymmetric in cross section, and associated on one or both sides with deeply alluviated basins. There is reason to believe that ranges of this type were formed by block-fault movements that occurred from time to time during the Tertiary and continued into the Pleistocene. These three topographic elements may be sharply distinct or they may blend from place to place, depending on the extent of canyon headward erosion and the recency of block faulting.

Detail of relief in the higher parts of the region is due largely to the effects of alpine glaciation. Areas above 9,000 feet $(2,800 \mathrm{~m})$ are generally characterized by matterhorn topography. In the 7,000 to $9,000(2,200$ to $2,800 \mathrm{~m}$ ) altitude zone, individual and coalescing cirques are cut in the flanks of rounded summits. Lower parts of the late mature upland were not glaciated during the late Pleistocene.

Moraines and outwash deposits on floors of some of the upland valleys indicate two late Pleistocene glacial stages. The younger of the two is represented by hummocky, boulder-strewn morainal ridges, clearly late Wisconsin. The deposits of the older stage are characterized by subdued morainal forms, and a degree of weathering suggesting an early Wisconsin age. A few widely scattered deposits of deeply decomposed till indicate a much greater extent of alpine glaciers during early Pleistocene time, but subsequent erosional modification of the region has been so complete that the effect of early Pleistocene glaciers on the geology of the placer deposits is negligible. For this reason, areas beyond the limits of early Wisconsin glaciers will be referred to as nonglaciated.

An essential requirement of a commercial placer deposit of the Idaho suites of radioactive minerals is a depth and extent of material capable of supporting a large-scale dredging operation over a period of years. Detailed investigations were therefore limited to thick alluvial fills, each of which is due to some local reversal of the normal process of stream downcutting. The principal causes of accumulation of the valley fills, and examples of each, are: (1) block faulting during Pleistocene time (monazite placers in the Cascade area); (2) late Pleistocene glacial derangement of drainage (euxenite-monazite placers of Big Meadow in the Bear Valley area; and (3), blocking of drainage lines by Pleistocene basalt flows (thorite placers in the Hailey area). (See fig. 127.) A contributing cause of valley fill was an increase in the loads of streams due to accelerated downslope movement of the weathered mantle under periglacial conditions during Pleistocene glacial stages.

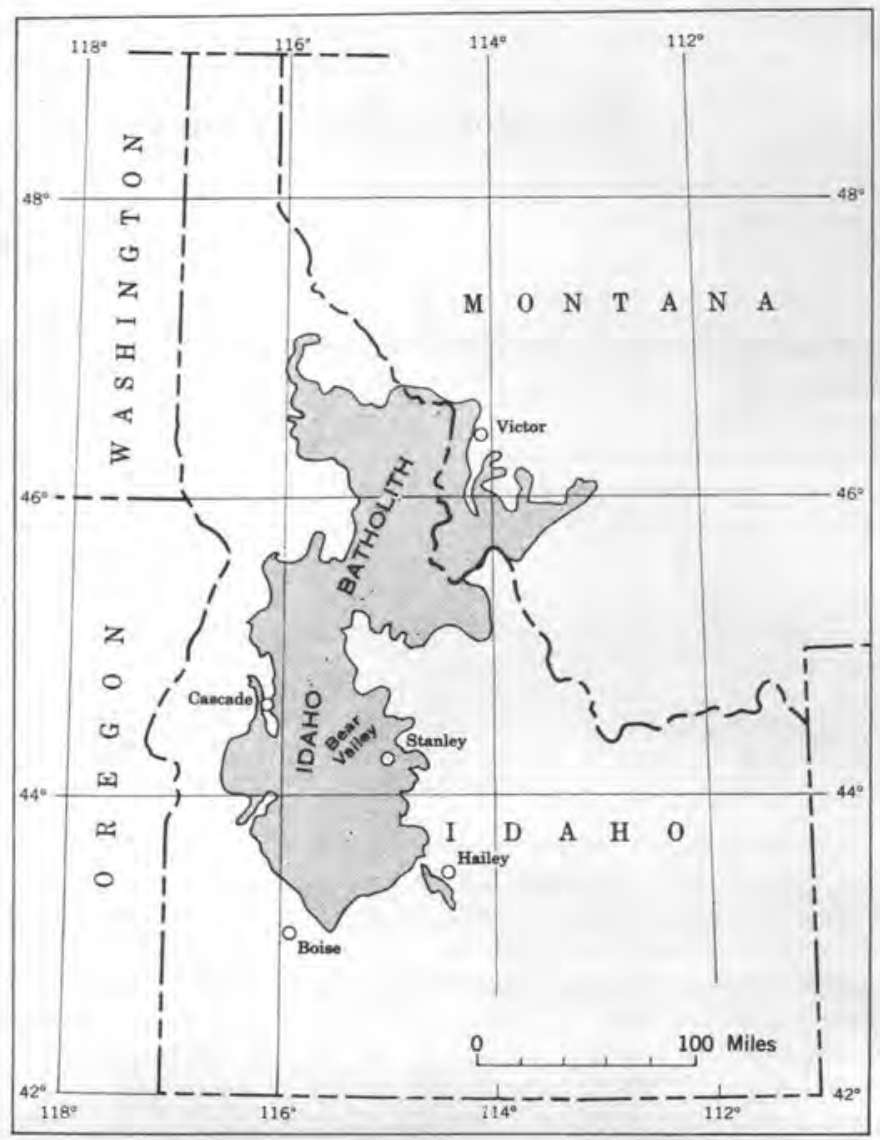

FIGURE 127.-Index map of Idaho.

\section{RADIOACTIVE MINERALS IN BEDROCK}

Monazite is the most widespread radioactive mineral in the granitic rock of the Idaho batholith. Reconnaissance pan sampling of minor streams and of weathered granitic rock over most of the southern part of the batholith indicates that monazite is more often present than not, and that its gross distribution is not uniform. The distribution of the monazite placer deposits drilled by the U. S. Bureau of Mines at Cascade near the western border of the batholith, at Bear Valley in the interior, and at Victor and Stanley near the east border indicates the scatter of the richer bedrock source areas. (See fig. 127.)

In the drainage basins from which the monazite of the Cascade placers was derived the mineral occurs as an accessory in a porphyritic granitic rock in the quartz diorite to quartz monzonite compositional range. The distribution is exceedingly erratic in detail, ranging from 
almost zero to as much as 0.3 pound per cubic yard $(0.18 \mathrm{~kg}$ per cu $\mathrm{m}$, or 0.01 percent) within a few tens of feet in apparently uniform granitic rock. There is no evident spatial relation between the distribution of the monazite and pegmatite or aplite dikes or quartz veins. The common associated heavy accessories are magnetite, ilmenite, garnet, apatite, and zircon; there is no consistent relation in the abundance of any of these minerals with the abundance of monazite.

The gross yield of a given drainage basin, as indicated by stream panning, appears to be a function of the number and richness of the local segregations of monazite in the granitic rock - the term "segregation" being used with a descriptive rather than a genetic meaning. The gravel of small streams heading in rich source areas may contain as much as 10 pounds of monazite per cubic yard (6 kg per cu m). By the same gross standard of tenor of stream deposits, the belt of migmatitic gneiss into which the granitic rock grades along the western border of the batholith is very nearly barren of monazite. However, local quartz-feldspar pods in the gneiss contain as much as 0.5 pound per cubic yard $(0.3 \mathrm{~kg}$ per cu $\mathrm{m}$, or 0.02 percent). Massive monazite replacements in phosphatic marble in the migmatite zone along the eastern border of the batholith, described by Abbott (1954, p. 21-22), have not been seen in the area covered by this study.

Euxenite occures in trace amounts in several localities widely scattered over the batholith. The only commercial placers now known in Bear Valley are supplied from a 6-square-mile $(15 \mathrm{~km})$ area of quartz diorite. The euxenite occurs as an accessory mineral in the granitic rock and in associated pegmatite dikes. The distribution in the granitic rock is spotty; pan samples of deeply weathered rock in a single exposure may range from a trace to 0.05 pound of euxenite per cubic yard $(0.03 \mathrm{~kg}$ per cu $\mathrm{m}$, or 0.002 percent), with the best ore sharply localized within an outcrop area of a few square feet. As with monazite, the yield of a given small drainage basin depends on the number and richness of the segregations. Associated heavy minerals commonly include monazite, magnetite, ilmenite, and zircon, and may include apatite, allanite, columbite, xenotine, and spinel. Well-washed gravel in favorably situated small streams may contain as much as 3 pounds of euxenite per cubic yard ( $2 \mathrm{~kg}$ per cu $\mathrm{m}$ ).

As far as is now known, thorite occurs in significant amounts only in an inlier of the Idaho batholith, an intrusive satellite in the vicinity of Hailey, Idaho. The thorite is an accessory mineral in quartz monzonite and has the same habit as the euxenite of Bear Valley; that is, it occurs in small segregations in rock not distinguishable megascopically from the surrounding rock. The segregations may contain as much as 1 pound of thorite per cubic yard $(0.6 \mathrm{~kg}$ per cu $\mathrm{m}$, or 0.04 percent), while the adjacent quartz monzonite averages 0.005 pound per cubic yard $(0.003 \mathrm{~kg}$ per $\mathrm{cu} \mathrm{m}$, or 0.0002 percent). Common associated heavy accessories are magnetite, sphene, hornblende, and apatite. Less abundant accessories include ilmenite, garnet, zircon, allanite, anatase, and rutile. Gravel deposits of small streams draining the richest source area contain as much as 0.3 pound of thorite per cubic yard $(0.2 \mathrm{~kg}$ per cu m).

The method of origin of the radioactive minerals is an open question. The field relations and relations observed in thin sections favor the view that they were formed at the same time as the enclosing rock rather than by later hydrothermal solutions. Monazite is associated with euxenite in the Bear Valley area, but the monazite-rich rock of the Cascade, Victor, and Stanley areas contains only trace amounts of euxenite or none at all. Euxenite and thorite have the same habits of occurrence as accessories in granitic rock, but there is no thorite in the euxenite-rich rock of the Bear Valley area, and no euxenite in the thorite-rich rock of the Hailey area. The thorite-rich rock of the Hailey area contains no monazite. Because of the favorable scatter of the areas studied in detail and the reconnaissance sampling done between the areas, any systematic distribution of the radioactive minerals within the batholith should be apparent. But the batholith is a composite mass, consisting in part of granitic rocks of metasomatic origin and in part of orthomagmatic intrusive rocks emplaced at different times. Much more extensive and detailed study of distribution of heavy-mineral suites in the batholith, particularly in relation to the boundaries between units of different rock type, origin, and age, is needed before any definite statement can be made of the origin and occurrence of the radioactive minerals.

\section{EFFECT OF GLACIATION ON THE SUPPLY OF PLACER MINERALS}

The effective concentration of heavy minerals in placer deposits requires: (1) disintegration of the source rock sufficient to free the heavy minerals; and (2) residual concentration of the heavy minerals by removal of the soluble and some of the light minerals by weathering and erosion in an accelerated movement of the thus enriched mantle to the streams (Jenkins, 1935). Primarily for these reasons, the distribution of late Pleistocene glaciers is thus a decisive factor in the localization and tenor of the Idaho placer deposits.

Gravel in the deposits of streams draining nonglacial areas commonly consists of vein quartz and various resistant dike-rock types; the granitic rock which makes up more than 99 percent of the drainage basin, 
is represented only by coarse sand. In the Bear Valley area, for example, alluvium deposited by minor streams entering Big Meadow from nonglaciated terrane during the early Wisconsin glacial stage averages 30 pounds of heavy-mineral concentrate per cubic yard (18 $\mathrm{kg}$ per cu $\mathrm{m})$. This high concentration is believed to be due to the thorough weathering of the bedrock during middle Pleistocene time and a quickened downslope movement of the enriched mantle under periglacial climatic conditions during the early Wisconsin. Yet, outwash deposits formed by streams entering Big Meadow from early Wisconsin glaciers and the morainal deposits of these glaciers consist predominantly of subrounded fragments of granitic rock, and average only 20 pounds of heavy-mineral concentrate per cubic yard (12 kg per cu m); probably this concentration is lower than in the alluvium from the neighboring nonglacial area because some of the heavy minerals are still locked up in the granitic pebbles. Late Wisconsin moraines and outwash deposits from the same drainage basins average 10 pounds of heavy concentrates per cubic yard $(6 \mathrm{~kg}$ per $\mathrm{cu} \mathrm{m})$. The difference between the amount of heavy-mineral concentrate in early and late Wisconsin deposits is probably due to the fact that a deep regolith, formed during a long period of pre-Wisconsin weathering, was available to the early Wisconsin glaciers, while erosion by the smaller late Wisconsin glaciers was confined within cirque basins that shortly before had been scoured in fresh bedrock by early Wisconsin ice.

Panning of large numbers of samples of deposits derived from nonglaciated drainage basins, early Wisconsin deposits, and late Wisconsin deposits, gives comparable average results in the other areas covered by this study. The ratio of the amount of total heavy-mineral concentrate in the three types of material is approximately $3: 2: 1$.

\section{EFFECT OF AGGRADATION ON THE TENOR OF THE PLACER DEPOSITS}

Changes in stream velocity accompanying seasonal variations in discharge cause cycles of scouring and redeposition of the alluvial materials making up the channel floor, each time with a winnowing of the materials on the basis of particle size and, within any given size range, on the basis of specific gravity and shape (Mackin, 1948). Because the vigor of this process varies greatly from place to place in the channel, and because of sidewise shifting and changes in alinement of the channel, the deposit is an aggregate of lenses differing markedly in degree of sorting. The lenses of gravel may contain as much as 100 times the amount of heavy-mineral concentrate as adjacent lenses of sand.
In streams that swing back and forth across valley floors for a long period of time with little change in grade, repeated reworking of the valley-floor alluvial deposit tends to develop concentrations of heavy minerals far higher than the average proportions of these minerals in the detritus annually delivered from the slopes of the drainage basin. In aggrading streams, on the other hand, this type of sorting is less effective because some part of the load handled each year is deposited in the accumulating fill where it is not subject to reworking. As the amount of material thus deposited in a given segment of the stream per year approaches the amount of material shed into that segment each year from the local valley sides or from the next upvalley segment, the winnowing action approaches zero. For this reason, other things being equal, the concentration of heavy minerals tends to be higher in deposits of graded streams than in deposits of aggrading streams, and in the latter, the concentration tends to be inversely proportionate to the rate of aggradation. In the Cascade area, for example, deposits of modern streams that are stable or slowly degrading are consistently higher in heavy-mineral concentrate than aggradational deposits in the same area formed during the Pleistocene time by similar streams.

\section{DOWNVALLEY CHANGES IN COMPOSITION OF THE HEAVY-MINERAL SUITES}

Changes in the total concentrate, and in the proportions of the different heavy minerals downstream from the source area are due principally to selective transportation, dilution, selective attrition, and selective weathering during periods when the detritus is temporarily at rest on the valley floor. Commonly two or more of these processes are in operation in the same stream at the same time. The following discussion is based on observations of stream segments in which it was possible, under favorable conditions, to arrive at an approximate evaluation of each of the different processes. In the selective sorting process outlined earlier the average rate of movement of the heavy minerals along the streambed, over a period of years, is slower than that of the light minerals in the same size range. But in a graded stream, in which the channel deposits mantling the valley floor are reworked over and over as the stream shifts laterally, this "running ahead" of the light minerals does not cause a change in the composition of the sand fraction of the bed load in a downstream direction. The heavy minerals move more slowly into a given segment of the valley, but they also move more slowly through and away from that segment, and the average composition of the sand fraction of the channel deposits is the same as though all the grains moved at the same rate. 
In the aggrading stream, on the other hand, the heavy-mineral grains, which are last lifted and first deposited in the seasonally expanding and contracting channel, actually lag behind the light grains because the raising of the level of the stream bed means that the deposits are not subject to continuous reworking. There is, in other words, a "permanent withdrawal from circulation" of the slower moving part of the bed load, and a resulting decrease in the proportion of the heavy minerals in the sand fraction in a downvalley direction.

Monazite serves best to show this relationship because the other factors, such as attrition, which affect the survival of this mineral are negligible in any short travel distance. In the Bear Valley and Caseade areas, where drilling data permit a comparison, the content of monazite decreases by 50 percent in a distance of a mile in Pleistocene valley-fill deposits, while there is no significant change in the content of monazite in the same distance in modern valley-floor deposits formed by graded streams.

Reduction by dilution in the weight percent of a given placer mineral in the heavy-mineral concentrate may be due to the entry of side streams which errode rocks low in content of heavy minerals or to the sidewise cutting of the trunk stream in bedrock or in older deposits containing lesser amounts of that mineral. The quantitative effects of dilution by side streams are obvious and need no discussion. The effect of exchange between the bed load and the materials forming the banks is well shown on Bear Creek, where the reduction in the weight percent of monazite is about twice as rapid in a segment where the creek is cutting laterally in barren glacial outwash as where the stream is meandering in its own alluvial deposits. It is evident that any general evaluation of the dilution effects of exchange must be in terms of the rate of bank cutting.

Monazite is in all respects the most durable of the radioactive placer minerals of central Idaho. In the Cascade area, for example, this mineral can be traced in alluvial deposits from a well-defined source for a distance of 25 miles $(40 \mathrm{~km})$ through areas from which local contributions of monazite to the stream are negligible. Monazite grains in pan samples in headwater rills in the source area are euhedral crystals and angular fragments of crystals in the 0.2 to $1.0 \mathrm{~mm}$ size range. The grains are very slowly rounded in transit along the streams. The median grain size decreases only by an estimated 50 percent in 25 miles $(40 \mathrm{~km})$ of stream travel, and an unknown but perhaps considerable part of this decrease in size may be due to selective transportation rather than to attrition. Even at this distance from the source, some of the grain boundaries are crystal faces.

Euxenite panned from residual soil in the Bear Valley area is in the form of euhedral crystals and angular fragments of crystals with a very wide range in grain size, from 0.1 to $5.0 \mathrm{~mm}$. The grains in the soil commonly carry a tan coating of gummitic material of the order of $0.01 \mathrm{~mm}$ in thickness; the fact that the completeness of coating decreases downward through the soil profile indicates that it is due to weathering. It is removed from the edges and flat surfaces of the grains within the first 1,000 feet $(300 \mathrm{~m})$ of travel along stream beds, remaining only in reentrant angles of irregular microfissures that characterize this mineral.

The average size of the larger euxenite grains decreases by 3 to 4 times, from $5.0 \mathrm{~mm}$ to $1.5 \mathrm{~mm}$, within the first mile $(1.6 \mathrm{~km})$ of movement along the stream beds. Five miles $(8 \mathrm{~km})$ from the source area the average larger grain size is $0.8 \mathrm{~mm}$, and very few of the larger grains show crystal faces. In another 5 miles $(8 \mathrm{~km})$ the larger grains are reduced to about $0.5 \mathrm{~mm}$. The next 15 miles $(24 \mathrm{~km})$ of travel causes little further reduction in size. The very rapid decrease in the size of the larger grains in the first 10 miles $(16 \mathrm{~km})$ of transportation (from $5 \mathrm{~mm}$ to $0.5 \mathrm{~mm}$ ) is due primarily to breakage under the impact of pebbles and bouldersthe tendency of euxenite to shatter readily is probably due in part to microfissuring associated with the metamict state of the mineral. Because the finer particles produced by shattering move with the suspended load, the weight percent of euxenite in the placer deposits decreases much more rapidly in a downvalley direction than the weight percent of the less brittle heavy minerals, as monazite.

The minerals of the thorite group occur in the residual soil and placer deposits of the Hailey area as crystals and fragments of crystals, euhedral to subrounded, ranging from 0.1 to $1.5 \mathrm{~mm}$ in greater dimension. The minerals vary widely in physical properties; the several varieties, probably including uranothorite and orangite, cannot be identified by sight in the pan concentrates. Field estimates of tenor were therefore based largely on scintillation-counter readings. A sharp decrease in tenor downvalley from the source area is certainly due in part to attritional wear, but it is also due in part to dilution and other factors. The laboratory studies needed for an evaluation of the factors have not been completed.

Although there are variations from place to place, magnetite and ilmenite are present in approximately equal amounts in residual soils and headwater streamdeposits in the granitic terranes, where these two minerals usually make up about 90 percent of the total heavy-mineral concentrate. But placer deposits formed by trunk streams draining the same areas may contain only a few percent of magnetite in a heavymineral concentrate consisting predominantly of ilmen- 
ite. Because magnetite is the least valuable of the heavy minerals, its drastic reduction in weight percent in the concentrate has the effect of a natural beneficiation, and is therefore a matter of considerable practical importance.

A first clue to the manner of destruction of the magnetite is provided by the fact that a stream entering a wet mountain meadow with a magnetite-ilmenite ratio of 1:1 may lose nearly all of its magnetite within a mile $(1.6 \mathrm{~km})$ of meandering on the meadow floor. Upstream from the meadow the magnetite is in the form of angular to subrounded crystals and grains with or without a film of hematite developed by oxidation in the normal weathering process. Samples of gravel taken from below the water table under the meadowpeat layer show no magnetite, or show only deeply pitted, skeletal grains with no hematite coatings - the associated sand and gravel are notable bleached. Numerous $\mathrm{pH}$ determinations of the meadow ground water range from 6.2 to 5.5 and average 6.0 , in contrast with a fairly consistent 7.1 for the stream water. These relations indicate that the magnetite is dissolved by the semistagnant acid water under the peat that mantles the flood plain. The vigor of the process is suggested by the fact that, at places where the meadow water is aerated as it seeps out from fresh meander cuts in the bleached gravel, a thick layer of ochreous ooze - accumulates within a period of a few months. It should be noted that the reduction in the amount of magnetite along the channel is not in any sense due to destruction of the mineral in the channel environment-it is due wholly to exchange, incident to lateral shifting of meanders in alluvium, in which the magnetite is destroyed by acid water.

Several lines of evidence, too involved for discussion here, indicate that in a wet-meadow peat environment, the weight percent of magnetite in the heavy-mineral suite in a gravel deposit may be reduced very nearly to zero in a few hundred years.

\section{AVERAGE HEAVY-MINERAL COMPOSITION OF THE PLACER DEPOSITS}

The heavy-mineral composition of the placer deposits is dependent on the mineral content of the source rock and on several physiographic factors bearing on concentration; namely, preliminary eluvial concentration by selective weathering, differences in the effectiveness of channel concentrations in graded and aggrading streams, selective transportation, dilution, selective attribution, and selective weathering during periods when the detritus is temporarily at rest on the valley floors. In the Bear Valley area, alluvial fills formed as a result of glacial derangement of drainage contain the following quantities of heavy minerals in pounds per cubic yard (kilograms per cubic meter): euxenite 1.0 (0.6); monazite $0.5(0.3)$; columbite $0.2(0.1)$; zircon 0.05 (0.03); garnet 5 (3); ilmenite 20 (12); magnetite 5.0 (3.0). In the same terms, the heavy-mineral content of deposits in valleys blocked by Pleistocene basalt flows in the Hailey area is as follows: thorite $0.5(0.3)$; zircon $0.5(0.3)$; sphene $1.0(0.6)$; garnet $0.1(0.06)$; magnetite $10(6.0)$. The Cascade deposits, which accumulated in a basin formed by block faulting during Pleistocene time, contain: monazite $1.5(0.9)$; zircon 0.2 (0.1); garnet $5.0(3.0)$; ilmenite $40(24)$; magnetite 1.0 $(0.6)$.

\section{REFERENCES CITED}

Abbott, A. T., 1954, Monazite deposits in calcareous rocks, northern Lemhi County [Idaho]: Idaho Bur. Mines and Geology, Pamph. 99, 24 p.

Anderson, A. L., 1952, Multiple emplacement of the Idaho batholith: Jour. Geology, v. 60, p. 255-265.

Capps, S. R., 1940, Gold placers of the Seesh Basin, Idaho County, Idaho: Idaho Bur. Mines and Geology, Pamph. 52, $42 \mathrm{p}$.

Fenneman, N. M., 1931, Physiography of western United States: New York, McGraw-Hill Book Co., Inc., 534 p.

Jenkins, O. P., 1935, New technique applicable to the study of placers: Calif. Jour. Mines and Geology, v. 31, p. 143-210.

Kirkham, V. R. D., and Johnson, M. M., 1929, The Latah formation in Idaho: Jour. Geology, v. 37, p. 483-504.

Mackin, J. H., 1948, Concept of the graded river: Geol. Soc. America Bull., v. 59, p. 463-511.

Mackin, J. H. and Schmidt, D. L., 1953, Placer deposits of radioactive minerals in Valley County, Idaho [abs.]: Geo]. Soc. America Bull., v. 64, p. 1549.

Reed, J. C., 1937, Geology and ore deposits of the Warren Mining district, Idaho County, Idaho: Idaho Bur. Mines and Geology, Pamph. 45, 65 p.

Ross, C. P., 1936, Some features of the Idaho batholith: 16th Internat. Geol. Cong. Rept., v. 1, p. 369-385.

Ross, C. P., 1938, Geology and ore deposits of the Bayhorse region, Custer County, Idaho: U. S. Geol. Survey Bull. 877, $161 \mathrm{p}$.

Stearns, H. T., Crandall, Lynn, and Stewart, W. G., 1938, Geology and ground-water resources of the Snake River plain in southeastern Idaho: U. S. Geol. Survey WaterSupply Paper 774, 268 p. 


\title{
URANIUM IN PREGIPITATES AND EVAPORITES
}

\author{
By Kenneth G. Bell, U. S. Geological Survey
}

\section{CONTENTS}

\begin{tabular}{|c|c|c|c|}
\hline & Page & & Page \\
\hline Introduction. & 381 & Caliche-type deposits.... & 385 \\
\hline Carbonate rocks & 382 & Siliceous precipitates. & 385 \\
\hline 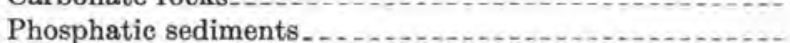 & 383 & References cited & 386 \\
\hline
\end{tabular}

\section{ABSTRACT}

Precipitates and evaporites, exeluding some carbonaceous and phosphatic sediments, contain only trace amounts of syngenetically deposited uranium. Carbonaceous sediments composed predominantly of sapropelic derivatives and marine-deposited phosphatic sediments may contain up to a few tenths of a percent uranium Epigenetic uranium deposits in all of these sediments may contain ore-grade material.

The low amounts of syngenetic uranium in carbonate sediments, from almost nil up to about 4 parts per million (ppm), can be attributed to deposition in oxidizing environments and to the inhibitory effects of high carbonate and bicarbonate ion concentrations on precipitation of uranium compounds. Uranium is deposited epigenetically in carbonate rocks from ground and surface water, hydrothermal solutions, and petroliferous residues.

All phosphatic marine sediments contain uranium up to about $1,500 \mathrm{ppm}$. The uranium is believed to be in isomorphous substitution for ealcium in ealcium phosphate minerals, and the amount of uranium is roughly proportional to organic content and inversely proportional to carbonate content.

Evaporite deposits appear to carry only traces of uranium even though the surrounding terranes may carry more than average. Uranium appears to be preferentially deposited in clay beds and particularly in black shale strata.

Siliceous precipitates such as opal, flint, and chalcedony formed in or near uraniferous terranes may contain up to a few tens of parts per million of uranium. The silica may be a product of weathering and decomposition of volcanic ash and transportation and deposition by ground and surface waters. Smaller amounts of uraniferous siliceous precipitates were deposited from hydrothermal solutions. The uraniferous siliceous precipitates generally are fluorescent.

Leaching of uraniferous volcanic ash, lignites, and mineral bodies by ground and surface waters in semiarid to arid regions may extract uranium and deposit it in calichelike deposits in soils and near-surface parts of rock formations. The uranium of such deposits generally does not constitute ore.

\section{INTRODUCTION}

Chemical sediments generally contain only trace amounts of syngenetically deposited uranium and are not commonly host rocks for epigenetic deposits of this element. The syngenetic uranium content of these rocks tends to be uniformly distributed within individual strata but may differ considerably between adjacent strata. Epigenetic uranium deposits in these rocks are generally small and erratic in shape and grade, and most of them have been found at shallow depths within the zone of oxidation.

Most precipitates and evaporites contain less than 4 parts per million (ppm) syngenetic uranium, owing to the chemical environments of deposition. Many chemical sediments are deposited in oxidizing environments where the uranium content of the waters is held in soluble uranyl and uranate ions. Other sediments are deposited from waters containing high carbonate and bicarbonate ion concentrations which inhibit precipitation and adsorption of uranium. Exceptions are found in some marine phosphatic sediments which may contain up to a few hundred parts per million uranium. This uranium appears to be present in isomorphous substitution for calcium in calcium phosphate minerals, and it may not be entirely syngenetic in origin.

Most chemical sediments do not form good host rocks for epigenetic uranium deposits. Low porosities and permeabilities characteristic of many limestones and stratified evaporites do not permit circulation of mineralizing solutions. Many of these rocks, in addition to limestones and dolomites, contain substantial amounts of carbonates which inhibit precipitation of uranium. Uranium is probably deposited epigenetically in such rocks only where slightly acid uraniferous ground waters or hydrothermal solutions are neutralized and only before the buildup of significant carbonate or bicarbonate ion concentrations.

Precipitates and evaporites rarely contain enough syngenetic uranium to make these materials valuable 
as ores under present conditions except as byproducts. Many occurrences of epigenetically deposited uranium minerals in these rocks are known, but the deposits are generally small and low grade.

\section{CARBONATE ROCKS}

The syngenetic uranium contents of carbonate rocks and sediments are among the lowest of all the rocks of the earth's crust. Marine limestones and dolomites have uranium contents ranging from almost nil to about $4 \mathrm{ppm}$. Data pertaining to spot samples taken from typical marine calcareous sediments, limestones, and dolomites in the United States are presented in the table below.
The low uranium content of the carbonate rocks is attributed to two factors: deposition of the sediments in oxidizing environments and the inhibitory effects of high carbonate and bicarbonate ion concentrations on precipitation and adsorption of uranium.

Some carbonate sediments are precipitated from marine and other waters as a result of changing conditions which reduce the dissolved carbon dioxide content. Conditions of changing temperature and turbulence at rather shallow depths are most effective. Shallow turbulent waters contain substantial amounts of dissolved oxygen and therefore generally form oxidizing environments unfavorable for the precipitation of uranium. Other carbonate sediments are deposited

Uranium contents of typical marine limestones and dolomites

\begin{tabular}{|c|c|c|c|}
\hline Formation & Age & Locslity & $\begin{array}{l}\text { Uranium } \\
\text { (parts per } \\
\text { million) }\end{array}$ \\
\hline Lomita marl, bioclastic limestone stratum 1. & Pleistocene & Los Angeles County, Calif & 3.8 \\
\hline Topanga formation, coquina stratum 1 & 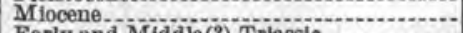 & .....do... & 3. 8 \\
\hline $\begin{array}{l}\text { Moenkopi formstion, Sinbad limestone member }{ }^{2} \ldots \ldots \ldots \\
\text { Moenkopi formation, Virgin limestone member }\end{array}$ & 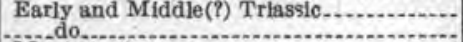 & $\begin{array}{l}\text { Emery County, Utah } \\
\text { Washington County, Ütah................ }\end{array}$ & $\begin{array}{l}\text { 2. } 0 \\
1.7\end{array}$ \\
\hline Redwall limestone ${ }^{3}$ & Míssissippian & Grand Canyon National Park, Ariz & \\
\hline Bright Angel shale, dolomite stratum $3 . . .$. & Middle Cambrian..... & do do & 1. 6 \\
\hline Tomstown dolomite, dolomite ${ }^{3} \ldots \ldots \ldots \ldots \ldots \ldots$ & Early Cambrian .............. & Jefferson County, W. Va & \\
\hline $\begin{array}{l}\text { Bass limestone }{ }^{3} \text {, dolomite stratum }{ }^{1} \\
\text { Altyn limestone }\end{array}$ & 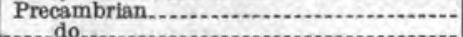 & Grand Canyon National Park, Ariz.......... & 2.4 \\
\hline $\begin{array}{l}\text { Altyn limestone, dolomite stratum } 1 \\
\text { Missonla group }\end{array}$ & do & 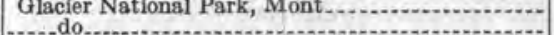 & $\begin{array}{l}1.1 \\
2.1\end{array}$ \\
\hline Siyeh limestone, algal stratum i..... & do & 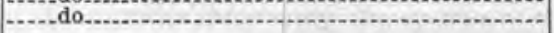 & .7 \\
\hline
\end{tabular}

1 Samples collected by George Neuerburg, U. S. Geological Survey.

s Samples collected by R. L. Cannon, U. 8, Geological Survey.

by biologic processes and consist wholly or in part of shells and other skeletal parts of organisms. The organisms live in oxygen-rich environments, and their remains generally accumulate on bottoms where conditions are oxidizing rather than reducing.

It has been known for many years that uranium in the oxidized state is soluble in the presence of high concentrations of carbonate and bicarbonate ions, and this property is utilized in making quantitative separations of uranium from several other elements (Fresenius and Hintz, 1895; Rodden, 1950 p. 31-32; Scott, 1952). The low syngenetic uranium contents of carbonate rocks and the negative relationship between carbonate and uranium in black shales and phosphatic sediments indicate that carbonate and bicarbonate ions are efficient agents for keeping uranium in solution during geochemical processes (McKelvey and Nelson, 1950).

Uranium may be deposited epigenetically in carbonate rocks by ground and surface waters containing uranium leached from other rocks, by hydrothermal solutions, and by petroliferous fluids. Most deposits are small or consist of low-grade material, but some provide substantial amounts of high-grade ore.

Ground and surface waters may leach uranium from mineral deposits and slightly uraniferous rocks and deposit it elsewhere. This action seems to be common in areas characterized by abundant pyroclastic debris. Deposition occurs in materials which readily adsorb uranium, such as carbonaceous rocks and clay; in rocks which can quickly change the chemical character of solutions moving through them, such as limestones and dolomites; and wherever evaporation causes solutions to reach saturation.

Deposits of secondary uranium minerals occur in Tertiary limestones of Wyoming and Utah. Some of the Mesozoic and Tertiary formations of these States include large amounts of pyroclastic material as beds of nearly pure volcanic ash or as debris distributed in other sediments. Weathering and alteration of the pyroclastic rocks probably releases a part of the uranium which is then leached by slightly acid ground waters. Deposition in the limestones probably occurs mainly as a result of neutralization of the slightly acid waters and consequent lowering of the solubility of uranium. It must occur before the buildup of a significant carbonate ion concentration. Evaporation at or near outerops causes additional deposition of uranium and probably plays a major role in forming the higher grade parts of the deposits.

In the Miller Hills area, Carbon County, Wyo., there are small uraniferous deposits in a limestone 
member of the Pliocene(?) North Park formation(?). This formation consists principally of waterlaid pyroclastic debris and includes several fresh-water limestone beds. Uranophane is the only uranium-bearing mineral that has been identified. It coats fracture surfaces and partially fills vugs. Small amounts of uranium are contained in opal and chalcedony which also coat fracture surfaces and partially fill vugs. The uranium is believed to have been leached from thick porous beds of tuffaceous sandstone by ground-water solutions and deposited as secondary concentrations in the limestone. These deposits are small and erratic. The higher grade parts of the deposits occur in brecciated zones in the limestone, especially where these zones are exposed on outcrops or lie under very thin cover (J. D. Vine, written communication, 1955).

In the Split Rock area, Fremont and Natrona Counties, Wyo., uraniferous tufa and travertine recently have been deposited upon a terrane underlain by a thick series of tuffaceous shale, sandstone, and pumicite strata of Pliocene(?) age. The stratified rocks contain up to $60 \mathrm{ppm}$ uranium, and the spring deposits contain up to three times this amount (J. D. Love, written communication, 1952). Ground-water solutions probably leached uranium from the tuffaceous material. Deposition at sites of springs probably was caused principally by evaporation, because it appears that the flow of water was small, and no significant drainage channels exist in the immediate vicinity of the deposits. There are no visible uranium minerals in the deposits.

The outcrops of some thin limestone beds in the upper part of the Green River formation near Myton in the Uinta Basin, Utah, are uraniferous. The limestones contain a small amount of tuffaceous material and are interbedded with tuffaceous shales and siltstones. The uranium content of the limestone is as much as $180 \mathrm{ppm}$; the content of the shales and silt stones has not been determined but is indicated by portable scintillometers to be much lower.

Hydrothermal solutions sometimes deposit uranium in carbonate rocks although the environment appears unfavorable. Deposition probably occurs as acid solutions are neutralized and before the carbonate ion concentration reaches significant proportions. Primary uranium minerals, which may be of hydrothermal origin, are found in the Jurassic Todilto limestone near Grants, McKinley County, N. Mex. Uraninite and uraniferous fluorite accompanied by pyrite and barite form disseminated deposits in the limestone. The richest uranium deposits contain a large proportion of secondary minerals principally concentrated on fracture surfaces and in vugs. The processes involved in the deposition of the primary uranium-bearing minerals are obscure, and the origin of the mineralizing solutions is controversial. The limestone is petroliferous and fetid. Acidic solutions were possibly neutralized by contact with the limestone, and the uranium was precipitated in a reducing environment caused by the organic material and sulfides. The secondary minerals appear to have been formed in part by alteration of primary uranium minerals and to a greater extent by deposition from solutions which leached uranium from other nearby uraniferous formations.

Heavy petroliferous residues, "dead oil" stains, and asphalt, which remain in rocks after the passage of liquid hydrocarbons, often contain substantial amounts of uranium and other metals. These heavy hydrocarbon residues have been found in all kinds of rocks, but not all of them are uraniferous, and no explanation can be offered to account for this difference. It has been shown that metals contained in crude oils are concentrated in the asphaltic fraction (Shirey, 1931; Thomas, 1938; Bonham, 1950) and that the heavier asphaltic fractions are adsorbed on the surfaces of some sediments (Nutting, 1934). The residues represent a small fraction of the original crude oil, but they may contain a large proportion of the metals originally present in the oil.

Solid asphaltite residues and pellets occur in the lower Permian dolomites of the Panhandle gas field, Texas, and in dolomites of the Seven Rivers gypsiferous member of the Chalk Bluff formation which crop out near Carlsbad, N. Mex. The pellets, less than a millimeter in diameter, generally form botryoidal masses, but some exceed a centimeter in diameter. The asphaltite appears to replace carbonate minerals rather than fill vugs. Pellets are most abundant near open fractures and may be distributed throughout the remainder of the rock in a random manner. Solid asphaltite also may coat fracture surfaces and form stylolitelike structures. In some localities all of this asphaltite appears to be uraniferous; in other localities similar asphaltite is not appreciably uraniferous. Asphaltite pellets from the Permian dolomites of the Panhandle gasfield have been found to contain as much as 1.6 percent uranium (Erickson and others, 1954). Even though the asphaltite itself contains abnormal quantities of uranium, no deposit has been found which contains enough of this material to permit its utilization as ore.

\section{PHOSPHATIC SEDIMENTS}

All marine phosphatic sediments are believed to be uraniferous. Phosphatic nodules found in some marine black shales also are uraniferous. The uranium content of these sediments appears to be concentrated in 
calcium phosphate minerals. In a general way uranium content increases with phosphate content, but the ratio is not constant thereby suggesting that some uranium probably is attached to clay or organic material (McKelvey and Nellon, 1950). Most of the uranium can be separated from phosphates only by chemical methods. Probably the greater part of the uranium is present in isomorphous substitution for calcium.

Marine phosphatic sediments probably are deposited along the edges of continental shelves where ascending cold phosphate-rich waters are warmed and the pressure of carbon dioxide partly decreases (McKelvey and Nelson, 1950). A large part of the uranium content, which may be as much as a few hundred parts per million, probably is truly syngenetic, but there is no reason to believe that adsorption of uranium ceases with precipitation of calcium phosphate. According to McKelvey and Nelson (1950), a strongly negative relationship exists between uranium and carbonate in the phosphorites of the Phosphoria formation. This relationship appears to be characteristic of all phosphatic sediments.

The Phosphoria formation of the Northwestern United States is a typical marine deposit in which thinly bedded uraniferous phosphate strata are separated by slightly phosphatic shales. The total uranium content increases westward from Wyoming into Idaho with corresponding increases in thickness and phosphate content of the formation. Although uranium content increases in a general way with increasing phosphate content, the most uraniferous beds are not the most phosphatic (McKelvey and Nelson, 1950). Phosphatic nodules enclosed in some black shales - as for example those at the top of the Checkerboard limestone and the Fort Scott limestone of Pennsylvanian age in Oklahomaare uraniferous, and such nodules generally contain more uranium than the enclosing shale (McKelvey and Nelson, 1950).

\section{EVAPORITES}

Evaporites deposited during desiccation of large bodies of water appear to have very small uranium contents even though the ingredients may have been derived from terranes having higher than average amounts of uranium. The meager analytical data pertaining to anhydrite, halite, and saline potash minerals indicate that these materials commonly carry less than $1 \mathrm{ppm}$ of uranium. The uranium contents of several samples of halite and sylvite collected from mines in the Carlsbad district, New Mexico, were found to be too small to be measured by routine chemical methods. W. Gentner and others (1954) report a uranium content of about $0.1 \mathrm{ppm}$ in sylvite from Baden, Germany. Gamma-ray logs of holes drilled through evaporite deposits show very low levels of radioactivity except where potassiumbearing minerals are present.

Waters in desiccating basins are likely to be shallow and subject to turbulence. The environment is oxidizing, and therefore uranium remains in solution. Calcium carbonate concentration reaches saturation during the early stages of desiccation and tends to be stabilized thereafter unless substantial dilution occurs. The carbonate ion concentration acts to hold uranium in solution. As a consequence, unless adsorbed by clays and organic material, uranium probably tends to concentrate in bitterns and is deposited during the final stage of complete desiccation. Such uraniferous evaporites appear to be uncommon because desiccation of the basins is rarely complete, and the salts may be blown away by winds or be leached when other sediments are deposited.

A substantial part of the uranium carried into desiccating basins may be adsorbed by clays and organic material and be deposited in clay or shale strata interspersed in the saline sequence. Analyses of 23 samples of clays and siltstones taken from drill cores of the saline sections of the Salado formation, Delaware Basin, N. Mex., show uranium contents of as much as $30 \mathrm{ppm}$ (Jones and others, written communication, 1955). The uranium content of the saline minerals is too low to be determined by standard chemical procedures. Corresponding gamma-ray logs show the radioactivity of clay and silt strata to be substantially greater than that of saline strata, except where the latter contain potassium minerals. The logs also show that the radioactivity of anhydrite and halite strata contaminated with clay, but not potassium minerals, is significantly higher than that of essentially pure saline strata. According to S. A. Wengerd and J. W. Strickland (1954), thin euxinic black shale lentils interbedded in the salt phase of the Paradox member of the Hermosa formation of Colorado and Utah can be correlated over wide areas by means of radioactivity logs. A probable concentration of uranium in the black shale is indicated.

Minor deposits of secondary uranium minerals which are of epigenetic origin have been found in gypsum beds. Some small ore-grade deposits occur in the basal 25 feet of nonmarine gypsum and gypsiferous clay facies of the Brule formation of Oligocene age about 12 miles northeast of Chadron, Neb. (Dunham, written communication). Uranium minerals present are carnotite occurring as vague irregular veinlets, poorly defined pore fillings, and minute aggregates in bedded gypsum; sabugalite, $\mathrm{HAl}\left(\mathrm{UO}_{2}\right)_{4} \cdot 16 \mathrm{H}_{2} \mathrm{O}$, occurring in a similar manner in bedded gypsum; and autunite occurring as fracture coatings and granular aggregates in gypsiferous clay directly above and below bedded mineralized gypsum. The larger and higher grade 
deposits are in gypsiferous clay. Within bedded gypsum, uranium minerals are restricted to parts containing substantial amounts of carbonaceous material. It is believed that the uranium was leached from overlying tuffaceous sediments by ground waters and carried downward and precipitated in the parts of the gypsiferous facies containing abundant carbonaceous material. Small amounts of secondary uranium minerals have been found in bedded gypsum of the Paradox member of the Hermosa formation in Gypsum Valley, San Miguel County, Colo. This uranium was probably leached from nearby deposits in sandstones.

\section{CALICHE-TYPE DEPOSITS}

Leaching of uraniferous volcanic ash, black shales, lignites, and mineral bodies by ground and surface waters in semiarid to arid regions may result in extraction of uranium and its subsequent deposition in calichelike deposits. Soluble minerals, such as schroeckingerite and zippeite, and slightly soluble minerals, such as carnotite, may be deposited in soils and near-surface parts of rock formations. These deposits are likely to be locally transient and move about with changing seasons and periods of precipitation. Generally, they are small, and the uranium content is too low to permit the material to be used as ore.

The best known uraniferous calichelike deposits in the United States are the Lost Creek schroeckingerite deposits in Sweetwater County, Wyo. According to L. R. Page (written communication, 1950) and D. G. Wyant and B. M. Sheridan (written communication, 1951), the schroeckingerite occurs as rounded aggregates as much as an inch in diameter in gently dipping clay and silt beds and as tiny flakes in sand or sandy clay. The mineralized part of each bed extends from the surface to a depth of about 8 feet, or a width of about 25 feet along the dip. The deposits appear to be associated with the Cyclone Rim fault, which is a major structural feature of the area. This fault is believed to have been the channel for the uraniumbearing solutions. The source of the uranium may be in uraniferous lignite beds lying between 300 and 500 feet below the surface or in primary vein material at depth slong the Cyclone Rim fault zone. The schroeckingerite is probably an efflorescent salt formed only near the surface and does not extend to any great depth. It is being dissolved and redeposited currently, and some probably is being formed by the evaporation of ground water containing more uranium from the same source. The grade of the deposits differs considerably, and little of the material meets present specifications for uranium ore.

In some parts of the Colorado Plateau and Wyoming, yellow coatings of carnotite, bayleyite, schroeck- ingerite, zippeite, and other less common, somewhat soluble uranium-bearing minerals appear on walls of mine workings and outcrops where evaporation of ground water occurs. These minerals have been described by A. D. Weeks and M. E. Thompson (1954). Deposits on outcrops or other surfaces exposed to the weather are likely to disappear during periods of precipitation, and new deposits follow when evaporation is resumed. Such superficial deposits generally do not provide ore-grade material, but they demonstrate that significant leaching and redistribution of uranium occurs in zones of ground-water movement.

\section{SILICEOUS PRECIPITATES}

Chert, flint, chalcedony, and opal formed in or near uraniferous terranes and in the vicinity of uranium deposits leached by ground waters commonly contain small amounts of uranium. Siliceous precipitates and replacements occurring with secondary uranium deposits also are commonly uraniferous. These siliceous rocks are abundant in some terranes characterized by large amounts of devitrified, weathered, and altered tuffaceous sediments and also may be present in nearby formations. Large amounts of silica are liberated during conversion of vitreous volcanic sediments to bentonitic clays (Waters and Granger, 1953); and upon neutralization or evaporation of the ground-water solutions, this silica is precipitated. If the tuffaceous sediments happen to be uraniferous, some uranium is liberated during devitrification and alteration and is removed in ground-water solutions. Part of this uranium may be adsorbed by siliceous precipitates, the uranium content of which may be as much as about $200 \mathrm{ppm}$.

Large amounts of uraniferous residual flint and chert nodules lie on erosional surfaces of tuffaceous Tertiary formations in many parts of the Rocky Mountains region, and secondary uraniferous siliceous deposits within the tuffaceous formations and nearby rocks are locally abundant. In the Monument Valley district and elsewhere on the Colorado Plateau, deposits of uraniferous secondary silica have formed in the vicinity of altered and leached uranium deposits in the Shinarump conglomerate. None of these siliceous materials are utilized as ores because of their low uranium contents and refractory character.

Many siliceous precipitates formed on uraniferous terranes and in the vicinity of uranium deposits are fluorescent, whereas similar materials found in other areas may not fluoresce. Fluorescence is useful in prospecting, but it does not necessarily indicate the presence of nearby minable ore bodies, and it does not always indicate uranium because other elements can fluoresce. Investigations by Lewis (written communi- 
cation, 1955) show that secondary silica occurring far from ore bodies in barren ground is nonfluorescent, that samples taken near ore contain larger amounts of uranium, and that the fluorescent color changes from a pale yellowish green to deep green with increase in uranium content. This property can be used as a guide in prospecting rim exposures and talus slopes and could be of value in the examination of drill cores.

\section{REFERENCES CITED}

Bonham, L. C., 1950, A geochemical investigation of certain crude oils: $\mathrm{Ph}$. D. thesis, Wash. Univ.

Erickson, R. L., Myers, A. T., and Horr, C. A., 1954, Association of uranium and other metals with crude oil, asphalt, and petroliferous rock: Am. Assoc. Petroleum Geologists Bull. 38 , p. $2200-2218$.

Fresenius, R., and Hintz, E., 1895, Bestimmung des Urans in Phosphorsäure und arsensäure enthaltenden Erzen: Zeitsch. anal. Chemie Band 34, p. 437-439.

Gentner, W., Goebel, K., and Präg, R., 1954, Argonbestimmungen an kalium-mineralien, III: Vergleichende messungen nach der kalium-argon-und uran-helium-methode, Geochim. Cosmochim. Acta 5, p. 124-133.

McKelvey, V. E., and Nelson, J. M., 1950, Characteristics of marine uranium-bearing sedimentary rocks: Econ. Geology, v. 45 , no. 1 , p. $35-53$.
Nutting, P. G., 1934, Some physical and chemical properties of reservoir rocks bearing on the accumulation and discharge of oil, in Wrather, W. E. and Lahee, F. H., eds., Problems of petroleum geology (Sidney Powers memorial volume): Tulsa, Okla., Am. Assoc. Petroleum Geologists, p. 825-832.

Rodden, C. J., ed., 1950, Analytical chemistry of the Manhattan project, Division VIII, Volume 1 of National Nuclear Energy Series: New York, McGraw-Hill Co., Inc., 748 p.

Scott, W. W., 1952, Standard methods of chemical analysis, Volume 1: New York, D. Van Nostrand Co., Inc., 5th ed., $1020 \mathrm{p}$.

Shirey, W. B., 1931, Metallic constituents of crude petroleum: Indus. Eng. Chemistry 23, p. 1151-1153.

Thomas, W. H., 1938, Inorganic constituents of petroleum in Dunstan, A. E., and others, eds., Science of Petroleum, Volume 2: London, Oxford University Press, p. 1053-1056.

Waters, A. C., and Granger, H. C., 1953, Volcanic debris in uraniferous sandstones and its possible bearing on the origin and precipitation of uranium: U. S. Geol. Survey Circ. 224, $26 \mathrm{p}$.

Weeks, A. D., and Thompson, M. E., 1954, Identification and occurrence of uranium and vanadium minerals from the Colorado Plateaus: U. S. Geol. Survey Bull. 1009-B, p. 13-62.

Wengerd, S. A., and Strickland, J. W., 1954, Pennsylvanian stratigraphy of Paradox Salt Basin, Four Corners region, Colorado and Utah: Am. Assoc. Petroleum Geologists Bull. 38, p. 2157-2199. 


\title{
URANIUM DEPOSITS IN LIMESTONE
}

\author{
By John W. Gabelman, U. S. Atomic Energy Commission
}

\section{CONTENTS}

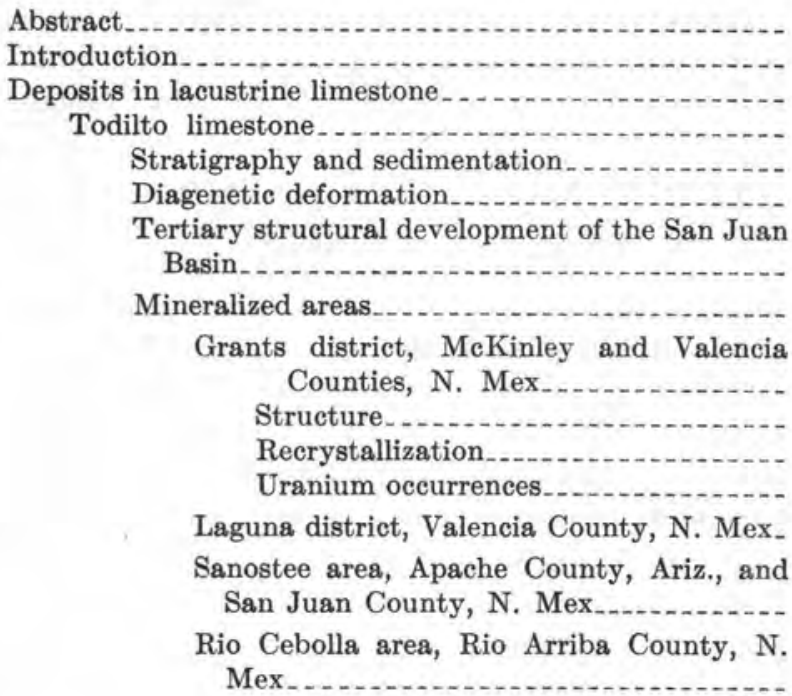

Page

388

388

388

388

389

389

391

391

391

391

392

396

399

399

400

Deposits in lacustrine limestone-Continued Todilto limestone-Continued Mineralized areas-Continued Arroyo del Agua area, Rio Arriba County, N. Mex. . . . . Browns Park formation Bidahochi formation ............................

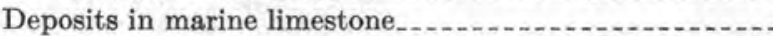
Kaibab limestone and San Andres formation....... Hermosa formation. . Sundance formation. Redwall limestone..............................

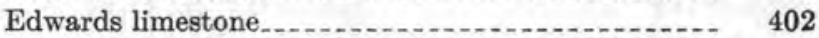

Hueco limestone... 402

Marine limestone of middle Paleozoic age ....... 402

Kittatinny limestone......... 403

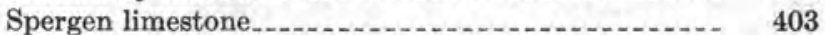

Deposits in marginal or littoral limestone...... 403

Bear River formation. . . ........... 403

References cited........... 404

\section{ILLUSTRATIONS}

Plate 10. Aerial views of pits in Gay Eagle area, Valencia County, N. Mex.......... Faces 392

Figure 128. Distribution of uranium deposits in limestone in the United States.....................

129. Index map of San Juan Basin, N. Mex....

130. Generalized geologic map showing Todilto limestone outcrops, facies, and areas containing uranium deposits in limestone, San Juan Basin and adjacent regions, New Mexico

131. Generalized correlation diagram, Todilto limestone and adjacent formations, San

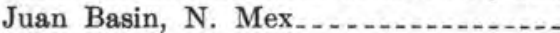

132. Structural features and Todilto outcrops, Grants district, McKinley and Valencia Counties, N. Mex.

133. Plan and sections of the Haystack mine, sec. 19 , T. 13 N., R. 10 W., McKinley County, N. Mex......................

134. Plan and sections of mine in W $1 / 2$ sec. 16 , T. 13 N., R. 10 W., Haystack area, Grants district, McKinley County, N. Mex
Figure 135. Correlation of ore bodies with minor folds, Todilto limestone, Grants district, New Mexico

136. Plan and sections of the Gay Eagle mine, showing relation of uranium mineralization to structural features and lithology, SE1/4 sec. 4, T. 12 N., R. 9 W., Gay Eagle area, Grants district, Valencia County, N. Mex

137. Plan and sections of the Black Hawk no. 1 mine, showing relation of uranium mineralization to structural features and lithology, SE $1 / 4$ sec. 4 , T. 12 N., R. 9 N., Gay Eagle area, Grants district, Valencia County, N. Mex

138. Plan of mines, showing relation of mines to minor anticlinal axes, Gay Eagle and Black Hawk groups, Gay Eagle area, SE $1 / 4$ sec. 4, T. 12 N., R. 9 W., Valencia County, N. Mex. 


\section{ABSTRACT}

Uranium deposits in limestone are known in 21 areas in the United States. Eleven areas are on the Colorado Plateau; five of these are in the lacustrine Todilto limestone around the edges of the San Juan Basin, northwestern New Mexico. Occurrences outside the Colorado Plateau are in Idaho, Missouri, New Jersey, New Mexico, Texas, Utah, and Wyoming.

The only major production has been from the Grants district, New Mexico, where the Todilto limestone is exposed in the northeast-dipping Thoreau homocline, between the San Juan Basin and the Zuni Mountains uplift. Greatest uranium concentration and production have been within fault zones striking north and northeast, parallel to major cross folds. Primary deposits are usually elongated, confined to minor anticlinal crests trending north, northeast, or east within larger shallow synclines. Primary ores consist of pitchblende, pyrite, fluorite, barite, hematite, and calcite, all replacing limestone. Selective recrystallization of limestone and bleaching of overlying redbeds accompanied ore deposition. Association with the faults suggests feeding of mineral solutions through fault channels, although no primary ore has been found in the faults. Primary minerals seemingly were introduced into the bosts laterally, and intimate intergrowth of pitchblende with fluorite suggests a hydrothermal origin. Secondary ore bodies are more irregular, commonly following reticulate patterns of joints and very small folds. Secondary oxidized minerals include carnotite, tyuyamunite, metatyuyamunite, uranophane, beta-uranophane, sklodowskite, gummite, limonite, and manganese oxide.

The only other important uranium production has been from the Laguna district, New Mexico. Here the Todilto limestone dips northwestward from the Lucero uplift into the southeast corner of the San Juan Basin. There has been production from only one deposit, confined to the crest of a small dome. Pitchblende, pyrite, and calcite have replaced limestone in small irregular pods, and are disseminated over small areas. Some secondary oxidation products have formed partly in place; others have been deposited in open fractures.

\section{INTRODUCTION}

Uranium occurrences are known in limestones of 13 ages in 21 areas in the United States (fig. 128). Of these areas 11 are on the Colorado Plateau, where virtually all limestone units contain uranium at some place. The other 10 areas are in Idaho, Missouri, New Jersey, Texas, Utah, and Wyoming. There has been important production from only the Grants and Laguna districts of New Mexico, both on the Colorado Plateau.

\section{DEPOSITS IN LACUSTRINE LIMESTONE}

\section{TODILTO LIMESTONE}

Except for extensions into central Colorado and across the northern Rio Grande Valley, the Todilto limestone of Late Jurassic age is limited to northwest New Mexico and southwest Colorado, where its extent roughly coincides with that of the San Juan Basin (fig. 129). The formation is exposed in a nearly complete ring around the margins of the basin (fig. 130).

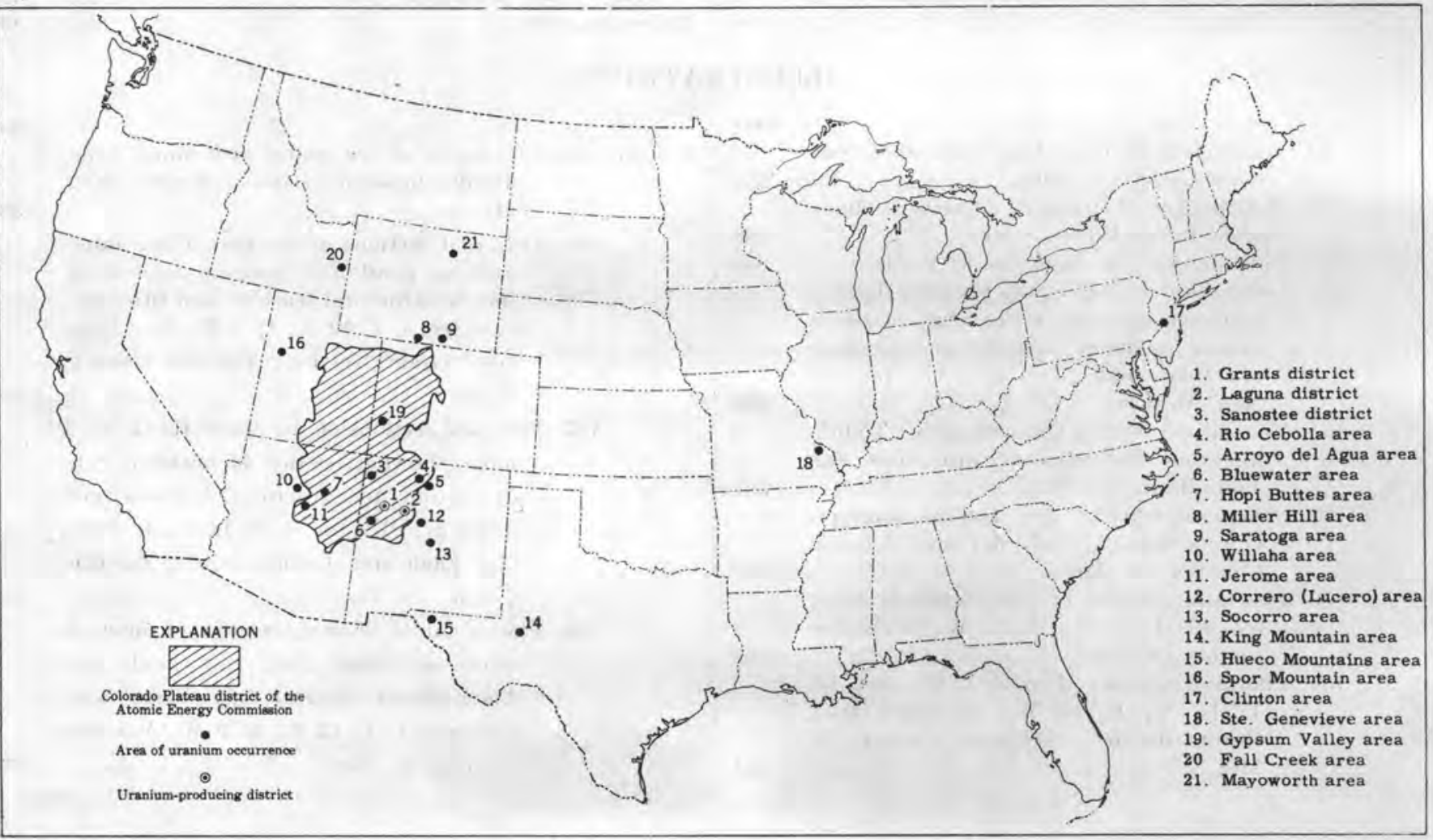

FIovRE 128.-Distribution of uranium deposits in limestone in the United States. 


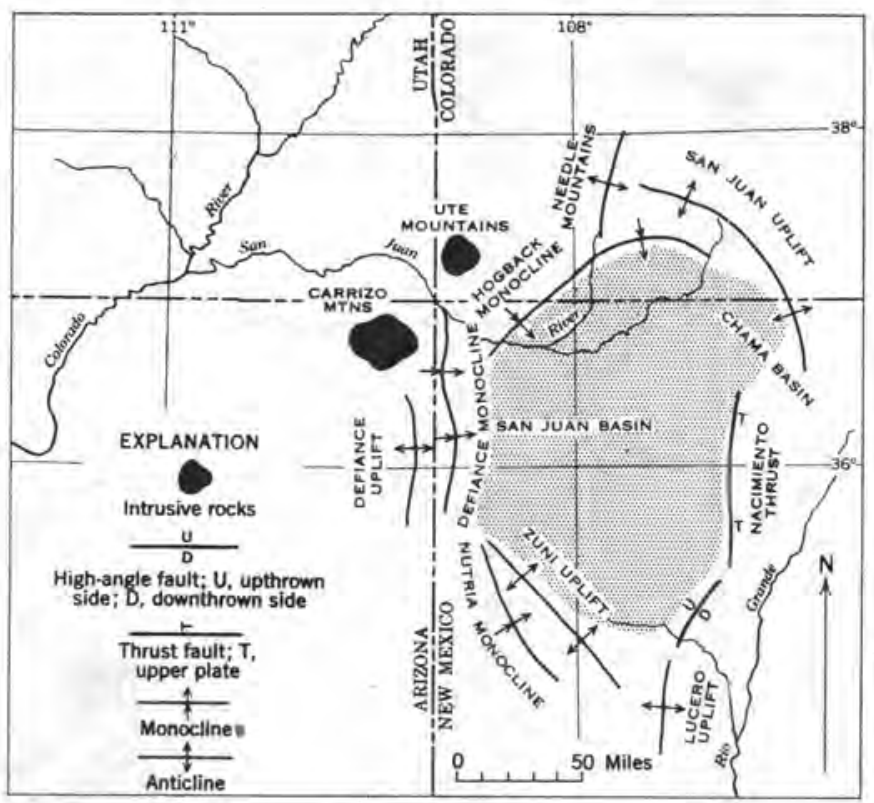

Figure 129.-Index map of San Juan Basin, N. Mex.

\section{STRATIGRAPHY AND SEDIMENTATION}

The Todilto overlies the Entrada sandstone (fig. 131) and locally interfingers with siltstone of the overlying Summerville formation. Lenses of siltstone similar to that of the Summerville occur in the upper part of the limestone, and there are lenses of limestone similar to that of the Todilto in the lower part of the Summerville. Uranium is essentially confined to the Todilto, but locally extends into the Summerville. In the eastern part of the area, the Summerville and overlying Bluff sandstone are missing, and the Todilto is unconformably overlain by the Morrison formation. In the southwest the Todilto is entirely limestone, up to 20 feet thick and thickening to 30 feet or more eastward along the southern margin of the basin. In the northeast, 5 to 10 feet of limestone are overlain by as much as 40 feet of gypsum which has formed from anhydrite with attendant swelling. Uranium deposits have not been found in areas where the Todilto contains gypsum, except in the Rio Cebolla area described in this paper. Generally the limestone is slightly petroliferous.

The Todilto limestone has been considered lacustrine, principally because of the fresh-water fossils found near its western limit (G. A. Williams, oral communication), although Smith (1951, p. 99-102) considers both the limestone and gypsum facies marine. The Todilto has been correlated with the marine Curtis formation of Utah (Smith, 1951, p. 100-101) and with the Pony Express member of the Wanakah formation in southwest Colorado. The upper gypsum bed has been cor- related with gypsum of the Wanakah of southwestern Colorado.

The Todilto limestone in the Grants district attains thicknesses up to 30 feet and contains three recognizable units (Fincher and Konigsmark, 1956) which have irregular boundaries: a basal platy, almost lithographic limestone, a middle finely wrinkled extremely thin-bedded limestone, and an upper massive recrystallized limestone. Thin siltstone partings are common in the platy unit and occur locally in the higher units. The three different types of bedding are generally continuous, but individual bedding planes are locally irregular and discontinuous, and some beds are lenticular. Each of the three limestone units contains uranium and related minerals at some place in the Grants district. In many areas, as the Gay Eagle area of the Grants district (fig. 132), the middle unit is indistinguishable from the lower unit, and the formation consists of only a lower platy limestone and an upper recrystallized limestone. The contact with overlying Summerville formation is reported to be both intertonguing (Blagbrough, 1956) and erosional (Dane, 1948). However, the contact as shown on mine maps (figs. 134, 135) is intertonguing.

\section{DIAGENETIC DEFORMATION}

Small folds of diagenetic origin are a factor in local control of mineralization, although economically important ore bodies are restricted to larger tectonic folds. The conspicuous deformation of the lower thin-bedded part of the Todilto occurred before and during recrystallization and extended throughout the upper limestone. Diagenetic deformation is principally in the form of minor folds which range in shape from broad upright to tight recumbent in the same or different larger folds within remarkably short distances. Folds range from several inches to over 30 feet in width, but most are less than one foot wide. Folds of similar width commonly are grouped together. The widespread occurrence, consistent irregularity of sizes and shapes, and erratic distribution of axes of these folds are distinctive features, and the principal evidence for their diagenetic origin. A few folds in limestone with siltstone cores, and a few folds in siltstone with limestone cores, probably originated as primary or diagenetic structural features, but may have been modified later. Locally, thrust faults break fold flanks, and many fault. zones and fold cores contain breccia. Deformation, principally from compression, is confined essentially to the Todilto limestone, particularly the small folds; but in a few places the folds extend short distances into the bounding formations. Many fold axes coincide with joint directions. 


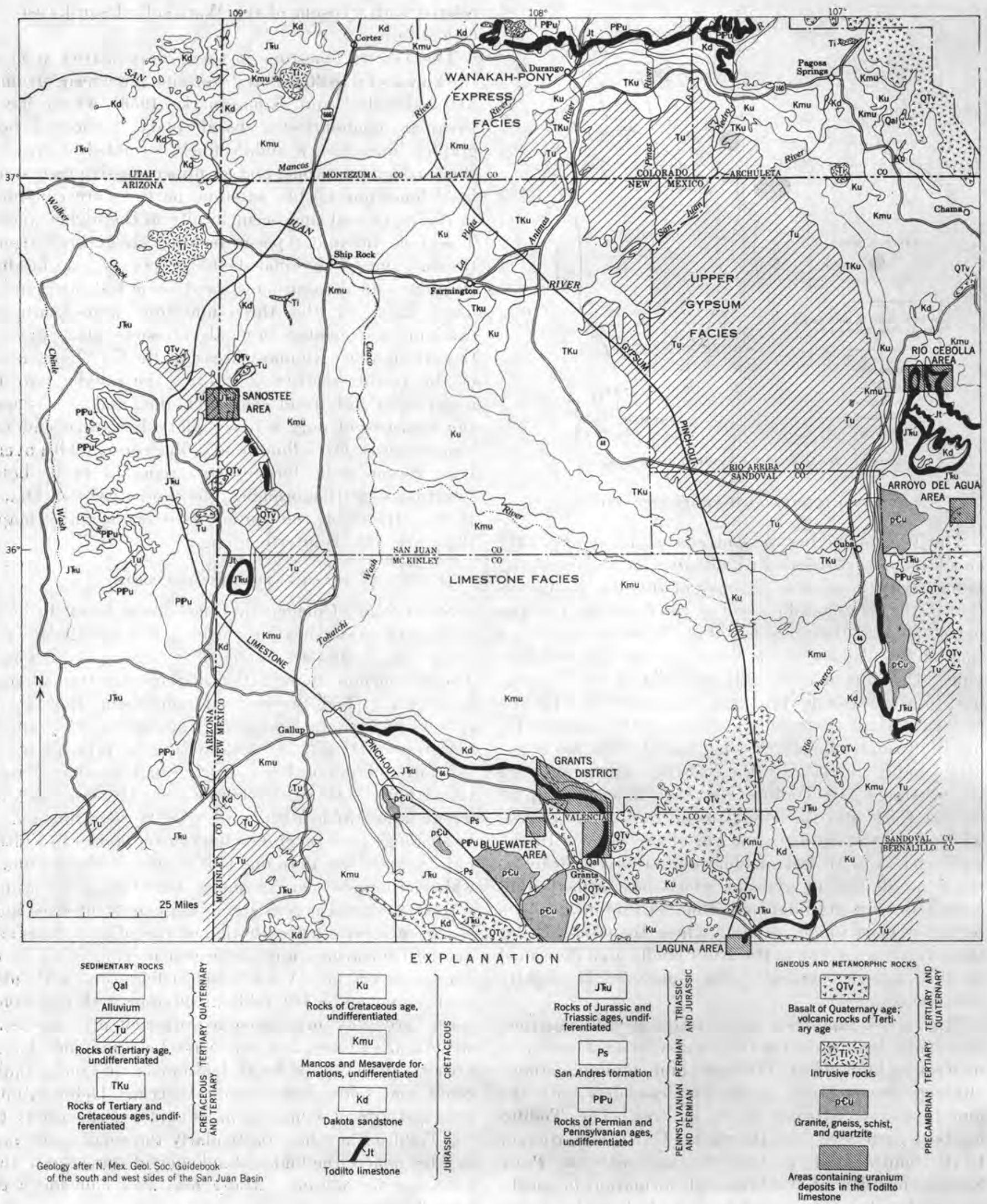

FIGURE 130.-Generalized geologic map showing Todilto-limestone outcrops, facies, and areas containing uranium deposits in limestone, San Juan Basin and adjacent regions, New Mexico. Uranium deposits in the Bluewater area are in the San Andres formation. 


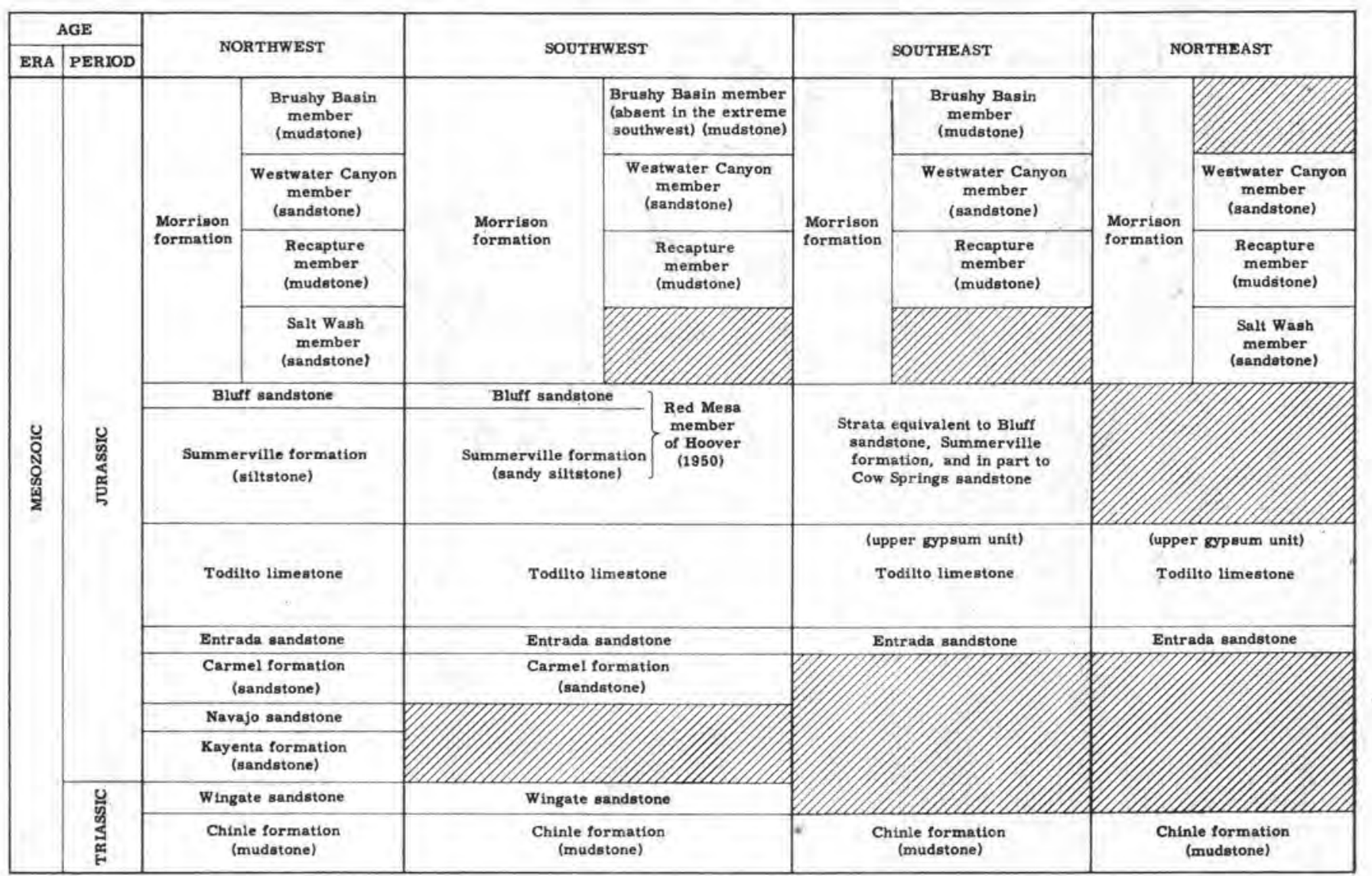

Figure 131.-Generalized correlation diagram, Todilto limestone and adjoining formations, San Juan Basin, N. Mex.

The earliest joints probably resulted from dehydration during diagenesis. It would be expected that a close genetic relation existed between such joints and the diagenetic folds and that the joints might form a crude pattern in relation to the diagenetic folds. Possibly other joints formed along fold axes during folding.

\section{TERTIARY STRUCTURAL DEVELOPMENT OF THE SAN JUAN BASIN}

The present shape of the San Juan Basin was established essentially during the Laramide revolution, by the formation of bounding ranges. Marginal deformation resulted in three major tectonic directions: north, northeast, and northwest, represented by pairs of major structural elements on opposite sides of the basin (fig. 129). The margins were further complicated by intrusion and voleanism of Miocene age on all sides and by late Tertiary block faulting on the east side, where the Colorado Plateau bounds the Rio Grande graben.

\section{MINERALIZED AREAS}

The Todilto limestone contains uranium deposits in five areas on the margins of the basin. The major district is near Grants, and minor production comes from the Laguna area. Unexploited prospects occur in the Sanostee, Rio Cebolla, and Arroyo del Agua areas (fig. 130).

GRAN TS DISTRICT, MCKINLEY AND VALENCIA COUNTIES, N. MEX. STRUCTURE

The Grants district is at the southeast end of the Thoreau homocline, on the northeast flank of the Zuni Mountains uplift, which borders the San Juan Basin on the south. The homocline is expressed physiographically by northeast-dipping cuestas. Broad cross folds plunge northeastward down the dip of the homocline, and there are also major fault zones of several hundred feet displacement, approximately parallel to the cross folds. The district coincides with the area of strongest faulting on the flank of the Zuni uplift and with the sharpest bend in the strike of the homocline. The location of the more economically important mines relative to the general geologic structural features is shown in figure 132 .

The two areas of greatest uranium concentration and production are within two zones of faults which strike north and northeast, respectively. The eastern productive zone is the Poison Canyon uranium area. It is $2 \frac{1}{2}$ miles wide and coincides with a syncline (fig. 


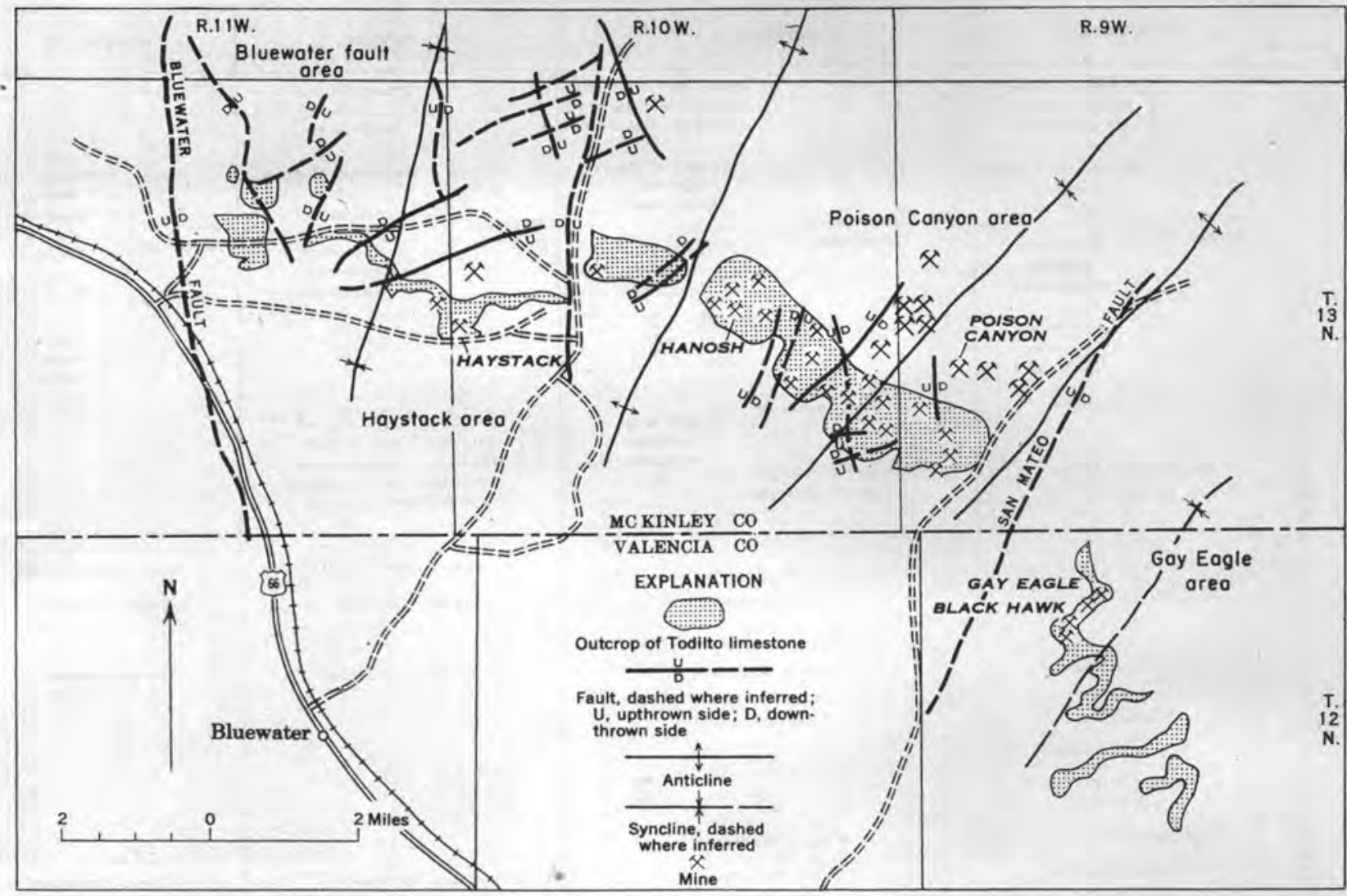

Figure 132.-Structural features and Todilto outcrops, Grants district, MeKinley and Valencia Counties, N. Mex.

132). The western belt of uranium deposits, which includes the Haystack Butte area, is only about 1 mile wide. It lies within a fault zone $2 \frac{1}{2}-3$ miles wide, which appears to be on the southeast flank of a syncline 3-4 miles wide, rather than along its axis. The 2 zones of faults and uranium belts are separated by a barren zone $2 \frac{1}{2}-3$ miles wide. Individual ore bodies occur chiefly along the axes of minor anticlines within the broader cross synclines (fig. 133).

A narrow northeast-trending uranium belt, the Gay Eagle area (fig. 132), less than half a mile wide, occurs about $1 \frac{1}{2}$ miles southeast of the San Mateo fault and is parallel to the fault. It coincides approximately with the axis of a very shallow syncline but contains no apparent zone of faults. This area is of less commercial importance than the Poison Canyon or Haystack Butte areas. Another very small uranium area occurs where the Bluewater fault intersects the Todilto limestone on the west side of the district. The Grants Mesa area is another narrow northeast-trending uranium belt several miles southeast of the Gay Eagle area. Very little is known of this area because of poor exposures. However, the uranium deposits occur within a northeast-trending zone of faults in which deformation is more severe than in most other fault zones cutting the Thoreau homocline.
RECRYSTALLIZATION

The top third of the Todilto limestone was recrystallized uniformly over large areas by a widespread mechanism, possibly hydrothermal solutions. Locally, a later alteration by hydrothermal solutions was quite irregular and in some areas penetrated the middle and also the lower part of the formation (figs. 134, 135). The close relation between intraformational folding and early recrystallization is illustrated by gradational contacts and by the destruction of bedding and earlier structural features along fold axes (fig. 135). Pressure recrystallization and solution recrystallization are in many places coextensive and indistinguishable. When examined in detail, recrystallization strongly resembles and is, in places, inseparable from the texture of replacement by introduced coarse-grained calcite before or during metallization. Most hydrothermally recrystallized rock, however, commonly has sharp, high-angle joint boundaries and is therefore fracture-controlled. At several places in the Gay Eagle area, a single fracture separates very coarse-from very fine-grained limestone. A color change from dark gray to light tan and even white accompanies the increase in grain size. Recrystallization is generally, though not consistently, associated spatially with mineralization, although 


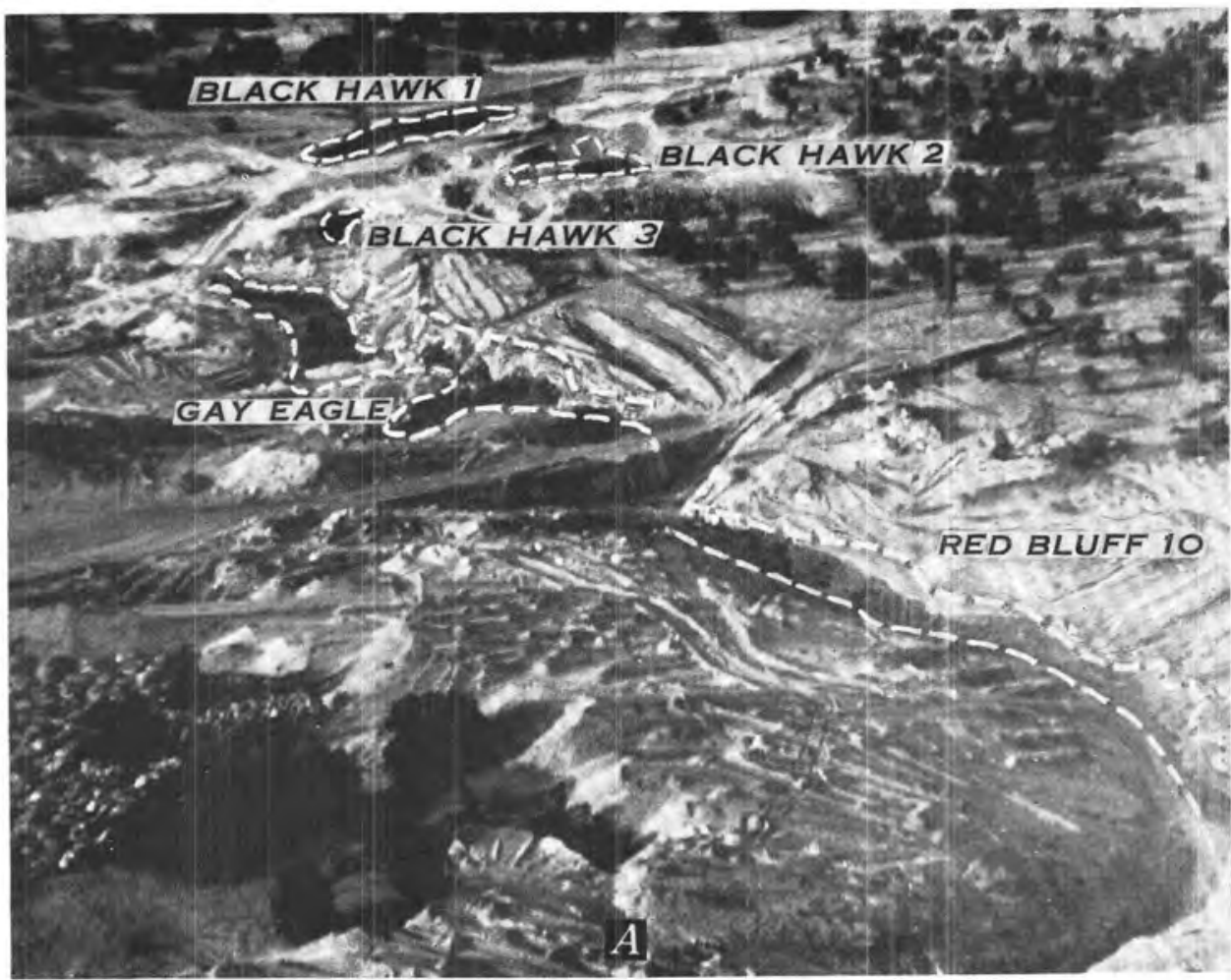

GAY EAGLE. RED BLUFF 10, AND BLACK HAWK GROUP, LOOKING NORTH. VORTHEAST

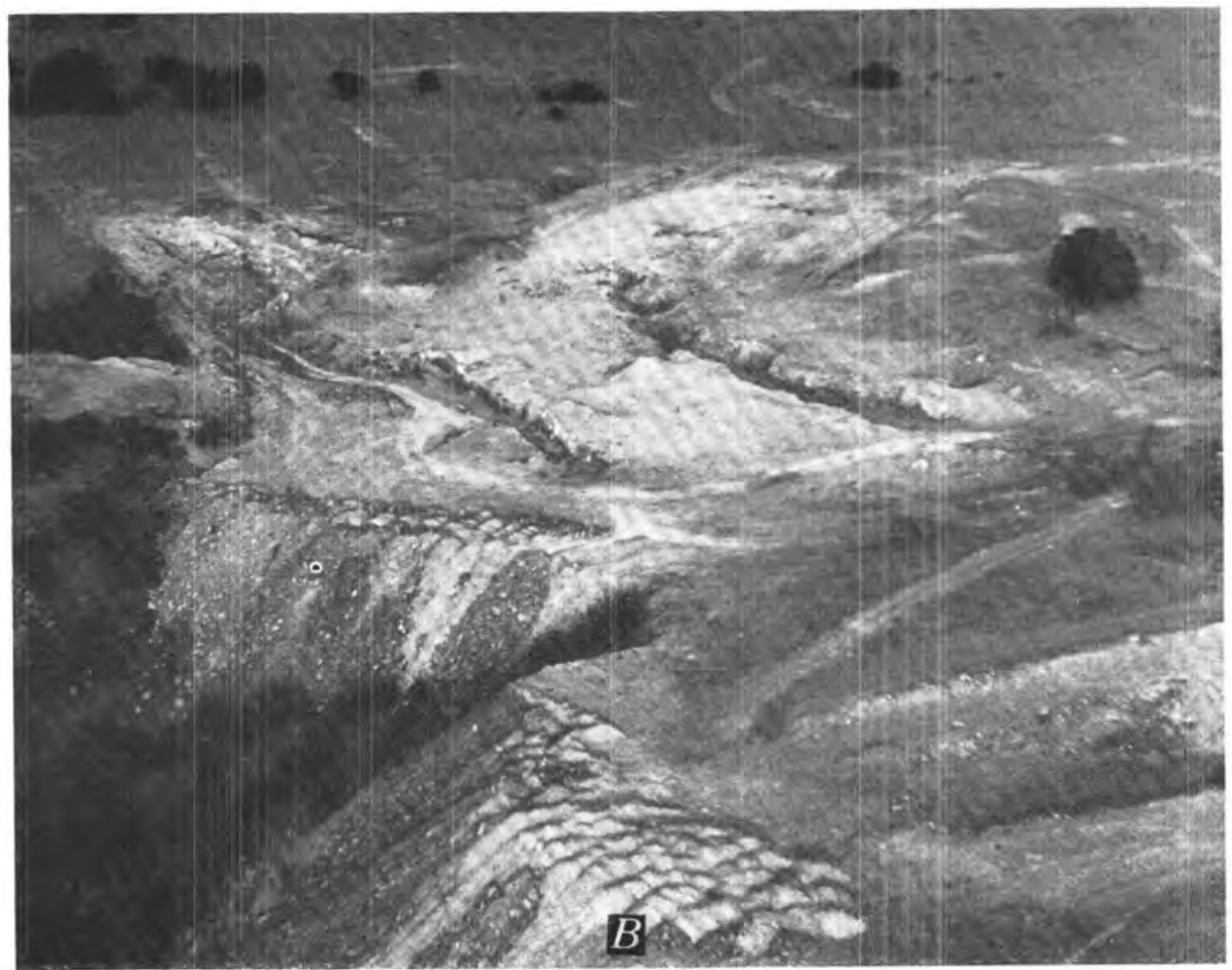

TWO NARROW PITS FOLLOWING MINERALIZED WEST-STRIKING ANTICLINAL AXIS, WESTERN EXTENSION OF RED BLUFF ORE ZONE, SE1/4 SEC. 4, T. 12 N., R. 9 W.

AERIAL VIEWS OF PITS IN GAY EAGLE AREA, VALENCIA COUNTY, N. MEX. 


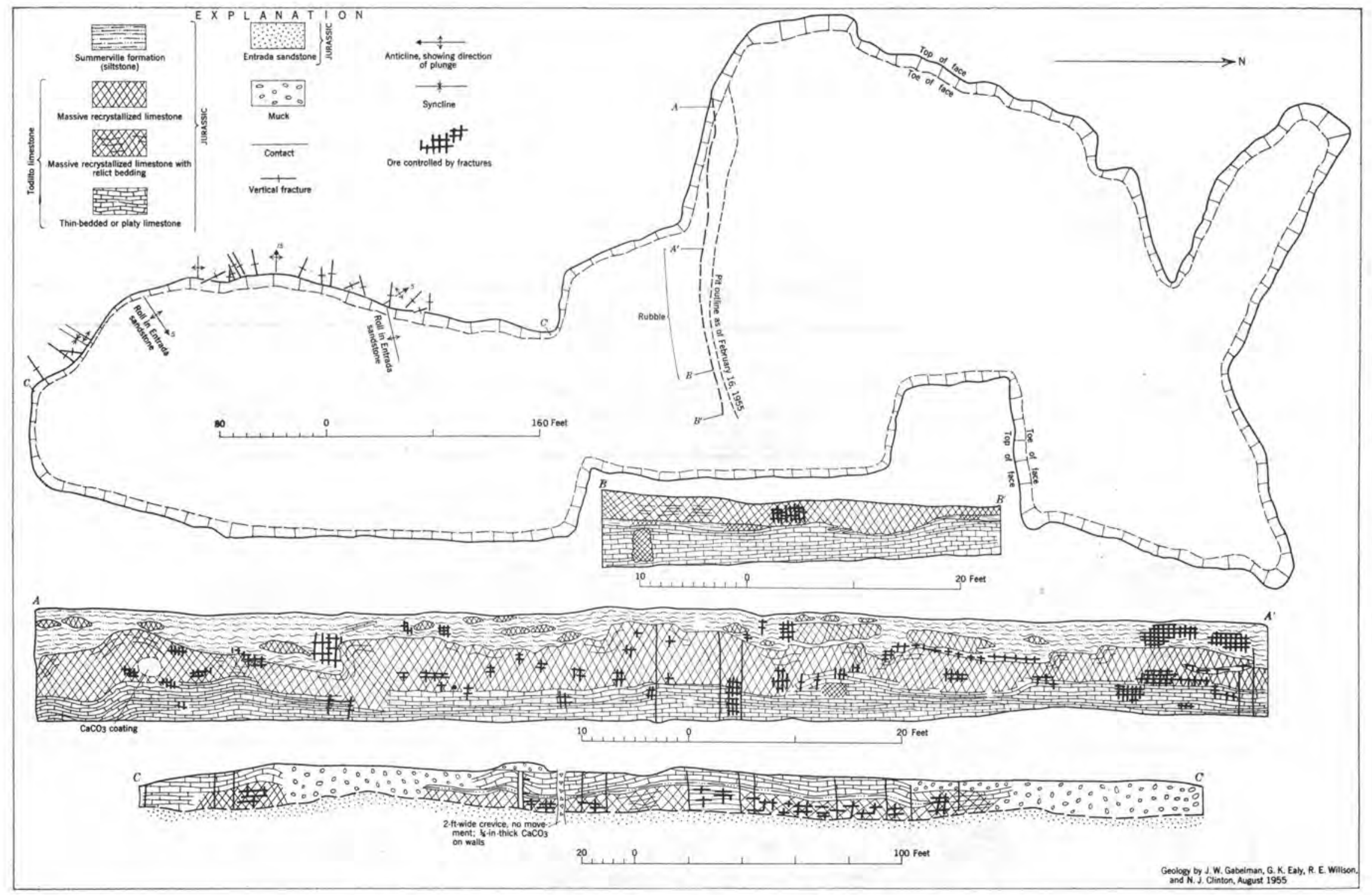

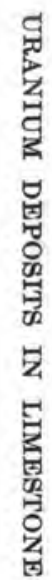

FIaURR 133.-Plan and sections of the Haystack mine, sec. 19, T. 13 N., R. 10 W., MeKinley County, N. Mex, 

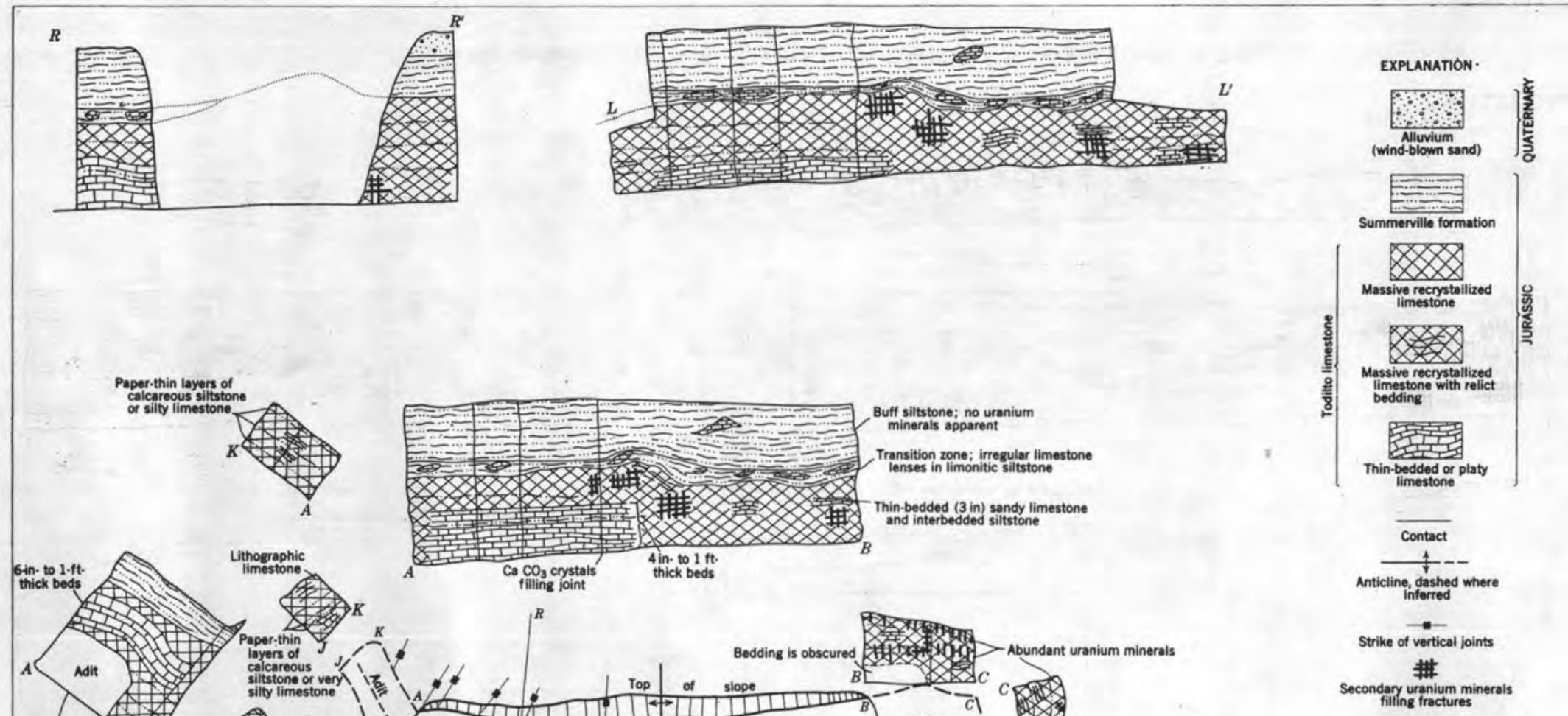

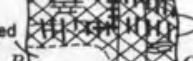

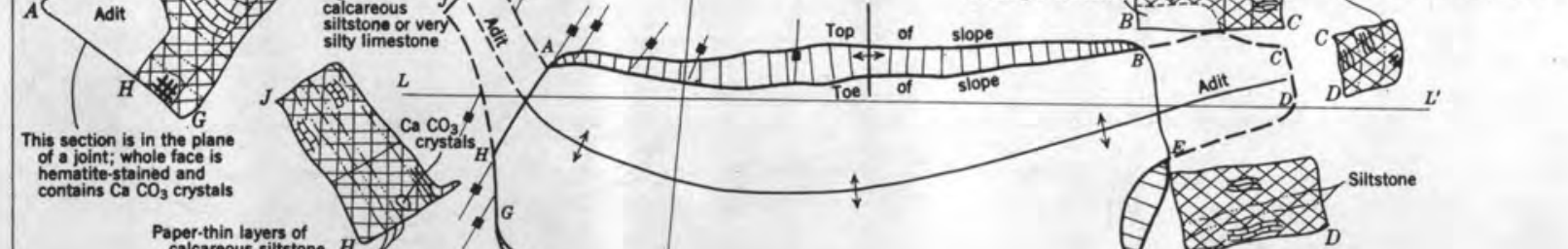

Secondary uranium minerais
filling fractures

\section{of ajoint; whole face is
hematte-stained and
contains $\mathrm{Ca}^{\circ} \mathrm{CO}_{3}$ crystals}

\section{Paper.thin layers of
calcareous siltstone}
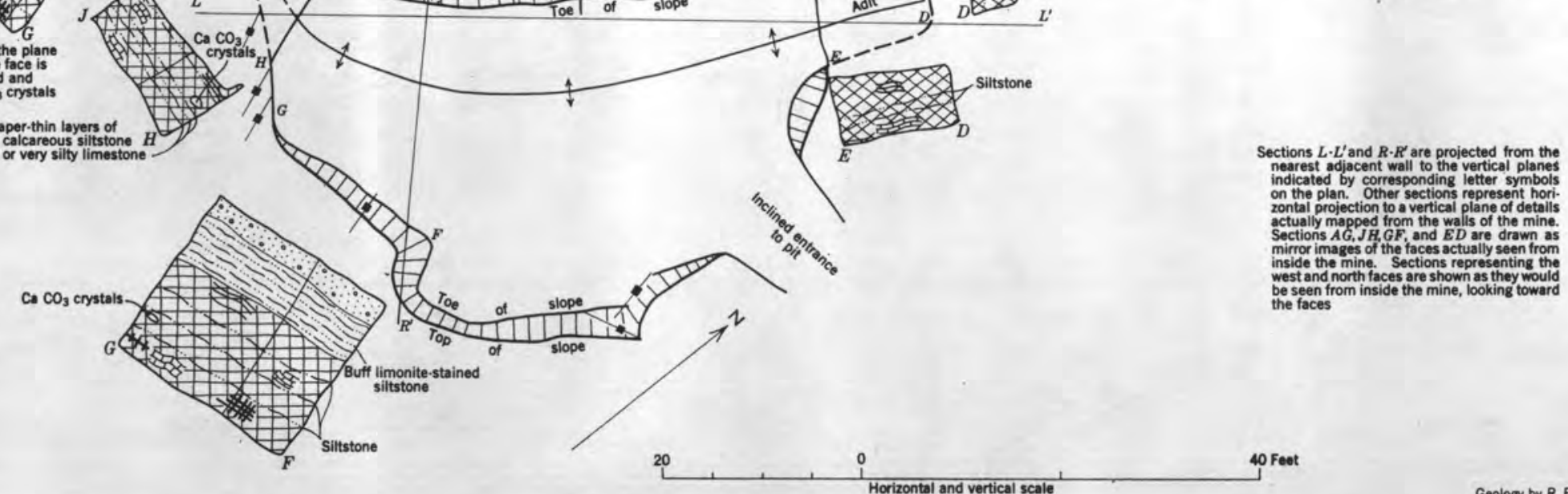

40 Feot

FIGURE 134.-Plan and sections of mine in W1/2 sec. 16, T. 13 N., R. 10 W., Haystack area, Grants district, MeKinley County, N. Mex. 
URANIUM DEPOSITS IN LIMESTONE

395

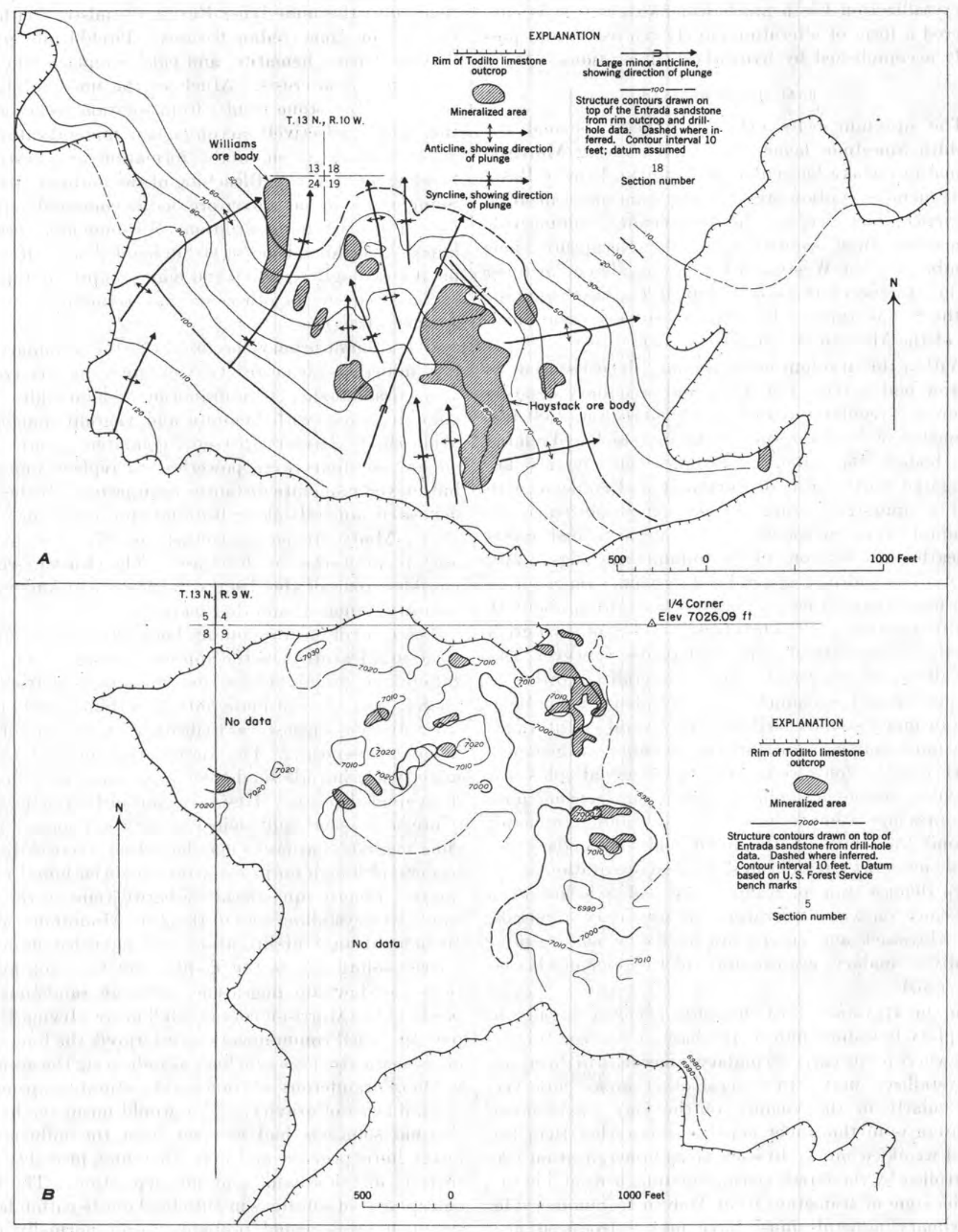

Figure 135. -Correlation of ore bodies with minor folds, Todilto limestone. Grants district, New Mexico. 
recrystallization has a much wider extent. It is considered a form of alteration closely related to and possibly accomplished by hydrothermal solutions.

URANIUM OCCURRENCES

The uranium belts extend northeast beyond the Todilto limestone bench into the overlying Morrison formation, where lenticular sands in the Brushy Basin shale member contain ore. No uranium mineralization is known, however, in the intervening Summerville formation, Bluff sandstone, or the Recapture shale member and the Westwater Canyon sandstone member of the Morrison formation, except in the basal siltstone of the Summerville. The Salt Wash sandstone member of the Morrison is absent (fig. 131).

Within the uranium belts, primary deposits occur as narrow bodies (figs. 136, 137), and secondary deposits occur as irregular rounded lenses more than 200 feet in maximum diameter, such as the Haystack and related ore bodies (fig. 133A). Primary ore bodies are elongated north, east, or northeast and coincide with axes of minor anticlines, suggesting emplacement of uranium from solutions trapped in anticlinal crests beneath shaly siltstone of the Summerville (figs. $133 B$, 136). The width of mineralized anticlines ranges from 5 to more than 30 feet. Lengths range from about 10 feet to a maximum of 5,000 feet. Bodies of such great length are discontinuous in most places, however; and not all are of ore grade. Most mineralized anticlines are not straight but sinuous (fig. 137), being a combination of many smaller anticlines of several orientations. The most common anticline is a compound group of short echelon folds connected by diagonal folds. A reticulate system of smaller folds and joints accompanies the anticline. Joints locally carry uranium minerals beyond the limits of the main fold. Secondary ore bodies are more irregular in shape and orientation as the sharp demarcation of primary ore bodies is lost even by short outward migration of secondary minerals. The Haystack and nearby ore bodies, which are principally secondary, are examples of irregular ore bodies (fig. 133A).

In the Haystack area, uranium occurs generally in the platy limestone unit at the base of the Todilto, except where joints carry secondary minerals into the upper recrystallized unit. In several other areas, however, particularly in the vicinity of the Gay Eagle mine, uranium is in the upper massive unit rather than the basal wrinkled unit. In such areas mineralization was controlled by the interfingering siltstone beds and lenses in the zone of transition from Todilto to Summerville.

Primary minerals must have been introduced into lenses and pods laterally because no trace of them ex- tends into the underlying Entrada sandstone either in the rock or along feeding fissures. Pitchblende, pyrite, fluorite, barite, hematite, and calcite replace limestone along anticlinal crests. Much of the massive character of the limestone results from solution recrystallization which selectively accompanied mineralization regardless of elevation in the formation and destroyed bedding and joints. Bleaching of the normally reddish Summerville in halos over ore bodies commonly accompanied primary mineralization. In some areas original limestone bedding is preserved in banded ore. Replacement is strongly selective and may occupy one thin bed to the exclusion of others or may terminate abruptly against a fracture.

Oxidation of primary ore produces the secondary yellow minerals carnotite, tyuyamunite, metatyuyamunite, uranophane, beta-uranotile, sklodowskite, and gummite along with limonite and vagrant manganese oxide (R. A. Laverty, personal communication). Secondary solutions were powerless to replace limestone but moved moderate distances from primary bodies and deposited minerals along bedding and joints (figs. 134, 135). Many ore bodies consist entirely of secondary ore in networks of fractures. The fracture-ridden wrinkled zone of the Todilto facilitated secondary ore deposition more than other features.

The control of uranium ore bodies by early Tertiary structural features sets the approximate age of mineralization (no uranium age determinations have been made), and the intimate intergrowth of pitchblende with fluorite suggests a hydrothermal origin for the limestone deposits. The termination of ore against underlying Entrada sandstone implies lateral feeding to individual deposits. However, the obvious clustering of ore bodies near fault zones cutting the Thoreau honocline suggests that faults may have been vertical district feeders, although no primary ore has been found in the faults. Fluorite-quartz-calcite-barite veins in the Precambrian crystalline core of the Zuni Mountains, about 10 miles distant updip, also could have fed uraniumfluorite solutions into the Todilto and Morrison formations for downdip migration, although sandstone deposits of the Morrison contain no fluorite. Irving Rapaport (personal communication) interprets the limitation of ore bodies to large synclines as indicating the accumulation of uraniferous solutions in structural sumps under the influence of gravity. This would mean the hydrothermal solutions had escaped from the influence of intratelluric pressure and were, therefore, probably telethermal in the area of uranium deposition. The local entrapment of solutions in anticlinal crests within larger synclinal areas would probably result normally from hydrostatic pressure at moderate depth. 


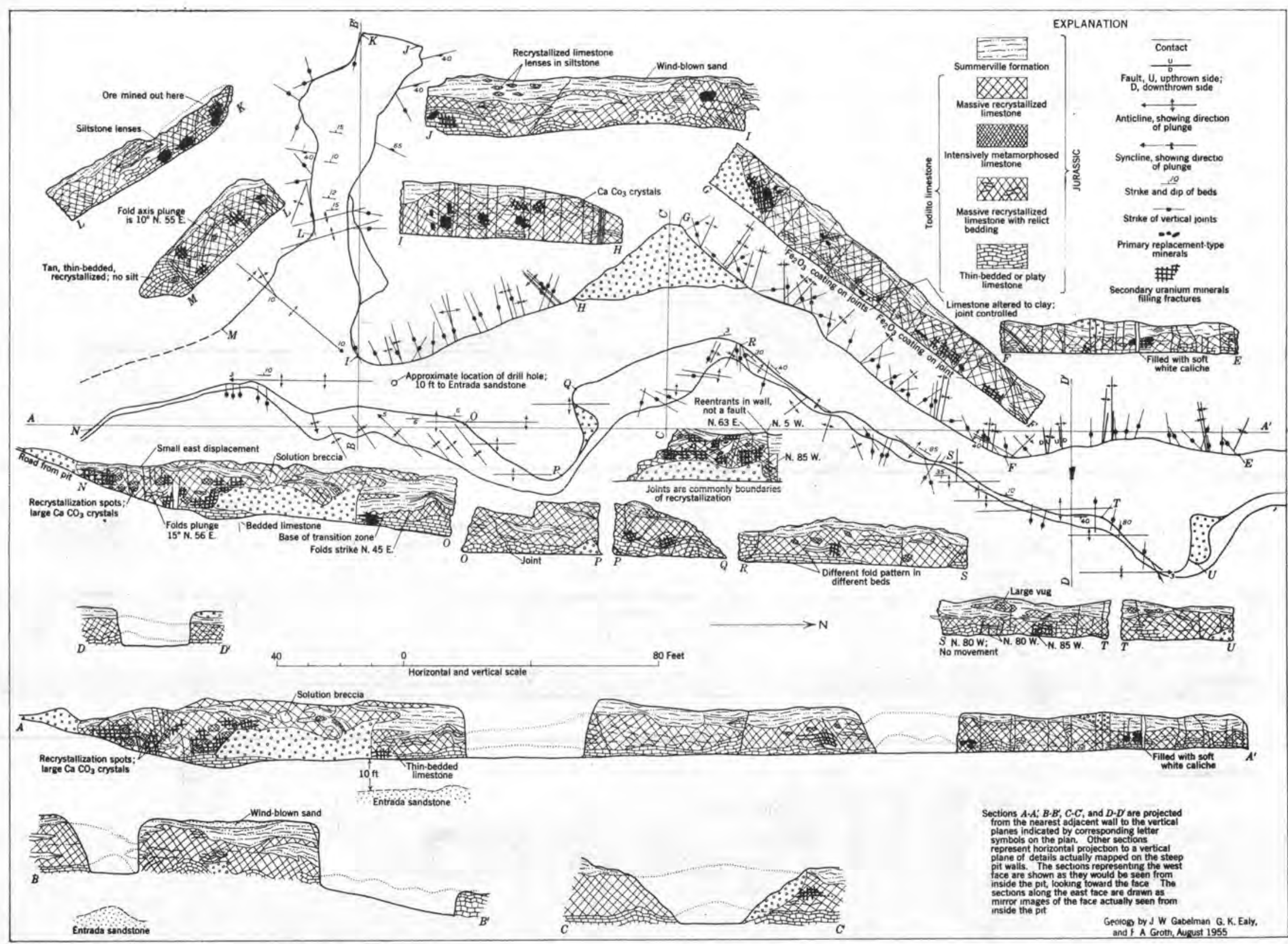

Figure 136.-Plan and sections of the Gay Eagle mine, showing relation of uranium mineralization to strueture and lithology, SE1/4 sec. 4, T. 12 N., R. 9 W., Gay Eagle area, Grants district, 


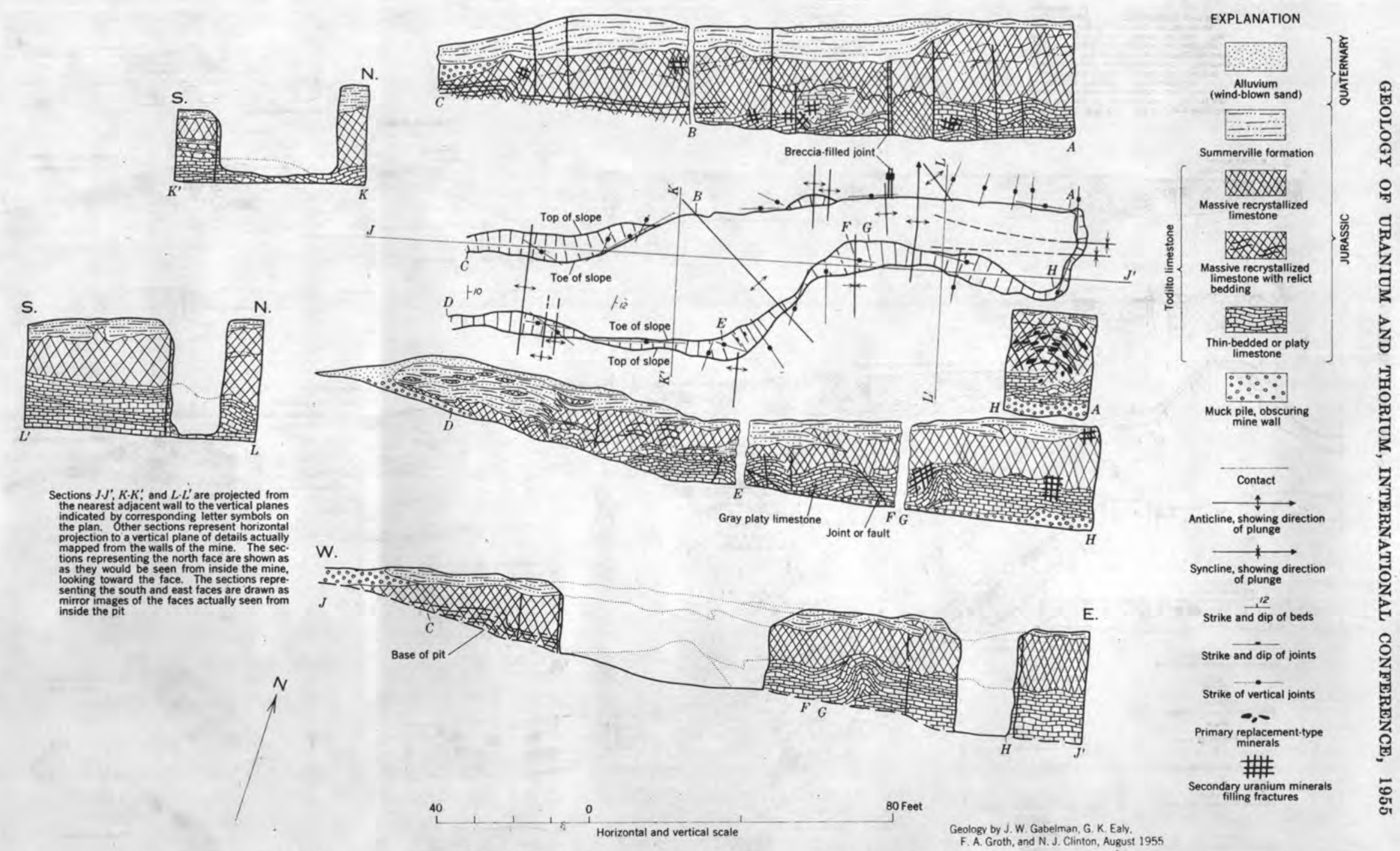

FiGURE 137.-Plan and sections of the Black Hawk no. 1 mine, showing relation of uranium mineralization to structure and lithology. SE1/4 sec. 4, T. 12 N., R. 9 W., Gay Eagle area, Grants district Valencia County, N. Mex. 


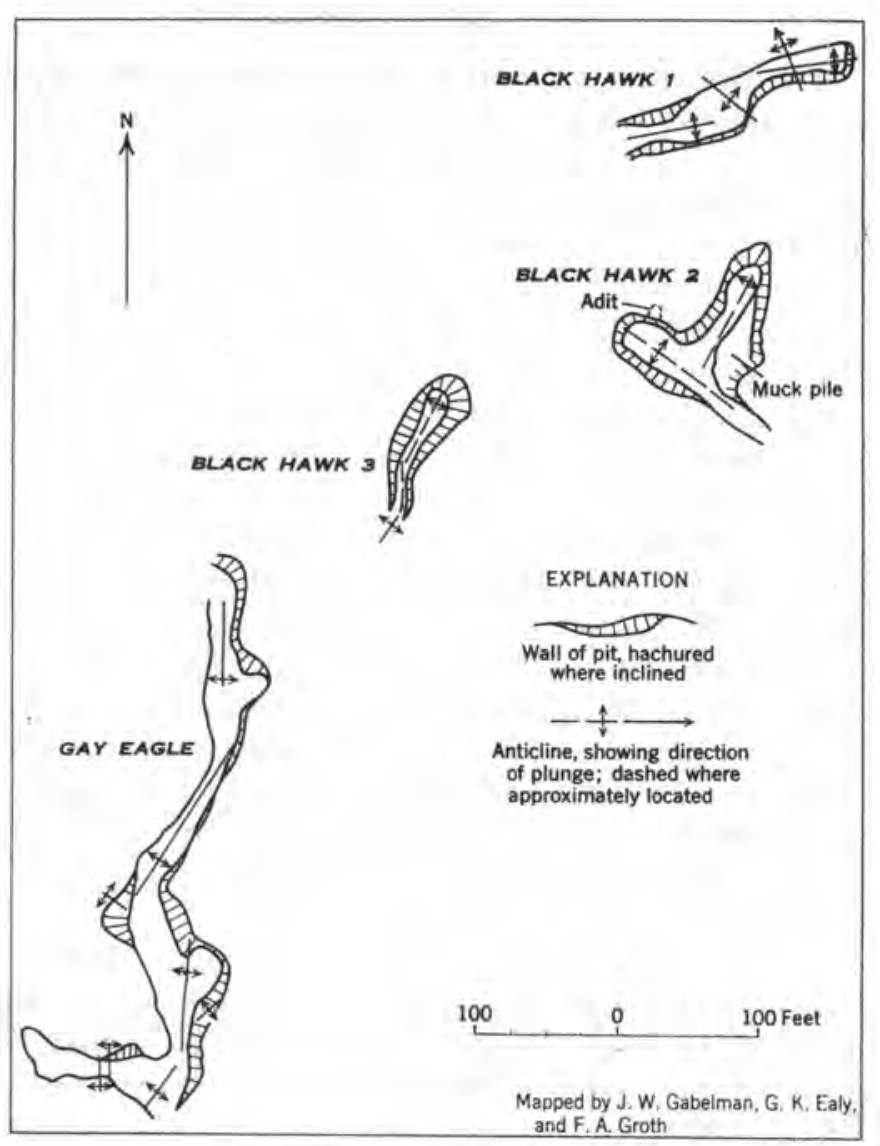

FroURE 138,-Plan of mines, showing relation of mines to minor anticlinsl axes. Gay Eagle-Black Hawk group, Gay Eagle area, SEy sec. 4, T. 12 N.. R. \& W., Valencia County, N. Mex.

LAGUNA DISTRICT, VALENCIA COUNTY, N. MEX.

The Laguna district is in the northwest part of the Lusero uplift (fig. 129), a large north-northeast-trending, strongly faulted fold, in the southeastern corner of the San Juan Basin. Jurassic sedimentary rocks crop out principally on the northwest side in the Rio Colorado, or Acoma, topographic basin. The southern strand line of the Todilto limestone (fig. 130) trends east and crosses the northern part of the Rio Colorado basin, and the Todilto is exposed only on Mesa Gigante and near Suwanee, in the southern part of the Laguna Indian Reservation. The limestone here is 10-22 feet thick and is exposed in a northeast-trending monocline which dips about $5^{\circ}$ northwestward. About 25 feet of gypsum overlies the limestone in the northern part of the area, but the gypsum pinches rapidly southward and is absent in the southern Laguna area. The Todilto is underlain by about 100 feet of the Entrada sandstone and overlain by an equal thickness of mudstone of the Summerville formation. The limestone consists of a basal very thin-bedded wrinkled limestone, a thin medium-bedded undeformed limestone in the middle, and an upper massive recrystallized limestone. The lower and middle units contain siltstone partings.

Several uranium deposits in the limestone are known; but only one, the Crackpot in sec. 8 , T. 8 N., R. 5 W., has yielded ore. This deposit occurs in an isolated dome of about 150 feet diameter on an otherwise uniform section of the monocline flanking the northwest side of the Lucerno uplift.

Uranium deposits are confined to the crest of the dome. Pitchblende, pyrite, and calcite have replaced limestone in small irregular pods and spots that are disseminated through the formation. These seem to be controlled by a similar distribution of finely disseminated carbonaceous material (R. Willson, personal communication). Oxidation products are yellow and green secondary uranium minerals and limonite, which occur principally in the basal crinkly zone on bedding planes and in irregular fractures on fold flanks and uncommonly as minute cavity-filling disseminations. Yellow minerals are a result of oxidation in place where disseminated; elsewhere, they have migrated to open fractures. However, two prominent joint systems in the dome are unmineralized.

SANOSTEE AREA, APACHE COUNTY, ARIZ, AND SAN JUAN COUNTY, N, MEX,

The Sanostee area (figs. 128, 130) in the Chuska Mountains is on the Defiance monocline, between the east side of the broad, flat Defiance uplift and the west side of the San Juan Basin. In this area the monocline trends northwestward and dips as much as $17^{\circ}$ northeastward.

The Todilto limestone at Sanostee is underlain by the Entrada sandstone and overlain by the Summerville formation and Bluff sandstone. The area is near the western strand line (fig. 130), and the formation thins from 10 feet in the south to 6 feet in the north. No gypsum is present. The formation consists of a lower thin-bedded unit and an upper thicker bedded unit which has been selectively recrystallized. Immediately beneath the Summerville lies a 6 -inch oolitic limestone bed (John W. Blagbrough, written communication). Diagnetic folding is confined essentially to the upper unit. Recrystallization is extensive along anticlinal axes. Most folds have a northeast orientation. Although not fully investigated, these folds are similar to those at Grants and may also represent the tectonic modification of early diagnetic folds.

Near Roy Mesa, about 5 miles southwest of Sanostee School, secondary uranium minerals are contained in limestone in a north-trending area 3 miles long and 1-2 miles wide.

Tyuyamunite, with calcite and small amounts of barite, occurs in joints along bedding planes and in 
vugs in the upper 5 feet of the Todilto. The uranium mineral occurs prineipally in the crests and flanks of small intraformational anticlines.

RIO CEBOLLA AREA, RIO ARRIBA COUNTY, N. MEX.

The Rio Cebolla area (fig. 130) is near the center of the Chama basin, a shallow depression perched shelflike on the east side of the San Juan Basin between the offset ends of the San Juan and Nacimiento uplifts. Sedimentary rocks in the mineralized area are flat lying and undeformed, although just east of the faulted northern end of the Nacimiento hogback.

The Todilto formation is underlain by the Entrada sandstone and overlain by the Salt Wash member of the Morrison formation. It is about 50 feet thick and consists of a lower limestone unit and an upper gypsum unit. The limestone is thin bedded and wrinkled by small diagenetic folds.

Uranium prospects occur at the junction of the Rio Cebolla and the Rio Chama in an area several miles long and about 2 miles wide. Secondary uranium minerals occur sporadically along bedding and joints in the wrinkled limestone. Secondary minerals are also associated with veinlets of radioactive red chert which fill high-angle joints.

ARROYO DEL AGUA AREA, RIO ARRIBA COUNTY, N. MBX.

Secondary uranium minerals fill fractures and cavities in Todilto limestone in the Arroyo del Agua area (fig. 130), at the junction of Arroyo de las Sillas and Coyote Creek, about 4 miles south of Coyote, Rio Arriba County, N. Mex. The Todilto here is entirely limestone although in the surrounding region the upper part is gypsum. The mineralized locality occupies a small hole, several hundred feet in diameter, in the gypsum blanket. The limestone is about 30 feet thick, thin bedded in the lower part, and massive in the upper part. The upper part has been recrystallized as in other parts of the San Juan Basin. Small folds, probably diagenetic, are present with as much as 8 feet of closure.

Mineralization has occurred only in the axes of anticlines, where it commonly extends from the base of the Todilto into the lower limy sandstone part of the overlying Salt Wash member of the Morrison formation. Mineralized limestone is thick locally as much as 60 feet.

The uranium deposit is in the only nongypsiferous patch of limestone within miles. This perhaps indicates that the greater solubility of the gypsum, relative to limestone, provided a strongly acid environment that prevented uranium precipitation and that the small amount of dissolved limestone might have had a neutralizing effect that caused precipitation of the uranium carried in the acid solution.

\section{BROWNS PARK FORMATION}

The Browns Park formation of southwest Wyoming and northwest Colorado is of fluvial and lacustrine origin. It was deposited probably during Miocene time in intermontane basins formed in northwestern Colorado and the Rocky Mountains in Wyoming during the Laramide revolution. It is relatively undisturbed.

Miller Hill area, Carbon County, Wyo.-In the Green River basin of Wyoming the Browns Park consists of a basal conglomerate, poorly sorted tuffaceous sandstones, and interbedded thin algal limestones. Secondary uranium deposits occur in a thin algal limestone in the Browns Park formation at Miller Hill (Love, 1953) on the Continental Divide, 20 miles south of Rawlins, Wyo. (fig. 128). Uranophane, minor amounts of meta-autunite, and uraniferous opal fill small fractures and cavities in association with erratically distributed lenses and nodules of dark chalcedony. (E. W. Grutt, personal communication). Sporadic mineralization is present in the host limestone for several square miles. Locally uranophane also impregnates thin lenticular sandstones.

Saratoga area, Carbon County, Wyo.-In the Saratoga area (fig. 128) of south-central Wyoming, according to J. G. Stephens (1954) small lenses and nodules of uraniferous chert occur in thin limestone beds in the Browns Park formation of Miocene age and the North Park formation of Pliocene age and also in overlying pediment gravels. Locally secondary yellow uranium minerals (carnotite or tyuyamunite) occur as cement in sand and gravel and as fracture fillings in limestone. The Browns Park and North Park formations are dominantly tuffaceous; they occupy an intermontane basin between the Medicine Bow and Sierra Madre ranges.

\section{BIDAHOCHI FORMATION}

Hopi Buttes area, Navajo County, Ariz.-The Bidahochi formation is confined to the Black Mesa basin of northeastern Arizona, west of the Fort Defiance uplift (fig. 129). In Pliocene time the basin was filled with lacustrine and fluvial sediments of the Bidahochi formation. On the southern edge of the basin where the Bidahochi truncates underlying beds of the Jurassic and Cretaceous, in Navajo County, Ariz., the volcanic rock of Hopi Buttes were erupted from numerous vents in Bidahochi time and interbedded with lake deposits to form the middle member of the formation.

In the Hopi Buttes voleanic field, the Bidahochi formation rests unconformably on gently dipping Wingate sandstone of Triassic age. The lower member contains banded gray, brown, and pink lacustrine mudstone and argillaceous sandstone, interbedded with white rhyolitic ash. The middle member rests uncon- 
formably on the lake deposits and contains 200 feet of an extremely complex mixture of volcanic breccia, tuff, and flows, which were extruded on a land surface and lake deposits. The upper member is fluvial and contains white to brown crossbedded poorly sorted and poorly bedded argillaceous sandstone and rhyolitic ash, covering the middle member through a transition from volcanic and lacustrine beds. It has been dated as Pliocene by fossil beaver remains (Stirton, 1936).

The plug-filled volcanic vents rise as vertical pipes through otherwise undisturbed sediments and must have been initially very explosive. Many late vents, which initially opened on a surface nearly coincident with the present one, do not contain plugs but have a complex posteruptive history which included subsidence of crudely bedded pyroclastic rocks into the vent and the filling of the resulting small basin with spring water rising from the vent to form a lake. The lakes were then filled with interbedded travertine, marl, and mud. Commonly the lake deposits were deformed by continued subsidence of the vent. Individual collapsed vents range from a few hundred feet to over a mile in diameter. Collapsed vents occurring near plug-filled vents are small and usually cluster around the base of the larger plug. All collapsed vents have steep margins dipping inward as much as $85^{\circ}$ toward flat or gently dipping centers. No marginal faults are known. Commonly the travertine or marl beds on the steep margins have been strongly folded, whereas the interbedded muds are undeformed. The calcium carbonate-bearing solutions unquestionably came from the volcanic vents, but there is much speculation as to whether the lime was juvenile or derived from the underlying Kaibab limestone.

Of the scores of collapsed vents, four widely separated ones are known to contain uranium. The Horseshoe vent (Fair, 1956), over 2 miles in diameter, contains anomalous radioactivity at two localities in water-laid pyroclastic rocks on the outer rim but no visible uranium minerals. At one locality anomalous radioactivity is in a filled channel scoured into underlying lake deposits and extends over 1,700 feet laterally. Another occurrence is in tuff immediately adjacent to a small subsidiary vent on the rim of the larger vent.

The Seth-la-Kai vent contains anomalous radioactivity, but no visible uranium minerals, in travertine and marl at several closely spaced localities on the rim of the collapsed basin. Travertine at the orifice of a dead feeder spring in the center of the basin is also mineralized. At the rim localities, from which several shipments of uranium ore have come, calcite, jarosite, limonite, and carbonaceous material are prevalent in the marl.
At the Hoskietso property, in a small collapsed vent marginal to a large plug-filled vent near Indian Wells, schroeckingerite coats fracture surfaces in mudstone between marl beds in the interior of the collapsed basin.

Anomalous radioactivity without visible uranium minerals occurs in travertine on the rim of the small "Donut" vent at the road junction east of Na-ah-tee Trading Post.

\section{DEPOSITS IN MARINE LIMESTONE}

Uranium deposits in marine limestone are insignificant at present. In all such occurrences, replacement is unimportant and secondary uranium minerals fill cavities as in any other rock type.

\section{KAIBAB IIMESTONE AND SAN ANDRES FORMATION}

The Kaibab limestone of Permian age and its New Mexican correlative, the San Andres formation, contain secondary uranium deposits at four localities.

Willaha area, Coconino County, Ariz.-According to H. E. Puttuck, anomalous radioactivity associated with chalcopyrite, bornite, covellite, chrysocolla, malachite, azurite, chalcocite, jarosite, goethite, and quartz, occurs in lenses of cherty arenaceous limestone and small associated fractures, in the uppermost part of the Kaibab limestone, in the Willaha area, Coconino County, Ariz.

Bluewater area, Valencia County, N. Mex.-Anomalous radioactivity is associated with marcasite, limonite, and calcite, which fill minute vugs and small fractures in silty limestone at the top of the San Andres formation where the limestone is cut by the Bluewater fault near the Grants district, Valencia County, N. Mex. (L. Baumgardner, personal communication).

Correro area, Valencia County, N. Mex.-Secondary uranium minerals fill vugs and fractures in massive limestone near the top of the San Andres formation 8 miles southwest of Correro in the Lucero uplift. An intrusive sill here overlies the San Andres formation.

Socorro area, Socorro County, N. Mex.-About 12 miles northeast of Socorro, Socorro County, N. Mex., secondary yellow uranium minerals occur in the matrix of brecciated limestone of the San Andres formation, associated with a fault contact between the Yeso formation of Permian age and the San Andres formation. Uranium deposition also penetrated unbrecciated limestone along fractures. No primary mineralization is known at present.

\section{HERMOSA FORMATION}

Gypsum Valley area, San Miguel County, Colo.-The limestone facies of the Hermosa formation contains uranium in San Miguel County, Colo., on the northeast 
flank of the Gypsum Valley anticline, 13 miles southwest of Naturita (Barge, 1953). Here the Hermosa is a thin-bedded limestone with shale partings. The beds are overturned to the southwest and form a steep hogback. Carnotite occurs in the Bald Eagle mine in closely spaced irregular fractures which give the rock a high permeability.

\section{SUNDANCE FORMATION}

Mayoworth area, Johnson County, Wyo.-According to R. R. Guilinger and P. K. Theobald (1955), metatyuyamunite coats joints and fractures and replaces oolites and cement in limestone of the Sundance formation, of late Jurassic age, on the southeast flank of the Bighorn Arch, in the Mayoworth area, Johnson County, Wyo. (fig. 128). Sedimentary rocks are deformed into smaller folds, south of a major thrust fault which separates sedimentary from crystalline rocks on the flank of the arch. The uranium deposits are exposed on the anticlinal flank that marks the eastern limit of the area of small folds.

The Sundance formation contains 3 units; a basal oolitic limestone 8-10 feet thick, a middle gray shale, and an uppermost white to buff sandstone. The oolites are formed principally around cores of colorless calcite, but also around fossil fragments and opaque detrital minerals. In the vicinity of the uranium deposits, the oolitic limestone contains small irregular intraformational folds and is crossbedded.

Anomalous radioactivity is concentrated along stream courses, but occurs only at or above the elevation of gravels of Quaternary age. These relations suggest uranium transportation by streams and concentration along bedding planes and joints where the streams entered the limestone area. Uranium is concentrated most strongly along joints striking parallel to the stream courses.

\section{REDWALL LIMESTONE}

Jerome area, Yavapai County, Ariz.-Yellow secondary uranium minerals locally fill vugs in white chalky Redwall limestone of Mississippian age, about 5 miles northeast of Jerome, Yavapai County, Ariz. (fig. 128). There are no other associated minerals.

\section{EDWARDS LIMESTONE}

King Mountain area, Upton County, Tex.-In the King Mountain area, northeast of McCamey, Upton County, Tex. (fig. 128), the Edwards limestone of Cretaceous age contains tyuyamunite and carnotite in joints, bedding surfaces, and small solution cavities, according to D. H. Eargle (1954, p. 132-133). The area of mineralization is about one-quarter of a mile wide. Mineralization was weak and controls or guides are not known. The uranium was possibly derived by leaching from the overlying Kiamichi formation, stratigraphically 40 feet above, or the higher Ogalalla formation of Tertiary age.

\section{HUECO ITMESTONE}

Hueco Mountains area, El Paso and Hudspeth Counties, Tex.-Carnotite, tyuyamunite and manganese oxide coating limestone boulders in caliche, and locally filling joints and bedding planes in the Hueco limestone of Permian age, in the Hueco Mountains of Ed Paso and Hudspeth Counties, Tex. (fig. 128), have been described by D. H. Eargle (1954, p. 133-134). Carnotite and mammillary calcite coat limestone pebbles and fill cracks in caliche beneath a landslide block of Hueco limestone on the east side of Sabina Mountain, an outlier of the Hueco Mountains. Mineralization extended into the bedrock limestone along bedding and joints on the west side of Sabina Mountain.

\section{MARINE LIMESTONE OF MIDDLE PALEOZOIC AGE}

Thomas Range, Juab County, Utah.-An unnamed dolomite of Silurian and Devonian age several thousand feet thick is cut by pipes and veins of slightly uraniferous fluorite on Spor Mountain, in the Thomas Range, Juab County, Utah (Thurston, Staatz, Cox, and others, 1954) (fig. 128). Spor Mountain is a west-tilted fault block cut by numerous longitudinal faults and diagonal cross faults. The mountain is separated by faults from Topaz Mountain to the east, the two together making the Thomas Range. Topaz Mountain is composed of rhyolitic tuffs and ash, capped by a thick rhyolite flow. The flow contains topaz crystals in gas cavities. The principal faulting was followed by volcanism and intrusion of rhyolite porphyry dikes, and these were followed by minor faulting. All deformation and volcanic activity is of Tertiary age. The dikes are probably contemporaneous with the flows.

Fluorite mineralization closely followed rhyolite porphyry intrusion and was earlier than second-stage faulting. Dense earthy purple radioactive fluorite replaces dolomite in high-angle pipes and along fractures, forming veins. The veins range from several inches to 14 feet in width and up to 250 feet in length. Locally veins cut rhyolite porphyry, and in such localities fluorite is a fracture filling as well as a replacement. The gangue consists of clay, dolomite, calcite, opal, quartz, and rarely carnotite. The veins are not economically important.

Ninety-five percent of the fluorite is produced from nearby circular pipes which occur in areas of faulting but rarely along faults. Pipes range from 15 feet to 175 feet in diameter and extend beyond the depth of exploration but probably terminate against the underlying nonreactive quartzite. The pipes are of two 
types; circular and irregular. Contacts of the circular pipes are regular and sharp, but small veinlets of fluorite radiate into the dolomite from the irregular pipes.

Locally the pipes contain a breccia of rounded dolomite fragments, and a small pipe, subsidiary to the Wilden pipe, contains rhyolite porphyry fragments mixed with dolomite fragments, with no known igneous dike nearby; otherwise, the pipes are filled entirely with replacement ore. The pipes have been interpreted as resulting from rapid "hydrothermal drilling" under intratelluric pressure, because the breccia is more a solution than a cataclastic (movement) breccia (Kenyon Richard, personal communication); however, both types of breccia occur. Cataclastic breccias were noted to be more common at depth, and are at different elevations in several different pipes. The mixture of dolomite with rhyolite fragments near the Wilden pipe is an extreme case. Probably the strong solution activity proceeded upward in advance of the gaseous or magmatic force required for brecciation, and both preceded the intrusion of a plug of rhyolite.

Carnotite is present in only the Eagle Rock, Fluoride, and Fluorine Queen pipes, and it occurs in the wallrock at the Bell Hill and Harrisite. In all occurrences it is a cavity filling. Twenty-five pipes examined were found to be anomalously radioactive, but none are known to be of commercial value for uranium at present. Where no uranium minerals can be observed, uranium possibly occurs as a microscopic intergrowth of pitchblend and fluorite. Much of the introduced clay is also radioactive.

W. R. Thurston, M. H. Staatz, D. C. Cox, and others (1954) have postulated that fluorine gas, derived from the same magmatic source as the rhyolite, formed topaz as it percolated through rhyolite and fluorite as it rose through dolomite. This theory, however, does not explain the source of clay, opal, quartz, and uranium minerals, which in other similar environments are considered hydrothermal.

\section{KITTATINNY LIMESTONE}

Clinton area, Hunterdon County, N. J.-F. A. McKeown, Harry Klemic, and P. W. Choquette (1954) have described uranium associated with fault zones cutting marine Kittatinny limestone of Cambrian and Ordovician age in Mulligan quarry near Clinton, Hunterdon County, N. J. (fig. 128). The limestone is massive, dolomitic, and cherty. Chert occurs in thin layers conformable with the bedding, as scattered lenses and nodules, and in brecciated zones, possibly as a secondary mineral. A northeast fault, possibly of Triassic age, cuts the limestone for at least 700 feet of strike length. The central brecciated zone is up to 15 feet wide. There are numerous other associated faults.
The breccia zone contains dolomite, chert, secondary quartz, feldspar (albite), pyrite, and uraniferous tan apatite.

Uranium occurs in fault breccia and fractured zones and in two undisturbed limestone beds. Many small faults of minor displacement are radioactive in zones about 10 feet long and 1 foot wide. The large fault zone is radioactive throughout its known length of 700 feet. Apatite occurs as a glassy coating on breccia and fracture surfaces. The maximum uranium content is 0.038 per cent. The 2 radioactive limestone beds are each 4 inches thick, black, shaly, and dolomitic and are cut by a fault that contains radioactive apatite. Carbonaceous shale containing uraniferous dolomite or apatite introduced from the fault zone is the source of the radioactivity.

The uranium is postulated to have been derived from leaching of overlying slightly radioactive Martinsburg shale but may have been introduced in hydrothermal apatite.

\section{SPERGEN LIMESTONE}

Ste. Genevieve area, Ste. Genevieve County, Mo.-G. B. Gott (1950; Gott and others, 1952) has briefly described carnotite joint and fracture fillings associated with detrital carbonaceous material and small purple fluorite replacements in the marine Spergen limestone of Mississipian age, in Bussen's quarry near Ste. Genevieve, Ste. Genevieve County, Mo. (fig. 128). The carnotite is in a part of the limestone that underlies a zone of black uraniferous marine shale partings and uraniferous stylolite fillings. The shale seams are up to 1 inch thick and contain up to 0.48 percent $\mathrm{U}_{3} \mathrm{O}_{8}$ and 2.39 percent $\mathrm{V}_{2} \mathrm{O}_{5}$. The occurrence of carnotite only beneath the uraniferous shale indicates it may have been derived secondarily from leaching of the shale. The deposits have not been mined.

\section{DEPOSITS IN MARGINAL OR LITTORAL LIMESTONE \\ BEAR RIVER FORMATION}

Fall Creek area, Bonneville County, Idaho.-Vine and Moore (1952) have described a uranium occurrence in the Bear River formation at Early Cretaceous age, in the Fall Creek area, Bonneville County, Idaho. The Bear River formation, about 150 feet thick, is composed of brackish- and fresh-water quartzites, thin coal beds, and carbonaceous limestone. It is underlain by marine clastic rocks and overlain by continental clastic rocks, limestones, and ash beds of the Wayan formation of Early and Late (?) Cretaceous age. The Cretaceous rocks have been deformed into tight folds and overthrust sheets in the Caribou Mountains during Larimide time. 
In the Fall Creek area the Bear River formation has been faulted against the Wayan formation, and all deformed sediments are unconformably overlain by flat-lying silicic volcanic rocks of Tertiary age. A 12foot thickness of carbonaceous limestone, coal, clay, and shale in the upper part of the Bear River formation contains uranium in a zone close to and parallel to the fault contact of the Bear River and Wayan formations. The zone terminates against the fault in the bottom of Fall Creek. The limestone is black, carbonaceous, and fossiliferous. Mineralization was greatest near the top of the coal bed and diminishes upward and downward through carbonaceous limestone and shale. No uranium minerals are known, and the uranium is presumed to be adsorbed by carbonaceous matter. The uranium content decreases downward in all mineralized beds, a fact interpreted as an indication of selection from downward percolating solutions. The uranium probably leached and migrated downward from the overlying silicic volcanic rocks of Tertiary age which are slightly radioactive.

\section{REFERENCES CITED}

Barge, E. M., 1953, Development drilling on the Early Morn group of claims, Gypsum Valley district, San Miguel County, Colo.: U. S. Geol. Survey Trace Elements Memo. Rept. 623 (unpub.).

Blagbrough, J. W., 1956, Geologic reconnaissance of the Sanastee area, San Juan County, New Mexico, and Apache County, Ariz.: U. S. Atomic Energy Comm. RME- - (in preparation).

Dane, C. H., 1948, Geologic map of part of eastern San Juan Basin, Rio Arriba County, N. Mex.: U. S. Geol. Survey Oil and Gas Inv. Prelim. Map 78.
Eargle, D. H., 1954, U. S. Geol. Survey unpub. inf.

Fair, C. L., 1956, The Horseshoe and other diatremes of the Hopi Buttes voleanic field, northeast Arizona: U. S. Atomic Energy Comm. rept. (in preparation).

Fincher, F. R., and Konigsmark, T. A., 1956, Exploration drilling in the Haystack Butte area, McKinley County, N. Mex.: U. S. Atomic Energy Comm. RME- - (in preparation).

Gott, G. B., 1950, U. S. Geol. Survey unpub. inf.

Gott, G. B., Wyant, D. G., and Beroni, E. P., 1952, Uranium in black shales, lignites, and limestones in the United States: U. S. Geol. Survey Circ. 220, p. 31-35.

Guilinger, R. R., and Theobald, P. K., 1955, Uranium deposits in oolitic limestone near Mayworth, Johnson County, Wyoming: U. S. Geol. Survey Bull.-(in preparation).

Hoover, W. B., 1950, Jurassic formations of part of Utah, Colorado, Arizona, and New Mexico: N. Mex. Geol. Soc. Guidebook First Field Conf., p. 76-81.

Love, J. D., 1953, Preliminary report on the uranium deposits in the Miller Hill area, Carbon County, Wyo.: U. S. Geol. Survey Circ. 278, $10 \mathrm{p}$.

McKeown, F. A., Klemic, Harry, and Choquette, P. W., 1954, U. S. Geol. Survey unpub. inf.

Smith, C. T., 1951, Problems of Jurassic stratigraphy of the Colorado Plateau and adjoining regions: N. Mex. Geol. Soe. Guidebook 2d Field Conf., p. 99-102.

Stirton, R. A., 1936, A new beaver from the Pliocene of Arizona with notes on the species of Dipoides: Jour. Mammalogy, v. 17 , no. 3 , p. 279-281.

Stephens, J. G., 1954, Uranium in limestone, Saratoga area, Carbon County, Wyo., in Geologic investigations of radioactive deposits, Semiannual progress report, June 1, 1954 to Nov. 30, 1954: U. S. Geol. Survey TEI-490, p. 131-132, issued by U. S. Atomic Energy Comm. Tech. Inf. Service, Oak Ridge, Tenn.

Thurston, W. R., Staatz, M. H., Cox, D. C., and others, 1954, Fluorspar deposits of Utah: U. S. Geol. Bull. 1005.

Vine, J. D., and Moore, G. W., 1952, Uranium-bearing coal and carbonaceous rocks in the Fall Creek area, Bonneville County, Idaho: U. S. Geol. Survey Circ, 212, 10 p. 


\title{
URANIUM-BEARING COAL IN THE UNITED STATES
}

\author{
By James D. Vine, U, S. Geological Survey
}

\section{CONTENTS}

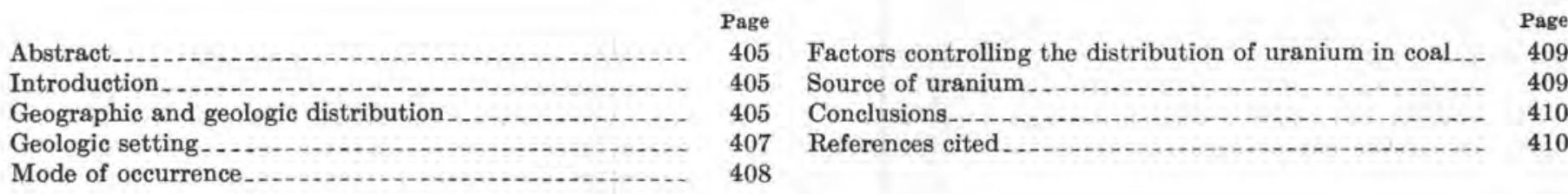

\section{ILLUSTRATION}

FIGURE 139. Index map showing distribution of uranium-bearing coal and carbonaceous shale in the United States

\section{ABSTRACT}

Large potential reserves of uranium are contained in coal and lignite, particularly in Cretaceous and Tertiary sedimentary rocks in some parts of the Rocky Mountains and northern Great Plains regions of the United States. The concentration of uranium in the ash of coal provides a possible means of recovering uranium as a byproduct. Ore-grade uranium in lignite is present locally in the northern Great Plains. Uranium-bearing lignite occurs in the Fort Union formation of Paleocene age in the northern Great Plains, in the Salt Lake formation of Pliocene age in southern Idaho, and in Tertiary sediments in Nevada and southern California. Uranium-bearing coal is present in the Wasatch formation of Eocene age in Wyoming, in the Laramie formation of Cretaceous age in Colorado, in the Mesaverde formation of Cretaceous age in New Mexico, and in the Bear River formation of Cretaceous age in southeastern Idaho. Bituminous coal and anthracite of Paleozoic age in North Central and Eastern United States contain only very small quantities of uranium.

The distribution of uranium in coal is erratic. In many areas uranium is preferentially concentrated at the top of the stratigraphically highest coal beds. In the Red Desert area of Wyoming, uranium is concentrated in coal beds adjacent to permeable units of the enclosing strata.

Uranium is thought to be held in coal as a fixed adventitious constituent of epigenetic origin. When more urgnium is available to the coal than can be chemically combined with the organic matter, uranium minerals including carnotite, autunite, torbernite, metazeunerite, and coffinite may form. In the northern Great Plains uranium is thought to be introduced into coal by ground water that leached uranium from unconformably overlying volcanic rocks.

\section{INTRODUCTION}

Unusually high concentrations of uranium in coal have been reported from many parts of the world
(Davidson and Ponsford, 1954; Szalay, 1954) even though coal is commonly considered to be one of the least radioactive rocks (Russell, 1945). Uraniumbearing coal was first reported in the United States in a description by E. L. Berthoud (1875) of the Leyden coal mine northwest of Denver, Colo. Recent interest, however, results from the discovery of uranium-bearing coal in the Red Desert area of central Wyoming in 1946 by Messrs. Slaughter and Nelson (written communication) and the discovery 2 years later of uranium-bearing lignite in the northern Great Plains by D. G. Wyant and E. P. Beroni (written communication). Since then, many coal-bearing strata in the United States have been examined, and numerous uranium-bearing coal, lignite, and carbonaceous shale localities have been reported.

A large potential low-grade reserve of uranium is contained in coal. Because uranium is concentrated in the ash when coal is burned as a fuel, some of the uraniferous coal may possibly be utilized as a commercial fuel and the uranium extracted from the ash as a byproduct. Recent discoveries of ore-grade uranium in coal in the northern Great Plains (Gill, 1954) may have immediate commercial importance as a source of uranium.

\section{GEOGRAPHIC AND GEOLOGIC DISTRIBUTION}

The principal deposits of uranium-bearing coal, lignite, and carbonaceous shale in the United States are in Cretaceous and Tertiary rocks of the northern Great Plains and Rocky Mountains regions (fig. 139). The following table gives the principal deposits. 


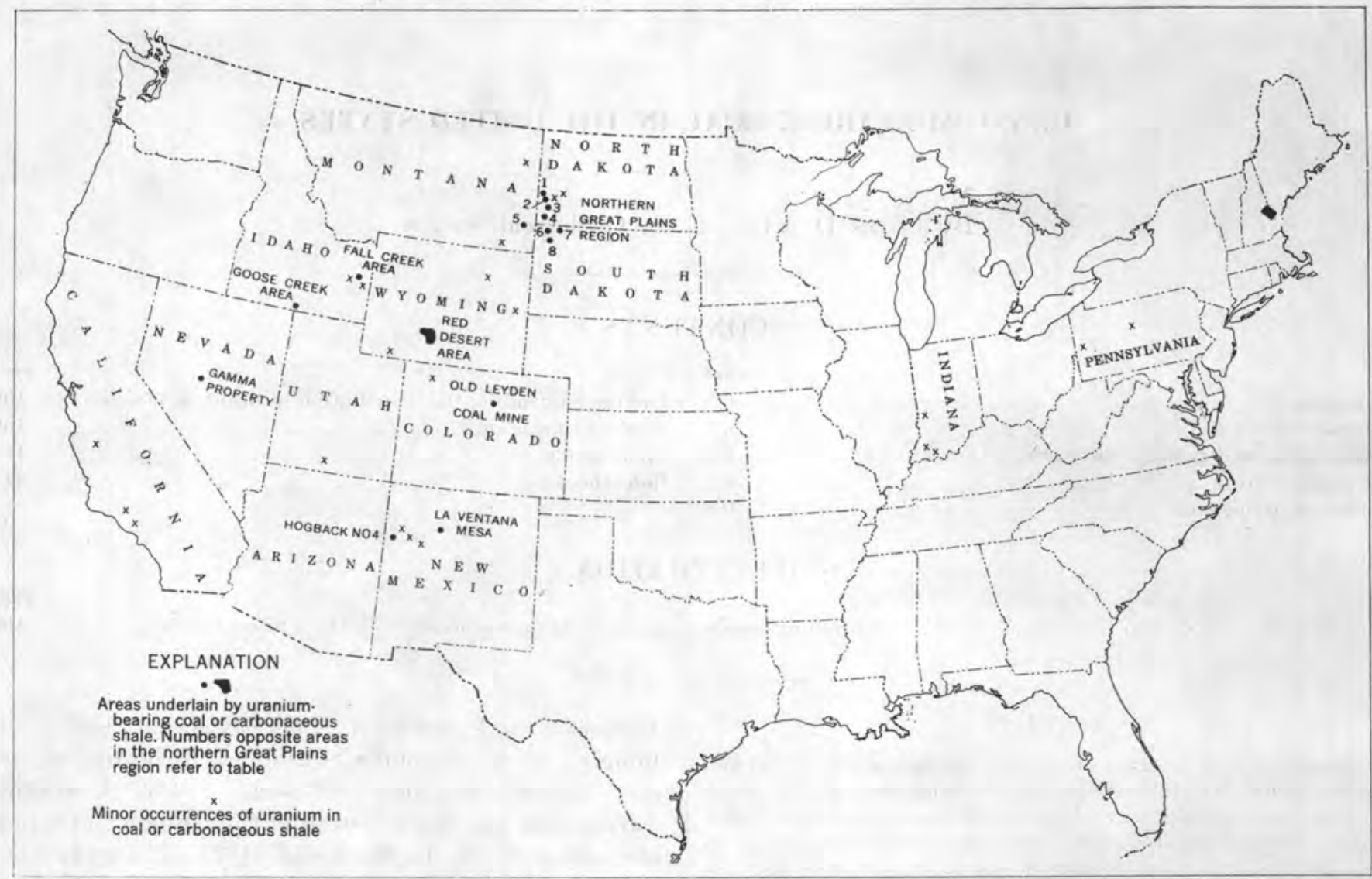

FInURE 139.-Index map show ing distribution of uranium-bearing coal and carbonaceous shale in the United States.

Principal deposits of uranium-bearing coal, lignite, and carbonaceous shale in the United States

\begin{tabular}{|c|c|c|}
\hline Name and location of area & Age and name of formation or group & Lithology \\
\hline $\begin{array}{l}\text { Northern Great Plains region: } \\
\text { Sentinel Butte, Golden Valley County, N. } \\
\text { Dak. } \\
\text { Bullion Butte, Billings County, N. Dak } \\
\text { Chalky Buttes, Slope County, N. Dak } \\
\text { Medicine Pole Hills, Bowman County, N. } \\
\text { Dak. } \\
\text { Ekalaka Hills, Carter County, Mont. } \\
\text { Cave Hills, Harding County, S. Dak. } \\
\text { Lodgepole district, Perkins County, S. Dak. } \\
\text { Slim Buttes, Harding County, S. Dak } \\
\text { Red Desert area, central Wyoming } \\
\text { Fall Creek area, southeastern Idaho. } \\
\text { Goose Creek area, southern Idaho } \\
\text { Gamma Property, Churehill County, Nev } \\
\text { Old Leyden Coal Mine, Jefferson County, Colo.- } \\
\text { La Ventana Mesa, Sandoval County, N. Mex.-. } \\
\text { Hogback No. 4, McKinley County, N. Mex.... }\end{array}$ & $\begin{array}{l}\text { Paleocene Fort Union (Sentinel Butte shale } \\
\text { mbr.). } \\
\text { Paleocene Fort Union (Tongue River mbr.) } \\
\text { Paleocene Fort Union (Ludllow and Tongue } \\
\text { River mbrs.). } \\
\text { Paleocene Fort Union (Tongue River mbr.) } \\
\text { Paleocene Fort Union (Ludlow mbr.) } \\
\text { Eocene Wasatch } \\
\text { Cretaceous Bear River } \\
\text { Pliocene Salt Lake } \\
\text { Tertiary (unknown) } \\
\text { Cretaceous Laramie } \\
\text { Cretaceous Mesaverde } \\
\text { Cretaceous Dakota. }\end{array}$ & $\begin{array}{l}\text { Lignite. } \\
\text { Do. } \\
\text { Do. } \\
\text { Do. } \\
\text { Do. } \\
\text { Do. } \\
\text { Do. } \\
\text { Do. } \\
\text { Coal. } \\
\text { Coaly shale. } \\
\text { Lignite and lignitic shale. } \\
\text { Lignitic shale. } \\
\text { Coal, partially silicified. } \\
\text { Coal and coaly shale. } \\
\text { Carbonaceous shale. }\end{array}$ \\
\hline
\end{tabular}

Uranium-bearing lignite occurs sporadically on or adjacent to high buttes and mesas throughout a vast area in the northern Great Plains, including parts of northwestern South Dakota, southwestern North Dakota, and eastern Montana (Denson and Gill, p. 413, this volume, and King, p. 419, this volume). The beds of uraniferous lignite and Young lie within a sequence of strata more than 1,500 feet thick, belonging to the Hell Creek formation of Cretaceous age and the Fort Union formation of Paleocene age. The coal bearing members of the Fort Union formation, from oldest to youngest, are the Ludlow, Tongue River, and Sentinel Butte shale members. These strata dip about 10-40 feet per mile to the northeast and are 
truncated unconformably by overlying tuffaceous sediments of Oligocene and Miocene age, erosional remnants of which form the cap rock 200-300 feet thick on many of the high buttes and mesas. The uranium content of the lignite ranges from less than 0.001 percent to about 10 percent; the average content of the uraniferous lignite is about 0.008 percent.

Uranium-bearing subbituminous coal is present in the generally flat-lying Wasatch formation of Eocene age in the Red Desert of the Great Divide basin, Sweetwater County, Wyo. (Masursky, p. 439, this volume, and Pipiringos, p. 433, this volume). Eocene sedimentary rocks, with an exposed thickness of about 3,400 feet in this area, range from coarse fluvial conglomerate in the Battle Spring formation on the north and east sides of the Red Desert area to lacustrine and paludal shale, siltstone, sandstone, and marl in the Green River and Wasatch formations on the south and west sides of the Red Desert area. Coal and carbonaceous shale beds were laid down in a northwesttrending zone where lacustrine and fluvial facies of Eocene age intertongue. Coal beds are thickest near the center of this zone and pinch out both to the northeast and southwest. The uranium content of the coal ranges from about 0.001 to 0.05 percent; the average for the entire area is about 0.003 percent.

Carbonaceous rocks of the Bear River formation of Early Cretaceous age contain uranium in the Fall Creek area, Bonneville County, Idaho (Vine, 1956). The area is in the Caribou Mountains, which are characterized by complex structural features including closely spaced parallel folds, overturned at many places and broken by both normal and thrust faults. Uranium occurs in a bed of sheared coaly shale and the directly overlying bed of carbonaceous limestone. Locally, the coal contains as much as 0.1 percent uranium; the average for the uraniferous zone is about 0.02 percent uranium.

In the Goose Creek intermontane basin of southern Cassia County, Idaho, and adjacent parts of Utah and Nevada, as much as 0.1 percent uranium is contained locally in lignite and carbonaceous shale in the Salt Lake formation of Pliocene age (Mapel and Hail, 1956). The carbonaceous beds occur in a sequence nearly 2,300 feet thick consisting chiefly of volcanic ash and welded tuff.

Uranium-bearing coal and carbonaceous shale occur in the Mesaverde and Dakota formations of Cretaceous age in the La Ventana area, Sandoval County, in northcentral New Mexico (Bachman and others, 1956). The area is situated on the east flank of the San Juan Basin adjacent to the Sierra Nacimiento and the Jemez volcanic plateau. As much as 0.6 percent uranium is contained in coal and carbonaceous shale in the strati- graphically highest carbonaceous zone in the Mesaverde formation on La Vantana Mesa.

Uranium-bearing coal and silicified coal are present in nearly vertical beds in the hogback of the Laramie formation of Late Cretaceous age northwest of Denver, Jefferson County, Colo. (Gude and McKeown, 1953). Individual samples of coal with fracture fillings of carnotite contain as much as 3 percent uranium.

Tertiary sediments at least 300 feet thick contain uranium-bearing impure lignite at the Gamma property on the west side of the Desatoya Range in Churchill County, Nev. (Startz and Bauer, 1954). As much as 0.05 percent uranium is contained in the top of a 3 -foot bed of impure lignite.

Other localities of uraniferous coal in the Western United States, shown on figure 139, include uraniumbearing coal in the Wasatch formation of Eocene age in the Pumpkin Buttes district in the Powder River Basin, northeastern Wyoming (Troyer and others, 1954); uranium in carbonaceous shale and coal in the Dakota and Mesaverde formations of Cretaceous age along the south flank of the San Juan Basin in McKinley County, N. Mex. (Gabelman, p. 303, this volume; Bachman, Baltz, and O'Sullivan, written communication, 1953); and uranium-bearing lignite and carbonaceous shale in Los Angeles and San Benito Counties, Calif. (Moore and Stevens, 1954).

Most coal of Mississippian, Pennsylvanian, or Permian age in the coal fields of North Central and Eastern United States contains less than 0.001 percent uranium, though some of the shales and underclays associated with these coals contain $0.002-0.005$ percent uranium (Snider, 1954a, 1954b); Welch, 1954a, 1954b; and Patterson, 1955a). E. D. Patterson (written communication) reports coal from Illinois as containing up to 0008 percent and black shales above coal as much as 0.017 percent uranium. Coal in Indiana locally contains as much as 0.002 percent uranium (Snider, 1954c), whereas that in western Pennsylvania contains as much as 0.007 percent uranium (Ferm, 1955) and that in central Pennsylvania contains as much as 0.019 percent uranium (Patterson, 1955b).

\section{GEOLOGIC SETTING}

Although there is stratigraphic control for the distribution of uranium in coal, emplacement is quite unlike the widespread uniformly disseminated uranium in some beds of marine black shale and phosphorite (Swanson, p. 451, this volume; McKelvey, p. 477, this volume).

In the northern Great Plains, N. M. Denson, G. O, Bachman, and H. D. Zeller (1956) have shown that uranium-bearing lignite is found throughout 1,500 feet of coal-bearing strata, but always within 150 
feet of the pre-Oligocene unconformity. The highest concentration of uranium is commonly contained in the stratigraphically highest bed of lignite below the unconformity. Lignite beds more than 3 feet thick generally contain more uranium at the top of the bed than at the bottom. Locally where the stratigraphically highest lignite is overlain by shale, it may be nonuraniferous. A similar emplacement of uranium in the stratigraphically highest beds was noted at La Ventana Mesa in New Mexico (Bachman and others, (1956) and in the Goose Creek area of southern Idaho (Mapel and Hail, 1956). A similar preferential enrichment of uranium in a thick bed was recorded in the Fall Creek area of southeastern Idaho (Vine, 1956) and at the Gamma property in Nevada (Staatz and Bauer, 1954).

The concentration of uranium in coal beds of the Wasatch formation in the Red Desert area is related to the permeability of the enclosing sediments (Masursky, p. 440, this volume; Pipiringos, p. 436, this volume). The greater concentrations of uranium are in coal beds adjacent to permeable sandstone beds regardless of the stratigraphic position. Locally where coal of Wasatch age has been truncated and is unconformably overlain by younger Tertiary sediments, there is a preferential distribution of uranium in the top of the stratigraphically highest bed of coal.

Although uranium-bearing coal beds range in attitude from nearly flat in the northern Great Plains, the Red Desert, and La Ventana Mesa to vertical in the Old Leyden coal mine, structural control during mineralization is evident in some of the deposits. The highest concentration of uranium in the Goose Creek area (Mapel and Hail, 1956) is along the trough and flanks of a broad syncline. Similar observations were made at La Ventana Mesa (Bachman and others, 1956) and in the Red Desert area (Pipiringos, p. 436, this volume). Locally in the northern Great Plains and at La Ventana Mesa, there is an increase in the uranium content of lignite and coal adjacent to joints (Denson and others, 1956; Bachman and others, 1956).

Uranium-bearing coal is associated with other types of uranium deposits in several districts. Schroeckingerite forms a surficial evaporite-type deposit that D. G. Wyant, E. P. Beroni, and H. C. Granger (1952) have postulated overlies uraniferous coal at Lost Creek in the northern Red Desert area. Carnotite, uranophane, and uraninite deposits in sandstone are interbedded with uraniferous coal in the Pumpkin Buttes area near the center of the Powder River Basin in northeastern Wyoming (Troyer and others, 1954). Uranophane, carnotite, and tyuyamunite occur in sandstone beds of the Fort Union formation of Paleocene age in the northern Great Plains (Gill, 1954).

\section{MODE OF OCCURRENCE}

Uranium is found chiefly in low-rank and impure coal, including lignite, subbituminous coal, and carbonaceous shale. High-rank, low-ash coals of the type most desired for fuels are rarely uraniferous, and no significant concentration of uranium has been found in a producing coal mine. Bituminous coal and anthracite occur principally in rocks of Paleozoic age in the North Central and Eastern United States, whereas lignite and subbituminous coal are most abundant in rocks of Cretaceous and Tertiary age in the Rocky Mountains and Western States. Therefore, it is not readily apparent whether the lack of significantly uraniferous coal in the North Central and Eastern United States is due to age, rank, or geologic setting. One line of evidence is afforded by the results of an experimental study by G. W. Moore (1954), who demonstrated that peat, lignite, and subbituminous coal extract 98 percent or more of the uranium from an aqueous solution, whereas bituminous coal and anthracite extract only 17 and 34 percent respectively.

Uranium minerals have not been recognized in coal that contains less than about 0.1 percent uranium. Fracture fillings of carnotite in silicified coal at the Old Leyden coal mine near Denver, Colo., have been described (Gude and McKeown, 1953), but the visible mineral is not sufficiently abundant to account for all the uranium present. Autunite, torbernite, and metazeunerite are disseminated in highly uraniferous lignite in the Cave Hills area in the northern great Plains (Gill, 1954), but here again it is doubtful if the visible mineral is sufficient to account for all the uranium present. Coffinite has been reported by J. W. Gruner (oral communication, 1955) in highly uraniferous coal from La Ventana Mesa in New Mexico.

Petrologic studies of uraniferous coal by J. M. Schopf and R. J. Gray (1954) show that no quantitative correlation exists between uranium content and the petrologic constituents of coal. However, large amounts of humic attrital matter, which results from decomposition and microbial decay, were recognized in the samples containing the most uranium. Because of this observation, they conclude that plant material that has been most subjected to decay is probably the most receptive to uranium emplacement. Mineralogical studies of low-grade uraniferous lignite from the northern Great Plains by I. A. Breger, Maurice Deul, and Samuel Rubinstein (1955) show that more than 90 percent of the uranium is associated with organic material in the lignite rather than with the extraneous mineral matter, which includes jarosite, quartz, gypsum, calcite, and clay minerals. They infer that uranium in coal is present in the form of organouranium complexes that are insoluble in the $\mathrm{pH}$ range of $3-6$ found in coal. 
The inorganic constituents of coal have been classified according to their source, age, and properties (Francis, 1954), as follows: (1) The inherent mineral matter derived from the inorganic constituents of the parent plants, (2) the fixed adventitious inorganic matter which consists of ehemically combined inorganic constituents added to the organic matter after the death of the plants, and (3) the free adventitious inorganic matter or extraneous minerals added to the deposit in an uncombined state. Both the fixed and the free adventitious constituents are further subdivided into the syngenetic mineral matter, which is added during the formation of coal; and the epigenetic mineral matter, which is added after coalification. Uranium could be added to a deposit of coal by any one or a combination of several of these methods. An understanding of where uranium fits into the classification of inorganic constituents of coal is needed in order to properly interpret the factors that control the distribution of uranium in coal.

At the time of the discovery of uranium in lignite in the northern Great Plains, G. B, Gott, D. G. Wyant, and E. P. Beroni (1952) considered that the even distribution of radioactivity in a sample of lignite, as revealed by an autoradiograph indicated that the uranium was an inherent or fixed adventitious constituent present in the coal at the time of coalification. Petrologic and mineralogic studies of uraniferous coal confirm the uniform distribution of uranium in individual samples and the association of the uranium with the organic constituents of the coal. However, the crosscutting relation of uranium to the regional dip of beds, especially in the northern Great Plains region, the common top preferential distribution of uranium in thick beds, and the concentration of uranium in the stratigraphically highest beds or in beds adjacent to zones of high permeability indicate an epigenetic origin for the uranium. Thus, it would seem that uranium is contained in coal as fixed adventitious inorganic matter of epigenetic origin. When more uranium is available to the coal than can be beld by the organic matter, different minerals, including carnotite, autunite, torbernite, metazeunerite, and coffinite, may be formed.

Slightly impure coal generally contains more uranium than carbonaceous shale or very pure coal. Carbonaceous shale probably contains less uranium because the uranium-fixing organic matter is diluted with extraneous mineral matter, whereas the very pure coal may be too impervious to solutions that introduce the uranium.

\section{FACTORS CONTROLLING THE DISTRIBUTION OF} URANIUM IN COAL

The mode of occurrence of uranium in coal indicates that ground water was probably the principal agent $385115-56-27$ for transportation and deposition of uranium from solution. The time of mineralization differs with each deposit. The close association of uranium-bearing lignite of Paleocene age in the northern Great Plains region to the pre-Oligocene unconformity implies a period of uranium mineralization during or after the time of erosion that produced the unconformity. Elsewhere, uranium-bearing solutions had access to coal soon after the accumulation of plant debris in the coal swamp. For example, in the Goose Creek area the uranium-bearing liginite is interbedded with volcanic ash beds of Pliocene age that are themselves slightly uraniferous. Redistribution of uranium from the volcanic ash and concentration in the lignite have probably been continuous since Pliocene time. In some areas of uraniferous lignite and coal, present-day ground water is enriched in uranium (Denson and others, 1956).

Regardless of the source for the uranium contained in the ground-water solutions, the primary factors that control the distribution of uranium in coal are the differences in permeability and attitude of the enclosing strata, as these largely control the volume and direction of flow of ground water. The physical and chemical characteristics of the coal, such as the rank, ash content, permeability, and degree of decay, probably determine the ability of the coal to hold uranium.

\section{SOURCE OF URANIUM}

No general agreement exists among geologists regarding the origin of uranium in coal. While investigating the uraniferous lignite in the northern Great Plains, Messrs. Beroni and Bauer (written communication, 1952) noted the large percentage of minerals of volcanic origin in the lignite-bearing strata of the Fort Union formation. This observation prompted the suggestion that uranium in lignite was derived from the redistribution of uranium originally disseminated throughout the volcanic material during or shortly after the deposition of the lignite. As a result of later regional and detailed studies, N. M. Denson, G. O. Bachman, and H. D. Zeller (1956) noted the close association of uraniferous lignite to the pre-Oligocene unconformity, as well as local epigenetic features, and proposed that uranium was derived from downward percolating meteoric water that leached uranium from the White River formation of Oligocene age and the Arikaree formation of Miocene age. The interbedded uraniferous lignite and voleanic ash in the Goose Creek area tend to confirm the origin of uranium from volcanic sediments. Evidence in many of the other areas is not as clear, though a similar origin is possible for nearly all the principal deposits. Uranium mineralization at the Old Leyden coal mine, only a few miles from uraniferous vein deposits of hydrothermal origin 
in the Colorado Front Range, might be an exception to the suggested origin for other uraniferous coals by leaching from volcanic sedimentary rocks.

The generally low uranium content of coal beds of Paleozoic age in the North Central and Eastern United States may be due to the absence of widespread volcanic activity in this region as compared with Tertiary volcanic activity in the Western States. Possibly the slight amount of uranium contained in the coals of Paleozoic age is of syngenetic origin, similar to deposits of marine black shale as described by V. E. Swanson (p. 451, this volume).

\section{CONCLUSIONS}

Uranium-bearing coal occurs in widely scattered localities in the United States. The principal deposits of uranium-bearing coal are in low-rank coals of Cretaceous and Tertiary age in the northern Great Plains and Rocky Mountains regions. In most deposits, uranium is thought to have been introduced into the coal by ground-water solutions and fixed by the organic matter of the coal. Visible uranium minerals form in coal only when the amount of uranium available is in excess of that which can be held by the organic matter. The association in some areas of uranium-bearing coal with rocks of volcanic origin indicates that volcanic rocks may be one source of the uranium.

\section{REFERENCES CITED}

Bachman, G. O., Vine, J. D., Read, C. B., and Moore, G. W., 1956, Uranium-bearing coal and carbonaceous shale in La Ventana Mesa area, Sandoval County, New Mexico: U. S. Geol. Survey Bull.-(in preparation).

Berthoud, E. L., 1875, On the occurrence of uranium, silver, iron, etc., in the Tertiary formation of Colorado Territory: Acad. Nat. Sci. Philadelphia proc., v. 27, p. 363-365.

Breger, I. A., Deul, Maurice, and Rubinstein, Samuel, 1955, Geochemistry and mineralogy of a uraniferous lignite: Econ. Geology, v. 50, no. 2, p. 206-266.

Davidson, C. F., and Ponsford, D. R. A., 1954, On the oceurrence of uranium in coals: Min. Mag. [London], v. 91, p. 265-273.

Denson, N. M., 1952, Summary of uranium-bearing coal, lignite, and carbonaceous shale investigations in the Rocky Mountains region during 1951, with descriptions of deposits by Bachman, G. O., Gill, J. R., Hail, W. J., Jr., Love, J. D., Masursky, Harold, Denson, N. M., Moore, G. W., Pipringos, G. N., Vine, J. D., and Zeller, H. D.: U. S. Geol. Survey TEM 341-A 44 p., issued by U. S. Atomic Energy Comm., Tech. Inf. Service, Oak Ridge, Tenn.

Denson, N. M., Bachman, G. O., and Zeller, H. D., 1956, Uranium-bearing lignite in northwestern South Dakota and adjacent states: U. S. Geol. Survey Bull.-(in preparation).

Ferm, J. C., 1955, Radioactivity of coals and associated rocks in Beaver, Clearfield, and Jefferson Counties, Pennsylvania:
U. S. Geol. Survey TEI-468 51 p., issued by U. S. Atomic Energy Comm., Tech. Inf. Service, Oak Ridge, Tenn.

Francis, Wilfrid, 1954, Coal, its formation and composition: London, Edward Arnold Ltd., p. 483-509.

Gill, J. R., 1954, Northwestern South Dakota, southwestern North Dakota and eastern Montana, in Geologic investigations of radioactive deposits, Semiannual progress report, June 1 to Nov. 30, 1954: U. S. Geol. Survey TEI-490 p. 149-155, issued by U. S. Atomic Energy Comm., Tech Inf. Service, Oak Ridge, Tenn.

Gott, G. B., Wyant, D. G., and Beroni, E. P., 1952, Uranium in black shales, lignites, and limestones in the United States, in Selected papers on uranium deposits in the United States: U. S. Geol. Survey Circ. 220, p. 31-35.

Gude, A. J., 3d, and McKeown, F. A., 1953, Results of exploration at the old Leyden coal mine, Jefferson County, Colo.: U. S. Geol. Survey TEM-292, 14 p. (open-file report in U. S. Geol. Survey offices in Denver and Grand Junction, Colo.).

Mapel, W. J., and Hail, W. J., Jr., 1956, U. S. Geol. Survey unpub. inf.

Moore, G. W., 1954, Extraction of uranium from aqueous solution by coal and some other materials, Econ, Geology, v. 49 , no. 6 , p. $652-658$.

Moore, G. W., and Stephens, J. C., 1954, Reconnaissance for uranium-bearing carbonaceous rocks in California and adjacent parts of Oregon and Nevada: U. S. Geol. Survey Circ. 313.

Patterson E. D., 1955a, Radioactive coal and shale of Pennsylvanian and Permian age in northern West Virginia: U. S. Geol, Survey TEI-494, U. S. Atomic Energy Comm. Tech. Inf. Service, Oak Ridge, Tenn.

- $1955 \mathrm{~b}$, Radioactivity of part of the bituminous coal region of Pennsylvania: U. S. Geol. Survey TEI-479, issued by U. S. Atomic Energy Comm., Tech. Inf. Service, Oak Ridge, Tenn.

Russell, W. L., 1945, Relation of radioactivity, organic content, and sedimentation: Am. Assoc. Petroleum Geologists Bull. 29 , no. 10 , p. $1470-1494$.

Schopf, J. M., and Gray, R. J., 1954, Mieroscopic studies of uraniferous coal deposits: U. S. Geol. Survey Circ. 343.

Snider, J. L., 1954a, Radioactivity of some coal and shale of Pennsylvanian age in Ohio: U. S. Geol. Survey TEI-404, issued by U. S. Atomic Energy Comm., Tech. Inf. Service, Oak Ridge, Tenn.

- 1954b, Reconnaissance for uranium in coal and shale in southern Virginia and southwestern Virginia: U. S. Geol, Survey TEI-409, issued by U. S. Atomic Energy Comm., Tech. Inf. Service, Oak Ridge, Tenn.

1954c, Reconnaissance for uranium in the Indiana coal field: U. S. Geol. Survey TEM-784 26 p., issued by U. S. Atomic Energy Comm., Tech. Inf. Service, Oak Ridge, Tenn.

Staatz, M. H., and Bauer, H. L., 1954, Gamma Property, in Lovering, T. G., Radioactive deposits of Nevada: U. S. Geol. Survey Bull. 1009-C, p. 76-77.

Szalay, S., 1954, The enrichment of uranium in some brown coals in Hungary: Acta Geological Academiae Scientiarum Hungaricae, Magyar Tudomanyos Akademia, v. 2, nos. 3-4, p. 299-310. 
Troyer, M. L., McKay, E. J., Soister, P. W., and Wallace, S. R., 1954, Summary of investigations of uranium deposits in the Pumpkin Buttes area, Johnson and Campbell Counties, Wyo.: U. S. Geol. Survey Circ. 338.

Vine, J. D., 1956, Geology and uranium deposits in carbonaceous rocks of the Fall Creek area, Bonneville County, Idaho: U. S. Geol. Survey Bull. - (in preparation).

Welch, S. W., 1954a, Radioactivity of coal and associated rocks in the anthracite field of eastern Pennsylvania: U. S. Geol.
Survey TEI-348, issued by U. S. Atomic Energy Comm., Tech. Inf. Service, Oak Ridge, Tenn.

- 1954b, Radioactivity of coal and associated rock in the coal fields of eastern Kentucky: U. S. Geol. Survey TEI347, issued by U. S. Atomic Energy Comm. Tech. Inf. Service, Oak Ridge, Tenn.

Wyant, D. G., Beroni, E. P., and Granger, H. C., 1952, Some uranium deposits in sandstones, in Selected papers on uranium deposits in the United States: U. S. Geol. Survey Circ. 220, p. 26-29. 



\title{
URANIUM-BEARING LIGNITE AND ITS RELATION TO VOLGANIC TUFFS IN EASTERN MONTANA AND NORTH AND SOUTH DAKOTA
}

\author{
By Norman M. Denson and James R. Gill, U. S. Geological Survey
}

CONTENTS

\begin{tabular}{ll|l} 
Abstract_age & $\begin{array}{r}\text { Page } \\
\text { Introduction }\end{array}$ & $\begin{array}{l}\text { Uranium-bearing lignite } \\
\text { Geography }\end{array}$ Potentialities_age \\
Geology & 415 & References eited
\end{tabular}

\section{ILLUSTRATIONS}

Figdre 140. Geologic map showing areas underlain by uranium-bearing lignite in eastern Montana and western North Page and South Dakota . .

141. Distribution of radioactive lignite $\ldots \ldots \ldots$

\begin{abstract}
The uranium-bearing lignite deposits occur in western North and South Dakota and southeastern Montans. The rolling prairie of this region is broken by small areas of badlands or by buttes and ridges. The uranium-bearing lignite deposits underlie the more prominent buttes. The mineralized lignite beds occur throughout 2,000 feet of fluviatile deposits of Paleocene and late Cretaceous age. The rocks generally strike northwest and dip about 10-40 feet per mile northeast into the Williston basin.

Overlapping the lignite-bearing sequence with marked regional unconformity are 250 feet or more of ash-gray mildly radioactive tuffs and bentonitic clays of Oligocene and Miocene age. Field evidence indicates leaching of uranium from the tuffs and concentration in the underlying lignite. Lignites are believed to have acted as receptors that extracted uranium by ion exchange or by formation of organometallic compounds. Chemical analyses of water from the tuff show abnormal concentrations of uranium in association with arsenic, vanadium, molybdenum, and copper. An epigenetic theory of origin of the uranium in the lignite is supported by the fact that the mineralized beds, irrespective of their ages, closely underlie the uneonformity at the base of the Oligocene and that greater uranium concentrations occur in the upper parts of the stratigraphically highest lignites.

Almost one-fifth of the uranium-bearing lignite is in beds 4 feet in thickness that can be strip mined. Analyses of approximately 500 surface and 1,000 eore samples indicate that the mineralized lignites contain 0.005-0.02 percent uranium with concentrations of $0.05-0.1$ percent uranium in the lignite ash. Molybdenum is also closely associated with uranium in the lignite in concentrations ranging from 0.01 to 1.0 percent in the lignite ash. Although the uranium content is generally only 0.008 , the tonnages of lignite are great, and may be of future

value particularly if uranium is extracted from ash of lignite used industrially. Development of new metallurgical and recovery techniques may allow eventual exploitation of these deposits. The discovery of autunite- and metazeunerite-bearing lignite containing as much as 5 percent uranium in beds 18-30 inches thick in the Cave Hills area of northwestern South Dakota increases interest in lignite as an economic source of uranium and indicates other deposits of comparable grade may be discovered.

\section{INTRODUCTION}

Uranium-bearing lignite in the Williston basin of North Dakota and South Dakota was discovered by D. G. Wyant and E. P. Beroni in 1948 (written communication). Detailed investigations were conducted from 1950 to 1954 by N. M. Denson, G. O. Bachman, J. R. Gill, H. D. Zeller, and others to evaluate economic possibilities of the radioactive lignite and to determine the geologic factors controlling the accumulation of uranium.

Geiger counters, scintillometers, and car-borne scintillation equipment guided the fieldwork and sampling program. A jeep-powered auger and core drills were used to obtain unweathered samples of lignite to determine correlation and areal extent of radioactive beds in selected areas. Approximately 500 surface and 1,000 core samples of lignite were analyzed for uranium. Chemical and semiquantitative spectrographic analyses for other trace elements and petrologic examinations of a few samples were made in conjunction with the routine determinations.
\end{abstract}




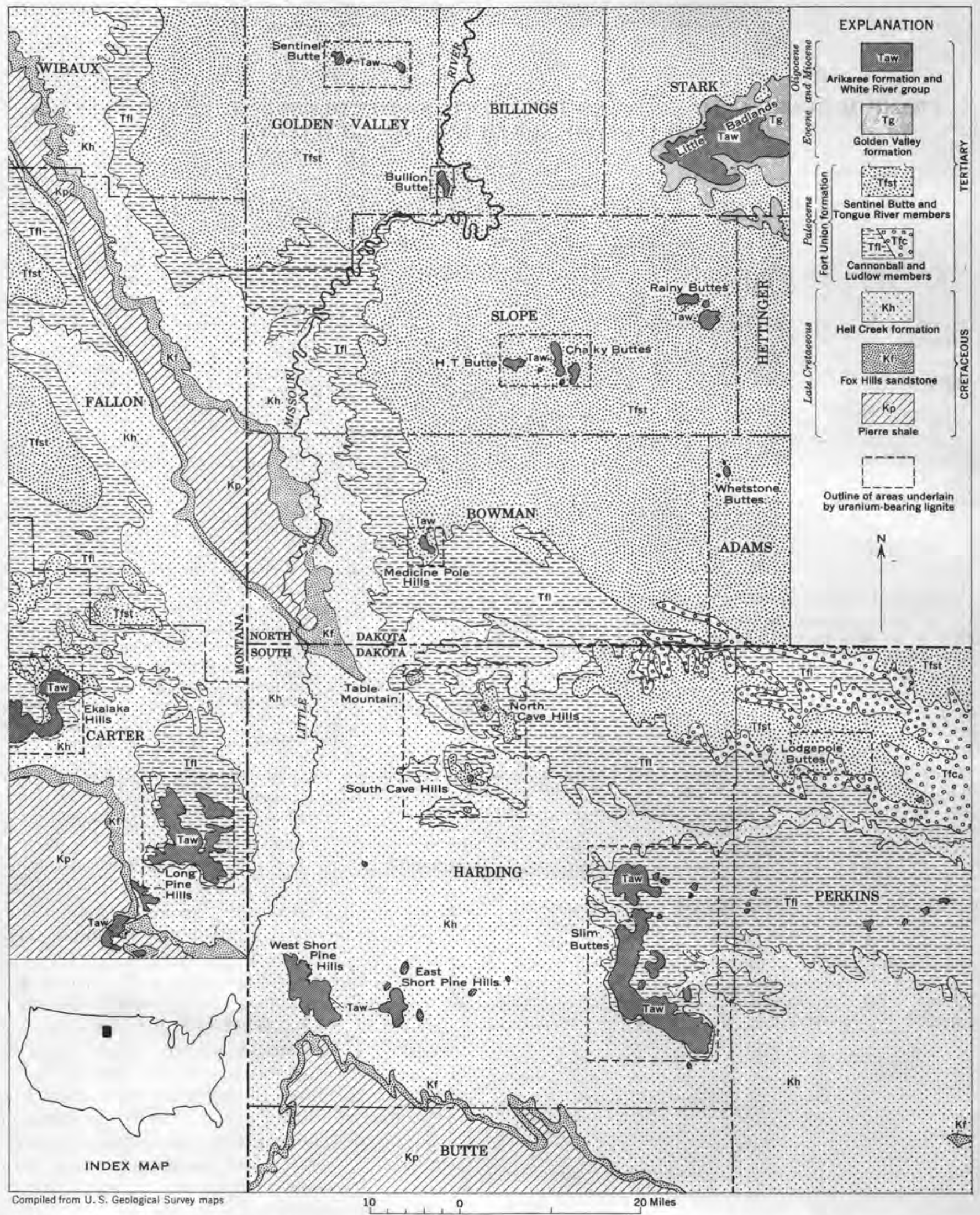

FraUkE 140.-Geologic map showing areas underlain by uraninm-bearing lignite in eastern Montana and western North and South Dakota. 


\section{GEOGRAPHY}

Uranium-bearing lignite deposits of eastern Montana and North and South Dakota occur in an area of about 13,000 square miles near the eastern margin of the Great Plains province, about 100 miles north of the Black Hills (fig. 140), The region is a rolling prairie, broken by small areas of badlands or by buttes and ridges which are rugged and precipitous. Most of the buttes and hills stand 300-500 feet above the surrounding country, and rock strata are well exposed in the cliffs around the buttes.

The eastward-flowing Grand River and the northward-flowing Little Missouri River and their tributaries drain most of the region. Low sandy hills and broad sandy flats adjoin the rivers, whereas away from the streams the divides in many places are capped by small rock buttes or by red baked rock and clinker caused by burning lignite. The altitude of the region ranges from 2,100 feet above sea level along the east border to about 4,000 feet on the Short Pine Hills. Many county roads and prairie trails, in addition to State and Federal highways, make most places in the region fairly accessible.

\section{GEOLOGY}

The stratigraphic section exposed in eastern Montana and adjacent parts of North and South Dakota includes rocks of Cretaceous, Tertiary, and Quaternary age, which have a combined thickness of approximately 3,800 feet. Drill tests for oil and gas indicate that about 7,600 feet of Paleozoic and Mesozoic rocks occur between the oldest exposed rocks and the top of the Precambrian granite.

Radioactive lignite occurs sporadically in the Hell Creek formation of Late Cretaceous age in the Ludlow, Tongue River, and Sentinel Butte shale members of the Fort Union formation of Paleocene age and in the overlying Golden Valley formation of Eocene age. These formations total 2,210 feet or more in thickness and consist predominantly of fluviatile deposits of somber soft sandy clay-shale and massive thick-bedded tan and gray-brown sandstone.

Overlapping the lignite-bearing sequence with marked regional unconformity is 300 feet or more of ash-gray mildly radioactive tuffaceous sandstone and bentonitic clay of the Chadron, Brule, and Arikaree formations of Pliocene and Miocene age. Erosional remnants unconformably capping many of the high buttes and escarpments indicate that these formations once extended over most if not all of the lignite-bearing rocks of the region. The table below gives the general lithologic characteristics of the rocks in the region.

The lignite-bearing formations herein described occupy the southwestern flank of the Williston basin, the

Generalized section of formations exposed in southeastern Montana and adjacent parts of North and South Dakota

\begin{tabular}{|c|c|c|c|c|c|}
\hline Bystem & Series & \multicolumn{2}{|c|}{ Group, formation, member } & $\begin{array}{l}\text { Thiokness } \\
\text { in feet }\end{array}$ & Lithologic characteristies \\
\hline Quaternary...- & $\begin{array}{l}\text { Recent and Pleis- } \\
\text { tocene. }\end{array}$ & \multicolumn{2}{|c|}{ 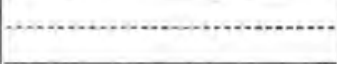 } & $0-100$ & Silt, sand, and gravel in dunes, terraces, and alluvial fans along main stream channels. \\
\hline \multirow{8}{*}{ Tertiary } & Miocene.......... & \multicolumn{2}{|c|}{ Arikaree formation.............. } & 260 & $\begin{array}{l}\text { Massive greenish-white to ash-gray tuffaceous sandstone and siltstone with a few thin beds } \\
\text { of quartzite and volcanic ash. Dominantly of aeolfan origin. Oontains local oocurrences } \\
\text { of carnotite in calcareous siltstone in the Short Pine Hills. Caps most of the high buttes } \\
\text { of eastern Montana and North and South Dakota. }\end{array}$ \\
\hline & \multirow{2}{*}{ Oligocene } & \multirow{2}{*}{$\begin{array}{l}\text { White } \\
\text { River } \\
\text { group }\end{array}$} & Brule formation...... & $0-240$ & $\begin{array}{l}\text { Massive buff to pinkish-tan tuffaceous siltstone and claystone. Contains abundant verte- } \\
\text { brate remains. Well exposed in Chalky Buttes and Little Badlands of North Dakots. } \\
\text { Preserved only in pre-Arikaree landslide blocks in Slim Buttes and Short Pine Hills of } \\
\text { South Dakots. Not present in southeastern Montans. }\end{array}$ \\
\hline & & & Chadron formation... & $0-160$ & $\begin{array}{l}\text { Dark-gray bentonite and light-gray tuffaceous claystone, siltstone, and sandstone. Basal } \\
\text { unit consists of coarse-grained conglomeratic sandstone. Lower part at many places } \\
\text { weathers golden yellow. Carnotite oecurs in upper part of formation in the Slim Buttes. }\end{array}$ \\
\hline & Eocene. & \multicolumn{2}{|c|}{ Golden Valley formation.......... } & $0-175$ & $\begin{array}{l}\text { Gray to yellow sandstone, siltstone, and purplish-gray to white kaolinitic clay. Contains } \\
\text { a few thin lenticular beds of lignite and carbonsceous shale. In the Little Badlands where } \\
\text { closely overlain by Oligocene and Miocene rocks, carbonseeous beds are radioactive. }\end{array}$ \\
\hline & \multirow{4}{*}{ Paleocene } & \multirow{4}{*}{$\begin{array}{l}\text { Fort } \\
\text { Union } \\
\text { forma- } \\
\text { tion }\end{array}$} & Bentinel Butte shale.. & $0-660$ & $\begin{array}{l}\text { Dark-gray bentonitic claystone and shale, buff to brown sandstone with numerous beds of } \\
\text { lignite which are radioactive in HT, Sentinel, Bullion, and Chalky Buttes. Contains } \\
\text { carnotite-bearing sandstone at Whetstone Butte. }\end{array}$ \\
\hline & & & $\begin{array}{l}\text { Tongue River mem- } \\
\text { ber. }\end{array}$ & $600+$ & $\begin{array}{l}\text { Massive gray to tan sandstone, siltstone, and shale. Contains many lenticular beds of } \\
\text { quartzite and thick persistent beds of lignite. Formation has large deposits of uranium- } \\
\text { bearing lignite in Medicine Pole and Cave Hills areas, and at Lodgepole Buttes. }\end{array}$ \\
\hline & & & Cannonball member.. & $0-300$ & $\begin{array}{l}\text { Marine dark-gray and brown sandstone and shale with large limey concretions. Inter- } \\
\text { tongues and thins to the west with the Ludlow member of the Fort Union formation. }\end{array}$ \\
\hline & & & Ludlow member...... & 350 & $\begin{array}{l}\text { Gray to light-yellow-tan sandstone, gray shale, and thick lenticular beds of lignite. Con- } \\
\text { tains radioactive lignite deposits in the Slim Buttes and Cave, Long Pine and Ekalaka } \\
\text { Hills. Local deposits of uranophane-bearing sandstone in the Slim Buttes. }\end{array}$ \\
\hline \multirow{3}{*}{ Cretaceous } & \multirow{3}{*}{ Upper Cretaceous } & \multicolumn{2}{|c|}{ Hell Oreek formation.......... } & 425 & $\begin{array}{l}\text { Dark-gray bentonitic claystone and gray-brown lenticular sandstone. Many concretions } \\
\text { and thin lenses of iron carbonate. Contains thin lenses of lignite in upper part. Loeal } \\
\text { occurrence of carnotite in sandstone in the Long Pine Hills. }\end{array}$ \\
\hline & & \multicolumn{2}{|c|}{ Fox Hills sandstone } & $25-75$ & Marine grayish-white to brown sandstone. \\
\hline & & \multicolumn{2}{|c|}{ Plerre shale......................... } & $\begin{array}{l}500 \pm \\
\text { exposed }\end{array}$ & $\begin{array}{l}\text { Marine dark-gray to brownish-black bentonitic claystone and shale containing large lime- } \\
\text { stone concretions and thin beds of bentonite. }\end{array}$ \\
\hline
\end{tabular}


axis of which trends northwest and lies along the eastern edge of the area. In general, the strike of the rocks is northwest, and the regional dip is $10-40$ feet per mile to the northeast. The dominant structural feature affecting the regional dip is the plunging north end of the Black Hills uplift, the axis of which trends north-northwest and passes to the west of the Short Pine Hills in western Harding County, S, Dak. All of the lignitebearing rocks are about equally deformed, with the younger rocks of the White River group and the Arikaree formation resting almost horizontally on the truncated edges of the older formations. Few faults or folds that extend to great depth are observed in the region, but at many places landslides of Recent and Miocene (?) age produced surficial faults and folds.

\section{URANIUM-BEARING LIGNITE}

Megascopically visible uranium minerals (metazeunerite, autunite, and torbernite) were discovered in 1954 in lignite and associated rocks in the Cave Hills area of northwestern South Dakota. There the uranium minerals impregnate fractures and joints in thin impure lignite beds $18-30$ inches thick which contain $0.3-5$ percent uranium. Several deposits of similar radioactive lignitic material have been found in the Slim Buttes in addition to commercial-grade deposits of uranophanebearing sandstone and metatyuyamunite-bearing carbonaceous shale.

Uranium minerals have not as yet been found in lignite in other areas of the region. Detailed microscopic and analytical studies on some of the lower grade deposits indicate that the uranium occurs as a disseminated constituent of the carbonaceous material. Petrographic and mineralogic studies by the Battelle Memorial Institute (R. A. Ewing, written communication, 1950), the U. S. Geological Survey (Schopf and Gray, 1954; Breger, Deul, and Rubinstein, 1955), and Pennsylvania State University (T. F. Bates, written communication, 1952) of the lignites of North and South Dakota demonstrated that the uranium, although not present as a distinct mineral, was closely associated with the organic carbonaceous material. Gypsum, analcite, jarosite, limonite, quartz, and other minerals, listed here in decreasing order of abundance, had no observed relation to the amount of uranium in the lignite. Semiquantitative spectrographic analyses of the ash from radioactive lignite cores from South Dakota (H. D. Zeller, written communication, 1952) show that most chemical elements are uniformly distributed through a vertical section of lignite. Uranium and molybdenum were among those which show a marked decrease downward from the top of the bed. The presence of small amounts of nickel, lead, and vanadium is indicated by spectrographic data, but the relationship between their distribution and that of uranium is less obvious.

Lignite from South Dakota has been shown to be a good extractor of uranium from solution (Moore, 1954). Nonradioactive lignite from the Slim Buttes, S. Dak., was immersed in a solution of uranyl sulfate containing 200 parts per million uranium (ppm). After 19 days the lignite contained 0.19 percent uranium, and the solution contained $2.0 \mathrm{ppm}$ uranium. The experiment confirms in a striking manner the affinities of carbonaceous material for uranium pointed out by I. M. Tolmachev (1943) and S. Szalay (1954). Similar absorptive relationships have been postulated by V. E. McKelvey and J. M. Nelson (1950) for the origin of uranium in marine black shale, and A. F. Frederickson (1948) has discussed the relation between uranium and other types of carbon.

Three hypotheses of origin have been proposed to explain the uranium-bearing lignite deposits of the South and North Dakota and Montana region. As a result of work in 1948 and 1949 D. G. Wyant and E. D. Beroni (written communication, 1950) proposed the following two hypotheses of origin: The uranium was deposited with other detrital minerals in sediments overlying or marginal to the lignite and subsequently leached from them, carried downward or laterally, and fixed by the carbon of the lignite; or the uranium was deposited from surface waters by the action of living organisms or dead organic matter at the same time as the carbonaceous debris from which the lignite formed.

Work of N. M. Denson, G. O. Bachman and H. D. Zeller in 1951 (1956) led to the formation of a third hypothesis; the uranium is epigenetic in origin, having been extracted by the lignite, subsequent to coalification, from ground water bringing uranium from overlying tuffaceous source rocks by percolating downward or by moving laterally along aquifers near the lignite beds.

The uranium ion is believed to have been held as a disseminated constituent in the volcanic ash or tuffaceous material in the rocks of the White River group and the Arikaree formation. Subsequent release or displacement of the uranium may have been accomplished by weathering and ultimate devitrification of the volcanic materials. Whatever the reason for the displacement, carbonaceous materials are believed to have acted as filters to concentrate and fix the uranium. Experimental work by I. A. Breger, Maurice Deul, and Samuel Rubinstein (1955, p. 226) with radioactive lignite from the Slim Buttes led these workers to conclude that the uranium is not held in the coal by ion exchange but seems to be present in the form of organouranium complexes or ionic organouranium compounds.

Subsequent fieldwork including extensive core drilling 


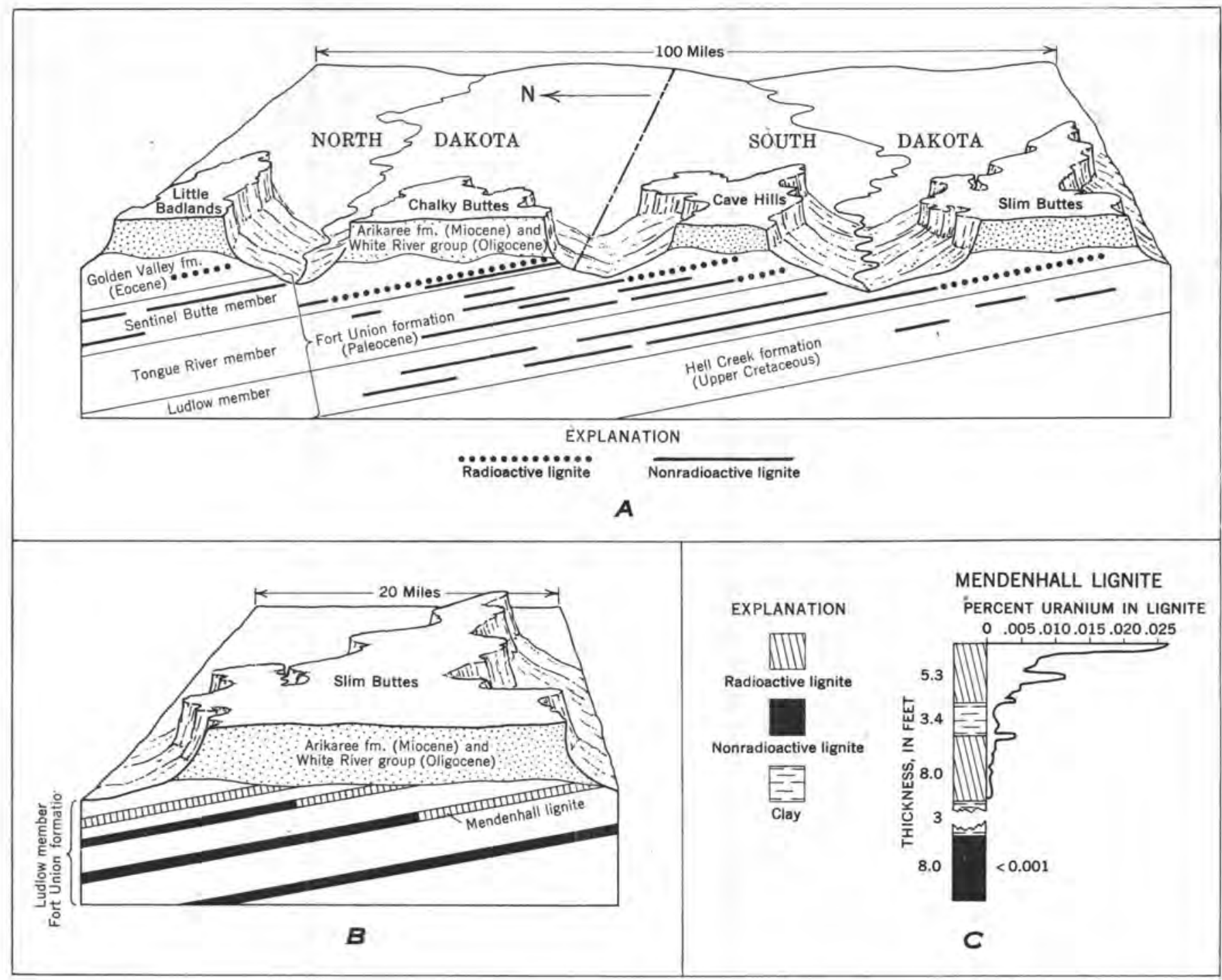

Figure 141.-Distribution of radioactive lignite. A.-Diagrammatio section across northwestern South Dakota snd southwestern North Dakota showing stratigraphic distribution of uranium-bearing lignite. B.-Diagrammatie section across Slim Buttes showing that the stratigraphically highest lignite beneath the pre-Oligocene unconformity is the most radioactive. C.-Diagram of radioactive lignite showing typical top preferential distribution of uranium.

in North and South Dakota has elaborated and confirmed this hypothesis now termed the "ash leach" or volcanic ash theory (Thomas, 1954; Hager, 1954, Miller and Gill, 1954). In 1954 discoveries of ore-grade deposits of autunite and metazeunerite-bearing lignite and of uranophane- and carnotite-bearing carbonaceous sandstones, closely underlying tuffaceous rocks in the Cave and Long Pine Hills and at Slim and Whetstone Buttes, gave additional confirmatory evidence for the theory.

Some observations supporting an epigenetic theory of origin are as follows: (1) All radioactive lignite deposits are within 40-140 feet of the unconformity at the base of Oligocene or Miocene rocks and bear no apparent relation to the age of the formation in which they occur (fig. 141A). Most of the radioactive lignites occur on $385115-56-28$ the flanks of the highest buttes capped with volcanic materials. (2) In general, within a series of nearly flat-lying beds the greatest concentrations of uranium occur at the top of a coal bed and diminishing progressively downward (fig. $141 A, B$ ). The stratigraphically and topographically higher lignites are the most radioactive (fig. 141B), (3) At many places throughout the region, differences in permeability of the rocks overlying the lignite beds are reflected in the intensity of uranium mineralization. Where a mineralized bed is directly overlain by a permeable sandstone, the bed is more highly mineralized than where it is overlain by clay or shale. (4) Rocks of the White River group and Arikaree formation show 2-6 times normal radioactivity and contain an average of about 0.0015 percent uranium, about 12 times that of the average sedimentary rock 
(Evans and Goodman, 1941). (5) Chemical analyses show that the water from rocks of the White River group and the Arikaree formation contains greater than normal concentration of uranium in association with arsenic, copper, phosphorous, vanadium, and molybdenum. In the Montana and North and South Dakota lignite areas, the uranium minerals metazeunerite $\left[\mathrm{CU}\left(\mathrm{UO}_{2}\right)_{2}\left(\mathrm{ASO}_{4}\right)_{2} \cdot 8 \mathrm{H}_{2} \mathrm{O}\right]$, autunite $\left[\mathrm{CA}\left(\mathrm{UO}_{2}\right)_{2}\left(\mathrm{PO}_{4}\right)_{2}\right.$. $10-12 \mathrm{H}_{2} \mathrm{O}$ ], torbernite [CU $\left.\left(\mathrm{UO}_{2}\right)_{2}\left(\mathrm{PO}_{4}\right)_{2} \cdot 8-12 \mathrm{H}_{2}\right)$ ], and carnotite $\left[\mathrm{K}_{2} \mathrm{O} \cdot 2 \mathrm{UO}_{3} \cdot \mathrm{V}_{2} \mathrm{O}_{5} \cdot 2 \mathrm{H}_{2} \mathrm{O}\right]$, which are found ocally in the lignitic rocks and associated sandstones, contain most of these elements.

\section{POTENTIALITIES}

Available incomplete data indicate that deposits of radioactive lignite aggregating about 90 million tons, in eastern Montana and adjacent parts of North Dakota and South Dakota average about 4 feet in thickness, contain $0.005-0.02$ percent uranium and average about 0.008 percent uranium. The uranium content of ash ranges from 0.05 to 0.1 percent.

Smaller higher grade uranium-bearing lignite and carbonaceous shale deposits in the region contain conspicuous uranium minerals such as autunite and zeunerite. Such deposits contain from a few hundredths to about 5 percent uranium. One deposit in the Cave Hills contains a significant tonnage of lignite averaging about 0.3 percent uranium.

\section{REFERENCES CITED}

Breger, I. A., Deul, Maurice, and Rubinstein, Samuel, 1955, Geochemistry and mineralogy of a uraniferous lignite: Econ. Geology, v. 50, no. 2, p. 206-226.

Denson, N. M., Bachman, G. O., and Zeller, H. D., 1956, Uranium-bearing lignite in northwestern South Dakota and adjacent states: U. S. Geol. Survey Bull.-(in preparation).

Evans, R. D., and Goodman, Clark, 1941, Radioactivity of rocks: Geol. Soc. America Bull., v. 52, no. 4, p. 459-490.

Frederickson, A. F., 1948, Some mechanisms for the fixation of uranium in certain sediments: Science, v. 108, p.184-185.

Hager, Dorsey, 1954, Uranium - the volcanic ash theory: Uranium, v. 1 , no. 1 , p. 12-13, 38 .

McKelvey, V. E., and Nelson, J. M., 1950, Characteristics of marine uranium-bearing sedimentary rocks: Econ. Geology, v. 45 , no. 1 , p. $35-53$.

Miller, R. L., and Gill, J. R., 1954, Uranium from coal: Sci. Am., v. 191, no. 4, p. 36-39.

Moore, G. W., 1954, Extraction of uranium from aqueous solution by coal and some other materials: Econ. Geology v. 49, p. $652-658$.

Schopf, J. M., and Gray, R. J., 1954, Microscopic studies of uraniferous coal deposits: U. S. Geol. Survey Circ. 343, 10 p.

Szalay, S., 1954, The enrichment of uranium in some brown coals in Hungary: Magyar Tudom. Akad. Aeta Geol., v. 2, nos. 3-4, p. 299-310.

Thomas, H. D., 1954, Wyoming's uranium prospects: Uranium, v. 1 , no. 1 , p. $8,46-47$.

Tolmachev, Ya. M., 1943, Adsorption of uranyl salts on solid adsorbents: Akad. Nauk SSSR, Izv. Otdel. Khimicheskikh Nauk, no. 1, p. 28-34 [Russian text and English summary]. 


\title{
HIGH-GRADE URANIFEROUS LIGNITES IN HARDING COUNTY, SOUTH DAKOTA
}

\author{
By John W. King and Harry B. Young, U. S. Atomic Energy Commission
}

\section{CONTENTS}

\begin{tabular}{|c|c|c|}
\hline \multicolumn{3}{|c|}{ Page } \\
\hline Abstract_- & 419 & Mineralogy-Continued \\
\hline Introduction ..... & 419 & Other minerals in the coal...... \\
\hline Geography... & 420 & Distribution of uraniferous lignite \\
\hline Stratigraphy _.... & 420 & Mode of occurrence \\
\hline Fort Union Formation (Paleocene) & 420 & Description of individual deposits_.... \\
\hline White River group (Oligocene) _....... & 420 & 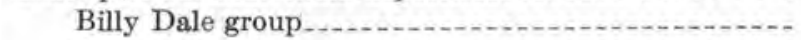 \\
\hline Arikaree formation (Miocene) & 420 & Hilltop mine . . . . . . . . \\
\hline Structure & 420 & Lonesome Pete claim \\
\hline Mineralogy & 423 & Summary and conclusions \\
\hline Coal petrography & 423 & Selected bibliography \\
\hline Uranium in the coal & 426 & \\
\hline
\end{tabular}

\section{ILLUSTRATIONS}

Figure 142. Index maps of uraniferous lignite area in contiguous parts of North Dakota, South Dakota, and Montana ....................

143. Geologic map of Harding County, S. Dak... 144. Generalized partial columnar section showing stratigraphic position of principal coal beds in Harding County, S. Dak., and adjacent areas .
Page 422 423
Frgure 145. Section from Short Pine Hills in Harding County, S. Dak., to HT Butte in Bowman County, N. Dak., showing relationship of lignitic beds to base of the White River group

146. Location of mines and prospects, Cave Hills, Harding County, S. Dak ..........

147. Loeation of mines and prospects, Slim Buttes, Harding County, S. Dak .........

\section{ABSTRACT}

Lignite beds, the uranium content of which ranges between 0.10 and 10 percent, were discovered in Harding County, northwestern South Dakota during the summer of 1954, and economically significant reserves have since been found. The lignite field lies in the Missouri Plateau section, unglaciated, of the Great Plains province between the Black Hills uplift and the Williston basin.

The uranium deposits are in thin lignitic beds of the Tongue River and Ludlow members of the Fort Union formation of Paleocene age. Uranium occurs principally in a urano-organic complex. Meta-autunite and other uranium minerals also oceur as coatings on fracture surfaces in the richest deposits,

Only weathered lignite deposits are known; the deeper unweathered zones have not yet been explored. Proximity to aquifers, joints at one deposit, and amount of degradation of the coal are factors that have been observed to control uranium deposition. Epigenetic origin of the uranium is favored by most observers. Other hypotheses regarding source are leaching of overlying weakly uraniferous tuffaceous beds and a modified hydrothermal origin.

\section{INTRODUCTION}

Lignite beds of Paleocene age, containing uranium in amounts ranging between 0.1 and 10 percent, were discovered in northwestern South Dakota during the summer of 1954. Many economically significant additional discoveries were made during the rest of the year. Physical exploration and the exploitation of known deposits have been undertaken only to a limited extent; as a consequence, details concerning geology, mode of occurrence, and habit of deposits are as yet incomplete.

Weakly radioactive lignites were studied by the U. S. Geological Survey in northwestern South Dakota and adjacent areas as early as 1948. A core drilling project was carried out between 1951 and 1953 which resulted in calculation of reserves of 47 million tons of uraniferous lignite containing 0.005 percent uranium (Gill, 1954). 
This report, however, concerns only the lignitic deposits discovered in 1954 and 1955 containing 0.10 percent or more uranium. Discoveries of such material have been made principally in Harding (the north westernmost) County, S. Dak., with scattered discoveries of unknown potential in adjacent areas of North Dakota and Montana. Inferred reserves approximate 100,000 tons containing more than 0.10 percent $\mathrm{U}_{3} \mathrm{O}_{8}$ and a potential of a million tons of similar grade is possible.

\section{GEOGRAPHY}

Harding County is located in the unglaciated portion of the Missouri Plateau section of the Great Plains province. The rolling topography of the plains is interrupted by steep-walled buttes and mesas, notably North and South Cave Hills, Table Mountain, and Slim Buttes (fig. 142). These features stand 300-500 feet above the surrounding plains.

The western part of Harding County drains north into the Little Missouri River; the eastern part drains eastward and empties into the Grand and Cannonball Rivers, both tributary to the Missouri River. The plains are grass covered and almost devoid of trees although parts of the larger mesas support a moderate growth of pine. Stock grazing is the most important occupation.

Buffalo, S. Dak. (population 350), is the county seat and largest town in Harding County. It is served from north and south by U. S. Highway 85 and from east and west by State Highway 8 . Nearest rail connections are the Milwaukee Road, 52 miles to the north at Bowman, N. Dak., and the Chicago and Northwestern, 73 miles to the south at Belle Fourche, S. Dak.

\section{STRATIGRAPHY}

The stratigraphic section exposed in Harding County includes rocks of Cretaceous, Tertiary, and Quaternary age. Figure 143 shows the Harding County portion of the geologic map of South Dakota published by the U. S. Geological Survey with minor modifications. Cretaceous rocks are not discussed in detail as they have no known bearing on the uraniferous lignite problem.

\section{FORT UNION FORMATION (PALEOCENE)}

Lignite beds containing more than 0.10 percent $\mathrm{U}_{3} \mathrm{O}_{8}$ are found at several horizons in the Ludlow member and at two horizons of the Tongue River member of the Fort Union formation of Paleocene age.

IC. The Ludlow and Tongue River members consist predominantly of dark-yellow and gray, fluviatile soft sandy shales and shales with scattered resistant massive sandstone units, particularly in the Tongue River member.

The Ludlow member intertongues, in the eastern part of Harding County, with the marine Cannonball member which is non-lignite-bearing. The Tongue River member, of which the resistant basal massive sandstone unit makes the rimrock on the Cave Hills and Table Mountain, is absent in the Slim Buttes. Pre-Oligocene erosion stripped the Tongue River member in the southern part of the area before deposition of the Oligocene White River group. The Sentinel Butte shale member of the Fort Union formation was similarly removed and is not present in Harding County. Significant uranium discoveries have been made recently in the Sentinel Butte shale member in North Dakota.

\section{WHITE RIVER GROUP (OLIGOCENE)}

The White River group (figs. 143-147) unconformably overlies the Fort Union formation in Harding County. From 40 to 200 feet thick, it is composed of light-gray, yellow-brown, and pink bentonitic clay; sandstone containing devitrified ash; and limestone lenses.

\section{ARIKAREE FORMATION (MIOCENE)}

The Arikaree formation forms the caprock of the Slim Buttes and several of the smaller buttes and mesas in the southern part of Harding County. It consists of about 200 feet of tuffaceous sandstones. The unit is more radioactive than any other formation of the area and is several times more uraniferous ( 0.0015 percent U) than average sedimentary rocks (Denson, Bachman, and Zeller, 1956).

\section{STRUCTURE}

Harding County, S. Dak., lies between the Black Hills uplift to the south and the Williston basin to the north. The Cedar Creek anticline trends approximately S. $60^{\circ} \mathrm{E}$. across Montana toward the point where North Dakota, South Dakota, and Montana join. The anticline flattens and loses its identity between the Cave Hills and Slim Buttes in Harding County, S. Dak. Regional dip is $30-40$ feet a mile northeastward into the Williston basin.

Jointing is a common feature in the indurated sandstones of the Cave Hills. Significant faulting has not been observed in the Cave Hills but has been noted in Slim Buttes. The Slim Buttes faults trend approximately N. $75^{\circ} \mathrm{W}$., dip vertically, and have caused displacements of as much as 200 feet. Seismic surveys by private companies have indicated as many as 10 such faults with displacements between 40 and 200 feet, 
HIGH-GRADE URANIFEROUS LIGNITES, HARDING COUNTY, S. DAK.
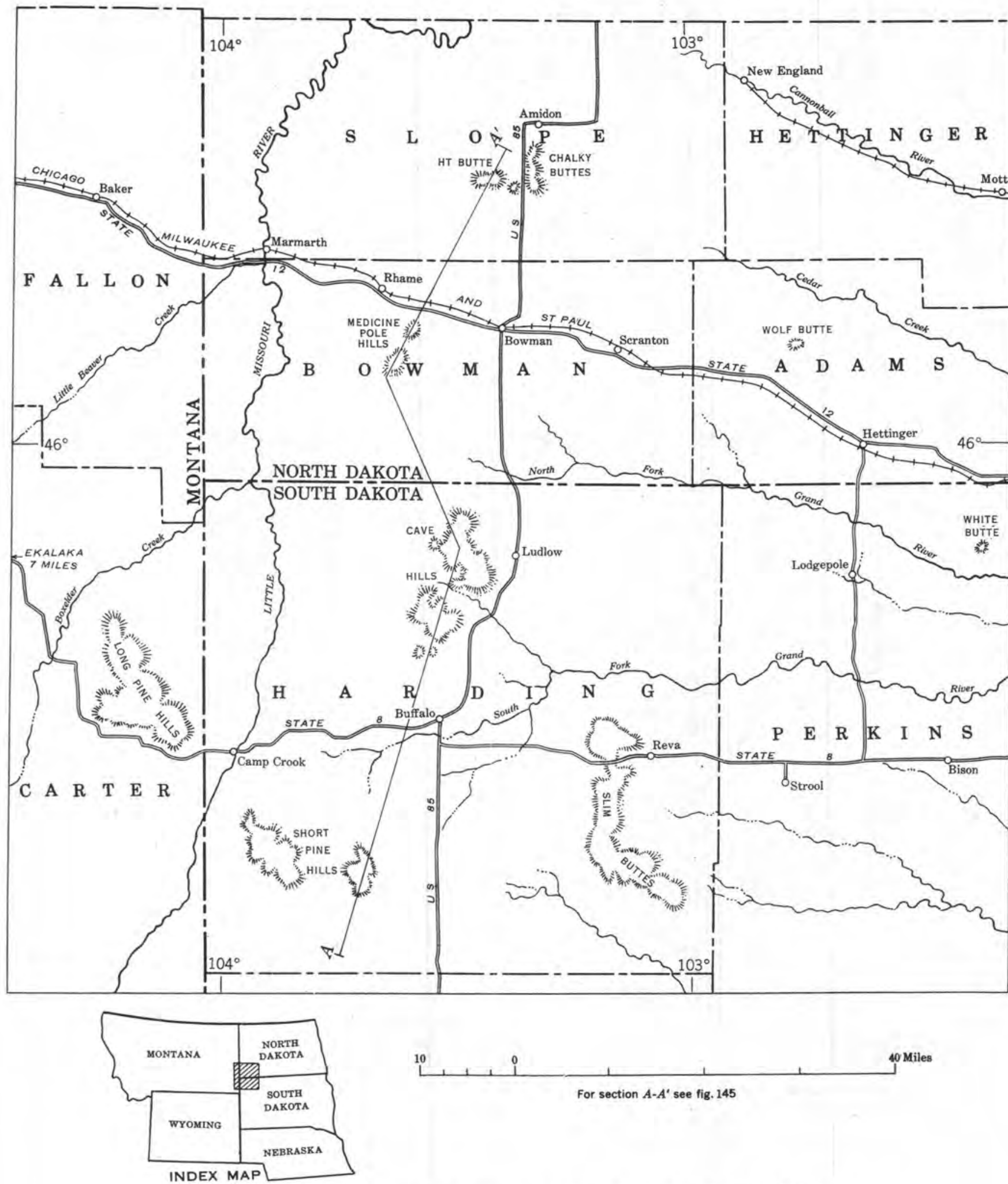

FIGURE 142,-Index maps of uraniferous lignite in contiguous parts of North Dakota, South Dakota, and Montans. 


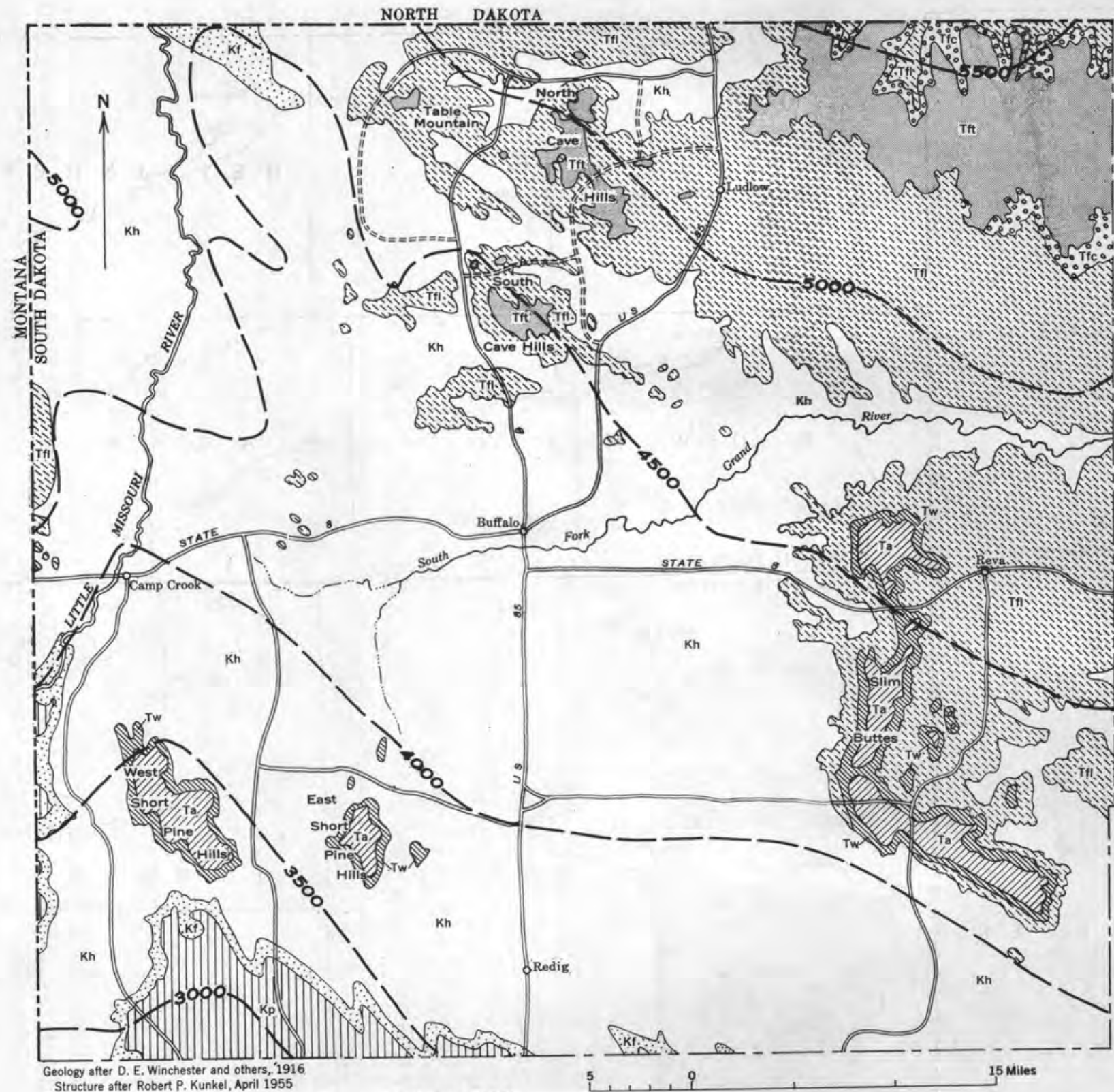

Structure after Robert P. Kunkel, April 1955
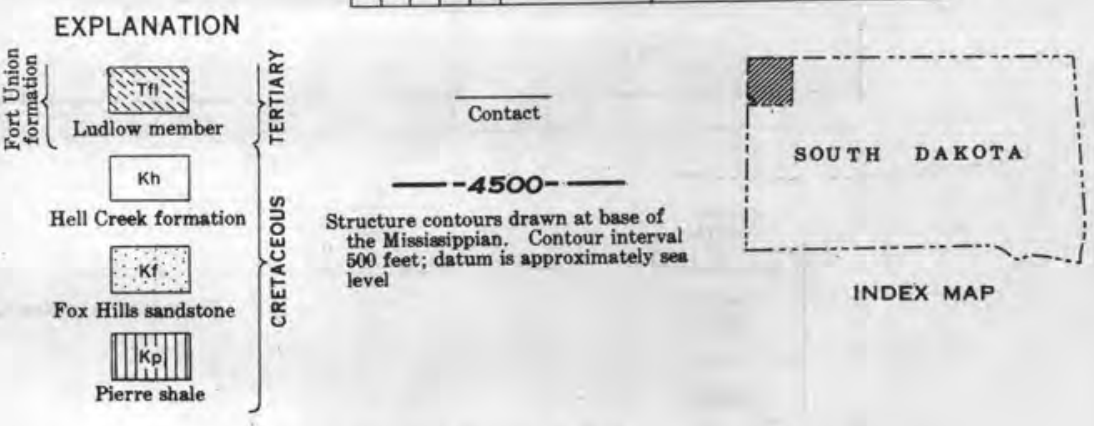

FIGURE 143.-Geologic map of Harding County, S. Dak. 


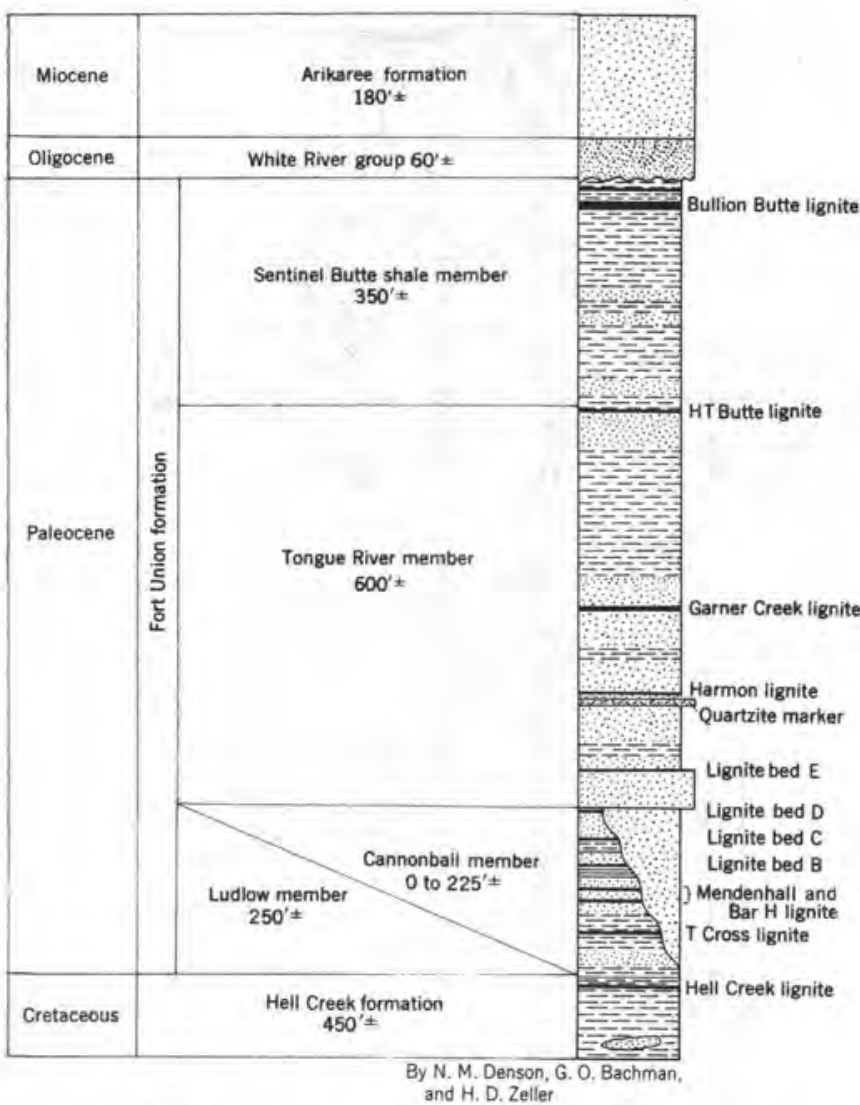

FIGURE 144.-Generalized partial columnar seetion showing stratigraphie position of principal coal beds in Harding County, 8. Dak., and adjacent areas.

across a 1-mile section. The direction of displacement is not consistent, but creates a horst and graben system.

Landsliding and slumping characterize the slopes of Slim Buttes and are common in the Cave Hills. Many of the lignitic units are involved, making stratigraphic correlation difficult in many areas.

\section{MINERALOGY}

\section{COAL PETROGRAPHY}

Limited petrographic work has been done on the strongly weathered abundantly uraniferous lignitic material from the Cave Hills. Specimens from most of the uraniferous lignite outcrops do not burn under a blowpipe flame. Moisture content differs, but the average of more than 500 tons shipped as uranium ore is approximately 32 percent. Lot samples range between 20 and 50 percent moisture. No unweathered material has yet been collected.

Auger drilling, which produced only fair to poor samples, indicated that the abundantly uraniferous lignitic material exists, and is reasonably consistent, as far as 350 feet horizontally from the outcrop and under a maximum overburden of 75 feet. Although no proximate or ultimate analyses are available from the thin uraniferous lignitic beds, extensive work has been done on the thicker beds having a uranium content of about 0.005 percent. Averages of 5 samples of weathered and 5 of unweathered lignite from the Mendenhall and Olesrud (or Bar $\mathrm{H}$ ) beds (near the middle of the Ludlow member) are as follows:

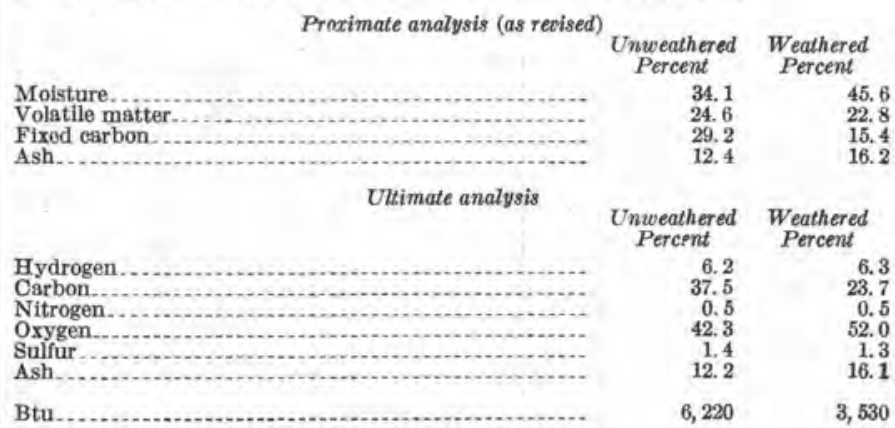

Weight of the lignitic material in place is assumed to be 1,750 wet short tons per acre foot or 27.3 cubic feet per ton.

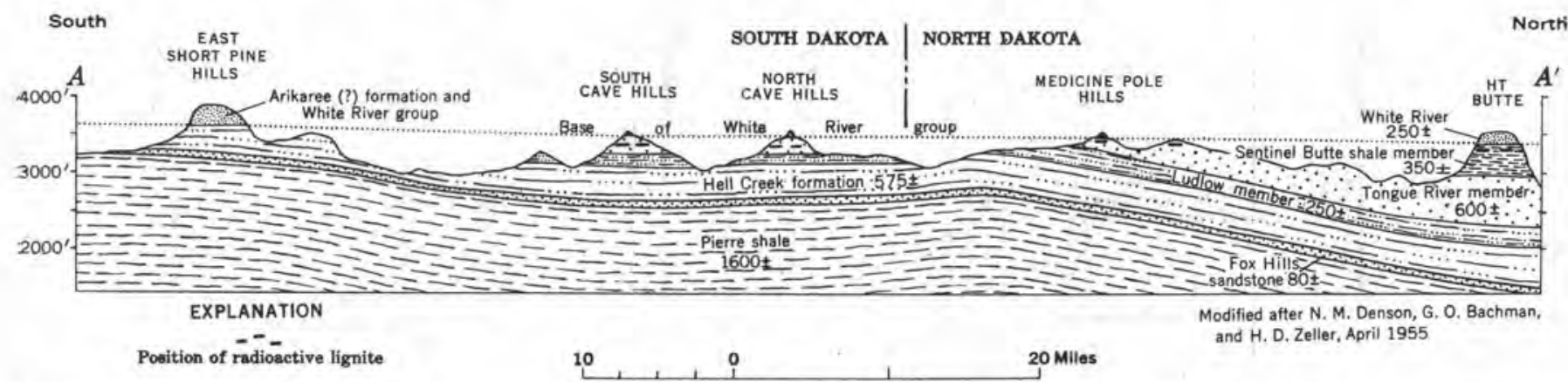

Figure 145.-Section from Short Pine Hills in Harding County, S. Dak., to HT Butte in Bowman County, N. Dak., showing relation of lignitic beds to base of the White River group. Figures following formation names refer to thickness of the formation, in feet. 


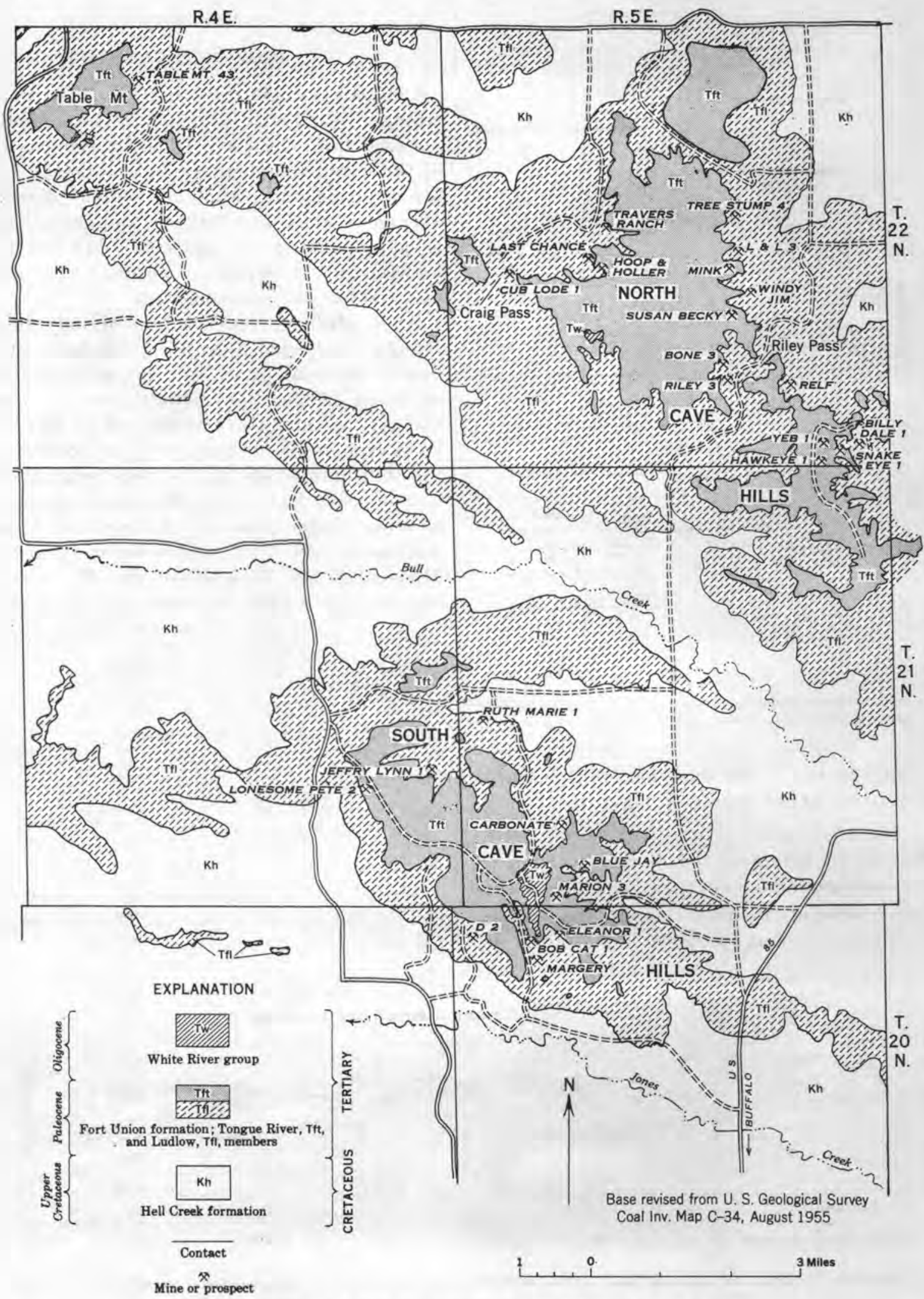

FIGURE 146,-Location of mines and prospects, Cave Hills, Harding County, S. Dak. 


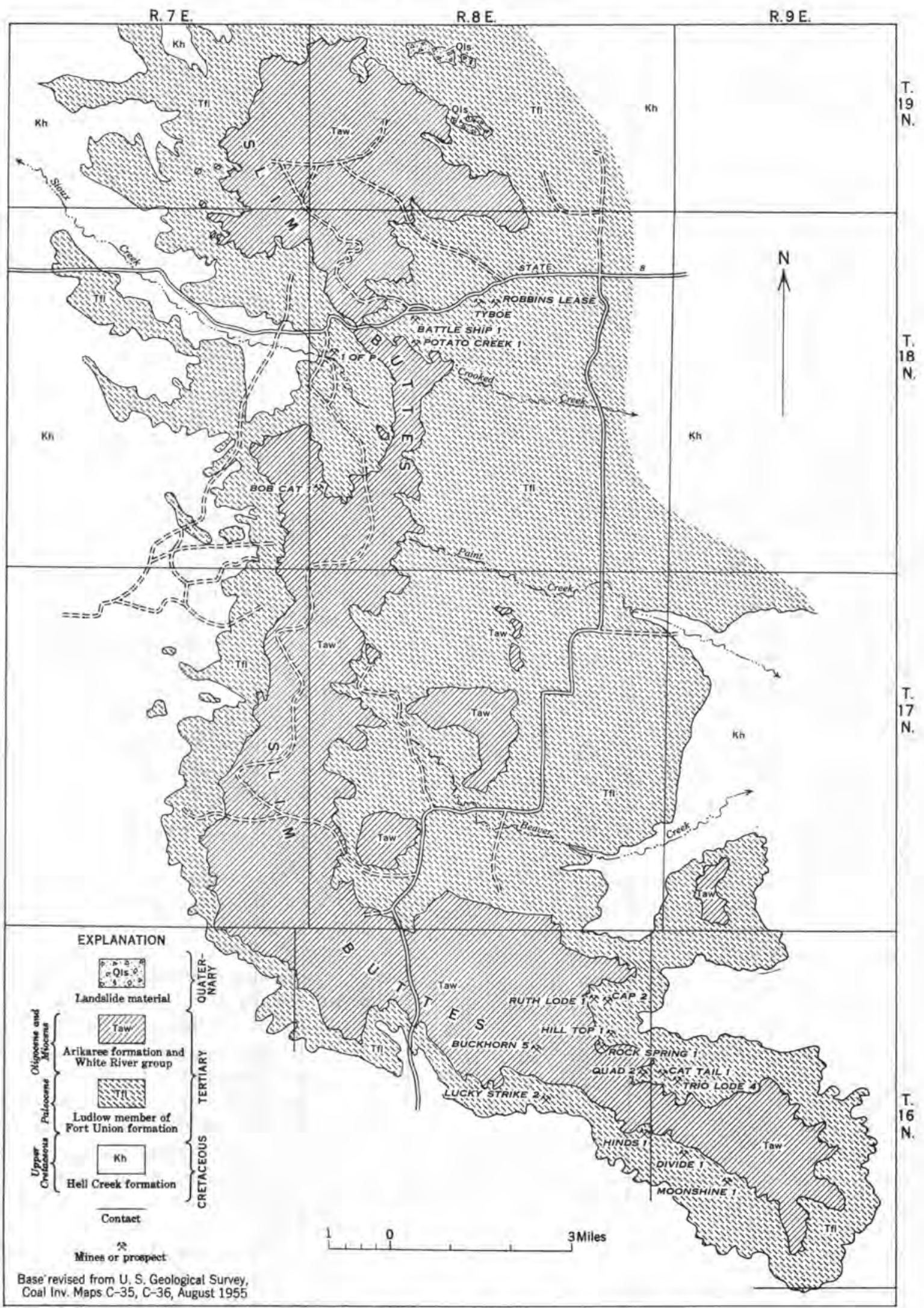

Figure 147.-Location of mines and prospects, slim Buttes, Harding County, 8. Dak. 


\section{URANIUM IN THE COAL}

Average, maximum and minimum assays of uranium, vanadium and calcuim carbonate in the first 600 dry short tons of lignitic uranium ore shipped from Harding County are as follows:

\begin{tabular}{lrrr} 
& $\begin{array}{r}\text { Average } \\
\text { (percent) }\end{array}$ & $\begin{array}{r}\text { Maximum } \\
\text { (percent) }\end{array}$ & $\begin{array}{r}\text { Minimum } \\
\text { (percent) }\end{array}$ \\
$\mathrm{U}_{3} \mathrm{O}_{5}$ & 0.39 & 0.86 & 0.10 \\
$\mathrm{~V}_{2} \mathrm{O}_{5}$ & .05 & .07 & .00 \\
\hline $\mathrm{CaO}_{3}$ & 3.0 & 10.8 & 1.2
\end{tabular}

Uranium in amounts up to 0.85 percent chemical $\mathrm{U}_{3} \mathrm{O}_{8}$ has been found in carbonaceous siltstone (in the Ludlow member) overlying a weathered black lignitic bed (" $\mathrm{B}$ " bed) which is essentially barren. It has been found also in Harding County in amounts up to 2,4 percent $\mathrm{U}_{3} \mathrm{O}_{8}$ in brown fissile lignitic material, in amounts up to 0.36 percent $\mathrm{U}_{3} \mathrm{O}_{8}$ in different grades of dull-black powdery lignite, in amounts up to 8.0 percent $\mathrm{U}_{3} \mathrm{O}_{8}$ in semilustrous weathered black lignitic material, and up to 3.5 percent in red, ashed material. The dull powdery material is characteristically the lowest in uranium; and the semilustrous material, the highest. At several localities where the semilustrous material is fractured into $1 / 2$-inch cubes, greenish fluorescent uranium minerals, principally meta-autunite, are visible. Metatorbernite and metazeunerite have been identified also (J. R. Gill, and J. W. Gruner, personal communication). I. A. Breger and others (1955) have shown that most of the uranium is associated with the organic constituents of the coal, rather than with its inorganic constituents. They established that the uranium is not held in the coal by ion exchange but is in the form of organouranium complexes or compounds soluble at a $\mathrm{pH}$ of less than 2.18. The same authors found no discrete uranium minerals in the low-grade ( 0.005 percent $U$ ) material studies.

No correlation between uranium content and standard coal petrographic constituents has been noted (Schopf and Gray, 1954) in the lignite containing a few thousandths to a few hundredths of 1 percent uranium. The ash content, however, is higher in some of the more uraniferous layers. This may be a result of introduction of other materials along with the uranium.

The correlation between microscopic plant materials, degradation products, and uranium has also been investigated (Schopf and Gray, 1954) in the same type of material. No direct correlation was found between any single coal component and the uranium content. These authors conclude that none of the samples owe their high or low uranium content to their relative position within the bed, a conclusion borne out by field relationships.

\section{OTHER MTNERALS IN THE COAL}

The most common accessory mineral in the lignitic material is analcite, which occurs as small spheroids and rosettes less than 1 millimeter in diameter, in differing amounts with no apparent relationship to the quantity of other minerals. No consistent vertical concentration has been noted within a given lignite bed, and the areal extent of the analcitic zones is unknown. Analcite is not confined to the lignite but is a common accessory constituent of the surrounding clastic beds. The analcite must form in alkaline water and it therefore seems improbable that the analcite is of sygenetic origin but must have been introduced subsequent to coalification (Denson, Bachman, and Zeller, 1956).

Limonite and jarosite in small masses, seams, and veinlets commonly cut across the bedding of the lignite units. Pyrite is common in the concretionary masses. There is no apparent correlation between the iron minerals and the uranium content.

Gypsum in seams and veinlets is common and appears to have been the latest mineral formed.

Semiquantitative spectrographic analyses have been made on about 25 samples of ashed lignite from the Cave Hills. The amount of ash ranged from 30 percent to 50 percent. Arsenic and molybdenum were found in the ash in maximum concentrations of 3.2 percent and 1.4 percent, respectively. A plot of uranium, arsenic, and molybdenum values indicates that all three elements tend to form peaks together (J. R. Gill, oral communication).

Copper, phosphate, and fluorine were determined in samples of uraniferous carbonaceous siltstone overlying a lignitic bed in the Lonesome Pete claim in South Cave Hills (fig. 146).

\section{DISTRIBUTION OF URANIFEROUS LIGNITE}

Individual lignite units extend over areas of several square miles and may cover several tens of square miles. Sufficiently detailed stratigraphy has not been worked out to assure correlations in all cases.

Lignites containing more than 0.10 percent uranium are characteristically 10-14 inches thick but are exceptionally $30-36$ inches thick. Lignites more than 10 feet thick exist in the area but are not known to contain more than trace quantities of uranium.

Although many of the beds probably containing uranium are regional in extent, uranium deposits are known only in certain areas. Lack of exploration seriously limits adequate determination of the distribution, and only a few areas are presently known to contain mineralized patches larger than an acre. At least 3 areas of approximately 10 acres each are estimated to be at least 50 percent mineralized.

Uraniferous lignitic units are known in Harding County through approximately 400 feet of the Tongue River and Ludlow members of the Fort Union forma- 
tion. Local exposures of the uranium-bearing lignite are believed to be the result of local erosion and do not constitute a limit of the favorable horizons.

The uppermost units of important uranium content in Harding County are the " $\mathrm{E}$ " and " $\mathrm{F}$ " beds of the Tongue River member (fig. 144). The "F" bed is locally uraniferous in the Riley Pass area of North Cave Hills, (fig. 146) where it lies approximately 15 feet stratigraphically above the "E" bed. The "E" bed lies immediately above the basal massive cliffforming sandstone of the Tongue River member. It is exposed over most of the top of North Cave Hills in thicknesses of 1-2 feet.

In Cave Hills the " $\mathrm{D}$ " and " $\mathrm{C}$ " beds of the Ludlow member are uraniferous locally. The " $\mathrm{D}$ " bed lies at or close to the top of the Ludlow member and beneath the lower massive Tongue River sandstone unit (fig. 144). The " $\mathrm{C}$ " bed lies within 100 feet of the top of the Ludlow member.

In Slim Buttes all known uraniferous lignite beds are confined to the Ludlow member. Pre-Oligocene erosion removed the Tongue River member and truncated the Ludlow, which dips gently northward. Thus, the White River group overlies progressively lower sections of the Ludlow to the south. Several lignitic beds are known to be uraniferous in the Slim Buttes from the northern extremity nearly to the southern tip. Detailed stratigraphy of the deposits has not yet been worked out sufficiently to assign each deposit to a specific bed. The Slim Buttes deposits are, however, at lower horizons than those exposed around the periphery of the Cave Hills.

\section{MODE OF OCCURRENCE}

Abundantly uraniferous lignite beds are not necessarily the uppermost of a stratigraphic series as early observations indicated. The deposits at Carbonate claims and those near the Travers Ranch in Cave Hills, the Ruth Lode in Slim Buttes (fig. 143), and the deposits at Table Mountain are examples where two or more barren lignitic beds overlie the most uraniferous bed. Although preference of uranium for the top, within lignitic units, has been noted in some of the lowgrade $( \pm 0.005$ percent $U$ ) beds, field evidence concerning high-grade $( \pm 0.10$ percent $U$ ) deposits shows no consistently preferred horizon of the most uraniferous part within a bed.

Proximity to aquifers is believed by the writers to be an important factor in mineralization of the lignite. The "E" bed of the Tongue River member at Cave Hills is in direct contact with the permeable underlying basal massive sandstone. It is overlain directly in some localities by a highly impermeable mudstone, and elsewhere such mudstone units occur only a few feet stratigraphically above the "E" bed. No uraniferous deposit of economic potential is known where highly impermeable beds enclose the lignite completely.

At Craig Pass (fig. 146) brown lignitic material predominates, and encloses black lignitic lenses and seams. Transition zones, a fraction of an inch in thickness, surrounding the black material are the most radioactive parts.

Structural control of uranium deposition has not been observed, but insufficient study precludes any conclusion. A broad basin in the vicinity of Riley Pass (fig. 146) contains several of the large deposits. The rock exposures are particularly extensive in this area; and this, not structural control, may be the reason why there are so many deposits in this basin. Strong joint control has been observed at the Carbonate group in North Cave Hills, but not elsewhere. At this deposit, 2 joints in argillaceous lignite, 2-3 feet apart, are filled with 1 or 2 inches of limonite-stained noncarbonate-bearing clastic rocks. The lignite between the joints and slightly less than a foot on either side is highly radioactive. Radioactivity decreases rapidly $3-4$ feet from the joints. At two other exposures on the carbonate group high radioactivity is associated with joints.

All known deposits are at shallow depths, and all are confined to weathered lignitic material, although weathering in itself is not believed to have an important bearing on the uranium content. No deep exploration has yet penetrated fresh lignite.

Chemical assay of the lignite commonly shows 2 times as much uranium as is indicated by the radioactivity assay. In two deposits in highly carbonaceous siltstone, however, the chemically determined uranium was less than that indicated by the radioactivity assay.

In view of the above relationships, the authors believe that the uranium was brought to the lignitic beds by solutions whose predominant direction of movement was lateral. A syngenetic theory of origin does not fit observed facts, and it does not appear logical that such locally abundant uranium content can be attributed to clastic deposition. Predominant vertical movement of mineralizing solutions is difficult to prove in view of many extensive overlying impermeable units and the presence at several localities of 1-4 barren lignitic units of comparable quality overlying the abundantly uraniferous unit. The presence of relatively large amounts of arsenic and molybdenum (at Cave Hills, As, 3.2 percent; Mo, 1.4 percent), however, is strongly suggestive to some observers of a modified hydrothermal origin, in which hydrothermal solutions mixed with ground waters would have moved, for considerable distances, through sedimentary rocks of diverse character. An alternative hypothesis of origin (Denson, 
Bachman and Zeller, 1956) states that the uranium was derived by leaching of weakly uraniferous $(0.0015$ percent $\mathrm{U}$ ) tuffaceous beds of the Arikaree formation and the White River group and transported by downward perculating waters to the present host beds.

\section{DESCRIPTION OF INDIVIDUAL DEPOSITS}

Of the 3 uranium deposits described below, 1 is in the Tongue River member and 2 are in the Ludlow member. These are the best known and are in geologic environments typical of most deposits.

\section{BILLY DALE GROUP}

The Billy Dale group comprises $3 \frac{1}{2}$ claims, located on parts of 3 buttes rising 300 feet above the surrounding plain immediately east of North Cave Hills (fig. 146).

Only rocks of the Tongue River member are exposed in the area. The " $\mathrm{E}$ " bed lies on the surface of the basal massive sandstone, a surface marked by small swells and swales 1-4 feet in extent with a maximum relief of 6 inches. The uranium-bearing " $\mathrm{E}$ " bed is overlain by a maximum of 75 feet of sandstones and shales. The " $F$ " bed, which is present on part of the buttes, is mineralized to ore grade locally. Regional dip is less than $0.5^{\circ}$ to the northeast. Jointing is sparse; faulting has not been observed.

A measured section from the top of the butte to the lower massive sandstone underlying the " $\mathrm{E}$ " bed is as follows:

Sandstone, pink to gray, very fine- to fine-grained, poorly sorted thin-bedded, slabby, moderately indurated; contains sparce carbon specks; weathers reddishbrown.

Not exposed

Lignite ("F" bed), distintegrated, blocky to powdery black, discontinuous and lenticular. Spotty mineralization . . .

Mudstone, dark-gray, fissile; contains abundant weathered analcite particles; abundant iron stain occurs on weathered surfaces....................................

Sandstone, medium-gray, very fine-grained, well-sorted, poorly indurated, heavily iron-stained, permeable. Some carbon specks and sparse analcite particles near contact with overlying mudstone

Sandstone, light-gray, very fine- to fine-grained, thinbedded, permeable; contains abundant carbon trash, sparse analcite, and some mica flakes. Intense limo-

nite stain along bedding planes.

Lignite ("E" bed), 6-14 inches of black to brownishblack.

Sandstone, mediumstained, very fine-to coarse-grained, thick to massively bedded, locally crossbedded. Base marks the base of Tongue River member

Feet

The uraniferous zone on the Billy Dale group of claims is exposed for about 90 feet along the outcrop 1
51 0. $5-0.8$ and 30 feet into the butte from the rim. The " $\mathrm{E}$ " bed can be followed completely around the butte, which covers about 11 acres of 1 claim above that horizon. Abnormal radioactivity is noted on all " $\mathrm{E}$ " bed outcrops around a large butte and at many places on the nearby hills.

The " $\mathrm{E}$ " bed, in the stripped area, is entirely black, weathered lignite, 9-10 inches thick. Some of the lignite is powdery, granular, and dull; the rest is composed of cubes less than one-half an inch in size with semilustrous surface. The cubes have the higher uranium content and locally exhibit on the fracture surfaces a yellow-green fluorescent uranium mineral, tentatively identified as meta-autunite. Picked samples assay up to 10 percent chemical $\mathrm{U}_{3} \mathrm{O}_{8}$.

Unlike the noncombustible lignite in many of the other uranium deposits, the material at Billy Dale claim burns with abundant smoke. Analcite is conspicuously rare at this deposit. Limonite and jarosite veinlets and stringers and clay stringers are moderately abundant.

Radiometric assays of samples from the property range from 1.17 percent $\mathrm{eU}_{3} \mathrm{O}_{8}$, in black strongly weathered lignite, to 0.07 percent $\mathrm{eU}_{3} \mathrm{O}_{8}$ in black powdery lignite. In general the chemical assays are twice as high as the radioactivity assays. An 8-ton shipment containing some barren rock assayed 0.10 percent chemical $\mathrm{U}_{3} \mathrm{O}_{8}$, but a cleaner 9-ton shipment contained 0.86 percent chemical $\mathrm{U}_{3} \mathrm{O}_{8}$. A reserve of several thousand tons, with an average grade of more than 0.5 percent $\mathrm{U}_{3} \mathrm{O}_{8}$, is estimated for this deposit.

\section{HILLTOP MINE}

The Hilltop mine is in the southern part of Slim of the Arikaree formation cap. Local relief is $250-300$ feet.

The deposit lies in and close to the base of the Ludlow member. Only the lower beds of the Ludlow were left in this area after pre-Miocene erosion. Slumping is extensive in the vicinity of the Hilltop mine, but the deposit itself is in undisturbed strata. The complete section of the White River group is not present in the area, as indicated by the proximity of the Ludlow member to the Arikaree formation. Dip of sediments in this vicinity is less than 50 feet per mile to the north.

The uraniferous zone, which has been traced for several hundred feet along the hillside, consists of 10-16 inches of brownish-black to black, weathered, powdery lignite containing lenses of hard semilustrous material of conchoidal fracture. Peacock irridescence, grading into a dark-brown coating, is present on fracture surfaces. Abundant limonite and some jarosite are present locally. Gypsum seams, commonly one-eighth 
of an inch thick, are present throughout the bed, and gypsum crystals as much as 2 inches thick occur in the upper part of the bed. No analcite was observed. A green micaceous mineral, commonly exhibiting green fluorescence, has been noted on cleat faces but is rare. Chemical assays as high as 5.0 percent $\mathrm{U}_{3} \mathrm{O}_{8}$ have been obtained from picked samples.

The mineralized zone is overlain by several feet of interbedded mudstones and unconsolidated sandstones and directly underlain by more than 2 feet of brown peaty impermeable mudstone. An incomplete section measured immediately above and below the uraniferous lignitic bed is as follows:

Mudstone, medium-gray to black, fissile; contains abundant carbon trash and casts of woody material. A thick brown coating present on fracture surfaces, and gypsum occurs as fracture fillings. Mudstone exhibits blocky fracture.

Sandstone yellowish-brown to light-gray, thin-bedded, silty to very fine-grained, limonite-stained; interbedded with mudstone; 1 - to 2 -inch gypsum rosettes on fracture surfaces. Bottom foot is fine-grained unconsolidated permeable sandstone with sparse carbon seams near top and abundant limonite stain near base.

Mudstone, light- to medium-gray, interbedded with light-brown to gray very fine-grained sandstone, containing carbon specks and some gypsum. Sandstone capped by 3 inches of dark-gray fissile mudstone....... Lignite, uraniferous, $10-16$ inches thick.

Mudstone, medium-gray to black, fissile, peaty; contains a high percentage of carbon specks, flakes, and seams. Jarosite and limonite occur as stringers. Gypsum present as fracture fillings _..........................

Mudstone, medium- to dark-gray; contains sparse carbon specks and some jarosite stringers. Slope below concealed.

More than 300 tons averaging 0.33 percent $\mathrm{U}_{3} \mathrm{O}_{8}, 0.04$ percent $\mathrm{V}_{2} \mathrm{O}_{5}$, and 3.4 percent $\mathrm{CaCO}_{3}$ have been shipped from the Hilltop mine.

\section{LONESOME PETE CLAIM}

The Lonesome Pete claim is in sec. 26, T. 21 N., R. 4 E., along the western side of South Cave Hills (fig. 146). Local relief is approximately 250 feet.

The lower massive sandstone of the Tongue River member caps the hills in this area, but the "E" bed is not present in the vicinity. The Ludlow member makes up the lower slope of the South Cave Hills.

The mineralized unit is just above the "B" bed of the Ludlow; that is, approximately 110 feet below the contact of the Ludlow and the Tongue River. Two, and possibly three, barren lignite beds overlie this deposit.

Regional dip is approximately 40 feet per mile to the northeast; heavy slumping in the Ludlow masks local structural features. Jointing is moderately spaced, but faulting has not been observed.

A section measured from the caprock of the lower massive sandstone of the Tongue River member to the " $\mathrm{B}$ " bed is as follows:

Sandstone, brown, fine- to medium-grained, thinbedded to massive, locally crossbedded. Heavy iron staining imparts a faint banded appearance. Tends to weather into slabs near the top; the more massive-bedded lower part weathers with characteristic wind-eroded pits.

Covered slope; contains the contact between Tongue Riveı member and underlying Ludlow member. " $\mathrm{D}$ " bed may be present at contact.

Sandstone, light-gray, silty to very fine-grained, massively bedded, friable. Heavy iron stain present on blocky surfaces; small ironstone concretions, partly altered to limonite are abundant. Thin beds of greenish-gray fissile mudstone containing carbon seams present throughout. Abundant weathered analcite associated with discontinuous carbonaceous seams $1 / 2-2$ inches thick. A prominent heavily ironstained joint strikes N. $50^{\circ} \mathrm{W}$

Mudstone, medium- to dark-gray; contains some carbon seams. Abundant gray-weathered analeite particles associated with the carbon seams. Limonite and jarosite present in short stringers $1 / 2-2$ inches

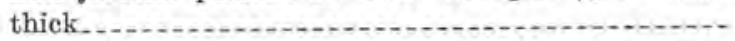

Lignite, black, earthy; contains abundant gray- to white-weathered analcite particles and some woody, fibrous material. Jarosite stringers present. Lignite bed pinches and swells, and is nonradioactive. Probably an unnamed bed of only local extent...........

Siltstone, gray to reddish-gray, sandy; contains abundant weathered analcite particles and some carbon trash. Abundant carbon flakes and a few mudstone partings occur in lower part. Jarosite present on fracture surfaces.

Lignite, "C" bed, black, earthy; contains abundant white-weathered analcite particles and jarosite. Iron minerals commonly occur as stringers and masses with a jarosite core and limonite halo. No abnormal radioactivity

Sandstone, medium-gray to buff, very fine-grained; interbedded with siltstone and mudstone. Some massive pyrite and sparse pyrite crystals associated with carbon in the mudstone. Abundant carbon flakes and specks occur in the sandstone, together with traces of analcite, near top of unit.............

Sandstone, medium-gray to brown, very fine- to finegrained, poorly consolidated, exhibits iron stain in thin bands. Abundant carbon associated with iron staining. Near the base, lenses of buff'to mediumbrown hard very calcarous, very fine-to fine-grained sandstone, $1-1 \frac{1}{2}$ feet thick, some with abundant carbon ... . . .

Sandstone, light-gray, very fine- to medium-grained, friable massive; contains small ironstone concretions with limonite halos
Feet 


\section{Uraniferous zone}

Clay, medium-gray, sandy; contains small rounded particles of unidentified black mineral _......... 0. 7-1. 2

Mudstone, medium-gray, sandy; contains same rounded black particles. Radioactive......................

Clay, green to greenish-gray; contains limonite and jarosite stringers.

Mudstone, medium-gray to black, sandy; contains abundant rounded particles of black mineral; richest part of ore zone

Claystone, medium-gray; contains abundant limonite as stringers and stain.

Lignite ("B" bed), earthy, black; contains some whiteto gray-weathered analeite particles. Limonite and jarosite occur as stringers. Upper part radioactive at this locality. Lower slope concealed.

The Lonesome Pete group represents a type of deposit distinct from the uraniferous lignites. The mineralized zone constitutes 6 inches to 2 feet of discontinuous carbonaceous mudstone and claystone, less than a foot above the "B" lignite bed of the Ludlow member. No uranium minerals are visible except at the exposed rim where weathering and oxidation have reached an advanced stage. The mineralized beds, under a few inches of cover, exhibit no oxidation and are gray to black. No uranium minerals have been identified from it although chemical assays of 0.85 percent $\mathrm{U}_{3} \mathrm{O}_{8}$ are common. Pyrite nodules are abundant; carbon content is about 5 percent.

A bulk sample (100 pounds) gave the following results:

e $\mathrm{U}_{3} \mathrm{O}_{8}, 0.85$ percent; chemical $\mathrm{U}_{3} \mathrm{O}_{8}, 0.85$ percent; $\mathrm{V}_{2} \mathrm{O}_{5}, 0.03$ percent; $\mathrm{CaCO}_{3}, 7.6$ percent; $\mathrm{Cu}, 0.02$ percent. Phosphate, in the amount of $12-13$ percent and fluorine in the amount of 1.5 percent were determined from another bulk sample.

The ore zone was exposed by mining operations for 550 feet along the bed and into the hill about 30 feet. The beds constituting the mineralized zone were revealed to pinch and swell unpredictably as they were exposed. Thirty feet from the outcrop, the uppermost gray sandy clay bed, described in the measured section, pinched out completely at one point in the mine. The 4 radioactive beds, whose aggregate thickness ranges between 1 and 2 feet, have been combined to make a product whose grade was more than 0.10 percent $\mathrm{U}_{3} \mathrm{O}_{8}$. The stratigraphically lowest radioactive bed consists of about 4 inches of medium-gray to black sandy mudstone with abundant rounded particles (1-3 $\mathrm{mm}$ ) of black carbonaceous material. This is the richest part of the ore zone, with channel samples assaying as much as 0.85 percent chemical $\mathrm{U}_{3} \mathrm{O}_{8}$. A bed of medium-gray claystone, 3 inches thick and containing abundant limonite stringers and stains, separates the uraniferous mudstone from the underlying
"B" lignite bed. Although less than 2 feet of the lignite has been uncovered, auger holes indicate that the bed ranges between 4 and 21 feet in thickness. The upper 2 feet consists of earthy, black-weathered lignite containing some analcite particles. Limonite and jarosite occur as stringers. The " $\mathrm{B}$ " bed is essentially barren at this claim.

\section{SUMMARY AND CONCLUSIONS}

Uraniferous lignite and carbonaceous siltstone represent a significant reserve of uranium source material in western North and South Dakota. The biggest known deposits are located in Harding County, S. Dak., but the area of potential deposits extends many miles into North Dakota and Montana.

Uranium deposits are found in the thin lignitic beds of all members of the Fort Union formation of Paleocene age. Although the stratigraphically highest lignite bed is not necessarily the most uraniferous, the known deposits are all within 200 feet of the pre-Oligocene erosion surface. Possibly pre-Oligocene weathering of the coals facilitated deposition of uranium in the lignites. Although some deposits show no oxidation, most have some oxidized minerals.

Chemical assays of lignite are commonly higher in uranium than the radiometric assays; the reverse is true of assays made of uraniferous carbonaceous shale or siltstone. Although a few uranium minerals have been identified, the uranium is overwhelmingly in association with the coal constituents. Visible minerals are a guide to high-grade parts of a deposit.

Deposits of several thousand tons in size are known at present, but the limits of the deposits have not been firmly established.

\section{SELECTED BIBLIOGRAPHY}

Breger, I. A., Deul, Maurice, Rubinstein, Samuel, 1955, Geochemistry and mineralogy of a uraniferous lignite: Econ. Geology, v. 50, pp. 206-226.

Curtiss, R. E., 1955, A preliminary report on the uranium in Soutb Dakota: S, Dak. Geol. Survey, Rept. Inv. 79, 102 p.

Denson, N. M., Bachman, G. O., Zeller, H. D., Gill, J. R., Moore, G. W., Melin, R. E., 1955, Uraniferous coal beds in parts of North Dakota, South Dakota, and Montana: U. S. Geol. Survey Map C-33.

Denson, N. M., Bachman, G. O., Zeller, H. D., 1955a, Geologic map of Cave Hills and Table Mountain area, Harding County, S. Dak.: U. S. Geol. Survey Map C-34.

Denson, N. M., Bachman, G. O., and Zeller, H. D., 1955b, Geologic map of Slim Buttes area, Harding County, S. Dak.: U. S. Geol. Survey Map C-35.

Denson, N. M., Bachman, G. O., Zeller, H. D., 1956, Uraniumbearing lignite and its relation to the White River and Arikaree formations in northwestern South Dakota and adjacent states: U. S. Geol. Survey Bull,-(in preparation). 
Gill, J. R., 1954, Results of core drilling for uranium-bearing lignite, Mendenhall area, Harding County, S. Dak.: U. S. Geol. Survey TEIR-456.

Miller, R. L., and Gill, J. R., 1954, Uranium from coal: Sci. Am., v. 191, no. 4, pp. 36-39.

Moore, G. W., and Gill, J. R., 1955, Geologic map of the southern part of the Slim Buttes area, Harding County, S. Dak.: U. S. Geol. Survey Map C-36.
Schopf, J. M., Gray, R. J., 1954, Microscopic studies of uraniferous coal deposits: U. S. Geol. Survey Circ. 343, 10 p.

Winchester, D. E., Hares, C. J., Lloyd, E. R., Parks, E. M., 1916, The lignite field of northwestern South Dakota: U. S. Geol. Survey Bull. 627, 169 p.

Zeller, H. D., 1955, Geologic map of the Bar H area, Slim Buttes, Harding County, S. Dak.: U. S. Geol. Survey Map C-37. 



\title{
URANIUM-BEARING COAL IN THE GENTRAL PART OF THE GREAT DIVIDE BASIN SWEETWATER COUNTY, WYOMING
}

\author{
By George N. Pipiringos, U. S. Geological Survey
}

\section{CONTENTS}

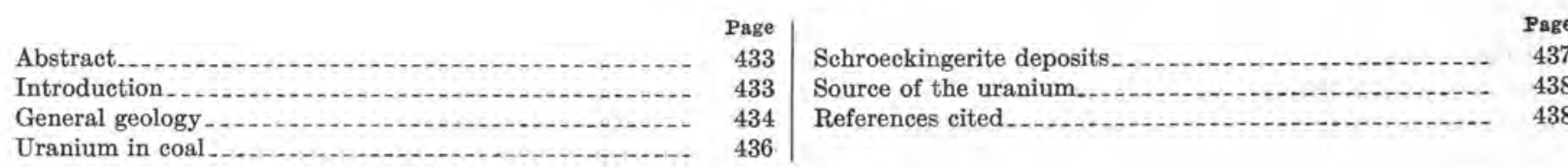

\section{ILLUSTRATIONS}

\begin{abstract}
Figure 148. Restored section of Tertiary rocks and index map showing area investigated in the central part of Great Divide Basin, Wyo
\end{abstract}

Page

FIGURE 149. Diagrams showing distribution of uranium in coal near axis of Red Desert syncline and structure in Great Divide Basin

\section{ABSTRACT}

Uranium-bearing coal of early Eocene age underlies about 750 square miles of the Great Divide Basin, Sweetwater County, Wyo. More than half of this area lies within the central part of the basin. Calichelike schroekingerite deposits occur near the northern edge of the coalfield. The schroekingerite occurs in alluvium and in the upper few feet of the underlying claystone and arkosic sandstone beds of early and middle(?) Eocene age.

Most of the coal contains less than 0.003 percent uranium, but locally parts of some coal beds contain as much as 0.016 percent uranium. The uranium content of the ash of these coal beds ranges from 0.003 to 0.023 percent.

In the central part of the Great Divide Basin, the thickest coal beds underlie a relatively narrow belt in the trough and on the west flank of the northwest-trending Red Desert syncline; those containing the most uranium are thinner and on the east flank. The Red Desert syncline also coincides with a zone of intertonguing of the highly permeable coarse-grained arkosic sandstone beds of the Battle Spring formation on the northeast and the less permeable, and locally impermeable, clay shale, siltstone, fine-grained sandstone, and low-grade oil-shale beds of the Wasatch and Green River formations on the southeast. These formations of early and middle Eocene age rest unconformably on the Fort Union formation of late Paleocene age and are overlain, in ascending order, by the Bridger and Browns Park formations of middle Eocene and Miocene age respectively.

A broad, gentle arch, trending about N. $70^{\circ} \mathrm{E}$., separates the Washakie Basin on the southeast from the Red Desert syncline, which plunges gently northwestward into the nearly circular structural Niland basin. The south flank of the arch dips southeast at an average rate of about 230 feet a mile; the north flank dips northeast about 140 feet a mile. The dominant structural
\end{abstract}

feature of the area north of the Niland basin is a graben which trends about N. $70^{\circ} \mathrm{W}$. This graben is about 3 miles wide and bounded on the north by a normal fault of about 3,000 feet vertical displacement. This fault extends for several miles northwest beyond the northern boundary of the Great Divide Basin and for an undetermined distance southeast across the northeastern part of the Great Divide Basin. The fault on the south side of the graben has a vertical displacement of a few hundred feet in the vicinity of the sehroekingerite deposits, appears to pass northwestward within a few miles into an anticline or a monoclinal flexure, and extends for an undetermined distance southeast of the schroekingerite deposits into the northeastern part of the Great Divide Basin.

The schroekingerite deposits in the nortb-central part of the Great Divide Basin occur within and along the southern edge of the graben. Weakly uraniferous tuffaceous sandstone beds of the Browns Park formation that once probably blanketed the entire Great Divide Basin are preserved today as erosional remnants less than 2 miles north and northwest of the schroekingerite deposits.

The source of uranium in the coal and in the schroekingerite deposits is probably the tuffaceous beds in the Browns Park formation localized in its present sites by ground-water circulation guided by the structure and the interfingering of sedimentary facies.

\section{INTRODUCTION}

The Eocene coal beds in the central and eastern parts of the Great Divide Basin, mapped in reconnaissance by E. E. Smith (1909), were discovered to be radioactive by A. L. Slaughter and J. M. Nelson (written communication, 1945). D. G. Wyant, W. N. Sharp, and 
D. M. Sheridan (1956) concluded, from reconnaissance investigations, that these areas contain large low-grade potential reserves of uranium-bearing coal and carbonaceous shale.

The author was associated with Harold Masursky in 1951 and 1952 in detailed investigations of the uraniumbearing coal in the eastern and central parts of the Great Divide Basin. This paper is based on the geology of the central part of the Great Divide Basin (fig. 148) which was mapped by the author in 1951-52 and by the author and J. C. MacLachlan in 1953. Field assistance in the 1952 season was provided by A. E. Burford, H. D. Gower, and G. W. Moore.

The Great Divide Basin is an oval undrained topographic depression on the Continental Divide and embraces about 4,000 square miles in Sweetwater, Carbon, and Fremont Counties, south-central Wyoming (fig. 148). The central part of the basin contains several dry lake flats; Battle Spring Flat, the lowest part of the area, is about 6,500 feet above sea level. The highest parts of this area are on the north and south branches of the Continental Divide and range from about 7,300 to 7,450 feet in altitude.

\section{GENERAL GEOLOGY}

Most of the great Divide Basin is underlain by approximately 5,000 feet of Tertiary rocks. The lower part of this sequence is the Fort Union formation of late Paleocene age (Tiffanian) according to C. L. Gazin (written communication, 1952) and consists of coalbearing clay shale, siltstone, and fine-grained sandstone. It rests unconformably on Cretaceous rocks and is overlain unconformably by Eocene rocks. The Fort Union formation is about 1,100 feet thick in the western part of the Great Divide Basin and about 1,000 feet thick in the northern part (Bell, 1954).

Near Steamboat Mountain, in the western part of the Great Divide Basin, Bradley (1926) has recognized, in ascending order, the main body of the Wasatch formation, the Tipton tongue of the Green River formation, the Cathedral Bluffs tongue of the Wasatch formation, the Laney shale and Morrow Creek members of the Green River formation and the Bridger formation-all of Eocene age. These units also occur in the central part of the Great Divide Basin, and their predominant lithologies and stratigraphic relationships are shown in the restored section figure 148. The stratigraphy of this area differs from that of the area described by Bradley in that the main body of the Wasatch is split into two coal-bearing sequences, the Red Desert and Niland tongues, by the Luman tongue of the Green River formation (Pipiringos, 1955), in that nearly all of the Green River and the Wasatch intertongues with and is replaced northeastward by the Battle Spring formation of early and middle Eocene age (Pipiringos, 1955), and in the presence of the Browns Park formation of Miocene age. The transition from fine-grained rocks of the Wasatch and the Green River to the very coarse-grained rocks of the Battle Spring formation takes place in a relatively narrow zone which coincides approximately with the Red Desert syncline, which trends southeast across the Great Divide Basin (fig. 148). The minimum thickness of the Wasatch, Green River and Battle Spring sequence is about 3,400 feet.

The overlying Bridger formation in the northern part of the map area ranges from 60 to 100 feet in thickness; and it, as well as the Morrow Creek member, contain fossils of probable middle Eocene age. The age of the Cathedral Bluffs tongue is less certain and is probably of middle Eocene age as suggested by Morris (1954). The stratigraphically highest fossil collection of probable early Eocene age was collected from the lower part of the Tipton tongue (D. M. Sheridan, written communication, 1954) in the vicinity of Lost Creek in the northeastern part of the map area. Thus the early Eocene and middle Eocene boundary probably lies within the upper part of the Tipton or in the lower part of the Cathedral Bluffs.

Unconformably overlying the Bridger formation is a sequence of interbedded conglomerate, very coarsegrained sandstone, and fine-grained tuffaceous sandstone at least 410 feet thick. W. G. Bell gas collected Miocene fossils from these rocks a few miles west of Lost Creek (written communication, 1955). On the basis of lithologic similarity and stratigraphic position, this sequence is correlated with the Browns Park formation a middle Miocene sequence described by P. O. McGrew (1951, p. 54-57) in the Split Rock area several miles to the northeast. The Browns Park and remnants of similar tuffaceous rocks occur along the northern and eastern margins of the Great Divide Basin, and probably once blanketed the entire Great Divide Basin.

Several isolated sand and gravel terrace deposits, at altitudes ranging from 6,750 to 6,900 feet, are scattered throughout an area extending from the north line of T. $19 \mathrm{~N}$. to the north edge of Niland basin and seem to be remnants of a single continuous layer. South of the middle of T. $21 \mathrm{~N}$. they are separated from the underlying bedrock by several feet of red or brown silty clay very similar to that in the floors of the dry lake flats. It seems probable that these deposits are of Pleistocene rather than Recent or Miocene age.

A broad, gentle arch whose axis trends about N. $70^{\circ}$ E. plunges eastward across the south-central part of the Great Divide (fig. 148). To the north the shallow Red Desert syncline plunges about N. $30^{\circ} \mathrm{W}$. into the nearly eircular struetural Niland basin. The axis of 

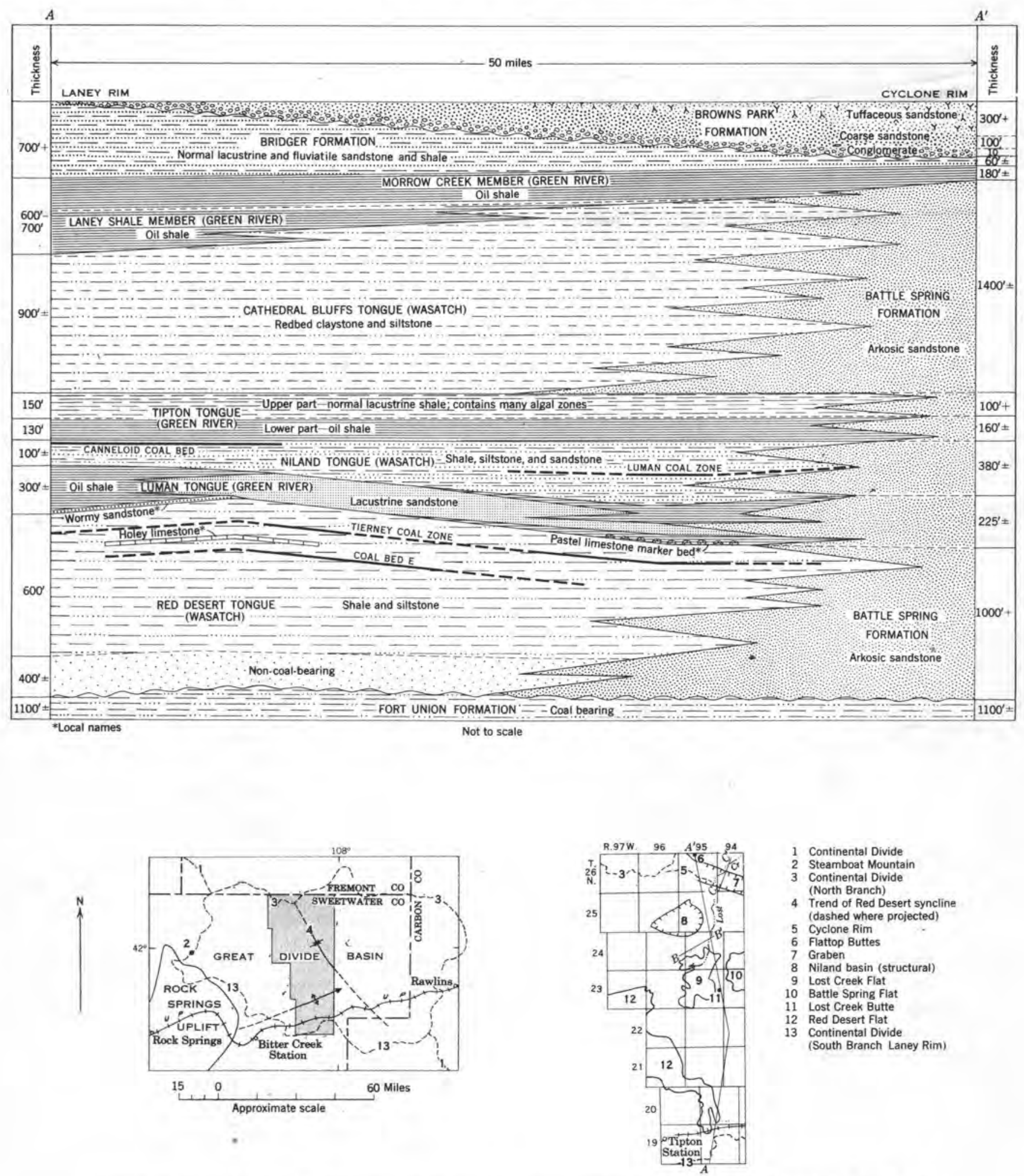
1 Continental Divide
2 Steamboat Mountain
3 Continental Divide
4 Trend of Red Desert syncline
(dashed where projected)
5 Cyclone Rim
6 Flattop Buttes
7 Graben
8 Niland basin (structural)
9 Lost Creek Flat
10 Battle Spring Flat
11 Lost Creek Butte
13 Red Desert Flat
(South Branch Laney Rim)

FIGURE 148,-Restored section of 'Tertiary rocks and index map showing area investigated in the central part of Great Divide Basin, Wyo 

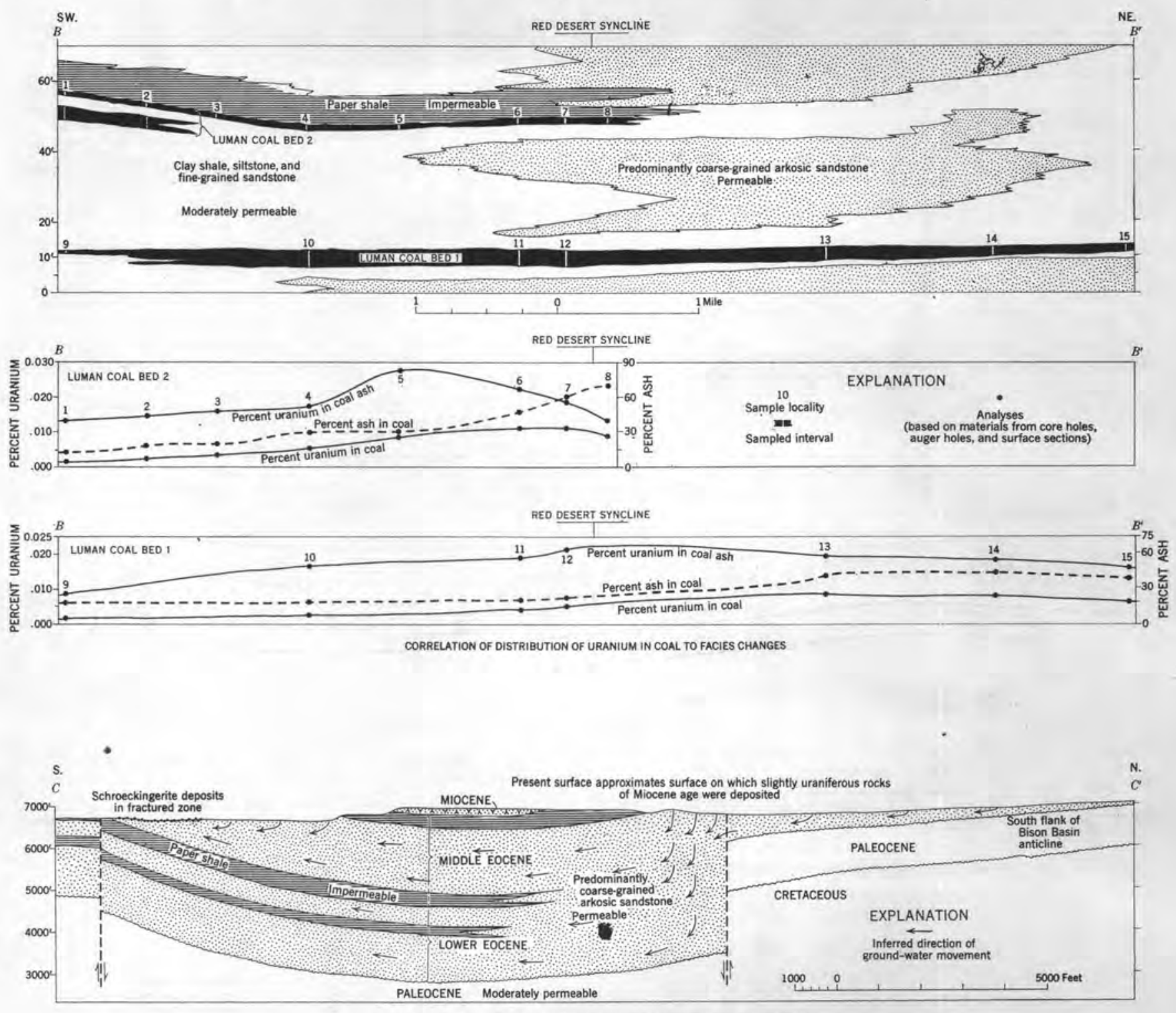

DIAGRAMMATIC SECTION ACROSS SCHROECKINGERITE LOCALITY, GREAT DIVIDE BASIN

FIGURE 149.-Diagrams showing distribution of uranium in coal near axis of Red Desert syneline and structure in Great Divide Basin.

the Red Desert syncline is associated with the thickest coal beds, with the transition from coal beds of relatively high uranium content in the northeast to coal beds of relatively low uranium content in the southwest, and with the transition from coarse-grained rocks of good permeability in the northeast to fine-grained rocks of moderate to slight permeability on the southwest (fig. 149).

A graben, about 3 miles wide, trends about N. $70^{\circ} \mathrm{W}$. across the northeast corner of the map area and is outlined for the most part by remnants of the Browns Park formation. The normal fault on the north side of the graben has a vertical displacement of about 3,000 feet and extends for several miles to the northwest and for an undetermined distance to the southeast. The nor- mal fault on the south side has a vertical displacement of from about 200 to 300 feet in the vicinity of Lost Creek, but a few miles northwestward it passes into an anticline or monocline. It appears to extend for a few miles to the southeast.

\section{URANIUM IN COAL}

Uraniferous coal beds crop out in the central part of the Great Divide Basin in an area that extends from T. $19 \mathrm{~N}$. to T. $24 \mathrm{~N}$. The least uraniferous are those in the western and southern parts of the coal-bearing area; the most uraniferous are in the central and northeastern parts. Two coal groups, those in the Niland tongue (Pipiringos, 1955), which includes the Luman coal zone, and those in the Red Desert tongue, which 
are separated by the non-coal-bearing Luman tongue of the Green River formation (180-390 feet thick). The stratigraphic interval between the highest and the lowest exposed coal beds is about 1,000 feet. The coal beds of the Red Desert tongue are subbituminous B rank; those of the Niland tongue are subbituminous B and C. The restored section (fig. 148) shows only a few of the many coal zones that occur in this area.

Figure 149 (section $B-B^{\prime}$ ) shows the apparent relationship of uranium content in the Luman coal zone to facies changes across the Red Desert syncline. The coal zone contains 2 beds, the Luman 1 and 2 (fig. 149), and is second from the bottom of the 4 coal zones in the Niland tongue. The geologic setting of the Luman coal zone is similar to that of all the coal zones in this area. The average uranium and ash content shown in the graphs for each locality is the weighted average of the coal bed exclusive of clay shale and carbonaceous shale partings. As shown in figure 149, the uranium content of the Luman 2 coal bed ranges from about 0.002 at the left or west side of the diagram to about 0.012 in the middle, near the axis of the syncline. From locality 1 to locality 4 , about 1.8 miles apart, the uranium content ranges from 0.0023 to 0.0055 , an increase of 0.0032 percent. From locality 4 to locality 5 , about 0.7 mile apart, the uranium content rises to 0.009 , an inerease of 0.0035 percent in less than half the distance between localities 1 and 4. Eastward from locality 5 the uranium content increases to a maximum of 0.012 percent at locality 7 and then decreases again at locality 8 , beyond which the Luman 2 coal bed grades into a carbonaceous shale and then pinches out. At locality 15, the Luman 2 consists of a few inches of carbonaceous shale and contains 0.002 percent uranium.

The relatively sharp rise in uranium content of the Luman 2 coal bed between localities 4 and 5 coincides with the first appearance in the section of coarse-grained permeable rocks, and all the localities $(5-8)$ with the relatively higher concentrations of uranium are in or near the lowest part of the syncline.

The Luman 1 coal bed also shows a rise in uranium content from southwest to northeast (fig. 149). The uranium eontent rises from 0.002 at locality 9 to a maximum of 0.0081 at locality 13 and gradually diminishes to 0.006 percent uranium at locality 15 . About 3 miles east of locality 15, the Luman 1 consists of about 5 feet of carbonaceous shale with a uranium content of 0.002 percent. The greatest concentration of uranium in the coal coincides with that part of the section containing the largest amounts of coarse-grained permeable rocks. The maximum concentration is at the first locality east of the axis of the syncline. At locality 15 where there is a local decrease in the permeability of the rocks, the uranium content likewise decreases.

This general relationship was observed in all the coal beds of this area, and it seems highly probable that the uranium entered the coal beds from ground water moving down-strueture along permeable beds.

Locally, relatively high uranium concentrations in coal beds appear to be related to sand and gravel deposits of probable Pleistocene age. At a locality about a mile south of Lost Creek Butte, a layer of sand and gravel about 20 feet thick rests on a 10 -foot sequence of coarse-grained sandstone that directly overlies a 10 -inch coal bed. The average uranium content of the coal bed is 0.009 . Two other samples of the coal bed collected from outcrops 500-1,000 feet east of the first locality contained 0.005 and less than 0.001 percent uranium respectively. The eastward decrease in uranium content is associated with an increase in distance between the coal bed and the sand and gravel layer, the decrease also is associated with a gradation from coarse-grained sandstone to a clay shale in the rocks directly above the coal.

At a locality about 8 miles south of Lost Creek Butte, the uranium content of 5 coal beds distributed through 80 feet of section decreases with lower stratigraphic position. The highest bed contains 0.014 percent uranium, but the lowest contains none. The highest coal bed is directly overlain by a 20 -foot sequence of medium-grained sandstone beds which is capped by a layer of sand and gravel about 10 feet thick. The 4 lower coal beds are interbedded with clay shale, siltstone, and fine-grained sandstone.

\section{SCHROECKINGERITE DEPOSITS}

In the southern part of T. 26 N., R. 94 W., calichelike schroeckingerite deposits occur in alluvium and the upper several feet of the underlying bedrock (Sheridan, Maxwell, and Collier, 1956). The schroeckingerite deposits are on the southern border of the graben (fig. 149). Only major stratigraphic units and structural features are shown in figure 149 , and a structure section drawn nearly normal to section $C-C^{\prime}$ (fig. 149) would show that the eastward plunge of the syncline flattens northwest of the schroeckingerite deposits and then rises again to the east. Thus, the ground water north of the schroeckingerite deposits presumably is under hydrostatic pressure from the west, north, and east. The stratigraphic and structural circumstances and the calichelike nature of the schroeckingerite make it highly probable that the deposits formed by the evaporation of uranium-charged ground water brought to the surface by a combination of artesian conditions and capillary action. 


\section{SOURCE OF THE URANIUM}

The uranium in the coals and in the schroeckingerite could have come from a deep-seated source, from granite-derived uranium minerals in the arkose, or from overlying uraniferous rocks. The writer believes that the evidence favors the last. Remnants of the weakly radioactive tuffaceous sandstone beds of the Browns Park formation crop out less than 2 miles from the schroeckingerite deposits, and at one time these tuffaceous rocks probably covered the entire Great Divide Basin. Chemical analyses of the tuffaceous beds in the Browns Park formation of the map area indicate that they contain 0.001 percent uranium and 0.003 percent equivalent uranium. The most probable source of uranium in the coal beds and schroeckingerite deposits in the central part of the Great Divide Basin was and is the weakly uraniferous tuffaceous sandstone beds of the Browns Park formation. The uranium contained in these tuffaceous rocks is subject to leaching and transport by ground water as indicated by the field relationships of the uranium-bearing coal to the closely overlying tuffaceous beds described by N. M. Denson, G. O. Bachman, and H. D. Zeller (1956) and by N. M. Denson and J. R. Gill (this volume) for areas in North and South Dakota and eastern Montana.

Transfer of the uranium from these source rocks directly downward was prevented throughout most of the coal-bearing area by intervening thick sequences of nearly impermeable beds of the Green River formation. Where the source rocks rested on the permeable Battle Spring formation, uranium-bearing water percolated downward and laterally for several miles in response to structural and permeability controls such as the Red Desert syncline and the described zone of facies changes. The coal beds nearest the permeable tongues of the Battle Spring formation accumulated higher concentrations of uranium than did the coal beds farther away. The process of leaching and transporting of uranium from the Browns Park formation to its present sites of deposition presumably commenced as soon as that formation came into existence and probably reached a climax in the wet periods of the Pleistocene, but continues at a greatly diminished rate today. The vast areas once underlain by the Browns Park formation are now represented by relatively small remnants; and only in their near vicinity, as at the schroeckingerite locality, is the process of leaching, transport, and deposition of uranium noticeably operative.

\section{REFERENCES CITED}

Bell, W. G., 1954, Stratigraphy and geologic history of Paleocene rocks in the vicinity of Bison Basin, Wyo. [abs.]: Geol. Soc. America Bull., v. 65, p. 1371.

Bradley, W. H., 1926, Shore phases of the Green River formation in northern Sweetwater County, Wyo.: U. S. Geol. Survey Prof. Paper 140-D, p. 121-131.

Denson, N. M., Bachman, G. O., and Zeller, H. D., 1956, Uranium-bearing lignite in northwestern South Dakota and adjacent states: U. S. Geol. Survey Bull.-(in preparation).

Masursky, Harold, and Pipiringos, G. N., 1956, Preliminary report on uranium-bearing coal in the Red Desert, Great Divide Basin, Sweetwater County, Wyo.: U. S. Geol. Survey Bull.-(in preparation).

McGrew, P. O., 1951, Tertiary stratigraphy and paleontology of south-central Wyoming: Wyo. Geol. Assoc., Guidebook 6th Ann. Field Conf., p. 54-57.

Morris, W. J., 1954, An Eocene fauna from the Cathedral Bluffs tongue of the Washakie Basin, Wyo.: Jour. Paleontology, v. 28 , p. $195-203$.

Pipiringos, G. N., 1955, Tertiary rocks of the central part of the Great Divide Basin, Sweetwater County, Wyo.: Wyo. Geol. Assoc., Guidebook 10th Ann. Field Conf., p. 100-104.

Sheridan, D. M., Maxwell, C. H., and Collier, J. T., 1956, U. S. Geol. Survey unpub. inf.

Smith, E. E., 1909, The eastern part of the Great Divide Basin coal field, Wyo.: U. S. Geol. Survey Bull. 341, p. 220-242.

Wyant, D. G., Sharp, W. N., and Sheridan, D. M., 1956, Uranium deposits in the Red Desert of the Great Divide Basin, Sweetwater County, Wyo.: U. S. Geol. Survey Bull. 1030(in preparation). 


\title{
TRAGE ELEMENTS IN COAL IN THE RED DESERT, WYOMING
}

\author{
By Harold Masursky, U. S. Geological Survey
}

\section{CONTENTS}

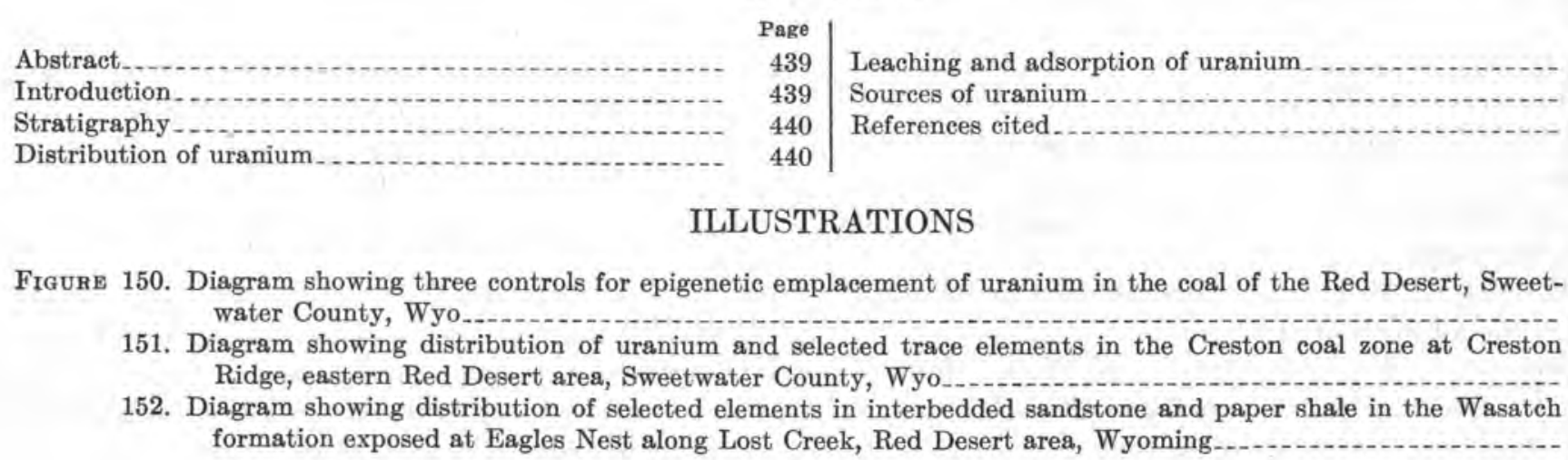

\begin{abstract}
Uranium-bearing coal underlies paproximately 300 square miles of the Red Desert, near the central part of the Great Divide basin, a large topographic basin of interior drainage along the Continental Divide in south-eentral Wyoming. The coal-bearing rocks were cyclically deposited in swamps marginal to the lakes formed in Green River time and are interbedded with coarse-grained fluviatile arkose of the Wasatch formation to the northeast and organic lacustrine shale of the Green River formation to the southwest. The sequence is about 1,200 feet thick and is of early Eocene age. The axis of maximum coal deposition trends northwest; the coal beds are lenticular in cross section and grade into shale to the east and west. The coal strata dip $1^{\circ}-2^{\circ}$, so that the coal beds, which are as much as 40 feet thick, could be strip mined over large areas. The coal is subbituminous B in rank.

The highest uranium concentrations are in coal overlain by gravels of Miocene age, as at Creston Ridge, where the uppermost coal bed contains as much as 0.051 percent uranium near its top and 0.001 percent 40 feet lower.

Lower widespread concentrations of uranium in the coal, averaging about 0.003 percent, are apparently related to the permeability of the rocks enclosing the coal beds. Areally the uranium content of the coal beds inereases toward the northeast as the lithofacies ehange and become coarser-grained and more permeable. In the eyclically deposited sequence several coal beds in vertical succession are enriched in uranium adjacent to the intercalated beds of coarse-grained sandstone which generally underlie the coals. The close relationship between the uranium content of the coal and the permeability of the surrounding rocks indicates that the uranium was probably epigenetically emplaced.

Gallium, germanium, iron, molybdenum, lead, vanadium, and
\end{abstract}

the rare earths have parallel distribution in the carbonaceous roeks, as does uranium, according to semiquantitative spectrographic analyses, and may have been similarly emplaced. Three possible sources for the uranium and other trace elements partly supported by available evidence are hydrothermal solutions rising along faults, leaching from the trace-elementsbearing granite during its weathering and erosion, and leaching from the overlying trace-elements-bearing tuffaceous rocks. Laboratory experiments on the solubility of uranium demonstrate the effectiveness of the Red Desert coal as an adsorbent of uranium from natural waters. Investigation of the sedimentary rocks included studies of mineralogic composition, grain size and shape, and porosity and permeability.

The investigation indicates that the coal in the Red Desert is of interest primarily as a fuel and that uranium probably can only be produced as a byproduct. However, thin earbonaceous shales in the coarse-grained clastic facies to the northeast of the principal coal area may be the sites of localization of higher-grade uranium deposits.

\section{INTRODUCTION}

Geological mapping and exploratory core drilling from 1951 to 1953 to determine the areal distribution, thickness, and uranium content of coal in the eastern part of the Red Desert area, Sweetwater County, Wyo., resulted in much data concerning the distribution of uranium and other trace metals, and their origin and mode of emplacement.

The area investigated includes about 300 square miles in the east-central part of the Great Divide Basin, a 
region of internal drainage along the Continental Divide, with an altitude ranging from 6,500 to 7,200 feet. During the course of the fieldwork, 60 core holes, 140 power-auger holes, and 80 surface sections were dug. Chemical uranium analyses were made of 1,700 core samples and 500 surface samples, and semiquantitative spectrographic analyses were made of about 100 samples.

Detailed investigations of uranium-bearing coal in the region were begun by the writer and G. N. Pipiringos in 1951. The writer was assisted by J. R. Peirson, Jr., H. D. Gower, and G. W. Moore during part of 1952. J. G. Stephens, R. F. Gantnier, R. L. Sutton, and J. H. Sindelar assisted in the field in 1953; Stephens and Gantnier assisted in compilation of the drilling data during the winter of $1953-54$. J. M. Schopf processed coal cores and provided detailed description of the coal from 16 drill holes. Chemical, spectographic, and permeability determinations are by the U. S. Geological Survey. Wayne Montjoy performed the experimental work on the adsorption of uranium.

Reports by E. E. Smith (1909) and W. H. Bradley (1945) described the geology, coal, and oil-shale deposits of the area; more recent investigations of the uranium occurrences were made by Messrs. Slaughter and Nelson (written communication, 1946) and Messrs. Wyant, Sharpe, and Sheridan (written communication, 1951).

\section{STRATIGRAPHY}

The Wasatch and Green River formations of Eocene age are the principal stratigraphic units in the area studied. About 1,200 feet of the upper part of the main body of the Wasatch formation is exposed. In the northeast corner of the mapped area the sandstone facies of the Wasatch formation comprises fluviatile cream to buff coarse-grained massive cross-laminated arkose that is variegated in places, green to gray sandy claystone, and a few thin beds of carbonaceous shale. The rocks change facies markedly to the southwest, becoming finer grained and even bedded, having been deposited under alternating paludal and lacustrine conditions. This coal-bearing facies consists of gray siltstone, carbonaceous shale, coal, brown organic paper shale, and fossiliferous, calcareous sandstone. The Tipton tongue of the Green River formation is exposed at the northwest corner of the area and comprises about 300 feet of lacustrine organic paper shale and fossiliferous sandstone.

The locus of maximum coal deposition was along the transition zone between the fluviatile arkose similar to the Wasatch and the lacustrine organic shale and sandstone similar to the Green River. The transition zone is about 15 miles wide and trends northwest. Each coal bed is lenticular in cross section and grades into shale to the northeast and southwest. The coal beds range from a few inches to 42 feet in thickness and average about 7 feet. The coal is black, vitreous, banded, dominantly attrital, and subbituminous B in rank. Deposition of the "coal measures" was cyclic; the usual sequence in each cyclothem (Moore, 1935, p. 1269), in ascending order, is sandstone, coal, and organic shale. Extensive terrace surfaces are covered with gravel tentatively correlated with the Browns Park formation of Miocene(?) age. Pleistocene and Recent playa lake deposits, alluvium, and sand dunes mantle the bedrock over large areas.

Sedimentary rocks of Oligocene, Miocene, and Pliocene age, consisting principally of volcanic material, are well exposed in the surrounding area; and remnants of these younger rocks overlie the Eocene strata in places within the area (fig. 150).

\section{DISTRIBUTION OF URANIUM}

The greatest uranium concentrations in coal occur in the beds that are closest to the overlying conglomerate. At Creston Ridge (fig. $150 \mathrm{~A}$ ), when a coal bed in the Wasatch formation is directly overlain by a conglomerate of possible Miocene age, the coal bed contains as much as 0.051 percent uranium, whereas a bed 40 feet lower contains less than 0.001 percent uranium. Similar relations were observed at Bison basin north of the mapped area where a coal bed in the Fort Union formation of Paleocene age has a higher concentration of uranium where it is overlain by conglomerate of Miocene(?) age.

More extensive concentrations of uranium in the coal and thin claystone are related to the permeability of the adjacent rocks. In vertical section the uranium content of a coal bed or thin claystone is high where adjacent to permeable sandstone. Because sandstone usually underlies the coal in the cyclic deposits, the coal commonly contains more uranium at the bottom of the bed (fig. 150B). Each coal bed in the several cycles contains uranium. Determinations show that the underlying sandstone has an aqueous permeability of about 270 millidarcys, whereas the overlying shale has a permeability of less than 0.1 millidarcy. Detailed sampling of the coal shows that the highest uranium content within a coal bed is adjacent to clay or carbonaceous shale partings, whereas the lowest uranium concentration is in the central part of the impermeable (0.02-0.5 millidarcy) pure coal layers. The relation of the uranium content of a coal bed to the change in lithofacies is shown in figure 150. Data from six core holes show that the uranium content of the Luman coal zone and the weighted average permeability of the 20 feet of strata enclosing the coal rises to the east as the rocks become coarser grained. 
TRACE ELEMENTS IN COAL, RED DESERT, WYO.

EXPLANATION

$$
0: \because ?
$$$$
\therefore 0
$$

conglomerate

$\because \because$

$\because \because$

Coarse-graines

sandstone

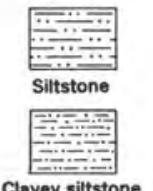

Clayey siltstone

拝严录

Claystone
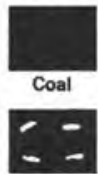

Impure coal

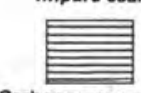

Carbonaceous shale

Core hole

Surface
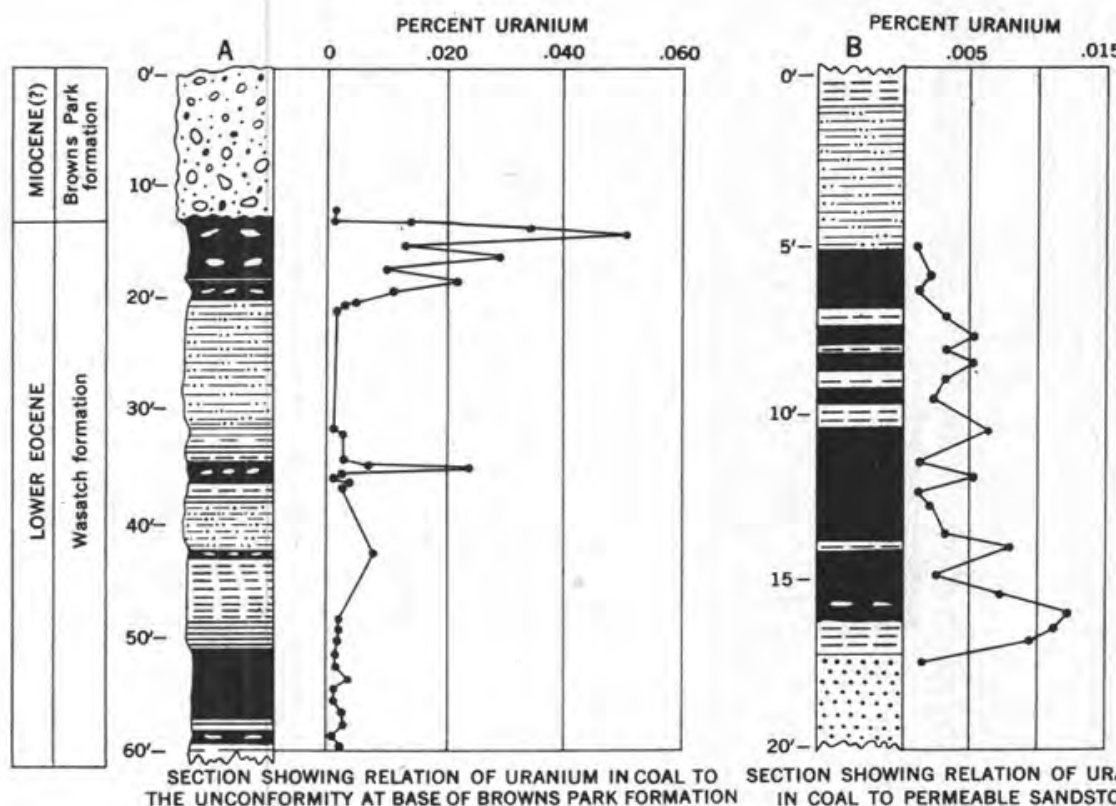
THE UNCONFORMITY RT BASE OF BROWNS PARK FORMATION

SECTION SHOWING RELATION OF URANIUM

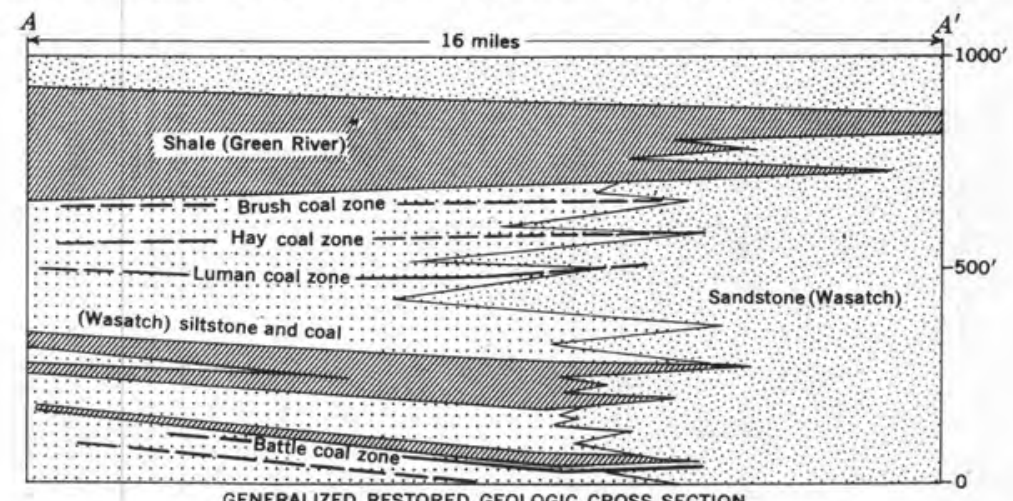

GENERALIZED RESTORED GEOLOGIC CROSS SECTION

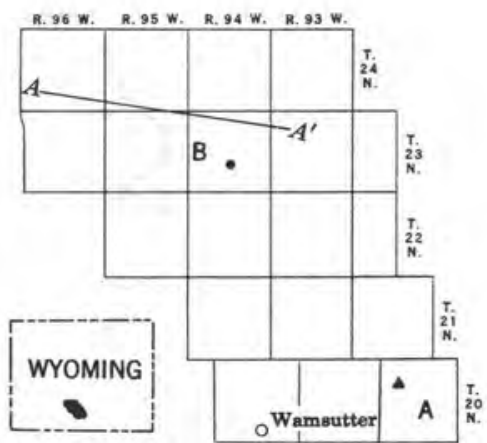

INDEX MAP

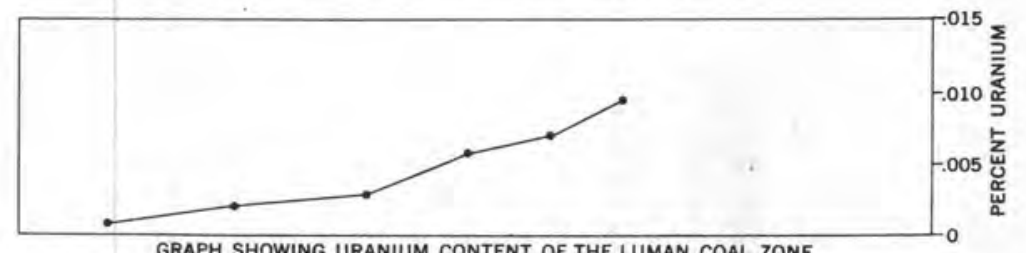

IN CORE HOLES PROJECTED INTO LINE OF SECTION

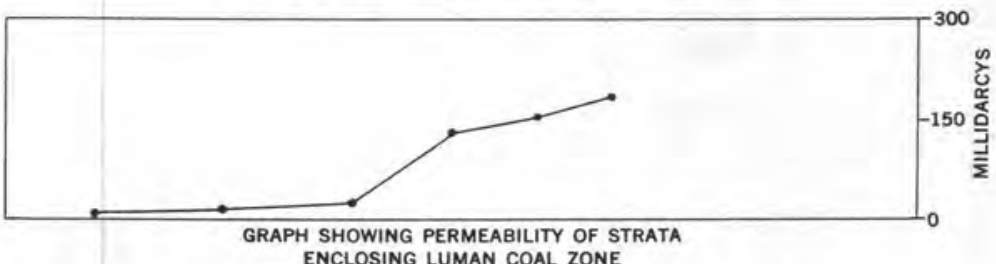

SECTION AND GRAPHS SHOWING RELATION BETWEEN URANIUM CONTENT OF LUMAN COAL ZONE AND LATERAL CHANGE IN LITHOFACIES AND PERMEABILITY

Figure 150.-Diagram showing three controls for epigenetic emplacement of uranium in the coal of the Red Desert, Sweetwater County, Wyo.

$385115-56-29$ 


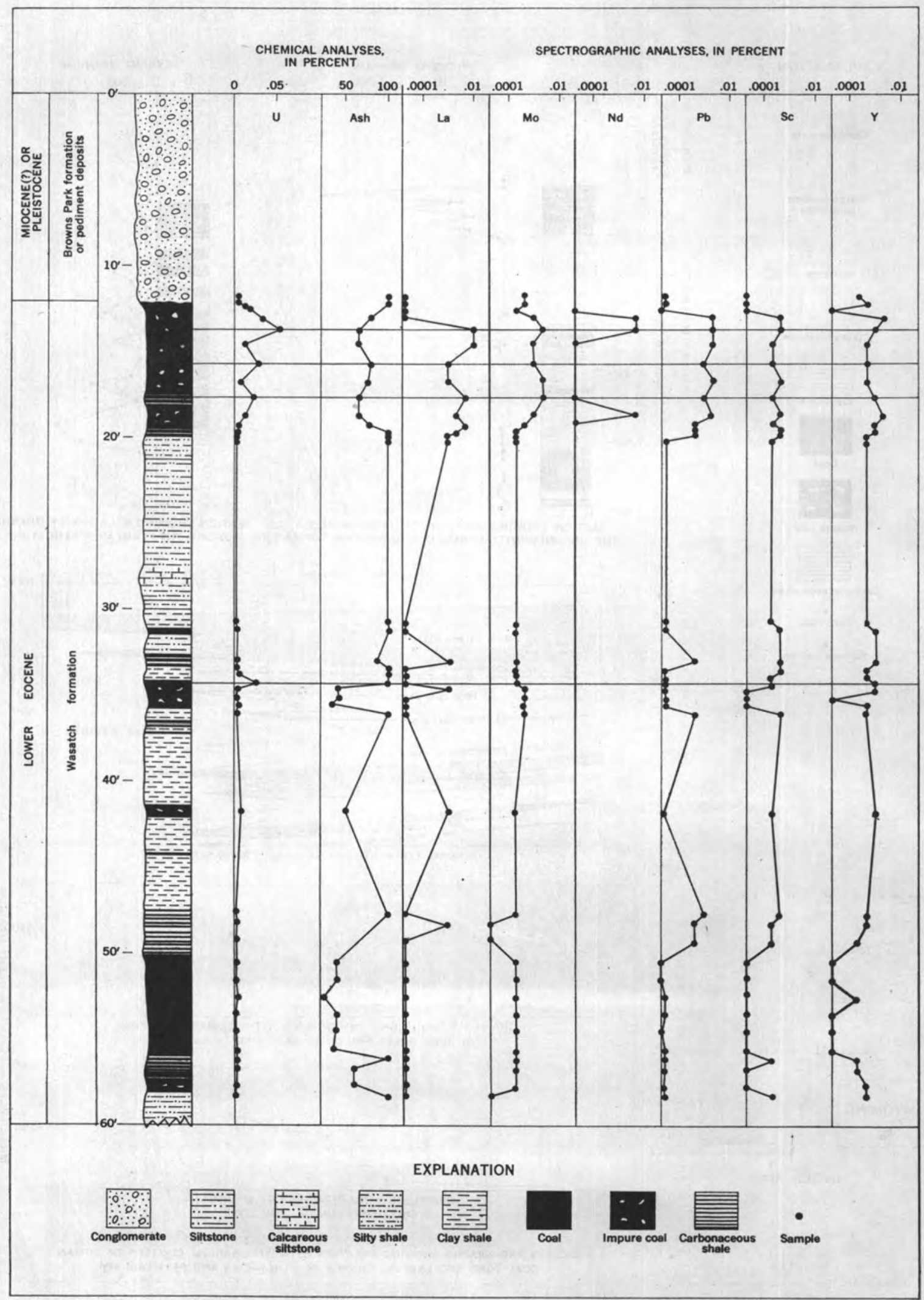

Figure 151.-Diagram showing distribution of uranium and selected trace elements in the Creston coal zone at Creston Ridge, eastern Red Desert area, Sweetwater County, Wyo. 
Lanthanum, molybdenum, neodymium, lead, scandium, and yttrium have distribution patterns similar to uranium in the coal at Creston Ridge (fig. 151) and may have been similarly emplaced. The content of uranium and other selected elements in organic paper shale interbedded with coarse-grained permeable sandstone exposed at Eagle's Nest is shown in figure 152.

The widespread concentration of uranium and some other trace elements in beds of coal, organic shale, and claystone adjacent to permeable coarse-grained sandstone suggests that these constituents have been epigenetically emplaced, perhaps by ground water circulating through the sandstone.

\section{LEACHING AND ADSORPTION OF URANIUM}

Previous work (Tolmachev, 1943; Moore, 1954; Szalay, 1954; Breger, Deul, and Rubinstein, 1955) has shown that uranium is readily asdorbed by coal and is held irreversably as a disseminated adsorbed constituent, probably forming an organometal compound. Experiments were carried out to determine whether coal would adsorb uranium from aqueous solution at the concentration and $\mathrm{pH}$ expectable in Red Desert ground water.
Several drill holes in the northwestern part of the area topped strong artesian flow of water containing as much as 47 parts per billion uranium. Surface water in Lost Creek 7 miles north of the area contains as much as 60 parts per billion uranium near the schroeckingerite $\left[\mathrm{NaCa}_{3}\left(\mathrm{UO}_{2}\right)\left(\mathrm{CO}_{3}\right)_{3}\left(\mathrm{SO}_{4}\right) \mathrm{F} \cdot 10 \mathrm{H}_{2} \mathrm{O}\right]$ deposit. Schroeckingerite is a secondary uranium mineral which occurs in calichelike masses near the surface along the Cyclone Rim fault zone. It probably forms by the evaporation of ground water escaping and rising to the surface along the fault zone from a small artesian basin. Water with the same mineral content and $\mathrm{pH}$ as that from Lost Creek was mixed with schroeckingerite-bearing rock and the leach passed over Red Desert coal. The water dissolved 87 percent of the uranium from the schroeckingerite-bearing rock, and the coal adsorbed 95 percent of the uranium from the leach. The coal also effectively adsorbed uranium from water containing 47 parts per billion. Coal immersed in a uranyl nitrate solution adsorbed up to 8.6 percent uranium; $\mathrm{X}$-ray analysis of this sample showed that no crystalline uranium mineral had formed.

Investigation showed that the $\mathrm{pH}$ of ground and surface water is about $7.9-8.6$, whereas the $\mathrm{pH}$ of a

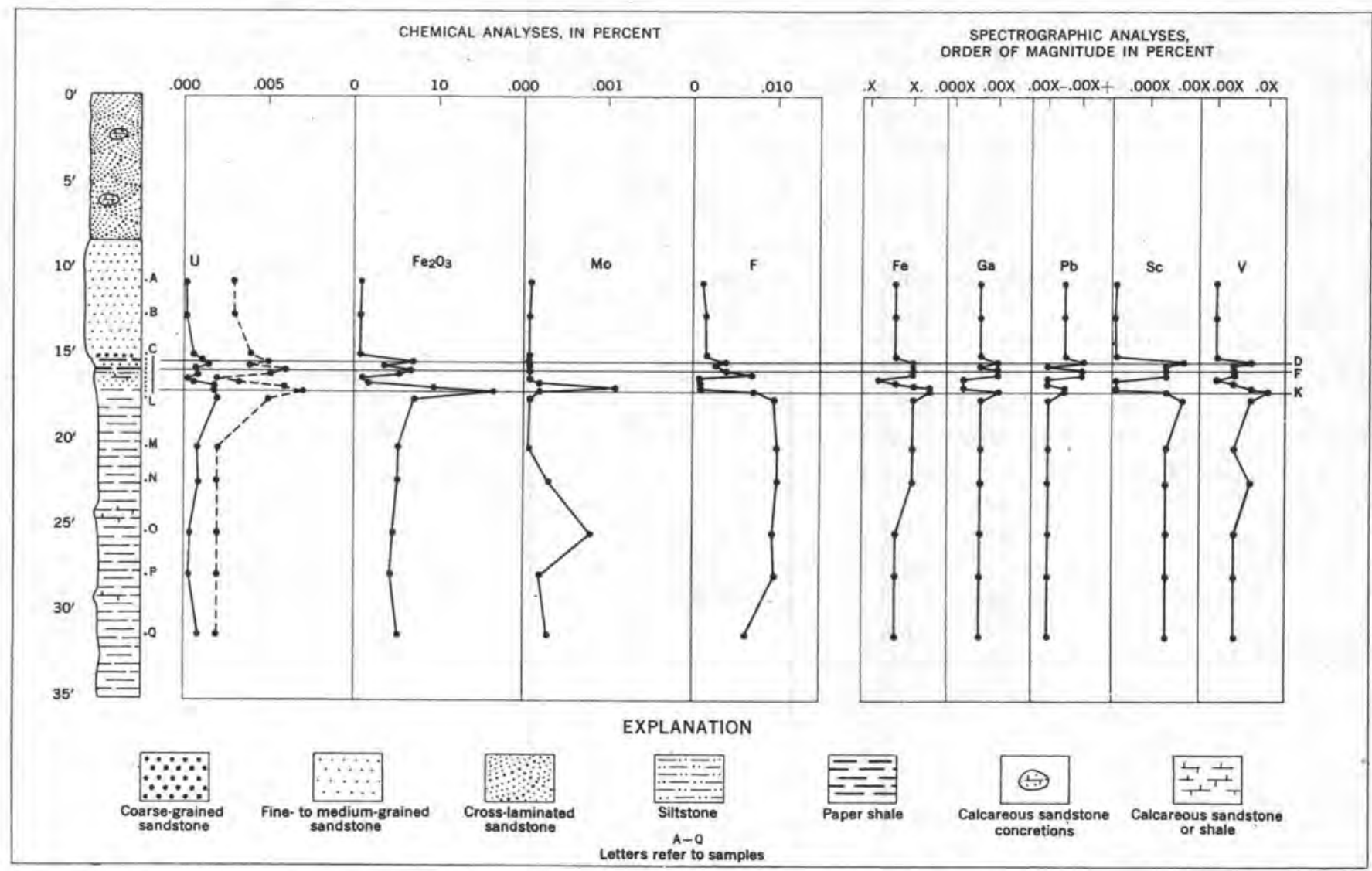

FigURE 152.-Diagram showing distribution of selected elements in interbedded sandstone and paper shale in the Wasatch formation exposed at Eagles Nest along Lost Creek, Red Desert area. Wyo. 
slurry of crushed fresh coal from core samples is 6.0 and that of weathered coal from surface section is 3.2-3.5. The redox potential (ZoBell, 1946) of the carbonaceous rocks is very different from that of the clastic sediments. The Eh of siltstone from Eagles Nest is plus 0.391 volts at $\mathrm{pH} 8.2$; the Eh of organic shale from the same section is plus 0.066 at $\mathrm{pH} 7.8$.

Results of the experiments indicate coal can absorb uranium from the ground water passing through it at the present time, water from Lost Creek will leach uranium from schroeckingerite and deposit it on coal, coal not only removes uranium from solution by formation of an organometallic compound but can markedly depress the $\mathrm{pH}$ and $\mathrm{Eh}$ of solutions in its vicinicy.

\section{SOURCES OF URANIUM}

Although the epigenetic emplacement of uranium in the coal by means of circulating ground water seems probable, the ultimate source of the uranium is equivocal. Field and laboratory evidence partly supports all three of the following hypotheses:

Hydrothermal solutions.-Uranium mineralization along the thrust fault north of Crooks Gap and along the Cyclone Rim fault zone could mean that uraniferous hydrothermal solutions have risen along these faults and spread laterally into the ground-water system.

Granite leach.-Piggott (1929), Hurley (1950), and Brown and others (1953) have shown that most of the uranium in granite is held interstitially and is removed easily by leaching. The granite of Sweetwater Mountain, the source of the coarse fractions of Wasatch sediments of the Red Desert area and boulders derived from the granite contain $0.002-0.003$ percent uranium. The arkose (sand-size material) contains about 0.0005 percent uranium in the resistant heavy minerals, which are in about the same proportions in the granite and arkose. The other 75-85 percent of the uranium in the intergranular films is released during weathering and erosion. As the Wasatch sediments are 2,000-4,000 feet in thickness, large amounts of uranium would have been released during their formation.

Volcanic-ash leach.-N. M. Denson, G. O. Bachman, and H. D. Zeller (written communication, 1950) proposed that uranium leached from overlying volcanic ash by ground water was adsorbed by the coal in North and South Dakota. Similar tuffaceous rocks of the Browns Park formation are preserved north, east, and south of the Red Desert and undoubtedly once blanketed the area. Water from wells in the Browns Park formation contains from 39-50 parts per billion uranium indicating mobility of its contained uranium. Coal directly overlain by the tuffaceous rocks at Creston Ridge and Bison basin has a high uranium content. In other places where the tuffaceous rocks overlie the sandstone facies of the Wasatch formation, the uraniferous water from the tuffaceous rocks might travel downward and laterally, reaching and mineralizing a coal bed.

Results of the investigation indicate that the large reserves of coal in the Red Desert are of interest primarily as a fuel and that uranium can only be produced as a byproduct. However, thin carbonaceous shales in the coarse-grained clastic facies to the northeast of the principal coal area may be the sices of localization of higher-grade uranium deposits.

\section{REFERENCES CITED}

Bradley, W. H., 1945, Geology of the Washakie basin, Sweetwater and Carbon Counties, Wyo. and Moffat County, Colo.: U. S. Geol, Survey Oil and Gas Inv. Prelim. Map 32.

Breger, I. A., Deul, Maurice, and Rubinstein, Samuel, 1955, Geochemistry and mineralogy of a uraniferous lignite: Econ. Geology, v. 50, no. 2, p. 206-226.

Brown, Harrison, and others, 1953, Leaching studies of interstitial material in igneous rocks [abs.]: Geol. Soc. America Bull, v. 64 , no. 12 , p. $1400-1401$.

Hurley, P. M., 1950, Distribution of radioactivity in granites and possible relation to helium age measurement: Geol. Soc. America Bull., v. 61 , no. 1, p. 1-7.

Moore, G. W., 1954, Extraction of uranium from aqueous solution by coal and some other materials: Econ. Geology, v. 49, no. 6 , p. $652-658$.

Moore, R. C., 1935, Stratigraphic classification of the Pennsylvanian rocks of Kansas: Kansas Geol. Survey Bull. 22, 256 p. [1936].

Piggott, C. S., 1929, Radium in rocks, I.-The radium content of some representative granites of the eastern seaboard of the United States: Am. Jour. Sci., 5th ser., v. 17, p. 13-34.

Smith, E. E., 1909, The eastern part of the Great Divide Basin coal field, Wyoming: U. S. Geol. Survey Bull. 341, p. 220-242.

Szalay, S., 1954, The enrichment of uranium in some brown coals in Hungary: Magyar tudom. akad., Acta Geol., v. 2, nos. 3-4, p. 299-310.

Tolmachev, A. M., 1943, Adsorption of uranyl salts on solid adsorbents: Akad. Nauk SSSR, Izv. Otdel. Khimicheskikh Nauk no. 1, p. 28-34 [Russian text and English summary].

ZoBell, C. E., 1946, Studies on redox potential of marine sediments: Am. Assoc. Petroleum Geologists Bull., v. 30, no. 4, p. $477-511$. 


\title{
URANIUM DEPOSITS IN SANDSTONES OF MARGINAL MARINE ORIGIN
}

\author{
By N. J. Chinton and L. W. CArithers, U. S. Atomic Energy Commission
}

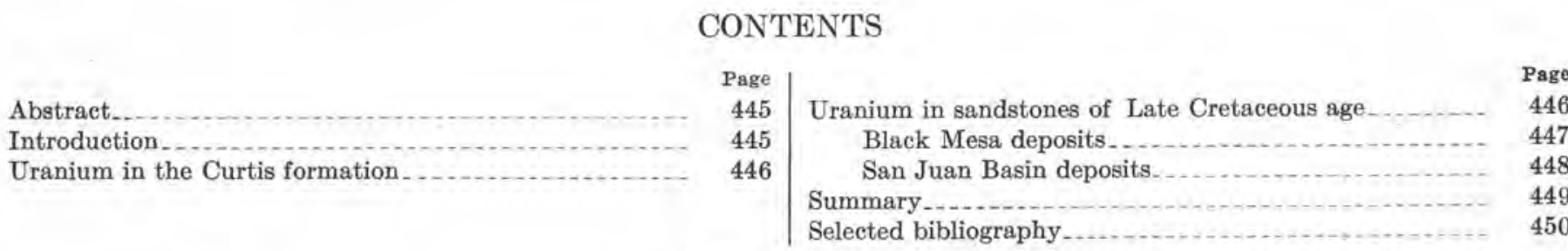

\section{ILLUSTRATIONS}

Frgure 153. Map of Colorado Plateau showing uranium occurrences in the Curtis formation of Jurassic age and sandstones of Late Cretaceous age

154. Diagrammatic section showing time and space relations of some sandstones of Late Cretaceous age in the San Juan Basin, N. Mex
Page

FigURE 155. Tectonic structure of Black Mesa, Navajo County, Ariz .................................. 156. Mineralized outcrop no. 5, Black Mesa, Navajo County, Ariz

157. Radioactivity, paleostream direction, and sections of mineralized outcrop no. 2, Black Mesa, Navajo County, Ariz .......
Page 447

\section{ABSTRACT}

Uranium deposits are now known to occur on the Colorado Plateau in sandstones deposited in a marine or a nearshore terrestrial environment. This is in contrast to the wholly continental origin of the highly productive Morrison formation of Jurassic age and Chinle and Shinarump formations of Triassic age. The shoreline sandstones originated as beach and fluvial deposits which commonly intertongue with shales and carbonaceous beds of marine and paludal origin.

Uranium is known in the marine Curtis formation of Jurassic age and also in several marine and terrestrial sandstones related to the Late Cretaceous sea. Occurrences are associated with local changes of facies, accumulations of carbonaceous material, or both. All are within or near regions of post-Cretaceous tectonic disturbanees.

The potential production of uranium from the shoreline sandstones on the Plateau is not known; to date only a small tonnage of marginal grade has been mined. It is only recently that commercial uranium deposits have been discovered in rock of this origin, and an increasing number of discoveries is being made.

\section{INTRODUCTION}

Nearly 90 percent of the uranium ore produced on the Colorado Plateau has come from fluvial sandstones, represented chiefly by members of the Morrison and Chinle formations and by the Shinarump conglomerate. However, uranium also occurs on the Plateau in units that originated in marine, littoral marine, and coastal plain environments. Some of these are beach sandstones, others are fluviomarine sandstones, lagoonal deposits of mudstone, carbonaceous shale, and coal. All of these are related to transgression and regression of the strand line.

Shoreline sandstones have at many places the same lithologic and sedimentary features generally associated with uranium in the highly productive fluvial sandstones: shales or mudstones interbedded with sandstone in an approximate 1 to 2 or 1 to 3 ratio; carbonized plant matter; light-tan or gray color rather than the prevailing reddish; and feldspar or mica. The uranium occurrences are generally clustered on or near positive tectonic structures, but their genetic relation to these is yet to be proven.

The known uranium occurrences in sandstones of shoreline origin are shown in figure 153. These are in two general groups on the Plateau; the first is in the Curtis formation of Jurassic age (at Skull Creek, Moffat County, Colo.), which accumulated in a sea that invaded the northern part of the Colorado Plateau.

The second group is in sandstones of Late Cretaceous age deposited along the shore of a sea that extended 


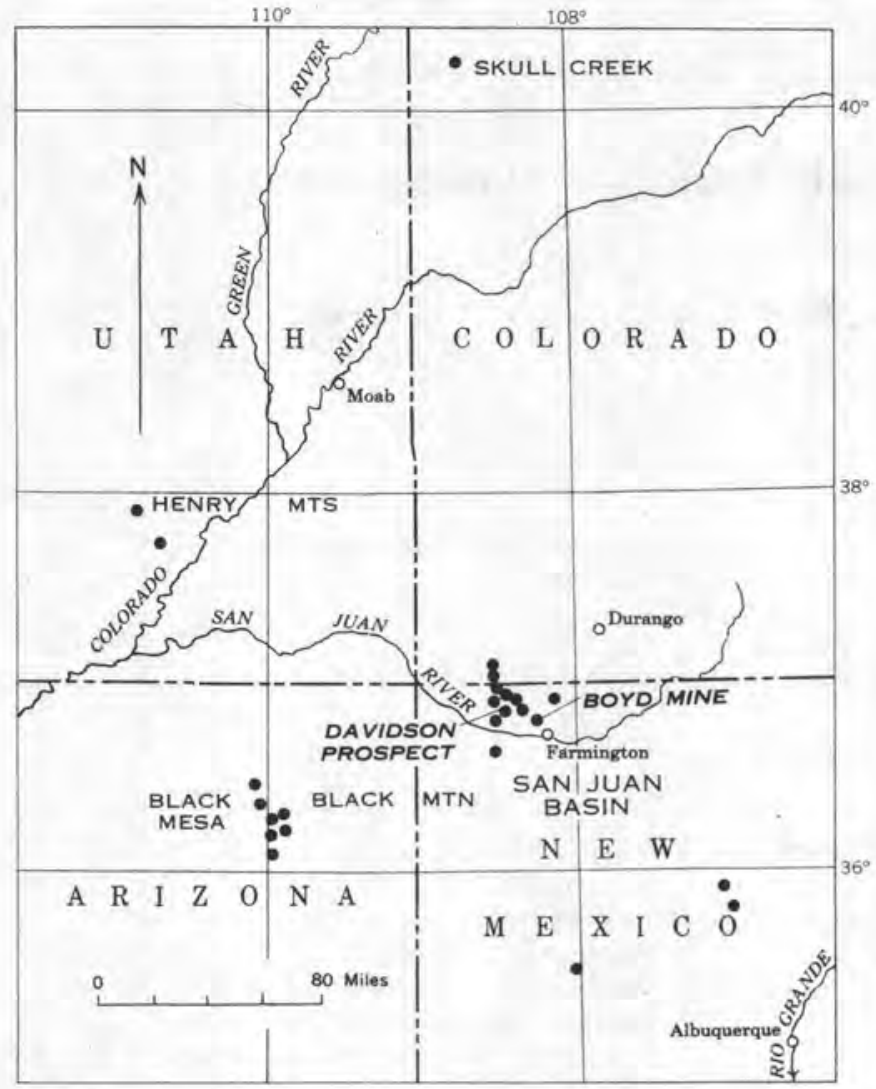

Figure 153.-Map of Colorado Plateau showing uranium occurrences in the Curtis formation of Jurassic age and sandstones of Late Cretaceous age.

northwestward across the Plateau from the Gulf of Mexico. Uranium occurs in the Toreva formation of the Mesaverde group on Black Mesa, northeastern Arizona. In the San Juan Basin of northwestern New Mexico uranium occurs in the Dakota sandstone, in the Menefee and the Hosta tongue of the Point Lookout formations of the Mesaverde group, in the Pictured Cliffs sandstone, and in the Fruitland formation. Uranium is also reported in the Ferron and Emery sandstone members of the Mancos shale in southeastern Utah.

\section{URANIUM IN THE CURTIS FORMATION}

Uranium occurs in the Curtis formation at Skull Creek, Moffat County, Colo. A few hundred tons have been mined during the past 50 years, first for radium, later for vanadium, and currently for uranium.

The Curtis formation, which accumulated as a nearshore marine deposit in the Jurassic sea that advanced over the northern part of the Colorado Plateau from the north or northwest (Baker, Dane, and Reeside, 1936), is composed of conglomerate, sandstone, limestone, and shale containing Upper Jurassic fossils. The Curtis, which may reach a thickness of 200 feet, is predominantly a thinly laminated, very fine grained sandstone.

The ore deposits (McDougald, 1955) are at the base of the Curtis, which overlies the eolian Entrada sandstone. The basal part of the Curtis is water-laid ripplemarked thin-bedded sandstone ranging in thickness from 6 to 36 inches, and grades upward into fossiliferous marine sandstone. The ore zone is considered to be a marginal marine facies.

The deposits are tabular, 1 or 2 feet thick, and generally contain less than 100 tons of carnotite ore disseminated in sandstone. Associated with the carnotite are other vanadium, iron, and copper minerals, together with varying amounts of organic material. The uranium content of the deposits is generally low, but at places there are concentrations of as much as 7 percent $\mathrm{U}_{3} \mathrm{O}_{8}$.

The Skull Creek deposits are on the south flank of the east-trending Skull Creek anticline. Locally, cross folding has resulted in erratic changes in strike and dip and has developed many small fracture zones, some of which show a few inches displacement. In one deposit fractures appear to have influenced the deposition of ore.

\section{URANIUM IN SANDSTONES OF LATE CRETACEOUS AGE}

During Late Cretaceous time a section of rocks about 5,000 feet thick was deposited in the Colorado Plateau region near the western edge of a geosynclinal sea that extended across the region from the Gulf of Mexico into Alberta, Canada (Pike, 1947; Sears, Hunt, and Hendricks, 1941). This sea is believed to have been separated from highlands to the west by a broad coastal plain. As marine waters transgressed and regressed during Late Cretaceous time, the coastline oscillated from west to east many times (Pike, 1947; Silver, 1951). These changing environments are reflected in the intertonguing of marine, littoral marine, swamp, and terrestrial deposits of shale, carbonaceous material, and sandstones (fig. 154). Terrestrial deposits are mostly to the southwest and marine deposits to the northeast.

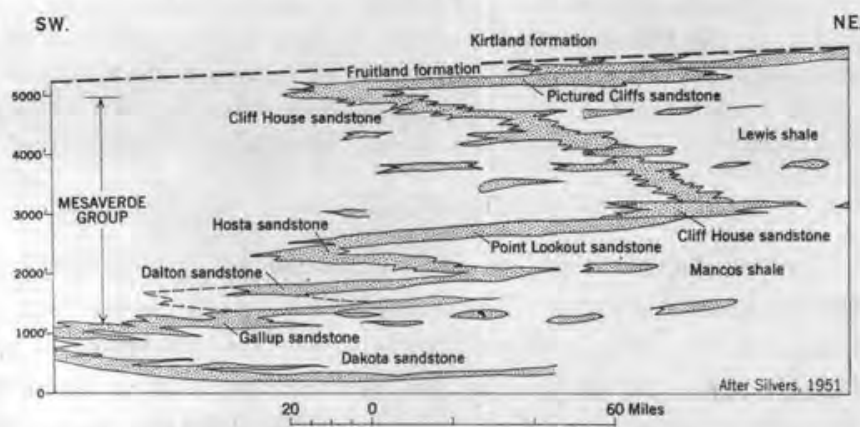

FIGURE 154.-Diagrammatic section showing time and space relations of some sandstones of Late Cretaceous age in the San Juan Basin, N. Mex. 
The Dakota sandstone, of Early(?) and Late Cretaceous age, unconformably overlies Lower Cretaceous and Jurassic rocks throughout the Plateau except where it has been removed by erosion. The Dakota is overlain by thick marine shales and interbedded with tongues of sandstone and thinner carbonaceous deposits. Most of the sandstone units are members of the widespread Mesaverde group. In the southeastern part of the Plateau the Mesaverde and overlying Lewis shale are overlain by the Pictured Cliffs sandstone, the Fruitland formation, and later sediments which mark the final retreat of the Late Cretaceous sea from the region and the transition from marine through littoral marine to continental environments.

Uranium occurs in a single sandstone formation of the Upper Cretaceous on Black Mesa, Ariz., and in several formations in the San Juan Basin, N. Mex.; other deposits are reported in Cretaceous rocks in the Henry Mountains, Utah. Uranium also occurs in carbonaceous shale and coal of Late Cretaceous age (Gabelman, 1956).

\section{BLACK MESA DEPOSITS}

Black Mesa is a topographically high and structurally low area in the middle of the Navajo Indian Reservation, Apache and Navajo Counties, Ariz. (fig. 153).

Regional structure.-Black Mesa basin is a saucerlike depression tilted to the southwest. Northwest-trending anticlines, synclines, and monoclines, superimposed on this structure (fig. 155) tend to bifurcate. They are probably post-Cretaceous (Kelley, 1955).

Although figure 155 indicates uniform structure, the greatest deformation occurs in the northeast part of the mesa. The asymmetrical Black Mountain anticline, with a steep northeast flank, has the greatest structural relief in the Black Mesa area.

The principal joint set is parallel to the axes of the structures; another set is perpendicular and a third set oblique to the structural axes. A normal fault 100 feet long and having a 20 -foot vertical displacement occurs in the Black Mountain-Yale Point area. No relation of joints or faults to uranium deposition is apparent.

Stratigraphy and sedimentation.-On Black Mesa the Toreva formation (Repenning, C. A., oral communication) of the lower part of the Mesaverde group is divided into three members: an upper thin littoral marine quartzose sandstone, a middle thin carbonaceous shale, and a lower, thick, ore-bearing arkosic sandstone resting on Mancos shale.

The basal unit of the lower member is a beach-type sandstone, 10 to 15 feet thick, which grades upward into a 250 - to 350 -foot arkosic sandstone interbedded with carbonaceous siltstones and mudstones.

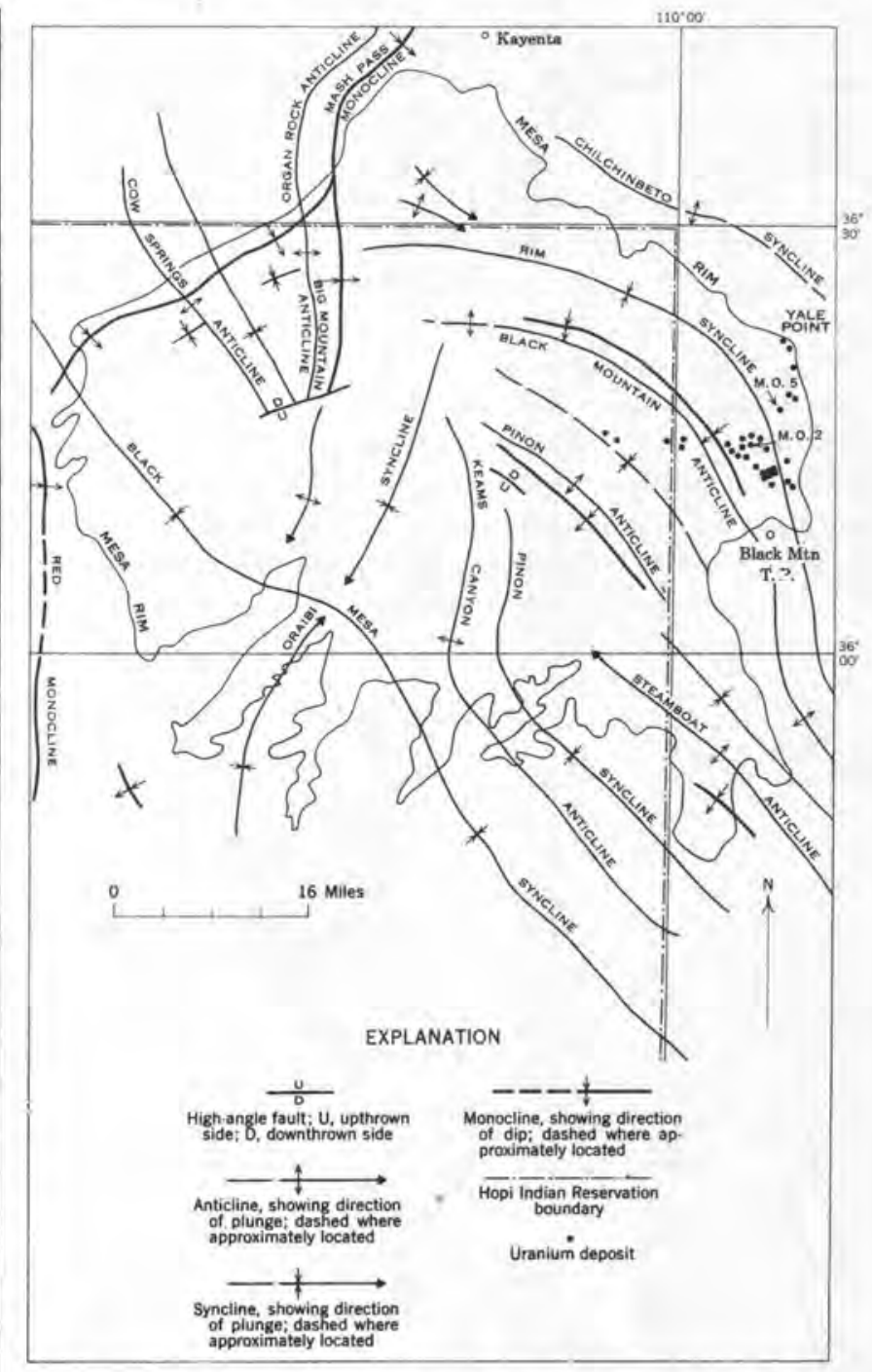

FigURE 155.-Tectonic structure of Black Mesa, Navajo County, Ariz.

The arkosic member is a light-gray to buff crossbedded sandstone consisting chiefly of subangular fineto coarse-grained quartz and unweathered feldspar grains, and contains minor amounts of amphibole, magnetite, zircon, rutile, garnet epidote, apatite, ilmenite, tourmaline, and biotite. This mineral suite strongly suggests a crystalline source nearby.

Economic geology.-Uranium deposits occur on Black Mesa in areas where the structural relief of the superimposed flexures is most pronounced. Radiometric and geologic reconnaissance, made in areas where no local tectonic structures exist, revealed no commercial deposits of uranium. A concentration of deposits does occur on the steeper, more sharply flexed, northeast flank of the Black Mountain anticline (fig. 155).

All known uranium occurrences are in the light-tan or brown to light-gray 35 - to 50 -foot zone of quartzose 
lenses at the top of the arkasic member of the Toreva formation. Tongues of carbonaceous siltstone and mudstone occur within this zone. The deposits are about 20 feet long, 5 to 10 feet wide, and 0.5 to 2.5 feet thick. Present petrographic studies are too inconclusive to explain why the uranium is restricted to this single zone, although it is noted that ore-bearing sandstone contains no feldspar.

Paleostream directions in the ore-bearing zone were determined by studies of cross stratification. According to Stokes (1953), uranium is most likely to exist where paleostream directions change. Chemical assays of samples taken along the rim and a radiometric survey on top of the mesa indicate increased uranium content in areas of ancient channels and changes in paleostream directions (figs. 156 and 157). Recent mining

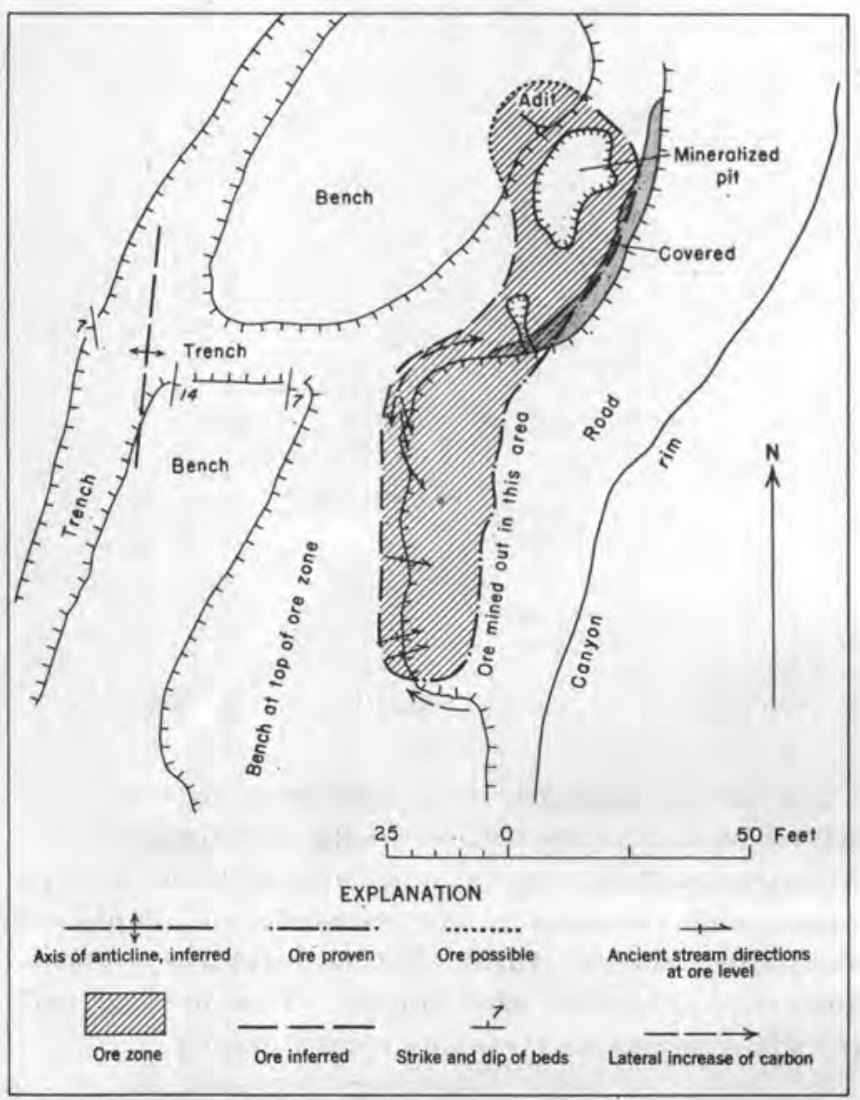

Figure 156.-Mineralized outerop no. 5, Black Mesa, Navajo County, Ariz.

has uncovered a promising deposit in the Yale Point area where uranium lies within an ancient channel or "festoon" (Stokes, 1953).

Mineralogy.-Without exception, the uranium minerals are secondary and either carnotite or tyuyamunite. No unoxidized minerals have been reported but they may occur under deeper cover. The vanadium assemblage accompanying the uranium vanadates is composed

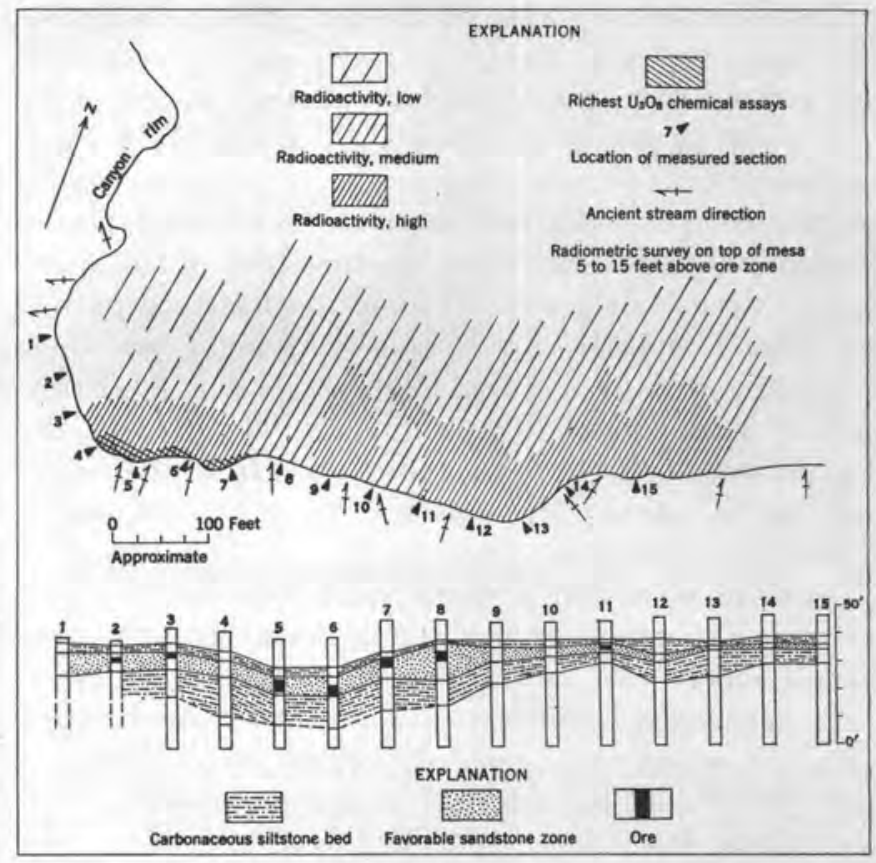

FIGURE 157.-Radioactivity, paleostream direction, and sections of mineralized outcrop no. 2, Black Mesa, Navajo County, Ariz.

of vanadium-bearing clay minerals, metahewettite, and melanovanadite.

The bulk of the host-rock mineral assemblage is composed of quartz in the form of subangular sand grains. The amount of calcium carbonate cement is low, averaging between 0.50 and 0.75 percent for the entire area. The remainder of the host rock consists of the following in varying minor amounts: hematite, goethite, jarosite, pyrite, feldspar, rutile, ilmenite, tourmaline, topaz, zircon, garnet, biotite, magnetite, and epidote.

Paragenesis indicated from petrographic analyses of samples taken from several outcrops shows that the uranium minerals replaced the original cement. The carnotite or tyuyamunite is later than the vanadiumbearing clay and replaced the carbonaceous material. The ore is postlithification (E. B. Gross, written communication).

\section{SAN JUAN BASIN DEPOSITS}

The San Juan Basin, a region of several thousand square miles in northwestern New Mexico and southwestern Colorado, is rimmed by Upper Cretaceous rocks. In its middle there is an extensive exposure of lower Eocene sandstone and shale.

Before 1955 two uranium occurrences (the Boyd deposits in the Fruitland formation and the Davidson prospect in the Menefee formation) were known in the northern part of the San Juan Basin. Early in 1955 an airborne radiometric survey by the Atomic Energy Commission detected several radioactive deposits at out- 
crops of the Point Lookout and the Pictured Cliffs sandstones. These are similar to the Boyd and Davidson deposits in that they are all on or near the Hogback monocline, a major structure of the area, and are associated with carbonaceous material.

The Boyd deposit is in a tuffaceous sandstone of the Fruitland formation on a mesa 12 miles northwest of Farmington, N. Mex. About 40 tons of ore containing 0.15 to 0.20 percent $\mathrm{U}_{3} \mathrm{O}_{8}$ have been mined from a sharply defined light-pink zone at the base of the tuffaceous sandstone. Just above the ore zone is 1 foot of gray sandstone that grades upward into barren buffcolored, tuffaceous sandstone. Beneath the ore there is a thin zone of gray sandstone; this in turn is separated from a 1 -foot bed of mudstone and sandstone containing carbonaceous fragments and marine (or brackish water?) gastropods by a sharp, scoured contact. Bentonitic and tuffaceous beds underlie the fossiliferous unit. The uranium mineral is too fine to be readily identified.

The ore, exposed in an area of about 25 by 50 feet in an open pit, is from 3 inches to 36 inches thick. The ore body occupies a shallow depression scoured into the subjacent, tuffaceous sediments. It is on the flank of the Hogback monocline in beds dipping $12^{\circ} \mathrm{SE}$. The pink color of the ore unit is due to iron oxide.

The Davidson occurrence is in the Menefee formation of the Mesaverde group, about 9 miles east of Ship Rock, N. Mex., where the stratigraphic sequence from top to bottom is:

Coal

Feet

Sandstone, uranium-bearing, dark gray-green-2.- 1 to 2

Sandstone, light-gray ........................ Not measured

The gray-green uranium-bearing sandstone consists of iron-stained fine-grained quartz sandstone containing mica, feldspar, clay, tiny flecks of hydrocarbon, and a few grains of an unidentified pink mineral. The uranium minerals have not been identified. Pyrite and calcium carbonate concretions are abundant just above and below the mineralized zone. No ore has been shipped from this deposit. Surface material contains less than 0.10 percent $\mathrm{U}_{3} \mathrm{O}_{8}$.

Carnotite occurs in sandstone lenses associated with carbonaceous material in the Dakota sandstone (Gabelman, 1956) and in the Hosta tongue of the Point Lookout sandstone of the Mesaverde group (Vine, Bachman, Read, and Moore, 1953) in the southern part of the San Juan Basin.

\section{SUMMARY}

Production of uranium from marginal marine sandstone has been minor in comparison with production from fluvial sandstones. Two of the features considered favorable for the occurrence of uranium deposits in the fluvial Morrison formation (Weir, 1952) are also considered favorable for deposits in marginal marine sandstone: Color is altered from red to brown or light gray in the vicinity of ore deposits, and ore deposits occur near concentrations of carbonized plant fossils. Other favorable features are ancient stream channels, a littoral zone of deposition, and local folding.

\section{SELECTED BIBLIOGRAPHY}

Baker, A. A., Dane, C. H., and Reeside, J. B., Jr., 1936, Correlation of the Jurassic formations in parts of Utah, Arizona, New Mexico, and Colorado: U. S. Geol. Survey Prof. Paper $183,66 \mathrm{p}$.

Darton, N. H., 1910, A reconnaissance of parts of northwestern New Mexico and northern Arizona: U. S. Geol. Survey Bull. 435 , p. 11-45.

Eardley, A. J., 1951, Structural geology of North America: New York, Harper \& Bros., p. 393-409, pl, 16.

Gabelman, J. W., 1956, Uranium deposits in Cretaceous paludal shales, San Juan Basin, N. Mex.: this volume.

Harshbarger, J. W., 1949, Petrology and stratigraphy of Upper Jurassic rocks of central Navajo Reservation, Arizona: Ariz. Univ., doctoral thesis.

Kelley, V. C., 1955, Regional tectonics of the Colorado Plateau and relationship to the origin and distribution of uranium: N. Mex. Univ. Pub. in Geology, 5, 120 p.

MeDougald, W. D., 1955, Wagon drilling in the Skull Creek area, Moffat County, Colo.: U. S. Atomic Energy Comm. RME-80, pt. 1, 15 p., issued by U. S. Atomic Energy Comm. Tech. Inf. Service, Oak Ridge, Tenn.

Pike, W. S., Jr., 1947, Intertonguing marine and nonmarine Upper Cretaceous deposits of New Mexico, Arizona, and southwestern Colorado: Geol. Soc. America Mem. 24, 103 p.

Reeside, J. B., and Baker, A. A., 1929, The Cretaceous section in Black Mesa, northeastern Arizona: Washington Acad, Sci. Jour., v. 19 , no. 2 , p. $30-37$.

Sears, J. D., Hunt, C. B., and Hendricks, T. A., 1941, Transgressive and regressive Cretaceous deposits in southern San Juan Basin, N. Mex.: U. S. Geol. Survey Prof. Paper 193-F. p. 101-121.

Silver, Caswell, 1951, Cretaceous stratigraphy of the San Juan Basin: N. Mex. Geol. Soc. Guidebook of the south and west sides of the San Juan Basin, p. 104-118.

Spieker, E. M., 1946, Late Mesozoic and early Cenozoic history of central Utah: U. S. Geol. Survey Prof. Paper 205-D. p. 117-161.

Stokes, W. L., 1953, Primary sedimentary trend indicators as applied to ore finding in the Carrizo Mountains, Ariz. and N. Mex.: U. S. Atomic Energy Comm. RME-3043 (pt, 1), issued by U. S. Atomic Energy Comm. Tech. Inf. Service, Oak Ridge, Tenn.

Weir, D. B., 1952, Geologic guides to prospecting for carnotite deposits on Colorado Plateau: U. S. Geol. Survey Bull. 988-B, p. 15-27.

Vine, J. D., Bachman, G. O., Read, C. B., and Moore, G. W., 1953 , unpub. inf.

Williams, G. A., 1951, The coal deposits and Crecaceous stratigraphy of the western part of Black Mesa, Ariz.: Arizona Univ., doctoral thesis.

Wright, R. J., 1955, Ore controls in sandstone uranium deposits of the Colorado Plateau: Econ. Geology, v. 50, p. 135-155. 



\title{
URANIUM IN MARINE BLACK SHALES OF THE UNITED STATES
}

\author{
By Vernon E. Swanson, U. S. Geological Survey
}

\section{CONTENTS}

\begin{tabular}{|c|c|c|}
\hline \multicolumn{3}{|c|}{ Page } \\
\hline Abstract & 451 & Phosphatic carbonaceous shales, Phosphoria formation.- \\
\hline Introduction... & 451 & 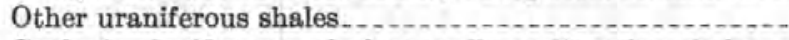 \\
\hline Lithologic and chemical characteristics. & 452 & Geologic significance of abnormally radioactive shales.. \\
\hline Chattanooga shale & 453 & References cited \\
\hline
\end{tabular}

\section{ILLUSTRATION}

\begin{abstract}
Uranium is disseminated in minor amounts, generally not exceeding 0.02 percent, in many of the marine organic-rich black shales in the United States. Two hundred or more stratigraphic units, ranging in age from Precambrian to Tertiary, consist wholly or in part of black shale, and one or more of these units are present in nearly every State. Broad reconnaissance and scattered sampling of many of these units and also a few detailed geologic studies have been made; several thousand samples of black shale have been analyzed for uranium, and many for organic content, oil yield, and specific chemical constituents.

The most uraniferous shales are those rich in organic matter (mainly plant debris), pyrite, and phosphatic matter. They are also low in calcium carbonate content, and yield oil by destructive distillation. Most uraniferous black shale units are thin blanketlike deposits of Paleozoic age that have very little variation in thickness or lithology over wide areas and were deposited at an exceedingly slow rate. The Chattanooga shale and its equivalents, such as the New Albany, Ohio, and Woodford formations, which range from Late Devonian to early Mississippian age, make up such a blanket deposit that was laid down in the eastern and central parts of the United States; this shale averages about 50 feet in thickness over much of this area and contains between 0.001 and 0.035 percent uranium. Several thin and widespread black shales of Pennsylvanian age in the Midcontinent and thin beds of phosphatic black shales in the Phosphoria formation of Permian age in Idaho, Montana, and Wyoming have comparable uranium contents.

Both field and laboratory studies show that uranium is evenly disseminated throughout the black shale and is believed to have accrued contemporaneously with the deposition of the enclosing organic-rich muds. Areal variations in uranium content are related directly to regional paleogeographic trends; vertical variations are related directly to lithologic changes, particularly in the ratio of organic matter to detrital minerals. The form of the uranium in the shale is not completely known and no
\end{abstract}

uranium-bearing minerals have been identified; however, laboratory studies indicate that uranium ions in the sea water were adsorbed by the organic matter.

In order to evaluate the uranium potential of marine black shales, they may be classified by the tectonic and paleogeographic setting of the area during time of accumulation of organicrich muds. Thus, four general categories are considered: epicontinental areas similar to the Chattanooga, geosynclinalfringe areas similar to the Marcellus, miogeosynclinal areas similar to the Normanskill, and eugeosynclinal areas similar to the Mariposa. As inferred from geologic studies, each is characterized by definite water conditions (chemistry, depth, circulation, life regimen), climatic conditions, rate and amount of subsidence, and relation to the source of sediments (distance, topography and drainage, rock composition). The more uraniferous shales known in the United States were deposited in epicontinental seas. Further study and refinement of these or similar characteristics that serve to identify uraniferous shales may result in the finding of additional marine shales of higher grade.

\section{INTRODUCTION}

For the past decade black shales have been regarded as possible low-grade sources of uranium, and numerous black shale units in the United States have been tested for their uranium content. Of those tested, a few widespread shales of Paleozoic age contain about 0.007 percent uranium.

To date, the search for uraniferous shales has been mainly a broad-scale surface reconnaissance, utilizing radiation-detecting instruments. The general radioactivity of many black shales in the subsurface has been determined from gamma-ray logs of oil and gas wells (Gott and Hill, 1953), and many well cores have 
been scanned radiometrically and analyzed chemically for uranium. Hundreds of exposed black shale units that range in age from Precambrian to Tertiary, and from a few feet to several thousand in thickness, have been cursorily examined. Several have been studied in detail and hundreds of samples collected and chemically analyzed for uranium and other constitutents; many are represented by only a few samples that have been measured chemically or by field radioactivity methods. The possibilities in the United States for finding black shales more uraniferous than those now known certainly have not been exhausted; and it is believed that further study of the paleogeology of marine shales may be of help in finding shales of higher uranium content than are now known.

No uranium has been produced from black shale in the United States, because a large number of high-grade deposits of other types have been discovered and because black shale units of sufficiently high grade and large volume have not been found. Despite the low uranium content of black shales, the tonnage of metallic uranium in shales is extremely large, and it is possible that the amount of uranium required in the future may necessitate developing this large low-grade reserve. For example, central Tennessee and parts of adjoining states have about 85 billion $\left(85 \times 10^{9}\right)$ tons of shale averaging slightly more than one-tenth of a pound of uranium per ton; this represents a reserve of 5 to 6 million tons of uranium (Johnson, 1955).

Many references to the radioactivity of black shales exist in the literature. An extensive bibliography is listed by McKelvey and Nelson (1950), and a comprehensive review of theories on the depositional origin of black shales is given by Twenhofel (1939). The distribution of significantly uraniferous black shales is shown in figure 158.

\section{LITHOLOGIC AND CHEMICAL CHARACTERISTICS}

With few exceptions the uranium content of known marine black shales of the United States does not exceed 0.02 percent, and the contents of few shale units having a thickness of more than 2 feet exceed 0.005 percent uranium. Black vitreous layers of coalified plant tissue that are fractions of an inch thick and abundant in black shales of Devonian age contain as much as 0.035 percent uranium. Specially selected

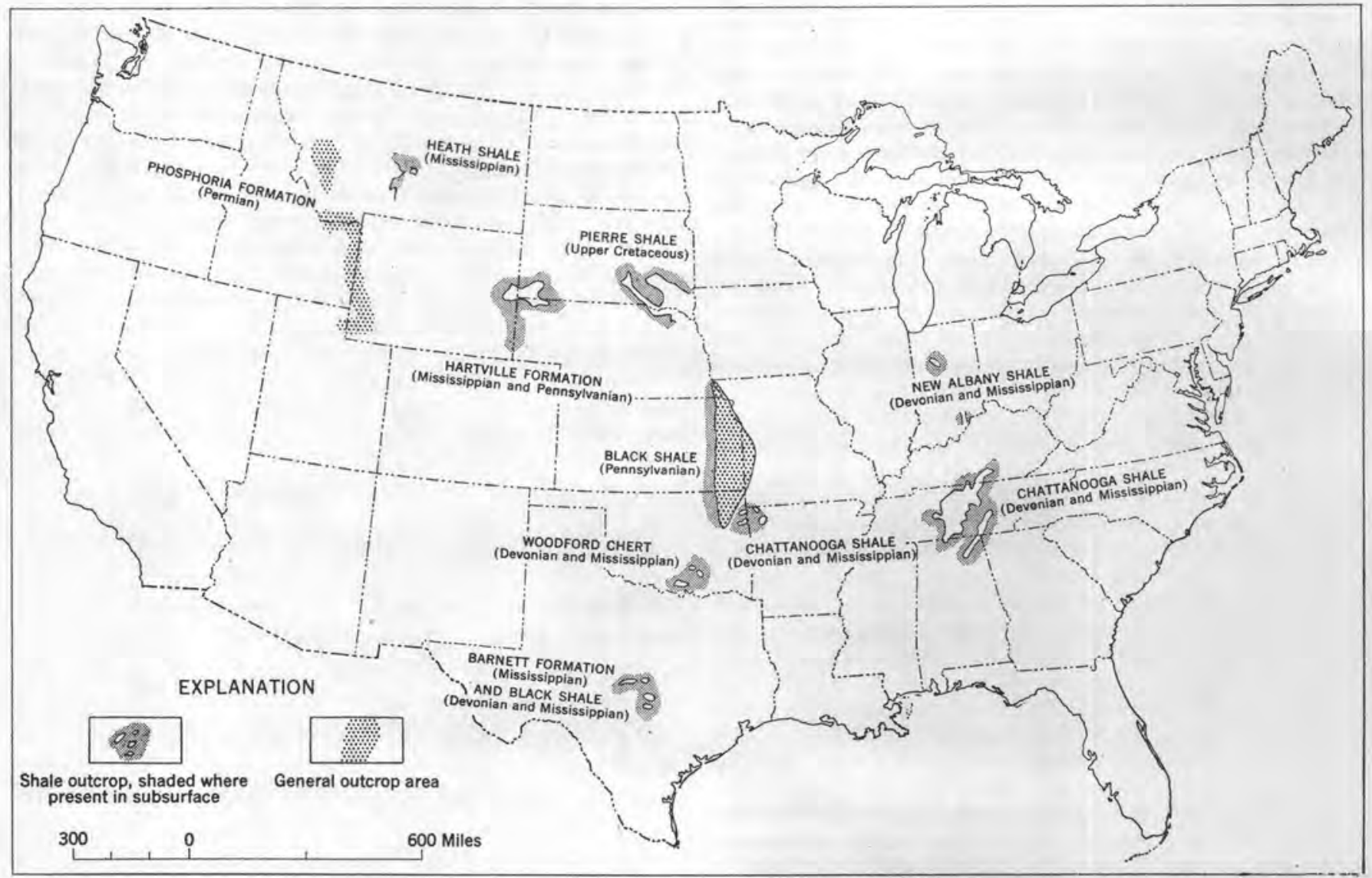

FIGURE 158.-Distribution of significantly uraniferous black shale. 
samples of highly phosphatic material in some black shales may have more than 0.035 percent uranium. These and a few secondarily mineralized shales, which have sporadic uranium concentrations, are the only ones known to have more than 0.02 percent uranium.

Several marine black shales are almost nonradioactive, having uranium contents comparable to the average sedimentary rock. Parts of the Eagle Ford shale of Late Cretaceous age in east-central Texas, for example, contain less than 0.001 percent, though this formation has several lithologic characteristics typical of other uraniferous shales (Eargle, written communication, 1955).

The total radioactivity of the more uraniferious black shales is primarily due to uranium, though thorium and the radioactive isotope of potassium are probably important constituents of some radioactive shales.

To date, laboratory experiments have failed to isolate and identify the uranium mineral or minerals in black shales. The uranium is apparently thoroughly disseminated in the shale but is associated most closely with the contained organic matter which is also finely dispersed. The rapid adsorption of uranium by carbonaceous material immersed in a uranyl solution (Szalay, 1954; Moore, 1954) supports the theory that uranium in the sea water was adsorbed by the organic debris contemporaneously with the deposition of the enclosing muds (Conant, p. 463, this volume). The mineralogical association of the uranium and the phosphatic material common to many black shales is discussed in detail by McKelvey (p. 477, this volume).

In addition to the organic matter, other common components of uraniferous shales are pyrite lenses, nodules, and minute crystals and phosphate as nodules as much as a foot in diameter or as disseminated particles. Also, abnormal amounts of certain trace elements, such as copper, nickel, vanadium, germanium, and molybdenum, are common in some uraniferous black shales. The uranium content generally decreases sharply with small inereases of ealcium carbonate.

Many uraniferous black shales have long been known as oil shales. The marine Chattanooga shale, noted for its comparatively high radioactivity, is a low-grade oil shale, yielding on the average 5 to 10 gallons of oil per ton of shale by destructive distillation methods; further, a crude relationship can be shown between the increase of oil content and uranium content in this formation. Some oil-bearing shales, however, are not particularly uraniferous. For example, the oil shale units of the nonmarine Green River formation in Colorado and Utah contain 0.001 percent uranium or less.

\section{CHATTANOOGa SHALE}

Among the radioactive marine black shales that have been studied in the United States, the Chattanooga shale of Late Devonian and early Mississippian age in central Tennessee is best known and is currently considered as a possible low-grade source of uranium. Other shale units in the United States locally contain more uranium, but such shales are less extensive, thinner, or are deeply buried. The reader is referred to papers by Brown (p. 457, this volume), Conant. (p. 463, this volume), and Hass (1956) for more detailed descriptions of the Chattanooga shale.

The Chattanooga shale in Tennessee, Kentucky, and Alabama is the generally more radioactive part of a thin blanket of black shale that once covered a large part of eastern and central United States. Correlatives of the Chattanooga, all slightly radioactive, are the New Albany shale of Illinois, Indiana, and Kentucky; the Antrim shale of Michigan; the Sunbury and Ohio shales of Ohio and Kentucky; the Genessee group, the Dunkirk member of the Perrysburg formation, and other thin shales of New York; the Chattanooga shale of Kansas, northern Arkansas, and northern Oklahoma; and the Woodford chert of Oklahoma and Texas. Except in mountainous areas, these shales are flatlying or locally warped into gentle folds.

The thickness of these Upper Devonian and lower Mississippian shales ranges from a feather edge to several hundred feet, but in central Tennessee, where mining of the shale is most feasible, the Chattanooga shale is less than 35 feet thick. These shales consist chiefly of black siliceous shale and gray claystone, and locally include thin sandstone beds, calcareous lenses, chert layers, and phosphatic nodules. They contain abundant plant remains (such as stems, spores, and macerated debris) as well as linguloid brachiopods, conodonts, and fish bones.

The more radioactive black shale units of the Chattanooga in central Tennessee are composed of silt-sized grains of quartz (about 25 percent), clay, feldspar, and mica (about 35 percent), organic matter (about 20 percent), pyrite (about 15 percent), and minor amounts of chlorite, phosphatic material, calcite, and heavy minerals. The rock yields 3 to 15 gallons of oil per short ton by destructive distillation.

The uranium content ranges from 0.001 to 0.035 percent and is remarkably persistent and uniform, as are the lithologic units, over large areas. In central Tennessee an upper member of predominantly black shale, about 15 feet thick, averages about 0.007 percent uranium, and a coalified plant fragment from this area contained 0.035 percent uranium. Parts of the Woodford chert in southeastern Oklahoma contain as much 
as 0.008 percent uranium, but the average content of known units of minable thickness does not exceed 0.005 percent uranium. In central Texas an irregularly distributed unit of black shale, correlated with and megascopically similar to the Chattanooga shale, is about 5 feet thick and contains an average of 0.008 percent uranium. Phosphate nodules in the Chattanooga and its equivalents contain as much as 0.013 percent uranium, but, at least in the Southeastern States, their average content is less than that of the enclosing shale. In areas where gray shales are more abundant, and where sandstones, calcareous siltstones, or limestone lenses are common, the formation generally contains 0.001 to 0.003 percent uranium. A direct relationship appears to exist between the uranium and organic content, and between the uranium and the pyrite (although the uranium is not contained in the pyrite).

The Chattanooga shale and its correlatives accumulated in a widespread, relatively shallow, epicontinental sea that covered a vast area of the North American continent. It was deposited under conditions that resulted in extremely slow accumulation of mineralbearing detritus and proportionately high accumulation of carbonaceous debris. Presumably uranium in solution in the sea was absorbed by the organic debris.

\section{MIDCONTINENT SHALES OF PENNSYLVANIAN AGE}

Approximately 2,500 feet of gently dipping rocks of Pennsylvanian age are exposed in eastern Kansas (Moore and others, 1951) and parts of Oklahoma and Missouri nearby. Marine black shale beds, generally only a few feet thick, are scattered throughout the sequence; many of them are units of cyclic deposition that include sandstone, coal, and limestone.

About 20 of these black shale beds are abnormally uraniferous, containing more than 0.003 percent uranium; several contain 0.010 percent uranium; and, locally at least, beds of black shale 0.5 to 2.0 feet thick contain as much as 0.017 percent uranium, as in the Pleasanton group of late Pennsylvanian age. Most of the thin coal beds are practically nonradioactive, the highest known uranium content being 0.002 percent. The rest of the lithologic units are in effect nonuraniferous.

Many of these black shales of Pennsylvanian age are characterized by irregularly distributed small phosphatic concretions or nodules, containing as much as 30 percent $\mathrm{P}_{2} \mathrm{O}_{5}$, and, at some localities, making up as much as 5 percent of the thin shale beds. The radioactivity of the nodules is generally higher than that of the enclosing shale, their average equivalent uranium content being about 0.035 percent and the average uranium content 0.015 to 0.020 percent. A few samples of phosphatic nodules contained slightly less than 0.1 percent uranium. Except for the general observation that the nodules are typically present in the uraniferous black shales, no correlation appears to exist between the abundance of the nodules and their uranium content; nor does their uranium content appear to be related to the thickness, lithology, and uranium content of the enclosing shales.

Of the several black shales of Pennsylvanian age in the southeastern Kansas area that are abnormally uraniferous, only two are mentioned here to illustrate their geologic characteristics and distribution.

The Hushpuckney shale member of the Swope limestone (upper Pennsylvanian) of Moore (1933) is composed of an upper unit of almost nonradioactive greenish clay shale about 4 feet thick, and a lower unit of black fissile shale, devoid of phosphatic nodules, about 2 feet thick; the member is both overlain and underlain by persistent but thin limestone units. This uraniferous black shale crops out from southeastern Kansas northnortheastward into Missouri, and analyses of scattered samples suggest that this shale contains about 0.010 percent uranium throughout most of this area. It is present westward in the subsurface for 100 or more miles, but its radioactivity beyond the outcrop is not known.

The Cherokee formation of middle Pennsylvanian age is exposed in a belt about 25 miles wide cutting across the southeastern corner of Kansas and into adjacent parts of Missouri and Oklahoma. It is of cyclic deposition, the cycle being crudely repeated about 14 times and generally consisting of sandstone, "underclay," coal, black shale, limestone, and claystone. Although the radioactivity of the Cherokee has not been systematically studied, most of the black shale units are uraniferous, and channel samples of a few beds as much as 2 feet thick contained 0.009 to 0.013 percent uranium; adjacent units, regardless of lithology, contain less than 0.002 percent uranium.

The thin but persistent units of black fissile shale in the Pennsylvanian indicate deposition in extremely shallow water, too shallow for circulation and effective wave or tidal action (Moore, 1929, p. 459-487). The influx of sediment into the wide expanse of the shallow seas was apparently meager, and the reducing environment in the lower waters of the sea permitted the slow accumulation and preservation of organic debris. Available uranium in the sea water was adsorbed in this bottom sludge, and a chemical exchange bonded the uranium and the phosphate during the accretionary growth of the nodules. Apparently, slight but widespread, tectonic movements permitted oxygenation of the waters, destroying the environment favorable for 
the accumulation of carbonaceous material and uranium and permitting the deposition of calcium carbonate.

Several thin beds of marine black shale in the subsurface Hartville formation of Pennsylvanian age in eastern Wyoming and western Nebraska contain as much as 0.019 percent uranium. The most radioactive shales are several thousand feet below the surface in eastern Niobrara and Goshen Counties of easternmost Wyoming and western Sioux County in westernmost Nebraska, as indicated by samples and gamma-ray logs from a few wells. The subsurface distribution of these abnormally radioactive shales has not been fully defined, but they are not present in the outcrop area of the Hartville uplift 25 to 50 miles to the west in Wyoming, where their stratigraphic equivalents are dolomitic rocks.

Available data show that the midcontinental black shale beds less than 1 foot thick generally contain more than 0.01 percent uranium, but the thicker beds, which may be as much as 10 feet thick, generally contain 0.005 percent uranium or less. This relationship between uranium content and thickness and the lateral change from black shale into dolomitic facies in Nebras$\mathrm{ka}$ and Wyoming probably are the significant guides to the more uraniferous parts of these shales of Pennsylvanian age.

\section{PHOSPHATIC CARBONACEOUS SHALES, PHOS PHORIA FORMATION}

The rocks of the Phosphoria formation of Permian age, which are present in an area of some 100,000 square miles in Idaho, Montana, and Wyoming, are marine sediments that are significant because of their contained phosphate and uranium (McKelvey and Carswell, p. 483, this volume).

Two dark phosphatic shale members characterize the Phosphoria formation; chert, sandstone, and limestones make up the rest of it. The lower member is about 150 to 200 feet thick and contains as much as 38 percent $\mathrm{P}_{2} \mathrm{O}_{5}$ in southeastern Idaho, but the member oinches out in southern Montana, central Wyoming, and eastern Utah. Its average uranium content is about 0.010 percent, but some thin units contain as much as 0.033 percent uranium. The upper member is about 75 feet thick in southwestern Montana, but thins in most directions away from this area. The $\mathrm{P}_{2} \mathrm{O}_{5}$ content of minable beds is about 30 percent, and the uranium content is about 0.010 percent. Pyrite is an important constituent of both members.

The Phosphoria formation (Swanson, McKelvey, and Sheldon, 1953) may be roughly divided into a miogeosynclinal facies (Kay, 1947) on the west and a platform facies on the east. In the western facies the rocks are generally finer grained, principally dark phosphatic shales and cherts, and are thicker than in the eastern platform facies where conspicuous unconformities are common.

The organic and phosphatic material are apparently the constitutents that contain the uranium in the Phosphoria formation (Thompson, 1953); and as the phosphate and carbonaceous matter increase together, the uranium content increases also.

Although ideas of the configuration and depth of the Phosphoria sea differ, the coincidence of abnormal phosphate accumulation, preservation of carbonaceous matter, limited supply of fine-grained sediment, and high uranium content unmistakably suggest a genetic similarity to the other black shales described. Presumably the sediments accumulated more rapidly than most uranium-bearing shale, but possibly an accelerated supply of phosphate and plant material resulted in concentrations comparable to those in other uraniferous shales.

\section{OTHER URANIFEROUS SHALES}

The Sharon Springs member of the Pierre shale of Cretaceous age - a hard, black, pyritic, organic-rich shale similar to the Chattanooga shale-is slightly radioactive throughout a large part of South Dakota, Nebraska, northern Kansas, and northeastern Colorado (Tourtelot, 1956). The unit ranges in thickness from a few feet to about 500 feet. Thin beds of the shale locally contain as much as 0.01 percent uranium, but generally the content is less than 0.003 percent.

Several thin black shale beds in the Hermosa formation including the Paradox members of Pennsylvanian age in western Colorado contain from 0.003 to 0.004 percent uranium.

In the predominantly calcareous rock of Mississippian age in Montana and Utah, thin black shale beds are commonly present at the base of thick limestone units and in places contain 0.005 percent uranium or more (Mapel, p. 469, this volume).

In central Montana parts of the Heath shale of late Mississippian age contain as much as 0.009 percent uranium, the most highly uraniferous shale of any thickness being at one locality in Fergus County, where 4 feet of black shale near the top of the formation contains 0.006 percent uranium.

Along an abnormally radioactive outcrop area in central Texas the Barnett formation of middle Mississippian age includes thin beds of phosphatic black shale that contain about 0.015 percent uranium. One sample of phosphatic rock from this formation had as much as 33.8 percent $\mathrm{P}_{2} \mathrm{O}_{5}$ and 0.033 percent uranium.

Existing sample and analytical data on the many thick dark marine shales in the states bordering the Atlantic and Pacific Oceans are very meager, but, they, together with data obtained from radiometric traverses, 
indicate that these shales generally have less than 0.003 percent uranium. Those along the East Coast are mainly early Paleozoic in age, those along the West Coast chiefly late Paleozoic and Mesozoic.

\section{GEOLOGIC SIGNIFICANCE OF ABNORMALLY RADIO- ACTIVE SHALES}

The potential uranium content of marine black shales can be classified by their tectonic and paleogeographic environment during the time of accumulation. Four general categories of these shales correspond to four depositional environments: epicontinental areas, geosynclinal fringe areas, miogeosynclinal areas, and eugeosynclinal areas. The characteristics of each depositional area are described by Kay (1951).

Several formations composed in whole or in part of black shale can be assigned to each of the four categories of geologic environment. Those originating in epicontinental areas (or on the craton of Kay) are relatively thin formations having great horizontal extent, as exemplified by the Chattanooga shale and the shales of Pennsylvanian age already described. Between the epicontinental and miogeosynclinal areas is a belt where formations change rapidly in thickness and rock type; shales in the Hamilton and Marcellus formations of Devonian age in the eastern States can be considered typical of the geosynclinal-fringe deposits. Within the thick, predominantly clastic sequence of miogeosynclinal deposits, laid down in a belt lacking volcanism, the graptolitic shale of the Deepkill and Normanskill formations are examples. And, fourth, representative of the eugeosynclinal deposits, which typically are rapidly deposited sediments, measured in thousands of feet, that were laid down in belts of active volcanism, are the Mariposa slate and other dark argillites and siltstones common in the Mesozoic sequence in the West Coast region.

The general tectonic and paleogeographic category into which most uraniferous shales fall is that of the epicontinental area. This environment was common in much of the interior of the United States during several intervals of the Paleozoic. The long-term innundation of a broad expanse of a relatively flat surface, and the lack of a source of a large amount of clastic sediment made possible the development of specific geochemical conditions that controlled the accumulation and preservation of uraniferous carbonaceous muds.

\section{REFERENCES CITED}

Gott, G. B., and Hill, J. W., 1953, Radioactivity in some oil fields of southeastern Kansas: U. S. Geol. Survey Bull. 988-E, p. 69-122.

Hass. W. H., 1956, Age of the Chattanooga shale and Maury formation: U. S. Geol. Survey Prof. Paper 286 (in press).

Johnson, J. C., 1955, Uranium resources for industrial power: U. S. Atomic Energy Comm. press release (April 5, 1955).

Kay, G. M., 1947, Geosynclinal nomenclature and the craton: Am. Assoc. Petroleum Geologists Bull. v. 21, no. 10, p. 1289-1293.

1951, North American geosynclines: Geol. Soc. America Mem. 48, 143 p.

McKelvey, V. E., and Nelson, J. M., 1950, Characteristics of marine uranium-bearing sedimentary rocks: Soc. Econ. Geologists Bull. 45, p. 35-53.

Moore, G. W., 1954, Extraction of uranium from aqueous solutions by coal and some other materials: Soc. Econ. Geologists Bull. v. 49 , p. $652-658$.

Moore, R. C., 1929, Environment of Pennsylvanian life in North America: Am. Assoc. of Petroleum Geologists Bull. v. 13, no. 5 , p. $459-487$.

- 1933, A reclassification of the Pennsylvanian in the northern Midcontinent region: Kansas Geol. Soc. Guidebook, 6th Ann. Field Conf. p. 79-98.

Moore, R. C., and others, 1951, the Kansas rock column: Kan. State Geol. Survey Bull. 89, 132 p.

Swanson, R. W., McKelvey, V. E., and Sheldon, R. P., 1953, Progress report on investigations of western phosphate deposits: U. S. Geol. Survey Cire. 297.

Szalay, S., 1954, The enrichment of uranium in some brown coals in Hungary: Acta Geologica [Hungaricae], Magyar tudom. Akad. II, p. 299-310.

Thompson, M. E., 1953, Distribution of uranium in rich phosphate beds in the Phosphoria formation: U. S. Geol. Survey Bull. 988-D, p. 45-67.

Tourtelot, H. A., 1956, Radioactivity and uranium content of some Cretaceous shales, central Great Plains: Am. Assoc. Petroleum Geologists Bull. v. 40, no. 1, p. 62-83.

Twenhofel, W. H., 1939, Environments of origin of black shales, Am. Assoc. Petroleum Geologists Bull. v. 23, no. 8, p. 1178-1198. 


\title{
URANIUM IN THE CHATTANOOGA SHALE OF EASTERN TENNESSEE
}

\author{
By Andrew Brown, U. S. Geological Survey
}

\section{CONTENTS}

\begin{tabular}{|c|c|c|}
\hline & Page & \\
\hline Abstract.. & 457 & Uranium in the Chattanooga shale \\
\hline Introduction..... & 457 & Distribution \\
\hline Geography and topography. & 458 & Relations of uranium content to other constituents \\
\hline Stratigraphy ............. & 458 & $\begin{array}{l}\text { and characteristics of the shale................... } \\
\text { Origin of uranium in the shale }\end{array}$ \\
\hline Structure........ & 459 & $\begin{array}{l}\text { Origin of uranium in the shale } \\
\text { Conclusions... }\end{array}$ \\
\hline Composition of the shale & 459 & References cited.......... \\
\hline
\end{tabular}

FIGURE 159. Sketch map showing distribution of the most uraniferous part of the Chattanooga shale

Page

460

460

460

461

462

462

Page

458
ABSTRACT

The Chattanooga shale contains in places suffieient uranium to make it a potential low-grade ore. The most promising areas are the Eastern Highland Rim in Tennessee, between the Alabama State line and approximately the latitude of Smithville, and the Walden Ridge area east of the Sequatchie Valley, Tenn.

The Chattanooga shale in this area is of late Devonian age and is divided into the Dowelltown and Gassaway members. The Dowelltown, or lower, member is of no present interest as a source of uranium, only the Gassaway member being considered a potential source. The Gassaway member includes three units: a lower black shale 3.5 to 10.5 feet thick and averaging 7 feet; a middle unit composed predominantly of black shale, with minor thin beds of gray shale, averaging about 2.5 feet thick and thinning eastward; and an upper black shale from 2 to 8 feet thick and averaging 6 feet. In the Eastern Highland Rim the total thickness of the Gassaway ranges from 13.5 to 18.5 feet; the average is 16 feet in the Eastern Highland Rim. In Walden Ridge the range is 10 to 17 feet; the average is 14 feet.

The black shale units of the Chattanooga are nearly massive in appearance and the rock breaks with a conchoidal fracture, but weathered outcrops show a marked fissility and a thin coating of iron oxide. Data from many outerops and drill holes show that the Gassaway as a whole contains from 0.005 to 0.008 percent uranium. The highest average uranium content is in the upper unit; the lowest content is in the middle unit. The lower unit is of intermediate grade.

The lateral distribution of uranium in each unit of the Gassaway in eastern Tennessee is remarkably uniform, though it is, somewhat higher than average in an area southeast of Smithville, and in Walden Ridge.

No uranium minerals have been identified in the shale, and the form in which the element occurs is not now known. It is considered to be of syngenetic origin.

\section{INTRODUCTION}

The uraniferous Chattanooga shale is one of the bituminous shales of Late Devonian and early Mississippian age which were deposited over much of the central United States from New York to Texas. Over this wide region the shale sequence varies widely in lithology and thickness and is known by several formational names. The name Chattanooga is used for this bituminous shale sequence in a large area including Tennessee, Arkansas, and adjoining States.

Reconnaissance in 1942 around the Nashville dome, now a topographic basin, showed that the Chattanooga shale is much more radioactive than other rocks in the area. Investigations in 1947 and later showed that the most uraniferous shale is in the Eastern Highland Rim of Tennessee and in Walden Ridge north and west of the city of Chattanooga; the favorable area also may extend southward into Alabama. This report is therefore concerned with the roughly triangular region bounded on the southeast by the folded Appalachians of Tennessee and Alabama, and on the west by the axis of the Nashville dome. The northern boundary is somewhat indefinite but follows in a general way the route of Tennessee Highway 26 and U. S. Highway 70 from Smithville, through Crossville to the Cumberland escarpment south of Rockwood (fig. 159). South of that line, the Chattanooga shale is generally less than 35 feet thick; to the north it thickens rapidly. 
The geologic investigation of the Chattanooga shale was in charge of L. C. Conant. His contributions to this report, and those of W. H. Hass, R. C. Robeck, and R. E. Smith, who assisted in the field work, are gratefully acknowledged.

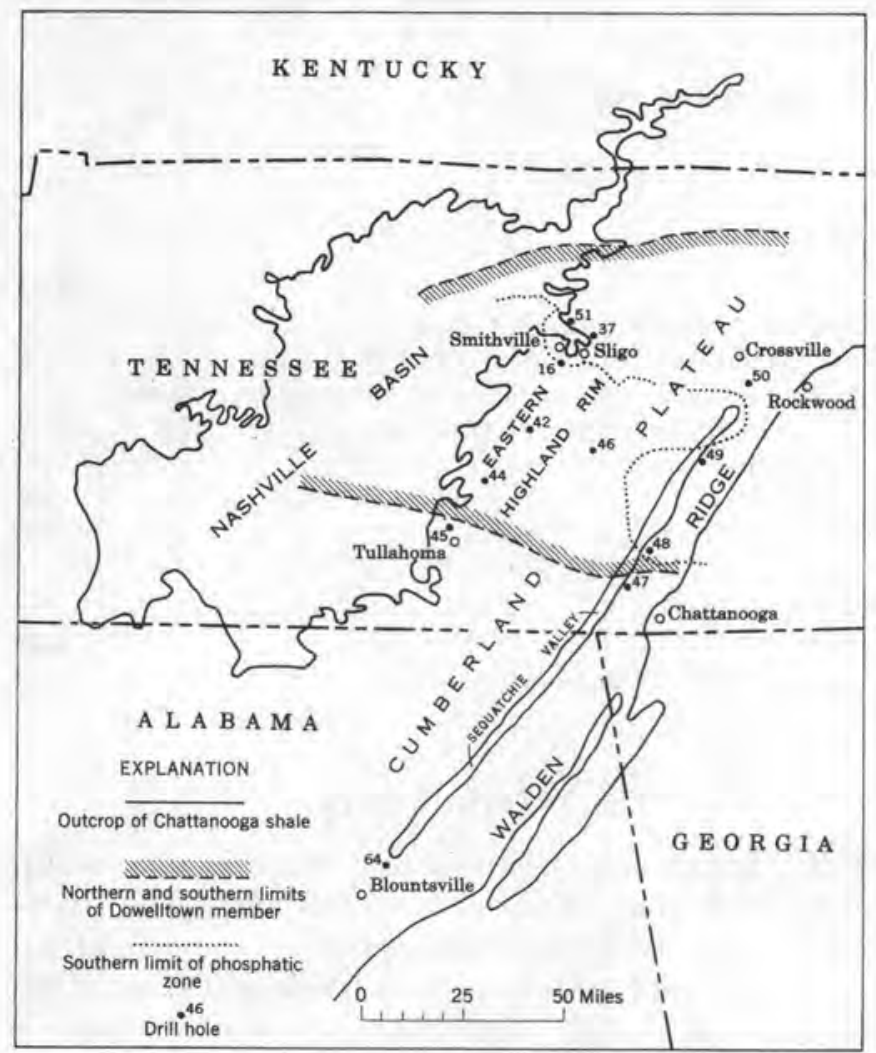

FIGURE 159,-Sketch map showing distribution of the most uraniferous part of the Ohattanooga shale.

\section{GEOGRAPHY AND TOPOGRAPHY}

The Nashville Basin extends across the State of Tennessee in a northeasterly direction and is about 125 miles long and 60 miles wide. Structurally it is a domal part of the Cincinnati arch (Wilson, 1949, p. 407). The present lowland surface is about 500 feet above sea level and is underlain by bevelled limestones of Ordovician age. The Highland Rim is a topographic terrace, averaging about 25 miles in width, and surrounds the basin. The part east of the basin, known as the Eastern Highland Rim, rises 500 to 600 feet above the basin floor. The edge of the Highland Rim is highly dissected and many outcrops of the Chattanooga shale are well exposed. To the east of the rim the topography rises 900 to 1,000 feet to the Cumberland Plateau, which extends eastward to the folded rocks of the Tennessee River valley. The plateau is cut by the anticlinal Sequatchie River valley, parallel to and about 25 miles west of the edge of the Cumberland Plateau (fig. 159). East of the valley is Walden Ridge, a shallow syncline of about the same height as the plateau, in the western side of which the Chattanooga shale is exposed.

The Chattanooga shale underlies the Eastern Highland Rim, the Cumberland Plateau proper, and Walden Ridge and apparently has much the same composition and thickness throughout the entire region.

\section{STRATIGRAPHY}

In the Eastern Highland Rim the Chattanooga shale rests on the Leipers limestone of Late Ordovician age and in Walden Ridge on Silurian rocks. The shale was deposited on a very flat surface; the relief at the most was a few tens of feet (Wilson, 1949).

The Chattanooga shale is of Late Devonian age and consists of two members, the Dowelltown and the Gassaway, each containing several units (Campbell, 1946, p. 829-908.)

The Dowelltown member consists from oldest to youngest, of three units: basal sandstone, lower black unit, and middle gray unit.

The basal sandstone is a fine-grained conglomerate commonly 2 inches or less in thickness. The lower black unit is a tough, black, relatively thin-bedded bituminous shale that underlies part of the Eastern Highland Rim. It is absent south of Tullahoma and north of a line about 20 miles south of the KentuckyTennessee State line (fig. 159). It was thus deposited in a trough about 75 miles wide, the eastern and western limits of which cannot now be determined. In the central part of this trough the lower black unit is commonly 6 to 7 feet thick, though thicknesses of 4 and 12 feet are known.

The middle gray unit is a series of interbedded gray and black shales forming the top of the Dowelltown member. Gray beds comprise about three-fourths of the unit; black beds, generally 2 inches thick or less, are abundant in the lower and upper thirds. A persistent 0.1-foot of bentonite near the top of the unit is a useful stratigraphic marker (Hass, 1948, p. 816-819). The thickest measured sections of the middle gray unit in the Eastern Highland Rim are about 12 feet thick and in Walden Ridge about 5 to 6 feet thick. Like the lower black unit, the middle gray unit thins to both the north and south and is absent not far beyond the limits of the lower black unit.

The Gassaway member comprises, from oldest to youngest, four units: the middle black unit, upper siltstone, top black unit, and phosphatic zone. The middle black unit is a black, butuminious shale similar to the lower black unit of the Dowelltown member but somewhat thicker bedded. It is 7 to 8 feet thick near Smithville, but thins to the north, south, and possibly east. 
Overlying the middle black unit is the upper siltstone, a black shale sequence that contains a few thin beds of gray shale or siltstone. It is 2 to 3 feet thick in the vicinity of Smithville but thins to the west, south, and north. It has not been recognized south of Tullahoma. In Walden Ridge the gray beds, though recognizable in some drill cores, are hard to detect at the outcrops.

The top black unit of the Gassaway member is the most widespread and most uraniferous unit of the Chattanooga shale. It is darker than the other "black" units, and its outcrops are commonly massive. It is 4 to 10 feet thick. Local differences in thickness are interpreted as being due to local erosion of the top of the unit. This variation in thickness, together with paleontologic data (Hass, 1953), indicates a minor unconformity at the top of the Gassaway member south of Smithville and in Walden Ridge.

North of the Smithville-Rockwood line, at a few localities to the south, and in parts of Walden Ridge, the massive top black unit is overlain by somewhat lighter colored shales that contain scattered phosphatic nodules. The nodules are commonly about 1 inch in diameter but some are larger. The contact between the top black unit and the phosphatic zone is not sharp but can be detected in the field by the difference in color of the rocks and the presence or absence of the nodules.

In summary, the Chattanooga shale in the Eastern Highland Rim and Walden Ridge areas has a maximum thickness of about 35 feet. The Dowelltown member reaches a maximum thickness of about 18 feet; the Gassaway member ranges from 7 feet near Tullahoma to 18 feet near Smithville and from 11 to 21 feet in Walden Ridge.

The Chattanooga shale is immediately overlain by the soft, light-green shale of the Maury formation which weathers to yellow or brown. Locally, the base of the Maury in the northern part of the area is a 4-inch to 2 -foot bed of large, flattened phosphatic nodules in black shale. Hass (1953), on the basis of its conodont fauna, considers this bed.to be of latest Devonian age. He assigned the green shale, also from fossil evidence, to early Mississippian.

In the Eastern Highland Rim and Walden Ridge the Maury formation is from 1 to 3 feet thick. It is overlain by the Fort Payne chert, which forms cliffs along the Eastern Highland Rim and Walden Ridge.

\section{STRUCTURE}

The Chattanooga shale dips eastward from the axis of the Nashville dome to the Sequatchie Valley at the rate of about 30 feet to the mile. Folds in the monocline trend northeast and are of minor importance.
The highest observed local dips are about $5^{\circ}$. The one fault observed, though others are doubtless present, has cut out all but 3 feet of the Chattanooga shale by horizontal thrusting.

The monoclinal structure is broken along the west side of the Sequatchie Valley by the Sequatchie fault, overthrust from the southeast. The fault brings the Chattanooga shale, which is under about 2,000 feet of cover west of the valley, to the surface in its eastern escarpment, Walden Ridge. In the ridge the Chattanooga shale dips southeast at an average rate of about $8^{\circ}$, the maximum observed dip being $15^{\circ}$. All outcrops in Walden Ridge are fractured but cores from drill holes not far behind the outcrops show less disturbance of the rocks than the exposures would indicate.

\section{COMPOSITION OF THE SHALE}

The predominant components of all units of the Chattanooga shale are fine silt and clay particles, most of which could have been transported by either wind or water. The black units contain abundant pyrite and organic material (Rich, 1951, p. 2017-2040; Strahl, Silverman, O'Neill, and others, 1955), some in the form of plant debris but most as a translucent, yellow or brown material known as kerogen. The gray units contain much smaller quantities of carbonaceous matter and pyrite than do the black beds.

Analyses of two cores from drill holes about 5 miles apart between Smithville and Sligo (fig. 159) show that silicates make up the bulk of all units of the Chattanooga shale, and that pyrite and carbon are next in importance. The amounts of these constituents are shown below (Strahl, Silverman, O'Neill, and others, 1955):

Silicate, pyrite, and carbon content of the units of the Chattanooga

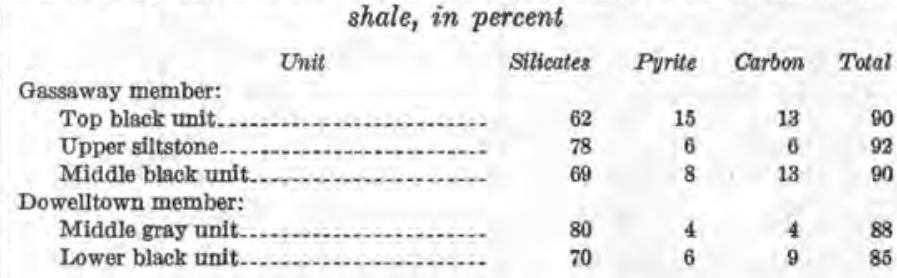

The amount of silica varies in indirect proportion to the amount of pyrite and carbon in all units, but particularly in those of the Gassaway member. The pyrite and carbon content of the upper siltstone in these cores probably is lower than it is in the Eastern Highland Rim as a whole, as the gray beds of the unit are best developed in the Smithville area.

Kerogen, which makes up much of the organic material in the shale, is derived largely from spores. In the lower part of the shale Foerstia, a planktonic marine algae, is common, and rarely a large algoid plant, 
Prototaxes, has been found. The most common woody material, both silicified and as bituminous coaly streaks, is drift wood of Callixylon. Most of the uranium-rich stringers formerly identified as asphaltite are now known to be Callixylon fragments (Schopf, 1953 , p. $146-152)$.

Semiquantitative spectrographic analyses of three cores of the total thickness of the Chattanooga shale and 15 cores across the Gassaway member show that the chemical composition of the shale is fairly constant, both vertically and laterally, from northeast of Smithville (holes 37 and 51, fig. 159) to the vicinity of Blountsville, Ala. (hole 64, fig. 159) and in Walden Ridge (holes 48 to 50, fig. 159). The amount of the following elements is in percent:

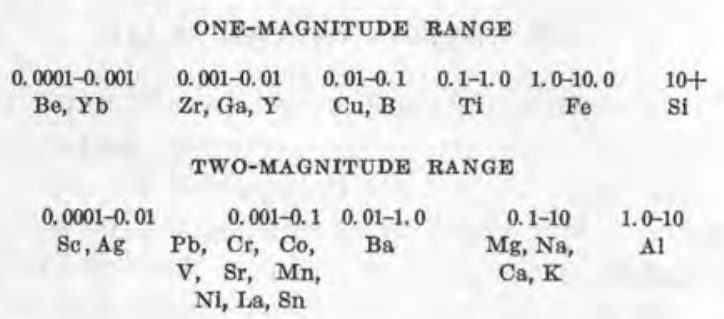

The abundance of cobalt, molybdenum, and nickel in the middle gray shale is one order of magnitude below the average -0.01 percent - of the other units. The vertical distribution of elements in the Gassaway is uniform except that aluminum is less than 10 percent in most samples of the top black unit, and is more than 10 percent in the other units. The barium content is more than 0.1 percent in the top black unit and less than 0.1 percent in the lower units. Strontium is most abundant -0.001 percent-in the top black unit. The amount of calcium in about half of the samples is more than 1.0 percent and apparently is never as much as 2 percent.

Variations in the content of minor constituents are greater laterally in the Chattanooga than the changes across its Gassaway member. The amounts of lead, cobalt, and sodium in samples from the Eastern Highland Rim vary in indirect proportion to the amount of vanadium. Magnesium, sodium, lead, manganese, and strontium are more abundant in rocks from hole 49 in Walden Ridge than in hole 48 to the south and hole 50 to the north.

Lanthanum was found only in holes 48 and 50 in Walden Ridge and in hole 42 in the Eastern Highland Rim; silver occurs only in holes 48,49 , and 50 in Walden Ridge and holes 44, 45, 64, and 51 in the southern part of the Eastern Highland Rim; and tin is found in all holes in the Eastern Highland Rim and in hole 49 in Walden Ridge. No correlations can be made between uranium and minor metal content.

\section{URANIUM IN THE CHATTANOOGA SHALE}

\section{DISTRIBUTION}

All units of the Chattanooga shale contain more uranium than most marine shales, but the content varies considerably from unit to unit as shown below.

\begin{tabular}{|c|c|}
\hline assaway member: & $\begin{array}{l}\text { Range of } \\
\text { uranium } \\
\text { content, } \\
\text { in percent }\end{array}$ \\
\hline Phosphatic zone & $0.0016-0.0036$ \\
\hline Top black unit.- & $.0060-.0086$ \\
\hline Upper siltstone & $.0028-.0058$ \\
\hline Middle black unit & $.0039-.0066$ \\
\hline \multicolumn{2}{|l|}{ Dowelltown member: } \\
\hline Middle gray unit. & $.0011-.0020$ \\
\hline Lower black unit. & $.0024-.0052$ \\
\hline
\end{tabular}

The wide range of uranium content in the upper siltstone unit reflects the relative abundance of interbedded gray, slightly uraniferous shale in that unit.

The presence of the thick, almost barren middle gray unit above the relatively thin lower black unit rules out the Dowelltown member as a source of uranium, and only the Gassaway member can be considered a potential producer under present conditions.

Throughout most of the Eastern Highland Rim area the highest uranium content of the Gassaway member is in the upper part of the top black unit. At the northernmost and southernmost holes in Walden Ridge (holes 47 and 50, fig. 159) the vertical distribution of uranium is the same as in the Eastern Highland Rim. In the central area (holes 48 and 49 ) the high uraniumcontent zone parallels the bottom of a tongue of the phosphatic zone. The upper siltstone is not conspicuous in Walden Ridge, and the Gassaway member beneath the phosphatic zone is about 20 percent higher in uranium content than is the same member in the Eastern Highland Rim.

No uranium minerals have been identified in the shale. The element is present as a separate colloidal phase disseminated through the organic matrix and is not chemically combined with the organic matter (Deul and Breger, 1955, p. 187-189). Autoradiographic studies by Bates, Strahl, Short, and others (1954) demonstrate that the alpha-particle source material is localized around concentrations of organic matter and pyrite.

RELATIONS OF URANIUM CONTENT TO OTHER CONSTITUENTS AND TO CHARACTERISTICS OF THE SHALE

Uraniferous black shales are generally characterized by the relative thinness of the formations, fairly higb phosphate content or the presence of phosphatic nodules, high oil content and low calcium content, (McKelvey, Everhart, and Garrels, this volume, p. 41). The Chattanooga shale is very thin and has a low cal- 
cium content. The phosphate and oil contents of the rock, however, are relatively low and in these two ways the Chattanooga differs from the "typical" uraniferous black shale as described above and by other writers.

The relation between the thinness of the Chattanooga shale and its uranium content is obvious; the 35 -foot thickness of the formation represents all of Late Devonian time and is equivalent to 10,000 or more feet of sediments in other areas (Rich, 1951). Thinness, however, is only one factor, as the distribution of uranium in the Chattanooga shale itself shows. The formation is of about the same thickness on all sides of the Nashville dome; yet the uranium content is much higher on the eastern side of the dome than elsewhere.

The most uraniferous part of the Chattanooga shale contains only 0.2 to 0.3 percent phosphate and does not contain visible phosphatic nodules. West of Nashville, where such nodules occur near the base of the formation, the uranium content is low. The phosphatic zone on the Highland Rim and in Walden Ridge also contains appreciably less uranium than do the other black units of the formation.

The oil content of the most uraniferous part of the Chattanooga shale, the top black unit of the Gassaway member, appears from scattered analyses to be less than the average for the Gassaway member or for the lower black unit of the Dowelltown member (Cuttitta, 1951).

A rough correlation between the relative blackness of the shale and its uranium content was noted in the field; in general, the darker the color, the higher the uranium content. Reflectance studies by Flanagan (1953), p. 163-164) and Bates, Strahl, Short, and others (1954) confirm this relationship.

The color of the shale is a factor of its carbon and sulfide content. One of the first correlations noted by students of uraniferous black shales was that between uranium and carbonaceous material, particularly bituminous material (McKelvey and Nelson, 1953, p. 3553). Analyses of 24 samples taken in 1948 from various localities and different units of the Chattanooga shale show a direct relation between the contents of total sulfur and uranium. Recent studies by Bates, Strahl, Short, and others (1954) show high correlations between uranium and pyrite and uranium and carbon, and low correlations between uranium and the other components of the shale. It thus seems clear that the concentration of uranium in the Chattanooga is associated with pyrite and carbonaceous materials, and not with other constituents of the rock.

\section{ORIGIN OF URANIUM IN THE SHALE}

The hypothesis that uranium in black shales was concentrated by means of upwelling of currents from oceanic depths upon a continental shelf (McKelvey,
Everhart, and Garrels, this volume) can hardly be applicable to the Chattanooga shale. Although the southeastern limit of the Chattanooga sea cannot be determined because of later structural changes, the preponderance of evidence points to deposition of the shale in a landlocked, comparatively shallow sea. The uraniferous Eastern Highland Rim-Walden Ridge area was apparently in the central and deepest part of this sea, as evidenced by the small amount of coarse clastic material it contains and the fact that the shale is noticeably sandier toward the west (Mellen, 1947, p. 1811) and north (Maher, 1954). Lack of circulation on the bottom of such a sea would provide anaerobic conditions and permit carbonaceous material, which has a strong affinity for uranium, to accumulate.

The relatively nonuraniferous gray beds in the upper siltstone have been generally considered to represent periods when additional clastic material was brought into the sea. These beds, however, are best developed near Smithville and thin in all directions from that central area. They thus may represent periods during which the reducing conditions within the sea were halted for short periods and replaced by oxidizing conditions. This could have been accomplished by (1) periods of storm which would have introduced oxygen into the water, (2) influx of water into the epicontinental sea which would have provided more bottom circulation, or by (3) conditions unfavorable for plant life in the sea and on the surrounding land. The same hypothesis may, to a certain extent, be applicable also to the middle gray unit of the Dowelltown member.

Phosphate is formed in shallower, better aerated water than the nonphosphatic black shales (McKelvey, Everhart, and Garrels, p. 41, this volume). Thus the extreme reducing conditions which permitted concentration of uranium in the shales of the Eastern Highland Rim-Walden Ridge area probably did not prevail west of the Nashville dome when the phosphatic part of the Chattanooga shale was deposited there, nor in the northeast when the phosphatic zone was laid down. This change in environment could account for the lower uranium content of those units as compared to the blacker shales.

The suggestion (McKelvey, Everhart, and Garrels, p. 41 , this volume) that the high uranium content of certain black shales represents concentration of only normal quantities of the element in sea water over tremendously long periods of geologic time, and that no particularly uraniferous source material is necessary, may not apply to the Chattanooga shale; other black shales formed under much the same conditions are not nearly so uraniferous. It has been suggested that the granitic landmass of Appalachia east of the Chattanooga sea could have provided more than average 
amounts of uranium; another possible source is volcanic ash. The bentonite bed in the Chattanooga shale is evidence of volcanic activity, and Rich (1951, p. 20172040) has noted that some of the clastic material throughout the Chattanooga shale is of possible volcanic origin. It is altogether likely that small quantities of ash fell into the sea almost continuously during Chattanooga time and increased the amount of uranium available for concentration. Streams also could have brought in ash from the surrounding land.

\section{CONCLUSIONS}

Conclusions drawn from field and laboratory studies of the Chattanooga shale in the Eastern Highland Rim and Walden Ridge are:

1. The Chattanooga shale differs from "typical" uraniferous black shale in its'low content of phosphate and oil.

2. Only the upper, or Gassaway, member of the formation is of present interest as a potential source of uranium.

3. The phosphatic part of the shale contains considerably less uranium than the other black units of the formation.

4. The uranium in the shale is associated with carbon and pyrite, and no relationship between uranium and other constituents has been observed.

5. The uranium was probably concentrated under anaerobic conditions in the central part of a practically landlocked sea. Some of the uranium may have entered the sea in volcanic ash.

\section{REFERENCES CITED}

Bates, T. F., Strahl., E. O., Short, N. M., and others, 1954, Mineralogy and petrography of the Chattanooga shale: Geol. Soc. America Bull., v. 65, p. 1230.

Campbell, Guy, 1946, New Albany shale: Geol. Soc. America Bull., v. 57, p. 829-908.
Cuttitta, Frank, 1951, A photometric method for the estimation of oil shale yield: U. S. Geol. Survey TEI-152, 30 p., issued by U. S. Atomic Energy Comm. Tech. Inf. Service, Oak Ridge, Tenn.

Deul, Maurice, and Breger, Irving, 1955, Geochemistry of uranium-bearing carbonaceous rocks, in Geologic investigations of radioactive deposits - Semiannual progress report, December 1, 1954 to May 31, 1955: U. S. Geol. Survey TEI-540, p. 183-190, issued by U. S. Atomic Energy Comm. Tech. Inf. Service, Oak Ridge, Tenn. (See p. 187-189 on uranium in black shales.)

Flanagan, F. J., 1953, Relationship of color of shale to uranium content, in Geologic investigations of radioactive deposits Semiannual progress report, June 1 to November 30, 1953: U. S. Geol. Survey TEI-390, p. 163-164, issued by U. S. Atomic Energy Comm. Tech. Inf. Service, Oak Ridge, Tenn.

Hass, W. H., 1948, Upper Devonian bentonite in Tennessee: Am. Assoc. Petroleum Geologists Bull., v. 32, no. 5, p. 816-819.

1953, Age of the Chattanooga shale and the Maury formation: Geol. Soc. America Bull., v. 64, p. 1532.

Maher, S. W., 1954, Sandy zones in the Chattanooga of the Eastern Highland Rim, Tennessee: Geol. Soc. America Bull., v. 65 , p. 1363 .

McKelvey, V. E., and Nelson, J. M., 1953, Characteristics of marine uranium-bearing sedimentary rocks: Econ. Geology, v. 45 , p. $35-53$.

Mellen, F. F., 1947, Black Warrior Basin, Alabama and Mississippi: Am. Assoc. Petroleum Geologists Bull,, v. 31, no. 10, p. 1801-1816.

Rich, J. L., 1951, Probable fondo origin of Marcellus-Ohio-New Albany-Chattanooga bituminous shales: Am. Assoc. Petroleum Geologists Bull., v. 35, p. 2017-2040.

Schopf, J. M., 1953, Organic matter of the Chattanooga shale, in Search for and geology of radioactive deposits-Semiannual progress report, December 1, 1952 to May 31, 1953: U. S. Geol. Survey TEI-330, p. 146-152, issued by U. S. Atomic Energy Comm. Tech. Inf. Service, Oak Ridge, Tenn.

Strahl, E. O., Silverman, E. N., O'Neil, R. L., and others 1955 , An investigation of the mineralogy, petrography and paleobotany of uranium-bearing shales and lignites. Scope A-shales. Fourth Annual Report. Period of April 1, 1954 to March 31, 1955: U. S. Atomic Energy Comm. NYO-6068, $79 \mathrm{p}$.

Wilson, C. W., Jr., 1949, Pre-Chattanooga stratigraphy in central Tennessee: Tenn. Dept. Conserv. Div. Geology, Bull. 56, $407 \mathrm{p}$. 


\title{
ENVIRONMENT OF ACGUMULATION OF THE GHATTANOOGA SHALE
}

\author{
By Louis C. Conant, U. S. Geological Survey
}

\section{CONTENTS}

\begin{tabular}{|c|c|c|c|}
\hline & Page & & Page \\
\hline ........................... & 463 & Inferences regarding environment of accumulation....... & 465 \\
\hline Description of the Chattanooga shale & 464 & References cited. & 467 \\
\hline
\end{tabular}

Figure 160. Setting of the Chattanooga shale

\section{ABSTRACT}

The black Chattanooga shale in Southeastern United States accumulated slowly on an extensive peneplain that was gradually inundated by a sea that had an irregular shoreline, scattered islands, a gently sloping bottom, and distant connections with the ocean. Some of the shale must have accumulated soon after submergence in shallow water, for it is separated from the underlying formations of Ordovician and Silurian age only by a basal sandstone a few millimeters thick, and locally even that is absent. Other considerations suggest that the sea was shallow at all times.

Studies of the conodonts by W. H. Hass indicate that the 30 to 35 feet of shale represents most of Late Devonian time. The presence of the conodonts and of assorted other marine fossils shows connections with the ocean. Abundant plant remains, a pyrite content of 10 percent, and the absence of calcareous detritus indicate a reducing environment. A thin oxygenated upper zone, however, must have supported both plant and animal life.

Sluggish streams from surrounding lowlands, gentle sea drift, and winds probably brought only small amounts of sediment to the area. According to J. M. Schopf, the plant matter is a mixture of planktonic marine organisms and land plants, and includes spores, macerated particles of Foerstia, and logs of Callixylon several feet long and a few millimeters thick.

Though shallow, the sea was rarely agitated enough to disturb greatly the bottom muds. Those muds, however, were agitated gently and repeatedly so that they are well stratified, and they shifted sufficiently to fill any areas that subsided more rapidly. Scour channels and other evidences of strong agitation of the bottom muds are present locally, but are not common. The absence of strong wave action on the bottom, in spite of the size of the sea, is explained by the gently sloping bottom, irregular shore, scattered islands, and abundant planktonic life.

The uranium was probably abstracted from the sea water by the organic matter, presumably the plants, which had ample time to become uraniferous before burial. The uranium concentration is believed to result from the abundant plant matter and relatively small amount of mineral matter. Some of the logs, which are now films of high-volatile bituminous coal, contain as much as 0.02 percent uranium, which is several times the uranium content of the shale, probably because of longer exposure to the sea water and the absence of mineral matter.

\section{INTRODUCTION}

The black Chattanooga shale of Soutbeastern United States is clearly of marine origin. For many years geologists have argued whether it is of Devonian or Mississippian age, and whether it accumulated in a shallow or deep sea. Recent studies of conodonts by W. H. Hass (1953) have apparently fixed the age in central Tennessee as Late Devonian, but the question of depth of water is still debated. This report presents evidence that the sea was shallow.

This discussion concerns only that part of the Chattanooga shale in the Southeastern United States in and near Tennessee (fig. 160), where the shale underlies

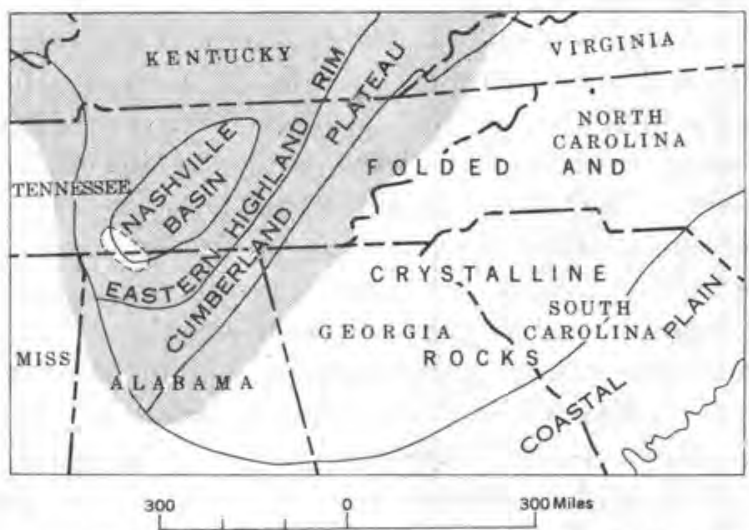

FigURE 160.- Setting of the Chattanooga shale. Shading shows the supposed approximate area of shale accumulation. 
about 40,000 square miles (about 100,000 square kilometers). The shale is unusual because of its lithologic and stratigraphic uniformity, its thinness, and its uranium content. Also notable is the remarkably smooth peneplain on which the shale was deposited. Before deposition of the shale the Nashville arch, which dominates the regional structure, had already undergone some of its many uplifts and had been peneplained. This erosion surface beveled gently dipping limestones, shales, and sandstones ranging in age from Middle Ordovician to Early Devonian; yet rarely does an outcrop 100 feet long show even a few inches of irregularity.

To the northeast an ancient Appalachian upland was supplying sediments to a submerging trough on its western side. To the west was the upland of Ozarkia. The peneplain lay between those two widely separated uplands.

\section{DESCRIPTION OF THE CHATTANOOGA SHALE}

The Chattanooga shale consists mostly of fine-grained black shale, but throughout large areas the upper part is more massive and is separated from the lower part by an apparent minor diastem. The lower part is the Dowelltown member, the upper the Gassaway member. This terminology is adapted from Campbell (1946). In the Eastern Highland Rim area of Tennessee two units are present in which gray claystone is interbedded with black shale. This makes it possible to divide the Chattanooga further into 5 traceable units, 2 in the Dowelltown, 3 in the Gassaway. Recognition of these units permits easy regional correlation of the shale and aids in interpreting the depositional history. A bentonite bed, about an inch thick, near the top of the Dowelltown member is an especially valuable marker (Hass, 1948).

A few scour channels as much as a foot deep and a few tens of feet wide have been found in the Chattanooga shale, but such evidence of contemporary erosion of the beds is not common.

The lower parts of the Chattanooga shale, especially the Dowelltown member, are absent at many places, notably to the south, but no place is known where the Gassaway member is absent and the lower part is present. The topmost beds of the Gassaway, however, which are marked by scattered phosphate nodules and by a different conodont fauna, are not present in part of Tennessee and in the area farther south. This may indicate an inconspicuous hiatus at the top of the Chattanooga. Everywhere the shale is overlain abruptly by a greenish-gray claystone unit only about 1 to 6 feet thick, and this claystone unit by chert, gray shales, and limestones, all of early Mississippian age (Kinderhook and Osage). The conodont faunas (Hass, 1953) indicate that the Chattanooga shale, thin as it is, represents most of the Upper Devonian series. D. H. Dunkle (personal communication) has identified bones of Dinichthys terreli and scales of the ray-fin fishes Rhadanichthys devonicus and $R$. antiquus from a rare bone assemblage at one place near the top of the formation. These vertebrates indicate a Late Devonian age. Other marine organisms include radiolaria (Henbest, personal communication), Lingula, and Orbiculoidea. It is apparent that the Chattanooga sea was connected with the open ocean, presumably continuously and perhaps at a considerable distance.

The identifiable plant matter (Schopf, personal communication) includes marine spores, macerated particles of Foerstia, Protosalvinia, and Prototaxites, and the land spores Tasmanites. Logs of Callixylon have been found that are several feet long, a foot or more wide, and a fraction of an inch thick. The large plant remains, which have the appearance of films of bitumen, are high-volatile bituminous coal and have a uranium content as high as 0.02 percent.

The conodonts, bones, plants, and other fossils have a tendency to be more abundant in certain layers, though all types are not necessarily associated in a fossil-rich layer.

The mineral composition of the black shale has been extremely difficult to determine because of the fine grain size and the masking effect of the abundant organic matter. Detailed studies conducted at Pennsylvania State University under the supervision of T. F. Bates (Bates, 1953; Bates and others, 1953; Strahl and others, 1955) have employed chemical analyses, light and electron microscopes, electron and X-ray diffraction equipment, and various other techniques. These studies have shown that the denser and darkest parts of the shale, whicb have the most uranium, contain about 10 to 15 percent pyrite, 20 to 25 percent quartz, 10 percent feldspar, 25 to 30 percent clay and mica, 15 to 20 percent organic matter, and about 5 percent chlorite, free ferric oxides, and miscellaneous minerals. Zircon constitutes about 90 percent of the nonmetallic heavy minerals. These studies have also shown that most of the minerals range downward in size to particles considerably below the resolving power of the light microscopes. The larger quartz grains are near the upper limit of silt in size, about $0.06 \mathrm{~mm}$. in diameter, but most of the mineral grains are very much smaller.

Sandstone is a minor part of the formation except at a few places that are believed to have been near shore. A basal sandstone, present at most places, is commonly only a fraction of an inch thick, though at some places it is absent, and locally it is several inches thick. At most places it is nearly black. The sandstone consists chiefly of insoluble detritus from the underlying forma- 
tions, chiefly quartz and chert sand, fragments of phosphatized shells, and such phosphatic objects as conodonts and teeth. At some places the sandstone is underlain by a few millimeters of black shale, and at some other places it has a thin parting of black shale. The significance of this sandstone is referred to later. Locally another sandstone bed is at the base of the Gassaway member and still another is at the base of the upper unit of gray beds. Other beds of sandstone are present in some areas, especially in the lower part of the formation.

One of the most striking characteristies of the shale, even in thin section, is the perfection of its paper-thin laminae. These are, for the most part, alternations of films of quartz grains and layers of mixed organic and mineral detritus. Many of the quartz layers are hardly more than films of dust three or four grains in thickness. None of the laminae are interpreted as varves. Some of the thinnest quartz laminae recognizable on an outcrop can be traced for several hundred feet and apparently continue cropping out a mile or more away. Other laminae pinch and swell markedly, even within the length of a thin section.

The full thickness of shale is only about 30 to 35 feet (about 9-11 meters) in most of the area. At many places it is much thinner because the lower units are absent. The entire formation is absent in a few places, which were islands in the Chattanooga sea. Northward, through Kentucky, the Chattanooga shale merges into the almost identical Ohio and Sunbury shales and New Albany shale, which are considerably thicker. To the northeast, in Kentucky, Virginia, and West Virginia, it merges into Middle and Upper Devonian sedimentary rocks, several thousand feet thick, which formed in the exogeosynclinal area between the interior platform and the Appalachian highlands.

It is clear that the sea spread slowly over the vast peneplain, perhaps from the direction of the geosyncline to the northeast. Parts of Kentucky and northern Tennessee were inundated early in the Late Devonian and sediments of the Dowelltown member were deposited. In most of southern Tennessee and in the northern parts of Alabama and Georgia the area was not submerged until later and only the Gassaway member is present. Some relatively small areas (one of them of about 1,500 square miles) seem to have been low island areas throughout Late Devonian time, for the Chattanooga is absent, and lower Mississippian rocks of Kinderhook age lie on the pre-Chattanooga strata. It is not thought that the Chattanooga shale is missing because of erosion at the end of the Devonian, because no place is known where the Chattanooga thins toward those island areas by progressive loss of its upper beds. Instead, there is everywhere a progressive loss of the older beds towards those areas, indicating onlapping.

If the age interpretations are correct, and sedimentation was as nearly continuous as it appears to have been, 30 feet of shale seems to represent fully 10 million years - a phenomenally slow rate of sedimentation.

\section{INFERENCES REGARDING ENVIRONMENT OF ACCU- MULATION}

The following inferences regarding the conditions under which the shale accumulated are based on the foregoing facts of composition and on regional, stratigraphic, and structural relations. Various considerations have required alternative possibilities to be abandoned.

A reducing environment at the bottom of the sea is indicated beyond reasonable doubt by the abundance of pyrite and undecomposed plant matter, and by the almost total absence of calcareous fossils and minerals. An oxygenated upper layer of water seems necessary to have supported planktonic marine plant life and is strongly suggested by the conodont, fish, and other animal remains. As will be seen later, the strata must have been thin; yet the waters of the two layers were apparently mixed only occasionally.

Any hypothesis that the shale accumulated in relatively deep water, as expressed by several earlier workers, and more recently by Rich $(1948,1951,1953)$, appears untenable in the Tennessee area. Any explanation of a deep-water sea seems to ereate more serious problems than it solves.

If one maintains that the black shale required deep water for its formation, he must assume that until the water reached the required depth any sediments reaching the sea were swept away. But no accumulation of coarse material is known that could reasonably be interpreted as those sweepings. It is highly improbable that all shallow-water sediments would have escaped preservation and yet that the first sediment to accumulate when the water became deep was a nearshore type of detritus.

It is entirely unreasonable to assume that the area sank so rapidly that only a thin basal sandstone could form, because the area of the Nashville dome has been a notably stable and positive area since early Paleozoic time.

At the close of Devonian time the sea spread over considerably larger areas, including the islands of the Chattanooga sea. Seemingly this Mississippian sea would have been at least as deep as the Chattanooga sea; yet the abundant and diverse fossils of those rocks are commonly thought to indicate a shallow epicontinental sea. 
At nearly all places in the Chattanooga sea, regardless of the apparent time of inundation, the first sediment to accumulate was the basal sandstone, which is commonly less than an inch thick, and which is composed of detritus that was lying on the old land surface. It seems especially significant that at some places this sandstone bed has one or more partings of black shale, is underlain by a few millimeters of black shale, or is missing. Apparently a reducing environment existed close to the shore where the first sediments accumulated. It is probable that the first of these sediments accumulated close to shore, in water only a few feet deep. This idea should not be difficult to accept, for similar muds have been reported in shallow water of the Baltic Sea (Twenhofel, 1915), the Norwegian fjords (Strøm, 1948), and in a few other places. The erosion surface at the top of the Dowelltown member suggests either withdrawal of the sea or marine planation. In one area of about 100 square miles the bentonite bed and its associated beds are missing. In the surrounding area the 1 or 2 feet of Dowelltown strata that normally are above bentonite are gently beveled toward the central region. Clearly the muds were removed, probably by marine planation, as a result of a slight upwarp of the sea bottom. This condition suggests a delicate balance between deposition and erosion in a shallow and quiet sea.

The perfection of the lamination and the sorting of the fine sediments suggest frequent mild disturbance of the muds. Associated with this is evidence that the muds moved appreciable distances along the bottom and filled local areas that were subsiding. It is believed that gentle movements of the water frequently worked over the muds, shifted them to lower places, and sorted them. The extremely thin laminae, which do not commonly grade upward or downward into one another suggest no gravitational sorting of large amounts of mud that have been stirred up or washed into the sea.

The fineness of the muds and the slowness of accumulation seem to result from the extensive surrounding peneplain, which was developed chiefly on limestone. From such a source only a small amount of sediment could be expected, and it would be mostly fine mud: Most of the sediments from the Appalachian upland were trapped by the geosyncline, and only the finest or most bouyant of the particles would have reached the Chattanooga sea. Windblown dust from greater distances may also have contributed materially to the sediments.

The perfection and continuity of the stratification and the general lack of storm waves in a shallow sea require either the absence of storms or the existence of conditions unfavorable to the generation of large waves. It is unreasonable to assume that during all of Late
Devonian time an extensive sea was not exposed to storms. More likely, conditions in the Chattanooga sea did not favor the frequent generation of large waves and strong currents. Scattered islands and an irregular shoreline also doubtless interfered with the formation of storm waves.

A well-graded sea bottom may have been an important factor in preventing the generation of strong waves. Keulegan and Krumbein (1949) have shown that in a sea having a sufficiently gently sloping bottom storm waves will lose their energy so gradually in their approach to shore that breakers do not form. Under these conditions, which must have existed in the Chattanooga sea, much of the bottom may have been protected from any strong wave action.

Another obstacle to the development of large waves, and perhaps an important one, may have been a luxuriant growth of seaweeds and other types of floating plants.

Some of the conditions here set forth are almost certain to have existed, and the others apparently could have existed. The combination may well have brought about the environment thought to have existed in the Chattanooga sea. Strong wave action would have been uncommon, and the waves that did exist would have supplied the gentle agitation that appears to bave reworked the muds so frequently. Occasional storm waves probably did disturb the waters enough to poison the upper layer and kill the large numbers of animals or plants that are found in some beds.

As stated, it seems highly probable that the first sediments at any given place accumulated in water close to shore, probably only a few feet deep. These sediments include interbedded black sandstone and black shale. Other evidence, not cited here, suggests that the sea floor was well graded and had slopes of only a few inches per mile. Projections of those slopes between probable land areas indicate that the depth of water at most places was not more than a few tens of feet.

\section{URANIUM CONTENT}

The uranium content is highest in the Gassaway member, which contains slightly more than 0.005 percent uranium. The uranium was probably brought to the sea by streams from the surrounding land areas in normal quantities, and any inflow of sea water would have brought more. The abundant organic matter that was exposed on the bottom, or that was in suspension, is believed to have extracted the uranium in some unknown manner. The form and association of the uranium have so far defied exact determination, but much of the metal is probably associated with the plant matter in an ionic form. Moore (1954) has shown that 
low-rank coals have a strong affinity for uranium, and the same is true for plant matter in earlier stages of coal formation. Significant in this respect is the much higher uranium content of the coalified logs that have been isolated and analyzed. This higher uranium content of the logs probably results from the absence of mineral matter, and perhaps from longer exposure to the water.

The relatively high uranium content of the Chattanooga shale probably results from the extremely slow accumulation of mineral matter in an environment favorable to the removal of the uranium from the water. If even less mineral matter were present, or if the surrounding land masses had supplied more uranium to the sea, the shale would have been even richer.

\section{REFERENCES CITED}

Bates, T. F., 1953, Mineralogy, of the Chattanooga shale [abs.]: Geol. Soc. America Bull., v. 64, p. 1529.

Bates, T. F., Wright, H. D., Camilli, Elena, and others, 1953, An investigation of the mineralogy, petrography and paleobotany of uranium-bearing shales and lignites (Scope Ashales): U. S. Atomic Energy Comm. NYO-3363, 41 p.

Campbell, Guy, 1946, New Albany shale: Geol. Soc. America Bull., v. 57, p. 829-908.
Hass, W. H., 1948, Upper Devonian bentonite in Tennessee: Am. Assoc. Petroleum Geologists Bull, v. 32, p. 816-819.

Hass, W. H., 1953, Age of the Chattanooga shale and the Maury formation [abs.]: Geol. Soc. America Bull., v. 64, p. 1532.

Keulegan, G. H., and Krumbein, W. C., 1949, Stable configuration of bottom slope in a shallow sea and its bearing on geological processes: Am. Geophys. Union Trans., v. 30, p. 855-861.

Moore, G. W., 1954, Extraction of uranium from aqueous solution by coal and some other materials: Econ. Geology, v. 49 , p. $652-658$.

Rich, J. L., 1948, Probable deep-water origin of the MarcellusOhio-New Albany-Chattanooga shale [abs.]: Geol. Soc. America Bull., v. 59, p. 1346-1347.

Rich, J. L., 1951, Probable fondo origin of Marcellus-Ohio-New Albany-Chattanooga bituminous shales: Am. Assoc. Petroleum Geologists Bull., v. 35, p. 2017-2040.

Rich, J. L., 1953, Paleographic implications of evidences pointing to fondo origin of the Chattanooga-New Albany-Ohio bituminous shales [abs.]: Geol. Soc. America Bull., v. 64, p. $1535-1536$.

Strahl, E. O., Silverman, E. N., O'Neil, R. L., and others, 1955, An investigation of the mineralogy, petrography, and paleobotany of uranium-bearing shale and lignites (Scope Ashales): Atomic Energy Comm. NYO-6068, 79 p.

Strøm, K. M., 1948, A concentration of uranium in black muds: Nature (London), v. 162, p. 922.

Twenhofel, W. H., 1915, Notes on black shale in the making: Am. Jour. Sci., 4th ser., v. 40, p. 272-280. 



\title{
URANIFEROUS BLACK SHALE IN THE NORTHERN ROCKY MOUNTAINS AND GREAT PLAINS REGIONS
}

\author{
By William J. Mapel, U. S. Geological Survey
}

\section{CONTENTS}

\begin{tabular}{|c|c|c|c|}
\hline \multicolumn{3}{|c|}{ Page } & Page \\
\hline Introduction & 469 & 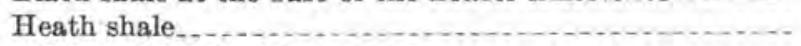 & 472 \\
\hline $\begin{array}{l}\text { Black shale at the base of the Madison limestone and } \\
\text { equivalents. }\end{array}$ & 471 & $\begin{array}{l}\text { Other radioactive black shales. } \\
\text { Selected bibliography }\end{array}$ & $\begin{array}{l}476 \\
476\end{array}$ \\
\hline
\end{tabular}

\section{ILLUSTRATIONS}

Figure 161. Index map showing black-shale localities examined for uranium in the northern Rocky Mountains and Great Plains regions, 1953

162. Graphic sections showing uranium content of basal black shale of Mississippian age at outcrops in the northern Rocky Mountains region.
Page

Figure 163. Maps and sections showing thickness and radioactivity of the Bakken formation as used by Nordquist (1953) northern Great Plains

164. Map showing thickness and distribution of the Heath shale in central Montana and the Heath and Otter formations in eastern Montana and adjacent parts of North and South Dakota

\section{ABSTRACT}

Deposits of black shale that range in age from Precambrian to Late Cretaceous crop out or were penetrated in drilling test wells for oil and gas at many places in the northern Rocky Mountains and Great Plains regions of the United States and southern Canada. The radioactivity and uranium content of many of these formations has been investigated by sampling outcrops and drill cuttings and by the examination of gamma-ray logs of oil and gas wells. The investigations show that certain black shales contain from 0.005 to 0.01 percent uranium.

Of particular interest for its radioactivity is a black shale of early Mississippian (Kinderhook) age that is known variously as the Bakken formation, the Kinderhook shale, or the Exshaw formation. This formation was penetrated in drilling wells in much of the Williston basin region of Montana, North Dakota, and adjacent parts of Canada. It ranges in thickness from a few inches to as much as 100 feet and at many places consists of 2 highly radioactive beds of black shale separated by a bed of gray ealeareous sandstone, siltstone, or dolomite. Samples of black shale from this formation in 4 oil and gas test wells in Montana and North Dakota contain from 0.005 to 0.008 percent uranium. In the mountainous regions of Montana and northern Utah, a thin bed of black shale of the same age and at the same stratigraphic position contains as much as 0.005 percent uranium. An isoradioactivity map of the Bakken formation as used by Nordquist (1953) based on gamma-ray logs, suggests that the radioactivity is greatest near the northeastern corner of Montana and decreases concentrically outward from this point. The area of maximum radioactivity coincides roughly with the area in which the formation is thickest.

Other formations that contain beds of black shale of unusually high radioactivity include the basal part of the Brazer limestone of late Mississippian age in northern Utah, the Heath shale of late Mississippian age in central Montana, the Minnelusa sandstone of Pennsylvanian age in eastern Wyoming and western South Dakota, and parts of the Pierre shale of late Cretaceous age in eastern Montana and parts of adjacent States.

\section{INTRODUCTION}

Deposits of black shale that range in age from Precambrian to Late Cretaceous crop out or were penetrated in drilling test wells for oil and gas at many places in the northern Rocky Mountains and Great Plains regions of the United States and southern Canada. A reconnaissance search for uranium in black shale in this region was carried out during the summer of 1953. Localities that were visited are in southwestern and central Montana, central and southeastern Idaho, and northwestern Utah.

Previous reconnaissance in the Western States by other geologists indicates that the Heath shale of late Mississippian age; a thin black shale sequence known 


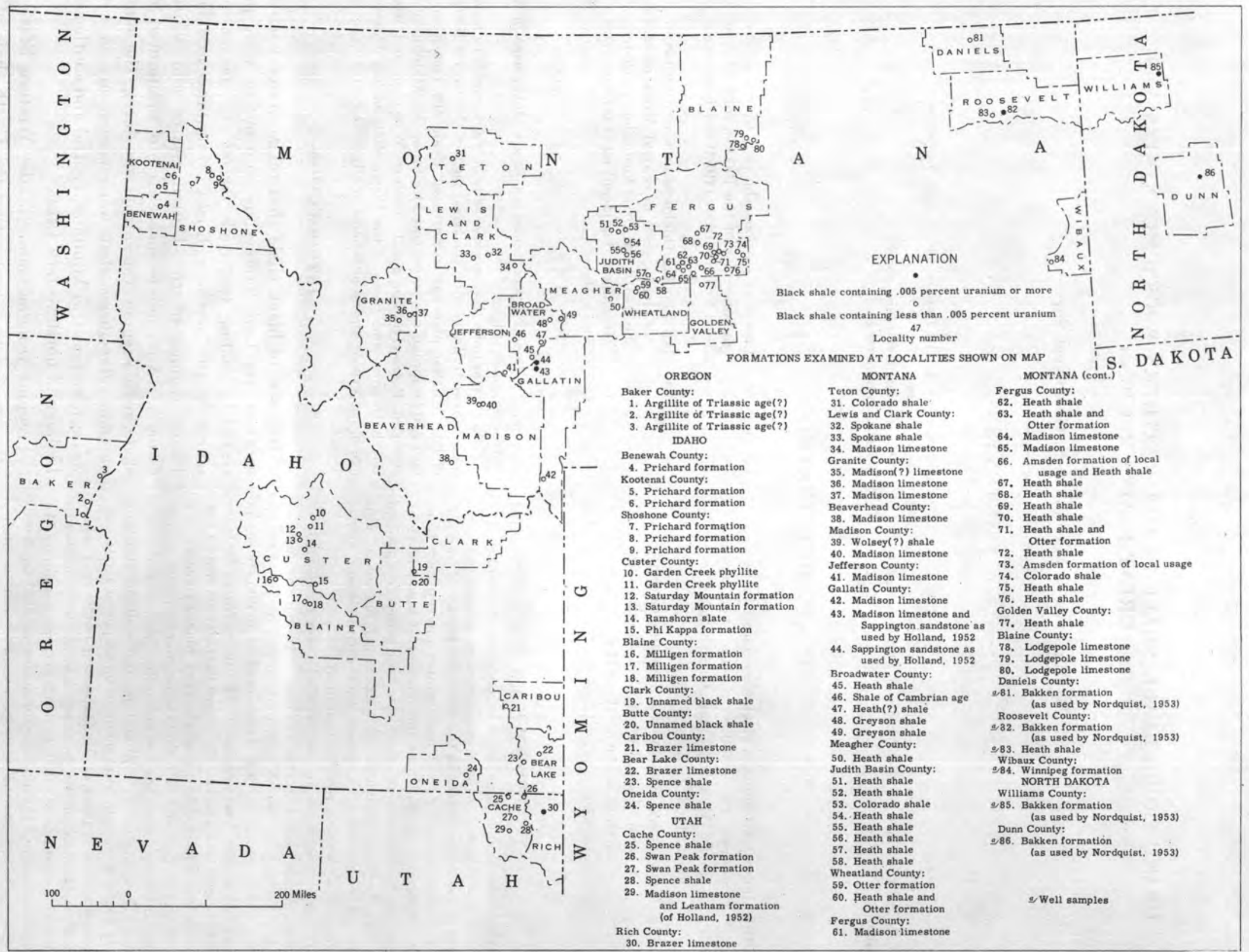


locally as the Bakken formation, the Kinderhook shale or the Exshaw formation of early Mississippian age; and a black shale at the base of the Brazer limestone or late Mississippian age, at some places contain 0.005 percent or more uranium. These and 17 other formations (fig. 161 and the following table) that contain black shale were examined at one or more places at their outcrop or by means of drill cuttings and cores, and more than 100 commercial gamma-ray logs of oil and gas wells - mostly in Montana and North Dakotawere scanned for highly radioactive zones.
The work reported here is a continuation of reconnaissance studies made between 1951 and 1955 in the Western States by D. C. Duncan, W. J. Hail, Jr., J. R. Gill, G. W. Moore, and J. D. Vine (Duncan, 1953). D. C. Duncan, R. J. Ross, J. E. Smedley, R. P. Kunkel, P. W. Richards, Roy Kepferle, and H. D. Hadley supplied samples of black shale or guided the writer to exposures of shale in Utah, Montana, and North Dakota. W. J. Hail, Jr., compiled information from the gamma-ray logs and assisted in interpreting the results of this work.

Relative stratigraphic positions and maximum known uranium content (in percent) of formations examined

[Localities at which the formations were sampled are shown on fig. 161]

\begin{tabular}{|c|c|c|c|c|c|c|c|}
\hline \multicolumn{3}{|c|}{ Age } & $\begin{array}{l}\text { Central and northern Idaho, } \\
\text { eastern Oregon }\end{array}$ & $\begin{array}{l}\text { Southeastern } \\
\text { Idsho }\end{array}$ & Northwestern Utah & $\begin{array}{c}\text { Central and southwestern } \\
\text { Montana }\end{array}$ & $\begin{array}{l}\text { Eastern Montans and } \\
\text { North Dakota }\end{array}$ \\
\hline \multicolumn{3}{|c|}{ Cretaceous } & & & & $\begin{array}{l}\text { Colorado shale } \\
(0.002) .\end{array}$ & \\
\hline \multicolumn{3}{|c|}{ Triassic } & Unnamed argillite ${ }^{1}$ & & & & \\
\hline \multirow{2}{*}{ 总 } & \multirow{2}{*}{ 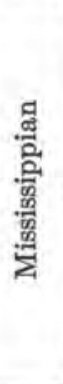 } & Upper & \multirow{2}{*}{$\begin{array}{l}\text { Unnamed shale }{ }^{1} \\
\text {-Milligen formation } \\
\text { - }\end{array}$} & $\begin{array}{l}\text { Brazer lime- } \\
\text { stone. } 1\end{array}$ & $\begin{array}{l}\text { Brazer limestone } \\
(0.009) .\end{array}$ & $\begin{array}{l}\text { Amsden formation } \\
\text { (lower part) } \\
(0.003), \text { Heath } \\
\text { shale (0.006), } \\
\text { Otter formation } \\
(0.003) .\end{array}$ & Heath shale. ${ }^{12}$ \\
\hline & & Lower & & ' & $\begin{array}{l}\text { Madison limestone } \\
(0.003), \text { Leatham } \\
\text { formation of Hol- } \\
\text { land }(1952) \\
(0.003) .\end{array}$ & $\begin{array}{l}\text { Madison limestone } \\
(0.005) .^{3}\end{array}$ & $\begin{array}{l}\text { Lodgepole limestone } \\
(0.002), \text { Bakken } \\
\text { formation }{ }^{2} \text { as } \\
\text { used by Nord- } \\
\text { quist (1953) } \\
(0.007) .\end{array}$ \\
\hline \multicolumn{3}{|c|}{ Cambrian } & $\begin{array}{l}\text { Garden Creek phyl- } \\
\text { lite. }^{1}\end{array}$ & $\begin{array}{l}\text { Spence shale } \\
\text { member. }{ }^{1}\end{array}$ & $\begin{array}{l}\text { Spence shale member } \\
(0.003) \text {. }\end{array}$ & Wolsey shale $(0.001)$. & \\
\hline \multicolumn{3}{|c|}{ Precambrian } & Pritchard formation & & & $\begin{array}{l}\text { Spokane shale, }{ }^{1} \\
\text { Greyson shale } \\
(0.003) .\end{array}$ & \\
\hline
\end{tabular}

1 Samples contain 0.003 percent or less equivalent uranium; not analyzed chemically.

Not exposed; drill cuttings or cores examined.

Underlain by Bappington sandstone member of Three Forks shale in this area. The age of the Bappington is considered to be Mississippian by some geologists and

\section{BLACK SHALE AT THE BASE OF THE MADISON LIME- STONE AND EQUIVALENTS}

A black shale sequence of early Mississippian (Kinderhook) age, a few inches to 100 feet thick, occurs locally at the base of the Madison limestone or its equivalents in southwestern and central Montana and in the Williston basin of Saskatchewan, Manitoba, Montana, and North and South Dakota. The term "Bakken formation" has been used to identify this unit in the subsurface in the Williston basin, where it is described by J. W. Nordquist (1953, p. 72) as ". . . two thin highly radioactive black shales separated by a gray calcareous sandstone, siltstone, or dolomite." According to $\mathrm{Mr}$. Nordquist, the upper shale unit may be correlative with a bed of black shale a few inches to 30 feet thick at the base of the Madison or Lodgepole limestone in different parts of southwestern Montana and northeastern Utah. The lower shale and medial sandstone-dolomite units may correlate with the Sappington sandstone member, a shale and sandstone sequence as much as 60 feet thick that occurs below the Madison limestone in parts of southwestern Montana. 
In most parts of the northern Rocky Mountains region, the Bakken formation as used by Nordquist (1953) and its equivalents unconformably overlie the Three Forks or Jefferson formations of late Devonian age.

The black shale sequence at the base of the Madison limestone was sampled at 17 localities in the mountainous parts of southwestern and central Montana and northwestern Utah. The maximum observed uranium content of the sequence is 0.005 percent in the lower half of a $2 \frac{1}{2}$-foot-thick bed of black shale near Three Forks, Mont. (loc. 43, fig.162), and 0.005 percent in the basal part of a 10-foot-thick bed of brownishblack shale nearby (loc. 44).

The Bakken formation as used by Nordquist (1953) was sampled in 4 wells, 2 in northeastern Montana and 2 in northwestern North Dakota. The lithology, radioactivity, and uranium content of the formation in 3 of these wells are shown by figure 163 .

The samples from the Carter no. 1 Danielson well are anomalous in that they are decidedly out of balance in favor of equivalent uranium as indicated in the following table. J. N. Rosholt, Jr., of the U. S. Geological Survey Trace Elements Laboratory, investigated the source of the high radioactivity in sample 204067 from the Danielson well (below). The sample contained 0.003 percent thorium ${ }^{232}$, and excess thorium ${ }^{230}$ and radium. His data indicate that thorium ${ }^{230}$ and radium, both daughter products of uranium, are the principal contributors of excess radioactivity. The relatively high concentrations of these elements in comparison to uranium suggest that leaching of uranium or addition of thorium ${ }^{230}$ and radium has occurred in this deeply buried shale in comparatively recent time.

Description of samples from the Carter no. 1 Danielson well, Danielson County, Mont.

\begin{tabular}{|c|c|c|c|c|}
\hline Sample & $\begin{array}{l}\text { Depth } \\
\text { (leet) }\end{array}$ & Lithology & $\begin{array}{c}\mathrm{eU} \\
\text { (percent) }\end{array}$ & $\underset{\text { (percent) }}{\mathrm{U}}$ \\
\hline \multirow{5}{*}{$\begin{array}{l}204065 \\
204066 \\
204067 \\
204068 \\
204069 \\
204070\end{array}$} & \multirow{5}{*}{$\begin{array}{l}6,964 \\
66,966 \\
6,968 \\
6,970 \\
6,971 \\
6,974\end{array}$} & Core chip, nonealcareous black shale. & \multirow{5}{*}{$\begin{array}{r}0.006 \\
.005 \\
.010 \\
.007 \\
.008 \\
.003\end{array}$} & \multirow{5}{*}{$\begin{array}{r}0.002 \\
.002 \\
.003 \\
.004 \\
.004 \\
.002\end{array}$} \\
\hline & & do & & \\
\hline & & Same as above, some disseminated & & \\
\hline & & do & & \\
\hline & & $\begin{array}{l}\text { Core chip, dark-gray shale with light-gray } \\
\text { calcareous lammae. }\end{array}$ & & \\
\hline
\end{tabular}

The thickness and areal distribution of radioactivity in the Bakken formation, as used by Nordquist (1953), as determined from published sample descriptions and gamma-ray logs is shown by figure 163 . These maps suggest that black shale in the Bakken formation of Nordquist (1953) is thickest in northwestern North Dakota and that the formation is most radioactive slightly east of this area near the northeastern corner of Montana. Perhaps no convincing conclusions can be drawn from the data presented, but it seems evident that radioactivity in Nordquist's Bakken formation differs appreciably and with a definite pattern from place to place. Recognition of the pattern doubtless will help in outlying areas in which maximum concentrations of uranium in the formation might be expected.

\section{BLACK SHALE AT THE BASE OF THE BRAZER LIME- STONE}

In parts of Utah and Idaho, the Brazer limestone of late Mississippian age includes at its base a black phosphatic shale sequence a few inches to about 75 feet thick. Exposures of this black-shale sequence were tested at two places in southeastern Idaho (locs. 21 and 22 , fig. 161) and at one place in northwestern Utah (loc. 30, fig. 161). Beds of black shale in sequence at the two Idaho localities are essentially nonuraniferous, but in sec. 32 , T. 13 N., R. 6 E., Rich County, Utah, a bed of phosphatic shale 14 feet thick in the upper part of the sequence contains as much as 0.006 percent uranium, and one 8 feet thick in the lower part contains as much as 0.009 percent uranium.

Duncan $(1953$, p. 68$)$ reported that at Ogden Canyon, Weber County, Utah, about 45 miles southwest of the Rich County locality, phosphatic shale about 1 foot thick contains as much as 0.005 percent uranium, 0.18 percent vanadium oxide, and 17.3 percent phosphate.

\section{HEATH SHALE}

The Heath shale of late Mississippian age crops out along the margins of the Little Belt and Big Snowy Mountains in central Montana, and it has been penetrated in drilling throughout a large area in eastern Montana and western North Dakota (fig. 164). The formation consists largely of marine black shale with subordinate amounts of gray limestone and fine- to coarse-grained sandstone. The Heath shale is underlain by green and black shale and gray limestone of the Otter formation of late Mississippian age. It is overlain by red shale and sandstone and minor interbedded gray limestone and dolomite of the Amsden formation of late Mississippian and Pennsylvanian age.

The most highly uraniferous black shale thus far found in the formation was discovered by Hail and Gill (in Duncan, 1953, p. 42, 43) 3 miles southeast of Forestgrove, Fergus County, Mont. At this locality, the upper 4 feet of a 6 -foot-thick bed of black shale near the top of the formation contains 0.006 percent uranium. Samples of black shale from the Heath shale elsewhere in central Montana contain a maximum of 0.003 percent uranium.

Gamma-ray log data from oil and gas wells suggest that a bed 10 feet thick in the Heath shale penetrated 


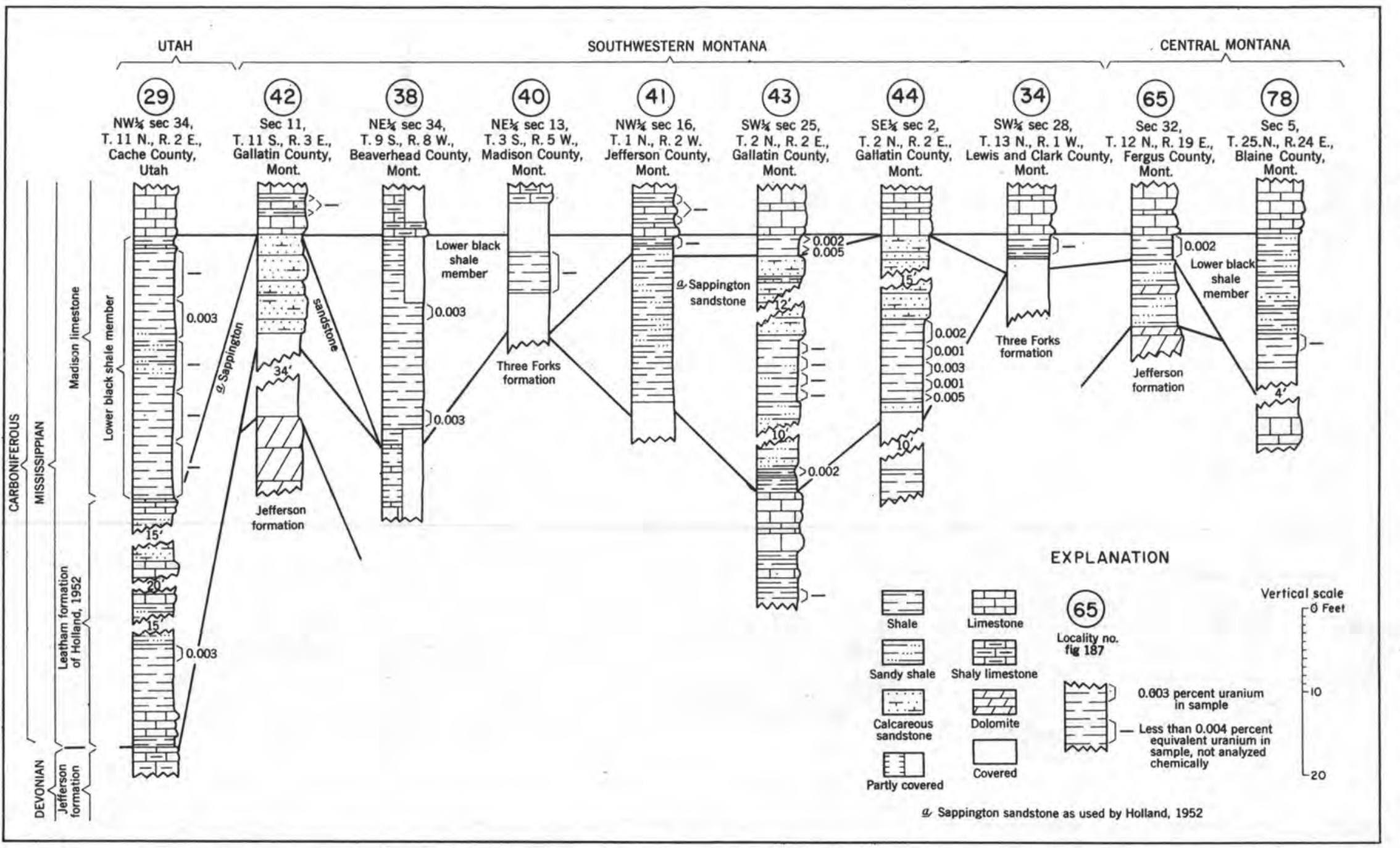

FIGURE 162.-Graphic sections showing uranium content of basal black shale of Mississippian age at outerops in the northern Rocky Mountains region. 


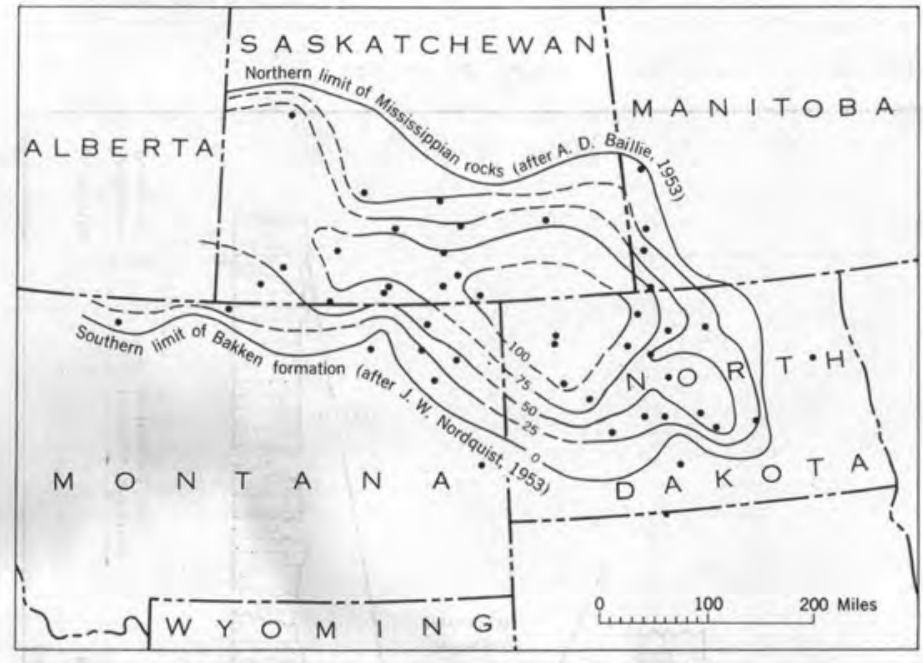

THICKNESS MAP OF THE BAKKEN FORMATION

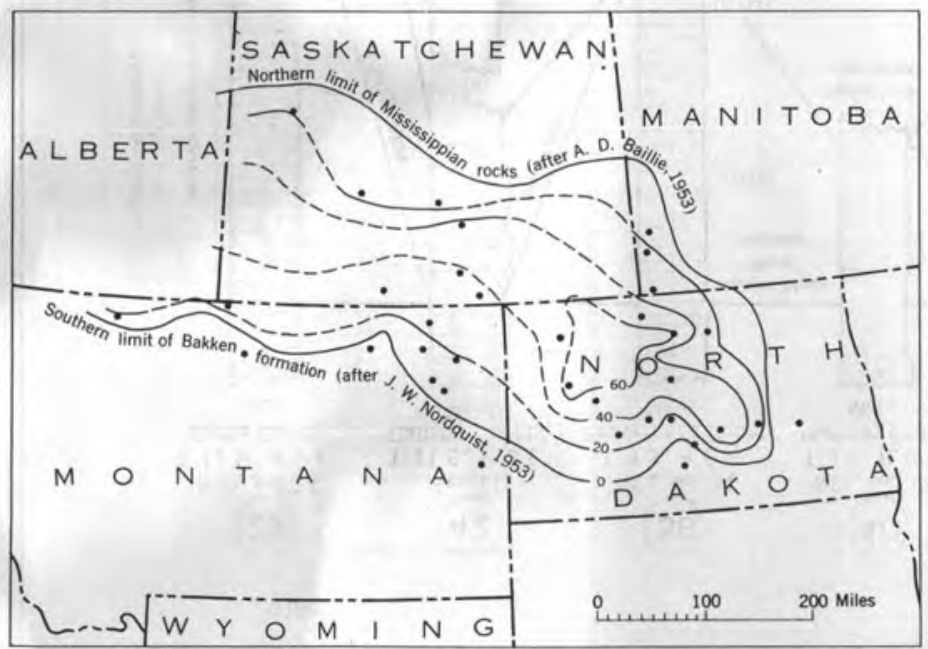

THICKNESS MAP OF BLACK SHALE IN THE BAKKEN FORMATION

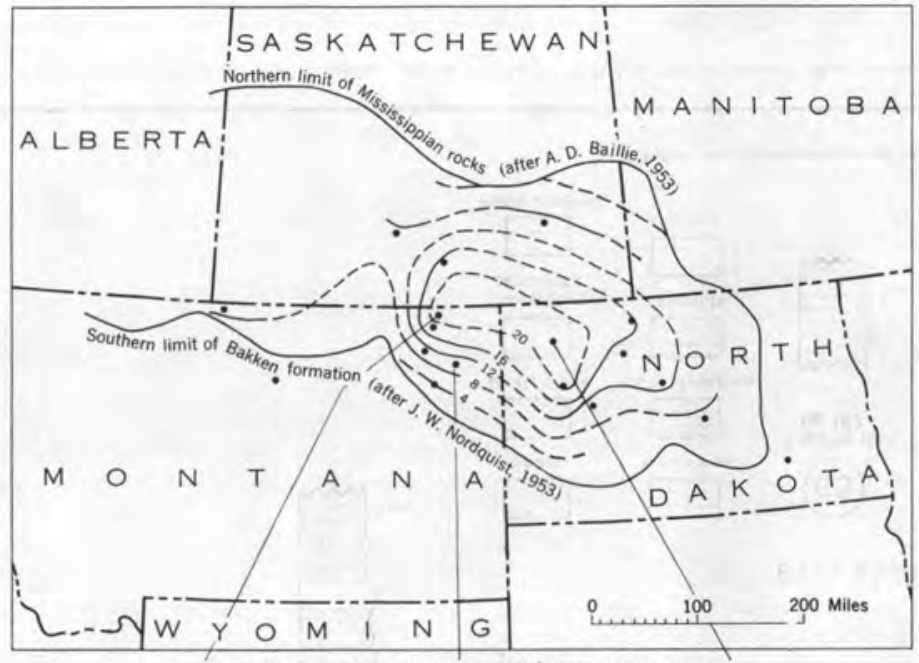

RADIOACTIYITY MAP OF THE BAKKEN FORMATION
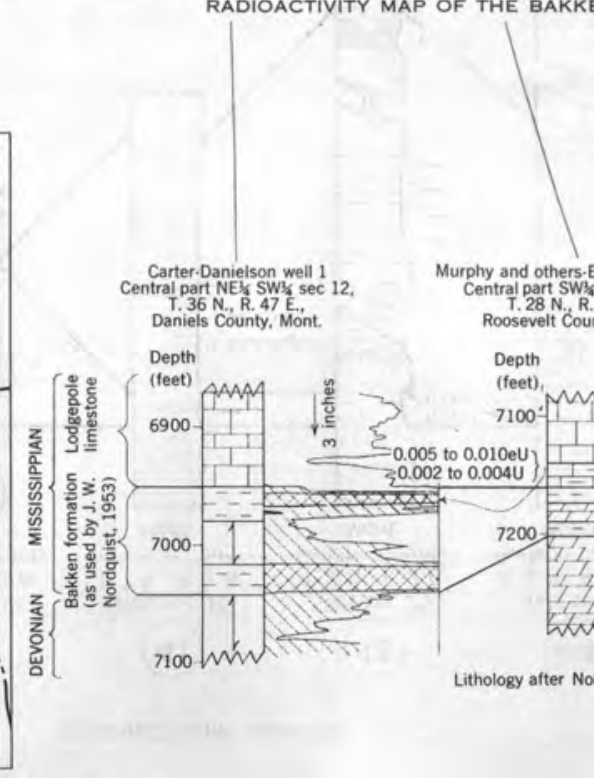

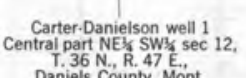

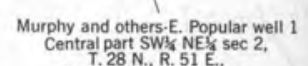
Roosevelt County, Mont
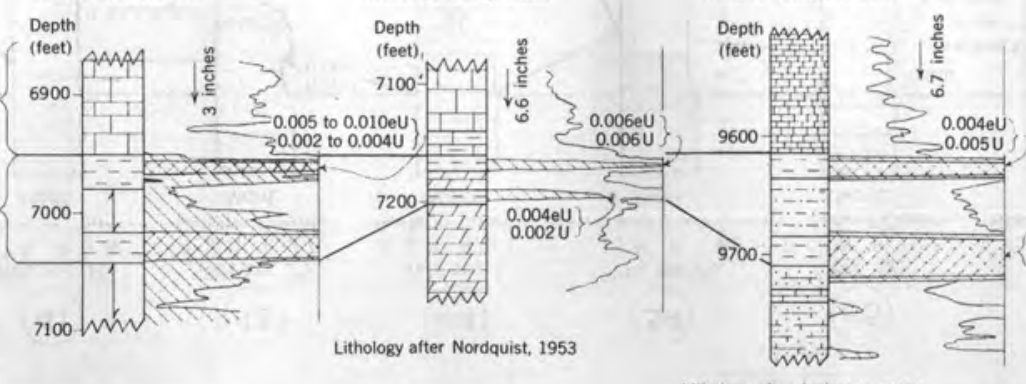

Lithology after Nordquist, 1953

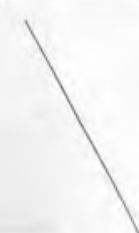

EXPLANATION

$\therefore \cdot$

Locations of oil or gas wells from which
thickness or radioactivity measurements

Thickness in feet, line is dashed where
control is poor

Maximum deflection on gammagar log in
inches, calculated to Lane Wells sensitivs of 10 , line is dashed where control is poor
(Eight inches deflection represents approx. (Eight inches defiection represents approx
imately 0.005 percent equivalent uranium

III

Sandy shale Calcareous sandstone $\underset{\text { Shaly limestone }}{[1]}$ Radioactivity increases $\overrightarrow{1}^{0} \overrightarrow{1}^{3}$ inches $\frac{2}{0.005 e}$

Gamma-ray log curve, showing abnorma column.) $0.005 \mathrm{e} U$ is percent equival in sample

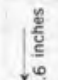

r.

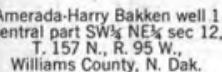

$\left\{\begin{array}{l}0.009 \mathrm{eu} \\ 0.0070\end{array}\right.$

GRAPHIC SECTIONS SHOWING RADIOACTIVITY AND URANIUM CONTENT OF THE BAKKEN FORMATION

FIGURE 163.-Maps and sections showing thickness and radioactivity of the Bakken formation as used by Nordquist (1953), northern Great Plains. 


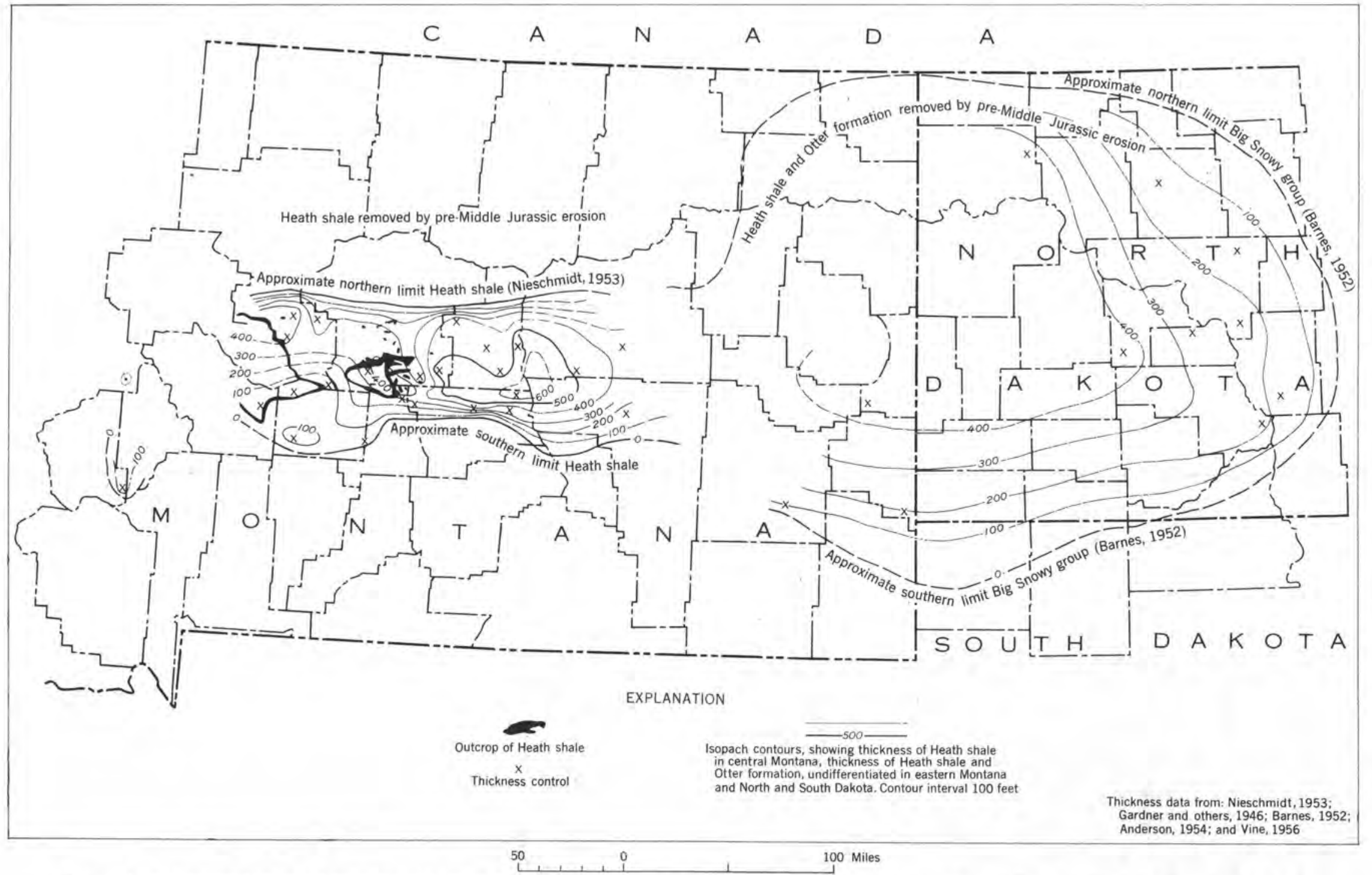

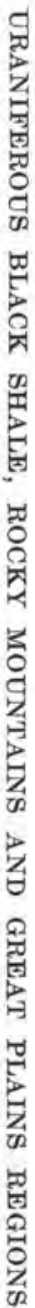

FIQURE 164.-Map showing thickness and distribution of the Heath shale in central Montana and the Heath and Otter formations in eastern Montana and adjacent parts of North and South Dakota. 
in drilling a well in McCone County, Mont., may contain more than 0.01 percent equivalent uranium and that parts of the formation in Musselshell County, Mont., may be nearly as radioactive.

\section{OTHER RADIOACTIVE BLACK SHALES}

Examination of commercial gamma-ray logs of oil and gas wells in Montana and North and South Dakota indicate that certain black-shale-bearing formations other than the ones discussed above are appreciably radioactive locally and may contain significant amounts of uranium. One of these formations is the Minnelusa sandstone of Pennsylvanian age, which crops out in the Black Hills in northeastern Wyoming and northwestern South Dakota. Beds of black shale as much as 6 feet thick which may be equivalent to beds of black shale Minnelusa sandstone were sampled by J. D. Love (written communication, 1951) in 2 oil and gas wells in southeastern Wyoming and found to contain 0.0050.019 percent uranium.

Gamma-ray logs of the Colorado shale of Cretaceous age in central Montana indicate that its radioactivity at most places ranges from 0.002 to 0.005 percent equivalent uranium; in Musselsheld County, Mont., however, a thin zone of shale near the middle of the formation may contain as much as 0.008 percent equivalent uranium.

Gamma-ray logs of wells in northeastern South Dakota indicate that a thin zone of black shale in the lower part of the Pierre shale of Cretaceous age is more highly radioactive than average and may contain 0.008 percent equivalent uranium. H. A. Tourtelot (1956) has observed that a black organic-rich shale known as the Sharon Springs member of the Pierre shale may contain as much as 0.01 percent equivalent uranium in southwestern Nebraska and about the same amount along the Missouri River valley in central South Dakota.

\section{SELECTED BIBLIOGRAPHY}

Anderson, S. B., 1954, Stratigraphic sections of the Mississippian system in North Dakota: N. Dak. Geol. Survey, Rept. Invs. no. 16,2 sheets.

Baillie, A. D., 1953, Devonian system of the Williston Basin area: Manitoba Dept. Mines and Nat. Res., Mines Br., pubs. $52-55,105 \mathrm{p}$.

Barnes, T. R., 1952, The Williston Basin-a new province for oil exploration, in Billings Geol. Soc. Guidebook, 3d Ann. Field Conf., p. 97-117.

Duncan, D. C., [compiler], 1953, Reconnaissance investigations for uranium in black shale deposits of the western states during 1951 and 1952: U. S. Geol. Survey TEI-381, 87 p., issued by U. S. Atomic Energy Comm. Tech. Inf. Service, Oak Ridge, Tenn.

Gardner, L. S., Hendricks, T. A., Hadley, H. D., and Rogers, C. P., Jr., 1946, Stratigraphic sections of upper Paleozoic and Mesozoic rocks in south-central Montana: Mont. Bur. of Mines and Geology Mem. 24, 100 p.

Holland, F. D. Jr., 1952, Stratigraphic details of lower Mississipian rocks of northeastern Utah and southwestern Montana: Am. Assoc. Petroleum Geologists Bull., v. 36, no. 9 , p. $1697-1734$.

Nieschmidt, C. L., 1953, Subsurface stratigraphy of the Heath shale and Amsden formation in central Montana: U. S. Geol. Survey Oil and Gas Inv.. Chart OC-50.

Nordquist, J. W., 1953, Mississippian stratigraphy of northern Montana, in Billings Geol. Soc. Guidebook, 4th Ann. Field Conf., p. 68-82.

Tourtelot, H. A., 1956, Radioactivity and uranium content of some Cretaceous shales, Central Great Plains: Am. Assoc. Petroleum Geologists Bull., v. 40, no. 1, p. 62-82.

Vine, J. D., 1956, Geology of the Stanford-Hobson area, Judith Basin and Fergus Counties, Mont.: U. S. Geol. Survey Bull. 1027-J (in press). 


\title{
URANIUM IN PHOSPHATE ROCK
}

\author{
By Vincent E. McKelvey, U. S. Geological Survey
}

\section{CONTENTS}

Abstract
Mintroduction
Types of phosphate deposits
Igneous apatites
Marine phosphorites
Residual phosphorites

\begin{tabular}{|c|c|c|}
\hline Page & & Pag \\
\hline 477 & Types of phosphate deposits-Continued & \\
\hline 477 & River-pebble deposits & 48 \\
\hline 477 & Guano_.. & 48 \\
\hline 478 & Phosphatized rock. & 48 \\
\hline 478 & Fossil bone ......... & 48 \\
\hline 478 & Conclusions_. & 48 \\
\hline 479 & References cited & 48 \\
\hline
\end{tabular}

\section{ABSTRACT}

Marine phosphorites commonly contain 0.005 to 0.03 percent uranium. The uranium content increases roughly with increasing phosphate content but is generally low in rocks that contain more than a few percent $\mathrm{CO}_{2}$. Aluminum phosphate deposits that have been derived from the weathering of marine phosphorites and phosphatic nodules in some marine black shale formations contain similar amounts of uranium. Most of the uranium in these materials does not occur as a separate mineral phase but substitutes for caleium in carbonate fluorapatite or crandallite. A few occurrences of tyuyamunite and torbernite have been reported from highly weathered marine phosphorites, however, and these and other secondary uranium minerals, such as earnotite and autunite, are not uncommon in fossil bones and teeth that have been exposed to uranium-bearing solutions after burial. Because the marine phosphorites are of wide extent they contain large tonnages of uranium, some of which ean be recovered under favorable conditions as a byproduct of the manufacture of triple superphosphate.

\section{INTRODUCTION}

Uranium and phosphate are associated in many different kinds of deposits and minerals. About onesixth of the ninety-odd minerals (Frondel and Fleischer, 1955) in which uranium is one of the major essential constituents are phosphates; uranium occurs also as a frequent minor constituent of xenotime $\left[\mathrm{YPO}_{4}\right]$, monazite $\left[(\mathrm{Ce}, \mathrm{La}, \mathrm{Y}, \mathrm{Th}) \mathrm{PO}_{4}\right]$, crandallite $\left[\mathrm{CaAl}_{3}\right.$ $\left.\left(\mathrm{PO}_{4}\right)_{2}(\mathrm{OH})_{5} \cdot \mathrm{H}_{2} \mathrm{O}\right]$, and apatite $\left[\mathrm{Ca}_{5}\left(\mathrm{PO}_{4}\right)_{3}(\mathrm{~F}, \mathrm{Cl}\right.$, $\mathrm{OH})$ ]. Because of their greater abundance, apatite and crandallite are the chief source of phosphate and, potentially, the greatest source of uranium from the uraniferous phosphates. The phosphate minerals in which uranium is a major essential constituent occur mainly as secondary minerals formed during the weathering of ore deposits. Locally they provide clues to the presence of uranium ores, and two uranium phosphates, autunite and torbernite, are the dominant minerals in a few uranium ores. As a group, however, the uranium phosphates are quantitatively unimportant as carriers of uranium in either an economic or a geochemical sense. Monazite and xenotime are widespread accessory minerals in silicic igneous rocks, pegmatites, and migmatites, and are locally concentrated in placers. They are the chief sources of rare earths, and monazite is at present the chief source of thorium. Some uranium may be recovered from monazite and xenotime as a byproduct, but these minerals are not such important potential sources of uranium as are the apatite and crandallite deposits. This review of uranium in phosphates therefore will be concerned chiefly with the distribution of uranium in deposits valued primarily for their phosphate content.

\section{MINERALOGY}

The principal minerals in the commercially valuable phosphate deposits are calcium phosphates, mainly those of the apatite group, and aluminum phosphates, chiefly erandallite and wavellite $\left[\mathrm{Al}_{3}(\mathrm{OH})_{3}\left(\mathrm{PO}_{4}\right)_{2} .5 \mathrm{H}_{2} \mathrm{O}\right]$. The structural complexity of apatite favors many isomorphous substitutions. Thus, small amounts of $\mathrm{VO}_{4}, \mathrm{AsO}_{4}, \mathrm{SiO}_{4}$, and $\mathrm{CO}_{3}$ or $\mathrm{CO}_{4}$ may substitute for $\mathrm{PO}_{4}$. The fluorine position is generally occupied by fluorine, forming fluorapatite, but may also be occupied by $\mathrm{Cl}$ (chlorapatite), or $\mathrm{OH}$ (hydroxyapatite). Fluorapatite and hydroxyapatite may be $\mathrm{CO}_{3}$-bearing; these varieties are called carbonate-hydroxyapatite and 
carbonate-fluorapatite. These anionic substitutions for $\mathrm{PO}_{4}$ are electrostatically compensated by cationic substitutions of $\mathrm{Mg}, \mathrm{Mn}, \mathrm{Sr}, \mathrm{Pb}, \mathrm{Na}, \mathrm{U}$, or rare earths (McKelvey, Cathcart, Altschuler, and others, 1953, p. 347; McConnell, 1953; Palache, Berman, and Frondel, 1951, p. 882). In crandallite, $\mathrm{Ba}, \mathrm{Sr}$, rare earths, and $\mathrm{U}$ may substitute for $\mathrm{Ca}$, and $\mathrm{OH}$ for $\mathrm{PO}_{4}$ (Palache, Berman, and Frondel, 1951, p. 836); in wavellite, F may substitute to a small extent for $\mathrm{OH}$; $\mathrm{Fe}^{3}, \mathrm{Cr}^{3}, \mathrm{Ga}$, and perhaps $\mathrm{Ca}$ and $\mathrm{Mg}$ for $\mathrm{Al}$; and $\mathrm{SiO}_{4}$ for $\mathrm{PO}_{4}$ (Palache, Berman, and Frondel, 1951, p. 963; MeKelvey, Catheart, Altschuler, and others, 1953, p. 354).

From this account it may be seen that uranium in the phosphate deposits occurs mainly in apatite or crandallite. The uranium is in acid-soluble form, is tetravalent, and is believed to substitute isomorphously for calcium (Altschuler, Clark, and Young, 1954). Although uranium has been reported in wavellite deposits and in other aluminum phosphates, notably turquoise (Davidson and Atkin, 1953, p. 21-23), evansite, and fischerite (Frondel and Fleischer, 1953, p. 206), Altschuler (oral communication) considers it probable that the uranium associated with aluminum phosphates in Florida is in crandallite rather than wavellite. Moreover, several specimens of pure turquoise analyzed by Davidson and Atkin (1953) contain 0.002 percent $\mathrm{eU}$ (equivalent uranium) or less. In view of these observations, as well as the improbability of the substitution of the large uranium ion for the much smaller aluminum ion, the occurrence of uranium in the aluminum phosphate minerals seems doubtful.

\section{TYPES OF PHOSPHATE DEPOSITS}

Phosphate in minable quantities is concentrated by igneous, sedimentary, weathering, and biologic processes and hence is found in a wide variety of deposits (McKelvey, Cathcart, Altschuler, and others, 1953, p. 348): Chief among these are igneous apatites, marine phosphorites, residual phosphorites, riverpebble deposits, phosphatized rocks, guano, and fossil bone. Only the main features of these deposits that may aid in the search for or appraisal of uraniferous phosphates are described here. The reader is referred elsewhere for a fuller account of their characteristics (McKelvey, Cathcart, Altschuler, and others, 1953) and for information on the uranium content of individual deposits (Davidson and Atkin, 1953).

\section{IGNEOUS APATITES}

Apatite of igneous origin is found as an accessory mineral in many igneous rocks, and it is concentrated in deposits of minable size in certain intrusive rocks associated with alkalic igneous rocks, in pegmatites, in hydrothermal veins or disseminated replacements, and in marginal differentiations along or near the boundaries of intruded bodies. The apatite in most of these deposits is fluorapatite. It may contain as much as several percent rare earths (Palache, Berman, and Frondel, 1951, p. 883; McKeown and Klemic, in preparation), but it rarely contains more than 0.005 percent U (Altschuler, Clark, and Young, 1954; Larsen and Phair, 1954). A recently discovered exception is apatite from a magnetite ore body in New York; 14 samples of this apatite average 0.032 percent $\mathrm{U}, 0.15$ percent $\mathrm{Th}$, and 11.14 percent rare-earth oxides (McKeown and Klemic, in preparation). Some of the is neous apatite deposits contain enormous reserves of phosphate, but they are not promising sources of uranium, compared to the marine phosphorites. Because much of the uranium in igneous rocks is concentrated in apatite, however, it is probable that much, perhaps most, of the uranium in the earth's crust is present in this mineral.

\section{MARINE PHOSPHORITES}

Most of the world's production of phosphate comes from marine phosphorites. They generally contain 0.005 to 0.03 percent $U$ and most high-grade deposites (those containing more than 30 percent $\mathrm{P}_{2} \mathrm{O}_{5}$ ) contain more than 0.01 percent. Despite their low uranium content as compared to other ores, they are a promising source of uranium as a byproduct of the manufacture of triple superphosphate (Ruch, 1954).

The marine phosphorites are composed mainly of carbonate-fluorapatite (Altschuler, Cisney, and Barlow, 1953 ) in the form of fine crystals (unaggregated), structureless pellets, oolites, pisolites, nodules (either structureless or composed of one or more of the other types of grains), and fossil remains, including those originally phosphatic, such as fish scales, teeth, and linguloid brachiopod shells, and those that were originally calcareous and have since been phosphatized. These various types of grains may be present in the same beds but one or two types generally predominate in a given layer. Other constituents associated with the carbonate-fluorapatite are quartz, chert, hydromica, and other silicates, carbonaceous matter, carbonates, and glauconite. The phosphorite formations as a group are thin compared to the period of geologic time required for their accumulation, they form only in the absence of significant deposition of clastic sediments or carbonates.

Despite the similarities in the phosphorites, there are some systematic differences. Generally, the deposits richest in phosphate, in terms of total phosphate in the rocks and thickness of high-grade beds, are fine grained, pelletal or oolitie; they are associated vertically with carbonaceous mudstones and cherts. The thinner, 
less phosphatic deposits are coarse grained and bioclastic in many places; they contain appreciable quantities of carbonate, quartz sand, glauconite, and carbonaceous matter and are associated vertically with rocks composed largely of these constituents. Many of the deposits having these diverse characters are lateral equivalents. Because the deposits richest in phosphate are generally present in geosynclines (recognizable not only by their thicker sections but by complexity of structure) and the second is typically developed on cratons or platforms, Kazokov (1937) termed them geosynclinal and platform facies respectively. Neither are polar types in a strict sense; vertical sections of the phosphorite zones include some petrographic types common to both the geosynclinal and platform facies, but the assemblages are nevertheless contrasting in the aggregate.

Geosynclinal facies are richer in phosphorites than platform facies, and since the uranium content of phosphorites increases roughly with increasing phosphate content, geosynclinal facies generally have the higher uranium content. At places in the Phosphoria formation where the phosphate content of the phosphorites is the same in both facies, the uranium content is higher in the geosynclinal than the platform facies. An exception to this is found in moderately or highly uraniferous phosphatic nodules in black shales on the craton, such as the uraniferous phosphatic nodules in Pennsylvanian black shales in Kansas and Oklahoma (Runnels, Schleicher, and Van Nortwick, 1953; McKelvey and Nelson, 1950). Not all such nodules are appreciably uraniferous; for example, those at the top of the Devonian and Mississippian Chattanooga shale in Tennessee contain less than 0.005 percent $\mathrm{U}$.

In addition to the gross differences in the uranium content of the phosphorites of the geosynclinal and platform facies, variations in the uranium content of phosphorites in the Phosphoria formation have been related to specific textural and ehemical properties. These are discussed more fully in a companion paper (McKelvey and Carswell, p. 483, this volume) and it will suffice to say here that uranium appears to be lower in bioclastic than in pellet phosphorites, in weathered than in fresh rocks, and in rocks that contain less than 3 or 4 percent $\mathrm{P}_{2} \mathrm{O}_{5}$.

The uranium in marine phosphorites is believed to be derived from sea water during deposition or at a later time by percolating solutions (McKelvey and Nelson, 1950). Its removal from these source solutions and its emplacement in carbonate-fluorapatite is hindered by the abundance of calcium, carbonate, and hydroxyl ions (Neuman, Neuman, Main, and Mulryan, 1949), but it is influenced also by the length of time the phosphate grains are exposed to the source solutions, by the uranium content of the source solutions, by the size of the phosphate grains, and by the permeability of the phosphatic beds. These relations may explain the lower uranium content of the more calcareous phosphorites and the bioclastic phosphorites (which are commonly rather dense), as well as some of the variations in the uranium content of otherwise similar phosphorites.

\section{RESIDUAL PHOSPHORITES}

Apatite is a more resistant mineral to weathering than carbonates, carbonaceous matter, and other minerals with which it is commonly associated. Weathering, therefore, generally leads to the enrichment of $\mathrm{P}_{2} \mathrm{O}_{5}$, even in a high-grade phosphorite; and it may lead to the formation of a minable phosphate deposit from a phosphatic limestone, too weakly phosphatic to be workable in its unweathered state. More prolonged weathering of phosphorites or of residues derived from phosphatic carbonate rocks may partly destroy the apatite and some silicate and form crandallite, wavellite, or other aluminum phosphates.

The phosphatic limestone residues, of which the brown-rock deposits of Tennessee (Smith and Whitlatch, 1940) are examples, are composed of phosphatic particles of the same texture as those in the source rock, in a matrix of sand and clay. They often lie on a highly irregular, deeply etched limestone surface. The phosphate minerals in these deposits are of the same type as those found in the parent deposits - generally carbonate-fluorapatite - though soluble impurities may have been leached out. The uranium content of these deposits is generally less than 0.005 percent, partly because phosphatic particles in earbonatic rocks, which are the source for such residues, are generally weakly uraniferous, and partly because some uranium is differentially leached from carbonate-fluorapatite during weathering.

The aluminum phosphate deposits, of which those in Florida (Cathcart, Blade, Davidson, and Ketner, 1953), Senegal (Guntz and Arene, 1953; Capdecomme, 1953), and Nigeria (Davidson and Atkin, 1953), are examples, consist of crandallite, wavellite, or other aluminumbearing phosphate minerals, kaolin, quartz sand, and perhaps some relatively unweathered remnants of the unaltered minerals of the original deposits. The rock may be firm and vesicular, or soft and clayey; in either case, most of the phosphate is clay sized and is separable from the sand by washing. The uranium content of aluminum phosphate deposits derived directly from phosphatic limestones is negligible. In deposits derived from high-grade phosphorites the uranium content generally ranges from 0.01 to 0.03 percent, but it may be much higher locally. 
Weathered phosphates may contain secondary uranium minerals. Tyuyamunite has been found in weathered deposits in the Phosphoria formation, tyuyamunite or ferghanite in the phosphates of Morocco (Arambourg and Orcel, 1951) and autunite in the Florida deposits (Z. S. Altschuler and C. E. Boudreau, written communication). None of these occurrences, however, are of more than academic interest.

\section{RIVER-PEBBLE DEPOSITS}

Detrital phosphates derived from the erosion of phosphatic residues have been mined from fluvial deposits in both Florida and South Carolina (McKelvey, Cathcart, Altschuler, and others, 1953, p. 354). These deposits, called river pebble, are mostly apatite placers. The deposits in Florida and South Carolina seem to contain less phosphate than those in the formations from which they are derived, presumably as the result of leaching in the stream. Their uranium content has.not been tested but, judging from the phosphate content, is probably low.

\section{GUANO}

Guano deposits, formed from the accumulation of sea-fowl and bat droppings, are rich in nitrogenous materials and phosphates. Their mineralogy is complex; slightly decomposed deposits consist of soluble ammonium and alkali oxalates, sulfates, and nitrates, and a variety of magnesium phosphates and ammonium-magnesium phosphates. Largely decomposed guano consists principally of calcium phosphates. Guanos tested by both the U. S. Geological Survey (unpublished data) and Davidson and Atkin (1953) contain only negligible amounts of uranium.

\section{PHOSPHATIZED ROCK}

Some of the phosphate leached during the weathering of phosphorites or in the decomposition of guano is reprecipitated after traveling only a short distance, particularly if the phosphatic solutions contact aluminous or iron-bearing rock in a different chemical environment. These deposits, of which the white-rock deposits of Tennessee (Smith and Whitlateh, 1940) and some of the insular deposits (Rodgers, 1948) are examples, consist of encrustations on joint surfaces or in cavities or of irregular replacements of bedrock or residual boulders. The minerals formed reflect the composition of the host rock, and thus range from iron and aluminum phosphate minerals to calcium phosphates. As far as known, none of these deposits contain significant amounts of uranium.

\section{FOSSIL BONE}

Bone consists mainly of nonuraniferous carbonateapatite at the time of its formation, but fossil bones show an increasing content of uranium (Jaffe and Sherwood, 1951) with increasing age. The uranium content of fossil bone associated with phosphorite deposits is of the same order of magnitude as that of the phosphorites themselves -0.005 to 0.03 percent-but isolated specimens in pervious rocks may contain much more. The maximum uranium content in bone that does not contain a discrete uranium mineral is 0.55 percent (eU), reported by Davidson and Atkin (1953) from the Old Red Sandstone, but on the Colorado Plateau and elsewhere fossil bone is commonly replaced, either partly or completely, by uranium minerals.

Fossil bone piles have been mined in the past as a source of phosphate, but known reserves are too small to be of significance now. For this reason, fossil bone is not likely to be an important source of uranium, except as it is a constituent of marine phosphorites, but it is of scientific interest in showing that apatite acquires uranium from percolating solutions.

\section{CONCLUSIONS}

Although the uranium content of phosphatic rocks varies widely, some criteria may be listed as helpful in appraising the potential of unsampled deposits. No known guanos, no phosphatic limestones or residual deposits derived directly from them, no phosphatized rocks, and few igneous apatite deposits contain as much as 0.01 percent U. Generally, the high-grade marine phosphorities and residual deposits derived from them contain 0.01 percent $\mathrm{U}$ or more. Their uranium content is variable but generally increases with increasing phosphate content, measured not only by the phosphate content of individual beds but by the phosphate content of the section as a whole. Amongst less phosphatic deposits, most but not all of those consisting of phosphatic nodules in black shale contain more than 0.01 percent U. Phosphates in sand or other unconsolidated materials amenable to mechanical separation are unlikely to yield a concentrate containing as much as 0.01 percent $\mathrm{U}$ if the matrix is highly calcareous or if the phosphatic particles themselves contain less than 25 percent $\mathrm{P}_{2} \mathrm{O}_{5}$. Residual deposits reworked by marine waters may also contain uranium. Thus the phosphorite particles in the Miocene Hawthorn limestone in Florida contain 0.005 to 0.008 percent $\mathrm{U}$, but those in the overlying Pliocene Bone Valley formation, derived in large part from marine reworked Hawthorn residuum, contain 0.01 to 0.02 percent $U$.

Though these and other generalizations that may be made concerning the uranium content of phosphorites hold good for most known deposits, the fact that uranium can be emplaced or displaced from the structure of apatite and perhaps other phosphate minerals 
introduces a large element of uncertainty in any predictions concerning the uranium content of unsampled deposits, particularly those whose geologic history is also unknown.

\section{REFERENCES CITED}

Altschuler, Z. S., and Cisney, E. A., 1953, X-ray evidence of the nature of carbonate-apatite [abs.]: 19th Internat. Geol. Cong. Comptes rendus, v. 11, p. 9.

Altschuler, Z. S., Clarke, R. S., Jr., and Young, E. J., 1954, Uranium in apatite [abs.]: Geol. Soc. Ameriea Bull, v. 65, pp. $1225-1226$.

Arambourg, C., and Orcel, J., 1951, Observations preliminaires sur la presence d'un vanadate d'urane dans les gisements de phosphates du Maroc: Acad. sci. Paris Comptes rendus, v. 233 , pp. $1635-1636$.

Capdecomme, L., 1953, Etude Mineralogique des gites de phosphates alumineux de la region de Theis (Sénégal): 19th Internat. Geol. Cong. Comptes rendus, v. 11, pp. 103-118.

Catheart, J. B., Blade, L. V., Davidson, D. F., and Ketner, K. B., 1953, The geology of the Florida land-pebble phosphate deposits: 19 th Internat. Geol. Cong., Comptes rendus, v. 11 , pp. $77-91$.

Davidson, C. F., and Atkin, D., 1953, On the occurrence of uranium in phosphate rock: 19th Internat. Geol. Cong. Comptes rendus, v. 11 , pp. 13-31.

Frondel, J. W., and Fleischer, Michael, 1955, Glossary of uranium- and thorium-bearing minerals: U. S. Geol. Survey Bull. 1009-F, pp. 169-209.

Guntz, A. A., and Arene, Micheline, 1953, Sur la présence de l'uranium dans les phosphates africains [abs.]: 19th Internat. Geol, Cong., Comptes Rendus, v. 11, p. 11.

Jaffe, E. B., and Sherwood, A. M., 1951, Physical and chemical comparison of modern and fossil tooth and bone materials: U. S. Geol. Survey TEM-149, 19 pp., issued by U. S. Atomic Energy Comm., Tech. Inf. Service, Oak Ridge, Tenn.

Kazakov, A. V., 1937, The phosphorite facies and the genesis of phosphorites, in Geological investigations of agricultural ores, USSR: Sci. Inst. Fertilizers and Insectofungicides Trans. (U. S. S. R.), no. 142, pp. 95-113. (Special issue in English published for the 17th Internat. Geol. Cong.).
Larsen, E. S., Jr., and Phair, George, 1954, The distribution of uranium in thorium and igneous rocks, in Faul, Henry, ed., Nuclear geology, New York, John Wiley \& Sons, Inc., pp. 75-89.

MeConnell, Duncan, 1953, Radioactivity of phosphatic sediments: Econ, Geology, v. 48, pp. 147-148. (Discussion of paper by V. F. Ross, 1952 , same journal, v. 47 , pp. 783-793.)

McKelvey, V. E., and Nelson, J. M., 1950, Characteristics of marine uranium-bearing sedimentary rocks: Econ. Geology, v. 45 , pp. $35-53$.

McKelvey, V. E., Cathcart, J. B., Altschuler, Z. S., and others, 1953, Domestic phosphate deposits, in Pierre, W. H., and Norman, A. G., ed., Soil and fertilizer phosphorus in crop nutrition, v. IV, pp. 347-376, of Agronomy, a series of monographs, prepared under auspices American Society of Agronomy: New York, Academic Press, Ine.

McKelvey, V. E., Swanson, R. W., and Sheldon, R. P., 1953, The Permian phosphorite deposits of western United States: 19th Internat. Geol. Cong. Comptes rendus, v. 11, pp. 45-64.

MeKeown, F. A., and Klemic, H., in preparation, Rare-earthbearing apatite at Mineville, Essex County, N. Y.: U. S. Geol. Survey Bull.

Neuman, W. F., Neuman, M. W., Main, E. R., and Mulryan, B. J., 1949, The deposition of uranium in bone, VI-Ion competition studies: Jour. Biol. Chemistry, v. 179, pp. 341-348.

Palache, Charles, Berman, Harry, and Frondel, Clifford, 1951, Dana's system of mineralogy, v. $\mid 2,7$ th ed.: New York, John Wiley \& Sons, Inc., 1124 pp.

Rodgers, John, 1948, Phosphate deposits of the former Japanese islands in the Pacific, a reconnaissance report: Econ. Geology, v. 43, pp. 400-407.

Ruch, J. W., 1954, Status of uranium recovery from low-grade sources, Mines Mag. (Denver), v. 44, no. 3, pp. 105-106.

Runnels, R. T., Schleicher, J. A., and Van Nortwick, H. S., 1953, Composition of some uranium-bearing phosphate nodules from Kansas shales: Kansas Geol. Survey Bull. 102, Part 3, pp. 93-104.

Smith, R. W., and Whitlatch, G. I., 1940, The phosphate resources of Tennessee: Tenn. Dept. Conserv. Div. Geol. Bull, 48, 444 pp. 



\title{
URANIUM IN THE PHOSPHORIA FORMATION
}

\author{
By Vincent E. McKelvey and Louis D. Carswell, U. S. Geological Survey
}

\section{CONTENTS}

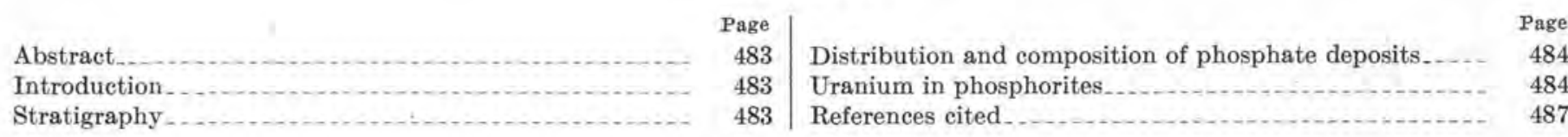

\section{ILLUSTRATIONS}

\begin{abstract}
Figure 165. Total phosphate in phosphatic parts of the Phosphoria formation and its stratigraphic correlatives.

166. Comparison of $\mathrm{P}_{2} \mathrm{O}_{5}$ and $\mathrm{eU}$ content of all samples from the phosphatic shale member of the Phosphoria formation at Mabie Canyon and the 300 -foot level of the Conda mine, Idaho
\end{abstract}

Page

Figure 167. Comparison of $\mathrm{CO}_{2}$ and eU content of all samples from the phosphatic shale member of the Phosphoria formation at Coal Canyon, Wyo.

168. Generalized maximum percent of eU content of rocks of the Phosphoria formation and stratigraphic correlatives.
Page

48

487

Page

\section{ABSTRACT}

The Phosphoria formation, of Permian age, and its close stratigraphic correlatives consist of two overlapping couplets, each composed of a lower carbonaceous phosphatic unit, overlain by a cherty or carbonate-bearing unit. Phosphate deposits are found in the Phosphoria formation over an area of about 135,000 square miles in Montana, Idaho, Utah, and Nevada, but the richest deposits are confined to a central area in eastern Idaho and adjacent parts of Montana, Wyoming, and Utah. Nearly all the phosphatic beds are uraniferous, but their uranium content ranges from about 0.001 to 0.065 percent. Although some highly phosphatic beds are only weakly uraniferous, the phosphate beds that are more than 3 feet in thickness and that contain more than 31 percent $\mathrm{P}_{2} \mathrm{O}_{5}$ generally contain $0.01-0.02$ percent uranium. Most of the differences in uranium content of the phosphate rocks cannot be correlated with other observable differences in their physical or chemical properties. As a rule, however, beds composed of pellets and oolites are more uraniferous than those composed of fish scales, brachiopod shells, and other organic remains; and highly weathered phosphate beds contain less uranium than their unweathered equivalents.

Most of the uranium seems to occur in carbonate-fluorapatite, where it probably substitutes for calcium; but tyuyamunite has been discovered in one area where the rocks are highly weathered.

\section{INTRODUCTION}

The Permian Phosphoria formation and its close stratigraphic correlatives contain marine phosphorite beds over an area of about 135,000 square miles in
Montana, Idaho, Wyoming, Utah, and Nevada. The phosphorites contain 0.005-0.03 percent uranium (McKelvey and Nelson, 1950) and locally, in very thin layers, as much as 0.06 percent uranium (Thompson, 1953 , p. 56). The description of the occurrence of uranium in these rocks is prefaced by the following brief account of the stratigraphy of the Phosphoria rocks and the distribution of the phosphorites themselves.

\section{STRATIGRAPHY}

The Phosphoria formation ranges from about 200 to 1,500 feet in thickness. It consists of two overlapping couplets, each composed of a carbonaceous phosphatic shale member, overlain by a chert member. The lower couplet is thickest (400-1,300 feet) in southeastern Idaho and closely adjacent parts of southwestern Wyoming and Utah; the upper couplet is thickest (100-300 feet) in northwestern Wyoming and Montana. Eastward and southward from these areas the phosphatic and cherty rocks thin and interfinger with sandy and carbonate-bearing rocks, which in turn tongue out into redbeds and evaporites along the fringe of the phosphate field (McKelvey and others, 1953a; Cheney, 1955). The lateral sequence of facies is carbonaceous mudstone and phosphorite, chert, carbonate rock and 
sandstone, and redbeds and evaporites. The lateral sequence is reproduced, either partially or completely, in the same order. and in reverse order in vertical sections. The lateral sequence is interpreted as the product of deposition on a shelving bottom. The vertical sequence from carbonaceous mudstone to evaporites is interpreted as the product of deposition on a rising bottom, and vice versa. The rocks of the Phosphoria thus record nearly two cycles of transgression and regression in depositional environments.

\section{DISTRIBUTION AND COMPOSITION OF PHOSPHATE DEPOSITS}

The phosphate content of the Phosphoria formation and its correlatives is greatest in southeastern Idaho and decreases rather steadily away from this area to the fringe of the phosphate field (fig. 165). The phosphate content of individual beds also diminishes in the same direction; thus, no beds in west-central Wyoming and eastern Utah contain as much as 30 percent $\mathrm{P}_{2} \mathrm{O}_{5}$, whereas many beds in southeastern Idaho contain $30-36$ percent $\mathrm{P}_{2} \mathrm{O}_{5}$ (Swanson and others, 1953, p. 13). Where the shale member is phosphatic, it is most phosphatic either both at the top and at the bottom or at the bottom only. The greatest concentration of phosphate is in the lower phosphatic shale member in southeastern Idaho. There the member is $175-225$ feet thick, and the whole thickness of the phosphatic shale member averages $11-12$ percent $\mathrm{P}_{2} \mathrm{O}_{5}$; beds $5-10$ feet thick near the base and the top contain 25-33 percent $\mathrm{P}_{2} \mathrm{O}_{5}$. The lower bed and the upper bed are respectively overlain and underlain by a phosphatic zone, each of which is 10-25 feet thick and contains 15-25 percent $\mathrm{P}_{2} \mathrm{O}_{5}$. The phosphate content of the lower phosphatic shale member as a whole, and of most individual beds as well, decreases in all directions away from southeastern Idaho. The upper phosphatic shale member is most phosphatic in southwestern Montana (Cressman, 1955), where it is $50-80$ feet thick and averages 9-11 percent $\mathrm{P}_{2} \mathrm{O}_{5}$. Although where thickest the shale member contains no high-grade beds of minable thickness, in some of the surrounding area $3-$ to 20-foot thicknesses contain 3-6 feet of phosphate rock averaging 30 percent $\mathrm{P}_{2} \mathrm{O}_{5}$ or more.

Most of the phosphate beds consist of submicrocrystalline carbonate-fluorapatite, generally aggregated into fine-grained structureless pellets (Altschuler and others, 1953) and different amounts of quartz, silicates, carbonates, and carbonaceous matter. In some beds, the phosphatic grains are oolitic or pisolitic, and in others they consist mainly of fragments of phosphatic brachiopods, fish scales, or phosphatic casts of small gastropods. Generally speaking, the phosphorites in the areas where the phosphatic members are thickest are composed of

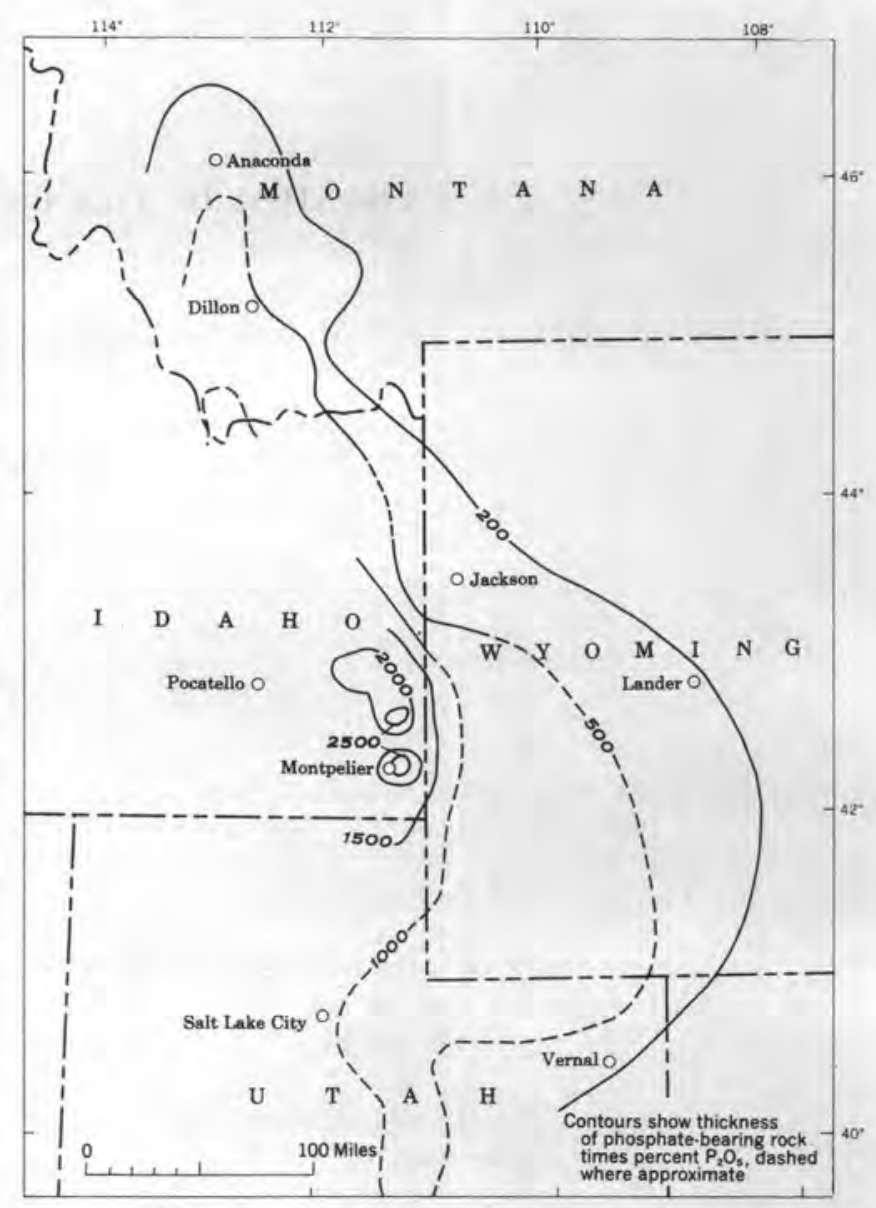

Figure 165,-Total phosphate (in feet times percent $\mathrm{P}_{2} \mathrm{O}_{3}$ ) in phosphatic part of the Phosphoria formation and its stratigraphic correlatives.

fine-grained structureless pellets; coarse-grained oolitic or pisolitic and bioclastic phosphorites are more common in the fringe areas.

The phosphorites are hard and dark brown or black where fresh, but in weathered sections they are often friable and range from brown to light gray, buff, or pink. Comparison of fresh and highly weathered rocks shows that phosphate is enriched on weathering at the expense of carbonaceous matter, carbonates, minor metals, and possibly iron sulfides and alkalies.

\section{URANIUM IN PHOSPHORITES}

Athough the phosphatic shale members of the Phosphoria formation contain some black shale beds that resemble the uraniferous black shales of certain other formations, only the phosphatic beds are appreciably uraniferous. Thin coatings of tyuyamunite have been found along joints in the phosphate mines in the Crawford Mountains, Rich County, Utah, but most of the uranium is in dispersed form. It is acid soluble, tetravalent, and, as shown by autoradiographs, mainly concentrated in the carbonate-fluorapatite grains, 
where it is presumed to substitute isomorphously for ealcium (Altschuler and others, 1954).

As a general rule, the uranium content of the phosphatic beds increases roughly with increasing $\mathrm{P}_{2} \mathrm{O}_{5}$ content, but there are many exceptions (fig. 166). The reasons for tha lack of a constant relationship between uranium and phosphate are not fully understood, but at least several factors seem contributory. Uranium is believed to enter carbonate-fluorapatite either at the time of its precipitation or after burial (McKelvey and Nelson, 1950 , p. 48-50); the amount of uranium in the apatite might thus be a function of the uranium content of the source solutions and the length of time apatite was exposed to them. Beyond this possibility, however, differences in the uranium content seem correlatable with certain differences in the rocks themselves. Thompson $(1953$, p. 62$)$ found that the uranium- $\mathrm{P}_{2} \mathrm{O}_{5}$ correlation is stronger in groups of samples that have a high average $\mathrm{eU}$ content than in groups tbat have a low average $\mathrm{eU}$ content. Thompson also found that groups of samples with a high average eU content show a strong inverse correlation between $\mathrm{eU}$ and percent organic matter and that this inverse correlation shifts gradually to a direct correlation with decreasing average uranium content. In the one group of samples that show a direct correlation of uranium and organic matter, better correlation exists between uranium and the product of the organic matter and $\mathrm{P}_{2} \mathrm{O}_{5}$ contents than with either alone. These relationships suggest that small amounts of uranium are present in organic matter, and possibly other constituents as well as apatite, but that higher amounts are concentrated only in apatite. Increasing amounts of organic matter

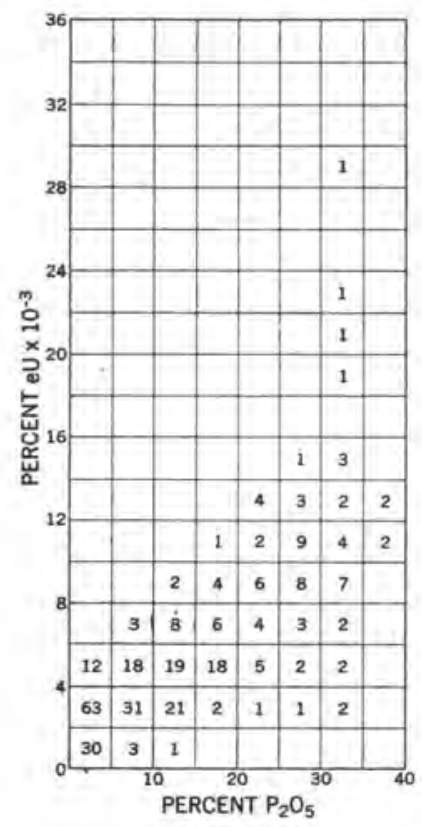

FIGURE 166.-Comparison of $\mathrm{P}_{2} \mathrm{O}$ and $\mathrm{eU}$ content of all samples from the phosphatic shale member of the Phosphoria formation at Mabie Canyon and the 300-foot level of the Conda mine, Idaho. Numbers within graph refer to number of samples falling within each block.
FInve 167.-Comparison of $\mathrm{CO}_{2}$ and $\mathrm{eU}$ content of all samples from the phosphatic shale member of the Phosphoris formation at Coal Canyon, Wyo. Numbers within graph refer to number of samples falling within each block.

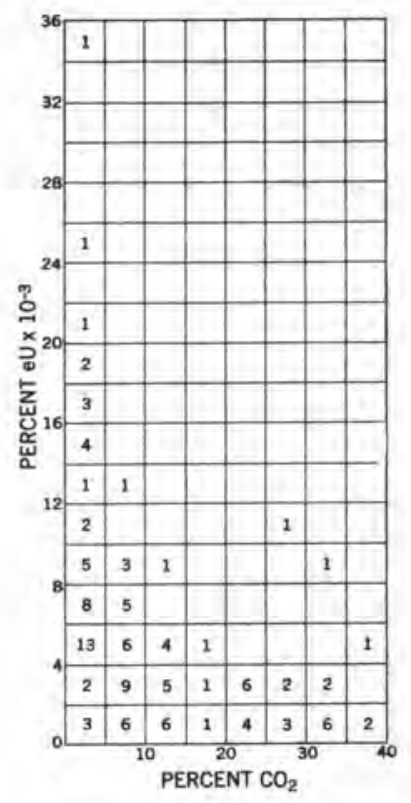

and other constituents serves only to dilute the uranium present in apatite and therefore yields an inverse correlation with uranium. The uranium content is also inversely proportional to the $\mathrm{CO}_{2}$ content (fig. 167). This relationship seems to be more than that expected if $\mathrm{CO}_{2}$ were acting only as a diluent, for few samples that contain more than 0.01 percent uranium also contain more than 3-4 percent $\mathrm{CO}_{2}$.

The relation between uranium content and texture of Phosphoria rocks has not been much investigated, but some of the differences in uranium content may possibly be related to textural differences. For example, phosphorites composed of well-cemented fish scales and shell fragments are generally less uraniferous than pellet phosphates of the same $\mathrm{P}_{2} \mathrm{O}_{5}$ content. M. E. Thompson (1954, p. 120) found a moderate direct correlation between uranium content and the modal diameter of pellets at two localities.

Part of the difference in uranium content observed in phosphatic rocks of the Phosphoria is due to the effects of weathering. Because carbonate-fluorapatite resists decomposition in this climate, weathered sections are enriched in phosphate; in fact, data from the Conda mine in southeastern Idaho suggest that the lower phosphate bed contains only about 29 percent $\mathrm{P}_{2} \mathrm{O}_{5}$ at depths of a few hundred feet, whereas in trenches and open pit mines throughout southeastern Idaho it contains $32-34$ percent $\mathrm{P}_{2} \mathrm{O}_{5}$. Uranium, on the other hand, seems to be slightly impoverished in weathered sections, suggesting that it may be leached from the apatite. Evidence of the migration of uranium leached from the apatite on weathering is the presence of tyuyamunite in the phosphate mines in the north Crawford Mountains, where the phosphate rocks near the surface are 
$\mathrm{P}_{2} \mathrm{O}_{8}$, eU, and $\mathrm{U}$ content of samples from upper phosphate zone, Sublette Ridge, Lincoln County, Wyo.

\begin{tabular}{|c|c|c|c|c|c|c|c|}
\hline Bed nos. & Lot no. ${ }^{1}$ & Locality & $\begin{array}{l}\text { Elevation } \\
\text { (feet) }\end{array}$ & $\begin{array}{c}\text { Thickness } \\
\text { (feet) }\end{array}$ & $\underset{\text { (percent) }}{\mathrm{P}_{2} \mathrm{O}_{5}}$ & $\mathrm{eU}$ (percent) & $\underset{\text { (percent) }}{\mathrm{U}}$ \\
\hline $\begin{array}{r}95-97 \\
92-98 \\
6-11\end{array}$ & $\begin{array}{l}1202 \\
1201 \\
1312\end{array}$ & $\begin{array}{l}\text { Layland Canyon. } \\
\text { Coal Canyon } \\
\text { Raymond Canyon. }\end{array}$ & $\begin{array}{l}7,000 \\
6,850 \\
6,400\end{array}$ & $\begin{array}{l}6.8 \\
6.7 \\
6.4\end{array}$ & $\begin{array}{l}30.5 \\
29.2 \\
22.8\end{array}$ & $\begin{array}{r}0.016 \\
.020 \\
.022\end{array}$ & $\begin{array}{r}0.010 \\
.018\end{array}$ \\
\hline
\end{tabular}

1 Refers to McKelvey and others (1943a) and Sheldon and others (1953) for descriptions of the localities and beds

extremely weathered. Additional evidence of the migration of leached uranium is the presence of as much as 0.022 parts per million (ppm) uranium in certain mine waters, compared with the $0.001 \mathrm{ppm}$, or less, common in ordinary surface and ground waters. The effects of weathering are also seen in the progressively lower $\mathrm{P}_{2} \mathrm{O}_{5}$ and higher $\mathrm{U}$ content of the upper phosphate zone at successively lower elevations in Sublette Ridge, Lincoln County, Wyo., as recorded in the table above: The beds in this area lie on the east limb of a northward-plunging anticline (the decrease in thickness from Layland Canyon to Raymond Canyon probably is a function of increasing dip of the beds) that was truncated by an erosion surface before the deposition of the Eocene Wasatch formation. Elsewhere in the region, beds immediately below this surface are bleached and leached to an advanced degree; although the outcrop of the Phosphoria formation has been reduced below the pre-Wasatch surface by subsequent erosion, it seems likely that the enrichment of phosphate and impoverishment of uranium were accomplished by weathering related to the pre-Wasatch surface rather than to the present topography.

The uranium content also differs areally (fig. 168) in much the same way as does the total phosphate content of the formation (fig. 165). The westward increase in the maximum uranium content of individual beds is partly related to the increase in maximum phosphate content of individual beds in the same direction (Swanson and others, 1953, p. 13-15), but it is partly due to other causes, for the uranium content of beds of the same $\mathrm{P}_{2} \mathrm{O}_{5}$ content increases as the total phosphate content of the phosphatic members increases. This is shown in the following tabulation of the eU content of all beds

Variation in eU content in beds containing 20-25 percent $\mathrm{P}_{2} \mathrm{O}_{5}$

\begin{tabular}{|c|c|c|c|}
\hline \multirow{2}{*}{ Locality } & \multirow{2}{*}{$\begin{array}{l}\text { Thickness in } \\
\text { feet times } \\
\text { percent } \mathrm{P}_{2} \mathrm{O}_{5} \\
\text { in Phos- } \\
\text { phoria for- } \\
\text { mation or } \\
\text { equivalents }\end{array}$} & \multicolumn{2}{|c|}{$\begin{array}{l}\text { eU content (percent) of beds } \\
\text { containing 20-25 percent } \\
\mathrm{P}_{2} \mathrm{O}_{5}\end{array}$} \\
\hline & & Average $\mathrm{eU}$ & Range in eU \\
\hline $\begin{array}{l}\text { Lander, Wyo } \\
\text { Wyoming Range, Wyo... } \\
\text { Sublette Ridge, Wyo_. } \\
\text { Aspen Range, Idaho } \\
\text { Fort Hall, Idaho } \\
\text { Mud Springs, Idaho }\end{array}$ & $\begin{array}{r}260 \\
500-700 \\
1,400 \\
2,000-2,600 \\
1,100-1,200 \\
800\end{array}$ & $\begin{array}{l}0.0035 \\
.0065 \\
.0075 \\
.0080 \\
.007 \\
.005\end{array}$ & $\begin{array}{l}0.001-0.007 \\
0.004-0.010 \\
0.004-0.017 \\
0.002-0.018 \\
0,004-0.009 \\
0.004-0.006\end{array}$ \\
\hline
\end{tabular}

containing 20-25 percent $\mathrm{P}_{2} \mathrm{O}_{5}$ in several districts across the field, listed in east to west order.

The reasons for these areal differences are not understood - they may be partly attributed to differences in the composition of sea water (perhaps content of carbonate ion) at the time of deposition or with compositional or textural differences in the phosphate beds that might affect the amount of uranium they could take up from sea water or from later percolating solutions. Thickening or thinning, caused either by deformation or sedimentation, of layers of either very high or very low uranium content may affect the uranium content of beds that appear homogeneous.

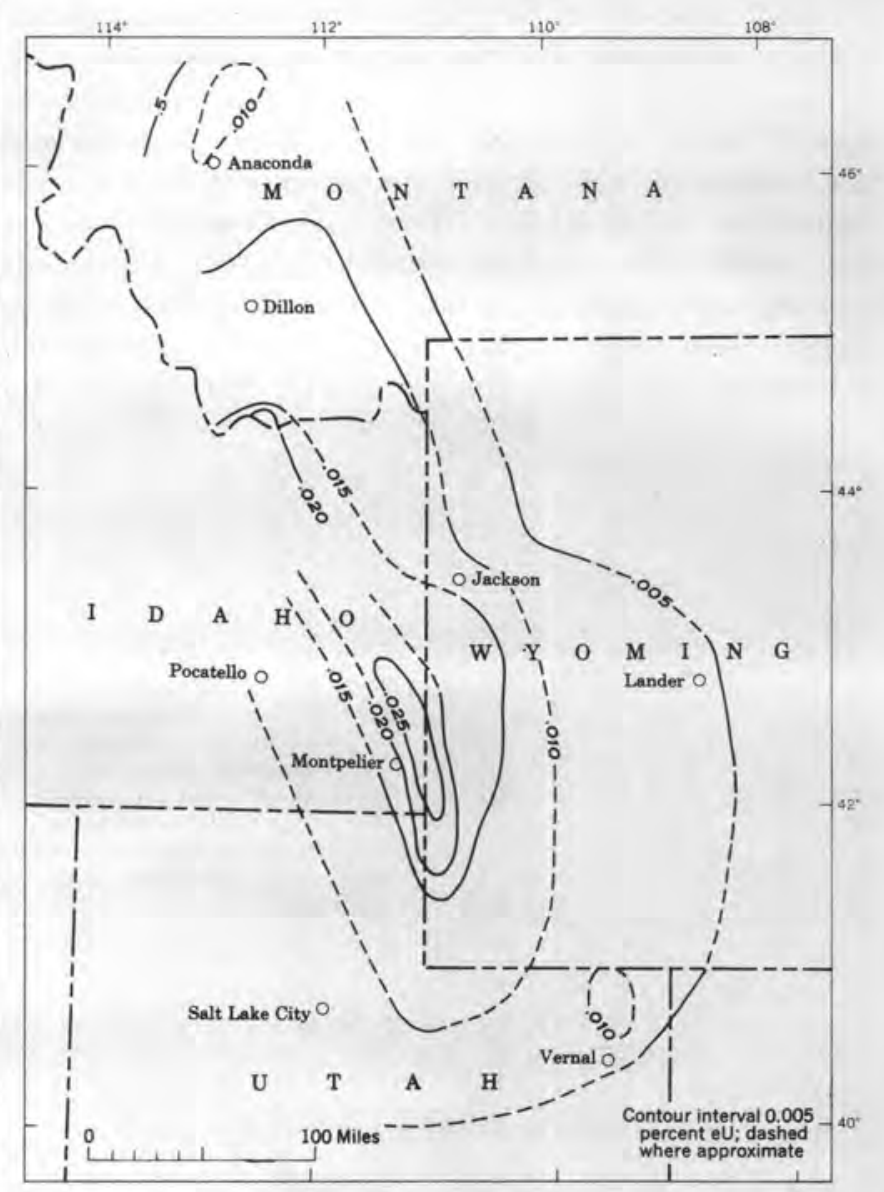

Figure 168.-Generalized maximum percent of eU content of rocks of the Phose phoria formation and stratigraphic correlatives. 
Thus, M. E. Thompson $(1953$, p. 46,56$)$ found that the eU content of a layer only 0.5 foot thick at Coal Canyon, Wyo., ranged from 0.006 to 0.025 in the lower half and from 0.039 to 0.065 in the upper half; thinning or elimination by faulting (a common occurrence in these rocks) of the upper half of this layer would have a marked effect on the uranium content of the upper phosphate bed as a whole. Similarly, the lower phosphate bed in southeastern Idaho may be divided into 3 parts on the basis of uranium content, though it is mined and often sampled as 1 homogeneous unit. For example; at 5 sections where no faulting is evident, the middle part contains $0.018-0.027$ percent $\mathrm{eU}$, compared with $0.008-0.014$ percent $\mathrm{eU}$ for the upper and lower parts. The relative differences in thickness of the middle part, however, are such that it makes up 15-27 percent of the thickness of the bed as a whole.

Although the differences in uranium content of the phosphorites of the Phosphoria are thus diverse in origin, they are not large in absolute values. Beds of minable thickness that contain more than 31 percent $\mathrm{P}_{2} \mathrm{O}_{5}$ generally contain about $0.01-0.02$ percent uranium at or near the surface. Possibly zones of slight secondary enrichment may be found locally below highly weathered zones, but the chances of finding minable thicknesses and tonnages of phosphate rock that contain more than 0.03 percent are not at all high.

\section{REFERENCES CITED}

Altschuler, Z. S., Cisney, E. A., and Barlow, I. H., 1953, X-ray evidence of the nature of carbonate-apatite [abs.], in Saint Guilhem, P. L. R., ed., Origine des gisements des phos- phates des chaux: Internat. Geol. Cong., 19th, Algiers, Comptes rendus, sec. 11 , fasc. 11 , p. 9 .

Altschuler, Z. S., Clarke, R. S., Jr., and Young, E. J., 1954, Uranium in apatite [abs.]: Geol. Soc. America Bull., v. 65 , p. $1225-1226$.

Cheney, T. M., 1955, Facies and oil possibilities of the Phosphoria formation and equivalent strata in eastern Utah and southwestern Wyoming: Wyo. Geol, Assoc., Guidebook 10th Ann. Field Conf.

Cressman, E. R., 1955, Physical stratigraphy of the Phosphoria formation in part of southwestern Montana: U. S. Geol. Survey Bull. 1027-A, 31 p.

McKelvey, V. E., and Nelson, J. M., 1950, Characteristics of marine uranium-bearing sedimentary rocks: Econ. Geology, v. 45, p. $35-53$.

MeKelvey, V. E., Swanson, R. W., and Sheldon, R. P., 1953 a, The Permian phosphorite deposits of Western United States, in Saint Guilhem, P. L. R., ed., Origine des gisements des phosphates des chaux: Internat. Geol. Cong., 19th Algiers, Comptes rendus, sec. 11, fasc. 11, p. 45-64.

McKelvey, V. E., Smith, L. E., Hoppin, R. A., Armstrong, F. C. $1953 \mathrm{~b}$, Stratigraphic sections of the Phosphoria formation in Wyoming, 1947-48: U. S. Geol. Survey Circ. 210, 35 p.

Sheldon, R. P., 1956, Physical stratigraphy of the Phosphoria formation in northwestern Wyoming: U. S. Geol. Survey Bull. 1042-(in preparation).

Sheldon, R. P., Waring, R. G., Warner, M. A., and Smart, R. A., 1953, Stratigraphic sections of the Phosphoria formation in Wyoming, 1949-50: U. S. Geol. Survey Cire. 307, 45 p.

Swanson, R. W., McKelvey, V. E., and Sheldon, R. P., 1953, Progress report on investigations of western phosphate deposits: U. S. Geol. Survey Circ. 297, 16 p.

Thompson, M. E., 1953, Distribution of uranium in rich phosphate beds of the Phosphoria formation: U. S. Geol. Survey Bull. 988-D, p. 45-65.

- 1954, Further studies of the distribution of uranium in rich phosphate beds of the Phosphoria formation: U. S. Geol. Survey Bull. 1009-D, p. 107-122. 



\title{
DISTRIBUTION AND OCCURRENCE OF URANIUM IN THE GALGIUM PHOSPHATE ZONE OF THE LAND-PEBBLE PHOSPHATE DISTRICT OF FLORIDA
}

\author{
By James B. CathCart, U. S. Geological Survey
}

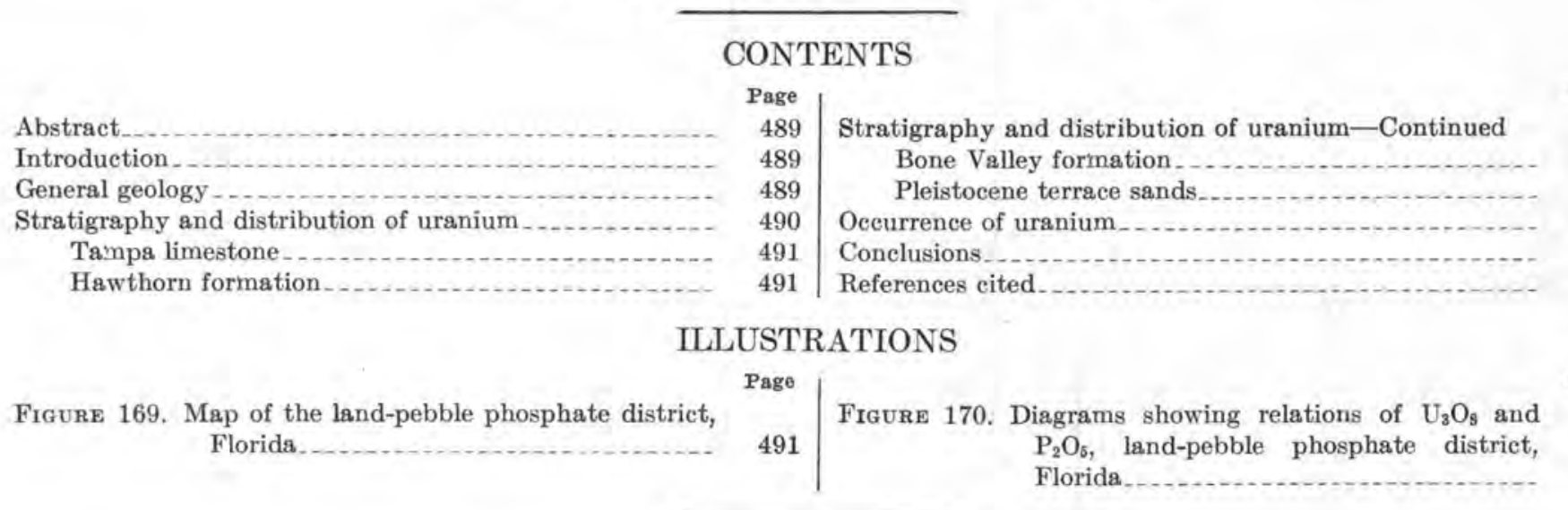

Page

491

492

492

494

494

Page

\section{ABSTRACT}

The land-pebble phosphate district, in west-central peninsula Florida, comprises more than 1,000 square miles, mostly in Polk and Hillsborough Counties. Lower grade phosphate deposits also occur in the south.

The Tampa limestone of early Miocene age is exposed only in the northernmost part of the area, where the Hawthorn formation of early and middle Miocene age thins to a feather edge. The Hawthorn formation contains minor to trace amounts of phosphate particles; and where the earbonate has been removed by weathering, the residual concentration of phosphate particles and quartz sand is called "bedclay," and may form a part of the matrix.

The Bone valley formation of Pliocene age has been leached by acid ground waters, forming a zone characterized by aluminum phosphate minerals. This zone, locally called the "leached zone," commonly contsins between 0.010 and 0.015 percent uranium.

The matrix, or calcium phosphate zone, constituting the lower phosphorite part of the Bone Valley formation, and the upper residual part of the Hawthorn formation, consists essentially of equal parts of quartz sand, phosphate particles (+150 mesh), and slime $(-150$ mesh). The central area of the Bone Valley formation contains predominantly coarse $(+14 \mathrm{mesh})$ phosphate, and the surrounding areas contain predominantly fine $(-14+150$ mesh) phosphate. The analysis of many thousands of samples has shown that the coarser phosphate particles are higher in uranium and lower in $\mathrm{P}_{2} \mathrm{O}_{5}$ content than the finer material. Uranium content of the coarser material (pebble) averages between 0.010 and 0.020 percent, and the $\mathrm{P}_{2} \mathrm{O}_{5}$ content averages about 31.5 percent. The uranium content of the finer materials (concentrates) is commonly between 0.005 and 0.015 percent, and the $\mathrm{P}_{3} \mathrm{O}_{5}$ content averages about 34 percent. A direct relation between $\mathrm{P}_{2} \mathrm{O}_{5}$ content and $\mathrm{U}$ content is present, however, within a size fraction: in pebble samples of the same size, the $U$ content tends to increase as the $\mathrm{P}_{2} \mathrm{O}_{5}$ increases.

The uranium content of the quartz sand fraction of the matrix is less than 0.001 percent, and the slime fraction of the matrix usually contains small amounts of uranium, averaging less than 0.005 percent, although some samples very high in $\mathrm{P}_{2} \mathrm{O}_{6}$ content have a higher uranium content.

It is believed that the uranium is syngenetic, and was absorbed by the phosphate particles as they formed on the sea floor. This might account for the observed higher uranium content of the coarser materials, because they were probably exposed for longer periods of time to the action of sea water than were the smaller particles.

\section{INTRODUCTION}

The land-pebble phosphate district comprises more than 1,000 square miles in west-central peninsular Florida. The district has been divided on the basis of phosphate content and recoverable tonnage into a northern, high-grade part in Polk and Hillsborough Counties and a southern, lower grade part in Hardee and Manatee Counties (fig. 169).

Mining of the deposits started in 1888 , and production has increased steadily. In 1954 over 9 million long tons of phosphate rock was produced. Mining has been confined to the northern part of the district.

During this study the cooperation of the mine owners and operators of the district was wholehearted, and much of the analytical data on which this report is based were furnished by companies. The writer also wishes to thank L. J. McGreevy and A. M. Coleman, of the Geological Survey, for their assistance in computing and compiling data.

\section{GENERAL GEOLOGY}

The land-pebble phosphate district is a part of the Florida section of the Coastal Plain. King (1951) 
points out that the geology of peninsular Florida differs from that of the rest of the Coastal Plain in that Florida was a positive, relatively stable area during a large part of Mesozoic and Cenozoic time; and because of its distance from the main part of the North American continent, it received relatively small amounts of land-derived sediment.

The rocks in the land-pebble phosphate district are the lower Miocene Tampa limestone, lower and middle Miocene Hawthorn formation, middle Pliocene Bone Valley formation, and Pleistocene terrace sands (Cooke, 1945; MacNeil, 1950).

The Tampa and Hawthorn formations dip very gently to the south and east. The Tampa limestone is exposed only in pits in the northernmost part of the district where the Hawthorn formation is absent owing to erosion. The Hawthorn formation underlies the rest of the district. The Bone Valley formation overlies the Hawthorn throughout the district, except along the Peace and Alafia Rivers, where the Hawthorn formation is exposed. Quartz sands, generally assigned to the Pleistocene (MacNeil, 1950) overlie the Bone Valley formation in most of the district.

Phosphate nodules are present in the Tampa, Hawthorn, and Bone Valley formations. According to Altschuler, Cisney and Barlow (1952), the phosphate mineral is a carbonate-fluorapatite.

\section{STRATIGRAPHY AND DISTRIBUTION OF URANIUM}

Stratigraphic relations, mining terminology, mineralogy, and average uranium content are summarized in the following table.

Correlation of stratigraphy, mineralogy, average uranium content, and mining terminology, land-pebble phosphate district, Florida

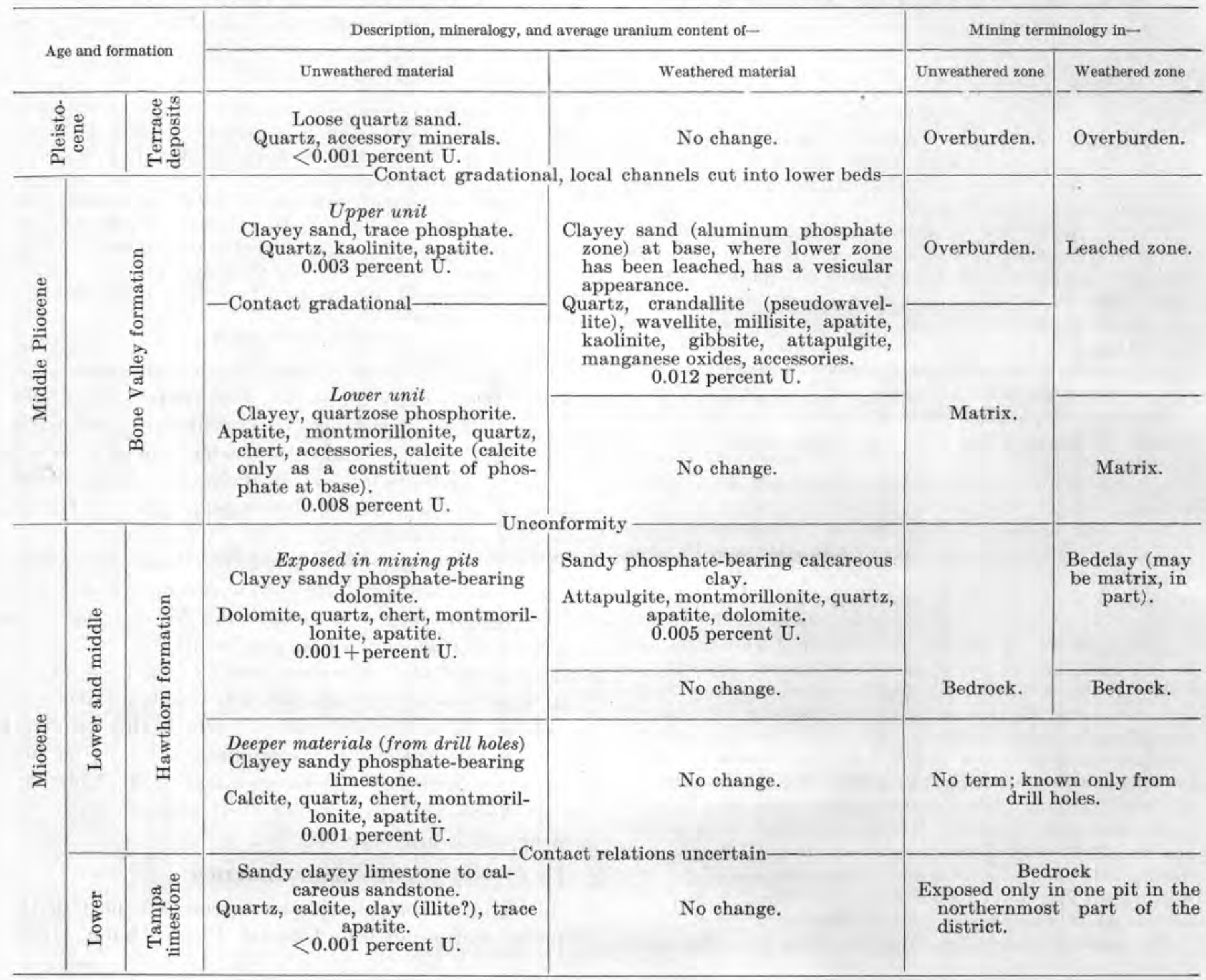




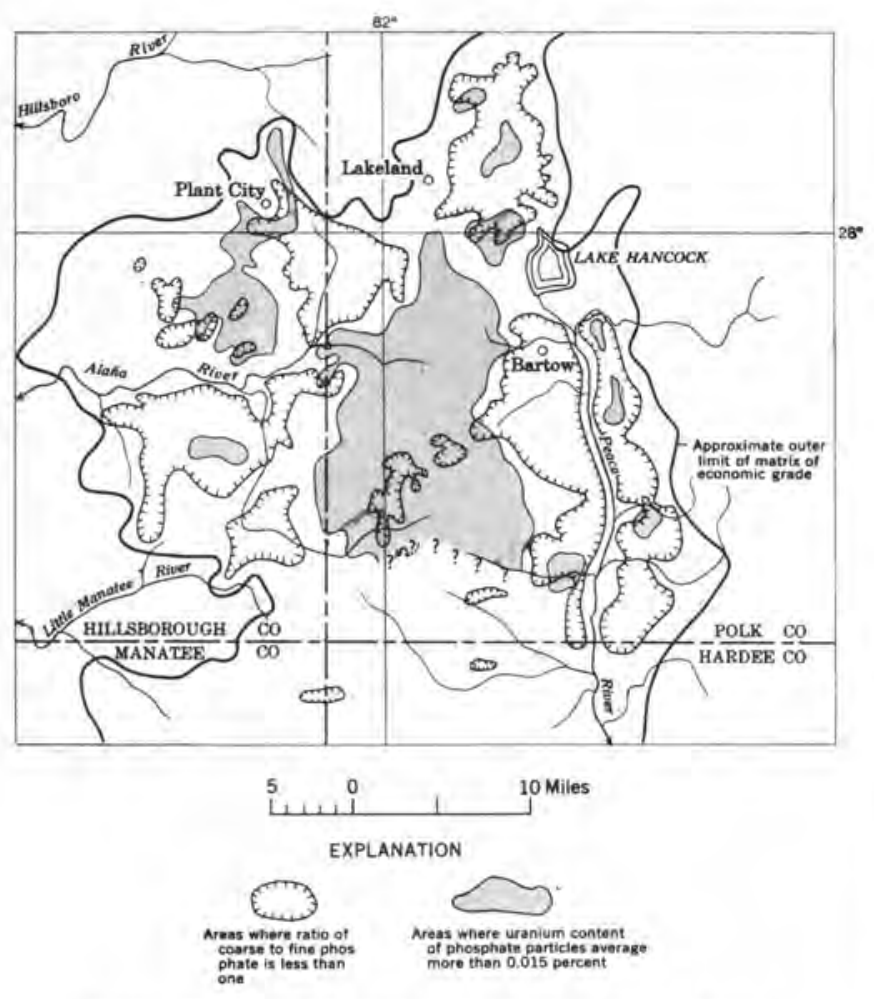

Figure 169.-Map of the land-pebble phosphate district, Florida.

TAMPA LIMESTONE

The Tampa limestone (lower Miocene) is exposed in only one pit but may form the so-called bedrock in some drill holes in the northernmost part of the district. Only a few feet are exposed at any one locality, but drill records indicate a total thickness of about 70 feet in Hillsborough County. The Tampa is an impure limestone or a calcareous clayey sand, containing traces of phosphate nodules. Carr and Alverson (1954) report that 16 samples of Tampa limestone contain an average of 0.3 percent $\mathrm{P}_{2} \mathrm{O}_{5}$. The uranium content of the formation is also very low, probably averaging less than 0.001 percent.

\section{HAWTHORN FORMATION}

The Hawthorn formation (lower and middle Miocene) (MacNeil, 1947) comformably overlies the Tampa limestone in some places, but elsewhere the contact is seemingly unconformable (Carr and Alverson, 1953). The Hawthorn formation ranges from a feather edge in the northern part of the land-pebble district to several hundred feet in thickness in the south and east. Where exposed in the pits, the Hawthorn formation is a soft buff to yellow sandy clayey phosphatebearing dolomite. In studying cuttings from a deep well, Robert Berman (written communication) found an abrupt change at 80 feet from a dolomite to a sandy limestone containing some phosphate. The change from dolomite to limestone may be significant, and it is believed that the upper dolomitic zone may be a replacement of the limestone.

"Bedrock," the term used for material too hard to penetrate with a hand-auger, is generally the hard dolomite of the Hawthorn formation. Although few samples have been analyzed, the bedrock is typically low in both phosphate and uranium, probably averaging less than 5.0 percent $\mathrm{P}_{2} \mathrm{O}_{5}$ and about 0.001 percent $\mathrm{U}_{3} \mathrm{O}_{8}$. Apatite nodules in the bedrock are also low in both phosphate and uranium. Although individual samples of nodules may contain as much as 32 percent $\mathrm{P}_{2} \mathrm{O}_{5}$, and 0.010 percent $\mathrm{U}_{3} 0_{8}$, most are much lower. The average $\mathrm{P}_{2} \mathrm{O}_{5}$ content of apatite nodules in the bedrock is probably less than 20 percent, and the average uranium content is less than 0.005 percent. The rest of the minerals that make up the bedrock (dolomite, quartz, and montmorillonite) contain practically no uranium.

A thin discontinuous deposit of soft, water-saturated plastic sandy clay overlies the dolomite of the Hawthorn formation. This clay grades into the material below, is unconformably overlain by bedded phosphorite deposits, and obviously was derived from the hard dolomite beneath by carbonate leaching. This material, called bedclay, is mined where the residual concentration of phosphate particles and the $\mathrm{P}_{2} \mathrm{O}_{5}$ content of the particles is economically significant. The bedclay often has more uranium than the minable material (matrix) directly above it, but most of the uranium is concentrated in the slime ( -150 mesh) fraction. The matrix above the bedclay contains a higher percentage of recoverable phosphate nodules and usually less clay. The bedclay ranges from 7 to about 28 percent $\mathrm{P}_{2} \mathrm{O}_{5}$, and from 0.002 to 0.015 percent $\mathrm{U}_{3} \mathrm{O}_{8}$ but averages only about 8 percent $\mathrm{P}_{2} \mathrm{O}_{5}$ and about 0.005 percent $\mathrm{U}_{3} \mathrm{O}_{8}$. Most of the uranium is concentrated in the phosphate minerals of the bedclay; the other minerals, attapulgite, montmorillonite, quartz, and dolomite, contain practically no uranium.

\section{BONE VALLEY FORMATION}

The Bone Valley formation is generally regarded as Pliocene in age on the basis of land vertebrates (Simpson, 1929), although it may be uppermost Miocene. Bergendahl (1956) shows an interfingering of his "undifferentiated phosphate," in part equivalent to the Bone Valley formation, with a sand containing marine invertebrates that have been regarded as very late Miocene in age. At present, this discrepancy in age assignment has not been resolved.

The Bone Valley formation unconformably overlies the Hawthorn formation. In the northern part of the land-pebble district, the Bone Valley formation may 
be divided into a lower and an upper unit. The lower unit, which ranges from a feather edge to 50 feet in thickness, averages about 20 feet in thickness. The lower unit is a pebbly clayey phosphate sand, characterized by crude-graded bedding, but in places it is laminated and crossbedded. The unit consists essentially of quartz, apatite, and montmorillonite. Individual beds may range from nearly pure clay or quartz sand to apatite sand or conglomerate. The base of the lower unit is marked by a persistent phosphate conglomerate or sand below which Pliocene land mammals have not been found.

The upper unit of the Bone Valley formation is composed essentially of quartz and montmorillonite clay, with only trace amounts of apatite. The unit ranges in composition from a clayey sand to a sandy clay.

The contact between the upper and lower unit is a gradational zone of a few inches to a foot or more. The basal part of the upper unit contains a small percentage of phosphate nodules, but the upper part of the unit contains little, if any, clastic phosphate.

The lower part of the Bone Valley formation plus the economic part of the residual Hawthorn is the calcium phosphate zone, or matrix, in the district. Although both lithology and thickness differ greatly, the material as mined consists of nearly equal amounts of quartz sand, slime ( -150 mesh material), and recoverable apatite nodules. Average matrix contains slightly less than 20 percent $\mathrm{P}_{2} \mathrm{O}_{5}$ and about 0.008 percent $\mathrm{U}_{3} \mathrm{O}_{8}$. After disintegration the matrix is washed over a 14-mesh screen. The oversize, a product called pebble, contains between 29 and 34 percent $\mathrm{P}_{2} \mathrm{O}_{5}$ and between 0.008 and 0.050 percent $\mathrm{U}_{3} \mathrm{O}_{8}$. The undersize is treated in a hydroseparator; the overflow, usually slime, is a waste product. The slime fraction contains an average of about 15 percent $\mathrm{P}_{2} \mathrm{O}_{5}$ and 0.005 percent $\mathrm{U}_{3} \mathrm{O}_{8}$. The underflow of the hydroseparator is the flotation feed. It is treated in a froth flotation mill, where the quartz and apatite sands are separated. The quartz sands, a waste product, contains less than 4.0 percent $\mathrm{P}_{2} \mathrm{O}_{5}$, and less than 0.001 percent $\mathrm{U}_{3} \mathrm{O}_{8}$. The apatite sands, or concentrate, contain between 32 and 37 percent $\mathrm{P}_{2} \mathrm{O}_{5}$ and between 0.004 and 0.030 percent $\mathrm{U}_{3} \mathrm{O}_{8}$. Because of the loss of $\mathrm{P}_{2} \mathrm{O}_{5}$ in the slime fraction, about two-thirds of the total phosphate in the matrix is recovered.

The Bone Valley formation has been altered by downward-percolating acid ground water, and this zone of alteration is called the leached or aluminum phosphate zone by the mining companies. The leached zone is not a stratigraphic unit, but may affect either the upper unit or the lower unit, or both. The zone is characterized by the presence of aluminum phosphate minerals and by a relatively high uranium content. The leached zone ranges from a knife edge to almost 50 feet in thickness and averages about 8 feet in thickness, about half the average thickness of the matrix. The uranium and phosphate contents of the zone differ widely, depending on whether the upper or lower parts of the Bone Valley formation were leached. The average composition of the zone is difficult to estimate, but it may contain about 0.012 percent $\mathrm{U}_{3} \mathrm{O}_{8}$ and less than 10 percent $\mathrm{P}_{2} \mathrm{O}_{5}$.

The uranium content of the Bone Valley formation is closely associated with the phosphate minerals. Clay minerals, montmorillonite in the unleached material and kaolinite in the leached zone, contain practically no uranium; the quartz sand is essentially barren; and while accessory heavy minerals may contain small amounts of uranium, they are usually not present in more than trace amounts.

\section{PLEISTOCENE TERRACE SANDS}

Loose quartz sands overlying the Bone Valley formation have been called Pleistocene and have been divided into terraces by several writers (Cooke, 1945; MacNeil, 1950). With the exception of the 30-foot terrace, which contains abundant invertebrate fossils, the vertebrates are represented by only a few horse teeth of Pleistocene age that have been found in these sands. The contact with the underlying clayey sands of the upper unit of the Bone Valley formation is commonly gradational, but disconformable relations (channel cutting and filling) have been seen in a few of the mines. The terrace sands commonly contain less than 0.001 percent $\mathrm{U}_{3} \mathrm{O}_{8}$ and less than 0.5 percent $\mathrm{P}_{2} \mathrm{O}_{5}$.

\section{OCCURRENCE OF URANIUM}

Uranium is associated with the phosphate minerals in the land-pebble field. No uranium minerals have been found, except in one locality in the leached zone where small amounts of autunite were identified by Z. S. Altschuler, of the Geological Survey. The highest uranium contents in the field are associated with a bed of soft white phosphate nodules at the base of the leached zone. The highest uranium contents seem to be associated with the calcium phosphate minerals. Spherulites of wavellite found in the leached zone contain practically no uranium (Bergendahl, 1952).

Several hundred samples of the leached zone were chemically analyzed for uranium, phosphate, alumina, iron, fluorine, calcium, and silica. Each sample was of the total thickness of the leached zone as determined from a gamma-ray log. The following tabulation shows the coefficients of correlation (Snedecor, 1946) for these samples. 
Coefficients of correlation, leached zone

Uranium/phosphate

Uranium/fluorine

Uranium/ealcium

Uranium/aluminum

Uranium/iron

Uranium/silica

The coefficients of correlation show that the uranium is associated with apatite and not particularly with the aluminum phosphate mineral. The inverse correlation of uranium and silica is expectable, because silica, in the form of quartz sand, is the principal diluent in the leached zone.

Uranium in the matrix occurs almost exclusively with apatite. Samples of coarse apatite nodules in the matrix are in general higher in uranium content but lower in phosphate content than the finer nodules. Many of the finer nodules are primary granules, reworked, at least in part, from the Hawthorn formation, while the coarser nodules are phosphatized limestone. Many coarse nodules contain fossils of Hawthorn age or apatite pseudomorphs after calcite. Figure $170 \mathrm{~A}$ is a scatter diagram of $\mathrm{U}_{3} \mathrm{O}_{8}$ plotted against $\mathrm{P}_{2} \mathrm{O}_{5}$ for both coarse- and fine-grained samples. Each point on the scatter diagram is a weighted average of the phosphate and uranium content of apatite nodules from many drill holes, and each sample represents from $1 \times 10^{5}$ to $1 \times 10^{7}$ long tons of phosphate. The samples are from all the mining companies and are representative of the district. The coefficient of correlation $(r)$ is -0.64 , a strong inverse correlation, which shows that for all nodules the uranium content increases as the phosphate content decreases.

To relate the uranium and phosphate content to nodule size, analytical results were tabulated from deposits with different characteristics. Phosphate deposits in the district can be divided into three classes, based on phosphate content and particle size: lowgrade deposits, predominantly coarse pebble; mediumgrade deposits of mixed pebble and concentrate (apatite sands); and high-grade deposits, predominantly concentrate. Weighted averages of hundreds of samples for each of the types of deposit are shown on figure $170 \mathrm{C}$. This diagram clearly shows that the phosphate content increases and uranium content decreases as the size of the nodules decrease. The total uranium content of the high phosphate deposits is shown to be less than the total uranium content of the lower grade phosphate deposits. Coefficients of correlation were computed for nodules of the same size and from the same deposits, but the results are not conclusive. In general, there is a slight tendency for the sized fractions of apatite nodules to show a small direct

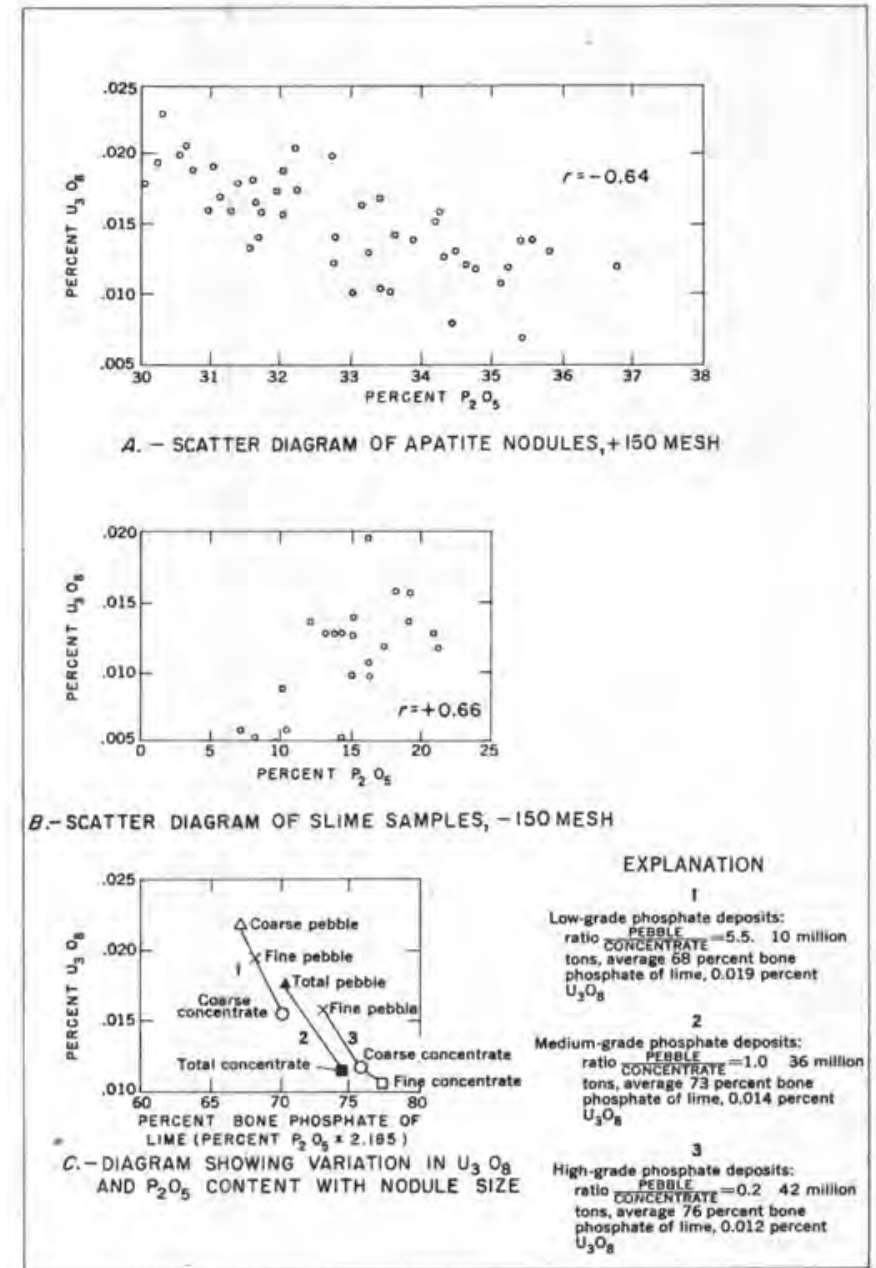

FigUre 170.-Diagrams showing relations of $\mathrm{U}_{3} \mathrm{O}_{8}$ and $\mathrm{P}_{2} \mathrm{O}_{5}$ land-pebble phosphate district. $r$ is the coefficient of correlation.

correlation, but the coefficients of correlation range from +0.60 through no correlation (close to zero) to -0.26 . The slime from these samples, however, did not differ nearly as much, and the average for all samples of slime is +0.66 , a good direct correlation (fig. $170 \mathrm{~B}$ ). In summary, a definite inverse correlation is shown between uranium and phosphate content for apatite nodules of all sizes, and an equally definite direct correlation is shown between uranium and phosphate in the slime of the matrix, but the coefficient of correlation within a size grade for the apatite nodules is not as good, and in individual groups of samples may be either direct or inverse.

Differences in grain size and in phosphate and uranium content of the apatite nodules in the matrix have been mapped (fig. 169). Deposits dominantly composed of coarse rock occupy the north-central part of the land-pebble district; the deposits of finer grained material occupy peripheral areas in the drainages of the Peace and Alafia Rivers. The same figure also 
shows the higher grade uranium areas which coincide with the areas of coarser rock and are lowest in phosphate content.

\section{CONCLUSIONS}

C. F. Davidson and D. Atkin (1953) have pointed out that, in general, throughout any single sample, there is a constant ratio of $\mathrm{U}_{3} \mathrm{O}_{8}$ to $\mathrm{P}_{2} \mathrm{O}_{5}$ and that on acidulation of phosphate rock the uranium taken into solution is directly proportional to the phosphate dissolved. In addition, abundant evidence from chemical work shows that uranium, which has about the same ionic radius as calcium, proxies for calcium in the apatite of bone (Neuman, Neuman, Main, and Mulryan, 1948, 1949 $\mathrm{a}, \mathrm{b}, \mathrm{c})$. An ionic replacement of this type is a satisfactory explanation for the radioactivity of phosphate deposits. In the land-pebble phosphate deposits of Florida the highest radioactivity is associated with calcium phosphate minerals; and although the aluminum phosphate minerals do contain higher than average amounts of uranium, at least some of the samples collected contain practically no uranium. This indicates that although uranium probably shows a preference for calcium phosphate, it is present in aluminum phosphates, probably in some way other than ionic replacement.

The inverse relation between grain size of the apatite nodules and their uranium content is constant throughout the district. This relation precludes downward percolation of ground waters as a source for the uranium, because the relation holds even in deposits that contain more than 95 percent of fine-grained apatite nodules. Any downward movement of uranium-bearing solutions through this type of deposit would almost certainly enrich the finer grained nodules. In addition, the nodules in the Hawthorn formation contain less uranium than do those in the Bone Valley formation. These relations can best be explained by assuming that the uranium in these deposits is syngenetic, and was absorbed by the phosphate particles as they formed on the sea floor. The period of weathering that followed the deposition of the Hawthorn formation resulted in the formation of a residuum, and this material was available for reworking into the Bone Valley. Thus, phosphate particles originally formed in the Hawthorn sea were exposed a second time to the action of sea water, and are consequently higher in uranium content. In addition, the explanation for the higher uranium content of the coarser particles may be that the coarser particles were exposed for a longer time to the action of sea water by virtue of their size and consequent slower burial.

\section{REFERENCES CITED}

Altschuler, Z. S., Cisney, E. A., and Barlow, I. H., 1952, X-ray evidence of the nature of carbonate-apatite [abs.]: Geol. Soc. America Bull., v. 63 , p. 1230-1231.

Bergendahl, M. H., 1953, Wavellite spherulites in the Bone Valley formation of central Florida: Nuclear Sci. Abs., v. 7, no. 11 , p. $375-376$.

1956, Stratigraphy of parts of DeSoto and Hardee Counties, Fla.: U. S. Geol. Survey Bull. 1030-B (in press).

Carr, W. J., and Alverson, D. C., 1953, Stratigraphy of Suwannee, Tampa, and Hawthorn formations in Hillsborough and parts of adjacent counties, Fla., in Geologic investigations of radioactive deposits - Semiannual progress report, June 1 to Nov. 30, 1953: U. S. Geol. Survey TEI-390, p. 179-185, issued by U. S. Atomic Energy Comm. Tech. Inf. Service, Oak Ridge, Tenn.

- 1954, Stratigraphy of middle Tertiary rocks in part of west-central Florida, in Geologic investigations of radioactive deposits-Semiannual progress report, Dec. 1, 1953, to May 31, 1954: U. S. Geol. Survey TEI-440, p. 152-156, issued by U. S. Atomic Energy Comm., Tech. Inf. Service, Oak Ridge, Tenn.

Cook, C. W., 1945, Geology of Florida: Fla. Geol. Survey Bull. 29, $339 \mathrm{p}$.

Davidson, C. F., and Atkin, D., 1953, on the occurrence of uranium in phosphate rock, in Saint Guilhem, P. L. R., ed, Origine des gisements des phosphates des chaux: Internat. Geol. Cong., 19th, Algiers, Comptes rendus, sec. 11, fase. 11, p. 13-31.

King, P. B., 1951, The tectonics of middle North AmericaMiddle North America east of the Cordilleran System: Princeton, N. J., Princeton Univ. Press, 203 p.

MacNeil, F. S., 1947, Correlation chart for the outcropping Tertiary formations of the eastern gulf region: U. S. Geol. Survey Oil and Gas Inv. Prelim. Chart no. 29, with text. - 1950, Pleistocene shore lines in Florida and Georgia: U. S. Geol. Survey Prof. Paper 221-F, p. 19-25 (1951).

Neuman, W. F., Neuman, M. W., Main, E. R., Mulryan, B. J., 1948, The deposition of uranium in bone, I-Animal studies: Jour. Biol. Chemistry, v, 175, p. 705-709.

-1949a, The deposition of uranium in bone, IV-Adsorption studies in vitro: Jour. Biol. Chemistry, v. 179, p. 325-333.

- 1949b, The deposition of uranium in bone, V-Ion exchange studies: Jour. Biol. Chemistry, v. 179, p. 335-340.

- $1949 \mathrm{c}$, The deposition of uranium in bone, VI-Ion competition studies: Jour. Biol. Chemistry, v. 179, p. 341-348.

Simpson, G. G., 1929, The extinct land-mammals of Florida: Fla. Geol. Survey 20th Ann. Rept., p. 257-279.

Snedecor, G. W., 1946, Statistical methods applied to experiments in agriculture and biology: Ames, Iowa, The Collegiate Press, Inc., $485 \mathrm{p}$. 


\title{
THE ALUMINUM PHOSPHATE ZONE OF THE BONE VALLEY FORMATION, FLORIDA, AND ITS URANIUM DEPOSITS
}

\author{
By Zalman S. Altschuler, Elizabeth B. Jaffe, and Frank Cuttitta, U. S. Geological Survey
}

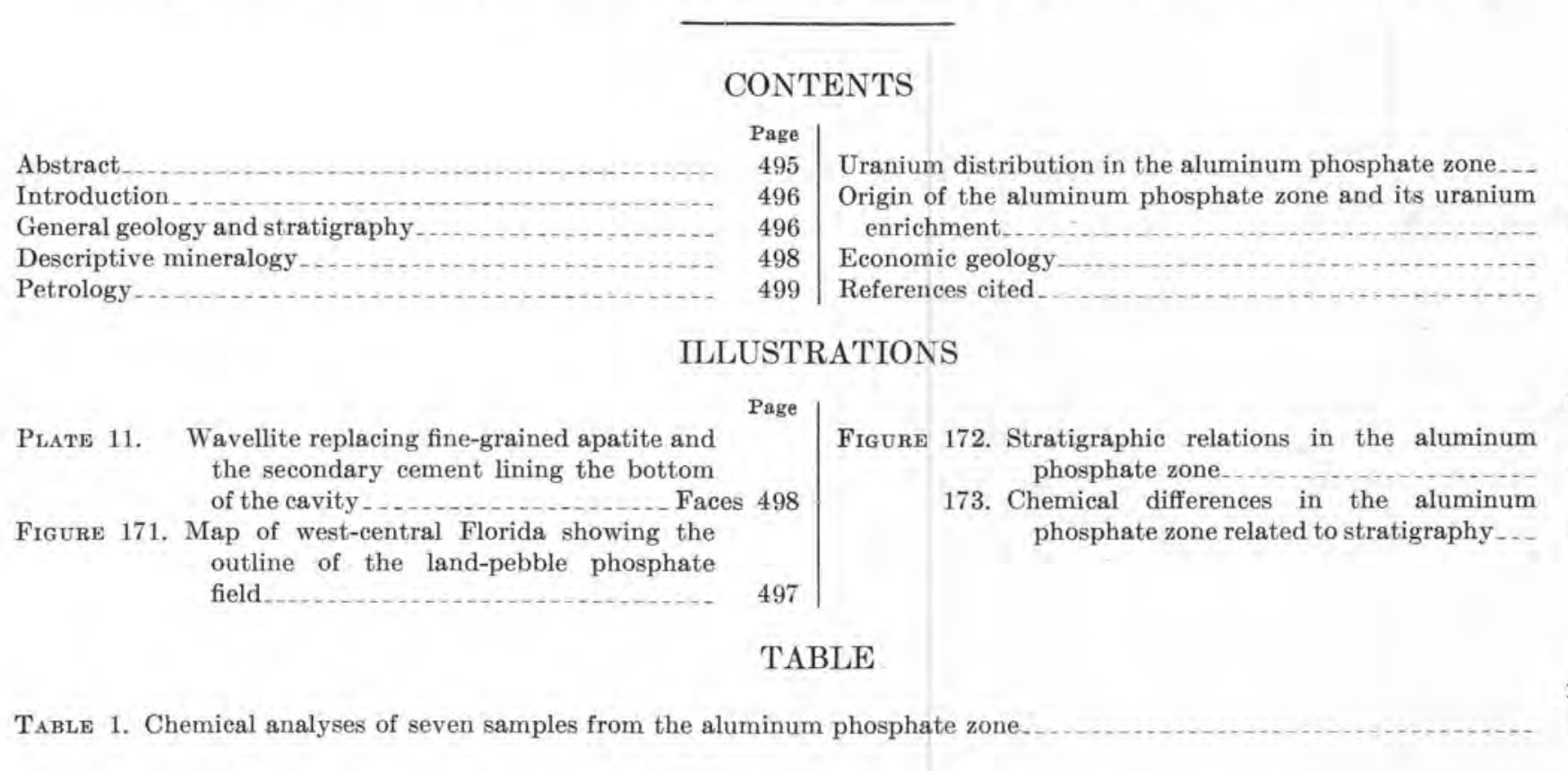

\section{ABSTRACT}

The Bone Valley formation of Pliocene age, which contains most of the land-pebble phosphates, occurs in west-central Florida, east of the Tampa Bay region. It unconformably overlies the Hawthorn formation of early and middle Miocene age and is covered by a surface mantle of quartz sands. It contains graded bedded pebbly and clayey phosphatic sands in its lower two-thirds, which are mined, and a less phosphatic massivebedded clayey sand, approximately 8-10 feet thick, in its upper third, which is disearded.

The upper part of the Bone Valley formation has been leached, altered to aluminum phosphates, and enriched in uranium in a widespread though discontinuous zone which averages about 6-7 feet in thickness and underlies several hundred square miles of the Peace and Alafia drainage basins. The areal distribution patterns with respect to the thickness, tonnage, and grade of the aluminum phosphate zone conform strikingly to the topography of the river valleys.

The Bone Valley formation was altered by weathering and ground water, and the vertical changes through the aluminum phosphate zone show a progressive change in mineralogy and texture. In typical sections carbonate-fluorapatite still prevails at the base, incipiently leached and altered. In the middle of the zone, the calcium aluminum phosphates crandallite and millisite are found, and at the top the aluminum phosphate wavellite predominates. The changes have been brought about by phosphatization of clay and by alumina alteration of apatite.

Much apatite and clay have been leached and replaced in the aluminum phosphate zone, and its rock is generally white, friable, and highly porous; however, its character has been greatly influenced by the primary Bone Valley petrography. Thus, where graded bedded pebbly rock is altered, coarse, frequently graded, vesicularity results; where massive clayey sand is altered, fine porosity prevails, and aluminum phosphates are more common.

The uranium content of unaltered rock of the lower part of the Bone Valley is approximately 0.008 percent; its $\mathrm{P}_{2} \mathrm{O}_{5}$ content is about 15 percent. Unaltered rock of the upper part of the Bove Valley contains much less uranium and $\mathrm{P}_{2} \mathrm{O}_{5}$. By contrast, a well-developed section of aluminum phosphate zone typically has 0.012 percent uranium and approximately 8-10 percent $\mathrm{P}_{2} \mathrm{O}_{5}$. Within the aluminum phosphate zone, uranium increases as calcium does, and the more ealcic phosphates are more uraniferous. In addition, supergene processes have caused a subzone of basal enrichment in the aluminum phosphate zone in which individual apatite specimens contain as much as $0 . \mathrm{X}$ percent uranium. Except for a single trace occurrence of autunite, no uranium minerals have been found in the Bone Valley formation.

The aluminum phosphate zone is a potentially valuable resource of uranium, phosphate, and alumina, particularly as it 
must be stripped anyway to mine the underlying apatite deposits, and its rock can be readily beneficiated by removal of quartz, the major diluent.

\section{INTRODUCTION}

In the upper part of the Bone Valley formation, Florida, a discontinuous zone of alteration containing aluminum phosphate overlies the commercially mined apatite which constitutes the land-pebble phosphates. This aluminum phosphate zone has been known for many years. In 1949, however, during the U. S. Geological Survey's exploration studies for uranium, it was found to be fairly widespread and enriched in uranium; this greatly enhances its value as a potential resource, not alone of uranium but also of alumina and phosphate. The aluminum phosphate-desposits result from the lateritic alteration of the Bone Valley formation by ground water and represent the progressive replacement of clay and apatite in a paragenetic sequence which has recently been reported from other similarly altered phosphate deposits - those of Nigeria (Russ, 1924) and Sénégal (Capdecomme, 1953). Thus, in addition to its economic interest, the aluminum phosphate zone is intrinsically interesting to the geologist because it represents a general type of alteration in the particular petrogenetic domain of phosphorites.

Much of the work reported here was originally published in an administrative report to the U. S. Atomic Energy Commission in December 1949. The authors are much indebted to associates in the U. S. Geological Survey for more recent contributions to their efforts: to J. P. Owens and R. M. Berman for X-ray investigations of pseudowavellite and millisite, to E. J. Young for field and laboratory studies on the genesis and distribution of zones of weathering and surficial deposits; to J. B. Catheart, the highlights of whose economic studies have been freely drawn on, and to C. B. Hunt for his stimulating guidance and criticism in many of the field problems.

\section{GENERAL GEOLOGY AND STRATIGRAPHY}

The Bone Valley formation of Pliocene age (Catheart and others, 1953) underlies 2,600 square miles in westcentral peninsular Florida, east of the Tampa Bay region, in Polk and Hillsboro Counties and extending into adjoining counties (fig. 171). The region is generally flat and exposures are limited to the phosphate mines and to a few spots in the banks of the Alafia and Peace Rivers, which drain the area. A low northtrending ridge of subdued karst topography divides the Peace and Alafia drainages in the center of the region. The Bone Valley unconformably overlies the Hawthorn formation of early and middle Miocene age
(MacNeil, 1947) and is covered by a mantle of loose quartz sand.

The Hawthorn formation consists mainly of quartzose and slightly phosphatic limestone and marl. Its upper part has been irregularly altered to dolomite; and its clay, normally montmorillonite, has been transformed to attapulgite. The Hawthorn's surface is irregular, its rock is solution pitted, and it contains many small slumps, and locally large ones, within which the overlying Bone Valley thickens (Cathcart, 1950). In addition the Bone Valley strata drape over irregularities of the Hawthorn surface, owing to postdepositional solution and slumping. Probably the Hawthorn was exposed and weathered during late Miocene time, forming an irregular karst topography and accumulations of phosphatic residuum consisting of primary apatite nodules and secondary phosphatized limestone pebbles. Marine transgression during the Pliocene dolomitized the weathered limestone and reworked the clastic residuum and phosphatized limestone into the Bone Valley formation, at the same time adding unknown amounts of quartz, clay, and phosphate. Later uplift, continuing in the Recent, induced new subterranean solution and slumping, and is responsible for the present karst topography.

The Bone Valley formation is a pebbly and clayey sand of quartz and phosphate. Much of its clastic material is transgressively reworked residue of the Hawthorn. The formation is normally 25-30 feet thick and is characteristically graded bedded in its lower two-thirds, which is the pebbly phase that is mined and known commercially as matrix (fig. 172). The materials in the graded bedded phase range from pebbly sand through sand, clayey sand, and clay. In the upper third of the Bone Valley, the graded bedded deposits change rapidly to massive-bedded clayey quartz sand containing only minor amounts of clastic phosphate. This upper zone and the overlying quartz sand are discarded as overburden during mining.

The Bone Valley is composed of approximately equal amounts of quartz, clay, and phosphate minerals. Their distribution is uneven, however, because the upper part of the Bone Valley is $60-70$ percent quartz sand in a groundmass of clayey cement, and the lower part of the Bone Valley is correspondingly higher in phosphate particles and lower in quartz.

The phosphate in Hawthorn and unaltered rock of the Bone Valley occurs primarily as nodules and pebbles of carbonate-fluorapatite (Altschuler and others, 1953). The clay in the lower part of the Bone Valley is an iron-rich montmorillonite, and in the upper, massivebedded Bone Valley it is a kaolinite. The change from montmorillonite to kaolinite is a postdepositional alteration and does not conform precisely to the 


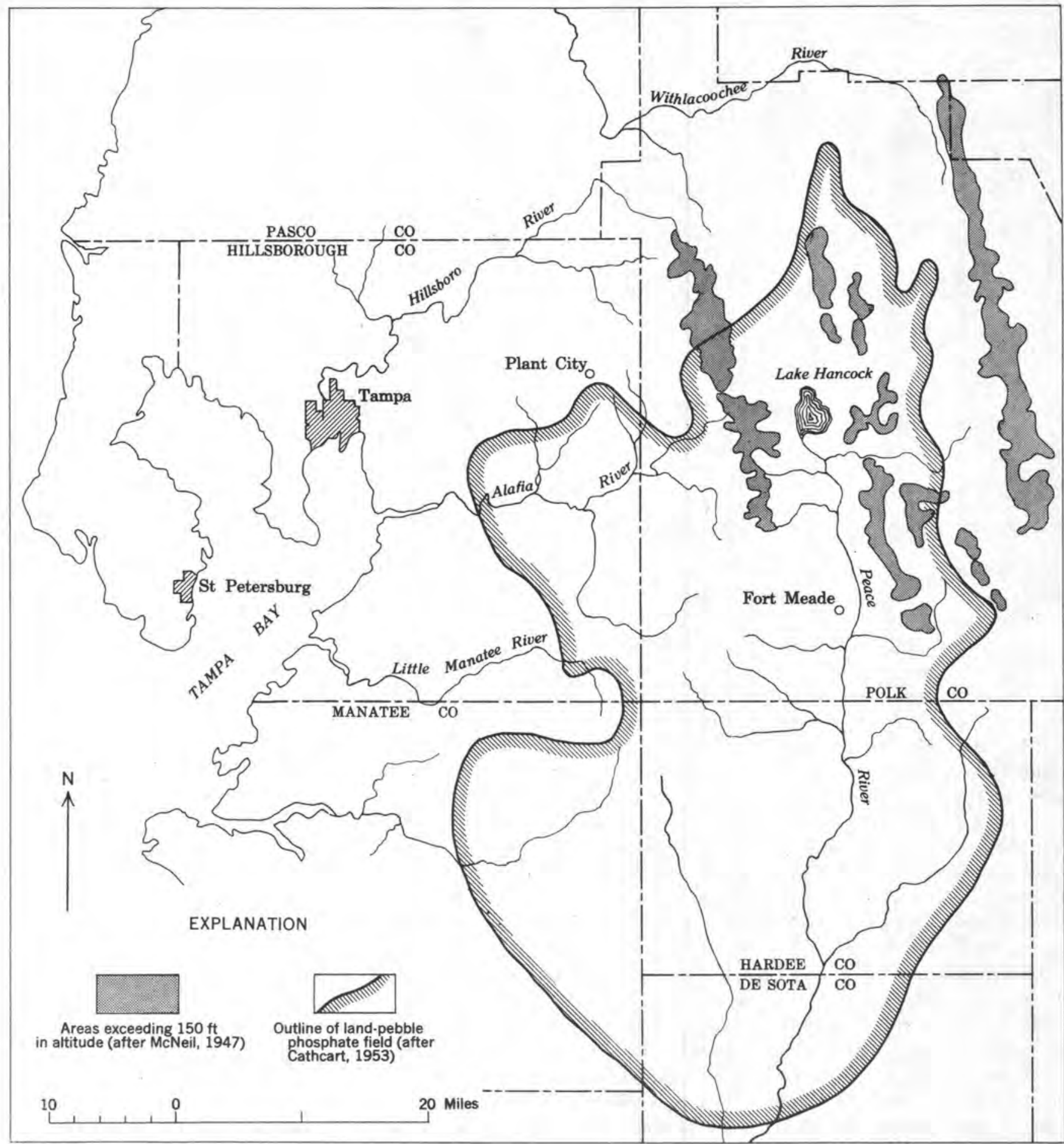

FIGURE 171.-Map of west-central Florida showing the outline of the land-pebble phosphate field. Shaded areas are belts of ridgeland enclosed by 150-foot eontour.

boundary between the upper and lower units of the Bone Valley.

Generally the Bone Valley formation is compact although not indurated, and it is gray or greenish gray owing to the ever-present clay. In places red-brown or orange is superimposed irregularly by oxidative weathering of clay. In the mines of the Peace and
Alafia drainage basins, a white zone of leaching and alteration irregularly transgresses the upper part of the section (fig. 172). This is the aluminum phosphate zone. Its rock is vesicular, friable, light in weight, and composed of quartz sand that is cemented and indurated by the secondary minerals wavellite, crandallite, and, locally, millisite. In the aluminum phosphate 


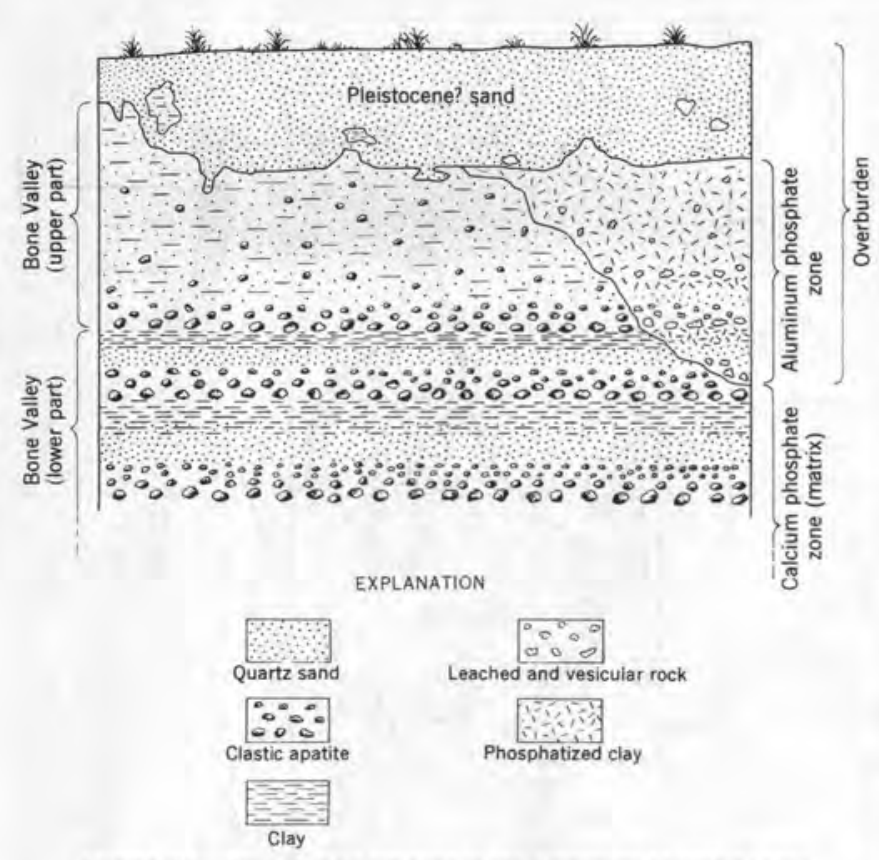

Figure 172.-Stratigraphic relations in the aluminum phosphate zone.

zone, therefore, the lithology of the section as previously outlined has been modified by leaching, secondary precipitation, and replacement. These modifications, as well as the chemical characteristics and uranium contents of the rock, depend greatly on whether only the upper or both of the primary lithologic zones of the Bone Valley formation have been altered. Thus, coarsely vesicular rock is confined to originally pebbly strata (fig. 172); and because these were the apatite-rich layers, the calcium aluminum phosphates crandallite and millisite are abundant in such rock. Where the alteration is restricted to the upper part of the Bone Valley, however, the aluminum phosphate wavellite is the dominant mineral, the porosity is more uniform, and the rock is finely vesicular.

Secondary precipitates underlie the aluminum phosphate zone in irregular, discontinuous seams of hardpan which cement layers of sand and encrust upper surfaces of clay. The cement consists of dark apatite and, subordinately, of limonite and chert. The chert represents silica released during the phosphatization of clay to wavellite and crandallite. Seams of silica can be seen closely associated with clay in process of such alteration higher in the section. The hardpans are formed by material leached from above and redeposited at the ground-water table during the early stages of leaching; hence, apatite, rather than secondary phosphate, prevails.

Pebbles of apatite at the base of the leached zone record the onset of alteration. They are softened, highly porous, and rimmed by a bleached and whitened zone of crandallite and wavellite. Within the next 2 feet the pebbles are completely altered and white, and, finally, cavities occur that are comparable in size and sorting to the pebbles in the adjoining rock. Where the leaching is most intense, holes coalesce, and all parts of the rock are affected. Higher in the section, uniformly porous phosphatic sandstone prevails where the rock was originally well-sorted clayey sand.

Another important modification within the aluminum phosphate zone is the fine-grained secondary cement that coats most fractures and cavities (pl. 11). Much of it is layered and built up from the floors of the cavities in concave, lenslike masses that are devoid of silt. The secondary cement is a mixture of kaolinite, apatite, and aluminum phosphates. Its habit implies deposition from descending solutions from which phosphate minerals were precipitated; kaolinite, either reforming from solution or carried in suspension, was deposited synehronously. From bottom to top of the section, the composition of the secondary cements shows the same change from calcium to aluminum phosphates as does the zone as a whole. Thus, apatite drops out as crandallite and wavellite become successively predominant. Microscopic examination reveals wavellite needles discordantly replacing the previously deposited mixtures, thus representing not merely the percipitation of a later phase but progressive alteration (pl. 11).

The precipitation of secondary cement is dependent both on degree of leaching and stratigraphic position. At the base of the aluminum phosphate zone, cavity fillings are microscopic and secondary cements occur only as fracture fillings and coatings around partly leached grains. In the middle of the zone where leaching is more pronounced, secondary cements may constitute 10 percent of the rock, mainly in the form of layered cavity fillings. Toward the top of the section, leaching has been most pronounced; however, eluviation predominates and secondary cements diminish again. In the uppermost few inches a sharp increase in cement content underlies the boundary with the loose sands and probably represents a caliche deposited during occasional periods of desiccation.

\section{DESCRIPTIVE MINERALOGY}

The principle minerals of the aluminum phosphate zone are apatite, crandallite, millisite, and wavellite. Of these, crandallite and wavellite are the most typical, because apatite is generally confined to the basal part of the zone and millisite is important only locally.

Carbonate-fluorapatite.-The fine-grained apatite in the aluminum phosphate zone, like that in the rest of the Bone Valley formation and other marine phosphorites, is characterized by a deficiency in $\mathrm{P}_{2} \mathrm{O}_{5}$ content of 3-6 percent, an excess of $\mathrm{F}$ or $(\mathrm{F}+\mathrm{OH})_{2}$ of $0.5-1$ percent, and the presence of approximately 3 percent of 


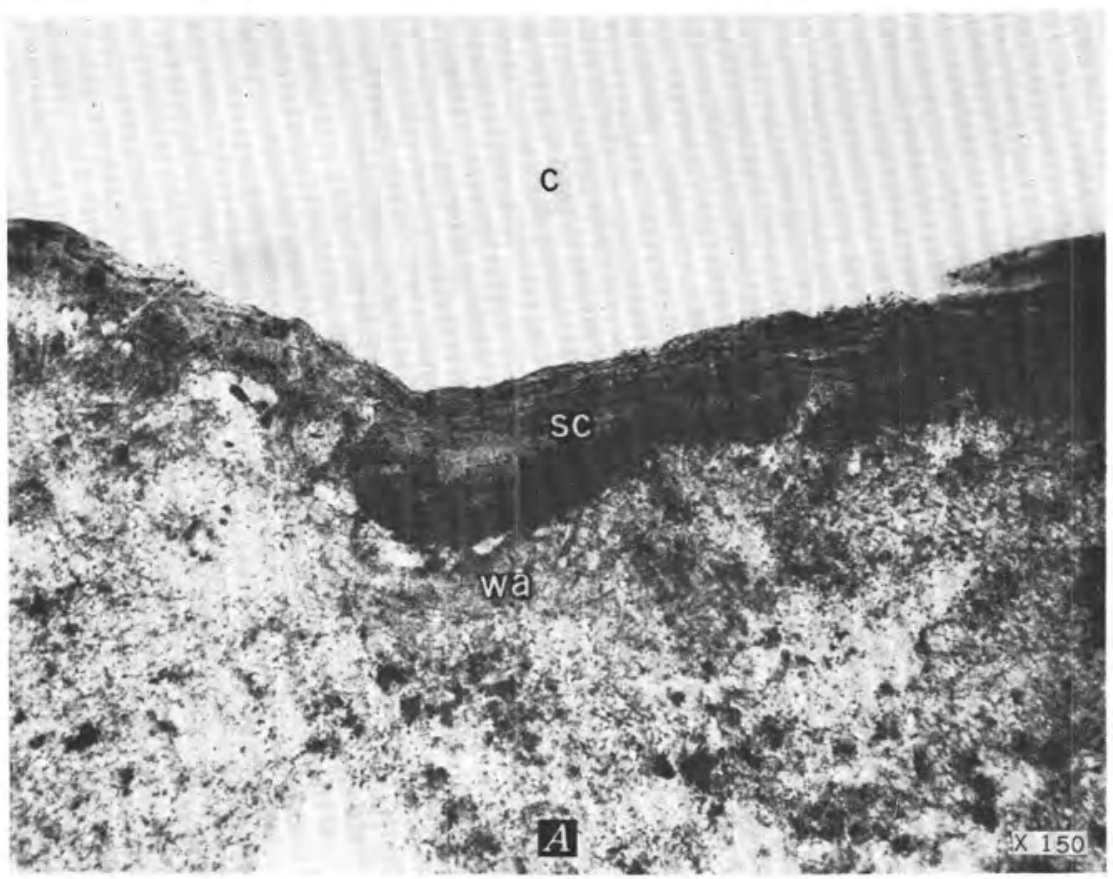

UNCROSSED NICOLS

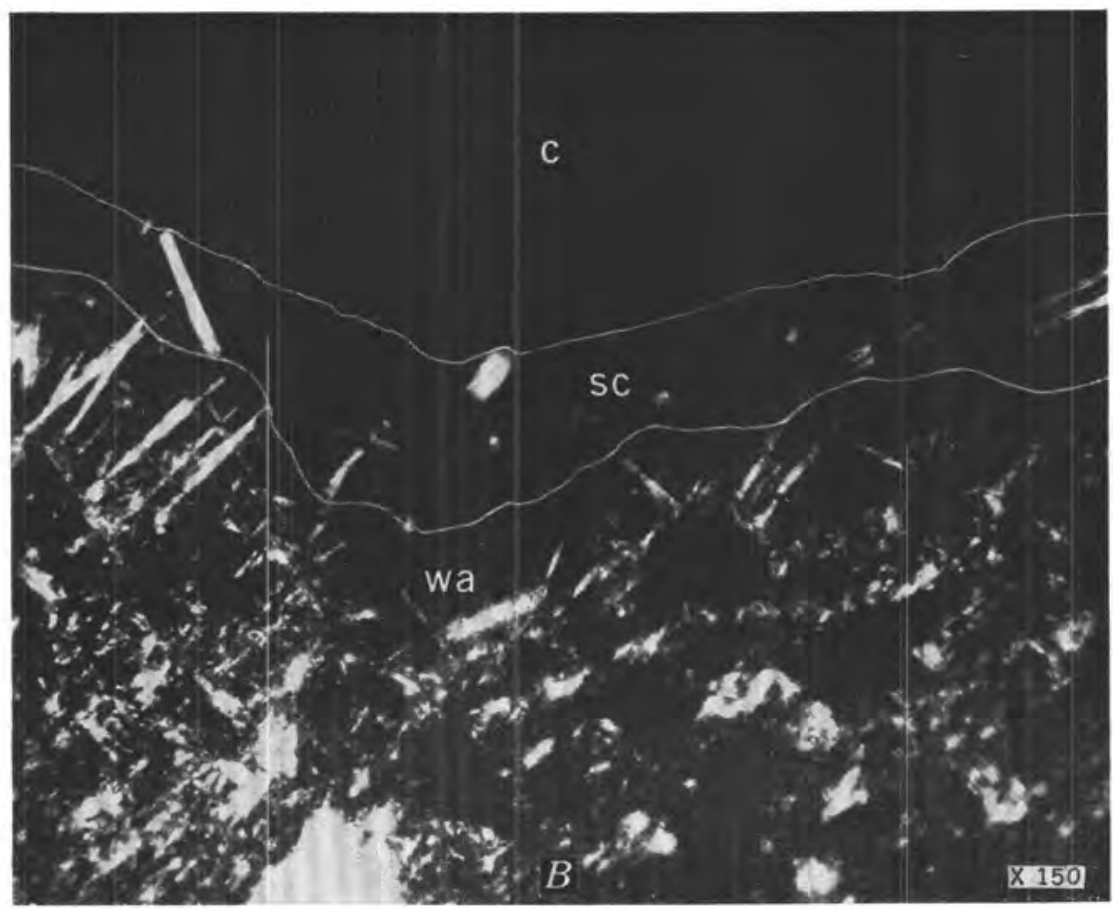

CROSSED NICOLS

WAVELLITE REPLACING FINE-GRAINED APATITE (wa) AND SECONDARY CEMENT (sc) LINING THE BOTTOM OF THE CAVITY (c). 

carbonate (Altschuler and others, 1953; Jacob and others, 1933). In addition, the apatite is demonstrably smaller in unit-cell dimensions than igneous fluorapatite (Altschuler and others, 1953). The structural differences revealed by the characteristically smaller cell dimensions are best explained by the chemical deviations, which can be expressed in the formula $\mathrm{Ca}_{10}\left(\mathrm{PO}_{4} \mathrm{CO}_{3}\right)_{0} \mathrm{~F}_{2-3}$.

The apatite always occurs as aggregates of submicroscopic crystals. Its index of refraction ranges from 1.575 to 1.625 and is typically about 1.605 . It is generally isotropic, but fibrous varieties show birefringence of about 0.003 , positive elongation, and parallel extinction. The specifie gravity of the pure apatite nodules is $2.96-2.99$.

Crandallite $\left[\mathrm{CaAl}_{3}\left(\mathrm{PO}_{4}\right)_{2}(\mathrm{OH})_{5} \cdot \mathrm{H}_{2} \mathrm{O}\right]$. - Crandallite $(\mathrm{Pa}$ lache and others, 1951) in the aluminum phosphate zone is entirely secondary. It replaces either apatite or kaolinite and is intimately mixed with them. It inherits their fine-grained textures and is predominantly isotropic. It may also be associated with the secondary minerals, millisite, wavellite, and goethite. Depending on the amount of intermixed minerals, the index of refraction of crandallite ranges from 1.590 to 1.630. Purest varieties are least birefringent and have an index of 1.615. Crandallite is white to pale gray in reflected light and colorless to brown in transmitted light. The composition of crandallite departs from the ideal formula in having 11-12 percent $\mathrm{CaO}$ instead of 13.55 . The specific gravity of this crandallite is approximately 2.75-2.78.

Millisite $\left[(\mathrm{NaK}) \mathrm{CaAl}_{6}\left(\mathrm{PO}_{4}\right)_{4}(\mathrm{OH})_{9} \cdot 3 \mathrm{H}_{2} \mathrm{O}\right]$.-Millisite (Palache and others, 1951) is known to occur as a major component of the aluminum phosphate zone within one area of several square miles and is present only in minor or trace amounts elsewhere. Like erandallite, with which it occurs as a microcrystalline intergrowth, millisite is fine grained and virtually isotropic. The presence of millisite was demonstrated in X-ray studies of J. P. Owens and R. Berman, of the Geological Survey. Its mass index refraction is 1.630 , and it is pale greenish white. The specific gravity of millisite in the aluminum phosphate zone is the same as that of crandallite.

Millisite requires alkalies; hence, its restricted ocurrence, in contrast to crandallite, is probably related to the distribution of montmorillonite. In most areas montmorillonitehad been transformed to kaolinite before the phosphatization of clay, and crandallite developed in preference to millisite.

Wavellite $\left[\mathrm{Al}_{3}\left(\mathrm{PO}_{4}\right)_{2}(\mathrm{OH})_{3} \cdot 5 \mathrm{H}_{2} \mathrm{O}\right]$. - Wavellite (Palache and others, 1951) occurs in the aluminum phosphate zone in two ways: as bands of cryptocrystalline fibrous material of low birefringence, index of refraction of 1.580 , and as euhedral white bladed crystals, crystal aggregates, and spherulites. The euhedral material is most common and can be readily identified by its optical properties and mode of occurrence. Its indices of refraction are $\alpha 1.52-1.53, \beta 1.535$, and $\gamma 1.546$. Its specific gravity is between 2.30 and 2.33 . The wavellite occurs as druses and vein fillings, as spherules in cavities, or replacing clay and apatite (pl. 11). The cryptocrystalline variety is primarily a clay replacement.

\section{PETROLOGY}

The nature of the alteration in the aluminum phosphate zone is shown in table 1 , a series of chemical analyses from the Homeland mine of the VirginiaCarolina Chemical Corp., at Homeland, Fla. These samples are representative of the thickest section of the aluminum phosphate zone in figure 172. Sample Ho-20 is from the basal part of the zone, and Ho-25 is a sample of the uppermost material. Quartz and clay as reflected by $\mathrm{SiO}_{2}$ content are higher on the average in the upper part of the section; and $\mathrm{CaO}, \mathrm{CO}_{2}$, and $\mathrm{F}$, all of which reflect apatite, drop off sharply from bottom to top. The relative changes are shown in figure 173 where the major oxides are recomputed and plotted on a silica-free basis according to their stratigraphic position. As very little clay remains in this particular section, this is equivalent to removal of quartz, which being relatively inert, is unaffected by the alteration.

It can be seen in figure $173 \mathrm{~A}$ that $\mathrm{CaO}$ and $\mathrm{Al}_{2} \mathrm{O}_{3}$ have a complementary relation in the aluminum phosphate zone but that $\mathrm{P}_{2} \mathrm{O}_{5}$ shows a slight, though steady decline toward the top of the section, reflecting general leaching of phosphate minerals. The abrupt drop in $\mathrm{P}_{2} \mathrm{O}_{5}$ in sample $\mathrm{Ho}^{-}-22$ and the corresponding peak in $\mathrm{Al}_{2} \mathrm{O}_{3}$ are due to the presence of kaolinite in an originally thick clay layer. Otherwise, the respective upward and downward trends of the $\mathrm{Al}_{2} \mathrm{O}_{3}$ and $\mathrm{CaO}$ curves correspond almost exactly to a gradual replacement of apatite $\left(3.3 \mathrm{CaO}: 1 \quad \mathrm{P}_{2} \mathrm{O}_{5}\right)$ by crandallite and wavellite (both $3 \quad \mathrm{Al}_{2} \mathrm{O}_{3}: 2 \quad \mathrm{P}_{2} \mathrm{O}_{5}$ ). Thus, $\mathrm{Al}_{2} \mathrm{O}_{3}$ increases half as rapidly as $\mathrm{CaO}$ falls, because $\mathrm{Al}_{2} \mathrm{O}_{3}$ in crandallite and wavellite requires about twice as much $\mathrm{P}_{2} \mathrm{O}_{5}$ as does $\mathrm{CaO}$ in apatite.

The reversal of trend in $\mathrm{CaO}$ content in the uppermost material $(\mathrm{Ho}-25)$ results from the aforementioned increase of secondary cement containing crandallite. An increase merely in the amount of cement might represent only textural control or material introduced from above during last stages of weathering. However the concomitant increase in calcium phosphate content indicates transport of material from below and deposition by evaporation, particularly as calcium phosphate has disappeared in several feet of subjacent section.

The mineral composition at Homeland is reflected in the ratios of $\mathrm{CaO}$ to $\mathrm{P}_{2} \mathrm{O}_{5}$ and $\mathrm{Al}_{2} \mathrm{O}_{3}$ to $\mathrm{P}_{2} \mathrm{O}_{5}$ in figure 
173B. Apatite is not found in any samples above Ho-21. Crandallite is a major mineral only in sample Ho-21 and Ho-22. From this point to the top of the section crandallite is of minor importance, and the ratio of $\mathrm{CaO}$ to $\mathrm{P}_{2} \mathrm{O}_{5}$ declines sharply above $\mathrm{Ho}-21$ and remains small thereafter. Wavellite is a major component throughout the section, and the ratio of $\mathrm{Al}_{2} \mathrm{O}_{3}$ to $\mathrm{P}_{2} \mathrm{O}_{5}$ is large initially and increases upward.

Experiments by Warrenton, eited by A. L. DuToit (1917), have shown that calcium phosphates in the presence of carbonated water can be dissolved by aluminum hydroxides with the formation of aluminum phosphates. Laboratory and soil fertilization studies indicate that clays may be transformed to calcium aluminum and aluminum-phosphates in acid conditions. Field and microscope evidence for such reactions in the aluminum phosphate zone have been described above, namely, the progressive replacement of clays and apatite by crandallite and wavellite and the occurrence of chert seams adjacent to wavellitized clay. We may state that these reactions proceed from the top of the section downward and are still incomplete at the base. This is evident from the vertical sequence. Thus, the most acid phase, wavellite, dominates at the top; and the less stable, more basic phases, crandallite and apatite, are successively more dominant downward. also, wavellite needles ean be seen replacing earlier deposited secondary cements at the base.

\section{URANIUM DISTRIBUTION IN THE ALUMINUM PHOSPHATE ZONE}

The uranium in the Bone Valley formation, and indeed in most other phosphorites, is associated intimately and almost entirely with the phosphate minerals. In 1949 a single trace occurrence of autunite, $\mathrm{Ca}\left(\mathrm{UO}_{2}\right)_{2}$ $\left(\mathrm{PO}_{4}\right)_{2} \cdot 12 \mathrm{H}_{2} \mathrm{O}$, was found by the authors in the aluminum phosphate zone, and C. Arambourg and J. Orcel (1951) and A. A. Guntz (1952) have reported trace occurrences of torbernite-group minerals in Morocacn phosphates. These oceurrences are quantitatively insignificant. In laboratory experiments uranium is not differentially leached from apatite or aluminum phosphate rock with complexing or noncomplexing acids. Further, the clay, quartz, carbonate, and other minerals associated with apatite in phosphorites always contain less than 0.001 percent uranium.

Unaltered phosphorite in the lower part of the Bone Valley formation averages 0.008 percent uranium and contains 10-15 percent $\mathrm{P}_{2} \mathrm{O}_{5}$. Unaltered clayey sand from the upper part of the Bone Valley contains only minor amounts of $\mathrm{P}_{2} \mathrm{O}_{5}$ and approximately $0.002-0.003$ percent uranium. In contrast, typical rock from wellformed sections of the aluminum phosphate zone has 8-12 percent $\mathrm{P}_{2} \mathrm{O}_{5}$ and approximately 0.012 percent uranium. Furthermore, the rock in the aluminum phosphate zone generally contains $60-70$ percent quartz and 5-10 percent kaolinite, both relatively nonuraniferous diluents. The aluminum phosphate zone has thus had twofold to fourfold enrichment in uranium, even in contrast to the matrix.

Although there is much and expectable difference in the composition and uranium content of the aluminum phosphate zone, the distribution of uranium within it generally exhibits the pattern illustrated in figure 173 and reflects the mineral, chemical, and stratigraphic relations. As shown in figure $173 A$, the uranium content increases sharply just above the base of the zone, declines gradually in the middle, and is relatively low in the upper half. Moreover the distributions of uranium and lime are strikingly similar. Analyses of pebbles, cements, and mineral concentrates for uranium show that the apatite pebbles are the most enriched of the aluminum phosphate zone components and that the pebbles in the base of the zone are richer than those in the middle. Individual pebbles from the base of the zone commonly have tenths of a percent of uranium, although pebbles from the same strata outside the zone of alteration contain only 0.02 percent of uranium. Concentrates of crandallite and millisite generally contain 0.03-0.04 percent uranium. In contrast, pure wavellite contains only $0.002-0.004$ percent uranium. Despite the low uranium content of wavellite, the upper part of the aluminum phosphate zone (table 1 and fig. $173 A$ ) generally contains about 0.01 percent uranium; however, this is attributable to minor amounts of crandallite.

Thus, uranium associates most strongly with the more calcic phases, preferentially with apatite. When apatite is depleted uranium is enriched in crandallite. This is elearly-demonstrated by the virtually identical curves for uranium and $\mathrm{CaO} / \mathrm{P}_{2} \mathrm{O}_{5}$ (fig. $173 B$ ) for samples $\mathrm{Ho}-20$ to $\mathrm{Ho}-22$. $\mathrm{Ho}-22$ is the first sample in which apatite is missing, and the $\mathrm{CaO} / \mathrm{P}_{2} \mathrm{O}_{5}$ drops accordingly as the remaining lime is fixed in crandallite. At this point the uranium curve abruptly departs from the $\mathrm{CaO} / \mathrm{P}_{2} \mathrm{O}_{5}$ curve although it generally parallels its trend through the remainder of the section.

The correspondence between $\mathrm{CaO}$ and uranium and the basal enrichment of uranium in apatite suggest that uranium substitutes for calcium in the apatite structure. This is plausible on crystallochemical grounds because the ionic radii of quadrivalent uranium (1.05A) and bivalent calcium (1.06A) (Goldschmidt, 1954) are virtually identical, and both V. E. MeKelvey and J. M. Nelson (1950) and V. M. Goldschmidt (1954) have proposed the substitution. Recent work (Altschuler and others, 1954) demonstrating that much of the uranium in apatite is quadrivalent essentially 
TARLE 1.-Chemical analyses of seven samples from the aluminum phosphate zone

[Anlayst, F. Cuttitta]

\begin{tabular}{|c|c|c|c|c|c|c|c|}
\hline Constituent & Но-20 & Ho-20A & Ho-21 & Но-22 & Но-23 & Ho-24 & Но-25 \\
\hline $\begin{array}{l}\mathrm{SiO}_{2} \\
\mathrm{Al}_{2} \mathrm{O}_{3} \\
\mathrm{Fe}_{2} \mathrm{O}_{3}{ }_{\mathrm{a}} \\
\mathrm{MnO} \\
\mathrm{MgO}\end{array}$ & $\begin{array}{l}51.48 \\
8.26 \\
2.76 \\
.70 \\
.01\end{array}$ & $\begin{array}{r}62.60 \\
5.98 \\
2.86 \\
.53 \\
.01\end{array}$ & $\begin{array}{r}40.92 \\
12.48 \\
2.61 \\
2.14 \\
.01\end{array}$ & $\begin{array}{r}57.24 \\
14.17 \\
2.17 \\
.16 \\
.01\end{array}$ & $\begin{array}{r}69.46 \\
8.16 \\
1.32 \\
.16 \\
.01\end{array}$ & $\begin{array}{r}68.08 \\
9.40 \\
1.33 \\
.14 \\
.01\end{array}$ & $\begin{array}{r}\text { 51. } 32 \\
\text { 14. } 91 \\
2.19 \\
.13 \\
.01\end{array}$ \\
\hline $\begin{array}{l}\mathrm{CaO} \\
\mathrm{Na}_{2} \mathrm{O} \\
\mathrm{K}_{2} \mathrm{O} \\
\mathrm{TiO}_{2} \\
\mathrm{P}_{2} \mathrm{O}_{5}\end{array}$ & $\begin{array}{r}8.98 \\
.23 \\
.00 \\
.37 \\
19.72\end{array}$ & $\begin{array}{r}8.25 \\
.13 \\
.00 \\
.40 \\
13.60\end{array}$ & $\begin{array}{r}8.00 \\
.12 \\
.00 \\
.63 \\
20.79\end{array}$ & $\begin{array}{r}3.10 \\
.15 \\
.00 \\
.63 \\
12.79\end{array}$ & $\begin{array}{r}.90 \\
.06 \\
.00 \\
.31 \\
11.61\end{array}$ & $\begin{array}{r}.20 \\
.04 \\
.00 \\
.42 \\
11.32\end{array}$ & $\begin{array}{r}\text { 1. } 20 \\
.03 \\
.00 \\
.65 \\
16.35\end{array}$ \\
\hline $\begin{array}{l}\text { Loss on ignition }{ }^{b} \\
\mathrm{CO}_{2} \\
\mathrm{~F}_{2} \\
\mathrm{SO}_{3} \mathrm{C}_{2} \mathrm{O}_{3} \\
\mathrm{~V}_{2} \mathrm{O}_{3} \\
\mathrm{U}^{\mathrm{d}}\end{array}$ & $\begin{array}{r}6.76 \\
.80 \\
1.15 \\
.03 \\
.01 \\
.01 \\
.00 \\
.01\end{array}$ & $\begin{array}{l}6.09 \\
.24 \\
.52 \\
.02 \\
.01 \\
.01 \\
.00 \\
.03\end{array}$ & $\begin{array}{r}11.72 \\
.26 \\
.63 \\
.04 \\
.01 \\
.01 \\
.00 \\
.02\end{array}$ & $\begin{array}{l}9.96 \\
.05 \\
.59 \\
.01 \\
.01 \\
.01 \\
.00 \\
.01\end{array}$ & $\begin{array}{l}\text { 7. } 91 \\
.02 \\
.51 \\
.03 \\
.01 \\
.01 \\
.00 \\
.01\end{array}$ & $\begin{array}{l}9.18 \\
.02 \\
.70 \\
.02 \\
.01 \\
.01 \\
.00 \\
.01\end{array}$ & $\begin{array}{r}13.24 \\
.05 \\
.53 \\
.01 \\
.01 \\
.01 \\
.00 \\
.01\end{array}$ \\
\hline $\mathrm{H}_{2} \mathrm{O}-\left(110^{\circ} \mathrm{C}\right)$ & $\begin{array}{r}100.79 \\
.35\end{array}$ & $\begin{array}{r}101.05 \\
.49\end{array}$ & $\begin{array}{r}\text { 100. } 11 \\
\text { 1. } 13\end{array}$ & $\begin{array}{r}100.81 \\
.64\end{array}$ & $\begin{array}{r}100.26 \\
.73\end{array}$ & $\begin{array}{r}100.58 \\
.39\end{array}$ & $\begin{array}{r}100.43 \\
.88\end{array}$ \\
\hline
\end{tabular}

- This represents total iron, some of which may be present as ferrous iron.

b The figures for loss on ignition include adsorbed water ( $\left.\mathrm{H}_{3} \mathrm{O}_{-}\right)$and exclude $\mathrm{CO}_{2}$.

- This represents total sulfur; no sulfides were found.

¿ Uranium is reported as a metal, as its valence state was not determined.

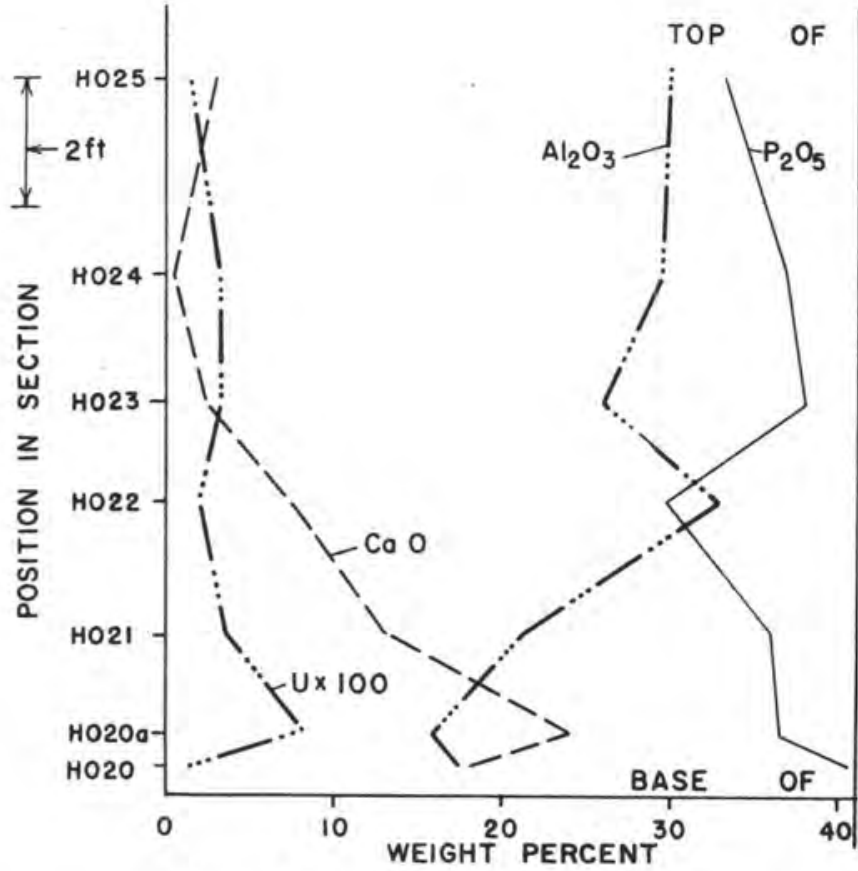

A. Oxides recalculated on silica-free basis

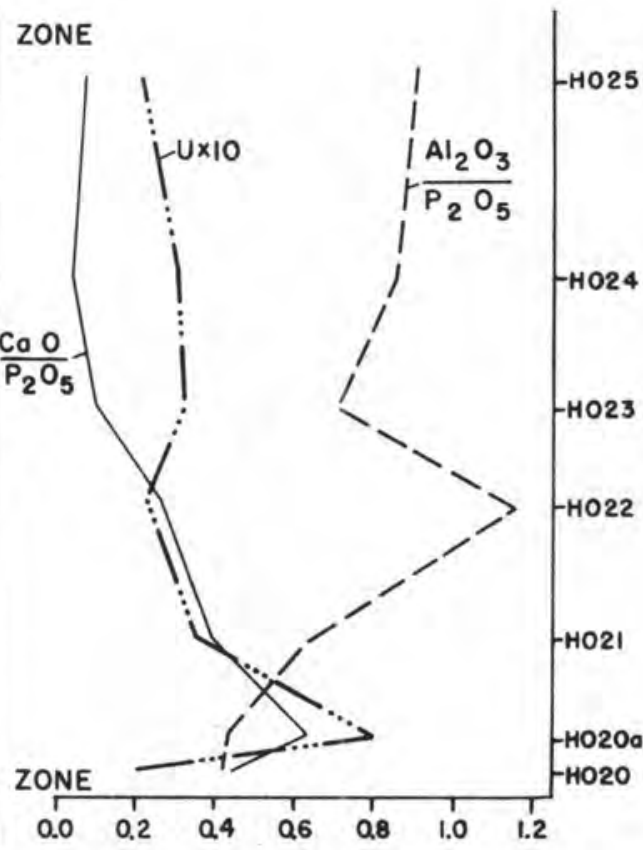

B. Ratios of oxides on silica-free basis

FiGURE 173.-Chemical differences in the aluminum phosphate zone related to stratigraphy, $A$, oxides recalculated on silica-free basis; $B$, ratios of oxides on silica-free basis. 
establishes the proof. Considering that uranium occurs in apatite in amounts of one atom per several thousand unit cells, the excess charge involved in the substitution of uranium for calcium can easily be balanced by a number of substitutions known to occur in apatite or by excess fluorine. The replacements of calcium by sodium and of phosphate by silicate are both of far greater magnitude than the replacement of calcium by uranium. The sexivalent uranium in apatite can usually be explained by postdepositional weathering or by oxidation incident to radioactive decay. Thus a mechanism is supplied for explaining the zone of basal enrichment within the aluminum phosphate zone. The amount and manner of enrichment in the entire zone are discussed below.

\section{ORIGIN OF THE ALUMINUM PHOSPHATE ZONE AND ITS URANIUM ENRICHMENT}

The following are the distinctive features of the aluminum phosphate zone: (1) It transgresses the stratigraphy and always extends downward from the top of the Bone Valley formation, (2) it is commonly underlain by hardpans reflecting old ground-water levels, (3) its mineralogic and textural changes progress vertically through the section and diminish downward, and (4) it is characterized by leaching and reprecipitation involving the depletion of $\mathrm{CaO}, \mathrm{Na}_{2} \mathrm{O}$, silicate silica, and some phosphate, and the complementary increase in $\mathrm{Al}_{2} \mathrm{O}_{3}$, coordinated as acid aluminum phosphates which yield downward to basic calcium phosphates.

This combination of features implies postdepositional lateritic alteration by acid ground water. It also implies downward percolation controlled by the groundwater table. The ground water of the region was probably rich in humic "acids" derived from soils, bogs, and ground-water podzols of Pleistocene age; "fossil" and current examples of these occur in the area. One of the first changes in the alteration sequence is the transformation of montmorillonite to kaolinite. Thus, although the unaltered clayey sand is kaolinitic, the change from montmorillonite to kaolinite transgressed the primary stratigraphic horizon separating pebbly graded beds from massive clayey sands. Moreover, minor amounts of montmorillonite are found in many sections of the kaolinitic clayey sand, and discrete residual patches of montmorillonite containing appreciable apatite sand have been found in one section of otherwise fresh-looking kaolinitic sand containing only minor amounts of apatite.

Coincident with the alteration of montmorillonite to kaolinite, or shortly thereafter, clay and apatite were dissolved, and the phosphoric acid thus generated reacted with clay to produce crandallite and wavellite.
Aluminum hydroxides reacted with apatite and also produced crandallite and wavellite. Further, crandallite was precipitated as a secondary cement from acid solutions which percolated downward and were neutralized in the more basic zone containing apatite. During early stages of leaching, calcium was more abundant, and crandallite was the main secondary phase. With additional acid-ground-water percolation, the more stable end product (wavellite) gradually replaces the intermediate phase (crandallite).

The picture of downward leaching and redeposition accords well with the pattern of uranium distribution. Uranium is liberated during the leaching of apatite pebbles in the upper part of the zone. It is kept soluble in the descending acid waters, probably as complexed uranyl and uranous ions, and it is secondarily enriched (Altschuler and others, 1954) in the porous partly leached apatite pebbles at the base of the zone by structural replacement of calcium. Work by C. F. Baes, Jr., (1954) demonstrates that sexivalent uranium can be reduced to quadrivalent uranium by the oxidation of ferrous iron in acid solutions and that this reaction is furthered by the presence of fluorine and phosphate. Thus, even under oxidizing conditions some low-valence uranium could persist after release from apatite and be available for uptake in the manner proposed. It is necessary to postulate the presence of the uranyl ion because of the thermodynamic relations favoring the transformation of $\mathrm{U}^{4+}$ to $\mathrm{UO}_{2}{ }^{++}$(Garrels, $1955)$ and also because of the trace occurrence of autunite which indicates local concentration of $\mathrm{UO}_{2}{ }^{++}$.

Presumably only low-valence uranium would be fixed by diadochy, and uranium could also be adsorbed by apatite as uranyl phosphate. Experimental evidence has shown that apatite can fix appreciable uranyl ion (Neuman and others, 1949; Moore, 1954). Valence analysis of the uranium in apatite from the base of the leached zone has shown that the ratio of quadrivalent to sexivalent uranium is lower than in comparable unenriched apatite; however, the total amount of quadrivalent uranium may be higher. This indicates that the apatite in the aluminum phosphate zone may have taken up both uranous and uranyl ions. It is equally possible that the initial uptake was largely of uranous ion and that continual weathering and decomposition of the host apatite have caused oxidation to the uranyl state.

The mode of occurrence of uranium in crandallite and wavellite is not known. It is assumed to be intimately associated as uranyl phosphate. The downward secondary enrichment of uranium is based on the properties of the entire aluminum phosphate zone, however, and applies equally to these minerals. L. Capdecomme 
and R. Pulou (1954) also report uraniferous crandallite deposits that are more radioactive in the basal zone.

The presented theory of supergene enrichment of uranium demands the original presence of 2 or 3 times more apatite than now occurs in the aluminum phosphate zone. Although the initial content of apatite in the zone was undoubtedly higher than the amount remaining, it is not possible to assume a twofold to threefold increase in percent of apatite in view of the primary stratigraphic change to a less phosphatic clayey sand that can be observed in relatively unaltered outerops. It is known from field and laboratory evidence, however, than an originally thicker section was available for leaching of apatite to provide the present enrichment in uranium. Briefly, the contacts between the loose sands and the upper part of the Bone Valley are gradational in detail, and the sands of both zones are virtually identical in size, sorting, and heavymineral content. Therefore, part of the loose sand mantle is a blanket of lateritically weathered and eluviated upper part of the Bone Valley and hence not a Pleistocene deposit, and the present contact is a lowered one.

J. B. Cathcart mapped the regional occurrence of the aluminum phosphate zone and established that its isopach and isograde contours generally conform to the topography of the river valleys. The zone is thickest and richest in uranium under the outer slopes of the flood plains, and the changes in grade and thickness of the zone migrate upstream in most of the tributaries and toward the master streams on all the interfluves in the manner of topographic contours.

The degree of accord between equivalent uranium and chemically determined uranium in the aluminum phosphate zone indicates that the zone and its distribution and grade patterns originated in Pleistocene time and are probably preglacial. Precise ages cannot be proposed at this time.

The relation of the aluminum phosphate zone both to the ground-water table and to the stream valleys indicates that the weathering and leaching are related to stream incision and a lowering of the ground-water table, probably caused by slight regional uplift during Pleistocene time. The downcutting and the adjustment in the ground-water system would have been most pronounced in the lower reaches of the rivers, and the resultant ground-water leaching and deposition are therefore most profound on the slopes of the masterstream valleys. The formation of postdepositional subterranean solution caves and their collapse reflect the present topography, cause supratenuous folding in the Bone Valley, and are related to this initial uplift as well as to later movement.

\section{ECONOMIC GEOLOGY}

The aluminum phosphate zone underlies several hundred square miles in the valleys of the Peace and Alafia Rivers, and it averages $6-7$ feet in thickness. Known reserves exceed 800 million tons according to V. E. McKelvey (and others, 1953). Several million tons of aluminum phosphate zone rock are stripped annually in mining the calcium phosphate deposits. The aluminum phosphate zone generally averages 0.01 0.02 percent uranium and is therefore a potential source of tens of thousands of tons of uranium.

The average content of phosphate minerals in the aluminum phosphate zone is $20-30$ percent. The potential reserves of alumina and phosphates with which uranium is associated are thus bundreds of millions of tons.

Certain petrographic features of the aluminum phosphate zone are, particularly auspicious for economic exploitation. The rock is a friable phosphatic sandstone. More than 60 percent of the rock is quartz that is coarser than 150 mesh $(0.1 \mathrm{~mm})$. Virtually all of the phosphatic material is finer than the quartz or can be reduced to finer size during disaggregation. Thus, by a separation into appropriate coarse and fine fractions, a twofold to threefold concentration of the phosphate, alumina, and uranium can be obtained with moderately high recovery. Furthermore, because of its characteristic basal enrichment in uranium, the aluminum phosphate zone can be easily delimited in prospecting by shallow radioactivity logging.

In view of the auspices under which these discussions are assembled, it is appropriate to emphasize not only the inberent geologie interest of the aluminum phosphate zone but also the benefits that would result from its utilization. The added stimulus of great quantities of recoverable uranium makes possible the exploitation of vast deposits of alumina and phosphate which would normally be lost or unused, and much research is currently in progress in the United States on the extraction of uranium and the production of alumina and phosphate fertilizer from the aluminum phosphate zone.

\section{REFERENCES CITED}

Altschuler, Z. S., Cisney, E. A., and Barlow, I. H., 1953, X-ray evidence of the nature of the carbonate-apatite [abs.], in Saint Guilhem, P. L. R., ed., Origine des gisements des phosphates, des chaux: Internat. Geol. Cong., 19th Algiers, Comptes rendus, sec. 11, fasc. 11, p. 9.

Altschuler, Z. S., Clarke, R. S., and Young, E. J., 1954, Uranium in apatite [abs.]: Geol. Soc. America Bull., v. 65, p. 1539.

Arambourg, Camille, and Orcel, Jean, 1951, Observations preliminaires sur la présence d'un vanadate d'urane dans les gisements de phosphates du Maroc: Acad. sci. Paris Comptes rendus, v. 233, p. 1635-1636. 
Baes, C. F., Jr., 1954, The production of $\mathrm{U}^{\text {1+ }}$ by ferrous ion in phosphoric acid solution; the formal electrode potential of the $\mathrm{U}^{4+}-\mathrm{U}^{6+}$ couple: U. S. Atomic Energy Comm. ORNL-1581 or AECD-3594 (Microcard copy on file in U. S. Atomic Energy Comm, depository libraries).

Capdecomme, Laurent, 1953, Etude minéralogique des gites de phosphates alumineux de la region de Thiès (Sénégal), in Saint Guilhem, P. L. R., ed., Origine des gisements des phosphates des chaux: Internat. Geol. Cong., 19th, Algiers, Comptes rendus, sec. 11 , fasc. 11 , p. 103-117.

Capdecomme, Laurent, and Pulou, Réne, 1954, Sur la radioactivite des phosphates de la region de Thiès (Sénégal): Acad. sci. Paris Comptes rendus, v. 239, p. 288-290.

Cathcart, J. B., 1950, Notes on the land-pebble phosphate deposit of Florida, in Snyder, F. G., ed., Symposium on mineral resources of the Southeastern United States: Knoxville, Tenn. Univ. Press, p. 131-151.

Cathcart, J. B., Blade, L. V., Davidson, D. F., and Ketner, K. B., 1953, The geology of the Florida land-pebble phosphate deposits, in Saint Guilhem, P. L. R., ed., Origine des gisements des phosphates des chaux: Internat. Geol. Cong., 19th, Algiers, Comptes rendus, sec. 11, fasc. 11, p. 77-91.

DuToit, A. L., 1917, The phosphates of Suldanha Bay: South African Geol. Survey Mem. 10, 34 p.

Garrels, R. M., 1955, Some thermodynamic relations among the uranium oxides and their relation to the oxidation states of the uranium ores of the Colorado Plateaus: Am. Mineralogist, v. 40, p. 1004-1021.

Goldschmidt, V. M., (edited by Alex Muri), 1954, Geochemistry: Oxford, Clarendon Press, 730 p.
Guntz, A. A., 1952, Sur la présence d'uranium dans les phosphates Nord-Africains: Acad. sci. Paris Comptes rendus, v. 234, p. 868-870.

Jacob, K. D., Hill, W. L., Marshall, H. L., and Reynolds, D. S., 1933, The composition and distribution of phsophate rock with special reference to the U. S.: U. S. Dept. Agr. Tech. Bull. 364,90 p.

McKelvey, V. E., Cathcart, J. B., Altschuler, Z. S., Swanson, R. W., and Buck, K. L., 1953, Domestic phosphate deposits, in Pierre, W. H., and Norman, A. G., eds., Soil and fertilizer phosphorus in crop nutrition, Volume IV of Agronomy: New York, Am. Soc. Agronomy-Academic Press, Inc., p. 347-376.

MeKelvey, V. E., and Nelson, J. M., 1950, Characteristies of marine uranium-bearing sedimentary rocks: Econ. Geology, v. 45 , p. $35-53$.

MacNeil, F. S., 1947, Correlation chart for the outcropping Tertiary formations of the eastern gulf region: U. S. Geol. Survey Oil and Gas Inv. Prel. Chart 29 (with text).

Moore, G. W., 1954, Extraction of uranium from aqueous solution by coal and other materials: Econ. Geology, v. 49, p. 652-658.

Neuman, W. F., Neuman, M. W., Main, F. R., and Mulryan, B. J., 1949, The deposition of uranium in bone, V-Ion exchange studies: Jour. Biol. Chemistry, v. 179, p. 335-340.

Palache, Charles, Berman, Harry, and Frondel, Clifford, 1951, Dana's system of mineralogy, v. 2, 7th ed.: New York, John Wiley and Sons, Inc., $1224 \mathrm{p}$.

Russ, W., 1924, The phosphate deposits of Abeokuta province: Nigeria Geol. Survey Bull. 7, p. 9-38. 


\title{
THE ORGANIC GEOCHEMISTRY OF URANIUM
}

\author{
By Irving A. Breger and Maurice Deul, U, S. Geological Survey
}

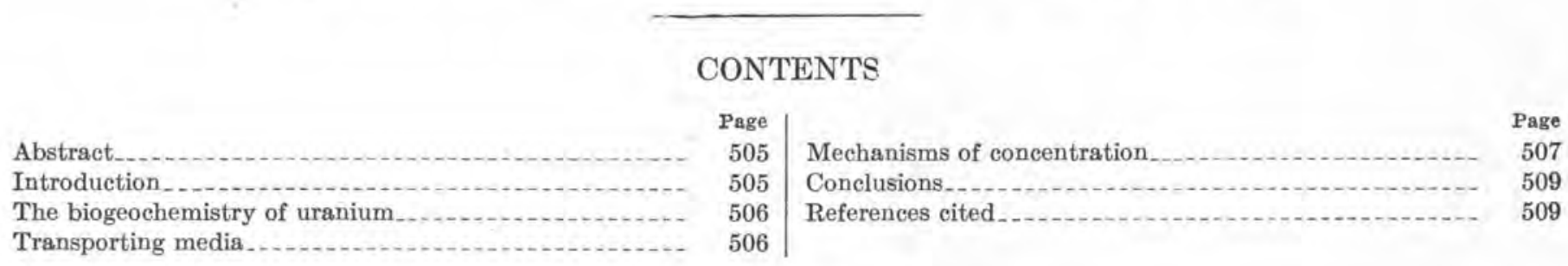

\section{ABSTRACT}

The common association of uranium with naturally occurring carbonaceous materials is well established. Recent investigations have been couducted to determine the manner in which the uranium and naturally occurring carbonaceous substances are related.

Uranium can become associated with carbonaceous materials by at least three mechanisms. By the first mechanism, as yet untested, it has been suggested that the organic material serves as a reducing agent which converts the soluble uranyl ion $\left(\mathrm{UO}_{2}{ }^{++}\right)$to an insoluble uranous form. A second mechanism involves the sulfide ion ( $\mathrm{S}^{--}$), which is normally associated with earbonaceous substances, as a redueing agent to convert the uranyl ion to the uranous form. The third mechanism involves the use of the carbonaceous material as a chemical precipitant for the uranyl ion. This last mechanism has been found to be operative where coals absorb uranium from eirculating ground water, with the formation of insoluble uranyl humates.

Carbonaceous materials, taken as a group, are but one of many possible precipitants, both chemical and physical, which influence the deposition of uranium. They can be effective only when the element comes into contact with them under the proper chemical conditions.

\section{INTRODUCTION}

The large number of occurrences of uranium in carbonaceous rocks precludes a purely fortuitous association. Despite this, the role of organic substances in the geochemical cycle of uranium is not well understood. It is the purpose of this paper to review information regarding several organo-uranium associations and to suggest geochemical mechanisms responsible for their formation.

Much of the difficulty in studying the relation of uranium to organic substances has revolved about a lack of understanding of the nature and origin of the substances. With the development of modern diagnostic techniques there now is hope for the solution to such problems and a correct evaluation of the roles of various naturally occurring carbonaceous substances in the geochemical cycle of uranium. Studies now being conducted will help to establish the relative importance of crude oils, coals, marine organic aggregates, and other materials in the collection, migration, and fixation of uranium.

Among the earliest recognized geological associations of uranium with organic matter were the black, carbonaceous marine shales. About the end of the 19th century, studies were carried out on the Swedish alum shale and on the highly carbonaceous and uraniferous kolm lenses which occur in certain strata of the shale (Nordenskiold, 1893, 1903; Landin, 1905). A summary of these studies appeared in 1923 (Holmberg, 1923). Studies of the Swedish shale and the kolm led to the conclusion that the uranium had been precipitated in the shale by means of organisms. This view has been maintained in studies of other radioactive shales where apparent relations have been observed between the organic carbon and uranium (Beers, 1945; McKelvey and Nelson, 1950; Strahl, Camilli, Short, and Silverman, 1954).

It is known that marine carbonaceous shales are usually more uraniferous than the associated marine sediments. Study of several such shales that were considered to be unusually radioactive has, however, shown them to contain less than 20 parts per million (ppm) of uranium (Breger, 1955). This content is considerably lower than those for certain shales such as the Swedish alum formation and the Chattanooga shale. Few marine shales contain more than 50 parts per million of uranium.

Although most coals are not uranium bearing, some 
that occur within or close to uraniferous provinces contain small but significant percentages of uranium. Study of several of these coals indicates that uranium became associated with the coal after decomposition (Vine and Moore, 1952). The ability of coals to absorb uranium from solution has been shown by Moore (1954) and Szalay (1954), and Breger, Deul, and Rubinstein (1955) have studied the nature of the organo-uranium association in detail. Besides the reported absorption of uranium by bedded coals (Miller and Gill, 1954), many associations of uranium with coalified logs and coalified wood fragments have also been noted on the Colorado Plateau (Gott and Erickson, 1952) and in other areas. It has become clear within recent years that coals or materials derived from plants are avid receptors for uranium.

Uranium occurs in appreciable percentages in carbonaceous materials of unknown origin found in various parts of the world. Cellular structure, which can be used to identify carbonaceous substances as being of plant or animal origin, has not been recognized in these substances. One such substance, dated as Precambrian in age (Davidson and Bowie, 1951; Louw, 1955), is the carbonaceous gold- and uraniumbearing "carbon leader" of the Witwatersrand; thucholite from Canada is reported to be of igneous origin (Ellsworth, 1932). Other substances, such as the carbonaceous pellets that occur in the sandstones of Cretaceous age in Emery County, Utah (Gott and Erickson, 1952) or in the dolomites and limestones of early Pennsylvanian to Permian age in the AmarilloWichita uplift area of Oklahoma and Texas (Gott, $1953,1954)$, also contain significant percentages of uranium. Uranium-bearing carbonaceous materials likewise occur in Australia, Russia, and on the Isle of Man (Davidson and Bowie, 1951). The lack of information regarding the origin of these substances and their relations to one another has resulted in the use of such names as "uraniferous hydrocarbon," "asphaltite," "carbocer," "carbon," and "thucholite."

\section{THE BIOGEOCHEMISTRY OF URANIUM}

Concentrations of uranium in carbonaceous material have led to speculation regarding absorption of the element by living plants and animals. To investigate the possibility that living plants might concentrate appreciable percentages of uranium, Hoffman (1941a, 1942) analyzed various woods, algae, and other materials and obtained the data summarized in the table below. The plant samples, collected from nonuraniferous areas near Vienna, contained very small amounts of uranium, far below the range of 1 to $3 \mathrm{ppm}$ which is usually taken as the average uranium content of terrestrial sediments. Only the algae, growing in an aqueous environmẹnt subject to continuous replenishment of uranium, contained any appreciable amount of the element. It must be concluded from these data that plants absorb extremely small percentages of uranium. Even after maximum concentration due to decay and compaction of plant material, the amount of uranium absorbed is insufficient to account for the large quantities of uranium observed in some carbonaceous substances. Similar studies (Hoffman, 1941b) have shown that animals absorb uranium from plants through nutritional processes and contain the element in quantities similar to those found in living plants.

Certain plants growing in uraniferous provinces, such as the Colorado Plateau, are able to absorb uranium (Cannon, 1952), but it is evident that neither plants nor animals normally contain appreciable percentages of the element. Secondary processes must, therefore, be responsible for the introduction of uranium into carbonaceous deposits.

Uranium content of woods, seeds, algae, and other substances (Hoffman, 1941a, 1942)

\begin{tabular}{|c|c|c|c|c|}
\hline Substanee & Condition & $\begin{array}{l}\text { Ash (per- } \\
\text { cent) }\end{array}$ & $\begin{array}{l}\text { Uranium } \\
\text { in ash } \\
\text { (ppm) }\end{array}$ & $\begin{array}{l}\text { Uranium } \\
\text { content of } \\
\text { plant sub- } \\
\text { stance } \\
\text { (ppm) }\end{array}$ \\
\hline $\begin{array}{l}\text { Apricot (wood) } \\
\text { Bireh (wood) } \\
\text { Plum (wood) } \\
\text { Grapevine } \\
\text { Cornstalk. } \\
\text { Tobacco } \\
\text { Grasses } \\
\text { Corn (kernels) } \\
\text { Beans } \\
\text { Algae (fresh water) }\end{array}$ & 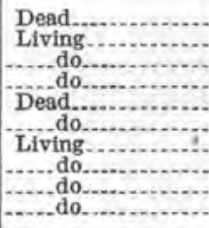 & $\begin{array}{r}1.73 \\
.65 \\
1.45 \\
1.66 \\
15.72 \\
15 \\
.58 \\
.5\end{array}$ & $\begin{array}{l}7 \\
.059 \\
.008 \\
.0048 \\
.11 \\
.0255 \\
.00008 \\
.0071 \\
.014 \\
9.1\end{array}$ & $\begin{array}{l}0.12 \\
.0004 \\
.0001 \\
.00008 \\
.0008 \\
.004 \\
.00008\end{array}$ \\
\hline
\end{tabular}

\section{TRANSPORTING MEDIA}

Because uranium is not genetically associated with carbonaceous substances, it is necessary to consider those media through which the element can migrate from a source to its eventual association with carbonaceous materials. The most important transporting media that are to be considered are water, petroleum, and compressed gas.

Uranium, with many possible valence states and with an ability to form complexes, can be transported in aqueous solution under widely varying chemical conditions. The uranyl ion is stable even at low concentrations in solutions from which it is precipitated when present in high concentrations (Milkey, 1954). The uranyl ion, which is stable in acidic solution, can complex with carbonates to form alkaline or alkaline-earth uranyl carbonates stable above a $\mathrm{pH}$ of 7.0 (Bachelet, Cheylan, Douis, and Goulette, 1952a, b). As the uranyl ion the element can, therefore, travel in either alkaline or acidic media. The ability of the uranous ion to form carbonate complexes is as yet unknown. 
Water is an excellent medium for the transport of uranium because of the general solubility of uranium salts in aqueous solutions.

Crude oil has been suggested as a transporting medium for uranium (Erickson, Myers, and Horr, 1954). Although this idea is attractive in that petroleum is a transporting medium and also represents an organouranium association, the fact remains that crude oils from nonuraniferous provinces carry only negligible amounts of uranium (Erickson, Myers, and Horr, 1954).

Compressed carbon dioxide has recently been suggested as a medium for transporting materials under certain geologic conditions (Garrels and Richter, 1955). The nonpolar nature of carbon dioxide, however, renders it an unlikely carrier of the uranyl or other uranium ions.

Because of its abundance and its solvent power, water is probably the most effective medium for transporting uranium from its source to its eventual concentration in carbonaceous substances.

\section{MECHANISMS OF CONCENTRATION}

Mechanisms must now be considered that can result in precipitation or concentration of uranium that has been carried in aqueous solution from its source into contact with carbonaceous substances.

It has been suggested that organic matter reduces uranium to the insoluble uranium dioxide, $\mathrm{UO}_{2}$, or that it adsorbs uranium as a result of surface activity, such as would be expected of clay. More recently it was found that organic matter can combine with uranium to form insoluble organo-uranium compounds. Known mechanisms as well as those considered geochemically tenable are outlined below.

Studies have shown that uranium is retained in some coals by purely chemical processes (Breger, Deul, and Rubinstein, 1955). The uranyl ion on coming into contact with the coal forms an organo-uranium complex, probably a uranyl humate, which is insoluble above $\mathrm{a} \mathrm{pH}$ of about 2.2. Below this $\mathrm{pH}$ the uranium can be stripped from the coal. The organic components of the coal probably provide the acidic environment for release of the element from complexes and the chemical components for the retention of the element.

The association of uranium with coalified wood is extremely common on the Colorado Plateau. If uranium, in the form of the uranyl ion $\mathrm{UO}_{2}{ }^{++}$, came into contact with the coalified wood, an explanation is necessary to account for the fact that the uranium is now found in the black ores in the reduced $\left(\mathrm{U}^{+4}\right)$ state. Recent work by A. M. Pommer of the U. S. Geological Survey (oral communication) has shown that vanadium can be reduced under relatively mild conditions by wood, degraded wood, and lignite. If, as theoretical considerations indicate, uranium can also be reduced by coalified wood, then such a reduction would account for the observations.

Recent studies of the U. S. Geological Survey indicate physical rather than direct chemical association of uranium with the organic components of certain shales. It has been postulated that the organic matter established the chemical conditions leading to precipitation of uranium from an overlying sea perhaps slightly enriched in the element. Specifically, it has been proposed that the decomposition of the organic matter under reducing conditions leads to the formation of hydrogen sulfide, which is known to reduce the uranyl ion to the insoluble uranium dioxide (Gruner, 1954). The carbonaceous material, in this instance, would have only an indirect association with the uranium, but the possibility cannot be overlooked that the organic matter complexed and carried uranium down from the sea, thereby serving as a primary precipitant. If this was the mechanism of fixation, then the chemical bonds between the uranium and the organic compounds have been broken since the time the shale components were deposited.

Studies of coalified wood in the Chattanooga shale (Breger and Schopf, 1955) indicate that some of the organic constituents of that shale were derived from terrestrial plants. If that is true, then part of the uranium in the shale might be there as a result of the "reduction" mechanism, and part of the uranium might be in actual chemical association with humic compounds derived from terrestrial coal or coalified logs that were washed into the shale during its formation.

Limestones that contain no carbonaceous matter contain no appreciable syngenetic concentrations of uranium, but some carbonaceous limestones are known to be unusually radioactive. The black carbonaceous La Luna limestone of Venezuela (Smith, 1951a, b), thought to be a source bed for petroleum, is known to be the most radioactive and presumably most uraniferous formation in the region. Similar radioactive black limestones are reported from the Middle East (Ion, 1951).

The absence of uranium in noncarbonaceous limestones probably has a simple explanation. Carbonates are deposited or precipitated from carbonate-saturated water. Under these conditions, the uranyl ions normally present in sea water will remain in solution as complex uranyl carbonates (Bachelet, Cheylan, Douis, and Goulette, 1952a, b). The presence of carbonaceous material in the limestone that is being deposited, however, may lead to the absorption and retention of uranium from the sea water as a result of direct or indirect chemical activity. To illustrate such activity, 
it can be postulated that the acidic character of the decomposing organic sediment leads to destruction of the complex uranyl carbonate, thereby releasing the uranyl ion for retention by the organic matter, in much the same fashion as the humic material in coals retains the uranyl ion (Breger, Deul, and Rubinstein, 1955). Subsequent reduction of the uranyl ion by the hydrogen sulfide present in marine organic sediments could result in conversion of the sexivalent uranium to insoluble uranium dioxide. It should be noted that reduction of the uranyl ion to uranium dioxide is not accompanied by transfer of oxygen. In inorganic reactions, such as are shown below, oxidation involves only a transfer of electrons; with organic substances it more nearly resembles dehydrogenation.

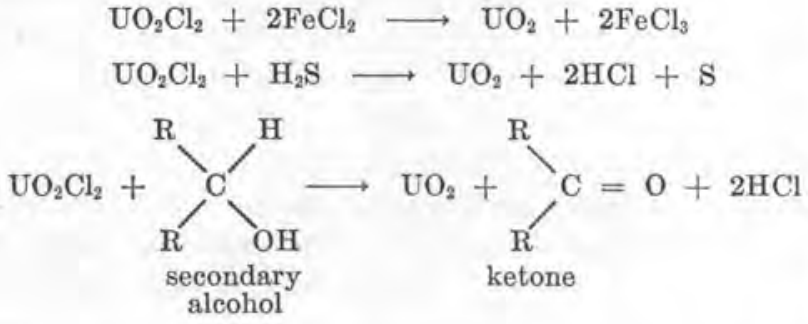

The presence of carbonaceous matter, most of which is probably of algal origin, in vugs and cracks in limestones has frequently been reported. In one such formation, the Little Falls dolomite of New York State (Dunn and Fisher, 1954), the carbonaceous matter is not uranium bearing ( $0.25 \mathrm{ppm}$ uranium), thus indicating that it was deposited from a sea containing only normal or below normal percentages of the element. The presence of uranium in carbonaceous limestones may indicate that the sea from which precipitation took place had a higher than normal uranium content. The uranium-bearing carbonaceous pellets and impregnations that occur in the dolomites and limestones of early Pennsylvanian to late Permian age of the Texas Panhandle are probably of algal origin. Paragenetic studies indicate that the carbonaceous material is later than the dolomite and limestone, but the fact that pellets fill voids left by solution of anhydrite indicates that redistribution of the algal material may have taken place within the formation. Evidence that crude oils can absorb and carry uranium during migration suggests the mechanism for transport of the uranium during redistribution of the carbonaceous material. Solidification of the original organic substances is dependent upon diagenetic processes which are yet unknown. Very old organic material, such as that from the Iittle Falls dolomite, is completely solid; other limestones contain organic material that is asphaltic in character.
The high uranium contents of some of the pellets from Texas (10 percent or higher) can be attributed to concentration of considerable uranium from the aqueous environment into small discrete accumulations of organic material. The converse situation exists in other radioactive limestones where the uranium is finely distributed throughout the formation and associated with relatively large quantities of disseminated organic matter, thus resulting in relatively low concentrations of the element.

Little can be said about the processes by which uranium became associated with various unusual carbonaceous substances because there is no definitive information regarding the origin of these substances and their interrelationships. Despite suggestions that some of the very old organic complexes, such as the Precambrian Babrosco carbon of South Africa, may be derived from methane or other gases polymerized by alpha-particle radiation (Davidson and Bowie, 1951), it seems more likely that this material is of algal origin. The Cambrian kolm of Sweden is probably also of algal origin. Although it has been thought that the thucholite which occurs in Canada is of igneous origin, the possibility exists that the organic material was derived from oil that seeped downward from rocks of Paleozoic age (Quirke, 1936). With little more than morphological descriptions of the substances, little can be said regarding the mechanisms by which uranium has become associated with these carbonaceous materials.

Review of the literature on occurrences of uranium with carbonaceous materials shows that much confusion exists. The confusion results in part from lack of knowledge regarding the origin of the carbonaceous substances, their relations to each other, and their importance in the geochemical cycle of uranium. These difficulties have been magnified by the use of inaccurate nomenclature and, even worse, by descriptive names having an implication of origin. Associations of radioactive daughter products from uranium with natural gas, petroleum, or other carbonaceous substances have often been referred to as indicating primary and fundamental geochemical relationships, but natural channels for the movement of gas, petroleum, or aqueous solutions also permit dispersal of radon or uranium solutions. Therefore, associations that have been considered to be primary may only be apparently so and may actually have little or no significance in the geochemical cycle of uranium.

The associations of uranium with coals, coal derivatives, or coalified fragments of wood are probably those of major economic importance. Among unclassified types of carbonaceous materials, those occurring in South Africa are probably the only significant ones. 


\section{CONCLUSIONS}

There can no longer be any question but that carbonaceous materials of various types play an important role in the secondary concentration of uranium. Some coals are avid collectors of the uranyl ion. Organic material of algal origin that occurs in limestones apparently has the capacity to absorb the uranyl ion from overlying water saturated with calcium carbonate, an environment in which that ion is normally retained in solution. Eventual reduction of the uranyl ion may result from its interaction with the sulfide ion that accompanies organic material undergoing biochemical decomposition under reducing conditions.

The association of uranium with petroleum is undoubtedly a result of the ability of petroleum constituents with certain functional groups to pick up and carry the element. Although porphyrins have long been considered important in the transport of metals by crude petroleum, it seems likely that asphaltenes, which are known to have carboxyl groups, and naphthenic acids may be more important as carriers. The association of uranium with petroleum is anomalous, and further studies may show such associations to be useful as exploration guides in searching for uranium.

Uranium is not genetically associated with the carbonaceous substances, but it is collected by these substances during its migration. Thus, it is essential for an organo-uranium association that there be available not only organic matter and uranium but also a medium to transport the uranium into contact with the organic matter. The essential character of all three requirements-organic matter, transporting medium, and uranium-is demonstrated in areas of the Colorado Plateau where coalified wood fragments in close proximity are either uraniferous or nonuraniferous, a condition resulting from the localized channeling of uranium-bearing solutions. Thus, carbonaceous matter may or may not serve as a precipitant or absorbant for uranium, even within a uraniferous province.

\section{REFERENCES CITED}

Bachelet, M., Cheylan, E., Douis, M., and Goulette, J. C., 1952a, Preparation et propriétés des uranylearbonates; Uranylearbonates de sodium: Soc, chim. France Bull., p. 55-60.

-1952b, Preparation et propriétés des uranylcarbonates; Uranylearbonates alcalino-terreux: Soc. chim. France Bull. p. 565-569,

Beers, R. F, 1945, Radioactivity and organic content of some Paleozoic shales: Am. Assoc. Petroleum Geologists Bull., v. 29 , p. $1-22$.

Breger, I. A., 1955, Radioactive equilibrium in ancient marine sediments: Geochim. Cosmochim. Acta, v. 8, p. 63-73.

Breger, I. A., Deul, Maurice, and Rubinstein, Samuel, 1955, Geochemistry and mineralogy of a uraniferous lignite: Eeon. Geology, v. 50, p. 206-226.
Breger, I. A., and Schopf, J, M., 1955, Germanium and uranium in coalified wood from Upper Devonian black shale: Geoehim. Cosmochim. Acta, v. 7, p. 287-293.

Cannon, H. L., 1952, The effect of uranium-vanadium deposits on the vegetation of the Colorado Plateau: Am. Jour. Sci, v. 250 , p. $735-770$.

Davidson, C. F., and Bowie, S. H. U., 1951, On thucholite and related hydrocarbon-uraninite complexes, with a note on the origin of the Witwatersrand gold ores: Geol. Survey Great Britain Bull. 3, p. 1-18.

Dunn, J. R., and Fisher, D. W., 1954, Occurrence, properties, and paragenesis of anthraxolite in the Mohawk Valley: Am. Jour. Sci., v. 252, p. 489-501.

Ellsworth, H. V., 1932, Rare-element minerals of Canada: Canada Geol. Survey, Eeon. Geology ser. 11, p. 244-247, $272 \mathrm{p}$.

Erickson, R. L., Myers, A. T., and Horr, C. A., 1954, Association of uranium and other metals with crude oil, asphalt, and petroliferous rock: Am. Assoc. Petroleum Geologists Bull., v. 38 , p. $2200-2218$.

Garrels, R. M., and Richter, D. H., 1955, Is carbon dioxide an ore-forming fluid under shallow earth conditions?: Econ. Geology, v. 50, p. 447-458.

Gott, G. B., 1953, Radon and helium studies, in Geologic investigations of radioactive deposits-Semiannual progress report, June 1 to Nov. 30, 1953: U. S. Geol. Survey TEI-390. p. 256-258, issued by U. S. Atomic Energy Comm. Tech. Inf. Service, Oak Ridge, Tenn.

1954, Radon and helium studies, in Geologic investigations of radioactive deposits - Semiannual progress report. Dec. 1, 1953, to May 31, 1954: U. S. Geol. Survey TEI-440, p. 217-219, issued by U. S. Atomic Energy Comm. Tech. Inf. Service, Oak Ridge, Tenn.

Gott, G. B,, and Erickson, R. L., 1952, Reconnaissance of uranium and copper deposits in parts of New Mexico, Colorado, Utah, Idaho, and Wyoming: U. S. Geol. Survey Circ. 219, 16 p.

Gruner, J. W., 1954, Further experiments on the synthesis of uraninite, in Annual report, April 1, 1953 to Mareh 31, 1954: U. S. Atomic Energy Comm. RME-3094, p. 28-30, issued by U. S. Atomic Energy Comm. Tech. Inf. Service, Oak Ridge, Tenn.

Hoffman, Josef, 1941a, Experimentelle Erfassung von Uran in lebenden Süsswasseralgen (Experimental determination of uranium in living freshwater algae): Naturwissenschaften (Berlin), v. 29, p. 403-404.

$1941 b$, Uran in tier; Organismus (Uranium in the animal organism): Wien. tierarztl. Monatsschr., v. 28, p. 561-566

1942, Nachweis von Uran in lebenden und toten Pflanzen (Determination of uranium in living and dead plants): Bodenkunde u. Pflanzenernährung, v. 26, p. 318-327.

Holmberg, Bror, 1923, Skifferundersökningar II, Frösök med Billingens kolm (Studies on Billingen kolm): Ingeniörsvetenskapsakademiens (Stockholm), Handl., no. 16, p. 71-78 ( 80 p.; p. $79-80$, summary in English).

Ion, D, C., 1951, Discussion: Third World Petroleum Congress Proc., sec. 1, p. 427.

Landin, John, 1905, Radium i Sverge: Arkiv för kemi, mineralogi, och geologi (Stockholm), v. 2, no. 2, p. 1-7.

Louv, J. D., 1955, Geological ages of Witwatersrand uraninites: Nature (London), v. 175, p. 349-350.

McKelvey, V. E., and Nelson, J. M., 1950, Characteristies of marine uranium-bearing sedimentary rocks: Econ. Geology, v. 45, p. $35-53$. 
Milkey, R. G., 1954, Stability of dilute solutions of uranium, lead, and thorium ions: Anal. Chemistry, v. 26, p. 1800-1803.

Miller, R. L., and Gill, J. R., 1954, Uranium from coal: Sci. Am., v. 191 , no. 4, p. 36-39.

Moore, G. W., 1954, Extraction of uranium from aqueous solution by coal and other materials: Econ. Geology, v. 49, p. 652-658.

Nordenskiold, A. E., 1893, Rémarques sur le fer natif d'Ovifak et sur le bitume des roches cristallines de Suede (Remarks on the native iron of Ovifak and on the bitumen of crystalline rocks of Sweden): Acad. sci. Paris Comptes rendus, v. 116, p. $677-678$.

- 1903, Einige Bemerkungen zu der Vorstehenden Brieflichen Mittheilung des Herrn Prof. Clemens Winkler (Several comments on the preceding short communication by Prof. Clemens Winkler): Zeitschr. Kristallographie u. Mineralogie, v. 37, p. 286-288.

Quirke, T. T., 1936, Origin of watereourses near French River, Ontario: Geol. Soc. America Bull., v. 47, p. 267-287.
Smith, J. E., 1951a, The Cretaceous limestone-producing area of the Mara and Maracaibo district-Venezuela: Third World Petroleum Congress Proc., sec. 1, p. 56-71; discussion, p. 71-72.

1951b, Discussion: Third World Petroleum Congress Proc., sec. 1. p. 427.

Strahl, E. O., Camilli, Elena, Short, N. M., and others, 1954, An investigation of the mineralogy, petrography, and paleobotony of uranium-bearing shales and lignites, Scope AShales; Third annual report, Apr. 1, 1953 to March 31, 1954: U. S. Atomic Energy Comm. NYO-6060, 70 p., issued by U. S. Atomic Energy Comm. Tech. Inf. Service, Oak Ridge, Tenn.

Szalay, S., 1954, The enrichment of uranium in some brown coals in Hungary: Magyar Tudom. Akad. Acta Geol., v. 2, p. 299-310.

Vine, J. D., and Moore, G. W., 1952, Uranium-bearing coal and carbonaceous rocks in the Fall Creek area, Bonneville County, Idaho: U. S. Geol. Survey Circ. 212, 10 p. 


\title{
URANIUM AND OTHER TRACE METALS IN CRUDE OILS OF THE WESTERN UNITED STATES
}

\author{
By Harold J. Hyden, U. S. Geological Survey
}

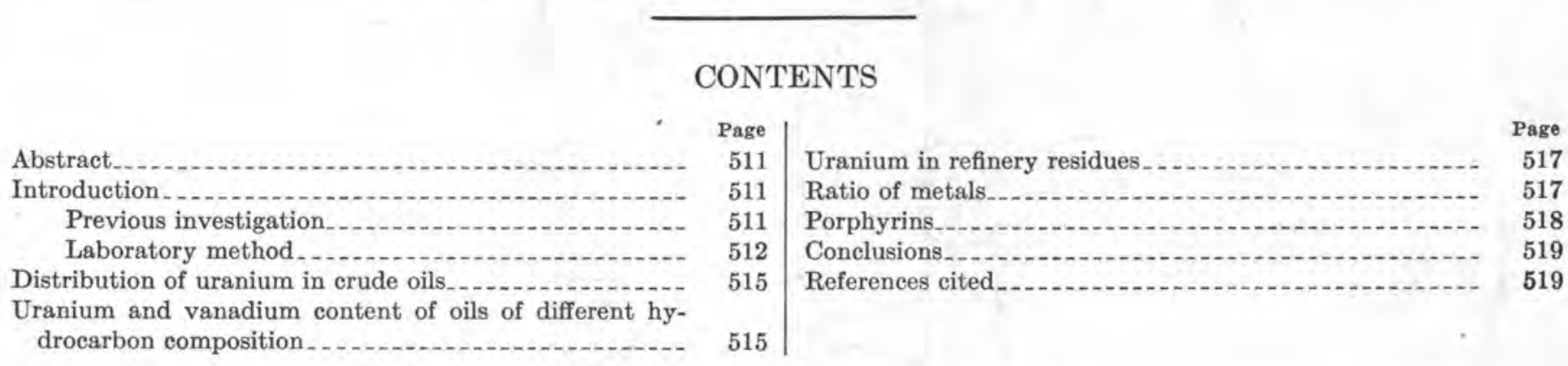

\section{ILLUSTRATION}

Page

Figure 174. Map of the Western United States showing localities where samples of crude oil were collected

\section{TABLES}

TABLE 1. Summary of analytical data on crude oils

2. Uranium and vanadium content of oils
Page

513

516

TABLE 3. Uranium content of residues from petroleum refineries...................................

4. Trace-metals content in ash of crude oil......

Page

\section{ABSTRACT}

A total of 107 samples of crude oil and 16 samples of oilrefinery residues was collected in the Western United States for uranium and other trace-metal determinations. The crude oils and refinery residues were converted by ignition to ash. The uranium content was determined fluorimetrically, and the content of vanadium, nickel, and copper was determined spectrographically.

Results of the study show that uranium is not preferentially distributed with respect to age, lithologic character, or geographic location of the reservoir rocks, nor does it show any preferential distribution with respect to oil types as established from U. S. Bureau of Mines crude-petroleum analyses. The uranium content of crude oil is insuffieient for commercial production but may serve as a prospecting guide to uranium deposits. Vanadium and nickel are known to exist in crude oils as metallo-organic porphyrin complexes. A comparison of vanadium-nickel and vanadium-uranium ratios in the present investigation shows that most of the uranium is not present as a porphyrin complex in crude oil.

\section{INTRODUCTION}

Crude oils from the midcontinent region which had been classified on the basis of composition (Tulsa Geol. Soc. Research Comm., 1949) were selected for investi- gation of the distribution of uranium and other trace metals in oil. In addition, crude oils from the Rocky Mountain States and California were selected on the advice of Harold M. Smith and John S. Ball of the U. S. Bureau of Mines who had made an extensive investigation of the composition of these crude oils with especial attention to their nitrogen content (Ball, Whisman, and Wenger, 1951). Only the distribution in oil of the metals uranium, vanadium, nickel, and copper are considered in the present report.

The location of the oilfields sampled for this investigation are shown in figure 174. The fields are grouped, for the purposes of this report, into three regions: midcontinent, Rocky Mountain, and western. Analytical data on the crude-oil samples, arranged by regions, ages, and states, are summarized in table 1 .

\section{PREVIOUS INVESTIGATION}

The association of metals with organic material was described by Hewett in 1909. Following this, other investigators cited many occurrences of metals both in 


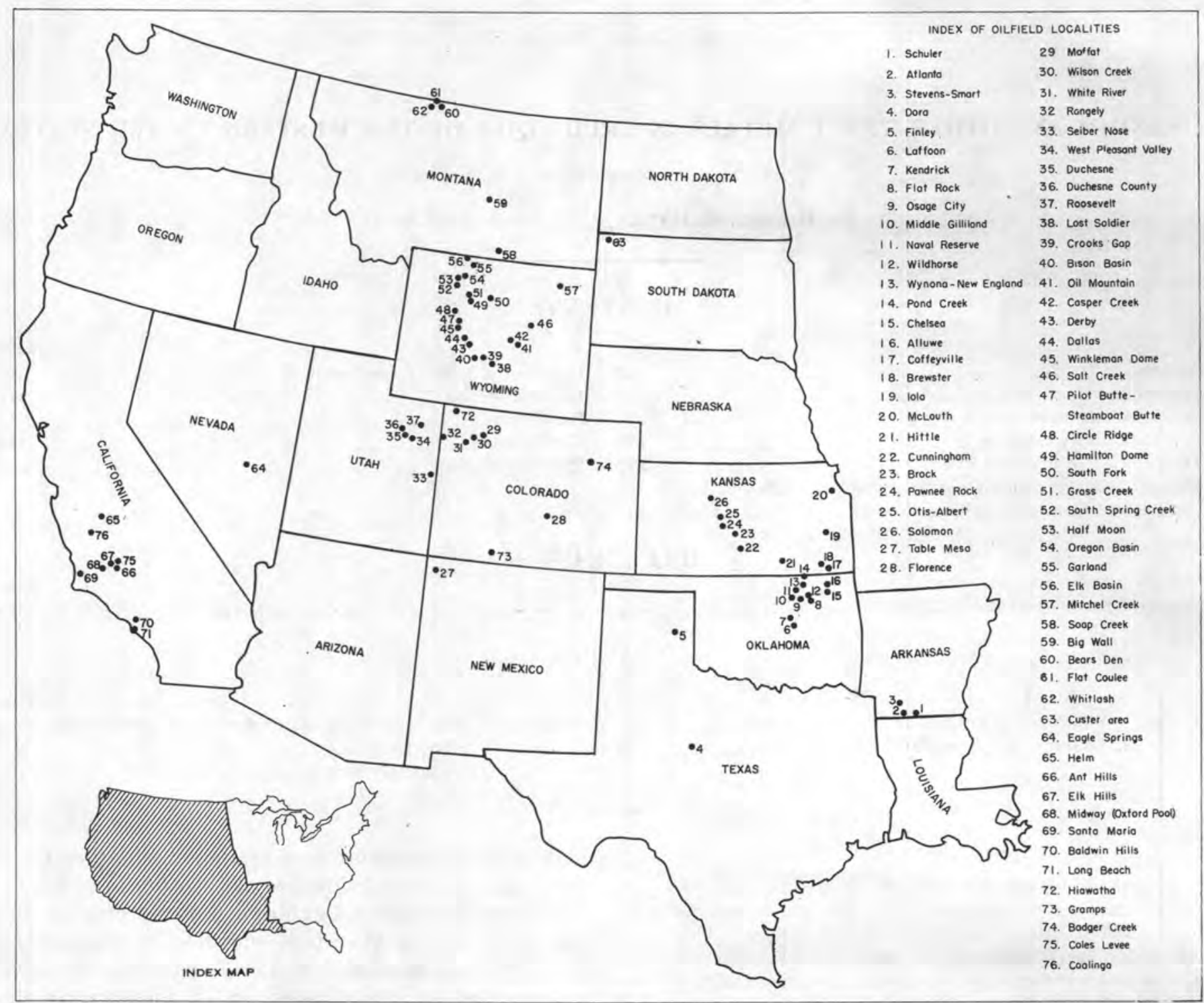

Figure 174.-Map of the Western United States showing localities where samples of crude oil were collected for analysis of uranium and other trace-metals content.

living organisms and in naturally occurring carbonaceous materials. That uranium is commonly associated with carbonaceous material has been demonstrated in many uranium deposits.

The presence of vanadium in a metallo-organic complex in crude oil and bituminous rocks was noted by Treibs (1935). Many investigators (Bird, 1914; Ramsay, 1924; Shirey, 1931; Fester and Cruellas, 1936; Katchenkov, 1949; Southwick, 1951; Skinner, 1952; and Jones and Hardy, 1952) have reported the presence of relatively large amounts of vanadium and nickel and minor amounts of many other metals in the ash of crude oils. Erickson, Myers, and Horr (1954) reported that the percentage of uranium in the ash of 29 crude oils which were investigated by them ranged from 0.0002 to 0.014 percent; they suggested that uraniferous asphaltite deposits may have formed by alteration of uraniferous crude oils.

\section{LABORATORY. METHOD}

Analyses of the trace elements of the crude oils for this investigation were done in the U. S. Geological Survey's laboratory at Denver, Colo., under the supervision of A. T. Myers. Each sample of crude oil was first reduced by ignition to ash. The resultant ash was split. One split was analyzed fluorimetrically for uranium content, the other split was analyzed spectrographically for trace-metals content. Mary Curtis and Sylvia Furman did the ashing and made fluorimetric analyses under the supervision of C. A. Horr; Pauline J. Dunton made the spectrographic analyses. 
URANIUM AND OTHER TRACE METALS IN CRUDE OILS, WESTERN UNITED STATES

TABLE 1.-SUmmary of analytical data on some crude oils, listed according to geographic distribution, age, and lithologic character of the reservoir rocks

\begin{tabular}{|c|c|c|c|c|c|c|c|c|c|c|c|}
\hline $\begin{array}{c}\text { Seri- } \\
\text { al } \\
\text { no. }\end{array}$ & $\begin{array}{c}\text { Age, rock type, State, and } \\
\text { no. on fig. } 174\end{array}$ & Oilfield & Producing unit & $\begin{array}{l}\text { Oil } \\
\text { group }\end{array}$ & $\begin{array}{l}\mathrm{U} \text { in ash } \\
\text { (percent) }\end{array}$ & $\begin{array}{l}\mathrm{U} \text { in ofl } \mathrm{t} \\
\text { (parts per } \\
\text { bilition } \\
{\left[10^{\circ}\right] \text { ) }}\end{array}$ & $\begin{array}{c}\mathrm{V} \text { in } \\
\text { ash }^{2} \text { (per- } \\
\text { cent) }\end{array}$ & $\begin{array}{c}\text { Ni in } \\
\text { ash }^{3} \text { (per- } \\
\text { cent) }\end{array}$ & $\begin{array}{c}\mathrm{Cu} \text { in } \\
\text { ash }^{2} \text { (per- } \\
\text { cent) }\end{array}$ & $\begin{array}{l}\text { Ash } \\
\text { (per- } \\
\text { cent) }\end{array}$ & $\underset{\text { (per- }}{\mathrm{N}}$ \\
\hline
\end{tabular}

\begin{tabular}{|c|c|c|c|c|c|c|c|c|c|c|c|}
\hline \multicolumn{12}{|c|}{ Midcontinent region } \\
\hline 1 & $\begin{array}{c}\text { Sandstone of Cambrian age: } \\
\text { Kansas: } 25 . . .\end{array}$ & Otis-Albert..... & Sandstone of Cambrian & & 0.0003 & 0.291 & 22.0 & 6. 2 & 0.04 & 0.0097 & \\
\hline 2 & Texas: 4 & Dora... & age. & II-3 & .0007 & .0427 & & & & .00061 & 0.028 \\
\hline & Regional average & & & & 0.0005 & 0.17 & & & & & \\
\hline 3 & $\begin{array}{l}\text { Sandstone of Ordovician age: } \\
\text { Oklahoms: } \\
10\end{array}$ & Middle Gilliland. & $\begin{array}{l}\text { Hominy sand of drillers } \\
\text { (Bimpson group). }\end{array}$ & & .0017 & .85 & .30 & .22 & .31 & .0050 & \\
\hline 4 & $6 \ldots$ & Laffoon .... & $\begin{array}{l}\text { Wilcox of drillers (Simp- } \\
\text { son group). }\end{array}$ & XI-27 & .0009 & 1. 98 & 20.0 & 9.2 & .08 & .022 & .38 \\
\hline & Oklahoma average & & & & 0.0013 & 1.4 & & & & & \\
\hline 5 & $\begin{array}{l}\text { Limestone of Cambrian and } \\
\text { Ordovician age: } \\
\text { Oklahoma: } 14\end{array}$ & Pond Oreek. & Arbuckle limestone...... & VII-19 & .0004 & .056 & & & & .0014 & \\
\hline & Kansas: & 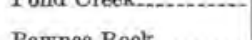 & & $\sqrt{10-19}$ & $.000 t$ & .000 & & & & tourt & \\
\hline $\begin{array}{l}6 \\
7\end{array}$ & $24 \ldots$ & Pawnee Rock. & 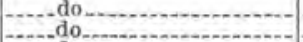 & & $\begin{array}{l}.0004 \\
.0002\end{array}$ & $\begin{array}{r}.56 \\
1.35\end{array}$ & $\frac{8.8}{x}$ & $2.4 \mathrm{x}$ & $.0 \mathrm{x}$ & .0140 & \\
\hline 8 & 18. & Brewster.... & do & ViIII-18 & .0014 & .22 & 13.0 & 8.4 & 1.6 & .00157 & $\cdots$ \\
\hline 9 & .......... & . & - do & VIII-18 & .0213 & 2. 77 & $\bar{x}+$ & $\cdot \frac{\mathrm{X}}{\mathrm{X}}$ & $.0 \mathrm{X}$ & .0013 & (n) \\
\hline $\begin{array}{l}10 \\
11\end{array}$ & $26 \ldots$ & Solomon..... & - - do & $\rightarrow+\infty$ & $\begin{array}{l}.0009 \\
.0002\end{array}$ & $\begin{aligned} 104,4 \\
2.06\end{aligned}$ & $\mathrm{x}^{.86}$ & xt & .002 & $\begin{array}{r}1.160 \\
.103\end{array}$ & $\ldots$ \\
\hline 12 & (n............. & Brock & - & 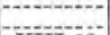 & .0013 & $\begin{array}{l}2.00 \\
.442\end{array}$ & $\hat{x}$ & $x^{\prime+1}$ & $.0 \mathrm{X}+$ & .0034 & $=$ \\
\hline 13 & 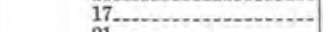 & Coffeyville & _._._do_.._. & VIII-19 & .001 & .24 & 16. 0 & & .22 & .0024 & .105 \\
\hline $\begin{array}{l}14 \\
15\end{array}$ & $21 \ldots \ldots$ & 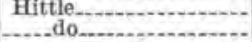 & $\mid \begin{array}{l}\mid \\
\end{array}$ & $\begin{array}{l}\text { IV-10 } \\
\text { IV-10 }\end{array}$ & .0014 & $\begin{array}{l}.0728 \\
.03\end{array}$ & & & & $\begin{array}{l}.00052 \\
.001\end{array}$ & \\
\hline & Kansas average..... & & & & 0.0028 & 11 & & & & & \\
\hline & $\begin{array}{l}\text { Regional average... } \\
\text { Sandstone of Pennsylvanian }\end{array}$ & & & & ;0026 & 10 & & & & & \\
\hline 16 & $\begin{array}{l}\text { Sandstone of Pennsylvanian } \\
\text { age: } \\
\text { Oklahoms: }\end{array}$ & Flat Rock.. & Lower part of Bartlesville & B-3 & .0004 & .604 & & & & .0151 & \\
\hline $\begin{array}{l}17 \\
18\end{array}$ & & Wynons.... & $\begin{array}{l}\text { sand. } \\
\text { Bartlesville sand }\end{array}$ & $y-2$ & .0050 & .35 & $\mathrm{x}-$ & & & .0007 & \\
\hline 19 & $13 \ldots$ & Wildhorse..... & Cleveland sand of local & $\begin{array}{l}\mathrm{V}-2 \\
\mathrm{~B}-3\end{array}$ & .0045 & 585 & $\begin{array}{r}7.9 \\
20.0\end{array}$ & 5. 2 & 3.4 & .0006 & \\
\hline 20 & 11. & Naval Reserv & $\begin{array}{l}\text { usage. } \\
\text { Burbank sand. }\end{array}$ & B-3 & .0010 & .000 & & 7.6 & 1.3 & .0013 & -.......... \\
\hline 21 & $13 \ldots$ & New England. & Burgass sand of local usage. & $\begin{array}{l}\text { II }-4 \\
\text { VI-15 }\end{array}$ & .0004 & .812 & $\cdot \mathrm{x}-$ & $.0 \mathrm{X}+$ & $\cdot \frac{\mathrm{X}}{\mathrm{X}}=$ & .0203 & .103 \\
\hline 22 & $9 \ldots$ & Osage City..... & Buzzard sand of loeal us- & $\begin{array}{l}11-10 \\
\text { III-6 }\end{array}$ & .0010 & .74 & 13. & $7.0 x+$ & $.84-$ & .0074 & ..... \\
\hline${ }_{24}^{23}$ & $16 \ldots \ldots$ & $\begin{array}{l}\text { Alluwe........... } \\
\text { Chelsea }\end{array}$ & Bartlesville sand............ & IV-11 & .045 & 4. 5 & $\mathrm{X}$ & $\mathbf{x}$ & $.0 \mathrm{X}+$ & .001 & \\
\hline & Oklahoma average & Chels & -ndo & IV -11 & .040 & 8.0 & $\mathrm{X}$ & $\overrightarrow{\mathrm{X}}$ & $.0 \mathrm{X}+$ & .002 & \\
\hline 25 & $\begin{array}{l}\text { Oklahoma average. } \\
\text { Texas: } 5 \text {................ }\end{array}$ & Finley Pool. & Granite wash ......... & & $\begin{array}{l}0.01225 \\
.0031\end{array}$ & $\begin{array}{l}\text { 2. } 0 \\
\text { 2. } 54\end{array}$ & 3.2 & 2.5 & 2,5 & .0082 & \\
\hline 26 & $\begin{array}{r}\text { Kansas: } \\
21 . . . .\end{array}$ & Hittle.. & Peru sand of local usage... & & .002 & .28 & & & & & \\
\hline 27 & $20 \ldots$ & MeLouth... & MeLouth sand of local & $\mathrm{I}-1$ & .0051 & 1.07 & $\mathrm{x}+$ & $\mathrm{x}+$ & $.0 \mathrm{x}+$ & .0021 & \\
\hline 28 & $19 \ldots$ & Iola........... & Upper part of Bartles. & VIII-20 & .0002 & 2. 6 & 1.2 & .69 & .007 & .13 & \\
\hline $\begin{array}{l}29 \\
30\end{array}$ & $19 \ldots \ldots$ & do do & vindo sand........... & VIII-20 & .0001 & .15 & $\underset{x}{x}$ & $\mathrm{x}+$ & $.0 \mathrm{x}+$ & .015 & \\
\hline & Kansas avera & Otis-Albert ${ }^{3}$. & ............ & & .0004 & .52 & $\mathrm{xx}$ & & $.0 \mathrm{x}+$ & .013 & \\
\hline & Regional average.... & w... & 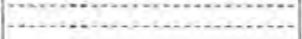 & & $\begin{array}{r}0.0015 \\
.0077\end{array}$ & $\begin{array}{l}0.92 \\
1.7\end{array}$ & & & & & \\
\hline & $\begin{array}{l}\text { Limestone of Pennsylvanian } \\
\text { age: }\end{array}$ & & & & & & & & & & \\
\hline 31 & Oklahoma: $7 \ldots$ & Kendrick. & Fort Scott limestone. & & .0032 & .32 & 8.4 & 2.2 & 13.2 & .001 & .046 \\
\hline 32 & Kansas: & Cunningham. & Lansing group.. & & .0008 & 1.04 & 34.0 & 7.6 & .48 & .013 & \\
\hline 33 & $22 \ldots \ldots \ldots \ldots \ldots \ldots$ & $\cdots$ & (n)............. & & .0005 & .40 & $\mathrm{xx}$ & $x \mathrm{x}$ & $.0 \mathrm{x}-$ & .008 & \\
\hline & $\begin{array}{l}\text { Kansas average..... } \\
\text { Regional average.... }\end{array}$ & ... & & & $\begin{array}{r}0.0006 \\
.0015\end{array}$ & 0.72 & & & & & .. \\
\hline 34 & 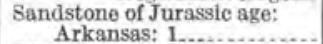 & Schule & Jones sand & & & ret & & & & & \\
\hline 35 & $\begin{array}{l}\text { Limestone of Jurassic age: } \\
\text { Arkansas: }\end{array}$ & & & & & 2 & & & & & .075 \\
\hline so & $\begin{array}{l}\text { Arkansas: } 2 \\
\text { Sandstone of Oretaceous age: }\end{array}$ & West Atlanta. & Smackover formation..... & & .0065 & .299 & $.0 \mathrm{X}+$ & $.0 \mathrm{X}$ & $. \mathrm{X}-$ & .00046 & .015 \\
\hline 36 & Arkansas: 3 .. & Stephens-Bmart & Travis Peak formation.... & & .0012 & 11.75 & 4.4 & 5.4 & .84 & .098 & .0042 \\
\hline
\end{tabular}

Rocky Mountain region

\begin{tabular}{|c|c|c|c|c|c|c|c|c|c|c|c|}
\hline 37 & $\begin{array}{l}\text { Sandstone of Cambrian age: } \\
\text { Wyoming: } 38\end{array}$ & Lost Soldier.. & Flathead sandstone.... & $V-13 A$ & 0.0031 & 0.217 & $x+$ & $\mathrm{x}$ & $0 . x-$ & 0.0007 & 0.084 \\
\hline 38 & $\begin{array}{l}\text { Limestone of Ordovician age: } \\
\text { South Dakota: } 63 . . . . . .\end{array}$ & Custer... & Red River formation of & & .0006 & .048 & & & & .0008 & .162 \\
\hline $\begin{array}{l}39 \\
40 \\
41 \\
42\end{array}$ & $\begin{array}{l}\text { Limestone of Mississippian } \\
\text { age: } \\
\text { Wyoming: } \\
49 \\
54 \\
48\end{array}$ & $\begin{array}{l}\text { Hamilton Dome....... } \\
\text { North Oregon Basin. } \\
\text { Oircle Ridge. } \\
\text { South Spring Creek... }\end{array}$ & $\begin{array}{c}\text { Madison limestone.... } \\
\text { do }\end{array}$ & $\begin{array}{l}\mathrm{IX}-23 \mathrm{~B} \\
\mathrm{IX}-21 \\
\mathrm{IX}-23 \mathrm{~B}\end{array}$ & $\begin{array}{l}.0003 \\
.0022 \\
.00026 \\
.00095\end{array}$ & $\begin{array}{l}1.14 \\
7.634 \\
.429 \\
3.19\end{array}$ & $\begin{array}{r}28.0 \\
22.0 \\
\mathrm{XX} \\
\mathrm{XX}\end{array}$ & $\begin{array}{r}7.0 \\
6.4 \\
\mathrm{X}+ \\
\mathrm{XX}\end{array}$ & $\begin{array}{l}.07 \\
.03 \\
\mathrm{X}+\end{array}$ & $\begin{array}{l}.038 \\
.0347 \\
.0165 \\
.0336\end{array}$ & $\begin{array}{l}.41 \\
.35 \\
.23 \\
.48\end{array}$ \\
\hline & Wyoming average. & & & & 0.00093 & 3.1 & & & & & \\
\hline
\end{tabular}

See footnotes at end of table.

$385115-56-34$ 
TABLE 1.-Summary of analytical data on some crude oils, listed according to geographic distribution, age, and lithologic character of the reservoir rocks-Continued

\begin{tabular}{|c|c|c|c|c|c|c|c|c|c|c|c|}
\hline $\begin{array}{c}\text { Ser1- } \\
\text { al } \\
\text { no. }\end{array}$ & $\begin{array}{c}\text { Age, rock type, State, and } \\
\text { no. on fig. } 174\end{array}$ & Oilfield & Producing unit & $\begin{array}{l}\text { Oil } \\
\text { group }\end{array}$ & $\begin{array}{l}\mathrm{U} \text { in ash } \\
\text { (percent) }\end{array}$ & $\begin{array}{l}U \text { in oil } 1 \\
\text { (parts per } \\
\text { billion } \\
{[10.1)}\end{array}$ & $\begin{array}{c}V \text { in } \\
\text { ash }{ }^{2} \text { (per- } \\
\text { cent) }\end{array}$ & $\begin{array}{c}N 1 \text { in } \\
\text { ash }^{2} \text { (per- } \\
\text { cent) }\end{array}$ & $\begin{array}{l}\mathrm{Cu} \text { in } \\
\operatorname{ash}^{2} \text { (per- } \\
\text { cent) }\end{array}$ & $\begin{array}{l}\text { Ash } \\
\text { (per. } \\
\text { cent) }\end{array}$ & $\begin{array}{c}\mathrm{N} \\
\text { (per- } \\
\text { cent) }\end{array}$ \\
\hline
\end{tabular}

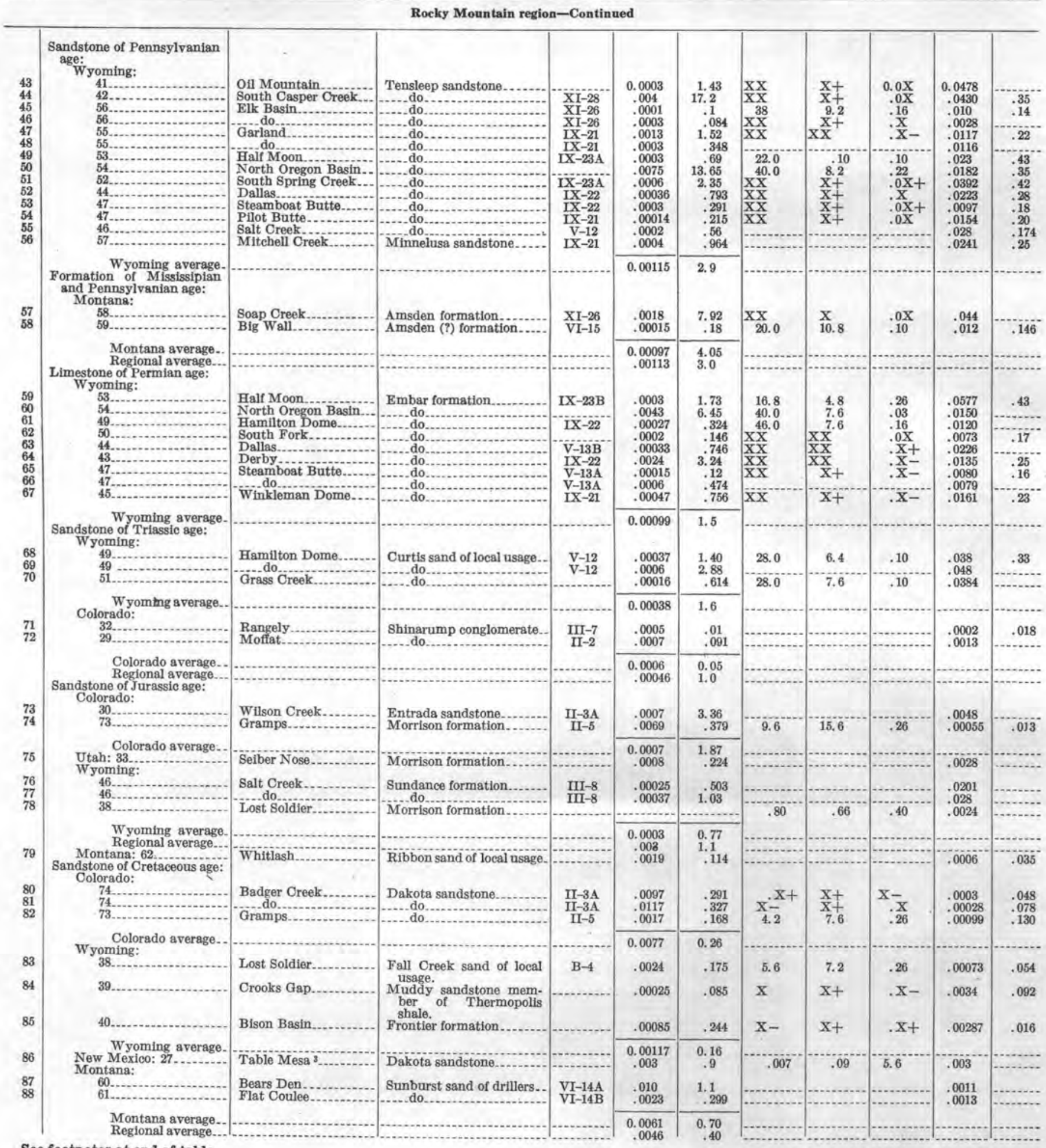


TABLE 1.-Summary of analytical data on some crude oils, listed according to geographic distribution, age, and lithologic character of the reservoir rocks-Continued

\begin{tabular}{|c|c|c|c|c|c|c|c|c|c|c|c|}
\hline $\begin{array}{l}\text { Ser1- } \\
\text { al } \\
\text { no. }\end{array}$ & $\begin{array}{l}\text { Age, rock type, State, and } \\
\text { no, on fig. } 174\end{array}$ & Ollfield & Produeing unit & $\underset{\text { group }}{\text { O1l }}$ & $\begin{array}{l}\text { U in ash } \\
\text { (percent) }\end{array}$ & $\begin{array}{c}\text { U In oil } 1 \\
\text { (parts per } \\
\text { billion } \\
{\left[10^{\circ}\right] \text { ) }}\end{array}$ & $\begin{array}{c}\mathrm{V} \text { in } \\
\begin{array}{c}\text { ash }^{2} \text { (per- } \\
\text { cent) }\end{array}\end{array}$ & $\begin{array}{l}\text { Ni in } \\
\text { ash' } \\
\text { cent) }\end{array}$ & $\begin{array}{c}\text { Cu in } \\
\operatorname{ash}^{2} \text { (per- } \\
\text { cent) }\end{array}$ & $\begin{array}{l}\text { Ash } \\
\text { (per- } \\
\text { cent) }\end{array}$ & $\begin{array}{l}N \\
\text { (per- } \\
\text { cent) }\end{array}$ \\
\hline
\end{tabular}

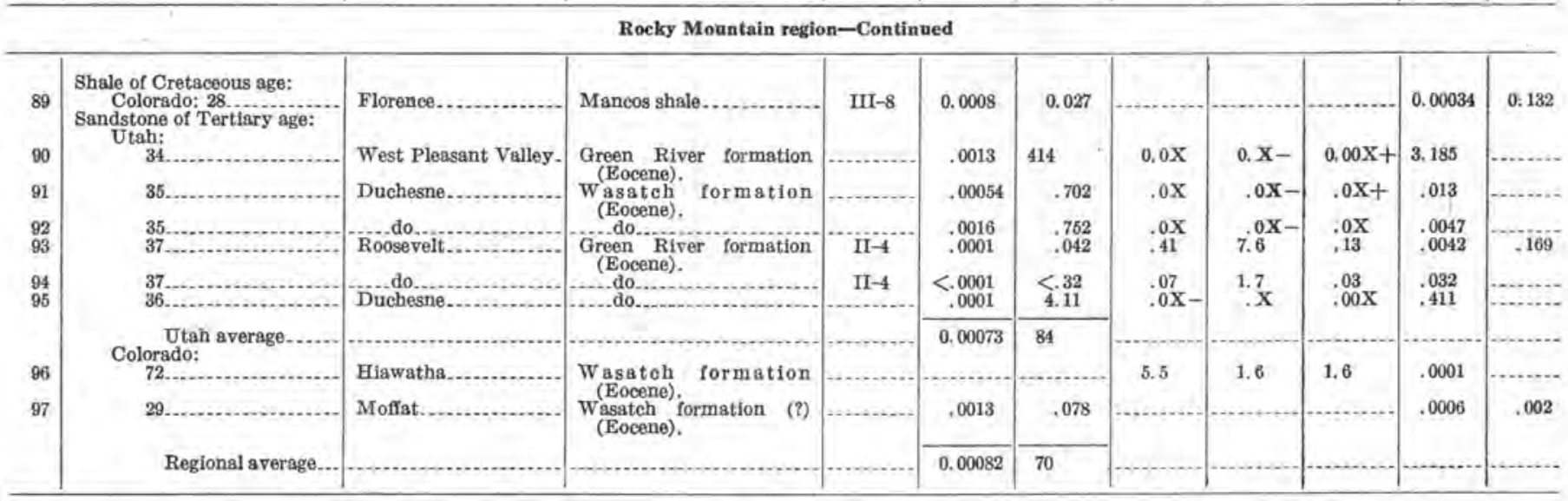

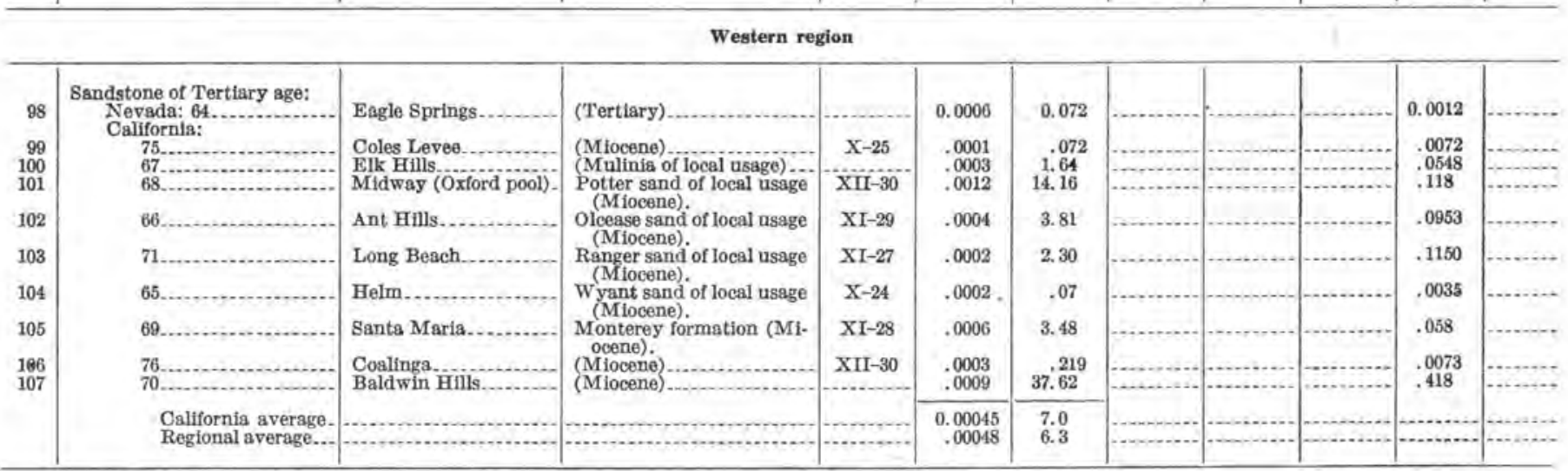

1 Recaloulated: $100,000 \times$ percent ash $X$ percent $\mathrm{U}$ in ash.

${ }_{1}$ Arabic values are results of quantitative ppectrographicanalyses; $X$ values are results of semiquantitative spectrographic analyses: $0 . X+=0.464$ to 1.0 percent, $0 . X=0.215$ to 0.463 percent, $0 . \mathrm{X}-=0.10$ to 0.214 percent, $\mathrm{XX}=$ more than 10 percent.

\section{DISTRIBUTION OF URANIUM IN CRUDE OILS}

The uranium content in the ash of the crude oils investigated ranges from less than 0.0001 percent to 0.045 percent. The uranium content calculated as parts per billion $\left(10^{\circ}\right)$ in the crude oil ranges from 0.01 to 414 . The data shown in table 1 suggest that the uranium content is apparently unrelated to the age or lithologic character of the reservoir rock.

The low percentage of uranium in even the most uraniferous crude oils investigated suggests that crude oil is not an economic source of the metal. On the other hand, the great range in uranium contents presents the possibility of using uranium analyses of crude oils as a prospecting guide; thus, several of the oil samples show interestingly large uranium contents. Oil from the Bartlesville sand in Oklahoma (serial nos. 23 and 24), for example, has the largest percentage of uranium in the ash of all oils investigated. Crude oils 9,81 , and 87 (table 1 ) have relatively large percentages of uranium in the ash. The ash of samples 10 and 90 have relatively large percentages or uranium, but these values merely reflect the large ash content of the oils. Most of the crude oils from California that were investigated are heavy (low gravity) oils and have relatively small percentages of uranium in the ash but have a relatively large uranium eontent in the oil.

\section{URANIUM AND VANADIUM CONTENT OF OILS OF DIFFERENT HYDROCARBON COMPOSITION}

In order to compare the trace-metals content of the crude oils of varying composition, the oils were separated into groups containing oils of similar composition. This grouping was done by comparing graphs of the correlation indices reported by U. S. Bureau of Mines routine-distillation analyses of the crude oils investigated. The correlation index for each of the 15 distillation fractions in an analysis is a number which represents the relation of the average boiling point and the average specific gravity of the fraction (Smith, 
1940). The 13 groups and 31 subgroups thus deter- $\mid$ to variation in gravity, asphaltic character (napthenic mined are shown in table 2 and are arranged according 1 and aromatic constituents), and paraffinic character.

Table 2.-Uranium and vanadium content of some oils, grouped according to results of $U$. S. Bureau of Mines crude-petroleum analysis

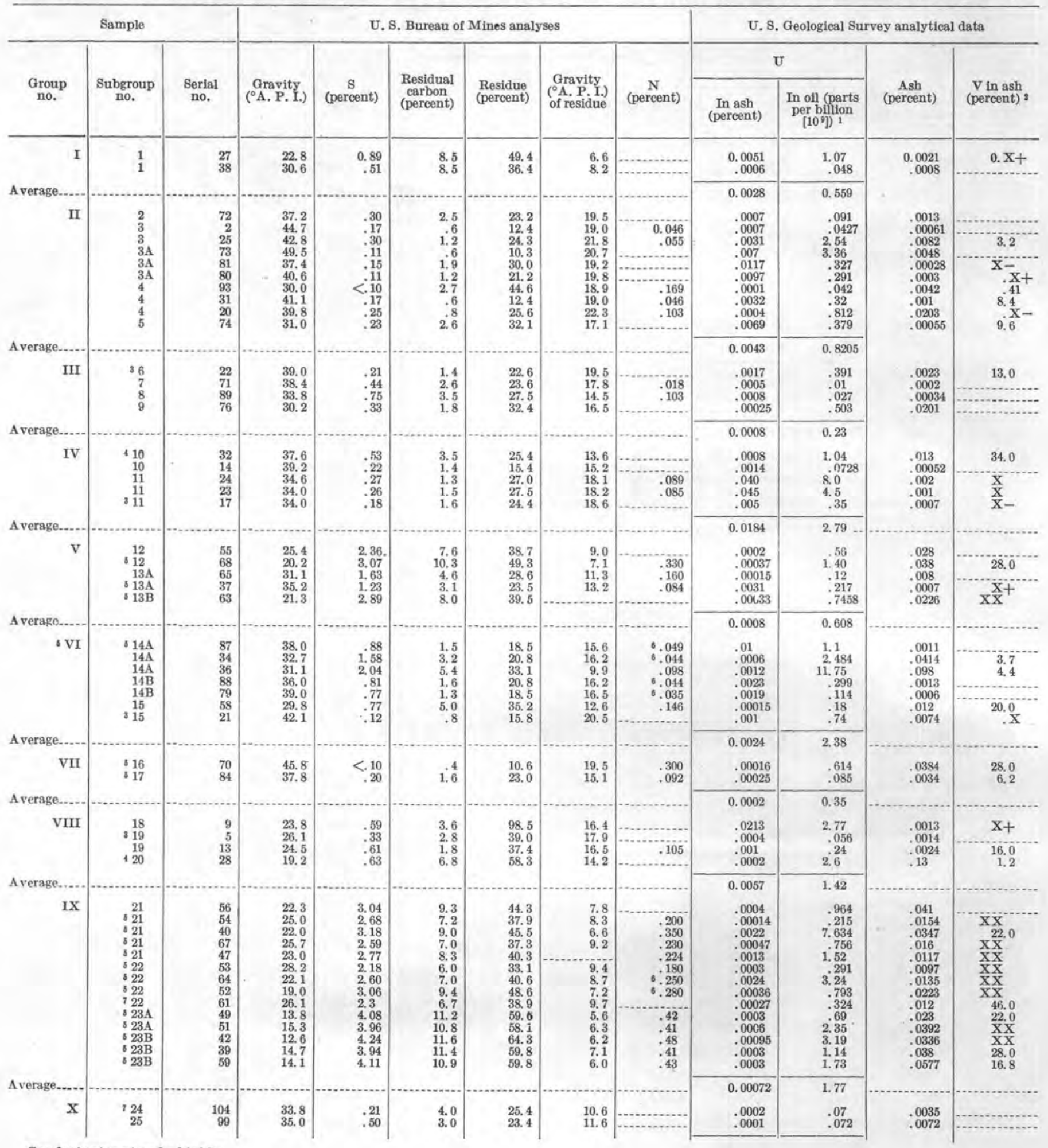

See footnotes at end of table. 
URANIUM AND OTHER TRACE METALS IN CRUDE OILS, WESTERN UNITED STATES

Table 2.-Uranium and vanadium content of some oils, grouped according to results of U.S. Bureau of Mines crude-petroleum analysis-Continued

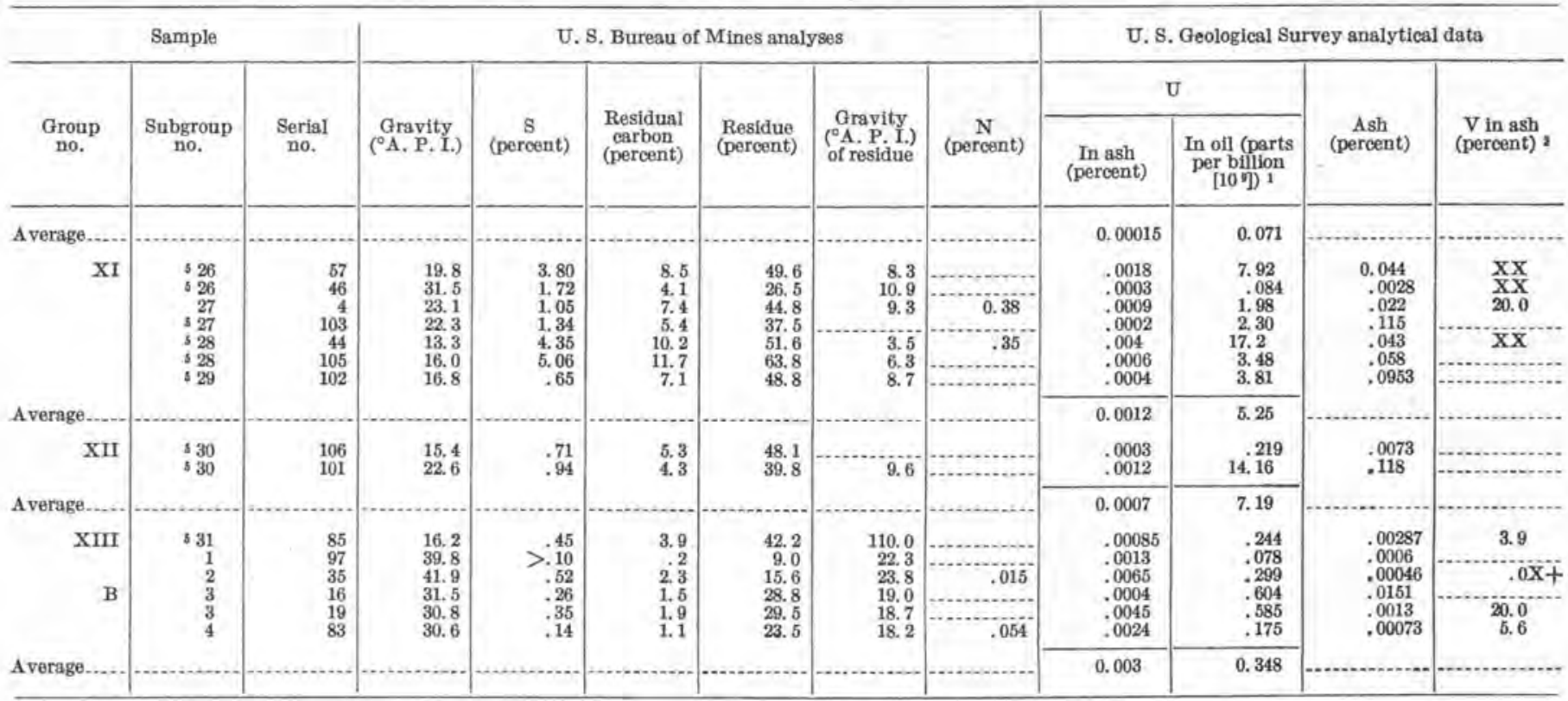

1 Recalculsted: $100,000 \times$ percent ash $\times$ percent $U$ in ash

2 Arabic values are results of quantitative spectrographic analyses. $X$ values are results of semiquantitative spectrographic analyses: $0 . \bar{X}+=0.464$ to 1.0 percent, $0 . \mathrm{X}=0.215$ to .463 percent, $0 . \mathrm{X}-=0.10$ to
a Crude-oil analyses from Blade (1945).

The data suggest that no oil group or subgroup shown has a consistently large or consistently small uranium content. The difference between the maximum and minimum content of uranium in each group is generally greater than the average uranium content of the group. The average uranium content in the ash of oils in groups VI-XIII is not greater than the average uranium content of groups $\mathrm{I}-\mathrm{V}$ and group B. Neither asphaltic nor paraffinic oils show a greater capacity or affinity for uranium. Generally, a larger content of uranium appears to be present in the oils of groups IX-XIII; these values, however, reflect a larger ash content in the heavier, more asphaltic oils.

It is noteworthy that although the uranium content does not appear to be preferentially distributed in the groups of oils, vanadium concentrations of greater than 10 percent in the ash are most common in the heavier oils.

\section{URANIUM IN REFINERY RESIDUES}

The uranium content of each of 16 residues from 10 refineries was determined; the results are shown in table 3. The uranium content in ash of the refinery residues is within the range of the uranium content for the crude oils investigated. Only 2 of the 16 samples contain enough uranium (0.024 and 0.023 percent in the ash of the oil) to warrant consideration of recovery of uranium from refinery residues.
: Crude-oil analyses from Lane and Garton (1943).

5. Crude-ofl analyses are of oll from wells near those sampled in this investigation

7 Ball, Whisman, and Wenger (1951).

TABLE 3,-Uranium content of residues from petroleum refineries

\begin{tabular}{|c|c|c|c|c|c|}
\hline \multirow[b]{2}{*}{ Source area of crude ofl } & \multirow[b]{2}{*}{$\begin{array}{l}\text { Location of } \\
\text { reflnery }\end{array}$} & \multirow[b]{2}{*}{$\begin{array}{l}\text { Kind of } \\
\text { residue }\end{array}$} & \multirow[b]{2}{*}{$\begin{array}{l}\text { Ash } \\
\text { (per- } \\
\text { cent) }\end{array}$} & \multicolumn{2}{|c|}{ U } \\
\hline & & & & $\begin{array}{l}\text { In ash } \\
\text { (per-) } \\
\text { cent) }\end{array}$ & $\begin{array}{l}\text { In oll } \\
\text { (parts } \\
\text { per } \\
\text { billion } \\
{\left[10^{0} \text { ) }\right.}\end{array}$ \\
\hline Wyoming - & Sinclair, Wyo.... & No. 6 fuel & 0.012 & 0.0006 & 0.72 \\
\hline $\begin{array}{l}\text { Do } \\
\text { Wind River and Bighorn }\end{array}$ & Casper, wyo. & $\begin{array}{l}\text { An. } \\
\text { Asphalt... } \\
\text { Coke...... }\end{array}$ & $\begin{array}{l}.022 \\
.425\end{array}$ & $\begin{array}{l}.0004 \\
.024\end{array}$ & $1,070.0$ \\
\hline $\begin{array}{l}\text { Basins, W yo. } \\
\text { Salt Creek fleld, Wyo- } \\
\text { ming. }\end{array}$ & Cusper, wyon & 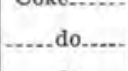 & .126 &, 023 & 289.80 \\
\hline $\begin{array}{l}\text { Wyoming } \\
\text { Williston basin, Mont., } \\
\text { N. Dak. }\end{array}$ & Laurel, Mon & Asphalt. & $\begin{array}{l}.120 \\
.033\end{array}$ & $\begin{array}{l}.015 \\
.0001\end{array}$ & $\begin{array}{r}180.0 \\
.33\end{array}$ \\
\hline $\begin{array}{l}\text { Oregon Basin field, Wyo- } \\
\text { ming. }\end{array}$ & Cody, Wyo. & ......do.. & .026 & .0003 & .78 \\
\hline $\begin{array}{l}\text { Elk Basin field, Wyoming } \\
\text { Oregon Basin, Pitehfork, } \\
\text { and Half Moon fields, }\end{array}$ & ......do... & .....do... & $\begin{array}{l}.049 \\
.072\end{array}$ & $\begin{array}{l}.0005 \\
.0004\end{array}$ & $\begin{array}{l}2.45 \\
2.88\end{array}$ \\
\hline $\begin{array}{l}\text { Wyoming. } \\
\text { Hamilton dome, wyom- } \\
\text { ing. }\end{array}$ & $\begin{array}{l}\text { Thermopolis, } \\
\text { Wyo. }\end{array}$ & 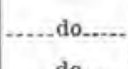 & .074 & .0004 & 2. 96 \\
\hline $\begin{array}{l}\text { Central and eastern Okla- } \\
\text { homa. }\end{array}$ & Tulsa, Okla & $d$ & $\begin{array}{r}.014 \\
028\end{array}$ & .0003 & .42 \\
\hline $\begin{array}{l}\text { Osage and Tulsa Coun- } \\
\text { ties, Okla. }\end{array}$ & & ....do......... & .024 & .0007 & $\begin{array}{l}1.96 \\
1.88\end{array}$ \\
\hline $\begin{array}{l}\text { Laffoon and Prague } \\
\text { fields, oklahoma. }\end{array}$ & Stroud, Okla & ...... do & .058 & .001 & 5.8 \\
\hline $\begin{array}{l}\text { Franne fleld, W yoming, } \\
\text { and Elk Basin, W yom- } \\
\text { ing and Montans. }\end{array}$ & Billings, Mont.... & ........... & .020 & .0053 & 10.60 \\
\hline Panhandle field, Texas... & Phnllips, Tex & ......do.... & .131 & .0053 & 69.43 \\
\hline
\end{tabular}

\section{RATIO OF METALS}

Katchenkov (1949) observed a relative constancy of the ratio of vanadium to nickel in crude oils in Russia. This ratio was about 3 to 1 for crude oil from rocks of 
Paleozoic age and less than 1 for crude oil from rocks of Cenozoic age. A constancy of the ratio of vanadium to nickel in crude oils from Cretaceous rocks in Canada has also been observed.

CQuantitative spectrographic analyses for vanadium, nickel, and copper were performed for this investigation on the ash from 37 samples of crude oil. The results of these analyses are shown in table 4. Except for oil sample 49, the ratio of vanadium to nickel in the ash of the oils in rocks of Paleozoic age ranges from 1.24 to 6.05. The ratio of vanadium to nickel is less than 1 for many of the oils from rocks of Mesozoic and Tertiary age. In contrast, the ratios of vanadium to copper and vanadium to uranium are extremely variable in oils from rocks of all ages represented.

\section{PORPHYRINS}

In 1934 Treibs made the important discovery of porphyrins in crude oil. Porphyrins are organic complexes, the derivatives of hemoglobin and chlorophyl. Later Treibs (1935) was able to isolate and synthesize a vanadium-porphyrin complex. Later a nickel-porphyrin complex was identified by Glebovskaya and Vol'kenshtein (1948). Skinner (1952) identified the vanadium-porphyrin complex in oil from the Santa Maria field in California and concluded that the porphyrin material probably accounted for all the vanadium.

Treibs observed the association of porphyrins with natural asphalts and with asphaltic oils (1934). The general association of large vanadium contents with the

TARLE 4.-Trace-metals content in ash of crude oil grouped by age and kind of reservoir rocks

\begin{tabular}{|c|c|c|c|c|c|c|c|c|c|}
\hline \multirow[b]{2}{*}{ Rock type } & \multicolumn{2}{|c|}{ Oil sample } & \multirow[b]{2}{*}{$\underset{\text { (percent) }}{\mathbf{V}^{1}}$} & \multirow[b]{2}{*}{$\begin{array}{c}\mathrm{Ni}^{1} \\
\text { (percent) }\end{array}$} & \multirow[b]{2}{*}{$\underset{\text { (percent) }}{\mathrm{Cu}^{\mathrm{I}}}$} & \multirow[b]{2}{*}{$\begin{array}{c}\mathrm{U}^{2} \\
\text { (percent) }\end{array}$} & \multirow[b]{2}{*}{$\mathrm{V}: \mathrm{Ni}^{3}$} & \multirow[b]{2}{*}{$\mathrm{V}: \mathrm{Cu}^{3}$} & \multirow[b]{2}{*}{$\mathrm{V} ; \mathrm{U}^{3}$} \\
\hline & Serial no. & $\begin{array}{l}\text { Locality } \\
\text { no. } \\
\text { (fig. 174) }\end{array}$ & & & & & & & \\
\hline \multicolumn{10}{|c|}{ Reservoirs in rocks of Paleozoic age } \\
\hline Sandstone of Cambrian age.... & 1 & 25 & 22.0 & 6. 2 & 0.04 & 0.0003 & 3.55 & 550.0 & 7,330 \\
\hline Sandstone of Ordovician age... & $\begin{array}{l}3 \\
4\end{array}$ & $\begin{array}{r}10 \\
6\end{array}$ & 20.0 & 9.22 & .31 & .0017 & $\begin{array}{l}1.32 \\
2.17\end{array}$ & $250.0^{.968}$ & $\begin{array}{r}176 \\
22,200\end{array}$ \\
\hline Limestone of Ordovician age & $\begin{array}{r}8 \\
6 \\
10 \\
13\end{array}$ & $\begin{array}{l}18 \\
24 \\
26 \\
17\end{array}$ & $\begin{array}{c}13.0 \\
8.8 \\
1.86 \\
16.0\end{array}$ & $\begin{array}{l}8.4 \\
2.4 \\
0.19 \\
5.0\end{array}$ & $\begin{array}{l}1.6 \\
.15 \\
.002 \\
.22\end{array}$ & $\begin{array}{l}.0213 \\
.0004 \\
.0009 \\
.0012\end{array}$ & $\begin{array}{l}1.55 \\
3.66 \\
4.52 \\
3.20\end{array}$ & $\begin{array}{c}8.13 \\
58.7 \\
430.0 \\
72.7\end{array}$ & $\begin{array}{r}610 \\
22,000 \\
956 \\
13,300\end{array}$ \\
\hline 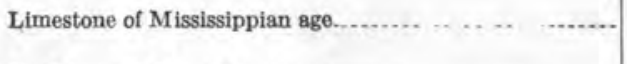 & $\begin{array}{l}40 \\
39\end{array}$ & $\begin{array}{l}54 \\
49\end{array}$ & $\begin{array}{l}22.0 \\
28.0\end{array}$ & $\begin{array}{l}6.4 \\
7.0\end{array}$ & .03 & .0022 & $\begin{array}{l}3.44 \\
4.00\end{array}$ & $\begin{array}{l}733.0 \\
400.0\end{array}$ & $\begin{array}{r}10,000 \\
7,000\end{array}$ \\
\hline Sandstone of Pennsylvanian age & $\begin{array}{l}22 \\
18 \\
19 \\
28 \\
58 \\
45 \\
49 \\
50 \\
25\end{array}$ & $\begin{array}{r}9 \\
13 \\
12 \\
19 \\
59 \\
56 \\
53 \\
54 \\
5\end{array}$ & $\begin{array}{r}13.0 \\
7.9 \\
20.0 \\
1.2 \\
20.0 \\
38.0 \\
22.0 \\
40.0 \\
3.2\end{array}$ & $\begin{array}{c}8.4 \\
5.2 \\
7.6 \\
.69 \\
10.8 \\
9.2 \\
.10 \\
8.2 \\
2.5\end{array}$ & $\begin{array}{l}1.6 \\
3.4 \\
1.3 \\
.007 \\
.10 \\
.16 \\
.10 \\
.22 \\
2.5\end{array}$ & $\begin{array}{l}.0017 \\
.0045 \\
.0002 \\
.00015 \\
.0001 \\
.0003 \\
.0075 \\
.0031\end{array}$ & $\begin{array}{c}1.55 \\
1.52 \\
2.63 \\
1.74 \\
1.85 \\
4.13 \\
220.0 \\
4.88 \\
1.24\end{array}$ & $\begin{array}{c}8.13 \\
2.32 \\
15.4 \\
171.0 \\
200.0 \\
231.2 \\
220.0 \\
182.0 \\
1.28\end{array}$ & $\begin{array}{r}7,650 \\
4,440 \\
6,000 \\
133,000 \\
380,000 \\
73,300 \\
5,330 \\
1,030\end{array}$ \\
\hline Limestone of Pennsylvanian age............. & $\begin{array}{l}32 \\
31\end{array}$ & $\frac{22}{7}$ & $\begin{array}{r}34.0 \\
8.4\end{array}$ & $\begin{array}{l}7.6 \\
2.2\end{array}$ & 13.48 & $\begin{array}{l}.0008 \\
.0032\end{array}$ & $\begin{array}{l}\text { 4. } 47 \\
3.81\end{array}$ & $\begin{array}{l}70.8 \\
.630\end{array}$ & $\begin{array}{r}42,500 \\
2,640\end{array}$ \\
\hline Limestone of Permian age.... & $\begin{array}{l}59 \\
60 \\
61\end{array}$ & $\begin{array}{l}53 \\
54 \\
49\end{array}$ & $\begin{array}{l}16.8 \\
40.0 \\
46.0\end{array}$ & $\begin{array}{l}4.8 \\
7.6 \\
7.6\end{array}$ & $\begin{array}{l}.26 \\
.03 \\
.16\end{array}$ & $\begin{array}{l}.0003 \\
.0043 \\
.00027\end{array}$ & $\begin{array}{l}3.50 \\
5.26 \\
6.05\end{array}$ & $\begin{array}{r}60.9 \\
1,330.0 \\
287.0\end{array}$ & $\begin{array}{r}56,000 \\
9,300 \\
167,000\end{array}$ \\
\hline \multicolumn{10}{|c|}{ Reservoirs in rocks of Mesozoic and Cenozoic age } \\
\hline Sandstone of Triassic age...... & $\begin{array}{l}68 \\
70\end{array}$ & $\begin{array}{l}49 \\
51\end{array}$ & $\begin{array}{l}28.0 \\
28.0\end{array}$ & $\begin{array}{l}6.4 \\
7.6\end{array}$ & $\begin{array}{r}0.10 \\
.10\end{array}$ & $\begin{array}{r}0.00037 \\
.00016\end{array}$ & $\begin{array}{l}4.38 \\
3.63\end{array}$ & $\begin{array}{l}280.0 \\
280.0\end{array}$ & $\begin{array}{r}7,570 \\
175,000\end{array}$ \\
\hline Sandstone of Jurassic age ......... & $\begin{array}{l}78 \\
74 \\
34\end{array}$ & $\begin{array}{r}38 \\
73 \\
1\end{array}$ & $\begin{array}{l}.80 \\
9.6 \\
3.7\end{array}$ & $\begin{array}{c}.66 \\
15.6 \\
2.5\end{array}$ & $\begin{array}{l}.40 \\
.26 \\
.35\end{array}$ & .0006 & $\begin{array}{l}1.21 \\
.679 \\
1.48\end{array}$ & $\begin{array}{r}2.0 \\
36.9 \\
10.6\end{array}$ & 6,170 \\
\hline Sandstone of Cretaceous age..... & $\begin{array}{l}85 \\
84 \\
83 \\
82 \\
86\end{array}$ & $\begin{array}{l}40 \\
39 \\
38 \\
73 \\
27\end{array}$ & $\begin{array}{l}3.9 \\
6.2 \\
5.6 \\
4.2 \\
.007\end{array}$ & $\begin{array}{l}9.2 \\
6.4 \\
7.2 \\
7.6 \\
.09\end{array}$ & $\begin{array}{l}.60 \\
.07 \\
.26 \\
.26 \\
5.6\end{array}$ & $\begin{array}{l}.00085 \\
.00025 \\
.0024 \\
.003\end{array}$ & $\begin{array}{l}.422 \\
.970 \\
.779 \\
.550 \\
.077\end{array}$ & $\begin{array}{l}6.5 \\
88.6 \\
10.6 \\
16.2 \\
.001\end{array}$ & $\begin{array}{r}45,900 \\
24,800 \\
2,330 \\
2\end{array}$ \\
\hline 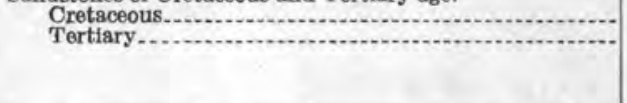 & $\begin{array}{l}36 \\
93 \\
94 \\
96\end{array}$ & $\begin{array}{l}3 \\
37 \\
37 \\
73\end{array}$ & $\begin{array}{c}4.4 \\
.41 \\
.07 \\
5.5\end{array}$ & $\begin{array}{l}5.4 \\
7.6 \\
1.7 \\
1.6\end{array}$ & $\begin{array}{r}.84 \\
.13 \\
.03 \\
1.6\end{array}$ & $\begin{array}{l}.0012 \\
.0001 \\
.00009 \\
\end{array}$ & $\begin{array}{r}.816 \\
.054 \\
.041 \\
3.44\end{array}$ & $\begin{array}{l}5.2 \\
2.4 \\
2.3 \\
3.4\end{array}$ & $\begin{array}{l}3,670 \\
4,100 \\
778\end{array}$ \\
\hline
\end{tabular}

1 Determined by quantitative spectrographic analysis. Determined fluorimetrically.

S Calculated. 
asphaltic oils that is shown in table 3 is in confirmation of Treib's observation.

The porphyrin complexes are nitrogenous (Treibs, 1934), and in order to examine the possibility of a uranium-porphyrin complex accounting for the uranium content of crude oils, the following coefficients of linear correlation between nitrogen content and vanadium, nickel, and uranium content were computed for 21 oil samples.

\begin{tabular}{lrr} 
V & $\begin{array}{r}\text { Ash of oil } \\
0.6985\end{array}$ & $\begin{array}{c}\text { Oil } \\
0.8407\end{array}$ \\
\hline $\mathrm{Ni}$ & .2019 & .70871 \\
$\mathrm{U}$ & .11733 & .25664
\end{tabular}

A high positive correlation ${ }^{1}$ between vanadium and nitrogen is indicated. Nickel has a lower positive coefficient with nitrogen. The low positive coefficient and the negative coefficient of uranium to nitrogen constitute evidence against the existence in quantity of uranium-porphyrin complexes.

Treibs (1935) observed the stability of the vanadium complex, noting that it decomposed only in the strongest acids. Presuming from the correlation coefficients that porphyrin complexes account for most of the vanadium and nickel in crude oils, the inference may be drawn that the nickel-porphyrin complex is less stable than the vanadium-porphyrin complex and that the ratio of vanadium to nickel increases with increase in age of the reservoir rocks.

\section{CONCLUSIONS}

Uranium is not present in sufficient quantity in crude oil to be of commercial interest except as a possible byproduct from crude-oil refinery residues. The presence of a relatively large amount of uranium in crude oil might serve as a guide to prospecting for uranium.

The uranium content of any crude oil is independent of the character of the crude oil. Uranium is probably not present in crude oil as a uranium-porphyrin complex.

\section{REFERENCES CITED}

Ball, J. S., Whisman, M. L., and Wenger, W. J., 1951, Nitrogen content of crude petroleums: Indus. and Eng. Chemistry, v. 34 , p. $2577-2581$.

1 Linear-correlation coefficients may vary from -1.0 to +1.0 ; a positive coefficient Indicates that the values of the variables vary directly, a negative one that they vary inversely.
Bird, R. M., and Calcott, W. S., 1914, The association of vanadium with petroleum and asphalt: Philos. Soc. Bull. Va. Univ., v. 1, p. 365-371.

Blade, O. C., 1945, Analyses of crude oils from some fields in Oklahoma: U. S. Bur. Mines Rept. Inv. 3802.

Erickson, R. L., Myers, A. T., and Horr, A. C., 1954, Association of uranium and other metals with crude oil, asphalt, and petroliferous rock: Am. Assoc. Petroleum Geologists Bull., v. 38 , p. $2200-2218$.

Fester, G. A., and Cruellas, José, 1936, Petroleo, asfaltita y vanadio: Univ. Nac. Litoral Santa Fe, Facultad Química Indus. y Agr. Rev., v. 4, p. 186-201.

Glebovskaya, Ye. A., and Vol'kenshtein, M. V., 1948, Spektry porfirinov $\mathrm{v}$ neftyakh i bitumakh: Zhur. obschey khimii, v. 18, p. $1440-1451$.

Goldschmidt, V. M., 1954, Geochemistry: Oxford, Clarendon Press.

Hewett, D. F., 1909, Vanadium deposits in Peru: Am. Inst. Min. Metall. Eng. Trans., v, 40, p. 274-297.

Jones, M. C., and Hardy, R. L., 1952, Petroleum-ash components and their effect on refractories: Indus. and Eng. Chemistry, v. 44, p. 2615-2619.

Katchenkov, S. M., 1949, Korrelyatsiya neftey po mikroelementam: Akad. nauk SSSR Doklady, v. 67, p. 503-505.

Lane, E. C., and Garton, E. L., 1943, Analyses of crude oil from some fields in Kansas: U. S. Bur. Mines Rept. Inv. 3688.

McKinney, C. M., and Blade, O. C., 1948, Analyses of crude oils from 283 important oil fields in the United States: U. S. Bur. Mines Rept. Inv. 4289.

Ramsay, William, 1924, The significance of nickel in petroleum: Inst. Petroleum Technologists Jour., v. 10, p. 87-91.

Shirey, W. B., 1931, Metallic constituents of crude petroleum: Indus. and Eng. Chemistry, v. 23, p. 1151-1153.

Skinner, D, A., 1952, Chemical state of vanadium in Santa Maria Valley crude oil: Indus. and Eng. Chemistry, v. 44, p. 1159-1165.

Smith, H. M., 1940, Correlation index to aid in interpreting crude-oil analysis: U. S. Bur. Mines Tech. Paper 610.

Southwick, S. H., 1951, Inorganic constituents of crude oil; Mass. Inst. Tech., Ph.D. thesis.

Thomas, W. H., 1924-1925, Petroleum ash: Inst. Petroleum Technologists Jur., v. 10, p. 216.

Treibs, Alfred, 1934, Chlorophyll- and Häminderivate in bituminösen gesteinen, erdölen, erdwachsen, und asphalten: Annalen Chemie, v. 510, p. 42-62.

- 1935, Chlorophyll, und Häminderivate in bituminösen gesteinen, erdölen, kohlen und phosphoriten: Annalen Chemie, v, 517, p. 172-196.

Tulsa Geological Society Research Committee, 1947, Relationship of erude oils and stratigraphy in parts of Oklahoma and Kansas: Am. Assoc. Petroleum Geologists Bull., v, 31, p. 92-148. 


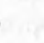




\title{
URANIUM IN ASPHALT-BEARING ROCKS OF THE WESTERN UNITED STATES
}

\author{
By William J. Hail, Jr., Alfred T. Myers, and C. Albert Horr, U. S. Geological Survey
}

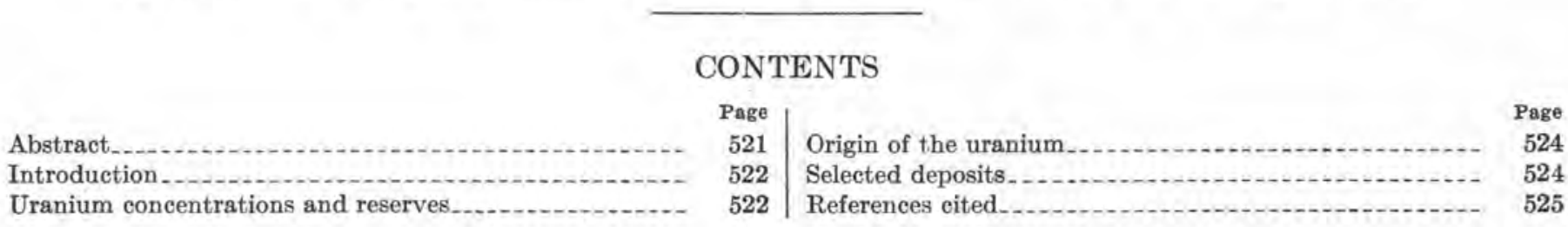

\section{ILLUSTRATION}

Figure 175. Map of the Western United States showing areas examined for uranium in asphalt-bearing rocks_

\section{ABSTRACT}

Asphalt-bearing rocks in 45 areas in California, Utah, Wyoming, Montana, New Mexico, Texas, Oklahoma, and Missouri were examined as potential sources of uranium. A total of 202 samples from these areas was analyzed for uranium. The oldest rocks sampled were Ordovician in age, and the youngest were Recent. Host rocks containing the asphalt include sandstone, arkose, conglomerate, limestone, diatomite, and alluvium. The asphalt was extracted from the host rock, reduced to dry ash, analyzed chemically for uranium, and analyzed spectrographically for other elements by semiquantitative methods.

Significant amounts of uranium in the ash of the extracted oil, whose average uranium contents range from 0.028 to 0.376 percent, were found in samples from 7 of the 45 areas examined. All except 1 area contain large estimated reserves of asphalt-bearing rock, ranging from 15 million to almost 2 billion $\left(10^{9}\right)$ tons. The average uranium content of samples from 13 additional areas ranges from 0.02 to 0.68 percent uranium in the ash of the extracted oil. Many of these areas contain very large reserves of asphalt-bearing rock.

It is believed that most of the uranium was present either as an original constituent of the oil or was introduced during the migration of the oil. Chemical analyses of the extracted asphalt and of the rock residue show that the uranium is concentrated as an organo-uranium complex in the asphalt and not in the host rock. Preliminary evaluation of the field data indicates that the amount of uranium in the asphalts may be closely related to the mineralogical composition of the sediments in which the oil originated, or the rocks through which the oil migrated.

\section{INTRODUCTION}

Field investigations and laboratory research on uranium in asphalt-bearing rocks were carried on during 1953 and 1954 by the U. S. Geological Survey. Previous work by the Geological Survey (Erickson, Myers, and Horr, 1954, p. 2213-2214) showed that the uranium content of the ash of natural asphalt and oil extracted from petroliferous rock is significantly high compared with crude oil, sea water, and granitic rock. This sug- gested that some of the numerous deposits of asphaltbearing rocks of the Western United States might contain appreciable amounts of uranium. The term "asphalt-bearing rocks" is here used to designate rocks that contain any type of naturally occurring petroleum residue.

Selected deposits of asphalt-bearing rocks were examined, tested for radioactivity in the field, and sampled in 45 areas in 8 Western States to evaluate this type of rock as a possible source for uranium (fig. 175). Deposits in 23 geologic formations including rocks of Ordovician, Pennsylvanian, Permian, Triassic, Jurassic, Cretaceous, Paleocene, Eocene, Miocene, Pliocene, and Pleistocene ages, and Recent alluvium were sampled. Host rocks containing the asphalt include sandstone, conglomerate, arkose, limestone, alluvium, and diatomite. Many of the asphalt-bearing rock deposits are large and have been quarried commercially for asphalt.

Laboratory research was directed toward perfecting analytical techniques and determining the nature of the occurrence of uranium in asphalt-bearing rocks. Chemical analyses for uranium of several selected samples of the asphalt and of the rock from which the oil was extracted showed that the uranium is concentrated as an organo-uranium complex in the asphaltic part of the sample and not in the rock. Similar analyses by Erickson, Myers, and Horr (1954, p. 2215) also showed that the uranium is concentrated in the oil and not in the rock. About 200 representative samples from the 45 areas were analyzed for uranium and oil content by the following analytical procedures.

The samples of asphalt-bearing rocks were crushed, and the oil was exhaustively extracted with a hot 


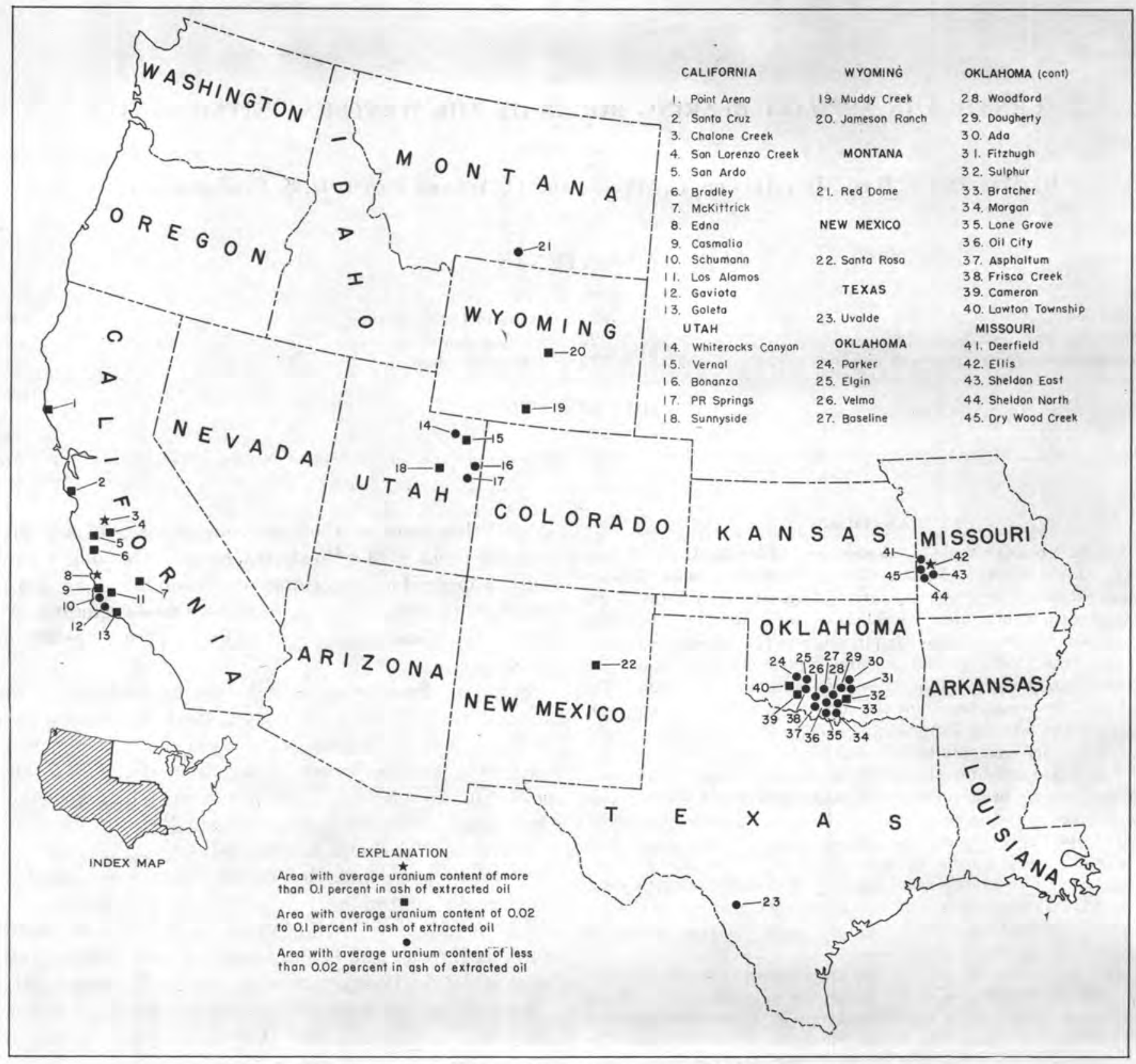

FIgURE 175.-Map of the Western United States showing areas examined for uranium in asphalt-bearing rocks.

mixture of 75 parts benzene, 15 parts acetone, and 10 parts methanol. This mixture is a modification of that used by Smith (1952). The extract was evaporated to reduce possible loss of ash by rapid burning of the benzene-acetone-methanol mixture and then was dry ashed with final ignition at $500^{\circ} \mathrm{C}$ under oxidizing conditions. The ash was weighed, ground in an agate mortar, and analyzed chemically for uranium. The chemical analysis for uranium is essentially the same as that described by Grimaldi, May, and Fletcher (1952), with a few modifications. The writers are indebted to Mary C. Curtis who made the asphalt extractions.

\section{URANIUM CONCENTRATIONS AND RESERVES}

The average concentrations of uranium in asphaltbearing rocks from the 45 areas examined ranged trom 0.001 to 0.376 percent in the ash of the extracted oil (see table below). Whether any of the asphalt deposits might provide a low-grade source for uranium probably depends upon recovery methods in the utilization of the asphalt for other purposes.

The ash of extracted oil from deposits in seven areas contained significant amounts of uranium. These areas, with the uranium content of their richest sample 
URANIUM IN ASPHALT-BEARING ROCKS

Summary of data from areas examined for uranium in asphalt-bearing rocks

\begin{tabular}{|c|c|c|c|c|c|c|c|}
\hline $\begin{array}{l}\text { Locality } \\
\text { no. (fig. } \\
175)\end{array}$ & Area & Formation & Age & $\begin{array}{l}\text { Number of } \\
\text { samples }\end{array}$ & $\begin{array}{l}\text { A verage oil } \\
\text { in samples } \\
\text { (percent) }\end{array}$ & $\begin{array}{l}\text { Average } \\
\text { ash in oil } \\
\text { (percent) }\end{array}$ & $\begin{array}{l}\text { Average } \\
\text { U in ash } \\
\text { (percent) }\end{array}$ \\
\hline \multicolumn{8}{|c|}{ California } \\
\hline $\begin{array}{r}8 \\
9 \\
10 \\
11 \\
12 \\
13\end{array}$ & $\begin{array}{l}\text { Point Arena. } \\
\text { Santa Cruz } \\
\text { Chalone Creek } \\
\text { San Lorenzo Creek } \\
\text { San Ardo } \\
\text { Bradley } \\
\text { MeKittrick } \\
\text { Edna. } \\
\text { Casmalia. } \\
\text { Schumann } \\
\text { Gaviota. } \\
\text { Goleta. }\end{array}$ & $\begin{array}{l}\text { Monterey shale } \\
\text { Vaqueros sandstone } \\
\text { Unnamed formation } \\
\text { Santa Margarita formation } \\
\text { Unnamed formation } \\
\text { Etchegoin formation } \\
\text { Tulare formation } \\
\text { Alluvium } \\
\text { Pismo formation } \\
\text { Sisquoc formation } \\
\text { Monterey shale. do }\end{array}$ & 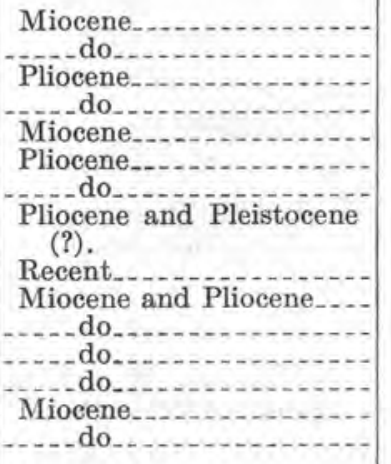 & $\begin{array}{l}6 \\
8 \\
3 \\
3 \\
2 \\
1 \\
5\end{array}$ & $\begin{array}{r}4.13 \\
10.34 \\
11.18 \\
10.54 \\
6.24 \\
10.49 \\
26.91\end{array}$ & $\begin{array}{r}0.80 \\
.39 \\
.48 \\
.23 \\
.49 \\
.44 \\
1.66\end{array}$ & $\begin{array}{l}0.030 \\
.027 \\
.182 \\
.032 \\
.068 \\
.045 \\
.047\end{array}$ \\
\hline \multicolumn{8}{|c|}{ Utah } \\
\hline $\begin{array}{l}14 \\
15 \\
16 \\
17 \\
18\end{array}$ & $\begin{array}{l}\text { Whiterocks Canyon.- } \\
\text { Vernal } \\
\text { Bonanza... } \\
\text { PR Springs_. } \\
\text { Sunnyside...... }\end{array}$ & $\begin{array}{l}\text { Navajo sandstone } \\
\text { Uinta formation } \\
\text { Green River and Uinta forma- } \\
\text { tions. } \\
\text { Green River formation }\end{array}$ & $\begin{array}{l}\text { Jurassic and Jurassic (?) } \\
\text { Eocene. }\end{array}$ & $\begin{array}{r}4 \\
21 \\
7 \\
10 \\
11\end{array}$ & $\begin{array}{r}5.59 \\
8.10 \\
100.00 \\
\text { 6. } 55 \\
5.38\end{array}$ & $\begin{array}{r}0.66 \\
2.68 \\
.48 \\
\text { 1. } 11 \\
\text { 1. } 10\end{array}$ & $\begin{array}{r}0.009 \\
.028 \\
.003 \\
.014 \\
.021\end{array}$ \\
\hline \multicolumn{8}{|c|}{ Wyoming } \\
\hline $\begin{array}{l}19 \\
20\end{array}$ & $\begin{array}{l}\text { Muddy Creek...... } \\
\text { Jameson Ranch..... }\end{array}$ & $\begin{array}{l}\text { Fort Union formation } \\
\text { Teapot sandstone member of } \\
\text { Mesaverde formation. }\end{array}$ & $\begin{array}{l}\text { Paleocene } \\
\text { Cretaceous }\end{array}$ & $\begin{array}{l}4 \\
2\end{array}$ & $\begin{array}{l}\text { 6. } 04 \\
\text { 3. } 81\end{array}$ & $\begin{array}{r}0.36 \\
.59\end{array}$ & $\begin{array}{r}0.040 \\
.023\end{array}$ \\
\hline \multicolumn{8}{|c|}{ Montana } \\
\hline 21 & Red Dome_............. & Chugwater formation & Triassic & 5 & 4. 91 & 0.60 & 0.010 \\
\hline \multicolumn{8}{|c|}{ New Mexico } \\
\hline 22 & Santa Rosa ............ & Santa Rosa sandstone......... & Triassic .................. & 6 & 3. 99 & 1. 24 & 0.025 \\
\hline \multicolumn{8}{|c|}{ Texas } \\
\hline 23 & Uvalde_................ & Anacacho limestone......... & Cretaceous ............... & 11 & 8. 52 & 0. 43 & 0.002 \\
\hline \multicolumn{8}{|c|}{ Oklahoma } \\
\hline $\begin{array}{l}24 \\
25 \\
26 \\
27 \\
28 \\
29 \\
30 \\
31 \\
32 \\
33 \\
34 \\
35 \\
36 \\
37 \\
38 \\
39 \\
40\end{array}$ & $\begin{array}{l}\text { Parker } \\
\text { Velgin } \\
\text { Baseline... } \\
\text { Woodford. } \\
\text { Dougherty } \\
\text { Ada } \\
\text { Fitzhugh } \\
\text { Sulphur } \\
\text { Bratcher } \\
\text { Morgan } \\
\text { Lone Grove... } \\
\text { Oil City } \\
\text { Asphaltum. } \\
\text { Frisco Creek... } \\
\text { Cameron } \\
\text { Lawton Township... }\end{array}$ & 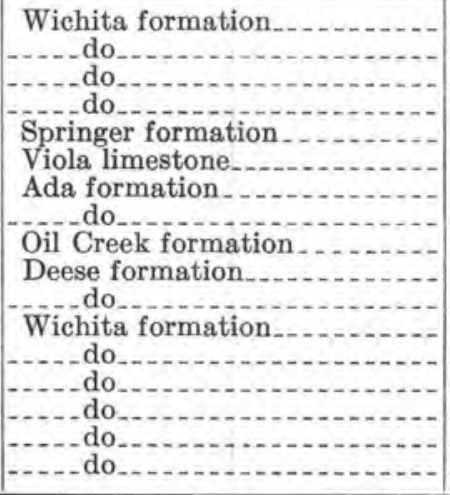 & 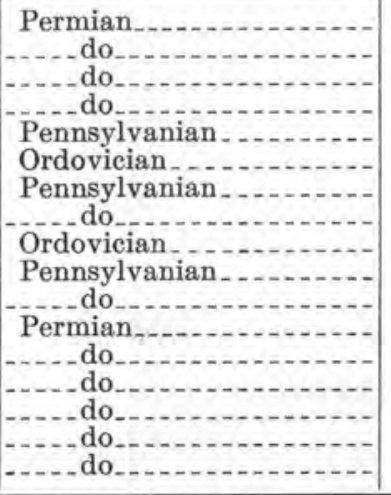 & $\begin{array}{l}1 \\
1 \\
1 \\
2 \\
2 \\
3 \\
3 \\
4 \\
2 \\
7 \\
3 \\
1 \\
1 \\
1 \\
1 \\
5 \\
2 \\
1 \\
1\end{array}$ & $\begin{array}{r}\text { 2. } 16 \\
\text { 1. } 76 \\
.94 \\
.98 \\
\text { 2. } 79 \\
\text { 3. } 18 \\
\text { 3. } 29 \\
\text { 1. } 35 \\
\text { 4. } 56 \\
\text { 8. } 72 \\
\text { 5. } 71 \\
.87 \\
\text { 12. } 28 \\
\text { 6. } 15 \\
\text { 2. } 08 \\
\text { 5. } 70 \\
\text { 1. } 19\end{array}$ & $\begin{array}{r}1.62 \\
1.98 \\
1.68 \\
2.85 \\
4.95 \\
.07 \\
1.95 \\
2.00 \\
.70 \\
.59 \\
.76 \\
3.31 \\
4.49 \\
1.60 \\
10.39 \\
2.06 \\
3.14\end{array}$ & $\begin{array}{r}0.004 \\
.006 \\
.001 \\
.005 \\
.010 \\
.001 \\
.014 \\
.002 \\
.043 \\
.008 \\
.005 \\
.010 \\
.002 \\
.007 \\
.004 \\
.054 \\
.020 \\
\end{array}$ \\
\hline \multicolumn{8}{|c|}{ Miseouri } \\
\hline $\begin{array}{l}41 \\
42 \\
43 \\
44 \\
45\end{array}$ & $\begin{array}{l}\text { Deerfield } \\
\text { Ellis } \\
\text { Sheldon East, } \\
\text { Sheldon North.... } \\
\text { Dry Wood Creek.... }\end{array}$ & \begin{tabular}{|c|c|} 
& \multicolumn{2}{|c|}{ Sandstone in Cherokee shale } \\
& do
\end{tabular} & 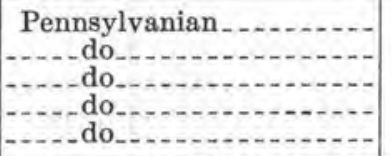 & $\begin{array}{r}7 \\
3 \\
4 \\
3 \\
16\end{array}$ & $\begin{array}{l}\text { 4. } 63 \\
\text { 4. } 64 \\
\text { 3. } 99 \\
\text { 1. } 43 \\
\text { 2. } 30\end{array}$ & $\begin{array}{l}0.79 \\
.62 \\
\text { 1. } 46 \\
\text { 1. } 27 \\
\text { 1. } 58\end{array}$ & $\begin{array}{r}0.006 \\
.145 \\
.016 \\
.004 \\
.004\end{array}$ \\
\hline
\end{tabular}


of oil ash, are the Chalone Creek ( 0.50 percent U), McKittrick (0.15 percent U), Edna (1.9 percent U), and Los Alamos ( 0.33 percent $U)$ areas in Calitornia; the Vernal area, Utah ( 0.15 percent $U)$; the Sulphur area, Oklahoma ( 0.22 percent $\mathrm{U})$; and the Ellis area, Missouri $(0.40$ percent $U)$. The average uranium content of samples from these seven areas ranges from 0.028 percent in the Vernal area to 0.376 percent in the Edna area. All the deposits except those in the Chalone Creek area contain large estimated reserves of asphaltbearing rock, ranging from about 15 million tons to almost 2 billion $\left(10^{9}\right)$ tons.

The average uranium content of samples from 13 other areas ranges from 0.020 to 0.068 percent in the ash of the extracted oil. These areas are the Point Arena, Santa Cruz, San Lorenzo Creek, San Ardo, Bradley, Casmalia, and Goleta areas, California; the Sunnyside area, Utah; the Muddy Creek and Jameson Ranch areas, Wyoming; the Santa Rosa area, New Mexico; and the Cameron and Lawton Township areas, Oklahoma. Reserves of asphalt-bearing rocks in these 13 areas range from a few thousand tons to about 2.8 billion $\left(10^{9}\right)$ tons.

\section{ORIGIN OF THE URANIUM}

Some of the uranium in the asphalt was probably an original constituent of the oil, but some may have been introduced during the migration of the oil. The concentration of uranium in the asphalts appears to bear no consistent relation to the age of the host rock or to the age of the original oil. High concentrations of uranium were found in one or more samples of rocks ranging in age from Ordovician to Pliocene. Most of the California deposits, which are Tertiary in age, generally have a high uranium content, whereas most of the Oklahoma deposits, which are Paleozoic in age, generally have a low uranium content, but this difference is believed due not so much to the relative age of the deposits as to the geologic environment during the origin or migration of the oil. The uranium-rich California asphalts, for example, occur in tuffaceous, arkosic, and diatomaceous rocks that have a relatively high uranium content, whereas the uranium-poor Oklahoma asphalts occur in quartzose sandstones and in limestones that have a relatively low uranium content.

\section{SELECTED DEPOSITS}

California.-The asphalt-bearing rocks in California appear to be more favorable for the occurrence of uranium than those examined in other Western States. In 11 of the 13 California areas sampled, the average uranium in the ash of the extracted oil ranged from 0.023 percent to 0.376 percent. Most of the California asphalts occur in formations of Miocene or Pliocene age, and it is possible that the asphalt in most of these formations originated in the Monterey shale and equivalent formations, of Miocene age. The Monterey shale and most of the other formations in which the asphalt occurs contain abundant volcanic and granitic material. Typical rocks in these formations are arkosic sandstone and conglomerate, tuffaceous sandstone, diatomaceous sandstone and shale, organic siliceous shale, and chert. These rocks are relatively rich in uranium, and they may have supplied uranium to the asphalts at the time of their origin or during their migration into the present host rocks. Another factor favoring a higher concentration of uranium in the California asphalt is that California crude oils are generally heavy oils, and uranium tends to be concentrated in the heavier, more asphaltic portions of petroleum (Erickson, Myers, and Horr, 1954, p. 2211).

The deposits of asphalt-bearing rock in the Edna area, San Luis Obispo County, contain the highest concentration of uranium of all the deposits examined in the Western States. The uranium content of 7 samples collected in the Edna area ranges from 0.035 to 1.9 percent in the ash of the extracted oil. The asphalt occurs in the Pismo formation of Miocene and Pliocene age, which unconformably overlies the Monterey shale of Miocene age. The Pismo formation consists of arkosic conglomerate and sandstone, siliceous shale, and chert. Monterey shale in the Edna area consists of tuff, diatomaceous and siliceous shale, and chert. The asphalt occurs mostly in lenticular and discontinuous beds of arkosic sandstone, which range in thickness from a few feet to almost 300 feet (Page, Williams, Henrickson, and others, 1944).

The uranium content of 7 samples collected in the Los Alamos area, Santa Barbara County, ranges from 0.010 to 0.330 percent in the ash of the extracted oil. The asphalt occurs in the Sisquoc formation of Miocene and Pliocene age, which in this area is composed mainly of quartzose sandstone (Eldridge, 1901, p. 433). The Sisquoc formation is unconformably underlain by the Monterey shale, which consists of porcelaneous diatomite, siliceous shale, and chert. In the Los Alamos area, the exposed asphalt-bearing beds have a total thickness of about 225 feet, and the intervening barren zones a total thickness of about 35 feet. The asphaltbearing beds extend for a distance of about 5 miles along their outcrop and probably underlie an area of at least 5 square miles.

Utah.-In Utah all five of the asphalt-bearing areas. sampled are in the Uinta Basin in the east-central part. of the State. The deposits in the Vernal, Bonanza, PR Springs, and Sunnyside areas are in the Uinta or Green River formations of Eocene age, and the deposits in the Whiterocks Canyon area are in the Navajo sand- 
stone of Jurassic and Jurassic (?) age. The asphalt deposits in the Bonanza area are gilsonites, and the deposits in the other areas are asphalt-bearing sandstones.

The asphalt in the Vernal area, Uintah County, was the most uraniferous found in Utah. It occurs mainly in the Uinta formation of Eocene age (Spieker, 1930, p. 96-97) in lenticular sandstone beds ranging in thickness from a few feet to 190 feet within a section which may be as much as 300 feet thick. The uranium content of 21 samples collected in the Vernal area ranges from 0.001 to 0.150 percent in the ash of the extracted oil. Ash of 3 of the samples contains more than 0.1 percent uranium.

The Sunnyside area contains one of the largest asphalt-bearing sandstone deposits in the United States (Holmes, Page, and Averitt, 1948). The uranium content of 11 samples collected in the Sunnyside area ranges from 0.003 to 0.048 percent in the ash of the extracted oil. Samples collected from the other Utah deposits generally have a low uranium content.

Wyoming.-Lenticular beds of weathered asphaltbearing sandstone in the Fort Union formation of Paleocene age crop out in the Muddy Creek area, Carbon County. The asphalt occurs throughout a section of sandstone that is about 100 feet thick, but the richest impregnation is in the lowest 15 feet and in a 5-foot-thick zone in the upper part of the section. The outcrop of the asphalt-bearing sandstone extends about 2 miles. The uranium content of 4 samples collected in the area ranges from 0.015 to 0.091 percent in the ash of the extracted oil.

Montana.-The only area examined in Montana was at Red Dome, Carbon County. In this area, asphaltbearing sandstone in the Chugwater formation of Triassic age is exposed on the crest of a breached anticline (Knappen and Moulton, 1930, p. 58). The uranium content of the richest of 5 samples was 0.013 percent in the ash of the extracted oil.

New Mexico.-The asphalt of the Santa Rosa area in New Mexico occurs in the Santa Rosa sandstone of Triassic age. Exposures of the asphalt-bearing sandstone-range from 4 to 18 feet in thickness, but core-dril holes have penetrated a thickness of as much as 100 feet (Gorman and Robeck, 1945). The uranium content of 6 samples collected in the area ranges from 0.002 to 0.052 percent in the ash of the extracted oil.

Texas,-Asphalt-bearing limestone in the Anacacho limestone of Cretaceous age crops out in Uvalde County (Gorman and Robeck, 1945), The uranium content of the asphalt is exceptionally low, ranging in 11 samples from 0.001 to 0.004 percent in the ash of the extracted oil.
Oklahoma.-The asphalt deposits examined in Oklahoma occur in formations of Ordovician, Pennsylvanian, and Permian age. One of the asphalt deposits is in limestone, the rest in quartzose sandstones. Most of the areas examined do not contain large amounts of uranium in the ash of the extracted oil. Asphaltbearing limestone from the Dougherty area has an exceptionally low uranium content.

The asphalt-bearing sandstone in the Sulphur area, Murray County, is the only large asphalt deposit in Oklahoma that yielded samples containing significantly large amounts of uranium. The uranium content of 7 samples collected in the Sulphur area ranges from 0.001 to 0,22 percent in the ash of the extracted oil. The asphalt occurs in the Oil Creek formation of Ordovician age. Beds of the asphalt-bearing sandstone crop out in an area of about 1 square mile and range in thickness from about 6 to 90 feet, although a well is reported to have penetrated a thickness of more than 240 feet (Gorman, Flint, Decker, and Ham, 1944).

Missouri.-The asphalt deposits in all 5 areas examined in Missouri occur in 1 or more lenticular sandstone beds in the Cherokee shale of Pennsylvanian age. This sandstone probably correlates with the Bartlesville sand of the midcontinent oil fields. It is mainly a fine-grained quartzose sand containing mica (Greene and Pond, 1926, p. 45).

Three samples of asphalt-bearing sandstone collected in the Ellis area, Vernon County, contain uranium in amounts ranging from 0.011 to 0.40 percent in the ash of the extracted oil. The asphalt-bearing sandstone is exposed in an abandoned quarry 160 feet wide and 265 feet long, and the thickness of the beds ranges from 15 to 30 feet. The asphalt-bearing beds probably extend over a much wider area under a shallow cover.

\section{REFERENCES CITED}

Eldridge, G. H., 1901, The asphalt and bituminous-rock deposits of the United States: U. S. Geol. Survey, Ann, Rept. 22, pt. 1, 1900-1901, p. 209-452.

Erickson, R. L., Myers, A. T., and Horr, C. A., 1954, Association of uranium and other metals with crude oil, asphalt, and petroliferous rock: Am. Assoc. Petroleum Geologists Bull., v. 38, p. $2200-2218$.

Gorman, J. M., Flint, G. M., Jr., Decker, C. E., and Ham, W. E., 1944, Geologic map of the Sulphur asphalt area, Murray County, Okla.: U. S. Geol. Survey Oil and Gas Inv. Prelim. Map 22.

Gorman, J. M., and Robeck, R. C., 1945, Asphalt deposits near Uvalde, Tex.: U. S. Geol. Survey open-file rept.

Greene, F. C., and Pond, W. F., 1926, The geology of Vernon County: Mo. Bur. Geology and Mines, 2d ser. v. 19, 152 p.

Grimaldi, F. S., May, Irving, and Fletcher, M. H., 1952, U. S. Geological Survey fluorimetric methods of uranium analysis: U. S. Geol. Survey Cire. 199, 20 p. 
Holmes, C. N., Page, B. M., and Averitt, Paul, 1948, Geology of the bituminous-sandstone deposits near Sunnyside, Carbon County, Utah: U. S. Geol. Survey Oil and Gas Inv. Prelim. Map 86.

Knappen, R. S., and Moulton, G. F., 1930, Geology and mineral resources of parts of Carbon, Big Horn, Yellowstone, and Stillwater Counties, Mont.: U. S. Geol. Survey Bull. 822 p. 1-70.
Page, B. M., Williams, M. D., Henrickson, E. L., and others, 1944, Geology of the bituminous-sandstone deposits near Santa Cruz, Santa Cruz County, Calif.: U. S. Geol. Survey Oil and Gas Inv. Prelim. Map 27.

Smith, Paul V., Jr., 1952, The occurrence of hydrocarbons in recent sediments from the Gulf of Mexico: Science, v. 116 , p. $437-439$.

Spieker, E. M., 1930, Bituminous sandstone near Vernal, Utah: U. S. Geol. Survey Bull. 822-C, p. 77-98. 


\title{
RADIOACTIVE ELEMENTS AND THEIR DAUGHTER PRODUCTS IN THE TEXAS PANHANDLE AND OTHER OIL AND GAS FIELDS IN THE UNITED STATES
}

\author{
By Arthur P. Pierce, J. W. Mytton, and Garland B. Gott, U. S. Geological Survey
}

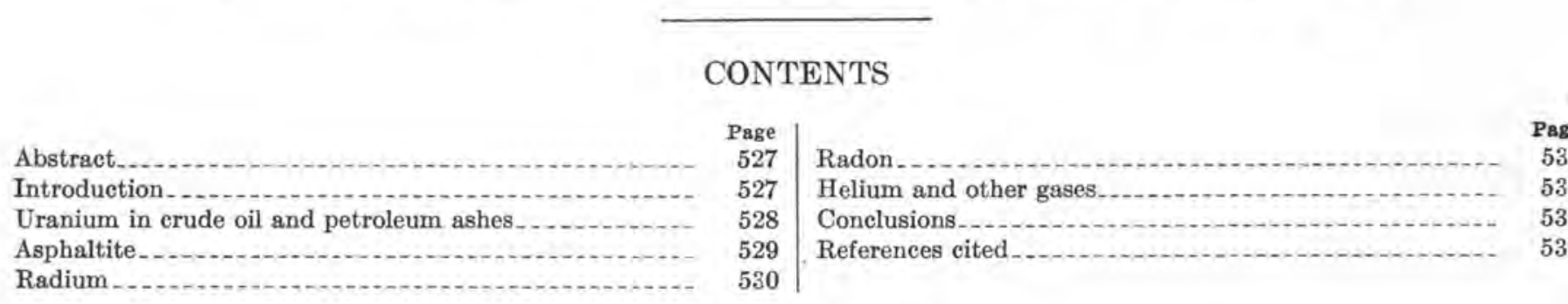

\section{ILLUSTRATION}

FIGURE 176. Distribution of radiosetive elements and their daughter products in some petroliferous provinces.

\section{ABSTRACT}

Abnormal concentrations of radioelements and their daughter products, including radon, helium, argon, radium, uranium, and thorium, are present in some oil and gas fields of the United States. Different natural hydrocarbon gases contain as much as $10^{4}$ micromicrocuries of radon per liter (at reservoir pressure), several percent of helium, and several tenths of 1 percent of argon. Oilfield brines have fairly high concentrations of radium, some containing as much as $10^{-9}$ grams of radium per liter. Precipitates from these waters on pipes in oil wells contain as much as $10^{-8}$ grams of radium per gram, The uranium content of oilfield brines that have been analyzed is as much as 0.2 parts per million uranium.

Analyses of uranium and trace metals have been made of a number of crude oils, oil seeps, and petroliferous rocks throughout the Central and Western United States. The results indicate that uranium is generally enriched in oil-seep soil and in the heavy surface-active fractions of petroleum wbich adhere to the rocks, as compared with the crude-oil fraction of petroleum that is produced at the wellhead. Epigenetic concentrations of uranium in the form of metalliferous asphaltite, a carbonaceous mineraloid similar to thucholite, carburan, and huminite, have been found in oil and gas reservoirs and associated rocks in the Wichita-Amarillo uplift of Oklahoma and Texas and in other areas. Abnormal concentrations of radon and helium in the natural gases of the Panhandle oilfield of Texas are associated with uraniferous asphaltite nodules and impregnations in and adjacent to the reservoir rocks. The minerals uraninite, coffinite, and thorite have been found in some nodules, but in many the uranium-bearing compound, which may be an organometallic complex, has not been identified. The trace-metal suite of the asphaltite is similar to that found in the ash of associated crude oils and in crude oil in general.

More information about the geochemistry of uranium in petroleum and petroleum waters is necessary to a complete understanding of the genesis of the helium and the assoeiated
\end{abstract}

uraniferous asphaltites. The evidence now available on the origin of the asphaltite indicates that the process responsible for its localization must have operated in the presence of petroleum or in a combination of petroleum and water within the rock pores, must have been eapable of concentrating uranium and the other metals in the form of disseminated small segregations, must have operated independently of the type of rock in which concentration took place, and must have been effective over broad structural provinces,

\section{INTRODUCTION}

Abnormal concentrations of radioelements and their daughter products, including radon, helium, argon, radium, uranium, and thorium have been found in some oil and gas fields in the United States. Helium in natural gas was discovered by Cady and McFarland in 1905 (Cady and MeFarland, 1907) at Dexter, Kans. Investigations by the U. S. Bureau of Mines (Anderson and Hinson, 1951) since that time have provided quantitative information regarding the distribution of helium in all natural gas fields and significant exploratory test wells in the United States.

Significant quantities of helium were first noted in the natural gas of the Panhandle field of Texas in the early 1920's, and in 1949 the Geological Survey found abnormal concentrations of radon in natural gas from flowing wells in the oilfield. Intensive studies, particularly in the Panhandle field, have been made in recent years because of the possibility that appreciable amounts of the helium in these natural gases may have been derived from sources abnormally high in uranium 

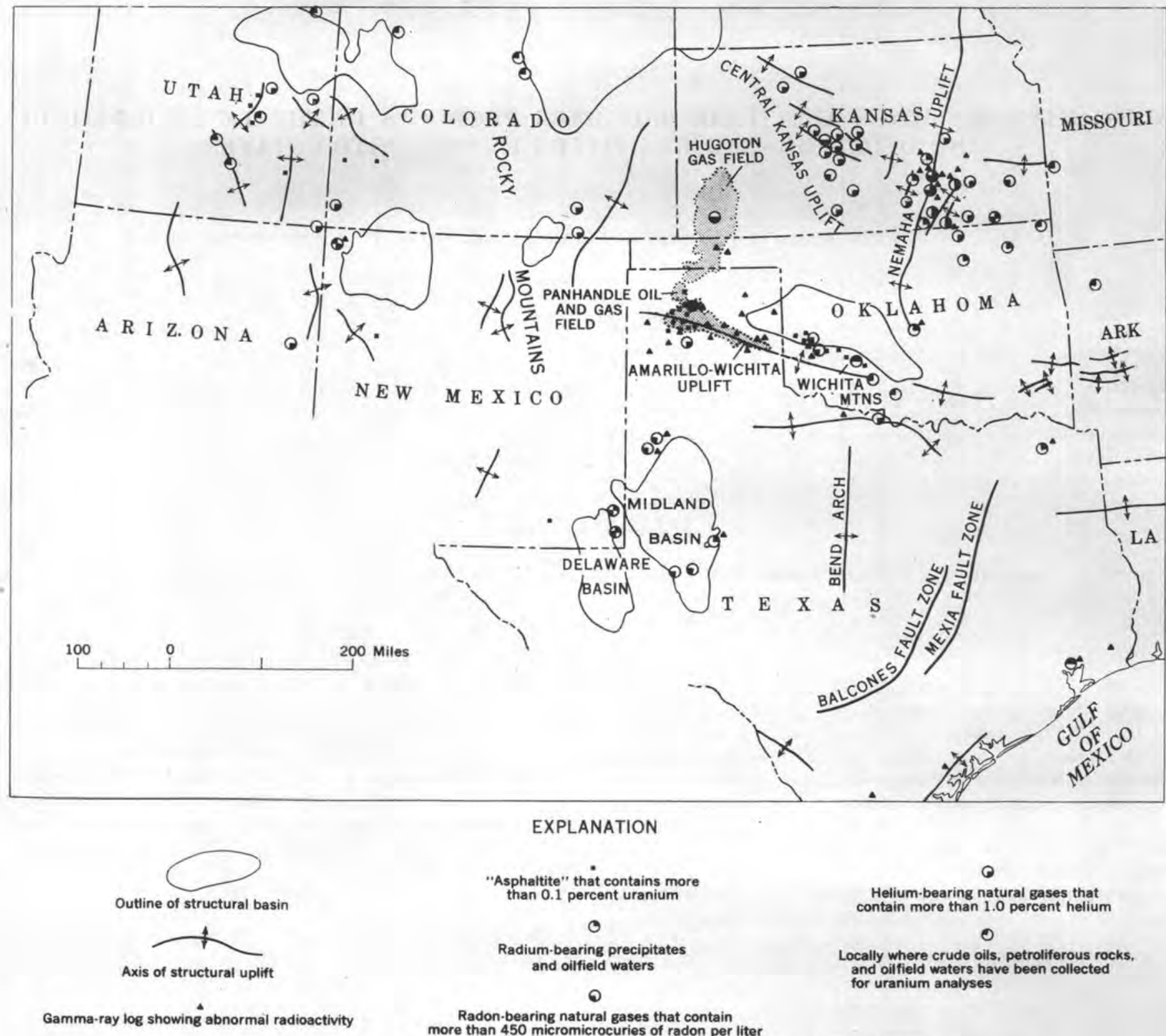

Figure 176.-Distribution of radioactive elements and their daughter products in some petroliferous provinces.

or thorium. These have included studies of radium in oil-well precipitates and brines, a survey of radon in the Panhandle and other gas fields, and a study of asphaltite (a carbonaceous mineraloid similar to thucholite) found in various places in the Western United States, in an effort to determine the distribution and source of the radon, helium, and their parent elements in the gas reservoir. (See fig. 176.)

\section{URANIUM IN CRUDE OIL AND PETROLEUM ASHES}

Analyses for uranium and other elements have been made of the ashes of a variety of crude oils, oil seeps, and extracts from petroliferous rocks from several of the Western States (Erickson, Myers, and Horr, 1954). (See fig. 176.) These and additional analytical data show that petroleum ashes are generally enriched in $\mathrm{U}$ and an assemblage of other metals including As, $\mathrm{V}, \mathrm{Ni}, \mathrm{Co}, \mathrm{Cu}, \mathrm{Pb}, \mathrm{Zn}$, and $\mathrm{Sn}$. The total concentration of these elements in petroleum averages only a few parts per million, but their concentration in the ash relative to that of the common elements is unusual. The percentage ratio of $U$ to the common rock-forming elements (the sum of $\mathrm{Ca}, \mathrm{Na}, \mathrm{Si}, \mathrm{Mg}, \mathrm{Al}, \mathrm{K}, \mathrm{Sr}, \mathrm{Ba}$, and $\mathrm{Ti}$ ) in petroleum ashes and associated brines and rocks is as follows:

Common sedimentary rocks ( $1 \mathrm{ppm} \mathrm{U})$

Average in crude-oil ashes from 26 different petroliferous rocks_._._. 01

Average in ash of petroleum extracts from 20 different petroliferous rocks_........... . 1 
Average in crude-oil ashes from 12 different oil wells in

West Panhandle field, Texas

Average in 31 samples of oilfield water from the West

Panhandle field, Texas.

The uranium and associated metals may be present in the petroleum as colloidal-sized impurities derived from the interstitial parts of the reservoir rocks, or they may be present as organometallic complexes soluble in the petroleum. If the metals occur as impurities, the concentration of uranium in the source material must be on the order of 0.01 to 0.1 percent; if the metals occur as organometallic complexes, they probably are concentrated in a surface-active fraction of petroleum which tends to adhere to the pore walls of the reservoir rock. The increased uranium content in the ash of petroleum extracts compared to the uranium in the ash of crude oils suggests that the latter is the case.

\section{ASPHALTITE}

Uraniferous asphaltic materials, possibly derived from the surface-active fractions of petroleum, are widely distributed in oil and gas fields along the Amarillo-Wichita uplift (fig. 176).

Concentrations of uranium in the form of epigenetic carbonaceous material, termed asphaltite, have been found in drill cuttings of the oil and gas reservoirs and associated rocks in the Texas Panhandle field and also in numerous places in the western part of the United States including the north flank of the Wichita Mountains, Okla., the northwest rim of the Delaware basin in southeastern New Mexico, and in southeastern Utah and southwestern Colorado.

The asphaltite occurs as botryoidal nodules and as impregnations filling secondary pore spaces and fractures. The nodular asphaltite is a metalliferous carbonaceous mineraloid similar to thucholite, carburan, and huminite (Davidson and Bowie, 1951). The asphaltite is a brittle highly lustrous black solid that is essentially insoluble in organic reagents and is combustible at high temperatures. The hardness is between 4 and 5 , the average specific gravity is 1.3 , and the index of refraction is about 1.7 .

The metal content of the asphaltite is consistently high, on the average about 3 percent As, 1 percent $\mathrm{U}$, and 0.1 percent each of $\mathrm{Ni}, \mathrm{Co}$, and $\mathrm{Cu}$. Rare-earth elements of the yttrium group are always present in amounts as much as 0.1 percent. The Fe content is erratic but generally appreciable. Silver is consistently present in amounts that range from a trace to as much as 0.03 percent. The $\mathrm{V}$ content is generally on the order of 0.01 percent. Alpha tracks recorded on nuclear emulsion indicate that the $\mathrm{U}$ is rather evenly distributed throughout the asphaltite.
Polished sections of the asphaltite reveal numerous micron-sized metallic inclusions. These minerals are finely dispersed within the carbonaceous matrix, generally in nebular patterns concentric to the center of the asphaltite nodules. In some samples the fine crystals grade into larger crystals which possess euhedral boundaries and show definite evidence of having been fractured and floated apart in the asphaltite matrix prior to its solidification. Another feature relating to the micron-sized mineral dispersions is the occurrence of patches of fine mineral-filled pores that resemble the "fingerprint structure" of the thucholite of Boliden, Sweden, described by Grip and Odman (1944).

$\mathrm{X}$-ray analyses of the asphaltite have shown the presence of uraninite, coffinite, thorite, chloanthitesmaltite, pyrite, dolomite, celestite, quartz, and submicrocrystalline carbon. Although uraninite and coffinite have been identified in some of the nodules, in the majority of them the uranium-bearing compound, which may be an organometallic complex, has not been identified. Other metallic minerals that are associated with asphaltite in the host rock are galena, sphalerite, chalcopyrite, and native copper. The principal organic elements in the asphaltite are $\mathrm{C}, \mathrm{H}, \mathrm{O}, \mathrm{S}$, and in some samples, a trace of $\mathrm{N}$.

The botryoidal character of the nodules is evidently caused by an aggregation of numerous tiny pellets of asphaltite that appear to have been welded together into one rounded and knobby nodule. These nodules ordinarily are not more than 5 millimeters in diameter, but larger nodules probably are shattered and lost during drilling. Much of the veinlet type of asphaltite is composed of closely packed pellets. Similar features have been noticed in the warty hydrocarbon granules of the Witwatersrand, South Africa (Young, 1917) and in the nodular thucholite of Boliden, Sweden (Grip and Odman, 1944).

The asphaltite in the Panhandle field is found in rocks of Pennsylvanian through lower Permian age which comprise the reservoir and caprocks of the gas field. Most of the asphaltite is associated with secondary crystalline anhydrite and celestite that occur as cements in siltstones and as fillings in fractures and solution cavities in dolomites. Some of the nodules are completely occluded by secondary anhydrite crystals.

The evidence now available on the origin of the asphaltite indicates that the process responsible for its localization must have operated in the presence of petroleum or in a combination of petroleum and water within the rock pores, must have been capable of concentrating uranium and the other metals in the form of disseminated segregations, must have operated independently of the type of rock in which concentration 
took place, and must have been effective over broad structural provinces.

\section{RADIUM}

Radium is concentrated in precipitates derived from brines in many oilfields in the central and southwestern United States (fig. 176). The precipitates are composed predominantly of strontium, barium, and calcium sulfates and small amounts of ferrous oxide in the form of celestite, barite, gypsum, and limonite. The $\mathrm{Ra}$ content in these precipitates is as much as $6 \times 10^{-8} \mathrm{~g}$ per liter, depending on the amount of $\mathrm{Ra}$ in the brines from which the precipitates were derived. The $\mathrm{U}$ content ranges from less than 1 part to 30 parts per million.

The $\mathrm{Ra}$ content in the brines that are associated with the precipitates is as much as $7.3 \times 10^{-9} \mathrm{~g}$ per liter, and the $U$ content varies from 0 to $200 \times 10^{-6} \mathrm{~g}$ per liter. No correlation has been observed between the $\mathrm{Ra}$ and $\mathrm{U}$ content of the brines that have been investigated. The brine having the highest $\mathrm{Ra}$ concentration $\left(7.3 \times 10^{-9} \mathrm{~g}\right.$ per liter) had only $1.3 \times 10^{-6} \mathrm{~g}$ U per liter, less than one thousandth the amount of $\mathrm{U}$ required to "support" the Ra. The radium-bearing precipitates have resulted from the coprecipitation of $\mathrm{Ra}$ with $\mathrm{Ba}$ and $\mathrm{Sr}$ because of changes in solubility during the process of pumping oilfield brines. These precipitates also have resulted from the mixing of 2 waters, 1 rich in $\mathrm{Sr}$ and $\mathrm{Ba}$ and the other rich in sulfate (Vernadski and Khlopin, 1932; Gott and Hill, 1953).

Radiochemical analyses have shown that $\mathrm{Ra}^{226}$, $\mathrm{Ra}^{223}$, and $\mathrm{Ra}^{228}$ are present in the brines and precipitates. This has a bearing on the interesting problem of whether the $\mathrm{Ra}$ was leached from rocks having normal or enriched amounts of its parent radioelements. The presence of $\mathrm{Ra}^{223}$ (half life 11.2 days) indicates that the time required for leaching of Ra by the brines is short, especially compared to the half lives of $\mathrm{Ra}^{226}$ (1620 years) and $\mathrm{Ra}^{228}$ (6.7 years). The ratio of $\mathrm{Ra}^{226}$ to $\mathrm{Ra}^{228}$ should therefore reflect the ratio of eU to $\mathrm{Th}$ in the source rock. The ratios of $\mathrm{eU}$ to Th based on measurements of radium isotopes in precipitates from three oilfields that have been investigated are $0.5: 1$, $1: 1$, and $5: 1$. The ratio of $\mathrm{U}$ to $\mathrm{Th}$ in common rocks is about $0.3: 1$. These ratios indicate that there is some enrichment of $\mathrm{U}$ or its long-lived daughter Io relative to Th in the source rock. Concentrations of Jo that were in excess of the equilibrium amount of Io due to the U present have been found on the pore walls of reservoir rocks in the Augusta and Panhandle fields.

The presence of high concentrations of $\mathrm{Ra}$ and other radioelements in many oilfields indicates that extensive migrations of aqueous and organic solutions throughout effectively permeable sedimentary rocks have resulted in the redistribution and concentration of $U$ within the interstices of the rocks where its daughter products are readily accessible to the same solutions and associated gases.

\section{RADON}

Radioactivity anomalies observed on gamma-ray logs of wells in the vicinity of helium-bearing gas wells (fig. 176) suggested possible correlation between radon and helium in the natural gases. In order to test this possibility a detailed survey was made of $\mathrm{Rn}^{222}$ in gas wells of the West Panhandle field, Texas (Faul, Gott, Manger, and others, 1954) and in the gases of 66 other natural gas fields in Central and Southwestern United States.

The average $\mathrm{Rn}$ content of the gases from all fields tested was 460 micromicrocuries per liter at reservoir temperature and pressure (RTP), while the most frequent $\mathrm{Rn}$ concentration measured was about 200 micromicrocuries per liter RTP. In 42 of 66 gas fields tested, gases contained as much as 200-400 micromicrocuries $\mathrm{Rn}$ per liter RTP. In 11 other fields the $\mathrm{Rn}$ concentrations were greater than 1,000 micromicrocuries per liter RTP, and in the Panhandle, Pegasus, and Elk City fields gases contained as much as 8,000 10,000 micromicrocuries $\mathrm{Rn}$ per liter RTP. In comparison, the average $\mathrm{Rn}$ content of most soil gases is 200-400 micromicrocuries per liter at soil temperature and pressure (STP) (Botset and Weaver, 1932), and the average $\mathrm{Rn}$ content in the open pore spaces of a rock with $1 \mathrm{ppm}$ U, 5 percent emanating power, and 10 percent porosity is about 400 micromicrocuries per liter STP.

No direct correlation was found between the $R n$ and He contents of the gases tested. However, the highest $\mathrm{Rn}$ concentrations in the helium-bearing gases of the Panhandle field coincide with occurrences of uraniferous asphaltite in the reservoir rock.

Many of the gases tested had Rn contents of less than 100 micromicrocuries per liter. These subnormal values are believed to have resulted from the absorption of $\mathrm{Rn}$ by petroleum in the pore spaces of the gasproducing rocks. This, and other effects, make it difficult to interpret $\mathrm{Rn}$ data without detailed information upon the nature of the gas reservoir and the behavior of $\mathrm{Rn}$ in it. Although some of the gas fields contain high amounts of $\mathrm{Rn}$ in their natural gases, the absence of high $\mathrm{Rn}$ concentrations in natural gases of a field cannot be interpreted to mean that the reservoir is not abnormally radioactive.

\section{HELIUM AND OTHER GASES}

The major helium-bearing gas fields of the United States occur in the central Kansas, Bend arch, AmarilloWichita, and Nemaha uplifts, and on parts of the 
Colorado Plateau (fig. 176). Structurally these fields are located on uplifts marginal to large sedimentary basins, and the gases are produced from formations that extend with little change into the adjacent basins. The association of helium with accumulations of petroleum and natural gas suggests that an important part of the helium may have been derived from the petroleum source rocks and the rocks through which the petroleum migrated. Furthermore, the presence of epigenetic uranium-bearing asphaltite, radium-bearing brines, and gamma-ray anomalies in these rocks indicates that migration of petroleum and associated water through them has resulted in redistribution and concentration of uranium, thereby creating a favorable condition for accumulation of Jarge quantities of helium in the natural gas traps.

An analysis of data published by the U. S. Bureau of Mines (Anderson and Hinson, 1951) shows that the helium content of natural hydrocarbon gases increases with the age of the gas-producing reservoir. A summary of these data is shown below. The results indicate that the major part of the helium has accumulated in the gas fields subsequent to migration and accumulation of the major part of the associated hydrocarbons.

The U.S. Bureau of Mines data also show that there is a parallel enrichment of $\mathrm{N}$ with $\mathrm{He}$, The mean ratio of $\mathrm{N}$ to $\mathrm{He}$ is $30: 1$ with a standard deviation of \pm 10 . Virtually none of the gases analyzed had N:He ratios of less than 6; many of the gases sampled from shallow wells have excessively high proportions of $\mathrm{N}$, probably the result of atmospheric contamination. Somewhat higher $\mathrm{N}: \mathrm{He}$ ratios are found in solution gases produced from petroleum compared to dry natural gases.

\begin{tabular}{|c|c|c|c|c|c|c|}
\hline \multirow{2}{*}{$\begin{array}{l}\text { Age of reservolr } \\
\text { rock }\end{array}$} & \multirow{2}{*}{$\begin{array}{l}\text { Number } \\
\text { of gas } \\
\text { fields }\end{array}$} & \multicolumn{5}{|c|}{$\begin{array}{l}\text { Gas flelds (percent) yielding indicated amounts } \\
\text { (percent) of He }\end{array}$} \\
\hline & & $<0.001$ & $0.001-0.01$ & $0.01-0.1$ & $0.1-1.0$ & $1.0-10.0$ \\
\hline $\begin{array}{l}\text { Tertiary } \\
\text { Mesozole............. } \\
\text { Paleozole......... }\end{array}$ & $\begin{array}{l}178 \\
183 \\
609\end{array}$ & $\begin{array}{r}45 \\
12 \\
1\end{array}$ & $\begin{array}{r}38 \\
16 \\
4\end{array}$ & $\begin{array}{l}15 \\
51 \\
23\end{array}$ & $\begin{array}{r}2 \\
19 \\
61\end{array}$ & $\begin{array}{r}0 \\
2 \\
11\end{array}$ \\
\hline
\end{tabular}

Hydrogen, which many experiments (Lind, 1921; Sheppard and Whitehead, 1946) have shown to be the major reaction product of the irradiation of organic materials, is present among the gases of the Panhandle field. The $\mathrm{H}$ is about one twentieth as abundant as the $\mathrm{He}$ (Brewer and Dibeler, 1945).

The average ratio of $\mathrm{He}^{3}$ to $\mathrm{He}^{4}$ in the Panhandle field is about $1.5 \times 10^{-7}$, compared to an average of $1.7 \times 10^{-7}$ for the $\mathrm{He}$ in all the natural gases that have been investigated (Aldrich and Nier, 1948), a calculated ratio of $2 \times 10^{-7}$ for $\mathrm{He}$ originating from nuclear reactions in rocks of the composition of the earth's crust (Morrison and Beard, 1949), and a ratio of $12 \times 10^{-7}$ for $\mathrm{He}$ in the atmosphere.

Argon is also present in the gases of the Panhandle field (Faul, 1954). The ratio of $\mathrm{He}$ to $\mathrm{A}$ is approximately $10: 1$, which is close to the calculated ratio of $\mathrm{He}^{4}$ and $\mathrm{A}^{40}$ resulting from decay of the amounts of $\mathrm{U}$, $T h$, and $K^{40}$ present in the rocks of the composition of the earth's crust. This ratio has been calculated as between $8: 1$ and $12: 1$, depending on the value that is assumed for the branching ratio of $K^{40}$.

The close agreement between the amounts of $\mathrm{A}, \mathrm{He}^{3}$, and $\mathrm{He}^{4}$ measured and the amounts calculated to be present in rocks indicates that the major part of the $\mathrm{He}$ in the gases of the Panhandle field is of radiogenic origin.

Studies on the quantitative distribution of asphaltite in the Panhandle field have indicated that the $\mathrm{He}$ contained in the gases of one of the smaller gas reservoirs can be entirely accounted for by the decay of the U present in the asphaltites of the gas-producing rocks.

\section{CONCLUSIONS}

Uranium has been redistributed and concentrated within the interstices of rocks through which petroleum has migrated or in which it has accumulated. The concentration and redistribution of uranium bas been associated in time with structural and diagenetic events including recrystallization, solution, cementation, and adsorption of metalliferous surface-active fractions of migrating petroleum. The result has been to make uranium and its daughter produets easily accessible to fluids and gases.

It is believed that a large part of the helium present in natural gases may have been derived from the radioelements that have been distributed in this manner. More information about the geochemistry of uranium in petroleum and petroleum waters, however, is necessary to a complete understanding of the genesis of the belium and the associated uraniferous asphaltites.

\section{REFERENCES CITED}

Aldrich, L. T., and Nier, A. O., 1948, The occurrence of $\mathrm{He}^{3}$ in natural sources of helium: Phys. Rev., v. 74, no, 11, p. 1590-1594.

Anderson, C. C., and Hinson, H. H., 1951, Helium-bearing natural gases of the United States-analyses and analytical methods: U. S. Bur. Mines Bull, 486, 141 p.

Botset, H. G., and Weaver, Paul, 1932, Radon content of soil gas: Physics, v. 2, p. 376-385.

Brewer, A. K., and Dibeler, V. H., 1945, Mass spectrometric analyses of hydrocarbon and gas mixtures: U. S. Nat, Bur. Standards Jour. Research, v. 35, no. 2, p. 125-139.

Cady, H. P., and MeFarland, D. R., 1907, On the oceurrence of helium in natural gas and the composition of natural gas: Am. Chem. Soe. Jour., v. 29, p. 1523-1536. 
Davidson, C. F., and Bowie, S. H. U., 1951 On thucholite and related hydrocarbon-uraninite complexes, with a note on the origin of the Witwatersrand gold ores: Geol. Survey Great Britain Bull. 3, p. 1-19.

Erickson, R. L., Myers, A. T., and Horr, C. A., 1954, Association of uranium and other metals with crude oil, asphalt, and petroliferous rock: Am. Assoc. Petroleum Geologists Bull., v. 38 , p. $2200-2218$.

Faul, Henry, 1954, Helium, argon, and radon, in Faul, Henry (editor), Nuclear geology: New York, John Wiley and Sons, Inc., p. 133-143.

Faul, Henry, Gott, G. B., Manger, G. E., and others, 1954, Radon and helium in natural gas: 19th Internat. Geol. Cong., Algiers, Comptes rendus, v. 9, p. 339-348.

Gott, G. B., and Hill, J. W., 1953, Radioactivity in some oil fields of southeastern Kansas: U. S. Geol. Survey Bull. 988-E, p. 69-122.
Grip, Erland, and Odman, O. H., 1944, On thucholite and natural gas from Boliden: Sveriges geol. undersokning Arsbok; (Stockholm), 38, no. 6; Ser. C, Avhandlingaroch Uppsatser, no. 464, 14 p.

Lind, S. C., 1921, Chemical effects of alpha particles and electrons: New York, Chemical Catalog Co.

Morrison, P., and Beard, D. B., $1949, \mathrm{He}^{3}$ and the origin of terrestrial helium: Phys. Rev., v. 75, no. 8, p. 1332-1333.

Sheppard, C. W., and Whitehead, W. L., 1946, Formation of hydrocarbons from fatty acids by alpha-particle bombardment: Am. Assoc. Petroleum Geologists Bull., v. 30, p. 32-51.

Vernadski, V. I., and Khlopin, V. G., 1932, Ob issledovanii na radii neftyanykh mestorozhdenii soyuska (On investigations of oilfields of the U.S.S.R. for radium): Adka. Nauk. S.S.S.R. Doklady, Ser. A, no. 3, p. 55-59.

Young, R. B., 1917, The banket: London, Gurney and Jackson, $125 \mathrm{p}$. 


\title{
RELATIONS OF THE ORIGIN OF HOST ROCKS TO URANIUM DEPOSITS AND ORE PRODUGTION IN WESTERN UNITED STATES
}

\author{
By Hiram B. Wood, U. S. Atomic Energy Commission
}

\begin{abstract}
CONTENTS
Abstract

Introduction and acknowledgments

Explanation and discussion of the tables.

Conclusion.

References cited.

\section{ILLUSTRATIONS}

Figure 177. Map of Western United States showing location of deposits described in table 1...
178. Map of Colorado Plateau district of Atomic Energy Commission showing location of deposits described in table 2 .
\end{abstract}

\section{TABLES}

TABLE 1. Relations of host rocks to uranium deposits and ore production, Western United States, exeluding the Colorado
Plateau
2. Relations of host rocks to uranium deposits and ore production Colorado Plateau
3. Uranium-producing rock units of the United States and percent of national production...

\begin{abstract}
Compilation of data on 110 selected uranium deposits in the western part of United States shows that their host rocks were formed in a wide range of petrogenic environments, that every unit of geologic time from Proterozoic to Recent except Devonian and Mississippian is represented, and that the deposits are widely distributed geographically.

The environments represented include fluvial, igneous, littoral, marine, metamorphic, lacustrine, paludal, eolian, and terrestrial efflorescent. Fluvial sandstones and mudstones appear to be the most favorable host rocks. About 96 percent of the uranium ore that had been produced in the United States by June 30, 1955 , came from fluvial and lacustrine sedimentary formations within the Colorado Plateau. It is expected that this source will continue to lead in production for some time.
\end{abstract}

\section{INTRODUCTION AND ACKNOWLEDGMENTS}

Information on the distribution and occurrence of uranium deposits is scattered among many publications and reports. In the United States the number of known uranium-bearing stratigraphic units and the variety of occurrences have increased tremendously since 1950. In order to demonstrate this wide divergence in type of uranium occurrences now known in the western United States, and the relations of the petrogenic environment of the host rocks to the mode of occurrence of the uranium minerals, a compilation has been made of the stratigraphic and geographic distribution of selected deposits, the petrogenesis of the host rocks, the mode of occurrence of the uranium minerals, and the relative importance of ore production from the various deposits. Relative production from the major ore-bearing rock units is shown in three tables, which may serve as guides to the most favorable host rocks for uranium in any particular region, and as references to the environmental origin of uranium host rocks.

The forerunner of this paper, limited in scope to the Colorado Plateau, was prepared by Isachsen, Mitcham, and Wood (1955). Most of the information on the uranium deposits listed in table 1 was submitted by geologists of the Denver and Salt Lake City Branches of the Exploration Division, Atomic Energy Commission. They include Jack J. Foran, Eugene W. Grutt, John W. King, Harold D. Wolfe, Stephen R. Steinhauser and B. S. Sharp. Table 3 was compiled by Florence P. Berg, with the aid of Henry R. Wardwell, of the Grand Junction Exploration Division. 


\section{EXPLANATION AND DISCUSSION OF THE TABLES}

Tables 1 and 2 describe selected uranium deposits which represent uranium occurrences in host rocks of different petrogenic eavironments for various geologic ages. The geologic aye of the host rock does not imply the age of the mineralizing solutions. The order of listing only approximates the chronologic position of the host rocks, some of which are of questionable age. Host rocks exemplifying the entire known variety of original enviroiments of uranium deposits of each geologic age were purposely selected to show that such deposits occur in rocks formed under widely varying conditions; however, the tables reveal that some of these petrogenic environments are relatively unimportant economically.
A particular petrogenic environment listed in either table 1 or table 2 may be duplicated, within the same geologic period, in the other of these two tables, but duplication of this kind within the same table has been avoided unless the deposits are widely separated geographically. A list of uranium minerals and their mode of occurrence is presented for each deposit to show any prevailing mineralogic similarities. Each selected example is numbered to correspond with numbers shown on figures 177 or 178 . To separate the innumerable minor deposits from the commercially significant deposits, each deposit is classified as having produced at least 1,000 tons of ore-grade material, as having produced less than 1,000 tons, or as being a prospect. Prospects are deposits that have ore of 0.10

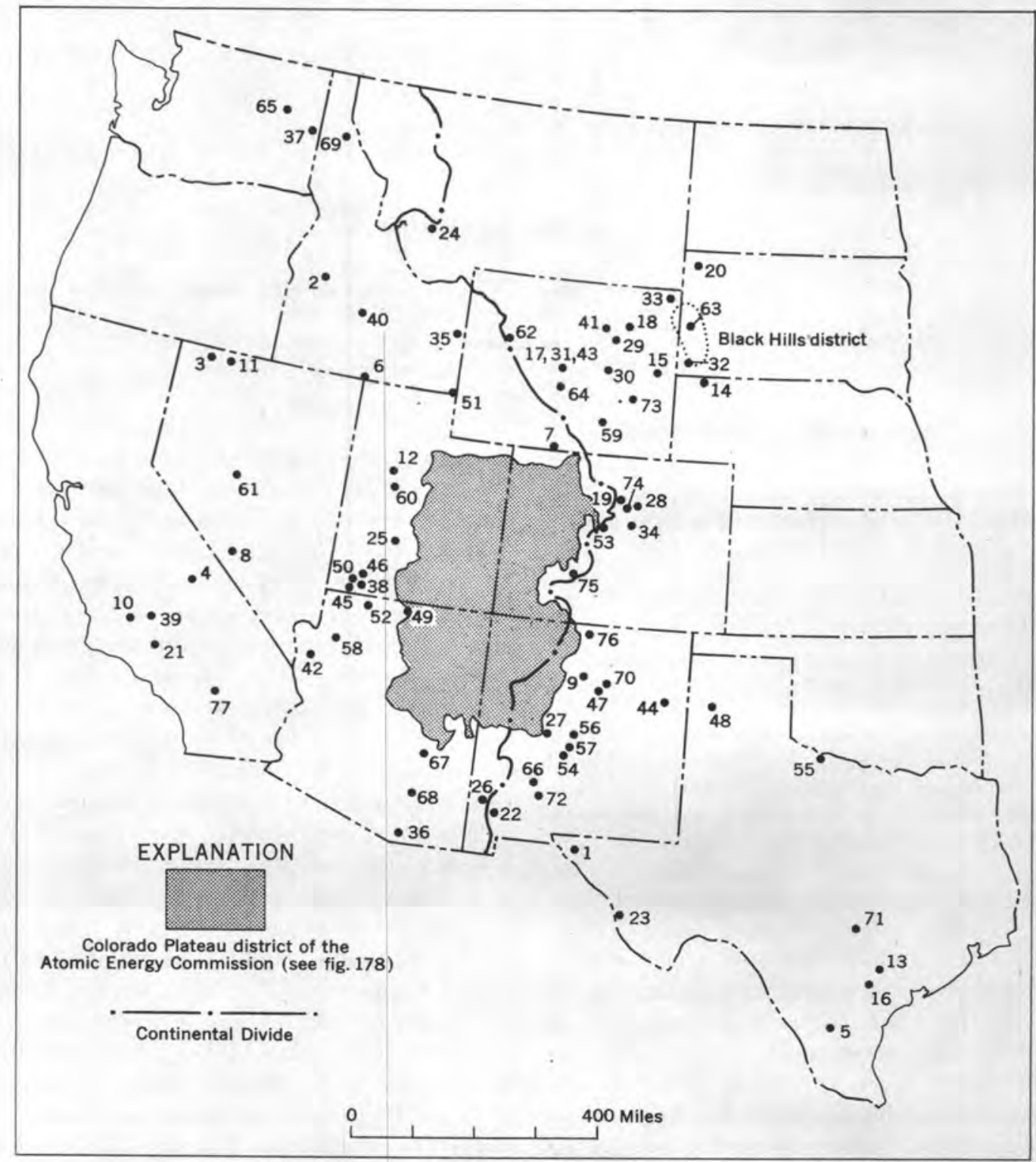

Figure 177.-Map of Western United States showing location of deposits described in table 1. 


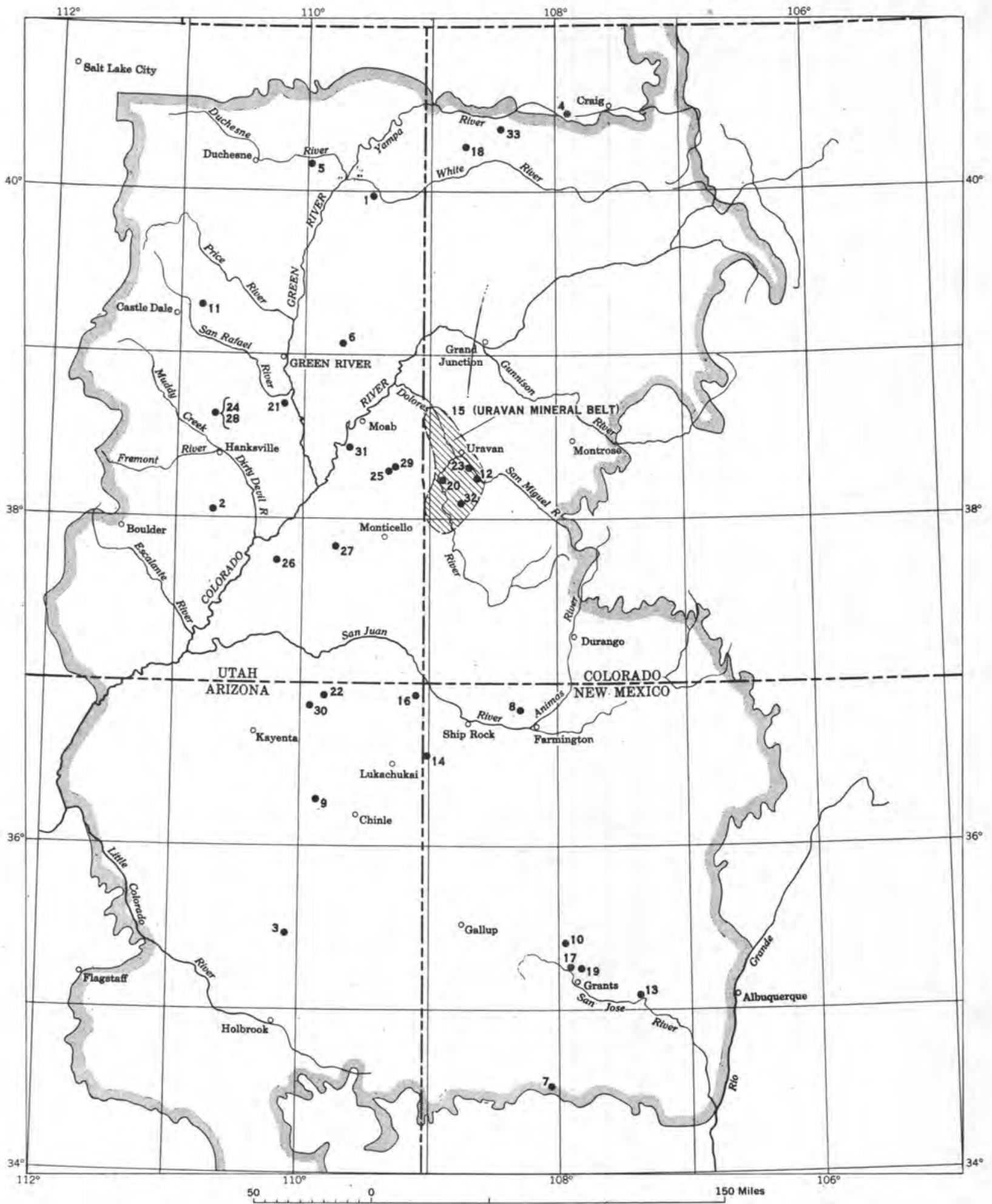

Finure 178.-Map of the Colorado Plateau district of the Atomic Energy Commission showing location of the deposits described in table 2.

percent $\mathrm{U}_{3} \mathrm{O}_{8}$ or better, by chemical assay unless otherwise stated, but from which not more than about 25 tons of ore have been produced.

Uranium deposits within the Colorado Plateau are listed separately in table 2 and shown in figure 178 , because of their distinctive mode of occurrence and because they have been mined and studied much more extensively than those elsewhere. 
TABLe 1.-Relation of host rocks to uranium deposits and ore production in Western United States excluding the Colorado Plateau ${ }^{1}$

\begin{tabular}{|c|c|c|c|}
\hline No. & & Lost rock & \\
\hline fig. & Age & Name & $\begin{array}{c}\text { Original } \\
\text { environment }\end{array}$ \\
\hline
\end{tabular}

Alluvium.

Fluvial,

3 Miocene Virgin Valley Lacustrine
beds of Merriam (1907). of Sehultz

5 Plioeene........ Goliad sand.... Fluvial.-

6 Pliocene

Barrett coal Paludal. Barre
bed.

7 Miocene(?) ...... Browns Park Fluvial. formation.

8 Miocene and Esmeralda for- Lacustrine. Pliocene. mation. 9 Miocene and Santa Fegroup. Lacustrine-flu-
Pliocene.

10 Miocene....... Undifferen- Marine.........

10 Miocene....... Undifferen- Marine.........

11 Miocene

Acid flows..... Igneous.

12 Miocene Intrusive rocks Igneous. at Sheeprock.

13 Miocene(?).... Catahoula tuff. Fluvial Disseminated in gray to brown crossbedded, coarse, basal,
fied tuffaceous sandstone. 14 Oligocene....... - Brule forma- Lacustrine-litWhite River for- Fluvial.
mation.

16 Eocene.

Jackson group.. Fluvial

17 Eocene. Wind River for- Fluvial.
mation.

18 Eocene. Wasatch forma- Fluvial tion.

19 Eocene.

Monzonite .. Igneous Fort Union
mation.

20 Paleocene stone and mudstone. stone and siltstone.

Fills fractures in lava.

As irregular replacement veinlets and fracture coatings in lower part of gypsiferous clay. fracture coatings. and crossbedded gray sandstone with interbedded shale.

Disseminated in buff coarsegrained crossbedded arkosic sandstone with manganese
4 Pliocene or Pleis- Coso formation Lacustrine.

15 Oligocene

$\frac{\text { Mode of occurrence }}{\text { Coating Hueco limestone frag- }}$

ments in caliche zone.
Uranium deposits

$\frac{\text { Uranium minerals }}{\begin{array}{c}\text { Secondary uranium } \\ \text { minerals. }\end{array}}$

Disseminated in unconsolidated Samarskite, euxenite sands and gravels.

Disseminated in opalized tuff and Tyuyamunite, uranifbeds of diatomaceous earth.

Disseminated in tuffs altered to Autunite
green clay. green clay.

Fills fractures and is disseminated Carnotite(?). in silicified coarse sandstone and conglomerate.

Disseminated in lignitic

Disseminated in brown silty erossbedded sandstone interbedded with shale.

Disseminated in stratifled tuffs and diatomaceous earth and in opal lenses.
Urano-organie com- Idaho (Utah-Nevada corner), Prospect. plex.

Uranophane, meta- Wyoming, Sweetu

twater County, Less than 1,000 nite(?).

Uraniferous collopha- Nevada, Esmeralda County, 3 Less than 1,000 nite, uraniferous miles west of Tonopah. opal.

6 miles east of Baggs.

tons.
Ore production category

Texas, E1 Paso and Hudspeth Prospect; 0.05 El Paso.

northeast of Boise.
nointes Less that
tons.

Nevada, Humboldt County, Prospect.

California, Inyo County, 5 Prospect. miles east of Olancha.

Texas, Webb County, 17 miles Prospect. southwest of Freer.

isseminated in lenses of sand- Schroeekingerite(?)... New Mexico, Santa Fe County, Prospect.

15 miles northwest of Santa

Disseminated in interbeddedsand- Autunite(?) California, Kern County, 30 Prospect.
miles west of Bakersfield, Autunite, torbernite, Nevada, Humboldt County, 74 Less than 1,000 gummite, uraninite. miles north of Winnemucca. tons.

Fills small fissures in granite..... Pitchblende.......... Utah, Tooele County, Erick- Prospect. son district

Texas, Gonzales County, Jacobs Prospect. ranch, 3 miles south of Sample.

sabugalite.

Nebraska, Dawes County, W1/2 Prospect. sec. 3, T. 34 N., R. 47 W., 12

and arkosie sandstone and as
tyuyamunite.

Disseminated in tuffaceous arko- Autunite, carnotite, Texas, Karnes County, Lyssy- Less than 1,000 sie sandstone and siltstone with schoepite. west of Falls City.

Disseminated in conglomerate

Uraninite; coffinite; Wyoming. Fremont County, More than 1.000 uranium phos- Gas Hills, T. 33 N., R. 90 W., tons. phates, arsenates, 35 miles south of Moneta. and carbonates.

tyuyamu- Wyoming, Campbell County, More than 1,000 ite, nranophane, '45 miles southwest of Gillette. tons. nite, uran
uraninite.

Pitchblende.

Colorado, Boulder County, 4 Prospect.

miles northwest of Nederland.

Urano-organic com- South Dakota, Harding County, Less than 1,000 plex, meta-autunite, Cave Hills area. tons. metatorbernite, metazeunerite, carnotite.

21 Tertiary

Andesite

Igneous

Disseminated in andesite dikes Autunite and volcanic tuffs. California, Kern County, near Prospect.
Rosamond.

22 Tertiar

Latite dike...... Igneous Fills fract
in latite.

23 Tertiary

Rhyolite flows. Igneous

In vesicles and along joints

20 miles south of Silver City. Less that

24 Tertiary Boulder

25 Tertiary

In veinlets in silicified

Texas, Presidio County, sec. Prospect. 34 , block $3, D$ and P Survey.

In veins filling shear zones in nontana,
near Butte.

ess than 1,000

tons.

quartz monzonite and aplite

raninite, torbernite, at Marysvale in Bullion

26 Tertiary

Gneiss.

Igneous

With nickel, cobalt, and silver in Uraninite. carbonate fissure veins cutting metamorphic rocks. tah, Piute County, Bullion More than 1,000 Monarch mine, 2 miles north- tons. east of Marysvale.

New Mexico, Grant County, Prospect. 
TABLE 1.-Relation of host rocks to uranium deposils and ore production in Western United States excluding the Colorado Plateau 1 -Con.

No.
on
fig.
$\frac{177}{27}$$\frac{\text { Age }}{\text { Tertiary _......... }} \frac{\text { Nost rock }}{\frac{\text { Popotosa forma- }}{\text { tion. }}} \frac{\begin{array}{c}\text { Original } \\ \text { environment }\end{array}}{\text { Igneous.......... F }}$

28 Late Cretaceous. Laramie forma- Paludal......... tion.

29 Oretaceons...... Lance forma- Fluvial-1ittoral.

30 Cretaceous

$$
\begin{aligned}
& \text { M es a } \\
& \text { group. }
\end{aligned}
$$

31 Cretaceous

$$
\underset{\text { shale }}{\text { Thermopolis Marine }}
$$

all River sand- Fluvial stone of Inyan

32 Oretaceous skota sandstone of Inyan
Kara group

23 Oretaceous

34 Cretaceous..... Dakota sand-

35 Cretaceous ..... Bear River for- Paludal mation

36 Cretaceous.

Rocks of

37 Cretaceous. Comanche age granite of Weaver (1920)

Cretaceous and
Jurassic $\quad \begin{gathered}\text { Lower part of } \\ \text { Dukota sand- }\end{gathered}$ Dukota sam
stone and upper part of Summerville formation

39 Jurassic Sierra Nevad
batholith

40) Jurassic (?) Idaho batholith

$₫ 1$ Epper Jurassic.. Sundance formation

Marine Intrusive rocks Igneous. at Hualapai

42 Jumssie. Morrison forma- Fluvial.
tion

43 Jurassic

44 Jurassic. Morrison forms- Fluvial tion

45 Triassic Shinarump. conglomerate

Fluvial. Chinle formation

46. Triassic

47 Triassic Chin

48 Triassic Dockum group. Fluvial. Fluvial.

(n)

Plavisl.

49 Triassic... Moenkopi formation

B) Permian Kaibab limestone

51 Permian. Phosphoria or Park City
formation or formatioth

See footnote at end of table. $385115-56-35$

Marine Uranium deposits

Mode of occurrence
$\begin{aligned} & \text { FUlls fractures in opalized and } \\ & \text { arginlitle volcanie tuffs, imme- } \\ & \text { diately above granite. }\end{aligned}$

Disseminated in fractured and Carnotite. partly silicified coal beds, interbedded with clays and sandstones,

Uranium minerals
$\begin{aligned} & \text { Paraschoepite, autu- } \\ & \text { nite, soddyite, meta- } \\ & \text { torbernite. }\end{aligned}$

$\frac{\text { Location }}{\text { New Mexico, Socorro County, }} \frac{\begin{array}{c}\text { Ore production } \\ \text { category }\end{array}}{\begin{array}{c}\text { Ladron Mountains, 25 miles than 1,000 } \\ \text { northwest of Socorro }\end{array}}$

Colorado, Jefferson County, Prospect. sec. 28, T. 2 S., R. 71 W. Loyden m

isseminated in gray-brown fine- Unidentffied. grained massive sandstone with coaly material.

Wyoming, Johnson County, Prospect.
T. 42 N., R. 78 W., near

Wyoming, Natrona County, Prospect. 9 miles north of Caspor bonnceous in lenses of carbrown sandstone.

Coatings on bedding planes and Unidentified.

Wyoming, Fremont County, Prospect. Gas Hilis area, 35 miles south of Moneta

Disseminated in fine-grained Carnotite, rauvite.... South Dakota, Fall River Coun- More than 1,000 quartz sandstone with shaly laminations and carbon flecks ty, Virginia $C$ mine, 8 miles tons. Disseminated in gray fine- to Carnotite.
medium-grained cross-laminated sandstone with earbon trash

Wyoming, Crook County, Belle More than 1,000 Fourche River ares, 18 miles tons. north of Moorecroft

Disseminated in slightly carbonaceous pyritic sandstone within a shear zone; non-uraniferou

Uraninite, carnotite..

Colorado, Jefferson County, on Less than 1,000 Turkey Creek near Morrison tons.

Disseminated in lignitic coal inter- Unidentified. bedded with sandstone, marl, and bituminous shule

Idaho, Bonneville County, Fall Prospect. Creek, sec. 4, T. 1 8., R. 42 E.

Scattered within interbedded Uranophane, kaso-

Arizona, Santa Cruz County, 21 More than 1,000 sandstone, shale, and limestone lite, autunite miles north of Nogales tons.

In vugs and flling minute frac- Antunite tures in fine-grained granite

Washington, Spokane County, Lass than 1,000 Day Break mine, 10 miles tons. northeast of Spokane

Utah, Kane County, T. 40 8., Less than 1,000 R. 9 W., Orderville Gulch, tons. Bullock group, 15 miles north west of Orderville

conglomerate; associated with carbonsceous trash, elay lenses, and iron oxide concretions

Carnotite, sutunite.

Costings along shear fractures in Carnotite, antunite, granodiorite

arnotite, antunite, California, Kern County, Mir- Less than 1,000 acle mine, 30 miles east of tons.

Disseminsted or in lenses and Uraninite, metator- Id daho, Blaine County, T. 1 N., Prospect. pods in quartz veins in quartz bernite $\quad$ R. 17 E. Primitive group, pods in quartz veins in quartz bernite
monzonite

Filling interstices in buff to gray, Uranophane, metatythin- to thick-bedded oolitic uyamunite limestone

Fills fractures in granite.

Pitchbiende

Wyoming, Johnson County, J. Prospect. east of Mayoworth

Disseminated in gray flne- to Meta-sutunite medium-grained silty crossbedArizons, Mojave County, 15 Prospect. miles north of Kingman

Wyoming, Fremont County, Less than 1,000 Gas Hills area, 35 miles south tons.
of Monets

Associated with petrified logs

Carnotite (?)

New Mexico, Quay County, 12 Prospect. miles west of Tucumeari

Disseminated with carbonsceous Torbernite, autunite, Utah, Washington County, near More than 1,000 debris in interbedded gray- carnotite tons. green sandstone and shale

Disseminated in sandstone lenses; Carnotite, autunite... associated with silver and copper minerals

Wh, Washington County, Sil- Less than 1,000 Bilver Oity

Disseminated in a lime pellet Tyuyamunite.

New Mexico, Sante Fe County, Prospect. 30 miles southesst of Santa Fe

Disseminated in bassl sandstone Autunite, uraninite Texas, Oldham County, 10 Prospect. lense: (?), uranocireite, miles north of Vega

Fluvial-littoral. Disseminated in siltstones and Unidentified Arizons, Coconino County, Lees Prospect. Ferry area

Marine.......... In dark-grsy dense fossiliferous Autunite limestone

Wtah, Washington County, 6 Iess than 1,000 miles south of Kanarraville tons.

Associated with apatite and organic matter in dark hard silt

Wutheast Idaho, southwest Prospect; $0.01-$

Utah; Bear Lake district $\quad \mathrm{U}_{3} \mathrm{O}_{3}$ 
TABLE 1.-Relation of host rocks to uranium deposits and ore production in Western United States excluding the Colorado Plateau ${ }^{1}$

No.
on
fip.
177 $\frac{\text { Age }}{52} \frac{\text { Host rock }}{\text { Permian......... }} \frac{\text { Name }}{\begin{array}{c}\text { Hermit shale } \\ \text { and Coconino } \\ \text { sandstone }\end{array}} \frac{\begin{array}{c}\text { Original } \\ \text { environment }\end{array}}{\text { Fluvial.......... }}$

53 Permian.

54 Permian Red beds. Marine-littoral.

San Andres for- Marine mation.

55 Permian Wichita group. Fluvial

56 Permian

ial...
Disse

57 Pennsylvanian.- Magdalena Marine. group. clayey and silicifled limestone,

Uranium deposits

Mode of occurrence
$\begin{gathered}\text { Disseminated in bleached sand- } \\ \text { stone }\end{gathered}$

Fills fractures in shear zone in Metatorbern

Disseminated in sendston

Carnotite(?)

58 Pennsylvanian Supai forma- Littoral-fluvial. D

Disseminated in bleached grayAbo formation. Fluvial

- In fractures and disseminated in Carnotite(?)

Carnotite, volborgreen sandstone and shale on
hanging wall of a copper vein.

59

Pennsylvanian.. Tensleep sand- Marine-littoral. Disseminated in sandstone....... Metatyuyamunite.... stone.

60 Silurian and Or- I dovician.

61 Silurian(?) Cambrian(?).

Laketown and Marine Fish Haven

In dolomite, associated with fluo- Uraninite(?) rite. olomites.

nite and mets. sediments.

Igneous a $\mathrm{nd}$ In metam orments.

62 Cambrian. Gallatin lime- Marine
stone.

monzonite and metasediments, Autunite, near contact.

63 Cambrian. Deadwood for- Marine mation.

Fills fractures in gray to brown sil- Carnotite

Along bedding planes at intersec- Autunite, tion of syenite-porphyry dikes (?)
with dolomite members.

(?).
(unite, uraninite $\mathrm{S}$

64

Cambrian....... Gros Ventre formation.

Marine; shales Coats fractures in dense gray-green Autunite now meta- phyllite.

65 Paleozoic. Deer Trail ar- L

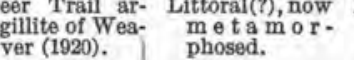

66 Early Paleozoic Limestone and

Marine. Fills fractures within shear zone Autunite, uran in sehists quartzite.

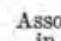

Associated with fluorite veinlets Uraninite(?), uranoin a brecciated zone cutting lime- phane. stone and quartzite.

67 Later Protero- Dripping Sprin
zoic.

Sedimentary, Coats and fllls fractures in potashnow meta. rich quartzite, argillite, and Metatorbernite, uramorphosed. slate. quartzite, argillte, and ninite,

68 Later Protero- Pinsl schist.... Littoral, n ow In association with fluorite, filling Pitchblende met a m or - fractures in greenish-gray quartz phosed.

69 Proterozoic...... Belt series....... Littoral, n o w In veinlets in interbedded quartz- Uraninite metam or- ites, slates, and argillites.
phosed.

70 Proterozoic....... Pegmatite dikes Igneous In primary pegmatite minerals.. Samarskite, monazite. morphic. granite and gneiss. 71 Proterozoic.....- Pegmatite, gran-

72 Proterozoic......- Granite

Igneous With fluorite;
tered granite.

actures in al-

Uraninite(?), uranothorite(?), uraniferite.

73 Proterozoic. Granite.

Igneous. Uraninite,
phane. granite, with quartz, pyrite, and pyrrhotite.

74 Proterozoic...... Idaho Spring

Metamorphic.. Cog Coats fragments in parallel breccia veins cutting schists and
gneisses.

75 Proterozoic and Metasediments Jurassic. $\quad$ and Morriso

Metamorphie Impregnations and fracture fillings in silicified sandstone and stringers in schist and quartzite,

76 Proterozoic...... Hopewell series Metamorphic.. Associated with schist inclusions of Just (1937). in granite.

77 Earlier ProteroGneisses

Uraninite. uranophane.

Unidentified Igneous-meta - In primary pegmatite minerals

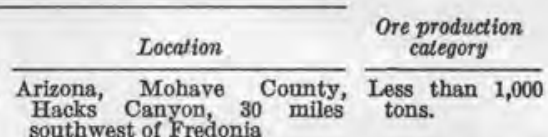
southwest of Fredonia Oolorado, Park County, 9 miles Less than 1,000
south of Fairplay

New Mexico, Socorro County, Less than 1,000 10 miles east of Socorro. tons.

Texas: Wichita, Wilbarger and Prospect. Clay Counties.

New Mexico, Torrance County, Prospect. 10 miles east of Mountainair.

New Mexico, Socorro County, Prospect. 15 miles northeast of Socorro.

Arizons, Mohave County, 30 Prospect. miles north of Peach Springs.

Wyoming, Carbon County, sec. Prospect. 36, T. 25 N., R. 82 W., 20 miles

Utah, Juab County, 30 miles Less than 1,000 north of Delta.

Nevada, Lander County, 3 Less than 1,000 miles south of Austin.

Wyoming, Fremont County, 8 Prospect. miles southwest of Dubois.

South Dakota, Lawrence Coun- Prospect. ty, Bald Mtn. mining area, near Lead.

Wyoming, Fremont County, Prospect. Green Mts. at Crooks Gap.

Washington, Stevens County, More than 1,000 Spokane Indian Reservation, tons.

New Mexico, Sierra County, 2 Less than 1,000 miles north of Monticello. tons.

Arizona, Gila County

More than 1,000 tons. Arizona, Pima County, 30 miles Less than 1,000
northeast of Tucson.

Idaho, Shoshone County, 9 Less than 1,000 miles east of Kellogg.

New Mexico, San Miguel Coun- Prospect. ty, 9 miles northesst of Pecos.

Texas, 11 miles west of Burnet.. Prospect.

New Mexico, Sierra County, 5 Prospect. miles southeast of Caballo.

Wyoming, Converse County, Less than 1,000 Esterbrook area 35 miles tons. south of Douglas.

Uraninite, metator- Colorado, Jefferson County, Less than 1,000 Swartzwalder mine, 7 miles tons. northwest of Golden.

Uraninite, autunite, Colorado, Saguache County, More than 1,000 metazeunerite, Cochetops mining district, tons.
uranophane.

Uraninite(?), sabuga- New Mexico, Rio Arriba Coun- Less than 1,000 lite, metatorber- ty, 12 miles northwest of Tres tons.

Californis, San Bernardino Less than 1,000 Mts.; sec. 28, T. 2 N., R. 2 E. tons.

1 The Colorado Plateau, as defined by the Atomie Energy Commission administrative district, does not correspond exactly with the physiographic province. 
TABLE 2,-Relation of host rocks to uranium deposits and ore production on the Colorado Plateau ${ }^{1}$

\begin{tabular}{|c|c|c|c|c|c|c|c|c|}
\hline \multirow{2}{*}{$\begin{array}{l}\text { No. } \\
\text { on } \\
\text { fig. } \\
178\end{array}$} & \multicolumn{3}{|c|}{ Host rock } & \multicolumn{3}{|c|}{ Uranium deposits } & \multirow{2}{*}{\multicolumn{2}{|c|}{$\begin{array}{l}\text { Oro production } \\
\text { category }\end{array}$}} \\
\hline & Age & Name & $\begin{array}{l}\text { Original } \\
\text { environment }\end{array}$ & Mode of occurrence & Uranium minerals & Location & & \\
\hline 1 & Recent............. & Caliahe.......... & $\begin{array}{l}\text { Terrestrial efflo- } \\
\text { rescent }\end{array}$ & $\begin{array}{l}\text { Costing caliche veins filling near- } \\
\text { surface fractures in sandstone } \\
\text { and mudstone }\end{array}$ & $\begin{array}{l}\text { Uranophsne, ursutfer- } \\
\text { ous opal }\end{array}$ & $\begin{array}{l}\text { Utah, Uintah County, } 24 \text { miles } \\
\text { southeast of Ouray }\end{array}$ & Prospect. & \\
\hline 2 & Tertisry .......... & $\begin{array}{l}\text { Monzonite por- } \\
\text { phyry. }\end{array}$ & Igneous.......... & $\begin{array}{l}\text { In veinlets in monzonite porphyry } \\
\text { plug. }\end{array}$ & $\begin{array}{l}\text { Uraninite, ursno- } \\
\text { phane. }\end{array}$ & $\begin{array}{l}\text { Utah, Garfield County, Henry } \\
\text { Mts., } 30 \text { miles south of Hanks- } \\
\text { ville. }\end{array}$ & Prospeet. & \\
\hline 3 & Pliocene........... & $\begin{array}{l}\text { Bidahochi for- } \\
\text { mation. }\end{array}$ & Lacustrine..... & $\begin{array}{l}\text { Disseminated in tuffaceous pyro- } \\
\text { clastic rocks and in travertine } \\
\text { within a diatreme. }\end{array}$ & Carnotite................. & $\begin{array}{l}\text { Arizons, Navajo County, } 40 \\
\text { miles north of Holbrook. }\end{array}$ & $\begin{array}{l}\text { Less than } \\
\text { tons. }\end{array}$ & 1,000 \\
\hline 4 & Miocene(?)....... & $\begin{array}{l}\text { Browns Park } \\
\text { formatlon. }\end{array}$ & Fluvial......... & $\begin{array}{l}\text { Disseminated in sandstone; depos- } \\
\text { its alined along fracture zone. }\end{array}$ & $\begin{array}{l}\text { Meta-autunite, sabu. } \\
\text { galite. }\end{array}$ & $\begin{array}{l}\text { Colorado, Moffat County, north } \\
\text { of Lay. }\end{array}$ & $\begin{array}{l}\text { Less than } \\
\text { tons. }\end{array}$ & 1,000 \\
\hline 5 & Eocene............. & Uints formstion & Fluvial.... & $\begin{array}{l}\text { Disseminsted in gray carboni- } \\
\text { ceous crossbedded sandstone } \\
\text { lenses. }\end{array}$ & Metatorbernite........ & $\begin{array}{l}\text { Utah, Duchesne and Uintah } \\
\text { Counties, south of Myton. }\end{array}$ & $\begin{array}{l}\text { Less than } \\
\text { tons. }\end{array}$ & 1,000 \\
\hline 6 & Eocine............. & $\begin{array}{l}\text { Wassteh formu- } \\
\text { tion. }\end{array}$ & Fluvial.......... & $\begin{array}{l}\text { Disseminated in coslified logs and } \\
\text { in clayey limestone pebble con- } \\
\text { glomerate flling scours. }\end{array}$ & Carnotite............... & $\begin{array}{l}\text { Utah, Emery County, Book } \\
\text { Oliffs area six miles north of } \\
\text { Thompson. }\end{array}$ & $\begin{array}{l}\text { Less than } \\
\text { tons. }\end{array}$ & 1,000 \\
\hline 7 & Eocene(?)........ & Bacs formation. & Fluvial.......... & $\begin{array}{l}\text { Disseminated in tuffaceous sand. } \\
\text { stone, associated with lignite } \\
\text { beds. }\end{array}$ & Tyuyamunite(?)..... & $\begin{array}{l}\text { New Mexico, Oatron County. } \\
15 \text { miles north of Datil. }\end{array}$ & $\begin{array}{l}\text { Less than } \\
\text { tons. }\end{array}$ & 1,000 \\
\hline 8 & Cretaceous....... & $\begin{array}{l}\text { Fruitland for- } \\
\text { mation. }\end{array}$ & Littoral.......... & $\begin{array}{l}\text { Disseminated in arkosic sandstone } \\
\text { filling \& scour in underlying } \\
\text { shale. }\end{array}$ & Unidentiffed.......... & $\begin{array}{l}\text { New Mexico, Ssn Jusn County, } \\
10 \text { miles northwest of Farm: } \\
\text { lagton. }\end{array}$ & Prospect. & \\
\hline 9 & Cretaceous....... & $\begin{array}{l}\text { Toreva forma- } \\
\text { tlon of Mesa- } \\
\text { verde group. }\end{array}$ & Fluvial-1ittoral. & $\begin{array}{l}\text { Disseminated in gray to buff ar- } \\
\text { kosie sandstone with interstltial } \\
\text { woody trash. }\end{array}$ & Carnotite................ & $\begin{array}{l}\text { Arizona, Apache County, } 12 \\
\text { miles northwest of Black Mesa } \\
\text { Trading Post. }\end{array}$ & $\begin{array}{l}\text { Less than } \\
\text { tons. }\end{array}$ & 1,000 \\
\hline 10 & Cretaceous....... & $\begin{array}{l}\text { Dakota sand- } \\
\text { stone. }\end{array}$ & $\begin{array}{l}\text { Lagoonal-palu. } \\
\text { dal. }\end{array}$ & $\begin{array}{l}\text { Disseminated in black carbons- } \\
\text { ceous shale interbedded with } \\
\text { sandstone. }\end{array}$ & Carnotite........ & $\begin{array}{l}\text { New Mexico, MoKinley County, } \\
\text { 8ilver Spur mine, } 10 \text { miles } \\
\text { north of Bluewater. }\end{array}$ & $\begin{array}{l}\text { More than } \\
\text { tons. }\end{array}$ & 1,000 \\
\hline 11 & Cretaceous....... & $\begin{array}{l}\text { Cedar Mountain } \\
\text { formation. }\end{array}$ & Lacustrine...... & $\begin{array}{l}\text { Disseminated in dark-gray sultstone } \\
\text { lenses interbedded witn bentonitic } \\
\text { shales. }\end{array}$ & Unidentifled........... & $\begin{array}{l}\text { Utah, Emery County, Cedar } \\
\text { Mtn., } 10 \text { miles east of Hunt- } \\
\text { Ington. }\end{array}$ & Prospect. & \\
\hline 12 & Cretaceous...... & $\begin{array}{l}\text { Burro Canyon } \\
\text { formation. }\end{array}$ & Fluvial.......... & $\begin{array}{l}\text { Disseminsted in carbonaceous } \\
\text { conglomeratic sandstone with } \\
\text { lenses of green mudstone. }\end{array}$ & Carnotite.............. & $\begin{array}{l}\text { Colorado, Montrose County, } 7 \\
\text { miles northwest of Naturita. }\end{array}$ & Prospect. & \\
\hline 13 & Jurassic........... & $\begin{array}{l}\text { Brushy Basin } \\
\text { member of } \\
\text { Morrison for- } \\
\text { mation. }\end{array}$ & Fluvial........... & $\begin{array}{l}\text { Disseminated in massive sand- } \\
\text { stone with clay galls and carbo- } \\
\text { naceous trash, cut by diabase } \\
\text { sill. }\end{array}$ & $\begin{array}{l}\text { Coftinite, tyuyamu- } \\
\text { nite, uranophane. }\end{array}$ & $\begin{array}{l}\text { New Mexico, Valencia County, } \\
\text { Jack Pile mine, } 6 \text { miles north } \\
\text { of Laguna. }\end{array}$ & $\begin{array}{l}\text { More than } \\
\text { tons. }\end{array}$ & 1,000 \\
\hline 14 & Jurassic........... & $\begin{array}{l}\text { Recapture mem- } \\
\text { ber of Morri- } \\
\text { son formation. }\end{array}$ & Eluvial.......... & $\begin{array}{l}\text { Disseminated in highly blesched } \\
\text { sandstone and mudstone. }\end{array}$ & Carnotite.............. & $\begin{array}{l}\text { New Mexico, San Juan County, } \\
\text { Enos Johnson claim, } 8 \text { miles } \\
\text { west of Sanosteo. }\end{array}$ & $\begin{array}{l}\text { More than } \\
\text { tons. }\end{array}$ & 1,000 \\
\hline 15 & Jurissie, - & $\begin{array}{l}\text { Salt Wash mem- } \\
\text { ber of Morri- } \\
\text { son formation. }\end{array}$ & Fluvial & $\begin{array}{l}\text { Disseminated in crossbedded fine- } \\
\text { to medium-graned sandstone } \\
\text { interbedded with greenish-gray } \\
\text { mudstone. }\end{array}$ & $\begin{array}{l}\text { Carnotite, tyuysmu- } \\
\text { nite, uranlnite, col- } \\
\text { finite. }\end{array}$ & $\begin{array}{l}\text { Colorado, San Miguel, Mess, } \\
\text { and Montrose Counties, Ura- } \\
\text { van mineral bolt. }\end{array}$ & $\begin{array}{l}\text { More than } \\
\text { tons. }\end{array}$ & 1,000 \\
\hline 16 & Jurassic ........... & Bluff sandstone. & Eollan $(q)$ & $\begin{array}{l}\text { Disseminated in crossbedied } \\
\text { sandstone, } 10 \text { feet above base. }\end{array}$ & Carnotite................ & $\begin{array}{l}\text { Arizons, Apache County, } 2 \\
\text { miles northwest of Carrizo } \\
\text { Mts. }\end{array}$ & Prospect. & \\
\hline 17 & Jurassic............ & $\begin{array}{l}\text { Summerville } \\
\text { formation. }\end{array}$ & $\begin{array}{l}\text { Lacustrine- } \\
\text { fluvial. }\end{array}$ & Disseminsted in basal sandstone.. & $\begin{array}{l}\text { Tyuyamunite, urant- } \\
\text { nite. }\end{array}$ & $\begin{array}{l}\text { New Mexieo, MeKinley Coun- } \\
\text { ty, Haystak Butte, north- } \\
\text { west of Grants. }\end{array}$ & $\begin{array}{l}\text { More than } \\
\text { tons. }\end{array}$ & 1,000 \\
\hline 18 & Jurassic.t........ & $\begin{array}{l}\text { Curtis forms. } \\
\text { tion. }\end{array}$ & $\begin{array}{l}\text { Marginal ms. } \\
\text { rine. }\end{array}$ & $\begin{array}{l}\text { Disseminated in thin-bedded car- } \\
\text { bonaceous facies of reworked } \\
\text { Entrada sandstone. }\end{array}$ & $\begin{array}{l}\text { Unidentifed uranium } \\
\text { and vanadium min- } \\
\text { erals. }\end{array}$ & $\begin{array}{l}\text { Colorado, Moffat County, } 2 \\
\text { miles northwest of Bkul } \\
\text { Creek. }\end{array}$ & $\begin{array}{l}\text { Less than } \\
\text { tons. }\end{array}$ & 1,000 \\
\hline 19 & Jurassic ............ & $\begin{array}{l}\text { Todilto limes. } \\
\text { stone. }\end{array}$ & Lacustrine...... & $\begin{array}{l}\text { On crest of minor folds in dense } \\
\text { gray bituminous limestone with } \\
\text { minute sllty laminae. }\end{array}$ & $\begin{array}{l}\text { Tyuyamunite, urani- } \\
\text { nite. }\end{array}$ & $\begin{array}{l}\text { New Mexico, Valencla County, } \\
\text { Gay Eagle mine, } \theta \text { miles north } \\
\text { of Grants. }\end{array}$ & $\begin{array}{l}\text { More than } \\
\text { tons. }\end{array}$ & 1,000 \\
\hline 20 & Jurassic........... & $\begin{array}{l}\text { Entrada sand. } \\
\text { stone. }\end{array}$ & Eolian_......... & $\begin{array}{l}\text { Disseminated in crossbedded } \\
\text { highly fractured sandstone in a } \\
\text { graben. }\end{array}$ & Carnotite... & $\begin{array}{l}\text { Colorado, Montrose County, } \\
\text { Joker mine, } 21 \text { miles west of } \\
\text { Naturita. }\end{array}$ & $\begin{array}{l}\text { Less than } \\
\text { tons. }\end{array}$ & 1,000 \\
\hline 21 & Jurassie........... & $\begin{array}{l}\text { Carmel forma- } \\
\text { tion. }\end{array}$ & Littoral........ & $\begin{array}{l}\text { Disseminated in greenish-gray } \\
\text { laminated siltstone near top of } \\
\text { formation. }\end{array}$ & Unidentified........... & $\begin{array}{l}\text { Utah, Emery County, Saucer } \\
\text { Basin, } 30 \text { miles south of Green } \\
\text { River. }\end{array}$ & Prospect. & \\
\hline 22 & $\begin{array}{l}\text { Jurassic and Ju. } \\
\text { rassio(\%). }\end{array}$ & $\begin{array}{l}\text { Navajo sand- } \\
\text { stone. }\end{array}$ & Eolisn........... & $\begin{array}{l}\text { Disseminated in massive gray } \\
\text { sandstone; ore pods along par- } \\
\text { allel fractures and walls of basto } \\
\text { dike. }\end{array}$ & $\begin{array}{l}\text { Unldentifled copper, } \\
\text { urantum and vana- } \\
\text { dium minerals. }\end{array}$ & $\begin{array}{l}\text { Arizona, Apache Coiunty, Gar- } \\
\text { net Ridge, } 10 \text { miles north of } \\
\text { Dinnehotso Trading Post. }\end{array}$ & Prospect. & \\
\hline 23 & Jurassic(?) ...... & $\begin{array}{l}\text { Kayenta forms- } \\
\text { tion. }\end{array}$ & Fluvial .......... & $\begin{array}{l}\text { Disseminated in medium-grained } \\
\text { sandstone, and coating fractures. }\end{array}$ & Carnotite................. & $\begin{array}{l}\text { Colorado Montrose County, } \\
\text { Big Chlef claims, 11 miles } \\
\text { northwest of Naturita. }\end{array}$ & $\begin{array}{l}\text { Less than } \\
\text { tons. }\end{array}$ & 1,000 \\
\hline 24 & Triassic........... & $\begin{array}{l}\text { Wingate sand- } \\
\text { stone. }\end{array}$ & Eollan & $\begin{array}{l}\text { Seattered pockets and lenses with- } \\
\text { in bleached, dolomitized mas- } \\
\text { sive sandstone. }\end{array}$ & $\begin{array}{l}\text { Uranfuite in asphal- } \\
\text { tite. }\end{array}$ & $\begin{array}{l}\text { Utah, Emery County, Temple } \\
\text { Mtn. collapse, 44 miles south- } \\
\text { west of Green River. }\end{array}$ & $\begin{array}{l}\text { Less than } \\
\text { tons. }\end{array}$ & 1,000 \\
\hline
\end{tabular}


GEOLOGY OF URANIUM AND THORIUM, INTERNATIONAL CONFERENCE, 1955

TABLE 2.- Relation of host rocks to uranium deposits and ore production on the Colorado Plateau ${ }^{1}$ - Continued

\begin{tabular}{|c|c|c|c|c|c|c|c|}
\hline \multirow{2}{*}{$\begin{array}{l}\text { No. } \\
\text { on } \\
\text { fig. } \\
178\end{array}$} & \multicolumn{3}{|c|}{ Host rock } & \multicolumn{3}{|c|}{ Uranium deposits } & \multirow[b]{2}{*}{$\begin{array}{l}\text { Ore production } \\
\text { category }\end{array}$} \\
\hline & Age & Name & $\begin{array}{l}\text { Original } \\
\text { environment }\end{array}$ & Mode of occurrence & Uranium minerals & Location & \\
\hline$\overline{25}$ & Triassic ........... & $\begin{array}{l}\text { Moss Back } \\
\text { member of } \\
\text { Chinle forma- } \\
\text { tion. }\end{array}$ & Flnvial... & $\begin{array}{l}\text { Disseminated in medium-gratned } \\
\text { arkosic crossbedded sandstone } \\
\text { with mudstone galls. }\end{array}$ & $\begin{array}{l}\text { Uraninite, coffinite, ty- } \\
\text { nyamunite. }\end{array}$ & $\begin{array}{l}\text { Utah, San Juan County, Big } \\
\text { Indian Wash, Mi Vida mine, } \\
30 \text { miles southeast of Moab. }\end{array}$ & $\begin{array}{l}\text { More than } 1,000 \\
\text { tons. }\end{array}$ \\
\hline 26 & Triassic ........... & $\begin{array}{l}\text { Shinarump } \\
\text { conglomerate. }\end{array}$ & Fluvial. & $\begin{array}{l}\text { Disseminated in cosrse-gratned } \\
\text { crossbedded friable carbona- } \\
\text { ceous sandstone and mudstone. }\end{array}$ & $\begin{array}{l}\text { Uraninite copper- } \\
\text { uranium sulphates. }\end{array}$ & $\begin{array}{l}\text { Utah, San Juan County, Happy } \\
\text { Jack mine, } 70 \text { miles west of } \\
\text { Blanding. }\end{array}$ & $\begin{array}{l}\text { More than } 1,000 \\
\text { tons. }\end{array}$ \\
\hline 27 & Triassic _.......... & $\begin{array}{l}\text { Moenkopl for- } \\
\text { mation. }\end{array}$ & Fluvial......... & $\begin{array}{l}\text { Disseminated in fine-grained, gray } \\
\text { sandstone with mudstone galls, } \\
\text { underlying channel shinarump, } \\
\text { rocks. }\end{array}$ & $\begin{array}{l}\text { Uraninite associated } \\
\text { with hydrocarbons. }\end{array}$ & $\begin{array}{l}\text { Utah, San Juan County, Elk } \\
\text { Ridge, } 34 \text { miles west of Bland- } \\
\text { ing. }\end{array}$ & $\begin{array}{l}\text { Less than } 1,000 \\
\text { tons. }\end{array}$ \\
\hline 28 & Permisn......... & $\begin{array}{l}\text { Kaibab lime- } \\
\text { stone. }\end{array}$ & Marine-residusl. & $\begin{array}{l}\text { Disseminated in asphalt-cemented } \\
\text { cherty breccia. }\end{array}$ & $\begin{array}{l}\text { Uranium and vana. } \\
\text { dium in asphaltite. }\end{array}$ & $\begin{array}{l}\text { Utah, Emery County, Temple } \\
\text { Mtn. collapse, } 44 \text { miles south. } \\
\text { west of Green River. }\end{array}$ & Prospect. \\
\hline 29 & Permian ......... & $\begin{array}{l}\text { Cutler forma- } \\
\text { tion. }\end{array}$ & Fluvial......... & $\begin{array}{l}\text { Disseminated and in concretions } \\
\text { in arkosic lenses; enriched along } \\
\text { fractures. }\end{array}$ & Carnotite, becquerelite. & $\begin{array}{l}\text { Utah, San Juan County, Blg } \\
\text { Buck claims, } 32 \text { miles south- } \\
\text { east of Moab. }\end{array}$ & $\begin{array}{l}\text { More than } 1,000 \\
\text { tons. }\end{array}$ \\
\hline 30 & Permian.......... & $\begin{array}{l}\text { De Chelly sand- } \\
\text { stone member } \\
\text { of Cutler for- } \\
\text { mation. }\end{array}$ & Eolian ............ & $\begin{array}{l}\text { Disseminated in erossbedded } \\
\text { sandstone underlying a channel } \\
\text { in Shinarump conglomerste. }\end{array}$ & Carnotite .............. & $\begin{array}{l}\text { Arizons, Apache County, Mon- } \\
\text { ument No. } 2 \text { mine, } 30 \text { miles } \\
\text { northeast of Kayenta. }\end{array}$ & $\begin{array}{l}\text { More than } 1,000 \\
\text { tons. }\end{array}$ \\
\hline 31 & $\begin{array}{l}\text { Pennsylvanian } \\
\text { and Permian } \\
\text { (?). }\end{array}$ & Rieo formation. & Fluvial......... & $\begin{array}{l}\text { Impregnations in bleached sand. } \\
\text { stone along a fault. }\end{array}$ & Unidentified & $\begin{array}{l}\text { Utah, San Juan County, } 10 \\
\text { miles southwest of Moab. }\end{array}$ & Prospect(?). \\
\hline 32 & Pennsylvanian. - & $\begin{array}{l}\text { Hermoss forms- } \\
\text { tion. }\end{array}$ & Marine & $\begin{array}{l}\text { Costs closely spaced fracture } \\
\text { planes in limestone. }\end{array}$ & Carnotite.............. & $\begin{array}{l}\text { Colorado, Montrose County, } \\
13 \text { miles southwest of Naturita. }\end{array}$ & $\begin{array}{l}\text { More than } 1,000 \\
\text { tons. }\end{array}$ \\
\hline 33 & Pennsylvanian.- & $\begin{array}{l}\text { Weber sand- } \\
\text { stone. }\end{array}$ & Littoral........... & $\begin{array}{l}\text { Disseminated in a massive friable } \\
\text { quartz-rich sandstone; associ- } \\
\text { ated with limonite. }\end{array}$ & Carnotite.... & $\begin{array}{c}\text { Colorado, Moffat County, } 7 \\
\text { miles southwest of Elk Springs. }\end{array}$ & Prospect. \\
\hline
\end{tabular}

1 The Colorado Plateau, as defined by the Atomic Energy Commission administrative distriet, does not correspond exactly with the physiographic province.

Table 3 is a compilation of the approximate percent of the total production from July 1, 1953, to June 30, 1955, of each major ore-bearing rock unit in the United States. These figures are based on the grade and quantity of ore received at the mills.

Study of the tables reveals that uranium deposits in the western part of the United States occur in rock units of every geologic age from Proterozoic to Recent, except Devonian and Mississippian. Host rocks were formed under fluvial, igneous, littoral, marine, lacustrine, paludal, eolian, metamorphic and terrestrial efflorescent environments. Separate examples of uranium deposits in host rocks of the same age but representing different petrogenic environments (table 2, no. 24 Wingate sandstone, eolian, and no. 25 Chinle formation, fluvial; and table 1, no. 34 Dakota sandstone, fluvial, and table 2, no. 10 Dakota sandstone, paludal) illustrate that although age of host rock is of significance, petrogenesis of the host rock may not be. In contrast, examples may be selected in which petrogenesis of host rocks is important, and age of the host rock is not (table 1, no. 7 Browns Park formation, Miocene(?), fluvial, and no. 45, Shinarump conglomerate, Triassic, fluvial).

Further study of the examples described in the tables shows that uranium minerals occur either in typical continental sedimentary formations or are found filling fractures in igneous rocks. It is also noted that there are five occurrences of uranium deposits in a
TABLE 3.-Major uranium-producing rock units in the United States and percent of national production of uranium oxide, July 1, 1953 to January 1, 1955

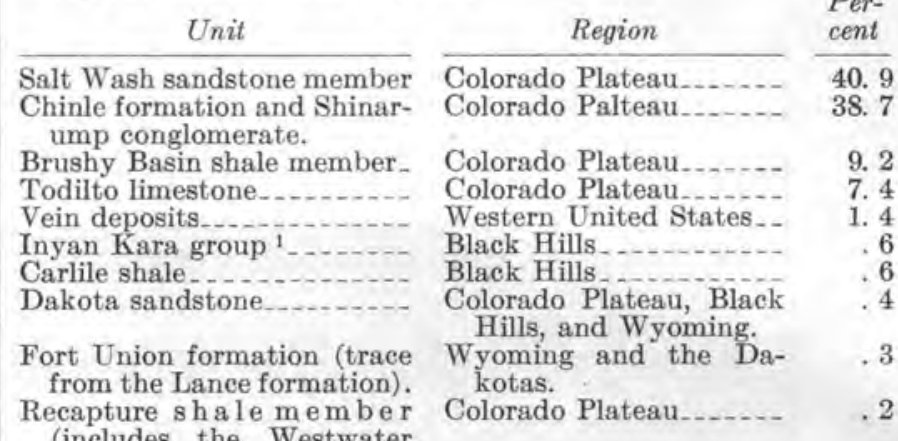
(ineludes the Westwater Canyon sandstone member).

Entrada sandstone Dripping Springs quartzite.. Cutler formation........... Others $^{2}$

Colorado Plateau....... Southern Arizona........ Colorado Plateau......... Colorado Plateau, Wyoming, the Dakotas, and New Mexico.

1 Includes the Fall River sandstone and for this table the Dakota sandstone. 2 Ineludes Mesaverde and Santa Fe groups; Browns Park, Bidahoehi, Hermosa, Wind River, Wingate, and Uinta formations.

sandstone host rock of eolian origin (table 2, nos. 16, $20,22,24$ and 30 ), although eolian rocks are generally classified as unfavorable for uranium. All of these deposits in eolian sandstone occur under special physical conditions and stratigraphic relations, and their economic importance ranges from limited prospects to major producer. 


\section{CONCLUSION}

It appears from the tables that fluvial sandstones are the most favorable host rocks for uranium ore and that the continental sedimentary rocks of fluvial and lacustrine origin within the Colorado Plateau are the most productive. About 96 percent of the uranium ore that had been produced in the United States by June 30, 1955, came from fluvial and lacustrine sedimentary rocks of Triassic and Jurassic age, occurring within the Colorado Plateau.

Although several potentially rich vein deposits have been found recently in igneous and metamorphic rocks throughout the western United States, their potential ore tonnage is small, and only a relatively slight increase in the total United States production is expected from this type of deposit for some time. In 1954 a few new uranium deposits which have potentially large tonnages were found in paludal (lignitic) and lacustrine sedimentary rocks, and a proportional increase in production from these rock types is expected when a method of processing this type material has been perfected.
The wide stratigraphic range, the variety of petrogenic environments, and the different modes of occurrence of the uranium minerals strongly support an epigenetic theory of the origin of the sedimentary uranium deposits.

\section{REFERENCES CITED}

Isachsen, Y. W., Mitcham, T. W., and Wood, H. B., 1955, Age and sedimentary environments of uranium host rocks, Colorado Plateau: Econ. Geology, v. 50, no. 2, p. 127-134.

Just, Evan, 1937, Geology and economic features of the pegmatites of Taos and Rio Arriba Counties, N. Mex.: N. Mex. Sehool Mines Bull. 13, 73 p.

Merriam, J. C., 1907, The occurrence of middle Tertiary mammalbearing beds in northwestern Nevada: Science, new ser., v. 26 , p. $380-382$.

Schultz, J. R., 1937, A late Cenozoic vertebrate fauna from the Coso Mountains, Inyo Canyon, Calif.: Carnegie Inst. Wáshington Pub. 487, p. 75-109.

Weaver, C. E., 1920, The mineral resources of Stevens County: Wash. Geol. Survey Bull. 20, 350 p. 


\title{
ISOTOPE GEOLOGY OF SOME URANIUM MINERALS
}

\author{
By Henry R. Hoekstra and Joseph J. Katz, Argonne National Laboratory
}

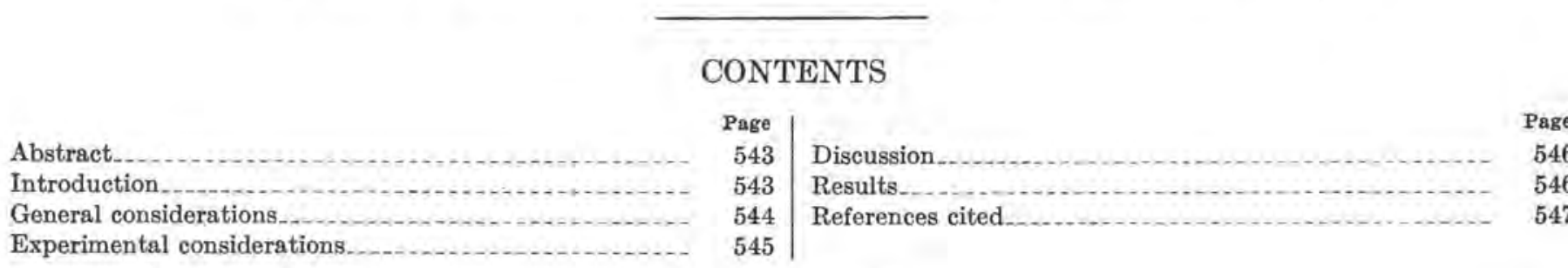

\section{IULUSTRATION}

Figure 179. Variations in $\mathrm{O}^{18} / \mathrm{O}^{16}$ ratio.

\section{TABLES}

TABLE 1. Exchange experiments with uranium oxides

2. Oxygen isotope ratios in water.

3. Isotope ratios in pitchblende and uraninite

\section{ABSTRACT}

This paper is concerned with variation of $\mathrm{O}^{18} / \mathrm{O}^{16}$ in uraninite and pitchblende from which might be deduced the temperature of formation of these minerals. Efforts have been concentrated on determining isotope ratios in a number of ores and in correlating results with the nature of the ore. Decomposition of the samples is effected by bromine trifluoride. Oxygen is separated from the remaining products as pure molecular oxygen. Isotopic ratios are determined directly on this material.

Results show variation of isotope ratios amounting to 1.6 percent. Seemingly oxygen isotope ratios are not affected by treatment with water at or near room temperature. Experiments on synthetic uranium oxides indicate that temperatures approaching $300^{\circ} \mathrm{C}$ are required to obtain a measurable rate of exchange of oxygen isotopes. Impurities in the samples often result in a measurable variation in isotope ratio. Weathered samples show higher $\mathrm{O}^{18}$ contents than unweathered samples from the same location.

Uranium oxides from pegmatites show a somewhat lower $\mathrm{O}^{18}$ content than those from hydrothermal or sedimentary deposits, but no reasonable estimates of temperature of formation of the ores is as yet possible. The only correlation obtainable with the samples is with the isotopic content of the ground waters assoeiated with the ores. Impurities in the ores and weathering cause some variations from the $\mathrm{O}^{18}$ content of the ground water.

Exchange experiments with the same minerals and with synthetic oxides indicate that exchange rates are dependent upon temperature of formation of the mineral.

\section{INTRODUCTION}

Variations in the isotopic ratio of $\mathrm{O}^{18} / \mathrm{O}^{16}$ in atmospheric oxygen and in oxygen-containing compounds have been the subject of many investigations. The normal abundance of $\mathrm{O}^{18}$ has been found to be approximately 0.2 percent; but variations of several percent above and below the normal isotopic ratio, obtained by different investigators, are summarized in figure 179 . The $\mathrm{O}^{18}$ values reported have been recalculated for the most part, using the average of 20 samples of ocean water (Epstein and Mayeda, 1953) as a standard. In some studies, no direct comparison between the standards used by individual investigators and the ocean-water standard was available, but the estimated values given in figure 179 are probably accurate to \pm 0.2 percent. The results of uraninite and pitchblende ${ }^{x}$ studies reported in this paper are included at the end of the figure.

Determination of oxygen isotope ratios for uranium ores may provide answer to the questions, Is there a variation in the isotopic ratio which can be of assistance in explaining the origin of uranium deposits, and can any observed variation in isotopic ratio be correlated with the temperature of formation of the ore? Work done in search of answers to these questions was aided by the cooperation of $\mathrm{H}$. C. Urey and by spectrometer analyses by George Edwards and Harmon Craig.

In this puper, the term "uraninite" refers to uranium oxides of pegmatitic origin; and "pltchblende," to oxldes precipitated from aqueous solution. 


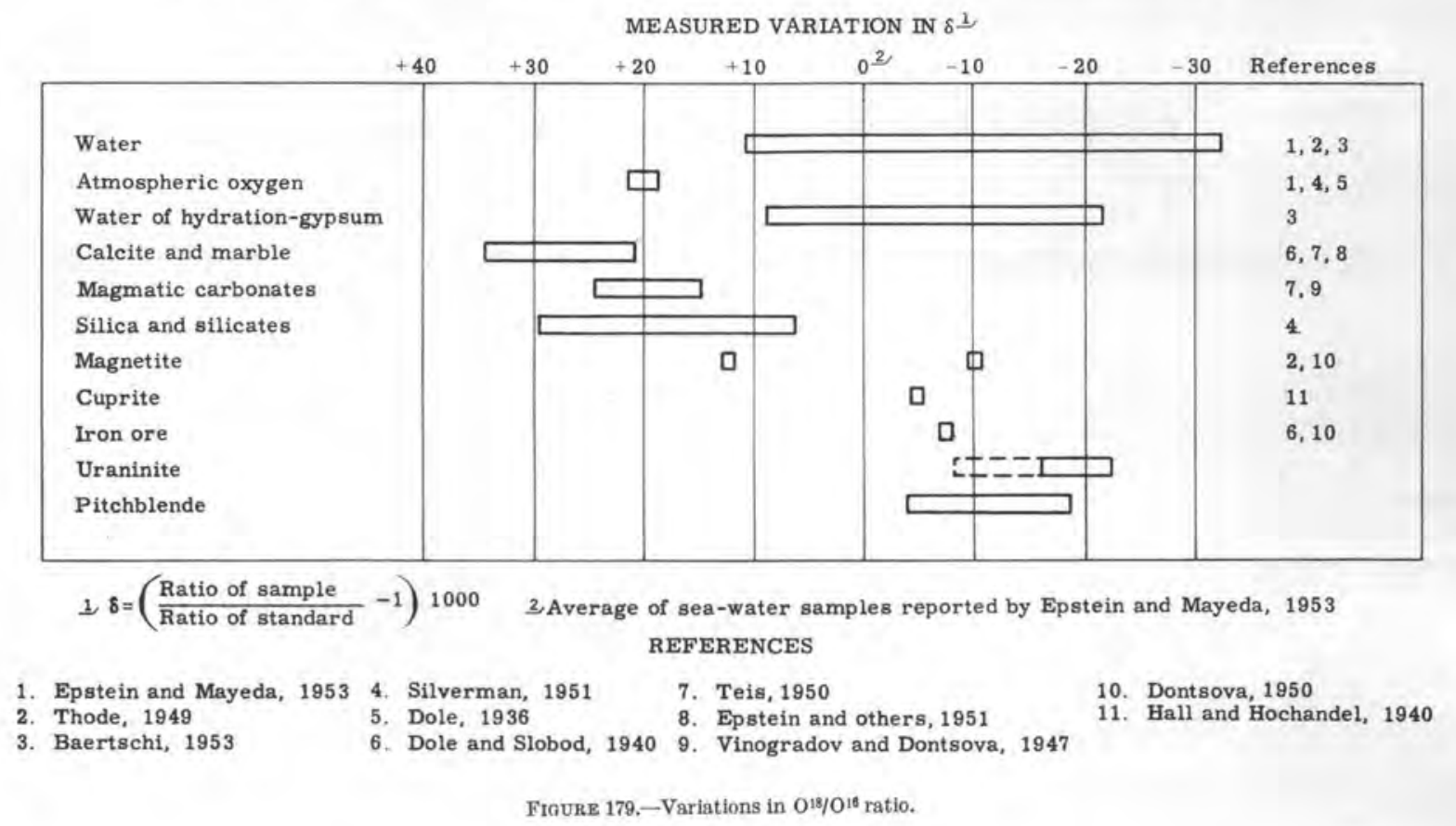

The origin of some uranium deposits has been the subject of considerable controversy, and interpretation of their history would be aided by use of an isotopic thermometer scale, similar to that developed by $\mathrm{H}$. C. Urey and his coworkers (Epstein, and others, 1951) for the carbonate-water system, would be particularly useful. It was realized at the outset that an isotopic temperature scale for uranium ores would, at best, be an approximation. As has been shown (Urey, 1947), isotopic fractionation effects decrease as temperature increases. Because most uranium deposits are formed at high temperatures, little fractionation should be expected. However, it should be possible to distinguish between deposits formed at several hundred degrees and those formed at ambient temperatures.

\section{GENERAL CONSIDERATIONS}

In measuring variations in oxygen isotope ratios of uraninites and pitchblendes, several factors must be considered relative to the significance of measurements:

1. Exchange of uranium oxides with water.-The rate of exchange as a function of temperature for the reaction-

$$
\mathrm{UO}_{\mathbf{x}}{ }^{16}+\mathrm{xH}_{2} \mathrm{O}^{18} \rightleftharpoons \mathrm{UO}_{\mathrm{x}}{ }^{18}+\mathrm{xH}_{2} \mathrm{O}^{16}
$$

should be known. The minimum temperature at which measureable exchange occurs will set an upper limit on a hydrothermal pitchblende temperature scale.

Exchange studies by Katz and Johnson (unpublished) on synthetic uranium oxides indicated that $\mathrm{UO}_{2}$ and $\mathrm{U}_{3} \mathrm{O}_{8}$ did not exchange at a measurable rate below

$200^{\circ} \mathrm{C}$, while $\mathrm{UO}_{3}$ (probably as a result of hydrate formation) exchanges slowly at $25^{\circ} \mathrm{C}$ and rapidly at $100^{\circ} \mathrm{C}$. There was some indication that rate of exchange depends on mode of preparation of the sample, presumably a result of variation in particle size. Some of the results are given in table 1.

TABLE 1.-Exchange experiments with uranium oxides

\begin{tabular}{|c|c|c|c|}
\hline Oxide & $\begin{array}{l}\text { Temper- } \\
\text { ature (in } \\
\text { degrees } \mathrm{C} \text { ) }\end{array}$ & $\begin{array}{l}\text { Time } \\
\text { (in hours) }\end{array}$ & $\begin{array}{c}\text { Fraction } \\
\text { exchanged } \\
\text { (percent) }\end{array}$ \\
\hline $\begin{array}{l}\mathrm{UO}_{2} \\
\mathrm{UO}_{2} \\
\mathrm{UO}_{2} \\
\mathrm{U}_{3} \mathrm{O}_{8} \\
\mathrm{U}_{3} \mathrm{O}_{8} \\
\mathrm{UO}_{3} \\
\mathrm{UO}_{3}\end{array}$ & $\begin{array}{r}290 \\
350 \\
400 \\
360 \\
360 \\
25 \\
100\end{array}$ & $\begin{array}{r}16 \\
3 \\
3 \\
2 \\
2 \\
24 \\
4\end{array}$ & $\begin{array}{r}23.6 \\
36.7 \\
73.2 \\
38.1 \\
57.3 \\
23.6 \\
100\end{array}$ \\
\hline
\end{tabular}

Type of deposit.-If uranium oxides (uraninite and pitchblende) show fractionation of oxygen isotopes during precipitation, the effect should be found to increase in the order of decreasing temperature of formation: uraninite, hydrothermal pitchblende, secondiary pitchblende. Isotopic composition of the medium from which precipitation occurs must also be considered, because this composition serves as a baseline from which fractionation digresses. Uraninite is generally associated with a high percentage of quartz and silicates. These have been shown (Dole, 1936) to concentrate $\mathrm{O}^{18}$; thus, one might expect uraninite to be depleted in the heavier oxygen isotope. 
Hydrothermal pitchblende precipitation should involve principally the uranium dioxide-water equilibrium. As shown in figure 179, water shows the largest variation in $\mathrm{O}^{18} / \mathrm{O}^{16}$ ratio of any of the compounds measured. Table 2 presents analyses of water from different sources and should aid in selection of a baseline for determination of the presence or absence of fractionation effect in the precipitation of uranium oxides.

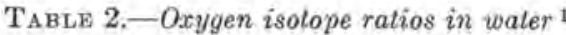

Source

Dead Sea water

Source

Condensate from fumarole (Parícutin) ........

Sea water (average of 20 samples) ...........

Mississippi River (Baton Rouge, La.) .......

Lake Michigan (Chicago, Ill.) .............

Rain . . . .

Snow .............. -15.2 to

Columbia River (Trail, British Columbia) ...

Glacier water (Lake Louise, Alberta).

$$
\begin{array}{r}
{ }^{3} \\
+11.0 \\
+6.8 \\
2.0 \\
-4.9 \\
-6.1 \\
-3.4 \text { to }-10.7 \\
15.2 \text { to }-17.0 \\
-17.5 \\
-32.0
\end{array}
$$

I. Epstein and Mayeda (1953), Thode (1049), Baertschl (1953).

i Standard.

If it is assumed that magmatic, or juvenile, water is the medium from which hydrothermal pitchblendes are precipitated, its isotopic composition is probably most closely approximated by the fumarole condensates. Corroboratory evidence is supplied by S. R. Silverman's (1951) silicate analyses which indicate a $\delta$ of 6.4-7.0 for primary igneous rocks. However, dilution of juvenile water by ground water would cause a change in isotopic composition of the solution, and in the pitchblende precipitated from it. Secondary pitchblende should reflect the composition of the associated ground water.

Sample purity.--Uraninite and pitchblende never are found in a pure state. It is imperative to obtain samples of maximum purity to minimize the fractionation effects of other constituents. Thorium is not considered to be an impurity, because its reactions should, for these purposes, parallel those of uranium. Nor is lead, resulting from radioactive decay, considered as an impurity, since the oxygen associated with the lead was originally part of the uranium oxide crystal lattice. Most of the samples used in our work were obtained through the courtesy of L. R. Stieff and T. W. Stern, of the United States Geological Survey; M. Mathez, of the Raw Materials Office of the Atomic Energy Commission; S. C. Robinson, of the Geological Survey of Canada; and Professor J. W. Gruner, of the University of Minnesota.

Weathering.-Another factor to be considered is the effect of weathering on the uranium ores. As shown by figure 179, atmospheric oxygen is enriched in $\mathrm{O}^{18}$ relative to water oxygen, thus dissolved oxygen in water taking part in weathering of uranium ores will increase the fraction of $\mathrm{O}^{18}$ present in the resulting oxidized ore. The fact that pitchblendes almost invariably have smaller lattice parameters than uraninites, as shown by X-ray crystallography, suggests that oxidation beyond $\mathrm{UO}_{2}$ has taken place. This may have occurred before precipitation as a result of contact with ground water containing dissolved oxygen. Oxidation may also have occurred after precipitation, because uranium oxides crystallized at low temperatures are more readily oxidized than those formed at high temperatures.

\section{EXPERIMENTAL CONSIDERATIONS}

Molecular oxygen was obtained from the uranium oxides by the use of bromine trifluoride. The equation for the reaction is-

$$
\mathrm{UO}_{2}+2 \mathrm{BrF}_{3} \rightarrow \mathrm{UF}_{6}+\mathrm{Br}_{2}+\mathrm{O}_{2} .
$$

Oxygen is easily separated from the other products by condensing them with liquid nitrogen. The equipment and procedure have been described elsewhere (Hall and Hochandel, 1940) and will not be discussed here. Complete oxygen evolution was obtained in 2 hours at $75^{\circ} \mathrm{C}$, except for a few of the least pure ore samples. Twelve runs on two different batches of $\mathrm{U}_{3} \mathrm{O}_{8}$ ignited at $750^{\circ} \mathrm{C}$ in air were made to test the accuracy and precision of the procedure. Oxygen to uranium ratios of $2.66 \pm 0.01$ were obtained.

Isotopic analyses of the oxygen samples as well as all other samples included in this report were made using a high-precision mass spectrometer. By comparing oxygen from an unknown with a standard working sample, the probable error in isotope ratio was found to be about 0.02 percent. The 12 reproducibility runs on oxygen from $\mathrm{U}_{3} \mathrm{O}_{3}$ showed an average deviation in the $\mathrm{O}^{18} / \mathrm{O}^{16}$ ratio of less than \pm 0.1 percent. The average of these 12 results was taken as the composition of atmospheric oxygen $(+22$ percent relative to ocean water).

An attempt has been made to calculate a theoretical fractionation curve for the $\mathrm{UO}_{2}-\mathrm{H}_{2} \mathrm{O}$ system from infrared data. The infrared spectrum of a potassium bromide disk containing 1 pereent $\mathrm{UO}_{2}$ showed a single broad absorption at $425-475 \mathrm{~cm}^{-1}$ near the longwave-length limit of the potassium bromide prism. Measurements on the Raman spectrum have not been run as yet.

Attempts were also made to obtain an experimental $\mathrm{UO}_{2}-\mathrm{H}_{2} \mathrm{O}$ fractionation curve by precipitation of synthetic pitchblende at $25^{\circ}$ and $100^{\circ} \mathrm{C}$. Unfortunately uranium dioxide precipitated at these low temperatures is extremely reactive to oxygen. This fact demands that precipitation, washing, and drying of the sample be carried out in a completely oxygen-free atmosphere, and further, that no opportunity for isotopic fraction- 
ation of the water occur during drying of the sample, because the freshly precipitated oxide will exchange with water at room temperature. Before the dioxide can be safely exposed to air without danger of oxidation, it must first be deactivated by heating to $500^{\circ}-600^{\circ} \mathrm{C}$, in vacuum or in an inert atmosphere. Our synthetic pitchblendes, precipitated as nearly as possible under equilibrium conditions, analyzed $\mathrm{UO}_{2.07}$ to $\mathrm{UO}_{2.12}$, but did not show reproducible isotopic ratios.

\section{DISCUSSION}

A number of observations can be made from the results tabulated in table 3 . 1. In general, uraninites show a smaller $\mathrm{O}^{18}$ content than pitchblendes. Because uraninites form at higher temperatures, this might be considered evidence for isotopic fractionation in the uranium oxide-water system, but the effect can probably be traced to the large amounts of silicates associated with the uraninite. As indicated earlier, concentration of $\mathrm{O}^{18}$ in the quartz and silicates will serve to deplete the supply available for the uraninite. 2. Ore from the Belgian Congo treated with high-pressure steam at the Geophysical Laboratories of the Carnegie Institution of Washington and synthetic pitchblendes prepared by J. W. Gruner (table 3) show $\mathrm{O}^{18}$ contents close to that expected from tap waters from these locations. In general, the least oxidized pitchblendes, show $\mathrm{O}^{18}$ contents quite close to that expected for the ground waters in their immediate vicinity. These observations suggest that exchange rates even at low temperatures are appreciable on a geologic time scale involving millions of years. 3. Impurities may play an important part in the results obtained as indicated by the variation in $\delta$ of tests 3 and 4 , table 3 , and the Beaverlodge district samples (tests $9-12$, table 3). 4. Oxidation, as expected, causes an increase in $\mathrm{O}^{18}$ content. This is best illustrated by the Spruce Pine samples (nos. 16, 17, table 3). The Congo samples (nos. 5, 7, table 3) also show this effect, but differences in purity may play some part.

\section{RESULTS}

TABLE 3.-Isotope ratios in pitchblende and uraninite

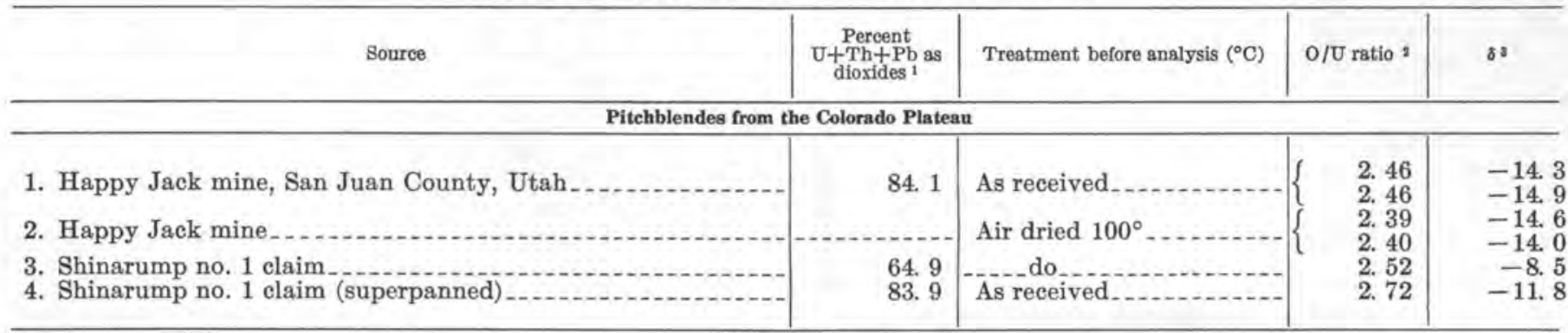

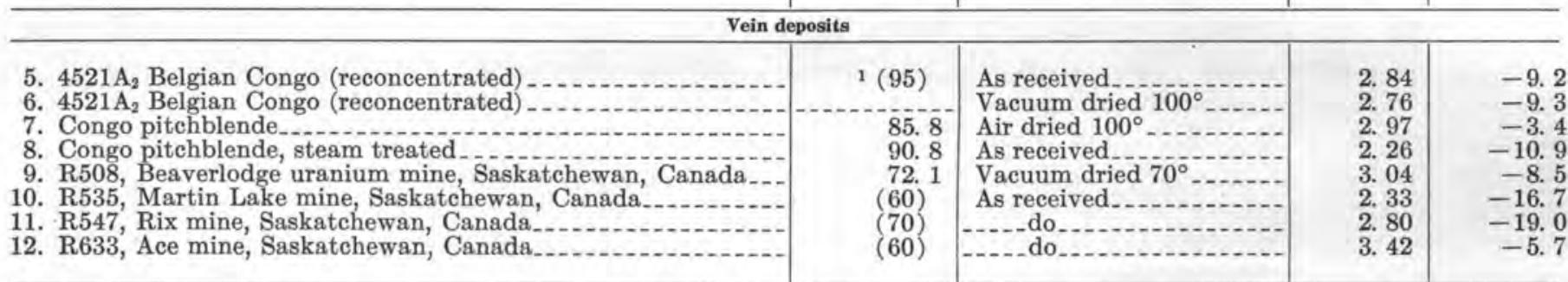

Synthetic pitchblende-J. W. Gruner

13. $217^{\circ} \ldots$

14. $210^{\circ} \ldots$ Pegmatític deposit 15. Karelia, U. S. S. R. (hand-picked sample)
16. Spruce Pine, N. C. (hand-picked, no secondary or coaly ma-
terial).

17. Spruce Pine, N. C. (hand-picked, coaly material)

18. Cardiff T., Ontario (hand-picked separate)

19. Cardiff T., Ontario (methylene iodide separate)

20. Cardiff T., Ontario (selected fragments)

21. Lot 6 , concession XV, Cardiff $T$, $-80+100$ mesh

22. Lot 6 , concession XV, Cardiff T $-100+150$ mesh

23. Lot 6 , eoneession XV Cardiff T $-150+200$ mesh ---2

24. Boqueirao pegmatite, Rio Grande de Norte, Brazil ......

25. Viking Lake, Beaverlodge dist., Saskatchewan, Canada......

1 Values in parentheses are estimates obtained by subtracting impurities reported

in spectrographic analyses.

The O/U ratio is caleulated on the assumption that the sample is pure uranium

Vacuum dried $70^{\circ}$

$(99)$

$\mid$

$(90)$

As received.

2. 33

$-11.1$ $-11.9$

$(9 \overline{3})$ Vacoumo do Vdo do As received. $(90)-10.00$ Vacuum dried $70^{\circ}$ oxide. The ratio is given only as an indication of the true oxidation state of urantur. since oxygen from most oxide impurities is also included.
The $\delta$ 's are given relative to standard sea water (fig. 179). 
In order to check isotopic exchange of pitchblendes and uraninites, a series of tests were made on some of the ore samples listed in table 3 . These were heated to $100^{\circ} \mathrm{C}$ in water which had been slightly enriched in $\mathrm{O}^{18}(\delta=+100)$. The Colorado Plateau samples, from deposits generally conceded to have been formed at relatively low temperatures, showed the greatest exchange rate ( 30 and 20 percent in 4 days). The Spruce Pine sample also showed $\sim 20$ percent exchange in 24 days, which can be attributed to its relatively high oxidation state. The other pegmatitic samples showed relatively little exchange (2-10 percent), most of which occurred during the first day and is probably due to the presence of readily exchangeable impurities. In general, the exchange experiments served to indicate that pitchblendes are in isotopic equilibrium with their present environment, while uraninites, if relatively unweathered, may not be. It should be noted that nearly all of the pegmatitic samples are from regions of relatively cold climate. Because snow has been shown to be low in $\mathrm{O}^{18}$, the observed isotopic ratio in these uraninites may also be due to equilibration with ground water rather than retention of the original low $\mathrm{O}^{18}$ content. Analysis of a number of uraninites from regions where the isotopic ratio of $\mathrm{O}^{18}$ is known to be high should answer this problem.

From the observations cited above, it becomes evident that the measured differences in $\mathrm{O}^{18} / \mathrm{O}^{16}$ ratio of uraninites and pitchblendes are traceable to a number of variables (composition of the precipitating medium, possible exchange subsequent to precipitation, impurities, and weathering) which effectively mask any contribution due to the fractionation factor inherent in the uranium dioxide-water system.

\section{REFERENCES CITED}

Baertschi, P., 1953, The relative difference in $\mathrm{H}_{2} \mathrm{O}^{1 s}$ content of natural waters: Helvetica Chim. Acta, v. 36, p. 1352-1369 (German text).

Dole, Malcolm, 1936, The relative atomic weight of oxygen in water and in air: Jour. Chem. Physics, v, 4, p. 268-275.

Dole, Malcolm, and Slobod, R. L., 1940, Isotopic composition of oxygen in carbonate rocks and iron oxide ores: Am. Chem. Soc. Jour., v. 62 , p. 471-479.

Dontsova, E. I., 1950, Issledovaniye uslovii obrazovaniya nekotorikh mineralov s pomoshchiyu izotopnogo metoda (Investigation by the isotope method of the conditions of formation of some minerals): Akad. nauk SSSR., Doklady, Navaya ser., v. 71, p. 905-906.

Epstein, Samuel, Buchsbaum, Ralph, Lowenstam, H. A., and Urey, H. C., 1951, Carbonate water isotopic temperature scale: Geol. Soc. America Bull., v, 62, p. 417-426.

Epstein, Samuel, and Mayeda, T., 1953, Variation of $\mathrm{O}^{18}$ content of waters from natural sources: Geochim. Cosmochim. Acta, v, 4, p. 213-224.

Hall, W. H., and Hochandel, Clarence, 1940, Isotopic composition of cuprite oxygen: Am. Chem. Soc. Jour, v, 62, p. $3259-3260$.

Hoekstra, H. R., and Katz, J. J., 1953, Direct determination of oxygen in less familiar metal oxides: Anal. Chemistry, v. 25 , p. $1608-1612$.

Silverman, S. R., 1951, The isotope geology of oxygen: Geochim. Cosmochim. Acta, v, 2, p 26-42.

Teis, R. V., 1950, Izotopnii sostav kislovoda karbonatov i yevo temperaturniye izmeneniya (Isotopic composition of the oxygen of carbonates and its temperature dependence): Akad. nauk SSSR., Novaya ser., v. 72, p. 73-76.

Thode, H. G., 1949, Variations in abundances of isotopes in nature: Research (London), v. 2, p. 154-161.

Urey, H. C., 1947, Thermodynamic properties of isotopic substances: Chem. Soc. Jour. (London), p. 562-581.

Vinogradov, A. P., and Dontsova, E. I., 1947 (Isotopic composition of the oxygen of some minerals): Akado nauk SSSR, v. 56, p. 391-392. 


\title{
INTERPRETATION OF THE DISCORDANT AGE SEQUENGE OF URANIUM ORES
}

\author{
By Lorin R. Stieff and Thomas W. Stern, U. S. Geological Survey
}

\section{CONTENTS}

\begin{tabular}{|c|c|c|}
\hline \multicolumn{3}{|c|}{ Page } \\
\hline Abstract ... & 549 & $\mathrm{~Pb}^{207} / \mathrm{Pb}^{200}$ ages $\ldots . . . . .$. \\
\hline Introduction... & 549 & Original radiogenic lead. \\
\hline Loss of radioactive daughter products. & 550 & The $\mathrm{Pb}^{206} / \mathrm{U}^{238}$ age ..... \\
\hline 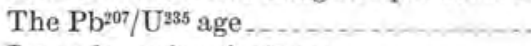 & 551 & Conclusions........ \\
\hline Loss of uranium isotopes. & 551 & 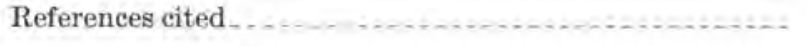 \\
\hline Loss of lead isotopes.. & 552 & \\
\hline
\end{tabular}

Page

\section{ILLUSTRATION}

Frgure 180. Some factors affecting age calculations.

\section{ABSTRACT}

Several recent reports on the calculated ages of uranium ores have consistently shown the following discordant age sequence: The $\mathrm{Pb}^{206} / \mathrm{U}^{238}$ age is less than the $\mathrm{Pb}^{207} / \mathrm{U}^{235}$ which is much less than the $\mathrm{Pb}^{207} / \mathrm{Pb}^{206}$. Five hypotheses have been proposed to explain these discrepancies: the loss of radon, loss of lead or uranium, presence of original radiogenetic lead, and reworking of uranium deposits or multiple periods of deposition or both. The choice of one of these hypotheses will determine which of the three ages is believed to approximate most nearly the "true age" of the ore.

None of these five hypotheses has been satisfactorily established by detailed mineralogic or isotopic studies nor have the ehosen ages been confirmed by stratigraphic or paleontologic evidence. Agreement between the calculated $\mathrm{Pb}^{206} / \mathrm{Pb}^{210}$ and $\mathrm{Pb}^{206} / \mathrm{U}^{238}$ ages of uranium ores with much higher calculated $\mathrm{Pb}^{207} / \mathrm{Pb}^{206}$ ages strongly suggests that radon loss is not the major reason for the discrepancies. Loss of lead can not account for $\mathrm{Pb}^{207} / \mathrm{Pb}^{206}$ ages being appreciably more than stratigraphers' "best" estimates of the age of the uranium ores or the enclosing rocks. Some investigators believe that the presence of original radiogenic lead does not account for the observed differences in the radiogenic lead content of the galena within uraninite specimens and free galena, both from the same deposits.

One of the most important problems at the present time in determining the age of uranium ores is to recognize the geologic process or processes that result in the $\mathrm{Pb}^{206} / \mathrm{U}^{238}<\mathrm{Pb}^{207} / \mathrm{U}^{235} \ll$ $\mathrm{Pb}^{207} / \mathrm{Pb}^{206}$ age sequence. Until this problem has been clarified, caution should be used in assuming the cause of the discrepancy and in selecting one age from the sequence when the necessary geologic, mineralogic, and analytical data are not available.

\section{INTRODUCTION}

During the past few years several workers have used the calculated lead:uranium and lead:lead ratio ages as geologic tools in the study of uranium ore deposits and in the study of other metal deposits that contain sufficient uranium for age determinations. These workers include Bain (1952), Kerr and Kulp (1952), Davidson (1953), Stieff, Stern, and Milkey (1953), Collins, Farquhar, and Russell (1954), Louw (1955), Louw and Strelow (1955), Robinson (1955), and Eckelmann and Kulp (1956). Many of the age determinations of uranium ores reported by these workers and by Nier (1939; Nier, Thompson, and Murphey, 1941) showed significant differences between the lead:uranium ratio ages and the lead:lead ratio age; the $\mathrm{Pb}^{206} / \mathrm{U}^{238}$ age being the youngest, the $\mathrm{Pb}^{207} / \mathrm{U}^{235}$ age being slightly older than the $\mathrm{Pb}^{206} / \mathrm{U}^{238}$ age, and the $\mathrm{Pb}^{207} / \mathrm{Pb}^{206}$ age being much older than either of the lead:uranium ratio ages. These reported ages can be used to show that the discrepancies in age as determined by lead:uranium and lead:lead ratio methods are not necessarily related to the following: (1) age of the sample; (2) the correction for original common lead as indicated by the percent of $\mathrm{Pb}^{204}$ in the isotopic analysis of the lead extracted from the radioactive ore; (3) the analyst; (4) the environment of the uranium ore; and (5) the grade of the uranium ore.

When widely different ages have been determined for a uranium ore, the investigations already mentioned here, and Holmes (1945), Wickman (1942), and Kuroda (1955), have attributed the discrepancies to one or more of the following causes: (1) variations in the $\mathrm{U}^{236} / \mathrm{U}^{235}$ abundance ratio; (2) selective loss of radon or other radioactive daughter products; (3) loss of lead or uranium or both by alteration; (4) deposition of original 
radiogenic lead; that is, radiogenic lead that had formed before the deposition of the uranium ore and that was deposited with the uranium; and (5) analytical errors, both chemical and instrumental.

In this report, explanations that have been advanced for the $\mathrm{Pb}^{206} / \mathrm{U}^{238}<\mathrm{Pb}^{207} / \mathrm{U}^{235}$ which is much less than $(\ll)$ the $\mathrm{Pb}^{207} / \mathrm{Pb}^{206}$ age sequence of uranium ores will be briefly discussed and our evaluation of the choice of a "true age" from the sequence based on these explanations will be made. The geologic consequence of this selection of "true age" may be far-reaching both in terms of the proposed origin of the uranium deposit and in terms of the possible controls that could have operated to localize the ore at a particular time. It is, therefore, important to determine whether the age discrepancies observed in uranium ores are due to variations in the half-lives used in calculations, to analytical errors, to geologic processes of alteration and diffusion, or to the presence of at least two generations of radiogenic lead.

\section{LOSS OF RADIOACTIVE DAUGHTER PRODUCTS}

Nier, in the first paper on isotopic age determination (1939, p. 153-163), reported a difference between the lead:uranium and lead:lead ratio ages and briefly suggested that this might be due to "a partial loss of the intermediate products of the uranium series." Three years later Wickman (1942, p. 465-476) in interpreting Nier's discrepancies in age for Swedish kolm and several other samples proposed a quantitative explanation for the discordant sequence: the relatively greater diffusion of radon $\left(\mathrm{Rn}^{222}\right)$ than of actinon $\left(\mathrm{Rn}^{219}\right)$, both gaseous daughter products in the $\mathrm{U}^{238}$ and $\mathrm{U}^{235}$ series, respectively. His explanation was based on the fact that radon has a half-life of 3.82 days and actinon a half-life of 3.9 seconds; that is, radon has 84,000 times as long for diffusion to take place as does actinon. Since loss of radon ultimately results in the loss of $\mathrm{Pb}^{206}$, the relatively greater diffusion of radon compared to actinon causes the $\mathrm{Pb}^{208} / \mathrm{U}^{238}$ age to be lower than the true age, and the $\mathrm{Pb}^{207} / \mathrm{Pb}^{206}$ age is much higher than the true age which is closely approximated by the $\mathrm{Pb}^{207} / \mathrm{U}^{235}$ age.

A graphical treatment of the "radon diffusion age" for a sample having a hypothetical age of one billion years $\left(10^{\circ}\right)$ is shown in figure $180 \mathrm{~A}$. A 25-percent loss of radon in this sample results in a $\mathrm{Pb}^{208} / \mathrm{U}^{238}$ age of approximately 800 million years. The increase in the $\mathrm{Pb}^{207} / \mathrm{Pb}^{206}$ age to 1,570 million years is a result of the extreme sensitivity of this method of calculation to relatively small changes in the amounts of either $\mathrm{Pb}^{207}$ or $\mathrm{Pb}^{206}$ present. As the graph shows, determinations of the true age of uranium ores are not subject to error due to loss of radon when the $\mathrm{Pb}^{207} / \mathrm{U}^{235}$ age is calculated.

(It is assumed in figure $180 \mathrm{~A}$ that errors due to other causes are negligible.)

Recently Kuroda (1955) proposed an alternative explanation for the discrepancies between the lead:uranium and lead:lead ratio ages based on his studies of the $\mathrm{Ra}^{223} / \mathrm{Ra}^{226}$ activity ratios. His study of about 30 samples of uranium ore has shown that the $\mathrm{Ra}^{223} / \mathrm{Ra}^{226}$ activity ratios are variable and usually larger than the presently accepted activity ratio for $\mathrm{U}^{235} / \mathrm{U}^{238}$ of 0.046 determined by Nier (1939). (If the daughter products are in radioactive equilibrium and the isotopic abundances of $\mathrm{U}^{225}$ and $\mathrm{U}^{238}$ are constant, the activity ratios of the daughter products and their parents should be the same.) Using his own data, Kuroda was able, with many samples, to reduce greatly or to eliminate the discrepancy between the lead:uranium and lead:lead ratio ages.

Kuroda interprets his generally higher $\mathrm{Ra}^{223} / \mathrm{Ra}^{220}$ activity ratios as evidence of enrichment of $\mathrm{U}^{235}$ produced by the neutron-capture reaction of $\mathrm{U}^{238}$ by alpha disintegration. He concludes that the enrichment of $\mathrm{U}^{235}$ of the carnotite ores of the Colorado Plateau took

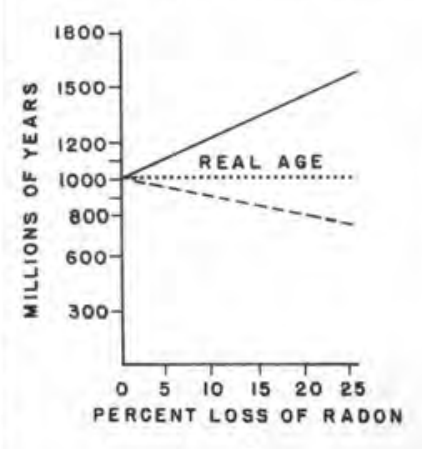

A

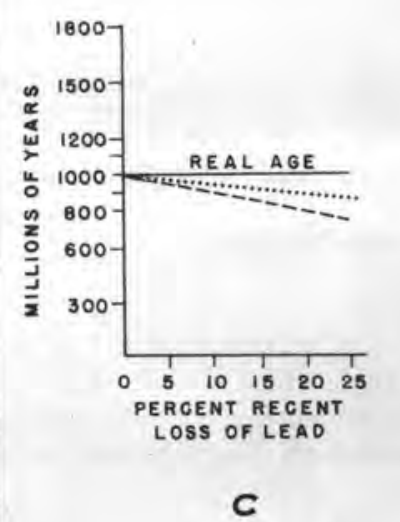

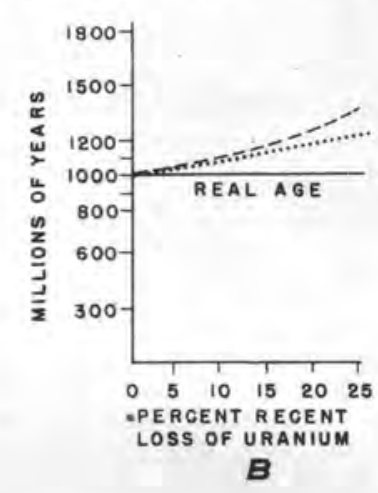

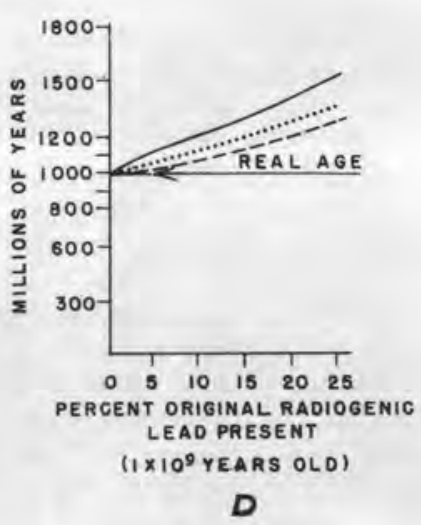

$D$
EXPLANATION

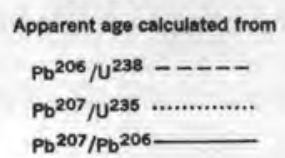

Figure 180.-Graphs showing four factors affeeting age calculations. 
place before the ore formed. However, isotopic analyses made by the Mass Assay Laboratory, Oak Ridge, Tenn., of uranium extracted from Colorado Plateau ores, and analyses of other ores by Kuroda have not shown a variation greater than 1 percent in the $\mathrm{U}^{238} / \mathrm{U}^{235}$ abundance ratio. Kuroda's results must, for the present at least, remain unexplained. Enrichment of the daughter products of $\mathrm{U}^{225}$, however, would introduce smaller errors in the $\mathrm{Pb}^{207} / \mathrm{U}^{235}$ age than in the $\mathrm{Pb}^{207} / \mathrm{Pb}^{206}$ age.

\section{THE $\mathrm{PB}^{207} / \mathrm{U}^{235}$ AGE}

In their recent paper, Kulp, Bate, and Broecker (1954) state a strong preference for the $\mathrm{Pb}^{207} / \mathrm{U}^{235}$ age because it is unaffected by radon loss. They say that the $\mathrm{Pb}^{208} / \mathrm{U}^{238}<\mathrm{Pb}^{207} / \mathrm{U}^{235} \ll \mathrm{Pb}^{207} / \mathrm{Pb}^{206}$ age sequence could be explained by (1) radon leakage, (2) an uncertainty of the half-life of $\mathrm{U}^{235}$, and (3) neutron capture of $\mathrm{Pb}^{206}$, but conclude that radon leakage is the primary cause of the discrepancies. This conclusion was based in part on their own studies of the measured leakage of radon at room temperature and their observations that the rate of leakage increased as the temperature increased.

These writers think that the effects of systematic mass-spectrometer errors and errors resulting from failure to make the exact corrections for the isotopic composition of the original common lead in the sample will produce relatively small errors in the lead:uranium and lead:lead ratio age determinations. They do not consider correction for the presence of original radiogenic lead. We have found that these three factors introduce larger errors in the $\mathrm{Pb}^{207} / \mathrm{U}^{235}$ age than in the $\mathrm{Pb}^{206} / \mathrm{U}^{238}$ age.

The effects of leaching and alteration of uranium ore are, in the opinion of Kulp, Bate, and Broecker, mostly limited to the loss of uranium rather than lead. They support this opinion by citing the recent work by Phair and Levine (1953), which has shown that leaching in and around pyritic uranium ore affects uranium so much more than lead that it is impossible to lower the $\mathrm{Pb}^{206} / \mathrm{U}^{238}$ age by leaching with $\mathrm{H}_{2} \mathrm{SO}_{4}$.

The preference of Kulp and his coworkers (p. 357) for the $\mathrm{Pb}^{207} / \mathrm{U}^{235}$ age was apparently based on the opinion that radon loss is significant and that "**** since uranium minerals seldom show evidence of even 5 percent leaching, this does not seem to be an important factor." The published analyses (Nier, 1939; Nier, Thompson, and Murphey, 1941; Ellsworth, 1932; Kovarik, 1931) contain, however, a sequence of ages that can best be explained by the loss of uranium considerably in excess of 5 percent. Unless great care is taken in the selection of wholly fresh, externally unaltered uranium ores for analysis, it is our opinion that loss of uranium may be a possible source of significant errors.

It is emphasized that those who prefer the "radon diffusion age" assume that the $\mathrm{Pb}^{207} / \mathrm{U}^{235}$ age is the most reliable and that errors due to mass-spectrometer analyses, to the presence of original common and original radiogenic lead, and to the possible loss of lead or uranium by alteration - are negligible. The mathematical manipulations required to produce agreement of the two lead:uranium ratio ages and the lead:lead ratio age by restoring the amount of $\mathrm{Pb}^{208}$ equivalent to the assumed radon loss in no way improves the reliability of the $\mathrm{Pb}^{207} / \mathrm{U}^{235}$ age, and the agreement in ages does not establish the fact that radon loss has occurred.

The most convincing argument against radon loss as the most important process producing the observed discrepancies between the $\mathrm{Pb}^{207} / \mathrm{U}^{238}$ and $\mathrm{Pb}^{207} / \mathrm{Pb}^{206}$ ages is the agreement of $\mathrm{Pb}^{208} / \mathrm{Pb}^{210}$ and $\mathrm{Pb}^{208} / \mathrm{U}^{238}$ ages for massive unaltered uranium ores. The presence of $\mathrm{Pb}^{210}$ in radioactive equilibrium with $\mathrm{U}^{238}$ indicates that radon loss is not now and presumably has not been large. Also, at the present time there is no other evidence, such as abnormal concentrations of only $\mathrm{Pb}^{206}$, that the largescale diffusion of radon from uranium ores during most of their history has been a significant geologic process. As Collins, Farquhar, and Russell $(1954$, p. 20$)$ have observed, "Other arguments must be considered in order to establish the most probable age for a mineral from considerations of the experimental data without any adjustment of that data."

\section{LOSS OF URANIUM ISOTOPES}

Collins, Farquhar, and Russell (1954) have recently published about a hundred $\mathrm{Pb}^{207} / \mathrm{Pb}^{206}$ age determinations. Their preference for the lead:lead ratio age follows the original suggestion of Nier that the isotopic composition of the lead in a uranium ore would be practically unaffected by recent loss of lead or uranium or both by alteration and weathering. The effects on the lead:uranium ratio and lead:lead ratio determinations of a recent loss of as much as 25 percent of the uranium are shown in figure $180 \mathrm{~B}$. As can be seen, the $\mathrm{Pb}^{207} / \mathrm{Pb}^{200}$ age is unaffected. Loss of uranium during even most of the life of the specimen results in smaller errors in the $\mathrm{Pb}^{207} / \mathrm{Pb}^{206}$ age than for the lead: uranium ratio ages (Holmes, 1945), which are affected enough to cause the reverse sequence, so that it becomes $\mathrm{Pb}^{206} / \mathrm{U}^{238}>\mathrm{Pb}^{207} / \mathrm{U}^{235} \gg \mathrm{Pb}^{207} / \mathrm{Pb}^{206}$.

Because of the inadequacy or the complete omission of the descriptions of the samples, it is generally difficult, if not impossible, to determine why published lead: uranium ratio ages are much greater than lead:lead 
ratio ages. One exception, the yellow ore from Katanga analyzed by Nier $(1939$, p. 159$)$ has been stated to be an alteration product of the approximately 600 -millionyear-old unaltered pitchblende ores. The $\mathrm{Pb}^{206} / \mathrm{U}^{238}$, $\mathrm{Pb}^{207} / \mathrm{U}^{235}$, and $\mathrm{Pb}^{207} / \mathrm{Pb}^{206}$ ages for the yellow Kantanga ore are 973 million, 858 million, and 635 million years, respectively. This sequence of ages is precisely the sequence that is predicted on purely theoretical grounds. It is reasonable to assume that loss of uranium will result in a similar sequence of ages for the rest of the samples whose state of oxidation and freedom from alteration are not known.

It would unquestionably be desirable to make age determinations only of completely fresh, unaltered uranium ores. Unfortunately the geologist seldom has such excellent material for study, and he is forced to use the best material that is available. The problem of interpreting and evaluating the results, however, would be greatly simplified if there were included along with calculated isotopic ages, an adequate description of the uranium ore sample, including its geologic setting, associated minerals, an estimate of the degree of alteration, its specific gravity, and - for pitchblende or uraninite - the size of the unit cell as determined from X-ray diffraction studies.

\section{LOSS OF LEAD ISOTOPES}

The effects on the lead:uranium ratio and lead:lead ratio ages of a recent loss of as much as 25 percent of the radiogenic lead produced are shown in figure $180 \mathrm{C}$. As can be seen, the $\mathrm{Pb}^{207} / \mathrm{Pb}^{206}$ age is unaffected. Even the loss of lead during most of the life of the specimen results in smaller errors for the $\mathrm{Pb}^{207} / \mathrm{Pb}^{206}$ age than for the lead:uranium ratio ages (Holmes, 1948, p. 121).

Loss of lead results in a sequence of ages similar to that produced by the loss of radon. It is possible to bring the lead:uranium ratio ages into agreement with the lead:lead ratio ages by restoring the lead assumed to have been lost. If there is loss of lead, however, the $\mathrm{Pb}^{207} / \mathrm{Pb}^{206}$ age is considered to be the most nearly correct, rather than the $\mathrm{Pb}^{207} / \mathrm{U}^{235}$ age, which is preferred if radon loss is considered to be the significant process. In the evaluation of age determinations, it is important to recognize that analytical errors in the quantitative determination of uranium and lead can produce age patterns indistinguishable from those produced by geologic processes resulting in the loss of lead or uranium.

\section{THE $\mathbf{P b}^{207} / \mathbf{P b}^{200}$ AGE}

The $\mathrm{Pb}^{207} / \mathrm{Pb}^{206}$ method of age calculations is almost free from the effects of recent loss of either uranium or lead due to alteration. Also, this method does not require quantitative chemical analysis of either lead or uranium. The lead:lead ratio age determination is not, however, without its serious limitations. Figure $180 A$ and $D$ show the considerable changes in the $\mathrm{Pb}^{207} / \mathrm{Pb}^{206}$ age that accompany even small changes in the relative amounts of radiogenic $\mathrm{Pb}^{206}$ or $\mathrm{Pb}^{207}$ used in this age calculation. This method of age calculation becomes increasingly sensitive to small errors with younger samples. Unless great care is taken, the $\mathrm{Pb}^{207} / \mathrm{Pb}^{206}$ age of uranium ores younger than 200 million years may be almost meaningless.

The sources of error in the $\mathrm{Pb}^{207} / \mathrm{Pb}^{206}$ method of age calculation may lie in: (1) mass spectrometer analysis; (2) assumptions concerning the isotopic composition of the original lead, both common and radiogenic; (3) loss or diffusion of radon or other daughter products; and (4) uncertainties about the disintegration constants.

Although the mass spectrometer errors can be significant, it seems unlikely that these could account for most of the discrepancy between the lead:lead ratio and lead:uranium ratio ages. It should be notad, however, that most if not all, of the mass spectrometer errors result in $\mathrm{Pb}^{207}$ abundances that are too high and greater increase in the lead:lead ratio ages than in the lead:uranium ratio ages.

Like the errors of mass analyses, any error in the disintegration constants used in the age calculations will also result in greater errors in the lead:lead ratio age than in the lead:uranium ratio ages.

To avoid some of the difficul ties resulting from corrections for the original common lead, Collins and his coworkers (1954) have published lead:lead ratio ages only of samples that contain extremely small amounts of $\mathrm{Pb}^{204}$ (the nonradiogenic index of common lead) and that were assumed to contain no original radiogenic lead. This latter condition, however, is not explicitly stated. We have found that the low $\mathrm{Pb}^{204}$ content unfortunately cannot be used as a guide to the amount of original radiogenic lead deposited with the sample. The presence of original radiogenic lead may be inferred from an isotopic study of the associated lead minerals and from the lack of agreement between the $\mathrm{Pb}^{207} j \mathrm{~Pb}^{206}$ ages of a suite of unaltered uranium ore samples from the same mine.

The $\mathrm{Pb}^{207} / \mathrm{Pb}^{206}$ method, when used alone, should be limited, therefore, to uranium ores that are uncontaminated by original lead, either common or radiogenic. This condition eliminates the large number of uranium ores that contain significant amounts of both original common lead and radiogenic lead and that otherwise would be perfectly satisfactory for age studies.

Collins and coworkers (1954) have attempted to establish the greater reliability of the $\mathrm{Pb}^{207} / \mathrm{Pb}^{206}$ age, not only on the basis of the improbability of radon loss but also by analysis of the age sequence for a uraninite 
specimen and a monazite specimen, both collected from Huron claim, Manitoba. The $\mathrm{Pb}^{207} / \mathrm{Pb}^{206}$ ages as originally reported by Nier were in agreement with each other within 100 million years. Collins has modified Nier's data to bring the lead:uranium ratio ages and lead:lead ratio ages into agreement, assuming a loss of 42.1 percent of the radiogenic lead present in the uraninite and a loss of 22.1 percent of the uranium present in the monazite. The interpretation of the $\mathrm{Pb}^{206} / \mathrm{U}^{238}>$ $\mathrm{Pb}^{207} / \mathrm{U}^{235} \gg \mathrm{Pb}^{207} / \mathrm{Pb}^{206}$ age sequence for the monazite as a result of loss of uranium seems to be reasonable. As has been mentioned (Kulp, Bate, and Broecker, 1954; Phair and Levine, 1953), the interpretation of the $\mathrm{Pb}^{206} / \mathrm{U}^{238}<\mathrm{Pb}^{207} / \mathrm{U}^{225} \ll \mathrm{Pb}^{207} / \mathrm{Pb}^{206}$ age sequence for the uraninite as a result of loss of 42.1 percent lead secms to be less satisfactory.

In summary, it should be noted that, with the exception of analytical errors in the determination of lead or uranium and the loss of lead or uranium by geologic processes, the remaining sources of error tend to introduce greater uncertainties in the lead: lead ratio ages than in the lead: uranium ratio ages. Collins, however, has emphasized the approximate agreement in the $\mathrm{Pb}^{207} / \mathrm{Pb}^{208}$ ages of the two uraninite and monazite samples (2,468 million years and 2,590 million years, respectively), and observed that, in view of the discrepancies in the lead:uranium ratio and lead:lead ratio ages, the $\mathrm{Pb}^{207} / \mathrm{Pb}^{206}$ ages were the most reliable. He concluded (1954, p. 20):

"The original findings of Nier (1939, p. 162) and of Nier, Thompson, and Murphey (1941) that ages from the $\mathrm{Pb}^{207} / \mathrm{Pb}^{206}$ ratio are usually close to the true age of the mineral, even when that mineral had been subjected to alteration and loss of lead or uranium, is still the most important experimental evidence we have."

\section{ORIGINAL RADIOGENIC LEAD}

In 1931 (p. 74) Kovarik wrote:

"If we assume that besides common lead, we have also radium $\mathrm{G}\left[\mathrm{Pb}^{206}\right]$, thorium $\mathrm{D}\left[\mathrm{Pb}^{208}\right]$, and actinium $\mathrm{D}$ $\left[\mathrm{Pb}^{207}\right]$ in separate quantities so that at time, $t=0$, the atomic weight of the lead isotopes is different from 207.20 (common lead) or different from zero (no common lead: a possibility) then we shall have more unknown quantities than equations connecting them and the problem becomes insolvable unless we have many minerals of varied contents but of the same geological age."

Following Kovarik's suggestion, investigators generally define original common lead as the $\mathrm{Pb}^{204}, \mathrm{~Pb}^{206}$, $\mathrm{Pb}^{207}$, and $\mathrm{Pb}^{208}$ present and precipitated with the uranium and thorium at the time of formation $(t=0)$ of the radioactive ore. The percent abundance of these four isotopes has considerable range but the maximum should not exceed that reported for lead in lead ore deposits or in igneous rocks with average concentrations of lead, uranium, and thorium.

Original radiogenic lead is here defined as the $\mathrm{Pb}^{206}$, $\mathrm{Pb}^{207}$, and $\mathrm{Pb}^{208}$ of radiogenic origin that was present and was precipitated with the uranium and thorium at the time of formation of the radioactive ore, $t=0$. The amount of radiogenic $\mathrm{Pb}^{206}, \mathrm{~Pb}^{207}$, and $\mathrm{Pb}^{208}$, and the $\mathrm{Pb}^{207} / \mathrm{Pb}^{206}$ ratio of the original radiogenic lead will depend, in part, on the age of the source material, the relative concentration of lead, uranium, and thorium, in the source material, and the chemical environment at the time of transportation and deposition.

Although the suggestions of Kovarik-that the presence of original radiogenic lead could considerably complicate the problem of age determinations-preceded the work of Nier, Wickman, Kulp, and Collins, current investigators apparently have not considered this correction in analyzing the discrepancy between the lead:uranium ratio and lead:lead ratio ages. The presence of original radiogenic lead in a uranium ore would also result in the $\mathrm{Pb}^{206} / \mathrm{U}^{238}<\mathrm{Pb}^{207} / \mathrm{U}^{235} \ll \mathrm{Pb}^{207} /$ $\mathrm{Pb}^{206}$ age sequence, and (see fig. $180 D$ ) the $\mathrm{Pb}^{206} / \mathrm{U}^{238}$ age, rather than the $\mathrm{Pb}^{207} / \mathrm{U}^{235}$ or $\mathrm{Pb}^{207} / \mathrm{Pb}^{206}$ ages, would most nearly represent the true age of the sample. Neither Kulp nor Collins agrees with this choice.

As Kovarik implied, the problem of correcting for the presence of original radiogenic lead is not an easy one; and, as he suggested, it can be resolved if there are isotopic analyses of many minerals of varied uranium or thorium content from the same locality and same period of deposition. We (1954) have made graphical analyses of many Colorado Plateau uranium ores and lead minerals from the same mine. These unpublished analyses show that it is possible to obtain agreement between the lead:uranium ratio and the lead:lead ratio ages without correcting for loss of either radon or lead. Of equal importance, the required isotopic composition of the original common lead plus the older generation of radiogenic lead used to bring the $\mathrm{Pb}^{207} / \mathrm{Pb}^{206}$ ages of mill-pulp samples into agreement with the lead:uranium ratio ages of unaltered uraninite specimens from the same mine actually falls within the limits of the experimentally determined isotopic composition of the galena from the mine. We are preparing for publication a detailed discussion of corrections for original radiogenic lead.

THE $\mathrm{Pb}^{206} / \mathrm{U}^{238}$ AGE

To Nier's experimental evidence that the $\mathrm{Pb}^{207} / \mathrm{Pb}^{206}$ ratios are least affected by loss of lead and uranium may now be added the experimental evidence that certain uranium-rich provinces contain an older type of radiogenic lead that does not appear to have been formed by the uranium after its deposition in its present sites; 
that is, the ores contain original radiogenic lead. Failure to correct for original radiogenic lead results in $\mathrm{Pb}^{207} / \mathrm{U}^{235}$ ages slightly greater than the $\mathrm{Pb}^{206} / \mathrm{U}^{238}$ ages, and in $\mathrm{Pb}^{207} / \mathrm{Pb}^{206}$ ages considerably greater than the $\mathrm{Pb}^{207} / \mathrm{U}^{235}$ ages. Although a little high, the uncorrected $\mathrm{Pb}^{206} / \mathrm{U}^{238}$ age most nearly approximates the actual age of the sample (fig. $180 \mathrm{D}$ ).

The most serious limitation of the $\mathrm{Pb}^{206} / \mathrm{U}^{238}$ age, its susceptibility to loss of uranium and possible loss of lead as a result of geologic processes, can be minimized in several ways. In each instance, the primary responsibility for reducing the uncertainty in the calculated ages falls on the geologists who collect and prepare the samples. A suite of radioactive ores and related common-lead-bearing materials, rather than a single ore specimen, should be collected for any age study at a given locality. Unfortunately, the practice of reporting a single age determination is too often followed.

The suite of samples should include the freshest, least-altered uranium ores available, as well as those of the more oxidized, altered ores. If possible, the unaltered ores should differ appreciably in grade. Composite samples have only a limited use in age studies. An exhaustive search should be made for specimens of nonradioactive lead minerals or, failing this, other nonradioactive ore minerals containing at least trace amounts of common lead.

Of prime importance in an age study are the field relations of the samples within the suite to each other and to the deposit from which they have been collected. A satisfactory appraisal of the geologic processes, as expressed in the age discrepancies, can best be made in terms of these field relations and in terms of the geologic history and environment of the area. In geologic literature, data on the age of the radioactive samples and the precise place of collection, accompanied by field descriptions adequate for isotope study, are uncommon.

The careful examination and preparation of samples for age study may also contribute substantially to the reduction of observed lead:uranium ratio and lead:lead ratio age discrepancies. From studies of polished sections it is frequently possible to determine the order in which the uranium and lead minerals were deposited, later periods of deposition of lead and uranium, and the type and extent of alteration. Careful separation and isotopic analysis of the primary and secondary radioactive phases and of the associated lead minerals, if present, will provide further data on the history of deposition and alteration of the sample. Complete mineralogic descriptions of the samples used for age study are as rare in the literature as are full field descriptions of the geologic setting of the samples.

\section{CONCLUSIONS}

The interpretation of the $\mathrm{Pb}^{206} / \mathrm{U}^{238}<\mathrm{Pb}^{207} / \mathrm{U}^{235} \ll$ $\mathrm{Pb}^{207} / \mathrm{Pb}^{206}$ age sequence of uranium ores presents several problems whose solution await detailed studies.

The available data, however, suggest that: (1) the natural variation in the $\mathrm{U}^{238} / \mathrm{U}^{235}$ ratio is less than 1 percent, (2) selective loss of large amounts of radon $\left(\mathrm{Rn}^{222}\right)$ does not occur in massive unaltered uranium ores, (3) recent alteration of pyritic uranium ores results in loss of uranium rather than loss of lead, (4) the $\mathrm{Pb}^{207} /$ $\mathrm{Pb}^{206}$ ratio is least affected by loss of lead or uranium, and (5) lead minerals associated with many uranium ores contain large amounts of radiogenic lead appreciably older than the surrounding uranium ores.

Preference for the $\mathrm{Pb}^{207} / \mathrm{U}^{235}$ "radon diffusion age" for massive unaltered uraninite seems to be diffcult to justify. Similarly, there seem to be serious objections to the selection of the much higher $\mathrm{Pb}^{207} /$ $\mathrm{Pb}^{206}$ age on the assumption of lead loss, particularly from the fresh, unaltered uranium ores. The selection of the $\mathrm{Pb} b^{208} / \mathrm{U}^{238}$ age as the most nearly correct on the basis of the presence of original radiogenic lead is suggested by the experimental data, at least in one area. The $\mathrm{Pb}^{206} / \mathrm{U}^{238}$ age, however, is the most sensitive of the three to losses of lead or uranium. In contrast, the $\mathrm{Pb}^{207} / \mathrm{Pb}^{206}$ ages are almost unaffected by recent loss of lead or uranium, although this age is the most sensitive of the three to the corrections for original lead, uncertainties in the decay constants, and mass spectrometric error.

The most serious limitation of the $\mathrm{Pb}^{206} / \mathrm{U}^{238}$ ages-its susceptibility to loss of uranium and lead-can be minimized by the selection of fresb, unaltered specimens for age study. Additional information about the suitability of the samples for age determinations should be obtained from polished section, semiquantitative spectrographic, specific gravity, and X-ray studies. The analysis of several pairs of uranium ore samples differing in uranium content and analyses of the associated lead minerals from the same ore body may, in favorable cases, establish the corrections for original radiogenic lead.

An independent geologic field method of evaluating the reasonableness of the three ages of a sample $\left(\mathrm{Pb}^{200} /\right.$ $\left.\mathrm{U}^{238} ; \mathrm{Pb}^{207} / \mathrm{U}^{235} ; \mathrm{Pb}^{207} / \mathrm{Pb}^{206}\right)$ is the comparison of these ages with the relative ages of the geologic events which preceded, which were contemporary with, and which followed ore deposition. $\mathrm{A} \mathrm{Pb}^{207} / \mathrm{Pb}^{206}$ age several times greater than the approximate age of the enclosing rocks is questionable. The analysis of extremely old samples for comparative age studies is particularly unfortunate because of the relative paucity of information on the sequence of geologic events in Proterozoic time. A choice of samples of Cambrian age or younger for such 
studies permits the great bulk of corroborative, geologic field data to be used. Studies of suites of geologically young samples are now being undertaken to provide better understanding of the discordant lead: uranium ratio and lead:lead ratio age sequences. Also the careful investigation of relatively young uranium ores offers a particularly fruitful approach to some of the geologic processes of alteration and weathering.

Before a valid choice can be made of one ratio for age calculation in preference to the remaining two, the geologic field and laboratory evidence for the process or processes producing the age discrepancies must be found. The conclusion that one age from the $\mathrm{Pb}^{206} /$ $\mathrm{U}^{238}<\mathrm{Pb}^{207} / \mathrm{U}^{235} \ll \mathrm{Pb}^{207} / \mathrm{Pb}^{206}$ sequence is preferable to the two remaining ages and that one geologic process is operative everywhere, without regard for the geologic history and environment of a particular sample, can only result in discrediting all methods of determination in general and in hopelessly confusing the young science of isotopic age measurements.

\section{REFERENCES CITED}

Bain, G. W., 1952, The age of the "lower Cretaceous" from Bisbee, Arizona, uraninite: Econ. Geology, v. 47, p. 305-315.

Collins, C. B., Farquhar, R. M., and Russell, R. D., 1954, Isotopic constitution of radiogenic leads and the measurement of geologic time: Geol. Soc. America Bull., v. 65, p. 1-21.

Davidson, C. F., 1953, The gold-uranium ores of the Witwaters-" rand: Mining Mag, v. 88 , p. 73-85.

Eckelmann, W. R., and Kulp, J. L., 1956, uranium-lead method of age determination, part I: Lake Athabasca problem: Geol, Soc. America Bull., v. 67 , p. 35-54.

Ellsworth, H, V,, 1932, Rare-element minerals of Canada: Canada Geol. Survey, Econ. Geol. ser. no. 11, p. 1-272.

Holmes, Arthur, 1948, Monazite from Bodmin Moor, Cornwall; A study in geochronology: Royal Soc. Edinburgh Proc., v. $63, \mathrm{p}, 121$,
Kerr, P. F., and Kulp, J. L., 1952, Pre-Cambrian uraninite, Sunshine mine, Idaho: Science, v. 115, p. 86-88.

Kovarik, A. F., 1931, in Knopf, Adolph (chairman), Physics of the earth. IV. The age of the earth: Calculating the age of minerals from radioactivity data and principles; Nat. Research Council Bull. 80, p. 73-123.

Kulp, J. L., Bate, G. L., and Broecker, W. S., 1954, Present status of the lead method of age determination: Am. Jour. Sci., 5th ser., v. 252 , p. $345-365$.

Kuroda, P. K., 1955, On the isotopic constitution of radium $\left(\mathrm{Ra}^{223} / \mathrm{Ra}^{226}\right)$ in uranium minerals and recent problems of geochronology: New York Acad. Sei. Annuals, v. 62, art. 8, p. 177-208,

Louw, J. D., 1955, Geological age of Witwatersrand uraninites: Nature, v. 179 , p. $349-350$.

Louw, J. D., and Strelow, F. W. E., 1955, Geological age determinations on Witwatersrand uraninites using the lead isotope method: Geol. Soc. South Africa Trans,, v. 57, p. 209-230.

Nier, A. O., 1939, The isotopic constitution of radiogenic leads and the measurement of geological time. II: Phys, Rev., v. 55 , p. $153-163$.

Nier, A. O., Thompson, R. W, and Murphey, B. F, 1941, The isotopic constitution of lead and the measurement of geological time. III: Phys. Rev., v. 60, p. 112-116.

Phair, George, and Levine, Harry, 1953, Notes on the differential leaching of uranium, radium, and lead from pitchblende in $\mathrm{H}_{2} \mathrm{SO}_{4}$ solutions: Econ. Geology, v. 48, p. 358-369.

Robinson, C. 8., 1955, Mineralogy of uranium deposits, Goldfields, Saskatehewan: Canada Geol. Survey Bull., 31, $128 \mathrm{p}$.

Stieff, L. R., and Stern, T. W., 1954, Original radiogenic lead, an additional correction for lead-uranium and lead-lead age calculations, (abs.): Geol. Soc. America Bull., v. 65, p. 1308.

Stieff, L. R., Stern, T. W., and Milkey, R. G., 1953, A preliminary determination of the age of some uranium ores of the Colorado Plateau by the lead-uranium method: U. S. Geol, Survey Circ, 271, p. 1-19.

Wickman, F. E., 1942, On the emanating power and the measure, ment of geological time: Geol. fören. Stockholm Förh., v.6-4 p. $465-476$. 

NATURAL OCCURRENCE OF THORIUM 



\title{
GEOLOGY OF THORIUM DEPOSITS IN THE UNITED STATES
}

\author{
By William S. Twenhofel and Katharine L. Buck, U. S. Geological Survey
}

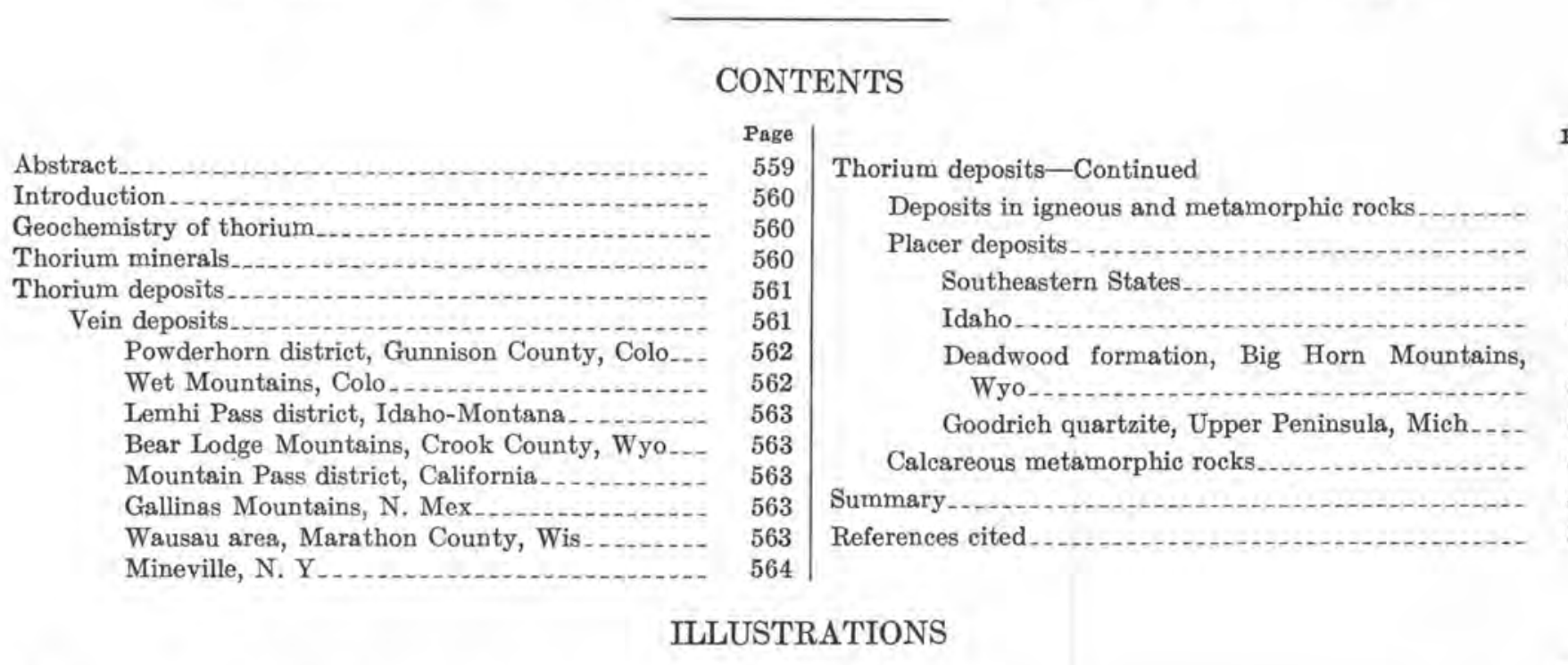

Frgure 181. Thorium deposits in the United States.

Page

564

564

564

565

565

565

565

565

566

\begin{abstract}
Thorium is a lithophilic and oxyphilic element closely related geochemically to zirconium, uranium, and the rare-earth metals. All its compounds are quadrivalent, and most of them are highly refractory. Available data indicate that many acidic rocks become enriched in thorium during magmatic differentiation.

The principal thorium-bearing minerals are thorite, a thorium silicate, and monazite, a complex phosphate of the rare-earth metals and thorium. Other thorium-containing mineralsbastnaesite, thorogummite, thorianite, euxenite, and fluorapatite -are not now of economic importance ss sources of thorium but are potential sources of byproduct thorium from certain localities.

Thorium minerals are most abundant in igneous rocks, pegmatites, veins, and placers. Placers are by far the most important commercial sources in the United States, although some veins may become important sources in the future. Nearly all the common and important thorium-bearing minerals resist natural decomposition and, hence, are not concentrated by secondary chemical processes. No important concentrations of thorium minerals, other than placers, have yet been found in sedimentary rocks.

Most thorium in vein deposits is associated with barite, ealcite, and rare-earth minerals, such as bastnaesite, rather than with base and precious metals, although lead and zinc minerals are found in some deposits. Thorium-and rare-earth-bearing veins
\end{abstract}

occur in California, Colorado, New Mexico, Montans, Wyoming, and Idaho.

Pegmatites rarely contain appreciable quantities of thorium minerals, and none of those known in the United States contains recoverable amounts of thorium.

Many igneous and metamorphic rocks, particularly biotite-rich granite and granite gneiss, contain monazite. At a few places in the United States, principally in North Carolina, South Carolina, Idaho, southern California, and New England, certain igneous and metamorphic rocks contain appreciable amounts of monazite. Some of these rocks have been the source for monazite-bearing placer deposits commonly occurring in the same terrane.

Pleistocene and Recent placer deposits of monazite-bearing sands and gravels are the source of most of the thorium produced in the United States. Important monazite-bearing placers are known in Idaho and Florida and in a belt extending from southern Virginia to Georgia; in these deposits the monazite has been derived from monazite-rich igneous and metamorphic terranes Other similar placer deposits containing monazite are known in California, Colorado, Oregon, and Washington.

Ancient placer deposits of monazite-bearing sands are known in the Goodrich quartzite of Precambrian age in the Upper Peninsula of Michigan and in the Deadwood formation of Cambrian age in Wyoming. None of these is a present-day source of thorium. 


\section{INTRODUCTION}

Thorium has long been used, in small quantities relative to most other metals, for a variety of industrial purposes. It was first used industrially during the period $1890-1911$ as an essential ingredient of gas mantles; the development and widespread use of the tungsten lamp since that time has largely supplanted the gas mantle and the consequent market for thorium. The manufacture of gas mantles is, however, still the principal use of thorium, although the amount consumed for such use is decreasing. Thorium is used also in tungsten lamp filaments, high-temperature refractories, polishing compounds, vacuum tubes, magnesium alloys, and as a catalyst.

Thorium has a potential use, which cannot yet be evaluated, as a source of fissionable material for the production of nuclear power. The future demands for thorium for the production of atomic energy will be determined by results of current experimentation.

Thorium, unlike uranium, does not have a natural fissionable isotope. However, natural thorium ${ }^{232}$ when bombarded by slow neutrons produces thorium ${ }^{233}$, which disintegrates through protactinium ${ }^{233}$ to uranium $^{233}$, a fissionable isotope.

Much of the data contained in this report was assembled from unpublished reports by our colleagues of the U. S. Geological Survey, whose assistance is gratefully acknowledged.

\section{GEOCHEMISTRY OF THORIUM}

Thorium is not known to occur in elemental form in nature; it occurs, chiefly as a minor constituent, combined with oxygen and other elements to form oxides, silicates, phosphates, carbonates, and fluorides. All thorium compounds are quadrivalent, and most of them are highly refractory to weathering. Thorium is associated with the rare-earth metals, zirconium, hafnium, and uranium.

According to Rankama and Sahama (1950, p. 570), thorium "is conspicuously concentrated in the lithosphere, particularly in the uppermost parts of this geosphere * * * and, hence, is strongly lithophilic.

Thorium is concentrated in felsic igneous rocks during magmatic differentiation, and granitic rocks contain 3-6 times as much thorium as do basaltic rocks (Rankama and Sahama, 1950, and Fleischer and Rabbitt, 1952). In this respect thorium is similar to hafnium, zirconium, the rare-earth metals, and uranium.

Data on the amount of thorium in different rocks are few because of the difficulties of measuring minute amounts of thorium. Published figures are of questionable validity because they were obtained by calculation from measurements of the thoron content and from measurements of radioactivity, assuming radioactive equilibrium. The available data indicate that the thorium content of most igneous rocks is not more than 25 parts per million $\left(25 \times 10^{-6} \mathrm{~g}\right.$ per $\left.\mathrm{g}\right)$, but some igneous rocks contain as much as several hundred parts per million.

Thorium and uranium seem to be closely associated in igneous rocks; the two elements are associated in the same minerals, and data indicate that the thoriumuranium ratio of various rocks throughout the world is approximately uniform. The average thoriumuranium ratio in igneous rocks is about 3 or 4 to 1 , with the ratio ranging from 0 to 20 .

The thorium-uranium ratio is much smaller in ocean waters than it is in igneous rocks. In fact, ocean waters contain more uranium than thorium, probably because thorium minerals are less soluble than are the uranium minerals.

The following data compiled by $\mathrm{K}$. Rankama and T. G. Sahama $(1950$, p. 573) suggest the order of magnitude of thorium content in sedimentary rocks:

Rock $\begin{gathered}\text { Approximate } \\ \text { Th content } \\ \text { in grams } \\ \text { per ton }\end{gathered}$

Rocks of arenaceous origin (Joly, 1910) _........... 5. 4

Rocks of argillaceous origin (Joly, 1910) _........... 12

Shales (Minami, 1935) _........................ 10.1

Limestones (Evans and Goodman, 1941).............. 1. 1

Where not occurring in igneous rocks, thorium and uranium display marked dissimilarities. In ore deposits minable concentrations of both thorium and uranium are rarely found together.

A possible explanation of the fact that thorium and uranium are associated in the magmatic cycle but are not associated in the hydrothermal environment, is offered by E. S. Larsen, Jr., and George Phair (1954, p. 88-89). In the magmatic cycle both thorium and uranium crystallize along similar paths because of their similarities in ionic radius and similarly low concentrations. However, in the very late magmatic cycle E. S. Larsen, Jr., and George Phair postulate a change to oxidizing conditions whereby 4 -valent uranium changes to 6-valent uranium, the latter being highly soluble in aqueous solutions, whereas the former is not. Thorium has only the 1 stable valence (4), and it is not rendered more soluble by the change to oxidizing conditions. Thus, because of the change in solubility of uranium and lack of change in solubility of thorium, the two elements naturally become separated under hydrothermal and later magmatic conditions.

\section{THORIUM MINERALS}

The most important thorium minerals are monazite, thorianite, thorite, and thorogummite. Other minerals that contain minor amounts of thorium are allanite, 
bastnaesite, xenotime, euxenite, fluorapatite, and zircon. Monazite is the principal ore mineral of thorium in the United States and elsewhere. It is a complex phosphate of the rare-earth metals (principally cerium and lanthanum) and thorium. The thorium content normally ranges from a few percent to 10.6 percent, but probably ean be as much as 26.4 percent thorium (Frondel and Fleischer, 1955, p. 185). Commercially recovered monazite contains from 55 to 65 percent of rare-earth oxides and thoria. Minable monazite deposits are found in the United States mostly in placers. Monazite also is an accessory mineral in many gneissic and granitic rocks and in calcareous metamorphic rocks and is a minor constituent of certain carbonate veins.

Thorianite $\left(\mathrm{ThO}_{2}\right)$ is isomorphous with uraninite $\left(\mathrm{UO}_{2}\right)$ and is a constituent of some placer deposits and a minor constituent of some igneous rocks. It is not now an ore mineral as its known occurrences are small and low grade.

Thorite $\left(\mathrm{ThSiO}_{4}\right)$ may contain from 25.2 to 62.7 percent thorium and as much as 10.1 percent uranium (Frondel and Fleischer, 1955, p. 190), It is typically a primary mineral of pegmatites and igneous rocks and certain hydrothermal veins recently discovered in the United States; it is considered to be a potential thorium ore mineral. Thorite and the variety uranothorite are the principal thorium-bearing minerals of certain placer deposits in Idaho.

Thorogummite (hydrothorite) is a hydrated silicate of thorium and uranium, containing 2.5-31.4 percent uranium and 18.2-50.8 percent thorium (Frondel and Fleischer, 1955, p. 191). It occurs in possibly significant amounts in veins or pegmatites in central Wisconsin and has been found elsewhere in the United States in very minor amounts associated with pegmatites and granitic rocks. Thorogummite probably is an important constituent of certain veins and mineralized shear zones in Colorado, Idaho, and California.

Allanite is a complex silicate containing as much as 3.2 percent thorium (Frondel and Fleischer, 1955, p. 197). Its characteristic occurrence is as an accessory mineral of plutonic igneous rocks and pegmatites; it also is found as a contact-metamorphic mineral associated with magnetite deposits. Allanite is not known in sufficient concentrations to be a source of thorium.

Bastnaesite is a fluocarbonate of the rare-earth metals, principally cerium and lanthanum, with less than 1 percent uranium and thorium (Frondel and Fleischer, 1955, p. 198). Though bastnaesite is not an ore mineral of thorium, it may become a source of byproduct thorium from the recovery of rare-earth metals. Most bastnaesite deposits are in contact metamorphic zones that are rich in rare earths, barium, carbon dioxide, and fluorine. Bastnaesite deposits have been mined at Mountain Pass, Calif., and in the Gallinas district, New Mexico (Anonymous, 1952, p. 108).

Xenotime, an yttrium phosphate, may contain as much as 2.2 percent thorium (Frondel and Fleiseher, 1955 , p. 203). It characteristically oceurs in pegmatites and as a minor accessory mineral in granitic and gneissoid rocks. Xenotime is not known in sufficient concentrations to be a source of thorium but would contribute to the total obtainable from placers.

Euxenite is a complex oxide of thorium, rare earths, niobium, tantalum, calcium, and titanium, containing as much as 4.3 percent of thorium (Frondel and Fleischer, 1955, p. 179). It typically occurs as an accessory mineral in granitic rocks and in some of the placer deposits in Idaho is the principal thorium-bearing mineral present.

Fluorapatite is a fluorine-bearing apatito which in some localities contains rare-earth metals and thorium. In the Mineville district of New York (McKeown and Klemic, 1956), thorium-bearing fluorapatite is associated with magnetite ore, where it might be a byproduct source of thorium.

At the present time, the only ore mineral of thorium is monazite, which is principally an ore mineral of rare earths, but from which thorium is recovered as a coproduct. Thorite and thorogummite are of importance as potential sources of thorium from several districts in the Western United States.

\section{THORIUM DEPOSITS}

Thorium minerals in possible economic concentrations are found in granitic rocks, pegmatites, veins, and placers. The principal thorium deposits of the United States are shown on figure 181.

No known thorium deposits are comparable in grade and size to the well-known uranium deposits of pitchblende. Similarly, because thorium is relatively insoluble and occurs in highly refractory minerals, no known commercial thorium deposits of supergene origin are known.

\section{VEIN DEPOSITS}

In recent years, as interest in radioactive minerals has increased, vein deposits containing rare earths and thorium in significant amounts have been found in Colorado, Idaho, Montana, Wyoming, California, and New Mexico. Monazite, thorogummite, and particularly thorite, are the principal thorium-bearing minerals of these veins. These thorium-bearing vein deposits are characterized by the association of such gangue minerals as barite, carbonates, and iron oxides, with different amounts of other minerals. Most thorium-bearing veins occur in igneous and metamorphic terranes that have been intruded by alkalic 


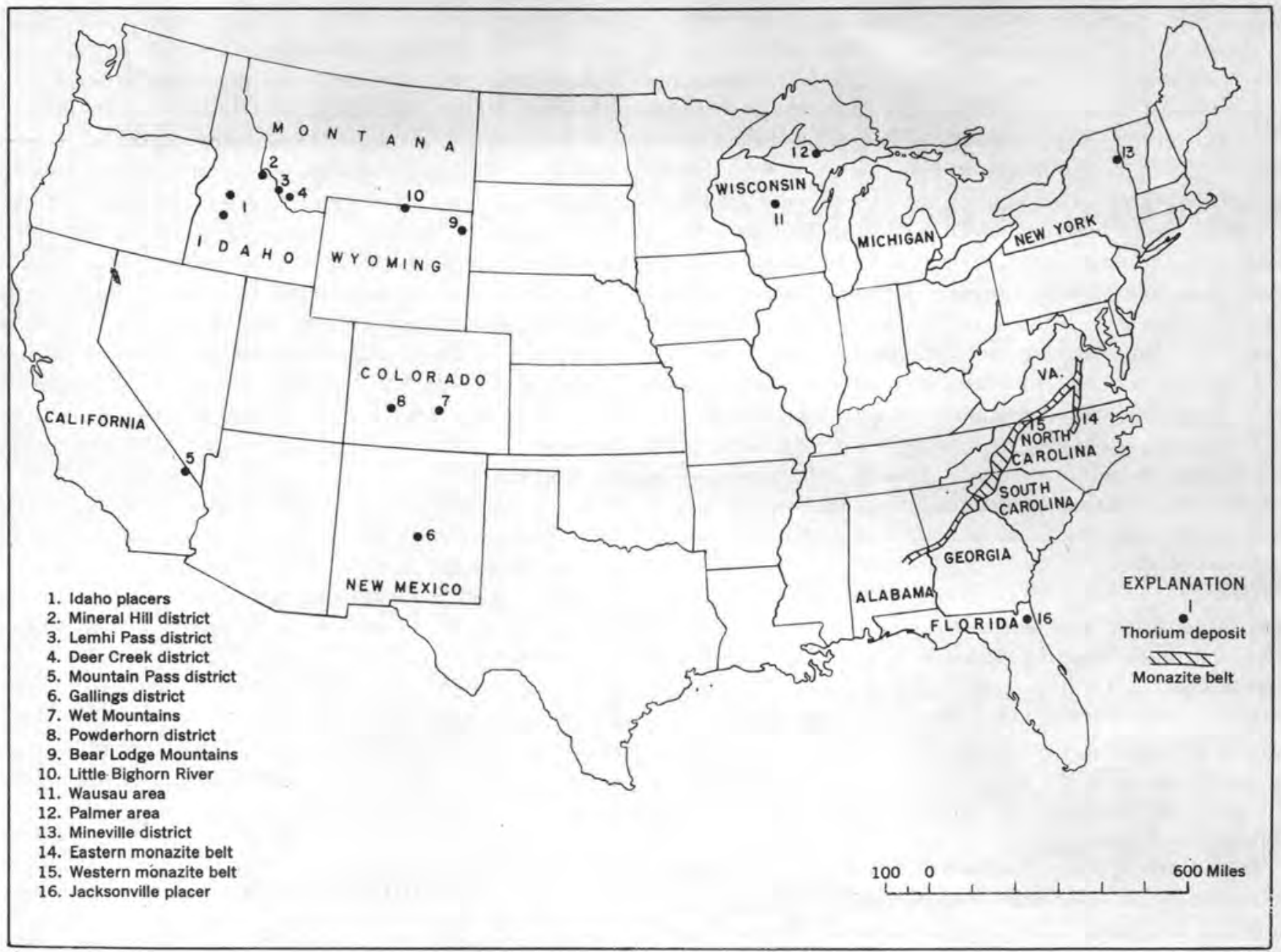

Fioure 181.-Thorium deposits in the United States.

igneous rocks, believed to be genetically related to the veins.

\section{POWDERHORN DISTRICT, GUNNISON COUNTY, COLO.}

At least 33 deposits of thorium are known in the Powderhorn district of Colorado in an area 6 miles wide and 20 miles long. The deposits and the general geology are described by Olson and Wallace (1956). The area is underlain principally by Precambrian metamorphic and igneous rocks which have been intruded by pre-Jurassic alkalic dikes and composite stocks of irregular shape. The thorium deposits occur as thorite-bearing carbonate-rich veins and mineralized shear zones in or near the alkalic igneous rocks.

Selected high-grade samples of vein material contain as much as 4 percent thoria; the average thoria content of the veins is less than 1 percent. The veins are a few inches to 18 feet wide, and a few feet to more than 3,500 feet long. The vein material is composed principally of carbonate, quartz, and feldspar, with minor amounts of barite, pyrite, sphalerite, galena, hematite, goethite, apatite, thorite, xenotime, and many other minerals.

The thorium-bearing veins are characterized by the presence of titanium, barium, strontium, niobium, phosphorus, and the rare-earth metals, which also are present in greater than average amounts in the alkalic igneous rocks with which the veins are associated; these relationships suggest a genetic tie between the veins and the alkalic igneous rocks. The thorium minerals are accompanied by both oxidized and unoxidized ironbearing minerals.

\section{WET MOUNTAINS, COLO.}

Thorium-bearing veins recently were discovered by the U. S. Geological Survey on the west flank of the Wet Mountains in Custer and Fremont Counties, Colo., (Christman and others, 1953). Over 350 thoriumbearing veins are known in the Wet Mountains area. Most of them are less than 5 feet wide and 100 to 1,000 feet long; a few are as much as 50 feet wide and 5,000 feet long. The country rocks of the area consist of a 
Precambrian eomplex of interlayered paragneisses, mig. matite, and granitic gneisses that have been transected by an abnormally radioactive albite syenite stock and by many northwest-trending dikes, veins, and fractures. The veins are composed principally of quartz, barite, and iron-bearing carbonates with an unidentified hydrated thoritelike mineral. Minor amounts of pyrite, chalcopyrite, tetrahedrice, galena, fluorite, and secondary copper minerals occur sparingly in the veins. The thorium mineral or minerals rarely are visible with the naked eye, because they are masked by ubiquitous iron oxides and hydroxides.

The thorium content is not uniform within the veins. Concentrations in the form of shoots, pockets, pods, and lenses are distributed erratically and discontinuously along the veins. Some parts of veins contain as much as 1.0 percent thoria, but large parts of the veins contain only 0.1 percent thoria. The thorium in the veins is thought to be genetically related to the albite syenite stock.

\section{LEMHI PASS DISTRICT, DAFO-MONTANA}

In the Lemhi Pass district, Idaho-Montana (Sharp and Cavender, 1953), there are four types of veins, two of which contain thorium minerals. They are quartzcopper veins, some of which have been mined for coppergold ore; quartz-hematite veins, none of which contains more than traces of thorium; quartz-baritehematite-thorite veins, containing zones rich in barite and thorite (these constitute the largest percentage of thorium-bearing material in the district); and quartzcopper-thorite veins, some of which contain significant quantities of thorite. The country rock consists of sandstone, argillite, and quartzite of the Precambrain Belt series,

The quartz-copper-thorite veins range from a few inches to 10 feet in width and are as much as 500 feet long; the quartz-barite-hematite-thorite veins range from less than 1 foot to 50 feet in width and from 10 to more than 700 feet in length (Trites and Tooker, 1953, p. 191-205). A. F. Trites and E. W. Tooker (1953) have estimated some of the samples of vein material to contain as much as 6.6 percent calculated thoria, but most contain 0.1 to 1.2 percent thoria.

BEAR LODGE MOUNTAINS, CROOK COUNTY, WYO.

In the Bear Lodge Mountains of Wyoming, thorium and rare-earth minerals occur in abnormal amounts in iron-manganese veins in Tertiary igneous rocks $(V, R$. Wilmarth and D, H, Johnson, written communication, 1953).

The iron-manganese veins are composed principally of hematite, limonite, manganese oxides, orthoclase, and chalcedony; they are in intrusive monzonite and syenite porphyry of Tertiary age. The thorium and rare-earth minerals have not been identified. The thoria content of the veins ranges from 0.04 to 0.25 percent. Rare earths are abundant within some veins, isolated specimens containing as much as 12.68 percent of rare earths.

\section{MOUNTAIN PASG DISTRICT, CALTF.}

Rare earths-barium-thorium deposits occur in a belt 6 miles long in Precambrian carbonate rocks associated with potash-rich igneous rocks in the Mountain Pass district, San Bernardino County, Calif. The geology of the district is described in detail by Olson and others (1954). The deposits are of value principally as a source of rare-earth metals, which occur chiefly in the mineral bastnaesite, and as a source of byproduct barite. However, some deposits contain between 0.02 and 0.5 percent thoria, with local concentrations as rich as 6 percent thoria.

Thorium minerals occur as small amounts of monazite in a large body of carbonate rock and as thorite and thorogummite in veins. The principal minerals of the thorium-bearing veins are calcite and quartz, with lesser amounts of hematite and hydrated iron oxides, bastnaesite, barite, thorite, and other minerals. The association of hematite with thorite is a conspicuous feature of these veins.

Late andesitic dikes cut the country rock and the thorium- and rare-earth-bearing veins. Some of the richer deposits are near andesitic dikes, suggesting that aqueous emanations accompanying the dikes may have redistributed thorium already in the veins and concentrated it as thorite near the dikes (Olson and others, 1954, p. 62).

\section{gaminnas mountatns, N. Mex.}

Bastnaesite occurs in the fluorspar deposits of the Gallinas Mountains, N. Mex. (Glass and Smalley, 1945), where the two minerals are associated with abundant barite and goethite (pseudomorphic after pyrite). The deposits occur along fissures and faults, and in breccias and shatter zones in clastic rocks of Permian age. Post-Permian intrusive quartz monzonites, rhyolites, and syenites form stocks, irregular bodies, and many small dikes and sills. The fluoritebastnaesite deposits are believed to have been formed by hydrothermal solutions related to the igneous activity. Bastnaesite is commercially recovered from these deposits (Anonymous, 1952).

\section{WAUSAU AREA, MARATHON COUNTY, WIS.}

Near Wausau, Marathon County, Wis., thorogummite and thorium-bearing zircon are found in residual soil in an area of Precambrian syenites. Samples 
from the more radioactive concentrations in the soil contain $0.21-1.0$ percent thorium, indicating possible thorium concentrations in the bedrock (R. C. Vickers, written communication, 1953).

\section{MINEVHLE, N. Y,}

The magnetite ore bodies of the Old Bed mine at Mineville, N. Y,, contain fluorapatite unusually rich in thorium and rare earths (McKeown and Klemic, 1956). Gangue minerals consist of hornblende, augite, quartz, and feldspar.

The fluorapatite is disseminated and in thin seams in the magnetite. Samples of the fluorapatite contain 4.28-32.4 percent rare-earth oxides, $0.01-0.38$ percent thoria, and 0.009-0.11 percent uranium.

The Old Bed mine is currently being mined for magnetite. Other nearby magnetite deposits are not known to contain thorium-bearing fluorapatite.

\section{DEPOSITS IN IGNEOUS AND METAMORPHIC} ROCKS

Many igneous and metamorphic rocks, particularly biotite-rich granites and granite gneisses, contain monazite. Such rocks, together with monazite-bearing pegmatites which commonly occur in the same terrane, are the source of placer monazite. None of the igneous rocks in the United States contain sufficient concentrations of monazite and thorium to be considered ore, and it is unlikely that igneous and related metamorphic rocks in the United States will become an ore of thorium in the near future. J. B. Mertie, Jr., (1953) estimated the granites and gneisses of the monazite belts of the Southeastern States to contain 0.00005-0.02 percent monazite.

Thorium- and monazite-bearing igneous and metamorphic rocks also are known in Idaho and Montana (Trites and Tooker, 1953), South Dakota (Vickers, 1954), and in San Bernardino County, Calif. (Olson and others, 1954; Moxham, 1952), but none of the rocks appear to be appreciably richer in thorium than similar rocks of the Southeastern States.

Many pegmatites contain thorium-bearing minerals, but none of the pegmatites known in the United States contain thorium minerals in economic concentrations. Two areas of thorium-bearing metamorphic rocks and pegmatites are known in Worcester County, Mass. (Johnson, 1951). At both of these localities the bedrock consists of alternating bands of feldspar gneiss and pegmatite, both of which contain thorium. The deposits are very large and probably average 0.03 percent thoria. Other pegmatites containing more-than-average quantities of thorium minerals are known in the Deer Creek district, Beaverhead County, Mont. (Trites and Tooker, 1953), and in the St. Peters dome area, El Paso County, Colo.

\section{PLACER DEPOSITS}

Monazite is the principal thorium-bearing mineral in placer deposits of the United States, although in some Idaho placer deposits thorite and euxenite are alşo important thorium-bearing minerals. Placer deposits of thorium-containing minerals are in central Idaho and in an area extending from southern Virginia to Florida. Associated minerals in thorium-bearing placers are the usual heavy minerals such as gold, zircon, magnetite, rutile, ilmenite, garnet, and others.

Stream placers were mined for monazite in the Piedmont province of North and South Carolina from 1887 to 1911 and from 1915 to 1917 (Mertie, 1953). Since 1911, monazite exported from Brazil and India has effectively competed with domestic monazite. Within the last few years, imports of monazite from foreign sources have been seriously curtailed (Mertie, 1953; Argall, 1954), and monazite now is recovered from placers in central Idaho and Florida.

\section{SOUTHEASTERN STATES}

The monazite in the placers of the Southeastern States is derived from the weathering and erosion of Precambrian igneous and metamorphic rocks of the Piedmont province. The monazite-bearing bedrocks are in two belts. Most of the rocks within these belts are not monazite-bearing; the belts delimit the areas within which monazite-bearing rocks are likely to be found. The western belt extends from east-central Virginia for 600 miles southwestward to Alabama; its width is $10-50$ miles and averages 20 miles. The eastern belt extends from Fredericksburg, Va., southwestward for 200 miles into North Carolina; it averages about 5 miles in width.

J. B. Mertie, Jr., (1953) sampled 52 placer localities in the Southern States. The mean content of these samples is 8.4 pounds of monazite to the cubic yard, but at some localities the tenor was as much as 41.9 pounds of monazite to the cubic yard. The mean tenor of the monazite as determined by J. B. Mertie, Jr., (1953) from 53 samples is 5.67 percent thoria and 0.38 percent $\mathrm{U}_{3} \mathrm{O}_{8}$, with tenor ranging from 2.48 to 7.84 percent for thoria and from 0.18 to 0.98 for $\mathrm{U}_{3} \mathrm{O}_{8}$.

A large volume of sediments that contain heavy minerals, including monazite, derived from the Piedmont rocks has been deposited since Paleozoic time on the Coastal Plain of the Southeastern States. In some areas workable deposits of heavy minerals are found where ocean currents and streams have reworked these sediments. Placer deposits near Jacksonville and Starke, Fla., and at Hollow Creek, S. C. are being mined for heavy minerals. At the Jacksonville and Hollow Creek deposits, byproduct monazite is being recovered, but at Starke monazite is not being recovered. 


\section{IDAFO}

Thorium-bearing placer deposits scattered over a wide area in central Idaho contain monazite, thorite, and euxenite as the principal thorium-bearing minerals. The placers also contain a variety of other heavy minerals; notably zircon, magnetite, ilmenite, garnet, and gold.

At the present time only the monazite placers in the Cascade area, Valley County, are being mined; the euxenite-bearing placers of the Bear Valley area, Valley County, and the thorite-bearing placers of the Hailey area, Blaine County, are not being mined. It is of interest, perhaps, to note that euxenite and thorite seem to be mutually exclusive in the Idaho placers and that the placers being worked for monazite contain only traces of euxenite and thorite (Mackin and Schmidt, this volume).

Dredging and recovery of monazite from Idaho placers began in 1950 (Argall, 1954) shortly after foreign shipments of monazite to the United States were curtailed. Three dredges are now actively engaged in the production of monazite from the Idaho placer deposits (Mertie, 1953).

The thorium-bearing and other heavy minerals found in the Idaho placers were derived from the Idaho batholith of central Idaho. The placer deposits lie within and around the borders of the batholith. The Idaho batholith is a complex of granitic rock units ranging from diorite to granite; data indicate that the thoriumbearing minerals are contained in appreciable amounts only in the quartz monzonite phases of the batholith (Mackin and Schmidt, this volume).

The quartz monzonite parts of the Idaho batholith do not contain a uniform amount of thorium-bearing minerals; some parts contain only a trace, others may contain as much as half a pound of monazite per ton. So far as known, there is no systematic pattern to the distribution of thorium-bearing minerals in the quartz monzonite phases of the Idaho batholith.

Weathering of the quartz monzonite phases of the Idaho batholith and transportation by streams of the thorium-bearing and other heavy minerals have resulted in placer deposits being formed in many stream valleys and basins of central Idaho.

Alluvial fills, of sufficient size to be worked as placers, have formed in Pleistocene time in central Idaho by several factors that have reversed the normal processes of stream erosion, According to J. H. Mackin and D. L. Schmidt (this volume), "the principal causes of accumulation of the valley fills $* * *$ are (1) Pleistocene block faulting; (2) late Pleistocene glacial derangement of drainage; and (3) blocking of drainage lines by Pleistocene basalt flows."
DEADWOOD FORMATION, BIG HORN MOUNTATNS, WYOMING

Monazite-bearing conglomerate is known in the basal part of the Deadwood formation of Cambrian age in Sheridan and Big Horn Counties, Wyo. The monazite occurs as detrital grains in the matrix of the basal conglomeratic facies of the formation. The monazitebearing parts of the formation attain a thickness of as much as 8 feet and crop out over long distances along the valley of the Little Big Horn River.

Sufficient data are not available to estimate the thorium content of the monazite and the monazite content of the conglomerate. Estimates have been made ranging between 8 and 30 pounds of monazite per ton.

\section{GOODRICH QUARTZITE, UPPER PENINSULA, MICHIGAN}

Monazite-bearing conglomerate beds in the Precambrian Goodrich quartzite occur in the vicinity of Palmer, Mich. (R. C. Vickers, written communication, 1955). Here the Goodrich quartzite is about 850 feet thick and is composed of a coarse basal conglomerate which grades upward into interbedded quartzites and pebble conglomerates. There are at least two monazite-bearing zones, one near the base of the formation and the other about 400 feet stratigraphically above the base. The continuity and thickness of these two zones are not yet known.

The monazite occurs as detrital grains in the matrix of layers and lenses of pebble conglomerates 1 inch to 2 feet thick.

The conglomeratic character of the monazite-bearing parts of the Goodrich quartzite and the detrital monazite crystals clearly indicate that parts of the Goodrich quartzite are ancient placers which subsequently have been metamorphosed and preserved essentially as originally formed.

\section{CALCAREOUS METAMORPHIC ROCKS}

Deposits of monazite in marble and calcareous schist recently have been discovered in the Mineral Hill district in northern Lemhi County, Idaho (Abbott, 1954). The monazite forms porphyroblasts in phosphatic calcareous rocks of the Precambrian Belt series. The economic potential of these deposits is poorly known because they have been explored only to a limited extent.

\section{SUMMARY}

Current data permit several generalizations on the characteristics of thorium deposits in the United States:

1. Placer concentrations of monazite are derived directly from monazite-bearing igneous and metamorphic rocks or by the reworking of sediments originally derived from such rocks. 
2. Vein deposits of thorium generally are associated with and genetically related to alkalic igneous rocks.

3. The principal tho ium vein minerals are thorite, thorogummite (hydrothorite), and monazite.

4. Barite, carbonates, quartz, and especially iron oxides are commonly associated with thorium minerals in veins.

5. The principal thorium-bearing veins were found in the Western United States and are believed to be either Precambrian or Cretaceous and Tertiary in age.

\section{REFERENCES CITED}

Abbott, A. T., 1954, Monazite deposits in calcareous rocks, northern Lemhi County, Idaho: Idaho Bur. Mines and Geology, Pamph. 99, 24 p.

Argall, G. O., 1954, New dredging techniques recover Idaho monazite: Min. World, v. 16, no. 2, p. 26-30.

Christman, R. A., Heyman, A. M., Dellwig, L. F., and Gott, G. B., 1953, Thorium investigations, 1950-1952, Wet Mountains, Colo.: U. S. Geol. Survey Circ. 290, 40 p.

Fleischer, Michael, and Rabbitt, J. C., 1952, Geochemistry, in Annual review of nuclear science, Volume 1: Stanford, Calif., Annual Reviews, Inc., p. 465-478.

Frondel, J. W., and Fleischer, Michael, 1955, Glossary of uranium- and thorium-bearing minerals: U. S. Geol. Survey Bull. 1009-F, p. 169-209.

Glass, J. J., and Smalley, R. G., 1945, Bastnaesite: Am. Mineralogist, v. 30, p. 601-615.

Johnson, D. H., 1951, Reconnaissance of radioactive rocks of Massachusetts: U. S. Geol. Survey TEI-69, 18 p., issued by U. S. Atomic Energy Comm., Tech. Inf. Service, Oak Ridge, Tenn.
Larsen, E. S., Jr., and Phair, George, 1954, The distribution of uranium and thorium in igneous rocks, in Faul, Henry [ed.], Nuclear geology: New York, John Wiley and Sons, p. 7589.

MeKeown, F. A., and Klemic, Harry, 1956, Rare-earth-bearing apatite at Mineville, Essex County, N. Y.: U. S. Geol. Survey Bull.-(in preparation).

Mertie, J. B., Jr., 1953, Monazite deposits of the Southeastern Atlantic States: U. S. Geol. Survey Circ. 237, 31 p.

Moxham, R. M., 1952, Airborne radioactivity surveys in the Mojave Desert region, Kern, Riverside, and San Bernardino Counties, Calif.: U. S. Geol. Survey TEM-360, 30 p., issued by U. S. Atomic Energy Comm., Tech. Inf. Service, Oak Ridge, Tenn.

Olson, J. C., Shawe, D. R., Pray, L. S., and Sharp, W. N., 1954, Rare-earth mineral deposits of the Mountain Pass district, San Bernardino County, Calif.: U. S. Geol. Survey Prof. Paper 261, 75 p. [1955].

Olson, J. C., and Wallace, S. R., 1956, Thorium and rare-earth minerals in the Powderhorn district, Gunnison County, Colo.: U. S. Geol. Survey Bull. 1027-O.

Rankama, Kalervo, and Sahama, T. G., 1950, Geochemistry: Chicago, Ill., Univ. of Chicago Press, 912 p.

Sharp, W. N., and Cavender, W. S., 1953, Thorium deposits of the Lemhi Pass district, Lemhi County, Idaho, and Beaverhead County, Mont. [abs.]: Geol. Soc. America Bull., v. 64, p. 1555.

Trites, A. F., and Tooker, E. W., 1953, Uranium and thorium deposits in east-central Idaho and southwestern Montana: U. S. Geol. Survey Bull. 988-H, p. 184-208.

Vickers, R. C., 1954, Occurrences of radioactive minerals in the Bald Mountain gold-mining area, northern Black Hills, S. Dak.: U. S. Geol. Survey Circ. 351, 8 p.

Anonymous, 1952, Companies join with Heim to develop bastnaesite: Eng. and Min. Jour., v. 153, no. 1, p. 108. 


\section{MINERALOGY OF THORIUM}

\section{By Clifford Frondel, U. S. Geological Survey and Harvard University}

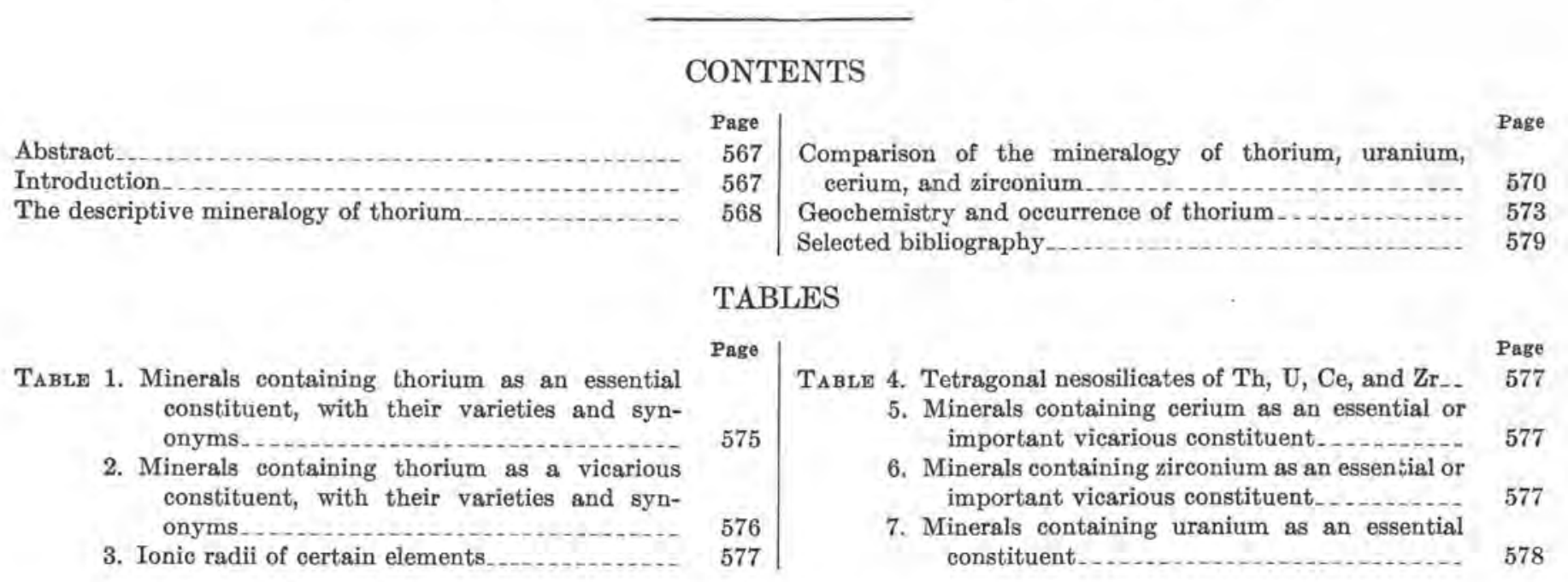

\begin{abstract}
The known minerals that contain thorium are divided into two groups: those that contain the element as an essential constituent, and those that contain thorium as a vicarious constituent. The first group contains 6 distinct species, of which only the silicates, thorite and thorogummite, and the oxide, thorianite, are of importance, together with 16 minor chemical variants of these species that have been accorded varietal names. The second group, numbering more than 60 minerals, in places contains variable and usually small amounts of thorium in solid solution. Some of these minerals, notably monazite, are of economic interest because of their occurrence in relatively large amounts.
\end{abstract}

\section{INTRODUCTION}

The average content of the element thorium in the outer crust of the earth is about 12 grams per ton. Thorium is a little less abundant than lead and about three times as abundant as uranium. Thorium in the lithosphere is contained chiefly in minerals in which it is a nonessential constituent. Of the six known thorium minerals, only the thorium silicates-thorite and thorogummite - and the thorium dioxide, thorianite, are of potential economic interest. Most of the earth's thorium is dispersed in small and variable amounts in solid solution in other minerals as an occasional, vicarious constituent. The distribution of thorium in this manner is a selective process. The principal ore mineral of thorium is the cerium phosphate, monazite, which contains variable amounts of thorium in solid solution.

The mineralogical expression and the geochemical distribution of thorium both as an essential and as a vicarious constituent show striking similarities, both genetically and economically, to certain other elements; namely, uranium, cerium, zirconium, and hafnium. The very similar elements hafnium and zirconium will be considered hereafter as a unit with the symbol $\mathrm{Zr}$. In the present paper, the mineralogy of thorium will be characterized in context with these elements, and the crystallochemical and other factors that influence their geochemical descent will be indicated.

That close geochemical relations should exist among these elements is suggested by similarities in their general chemical behavior and, more fundamentally, by similarities in their electronic structures. In the lanthanide series of elements extending from atomic number $58(\mathrm{Ce})$ to $71(\mathrm{Lu})$, the back filling in the $4 \mathrm{f}$ shell that causes the very close chemical resemblances in this series is paralleled in the actinide series of elements $90(\mathrm{Th})$ to $96(\mathrm{Cm})$ through back filling in the $5 f$ (or $6 d$ ) shell. Quadrivalent Ce thus is similar to Th. $\mathrm{Ce}^{4}$ also is analogous to both $\mathrm{Hf}(72)$ and $\mathrm{Zr}(40)$, through filling of the $5 d$ and $4 d$ shells. Quadrivalent 
uranium shows close analogies to thorium. The similarities between $\mathrm{Th}, \mathrm{U}, \mathrm{Ce}$, and $\mathrm{Zr}$ are illustrated by the isostructural relation of their dioxides and orthosilicates and by the extensive mutual solid solution series in these and other groups of compounds. The mineralogical and geochemical disimilarities between these elements are due primarily to the small size of the $\mathrm{Zr}^{4}$ ion as compared to $\mathrm{Th}^{4}, \mathrm{Ce}^{4}$, and $\mathrm{U}^{4}$ as a group, and to the assumption by uranium of the sexivalent state and by cerium of the trivalent state - both stable states under geologic conditions - in addition to the quadrivalent states of these elements.

\section{THE DESCRIPTIVE MINERALOGY OF THORIUM}

The element thorium which was named after Thor, the Scandinavian god of war, was discoverd in 1828 by the Swedish chemist J. J. Berzelius in a mineral from a pegmatite on the island of Lövö in the Langesund fiord, southern Norway. The name thorite was given to the mineral. Thorite and its hydroxyl-containing variant, thorogummite, and thorianite are the most important and widely distributed of the six known thorium minerals (table 1 ).

Thorite ideally has the formula $\mathrm{ThSiO}_{4}$, and material of this composition can be readily synthesized. The composition of the natural mineral, however, always is greatly modified both by the entrance of other elements into solid solution, notably $\mathrm{U}, \mathrm{Fe}, \mathrm{Ca}$, rare earths and $\mathrm{P}$, and by secondary alteration. The alteration is of two types, which operate concomitantly. Thorite is radioactive, and alpha particles together with beta and gamma radiation are emitted by it or its decay products in the passage to the stable end element lead 208. The internal emission and absorption of alpha particles disrupts the normal crystalline structure of the mineral and causes it to become partly or completely disordered (metamict). This type of alteration occurs in many other thorium and uranium minerals and in recent years has been the subject of much investigation (Pabst, 1952; Pellas, 1951, 1952). This structural disintegration is accompanied by chemical alteration, involving hydration-commonly to the extent of 8 to 10 percent by weight of $\mathrm{H}_{2} \mathrm{O}$-and oxidation of $\mathrm{U}^{4}$ to $\mathrm{U}^{6}$ and of $\mathrm{Fe}^{2}$ to $\mathrm{Fe}^{3}$. A partial leaching of $\mathrm{Si}$ also may take place at this stage. These features of thorite, together with difficulties in the chemical analysis of the mineral, have brought much confusion to the description of the species. No less than 14 different minerals described in the older literature as distinct species are now known or thought to be identical with thorite or its variant thorogummite (table 1). The analytical difficulties attending thorite led to the description of three supposed new elements, carolinium, donarium, and berzelium. Zireon also has a bulky nomenclatural halo of ill-defined or synonymous minerals that has arisen for similar reasons (table 6), and the analytical difficulties here resulted in the supposed new elements ostranium, norium, and jargonium. The identity of the orange-yellow isotropic substance called orangite with thorite was established only after controversy in the period 1850-70. The description and discrediting of supposed new minerals in these categories unfortunately is still an active matter.

Thorogummite is a recently established (Frondel, 1953) variant of thorite in which tetrahedral groupings of four $(\mathrm{OH})$ ions substitute vicariously for the $\left(\mathrm{SiO}_{4}\right)$ groups of the structure. The formula may be written $\mathrm{Th}\left(\mathrm{SiO}_{4}\right)_{1-\mathrm{x}}(\mathrm{OH})_{4 \mathrm{x}}$ in which $x$ is as much as 0.25 in natural material. In the uranium analogue, coffinite (Stieff, Stern, and Sherwood, 1955), $\mathrm{U}\left(\mathrm{SiO}_{4}\right)_{1-\mathrm{x}}(\mathrm{OH})_{4 \mathrm{x}}$, the value of $x$ is about 0.5 . Cyrtolite is an analogous hydroxyl-containing variety of zircon (table 4). The mechanism of hydroxyl substitution in these minerals is similar to that operating in the so-called hydrogarnets, in which a partial series in natural material and a complete series in synthetic material extend from $\mathrm{Ca}_{3} \mathrm{Al}_{2}$ $\left(\mathrm{SiO}_{4}\right)_{3}$ by way of $\mathrm{Ca}_{3} \mathrm{Al}_{2}\left(\mathrm{SiO}_{4}\right)_{3-\mathrm{x}}(\mathrm{OH})_{4 \mathrm{x}}$ to $\mathrm{Ca}_{3} \mathrm{Al}_{2}$ $(\mathrm{OH})_{12}$. Thorogummite always appears to be a lowtemperature secondary mineral in nature, produced by the recrystallization of metamict thorite by the weathering of other minerals, but the question of the entrance of $(\mathrm{OH})$ into high-temperature pegmatitic or vein thorite and zircon remains open. Thorogummite and cyrtolite have been synthesized hydrothermally at temperatures as low as $150^{\circ} \mathrm{C}$, and the occurrence of $(\mathrm{OH})$ in both synthetic and natural material has been verified by thermal and infrared analysis.

Thorite and thorogummite are tetragonal in erystallization and belong in the zircon structure type. The structure is based on isolated $\mathrm{SiO}_{4}$ tetrahedra (nesosilicates) with the thorium ions in 8-coordination with oxygen. Owing to its metamict character, thorite affords only faint and diffuse X-ray diffraction effects or gives no X-ray pattern at all. When metamict thorite is heated to $800^{\circ}-900^{\circ} \mathrm{C}$ or higher, it recrystallizes exothermally to an aggregate of minute crystals of either tetragonal or monoclinic $\mathrm{ThSiO}_{4}$, or to a mixture of one or the other of these with $\mathrm{ThO}_{2}$. The nature of the recrystallization products varies with the temperature and time of heating, the composition of the original material, and other factors not clearly understood. The recrystallization products give sharp X-ray diffraction effects, and this is a convenient means of identification. Thorogummite gives $\mathrm{X}$-ray patterns in unheated material. When thorogummite is heated, water including $(\mathrm{OH})$ is lost, and a small amount of $\mathrm{ThO}_{2}$ may appear, but the diffraction pattern remains 
that of tetragonal $\mathrm{ThSiO}_{4}$. Metamict thorite is isotropic with a relatively low and variable index of refraction. Thorogummite is anisotropic, but the particle size is much too small for satisfactory optical study and optical techniques generally are unsatisfactory as a means of identifying these minerals.

Following the discovery of thorite in 1828 , the next well-defined mineral containing thorium as an essential constituent to be discovered was thorianite, $\mathrm{ThO}_{2}$, in 1904. This was followed by the description of pilbarite in 1910, huttonite in 1951, cheralite in 1953, and the redefinition of thorogummite in 1953. The crystal structure of thorianite is analogous to that of fluorite, $\mathrm{CaF}_{2}$, with the thorium ions in 8-coordination with oxygen. The crystallochemical and mineralogical relations of $\mathrm{UO}_{2}, \mathrm{CeO}_{2}$, and $\mathrm{ZrO}_{2}$ to $\mathrm{ThO}_{2}$ are discussed in the following section. Natural thorianite contains considerable amounts of other elements in solid solution, particularly $\mathrm{U}$ and $\mathrm{Ce}$, and like all thorium and uranium minerals accumulates $\mathrm{Pb}$ due to radioactive decay. Helium also is present. The uranium is present as both $U^{4}$ and $U^{6}$. The content of $U^{6}$ probably is secondary, owing to oxidation of $\mathrm{U}^{4}$ with a concommitant entrance of oxgyen into the vacant 8-fold position of the structure, as in partly oxidized uraninite, but no study of the effect has been made. The oxidation of synthetic solid solutions of the composition (Th, $\mathrm{U}) \mathrm{O}_{2}$ has been studied experimentally by J. S. Anderson and coworkers (1954). Thorianite and uraninite, almost alone among radioactive minerals, do not become metamict, apparently because of the inherent stability of the fluorite-type structure.

Of the remaining thorium minerals, pilbarite is an ill-defined substance found sparingly as a secondary mineral in the weathered outcrop of a pegmatite in Western Australia. It needs further study. Huttonite, the monoclinic polymorph of $\mathrm{ThSiO}_{4}$, is known as detrital grains in the heavy-mineral fraction of beach sands in New Zealand. It may be more widely distributed as an accessory mineral in black sands than is known. Huttonite has not been found in place, but it probably occurs in pegmatites and quartz-segregation veins in metamorphic rocks. The factors that influence the formation of huttonite and thorite are not known. Both phases have been synthesized by sintering of $\mathrm{ThO}_{2}$ and $\mathrm{SiO}_{2}$, the formation of huttonite being favored at higher temperatures, and both phases have been obtained hydrothermally between $400^{\circ}$ and $700^{\circ} \mathrm{C}$ by reaction of coprecipitated gels of $\mathrm{ThO}_{2}$ and $\mathrm{SiO}_{2}$ in the presence of $\mathrm{ThF}_{4}$. Cheralite is monoclinic and isostructural with both monazite and huttonite. It represents an intermediate member of the system $\mathrm{ThSiO}_{4}^{-}$ $\mathrm{CePO}_{4}-\mathrm{CaTh}\left(\mathrm{PO}_{4}\right)_{2}$. In this system a considerable range of solid solution exists by the substitution of $\mathrm{Ce}^{3}$ and $\mathrm{Th}^{4}$ with valence compensation effected by the coupled substitution of $\mathrm{Ca}^{2}$ for $\mathrm{Ce}^{3}$ or of $\mathrm{Si}^{4}$ for $\mathrm{P}^{5}$. Material in this series near monazite in composition is quite common, but huttonite and cheralite are rare.

The first large-scale use for thorium came with the development by Welsbach about 1884 of the incandescent gas-mantle, composed of $\mathrm{ThO}_{2}$ with about 1 percent of $\mathrm{CeO}_{2}$. Thorium now also finds use as a catalyst, in refractories, and in thoriated tungsten filaments. It is of potential importance in the field of atomic energy, since the natural isotope of thorium, thorium-232, can be converted by neutron bombardment to thorium-233, which yields uranium-233, a fissionable isotope. The thorium for gas mantles was obtained from monazite. The radioactive element mesothorium is a byproduct. The occurrence of thorium in monazite was first described by Kersten in 1839. The amount of thorium present varies widely, although roughly constant in the material from a given locality or area, and thorium-free monazite is rare. The usual content is less than 8 to 10 percent by weight of $\mathrm{ThO}_{2}$, but in some specimens the content is as much as 30 percent $\mathrm{ThO}_{2}$. Monazite, it is said, averages about 1 part $\mathrm{U}_{3} \mathrm{O}_{8}$ per 50 parts $\mathrm{ThO}_{2}$. The manner in which the thorium is contained in monazite is discussed extensively in the literature. It was long thought to be present as mechanically admixed thorite or another thorium compound, and a few such occurrences have been observed, but it is now believed that the element is present in solid solution in substitution for Ce.

Other minerals in addition to monazite contain thorium as a vicarious constituent. Table 2 lists about 60 minerals - some are ill defined-that have been found at times to contain more than 0.1 percent by weight of $\mathrm{ThO}_{2}$. A great many minerals, including several in which thorium could be expected to occur for crystallochemical reasons, never have been examined for this element. The minerals that contain vicarious thorium are chiefly silicates, oxides, and niobate-tantalates. Almost all these minerals are primary, and occur chiefly in pegmatites associated with alkalic or granitic igneous rocks. Only five of them, monazite, xenotime, allanite, zircon, and, to a less extent, pyrochlore, have a wide distribution as accessory minerals in igneous or metamorphic rocks. The cations that occur associated with Th in these minerals are typically $\mathrm{Ce}$ and other rare earths, $\mathrm{Zr}$, $\mathrm{Ca}$, and $\mathrm{U}$. The main factors involved in this association are geochemical and crystallochemical. The former tend to associate these elements with thorium in the parent solutions or melts from which the minerals have formed, and the latter determine the entrance of thorium into the various mineral phases that are formed. 
The most effective host minerals for Th are compounds of $\mathrm{U}, \mathrm{Zr}$, or $\mathrm{Ce}$ that are isostructural with thorium compounds, such as zircon, uraninite, and monazite, or compounds in which mechanisms of coupled substitution are available for the housing of large, polyvalent ions, such as the niobate-tantalates and monazite.

\section{COMPARISON OF THE MINERALOGY OF THORIUM, URANIUM, CERIUM, AND ZIRCONIUM}

Thorium, uranium, cerium, and zirconium are markedly oxyphile, and the known minerals of these elements all contain oxygen with the exception of a few rare fluorides of cerium. Sulfides, sulfosalts, tellurides, and the native metals are not known as minerals. Thorium and uranium form synthetic sulfides and carbides, and the oxysulfides ThOS and UOS, but the formation of these substances in nature is unlikely on thermochemical grounds.

The common minerals that contain $\mathrm{Th}, \mathrm{U}$, and $\mathrm{Zr}$ as essential constituents are oxides and silicates. Cerium differs in that it does not occur directly as an oxide, although $\mathrm{CeO}_{2}$ is a well-known synthetic compound, and $\mathrm{Ce}_{4}$ is commonly present, sometimes in large amounts, in solid solution in natural $\mathrm{UO}_{2}$ and $\mathrm{ThO}_{2}$. Cerium is carried in minerals chiefly as phosphates and silicates. As vicarious constituents, $\mathrm{Th}, \mathrm{U}, \mathrm{Ce}$, and $\mathrm{Zr}$ again are found principally in oxides and silicates. Thorium also is an important vicarious constituent in the cerium phosphate, monazite. Further, these four elements are characteristic constituents of the niobatetantalates.

The principal differences in the mineralogy and geochemistry of $\mathrm{Th}, \mathrm{U}, \mathrm{Ce}$, and $\mathrm{Zr}$ stem from the valence states taken by these elements in nature. Thorium and zirconium always are quadrivalent. Uranium occurs both as quadrivalent and sexivalent ions, and cerium both as quadrivalent and trivalent ions. The diversity of the mineralogy of uranium - about 70 distinct species containing uranium as an essential constituent are known as compared to 6 for thorium and 15 for zirconium - is due primarily to the stability of the sexivalent $\mathrm{U}^{6}$ ion. More properly, $\mathrm{U}^{6}$ should be described as the uranyl ion. In crystal structures, $\mathrm{U}^{6}$ ordinarily is in distorted 6 -fold or 8 -fold coordination, and the two apical oxygen ions of the coordination group are more closely associated with the $\mathrm{U}^{6}$ to give a linear complex cation, $\left(\mathrm{UO}_{2}\right)^{-2}$. In $\left(\mathrm{UO}_{2}\right)\left(\mathrm{CO}_{3}\right)$ the $\mathrm{U}^{6}$ is in 8-fold coordination with 6 oxygen ions in a plane and 2 apical oxygen ions (Christ, Clark, and Evans, 1955). The $\mathrm{U}^{6}$ in partly oxidized $\mathrm{UO}_{2}$ presumably is in distorted 8-fold coordination. The bivalent uranyl ion is of sufficient stability to preserve its identity in solution. The known uranium minerals are listed in table 7. All the primary uranium minerals, including uraninite and coffinite, which contain $\mathrm{U}$ as an essential constituent, and the many minerals that contain $\mathrm{U}$ as a vicarious constituent, house the element only in the quadrivalent state, so far as is known. The 68 or so remaining minerals that contain $U$ as an essential constituent are built of the uranyl ion. All are of secondary origin. None of these minerals have analogues containing $\mathrm{Th}, \mathrm{Ce}$, or $\mathrm{Zr}$ in place of $\mathrm{U}$. This is due to the large size and unusual shape of the uranyl ion, which has no counterpart in the compounds of $\mathrm{Th}, \mathrm{Ce}$, or $\mathrm{Zr}$. It is only quadrivalent uranium that forms compounds isostructural with compounds of Th, $\mathrm{Ce}$, and $\mathrm{Zr}$. In these minerals the ions involved all are of the same charge and are of spherical shape with comparable radii (table 3) so that they play the same crystallochemical role. It also may be noted that the uranyl ion, so far as is known, does not occur as an important vicarious constituent in other minerals. This strongly contrasts with the behavior of $\mathrm{Th}, \mathrm{Zr}$, quadrivalent $\mathrm{U}$, and both quadrivalent and trivalent Ce. This behavior again is due to the size and shape of the uranyl ion, which does not allow it to proxy readily for the ordinary ions of crystal structures. The entrance of sexivalent uranium into solid solution in the structure of the silicates of igneous rocks and pegmatites also would be influenced by other factors, including the thermal instability of the uranyl ion at high temperatures and the oxygen content of the magma. Some rock silicates show a weak uranyl fluorescence at liquid air temperatures.

Uranium differs from thorium and zirconium in that it occurs in large amounts in hydrothermal deposits formed at relatively low temperatures. In hydrothermal veins, uraninite is typically associated with sulfides, arsenides, and sulfosalts of $\mathrm{Cu}, \mathrm{Fe}, \mathrm{Ni}, \mathrm{Co}, \mathrm{Zn}$, $\mathrm{Bi}, \mathrm{Ag}$, and other elements. These deposits are generally very low in their content of $\mathrm{Th}, \mathrm{Ce}$, and $\mathrm{Zr}$. On exposure to weathering, uraninite readily oxidizes to the uranyl ion, and the other minerals oxidize to relatively soluble sulfates and other oxysalts. This results in the formation in the oxidized zone of such deposits of a large variety of hydrated uranyl oxides, sulfates, arsenates or phosphates, for the most part also containing $\mathrm{Cu}, \mathrm{Ca}, \mathrm{Mg}, \mathrm{Ba}$ or other cations in addition to the uranyl ion. The alkaline-earth cations and the phosphate content are in part derived from associated gangue minerals but mostly come from the wall rock or the meteoric circulation. The uranyl oxysalts in general are relatively soluble and occur typically in gossans, as efflorescences on outcrops and the walls of mine workings, and in caliche-type deposits. Large amounts of uranium can be lost during oxidation by solution in the meteoric circulation, particularly in acid waters (Phair and Levine, 1953). This again 
contrasts with the behavior of $\mathrm{Th}$ and $\mathrm{Zr}$. The primary compounds of these elements are chemically stable and quite insoluble, and during the weathering cycle tend to accumulate in the detrital residues. Soluble salts of these elements hydrolyze readily to insoluble hydrous oxides. Zirconium does not form minerals in the zone of weathering, and thorium and cerium only very rarely.

Cerium, like uranium, differs from thorium and zirconium in that it possesses two valences that are stable under geologic conditions, $\mathrm{Ce}^{4}$ and $\mathrm{Ce}^{8}$. Both ions are mineralogically important, The $\mathrm{Ce}^{4}$ ion bears a close crystallochemical resemblance to the $\mathrm{Th}^{4}$ and $\mathrm{U}^{4}$ in particular. It has not yet been found in minerals as an essential constituent although the occurrence of $\mathrm{CeO}_{2}$ and $\mathrm{CeSiO}_{4}$ analogous to $\mathrm{ThO}_{2}$ and $\mathrm{ThSiO}_{4}$ could be expected. $\mathrm{Ce}^{4}$ does occur, however, dispersed in solid solution as a vicarious constituent in uranium, thorium, and other minerals. It may be noted in this relation that cerium apparently often has been reported in mineral analyses in the trivalent state, as $\mathrm{Ce}_{2} \mathrm{O}_{3}$, without knowledge of its actual valence state in the mineral. The $\mathrm{Ce}^{3}$ ion is considerably large: than the $\mathrm{Ce}^{4}$ ion (table 3) and has no mineralogically stable counterpart in Th, U, or Zr. The mineralogy of the $\mathrm{Ce}^{3}$ ion therefore stands alone among these elements. Trivalent cerium occurs in minerals both as an essential and as a vicarious constituent (tables 2 and 5) and it occurs in significant amounts as a vicarious constituent much more widely than does $\mathrm{Zr}$, although $\mathrm{Zr}$ is roughly five times more abundant than $\mathrm{Ce}$ in the lithosphere. This is due partly to the fact that the $\mathrm{Ce}^{3}$ ion is relatively close in size to certain other elements and enters readily into solid solution in their compounds. These elements include the trivalent rare earths and particularly the common element $\mathrm{Ca}$. Calcium is bivalent, and the substitution of $\mathrm{Ca}^{2}$ by $\mathrm{Ce}^{3}$ requires a concomitant substitution to compensate for the change in valence. In cerian fluorite, the substitution of $\mathrm{Ce}^{3}$ for $\mathrm{Ca}$ is compensated by the entrance of additional $\mathrm{F}$ into structural vacancies; in apatite and the apatitetype mineral britholite and its numerous analogues the substitution of $\mathrm{Ce}^{3}$ for $\mathrm{Ca}^{2}$ is compensated by a concomitant substitution of $\mathrm{Si}^{4}$ for $\mathrm{P}^{5}$; in sphene the entrance of $\mathrm{Ce}^{3}$ is compensated by the substitution of $\mathrm{Al}^{3}$ for $\mathrm{Ti}^{4}$, The initial content of $\mathrm{Ce}$, and especially of $\mathrm{Y}$, in alkalic igneous rocks retained in the magmatic stage of crystallization is much larger than that of Th, $\mathrm{Y}$ is taken into solid solution in accessory sphene, apatite, fluorite, and garnet more readily than in monazite (Sahama and Vähätalo, 1939).

Although $\mathrm{Zr}$ is a relatively abundant element, its mineralogy both as an essential and as a vicarious constituent is very much restricted. This is due primarily to the high charge and intermediate size of the $\mathrm{Zr}^{4}$ ion (table 3). Among the geologically important quadrivalent elements, $\mathrm{Zr}$ does not substitute appreciably for $\mathrm{Si}$ into the framework of silicates or for Ti because of the large difference in size. $\mathrm{Zr}$ ordinarily is 8coordinated with oxygen, whereas $\mathrm{Si}$ and $\mathrm{Ti}$ are 4and 6-coordinated, respectively. Among other geologically important elements, where bivalent $\mathrm{Fe}, \mathrm{Ca}$, and $\mathrm{Mg}$ and the univalent alkalies come into consideration, there is a somewhat closer approximation in ionic size to $\mathrm{Zr}^{4}$, but there is a larger difference in ionic charge, involving 2 or 3 units instead of but 1 as in the pair $\mathrm{Ce}^{3}-\mathrm{Ca}^{2}$. This latter circumstance severely limits the extent of a possible coupled substitution through both the demands of local electrostatic (Pauling rule) balance in the crystal structure and the lack of small, low-charged cations that can substitute concomitantly either for the central ion ( $\mathrm{Si}, \mathrm{Al}, \mathrm{P}, \mathrm{As}, \mathrm{S}$ ) of the anionic framework or for other cations in order to effect valence compensation. Actually the great bulk of $\mathrm{Zr}$ in nature is contained in but a single mineral, zircon, $\mathrm{ZrSiO}_{4}$. Almost all the known minerals containing $\mathrm{Zr}$ as an essential or vicarious element are silicates (table 6). None of these minerals, aside from zircon, are known to carry appreciable amounts of $\mathrm{Th}$ in solid solution, although minerals containing $\mathrm{Ce}^{3}$ commonly contain small amounts of $\mathrm{Th}^{4}$. $\mathrm{Th}^{4}$ is much closer in size to $\mathrm{Ce}^{3}$ than to $\mathrm{Zr}^{4}$.

The dioxides of $\mathrm{Th}^{4}, \mathrm{U}^{4}$, and $\mathrm{Ce}^{4}$ are isostructural, in the $\mathrm{CaF}_{2}$ structure type, and form a complete solidsolution series between all end compositions, (Th, U, Ce $\mathrm{O}_{2}$ at high temperatures in synthetic material (Magneli and Kihlborg, 1951; Rüdorff and Valet, 1952; Trzebiatowski and Selwood, 1950). In natural material, $\mathrm{CeO}_{2}$ or solid solutions with $\mathrm{Ce}>(\mathrm{Th}, \mathrm{U})$ is not known, but $\mathrm{Ce}^{4}$ is present in solid solution in considerable amounts in both natural $\mathrm{UO}_{2}$ and $\mathrm{ThO}_{2}$. Zirconium oxide has several polymorphs. The form stable at natural conditions is the monoclinic phase, baddeleyite, with a distorted $\mathrm{CaF}_{2}$-type structure, but one of the high-temperature polymorphs, not known in nature, is isometric with the $\mathrm{CaF}_{2}$ structure. In the synthetic system $\mathrm{UO}_{2}-\mathrm{ZrO}_{3}$ a series (Lambertson and Mueller, 1953) extends from $\mathrm{UO}_{2}$ to about 40 percent by weight of $\mathrm{ZrO}_{2}$, with a diphase region extending to about 50 percent by weight of $\mathrm{ZrO}_{2}$ and a tetragonal series extending from that point to $\mathrm{ZrO}_{2}$. There also is evidence of solid solubility of Th in synthetic monoclinic $\mathrm{ZrO}_{2}$. Very much smaller amounts of $\mathrm{Zr}$ occur in solid solution in natural $\mathrm{ThO}_{2}$ and $\mathrm{UO}_{2}$. There is question whether the $\mathrm{Zr}$ reported in some analyses of pegmatitic uraninite is present in solid solution or as admixed zircon, $\mathrm{CeO}_{2}$ forms only a partial series with $\mathrm{ZrO}_{2}$ in synthetic material (Duwez and Odell, 1950). The 
solubility relations of the dioxides of $\mathrm{Th}, \mathrm{U}$, and $\mathrm{Ce}$ on one hand and of $\mathrm{Zr}$ on the other clearly show the effect of the relatively small $\mathrm{Zr}$ ion. Trivalent rare earths such as La and $\mathrm{Y}$ go into limited solid solution in $\mathrm{ThO}_{2}$ in both natural and synthetic material (Brauer and Gradinger, 1951). The C-type polymorphs of $\mathrm{La}_{2} \mathrm{O}_{3}$, $\mathrm{Y}_{2} \mathrm{O}_{3}$, and such, have a structure related to that of $\mathrm{ThO}_{2}$, but with certain cation positions vacant, and the series from $\mathrm{ThO}_{2}$ involves the coupled entrance of vacancies to provide valence compensation.

In natural material the series between $\mathrm{ThO}_{2}$ and $\mathrm{UO}_{2}$ apparently has a large central gap. In general, the uraninite of pegmatites contains relatively large amounts of Th and $\mathrm{Ce}$ in solid solution, whereas the uraninite of hydrothermal veins and black-ore sandstone deposits of the Colorado Plateau is notably deficient in these elements. This is a problem of geochemical association rather than of the temperature dependency of the solid solubility.

Besides the dioxides, some of the elements under consideration form other oxides. $\mathrm{Ce}$ forms $\mathrm{Ce}_{2} \mathrm{O}_{3}$, not known as a mineral; $\mathrm{U}$ forms $\mathrm{U}_{3} \mathrm{O}_{8}$, several polymorphs of $\mathrm{UO}_{3}$, and other anhydrous oxides. None of these are known as minerals, although $\mathrm{U}_{3} \mathrm{O}_{8}$ might be expected to occur in nature. Uranium also forms a number of hydrated uranyl oxides, in part also containing Ba or $\mathrm{Pb}$, that are widespread in small amounts. None of these uranium compounds have counterparts with Th, $\mathrm{Ce}$, or $\mathrm{Zr}$.

The economic importance of the oxides of Th, U, Ce, and $\mathrm{Zr}$ varies widely. Uraninite (here referred to as $\mathrm{UO}_{2}$ but actually departing considerably from this composition owing to partial oxidation and solid solution) is the principal ore mineral of uranium. $\mathrm{CeO}_{2}$ does not occur in nature, and cerium is obtained almost wholly from the cerium phosphate, monazite. $\mathrm{ThO}_{2}$ is not an important actual or prospective ore mineral of thorium, although it is probably widely distributed as a very minor accessory mineral in beach and river sands. Small amounts of thorianite, however, have been obtained in Ceylon. Baddeleyite, $\mathrm{ZrO}_{2}$, although an extremely rare mineral as compared to zircon, is an important ore mineral at one locality, in the Poços de Caldas, Brazil (Guimarães, 1948), where it occurs in large amounts with zircon as fibrous crusts in hydrothermal veins derived from and situated in syenitic igneous rocks. The parent rocks contain much $\mathrm{Zr}$ as eudialyte and as a vicarious constituent in alkalic pyroxenes and other silicates. The complex $\mathrm{Zr}$ silicate eudialyte occurs in large deposits in alkalic rocks in southern Greenland (Bøggild, 1953) and the Kola peninsula and is a potential source of $\mathrm{Zr}$; it contains some Ce but lacks significant amounts of Th. Thorianite, $\mathrm{ThO}_{2}$, does not occur in hydrothermal deposits analogous to baddeleyite. Sodium metasomatism in alkalic rocks may result in the liberation, and hydrothermal concentration of $\mathrm{Zr}$ and certain other polyvalent ions (Luchitski, 1947).

The principal silicates of the elements here considered are those of the thorite and thorogummite groups (table 4 ). The available evidence indicates a very limited solid solubility between the isostructural phases $\mathrm{ThSiO}_{4}$ and $\mathrm{ZrSiO}_{4}$, extending perhaps to a few mol percent under natural conditions. In the ternary system $\mathrm{USiO}_{4}-\mathrm{ThSiO}_{4}-\mathrm{ZrSiO}_{4}$ there is extensive solid solubility of $\mathrm{U}$ into $\mathrm{ThSiO}_{4}$ and a very limited solid solubility, apparently of the order of a few atomic percent, of $\mathrm{U}$ into $\mathrm{ZrSiO}_{4}$. Anhydrous $\mathrm{USiO}_{4}$ does not occur in nature and has not been synthesized in spite of repeated attempts, but the solid solution (Th,U) $\mathrm{SiO}_{4}$ extends from $\mathrm{ThSiO}_{4}$ toward $\mathrm{USiO}_{4}$ at least as far as Th:U=1:1. $\mathrm{CeSiO}_{4}$ also does not occur in nature and has not yet been synthesized. The illdefined mineral freyalite may represent a Th-containing variety of $\mathrm{CeSiO}_{4}$ or its hydroxyl-containing analogue. Cerium is commonly present in considerable amounts in thorite and thorogummite but is lacking or present only in small amounts in zircon. The mutual solubility in the system $\mathrm{ThSiO}_{4}-\mathrm{USiO}_{4}-\mathrm{ZrSiO}_{4}$ and the entrance of $\mathrm{Ce}^{4}$ into the phases of this system clearly illustrate the role played by ionic size. The extent of solid solubility of $U$ in both natural and synthetic material appears to be greater in thorogummite and cyrtolite than in anhydrous thorite and zircon. Thorium is lacing in the uranium member of the thorogummite group, coffinite, in the Colorado Plateau area but this is due to the lack of thorium in this geochemical province.

Huttonite, a monoclinic polymorph of $\mathrm{ThSiO}_{4}$ isostructural with monazite, has no known analogues in $U$, $\mathrm{Ce}^{4}$, or $\mathrm{Zr}$ silicates. Among the eight monoclinic and tetragonal polymorphs possible between $\mathrm{ZrSiO}_{4}, \mathrm{ThSiO}_{4}$, $\mathrm{YPO}_{4}$, and $\mathrm{CePO}_{4}$, it may be noted that the tetragonal structure is taken by the small ions $\mathrm{Zr}$ and $\mathrm{Y}$ and the monoclinic structure by the large ion Ce. Only Th, intermediate in size, develops both polymorphs. Pure $\mathrm{CeSiO}_{4}$ presumably would be monoclinic and isostructural with huttonite. In synthetic material the solid solubility of $\mathrm{U}$ in monoclinic $\mathrm{ThSiO}_{4}$ appears to be less than that in tetragonal $\mathrm{ThSiO}_{4}$.

Thorium forms no natural silicates other than thorite, thorogummite, huttonite, and the ill-defined mineral pilbarite. Uranium forms no silicates that contain solely $\mathrm{U}^{4}$, other than coffinite, but does form a number or uranyl silicates (table 7). All of these are secondary in origin, and none have analogues with $\mathrm{Th}, \mathrm{Ce}$, or $\mathrm{Zr}$ in place of U. Cerium forms silicates containing essential $\mathrm{Ce}^{3}$, and $\mathrm{Ce}^{3}$ enters as a vicarious element into 
still others (tables 2 and 5 ). Some cerium silicates contain $\mathrm{Th}$ and $\mathrm{U}$ in solid solution, but others, such as cerite, have not yet been observed to carry significant amounts of these elements. Allanite, a common silicate of the epidote group, carries $\mathrm{Ce}, \mathrm{Th}$, and $\mathrm{U}$ in solid solution. The elements $\mathrm{Ca}, \mathrm{La}$, and $\mathrm{Y}$ also are close associates of $\mathrm{Ce}$ in silicates. In addition to zircon, zirconium forms a considerable number of silicates (table 6). Most of these are complex in constitution, and all are rare. Further, none of them have analogues with $\mathrm{Th}, \mathrm{Ce}$, or $\mathrm{U}$. The complex zirconium silicates generally contain alkalies in their composition; this feature is less marked with the cerium silicates and is lacking with uranium silicates.

$\mathrm{U}$ and $\mathrm{Zr}$ have not been found as phosphates. Th forms a silicate-phosphate, cheralite, that has already been discussed. Small amounts of $\left(\mathrm{PO}_{4}\right)$ are commonly found in thorite and thorogummite substituting for $\left(\mathrm{SiO}_{4}\right)$. This series, with accompanying valence compensation by substitution of $\mathrm{Ce}^{3}$ for $\mathrm{Th}$, leads to a hypothetical tetragonal polymorph of $\mathrm{CePO}_{4}$ isostructural with xenotime, $\mathrm{YPO}_{4}$, and zircon. Compared to monazite, xenotime carries negligible amounts of Th. Cerium has a marked affinity for $\mathrm{P}$ as compared to $\mathrm{U}^{4}, \mathrm{Th}$, and $\mathrm{Zr}$. Monazite is a very common mineral, and other cerium minerals contain $\mathrm{P}$ as an essential or vicarious constituent (tables 2 and 5). Some of these magmatic or pegmatitic minerals including britholite, abukamalite, belovite, and melanocerite are structural derivatives of apatite. The vicarious Th content of these apatitelike minerals is of interest in connection with the occurrence of $\mathrm{U}^{4}$ in small amounts in the apatite of phosphate rock. The substitution of Th is much larger than that of $U$, in part probably owing to factors favoring the entrance of compensating $\mathrm{Si}$ into magmatic rather than sedimentary apatite. Both the $\mathrm{Th}$ and the $\mathrm{U}$ substitute into the $\mathrm{Ca}$ positions of the apatite structure. In late magmatic and pegmatitic apatite the amount of substitution for $\mathrm{Ca}$ is in the order $\mathrm{Ce}^{3}>\mathrm{Th}>\mathrm{U}>\mathrm{Zr}$. This is not the order of closeness of approach in ionic size to $\mathrm{Ca}$, but it is the order of increasing electronegativity of the ions. In an isostructural group of phases, as in the present instance, increasing electronegativity of the cation is in a general way accompanied by a less ionic and weaker bond with the anion held in common. The entrance of $\mathrm{Ce}^{3}$ into solid solution in apatite is favored both by this factor and by the relative ease of valence compensation. The observed enrichment of $\mathrm{Ce}$ and other rare earths in pegmatitic rather than early magmatic Ca minerals also appears to be related to the relative electronegativity of the ions (Ringwood, 1955).

The only natural halogen-containing compounds of $\mathrm{Th}, \mathrm{U}, \mathrm{Ce}$, and $\mathrm{Zr}$ are those of $\mathrm{Ce}$ (table 5). Thorite is found with fluorite in pegmatites and in some vein deposits, and the fluocarbonates of cerium are typical associates, but fluorine does not occur as an essential constituent in any thorium mineral.

The many uranyl carbonates include rutherfordine and a considerable number of complex carbonates containing the uranyl ion together with other cations, chiefly $\mathrm{Cu}, \mathrm{Ca}, \mathrm{Mg}$, and $\mathrm{Na}$. These minerals, together with the carbonate-fluoride-sulfate schroeckingerite and with lanthanite, are relatively soluble secondary minerals that occur chiefly as efflorescences. The numerous fluorocarbonates of cerium, on the other hand, are relatively insoluble and form at much higher temperatures. These minerals appear to contain relatively little thorium in solid solution as compared to the silicates and phosphates of cerium.

The niobate-tantalates are characterized as a group by the presence, often in large amounts, of $\mathrm{Th}, \mathrm{U}, \mathrm{Zr}$, $\mathrm{Ti}, \mathrm{Fe}^{3}$, and rare earths. The relative amounts of these elements vary widely through mutual substitution, and commonly a distinction between essential and vicarious constituents is not significant. The yttrium group of rare earths usually predominates over the cerium group. The diverse and large content of ions of high valence in the niobate-tantalates offers opportunities for mutual substitution that are not available to the same ions as they occur individually in silicates and other compounds dominated by the presence of bivalent and univalent cations. The niobate-tantalates are not of economic importance as sources of Th or $\mathrm{U}$, because of their rarity and refractory chemical nature.

\section{GEOCHEMISTRY AND OCCURRENCE OF THORIUM}

The geochemistry of $\mathrm{Th}, \mathrm{U}, \mathrm{Ce}$, and $\mathrm{Zr}$, as these elements appear in igneous rocks, is similar and is governed largely by the low concentration and high valence of their ions. The activation energy of migration of their ions (E-value of Wickman, 1943) is relatively high, which would tend to freeze the ions in the main stage of crystallization of the magma, but their concentration is in general too low to permit the appearance of phases in which these elements are essential constituents. In broad terms, they either concentrate in residual solutions or are included in solid solution in the minerals that form the bulk of the rock. In the case of gallium, an element of roughly the same abundance as thorium, the identity in valence and near identity in ionic radius with aluminum causes virtually all of this element to become dispersed in solid solution in aluminosilicates of the magmatic stage. In thorium and uranium, however, the high charge and large size of their quadrivalent ions do not permit entrance into the normal rock minerals, and as crystallization proceeds the residual solutions become enriched in these 
elements. Zirconium, much commoner than uranium and thorium, in part crystallizes in the magmatic stage as accessory zircon and may then house a certain amount of Th and $\mathrm{U}$, a circumstance on which the age-determination method of E. S. Larsen, Jr., is based. Both monazite and xenotime, however, appear to house $\mathrm{Th}$ and $\mathrm{U}$ more readily than zircon (Hutton, 1947). Zirconium and the rare earths, notably $\mathrm{Ce}^{4}$, together with other polyvalent elements such as $\mathrm{Nb}$ and Ta also tend to concentrate in the residual solutions. Thorium, cerium, and uranium have a marked affinity for alkalic rather than granitic or intermediate igneous rocks in the broad course of magmatic differentiation. The bulk eomposition of the magma also influences the mineralogical expression of trace elements. The ratio of alkalies to aluminum was emphasized in this regard by A. E. Fersman and V. M. Goldschmidt in their concept of plumasitic and agpaitic magmas, Zirconium appears to be responsive to this factor. In highly aluminous magmas it crystallizes directly as a phase, zircon, but in highly alkalic magmas the excess of strongly electropositive elements complexes the $\mathrm{Zr}$, which is comparable in electronegativity to $\mathrm{Al}$, as a vicarious substitute for $\mathrm{Al}$ in silicates. Thorium and uranium, less electronegative and much larger in size than aluminum, are not as markedly dispersed in this way in the silicates of alkalic rocks.

The main types of deposits that carry concentrations of thorium minerals are pegmatites, hydrothermal veins, and detrital deposits. Pegmatites associated with alkalic igneous rocks, particularly nepheline syenites and their variants, are notably rich in thorium. Well-known and important occurrences of this type are in southern Norway (Brőgger, 1890), the Kola peninsula of Russia (Fersman, 1926; Fersman and Bohnstedt, 1937) and southern Greenland (Bøggild, 1953). These pegmatites also are relatively high in content of rare earths, with the cerium earths predominating over the yttrium earths, together with $\mathrm{Zr}, \mathrm{Nb}, \mathrm{Ca}, \mathrm{P}$, and $\mathrm{F}$. Tantalum and uranium are minor constituents. These pegmatites are feldspathic but generally lack quartz and may contain nepheline (often altered to zeolites), together with pyroxenes and a variety of complex silicates containing $\mathrm{Zr}$. Apatite is a characteristic accessory mineral in the pegmatites, and it sometimes occurs separately, as in the Kola peninsula (Antonov, 1934), as very large deposits associated with alkalic igneous rocks. This apatite typically contains $\mathrm{Ce}$ and $\mathrm{Si}$ and very small amounts of Th. Pegmatites derived from granitic rocks tend to contrast with those from alkalic rocks in containing, on the whole, a smaller amount of
Th and in being relatively enriched in $\mathrm{Y}$ over $\mathrm{Ce}$, Ta over $\mathrm{Nb}$, and $\mathrm{U}$ over Th. The granite pegmatites generally are quartz-rich, with $\mathrm{Zr}$ present chiefly as zircon. A small production of thorite has been obtained from alkalic pegmatites in Norway, but these deposits in general are not potential large-scale sources of Th. Thorium may possibly be obtained as a byproduct in the utilization of magmatic apatite, analogous to the production of uranium from sedimentary phosphate rock.

Hydrothermal vein deposits containing thorium have become known only during the past few years. They differ from the base-metal sulfide types of veins, in which thorium is lacking in significant amounts, and they show resemblances to the cerium- and thoriumrich pegmatites associated with alkalic rocks. The Powderhorn district, Gunnison County, Colo., contains veins and mineralized shear zones carrying thorite or thorogummite with calcite, dolomite, quartz, barite, cerian fluorapatite, and bastnaesite, according to J. C. Olson and S. R. Wallace (written communication). The deposits occur in and near alkalic igneous rocks, including the Iron Hill stock, that are notably rich in rare earths, $\mathrm{Ti}, \mathrm{Nb}, \mathrm{Ba}$, and $\mathrm{Sr}$. Concentrations of perovskite occur in the area. In the Mountain Pass area, San Bernardino County, Calif. (Olson, Shawe, Pray, and Sharp, 1954), large veins and irregular bodies containing bastnaesite with caleite, dolomite, barite, parisite, and sahamalite occur in association with alkalic igneous rocks. The deposit contains $\mathrm{Th}$ in small amounts as a vicarious constituent. In the Salmon Bay area on Prince of Wales Island, Alaska (Wedow and others, 1953), veins carrying thorite with carbonates, hematite, and monazite are associated with other veins lacking Th but carrying carbonates with parisite and bastnaesite. Some deposits of bastnaesite, as in the fluorite-barite veins of the Gallinas Mountains, N. Mex. (Glass and Smalley, 1945), and the contact metamorphic deposit at Bastnaes, Sweden, do not carry appreciable amounts of thorium. Vein deposits containing thorite or thorogummite but lacking rare earths are also known. In the Wet Mountains in Custer and Fremont Counties, Colo., a very large area contains veins containing a thoritelike mineral together with hematite, quartz, barite, carbonates, and minor fluorite and sulfides (R. A. Christman, written communication). The deposits appear to be related to albite syenite intrusive bodies. Quartz-hematite veins with a thoritelike mineral and minor amounts of monazite and allanite also occur in districts in east-central 
Idaho and southwestern Montana (Trites and Tooker, 1953). These vein deposits of Th and Ce minerals in general are extremely low in $\mathrm{U}, \mathrm{Zr}, \mathrm{Y}, \mathrm{Nb}$, and $\mathrm{Ti}$. They show that the geochemical descent of Th and $\mathrm{Ce}$, like that of $\mathrm{U}$, continues into the hydrothermal stage. The baddeleyite deposits of Brazil are roughly analogues of the $\mathrm{Th}$ and $\mathrm{U}$ vein deposits, but $\mathrm{Zr}$ in general is retained in high-temperature minerals. The separation of $\mathrm{U}$ and $(\mathrm{Th}, \mathrm{Ce})$ in the hydrothermal stage remains unexplained. Uranium apparently carries further into the lower-intensity hydrothermal zones, together with $\mathrm{S}, \mathrm{As}$, and heavy metals.

Thorium also occurs as a very minor constituent in deposits other than veins and pegmatites, such as with $\mathrm{Nb}$ in carbonatites and in a few contact metamorphic deposits. In the sedimentary cycle, thorium (Koczy, $1949 \mathrm{a}, 1949 \mathrm{~b})$, unlike uranium, is not a significant constituent of the carbonaceous marine black shales and apparently does not play an important biogeochemical role. Zirconium is like thorium in this respect and is deposited chiefly as detritral zircon in nearshore clastic sediments. In sea water, uranium is enriched relative to thorium.
Alluvial deposits contain the largest known reserves of thorium. The tborium-containing mineral, monazite, oceurs widely distributed as an accessory mineral in igneous and metamorphic rocks and in pegmatites. The content in gneiss and schist sometimes runs as high as 0.1 percent by weight of monazite, but efforts to mine and concentrate the mineral directly have been unsuccessful. The high specific gravity, hardness, and general stability of monazite cause it, when freed by weathering, to become mechanically concentrated in alluvial deposits. Important deposits of this kind are found in Travancore, Ceylon, the States of Bahia and Espirito Santo in Brazil, New South Wales, and Queensland. In the United States, alluvial deposits of monazite are found in Florida, the Appalachian region, Idaho, and elsewhere. The monazite is associated with ilmenite, zircon, magnetite, and garnet chiefly, and is separated and eoncentrated by magnetic methods. Thorite (Hutton, 1950) and thorianite are widespread in trace amounts in alluvial deposits. The known deposits of monazite sands are very large, and the world's supply of thorium is now and probably will continue to be largely drawn from them.

TABLE 1,-Minerals containing thorium as an essential constituent, with their varieties and synonyms

$\begin{array}{ccc}\text { Name } & \text { Composition } & \text { Content of ThO } \mathrm{O}_{2}(\text { percent }) \quad \begin{array}{c}\text { Refer- } \\ \text { ence } \\ \text { No. }{ }^{1}\end{array}\end{array}$

Cheralite
Huttonite
Pilbarite
Thorianite
Thorite
Thorogummite

Thorogummite

Aldanite.

Auerlite.

Calciothorite.

Chlorothorite

Enalite.

Eucrasite

Ferrothorite

Freyalite

Hyblite.

Hydrothorite

Mackintoshite

Maitlandite

Nicolayite

Orangite.

Uranothorianite

Uranothorite

Wisaksonite.

$(\mathrm{Th}, \mathrm{Ca}, \mathrm{Ce})\left(\mathrm{PO}_{4}, \mathrm{SiO}_{4}\right)$
$\mathrm{Th}(\mathrm{SiO})_{4}$
$\mathrm{ThO}_{2} \cdot \mathrm{UO}_{3} \cdot \mathrm{PbO} \cdot 2 \mathrm{SiO}_{2} \cdot 4 \mathrm{H}_{2} \mathrm{O}$
$\mathrm{ThO}_{2}$
$\mathrm{Th}\left(\mathrm{SiO}_{4}\right)$
$\mathrm{Th}\left(\mathrm{SiO}_{4}\right)_{1-\mathrm{x}}(\mathrm{OH})_{4 x}$
Varieties and synonyms

30 , variable

81.5 (ideal $^{2}$ )

31 , variable.

然

81.5 (ideal ${ }^{2}$ )

24 to 58 or more

\section{1,4}

1,5

1,6

1,2

1,2

1. 7

Variety of thorianite high in $\mathrm{Pb}$ and $\mathrm{U}$ content.

Variety of thorite or thorogummite relatively high in (PO) content

Variety of thorite or thorogummite relatively high in Ca content...............

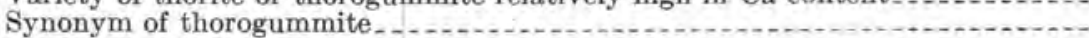

Variety of thorite or thorogummite relatively high in content of ' $U$, rare earths, and $\left(\mathrm{PO}_{4}\right)$ ? earths

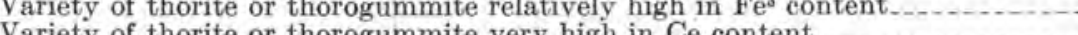

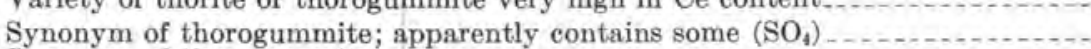

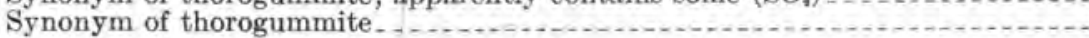
Synonym of thorogummite. Contains $\mathrm{U}^{4}$

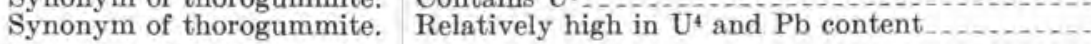
Synonym of thorogummite . .

Varietal name for yellow to orange metamict thorite

Varietal name for thorianite high in content of uranium [uranoan thorianite, $\left.(\mathrm{Th}, \mathrm{U}) \mathrm{O}_{2}\right]$ $\left.\left(\mathrm{SiO}_{4}\right)\right]_{\ldots} \ldots$ Synonym of thorite.
1,9

1,18

1

1,18

1,18

1,7

1,7

1,7

1,7

1,7

1,18

1 References cited at end of table 2 .

2 Usually less becanse of substitution of other elements for thorium. 
TABLE 2.-Minerals containing thorium as a vicarious constituent, with their varieties and synonyms

Name

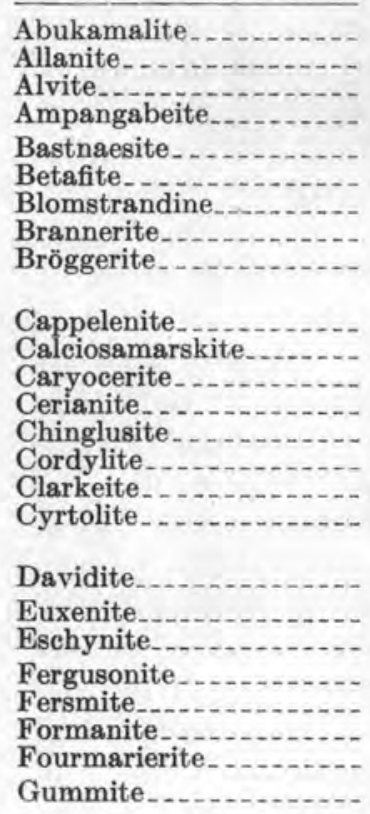

Hagatelite

Hokutolite

Irinite

Johnstrupite

Khlopinite.

Lovchorrite

Lyndochite.

Melanocerite

Mierolite _.

Muromontite

Monazite

Naegite

Orthite

Oyamalite

Perrierite

Pisekite

Pyrochlore

Polycrase...............

Polymignyte

Priorite.

Rinkite

Rinkolite.

Samarskite

Steenstrupine..........

Tanteuxenite

Thalenite

Tritomite

Tscheff kinite

Tengerite.

Uraninite

Uranophane
Composition

$(\mathrm{Ca}, \mathrm{Y}, \mathrm{Th})_{5}\left(\mathrm{Si}, \mathrm{P}, \mathrm{AlO}_{4}\right)_{3}(\mathrm{O}, \mathrm{F})$

$(\mathrm{Ca}, \mathrm{Ce}, \mathrm{Th})_{2}(\mathrm{Al}, \mathrm{Fe}, \mathrm{Mg})_{3} \cdot \mathrm{Si}_{3} \mathrm{O}_{12}(\mathrm{OH})$

Ill-defined substance, near zircon-

$\approx(\mathrm{Y}, \mathrm{Er}, \mathrm{U}, \mathrm{Ca}, \mathrm{Th})_{2}(\mathrm{Nb}, \mathrm{Ta}, \mathrm{Fe}, \mathrm{Ti})_{7} \mathrm{O}_{18}$

$(\mathrm{Ce}, \mathrm{La})\left(\mathrm{CO}_{3}\right) \mathrm{F}$

$\approx(\mathrm{U}, \mathrm{Ca})(\mathrm{Nb}, \mathrm{Ta}, \mathrm{Ti})_{3} \mathrm{O} 9 . n \mathrm{H}_{2} \mathrm{O}$

Synonym of priorite

$\approx(\mathrm{U}, \mathrm{Ca}, \mathrm{Fe}, \mathrm{Th}, \mathrm{Y})_{3} \mathrm{Ti}_{3} \mathrm{O}_{16}$ earths and thorium. Thorian uraninite.

$\approx \mathrm{BaY}_{6} \mathrm{~B}_{6}\left(\mathrm{SiO}_{4}\right)_{3} \mathrm{O}_{12}(\mathrm{OH})_{2}$

Variety(?) of samarskite relatively rich in $\mathrm{Ca}_{\text {. }}$................. $\approx(\mathrm{Ce}, \mathrm{La}, \mathrm{Th}, \mathrm{Ca})_{5}(\mathrm{Si}, \mathrm{B})_{3}(\mathrm{O}, \mathrm{OH}, \mathrm{F})_{13}$

$(\mathrm{Ce}, \mathrm{Th}) \mathrm{O}_{2}$

$\approx(\mathrm{Na}, \mathrm{K})_{4}(\mathrm{Mn}, \mathrm{Ca})_{5}(\mathrm{Ti}, \mathrm{Zr})_{3} \mathrm{Si}_{14} \mathrm{O}_{41} \cdot 9 \mathrm{H}_{2} \mathrm{O}$

$(\mathrm{Ce}, \mathrm{La})_{2} \mathrm{Ba}\left(\mathrm{CO}_{3}\right)_{3} \mathrm{~F}$

$\approx(\mathrm{Na}, \mathrm{Ca}, \mathrm{Pb})_{2} \mathrm{U}_{2}\left(\mathrm{O}, \mathrm{H}_{2} \mathrm{O}\right)_{7}$

Altered zircon containing $\mathrm{H}_{2} \mathrm{O}$ and often small amount of $\mathrm{U}$ and $\mathrm{Th}$.

$(\mathrm{Fe}, \mathrm{Ce}, \mathrm{U})(\mathrm{Ti}, \mathrm{Fe}, \mathrm{V}, \mathrm{Cr})_{3}(\mathrm{O}, \mathrm{OH})_{7}$

(Y,Ca, Ce, U,Th) $(\mathrm{Nb}, \mathrm{Ta}, \mathrm{Ti})_{2} \mathrm{O}_{5}$

(Ce, Ca, Fe, Th) (Ti,Nb) ${ }_{2} \mathrm{O}_{6}$

(Y, Er, Ce, U,Th) (Nb,Ta,Ti) $\mathrm{O}_{4}$

$(\mathrm{Ca}, \mathrm{Ce}, \mathrm{Na})(\mathrm{Nb}, \mathrm{Ti}, \mathrm{Fe}, \mathrm{Al})_{2}(\mathrm{O}, \mathrm{OH}, \mathrm{F})$

(Y,Er,U,Th) (Ta,Nb) O

$\approx \mathrm{PbO} .4 \mathrm{UO}_{3} .5 \mathrm{H}_{2} \mathrm{O}$

Generic term for orange-red to yellowish alteration products of uraninite; chiefly fourmarierite and vandendriesscheite.

Variety of zircon containing rare earths, $\mathrm{Nb}, \mathrm{Ta}$, and $\mathrm{Th}$

Radioactive variety of barite containing $\mathrm{Pb}$ and probable also $\mathrm{Ra}, \mathrm{U}$, Th.

Thorian variety of loparite (perovskite) with composition $(\mathrm{Na}, \mathrm{Ce}, \mathrm{Th})(\mathrm{Ti}, \mathrm{Nb})(\mathrm{O}, \mathrm{OH})$ s.

Silicate of $\mathrm{Ce}, \mathrm{Ca}, \mathrm{Ti}, \mathrm{Zr}, \mathrm{Na}$.

$\approx(\mathrm{Y}, \mathrm{U}, \mathrm{Th})_{3}(\mathrm{Nb}, \mathrm{Ta}, \mathrm{Ti}, \mathrm{Fe})_{7} \mathrm{O}_{20}$

$\approx \mathrm{Ce}_{4} \mathrm{Ca}_{10} \mathrm{Ti}_{3} \mathrm{Si}_{10} \mathrm{O}_{39} \mathrm{~F}_{6}$

$\approx(\mathrm{Na}, \mathrm{K})_{2}(\mathrm{Mn}, \mathrm{Ca}) \mathrm{ZrSi}_{6} \mathrm{O}_{16} \cdot 3 \mathrm{H}_{2} \mathrm{O} \ldots \ldots$

Variety of euxenite-polycrase relatively high in $\mathrm{Ca}$ and $\mathrm{Th}$.

$\approx(\mathrm{Ce}, \mathrm{Y}, \mathrm{La}, \mathrm{Ca})_{5}(\mathrm{Si}, \mathrm{B}, \mathrm{P})_{3}(\mathrm{O}, \mathrm{OH}, \mathrm{F})_{13} \ldots \ldots$ $(\mathrm{Na}, \mathrm{Ca})_{2}(\mathrm{Ta}, \mathrm{Nb})_{2} \mathrm{O}_{6}(\mathrm{O}, \mathrm{OH}, \mathrm{F})$

$\approx \mathrm{NaCa}_{6} \mathrm{Ce}_{2}(\mathrm{Ti}, \mathrm{Zr})_{2} \mathrm{Si}_{7} \mathrm{O}_{25}(\mathrm{OH}, \mathrm{F})_{7} \ldots \ldots \ldots$

Apparently a variety of allanite high in $\mathrm{Be}$ content.....

(Ce, Y, $\mathrm{La}, \mathrm{Th})\left(\mathrm{PO}_{4}\right)$

Variety of zircon containing rare earths, $\mathrm{U}$, and $\mathrm{Th} . . .$.

Ill-defined mixture

Synonym of allanite

Variety of zircon containing rare earths, ( $\left.\mathrm{PO}_{4}\right)$, and $\mathrm{Th}$ $(\approx 1$ percent)

Perhaps identical with allanite

Niobate-tantalate with U, Th, rare earths. Th present, amount not known.

$\mathrm{NaCa}(\mathrm{Nb}, \mathrm{Ta})_{2} \mathrm{O}_{6} \mathrm{~F}$

$(\mathrm{Y}, \mathrm{Ca}, \mathrm{Ce}, \mathrm{U}, \mathrm{Th})(\mathrm{Ti}, \mathrm{Nb}, \mathrm{Ta})_{2} \mathrm{O}$

$\approx(\mathrm{Ca}, \mathrm{Fe}, \mathrm{Y}, \mathrm{Zr})(\mathrm{Nb}, \mathrm{Ti}, \mathrm{Ta}) \mathrm{O}_{4}$

$(\mathrm{Y}, \mathrm{Er}, \mathrm{Ca}, \mathrm{Fe}, \mathrm{Th})(\mathrm{Ti}, \mathrm{Nb})_{2} \mathrm{O}_{6--}$

$\approx(\mathrm{Na}, \mathrm{Ca})_{12}(\mathrm{Ce}, \mathrm{Ti})_{5} \mathrm{Si}_{8}(\mathrm{O}, \mathrm{F})_{36}$

$\approx(\mathrm{Ca}, \mathrm{Na})_{22} \mathrm{Ce}_{2}(\mathrm{Si}, \mathrm{Ti})_{10} \mathrm{O}_{28}(\mathrm{~F}, \mathrm{OH})_{8}$

$(\mathrm{Y}, \mathrm{Er}, \mathrm{Ce}, \mathrm{U}, \mathrm{Fe}, \mathrm{Th})(\mathrm{Nb}, \mathrm{Ta})_{2} \mathrm{O}_{6}$

$\approx(\mathrm{Na}, \mathrm{Ca}, \mathrm{Ce}, \mathrm{La}, \mathrm{Th})_{3}(\mathrm{Mn}, \mathrm{Fe}, \mathrm{Ta})(\mathrm{Si}, \mathrm{Be}, \mathrm{P})_{3}(\mathrm{O}, \mathrm{OH}, \mathrm{F})_{12} \ldots$

Variety of euxenite relatively rich in Ta.

$\mathrm{Y}_{4} \mathrm{Si}_{4} \mathrm{O}_{13}(\mathrm{OH})_{2-}$

Hydrocarbon mixture containing much $\mathrm{U}$, Th, and rare earths in the ash.

Silicate with B, F, Ce, La, Ca, Th

Silicate of Ce, La, Th, Fe, Ti, Ca

$\approx \mathrm{CaY}_{3}\left(\mathrm{CO}_{3}\right)_{4}(\mathrm{OH})_{3} \cdot 3 \mathrm{H}_{2} \mathrm{O}$

$\mathrm{UO}_{2}$ (ideally); usually partly oxidized, with $\mathrm{Ce}, \mathrm{Y}, \mathrm{Pb}$ Th, ete.

$\mathrm{Ca}\left(\mathrm{UO}_{2}\right)_{2}\left(\mathrm{SiO}_{3}\right)_{2}(\mathrm{OH})_{2} \cdot 5 \mathrm{H}_{2} \mathrm{O}$
Content of $\mathrm{ThO}_{2}$ (percent)

$<1, \ldots$ to $\approx 3$.

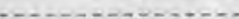

15 in one analysis............

1 to 2

$<1$.

0 to $\approx 1$

0 to 12

(l)

14

$<1$

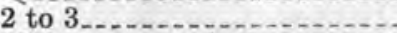

13.6 in one analysis.............

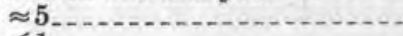

$<1$ 1 1 .

2.4 in one analysis...............

$<1$

0 to $\approx 5$

0 to 17

0 to $\approx 5$

$<1$

$\approx 1, \ldots$

small.

-ann.

Reference No.

$\frac{23}{23}$

23

$\frac{2}{2}$

2

1,2

1

18

2

18

24

1

$\approx 1.5$

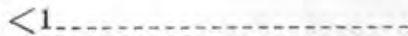

2.2 in only analysis ...........

$<1$ small amount.............. $\approx 5$.

1.7 in one analysis.

$<1$ in one analysis...........

$<1$ 1 1 (1)

0 to $\approx 30$, usually 10 to $12 \ldots$

$2.8 \ldots$

2 to $4 \ldots \ldots$

0 to $\approx 3$

-........................

4.6

0 to $\approx 5$

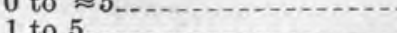

3.9 in one analysis......... 0 to $\approx 8$.

$<1$

small..

0 to $\approx 4$

2 to 7 .

2.8 in one analysis

$<1$.

$\approx 9 \ldots \ldots$

0 to 20 , usually $\approx 1 \ldots \ldots$

$\approx 1 \ldots \ldots$

0 to 14 at least

1,2

2

16

14
2

18

1,2

18

2

11,12

18

19

3

$\approx 2$ in one analysis

\section{1}

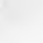

7

2

2

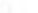


TABLE 2.-Minerals containing thorium as a vicarious constituent, with their varieties and synonyms-Continued

\begin{tabular}{|c|}
\hline Name \\
\hline $\begin{array}{l}\text { Vandendriesscheite...... } \\
\text { Vudyavrite. }\end{array}$ \\
\hline 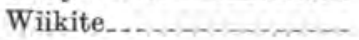 \\
\hline Xenotime \\
\hline Yttrialite \\
\hline Yttrocrasite \\
\hline Yttrotantalite \\
\hline Zircon $\ldots . .$. \\
\hline
\end{tabular}

Composition

$\approx \mathrm{PbO} .7 \mathrm{UO}_{3} .12 \mathrm{H}_{2} \mathrm{O}$

Altered variety of lovehorrite.

Ill-defined mixture.

$\mathrm{Y}\left(\mathrm{PO}_{4}\right)$

$\approx(\mathrm{Y}, \mathrm{Th})_{2} \mathrm{Si}_{2} \mathrm{O}_{7}$

$\approx(\mathrm{Y}, \mathrm{Th}, \mathrm{U}, \mathrm{Ca})_{2}(\mathrm{Ti}, \mathrm{Fe}, \mathrm{W})_{4} \mathrm{O}_{11} \ldots \ldots$

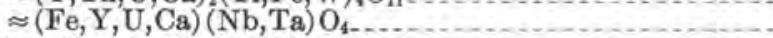

$\mathrm{Zr}\left(\mathrm{SiO}_{4}\right)$

$\approx(\mathrm{Ca}, \mathrm{Fe}, \mathrm{Th}, \mathrm{U})_{2}(\mathrm{Ti}, \mathrm{Zr})_{3} \mathrm{O}_{5}$

$\frac{\text { Content of } \mathrm{ThO}_{2} \text { (percent) }}{\text { small }}$
$\approx 1$
0 to 3.7
0 to 2.5
$\approx 12$
8.75 in only analysis.
$<1$
usually $<1$ or none; some
varieties higher.
7.3 in only analysis..........

\section{References for tables 1 and 2}

1. Frondel, Mineralogy of uraninum, (in preparation).

2. Palache, Berman, and Frondel, Dans's system of mineralogy, 7th ed., v, 1, 1944.

. Palache, Berman, and Frondel, Dana's system of mineralogy, 7th ed., v. 2, 1951

4. Bowle and Horne, Mineralog. Mag., v. 30, p. $93,1953$. 36, p. 66, 1951.

6. Simpson, Chem. News, v. 102 , p. $283,1910$.

7. Frondel, Am. Mineralogist, v. 38 , p. $1007,1953$.

8. Hats, Inst. Phys. Chem. Research Tokyo, Sci. Papers, v. 34, p. 455, 1938.

9. Bespalov, Problems Boviet Geology, no. 6, p. 105, 1941

10. Hutton, Am. Mineralogist, v. 39, p. 825, 1954.

11. Davidson and Bowle, Great Britain Geol. Survey, Bull. 3, p. 1, 1951

12. Barthauer, Rulfs, and Pearce, Am. Mineralogist, v. 38, p. 802, 1953.

TABLE 3.-Ionic radii of certain elements

[Goldschmidt's values, in $\mathrm{kX}$ units]

\begin{tabular}{|c|c|c|c|c|c|c|c|c|}
\hline \multirow{2}{*}{$\begin{array}{l}\text { Val- } \\
\text { ence }\end{array}$} & \multicolumn{8}{|c|}{ Usual coordination number with oxygen } \\
\hline & 4 & & 6 & & 8 & \multicolumn{3}{|c|}{8 or higher } \\
\hline 4 & $\mathrm{Si}$ & V & $\mathrm{Ti}$ & W & $\mathrm{Zr}$ & $\mathrm{Ce}^{4}$ & $\mathrm{U}$ & Th \\
\hline & 0.39 & 0.61 & 0.64 & 0.68 & 0.87 & 1.02 & 1.05 & 1.10 \\
\hline 3 & $\mathrm{Al}$ & $\mathrm{Al}$ & $\mathrm{Fe}^{s}$ & & & $\mathrm{Y}$ & La & $\mathrm{Ce}^{\mathrm{s}}$ \\
\hline & 0.57 & 0.57 & 0.67 & & & 1.06 & 1.22 & 1.18 \\
\hline 2 & $\mathrm{Be}$ & $\mathrm{Mg}$ & $\mathrm{Fe}^{2}$ & & & & $\mathrm{Ca}$ & \\
\hline & 0.34 & 0.78 & 0.83 & & & & 1.06 & \\
\hline 1 & & & & & & $\begin{array}{c}\mathrm{Na} \\
0.98\end{array}$ & $\underset{1.33}{\mathrm{~K}}$ & \\
\hline
\end{tabular}

TABLE 4.-Tetragonal nesosilicates of $T h, U, C e$, and $\mathrm{Zr}$

Thorite group

$\mathrm{Th}\left(\mathrm{SiO}_{4}\right)$, thorite...... $\mathrm{U}\left(\mathrm{SiO}_{4}\right)$ [not known] $\mathrm{Ce}\left(\mathrm{SiO}_{4}\right)$ [not known]

$\mathrm{Zr}\left(\mathrm{SiO}_{4}\right)$, zireon......... Thorogummite group $\mathrm{Th}\left(\mathrm{SiO}_{4}\right)_{1-x}(\mathrm{OH})_{4 x}$, thorogummite. $\mathrm{U}\left(\mathrm{SiO}_{4}\right)_{1-\mathrm{x}}(\mathrm{OH})_{4 x}$, coffinite. $(\mathrm{Ce}, \mathrm{Th})\left(\mathrm{SiO}_{4}\right)_{1-x}(\mathrm{OH})_{4 x}$, freyalite? $\mathrm{Zr}\left(\mathrm{SiO}_{4}\right)_{1-x}(\mathrm{OH})_{4 x}$, cyrtolite.

TABLE 5.-Minerals containing cerium as an essential or important vicarious constituent (data supplement table 2 )

Name

\section{Composition}

ESSENTIAL CONSTITUENT

Fluocerite.

Tysonite.

Bastngesite..........

Parisite

Roentgenite

Synchisite.

Cordylite.............

Ancylite...............

Calcio-ancylite......

Lanthanite.

Ambatoarinite......

Weibyite............

Beiyinite............

Oborite.

Rhabdophane

Florencite...........

Cerite.

Lessingite

Törnebohmite........

Hellandite..........

Cenosite .........

$385115-56-38$

renate of $\mathrm{Ce}, \mathrm{La}$, and $\mathrm{S}$.

Ill-defined rare-earth carbonate.

Ill-defined rare-earth carbonate.

$(\mathrm{Ce}, \mathrm{La}, \mathrm{Y})\left(\mathrm{PO}_{4}\right) \cdot \mathrm{H}_{2} \mathrm{O}$

$\mathrm{CeAl}_{3}\left(\mathrm{PO}_{4}\right)_{2}(\mathrm{OH})_{6}$

$(\mathrm{Ce}, \mathrm{Ca})_{2} \mathrm{Si}(\mathrm{O}, \mathrm{OH})_{5}$ ?

A calcium-rich variety of cerite.

Near cerite in composition.

$\mathrm{Ca}_{2}(\mathrm{Ce}, \mathrm{La}, \mathrm{Y}, \mathrm{Al}, \mathrm{Fe})_{8} \mathrm{Si}_{4} \mathrm{O}_{19}$ (?

$\mathrm{Ca}_{2}(\mathrm{Ce}, \mathrm{Y})_{2} \mathrm{Si}_{4} \mathrm{O}_{12}\left(\mathrm{CO}_{3}\right) \cdot \mathrm{H}_{2} \mathrm{O}$

13. Borodin and Kazakova, Akad. Nauk SSsR. Doklady, v. 97, p. 725, 1954.

14. Gerasimovsky, Acad, sci. U. S. S. R., Comptes Rendus 25, D. 753, 19

16. Borneman-starynkevich, Mat. Geochem. Khibina Tundra, Acad, sei. US8R, p. 43, 1953 .

17. Kimura, Japanese Jour. Chemistry, v. 2, p. 82, 84, 1925.

18. Brögger, Zeitsehr. Kristallographile, v. 16, 1890.

19. Kauffman and Jaffe, Am. Mineralogist, v. 31, p. 582, 1946

20. Shibata and Kimura, Chem. Soc. Japan Jour., v. 42, p. 1, 1921.

21. Bonatti and Gottardi, Rend. Soc. Min. Ital., v. 9, p. 242, 1053 .

22. Bøggild, Mineralogy of Greenland, Meddel, om Grónland, v. 149, no. 3, 1953

23. Hats, Inst. Phys. Chem. Research' Tokyo, Set. Papers, v, 34, p. 1018, 1938.

24. Graham, Am. Mineralogist, v. 40, p. 560, 1955.

TABLE 5.-Minerals containing cerium as an essential or important vicarious constituent (data supplement table 2)-Continued

Name

Composition
vICARIOUS CONSTITUENT

Abukumalite $\quad(\mathrm{Ca}, \mathrm{Y})_{5}(\mathrm{P}, \mathrm{Si})_{2} \mathrm{O}_{12}(\mathrm{OH}, \mathrm{F})$

Britholite_.......... (Na, Ca, Ce $)_{5}(\mathrm{P}, \mathrm{Si})_{3} \mathrm{O}_{12}(\mathrm{OH}, \mathrm{F})$

Cerorthite $\quad . . . \quad$ Variety of allanite rich in Ce.

Churchite $\ldots . . . \mathrm{Y}\left(\mathrm{PO}_{4}\right) \cdot 2 \mathrm{H}_{2} \mathrm{O}$

Codazzite......... Cerian variety of dolomite.

Erikite ............ Near abukamalite in composition.

Gadolinite .............. $\mathrm{Be}_{2} \mathrm{FeY}_{2} \mathrm{Si}_{2} \mathrm{O}_{10}$

Ishikawaite

Kalkowskite

Knopite.............

Metagadolinite

Nagatelite ...........

Weinschenkite

Yttrocerite............

$\mathrm{Be}_{2} \mathrm{FeY}_{2} \mathrm{Si}_{2} \mathrm{O}_{10}$
$(\mathrm{U}, \mathrm{Fe}, \mathrm{Y})(\mathrm{Nb}, \mathrm{Ta}$

$\mathrm{Fe}_{2} \mathrm{Ti}_{3} \mathrm{O}_{8}$

Cerian variety of perovskite.

Ill-defined silicate of $\mathrm{Fe}$ and rare earths.

$\mathrm{Ca}_{2}(\mathrm{Ce}, \mathrm{La})_{2} \mathrm{Al}_{4} \mathrm{Fe}_{2}(\mathrm{Si}, \mathrm{P})_{6} \mathrm{O}_{25}(\mathrm{OH})$

Synonym of churchite.

Cerian variety of fluorite.

TABLE 6.-Minerals containing zirconium as an essential or important vicarious constituent

\section{Name}

Composition

ESSENTIAL CONSTITUENT
Baddeleyite

Catapleite

Dalyite

Elpidite.

Eucolite.

Eudialyte.

Guarinite

Hiortdahlite

Låvenite.

Lovozerite

Loranskite.

Rosenbuschite

Wadeite.

Wöhlerite

Zircon

Zirkelite

$\mathrm{ZrO}_{2}$

$(\mathrm{Na}, \mathrm{Ca}) \mathrm{ZrSi}_{3} \mathrm{O}_{9} \cdot 2 \mathrm{H}_{2} \mathrm{O}$

$\mathrm{K}_{2} \mathrm{ZrSi}_{6} \mathrm{O}$

$\mathrm{Na}_{2} \mathrm{ZrSi}_{6} \mathrm{O}_{15} \cdot 3 \mathrm{H}_{2} \mathrm{O}$

Variety of eudialyte

$\mathrm{Na}_{4}(\mathrm{Ca}, \mathrm{Fe})_{2} \mathrm{ZrSi}_{6} \mathrm{O}_{17}(\mathrm{OH}, \mathrm{Cl})_{2}(?)$

$\mathrm{Na}, \mathrm{Ca}, \mathrm{Zr}$ fluosilicate (ill-defined)

$(\mathrm{Ca}, \mathrm{Na})_{13} \mathrm{Zr}_{3} \mathrm{Si}_{0}(\mathrm{O}, \mathrm{OH}, \mathrm{F})_{38}(?)$

$\mathrm{NaCa}_{2} \mathrm{ZrSi}_{2} \mathrm{O}_{8} \mathrm{~F}(?)$

$(\mathrm{Na}, \mathrm{K})_{2}(\mathrm{Mn}, \mathrm{Ca}) \mathrm{ZrSi}_{6} \mathrm{O}_{16} \cdot 3 \mathrm{H}_{2} \mathrm{O}$

$(\mathrm{Y}, \mathrm{Ce}, \mathrm{Ca})_{4} \mathrm{Zr}_{3} \mathrm{Ta}_{4} \mathrm{O}_{22}(?)$

$\mathrm{Z}_{3} \mathrm{Ti}_{2} \mathrm{O}_{10} \cdot 2 \mathrm{H}_{2} \mathrm{O}$ (doubtful species)

$(\mathrm{Ca}, \mathrm{Na})_{3}(\mathrm{Zr}, \mathrm{Ti}) \mathrm{Si}_{2} \mathrm{O}_{8} \mathrm{~F}($ ? $)$

$\mathrm{K}_{2} \mathrm{CaZrSi}_{4} \mathrm{O}_{12}$

$\mathrm{NaCa}_{2}(\mathrm{Zr}, \mathrm{Nb}) \mathrm{Si}_{2} \mathrm{O}_{8}(\mathrm{O}, \mathrm{OH}, \mathrm{F})(?)$

$\mathrm{ZrSiO}_{4}$

$(\mathrm{Ca}, \mathrm{Fe})(\mathrm{Zr}, \mathrm{Ti})_{2} \mathrm{O}_{5}$

Hydrated silicate of $\mathrm{Zr}$ and $\mathrm{Fe}$.

VICARIOUS CONSTITUENT

Acmite ............. Synonym of aergirine

Astrophyllite $(\mathrm{Na}, \mathrm{K})_{2}(\mathrm{Fe}, \mathrm{Mn})_{4} \mathrm{TiSi}_{4} \mathrm{O}_{14}(\mathrm{OH})$

Aegirine .......... $\mathrm{NaFeSi}_{2} \mathrm{O}_{6}$

Betafite ....... (U, Ca) (Nb, Ta, Ti) ${ }_{3} \mathrm{O}_{9} \cdot n \mathrm{H}_{2} \mathrm{O}$

Beckelite....

$(\mathrm{U}, \mathrm{Ca})\left(\mathrm{Nb}, \mathrm{Ta}, \mathrm{Ti}_{3}\right)_{3}$

$\mathrm{Ca}_{3}(\mathrm{Y}, \mathrm{Ca}, \mathrm{Ce}){ }_{4} \mathrm{Si}_{3} \mathrm{O}_{15}$
$\mathrm{Na}_{4} \mathrm{Mn}_{5} \mathrm{Ti}_{3} \mathrm{Si}_{14} \mathrm{O}_{41} \cdot 9 \mathrm{H}_{2} \mathrm{O}$ 
TABLE 6.-Minerals containing zirconium as an essential or important vicarious constituent-Continued

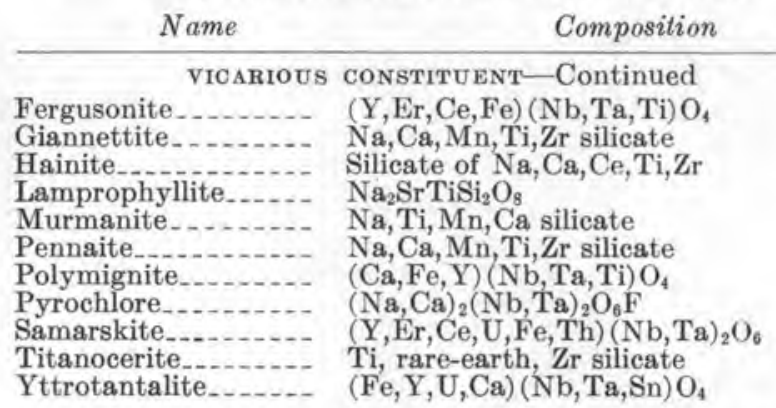

SYNONYMS AND VARIETIES OF ZIRCON AND CYRTOLITE

Alvite, Altered thorian variety of zircon.

Auerbachite. Altered zircon, or cyrtolite.

Adelpholite (part). Altered zircon, or cyrtolite.

Azorite. Synonym of zircon.

Anderbergite. Synonym of cyrtolite?

Beccarite. Synonym of zircon.

Calyptolite. Synonym of zircon.

Cyrtolite. Hydroxyl-substituted variant of zireon.

Engelhardite. Synonym of zireon.

Diocroma. Synonym of zircon.

Hagatelite. Variety of zircon with $\mathrm{Nb}, \mathrm{Ta}, \mathrm{Th}$, and rare earths,

Jargoon. Synonym of zircon.

Jacinth. Synonym of zircon.

Hyacinth. Synonym of zircon.

Malacon. Altered zircon, or cyrtolite.

Meta-zircon. Altered zircon.

Naegite. Variety of zircon with $\mathrm{Th}, \mathrm{U}, \mathrm{Nb}, \mathrm{Ta}$, and rare earths.

Ostranite. Synonym of zircon.

Polykrasilite. Variety of zircon.

Oyamalite. Variety of zireon with $\mathrm{PO}_{4}$ and rare earths.

Orvillite. Altered zireon, or cyrtolite?

Oerstedtite. Altered zircon, or cyrtolite?

Pseudo-zircon. Altered zircon, or cyrtolite?

Yamagutilite. Variety of zireon with $\mathrm{PO}_{4}$ and rare earths.

Zirconite. Synonym of zircon.

Zirconoid. Altered zircon.

Ribeiraite. Variety of zircon.

Tachyaphaltite. Altered thorian zircon or cyrtolite.

TABLE 7.-Minerals containing uranium as an essential constituent Name

\section{Composition}

\begin{tabular}{|c|c|}
\hline & \\
\hline & OXIDES \\
\hline $\begin{array}{l}\text { Uraninite } \\
\text { Ianthinite } \\
\text { Epi-ianthinite } \\
\text { Becquerelite } \\
\text { Sehoepite } \\
\text { Richetite } \\
\text { Masuyite } \\
\text { Vandendriesscheite } \\
\text { Fourmarierite } \\
\text { Curite } \\
\text { Billietite } \\
\text { Vandenbrandeite. } \\
\text { Uranospherite.... } \\
\text { Clarkeite... }\end{array}$ & $\begin{array}{l}\mathrm{UO}_{2} \\
2 \mathrm{UO}_{2} \cdot 7 \mathrm{H}_{2} \mathrm{O}(?) \\
\approx \mathrm{UO}_{3} \cdot 2 \mathrm{H}_{2} \mathrm{O} \\
7 \mathrm{UO}_{3} \cdot \mathrm{H}_{2} \mathrm{O} \\
2 \mathrm{UO}_{3} \cdot 5 \mathrm{H}_{2} \mathrm{O} \\
\mathrm{Hydrated} \text { oxide of } \mathrm{U} \text { and } \mathrm{Pb}(?) \\
\approx \mathrm{UO}_{3} \cdot 2 \mathrm{H}_{2} \mathrm{O} \\
\mathrm{PbO} \cdot 7 \mathrm{UO}_{3} \cdot 12 \mathrm{H}_{2} \mathrm{O} \\
\mathrm{PbO} \cdot 4 \mathrm{UO}_{3} \cdot 7 \mathrm{H}_{2} \mathrm{O} \\
3 \mathrm{PbO} \cdot 8 \mathrm{UO}_{3} \cdot 4 \mathrm{H}_{2} \mathrm{O} \\
\mathrm{BaO} \cdot 6 \mathrm{UO}_{3} \cdot 11 \mathrm{H}_{2} \mathrm{O} \\
\mathrm{Cu}(\mathrm{UO})_{2} \mathrm{O}_{2} \cdot 2 \mathrm{H}_{2} \mathrm{O} \\
(\mathrm{BiO})\left(\mathrm{UO}_{2}\right)(\mathrm{OH})_{3}(?) \\
(\mathrm{Na}, \mathrm{K}, \mathrm{Ca}, \mathrm{Pb})_{2} \mathrm{U}_{2} \mathrm{O}_{7} \cdot n \mathrm{H}_{2} \mathrm{O}\end{array}$ \\
\hline \multicolumn{2}{|c|}{ CARBONATES } \\
\hline 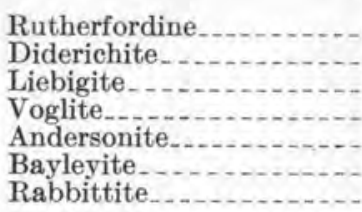 & $\begin{array}{l}\left(\mathrm{UO}_{2}\right)\left(\mathrm{CO}_{3}\right) \\
\text { Identical with rutherfordine } \\
\mathrm{Ca}_{2}\left(\mathrm{UO}_{2}\right)\left(\mathrm{CO}_{3}\right)_{3} \cdot 10-11 \mathrm{H}_{2} \mathrm{O} \\
\mathrm{Ca}, \mathrm{Cu}, \text { uranyl carbonate }(?) \\
\mathrm{Na}_{2} \mathrm{Ca}\left(\mathrm{UO}_{2}\right)\left(\mathrm{CO}_{3}\right)_{3} \cdot 6 \mathrm{H}_{2} \mathrm{O} \\
\mathrm{Mg}_{2}\left(\mathrm{UO}_{2}\right)\left(\mathrm{CO}_{3}\right)_{3} \cdot 18 \mathrm{H}_{2} \mathrm{O} \\
\mathrm{Ca}_{3} \mathrm{Mg}_{3}\left(\mathrm{UO}_{2}\right)_{2}\left(\mathrm{CO}_{3}\right)_{6}(\mathrm{OH})_{4} \cdot 18 \mathrm{H}_{2} \mathrm{O}\end{array}$ \\
\hline
\end{tabular}

TABLE 7.-Minerals containing uranium as an essential constituent-Continued

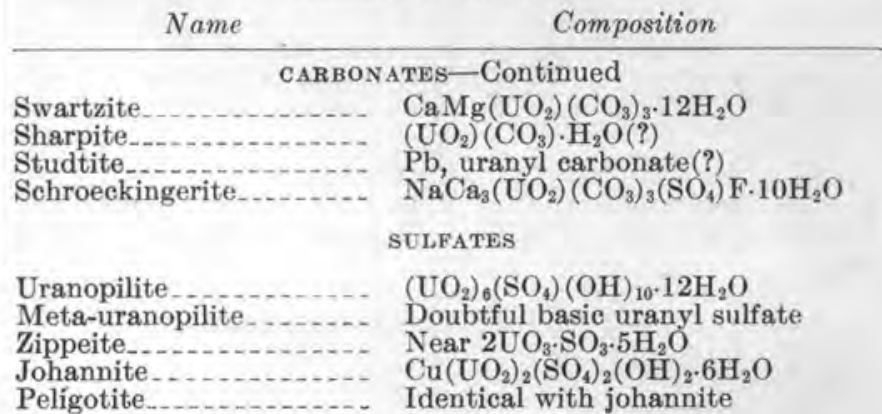

\section{PHOSPHATES-ARSENATES}

Autunite

Meta-autunite..........

Torbernite

Metatorbernite

Zeunerite.

Metazeunerite

Uranocireite.

Saleeite.

Bassetite.

Uranospathite.

Kahlerite.

Novacekite

Metanovacekit

Abernathyite

Troegerite

Uranospinite

Sabugalite.

Fritzscheite

Parsonite

Renardite.

(n)

Dewindtite .......................

Dumontite.

Walpurgite
$\mathrm{Ca}\left(\mathrm{UO}_{2}\right)_{2}\left(\mathrm{PO}_{4}\right)_{2} \cdot 8-12 \mathrm{H}_{2} \mathrm{O}$

$\mathrm{Ca}\left(\mathrm{UO}_{2}\right)_{2}\left(\mathrm{PO}_{4}\right)_{2} \cdot 6-8 \mathrm{H}_{2} \mathrm{O}$

$\mathrm{Cu}\left(\mathrm{UO}_{2}\right)_{2}\left(\mathrm{PO}_{4}\right)_{2} \cdot 12 \mathrm{H}_{2} \mathrm{O}$

$\mathrm{Cu}\left(\mathrm{UO}_{2}\right)_{2}\left(\mathrm{PO}_{4}\right)_{2} \cdot 6-8 \mathrm{H}_{2} \mathrm{O}$

$\mathrm{Cu}\left(\mathrm{UO}_{2}\right)_{2}\left(\mathrm{AsO}_{4}\right)_{2} \cdot 8-10 \mathrm{H}_{2} \mathrm{O}$

$\mathrm{Cu}\left(\mathrm{UO}_{2}\right)_{2}\left(\mathrm{AsO}_{4}\right)_{2} \cdot 8 \mathrm{H}_{2} \mathrm{O}$

$\mathrm{Ba}\left(\mathrm{UO}_{2}\right)_{2}\left(\mathrm{PO}_{4}\right)_{2} \cdot 8-10 \mathrm{H}_{2} \mathrm{O}$

$\mathrm{Ba}\left(\mathrm{UO}_{2}\right)_{2}\left(\mathrm{PO}_{4}\right)_{2} \cdot 8 \mathrm{H}_{2} \mathrm{O}$

$\mathrm{Mg}\left(\mathrm{UO}_{2}\right)_{2}\left(\mathrm{PO}_{4}\right)_{2} \cdot 8-10 \mathrm{H}_{2} \mathrm{O}$

$\mathrm{Fe}\left(\mathrm{UO}_{2}\right)_{2}\left(\mathrm{PO}_{4}\right)_{2} \cdot 8 \mathrm{H}_{2} \mathrm{O}$

$\mathrm{Cu}\left(\mathrm{UO}_{2}\right)_{2}\left(\mathrm{As}_{2} \mathrm{PO}_{4}\right)_{2} \cdot 16 \mathrm{H}_{2} \mathrm{O}($ ?

$\mathrm{Fe}\left(\mathrm{UO}_{2}\right)_{2}\left(\mathrm{AsO}_{4}\right)_{2} \cdot 8 \mathrm{H}_{2} \mathrm{O}$

$\mathrm{Mg}\left(\mathrm{UO}_{2}\right)_{2}\left(\mathrm{AsO}_{4}\right)_{2} \cdot 8-10 \mathrm{H}_{2} \mathrm{O}$

$\mathrm{Mg}\left(\mathrm{UO}_{2}\right)_{2}\left(\mathrm{AsO}_{4}\right)_{2} \cdot 8 \mathrm{H}_{2} \mathrm{O}$

$\mathrm{K}_{2}\left(\mathrm{UO}_{2}\right)_{2}\left(\mathrm{AsO}_{4}\right)_{2} \cdot 8 \mathrm{H}_{2} \mathrm{O}$

$\mathrm{H}_{2}\left(\mathrm{UO}_{2}\right)_{2}\left(\mathrm{AsO}_{4}\right)_{2} \cdot 8 \mathrm{H}_{2} \mathrm{O}$

$\mathrm{Ca}\left(\mathrm{UO}_{2}\right)_{2}\left(\mathrm{AsO}_{4}\right)_{2} \cdot 10 \mathrm{H}_{2} \mathrm{O}$

$\mathrm{HAl}\left(\mathrm{UO}_{2}\right)_{4}\left(\mathrm{PO}_{4}\right)_{4} \cdot 16 \mathrm{H}_{2} \mathrm{O}$

Doubtful Mn, uranyl phosphatevanadate

$\mathrm{Pb}_{2}\left(\mathrm{UO}_{2}\right)\left(\mathrm{PO}_{4}\right)_{2}(\mathrm{OH})_{4} \cdot 7 \mathrm{H}_{2} \mathrm{O}$

$\mathrm{Pb}\left(\mathrm{UO}_{2}\right)_{4}\left(\mathrm{PO}_{4}\right)_{2}(\mathrm{OH})_{4} \cdot 7 \mathrm{H}_{2} \mathrm{O}$

$\mathrm{Ca}\left(\mathrm{UO}_{2}\right)_{4}\left(\mathrm{PO}_{4}\right)_{2}\left(\mathrm{OH}_{4} \cdot 7 \mathrm{H}_{2} \mathrm{O}\right.$

Doubtful $\mathrm{Pb}$, uranyl phosphate

$\mathrm{Pb}_{2}\left(\mathrm{UO}_{2}\right)_{3}\left(\mathrm{PO}_{4}\right)_{2}(\mathrm{OH})_{4} \cdot 3 \mathrm{H}_{2} \mathrm{O}$

$\mathrm{Bi}_{4}\left(\mathrm{UO}_{2}\right)\left(\mathrm{AsO}_{4}\right)_{2} \cdot 3 \mathrm{H}_{2} \mathrm{O}$

VANADATES

Carnotite

Tyuyamunite.

Metatyuyamunite

Sengierite

Ferghanite.............

Rauvite................

Uvanite

Uvanite

Uranophane

Sklodowskite.

Cuprosklodowskite

Beta-uranophane .........

Soddyite_...............

Kasolite ..................

Pilbarite ........

Gastunite

$\mathrm{K}_{2}\left(\mathrm{UO}_{2}\right)_{2}\left(\mathrm{VO}_{4}\right)_{2} \cdot 1-3 \mathrm{H}_{2} \mathrm{O}$

$\mathrm{Ca}\left(\mathrm{UO}_{2}\right)_{2}\left(\mathrm{VO}_{4}\right)_{2} \cdot 7-11 \mathrm{H}_{2} \mathrm{O}$

$\mathrm{Ca}\left(\mathrm{UO}_{2}\right)\left(\mathrm{VO}_{4}\right)_{2} \cdot 5-7 \mathrm{H}_{2} \mathrm{O}$

$\mathrm{Cu}\left(\mathrm{UO}_{2}\right)\left(\mathrm{VO}_{4}\right)(\mathrm{OH}) \cdot 4-5 \mathrm{H}_{2} \mathrm{O}$

$\mathrm{U}_{3}\left(\mathrm{VO}_{4}\right)_{2} \cdot 6 \mathrm{H}_{2} \mathrm{O}$

$\mathrm{CaO} \cdot 2 \mathrm{UO}_{3} \cdot 2 \mathrm{~V}_{2} \mathrm{O}_{5} \cdot 16 \mathrm{H}_{2} \mathrm{O}(?)$

$\mathrm{U}_{2} \mathrm{~V}_{6} \mathrm{O}_{21} \cdot 15 \mathrm{H}_{2} \mathrm{O}(?)$

SILICATES

$\mathrm{Ca}\left(\mathrm{UO}_{2}\right)_{2}\left(\mathrm{SiO}_{3}\right)_{2}(\mathrm{OH})_{2} \cdot 5 \mathrm{H}_{2} \mathrm{O}$

$\mathrm{Mg}\left(\mathrm{UO}_{2}\right)_{2}\left(\mathrm{SiO}_{3}\right)_{2}\left(\mathrm{OH}_{2} \cdot 5 \mathrm{H}_{2} \mathrm{O}\right.$

$\mathrm{Cu}\left(\mathrm{UO}_{2}\right)_{2}\left(\mathrm{SiO}_{3}\right)_{2}(\mathrm{OH})_{2} \cdot 5 \mathrm{H}_{2} \mathrm{O}$

$\mathrm{Ca}\left(\mathrm{UO}_{2}\right)_{2}\left(\mathrm{SiO}_{3}\right)_{2}(\mathrm{OH})_{2} \cdot 5 \mathrm{H}_{2} \mathrm{O}$

$\left(\mathrm{UO}_{2}\right)_{5}\left(\mathrm{SiO}_{4}\right)_{2}(\mathrm{OH})_{2} \cdot 5 \mathrm{H}_{2} \mathrm{O}$

$\mathrm{Pb}\left(\mathrm{UO}_{2}\right)\left(\mathrm{SiO}_{3}\right)(\mathrm{OH})_{2}$

$\mathrm{UO}_{3} \cdot \mathrm{PbO} \cdot \mathrm{ThO}_{2} \cdot 2 \mathrm{SiO}_{2} \cdot 4 \mathrm{H}_{2} \mathrm{O}(?)$

$\mathrm{U}\left(\mathrm{SiO}_{4}\right)_{1-x}(\mathrm{OH})_{4 x}$

$\mathrm{Ca}, \mathrm{Pb}$, uranyl silicate

\section{NIORATE-TANTALATES}

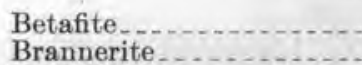

Prannerite ..............

Delorenzite

(U, $\mathrm{Ca})(\mathrm{Nb}, \mathrm{Ta}, \mathrm{Ti})_{3} \mathrm{O}_{0} \cdot n \mathrm{H}_{2} \mathrm{O}$

(U, $\mathrm{Ca}, \mathrm{Fe}, \mathrm{Th}, \mathrm{Y})_{3} \mathrm{Ti}_{5} \mathrm{O}_{16}(?)$ late

$(\mathrm{U}, \mathrm{Y}, \mathrm{Fe})(\mathrm{Ti}, \mathrm{Sn})_{3} \mathrm{O}_{8}$

MOLYBDATE

Umohoite

$\left(\mathrm{UO}_{2}\right)\left(\mathrm{MoO}_{4}\right) \cdot 4 \mathrm{H}_{2} \mathrm{O}$ 


\section{SELECTED BIBLIOGRAPHY}

Anderson, J. S., Edgington, D. N., Roberts, L. E. J., and Wait, E., 1954, The oxides of uranium-part IV. The system $\mathrm{UO}_{2}-\mathrm{ThO}_{2}-\mathrm{O}$ : Chem. Soc. London Jour., p. 3324-3331.

Antonov, L. V., 1934, Apatitoviye Mestorozhdeniya Khibinskoi Tundry (The apatite deposits of the Khibina Tundra), in Khibinskie Apatity, v. 7: p. 1-196, (Russian text), Leningrad, ONTI-Goskhimtekhizdat (State Chem. Tech. Pub.).

Bain, G. W., 1950, Geology of the fissionable materials: Econ. Geology, v. 45, p. 273-323.

Bøggild, O. B., 1953, The mineralogy of Greenland: Meddel. om Grønland, v. 149, no. 3, 422 p.

Brauer, G., and Gradinger, H., 1951, Utber anomale Mischkristalle im Bereiche des Fluoritgittertyps (Anomalous mixed crystals of the fluorite lattice type): Die Naturwissenschaften, v. 38 , p. 559-560 (German text).

Brögger, W. C., 1890, Die Mineralien der Syenitpegmatitgänge der Sudnorwegischen Augit und Nephelinsyenite: Zeitschr. Kristallographie, v. 16, 663 p.

Christ, C. L., Clark, J. R., Evans, H. T., Jr., 1955, Crystal structure of rutherfordine, $\mathrm{UO}_{2} \mathrm{CO}_{3}$ : Science, v. $121, \mathrm{p}$. 472-473.

Cooper, Margaret, 1953-55, Bibliography and index of literature on uranium and thorium and radioactive occurrences in the United States, parts 1-4: Geol. Soc. America Bull., v. 64, p. $197-234,1103-1172,1953$; v. 65 , p. $467-590,1954$; v. 66 , p. $257-326,1955$.

David, L. R., 1953, Thorium, a bibliography of unclassified literature: U. S. Atomic Energy Comm. TID-3044, 124 p., issued by U. S. Atomic Energy Comm. Tech. Inf. Service, Oak Ridge, Tenn.

Duwez, Pol, and Odell, Francis, 1950, Phase relationships in the system zirconia-ceria: Am. Ceramic Soc. Jour,, v. 33, p. 274-283.

Fersman, A. E., 1926, Minerals of the Kola Peninsula; Am. Mineralogist v. 11, p. 289-299; Die Mineralien der chibinaund Lujavr Tundren auf den Halbinsel Kola: Neues Jahrb., Beilage-Band $55 \mathrm{~A}$, p. 36 .

Fersman, A. E., and Bohnstedt,-E. M., ed. 1937, Minerals of the Khibina and Lovozero tundras (Brief contents of papers composing the Russian monograph under the same title) : 152 p. (English text), Lomonossov Institute, Acad, Sci, U. S. S. R, (Akad. Nauk SSSR, Inst. Lomonossov), MoscowLeningrad, Academy of Sciences Press.

Fleischer, Michael, 1954, The abundance and distribution of the chemical elements in the earth's crust: Jour. Chem. Education, v. 31, p. 446-455.

Frondel, Clifford, 1953, Hydroxyl substitution in thorite and zircon: Am. Mineralogist, v. 38, p. 1007-1018.

Frondel, J. W., and Fleischer, Michael, 1955, Glossary of uranium- and thorium-bearing minerals, $3 \mathrm{~d}$ ed.: $\mathrm{U}$. $\mathrm{S}$. Geol. Survey Bull. 1009-F, p. 169-209.

Glass, J. J., and Smalley, R. G., 1945, Bastnaesite: Am. Mineralogist, v. 30 , p. 601-615.

Goldschmidt, V. M. (edited by Alex Muir), 1954, Geochemistry: 730 p., Oxford, Clarendon Press.

Guimarães, Djalma, 1948, The zirconium ore deposits of the Poços de Caldas Plateau, Brazil, and zirconium geochemistry: Estado de Minas Gerais Instituto Teenologia Industrial Bol. 6, p. 41-79.

Hutton, C. O., 1947, Nuclei of pleochroic haloes: Am. Jour. Sei., v. 245, p. 154-157.

- 1950, Studies of heavy detrital minerals: Geol. Soc. America Bull., v. 61 , p. $635-716$.
Johnstone, S. J., 1954, Minerals for the ehemical and allied industries: New York, John Wiley and Sons, Inc., 692 p.

Koczy, F. F., 1949a, The thorium content of the Cambrian alum shales of Sweden: Sveriges geol. undersökning (Stockholm), Årsbok, v. 43, no. 7; Ser. C, Avhandlinger och Uppsater, no, $503,12 \mathrm{p}$.

- 1949b, Thorium in sea water and marine sediments: Geol. fören. i Stockholm Förh., v. 71, p. 238-242.

Lambertson, W. A., and Mueller, M. H., 1953, Uranium oxide phase equilibrium systems-III. $\mathrm{UO}_{2}-\mathrm{ZrO}_{2}: \mathrm{Am}$. Ceram. Soc. Jour., v. 36 , p. $365-368$.

Luchitski, V. I., 1947, Shchelochnyi metasomatoz na Territorii Ukrainskogo Kristallicheskogo massiva (Alkali metasomatism in the region of the Ukrainian crystalline massif: Akad. Nauk SSSR Doklady, Novaya ser,, v. 55, p. $49-52$.

Magneli, Arne, and Kihlborg, Lars, 1951, On the cerium dioxideuranium dioxide system and "uranium cerium blue": Acta Chem. Scandinavica, v. 5, p. 578-580.

Olson, J. C., Shawe, D. R., Pray, L. D., and Sharp, W. N., 1954, Rare-earth mineral deposits of the Mountain Pass distriet, San Bernardino County, Calif.: U. S. Geol. Survey Prof. Paper 261, 75 p. [1955].

Pabst, A., 1952, The metamict state: Am. Mineralogist, v. 37, p. 137-157.

Pellas, Paul, 1951, Sur la destruction spontanée des réseaux cristallins des mineraux radioactifs (The spontaneous disintegration of the erystal lattices of radioactive minerals): Acad. Sci. Paris Comptes rendus 233, p. 1369-1371.

-1952, Sur la transition ordre-désordre dans les réseaux cristallins des mineraux radioactifs (Order-disorder transitions in the crystalline lattices of radioactive minerals): Acad. Sei. Paris Comptes rendus 234, p. 538-540.

Phair, George, and Levine, Harry, 1953, Notes of the differential leaching of uranium, radium, and lead from pitchblende in $\mathrm{H}_{2} \mathrm{SO}_{4}$ solutions: Econ. Geology, v. 48, p. 358-369.

Rankama, Kalervo, and Sahama, T. G., 1950, Geochemistry: Chicago, Univ, Chicago Press, 912 p.

Ringwood, A. E., 1955, The principles governing trace element distribution during magmatic erystallization: Geochim. Cosmochim. Acta, v. 7, p. 189-202.

Rüdorff, Walter, and Valet, Gerhard, 1952, Úber das Ceruranblau und die Halbleifreigensehaften der Mischkristallreiche $\mathrm{UO}_{2}-\mathrm{CeO}_{2}$ (On cerium-uranium blue and the semiconductive properties of the mixed-crystal series $\left.\mathrm{UO}_{2}-\mathrm{CeO}_{2}\right)$ : Zeitschr. Naturf., v. 7b, p. 57.

Sahama, T. G., and Vähätalo, V., 1939, X-ray spectrographic study of the rare earths in some Finnish eruptive rocks and minerals: Comm. geol. Finlande Bull., no, 126 (Soc. géol. Finlande Comptes rendus 14), p. 50-83 (English text).

Stieff, L. R., Stern, T. W., and Sherwood, A. M., 1955, Preliminary deseription of coffinite - a new uranium mineral: Science, v. 121, p. 608-609.

Trites, A. F., and Tooker, E. W., 1953, Uranium and thorium deposits in east-central Idaho and southwestern Montana: U. S. Geol. Survey Bull. 988-H, p. 157-209.

Trzebiatowski, W., and Selwood, P. W., 1950, Magnetic susceptibilities of urania-thoria solid solutions: Am. Chem. Soc. Jour., v. 72 , p. 4504-4506.

Wedow, H., and others, 1953, Preliminary summary of reconnaissance for uranium and thorium in Alaska, 1952: U. S. Geol. Survey Circ. 248, 15 p.

Wiekman, F. E., 1943, Some aspects of the geochemistry of igneous rocks and of differentiation by crystallization: Geol. fören. Stockholm Förh., v. 65, p. 371-396. 


\title{
THORIUM DEPOSITS IN THE WET MOUNTAINS, COLORADO
}

\author{
By Q. D. Singewald and Maurice R. Brock, U. S. Geological Survey
}

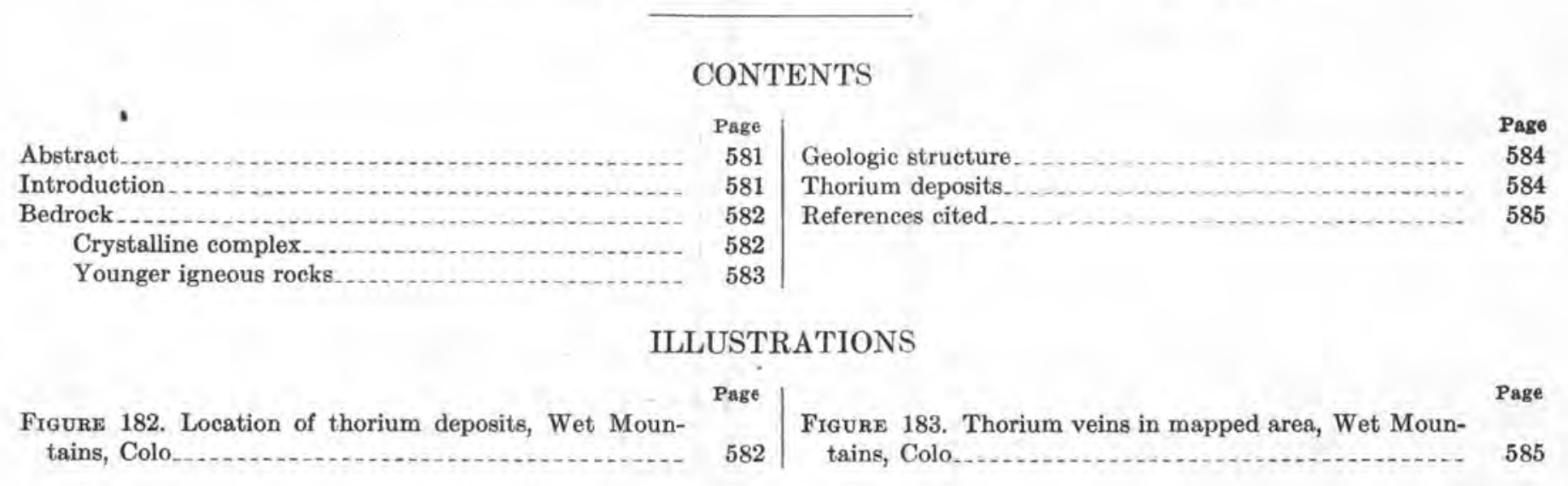

\begin{abstract}
Thorium in veins was discovered in the Wet Mountains of Colorado in 1950, and subsequently many deposits were found in an area about 25 miles long and 10 miles wide that trends north-northwestward along the western slope of the range. Bedrock throughout most of the range, including the thorium province, is a complex of crystalline rocks that has been transected by younger dikes and at least one stock. Most of the dikes and the stock are late Precambrian in age, but some dikes may be Tertiary. Paleozoic and younger sedimentary rocks extend along the eastern flank of the mountains and around the southern end. Tertiary volcanic rocks occur discontinuously along the lower western slope.

The crystalline complex consists of (1) products of high-grade metamorphism, either of sediments alone or sediments interlayered with tuffs, flows, or sills, and (2) products of magmatic intrusion, granitization, or differential melting. The rocks form an interlayered sequence whose individual members grade into one another. At few places are the individual members more than several tens of feet in thickness. Hornblende-plagioclase gneiss, biotite-quartz-plagioclase gneiss, and hornblende-pyroxene-plagioclase gneiss are the chief "metasediments", in their order of abundance. In addition, garnetiferous and sillimanitic gneisses, quartizite, and scapolite-pyroxene gneiss locally form long and narrow layers mapped as "marker beds". Migmatite, several varieties of granite, and metamorphosed gabbroic and ultramafic rocks comprise the products of magmatic intrusion, granitization, or differential melting. The foliation of these rocks in general dips steeply and strikes east-northeast. Decidedly younger dikes are syenitic, andesitic, and basaltic. Many syenitic dikes, and likewise an albite syenite stock, exhibit anomalous radioactivity ranging from 2 to 10 times normal background count. The prevailing trend of dikes, faults, and veins is northwest, transverse to the regional foliation.
\end{abstract}

The thorium-bearing veins are zones of shattered rock, mostly less than 10 feet wide, but locally as much as 50 feet wide, which have been extensively feldspathized and locally silicified. They are heavily impregnated with red and yellow iron oxide minerals. Many vein rocks emit a strong, stinking odor when freshly broken. Quartz, barite, carbonate minerals, and minor amounts of fluorite and sulphide minerals may or may not be present. The veins are most abundant along sinuous belts of faults, but many are scattered erratically elsewhere. Veins do not seem to be localized either by litbology or structure in the crystalline complex, but where the same vein crosses both granite and metasedimentary gneisses, the most intense local radioactivity anomalies are apt to be found in granite.

Thorium-rich concentrations occur erratically along the veins as pockets, pods, or lenses. A reddish-brown thorite-like mineral, probably thorogummite, is visible as blebs and veinlets at only a few places. Elsewhere the thorium-rich minerals, indicated by limonite, can be detected only by their radioactivity.

\section{INTRODUCTION}

In 1950 the Geological Survey discovered thorium in veins in the Wet Mountains of Colorado. Subsequent discoveries by prospectors and geologists have established a thorium metallogenic province that trends north-northwestward along the western slope of the range. The known deposits are irregularly scattered through an area about 25 miles long and 10 miles wide.

The Wet Mountains extend about 50 miles southsoutheastward from the Arkansas River (fig. 182) as an in-echelon extension of the Colorado Front Range. To the west is a narrow intermontane valley named the Wet Mountain Valley; to the east lie the Great Plains. 


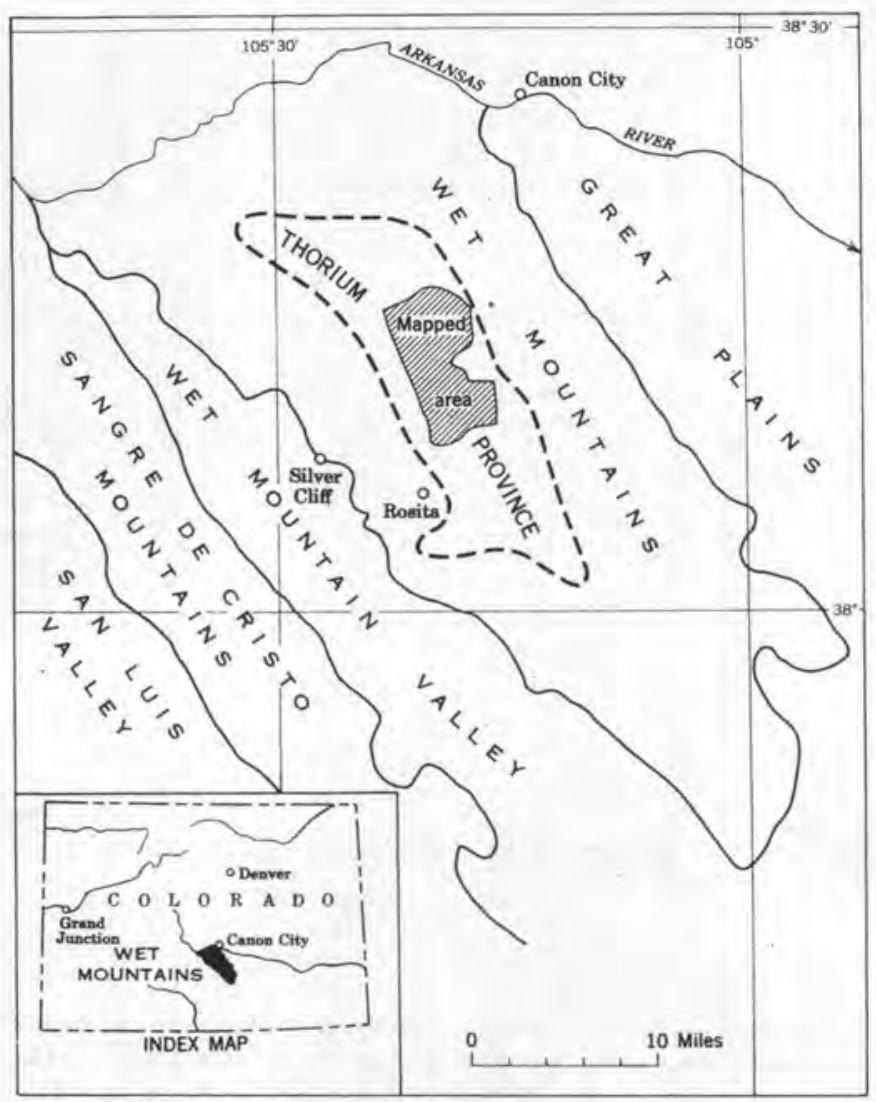

FIovre 182,-Location of thorium deposits, Wet Mountains, Colo.

The narrow crest of the central part of the range, adjoining the thorium province, stands at an average altitude of about 9,000 feet. The western slope is fairly rugged; local relief ranges from a few hundred feet to more than a thousand feet. Few of the valleys contain perennial streams, for the climate (despite the name of the mountains) is nearly semiarid. Thin, somewhat scrubby stands of evergreen cover many ridges, and good stands cover some of the north-facing slopes.

The prevailing bedrock of the Wet Mountains is complex erystalline rocks of Precambrian age. The complex is transected by many dikes, some of which may be later Precambrian in age, some Tertiary. It also is transected by at least one stock that is late Precambrian. Sedimentary rocks of Paleozoic and younger age extend along the eastern flank of the mountains and around the southern end. Tertiary volcanic rocks form a discontinuous belt along the lower western slope and in places cap the southern part of the range crest. An unknown thickness of alluvium covers bedrock throughout the Wet Mountain Valley.

Metal mines, worked mainly during the last century, have been the chief source of mineral wealth derived from the Wet Mountains. (See Emmons, 1896.) Except for one lead mine 10 miles northeast of Rosita, and perhaps several insignificant lead mines farther north, the metal mines are clustered within two districts in the vicinity of Rosita and Silver Cliff, respectively. The aggregate output of these districts has been about $\$ 7$ million worth of ore containing lead, silver, and gold. These base-metal deposits occur within areas of volcanic rocks and, less abundantly, within surrounding Precambrian terrane. By contrast, thorium-bearing veins have as yet been found only in Precambrian terrane - to the east, northeast, and north of Rosita. Perlite, derived from a glassy member of the volcanic series, is mined a few miles southwest of Rosita. Very small quantities of barite from veins, and vermiculite from bodies of reconstituted or altered gneiss have been mined at scattered localities in the Precambrian terrane.

\section{BEDROCK \\ CR YSTALLINE ROCK COMPLEX}

Essentially all that is known about the crystalline rock complex in the thorium province is derived from an area of 35 square miles, mapped in detail since 1952. The only previous studies were made by Cross (1896, p. 275-283), who described Precambrian rocks found near Rosita and Silver Cliff, but lumped them together on his geologic map, and by Christman and others (1953), who made plane-table maps of three small areas that contain thorium veins.

The crystalline rock complex is composed of products of high-grade metamorphism, (derived from sediments alone or sediments interlayered with tuffs, flows, or sills) and products of magmatic intrusion, granitization, or differential melting. These foliated rocks form interlayered sequences whose individual members grade into one another, both along the strike and across it. At few places do the individual members attain thicknesses exceeding several tens of feet. Mappable units are difficult to resolve. In general, wherever one type of rock constitutes more than 80 percent of the material in a sequence not less than 50 feet thick, the authors and their associates (Singewald and others, 1955) mapped the bedrock as a unit designated by the name of the prevailing rock. Elsewhere, the bedrock was divided into units designated by the names of two or more rocks, each of which constitutes more than 20 percent of the material in the sequence; these units are not less than 100 feet thick and, generally, are several hundred feet thick. Altogether, the crystalline complex was divided into 24 mappable units, of which 8 are designated by one rock name, and 16 are designated by two or more rock names. In addition, certain distinctive rocks, such as garnet-rich layers and quartzite, which occur as thin but long layers within both kinds of units, were mapped as "marker beds." 
Hornblende-plagioclase gneiss, biotite-quartz-plagioclase gneiss, and hormblende-pyroxene-plagioclase gneiss, in order of abundance, are the prevailing products of metamorphism either of sediments alone or of sediments interlayered with tuffs, flows, or sills. All gradations exist from the hornblende-plagioclase gneiss to the biotite-quartz-plagioclase gneiss on the one hand, and to the hornblende-pyroxene-plagioclase gneiss on the other. The rocks generally are thinly banded, owing to alternating layers or laminae having slightly different composition and texture. Mafic minerals (Christman and others, 1955, p. 13-15) constitute from about 35 to 85 percent of rocks that contain both hornblende and pryoxene. The biotite content of rocks essentially free of hornblende and pyroxene averages about 10 percent. The more leucocratic facies of biotite-quartz-plagioclase gneiss, which are difficult to distinguish in the field from alaskitic granite, contain subordinate microcline.

Garnetiferous gneiss, sillimanitic gneiss, quartzite, and scapolite-pyroxene gneiss are, in their order of abundance, subordinate types of metasedimentary gneiss. Garnet, probably almandite, locally is a conspicuous constituent in long and narrow layers or lenses of biotite-bearing rock, not only in metasedimentary gneiss, but also in migmatite and in alaskitic granite. The layers, ranging from less than a foot to several tens of feet in thickness, commonly serve as distinctive "marker beds." A few can be traced several miles along the strike. At few places is garnet a conspicuous constituent of hornblende gneiss. Sillimanite commonly is associated with garnet in "marker beds," but is somewhat less widespread than garnet. At some places, sillimanite occurs without garnet. Quartzite, mostly garnetiferous, has been found only as lenses, few of which are more than 100 feet long or more than 10 feet thick. They commonly are associated with garnet-rich gneiss. The relatively rare scapolite-pyroxene gneiss likewise is restricted to thin layers, lenses, and pods.

Alaskitic granite gneiss and associated mignatite are the most widespread representatives of rocks that may have formed by igneous intrusion, granitization, or differential melting. The alaskitie granite gneiss forms tabular bodies and lenses conformable with the regional foliation. Individual occurrences range from less than 1 foot to about 500 feet in thickness. Many have relatively sharp contacts, but others grade into the enclosing rocks, particularly into migmatite. The average rock (Christman and others, 1955, p. 19) contains about 42 percent of perthitic microcline, 33 percent of quartz, 22 percent of oligoclase, and 3 percent combined of biotite and acc ssory minerals. In places the alaskitic granite gneiss contains garnet-bearing layers.

Quartz monzonite gneiss and leucogranodiorite gneiss are conformable granitic members of the crystalline complex that are much less common than alaskitic granite gneiss. In addition a granite, slightly more radioactive than alaskitic granite gneiss, commonly cuts across the regional foliation. It may have been emplaced during the declining stage of the metamorphic orogeny or later. Pegmatites are widespread, but in general were not mapped. Metamorphosed gabbroic and ultramafic rocks are subordinate members of the crystalline complex. They are closely associated with hornblende-pyroxene-plagioclase gneiss and may be products of local melting. Their contacts in a few places seem to cut across enclosing rocks, but their long dimensions and internal foliation conform with the regional foliation.

\section{YOUNGER IGNEOUS ROCKS}

A nonfoliated albite stock that covers about 3 square miles contains inclusions of rocks of the crystalline complex and transects the foliation. The prevailing rock (Christman and others, 1955 , p. 24) contains 65-80 percent of albite (most of which is antiperthite), less than 25 percent of microcline, and less than 5 percent of quartz. Accessory minerals are hornblende, biotite, zircon, apatite, magnetite, and fluorite. Throughout the stock radioactivity readings with a gamma scintillation detector range from 2 to 10 times the normal background rate and average about 5 times that rate. Spectrographic analyses show that most of the radioactivity is due to thorium. An age determination by Howard Jaffe of the Geological Survey, Larsen's zircon method, indicates that the stock is about 600 million years old.

Dikes, whose relative ages are incompletely known, cut the crystalline complex and include many different facies, but syenite, melanocratic syenite, and basic rocks that range from andesite to basalt, predominate. Field relations suggest that syenite dikes are essentially contemporaneous with early facies of the albite syenite stock and that most basic dikes antedate the syenite dikes. Some basic dikes, however, are younger than syenite dikes. Thus, most dikes probably are late Precambrian in age, but some may be younger, perhaps Tertiary in age,

The syenite dikes are the most common and the most continuous; some have been traced for several miles: The rock generally is fine grained and composed of pink feldspar with only minor amounts of quartz, biotite, hornblende, aegirite, and secondary minerals. The melanocratic syenite dikes include a diversity of fine- 
grained and porphyritic facies, but in thin section all contain albite and soda-bearing amphiboles or pyroxenes. The basic dikes are predominantly dark-gray aphanitic to medium-grained rocks containing calcic andesine or sodic labradorite. Many are intensely altered, particularly in proximity to veins. Most syenite dikes and many melanocratic syenite dikes exhibit radioactivity anomalies comparable to those of the albite syenite stock. Basic dikes normally exhibit no anomalous radioactivity.

\section{GEOLOGIC STRUCTURE}

Foliation is well developed throughout most of the erystalline complex. In general, the strike is northeast, and the dip is steep to the north at most places, but steep to the south at others. At some places foliation is obscure in alaskitic granite gneiss, gabbroic and ultramafic bodies, and mafic varieties of hornblendic gneiss. Generally, outcrops are not sufficient to permit correlation of the obscure foliation with local structural details; however, at a few places foliation is obscure in alaskitic granite gneiss along the crests of relatively open minor folds or structural terraces.

The foliation at most places probably is inherited from original bedding. It conforms with differences in composition between layers of thinly banded rocks. It likewise conforms with long and narrow "marker beds" of distinctive rocks such as quartzite and garnet-sillimanite gneiss. One "marker bed" of garnet-sillimanite gneiss $10-50$ feet thick was traced more than 3 miles. On the other hand, at many places where lithologic units grade abruptly and complexly along the strike into other units, particularly within the belts of isoclinal folds, the foliation may represent axial-plane cleavage superimposed upon earlier folds, and may not be inherited from existing bedding.

Lineation at many places is indicated by grooves, crenulations, mineral lenticules, and alinement of elongated minerals. However, lineation is not apparent in most outcrops; perhaps this is due in part to the poor quality of outcrops. Lineations generally are consistent throughout large areas. They are either essentially parallel to major fold axes or subperpendicular.

Three longitudinal belts displaying different types of folds have been mapped in the crystalline complex. One belt is dominated by a broad, doubly plunging major anticline on whose limbs are subordinate folds and structural terraces; the lineation, essentially parallel to fold axes, generally plunges less than 40 degrees. Another belt is a homoclinal zone of steep dips in which lineation is mostly wanting. The third belt is one of crumpled isoclinal folds in which lineation is subper- pendicular to the strike of the foliation, but essentially parallel to minor fold axes.

The dominant trend of fractures that postdate the metamorphic orogeny is northwest to west, that is, transverse to oblique to the trend of regional foliation. The fracture pattern is represented by dikes, veins, faults, shear zones, and joints. The prevailing trend of dikes ranges from N. $50^{\circ}$ W. to S. $70^{\circ}$ W., whereas the prevailing trend of veins ranges from N. $30^{\circ}$ W. to N. $80^{\circ} \mathrm{W}$. Relatively narrow, sinuous zones of fractures may be traced for miles. The horizontal component of displacement along the larger faults may in places be as much as 500 feet. The vertical component of displacement cannot be determined.

\section{THORIUM DEPOSITS}

Thorium vein minerals - as distinct from thoriumbearing accessory rock minerals, such as zircon-oceur as irregularly distributed constituents of veins, as disseminations and small local concentrations in broader areas of shattered rock, and as continuously seattered components of bodies thought to be altered breccia pipes. Only the veins seem to hold economic potentialities at the present time.

Figure 182 outlines the province in which thoriumbearing veins were found before 1955. Systematic search has revealed hundreds of thorium-bearing veins in the mapped part. Hundreds of others doubtless will be found in the remainder. Details of the vein pattern are illustrated by Figure 183. Omitted are all veins that give radioactivity readings less than 3 times normal background count when the gamma-ray scintillation detector is held at hip level. Although a considerably number of veins are scattered erratically through the area of figure 183, many are concentrated along sinuous belts that follow major zones of discontinuous faults. No correlation has yet been found between the distribution of veins and either the metamorphic structure or the lithology of the rocks in the crystalline complex.

The veins occupy steeply dipping zones of shattered and altered rock. Most of them are less than 10 feet wide, but a few are as much as 50 feet wide. They may be traced along the outcrop for distances ranging from about 100 feet to 5,000 feet. The material in a vein zone near the surface normally is decomposed, friable, and heavily impregnated with yellow, brown, and red iron oxide minerals. Purplish-red hues among the iron oxide minerals are seen in nearly every strongly radioactive vein but are not diagnostic, because they also appear where veins are not radioactive. The vein rocks at many places emit a strong stinking odor when freshly broken, but the odor disappears in about a minute. Typical vein minerals such as quartz (including smoky quartz), barite, carbonate minerals, and minor amounts 


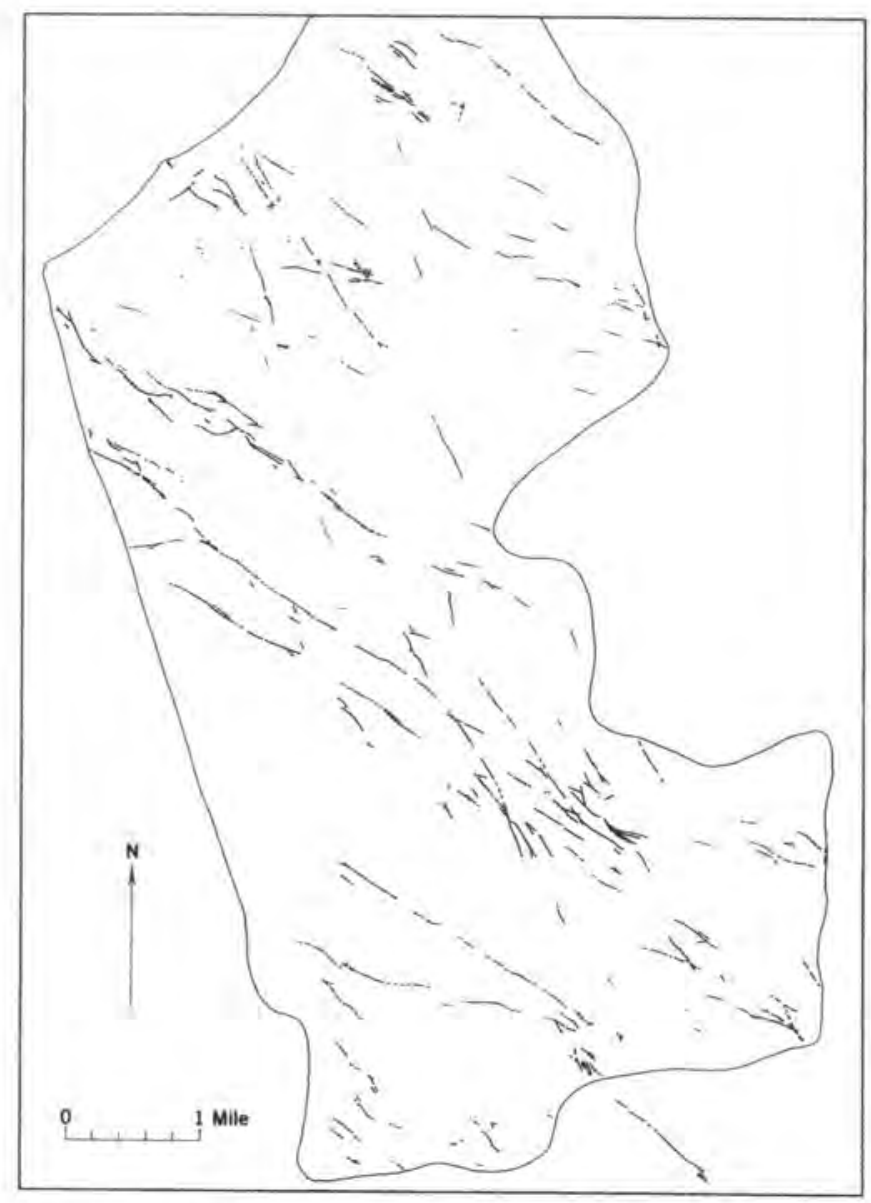

F1GUke 183.-Thorium veins in mapped area, Wet Mountains, Colo.

of fluorite, sulfide minerals, and copper stain may be present in radioactive veins.

The most widespread product of hypogene alteration in the veins and their walls is pink feldspar, commonly accompanied by quartz. In some places feldspathized veins grade laterally into coarse pink pegmatite. Intensely feldspathized rock tends to resist erosion, so the float may obscure the surrounding rock where exposures are poor. The feldspathized rock may have a spongy structure enclosing rounded pellets of limonite. Where hornblendic gneiss adjoins a feldspathized vein, the rock is commonly epidotized.

A second type of foirly widespread hypogene alteration may have beeri dominantly carbonatization. It seems to be especially common where veins adjoin or lie within basic dikes. The original products have been largely destroyed by weathering, but probably included carbonate minerals, a soda amphibole akin to arfvedsonite, and perhaps other mafic minerals.

Concentrations of thorium-rich minerals occur erratically along veins as predict, pods, or lenses. Not enough prospecting has been done to predict their sizes and grades. More than 100 selected samples from diverse localities contained from 0.02 to 12.5 percent of $\mathrm{ThO}_{2}$. Only one vein has uranium in greater than a trace amount. Diamond drilling at one locality (Christman and others, 1953, p. 7) delineated two ore shoots for which a cutoff grade was taken as 0.3 percent $\mathrm{ThO}_{2}$; one is $200-300$ feet long, $6-26$ feet thick, and at least 400 feet deep; the other is 160 feet long, 2-10 feet thick, and at least 140 feet deep. These ore shoots are doubtless considerably larger than average.

A reddish-brown thoritelike mineral is visible as blebs and veinlets at a few of the richest localities. Elsewhere, the thorium minerals, masked by limonite, can be detected only by their radioactivity. The thoritelike mineral collected at one locality (Christman and others, 1955 , p. 41,43 ) exhibits intimate intergrowths with barite and specularite under the microscope. The larger, euhedral grains are anisotropic and zoned. Chemical, optical, X-ray, and differential thermal data suggest that the mineral is a hydrated species, probably thorogummite. The age of the thoritelike mineral has not yet been determined.

\section{REFERENCES CITED}

Christman, R. A., Brock, M. R., Pearson, R. C., and Singewald, Q. D., 1955, Wet Mountain, Colorado, thorium investigations, 1952-1954; U. S. Geol. Survey open-file rept.

Christman, R. A., Heyman, A. M., Dellwig, L. F., and Gott, G. B., 1953, Thorium investigations 1950-52, Wet Mountains, Colorado: U. S. Geol. Survey Cire 290, 40 p.

Cross, Whitman, 1896, Geology of Silver Cliff and the Rosita Hills, Colorado: U. S. Geol. Survey 17th Ann. Rept., 1895-96, Part 2, p. 263-403, see p. 275-284.

Emmons, S. F., 1896, The mines of Custer County, Colorado: U. S. Geol. Survey 17th Ann. Rept., 1895-96, Part 2, p. 405-472.

Singewald, Q. D., Christman, R. A., Brock, M. R., and others, 1955, Geologic and radiometric maps of the McKinley Mountain srea, Wet Mountains, Colorado: U. S. Geol. Sruvey Mineral Inv. Field Studies Map MF 37, 4 sheets, 


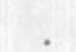




\title{
THORIUM IN THE POWDERHORN DISTRICT, GUNNISON GOUNTY, GOLORADO
}

\author{
By Stewart R. Wallace and Jerry C. Olson, U. S. Geological Survey
}

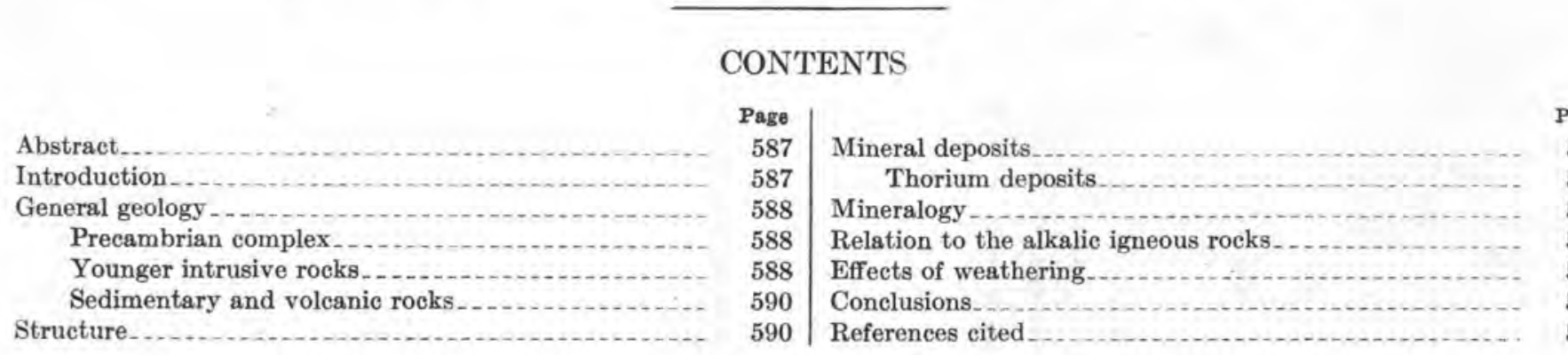

F1GURE 184. Generalized geologic map of the Powderhorn district, Colorado, showing localities examined.

\section{ABSTRACT}

Anomalous radioactivity was discovered in the Powderhorn district, Gunnison County, Colo., in 1949. Since then at least 32 additional localities showing abnormally high radioactivity have been found in an area 6 miles wide and 20 miles long. Analyses indicate that the known anomalous radioactivity is due almost entirely to thorium and its daughter products.

The Powderhorn district is an example of the association of thorium and other rare elements with alkalic igneous rocks. The district is underlain largely by foliated rocks of Precambrian age that are intruded by dikes, small stocks, and irregular bodies of nonmetamorphosed igneous rocks. Some, if not all, of the intrusive rocks are pre-Jurassic in age and may be as old as Precambrian. The metamorphic and intrusive rocks are overlain in places by erosional remnants of sandstone of the Morrison formation of Jurassic age and of volcanic rocks of the Alboroto rhyolite and Hinsdale formation of probable late Tertiary age.

The largest mass of intrusive igneous rocks is the Iron Hill composite stock, which occupies about 12 square miles in the southeastern part of the district. The stock is composed predominantly of pyroxenite, but includes a variety of alkalic igneous rocks and several masses of carbonatite; the largest body of carbonate rock crops out over an area of about 2 square miles on and adjacent to Iron Hill. The nonmetamorphosed igneous rocks that have been studied in other parts of the district show certain mineralogic and chemical similarities to the rocks of the Iron Hill complex and are probably genetically related to them.

The known thorium-bearing deposits in the Powderhorn district are of three main types: veins in silicified and ironstained shear zones in Precambrian foliated rocks, weakly radioactive zones in nontabular masses of carbonate rock such as the carbonatite of Iron Hill, and carbonate-rich veins, in persistent fractures, which are especially abundant in and near the Iron Hill eomplex. Carbonate minerals, quartz, barite, and alkali feldspar are the dominant minerals in many of the thoriumbearing veins; the thorium probably oceurs ehiefly in thorite or
\end{abstract}

hydrothorite. The known radioactive localities are most abundant in areas that contain alkalic intrusive rocks, and this plus the relative abundance of titanium, barium, strontium, niobium, phosphate, rare earths, and the alkalies in both the alkalic rocks and the vein material strongly suggest a genetic relation between the intrusive rocks and the thorium deposits.

The Little Johnnie vein, the most promising thorium deposit known in the district, is a mineralized shear zone, in foliated Precambrian rocks, that can be traced discontinuously for a distance of more than 3,500 feet; in this distance it ranges from less than 6 inches to about 5 feet in width. The thorium-bearing material occurs as irregular veinlets and thin films along the fault zone.

\section{INTRODUCTION}

In the Powderhorn district, Gunnison County, Colo., thorium occurs mainly in silicified iron-stained shear zones and in carbonate-rich veins. These thorium deposits are closely associated with a composite stock of alkalic igneous rocks at Iron Hill, southeast of Powderhorn, and with similar, and probably related, alkalic igneous rocks in other parts of the district. Larsen (1942) demonstrated that Ti, Ba, Sr, and P are relatively abundant in some of the Iron Hill igneous rocks. These elements are also present in greater-thanaverage concentrations in the thorium-bearing veins. The present study was undertaken to obtain more information on the geologic relation of these and other minor elements-particularly $\mathrm{Th}, \mathrm{Nb}$, and the rare earths - to the alkalic igneous rocks, and to evaluate the economic significance of the thorium-bearing deposits. 
The thorium deposits of the Powderhorn district (fig. 184) are in an elongate area about 20 miles long and 6 miles wide that trends northwestward from the vicinity of Iron Hill to the Lake Fork of the Gunnison River, in the southwestern part of Gunnison County.

Thorium was discovered in the Powderhorn district in 1949 on what is now the Little Johnnie group of claims (fig. 184, loc. 1). In 1950, soon after the original discovery was made, J. W. Adams and F. B. Moore of the U. S. Geological Survey examined the Little Johnnie, Jeanie, and Red Rock claims (fig. 184, loc. 2, 3, and 4). In 1951, during reconnaissance for radioactive materials in the San Juan Mountain region, Burbank and Pierson (1953) examined thorium-bearing deposits in the Lake Fork-Dubois area and in the vicinity of Iron Hill. Unpublished data obtained in these investigations contributed much to the present field study and the preparation of this report. A brief reconnaissance for thorium-bearing deposits was made by J. C. Olson during 3 weeks in July and August 1953, and the Little Johnnie thorium deposit was mapped by S. R. Wallace and J. E. Roadifer in August 1953.

\section{GENERAL GEOLOGY}

The Powderhorn district is underlain chiefly by Precambrian metamorphic and igneous rocks. These rocks are cut by small stocks, dikes, and irregular bodies of a variety of alkalic igneous rocks of preJurassic age. Flat to gently dipping strata of the Morrison formation of Jurassic age overlie these metamorphic and intrusive rocks and are in turn overlain unconformably by volcanic rocks of Tertiary age which were deposited on an erosion surface of low relief. The erosion surface beneath the Morrison formation and that beneath the volcanic rocks are locally nearly coincident, and in places the Tertiary volcanic rocks rest directly on Precambrian rocks. Erosional remnants of the Jurassic sedimentary and Tertiary volcanic flow rocks cap many mesas in the interstream areas.

\section{PRECAMBRIAN COMPLEX}

The Precambrian rocks, as mapped by Hunter (1925), are divided (fig. 184) into the Black Canyon schist, which is dominantly biotite schist, quartz-mica schist, and micaceous quartzite; the Dubois greenstone, which consists chiefly of hornblende schist, hornblende gneiss, amphibolite, metadiorite, and chlorite schist; and the Powderhorn granite, which consists of granitic rocks of relatively uniform composition but which includes such diversified textural varieties as schistose metarhyolite porphyry, granite gneiss, coarsely porphyrytic granite, and aplite. The Powderhorn granite cuts and is therefore younger than the Dubois greenstone, but it is in turn cut by foliated amphibolite dikes. The porphyritic texture and bipyramidal quartz phenocrysts of the metarhyolite porphyry suggest that this variety was either extrusive or intruded at relatively shallow depth; the other facies of the Powderhorn granite are almost certainly plutonic.

With the exception of some facies of the Powderhorn granite, all the rocks described above are well foliated and have been metamorphosed to a much higher degree than any of the lower Paleozoic sedimentary rocks of central or southwestern Colorado.

\section{YOUNGER INTRUSIVE ROCKS}

Many dikes and small irregular bodies of poorly foliated to massive igneous rock intrude the Precambrian metamorphic and igneous complex. These intrusive rocks include diorite, quartz diorite, gabbro, syenite, augite syenite, shonkinite, and the alkalic rocks of the Iron Hill complex. These rocks all have common chemical and structural features, and probably are genetically related.

The Iron Hill complex is a composite stock that occupies an area of about 12 square miles in the southeastern part of the district. The dominant rock type of the stock is pyroxenite. Dolomitic carbonate rock, the second most abundant rock in the complex, crops out over an area of about 2 square miles on and adjacent to Iron Hill in the east-central part of the stock. Calcite, apatite, phlogopite, magnetite, aegirite, and sodic amphibole are common accessory minerals in the carbonate rock, and locally they are abundant. The other rocks in the stock are uncompahgrite, ijolite, soda syenite, nepheline syenite, nepheline gabbro, and quartz gabbro.

The carbonatite is generally massive but locally has a conspicuous steeply plunging lineation formed mainly by streaks of apatite along shear planes. Persistent carbonate veins similar in composition to the main Iron Hill carbonate mass cut the pyroxenite, ijolite, uncompahgrite, and quartz gabbro; locally the massive carbonatite bodies are cut by thin pyroxenite and micaceous dikes. Thus carbonate rocks are both older and younger than some of the igneous rocks of the complex. Larsen (1942) favored the concept that the main carbonatite mass was formed hydrothermally in the throat of a volcano, though it may have been intruded as a carbonate magma or it may be an inclusion of Precambrian marble.

The Iron Hill complex probably is pre-Jurassic in age; Larsen (1942) found that the heavy-mineral suite of basal Morrison strata in the vicinity of Iron Hill contained minerals characteristic of those found in the Iron Hill alkalic rocks. The Iron Hill stock and similar intrusive rocks throughout the district, and the related thorium-bearing deposits, are younger than the main 


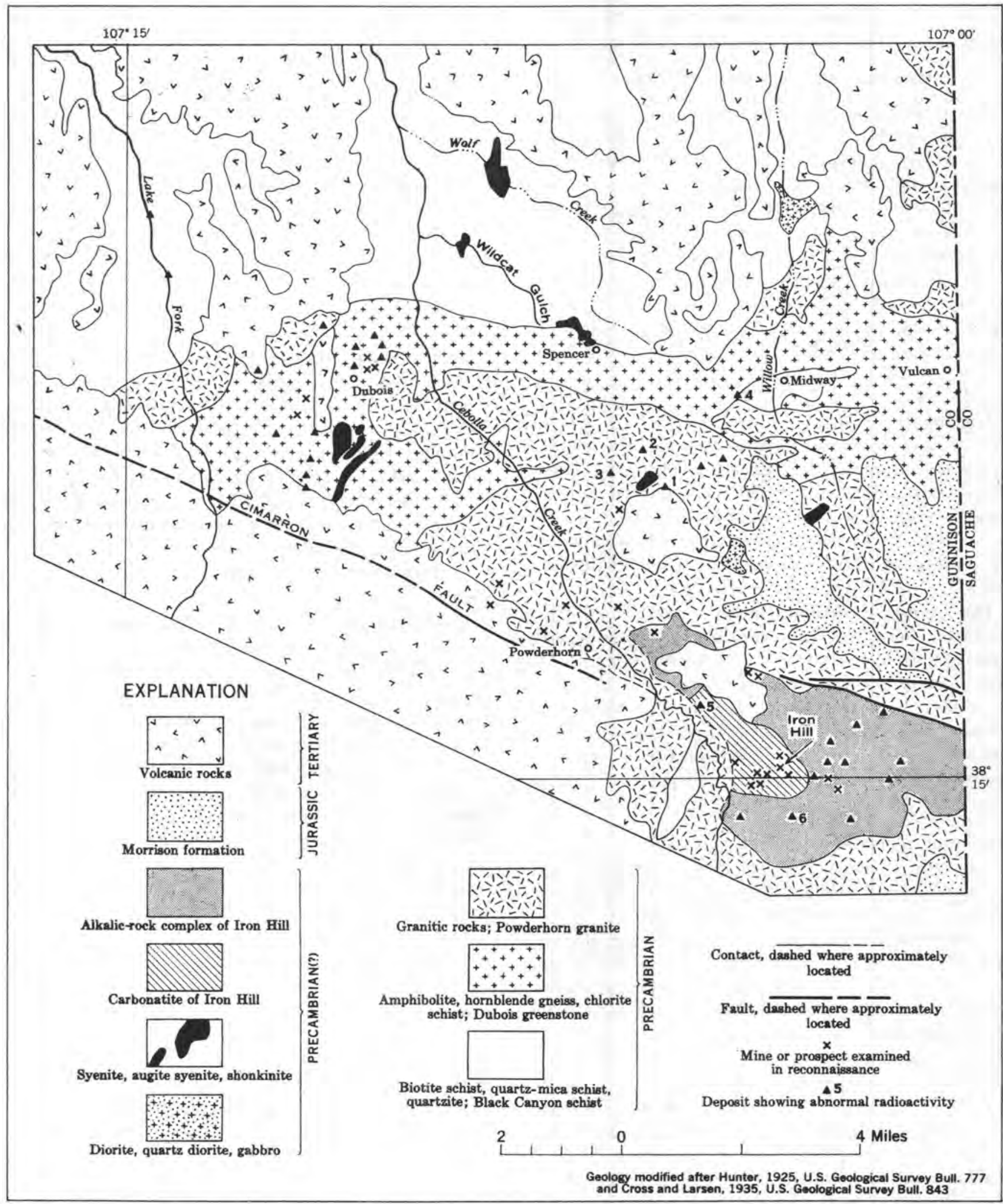

Flaure 184,-Generalized geologic map of the Powderhorn district, Colorado, showing localities examined. 
period of Precambrian metamorphism in the district and may possibly be later Precambrian in age.

\section{SEDIMENTARY AND VOLCANIC ROCKS}

The metamorphic-rock complex is overlain unconformably by thin remnants of sandstone and siltstone of the Morrison formation of Jurassic age, which were deposited on a nearly flat surface. Volcanic rocks of the Alboroto rhyolite of the Potosi volcanic series of Miocene age lie unconformably on the Morrison formation and in turn are overlain unconformably by rhyolite of the Hinsdale formation of Pliocene(?) age. The sedimentary and volcanic rocks are found chiefly as erosional remnants on mesas and ridges and have been removed from most of the district by erosion.

\section{-}

STRUCTURE

The foliation and individual layers of the Precambrian metamorphic rocks strike generally within $45^{\circ}$ of east and dip steeply throughout most of the district. Many of the dikes and veins in the district were emplaced parallel to this foliation and layering. The Mesozoic and Cenozoie sedimentary and volcanic rocks dip gently northward except locally where disturbed by faults.

The largest known fault in the region (fig. 184), the Cimarron fault of Hunter (1925), is a southwarddipping normal fault that has a throw of more than 1,500 feet in the Powderhorn district. It extends at least 35 miles northwestward from Powderhorn but has not been mapped southeast of Powderhorn; its probable location in the valley of Cebolla Creek is marked by hot springs and spring deposits.

\section{MINERAL DEPOSITS}

Mineral deposits of three distinct ages occur in the Powderhorn district. Precambrian quartz-chloritetourmaline veins containing pyrite, chalcopyrite, and sphalerite, near Dubois, Spencer, Midway, and Vulcan, were mined during the period $1870-1900$ for the minor amounts of gold and silver they contain, and a small quantity of sulfur was produced from massive sulfide bodies that replace chloritic sehist near Vulean. Iron and manganese oxides, vermiculite, and minerals containing titanium, rare earths, thorium, and niobium are associated with the alkalic igneous rocks and are present in sufficient quantity to encourage some prospecting. Narrow, discontinuous veins, fissures, and joint fillings in the volcanic rocks of Tertiary age have yielded a small amount of manganese oxides; these deposits are probably related to the Tertiary volcanism.

\section{THORIUM DEPOSITS}

The known thorium deposits in the Powderhorn district are of three principal types: mineralized shear zones (veins) in Precambrian metamorphic rock; layered carbonate-rich veins filling fissures, particularly in and near the Iron Hill stock; and weakly radioactive zones in nontabular masses of carbonate rock such as the Iron Hill mass. The radioactivity appears to be due almost entirely to Th and its daughter products. Analyses of 33 samples for U and 4 samples for $\mathrm{Ra}$ showed a maximum of 0.005 percent $U$ and $2.7 \times 10^{-11}$ percent $\mathrm{Ra}$. In contrast, the $\mathrm{ThO}_{2}$ content of 45 samples of various types of radioactive material averaged more than 0.3 percent, and a selected sample from the Little Johnnie vein contained more than 4 percent $\mathrm{ThO}_{2}$.

The mineralized shear zones that cut the Precambrian complex include the most highly radioactive deposits of the district. The shear zones range in width from less than a foot to as much as 18 feet and in length from a few tens to many hundreds of feet. The Little Johnnie vein has been traced intermittently for more than 3,500 feet along strike, and it probably extends for another 1,000 feet. Although outcrops are few, exposures in trenches and the pattern of anomalous surface radioactivity between trenches suggest that the zone may consist of several closely spaced in-echelon shears.

The mineralized parts of the shear zones are discontinuous and variable in thickness and commonly contain masses of relatively unmineralized wall rock. The deposits consist of closely spaced irregular veinlets and seams of quartz, iron oxides, alkali feldspar, thorium in the form of thorite or hydrothorite, and other minerals that have been introduced into the fractured rocks. Near the veinlets, the wall rock is greatly altered and commonly shows some replacement by the introduced minerals. In places the mineralized zones contain veinlike masses of coarse-grained barite or carbonate containing minor amounts of pyrite, galena, and sphalerite.

Most of the mineralized shears dip steeply and many are nearly vertical, but their strike varies from one part of the district to another. In general the veins on and near the Little Johnnie ćlaims strike east to northeast, whereas the strike of those in the Dubois-Lake Fork area ranges from northwest to northeast. With the exception of a few exposures underground in adits at Dubois the thorium deposits have not been exposed at depth. However, the length and tabular form of the deposits suggest that many of them persist to deptbs of hundreds of feet. Thorium-bearing shear zones are exposed in the bottom of Lake Fort Canyon, 1,000 feet below exposures of similar veins on the mesa to the east, and the Little Johnnie vein is exposed through a vertical range of more than 700 feet. 
Well-defined carbonate veins are particularly common in the Iron Hill complex, where they tend to have a crude radial arrangement with respect to the central mass of carbonate rock. The veins range from a few feet to more than 3,500 feet in length and from several inches to as much as 15 feet in width; locally the veins contain fragments of wall rock. The great length of some of these veins, the rather even widths, and the generally sharply defined walls suggest that they were emplaced in persistent fractures. Many of the veins have a foliation or banding shown by the concentration of mica, amphibole, and pyroxene crystals in streaks parallel to the walls of the vein. Euhedral prisms of aegirite more than 2 centimeters long embedded in calcite and arranged perpendicular to the walls in 1 vein suggest that open-vein filling was a dominant process of vein formation.

Abnormal radioactivity is found in at least 2 localities in nontabular bodies of the carbonate rock of Iron Hill-at locality 5 (fig. 184) near the north end of the Iron Hill carbonatite mass and at locality 6 (fig. 184) in a satellitic mass of carbonate rock about 0.5 mile south of the southwest edge of the Iron Hill carbonatite body. Rare-earth-bearing apatite, mica, and either magnetite or martite are present in the carbonate at these localities.

\section{MINERALOGY}

The Precambrian rocks cut by the mineralized shear zones have been strongly fractured, silicified, and iron stained. The Little Johnnie vein, which cuts quartzbiotite schist, metarhyolite porphyry, and amphibolite, is typical of many deposits of this type and is described below. Thin sections of the vein material show potash feldspar, albite, and quartz as the dominant constituents. Typically, these are intimately mixed in a fine-grained aggregate clouded with fine hematite, goethite, and some allophane. Euhedral crystals of hematite as much as 0.5 millimeters across are common, and many are partly altered to goethite. Associated with the hematite and goethite are small subhedral to anhedral masses of thorite or hydrothorite. Apatite, as a felted mat of needles in the feldspar, is abundant in 1 thin section studied but is rare in 2 other sections that were examined. Coarse-grained barite and carbonate are abundant in a few places in the vein but were not identified in thin section. Some of the barite fluoresces pink. Accessory minerals in the vein include pyrite, galena, sphalerite, clinozoisite(?), tourmaline, fluorite, and rutile. Small euhedral crystals of a uniaxial positive mineral were tentatively identified as xenotime and probably account for much of the yttrium content of the veias.
The mineralogy of the carbonate-rich veins varies considerably in different veins and in different parts of a single vein. Dolomite is the principal constituent of most of the veins, but calcite, ankerite, and siderite are present in many veins and predominate at some places. Accessory minerals present include apatite, pyrite, chalcopyrite, sphalerite, gale aa, fluorite, quartz, opal, chalcedony, albite, microcline, orthoclase, phlogopite, several pyroxenes and amphiboles, and other minerals (Larsen, 1942, p. 31-33). Barite, bastnaesite, cerite(?), and synchisite(?) are minor consituents Many of the veins are stained yellow by iron oxides.

\section{RELATION TO THE ALKALIC IGNEOUS ROCKS}

Most of the known thorium deposits are near Dubois and the Little Johnnie claims and in the Iron Hill complex (fig. 184); in each of these areas alkalic igneous rocks are present. Near the Little Johnnie vein the alkalic rocks comprise several small dikes of syenite that consist almost entirely of alkali feldspar; a small stock of augite syenite (Hunter, 1925) that contains biotite, microcline, sphene, calcite, and zarnet; and a large dike of pigeonite gabbro that contains accessory apatite, orthoclase, and sodic amphibole. Fracture surfaces in the gabbro are coated with films of anatase and brookite associated with minor amounts of aegirite, alkali feldspar, and quartz. Three small carbonate veins and a vein or dike of sodic amphibole rock about 2 inches wide were found on the Little Johnnie claims. The carbonate veins are stained yellowish brown by iron oxides and contain abundant apatite and accessory potash feldspar, quartz, and a green pleochroic pyroxene. The sodic amphibole rock contains abundant pleochroic blue amphibole intergrown with lesser amounts of zeolites, apatite, carbonate, and sodic pyroxene. Dahllite, brookite, aegirite, and zeolites occur in vugs. A comparison of the mineralogy of these rocks and veins with that of the thorium-bearing veins shows that maay minerals are common to both.

The relative abundance of certain elements in both the alkalic igneous rocks and the thorium deposits provides a further correlation between the intrusive rocks and associated veins. Larsen (1942) demonstrated that $\mathrm{Ti}, \mathrm{P}, \mathrm{Ba}$, and $\mathrm{Sr}$ are present in greaterthan-average concentrations in many of the Iron Hill igneous rocks, and spectrographic analyses in U. S. Geological Survey laboratories have shown that $\mathrm{Nb}$ and rare earths are contained in some of the minerals of the alkaline rocks. Rare earths are relatively abundant in apatite in the Iron Hill carbonatite and in apatite and perovskite from the pyroxenite. The $\mathrm{Nb}$ content of the peroyskite ranges from 0.X to 0.OX percent, and the brookite from the gabbro on the Little Johnnie claims contains 2 percent $\mathrm{Nb}$. 
The following table gives the results of semiquantitative spectrographie analyses of vein material from the thorium-bearing deposits. It is apparent that these elements are present in greater-than-average amounts in both the thorium deposits and the associated alkalic igneous rocks, and the spatial and geochemical relations of the thorium-bearing veins and the alkalic rocks definitely indicate a genetic tie between them.

\section{Abundance of certain minor elements in samples of mineralized shear zones and carbonate veins \\ [Spectrographic analyses by R. G. Havens and P. R. Barnett, U. 8. Geological} Survey]

\begin{tabular}{|c|c|c|}
\hline \multirow{2}{*}{10} & \multicolumn{2}{|c|}{$\begin{array}{l}\text { Number of samples in } \\
\text { which indicated ele- } \\
\text { ment exceeds } 0.1 \text { per- } \\
\text { cent }\end{array}$} \\
\hline & $\begin{array}{l}\text { Mineralized } \\
\text { shear zones } \\
\text { (6 samples } \\
\text { analyzed) }\end{array}$ & $\begin{array}{l}\text { Carbonate } \\
\text { veins } \\
\text { (8 samples } \\
\text { analyzed) }\end{array}$ \\
\hline 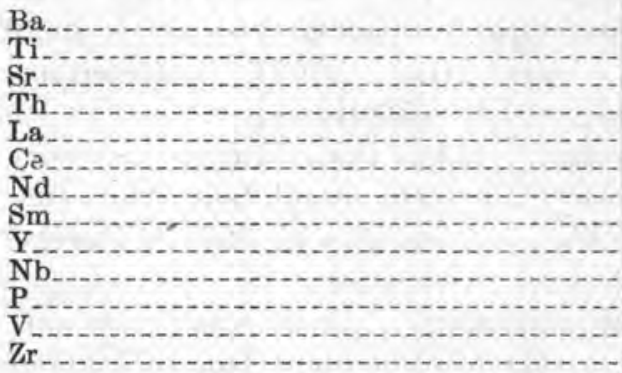 & $\begin{array}{l}6 \\
5 \\
0 \\
4 \\
0 \\
0 \\
0 \\
1 \\
3 \\
1 \\
0 \\
0\end{array}$ & $\begin{array}{l}8 \\
4 \\
4 \\
0 \\
4 \\
4 \\
4 \\
0 \\
0 \\
1 \\
3 \\
2 \\
2\end{array}$ \\
\hline
\end{tabular}

The abundance of potash in ma jy of the alkalic rocks outside the Iron Hill complex, in contrast to the relative abundance of soda and lime in the igneous rocks within the complex, has been pointed out by Larsen (1942). Thorium appears to be associated with both the potassic and the soda and lime rocks, but, as shown in the table, it seems to be more abundant in veins related to potassic rocks. The table reveals other contrasts between the carbonate-rich veins of the Iron Hill complex and the mineralized shear zones in other parts of the district. Veins in and near the soda- and lime-rich rocks of the Iron Hill complex generally contain more carbonate, $\mathrm{Sr}$, and $\mathrm{P}$ than do the mineralized shear zones outside the Iron Hill stock. It may also be significant that the ratio of cerium-group to yttriumgroup rare earths is much greater than 1 in the carbonate veins and the rare earth-bearing minerals of the Iron Hill rocks but is less than 1 in the samples of mineralized shear zones in other parts of the district.

\section{EFFECTS OF WEATHERING}

The sedimentary rocks of Jurassic age and the Tertiary volcanic rocks were deposited on erosion surfaces of low relief that were closely coincident (Burbank and Pierson, 1953); generally flat-lying Tertiary volcanic rocks rest either directly on Precambrian rocks or on nearly horizontal beds of the Morrison formation. The vein material in deposits near these surfaces has thus been subjected to at least 1 and possibly 2 periods of extensive weathering and erosion prior to exposure by the present erosion cycle, which has cut deep canyons in the older surfaces.

During either or both of the pre-middle Tertiary erosion cycles the veins were jasperized. At some places, the carbonate of the vein material is extensively replaced by jasper as much as $50-100$ feet below the old surfaces. Several deposits show some evidence of increase in amount of radioactivity, and presumably an increase in thorium content, with depth. The apparent variation may indicate dispersal of some thorium by jasperization, leaching, and oxidation of vein material at and near the present surface; at least part of this alteration has occurred during the current cycle of erosion.

\section{CONCLUSIONS}

Two principal types of thorium-bearing deposits occur in the Powderhorn district: silicified and iron-stained mineralized shear zones in Precambrian rocks; and carbonate-rich veins, filling persistent fissures, which are especially abundant in and near the Iron Hill composite stock. Both types of deposit contain relatively high concentrations of several or all of the following elements: $\mathrm{Ti}, \mathrm{P}, \mathrm{Ba}, \mathrm{Sr}, \mathrm{Th}, \mathrm{Nb}$, and rare earths; carbonate- and alkali-bearing minerals are common in many of the deposits. The veins are associated with alkalic igneous rocks of pre-Jurassic age that contain abnormal amounts of the elements listed above as characteristic of the veins. The content of minor elements in both the igneous rocks and the thorium-bearing deposits is reflected in their similar accessory mineral assemblages. The spatial and geochemical associations of the alkalic igneous rocks of the district with the thorium-bearing deposits indicate a genetic relationship between them.

\section{REFERENCES CITED}

Burbank, W. S., and Pierson, C. T., 1953, Preliminary results of radiometric reconnaissance of parts of the northwestern San Juan Mountains, Colo.: U. S. Geol. Survey Circ. 236, 11 p.

Cross, Whitman, and Larsen, E. S., 1935, A brief review of the geology of the San Juan region of southwestern Colorado: U. S. Geol. Survey Bull. 843, 138 p.

Hunter, J. F., 1925, Precambrian rocks of Gunnison River, Colo.: U. S. Geol. Survey Bull. 777, 94 p.

Larsen, E. S., 1942, Alkalic rocks of Iron Hill, Gunnison County, Colo.: U. S. Geol. Survey Prof. Paper 197-A, p. 1-64. 


\title{
GEOLOGY AND MONAZITE CONTENT OF THE GOODRICH QUARTZITE, PALMER AREA, MARQUETTE COUNTY, MICHIGAN
}

\author{
By Rollin C. Vickers, U. S. Geological Survey
}

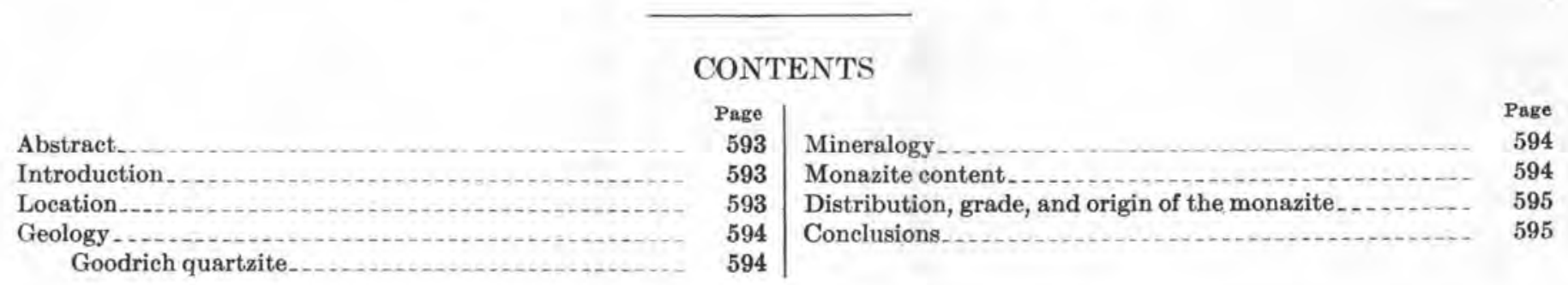

ABSTRACT

Monazite, containing about 7.5 percent thorium, is concentrated in quartzite of Precambrian age in part of the Marquette iron-bearing district in northern Michigan. The Palmer area, which is on the south limb of the Marquette synclinorium, is a down-faulted block of metasediments about 4 miles long and three-quarters of a mile wide. The strata are mainly the Ajibik quartzite and the Negaunee iron-formation of middle Huronian age overlain unconformably by the Goodrich quartzite of upper Huronian age. Monazite occurs in the Goodrich quartzite as rounded to subrounded detrital grains concentrated mainly in the matrix of quartz-pebble conglomerate which is interbedded with coarse-grained quartzite. The brownish-red to honey-colored monazite grains are generally $0.10-0.20$ millimeter in diameter and locally make up more than 50 percent of the matrix in the pebble-conglomerate beds. Heavy minerals other than monazite in the quartzite are mainly hematite, magnetite, ilmenite, and rutile. The monazite content of specimens of quartzite can be rapidly and accurately determined by radiometric counting methods because of the paucity of other radioactive minerals.

The stratigraphic position and lateral extent of the monazitebearing beds are known from samples of outcrops, gamma-ray logs of 3 core-drill holes that penetrate an apparent thickness of 1,100 feet of the Goodrich quartzite, several drill-core specimens, and samples from mine dumps and locally derived glacial erratics. A content of about 3 pounds of monazite per ton is common in outcrops of Goodrich quartzite; outcrops are practically restricted to the lower 200 feet of the formation. A study of the gammaray logs of the drill holes shows that most of the monazite occurs more than 300 feet above the base of the formation. Drill-core specimens contain as much as $\mathbf{5 4}$ pounds of monazite per ton of rock, and samples from mine dumps and glacial erratics contain as much as 110 pounds of monazite per ton. Additional exploration would be necessary to determine the amount of monazitebearing rock available and its amenableness to mining by openpit methods. Laboratory work has shown that about 92 percent of the monazite is recoverable by gravity separation after grinding to minus 100 mesh.

The presence of large tonnages of monazite-bearing quartzite suggests that the area should be considered as a potential low- grade monazite resource and that larger and higher grade monazite concentrations in consolidated sediments may be present in other areas.

\section{INTRODUCTION}

Monazite is now the principal source of thorium and rare earths. Although beach and stream placers supply practically all of the monazite used today, deposits of monazite in consolidated sediments (ancient placers) may also be of economic importance because of the relatively high value of monazite concentrates. For example, at a price of 18 cents per pound for monazite concentrates (in March 1954), rocks containing 20 pounds of monazite per ton would be comparable in value to copper ores being mined in the United States that contain about 0.75 percent copper or to the taconites that are beneficiated for their iron content in the Lake Superior region.

Beach and stream gravels throughout the world have received considerable attention during the past several years because of the increased demand for such minerals as ilmenite, monazite, rutile, and zircon. Consolidated gravels, on the other hand, are usually not regarded as an economic source of these minerals. However, several rich concentrations of monazite in sedimentary rocks have been found recently in the United States by uranium prospectors. The purpose of this paper is to describe one of these ancient monazite placers which may have present economic importance.

\section{LOCATION}

The Palmer area in Marquette County, Mich., is a part of the Marquette iron-bearing district of the Lake Superior region. Abnormal radioactivity in specimens 
of pebble conglomerate on rock dumps at several abandoned iron mines in the Palmer area was detected in 1951 by geologists of the U. S. Atomic Energy Commission. The locality was brought to the attention of the author during a detailed study of the known occurrences of radioactive minerals in northern Michigan. Preliminary sampling and laboratory work indicated that most of the radioactivity is caused by detrital grains of thorium-bearing monazite in the matrix of the conglomerate and that samples contained as much as 5 percent monazite. Further work in the area provided information concerning the areal extent, thickness, and grade of the monazite-bearing strata.

\section{GEOLOGY}

The Palmer area is on the south limb of the Marquette trough, a westward-plunging synclinorium about 40 miles long and 1-6 miles wide. This synclinorium contains middle Precambrian (Huronian) rocks that are mainly quartzite, slate, dolomite, and rocks of the Negaunee iron-formation. The Palmer area is a downfaulted block of Huronian sedimentary rocks about 4 miles long and three-quarters of a mile wide separated from the main part of the Marquette synclinorium by an eastward-trending fault. Within this fault segment the rocks generally dip northward. Most of the bedrock is covered by glacial deposits.

According to Van Hise and Leith ${ }^{1}$ the sequence of Precambrian rocks in the Palmer area is as follows:

\begin{tabular}{|c|c|c|}
\hline Series & Formation & $\begin{array}{c}\text { Approrimate } \\
\text { thickness } \\
\text { (feet) }\end{array}$ \\
\hline Upper Huronian _. & Goodrich quartzite... & 850 \\
\hline Middle Huronian. & Negaunee iron-formation .... & 1,000 \\
\hline & Ajibik quartzite. & 150 \\
\hline ntia & Palmer gneiss & \\
\hline
\end{tabular}

\section{GOODRICH QUARTZITE}

In the Palmer area the Goodrich quartzite is composed of a locally developed basal cobble or boulder conglomerate, which grades upward into interbedded coarse-grained quartzite and pebble conglomerate. The lithologic character of the basal conglomerate is dependent upon the character of the subjacent formation. In part of the area the basal part of the Goodrich quartzite is predominantly cobbles and boulders of granite and schist derived from the lower Precambrian to the south and abundant jaspilite derived from the underlying Negaunee iron-formation. In some places the basal part of the Goodrich contains enough specular hematite fragments to constitute ore. Except for the development of boulder and cobble conglomerate at the base of the formation, the Goodrich quartzite consists almost entirely of alternating beds of coarse

t Van Hise, C. R., and Leith, C. K., 1911, The geology of the Lake Superior region: U. S. Geologieal Survey Mon. 52, p. 251-265, pl. 17 . quartzite and arkosic quartz-pebble conglomerate. The observed pebble conglomerate beds range from about 1 inch to 2 feet in thickness and are separated by beds of coarse sand, which are 1-10 feet or more thick. These lithologic relationships are based on outcrops of only the lower 200 feet of the Goodrich. The lower part of the quartzite is fairly well exposed in the Palmer area, but only 1 exposure is definitely more than 200 feet above the base. Because monazite is most abundant in beds of pebble conglomerate and because gamma-ray logs show an increase in monazite content in the middle and upper parts of the formation, the percentage of pebble beds is believed to increase similarly in those parts of the formation.

The maximum thickness of Goodrich quartzite penetrated by diamond drilling in the Palmer area is about 1,100 feet. The true stratigraphic thickness of the formation is not known because no sediments younger than the Goodrich quartzite were penetrated in the diamond drilling in the area, and no information is available on possible folding.

\section{MINERALOGY}

The monazite occurs as rounded to subrounded detrital grains in the matrix of quartz-pebble conglomerate. The brownish-red to honey-colored monazite grains are generally $0.10-0.20$ millimeter in diameter. The identification of the monazite was confirmed by X-ray powder-diffraction photographs. Locally the monazite grains make up more than 50 percent of the matrix in the conglomerate, and several lenses of monazite grains as much as 2 millimeters thick were noted in thin sections. Heavy minerals other than monazite in the Goodrich quartzite are mainly hematite, magnetite, ilmenite, and rutile.

A sample of monazite (about 92 percent pure) was extracted from composite chips of several glacial boulders and selected mine-dump specimens. The sample is believed to be representative of the monazite in the Palmer area. The monazite was concentrated by gravity separation on a Wilfley table after grinding to minus 100 mesh and then was further purified magnetically. Chemical analyses (calculated to 100 percent) of the monazite showed 8.3 percent $\mathrm{ThO}_{2}$ and 0.22 percent $\mathrm{UO}_{2}$. The specific gravity of several grains was 4.63 .

\section{MONAZITE CONTENT}

The monazite content of all samples of Goodrich quartzite was determined by comparing the betagamma activity of the material with prepared standards. The standards were prepared by separating out relatively pure monazite from a composite of several glacial boulders and mine-dump specimens of Goodrich 
quartzite and then remixing various proportions of the monazite with the crushed rock from which the monazite had been separated. A graph was then plotted which showed a straight-line relation between the monazite content of the standards and their radioactivity. This method of monazite determination was used because a study of alpha-sensitive stripping film on thin seetions of the quartzite indicated that almost all the radioactivity was due to monazite. The accuracy of determining the amount of monazite by measuring the radioactivity of a sample was checked by two other methods; the results are tabulated below.

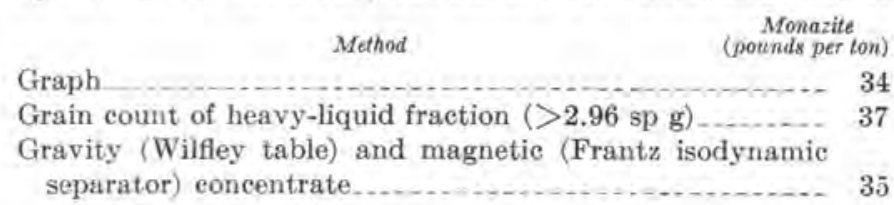

\section{DISTRIBUTION, GRADE, AND ORIGIN OF MONAZITE}

The stratigraphic position, lateral extent, and grade of the monazite-bearing beds are known from (1) samples of outcrops, that are mainly restricted to the lower 200 feet of the formation, (2) gamma-ray logs of 3 diamond-drill holes that penetrate an apparent thickness of 1,100 feet of the Goodrich quartzite, (3) analyses of several diamond-drill core samples, and (4) mine-dump and glacial-boulder samples.

In most of the outcrops examined, the monazite is concentrated in narrow beds of pebble conglomerate, 1 inch to 2 feet thick, separated by beds of coarse-grained quartzite 1-10 feet or more thick. Chip-channel samples of the lower part of the quarzite contained a weighted average of about 3 pounds of monazite per ton. However, gamma-ray logging suggests that most of the monazite occurs more than 300 feet above the base of the formation. A sample of pebble conglomerate from the only outcrop that is believed to be more than 300 feet above the base of the formation contained 21 pounds of monazite per ton. A scintillation-counter survey of the outcrop containing the pebble-conglomerate bed indicated an average monazite content of about 6 pounds per ton. Specimens of core representing about 3 percent of the total from 2 diamond-drill holes aggregating 1,530 feet in length were scanned with a scintillation counter, and several monazite-bearing specimens were found which contained as much as 50 pounds of monazite per ton. Locally derived glacial erratics and mine-dump samples contained as much as 90 pounds of monazite per ton, but material of this grade was not observed in outcrop or in drill-core specimens. Samples of Goodrich quartzite containing more than 20 pounds of monazite per ton were found on mine dumps for a distance of about $1 \frac{1}{2}$ miles along the strike of the formation.
The average grade of monazite-bearing quartzite that would be amenable to open-pit mining methods is not accurately known. Small tonnages of material containing more than 20 pounds of monazite per ton are present, and the author believes that large tonnages are available that would contain about 10 pounds of monazite per ton. Additional exploration would be necessary to determine the amount and grade of monazite-bearing rock present.

Although the Goodrich quartzite crops out over an area of several hundred square miles in northern Michigan, concentrations of monazite have been found mainly in an an area of about 3 square miles. Outside the Palmer area, small local concentrations of monazite may be found in an outlier of Goodrich quartzite about 12 miles to the southeast. The quartzite in this area is arkosic and overlies older granite.

Because monazite in the Goodrich quartzite seems to be restricted to a relatively small area, the mineral is believed to be derived from a local source. Because of the increase in the size and angularity of the monazite grains in the area southeast of Palmer, the source of the monazite may be to the southeast, which is an area underlain mainly by abnormally radioactive porphyritic granite. Monazite, allanite, and zircon were observed in thin sections of specimens of granite taken about 7 miles southeast of Palmer, but the monazite in the few granite specimens examined was finer grained than in the Goodrich quartzite.

\section{CONCLUSIONS}

Concentrations of monazite may be expected in consolidated sediments in other areas, formed perhaps under much the same conditions as present-day monazite placers. Sandstones and conglomerates derived from a monazite-bearing source rock would warrant attention. Both present and ancient monazite placers are commonly small relative to the area covered by the strata in which they are contained; detailed reconnaissance must be done before a particular area can be classified as unfavorable. The presence of monazite in consolidated sediments may also be used as a guide to concentrations of zircon, rutile, ilmenite, or other heavy minerals that might be recovered in addition to the monazite.

Owing to the small amount of thorium in many monazites, an economically important deposit of monazite in consolidated sediments may not be sufficiently radioactive to attract attention. For example, a monazite deposit containing 20 pounds of monazite per ton would have a radioactivity equivalent to material containing about 0.02 percent uranium, if it is assumed that the monazite contains about 7.5 percent 
thorium and 0.20 percent uranium and that the ratio $\mid$ radioactivity of sandstones and conglomerates and of other radioactive minerals to monazite is very low.

During the intensive search for uranium deposits the their metamorphic derivatives may be caused by potentially valuable concentrations of thorium-bearing possibility should not be overlooked that the abnormal monazite or other radioactive detrital minerals. 


\title{
MONAZITE IN SOUTHEASTERN UNITED STATES
}

\author{
By William C. Overstreet, Norman P. Cuppels, and Amos M. White, U. S, Geological Survey
}

\section{CONTENTS}

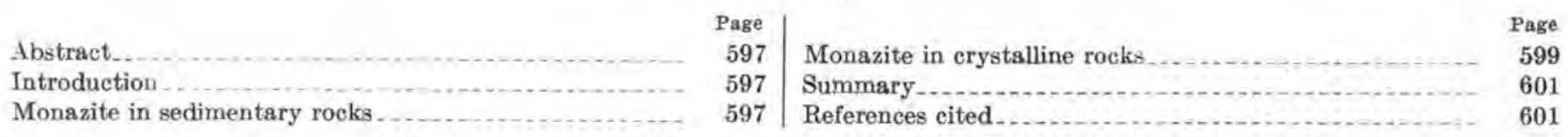

\section{ABSTRACT}

Monazite is a minor accessory mineral in some crystalline rocks occurring in two narrow belts in the Southeastern United States. It is widely but sparsely distributed as a detrital mineral in Cretaceous, Tertiary, and Quaternary sedimentary rocks exposed across the Coastal Plain. The detrital monazite was derived from crystalline sources in the interior and was deposited with alluvial and littoral sediments between these sources and the Atlantic Ocean. Except in rare areas where the deposits have been reworked, monazite constitutes less than 0.1 percent of the sediment.

J. B. Mertie, Jr., has suggested that the western of two belts of monazite-bearing rocks trends 550 miles northeastward across the Piedmont from Alabama to Virginia where it is joined by a shorter eastern belt. From their junction a single belt extends 50 miles farther north. Little is known of their structure.

Originally pelitic sediments in the central 300 miles of the western belt have been converted to schists and gneisses of the highest grade of regional metamorphism attained in the Piedmont: the sillimanite-garnet subfacies of the amphibolite facies. Grade of metamorphism declines away from the area of highestgrade metamorphic rocks, both across and along the strike of the belt, to the staurolite-kyanite subfacies of the amphibolite facies and ultimately to the greenschist facies. Sillimanitic and isofacial sillimanite-free rocks at the core of the belt form an injection gneiss complex with masses of concordant, gneissic, synkinematic quartz monzonite and related bodies of pegmatite and quartz veins. This zone of injection gneiss is the chief source of monazite in the Piedmont.

The surrounding lower-rank metamorphic rocks, which are poor sources of monazite, lack the widespread synkinematic intrusive rocks typieal of the core of the belt. In these lowerrank metamorphic rocks, concordant to discordant, massive to gneissic post-kinematic plutons, mainly of quartz monzonite, were introduced under temperature and pressure less than that reached at the core during emplacement of the synkinematic rocks. Accessory monazite is sporadically distributed in these marginal rocks where it is commonly accompanied by epidote. Epidote is rarely found in the core of the belt. Monazite from the post-kinematic plutons differs in composition from monazite that crystallized in the synkinematic rocks. Ages of zircon and monazite from quartz monzonite at the core and on the margins of the western belt are consistent with interpretations of struc- ture and suggest that granitic rocks at the margins were emplaced after similar rocks in the core. What little is known of the eastern belt indicates that it probably is similar to the marginal parts of the western belt.

The apparent preferential precipitation of monazite in quartz monzonite and associated injection gneiss in areas where regional metamorphism has attained the highest grade of the amphibolite facies suggests that monazite will be found elsewhere in areas of injection gneiss that are in the sillimanite-garnet subfacies, no matter whether they are sillimanitic or isofacial sillimanitefree gneisses.

\section{INTRODUCTION}

Monazite-bearing crystalline rocks follow two narrow belts in Southeastern United States (Mertie, 1953, pl. 1). A long western belt leads northeastward from the inner edge of the Coastal Plain deposits in central Alabama across the Piedmont of Georgia, South Carolina, and North Carolina to the inner edge of the Coastal Plain sediments in northeastern Virginia. A short eastern belt extends northward from central North Carolina to the western belt in Virginia. The two belts are 550 and 200 miles long south of their junction and 50 miles long northeast of the junction.

Detrital monazite derived from crystalline rocks in the western belt has wide geographic distribution in the Piedmont and Coastal Plain. Monazite was mined on a small scale from colluvial and alluvial placers in the Carolinas along the western belt from 1887 until 1917 when the domestic industry succumbed to lower priced, imported monazite. Little is known of alluvial placers along the eastern belt or of this belt as a source of monazite found in Coastal Plain sediments.

\section{MONAZITE IN SEDIMENTARY ROCKS}

Detrital monazite has been found in residual soil mantling monazite-bearing crystalline rocks in the Piedmont, in colluvial and alluvial sediments deposited 
in or downstream from the belts, and in Cretaceous to Recent sediments across the Coastal Plain.

Residual deposits in the Piedmont consist of clayey sand and rock fragments that have accumulated on interstream divides through the disintegration of saprolite. Residual deposits grade downslope into poorly sorted, unconsolidated colluvial sediments, the most typical and widespread of which are sheet-wash deposits that unconformably overlie the crystalline rocks. Colluvium is commonly a clayey sand and is underlain by a thin layer of quartz pebbles. The colluvial deposits range widely in stratigraphic position and age: they grade into, are truncated by, or lap upon alluvial fill in the valleys; some are of possible preWisconsin age (Cain, 1944, p. 19-20), and other deposits are obviously forming at the present time.

Processes forming colluvial sediments and residual deposits have produced an initial concentration of monazite greater than that obtaining in bedrock, and where these deposits have been reworked by the streams the resulting alluvium is of highec tenor than sediment derived directly from saprolite. Rarely, some colluvial sediments are eluvial placers that contain monazite in concentrations 10 to 15 times greater than its abundance in the underlying rock.

Placers in alluvial sediments deposited in valleys along the western monazite belt in North and South Carolina are the historic source of monazite in Southeastern United States. Within the belt the valleys typically are small; large valleys are common on either side of the belt, but those on the west are barren of monazite, and the ones on the east, which have collected part of their fill from the belt, are poor. in monazite. Sediments filling the valleys are finer grained in the eastern and southern parts of the belt than in the western and northern parts. The age of the alluvium, as determined by pollen and carbon- 14 analyses, is postWisconsin except for a few late Pleistocene deposits that survive in isolated upland depressions where they have escaped erosion. Sand and silt make up about 65 percent of the alluvium, clay is 25 percent of the total, and gravel is 10 percent.

Stream sediments possess a rude uniformity in stratigraphic sequence that, from top to bottom, commonly is: sandy silt, silt, sand, clay, gravel, bedrock.

These units vary in composition and appearance, but some properties are consistent.

The sandy silt is red brown to brown and has the most uniform composition and distribution of the alluvial sediments in the monazite belt. Where it is particularly well stratified it is generally more sandy than at its massive exposures. A layer of buff, brown, or gray clayey silt, whose color changes horizontally in a few feet, underlies the red-brown sandy silt, and, as depth below the top of the flood plain increases, the amount of clay increases. Sand is the most abundant sediment. It is buff, brown, gray, or white and ranges in grade from coarse to very fine. At most places it occurs as lenticular or prismatic bodies, but it may be absent or it may be the only sediment in a valley. The clay near the bottom of the sedimentary sequence has the widest range of physical characteristies. In some places it is blue gray and has a uniform texture; elsewhere it is a dark gray or black muck eontaining abundant fragments of fresh or carbonized wood and peat. Clay in many exposures contains fine white sand and scattered, angular quartz pebbles. It almost invariably overlies the basal gravel, or if that is absent, lies on bedrock. At the bottom of the sequence is a quartzpebble gravel and minor amounts of feldspar and rock fragments bound in a matrix of white, yellow, or buff sandy clay. All degrees of angularity are represented among the components; subangular to subrounded fragments are most abundant. Distribution of the gravel is irregular. In any valley the gravel is persistent but irregular in thickness close to the head of the stream, but farther downstream it is discontinuous and thin.

Coarse sediments are scarce because there was little coarse detritus available for alluvial deposition in the Piedmont, where deep chemical weathering has reduced most of the rock to saprolite. Saprolite underlies 85 percent of the valley floors and is even more abundant along the valley walls. In these areas only rare fragments of unweathered rock and quartz from veins and pegmatite are available to form gravel.

The richest concentrations of monazite in the belt are in gravel and coarse sand near the base of the sedimentary sequence, but monazite is present in the alluvium from grass roots at the top of valley fill to bedrock at the bottom. Silt and clay carry only small concentrations of monazite, a fact that explains the low average tenor of large downstream flood plains where a thin sheet of gravel may be buried under 20 feet or more of fine-grained sediment. The abundance of monazite can be related to the way the sediment was deposited: the least monazite is in sediments dropped from suspended load in water spread out on flood plains during periods of overbank flooding; the most monazite is in coarse material left in the channels during normal stream action.

The mineralogic composition of a concentrate taken from alluvium is determined by the kinds of rocks in the drainage basin and by the mode of deposition of the sediment from which the concentrate is recovered. What might be called an average concentrate from the monazite belt consists, in order of decreasing abundance, of ilmenite, garnet, monazite, sillimanite, zircon, and 
rutile. If the stream drains areas underlain by metamorphic rocks of lower rank than those typical of the belt or flows over intrusive masses of basic igneous rocks, minerals such as staurolite, kyanite, epidote, magnetite, and hornblende enter the concentrate. Along the margins of the belt the increase in these minerals is notable. The mode of deposition of the sediment from which the concentrate is recovered influences the relative abundance of the heavy minerals: at a given point in a stream, sediment deposited from suspended load will contain less of the minerals of high specific gravity than will sediment moved in the bed load. Thus a silt or clay will contain proportionately less monazite, rutile, and ilmenite and more sillimanite, kyanite, epidote, staurolite, garnet, and hornblende than will coarse sand or gravel from the same part of the stream.

Monazite placers in the Carolinas were mined by hand in the late 1800's and early 1900's. Even though the industry failed in 1917, none of the stream beds were permanently depleted by mining because every rain swept additional monazite into the valleys. Surface runoff from cultivated fields in monazite-rich areas replenished some streams with enough monazite to permit their channels to be profitably mined every few years. Streams with narrow valleys bordered by tilled hillsides could be reworked every year, and sundry small creeks were rewashed after every hard rain.

The weathered and unweathered crystalline rocks of the Piedmont are overlain on the Coastal Plain to the east and south by loosely consolidated Cretaceous and Tertiary sediments. These nearly horizontal beds of sand, silt, clay, and marl have an exceedingly sinuous contact with the crystalline rocks along the Fall Line. Locally, where the Coastal Plain sedimentary beds have been removed and an old, weathered surface of the crystalline rock reexposed to erosion, the inland edge of these beds makes a northwest-facing scarp (Lang, King, Bramlette, and others, 1940, p. 31). The Cretaceous and Tertiary sediments have served as intermediate hosts for monazite between the crystalline source rocks and alluvial and littoral placers on the Coastal Plain.

Alluvial placers are in Wisconsin(?) and later fluvial deposits in the valleys of streams draining Cretaceous sediments near the landward side of the Coastal Plain. These fluvial deposits are debris reworked from the Cretaceous sediments and contain the same heavy minerals-but in greater abundance - than the Cretaceous sedimentary rocks. Ilmenite, rutile, monazite, zircon, staurolite, kyanite, and sillimanite are the dominant minerals; magnetite is rare; and epidote, hornblende, and garnet are absent.

The littoral placers are late Pleistocene to Recent deposits of well-sorted sand that generally rest about 30 to 50 feet above sea level but include deposits as low as the present beaches and as high as 250 feet above sea level. They are on the seaward part of the Coastal Plain and preserve recognizable features of beaches, dunes, spits, and bars.

The composition of heavy-mineral suites from wide areas of Coastal Plain deposits, especially Pleistocene and recent sediments, has recently been investigated by Lincoln Dryden and G. A. Miller (written communication) who report that Cretaceous, Tertiary, and the older Pleistocene deposits lack hornblende, epidote, and garnet, but that these minerals are common, often dominant, in younger Pleistocene and Recent deposits. According to Dryden and Miller, the most probable explanation for the absence of epidote, hornblende, and garnet from the older sediments is the leaching of these minerals from the source rocks in the Piedmont by profound weathering with possibly some postdepositional leaching. A study of modern saprolite in the Piedmont shows that, though hornblende and garnet are vulnerable to saprolitic weathering, both are present in exposed saprolite. Epidote appears to be unaffected. Thus deep weathering of the Piedmont rocks could have reduced the quantity of garnet and hornblende entering the Coastal Plain and possibly could have deprived the sediments of these minerals. The effect of leaching after deposition is shown in the smaller amounts of hornblende, epidote, and garnet in Pleistocene deposits than in modern sediments in the same valleys in the western monazite belt. The relative importance of the two processes has not been evaluated.

Ilmenite deposits with scant monazite are the only commercial placers that are being worked in the Coastal Plain at the present time. None of the colluvial, alluvial, or littoral deposits are monazite placers. Except in rare areas where the deposits have been reworked, monazite constitutes less than 0.1 percent of the sediment. In general the proportion of monazite to other heavy minerals is greatest in alluvial placers along small streams draining crystalline rocks in the western monazite belt, but the highest-tenor, largevolume deposits are the alluvial placers in streams that rework Cretaceous sediments at the western edge of the Coastal Plain. The littoral placers have the least monazite.

\section{MONAZITE IN CRYSTALLINE ROCKS}

This discussion of monazite in crystalline rocks will be restricted to the western monazite belt because the geology of the eastern belt is practically unknown. The western monazite belt possesses regional tectonic and metamorphic symmetry. It lies in a zone of injec- 
tion gneiss whose northwestern edge is discontinuously bounded by a narrow belt of phyllite and low-grade metamorphic rocks called the Brevard schist (Stose and Smith, 1939). Its southeastern edge is partly defined by somewhat similar low-grade metamorphic rocks called the Pine Mountain series in Georgia (Stose and Smith, 1939) and the Battleground schist, Kings Mountain quartzite, and Blacksburg schist (Keith and Sterrett, 1931, p. 4-5) in North and South Carolina. Neither of these narrow belts of low-grade metamorphic rocks continues the full length of the monazite belt: they are absent or unrecognized northeast of central North Carolina. Both the Brevard schist and the Pine Mountain series are separated from the zone of injection gneiss by faults. The Brevard schist and the Battleground schist, Kings Mountain quartzite, and Blacksburg schist are regarded as groups of synclinally depressed younger rocks resting unconformably on the older injection gneiss, but, though the structure appears to be well defined, the unconformities and age relations are not clear. The Pine Mountain series, which is anticlinally folded, is thought to be younger (Hewett and Crickmay, 1937, pl. 1) than the injection gneiss of the monazite belt.

The zone of injection gneiss includes metamorphosed sedimentary rocks, metamorphosed basic rocks in part of igneous origin, intrusive granitic bodies, and diabase dikes. No indisputable relict bedding has been generally recognized though it has been seen locally and is suggested by compositional layering in the metamorphosed sedimentary rocks. Basement rocks on which the gneisses rest have not been discovered.

The original sediments deposited in the zone of injection gneiss were not uniform in composition. Northeastward along the strike psammitic sediments appear in the pelites, and westward across the strike there is an increase in the abundance of calcareous sediments and basic volcanic rocks. Some layers, probably originally arkosic, are richer in potash than others.

These original sediments were affected by a progressive regional metamorphism whose intensity increases westward across the strike to the central core of a metamorphic climax, then declines. The central core, which is at least 300 miles long and 20 to 25 miles wide, is the area of highest grade regional metamorphism attained in the Piedmont: the sillimanite-garnet subfacies of the amphibolite facies. Where conditions of less temperature and pressure obtained between the central core and the Brevard schist and Battleground schist, the regional metamorphism produced muscovite schist and biotite-muscovite schist from sediments of the same composition that became sillimanite schist in the core. These lower rank rocks are characterized by such accessory minerals as staurolite, kyanite, epidote, and magnetite, whereas in rocks at the core the typical accessory minerals are sillimanite, ilmenite, rutile, garnet, and monazite. Bordering the sillimanitic core are rocks of the staurolite-kyanite subfacies of the amphibolite facies, and in the northeastern part of the western belt at the border between North Carolina and Virginia the rocks decline in metamorphic grade to the greenschist facies.

The injection gneiss was formed by masses of concordant quartz monzonite - commonly gneissic-and related bodies of pegmatite and quartz veins that were introduced into sillimanitic and isofacial sillimanitefree rocks at the core of the belt. These synkinematic intrusive rocks were emplaced when their host rocks were being plastically deformed and metamorphism was most intense. Later the rocks of the staurolitekyanite subfacies between the core and the Brevard and Battleground schists were intruded by concordant to discordant, massive to gneissic plutons. These post-kinematic plutons are mainly quartz monzonite and were introduced under conditions of nonplastic deformation when temperatures and pressures were lower than those reached at the core during the earlier intrusion. The widespread injection phenomena typical of the core are absent from the marginal staurolitekyanite zones.

It seems probable that the origin of the western monazite belt is closely related to the tectonic and metamorphic history of the area. The attitude of the sillimanite zone and its flanking staurolite-kyanite zones between the narrow synclinal depressions of the Brevard and Battleground schists suggests a broad, much contorted geanticline. The sillimanite zone and the monazite belt are parallel and coincident: the highest concentrations of monazite are in the core of the sillimanite-garnet zone; as the staurolite-kyanite zones are entered, monazite decreases markedly in abundance, and in the greenschist facies no monazitebearing rocks are found. In the sillimanite-garnet zone magnetite is virtually absent; it is abundant in metamorphic rocks in the staurolite-kyanite zone and in posttectonic granitic rocks intruded into the zone, and is a conspicuous accessory in the greenschists. From these mineralogic and spatial relations the following hypothesis for the origin of the western monazite belt is suggested.

The western monazite belt and its flanking staurolitekyanite zones represent the metamorphosed product of a sequence of marine sediments that have been folded into a northeasterly elongated geanticline. It is an uplift of tightly compressed isoclinal folds that are generally overturned to the northwest. In the core of the geanticline, where quartz monzonite and related bodies of pegmatite and quartz were emplaced at the 
peak of metamorphic intensity, the conditions of temperature and pressure promoted precipitation of the rare-earth phosphate during erystallization of the granitic rocks and metamorphic differentiation of the sedimentary rocks. Thus the tectonic and metamorphic environment established the position and trend of the monazite belt by promoting the conditions under which monazite crystallizes. In the staurolite-kyanite zone the lower temperatures and pressures obtaining during emplacement of later granitic rocks did not promote the precipitation of monazite, and most of the available rare earths and thorium were collected by other accessory minerals, such as epidote, biotite, and garnet.

Absolute ages of zircon and monazite from quartz monzonite in the core of the belt have been determined by H. W. Jaffe and David Gottfried (written communication) by the Larsen method and conform to structural interpretations. The ages suggest that the granitic rocks at the margins were emplaced after those in the core. Zircon and monazite from the metamorphosed sedimentary rocks in the core of the belt are the same age as zircon and monazite from the early quartz monzonite. We infer that any detrital zircon and monazite in the schists recrystallized under the conditions of temperature and directed stress that were reached at the climax of regional metamorphism; and, since this climax and the introduction of the quartz monzonite were synchronous, the radiometric ages of zircon and monazite from diverse sources are the same.

The ages of zircon and monazite from the quartz monzonite of the core and from metamorphosed sediments in the sillimanite-garnet zone are consistently Early Ordovician (about 400 million years). Zircon from a later quartz monzonite in the eastern staurolitekyanite zone (about 285 million years) and from two areas of later granite in the western staurolite-kyanite zone (about 300 million years) are probably Devonian in age (Jaffe and Gottfried, written communication). Thus, we infer that the most intense metamorphism in the Piedmont took place in Early Ordovician time. Subsequent movements allowed intrusion of Devonian granitic rocks. Because these Devonian intrusive rocks are undeformed, it appears that no late Paleozoic orogeny disturbed the western monazite belt.

\section{SUMMARY}

Placers in streams draining monazite-bearing crystalline rocks are likely to be poorer sources of monazite than fluvial placers formed by the reworking of detrital monazite deposited in an earlier cycle of erosion.

The apparent preferential precipitation of monazite in syntectonic quartz monzonite and associated injection gneiss in areas where regional metamorphism has attained the highest grade of the amphibolite facies suggests that monazite occurs elsewhere in areas of injection gneiss that are at the sillimanite-garnet subfacies whether they are sillimanitic or isofacial sillimanite-free gneisses.

\section{REFERENCES CITED}

Cain, S. A., 1944, Pollen analysis of some buried soils, Spartanburg County, S. C.: Torrey Bot. Club Bull, v. 71, no 1, p. 11-22.

Hewett, D. F., and Crickmay, G. W., 1937, The warm springs of Georgia, their geologic relations and origin, a summary report: U. S. Geol. Survey Water-Supply Paper 819.

Keith, Arthur, and Sterrett, D. B., 1931, Description of the Gaffney-Kings Mountain quadrangle, South CarolinaNorth Carolina. U. S. Geol. Survey Geol. Atlas (folio 222),

Lang, W. B., King, P. B, Bramlette, and others, 1940, Clay investigations in the Southern States, 1934-35: U. S. Geol. Survey Bull. 901.

Mertie, J. B., Jr., 1953, Monazite deposits of the southeastern Atlantic States: U. S. Geol. Survey Circ. 237.

Stose, G. W., and Smith, R. W., 1939, Geologic map of Georgia: Ga. Div. Mines, Mining, and Geology. 


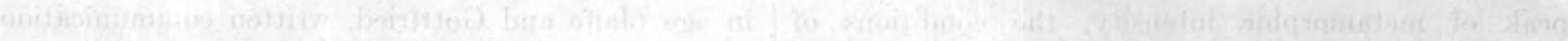

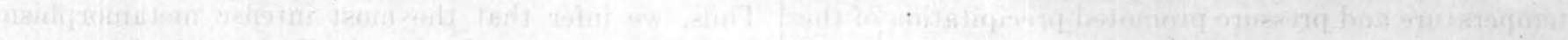

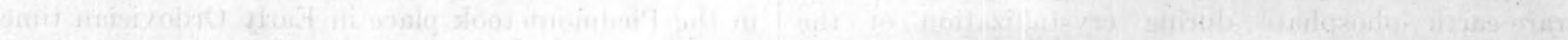

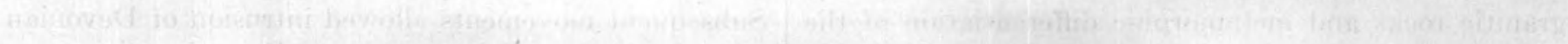

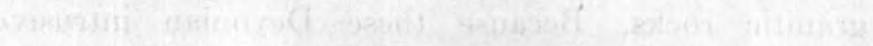

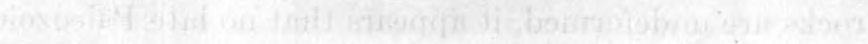

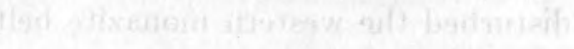

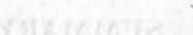

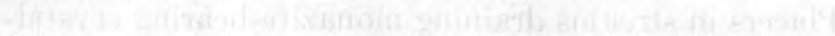

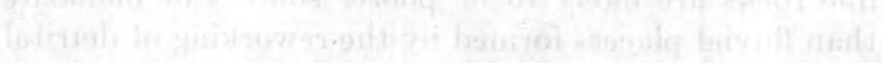

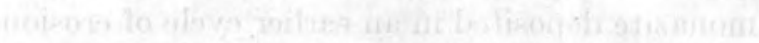

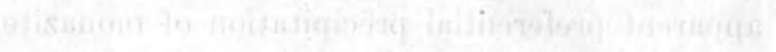

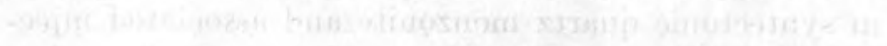

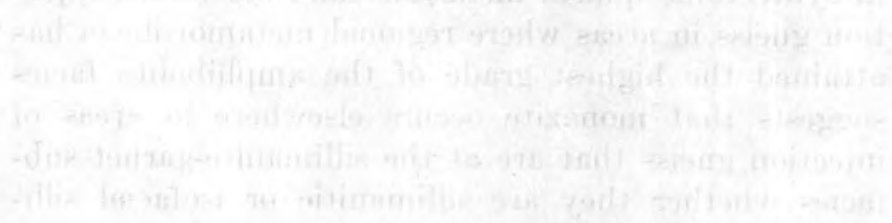

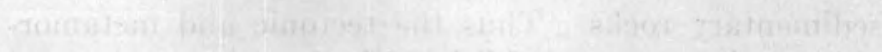

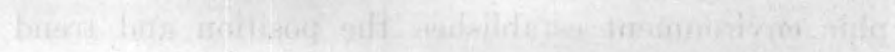

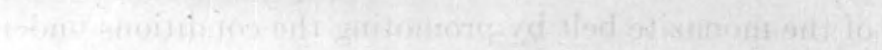

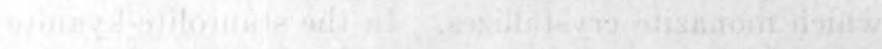

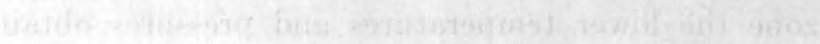

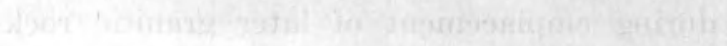

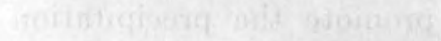

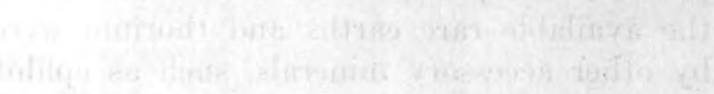

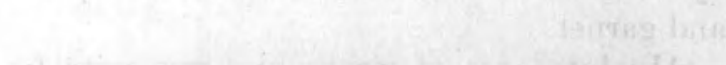

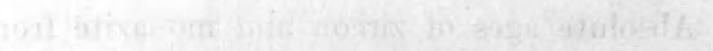

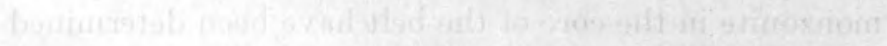

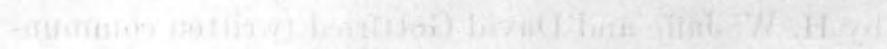

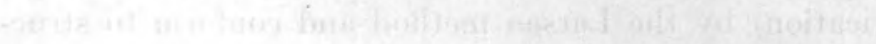

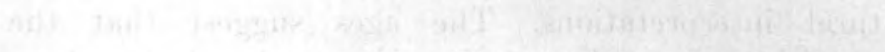

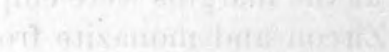

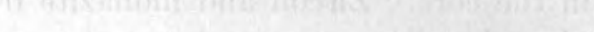

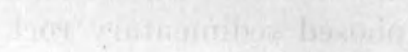

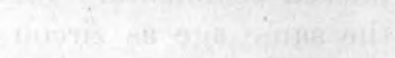

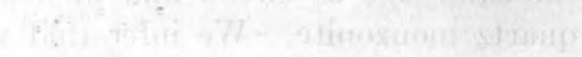

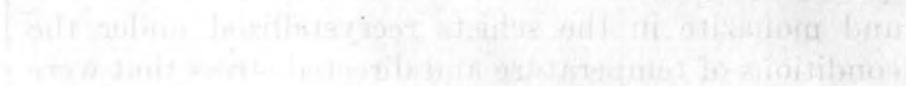

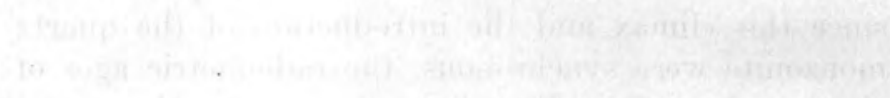

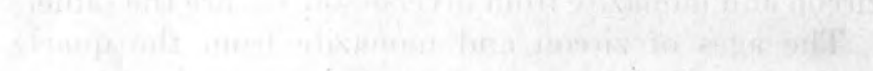

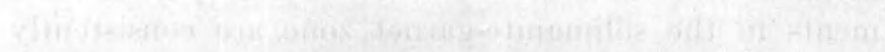

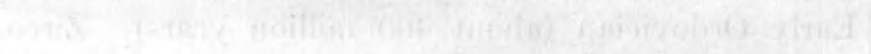

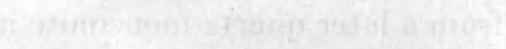

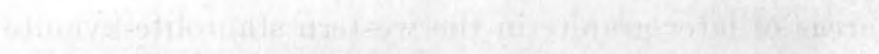

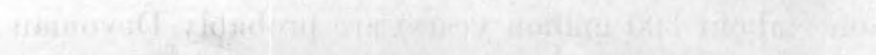


ANALYTICAL CHEMISTRY OF URANIUM AND THORIUM 


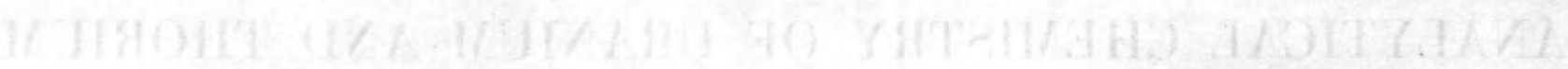




\title{
THE ANALYTICAL GHEMISTRY OF URANIUM AND THORIUM
}

\author{
By Frank S. Grimaddi, U. S. Geological Survey
}

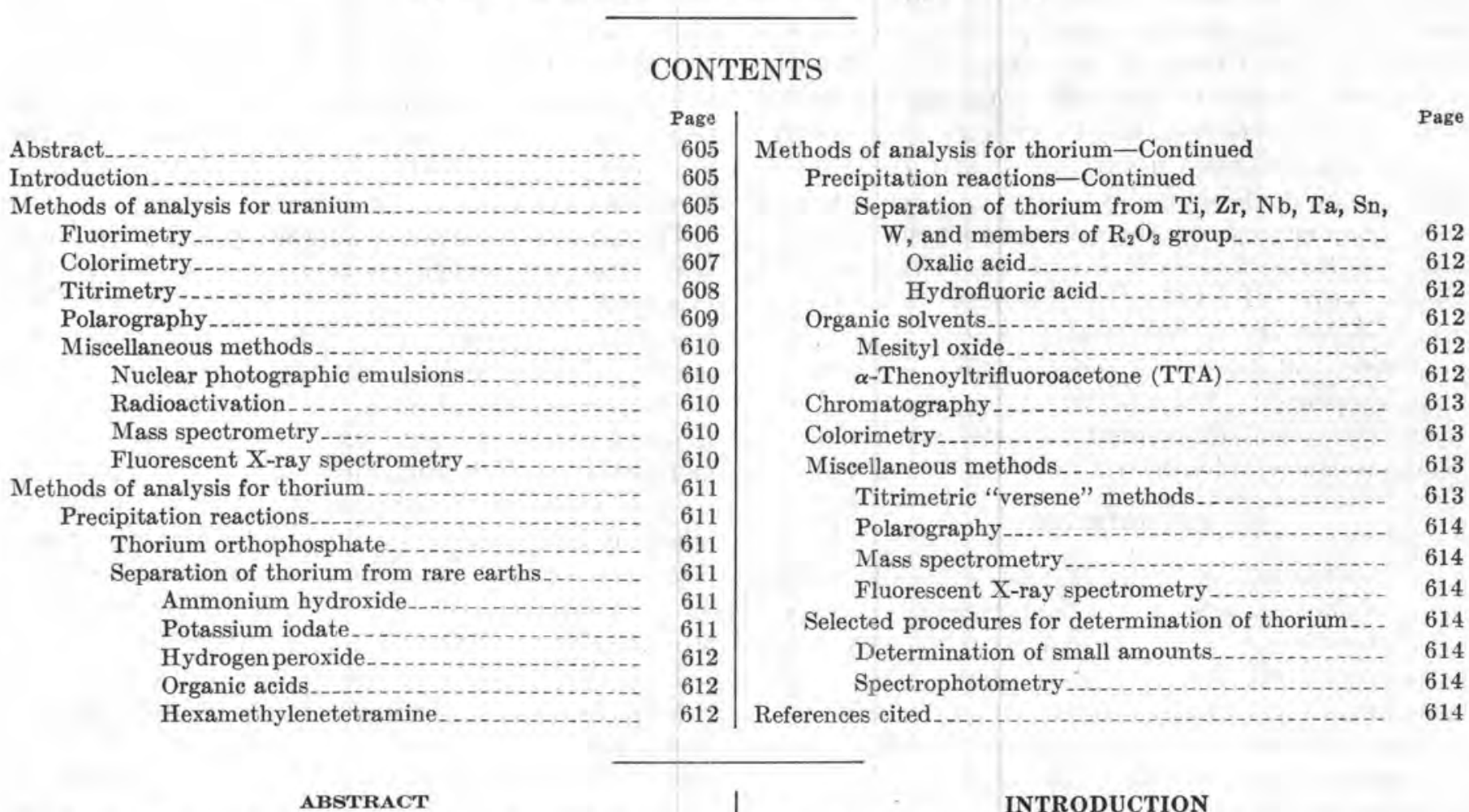

Under the impetus of the Atomic Energy program intensive investigations of the analytical chemistry of uranium have been made both in the United States and abroad and a considerable literature has accumulated. There has been less research on thorium chemistry.

In discussing current analytical methods and recent advances in the analytical chemistry of uranium and thorium the emphasis is on wet chemical methods, but for a proper perspective other approaches and techniques are considered.

Uranium is usually separated by organic solvent extraction of uranyl nitrate from solution salted with nitrates, by chromatographic methods, or by precipitation and extraction methods involving the use of cupferron. Uranium is determined by fluorimetric, colorimetric, volumetric, polarographic, coulometric, radioactivation, X-ray spectrometric, and nuclear photographicplate techniques.

Separations of thorium are based on the precipitation of thorium with phosphate, ammonia at controlled acidity, potassium iodate, potassium iodate-oxalic acid, organic acids, hexamine, oxalic acid, and hydrofluoric acid. Thorium may also be separated by chromatographic techniques and by solvent extraction such as with mesityl oxide. It may be determined spectrophotometrically with thoron as well as by polarographic, titrimetric, mass spectrometric, and fluorescent X-ray spectrometric methods.
With the impetus of the Atomic Energy program, intensive investigations of the analytical chemistry of uranium have been made both in the United States and abroad and considerable literature has accumulated. There has been less research on thorium chemistry.

The present report does not attempt a critical review of the voluminous literature on methods for the determination of uranium and thorium but deals primarily with current techniques of analysis. The emphasis is on wet chemical methods, but for a proper perspective other approaches and techniques are discussed briefly, stressing principles rather than details. A selected bibliography is included to serve both novice and advanced workers. Some items listed are not readily available, but are included to give credit to the early workers in this field.

\section{METHODS OF ANALYSIS FOR URANIUM}

Many methods are used for the determination of uranium. These include fluorimetric, colorimetric, volumetric, coulometric, radiometric, polarographic, 
X-ray spectrometric, mass spectrometric, radioactivation, and nuclear-emulsion methods. The choice of method is determined by many factors such as the concentration of uranium in the sample, its chemical complexity, the accuracy sought, the speed required, and the availability of the instrumentation. The ranges of all methods overlap to a considerable degree, and the more sensitive methods can readily be applied even to samples of high uranium content provided the limits of accuracy of such methods are acceptable. Classified loosely on the basis of the smallest amount of uranium that can be detected, the fluorimetric, radiometric, radioactiviation, mass spectrometric, and photographic emulsion methods are highly sensitive; the coulometric, polarographic, and colorimetric methods are sensitive; and the X-ray fluorescence and volumetric methods least sensitive. Excluding the photographic method, in which at present the results are less accurate, the relative error in all methods of determination is usually less than \pm 5 percent. The relative error in the coulometric, colorimetric (with differential methods), and volumetric methods can be as low as \pm 0.1 percent.

\section{FLUORIMETRY}

Melts obtained by fusing uranium salts with sodium fluoride fluoresce a brilliant yellow green when exposed to ultraviolet light (Nichols and Slattery, 1926). The intensity of the fluorescence is proportional, within wide limits, to the amount of uranium present, and this relationship is the basis for the quantitative fluorimetric determination of uranium. As little as $10^{-10} \mathrm{~g}$ of uranium can be detected.

The fluorescence test for uranium is specific when the excitation is with long-wavelength $(3650 \mathrm{~A})$ ultraviolet light. Niobium fluoresces only weakly when exposed to short wavelength light (2536 A). In spite of this specificity, many elements may interfere by quenching the uranium fluorescence. For example, a few micrograms of $\mathrm{Co}, \mathrm{Cr}, \mathrm{Ni}$, or $\mathrm{Mn}$ will reduce the fluorescence of uranium by more than 10 percent. The magnitude of quenching produced by various elements is described in several publications (Grimaldi and others, 1952, 1954; Rodden and Warf, 1950; Zebroski and Newton, 1946).

Two techniques are commonly used to reduce or eliminate interference due to quenching. One called the "dilution" method, originated with Price, Ferretti, and Schwartz (1953) who found it possible to reduce quenching to a negligible factor by using sufficiently small samples for analysis. The degree of quenching depends only on the concentration of the quencher in the flux and not on the ratio of concentration of quencher to concentration of uranium.

In the second technique the uranium is separated from quenching elements before the fluoride phosphor is prepared. Uranium may be free from quenching elements by precipitating them with alkali carbonate solution (Grimaldi and others, 1952, 1954); the uranium remains in solution as a complex carbonate. Alternatively, the separation may be accomplished by extraction of uranyl nitrate by organic solvents.

The "dilution" fluorimetric method (Price, Ferretti, and Schwartz, 1953) consists of taking a small aliquot of an acid solution of the sample, evaporating it in a standard platinum container, adding the fluoride flux, and preparing the phosphor by fusing it at controlled temperature. The relative fluorescence intensity of the melt can be compared visually or, preferably, in a fluorimeter.

The size of the aliquot in the "dilution" method should contain negligible amounts of quenching elements and would thus depend on the composition of the material to be analyzed, the uranium content of the sample, and the sensitivity of the fluorimeter in use. This size may range from a few micrograms of sample (for materials containing very strong quenchers such as manganese) to a few milligrams of sample (for materials with low concentration of quenchers and (or) containing relatively mild quenchers). In general, a $0.1-\mathrm{mg}$ sample results in negligible quenching for most rock samples. The measurement of very low fluorescence intensity levels requires the use of sensitive fluorimeters.

The extraction-fluorimetric method involves the extraction by means of organic solvents of uranyl nitrate from nitric acid solution after the addition of a salting agent. A portion of the solvent is then transferred to the standard container and the phosphor is prepared after the evaporation of the solvent. The fraction of uranyl nitrate extracted depends both on the solvent and on the salting agent used, and thus a particular procedure may lend itself either to batch or to continuous extraction. For example, with ammonium nitrate as the salting agent and ether as the solvent, continuous extraction is recommended. The Geologieal Survey procedures (Grimaldi and others, 1952, 1954) use batch extraction with aluminum nitrate as the salting agent and ethyl acetate as the solvent. Aluminum nitrate serves also to complex $\mathrm{F}^{-}, \mathrm{PO}_{4} \equiv$, and $\mathrm{SO}_{4}=$ ions which otherwise seriously hinder the extraction of uranium. Use of aluminum nitrate is also advantageous in that any aluminum extracted does not quench the uranium fluorescence. Vanadium, cerium (IV), thorium, and zirconium are partly extracted. Vanadium does not quench the uranium fluorescence significantly. Although zirconium is not a quencher, the small amount that does extract may cause low results.

Refractory $\mathrm{ZrO}_{2}$ may be formed during the preparation of the phosphor, and the uranium it may occlude is not available to the flux. A small amount of phosphate 
can be added to the solution before the extraction to prevent the extraction of zirconium. Quenching from cerium and thorium may interfere seriously, and special techniques are used when these elements are major constituents of the sample.

In the carbonate-fluormetric method an aliquot of a sulfuric acid solution of the sample, representing $15 \mathrm{mg}$ or less of the sample, is treated with alkali carbonate solution in excess to precipitate quenching elements. An aliquot of the filtered solution is transferred, and after evaporation the standard melt is prepared as before. Cerium, cobalt, copper, and thorium may interfere in this procedure. With suitable modification the procedure may be used even for the determination of uranium in monazite. Cobalt is quantitatively removed when another element in addition to cobalt is precipitated with alkali carbonate. A small amount of hydroxylamine is added during the precipitation with alkali carbonate to precipitate $\mathrm{Cu}_{2} \mathrm{O}$ if copper is a major constituent of the sample.

The flux employed at the Geological Survey is a mixture of 9 parts by weight $\mathrm{NaF}, 45.5$ parts by weight $\mathrm{Na}_{2} \mathrm{CO}_{3}$, and 45.5 parts by weight $\mathrm{K}_{2} \mathrm{CO}_{3}$. This flux melts at about $605^{\circ} \mathrm{C}$, does not stick to the platinum fusion vessels, produces mechanically strong melts, and gives about the same sensitivity as pure $\mathrm{NaF}$. For the measurement of fluorescence obtained from less than $10^{-8} \mathrm{~g}$ of uranium, a flux that yields reproducible blanks at high instrumental sensitivity is necessary. This flux is prepared by fusing together in platinum the three components in large batches and grinding the melts, preferably in an agate mortar. For amounts of uranium greater than $10^{-8} \mathrm{~g}$, the instruments are used at a lower sensitivity; a sufficiently uniform flux is obtained by simple mixing or grinding of the components in a ball mill.

The fluorimeters, and details on the fluorimetric methods in use, are described by Grimaldi and others (1952, 1954), Center (1948), Galvanek and Morrison (1954), Kaufman and others (1950), Kelley and others (1954), Kennedy (1950), Kinser (1954), Koskela and Kaufman (1949), Price (1948), Zimmerman (1951), and Zimmerman and others (1951). Until very recently no instrument was commercially available and many laboratories have had to design and build their own. The GM fluorimeter (Galvanek and Morrison, 1954), now commercially available, is very sensitive, detecting as little as $4 \times 10^{-10} \mathrm{~g}$ of uranium.

\section{COLORIMETRY}

Many reagents have been used for the colorimetric determination of uranium. The most popular at present are hydrogen peroxide in sodium hydroxide solution and ammonium thiocyanate in acid solution.
In the alkaline-peroxide procedure provision must be made not only to remove elements that precipitate in sodium hydroxide solution but also to remove vanadium and chromium that give yellow solutions similar to that given by uranium. Iron, manganese, and cerium disturb the system because of their catalytic destruction of $\mathrm{H}_{2} \mathrm{O}_{2}$, and in the case of $\mathrm{Fe}$ and $\mathrm{Mn}$ extinction may be caused by hydroxides that precipitate in a highly dispersed state. Iron and manganese may also interfere by adsorption of uranium when these elements are separated by filtration. Phosphate, sulfate, nitrate, chloride, silicate, and fluoride ions do not interfere.

Several separation procedures may be used. One procedure used at the Geological Survey is based on the extraction of uranyl nitrate by ethyl acetate from solutions salted with aluminum nitrate as described previously. As a small amount of vanadium accompanies uranium in the extraction, it can be removed by cupferron before the colorimetric estimation of uranium, or the vanadium can be stripped from the organic solvent by several washings with a solution $2,5 \mathrm{M}$ in aluminum nitrate and $0.6 \mathrm{~N}$ in $\mathrm{HNO}_{3}$. Alternately, the vanadium color may be destroyed by heating the alkaline peroxide solution (Goldbeck and others, 1945). A separation procedure especially useful for rocks utilizes cupferron (Grimaldi and others, 1954). The uranium is first reduced by means of a Jones reductor and the reduced uranium precipitated with cupferron using titanium as a carrier. The cupferron precipitate is ignited and dissolved, and uranium is oxidized to the sexivalent state and separated from elements that accompanied uranium by extracting the cupferrates of these elements with ethyl acetate. Uranium remains in the water layer and is then determined colorimetrically with hydrogen peroxide in sodium hydroxide solution after the destruction of organic matter. Transmittancy measurements are made with the Beckman spectrophotometer at $400 \mathrm{~m} \mu$. With a $0.1-\mathrm{mm}$ slit width, 1-cm light path, and water as the reference solution, an absorbance of about 0.9 is obtained for solutions of concentration $0.2 \mathrm{mg}$ of uranium per milliliter of solution. With the spectrophotometer a precision of \pm 1 percent of the uranium content can be obtained. For details and modifications of the peroxidecolorimetric method for uranium see Rodden and Warf (1950), Assayer's Guide (1949), Begg and others (1948), Kaufman and Galvanek (1950), and Guest and Zimmerman (1955).

The thiocyanate method, described by Crouthamel and Hubbard (1952), Crouthamel and Johnson (1952), Currah and Beamish (1947), and Nelson and Hume (1945), for the spectrophotometric determination of uranium is probably the most useful of the present day colorimetric procedures for uranium. In water-acetone 
medium (Crouthamel and Hubbard, 1952; Crouthamel and Johnson, 1952) and in ethyl acetate-acetone-water medium (DeSesa and Nietzel, 1954) the method is relatively free from both anionic and cationic interferences. Relatively large amounts of copper, zirconium, tin, mercury, manganese, sulfate, fluoride, acetate, chloride, and nitrate do not interfere. More than unit molar ratios of foreign ion to uranyl ion may be present for fluosilicate, phosphate, citrate, nickel, cbromium, and iron. Ordinarily iron would be a serious interference, but the addition of stannous chloride to the system prevents the interference of milligram amounts of iron.

Molybdenum and hydrogen peroxide interfere seriously. Small amounts of cobalt interfere if absorbance of the uranium thiocyanate is measured at $375 \mathrm{~m} \mu$. At higher wavelengths the interference is considerably decreased. Vanadium and lead interfere moderately. Copper may give a thiocyanate precipitate. Thiocyanate ion polymerizes if the acidity is not controlled and yields a colored solution whose color becomes intensified with time.

The extraction of uranyl nitrate overcomes all interferences except vanadium. In the Geological Survey's modification of the thiocyanate method, the vanadium accompanying uranium in the ethyl acetate extract is stripped from the solvent layer by several washings with aluminum nitrate solution as described previously. The uranium is then stripped with water. The procedure has been applied even to carnotite ores. Absorbance measurements are made with a spectrophotometer at $375 \mathrm{~m} \mu$. With a slit width of $0.13 \mathrm{~mm}$, a $1-\mathrm{cm}$ light path, and water as reference solution, an absorbance of about 0.62 is given by a concentration of $1 \mathrm{mg}$ of uranium per 25 milliliters of solution. Uranyl thiocyanate is soluble in organic solvents and may be extracted and concentrated in this manner. Details are given in the papers by Silverman and Moudy (1953) and Gerhold and Hecht (1951).

Ammonium thioglycolate has been proposed by Davenport and Thomason (1949) as a colorimetric reagent for uranium. The method is not affected by relatively large amounts of chloride, nitrate, sulfate, perchlorate, oxalate, tartrate, citrate, acetate, and fluoride. The concentration range is $0.1 \mathrm{mg}$ to $1.6 \mathrm{mg}$ uranium per $25 \mathrm{ml}$ of solution. The $\mathrm{pH}$ may range from 7.6 to 10.7 . In addition to elements that precipitate from alkaline solution, $\mathrm{Fe}, \mathrm{Cu}, \mathrm{Ni}, \mathrm{Pb}$, and $\mathrm{Co}$ interfere. Uranium can be determined in the presence of iron if the absorbances are measured at two wavelengths ( $380 \mathrm{~m} \mu$ and $600 \mathrm{~m} \mu)$.

Yoe, Fritz, and Black (1953) have proposed dibenzoylmethane for the spectrophotometric determination of uranium. The reagent has a sensitivity that is several times that of the thiocyanate, 250 micrograms of uranium per $50 \mathrm{ml}$ of solution giving an absorbance of about 0.39 at $395 \mathrm{~m} \mu$ with a $1-\mathrm{cm}$ light path. The reaction proceeds best at a $\mathrm{pH}$ of 7 where unfortunately many elements interfere. Separation of uranium is made by ether extraction of uranyl nitrate from solutions heavily salted with ammonium nitrate. Adams and Maeck (1954) have applied the method to the determination of as little as 1 ppm of uranium in rocks.

A very rapid direct spectrophotometric method for the determination of uranium is based on the reduction of uranium (VI) to uranium (IV) by ferrous sulfate in 40 volume-percent phosphoric acid solution (Canning and Dixon, 1955). With liquid samples estimations may be completed in an hour with a standard deviation of about 1.5 percent over the range 0.5 to 5.0 grams per liter of $\mathrm{U}_{3} \mathrm{O}_{3}$. A two-wavelength method using wavelengths of 660 and $700 \mathrm{~m} \mu$ is applied in the presence of vanadium. A satisfactory reference solution is obtained in the same concentration of phosphoric acid by treating half of the solution with hydrogen peroxide to oxidize all components fully, boiling to destroy peroxides of vanadium and titanium, and then treating with sodium sulfite to destroy any remaining peroxide. The other half of the solution is treated similarly and then ferrous sulfate is added to form the reduced solution. The uranium concentration is determined from calculations based on absorbance "difference" curves of uranium and vanadium. The method is applicable in estimating uranium in sulfate solutions containing vanadium, chromium, and rare earths in concentrations of 1 to 2 grams per liter of the respective oxides, titanium up to 10 grams per liter of titanium oxide, and ferrous and ferric iron up to a total of 40 grams per liter of ferric oxide. Molybdenum and copper (in the presence of chloride) interfere. Nitrate should be removed.

\section{TITRIMETRY}

The volumetric method is the standard procedure for the determination of macro amounts of uranium. It has been used also for the determination of as little as a few tenths of a milligram of uranium. The most common procedure depends on the reduction of uranium to the quadrivalent state and titration with a standard oxidizing solution. The reduction of uranium is generally accomplished by means of amalgamated zinc or lead in the Jones reductor (Carson, 1953; Cooke and other, 1950; Sill and Peterson, 1952). The cadmium amalgam (Furman and others, 1950) has also been used. Some trivalent uranium is formed during reduction with amalgamated zinc. $\mathrm{U}$ (III) is oxidized readily to U(IV) by passing air through the solution before titration. $\mathrm{U}(\mathrm{IV})$ is stable to air in acid solutions but auto-oxidation may occur in the presence of traces of cupric ion. 
The most common oxidizing agents for titrating $\mathrm{U}(\mathrm{IV})$ to $\mathrm{U}(\mathrm{VI})$ are potassium permanganate, ceric sulfate, and potassium dichromate. Standard uranium solutions should be used in the standardization of all three oxidizing agents. For example, it has been observed that potassium permanganate gives a slightly different titer when standardized against sodium oxalate. The oxidizing agent should be standardized against various amounts of uranium solution and a working curve prepared. As much as 4 percent difference has been observed at the Geological Survey when the titer of the oxidants against $10 \mathrm{mg}$ and $150 \mathrm{mg}$ of uranium are compared.

No indicator is needed with potassium permanganate but ferroin may be used. The titration is sharp with potassium permanganate but sluggish with ceric sulfate and especially with potassium dichromate. Sharp end points are obtained with ceric sulfate if excess ferric iron is added before titration. Phosphoric acid also has been recommended to speed the uranium reaction. Ferroin is used as indicator. In titrations with potassium dichromate, ferric chloride followed by a mixture of phosphoric-sulfuric acid are added to catalyze the reaction. Sodium diphenylamine sulfonate is used as an indicator. Heavy metals are removed by a hydrogen sulfide precipitation although thioacetamide is preferred by some (Sill and Peterson, 1952). The remaining interfering elements are removed by extraction of their cupferrates from $(1+9)$ mineral acid solution using such solvents as chloroform or ethyl acetate. Uranium in the sample must be in the sexivalent state, and as such it is not extracted. After organic matter is destroyed, the uranium is reduced and titrated with a standard oxidizing agent. Details of the procedures are given by Rodden and Warf (1950), Assayer's Guide (1949), Sill and Peterson (1952), Furman and others (1953), Kennedy and Kaufman (1949), Pepkowitz (1945), and Rodden and Tregoning (1955). Nickel is not removed in the separations discussed and may interfere with zinc reductors amalgamated with 2 to 3 percent mercury. The plating out of nickel on such reductors is accompanied by excessive evolution of hydrogen and incomplete reduction of uranium. Grimaldi (1954) has found that a zine reductor amalgamated with 10 percent mereury is not poisoned by nickel-bearing solutions.

Tillu (1954) isolates $\mathrm{UF}_{1}$ after the reduction of uranium with stannous chloride from minerals such as samarskite, columbite-tantalite, and titano-niobates. The $\mathrm{UF}_{4}$ is dissolved, fluoride expelled with acid, and the uranium determined volumetrically. Reports by Carson (1953) and Furman and coworkers (1953) deal with the coulometric determination of uranium. As little as 5 micrograms can be determined.
In another interesting titrimetric method, Main $(1953,1954)$ reduces $\mathrm{U}$ (VI) to U (IV) with stannous chloride in nearly boiling 6 to $12 \mathrm{~N} \mathrm{HCl}$. The reaction is catalyzed by ferric iron and driven to completion by orthophosphate. The excess stannous chloride is oxidized in the cold with mercuric chloride, and the uranium and iron catalyst are titrated with standard dichromate. Molybdenum, copper (II), vanadium, and titanium interfere.

Workers in the British Commonwealth countries have made extensive investigations on the separation of uranium (and also of thorium) by inorganic chromatography on cellulose columns or compound columns of alumina and cellulose in combination with solvent (ether-nitric acid) extraction of uranium (Arden and others, 1949; Burstall and Wells, 1951; Kember, 1952; Overton and Williams, 1950; Rabbitts, 1952 ; Ryan and Williams, 1949, 1952; Smith and Williams, 1950; and Williams, 1952). Uranium as uranyl nitrate is dissolved and moves with the solvent front. Most other metals remain stationary or move only slowly in comparison with uranium. The uranium in the eluent is determined by fluorimetric, colorimetric, polarographic, volumetric, and other techniques.

\section{POLAROGRAPHY}

Harris and Kolthoff $(1945,1947)$ have studied systematically the polarographic properties of uranium in acid, neutral, and alkaline solutions. In $0.01-0.2 \mathrm{~N}$ $\mathrm{HCl}$ the diffusion current at -0.3 volt saturated calomel electrode (S. C. E.) of the first polarographic wave $[\mathrm{U}(\mathrm{VI})-\mathrm{U}(\mathrm{V})]$ is proportional to the uranium concentration between $5 \times 10^{-4}$ and $4 \times 10^{-3}$ moles per liter. A precision of 2 percent is obtained. As $5 \mathrm{ml}$ of solution is often polarographed, about $0.5 \mathrm{mg}$ can be determined within \pm 2 percent. In the concentration range down to $2.4 \times 10^{-5}$ molar where the diffusion current diverges from proportionality by about 10 percent, approximately 30 micrograms ean be determined. Using a supporting medium of $0.1 \mathrm{~N} \mathrm{HCl}$, Tishkoff (1948) has applied the method to the determination of $\mathrm{U}(\mathrm{VI})$ in $\mathrm{UO}_{2}$ and in $\mathrm{U}(\mathrm{IV})$ salts.

The two-electron uranyl reduction wave in $1 \mathrm{~N}$ to $2 \mathrm{~N}$ sulfuric acid, measured at about -0.3 volt (S. C. E.), has also been used (Ballinger, 1948). The sensitivity is twice as great compared to hydrochloric acid supporting medium. The most serious interferences in sulfuric acid as well as hydrochloric acid media are $\mathrm{Fe}$ (III), $\mathrm{Cu}, \mathrm{Mo}, \mathrm{Ti}$, and V. Lead interferes in hydrochloric acid media but can be precipitated as sulfate and determined in hydrochloric acid media (Holmes and Smales, 1948). Hydroxylamine hydrochloride prevents iron interference (Strubl, 1938). Kilner (1948) determined uranium in ferric hydroxide using a 
supporting electrolyte of $2 \mathrm{~N}$ hydroxylamine hydrochloride and $0.1 \mathrm{~N}$ hydrochloric acid. Other media such as citrate and tartrate have been used; only lead or phosphate is stated to interfere in citrate media (Rodden and Warf, 1950). Legge (1954) separates uranium by eluting with a nitric acid-ether solution through a short column of cellulose pulp. The uranium is determined polarographically in an electrolyte containing oxalic and sulfuric acids. The diffusion current is observed at -0.5 volt. The minimum concentration of uranium that can be determined is about $10^{-5}$ molar (2.4 $\gamma$ per $\mathrm{ml})$.

Šušic, Bal, and Cuker (1954) determine uranium polarographically at $\mathrm{pH} 3.6$ to 4.0 with ascorbic acid as a supporting electrolyte. The diffusion current is observed at -0.36 (S. C. E.). Ascorbic acid reduces $\mathrm{Fe}(\mathrm{III}), \mathrm{V}(\mathrm{V}), \mathrm{Mo}(\mathrm{VI})$, and $\mathrm{Cr}(\mathrm{VI})$, and the reduced forms of these ions does not interfere with the uranium wave. Titanium is complexed with ascorbic acid, and the titanium wave is more negative than that of uranium. Tellurium, thallium, lead, and moderate amounts of copper and antimony interfere. The method is suitable for ore samples with more than 0.01 percent uranium. The relative error, in the range 0.01 to 0.05 percent uranium, is 5 to 9 percent.

\section{MISCELLANEOUS METHODS}

\section{NUCLEAR PHOTOGRAPHIC EMULSIONS}

In the nuclear emulsion photographic plate technique, as described by Bremner (1951), Delaney and others (1953), Isaac and Picciotto (1953), Poole and Matthews (1951, 1952), and Senftle, Farley, and Stieff (1954), the material to be analyzed is placed in contact with the nuclear emulsion or the nuclear emulsion is loaded with a solution of the sample and then dried. After suitable exposure and development $\gamma$-ray tracks or stars from atoms that had undergone disintegration can be observed. The length of the $\gamma$-ray tracks or the number of 3-, 4-, and 5-branched stars per unit area can be correlated to the uranium and thorium contents of the sample. Less than microgram amounts of uranium and thorium may be determined.

\section{RADIOACTIVATION}

The method of radio activation analysis is based on the measurement of nuclear radiation from radioactive isotopes produced by interaction of nuclear particles with a stable isotope (or isotopes) of an element. The method is specific, each induced radionuclide having its own decay scheme and decay constant. For most elements the sensitivity is extremely high.

In one method (Singer, 1952; Smales, 1952) microgram amounts of uranium in rocks and minerals ean be determined by neutron irradiation followed by radio- chemical separation and measurement of the activity of the fission product, barium formed according to the scheme: ${ }_{02}^{234} \mathrm{U}(\mathbf{n}, \boldsymbol{\gamma})$ fission products. The ultimate sensitivity is estimated to be $10^{-8}$ grams of uranium.

In another method, of Mahlman and Leddicotte (1955), the activity of neptunium, produced according to the scheme

$$
{ }_{92}^{238} \mathrm{U}(\mathrm{n}, \gamma) \underset{\beta^{2}}{239} \mathrm{U} \underset{\beta_{3}}{{ }_{23}^{239} \mathrm{~Np}}
$$

is detected by means of a gamma scintillation counter. About 0.1 microgram of uranium per gram of sample can be determined with a relative error of about 10 percent. Mahlman and Leddicotte believe that it is possible to extend the method to as small a concentration of uranium as 0.0001 microgram per gram of sample.

\section{MASS SPECTROMETRY}

In the isotope-dilution mass-spectrometric technique the general requirements, according to Tilton (1954), are as follows:

1. A standardized solution (usually called the spike) of an isotopically altered carrier of the element to be determined.

2. A procedure for equilibrating a known weight of the carrier (spike) with the sample to be analyzed and for extracting enough of the element to be determined to permit isotope analysis.

3. A mass spectrometer to perform isotopic analyses of the carrier, of the carrier plus sample, and (for elements of variable isotopic composition) of the sample alone. In addition a blank is usually necessary.

Chemical processing need be quantitative only during the dissolution of the sample and its equilibration with the spike. Beyond this point the result will depend only upon the new ratio(s) produced in the carrier by the sample rather than upon the degree of recovery of the element under analysis.

Hess and coworkers (1953) have used the isotope-dilution technique for the determination of traces of uranium in minerals and meteorites. The spike used is uranium enriched in $\mathrm{U}^{235}$. The principal uranium separation was accomplished by extraction of uranyl nitrate into methyl isobutyl ketone (hexone) from a solution salted with nitrate ion. A few micrograms of uranium were analyzed with the mass spectrometer. According to Tilton, the sensitivity of the mass spectrometric method for uranium ean be made to surpass that of the fluorimetric method. The relative error is generally of the order of \pm 2 percent.

\section{FLUORESCENT X-RAY SPECTROMETRY}

A few methods using X-ray spectroscopy have been published by Rodden and Warf (1950). Birks and Brooks $(1951,1953)$ determine uranium in aqueous solution in concentrations as low as $0.05 \mathrm{~g}$ per liter. The 
procedure is fașt, requiring less than 10 minutes for each analysis. Heavy elements, such as lead, interfere if present in concentration exceeding 10 percent of the uranium concentration. Kerr and Pill (1951) have determined uranium in uraninite by X-ray spectroscopy.

\section{METHODS OF ANALYSIS FOR THORIUM}

Chemical methods for the determination of thorium are complex, involve difficult and tedious manipulation, and require the services of thoroughly experienced analysts. The analytical chemistry of thorium is complicated by the colorless nature of the ion, by its single valence state, by the lack of selective and sensitive reagents, by the refractory nature of its ores, and by its association with elements that present difficult analytical problems.

In most thorium analyses, provisions must be made for the separation of thorium not only from elements commonly determined in rock and mineral analyses, but also from the rare earths, from the quadrivalent elements such as $\mathrm{Sn}, \mathrm{Ti}$, and $\mathrm{Zr}$, from quinquevalent elements such as $\mathrm{Nb}$ and $\mathrm{Ta}$, and from sexivalent elements such as W. There are many procedures for the separation of thorium from the rare earths; few procedures are available for the separation of thorium from $\mathrm{Sn}, \mathrm{Ti}, \mathrm{Zr}, \mathrm{Nb}, \mathrm{Ta}$, and $\mathrm{W}$.

\section{PRECIPITATION REACTIONS THORIUM ORTHOPHOSPHATE}

With zirconium as a carrier, thorium is precipitated quantitatively as the phsophate from solutions 2.5 percent by volume in hydrochloric acid (that is, $0.3 \mathrm{~N}$ ) and containing $2 \mathrm{~g}$ diammonium phosphate per $100 \mathrm{ml}$ of solution (Grimaldi and others, 1954). The precipitation reaction separates thorium from most of the major constituents of rock samples and is a useful concentration procedure in the analysis of rocks. In addition to titanium and zirconium, some rare-earth phosphates and members of the acid-insoluble group are also precipitated. This same procedure has been used also by Tillu and Athavale (1954a).

\section{SEPARATION OF THORIUM FROM RARE EARTHS}

Ammonium hydroxide-Thorium is separated from calcium, magnesium, manganese, and most of the rare earths by ammonium hydroxide precipitations at controlled acidity (Grimaldi and others, 1954). At a pH corresponding to the neutral color of methyl red, thorium is precipitated quantitatively, whereas most of the trivalent cerium and the other rare earths remain in solution. Either nitrate or chloride solutions of thorium may be used, but the sulfate ion must be absent. If much sulfate is present, considerable loss of thorium results at the methyl red end-point, although precipitation of thorium is complete when excess ammonia is used. Sulfate can be removed by preliminary precipitations of thorium with sodium hydroxide.

Complete separation of thorium from the rare earths is not obtained in this separation, as the last few milligrams of rare earths are retained persistently by the thorium precipitate. The separation, however, is simple and exceedingly useful for removing most of the rare earths. Zirconium and titanium are not separated.

Potassium iodate.-The separation of thorium from the rare earths by precipitation as iodate (Rodden and Warf, 1950; Meyer, 1911) is one of the best procedures. For macro amounts the reaction is carried out in $6 \mathrm{~N}$ nitric acid solution. For quantities less than a few milligrams the final acidity of the solution (after all reagents are added) should not exceed $1 \mathrm{~N}$ nitric acid because loss of thorium results at higher acid concentrations. Two precipitations of thorium iodate from $6 \mathrm{~N}$ nitric acid solutions are usually sufficient for separating the rare earths; four or five precipitations may be necessary at low acidities. Lead, mercury, tin, niobium, tantalum, cerium (IV), uranium (IV), zireonium, titanium, and to a lesser extent, iron, bismuth and silver also are precipitated by iodate. Cerium (IV) can be reduced by hydrogen peroxide to cerium (III). More elements tend to coprecipitate with thorium iodate at low acidity than at high. At high acidities the precipitation of thorium iodate is made by adding $50 \mathrm{ml}$ of nitric acid and $100 \mathrm{ml}$ of 15 percent solution of potassium iodate in $(1+1)$ nitric acid to $100 \mathrm{ml}$ of slightly acid solution of the sample. For low acidities $3 \mathrm{ml}$ of nitric acid and $8 \mathrm{ml}$ of 7.5 percent water solution of potassium iodate are added to the slightly acid solution of the sample, and the total volume of the solution is made to $50 \mathrm{ml}$ by the addition of water (Grimaldi and others, 1954). Thorium iodate can be dissolved by reducing acids, such as hydrochloric acid, and also by concentrated nitric acid.

Tillu and Athavale (1954b) precipitated thorium iodate from 40 percent nitric acid solution containing oxalic acid. Up to $20 \mathrm{mg} \mathrm{Ti}, 40 \mathrm{mg} \mathrm{Zr}$, and $20 \mathrm{mg} \mathrm{Bi}$ did not precipitate and the authors outlined a rapid method for the determination of thorium where the iodate-oxalic acid separation is the only one used. No information is given on the behavior of $\mathrm{Pb}, \mathrm{Hg}, \mathrm{Sn}$, $\mathrm{Nb}$, Ta, and larger amounts of $\mathrm{Ti}$, which would be expected to interfere. The procedure has great promise but unfortunately cannot be applied to low-grade thorium ores except at low acidity where it loses its effectiveness as a major separation. Stine and Gordon (1953) precipitate thorium iodate from homogeneous solution in a dense and granular form with iodate produced by the reduction of periodate with ethylene glycol, which is slowly produced by the hydrolysis of $\beta$-hydroxyethyl acetate. 
Hydrogen peroxide.-Thorium is precipitated by - hydrogen peroxide as the peroxynitrate from solutions $0.03 \mathrm{~N}$ or less in nitric acid. The concentration of hydrogen peroxide used is $5 \mathrm{ml}$ of 30 percent hydrogen peroxide per $100 \mathrm{ml}$ of solution. The method adopted by the Geological Survey (Grimaldi and others, 1954) uses $0.03 \mathrm{~N}$ nitric acid because few elements are precipitated at this higher acidity. The precipitation of thorium with hydrogen peroxide is somewhat sensitive to changes in conditions of precipitation. Zirconium causes low recovery of thorium and must be removed completely before applying the peroxynitrate precipitation. Very slight losses of thorium (about $1 \mathrm{mg}$ or less of thorium oxide) occur in the presence of the sulfate ion.

Organic acids.-A large number of organic acids such as m-nitrobenzoic acid, sebacic acid, and m-cresoxyacetic acid (Venkataramaniah and others, 1952) have been proposed for the separation of thorium, especially from uranium and rare earths. Venkataramaniah and Rao have done a considerable amount of work in this field. An article by Banks and Byrd (1953) includes most of the references on this subject.

Hexamethylenetetramine (hexamine) was originally proposed by Ismail and Harwood (1937) and has received much attention. Details concerning its use are given by Rodden and Warf (1950), Assayer's Guide (1949), and Rodden and Tregoning (1955). Phosphate, $\mathrm{Zr}$, and Ti must be absent.

SEPARATION OF THORIUM FROM Tl, Zr, Nb, Ta, Sn, w, AND MEMBERS OF $\mathrm{R}_{3} \mathrm{O}_{3}$ GROUP

Oxalic acid.-The separation of thorium by precipitation as the oxalate is a standard method for the separation of thorium and rare earths and is widely used. Kall and Gordon (1953) have shown that losses of from a few tenths of a milligram to more than $1 \mathrm{mg}$ of $\mathrm{ThO}_{2}$ may result when conditions are not controlled. These authors studied the effects of ammonium salts and acidity on the solubility of thorium oxalate precipitated either heterogeneously with oxalic acid or from homogeneous solution with dimethyl oxalate. It seems desirable to precipitate thorium oxalate in the absence of ammonium salts. In the absence of rare earths, a $\mathrm{pH}$ of 0.7 is most suitable whereas in the presence of rare earths a $\mathrm{pH}$ of 1 to 2 is recommended. Prolonged digestion periods are also desirable. For heterogeneous precipitation Kall and Gordon found that the procedure of Ewing and Banks (1948) gave the smallest losses of thorium. These workers precipitate thorium from solutions containing $5 \mathrm{ml}$ of $\mathrm{HClO}_{4}$ and $5 \mathrm{~g}$ of oxalic in a total volume of $300 \mathrm{ml}$.

Willard and Gordon (1948) recommend precipitation of thorium oxalate from homogeneous solution through the hydrolysis of dimethyl oxalate. In this manner dense, easily filterable precipitates are obtained. The solubility of thorium oxalate is such, that for small amounts of thorium (less than a few milligrams) precipitation as the oxalate is not always applicable.

Hydrofluoric acid.-Hydrofluoric acid provides approximately the same separations as oxalic acid. It is especially useful in the concentration of traces of thorium. Lanthanum is frequently used as a carrier. Hydrofluoric acid separations have been used at the Geological Survey for both small and large amounts of thorium (Grimaldi and others, 1954). In the presence of alkalies and alkaline earths the precipitates from hydrofluoric and oxalic acid tend to occlude zirconium and titanium.

\section{ORGANIC SOLVENTS}

Mesityl oxide.-This procedure originated at the Geological Survey (Grimaldi and others, 1954) and has received wide attention. Thorium nitrate is quantitatively extracted by mesityl oxide from solutions $2.5 \mathrm{M}$ in aluminum nitrate and $1.2 \mathrm{M}$ in nitric acid. The concentration of nitric acid is not critical. We have used the procedure for amounts of thorium ranging from a few tenths of a milligram to several hundred milligrams of thorium dioxide. Marechal-Cornil and Picciotto (1953) have shown that thorium in concentrations as small as $10^{-12} \mathrm{~g}$ of thorium per $\mathrm{ml}$ of solution may be extracted quantitatively. The extraction is a batch extraction. All of the uranium and about 75 percent of the zirconium is extracted with thorium. Small amounts of vanadium, rare earths, and iron are extracted, but these elements may be stripped from the mesityl oxide by several washings with a solution $2.5 \mathrm{M}$ in aluminum nitrate and $1.2 \mathrm{M}$ in nitric acid. Tin, $\mathrm{Ti}, \mathrm{Pb}$, and most other elements are not extracted. Marechal-Cornil and Picciotto (1953) report that bismuth and polonium are quantitatively extracted and found the procedure especially useful in radiochemical work where it is desired to separate members of radioactive series. Thorium is stripped from the mesityl oxide with water.

The mesityl oxide separation is a useful means of concentrating trace quantities of thorium and may be applied in the presence of phosphate and arsenate. The separation is especially important for the separation of large amounts of thorium from small amounts of rare earths where precipitation reactions may not be effective. Banks and Edwards (1955) have shown that lithium nitrate can also be used as a salting agent in the mesityl oxide extraction method.

Warf (1949) has indicated that tributyl phosphate may be a useful solvent for the extraction of thorium nitrate.

$\alpha$-Thenoyltrifluoroacetone (TTA).- Solutions of TTA in benzene have been used for the "chelating extrac- 
tion" of tracer to gram amounts of thorium by Hageman (1950), Meinke and Anderson (1952), and Tilton and Aldrich (1954). A pH of 2 to 2.5 is generally used. This reagent has been especially useful for the separation of macro amounts of thorium from highly radioactive spallation and fission products.

\section{CHROMATOGRAPHY}

British investigators have developed two important chromatographic separation procedures. In one, developed by Kember $(1948,1952)$, thorium nitrate is adsorbed on activated cellulose and eluted with ether containing 12.5 percent $(\mathrm{v} / \mathrm{v})$ of nitric acid. Cerium (IV), $\mathrm{Zr}$, and $\mathrm{Sc}$ in part, and to a lesser extent $\mathrm{Fe}$, accompany thorium. Phosphate interferes. Zirconium and Se can be held on the column if tartaric acid is added to the nitric acid solution of thorium before extraction. Phosphate is removed by preliminary treatment of the sample with HF. The determination of thorium is completed gravimetrically after precipitation of thorium oxalate and ignition to oxide. The procedure has been applied to the determination of thorium in monazite and uranothorianite.

In another procedure (Williams, 1952; Guest and Proulx, 1952) activated alumina is used with activated cellulose, alumina being the principal absorbent. The thorium nitrate is eluted with the same solvent as before. The great advantage of this procedure is that ores containing phosphate can be handled directly. The movement of zirconium is suppressed by adding phosphate ion, which is in turn complexed by ferric nitrate. The procedure has been applied to the determination of thorium in monazite, samarskite, fergusonite, euxenite, and pyrochlore. Macro amounts of thorium are determined by the conventional oxalate precipitation; small amounts are determined spectrographically.

\section{COLORIMETRY}

Few colorimetric procedures have been developed for the determination of thorium. p-Dimethylaminoazophenylarsonic acid has been used at the Geological Survey (Grimaldi and others, 1954). Thoron, the sodium salt of 2-(2-hydroxy-3,6,-disulfo-1-naphthylazo)benzene arsonic acid, is the most widely used reagent for the spectrophotometric determination of thorium (Thomason and others, 1949). In acid solution ( $\mathrm{pH}$ 0.5 to 1.5$)$ a red-colored complex is formed with thorium which absorbs strongly at $545 \mathrm{~m} \mu$. As thoron also absorbs at this wavelength the absorbance of the thorium-thoron solution is measured against a reagent blank. The sensitivity is high; a net absorbance of 0.25 is given by solutions containing 100 micrograms of $\mathrm{ThO}_{2}$ in $25 \mathrm{ml}$ volume for a 1-cm light path. $\mathrm{Zr}$, Ti, $\mathrm{Bi}, \mathrm{Fe}$ (III), Sn, Ta, Nb, Sc, Ce (IV), and U (IV) are serious interferences. The interference of $\mathrm{Fe}$ (III) is somewhat lessened by the addition of hydroxylamine hydrochloride. Many other elements such as the cerium earths cannot be tolerated in amounts greater than several tenths of a milligram.

Thoron has been used successfully for the determination of thorium in monazite and black sands by Banks and Byrd (1953) and by Banks and others (1953), and in waters by Taylor and Dillon (1952). A report based on a $\mathrm{Ph} . \mathrm{D}$, thesis by Byrd (Byrd and Banks, 1953) is comprehensive. Ingles (1951) examined a number of procedures for the separation and determination of thorium and discusses the determination of thorium with thoron.

Frank Cuttitta of the Geological Survey (written communication) adds a small amount of phosphate to prevent the extraction of zirconium in the mesityl oxide separation. The colorimetric determination of thorium in zircon with thoron is thus facilitated.

Morin has been studied at the Geological Ssrvey both as a colorimetric and fluorimetric reagent for thorium (Fletcher and Milkey, 1954). At a pH of 2 the sensitivity of the color reaction is about $2 \frac{1}{2}$ times that given by thoron. The thorium-morin complex has a maximum absorbance of $410 \mathrm{~m} \mu$. Zirconium and aluminum seriously interfere. The method has not been applied to the analysis of rocks and ores.

\section{MISCELLANEOUS METHODS}

TTTRIMETRIC "VERSENE" METHODS

In the method of Fritz and Ford (1953) thorium is titrated directly with the disodium salt of ethylenediaminetetraacetic acid (versene), a soluble complex being formed. Stoichiometric results are obtained in the $\mathrm{pH}$ range 2.3 to 3.4. With Alizarin Red S indicator the following ions interfere, either by forming stable versene complexes or by reacting with the indicator: $\mathrm{Ti}, \mathrm{Zr}, \mathrm{Ce}, \mathrm{V}, \mathrm{Fe}, \mathrm{Ni}, \mathrm{Cu}, \mathrm{Sn}, \mathrm{Pb}$, and $\mathrm{Bi}$. Sulfate, phosphate, fluoride, and oxalate also interfere. Extraction of thorium with mesityl oxide separates thorium from all metals except $\mathrm{Zr}$, U, and $\mathrm{V}$. Six to $50 \mathrm{mg}$ of thorium in $25 \mathrm{ml}$ of solution and 0.12 to 0.24 $\mathrm{g}$ of thorium in $100 \mathrm{ml}$ of solution can be determined rapidly with less than 1 percent relative error.

In the indirect titration of thorium (Malmstadt and Gohrbrandt, 1954) a known excess of versenate solution is added to the thorium solution, the solution is diluted to about 100 to $150 \mathrm{ml}$ and buffered with acetate, a suitable wavelength is selected (290 or $320 \mathrm{~m} \mu$ ), and the excess versenate is titrated with standard copper solution. The strong ultraviolet absorption band of copper versenate is used to determine the end point. A precision of about 1 part per thousand in the range of $1 \mathrm{mg}$ to $50 \mathrm{mg}$ of thorium per $125 \mathrm{ml}$ of solution is obtained. 


\section{POLAROGRAPHY}

Amperometric titration of thorium with molybdate has been reported by Smales and Airey (1952) and by Gordon and Stine (1953). In the $\mathrm{pH}$ region 2.3 to 2.7, quantities as small as $1 \mathrm{mg}$ may be titrated with a relative error of 10 percent. Gordon and Stine (1953) titrate at an applied potential of -0.95 volt versus S. C. E. A sodium chloride medium at $\mathrm{pH}$ of 1.8 is used. Nitrate, perchlorate, and sulfate ions interfere seriously. The procedure permits the determination of 10 to $30 \mathrm{mg}$ of thorium oxide in the presence of up to $800 \mathrm{mg}$ of rare earth oxides.

Thorium has also been determined, by Komarek (1950), indirectly by precipitation of thorium iodate and determination of the iodate ion polarographically. The method yields good results for as little as 20 micrograms of thorium.

\section{MASS SPECTROMETRY}

The isotope dilution-mass spectrometric technique has been used by Tilton, Aldrich, and Inghram (1954) for the determination of thorium in minerals of igneous rocks.

The preparation of the isotopic carrier $\mathrm{Th}^{230}$ is described. The sample is completely dissolved and an aliquot of the $\mathrm{Th}^{230}$ carrier is equilibrated with the solution of the sample. From this point three methods were found useful for the separation and purification of thorium: extraction at a $\mathrm{pH}$ of 2 into a $0.1-\mathrm{M}$ solution of thenoyltrifluoroacetone in benzene, extraction from a nearly saturated solution of aluminum nitrate into hexone, and precipitation of thorium oxalate using lanthanum as carrier. One microgram of thorium is more than sufficient for a satisfactory analysis using multiplier and surface ionization techniques. The accuracy of a single determination is about \pm 1.5 percent.

\section{FLUORESCENT X-RAY SPECTROMETRY}

A fluorescent X-ray spectrographic method for the determination of thorium in rocks and in a variety of thorium ores is described by Adler and Axelrod (1955). Measurements are made with a two-channel spectrometer equipped with quartz analyzing crystals. Thallium is used as internal standard. Because the relatively weak L spectra must be used, sensitivities are limited, 0.2 percent $\mathrm{ThO}_{2}$ being considered the lower limit of detection. Uranium, niobium, barium, strontium, and iodine in large concentrations interfere.

\section{SELECTED PROCEDURES FOR DETERMINATION OF THORIUM}

DETERMINATION OF SMALL AMOUNTS

The procedure of Tillu and Athavale (1954a) outlined below is similar in many respects to the Geological
Survey method (Grimaldi and others, 1954). The features of the method include:

1. Decomposition of the sample with $\mathrm{Na}_{2} \mathrm{O}_{2}$.

2. Precipitation of thorium as phosphate with $\mathrm{Zr}$ as carrier.

3. Separation and concentration of $\mathrm{ThF}_{4}$ using lanthanum as carrier.

4. Precipitation of thorium as iodate in potassium iodateoxalic acid mixture.

5. Estimation of thorium by titrating against thiosulfate, the iodine having been liberated in acid solution with KI.

\section{SPECTROPHOTOMETRY}

The procedure of Banks and coworkers (1953a) is applicable to both high- and low-grade ores. The features of the method include:

1. Decomposition of the sample by fusion with $\mathrm{KHF}_{2}$.

2. Digestion of the melt with HF.

3. Centrifugation of the insoluble fluorides.

4. Solution of the insoluble fluorides by heating with aluminum nitrate solution.

5. Extraction of thorium with mesityl oxide.

6. Stripping the thorium from mesityl oxide with water.

7. Spectrophotometric determination with thoron.

\section{REFERENCES CITED}

Adams, J. A. S., and Maeck, W. J., 1954, Fluorometric and colorimetric microdetermination of uranium in rocks and minerals: Anal. Chemistry, v. 26, p. 1635-1639.

Adler, Isidore, and Axelrod, J. M., 1955, Determination of thorium by fluorescent X-ray spectrometry: Anal. Chemistry, v. 27, p. 1002-1003.

Arden, T. V., Burstall, F. H., and Linstead, R. P., 1949, A new method for the detection and determination of uranium: Chem. Soc. (London) Jour., Supplementary Issue no. 2, p. S311-S313.

Assayer's Guide, [New Brunswick Laboratory], 1949, U. S. Atomic Energy Comm., AECD-2640, 82 p., declassified 1949.

Ballenger, H. F., 1948, Polarographic method for the quantitative determination of uranium in atmospheric dust: U. S. Atomic Energy Comm. AECD-2065, 11 p., 1944, (declassified) 1948, issued by U. S. Atomic Energy Comm. Tech. Inf. Service, Oak Ridge, Tenn.

Banks, C. V., and Byrd, C. H., 1953, Spectrophotometric determination of thorium in monazite sands: Anal. Chemistry, v. 25, p. $416-419$.

Banks, C. V., and Edwards, R. E., 1955, Separation and determination of thorium and aluminum: Anal. Chemistry, v. 27 , p. $947-949$

Banks, C. V., Klingman, D. W., and Byrd, C. H., 1953, Spectrophotometric determination of thorium in black sands: Anal. Chemistry, v. 25, p. 992-993.

Begg, M. R., Williams, A. F., and Wood, G. A., 1948, Chem. Research Lab., Teddington [England], unpub. inf.

Birks, L. S., and Brooks, E. J., 1951, Analysis of uranium solutions by X-ray fluorescence: Anal. Chemistry, v, 23, p. $707-709$.

Birks, L. S., Brooks, E. J., and Friedman, H., 1953, Fluorescent X-ray speetroscopy: Anal. Chemistry, v. 25, p. 692-697.

Bremner, J. W., 1951, A method for determining uranium and thorium in rocks by the nuclear photographic plate: Physical Soc. (London) Proc., v. 64A, p. 25-31. 
Burstall, F. H., and Wells, R. A., 1951, Inorganic ehromatography on cellulose-part V. The use of columns of cellulose in combination with organic solvent extraction for the separation of uranium from other metals: Analyst, v. 76, p. $396-410$.

Byrd, C. H., and Banks, C, V., 1953, Spectrophotometric determination of thorium with the trisodium salt of 2-(2-hydroxy-3,6-disulfo-1-naphthylazo)-benzenearsonic acid and some properties of complexes involved: U. S. Atomic Energy Comm. ISC-456, 96 p., issued by U. S. Atomic Energy Comm. Tech. Inf. Service, Oak Ridge, Tenn.

Canning, R. G., and Dixon, P., 1955, Direct spectrophotometric determination of uranium in aqueous solutions: Anal. Chemistry, v. 27, p. 877-880.

Carson, W. N., Jr., 1953, coulometric determination of uranium: Anal. Chemistry, v. 25, p. $466-470$.

Center, E, J., 1948, Topical report on the direct micro-determination of uranium using a modified fluorophotometer: U. S. Atomic Energy Comm. AECD-3006, 22 p., issued by U. S. Atomic Energy Comm. Tech, Inf. Service, Oak Ridge, Tenn.

Cooke, W. D., Hazel, Fred, and McNabb, W. M., 1950, Application of the lead reductor to the determination of uranium. Anal. Chemistry, v. 22, p. 654-655.

Crouthamel, C. E., and Hubbard, H. M., 1952, The application of differential colorimetry to the thiocyanate-acetone analysis for uranium. U. S. Atomic Energy Comm. ANL$4940,11 \mathrm{p}$

Crouthamel, C. E., and Johnson, C. E., 1952, Spectrophotometric determination of uranium by thiocyanate method in acetone medium. Anal. Chemistry, v, 24, p. 1780-1783.

Currah, J. E., and Beamish, F. E., 1947, Colorimetric determination of uranium with thiocyanate. Anal. Chemistry, v, 19 p. 609-612.

Davenport, W. H., Jr., and Thomason, P. F., 1949, Determination of uranium (VI) in presence of anions-Ammonium thioglycolate as a colorimetric analytical reagent. Anal. Chemistry, v. 21, p. 1093-1095.

Delaney, C. F. G., Matthews, C. M. E., and Poole, J. H. J., 1953, The uranium content of some specimens of phosphate rock. Royal Dublin Soc. Sci. Proc, v, 26, no. 10, p.165-172.

DeSesa, M. A., and Nietzel, O. A., 1954, Spectrophotometrie determination of uranium with thiocyanate: U. S. Atomic Energy Comm. ACCO-54, 19 p. (Microcard copy on file in U. S. Atomic Energy Comm, depository libraries.)

Ewing, R. E., and Banks, C. V., 1948, Analysis of thoriumchromium mixtures: Anal. Chemistry, v. 20, p. 233-235.

Fletcher, M. H., and Milkey, R. G., 1954, U. S. Geol. Survey unpub. inf.

Fritz, J. S, and Ford, J. J, 1953, Titrimetric determination of thorium: Anal. Chemistry, v. 25, p. 1640-1642.

Furman, N. H., Bricker, C. E., and Dilts, R. V., 1953, Titration of uranium (IV) by electrolytically generated ceric ion: Anal. Chemistry, v. 25 , p. $482-486$.

Galvanek, Paul, Jr., and Morrison, T. J., Jr., 1954, A new fluorimeter for the determination of uranium: U. S. Atomic Enery Comm, ACCO-47, 38 p., issued by U. S. Atomic Energy Comm. Tech. Inf. Service, Oak Ridge, Tenn,

Gerhold, Max, and Hecht, Friedrich, 1951, Die photometrische Bestimmung kleiner Uranmengen mit Kaliumrhodanid: Mikrochemie ver. Mikrochim. Acta, Band 37, p. 1100-1105.

Grimaldi, F. S., May, Irving, and Fletcher, M. H., 1952, U. S. Geological Survey fluorimetric methods of uranium analysis: U. S. Geol. Survey Circ. 199, 20 p.
Grimaldi, F. S., May, Irving, Fletcher, M. H., and Titcomb, Jane, 1954, Collected papers on methods of analysis for uranium and thorium: U. S. Geol. Survey Bull. 1006, 184 p.

Goldbeck, C. G., Petretic, G. J., Minthorn, M. L., and Rodden, C. J., 1945, Colorimetric determination of uranium by means of peroxide: Natl. Bur. Standards (Washington, D. C.), Rept. A-1074, 14 p.

Gordon, Louis, and Stine, C. R., 1953, Amperometric titration method for thorium in the presence of the rare earths of monazite sand: Anal. Chemistry, v. 25, p. 192-194.

Guest, R. J., and Proulx, E. I., 1952, The determination of thorium in ores by the column method: Canada Dept. Mines Tech, Surveys, Mines Branch, Radioactivity Div., Topical Rept., TR-94/52, 8 p.

Guest, R. J., and Zimmerman, J. B., 1955, Determination of uranium in uranium concentrates. Use of ethyl acetate: Anal. Chemistry, v. 27, p. 931-936.

Hageman, French, 1950, The isolation of actinium: Am. Chem. Soc. Jour., v. 72, p. 768-771.

Harris, W. E., and Kolthoff, I. M., 1945, The polarography of uranium-1, Reduction in moderately acid solutions. Polarographic determination of uranium: Am. Chem. Soc. Jour., v, 67, p. 1484-1490.

-1947, The polarography of uranium-3, Polarography in very weak acid, neutral or basic solutions: Am. Chem. Soc. Jour., v. 69 , p. $446-451$.

Hess, D. C., Brown, Harrison, Ingraham, M. G., Patterson, Claire and Tilton, George, 1953, Measurement of trace quantities of uranium and lead in minerals and meteorites: Natl. Bur, Standards [Washington, D. C.], Circ. 522, p. 183-187.

Holmes, Arthur, and Smales, A. A., 1948, Monazite from Bodmin Moor, Cornwall-A study in geochronology, Part 2. Analysis of Bodmin Moor monazite for lead, thorium, and uranium, by A. A. Smales: Royal Soc. Edinburgh Proc., v. 63B, p. 125-129.

Ingles, J. C., 1951, The chemical determination of thorium in its ores: Canada Dept. Mines Tech. Surveys, Mines Branch, Memo. Ser., No. 110, 26 p.

Isaac, N., and Picciotto, E. E., 1953, Ionium determination in deep-sea sediments: Nature, (London) v. 171, p. 742-743.

Ismail, A. M., and Harwood, H. F., 1937, The use of hexamine (hexamethylenetetramine) for the separation of thorium from the rare earths and its application to the determination of thorium in monazite sand: Analyst, v. 62, p. 185-191.

Kall, H. L., and Gordon, L., 1953, Quantitative insolubility of thorium oxalate: Anal. Chemistry, v. 25, p. 1256-1258.

Kaufman, David, Castillo, Mario, Koskela, Urpo, 1950, New fluorimeters for the determination of uranium, MIT Models I, II, III and IV: U. S. Atomic Energy Comm. MITG-A70, 32 p. (Microcard copy on file in U.S. Atomic Energy Comm. depository libraries.)

Kaufman, David, and Galvanek, Paul, Jr., 1950, Modifications in the peroxide-colorimetric method for uranium developed at the MIT Mineral Engineering Laboratory: U. S. Atomic Energy Comm. MITG-A67 (AECD-3137), 19 p., declassified 1951. (Microcard copy on file in U. S. Atomic Energy Comm. depository libraries.)

Kelley, M. T., Hemphill, H. L.y and Collier, D. M,, 1954, An improved fluorophotometer for determination of uranium in fused sodium fluoride pellets: U. S. Atomic Energy Comm. ORNL 1445, 15 p., issued by U.S. Atomic Energy Comm. Tech. Inf. Service, Oak Ridge, Tenn. 
Kember, N. F., 1948, Chem. Researeh Lab., Teddington [England], unpub. inf.

-1952, Inorganic chromatography on cellulose. Part VII. The determination of thorium in monazite and of thorium and uranium in uranothorianite: Analyst, v. 77 , p. 78-85.

Kennedy, R. H., 1950, The use of the paper column separation in the estimation of microgram quantities of uranium: U. S. Atomic Energy Comm., MITG-A84 (AECD-3187), 21 p., declassified 1951.

Kennedy, R. H., and Kaufman, D., 1949, MITG-A60, U. S. Atomie Energy Comm. unpub. inf.

Kerr, P. F., and Pill, R. J., 1951, X-ray fluorescent data on Marysvale uraninite, in Annual report for July 1, 1950 to June 30, 1951: U. S. Atomic Energy Comm. RMO-797, p. 8-23, issued by U. S. Atomic Energy Comm., Oak Ridge, Tenn.

Kilner, S. B., 1948, Determination of small amounts of uranium by the polarographic method: U. S. Atomic Energy Comm., AECD-2059, 1 p., 1942, declassified 1948, issued by U. S. Atomic Energy Comm., Tech. Inf. Service, Oak Ridge, Tenn.

Kinser, C. A., 1954, The Model VI transmission fluorimeter for the determination of uranium: U. S. Geol. Survey Cire. 330,9 p.

Komarek, K., 1950, Polarographic determination of thorium: Chemicke Listy, v. 44, p. 255-259.

Koskela, U., and Kaufman, D., 1949, U. S. Atomic Energy Comm. unpub, inf.

Legge, D. I., 1954, Polarographic determination of uranium: Anal. Chemistry, v. 26, p. 1617-1621.

Mahlman, H. A., and Leddicotte, G. W., 1955, Determination of microgram and submicrogram quantities of uranium by neutron activation analysis: Anal. Chemistry, v. 27, p. 823-825.

Main, A. R., 1953, The determination of uranium by reduction with stannous chloride: Canada Dept. Mines Tech. Surveys, Mines Branch, Radioactivity Div., Topical Rept. TR-111 53, 16 p.; also, Anal. Chemistry, v. 26, p. 1507$1509,1954$.

Malmstadt, H. V., and Gohrbandt, E. C., 1954, Determination of milligram quantities of thorium by automatic spectrophotometric titration: Anal. Chemistry, vi 26, p. 442-445.

Marechal-Cornil, J., and Picciotto, E. E., 1953, Separation des radioelements naturels par l'oxyde de mesityle: Soc chim. Belge Bull., v. 62, p. 372-382.

Meinke, W. W., and Anderson, R. E., 1952, Method for continuous extraction with a ehelating agent: Anal. Chemistry, v. 24 , p. $708-710$.

Meyer, R. J., 1911, Der Nachweis und die Bestimmung des Thoriums mit Jodsaure: Zeitsch. anorg. Chemie, v. 71, p. 65-69.

Nelson, C. M., and Hume, D. W., 1945, The spectrophotometric determination of microgram amounts of uranium by means of ammonium thioeyanate: U. S. Atomic Energy Commission. Mon-C-28, $18 \mathrm{p}$.

Nichols, E. L., and Slattery, M. K., 1926, Uranium as an activator: Optical Soc. America Jour., v. 12, p. 449-466.

Overton, K. C., and Williams, A. F., 1950, Chem. Research Lab. Teddington [England], unpub. inf.

Pepkowitz, L. P., 1945, Mierovolumetric assay of uranium: U. S. Atomic Energy Comm. MDDC-727, 9 p., declassified 1947.
Poole, J. H. J., and Matthews, C. M. E., 1951, The theory of the use of alpha ray ranges in nuclear emulsions for the determination of the radioactive contents of materials: Royal Dublin Soc. Sci. Proc., v. 25, no. 23, p. 305-316.

- 1952, Use of nuclear plates for the determination of the uranium and thorium contents of radioactive ores: Nature (London), v. 169, p. 408-409.

Price, G. R., 1948, The design and construction of sensitive fluorophotometers Part 1, Principles: U. S. Atomic Energy Comm. AEC-2677, 51 p., declassified 1949 (Microcard copy on file in U. S. Atomic Energy Comm. depository libraries)

Price, G. R., Ferretti, R. J., and Schwartz, Samuel, 1953, Fluorophotometric determination of uranium: Anal. Chemistry, v. 25, p, 322-331; also, 1945, The microfluorometric determination of uranium: U. S. Atomic Energy Comm. AECD-2282, 52 p., declassified 1948.

Rabbitts, F. T., 1952, Determination of uranium in ores. Review of chemical methods; cellulose column method: Canadian Min. Met. Bull., v. 45, no. 477, p. 27-29.

Rodden, C. J., and Tregoning, J. J., 1955, Manual of analytical methods for the determination of uranium and thorium in their ores: 51 p., Washington, U. S. Government Printing Office.

Rodden, C. J., and Warf, J. C., 1950, Uranium, Thorium, Chap. 1 and 2, in Rodden, C. J., ed., Analytical chemistry of the Manhattan Project: National Nuclear Energy Series, Div. VIII, v. 1, 748 p., New York, MeGraw-Hill Book Company, Ine.

Ryan, W., and Williams, A. F., 1949, Chem. Research Lab., Teddington [England], unpub. inf.

- 1952, Inorganic chromatography of cellulose Part 8, The use of a "compound" column of alumina and cellulose for the determination of uranium in minerals and ores containing arsenic and molybdenum: Analyst, v. 77, p. 293-296.

Schreyer, J. M., and Baes, C. F., Jr., 1953, Volumetric determination of uranium (VI) in phosphate solutions: Anal. Chemistry, v. 25, p. 644-645.

Senftle, F. E., Farley, T. A., and Stieff, L. R., 1954, A theoretical study of alpha star populations in loaded nuclear emulsions: Geochim. Cosmochim. Acta, v. 6, p. 197-207.

Sill, C. W., and Peterson, H. E., 1952, Volumetric determination of milligram quantities of uranium: Anal. Chemistry, v. 24, p. 1175-1182.

Silverman, L., and Moudy, L., 1953, Photometric determination of uranium as thiocyanate; Penta-ether extraction method: U. S. Atomic Energy Comm. NAA-SR-244, 25 p.

Singer, S. F., 1952, Radioactivation method for the determination of micro-quantities of uranium: Office Naval Research, London, England, ONRL-76-52, 3 p.

Smales, A. A., 1952, The determination of small quantities of uranium in rocks and minerals by radioactivation: Analyst, v. 77 , no. 920 , p. $778-789$.

Smales, A. A., and Airey, L., 1952, A method for the amperometric titration of thorium: Atomic Energy Research Establishment, Harwell, (England) 6 p.

Smith, G. H., and Williams, A. F., 1950, Chemical Researeh Laboratory, Teddington [England], 10 p., unpub. inf.

Stine, C. R., and Gordon, Louis, 1953, Precipitation of iodates from homogeneous solution. Separation of thorium iodate: Anal. Chemistry, v. 25, p. 1519-1522. 
Strubl, R., 1938, Polarographic studies with the dropping mercury cathode. Part 75, The estimation of uranium and other heavy metals in the excess of iron: Collection des Travaux Chimiques de Tchecoslovaquie, v. 10, p. 466-474.

Šušic, M., Gal, Ivan, and Cuker, E., 1954, Polarographic determination of uranium in ores in ascorbic acid supporting electrolyte: Anal. Chim. Acta, v 11, p. 586-589.

Taylor, A. E., and Dillon, R. T., 1952, Determination of microgram quantities of thorium in water: Anal. Chemistry, v. 24, p. 1624-1625.

Thomason, P. F., Perry, M. A., and Byerly, W. M., 1949 , Determination of microgram amounts of thorium: Anal. chemistry, v. 21, p. 1239-1241.

Tillu, M. M., 1954, Rapid determination of uranium in complex minerals like samarskite, columbite-tantalite, and titanoniobates-1. Volumetric determination: Indian Acad. Sci. Proc., sect. A, v. 40, No. 3, p. 110-113.

Tillu, M. M., and Athavale, V. T., 1954a, Rapid determination of thorium in ores-2. Estimation of trace amounts of thorium in complex minerals and ores: Anal. Chim. Aeta, v. 11 , p. $324-328$.

$1954 \mathrm{~b}$, Rapid determination of thorium in ores-1, Separation as iodate in presence of oxalic acid: Anal. Chim. Acta, v. 11 , p. $62-67$.

Tilton, G., 1954, Isotope dilution techniques, in Faul, Henry, ed. 1954, Nuclear Geology; New York, John Wiley and Sons, Inc., p. 70-73.

Tilton, G. R., Aldrich, L. T., and Inghram, M. G., 1954, Mass spectrometric determination of thorium: Anal. Chemistry, v. 26 , p. $894-898$.

Tishkoff, G. H., 1948, Polarographic analysis of uranium: U. S. Atomic Energy Comm. AECD-2005, 4 p., 1944, declassified 1948, issued by U. S. Atomie Energy Comm. Tech. Inf. Service, Oak Ridge, Tenn. (Superseded by: Flagg, J. F., 1949,
Analytical methods, in Voegtlin, C., and Hodge, H. C., eds., Pharmacology and toxicology of uranium compounds: p. 125-143, National Nuclear Energy Series, Div. VI, 1, pt. 1, New York, McGraw-Hill Book Co., Inc.)

Venkataramaniah, M., Raghava Rao, B. S. V., and Lakshmana Rao,C., 1952, m-Cresoxyacetic acid as a reagent for thoriumSeparation of thorium from the rare earth of monazite and from uranium: Anal. Chemistry, v. 24, p. 747-749.

Warf, J. C., 1949, Extraction of cerium (IV) nitrate by butyl phosphate: Am. Chem. Soc. Jour., v. 71, p. 3257-3258.

Willard, H. H., and Gordon, Louis, 1948, Thorium in monazite sand. Separation and determination by precipitation from homogeneous solution: Anal. Chemistry, v. 20, p. 165-169.

Williams, A. F., 1952, Inorganic ehromatography on cellulosePart 9, The use of alumina and cellulose adsorbents for the determination of thorium and the simultaneous determination of thorium and uranium in minerals and ores: Analyst, v. 77, p. $297-306$.

Yoe, J. H., Fritz, W., 3d, and Black, R. A., 1953, Colorimetric determination of uranium with dibenzoylmethane: Anal. Chemistry, v. 25, p. 1200-1204.

Zebroski, E., and Newton, T. W., 1946, Fluorescence analysis for uranium: U. S. Atomic Energy Comm. MDDC-443, 16 p., declassified 1946 (Microcard copy on file in U. S. Atomic Energy Comm. depository libraries.)

Zimmerman, J. B., 1951, The determination of uranium in ores; fluorophotometric method: Canada Dept. Mines Tech. Surveys, Mines Branch, Memo. Ser. 114, 29 p.

Zimmerman, J. B., Rabbitts, F. T., and Kornelsen, E. D., 1953, The determination of uranium in concentrates by the fluorophotometric method: Canada Dept. Mines Tech. Surveys, Mines Branch, Radioactivity Div., Topical Rept TR-112/53, 8 p. 



\section{METHODS OF PROSPECTING FOR URANIUM AND THORIUM}

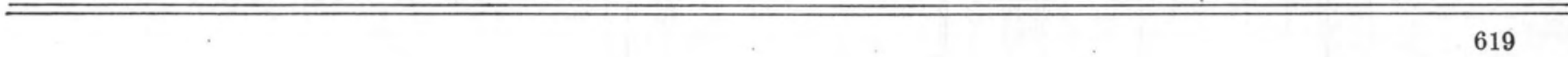





\title{
TECHNIQUES FOR PROSPECTING FOR URANIUM AND THORIUM-A SUMMARY
}

\author{
By Royal S. Foote, U. S, Atomic Energy Commission, and Lincoln R. Page, U. S. Geological Survey
}

\section{CONTEN'TS}

\begin{tabular}{|c|c|c|c|}
\hline & Page & & Page \\
\hline Introduetion............. & 621 & Geophysical prospecting. & 624 \\
\hline Geological prospecting & 622 & Drilling techniques........ & 625 \\
\hline
\end{tabular}

\begin{abstract}
Successful prospecting and physical exploration for uranium and thorium require a thorough knowledge of geologic, geochemical, and geophysical techniques. The favorability of each distinct geological unit, within large areas not previously known to contain deposits of these elements, can be evaluated on the basis of existing knowledge. Prospecting for epigenetic deposits would be emphasized in areas of deep-seated tectonic structures, particularly those related to near-surface intrusions and associated extrusives, depositional basins containing terrestrial sediments, and granite batholiths. Ultra-mafic and plateau basalt igneous terranes appear unfavorable. Low-grade syngenetic deposits would be sought in (1) marine continental shelf sediments of the black shale and phosphate types, (2) terrestrial and marine placers, (3) alkalic igneous stocks, sills, and dikes, and (4) granitic pegmatites. Marine sandstones, conglomerates, mudstone, and carbonate rocks rarely contain syngenetic deposits.
\end{abstract}

Preliminary geophysical reconnaissance of the favorable areas is best made by gamma-radiation detectors carried by the geologist-prospector on the ground or in low-flying aireraft. Self-recording gamma-detection equipment, capable of measuring increments in radiation rates of 0.5 micro-roentgens per hour, mounted in a variety of mobile earriers has been effective in radiometrie reconnaissance. These techniques locate only exposed or slightly buried deposits, but they commonly result in opening up new districts where concealed deposits are found by other methods.

Where ore minerals are not exposed anomalous radioactivity is a less effective guide to ore, but soil, rock, water, and plant sampling, and panning, are useful supplements to radiation and geologic criteria. In the search for deeply buried deposits useful structural, lithologic, and mineralogic guides have been determined for most major districts in the United States. Some of these such as favorable structural and lithologic hosts are effectively outlined by geophysical techniques.

Lithologic logging of drill holes supplemented by gamma-ray and electric logging is essential to prospecting in depth. Gammaray logging techniques in drill holes give accurate thickness and position of uranium mineralization intersected, and, with chemical assay control, give the approximate grade of ore surrounding the hole. Iso-radiation maps of subsurface units are used to guide drilling exploration.

Electric logs supply valuable lithologic information and can be interpreted as indicating favorable zones in specific formations.

Seismic refraction methods have successfully delineated welldeveloped paleo-channels favorable for ore localization.

Some new and promising experimental techniques are coming into use. Electrical-resistivity measurements indicate unique electrical characteristics associated with ore in some sedimentary formations. Shallow-reflection high-resolution seismie methods and acoustical logging may help outline subsurface geologic guides.

Recent developments of geochemical exploration methods alone and in combination with electrical and radiation techniques presage new procedures in the near future.

\section{INTRODUCTION}

In 1945 , when the potential of atomic power became public knowledge, prospecting for radioactive minerals in the United States was but a very minor activity of government and industry. Consequently, the techniques employed then were, by today's standards, exceedingly crude. Since then the efforts of thousands of workers have perfected many new instruments and techniques for finding uranium and thorium.

The reports submitted by some of these men to the 1955 conference at Geneva describe the most important advances in the techniques of prospecting by many geologists, geochemists, botanists, and geophysicists. This brief summary cannot make specific reference to the authors of the reports that follow, but it is a pleasure to acknowledge their fine work and also that of their colleagues who have done so much to advance the arts of prospecting and exploring for uranium and thorium.

Successful prospecting and physical exploration for uranium and thorium require the application of many geological, geochemical, and geophysical techniques. 
Each technique has its place in the difficult task of finding, exploring, and developing these deposits; commonly several techniques must be used in combination. Fortunately, these two elements have one unusual property in common-radioactivity-that makes possible techniques not applicable to the prospecting for other minerals. Radiation detection devices consequently have played a major role in the finding and developing of uranium and thorium deposits.

\section{GEOLOGICAL PROSPECTING}

The application of geologic knowledge in the search for uranium and thorium deposits has greatly increased the rate of discovery of new districts and of ore deposits within new and old districts. Many deposits have been found in environments previously believed to be unfavorable for the occurrence of these metals. This emphasizes the fact that good prospecting requires that all theories and hypotheses - not just the one in favor at the moment-be considered carefully.

The favorability of each distinct geologic unit within large areas not previously known to contain uranium and thorium deposits can be evaluated, with a reasonable degree of assurance, on the basis of existing knowledge. This is in a large part due to the large number of man-years of experience that have been put into the search for uranium.

Prospecting for epigenetic deposits of uranium should emphasize, on the basis of existing knowledge, areas of deep-seated tectonic structures, particularly those related to (1) near-surface intrusions, and associated extrusives, (2) depositional basins containing terrestrial sediments, and (3) granite batholiths. Ultra-mafic and plateau basalt igneous terranes appear unfavorable. Low-grade syngenetic deposits should be sought in marine, continental shelf sediments of the black shale and phosphorite types; terrestrial and marine placers; alkalic igneous stocks, sills, and dikes; and granitic pegmatites. Marine sandstones, conglomerates, mudstones, and carbonate rocks rarely contain syngenetic concentrations of uranium. Epigenetic deposits of thorium are largely restricted to metamorphic and igneous terranes where they are associated with alkalic igneous rocks and carbonatite masses, that in themselves may contain syngenetic concentrations.

Within these favorable terranes the ore deposits commonly occur in clusters or districts; the individual ore bodies are of various sizes and grades. The guides to concealed deposits are largely structural, lithologic, mineralogic, and chemical. Within any ore district or region specific stratigraphic horizons, or specific types of lithology, mineralogy, or structure may be the most important guides to ore. These phenomena are amenable to mapping and have served as extremely useful aids in planning exploration; as yet such maps have been used only to a limited extent in surface prospecting. In some areas, such as the Black Hills of South Dakota and Wyoming, where the favorable host rock is capped by impermeable beds, structure-contour maps of the upper surface of the porous host rock reveal areas of irregular structure, such as anticlines, structural terraces, and zones of interfingering that seem to have localized the ore deposits. In the Colorado Plateau area similar maps of the lower surface of the host rock indicate the channels and swales that are favorable structures for localizing ore.

Isopach maps indicate the thicker, more favorable parts of sandstone host rocks in the Colorado Plateau and of uraniferous parts of the lignites of the Great Plains region and other areas. Similar maps of alteration zones in siltstone below sandstone host rocks; and of color zones within them have also proved their worth. Contour maps of the upper surface of ground water and of abundance of critical elements, such of fluorine, in the water, are useful in areas of caliche-type deposits such as the schroeckingerite of the Red Desert region, Wyoming.

Maps have also been made of the direction of flow in ancient stream channels, using crossbedding, linearity of grains, logs, scours and channels, current ripples, and other sedimentary structures that control in detail the shape and distribution of ore bodies in sandstones. Iso-abundance maps of pebbles, grain sizes, heavy minerals, metals, and rock types have been used both in prospecting and as guides to exploration. Maps showing similar rates of change in facies together with mudstone frequency have been useful in guiding exploration on the Colorado Plateau. Mapping of alteration zones, both of clay and hematitic impregnated materials associated with veins in igneous and metamorphic rocks, as at Marysvale, Utah, or in sandstones as at Temple Mountain, Utah, aids in the predietion of ore shoots and deposits.

A system of geologic prospecting for monazite based on studies of the distribution of detrital heavy minerals has been developed to show regional relations of monazite to other heavy minerals. It is especially suited to regions of intense weathering and deep residual soil, but it might be used wherever there is adequate stream density and no interference from glacial deposits.

Heavy-mineral concentrates are taken by panning riffle gravel from the beds of small streams whose distributive provinces, above the sites of the samples, do not exceed 2 square miles. Equal volumes of sediment of reasonably similar mechanical composition are used for all samples. The mineralogical composition of each concentrate obtained by grain count, converted by nomogram to 100 percent on a quartz-free basis, is 
plotted on a group of maps showing sampling localities. The abundance of each mineral is contoured at suitable intervals of weight percent on the map. The "grain" of the information obtained from the contours is generally coarse, thus samples should be taken over a minimum of several thousand square miles. Highs formed by monazite or "indicator minerals" become the loci of normal geologic search for monzaite deposits.

\section{GEOCHEMICAL PROSPECTING}

Sampling of known uranium ore bodies and the surrounding materials has been undertaken in an attempt to delineate the primary geochemical halo which theoretically surrounds every ore body to some degree. The three-dimensional distribution of trace elements related to an ore body is a function of differential ion mobilities of the chemical elements related to the ore emplacement. Primary geochemical halos have been of great assistance in locating hidden ore bodies of nonferrous metals and the same criteria may apply in uranium exploration.

Most geochemical studies have been directed toward delineating secondary geochemical halos, considered a most fruitful line of investigation because many areas of interest are covered by soil. During weathering and erosion, capillary attraction and plant growth and decay have an additive effect, tending to concentrate metals in soils from ore deposits and primary geochemical halos in country rock. Soil analysis is a valuable tool, both in areas where soils are in place and also where they have been transported. Both ground water and surface stream sampling can delimit favorable uranium formations and districts.

The application of geochemical techniques to exploration is not materially different from geophysical methods, in that all related geological factors must be evaluated in relation to the geochemical technique used. To be effective it must be rapid and relatively cheap. Trace amounts of uranium can be measured directly and the results can be related to potential concealed ore bodies or favorable areas. The amount of leachable uranium in sedimentary rocks has been measured by paper chromatographic and fluorimetric methods. These methods can discriminate as little as $0.5 \mathrm{ppm}$ at a background of $10 \mathrm{ppm}$. The direct measurement of uranium in conjunction with radioactivity measurements has been valuable in distinguishing uranium from its highly radioactive daughter products. The mobility of the uranyl ion is very high and hence its direct detection holds promise for locating ore deposits.

The indirect approach involving the measurement of concentrations of other elements associated with uranium has been applied in several areas in the United States. This method assumes that at some stage during ore emplacement, solutions carrying metallic ions other than uranium may have travelled further and enlarged the target for geochemical exploration. The well known dithizone analytical methods are used for determination of base metals and new methods have been developed for measuring trace concentrations of $\mathrm{V}, \mathrm{Mo}, \mathrm{Se}, \mathrm{Ca}$, and $\mathrm{Nb}$.

The sampling of ground water and measurement of its uranium content has resulted in the indication of areas favorable for uranium that have subsequently been found to contain commercial deposits. Most ground water contains less than $2 \mathrm{ppb}$ (parts per $10^{\circ}$ ) uranium and water from volcanic and tuffaceous sediments considered favorable for uranium deposits may contain 10 to $250 \mathrm{ppb}$. In many areas sampling indicates that leaching of uranium is now taking place. Variations in the uranium content of ground waters vary with the transmissivity of the host rock which, in turn, effects the availability of uranium.

Analyses of surface water in streams indicate that uranium concentration decreases down stream by dilution and that nearly all large streams traversing uraniferous areas commonly contain 1 to $10 \mathrm{ppb}$. The threshold of significance is 3 to 10 times background, depending upon geological factors. In the Florida phosphate area, the background is $0.1 \mathrm{ppb}$ and the threshold of significance is approximately $0.3 \mathrm{ppb}$. Here a uranium content of 1 to $3.5 \mathrm{ppb}$ is regarded as a strong indication of the presence of uraniferous phosphate. In the Colorado Plateau, surface streams have a background of about 0.5 to $3.0 \mathrm{ppb}$ and a threshold of significance of about 4 $\mathrm{ppb}$ in the major streams. Anomalies in or near uraniferous areas range from 5 to $12 \mathrm{ppb}$ for streams free of contamination.

Botanical methods of prospecting are based on the premise that concealed mineral deposits may be reflected chemically in surface vegetation. Results suggest that ore bodies under a cover of barren sandstone as much as 25 meters thick may be detected by testing plants growing above them for uranium and associated elements.

One botanical method in use is based upon the presence of uranium in all plants in small but measurable amounts. The uranium content of plants rooted in ore, however, is detectably greater than the uranium content of plants rooted in barren ground. The uranium content of the ash of plants rooted in unmineralized sandstone is generally less than $1 \mathrm{ppb}$. A content of several parts per million is common in the ash of plants rooted in ore. Plant ash is analyzed directly for uranium by the fluorimetric method.

Another botanical method of prospecting, that of mapping the distribution of indicator plants, has 
been used in ecologically favorable areas. A plant may be used as an indicator plant in prospecting if its distribution is controlled by any factor related to the chemistry of the deposit. Carnotite ore and other oxidized uranium ores contain appreciable amounts of available selenium and sulfur. The distribution patterns of plants requiring one of these elements in quantity may indicate favorable ground.

Botanical prospecting in advance of drilling for shallow ore deposits may substantially reduce the number of holes required and can be used in unprospected country to suggest areas worthy of intensive geologic study.

\section{GEOPHYSICAL PROSPECTING}

The development of highly sensitive radiation detection equipment, especially the scintillation counter, has made possible the airborne detection of radiation from exposed or near-surface uranium deposits. Light single-engine aircraft equipped with scintillation counters, flying at 50 to 100 feet above the ground and at ground speeds of approximately 60 miles per hour, have been effective in discovery of commercial uranium deposits. The technique is most effective in areas of well exposed formations known to be favorable for uranium or thorium; it is especially effective where favorable formations are horizontal and exposed in vertical cliffs. The greatest success has been in rapid prospecting of known mineralized formations. The aircraft is flown within 100 feet of the vertical exposure, following the contour of the outerop. In areas of low relief and poor exposure, a rectangular grid pattern is flown at low altitude and the positions of radiation anomalies are plotted on aerial photographs.

Airborne surveying at altitudes of 500 feet with multiengine aircraft is used to delineate radioactivity in broad areas not previously known to contain uranium or thorium deposits, thus indicating the favorability of these areas for more detailed prospecting and exploration. Crystalline rocks of different ages and types also can easily be distinguished by their characteristic radioactivity as recorded by this method. Five hundred feet of air distance is an effective upper limit to the application of airborne radiation prospecting, and 200 feet is probably the most efficient altitude considering the attenuation of radiation with air distance and the width of the zone from which anomalous radioactivity can be detected. The width of this zone of effective detection is about twice the distance of the aircraft above the ground.

Quantitative interpretation of airborne radiation data has been shown possible for broad sources and the equivalent uranium of these sources can be estimated to within a few thousandths of one percent. The quantitative relationships between the peak intensity and area under the curve as recorded by a counting ratemeter and the source strength and size have been empirically established as a function of the velocity and distance of a detector from the source. Excellent equipment and instruments are available commercially for detailed airborne radiation surveys for both high-level and lowlevel flying and the technique is finding wide application in private uranium exploration.

The application of gamma-ray detection in subsurface exploration has become increasingly important in the past several years. Radiation detection in drill holes supplies valuable information on the position and character of uranium mineralization. Gamma-ray radiation is measured with highly sensitive scintillation detectors raised through drill holes on eables which transmit data to the mechanical recorder at the surface. Geologic units can be correlated between drill holes; thickness and general type of geologic members can be determined, and the approximate grade or ore can be obtained by correlating core assays from a number of holes with radiation data. . One field procedure involves the recording of the maximum gamma-ray $\log$ deflection recorded in a favorable geologic member and plotting this as a function of depth for each drill hole. A map is drawn showing lines of equal radioactive intensity and effective placing of drill holes is based on the results. Scintillation gamma-ray logging instruments in use at the present time are limited to holes with a nominal diameter of greater than 2 inches. Geiger tube logging instruments are used for holes smaller than 2 inches. Quantitative assay results based on scintillation gamma-ray logging techniques are limited by disequilibrium and thickness variables, and are not generally reliable for reporting ore reserves. Electric logging equipment is being used in conjunction with gamma-ray logging instruments to provide more detailed lithologic and other geologic information. Effective single-point electrode design makes in-hole electric logging of dry holes possible in conjunction with gamma-ray logs and expands the usefulness of the combination logging procedure. Evidence indicates that the single-point electric log data can be used for quantitative interpretation of resistivity parameters.

Detailed radiation surveys at the surface are most effectively made by a geologist using a scintillation or a Geiger counter and are usually made on a rectangular grid pattern from which maps are drawn showing lines of equal radiation. Reconnaissance surveys on outcropping ore bodies known to be favorable are made 
by walking the outerops. Regional reconnaissance radiation surveys are commonly made with car-mounted scintillation instruments of the continuously recording type, which provide the location of radioactivity anomalies leading to more detailed ground studies and provide data on the surface distribution of radioactivity in large areas.

Unexposed uranium deposits have not proved susceptible to direct detection by geophysical methods because of the lack of contrast in physical properties between ore-bearing material and host rock. This is true because of the low concentration of uranium ore. Some geophysical methods have proved to be of value, however, in the detection and delineation of indirect geologic guides to ore.

Electrical resistivity methods indicate that uranium mineralization is accompanied by variations in the resistivity of the containing sediments which are detectable by electrical means. Surface and in-hole logging results indicate that there is no known difference in electrical properties attributable to the uranium mineralization. One set of data, however, shows high resistivity values near deposits in South Dakota; another set of data shows low resistivity values associated with deposits in Wyoming, where ore minerals are of a completely different type. Electric resistivity measurements on surface, made with direct current equipment and nonpolarizable electrodes, delineate thicker parts of the Salt Wash sandstone member of the Morrison formation in Colorado as areas of anomalous high resistivity. These thick parts of sandstone units are considered favorable for ore in some areas. The Shinarump conglomerate filling paleochannels cut in the less indurated Moenkopi formation in the Colorado Plateau have been successfully outlined by using seismic refraction surveys with standard equipment. Continuous profiling with reversed shots has resulted in location of previously unknown mineralized channels. Channels filled with Shinarump conglomerate have also been located by a combination of vertical and horizontal resistivity profiling.

Extensive experimental investigations have been made of the application of reflection seismic methods, surface-inhole electrical methods, and natural potential methods without conclusive results. Further research is planned to evaluate the shallow seismic reflection method using continuous velocity logging equipment, in conjunction with the high resolution seismic equipment. Work is also planned to test the applicability of induced polarization, radio frequency, and electromagnetic induction methods to uranium exploration problems.

\section{DRILLING TECHNIQUES}

Specialized drilling techniques have been developed to fit unusual problems in uranium exploration on the Colorado Plateau. Paleostream channels in the Shinarump conglomerate, in which many ore deposits of the Colorado Plateau occur, may be from hundreds to thousands of feet long and from tens to hundreds of feet wide, with scours as much as fifty to sixty feet deep. One drilling technique developed to outline such channels involves drilling a row of holes a short distance behind the cliff exposure of the channel and perpendicular to the projected trend of the channel. The axis of the channel is then determined by alignment of the structurally lowest hole drilled with the lowest point of the channel in the Shinarump on the exposure. A line of holes is then drilled on the projected axis and if the axis orientation changes as noted by drill data, a new perpendicular row is drilled for reorientation of axis and drill pattern.

Grid patterns are used for drill hole guidance where little is known regarding the geology or the trend of favorable ground. Hole spacing is contingent on the target size for the particular formation being drilled or on the purpose of the drilling if other than to intersect ore (that is, for geologic information). Preliminary drilling is usually done on wide spacing with secondary drilling in the search for ore bodies much closer, offsets commonly being from about 25 to 60 feet. Nearly all of the common type of drilling rigs are used on the Colorado Plateau; there is a trend toward the use of more mobile heavy-duty drills and accessories, improved sampling in dry drilling, and increased use of air as a circulating medium. Drilling costs have decreased markedly since the beginning of the program due to increased efficiency and competition.

A unique method has been developed to extend favorable zones for uranium mineralization in the Salt Wash member of the Morrison formation in the Colorado Plateau. Data are collected from wide-spaced drill holes from which is plotted a lithofacies map employing the ratio of mudstone to sandstone content of a depositional unit. In this type of subsurface map, there is more than a random coincidence displayed between the location of the mineral deposits and the position of facies or environment change. This information is available to the geologist from data supplied by drill holes spaced from 500 to 1,000 feet apart. 



\title{
GEOLOGIC PROSPECTING FOR URANIUM AND THORIUM
}

\author{
By Lincoln R. PAge, U. S. Geological Survey
}

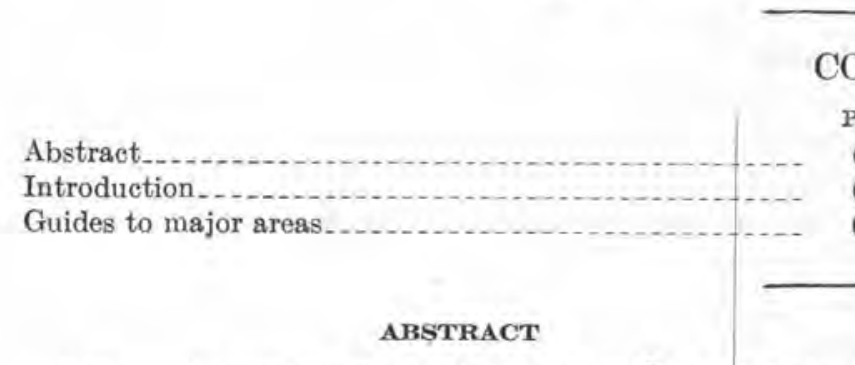

The search for uranium and thorium in the United States has emphasized the value of geologie guides in prospecting. The application of these guides in conjunction with radiometric, geochemical, botanical, panning, and geophysical techniques has greatly increased the rate of discovery. Prospecting for new districts is based on very general geologic criteria; prospecting for individual ore deposits in new or old districts requires speeifie guides that in part are of only local significance.

New districts of high-grade epigenetic deposits are sought in (1) broad areas in the vicinity of small potassic or sodic intrusives, exposed or buried, and associated pyroclastic materials, (2) areas of terrestrial sedimentary rocks in depositional and structural basins, and (3) areas of deeply eroded batholithic rocks. Such areas are commonly characterized by relatively recent crustal instability. Ultrabasic and plateau-type basaltic igneous and marine sedimentary terranes are rarely favorable host rocks. Syngenetic deposits, commonly uniformly of lowgrade, oceur in areas of (1) marine continental shelf sedimentary rocks of the organic-rich black shale and phosphorite types, (2) terrestrial and marine placers, (3) alkalic stocks, sills, and dikes, and (4) granitic pegmatites. Most marine clastic and earbonate rocks do not contain syngenetic deposits.

Geologic guides to ore deposits vary for each major uranium and thorium district; however, sandstone-type uranium deposits are most common where the host rock shows (1) abnormal variation in shape and attitude as a result of tectonic, erosional, or depositional processes; (2) abrupt changes in texture, sedimentary structure, degree of fracturing, cementation, and composition of component fragments; (3) color contrasts resulting from ehemical alteration; (4) abundant carbonaceous material; and (5) abnormal concentrations of copper, vanadium, selenium, iron, phosphorus, or arsenic. Thorium and uranium placers are in or adjacent to deeply weathered metamorphic and igneous terranes containing syngenetic refractory minerals; some nonsilicate uranium minerals, such as pitchblende, decompose before aceumulation.

Structure is a primary guide to vein deposits because veins occur in faults, shear zones, and other tectonic features in otherwise impermeable rocks; secondary guides are zonsl distribution of metals, mineral associations, alteration, and type of wall rocks.

Pitchblende or uraninite ore is closely associated with (1) dark colored fluorite and quartz; (2) mixed lead, zinc, copper, and silver or cobalt, nickel, and silver minerals; (3) ferrous iron- and carbonate-rich parts of wall rocks; and (4) hematitic and argillic alteration with or without silicification. Scattered yellow and green oxidized minerals are guides to pitchblende and uraninite in depth. Molybdenite in radioactive veins commonly indicates the presence of brannerite.

Alkalic igneous rocks and carbonates are guides to areas containing thorite and monazite veins; barite, rare-earth minerals, hematitic alteration, and dark quartz are guides to concentrations in veins.

Numerous other guides to ore are known but many of these are of only local significance.

\section{INTRODUCTION}

The search for uranium and thorium ores in the United States during the past 10 years has emphasized the value of geologic guides in prospecting. The discovery of many new districts is in a large part the result of prospecting based on the geologic appraisal of large regions and subsequent reconnaissance examinations. The guides used at the start were of a very general nature, but they have been and are being constantly refined. Within both new and old districts, hundreds of new deposits have been found by the application of specific geologic guides to the problem of ore-finding used in conjunction with detailed radiometric, panning, geochemical, botanical, and geophysical studies in advance of physical exploration.

All known characteristics of uranium and thorium deposits must be used to make geologic prospecting successful, and because our knowledge changes from day to day, good prospecting is the result of theories based on continuously changing hypotheses. Although only two main groups of deposits are sought-epigenetic and syngenetic - there are many theories to explain the origin and localization of each deposit.

Many of the geologic guides described in this paper have been developed and tested over a period of time by a large number of individuals. It is, therefore, con- 
sidered inappropriate to attempt to give specific credit for each guide, rather the reader is referred to the more general papers on the subject. Grateful acknowledgment is made of the assistance of colleagues and coworkers who, through discussion, have contributed greatly to the formulation of this summary of the writer's ideas on the application of geology to prospecting.

The search for epigenetic and syngenetic deposits can be narrowed down to specific types of terrane that have little or no relation to stratigraphic or geologic time tables, but rather are related to the depth of erosion and to major magmatic, sedimentary, or tectonic environments. In the United States epigenetic deposits of ore grade are most abundant in (1) areas of deep-seated tectonic structures, particularly those related to small, near-surface intrusive and associated extrusive rocks of alkalic affinities, (2) depositional basins containing terrestrial sediments, particularly sandstones; and (3) deeply eroded granitic batholiths. The syngenetic deposits, mostly below ore grade, are limited to areas of (1) granitic igneous rocks, (2) continental shelf organicor phosphatic-rich sediments, (3) placers derived from granitic batholiths and high-grade metamorphic rocks, and (4) terrestrial and near shore marine sediments. Areas of ultramafic rocks and plateau basalts, as well as marine sandstones and limestones, have as yet yielded little radioactive material.

If we assume an ultimate magmatic source of uranium or thorium (or both) for each of the terranes mentioned, different structural, lithologic, and chemical environments delimit the distribution of ground favorable for the occurrence of uranium or thorium regions or districts and within this favorable ground determine the localization of ore deposits.

\section{GUIDES TO MAJOR AREAS}

The localization of uranium and thorium regions within the earth's crust is the result of the interplay of complex geologic processes that tend to concentrate these metals in particular petrographic and metallogenic provinces. The search for new major ore regions is, therefore, fundamentally one of applying our knowledge of the geochemical cycle of uranium and thorium in the earth's crust.

All major areas of relatively high grade uranium deposits in the United States contain intrusive or extrusive igneous rocks of alkalic or calc-alkalic affinity. The deposits are closely or distantly related to exposed or unexposed intrusives depending upon the available conduits for ore solutions. In impermeable igneous and metamorphic terranes where the porous structures are relatively short fractures, faults, and shear zones, the source rocks and the deposits show a close spatial relation. In terranes of permeable sedimentary rocks where single beds or groups of interfingering beds are continuous aquifers over large areas, the source rocks and uranium deposits may be either close together or many miles apart. Thorium, however, has a different field of chemical stability and consequently is deposited much more closely to its parent alkalic igneous rocks in associated carbonatites and veins; in fact, it occurs in the igneous rock itself and rarely is concentrated in porous sedimentary rock, except as detrital grains.

Apparently the most favorable terranes for both metals in the United States are those containing small near-surface intrusive, and associated extrusive, alkalic igneous rocks that cut Mesozoic and Cenozoic terrestrial sedimentary rocks; less favorable are terranes that contain deeply eroded granitic batholiths and their related pegmatites that cut Paleozoic and Precambrian rocks. The absence of associated uraniferous pegmatites, of similar age, with most veins or bedded deposits of uranium indicates that deeper parts of igneous intrusives are less favorable loci for deposits than the upper and peripheral parts of these masses. Marine sedimentary rocks rich in organic and phosphatic matter may be sources of low-grade syngenetic uranium deposits of large extent; they, like the impermeable terrestrial sediments, are hosts for high-grade epigenetic deposits only where adjacent to favorable tectonic structures that have been mineralized.

Broad geologic features commonly are delimited on maps at scales of $1: 2,500,000$ or larger in sufficient detail to focus attention on regions favorable for prospecting. Examples of favorable regions of igneous and terrestrial rocks of this order of magnitude include the Colorado Plateau and the Precambrian, Paleozoic, and Triassic areas intruded by Triassic dikes and sills in the northeasteri United States. The central mineral belt of Colorado and its possible extensions are an example of combined igneous and metamorphic terrane. By inspection of stratigraphic charts, drill-hole logs, and maps, it is possible to pick marine tarranes favorable for syngenetic deposits such as the northwest phosphate area of Idaho and Montana, the phosphate area of Florida, and the Chattanooga shale area in Tennessee.

Because small-scale maps of major regions show only the larger intrusives exposed at the surface, the outer borders of favorable areas may be as much as several hundred miles beyond the limits of the igneous rocks mapped, depending upon the presence or absence of permeable rocks and broad zones of deep-seated tectonic structures along which buried intrusives occur.

\section{GUIDES TO NEW DISTRICTS}

Within the brosd regions the search for epigenetic deposits can be narrowed down to the smaller areas 
characterized by large faults, shear zones, folds, cryptovolcanic structures, diatremes, and buried or exposed intrusives. Structure contour maps of basement and other surfaces showing these important structures are most useful in conjunction with maps of structural features at the surface, in delimiting the most likely areas of new districts. These favorable areas are in some places associated with abnormal though local increases in geothermal gradients as indicated by hot springs and high temperatures at bottoms of deep wells. Such districts may be tens of square miles in area, although generally their shapes are irregular, and within them the ore deposits are commonly localized in clusters.

The problem of finding new districts in permeable sedimentary terranes is one of finding large areas where physical traps favorable for the precipitation of uranium are numerous. Various guides have been successfully used in this phase of prospecting. These are the presence of favorable structures, host rocks, and chemical environment. Especially favorable are anticlines or terraces-tectonic, erosional, or depositional in origin - or other features that might cause the accumulation of gases or liquids sucb as carbon dioxide, hydrogen sulfide, natural gas, and oil that could result in direct precipitation of uranium or in precipitation of other solutes that in turn would reduce the solubility of uranium compounds. Some of these structural features are places where fractures allow the escape of dissolved gases and result in precipitation. Fault, shear, and fracture zones crossing sedimentary rocks at an angle to the direction of flow of solutions and primary sedimentary features (such as channels, crossbedded rocks, and interfingering porous and less porous beds) may ehange the velocity and pressure relationships and thereby bring about precipitation of uranium minerals.

Uranium or other metallic minerals can be precipitated where the host rocks are not only structurally but chemically favorable; commonly both physical and chemical conditions must be favorable before an ore deposit can form. In metamorphic and igneous rocks porosity is generally low, except where influenced by tectonic structure; favorable chemical environments in these rocks are rare except in areas of marbles and ferrous iron-rich rocks such as hornblende schist and gneiss. In the unmatamorphosed sedimentary rocks the porosity is greater and the ore is deposited as pore fillings. Coarse-grained sandstones with varied texture commonly make the best host for ore minerals; many uniformly sorted sands, though of high porosity and occurring in uraniferous terranes, are barren of ore. Below the zone of oxidation wood and plant and other carbonaceous materials, carbonates, and clay minerals change the $\mathrm{pH}$ or otherwise cause reactions that result in precipitation; under oxidizing conditions iron and manganese oxides fix uranium readily (Lovering, 1955).

The batholithic areas of the United States have been relatively unproductive of uranium deposits. Few occurrences, other than in relatively small high-grade veins, have been found. The Boulder batholith in Montana has a few veins in which base metals, silver, uranium, and chalcedony are associated; the Sierra Nevada batholith contains only a few fissure-filling deposits; post-Devonian batholiths of the Eastern United States contain pegmatites, but few veins; the Pikes Peak and associated batholiths of the Rocky Mountains contain some deposits, but these are much younger than the batholith. Thus it seems that unless the batholith is cut by much younger rocks such areas are not good prospecting ground for epigenetic deposits. Uraniferous pegmatites, however, are commonly associated with the Precambrian, late Paleozoic, and in places Jurassic and Cretaceous batholiths. Thorium, as monazite, allanite, or thorite in igneous rocks, veins, and carbonatites, is not uncommonly associated with the satellitic bodies of the batholiths.

In prospecting bátholithic terranes particular attention should be given (1) the smaller satellitic alkalic intrusives and associated carbonatites and veins as possible sources of thorium; (2) pegmatites, particularly those in country rocks of high metamorphic grade; and (3) veins that may be of younger age than the batholith.

Monazite, zircon, and other minerals refractory to weathering that contain thorium and uranium are generally present in granitic batholiths in small amounts. Upon weathering of the batholiths these minerals commonly accumulate as placers, either as colluvial or alluvial material, and as beach sands. Prospecting for such syngenetic deposits is based on knowladge of the petrology and mineralogy of the igneous rocks of the area and on interpretation of recent or past drainage patterns and coastal history. Panning, rather than radiometric techniques, is the most useful method of prospecting alluvial placers, but airborne surveying is efficient for scouting present-day and fossil-beach placers. Airborne equipment also is very useful in delimiting source areas for placers.

Phosphorites and black shales are the only marine sediments that are known to contain abnormal amounts of syngenetic uranium. Prospecting for such lowgrade deposits is a matter of analyzing radiometrically or chemically those shales and phosphorites found in field mapping, or in prospecting for petroleum. In the United States the gamma-ray logging records of oil and other deep wells in sedimentary terranes is a common starting point, although usually an evaluation 
of the area to be considered involves the delimiting of continental shelf areas favorable for such sedimentation. The relative horizontal uniformity of composition of the shales and phosphorites over large areas necessitates prospecting for minor differences, but rarely is the order of magnitude of the grade changed.

Many near shore marine sediments formed in deltaic, lagoonal deposits, and other shore environments contain interlayered terrestrial phosphatic sands, carbonaceous debris, or coals that are capable of adsorbing uranium from sea water. Such rocks may then become lowgrade syngenetic sources of uranium.

\section{GUIDES TO ORE DEPOSITS}

Once a district has been found to contain abnormal concentrations of uranium, even though well below ore grade, various guides can be applied in the search for ore deposits. These can be grouped as structural, lithologic, mineralogic, and chemical; no single guide, or group of guides, is infallible.

Many methods have been used to show graphically these geologic guides. Structure contour and isopach maps, on scales commensurate with the size of the feature being studied, have been used to good advantage to show the configuration and thickness of favorable formations, beds, lenses, and channel fills as well as ore bodies, ore shoots, mineralized ground, and alteration zones. In the Black Hills of South Dakota and Wyoming, where uranium deposits appear most abundant on anticlinal and terrace structures, structure contours drawn on the top of the sandstone host rock have been used successfully in finding concealed deposits. Similar maps drawn on the base of the sandstone host in the Colorado Plateau have been used to delimit channels in which concealed deposits were found by drilling. Such maps used in conjunction with isopach maps of the sandstone fill in channels and of alteration zones in the underlying siltstones allow more accurate prediction of buried ore. Structure contour and isopach maps also allow the location of zones of interfingering of sandstones and shales, a favorable area for deposits. Contour maps of facies changes and of the sandstone: shale ratio are also used; areas with a sandstone: shale ratio of $1: 1$ are very favorable for ore.

Maps showing the frequency of distribution of rock types, mineral types, grain size, and element or compound content of rocks, soils, plants, and waters are commonly used (together with other data) to outline areas for prospecting, and in some places, to direct exploration. Contour maps of the ground-water surface, together with maps of fluorine content in the water, have been used by D. M. Sheridan (oral communication), in the Red Desert area, Wyoming, as guides to the caliche-type schroeckingerite deposits. In North and South Carolina, heavy-mineral content determined by panning gravels has been used to contour the favorability of broad areas as sources of monazite. These and many other techniques in common use by scientists have been adapted to the search for uranium and thorium with considerable success.

Epigenetic deposits of uranium in igneous and metamorphic terranes occur as fillings in fractures, faults, and shear zones; less commonly as replacements of limestone and other wall rocks. Veins containing $\mathrm{Co}$, $\mathrm{Ni}$, and $\mathrm{Ag}$ or $\mathrm{Cu}, \mathrm{Pb}, \mathrm{Zn}$, and $\mathrm{Ag}$ minerals appear more favorable for pitchblende deposits than do other metal associations (Everhart and Wright, 1953); Mo minerals commonly occur with brannerite; and Ti minerals with davidite. In the United States the epigenetic deposits are commonly clustered in areas close to post-Cretaceous igneous rocks and structural features. Guides useful for finding ore in districts of this type are:

Structural guides.-Explosion breccia and solution pipes, diatremes, or dikes, open or tensional parts of faults, fractures, and shear zones; contacts of dikes and sills; ore shoots at intersection of faults and fractures.

Lithologic guides.-Dikes, sills, and small stocks of alkalic and fluorine-rich intrusives; carbonate, hornblende-biotite-, or garnetrich wall rocks.

Mineralogic guides.-Seattered yellow and green secondary stains and minerals on fractures or in altered wall rock; radioactive iron and manganese gossans; $\mathrm{Co}, \mathrm{Ni}$, and $\mathrm{Ag}$ minerals; $\mathrm{Pb}, \mathrm{Zn}, \mathrm{Cu}, \mathrm{Ag}$ minerals; Mo minerals; Ti minerals; fluorescent silica druses; smoky quartz; dark-purple to black fluorite; golden beryl; carbonate-feldspar gangue.

Chemical guides,- More $\mathrm{K}$ than $\mathrm{Ca}$ and abnormal $\mathrm{F}$ in probable source rocks; more $\mathrm{Fe}$ (II) than $\mathrm{Fe}$ (III) or high $\mathrm{Ca}$ in wall rocks; more $\mathrm{Fe}$ (III) than $\mathrm{Fe}$ (II) in the veins; $\mathrm{Bi}, \mathrm{Co}, \mathrm{Ni}, \mathrm{Ag}$ in vein material.

The guides to epigenetic deposits of thorium are similar to those for uranium except that ferrous iron in wall rocks does not appear to control deposition; secondary yellow stains are rare; abundant deep-red to purplish-red iron oxides are common; $\mathrm{Nb}, \mathrm{Ba}, \mathrm{P}$ and rare earths are abundant; carbonatite masses or veins are distinctive lithologic guides.

In the United States inereasing numbers of uranium deposits are being found in depositional and structural basins filled with terrestrial sandstones, mudstones, and low-rank coal. Geochemical, botanical, and radiometric prospecting in such areas have been useful. Abnormal amounts of selenium, arsenic, iron, zinc, manganese, and also uranium and vanadium in plants, soils, waters, and petroleum products, aid in outlining areas favorable for the occurrence of uranium deposits. Many of these rocks are of Tertiary age and many contain, or are associated with, abundant volcanic debris as ash beds or as ash mixed with sand or mud. Considerable success in prospecting has been had by examining areas of porous or carbonaceous beds beneath 
formations rich in volcanic debris on the assumption that uranium has been leached from this debris and concentrated in favorable beds at depth (Love, 1952). These basins, which lie at altitudes of 3,000 to 8,000 feet and are areas of relatively recent crustal movement, may have been much closer to sea level at the time of formation and later uplifted with concurrent mild flexing and faulting. In some places subsurface data shows a general geographic correlation of "basement" highs-possible intrusive rocks or deepseated tectonic structures - and uranium districts; in other places buried faults appear important. However, the localization of individual deposits (Weir, 1952) seems to be more closely related to favorable local sedimentary structure features host rocks, and chemical environment. Any of these factors may predominate in an ore deposit, within a single area or between several areas. Guides that have been used to locate deposits are summarized below.

Structural guides.-Low anticlines, terraces, domes, or other features showing abrupt changes in dip of permeable host rock below an impermeable cap rock; channels and swales cut in a relatively impermeable formation below the channel-filling sandstone host rocks; faults, fracture and shear zones, and breccia pipes cutting porous or nonporous beds; zones of sandstone interfingering with shales; thickened parts of lenses.

Lithologic guides.-Crossbedded, medium to coarse, variable textured sandstone; carbonaceous sandstones and shales; sub- bituminous coal and lignite, especially in contact with porous beds; pyroclastic-rich beds overlying coal and sandstone; areas of abnormal quantities of iron and manganese oxides, carbonate, silica, or clay cements; clay pellet conglomerate and sandstone; carbonized wood; sandstone and shale in about equal proportion; unusual colors in sandstone or shale, for example, white sandstone or mudstone grading into buff, yellow, red, brown, pink, or purple; colored sandstone altered irregularly to white, gray, or green; red shale or siltstone altered to gray, green, or white below sandstone; abundant concretions of iron oxide or manganese oxide, carbonate, silica; arkosic rocks.

Mineralogic guides.-Yellow or green secondary encrustations or grains; jarosite; iron-manganese carbonates; vanadium, silver, or copper minerals; carbon.

Chemical guides.-Unusual quantities of V, As, Se, Mo, Zn, $\mathrm{Cu}, \mathrm{Co}, \mathrm{Ni}, \mathrm{Mn}, \mathrm{Fe}, \mathrm{Ra}, \mathrm{He}$ in rocks, soils, natural gas, petroleum, asphaltic residues, surface and subsurface water; silicification of sandstone and shale enclosing carbonate-cemented sandstone; phosphate-rich sandstone.

\section{REFERENCES CITED}

Everhart, D. L., and Wright, R. J., 1953, The geologic character of typical pitchblende veins: Econ. Geology, v. 48, p. 77-96.

Love, J. D., 1952, Preliminary report on uranium deposits in the Pumpkin Buttes area, Powder River Basin, Wyoming: U. S. Geol. Survey Cire, 176, 37 p.

Lovering, T. G., 1955, Progress in radioactive iron oxides investigations: Econ. Geology, v. 50, p. 186-195.

Weir, D. B., 1952, Geologic guides to prospecting for carnotite deposits on Colorado Plateau: U. S. Geol. Survey Bull. 988-B, p. 15-27. 



\title{
ROCK ALTERATION CRITERIA IN THE SEARCH FOR URANIUM
}

\author{
By PaUl F. Kerr, Columbia University
}

\section{CONTENTS}

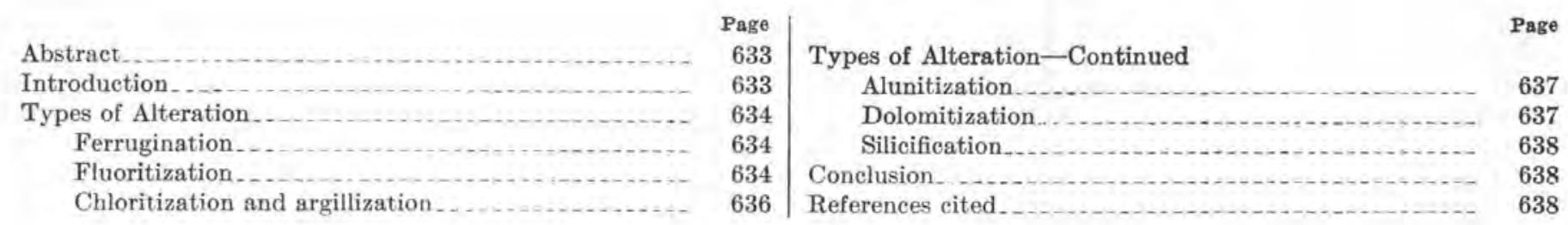

\section{ILLUSTRATIONS}
Plate 12. Areas of ferrugination bordering a collapse feature at Temple Mountain, Utah..... Facing 634
13. Big Rock Candy Mountain near Marysvale, Utah. Following 634
14. Vanadium King workings east of Temple Mountain, Utah. Following 634

Figure 185. Map showing alteration zones or channels.186. Sketeh showing a section of a pyrite-native arsenic nodule from Temple Mountain, Utah (after Kerr and Lapham, 1954) ....... 187. Uranium vein at Marysvale, Utah .........

188. An eariy reconnaissance map in the vicinity

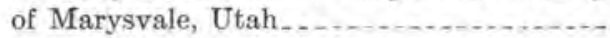

Page

\begin{abstract}
Rock alteration may serve as a guide in the search for uranium. Although the criteria are more obvious in igneous and metamorphic rocks, they are also observed in places in sediments. An outstanding example of rock alteration associated with uranium mineralization occurs at Marysvale, Utah, where solutions primarily responsible for the deposition of pitchblende seem to have reacted with the wall rock to form a halo of clay, chlorite, sericite, and quartz. At some uranium-bearing ore zones in northwestern Canada and in the Sunshine mine, Idaho, red hematitic coloration is associated with the ore. Alteration associated with uranium deposition in the Colorado Plateau sediments has recently been recognized. However, its extent and signifieance is only partly established. In several isolated sites at Temple Mountain, Utah, solutions have penetrated sediments, dissolved underlying limestone and appear to have caused the collapse of the overlying sandy strata. This has been accompanied by local deformation, bleaching, upward chemical transfer and, in places, uranium deposition.

Evidence is increasing that study of rock alteration may be of value in prospecting for uranium, and that is should be used with the generally recognized geological and geophysical methods.
\end{abstract}

\section{INTRODUCTION}

Alteration features associated with uranium mineralization have received somewhat less attention than the phenomenon merits because: radioactivity counters and scintilation devices often furnish a direct indication of ore bodies; thick sedimentary sections in which alteration criteria often are not recognized; very localized effects such as the red stain that accompanies some pitchblende veins.

Alteration effects associated with uranium mineralization in igneous or metamorphic rocks appear to be more readily detected than those in sediments. The argillic halos that accompany veins in quartz monzonite at Marysvale, Utah, are easily recognized features. On the other hand, alteration effects in the Colorado Plateau sediments may receive little attention. This paper outlines the types of alteration which are found with uranium mineralization excepting those in pegmatite occurrences since the latter have not proved to be of economic significance.

This investigation is based on datafrom the literature as well as recent detailed studies of uranium deposition at Marysvale, Utah; a current investigation of Temple Mountain on the San Rafael Swell, Utah; reconnaissance in the western United States and Canada; and previous studies of hydrothermal alteration associated with copper mineralization at Santa Rita, N. Mex., and Silver Bell, Ariz. 
F€w of the alteration criteria associated with uranium deposits differ appreciably from those of copper, zinc, tungsten, and other metals. However, their applicability to uranium is selective. The term alteration is applied here to the development of clay mineral halos, chloritization, alunitization, fluoritization, carbonatization, silicification and ferrugination. It is noteworthy that the criteria of contact metamorphism in general have not been applicable to the United States uranium deposits.

\section{TYPES OF ALTERATION}

Significant alteration effects in certain uranium and metal deposits are believed to be indicative of hydrothermal activity. Much applicable information is found in the studies of Lovering (1949) at Tintic, Utah; Sales and Meyer (1948) at Butte, Mont.; Peterson, Gilbert, and Quick (1946) at Castle Dome, Ariz.; Stringham (1953) at Bingham, Utah; Williams (1952) at Park City, Utah; and Leroy (1945) at Santa Rita, N. Mex.

Hydrothermal solutions traversing faults, fractures, or shear zones generally react with the wall rock so that a sequence of alteration develops. Although these vary with the character of the rock, chlorite and montmorillonite are two of the earliest minerals to form at the expense of the wall rock; they tend to be prevalent around the margins of altered areas. Somewhat later, and in a more centralized position, kaolinite, some montmorillonite and often illite (hydrous mica) occur. At the core of the altered area dickite may be associated with kaolinite, or kaolinite with illite. Often sericite and silicification are found at the center. Although no two districts in which alteration of this type has been described are identical, most exhibit a progressive sequence of various degrees of wall rock replacement. Maps of these altered areas frequently reveal important trends in metallic mineralization which may favor certain of the alteration stages. Such maps have been made of the copper deposits at Santa Rita, N. Mex. (Kerr and others, 1950) and Silver Bell, Ariz. (Kerr, 1951). More recently a similar study (fig. 185) has been made of the uranium-bearing area at Marysvale, Utah (Kerr and others, 1956).

Types of hydrothermal alteration, believed to be related to the general process of uranium emplacement, particularly in the western United States include ferrugination, fluorization, chloritization and argillization, alunitization, and dolomitization.

\section{FERRUGINATION}

Iron is one of the most common elements associated with uranium. In fact, the identification of pitch- blende may be hindered by the intimate mixture of finegrained pyrite. In the replacement of wood siructure in logs and of other plant remains in the Shinarump conglomerate at White Canyon, Utah (Miller 1953), cells of wood structure may be filled either with pyrite, chalcopyrite or bornite, and cell walls may be replaced by pitchblende. $\mathrm{H}_{2} \mathrm{~S}$ derived from decayed vegetation is thought to have fixed the iron in the sulfide form.

Hematitic alteration produces shades of red which are found with certain veins in the Canadian Shield, and in the Sunshine mine, Idaho (Kerr and Robinson, 1953) where color intensity varies directly with the amount of pitchblende. It is thought that during hypogene vein formation, given sufficient temperature, the ferrous ion may change the uranyl ion to the uranous ion and thus cause the precipitation of pitchblende. At the same time the resultant ferric iron forms hematite which is essentially colloidal and acts as a pigment for the accompanying colloidal silica. Dawson (1951) has called attention to the hematitic alteration of wall rock with pitchblende-bearing veins in the Goldfields region, Saskatchewan, Canada. A somewhat similar coloration is found at depth in some of the Marysvale veins.

Masses of siderite are found near the uranium ores of Temple Mountain, Utah (pl. 12). Field and analytical data seem to indicate that the upward-moving thermal solutions removed iron from the underlying ferruginous sediments and redeposited it as siderite in veins and replacement masses at a higher level. Although the uranium occurs in asphaltite, it may be closely associated with pyrite. A nodule (Kerr and Lapham, 1954) of this material is illustrated in Figure 186.

\section{FLUORITIZATION}

Because the oxides $\mathrm{UO}_{2}, \mathrm{ThO}_{2}, \mathrm{CeO}_{2}$ and $\mathrm{CaF}_{2}$ all have a face-centered cubic "fluorite" lattice with a unit cell close to $5.50 \AA$, it is not astonishing that they prefer the same geochemical enviro ument. According to Phair and Shimamoto (1952) who describe euhedral uranothorite inclusions in fluorite, it seems probable that the association of uranium, thorium, and rare earth minerals may prove extensive in fluorite-rich hydrothermal deposits. Kerr and Dahl (1953) note microscopic particles, presumably pitchblende, in highly radioactive fluorite at Grants, N. Mex. Brown, Emery, and Meyer (1954) note an interesting radioactivity anomaly which is associated with fluorite at Hicks' Dome, III. Bray (1942) reports pitchblende in fluorite which is associated with pyrite, galena and sphalerite at Jamestown, Colo., and Lovering (1954) describes radioactive fluorite in veins and pipelike bodies east of Beatty, Nev. Black or extremely dark- 


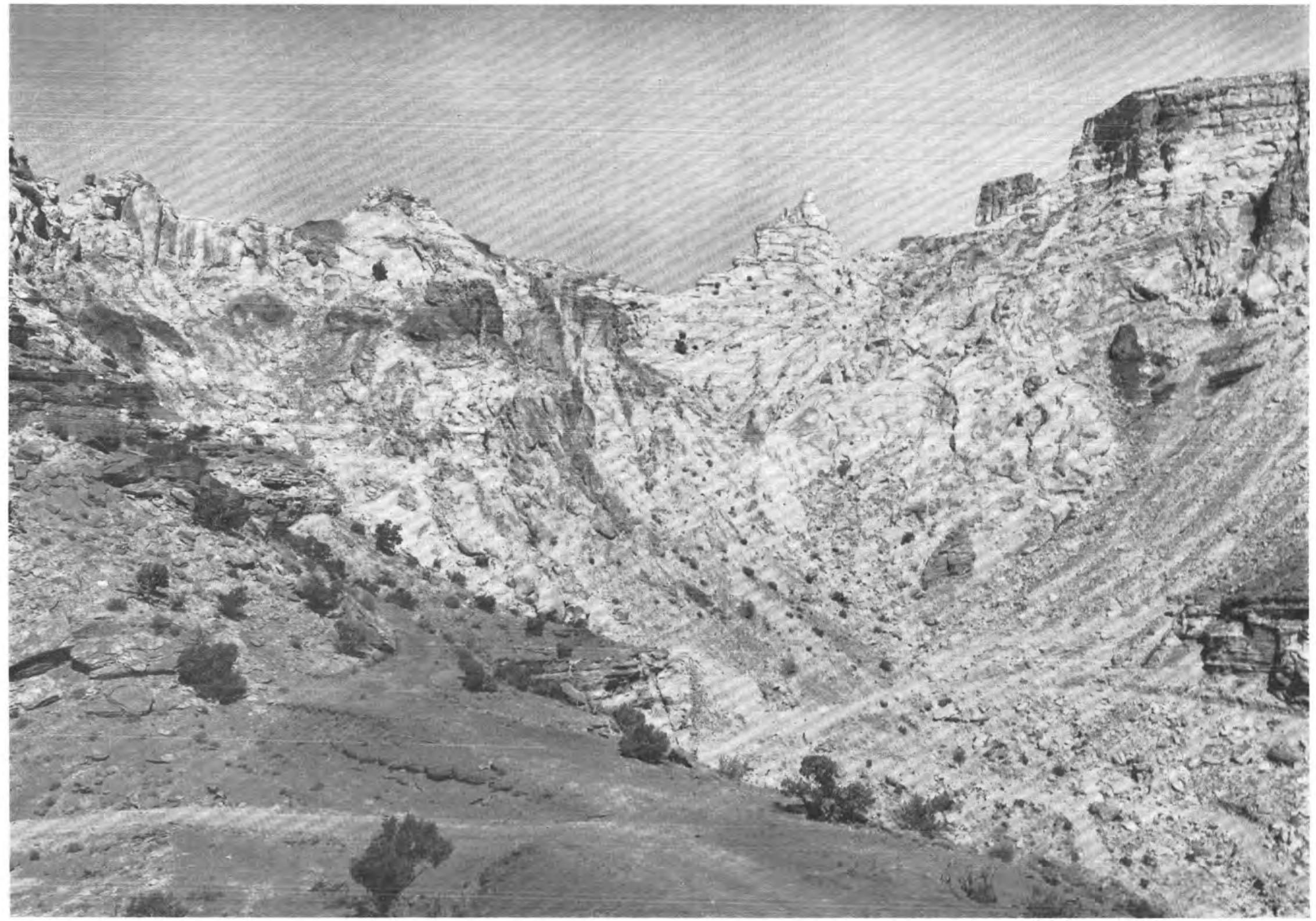

AREAS OF FERRUGINATION (DARK) BORDERING A COLLAPSE FEATURE AT TEMPLE MOUNTAIN, UTAH 


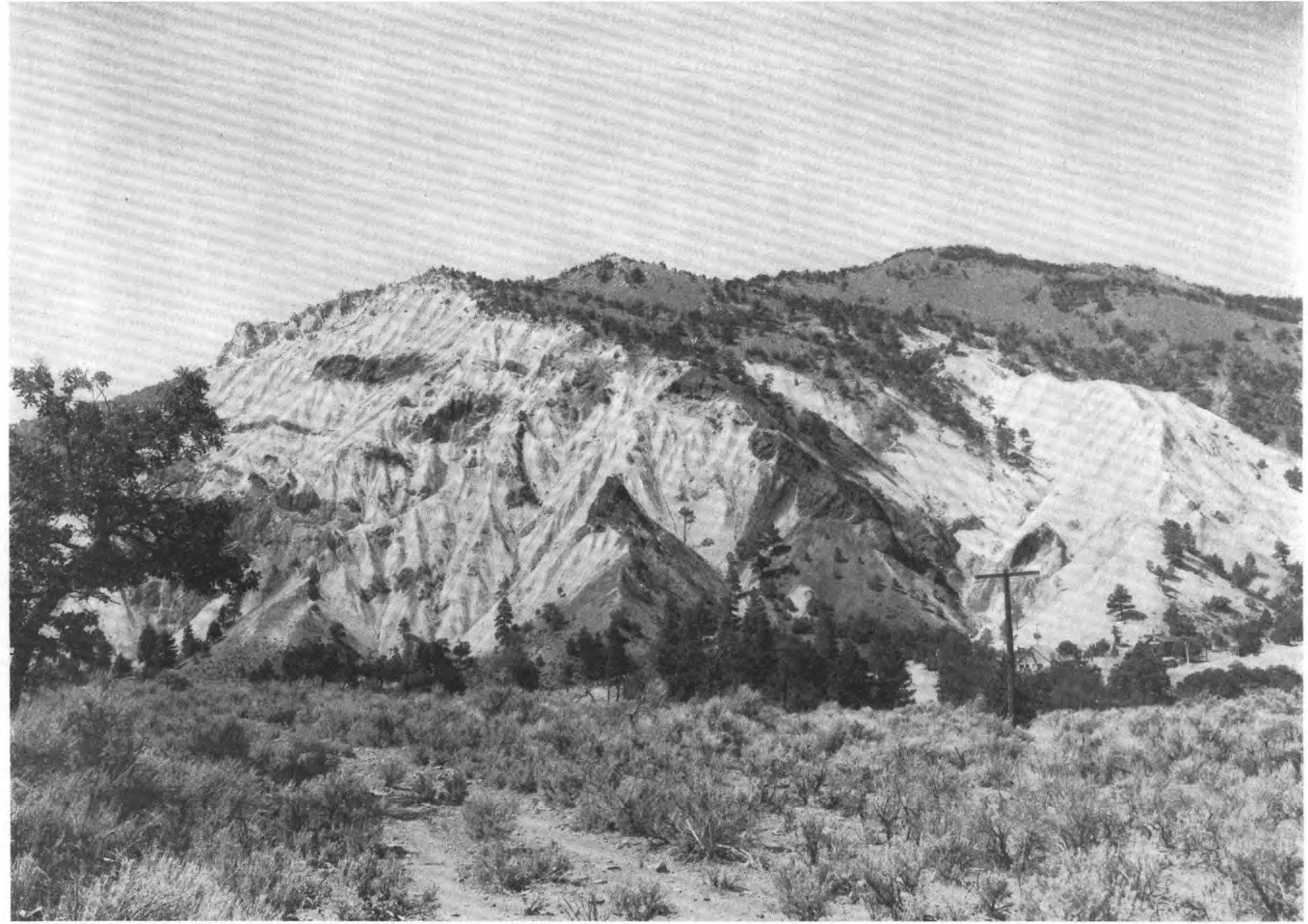

AN ARGILLIC AND ALUNITIC AREA FORMED BY ALTERATION OF A VOLCANIC AGGLOMERATE AT BIG ROCK CANDY MOUNTAIN NEAR MARYSVALE, UTAH 


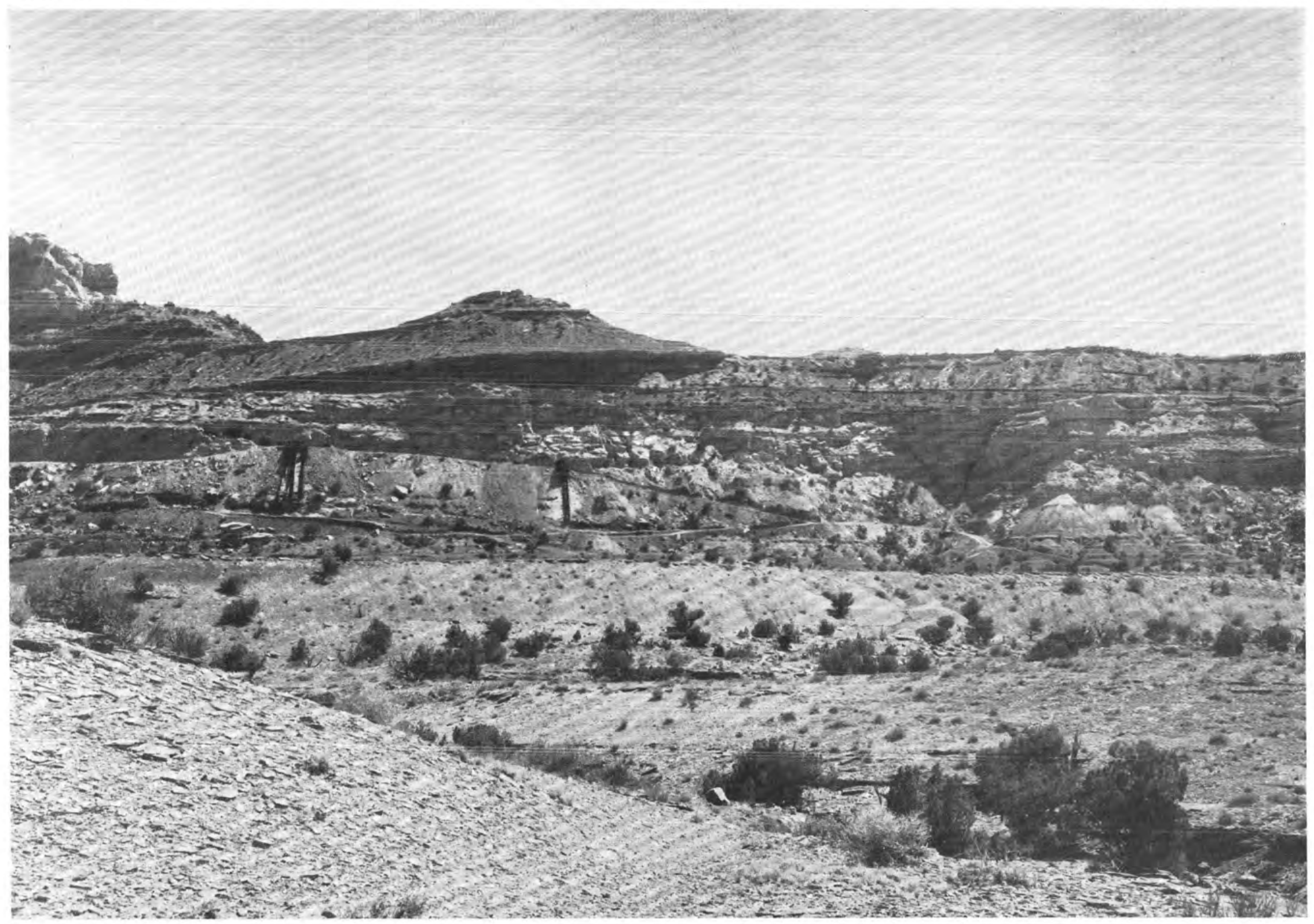





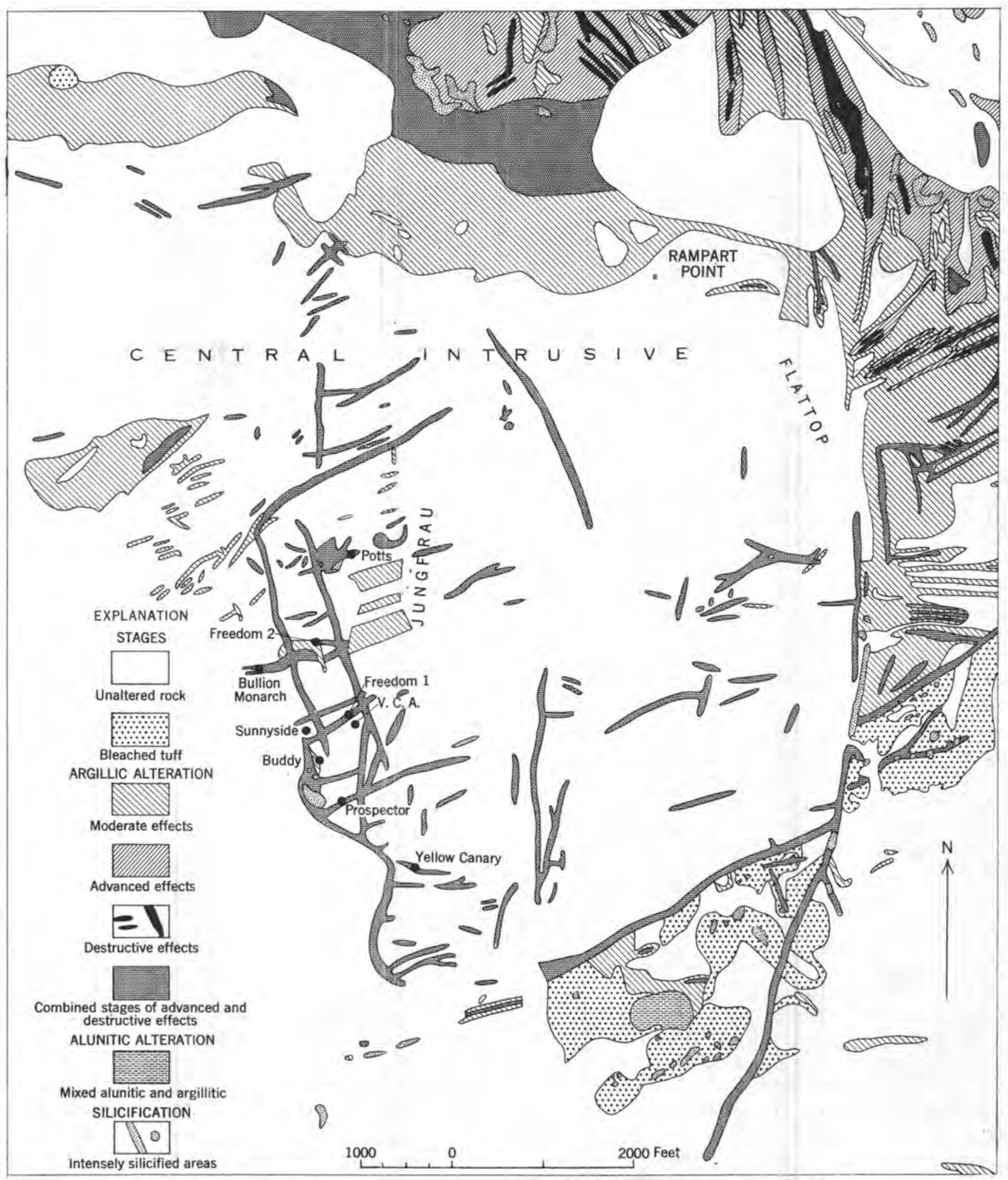

FIGURr 185.-Map showing aiteration zones or channels in part of the Marysvale dlstrlet, Utab. 

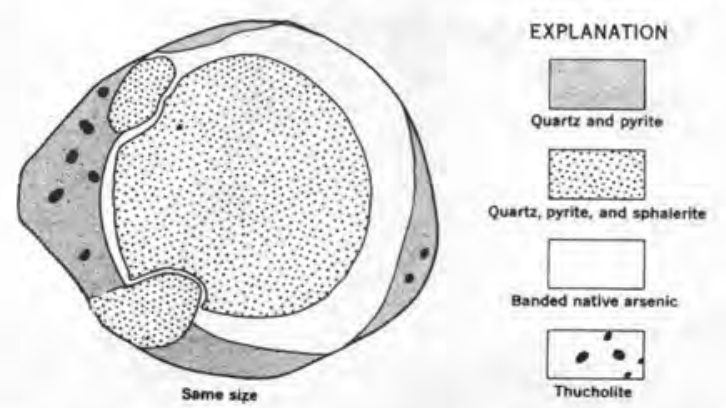

FIGURE 186.-Sketch showing a section of a pyrite-native arsenic nodule from Temple Mountain, Utah (after Kerr and Lepham, 1954).

purple fluorite is commonly associated with radioactivity at Marysvale. In fact, in western areas the widespread occurrence of such fluorite is frequently considered significant in the search for uranium.

\section{CHLORITIZATION AND ARGILIIZATION}

Argillic alteration associated witb uranium mineralization is illustrated at Marysvale, Utah (Kerr and others, 1956) where an airborne radiometric survey of the mining area shows radioactivity anomalies that correspond to areas of alteration. The area in which the effects (pl. 13) are most noticeable is about 7 miles square, and it is clearly outlined by white or iron stained clay. The clay-filled channels (figure 185) which constitute the veins at Marysvale have a wide range in clay and uranium content. They provided the conduits along which uranium-bearing solutions migrated upward, as shown by a radiometric comparison of the wall-rock and vein. The principal uranium mineral of the veins is pitchblende (fig. 187) although secondary uranium minerals are found near the surface, and the rare uranium molybdenum mineral umohoite (Brophy and Kerr, 1953), occurs in one of the mines.

The association of argillic alteration and pitchblende is most common at Marysvale in quartz monzonite. Preceding alteracion the feldspar grains are lustrous and the ferro-magnesian minerals, if present, are generally unchloritized. As alteration begins a cbloritie zone develops in which plagioclase tends to become dull and biotite to be chloritized. This occurs not only at Marysvale but at places in the Boulder batholith in Montana (Sales and Meyer, 1948), in southwestern New Mexico near Silver City (Kerr and others, 1950) and along the Colorado Front Range. Rocks in which ferromagnesian minerals are scarce may yield a montmorillonite rather than a chloritic zone.

The two most conspicuous clay minerals of the dominantly argillic stage at Marysvale are montmorillonite and kaolinite. As alteration becomes more intense, rock texture is destroyed, and illite develops. In places this stage is accompanied by the introduction

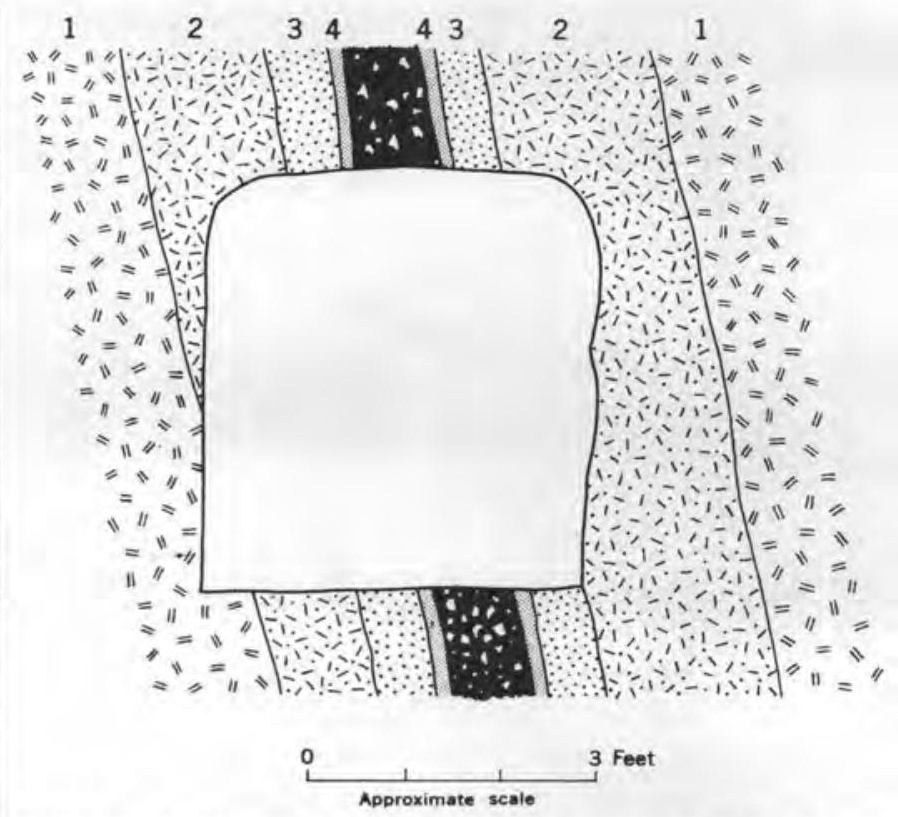

Figure 187,-Pitchblende vein at Marysvale, Utah, showing (1) unaltered quartz monzonite, (2) chlorite-bearing zone, (3) montmorillonite-illite zone, and (4) kaolinite-illite (or hydrous mica) zone which borders the fluorite-quartz-uraninite breccia zone (black).

of fluorite. Toward the close of the argillic stage, or perhaps later, the main precipitation of pitchblende and pyrite is believed to occur.

Patches of altered rock similar to those at Marysvale are found within a radius of 20 miles. It seems, therefore, that the alteration is widespread, and comparatively recent as determinations of the Marysvale pitchblende by J. L. Kulp (oral communication 1955) indicate an age of about 10 million years. Altered patches, perhaps an extension of the Marysvale pattern, have been observed in volcanic rocks near the margin of the Colorado Plateau. A center of hydrothermal activity concealed beneath the sediments of the Plateau could have provided a source for the accumulation of uranium in sediments.

Recent studies along the San Rafael Swell (Kerr and others, 1956) and elsewhere contribute criteria which may provide an approach to the problem of alteration and uranium in sediments. Weeks (1952, written communication) reports gray shale at the Scenic No. 4 claim in the White Canyon area, Utah, which is completely kaolinized. Green clay zones, although widely distributed in the Moss Back sandstone of the San Rafael Swell, have not as yet been found to be related to ore deposition. However, around the inward-facing escarpment faults, which are accompanied by bleaching and in places by uranium mineralization, cut the Moss Back and other members of the Chinle formation. These bleached rocks (pl. 14) are yellowish brown (in contrast to the adjoining red or 
dark brown strata) and appear to extend up along fault lines, with an appearance of enlargement in the siltstone below the Shinarump.

Laboratory study of this bleached material indicates the presence of kaolinite and illite. Although further investigation is necessary, the form and mineralization of the bleached zones suggests upward-migrating solutions. Since significant uranium mineralization occurs in association with such a zone at Temple Mountain, this criterion seems worthy of consideration.

\section{ALUNITIZATION}

Alunite occurs commonly near uranium deposits, although the relationship and significance of such association remain largely undetermined. At Marysvale extensive areas of alunite (fig. 188) have formed by hydrothermal alteration of tuffs and pyroxene andesites. The major hydrothermal alunitization seems to precede uranium mineralization, but there is some alunite which is an end-stage product.
Alunite and kaolinite have been found in veinlets in conglomerate of the Moss Back member at Temple Mountain where they occur around the margin of the ore-bearing area, and seem to resemble caliche in outcrop. Alunite is reported in several of the other Plateau uranium deposits. Gruner and Gardiner (1952) report it in the Moenkopi of the Capitol Reef area, Utah; at Deer Flats north of White Canyon, and southeast of Fruita, Utah. Weeks (written communication, 1952) finds alunite at the Skyline claim, Monument Valley, Ariz., where it fills joint cracks in altered arkosic sandstone.

\section{DOLOMITIZATION}

Dolomitization appears to have attracted less attention than it warrants in the study of uranium deposition in sediments. Dolomitization of the Wingate sandstone occurs at several places on Temple Mountain, where it forms distinctive brown patches. This remarkable change from a rather pure eolian sandstone

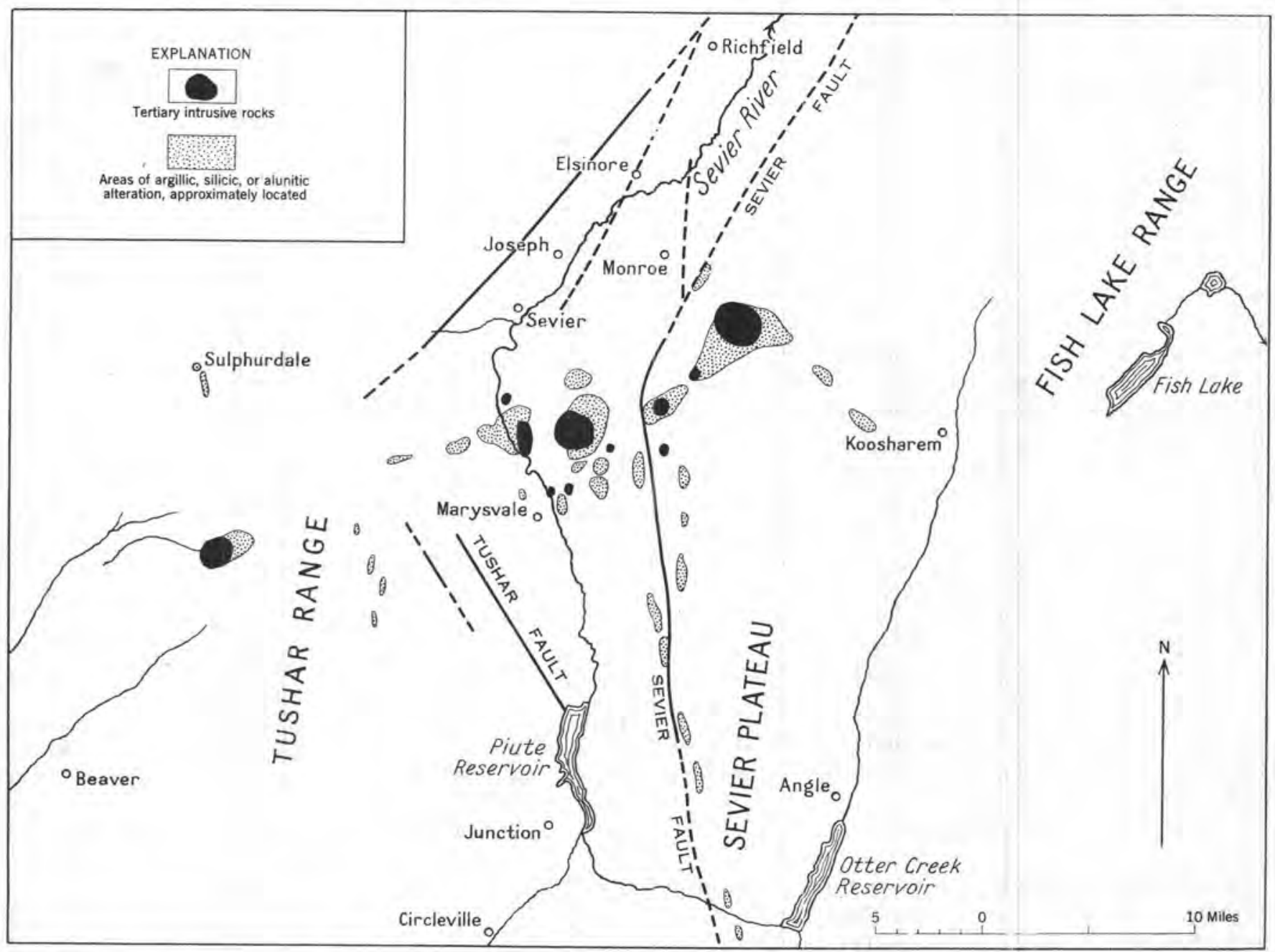

FIOURE 188,-An early reconnaissance map in the vicinity of Marysvale, Utah, showing the general distribution of clay zones, silifcation, and alunite bodies. 
to a massive dolomite is gradual, but it occurs in three recognizable stages.

The first stage of dolomitization is "nodular impregnation" in which nodular dolomite surrounds suspended unaltered sand. These nodules have an average diameter of about one-half inch, and occur in patches from a few to hundreds of feet across. They tend to follow the Wingate sandstone, but may extend across the beds or occur in irregular masses which penetrate the underlying sandstone of the Chinle formation. The second stage is "interstitial impregnation" in which dolomite replaces quartz grains within the nodules as well as in the areas between the nodules. In thin section a radial strain which is relict of the nodular form may be present. The third stage is "massive replacement" in which the nodular development is completely obliterated and sand grains of the Wingate are completely replaced.

The relation between dolomitization and uranium deposition is indirect. The dolomite at Temple Mountain occurs near areas of solution stoping which are referred to as "collapse features" (Kerr and others, 1955). These have been interpreted as breccia pipes, but it seems likely that they result rather from solution and collapse. Thermal solutions that penetrated carbonate and arenaceous sediments have produced cavities into which great blocks of overlying strata have fallen. The collapsed zones seem to be funnel shaped in cross section and to originate along faults. Their surface exposure is circular or elliptical, with a maximum diameter of 1,000 feet. Although uranium is sparse in these areas, it occurs nearby in greater concentration. The uranium-bearing asphaltite is found in veinlike masses that cut the dolomite. The emplacement of uranium seems, therefore, to be later than dolomitization.

It seems reasonable that the sequence of solutions that removed calcium and magnesium from the underlying strata and deposited them in the Wingate sandstone as dolomite also could have introduced the uranium. Scattered uranium occurrences throughout a vertical length of 1,500 feet of exploratory drilling seem to support this theory. It is likely, therefore, that the dolomitic areas at Temple Mountain are indicative of solution action on sediments. In turn, this suggests that (on the San Rafael Swell at least) dolomitization may indicate nearby uranium emplacement.

\section{SIIICIFICATION}

The relation of silicification to uranium mineralization is worthy of consideration. Often there is no immediate application to uranium discovery, as illustrated by the silicified logs in the uranium deposits of the San
Rafael Swell. Large masses of conglomerate of the Moss Back are silicified, but thus far they have failed to yield uranium. Nevertheless, bodies of silicified rock in the vicinity of uranium deposits merit investigation. One surface mass of silicified rock at Marysvale overlies an extension of the Bullion Monarch vein system, a system that has been highly productive of uranium. In this area, cherty quartz stringers are associated with high-grade pitchblende ore, and the fluorescence of chalcedonic nodules may be due to contamination by uranium. The role of silicification probably varies with the type of deposit, the generations of mineralization, and the associated rock types.

\section{CONCLUSION}

The criteria of rock alteration that are useful in the search for uranium bear a striking resemblance to those for other metals. However, conditions may vary with the locality, and render recognition much more difficult. This is true of the Colorado Plateau sediments in comparison with areas of igneous or metamorphic rocks. Argillic alteration and dolomitization are believed to represent earlier stages in the ore-forming process in the sediments at Temple Mountain. Significant alteration features in hydrothermal uranium deposits appear to include: ferrugination, as shown by widely distributed pyrite and hematitic coloration; fluoritization, as shown by the association of fluorite and pitchblende; chloritization and argillization, as shown by wall rock alteration which follows or accompanies uranium emplacement; alunitization, depending upon depositional environment; and dolomitization, as shown by its proximity to uranium deposition.

\section{REFERENCES CITED}

Bray, J. M., 1942, Minor chemical elements in fluorites from Jamestown, Colo.: Am. Mineralogist, v. 27, p. 769-775.

Brophy, G. P., and Kerr, P. F., 1953, Hydrous uranium molybdate in Marysvale ore; in Annual report for June 30, 1952 to April 1, 1953: U. S. Atomic Energy Comm. RME-3046, p. 26-44, issued by U. S. Atomic Energy Comm. Tech. Inf. Service, Oak Ridge, Tenn.

Brown, J. S., Emery, J. A., and Meyer, P. A., Jr., 1954, Explosion pipe in test well on Hicks Dome, Hardin County, Ill.: Econ. Geology, v. 49, p. 891-902.

Dawson, K. R., 1951, A petrographic description of the wallrocks and alteration products associated with pitchblendebearing veins in the Goldfields region, Saskatchewan: Canada Geol. Survey Paper, no. 51-24, 58 p.

Gruner, J. W., and Gardiner, Lynn, 1952, Mineral associations in the uranium deposits of the Colorado Plateau and adjacent regions with special emphasis on those in the Shinarump formation, Part III, Annual report, July 1, 1951 to June 30, 1952: U. S. Atomic Energy Comm. RMO-566, 40 p., issued by U. S. Atomic Energy Comm. Tech. Inf. Service, Oak Ridge, Tenn. 
Kerr, P. F., 1951, Alteration features at Silver Bell, Ariz.: Geol. Soc. America Bull., v. 62, p. 451-480.

Kerr, P. F., Kulp, J. L., Patterson, Claire, and Wright, R. J., 1950, Hydrothermal alteration at Santa Rita, N. Mex., Geol. Soc. America Bull. 61, no. 4, p. 275-347.

Kerr, P. F., Brophy, G. P., Dahl, H. M., Green, Jack, and Woolard, L. E., 1956, Alteration and uranium mineralization, Marysvale, Utah: Geol. Soc. America Bull. (in press).

Kerr, P. F., and Dahl, H. M., 1953, Uranium-fluorite association in the Todilto limestone, Grants, N. Mex.: U. S. Atomic Energy Comm. RME-3051, 6 p., issued by U. S. Atomic Energy Comm. Tech. Inf. Service, Oak Ridge, Tenn.

Kerr, P. F., Kelley, D. R., Keys, W. S., Bodine, M. W., Jr., 1955, Annual report for June 30, 1954 to April 1, 1955, Part III. Collapse features, Temple Mountain uranium area, Utah: U. S. Atomic Energy Comm. RME-3110 (Pt. 3), 138 p., issued by U. S. Atomic Energy Comm Tech. Inf. Service, Oak Ridge, Tenn.

Kerr, P. F., and Lapham, D. M., 1954, Report on a nodule from Temple Mountain, in Annual report for June 30, 1953 to April 1, 1954, Part I: U. S. Atomic Energy Comm. RME3096, p. 7-15, issued by U. S. Atomic Energy Comm. Tech. Inf. Service, Oak Ridge, Tenn.

Kerr, P. F., and Robinson, R. F., 1953, Uranium mineralization in the Sunshine Mine, Idaho: Min. Eng., v. 5, p. 495-511.
Leroy, P. G., 1954, Correlation of copper mineralization with hydrothermal alteration in the Santa Rita porphyry copper deposit, New Mexico: Geol. Soc. America Bull., v. 65, p. 739-768.

Lovering, T. S., 1949, Rock alteration as a guide to ore-East Tintic district, Utah: Econ. Geology, Monograph 1, 65 p.

1954, Radioactive deposits of Nevada: U. S. Geol. Survey Bull. 1009-C, p. 63-106.

Miller, L. J., 1953, Uranium ore controls of the Happy Jack deposit, White Canyon, San Juan County, Utah: U. S. Atomic Energy Comm., RME-33, 34 p., issued by U. S. Atomic Energy Comm. Tech. Inf. Service, Oak Ridge, Tenn.

Peterson, N. P., Gilbert, C. M., and Quick, G. L., 1946, Hydrothermal alteration in the Castle Dome copper deposit, Ariz.: Econ. Geology, v. 41, p. 820-840.

Phair, G., and Shimamoto, K. O., 1952, Hydrothermal uranothorite in fluorite breccias from the Blue Jay mine, Jamestown, Boulder County, Colo.: Am. Mineralogist, v. 37, p. 659-666.

Sales, R. H., and Meyer, Charles, 1948, Wall rock alteration, Butte, Mont.: Am. Inst. Min. Metall. Eng. Trans., v. 178, p. 9-35.

Stringham, B., 1953, Granitization and hydrothermal alteration at Bingham, Utah: Geol. Soc. America Bull., v. 64, p. 945991. 



\title{
SUBSURFACE TECHNIQUES FOR OUTLINING FAVORABLE ZONES BY WIDELY SPACED CORE DRILLING
}

\author{
By Robert K. Pitman, Philip H. Dodd, and Charles W. Tom, U. S. Atomic Energy Commission
}

\begin{abstract}
Subsurface mapping techniques for outlining zones favorable for the occurrence of uranium-vanadium ores were tested in the Cottonwood Wash mining area, San Juan County, Utah, by holes spaced 500 to 1,000 feet apart. This is considered wide spacing in the search for the small uranium deposits in the Morrison formation. The techniques employed may be useful in uranium search in other areas where outcrops are few or nonexistent.
\end{abstract}

\section{INTRODUCTION}

The uranium-vanadium ore of the Cottonwood Wash mining area was discovered in the Salt Wash sandstone member of the Morrison formation in 1930 but little ore was mined until 1936.

The area is on the east flank of the Comb Ridge monocline where the eastward dip of the sedimentary rocks flattens from six degrees near the monocline to one degree near the mines. On the eastern flank of the Comb Ridge monocline and in the area of drilling the formations range from the Navajo sandstone of Jurassic and Jurassic (?) age to the Mancos shale of Late Cretaceous age which overlies the Dakota sandstone of Figure 189. The Bluff sandstone of Jurassic age pinches out north and east along an irregular line through the Cottonwood drilling area. Of special interest is the overlying Morrison formation, which includes the Salt Wash and Westwater Canyon sandstone members, and the Brushy Basin shale member. Sand- stone, siltstone, and mudstone beds of the Salt Wash member total about 210 feet in thickness in the mining area. They interfinger with the brown shale of the Recapture shale member of the Morrison about 12 miles to the south, although remnants of Recapture may extend nearly to the mining area. The Westwater Canyon member which is about 150 feet thick, pinches out a few miles north of the Cottonwood mining area. The Brushy Basin shaly member of the Morrison averages 400 feet in thickness.

Vanadium and uranium deposits in the Cottonwood Wash area are mostly of the earnotite type; mill settlement sheets indicate an average ratio of vanadium to uranium of $10: 1$.

\section{DRILLING}

Drilling to discover and block out orebodies during 1950-52 covered an area of about 11 square miles.

Mapping of stream lineation and crossbedding (Stokes, 1954) indicates that streams which deposited the Salt Wash flowed from west to east, which agrees with the regional trends established by Craig and others (1955).

The latest drilling program was designed to extend geologic information east of the known mines and under deeper cover. Holes were drilled at 500-foot intervals along north-south lines; the lines were spaced 


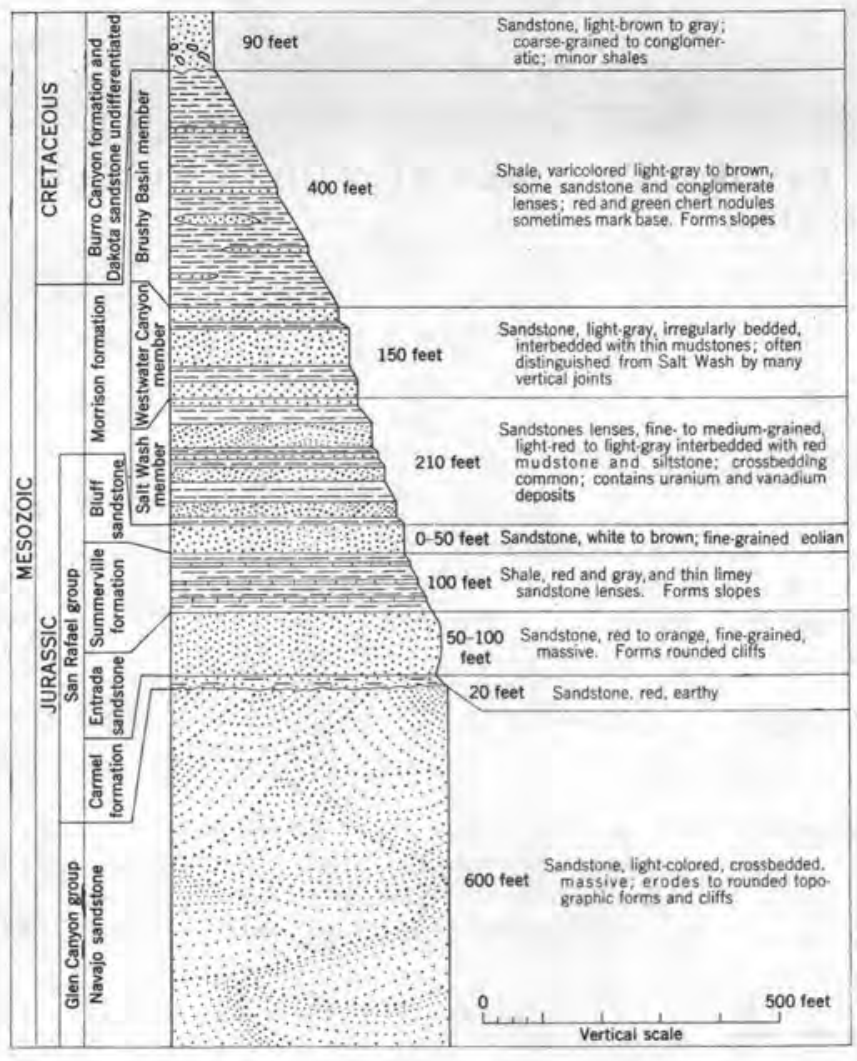

FIGURE 189.-Generalized section in Cottonwood Wash mining area, San Juan County, Utah.

about 1,000 feet apart along the indicated easterly direction of flow of the Salt Wash streams. Drilling depths range from 300 feet in the western part to 850 feet in the eastern part of the drilling area. Maps of the subsurface formations were based on the data thus obtained, supplemented by information collected in earlier drilling.

\section{SALT WASH MEMBER}

Geological investigation of the Salt Wash member has resulted in a concept of deposition of the Salt Wash by a multitude of anastomosing water courses that became filled with sand and smaller particles. The resulting deposition throughout Salt Wash time formed sediments that are today represented by tens to hundreds of feet of interbedded sandstone and mudstone.

Facies of fluvial deposits are believed to reflect environments of deposition in various zones in and adjacent to streams: fast water channel zones, slow water channel margin zones, and slack to semistagnant flood-plain zones which were periodically inundated. Each facies is elongate parallel to flow direction, thus abrupt facies changes are observed in directions normal to the flow. Many facies, both similar and varied, are superimposed one above the other tbroughout the Salt
Wash section. No extensive time horizons are recognizable within the Salt Wash member, and rock units do not represent exact time units. Abrupt lateral facies changes resulting from contemporaneous but different environments of deposition of sandstone and mudstone require acceptance of different rock types witbin small time units.

The direction of flow and deposition by a single stream in a restricted time interval is not necessarily, in fact probably is not, the same as the mean direction of all the Salt Wash streams in one locality. Lack of recognizable time units requires correlation of rock units within a small area, then division into depositional units or cycles. It has been assumed that in general, during a single depositional cycle, the first sediment laid down is sand in the channel and mud on the flood plain; and that, as the depositional cycle progresses, the channel zone becomes filled with sand and mud, and the final layer of the unit is a mud which covers deposits in the old stream bed as well as in the flood plain.

If such a depositional unit is found to contain uranium deposits, and is suspected of containing others, it becomes necessary to trace this unit with a minimum number of drill holes. If several such units are known to be ore bearing each must be treated as a separate entity. This is especially desirable if the facies within a single depositional unit are to be projected.

Because the thickness of depositional units is not constant, the unit, rather than a constant interval, is believed to be the best vehicle in subsurface mapping. Mapping of a single unit is preferred over mapping several combined units or the entire Salt Wash member. Mapping a combination of units results only in the assumed distribution of a synthetic mean facies of a number of noncoeval discrete units.

\section{METHOD OF CORRELATION}

The initial step in correlation is the construction of an isometric diagram showing all holes drilled. With such a diagram it is easier to trace time equivalents because all plotted holes are in their proper spatial relationships. With drill logs plotted, the sandstones and mudstones are correlated (fig. 190). Where a sandstone or a mudstone cannot be correlated from one hole to the next, but adjacent beds do correlate, it is shown as pinching out. After all units are correlated, the top of the first dominant and persistent mudstone below the potentially ore-bearing sandstone is selected as the base of the depositional unit, and the top of the first persistent mudstone above this sandstone is selected as the top of the unit.

Preparation of such a correlation diagram of the same area by more than one geologist may reveal 


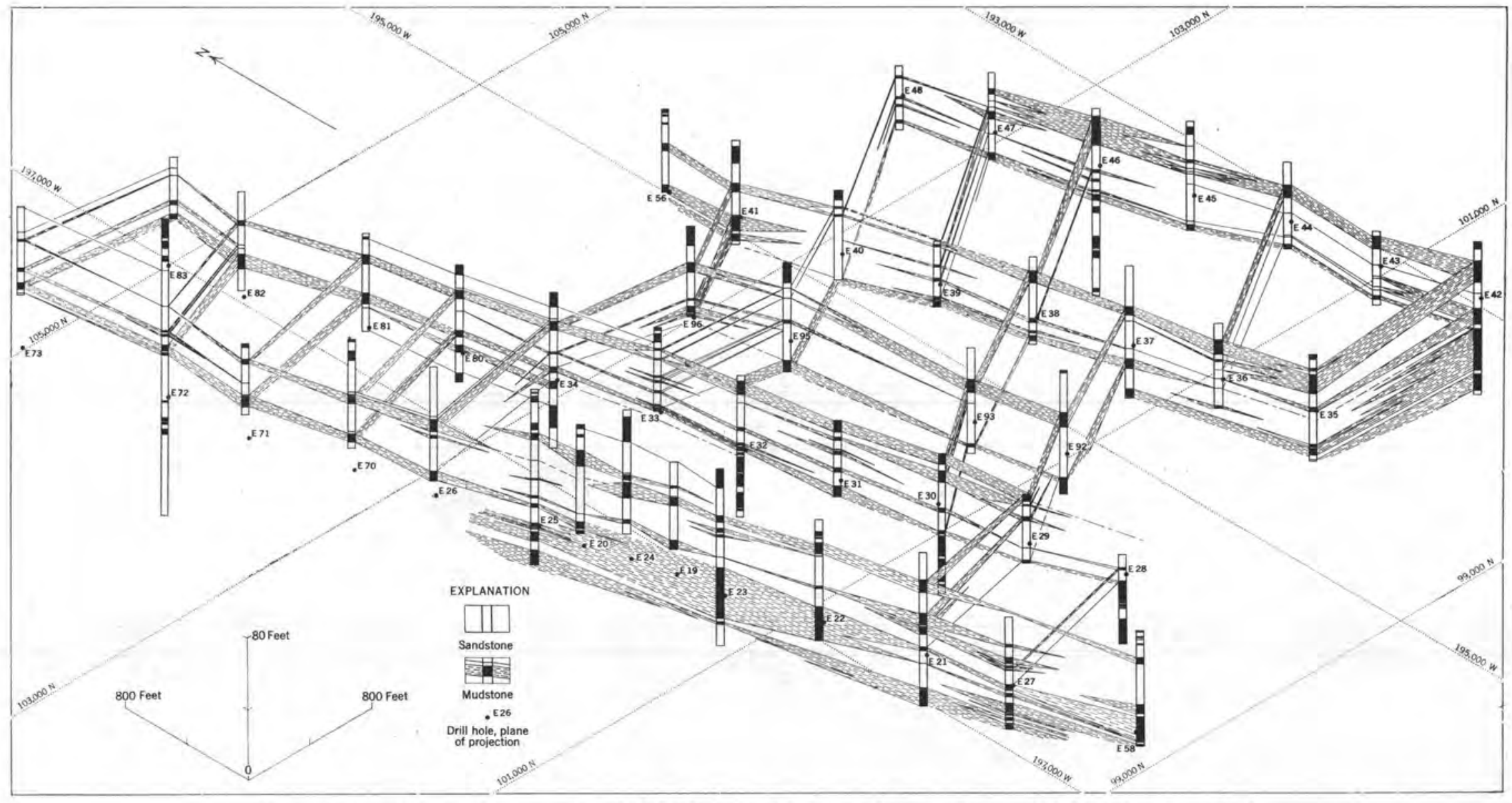

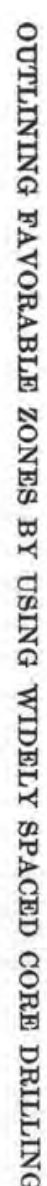

FIGURE 190.-Isometric correlation diagram of part of Salt Wash member of the Morrison formation, Cottonwood Wash, San Juan County, Utah. 


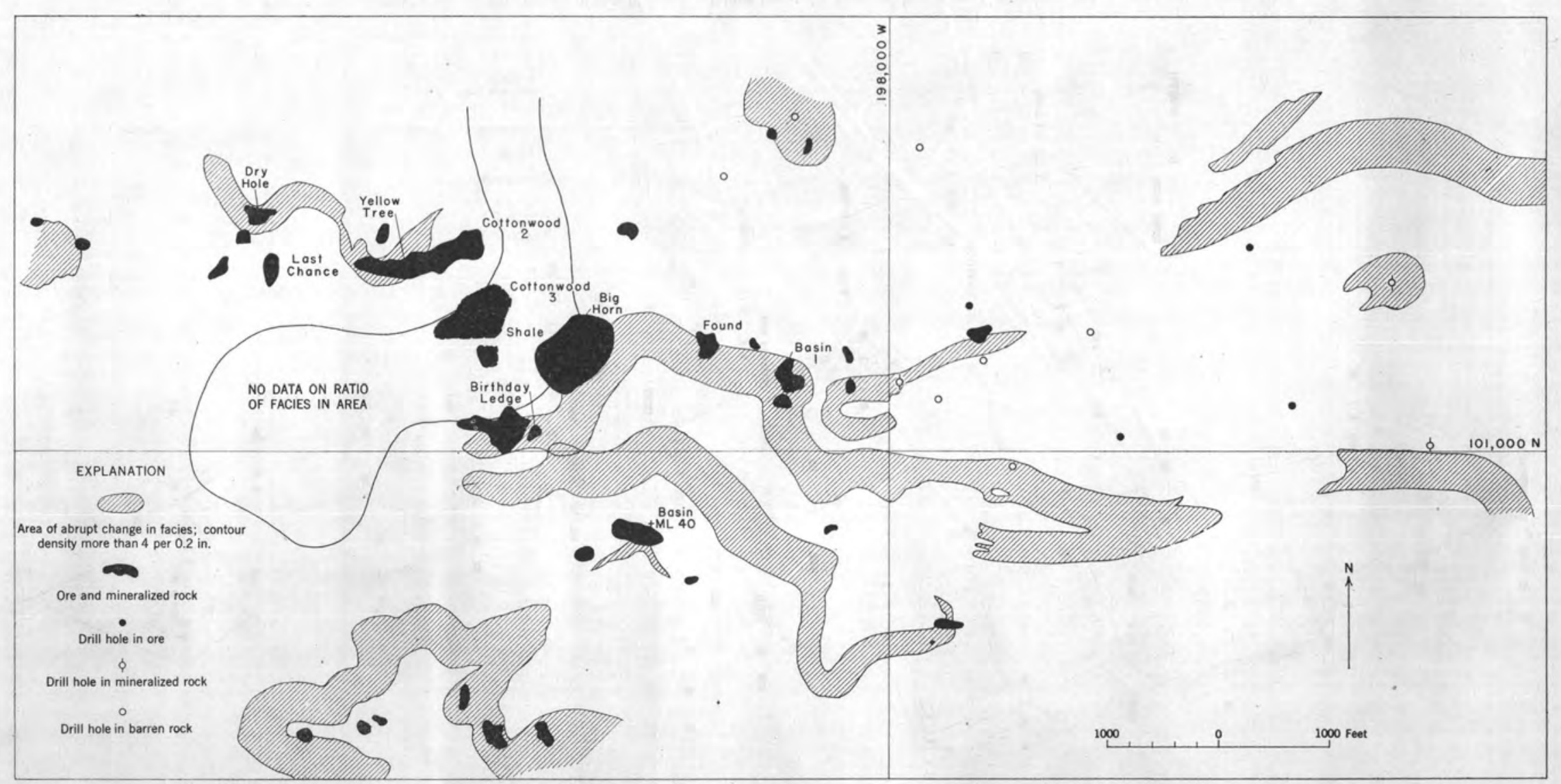

FroURE 191.-Ares of abrupt change in ratio of mudstone to sandstone facies, Cottonwood Wash, San Juan County, Utah. 
fallacious correlation where personal opinion might substitute for concrete and adequate evidence.

When a depositional unit has been established it is possible to construct subsurface maps of the various features of the unit. The accuracy of any map is dependent upon the relationship between the persistency of the feature mapped and the density of observation points. Many types of subsurface maps are possible where hole density is sufficient, but for reconnaissance drilling with widely spaced holes, only features of considerable magnitude and persistence can be mapped.

\section{SUBSURFACE MAPS}

A lithofacies map employing the ratio of mudstone to sandstone content of the depositional unit was found to be most diagnostic where holes are spaced 500 to 1,000 feet apart (pl. 15). The ratio type map is preferred over a sandstone isopach or percentage map, The use of a relatively small contour interval served best to define areas of facies change and to force careful interpretation. Although a numerical interval was used to contour the mudstone-sandstone lithofacies, zones of significant differences may be outlined by shading areas between contours of limiting values of ratios,

Elongate patterns representing similar mudstonesandstone facies not only indicate the trend of deposition, which can be projected for at least 1,000 feet along the trend, but also present a close approximation to distribution of environments represented by the facies.

\section{HYPOTHESIS CONCERNING FAVORABLE GROUND}

Criteria for recognition of favorable ground, other than by mineralization itself, have long been a subject of conjecture. It is believed that the ore deposits are localized in zones of change. The single effective change or combination of changes is unproven. This could be tectonic or sedimentary structure, wall-rock chemistry, physical properties of the host rock, some unknown change, or combinations of these.

The mudstone-sandstone lithofacies map of a depositional unit of the Salt Wash in the Cottonwood area indicates the position of a significant facies change by an increase in density of contours (pl. 15). The interface between a dominantly sandy section and a dominantly muddy section is interpreted as the interface of change for many physical phenomena such as porosity, permeability, and resulting transmissivity. At this interface there is also variation in mineral content and chemical composition, such as variation in abundance of carbon and of iron and sulfide content with the related changes in $\mathrm{Eh}$ and $\mathrm{pH}$.
Several worthy attempts have been made statistically to relate the ore deposits in the Salt Wash to a favorable thickness of host sandstone (Weir, 1952). The values determined by such studies are presumably correct for the areas investigated but do not agree numerically. Possibly all thicknesses designated as favorable in each of the areas represents a similar environment between the fast- and slow-water sedimentation for that particular area. The same may be true for other features found to be statistically favorable in some localities, but the parameter values of these do not agree among the several areas.

In the mudstone-sandstone lithofacies map more than random coincidence is displayed between the location of mineral deposits and the position of facies or environment change (pl. 15). This empirically derived evidence indicates that the interface area between the clean sandstone and the mudstone is the most favorable for ore accumulation. Such interfaces can be located by using data from widely spaced drill holes. Better maps, outlining more types of change, can be drawn if density of control is iacreased by closer spacing of drill holes.

The method described below was used to map quantitatively rates of change. A circle is inscribed on acetate sheet, and a hole punched in the center. The size of the circle is purely arbitrary and must be suited to map scale, relative contour density, and refinement of information required. By placing a pencil in the center hole of the circle and placing the circle on a tracing paper overlay of the contour map, it is possible to draw a line while moving the circle in such a manner that the same number of contours always appear within the circle. This system can be used to circumscribe the area of equal rate of change. It can be seen by superimposing the outline of mineral deposits on the resulting rate of change map that a good correlation exists (fig. 191).

\section{REFERENCES CITED}

Craig, L. C., Holmes, C. N., Cadigan, R. A., and others, 1955, Stratigraphy of Morrison and related formations of the Colorado Plateau region-a preliminary report: U. S. Geol. Survey Bull. 1009-E, p. 125-168.

Stokes, W. L., 1954, Relation of sedimentary trends, tectonic features, and ore deposits in the Blanding district, San Juan County, Utah, Technical report for Apr. 1, 1953 to Mar. 31, 1954: U. S. Atomic Energy Comm. RME-3093 (pt. 1), 33 p., issued by U. S. Atomic Energy Comm. Tech. Inf. Service, Oak Ridge, Tenn.

Weir, D. B., 1952, Geologic guides to prospecting for carnotite deposits on Colorado Plateau: U. S. Geol. Survey Bull, 988-B, p. 15-27. 



\title{
HEAVY-MINERAL PROSPECTING
}

\author{
By William C. Overstreet, Paul K. Theobald, Jr., Jesse W. Whitlow, and Jerome Stone, U. S. Geological
} Survey

\begin{tabular}{|c|c|c|c|}
\hline \multicolumn{4}{|c|}{ CONTENTS } \\
\hline & Page & & Page \\
\hline Abstract_....... & 647 & Interpretation_. & 649 \\
\hline Introduction.. & 647 & Summary .... & 650 \\
\hline Methods....... & 647 & & \\
\hline
\end{tabular}

\begin{abstract}
A system of geologic prospecting based on studies of the distribution of detrital heavy minerals has been developed to show regional relations of monazite to other heavy minerals. It is especially suited to regions of intense weathering and deep residual soil, but it might be used wherever the stream pattern is dense and glacial deposits do not interfere. The system is potentially adaptable to rapid reconnaissance studies of the distribution of many economic minerals.
\end{abstract}

Heavy-mineral concentrates are taken by panning riffle gravel from the beds of small streams whose distributive provinces, above the sites of the samples, do not exceed 2 square miles. Equal volumes of sediment of reasonably similar mechanical composition are used for all samples. After panning, which produces a concentrate containing from 5 to 20 percent of quartz, no further eleaning is performed in the field or laboratory.

In the laboratory each concentrate is weighed, separated into three to five sieve fractions, and the weights of the fractions are recorded. Splits of 100-200 grains from every fraction of each concentrate are examined under a binocular microscope and the number of grains of each mineral is counted. These spot identifications of the minerals are supplemented as required by oil immersion, spectrographic, and X-ray techniques.

The grain counts (frequency) in each size fraction are converted to the weight percent of the given mineral in the whole concentrate. The mineralogical composition of each concentrate, converted by nomogram to 100 percent on a quartz-free basis, is plotted on a group of maps showing localities of samples. The abundance of each mineral is contoured at suitable intervals of weight percent on the map.

The contour pattern developed from this information is generally crude, therefore samples should be taken from an area of several thousand square miles. Within the general pattern, which is ideal for demonstrating such features as progressive regional metamorphism, local mineralogical "highs" develop that reflect small but significant changes in lithology. Similar "highs" formed by ore minerals or "indicator minerals" become the centers of more usual kinds of geologic search for ore deposits.

Modifications of the technique, such as use of contours based on weight rather than weight percent of the minerals, readily suggest themselves to fit special conditions. Little help is gained by reducing the sample interval from 1 per 2 square miles to, for example, 1 per square mile. Significantly greater resolution can be attained by increasing the number of samples to scores per square mile.

\section{INTRODUCTION}

During the course of a study of monazite deposits in southeastern United States done by the Geological Survey on behalf of the Division of Raw Materials of the Atomic Energy Commission a method of geologic prospecting was developed for use in areas underlain by crystalline rocks whereby the relative abundance and distribution of detrital heavy minerals are compared to show regional relations among the rocks and minerals. It is based on the assumption that differences among the suites of detrital minerals from streams with small drainage basins reflect variations in the composition of bedrock if other factors, such as hydraulic influence, are similar. As originally developed the method was used to determine the occurrence of monazite in igneous and metamorphic rocks, but the system is adaptable to rapid reconnaissance studies of the distribution of other economic minerals.

The method is well suited to intensely weathered regions with deep residual soil where heavy minerals recovered from the headwaters of small streams have been derived from underlying or adjacent rocks. Similar methods can be used for geologic prospecting wherever the streams are close enough together and there is no contamination from glacial deposits.

\section{METHODS}

Normally, heavy-mineral prospecting is divisible into field, laboratory, and office stages, hence discussion of methods will follow that order. 
Field work consists of taking heavy-mineral concentrates and making normal reconnaissance geologic studies. Collecting concentrates is done first because it is merely manual labor, progresses rapidly, and allows the geologist to become acquainted with the terrain. It is followed by geologic studies at a reconnaissance scale suited to the overall needs of the problem. No innovations have been introduced into the reconnaissance: it involves familiar geologic procedures planned to give the needed knowledge of types, trends, and distribution of the rocks.

Heavy-mineral concentrates are collected from equalsize samples of gravel taken from riffles in the channels of small streams. Areas of the distributive provinces of the streams above the sites sampled should not exceed 2 square miles. Uniformity in the position in the stream channel and grain-size distribution of the samples is desirable to reduce the effect of variable hydraulic influences upon the heavy-mineral suite. If external influences are similar, then changes in the mineral content of the concentrates will reflect differences in the aggregate composition of the rocks underlying the distributive provinces of the streams.

Similarity in position of the alluvial samples can be assured by adequate planning before entering the field. The most desirable localities, as regards size of distributive province, length and gradient of stream above locality sampled, and proximity to adjoining samples, are plotted on suitable maps. Once field work is begun the net of proposed localities is modified to fit conditions and to increase uniformity among the samples.

Uniformity in grain size distribution is maintained by visual inspection and selection of samples that contain gravel whose largest grains have the same maximum intermediate dimension. Equal-sized samples of alluvium are measured volumetrically as no system of dry weighing is adapted to rapid reconnaissance, and the wet weights of the samples are too variable to be meaningful. Enough gravel is taken from the stream (generally 0.3 cubic foot) to provide a volume (after sereening out grains larger than $1 / 8$ inch and the clay and silt), adequate to make one charge for a standard 16-inch gold pan.

The charge is panned to produce a concentrate that contains from 5 to 20 percent of quartz and other minerals of low specific gravity. Panning, which takes about 20 minutes per sample, is done carefully and is the only form of concentration used either in the field or laboratory. No further cleaning is required.

The gold pan is not used as a quantitative tool: mineral distribution is interpreted on a comparative basis; hence, total recovery of the heavy minerals is not required. All that is needed is uniform panning of samples to insure similar effective concentrations.
Heavy-mineral concentrates are also prepared from bulk samples of bedrock or residual soil so that relations can be determined between the suites of detrital minerals and rocks in the area. There is some danger that this might become a study in itself and impede heavymineral prospecting. To forestall such a shift in emphasis during reconnaissance, not more than 5 percent of the total number of samples should be taken from bedrock.

No improvement in geologic resolution is gained by doubling the number of samples taken in a given area. Significantly greater resolution can be attained if the number of samples is increased to scores per square mile, but the method can then no longer be regarded as reconnaissance.

Periodically the samples are shipped to a central laboratory for examination. Mineralogical identification, grain counts, and computations are done in the laboratory by a staff who are acquainted with the field problem. Because such study usually involves several thousand samples per year, mineralogic work must be reduced to a routine consonant with the time available and the accuracy required. Mineralogic analyses of the concentrates are done most efficiently along "assemblyline" plans with the operation divided into: removal of magnetite from the concentrate and weighing, sieving the magnetite-free concentrate and weighing the fractions, splitting, counting, and calculating. The first three operations are done by an aid, the fourth is done by the mineralogist, and both participate in the calculations.

Magnetite is removed from the concentrate with a hand magnet and weighed. The magnetite-free concentrate is separated into three to five sieve fractions, depending upon the range in size of grains in the concentrate, and the weight of the fractions are recorded. A split of 100-200 grains from each fraction is poured into a narrow groove milled in a plastic slide designed for use with a binocular microscope. The slide is placed on the stage of the microscope and passed along as the split is examined. All the grains of one mineral are counted in one traverse; all the grains of a second mineral are counted in the second traverse, and so on until all mineral species in that sieve fraction of the concentrate are counted. Two concentrates can be counted per hour. Use of the binocular microscope decreases the time consumed in preparing slides for counting, reduces fatigue, and permits other analyses to be made on any grain.

Large splits are counted periodically to determine reliability of the smaller cuts, and the spot identifications of minerals are supplemented as required by oil immersion, spectrographic, and X-ray techniques.

Computations performed in the laboratory are those 
needed to convert grain counts to weight percents of the concentrate. Conversions relate specific gravity, size, and frequency distribution to weight percent through assumptions that specific gravity is constant in a given species, and that all species in a given sieve fraction have the same volume. Obviously, the specific gravity of a given species and the volume of grains in a given sieve fraction vary, but so long as all grain counts are recalculated in the same fashion, the relative differences among the concentrates are preserved.

The calculations can be performed in about 5 minutes and consist of the following steps: (1) weight percents of the magnetite and the sieve fractions are calculated directly from their weights and that of the concentrate, (2) the grain counts of each mineral are converted by specific gravity factors into units equivalent to the number of similar-sized grains of quartz needed to equal the weight of the heavy mineral, (3) the units in each sieve fraction are totaled, (4) the weight percent of a sieve fraction is divided by the total number of units in the fraction and the quotient is multiplied by the number of units of each mineral in the fraction to give weight percent of that mineral in that fraction, (5) the last three operations are repeated for each sieve fraction, and (6) the sum of the weight percents of a given mineral in all the sieve fractions equals the weight percent of that mineral in the concentrate.

The mineralogical analyses are reported to the field office, where they are plotted on maps and interpreted in the office stage of the investigation.

Mineralogic analyses of the alluvial concentrates are compiled on maps showing sample numbers and localities. A different map is used for each mineral. The compositions of concentrates obtained from bedrock or residual soil are not shown on maps used for plotting alluvial concentrates.

The weight percent of a mineral is indicated for each locality where it makes up 1 percent or more of the quartz-free concentrate. Recalculation of the mineralogic analyses reported from the laboratory to a quartzfree basis is done readily by means of a nomogram. Recalculation is most conveniently done as the minerals are plotted on maps, because the geologist may wish to exclude several minerals other than quartz, such as feldspar, biotite, and hematite, from the recalculated concentrate.

The abundance of each mineral, expressed as weight percent of the quartz-free concentrate, is contoured at suitable intervals on a transparent overlay, thus protecting the base map from the corrections ineident to contouring. Final copy is prepared from the overlay and is reduced photographically to a scale appropriate to the area and the density of sampling. A compilation scale of 1 inch equals 2 miles and a final scale of 1 inch equals 4 miles was satisfactory for an area of 4,000 square miles where 2,500 samples were taken.

Contours are drawn at intervals suited to the range in weight percents spanned by the different heavy minerals. Intermediate contour lines are an excellent means of showing detail in critical ranges of weight percent. The following contour intervals were used satisfactorily in the 4,000 square mile area mentioned above:

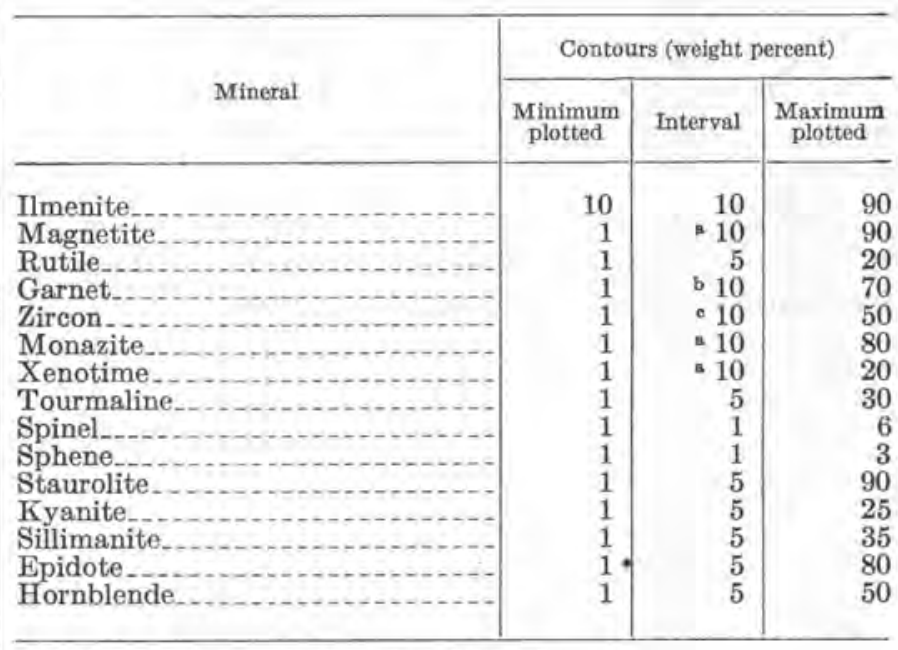

- Included a supplementary contour at 5 percent.

included supplementary contours at 5 and 15 percent.

Black and white patterns or color introduced between the contours emphasize the distribution of the minerals.

The mineralogic analyses of concentrates from bedrock and residual soil are plotted at the same scale, and data from the reconnaissance geologic studies are similarly compiled to facilitate interpretation of observations.

\section{INTERPRETATION}

The heavy-mineral contours are interpreted to guide selection of areas where further geologic studies would have the greatest probability of revealing ore deposits.

The sources of most of the detrital minerals are shown by the heavy minerals concentrated from bedrock or residual soil. Thus the general pattern made by the mineralogical contours can be related to changes in proportions of the different major rocks in the area examined, and the pattern of the contours will conform to the regional trends discovered in reconnaissance. The patterns revealed by the heavy-mineral contours are generally crude. The structural features and nature of the rocks are broadly outlined, and, ideally, abrupt mineralogic differences locally refine the pattern. Examples of resolution are cited below to show features that can be recognized. 
650

GEOLOGY OF URANIUM AND THORIUM, INTERNATIONAL CONFERENCE, 1955

Antipathetic zones of metamorphic minerals reflect different grades of regional metamorphism and differences in the composition of the bedrock. The first appearance of detrital chloritoid, staurolite, kyanite, garnet, and sillimanite is as precise a guide to the position of an isograd as is location by petrographic study.

The general concordance or discordance of granitic rocks is shown by the conformity of contours for zircon and monazite to the contours of metamorphic minerals: an angular difference between the contours shows the trend of discordant plutons. Typical contact metamorphic minerals appear peripheral to the bodies that produced them.

Local mineralogic "highs," where one or more minorals abruptly increase in abundance over their average distribution, reflect changes in the gross composition of the bedrock. Such "highs," where resistant ore minerals or resistant heavy minerals associated with soluble ore are concentrated, become the loci for normal geologic study.

SUMMARY

Geologic reconnaissance based on systematic studies of the distributive pattern of detrital minerals, here called heavy-mineral prospecting, is best suited to regional search for ore deposits. Various modifications of the technique, such as contouring weights rather than weight percents, and integrating heavy-mineral with appropriate geochemical and geophysical methods, readily suggest themselves to fill special exploratory needs. Heavy-mineral prospecting should precede and guide, but not supplant, usual geologic studies. 


\title{
TECHNIQUES AND GUIDES IN EXPLORATION FOR URANIUM IN SHINARUMP GHANNELS ON THE COLORADO PLATEAU
}

\author{
By Hram B. Wood and W. D. Grundy, U. S. Atomic Energy Commission
}

\begin{tabular}{|c|c|c|c|}
\hline & $\mathrm{CON}^{\prime}$ & ENTS & \\
\hline & Page & & \\
\hline Abstract_. & 651 & Exploration technique & \\
\hline Introduction ..... & 651 & Mapping techniques for reconstruction of paleotopog- & \\
\hline Geology of ancient stream channels & 653 & raphy & \\
\hline Uranium ore in channels & 653 & Drilling patterns & \\
\hline Size, shape, and distribution of ore deposits........ & 653 & References cited. & \\
\hline 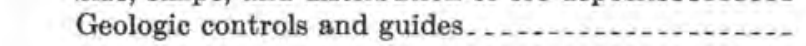 & 653 & & \\
\hline
\end{tabular}

\section{ILLUSTRATIONS}

Plate 16. Shinarump channels on the Colorado Plateau ................................ Faces

FigURe 192. Outcrop of Chinle and Shinarump formations and laccoliths on the Colorado Plateau

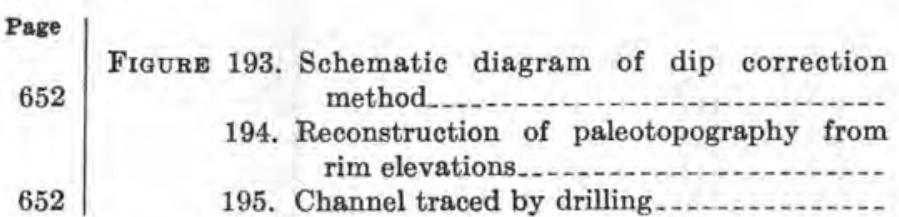

Page 655 656 657

\section{ABSTRACT}

Detailed studies have been made of three areas on the Colorado Plateau in which uranium ore deposits occur under similar geologic conditions in the Shinarump conglomerate of Late Triassic age: Circle Cliffs and White Canyon regions of southeastern Utah, and Monument Valley region of Utah and Arizona. In these areas, large asymmetric anticlines with irregular axes are the dominant structural features. Commercial uranium deposits occur in fluvial sediments which fill ancient stream channels incised in the pre-Shinarump erosion surface. These paleostream channels are widespread and variable in size and shape. In White Canyon, 22 channels, 6 containing ore, and in Monument Valley, 14 channels, 7 containing ore, were located by recognition of certain geologic criteria and traced by drilling based on information provided by paleotopographic maps. The formations involved are continental in origin and include the Moenkopi formation, the Shinarump conglomerate, and the Chinle formation, all Triassic in age.

The following are recommended as guides to ore in the regions: (1) uranium ore is confined to the bottoms and sides of channels and scours; (2) ore is most likely to occur in a poorly sorted permeable, argillaceous, arkosic sandstone or conglomerate interbedded with mudstone lenses and clay galls; (3) irregular channels with deep and narrow cross sections and with variations in depth of scour are favorable for the occurrence of this type of lithology; (4) the presence of carbonaceous material and some clay lenses is important for uranium concentration; (5) an appreciable thickening of the zone of bleaching in the underlying Moenkopi may indicate a mineralized channel; (6) the nearby presence of copper sulfides, sulfates and earbonates; iron sulfides. sulfates and hydrous oxides; and cobalt arsenate. The reconstruction of the paleotopography is desirable in exploration to determine the presence and trend of a buried channel.

\section{INTRODUCTION}

Paleostream channels filled with Upper Triassic Shinarump clastics, which in many places on the Colorado Plateau contain uranium ore bodies, may be traced by drilling on a pattern based on information derived from contour maps of the lower contact of the Shinarump. Such maps, if corrected for the effects of regional dip, are reasonable approximations of the pre. Shinarump erosion surface. The presence of ore in the channel fill may be indicated by various empirical criteria. In White Canyon 22 channels drilled in 1952 and 1953, and in Monument Valley 14 channels drilled in 1954, were located by recognition of certain geologic criteria and traced by drilling guided by information provided by paleotopographic maps. In White Can. yon, 6 new uranium ore bodies: 2 on Frey Point, one in the Ears Channel (Gizmo mine), one in the Cub Channel (Maybe mine), one in the Cairns Channel (Spook and Bulls Eye mines) and one in the Blue Lizard Channel (Redd's No. 2 mine), were located using this method. In Monument Valley, seven new ore bodies were located using this method. 


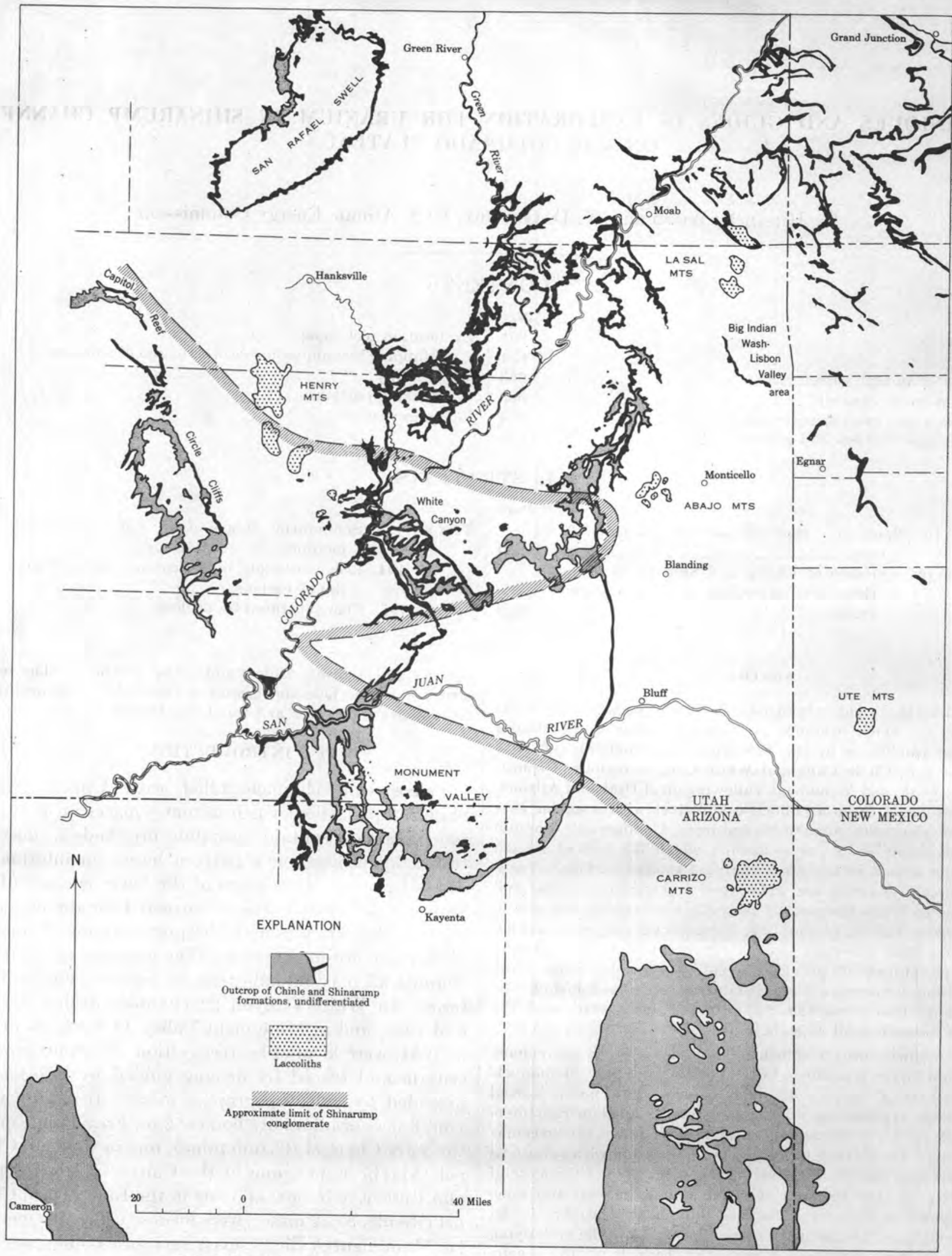

FrgURE 192.-Outcrop of Chinle and Shinarump formations and laccollths on the Colorado Plateau. 


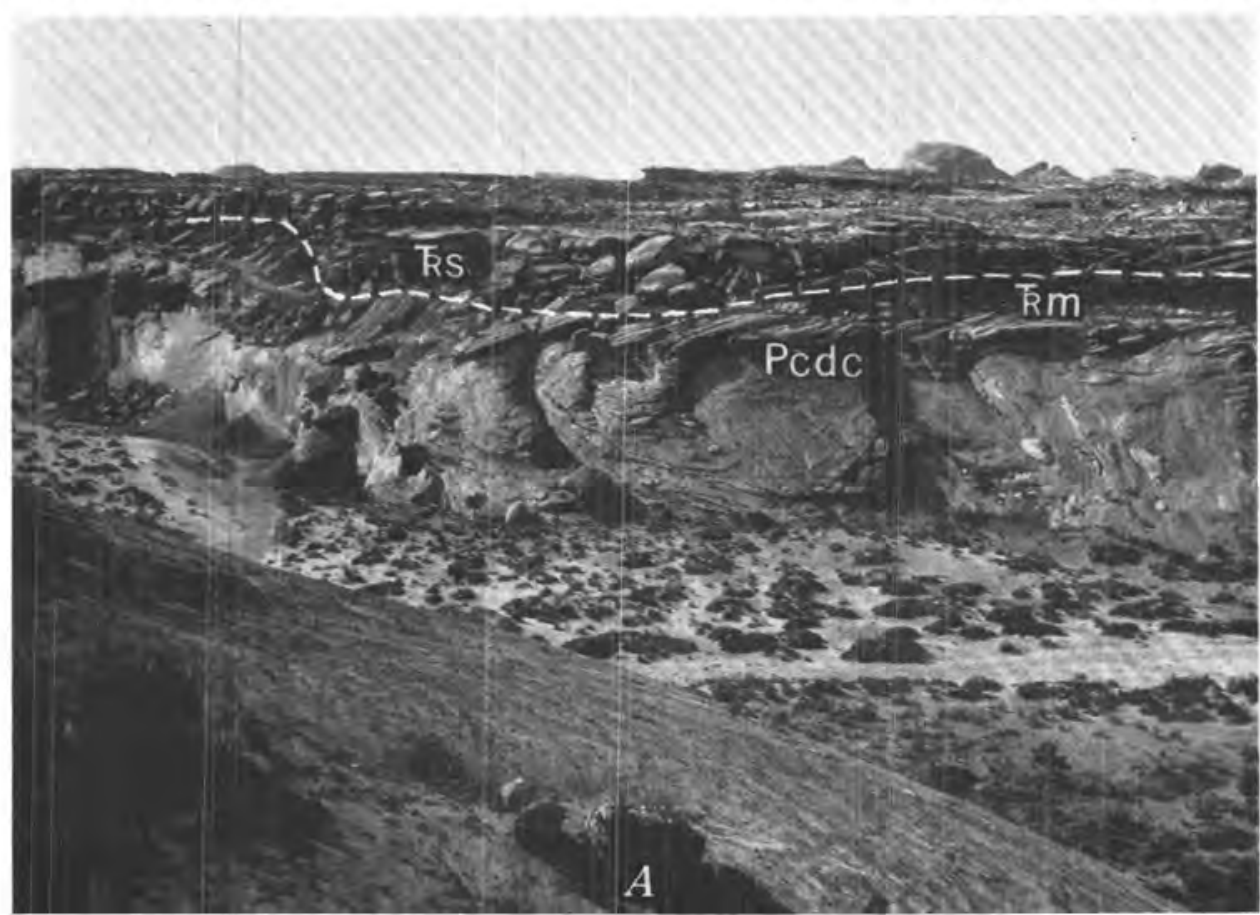

SHINARUMP (Trs) CHANNEL CUT THROUGH MOENKOPI FORMATION (Trm) AND INTO DE CHELLY MEMBER (Pede) OF THE CUTLER FORMATION NEAR MONUMENT MINE NO. 2

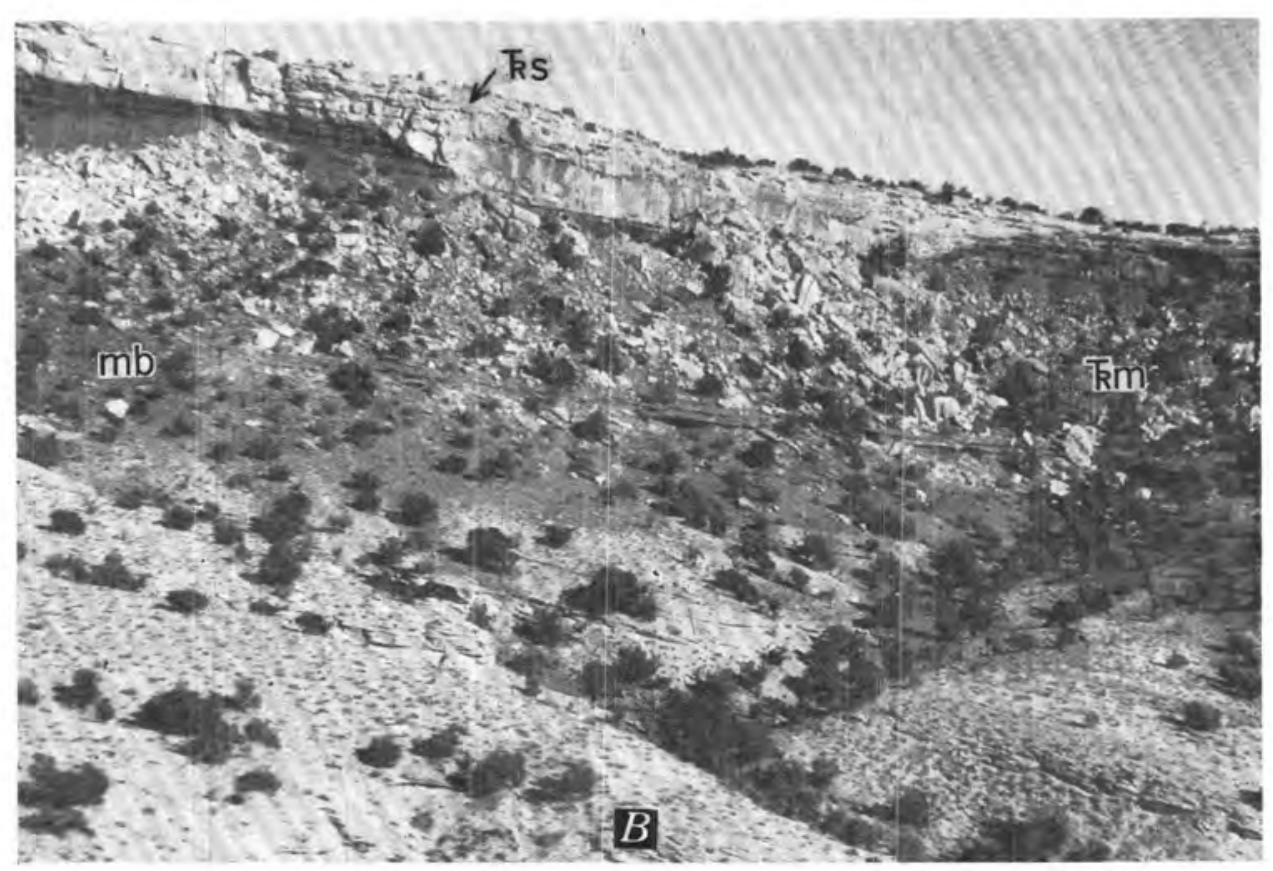

SHINARUMP CHANNEL-NOTE DISTINCT MARKER BED (mb) IN MOENKOPI FORMATION (Trm)ON COLT MESA, CIRCLE CLIFFS, UTAH

SHINARUMP CHANNELS ON THE COLORADO PLATEAU 


\section{GEOLOGY OF ANCIENT STREAM CHANNELS}

Ore deposits in Shinarump channels are found in Monument Valley at the southern end of the Monument uplift, in White Canyon on the west flank of the same anticline, and in Circle Cliffs, a northwest-trending uplift farther west in Utah (fig. 192). These structural features postdate the channeling. Ore deposits discussed in this paper occur in channels on the crests and flanks of these structural features, but the influence of these structures on primary uranium mineralization and subsequent redistribution is not clear.

Clastic rocks of the Shinarump conglomerate generally overlie the redbeds of the Moenkopi formation of Triassic age. However, the clastic rocks rest on Permian where the Moenkopi was removed by the erosion of ancient streams which cut channels of various sizes in the erosion surface. Areas between channels were eroded to irregular surfaces of low relief. A period of deposition of the Shinarump followed, filling the old stream channels and covering much of the erosion surface with clay, silt, sand, and gravel (pl, 16). Some higher areas remained free of Shinarump deposits and at various places the overlying Chinle formation, into which the Shinarump grades laterally and vertically, rests directly on the Moenkopi.

Paleostream channels within a region vary in length, width, depth, cross-sectional profile and trend. Most channels resemble buried stream courses, but others seem to be elongated basins. They may be subparallel or convergent; some meander; bifurcate and rejoin; some seem to die out against ancient highlands. A few channels may be traced for miles, others only a few thousand feet.

Like their modern equivalents, paleostream channels have irregular cross sections; they may be symmetrical or asymmetrical, and flanks may be gently sloping to nearly vertical; channel floors may be nearly flat or contain local scours. Most channels in Circle Cliffs and Monument Valley are from 300 to 3,000 feet wide and 30 to 275 feet deep. Scour depth along the axis of a channel differs as much as 60 feet, a condition similar to that in the channel of the modern Platte River in Nebraska. Channels in White Canyon are from 75 to 300 feet wide and 10 to 50 feet deep, and depth of scouring along the axis of the same channel differs as much as 40 feet.

Many channels are easily recognized at their outcrops by truncation of underlying Moenkopi strata and by thickening of sandstones in the Shinarump. Others, such as the broad basin at the Happy Jack mine in White Canyon, are difficult to recognize at the outcrop, but are clearly indicated by paleotopographic maps based on data obtained by drilling.
The sediments filling these channels are a heterogeneous mixture of cross-stratified sandstones, with lenses of mudstone and conglomerate. In general, the coarser sandstone and conglomerate are most abundant in the lower parts of a channel, but sandstone predominates throughout the channel-fill. Carbonaceous material, silicified wood, and asphaltic material are generally present in minor quantities, although there are local concentrations. The asphaltic material may extend downward into the underlying Moenkopi.

\section{URANIUM ORE IN CHANNELS}

\section{SIZE, SHAPE, AND DISTRIBUTION OF ORE DEPOSITS}

The largest ore bodies in Monument Valley and in White Canyon are measured in hundreds of thousands of tons, and in Circle Cliffs, in thousands of tons. All ore bodies in these regions are roughly tabular, generally parallel to stratification and to the trend of the channels.

Most ore bodies are in the coarser sediments near the base of a channel, and may extend across the contact into the underlying formation. In Circle Cliffs nearly all uranium deposits occur along channel flanks; about 80 percent of the ore has come from the Moenkopi formation, underlying the channels, and the balance from the Shinarump. At Monument No. 2 mine in Monument Valley (pl, 16), the upper 6 feet of the De Chelly sandstone member of the Cutler formation of Permian age, underlying the Shinarump cbannel, contains ore. In this exceptionally large deposit most ore is near the channel base, but some occurs in the uppermost part of the channel fill. At White Canyon and in Monument Valley, most ore is in sandstone filling the deeper scours within channels; a lesser quantity occurs along channel flanks.

\section{GEOLOGIC CONTROLS AND GUIDES}

"Controls" are the geologic conditions that influenced the movement of uranium-bearing solutions and tbe precipitation of uranium minerals. "Guides" are the mineralogic and geologic features that are generally observed associated with uranium deposits. The importance of recognized controls and reliability of guides differ from region to region, and none are positive indicators; however, the probability of finding ore at a given locality increases with the number of indicators found.

1. A paleostream channel filled with clastics of the Shinarump is important in the control of mineralizing solutions and as a guide in exploration.

2. A poorly sorted porous arkosic, argillaceous sandstone and (or) conglomerate containing moderate amounts of interstitial clay, claystone seams and clay pellets associated with carbonaceous material is favor- 
able to localization of ore. Argillaceous material in the lower $10 \cdot$ to 20 feet of a channel fill should make up about one-fourth of the deposit.

3. Irregular channels with deep and narrow cross sections and with variations in depth of scour are favorable for this type of deposition.

4. The presence of carbonaceous material in the lower part of a channel is favorable for precipitation of uranium ore; however, many uranium ore bodies are locally devoid of carbonized plant debris, and many channel fills containing an abundance of carbonaceous material are devoid of uranium.

5. A thin zone of bleached Moenkopi rock immediately beneath the Shinarump is almost universal; however, a thickening and intensification of the bleaching occurs beneath many mineralized channels.

6. Copper sulfides, sulfates, and carbonates; iron sulfides, sulfates, and hydrous oxides; and cobalt arsenate, sulfate, and carbonate are conspicuous associates of many uranium deposits; hence their presence on an outcrop of channel sand is a suggestion that ore may lie nearby.

7. In regions of nonvanadiferous uranium deposits, channels extending beneath thick and relatively impervious cover, or below a water table, offer ground more favorable for exploration than channels under thin pervious cover which have been exposed to oxidation and leaching by ground water. The White Canyon and Circle Cliffs nonvanadiferous uranium ores of pitchblende associated with base-metal sulfides commonly form soluble uranyl sulfates when oxidized. The larger White Canyon deposits have been protected from oxidizing ground waters by thick impervious cover (Dodd, 1950), whereas in Circle Cliffs nearly all known deposits underlie pervious sandstone benches and have been oxidized and leached. The uranium-vanadium ores of Monument Valley form relatively insoluble uranyl vanadates when oxidized, so the thickness or permeability of the cover is less important.

The above list of controls and guides is not complete. Those omitted have not yet proved to be applicable to the regions under discussion. A more complete listing of potential guides is given by Leo J. Miller (1953) and Mitcham and Evensen (1955).

\section{EXPLORATION TECHNIQUE}

MAPPING TECHNIQUES FOR RECONSTRUCTION OF PALEOTOPOGRAPHY

Because all uranium ore bodies in the regions under discussion are in Shinarump channels, prospecting has been confined to a search for paleostream channels using the criteria listed above. Where such a channel or indication of a channel is found, the base of the
Shinarump and at least three points on some key bed below it are mapped with a planetable and alidade. Altitudes measured on a key bed are used for the determination of local dip and strike.

Structure contour maps of the base of the Shinarump reveal the channel trends and shape in relation to the present structural attitude of the beds, but it is preferable to correct for the effects of regional dip and to reconstruct the paleotopography as accurately as possible by detailed mapping methods. The reconstruction shows the shape of the channel and some scours in the channel that are normally obscured by regional dip. Various methods are used in reconstructing the initial dip, but the procedures outlined below are considered most suitable for the structures encountered on the Colorado Plateau.

Credit for the first application of dip correction to exploration of Shinarump channels belongs to L. J. Miller (1953). This method, with slight modifications, is described herein.

A line of bearing (hinge line) parallel to the regional strike is drawn on the map of an area over which there is no appreciable change in regional dip (fig. 193). To the altitude of each surveyed point on the base of the Shinarump downdip from the hinge line is added that figure (dip correction) which is the product of the horizontal distance of the point from the hinge and the tangent of the dip angle (dip factor). Altitudes on the hinge remain unchanged, but the dip correction is subtracted from the elevation of each point on the base of the Shinarump updip from the hinge line.

Should there be changes in amount of regional dip within an area, a hinge must be drawn for each successive change and the proper dip factors applied. Where both strike and dip vary across an area, a method used by C. G. Evensen (oral communication) may be applied. This method requires numerous exposures of a marker bed around the area (pl. 16). The base of the Shinarump is mapped as before. A marker bed below that horizon is mapped and contours connecting points of equal altitude are drawn for the the marker bed. The highest contour is used as a hinge (line of no correction), then to each surveyed elevation point on the base of the Shinarump is added that figure (dip correction) which is the difference between the altitude of the hinge and that of the contour on the marker bed immediately below that point on the Shinarump. To altitudes on the Shinarump that fall between contours an interpolated correction must be applied.

Although this method (fig. 193) introduces horizontal distortion in the location of the corrected survey points, for all practical purposes this distortion may be ignored. 


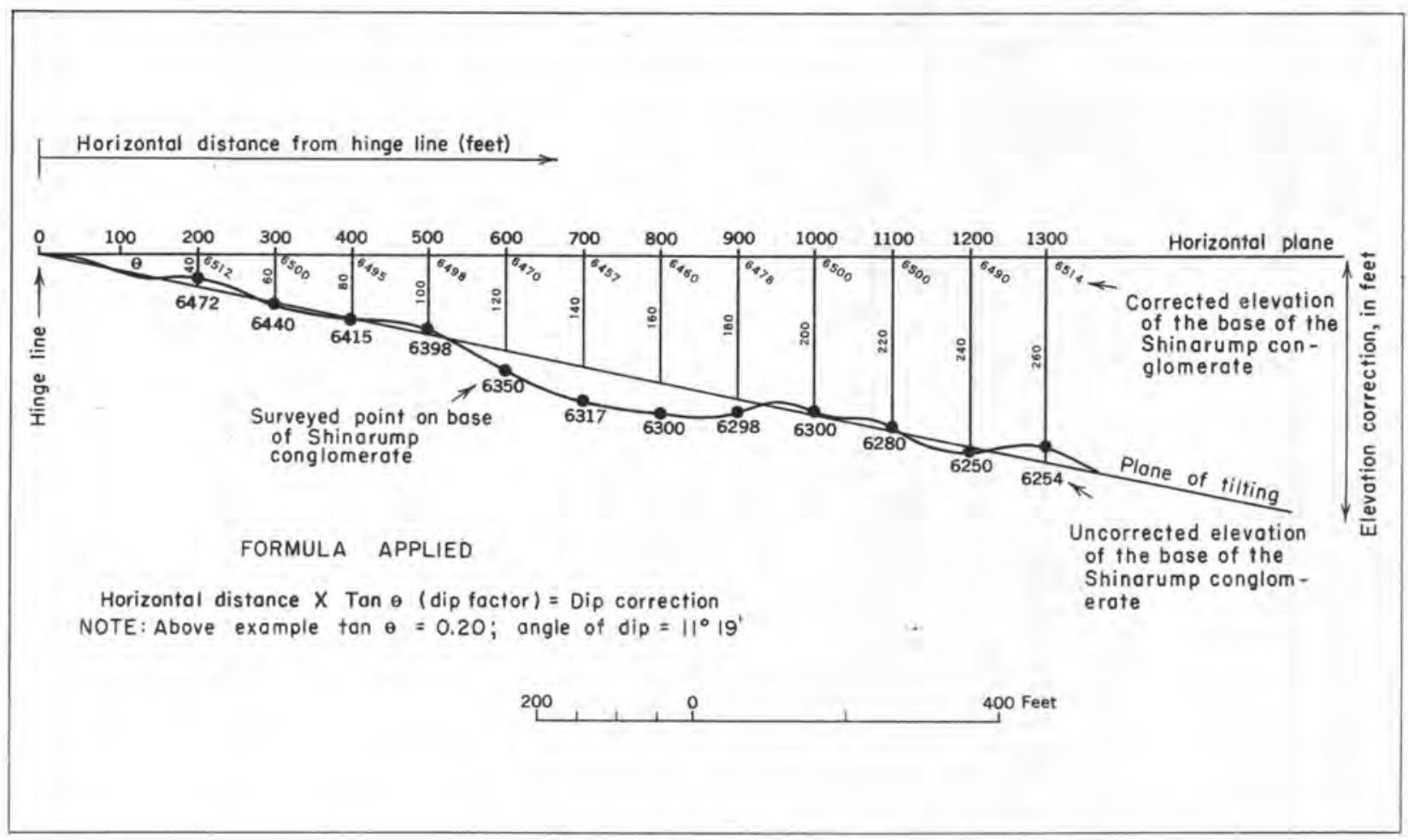

Fioure 193.-Schematie diagram of dip-correction method.

Using the dip-corrected altitudes of the base of the Shinarump, contours are drawn connecting points of equal altitude; the resulting map reconstructs preShinarump paleotopography (fig. 194). The trend of the trough or "low" indicated by the contours is projected from the rim outcrop and accuracy of the projection is tested by drilling.

\section{DRILIING PATTERNS}

Exploration of a Shinarump channel should be divided into two stages: an investigational program wherein the channel is delineated and favorable ground within it is outlined; and a development program by close-spaced drilling in favorable ground.

Delineation of a channel should begin with a row ("fence") of holes a short distance downdip from the outcrop and across the projected trend (fig. 195, holes 1-5) to determine the channel axis by an alinement of the lowest point on the rim with the lowest point as interpreted from drill holes. This first fence should consist of at least five holes spaced at intervals less than the width of the channel at the outcrop.

The drilling pattern is extended along the axis projection where topography permits holes to be spaced less than twice the width of the channel. This rule-of-thumb spacing is based on experience which has shown that the Shinarump-type channel does not, on the average, make a $90^{\circ}$ change in direction within a distance of less than twice its width.
Immediately after completion of each hole, the altitude of the basal Shinarump contact is corrected to the horizontal datum, closely simulating the original attitude, the inferred contours are extended (or revised if necessary) and additional holes are located.

If the last hole along a projected axis finds the basal Shinarump contact at a much higher corrected elevation than predicted from the extended contours, it may have been drilled either on a flank near a change in channel trend, or on a rise in the channel floor (fig. 195, hole 8 or 15). The uncertainty of the interpretation is resolved by drilling a fence of at least 3 holes halfway between the last 2 holes and at right angles to the last known channel trend (fig. 195 , holes 9-12). If the results of any fence are inconclusive, the fence is extended on either end, or additional holes are drilled between the primary holes of the fence. Wherever the interpretation of subsurface data is in doubt, fences rather than single holes should be drilled.

In channels where ore most frequently occurs in troughs, the distance between single holes should not exceed the maximum size of anticipated ore bodies. In areas where ore occurrences are known to be predominantly on the flanks of channels, it is necessary to test the flanks between fences with additional holes after the channel is delineated. After the channel is delineated, development drilling follows in those 


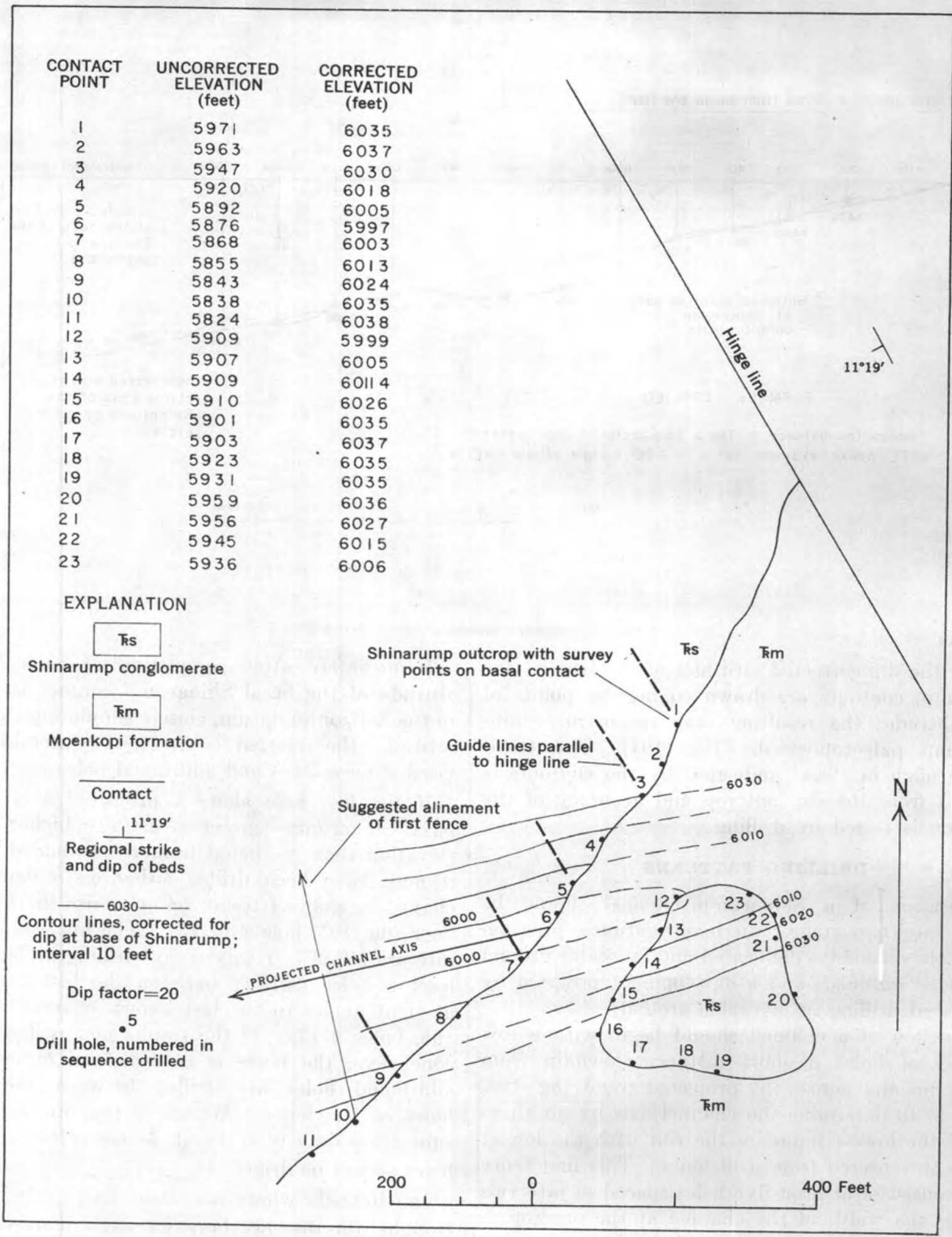

FIGURE 194.-Reconstruction of paleotopography from rim-elevations. 


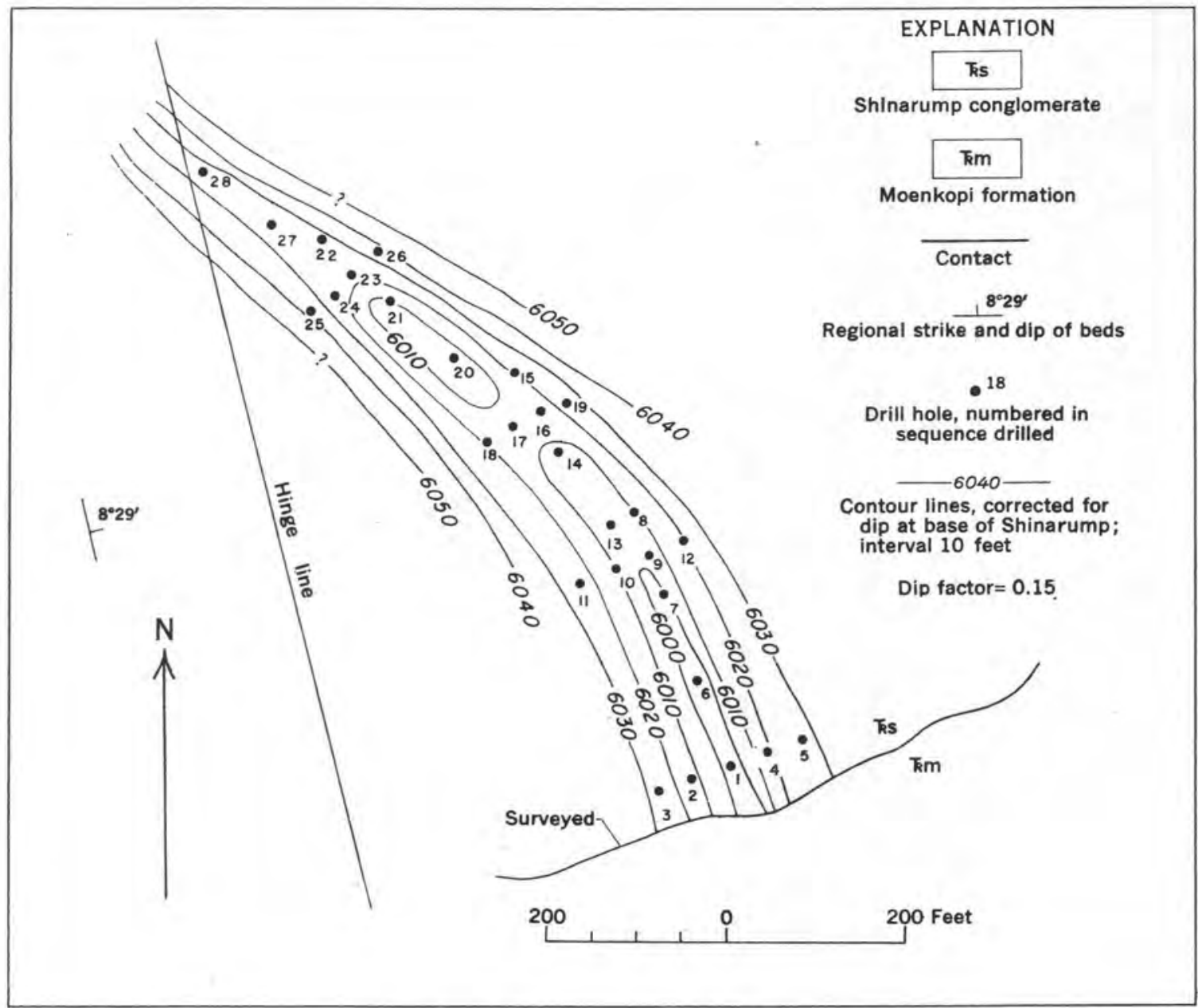

FIGURE 195.-Channel traced by drilling.

parts of the channel considered favorable as a result of a study of ore deposits in the region.

\section{REFERENCES CITED}

Dodd, P. H., 1950, Happy Jack mine, White Canyon, Utah: U. S. Atomic Energy Comm. RMO-660, issued by U. S. Atomic Energy Comm. Tech. Inf. Service, Oak Ridge, Tenn.
Miller, L. J., 1953, Uranium ore controls of the Happy Jack deposit, White Canyon, San Juan County, Utah: U. S. Atomic Energy Comm. RME-33, issued by U. S. Atomic Energy Comm. Tech. Inf. Service, Oak Ridge, Tenn.

Mitcham, T. W., and Evensen, C. G., 1955, Uranium ore guides, Monument Valley district, Arizona: Econ. Geology, v. 50, p. $170-176$. 


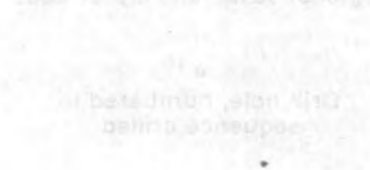

得

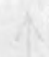

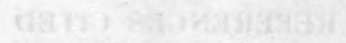




\title{
THE USE OF GEOCHEMICAL TECHNIQUES AND METHODS IN PROSPECTING FOR URANIUM
}

\author{
By Thomas S. Lovering, Hubert William Lakin, Frederick N. Ward, and Frank C. Canney, \\ U. S. Geological Survey
}

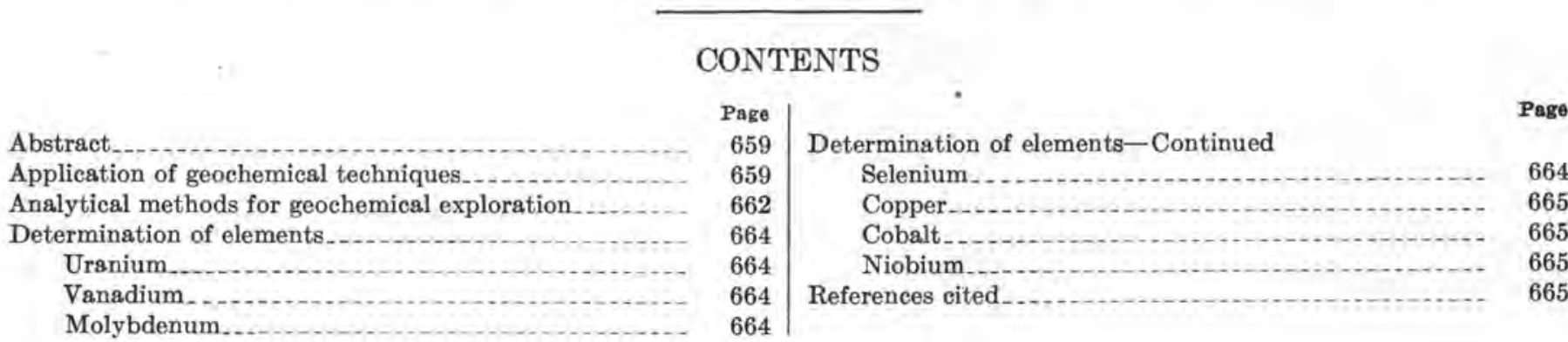

\begin{abstract}
The art of successfully applying the fundamental principles of geochemical dispersion of the elements to the practical problem of finding hidden ore bodies depends on establishing diagnostic patterns of dispersed metals in the vicinity of ore deposits. Geochemical prospecting, or the techniques of using variations in trace amounts of metals to delineate such patterns or "anomalies" has long been applied successfully to the search for other metals, and is now being used in the search for uranium and thorium.
\end{abstract}

The anomalies most commonly investigated in geochemical prospecting are those formed at the earth's surface by agents of weathering, erosion, or surficial transportation. Anomalies of this type-secondary anomalies - are responsible for most of the discoveries credited to successful geochemical prospecting. Analysis of soil derived from the direct weathering of rock in place gives the most reliable and consistent indication of ore lying immediately beneath the soil, although the distribution of traces of metals in transported cover, resulting from the upward migration of metal from bedrock ore, shows promise where the bedrock is buried beneath a blanket of glacial or alluvial material. Attention also is being given to primary anomalies found in bedrock, and several studies have indicated the presence of dispersion halos containing anomalous traces of epigenetic metals in the unweathered rocks adjoining and overlying some buried ore bodies-dispersions that seemingly are related to the ore depositing processes.

Owing to the different mobilities of elements, some of these diagnostic halos, both primary and secondary, extend over large areas and form broad targets that are useful in general reconnaissance; others, restricted to the vicinity of the ore body itself, are more useful for detailed studies.

Before undertaking any geochemical survey, preliminary orientation studies must be made to evaluate the local geochemical prospecting problems. As with geophysical methods, geochemical methods are most effective when used in conjunction with other proved methods of prospecting. To be successful, the geological techniques and the necessary anslytical methods should be rapid, inexpensive, and adequate for the purpose. Low-cost personnel should operate with relatively little training.
In applying geochemical methods to the search for uranium, two general techniques can be followed: First, the direct search, where uranium itself is detected by a simple, sensitive, and inexpensive field method. This approach may detect important anomalies with low radiometric readings and eliminates radiometric anomalies caused by the long distance migration of daughter products. Second is the indirect search, where primary or secondary halos of associated elements are sought. This method is advantageous in searching for ore bodies that have Iarger sized targets of associated metals than of uranium, because of greater mobility of these elements during the emplacement of the ore and in the weathering cycle.

Colorimetric and spectrographic methods of trace analysis are used by the U. S. Geological Survey for geochemical prospecting. Wet methods for determination of $\mathrm{U}, \mathrm{V}, \mathrm{Mo}, \mathrm{Se}, \mathrm{Cu}, \mathrm{Co}$, and $\mathrm{Nb}$ are briefly described.

\section{APPLICATION OF GEOCHEMICAL TECHNIQUES}

Geochemistry is a broad borderland field of science concerned with the relative and absolute abundance of the elements in the earth and the laws covering their distribution, dispersion, and concentration. Most scientific prospecting, whether geological or geophysical, uses geochemical facts and principles to help interpret observations in an effort to hasten and cheapen the discovery of mineral deposits. By general consent, however, the term "geochemical prospecting" refers to the search for concealed mineral deposits through the detection and proper interpretation of the subtle, yet diagnostic, chemical patterns that may be present in naturally occurring materials in the vicinity of an ore body. The patterns most commonly sought are variations in the content of certain diagnostic minor elements in readily accessible material-variations either in the ore metals or in associated indicator elements. All 
good prospecting techniques fulfill three requirements: they must be adequate, relatively cheap, and rapid. Geochemical prospecting has been very successful in attaining these requirements.

Geochemical techniques were first used about 1935 by Scandinavian and Russian geologists to locate certain types of ore deposits, but it was not until after World War II that the use of geochemical prospecting became widespread. Geochemical techniques have had their greatest success in the search for deposits of copper, lead, and zinc, but many of the techniques and principles established are of value in the search for deposits of uranium and thorium.

A significant departure from the average abundance or "background value" of an element in materials where the distribution has not been disturbed by mineralization is called a geochemical anomaly, values less than background would be called a negative anomaly, whereas those above background constitute a positive anomaly or simply "an anomaly." Although background values can vary widely as a result of natural processes, in most barren materials the distribution of elements has a log normal distribution as recently suggested by Ahrens (1954), and there is a figure near which most of the values lie, with higher and lower figures in rapidly diminishing frequency on either side. The threshold of significance is commonly about twice the value of the peak for the background, and the importance of a geochemical anomaly is best brought out by using a geometric ratio for isograms; when representing geochemical results on a map the isograms would represent $2,4,8,16$, and 32 times the background value of an element, rather than $2,3,4,5$, and 6 times the background figure. Our present knowledge concerning the mechanisms by which anomalies form is so seanty that there is considerable risk in any attempt to correlate the contrast and size of an anomaly with the tenor of the underlying mineralized body. Nevertheless, an area surrounded by several such isograms would seem more worthy of immediate attention than an area with but one.

Geochemical anomalies are of two general types: primary anomalies are genetically related directly or indirectly to ore-depositing processes and may be regional or local. Secondary anomalies are those formed at the surface of the earth by agents of weathering, erosion, surficial transportation, or biological activity. Evidence is accumulating that suggests certain broad regions having a very marked increase in the background value of an element may be considered geochemical or metallogenetic provinces. Intrusive rocks in some uranium-rich regions show a much higher background of uranium than similar rocks in regions lacking uranium deposits. Similar relations hold for cobalt, nickel, tin, thorium, niobium, chromium, and some other elements. High cobalt content is characteristic of the country rock of the Blackbird district in Idaho, miles distant from the known cobalt deposits, and high antimony content is characteristic of rocks some distance from ore in the antimony districts of Alaska. In establishing a regional anomaly, it is necessary to compare the metal content within specific rock types, as there may be a far greater variation between different rock types within a metallogenetic province than between the metal content of a specific rock type within and outside the province.

Metallogenetic provinces generally have a background several times that of the average for a given rock type, and within the province there may be local concentrations near individual ore deposits - district anomalies-which may run several times the background of the metallogenetic province. Many uraninite-bearing veins have been found in the early Tertiary mineral belt of the Colorado Front Range, and both Precambrian and Tertiary intrusive rocks have a much higher uranium content than the average of their types. In addition, regional variations within a given variety of igneous rocks have a uranium content severalfold greater in districts containing uraninite veins than elsewhere.

The background that is characteristic of different rocks, such as granite in contrast to gabbro, may vary severalfold, or even by an order of magnitude. The anomalies that reflect this kind of variation in the original composition of the rock yield primary anomalies of little value in the search for individual ore deposits and must be distinguished from other anomalies caused by the impregnation of rocks by ore-bearing fluids. These other primary anomalies may be more closely limited but are of the utmost importance and include chiefly wall-rock and leakage halos. Wall-rock halos probably form during the emplacement of the ore by the impregnation of a sheath of the surrounding wall rock with those associated elements that are relatively mobile. Leakage halos are similar in nature but follow the channelways along which the ore-forming fluids moved.

Each area studied is different and requires its own adaptation of geochemical techniques, but certain principles can be used in selecting the most suitable method or methods. The study of primary anomalies must be based on a knowledge of the geology and mineralogy of the mineral deposits. It is also important to realize that a primary leakage halo may be either on the outlet side of a blind ore body or on the inlet side of an eroded ore body and, furthermore, that an anomaly at the surface may not be vertically over the ore. Leakage of solutions that moved upward 
at an angle would result in an anomaly that was offset from a vertical position over the buried ore body sought-a "displaced anomaly." Pyritic halos that are so commonly associated with uranium ore deposits, whether of the sandstone type or of the crosscutting vein variety, may be regarded as the outer ring of a target area; the problem of the prospector is to find the "bull's eye" which may be at the side, the center, or in between. Similar dispersion of niobium around some thorium deposits has been observed, and it is known that minor amounts of vanadium, copper, lead, zinc, and other metals are locally associated with certain uranium deposits. Some sandstone-type uranium deposits have only a small primary anomaly of uranium itself but may be prospected geochemically by a search for the more extensive primary anomalies of these associated metals.

Anomalies of surficial origin-secondary anomaliesresult from the weathering of rocks and ores, from biogeochemical processes, and from dispersion of ore minerals and metals through transportation by glacial ice, by slide and creep of colluvium, and by moving ground water and surface water. The shape and size of the secondary anomaly depends on the climate and topography, and on the mobility of the various elements present under the conditions of weathering that obtain where the deposits crop out or underlie the soil, Mobility, as the term is generally used, is a measure of the tendency of an element to dissolve in the zone of weathering and to migrate from the original deposit. The dispersion pattern reflects the chemical equilibria characteristic of the local environment, the abundance of the element in the disintegrating rock, and the movement of earth material from one environment to another. Dispersion patterns that are mapped at the surface are usually regarded as 2-dimensional features, but the fact that dispersion has 3-dimensional geometry is important whea interpreting secondary anomalies and is vital to success when considering primary anomalies.

Dispersion patterns are commonly classified as halos, fans, and trains, depending upon the characteristic shape of the pattern and its relation to the point of primary concentration. A halo encloses the source of the material, a fan is a pattern spreading outward in a fan-shaped mass from a source at the apex of the fan; a train is a linear dispersion pattern commonly trending downgrade away from the deposit in secondary anomalies and downgrade toward the deposit in a primary anomaly.

In areas where pyritic halos have weathered to form limonite, the edge of the limonitic area commonly will be enriched in manganese and zinc and the weathered pyritic area will commonly be impoverished in these metals. This distribution causes a negative anomaly in the weathered pyritic area and an encircling positive anomaly where the metals have been concentrated by precipitation from supergenesolutions. These anomalies obviously do not indicate an ore deposit but only decreased acidity in the surface solutions and surrounding rocks lacking high sulfur, and demonstrate the necessity of appropriate geochemical interpretation of anomalies and the importance of distinguishing between anomalies related to ore-forming processes and those that are not.

In many areas the analysis of soils for uranium or other ore metal gives a fairly reliable and consistent indication of ore that is concealed beneath. Biogeochemical processes tend to concentrate certain elements at the surface even though the source of the element may be at a depth of many meters. The accumulation of zinc, uranium, vanadium, selenium, sulfur, and other elements in plant tissues has long been known, and convincing evidence has been found that these elements tend to enrich the surface layers as the organic material in which they were concentrated is decomposed through biogeochemical agencies at the surface. In areas where there is an appreciable zone of plant litter, samples of the underlying soil must be studied with the possibility in mind that the minor-element content has been pumped to the surface through the root systems of plants. It is quite possible, however, to establish "target" areas on the basis of geochemical anomalies produced in this way. In semiarid regions where little or no plant debris accumulates, analysis of the vegetation itself for uranium or other ore metal may provide the information necessary to disclose the presence of a hidden ore body tapped by the root systems of the plants.

Under favorable conditions metals in small amounts are also introduced into transported soil which covers a truncated ore deposit. Unlike the anomalies caused by concentration in decaying vegetation these superimposed halos show a concentration gradient increasing downward and probably reflect diffusion or capillary movement in moist regolith overlying an oxidizing ore body. Such anomalies may be the geochemical analogue of geophysical selfpotential anomalies related to decomposing sulfide ores. The more mobile elements, such as sulfur, zinc, cobalt, uranium, and - under alkaline conditions-molybdenum, are the elements most likely to be found in superimposed or diffusion halos. These are also the metals most likely to be leached from residual soil or gossan over an ore body. The metals sought in residual material over an ore body would be those of low mobility, such as thorium, lead, copper, vanadium, niobium, selenium, and arsenic, although there is generally a perceptible rise in the concentration of the more mobile elements associated with the ore in 
the vicinity of the ore deposits as contrasted with the barren rocks surrounding it.

The search for geochemical anomalies in transported material is most commonly directed toward finding a dispersion train or fan that may lead the prospector back to the bedrock source of detrital ore minerals. Such a search is merely a modern extension of the ageold techniques of searching out lodes by panning gravels for gold or other heavy minerals and of following the increasing concentration of the detrital minerals upstream to their source.

In using geochemical methods to search for uranium, both the direct search for uranium and the indirect method where primary or secondary halos of asociated elements are sought have considerable promise. Although geochemical methods have not been widely used to detect uranium because radiometric anomalies can be found easily by airborne, truck-borne, and hand-carried instruments, the importance of a radiometric high must always be ascertained by chemical analyses. In areas subject to radioactive fallout from atomic fission devices, contamination may make radiometric techniques nearly useless without constant chemical check. A simple, sensitive, and inexpensive field method of analysis for uranium (see p. 664) allows quick evaluation of such anomalies and makes it possible to discriminate between anomalies caused by uranium in contrast to those related to thorium, or to daughter products. This chemical method is also of value in testing nonradioactive materials for recently deposited uranium, or in areas where there is a substantial cover over uranium bodies and, as a consequence, the radioactivy of the ore bodies is not appreciable at the surface. In the surface soil horizons of such localities, a very slight concentration that diminishes downward may be highly significant and suggests the probability of biogeochemical concentration from depth.

It is always desirable to make preliminary orientation surveys in geochemical investigations so that the geochemical problems can be evaluated before embarking on a full-scale program. The use of geochemical techniques is especially advantageous when searching for ore bodies that have primary or secondary halos much larger than the ore deposits themselves; the size of such halos can be determined by studies near known ore deposits. Geochemical surveys may fail needlessly, although the analytical work is satisfactory, if the type of anomaly sought does not exist or if the samples were taken in the wrong places, in the wrong materials, or with the wrong spacing. Preliminary work should establish the proper procedure to be followed.

For successful geochemical work five problems must be considered: the element to be sought and the estab- lishment of valid background values, the material best suited for sampling, the geometric pattern for sampling best suited to the geology, the maximum permissible spacing of the samples necessary to reveal anomalies, and the most effective analytical procedure. The answers to these problems depend on the kind, size, contrast, and homogeneity of the anomaly, and on the chemical facilities available. As most geochemical anomalies result from movement of solutions, soil, or rock, it is apparent that the climate, the topography, and the size and shape of the source of the material are the most important factors determining the geometry of a sampling pattern. After some information has been obtained from preliminary orientation studies concerning the probable general size and sbape of the dispersion pattern to be sought, the geometry and spacing of the samples are chosen so as to assure that at least two, and preferably more, samples will fall within the zone of an anomaly. Where the size and shape of the mineral deposit are unknown, it is common practice to run traverses parallel and at right angles to topographic features, such as ridge crests and valleys. Anomalies developed by diffusion into barren material above ore are generally of small extent and may require spacing samples 3 to 20 meters apart. In glacial till a spacing of 100 meters to as much as 500 meters may be effective in locating ore-bearing detritus in dispersion trains or fans.

Ore deposits of uranium and of thorium make up a very small fraction of the earth, and one of the principal objectives of the prospector is to select the most favorable area for intensive study as quickly and cheaply as possible. To explore a new region the geologist must use rapid reconnaissance methods so far as is feasible, striving to eliminate the least favorable areas quickly so that an increasingly intensive study of the favorable zones may be made in a progressive effort to reduce the size of the target that must ultimately be proved by physical investigation. Geochemical methods provide an additional technique that may be of great value in supplementing geological and geophysical guides to ore.

\section{ANALYTICAL METHODS FOR GEOCHEMICAL EXPLORATION}

The analytical methods used should be simple, rapid, inexpensive, and adequate. Low-cost personnel should be able to operate them with little training. A fair degree of precision-reproducibility of results-rather than a close quantitative accuracy is the end sought in applied geochemical prospecting. The accuracy need only be adequate to distinguish between areas appreciably above or below background.

Colorimetric and spectrographic methods of chemical analysis that find wide use in geochemical prospecting 
must meet several exacting requirements, which range from those directly related to the methods themselves such as simplicity, brevity, and accuracy, to those unrelated but important factors of cost and ease of application to large numbers of samples. These requirements are discussed separately for convenience.

If two or more types of analytical methods possessing the desired sensitivity and precision are available, the type selected for a given geochemical prospecting program depends partly on the size of the program. The number of samples processed may be a few hundred performed by an individual prospector on a small program or several hundred thousand for a large-scale exploration program. The initial cost of a truckmounted spectrographic laboratory, which would provide one type of useful analytical method for certain elements, would be prohibitive in a small program but economically feasible and desirable in a large one.

A productive analytical method in geochemical prospecting must be simple enough to be performed by technicians rather than by professional personnel. The term "simplicity" connotes in colorimetric analytical methods few chemicals and a minimum of apparatus so that the work is reduced essentially to "test tube" analysis, and in spectrographic methods it means short procedures and quick comparisons made on sturdily built equipment.

Useful chemical procedures in geochemical prospecting should be moderately accurate, but what constitutes sufficient accuracy varies greatly with the element concerned. The desired accuracy will often be determined by the type of material sampled, as well as by the significant variation in concentration of the element in the material. For example, biogeochemical prospecting by determining small amounts of molybdenum in plant materials requires that the useful method be sufficiently accurate to detect differences in the molybdenum content of plants growing in soils containing relatively large amounts of molybdenum and in plants growing in soils relatively free of molybdenum, but the useful method need not detect small variations caused by factors such as the health of the plant, differences in soil moisture, and other unrelated ecological components (Reichen and Ward, 1951).

The analytical methods used in geochemical prospecting are those of trace analysis - the determination of exceedingly small amounts of the desired constituent in the presence of large amounts of other elements, many of which may interfere seriously in the reactions involved. Consequently, the simple methods involved in determining a very small amount of the desired element in the pure state are not adequate. However, if such a method exists, the problem of determining the desired element in various natural materials such as soil, rock, water, or vegetation, may be relatively simple or complex, depending on the nature of the reaction used in the method and the ease with which interferences may be overcome, If a method of trace analysis applicable to these materials is available, the development of a suitable field method becomes one of engineering and adaptation - volumes and weights are decreased, apparatus and operations are modified. Separations are held to a minimum by the use of complexing agents and changes in valence, but unavoidable separations are made by using immiscible solvents, usually with a relatively small volume, to concentrate the element being measured. For example, the molybdenum method described below is an adaptation of a method that originally required a high-temperature furnace, platinumware, large separatory funnels, and a spectrophotometer.

Similarly, spectrographic methods and equipment that find use in geochemical prospecting are engineered and adapted to use under field conditions. In contrast to the usual techniques of quantitative spectrography, which involve measurements of intensity ratios of line pairs on a photographic plate or film, semiquantitative methods are used, and the concentration of an element is determined by visually comparing the blackness of a line of an element with the blackness of the same line emitted from standards having known amounts of that element. Standard and unknown samples should be as nearly alike as possible in chemical composition and physical characteristics, and must be treated alike in the procedure used to produce the spectra. It is expected that spectrographic methods will find their maximum usefulness in large-scale programs where each sample must be analyzed for several elements in an early survey to help select the most diagnostic group of elements.

Although the preceding discussion is limited to colorimetric and spectrographic analytical methods, the U.S. Geological Survey is investigating the applicability of techniques involving X-ray fluorimetry, polarography, and paper chromatography including paper electrophoresis.

Specific applications of paper chromatography and colorimetry to methods useful in prospecting for uranium and for possible associated elements are made below. Each method is fast, simple, and moderately accurate. Each is designed to give positive tests for background material in large areas of the United States and to give results within 30 to 50 percent of the correct value for materials containing anomalous amounts of a given element.

Many comparisons of the results obtained by these methods with those obtained using established procedures show that they have adequate accuracy for use 
in geochemical prospecting for uranium and associated elements.

Some of the elements most commonly associated with uranium deposits in the United States are vanadium, molybdenum, selenium, niobium, copper, and cobalt; the methods used to determine uranium and these indicator elements by the U. S. Geological Survey are outlined below. All the methods described below have been used to delineate areas of mineralization in various parts of the United States; with the exception of selenium all the methods have been used by technicians in the field and in the analytical laboratory to analyze 30 to 80 samples in an 8-hour day.

\section{DETERMINATION OF ELEMENTS}

Uranium.-This method, without modification, permits the determination of 4 to $400 \mathrm{ppm}$ of uranium in a soil or sedimentary rock. It is unsatisfactory for the determination of uranium occurring as a constituent of a refractory mineral. The method described below is a modification of a paper chromatographic procedure for use in geochemical prospecting described by Hunt, North, and Wells (1955). A 1-gram sample is digested for 1 hour in a boiling water bath with $2 \mathrm{ml}$ of $1+3$ nitric acid saturated with aluminum nitrate. A $0.01-\mathrm{ml}$ aliquot of the supernatant solution is placed on a Whatman CRL/ 1 filter paper and dried in a desiccator over calcium chloride for 8 minutes at ambient temperatures of $60^{\circ}$ to $90^{\circ} \mathrm{F}$ and for 5 minutes when temperatures exceed $90^{\circ} \mathrm{F}$. The lower end of the dry paper is immersed in a developing solution $(30 \mathrm{ml}$ ethyl acetate, $3.5 \mathrm{ml}$ concentrated nitric acid, and $10 \mathrm{ml}$ of water contained in a $600-\mathrm{ml}$ beaker) until the solution has risen about $8 \mathrm{~cm}$ in the paper. Then the paper is removed from the developing solution, dried, sprayed with a 5-percent aqueous solution of potassium ferrocyanide, and the resulting stain of the brown-colored uranium complex is compared with standards similarly prepared.

This procedure differs from that of Hunt, North, and Wells by the addition of a relatively large amount of aluminum nitrate to the sample solution to facilitate the determination of uranium in phosphatic materials. In addition, the residual salts on the filter paper after evaporation are essentially constant, and differences resulting from varying solubility of the sample are nullified.

Vanadium.-Without any modification the vanadium method given here (Ward and Marranzino, 1953a) is useful on soils or rocks containing from 0.03 to 2.0 percent vanadium. It is particularly applicable to oxidized materials and suffers from no interferences except that of niobium.

This wet chemical method for determining small amounts of vanadium in soils or rocks is based on a hitherto unused reaction of vanadium (III) with thiocyanate in acid medium. A 0.1-gram sample is heated with $1 \mathrm{ml}$ of 9 molar sulfuric acid, and after cooling, is treated successively with $4 \mathrm{ml}$ of 10 percent aqueous sodium citrate, $2 \mathrm{ml}$ of 2 percent disodium ethylenediamine-tetraacetic acid, $3 \mathrm{ml}$ of 15 percent stannous chloride in concentrated hydrochloric acid, and $2 \mathrm{ml}$ of 20 percent aqueous potassium thiocyanate. The yellow-colored complex is extracted into $1 \mathrm{ml}$ of ethyl ether, and the intensity is compared with that obtained from standard solutions to determine the vanadium content.

Molybdenum.-The field method for molybdenum can be applied to soils and rocks containing from about $I$ to $32 \mathrm{ppm}$ of molybdenum, and in this concentration range the precision of repeat determinations is within a few parts per million.

This method for determining traces of molybdenum in soils and rocks (Ward, 1951) is based on the reaction of molybdenum (V) with thiocyanate in dilute hydrochloric acid and subsequent extraction of the complex into isopropyl ether.

A 0.1 -gram sample is fused with 0.5 gram of a $1+1$ mixture of sodium carbonate and potassium nitrate, in a borosilicate glass test tube, and the fused mass is extracted with $4 \mathrm{ml}$ of hot water. A 1-ml filtered aliquot of the aqueous extract is neutralized with molar hydrochloric acid and treated with $0.5 \mathrm{ml}$ of 10 percent aqueous potassium nitrate and 0.2 gram solid sodium tartrate. The volume is adjusted to $5 \mathrm{ml}$ with water and treated successively with $0.5 \mathrm{ml}$ concentrated hydrochloric acid, $0.3 \mathrm{ml}$ of 5 percent aqueous potassium thiocyanate, and $0.5 \mathrm{ml}$ of 10 percent stannous chloride in 2 molar hydrochloric acid. The amber-colored molybdenum complex is extracted into $0.3 \mathrm{ml}$ of isopropyl ether to concentrate the colored complex and increase the overall sensitivity of the method. The colored ether layer obtained from a sample is compared with that obtained from standard solutions to determine the molybdenum content of the sample.

Selenium.-This method is useful for the semiquantitative determination of selenium in soils, rocks, and vegetation containing from 2 to $100 \mathrm{ppm}$ of selenium. It is not suitable for field use. The method is a microchemical adaptation of the well-known distillation procedure of Hillebrand and others (1953), combined with Franke's confined spot method of estimation (Franke, Burris, and Hutton, 1936). A 1.0-gram sample of the soil, rock, or vegetation is evaporated slowly with $10 \mathrm{ml}$ of nitric acid containing $10 \mathrm{mg}$ each of mercuric oxide and ammonium metavanadate, until $2 \mathrm{ml}$ remains. The mixture is fumed with $10 \mathrm{ml}$ of concentrated sulfuric acid and then centrifuged at $1500 \mathrm{rpm}$ 
for 10 minutes, after which the supernatant liquid is decanted into a 125-ml distillation flask. Ten milliliters of concentrated hydrobromic acid and a few drops of bromine are added, and 8 to $10 \mathrm{ml}$ is distilled into a beaker containing $2 \mathrm{ml}$ of water and a few drops of bromine. The distillate is reduced with sulfur dioxide and $1 \mathrm{ml}$ of a saturated aqueous hydroxylamine hydrochloride solution, digested on a steam bath for 20 minutes, and set aside for 12 hours. The precipitated selenium is collected on a paper disc covered with a barium sulfate mat by filtering the distillate through the disc fixed between two sections of glass pipe held firmly together with a suitable coupling. The pink selenium spot is compared with standard spots prepared similarly.

Copper.-The colorimetric method described here is designed for the estimation of copper in soils and rocks containing 20 to $4,000 \mathrm{ppm}$ (Bloom and Crowe, 1953). The method is based on the reaction of copper in an acidic solution with diphenylthiocarbazone (dithizone) to form a pink copper dithizonate soluble in carbon tetrachloride. A 0.1-gram sample of soil or rock is digested for 1 hour on a boiling water bath with $3 \mathrm{ml}$ of $1+3$ nitric acid and then diluted to $10 \mathrm{ml}$ with metalfree water. A suitable aliquot is transferred to a test tube containing $1 \mathrm{ml}$ of 10 percent sodium citrate solution and 2 drops of thymol blue solution. The $\mathrm{pH}$ is adjusted to 2,5 with $1 \mathrm{~N}$ hydrochloric acid. To this solution $2.5 \mathrm{ml}$ of 0.001 percent dithizone solution in carbon tetrachloride is added, the mixture is shaken vigorously for 2 minutes, and the resulting color of the organic phase is compared with that of standards similarly prepared.

Cobalt.-The cobalt method (Almond, 1953) is applicable to soils and rocks containing from 10 to $500 \mathrm{ppm}$ of cobalt. It is based on the reaction of cobalt with 2-nitroso-1-naphthol to form a pink-colored complex soluble in carbon tetrachloride. A 0.1-gram sample is fused with 0.5 gram of potassium pyrosulfate, and the cool melt is extracted with $10 \mathrm{ml} 0.5$ molar hydrochloric acid. A 2-ml aliquot is treated with $1 \mathrm{ml}$ of 10 percent sodium citrate and $4 \mathrm{ml}$ of 2 percent aqueous disodium hydrogen phosphate dodecahydrate. The $\mathrm{pH}$ is adjusted to $6.5 ; 3 \mathrm{ml}$ of 0.01 percent aqueous 2-nitroso-1-naphthol and $1 \mathrm{ml}$ of carbon tetrachloride are added. The pink-colored cobalt complex is extracted into the organic layer, which is separated and shaken with $10 \mathrm{ml}$ of 0.05 percent aqueous potassium cyanide to decompose the nickel and copper complexes.

The intensity or shade of pink is a measure of the cobalt present, and the comparison of the color produced by a sample with that produced by a cobalt standard provides a means of measuring the cobalt content of the sample.

$$
385115-56-43
$$

Niobium.-The method given below can be applied to materials containing from 20 to $2,000 \mathrm{ppm}$ of niobium. It is based on the reaction of niobium (V) with thiocyanate in hydrochloric acid and subsequent extraction of the niobium complex into ether (Ward and Marranzino, 1953b). A 0.2-gram sample is fused with 4 grams of potassium pyrosulfate and extracted with $10 \mathrm{ml}$ of 1 molar aqueous tartaric acid. A $1-\mathrm{ml}$ filtered aliquot is treated with $5 \mathrm{ml}$ of 9 molar hydrochloric acid, which is also 1 molar in tartaric acid. To the cool solution $\left(20^{\circ}\right.$ to $\left.25^{\circ} \mathrm{C}\right) 5 \mathrm{ml}$ of 20 percent ammonium thiocyanate and $5 \mathrm{ml}$ of ethyl ether are added. After shaking, the ether phase is separated and treated successively with small portions of 10 percent stannous chloride in 2 molar hydrochloric acid to remove iron, titanium, and other reducible metals whose lower valences are insoluble in ether. The yellow-colored ether phase is diluted with an equal volume of acetone to stabilize the solution and inhibit side reactions, Niobium is determined by comparing the intensity of the yellow color of the ether solution obtained from a sample with that obtained from a standard. The niobium can also be determined by measuring the absorbance of the yellow-colored ether solution at 385 millimicrons and referring to a previously established standard curve.

\section{REFERENCES CITED}

Ahrens, L. H, 1954, The lognormal distribution of the elements: Geochim. Cosmochim. Acta, v. 5, p. 49-73.

Almond, $\mathrm{Hy}, 1953$, Determination of traces of cobalt in Eoils. A field method: Anal. Chemistry, v. 25, p. 166-167.

Bloom, H., and Crowe, H. E., 1953, Determination of readily soluble copper, zine, and lead in soils and rocks; nitric acid digestion, in Additional field methods used in geochemical prospecting by the U. S. Geological Survey: U. S. Geol. Survey Open File (in Washington) Rept. 208, p. 16-24.

Franke, K. W., Burris, Robene, and Hutton, R. S., 1936, A new colorimetric procedure adapted to selenium determination: Indus. Eng. Ohemistry, Anal. Ed., v. 8, p. 435.

Hillebrand, W. F., Lundell, G. E. F., Bright, M. S., and Hoffman, J. I., 1953, Applied inorganic analysis, 2d Edition: New York, John Wiley and Sons, Inc., p. 330.

Hunt, E. C., North, A. A., and Wells, R. A., 1955, Application of paper-chromatographic methods of analysis to geochemical prospecting: Analyst, v, 80, p. 172-194.

Reichen, L. E., and Ward, F. N., 1951, Field method for the determination of molybdenum in plants: U. S. Geol. Survey Circ, 124, 4 p.

Ward, F. N., 1951, Determination of molybdenum in soils and rocks. A geochemical semimicrofield method: Anal. Chemistry, v. 23, p. 788-791.

Ward, F. N., and Marranzino, A. P., 1953a, The field determination of small amounts of vanadium in rocks, in Additional field methods used in geochemical prospecting by the U. S. Geological Survey: U, S. Geol. Survey Open File (in Washington) Rept. 208, p. 39-41.

$-1953 b$, Determination of microgram quantities of niobium in rocks, in Additional field methods used in geochemical prospecting by the U. S. Geological Survey: U. S. Geol. Survey Open File (in Washington) Rept. 208, p, 34-38. 


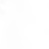




\title{
HYDROGEOCHEMICAL EXPLORATION FOR URANIUM
}

\author{
By Philip F. Fix, U. S. Geological Survey
}

\section{CONTENTS}

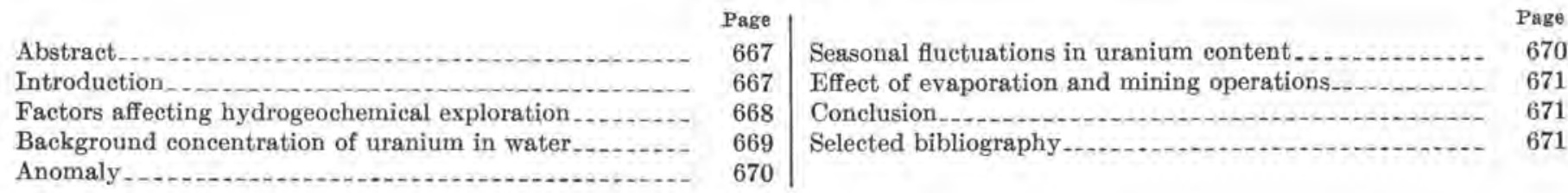

\begin{abstract}
Ground water and surface water take up uranium in different amounts dependent on the $\mathrm{pH}$ and chemical composition of the water and the composition and permeability of the geologic material with which the water is in contact. With due regard for these variables, the uranium content of water serves as a rough index of the uranium concentration in nearby geologic materials. The concentration of uranium in streams flowing through a uraniferous area usually drops off downstream chiefly because of dilution by addition of ground water from underflow and of surface water from tributaries that traverse barren areas and consequently have a low uranium content. In most uraniferous areas the surface waters commonly contain from 1 to 10 $\mathrm{ppb}^{1}{ }^{1}$ but acid underground waters may carry several thousand $\mathrm{ppb}$ of uranium. Where ground has been disturbed by mining or water has been partly evaporated, abnormally high uranium concentrations may result, and interpretation must always be made with such factors in mind. Except just downstream from uraniferous districts, large streams are generally close to regional background because of dilution of the relatively few uraniferous waters by the many tributaries and ground-water sources coming from barren ground. Background for major streams in the United States is commonly about $0.1 \mathrm{ppb}$, but may be somewhat higher or lower, depending on the geologic character of the terrane traversed. The threshold of significance is taken at 3 to 10 times the background, depending on the geologic and chemical factors involved.

In the Florida phosphate area the background is $0.1 \mathrm{ppb}$ and the threshold of significance is approximately $0.3 \mathrm{ppb}$; here a uranium content of 1 to $31 / 3 \mathrm{ppb}$ is regarded as a strong indication of the presence of uraniferous phosphate. In contrast, the Colorado Plateau area has a background in surface streams of about 0.5 to $3.0 \mathrm{ppb}$ and the threshold of significance is about $4 \mathrm{ppb}$ in the major streams; anomalies in or near uraniferous areas range from 5 to $12 \mathrm{ppb}$ where the streams are free of contamination. Ground water is usually much higher, about 1 to $10 \mathrm{ppb}$ in barren aquifers and 5 to several hundred $\mathrm{ppb}$ in mineralized aquifers.
\end{abstract}

${ }^{1} \mathrm{Ppb}$ is used for parts per blllion, where billion is defined as $10^{\circ}$. Thus, $0.1 \mathrm{ppb}$ is $0.0001 \mathrm{ppm}$, or $10^{-4}$ percent.
Water samples from uraniferous areas in the Boulder batholith in Montana show a regional background of about $0.1 \mathrm{ppb}$ with a threshold of significance of about $1.0 \mathrm{ppb}$. Near uraniferous deposits anomalies correspond with 2 to $5 \mathrm{ppb}$ of uranium in the surface water and $10 \mathrm{ppb}$ in ground water. Drainage from veins that earry radioactive minerals may carry 20 to more than $200 \mathrm{ppb}$.

Carefully planned sampling of surface waters is a rapid way of indexing the uranium probabilities in unexplored areas, and detailed work in mineralized districts and active mines is useful in guiding both physical exploration and detailed local geologic work. Analyses of more than 700 samples have established the validity of this method, and comparisons with geologic and geophysical methods of prospecting show excellent agreement.

\section{INTRODUCTION}

Hydrogeochemical methods of finding and estimating the economic possibilities of uranium deposits, based upon differences in the uranium content of natural waters, were developed and tested under known conditions in uranium mining areas in 1952 after earlier work had shown promise. These methods have been made more sensitive and accurate as a result of continuing refinement of field and laboratory techniques and standardization for different types of environment in which uranium may occur. Their validity has been proved by data from more than 700 water samples from uraniferous localities in the United States. Results agree closely with those of radiometric and geologic methods, but hydrogeochemical methods, because of the deep penetration by water underground far below the reach of instruments at the surface, also can be used in some places where other methods fail.

Comparative studies were made with both borosilicate glass and polyethylene bottles (in various sizes), with and without stabilization by hydrochloric or nitric 
acid. Hydrochloric acid is used in the standard procedure adopted. The few samples that contained sediment were decanted into clean bottles after standing for a short time. Filtering was avoided. Uranium is determined fluorimetrically in laboratories of the Geological Survey, and as yet there is no field method for the determination of the small amounts of uranium present in most samples.

The present report summarizes some results of more than 700 uranium determinations, 170 semiquantitative spectrographic analyses in which 60 elements were sought, and 230 chemical analyses for major and some minor elements in samples representing waters from most of the Western United States and Southeastern States. In addition to these data, 2,400 uranium determinations were made on water samples collected by other members of the Geological Survey.

\section{FACTORS AFFECTING HYDROGEOCHEMICAL EXPLORATION}

Uranium deposits seldom occur under simple geochemical conditions, hence a hydrochemical search for them involves appraisal of the net relative effect of such complex variables as the mineralogy of the deposit; the oxidation of associated sulfide minerals; the geology of the area; the $\mathrm{pH}$, chemical composition, oxidation-reduction potential, temperature, and content of colloids, clays, and organic matter of the waters; the season; the climate; the relationship between stream underflow and surface flow; and the circulation pattern of the ground water. With due regard for these variables, the uranium content of the water serves as a rough index of the uranium concentration in the geologic materials hydrologically tributary to the sample site.

Hydrogeochemical methods of finding and appraising uranium deposits are based upon the fact that weathering and erosion produce a secondary dispersion aura of uranium dissolved in ground and surface waters. The aura ordinarily resembles the deposit in ground plan, although it is much more extensive, except in the direction of water flow where it is sharply asymmetric owing to the ease with which most waters can dissolve and carry uranium.

Most of the uranium is carried away in ground water and appears ultimately at the land surface in streams. Ordinarily, little is carried away directly in surface water, but the amount may be large where easily soluble uranium minerals in dry-season efflorescences or uraniferous dusts from mining operations or haulage are swept away by storm waters.

The effect upon the uranium content of ground waters by snow melt or storm waters ordinarily is one of pro- portional dilution, but where ground water at low stage is reduced to virtual stagnancy by a dry season or drought, the sudden influx from the surface above may flush the ground water from crevices where it has been enriched by long soaking contact with uranium minerals. The sudden addition of such water to other ground water that has been circulating may cause a large increase in the net uranium content in the immediately surrounding ground water until dilution by the surface water takes effect.

Because ground water enters streams as underflow and hillside springs, analyses of stream water can be used to detect uranium deposits by hydrogeochemical methods. Dispersion auras can be detected at great distances in streams. The sampling pattern resembles that of gold panning. Water samples are collected from streams above their confluences and at all geologically promising intermediate points. Samples are taken far enough above confluences to be beyond the effect of underflow from the other fork of the stream. Samples are never taken just below confluences, as the chemical blending of two streams requires distances ranging from several hundred meters in small streams to several kilometers or more in rivers.

A single aura, even from a small deposit, ordinarily is easily deteeted and evaluated downgradient at distances of hundreds of meters in ground water, and at least 20 kilometers in streams. The auras of closely spaced deposits blend into a single composite aura. The greater the number of deposits per unit area and the greater the solubility of the uranium minerals, the shorter is the distance at which an individual aura can be distinguished from its neighbors.

Under favorable conditions, the dense aura of a large uranium deposit, or a major composite aura, is easily detectable quantitatively downgradient as far away as several kilometers in ground water, and probably at least a hundred kilometers in streams. Work in progress on the Dolores River in the semiarid Colorado Plateau suggests that where dilution by large tributaries is a minor factor the effect of a major aura may decrease only 50 percent in a distance of about 80 kilometers downstream.

A typical example, taken from the Boulder batholith in Montana, includes detection of an individual aura and tracing its effect through a neighboring composite aura from a uranium mine and several prospects. The climate in the region is semiarid, and the samples were taken after a dry summer when both surface and ground-water inflow to the streams were at a minimum. Mine water from a sulfide base-metal vein with some radioactive black mineral contains $11 \mathrm{ppb}$ (parts per billion) uranium at the portal. Uranium in this mine 
was discovered by the writer with the following suite of samples, after an earlier sample at the 3-kilometer point had disclosed the presence of uranium in the drainage basin. The effect downstream from the mine is shown in the table below.

\begin{tabular}{|c|c|c|}
\hline $\begin{array}{c}\text { Distance } \\
(\mathrm{km})\end{array}$ & $\begin{array}{c}U_{(p p \delta)}^{\prime} \\
\text { (a) }\end{array}$ & Source of toater sample. \\
\hline 0 & 11 & Mine water at portal. \\
\hline 0 & .9 & Creek above mine portal. \\
\hline 1 & 4. 3 & Creek after blending with mine water. \\
\hline 1. 5 & .8 & Small tributary. \\
\hline 2.3 & 2. 7 & Small tributary. \\
\hline 3 & 4.3 & Creek after blending with tributaries. \\
\hline 4. 7 & 1. 0 & Large tributary. \\
\hline 6 & 2. 3 & Creek after blending with large tributary. \\
\hline 9 & 5. 9 & Small tributary at edge of composite sura. \\
\hline 9.5 & 3. 2 & Creek above confluence with master oreek. \\
\hline & 1. 3 & Master creek $0.3 \mathrm{~km}$ above confluence. \\
\hline 10 & 1. 7 & Master creek after blending with creek. \\
\hline 18 & 3. 0 & $\begin{array}{l}\text { Master creek at lower end of composite aura, } \\
\text { after jnflux of ground water and large tribu- } \\
\text { taries ranging from } 4.1 \text { to } 7.9 \text { ppb U. }\end{array}$ \\
\hline
\end{tabular}

Influx of ground water in the first 9 kilometers is very small, and probably none contains more than $2.7 \mathrm{ppb} \mathrm{U}$. The changes in uranium content of water in the 18 kilometers are in almost exact proportion to the volume and uranium content of incoming streams and rather accurate estimates of ground water influx. The effect of the first aura downstream decreases about 50 percent in the first 6 kilometers, considering the additive effect of the second small tributary. The following effects are shown successively: the additive effect of the tributary from the first unit of the composite aura, the effect of the creek upon the uranium content of the master creek, and the net effect of all at the lower end of the composite aura. At that point, the effect of the first aura can still be detected when relative volume of water is considered. Its effect has been detected several kilometers farther downstream.

Standardization of appraisal techniques for the many types of environments requires detailed geochemical information from as many diverse types of uraniferous waters as possible. The great diversity in the large number of samples examined is shown by the following index of selected major items:

$\begin{array}{lrc}\text { U }(\mathrm{ppb}) & \begin{array}{r}\text { Maximum } \\ 5,300\end{array} & <0.02 \pm \\ \mathrm{Fe}(\mathrm{total}) \text { (ppm) } & 2,310 & <.1 \\ \mathrm{Ca}(\mathrm{ppm}) & 1,190 & 6 \\ \mathrm{Mg}(\mathrm{ppm}) & 1,520 & .1 \\ \mathrm{Na}(\mathrm{ppm}) & 13,400 & .3 \\ \mathrm{~K}(\mathrm{ppm}) & 1,100 & .1 \\ \mathrm{HCO}(\mathrm{ppm}) & 2,630 & 0 \\ \mathrm{SO}(\mathrm{ppm}) & 8,820 & , 7 \\ \mathrm{Cl}(\mathrm{ppm}) & 25,000 & <.1 \\ \text { Total dissolved solids } & 42,200 & 23 . \\ \text { Total carbonate hardness } & 7,250 & 2.0 \\ \text { pH } & 9.3 & 2.5\end{array}$

Thermal springs are lower in uranium content than cold waters under equivalent conditions. This is probably due to the increased chemical reactivity of hot waters and the removal of uranium minerals early in the life of the springs. The highest uranium content found to date is $7.0 \mathrm{ppb}$ in the Alhambra hot spring in Montana. Cold water in a uranium prospect only a few hundred meters distant on the same mineralized structure contains $140 \mathrm{ppb}$ U.

\section{BACKGROUND CONCENTRATION OF URANIUM IN WATER}

The background concentration of uranium in natural waters, expressed in parts per billion ( $\mathrm{ppb}$ ), is roughly analogous to the background intensity of radioactivity, expressed in milliroentgens per hour (m per hr); but, as one measures uranium directly and the other does not, they are not to be equated. The standards of reference are entirely different.

For elarity two types of hydrogeochemical background are distinguished in appraising uranium deposits. The regional background is the average uranium content of waters in a given region that are not appreciably affected by dispersion auras. The areal background is the average for waters in a given area, ordinarily much smaller than a region, that are materially affected by dispersion auras, yet are not actually in or immediately adjacent to economic or near-economic deposits.

Regional background is represented by 108 of some 700 water samples from 11 States and Alaska. The average of all 108 is $0,10 \mathrm{ppb}$, and this is thought to be reasonably representative of background for the United States and Alaska. The observed maximum is $0.5 \mathrm{ppb}$, and the minimum is $0.02 \pm \mathrm{ppb} \mathrm{U}$.

\begin{tabular}{|c|c|c|c|c|}
\hline \multirow{2}{*}{ State } & \multirow{2}{*}{$\begin{array}{l}\text { No. of } \\
\text { samples }\end{array}$} & \multicolumn{3}{|c|}{ Uranium content (ppb) } \\
\hline & & Average & Maximum & Minimum \\
\hline $\begin{array}{l}\text { Colorado } \\
\text { Montana } \\
\text { Georgia } \\
\text { Washington } \\
\text { South Carolina. } \\
\text { Utah } \\
\text { Wyoming } \\
\text { Florida } \\
\text { Idaho } \\
\text { North Carolina }\end{array}$ & $\begin{array}{r}33 \\
22 \\
14 \\
9 \\
7 \\
7 \\
6 \\
5 \\
3 \\
2\end{array}$ & $\begin{aligned} & 0 . 19 \\
&< 16 \\
&<.1 \\
& .07 \\
& 1 \\
& 1 \\
& 10 \\
&<.1 \\
& .12 \\
& .1\end{aligned}$ & $\begin{array}{r}0.5 \\
3 \\
2 \\
2 \\
.2 \\
.2 \\
.4 \\
1 \\
3 \\
3 \\
1\end{array}$ & $\begin{array}{l}<0.1 \\
<1 \\
<.1 \\
<.02 \pm \\
<.1 \\
<.1 \\
<.1 \\
1 \\
.1\end{array}$ \\
\hline $\begin{array}{l}\text { Total number of sam- } \\
\text { ples and average } \\
\text { uranium content }\end{array}$ & 108 & 0. 10 & 0.5 & $<0.02 \pm$ \\
\hline
\end{tabular}

Areal background is represented by 195 water samples from 9 States and 8 from Alaska. The average of the 195 samples is $0.80 \mathrm{ppb} \mathrm{U}$, and this is thought to be reasonably representative for the uraniferous areas of the United States, although in the Colorado Plateau it may be considerably more. The observed 
maximum for all 203 samples is $2.5 \mathrm{ppb}$, and the minimum is $0.2 \mathrm{ppb} \mathrm{U}$.

\begin{tabular}{|c|c|c|c|c|}
\hline \multirow{2}{*}{ State } & \multirow{2}{*}{$\begin{array}{c}\text { No. of } \\
\text { samples }\end{array}$} & \multicolumn{3}{|c|}{ Uranium content (ppb) } \\
\hline & & Average & Maximum & Minimum \\
\hline $\begin{array}{l}\text { Montana } \\
\text { Colorado } \\
\text { Texas } \\
\text { Utah } \\
\text { South Carolina } \\
\text { Florida } \\
\text { New Mexico } \\
\text { Wyoming } \\
\text { Idaho }\end{array}$ & $\begin{array}{r}91 \\
52 \\
32 \\
9 \\
3 \\
2 \\
2 \\
2 \\
2\end{array}$ & $\begin{array}{l}0.69 \\
.62 \\
1.47 \\
1.13 \\
.2 \\
.2 \\
.55 \\
.65 \\
.65\end{array}$ & $\begin{array}{l}1.7 \\
1.8 \\
2.5 \\
2.0 \\
.2 \\
.2 \\
.6 \\
.8 \\
.8\end{array}$ & $\begin{array}{r}0.3 \\
<.3 \\
<.5 \\
.4 \\
.2 \\
.2 \\
.5 \\
.5\end{array}$ \\
\hline $\begin{array}{l}\text { Total number of sam- } \\
\text { ples and average } \\
\text { uranium content... }\end{array}$ & 195 & 0.80 & 2. 5 & 0.2 \\
\hline
\end{tabular}

\section{ANOMALY}

The threshold of anomaly - a rough guide to waters requiring further investigation - is about $1.0 \mathrm{ppb} \mathrm{U}$, or 10 times the regional background in the western United States generally. In the tuffaceous rocks of the Great Plains it is about $2 \mathrm{ppb}$ in surface waters and $5 \mathrm{ppb}$ in ground waters. In the Colorado Plateau, it is about $4 \mathrm{ppb}$ in surface waters and at least $5 \mathrm{ppb}$ in ground waters.

The threshold for uraniferous phosphate deposits is about $0.3 \mathrm{ppb} \mathrm{U}$. This is not to be equated with the threshold level in other terranes, because it actually refers to phosphate deposits rather than to uranium itself, which at best can be mined only as a byproduct.

The upper limits of anomaly differ greatly between ground and surface waters, and also within each type with differences in geochemical conditions. The following data concerning the range found in the two types refer only to true natural uranium content unbeneficiated by evaporation or recent mining operations, the effects of which are discussed later.

Surface waters in most uraniferous areas ordinarily contain from 1 to $10 \mathrm{ppb} \mathrm{U}$. The greatest content found to date in small streams is $32 \mathrm{ppb}$ in Bishop Creek in southwestern Montana, 2 kilometers below drainage from a uraniferous base-metal mine. In rivers, the greatest content found is $4 \mathrm{ppb}$ in the Sevier River below the Marysvale uranium-mining district in Utah. The chief controls in surface waters seem to be the extent of dilution by waters of low uranium content from barren areas, and the $\mathrm{pH}$. The $\mathrm{pH}$ in most surface waters sampled ranges from 5.5 to 7.5 ; a high uranium content does not occur in this $\mathrm{pH}$ range. Other things being equal, the more acid the waters the greater the uranium content.

Ground waters in most uraniferous areas ordinarily contain from 1 to about $120 \mathrm{ppb} \mathrm{U}$. Those within the
$\mathrm{pH}$ range of 5.5 to 7.5 contain moderate amounts, but strongly acid waters may contain very large amounts of uranium if they have access to sufficient uranium mineralization. The greatest uranium content found to date is $5,300 \mathrm{ppb}$ in water with a $\mathrm{pH}$ of 2.5 in a large uraniferous base-metal mine in Arizona.

The uranium content of any water must be appraised in terms of the net effect of the conditions controlling that particular water, including the degree of access it has had to uranium. Unevaluated data where uranium contents alone are cited have little significance. For example, waters that contain as little as $4.8 \mathrm{ppb}$ uranium are known from mines that have actually produced uranium, whereas waters from mines that have produced no uranium ore are known to contain more than 100 ppb $\mathrm{U}$, and one very acid water in a mine that to date has produced no uranium contains the maximum found $-5,300 \mathrm{ppb}$ U.

The observed range in uranium content of waters in mines that have produced at least some uranium ore is from $4.8 \mathrm{ppb}$ at the Free Enterprise uranium mine in the Boulder Batholith area of Montana, to as much as $535 \mathrm{ppb}$ in some uranium mines of the Colorado Plateau where the waters have been beneficiated to some extent by recent mining operations and by excessive evaporation caused by arid climate. The low content in the Free Enterprise mine water is the result of rapid circulation of a large volume of ground water that allows the unit volume of water minimum time to dissolve uranium.

The true natural uranium content of water in uranium mines under ordinary conditions is thought to range from about 15 to $400 \mathrm{ppb}$, but when $\mathrm{pH}$ is lower than about 4.0, the content may be much larger.

Uranium deposits differ in the amounts of major elements, and particularly in the amounts of minor elements they contain. These differences inevitably modify the chemical nature of waters passing through them. Hence the location, size, and economic possibilities of deposits are appraised on the basis of the peculiarities of chemical makeup disclosed by analysis of the waters. This consists of semiquantitative spectrographic analysis for 60 elements, chemical analyses for major elements and some minor ones, and fluorimetric analysis for uranium. These data are interpreted with respect to such geologic controls as faults, concealed bedrock ground-water dams, and permeability of formations.

\section{SEASONAL FLUCTUATIONS IN URANIUM CONTENT}

The uranium content of waters fluctuates seasonally because of dilution by snow-melt and storm waters low in uranium. Ordinarily the content is inversely proportional to the abundance of surface water, but it may be somewhat proportional if the surface water has taken 
up an abundance of uranium from dry-season efflorescences or dust. The fluctuation in ground water ordinarily is much less than in streams.

A typical example of fluctuations in smaller streams draining uraniferous areas is Prickly Pear Creek, Mont,, at the mouth of its canyon. The uranium content at seasonal peak discharge in June 1954 was $1.5 \mathrm{ppb}$, but at low stage in September 1953 it was 4.2 ppb. A typical creek in the uranium-mining area of the Front Range near Denver, Colo., contained $4.2 \mathrm{ppb}$ late in November 1954 when drought had materially reduced the water supply, but the content was $1.5 \mathrm{ppb}$ $\mathrm{U}$ in March 1955 as the result of dilution of groundwater increment by snow-melt water.

Seasonal fluctuations in the uranium content in shallow ground waters resemble those in surface waters, but in deep ground waters the fluctuations are less. Water from the Argo Tunnel that drains the uraniferous Central City mining district near Denver, Colo., contained $76 \mathrm{ppb} \mathrm{U}$ in May 1954 when snowmelt water descending through old workings was diluting the ground water, $89 \mathrm{ppb}$ in September 1954 when the ground-water level was low, and $81 \mathrm{ppb}$ in April 1955 when dilution by surface water was unusually low because of drought.

\section{EFFECT OF EVAPORATION AND MINING OPERATIONS}

The uranium content of water may be increased greatly by excessive evaporation, recent drilling or blasting, or disturbance of ground as in placer mining. The increase may be as much as several hundred times the true natural value. Evaporation effect ordinarily is negligible, but an arid climate, power ventilation in mines, or evaporation-basin conditions may have great effect.

Recent drilling or blasting may increase the uranium content as the result of comminution or fine grinding of uranium mineral to allow water to attack more surface area per unit volume per unit time. The increase is thought to range from about 25 to 250 times the true natural value, depending on the uranium content of the ground. The increase is about 25 times true natural value in one uraniferous Montana base-metal mine where conditions are closely evaluated. In a uranium mine with rich ore near Denver, Colo., the increase caused by drill-hole water seeping through normally dry workings is about 250 times. The effect decreases more rapidly where drainage is good but is thought to require about a year to be eliminated under ordinary conditions in mine workings. In drill holes the effect may last longer. The effect hás been noted in samples from deposits affected by placer mining in Idaho and Alaska, but its extent and duration are not yet known.

The effects of evaporation by mine ventilation and of drilling and blasting are commonly found together, as in the Sligo adit, which is in Chattanooga black shale in central Tennessee. A stagnant pool near the face, 150 feet from the portal, contained $690 \mathrm{ppb} \mathrm{U}$ when sampled, but after the pool was drained and samples were obtained from seepage in the walls, the uranium content was about $1 \mathrm{ppb}$. The combined effect of evaporation and mining was to increase the uranium content about 500 or 600 times the true natural value.

\section{CONCLUSION}

The large number of analyses now available establishes hydrogeochemical exploration for uranium as a valid means of appraising the uranium possibilities of regional and local areas. The many factors that must be taken into consideration can be evaluated as suggested in the foregoing test. It is very apparent that data on the uranium content of a water by itself mean little without geologic data and a satisfactory sample pattern in which to place the figure. Given the required information, however, the uranium content of natural waters, both surface and underground, should reveal the presence of much uranium ore at present undiscovered.

\section{SELECTED BIBLIOGRAPHY}

Grimaldi, F. S., May, Irving, and Fleteher, M. H., 1952, U. S, Geological Survey fluorimetric methods of uranium analysis: U. S. Geol. Survey Circ. 199, 20 p,

Judson, Sheldon, and Osmond, J. K., 1955, Radioactivity in ground and surface water: Am. Jour. Sci., v. 253, p. 104-116.

Ostle, D., 1954, Geochemical prospecting for uranium; Mining Mag., v. 91, p. 201-208. 


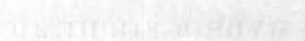




\title{
WATER SAMPLING AS A GUIDE IN THE SEARCH FOR URANIUM DEPOSITS AND ITS USE IN EVALUATING WIDESPREAD VOLCANIC UNITS AS POTENTIAL SOURCE BEDS FOR URANIUM
}

\author{
By Norman M. Denson, Howard D. Zeller, and James G. Stephens, U. S. Geological Survey
}

\section{CONTENTS}

\begin{tabular}{|c|c|c|c|}
\hline \multicolumn{4}{|r|}{ Other troea oloments } \\
\hline Abstract & - & 673 & \multirow{2}{*}{$\begin{array}{l}\text { Other trace elements } \\
\text { Summary of results }\end{array}$} \\
\hline Introdue & 1.2-1, & 673 & \\
\hline \multicolumn{2}{|c|}{ Uranium in ground water. } & 674 & \\
\hline \multicolumn{4}{|c|}{ ILLUSTRATIONS } \\
\hline \multirow{4}{*}{ FIGURE } & & Page & \multirow{4}{*}{$\begin{array}{l}\text { F1GURE 199. Generalized geologic map showing distribu- } \\
\text { tion of uranium in water in the Gas Hills } \\
\text { area, Wyo } \\
\text { 200. Generalized geologic map showing the ura- } \\
\text { nium content of water in the Crooks Gap } \\
\text { area, Fremont County, Wyo... }\end{array}$} \\
\hline & $\begin{array}{l}\text { 196. Index map showing locations of ground- } \\
\text { water samples from Tertiary rocks, ana- } \\
\text { lyzed for selected trace elements.... }\end{array}$ & 674 & \\
\hline & $\begin{array}{l}\text { 197. Map showing distribution of uranium in } \\
\text { water from Slim Buttes and vicinity, } \\
\text { Harding County, S. Dak. }\end{array}$ & 675 & \\
\hline & $\begin{array}{l}\text { 198. Map showing variation in uranium content } \\
\text { of ground water in the southern part of } \\
\text { the Powder River Basin, Wyo }\end{array}$ & 677 & \\
\hline
\end{tabular}

Page

675

680

Page

\begin{abstract}
During the investigations of the occurrence and emplacement of uranium in coal and related carbonaceous materials in the Western United States, several thousand samples of water issuing from the various widespread volcanic rock units of Tertiary age and many samples of water from the underlying sedimentary rocks were analyzed for uranium. These analyses have proved a useful guide in delimiting areas where uranium deposits are likely to occur. Largely on the basis of the uranium content of their waters, areas previously not thought favorable for the occurrence of uranium have been recommended for ground and airborne radiometric surveying, and subsequently found to contain commercial deposits of uranium.

Most ground water contains less than 2 parts per billion $\left(10^{\circ}\right)$ uranium. However, water from seeps and springs in volcanic and tuffaceous sedimentary terranes and water from areas of known uranium deposits may contain as much as 10 to 250 parts per billion. These analyses have served to delimit areas where the abnormally high uranium content of water reflects present-day leaching of hidden ore deposits and to help evaluate the relative potentialities of various voleanic units as source beds for uranium.

Volcanic rocks ranging from Late Cretaceous to Pliocene in age were examined in detail in the Rocky Mountain and Great Plains provinces and samples of water issuing from them were collected for chemical analyses. Although many of the voleanic rocks of Tertiary age contain appreciable amounts of uranium, not all of the units make the uranium available to the
\end{abstract} $385115-56-44$ ground water system in equal amounts. The units of Oligocene and Miocene age, irrespective of their geographic location, were notable for the significantly high uranium content in ground water issuing from them.

The investigations here reported are primarily concerned with uranium carried in ground water, and secondarily with that in surface water. Brief consideration is given to trace-metal suites. determined by chemical analyses of residues obtained by evaporation of bulk samples of water from the better-known and more widely distributed Tertiary voleanic units. Regional variation in the uranium content of water as influenced by the presence of uranium deposits or volcanic rocks are discussed and shown on geologic maps.

\section{INTRODUCTION}

As part of the investigations of uranium occurrences in carbonaceous rocks and sandstones the present writers and their associates collected a large number of water samples for analyses of their uranium and other tracemetal content in several areas in the Great Plains and in Tertiary basins of the Rocky Mountain region. (See fig, 196.) The samples were obtained during the years 1950-54 to accumulate data on the uranium content of water in different rock types and stratigraphic units and to evaluate water sampling as a technique in search for uranium deposits. Most of the water samples were 
collected from seeps, springs, and wells and the water was derived from underground sources. A smaller number of surface-water samples were collected from streams, lakes, and reservoirs. Attention was directed mainly toward terranes underlain by tuffaceous sedimentary rock equivalents of acid volcanic rocks, fluviatile arkosic sandstone and shale, and areas containing occurrences of secondary uranium.

The writers are indebted to many of their colleagues who collected and supplied data on a number of water samples. The analyses were made by personnel of the U. S. Geological Survey.

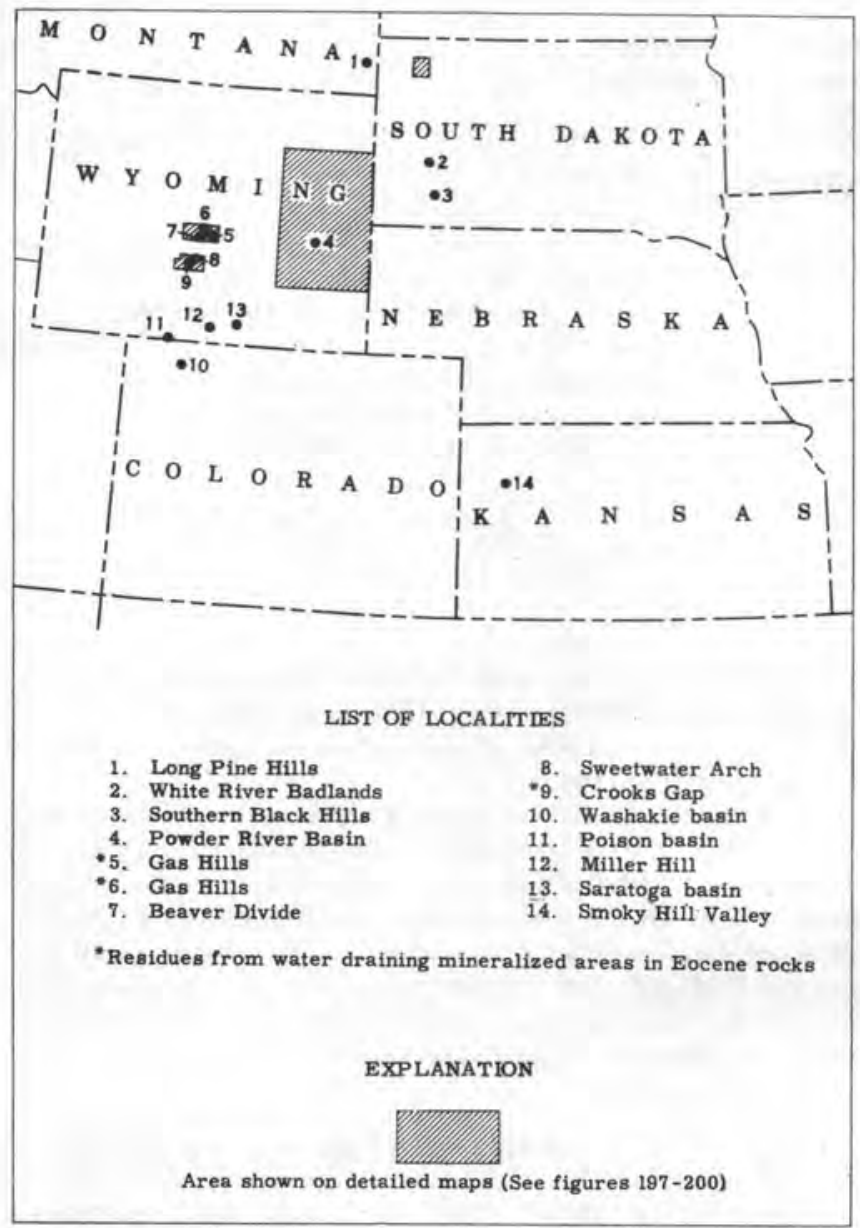

FIoURE 196.-Index map showing locations of ground-water samples from Tertlary rocks, analyzed for selected trace elements.

Pint samples of ground water were collected in polyethylene bottles, and acidity of the water was determined in the laboratory with a $\mathrm{pH}$ meter, with a glass electrode. The uranium content was determined by ethyl

acetate extraction method as follows: An acidified aliquot of the sample, usually 100 to $500 \mathrm{ml}$, was evaporated nearly to dryness and then diluted with distilled water acidified with nitric acid. An aliquot of this solution was salted with recrystallized aluminum nitrate, and the uranium was extracted with ethyl acetate. The extract was then burned off in a platinum dish, and the residue was fused with a sodium fluoride carbonate flux. A sensitive fluorimeter was used to compare the fluorescence of the unknown with standards treated in a similar manner, and the uranium content was calculated in parts per billion. The probable limits of accuracy of this method range from about $1 \mathrm{ppb}$ (parts per $10^{\circ}$ ) for samples containing $10 \mathrm{ppb}$, to about $10 \mathrm{ppb}$ for samples containing $100 \mathrm{ppb}$ uranium. A few large samples of water were collected for use in determining other trace elements.

\section{URANIUM IN GROUND WATER}

Results of systematic sampling in four areas in South Dakota and Wyoming showing the average uranium content of ground water in the different geologic environments in each area are summarized below. The variation in uranium content of water is shown on the generalized geologic maps (figs. 197-200).

Summary of the uranium content of 277 water samples from South Dakota and Wyoming

\begin{tabular}{|c|c|c|c|}
\hline Units from which water was sampled & $\begin{array}{l}\text { Springs } \\
\text { and wolls } \\
\text { sampled }\end{array}$ & $\begin{array}{c}\text { Average } \\
\text { uranium } \\
\text { content of } \\
\text { toater }(p p b)\end{array}$ & $\begin{array}{c}\text { Average } \\
p H\end{array}$ \\
\hline
\end{tabular}

Slim Buttes, S. Dak.

\begin{tabular}{|c|c|c|}
\hline Oligocene and Miocene_. & 49 & 34 \\
\hline Cretaceous and Paleocene.......... & 34 & 4 \\
\hline Mineraiized areas_..... & 5 & 72 \\
\hline 1 sample: & 8 & \\
\hline
\end{tabular}

Powder River Basin, Wyo.

Oligocene and Miocene........... 28

Mineralized areas..................

Total samples Gas Hills, Wyo.

Oligocene and Miocene...........

Precambrian and Tertiary intrusive

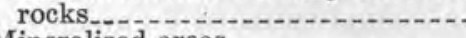

Mineralized areas..................

Total samples

Crooks Gap, Wyo.

Miocene-1._.

Eocene and older................

Mineralized areas

Total samples.

$\begin{array}{rr}46 & 8.1 \\ 4 & \end{array}$

44

57

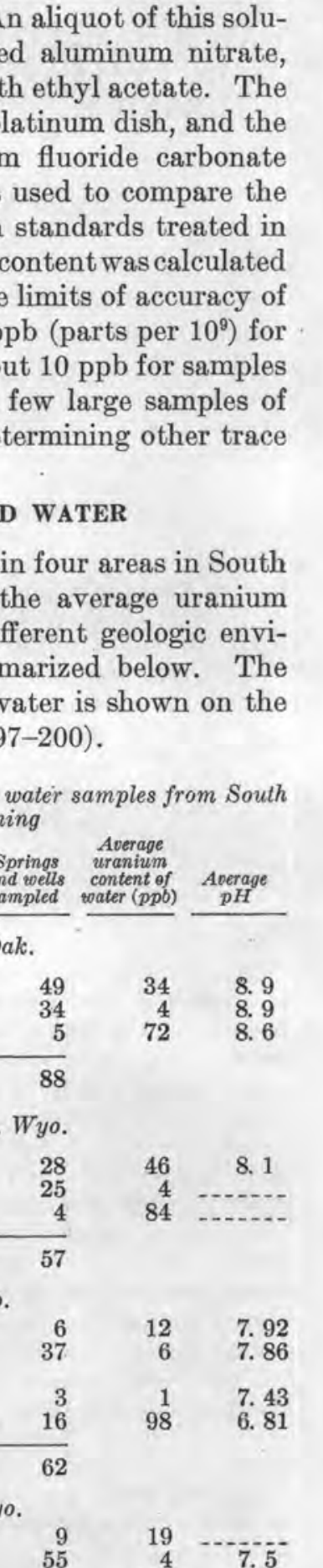

37

3

16

62

7. 92

7. 86

$\begin{array}{rr}1 & 7.43 \\ 98 & 6.81\end{array}$

7. 43
6. 81

$$
\text { . }
$$

$\begin{array}{rrr}9 & 19 & \\ 55 & 4 & 7.5 \\ 6 & 124 & 7.5\end{array}$

70 


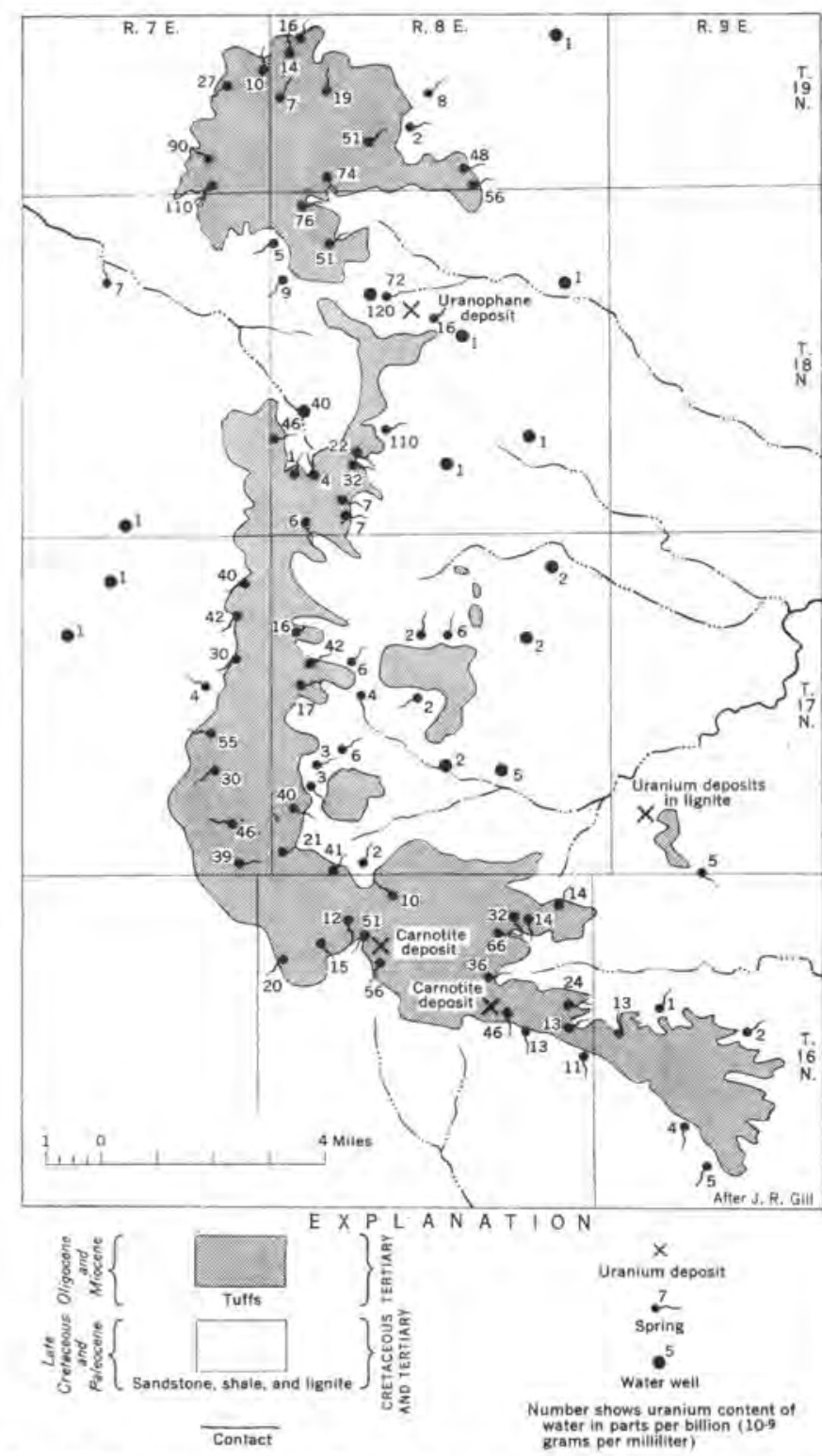

FIoure 197.-Map showing distribution of uranium in water from slim Buttes and vicinity, Harding County, S. Dak.

At Slim Buttes in southwestern Harding County, S. Dak. (fig. 197), some lignites of Paleocene age contain small amounts of uranium. Uranophane and autunite locally impregnate carbonaceous sandstones in rocks of the same age. Both the uranium-bearing lignite and sandstone closely underly tuffaceous rocks of Oligocene and Miocene age. Carnotite occurs locally in tuffaceous sandstone and claystone of the Oligocene rocks.

In the Powder River Basin in eastern Wyoming, (fig. 198) carnotite and uranophane occur in fluviatile sandstones of Eocene age. Erosional remnants of Oligocene and Miocene tuffaceous sediments in the basin indicate that most of the basin was once covered by these sediments. In the Gas Hills area, Wyoming, (fig. 199) uranium deposits occur in the Wind River formation of Eocene age, with the exception of two minor occurrences in subjacent Mesozoic rocks. Meta-autunite and an unnamed yellow uranium phosphate are the most common ore minerals and generally occur as interstitial fillings in coarse-grained, arkosic sandstone of fluviatile origin. Metazeunerite, uraninite, and other uranium minerals also are found in the area. In the Crooks Gap area, Fremont County, Wyo., (fig. 200) uranium minerals, principally uranophane and minor amounts of autunite impregnate arkosic sandstone of the Wasatch formation of Eocene age.

\section{OTHER TRACE ELEMENTS}

Trace elements other than uranium were determined by chemical and spectrographic analyses of residues obtained by evaporation of large water samples from ground water in late Tertiary tuffaceous units from localities in Kansas, Montana, South Dakota, and Wyoming. A comparison of the trace elements present in these residues with those elements present in the uranium minerals found in the region shows that most of the elements in uranium minerals are also present in the water residues. For example, the important secondary minerals common to a number of the deposits in the areas considered in this report are carnotite $\left(\mathrm{K}_{2}\left(\mathrm{UO}_{2}\right)_{2}\left(\mathrm{VO}_{4}\right)_{2} \cdot 1-3 \mathrm{H}_{2} \mathrm{O}\right)$, autunite $\left(\mathrm{Ca}\left(\mathrm{UO}_{2}\right)_{2}\left(\mathrm{PO}_{4}\right)_{2} \cdot 10-12 \mathrm{H}_{2} \mathrm{O}\right)$, and metazeunerite $\left(\mathrm{Cu}\left(\mathrm{UO}_{2}\right)_{2}\left(\mathrm{AsO}_{4}\right)_{2} \cdot 8 \mathrm{H}_{2} \mathrm{O}\right)$. In addition to uranium ore samples contain various amounts of vanadium, phosphorous, arsenic, and copper. Analyses of the water residues from the tuffaceous units shown in the tables below indicate the presence of more than normal amounts of these elements. 
Quantitative analyses of selected trace elements in water from Late Tertiary tuffaceous rocks and Early Tertiary arkosic rocks in mineralized areas

\begin{tabular}{|c|c|c|c|c|c|c|c|c|c|c|c|c|}
\hline \multirow[b]{2}{*}{ Rock Unit } & \multirow[b]{2}{*}{ Area } & \multicolumn{8}{|c|}{ In parts per billion $\left(10^{\circ}\right)$} & \multicolumn{3}{|c|}{$\begin{array}{l}\text { In parts per } \\
\text { million }\end{array}$} \\
\hline & & As & $\mathrm{Se}$ & $\mathbf{P}$ & $\mathrm{Cu}$ & V & Mo & $\mathrm{Zn}$ & $\mathrm{U}$ & $\mathrm{Na}$ & $\mathrm{Ca}$ & $\mathrm{pH}$ \\
\hline North Park formation (Pliocene?). & Miller Hill, Wyo. & 2 & $<1$ & 732 & 3 & 17 & 10 & 37 & 14 & & & \\
\hline Ogallala formation (Pliocene) & Smoky Hill, Kans. & 28 & 14 & $<42$ & 10 & 10 & 477 & 70 & 49 & 230 & .... & 7.8 \\
\hline Arikaree formation (Miocene) & Long Pine Hills, Mont. & 16 & 32 & 38 & 4 & 85 & 2 & 11 & 10 & 86 & & 8.8 \\
\hline Browns Park formation (Miocene?) & Sweetwater arch, W yo ....... & 6 & 1 & 26 & 9 & 42 & 4 & 66 & 50 & $\cdots$ & 29 & 7.6 \\
\hline & $\begin{array}{l}\text { Saratoga basin, Wyo } \\
\text { Poison basin, Wyo }\end{array}$ & $\begin{array}{l}<7 \\
60\end{array}$ & $\frac{2}{7}$ & $\begin{array}{l}71 \\
82\end{array}$ & $\begin{array}{l}5 \\
9\end{array}$ & 11 & $\begin{array}{r}24 \\
0\end{array}$ & $\begin{array}{l}43 \\
32\end{array}$ & $\begin{array}{l}16 \\
11\end{array}$ & (n). & 368 & $\begin{array}{l}7.4 \\
7.5\end{array}$ \\
\hline & 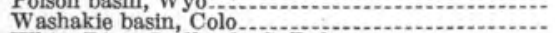 & $\begin{array}{l}00 \\
19\end{array}$ & $<4$ & 96 & 13 & 6 & 0 & 2882 & 8 & $\cdots$ & 300 & 7.7 \\
\hline White River formation (Oligocene) & White River Badlands, S, Dak & 20 & 4 & 15 & 8 & 17 & 170 & 25 & 13 & 125 & $\ldots$ & 8.5 \\
\hline & Southern Black Hills, S. Dak ................... & 19 & 5 & 22 & 3 & 15 & 15 & 27 & 8 & 132 & .... & 8.2 \\
\hline & 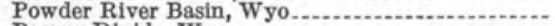 & 18 & 11 & 44 & 14 & 139 & 30 & 71 & 150 & 255 & $\ldots$ & 8. 6 \\
\hline & Beaver Divide, Wyo.......... & & & 19 & 3 & 13 & 1 & $<7$ & 13 & 71 & ... & \\
\hline Wind River and Wasatch formations (Eocene) ...... & Gas Hills No. 1 , Wyo.......... & $<11$ & $<1$ & & 18 & 3 & 3 & 233 & 270 & .... & $\because$ & 3.9 \\
\hline & $\begin{array}{l}\text { Gas Hills No, 2, Wyo } \\
\text { Crooks Gap, Wyo }\end{array}$ & $<25$ & $\begin{array}{r}10 \\
1\end{array}$ & $<125$ & $\begin{array}{r}113 \\
9\end{array}$ & $\begin{array}{l}8 \\
2\end{array}$ & $\begin{array}{r}85 \\
0\end{array}$ & $\begin{array}{l}50 \\
19\end{array}$ & $\begin{array}{l}310 \\
271\end{array}$ & 30 & $\begin{array}{r}503 \\
53\end{array}$ & $\begin{array}{l}7.7 \\
8.3\end{array}$ \\
\hline
\end{tabular}

Elements detected in water residues by spectrographic methods

[ $X$ indicates presence of element in residue; leaders indicate element looked for but not found.]

\begin{tabular}{|c|c|c|c|c|c|c|c|c|c|c|c|c|c|c|c|c|c|c|c|c|c|c|c|c|c|}
\hline Age and area & $\mathrm{Si}$ & $\mathrm{Al}$ & $\mathrm{Fe}$ & $\mathrm{T1}$ & Mn & $\mathrm{Ca}$ & $\mathrm{Mg}$ & $\mathrm{Na}$ & $\mathbf{K}$ & B & $\mathrm{Ba}$ & $\mathrm{Be}$ & $\mathrm{Cr}$ & $\mathrm{Cu}$ & Mo & $\mathrm{Ni}$ & $\mathrm{Pb}$ & $\mathrm{Sr}$ & V & $\mathrm{Zr}$ & $\mathrm{Ag}$ & Sn & $\mathbf{L i}$ & $\mathrm{Zn}$ & $\mathrm{U}^{1}$ \\
\hline $\begin{array}{l}\text { Pliocene tuffaceous rocks: } \\
\text { Miller Hill, Wyo } \\
\text { Smoky Hill, Kans } \\
\text { Miocene tuffaceous rocks: }\end{array}$ & $\stackrel{x}{x}$ & $\stackrel{x}{x}$ & $\stackrel{x}{x}$ & $\times$ & $\cdots$ & $\stackrel{x}{x}$ & $\underset{x}{x}$ & $\underset{x}{x}$ & $\underset{x}{x}$ & $\stackrel{x}{x}$ & $\underset{x}{x}$ & $\times$ & X & $\underset{x}{x}$ & $\ddot{x}$ & $\cdots$ & 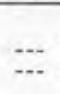 & $\underset{x}{x}$ & $\underset{x}{x}$ & $\cdots$ & $\cdots$ & $\ldots$ & $\ddot{x}$ & $\cdots$ & $\begin{array}{l}14 \\
49\end{array}$ \\
\hline 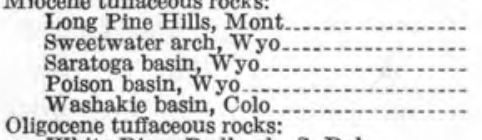 & 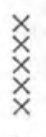 & $\begin{array}{l}\stackrel{x}{x} \\
\stackrel{x}{x} \\
\times \\
x\end{array}$ & $\begin{array}{l}\underset{x}{x} \\
\underset{x}{x} \\
x\end{array}$ & $\begin{array}{ll}\cdots \\
x \\
\cdots\end{array}$ & $\begin{array}{l}\ddot{x} \\
\stackrel{x}{x} \\
\dot{x}\end{array}$ & $\begin{array}{l}\stackrel{x}{x} \\
\stackrel{x}{x} \\
\times \\
\times\end{array}$ & $\begin{array}{l}x \\
x \\
x \\
x \\
x\end{array}$ & $\begin{array}{l}\underset{x}{x} \\
\underset{x}{x} \\
x\end{array}$ & $\begin{array}{l}\underset{x}{x} \\
\stackrel{x}{x} \\
\stackrel{x}{x}\end{array}$ & $\begin{array}{l}\underset{x}{x} \\
\times \\
x \\
x\end{array}$ & $\begin{array}{l}x \\
x \\
x \\
x \\
x\end{array}$ & $\begin{array}{ll}\cdots \\
\cdots \\
\cdots\end{array}$ & 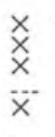 & $\begin{array}{l}x \\
x \\
x \\
x \\
x\end{array}$ & 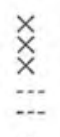 & $\begin{array}{l}-\bar{x} \\
\cdots \\
\cdots\end{array}$ & $\begin{array}{l}\ddot{x} \\
x \\
\cdots\end{array}$ & $\begin{array}{l}\underset{x}{x} \\
\underset{x}{x} \\
\underset{x}{x}\end{array}$ & $\begin{array}{l}\underset{x}{x} \\
\stackrel{x}{x} \\
x \\
x\end{array}$ & $\begin{array}{l}\cdots \\
\ddot{x} \\
\cdots\end{array}$ & $\begin{array}{ll}\cdots \\
\cdots \\
\cdots\end{array}$ & $\begin{array}{ll}\cdots \\
\cdots \\
\cdots\end{array}$ & $\begin{array}{l}x \\
\ddot{x} \\
\cdots\end{array}$ & $\ddot{x}$ & $\begin{array}{r}10 \\
50 \\
16 \\
11 \\
8\end{array}$ \\
\hline 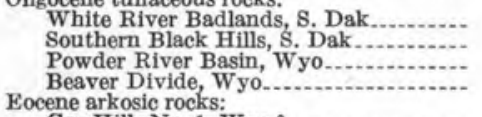 & $\begin{array}{l}\underset{x}{x} \\
\underset{x}{x}\end{array}$ & $\begin{array}{l}\underset{x}{x} \\
\underset{x}{x}\end{array}$ & $\begin{array}{l}\underset{x}{x} \\
\underset{x}{x}\end{array}$ & 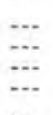 & $\cdots$ & $\begin{array}{l}\underset{x}{x} \\
\stackrel{x}{x}\end{array}$ & $\begin{array}{l}x \\
x \\
x \\
x\end{array}$ & $\begin{array}{l}\underset{x}{x} \\
\underset{x}{x}\end{array}$ & $\begin{array}{l}x \\
x \\
x \\
x\end{array}$ & $\begin{array}{l}\underset{x}{x} \\
\underset{x}{x}\end{array}$ & $\begin{array}{l}\underset{x}{x} \\
x \\
x\end{array}$ & $\bar{x}$ & $\begin{array}{l}\underset{x}{x} \\
\underset{x}{x}\end{array}$ & $\begin{array}{l}x \\
x \\
x \\
x\end{array}$ & $\underset{-x}{x}$ & $\underset{x}{\ddot{X}}$ & $\begin{array}{l}x \\
\ddot{x} \\
-\end{array}$ & $\begin{array}{l}\underset{x}{x} \\
\underset{x}{x}\end{array}$ & $\begin{array}{l}\underset{x}{x} \\
\underset{x}{x}\end{array}$ & $\ldots$ & \begin{tabular}{c}
$\underset{x}{x}$ \\
\hdashline-
\end{tabular} & 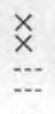 & $\begin{array}{l}\underset{x}{x} \\
\underset{x}{x}\end{array}$ & $\ldots$ & $\begin{array}{r}13 \\
8 \\
150 \\
13\end{array}$ \\
\hline $\begin{array}{l}\text { Gas Hills No. 1, Wyo.2 } \\
\text { Gas Hills No. 2, Wyo } \\
\text { Crooks Gap, Wyo }\end{array}$ & $\stackrel{x}{x}$ & $\stackrel{x}{x}$ & $\underset{x}{x}$ & $\begin{array}{l}x \\
\ddot{x}\end{array}$ & $\underset{x}{x}$ & $\begin{array}{l}x \\
x \\
x\end{array}$ & $\begin{array}{l}x \\
x \\
x\end{array}$ & $\stackrel{x}{x}$ & $\underset{x}{x}$ & $\underset{x}{\stackrel{x}{x}}$ & $\stackrel{x}{x}$ & $\begin{array}{l}\times \\
-\cdots\end{array}$ & $\begin{array}{l}x \\
\ddot{x}\end{array}$ & $\stackrel{x}{x}$ & $\ddot{x}$ & $\frac{x}{x}$ & $\begin{array}{l}x \\
\ddot{x}\end{array}$ & $\stackrel{x}{x}$ & $\stackrel{x}{x}$ & $\ddot{x}$ & $\cdots$ & $\times$ & $\underset{x}{x}$ & $\ldots$ & $\begin{array}{l}270 \\
310 \\
271\end{array}$ \\
\hline
\end{tabular}




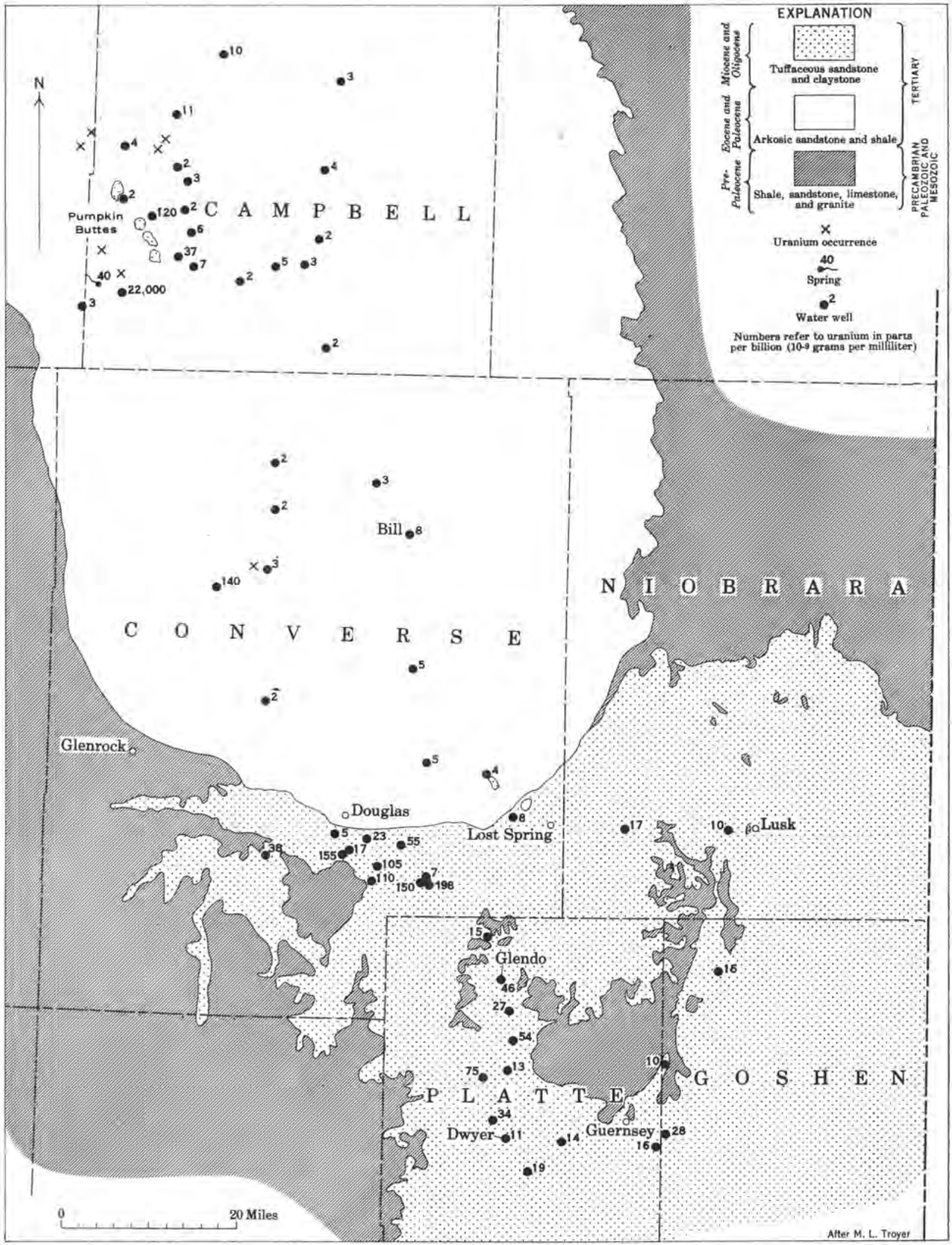

Fuavre 198,-Map showing variation in uranium content of ground water in the southern part of the Powder River Basin, Wyo. 


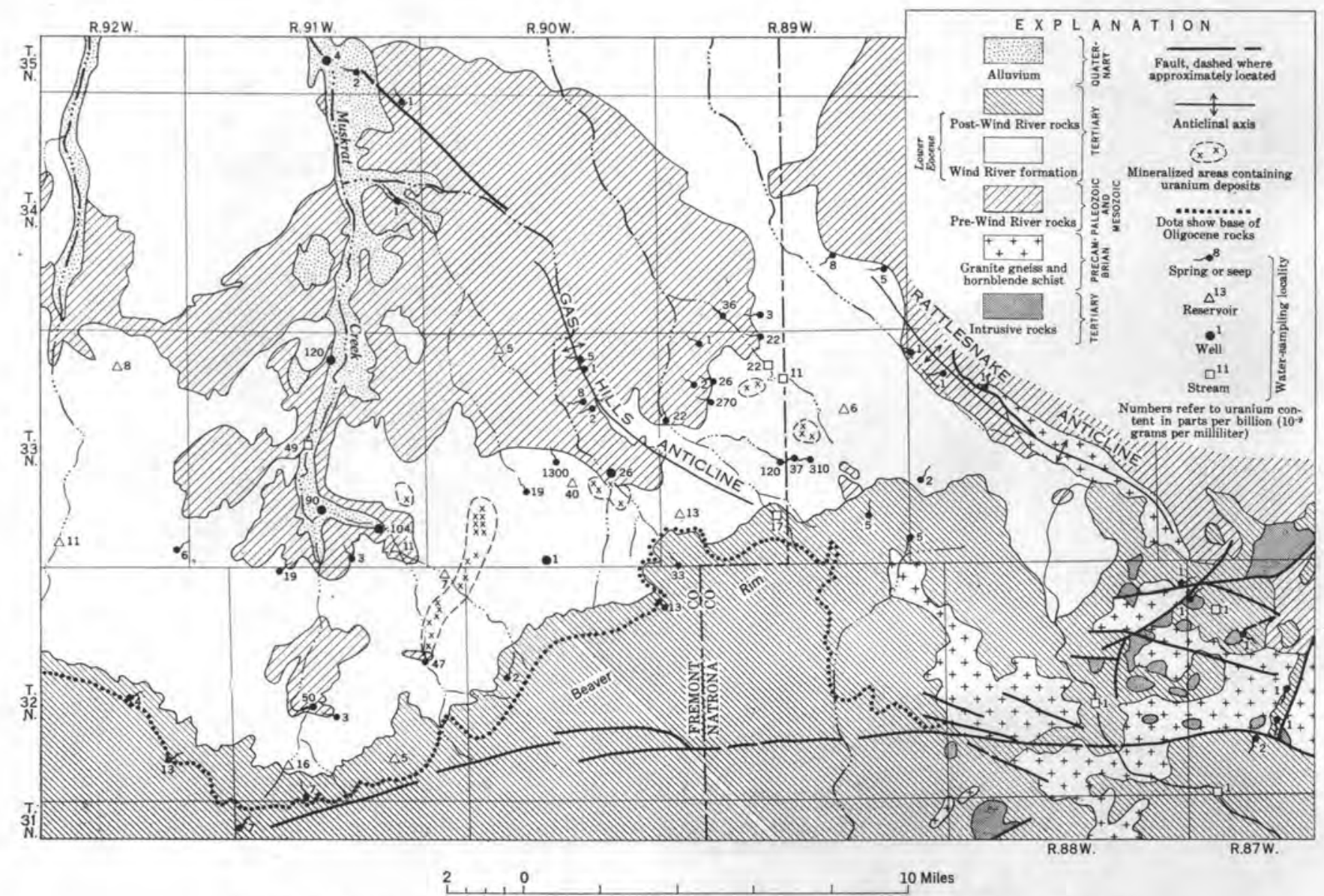

FIGURE 199.-Generalized geologic map showing distribution of uranium in water in the Gas Hills area, Wyoming. 


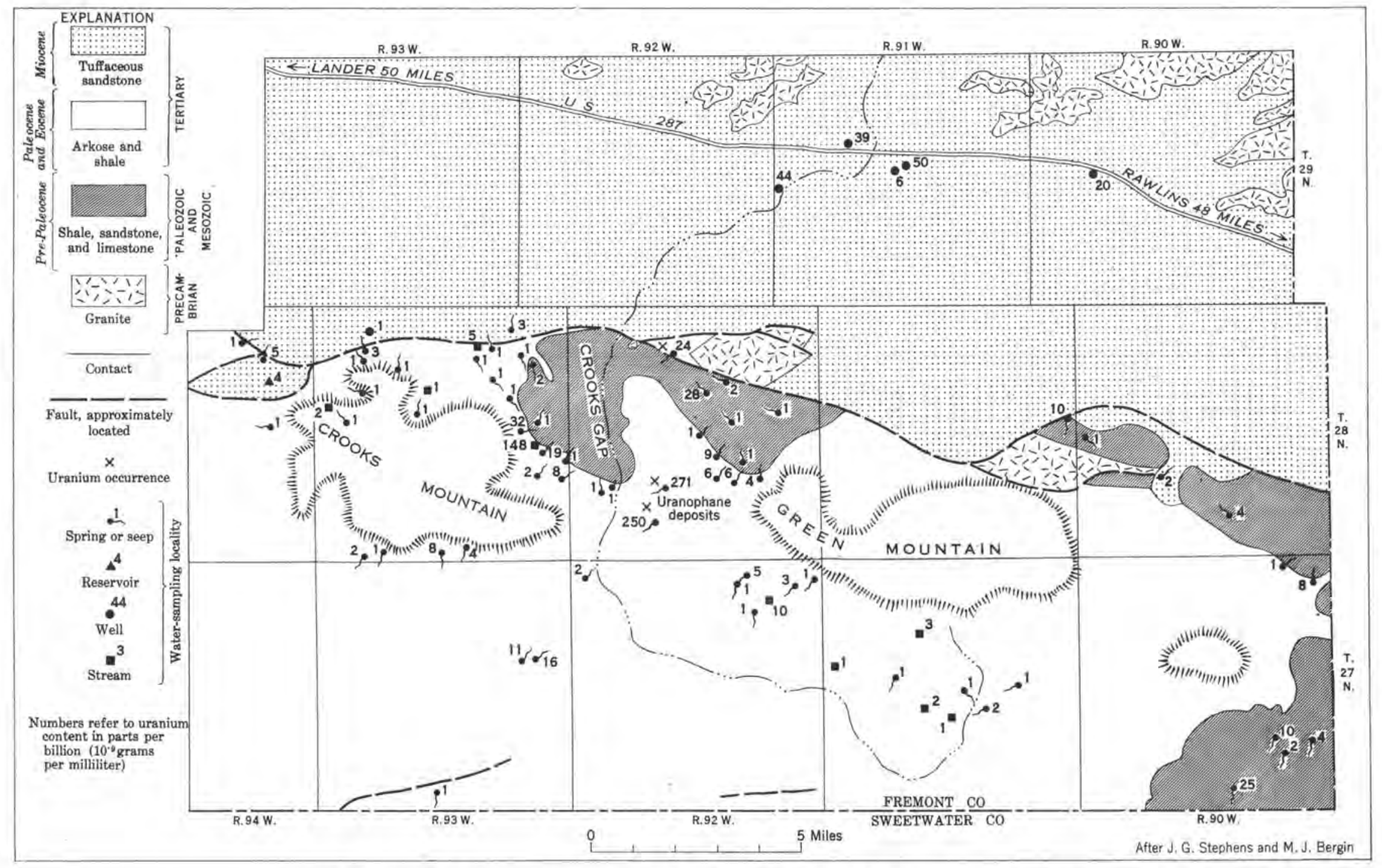

FIoUne 200.-Generalized geologic map showing the uranium content of water in the Crooks Gap area, Fremont County, Wyo. 


\section{SUMMARY OF RESULTS}

The uranium contents of ground water of the different sedimentary terranes in the areas studied show marked variations. The highest concentrations of uranium in ground water are generally found in areas near known uranium deposits; greater than normal concentrations of uranium in ground water are found in acidic tuffs and tuffaceous sedimentary rocks of Oligocene and Miocene age; and ground water from arkosic and other sedimentary terranes that are not near uranium deposits generally contain only a few parts per billion of uranium. The most highly mineralized water in tuffaceous terranes has an alkaline $\mathrm{pH}$ range of 7.5 to 9.5. In general the more alkaline waters from these rocks carry the most uranium in association with proportionally larger amounts of sodium and calcium, the Oligocene being more sodic and the Miocene more calcic. The relationship of other trace elements to the uranium content of these waters has not been determined, but laboratory data show that they also contain greater than normal amounts of molybdenum, vanadium, copper, phosphorous, zinc, and arsenic.

The relatively high uranium concentrations in the water from the Oligocene and Miocene units probably is due to the uranium content of its tuffaceous constituents. These rocks are mostly water laid and contain large quantities of airborne volcanic sediments. Owing to their high porosity and permeability, water is permitted relatively easy circulation. Although the uranium content of these rocks differs markedly from place to place as well as within short distances along the same stratigraphic unit, chemical analyses show a maximum uranium content of 0.0030 percent and an average of about 0.0015 percent. Uranium disseminated in these rocks may have been an important primary source of uranium later concentrated in the secondary deposits in the underlying sedimentary rocks through ground-water circulation. 


\title{
BOTANICAL METHODS OF PROSPECTING FOR URANIUM
}

\author{
By Helen L. Cannon and Frank J. Kleinhampl, U. S. Geological Survey
}

\section{CONTENTS}

\begin{tabular}{|c|c|c|c|}
\hline & Page & & \\
\hline Abstract. & 681 & Prospecting by chemical analyses of indicator plants.... & \\
\hline Prospecting by ehemical analysis of trees.................. & 682 & Summary & \\
\hline
\end{tabular}

\section{ILLUSTRATION}

Plate 17. Astragalus pattersoni, Patterson's Loco, a selenium-indicator plant useful in prospecting for uranium ore_...- Facing 684

\begin{abstract}
Botanical methods of prospecting are based on the premise that concealed mineral deposits may be reflected chemically in surface vegetation. Results indicate that ore bodies under a cover of barren sandstone many feet thick may be detected by testing plants growing above them for uranium and associated elements. Two methods of such prospecting for uranium have been developed,

The first method is based upon the presence of uranium in all plants in small but measurable amounts. The uranium content of plants rooted in ore, however, is detectably greater than the uranium content of plants rooted in barren ground. In semiarid country, similar parts collected from identical species of trees or deep-rooted shrubs show differences in uranium content, which may indieate mineralized ground buried to a maximum depth of 60 feet. Plant ash is analyzed directly for uranium by the fluorimetric method. The uranium content of the ash of plants rooted in unmineralized sandstone is generally less than 1 part per million. A content of several parts per million is common in the ash of plants rooted in ore.

A second method of prospecting, that of mapping the distribution of indicator plants, has been used in ecologically favorable areas. A plant may be used as an indicator plant in prospecting if its distribution is controlled by any factor related to the chemistry of the deposit. Carnotite ore and other oxidized uranium ores contain appreciable amounts of available selenium and sulfur. The distribution patterns of plants requiring one of these elements in quantity may indicate favorable ground. Which species of plants are useful as indicators in an area depends directly upon the chemical composition of the ore and the position of the ground-water table.

Experimental studies show that the availability of selenium is greatly increased in the presence of carnotite. Astragalus pattersoni, the most reliable indicator of uranium ore, is deep rooted and capable of extracting selenium directly from ore bodies as deep as 75 feet. In some ores soluble salts have mi-
\end{abstract}

grated upward into the surface soil and there become available to plants that have shallow roots. Ore has been found as much as $\mathbf{2 5}$ feet below the surface in ground indicated as favorable by the distribution of onions and other sulfur-absorbing ephemerals. Prospecting by both plant analysis and indicator-plant mapping in widely separated areas of the Colorado Plateau has shown a positive correlation between botanically favorable ground and major ore deposits.

Botanical prospecting in advance of drilling for shallow ore deposits substantially reduces the number of holes required and may be used in unprospected country to suggest areas worthy of intensive geologic study.

\section{INTRODUCTION}

Prospecting for mineral deposits at depth by observing unusual growth characteristics or distribution patterns in surface vegetation has been used through the ages in the search for many metals. Botanical methods of prospecting are dependent upon the absorption and accumulation of metals and associated elements by plants growing over metalliferous deposits.

Two methods of botanical or biogeochemical prospecting have been developed and used by the Geological Survey to locate uranium deposits on the Colorado Plateau, which includes parts of Colorado, New Mexico, Utah, and Arizona. The deposits are chiefly of the carnotite type and occur as irregular tabular masses in rocks of Triassic and Jurassic age. The ore commonly contains about 2 percent $\mathrm{V}_{2} \mathrm{O}_{5}$ and 0.25 percent $\mathrm{U}_{3} \mathrm{O}_{8}$ with minor amounts of selenium, sulfur, arsenic, cobalt, and copper, and with traces of other metals. One method of botanical prospecting currently used is 
based upon the uranium content of plants; another is based upon the distribution of indicator plantsthose that are dependent either directly or indirectly upon the presence of abnormal amounts of uranium and associated elements. Basic studies in the development of the methods have been described by Cannon $(1952,1953)$. Subsequent laboratory and experimental plot studies have supplemented field observations.

During the past 5 years, nearly 10,000 samples have been analyzed for uranium, and distribution studies of indicator plants have been made along 50 miles of outcrop. A positive correlation between botanically favorable ground and major ore deposits, has been demonstrated, and preliminary results indicate that ore may be found at depths to 80 feet by botanical methods of prospecting.

\section{PROSPECTING BY CHEMICAL ANALYSIS OF TREES}

Prospecting by analysis of tree material is based on the uranium content of plants growing in the area to be prospected. Uranium occurs in all plants in small but measurable amounts. Plant ash normally contains 0.2 to $1.0 \mathrm{ppm}$ (parts per million) uranium. The uranium content of plants rooted in ore, however, may range from 1 to $100 \mathrm{ppm}$ uranium. Therefore, the uranium content of plants rooted in ore or within the chemical halo of the ore body may be used as an indication of mineralized ground.

The uranium content of vegetation varies for many reasons, which should be understood and evaluated before a project of plant analysis is undertaken. The uranium content of trees and herbaceous plants varies slightly with the seasons and the amount of rainfall, but in an area being prospected by day-to-day sampling, this small variation can be discounted. A large part of the uranium absorbed by the plant root is precipitated within the root cells. A lesser amount is transported to the leaves and branches and is present in direct proportion to the total uranium absorbed by the roots, so that the presence or absence of mineralized ground may be inferred from leaf or twig analyses. Of importance in prospecting is the variation in uranium content from one side of the tree to another. As the roots of one side of the tree are directly connected to a particular set of branches, the uranium content of the branches may vary depending upon the position of the mineralized ground. It is important, then, to sample a tree on all sides to obtain a representative sample.

Some plant species absorb much more uranium than others. The mechanism by which plants absorb uranium is not a matter of ion transport in a water solution but of ion exchange. Plant families differ in regard to the amounts of the various ions absorbed because they have different and characteristic buffer systems and resulting variations in cell-sap $\mathrm{pH}$. Studies of experimentalplots indica te that those plants that readily absorb large amounts of sodium, sulfur, selenium, and calcium but small amounts of potassium will also absorb uranium readily. These plants generally have a low cellsap $\mathrm{pH}$. For this reason, conifers and desert shrubs of the rose family that have these characteristics and are common in uranium districts of the Colorado Plateau can be used successfully in sampling programs.

The amount of uranium absorbed by plants is dependent also upon the percentage of water-soluble uranium in the vicinity of the plant roots. The amount of water-soluble uranium present is due in part to the interaction of uranium with other ions present in unusual amounts and does not necessarily reflect the total amount of uranium present. For instance, the percentage of water-soluble uranium in the soil is increased when gypsum, selenium, or lime is added. The addition of carnotite increases the percentage of water-soluble sulfur and selenium. The latter relationship is important in the localization of sulfur- and selenium-bearing indicator plants. The described changes in solubility of uranium take place under oxidizing conditions, and important differences in the relative absorption of uranium by deep-rooted trees and shrubs have been observed only in areas of oxidizing ore.

The depth to which ore can be detected by plant analysis depends upon the root habits of the species sampled and upon the availability of water. In semiarid country, shrubs and trees commonly have root systems 50 to 75 feet in length. In many uranium districts of the Colorado Plateau, the ore-bearing rock is an aquifer. The roots of junipers, pinyons, and many desert shrubs penetrate long distances through cracks and crevices connecting with the water-bearing zone, and act as phreatophytes or ground-water plants Mineralized areas of a coal bed on La Ventana Mesa, N. Mex., were outlined by analysis of pinyon and juniper whose roots penetrated an 80-foot sandstone capping the mesa (Cannon and Starrett, 1955). It is probable, however, that plant analysis is not generally effective in prospecting at depths of more than 75 feet.

In prospecting by the plant-analysis method, a preliminary study must first be made of the geologic relations. This should include observations on the extent, depth, and inclination of the ore-bearing strata, the size and habits of the ore bodies, the probable grade of the ore, the presence or absence of a chemical halo in the surrounding barren rock, and the relation of the ore-bearing bed to the water table and the plant roots. Botanical studies should be made of the growth habits of species available for sampling. Preliminary samples 
should be collected on both mineralized and barren ground and then analyzed to determine the amount of uranium absorbed by trees in the area under study. Finally, from this geological and botanical information, the sampling medium, the sampling pattern, and sampling interval may be determined.

Several coniferous species have a wide range on the Colorado Plateau, have deep roots, and absorb about the same amounts of uranium. The species listed below have been used as the sampling medium on several projects.

$$
\begin{aligned}
& \text { Tree } \\
& \text { Pinus ponderosa Doug. (Ponderosa, pine) - } \\
& \text { Pseudotsuga taxifolia Britt (Douglas-fir) } \ldots \text { feet) } \\
& \text { Abies concolor Lindl. (White fir) } \\
& \text { Pinus edulis Engelm. (pinyon) } \\
& \text { Juniperus scopulorum Sarg. (Rocky Mtr. }\} \text { to } 9,000 \text { to } 9,000 \\
& \text { juniper). } \\
& \text { Juniperus utahensis Sarg. (Utah juniper) } 7,000 \\
& \text { Juniperus monosperma Engelm. (oneseed } \\
& \text { juniper). }
\end{aligned}
$$

Samples of the last year's growth of needles or branch tips collected from the entire periphery of the tree have given the most consistent results.

In areas where the ore-bearing bed occurs in a broad flat bench with a uniform vegetative cover, systematic tree sampling on a grid pattern may be used. Favorable areas may be found by establishing isograms based on uranium content. In areas where the ore-bearing bed crops out in sharp cliffs, line traverses with special emphasis on close-spaced samples collected on talus-covered areas may prove to be the best collecting pattern.

The distance between trees sampled depends in part upon the objective of the project. For rapid reconnaissance, an initial spacing of 250 feet is usually adequate, and in anomalous areas later fill-in samples with 50 -foot spacing may be desirable. An interval of 15 to 30 feet is useful for sampling across talus-covered rim or cliff outcrops.

\section{ANALYTICAL METHODS}

A fluorimetric method of analysis is used by the Geological Survey for the determination of uranium in plant ash; the method has been described by Grimaldi and others $(1952,1954)$. A portable fluorimeter, powered by batteries, has been designed for field use, and a chromatographic field test for uranium in soils and in plant ash has also been used in Survey laboratories. A method of analyzing the radioactivity of plant ash by $\alpha$-ray count has been developed at the University of Arizona and has been described in a recent paper by Anderson and Kurtz (1955).

A pint container of fresh plant material is collected for fluorimetric analysis under present laboratory procedure. The precision to be expected from the method is $0,5 \mathrm{ppm}$ uranium in the range from 0.3 to $5.0 \mathrm{ppm}$ uranium. The chromatographic and $\alpha$-ray count methods require much less sample, but are not so accurate in the low ranges as the fluorimetric method.

\section{INTERPRETATION OF RESULTS}

Although the amount of uranium absorbed by plants rooted in ore varies slightly with the type of ore and the species of plant sampled, contents above 1 $\mathrm{ppm}$ uranium in the ash are considered to indicate favorable and possibly mineralized ground in many areas sampled on the Colorado Plateau. This figure was arrived at empirically from early plant analysis studies and from a statistical analysis of 2,000 tree samples. Trees rooted in barren ground were found to average $0.3 \mathrm{ppm}$ uranium in the ash; trees rooted in mineralized ground averaged $1.5 \mathrm{ppm}$ uranium.

Statistical study verifies the conclusions of other workers that a sampling program should be restricted to one kind of tree. However, when it is necessary to use more than one species of tree, special factors relating the different species to one another could be employed. These factors would be obtained by relating the statistical measures of the assay data of each population to the other populations used. The results thus obtained would define anomalously high values more exactly and make the results obtained from the different species comparable.

\section{PROSPECTING BY CHEMICAL ANALYSIS OF INDICATOR PLANTS}

A plant may be used as in indicator plant in prospecting for metalliferous deposits if its distribution is affected by the availability of chemical constituents present in the ore. The plants used in prospecting for a particular type of deposit may not all be controlled by the same factor. They are usually common rather than unusual plants. Indicator plants for uraniferous sandstone deposits are controlled not only by the presence of unusual amounts of selenium and sulfur but by an increased availability of these elements in watersoluble form and by the increased availability of the major plant nutrients calcium and phosphorous. Selenate and sulfate were found by plot experiments to be more readily absorbed by plants in the presence of carnotite, and uranium to be more readily absorbed in the presence of selenate and sulfate. The availability of calcium and phosphorous was also increased in the plots to which carnotite has been added. In addition, each indicator plant, depending upon the specific metabolic processes inherent in the species, reacted differently to the excess materials available for absorption. These 
experiments explain many irregularities in plant distribution noted in the field.

A correlation between the distribution of selenium indicator plants and carnotite deposits of the Morrison formation was first noted by O. A. Beath (1943) in conjunction with toxicity studies of range land. The Geological Survey has since established the use of selenium indicator plants in prospecting for uranium In general the plants are perennjals with long tap roots; roots of Astragalus have been traced to a depth of more than 30 feet in mine workings. Under favorable conditions the use of Astragalus has led to the discovery of ore bodies 75 feet below the surface. Astragalus (pl. 17) and other seleniferous genera have distinct distribution patterns depending upon the amount of selenium in the ore and the amount required by the plant. Preliminary studies are mandatory in advance of prospecting in each new area to determine the species best correlated in distribution with mineralized ground.

Astragalus pattersoni, A. Gray, belonging to the vetch group is the most useful indicator plant on the Colorado Plateau (pl. 17). The plant requires large amounts of selenium and commonly absorbs several thousand ppm selenium from uranium ores. Experimental plot results indicate that the presence of carnotite increases the absorption of selenium by this plant many fold.

The following species of Astragalus are also useful in some areas of the Plateau:

A. preussi A. Gray

A. thompsonae $\mathrm{S}$. Wats

A. confertiflorus A. Gray

A. bisulcatus (Hook) A. Gray

A. lonchocarpus Torr.

A. dodgeanus M. E. Jones

Other selenium indicator genera that require only small amounts of selenium may act as indicators of uranium ore containing less than $2 \mathrm{ppm}$ selenium. These include:

Aster venustus, M. E. Jones (woody aster)

Grindelia spp. (gumweed)

Oryzopsis hymenoides, (R. and S.) Rick (Indian-ricegrass)

Stanleya spp. (princesplume)

Many uranium ores contain sulfides that commonly form gypsum upon weathering. Sulfur- and calciumabsorbing ephemeral plants occur where this gypsum moves upward into surface soil within reach of shallow plant roots. Sulfur- and calcium-absorbing ephemerals include:

Allium spp. (wild onion)

Calachortus spp. (Sego lily)

Zigadenus spp. (Camas lily)

Sisymbrium spp. (tumblemustard)

Lepidium spp. (pepperweed)

Eriogonium inflatum Torr. (desert trumpet)

Cryptantha spp. (cryptanth)

Oenothera caesiptosa Nutt. (tufted evening primrose)
Oenothera albicaulis Pursh. (white-stemmed evening primrose)

Stipa comata Trin. and Rupr. (needle-and-thread)

Elymus salina Jones (Salina wildrye)

Aplopappus armeriodes A. Gray (goldenweed)

Senecio longilobus Benth (threadleaf groundsel)

Mentzelia multiflora Nutt. A. Gray (desert blazingstar)

The plants used as indicators in prospecting may be common roadside weeds in other areas of the country. The chemical elements that control their distribution around metalliferous deposits, particularly selenium and sulfu', are present in all rocks but their concentration differs greatly in different stratigraphic units. The plants may be useful prospecting tools where the difference in chemical composition between barren parts of the ore-bearing bed and the ore itself is enough to affect the flora.

The effectiveness of indicator plants as a guide to uranium deposits depends largely on the depth to mineralized ground and the availability of selenium and sulfur to the plant roots. In turn, species of indicator plants differ in their root habits and in their capacity to absorb selenate and sulfate ions. Much depends on whether the elements in question are present only at ground-water level or have migrated to the soil surface along fractures or through permeable beds.

The distribution of indicator plants can be plotted directly on maps or photographs as a result of field observation without the necessity of collection or analysis. Indicator-plant prospecting is rapid and inexpensive and therefore if conditions permit is preferable to prospecting by plant analysis.

Preliminary studies are necessary in each area to be prospected to determine what plants in the area correlate most closely with the extent of the mineralized ground. An initial mapping of several dozen plants may eventually resolve itself into a final mapping of 2 or 3 species which may be plotted by symbol on maps or on airphotos. From a study of the resulting plant maps, favorable areas may be delineated for detailed geologic evaluation and possibly for exploration.

For the most effective use of plant distribution maps, a careful study should also be made of the sedimentary features, direction of ground-water movement, joint fracture patterns, folding, and other topographic and geologic features. Many drill holes have been inauspiciously placed in a futile attempt to test plant information without due regard to the probable origin and migration of water-soluble ions.

\section{RESULTS OF BOTANICAL PROSPECTING ON THE COLORADO PLATEAU}

Botanical prospecting studies have been made in advance of exploration in five districts of the Colorado Plateau. Of these only one area has subsequently 


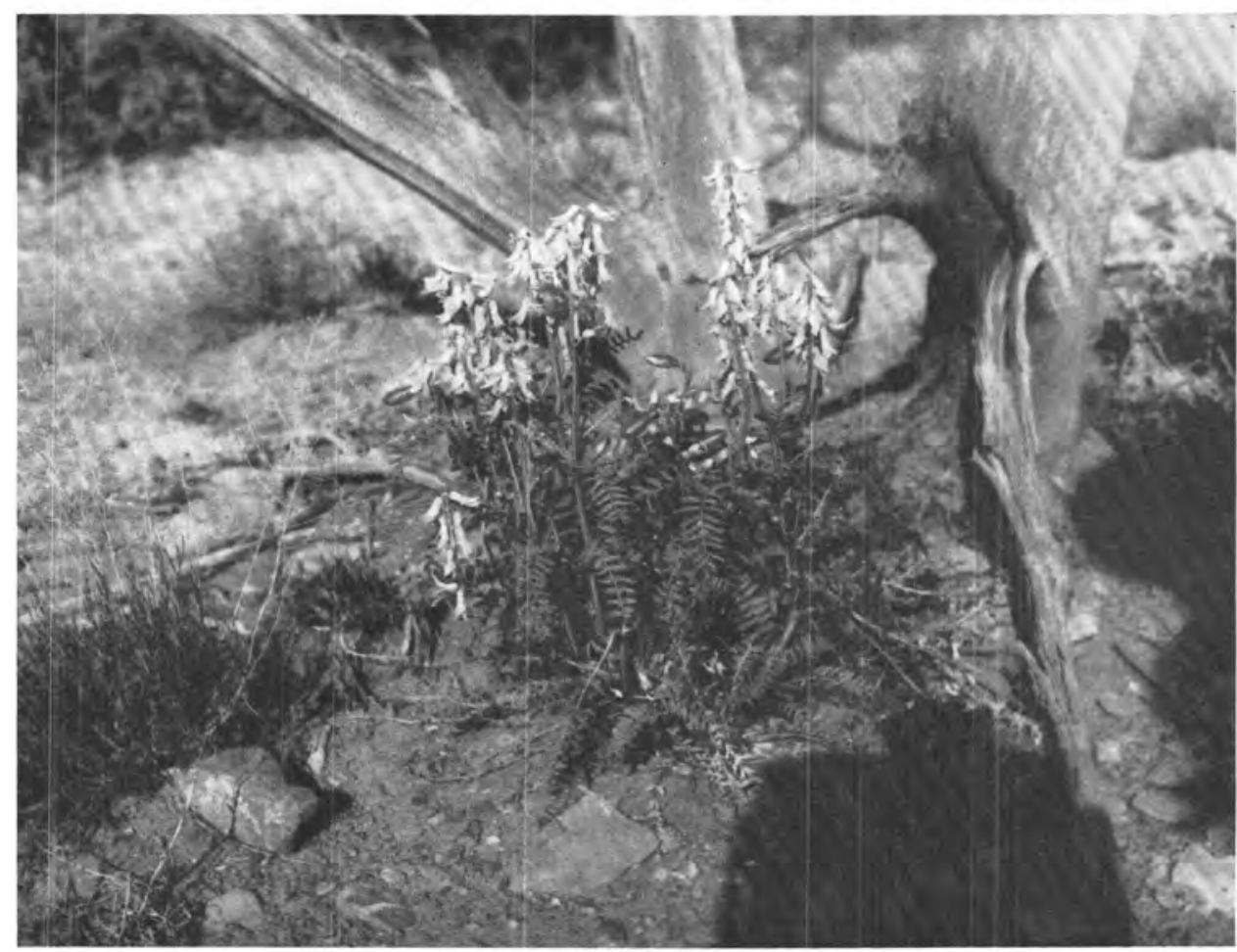

ASTRAGALUS PATTERSONI, PATTERSON'S LOCO, A SELENIUM-INDICATOR PLANT USEFUL IN PROSPECTING FOR URANIUM 

been completely explored by diamond drilling. Preliminary drilling programs have been started in two other districts. Results indicate that prospecting by indicator plants is advantageous in areas of the plateau where uranium ores average about 0,01 percent selenium and are at an average depth of not more than 40 feet beneath the ground surface. Prospecting by tree analysis is advantageous in areas where the tree cover is continuous and the ores are not more than 80 feet in depth. It is also important that the ore-bearing formation be an aquifer.

Prospecting by indicator plants has been tested in the Yellow Cat area, Grand County, Utah, where plants were mapped over an area of about 6 square miles and nearly 2,000 holes were subsequently drilled. The ore in this area occurs in the Salt Wash sandstone member of the Morrison formation and contains vanadium, uranium, selenium, and sulfur. The distribution patterns of 9 species of plants were originally mapped on a scale of $1: 6000$. Final maps of the distribution of four species were compiled.

An analysis has been made of the relation of plant distribution patterns to results of the first 1,000 holes drilled in the area. Holes ranged in depth from 10 to 250 feet. A total of 26 holes were in ore in the first 1,000 holes drilled, and all 26 penetrated ore at a relatively shallow depth. Twenty-one of the holes containing ore were in areas of indicator plants. Five ore bodies out of a total of 10 were found entirely on plant data. Indicator plants were found to reflect mineralized ground to an average depth of 68 feet but proved to be a more dependable ore guide where ore is confined to depths of less than 50 feet. Ten percent of the barren holes, 50 percent of the mineralized holes, and 80 percent of the ore holes were drilled in areas of indicator plants.

A comparison of the effectiveness of indicator species in the area showed that the selenium indicators Astragalus pattersoni and $A$. preussi are the mosi reliable indicators of mineralized ground and that the sulfur plants Allium acuminatum and Eriogonum inflatum may act as competent indicators where the ore lies at depths of no more than 33 feet.

Several ore bodies have also been found in the Grants district, McKinley County, N. Mex., as a result of indicator-plant prospecting. A project of prospecting by plant analysis was conducted during $1952-54$ on the ore-bearing Jurassic Todilto limestone. About 5,000 pinyon and juniper samples were collected from the Todilto bench west of Grants. Results of the program show that botanically defined anomalies delimit areas that are favorable for the discovery of uranium deposits, and preliminary drilling information indicates that botanical anomalies correlate with mineralized ground.
On Elk Ridge, Utah, the analyses of 3,000 tree samples have defined areas where physical exploration for uranium may be warranted, as a study of the outcrop near botanically defined anomalies shows a positive correlation with geologically favorable criteria such as secondary copper and iron staining, carbonaceous trash, pyrite, and channel fillings. A drilling program is in progress.

On La Ventana Mesa, Sandoval County, N. Mex., a uranium-bearing coal bed is capped by a 65 -foot sandstone through which the roots of a pinyon-juniper forest penetrate. More than 200 tree samples have been analyzed, and the resulting uranium values plotted to indicate probable areas of mineralized coal (Cannon and Starrett, 1955). A private company is drilling in the area.

\section{SUMMARY}

Two methods of botanical prospecting have been used in prospecting for uranium on the Colorado Plateau; first by analyzing for uranium content the foliage of trees collected on a grid or linear pattern; second by mapping the distribution of indicator plants.

Analysis of tree material depends on the absorption of anomalous amounts of uranium by trees rooted in ore. In general trees rooted in barren ground average less than $0.5 \mathrm{ppm}$ uranium but trees rooted in ore average $1.5 \mathrm{ppm}$ or more. The uranium content of a plant varies with the organ of the plant sampled, the season, the amount of rainfall, the species, and the form in which the uranium occurs in the soil. The solubility of uranium has been shown experimentally to increase in the presence of selenium, sulfur, and calcium. The depth to which ore can be detected depends on the root habits of the plant and on groundwater conditions. Plants have been used effectively in outlining mineralized ground at depths of 80 feet.

Samples of plant ash may be analyzed by fluorimetric, radiometric, or chomatographic methods. At the present time fluorimetric analysis is the most satisfactory method for uranium detection in low ranges. The results may be plotted on maps of the area with suitable isopleths showing areas of anomalously high uranium content.

The indicator plant method is dependent on changes in the distribution pattern of individual species in the vicinity of ore deposits. The factors controlling indicator plants for uranium deposits are the presence of anomalous amounts of available selenium, sulfur, calcium, and phosphorus in the surface soil. The most useful indicator plants on the Colorado Plateau, species of Astragalus, are able to concentrate large quantities of selenium from the ore deposits. Locally, plants of the lily, mustard, and buckwheat family, indicative of gypsum, are also useful. Areas favorable for geologic 
investigation can be delineated from maps of indicator plants in areas where the deposits lie at shallow depths and where the geologic setting is thoroughly understood.

Results of botanical prospecting on the Colorado Plateau suggest that prospecting by indicator plants is advantageous where the uranium content is 0.01 percent or more and the selenium content is also at least 0.01 percent, if the upper limits of the ore bodies are at an average depth of not more than 40 feet beneath the ground surface. Prospecting by analysis of tree material is advantageous in areas of continuous vegetative cover where the average depth to the ore-bearing stratum is no more than about 60 feet. Physical exploration of several areas prospected by botanical methods has shown a positive correlation between botanically defined favorable areas and mineralized ground and suggests that this technique has much promise as a method of finding worthwhile mineralized areas elsewnere.

\section{REFERENCES CITED}

Anderson, R. Y., and Kurtz, E. B., Jr., 1955, Biogeochemical reconnaissance of the Annie Laurie uranium prospect, Santa Cruz County, Ariz.: Econ. Geology, v. 50, p. 227-232.

Beath, O. A., 1943, Toxic vegetation growing on the Salt Wash sandstone member of the Morrison formation: Am. Jour, Botany, v. 30, p. 698-707.

Cannon, H. L., 1952, The effect of uranium-vanadium deposits on the vegetation of the Colorado Plateau: Am. Jour. Sci., v. 250 , p. $735-770$.

1953, Geobotanical reconnaissance near Grants, N. Mex.: U. S. Geol. Survey Circ. 264, 8 p.

Cannon, H. L., and Starrett, W. H., 1955, Botanical prospecting for uranium on La Ventana Mesa, Sandoval County, N. Mex.: U. S. Geol. Survey Bull. 1009-M, p. 391-407.

Grimaldi, F. S., May, Irving, and Fletcher, M. H., 1952, U. S. Geological Survey fluorimetric methods of uranium analysis: U. S. Geol. Survey Circ. 199, 20 p.

Grimaldi, F. S., May, Irving, Fletcher, M. H., and Titcomb, Jane [compilers], 1954, Collected papers on methods of analysis for uranium and thorium: U. S. Geol. Survey Bull. 1006, 184 p. 


\title{
GEOPHYSICAL-GEOCHEMICAL PROSPECTING FOR URANIUM
}

\author{
By M. Elmer Denson, U. S. Atomic Energy Commission
}

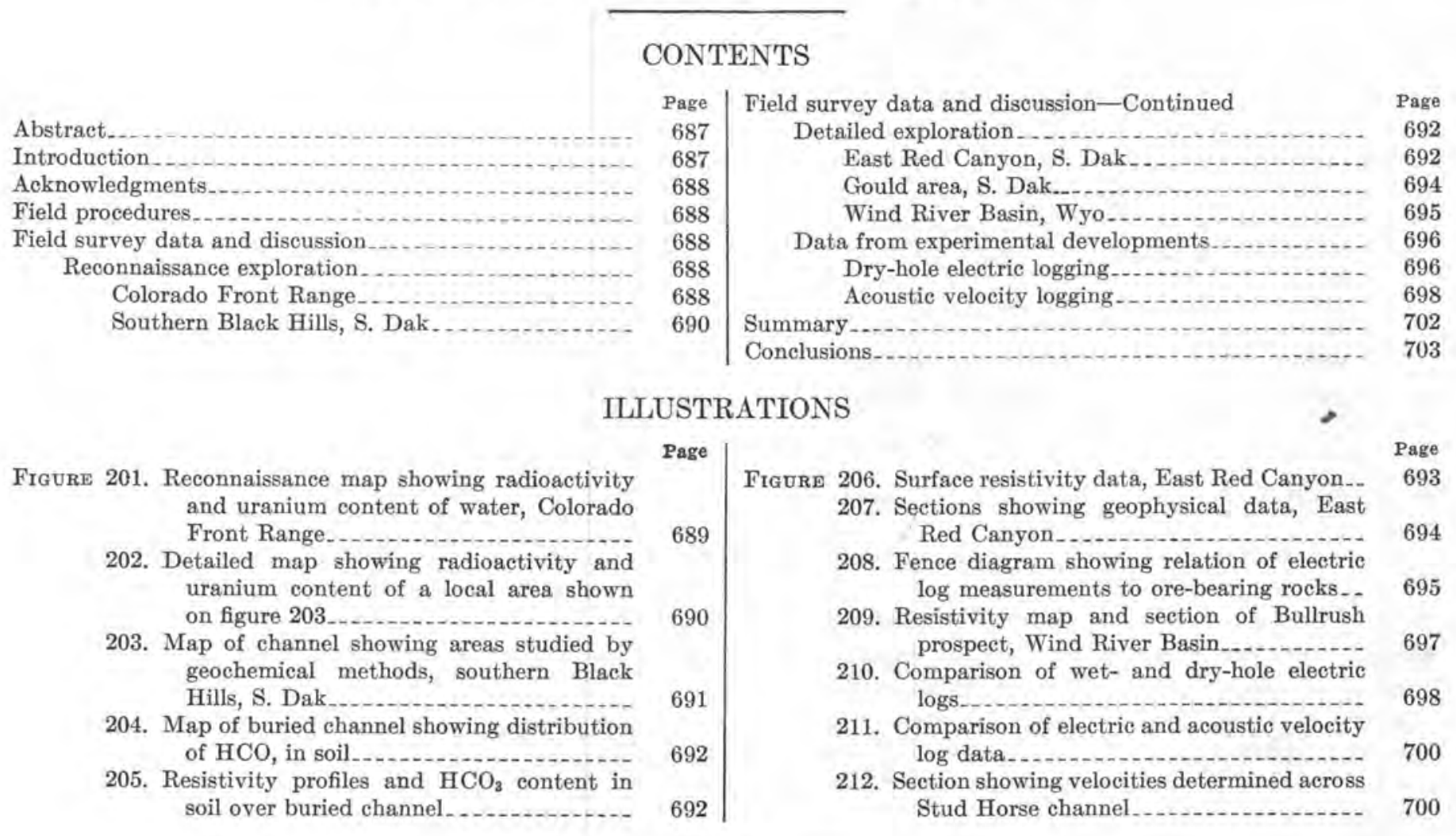

\begin{abstract}
Exploration for uranium can be made more effective by combining geophysical and geochemical surveys. Physical and chemical data not only help to clarify geological problems, but also provide information useful in guiding an exploration or evaluation program. Examples of surface survey data, or of logging data and sample analysis data demonstrate the usefulness and significance of information obtainable by geophysical and geochemical techniques. This paper reports initial results obtained in an evaluation and development program by geophysical and geochemical exploration.
\end{abstract}

\section{INTRODUCTION}

Largely because different principles and concepts are involved in applying physics and chemistry to geology, programs of geophysics and of geochemistry are ordinarily conceived, organized, and directed separately. This paper is a progress report on the initial results of an integrated program in geophysical and geochemical exploration research.
One advantage of integrating exploration tecbniques is that greater economy and wider success can be attained from the sequencing and directing of techniques to obtain a reliable result more simply. Another advantage is that data of one kind may facilitate interpretation of data of another kind. This in tarn extends the range of useful application of any particular technique. As in other fields, there is no single "best" method in the world of exploration.

Geophysical and geochemical exploration methods are based upon the determination of variations in some physical or chemical property associated with or resulting from mineral deposition.

Efforts to find deposits of uranium and thorium minerals have been concerned chiefly with phenomena peculiar to the unique property of radioactive disintegration. However, if the deposit is buried, even to shallow depths no clear-cut evidence of the radioactive property may be observed at the surface of the earth. 
To assist in finding subsurface deposits, other geophysical and geochemical techniques have been successfully applied.

Methods under investigation include modifications of known methods of seismic reflection and refraction, continuous interval velocity logging, electromagnetic induction, electrical well logging, surface resistivity, and surface radiometric surveys all used in conjunction with geochemical determinations of trace elements and associated anions in the associated rocks, soils, and waters. The results of research investigations which have been carried out help to clarify the geological problems involved. Some of the techniques developed to date may prove to be powerful tools of geologic study; other serve to provide information useful in guiding exploration activity.

\section{ACKNOWLEDGMENTS}

The writer acknowledges the assistance of the following members of the Geophysical Research and Developithent Branch of the Atomic Energy Commission: Robert Casey, Claude Daum, Joan Davlin, Fred Geier, William Holland, Charles Illsley, and James Scott.

\section{FIELD PROCEDURES}

Field activity in the program of the Geophysical Research and Development Branch has been so organized that geophysical and geochemical methods of exploration may be used together rather than as separate exploration tools. Mobile geochemical and geophysical field units have been developed for better implementation of this aim.

Decisions as to the kind and sequence of geophysical and geochemical methods which may be most suitable for a given area are based upon the geological, geophysical and geochemical properties which pertain to that area. To this end, and also for interpretation, representative samples of soil, rock, water, and gas are analyzed for physical properties or petrographic characteristics and chemical content.

Inherent variations attributable to topographic, geographic, and climatic or atmospheric effects are recognized in field data. These effects are evaluated empirically or statistically.

\section{FIELD SURVEY DATA AND DISCUSSION}

The following examples of data from the Geophysical Research and Development Branch, Division of Raw Materials of the Atomic Energy Commission illustrate some applications of geophysics and geochemistry in exploration for uranium.

Data from the Colorado Front Range and the southern Black Hills illustrate how geochemistry and geo- physies may be used in reconnaissance work. Examples of results from other detailed studies and developments are also presented and discussed.

\section{RECONNAISSANCE EXPLORATION}

COLORADO FRONT RANGE

Most of the uranium exploration carried out to date has been concerned with searching for large, easily recognizable variations in the count of gamma rays emanating from the ground surface. Airplanes and automobiles have been specially equipped to find the so-called hot spots. However, little time or study has been spent on determining whether small, low-level changes in surface radioactivity are significant in locating uranium, especially at depth. The preliminary results of a field program directed to this end are described below.

The area shown in figure 201 lies to the north and west of Denver. Although no known uranium deposits are located within this area, commercial deposits have been found in adjacent districts. The geologic features as shown on figure 201 have been generalized to facilitate interpretation of the radiometric and geochemical data. Sedimentary rocks of Mesozoic age, flat-lying to the east, are upturned along the flank of the Front Range to the west. Surface drainage and ground waters flow to the east from the upland and intake of the outcrop belt.

The first phase of this study was a radiometric reconnaissance of the area. The radiometric data obtained from this reconnaissance and shown in figure $201 A$ were taken along traverses about one-half to a mile apart, along roads, trails, and cross country. Variations were measured by using a jeep-mounted, scintillation counter having a sensitivity of about 120 counts per second per microroentgen per hour. A record of the variations was obtained by using a recorder synchronized with the jeep to run at a chart speed of 3 inches per mile. These radiometric variations were then transposed to a base map and contoured. Corrections of the raw data, shown in figure $201 \mathrm{~A}$, consist of evaluating the variations attributable to topography, geology, and cosmic-ray effects. In this case cosmic variations were determined by repeating base line traverses and correcting all data accordingly. Variations caused by topography were determined experimentally by laying out special traverses with respect to topographic forms; hence, the correction applied here has been empirical. Corrections for the geologic variations were determined by taking hand-counter readings of the different lithologic units in place. Only variations of appreciable areal extent were considered in the correction and compilation of data. 
Figure $201 B$ shows the pattern of surface radioactivity obtained after the raw field data have been corrected. During the correction and compilation of these data it was observed that the drainage-ways exhibited abnormal, low-level radioactive highs that could not be accounted for either lithologically or topographically. The data of figure $201 B$ represent anomalous surface radioactivity or, alternatively expressed, those variations above background which could not be attributed with certainty to any known cause.

The second phase of this study was the sereening of the radioactivity data by geochemical means. To this end, all natural waters in the area were analyzed for uranium content. The two well-water samples containing greater than $50 \mathrm{ppb}\left(10^{-9}\right)$ of uranium (fig. $201 \mathrm{C}$ ) were considered of sufficient significance to warrant further evaluation of this test area. The Geological Survey has pioneered investigation of natural waters in regard to uranium exploration and has demonstrated that waters in the neighborhood of secondary deposits may contain appreciable quantities of dissolved uranium. The content of uranium in natural waters varics widely depending upon the type of water (river, well, spring, or other), the area of drainage, the lithologic character of the aquifer, the chemical quality of the water, and the nearness to deposits of uranium. From the results of the water analyses the normal background content of the well waters of the area shown is considered to be about $5 \mathrm{ppb}$.

To investigate further the meaning of the anomalous relations, soil samples were taken on a modified grid pattern over the area enclosed by the small rectangle

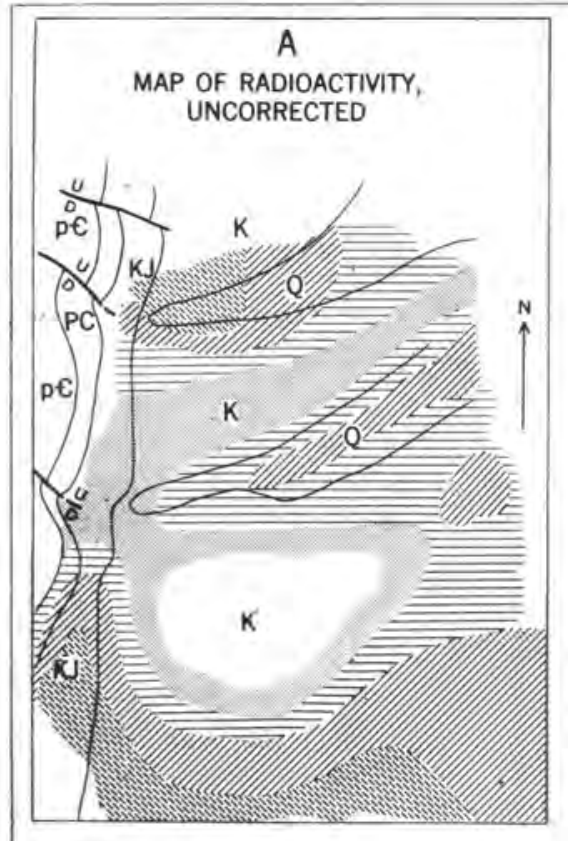

RADIOMETRIC ACTIVITY, COUNTS PER SECOND

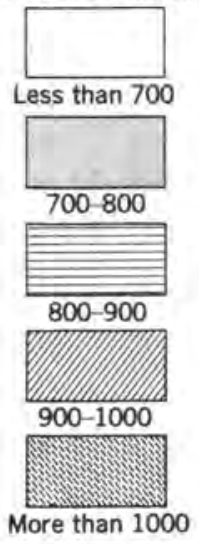

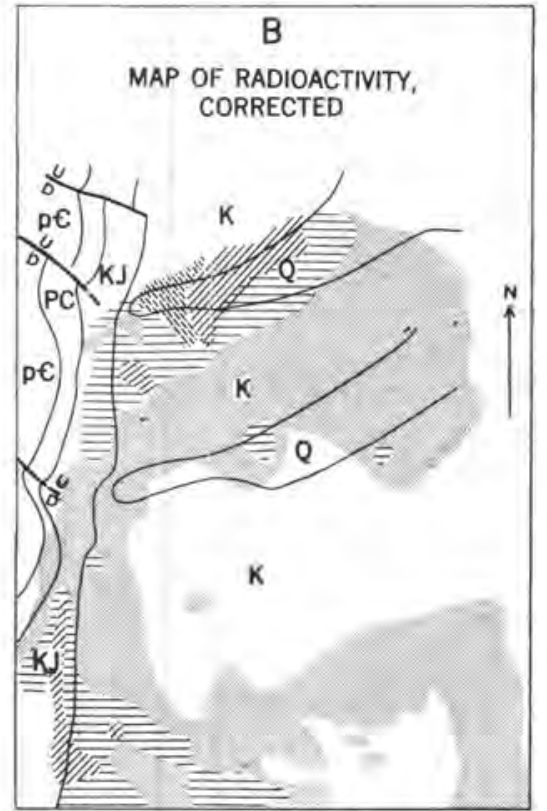

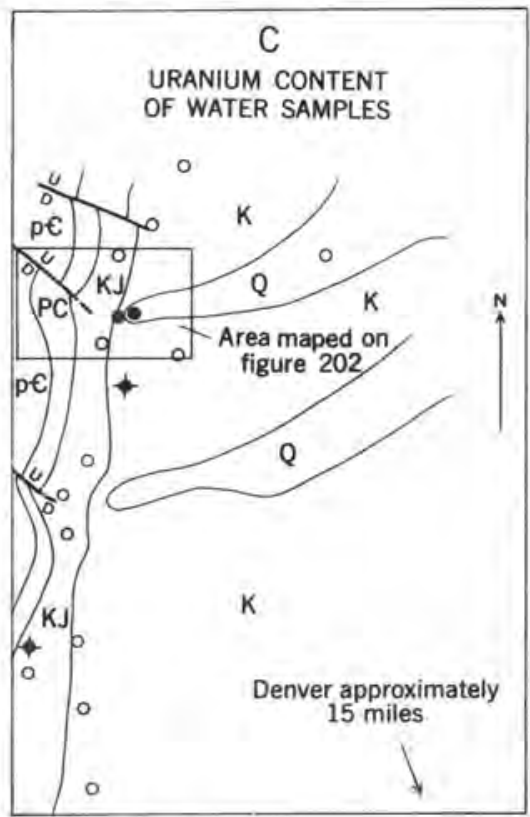

EXPLANATION

GEOLOGIC SYMBOLS

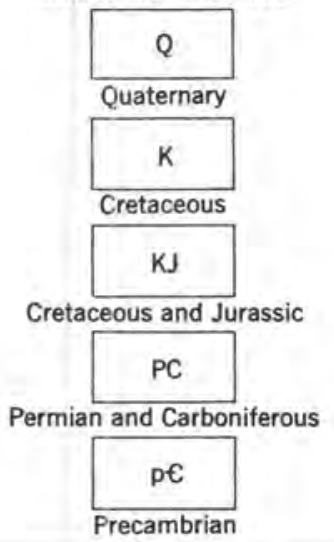

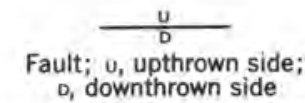

URANIUM CONTENTS, IN PARTS

PER BILLION $\left(10^{-9}\right)$
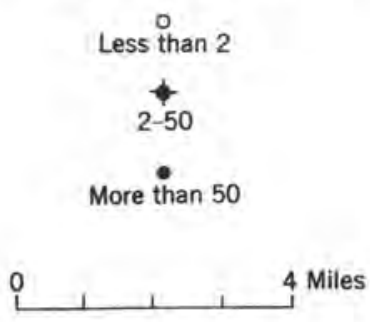

FroURE 201.-Reconnaissance map showing radiosctivity and uranium content of water, Colorado Front Range. $A$, Map of radioactivity, uncorrected; $B$, Map of radioactivity, corrected; $C$, Uranium content of water samples. (See fig. 202.) 
on figure 201C. The same area is shown on Figure 202 at an enlarged scale. The grid pattern was laid out so that representative samples were obtained from each different lithologic unit crossed by the anomalous zone. Additional samples were taken along traverses extending outward over the watershed of the anomalous area. Where possible, the soil samples were taken from a depth of 2 feet; however, at some stations only weathered rock samples could be obtained. Acid extracts from these samples were analyzed fluorimetrically for uranium contents greater than $1 \mathrm{ppm}$ (part per million), this figure being arbitrarily fixed as being the threshold of possible significance. Diagonal pattern areas on figure 202 represent soils containing uranium in concentrations greater than $1 \mathrm{ppm}$; highest concentrations found were $2.5 \mathrm{ppm}$. Surface radiometric readings were taken with a portable scintillometer; the corrected radiometric readings are shown by the dashed contour lines on figure 202 .

The data shown on figures 201 and 202 reveal several interesting points: (1) The radioactivity anomaly transects formational units. This could result from the surfaceward movement of disintegration products

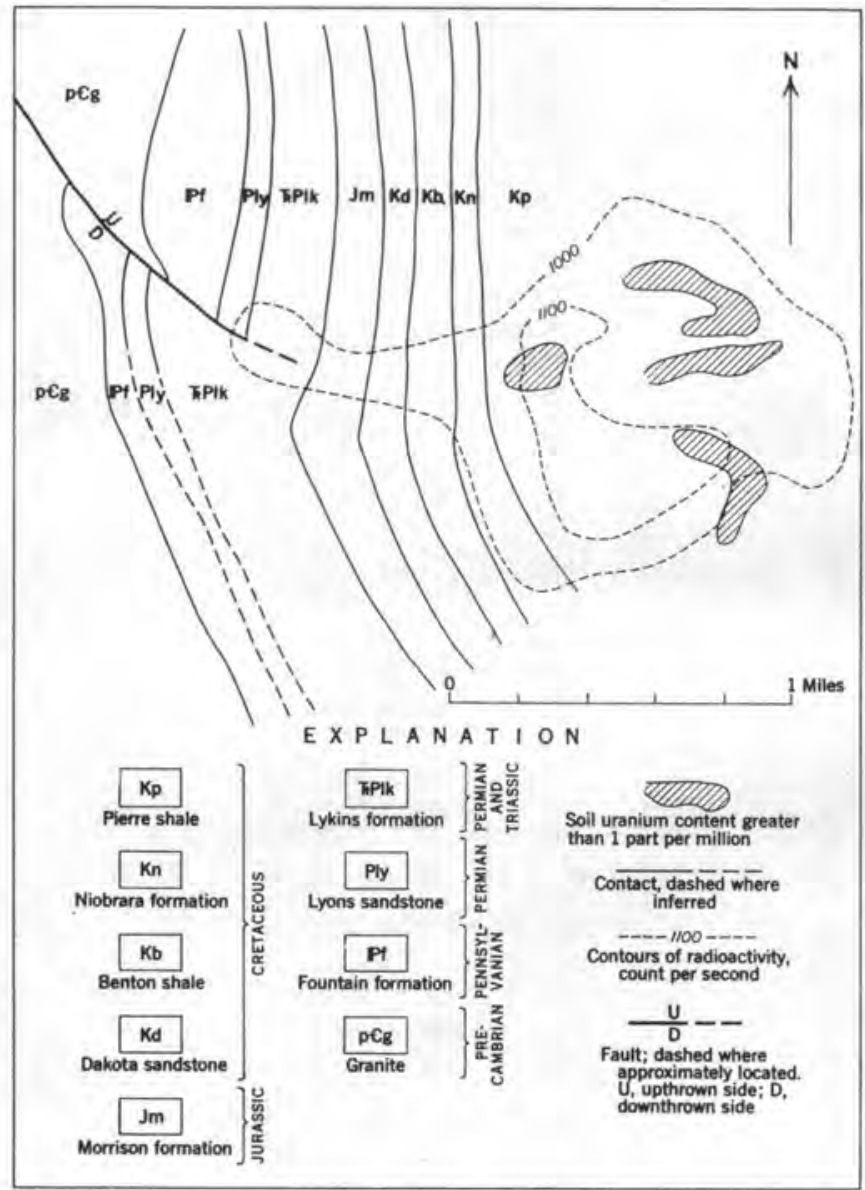

FigUre 202.-Detailed map showing radioactivity and uranium content of local area shown on figure 201 . whose migrations are controlled in part by the distribution of permeable channels. (2) The uraniumcontent anomaly is displaced downslope (topographically) from the radioactive anomaly which may suggest the effluence of ground waters accompanied by deposition of uranium dissolved in the water. (3) Areas with anomalous uranium abundances in the soil all lie within the outcrop belt of the Pierre shale, which may mean that the uranium concentrations are attributable to variations within that unit.

Further studies to extend and to define the results discussed will include geochemical and radiochemical research on the soils and waters. Geophysical studies will be carried out to determine the geometry and structure of the subsurface. More research data are being obtained to outline specifically the general conditions and controlling factors that govern the relationship between a radioactive uranium anomaly and oreparticularly as to limiting depth and possible distribution.

The association shown between low intensity radiometric anomalies and above normal occurrences of uranium in the soil confirms the hypothesis that such radiometric measurements over a large area can be of significance in exploration. In the interpretation of data such as those presented above, pertinent hydrogeological and hydrogeochemical factors must be considered. Furthermore, the attitudes of the underlying beds, the presence of faults and fracture systems, the area of the watershed, the amount and movements of ground waters, and the chemistry of the formations and contained waters all command consideration.

There is little evidence that anomalies of the type described have been considered of importance by the uranium exploration industry. Although perhaps no commercial ore will be discovered in the area discussed, the principles involved are firmly enough established to warrant searching for patterns of low-intensity radiometric anomalies in airborne and carborne reconnaissance surveys.

\section{SOUTHERN BLACK HWLS, S. DAK.}

The area shown on figure 203 represents part of the southern flank of the Black Hills uplift. The topographic surface slopes to the south and west at a rate nearly equal to the regional dip of the beds. Outcropping units which are chiefly confined to the canyons, are Lower Cretaceous rocks of the Inyan Kara group which includes, from youngest to oldest, the Fall River, Fuson, and Lakota formations. Vegetation supported in this semiarid climate consists chiefly of native grasses, sagebrush and evergreens.

Personnel of the Geological Survey bave recognized and mapped a broad channel of early Fall River age 
in the area, approximately as shown by Figure 203. The northeast flank of the channel and the caprock ${ }^{1}$ are well exposed in the western portion of the area where the channel was scoured into beds of Lakota age. Outcrops of the channel rocks to the south and east in the area shown are poor and indefinitely recognized; in addition, to the south and east the channel lies at a greater depth (an estimated 150-200 feet) below the surface. Hence, except along the western portion of the area, the location and outline of the channel are not well known. The Geological Survey also has established from outcrops that the amount of calcite cement in the channel rocks varies from area to area. The channel rocks bear lithologic evidence that the ore-bearing and the calcite-bearing solution were related. Hence, the location both of the channel and of the transitional lithologic variations within the channel rocks are of particular importance to exploration personnel.

Subsurface delineation of the channel involves differentiation of the poorly defined sandstone units of the channel from the caprock sandstones and from bounding sandstone and shale units which vary laterally and vertically. Delineation also entails recognition of stratigraphic variations within the channel itself (aside from those lithologic variations attributable to cementation) in view of the great width involved (about a mile) and, also, variations arising from the presence of other younger channels of lesser areal extent.

This problem has been approached by using geochemical techniques for reconnaissance work, followed or accompanied by geophysical techniques. Results from previous studies on soil samples collected in the area showed that the variations in the amount of bicarbonate, as well as other water-soluble ions (Ca, $\mathrm{Mg}, \mathrm{Na}, \mathrm{K}, \mathrm{SO}_{4}$ ), contained in the soils strongly suggested an association with ore deposits. To this end profiles were laid out across the projected or expected location of the channel, as well as in those areas where the location was more clearly defined. Soil-sample cores obtained along these profilas were analyzed in the field in a complete geochemical laboratory housed in a trailer.

Water leached from soil samples were analyzed for content of bicarbonate to determine whether variations could be attributed to the channel. Qualitative results representing analyses of about 150 samples

\footnotetext{
II this paper the flank of a channel is defined as that lateral portion adjacent to the basal or deepest part of the scour, and along which the thickness of channel-filling sediments decreased from the basal part of the scour to the stratigraphic top of the channel. The caprock of a channel is defined as that rock which mushrooms over and caps both the country rock adjacent to the upper portions of the flank, as well as the channel-filling rocks. Thls caprock, which may be present on either, neither, or both sides of the channel, is likened to s flood plain type of deposit and was probably deposited during the late aggrading life of the stream.
}

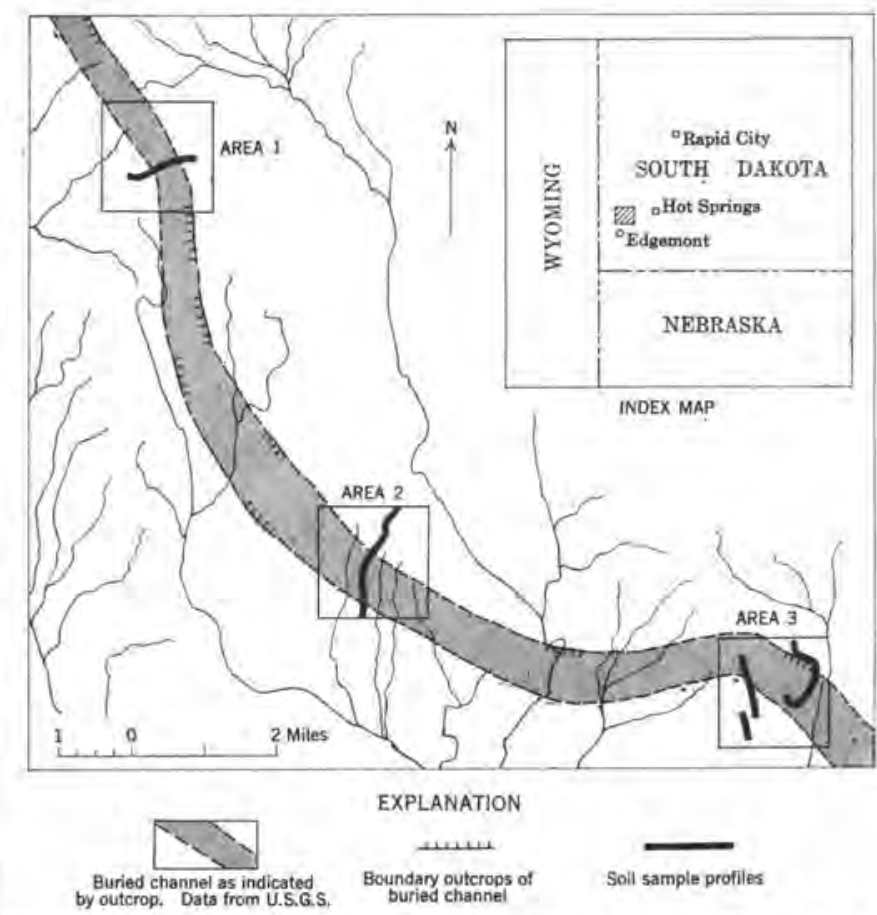

FigUre 203,-Map of channel showing areas studied by geochemieal methods, southern Black Hills, S. Dak.

are shown diagrammatically in figure 204. From this preliminary work an association between channel location and bicarbonate anomaly is recognized. Meaning of these geochemical data is imperfectly understood, insofar as explicit reasons for the anomalies are concerned, because no subsurface analyses or results have been obtained.

Geochemical investigations were accompanied by surface resistivity surveys to provide further basis for interpretation of the geochemical data and to determine whether further lithologic definition could be attained. Data were obtained using equipment designed for use with three current and three potential electrodes and having a known variable power supply. One man can run at least 8 depth profiles per day using this equipment; 3 men, 30 to 40 profiles. Depth profiling ("electrical drilling") was carried out using the four equidistant electrode Wenner arrangement and the five-electrode Lee configuration.

Results from previous resistivity measurements on core-rock samples and from electric logging in the area had indicated an association between resistivity and ore location. An example of the relations found between the electrical depth profiles and the geochemical data which were obtained along the same profile as that represented in area 2, figure 204, is shown in figure 205, In this instance a marked bicarbonate anomaly associated with a resistivity high is obtained across the projected location of the channel, which is believed to lie 150-200 feet below the surface in this area. Sur- 


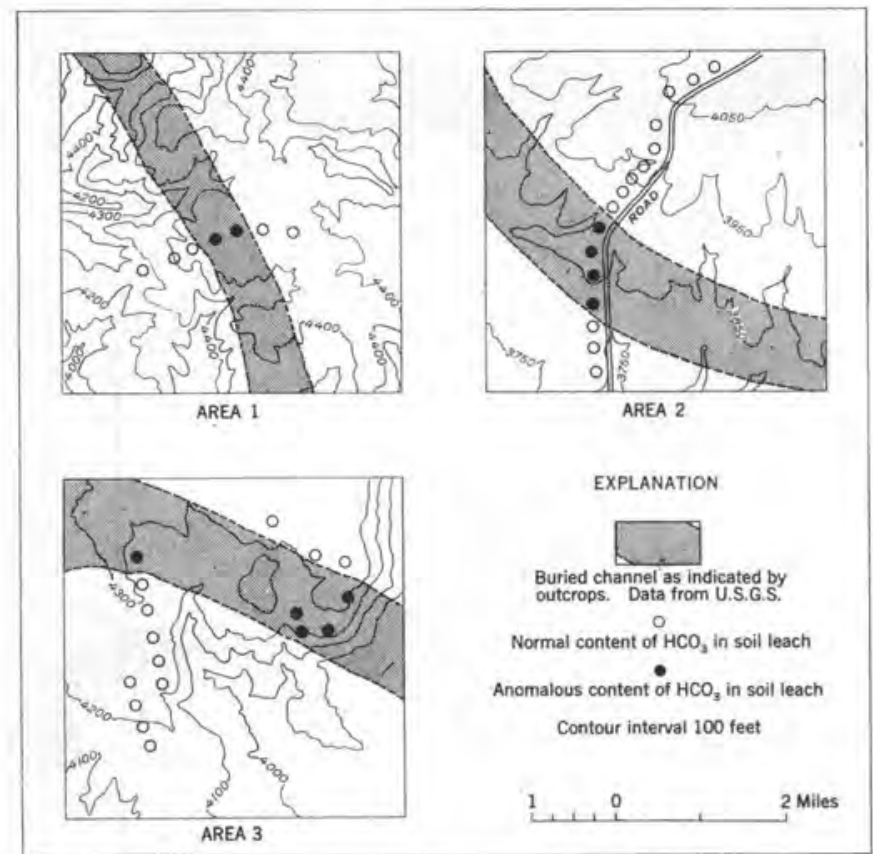

Figure 204.-Map of buried channel showing distribution of $\mathrm{HCO}_{3}$ in soil, southern Black Hills, S. Dak. (Area shown in fig. 203.)

face resistivity surveys are not capable of yielding clear-cut indications of resistivity highs at depth and, hence, the resistivity high does not seem significant.

The lithologic factor which is of chief interest, and of most probable significance insofar as these data are concerned, is the amount of calcite cement in the channel rocks. Because calcification and mineralization are associated, and because the amount of calcite cement is observed to vary from area to area, it is expected and hoped that inverse relations will be found between geophysical and geochemical results. Although the different profile data obtained thus far display this inverse type of relationship, no attempt at quantitative correlation or interpretation will be made until additional data are obtained.

Uranium analyses on the soil samples, and also additional analyses for carbonates and for other soluble ions are under way, but as yet there are too few results to be definitive. Subsurface velocity variations along the traverses already laid out will be measured in an attempt to define the scour pattern of the channel, and to substantiate large-scale variations in lithology suggested by the other geochemical and geophysical data.

Geochemical reconnaissance, followed by geophysical surveys to improve interpretations and to guide the extension of the geochemical work, is a procedure now believed to be firmly established by the data which have been obtained. It is anticipated that delimitation of the channel over an area exceeding 10 square miles will be successfully and rapidly completed at small cost by the procedures described. Considering
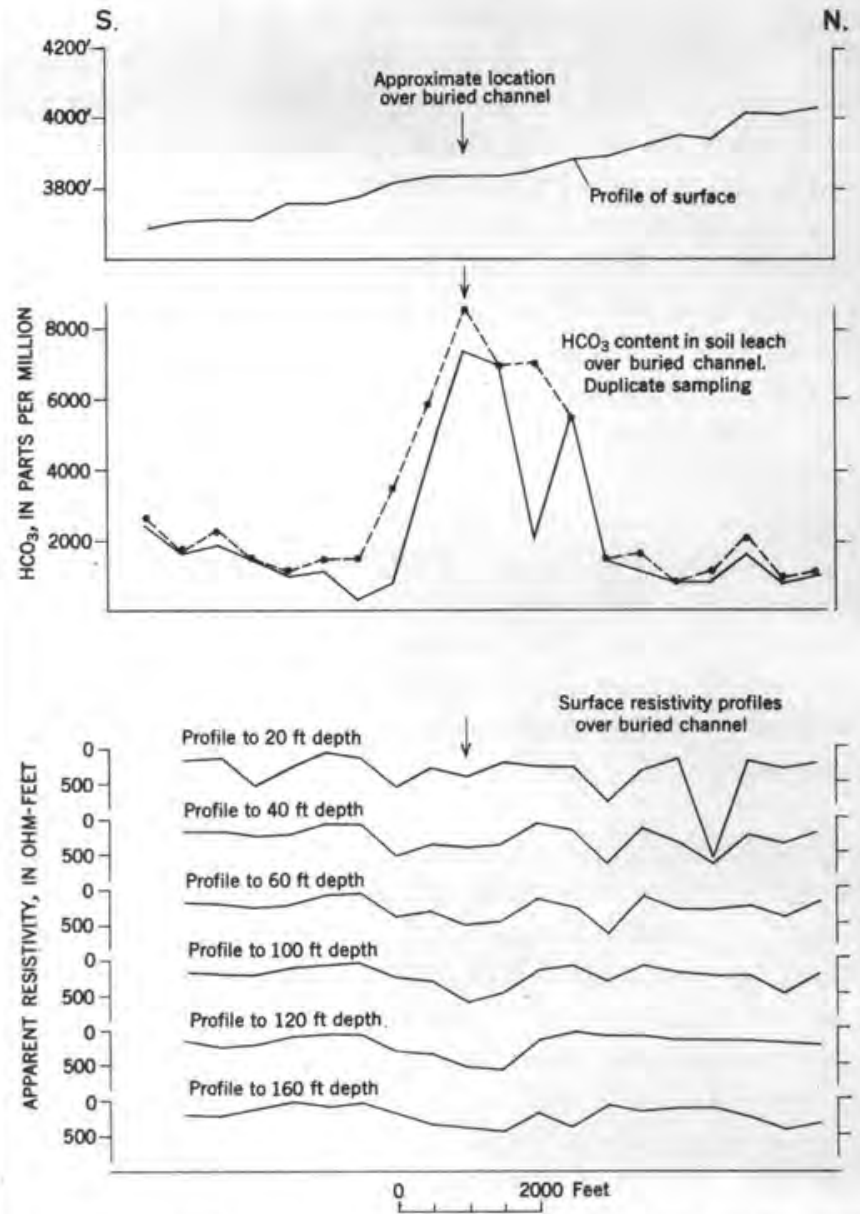

FIGURE 205.-Resistivity proflles and $\mathrm{HCO}_{3}$ content in soil over buried ehannel, southern Black Hills, S, Dak,

the extremely complex stratigraphic relationships associated with this problem, the writer believes that the application of any single geophysical or geochemical technique probably would have resulted in only vague and indefinite conclusions.

\section{DETAILED EXPLORATION}

EAST RED CANYON, S. DAK.

Surface resistivity studies which have been carried out at the various locations in the soutbern Black Hills of South Dakota were intended to determine if there was a relationship between permeable fracture systems and mineralized areas. Continuation of these studies has been carried on primarily to outline known ore bodies and to evaluate other areas where similar relationships appeared favorable for the occurrence of uranium deposits.

Surface resistivity data obtained from East Red Canyon area are shown in figure 206. Rocks of this area are in the Lakota sandstone of Early Cretaceous age. The trace of a westerly dipping monocline strikes west of north across the area between holes ER 19 and 
ER 28. The results, which show apparent resistivity to a depth of 70 feet, clearly indicate that mineralization in the Red Canyon area is associated with anomalous values of resistivity. Both the ore-bearing horizons and the overlying rocks exhibit resistivity values abnormally high considaring the amount of clays, mudstones, or clayey silts and sands in the section. Theoretical calculations to determine true resistivity were not make in view of the numerous lateral and vertical changes in the stratigraphic sequence.

An insight to the physical-property variations that are peculiar to the rocks of this deposit is afforded by the data shown in figure 207, Electric logs (single electrode resistance), courtesy of Eastman Oil Well Survey, Denver, Colo., were run in the holes drilled along profile $A-A^{\prime}$ (fig. 206). The surface resistivity depth profiles shown were run along the same line of section. The velocity logs were computed from continuous interval velocity data obtained using an acoustic velocity logger. The velocity data were obtained to determine whether significant relations between velocity and resistivity characterize such ore bodies, and whether velocity-reading variations in a deposit are such that seismic reflection or refraction techniques could be used successfully in exploration for this type of deposit.

The in-hole electric logs demonstrate that the contrasting variations shown by the surface electrical data are related primarily to differences in lithologic characteristics of the stratigraphic sequences. Fracture systems may be of significance since different results were obtained (as shown on fig. 207) from depth profiles run over the same points but in different directions. However, electric logs from holes ER 5 and ER 19 at the ends of the section show rock units that clearly indicate they were deposited under similar environmental conditions. These rocks are totally different from the mineralized transgrassive-regressive type of sedimentary units between holes 5 and 19. Ore is confined to certain stratigraphic zones between holes ER 30 and ER 35.

Physical property determinations and petrographic inspection of cores indicate that the major sand unit at holes ER 5 and ER 19 contains minor amounts of silica cement (locally recrystallized) and abundant claysized material which fill the interstices. The porosity of this main unit is abouc 27 percent with permeabilities generally ranging below 1,000 millidarcys. Preliminary analyses suggast that the porosities of the sharply bounded sandstone units in the intervening holes average 23 percent or less with permeabilities considerably higher than those of holes ER 5 and ER 19. As the beds lie above the water table and are not completely watar saturated, infiltration of water from the bore hole takes place during logging operations. This

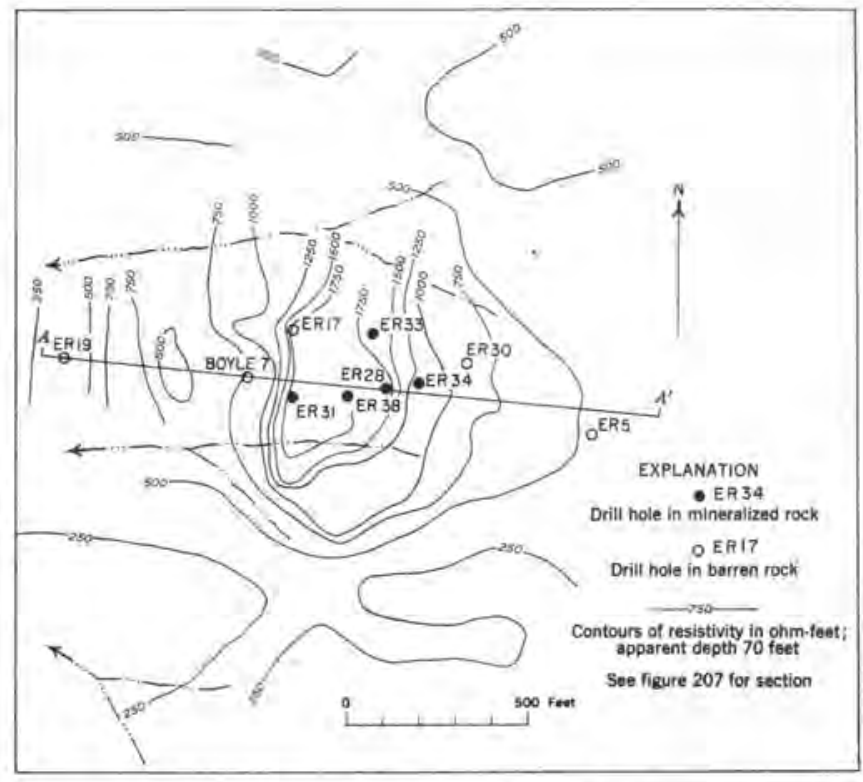

Fioure 206.-Surface resistivity data, East Red Canyon, Fall River County, S. Dak. [Note: Drill-hole ER 38 shonld read ER 35.]

precludes quantitative comparison of the departure magnitudes of the electric logs; however, the lower resistance values of the sandstone units at holes 28,30 , 31,34 , and 35 denote a high water imbibition and hence a high permeability,

The profile of the velocity data does not coincide with the profiles of the other data but is closely adjacent as may be seen from hole locations shown below each profile on figure 207. These data show how the acoustic or elastic velocity of the rocks changes continuously with depth, subject to possible differences in interpretation of the original records that were expressed as a function of time. Aside from the significance of relations that are discussed later in this paper, these data illustrate the complexity of the elastic velocity distribution across the ore-bearing rocks. In some holes, for example at ER 5, the resistance log correlates closely in form with the velocity $\log$ indicating a relation between velocity and resistivity. However, clear-cut differences between the barren and the mineralized rocks do not persist in the velocity data, as are pointed out by the surface resistivity and the electric logging profile data. While a difference in the velocity-depth function can be calculated from the data shown, the difference is not so great that a general statement regarding the relation of velocity with other properties over an ore body can be made. Nonetheless, the surface resistivity data, electric logs, and physical-property measurements firmly substantiate that mineralization in this deposit is controlled by (or associated with) lithologic differences that are governed by stratigraphic and structural features. 
GOULD AREA, S. DAK.

The channel discussed on pages $690-692$ has been recognized in the Gould area, which lies about 5 miles to the south and east of East Red Canyon. Surface rocks consist largely of Fall River sandstone filling scours cut into the Lakota sandstone and Fuson shale.

Surface geochemical, surface resistivity, electric logging, and velocity logging studies were carried out on the Gould lease. Geochemical data are those shown on figure 204. Results from surface resistivity work did not indicate a clear-cut correlation between mineralization and high resistivity as at East Red Canyon. Mineralization on the Gould lease is found within sandstone units of the Fall River and its occurrence correlates with changes in the magnitudes of the rock resistivities.

Correlations on the cross sectional fence diagram (fig. 208) made from single electrode in-hole electric logs (courtesy Well Instrument Developing Company, Houston, Tex.) illustrate the complexity and variability of the channel rocks in this area. Magnitudes of the electric log departures are not comparable since some holes would not hold water without continuous re- plenishment during logging operations. However, the types of departures at holes 1,7 , and 9 illustrate scour and fill deposition where the high-resistance sandstones (marked A) lie directly over impermeable mudstones of varying thickness. This type of departure contrasts sharply with the gradational upward transitions from mudstones to sandstones (marked B) on logs from holes $11,27 \mathrm{~N}$, and 135 . Such gradational transitions could result from an advancing shore line or from the lateral migration of a locally aggrading stream. The locations of core holes showing gradational transitional zones on the electric logs correspond with the locations of transitional zones determined from surface electrical data. Surface data show high resistivity areas grading to low resistivity areas near holes $27 \mathrm{~N}, 11$, and 148 and at these locations the in-hole electric logs indicate transitional deposition.

The greatest abundance of ore minerals occurs at holes $11,27 \mathrm{~N}$, and 135 in or near the transitional zones shown by surface resistivity and electrical log data. The slight mineralization at holes 1 and 9 at the base of the channellike sand units may suggest that these

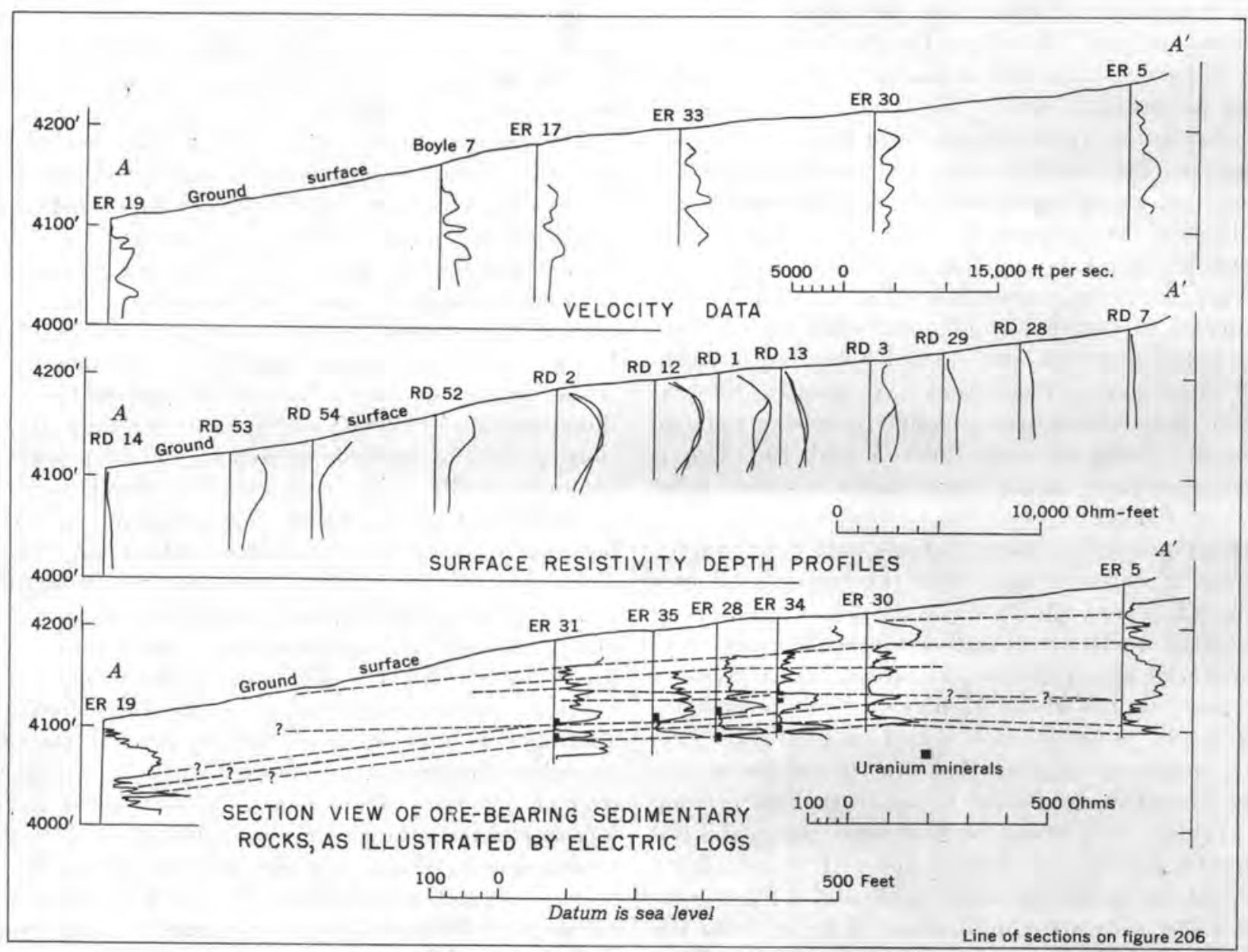

FIGURE 207.-Sections showing geophysical data, East Red Canyon, Fall River County, S. Dak. 
permeable units have served as conduits for the mineralizing solutions. Variations in surface electrical data are believed to be related primarily to changes in permeability between channel and transitional zone rocks. Such variations are a useful exploration guide. Although no faulting is evident from the field data it is reasonable that small scale faulting is one of the controls on mineralization, in addition to lithologic variations attributable to depositional factors.

The single electrode electric log (see below, Dry Hole Electric Logging) should become a powerful and practical tool for the study of the rocks enclosing uranium deposits. This geophysical technique affords practical opportunity for an insight to the poorly understood, yet economically important, lithologic and stratigraphie peculiarities of continental or terrestrial sedimentary rocks that contain the most of known uranium deposits.
WIND RIVER BASIN, WYO.

Results of in-hole electric logging studies and surface electrical surveys over the Bullrush prospect, Gas Hills area, of the Wind River Basin (area 2, index map fig. 208) are shown on figure 209. Surface rocks are in the Wind River formation of Eocene age.

These data are presented to show the contrasting differences between the resistivity variations accompanying mineralization at this location and those at the Gould and the East Red Canyon properties in South Dakota. The resistivity variations (apparent depth, 80 feet) in figure 209, though clear, are small, implying a high degree of water saturation. The concave low resistivity pattern on figure 209 , which is bounded by higher resistivities, suggests an overlapping transitional sedimentary sequence. Shallower resistivity data display a northwestward-trending anomaly suggestive of a fault.

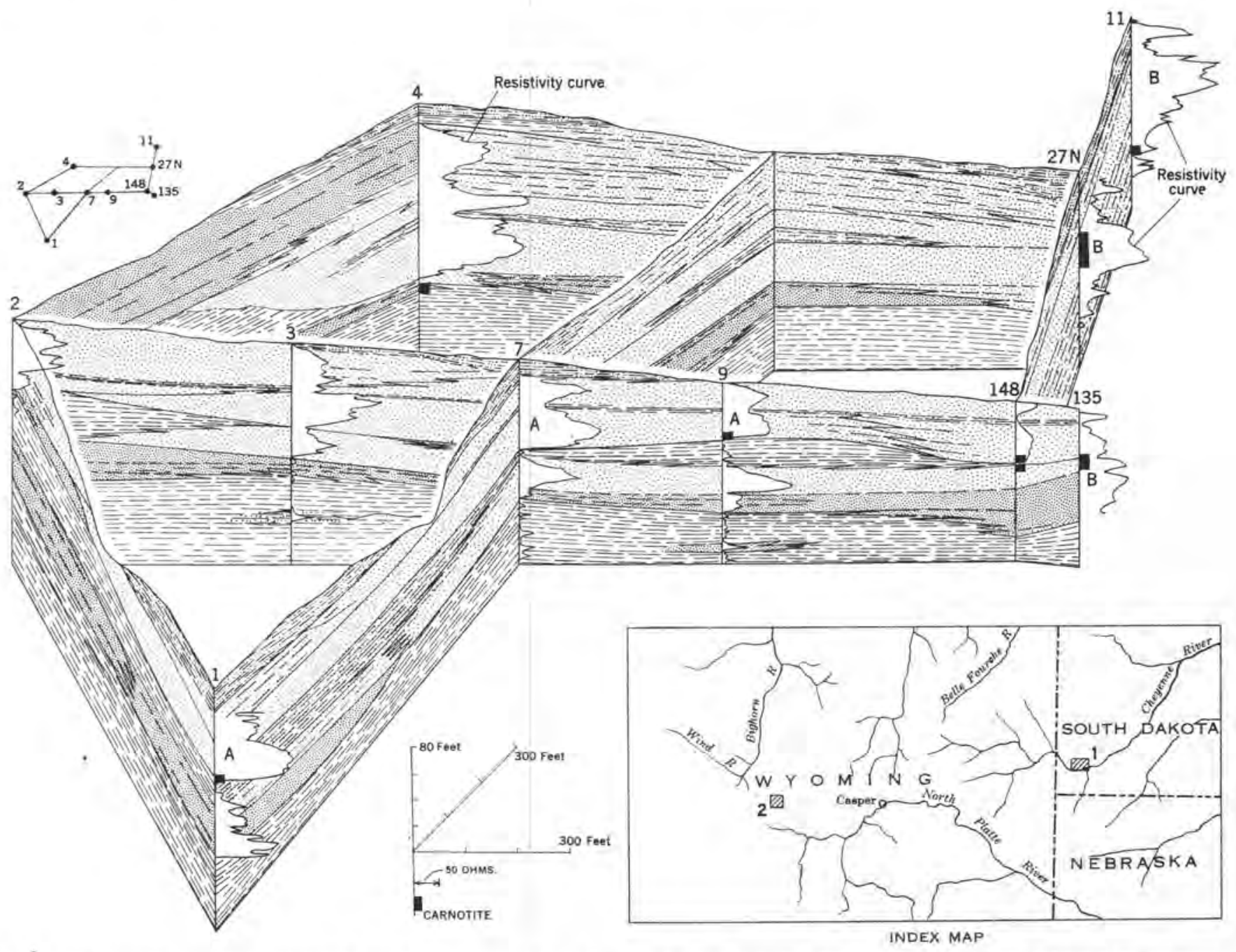

Ficure 208.-Fence diagram showing relation of electric $\log$ measurements to ore-bearing rocks, Gould area, Fall Ríver County, 8. Dak. The index map shows location of this area (1) and of the Bullrush prospect in the Wind River Basin, Wyo. (2). 
Correlations of the dry-hole electric logs obtained from the available holes which were not plugged along the N-S profile, figure 209 , illustrate the factors controlling the resistivity variations of the surface data. The logs indicate a transitional sequence of sandstone and claystone beds dipping slightly to the south. The overlap or gradation of the predominant sandstones at hole A-9 to predominant sandy clays or mudstones at hole $\mathrm{A}-13$ cause the change from higher to lower resistivity as determined from surface data. The slight southward dip of the beds intersecting the topographic nose causes the anomalous pattern to be bow-shaped.

Whether the sediments close to hole $\mathrm{A}-15$ change in dip or in facies is not clear because of lack of electric logs from the nearby holes. However, a small northwestward-trending fault, accompanied by dip changes near hole $\mathrm{A}-15$, appears most reasonable and would be consistent with available data. The above data illustrate structural and stratigraphic controls on mineralization that are characterized by physical property variations markedly different from those previously described.

\section{DATA FROM EXPERIMENTAL DEVELOPMENTS}

\section{DRY-HOLE ELECTRIC LOGGING}

A major problem in exploration drilling is that of obtaining reliable and meaningful lithologic and stratigraphic information from bore holes. Core drilling has been carried out extensively - with great expenditures of time and money and with inherent limitations due to incomplete core recovery and associated differences in core logging which arise from human partiality. The combined high cost and long time required for coring minimize the amount of geologic information that can be obtained.

To meet the need for simple and reliable means of obtaining lithologic and stratigraphic information economically, electric logging research has been carried out. Experience of oil companies has demonstrated that electric logging provides useful lithologic and stratigraphic information cheaply, although electric logging has been confined chiefly to marine sedimentary rocks. Most of the uranium exploration drilling carried out to date by governmental, as well as by private, agencies has been in sedimentary rocks of continental or terrestrial type. Two factors of paramount importance in the electric logging of those continental type sedimentary rocks are: The shallow sandstones in semiarid regions are frequently not fully water-saturated thus giving very high resistivity reading; the beds and ore zones are thin.

The problem of determining the true or relative resistivity of a thin, highly resistant bed penetrated by a bore hole is difficult. Induction techniques are precluded by reason of instrumental complexities associated with obtaining sufficient signal response from a highly resistant bed and by reason of lack of definition obtainable from a series of thin beds. Multielectrode logging arrangements are precluded by cost, complexity of instrumentation, and the lack of necessary definition of thin beds.

Not to be overlooked as a formidable factor in electric logging is the importance and availabliity of water ordinarily used to make electric contact between electrode and formation. In this regard three items require consideration: Water is scarce and expensive to obtain in most of the ore-bearing districts; frequently, it is impossible to fill a hole with water because of fracture systems or high permeability of the rocks; electrical measurements involved in electric logging are directly related to the kind and amount of water in a rock. Water, which is poured into a bore hole and is imbibed by the rocks or fills fractures, is a contaminant. Such contamination makes quantitative interpretation of a $\log$ virtually impossible, let alone practical.

The above difficulties were overcome by using a dry hole electric logging unit developed by the Geophysical Research and Development Branch (patent application filed). This unit, which is being used by the exploration units of the Atomic Energy Commission provides detailed lithologic defiaition and makes possible reliable determinations of the true resistivity of the beds in a bore hole. Beds an inch or more thick can be defined and quantitative lithologic interpretation of beds greater than about six inches in thickness is possible.

Another problem met in electric logging of bore holes is the location of the water table. Some holes which penetrate below the local water table are partially filled with water. To log these holes a combined dry-hole and wet-hole sonde was developed that permits continuous logging across the water surface.

An example of an electric log obtained from a dry hole is shown in figure 210. The wet-hole log, obtained from the same hole and with the same instrument except for the electrode, is shown for comparison. The righthand graph of each log reveals that the detail and definition on the dry-hole log far exceeds that on the wet-hole $\log$. For example, not only are the sandstone beds at 109,80 , and 70 feet more clearly defined, but the lithologic character of these units is more clearly represented. The siltstone beds at 35 feet and just below are poorly defined on the wet-hole log. However, even the degree of siltiness of the mudstone and shale beds, which is barely perceptible on the wet-hole log, is clearly revealed by the dry-hole unit, for example, from 42 to 68 feet and from 92 to 103 feet. 


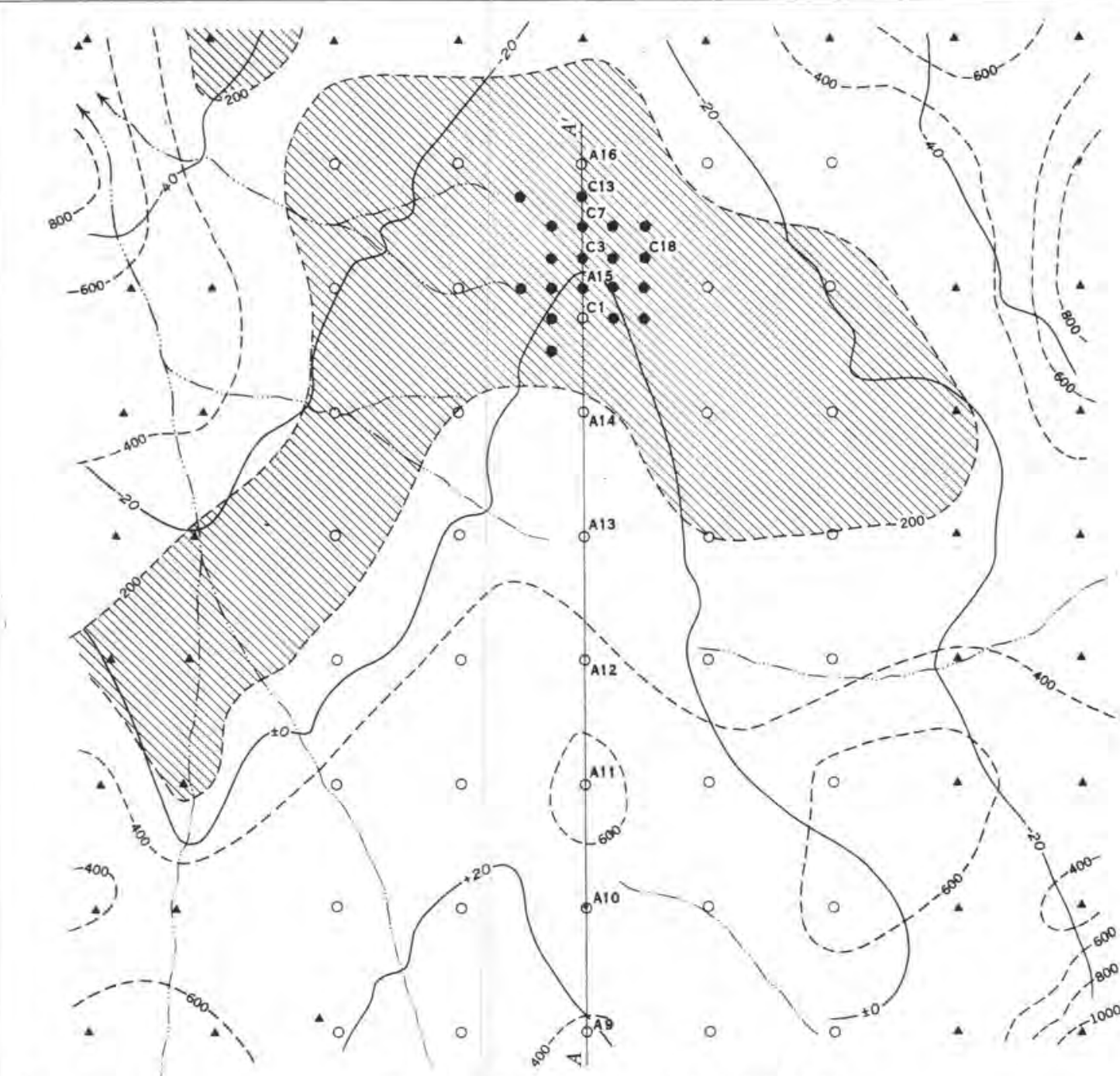

$A$

SURFACE RESISTIVITY DATA, APPARENT DEPTH 80 FEET

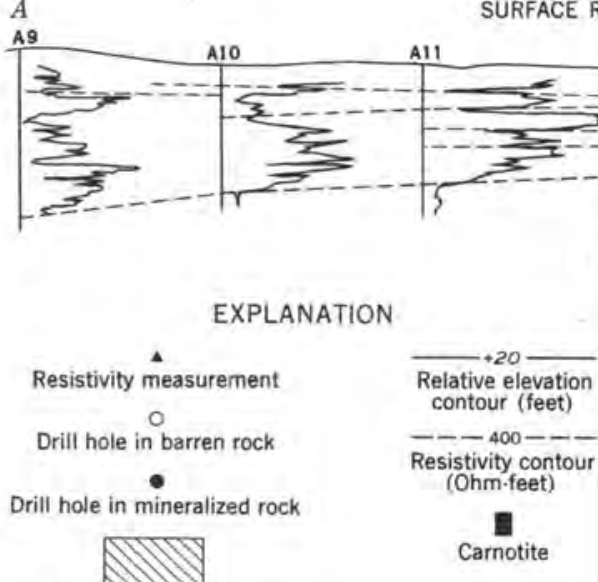

Resistivity 200 ohm-feet

200

400 Feet

FigUre 209.-Resistivity map and section of Bullrush prospect, Wind River Basin, Fremont County, Wyo. Location of the Bullrush prospect is shown on figure 208.

$385115-56-45$ 

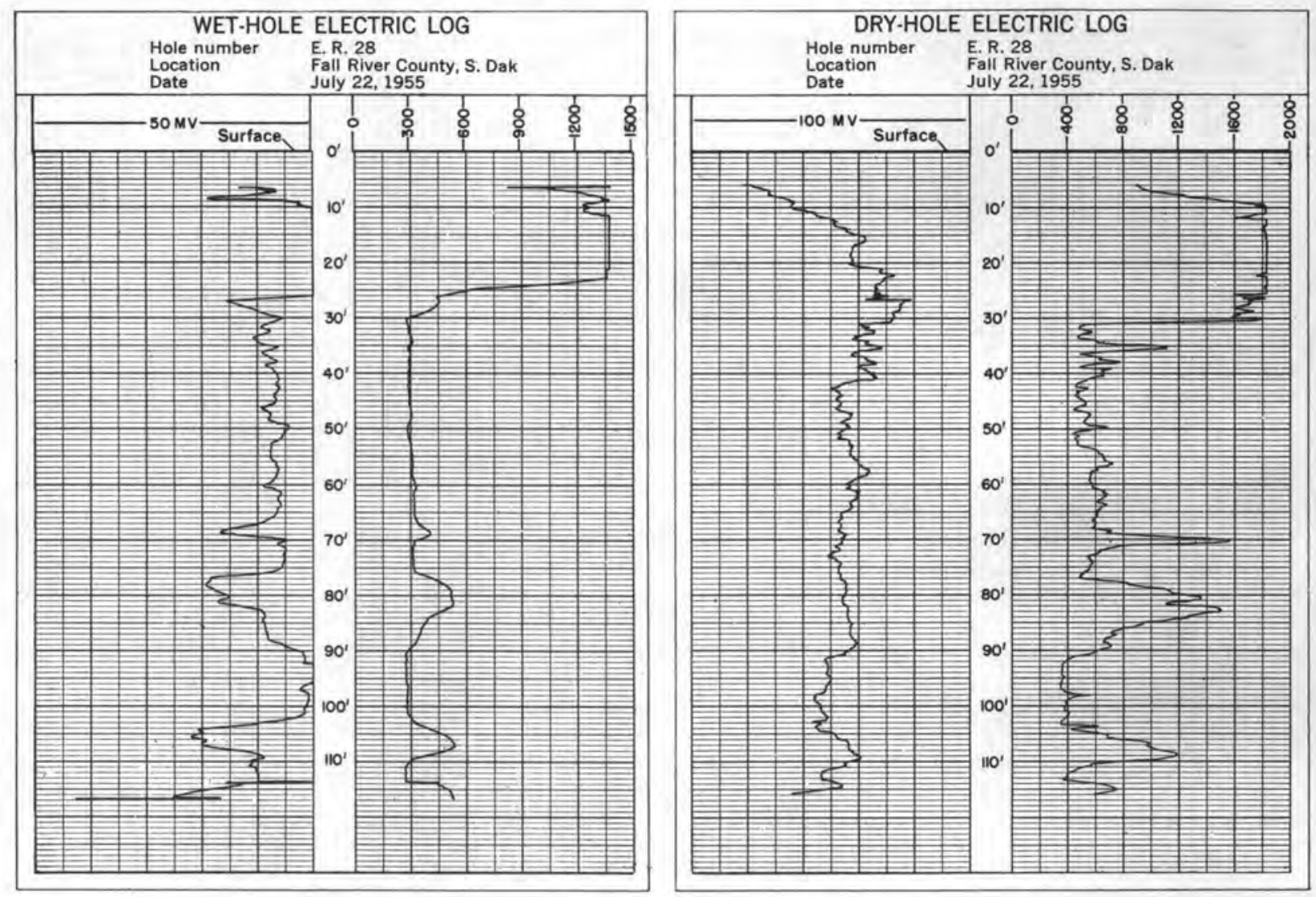

FIOURE 210.-Comparison of wet- and dry-hole electric logs.

The left-hand graphs of each log are the so-called selfpotential parameter. That of the wet-hole log cannot be used for quantitative interpretation because an unknown amount of the measured potential differences are attributable to electro-filtration effects that accompany the imbibition of water. Variations represented by the self-potential curve on the dry-hole log have not been known to exist theretofore. Analyses and study are being continued to determine the significance of this potential reading obtained from a dry hole.

This logging development, with its inherent opportunity for quantitative lithologic interpretation and correlation, makes electric logging in uranium exploration a practical and economic procedure. Further, it makes possible, to any degree of detail desired, the study of the poorly understood lithologic and stratigraphic peculiarities of continental sedimentary rocks that contain the highest percentage of our uranium deposits.

Added advantage can be realized by combining sensitive gamma-ray logging with electric logging. This combined application is not a complete substitute for coring. However, in areas near deposits where control points have been established from an adequate number of cored holes, need for additional core drilling can be eliminated by use of combined electric and gamma-ray logging.

\section{ACOUSTIC VELOCITY LOGGING}

The acoustic velocity logger, or continuous velocity logger, is a recent industrial development which has proved to be of tremendous value in the field of seismic exploration. Data that can be obtained with this equipment provide information on the acoustic velocity variations in rocks penetrated by boring. The velocity variations, which are attributable to the elastic properties of the rocks involved, are a function of such factors as porosity, cementation and gross lithologic character. Results have proved useful not only for determining variations in lithologic character, but also for making correlations and for furnishing velocity data necessary for accurate interpretation of seismic exploration data.

A program of velocity logging was started by this Branch to obtain data on the laterai and vertical velocity variations of the rocks enclosing ore bodies and to determine whether velocity data could be correlated with other physical property data that would indicate applicability of combined exploration techniques. Ex- 
amples of results from the velocity-logging data, shown in figures 211 and 212 , illustrate some interesting relations found to be associated with uranium deposits.

Velocity logs, accompanied by wet-hole electric logs, figure 211, show an average comparison between mineralized and nonmineralized ore holes.

The following generalizations from these and other results are significant:

1. Intervals of high radioactivity are characterized by low velocities indicating high porosity and minor cementation.

2. Velocity distributions within the shale units show a decrease in velocity with increasing distance from permeable sandstone units, indicating a cementation or diffusion phenomenon which apparently is connected with the migration of material from the permeable sandstones out into the adjacent rocks.

Unfortunately, dry-hole logs could not be obtained and the electric logs of figure 211 do not reflect the true magnitudes of the resistances of the rocks because water poured into the holes during the logging process is imbibed by porous permeable units. The resulting resistivity measurement is therefore not a true indication of the resistivity of the rock. Nonetheless, these and other data indicate that the porous, permeable sandstones of this district have a high relative resis. tivity. The combination of low velocity and high resistivity in the ore zones presents a target for exploration. However, no practical means of finding such zones has yet been worked out, largely because of the thinness of the units involved.

An interesting relation is shown on the velocity log of the hole through a barren zone (fig. 211). The velocity decrease at depths of about 80 to 175 feet is abnormal and probably can be explained in terms of the above-mentioned cementation or diffusion phenomenon around permeable sandstone. Routine wave propagation depth determinations carried out in seismic refraction work would not be accurate in this case. Further, this log shows that reflection techniques could not be used to map either of the predominant sandstone units shown on the electric $\log$ at the 95 foot and 40 foot depths.

The significance of channels (here discussed with reference to fig. 212) in relation to the occurrence of uranium, particularly in the formations of Triassic age on the Colorado Plateau, has long been recognized. Of importance in this connection are lithologic character and variations of it, and the relative location and stratigraphic position of lithologic changes with respect to the major features of the channel. A program of research was begun to obtain a better understanding of the features of buried channels and of the properties of channel rocks in order to bring about more effective exploration. The long-range goal of this program includes correlation and study of data from bore holes, from surface surveys, and from analyses of cores. This study was commenced on channels in the Circle Cliffs area, Garfield County, Utah, because drilling by governmental units could be directed, in part, to further the study.

The question, "How effective and what are the limitations of seismic techniques in channel exploration?" is of primary importance and interest to exploration enterprise. Although valuable seismic surveys on channels have been earried out with various degrees of success by the Geological Survey, by the Bureau of Reclamation, and by private industry, an understanding and statement of the unknowns peculiar to seismic channel exploration do not prevail. To obtain a statement and better understanding of these unknowns, continuous velocity-logging data were obtained under contracts with the Texas Company and with the Seismograph Service Corporation. An example of representative data from these sources is shown on figure 212 , and the following preliminary observations are made in reference to this work.

The data shown on figure 212 were obtained from a row of bore holes, the basal parts of which were cored, across northeastward trending Stud Horse channel in the Shinarump conglomerate of Late Triassic age. This channel was scoured into the Moenkopi formation of Early and Middle (?) Triassic age. Lithologic differences between the siltstones and mudstones of the Moenkopi and of the channel-filling sandstones creates a potential geophysical-geochemical target-partly obscured by the clayey rocks of the overlying Chinle formation of Late Triassic age.

The data on figure 212 , as well as data of like kind from other channels, permit some observations of interest and importance in seismic exploration which were heretofore unknown, at least to the writer.

1. Average velocities within the Moenkopi rocks under the flanking ${ }^{1}$ portions of the channel scour are higher. This is illustrated by average velocities around $12,000 \mathrm{ft}$ per sec in the Moenkopi at holes $\mathrm{AC} 22, \mathrm{AC} 26$, and $\mathrm{AC} 27$, which penetrate the flanks of the channel. At holes AC 20, AC 21, and $\mathrm{AC} 23$, which penetrate the central part of the channel, average velocities in the Moenkopi are around $10,000 \mathrm{ft}$ per sec.

Holes $\mathrm{AC} 24$ and $\mathrm{AC} 25$ were plugged at depth. Nonetheless, if we assume that velocities in the Moenkopi at these locations are similar to those at the other central locations (AC 20, $\mathrm{AC} 21$ and $\mathrm{AC} 23$ ) the following generalization can be made: Velocities in the Moen1 Terms used in the following diseussion of channels are defined on page 691. 

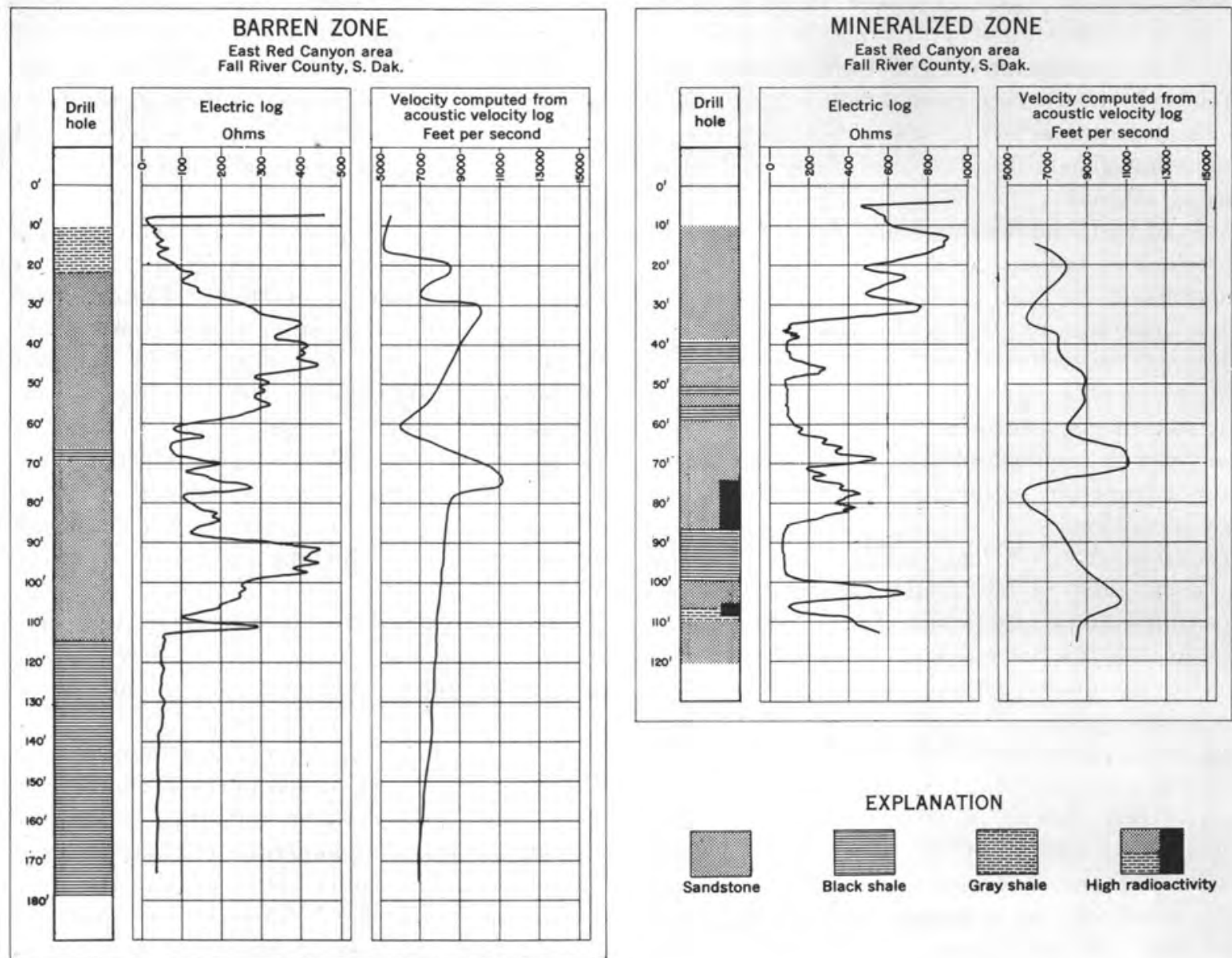

FraUre 211.-Comparison of electric and acoustic velocity log data.

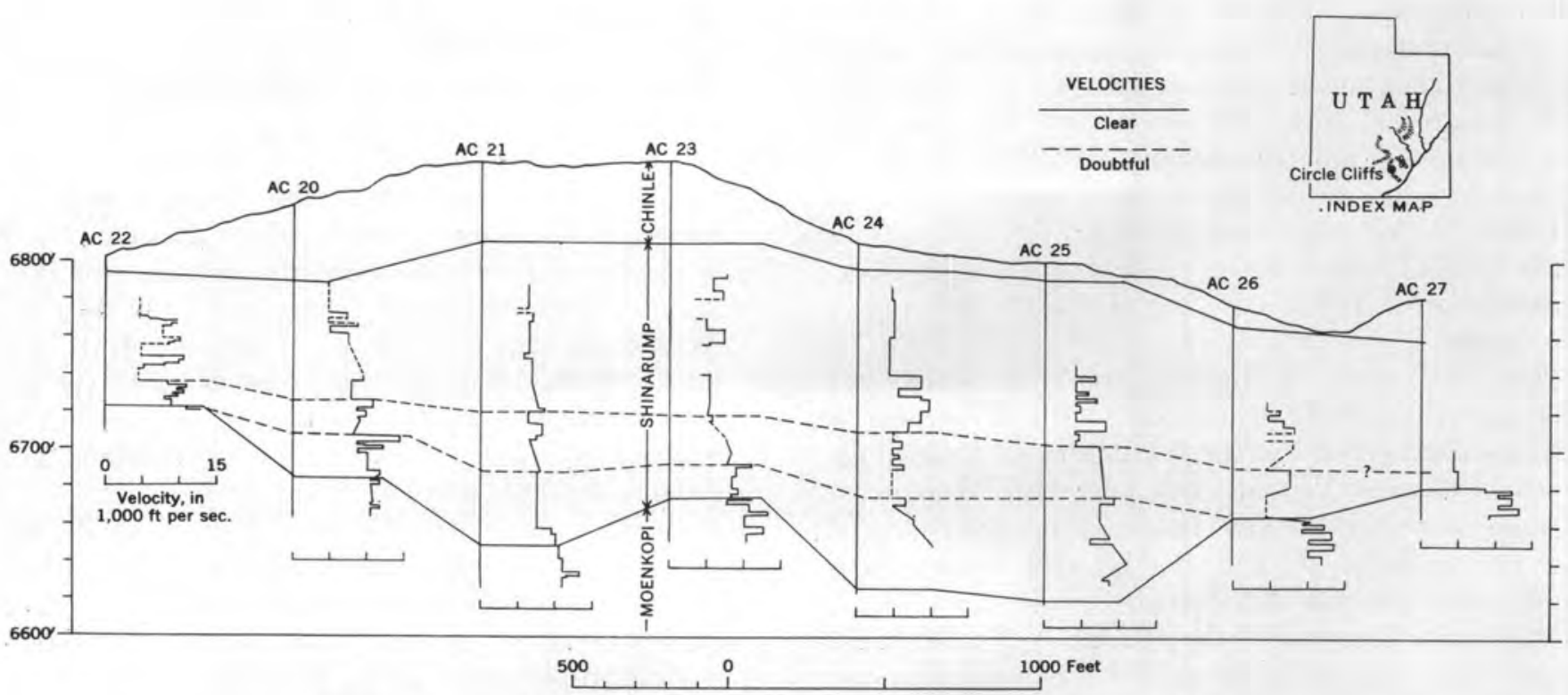

FigURE 212.-Section showing velocities determined across Stud Horse channel, Circle Cliffs, Utah. 
kopi are higher under the flanks of the channel than under the central portions of the channel. This difference, which amounts to about $2,000 \mathrm{ft}$ per sec is of importance in connection with the mapping of the scour pattern of the channel by geophysical techniques. Logging and core analyses are being carried forward to determine the cause and significance of this velocity difference in relation to mineralization. This difference seems to be caused by diagenetic changes and also may be related to bleaching observed in the Moenkopi rocks underlying the channel.

2. The contact between the Chinle and Shinarump rises about 30 feet over the central portion of the channel, or alternatively expressed, a higher percentage of compactible sediments was deposited along the flanks of the channel. This may be explained in terms of stream carrying power. Sands, which are less compactible than elays and muds, are deposited in the central and deeper portions of a stream where velocity and volume are largest. As the water velocities subside and the stream starts to aggrade, the larger sand particles are dropped first while the muds, clays, and silts are winnowed out and deposited under conditions where lower velocity and lesser volume of water persist, which are found, for example, along the edges or flanks of a stream. As the aggrading process continues, a higher percentage of sand is deposited in the deeper portions of the channel. Hence, the following generalization may be hypothesized-subject to reservations: The more sandy the stratigraphic section of a channel, the greater should be the relative thickness of that section. Changes in thickness and in the distribution of lithologic units (controlled in the main by the size and regimen of the original stream) are considered important factors in mineral deposition.

The rise of the contact between the Chinle and Shinarump over the channel is a circumstance in Circle Cliff's which provides supporting evidenee for the hypothesis, advanced by Mitcham and Evensen, ${ }^{2}$ that such is probably the case over channels in Monument Valley, Ariz.

3 . Observations in relation to the channel itself are perhaps most interesting from the exploration point of view, These observations concern velocity zones and distributions within the channel-filling and overlying rocks. On figure 212 the Shinarump conglomerate has been divided into three zones - a basal zone, a channel cap zone, and the uppermost zone. The outstanding features characterizing these zones are as follows:

2 Mitchnm, T. W., and Evensen, C. G., 1955, Utanium ore guides, Monument Valley distriot, Arizona: Econ. Geology, v. 50, D. 174. a. The basal zone predominates in the central portion of the channel and is either absent or too thin for recognition high on the flanks. Highest seismic velocities are measured within this zone. The upper boundary is marked by high velocity sandstone stringers above which velocities begin to show a persistent decrease. These observations arê consistent with the generalized hypothesis discussed under observation number 2 . Higher velocities are associated with those compact rocks having high rigidity as would result from cementation. Because the central and deeper channel rocks are more sandy, movement of water is facilitated, thus giving rise to opportunity for cementation of these rocks. Some of the thicker basal zones of channels in the Circle Cliffs area have velocities greater than 12,000 ft per see and cores from these zones consist of silica cemented sands. From the sectional data the reader can verify that the velocity contrasts between the basal zone and the underlying Moenkopi are approximately as follows: $\mathrm{AC} 20,1,000 \mathrm{ft}$ per sec; $\mathrm{AC} 21,3,000 \mathrm{ft}$ per sec; and $\mathrm{AC} 23,1,500 \mathrm{ft}$ per sec. These differences accompanied by variations in the overlying rocks do not lend themselves to accurate or acceptable determinations by known seismic means of the contact of the Moenkopi and Shinarump along the central portions of the channel.

b. The channel cap zone is characterized by average velocities which range between 7,000 to $9,000 \mathrm{ft}$ per sec, lower than those of the basal zone. Rocks in this zone form the cap which extends out beyond the scour of the channel and probably interfingers or lenses out to a featheredge over the flood plains of the original stream. Lower velocities in this zone are probably attributable to lack of cementation arising from changes in lithology of the rocks. It is to be expected that in many cases the cap rock would be absent beyond the confines of the channel proper and even where present difficult to to recognize from outcrops. The top of this zone is poorly defined but is probably marked by transitional or gradational sedimentary sequences as the stream aggraded more slowly with increased meanderings. On figure 212 this contact is arbitrarily picked where the velocities become more erratic or decrease. Alternatively expressed, averaged rock velocities in the channel below the top of this zone are higher than averaged rock velocities above, This difference, which amounts to as much as $4,000 \mathrm{ft}$ per sec, appears to be the best, though erratic, seismic target associated with the channel. The top of this zone could be mapped with varying degrees of success by seismic refraction techniques if topographic changes were not too extreme.

c. The uppermost zone is nearly equivalent in stratigraphic position and thickness to the "normal" Shinarump sequence. Average velocities in this zone 
range from about $5,000 \mathrm{ft}$ per sec to about $7,000 \mathrm{ft}$ per sec and are comparatively constant over the zone, except for increases noted in the well-indurated and cemented sandstone intervals. Data from hole AC 22, if representative, indicate a higher averaged (though less constant) velocity than in the "normal" Shinarump section.

The boundary between the Shinarump and Chinle at Circle Cliffs displays a gradational transition from the predominance of sandstones of the Shinarump to the predominance of siltstones and mudstones of the Chinle. This contact, which was detected on electric $\operatorname{logs}$, is presumably accurate and representative, and reveals a thickening of the uppermost zone of the Shinarump over the central portion of the channel. If this thickening is representative, it indicates that the sedimentation and subsequent differential compaction of the uppermost zone was affected or controlled by the presence of the two lower zones. Thickening is consistent with differences noted between velocitydepth functions of the uppermost zone over the channel and of the "normal" Shinarump sequence outside of the channel (hole AC 20). However, insufficient data on the "normal" sequence prevent firm conclusion in this regard. That such differences between velocities in the uppermost "channel" zone and velocities in the "normal" sequences are susceptible to detection and interpretable significance by surface seismic methods is doubtful, unless surface conditions are ideal. Nonetheless, these inconclusive data give added information and suggest a further difference of interest and importance in exploration for channels.

\section{SUMMARY}

Preliminary results from two different field reconnaissance projects are presented to illustrate the effectiveness of combined methods of prospecting. The first of these examples concerns low intensity radiometric surveying combined with geochemical techniques in reconnaissance work.

Measurement of small radiometric changes which extend over an appreciable area and which are not attributable to background variations, is a little used but a potential indicator of hidden subsurface deposits. The significance of evaluation of radiometric data showing small variations over a large area can best be ascertained from the amounts of uranium contained in the soils, rocks, and waters of the area. However, caution must be used in the interpretation of these geochemical results. In this connection adequate recognition must be taken of hydrogeochemical and hydrogeological factors. Data presented illustrate the coincidence of surface radiometric anomalies of small magnitude and anomalous uranium contents in the soil, accompanied by anomalous uranium contents in the ground waters. Though the preliminary results described herein are inconclusive, and information on depth limitations and critical geologic conditions are not yet known, documentation of the principles involved is sufficient to warrant recommendation of the combined geophysicalgeochemical procedures described.

The second example discussed illustrates the effectiveness of combined geochemical and geophysical techniques for reconnaissance work in channel delineation. In this case bicarbonate determinations on soil leaches combined with surface resistivity surveys are being used successfully for the twofold purpose of (a) delineating a buried channel at depths of as much as 200 feet and (b) outlining lithologic variations within the channel which are believed to be of significance in localizing mineralization. Reliable sampling entails recognition and knowledge of soil profiles, and due caution must be exercised in choosing the site from which soil samples are taken. An illustration of the magnitudes of properties being mapped is included to show the coincidence of the different types of anomalous relations. The geochemical or the geophysical data when viewed singly have but little satisfactory interpretable significance. When combined with geophysical surveys, particularly in reconnaissance work, both geochemical and geophysical techniques become more useful and economic.

Physical-property analyses, detailed geophysical surveys, and experimental studies have revealed some of the differences characterizing the rocks enclosing uranium deposits. These differences are related to lithologic changes which are attributable to both stratigraphic and structural features and to secondary effects accompanying mineralization, in space at least. Results from logging and core analyses point up these differences to which the anomalies determined from surface work are attributed.

Secondary uranium deposits are associated with, or perhaps controlled by, lithologic differences in porosity, permeability, and amount and kind of cementation. Lithologic differences are in turn attributable to stratigraphic channellike features or facies changes in the enclosing rocks. These stratigraphic features which are peculiar to continental or terrestrial type sedimentary rocks, influence the migration or flow of ground waters, and perhaps the movement of mineralizing solutions. In view of the high resistivities associated with carnotite-type deposits confined to certain channellike strata in the southern Black Hills and the low resistivities associated with the uraniferous calcite deposits in proximity to facies changes in the Wind River Basin, it is interesting to speculate that geophysical and geochemi- 
cal measurements reflect conditions which relate to the types of mineralization involved.

Dry-hole electric logs and velocity logging data from the channels filled by the Shinarump at Circle Cliff's, Utah, point out some significant facts concerning buried channels. In this regard the following are of particular interest:

1. Over the central or deepest part of the channel, the contact with the overlying Chinle rises. This change is attributed to increased compaction of the muddy sands deposited along the flanks of the channel, and reflects percentage of sand in the section $-\mathbf{a}$ factor of importance in regard to possible minèralization.

2. Velocity differences occur within the Moenkopi rocks underlying the channel and are generally lower under the central part of the channel. These differences may be related to bleaching of these rocks or to some other diagenetic phenomenon which gives rise to velocity gradients in the rocks adjacent to porous permeable sandstones.

3. Velocity differences occur within the Shinarump rocks filling the channel. These differences, by which the rocks have been divided into a basal zone, a channel cap zone, and an uppermost zone, are believed to reflect significant differences in the original pattern of sedimentation. This pattern controls migration of fluids within the channel rocks and, hence, changes to which the rocks may become subject.

4. Dats obtained indicate that the depositional influence of a channel can persist upward through the overlying rocks (uppermost zone) of the formation. Consequently, this influence or control causes significant physical and chemieal differences of the rocks overlying the basal and cap zone rocks of the channel proper.

Velocity contrasts between the Moenkopi and the overlying Shinarump filling the channel at the locations studied are not such that successful mapping of the channel scour could be carried out by seismic means. Cementation of the rocks in the basal zone of the chan- nel frequently gives rise to velocities equal to or greater than those of the underlying Moenkopi rocks, thus precluding successful seismic mapping of the scour of the channel. However, the flanking and marginal portions of the channel as well as the uppermost zone of the channel are a potential target for refraction seismic work.

\section{CONCLUSIONS}

Examples of successful geophysical and geochemical exploration surveys for uranium in reconnaissance work and in channel delineation have been demonstrated. The combination of geophysics and geochemistry portends to be a most useful, as well as a most economic, exploration procedure.

Better understanding and knowledge of the factors relating to mineralization can be obtained from study of physical and chemical properties of cores combined with logs from available holes over known deposits. In particular, dry hole electric logging and continuous interval velocity logging show outstanding promise in this regard.

Combined methods of exploration indicate variations in the uranium-bearing rocks which appear to be both directly and indirectly related to mineralization. Preliminary though incomplete data indicate that differences in permeability, porosity, and degree or kind of cementation of the enclosing rocks, controlled in part by sedimentary depositional factors and modified by structure, are significant. Surface surveys (electrical, geochemical, seismic, or radiometric), subsurface logging (electrical and velocity) and water analyses can, with certain reservations, be used successfully to detect these differences. 



\title{
INSTRUMENTS AND TECHNIQUES FOR MEASURING RADIOACTIVITY IN THE FIELD
}

\author{
By Frank W. Stead, U. S. Geological Survey
}

\section{CONTENTS}

\begin{tabular}{|c|c|c|c|}
\hline Abstract_ & $\begin{array}{r}\text { Page } \\
705\end{array}$ & Techniques-Continued & Page \\
\hline Introduction. & 705 & Subsurface investigation techniques.................. & 709 \\
\hline Instruments. & 706 & 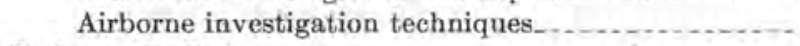 & 710 \\
\hline echniques... & 707 & 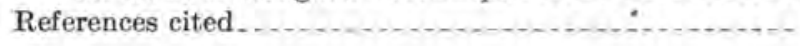 & 712 \\
\hline
\end{tabular}

\section{ABSTRACT}

The radioactivity emitted by uranium and thorium offers a unique means of detection and identification of these elements. With the possible exception of abnormal geothermal gradients caused by radioactive decay, the standard geophysical methods of exploration do not provide any direct indication of radioactive materials, although standard methods may be used to locate geologic struetures favorable for the occurrence of ore.

The principal instruments now used to prospect for radioactive raw materials are the well-known Geiger counter and the more recently developed scintillation counter. The portable Geiger counter is a light-weight, rugged, and highly reliable instrument used to detect, primarily, gamma radiation and, secondarily, beta radiation. The Geiger counter has been fully developed during the last decade, mainly by health physieists in the atomic energy program. The more efficient portable scintillation counter is not as rugged or reliable as the Geiger counter, is used almost exclusively for measuring gamma radiation, and is in the early stages of development. Most scintillation instruments utilize thallium-activated sodium iodide crystals as the radiation detector. The use of plastic and liquid phosphors as the radiation detector is increasing, and significant new developments in scintillation counters may be anticipated.

Techniques for measuring radioactivity in the field can be grouped roughly as surface, subsurface, and airborne. Surface methods include both detailed local surveys and broad regional surveys, using Geiger and seintillation counters specifically adapted to particular field conditions. Detailed surveys are made to locate accurately ore deposits, contacts, veins, or other features; data are occasionally compiled as isoradioactivity contour maps, Regional reconaissance surveys usually are made with car-mounted seintillation instruments of the continuously recording type; such surveys locate radioactivity anomalies for more detailed surveys and also provide data on the surface distribution of radioactivity in large areas.

Subsurface techniques include gamma-ray and neutron logging of exploratory drill holes and measurement of the radon content of gases issuing from soils, springs, and drill holes. The Geiger counter is almost universally used in logging smalldiameter holes; scintillation counters and ionization chambers are widely used where the hole diameter is sufficiently large. Logging techniques have been applied semiquantitatively in exploration for uranium, thorium, uraniferous phosphates, and potash. Accurate measurement of radon content of gases requires car-mounted complex ionization chamber apparatus; such measurements are restricted in application and difficult to interpret,

Airborne-instrument techniques make use of highly sensitive radiation detectors in single- and multiengine aireraft. Although portable Geiger and scintillation counters can be used effectively in aireraft flying close to the ground, most airborne instruments are semipermanent installations of the continuously recording scintillation detector type, Airborne surveys cover large areas rapidly and economically, and are widely and successfully used to locate points of anomalous radioactivity that may indicate radioactive ore deposits.

\section{INTRODUCTION}

The steadily increasing demand for radioactive raw materials has stimulated the rapid development of radiation detection instruments and techniques for measuring radioactivity in the field. Many types of instrument are now commercially available, ranging from simple Geiger counter detectors obtainable at low cost, to highly precise and sensitive instruments costing many thousands of dollars. The older techniques of measurement have been refined, and newer techniques based on instruments mounted in aircraft and automobiles have been developed.

The radioactivity characteristic of uranium- and thorium-bearing materials offers a unique means of direct detection of significant concentrations of these elements. Unfortunately, even the most penetrating gamma radiation from radioactive materials is effectively absorbed by a few inches of intervening materials. Radioactivity measurements - whether at the outcrop, in drill holes, or in mine openings - will detect only those radioactive materials exposed at a surface or concealed by a small amount of other materials. 
It is now commonplace that prospectors, mining engineers, and geologists carry radiation detection instruments, whether they are searching primarily for radioactive materials or for other ores. Using sensitive radiation detectors, uranium prospectors need not be able to identify radioactive minerals nor to have more than a cursory knowledge of geology; a marked increase in radioactivity indicates where further work should be done. Many important uranium deposits in the Western United States have been discovered as the direct result of radioactivity surveys.

A detectable change in radioactivity is frequently associated with other ores, and it has been clearly demonstrated that radioactivity measurements are valuable in determining the extent and distribution of such materials. The use of radioactivity techniques for other than radioactive minerals is continually expanding and may ultimately become more important than in the search for uranium and thorium ores.

\section{INSTRUMENTS}

The principal instruments now used to prospect for radioactive raw materials are the Geiger counter and the more recently developed scintillation counter. From a relatively crude and cumbersome device (Rajewsky 1943; Ridland 1945), the portable Geiger counter has been developed by health physicists in the atomic energy program into a light-weight, rugged, and highly reliable instrument. Primarily, this instrument was developed and is used for monitoring the radiation intensities in laboratories and manufacturing plants handling high concentrations of radioisotopes. Secondarily, the instrument is widely used to prospect for uranium, and probably more portable Geiger counters are in use today than all other geophysical instruments. The portable scintillation counter, because of its greater sensitivity, is more useful than the Geiger counter in areas of low radiation intensity, particularly at or near the level of background radiation.

The Geiger counter tube is fundamentally unchanged since first developed by Geiger and Müller $(1928,1929)$. Excellent reviews of modern Geiger-Müller theory, technique, and application have been published by Curtiss (1950) and Friedman (1949). Most counter tubes used in portable instruments have thin-wall glass or aluminum cathodes that will admit the more energetic beta radiation in addition to gamma radiation. Counter tubes with bismuth cathodes or with multiple cathode-anode construction to increase the efficiency of gamma-ray detection are used in some portable instruments.

The present-day scintillation counter is essentially a phosphor viewed by an electron-multiplier phototube. Excellent reviews of current theory and techniques have been prepared by Swank (1954), Linden (1954), and Birks (1953). Almost all portable gamma-ray scintillation instruments use thallium-activated sodium iodide crystals (Harshaw and others, 1952) as the phosphor. Semiportable instruments in aircraft and automobiles occasionally use large plastic phosphors (Buck and Swank, 1953; Wouters, 1954) and, experimentally, large-volume liquid scintillators (Harrison and others, 1954).

The portable scintillation counter (Wilson and others, 1954; Davis, 1954) has several advantages over the Geiger counter: higher efficiency for gamma-ray detection; lower relative cosmic-ray background because of the higher gamma-ray efficiency; and relatively short resolving time, allowing higher counting rates without serious coincidence loss. Comparative disadvantages of the scintillation counter are: present high cost and scarcity of large thallium-activated sodium iodide crystals; small pulse output from the photomultiplier requiring a better amplifier circuit than for the Geiger counter tube; and high-voltage regulation for the photomultiplier is far more critical than regulation for the Geiger counting tube. In small lightweight portable instruments adequate high-voltage regulation is difficult to achieve.

Ionization chambers, discussed by Victoreen (1949) and Rossi and Staub (1949), are seldom used in portable instruments. Integrating chambers find their greatest use in logging of drill holes (Swift 1952), and minor use in detailed surveys of local areas. Pulse-type chambers are used in mobile laboratory installations (Faul and others, 1954).

The amplifier circuits used in portable equipment to count the random pulses from radiation detectors are mainly counting-rate meters and, to a very small extent, scalers. A large variety of counting-rate meters has been used, all involving pulse shaping to uniform size followed by integration into a direct current which is recorded either by visual or a graphic meter. Initial development of a "total-intensity" rather than a pulse counting-rate meter for scintillation detectors has been completed (Wilson and others, 1954; LeVine 1954); as yet, development and testing of this amplifier have been insufficient to determine its applicability in portable instruments. Scaling circuits for portable instruments have been developed from the basic scale-of-two circuit; portable scale-of-eight instruments are electronically limited to low counting-rate applications.

Most portable instruments of the counting-rate meter type are relatively stable and reliable and do not exhibit great variations in response to temperature change, decrease in battery voltage, or shifting detector sensitivity. Simple direct-indicating instruments, in which a pulse is recorded as a click in earphones or as the flash 
of a neon bulb, are now rarely used because of their limitation to low counting rates. Semiportable instruments, where size and weight are not limiting factors, are designed to use laboratory-type amplifiers and recorders.

\section{TECHNIQUES}

Techniques for measuring radioactivity in the field can be grouped roughly as surface, subsurface, and airborne. Reviews of field techniques have been published by Johnson (1954), Wright (1954), Stead (1952), Russell (1951), and Faul (1948). Many of the present techniques of measurements were established prior to and during World War II and, since then, have been modified slightly to utilize improved instrumentation. The development and wide application of the newer techniques such as airborne and carborne surveying reflect the recent advances in radiation instrumentation; particularly the portable scintillation counter.

Essentially all field techniques are based on the detection of gamma radiation, Supplemental detection of beta radiation is useful in picking out the highly radioactive rock and mineral fragments from mineralized outcrops, and many portable Geiger counters are designed to be both beta and gamma sensitive. Because of the short range of alpha radiation, its detection has not proved to be practical in the field.

As commonly used in prospecting for uranium, field techniques of measurement are essentially qualitative. A moderate increase in radioactivity has long been considered sufficient evidence to collect samples or to file a mining claim.

To have semiquantitative significance, field techniques of measurement must be applied with a clear understanding of the many factors involved, Reviews of the factors affecting the interpretation of radioactivity measurements have been published by Faul (1949), Johnson (1954), Russell and Scherbatskoy (1951), and Wright (1954). These factors include the background component of measurement, the solid-angle or mass effect, the absorption and scattering of radiation by various media, radioactive equilibrium in natural materials, and natural and artificial contamination, Simple relationships can not be established among these factors, and considerable experience is usually necessary for proper interpretation of field measurements.

Valid semiquantitative interpretation of field measurements requires that the radiation detection instruments should be standardized and calibrated at all times. Standardization involves testing the instrument response with a moderately strong radioactive standard, To be satisfactory for extended use, a portable field instrument should reproduce the measurement of the standard within a stated amount, commonly 10 percent. Calibration in absolute units is usually based on first flight, or direct, quanta from a radium source, and is then expressed as milliroentgens per hour (Wilson and others, 1954). Theoretically, if all portable Geiger and scintallation instruments are correctly calibrated in terms of milliroentgens per hour, measurements made with different instruments should be directly comparable, provided that the spectral energy distribution of the gamma radiation measured is effectively the same as from radium. Practically, several difficulties arise in the large-scale quantitative calibration of instruments. Gamma radiation from natural sources is always much scattered so that the effective energy spectrum is greatly enriched on the low-energy end. Instruments calibrated with first-flight quanta from a point radium source will not show the correct intensity in milliroentgens per hour when the measured radiation is partly scattered. The gross readings will still be comparable from counter to counter of the same energy response, but units such as milliroentgens per hour are essentially meaningless in field practice, where many instruments of different types may be used. Specific difficulties in calibration are: the different response of the Geiger and scintillation counters to various energy levels of gamma radiation, particularly as the scintillation counter has good sensitivity for very low energies and the Geiger counter does not; the variation in electron-multiplier phototubes, and the consequent variation in sensitivity of scintillation counters; the nonlinearity of the amplifier circuits in portable instruments at high counting rates.

Other units, such as counts per minute or multiples of background radiation, have been used to calibrate instrument response. In most cases, these units indicate a standardization of response, not a calibration in the absolute sense. Measurements expressed in counts per minute are meaningless except for instruments of essentially identical response characteristics and for similar geometry of measurement. Multiples of background are useful for distinguishing significant variations of radioactivity within a small area, but, as the regional background radiation varies from area to area, multiples of background are not directly comparable unless expressed in absolute units.

The most useful calibration would be in absolute units for the principal element sought, uranium. That is, the calibration would be based on measurements of the radiation intensity from materials containing a known amount of uranium oxide in equilibrium with the disintegration products. The calibration would then be expressed as percent equivalent uranium oxide, and some individual instruments have been so calibrated. Where adequate consideration has been given to the 
factors affecting the interpretation of measurement, individual instruments have provided measurements of the uranium content accurate to within a few thousandths of a percent (Stead, 1952). The same difficulties in large-scale calibration arise as in the use of microroentgens per hour, and no major effort has been made to calibrate the response of portable instruments in terms of equivalent uranium, equivalent thorium, or equivalent potassium.

Almost all portable instruments now used by Government agencies are calibrated in milliroentgens or microroentgens per hour using gamma radiation from a point radium source. Although such calibration is not entirely satisfactory for field measurements of radioactivity, it is the easiest to use and is the best compromise among various possible means of calibration. Measurements in milliroentgens per hour, made in widely separated areas with different type instruments, can be correlated roughly, particularly where the general nature of divergence in response among the instruments is known.

Because of the many varieties of portable instruments now available, instruments can be selected that are statistically adequate over the anticipated range of measurement. Statistical uncertainty introduced by very low counting rates is seldom a factor of importance in present-day measurements.

\section{SURFACE INVESTIGATION TECHNIQUES}

Surface investigation techniques include local surveys or spot examinations, detailed surveys, and regional surveys. The application of surface investigations, when combined with geologic appraisal and evaluation, has generally been described as reconnaissance for radioactive raw materials. Numerous reports describing procedure, techniques, and results of reconnaissance have been issued by the Geological Survey, the Atomic Energy Commission, and other groups. Most of these are listed in Nuclear Science Abstracts and in the bibliography of Survey reports (Wallace and Smith, 1955).

Local surveys.-Local surveys, also termed "spot examinations" or prospecting, are planned either to find localities of anomalously high radioactivity or to evaluate reported occurrences of radioactive minerals. Such surveys are normally done on foot and are guided by rock types, mineralized zones, and mineral assemblages favorable for the occurrence of radioactive materials.

To indicate possible economic concentrations of radioactive materials, a radioactivity anomaly must show at least a severalfold increase over the local background gamma radiation. The minimum increase is frequently considered to be fourfold for measurements made with a portable Geiger counter and twentyfold for measurements made with a scintillation counter. Multiples of the background radiation are ocasionally used to define geological groupings of anomalies in an area (Pierson and Singewald, 1953).

In evaluating an outcrop or a new mine development, a beta-gamma-sensitive Geiger counter is frequently used to scan the outcrop or mine face and thus to select the most radioactive rock and mineral samples for identification and analysis. Using standardized and calibrated detection instruments such as portable scalers, the equivalent uranium oxide content of rock and mineral samples can be determined in the field within plus or minus 0.002 percent (Stead, 1952).

Detailed surveys.-Detailed surveys are made to determine accurately the distribution of radioactivity within an area ranging from a few thousand square feet to many square miles. The objectives may be specific, such as locating and evaluating radioactive ore deposits, or may be general, such as locating fissures, veins, and other structures or determining the variation of radioactivity in and among rock types. In contrast to local surveys where qualitative measurements of radioactivity with simple portable instruments are frequently sufficient, detailed surveys require semiquantitative measurements made with standardized and calibrated instruments.

Detailed surveys, accurately located as to topography and geology, are usually made either on a grid pattern or along widely spaced traverse lines. The measurements are shown either as point values (Wright, 1951) or are compiled as isoradioactivity contours (Moxham and others, 1955). As an aid in geologic mapping, detailed radioactivity surveys have proved useful in tracing fissures, sills, and dikes, particularly where such features are concealed by talus or residual solls (Christman and others, 1953).

In general, little if any correlation can be demonstrated between small radioactive ore bodies at shallow depth and the surface distribution of radioactivity (Rosenzweig, 1952). Occasionally, a closely spaced survey may assist in guiding exploration for concealed deposits. A scintillation counter survey in the Black Hills of South Dakota outlined all known uranium deposits within the 10 microroentgen-per-hour contour interval, where the background radiation intensity was 7 microroentgens per hour. The 20 microroentgen contour, roughly three times the regional background radiation, outlined small areas within which additional deposits were later discovered by drilling. These deposits were as much as 60 feet below the surface. Obviously, gamma radiation from the uranium ore could not penetrate 50 or more feet of rock; uranium or some of its disintegration products must have 
migrated from the ore to the surface. The application of detailed radioactivity surveying to the search for concealed deposits has been demonstrated to be valuable; however, such application is restricted to a few geologic environments where migration of uranium and its disintegration products either is known or likely to occur.

Regional surveys.-Regional surveys, generally covering several thousand square miles, have been successful in locating radioactivity anomalies for more detailed investigations and in providing basic data on the surface distribution of radioactivity. Normally such surveys are made with car-mounted scintillation counters of the continuously recording type (Wilson and others, 1954), but occasionally, light portable instruments are used on foot or horseback. The technique of using carmounted equipment has been described by Nelson (1953). A typical regional survey of several thousand square miles, using primarily car-mounted equipment, has been reported by McKeown (1951). Quantitative differences in radioactivity equivalent to about 0.002 percent $\mathrm{U}_{3} \mathrm{O}_{8}$ can easily be determined (Stead, 1952; Nelson, 1953). Instruments mounted in 4-wheel-drive vehicles have been used successfully for cross-country traversing of relatively open terrain.

\section{SUBSURFACE INVESTIGATION TECHNIQUES}

Subsurface investigation techniques include gammaray and neutron logging of exploratory drill holes and measurement of the radon content of gases issuing from soils, springs, and drill holes. The Geiger counter is almost universally used in logging small-diameter drill holes (Faul, 1954b). The scintillation counter (Di Giovanni and others, 1953) and the ionization ehamber (Swift, 1952) are widely used where the hole is wide enough. Most logging instruments are installed in heavy-duty trucks, but lightweight portable equipment has been developed for logging shallow holes in remote locations (Wilson and others, 1954). Measurements of radon in gas samples are made with ionization-chamber equipment in mobile laboratories (Faul and others, 1954).

In exploration for radionetive raw materials, the gamma-ray $\log$ of small-diameter drill holes has provided highly valuable information (Comstock, 1951), Gamma-ray logs are used for correlating stratigraphic horizons, preparing lithologic logs where core recovery is poor or lacking, determining depth and thickness of ore-bearing zones, and estimating semiquantatively the thickness and grade of radioactive ore bodies. Most of these uses have long been well established in the petroleum industry (Tittle, 1954). The significant advances in the applieation of gamma-ray logging to exploration for radioactive materials are the direct quantitative assaying of ore in place (Stead, 1952; Faul, 1954b), and the preparation of subsurface isoradioactivity contour maps to guide further exploration at depth (Hinckley, 1952). The gamma-ray logging technique has been applied semiquantatively in exploration for uranium, thorium uraniferous phosphates, and potash.

The development of highly sensitive scintillation logging instruments (Di Giovanni and others, 1953; Wilson and others, 1954) offers promise both by distinguishing among uranium, thorium, and potassium by spectrometry in the drill hole, and by making possible improved lithologic interpretation of the gamma-ray log. One continuing difficulty in semiquantitative application of gamma-ray logs is the wide range of radioactivity intensity, from less than 0.001 percent to more than 10.0 percent $\mathrm{U}_{3} \mathrm{O}_{8}$. Thus far, with one particular detector or in a single logging operation, it has not been possible to obtain satisfactory measurements over so wide a range of radioactivity.

Neutron-logging techniques have been widely applied in the petroleum industry (Russell, 1952) but have not been specifically developed to assist in exploration for radioactive materials. Measurement of the natural flux in drill holes (Stead, 1952) and to neutron-gamma and neutron-neutron logging have been considered. As a practical exploration technique, neutron logging does not now seem promising as a direct aid in finding uranium and thorium ores. Combined gamma-ray and neutron logging has proved useful in estimating the grade and thickness of potash salts, and in distinguishing anhydrous from hydrous potash salts (Stead, 1952).

Migration of radon, a radioactive inert gas, offers a possible long-range method of detecting concealed radioactive materials (Faul, 1954a). Ridland (1945) noted a surface concentration of radon in a fissure 60 feet above intersection with a pitchblende vein. In gamma-ray logging of exploratory drill holes on the Colorado Plateau, small sharp anomalies detected several hundred feet downdip from carnotite ores are presumably caused by radon migrating in ground waters along permeable channels. Radon concentration in helium-bearing natural gases is being investigated both to determine whether abnormally high radon concentration might indicate significant localized concentrations of uranium and radon at depth, and to clarify the relationship between radon and helium (Faul and others, 1954). Extremely high and variable concentrations of radon have been found in mine openings and in drill holes in uranium ores; in rare cases as much as $1 \times 10^{-6}$ curies of radon per liter (STP) has been found. No clear-cut relationship has been established between the radon concentration in mine open- 
ings and drill holes, and the uranium content of the country rock. Qualitatively, a high concentration of radon is suggestive of possibly significant uranium concentration nearby, but no quantitative conclusions can be based on the radon content of gas samples from drill holes and mine openings.

\section{AIRBORNE INVESTIGATION TECHNIQUES}

The development and application of airborne investigation techniques in the search for radioactive raw materials have been made mainly since 1949 (Stead, 1950; Peirson and Franklin, 1951; Cowper, 1954). Since the first systematic airborne radioactivity survey of an area of 1,600 square miles was published (Stead and others, 1950), numerous surveys throughout the United States have been made by Government agencies and private companies. ${ }^{1}$

Instruments used in airborne surveying must be sensitive enough to measure unambiguously small changes in radioactivity at safe flying height. Largevolume thallium-activated sodium iodide crystals (Cowper, 1954) or plastic scintillators (Buck and Swank, 1953) are almost universally used as the radiation detector. High-efficiency Geiger counter tubes having a multiple-plate cathode structure are occasionally used as the detector. Most instruments are counting-rate meters of the continuously recording type, and are specifically designed for installation in aircraft. In addition to the radiation-detection instruments, equipment in multi-engine aircraft usually includes instruments for accurately locating the position of the aircraft in respect to ground (Stead 1950; Cowper, 1954).

Helicopters, light single-engine aircraft, and longrange multi-engine aircraft have been used for airborne surveys, dependent on the objectives of the particular survey and on the location of the area in respect to the operating base. In objective, airborne investigations are analogous to surface work in that local, detailed, and regional surveys can be distinguished. In selecting an aircraft, it is essential that the aircraft have sufficient range to spend a high proportion of the total flying time over the area to be surveyed.

The spacing of flight lines for airborne surveys is governed largely by the problem involved. The width of the zone from which anomalous radioactivity can be detected is about twice the distance of the aircraft above the ground. As a detector at the 500-foot flight level covers a swath about 1,000 feet wide, a flight line spacing of 1 mile results in about 20 percent of the area actually being surveyed. For detailed surveys the flight level

\footnotetext{
1 See listing under "Airborne radioaetivity surveys" in Wallace and Smith, 1955, and also under "Geology and mineralogy, airborne radioactivity surveys," in Nuclear Sclence Abstracts. Airborne anomaly location maps released on the 15th of each month by the U. S. Atomic Energy Commission are obtainable on subscription basis from Government Printing Office, Washington 25, D. C.
}

and spacing of flight lines are decreased but for regional surveys the spacing may be increased to give proportionately less coverage.

The absorption and scattering of gamma radiation at considerable air distances from a natural radioactive source place an effective upper limit on the flight level of airborne surveys. The initial radiation intensity from a natural point source of radiation is decreased to about one one-thousandth at an air distance of 500 feet. Few airborne surveys are made at air distances greater than 500-600 feet, and most surveys are made at air distances of less than 200 feet. Although light portable instruments can be used effectively in aircraft flying very close to the ground, the rapid attenuation of gamma radiation with distance from the source requires relatively large instruments of the highest possible sensitivity to obtain satisfactory measurements at higher flight levels.

Quantitative interpretation of airborne survey data is not necessary for most applications. The sought-for target is a radioactivity anomaly, a sharp local increase in radiation intensity. The results of most airborne radioactivity surveys are reported without semiquantitative or quantitative distinction among the anomalies. Anomalies simply indicate localities of more-thanaverage radioactivity where there is increased probability of the occurrence of uranium and thorium deposits.

The possibility of quantitative interpretation of airborne survey data has been extensively investigated (Peirson and Franklin, 1951; Stead, 1952; Cook, 1952; Lundberg, 1952; Cowper, 1954; Pederson, 1954). Based on experimental measurements at various air distances over known broad sources of radiation and over a simulated outcrop of uranium ore, considerable progress has been made in establishing the interpretation of airborne radioactivity measurements in terms of the, equivalent uranium content of the source (Sakakura, 1954a, 1954b). The radiation from broad sources of semi-infinite extent, such as a sedimentary layer, can be estimated satisfactorily to within a few thousandths of a percent equivalent uranium; for example, airborne radioactivity measurements at 500 feet above a shale were interpreted at $1.7 \times 10^{-3}$ percent equivalent uranium, and laboratory analyses of representative shale samples showed from $1 \times 10^{-3}$ to $2 \times 10^{-3}$ percent equivalent uranium (Sakakura, 1954a, 1954b).

The radiation from a naturally occurring "point" source, such as uranium ore exposed over a few thousand square feet, has proved difficult to interpret in terms of the probable equivalent uranium content and the area of exposure. No simple means of distinguishing between a small outcrop of high-grade ore and a large area of slightly above normal radioactivity has as yet been developed (Stead, 1952; Cowper, 1954). 
It is probable that current research on the seattering and absorption of gamma radiation in two media, air and the source proper, will improve the interpretation of airborne survey data (Sakakura, 1954b).

Local surveys.-Local airborne surveys are usually made with light single-engine aircraft flown at 100 feet or less above the ground. A scintillation counting-rate meter of the nonrecording type is frequently adequate (Foote, 1954). An observer, preferably a geologist familiar with the area, records on a suitable base map the localities where a sharp increase in radioactivity is shown on the meter. This application is qualitative and is essentially an extension of prospecting on foot, Although random surveying of outcrops may be done, the usual method is to follow favorable outcrops whether on a cliff face (rim flying) or on a horizontal surface. The most successful application of low level airborne surveying has been in locating additional deposits in and adjacent to uranium mining districts.

Detailed surveys.-Detailed airborne surveys can be made with any type of aircraft, and are applicable to areas ranging from a few square miles to a few hundred square miles. The prime requirement is that the radioactivity measurements must be accurately located with respect to the ground by visual recognition, by photographic methods, or by electronic navigation methods (such as radar, shoran, or decea). The radiation-detection instruments are usually of the continuously-recording type, and the radioactivity measurements have been reported as spot anomalies, radioactivity profiles, or isoradioactivity contour maps.

Detailed surveys are best applied to areas that might contain extensions of known uranium deposits, or that contain rock types and structure known to be favorable for the occurrence of uranium. Surveys flown on a predetermined grid pattern have been highly successful in many parts of the Western United States, and the results of many such surveys have been released as maps showing the spot location of radioactivity anomalies. (See Wallace and Smith, 1955, and footnote 1, p. 710 .)

The results of a few surveys have been released as maps showing relatively large areas of anomalous radioactivity (Moxham, 1954). Isoradioactivity contour maps have been compiled from detailed airborne surveys made by helicopter (Rosenzweig, 1952).

Moxham, Walker, and Baumgardner (1955) investigated the relation between the anomalously high radioactivity recorded during a detailed airborne survey and the surface distribution of radioactive materials. The data both from a detailed ground radioactivity survey and from the airborne survey made at the 500-foot flight level are presented as isoradioaetivity contour maps. Comparsion of the 2 contour maps indicate close conformity, and that the airborne survey lost only minor detail at the 500-foot level. Also, comparison of the two isoradioactivity contour maps with the geologic map indicates that some crystalline rocks of various ages and types can be distinguished by their characteristic radioactivity. The radioactivity measurements made at the 500-foot level could discriminate changes equivalent to 0.001 percent uranium, and were made far more rapidly and cheaply than were the ground measurements.

Regional surveys.-Regional airborne surveys covering from hundreds to thousands of square miles are usually made with multi-engine aircraft flying at a nominal 500-foot altitude and at a flight-line spacing of one-quarter of a mile (Stead, 1950). Normally, highly sensitive scintillation counting equipment is used. Associated instruments are carried for determining continuously the position of the radioactivity measurement with respect to ground (Cowper, 1954). Frequently, aeromagnetic measurements are made in conjunction with the radioactivity measurements, thus providing valuable data at little increase in cost.

Regional airborne surveys differ from detailed surveys partly in the scale of operation and partly in that the objective is to find large and new areas in which radioactive raw materials might oceur. Areas for survey are selected largely on geologic inferences as to where uranium and thorium are most likely to occur, rather than being selected on direct evidence such as known favorable rock types and structures or uranium deposits in the area. Regional surveys have proved quite successful in locating new areas not previously known to contain uranium (Meuschke and Moxham, 1953; Stead, Balsley, Moxham, and Reinhardt, 1953).

Under favorable conditions, airborne surveys of large areas offer promise as a rapid and cheap method of reconnaissance geologic mapping. Many rock and residual soil units show a characteristic radioactivity that could be correlated with particular formations by examination on the ground.

Currently, the surface variation in overall radioactivity between and within rock units is being investigated as a means of delimiting large areas favorable for radioactive ores. Recent data suggest that in metamorphic and igneous terranes the uranium deposits may occur in large but definable areas where the radioactivity of the country rock is significantly different from adjacent areas of similar rock types. The target or favorable areas in crystalline rocks might be measurable in square miles rather than in hundreds of square yards as is the case in sedimentary terranes. The possible application of regional airborne surveys in locating such large targets is highly attractive, partic- 
ularly as the survey could be made at wide spacing of flight lines and at a flight level of as much as 1,000 feet.

\section{REFERENCES CITED}

Birks, J. B., 1953, Scintillation counters: New York, MeGrawHill Book Co., 148 p., and London, Pergamon Press.

Buck, W. L., and Swank, R. K., 1953, Preparation and performance of efficient, plastic scintillators: Nucleonics, v. 11, no. 11 , p. $48-52$.

Christman, R. A., Heyman, A. M., Dellwig, L. F., and Gott, G. B., 1953, Thorium investigations, 1950-1952, Wet Mountains, Colo.: U. S. Geol. Survey Cire. 290, 40 p.

Comstock, S. S., 1951, Progress report on gamma-ray logging activities: U. S. Atomic Energy Comm. RMO-904, 27 p., issued by U. S. Atomic Energy Comm. Tech. Inf. Service, Oak Ridge, Tenn.

Cook, J. W., 1952, An analysis of airborne surveying for surface radioactivity: Geophysics, v. 17 , no. 4 , p. $687-706$.

Cowper, G., 1954, Aerial prospecting with scintillation counters: Nucleonies, v. 12 , no. 3 , p. 29-32.

Curtiss, L. F., 1950, The Geiger-Müller counter: Nat. Bur. Standards (Washington, D. C.), Circ, 490, 25 p.

Davis, F. J., 1954, Scintillation counters, in Faul, Henry, editor, Nuclear geology: New York, John Wiley and Sons, Inc., p. $31-35$.

DiGiovanni, H. J., Graveson, R. T., and Yoli, A. H., 1953, Scintillation unit for drill-hole logging: Nucleonies, v. 11, no. 4, p. 34-39.

Faul, Henry, 1948, Radioactivity exploration with Geiger counters: Am. Inst. Min. Metall. Engineers Trans,, v. 178, p. $458-475$.

-1949, Radioactivity methods, in Jakosky, J. J., Exploration geophysics, 2d ed.: Los Angeles, Trija Publishing Co., chap. 10, p. 987-1015.

- 1954a, Helium, argon, and radon, in Faul, Henry, editor, Nuclear geology: New York, John Wiley and Sons, Inc., p. 133-143.

-1954b, Nuclear logging of drill holes for mineral exploration and soil studies, in Faul, Henry, editor, Nuclear geology: New York, John Wiley and Sons, Inc., p. 250-255.

Faul, Henry, Gott, G. B., Manger, G. E., Mytton, J. W., and Sakakura, A. Y., 1954, Radon and helium: 19th Internat. Geol, Cong., Comptes rendus, v. 9, p. 339-348.

Foote, R. S., 1954, Airborne exploration for uranium: Mines Mag. (Denver), v. 44 , no. 10 , p. 31-32.

Friedman, Herbert, 1949, Geiger counter tubes: Inst. Radio Engineers Proc., v. 37, p. 791-808.

Geiger, Hans, and Müller, Walther, 1928, Das Elektronenzählrohr (The electron counter tube): Physikal. Zeitsch., Band 29 , p. 839-841.

1929, Technische Bemerkungen zum Elektronenzählrohr (Technical observations on the electron counter tube): Physikal. Zeitsch., Band 30, p. 489-493.

Harrison, F. B., Cowan, C. L., Jr., and Reines, F., 1954, Largevolume liquid scintillators-their applications: Nucleonics, v. 12 , no. 3 , p. $44-47$.

Harsha, J. A., Kremers, H. C., Stewart, E. C., Warburkton, E. K., and Hay, J. O., 1952, Preparation and performance of some scintillation crystals: U. S. Atomic Energy Comm. NYO-1577, 77 p., issued by U. S. Atomic Energy Comm. Tech. Inf., Service, Oak Ridge, Tenn.

Hinckley, D. N., 1952, Investigation of subsurface isorad methods, Temple Mountain, San Rafael district, Utah: U. S.
Atomic Energy Comm. RME-4019, 26 p., issued by U. S. Atomic Energy Comm. Tech. Inf. Service, Oak Ridge, Tenn.

Johnson, D. H., 1954, Radiometric prospecting and assaying, in Faul, Henry, editor, Nuclear geology: New York, John Wiley and Sons, Inc., p. 219-241.

LeVine, H. D., 1954, Logarithmic D-C ratemeters for scintillation counters: Nucleonics, v. 12, no. 2, p. 36-39.

Linden, B. B., 1954, New photomultipliers and operating data: Nucleonics, v. 12 , no. 3 , p. 20-23.

Lundberg, Hans, 1952, Airborne radioactivity surveys: Oil and Gas Jour., v. 50, no. 49, p. 165-166.

McKeown, F. A., 1951, Reconnaissance of radioactive rocks of Vermont, New Hampshire, Connecticut, Rhode Island, and southeastern New York: U. S. Geol. Survey TEI-67, 48 p., issued by U, S. Atomic Energy Comm. Tech. Inf. Service, Oak Ridge, Tenn.

Meuschke, J. L., and Moxham, R. M., 1953, Airborne radioactivity survey of the Miller Hill Area, Carbon County, Wyo.: U. S. Geol. Survey TEM-606. (U. S. Geol. Survey open-file report.)

Moxham, R. M., 1954, Airborne radioactivity surveys for phosphate in Florida: U. S. Geol. Survey Circ. 230, 4 p.

Moxham, R. M., Walker, G. W., and Baumgardner, L. H., 1955, Geologic and airborne radioactivity studies in the Rock Corral Area, San Bernardino County, Calif.: U. S. Geol. Survey Bull. 1021-C, p. 109-125.

Nelson, J. M., 1953, Prospecting for uranium with car-mounted equipment: U. S. Geol. Survey Bull. 988-I, p. 211-221.

Pedersen, Ole, 1954, Mathematical evaluation of airborne radiological survey data: U. S. Atomic Energy Comm. NYO4577 (Rev.), 8 p., issued by U. S. Atomic Energy Comm. Tech. Inf. Service, Oak Ridge, Tenn,

Peirson, D. H., and Franklin, E., 1951, Aerial prospecting for radioactive minerals: British Jour. Applied Physics (London), v, 2, p. 281-291.

Pierson, C. T., and Singewald, Q. D., 1953, Results of reconnaissance for radioactive minerals in parts of the Alma District, Park County, Colo.: U. S. Geol. Survey Cire. 294, 9 p.

Rajewsky, B., 1943, Das Geiger-Müller Zählröhr im Dienste des Bergbaues [The Geiger-Müller counter applied to mining]: Zeitschr. Physik, Band 120, p. 627-638.

Ridland, G. C., 1945, Use of the Geiger-Müller counter in the search for pitchblende-bearing veins at Great Bear Lake, Canada: Am. Inst. Min. Metall, Engineers Trans., v. 164, p. 117-124.

Rosenzweig, Abraham, 1952, Evaluation of the Texas Company airborne radioactivity survey at Blanding, Utah: U. S. Atomic Energy Comm. RMO-813, 10 p., issued by U. S. Atomic Energy Comm. Tech. Inf. Service, Oak Ridge, Tenn.

Rossi, B. B., and Staub, H. H., 1949, Ionization chambers and counters, Experimental techniques: New York, MeGrawHill Book Co., 243 p.

Russell, W. L., 1952, Interpretation of neutron well logs: Am. Assoc. Petroleum Geologists Bull., v. 36, no. 2, p. 312-341.

Russell, W. L., and Scherbatskoy, S. A., 1951, The use of sensitive gamma ray detectors in prospecting: Econ. Geology, v. 46 , p. $427-446$.

Sakakura, A. Y., 1954a, Absorption and seattering of gamma radiation, in Geologic investigations of radioactive deposits: Semiannual progress report, December, 1953 to May 31, 1954: U. S. Geol. Survey TEI-440, p. 242-243, 
issued by U. S. Atomie Energy Comm. Tech. Inf. Service, Oak Ridge, Tenn.

Sakakura, A. Y., 1954b, Adsorption and scattering of gamma radiation, in Geologic investigations of radioactive deposits: Semiannual progress report, June 1 to Nov. 30, 1954: U. S. Geol. Survey TEI-490, p. 296-297, issued by U. S. Atomic Energy Comm. Tech. Inf. Service, Oak Ridge, Tenn.

Stead, F. W., 1950, Airborne radioactivity surveying speeds uranium prospecting: Eng. Min. Jour., v. 151, no. 9, p. $74-77$.

1952, The Geological Survey's work on development of prospecting tools, instruments, and techniques: U. S. Geol. Survey TEI-211, 29 p., issued by U. S. Atomic Energy Comm. Tech. Inf. Service, Oak Ridge, Tenn.

Stead, F. W., Balsley, J. R., Moxham, R. M., and Reinhardt, P. W., 1953, Airborne radioactivity survey of the Pumpkin Buttes area, Campbell and Johnson Counties, Wyo.: U. S. Geol. Survey TEM-508. (U. S. Geol. Survey openfile report.)

Stead, F. W., Davis, F. J., Nelson, R. A., and Reinhardt, P. W., 1950, Airborne radioactivity survey of parts of Marquette, Dickinson, and Baraga Counties, Mich.: U. S. Geol. Survey Geophys. Iny, Map, with explanatory text.
Swank, R. K., 1954, Recent advances in theory of scintillation phosphors: Nucleonics, v. 12 , no. 3, p. 14-19.

Swift, Gilbert, 1952, Simultaneous gamma-ray and neutron well logging: Geophysics, v. 17, no. 2, p. 387-394.

Tittle, C. W., 1954, Gamma-ray and neutron logging in the petroleum industry, in Faul, Henry editor. Nuclear Geology: New York, John Wiley and Sons, Inc., p. 241-250.

Victoreen, J. A., 1949, Ionization chambers: Inst. Radio Engineers Proc., v. 37, p. 189-199.

Wallace, J. H., and Smith, H. B,, 1955, Bibliography of U. S. Geological Survey Trace Elements and related reports to June 1, 1954: U. S. Geol. Survey Bull. 1019-B, p. 63-144.

Wilson, E. E., Rhoden, V. C., Vaughn, W. W., and Faul, Henry, 1954, Portable scintillation counters for geologic use: U. S. Geol. Survey Circ. 353, 10 p.

Wouters, L., 1954, Production of plastic phosphors in quantity; Nucleonies, v. 12 , no. 3 , p. 26.

Wright, R. J., 1951, Annie Laurie Prospect, Santa Cruz County, Ariz.: U. S. Atomic Energy Comm. RMO-677, 8 p., issued by U. S. Atomic Energy Comm. Tech. Inf. Service, Oak Ridge, Tenn.

Wright, R. J., 1954, Prospecting with a counter: 68 p., (revision of U. S. Atomic Energy Comm. RME-4028), Washington, Government Printing Office. 


\title{
AIR SCATTERING OF GAMMA RAYS FROM THICK URANIUM SOURCES
}

\author{
By Arthur Y. Sakakura, U. S. Geological Survey
}

\section{CONTENTS}

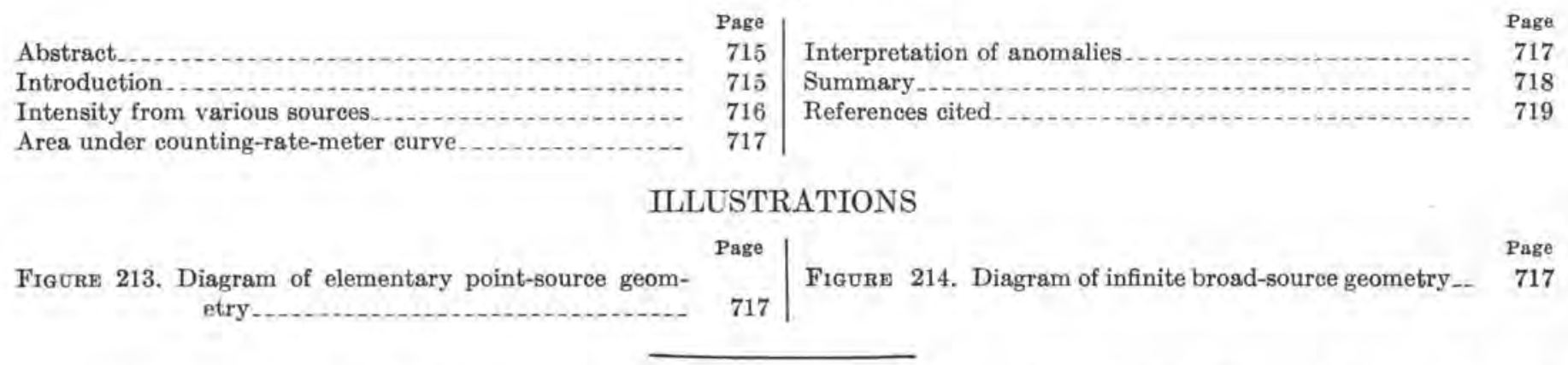

\begin{abstract}
To develop means of interpreting gamma-ray intensities measured at considerable air distances between natural sources and a detector, a knowledge of radiation-intensity distribution from sources of various strengths and configurations is necessary. This distribution can best be determined by superposition of elementary sources over suitable geometrical configurations, In the past, this method entailed the integration of the pointsource expression over a suitable source volume assuming either an inverse-square exponential attenuation or the former expres. sion modified by a build-up factor deduced from experiments in homogeneous media and in back-scattering geometry. The first assumption not only neglects seattering, which predominates at any great distance from the source, but also attempts to represent the multitudinous lines of the average uranium series, gamma-ray spectrum by a single absorption cross section. The second assumption does not take into account the variation of build-up factor with geometry.

To eliminate these difficulties, the intensity from an infinitely thick elementary source was measured as a function of the air distance above and to the side of the source, and a semiempirical expression composed of the following three factors was fitted to the experimental data: The usual inverse-square exponential law corresponding to the hardest gamma ray; a build-up factor, a polynomial in air distance to account for scattering and the complexity of spectra; an obliquity factor, a function of the angle of view from source to detector. The above expression was integrated over various surface areas; that is, the integration in depth has been incorporated into the original data.

From the integrations, the area under the curve recorded on a counting ratemeter was calculated. Quantitative relationships between the two observables recorded by a counting ratemeter (the peak intensity and the area under the curve) and the source strength and size are established as functions of the velocity and distance of a detector from the source. Furthermore, dependent upon the nature of the source and the parameters of height and speed of an aircraft, more than one line of measurement may be required for interpretation of the source characteristics.
\end{abstract}

Although specific application of this method has been made to airborne radioactivity surveys as undertaken by the U. S. Geological Survey, the method is broadly applicable to measurements made with comparable detectors at considerable air distances from natural sources.

\section{INTRODUCTION}

A knowledge of the air scattering of gamma rays from naturally occurring thick uranium sources is necessary to interpret radioactivity measurements made at considerable air distances from sources. As now applied, airborne radioactivity surveying is essentially a qualitative technique, that is, anomalously high radioactivity relative to the immediate surroundings is used to guide ground investigations to localities where radioactive deposits of economic importance might occur. The interpretation of measurements should be placed on a quantitative basis if the technique of airborne radioactivity surveying is to be developed further as a geophysical tool. For satisfactory interpretation, the various observable quantities recorded by a countingrate meter, such as the peak intensity (counts per second), total number of counts (the area under the curve), and the shape of the curve must be correlated with the principal characteristics of a natural source, namely, the grade in terms of the equivalent uranium oxide content and the configuration in terms of the surface dimensions.

As the fundamental properties of gamma radiation are well known for the energy range from natural sources, the ideal method of interpretation would be based on the theoretical computation of the radiation intensity emanating from sources of various configura- 
tions. The advantage of the computational approach is that the results do not have to be resolved in terms of the response characteristics of a particular detector. Where the radiation source is distributed in one medium (rocks and soils) and is measured at considerable distances from the source in another medium (air) the intensity of scattered radiation predominates over that of primary radiation; thus, a numerical solution of the Boltzmann equation for the gamma-ray transport in two media is necessary. The solution of this equation is, in general, a function of 3 space variables (coordinates of the point at which the radiation intensity is computed), 2 angular variables (scattering), and an energy variable for any given source configuration. Once such a solution is obtained, the response of any detector, knowing its spectral and angular characteristics, could be computed.

Unfortunately, no satisfactory general solutions to 2-media problems have been published, although the U. S. Geological Survey with the cooperation of the computing facility of the U. S. Atomic Energy Commission at New York University is now engaged in solving the 2-media problem with plane symmetry. However, analytical approximations and a vast quantity of numerical solutions to 1-media problems in various geometries exist (Goldstein and Wilkins, 1954), from which one can predict trends of solutions in two media. Moreover, for high-energy radiation traveling in a forward direction, the presence of the boundary is immaterial. The general procedure in solving the Boltzmann equation was developed by Spencer and Fano (Fano, 1953a, 1953b and 1953c; Spencer and Fano, 1951) at the U. S. National Bureau of Standards. A topical summary and pertinent bibliography are given in three recent articles by Fano $(1953 a-c)$, the first reference containing the mathematical details. Many of the physical arguments that follow are based on his discussions. A further source of difficulty in detail, if not in principle, in solving the Boltzmann equation is that the uranium source spectrum is very complex, necessitating the solution of many problems with different primary source energies and the superposition of these individual solutions. An alternative approach to the approximate solution of the 2-media Boltzmann equation consists of using the existing solutions computed for simple geometries and the knowledge of the gamma-ray spectrum of uranium. Then these solutions are combined according to educated guesses as to what the 2-media solutions should be from a previous knowledge of simple geometric solutions and analytical behavior of the solutions.

However, the simplest approach is a semiempirical one, wherein an experimentally or assumed form of radiation-intensity law for an elementary source is integrated over a suitable geometric configuration to obtain the intensities from various sources. Peirson and Franklin (1951) made such an integration assuming an inverse-square exponential law, which not only neglects the effect of scattering but also the many lines of the uranium spectrum. Cowper (1954) used the inverse-square law but considered air scattering by experimentally determining the "effective absorption coefficient" from measurements of the radiation from radium sources. Cook (1952) assumed an "effective" energy and used effective computed cross section and the inverse-square law. However, there is no a priori reason why an effective cross section measured or calculated in one source-to-medium orientation should be applicable to others.

To avoid this conceptual difficulty, measurements were made on infinitely-thick, "point," and broad sources. In this way the integration in depth has already been performed. An effective "point" source can be obtained when the areal extent of the source is small compared to the air distances at which measurements are made. Other sources are synthesized from the point-source data through integration over a surface.

Although a semiempirical approach is adopted it is convenient to retain the structure of the theory, especially for extrapolating the data to areas not covered by the experimental measurements. Thus, the intensity is represented by the product of the unscattered contribution of the most penetrating component and a build-up factor for the scattered radiation, which for moderate penetration is a polynomial in the distance variable (Fano, 1953a, b; Spencer and Fano, 1951).

A more detailed treatment, especially of the mathematical aspects, of what follows is in preparation.

The author is grateful to L. V. Spencer of the U. S. National Bureau of Standards for an illuminating discussion on the subject of this paper.

\section{INTENSITY FROM VARIOUS SOURCES}

The two fundamental sources are the elementarypoint source (the line shown in fig. 213), and the infinite broad source (the region $x=0$ filled uniformly with radioactive material, shown in fig. 214).

Obviously, in this latter case, the source is an infinite superposition of the elementary sources. Thus, a functional form dictated by theory is chosen for the elementary source, and the constants are selected so that the expression fits the elementary-source experimental data, and the result of integrating this expression over an infinite surface fits the infinite-source experimental data. 


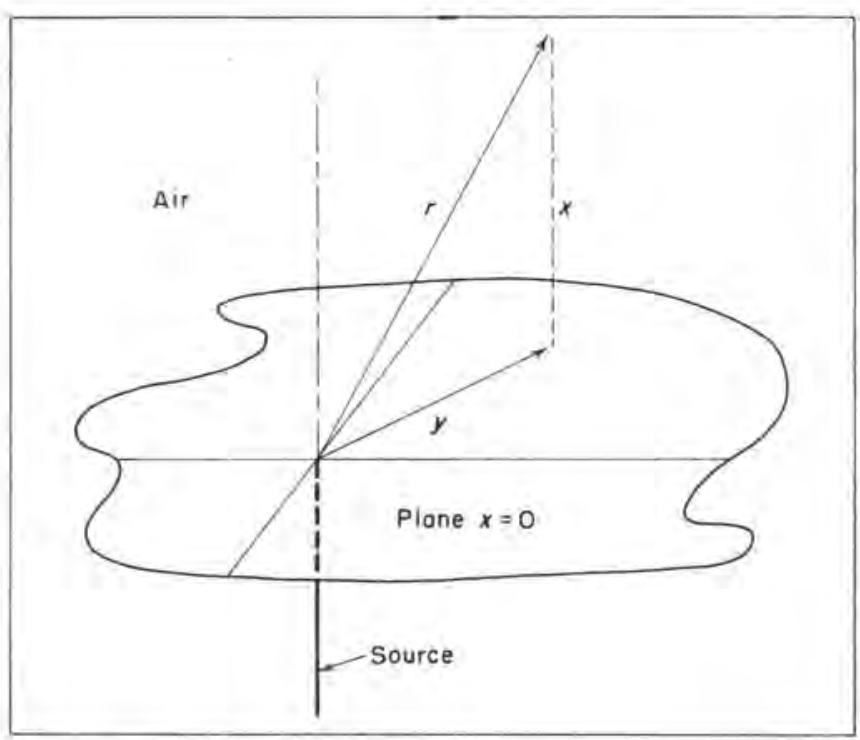

Frgvae 213.-Diagram of elementary point-source geometry.

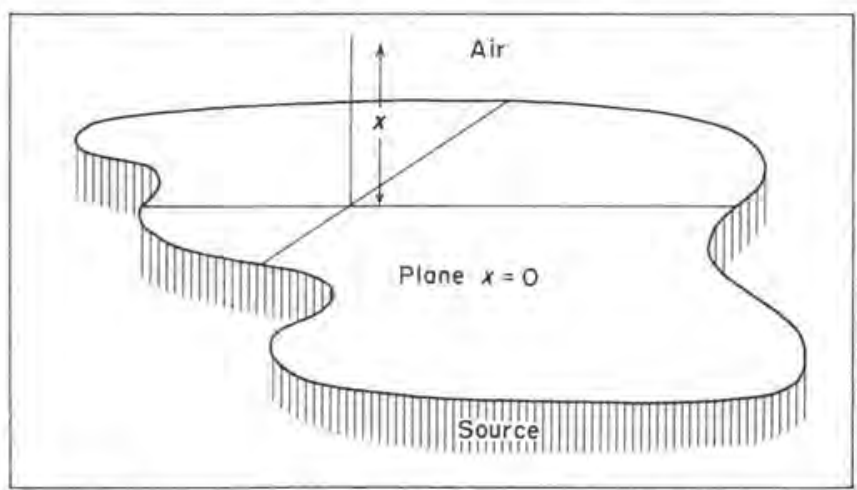

Figure 214.-Diagram of infinite broad-source geometry.

The intermediate souree types are:

a) Line source, an infinitely long source of breadth, $a$, much less than the diameter of the elementarypoint source. The intensity $I_{e}(x, y, a)$ is a function of altitude $x$, and $y$ the distance from the point of observation to the axis of the source, projected onto the plane of the source.

b) Slab source, an intermediate source between the line source and the infinite broad souree. Its length is assumed to be infinite. The intensity $I_{a}(x, y, a)$ is a function of altitude $x$, the ground projection $y$ of the distance from the observation point to the center axis of the source, and the breadth, $a$.

c) Finite source, a circular source of diameter greater than an elementary source and less than an infinite source. The intensity $I_{1}(x, y, a)$ is a function of the altitude $x$, the ground projection $y$ of the distance between the detector and the center of the source, and the diameter $a$.

All the solutions can be expressed in closed form except for the last source. Numerical computations show that, for a detector at an altitude of 500 feet, the following conclusions can be drawn:

Finite sources of diameter greater than 1,700 feet and slab sources greater than 1,200 feet in breadth are infinite sources,

Finite sources less than 550 feet in diameter are point sources.

Slab sources less than 800 feet in breadth are line sources.

Line and slab sources must be 1,700 feet in length to be considered infinitely long.

\section{AREA UNDER COUNTING-RATE-METER CURVE}

Knowing the response of the instrument and the velocity of the detector, the areas under the curves can be computed for various source configurations and grade as follows:

Elementary point source: The area $H_{p}(v, x, \xi, a)$ is a function of the altitude $x$, ground projection $\xi$ of the distance of closest approach between the detector and the center of the source, velocity $v$ of the detector, and diameter $a$.

Finite source: The area $H_{f}(v, x, \xi, a)$ is a function of the same variables as above.

Line source; The area $H_{e}(v, x, \theta, a)$ is a function of altitude $x$, velocity $v$, breadth $a$, and $\theta$, the acute angle between the normal to the axis of the source and the ground projection of the flight line.

Slab source: The area $H_{s}(v, x, \theta, a)$ is a function of the same variables as above.

Areas for finite and slab sources have been evaluated numerically for a 500 -foot altitude. The others ean be expressed in closed form.

\section{INTERPRETATION OF ANOMALIES}

The unknown factors that enter into the interpretation of an anomaly are the source position relative to the detector, its size and its grade. As the usual practice is to make continuously recorded measurements along equally spaced, constant-altitude flight lines, the location of the anomaly along the direction of flight can be determined approximately. The source would be located along a line which passes through the peak position of the anomaly and which is at right angles to the flight path. Assuming the source symmetries described above, the shape of the source is reduced to 1 variable (breadth of line of slab source or radius of a point or finite source). Thus, there are 3 unknowns to relate to the observable quantities. The most obvious one is the peak-intensity reading, another the area under the curve. The third is the shape of the anomaly, such as its slope and its half-maximum value. However, examination of the computed values shows that the slope varies slightly as the grade-area of the source is increased. Moreover, 
if one were not flying directly over the source, the anomaly would broaden considerably. An objection to analysis of shape is the fact that the shape would be most susceptible to the variation in position of an airborne detector. Thus, on a given line of observation, one has 2 observables and 3 unknowns on 1 line, or 4 observables and 3 unknowns on 2 lines. Consequently, there are 2 categories of anomalies: those that are visible on 2 or more adjacent lines and those that are visible on only 1 . On the latter, the information is necessarily incomplete.

Computations reveal that at a nominal 500 -foot flight altitude and at a line spacing of one-fourth of a mile, an ore-grade body ( 0.1 percent $\mathrm{U}_{3} \mathrm{O}_{8}$ ) with a minimum radius of 60 feet midway between the 2 flight lines is detectable. As any finite source under 275 feet in radius can be considered a point source, which really has only 2 observable quantities (the grade-area and the distance from the detector) any ore-grade body visible on only 1 flight line is completely specified. In this case, the grade-area can be mathematically expressed in terms of the 2 observables; that is, the peak intensity and the area under the curve.

If the anomaly were visible on 2 adjacent lines, there are 4 observables on hand: $H_{t}(x, \xi), I_{f}(x, \xi), H_{t}(x, d-\xi)$, and $I_{t}(x, d-\xi)$ where $d$ is the spacing of the lines. As the grade of deposits ranges widely, one requires gradeindependent quantities. Two of these are-

$$
\begin{aligned}
& \frac{\mathrm{H}_{f}(x, d-\xi)}{I_{t}(x, d-\xi)}=R_{1}(x, d-\xi) \\
& \frac{H_{t}(x, \xi)}{I_{f}(x, \xi)}=R_{f}(x, \xi)
\end{aligned}
$$

If one were to use the computed quantities and plot $R_{t}(x, d-\xi)$ vs. $R_{f}(x, \xi)$, a series of curves for different values of $a$ would be obtained. With the use of observed quantities $a$ can be determined from this plot. Moreover, it is found that when the point-source formulas relating grade-area to $I_{p}$ and $H_{\mathrm{D}}$ are applied to finite source values at $d-\xi$ and $\xi$ and the resulting grade-area values are then averaged, the averages are constant for all values of $\xi$ at fixed $a$. These averages can be corrected with true grade-areas by multiplication with a conversion factor. The procedure is then:

1. Compute $\frac{H(x, \xi)}{I(x, \xi)}$ and $\frac{H(x, d-\xi)}{I(x, d-\xi)}$ to determine $a$ from a precalculated plot of $R_{f}(x, d-\xi)$ vs. $R_{f}(x, \xi)$;

2. Compute grade-area at $\xi$ and $d-\xi$ using the pointsource formula and take the average of the two values.
3. Multiply the average by a precalculated factor for a given $a$.

This procedure gives the grade-area of the finite source, and from the grade-area and $a$, the grade.

The preceding discussion refers only to finite sources. Line and slab sources, by definition, will yield the same peak reading and area on two adjacent lines. The ratio $\frac{H_{s}(x, \theta)}{I_{s}(x, \theta)} \operatorname{Cos} \theta=\frac{H_{s}(x, 0)}{I_{s}(x, 0)}$ yields the value of $a$ for line and slab sources. The factor $\theta$ is determined from the relative position of the anomaly on two adjacent flight lines. Then the application of the expression for the slab source area under the curve yields the gradebreadth and, consequently, the grade.

If the anomalies show decided flattening at the peak, application of the expression for an infinite source evidently will yield the grade. Moreover the breadth at one-half peak intensity denotes the breadth of the source. This aspect of the calculations has been amply confirmed by investigations on the ground.

In the case of a compound anomaly reflecting two or more separate point sources, the separation into individual sources and the determination of the respective $H_{s}$ and $I_{z}$ presents some difficulties.

\section{SUMMARY}

Certain general concepts underlying the semiempirical approach to the interpretation of airborne radioactivity measurements warrant attention, although the particular method presented herein is not entirely satisfactory for all aspects of interpretation. These concepts are:

1. Use of an elementary "point" source of infinite thickness. This eliminates the necessity of assumptions that scattering and absorption of gamma radiation are not influenced by the presence of a boundary between media and that the scattering effect of a medium is dependent only on the electronic density.

2. Use of "point" and infinite broad source behavior to fix the analytical form of the elementary function.

3. The investigation, numerically and analytically, of relationships among observables and source characteristics.

The combination of observable quantities selected for analysis is not uniquely valid to an adequate interpretation. Other combinations yielding an equal or greater amount of information would also be valid. For example, after identifying the source type, the grade could be computed as though the source were either directly under the detector or at the point mid- 
way between two adjacent flight lines, thus obtaining values for the two extremes of grade.

It must be stressed that there are many approaches to this problem. The interpretation of anomalies presented here has been sufficiently confirmed by investigation on the ground and sampling of the natural materials to make it seem that this method as now developed is reasonably useful.

\section{REFERENCES CITED}

Cook, J. C., 1952, An analysis of airborne surveying for surface radioactivity: Geophysics, v. 17, no. 4, p. 687-706.

Cowper, G., 1954, Aerial prospecting with scintillation counters: Nucleonics, v. 12 , no. 3, p. 29-32.

Fano, U., 1953a, Penetration of X-and gamma rays to extremely great depths: Natl. Bur. Standards (Washington, D. C.) Jour. Research, v. 51, no. 2, p. 95-122.
Fano, U., 1953b, Gamma ray attenuation-part I, Basic processes: Nucleonics, v. 11 , no. 8 , p. 8-12.

Fano, U., 1953c, Gamma ray attenuation-part II, Analysis of penetration: Nucleonies, v. 11, no. 9, 55-61.

Goldstein, Herbert, and Wilkins, J. E., Jr.. 1954, Calculations of the penetration of gamma rays, final report: U. S. Atomic Energy Comm. NYO-3075, 196 p., issued by U. S. Atomic Energy Comm. Tech. Inf. Service, Oak Ridge, Tenn.

Peirson, D. H., and Franklin, E., 1951, Aerial prospecting for radioactive minerals: British Jour. Applied Physics (London), v. 2, p. 281-291.

Spencer, L. V., and Fano, U., 1951, Penetration and diffusion of X-rays-Calculation of spatial distribution by polynomial expansion: Natl. Bur. Standards (Washington, D. C.), Jour. Research, v. 46 , no. 6, p. $446-456$. 



\title{
GEOPHYSICAL EXPLORATION FOR URANIUM ON THE COLORADO PLATEAU
}

\author{
By Rudolph A. BLACK, U. S. Geological Survey
}

\section{CONTENTS}

Abstract_...
Introduction
Surface electrical methods
$\quad$ Electrical resistivity
$\quad$ Natural potential
Seismic methods....
$\quad$ Seismic refraction
$\quad$ Shallow seismic reflection

Page

725

725

725

725

726

726

\section{ILLUSTRATIONS}

Page

Figure 215. Resistivity depth curves and horizontal profile, and corresponding geologic eross section

216. Electrical resistivity horizontal profiles over Shinarump conglomerate, Monument Valley, Ariz.

7

FIGURE 217. Section showing Shinarump-Moenkopi contact computed from the illustrated traveltime plots and delay times..............

218. Subsurface contour map of top of Moenkopi formation as determined from seismic data

\section{Page}

\begin{abstract}
Geophysical investigations other than radiometric have been conducted in the Colorado Plateau region both by Federal agencies and private contractors to test the applicability of standard geophysical methods in exploration for uranium. Since 1949 the U, S. Geological Survey has made field tests of electrical, seismic, magnetic, gravimetric, and electromagnetic methods and seismic and electrical studies have been carried on also by the Atomic Energy Commission and the Bureau of Reclamation. Although the uranium deposits occur at many different stratigraphic horizons, most of the geophysical work has been in areas where the uranium is concentrated in the Morrison formation of Jurassic age and the Shinarump conglomerate of Triassic age.
\end{abstract}

Methods so far tested have not proved capable of detecting the uranium minerals directly because of the small proportion of uranium ore in relation to the amount of host rock but some have proved to be of value in the detection and delineation of such geologic guides to ore as thickening of the ore-bearing Salt Wash member of the Morrison formation and the channels filled with Shinarump conglomerate.

The seismic refraction method has been proved capable of delineating these channels filled with Shinarump conglomerate and in several surveys channel trends were thus outlined before drilling. Experimental shallow reflection surveys have also been made but have not been sufficient to permit evaluation of the method in uranium exploration.
The electrical resistivity method has been used to delineate the thicker and therefore more favorable sandstone beds in the Salt Wash and to locate buried channels filled with Shinarump conglomerate. The natural-potential method has been extensively tested but results have been poor or inconclusive except in one place.

Results of ground magnetic surveys made on the Plateau and the lack of any significant quantities of magnetic minerals in association with the uranium ore suggest that the magnetic method has little direct use in uranium exploration. Gravity surveys were unsuccessful.

Electric logging studies have shown the usefulness of combining electric logs with gamma-ray logs in any drilling program in which there is no detailed coring. Experimental surfaceinhole electrical measurements have been made in an attempt to increase the effective radius of any given drill hole by mapping radial resistivity trends, but the measurements have not yet been fully evaluated. Induced polarization, radio frequency, and electromagnetic measurements have not yet been extensively tested in the Colorado Plateau but may prove useful in future uranium exploration.

\section{INTRODUCTION}

Uranium deposits are widely scattered over the Colorado Plateau region of Colorado, New Mexico, Arizona, and Utah. The major uranium-bearing formations are the Shinarump conglomerate and the 
Chinle formation of Late Triassic age, and the Entrada sandstone, the Todilto limestone, and the Morrison formation of Late Jurassic age. The deposits in the Shinarump and Morrison have been the chief target of the geophysical methods. The Morrison formation in western Colorado consists of an upper member, the Brushy Basin and a lower member, the Salt Wash. The Brushy Basin member consists of alternate layers of sandstone and shale, and the Salt Wash member consists of beds of sandstone separated by mudstone splits. The uranium deposits of the Morrison are commonly found in the sandstone strata of the Salt Wash member as thin irregular tabular layers ranging in width from a few feet to several hundred feet. Their lateral distribution is irregular and they tend to occur in clusters. The ore-bearing sandstone is commonly lenticular, is interbedded with mudstone, and in many places contains mudstone splits. The most favorable geologic conditions for the occurrence of uranium deposits in the Salt Wash member are considered to be the thickening of the lenticular sandstone, the palebrown to light-brown color of the sandstone, and the presence of altered gray-green mudstone underneath the Salt Wash member (Weir, 1952). In the more unfavorable areas the sandstone is thin, contains many mudstone splits, is red brown, and is underlain by redbrown mudstone.

The Shinarump conglomerate ranges in composition from a fine-grained sandstone to a coarse conglomerate, is crossbedded, and contains local lenses of shale and mudstone and much silicified wood. The Shinarump conglomerate unconformably overlies the Moenkopi formation of Early and Middle(?) Triassic age. The Moenkopi is composed of thin hard red shale, red sandy mudstone and siltstone, and a few layers of sandstone. The top of the Moenkopi formation is generally considered to be an erosion surface over which the conglomerates and sandstones of the Shinarump are spread. The uranium deposits in the Shinarump occur mainly in channel fillings in the Moenkopi formation, particularly where the channels contain carbonaceous matter and mudstone beds. The Shinarump conglomerate in turn is overlain by the Chinle formation, which consists of a thick series of mudstone, sandstone, and conglomerate units.

Since 1949 the applicability of many geophysical techniques to the search of this ore have been tested. These techniques include magnetic, electrical resistivity, natural potential, electric logging, seismic refraction and reflection, and surface-inhole electrical methods. The methods have been tested by making measurements over known ore deposits in the Morrison and Shinarump and over terrane known to be favorable for ore deposition, first in areas where the Salt Wash sandstone member and the Shinarump conglomerate were exposed at the surface, and then in areas where the Salt Wash and the Shinarump are overlain by rocks of different thicknesses and types. The various exploration methods were then used in areas that were geologically similar to those in which the particular method had been demonstrated to be successful.

\section{SURFACE ELECTRICAL METHODS}

\section{ELECTRICAL RESISTIVITY}

Electrical resistivity methods were among the first geophysical methods tested on the Colorado Plateau. Tests of the resistivity method were made over known ore bodies in the Salt Wash member during 1949-50. During 1951-52 several electrical resistivity surveys were made to map favorable ground before drilling. In 1952 the electrical resistivity method was successfully used in locating buried channels filled with Shinarump conglomerate.

Measurements were made with direct-current equipment and nonpolarizable electrodes; both the vertical and horizontal profiling techniques with the Lee partitioning configuration were used. In vertical profiling the electrode configuration is expanded outward from the station center, using increasing increments of electrode spacing. In horizontal profiling, several profiles are made with different electrode spacings, and after the optimum spacing is determined that spacing is used for the remainder of the profiles. The field procedures used on the Colorado Plateau are substantially the same as those in common use throughout the more arid sections of the world. One of the biggest problems is that of making satisfactory electrode contact with the earth. In many places on the Colorado Plateau the surface layer consists of thin sandy alluvium overlying sandstone and shale beds that crop out in places. The potential electrodes are usually placed in shallow water-filled holes to establish a moist contact zone between the potential electrodes and the earth. In areas of exposed bedrock, small sections of copper screening eovered with earth and saturated with water are used for potential electrodes. In areas of poor electrode contact it is necessary to balance the current electrode contact resistances to get reliable data.

The electrical resistivity methods used on the Colorado Plateau have been concerned primarily with exploration for uranium deposits in the Morrison formation and in the Shinarump conglomerate. In areas where the deposits are in the Morrison formation, the resistivity depth profiling method proved capable of delineating the thicker and thus more favorable parts of the ore-bearing Salt Wash sandstone in areas where it was not overlain by great thicknesses of the 
Brushy Basin member of the Morrison formation. The resistivity depth curves could be used to determine the relative thickness of the ore-bearing sandstone, and the relative amounts of mudstone present in the sandstone. In general, the thicker, more favorable parts of the ore-bearing sandstone exhibited a higher resistivity than the less favorable sandstone. By making several vertical depth profiles on a grid pattern and evaluating each profile as favorable, semifavorable, or unfavorable on the basis of the indicated thickness of sandstone, amount of mudstone in the sandstone, and the resistivity of the sandstone, maps could be prepared showing the areas to be considered favorable, semifavorable, and unfavorable. Resistivity horizontal profiles were also made to detect the more favorable spots to drill for uranium deposits. The thicker, more favorable parts of the ore-bearing sandstone could often be found as zones of anomalously high resistivity on the horizontal profiles.

Channels filled with Shinarump are the principal target for resistivity surveys made to guide exploratory drilling for uranium deposits in the Shinarump. The Shinarump conglomerate in the Monument Valley area of southeastern Utah and northeastern Arizona forms two electrical layers in many places. The upper is a thin layer of high resistivity, ranging from 100,000 to $200,000 \mathrm{ohm}-\mathrm{cm}$. The high resistivity in the thin upper layer is probably due to the very dry well-cemented surface. In the thicker, main body of the Shinarump the resistivity is somewhat lower. The Shinarump is underlain by shale and siltstone zones of the Moenkopi in which the resistivity ranges from 0.1 to 0.01 of that in the Shinarump. Thus, there is a satisfactory electrical contrast.

Generally, a combination of vertical and horizontal profiling techniques is used in the search for buried channels. The size of the channels may have a considerable range but an average channel is perhaps 100-200 feet wide, with a depth of scour of 20-100 feet. In areas where there are no channels the Shinarump conglomerate is some $20-100$ feet thick.

Figure 215 shows electrical resistivity depth curves and the resistivity horizontal profile over a Shinarump channel. The depth curves and the horizontal profile show definite evidence of the buried channel. Methods used to interpret the depth curves range from matching the field curves to theoretical 2- and 3-layer curves, to simply correlating changes in curve character with known geology and extrapolating into unknown areas. The horizontal profiles are plotted as the ratio of the differences to the sum of the resistivities on either side of the Lee partitioning configuration. The area between the dashed lines represents "background noise"

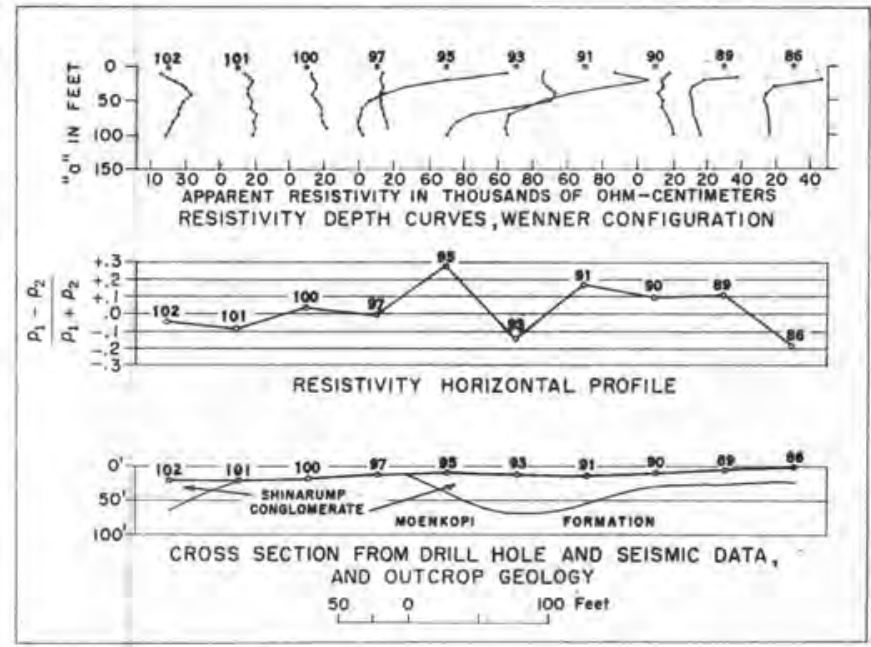

Figure 215.--Resistivity depth curves and horizontal profile, and corresponding geologic cross section.

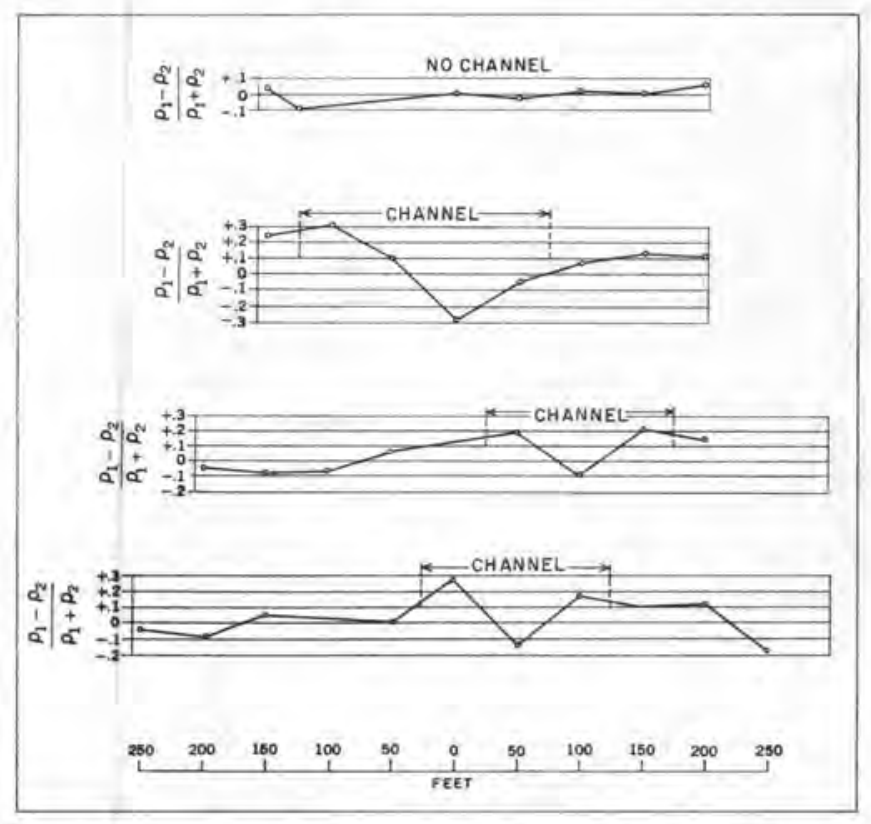

FIGURE 216,-Electrical-resistivity horizontal profiles over Shinarump conglomerate, Monument Valley, Ariz.

due to surface lateral variations and contact resistances. Figure 216 shows several resistivity horizontal profiles, made at an electrode separation of 60 feet over known Shinarump channels, and a profile over an area without channels for comparison.

\section{NATURAL POTENTIAL}

The natural potential method, where applicable, is one of the cheapest and most rapid methods of exploration for shallow ore deposits. Natural potential methods have for this reason been extensively tested in various areas of the Colorado Plateau. Measurements have been made over uranium ore bodies buried at 
shallow depths and known to be undergoing active oxidation, but no significant natural potential anomalies have been detected over these ore bodies.

\section{SEISMIC METHODS}

\section{SEISMIC REFRACTION}

The seismic refraction method was first used for mapping buried channels in exploration for uranium on the Colorado Plateau by Wantland and Casey of the U. S, Bureau of Reclamation (Wantland and Casey, 1952). Additional field tests were made by the Geological Survey in 1953. These tests showed that the seismic refraction method could be used to locate buried channels filled with Shinarump where there was no Chinle overburden, and during 1953 and 1954 numerous seismic refraction surveys were made in Monument Valley, Ariz., to outline major channel trends prior to exploratory drilling.

The seismic-refraction measurements were made with standard portable seismograph equipment, installed in a 4 -wheel-drive vehicle to permit more rapid coverage of rough areas.

The method of continuous profiling with reversed shots was used in making the seismic-refraction surveys. To map the average Shinarump channel, shot points were 500 feet apart and the geophones were spaced at 25 and 50 foot intervals. Air shooting was extensively used for the refraction seismic work. Single charges of 5 to 10 pounds of 60 percent seismic dynamite were fired from special shooting poles at heights of 3 to 5 feet above the ground. The records obtained from these air shots were comparable to those obtained from
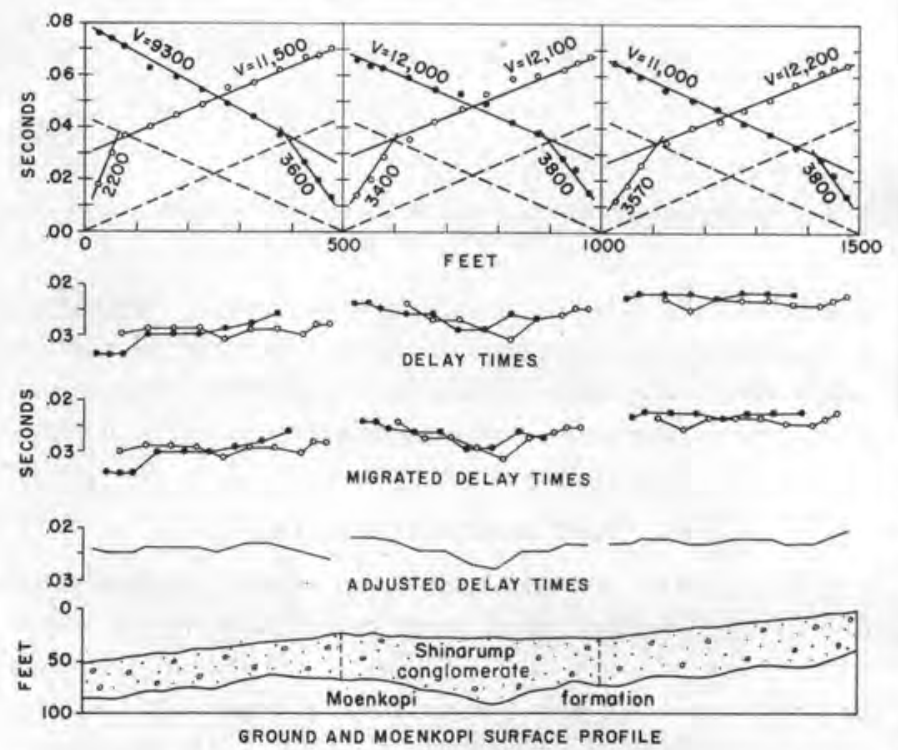

FIoURE 217.-Section showing Shinarump-Moenkopi contact computed from the illustrated travel-time plots and delay times.

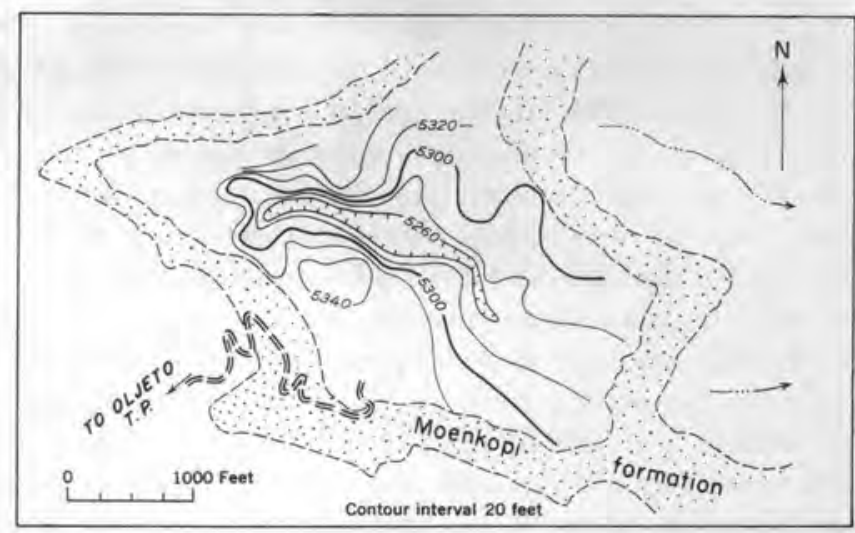

Fioure 218.-Subsurface contour map of top of Moenkopi formation, as determined from seismic data.

hole shots, and air shooting proved to be more economical because of its greater speed.

Inhole velocity surveys were usually made to provide advance information on velocity characteristics of the formations to be investigated. These inhole velocity measurements were made with inhole piezoelectric detectors and surface shots.

To date, use of the seismic refraction method on the Colorado Plateau has been restricted to the problem of locating buried channels filled with Shinarump. The velocity in the Shinarump conglomerate ranges from 3,000 to $6,000 \mathrm{fps}$, and in the underlying shale of the Moenkopi the velocity is 10,000 to $15,000 \mathrm{fps}$. Figure 217 shows a series of time-distance plots drawn from records obtained by continuous profiling and reverse shooting.

The method of interpreting the seismic data is a modification of a method suggested by A. J. Barthelmes (1946) for calculating the depth to curved surfaces by the use of delay times. Depths to the ShinarumpMoenkopi contact at each shot were computed by conventional critical-distance or time-intercept methods. The dashed lines on the time-distance plots represent an average velocity in the Moenkopi in this area. Using this average velocity line and the apparent Moenkopi velocity line, delay times were plotted as shown. These delay times were migrated toward their respective shot points and then averaged. The adjusted delay-time curves for the zones between the shot points were converted to differential depths, and using the shot-point depth computations as control, the topography of the Shinarump-Moenkopi eontact was determined. In this particular instance, a small channel was revealed that did not appear from the computed shot-point depths alone.

Figure 218 is a subsurface contour map of the Shinarump-Moenkopi contact in an area in Monument 
Valley, Ariz. A channel clearly indicated by the seismic data was verified by subsequent drilling in this area.

\section{SHAILOW SEISMIC REFLECTION}

In the summer of 1954, experimental shallow reflection measurements were made to determine if usable shallow reflections could be obtained under the stratigraphic conditions present on the Colorado Plateau, The equipment used to make these experimental measurements consisted of a 12-channel portable reflection seismograph with high frequency response, high paper speed, and variable presuppression control (Pakiser and others, 1954). The equipment is a conventional reflection seismograph modified to permit the recording of higher frequencies, at shorter time intervals after the first energy arrivals.

Shallow reflection tests were made in three areas representing geologic conditions typical of uranium deposits in the Morrison and Shinarump. Shallow reflections were recorded in all three test areas, although they were often discontinuous and showed erratic stepouts which made interpretation difficult. More work is planned, using pattern charges and multiple geophones, to improve the character of the reflections. If record quality can be improved, it is possible that the shallow reflection technique will prove a valuable ajd to uranium exploration.

\section{BOREHOLE GEOPHYSICAL METHODS}

\section{ELECTRIC LOGGING}

Although surface electrical resistivity methods have been successfully used in exploration for relatively shallow uranium deposits in the Morrison, such methods could not be used where the overburden is thicker than 800 feet.

Experimental electric logging tests were made in 1953 by G. V. Keller (1954) and in 1954 by R. E. Miller (personal communication) using multiple electrode equipment, capable of recording self-potential logs, single-point resistance logs, 4-inch and 24-inch normal resistivity logs, and 18 -inch lateral logs.

The electric logging tests suggested several possibilities that deserve further investigation. The singlepoint resistance $\log$ can furnish an accurate lithologic $\log$ which can be used for stratigraphic correlation between drill holes from which there is poor or no core recovery. A combination of a single-point resistance $\log$, a gamma-ray $\log$, and wagon drilling would be a cheap, efficient exploration method. Electric logs, combined with inhole-velocity logs, provide an excellent means of evaluating the possibilities of surface geophysical work in any new areas in which the physical properties of the formations are unknown or in doubt. The discovery by G. E. Manger (1954) of the possible association of changes of amount and salinity of pore water with uranium mineralization may mean that variations in pore-water saturations-thus proximity to uranium ore deposits - can be mapped with electric logs.

\section{SURFACE-INHOLE ELECTRICAL METHODS}

Tests have also been made of combinations of surface and inhole electrical methods in an attempt to extend the effective radius of drill holes by mapping directional resistivity trends from these drill holes. Variations in apparent resistivity were measured in a radial pattern around drill holes, employing both surface and inhole electrodes. A modified electric logging unit was used with surface electrode configurations to make the directional resistivity measurements. A number of different electrode configurations (Black, 1954) were tested using a 16 cycles-per-second current and recording the potential readings continuously as the inhole electrode moved up the hole.

Lateral resistivity changes can be mapped with this method, but great care must be taken to avoid false directional resistivity anomalies due to variable contact resistances between the surface electrodes and the earth. Surface-inhole electrical methods may prove to be of value by effectively increasing the radius of the area investigated by a drill hole from a few inches to as much as 200 feet.

\section{OTHER GEOPHYSICAL METHODS}

The electrical properties have been determined for several cores of the Morrison formation obtained by special drilling procedures to preserve the natural water content. These measurements indicate that significant differences exist between the dielectric constants of the mudstones and sandstones of the Morrison, when measured at low frequencies. The measurements of charge-discharge curves may be useful in tracing lithologic variations in the Salt Wash sandstone member of the Morrison formation.

The laboratory measurements on natural-state Morrison cores also indicate that radio waves may be useful in investigating lithologic variations in the sandstones of the Morrison. The rate of attenuation of radio waves in mudstones in the Morrison is many times greater than in sandstones of the Morrison, and the sandstones may thus act as dielectric wave guides. It is possible that measurements of the rates of decay of radio waves initiated within the sandstone may permit mapping of lithologic variations within the sandstone. 
The electromagnetic induction method may also prove applicable to prospecting for uranium deposits. Arid country, with its dry surface layer, is particularly favorable for the electromagnetic induction method as a nonconducting surface layer permits greater depth penetration. Experimental surveys were begun in the summer of 1955 .

\section{SUMMARY}

The Geological Survey has tested many geophysical methods on the Colorado Plateau to determine which could be used to aid in exploration for uranium deposits. The seismic refraction and the electrical resistivity methods have proved particularly applicable to uranium exploration. Magnetic and natural potential methods have not as yet proved to have a direct application to exploration for uranium.

Shallow seismic reflection, electric logging, and surface-inhole electrical methods have been tested, but not enough information has been obtained to determine fully their application to exploration for uranium. Induced polarization, radio frequency, and electromagnetic induction methods seem promising and will be further developed in the near future.

\section{REFERENCES CITED}

Barthelmes, A. J., 1946, Application of continuous profiling to refraction shooting: Geophysics, v. 11, no. 1, p. 24-42.

Black, R. A., 1954, District geophysical studies, in Geologic investigations of radioactive deposits, semiannual progress report, June 1 to November 30, 1954: U. S. Geol. Survey TEI-490, p. 78-85, issued by U.. S. Atomic Energy Comm. Tech. Inf. Service, Oak Ridge, Tenn.

Keller, G. V., 1954, The application of electric logging to a mineral exploration program [abs.]: Geophysies, v. 19, no. 3, p. 631-632.

Manger, G. E., 1954, Original state core studies, in Geologic investigations of radioactive deposits, semiannual progress report, June 1 to November 30, 1954: U. S. Geol. Survey TEI-490, p. 92-99, issued by U. S. Atomic Energy Comm. Tech. Inf. Service, Oak Ridge, Tenn.

Pakiser, L. C., Mabey, D. R., and Warrick, R. E., 1954, Mapping shallow horizons with reflection seismograph: Am. Assoc. Petroleum Geologists Bull., v. 38, no. 11, p. 2382-94.

Wantland, Dart, and Casey, R. D., 1952, Field tests for the United States Atomic Energy Commission on the use of the seismic geophysical method for tracing "buried channels" in the Monument Valley area, Ariz.: U. S. Bureau of Reclamation Geol. Rept. G-123, 26 p., issued by U. S. Atomic Energy Comm. Tech. Inf. Service, Oak Ridge, Tenn.

Weir, D. B., 1952, Geologic guides to prospecting for earnotite deposits on the Colorado Plateau: U. S. Geol. Survey Bull. 988-B, p. 15-27. 


\section{SUBJECT INDEX}

"A" unit of Gregory member. See Chinle formation.

Abajo Mountains, Utah _...160,177

Abo formation......__..... 324

Absorption of uranium by plants....... 505-509, 682

Acoustic velocity logging. See Logs.

Adsorption of uranium...... 49, 50, 50-60, 62, 63, 306

Adularia, pitchblende associated with ........ 125

Age of uranium deposits, Colorado Plateau. ... 164

Colorado Plateau, absolute …........... 44

Inyan Kara group.

reasons for discordant isotope determins-

tions.... $549-555$

summarized by type of deposit and area.... 28-39

Witwatersrand, absolute.................... 44

other mention...... 102-103,

$105,110,153,300,342,361-370,448$

Alaska, Prince of Wales Island, Salmon Bay area

Alhambra hot spring, Montans, uranium content. 600

Alkalic and cale-alkalic associations, relation to uranium content............. $57,63,73$

Alkalic late-stange differentiates, uranium con-

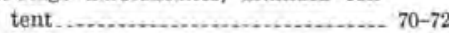

Allanite..................... 19, 72,561, 569, 573

Allium acuminatum ....._............. 685

Alteration, alunitization_..................... 125, 637 argillization, adjacent to veins.... 101, 102, 636-637 brecciati

by ground wster..._. 492,502

ealcite ......................

chloritization, relation to uranium, dis. cussed _.......102, 636-637 clay to illite (?)

dolomitization, relation to uranium dis-

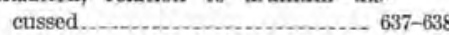

discussion of types of hydrothermal......... 634 effect on uranium content of igneous rocks.. 61-62 feldspathization . 114 ferrugination, relation to uranium discussed. 634 fluoritization, relation to uranium discussed. 201, 634-636

hematitic - 324 hydrothermal......................... $61,102,103$, $124,125,140,141,153,201,270-272,634$

ilmenite to leucoxene .................... 217 kaolinization _...___._........... 140,291 limonitie, as a guide to ore _............. 244, 245 oxidation of magnetite.................... 217 relation to carnotite deposits, Morrison formation................................. 217 sericitization.................. 20,88, 114, 12 silicification, adjacent to veins............... 101 overgrowths_................................ 217 relation to uranium discussed .......... 638 other mention .... 20, 120, 121, 125, 140, 201, 291 structural and chemieal of thorium minerals. 568 supergene............................ 109, 268 Temple Mountain collapse. ...___._. 291 uraninite............_. 189 wall rock ..... 57, 106, 108 , $109,113-116,120,124,125,126,29 !$ Amarillo-Wichita uplift, Texas and Oklahoma . 529 ,
Page

limestone 525

Analytical ehemistry, thorium .......... 605-617 uranium

Andersonite

Anhydrite, uranium content of ............... 384

Ankerite, pitchblende coating crystals of..... 113

Anomaly, defined.............................. 660

interpretation by kinds of sources........ $717-718$

radioactivity, ratio to background gamms radiation..................... 708

thresholds in ground and surface waters.... 670

other mention....... 113,119, 120,121, 362, 402, 472

Anorthosites, uranium content................ 56

antiquus, Rhadanichthys.

Apatite

$477,478,479,493,499,561,561$

Apatitelike minerals............................... 573

Argillite, as host rock ........................... 86

Argo Tunnel water, uranium content......... 671

Argon, in natural gas................... 527, 531

Arikaree formation .............. 325, 415, 120, 676

Arizona mines, claims, and prospects, Black

Mesa deposit........................ 447-448

East Side mines.................... _... 189

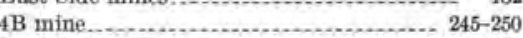

Hoskietso property ............................. 401

Morale elaim _.... 184

709 mine.

246

Arizona mining districts and areas, Apache and Navajo Counties .................233$237,245-250,399,539,540$

Barber Peak 182

Bidahochi Butte ........................... 184

Cameron mining district........... 9, 264, 278-279

Coconino County .......................... 401, 537

Garnet Ridge .......................... 167, 182, 539

Gila County .

Hacks Canyon ...................... 538

Hopi Buttes area........................ 167, 400-401

Jerome area _................................. 402

Lukachukai Mountsins _...... 198, 245-250

Mohave County....................... 537, 538

Monument Valley _._.................... 9, 151, 233-237, 264, 267, 385, 653, 654, 701, 723

Navajo County $233-$ $237,245-250,399,400-401,539,540$

Navajo-Hopi Reservation....... 179-185, 447-448

Pima County . 538

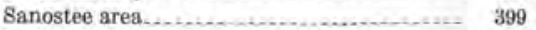

Santa Cruz County ........................ 325, 537

Ship Rock..

Willaha sres

Yale Point area ................................ 448

Yavapai County, Jerome_................. $\quad 402$

Arkose, as a host rock ..................321, 323, 325, 524 Arsenic, relation to uranium content' of water... 680 Asphalt-bearing rocks, Western United States. $521-526$ uranium content ........ $522-525$

Asphaltite, age, character, and distribution of uranium in.

\begin{tabular}{ll} 
summary of uranium in & 38 \\
\hline
\end{tabular}

other mention . . . $254,273,292,295,383,528,529-530$

Astragalus pattersoni....... 684

Aura. See Halo.

Autoradiograph studies.
$58,59,62,460$
Page

Autunite $\quad 80,81,83,86,88,102,110$ $126,323,326,342,346,358,477,479,675$ $\Delta \mathrm{xes}$ of folds, as ore controls ............ 315

B

Background values of radioactive elements.- 660 Baddeleyite................. 572

Bakken formation .......................... $470-471$

Barite

Barnett formation, uranium content_............ $\quad 455$

Basalts, Western United States, uranium content.... 5

Base-metal ores, uranium deposits with ..... 30,32-33

uranium deposits with sparse or no......... 30,32

Basin and Range province, uranium deposits in elastic roeks

$351-359$ uranium deposits in volcanic rocks ......... 79-83 Busins of Tertiary age, uranium deposits..... 337-344 uranium districts, listed . . . 338

Bastnaesite....................................... 561

Battle Spring formation.......................... 407

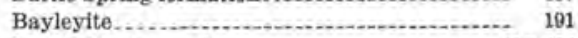

Bear River formation. ......................... 403-404 Bearpaw Mountains, Mont., uranium content.. $\quad 72$,

Becquerelite, in sandstone._. 73 (table)

Bedded ore bodies . 151, 152

Bedding planes, control of deposits by........ 295 distribution of asphaltite along .............. 402

Belknap rhyolite............................... 99

Belt series.

Belts, mineral ............................ 151

Bend Arch uplift, Texas............. $\quad 530$

Bentonitic clay, as host rock ..................... 355

Betafite, igneous rocks, origin .................... 58

Biearbonate, relstion in soil of uranium to ...... 691 Bidahochi formation .................... 10,400-401

Bighorn arch, Wyoming ............... 402

Biogeochemical concentration of metals ...__.... 661

Bishop Creek, Mont, uranium content....... 670

Black marine shales, age, character, and distribution of uranium in .................. 36-37

Black Mountain antícline, Arizona_........... $\quad 447$ Blanding basin................................................ 177

Bleaching, Temple Mountsin collapse ........ 289, 291 Blowout pipe, Thomas Range, Utah ..._..... 133 Bluewater fault, New Mexico ................ 250 Bluff formation. See San Rafael group.

Bob Ingersoll dike, South Dakota .............. $\quad 30$ Boltzman equation........................... 716 Bone Valley formation ...... 37, 50, 480, 489-494, 495-504 Borehole methods of prospecting............ 725

Bostonite, ursnium in ...................... 29, 110 Boulder batholith, Montans, uranium content downstream.

uranium deposits

117-121

Boulder Creek batholith, Colorado, origin of uranium.

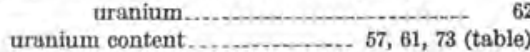

Boxwork-type ore, Thomas Range, Utah ...... 132 Brazer limestone............................ 470-471, 472 Breecia pipes, La Sal Mountains............ 160 reefs, description of _........................ 113

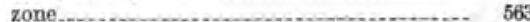

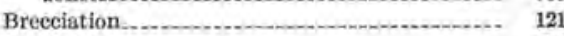
Britholite ........ 571 Browns Purk formation, uranium deposits...... 101,

$325,362,370,400,676$ 
Page

Brule formation ............................ 384,415 Brushy Basin member. See Morrison formation. Bullion Canyon volcanic series, phosphyranylite in...

vein deposits.

Burro Canyon formation.

Byproducts, uranium.

Bysmaliths

\section{C}

Calc-alkalie rocks, variation of uranium eontent with $\mathrm{SiO}_{2}$ and $\mathrm{K}_{2} \mathrm{O}$................... 66 , and $U$ tah), uranium content........

Calcification of ancient channel fill, relation to uranium.

Calcite-bearing solutions, relation to ore-bearing solutions... Calcium content, relation to uranium content. Calcium-fluorapatite.

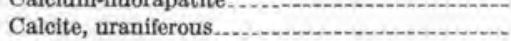
Caliche.

sits, schroeckingerite................. 437

Calichelike accumulations_.................... 342,385

California, lakebeds ............................ 325

California mining districts and areas, Antelope Range area

Bradley area.

Casmalia area...

Chalone Creek area.

Edna area.

Goleta area

Inyo County.

$32,326,536,537$

Los Alamos area............................. 524

MeKittrick area........................... 524

Mountain Pass district, San Bernardino County

$32,563,574$

Olancha district............................ $355-358$

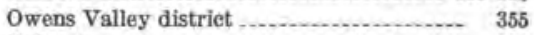

Point Arena area ............................ 524

Rosamond area_..._............. 81-83, 326

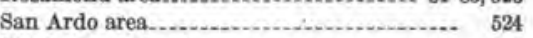

San Lorenzo Creek area ...................... 524

San Luis Obispo County .................. 524

Santa Barbara area._......................... 524

Santa Cruz area..

Sierra Nevada batholith, uranium-bearing vein deposits in.......................... 102

Callixylon ..... 460, 464

Cane Creek antieline, Utah ...................... 157

Caprock, definition of ancient-channel-covering. 691

variations of acoustic velocity in aneient channel...

Carbonaceous matter, replacement of by uranium minerals. ............ 188, 505-506

$\begin{array}{ll}\text { Carbonaceous shale of Late Cretaceous age.... } & 447\end{array}$

Carbonate rocks, syngenetic uranium contents of ......... 382-383

Carbonate-fluorapatite _._._._._. 477, 478, 479, 483-487 Carbonate-hydroxyapatite....................... 477

Carbonate-impregnated sandstone, as an ore control .................. 245, 247-250

Caribou quartz monzonite stock............ 100

Carnotite, relation to solubility of sulfur and selenium

other mention.

$133,144,165,168,184,190,239,278,306$, $315,316,323,324,325,340,342,346,347$, $349,358,359,446,448,449,641,675$.

Carnotite deposits, position and shape......... 214

Carnotite-type ores........................... 306

Carrizo Mountains, Ariz . . . .

Cation-exchange position, uranium in igneous rocks... $59,62,63$
Calcareous rocks of Mississippian age (Montana

Calcium carbonate, relation to uranium content

Mojave County .................. $\quad 326$

Castle Valley, Utah..............................

Cements, uranium as............................ 20 Central Kansas uplift ...................... 331, 530 Cerium minerals, table of names and formulas.. $\quad 577$ Cerium mineralogy. See under Mineralogy.

Cerium phosphate. See Minerals, monazite.

Chadron formation. 415

Chalcedony, uranium-bearing ............ 119, 121, 125 Chalk Bluff formation, Seven Rivers gypsiferous member, New Mexico.

Channels, ancient, as guides to ore deposits _. 268-269 ancient, at base of Shinarump, Monument Valley .................................. delineation by geochemical methods.... 691 flank defined.................................. 601 geology of those flled with Shinarump on Colorado Plateau.................. guides to ore-bearing Shinarump flling

Happy Jack mine, Utah $653-654$

Holiday Mesa, Utah

relation of acoustic velocity to filling,

Stud Horse channel ............... 699-701 techniques for locating ................... 237 other mention ............................. 151, $189,227,229,230,231,233-237,240,254$, $260,282,312,315,316,319,448,449,464$. $492,653-654$.

Chattanooga shale, as a potential source of uranium 453 character and extent................ 453-454, 457-460 environment of gecumulation........... 463-467 origin of uranium.............. 454, 461-462, 466-467 uranium content ........................... 37 , $48,453-454,460-462,466-467,479,505,507$ Dowelltown member, eharacter and extent. 458,

uranium content .................... 460,46 Gassaway member, character and extent 458-459, 464-465

uranium content _.......... 460, 461, 466

Checkerboard limestone, Oklahoms .......... 384 Chemical composition, relation to ore deposition 214 Chemieal precipitates, summary of uranium in.- 10

Chemistry, thorium. See under Analytical chemistry.

uranium. See under Analytical chemistry.

Cheralite

Cherokee shale $\quad 37,48,454$

Chert, as host rock....................... 524

Chilson anticline, South Dakota................. $\quad 349$

Chinle formation, geology of ore deposits.... 263-280 major ore-producing areas in................. $\quad 264$ percent of uranium deposits in.

Silver Reef, Utah, silver-bearing

uranium production $147,168,195,204,230,233,287,699,722$

Monitor Butte member ................... 287, 297

Moss Back sandstone, direction of sediment transport.

other mention

148

Chlorapatite.

$198,204,264,272,285,287$

Chloritization.......... $\quad 477$

Chromium, Temple Mountain, Utah.......... 168

Chngwater formation _........ 362,525

Chuska Mountains, Arizona and New Mexico._ $\quad 157$

Cimarron fault, Colorado........... 590

Cincinnati arch, Tennessee................... 458

Circle Cliffs uplift, Utah ........................ 162

Classification, ore deposits.................... 98-101, $106,145-146,149,188$

Clastic rocks, uranium deposits in Basin and Range province 351-359 summary of uraninm in ................ 8 Clay, association with uranium materials... $80,81,83$ Clay galls, relation to localization of ore....... 214, $254,302,324,315$ Catskill formation 323
Claystone, uranium in, Bidahochi Butte, Ariz-- 184

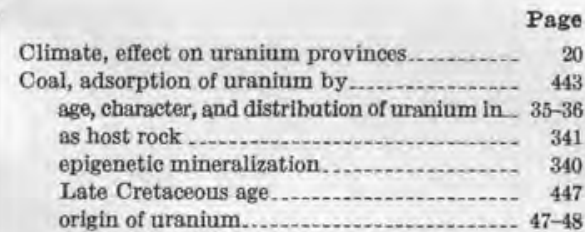
relation to localization of uranium. $306,312,315,318$ summary of uranium in............. 10-11 trace elements in, Red Desert, Sweetwater County, Wyo.................... 439-444 uranium-bearing in Great Divide Basin, Wyo.......... 433-438 Also see Lignite.

Coatings on sand grains .......................... 346

Cobalt, soil and rock analyses................. 665

Coconino sandstone.............................. 286-287

Coffinite.................. 253, 273, 274, 306, 342, 529, 572

Collapse structures, relation of mineral belt to.. 297 Black Hills, S. Dak. .................. 9 Temple Mountain, Utah, deseribed ...... 161, 638

Temple Mountain, Utah, relation to uranium deposits................ 167-168, 295

Collins, C. B., Farquhar, R. M., and Russell, R. D., quoted .

Collophonite, uraniferous.................... 352, 355, 359

Colorado Front Range, reconnaissance explora-

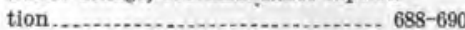

Colorado mines, prospects, and deposits, Bald Eagle.

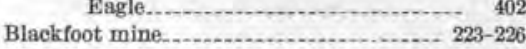

Club Group_..._.......................... 192

Gertrude claims ............................ $\quad 370$

Iron mine........................................ 110

Jacknife mine.................................... 260

Jeanie elaim _............. 588

Little Johnnie claims_................... 588, 580, 591

Los Ochos deposits......................... 137-141

Lower Group mines.

MoKay shaft .............................. 110

Martha E mine _.......................... 110

Maybell-Lay deposit_...................... 341, 342

Old Leydon mine........................... 47

Peanut mine.................................... 191

R. H. D. mine....... 110

Red Rock claim. _........................ 588

Swartzwalder mine_.......................... 538

Thornburg mine....................... 139

Two Sisters mine........... 110

Union Pacific prospect...................... 113

Wedding Bell mines....................... 257-261

Wood mine................................... 110

Colorado mining districts and areas, Atkinson Mesa area........................... 223

Bull Canyon . 257-261

Central Oity ........... 6, 7, 29, 32, 33, 105-111, 446

Chicago Creek............. 105

Club Mesa................................... 192, 223

Custer County, Wet Mountains _.......... 562-563

El Paso County _..................... 564

Fremont County, Wet Mountains......... 562-563

Gilpin County, Quartz Hill .............. 7, 29, 102

Golden Gate Canyon.................. 113-116

Gunnison County, Powderhorn .. 562, 574, 587-592

Gypsum Valley, San Miguel County_- 15, 385, 401

Huerfano County, Cucharas................. 324

Idaho Springs ........ 30,105

Iron Hill . ...

Jefferson County ......... 7, 101, 113-116, 537, 538

Lake Fork Canyon..................... 590

Lawson-Dumont-Fall River.................. 105

Long Park............................................ 223

Maybell ..................................... 370

Mesa Creek .................................. 221

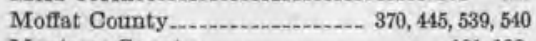

Montrose County........................ 191, 192,

Nigger Hill

$221-226,257-261,539,540$

Park County ........... 324, 538

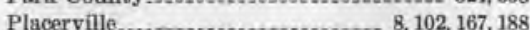

.


Colorado mining districts and areas-Con. Powderhorn, Gunnison County _. 562, 574, 587-592 Quartz Hill .............................. 102 Rifle.

Saguache County, Los Ochós _.... 137-141, 538 San Juan Basin ................. 338, 447, 448-449 San Juan Mountains....................... 153 San Miguel County ........................... 101, $102,188,192,385,401,402,539$ Saucer Basin . ............................. 223 Skull Creek.

Slickrock, San Miguel County, Lower Group mines.

Uravan mineral belt......... 151, 190, 221-226, 539

Wet Mountains, Custer and Fremont.

Counties.......... 562-563

Colorado Plateau, as a structural province ..... 171

geology of uranium deposits of Chinle formation.................. 26 uranifum deposits of Shinarump

geology of uranium deposits of Bhinarump conglomerate.................. 263-280

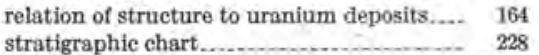
tectonic history............. 161, 175-178 uranium deposits in relation to structural features.............................. 155-170

Colormetrie analysis, thorium $\quad 613$ uranium _........... $607-608$ Comagmatic provinces, Western Enited States. $76-77$ Concretionary deposits.............. 325 Coneretions............................. 340

Conglomerate, as a host rock ......... $323,524,594,595$ transmissivity in relation to deposits. ..... 207-211 Conichalcite.

Contacts, metamorphic and igneous rocks, as an ore control........

Control of ore. See Ore control.

Conway granite, uranium content... 29, 70, 72 (table)

Copper, associated with uraninite in yein deposits......................... 102 relation to uranium content of water....... 680 secondary minerals of ................... 102, 191 soil and rock analyses.......................... 665

Copper-uranium deposits.......... 149, 166, 167-323, 324

Copper-vansdium-uranium deposit........... 323, 324

Cordilleran foreland, structural elements ..... 329-331

Corvusite................... 190, 192, 324, 346, 348

Coso formation of Schultz (1937) ___........ 355

Counting-rate meter, curves of radiation measured by ........ 717 description and use......................... 706-707 Crandallite................................... 477, 478, 479

Craven Canyon, 8. Dak..................... 349

Cretaceous rocks, productive uratium deposits in ............................. 300

Cretsceous shoreline, position on Colorado Plateau.......................... 176

Crossbedding ................................ 222, 251, 260

Cross-stratification, planar................... 229-230, 231 relation to uranium deposits .................. 448 studies ... trough $\ldots . . . \ldots \ldots \ldots \ldots \ldots \ldots . . .229-231,240$

Crude oils, Western United States, uranium content................... 511-519, 528-529

Cryptovoleanic structures, deseribed.......... 161

Crystal structures, igneous rocks, uranium in... 92

Crystallization, distribution of uranium during. 60-61

Cumberland Plateau, Tenn................ 458

Current linestion, description.................... 229 guide to ore................214, 227, 231, 240, 251, 254 marks .................................. 222

Curtis formation. See San Rafael group.

Cutler formation...................... 273, 274, 281

Cyclone Rim fault.............................. 443

Cyclone River fault, Wyoming .................. 385

Cyclothems.

Cyrtolite.
Dacite, as host rock D Pago

Dakota hogback, New Mexico _................ 308, 310

Dakota sandstone, character and extent ....... 304-306 diagenetic structures........................... 306

lens-shaped ore bodies.................. $\quad 315$

origin of deposits................ 306, 315, 318-319

pod-shaped ore bodies. ..................... 315,316

uranium deposits in paludal black shales. 303-319

uranium deposits in San Juan Basin, $\mathrm{N}$. Mex........................... 303-319

other mention............. 138, 250, 407, 446, 447, 449 Deadwood formation, Big Horn Mountains, Wyo .................................. 565

De Chelly member. See Cutler formation.

Deepkill formation........................... 456

Deer Train argillite of Weaver................... 86

Defiance uplift, Arizona and New Mexico..... 156,

$\begin{array}{lr}\text { Deformation, diagenetic } & 162,168,245 \\ & 389\end{array}$

Denver, Colo., stream, uranium content........ 67

Deposition, conditions of uranium.............. 374

Depth profiles, figure showing geophysical and geochemical data.

rate of making

Detrital grains, uranium as..................... 201

devonicus, Rhadanichthys ......................... 464

Diagenesis $\quad 389$

Diatomite, as host rock...................... 358,524

Diatremes, ares of, and description .......... 160, 180

character of uranium fn ..................... 167

location on Colorado Plateau .............. 160-161

Navajo-Hopi Reservation, Arizona, New Mexico, Utah..................... 179-185

other mention _..... 152, 400, 402-403 Differentiation, magmatic, concentration of thorium during ............. 560

uranium

Dikes, as a control of ore deposition _..... $83,88,160$ sandstone ...................................... 289

Dinichthys terreli.................................... 464

Dip correction, for base of Shinarump-fllled channels .

Dispersion patterns, explained .................... 661

in streams.......................................... 668

Disseminated deposits............. 325, 326, 332, 334, 446 Dissolved uraninm, igneous rocks............... 60, 63 Distribution of ore deposits, Colorado Plateau 145-

146,149

Dolomite, as host rock......................... 132, 507

Panhandle gasfleld, Texas................... 383

uranium content of ......................... 382

Dolores anticline, Colorado................. 150

Dolores formation............................... 101

Dolores River, uranium content downstresm... 668

Domes, structural, of Colorado Platean ........ 160

Drilling techniques. See under Prospecting.

Dripping Springs quartzite.................... 32,101

Dry-hole electrie logging. See Logs.

E

Eagle Ford shale, uranium content.

Tastern Highland Rim, Tenn - - -

Edwards limestone............................ 402 Effusive rocks, uranium content compared with intrusive equivglent.

19

Eh, relation to localization of ore.............. 261,444

El Paso limestone................................. 99 Electrical drilling. See Depth profles.

Electromagnetic induction surveys.............. 726

Elementary point source radiation........ $716,717,718$

Elements, methods of determining............ 664-665

Endogene horizontal transport_.................. $\quad 78$

Entrada formation. See San Rafael group.

Environment, geologic, of uranium. ........... 201

Epidote, radioactive.

Epigenetic deposits
Epigenetic origin of C-V-Cu ore ................ 153

Epithermal mineral assemblage, Saguache County, Colo........................ 140

Epithermal zone, deposition of uranlum in..... 103

Endogene horizontal transport of uranium ...... 78

Environments of deposition, characteristics.... 342

Eriogonum inflatum ............................ 685

Erosion, concentration of uranium through..... 20-21

Esmeralda formstion.......................... 358

Eudialyte_................................... 572

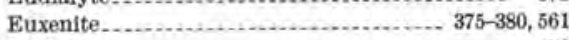

Evansite....................................... 478

Evaporation of uranlferous ground water..... 342,344

Evaporites, general character and distribution of uranium in............ $36,381-386$

See also Salt structures.

Exogene horizontal transport......................

Exploration for uranium and thorium. See Prospecting.

Exshaw formation........... 470-471

Extraction of uranium, by flotation.............. 15

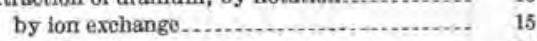

by solvents................................... 15

Extrusive rocks, summary of uranium in ...... $\quad 29$

Facies changes. See under Ore control.

Fall River formation............................. 690

Fan, dispersion ............................. 661, 662

Faults and Folds. See under Ore control.

Felsic intrusive rocks.................. 99

Fergahnite - 480

Ferron sandstone member. See Mancos shale.

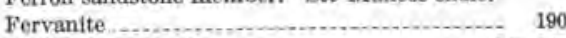

Festoon cross-laminstions .................... 222, 230

Finite source radiation........................... 717

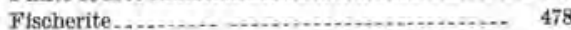

Fish Haven dolomite............................. 100

Fisher Valley, Utah.............................. 158

Flatiron Mesa, Utah........................... 267

Florida mining distriets and areas, Hillsboro County ............................ 496

land-pebble district, aluminum phosphate zone $\ldots$

calcium phosphate zone ........... 37, 489-49

Polk County ............................. 49

Fluorapatite................ 326, 477, 478, 483-487, 561, 564,

Fluorite deposits, uranium in .......... 30, 31, 634, 636

Fluori-metric analysis, uranium.............. $606-607$

Foerstia.......................................... 450,464

Fort Scott limestone

Eort Union formation..................... 10, 35, 325, 525

Cannonball member. . . _ .

Ludlow member ............................. 415, 420

Sentinel Butte shale member............... 415,420

Tongue River member..................... 415,420

Fossils, carbonized plant, Colorado Plateau.... 152

Fossil bone, uranium content................... 480

Fox Hills sandstone

Fracture fllings................................ 346

Freyslite ........................................... 572

Front Range, Colorado, age of uranium deposits. 164

Frontler formation................................ 362

Frultland formation............................ 446,448

Fumaroles, as originator of uranium minerals... 127

Fuson formation.......................... 690

G

Gulens-sphalerite vein deposits.............. 106, 109 Gallup hogback, New Mexico ............. 308, 310, 312 Gallup member. See Mesaverde formation.

Gamma rays, air seattering from uranium sources ............................... 715-719

Gamma-ray logging. See Logs.

Garber sandstone........................................... 324

Garo anticline, Colorado...................... 324

Gas Hills anticline area, Wyo.......... 204, 362, 674, 675 
Geiger-Müller counter, described................ 70

Genesis of uranium deposits, discussion and summary.

Also see under Origin.

Geochemical anomaly. See under Anomaly.

Geoehemical cycle...

Geochemical prospecting. See under Prospecting.

Geochemistry, of thorium .............. 560, 573-575

of uranium

organic, of uranium ........................ 505-510

Geologic prospecting. See under Prospecting.

Geosynclinal belts, world distribution of uranium ........................... 17-18

Glen Canyon group, Kayenta formation....... 165, 288 Navajo(?) sandstone, relation of roll and tabular bodies to ore.................. 240

other mention................. 183, 288, 524, 525 Wingate sandstone.............. 9, 167-168, 288, 638

Gold mining, uranium as a byproduct of ...... 110

Golden Valley formation.................... 415

Goodrich quartzite, character and extent. monazite content

origin of monazite

Upper Peninsula, Mich

Grand Hogback monocline

Granite, thorium content

uraninm content

Granitie rocks, concentration of uranium and thorium .......................... 29

Granodiorites, uranium content.................. 56

Green River formation............ 383, 407, 440,453, 524

Ground water. See under Waters.

Guano, uranium content

Guides to ore, arsenic minerals in Temple Mountain collapse..................... 295 earbonaceous matter. $189,198,201,240,241,244,251,253,254$. $260,261,267,270,272,274,276,278,279$, $284,296,297,302,366,367,370,404,416$, 449, 464 .

chemical 630,631

color alteration $214,244,245$, $254,260,261,267,268,297,315,461,634$

epigenetic.................

ferrous iron in wall rock.

fluorescence.- 385

fracturing, Big Indian Wash-Lisbon Valley area - 275

iron-oxide staining..................... $326,355,358$

lithologic .............................. 630,631

mineralogic.................................. 630,631

mixed and irregular bedding................ $\quad 326$

Morrison formation, Gallup-Laguna area, New Mexico ........................ 299-302 mudstone: sandstone ratios... 226, 253, 254, 267, 271 radon concentration ....... 709 structural ...................................... 630,631 syngenetic deposits............................. $630-631$ tested at Cottonwood Wash area, Utah ..... 645 thickness of host-rock strata water sampling _.............................. 673-680 White Canyon area, Utah .................... 284 Also see under Channels, Halos.

Guides to major ore-bearing areas ....... 628

Guides to new ore-bearing districts ............. $628-630$

Gummite....................................... 81, 83, 326

Gunnison uplift, Colorado ..................... 156

Gypsum, as host rock .......................... 340,384

Gypsum Valley, Colo........................ 157

Gypsum Valley anticline, Colorado.......... 257,401

Hafnium

Halo, defined.

567

geochemical

660,661

pyritic.

relation to hydraulic gradient

682

summary of primary and secondary
Hamilton formstion.

Hartville formation.

Hartville uplift, Wyoming .................... $331,333,455$

Hawthorn formation................ 480, 489-494, 495-504

Heath shale, uranium content ................ 455,472

Heavy-mineral concentrates, as guide to monazite deposits. 622-623 composition of Idaho placer deposits 380

Helium in natural gas

Hell Creek formation $527,530-531$

Hell Creek formationation.

325,415

Henry Mountains, Utah

Henry Mountains basin, Utah

Hermosa limestone

Hewettite.

Hicks dome, minois

High Plateaus, Utah

Highland Rim, Tenn.

Highwood Mountains, Mont., uranium content (table)

Hinsdale formation, uranium content (table) ... Hopewell series

Hopi Buttes, Arizons.

Hornblende gneiss, relation of to uranium distribution, Golden Gate Canyon, Colo.

Horseshoe vent, Arizona

Host rocks, tables showing relation to uranium deposits..

table of those in Tertiary basins, Wyo:ning and Great $\mathrm{Pl}$

table of those of vein deposits............... 99-101

Hueco limestone.

Hummerite

Hushpuckney member.

Huttonite.

Hydrocarbons, occurrence and distribution, Calyx mines..

Hydrodynamic ore deposits

Hydrogen, in natural gas.

Hydrothermal alteration. See under Alteration.

Hydrothermal deposits................... 20, 355,358

Hydrothermal solutions, deposition of uranium by _..................... $383,392,409,427,444$

Hydrothermal source of uranium, in limestone_. $\quad 396$ possibility for Colorado PIateau ores......... 46

Hydrothorite ....................... 561,590 Hydrous uranium molybdate ................... 127

Hydroxyapatite.

Hypogene deposits .......................... 342, 343, 355

Hypogene source of uranium, possibility for Colorado Plateau ores.

Hypothermal zone, deposition of uranium in....

I

Idaho batholith, geology and placer deposits _. 375-380 source of thorium-bearing minerals for Idaho

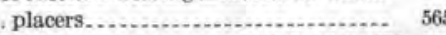
other mention................. 67 (table), 375, 565 Idaho, Conda mine............................... 485 Idaho mining distriets and areas, Bear Valley ... 375 380,565

Blaine County
Boise County. 537,565

Bonneville County, Fall Creek... 403-404, 407, 537 Cascade..

Fall Creek. $403-404,407,537$

Goose Creek

Hailey .....

Lemhi Pass..

Mabie Canyon

Mineral Hill.

Shoshone County.

Idaho Springs formation

Idaho, Wyoming, and Utah, Bear Lake......... 537

Igneous activity, localization of ore bodies by .. 152-153
Igneous rocks, as long-range supplies of uranium and thorium general distribution and character of uranium in...................... $6,29-30,55-63$

origin of uranium .......................... 42-43 processing commercially for uranium and thorium . 94-95 thorium content.................... 92-94, 560,564 uranium content................. 56-60, 65-73, 92-94 gircon content.

Ilsemannite...

Indicator plants. See Plants.

Indicator-plant prospecting, tested at Yellow

Cat area, Utah .......................
Infinite broad source radiation...............

Inhole velocity surveys.

Inorganic chromatography, separation of uranium by

Interstitial flllings, sandstone.

Interstitial uranium, igneous rocks

Intruded bodies, as structural features

Intrusive roeks, summary of uranium in.

Inyan Kars group, age of deposits.

concretion ore deposits

pod-shaped ore deposits

roll ore deposits.

tabular ore deposits

other mention

Fall River formation

Fuson formation.

Lakota formation

Ionization chambers.

Ions, mobility of uranyl.

table of radii.

uranyl, changed to uranous

$$
\text { described. }
$$

Isograms, use of geometric ratio for

Isotope, fissionable.

geology of in some uranium minerals

Isotope-ratio ages of uranium ores............ 549-555

Isotope-ratio methods of determining absolute

age of uranium ores.

$549-555$

Ithaca Peak granite.

Jackson formation, origin of deposits

Jemez volcanic plateau, New Mexico

Jasperization.

Johannite

Joints. See under Ore controls.

Jurassic deposits, age determinations.

$340,346,690$

$324,345,348,34$

$324,345,34$

523

634

570 ,

Kaibab limestone, uranium deposits _ 10, 156, 287, 401 Kaibab monocline, Arizona and Utah.......... 156

Kaiparowits basin, Utah......................... 156

Kaolinization ................................ 140, 29

Kasolite.......................................... 324, 32

Kayenta formation. See Glen Canyon group.

Kerogen......................................... 459

Kinderhook shale .......................... 470-47

Kittatinny limestone.......................... 403

Klondike Ridge, Colo .......................... 157

Kolm, occurrence and uranium content.... 48,505, 508

Kovarik, A. F., quoted....................... 553

\section{L}

La Plata Mountains, Colo.

160,17

La Sal Mountains, Utah...................... 159,177

La Ventana member. See Mesaverde formation.

Labile uranium, igneous rocks.....................

Laccoliths, relation of uranium deposits to....... 20

Laccolithic mountain groups, deseribed, Colmountain groups, described, Col-

Lakebeds, as host rocks ..................... 352, 35

Laketown dolomite................................ 100

Lakota formation. See Inyan Kara Group. 
Page

Lamprophyre, uranium content............... 57 Land-pebble phosphate deposits... 37, 489-494, 495-504

Lanthanite.

Laramide antíclines, Wyoming ..................... 331

Laramide intrusive rocks, relation or uranium content to $\mathrm{CaO}$

Laramide intrusive rocks (Colorado) uramium content..............................

Laramide orogeny

Lateral seeretion, as a source of uraniun-

Leachable radioactive granite ................... 19

Leachable thorium, igneous rocks- 92,93 (tables), 94,95

Leachable uranium, igneous rocks .............. 59, $60,67-68,72,02,03$ (tables) , 04, 95

Leaching, as origin of deposits........... 343-344, 592 ground water ........................... 383,385 of soils for bicarbonate ...................... 691 preferential in vein deposits ................ 109 relation of $\mathrm{pH}$ and Eh to.................. 444 surface water ............................... 385 other mention......... 109, 444, 472, 491, 492, 497, 502 See also Waters.

Lead, original radiogenic.

Lead isotopes, loss of .

559

Lead-207: lead-206 age ................... 552

Lead-207: uranium-235 age................... 551

Lead-206: uranium-238 age........................ 553

Liebigite .......................... 191,325

Lignite, as host rock, eastern Montans and North and South Dakota......... 413-418 as host rock, Harding County, S. Dak _... 419-431 relation of to volcanio tuffs, Montans and North and South Dakota..... 413-418 other mention ........................... 325, $332,340,344,362,385,405,416$

Also see Coal.

Limestone, thermal origin of at Hopi Buttes_... $\quad 180$ uranium deposits in. ............. 382-383, 387-404 other mention. .......................... 149, $324,325,340,362,507-508,524,525$

Limy clastic sediments, as host rocks............ 323 Line source radiation _........................... 717 Lingula .............................. 464

Lisbon Valley anticline, Utah_._.

Lisbon Valley fault, Utah_................ 273, 274, 275

Localization of ore. See under Ore control.

Logs, acoustic velocity, methods and evaluetion......................... 698-702 acoustie velocity, variations in Stud Horse (ancient) channel.

use dry-hole electric, method and evaluation... 696 electric, methods of nsing..................... showing stratigraplite relations -3 gamma-ray, evaluation . . .................... neutron, evaluation.

relation of resistivity to velocity

wet-hole electric, compared to dry-hole _. 698,699

Long-range sources of uranium and thorium, igneous rocks..................... $91-95,453$

Loon Lake granite ............................ 86

Los Ochos fault, Colorado _................... 138, 140

Lucero uplift, New Mexico _................. 399

Lucky Loule pipe, Thomss Range, Utah........ 132

Luman coal zone............................... 436

Luman no. 1 coal bed . . . ......................... 437

M

Madison limestone, black shale at base........ 471 Magma, quartz bostonite, relation to uranium in Central City district......... 110

Magmatic differentiation, concentration of thorium........................... 560 concentration of uranium ............. 18-19 general discussion of urunium in . ........... 65-74 uranitum and thorium......................... Magmatlc emanations, as a source of uranium.. $\quad 343$ Magmatie phase, igneous rocks, distribution of uranium............................ $60-61$
Magnetite, deposits containing thorlum-bearing fluorapatite

natural beneficiation from heavy minerals

by streamflow................. 379-380

Mancos shale, Emery sandstone member ...... 446

Ferron sandstone member - $\quad$ - no....... 446

Manganese oxide, associatlon of uranium with... 373

Mapping, method for rate of change of facles... 645

Maps, kinds showing frequency, used in prospecting...

ground-water surface as guide to schroeckingerite . . .................................

ratio of mudstone to sandstone facies...... 645

techniques for making paleotopographic.. 654-655

Marcellus formation....................... 456

Marine black shale, uranlferous................. 451-456

See also under Shale.

Marine sedimentary rocks, summary of uranlum in .............................. 11

Mariposa slate

$\begin{array}{ll}\text { Mass spectrometrle anaiysls, thorium............ } & 614\end{array}$ uranium............................... 610

Massachusetts, Worcester County ........ 564

Matrix, uranium in phosphatic ............... $489-494$

Meander anticline, Utah ......................... 159

Melanovanadite................................ 448

Mesaverde group _.................... 35, 209, 304, 407 Hosta sandstone, uranium deposits... 312, 446, 449 La Ventana sandstone, uranium deposits.. 312 Menefee formation....................... 446, 449

Polnt Lookout formstion ................... 446

Toreva formation........................... 446

Mesothermal zone, deposition of uraninm in.... 103

Mesozoic batholiths, Western United States, analyses................... $66-68$

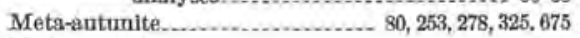
Metabewettite................................. 448

Motallurgy, uranium ......................... 15

Metals, with uranium in terrestrial sedimentary rocks....................... 34-35

Metamorphic rocks, as host roeks............. $88-89$ monazite-bearing, caleareous................. 565 thorium-bearing............................ 564

Metamorphism, effect on uranium content of Igneous rocks, ...................... 61

Metamorphism and ultrametamorphism, effect on uranium deposits........................... 21

Metamorphosed sedimentary rocks and granitie intrusive rocks, uranium deposits at contact . 85-89

Metasedimentary rocks as hosts............... 99, 102 Metatorbernite........................ 88, 109, 110, 278 Metatyuyamunite, in sandstone _.............. 250, $253,254,324,325,326,340$

Metavoleanle rocks as hosts.................. 99

Metazeunerite.................................... 675

Meteoric waters, lesehing ahd alteration by _. 109, 120 Mica schist, as host rock.................. 86 Michigan, age of vein deposits .................. 103 Michigan mining district and areas, Palmer $565,593-594$

Upper Penfnsular .......................... 30, 565

Mineralization, relation to calcite cement...... 602 Mineralogy, cerium compared with thorium, uranium, and zirconium ........... 570-573.

Colorado Plateau uranium ores . _._._._. 187-193 oxidized nonvanadiferous uranium ores... 190-191 Temple Mountain collapse sres ...... 291, 295, 296

thorium - 567-597 thorium compared with cerium, uranium, and zirconium ........... $570-573$ uranium compared with thorium, cerium, and $z$ trconlum. . . urantum, vanadium-copper deposits...... 150-151 vein deposits............................ 101-102 zirconium compared with cerium, thorlum, and uranimm....................... 570-573
Page

Minerals, abundance of principal uranium..... 28 containing cerium as essential or important vicarious constituent (table) ......... $\quad 577$ containing thorium as essentlal constituent (table).

containing thorium as vicarious constituent

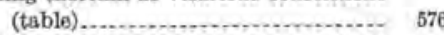
containing uranlum as essential constituent (table) ...............................

containing zlreoníum as essential or important vicarious constituent (table) ... 577

thorium group_..._....... 567,577 types of primary assemblages in veins...... 7 Mineral structures, uranium in, Igneous rocks. 58-69,

Mines, prospects, and deposits, Alta mine, Montans _ de 119 Anomaly no. 119, wyoming ............... 366-368 Bald Eagle mine, Colorado _...__ _ _ _...... 402 Basin no. 1 mine, Utah _............... 254-257 Becent1 deposit, New Mexico ............ 315-316 Bell Hill ore body, Thomas Range, Utah ... 132 Big Buck mines, Utah..................... 273,540 Blg Chief claims, Colorado_.................. 539 Billy Dale group, South Dakota............. 428 Black Hawk mine, New Mexdco.....___. 102 Black Mesa deposits, Arizona ............... 447-448

Blsckfoot mine, Colorado _............... 223-226 Blue Dike mine, Utah. See Happy Jack mine.

Boyd deposit, New Mexico _............... 448-449 Browns Ranch deposit, Wyoming .......... 368 Bull Rush prospect, Wyoming ............. 695, 697 Bullon Monarch mine, Utah........... 536, 638 Bullrush claims, Wyoming ................ 366 Butler deposit, New Mexico...... 308-312, 318, 319 Calys mine no. 3 , Utah ............... 272-273, 296 Club Group of mines, Colorado........... 192 Club Mesa, mine at, Colorsdo ............... 192 Comet mine, Montana _............. 119, 120 Conds mine, Idaho .......................... 485 Crackpot deposit, New Mexico ............. 399 Davidson prospect, New Mexico.......... 448, 449 Day Break mine, Washington................ 537 Dell ore body, Thomas Range, Utah....... 133 Delta mine, Utah ................... 189, 275-278 Delter prospect, New Mexico _............ 316, 319 Diamond no, 2 mine, New Mexico_..._.

Eagle Rock fluorspar vein, Utah ............ 133

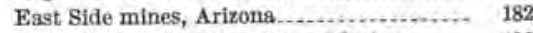
Eastside Carrizo mines, New Mexico _...... 192 Enos Johnson elaim, New Mexico _....... 539 4B mine, Arizona $245-250$ Free Enterprise mine, Montana _.......... 120, 670 Fumarole mine, Utah....................... 295 Gamma property, Nevada. ................. 407 Garnet Ridge deposits, Arizona_............. 167 Gas Hills deposits, Wyoming..... 341, 342, 343,344 Gay Eagle mine, New Mexico__.___...... 539 Gertrude claims, Colorado _..._............. 370 Gray Esgle mine, Montana................. 120 Happy Jack mine, Utah_ 189, 191, 269-272, 540,653 Harrisite property, Utah...................... 133 Hidden Treasure mine, Colorado_.......... 166 Hilltop mine, South Dakota.............. $428-429$ Hogback no. 4 mine, New Mexico ........ 307-308, $312,318,319$

Hoskietso property, Arizona ............. 401 Huskon clatms, Arizona_c..................2278, 279 Iron mine, Colorado ......................... 110 J. 8. Masek claim, Wyoming .................. 537 Jack Plle mine, New Mexico ................. 539 Jacknife mine, Colorado …….......... 260 Jacobs ranch, Texas .......................... 536 Jeanette mlne, Wyoming .................... 367 Jeanie claim, Colorado ........................ 588 Lance Creek, W yoming ..................... 536 Leyden mine, Colorado ..................... 537 Little Johnnie elsims, Colorado _..._. 588, 590, 591 
$\begin{array}{lr}\text { Mines-Continued } & \text { Page } \\ \text { Lone Eagle mine, Montana } & \\ \text { L.................. } & 121\end{array}$

Lonesome Pete claim, South Dakota ..... 429-430 Lopez mine, Utah........................... 296 Los Ochos deposits, Colorado........... 137-141, 538 Lost Creek schroeckingerite deposits, Wyoming ................................ 385,443 Lower Group mines, Colorado................. 192 Lucky Me mine, Wyoming ................ 362 Lucky Mac 20 mine, Wyoming Lyssy-Korzekwa property, Texas............. 536 McKay shaft, Colorado..................... $\quad 110$ Martha E mine, Colorado................... 110 Maybell-Lay area, Colorado _.............. 341, 342 Mesa Top mine, New Mexico ............. 204, 251 Mi Vida mine, Utah ................ 195, 198, 204, 540 Miracle mine, Californis _. 537 Monument No. 2 mine, Arizona........... 540, 653 Moonlight mine, Nevada_.................... 7,32 Morale claim, Arizona ........................ 184

Mulligan quarry, New Jersey ................ 403 Notch mines, Utah .......................... 198-199 Old Bed mine, New York.................... 564 old Leyden mine, Colorado.................. 36,47 Pat claims, Wyoming ....................... 368 Peanut mine, Colorado _...................... 191 Phillips mine, New York ................. $\quad 30$ Poison Basin claims, Wyoming Poison Canyon mine, New Mexico... 204, 250-254 Rajah mine, Colorado ..................... 165-166 Ralston Creek mine, Colorado ............... 33 Rattlesnake mine, Utah ..................... 192 Red Head deposits, Utah ..................... 165 Red Rock claim, Colorado ................... 588 Red Rock mine, Montans............. 120 Ruggles mine, New Hampshire............. 30 Scenie no. 4 claim, Utah...................... 636 709 mine, Arizona ........ Shinarump no. 1 mine, Utah.............. 191 Silver Spur mine, New Mexico ............ 316, 539 Sno-Ball mine, Wyoming .................... $368-370$ Sunshine mine, Idaho ................... 33, 634 Swartzwalder mine, Colorado ................ 538 Thornburg mine, Colorado.

Thursday fluorspar vein, Utah.............. 133

Two Sisters mine, Colorsdo .................. 110

U mine, New Mexico....................... 316

Union Pacific prospect, Colorado.......... 113, 115 Vanadium King mine, Utah ...... 297, 634 (pl. 14) Virginia C mine, South Dakota............. 537 W. Wilson mine, Montana................... 120 Wedding Bell mines, Colorado ............ 257-261

Wood mine, Colorado

Mining districts and areas, Abajo Mountains, Utah.

Antelope Range, Calif, and Nev ............. Apache County, Ariz. 233-237, 245-250, 399, 539, 540 Arroyo de Dos Gordos, N. Mex ............ 312 Arroyo del Agua, N. Mex................... 400 Atkinson Mesa, Colo .......................... 223 Atlanta, Nev ............................... 81 Austin, Nev ..................................... 32, 88-89 Baggs, Wyo_............................. 370 Bald Mountain, S. Dak .................. 538 Baraga County, Mich........................ 33 Barber Peak, Ariz ..

Bear Lake, Idaho, Wyo, and Utah .

Bear Lodge Mountains, Wyo................

Bear Valley, Idaho.

Beaver, Utah

Beaver Mesa, Utah

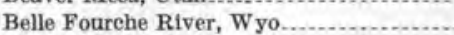

Betty, Nev .

Bidahochi Butte, Ariz..

Big Horn Mountains, Wyo

Big Indian Wash-Lisbon Valley, Utah..... 9,

\section{Mining districts and areas-Continued}

Black Hills, S. Dak. and Wyo $321,324,326,334,337,338,343,344,345-$ $349,690-692,708$.

Black Mesa basin, Arizons................. 447-448

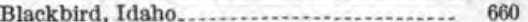

Blaine County, Idaho ....................... 537, 565

Bluewater area, N. Mex....................... 401

Boise County, Idaho........................ 536

Bonanza, Utah 524

Bonneville County, Idaho_....... 403-404, 407, 537

Book Cliffs, Utah............................ 539

Boulder batholith, Montans............... 7, 32, 33

Boulder County, Colo

Bowman County, N. Dak................ 413-418

Bradley, Calif.

Bucks County, $\mathrm{Pa} \ldots \quad 325$

Bull Canyon, Colo ......................... 257-261

Burnet, Tex .................................. 538

Butte County, 8, Dak...................... 413-418

Calyx, Utah

Cameron, Ariz .................... 9, 264, 278-279

Cameron Township, Okla .................. 524

Campbell County, Wyo...................... 536

Carbon County, Mont ................. 382, 383, 400

County, Wyo ........................... 525, 538

Caribou, Colo

Carter County, Mont - $2=0$

Cascade, Idaho .................................. 565

Casmalia, Calif.

Cassla County, Idaho

Catron County, N. Mex

Cave Hills, S. Dak

Cedar Mountain, Utah.

$6,7,29,32,33,105-111,446$

Chadron, Nebr ........................... 340,384

Chalone Creek, Calif ......................... 524

Chicago Creek, Colo ....................... 105

Church Rock, N. Mex ................. 316-317

Churchill County, Nev ................. 407

Circle Cliffs, Utah ....................... 653, 654, 699

Clay County, Tex.

Clear Creek County, Colo.................... 7

Clinton, N. J ............................... 403

Club Mesa, Colo ............................. 192, 223

Coal Canyon, 8. Dak......................... 349

Coal Canyon, Wyo

Coaldale, Nev .

Coastal Plain province.

Cochetopa, Colo.......

401, 537

Coeur d'Alene, Idaho .......................... 30

Converse County, Wyo ....................... 368,538

Correro, N, Mex............................ 401

Cotton County, Okla ........................ 324

Cottonwood Wash, Utah ......... 254-257, 641-642

Crawford Mountains, Utah.................. 484

Crook County, Wyo _537,563

Crooks Gap, Wyo .... 337, 338, 341, 342, 538, 674, 675

Cucharas, Colo ............................ 324

Custer County, Colo ....................... 562-563

Dacie Creek, Nev

Dawes County, Neb........................ 536

Deer Creek, Mont............................. 564

Delaware basin, New Mexico ................ $\quad 529$

Desatoya Range, Nev ........................ 407

Dougherty, Okla.............................. 525

Duchesne County, Utah.................. . 539

Eagle's Nest, Wyo ........................... 443

East Red Canyon, S. Dak.................. 692

Edgemont, S. Dak................. 334, 340, 345-349

Edna, Calif ................................... 524

EI Paso County, Colo $\ldots \ldots . . . . . . . . . . . . . . . .564$

Tex..................................... 402, 536

Elk Ridge, Utah................... 198-199, 540, 685

Ellis, Mo_. . . . . . . .................... 524, 525

Emery County, Utah...... 9, 189, 285-296, 539, 540

Erickson, Utah.................................. 536

Esmeralda County, Nev ....................... 536

Esterbrook, Wyo
Fall Creek, Idaho................... 403-404, 407, 537

Fall River County, 8. Dak $\ldots . . . . . . . . . . .537$

Fallon County, Mont...................... 413-418

Farmington, N. Mex.

Fremont County, Colo

Wyo ..... 204, 362-366, 368-370, 383, 536, 537, 538 Gallinas Mountains, N. Mex.............. 563, 574 Gallup hogback, N. Mex ................. 315-316

Gallup-Laguna, N. Mex ................... 299-302

Garfield County, Utah ..................... 539,699

Garfield Hills, Nev............................ 358

Garnet Ridge, Ariz ..................... 167, 182, 539

Gas Hills, Wyo ............................... 8, $204,341,342,344,362,537,674,675,695$

Gay Eagle, N. Mex......................... 392

Gila County, Ariz ......................... 538

Gilpin County, Colo ..................... 7, 29, 102

Golden Gate Canyon, Colo................. 113-116

Golden Valley County, N. Dak........... 413-418

Goleta, Calif

Gonzales County, Tex....................... 536

Goose Creek basin, Idaho ................... 407, 536

Gould, S. Dak................................. 694-695

Grand County, Utah .................. 190,192, 685

County, Colo ............................... 29

Grant county, N. Mex................... 102, 536

Grants, N. Mex .............................. 10,

$190,200,204,250-254,391,634,685$ Great Divide Basin, Wyo .............. 10,

$332,333,338,361,433-438$
Green Mountains, Wyo

Gunnison County, Colo............ 562, 574, 587-592 Gypsum Valley, Colo...................157, 385, 401

Hacks Canyon, Ariz ........................ 538

Hailey, Idaho 565

Hanksville, Utah............................. 167

Harding County, S. Dak....................... 10,

$413-418,419-431,536,675$

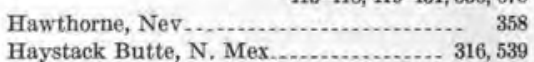

Henry Mountains, Utah.................... 447,539

Hettinger County N. Dak ............... 413-418

Hillsboro County, Fla......................... 496

Holiday Mesa, Utah.......................... 264-269

Hopi Buttes, Ariz ..................... 167,400-401

Hopi Indian Reservation, Ariz., N. Mex.,

Utah............................. 179-185

Hudspeth County, Tex.................. 402, 536

Hueco Mountains, Tex...................... 402

Huerfano County, Colo ...................... 324

Humboldt County, Nev................ 7, 80-81, 536

Hunterdon County, N. J.................. 325, 403

Idaho Springs, Colo ......................... 30, 105

Inyo County, Calif.......................... 536

Iron Hill, Colo ............................... 574

Iron River, Mich............................ 33

Jameson, Wyo ........ 524

Jamestown, Colo ............................ 31, 634

Jemez volcanic plateau, New Mexico...... 407

Jefferson County, Colo..... 7, 101, 113-116, 537, 538

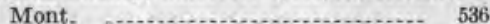

Okla.... .................................. 324

Jerome, Ariz ................................ 402

Johnson County, Wyo ..................... 402-537

Juab County Utah................. 7, 402-403, 538

Kane County, Utah......................... 537

Karnes County, Tex........................ 536

Kern County, Calif................. 32, 326, 536, 537

Kern River, Calif ........................ 30, 32

King Mountain, Tex....................... 402

Kings River, Nev ......................... $80-81$

La Ventana Mesa, N. Mex......... 36-312, 407, 685 Ladron Mountains, N, Mex................ $\quad 537$ Laguna, N. Mex............................. 399 Laguna-Gallup, N. Mex ................... 299-302 Lake Fork Canyon, Colo ...................... 590 Lake Fork-Dubois, Colo...................... 588 Lance Creek, Wyo........................ 334, 341, 342 Lander County, Nev...................... 88-89, 538 
Page

Mining distriets and areas-Continued Land-pebble district, Florida..37, 489-494, 495-504 Laramie Range, Wyo. Larimer County, Colo Lawrence County, S. Dek Lawson-Dumont-Fall River, Colorado..... 105 Lawton Township, Okla................... 52 Lees Ferry, Ariz Lemhi County, Idaho .......................... 565 Lemhi Pass, Idaho and Mont_............. 563 Lincoln County, Nev........................ 358

Wy 0 Lisbon Valley, Utah.................. 9, 192, 273-275 Long Park, Colo ............................. 223 Los Alamos, Calif .............................. 524 Los Pinos Canyon, N. Mex ................ 312 Lost Creek, Wyo.................... 341, 342, 344, 443

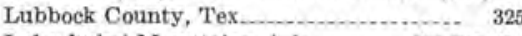
Lukschukal Mountains, Ariz _...... 198, 245-250 Lusk, Wyo Lysite, Wyo................................................. 341 Mabie Canyon, Idaho......................... 48 McKinley County, N. Mex__ 250-254. $312-317,383,391,539$

MeKittrick, Calif........................... 52 Marathon County, Wis............... 563-564 Marquette County, Mich............ 565, 593-594 Marysvale, Utah........................... 6,7 $30,31,32,80,102,123-129,201,636,670$

Maybell, Colo Mayoworth, Wyo ........................... 402 Mesa County, Colo ....................... 9, 539 Mesa Creek, Colo ............................ 221

Mesa Five, Ariz ......... 250 Mess 412, Ariz_................ 245, 250 Mesa One, Ariz ............................... 250 Miller Hill, Wyo......... 340, 342, 344, 382-383, 400 Mineral Hill, Idaho .......................... 565 Mineville, N. Y ........................... 564 Moab, Utah ................................... 151

Colo $\quad 370,445,539,546$ Mohave County, Ariz . . . . . 537,538 Mojave County, Calif................... 326 Montrose County, Colo.................... 191 , $192,221-226,257-261,539,540$ Monument Valley, Ariz. and Utah....... 9, 151 , $233-237,264,267,385,653,654,701,723$

Mora County, N. Mex

Mountain Pass, Calif _................... 563,574 Muddy Creek, Wyo._........ 524,525 Murray County, Okla........................ 525

Myton, Utah. 10

Nacimiento Mountains, N. Mex ......... 308-312 Natrona County, Wyo.................... 385, 537 Navajo County, Ariz _. 233-237, $245-250,399,400-401,539,540$ Navajo-Hopi Reservation, Ariz., N. Mex. Utsh ......................... 179-185, 447-448

New Haven, 8. Dak .......................... 340

Nigger Hill, Colo ............................. 109

Niobrara County, Wyo.......................... 536

North Cave Hills, 8. Dak .................... 428

Olanchs, Calif _... 355-35s

Oldham County, Tex....................... 537

Oljeto Trading Post, Utah................... 264

Owens Valley, Calif............................ $\quad 355$

Palmer, Mich ........................ 585, 598-594 Panaca, Nev . . ........................... 358 Panhandle gasfield, Texas .............. 383, 527, 529 Paradox basin, Utah, Colorado, Arizona, and New Mexico.............. 154,161

Park County, Colo........................... 324, 538 Perkins County, 8. Dak _.................. 413-418 Piedmont province.......................... 564 Pima County, Ariz ....................... 538 Plute County, Utah ................... 7, 123-129, 536 Placerville, Colo_................... 8, 102, 167, 188 Point Arens, Calif...................... 521 Poison Basin, Wyo..................... 341, 342, 370

Mining districts and areas-Contınued Poison Canyon, N. Mex.

Polk County, Fla

Powder River Basin, Wyo $340,341,342,362,366,371-374,674,675$ Powderhorn, Colo ................ 562, 574, 587-592 PR Springs, Utah.

Presidio County, Tex

Prince of Wales Island, Alaska............ 574

Pumpkin Buttes, Wyo ..................... 325, $338,340,341,342,367,368,371-374$

Quartz Hill, Colo 102 Quay County, N. Mex..................... 325, 537 Rattlesnake Hills, Wyo_....................... 338 Red Desert, Wyo_................. 340, 341, 439-444 Red Dome, Mont. 525

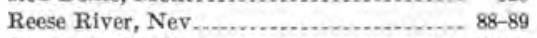
Rehoboth, N. Mex ................. 312-315

Rich County, Utah ........................ 484

Richardson Basin, Utah _..................... 152

Rifle, Colo ............................. 188

Rio Arriba County, N. Mex...............4 400, 538

Río Cebolla, N. Mex,

Rosamond, Callf ........................ 81-83,326 Saguache County, Colo................. 137-141, 538 Ste, Genevieve, Mo Salt Valley, Utah $\ldots . . . . . . . . . . . .158-159,165$ San Ardo, Calif ............................ 524 San Benardino County, Calif.......... 32, 563, 574 San Benardino Mountains, Callf....... 538 San Juan Basin, Colo, and N. Mex ......... 250, San Juan County N. Mex 303-319, 338, 447, 448-449 Vtah _ 189, 192, 254-257, 281-284, 539, 540 San Juan Mountalns, Colo ............._. 153 San Lorenzo Creek, Calif...................... 524 San Luis Obispo County, Calif._. 524

San Miguel County, Colo................... 101, $102,188,192,385,401,402,539$ N. Mex _. 538 San Rafael Swell, Utah ... 204, 264, 275-278, 285-296 San Saba County, Tex...................... 325 Sandoval County, N. Mex......... 10,308-312,407 Sanostee, Ariz. and N. Mex................. 399 Santa Barbara, Calif...................... 524 Santa Cruz, Calif _............................ 524 Santa Cruz County, Ariz .................. 325, 537 Santa Fe County, N. Mex............... 536, 537 Santa Rosa, N. Mex....................... 524,525 Saratoga, Wyo ........................ 342, 344, 400 Saucer Basin, Colo ......................... 223 Saucer Basin, Utah. $\quad 539$ Ship Rock, Ariz ............................. 182 N. Mex................. 192,449 Shoshone County, Idaho .................... 538 Sierra County, N. Mex__ 324, 538 Silver Peak Mountains, Nev ............ 81 Silver Reef, Utah............................ 144, 537 Skvll Creek, Colo Sliekrock, Colo ......................... 192 Slim Buttes, S. Dak _.......... 428-429, 674, 675 Slope County, N. Dak ................. 413-418 Socorro County, N. Mex 101, 401, 537, 538 South Cave Hills, 8. Dak .............. 429-430 Spantsh Valley, Utah......................... 159 Split Roek, Wyo _....................... 383 Spokane County, Wash $\ldots \ldots \ldots . . . . . . . . . .537$ Spokane Indian Reservation, Wash . ... 85-88, 538 Spors Mountain, Utah...................... 132 Spring Creek Mesa, Colo ...................... 223 Bpringdale, Wash.......................... 88 Stark County, N. Dak.................... 413-418 Stevens County, Wash.................. 85-88, 538 Sublette Ridge, Wyo _..................... 486 Sulphur, Okls _....... 524, 525 Sunnyside, Utah ........................ 524,525 Sussex County, N. J _...................... 29 Sweetwater County, Wyo .................. 10 $385,433-438,439-444,53$
Mining districts and areas-Continued

Page

Temple Mountain, Utah .................. 9, $161,167-168,204,205,285-297,539,540$

Thomas Range, Utah _.. 7, 31, 102, 131-136, 402-403 Thompson, Utah ............... 190 Tillman County, Okla........................ 324 Tonopah, Nev ............. $352-355$

Tooele County, Utah_...................... 536 Torrance County, N. Mex ................ 538 Toyabe Range, Nev ......................... 88 Uinta Basin, Utah _...................... 383,524

Uintah County, Utah _... 525,539 Upper Peninsula, Mich.................... 30, 565 Upton County, Tex.......................... 402 Uravan, Colo. and Utah _..... 151, 190, 221-226, 539 Uvalde County, Tex....................... 525 Valencia County, N. Mex ........ 391, 399, 401, 539 Valley County, Idaho..................... 565

Vernsl, Utah _ Virgin Valley, Nev ......................... 358 Washakie basin, Wyo _................ 338, 362, 370 Washington County, Utah .................. 537 Wausau, Wis . . Webb County, Tex............................ 536 Wellpinit, Wash.

Wet Mountains, Colo $562-563$

White Canyon, Utah $\ldots . . . . . . . . . . . . . . .9,9$ $264,269-272,281-284,634,651,653,654$

White Signal, N. Mex ....................... 30

Whiterocks Canyon, Utah _................. 524

Wibaux County, Mont _................. 413-418

Wichita County, Tex...................... 538

Wichita Mountains, Okla_............... 529

Wilbarger County, Tex..................... 538

Willaha, Ariz_............................. 401 Williston basin, Mont, and N. Dak _ 331, 332, 333 Wind River Basin, Wyo .................... 334 , $337,338,695-696,697$

Worcester County, Mass _.............. 564 Yale Point, Ariz_.............. 448

Yavapai County, Ariz ...................... 402 Yellow Cat, Utah........................... 685 Zuni Mountains, N. Mex......... 306, 312, 316, 391 Zuni Salt Lake, N. Mex...................... 180 Minnelusa sandstone............................ 476 Miocene lakebeds. .......................... 326 Missouri mining districts and areas, Ellis... 524, 525 Ste. Genevieve . Mosb Valley, Utah Mobility of elements ........................ 661 Modoc lava series, uranium content....69, 70 (table). Moenkopi formation ........................ 148, $264,267,281,287,653,699,722$

Molybdate, hydrous uranium.

Molybdenum, relation to uranium content of water.

soil and rock analyses.

Monazite, absolute age in Southeastern United States..................... 601 amount of thorium present in ....... 569 as a minor accessory with uranium....... 59,477 geochemistry and distribution _.... $375-380$ in Idaho placers ................. $597-601$
in Southeastern United States........... prospecting by heavy-mineral method .... $647-650$ uranium in accessory .................. 19 other mention................. 69,561 Monazite content, Goodrich quartzite ........ 503-598 Monazite deposits, system of geologic prospecting................ 622

Monchiquitic basalts............. 183, 184 Monitor Butte member. See Chinle formation. ,

Montana mines, prospects, and deposits, Alta . $\quad 119$ Comet_................... 119,120 Free Enterprise ............................. 120 Gray Eagle.................................... 120 Lone Eagle...................................... 121 Red Rock.................................... 120

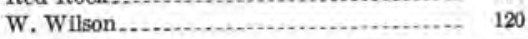




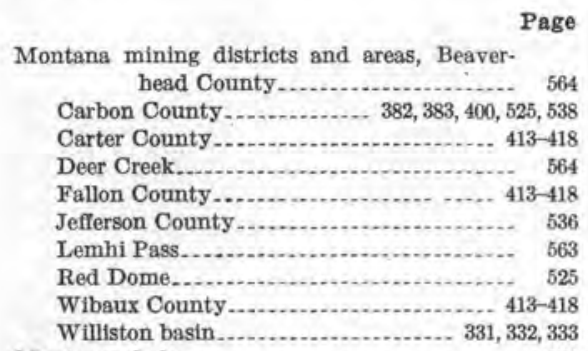

Monterey shale.................. 524

Montmorillonite, uranium in cation-exchange position......................... 59

$\begin{array}{rr}\text { Montroseite............ } & 188,268,273,274 \\ & 156,264,281\end{array}$

Morrison formation, age of uranium deposits. 164, 244 character................................... 213-219 examples of uranium deposits............. 243-262 ore-bearing strata........................... 214 origin of uranium .................................. 244, 261 percent of uranium deposits................. 164 permeability characteristics................ 214-217 position and shape of carnotite deposits..... 214

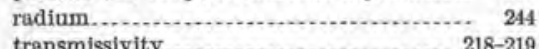
uranium and vanadium production......... 9 other mention............................ 35, 138, $140,146,209,230,233,324,325,641,722$ Brushy Basin member, direction of sediment transport.............................. 231 production............................... 222 other mention...... 9, 148, 204, 300, 301, 396, 722 Recapture shale member............... 148, 300, 396 Salt Wash member, alteration.............. 217 anclent channels......................... 223 character and extent........... 222-223, 257-258 direction of sediment transport.......... 231 ore-bearing strata........................... 214 origin of uranium....................... 226 roll ore deposits............ 214, 239-241, 260, 261 sedimentary features.................. 221-226 tabular deposits......................... 214, $239,240,241,245,247,260,261$ theory of deposition in Cottonwood

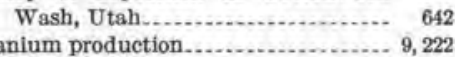
uranium production..................... 9, 222
other mention $192,245,250,254,257,260,396,685,722$

Westwater Canyon member, uranium in... 148 , $250,300,308,312$

Moss Back sandstone member. See Chinle formation.

Mount Belknap rhyolite..................... 80,81, 124 Mount Ellen, Utah ........................... 160

Mount Lassen, Calif., radium content_........... 159-160 Mountains, laccolithic gro
See also under names.

Mudstone, as host rock, Colorado Plateau..... 149, $189,214,323,325,362,369$

$\mathbf{N}$

Nacimiento fault, New Mexico..

Nashville Basin, Tennessee.................... 458

Nashville dome, Alabama, Tennessee, and Kentucky ...................... 457,458,459 Natural potential method of prospecting ...... $723-724$ Nature of the mineralizing fluid.............. 342-343 Navajo formation. See Glen Canyon group.

Navajo Mountain, Utah and Arizons............ 159 Navajoite_........................................... 190 Nebraska mining districts and areas, Chadron. 340, 384 Dawes County................. 536 Nemaha uplift, Kansas and Oklahoma ........ 530 Neosilicates of $\mathrm{Th}, \mathrm{U}, \mathrm{Ce}$, and $\mathrm{Zr} \ldots \ldots \ldots \ldots \ldots . . . . . .577$ Neutron logging. See Logs.

Nevada mine, Gamma property
Nevada mining districts and areas, Antelope

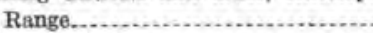

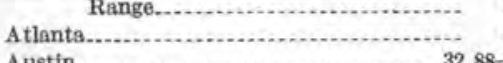
Austin......................... 32, 88-89 Churchill County ............................ 407 Coaldale............................................ 81 Dacie Creek.

Desatoya Range...

Esmeralda County

Garfield Hills.

Flawthorne.

Humboldt County.

Lander County..

Lincoln County

Panaca...

Reese River...

Silver Peak Mountains.................... 81

Tonopah ....................................... $352-355$

Toyabe Range.

88

Virgin Valley................................ 358

New Jersey mining district, Clinton........... 325,403 New Mexico mines, prospects, and deposits, Becent1.

315-316

Black Hawk..................................... 102

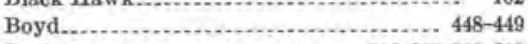
Butler................................ 308-312, 318, 319

Crackpot.

Davidson ...................................... 448, 449 Delter .......................................... 316, 319 Diamond No. 2 ...................... 306, 312-315, 319 Eastside Carrizo ............................... 192 Hogback No. 4 ................... 307-308, 312, 318, 319 Mesa Top................................... 204, 251

Poison Canyon.......................... 204, 250-254

Silver Spur..................................... 316

U.......................................... 316

New Mexico mining districts and areas, Arroyo de Dos Gordos..

Arroyo del Agua..

Bluewater...

Catron County.

Correro

Delaware basin

Farmington...

Gallinas Mountains

563, 574

Gallup-Laguna .............................. 299-302

Gay Eagle..................................... 392

Grant County .......................... 102, 536

Grants................................ 10, 190, 200, $204,250-254,312-317,391,634,685$

Haystack Butte .......................... 316, 539 Jemez volcanic platean ....................... 407

La Ventana .......................... 36, 312, 407,685 Laguna........................................ 399

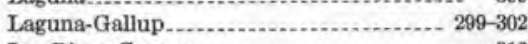
Los Pinos Canyon .......................... $\quad 312$ McKinley County ... 250-254, 312-317, 383, 391, 539 Mora County .............................. 324 Navajo-Hopi Reservation........ 179-185, 447-448 Poison Canyon ....................... 391-392 Quay County ............................. 325, 537 Rio Arriba County ........................ 400,538 San Juan Basin . ...... 250, 303-319, 388, 447, 448-449 San Juan County. ........................ 399, 539 San Miguel County .......................... 538 Sandoval County .................. 10, 308-312, 407 Sanostee ........................................ 399 Santa Fe County .......................... 536, 53i Santa Rosa .............................. 524, 525 Ship Rock................................ 192, 449 Sierra County ............................... 324, 538 Socorro County ..................... 101, 401, 537, 538 Thoreau homocline........................... 316 Torrance County ................................ 538 Valencia County ..................... 391, 399, 401, 539 Zuni Salt Lake_............................... 180 Zuni Mountains..................... 306, 312, 316, 391
New York mines, Old Bed...................... 564

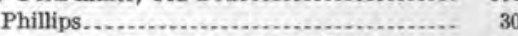

New York mining district, Mineville........... 564

Newark group.................................. 324

Nickel-cobalt-native-silver vein deposits........ 102

Niobium, analyses ............................. 665

Nitrogen, in natural gas........................ 531

Nodules, association with uranium........... 453,454

Nonvanadiferous ores 189

Normanskill formation ......................... 456

North Carolina, monazite belt.................. 598

North Dakota mining district. Williston basin . 331,

Billings County ......................... $413-418$

Bowman County .............................. 413-418

Golden Valley County ................... 413-418

Hettinger County .......................... 413-418

Slope County . . . . . . . . .

Stark County ............................ 413-418

North Park formation............... 325, 382-383, 676

Nuclear-emulsion photographic-plate analysis,

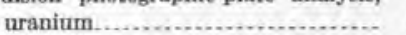

o

Occurrence, summary of uranium.

Ocean water. See under Waters.

Ogallala formation ............................. 676 Oil, uraniferous crude, tables of analyses..... $513-515$, 516-519

Oil and naturai gas, radioactive elements ..... $527-530$ Oil Creek formation............................. 525 Oil shales, relation of uranium content to ofl content

Oklahoma mining districts and areas, AmarilloWichita uplift.

Cameron Township.

Cotton County

Dougherty.

Jefferson County.

Lawton Township.

Murray County

Nemaha uplift.

Sulphur.

Tillman County.

Wiehita Mountains

Oligocene uranium-bearing rocks................. 362

Opal, uraniferous............................. 352, 355, 359

Orbiculoidea ...................................... 464

Ore bodies described, Colorado Platean........ 151

Ore controls, asphaltic residue................... 242

bedding planes............................. 295, 326 breccia zone............................ 113, 121, 563 earbon dioxide ................................ 507 carbonaceous material ....................... 214, $324,325,341,346,348,370,505-509$ cementing material ........................ 346,531 contact of metamorphic and intrusive rocks. $85-89$ continuity and thickness of lenses......... 346 facies changes.............. 214, 244, 254, 261, 455, 642 faults, relation to uranium on Colorado Plateau.................... 152, 164-166 other mention. $83,85,86,88,103,108,113,124,138,140$, $152,246-247,253,260,266-279,314,316$, $318,319,326,333,334,340,348,349,355$, $358,370,372,385,391,392396,401,402$, $403,404,407,415-416,420-423,436,443$, $444,563,565,590$

folds ..... $86,152,315,319,333,334,341$, $349,389,391,402,403,415-416,447$ geologic, effect on uranium content... $56-57,60-61$ glaciation, effect on placer minerals....... $377-378$ ground water...... $312,326,340,346,506-507,673-680$ in Shinarump-filled channels.............. 653-654 increase in energy levels ................... 334 intersection of major tectonic elements...... 334 interseetion of large-scale structures.......... 333 
Ore controis-Continued

Iron-beating minerals.

$269,281,288,296,308,315,326,396,402$, $430-423,436$.

Lisbon Valiv anticline _............. 275 Jasperization. . ........................... 592 lithologic, Black Hills ................... 346-348 margins of major tectonic units.............. 334 mechanisms of concentration _............ 507-509 mudstone, altered......................... 226 facies.

seims

nodules, iron

orogeny, stages and Influence on uranium concentration petroleum 341, 344, 507, 524, 531 $\mathrm{pH}$ changes. . . . . . . . . . preference for alkalic igneous rocks........ 591-592 pressure changes............... 261 puncture points.............................. 214 pitchblende deposits, Central City district.108-109 recrystallization............................... 531 regional structures..................... 332,341 regional unconformities................... $\quad 332$ roof pendants........................... $\quad 88$ sandstone, thick, coarse-grained ........ 253

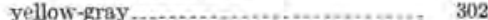
sedimentary structures.................... 221-226, $244,253,326,346,645$

shale caprock _....... 315,316 sills . . 160

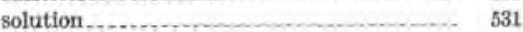
stocks ............................... 160 structural terraces ............. 324,348-349 tectonic elements in Precambrim rocks... 329-335 tectonism, relation to uranium deposits, Colorado Plateau _.................. 175

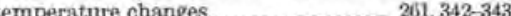
thickness of strata....._. 214, 348,455, 460-461 transmissivity and permesbility, Big Indian Wash-Lisbon Valley............... 275 carnotite of Morrison formation ....... 213-219 exposed rocks of Colorado Plateau .... 207-211 sandstone ...............................207-2II other mention......................... 226, $260,261,297,341,346,366,408,427,438$ trough cross-stratification.................... 214 uranium-vanadium-copper, Colorado Platean

Also see Alteration and Channels, ancient.

Ore dispersion, modes and patterns. 661

Organ Rock anticline, Utah

Organ Rock member. See Cutler formation.

Organic geochemistry of uranium ............. 505-510

Organic material, assoclation with uranium $453,454,455,456$

Origin of deposits, summary ….......... 12 penesyngenetic., .................. 153 overlying disseminated source ........... 344

Oxldation, alteration by ................ 592 earnotite................................... 190 Colorado Plateau uranitum ores ........... 187-193 corvusite-2- 190 effects.............................................. 103 relation to water table ................. 191-192 sequence of in vanadiferous uranium ores... 189 zones. 102, 109 other mention....................... 127, 190-101, 497 Oxidized deposits ........ $86,239,250,306,325,326,346,349$ Oxygen, isotope ratios of . _.................. 543-547

$$
\mathrm{P}
$$

Paleochannels, See under Channels, ancient. Paleostreams. See under Streams, ancient, Paletopography, techniques for mapping....... Panaea formation 654
358 Paradox anticline.
Paradox Valley, Colo_................. 221, 222, 223, 226 Paragenesis of uranium deposits _. 115, 141, 195-201, 205 Paramontroseite.n..... 188 Pascoite.

Patterson's loco

684

Peat, as host roek _. 306, 310,312, 318

Pediment gravel, us host rock................... $\quad 342$

Pegmatite, thorium-bearing ............... 564,574-575 uranium in .................... 19, 29-30,57,61 variations of trace-element content _..... 58 Pegmatite and migmatite, origin of uranium... 42-43 Pennsylvania, Bucks County, uranium in ...... 325 Permian red beds ............................ 324 Permian rocks, phosphatic .................... 483-487 Perovskite ....................................... 574

Petroleum, as source of uranium _._._._... $515,517,519$ reiation to uranium content _. $460,461,511-519$ summary of uranium it $60,461,511-519$ urantum-bearing

$\mathrm{pH}$, relation to leaching of uranium sensitivity of vanadium minerals to ...... 189, 190

Phosphate, aluminum, uranium in Bone Valley formation, Florida

caicium, uranium in land-pebble district, Florida............. 489-494 relation to uranlum content . . ...... $455,460,461$ urananiferous in sedimentary rocks... $383,483-487$ uranyl _. 128

Phosphate deposits, summary of uranium ..... 11

Phosphate roeks, origin of turanium in marine .. 49-51

Phosphatic material, association with uranium. 453

Phosphatíc nodules............ 454,464

Phosphatic rocks, age, character, and distribution of uranium in .................. $37-38$ uranium content. 477-481

Phosphoria formation, character and extent_... 455 general description of uranium. .......... 483-487 origin of uranium ............................ 455 other mention ‥ $34,37,50,383-384,455,479$

Phosphorites, marine, uranium content _.. $478-479,480$ residual, uranium content ................... 479-481 relation to uranium content of water ....... 680

Phosphuranylite

Physical-chemlcal factors, effect on uranium in igneous rocks.

Piceunce basin, Colorudo . . ................. 156, 157

Pietured Cliffs sandstone.......................... 446

Piercements. See Balt structures.

Pierre shale............................. 415, 455,476

Pilbarite .

Pismo formation ……...................... 524

Pitehblende, age at Marysvale, 0 tah ........... 636 sooty, Marysvale area, Utah . ............ 12k-127

Calyx mine, Utah relation of color to ........................ 634 relation to bostonite....................... $\quad 29$ relation to uraniferous intrusive rocks....... 71,72 veins, Placerville, Colo _.................. 167 structural control.

other mention......................... $306,334,342$

Placers, general character and distribution of uranium in........................ Idaho batholith area described _......... $375-380$ monazite source in Boutheastern United

States other mention ............................ 564-565, 591 Plants, Indicator ................................ 683-684 metals accumulated in tissues............... 661 Sulfur- and caleium-absorbing _. 684

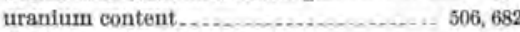
Plant ash, fluorimetric analysis............... 683

Plant analysis, uranium prospecting by ...... $682-083$

Plant cells, mineral filling .................. 634

Pleasanton group, uranium content.......... 454

Pneumatolytic action .......................... 403

Polarographio analysis, thorium _................ 614 uranium. ................................. 609-610

Polymerization, Calyx mines, Utah.

Porphyry lines, described.

Potach minergls, uranium content of - 172
Potassio magma series, uranium content........ $72-73$

Potassium, radioactive isotope................... 453

Potassium content, relation to uranium content. $\quad 57$

Potosi voleanic series, table showing uranium content. . ......... $60-70$

Pottsville formstion. 323

Precambrian Belt series, monazito-bearing calcareous metamorphic rocks in ....

Precambrian rocks, relation of tectonic elements to uranium deposits................ 329-335

Precambrian time, vein deposits formed during .............................. 102-103

Precious metal ores, with uranium deposits.. 30,32-35 Precipitation of uranium, bioehemlcal.......... 48 in precipitates and evaporites ............ 381-386 in sandstones of Colorado Platean......... 46 in veins . . other mention................ 109, 114, 201, 297, 366 Pre-Potosi rocks, table showing uranium content _....................................

Prickly Pear Oreek water, Montans, uranium content ........................... 671

Primary uranium minerals, origin in igneous rocks..................................

Primary and secondary uranlum minerals, significance $\ldots . . . .342-343$

Primary deposits.

Propylitization, first process in ore development. 114 Prospecting, application of ides of uranium

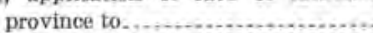

botanical, summarized ........................ 023 methods. 681-680 combined geophysical and geochemical methods................................ $687-703$

drilling techniques, for Shinarump-filled chsmmels.............................. 655-657

geochemieal, analysis of solls ............... 661 colorimetric analysis ...................... $662-664$ flve preliminary considerations ......... 662 fluorimetric analysis of plant ash _...... 683 spectrographic analysis _... . . . . . . $662-664$ summarized............................. $623-624$ techniques and methods ........ 659-662 verification of radioactivity surveys, Colorado Front Range .......... $689-690$

geologic, general discussion................ 627-631 guides to ore-bearing Shinarump channel-filling ............................. 653-654 method of relating monazite to detrital heavy minerals .................. 647-650 summarized . $621-625$ geophysical, air scattering of gamma rays from uranium sources .............. 715-710 airborne techniques.................. 710-712 electrical resistivity methods............. 625 instruments and techniques for measuring radiosetivity ................... 705-713

Interpretation of airborne radioactivity measurements..................... 717-718 low-level radiaactivity reconnaissance,

Black Hills, S. Dak ................ 690-692 Colorado Front Range .............. 688-690 subsurface techniques................... 709 summary of atrborne ..................... 624 summary of drilling techniques.......... 625 summary of refraction methods _........ 625 summary of resistivity methods_........ 625 summary of subsurface methods........ $62 \mathrm{~A}$ summary of surface methods ............ 625 surface techniques...................... 708-709 surface radiation methods .............. 624-625 (excluding radionetric) uranium on

Colorado Plateau............ 721-726 widely spaced core drilling .............. $641-645$ hydrogeochernical . ........................ $667-671$ water sampling as guide in uranium ...... $673-680$ Protosalrinia .................................... 464 Protolades ..................................... 460 Prototaxites:................................... 464

Province concept, application to prospecting... $\quad 23$ 
Provinces, definition and location of uranium $\begin{array}{r}\text { Page } \\ 17-18\end{array}$

Provinces, magmatic .................... 57-77 mineral, in Wyoming .......................... 362 monazite-bearing placer ........................ 564 processes that concentrate uranium ......... 18, 22 radioactivity of metallogenetic ............... 660

Pumice, as a host rock........................... 358

Puncture points, defined ......................... 240

Pyrite, association with uranium .... 81, 83, 86, 453, 465 relation to uranium content ............. 461

Pyrite-type vein deposit.....................106, 120, 125, 292

Pyrochlore ......................................... 569

Q

Quartz bostonite magma, relation to uranium in Central City district, Colorado..... 110 Quartz monzonite, as host rock......... 88, 124, 593-596 in Southeastern United States............ 599-601 vein deposits.

Quartzite, as host rock.............................. 99

Rabbittite 191

Radiation, finite source ............................ 717 intensity distribution. See under Radioactivity.

Radioactivation analysis, uranium $\quad 610$

Radioactive elements, oil and natural gas..... 527-530

Radioactivity, abnormal .......................... 284 as guide to ore deposits . calfbration of measuring instruments ....... 707 detailed surveys _.................. 708-709, 711 instruments and techniques for measuring. 705-713 intensity from kinds of sources _ 716-717 interpretation of airborne measure rents.. 717-718 local surveys _............................. 708,711 progressive decrease from point source ..... 710 regional surveys ...................... 709, 711-712 relation to acoustic velocity of rocks........ 699

Radium................................. $56,57,346$ in brines ............ 530

in oil-well precipitates and brines........... 528

in sandstone.........................................

in natural gas................................ 527,530

Radon concentration, as guide to radioactive

Rauvite...................................... 190, 346, 348

Recapture member. See Morrison formation.

Recrystallization, effect on uranium content of igneous rocks.

Red Desert syncline, control of deposition by...

Reduction of uranium ore, present costs.........

Redwall limestone

Refinery residues, uranium content.................

Replacement, carbonaceous matter by uranium minerals.

extent of, by uranium minerals.............. gneiss by metatorbernite. pyrite by uranium

418,444

Resistivity, limitations of surveys of surface ... 691 relation of uranium to core-rock ............... surface, East Red Canyon, S. Dak reasons for variations relation to acoustic velocity of rocks.... relation to uranium..................... 69

Resistivity profle, methods of making surface electrical.

Rhadanichthys antiquus..

Rhadanichthys devonicus

Rhyolite, as host rock. chemical composition, Thon Mount Belknap...

Tertiary gold deposits in, Bonlder batholith Montana ............... vein deposits.

Richardson Amphitheater, Utah

Rico Mountains, Colo

Rio Grande graben.
Ripple marks.

Page

River-pebble phosphate, deposits, uranium content

Roc Creek, Colo..

Roc Creek salt plug.

Rock fabric, igneous rocks, uranium $58-60$

Rolls, ore.................................... 192, 296

Roll ore bodies, alteration.

description...

mineral zoning

origin.

signifleance in genesis of uranium-vanadium deposits.

Rosamond formation (local usage) _............. 326

Rosamond series of Hershey.

Roscoelite.

Rubidoux Mountain, Calif, leschable-uranium content of rocks............... 67, 68 (table)

Rutherfordine. s

St. Peters dore, Colo., thorium.

Salinity, relation of uranium to ground-water

Salt anticlines. See under Salt structures.

Salt Lake formation........................... 407

Salt structures, as structural features.......... $158-159$

deseribed..

relation to uranium deposits.

158,175

uranium-bearing copper deposits.............. 166

Salt Wash member. See Morrison formation.

San Andres formation.

San Juan Basin, N. Mex., uranium deposits in

paludal black shale
San Juan Mountains, Colo....

69, 70 (table)

San Mateo fault, New Mexico...................... 392

San Miguel syncline, Colorado ................... 222

San Rafael group, Bluff sandstone

Curtis formation, correlation of with Totilto limestone.

other mention.

Entruda sandstone.-2...- 9.144, 148, 140, 188, 233

Summerville formation San Rafael Swell, Utah............. 161, 163, 204, 285-296 Santa Rosa sandstone.......................... 525 Sand, as host rock................................. 326 Sand (phosphatic), uranium covtent ........... 480 Sandstone, age, character, and distribution of uranium in.............................. 33-35

as host rock. 149 , $213-219,239-241,243-262,304,306,308,312-$ $318,321,323,324,325,326,332,340,341,344$, $345-349,358,362,372,524,525$.

marginal marine

im deposits in ............... 44-47

thick, coarse-grained, as an ore control.

Sandstone-mudstone, as host rock, Colorado Plateau.

Sandy elay, as host rock.

Sangre de Cristo formation

Schist, host rock

Scintillation counter, described

Scour-and-fill bedding.

Secondary uranium minerals, igneous rocks, origin. Sediment transport, direction on Colorido Plateau................... 228 (chart), 231

Sedimentary features, relation to uranium-vanadium deposits . 221-226

Sedimentary rocks (marine), age, character, and distribution of uranium in .......... 36-38

(terrestrial), distribution of uranium exclusive of Colorado Plateau. ........... 321-327

(terrestrial), general distribution and character of uranium ..........................

Tertiary, uranium deposits in Wyoming and Colorado...
Sedimentary structures, in stratigraphic correla-

tion ............................. 231 primary ................................ 221-226, 227-231 relation to ore deposits ..................... 46, 270 types ........................................... 227-230, 231 Sediments, phosphatic . _... 383 Seismic reflection surveys ........................ 725

Seismic refraction surveys....................... $724-725$

Selenium, at Yellow Cat area, Utah 685 minor element in carnotite of Colorado Plateau.............................. 681 soil, roek, and plant analyses............ $664-665$ other mention . 296, 366 Sequatchie fault, Tennessee......................... 459 Seth-la-Kai vent, Arizona .......................... 401 Sevier River, Utah, uranium content........... $\quad 670$ Shafer Dome, Utah $\ldots 157$ Shale, black paludal, as host rock ............. 303-319

black marine, distribution of uranium.... $451-456$ distribution of uranium ....... $451-456,457,462$ origin of uranium ................ $48,453,461-462$ uranium content............... 451-456, 457-462

black carbonaceous, origin of uranium ..... $47-48$ uranium deposits........................ 307-312

uraniferous................................... $469-476$

Swedish slum

Sheep canyon monocline, South Dakota Shinarump conglomerate, 1 ancient channels and related swales.................... 233-237 as ore-bearing channel fill on Colorado Plateau 651-657 character and extent .................... 233-237 direction of sediment transport .............. 231 drilling technique for channels filled with. $655-657$ geology of ore deposits _ 263-280 major ore-producing areas in ................. 264 ore deposits at Happy Jack mine_......... 269, 270 percent of uranium deposits................. 164 techniques for mapping base............. 654-655 uranium production............................ 9 other mention................................. 35 , $147-148,188,189,209,230,282,385,699,721$ Siderite, in proxinity to uranium ores......... 634 Siebert tuff of Spurr............................ 352 Sierra Nevada batholith, California, uranium. bearing vein deposits in.

table showing uranimen content

Silica content, relation to uraniu:n content, ig. neous rocks.

Bilica veinlets, association with uranium minerals.

Siliceous pyrite-galena vein deposits, Marys vale district, $\mathrm{Utah}$.................

Siltstone, as host rock........ 149, 184, 323, 324, 325, 430 Silver, association with uranium ............... 88 Silver-lead deposits, uranium-bearing ......... 119, 121 Sinbad Valley, Colorado Sisquoe formation.

Slab source radiation.

Sligo adit, Tennessee, uraniferous pool.

Skull Creek anticline, Colorado.

Soll samples, analyses of water leaches for bicar bonate..

analysis for uranium

uranium in

Solubility of uranium, in solution briefly in sea water.

South Carolins, monszite belt....................... South Dakota, mines, prospects, and deposits, Billy Dale group................... 428

Hilltop mine $\ldots . . . . .428-429$

Lonesome Pete claim...................... 429-430

Virginia $\mathrm{C}$ mine.............................. 537

1 Since this volume was edited, the Geologic Names Committee of the U. S. Geological Survey has classiffed the Shinarump conglomerate as a member of the Chinle formation. 
South Dakota mining districts and areas, Black Hills................. 8, 321, 324, 326, 337, $338,343,344,345-349,690-692,708$

Butte County. $\quad 413-418$ Cave Hills _................................... 337, 340, 416, 536 Edgemont .......................... 334, 340, 345-349 Fall River County ........... 537 Harding County ............ 10,413-419, 431, 536, 675 Lawrence County, Bald Mountain. ......... 538 New Haven................................ 340 North Cave Hills....................... 428 Perkins County................................. 413-418 Slim Buttes ................................. $428-429$ South Cave Hills ........................... 429-430

Southern California batholith, uranium content of rocks ............. 56, 62,66 (table), 68 Spatial relations, vein deposits................. 98 Spectrophotometric analysis, thorium .......... 614 Spergen limestone ............................. 403 Statistical relations among elements............. $76-77$ Steigerite, 190

Stratigraphic chart, strata of the Colorado

Streams, uranium in. See Waters, sulace.

Structural features. See name of feature.

Structure, Colorado Plate:

relation to uranium deposits on Colorado Platean . . .........................

relation to uranium deposits in Cordilleran foreland...............................

lsceolithic .................................. 175

Stud Horse (ancient) channel, Utah........ 690,700

Substitution, isomorphous, of uranium for

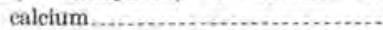

Sulfides, associsted with uraninite in vein deposits.

Summerville formation. See Ban Rafael group.

Sundance formation.

Supergene uranium

Surface water. See under Waters.

Surficial ore deposits..............

Swales. See Channels, ancient.

Sweetwater arch, Wyoming ..

Swope limestone, Hushpuckney shale member, character and extent

Syngenetic deposits...............................

Tabular deposits. $15,325,446$ $489-494$

Tampa limestone

Tasmaniles

Tectonic history, Colorado Platean _... 161-164

Telethermal deposits............................ ... 343

Temperature, of Colorado Plateau sandstones at

time of uranium deposition

of formation, vein deposits......................

Terrane, types favorable for uranium and thorium.

terreli, Dinichlhys

Terrestrial sedimentary rocks, exclusive of Colorado Plateau, origin of deposits_.. 325-326

Tertiary uplifts, Montana..................... 331

Texas mining districts and areas, AmarilloWichita uplift.-

Bend Arch uplift.

Burnet.

Gonzales County, Jacobs ranch.

Hueco Mountains area, El Paso and Hudspeth Counties.

Karnes County, Lyssy-Korzekwa property

King Mountain ares Upton County ........

Lubbock County.

Oldham County .......... 325

Panhandle gasfield dolomites.......... 383, 527, 529

San Sabs County ........................ $\quad 325$

Upton County, King Mountain area_...... 402

Uvalde County ........................... 525

Webb County ............................. 536

Wichita, Wilbarger, and Clay Counties.... 538

Thoreau homocline, New Mexico............ 316, 391
Page

Thorianite, descriptive mineralogy other mention.

569

Thorite, descriptive mineralogy _. 568-569

in Idaho placers ......................... $375-380$

other mention................ $58,69,72,529,561,590$

Thorite group............................ 572,577

Thorium, analysis, colorimetrie method ....... 613 analysis, mass spectrometrie methods....... 614 polarographic methods.................. 614 selected procedures...................... 614

separation methods............ 611-612 titrimetric "versene" methods........... 613 X-ray spectrographie method........... 614 explanation of absence in pitchblende veins. $\quad 42$ geochemistry and occurrence . ............. $573-575$ in oil and natural gas..................... 527 other mention............................... 56, 59, 564 Thotium-bearing veins, Wet Mountains, Colo.

Thorium deposits, Powderhorn district, Colorado $587-596$

Wet Mountains, Colo $581-585$ minerslogy. See under Mineralogy.

minerals, table of names and formulas ..... $\quad 577$

Thorogummite, deseriptive mineralogy ....... 568-569

other mention.

Thorogummite group ........................ 572,577

Threshoki of signifieance, geochemical ........... $\quad 660$ uranium in ground and surface waters..... $\quad 670$

Thucholite........................... 273, 506, 508, 529 Titrimetric "versene" analysis, thorium _...... 613 Todilto limestone character and extent ...... 388-400 correlation of with Ourtis formation, Utah... 389 correlation of with Pony Express member, Colorado..

uranium production -

other mention $\quad 34,35,148,200,250,383,722$

Torbernite............................ 80, 81, 825,477

Trace analysis. See under Prospecting, geochemieal.

Trace elements, Red Desert, Sweetwater County, Wyo ......................... 439-44

table of those in uranlferous water. 676

Train, dispersion . 661,662

Travertinelike coatings, uraniferous........... 342

Trees, species used in uraninm sampling ......... 683

Tuffs, volcanic, relation to lignite in Montana and North and South Dakota.... 413-418

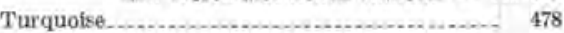

Tusas granite $\ldots$

Tyuyamunite................................ 165 $190,217,260,306,316,323,324,325,346,349$, $359,448,480,484$.

\section{U}

Uinta Busin, Utah and Colorado Uints formation, sge of uraninm deposits 164,524 Uinta Mountains, Utah and Colorado 169 Umohoite_................................. 127,636 Uncompahgre uplift, Colorado _......... 161-168 Upheaval dome, Utah, origin and description - 159, 161 Ute Mountains, Colo. Uplifts, formation on Colorado Plateau. ......... 175 Uplifts and basins, as structural features....... 156 Uraninite _......................................... 58 $80,81,86,189,239,253,254,268,270,273$. $274,278,306,324,342,345,346,529,570$, 572,675 .

Uranium, high-val

soil and sedimentary rocks analyses.......... 664

Uranium-bearing formations, original environment at 120 mines and prospects.. 536-540

Uranium-bearing formations and ore production category, Colorado Plateau...... 539-540

excluding Colorado Platesu $526-538$ Uranium-bearing formations (major) and percent of national production........

Uranium compounds, unidentifled.
Uranium content, of accessory minerals

Uranium deposits, age on Colorado Platesu..... 164 general discussion and summary of genesis.. 41-53 mode of occurrence at 120 mines and pros-

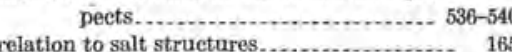
system of geologic prospecting

types 20

Uranium deposits and occurrences, map of principal.

Uranium isotopes, loss of

Uranium mineralogy. See under Mineralogy.

Uranium minerals, abundance of principal _. 28-29 at 120 deposits in Western United States.. 536-540 in igneous rocks ............................... 58,60 in uranium distriets in the Tertiary basins of Wyoning and northern Great Plains................... 338 (table) principal in large deposits.................... 18 table of names and formulas................ 578 types........................................ 18

Uranium ores, black, comparison of ......... 203-205 metals associated with, Colorado Plateau... 264 ore, milling cost.......... 15 Uranium phosphates......................... 323, 325, 326 Uranium-porphyrin complexes.............. 518-519 Uranium resources, summary of Western Nations.................................. 13-1 other mention............................. 324, 325, $326,337,348,446,449,452,524,525,595-596$

Uranium sllicates........................ $323,325,326$ Uranium-vanadium-copper deposits, Colorado Plateau 143-154 exclusive of Colorado Plateau.............. 323-324 Uranium-vansdium minerals................... 292 Uranium-vanadium ore...................... 195

Uranium: vanadium ratios ....................... 306, $308,310,315,316,319,346$ See also Vanadium: uranimm ratios.

Uranophane .n........ 80 $81,86,126,323,324,325,326,340,342,675$

Uranopilite . ............................... 126-127

Uranyl ion, change to uranous .............. 634

described ....................................... 570

mobility ...................................... 623

Utah mines, prospects, and deposits, Basin no. 1................................... 254-257

Calys no. 3 _.t.... 290

Corvusite........................................... 192

Dell ore body ..................................

Delta..................... 189

Eagle Rock flnorspar vein.................... 133

Fumarole................................. 295 Happy Jack ............ 189, 191, 269-272, 540, 653

Harrisite .................................... 133

Lopez . . _. . . . . 296

Lucky Louie pipe ......................... 132

Noteh. . . . . 198-199

Rattlesnake.............................. 192

Shinsrump no. 1 ........................... 191

Vanadium King ........................... 297

Utah mining districts and areas, Abajo Mountains.

Beaver Mesa.

Bell Hill ore body, Thomas Range......... 132

Bonanza

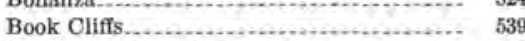

Calyx area, Temple Mountain _............ 292

Cedar Mountain . . 539

Círcle Cliffs............................. 653, 654, 699

Crawford Mountains, Rich County ...... 484

Duchesne and Uintah Countles............. 539

Elk Ridge, Notch . . _ 198-199, 540, 685 Emery County, Delts ....... 9, 189, 285-296, 539, 540 Emery County, Temple Mountain collapse,

San Rafael Swell _.. 9, 189, 285-296, 539, 540 Garfield County, Henry Mountains....... 539,699 Grand County, Thompson district... 190, 192, 685 Henry Mountains ares.................... 447, 539 


\begin{abstract}
Utah mining districts and areas-Continued
Page

Jusb County, Thomas Range...... 7, 402-403, 538

Kane County.

Lisbon Valley, Rattlesnake mine, San Juan County 0, 192, 273-275 Marysvale mining district............... 6, 7,30 , $31,32,80,102,123-129,201,636,670$

Moab mineral belt

Monument Valley district, uraniferous siliceous precipitates................... 9, 151, $233-237,267,385,653,654,701,723$

Navajo-Hopi Reservation diatremes ..... 179-185,

$447-448$

Oljeto Trading Post.

264

Plute County, Bullion Monarch mine...... 7

PR Springs area............................ 524

Rich County, Orawford Mountains........ 484

Richardson Basin......................... 152

San Juan County, Lisbon Valley, Rattlesnake mine... 192, 254-257, 281-284, 539, 540

San Rafael Swell........... 204, 264, 275-278, 285-296

Saucer Basin _... 539

Silver Reef ares . ............................ 144, 537

Sunnyside area. 524,525

Temple Mountain ares............ 9, 161, 167-168, $204,205,285-297,539,540$ Thomas Range, uraniferous fluorite deposits $7,31,102,131-136,402-403$

Thompson district, Grand County......... 190 Thursday fluorspar vein, Thomas Range ... 133

Tooele County, Erickson district............ 536

Uinta Basin ..................................... 383,524

Uintsh County _. 525,539

Uravan mineral belt........... 151, 190, 221-226, 539

Vernal area_................................ 524,525

Washington County.

537

White Canyon mining distriet, Happy Jack mine.................... 9, 264, 269-272 $281-284,634,651,653,654$

Whiterocks Canyon area ................ 52
\end{abstract} $\mathrm{V}$

Vadose ore deposits

Vansdium, relation to uranium content of water. 680 Vanadium-uranium deposits...... 149, 188-189, 324, 326

Vanadium: uranium ratios................ 250, 253, 257 Sec also Uranium: vanadium ratios.

Vein (and related) deposits, general distribution and character........................ 30-33

Veln deposits, age of ....................... 101, 102-103 Bullion Canyon volcanic series.............. 81 classification........................................ 106 Colorsdo Front Range ....................... $\quad 334$

distribution ................................... 97-98 distribution of pitehblende in............... 108 galens-sphalerite........................ 106, 109 gold-bearing pyrite type...................... 102

Hartville uplift..............................

importance of.

In quartz monzonite........................ 80

Marysvale mining district, Utah, summary.. 7

mineralogic types .............................. 101-102

Mount Belknap voleanic series.............. 81

nickel-cobalt-native silver type.............. 102

origin of uranium .................. 43-44

oxidized zones................................... 102

pitchblende, Central City district........ 105-111

preeipitation of uranium minerals .......... 43-44

Powderhorn district, Colorado ............... 590

pyrite-type ........................................ 106

siliceous pyrite-galena type ................... 102

spatial relations ............................. 98

summary of uranium. ............

table showing age, character, and host rocks............................. 99-101

thucholite-type.............................. 102

types ................................... $98-101$

uranium-bearing, United States........... 98-103

voleanie rocks................................ 80

Velocity logs. See Logs.
Page

Voleanle ash, as host rock ...................... 325,343

Volcanic rocks, composition of in diatremes.... 183 distribution of uranium in 112 felsic rocks 77 (table)

uranium and other trace-elements content.. 75-78 host rock................................... 101, 124 in California, uranium content .......... 70 (table) in western Colorado, uranium content 69-70 (table)

uranium deposits in Basin and Range province . 79-83

variations in uranium content.......... 57, 77-78

Volcanic sediments, uranium...................... 680

Volcanic structures, relation to uranium de. posits, Colorado Plateau........... 167-168

Volumetrie anslysis, uranium ................. $608-609$

Walden Ridge, Tenn...................... 457,458, 459 Wasatch formation, age of uranium deposits.... 164 Wasatch Platean, Utah

origin of deposits

uranium-bearing cosl in.

other mention. $36,325,340,362,367,372,440,486,675$

Washington mining distriets and areas, Spokane County ........................... 85-88, 537

Waters, age, character, and distribution of uranium in

associated trace elements in uraniferous (table) ...................................

ground water, as originator of uranium minerals......................... 127

deposition of uranium by - $153,201,344,443,444$ effect of rising water table on schroeckingerite...

effect on uranium content of Igneous rocks ............ 61-62

flow, Abajo Mountains................... 177 La Plata Mountains................. 177

La Sal Mountains..................... 177

Ute Mountains........................ 177

leaching of uranium by .................. 383,385 method of sampling for uranium content

$673-674$

relation of salinity to uranium ........... 725 relation of water table to oxidation .... 191-192 relation to uraniferous lignite deposits.. 427 relation to uranium deposits ........ 175-178, 409,437

uranium in ............................ 60,343

surface, as guide to schroeckingerite..... 630 method of sampling for uranium............ 674 paleohydrology of Colorado Platead..... 175-178 relation of alkalinity to uranium content... 680 river water, uranium content .............. 49 sampling as guide to uranium deposits... 673-680 ses water, uranium content................... 48, 49 solubllity of uranium in acid.

surface water, background concentration of uranium............................ 669-670

downvalley changes of heavy-mineral suites in placers. 378

effect on tenor of placer deposits ......... 378

leaching of uranium by ................. 385

method of sampling for uranium content $\ldots . . . . . . . . . . . . . . . . . . . .673-674$

relstion of distance from source to uranium content..................... 669 sampling pattern for uranium analysis.. 668 uranium content, Colorado Front Range $\quad 689$ other streams................ 49, 60,667-671

277 samples..

uranium distribution, Crooks Gap area, Wyoming . 674-675 Gas Hills area, Wyo.............. 674-675 Powder River Basin, Wyo........ 674-675 Slim Buttes area, South Dakota.. 674, 675 See also Leaching. luffe, as host rocks .

Waterpocket fold, Utah ........................... 156

Wavellite....................................... 478, 479

Weathering, concentration of uranium through .. 20-21

effect on isotope ratios...... 545

effect on uranium content of igneous rocks. 61-62 Westwater Canyon member. See Morrison formation.

Wet-hole electric logging. See Logs,

Wet Mountains, Colo., thorium deposits.... 581-585 White Mountain plutonic-volcanie serles, uranium content of rocks ....... 57,72 (table)

White River formation .... 47, 325, 340, 367, 372, 420, 676 Wichita uplift, Oklahoma..................... 324 Wilden pipe, Utah ............................... 403 Wind River formation.... 204, 205, 325, 341, 362, 366, 675 Wingate formation. See Glen Canyon group.

Wisconsin, Marathon County, Wausau mining area..................... 563-564

Woodford chert, uranium content............... 453 World distribution, uranium deposits............. 17-18 Wyoming, mines, prospects, and deposits, Anomaly No. 119 .

Browns Ranch............................... 368

Bullrush....................................... 366

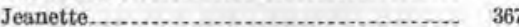

Lost Creek

Lueky Me........................................... 362-366

Lucky Mac 20................................. 204

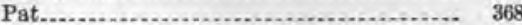

Poison Basin ................................. $\quad 370$

Sno-Ball ......................................... $368-370$

Wyoming mining districts and areas, Baggs area - $\quad 370$

Bear Lodge Mountains....................... 563 Big Horn Mountains........................ 565 Black Hills....... 8, 321, 324, 326, 334, 337, 338, 343, $344,345-349-690-692,708$

Carbon County ....................... 382-383, 400 Coal Canyon................................. 487 Converse County .................................. 368,538 Crook County.......... 537,563 Crooks Gap............ 337, 338, 341, 342, 538, 674, 675 Eagle's Nest_................................ 443 Fremont County ............................... 204, $362-366,368-370,383,536,537,538$ Gas Hill5.. 8, 204, 341, 342, 344, 362, 537, 674, 675, 695 Great Divide Basin... 10, 332, 333, 338, 361, 433-438 Jameson ...................................... 524 Johnson County . . ......................... 402,537 Lance Creek................................. 334, 341, 34 Laramie Range.

Lincoln County

Lost Creek. $341,342,344,443$

Lysite

Mayoworth area

Miller Hill $\quad 340,342,344,382-383,400$ Muddy Creek.............................. 524,525 Natrona County ............................... 383, 537 Niobrara County ........................... 536 old Woman snticline. .................. 334 Polson Basin ........................... 341, 342, 370 Powder River Basin..................... 332, 333, 338, $340,341,342,362,366,371-374,674,675$ Pumpkin Buttes. $325,338,340$, $341,342,367,368,371-374$

Rattlesnake Hills. Red Desert .......................... 340, 341, 439-444 Saratoga_................................... 342, 344, 400 Split Rock .................................... 389 Sublette Ridge.............................. 486 Sweetwater County ... 10, 385, 433-438, 439-444, 536 Washakie Basin. ......................... 338, 362, 370 Wind River Basin........ 334, 337, 338, 695-696, 697

$$
\mathrm{X}-\mathrm{Z}
$$

Xenotime, uranium in accessory ............... 18 other mention................... $72,477,561,569,573$ $\mathrm{X}$-ray spectrometric analysis, thorium.

$\mathrm{X}$-ray spectroscopic analysis, uranium. 614 610 


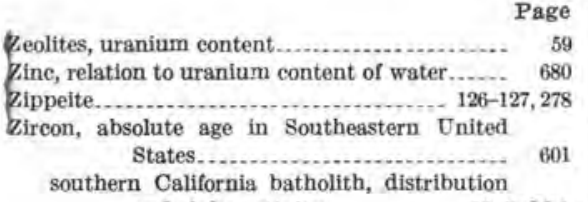
and alpha activity
Zircon-Continued structure...

uranium and thorium content. uranium in accessory zonal distribution of uranium within........ other mention.
Page 568 92
Zirconium mineralogy. See under Mineralogy. Zirconium minerals, table of names and formulas. Zoning of metals, vertical, in sandstone $\ldots 250$ Zonation of ores by mineralogic types............ 106 Zuni Mountains uplift, New Mexico ......... 156, 391

\section{AUTHOR INDEX}

\begin{tabular}{|c|c|}
\hline Page & Page \\
\hline Adams, J. W. & Grimaldi, F, S .... \\
\hline Altschuler, Z. S. & Gross, E. B........ \\
\hline & Grundy, W. D. \\
\hline Becraft, G. E... & Gruner, J. W... \\
\hline Bell, Henry, 3d. & Grutt, E. W., Jr. \\
\hline Bell, K. G.......... & \\
\hline Black, R. A..... & Hail, W. J., Jr.... \\
\hline Boardman, R. L... & Hetland, D. L.. \\
\hline Bowers, H. E..... & Hilpert, L. S... \\
\hline Breger, I, A...... & Hoekstra, H. R... \\
\hline Brock, M. R.... & Horr, C. A...... \\
\hline Brown, Andrew .. & Hyden, H. J..... \\
\hline Brown, Harrison. & \\
\hline Buck, K. L........ & Isachsen, Y. W.... \\
\hline Butler, A. P., Jr... & Jaffe, \\
\hline Canney, F, C. & Jobin, D. A ... \\
\hline ..... 681 & Johnson, J. C... \\
\hline Carithers, L. W.. & \\
\hline Carswell, L. D... & $\begin{array}{l}\text { Katz, J } \\
\text { Kelley, }\end{array}$ \\
\hline Catheart, J. B .... & $\begin{array}{l}\text { Kelley, V. C } \\
\text { Kerr, P. F... }\end{array}$ \\
\hline Clinton, N. J.... & $\begin{array}{l}\text { Kerr, P. F } \\
\text { Keys, W.... }\end{array}$ \\
\hline Coats, R. R... & $\begin{array}{l}\text { Keys, W. S } \\
\text { King, J. W....... }\end{array}$ \\
\hline t, L. C... & $\begin{array}{l}\text { King, J. W....... } \\
\text { Kleinhampl, F. J }\end{array}$ \\
\hline 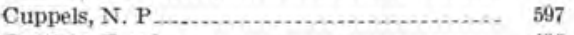 & $\begin{array}{l}\text { Kleinhampl, F.J. } \\
\text { Klepper, M. R... }\end{array}$ \\
\hline uttitta, Frank.. & Klepper, M. R... \\
\hline Davis, D. L... & Lakin, H. W... \\
\hline Denson, M. E.... & Larsen, E. S., Jr... \\
\hline 413,673 & Laverty, $R_{+} A_{-} \ldots$ \\
\hline Derzay, R. C............... 137 & Lovering. T. $\mathbf{8}$.. \\
\hline Deul, Maurice.......... 505 & McKay, E. J..... \\
\hline Dodd, P. H.......... & McKelvey, V. E........... \\
\hline Ekren, E. B.... & Mckeown, F. A................. 371 \\
\hline Evensen, C. G....... & 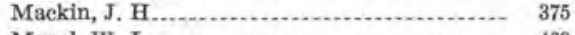 \\
\hline Everhart, D, L ........ & Mapel, W. J..... 469 \\
\hline & $\begin{array}{l}\text { Masursky, Harold.... } \\
\text { Myers, A. T }\end{array}$ \\
\hline (n....... & $\begin{array}{l}\text { Myers, A. T. W. } \\
\text { Mytton, J. W }\end{array}$ \\
\hline $\begin{array}{l}\text { Finne } \\
\text { Fische }\end{array}$ & \\
\hline R. P & Neuerburg, G. J .... \\
\hline Foote, R. S & Olson, J. \\
\hline 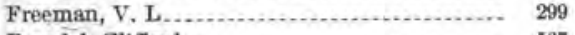 & Osterwald, F. W..... \\
\hline 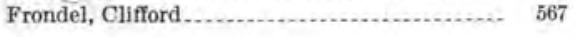 & Overstreet, W. C.... \\
\hline 303,387 & Page, L. R............. 5, 621, 627 \\
\hline (2). & 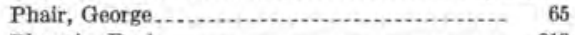 \\
\hline 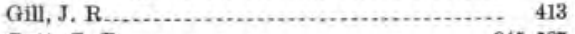 & Phoenix, D. A \\
\hline Zott, G. B........... 345, 527 & 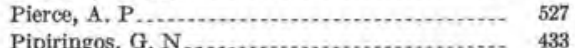 \\
\hline
\end{tabular}

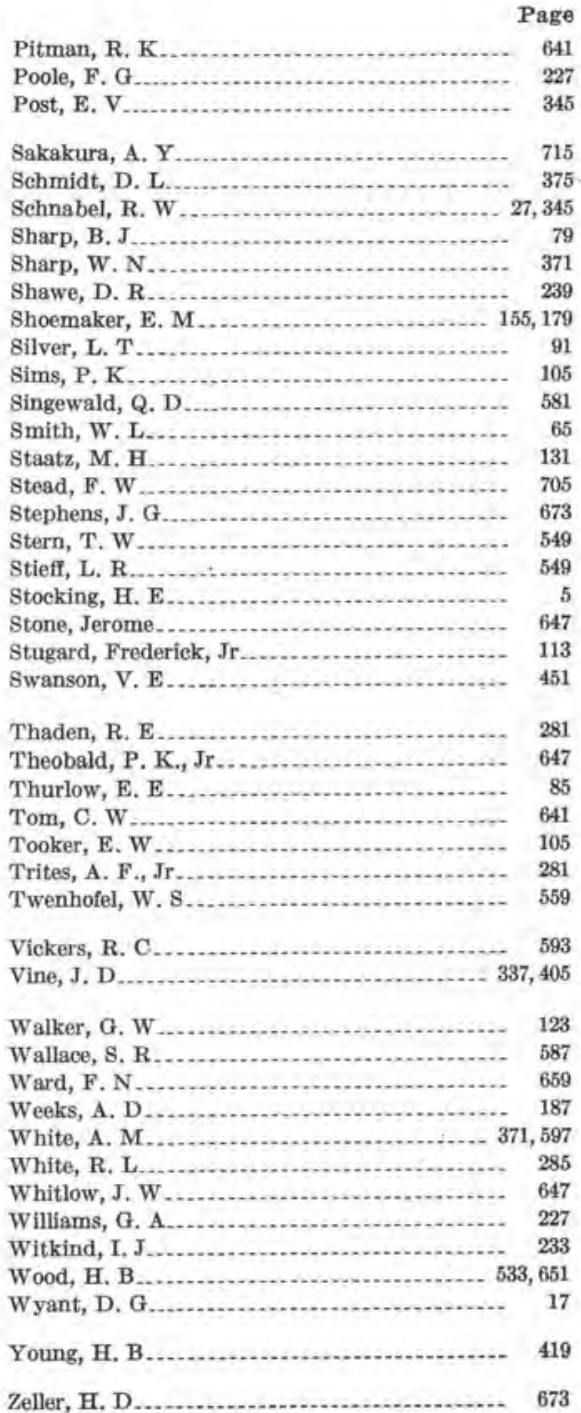

Pipiringos, G. N 